8 


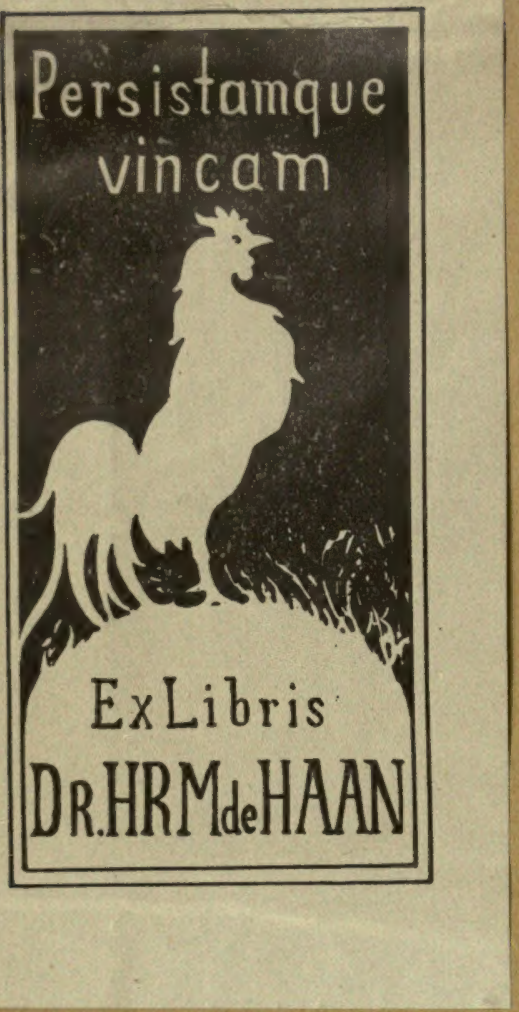




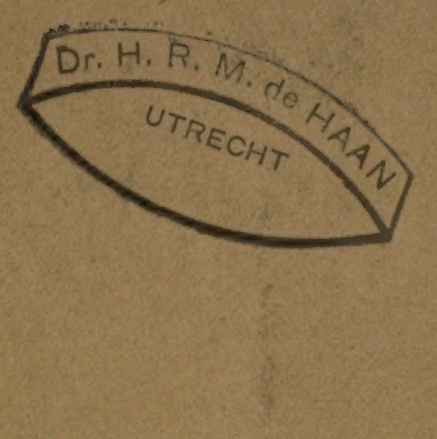

3. 

$1914-1918$

\title{
EUG. WARMING'S LEHRBUCH DER ÖKOLOGISCHEN PFLANZENGEOGRAPHIE
}

\author{
Dritte umgearbeitete Auflage
}

von

$\begin{array}{cc}\text { Eug. Warming und } & \text { P. Graebner } \\ \text { Prof., Dr. phil. et sc. } \\ \text { Kobenhavn }\end{array}$

IIlustrierte Ausgabe

mit 395 Abbildungen

\author{
Berlin \\ Verlag von Gebrüder Borntraeger \\ W 35 Schöneberger Ufer $12 a$ \\ 1918
}




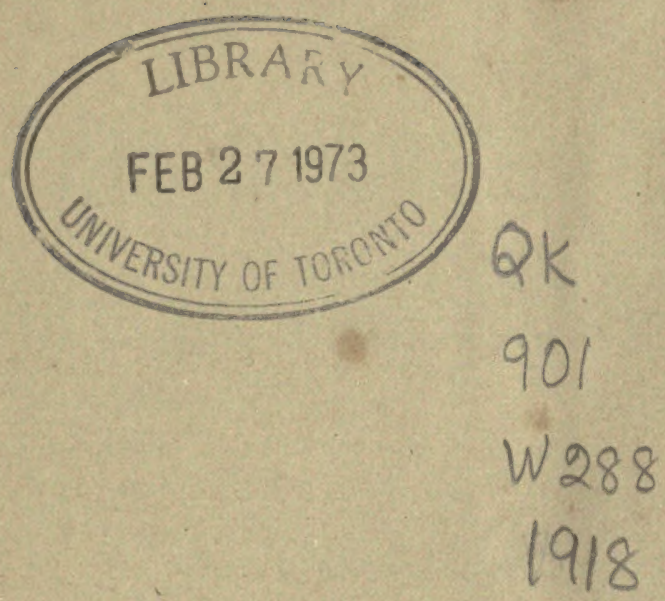

Alle Rechte,

insbesondere das Recht der Übersetzung in fremde Sprachen, vorbehaiten 


\section{Vorwort}

Wenige Monate nach dem Erscheinen meines „Plantesamfund. Kjöbenhavn 1895", welches aus den Vorlesungen für meine naturwissenschaftlichen Zuhörer an der Universität Kjöbenhavn hervorgegangen war, suchte Dr. Emil Knoblauch meine Erlaubnis nach, es ins Deutsche übersetzen zu dürfen, und in weniger als einem Jahre lag die Übersetzung gedruckt vor. Es war mir daher nur möglich gewesen ganz wenige Verbesserungen vorzunehmen.

Die Herausgabe der zweiten Auflage vertraute der Verleger Professor Graebner an; ich selbst habe bei dieser Ausgabe nicht mitgewirkt.

1909 erschien dann eine englische Ausgabe: Oecology of Plants (Clarendon Press, Oxford) unter meiner Leitung von Prof. Percy Groom und Prof. J. B. Balfour. Diese Ausgabe hatte ich in so hohem Grade umgearbeitet, daß es eigentlich ein neues Buch war; namentlich war die Anordnung des Stoffes gänzlich geändert. Ursprünglich hatte ich die Pflanzenvereine in vier Gruppen gesammelt: Hydrophyten-, Xerophyten-, Halophyten- und Mesophytenvereine. Unter den Xerophyten z. B. fanden sich dabei aber ökologisch so verschiedene Vereine wie Felsenvegetation, Kältewüsten, Moos-, Flechten- und Zwergstrauchheiden, Sandvegetation, tropische Wüsten, Steppen usw. Die geographisch-ökologische Seite trat allzusehr in den Hintergrund, und ich empfand es daher als notwendig, die Vereine mehr nach dem Standorte (Klima und Boden) zu verteilen; um dies so vollkommen wie möglich zu machen, suchte ich mir die Hilfe eines jungen, kenntnisreichen, dänischen Geographen zu sichern, dessen Spezialstudium Pflanzengeographie und Klimatologie war, nämlich Dr. Martin Vahl. Daraus resultierte dann die Gruppierung der Pflanzenvereine in 13 Klassen, welche sich wieder mit einigen Änderungen in dieser dritten deutschen Ausgabe vorfinden.

Auf Wunsch des Verlages (Gebr. Borntraeger) habe ich 1912 in Verbindung mit Prof. Dr. P. Graebner die Herausgabe dieser 3. Auflage übernommen. Mein Manuskript lag im wesentlichen fertig vor, und der Druck war schon in raschem Gange, als der 1. August 1914 plötzlich alles änderte; der Satz mußte vorläufig eingestellt werden und konnte später nur mit sehr großen Unterbrechungen fortgesetzt werden. Über 
drei Jahre sind verflossen, bis jetzt endlich der Abschluß gekommen ist. Es ist mir nicht möglich gewesen, die in den letzten drei Jahren erschienene pflanzenökologische Litteratur vollständig auszunutzen; andere Arbeiten, die ich erledigen mußte, hinderten mich; indessen ist ein großer Teil wenigstens in der Litteraturliste angeführt worden. Die pflanzenökologische Litteratur ist überhaupt in den letzten zwanzig Jahren so ungeheuer angeschwollen, daß es unmöglich wird für einen einzelnen, sie gebührend auszunutzen.

Was nun das Buch selbst betrifft, ist die Anordnung des Stoffes im wesentlichen dieselbe wie in der englischen Ausgabe, jedoch sind einige Änderungen vorgenommen, z. B. sind die Abschnitte über die Lebensformen und über das Zusammenleben der Organismen, namentlich die Begriffe Formation, Assoziation usw. (die in Übereinstimmung mit den Resultaten des internationalen Kongresses in Brüssel 1910 angewendet werden) wesentlich geändert worden; überhaupt ist der Umfang des Buches nach dem Wunsche des Verlegers etwa auf das Doppelte vermehrt worden. Eine sehr erhebliche Verbesserung bedeuten die fast 400 Illustrationen.

Es ist mir eine liebe Pflicht, einen herzlichen Dank an diejenigen zu richten, welche mir in verschiedener Weise Hilfe geleistet haben, namentlich Dr. C. H. Ostenfeld, der mein Manuskript über Meeresplankton durchgesehen hat; Dr. Ove Paulsen, der mir Aufschlüsse sowohl über Meeresvegetation als über Steppen und Prärien gab und einige diesbetreffende Korrekturen las; Dr. Vahl, der mir wieder einige klimatische Berichtigungen mitteilte, und Prof. Dr. Diels, der Mitteilungen über australische Wüsten usw. machte.

Von denjenigen, welche Photographien, Zeichnungen oder Klischees unentgeltlich zur Verfügung stellten, $\mathrm{mu} \beta$ ich besonders hervorheben: Dr. F. Börgesen, Dr. Hjalmar Jensen auf Java, Cand. A. Hesselbo, Dr. Ove Paulsen, Prof. Lindman in Stockholm, Prof. Dr. E. Pritzel, Dr. V. Madsen, Oberlehrer F. G. Meyer-Schöneberg, Frl. Käthe MeierKolberg, † Joh. Bath, die Pflanzengeographen Prof. Adamovié und Tanfiljew, Prof. Yendo in Japan und eine Anzahl Herausgeber dänischer wissenschaftlicher Zeitschriften.

Vor allem muß ich jedoch einen herzlichen Dank an Prof. Dr. P. Graebner richten, der mein ganzes Manuskript durchgelesen und mit wertvollen Ergänzungen sowie Litteraturnachweisungen versehen hat; ferner auch mit großer Sorgfalt die Mühe der Korrektur getragen hat. Das Sachregister hat Herr Bürgermeister a. D. H. Stange mit gewohnter Sorgfalt verfaß; auch ihm besten Dank!

Kjöbenhavn-Valby, August 1917

Eug. Warming 


\section{Inhaltsverzeichnis}

Einleitung

\section{Erster Abschnitt}

Der Standort (Statio, Habitat). Die ökologischen

Faktoren und ihre Wirkungen ...... 10

\section{Klimatische Faktoren}

1. Kap. Die Zusammensetzung der Luft . . . . . . . . . . . . . . . . . 10

2. ${ }^{n}$ Licht . . . . . . . . . . . . . . . . . . . . . . . 11

3. " Wärme . . . . . . . . . . . . . . . . . . . . . . 32

4. ก Luftfeuchtigkeit and Niederschläge . . . . . . . . . . . 47

5. " Luftbewegungen . . . . . . . . . . . . . . . . . . . 63

\section{Edaphische Faktoren}

6. " Die Besehaffenheit des Nährbodens . . . . . . . . . . . . . 72

7. " Der Bau des Bodens ?. . . . . . . . . . . . . . . . . 72

8. " Die Luft im Boden . . . . . . . . . . . . . . . . . . . . . . 79

9. $n$ Das Wasser im Boden .. . . . . . . . . . . . . . . . . . 80

10. " Die Wärme des Bodens . . . . . . . . . . . . . . . . . 89

11. " Die Mächtigkeit des Bodens. Die oberen Bodenschichten und der Untergrund . . . . . . . . . . . . . . . . . . 96

12. $n$ Die Nahrung im Boden . . . . . . . . . . . . . . . . . . . . . 99

13. " Die Bodenarten . . . . . . . . . . . . . . . . . . . 105

14. " Sind die chemischen oder die physikalischen Eigensehaften des Bodens die wichtigsten? . . . . . . . . . . . . . . . . . . . 118

15. " Kampf der Arten untereinander . . . . . . . . . . . . . . 126

16. " Die Wirkung einer leblosen Decke über der Vegetation . . . . . . . 128

17. $n$ Die Wirkungen einer lebenden Pflanzendecke auf den Boden . . . . 133

18. " Die Tätigkeit der Tiere und der Pflanzen im Boden . . . . . . . 136

19. " Einige orographische und andere Faktoren . . . . . . . . . . 140

\section{Das Wasser als Standort}

20. " Die ökologischen Faktoren in Wasser . . . . . . . . . . . . 143

\section{Zweiter Abschnitt}

\section{Die Lebensformen}

21. Kap. Die Lebensformen und ihre Grundformen . . . . . . . . . . . 151

22. "Übersicht der Grundformen des Lebens . . . . . . . . . . . . . 154 
23. Kap. Ökologische Anpassung (Epharmonie) der Lebensformen . . . . . . 195

24. Anpassungen der Landpflanzen . . . . . . . . . . . . . . . 199

25. Regulierung der Verdunstung .. . . . . . . . . . . 201

26. $n$ Regulierung der Beleuchtung . . . . . . . . . . . . 236

27. $n$ Ableitung von Regen .......... . . . . . . . 240

28. "Wasseraufnahme bei Landpflanzen . . . . . . . . . . . 242

29. $n$ Wasserbehälter . . . . . . . . . . . . . . 247

30. n Andere anatomische und morphologische Eigentümlichkeiten der Landpflanzen . . . . . . . . . . . . . . . . 261

31. „ Morphologische und anatomische Anpassung der Wasserpflanzen . . . 268

\section{Dritter Abschnitt}

Das Zusammenleben der Organismen. Sociale Anpassungen. Die Pflanzenvereine

32. Kap. Das Zusammenleben der lebenden Wesen . . . . . . . . . 275

33. " Die Eingriffe des Menschen . . . . . . . . . . . . . 275

34. " Das Zusammenleben mit den Tieren . . . . . . . . . . . . 276

35. " Das Zusammenleben der Pflanzen untereinander . . . . . . . . . 279

36. ๓ Der Kommensalismus. Die Pflanzenvereine . . . . . . . . . . 299

37. „ Der Standort als Basis für die Klassifikation der Vereine (Pflanzengesellschaften) . . . . . . . . . . . . . . 306

38. $"$ Physiognomie der Vereine . . . . . . . . . . . . . . 324

39. $n$ Formationen . . . . . . . . . . . . . . . . . . . . . 333

40. $n$ Assoziationen . . . . . . . . . . . . . . . . . . . . . 349

41. $n$ Succession. Sekundäre Veränderungen der Formationen und Assoziationen 356

\section{Vierter Abschnitt}

\section{Serie der Halophyten}

42. Kap. Salzwasservereine und Salzbodenvegetation . . . . . . . 358

43. „ Das Salzwasserplankton (Haloplankton) . . . . . . . . . . . . 361

44. $n$ Halonereïden (steinliebende Hydrophyten des Salzwassers) . . . . . 374

45. " Vereine der submersen Salz-Wasserpflanzen auf losem Boden . . . . 385

46. „ Formationen der Salz-Sümpfe . . . . . . . . . . . 396

47. i Halophytische Landvegetation . . . . . . . . . . . 411

48. " Formationen der Strandfelsen . . . . . . . . . . . . . . . 419

49. " Formationen des Strandgerölles . . . . . . . . . . . . 428

50. $\rightarrow$ Vegetation des losen salzigen Bodens (Sandboden) . . . . . . . 430

51. " Formationen des salzigen Tonbodens . . . . . . . . . . 447

52. „ Salzvegetation des Binnenlandes. Salzsteppen. Salzwüsten . . . . 455

II. Serie. An süßes Wasser gebundene Vereine

53. Kap. Süßwasservereine . . . . . . . . . . . . . . 461

54. n Formation der mikrophytischen Schwebepflanzen (Limnoplankton) . . 464

55. $n$ Formation des Saproplanktons . . . . . . . . . . . 470

56. $n$ Formation des Megaplankton oder Makroplankton . . . . . . . . 471

57. $"$ Vereine von steinliebenden (epilithischen) Süßwasserpflanzen (LimnoNereïden)

8. Vore. . . . . . . . . 478

Vereine von Süßwasserpflanzen auf losen Böden . . . . . . . . . 482 
59. Kap. Formation der Saprobien auf losem Boden . . . . . . . . . . 483

60. " Die autophyten Limnäen. Formationen auf losem SüBwasserboden . . 486

61. "Ufervegetation . . . . . . . . . . . . . . . . . . . 499

62. "Formationen der Sumpfpflanzen . . . . . . . . . . . . . . 501

63. " Rohrsümpfe . . . . . . . . . . . . . . . . 503

64. $n$ Formationen der Sumpfgebüsch $\theta$ und Brücher in Süßwasser . . . . 515

65. $n$ Vegetation der flachen, sandigen und kiesigen Ufer. Periodisch wechselnder Wasserstand . . . . . . . . . . . . . . . . 518

66. " Alluvialland der Flüsse. Uferwaldungen . . . . . . . . . . . 521

\section{Serie der mesophilen und hygrophilen Formationen}

67. Kap. Allgemeine Bemerkungen . . . . . . . . . . . . . 525

68. " Mikrotherme (arktische und alpine) Gras- und Krautmatten . . . . . 528

69. " Wiesen ................ . . 536

70. $n$ Hochstaudenfluren .. . . . . . . . . . . . 541

71. " Weiden auf Kulturland (Kultur- und Halbkulturassoziationen) . . . . 544

72. " Formation der mesuphilen Gebüsche kalter und kalttemperierter Klimate 546

73. " Formation der sommgergrünen Laubwälder . . . . . . . . . . 552

74. " Nadelwälder (Conifereta) . . . . . . . . . . . . . 574

75. " Laubwechselnde Nadelwälder (Lärchenwälder) . . . . . . . . . 577

76. " Die immergrünen Nadelwälder . . . . . . . . . . . . . . 578

77. " Subtropische und tropische Grasfluren und Wiesen . . . . . . . . 587

78. " Subtropische immergrüne Laubwälder . . . . . . . . . . . . 588

79. " Tropische Wälder . . . . . . . . . . . . . . . . 592

\section{Serie der Formationen auf Torfböden}

80. Kap. Eigentümlichkeiten der Vegetation auf torfhaltigen Böden . . . . . 618

81. $n$ Wiesenmoore . . . . . . . . . . . . . . . . 630

82. " Tussock-Vegetation . . . . . . . . . . . . . . . . . . . 637

83. " Moostundren. Moosheiden . . . . . . . . . . . . . 640

84. " Flechtenlreiden. Flechtentundren . . . . . . . . . . 649

85. " Sphagnummoore (Sphagneta, Heidemoore, Moosmoore, Hochmoore) . . 6อ2

86. " Formation der Zwergsträucher auf torfhaltigem Boden . . . . . . 66t

87. " Formation der Sträucher auf Torfboden . . . . . . . . . . . . 680

88. $n$ Wälder auf Torfboden . . . . . . . . . . . . . . 685

\section{Serie. Kältewüsten.}

89. Kap. Die subglazialen Formationen . . . . . . . . . . . . . 694

90. "Anpassungen der Pflanzen in den Kältewüsten . . . . . . . . . 701

91. $n$ Die Formationen der Kältewüsten (subglaziale Felsenfluren) . . . . 712

\section{Serie der Stein- und Sandböden.}

92. Kap. Allgemeines. Die eigentlichen Felsformationen (Lithophyten-Formationen) 721

93. " Flachgründiger Boden .. . . . . . . . . . . . 730

94. " Spaltenvegetation (Chasmophytische Vegetation) . . . . . . . . . 732

95. "Vegetation der Trümmerfelder von größeren Felsblöcken (Felsenmeere, Blockmeere) . . . . . . . . . . . . . . . 740

96. "Geröllhalden, Schutthalden (Geröllfluren) . . . . . . . . . . 745

97. $\pi$ Sandvegetation (Psammophile Formationen) . . . . . . . . . . 748

98. $n$ Lebensformen and Anpassungen .. . . . . . . . . . . 757 
99. Kap. Assoziationen der Sandvegetation in Europa . . . . . . . . . . 759

100. " Dünen außereuropäischer Länder . . . . . . . . . . . . 776

\section{Serie der Hartlaubformationen}

101. Kap. Hartlaubvegetation. Hartlaubformationen . . . . . . . . 785

102. " Formationeu von Halbsträuchern und Kleinsträuchern (Felsentriften, Felsensteppen, Halbstrauchsteppen) . . . . . . . . . 787

103. " Hartlanbgebüsche (Macchien) . . . . . . . . . . . 793

104. $"$ Hartlaubwälder . . . . . . . . . . . . . . 801

VIII. Serie der subxerophilen Formationen mit Grasboden

105. Kap. Subxerophile Gras- und Staudenvegetation (Steppen und Prärien) . . 807

106. " Die baumlosen Grassteppen . . . . . . . . . . . . . . . 809

107. "Baumsteppen (Savannen, Campos) . . . . . . . . . . . . 833

IX. Serie der ariden Gebiete (Einöden)

108. Kap. Aride Gebiete. Halbwüsten and Wüsten . . . . . . . . . . . 849

109. ๓ Trockenwälder . . . . . . . . . . . . . . . 850

110. ก Succulenten-Halbwüsten . . . . . . . . . . . 853

111. "Formation der Trockengebüsche. "Dornstrauchsteppen" . . . . . 861

112. " Hochgebirgssteppen . . . . . . . . . . . . . 867

113. " Dornenlose Halbstrauchsteppen . . . . . . . . . . . . . . 872

114. ก Hitzewüsten (Die Trockenwüsten) . . . . . . . . . . . . . 875

115. $n$ Lebensformen der Wüste . . . . . . . . . . . . . . 881

116. ๓ Die Wüstenregionen der Erde . . . . . . . . . . . . 886

\section{Fünfter Abschnitt}

Der Kampf zwischen den Pflanzenvereinen

117. Kap. Einleitende Bemerkungen . . . . . . . . . . . . 896

118. " Geogene Veränderungen; neuer Boden . . . . . . . . . . 898

119. "Klimatogene und biogene Änderungen . . . . . . . . . . . . . . 918

120. "Allgemeine Sätze über Besiedlung von Neuland. Waffen der Arten in ihren Kämpfen. Seltene Arten . . . . . . . . . . . . 930

121. " Die Entstehung der Arten . . . . . . . . . . . . . 941 


\section{Einleitung}

\section{Floristische und ökologische Pflanzengeographie}

Die Aufgabe der Pflanzengeographie ist, uns über die Verteilung der Pflanzen auf der Erde, sowie über die Gründe und die Gesetze dieser Verteilung zu belehren. Diese kann von zwei verschiedenen Gesichtspunkten betrachtet werden, nach denen man die Pflanzengeographie in die floristische und die ökologische teilen kann, die jedoch nur zwei verschiedene Richtungen derselben Wissenschaft sind, viele Berührungspunkte haben und an gewissen Punkten ineinander übergehen.

I. Die floristische Pflanzengeographie hat folgende Aufgaben. Die erste und leichteste ist, von den auf größeren oder kleineren Gebieten wachsenden Arten Listen, eine "Flora", herzustellen; diese Listen sind ein unentbehrliches Rohmaterial. Der nächste Schritt ist die Einteilung der Erdoberfläche in natürliche floristische Gebiete (Florenreiche usw. $)^{1}$ ) nach ihrer Verwandtschaft, d. h. nach der Menge von gemeinsamen Arten, Gattungen und Familien. Der floristische Charakter eines Ciebietes hängt von seinem Platze auf der Erde ab. Ferner sind die Florenreiche in natürliche Gebiete, Regionen und Bezirke einzuteilen und diese Gebiete zu kennzeichnen; man hat die Grenzen für die Verbreitung der Arten, Gattungen, Familien (deren Habitatio oder Wohngebiet, Area), ihre Verteilung und ihre Dichtigkeit des Vorkommens in verschiedenen Ländern, den Endemismus, das Verhältnis der Inselfloren zu den Floren der Festländer, das der Gebirgsfloren zu denen der Tiefländer u. v. a. festzustellen.

Der denkende Forscher wird bei der einfachen Feststellung von Tatsachen nicht stehen bleiben; er sucht nach den Gründen, weshalb alle diese Beziehungen gerade so sind, wie sie sind. Diese Gründe können teils gegen wärtige (geognostische, topographische, klimatische), teils historische Verhältnisse sein. Die Grenzen einer Art können nämlich auf den Bedingungen der Gegenwart beruhen, auf den Schranken,

1) Engler 1899; Drude 1884, 1886-87, 1890.

Warming-Graebner. 8. Anflage, illusts. 
welche Gebirge und Meere, Boden und klimatische Verhältnisse in der Gegenwart ihrer Verbreitung setzen, aber auch auf den geohistorischen oder den geologischen und den klimatischen Verhältnissen lange verflossener Zeiten und auf der ganzen Entwicklungsgeschichte der Art, den Stellen ihres Vorkommens, auf ihren Wanderungsmitteln und ihrer Wanderungsfähigkeit. Ferner sind die Fragen nach den Entwicklungszentren, nach dem Ursprung und dem Alter der Arten und Gattungen u.v. a. zu behandeln; und dahinter liegt die Frage nach der Entstehung der Arten (Genetische Pflanzengeographie; siehe Schröter 1913).

So wird Dänemarks noch nicht geschriebene floristische Pflanzengeographie zur Aufgabe haben, folgendes zu untersuchen: Die Verbreitung der vorkommenden Arten, ihre Verteilung im Lande, Dänemarks Einteilung in natürliche floristische Bezirke, Dänemark als floristischen Teil eines größeren natürlichen Gebietes oder seine floristische Verwandtschaft mit Skandinavien, Deutschland usw., die Fragen, wann und woher die Arten nach der Eiszeit einwanderten, die Wege ihrer Wanderungen und ihre Wanderungsmittel, die Frage nach Reliktenpflanzen, die Frage, ob neue Formen sich gebildet haben u. v. a. ${ }^{1}$ ).

II. Die ökologische Pflanzengeographie hat ganz andere Aufgaben; sie belehrt uns darüber, wie die Pflanzen und die Pflanzenvereine ihre Gestalt, ihre Haushaltung und ihre Verteilung auf der Erde nach den auf sie einwirkenden Faktoren, z. B. nach der ihnen zur Verfügung stehenden Menge von Wärme, Licht, Nahrung, Wasser u. a. einrichten ${ }^{2}$ ).

Ein flüchtiger Blick zeigt, daß die Arten über das ganze Gebiet ihrer Verbreitung keineswegs gleichmäßig verteilt sind, sondern sich in "Gesellschaften" oder "Vereinen", Assoziationen, mit sehr verschiedener Physiognomie gruppieren.

Die erste und leichteste Aufgabe ist, zu ermitteln, welche Arten an den gleichartigen Standorten (Stationes, Habitats) vereinigt sind. Dieses ist eine einfache Feststellung oder Beschreibung von Tatsachen:

Eine andere, auch nicht schwierige Aufgabe ist, die Physiognomie der Vegetation und der Landschaft zu schildern, eine Aufgabe, der sich besonders in allerneuester Zeit zahlreiche Forscher zugewandt haben.

1) Ein Entwurf zu Beantwortung dieser Fragen findet sich: Warming 1904.

Mit den übrigens interessanten und weitreichenden Aufgaben der floristischen Pflanzengeographie haben wir uns hier nicht $\mathrm{zu}$ befassen. Diese ist besonders von Wahlenberg, Schouw, Alph. de Candolle, Jos. Hooker, Grisebach, Ascherson, Engler, Drude und Hemsley behandelt worden.

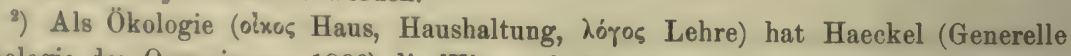
Morphologie der Organismen, 1866) die Wissenschaft von den Beziehungen der Organismen zur AuBenwelt bezeichnet. Reiter gebrauchte den Ausdruck etwa in demselben Sinne, indem er ihn in die Botanik einführte (1885; siehe Mac Millan 1897). Vergl.
anch Goobel 1879, Spalding 1909. 
Die nächste und sehr schwierige Aufgabe ist die Beantwortung der Fragen: Weshalb schließen sich die Arten zu bestimmten "Gesellschaften", Assoziationen zusammen und weshalb haben diese die Physiognomie, die sie besitzen?

Dadurch kommen wir zu den Fragen nach der Haushaltung der Pflanzen, nach ihren Anforderungen an die Lebensbedingungen, zu den Fragen, wie sie die äußeren Bedingungen ausnutzen und wie sie in ihrem äußeren und ihrem inneren Bau und ihrer Physiognomie angepaßt sind, und kommen zunächst zur Betrachtung der Lebensformen.

Schließlich begegnen wir auch hier der Frage nach der Entwicklungsgeschichte der Pflanzenvereine, - ein Zweig der genetischen Pflanzengeographie.

Auf die Wichtigkeit physiologischer Experimente für die Pflanzengeographie macht neuerdings Massart ${ }^{1}$ ) aufmerksam.

Die ökologische Pflanzengeographje muß folgendes behandeln:

\section{A. Der Standort}

Die Faktoren der AuBenwelt, die in der Haushaltung der Pflanzen eine Rolle spielen. Bei pflanzenökologischen Studien muß dann zuerst der Standort (Statio; Habitat) studiert werden, weil sein physikalisches und chemisches Verhalten die Grundlage sowohl für das Gedeihen der einzelnen Pflanzengestalten, als für die Verschiedenheiten der Pflanzenvereine darbieten. Der Charakter des Standorts wird durch die Kombination aller an ihm wirkenden Faktoren hervorrufen.

Die Faktoren und ihre Wirkungen werden im 1. Abschnitte (I, II, III) behandelt. Die verschiedenen Faktoren müssen jeder für sich behandelt werden, obgleich dieses ein Übelstand ist, teils weil sie nie einzeln, sondern meist zu vielen vereint wirken, teils weil wir keineswegs überall darüber im klaren sind, was dem einen oder was dem andern zuzuschreiben sei. Man kann sie mit Schouw in unmittelbar und in mittelbar wirkende Faktoren einteilen.

I. klimatische Faktoren sind die in großer Ausdehnung wirkenden Faktoren, weil sie an den Umlauf der Erde um die Sonne und an die geographische Breite gebunden sind: 1. Zusammensetzung der Luft, 2. Licht, 3. Wärme, 4. Niederschläge, 5. Luftfeuchtigkeit und 6. Luftbewegungen.

Diese werden im 1. Abschnitte Kap. 1-5 besprochen. - Alle gehören zu den unmittelbar wirkenden Faktoren.

II. edaphische Faktoren ${ }^{2}$, die innerhalb eines kleineren Rahmens, mehr örtlich, wirken, namentlich die chemische und die physikalische Natur des Bodens.

1) Massart 1912 .

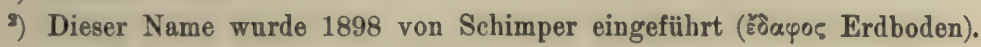


Während das Klima eine sehr große Rolle für den Charakter der Flora eines größeren Gebietes spielt, sind die edaphischen Faktoren äußerst wichtig für die Entstehung und Begrenzung bestimmter Vereine.

Die edaphischen Faktoren sind zweierlei Art, und zwar a) diejenigen, welche den festen Erdboden, und b) die, die das Wasser betreffen.

a) Fester Erdboden, dieses sind: 6. die Beschaffenheit des Nährbodens, ferner 7. der Bau, 8. die Luft, 9. das Wasser, 10. die Wärme, 11. die Mächtigkeit, 12. die Nahrung, 13. die Arten des Bodens und hieran schließt sich 14. die Frage nach seinem chemischen und seinem physikalischen Einflusse u. a.

Diese Faktoren werden im 1. Abschnitte Kap. 6-14 besprochen und gehören zu den unmittelbar wirkenden Faktoren.

Es ist noch zurzeit in vielen Fällen ganz unmöglich in jedem einzelnen Falle bestimmt zu sagen, welche Faktoren bei den verschiedenen Vereinsbildungen sich kombinieren und welcher resp. welche von ihnen etwa von ausschlaggebender Bedeutung für die Bildung des betreffenden Vereines sind. Was die Sache schwierig macht ist, daß klimatische und edaphische Faktoren einander ersetzen oder ergänzen können.

Mittelbar wirkende Faktoren des Erdbodens sind:

Das Relief der Erdoberfläche, die Gestaltung der Länder und der Meere, die Höhe über dem Meere, die geographische Breite sowie andere eingreifende und modifizierende Faktoren. Die Kap. 15-19 behandeln: 15. Der Kampf der Arten untereinander, 16. die Wirkungen einer leblosen Decke über der Vegetation, 17. die Wirkungen einer lebenden Decke, 18. die Arbeit der Tiere und der Pflanzen im Boden, 19. einige orographische u. a. Verhältnisse ${ }^{1}$ ).

b) Das Wasser als Standort. Luft, Licht, Wärme, Nährstoffe, Bewegungen, Farbe des Wassers. Die anatomischen usw. Anpassungserscheinungen der Wasserpflanzen im 2. Abschnitt.

Biotische Faktoren sind solche, deren Wirkung gerade durch das Zusammenleben der Pflanzen resp. durch ihre gegenseitigen Konkurrenzkämpfe hervorgerufen wird. Besonders sind es die klimatischen Verhältnisse, wie sie durch die verschiedenen Wirkungen von Luft, Licht, Wärme, Feuchtigkeit zustande kommen, welche durch sie im kleinen geåndert werden.

Sie werden teilweise im 3. bis 5 . Abschnitt besprochen.

1) Näheres hierüber wird man bei Sachsse, Dehérain, Vallot, Ramann, Drude, Graebner, Schimper, Clements u. ̊. finden. 


\section{B. Die Lebensformen}

Die Einwirkungen der verschiedenen Faktoren auf den äußeren und inneren Bau der Pflanzen, auf ihre Lebensdauer usw. ist der zweite umfassende Gegenstand ökologischer Forschung. Dieses führt uns zum Studium der Lebensformen und der Physiognomie der Pflanzen ${ }^{1}$ ).

Jede Art muß im äußeren und im inneren Bau mit den Naturverhältnissen, worunter sie lebt, im Einklange sein, und kann sie sich, wenn sich jene ändern, ihnen nicht anpassen, so wird sie von anderen Arten verdrängt werden oder ganz zugrunde gehen. Es ist daher eine der wichtigsten und ersten Aufgaben der ökologischen Pflanzengeographie: die Epharmonie ${ }^{2}$ ) der Art, die man ihre Lebensform (growth form, forme biologique) nennen kann, zu verstehen. Diese zeigt sich besonders in der Tracht und in der Gestalt und Dauer der Ernährungsorgane (im Bau des Laubblattes und des ganzen Laubsprosses, in der Lebensdauer des Individuums usw.: A utökologie ${ }^{3}$ ), weniger in denen der Fortpflanzungsorgane. Diese Aufgabe führt tief in morphologische, anatomische ${ }^{4}$ ) und physiologische Studien ein; sie ist sehr schwierig, aber sehr anziehend; sie kann noch in wenig Fällen befriedigend gelöst werden, aber die Zukunft gehört ihr. Bei ihr stoßen wir auch auf die Frage nach dem Ursprunge der verschiedenen Arten.

Was die Aufgabe sehr erschwert, ist z. B. der Umstand, daß es neben der gestaltenden Fähigkeit der vielen äußeren Faktoren und neben der Anpassung der Arten an diese, bei jeder Art bestimmte, natürliche erbliche Anlagen gibt, die aus inneren, unbekannten Ursachen Gestalten hervorbringen, welche wir zu den umgebenden Naturverhältnissen, jedenfalls zu den gegenwärtigen, in gar keine Beziehung bringen können und daher gar nicht verstehen. Diese nach der natürlichen Verwandtschaft verschiedenen inneren Anlagen bringen es mit sich, daß die Entwicklung der Arten unter der Einwirkung derselben Faktoren auf ganz

1) Vergl. darüber auch W. Lange, Gartengestaltung der Neuzeit, 3. Aufl.

$\left.{ }^{2}\right)$ Vesque bezeichnet (1882) „L'épharmonie“ als "l'état de la plante adaptée“ und "Epharmose" als die allmähliche Anpassung der pflanzlichen Formenkreise resp. ihrer einzelnen Organe an neue Lebenslagen, also an verschiedene Standorte (Pflanzenvereine) und abweichende Klimate.

2) Schröter, vergl. Flahault u. Schröter 1910.

4) Die Anatomie der Pflanzen ist in neuerer Zeit, namentlich durch Haberlandt und seine Schüler, in der Richtung gefördert worden, daß die Abhängigkeit zwischen dem innern Bau und den Lebensbedingungen der Umgebung in den Vordergrund gerückt wurde. Duval Jouve betonte schon 1875: „L'objet de la présente étude est de constater les principales dispositions des tissus dans les feuilles des Graminées, et de déterminer, autant que possible, le rapport de certaines dispositions avec les fonctions imposées par le milieu". 
verschiedenen Wegen zu demselben Ziele führen kann. Während sich z. B. eine Art an trockene Standorte durch eine dichte Haarbekleidung anpaßt, kann eine andere unter denselben Verhältnissen kein einziges Haar hervorbringen ${ }^{1}$ ), sondern zieht es z. B. vor, sich mit einer Wachsschicht zu bedecken oder ihre Laubblätter zu reduzieren und mit dem Äußeren der Stammsucculenten aufzutreten, oder wird in ihrer Entwicklung ephemer.

Einerseits haben in den wenigsten Familien der Blütenpflanzen die verschiedenen Arten dieselbe Lebensform, d. h. im Einklange mit denselben Lebensbedingungen im ganzen denselben Habitus, gleiche Anpassungen und Lebenserscheinungen angenommen (Beisp.: Nymphaeaceae). In der Regel weichen die verschiedenen Mitglieder einer Familie stark voneinander ab, sowohl in der Gestalt als in den Anforderungen an die Lebensbedingungen. Anderseits können Arten aus systematisch sehr verschiedenen Familien einander in den Formenverhältnissen des Ernährungsprozesses höchst auffallend ähulich sein (epharmotische Konvergenz). Ein gutes Beispiel für solche „biologischen" Charaktere bieten Kakteen, die kaktusähnlichen Euphorbien und die kaktusähnlichen Stapelien; sie liefern ein vortreffliches Beispiel für eine gemeinsame, sehr kennzeichnende Lebensform, die besonders deutlich an bestimmte Lebensbedingungen angepaßt ist und bei drei systematisch weit getrennten Familien auftritt. Dasselbe trifft für die den Nymphaeaceae so täuschend ähnliche Hydrocharitacee Hydrocharis, die Gentianacee Limnanthemum usw. zu.

Was hier Lebensform genannt wird, entspricht ungefähr dem Begriffe Vegetationsform einiger Pflanzengeographen. Der Ausdruck ist von Grisebach eingeführt worden und wird in der Litteratur oft verschieden gebraucht.

Eine Betrachtung der im Laufe der Zeit aufgestellten Übersichten (bisweilen sogar "Systeme" genannt) über die Lebensformen wird diesen Begriff weiter erläutern. Hierüber, sowie über die Grundformen des Lebens und ihre Anpassungen vergl. den 2. Abschnitt.

\section{Das Zusammenleben der Pflanzen und die Pflanzenvereine}

Die nächste Aufgabe der ökologischen Pflanzengeographie ist, die in der Natur vorkommenden Vereine zu untersuchen, welche meist viele Arten mit äußerst verschiedener Lebensform enthalten.

Bestimmte Arten schließen sich zu natürlichen Vereinen zusammen, d. h. zu solchen Vereinigungen, die uns mit derselben Zusammensetzung von Lebensformen und mit demselben Äußeren oft oder öfter begegnen (Pflanzenformationen). Beispiele für Pflanzenvereine sind eine Wiese

$\left.{ }^{1}\right)$ Vesque 1888, 1884; Volkens 1884, 1887. 
in Norddeutschland oder in Dänemark mit allen ihren Gräsern und Stauden, oder ein Buchenwald auf Seeland, in Jütland oder in Norddeutschland, der von der Rotbuche und allen Arten, die sie zu begleiten pflegen, gebildet wird. Arten, die einen Verein bilden, müssen entweder dieselbe Haushaltung führen, ungefähr dieselben Anforderungen an die Natur des Standortes (Nahrung, Licht, Feuchtigkeit usw.) stellen, oder die eine Art muß in ihrem Leben so von der anderen abhängen, daß sie bei dieser findet, was ihr nützt, vielleicht sogar am besten dienlich ist (Beisp.: Oxalis Acetosella und zahllose Saprophyten im Schatten der Buchen und auf deren humosem Waldboden); es muß eine Art Symbiose oder Syntrophie zwischen diesen Arten bestehen (vergl. auch 3. Abschnitt, Ungleiche Kommensalen).

Oft findet man sogar, wie bei dem eben erwähnten Buchenwald, daß die im Schatten und Schutze anderer Arten wachsenden Pflanzen aus den verschiedensten Familien untereinander ganz ähnliche Lebensformen zeigen, die von denen der oft gleichfalls untereinander übereinstimmenden Waldbäume sehr wesentlich abweichen ${ }^{1}$ ), so z. B. die ähnlichen Rot- und Weißbuchen mit den chlorophyllosen Saprophyten Neottia (Orchidacee), Lathraea und Monotropa (Pirolacee).

Die ökologische Pflanzengeographie soll darüber Rechenschaft ablegen, welche natürlichen Vereine vorkommen, welche Haushaltung sie kennzeichnet und weshalb Arten mit verschiedener Haushaltung so eng verknüpft sein können, wie es oft der Fall ist. Sie muß also das Verständnis der physikalischen u. a. Eigentümlichkeiten der Standorte zur Grundlage haben.

Die ökologische Analyse eines Pflanzenvereins führt zur Unterscheidung der ihn zusammensetzenden Lebensformen als seiner letzten Glieder. Aus dem über die Lebensformen Gesagten geht hervor, daß sich Arten mit sehr verschiedener Physiognomie sehr wohl in demselben natürlichen Vereine zusammenfinden können. Da außerdem, wie angeführt, nicht nur Arten, die eine ganz verschiedene Physiognomie haben, sondern auch eine ganz verschiedene Haushaltung führen, verbunden sein können, so müssen wir erwarten, sowohl einen großen Formenreichtum als verwickelte Wechselverhältnisse zwischen den Arten eines natürlichen Vereines finden zu können; man erinnere sich z. B. an die reichste aller Vereinsformen, an den tropischen Regenwald. Auch muß bemerkt werden, daß ein Pflanzenverein zu verschiedenen Jahreszeiten eine sehr verschiedene Physiognomie haben kann, indem ein gewisser Kreislauf der sich nacheinander entwickelnden Arten stattfindet.

Eine besonders aufällige Tatsache ist das Auftreten so sehr ähnlicher Lebensformen in scheinbar in ihren Lebensbedingungen so sehr

1) Warming 1901 . 
verschiedenen Vereinen, wie es etwa unser Buchenwald und die südeuropäische und orientalische Steppe sind. In beiden finden wir in großem Prozentsatz ausdauernde Kräuter mit nur sehr kurzer Frühjahrsentwicklung, die also den größten Teil des Jahres nur unterirdisch leben. In unserem Buchenwalde sind es die weißen und gelben Anemonen ( $A$. nemorosa, A. ranunculoides), der Aronsstab (Arum maculatum), die Corydallis-(Lerchensporn-) Arten u. a., deren oberirdische Teile mit dem Beginn des Sommers bereits verschwinden. Auf der sonnendurchglühten Steppe verhalten sich zahlreiche Pflanzen (Hyacinthus, Muscari, Crocus, Iris) genau ebenso. Das Gemeinsame, dem sich beide Bewohner so verschiedener Vereine angepaßt haben, ist, daß zur Sommerhöhe beiden das nötige Wasser fehlt. Im Buchenwalde leiden zur Trockenzeit alle Kräuter, da die den Boden durchwurzelnden Bäume alles verfügbare Wasser entziehen, auf der Steppe herrscht zu gleicher Zeit absoluter Wassermangel ${ }^{1}$ ).

Ferner ist es leicht verständlich, daß man dieselbe Vereinsform in sehr verschiedenen Ländern, aber mit einem ganz verschiedenen floristischen Inhalte wiederfinden kann (verschiedene "Assoziationen " derselben „Formation"). Wiesen in Nordamerika und in Europa, oder der tropische Wald in Afrika und der in Ostindien können dieselbe Totalphysiognomie, denselben Inhalt von Lebensformen zeigen und dieselbe natürliche Vereinsform (Formation) sein, sind aber natürlich in den Arten äußerst verschieden, womit kleinere physiognomische Formenunterschiede einhergehen. Dasselbe gilt für die verschiedenen Höhenzonen der Gebirge. Als einer der bemerkenswertesten Fälle sei hier das Vorkommen eines unseren Heiden physiognomisch und sicher auch ökologisch sehr ähnlichen Vereins auf den hohen Anden Südamerikas erwähnt, an dessen Zusammensetzung unsern Heidebewobnern in der Tracht äußerst ähnliche Pflanzen aus den Familien der Valerianaceae u. a. sogar der Melastomataceae beteiligt sind. Die Sammlungen von Ule und Weberbauer haben sehr absonderliche Formen gebracht ${ }^{2}$ ).

Es muß hinzugefügt werden, daß die verschiedenen Vereine selbstverständlich fast nie einander scharf abgegrenzt gegenüber stehen. Wie es in Boden, Feuchtigkeit u. a. Lebensbedingungen die allmählichsten Übergänge gibt, so gibt es auch solche zwischen den Pflanzenvereinen. Hierzu kommt, daß viele Arten in sehr verschiedenen Vereinen auftreten, Linnaea borealis z. B. wächst nicht nur in Nadelwäldern, sondern auch in Birkenwäldern, sogar hoch über der Baumgrenze auf den Fjelden in Norwegen, oder auf den Felsenfluren von Grönland (Warming). Es scheint, daß verschiedene Kombinationen von Faktoren einander ersetzen

1) Graebner. 1990, 1910 c.

2) Ule 1908; Weberbauer 1911. 
und ungefähr dieselben Vereine hervorbringen können, oder jedenfalls derselben Art in gleich hohem Grade zusagen, daß3 z. B. feuchtes Klima den Waldschatten trockener Klimate oft vollständig ersetzt, oder daß Wurzelkonkurrenz ähnliche Wirkungen wie klimatische Trockenzeiten ansübt (vergl. S. 8).

Es ist einleuchtend, daß alle diese Umstände sehr große Schwierigkeiten für die richtige wissenschaftliche Aufassung, die Begrenzung, die Kennzeichnung und die Anordnung der Vereine in über- und untergeordnetem Grade mit sich führen, besonders auf dem gegenwärtigen Standpunkt unserer Kenntnisse, wo wir die Lebensformen und die Vereinsformen gerade erst zu erforschen begonnen haben, wo unendlich viel unbekannt ist. Eine andere Schwierigkeit ist, für die mehr oder weniger umfassenden, über- oder untergeordneten Pflanzenvereine, die auf der Erde vorkommen und den Landschaften ganz verschiedene Physiognomien verleihen, treffende Namen zu finden und die Bedeutung der floristischen Unterschiede richtig $\mathrm{zu}$ würdigen.

Die Lehre von den Assoziationen und den Formationen der Erde (die Synökologie nach Schröter) wird im 3. bis 4. Abschnitte besprochen.

\section{Genetische Pflanzenökologie}

Zuletzt muß der Kampf zwischen den verschiedenen Pflanzenvereinen besprochen werden. "Das Nebeneinander (ökologisch) verwandter Formen ist oft nur ein Konkurrenzkampf" oder absolute Abhängigkeit. Dieses wird im 5. Abschnitte behandelt.

An den einzelnen Standorten wird die Entwicklungsgeschichte, Abstammungsgeschichte und genetische Verbindung zwischen den verschiedenen Vereinen eines Landes oder einer Gegend aufzuklären sein.

Namentlich amerikanische Forscher (Clements, Cowles u. a.) haben bei der Behandlung der ökologischen Pflanzengeographie großes Gewicht auf den Wechsel der Pflanzenvereine gelegt, auf die Folge eines nach dem andern („Succession“). Die Beständigkeit der einzelnen Vereine ist sehr verschieden. Während z. B. die Heide, deren Hauptbestandteil Calluna ist, anscheinend viele Generationen hintereinander auf demselben Gelände wachsen kann, werden manche bestandbildende Gewächse, auch Waldbäume, schnell „bodenmüde“, d. h. an ihre Stelle müssen nach einigen Generationen andere Arten treten. Aber auch Änderungen des Wasserstandes, Erosionsvorgänge können starke Veränderungen bringen ${ }^{1}$ ).

1) Graebner 1910 a, b. 


\section{Erster Abschnitt \\ Der Standort (Statio, Habitat) Die ökologischen Faktoren und ihre Wirkungen}

\section{Klimatische Faktoren}

\section{Kap. Die Zusammensetzung der Luft}

Indem wir vorläufig von der sehr wechselnden Feuchtigkeitsmenge der Luft sowie von den verschiedenen Niederschlägen absehen, haben wir hier nur die Gase zu behandeln und zwar namentlich die beiden, die in dem Pflanzenleben eine größere Rolle spielen, Sauerstoff und Kohlensäure. Obgleich die relative Menge beider, besonders die der Kohlensäure, je nach Ort und Zeit verschieden ist, scheinen diese Unterschiede doch für die Verteilung und die Form der Vegetation ganz unwesentlich zu sein, weil diese Gase in verhältnismäßig unbegrenzter Menge überall vorkommen. Sogar die Luft in den Wäldern stimmt mit der außerhalb der Wälder wesentlich überein. Wagner ${ }^{1}$ ) hat die Ansicht ausgesprochen, daß, da die Dichte der Luft mit der Höhe über dem Meere abnimmt, die Luft in den Hochgebirgen relativ weniger Kohlensäure als tiefer unten enthielte; und er meint, daß die Pflanzen der Hochgebirge deshalb einen loseren Blattbau und dadurch einen kräftigeren Assimilationsapparat erhalten hätten, um den geringeren Kohlensäurezutritt aufzuwiegen. Es ist jedoch sehr zweifelhaft, ob dieses richtig sei. Die Kohlensäuremenge in den höheren Luftschichten ist noch sehr strittig; während sie nach einigen mit zunehmender Höhe über dem Meere abnimmt, fanden andere sie (z. B. auf dem Pic du Midi) gleich der Menge an der Meeresoberfläche; die von Nansen aus den inneren Hochländern Grönlands (ca. $2700 \mathrm{~m}$ ) entnommenen Proben zeigten eine eben so große oder eine etwas größere Menge als in niedrigerem

1) Wagner 1892. 
Niveau ${ }^{1}$ ). Ferner sei darauf hingewiesen, daß Polarpflanzen aus dem Tieflande im ganzen fast denselben Bau zu haben scheinen, wie die Hochgebirgspflanzen derselben Species.

Von anderen Bestandteilen der Atmosphäre wirken, außer den an die Menschenvereine gebundenen Kohlenteilchen und den aus Fabriken und Vulkanen stammenden Ausdünstungen, wesentlich nur Salzteilchen. in der Luft der Meeresküsten auf die Pflanzen. Die Einwirkungen starker Rauchentwicklung in großen Städten, bei Fabrikanlagen und Eisenbahnen sind indessen oft sehr erheblich. Sie machen sich im wesentlichen durch das gänzliche Fehlen der Flechten und das Kränkeln fast aller Koniferen (wohl infolge des Einflusses der schwefligen Säure) bemerkbar ${ }^{2}$ ).

Das letztgenannte Gas wirkt auch in geringen Mengen außerordentlich schädlich ${ }^{3}$ ); so fand Morren, daß sich die charakteristischen Vergiftungserscheinungen an den Blättern bereits zeigten, wenn die Luft nur $1 / 50000$ ihres Volumens an schwefliger Säure enthielt, ja nach Schröder wirkt schon $1 / 1000000$ schädlich, sobald die Einwirkung längere Zeit dauert. Auch Leuchtgas wirkt auf die Dauer selbst in ganz geringen Mengen schädlich.

Der Salzgehalt der Luft wird an den Meeresküsten oft mit für das Zurückweichen des Baumwuchses hinter die Außenstreifen verantwortlich gemacht (vergl. Luftbewegungen; Kap. 5).

Wohl die einschneidendste pflanzengeographische Wirkung der Luftzusammensetzung ist im Wasser zu finden. Der Artenreichtum und auch die produzierte Stoffmenge hängt zweifellos im wesentlichen mit dem großen oder geringen Sauerstoffgehalt des Wassers zusammen, je sauerstoffreicher das Wasser ist, desto lebhafter die Vegetation $\left.{ }^{4}\right)$. Saure Gewässer oder solche, die zeitweise durch die Sonne usw. stark erwärmt werden, dann auch die armen (und zugleich sauren) Gewässer der Heide resp. der Hochmoore, sind oft sehr sanerstoff- und daher auch vegetationsarm. Über das Wasser als Standort vergl. III.

\section{Kap. Licht}

Die Bedeutung des Lichtes für die Vegetation ist sehr groß; es ist ein ausgeprägter geographischer Faktor, dessen Stärke nach Jahreszeit, geographischer Breite und Höhe über dem Meere verschieden ist. Es ist für die Lebensformen und die Vereine nicht minder wichtig als für

1) Vergl. Palmquist.

2) Sorauer 1909; Haselhoff u. Lindau 1903.

3) Morren 1866; Schröder 1872.

4) Vergl. auch Correns 1892; Buchenau; Focke. 
deren lokale Verteilung. Nach Wiesner hat das direkte Sonnenlicht (außer in den polaren und den alpinen Gegenden) weniger Bedeutung als das zerstreute Licht ${ }^{1}$ ). Die Veränderungen der Lichtstärke und der Beleuchtungsdauer haben einen wesentlichen Einfluß.

Erstere wird meist durch ihre Einwirkung auf Silbersalze usw. gemessen, wobei allerdings zu beachten ist, daß diese gerade durch die violetten und ultravioletten Strahlen am stärksten verändert werden, während die auf das menschliche Auge und für die Assimilation besonders wirksamen gelben und roten Strahlen die Platte wenig schwärzen $^{2}$ ).

Der von K. J. V. Steenstrup ${ }^{3}$ ) konstruierte Lichtmesser besteht aus einer Glasröhre, in welcher lichtempfindliches photographisches Papier unter dünnem Pauspapier angebracht worden ist. Das Pauspapier wird in gleichbreite $(20 \mathrm{~mm}$ ), aber ungleichlange (bis $20 \mathrm{~cm}$ die längsten) Streifen geschnitten; diese Streifen werden übereinander gelegt, stufenweise geordnet, so daß das Ganze successive dicker wird, mehr Schichten umfaßt; am dicken Ende werden sie durch Gummi vereinigt. Unter diesem Paket von Papierstreifen wird das lichtempfindliche Papier dem Lichte ausgesetzt. Je stärker das Licht, durch desto mehr Schichten vermag es zu dringen und desto größere Abschnitte vom Papier zu schwärzen. Auf dem Papier kann man also die ganze Wirkung des Lichtes z. B. während eines ganzen Tages ablesen und mit anderen Tagen oder Tageszeiten vergleichen. Das Instrument läßt sich überall im Freien anbringen, selbst ins Wasser versenken. Fig. 1, 2.

Bunsen und Roscoe stellten einen Normalton (1 Teil LampenruB auf 1000 Teile Zinkoxyd) und ein lichtempfindliches Normalpapier her. Als Einheit, 1,000 resp. 1000, wurde die Lichtmenge genommen, die das Normalpapier in 1 Sekunde auf den Normalton färbte. Die Zahlen der zu messenden Lichtintensität ergaben sich durch den Bruch, der durch den Normalton 1 dividiert durch die Zahl der Sekunden bis er erreicht wurde, entsteht; braucht das Papier also 3 Sekunden, so ist der Bruch $1 / 3=333$. - Wiesner hat nun diese Methode für die Abmessung des wirklichen Lichtgenusses einer Pflanze am Standort verwertet. Er maß zunächst das Gesamtlicht im Freien und dann das der Pflanze wirklich zukommende Licht (im Schatten usw.) und dividierte dann den ersten Wert I durch den zweiten 1, wodurch die relative Menge sich ergab.

Durch zahlreiche Versuche kommt Wiesner zu dem Resultat, daß, je wärmer die Jahreszeit ist, desto niedriger das Minimum des relativen

$\left.{ }^{1}\right)$ Unter den neueren Arbeiten über die Lichtwirkung auf die Pflanzen haben wegen ilures umfassenden Materials keine die Bedeutung der von Wiesner 1876 (a), 1876 (b), 1898, 1895 (b), 1898, 1900, 1904, 1905, 1907.

?) Wiesner a. a. 0 .

- K. J. V. Steenstrup 1901. 
und absoluten Lichtgenusses für eine Pflanze liegt; je kälter es also ist, desto mehr bedeutet das wirksame Licht einen Wärmegewinn. Je mehr wir uns also den Polen und den Gipfeln hoher Gebirge nähern,

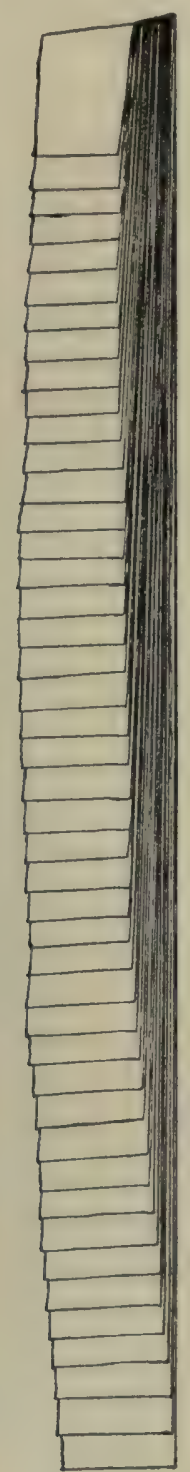

Fig. 1.

Steenstrups Lichtmesser.

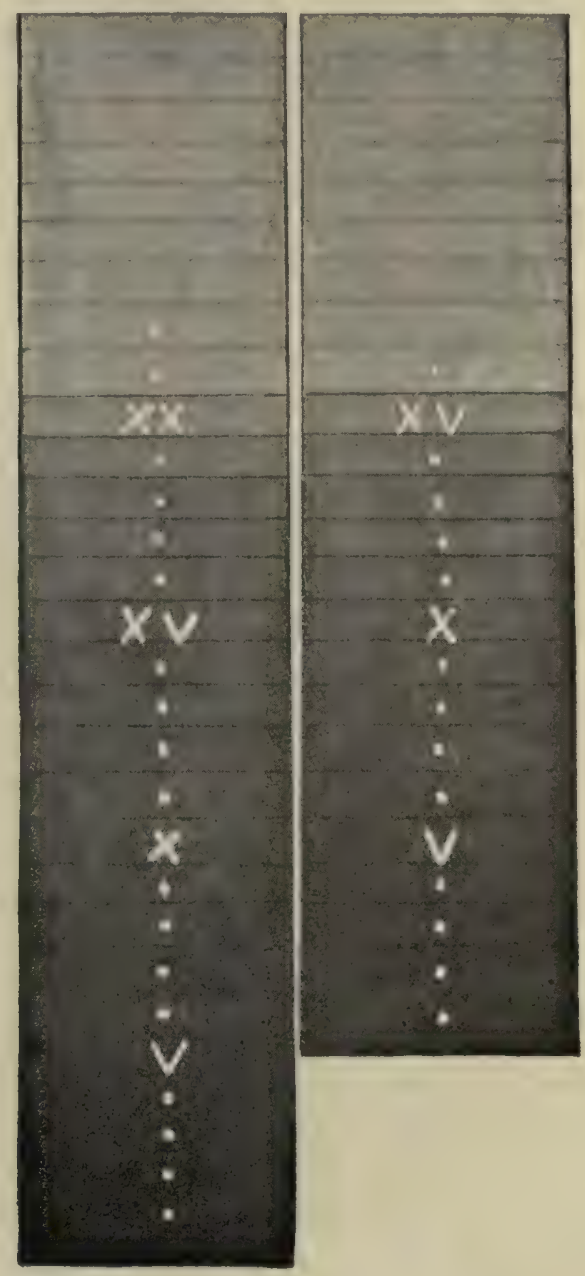

Fig. 2. Lichtmessungen mit Steenstrups Apparat; das Licht, welches das linke Papier färbte war um $1 / \mathrm{s}$ stärker als das des rechten. Links ist die Schicht XX genau so stark gefärbt wie rechts die Schicht $X V$.

desto mehr muß sich das Lichtbedürfnis der Pflanzen steigern, besonders natürlich in den im Sommer so lange belichteten hohen Breiten. So fand Wiesner, daß das Lichtbedürfnis bei Betula nana sich in der Nähe 
der Nordgrenze ihres Verbreitungsgebietes nicht langsam, sondern rapid steigert, die Pflanzen werden in ihrem Lichtbedürfnis immer weniger plastisch. Vergleicht man die Tageslichtsummen an der Adventsbay auf Spitzbergen zu Anfang August mit der von Wien Anfang Februar oder Anfang November, also zu Zeiten, wo an beiden Orten die Sonne etwa gleich hoch steht, so ist die Gesamtsumme des Tageslichts an der Adventsbay 2,5 mal so groß als in Wien ${ }^{1}$ ).

Rübel ${ }^{2}$ ) hat in seiner vortrefflichen Monographie des Berninagebietes auch alle klimatischen Faktoren gemessen und gibt umfangreiche Tabellen. Namentlich während der Wintermonate ist die Gesamtlichtmenge in den Höhen sehr groß; gegen Wien, wo sie von Dezember bis Februar etwa 2081 beträgt, maß er auf dem Bernina-Hospiz 5724 (darunter 1440 Lichtsumme des direkten Lichtes), ein Beweis für die starke Wirkung der Insolation der Höhe. Nach Niederschlägen ist die Intensität des Lichtes höher als nach einer Reihe von Tagen mit schönem Wetter. Je höher man steigt, desto erheblicher ist der Unterschied an verschieden geneigten Abhängen, besonders natürlich zwischen Süd und Nord.

Das Licht hat Bedeutung: 1. Für die Ernährung. Ohne Licht keine Chlorophyllbildung und daher keine Kohlensäure-Assimilation, kein Leben auf der Erde. Von einem gewissen (nach den Arten verschiedenen) Minimum ab wächst die Assimilation mit wachsender Lichtstärike, bis ein Optimum erreicht wird. $\mathrm{Zu}$ starkes Licht wirkt schädlich ${ }^{3}$ ). 2. Durch die Erzeugung von Wärme. Jede der starken Sonnenbeleuchtung ausgesetzte Pflanze hat eine erheblich höhere Temperatur als die umgebende Luft, während beschattete Teile durch die Strahlung und die Verdunstungskühle kühler werden als die Luft. 3. Für die Transpiration, indem ein Teil der Lichtstrahlen in der Pflanze in Wärme umgesetzt wird, die die Transpiration befördert. Auch hier muß sicher ein gewisses Optimum angenommen werden, dessen Lage gleichfalls nach den Arten verschieden ist und meist nicht mit dem Optimum für die Ernährung zusammenfällt ${ }^{4}$ ). Gegen zu starke Verdunstung richtet sich die Pflanze in verschiedener Weise. 4. Durch die Beeinflussung des Wachstums und der Bewegungserscheinungen. Die Lage der Laubblätter und fast alle anderen Lebenserscheinungen und Lebensprozesse werden durch das Licht beeinflußt, wobei wieder die Zusammensetzung des Lichtes je nach der Menge der vorhandenen kurz- und langwelligen Strahlen von großer Wichtigkeit ist (vorwiegend bedeckter,

1) Wiesner a. a. 0.; Engler 1914; Kluyver 1913.

3) Rübel 1912 .

9) Wiesner $1876 \mathrm{~b}$ und anderswo.

) Sachs 1865 . 
klarer usw. Himmel) ${ }^{1}$ ). 5. Bedeutung des Lichtes für die Verteilung der Pflanzen. Von der Erdoberfläche, im großen betrachtet, ist kaum ein Teil wegen unzureichenden Lichtes davon ausgeschlossen, Pflanzen zu tragen; denn obgleich das Licht zu gewissen Jahreszeiten zu schwach sein kann (z. B. in der Polarnacht), wird es zu anderen Zeiten stark genug sein, um Leben hervorzurufen. Gehen wir jedoch in die Tiefe, sowohl in der Erde als im Wasser, so hört das ans Licht gebundene Leben bald auf, und nur einige der am niedrigsten stehenden Pflanzen gehen tief hinab.

Die Lichtstärke hat für die Verteilung der Arten und für den Individuenreichtum der Vereine eine große Bedeutung. Bei ungenügender Beleuchtung gedeihen die Pflanzen schlecht, verkümmern oder sterben. Bekannt ist der Unterschied zwischen Licht- und Schattenpflanzen, z. B. in Wäldern ${ }^{2}$ ). Stebler und Volkart ${ }^{3}$ ) haben in der Schweiz vergleichende Messungen der Intensität des Lichtes unter Bäumen gemacht, ebenso Untersuchungen über das für Wiesenpflanzen erforderliche Licht. Danach teilen die beiden Forscher die Pflanzen in lichtbedürftige, lichtliebende, indifferente, lichtmeidende und lichtfürchtende Arten ein. Je nach diesen Eigentümlichkeiten ist die Verteilung der Arten an den verschiedenen Standorten wechselnd. In den Polarländern ruft sicher besonders die Beschaffenheit der Wolkendecke (die Anzahl der Sonnentage und die Häufigkeit von Wolken und Nebeln) den von vielen Reisenden erwähnten Gegensatz zwischen der reichen Flora und Vegetation im Inneren der Fjorde und der dürftigen draußen an den äußersten Küsten sowie anf den Inseln des Schärengebietes hervor ${ }^{4}$ ).

Hesselman ${ }^{5}$ ) zeigt den großen Unterschied in der Vegetation in höheren Breiten selbst an sanftgeneigten Abhängen. Während ein Abhang nach Süden noch niedrigen Wald tragen kann, kann der sonst ganz gleichartige danebenliegende, der nach Norden geneigt ist, typische Tundravegetation besitzen.

Daß Lichtstärke und Lichtfarbe bei der Verteilung der Wasserpflanzen in der Tiefe eine Rolle spielen, wird bei der Wasserpflanzenvegetation behandelt werden (III).

Die Entwicklung der Pflanzen hängt nicht nur von der Lichtstärke, sondern auch von der Dauer der Beleuchtung ab. Wie stark

1) Wiesner 1894 c; Kissling 1895; Sachs 1865; Graebner 1910, S. 186 ff. u. a. Leonh. Weber 1893.

2) Hesselman 1904 .

3) Stebler und Volkhart 1904.

4) Vergl. z. B. Nathorst 1883 über Spitzbergen, Hartz 1895 über Ostgrönland.

5) Hesselman 1905. 
dieser Einfluß ist, beweisen Versuche, die Kjellman ${ }^{1}$ ) in Nordsibirien an Cochlearia fenestrata anstellte, indem er 5 Wochen lang einen Teil der Keimpflanzen der vollen Tagesbeleuchtung aussetzte, einen andern Teil aber nur 12 Stunden belichtete, während der übrigen Zeit künstlich verdunkelte. Es ergab sich als Resultat, daß die während der ganzen Zeit belichteten doppelt soviel wogen als die übrigen. - Auf der andern Seite hat Bonnier ${ }^{2}$ ) die Wirkungen der Dauerbestrahlung bei elektrischem Lichte untersucht; er fand u. a. einen viel größeren Reichtum an Chlorophyll; in der Innenrinde, in den Markstrahlen und im Mark selbst, wo doch sonst kein Blattgrün gebildet zu werden pflegt, fand sich solches vor. Wenn sich die Gerste in Finnland oder im nördlichen Norwegen in 89 Tagen, von dem Tage der Aussaat gerechnet, zur Reife entwickeln kann, aber in Schonen zu derselben Arbeit 100 Tage braucht, trotz der höheren Wärme und des stärkeren Lichtes, so muß der Grund teilweise der sein, daß dort die lange Beleuchtung die Stoffbildung befördert. Die periodischen Lebensäußerungen der Pflanze treten im Norden im Sommer wegen der längeren Beleuchtungszeit viel schneller ein, als im Frühjahr. Nach Arnell vergehen, damit das Blühen der Pflanzen von Schonen aus einen Breitegrad nördlich fortschreite, im April 4,3 Tage, im Mai 2,3 Tage, im Juni 1,5 und im Juli 0,5 Tage.

Theoretisch ist doch am Äquator das Licht über das ganze Jahr gleichmäßig (12 Stunden Tag und 12 Stunden Nacht) verteilt, während nach den Polen die Tageslänge im Sommer immer mehr zunimmt, so daß an den Polen selbst 6 Monate Tag (in Wirklichkeit natürlich mehr) und 6 Monate Nacht wären. Zwischen beiden Extremen würde sich die Belichtung etwa folgendermaßen verteilen $\left.{ }^{3}\right)$ :

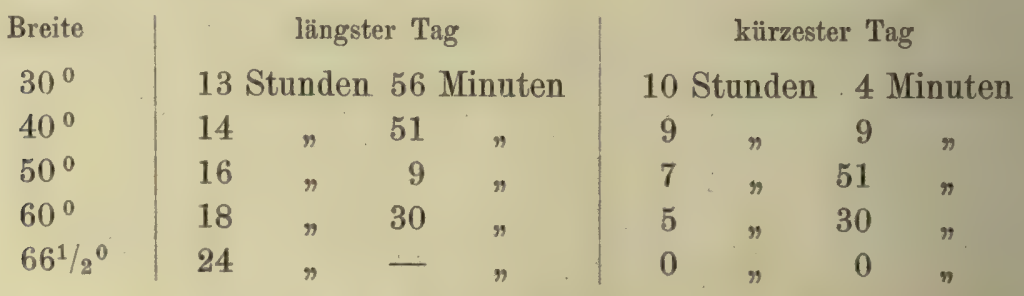

Schübeler $\left.{ }^{4}\right)$ zog aus der Entwicklungsbeschleunigung von Kulturpflanzen (Getreide usw.), die aus dem Süden nach Christiania gebracht waren, den Schluß, daß die Pflanzen Veränderungen ("Naturgesetzen“)

i) Kjellman 1884

2) Bonnier 1894 .

2) Schimper 1898; Graebner $1910 \mathrm{c}$.

4) Schübeler $1886-88$. 


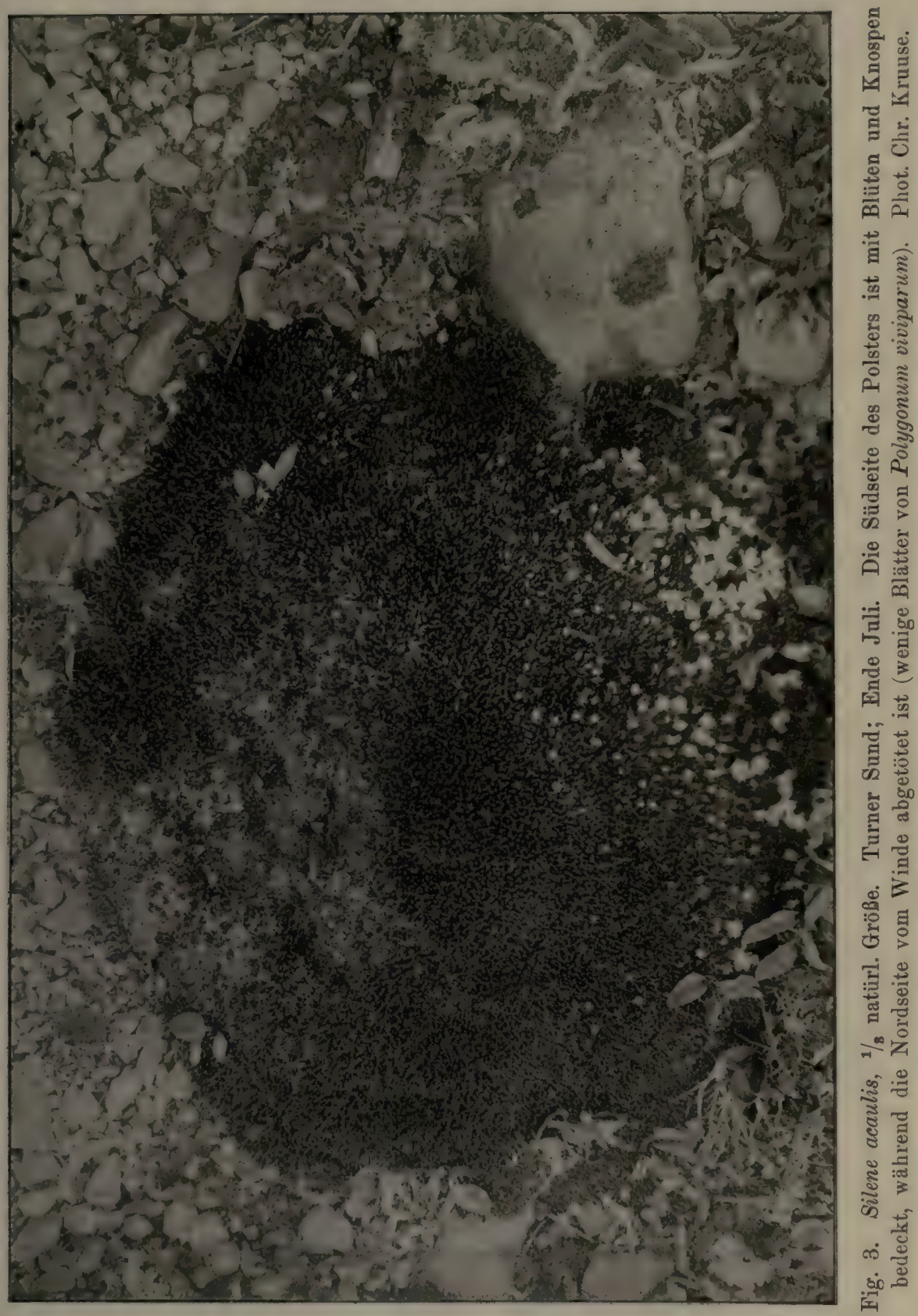


unterworfen seien, die direkte Anpassungserscheinungen wären. Wille ${ }^{1}$ ) weist nun aber darauf hin, daß Schübeler seine Versuche zufällig in einigen besonders warmen Sommern gemacht hat und daß derselbe auch die Intensität und Länge der Belichtung, sowie deren Wirkung nicht berechnen konnte.

Arnold Engler ${ }^{2}$ ) hat im Gegensatze zu den Annahmen Schübelers nachgewiesen, daß die Eigenschaften gewisser Formen von Nadelbäumen (Pinus silvestris usw.) aus höheren oder niederen Gebirgslagen sich in der Nachkommenschaft oft außerordentlich lange erhalten, wenn sie nicht durch Bastardierung verwischt werden. Dieselbe Erfahrung, sehr mangelhafte Anpassung an unsere klimatischen Verhältnisse, haben unsere Forstleute mit der Einführung fremder Gehölzsamen unserer heimischen Arten gemacht.

Belaubung und Blühen hängen von der Lichtstärke ab. Die gegen die Lichtquelle gewandte Seite eines Baumes belaubt sich oft vor der abgewandten: man kann sich brasilianische Ficus-Bäume auf der Nordseite belauben sehen, während die Südseite noch blattlos ist ${ }^{3}$ ); die Rasen von Silene acaulis sind in den arktischen Ländern oft auf der Südseite mit Blüten geschmückt, die zugleich südlich gerichtet sind, während die Nordseite blütenlos ist ${ }^{4}$ ). Der Unterschied zwischen Nordund Südseiten der Eisenbahndämme beruht auch auf der Verschiedenheit der Lichtstärke und derjenigen ökologischen Faktoren, welche damit in Verbindung stehen (Erwärmung, Trockenheit des Bodens).

Die Pflanzenformen werden von der Lichtstärke und der Lichtrichtung in hohem Grade beeinflußt.

Die Wirkungen des zu schwachen Lichtes sieht man nicht nur bei den Erscheinungen der Etiolierung, die eigentlich nur Krankheitszustände sind, sondern auch bei den gesunden, normalen Individuen. Hierfür können die Waldbäume vorzügliche Beispiele liefern.

Erstens hängt die Lebenszeit der Zweige teilweise von der Lichtstärke ab. Der Schatten der jüngeren Zweige behindert die Assimilationsarbeit in den Blättern der älteren, und macht dadurch an denselben die normale Entwicklung der Knospen und das Ausreifen des Holzes unmöglich, welches dann wenig widerstandsfähig gegen Fröste ist. Die Zweige sterben $a b$, werden spröde und brechen infolge von Stürmen und ihrer Schwere zuletzt $a b$; wegen jener Behinderung sind Bäume und Sträucher in ihrem Inneren blattlos. Eine freistehende Fichte ist

1) Wille 1905, 1913.

2) Arnold Engler 1913.

$\left.{ }^{3}\right)$ Warming 1892.

4) Rosenvinge 1889-90; Stefánsson 1894; Hartz u. Kruuse 1911; vergl. Fig. 3. 
kegelförmig und trägt von oben bis unten Äste, während die in einem dichten Walde stehende wegen des Beleuchtungsunterschiedes nur eine kleine grüne Krone hat und im übrigen astlos oder mit blattlosen toten Ästen bedeckt ist; freistehende Laubbäume, wie Rotbuche Eiche u. a., haben eine volle eiförmige Krone, aber die in dichtem Bestande wachsenden eine kleine Krone mit aufwärts gerichteten Ästen ${ }^{1}$ ) (Fig. 4).

Zweitens spielt das Verhältnis zum Lichte bei den Kämpfen der Bäume untereinander eine wichtige Rolle, wenn sie in Gesellschaft wachsen. Die Waldbäume können in solche eingeteilt werden, die
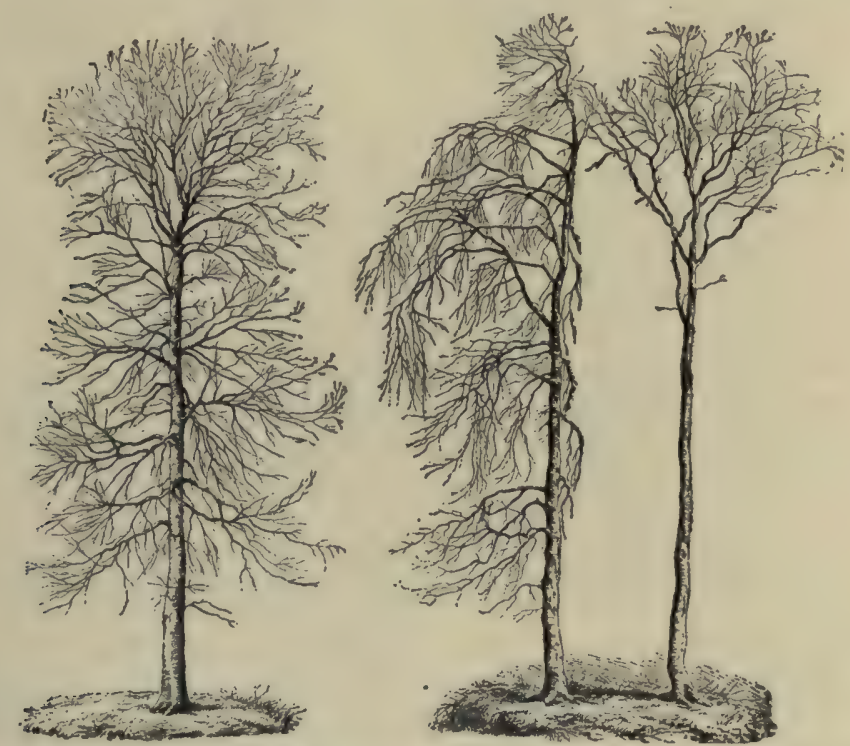

Fig. 4. Buchen. Links freistehendes Exemplar, in der Mitte ein solches vom Waldrande, das rechte mitten im Walde gewachsen.

(Nach Vaupell; Warming-Johanssen.)

a) viel Licht fordern und nur wenig Schatten ertragen (Lichtbäume) und in solche, die

b) sich umgekehrt mit weniger Licht begnügen und mehr Schatten ertragen können (Schattenbäume).

Die Gründe für diese Verschiedenheiten müssen zunächst in den spezifischen Eigentümlichkeiten des Chlorophylls gesucht werden, dann in der verschiedenen Architektonik der Arten (Sproßbau, Blattstellung, Blattform). Ordnet man unsere nordeuropäischen Waldbäume nach dem Lichtbedürfnis, welches sie zeigen, wenn sie als gleichaltrige Bäume miteinander kämpfen, und stellt man die, die am meisten Licht bedürfen, voran, so erhält man ungefähr folgende Reihen:

1) Vergl. Vaupell 1863; Boysen Jensen 1910. 
1. Lärche, Birke, Zitterpappel, Schwarzerle.

2. Pinus silvestris, $P$. strobus, Esche, Eiche, Ulme, Acer pseudoplatanus.

3. Pinus montana, Fichte, Linde, Weißbuche, Rotbuche, Weißtanne.

Bemerkenswert und biologisch wichtig ist es, daß fast alle Bäume in ihrer ersten Jugend mehr Schatten ertragen können als später. Diese Eigenschaft ist deshalb besonders wichtig, weil sie die Gehölze befähigt, als "Unterholz" lange im Schatten ihrer Erzeuger zu gedeihen, so daß sie bei deren Absterben sofort an ihre Stelle treten können. Ferner sei bemerkt, daß die Fähigkeit, Schatten zu ertragen, von der Fruchtbarkeit und dem Luftgehalt des Bodens beeinflußt wird.

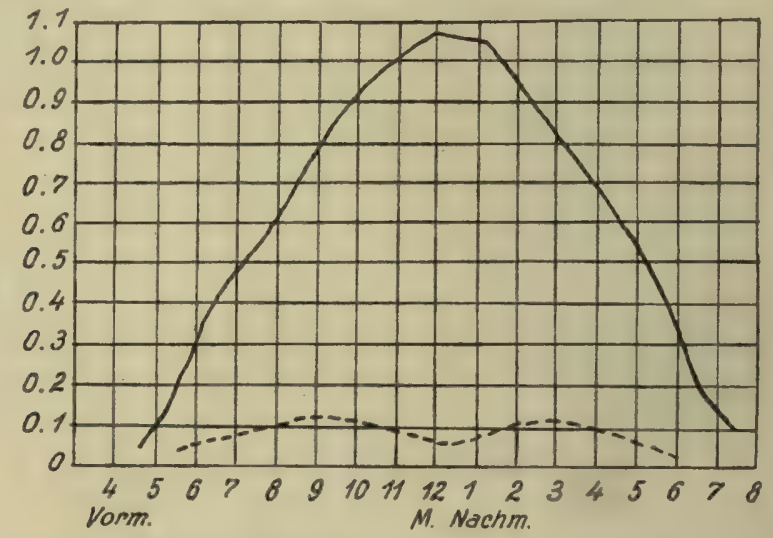

Fig. 5. Stündliche Lichtintensität. Ailantus. Obere Kurve außerhalb, untere innerhalb der Krone (Juni). (Nach Zon und Graves.)

Wiesner berechnete z. B. Ende März die Gesamtintensität des Lichtes an einem sonnigen Tage in der Nähe von Wien auf 0,712, 100 Schritt vom Rande eines noch unbelaubten Waldes 0,355 , die im Baumschatten 0,166. An einem anderen Tage betrug bei einer Gesamtintensität von 0,666 die im Schatten einer $8 \mathrm{~m}$ hohen fast bis unten beästeten Fichte nur noch 0,021 . Bei einer Gesamtintensität von 0,5 (Mai) maß er an Kronen von Roßkastanien 0,07, im Schatten des dichten Bestandes nur 0,017 , also nur $1 / 29$ der Gesamtintensität. Lichtintensitätskurven an den Baumkronen geben Zon und Graves ${ }^{1}$ ) (Fig. 5, 6).

Je nach der Stellung der Blätter und Zweige der Bäume wird das den Erdboden erreichende Licht im wesentlichen nur geschwächt, oder es wird stark gebrochen resp. zersetzt (starke Vernichtung der kurzwelligen Strahlen s. S. 12), letzteres z. B. im Buchenwald, dessen

3) Zon und Graves 1911. 
belaubte Kronen nur wenig direkte Strahlen durchlassen wegen der ineinander fahrenden Zweige. Die Eigentümlichkeit so vieler Waldbodenpflanzen, daß sie blaugrüne bis bläuliche oder bläulich schillernde Blätter besitzen, dürfte als Einrichtung eines Farbenfilters in dem an kurzwelligen Strahlen armen Licht $\mathrm{zu}$ deuten $\operatorname{sein}^{1}$ ).

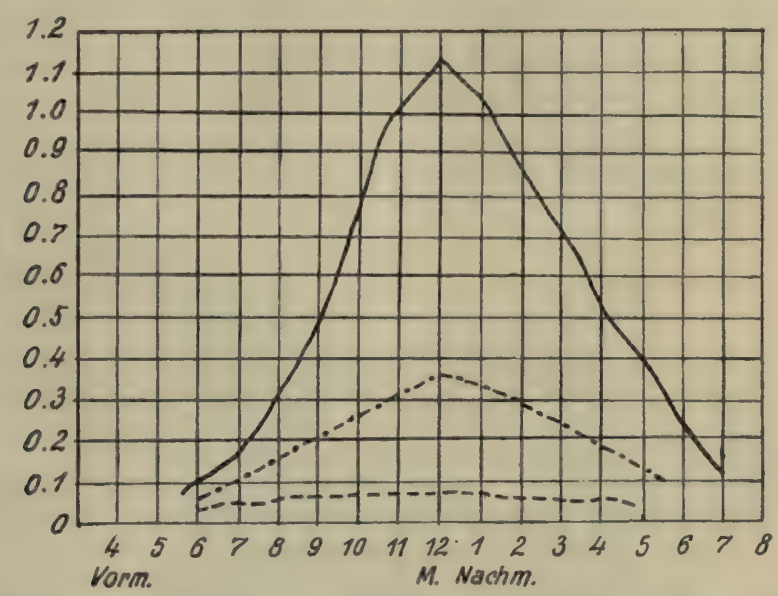

Fig. 6. Stündliche Lichtintensität. Robinia pseudacacia. Obere Kurve außerhalb, mittlere innerhalb einer lichten, untere innerhalb einer dichten Krone.

(Nach Zon and Graves.)

\section{Unterschied zwischen Sonnen- und Schattenpflanzen}

Zwischen sonnenliebenden und schattenliebenden (heliophilen [resp. photophilen] und heliophoben [resp. sciophilen]) Pflanzen bestehen große Unterschiede, sowohl in der äußeren Form als im anatomischen Bau.

1. Starkes Licht hemmt das Wachstum des Sprosses; daher sind die Sonnenpflanzen oft kurzgliedrig und kompakt, die Schattenpflanzen gestrecktgliedrig; die Waldbodenarten sind zum großen Teil hohe und langstengelige Arten. Die Blätter der Sonnenpflanzen sind oft klein, schmal, linealisch oder von ähnlicher Form, aber die der Schattenpflanzen unter denselben Verhältnissen groß und breit, sowie im Verhältnis zur Länge relativ breiter ${ }^{2}$ ); die Blätter von Maianthemum bifolium erreichen in der Sonne kaum ${ }^{1 / 3}$ der Größe, die sie im Schatten erlangen ${ }^{3}$ ), ebenso die Blättchen von Asplenum trichomanes u. a. (Fig. 7).

Die Blätter vieler Arten (bes. Kulturpflanzen) werden in nördlichen Gegenden größer als unter geringerer Breite, und dieses ist vermutlich

1) Graebner 1910 .

3) Warming 1901.

ग) Kissling 1895; Warming 1901. 
der langen Dauer des schwächeren Lichtes zuzuschreiben. So verschwinden in den Gärten der Westküste Norwegens z. B. die Blüten von Tropaeolum majus fast ganz unter der Masse der großen Laubblätter ${ }^{1}$ ).

2. Intensives Licht zersetzt das Chlorophyll. Um das letztere vor Zerstörung zu schützen, finden sich mannigfache Einrichtungen an den Pflanzen, die als Schutzmittel gedeutet werden ${ }^{2}$ ), so z. B.

a) Die Blätter der Sonnenpflanzen sind oft gefaltet (Gräser, Palmen, Pandanus u. a.), oder kraus und buckelig (Myrtus bullata), während
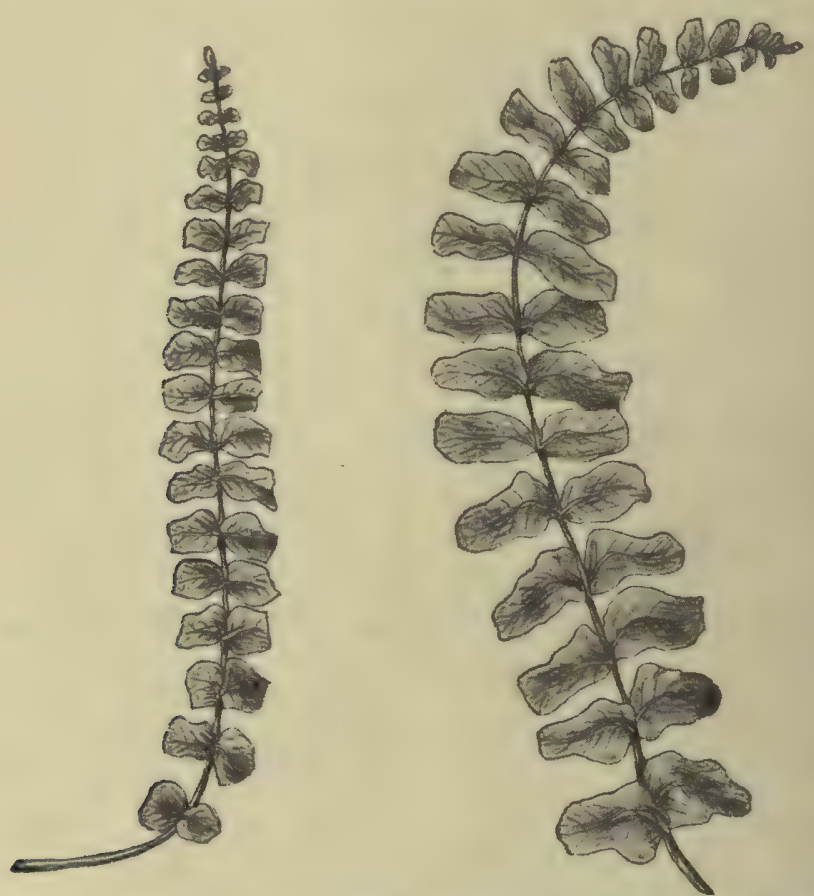

Fig. 7. Blätter von Asplenum trichomanes, links in der Sonne, rechts im Schatten gewachsen. (Nach Lämmermayr.)

die der Schattenpflanzen flach und glatt sind; die trockenen und heißen Gegenden Westindiens bieten hierfür viele Beispiele ${ }^{3}$ ).

b) Die Richtung der Blätter ist verschieden. Die Blätter können durch kleine Unterschiede der Beleuchtung beeinflußt werden und danach die besten Richtungsverhältnisse wählen. Die Blätter der Lichtpflanzen stehen oft steil aufwärts oder sogar fast senkrecht (z. B. Lactuca scariola Fig. 8, 9 an sonnigen Stellen und andere Kompaß-

1) Bonnier u. Flahault 1878, Schübeler 1886-88, Graebner 1902 und andere.

2) Wiesner $1870, \mathrm{~b}$.

3) Johow 1884 . 
pflanzen) ${ }^{1}$ ), oder sie hängen hinab namentlich in der Jugend (Mangifera Indica u. a. Tropenpflanzen), während die der Schattenpflanzen wagerecht ausgebreitet sind, was wir z. B. bei den Dikotylen unserer Buchenwälder sehen. Bei den Sonnenpflanzen treffen die Sonnenstrahlen oft die Blätter unter spitzen Winkeln und kommen daher nicht zur vollen Wirkung, während das gedämpfte Licht der Wälder die Blätter der Schattenpflanzen unter rechtem Winkel trifft. Oft wird bei den dikotylen Schattenpflanzen Blattmosaik ${ }^{2}$ ) gebildet, indem sich große und kleine Blätter, ihre Zwischenräume ausnutzend, zusammenfügen (Fagus, Trapa usw., dann Trientalis, Mercurialis und eine Reihe anderer Waldbodenpflanzen). Bei Pflanzen mit nadelförmigen und linealischen

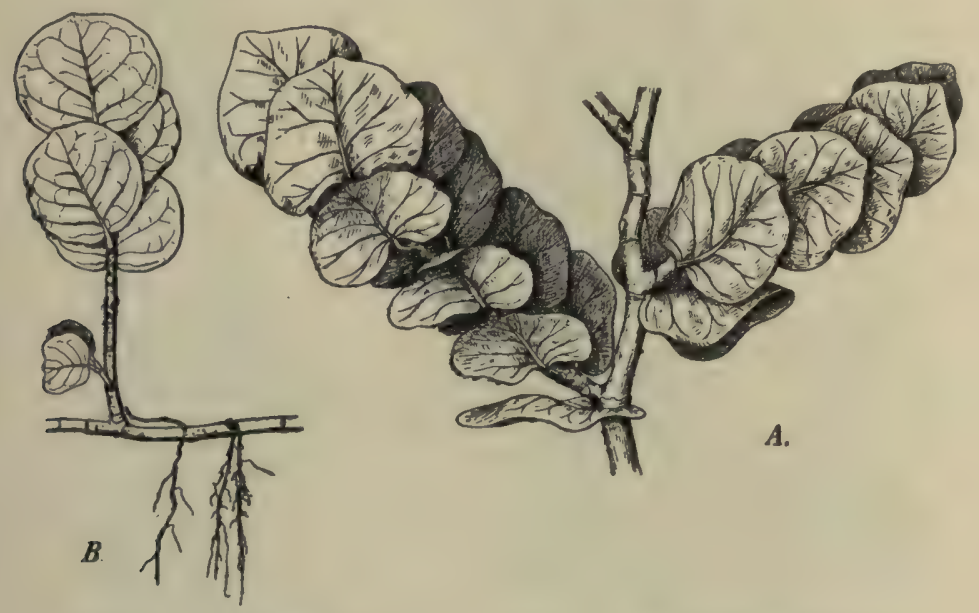

Fig. 8. Coccoloba uvifera; verkleinert. Dänisch-Westindien.

(E. Warming gez.)

Blättern, wie Juniperus und Calluna, besteht ein großer Unterschied zwischen Sonnen- und Schattenpflanzen: jene haben aufrechte und angedrückte, diese abstehende Blätter; jene haben bleibende Profilstellung, diese haben Flächenstellung; diese Stellungsverhältnisse müssen sie als junge, noch wachsende Pflanzen erwerben.

c) Hier sei auch an die photometrischen Bewegungen erinnert, die die Blätter vieler Pflanzen bei Lichtwechsel zeigen: in starkem (und in viele kurzwellige Strahlen enthaltendem) Licht erhalten die Blätter Profilstellung, in schwächerem (und solchem mit vorwiegend langwelligen Strahlen) Flächenstellung (vergl. 2. Abschn., 27. Kap.).

1) Stahl 1881, 1883. (Vergl. Fig. 8, 9.)

2) Kerner 1887; Warming 1901 mit mehreren Abbildungen. (Vergl. Fig. 10, 11.) 
Wiesner $\left.{ }^{1}\right)$ teilt die Blätter je nach ihrem Bau und ihrer Stellung ein in: a) aphotometrische, die keine deutlichen Beziehungen zu dem einfallenden Lichte zeigen, z. B. die Nadeln der Kiefer;
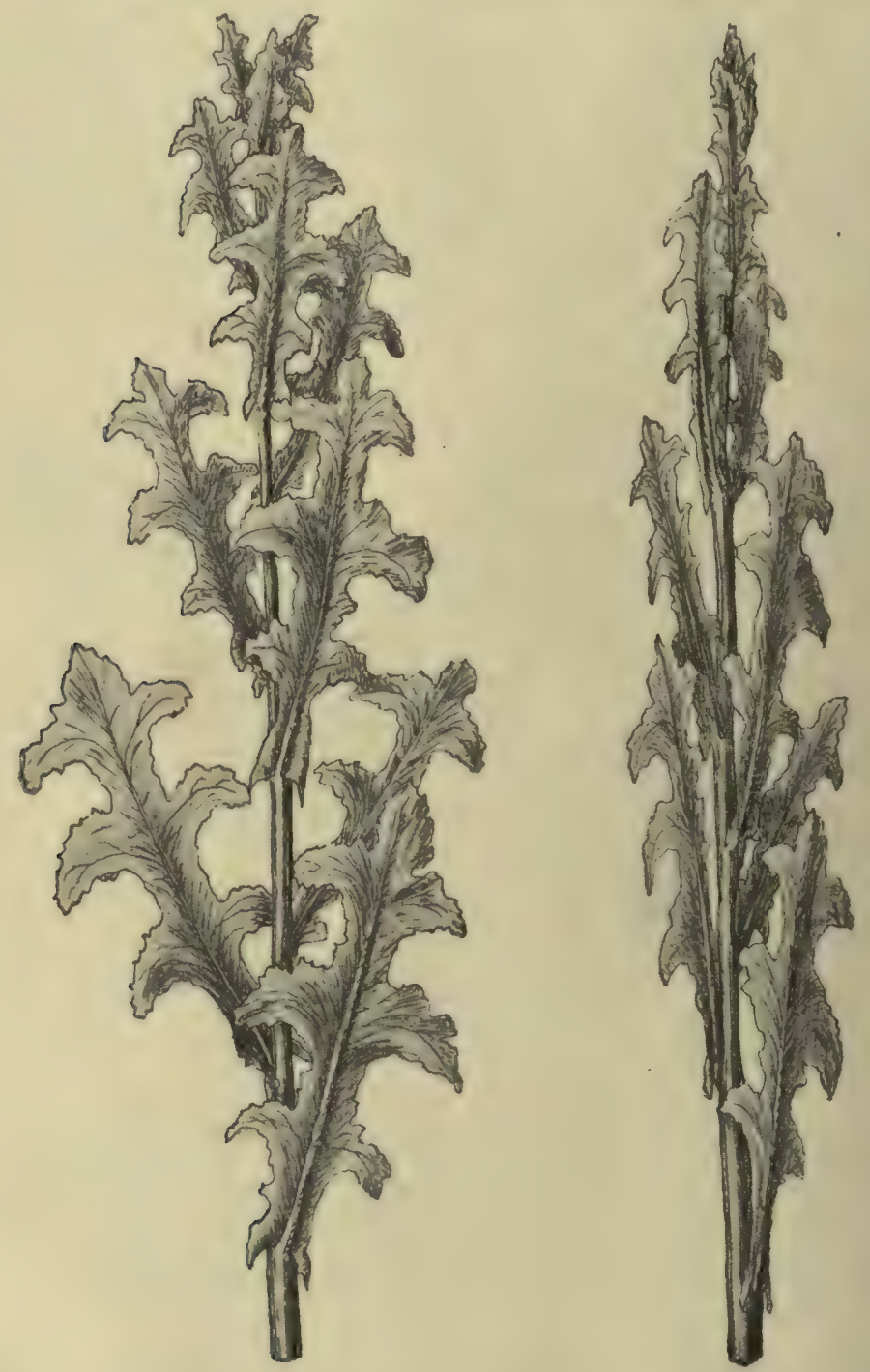

Fig. 9. KompaBpflanze, Lactuca scariola: links von Osten oder Westen, rechts fast von Süden oder Norden gesehen. (Z. T. nach A. Schmeil.)

b) photometrische, die deutliche Beziehungen zum einfallenden Lichte zeigen;

c) euphotometrische, die so gestellt sind, daß sie in der zweckmäßigsten Weise jeden Lichtstrahl ausnutzen, wie es z. B. die

2) Wiesner 1907. 
meisten Waldschattenpflanzen zeigen (vergl, auch oben Blattmosaik);

d) panphotometrische, die ihre Stellung je nach der Stärke und der Richtung des einfallenden Lichtes verändern können.

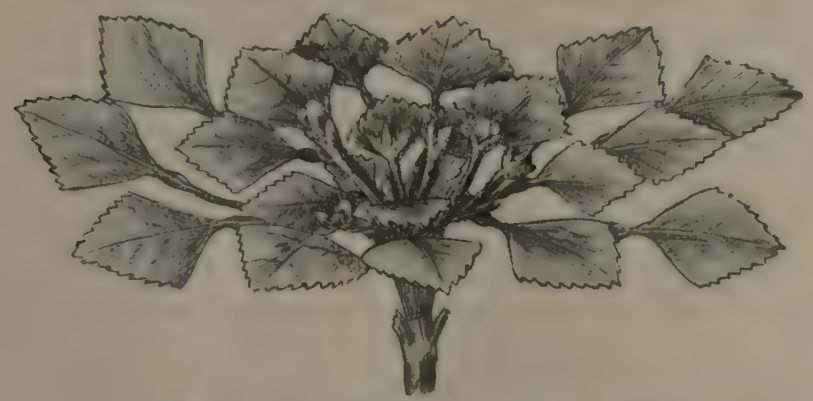

Fig. 10. Blattmosaik von Trapa natans.

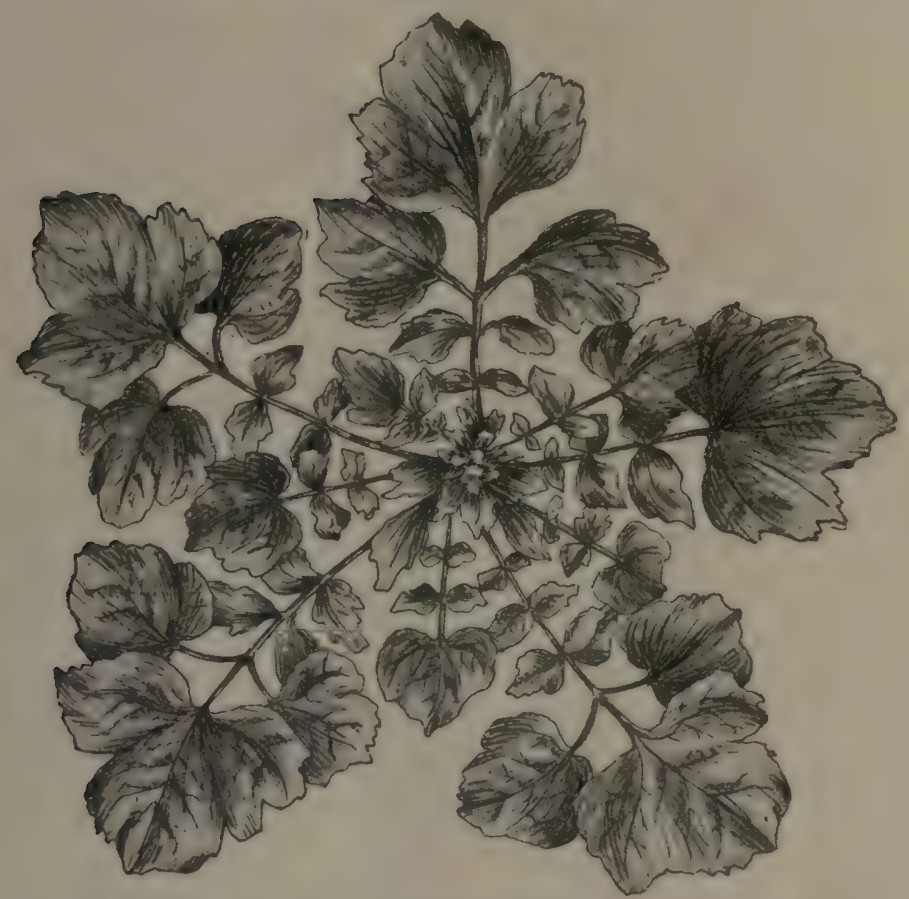

Fig. 11. Blattmosaik von Geum urbanum. (Nach der Natur.)

Albrecht kommt zu dem Resultat, daß neben der Epidermis der Blattunterseite die Oberseite in den meisten Fällen fähig ist, die Einstellungsbewegung des Blattes zu beeinflussen. Höher entwickelte Lichtsinnesorgane, wie sie Haberlandt für tropische Pflanzen beschreibt, sind in den gemäßigten Zonen sehr selten ${ }^{1}$ ).

2) Albrecht 1908; vergl. Haberlandt 1905. 
Der anatomische Blattbau ist bei Sonnen- und Schattenblättern nicht wenig verschieden. Die Sonnenblätter sind oft isolateral, wenn sie nämlich steil aufrechte Stellung haben, so daß sie auf beiden Seiten stark beleuchtet werden; Schattenblätter sind durchgehends dorsiventral ${ }^{1}$ ). Die Sonnenblätter haben ein hohes Palisadengewebe, in dem entweder die Palisadenzellen selbst hoch sind, oder indem es mehrschichtig ist, oder indem beide Verhältnisse auftreten (blattarme oder blattlose Stengel haben gleichfalls ein hohes Palisadengewebe rings um den Stengel); die Schattenblätter haben ein niedrigeres oder kaum ausgeprägtes Palisadengewebe (Fig. 15, 16). Die Palisadenzellen sind oft zur Oberfläche schräg gerichtet, dies scheint mit der Richtung der einfallenden Lichtstrahlen zusammenzuhängen ${ }^{2}$ ). Umgekehrt ist das Schwammparenchym in den Schattenblättern relativ mächtiger als in den Sonnenblättern. Die Sonnenblätter sind dicker als die Schattenblätter; die ausgeprägtesten Schattenpflanzen haben in ihren Blättern nur eine Zellschicht (Hymenophyllaceae, Fig. 12). Das Sonnenblatt hat zwischen den Zellen kleine,

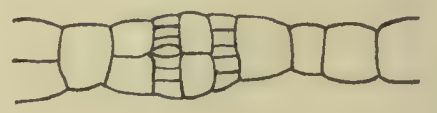

Fig. 12. Querschnitt durch ein Blattstück von Hymenophyllum.

(Nach Ladebeck.)

das Schattenblatt große Lufträume (Fig. 15). Die Sonnenblätter atmen intensiver als die Schattenblätter derselben Art und assimilieren stärker.

Die Epidermis ist beim Sonnenblatt dick (Fig. 15), hat meist kein Chlorophyll (jedenfalls auf der Blattoberseite) ${ }^{3}$ ), ist bisweilen durch Querteilung zu einem mehrschichtigen Wassergewebe umgebildet (Ficus elastica u. v. a. Tropenpflanzen), und ihre Kutikula oder ihre Kutikularschichten sind dick. Die Epidermis des Schattenblattes ist dünn, einschichtig, führt bisweilen Chlorophyll, und ihre Kutikula ist dünn. Das Sonnenblatt ist daher oft stark glänzend, reflektiert viel Licht, wofür besonders die Tropen viele Beispiele aufweisen ${ }^{4}$ ); das Schattenblatt ist glanzlos und welkt weit leichter als das Sonnenblatt, wenn es trockener Luft ausgesetzt wird. Die Epidermiszellen haben bei den Sonnenblättern minder wellige Seitenwände (sowohl auf der Oberseite als auf der Unterseite eines Blattes) als bei den.Schattenblättern. Spaltöffnungen finden sich gewöhnlich nur auf der Unterseite von dorsiventralen Sonnenblättern, oder hier zahlreicher als auf der Oberseite (Ausnahme gewisse Alpen-

1) Heinricher 1884 .

2) Pick 1881; Johow 1884; Heinricher 1884; Haberlandt 1886; Warming 1897.

8) Stöhr 1870.

4) Volkens 1890 . 
pflanzen), und sind oft unter das Niveau der Oberfläche eingesenkt; beim Schattenblatt liegen sie auf beiden Seiten, im ganzen wohl auf der Unterseite zahlreicher, und im Niveau oder über dem Niveau der Oberfläche. Viele tropische Schattenpflanzen haben sammetartige Blätter, welche mit lichtbrechenden Papillen besetzt sind, die dazu dienen, die schrägeinfallenden Strahlen zu sammeln ${ }^{1}$ ) (Fig. 13, 14).

Verholzte Teile sind bei Sonnenpflanzen viel allgemeiner als bei Schattenpflanzen, z. B. ist Dornbildung häufiger. Die Sonnenblätter sind teils deshalb, teils wegen der Dicke, teils wegen der Beschaffenheit der Epidermis oft steif und lederartig; die Schattenblätter sind dünn und, wenn groß, schlaff (viele unserer Waldbodenpflanzen, z. B. Corydallisund Circaea-Arten, Lappa nemorosa, Lactuca muralis, Oxalis acetosella, viele Farne, in den Tropen besonders Hymenophyllaceae, Moose u. a.).

Die Behaarung ist verschieden. Die Sonnenblätter haben oft eine dicke Bekleidung von Deckhaaren, sind graufilzig, silberglänzend

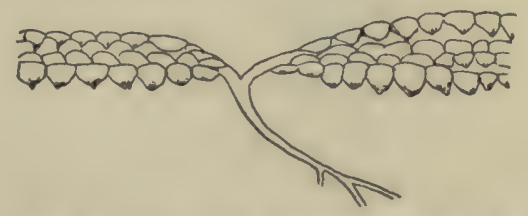

Fig. 13. Vorkeim des Leuchtmooses Schistostega mit den lichtreflektierenden Zellen. (Nach Migula.)

oder in anderer Weise behaart, besonders auf der Unterseite (viele Felsen-, Heide- und Steppenpflanzen); die Schattenblätter sind durchgehends weit kahler, oft ganz kahl.

In der Empfindlichkeit des Chlorophylls gegen das Licht bestehen wahrscheinlich große Unterschiede, indem das der Schattenblätter mutmaßlich empfindlicher ist, als das der Sonnenpflanzen, und daher das schwächere Licht besser ausnutzen kann; hiermit stimmt gut überein, daß der Alkoholauszug des Chlorophylls von Farnblättern im Lichte sehr leicht gebleicht wird (Gautier).

Über die Bedeutung des Lichtes für die Färbung der Pflanzen kann außer seiner Rolle bei der Chlorophyllbildung angeführt werden, daß es auch die Bildung von rotem Zellsaft (Anthocyan oder Erythrophyll) hervorrufen kann: kahle Pflanzenteile, die dem Lichte ausgesetzt sind, erhalten nicht selten rotgefärbte Epidermiszellen, was vermutlich dem darunterliegenden Protoplasma und Chlorophyll zum Schutze dient. Bei vielen jungen Sprossen, Keimpflanzen, arktischen und Hochgebirgspflanzen ${ }^{2}$ ) u. a. hat die Rotfärbung sicher andere Ursachen und

1) Stahl 1896; Haberlandt 1905.

2) Wulf 1902; Kerner 1887 . 
darf wohl als Kälteschutz angesehen werden; der rote Farbstoff ermöglicht eine Speicherung der Wärme, die den jungen Sprossen in kalten Lagen oder zu kühler Jahreszeit zugute kommt (Engelmann, Wille u. a.) ${ }^{1}$ ).

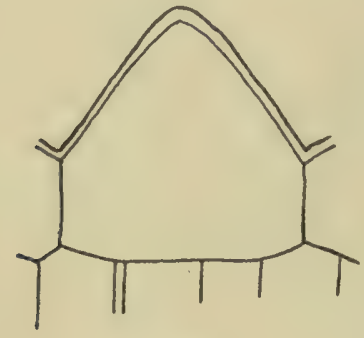

$A$

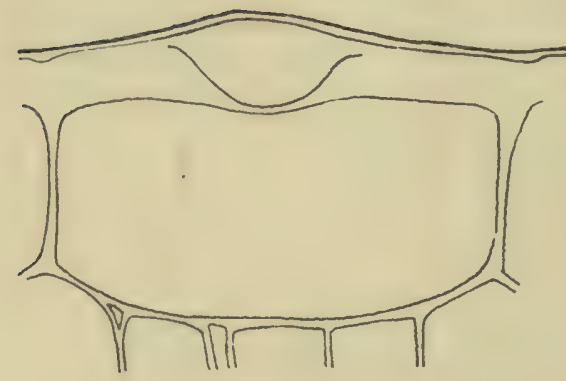

$C$

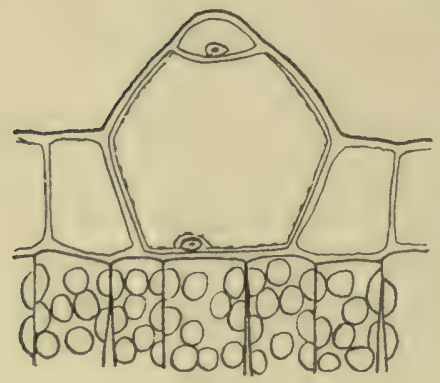

E

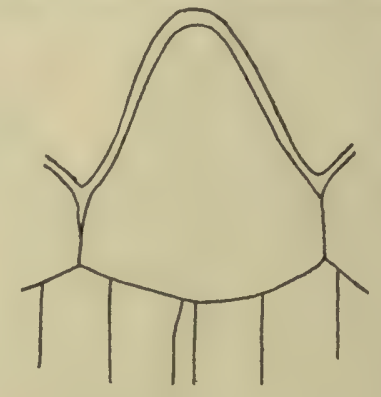

$B$

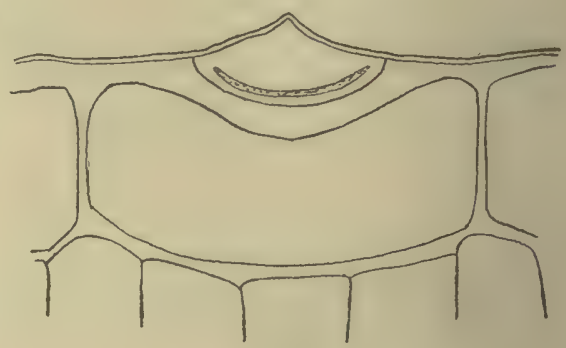

$D$

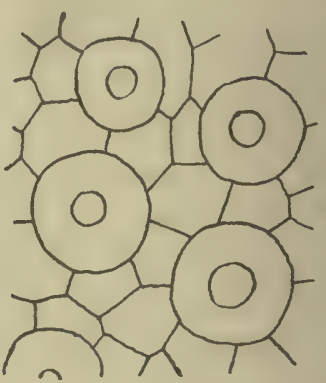

F

Fig. 14. Lichtsinnesorgane. Epidermiszellen, $A$ von Ruellia Daveauana, $B$ von Anthurium leuconeurum, $C$ von Campanula persicifolia, $D$ von Petraea volubilis (mit aufsitzender Linsenzelle), $E$ von Fittonia Verschaffeltii (mit Linsenzellen, Ocellen), $F$ dieselbe Epidermis von der Oberfläche gesehen.

(Nach Haberlandt.)

Ferner wird angeführt, daß die Farben von Blättern, Blüten und Früchten unter hohen Breiten tiefer werden ${ }^{2}$ ), was der fast ununter-

1) Stahl 1896; Overton 1899; Buscalioni u. Pollacci 1903; Jönsson 1903.

2) Bonnier und Flahault 1894; Schübeler 1886. 
brochenen Beleuchtung zugeschrieben werden müßte. Eine Reihe von Sonnenpflanzen besitzt in der Natur die dunkel- bis schwarzrote Färbung unserer Blutbuchen, -haseln usw. (Myrtus bullata, Perilla Nankinensis, Prunus Pissartii nsw.) ${ }^{1}$ ).

Die im vorhergehenden besprochenen Verhältnisse werden in den folgenden Abschnitten (bes. 2.) näher behandelt werden.

Daß das Licht für die äußeren und die inneren Formenverhältnisse der Pflanzen eine große Bedeutung hat, ist also sicher. Dieses geht, außer aus dem hier in allgemeinen Zügen angeführteu, auch daraus
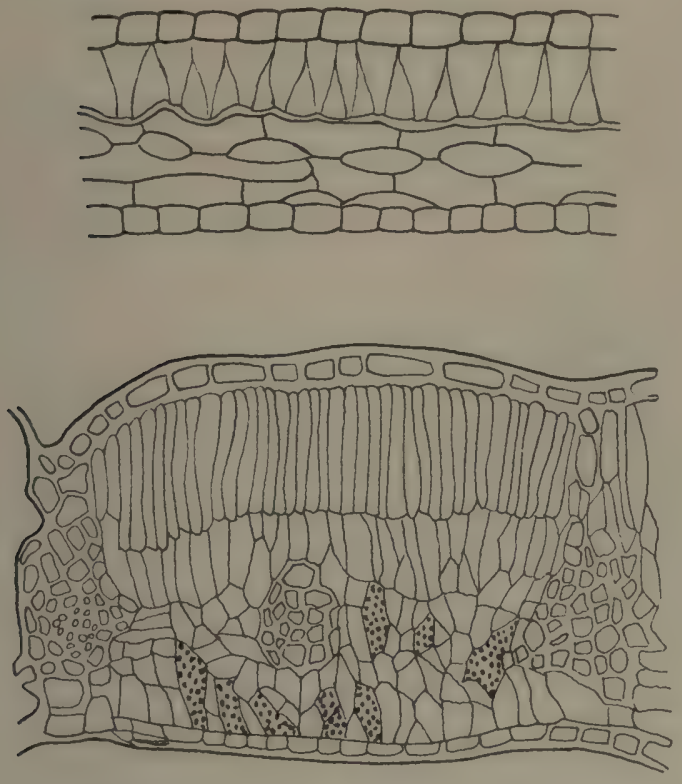

Fig. 15. Buchenblätter; unten in der Sonne, oben im Schatten gewachsen. (Nach Zon u. Graves.)

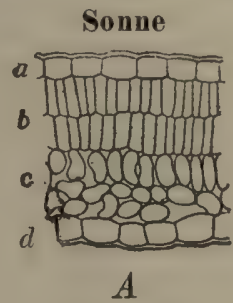

Schatten

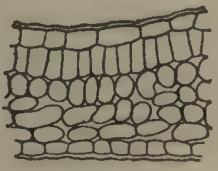

$B$

Fig. 16. Querschnitt durch Erdbeerblätter (Fragaria).

$A$ Blatt in der Sonne, $B$ Blatt im Schatten gewachsen. $a$ und $d$ Epidermis der Oberund Unterseite; $b$ Pallisadenparenchym; $c$ Schwammparenchym. (Nach Dufour.)

hervor, daß viele (vielleicht die meisten) Pflanzen ihren anatomischen Bau, besonders den der Blätter, nach der Stärke der Beleuchtung einrichten können ("plastische" Blätter). Ein Buchenblatt in der Sonne z. B. ist anders gebaut als ein solches im Schatten ${ }^{2}$ ) (Fig. 15-17).

Vöchting ${ }^{3}$ ) zeigte, daß bei schwachem Lichte resp. im Dunkeln blattförmige Kakteenstengel (Phyllocactus usw.) allmählich unter Änderung ihrer Blattstellung in stielrundliche übergehen. Über die Abhängigkeit des Wachstums von Gehölzen, und zwar sowohl an den Stengeln wie an den Blättern je nach der Lichtintensität, nach der Lichtzusammen-

3) Uber Anthocyan siehe Pick, Kny, Myoshi 1909.

2) Stahl 1880, 1883; Hesselman 1904; Woodhead 1906.

8) Vöchting 1894; vergl. auch Göbel 1889-91. 
setzung, ob direktes oder verschiedenartig reflektiertes Licht wirkt, haben neuerdings Zon und Graves ausführlich berichtet ${ }^{1}$ ). - Über die Einrichtungen, welche die Waldpflanzen getroffen haben, um dem geringen Lichtgenuß zu begegnen, hat M. Kästner ${ }^{2}$ ) umfangreiche Untersuchungen angestellt. Er macht besonders auf die Ausbildung resp. Erhaltung der Assimilationsorgane während der laublosen Zeit, die Ansiedlung einjährig überwinternder Pflanzen, die Verlängerung der Vegetations-
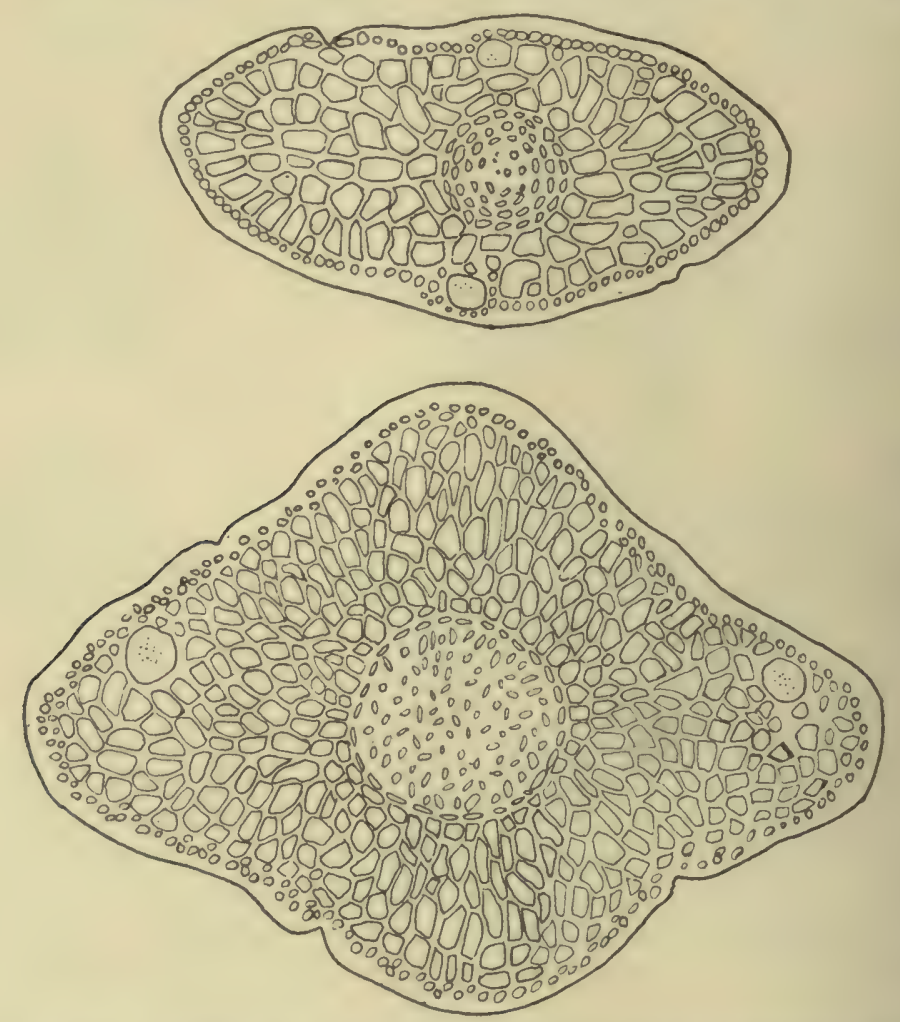

Fig. 17. Junge Fichtenblätter, unten in der Sonne, oben im Schatten gewachsen.

(Nach Zon u. Graves.)

periode usw. an schattigen Stellen aufmerksam. Die Lagerung und die Wanderungen der Chlorophyllkörner in den Zellen und deshalb auch die Farbe der Pflanzenblätter hängen vom Lichte $\left.a b^{3}\right)$ : das stärkere Licht ruft ein helleres Blatt, das schwächere ein dunkler grünes hervor. Fragt man jedoch nach dem eingehenden physiologischen Verständnis der Wirkungen des Lichtes, so sind wir über das Wie und Weshalb noch

2) Zon und Graves 1911.

?) Kästner 1913 .

s) Stahl 1880, Sachs n. a. 
vollständig im unklaren. Einige meinen, daß es das Licht selbst sei, welches nach seiner Stärke die erwähnten Unterschiede im Bau des Chlorophyllgewebes hervorrufe, können aber nicht sagen, wie das Licht wirke (Stahl, Pick, Mer, Dufour u. a.); andere schließen sich dem Gedanken an, daß die durch vermehrtes Licht vermehrte Transpiration der Grund sei (Areschoug, Vesque und Viet, Kohl, Lesage); wieder andere sind geneigt, auf die durch stärkeres Licht hervorgerufene stärkere Assimilation ein Hauptgewicht zu legen (Wagner, Mer, vergl. auch Eberdt). Über den Einfluß verschieden zusammengesetzten Lichtes auf die Tätigkeit des Protoplasmas und die Lagerung der Chlorophyllkörner vergl. Sachs, Kissling ${ }^{1}$ ).

Daß wir in diesen Unterschieden des Baues von Sonnen- und Schattenpflanzen ein Beispiel für die Selbstregulierung (direkte Anpassung, vergl. 5. Abschn.) der Pflanzen sehen müssen, ist kaum zweifelhaft; wir sehen sie bei den plastischen Pflanzen, die ihren Bau nach dem Lichte einrichten, vor unseren Augen vor sich gehen, während der Bau in anderen Fällen im Laufe der phylogenetischen Entwicklung geändert und durch Vererbung in zahlreichen Generationen befestigt worden ist. Der Nutzen der verschiedenen Bauverhältnisse muß in folgendem gesucht werden: Schutz des Chlorophylls gegen Zerstörung durch starkes Licht ${ }^{2}$ ), Schutz des Protoplasmas selbst (daß dieses durch starkes Licht leiden kann, sieht man unter anderem daran, daß Licht ein wirksames Zerstörungsmittel von Bakterien, ein Desinfektionsmittel, ist), ferner Schutz gegen zu starke Transpiration und Regulierung der Assimilation. Wenn man berücksichtigt, daß z. B. die Mächtigkeit des Palisadengewebes nicht nur durch stärkere Beleuchtung vermehrt wird, sondern auch, was durch Versuche nachgewiesen worden ist, durch starke Transpiration, sowie durch verschiedene Faktoren, die die Wasseraufnahme aus der Erde und dadurch die Transpiration beeinflussen (Salze im Nährboden, Beschädigung von Wurzeln u. a.), wenn man ferner berücksichtigt, daß jene Mächtigkeit usw. anscheinend an allen Standorten steigt, wo starke Lufttrockenheit herrscht, so liegt es nahe, den wesentlichsten Grund für die Unterschiede des Baues in einer Regulierung der Transpiration zu suchen. Diese wird durch vermehrtes Licht steigen, indem die Lichtstrahlen in Wärme umgesetzt werden; das Licht ist einer der wichtigsten Faktoren der Transpiration, und die Pflanze reguliert diese nach seiner Stärke, worüber jedoch die Zukunft näheres lehren muß.

Bekanntlich zeigt das Licht auch vielfachen Einfluß auf die Biologie der Blüten; viele, selbst unsere häufigsten Pflanzen öffnen ihre

1) Sachs 1865; Kissling 1895 .

?) Wiesner 1876 . 
Blüten nur bei hellem Tageslicht, manche andern sogar nur in der Sonne (Mesembrianthemum). Sobald Bewölkung eintritt, oder die Sonne sinkt (vergl. Linnés und Kernes Blumenuhren), schließen sie die Blïten wieder, so z. B. Bellis perennis, Taraxacum vulgare, Calendula arvensis u. a. Genaue Daten über diese Erscheinungen hat neuerdings R. Stoppel ${ }^{1}$ ) gegeben. Daß zahlreiche Nachtblüten sich umgekehrt bei intensiver Belichtung schließen, bei trübem (auch sehr warmem!) Wetter auch bei Tage geöffnet bleiben (Oenothera biennis), ist gleichfalls allgemein bekannt.

Über diese Fragen vergl. die Arbeiten von: Areschoug, Stahl, Pick, Dufour, Haberlandt, Heinricher, Vesque, Viet, Mer, Lothelier, Johow, Alb. Nilson, Eberdt, Schimper, Graebner, Wiesner, Hesselman, Woodhead, Stebler und Volkhart. Bezüglich der Lichtmessung vergl. die Arbeiten von Wiesner, K. J. V. Steenstrup (1901), Hesselman (1904), Clements (1905) und Zon u. Graves (1911).

\section{Kap. Wärme}

In weit höherem Grade als das Licht ist die Wärme ein ökologischer und geographischer Faktor, nicht nur im großen, sondern auch im kleinen; denn sie ist über die Erde viel ungleicher verteilt.

Jede der verschiedenen Lebenserscheinungen der Pflanze findet nur innerhalb bestimmter 'Temperaturgrenzen (Minimum und Maximum) und am besten bei einer gewissen Temperatur (Optimum) statt; diese Temperaturen können auch für verschiedene Funktionen derselben Art verschieden sein. Die Wärme ist von Bedeutung für die Chlorophyllbildung und die Assimilation, für die Atmung und die Verdunstung, für die Wurzeltätigkeit und für die Keimung, für die Belaubung und das Blühen, für das Wachstum und die Bewegungen usw. Es ist demnach erklärlich, daß die Wärmeverhältnisse der Verbreitung der Arten auf der Erdoberfläche Grenzen ziehen.

Da also die unteren und die oberen Temperaturgrenzen je nach der Art sehr mannichfach verschieden sind, so kann man im allgemeinen nur sagen, daß die unteren Grenzen (die „spezifischen Nullpunkte“ der Arten) in gewissen seltenen Fällen bis auf $0^{0}$ oder etwas tiefer gehen (manche Arten des hohen Nordens und der Hochgebirge, meist niedere Pflanzen; die Algen im Polarmeer an der Nordküste von Spitzbergen, etwa $80^{\circ} \mathrm{n}$. Br., wachsen und fruktifizieren im Winter lebhaft im Dunkeln bei $-1,8^{\circ}$ bis $0^{\circ}$; unter 27 Arten beobachtete Kjellman Fruktifikation bei 22); aber in der Regel beginnen die Lebenstätigkeiten erst bei einer Temperatur von mehreren Graden über Null, einige sogar

$\left.{ }^{2}\right)$ R. Stoppel 1910. 
erst zwischen $10^{\circ}$ und $15^{\circ}$ (besonders bei tropischen Pflanzen). Bei vielen unserer Moose fällt die Fruktifikationszeit in den Winter, aber trotzdem fand Irmscher, daß die meisten Arten nur Temperaturminima von $-10^{0}$ ohne wesentliche Schädigung ertragen, daß der Erfrierpunkt der Blätter vieler Arten über - $20^{\circ}$ liegt; bei $-30^{\circ}$ waren auch die resistentesten Arten tot. Beachtenswert ist, daß im allgemeinen Moose, wenn sie vor dem Einfrieren lufttrocken gewesen waren, auch wenn sie später wieder befeuchtet wurden, erheblich widerstandsfähiger gegen Kälte waren, als wenn sie nicht trocken geworden waren. Das läßt den Schluß zu, daß Baum- und Felsenmoose härter sind als solche feuchter, schattiger Orte ${ }^{1}$ ).

Die oberen Temperaturgrenzen erreichen $50^{\circ}$ nicht, im allgemeinen nicht einmal $45^{\circ}$ (vergl. z. B. Sachs, Pfeffer: Pflanzenphysiologie). Für sehr viele Pflanzen sind Temperaturen über $50^{\circ}$ tödlich, manche krautige Pflanzenteile sterben schon bei 40 bis $50^{\circ}$. Andere typische Sonnen-, besonders Felsenpflanzen ${ }^{2}$ ) ertragen aber mehrere Stunden bis zu $60^{\circ}$ und mehr (Sempervivum), die Mannaflechte (Lecanora esculenta) verträgt $70^{\circ}$ und mehr. Auch im Sande der Meeresküsten steigt die Oberflächentemperatur oft sehr hoch; so maß Pechuël-Lösche neben blühender Ipomoea $60^{\circ}$ und Massart ${ }^{3}$ ) in Belgien noch $58^{\circ}$ und $59^{\circ}$. In den Thermen von Venezuela leben Algen noch bei über $80^{04}$ ).

Im Ruhezustande können manche Pflanzen sehr viel höhere Temperaturen ertragen, als zur Zeit des Wachstums, so z. B. manche Bakterien vorübergehend über $100^{\circ}$, während sie in ihrer Vegetationszeit bei $50^{0}$ sterben. Lufttrockene Samen vertragen meist nicht $75^{0}$, manche dagegen sind nach kurzer Einwirkung von $100^{\circ}$ oder mehr noch lebend ${ }^{5}$ ).

Die verschiedenen Organe einer Pflanze haben verschiedene Fähigkeit, extreme Temperaturen zu ertragen. So gibt es Pflanzen, die in einem bestimmten Klima zwar keimen, wachsen und blühen können, die aber keine Samen zu erzeugen imstande sind (Acorus calamus in Europa $)^{6}$ ); diese können sich nur vegetativ vermehren; bei anderen Pflanzen sind die Keimlinge gegen Frost empfindlich. Die sehr frostempfindliche tropisch-amerikanische Galinsoga parviflora verdankt ihre völlige Einbürgerung im nördlichen Europa der Frostfestigkeit ihrer Samen. Die während des Winters wachsenden Wurzeln unserer laubabwerfenden Laubbäume $^{7}$ ) sind viel frostempfindlicher als die oberirdischen Teile

1) Irmscher 1912.

2) Hann; Askenasy 1875, 1890.

9) Massart 1908, a und b.

4) Cohn 1862: Rabinowitsch, Zeitschr. Hyg. XX; Warming.

s) Sorauer 1909 .

3) Ascherson in Kirchner, Loew und Schröter, Bd. I.

7) Arnold Engler 1903. 
derselben Pflanzen ${ }^{1}$ ). Auch bei den Moosen fand Irmscher eine verschiedene Empfindlichkeit einzelner Teile.

Außerdem hat die Wärme indirekte Bedeutung, namentlich dadurch, daß das Sättigungsdefizit der Luft und die Transpiration der Pflanze von ihre Höhe abhängen.

Die Temperaturen a Berhalb der Temperaturgrenzen der Arten brauchen nicht gleich tödlich zu sein; es besteht ein gewisser Spielraum, der unter dem spezifischen Nullpunkt am größten ist, d. h. die Pflanzen können, ohne zu sterben, Wärmegraden ausgesetzt werden, die unter dem Minimum tiefer liegen, als die tödlichen hohen Temperaturen über dem Maximum liegen (Ausnahme machen vielleicht nur manche Bakterien). Im übrigen sind die Temperaturen unter dem Minimum und über dem Maximum nicht immer für das Leben bedeutungslos, selbst wenn sie dafür nicht direkt nützlich sind.

Es gibt kaum eine Stelle auf der Erdoberfläche, wo das Pflanzenleben wegen der Wärmeverhältnisse absolut ausgeschlossen wäre; denn in Gegenden, wo die Temperatur monatelang weit unter den Nullpunkten der Arten bleibt, oder wo sie sogar die oberen Temperaturgrenzen übersteigt (z. B. in gewissen Gegenden Afrikas), werden die Pflanzen jedenfalls in gewissen Jahreszeiten gut gedeihen. Es kann jedoch für die Pflanzen notwendig sein, sich gegen die extremen Temperaturen und was damit einhergeht, namentlich gegen Temperaturwechsel zu schützen. Gegen diesen sind gewisse Pflanzen (z. B. Palmen) viel empfindlicher als gegen niedrige Temperaturen. Plötzliches Auftauen ist vielen Pflanzen schädlich, weil die Gewebe zerrissen werden; die Wälder leiden auf der Ostseite, auf östlichen Abhängen und an ähnlichen Orten, wo die Sonnenstrahlen sie früh treffen, oft von Nachtfrost. Über die Empfindlichkeit auch der Laubmoose von starken oder plötzlichen Temperaturschwankungen vergl. Irmscher.

Folgende Mittel werden zum Schutze gegen extreme, namentlich gegen $\mathrm{zu}$ niedrige Temperaturen angewandt ${ }^{2}$ ):

1. Der Zellinhalt hat bei einigen Pflanzen solche (bisher nicht erklärte) Eigenschaften, daß er extreme Temperaturen lange aushält; in der Pflanzengeographie kommt fast nur extreme Kälte in Betracht. Diese Eigenschaften können von denen des Protoplasmas selbst abhängen, oder davon, daß ihm oder dem Zellsafte Öle, harzartige Stoffe oder Zucker beigemischt sind. Einen solchen Schutz muß z. B. die Schneealge (Sphaerella nivalis) haben, deren einzeln liegende, dünnwandige Zellen die Kälte der arktischen Schnee- und Eisfelder aus-

1) Sorauer 1909.

?) Neuere Arbeiten über das Überwintern der Pflanzen und die Wirkungen des Gefrierens vergl. Mez (1904-05) und Lidforss (1907). 
halten ${ }^{1}$ ). Auch Cochlearia fenestrata muß geschützt sein; diese Pflanze hielt an Sibiriens Nordküste im Winter $1878 / 79$ eine unter $-46^{\circ} \mathrm{C}$. liegende Temperatur ohne Decke aus und setzte im nächsten Frühjahre das durch den Winter unterbrochene Blühen fort ${ }^{2}$ ) (Fig. 18).

Bei einer Reihe von Pflanzen wird im Herbst die Stärke in Fett umgewandelt ${ }^{3}$ ). Es ist wahrscheinlich, daß das fette Öl in Form von Emulsion die Unterkältung verhindert und die Widerstandsfähigkeit gegen den Frost erhöht. Fettspeichernde Bäume (Birke, Nadelhölzer) gehören zu denen, die noch in den kältesten Gebieten wachsen. Die Überführung von wasserunlöslicher Reservesubstanz in gelöste, besonders in Zucker, die während des Winters stattfindet, soll gleichfalls die Unterkältung des pflanzlichen Gewebes und den Tod der Pflanze verhindern ${ }^{4}$ ).

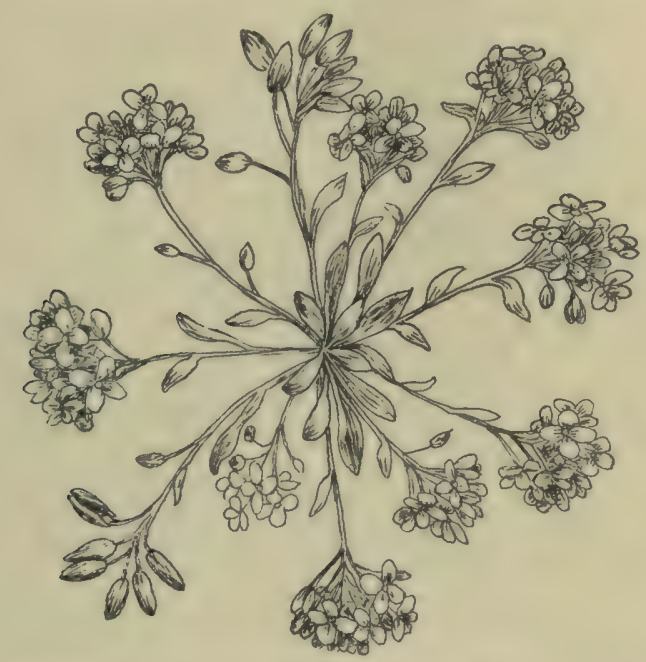

Fig. 18. Cochlearia fenestrata von der Bäreninsel; natürl. GröBe.

(Nach der Natur.)

2. Die Wassermenge. Der Wasserinhalt der Pflanzenteile spielt bei ihrem Vermögen, extreme Temperaturen zu ertragen, die größte Rolle; je wasserreicher, desto weniger widerstandsfähig, und umgekehrt. Daher leiden die jungen Sprosse unserer Bäume oft unter Nachtfrösten, während diese den älteren nicht schaden (wenn junge, sich belaubende Sprosse in den Polarländern ohne Schaden jede Nacht steif frieren, so ist dieses vielleicht eigentümlichen Eigenschaften des Protoplasmas zuzuschreiben); daher haben Samen, z. B. die von Weizen, in den Polarländern viele Jahre überwintern können, ohne zu leiden. Der geringe

1) Wittróck 1883; Lagerheim 1892.

2) Kjellman 1884 .

3) A. Fischer 1891; 0. G. Petersen 1896; Lidforss 1907.

4) Mez 1904-5; Lidforss 1907; Noll. 
Wassergehalt ist vielleicht auch der Grund $\mathrm{zu}$ dem Ausdauern vieler Moose (vergl. Irmscher, S. 25), Flechten und anderer niederer Pflanzen. Die Nadeln verschiedener Koniferen (bes. Weymutskiefer usw.) werden bei Eintritt des Frostes sofort schlaff. Verholzte Teile ertragen die

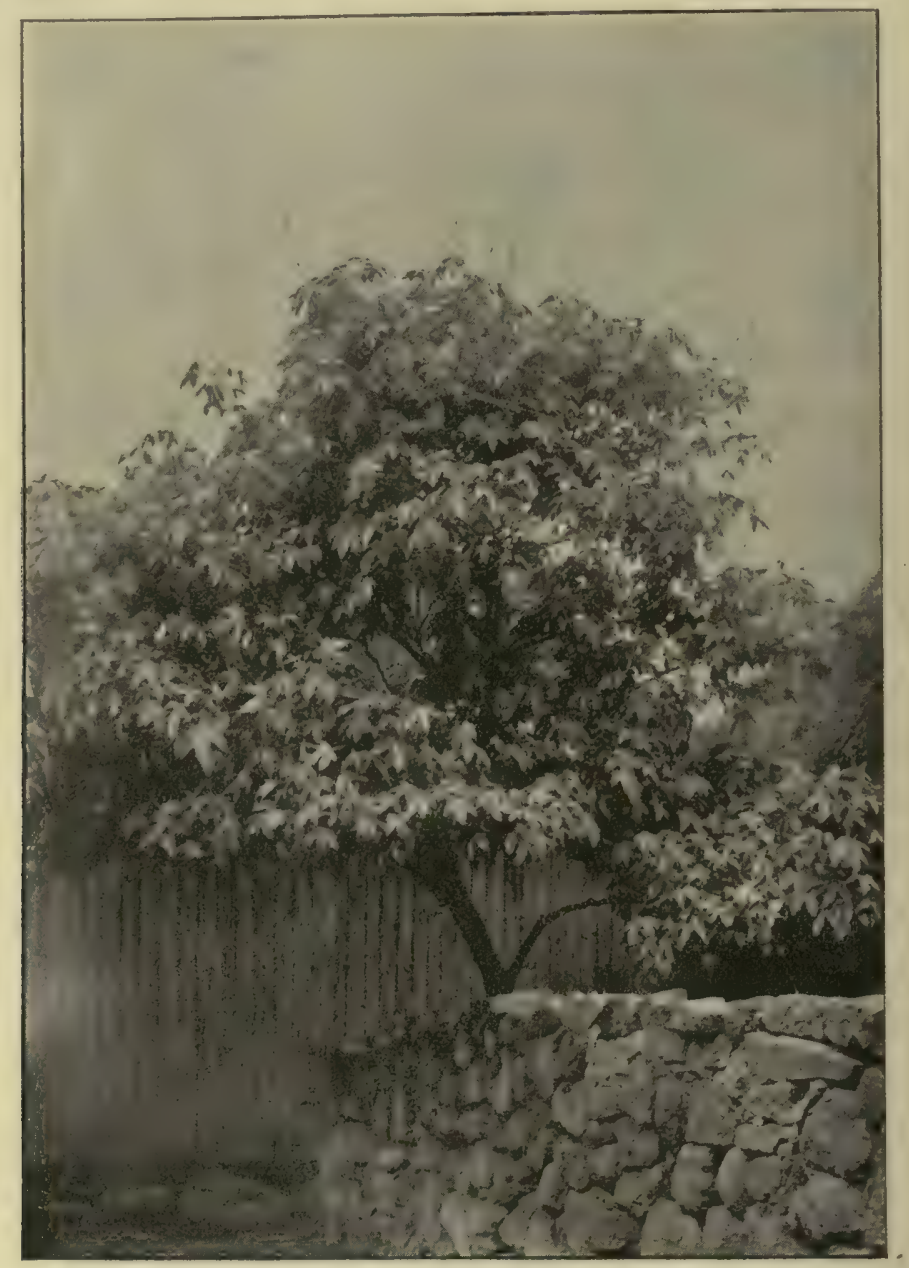

Fig. 19. Acer pseudoplatanus auf den Färöer. Die Zweigspitzen sind abgestorben, obgleich der Baum nicht vom Winde gelitten zu haben scheint. Juli. (Phot. F. Börgosen.)

Kälte leichter als die krautartigen ${ }^{1}$ ); daher sind wohl viele Arten in den Polarländern und den Hochgebirgen verholzt (Zwergsträucher). Die 'südländischen Sträucher erhalten in den Gärten des nördlichen Europa, ebenso wie Bäume und Sträucher auf den Färöer ${ }^{2}$ ) (Fig. 19) oft

1) Mohl 1848.

2) Börgesen 1905 in Botany of the Färöes. 
nicht genug Wärme, um ihr Holz zu reifen; die Zweigspitzen sterben dann durch die Winterkälte ab: die Sträucher werden Halbsträucher. In Gebieten mit langer Vegetationszeit halten dieselben Arten trotz der gleichen Winterkälte aus (Broussonetia, Tamarix u. v. a. in Ungarn); die immergrünen Gewächse des nördlichen Mittelmeergebietes ertragen dort in strengen Wintern ohne nennenswerten Schaden $-5^{0}$ oder gar bis zu $-7^{\circ}$, in den Gärten des nördlichen Europa erliegen sie einer geringen Abkühlung unter $0^{\circ}$ (Lorbeer, Oleander, Myrte usw.). Die Wälder um Sibiriens Kältepol halten Kälte bis zu $-70^{\circ} \mathrm{C}$. aus (in Werchojansk ist im Januar die mittlere niedrigste Temperatur $-61,3^{\circ}$, die höchste $-29^{\circ}$ und die Mitteltemperatur $-51,2^{\circ}$ ). Bei einer an Kälte zugrunde gegangenen Pflanze hat gewöhnlich Eisbildung in den Zellen stattgefunden, wodurch dem Zellsaft das Wasser entzogen wurde. Über die mechanische Wirkung des Frostes durch Zerspringen der Zellen usw. vergl. Sorauer ${ }^{\mathbf{1}}$ ).

Die Wassermenge der Zellen spielt sicher auch eine große Rolle bei der Wirkung der Fröste zu den verschiedenen Jahreszeiten. Während unsere Gehölze während der Hauptruhe (also während der Zeit des Vorhandenseins der geringsten Menge plastischen Materials in wasserlöslichem Zustande) tiefe Kältegrade ohne jeden Schaden ertragen, erliegen im Frühjahr und Sommer (Lüneburger Heide!) ihre grünen Sprosse wenigen Graden unter $0^{\circ}$. Bei unseren Obstgehölzen, die ja meist südlichen Ursprungs sind, bringt ein Frostschaden in der Ruhezeit z. B. den mindergefährlichen Frostbrand, in der Zeit der Saftbewegung dagegen den gefährlichen Frostkrebs ${ }^{2}$ ). Ähnliche Ursachen hat sicher das gelegentliche Auftreten des Krebses an Waldbäumen usw. - Arnold Engler ${ }^{3}$ ) hat nachgewiesen, daß unsere Laubhölzer während des ganzen Winters, soweit es die Temperatur gestattet, ein lebhaftes Wurzelwachstum zeigen; dies bedingt, daß die Wurzeln sehr viel frostempfindlicher sind, als zu gleicher Zeit die ruhenden Stämme und Zweige derselben Pflanze (s. S. 33).

3. Schlechte Wärmeleiter umgeben oft die zu schützenden Pflanzenteile, z. B. als Knospenschuppen oder als Haare; ihre Zellen sind meistens mit Luft erfüllt oder haben zwischeneinander Lufträume und müssen außerdem so wasserarm wie möglich sein. Sehr viele Schutzeinrichtungen haben die jungen Sprosse zur Zeit der Belaubung ${ }^{4}$ ); graufilzig oder weißwollig sind viele Polar- und Hochgebirgspflanzen (Leontopodium alpinum, das Edelweiß der Alpen; Frailejon, das sind

1) Sorauer 1906, a; 1909.

2) Sorauer 1906, a; 1909 .

3) Arnold Engler 1903. Vergl. auch O. G. Petersen 1898.

-) Grüss 1892. 
Kompositen der Gattungen Culcitium und Espeletia auf den Paramos von Südamerika ${ }^{1}$ ); alte, welke Blätter bleiben an den Sprossen dieser Pflanzen sitzen und hüllen sie ein, gleichwie wir im Herbste unsere empfindlichen Gartenpflanzen mit Stroh und Heu umgeben oder mit Laub u. ähnl. bedecken. Es ist jedoch zu bemerken, daß hierdurch die starken Kältegrade kaum ausgeschlossen werden (da diese wohl in das Innere der Pflanze eindringen), sondern zwei andere Verhältnisse werden abgewandt: nämlich schnelle Änderung der Temperatur und schnelles Auftauen sowie die zu starke Transpiration. Erfahrung und Versuche haben gezeigt, daß zwar bisweilen die Kälte selbst einen erfrorenen Pflanzenteil (Kartoffeln, Blütenblätter, tropische Pflanzen, z. B. in hochgelegenen Gegenden Brasiliens) getötet hat, indem Eisbildung unter Wasserentziehung vom Protoplasma stattfindet, daß jedoch das Auf-

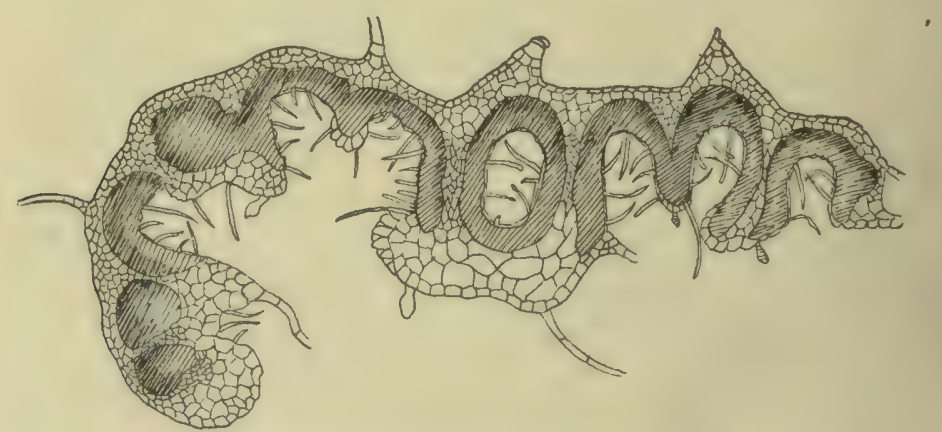

Fig. 19. Stück eines Blattquerschnittes von Espeletia.

Das Assimilationsparenchym ist schraffiert. Die Filzbekleidung ist weggelassen.

(Nach Goebel.)

tauen für manche Pflanze, die das Steiffrieren gut aushält, der kritische Punkt ist: es muß langsam vor sich gehen, und dazu helfen jene Bauverhältnisse, die sich daher gerade besonders in den subglazialen Vereinen finden (vergl. den 4. Abschn.). Mehrfaches plötzliches Gefrieren und Auftauen ertragen selbst die meisten unserer einheimischen. Pflanzen nicht (besonders Buchen, Eichen usw.) ${ }^{2}$ ).

Im scheinbaren Widerspruche hiermit behauptet Kihlman ${ }^{3}$ ), daß die außerordentlich große Widerstandskraft gegen große und plötzliche Temperaturschwankungen, selbst wenn innerhalb 24 Stunden der Gefrierpunkt mehrmals erreicht wird, eine Eigentümlichkeit der Tundraflora Lapplands sei (vergl. oben Eigentümlichkeiten des Zellinhalts).

\footnotetext{
2) Goebel 1892 .

2) Sorauer 1909.

ฐ) Kihlman 1890 .
} 
Untergetauchte Wasserpflanzen sind durch das umgebende Wasser gut geschützt. Viele von ihnen sinken im Herbst unter, haben im Schlamme ausdauernde Grundachsen oder Knollen, oder erzeugen Brutknospen, die abfallen und in gleicher Weise untersinken. Der Schutz des Wassers hat es z. B. auch möglich gemacht, daß während der Eiszeit mit den hochnordischen Landpflanzen im nördlichen Mitteleuropa Wasserpflanzen wuchsen, die nicht im arktischen Gebiete vorkommen (Potamogeton, Ceratophyllum usw.) $)^{1}$ ); natürlich spielt dabei auch die schnelle Erwärmung des Wassers durch die Sonnenstrahlen mit ${ }^{2}$ ).

Auch gegen starke Transpiration werden die besprochenen Mittel schützen, gegen Austrocknen durch die trocknen, kalten Winde, die für das Leben gefährlich sind, wenn die Erde kalt ist und die Wurzeltätigkeit deshalb stockt (Waldfeindliches Klima Schimpers).

In diesem Zusammenhang ist auch der Laubfall ${ }^{3}$ ) im Herbst als eine Anpassung an den Winter zu nennen; nach dem Abwerfen des Laubes ist der Baum von oben bis unten von schlechten Wärmeleitern umgeben (Knospenschuppen, Kork). Andere Verhältnisse werden im 2. Abschnitte genannt werden.

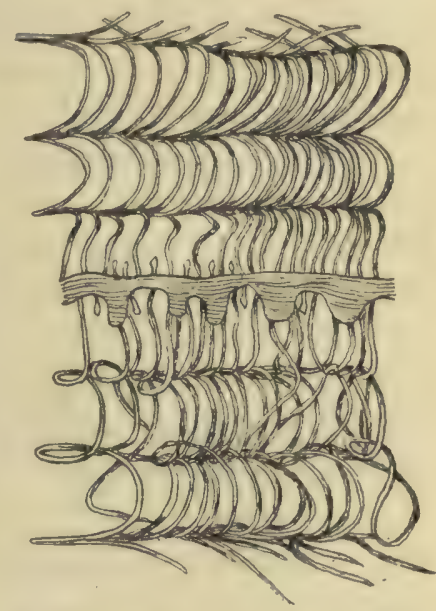

Fig. 21. Querschnitt durch ein Espeletiablatt $(8 / 1)$.

Auf jeder Seite der eigentlichen Blattfläche (siehe Fig. 19) liegt eine stark lufthaltige Filzbekleidung mit 3-4 Schichten (etwas schematisiert). (Nach Goebel.)

Die Temperaturen zwischen Maximum und Minimum (die zuträglichen Temperaturen). Es ist für die Lebensverhältnisse und die Verbreitung der Arten keineswegs gleichgültig, welche Temperaturen ihnen innerhalb der zuträglichen Grenzen geboten werden. Es kommt für das Leben der Individuen nicht nur auf die Höhe der Temperaturen, sondern auch auf die Menge der überhaupt zuträglichen Wärme, die der Pflanze zu teil wird, an, oder darauf, wie lange ihr zuträgliche Temperaturen geboten werden.

Jährliche Mitteltemperaturen haben keine Bedeutung für die Ausbildung des Pflanzenlebens. Nur die Zeit der zuträglichen Temperaturen

1) Graebner 1912.

2) Vergl. Wesenberg-Lund 1911.

3) Vergl. auch Dingler; Volkens 1912. 
ist von Wichtigkeit ${ }^{1}$ ). So wachsen im nördlichen Sibirien mit einer jährlichen Mitteltemperatur von unter $-15^{\circ} \mathrm{C}$. noch Wälder, während auf den Kerguelen, wo selbst der kälteste Monat über dem Gefrierpunkte bleibt, eine antarktische Flora herrscht.

Die Zeit, die zuträgliche Temperaturen bietet, kann so kurz sein, sogar nur einige Wochen betragen, daß viele Arten ganz ausgeschlossen werden, weil sie nicht genug Wärme erhąlten. Dieses ist gewiß der Grund dafür, daß einjährige Arten in Polarländern und in Hochgebirgen selten werden: sie brauchen für ihren Lebenslauf mehr Zeit, als ihnen geboten wird.

In den meisten Gegenden der Erde ruft der Wechsel der Jahreszeiten Ruhezeiten im Pflanzenleben hervor. In unseren nordischen Klimaten sind Wärmeunterschiede, namentlich die Kälte, die Ursache, in den Tropen hingegen Wassermangel. Während auch im nördlichen Gebiete eine Anzahl Pflanzen (Laubfall von Gehölzen usw.) in die Ruheperiode eintritt, auch wenn kein Frost geherrscht hat ${ }^{2}$ ), werden andere nur durch den Frost zur Ruhe gezwungen. Diese zeigen in anormalen Jahreszeiten viele Abweichungen, so beobachtet man in besonders milden Frühwintern resp. Herbstzeiten, daß manche Pflanzen weiterwachsen, weiterblühen oder auch in eine zweite Blüte eintreten. Andere Arten verlegen ihre Blütezeit aus dem Frühjahr in den Winter (Dezember usw.), so z. B. Potentilla arenaria, P. alba, Viola odorata, Cydonia Japonica, Jasminum nudiflorum usw. ${ }^{3}$ ).

Die mehrjährigen Kräuter in Polarländern und in Hochgebirgen zeigen eine vielfache Anpassung an das Klima, z. B. dadurch, daß sie überwinternde, bisweilen mit Vorratsnahrung versehene Laubblätter haben, denn solche können jeden güinstigen Augenblick zur Assimilation benutzen, und es geht kein Teil der Vegetationsperiode mit der Entwickelung von Assimilationsorganen verloren ${ }^{4}$ ). Eine andere Anpassung dieser Pflanzen ist, daß sie ihre Blüten im Jahre vor dem Blühen anlegen, wodurch erreicht wird, daß sie sogleich am Anfange des nächsten Frühjahres aufblühen, eine möglichst lange Zeit zum Blühen und zum Fruchtansetzen erhalten und die wärmste Zeit zur Samenreife benutzen können ${ }^{5}$ ).

Die Höhe der Wärme und die Länge der Vegetationszeit wirken selbstverständlich auch auf die Physiognomie der einzelnen Pflanzen und der ganzen Vegetation. Auf der einen Seite stehen die tropischen Länder, wo die Ruhezeiten fast unbemerkbar sind und wo sich hohe

1) Köppen 1884 .

2) Vergl. Ascherson 1881.

2) Vergl. auch Volkens 1912.

4) Kerner 1896.

5) Warming 1908a. 
Wärme mit Feuchtigkeit verbindet; hier entwickeln sich die immergrünen Tropenvereine mit ihren üppig wachsenden Arten, die den Boden mit der dichtesten Vegetation bedecken. Auf der anderen Seite stehen die Polarländer und die Hochgebirgsgegenden, wo die Natur ihre Gaben mit karger Hand nur etwa in 3 Monaten des Jahres austeilt; hier werden stellenweise nicht genug Pflanzen entwickelt um den Boden zu bedecken, und hier treten Zwergformen auf, unter anderem weil die Vegetationszeit zu kurz und die zuträgliche Wärme zu niedrig ist. Mit steigender Wärme steigt die Wachsstumsgeschwindigkeit bis zum Optimum; aber in den zuletzt genannten Gebieten müssen niedrige Vegetation, kurzgliedrige Sprosse, Rosettenbildung, kleine Blätter und Rasenform die Folge sein. Auch in den Tropen kann Zwergwuchs die Folge sein, wenn sich hohe Wärme mit Trockenheit verbindet, in allen Gebieten dagegen, wenn Nährstoff mangelt (Heide).

Man hat vielfach die Wärmesumme zu berechnen versucht, die die Arten für ihre verschiedenen Funktionen brauchen, und deren Dasein sich am deutlichsten im Frühjahre zeigt, wenn sich Blätter und Blüten in deutlicher Abhängigkeit von den Wärmeverhältnissen entfalten, in einem Jahre zu einer Zeit, im anderen zu einer anderen, an einer Stelle früher als an einer anderen. Indem man die Anzahl der Vegetationstage, von einem gewissen Zeitpunkt an gerechnet, und die auf jeder Stelle herrschenden Temperaturverhältnisse berücksichtigte, hat man die Entwicklungsunterschiede und die Verbreitungsverhältnisse zu erklären versucht; aber im einzelnen bestehen große Meinungsverschiedenheiten: einige suchen die Wärmesumme durch Addieren der täglichen Mitteltemperaturen zu berechnen; andere multiplizieren die Mitteltemperatur einer gewissen Periode mit der Anzahl der Tage; andere wenden die Quadrate der Mitteltemperaturen oder der Tage an; und wieder andere meinen, daß die täglichen Maxima über $0^{\circ}$, die das der Sonne ausgesetzte Thermometer zeigt (Insolationsmaxima) zu addieren seien. Diese Untersuchungen haben es in hohem Grade nötig, durch wirklich wissenschaftliche, experimentelle Bestimmungen der Haupttemperaturen für die Erscheinungen der einzelnen Arten gestützt zu werden. Übrigens werden die Ergebnisse dieser Bestimmungen nicht hinreichen, um die äußerst schwierige und verwickelte Frage über die Bedeutung der Wärmeverhältnisse für die Artenverbreitung und für die phänologischen Erscheinungen zu lösen, da andere Verhältnisse, z. B. das Licht, die Bodenwärme, die Nachwirkungen aus der vorigen Vegetationsperiode $u$. a. vielleicht teilweise eine höhere Temperatur ersetzen können. Mit den Wärmesummen allein läßt sich sicherlich keine Pflanzengrenze erklären. Viel wichtiger dürften absolute Kältegrade, Niederschlagsverhältnisse usw. sein. 
Graebner ${ }^{1}$ ) hat an der Flora des Norddeutschen Flachlandes gezeigt, wie die Pflanzengrenzen in diesem monotonen Gebiete im wesentlichen der Feuchtigkeitsverteilung folgen, daß also die Verteilung des atlantischen und kontinentalen Klimas einen einschneidenden Einfluß ausübt. Brockmann-Jerosch ${ }^{2}$ ) hebt gleichfalls diese starke Einwirkung hervor, der gegenüber die Mitteltemperaturen wenig bedeuten. So ist Labrador mit einer Mitteltemperatur von $-4^{0}$ bewaldet, während Grönland mit einer solchen von $+0,5^{\circ}$ unbewaldet ist. Vahl wendet dagegen ein, daß Brockmann-Jerosch die völlig verschiedene Sommerwärme vernachlässigt, die sicher bei der Bewaldung resp. Nichtbewaldug eine große Rolle spielt. Die Schneegrenze in den zentralen Teilen der Schweiz liegt höher als in den äußeren, da das Klima kontinentaler ist ${ }^{2}$ ).

Ein häufiger Irrtum ist, daß Schattentemperaturen und nicht solche bei voller Insolation bei den Berechnungen angewandt werden. Gerade die Summe der Temperaturen im vollen Sonnenlicht würde eine korrekte Grundlage für die Berechnung und den Vergleich der Temperaturen während einer bestimmten Periode ergeben. Die Erwärmung der Pflanze im vollen Sonnenlicht könnte z. B. eine solche Grundlage bieten, aber nur wenige solcher Messungen können als einigermaßen zuverlässig gelten (Vahl).

Ebenso ist der Unterschied zwischen der Lufttemperatur und der im Boden an den einzelnen Standorten sehr verschieden (vergl. auch unter Temperatur im Boden).

Auch bei folgenden Formverhältnissen spielt die Wärme eine Rolle.

Viele der erwähnten subglazialen Pflanzen, besonders die Holzpflanzen (Salix, Betula, Juniperus u. a.) haben die Spalierform resp. Teppichform, d. h. ihre Stämme liegen auf dem Boden, sind ihm angedrückt und verbergen sich mehr oder weniger zwischen anderen Pflanzen, Steinen und ähnlichem; erst die Spitzen richten sich auf, bisweilen fast unter einem rechten Winkel, erreichen aber nur wenige Zentimeter Höhe über dem Boden (vergl. Kap. 10). Zweifellos erlangen die Pflanzen bei diesem Wuchs eine größere Wärmemenge, als wenn sie aufrecht wüchsen, und entgehen den Winden; es ist aber die Frage, ob es nicht am ehesten die mit den trocknen, kalten Winden einhergehende Verdunstung sei, die sie in der erwähnten Weise umforme (Fig. 22).

Denselben Wuchs trifft man bei vielen Strandpflanzen (im Norden z. B. bei Atriplex, Suaeda und Salicornia, bei Matricaria inodora, am Mittelmeere z. B. bei Frankenia u. v. a.); es sind nicht nur die Seiten-

1) Graebner 1901.

2) Brockmann-Jerosch 1913. 
sprosse, die sich nach allen Seiten flach niederlegen, sondern der Hauptsproß biegt sich auch, bisweilen fast unter einem rechten Winkel, über
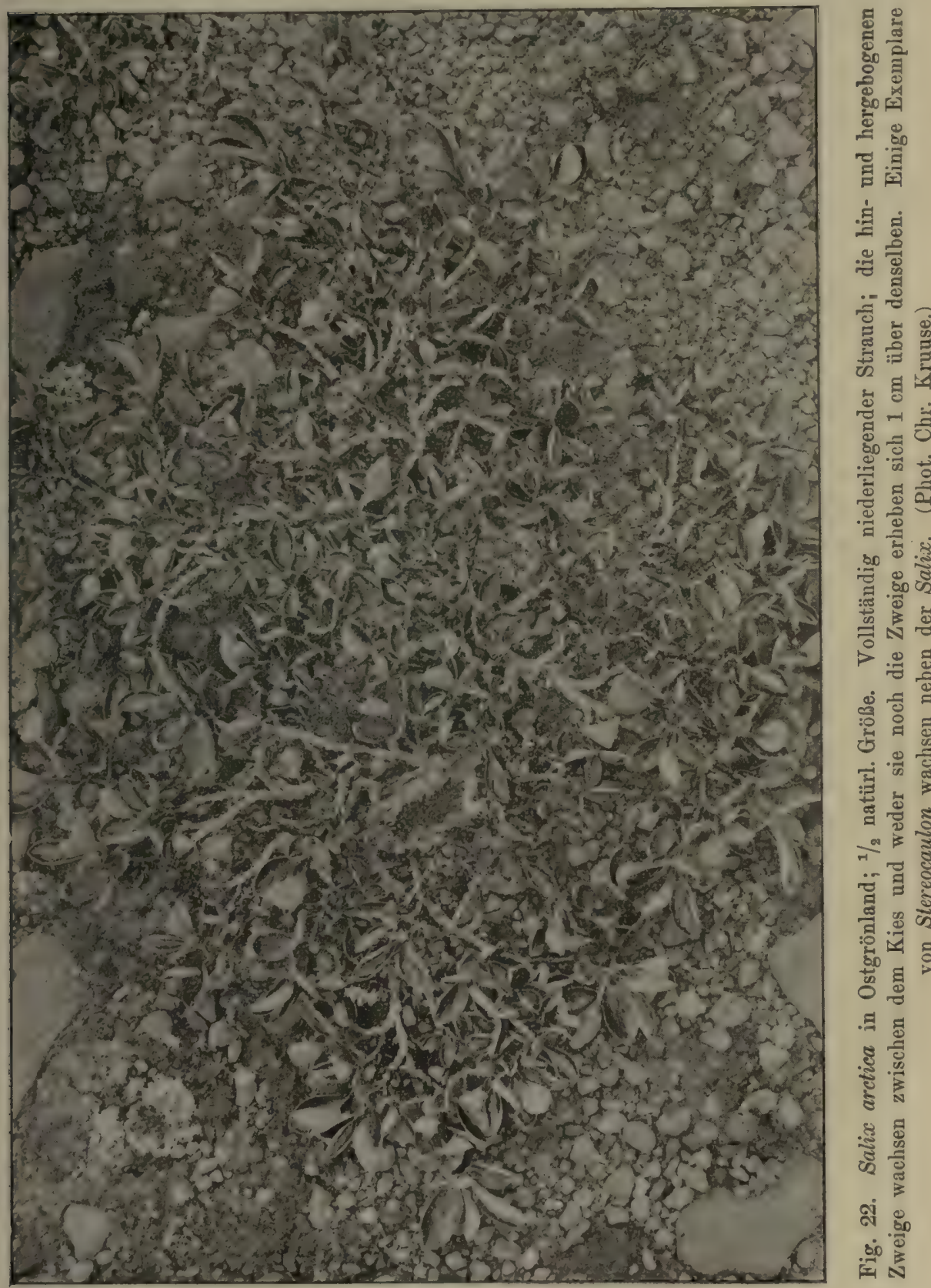

den Boden hin. Ferner beobachtet man dasselbe in Wüsten und auf Sandboden, der von der Sonne stark erwärmt wird (in Afrika z. B. bei 
Aizoon Canariense, Cotula cinerea, Fagonia Cretica nach Volkens, auf unseren Sandfluren z. B. bei Artemisia campestris, Herniaria glabra). In dem heißen trockenen Klima des Flachlandes von Madeira sind niederliegende Formen selten, und solche Formen sind geschützt durch Sukkulenz, dichte Haarbekleidung und ähnliche Einrichtungen ${ }^{1}$ ).

Die gemeinsamen Wuchsformen haben sicher z. T. einen gemeinsamen Grund. Mit der leicht gegebenen Erklärung, daß die Pflanzen „den Stürmen entgegen" wollen, kann sich die Wissenschaft nicht begnügen. Wahrscheinlich muß der Grund in dem Unterschiede der Wärme von Luft und Boden zu der Zeit, wo sich die Sprosse entwickeln, gesucht werden. Man kann oft aufrechte und niederliegende Exemplare untereinander antreffen, z. B. an den nordischen Küsten solche von Atriplex, Salicornia, Suaeda u. a., was darauf hindeutet, daß kein allgemeiner, zu allen Zeiten an dem betreffenden Standorte herrschender Faktor entscheidend ist. Auch die Winde und die Windrichtung können nicht bestimmend sein, da die Individuen einer Art an demselben Strande ihre Hauptsprosse nach den verschiedensten Seiten wenden können, was ein Studium der Pflanzen unserer Küsten leicht zeigt ${ }^{2}$ ). Die Erklärung dafür muß neben individuellen Eigentümlichkeiten wahrscheinlich in der verschiedenen Erwärmung gesucht werden, die den Pflanzen während ihrer Entwicklung vom Boden her zu teil wurde, so daß sie also thermotropische Bewegungen ausgeführt hätten. Übrigens führt Krašan an, daß die Pflanzen auf homothermischem Boden, namentlich in einem Klima mit warmer Luft, aufrechte und kräftige Sprosse erhalten, auf heterothermischem Boden mit besonders alpinem Klima niederliegende. Mit der Höhe über dem Meere nimmt die Höhe der Pflanzen überhaupt ab.

Die Psychroklinie ist in verschiedenen Fällen als wirksame Ursache für den spalierähnlichen, niederliegenden Wuchs angesehen worden, wie durch die Arbeiten von Vöchting ${ }^{3}$ ) und Lidforss ${ }^{4}$ ) hervorgeht. Auch Henslow ${ }^{5}$ ) geht von dem Standpunkt aus, daß der Thermotropismus eine Rolle spielt. - Vöchting stellte z. B. durch Versuche fest, daß Mimulus Tillingii im Eiskasten, wie im Freien sogar Sprosse, die sich in warmer Witterung bereits aufgerichtet hatten, in der Kälte sich dem Boden wieder anschmiegten. - Figur von Psychroklinie siehe Fig. 25.

Sehr bemerkenswert sind auch die Versuche von Bonnier ${ }^{6}$ ), welche zeigen, daß große Temperaturschwankungen ein höchst wirksamer Faktor

1) Vahl 1904, b.

2) Warming 1906 .

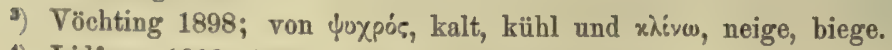

4) Lidforss 1902, 1906; vergl. Schröter 1904-8.

s) Henslow 1894.

6) Bonnier 1898 . 
für die Ausbildung der charakteristischen Tracht der Alpenpflanzen sind. Pflanzen, die er des Nachts starker Kälte aussetzte, nahmen untersetzte, kurze Stengel, schmalere, dickere und härtere Blätter an und blühten früher. Lichtverhältnisse zeigten dabei wenig Einfluß.

Auf Wegen und häufig betretenem Boden finden sich oft ähnliche niederliegende Wuchsformen, z. B. bei Polygonum aviculare. Der Grund ist hier wohl meist eine starke negative Heliotropie.

Rosettenbildung (s. auch Kap.22). Viele Kräuter haben rosettenständige, flach ausgebreitete Grundblätter; selbst wenn sie gestrecktgliedrige Rhizome oder unterirdische Ausläufer haben, werden die Sprosse kurzgliedrig, sobald sie zur Oberfläche kommen. Man weiß noch kaum, welche Faktoren hier entscheidend seien; aber vermutlich

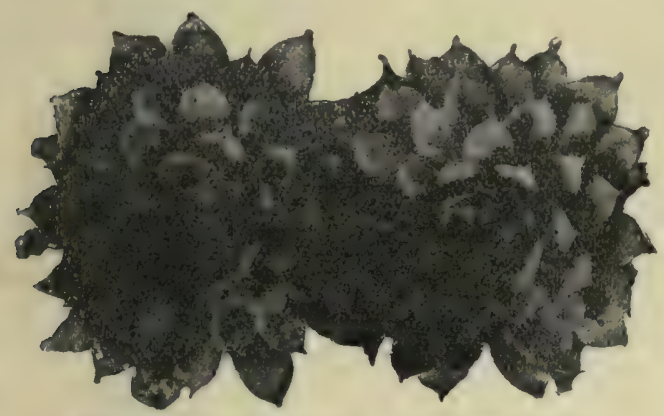

Fig 23. Blattrosetten von Sempervivum Aeclorum (Warming).

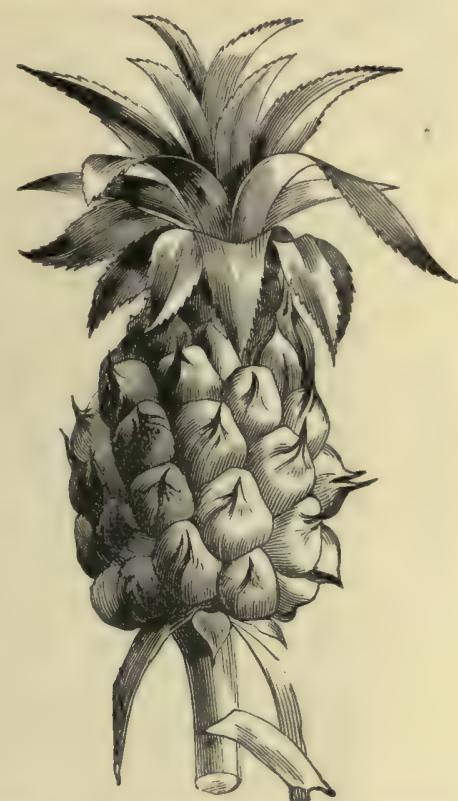

Fig. 24. Blattrosette der Ananas über dem Fruchtstand.

(Nach Warming-Johannsen.)

spielen, außer dem Lichte, auch die Wärmeverhältnisse eine wesentliche Rolle. Teils finden sich solche Rosettenpflanzen in den Tropen auf besonders heißen und trocknen Stellen (Blattsucculenten wie Echeveria, Aizoon, Agave, Bromeliaceae u. a.), teils auch unter höheren Breiten auf Felsenboden, der von der Sonne erwärmt wird, und wo die Luft heiß ist (Sempervivum u. a. Crassulaceen). In großer Zahl kommen solche Kräuter in gemäßigten Ländern vor und sind namentlich für die von einer niedrigen Vegetation bedeckten, sonnigen Weiden kennzeichnend; besonders zahlreich findet man sie in den Polarländern und den Hochalpen, auf den offenen Matten und Felsenfluren, indessen kommen sie auch in großer Menge auf den Wiesen der Ebenen, viel seltener dagegen in Wäldern vor ${ }^{1}$ ). Rosettenbildungen vergl, an den Fig. 23,24 u. 25.

1) Warming 1901. 
Rasenbildung (plantae caespitosae) und Gestrüppbildung sind in Klimaten mit extremen Temperaturen allgemein und werden in den Polarländern und in Hochgebirgen unter anderem durch die Kälte, in Wüsten durch die mit der Hitze einhergehende starke Trockenheit und Verdunstung hervorgerufen. Die Sprosse werden kurz und krumm, dort weil es für ihr Wachstum an Wärme fehlt, hier weil die Hitze sie der Feuchtigkeit beraubt. Näheres hierüber folgt im 5. Kap. unter den Wirkungen des Windes.

Es geht hieraus hervor, daß verschiedene Bauverhältnisse anscheinend durch die Wirkung der Wärme auf die Pflanzen erklärt werden

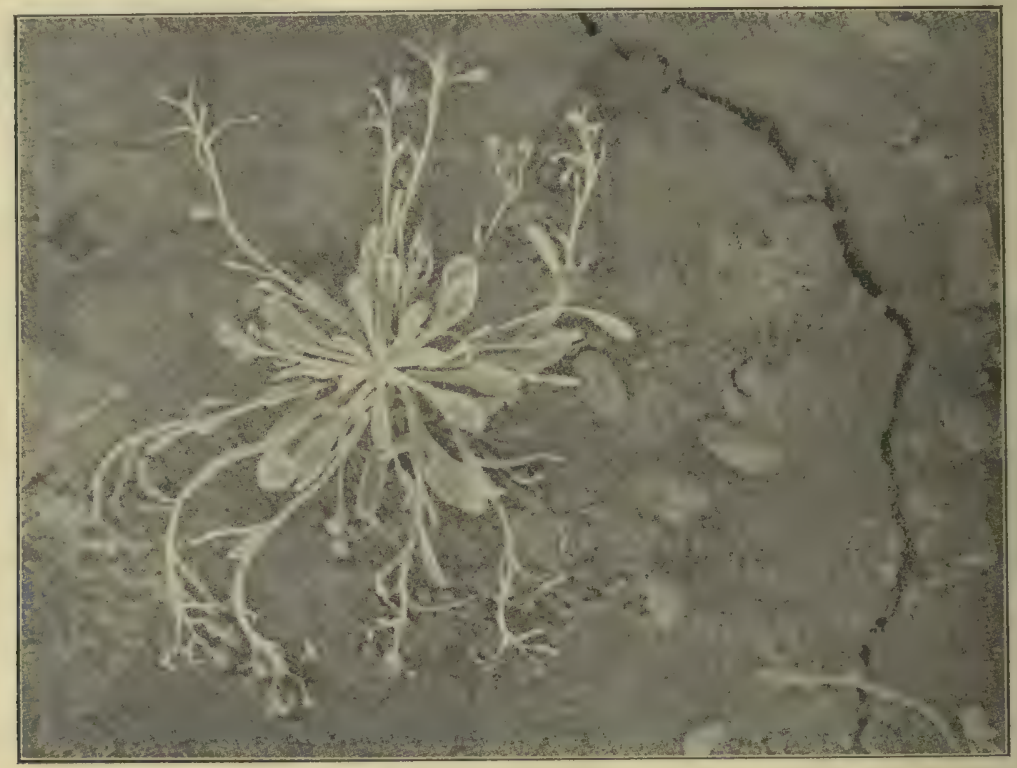

Fig. 25. Lesquerella arctica auf steinigem Boden.

Die blühenden Sprosse sind aufrecht, die fruktifizierenden niederliegend.

Ostgrönland. (Phot. Chr. Kruuse.)

müssen. Anderes wird später angeführt werden, unter anderem die große Bedeutung, die der Wärmegrad der Luft für ihr Sättigungsdefizit und für die Verdunstung der Pflanzen hat; auch diese Umstände wirken auf die Pflanzenformen ein.

Daß die Verbreitung und die Verteilung der Arten im großen von Wärmeverhältnissen abhängen, ist bekannt (Zonen der Erde, Höhestufen in den Gebirgen). Bei Landpflanzenarten mit sehr großer geographischer Verbreitung wird der Abstand zwischen Maximum und Minimum in der Regel besonders groß sein (bei Wasserpflanzen verhält es sich anders). Aber überall greifen die Wärmeverhältnisse auch in die Verteilung, die Haushaltung und die Kämpfe der Vereine ein. 
Die großen Unterschiede zwischen den Klimaten und der Vegetation der Küsten- und der Binnenländer beruhen auf ihnen; am deutlichsten zeigt sich dieses in den Polarländern bei der dürftigen Vegetation des kalten Küstengebietes und der Vegetation des wärmeren Binnenlandes, die sowohl an Arten als an Individuen verhältnismäßig reich ist und kräftigere Individuen enthält (über die Rolle des Lichtes vergl. S. 15).

Ferner zeigen die Polarländer große Gegensätze zwischen der dürftigeren Vegetation der Ebenen und der reicheren und üppigeren auf den sonnigen Bergabhängen; denn die Ebenen werden von den Sonnenstrahlen unter einem weit spitzeren Winkel getroffen als die Abhänge. Falls an den Polen selbst steile Berge vorkommen, so haben diese sicher eine relativ reiche Vegetation. Die Neigungswinkel und die Neigungsrichtungen (die Exposition) der Bergabhänge spielen selbstverständlich auch eine Rolle, inden der Boden und mit ihm die Luft nach den hierbei auftretenden Unterschieden verschieden erwärmt wird. Da diese und andere Verhältnisse jedoch zunächst auf die Wärme des Bodens Einfluß haben, so werden sie im 10. Kap. behandelt werden. Daß die Formenverbältnisse der Erdoberfläche sogar im kleinen pflanzengeographische Bedeutung haben können, sieht man oft auf Stellen, wo die kalte Luft in stillen Frostnächten in Einsenkungen und Tälern stehen bleibt und Erfrieren von Pflanzen verursacht. (Lauenburg i. P. verdankt seiner Lage zwischen Anhöhen, die ein verhältnismäßig mildes Klima besitzen, den Namen des „pommerschen Sibiriens“). Über das Abfließen kalter Luft und ihr Verhalten in den Gebirgen und Tälern vergl. Shreve (1912).

\section{Kap. Luftfeuchtigkeit und Niederschläge}

Das Wasser hat eine auBerordentliche ökonomische Bedeutung für die Pflanze, ja eine fast noch größere als Licht und Wärme. Ohne Wasser keine Lebenstätigkeit weder bei Pflanzen noch bei Tieren. Seine Rolle bei der in voller Lebenstätigkeit befindlichen Pflanze ist folgende:

1. Es ist in allem Protoplasma und in allen Zellwänden als Imbibitionswasser vorhanden.

2. Es findet sich in den Zellen als Zellsaft und spielt hier unter anderem bei dem Turgur und dem normalen Wachstum eine Rolle.

3. Es ist direkt ein Nahrungsstoff, der bei der Assimilation verarbeitet wird.

4. Jede Nahrungsaufnahme aus dem Boden, jede Osmose, jede Stoffwanderung geschieht nur mit Hilfe des Wassers. Die mineralische Nahrung der Pflanze muß in aufgelöster Form vorhanden sein.

5. Die Kohlensäure-Assimilatiou hängt vom Wasser ab, indem sie in der Pflanze, die nicht ihren vollen Turgor hat, erschwert 
ist, unter anderem, weil die Spaltöffnungen geschlossen sind, und indem sie in der welkenden ganz aufhört (Stahl u. a.).

6. Die Atmung hört auf, wenn der Wasserauftrieb unter eine bestimmte Grenze sinkt.

7. Ob die Spaltöffnungen geöffnet oder geschlossen sind und damit die Verdunstung des Wassers aus den Pflanzen steigt oder sinkt, hängt vom Feuchtigkeitsgrade des Bodens und der Luft ab. Größere Feuchtigkeit erhöht die Verdunstung.

8. Alle Bewegungen gehen nur mit Hilfe des Wassers vor sich, mögen sie auf Quellung beruhen oder Reizbewegungen sein.

9. Der Wassergehalt der Pflanze ist für ihr Leben oder Sterben außerhalb der extremen Wärmegrade entscheidend. Trockene Teile sind, wie S. 35 erwähnt, am widerstandsfähigsten.

Die Wasserversorgung ist die bedeutungsvollste Aufgabe im Haushalte einer Pflanze; es ist daher nicht auffällig, daß durch Wassermangel oder durch Austrocknen der Tod eintreten kann; aber viele Pflanzen oder Pflanzenteile können lange, starke Trockenheit aushalten. Die Grenzen des Austrocknens sind sehr verschieden; nur sehr wenige, meist niedrig stehende Pflanzen, Flechten, Moose, Selaginella lepidophylla und Verwandte scheinen fast vollständiges Austrocknen aushalten zu können. - Bei den Laubmoosen ${ }^{1}$ ) ist der Grad der Austrocknung, den eine Pflanze verträgt, nicht nur nach der Art verschieden, sondern schwankt bei den einzelnen Arten auch je nach dem am Standorte gebotenen Feuchtigkeitsgehalt; es zeigt sich eine große Anpassungsfähigkeit. Im Gegensatz zu einer ununterbrochenen Trockenperiode wirken schnelle Schwankungen schädlich. Die Blattzellen erweisen sich im allgemeinen weniger widerstandșfähig gegen Trockenheit als die Sproßanlagen in den Blattachseln.

Es ist auch nicht auffällig, daß nichts anderes dem inneren und äuBeren Bau der Pflanzen seinen Stempel in dem Grade aufdrückt, wie ihr Verhältnis zum Wasserreichtum der Luft und des Bodens (des Mediums), und daß nichts anderes so große und so augenfällige Vegetationsunterschiede hervorruft, wie der Unterschied in der Wasserzufuhr (vergl. Kap. 9). Daß eine größere Wassermenge eine reichere Ernte gibt (mehr Blätter, Stroh, Früchte, ein größeres Wurzelsystem), hat z. B. Hellriegel nachgewiesen; hat die Pflanze wenig Wasser, so tritt Zwergwuchs (Nanismus) ein ${ }^{2}$ ). Es sei jedoch bemerkt, daß eine gewöhnliche Landpflanze nicht desto besser gedeiht, je mehr Wasser ihr in unbegrenzter Weise zugeführt wird; auch hier gibt es ein nach der Zusammensetzung, der Durchlüftung usw. des Bodens sehr verschieden

1) Irmscher 1912.

2) Kraus 1906 a. 
liegendes Optimum. Der Zeitpunkt, in dem die Pflanze Wasser empfängt, kann von größerem Einfluß sein als die absolute Menge desselben; so sind z. B. zahlreiche Steppen- und Wüstenpflanzen zu ihren Ruhezeiten gegen Wasser im Boden und gegen Lufteuchtigkeit so empfindlich, daß sie sich in unserem Klima gar nicht auf die Dauer kultivieren lassen (Welwitschia [Tumboa] usw.). Viele Zwiebel- und Knollengewächse der Steppengebiete brauchen in ihrer Vegetationszeit viel Wasser, faulen aber, wenn sie auch nur etwas zu viel in ihrer Ruhezeit bekommen. Gewisse Einrichtungen zur Ausscheidung des im Übermaße aufgenommenen Wassers besitzt die Pflanze zwar (Wasserporen, Tropfenbildung, inneres „Bluten“); aber es besteht doch eine Grenze für die zuträgliche Feuchtigkeit, Trockenheit liebende Pflanzen gehen bei verstärkter Wasserzufuhr meist bald zugrunde (vergl. indes Heidepflanzen).

Auf zwei Wegen wird der Pflanze Wasser zugeführt; aus der Luft und aus dem Boden. Von dem Vermögen des letzteren, Wasser aufzunehmen und festzuhalten, wird im 9. Kap. die Rede sein. Hier werden nur die Feuchtigkeit der Luft und die Niederschläge béhandelt.

Die Feuchtigkeit der Luft. Es ist immer etwas Wasser in der Luft unsichtbar in Dampfform vorhanden, aber die Menge wechselt außerordentlich: sie steigt und fällt mit dem Wärmegrade der Luft, und die Wassermenge, die die Luft in Dampfform aufnehmen kann, ist nach der T'emperatur verschieden. Die kalte Luft nimmt nicht so viel Wasser wie die warme auf, bevor sie gesättigt ist; daher treten nach den verschiedenen Zeiten des Tages und des Jahres große Schwankungen auf.

Worauf es für das Pflanzenleben am meisten ankommt, ist nicht die absolute Feuchtigkeit der Atmosphäre, sondern ihr Sättigungsdefizit, d. h. die Wassermenge, die von ihr bei einer gewissen Temperatur noch aufgenommen werden kann, also daran fehlt, daß sie gesättigt wäre; denn von diesem Defizit hängt die Größe der Verdunstung ab. Die Verdunstung von Wassser mit gleicher Temperatur wie die Luft ist nahezu proportional dem Sättigungsdefizit. Folglich ist das Sättigungsdefizit einer der bestimmenden Faktoren für die verdunstende Wirkung des Klimas ${ }^{1}$ ), wenn man die Temperatur mit in Betracht zieht. In der Regel ist das Sättigungsdefizit in der Nacht am kleinsten und am Tage am gröBten. In Gebirgen sind diese Verhältnisse indessen oft umgekehrt, je nachdem tägliche Änderungen des in den Tälern und an den Hängen auf- und absteigenden Windes (vergl. z. B. Föhn) eintreten. Selhst in sehr feuchter Luft kann die Verdunstung beträchtlich sein, weil die Spaltöffnungen offen bleiben und die Pflanze durch die Lichtstrahlen erwärmt wird. Der Unterschied zwischen trock-

1) Vergl. Hann 1908-11. 
- nen und feuchten Klimaten beruht auf dem Grade der relativen Luftfeuchtigkeit. Diese hat eine große ökonomische Bedeutung für die Pflanze, z. B. für das Wachstum, indem sie die Größe der Verdunstung beeinflußt.

Da die Größe der Verdunstung indessen auch von mehreren anderen Verhältnissen abhängt, unter anderem von der Temperatur, der Größe und der übrigen Beschaffenheit der Oberfläche des verdunstenden Körpers, so ist es leicht verständlich, daß die Pflanzen sehr viele Anpassungen morphologischer und anatomischer Art hervorgebracht haben, die sie befähigen, das Leben unter verschiedenen Feuchtigkeitsverhältnissen zu fristen (vergl. namentlich den 2. Abschnitt). In einigen Fällen strengt sich die Pflanze an, die Verdunstung bis zu einem gewissen geringen Grade herabzusetzen, in anderen Fällen vielmehr zu fördern; gewisse Pflanzen können nur in sehr feuchter Luft assimilieren, z. B. viele Schattenpflanzen auf dem Waldboden (Moose, Farne, namentlich $\mathrm{Hy}-$ menophyllaceen u. a.), Pflanzen in der Nebelregion der Gebirge usw.; viele voh ihnen sind Epiphyten; man faßt sie unter dem Namen Hygrophyten zusammen ${ }^{1}$ ). Andere Arten sind an sehr trockene Luft angepaßt. Die Bauverhältnisse, die gegen trockene Luft schützen und auch die Verdunstung herabsetzen, sind teilweise dieselben, die gegen zu starkes Licht schützen (vergl. 2. Kap.). Es muß hier sogleich bemerkt werden, daß es sehr schwierig ist, zu entscheiden, was der Luftfeuchtigkeit und was anderen Faktoren zuzuschreiben sei, die mit jener zusammenarbeiten; die S. 26 ff. behandelten Eigentümlichkeiten der Schattenpflanzen werden kaum nur durch die größere Luftfeuchtigkeit verursacht, die im Schatten im Vergleich mit der Luft außerhalb des Schattens zu herrschen pflegt, sondern auch durch das schwächere Licht, gleichwie die Eigentümlichkeiten der Sonnenpflanzen sowohl durch starkes Licht, als durch starke Wärme und starke Verdunstung verursacht werden. Sorauer, Mer, Vesque und Viet, Lothelier u. a. haben gefunden, daß die Wirkungen von feuchter Luft den Wirkungen von Lichtmangel ähnlich sind. Die Pflanzen werden länger, gestrecktgliedrig, dünner, bleicher, die Blattflächen kleiner und dünner, durchsichtiger, und der dorsiventrale innere Bau wird verwischt, indem das Palisadengewebe nur schwach oder gar nicht entwickelt wird; die Gefäßbündel werden schwächer, die Intercellularen größer, das mechanische Gewebe schwächer oder gar nicht entwickelt u. a. Es sind sicher Transpirationsunterschiede, die sowohl in dem einen als in dem anderen Falle der Grund für diese Unterschiede des Baues sind.

Moose und Flechten können im lufttrockenen Zustande vermutlich Wasserdampf aus der Luft aufnehmen; es ist indessen sehr unsicher,

1) Grisebach schuf diesen Namen; von ơrppís feucht und ழ̣vtóv Pflanze. 
wie weit Blütenpflanzen zu ähnlicher Benutzung des Wasserdampfes befähigt sind. Möglicherweise können z. B. gewisse Haarbildungen oder die Außeuzellen der Luftwurzeln von Orchideen, Araceen usw. („Velamina" Fig. 27) die Verdichtung von Wasserdampf ermöglichen. Möglicherweise beruhen die vermeintlich wahrgenommenen Fälle auf einer durch Temperaturwechsel hervorgerufenen Ausscheidung von tropfbarflüssigem Wasser auf oder in den Pflanzenteilen. Daß welkende Pflanzen an warmen Tagen abends turgescent werden, braucht nicht auf der Verdichtung von Wasserdämpfen aus der abends feuchteren Luft zu beruhen, sondern ist unzweifelhaft besonders den Umständen zuzuschreiben, daß die Transpiration dann wegen des geringeren Sättigungsdefizits geringer ist und daß die Wurzeltätigkeit, die vielleicht ununterbrochen in die Pflanze Wasser heraufgeführt hatte, dann imstande ist, soviel oder mehr Wasser heraufzuleiten als verdunstet.

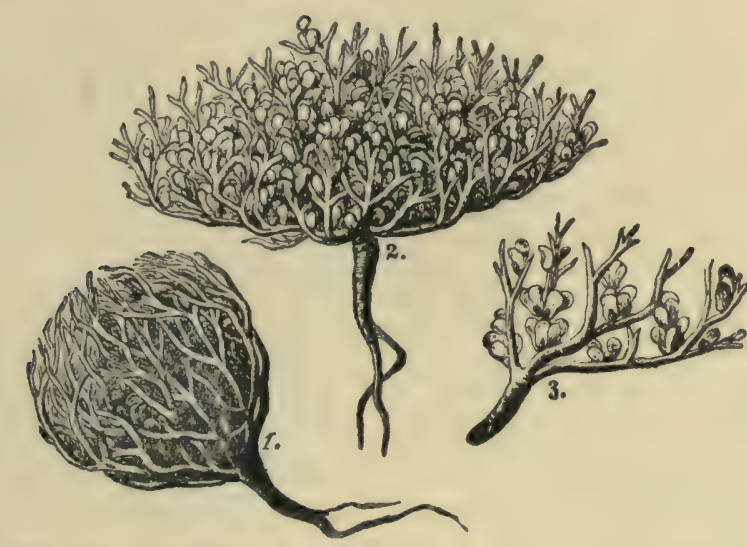

Fig. 26. Anastatica hierochuntica, "Rose von Jerichow".

1. in vertrocknetem, 2. in feuchtem Zustande (verkleinert); 3. ein Stück eines Zweiges in natürlicher GröBe. (Aus Warming-Johannsen.)

Ein anderes Verhältnis ist, daß gewisse Wüstenpflanzen hygroskopische Salze ausscheiden, die nachts aus der feuchteren Luft Wasser ansaugen; aber daß dieses Wasser, das die Oberfläche der Pflanze benetzt, auch von ihren Zellen aufgenommen und ausgenutzt werde, ist kaum richtig ${ }^{1}$ ).

Durch geringe Luftfeuchtigkeit auf der einen, die größere auf der anderen Seite sind sicher auch die Erscheinungen der Hygrochasie und der Xerochasie ${ }^{2}$ ) mit veranlaßt. Eine Anzahl Pflanzen aus Gebieten mit ausgeprägter Dürreperiode schließt nach der Fruchtreife die Samen resp. Früchte fest ein (Anastatica Hierochuntica, die "Rose von Jericho" (Fig. 26), Odontospermum pygmaeum, Lepidium spinosum, Ammi

1) Volkens 1887; Marloth 1887; Massart 1898 a; J. Schmidt 1904.

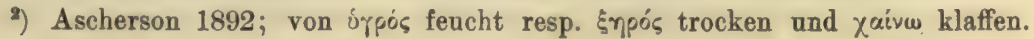


visnaga usw.) und erst durch eine Regenzeit werden die Samen frei und können keimen. In den kühleren und damit feuchteren Gebieten, z. B. in Mitteleuropa, überwiegt dagegen ganz auffällig die Xerochasie, in feuchten Zeiten bleiben Früchte und Samen eingeschlossen und erst im trockneren Frühjahr werden sie durch Ausspreizen der Fruchtköpfe usw. entlassen (z. B. Daucus carota), wenn die Winterfeuchtigkeit den Sämlingen der meist Pontischen Pflanzen nicht mehr schadet.

Niederschläge. Sinkt die Temperatur bis zu einem gewissen Punkte, so daß die Luft die aufgenommene Wassermenge nicht in Luftform behalten kann, so wird sie unter einer oder der anderen der drei bekannten sichtbaren Niederschlagsformen ausgeschieden: als Nebel (Wolken), Regen (Schnee) oder Ta u (Rauhfrost). Die Niederschläge werden teils vom Boden aufgenommen und kommen auf diesem Wege der Haushaltung der Pflanze zu gute (vergl. 9. Kap.), teils von den oberirdischen Teilen der Pflanzen aufgefangen, mit denen sie in unmittelbare Berührung kommen und die in gewissen Fällen zu ihrer Aufnahme angepaßt zu sein scheinen. Viele Pflanzen haben keine anderen Quellen für das Wasser als die unmittelbaren Niederschläge (Epiphyten, Felsenund Gesteinspflanzen, das Sphagnum vieler Heidemoore).

Anpassung an die Aufnahme von Niederschlägen. Es gibt Pflanzen, die sehr leicht und schnell mit ihrer ganzen Oberfläche tropfbarflüssige Niederschläge aufnehmen und dadurch turgescent werden, z. B. Flechten, Moose, gewisse Luftalgen; diese Pflanzen ertragen zugleich in hohem Grade Austrocknung. Andere Pflanzen können an gewissen Stellen der Oberfläche benetzt werden und Wasser aufnehmen, haben jedoch andere Stellen, wo dieses nicht geschehen kann oder die schwierig benetzt werden (wegen einer dicken Kutikula, wegen Wachsüberzügen u. a.). Einige Pflanzen haben besondere Organe für die Aufnahme von Wasser aus Niederschlägen (z. B. Luftwurzeln mit eigenem Sauggewebe (Fig. 27), alte, schwammige Pflanzenreste, die begierig Wasser einsaugen, Haare, die Wasser aufsaugen können (Bromeliaceen u. a., Fig. 28-31), eigentümliche Zellen in den Blättern mit durchlöcherten Wänden (Sphagnum) u. a.). Vergl. hierüber spätere Abschnitte, besonders den über die Anpassungen der Xerophyten (2. Abschnitt).

Aber im allgemeinen muß man annehmen, daß Wasser von den oberirdischen Organen nur aufgenommen wird, wenn die Wurzel der Pflanze kein Wasser zuführen kann und die Pflanze keinen Vorrat mehr enthält; jene Wasseraufnahme ist für die gewöhnlichen Pflanzen zunächst ein Notbehelf (Versuche von J. Boehm 1863, Detmer 1877, Tschaplowitz 1892, Kny 1895, Wille 1887) ${ }^{1}$ ).

1) Vergl. auch Burgerstein 1904. 
Platzregen, namentlich die heftigen, bei Gewittern fallenden, tropischen Regengüsse, können die Pflanzenteile, besonders die jungen, noch zarten, mechanisch beschädigen ${ }^{1}$ ).

Als Schutz gegen Platzregen sollen folgende Einrichtungen Bedeutung haben: 1. Die Blätter vieler, besonders tropischer Pflanzen sind aufwärts oder abwärts gerichtet, so daß der Regen sie unter spitzeren Winkeln trifft und minder heftig wirkt (dieses und anderes im folgenden Erwähnte spielt auch bei der Beleuchtung eine Rolle; vergl. S. 22 ff.); besonders viele junge Pflanzenteile, sowohl einzelne

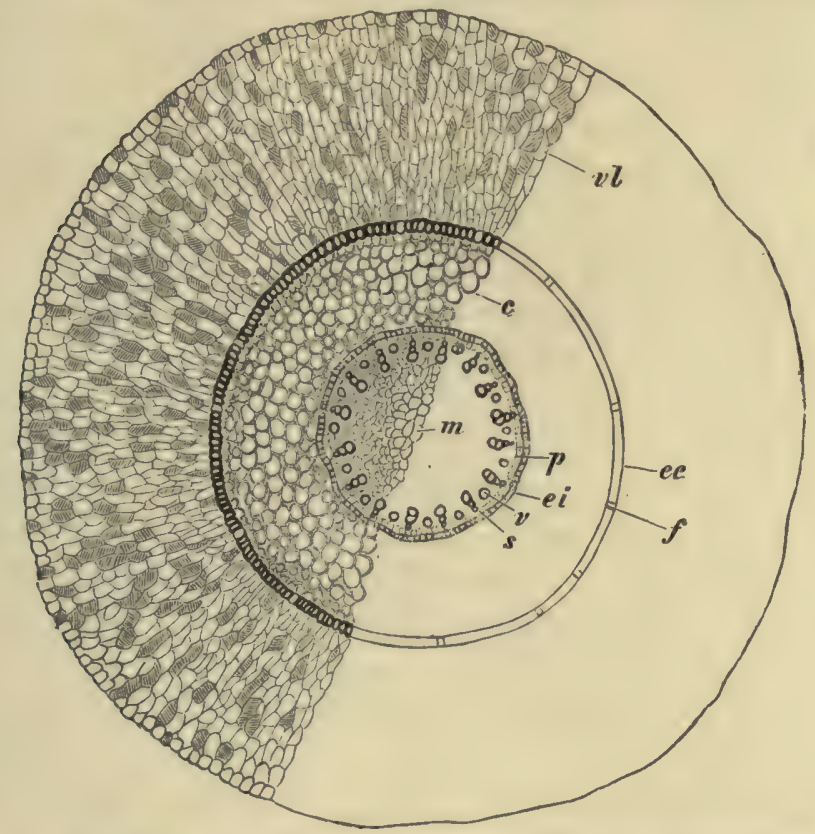

Fig. 27. Querschnitt durch die Wurzel der Orchidee Dendrobium nobile. $v l$ Velamen (Wurzelhülle), in vielen Zellen sind die Verdickungsleisten zu sehen; ee Exodermis; $f$ Durchlabzellen; $c$ Rinde der Wurzel; ei Endodermis; $p$ Pericykel;

$s$ Holzteile; $v$ Siebröhre; $m$ Mark. 28:1. (Nach StraBburger.)

Blätter als ganze Zweige, sind hängend und richten sich erst aufwärts, wenn sie einen festeren Bau haben (viele Tropenpflanzen, Picea usw.). 2. Faltungen und Kräuselungen der Blattspreiten können vielleicht ähnlich wirken ${ }^{2}$ ). 3. Andere Pflanzen, die zusammengesetzte Blätter haben, führen schon Variationsbewegungen aus, wenn sich der Himmel verdunkelt, bevor der Regen selbst gekommen ist; die Blättchen werden daher unter spitzeren Winkeln getroffen werden. 4. Die fein zusammen-

1) Nach Wiesner 1895 war das Gewicht des gröBten künstlich erzeugten Regentropfen $62 \mathrm{~g}$, während der größte wirklich beobachtete nur $16 \mathrm{~g}$ wog.

2) Kny 1895. 
gesetzten Blätter vieler Tropenbäume werden im ganzen eine weniger leicht angreifbare Spreite darbieten als ungeteilte und breite Blätter. 5. Die leichte Beweglichkeit der Blätter oder beblätterten Zweige bietet weiter einen äußerst wirksamen Schutz gegen deren Verletzung durch Regentropfen. Der stärkste fallende Regen kann an ihnen keine andere Wirkung hervorbringen als daß die beweglichen Organe hin- und hergeschüttelt werden ${ }^{1}$ ).

Hagel kann für die Pflanzen noch vernichtender als Regen sein, aber es gibt doch kaum besondere Anpassungen zum Schutze gegen die von Hagelwetter drohenden Gefahren, obgleich man dieses gemeint hat ${ }^{2}$ ).

Nebel (Wolken) absorbiert Licht und wird dadurch die Kohlensäureassimilisation hemmen können (vergl. S. 15). Er hindert auch die Erwärmung des Bodens, und da besonders die chemisch wirksamen Strahlen absorbiert werden, so wird er auch in anderer Weise auf die Vegetation einwirken können. Gegen ihn gibt es kaum einen Schutz.

Nebel kann unter Umständen von sehr großer Bedeutung für die Wasserversorgung der Pflanzen sein und die ganze Physiognomie der Vegetation beeinflussen. Auf vielen Bergen liegt täglich in einer bestimmten Höhe (Nebelregion) eine dichte Nebellage, die große Vegetationsverschiedenheiten hervorruft. Am Nordabhang der Pyrenäen z. B. fehlen in der Nebelregion viele alpine Arten, welche sowohl in höheren als in niedrigeren Lagen vorkommen, die Matten sind an jenen Stellen artenund blütenärmer, aber dafür vegetativ üppiger. Es ist dies der größeren Feuchtigkeit und Lichtschwäche zuzuschreiben ${ }^{3}$ ). Ganz ähnliche Erscheinungen schildert Marloth aus Südafrika: „Die untere Grenze der Bergregion liegt überall dort, wo der Einfluß der Südostwolken aufhört". Im Sommer kann das Land sumpfig werden bei längerem Bestehen der Südostwolken. - Thomas beobachtete in Thüringen, daß das regelmäßige Lagern einer Nebelkappe an bestimmten Abhängen das Ergrünen der Buchen erheblich verzögert.

Taubildung ist für regenarme Gegenden von größter Bedeutung; viele, besonders tropische Gegenden würden fast pflanzenlos sein, wenn der Tau in der trocknen Zeit nicht stark wäre. Die Taubildung ist in den Tropen viel stärker als unter höheren Breiten. Sie spielt z. B. im Pflanzenleben der Wüsten Afrikas eine außerordentliche Rolle ${ }^{4}$ ); sie muß es sein, die an vielen Stellen die Frühjahrserscheinungen hervorruft, obgleich in mehreren Monaten kein Regentropfen fiel ${ }^{5}$ ). Nach $\mathrm{Mez}^{6}$ )

1) Wiesner 1895 .

2) Kny 1895 .

3) Marchand u. Bouget.

D) Volkens 1887; vergl. die ihm entlehnte Fig. 31.

ङ) Warming 1892 .

6) Mez 1904 . 
sind einige epiphytische Bromeliaceen, z. B. Tillandsia usneoides, sehr befähigt, den Tau aufzunehmen, und zwar durch ihre eigentümlichen, schüppchenartigen, locker anliegenden Haare (Fig. 28-30); wenn die tauabsorbierenden Blätter ein Wassergewebe von beträchtlicher Ausdehnung haben, so liegt dies auf der unteren Seite des Blattes, auf der Oberseite aber bei Blättern, die an die Aufnahme von Regen angepaßt sind. In gemäBigten Regionen mag die Taubildung recht erheblich sein, in der größten Mehrzahl der Fälle wird sie für das Pflanzenleben aber nicht so sehr von Bedeutung sein als Quelle der Wasserlieferung, sondern weil durch sie die Verdunstüng herabgesetzt wird. Auch für das Leben unserer Heidemoore besonders der Sphagna ist der Tau höchst bedeutungsvoll; er ist auch hier in regenarmen Zeiten die einzige Wasserquelle.

Man muß annehmen, daß die Pflanzen überall an die gegebenen durchschnittlichen Wassermengen angepaßt sind. Viele Landpflanzen hängen von einer bestimmten Regenmenge $\mathrm{ab}^{1}$ ).

Schutz gegen Niederschläge. Wie die Pflanzen zu wenig Wasser erhalten können, können sie auch zu viel erhalten, von den Niederschlägen ungünstig beeinflußt werden und müssen sich gegen sie schützen. Es gibt auch hier große spezifische Unterschiede: einige Pflanzen sind nach Wiesner ${ }^{2}$ ) "regenfreundlich" (ombrophil) und können monatelang Regen ertragen, andere sind "regenschen" (ombrophob) und verlieren die Blätter schnell. Xerophyten sind meist regenscheu, Mesophyten sind regenfreundlich oder regenscheu. Regenscheue Pflanzen haben meist nicht oder schwer benetzbare Blätter, während die der regenfreundlichen Arten meist leicht benetzbar sind.

Manche Verhältnisse werden als Anpassung an die Ableitung von Regen betrachtet. Jungner und Stahl haben bei Pflanzen aus regnerischen Klimaten mehrere eigentümliche Bauverhältnisse nachgewiesen, die vermutlich dazu dienen, den Regen von den Blättern schnell abzuleiten, damit er nicht die Transpiration hemme, die Pflanzen zu stark belaste, und die zugleich zum Wegspülen von Parasitensporen und ähnlichem dienen. Dazu gehören namentlich die Träufelspitzen, d. h. die außerordentlich langen, besonders bei ganzrandigen Blättern der Tropen vorkommenden plötzlichen Zuspitzungen, wodurch das Regenwasser leicht weggeleitet wird, z. B. bei Ficus religiosa (Fig. 32), Theobroma cacao, Dioscorea-Arten u. a.

$\mathrm{Ob}$ gewisse andere Verhältnisse, worauf z. B. Lundström aufmerksam gemacht hat, einen ähnlichen Nutzen haben, ist nicht ganz sicher; so werden Haarleisten, z. B. bei Stellaria media und Veronica chamae-

1) Wiesner 1894, 1897.

2) Wiesner 1893. 
drys, als Mittel zur Wasserwegleitung aufgefaßt, desgleichen rinnenförmig vertiefte Blattnerven und Blattstiele (bei Lamium album, Humulus lupulus, Aruncus silvester) ${ }^{1}$ ) und Sammetblätter in dem Tropenwalde (vergl. 4. Abschn., Trop. Regenwald).

Die vitale und die morphologisehe Bedeutung des Wassers für die Pflanzen wird übrigens später behandelt werden können, teilweise unter den einzelnen Vereinsklassen. Hier sei nur noch einiges angeführt.

Ein feuchtes Klima verlängert die Lebensdauer der Individuen und der Blätter; der antarktische Wald, z. B. in den feuchten Klima von Neuseeland, ist immergrün; ebenso der an der Westküste von Südamerika im Gegensatze zu dem laubwechselnden Buchenwald an der Grenze des patagonischen Steppengebietes. Trockenheit hingegen verkürzt die Vegetationszeit, beschleunigt Blühen, Fruchtansatz und Samenreife, ruft eine ausgeprägte Ruhezeit und in Steppen und Wüsten die Entwicklung sehr vieler einjähriger Arten hervor.

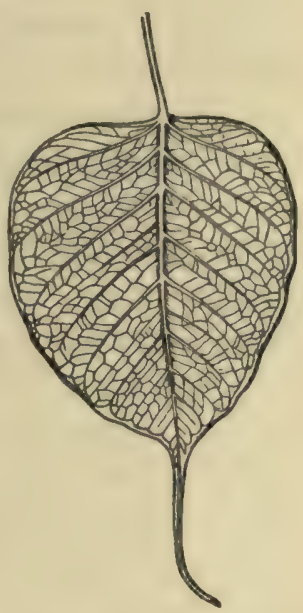

Fig. 32. Regenblatt mit Träufelspitze von

Ficus religiosa.

Die geographische Bedeutung des Wassers ist noch größer als die der Wärme, weil seine Verteilung noch ungleicher ist: dieses gilt nicht nur im großen, sondern auch, und vorzugsweise, im kleinen. Das Wasser ist einer der allerwichtigsten Faktoren für die Art und die Verteilung der Vereine, aber besonders ist es doch das an den Boden gebundene Wasser, das im kleinen geographische Unterschiede hervorruft (vergl. 9. Kap.).

Nicht nur die Größe der Niederschläge, sondern auch die verschiedene Verteilung der Luftfeuchtigkeit und der Niederschläge nach Zeit und Ort hat zunächst für die Unterschiede der Vegetation im großen Bedeutung. Darauf beruht die Entwicklung äquatorialer Waldzonen, wo es das ganze Jahr regnet, die von Wïstenzonen auf beiden Seiten des Äquators mit sehr spärlichen, auf wenige Monate beschränkten Niederschlägen und die der großen, gemäßigten Waldzonen: jene Verteilung ist also ein geographischer Faktor ersten Ranges. Die Verschiedenheit der Wasserkapazität der Bodenarten und der Verlauf resp. das Verhalten des oberflächlich ablaufenden oder stagnierenden Wassers bedingen mehr die Vegetationsunterschiede auf kleinen Strecken.

1) Stahl 1893. 
Die feuchteren Teile Deutschlands und die Mittelmeerländer haben ungefähr die gleiche Regenhöhe (etwa 700 bis $760 \mathrm{~cm}$ ), aber in Deutschland regnet es fast $z u$ allen Jahreszeiten, in Italien aber meist nur im Winter; der heiße Sommer dagegen ist trocken; daher hat Deutschland vorwiegend mesophile Vegetation, Italien aber überwiegend eine ausgesprochen xerophile.

In höheren Gebirgen hängt die Ausbildung der Regionen von der Verteilung der Niederschläge ab. Sehr oft kaun man drei Regionen unterscheiden: eine untere mit spärlichem Regen, eine mittlere, die Wolkenregion mit viel Nebel und Regen (diese ist in der Folge mit Wald bedeckt) und schließlich eine dritte trockene, die über die Wolken hinausragt (so ist es z. B. am Tian-Shan, auf Madeira, Teneriffa usw.). Gebirge zeigen oft eine trockene Leeseite und eine Wetter-(Luv-) Seite mit reichlichem Regen. Die Küstengebirge eines Landes können allen Regen abfangen, so daß im Binnenlande Steppe, Savanne oder ähnliche Vereine trockener Böden herrschen, während sich in der Küstenregion reichlicher Waldwuchs entwickelt (vergl. z. B. die Küstenregion Brasiliens und die Campos im Innern).

Sobald auf natürlichem oder künstlichem Wege auf trocknem Gelände mit nur wenig überschüssigem Wasser ein Pflanzenverein aufwächst, wie z. B. ein Kiefernwald, so wird durch die Verdunstung der Pflanzen die natürliche Bodenfeuchtigkeit derart beeinflußt, daß oft kaum irgendwelches Unterholz oder Nachwuchs sich anfindet. Die Nadelhölzer und andere immergrüne Gewächse verdunsten auch im Winter, die laubwechselnden im wesentlichen nur im Sommer, dann aber viel stärker. Beides wirkt auf den Nach- und Unterwuchs (auch die Krautflora ist oft äußerst ärmlich), wie auch auf den etwa nachfolgenden Pflanzenverein sehr $\operatorname{stark}^{1}$ ).

Es ist ein sehr großer Unterschied, ob dieselbe Regenmenge gleichmäßig über einen großen Zeitraum, wie in Mitteleuropa, verteilt wird, oder ob sie in einer sehr kurzen Zeit als heftiger Gewitterregen herabfällt, während die übrige Zeit des Jahres trocken ist; die Anzahl der Regentage ist insoweit wichtiger als die Regenmenge. Im ersten Falle wird diese der Vegetation viel besser zu gute kommen können; im anderen wird der ausgetrocknete Boden nicht imstande sein, das Wasser aufzunehmen, so daß das meiste auf der Bodenoberfläche, überschwemmend und zerstörend, abläuft oder in die Tiefe sickert. Im ersten Fall erhalten wir ganz andere (mesophile) Lebensformen und ganz andere Formationen als im anderen, wo wir es mit extremeren Verhältnissen zu tun haben ${ }^{2}$ ).

1) Vergl. auch Fuller 1911.

2) Weikof 1887; Köppen 1900. 
Es ist auffallend, wie selbst in kleineren Gebieten die verhältnismäßig geringfügigen Unterschiede in den Niederschlagsmengen große Verschiedenheiten der Vegetation bewirken können. So dominiert in den regenreicheren Teilen Norddeutschlands besonders im Nordwesten die Heide, in ihrer Begleitung wachsen eine ganze Reihe typisch atlantischer Pflanzen, die dem regenärmeren Osten fehlen. Im Osten ist dafür eine viel reichere Flora Trockenheit liebender Arten verbreitet, die sich (auch in der Kultur) gegen hohe Feuchtigkeit, besonders im Frühjahr und Herbst, sehr empfindlich zeigen ${ }^{1}$ ). - Die neuen Regenkarten der großen Stromwerke Preußens, sowie die Karten Hellmanns²) zeigen die Abhängig-

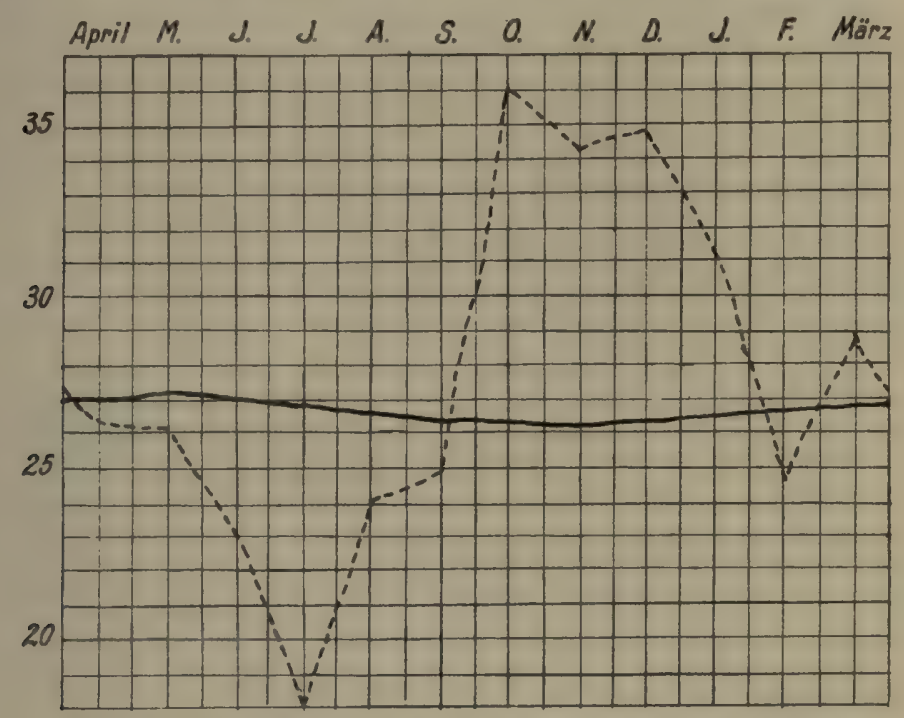

Fig. 33. Hydrothermfigur für Sumatra (nach Raunkiär).

Die Hydrothermfiguren stellen gleichzeitig Rengenmenge (punktierte Linie) in $\mathrm{cm}$ und Wärmemenge in Centigrade dar.

keit der Flora für Norddeutschland sehr deutlich ${ }^{3}$ ). In gebirgigen Ländern ist dieser Einfluß der Niederschlagsmengen natürlich noch viel stärker in die Augen springend ${ }^{4}$ ). Die Abhängigkeit der Landwirtschaft von diesen Dingen ist in neuerer Zeit namentlich von Engelbrecht ${ }^{5}$ ) studiert worden.

Schwache Regenmengen kommen der Vegetation oft in geringem Grade oder gar nicht zu gute, weil die Verdunstung zu stark ist und das Wasser verdunstet, bevor es in den Boden hinabdringen kann.

1) Graebner 1895, 1897, 1901, 1909, 1910 c.

z) Hellmann 1903, 1904 usw.

B) Vergl. auch Graebner 1901, 1904 (Karten).

4) Vergl. Ziegler 1886 (Main und Mittelrhein); Hellmann 1903 (Westfalen).

- Engelbrecht 1905. 
Die Zeit der Niederschläge (vergl. Fig. 33 und 34) ist von größter Bedeutung. Wo in den Tropen starke Regenfälle über das ganze Jahr verbreitet sind, überwiegt der immergrüne Regenwald; wo die Niederschläge gleichfalls sehr reichlich sind, aber nur in einigen Monaten des Jahres fallen, während der Rest trocken ist, kann noch Hochwald existieren, er wird aber aus laubwechselnden Gehölzen zusammengesetzt sein. Im Mittelmeergebiete und in Südwestaustralien ${ }^{1}$ ), wo, wie oben erwähnt, die Winterregen herrschen, ist der Typus der Vegetation gänzlich abweichend von solchen Ländern, in denen der Regen im Sommer fällt. Die beiden genannten Gebiete sind als Folge der Winterregen waldarm, dagegen reich an Steppen- und Buschland, während die Vegetation mit Sommerregen, beispielsweise in Ostaustralien, durch Regenwälder und baumreiche Savannen ausgezeichnet ist. Im Mittelmeergebiete und Südwestaustralien wird durch die heißen und trocknen Sommer (Fig. 34) eine xerophile Vegetation herrschen, in den Gebieten mit derselben Menge Sommerregen dagegen wird die Vegetation mehr mesophilen Charakter tragen; in den gemäßigten Gebieten mit einer gleichmäßigeren Verteilung der Niederschläge wird die Vegetation ein mehr mesophiles Gepräge erhalten ${ }^{2}$ ). - Axel Lange ${ }^{3}$ ) hat sicher mit Recht darauf hingewiesen, daß die zahlreichen Schädigungen des Winters 1908-9, wie sie im Botanischen Garten in Kopenhagen, aber auch anderwärts (!) auftraten, sehr wesentlich auf die Trockenperiode des Herbstes 1908 zurückzuführen waren.

Gegen trockene Jahreszeiten können sich Pflanzen schützen, indem sie ibre stark verdunstende Oberfläche abwerfen, laubwechselnd werden. Andere Pflanzen, die ihr Laub auch in der Trockenzeit behalten, müssen darum Einrichtungen haben, die ihnen genügenden Schutz für diese Zeit geben. In den tropischen Gebieten mit ausgesprochener längerer Trockenperiode sind die laubwechselnden Gehölze die Regel, aber auch nur dort, wo sehr ausgesprochene Trockenperioden vorhanden sind. Volkens ${ }^{4}$ ) betont in seinen vortrefflichen Untersuchungen über den Laubfall in den Tropen: „Die die Blätter völlig abwerfenden Arten in Buitenzorg, sowohl die indigenen als die meisten eingeführten, lassen nicht erkennen, daß der Wechsel zwischen einem regenreichen und einem regenarmen Jahresabschnitt mit dem Wechsel des Laubes in ursächlichem Zusammenhang steht. Es gibt Arten, die den Wechsel regelmäßig in Jahresperioden vollziehen. Darunter sind zum mindesten ebensoviele, die zu der Zeit der höchsten, als

1) Diels 1906 .

2 Vergl. 4. Abschnitt, mesophile Formationen.

刃) A. Lange 1909.

4) Volkens 1912, S. 22. 
zur Zeit der geringsten Niederschlagsmenge kahl werden. Es gibt andere Arten, bei denen der Wechsel regelmäßig in halbjährigen, wenige, bei denen er in vier- bis fünfmonatlichen Fristen eintritt, $d$. $h$. sowohl in der Trocken- als in der Regenzeit. Es gibt endlich Arten, bei denen die Periodizität keine regelmäßige und bestimmte Fristen innehaltende ist, bei denen Individualitätsunterschiede in so starkem Maße hervortreten, daß wir die einen Exemplare sich im feuchten, die anderen sich im trockenen Jahresabschnitt entlauben sehen."

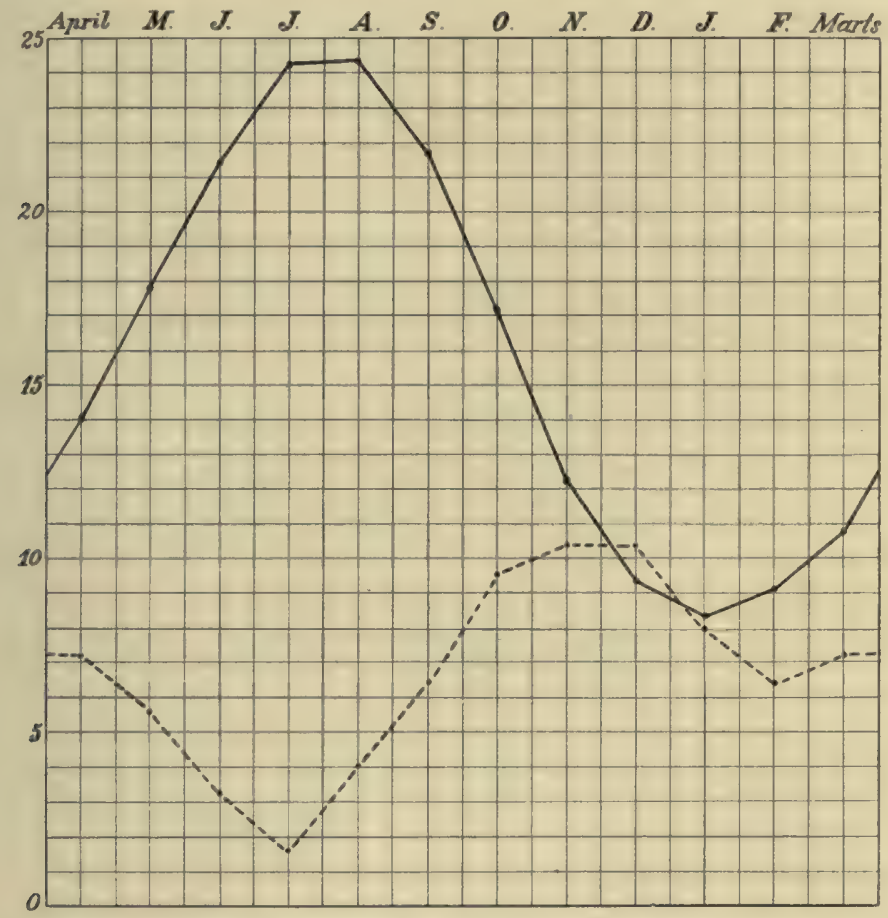

Fig. 34. Hydrothermfigur für Süditalien (nach Raunkiär, 1907).

In subtropischen (warm-temperierten) Zonen überwiegen immergrüne Bäume und Sträucher; viele Kräuter vertrocknen während der trockenen Jahreszeit. $\mathrm{W}_{0}$ in diesen Zonen Sommerregen fallen, mag vielleicht die verringerte Transpiration während der kühleren Winter die Ursache für die immergrüne Erhaltung der Blätter sein. In Gegenden mit Winterregen (Fig. 34) sind die Verhältnisse für winterkahle Gehölze ungünstig, weil die Sommer zu trocken sind; sommerkahle Gehölze sind dort nicht so häufig als immergrüne. In trockenen Gebieten mit sehr kurzer Vegetationszeit (Steppen und Wüsten) dörren alle oberirdischen Teile während der trockenen Zeit aus und die meisten Gehölze werfen ihre Blätter ab. Dabei mag erwähnt werden, daß in manchen Steppengebieten 
(z. B. in Siidrußland und Ungarn) die Sommermonate, in denen das Kraut vertrocknet, die regenreichsten des Jahres sind, aber einerseits ist die Regenmenge nicht groß, andererseits ist die Verdunstung in den heißen Sommermonaten bei der trockenen Luft so groß, daß das zur Verfügung stehende Wasser nicht für die Erhaltung der Pflanzen genügt. Die Frühjahrsregen sind trotz der geringeren Wassermenge erheblich wirksamer.

In kühlen gemäBigten Zonen ist der Winter im allgemeinen als eine "physiologisch trockene " Jahreszeit ${ }^{1}$ ) zu betrachten, weil während der Kälteperioden die Pflanzen kein Wasser aus dem Boden saugen können, die Verdunstung aber nicht aufhört. Die Gehölze sind deshalb entweder laubabwerfend, oder, wenn sie immergrün sind, haben sie Schutzeinrichtungen gegen zu starke Verdunstung (Nadelhölzer usw.). Nach Grisebach ${ }^{2}$ ) ist der Verdunstungsschutz bei den laubabwerfenden Gehölzen im Winter sehr wirksam, der Laubwechsel an sich aber nicht ökonomisch, weil ein gut Teil der Vegetationszeit mit der Hervorbringung neuen Laubes verbraucht wird; infolgedessen überwiegen die immergrünen Nadelhölzer in Gebieten, in denen die Länge der Vegetationszeit unter ein bestimmtes Minimum sinkt. Nach Köppen ${ }^{3}$ ) läuft die Südgrenze der Gebiete mit überwiegendem Nadelwaldbestande parallel den Linien, die die gleiche Dauer der Vegetationsperioden anzeigen. Die Kräuter in den kühleren gemäßigten Zonen sind zum 'großen Teil immergrün, weil sie im Winter Schutz unter der Schneedecke finden. Dasselbe gilt für die Kräuter und Zwergsträucher der arktischen Zonen.

Es ist selbstverständlich, daß die Umstände, die die Menge, die Verteilung und andere Unterschiede der Niederschläge beeinflussen, indirekt für die ökologische Pflanzengeographie Bedeutung erhalten. Solche Umstände sind besonders die topographischen Verhältnisse: Relief der Erdoberfläche, Höhe über dem Meere, Nähe des Meeres, herrschende Winde und deren Feuchtigkeitsgehalt (vergl. Kap. 19).

Wärme und Feuchtigkeit sind die beiden wichtigsten Faktoren für die Entwicklung der Vegetation. Nach den versehiedenen Mengeverhältnissen, worin sie den Pflanzen dargeboten werden und diese ihnen angepaßt sind, hat Alph. de Candolle die Pflanzen in folgende 6 Gruppen geteilt:

1. Hydromegathermen, d.h. Pflanzen, die an Wasser und an Wärme (mindestens $20^{\circ}$ mittlere Temperatur) die größten Anforderungen stellen; ihre Heimat sind gegenwärtig besonders die tropischen feuchten Gegenden; aber früher waren sie gewiß weit verbreiteter.

2. Xerothermen, die Trockenheitspflanzen, die viel Wärme verlangen, aber an Wasser die bescheidensten Ansprüche stellen. Hierher gehören Wüsten-, Steppenund Savannenpflanzen.

1) Schimper 1898 .

2) Grisebach 1872.

3) Köppen 1900.

4) Alph. de Candolle 1874 . 
3. Mesothermen, die eine jährliche Mitteltemperatur von $15-20^{\circ}$ und jedenfalls zu gewissen Zeiten eine recht reichliche Feuchtigkeit verlangen und anhaltende Trockenperioden nicht ertragen können. In der Tertiärzeit waren sie bis zu den Nordpolarländern verbreitet.

4. Mikrothermen, die eine jährliche Mitteltemperatur von $0-15^{\circ}$, geringe Sonnenwärme, gleichmäßig verteilte Niederschläge und eine durch Kälte hervorgerufene Ruhezeit beanspruchen.

5. Hekistothermen wachsen jenseits der Grenzen des Baumwuchses, wo die jährliche Mitteltemperatur unter $0^{\circ}$ sinkt; sie ertragen lange Lichtmangel.

6. In den früheren Erdperioden gab es Megistothermen, die hohe, gleichmäBige Temperaturen (über $30^{\circ}$ ) verlangten. Es waren besonders Sporenpfianzen.

A. de Candolles Gruppen sind insofern etwas unnatürlich, als es keine Pflanzen gibt, die von der jährlichen Mitteltemperatur abhängen, die Vegetation dagegen von der Dauer der Vegetationszeit und den zuträglichen Temperaturen, von dem Minimum der Temperatur und Feuchtigkeit stark beeinfluBt wird, so daß diese Daten nicht übergangen werden dürfen. Köppen ${ }^{x}$ ) schlägt deshalb folgende Anordnung vor:

1. Hydromegathermen: Mitteltemperatur im kältesten Monat mehr als $16^{\circ} \mathrm{C}$.

2. Xerophilen: Der feuchteste Monat hat weniger als 12 Regentage.

3. Mesothermen: Mitteltemperatur des kältesten Monats unter $16^{\circ} \mathrm{C}$, aber nicht für lange Zeit unter $0^{\circ}$.

4. Mikrothermen: Winter mit Perioden von längerem Frost (mit liegenbleibendem Schnee).

5. Hekistothermen: Mitteltemperatur des wärmsten Monats unter $10^{\circ} \mathrm{C}$.

Drude ${ }^{2}$ ) unterscheidet neuerdings 18 Klimagruppen.

\section{Kap. Luftbewegungen}

Die Winde haben teils für die Pflanzenformen, teils für die Verteilung der Pflanzen in der Landschaft große Bedeutung. Diese sieht man am deutlichsten da, wo sie über große Flächen hin wehen können, ohne daß Berge, Wälder, Städte u. a. ihre Macht brechen, also besonders an Meeresküsten und auf großen Ebenen, z. B. auf den asiatischen Steppen, in der Sahara usw.; ferner auch, wo ein bestimmter Wind, namentlich der Passat, vorherrscht. Einige Winde bringen Regen, andere Trockenheit.

Die Wirkungen zeigen sich in Gegenden mit losem Sandboden, z. B. an vielen Küsten und in Sandwüsten, in der Bildung von Dünen mit einer an sie gebundenen höchst eigentümlichen Vegetation. Sie zeigen sich auf hohen Gebirgsketten in der Verteilung der Niederschläge, indem die Windseite die von den Winden mitgebrachte Feuchtigkeit auffängt (vergl. Australiens Ost- und Südostküste, die West- und Ostseite der Anden), während die Leeseite ("Windschattenseite“) trocken

1) Köppen 1900 .

2) Drude 1913, S. $149 \mathrm{ff}$. 
bleibt; sie zeigen sich im Anschluß hieran in der Verteilung der verschiedenen Pflanzenvereine nach ihrem Feuchtigkeitsbedarf, darin, daß viele Arten und ganze Vereine in ihrer Höhe über dem Meere beschränkt werden, und in anderen Lebensgrenzen. Sehr bemerkenswert ist die Bedentung des Föhn für die Vegetation ${ }^{1}$ ). Der in den Gebirgen zum Aufsteigen gezwungene Wind verliert durch die Verdünnung und die damit Hand in Hand gehende Abkühlung seinen Wasserdampf als Regen. Durch die Verdichtung des Wassers wird latente Wärme frei und der Wind erhält dadurch einen Teil der verlorenen Wärme zurück. Jenseits des Berges senkt sich der Wind wieder zu Tal, wird dadurch wieder verdichtet und noch stärker erwärmt (Prinzip der Eismaschine) und bläst als sehr trockener warmer Wind (Föhn) das Tal entlang (vergl. Bezold). Diese Föhntäler sind wegen ihrer Vegetation wärmerer Klimate bekannt.

Die Winde ${ }^{2}$ ) üben, wo sie stark sind und vorzugsweise in einer Richtung wehen, namentlich auf die Formen des Baumwuchses und auf den Charakter der ganzen Landschaft einen außerordentlichen Einfluß aus. Die Bäume zeigen besonders folgende Eigentümlichkeiten in der Gestalt: sie werden niedrig, die Stämme sind oft in einer bestimmten Richtung gebogen, die Äste zugleich gekrümmt und verbogen, die Sprosse kurz, oft unordentlich verzweigt und miteinander verflochten; viele Sprosse werden auf der Windseite getötet, bisweilen findet man nur auf der Leeseite neue Sprosse; und die Kronen werden dadurch eigentümlich gestaltet, indem sie sich von der Windseite ab neigen und wie geschoren und abgerundet sind und gegen diese eine sehr dichte Oberfläche haben. Der ganze Wald oder das ganze Gebüsch neigt sich in derselben Weise von der Windseite $\left.a b^{3}\right)$. Bisweilen sind es nur die von den Wurzeln und vom Grunde der Stämme ausgehenden Sprosse, die auf der am meisten ausgesetzten Seite das Dasein einigermaßen behaupten können: ein Wald wird so auf Windseite zum Gestrüppe herabsinken können, und dieses wiederum zuletzt in zerstreut und einzeln stehende, haufenförmige Individuen aufgelöst werden können (z. B. auf den Heiden Jütlands). Die Blätter werden kleiner als sonst und erscheinen oft mehr oder weniger fleckig (wie angebrannt). Ähnliche Einwirkungen des Föhnes in Ostgrönland auf Zwergsträucher und Stauden haben Hartz und Kruuse ${ }^{4}$ ) behandelt und abgebildet; hier wirken die Sand- und Steinmassen, die die Stürme mit sich führen, auf der Windseite in besonderem Grade abschleifend und zerstörend („Sandgebläse“, Fig. 38).

1) Vergl. Hann 1897.

2) Utber die Wirkungen der Winde vergl. Fig. $35-38$.

s) Vergl. Früh 1901.

4) Hartz und Kruuse 1911; Hartz 1895. 
Über diese letztere Wirkung vergl, auch Adamović ${ }^{1}$ ). Nicht nur in den Polargegenden und Hochgebirgen, sondern auch in den heißen Wüsten, wo oft heftige Stürme wehen, kann man diese abschleifende Wirkung

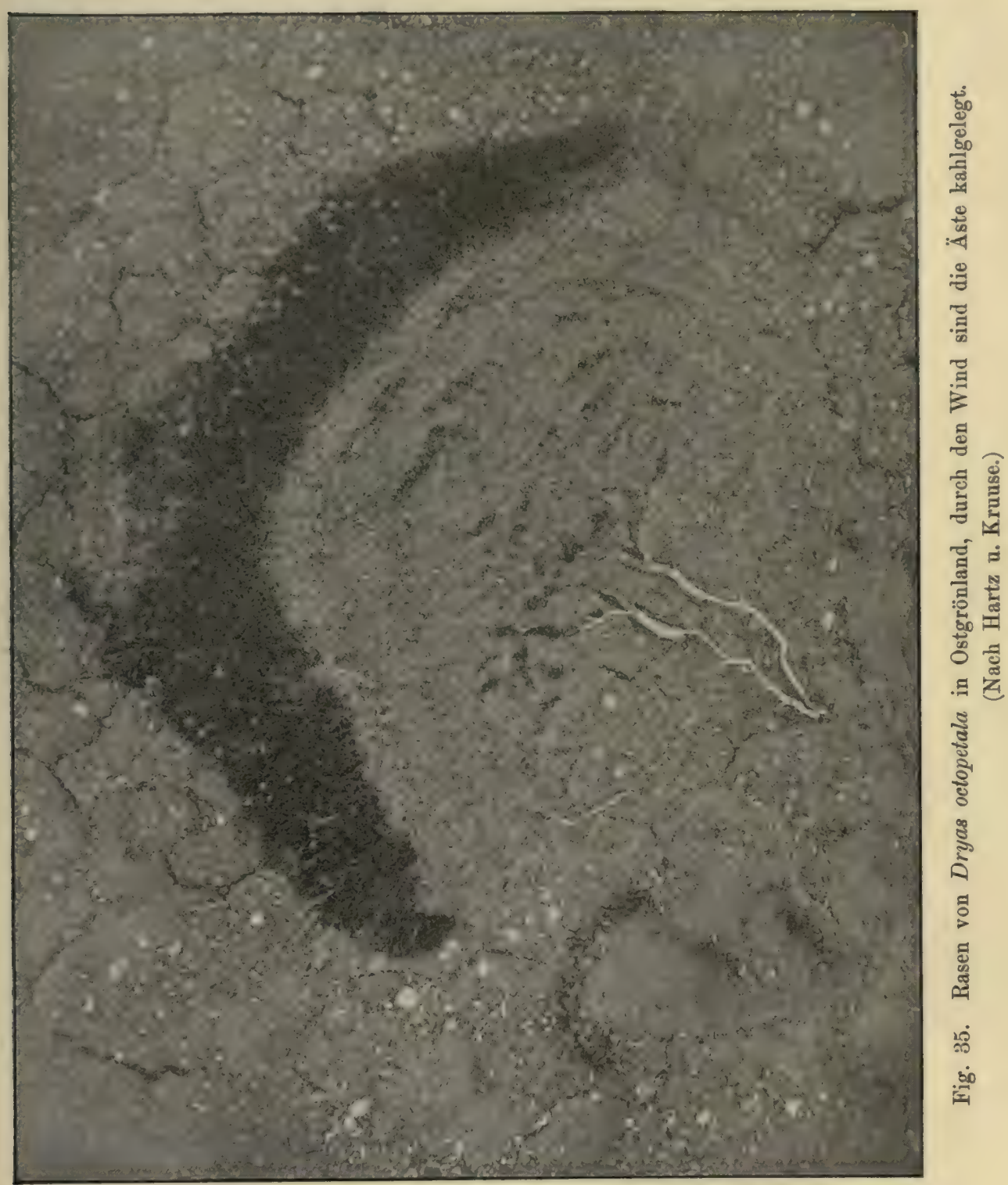

des Windes beobachten; in Nordafrika z. B. kann man die harten Polster von Anabasis aretioides stark abgeschliffen finden.

1) Adamović 1909; Bernátsky 1901.

Warming-Graebner. 3. Anflage, illustr. 
Windschäden könne eine allmähliche Herabdrückung der Waldgrenzen bewirken. Nach Flahault sind die „prairies pseudoalpines“ durch Austrocknung der Voralpenwiesen entstanden - die meisten Wiesenelemente gingen zugrunde und solche Flächen wurden dann mit xerophilen Gräsern, subalpinen und alpinen Sträuchern bedeckt.

Über die Gründe für diese Wirkungen des Windes sind die Meinungen sehr geteilt gewesen. A. Einige, z. B. Borggreve, nehmen an, $\mathrm{da} B$ alles dieses wesentlich durch die mechanische Wirkung des Windes auftrete, dadurch daß die Sprosse und die Blätter gegeneinander gebogen, geschüttelt und gepeitscht werden; daß die Stürme Bäume zerbrechen und Wälder umstürzen können, ist auch bekannt. B. Andere, z. B. Focke, meinen, daß es besonders die von den Meereswinden mitgeführten Salzteilchen (s. S. 11) seien, die den Pflanzen schaden; aber dieselben Formenverhältnisse beobachtet man auch weit innen in den Ländern, z. B. beim Eichengestrüppe im inneren Jütland. C. Andere meinen, daß die Kälte schuld sei; aber an den tropischen Küsten, z. B. in Westindien, sieht man unter der Einwirkung des Passates dieselben Formen auftreten, wie unter unseren Breiten, und jeder Gegenstand, der Schutz gewährt, hebt die Wirkung des Windes auf (Fig. 37).

Die Wahrheit ist wahrscheinlich, daß besonders die durch den Wind hervorgerufene Verdunstung, also die Austrocknung der Grund sei, was Wiesner 1887, Kihlmann 1890 und Warming 1884 und in meinen

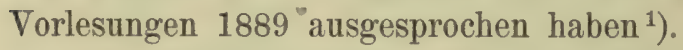

Das größte Gewicht legt Hansen ${ }^{2}$ ) auf die Wirkung des Windes, er will ihm einen entscheidenden Einfluß auf die Mehrzahl der Pflanzenvereine zuschreiben. In der recht einseitigen Behandlung der Frage geht er entschieden zu weit, auch erscheint die frühere Litteratur nicht genügend berücksichtigt. Warming ${ }^{8}$ ) hat sich deshalb energisch gegen ihn gewandt.

Der Wind wirkt austrocknend, desto mehr, je stärker er ist. Er trocknet den Boden aus, der dadurch fest und humusarm wird; dem Winde stark ausgesetzte Stellen erhalten eine verhältnismäßig xerophile Vegetation. Er trocknet die Pflanzen ans, und diese müssen, um sich gegen Austrocknung zu schützen, den Verhältnissen angepaßt sein. An Stellen, die gegen austrocknende Winde geschützt sind, entwickelt sich die Vegetation anders, als wo der Schutz fehlt.

In ruhiger Luft werden die den Pflanzen zunächst angrenzenden Luftteile dampfreich, und die Verdunstung wird gehemmt. Durch die Luftbewegung werden sie beständig weggeführt, und neue, weniger dampfreiche kommen mit den Pflanzenteilen in Berührung. Selbst wenn die Luft sehr reich an Wasserdampf ist, wird ihre ununterbrochene

1) Warming 1884, S. 99.

\%) Hansen 1901, 1903.

s) Warming 1902, 1903; vergl. auch Buchenau 1903. 
Erneuerung eine starke Verdunstung herbeiführen. Je trockener die Luft und je stärker der Wind ist, desto stärker wird selbstverständlich die Austrocknung werden. Föhnwinde wirken deshalb z. B. besonders austrocknend. Durch diese Verdunstung werden das Längenwachstum der Sprosse und der Blätter gehemmt (Zwergwuchs), viele Blätter und

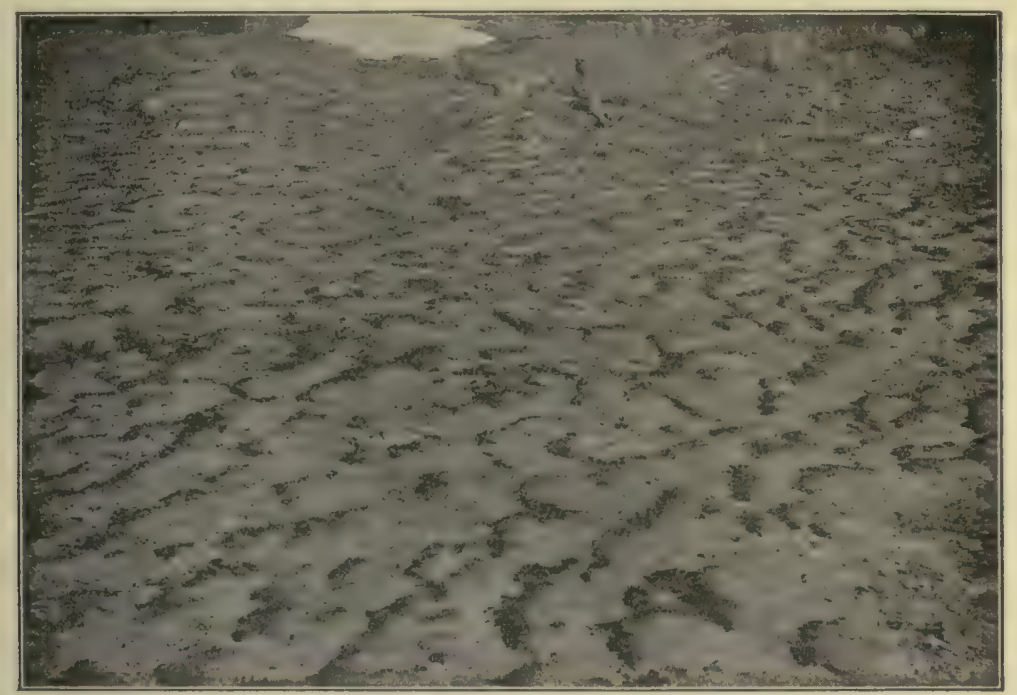

Fig. 36. Empetrum-Heide in Westgrönland, vom Winde deutlich beschädigt. (Phot. A. Jessen.)

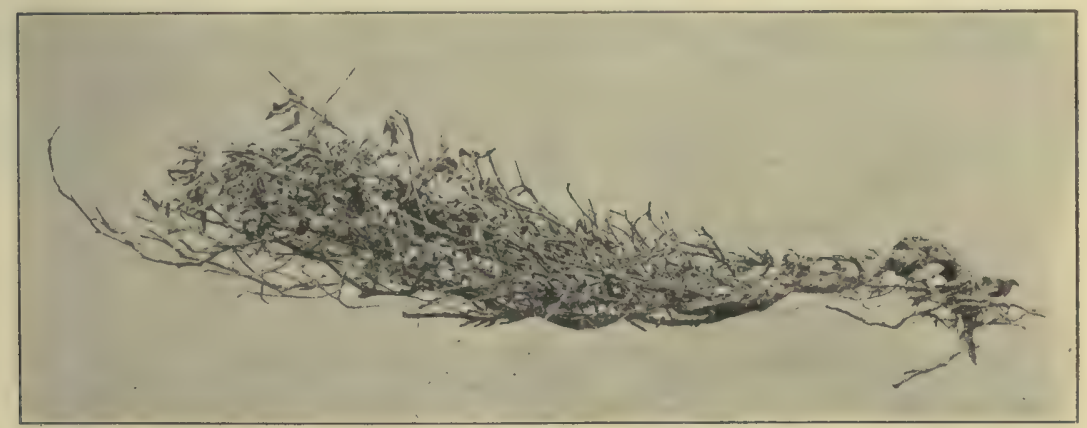

Fig. 37. Croton flavens von den dänischen westindischen Inseln, arg vom Passatwinde mitgenommenes Exemplar. (Phot. Dr. Börgesen.)

ganze Sprosse getötet, so daß unregelmäßige Verzweigung entsteht, und hierdurch werden alle beobachteten Erscheinungen ungezwungen erklärt. Daß die Kronen die gegen die Leeseite allmählich aufsteigenden Gestalten erhalten, wird durch den Umstand verursacht, daß die näher an der Windseite gelegenen Sprosse, sowohl tote als lebende, die auf der Leeseite befindlichen Teile gegen $\mathrm{zu}$ schnelle Lufterneuerung schützen. 
Wir werden also auch hier auf die wesentliche Bedeutung des Wassers für das Leben zurückgeführt.

Die Gefährlichkeit des Windes wächst, je jünger das Laub ist. Im Kaplande fällt die Wachstumsperiode der Hartlaubgewächse (Proteaceen u. a.) in eine Zeit, wo Winde selten sind, die der eingeführten Bäume dagegen in eine windige Zeit, daher leiden diese, jene nicht (Marloth).

Weiter wird die Gefährlichkeit des Windes vermehrt, wenn die Wurzeltätigkeit der Pflanze zugleich durch die Kälte des Bodens gehemmt wird, so daß der Wasserverlust nicht oder schwierig gedeckt wird (Schimpers Waldfeindliches Klima). Deshalb wintern bei uns in schneearmen Wintern Getreide und andere Pflanzen aus. Dieser Umstand ist namentlich in Polarländern und in Hochgebirgen wichtig.

Die Gewalt des Windes ist an der Erdoberfläche viel geringer als in einiger Höhe über ihr, daher erscheinen niedrige Pflanzen viel besser vor dem Winde geschützt, als sich höher erhebende ${ }^{1}$ ). Die S. 42 erwähnte Spalierform der in diesen Gegenden wachsenden Sträucher kann somit auch durch den Wind verursacht werden, und oft sieht man sich die Sprosse gerade von der Windseite wegwenden.

Die Rasen- und Polsterbildung bei den Kräutern, die unter ähnlichen ungünstigen Verhältnissen in windigen, kalten Gegenden leben, kann offenbar in derselben Weise hervorgerufen werden ${ }^{2}$ ). Selbst die arktischen Moose zeigen einen ähnlichen $\mathrm{Bau}^{3}$ ). Jene Kräuter erhalten wegen Wassermangel kurze Sprosse und kleine Blätter, werden im ganzen sehr niedrig, zwergig; sie haben eine reiche Verzweigung, daher einen oft außerordentlich dichten Wuchs und sind im kleinen den Sträuchern eines Gestrüppes sehr ähnlich. Oft werden Polsterpflanzen, z. B. von Silene acaulis, auf der Windseite ausgetrocknet und getötet (vergl. Fig. 3).

Daß die Trockenheit wirklich solche Formen hervorrufen kann, wird durch Pflanzen bestätigt, die in trockenen, heißen, aber ziemlich windstillen Wüstengegenden wachsen.

Auch die Querschnittsform der Baumstämme wird vom Winde beeinflußt, indem sie in der Windrichtung einen größeren Durchmesser erhält als senkrecht zu dieser (exzentrisch).

Die Pflanzen haben natürlich eine verschiedene Widerstandskraft gegen den Wind. Von den in Dänemark häufigen Bäumen sind folgende die widerstandsfähigsten: Pinus montana Mill., Picea Canadensis (=P. alba), sowie einige Weiden- und Pappelarten, die daher auch die Arten sind, die hier für Waldkulturen auf Dünen und Heiden den größten

1) Wiesner 1887.

? Vergl. Kjellman 1884, S. 174, Figur von Draba; Öttli 1903.

3) Kihlman 1890; G. Andersson 1902. 
Wert haben. Die Bedentung des Schutzes gegen den Wind wird dadurch einleuchtend. Einen solchen Schutz bieten im ganzen Erliöhungen im Gelände, sowie andere natürliche und künstliche Schutzwehren; ein genaues Studium wird oft lehren, daß nach der Dichtigkeit, der Höhe, dem Bau, den Entwicklungsverhältnissen und der Artenzusammensetzung eine sehr verschiedene Vegetation auf der Windseite und der Leeseite einer solchen Schranke auftreten kann, selbst wenn diese nur ein unbedeutender Fels, ein Stein oder ein Strauch ist. Gewisse Hügel im mittleren Jütland erscheinen, von Osten betrachtet, oft be-

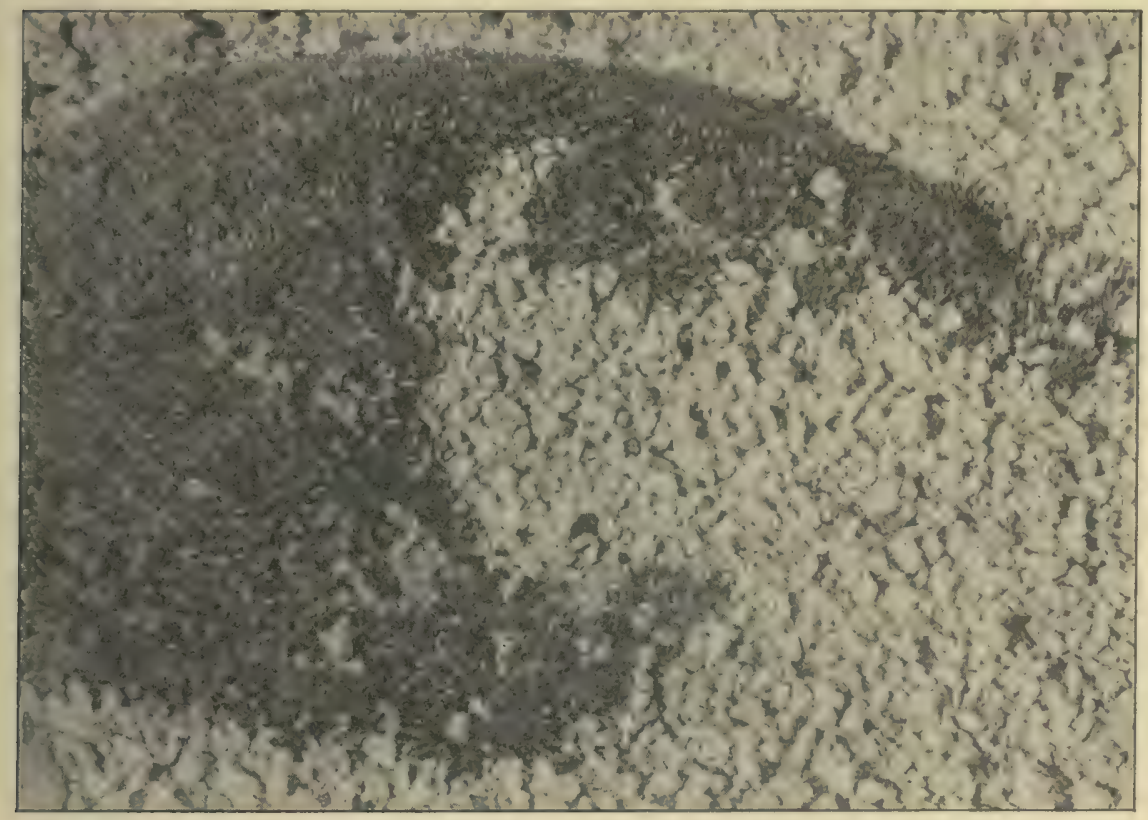

Fig. 38. Silene acaulis. Winderosion durch Grus verstärkt; Ostgrönland.

(Phot. Ch. Kruuse.)

waldet, aber mit Heide bedeckt, wenn man von Westen über sie hinsieht. In unseren Buchenwäldern ist die Bodenvegetation an den Stellen, wo Licht und Wind einwirken können, verschieden von der an den Stellen, wo sie ausgeschlossen sind. Der Wind wirkt hier zugleich indirekt schädlich, indem er die Laubdecke wegführt, die den Boden schützt und in dessen Natur auf verschiedene Weise eingreift (15. Kap.), und indem er die Veränderung des Humus in Rohhumus veranlaßt. Die arktische und die alpine Vegetation haben einen sehr wichtigen Schutz in dem Schnee [was z. B. Kihlman ${ }^{1}$ ) nachgewiesen hat], und da sich dieser

1) Kihlman 1890; vergl, auch Th. C. E. Fries 1913. 
besonders in den windstillen und ruhigeren Einsenkungen ablagert, wird die Vegetation in diesen auch aus diesem Grunde ein ganz anderes Gepräge erhalten, als bei den höheren, sturmumbrausten Stellen (Näheres C. Schröter 1904-8 und im 16. Kap.). Im allgemeinen kann gesagt werden, daß die Pflanzendecke an sehr windigen Stellen offen und undicht wird.

Die erwähnten Schutzwehren gegen den Wind sind topographisch. Viele Pflanzen haben durch Anpassung besondere Bauverhältnisse erworben, sowohl morphologische, als anatomische, wodurch sie geschützt werden. Hierher gehören namentlich Knospenschuppen, Deckhaare, alte Blatt- und Stengelreste, die lange sitzen bleiben, xerophil gebaute Blätter u. a., was später zu behandeln sein wird (vergl. auch S. 37-39).

Verteilung der Vegetation. Es sei noch angeführt, daß, wenn viele Gegenden der Erde baumlos sind, dieses großenteils den Winden zuzuschreiben ist, aber auch zugleich der Kälte und anderen für das Wachstum ungünstigen Verhältnissen. Die Winde tragen so teilweise dazu bei, die polaren Waldgrenzen sowie die Höhengrenzen für Wald und Gebüsch in den Hochgebirgen abzustecken.

Auf höheren Gebirgen beginnen die Wälder dort aufzuhören, wo sich die Gebirgskette in einzelne Gipfel teilt. Über diese Grenze kann Wald noch dort gedeihen, wo ein lokaler Schutz vor dem Winde vorhanden ist, z. B. in den Kratervertiefungen von Java ${ }^{1}$ ). Ebenso ist der Windschutz in Tälern der Grund, weshalb Wälder oft weiter in Arktische Gebiete vorschreiten; als Beispiel seien die die Lena und den MackenzieFluß begleitenden genannt. Middendorf ${ }^{2}$ ) war der erste, der darauf hinwies, daß der Wind der Verbreitung der Wälder häufig ein Ziel setzt. Neuerdings ist besonders Schimper für die starke Wirkung dieses Faktors eingetreten ${ }^{3}$ ).

Der Nutzen der Winde für die Vegetation muß besonders darin gesucht werden, daß ihr neue Kohlensäure zugeführt wird und daß die Windbestäuber (vergl. viele Nadel- und Laubbäume) bestäubt und daß die Samen verbreitet werden; viele unserer gemeinen Bäume haben gerade Samenverbreitung durch den Wind, die meisten anderen solche

1) Schimper 1893.

2) Middendorf 1867 .

$\left.{ }^{8}\right)$ Die Wichtigkeit des Windes ist in einer anziehenden und eingehenden Form von Kihlman (1890) behandelt worden, neuerdings noch von A. Hansen 1901, 1902, Warming 1902, 1903, Bernátsky 1901, Buchenau 1903, Massart 1907, 1910, Marloth 1909; vergl. sonst noch Früh 1901; Norton 1897; Ganong 1899; L. Klein 1899, 1905, 1914; Kraus 1905; Klinge 1890; Schimper 1898; Schenck 1905. - Litteratur über Windwirkungen vergl. Bernbeck, Engl. Jahrb. XLV, 471. 
durch Vögel ${ }^{1}$ ). Über die Eigentümlichkeiten der steppenlaufenden Pflanzen vergl. Steppen und Wüsten.

Anhangsweise sei hier auf die Wirkung der Elektrizität hingewiesen. Daß Blitzschläge den Bäumen stark zusetzen können, ist bekannt, ebenso, daß in bestimmten Lagen, besonders solchen mit hohem Grundwasserstande, in den die Wurzeln hineinragen, die Blitzschläge so häufig sind, daß die Lebensdauer der Waldbäume erheblich verkürzt wird. Neuere statistische Aufnahmen haben gezeigt, daß die alte Bauernregel, daß die Blitzgefahr unter den verschiedenen Baumarten äußerst verschieden ist, eine gewisse Berechtigung besitzt. Die Eiche wird sehr viel öfter getroffen als die Buche, und von der Weißbuche (Carpinus) scheinen nachgewiesene Fälle zum mindesten äußerst selten zu sein.

Besonderes biologisches Interesse bieten aber die neueren Untersuchungen von Tubeuf ${ }^{2}$ ). Dieser Forscher beobachtete, daß an exponierteren Lagen in Gebirgen, auf Kuppen usw., ja selbst auf kleinen Hügeln in der Fbene, Nadelhölzer, vorzugsweise Fichten, ohne jede erkennbare Ursache wipfeldürr wurden oder sogar abstarben. Selbst in Norddeutschland (z. B. im Gebiete der Lüneburger Heide!) sind solche Bilder zu sehen. Da weder irgendwelche Wirkungen von Parasiten, noch Verletzungen (Blitzschlag usw.) zu finden waren, kam Tubeuf auf den Gedanken, daß hier wohl die strahlende Elektrizität, wenn größere Spannungen zwischen der Erde und den Wolken ausgeglichen werden, das wirksame Agens sei. Umfangreiche Experimente im Laboratorium bestätigten seine Annahme; im verdunkelten Raume konnten die Entladungen photographisch aufgenommen werden, und die absterbenden Bäume zeigten das typische anatomische Bild.

1) Vergl. Warming 1867; Sernander 1901; P. Vogler 1901 b.

2) Tubeuf 1903, $1905,1906$. 


\section{Edaphische Faktoren}

\section{Kap. Die Beschaffenheit des Nährbodens}

Von der Beschaffenheit des Nährbodens (den edaphischen Faktoren; physikalischen und chemischen Faktoren) hängen die Standorte der Pflanzen, ihre topographische Verteilung, im höchsten Grade ab. Der Wasserreichtum und der Nährstoffgehalt des Bodens sind dessen allerwichtigste Eigenschaften.

Für die Autophyten gibt es zwei sehr verschiedene Formen des Nährbodens: Wasser und Erde (Boden). Beide müssen den Pflanzen Platz und Nahrung geben, sowie äußere Bedingungen für die Aufnahme und die Zubereitung der Nahrung enthalten; beide Formen besorgen dieses auf äußerst verschiedene Art und müssen jede für sich behandelt werden. Die Luft hingegen ist kein Nährboden für ein an sie besonders gebundenes Pflanzenleben, sondern nur ein einstweiliger Aufenthaltsort für Organismen, die fast alle unsichtbar, aber in unzähliger Menge vorhanden sind, welche nach den Jahreszeiten und den Örtlichkeiten wechselt, in der Nähe von menschlichen Wohnungen, namentlich in den großen Städten, am größten ist, auf Ozeanen, in Hochgebirgen und in Wäldern am kleinsten ist. Die wichtigste geographische Rolle der Luft ist, für. zahllose Organismen resp. deren Verbreitungsmittel Mittel und Weg zur Bewegung von einem Orte zum anderen zu sein (Luftströmungen).

Das Wasser im allgemeinen und seine für die ökologische Pflanzengeographie wichtigsten Eigenschaften werden Kap. 20, 31 behandelt. Die Eigenschaften des Bodens hingegen werden im folgenden erörtert; sie hängen von den physikalischen und den chemischen Verhältnissen der Bodenteile ab.

\section{Kap. Der Bau des Bodens}

Der Begriff Boden wird hier in weitem Sinne gebraucht und umfaßt 1. den festen Fels, 2. den losen, durch Verwitterung gebildeten Boden, sowie 3. den sekundären, von Verwitterungsprodukten an anderen Stellen gebildeten losen transportierten Boden.

1. Die Eigenschaften der festen Felsen hängen von der Natur der Gesteinsart ab und können nach Härte, Porosität, Erwärmungs- und Ausstrahlungsvermögen sehr verschieden sein, was z. B. solche Gegensätze wie Granit-, Schiefer- und Kalkfels zeigen. 
2. Verwitterungsböden: Durch mechanische Lockerung und chemische Zersetzung der Felsen entsteht loser Boden; die wirkenden Kräfte sind namentlich Wasser und Temperaturänderungen, sowie der Sauerstoff und die Kohlensäure der Luft. In gewissen Fällen spielen dabei niedere Pflanzen, z. B. Flechten und Bakterien, eine Rolle. Chemische Zersetzung und mechanische Lockerung gehen fast immer Hand in Hand.

3. Der sekundäre Boden entsteht durch Umlagerung und teilweise durch Trennung der verschiedenen Teile des Verwitterungsbodens; die umlagernden Kräfte sind namentlich Wasserströmungen (Alluvium), Gletscherablagerungen (Diluvium) und Winde. Die Flüsse häufen an

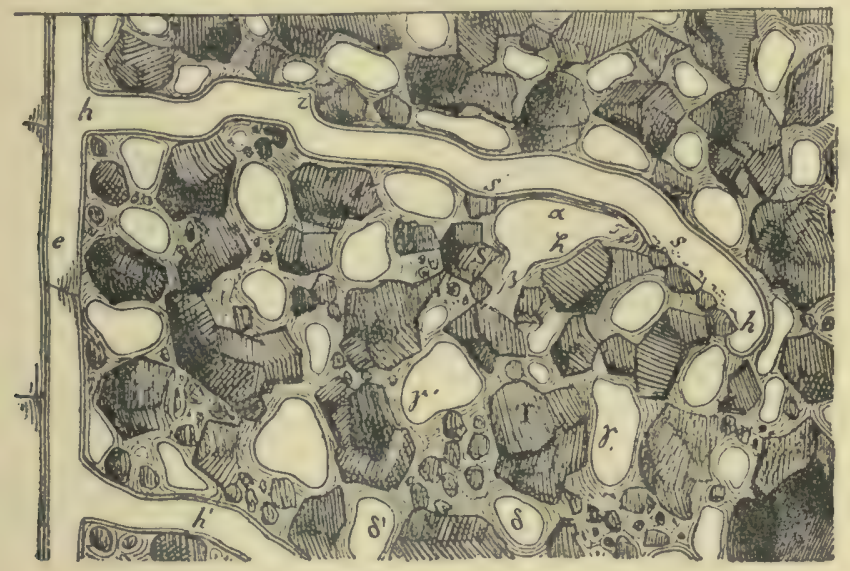

Fig. 39. Schema für die Zusammensetzung des Erdbodens. Links eine jüngere Wurzel, deren Epidermiszellen (e) Wurzelhaare $\left(h, h^{1}\right)$ bilden. Die Wurzelhaare wachsen zwischen den festen Bestandteilen des Bodens $(N, S$ usw.) hindurch. $\beta$ Wasser, $\gamma, \delta$ usw. Luft. (Nach Sachs, vergl. Warming-Johannsen.)

ihren Mündungen Massen loser Stoffe auf, die sie von den Gebirgen mitgeführt haben ( $\mathrm{P}_{0}$, Nil, Ganges u. a.); die Gletscher haben in der Eiszeit riesige Bodenmassen nach anderen Stellen geschafft (z. B. aus Schweden und Norwegen nach Dänemark und Norddeutschland) und tun dieses noch gegenwärtig; das Meer führt in seinen Strömungen andere Massen mit sich. Der Wind lagert Sand aus dem Meere und von sandigem Boden im Binnenlande in der Form von Dünen ab, er führt auch feine Bodenteilchen von der Bodenoberfläche weg und lagert sie auf Stellen ab, wo es Schutz gibt (LöB, vergl. v. Richthofen).

Die Eigenschaften des losen Bodens hängen von vielen verschiedenen Verhältnissen ab, namentlich von der Feinheit, der chemischen Beschaffenheit, der Lagerung, dem Zusammenhange usw. der Bestandteile, was im folgenden näher behandelt wird.

Oft entstehen aus Schwemmlandsboden neue Gesteinsarten, z. B. Sandstein, Schiefer, Konglomerate, mit anderen Eigenschaften als 
beim ursprünglichen Fels und mit anderer Rolle im Haushalte der Pflanze.

Der lose Boden hat folgenden Bau: Er ist ein Gemisch von 1. festen Teilen, 2. Luft (8. Kap.) und 3. Wasser (9. Kap.).

Die festen Teile des Bodens sind:

a) Größere mineralische Teile, von Steinen verschiedener Größe und Menge bis zu äußerst kleinen Sandkörnern hinab (Korngröße 0,25 bis $2 \mathrm{~mm}$ ); wird der Boden in Wasser geschlämmt, so schlagen sie sich schnell nieder.

b) Außerordentlich kleine, staubförmige Teile, die beim Schlämmen im Wasser lange schweben bleiben. Sie lassen sich von

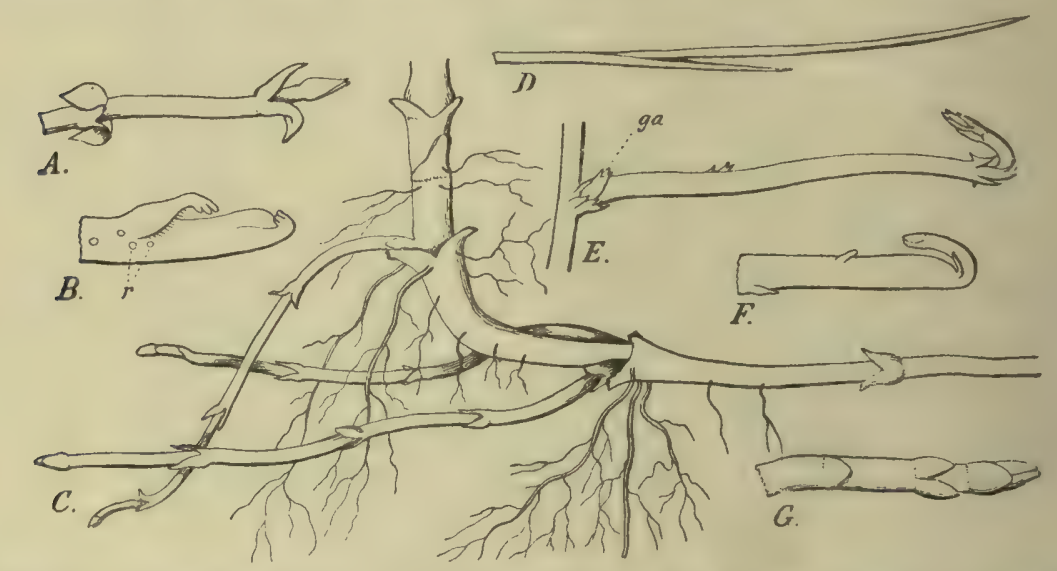

Fig. 40. Grundachsenbildung im losen Boden. Enden der unterirdischen Ausläufer von Stellaria nemorum $(A)$, Chrysoplenium alternifolium $(B)$, Circaea Lutetiana $(C)$, Agropyrum $(D)$, Vicia sepium $(E)$, Pirola umbellata $(\boldsymbol{F})$, Lysimachia thyrsiflora $(G)$. ga Beiknospe; $r$ Wurzeln. (Gez. von E. Warming.)

dem Sande sehr leicht abschlämmen. Thre chemische Zusammensetzung schwankt natürlich sehr stark; vorwiegend sind sie aber zusammengesetzt aus Aluminium-Silikaten und Eisen- und Calcium-Verbindungen. Sie alle und ihre verschiedenartige Mischung haben einen wesentlichen Einfluß auf die den Pflanzen verfügbaren Nahrungsmengen, auf die Absorptionskraft und viele andere physikalischen Eigenschaften des Bodens.

c) Humusstoffe, die von toten Körpern oder von ausgeschiedenen Teilen der Pflanzen oder der Tiere stammen. Durch Oxydation verschwinden sie. Viele Humusstoffe zeigen ihre organische Herkunft deutlich und geben dem Boden eine meist schwarze oder dunkelbraune Farbe.

Diese dreierlei Bestandteile findet man in fast allen Bodenarten.

Alle Teile, die so groß sind, daß sie nicht durch ein Sieb mit 0,3 mm Lochweite gehen können, werden nach W. Knop Bodenskelett 


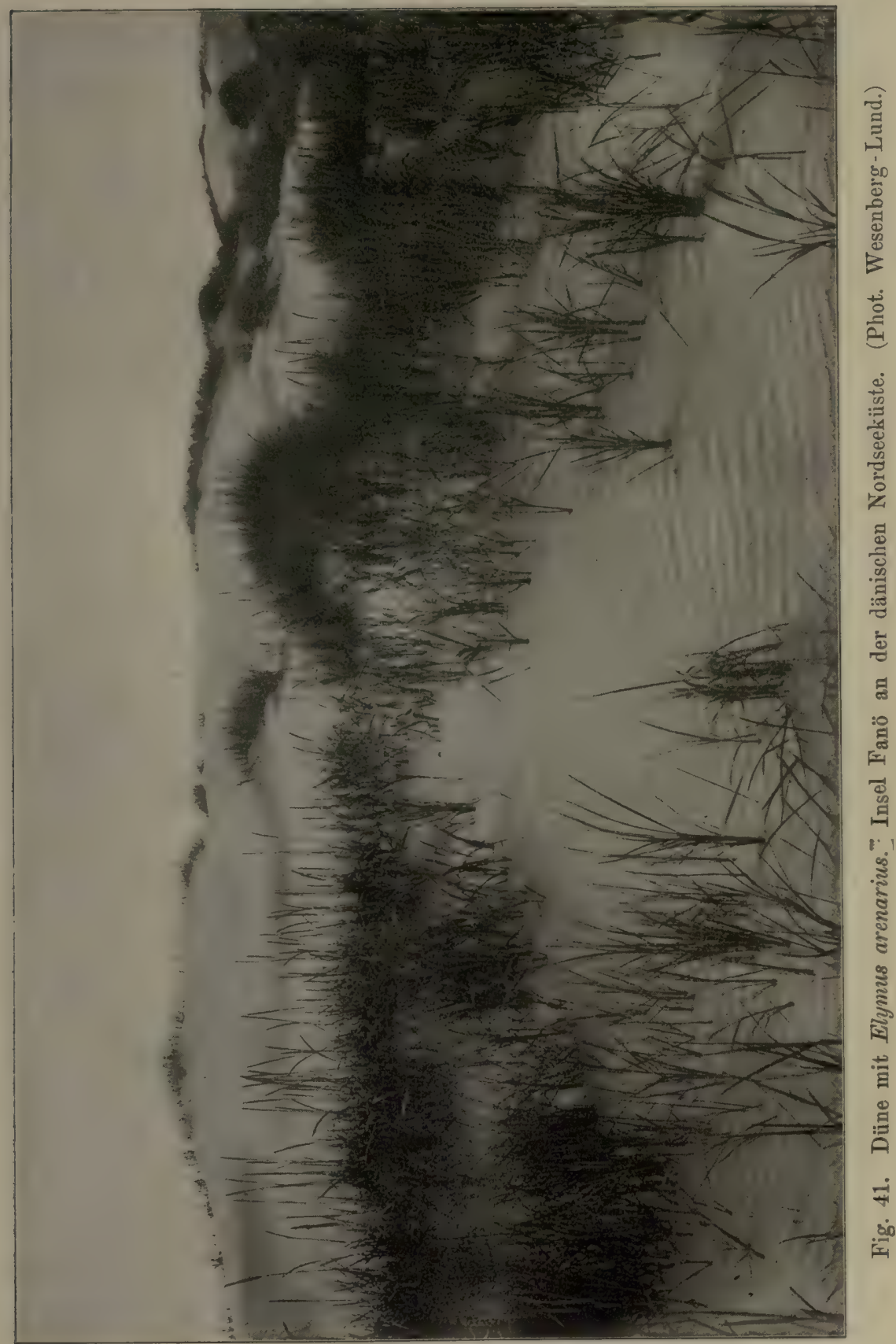


genannt (Grobsand, Kies und Steine, die durch das Sieb weiter in verschiedene Gruppen getrennt werden können), alle anderen Teile Feinerde. Namentlich die Feinerde spielt im Pflanzenleben eine Rolle, teils direkt als Pflanzennahrung, teils indirekt durch ihre Fähigkeit, wichtige Pflanzennahrungsstoffe zu absorbieren, und durch ihre rein physikalischen Eigenschaften. Beimischung von Steinen. und Kies verändert jedoch die physikalischen Verhältnisse des Bodens bedeutend.

Porenvolumen ${ }^{1}$ ). Die Mischung, die relativen Mengeverhältnisse und die Lagerung der genannten festen Bestandteile sind in verschiedenen Böden sehr verschieden. Diese lassen zwischen sich kleine Hohlräume ("Poren"). Die Summe dieser in einem gegebenen Boden befindlichen, nicht von festen Teilen erfüllten Räume nennt man sein Porenvolumen. Der Boden ist sehr reich an zusammenhängenden Räumen, die in desto höherem Grade Kapillarräume werden, je enger sie sind. Dieses erhält für die Vegetation große Bedeutung. Vergl. S. 73, Fig. 39.

Diese Poren werden von Luft und Wasser je nach ihrer Größe und nach anderen Umständen in verschiedener Menge erfüllt. Im Gebiete des Grundwassers sind die Poren wohl fast ganz mit Wasser erfüllt; an der Oberfläche einer Sanddüne, die langer Trockenheit ausgesetzt war, haben wir den anderen Gegensatz: den größten Luftgehalt und die kleinste Wassermenge.

Einige Bodenarten sind mehr oder weniger krümelig oder können es werden, d. h. ihre verschiedenen Körnchen bleiben nicht einzeln, sondern vereinigen sich zu größeren Körnern oder Klümpchen, die man Krümel nennen kann. Man findet die Krümel besonders im Humus; sie werden nach Darwin, P. E. Müller u. a. ${ }^{2}$ ) oft durch die im Boden lebenden Tiere, namentlich durch Regenwürmer und Insektenlarven, hervorgebracht, indem sie deren Exkremente oder Klumpen solcher sind (vergl. 18. Kap.). Krümeliger Boden erhält andere Eigenschaften als der aus Einzelkörner bestehende: er ist loser, wird leichter durchlüftet, nimmt Wasser leichter auf und läßt die Pflanzenwurzeln leichter hinabdringen. Beim Garten- und Ackerbau sucht man die Krümelbildung des Bodens zu befördern, indem man ihn umgräbt und pflügt, so daß sich sein Volumen durch physikalische Faktoren (besonders durch Frost) leichter ändert, und indem man anderen Boden oder andere Stoffe, namentlich Sand, Humus und Mergel beimischt, die seine Bindigkeit verändern.

Die Bindigkeit des Bodens. Die Kraft, womit die Bodenteilchen zusammenhängen, ist sehr verschieden; als Gegensätze können genannt werden: Die Düne, deren Sandkörner in trockenem Zustande

1) Vergl. Ramann 1893, $1905 \mathrm{ff}$.

?) Darwin 1881 ; P. E. Müller 1887 a. 
ganz lose liegen, und der Tonboden; auch Humus hat geringe Bindigkeit. Man unterscheidet festen, strengen (schweren), mürben (milden), lockeren, losen und flüchtigen Boden; der feste wird

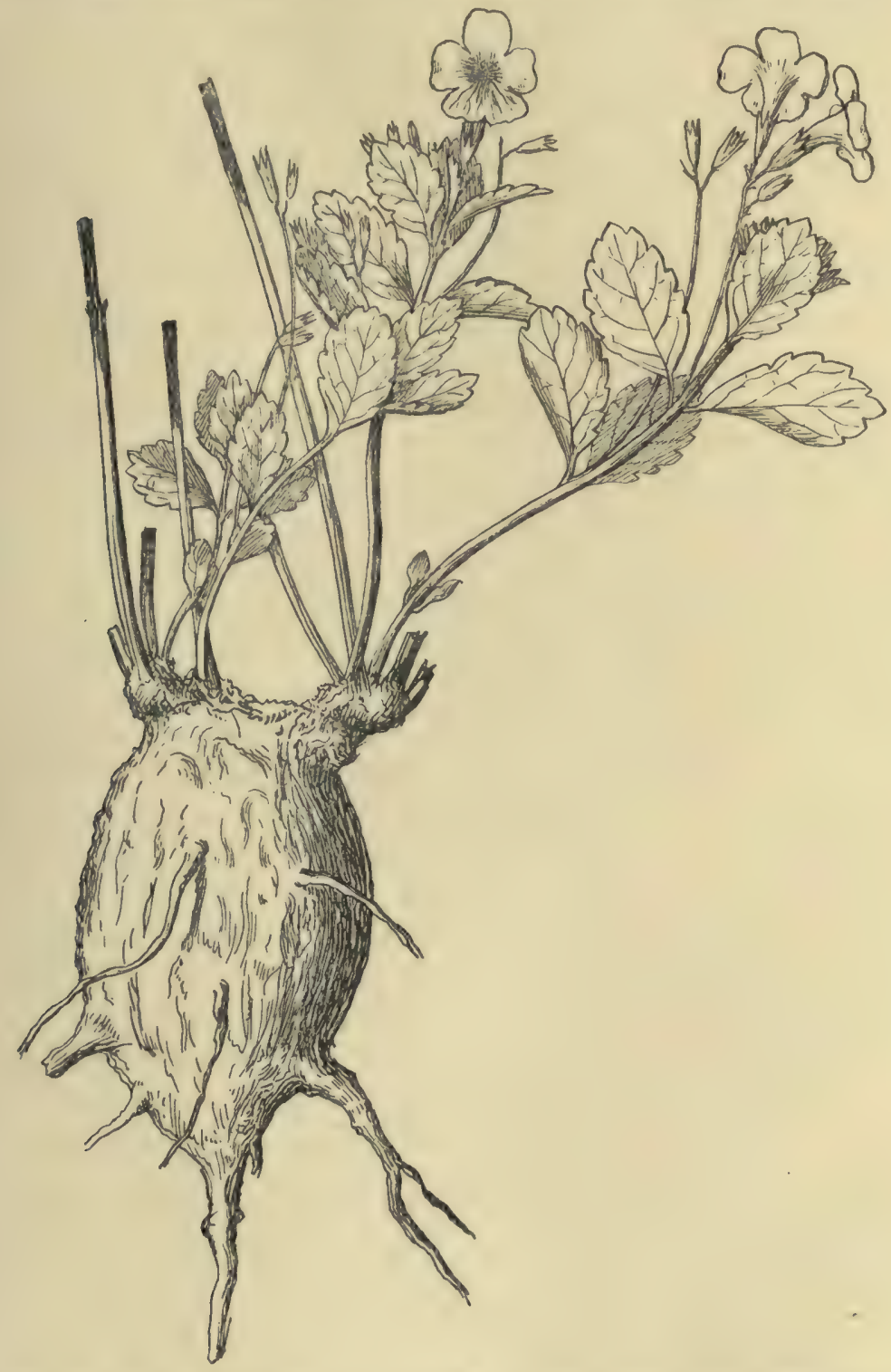

Fig. 42. Casselia-Wurzelknolle aus Lagoa Santa. Nat. Gr. (Nach Warming.)

durch Austrocknen hart, erhält Risse und bildet Krusten, wodurch die unterirdischen Teile der Pflanzen zerrissen werden können; die Teile des flüchtigen Bodens werden durch Austrocknen voneinander getrennt und sind so leicht, daß der Wind sie wegführen kann. Die Bindigkeit 
hängt unter anderem von der Größe und der chemischen Beschaffenheit der Körner ab; je kleiner die Körner, desto größer ist im allgemeinen die Bindigkeit.

Die Pflanzenformen und die Vegetation im ganzen werden von der Lockerheit oder Bindigkeit des Bodens sehr stark beeinflußt. In losem Boden (wie Sand, Schlamm, Humus in Wäldern, Sphagnum und ähnlichen) wird die Bildung langer, reich verzweigter und tiefgehender Wurzeln und langer, wagerechter, gestrecktgliedriger Grundachsen (Ausläufer Fig. 40, Rhizome) begünstigt, sicher deshalb, weil der Widerstand, der während des Wachsens überwunden werden muß, gering ist ${ }^{1}$ ); dadurch wird wiederum geselliges Auftreten befördert, und die Landschaft kann sogar eine besondere, gleichförmige Physiognomie erhalten, z. B. durch Ammophila und Elymus in Dünen (Fig. 41), Phragmites und Scirpus lacuster in Sümpfen. Ein solcher Boden trägt oft Bäume, und die Grundachsenbildung zeigt verschiedene Formen. Der feste, stark bindige Tonboden hingegen, der durch Austrocknen hart wird und Risse erhält, paßt für solche Pflanzen nicht gut; hier sind besonders Pflanzen mit senkrechten, kurzen, dicken Rhizomen (Knollen, Zwiebeln) oder mit mehrköpfigem Rhizom und mit Rasenbildung heimisch, z. B. auf den Campos Brasiliens, Fig. $42^{2}$ ). Der feste, plastische Ton ist für die Pflanzen kein günstiger Boden und kann, wenn er unter anderen Schichten auftritt, ein fast undurchdringliches Hindernis für die Pflanzen bilden. Derartiger Boden trägt oft eine extrem xerophil ausgeprägte Vegetation. Der feste Fels (ohne auflagernden losen Boden) ist für jene Pflanzen gleichfalls gar nicht passend, kann aber zulassen, daß sich Pflanzen der zweiten Art in seinen Spalten und Klüften als Chasmophyten $^{3}$ ) ansiedeln, und trägt im übrigen nur solche Pflanzen, die sich durch besondere Haftorgane auf seiner Oberfläche festsetzen können (Lithophyten).

Übrigens muß bemerkt werden, daß der Wurzelbau der verschiedenen Arten sehr wenig bekannt ist, und daß in den Unterschieden des Wurzelbaues oft die Erklärung des Vorkommens der Arten zu suchen sein dürfte.

Die Kapillarität des Bodens spielt bei seiner physikalischen Beschaffenheit eine sehr große Rolle. Sie hängt besonders von der Größe und der Lagerung der Körner ab. Je kleiner die Körner und je dichter sie gelagert sind, desto größer ist die Kapillarität; krümeliger Boden hat geringere Kapillarität als aus Einzelkörnern bestehender; Steine und Kies im Boden setzen gleichfalls die Kapillarität herab.

1) Henslow 1895 .

2) Warming 1892; Lindman (1900) nennt diese mehr oder weniger knollenförmigen und verholzten Grundachsen „Xylopodia".

?) Öttli 1903. Vergl. 4. Abschn., Felsvegetation. 


\section{Kap. Die Luft im Boden}

Diese hat für das Pflanzenleben eine äußerst eingreifende Bedeutung; alle lebenden unterirdischen Teile brauchen (wie alle anderen lebenden Teile) Luft (Sauerstoff), um atmen zu können; in sehr nassem. Boden ersticken gewöhnliche, an luftreichen Boden angepaßte Landpflanzen, es findet Alkoholgärung, Kohlensäurebildung, dadurch Absterben und dann Fäulnisprozesse statt (vergl. Sorauer 1909), und „Humussäuren" werden neben Kohlensäure in größerer Menge gebildet (der Boden wird "sauer") und ist oft kaum imstande Pflanzen zu tragen, ehe er nicht wieder durchlüftet ist. Die Durchlüftung des Bodens hängt wesentlich von seinem Bau ab; je poröser und loser er ist, desto leichter die Durchlüftung. Landmann und Gärtner bearbeiten den Boden mit Pflug und Spaten, durch Entwässern, Grabenziehen, Brachlegen unter anderem deshalb, um die Durchlüftung des Bodens zu veranlassen. Der holländische Landwirt senkt den Grundwasserspiegel seiner Wiesen in den Herbst- und Wintermonaten bis zu $1 \mathrm{~m}$ Tiefe, um den Boden zu durchlüften, aber in den übrigen Monaten (in der Vegetationszeit) nur bis zu $1 / 2 \mathrm{~m}$, und dasselbe geschieht auf den Wiesen von Söborg auf Seeland ${ }^{1}$ ) usw. Durch Rohhumusbildung in Wäldern wird auch ein Luftabschluß bewirkt, daher das Absterben solcher Wälder ${ }^{2}$ ) (P. E. Müller).

Die Bodenluft, die im Boden befindliche Luft, ist von der in der Atmosphäre etwas verschieden; sie enthält mehr Kohlensäure und weniger Sauerstoff, namentlich in den tieferen Schichten, und der Grund hierfür ist gerade die Atmung der unterirdischen Pflanzenteile, Pflanzen (Bakterien, Pilze) und Tiere, sowie die Zersetzung der organischen Massen. Die Kohlensäuremenge ist übrigens verschieden nach dem Reichtum des Bodens an organischen Stoffen, nach der Vegetation, der Neigung und der Feuchtigkeit des Geländes, nach der Größe der Bodenteilchen, nach der Tiefe (die obersten Bodenschichten haben weniger Kohlensäure als die tieferen) und nach der Wärme (Jahreszeiten).

Je größer der Sauerstoffgehalt des Bodens und damit des Bodenwassers ist, desto lebhafter wachsen die Wurzeln und desto stärker ist. die Stoffproduktion der betreffenden Pflanzen. Sauerstoff führenden Wasseradern folgen die Wurzeln mit großer Energie (Drainzöpfe usw.) ${ }^{3}$ ).

Der innere Bau der Pflanzenteile ist mit dem Luftgehalt im Einklange; in sehr nassem Boden können in der Regel nur solche Pflanzen gedeihen, die große innere Lufträume haben, welche in der

1) P. Feilberg 1891.

2) P. E. Müller 1884, 1887; Grebe 1896; Graebner bes. 1904, 1910.

3) Hesselman 1910. 
ganzen Pflanze miteinander in Verbindung stehen und wodurch die Luft der Atmosphäre selbst zu den entferntesten Wurzelspitzen und Rhizomteilen gelangen kann (Wasser- und Sumpfpflanzen; Schachtelhalme in festem Tonboden; abweichend davon die Pflanzen in den viel mehr Luft enthaltenden Heidemooren). Näheres im 2., 4. Abschnitte.

\section{Kap. Das Wasser im Boden}

Das Wasser ist der dritte Bestandteil des Bodens. Es wird von den festen Bodenteilen angezogen und umgibt sie mit einer dünneren oder einer dickeren Schicht, so daß die Luft im Wasser kleine Blasen bildet (Sachs; vergl. Fig. 37, S. 73).

Die Wassermenge ist an verschiedenen Stellen und an derselben Stelle zu verschiedener Zeit sehr verschieden. Man unterscheidet nach Norlin folgende Stufen, die in der Regel nur schätzungsweise bestimmt werden: $1=$ sehr trocken, $2=$ ziemlich trocken, $3=$ ziemlich frisch, $4=$ frisch, $5=$ etwas feucht, $6=$ feucht, $7=$ sehr feucht, $8=$ ziemlich naß, $9=$ naß, $10=$ sehr naß (vergl. Hult). Bei feineren wissenschaftlichen Untersuchungen muß die Wassermenge in Prozenten des Bodengewichtes oder -volumens ausgedrückt werden. Der Wassergehalt des Bodens wird praktisch am allerbesten nach den auf ihm wachsenden Pflanzen beurteilt; denn kein Faktor hat außer dem Nährstoffgehalt einen solchen Einfluß auf die Verteilung der Arten, wie der Wassergehalt des Bodens ${ }^{1}$ ).

Die Wassermenge im Boden ist für das Pflanzenleben wegen der S. 35 ff. behandelten außerordentlichen Bedeutung des Wassers in der Ökonomie der Pflanze einer der allerwichtigsten direkten Faktoren. Das Wasser muß in gewissen, für jede Art bestimmten Grenzen vorhanden sein (bei Kulturpflanzen gewöhnlich nicht dauernd etwa über $60 \%$ ); zu viel oder zu wenig ist hier wie allenthalben schädlich, nur viele Heidepflanzen können (natürlich nur auf nährstoffarmem Boden) sowohl im trockenen Sande als im ganz nassen Moore gedeihen. Die Bedeutung des Wasserreichtums des Bodens (das Vorhandensein einer genügenden Nährstoffmenge selbstredend vorausgesetzt) für das Pflanzenleben geht z. B. aus Versuchen von Fittbogen mit Hafer hervor; auf Böden, deren Feuchtigkeit zwischen 40 und $80 \%$ wechselte, war in dem Enteertrage kein großer Unterschied; aber bei einer Feuchtigkeit von $20 \%$ wurde nur die Hälfte geerntet, und bei $10 \%$ nur $1 / 8$ jenes Ertrages. Wassermangel im Boden verursacht stets eine mangelhafte Ernährung der Pflanzen, weil die Wurzeln die Nahrung aus solchem Boden nur mit Schwierigkeit aufnehmen können.

$\left.{ }^{1}\right)$ Hult 1881; Gola 1910; Clements 1905. 
Auch indirekt hat das Wasser Bedeutung, nämlich für das Tierleben, das sich im Boden entwickeln kann, und für die hier lebenden Bakterien; eine gewisse Feuchtigkeit ist für die Humusbildung notwendig.

Das Wasser im Boden ist 1. chemisch gebundenes Wasser, das in der Ökonomie der Pflanze meist keine große Rolle spielt (nur die üppig grünenden Pflanzen auf dürren Gipshügeln, zu Zeiten in denen am Granit alles verdorrt ist, scheinen wenigstens teilweise von dem Kristallwasser des gelösten Gipses zu leben: Südharz), 2. aus dem Wasserdampfe der Luft absorbiertes Wasser, 3. aus den Niederschlägen aufgenommenes und kapillar festgehaltenes Wasser, 4. emporgesogenes Grundwasser oder dieses selbst.

Das Grundwasser ist das über undurchlässigen Bodenschichten angesammelte Wasser, das sich nach dem Gesetze der Schwere bewegt oder in der Erde, ganz wie das oberirdische Wasser, in Seen stehen bleibt. Die chemische Zusammensetzung, die Kapillarität, das Wasserleitungsvermögen usw. des Bodens haben hier Bedeutung; eine Tonschicht dient meist als Unterlage des Grundwassers, auch Felsboden, selten Ortstein; Sand und Kies lassen das Wasser hindurchgehen. Das Grundwasser kann viele lösliche Teile, besonders Kalksalze, enthalten, ist aber, wenn es tief liegt, in der Regel arm an Pflanzennahrungsstoffen (es ist "rein"), weil die oberen Schichten diese zurückgehalten haben; auch von Bakterien ist es rein, da diese in den oberen Bodenschichten abfiltriert worden sind.

Der Stand des Grundwassers und dessen Schwankungen nach den Jahreszeiten hängen teils von der Größe der Niederschläge, teils von der Höhe der Verdunstung ab, sind von wesentlicher ökologischer Bedeutung und spielen besonders in den Wüsten eine sehr große Rolle. Seen, Wiesen-(Grünland-)moore und Wasserläufe sind eigentlich offene Grundwasserflächen. In vielen Fällen liegt das Grundwasser für gewisse Pflanzen zu hoch; in anderen Fällen tritt es so tief auf, daß die Pflanzenwurzeln es weder unmittelbar noch mittelbar benutzen können; in noch anderen Fällen in einer solchen Tiefe, daß sie es zu gewissen Jahreszeiten erreichen können, zu anderen nicht. In diesen Fällen spielt der Umstand eine große Rolle, wie hoch das Wasser kapillar emporgehoben werden kann.

An Fluß- und Seeufern kann man leicht die schnellere oder allmähliche Abnahme des Wassergehaltes (Zonation) mit der zunehmenden Entfernung vom Gewässer je nach der geringeren oder größeren Durchlässigkeit der das Gewässer umgebenden Böden beobachten.

Der Stand des Grundwassers beeinflußt selbstverständlich die Wärme des Bodens (vergl. 10. Kap.). 
Es hat für die Vegetation Bedeutung, ob das Grundwasser steht oder langsam strömt; in stehendem Wasser wird der Sauerstoff schnell verbraucht, es werden Säuren gebildet oder durch anaerobe Bakterien Fäulnisprozesse eingeleitet (Buttersäuregärung, Grubengasbildung u. a.); über stehendem Grundwasser findet man daher eine andere Vegetation als über langsam bewegtem. Der Unterschied zwischen Wiesen- (Grünland-) und Heide-(Hoch-) mooren beruht zum größten Teil darauf, aber auch auf den Schwankungen des Grundwassers nach den Jahreszeiten. Wiesenmoore leben fast ausschließlich vom Grundwasser, Heidemoore fast oder gar ganz ausschließlich von den atmosphärischen Niederschlägen (Schnee, Regen und Tau, vergl. S. 52, 4. Kap.).

Die Fähigkeit der Pflanzen, das Wasser nutzbar zu machen, ist sehr verschieden, schon wegen der verschiedenen Wurzeltiefe. Trockene Sommer haben eine große Bedeutung für die einzelnen Arten, also für ihre Verbreitung wie für ihren Anteil an den Pflanzenvereinen, gewisse Arten leiden leichter oder sterben eher ab als andere ${ }^{1}$ ). Bäume mit tief gehenden Wurzeln können selbst in trockenen Jahren gut gedeihen, wenn sie das Grundwasser erreichen. Nach Ototzky sinkt der Grundwasserstand stets in der Nachbarschaft der Wälder und liegt immer höher in einer an den Wald grenzenden Steppe, da eben die Bäume viel Wasser verbrauchen.

Wie stark die Jahresschwankungen resp. deren Einfluß auf den Wassergehalt sind, zeigt die Tatsache, daß nach den trockenen Sommern 1912 und 1913, trotz der letzten Winterfeuchtigkeit, in Norddeutschland stellenweise der Boden (besonders Diluviallehm) kaum mehr als $1 \mathrm{~m}$ von oben her durchfeuchtet war, die Bodenschichten darunter waren dort pulvertrocken. An den trockenen Formationen (sonnige Hügel usw.) waren schon 1913 zahlreiche Bäume abgestorben.

Die Bedeutung des Grundwasserstandes erkennt man besonders klar z. B. in Dänemark. Hier sind die chemischen Unterschiede des von den Gletschern zermahlenen und angesammelten Bodens kaum so groß wie in Gebirgsländern, wo der Fels der Oberfläche nahe liegt und durch seine chemische Natur vielleicht auf die Vegetation einwirkt. Ein Beispiel hierfür liefern die Sandebenen bei Skagen in Jütland. Grundwasser in 3 "Tiefe, im Sommer gibt es hier eine Juncus-Vegetation und Wiesenmoorbildung; bei solchem in 6"Tiefe spielen Moos (Hypnaceae usw.) und Cyperaceen noch eine Rolle, aber es beginnen Gräser zu erscheinen; bei 9 "Tiefe werden diese vorherrschend; bei 12" tritt in gewöhnlichen Sommern normaler Graswuchs auf; bei 15" gedeiht Getreide in etwas warmen Sommern gut, bei $18-24 "$ in kalten bis feuchten Sommern; bei $30-40 "$ ist der Boden für Getreide unbrauchbar, und es entwickeln

1) Vergl. Dehérain 1892 und andere. 
sich Trockenheitspflanzen ${ }^{1}$ ). Andere Beispiele findet man bei demselben Forscher, der überhaupt die Bedeutung des Grundwasserstandes stärker als vielleicht die meisten anderen - und mit Recht - hervorgehoben hat. Viele Bäume erhalten auf einem Boden mit hochliegendem Grundwasser eine besondere Tracht oder können gar nicht gedeihen. Andere

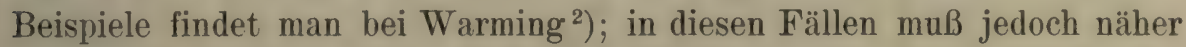
untersucht werden, welche Rolle der Grundwasserstand und welche das Wasserhebungsvermögen $u$. a. Eigenschaften des Bodens spielen.

Auch periodische, mehrere Jahre umfassende Schwankungen im Grundwasserstande kennt man; sie sind von großer pflanzengeographischer Bedeutung (Brückners 45 Jahrperiode). Hier sei auch an Blytts Theorie über wechselnde feuchte und trockene Erdperioden mit entsprechendem Wechsel der Vegetation erinnert, der wenigstens, soweit man in Norddeutschland beobachten kann, sicher z. T. auf Grundwasserschwankungen, Wasseraufstau, Erosion usw. zurückführbar ist ${ }^{3}$ ).

Für die Teile des Bodens, die über dem Grundwasserspiegel liegen, sind folgende Eigenschaften für ihren Wasserreichtum wichtig: das Filtrationsvermögen des Bodens, seine Hygroskopizität, sein Wasserhebungsvermögen, seine Wasserkapazität sowie die Menge der Niederschläge (vergl. 4. Kap.) und der Zufluß von Oberflächenwasser.

Das Filtrationsvermögen des Bodens. Die Niederschläge dringen nicht in allen Bodenarten gleich leicht hinab; der Unterschied zeigt sich z. B. deutlich, wenn man über Sand, Ton und Humus Wasser ausgießt. Folgende Faktoren spielen hierbei eine Rolle: Die Kapillarität des Bodens, die Art und die Trockenheit der Bodenteilchen.

Je stärker die Kapillarität ist, desto langsamer sinkt das Wasser ein. Sehr feinkörnige Böden, besonders Ton- und gewisse Humusböden, sind für Niederschläge fast undurchdringlich, wenn die Körner dicht gelagert sind, und umgekehrt sinken die Niederschläge desto leichter ein, je grobkörniger und loser der Boden ist. Falls der Boden reich an größeren Steinen oder an Spalten und Löchern ist, z. B. an Regenwürmergängen, so wird dieses auf die Geschwindigkeit des Einsinkens einwirken: Steine machen sie geringer, Spalten und Löcher größer.

Im übrigen dringt das Wasser am leichtesten in Quarzsand, schwieriger in Humus (einschließlich Heidehumus), am schwierigsten in Ton ein. Tonboden läßt also sowohl wegen der Feinheit als auch wegen der sonstigen Natur seiner Teile Wasser schwierig einsickern.

1) Feilberg 1890; vergl. S. 270, wo angegeben wird, wie sich die Vegetation eines Gebietes mit dem Fallen des Grundwasserspiegels allmählich verändert.

2) Warming $1887,1890,1891$.

3) Graebner 1901, 1909, besonders $1910 \mathrm{a}, \mathrm{b}$. 
Sind die obersten Erdschichten sehr trocken, so vergeht einige Zeit, bevor sie so benetzt werden, daß daß Wasser einzusickern beginnen kann.

Das Eindringen des Wassers ist für die Vegetation wichtig, namentlich in regnerischen Zeiten.

Die Hygroskopizität des Bodens. Jeder poröse und trockene Boden kann Wasserdampf absorbieren, aber in sehr verschiedenem Grade. Die Größe der Hygroskopizität hängt von der Porosität und der Temperatur des Bodens ab. Auch die chemische Beschaffenheit der Bodenteile spielt eine Rolle, was z. B. folgende Versuche von Schübeler zeigen. $5 \mathrm{~g}$ Quarzsand nahmen in 72 Stunden kein Wasser auf, Kalksand nahm $0,015 \mathrm{~g}$, Ackererde $0,1 \mathrm{~g}$, Tonboden $0,245 \mathrm{~g}$, Humus $0,6 \mathrm{~g}$ Wasser auf.

Es ist übrigens nicht ganz sicher, ob die beobachtete Aufnahme von Wasserdampf wirklich einer Absorption durch den Boden und nicht vielmehr einer Art Taubildung bei wechselnder Temperatur des Bodens zuzuschreiben sei (P. E. Müller, Ebermayer).

Der aufgenommene Wasserdampf wird für die Pflanzen immer zuträglich sein, weil er nur aufgenommen wird, wenn die Erde trocken ist; nie kann er zu viel Wasser zuführen. Aber anderseits ist er allein nicht imstande, trockene Erde mit Wasser zu versehen, das für die Pflanzen hinreicht; diese verwelken, bevor der Wassergehalt des Bodens so sehr gesunken ist, daß eine Absorption von Wasser stattfindet.

Das Wasserhebungsvermögen des Bodens. Das Vermögen des Bodens, aus den tieferen Schichten Wasser emporzuheben, ist für das Pflanzenleben selbstverständlich von Bedeutung. Es muß zwischen der Höhe und der Geschwindigkeit unterschieden werden, wohin und womit das Wasser gehoben wird. Sie hängen unter anderem von der Kapillarität und der Beschaffenheit der Körner ab. Quarzsand hebt das Wasser schnell, Tonboden und andere sehr feinkörnige Böden heben es langsam, Kalksand und Humus ziemlich schnell. Aber die Steighöhe ist bei Sandboden am kleinsten (nach Versuchen von Ramann ${ }^{1}$ ) bei feinkörnigem Sande nur ca. $40 \mathrm{~cm}$ über dem Grundwasserspiegel), größer bei Tonboden und am größten bei Torfboden. (Die weitverbreitete Ansicht indessen, daß die Sphagna in den Heidemooren das Wasser aus dem Grunde heraufheben, ist irrtümlich ${ }^{2}$ ). Werden die Körner eines Bodens über 2-3 mm groß, so werden seine Poren zu groß, um kapillar wirken zu können.

Das Wasserhebungsvermögen wird für die Vegetation namentlich dann wichtig, wenn die Verdunstung an der Bodenoberfläche stark

1) Ramann 1893, 1905 .

) Graebner 1901; C. A. Weber 1902. 
wird. Im übrigen kann ein geringes Wasserhebungsvermögen für wasserarmen Boden nützlicher sein als ein starkes, weil der Boden dann nicht leicht austrocknet.

Unter der Wasserkapazität des Bodens versteht man sein Vermögen, tropfbarflüssiges Wasser aufzunehmen und festzuhalten. Sie wird durch die Wassermenge gemessen, die ein gewisses Gewicht oder besser ein gewisses Volumen Boden festhalten kann, und hängt von der Adhäsion des Wassers an den Bodenteilen ab, die nach der Kapillarität des Bodens und nach der Natur der Körner verschieden ist.

Die Wasserkapazität ist desto größer, je zahlreicher und feiner die Kapillarräume im Boden sind und je gleichförmiger ihre Größe ist, weil die adhärierende Oberfläche dadurch wächst. Quarzsand mit 1-2 mm Korngröße hält nur etwa $1 / 10$ von dem fest, was solcher von $0,01-0,07 \mathrm{~mm}$ Korngröße festhalten kann (Wollny) ${ }^{1}$ ).

Die Wasserkapazität ist nach Versuchen (Schuebler, Wollny) bei Quarzsand am geringsten, bei Kalksand größer, bei Tonboden und feinem, reinem Kalkboden noch größer, bei den Humusböden am größten. Bei diesen wird die Wassermenge unter anderem durch das Imbibitionswasser, das sich in den organischen Teilen findet, vermehrt; Torfboden hat von allen Bodenarten die größte Wasserkapazität ${ }^{2}$ ).

Einige Bodenarten zeigen eine so starke Adhäsion des Wassers, daß sie bei Wasserzufuhr die Zwischenräume zwischen ihren festen Teilen erweitern und also ihr Volumen vergrößern, d. h. daß sie quellen, und sich umgekehrt bei Wasserverlust zusammenziehen, womit eine Veränderung der Eigenschaften verbunden ist; naß sind sie weich und teilweise plastisch, trocken hart und spröde. Dieses gilt namentlich von Ton- und Torf- (bes. Heidetorf-) boden.

Im allgemeinen ist der Boden nicht mit Wasser gesättigt (außer natürlich in Sümpfen und an ähnlichen Stellen in der Nähe des Grundwassers); in mit Vegetation bedecktem Boden wird das Maximum der Kapazität nicht erreicht werden, weil die Pflanzen wegen der Transpiration beständig Wasser verbrauchen. Viele Pflanzen gedeihen nur in Boden, der nicht mit Wasser gesättigt ist.

Die Austrocknung des Bodens hängt von verschiedenen Faktoren ab, teils von den erwähnten Eigenschaften des Bodens, teils vom Wasserverbrauche der Pflanzen und der Tiere, teils von der Verdunstung.

Die Verdunstung hat selbstverständlich auf den Wasserreichtum des Bodens und dadurch auf den Haushalt und die Beschaffenheit der Pflanzendecke großen Einfluß. Der Boden hält eine gewisse Menge

1) Vergl. Livingston 1901, 1903, 1905.

2) Uber die oft plötzlichen Verschiedenheiten dicht nebeneinander liegender Böden vergl. Kraus 1911. 
Wasser zurück, selbst wenn er der stärksten natürlichen Verdunstung ausgesetzt wird. Die Kraft, womit das Wasser festgehalten wird, ist für die Vegetation von großer Bedeutung. Sehr lehrreich ist hier das Verhalten verschiedener Humuserden. Heidetorf (aus Heidemooren, ist aus Sphagnumresten zusammengesetzt) trocknet gleichmäßig aus und bewahrt im Innern lange eine milde Feuchtigkeit. Wiesenmoorboden kann an der Oberfläche pulvertrocken sein, in geringer Tiefe noch schmierig naß, das Wasser gleicht sich schlecht aus. Diese Eigenschaft macht ihn für gärtnerische Kulturen unbrauchbar ${ }^{1}$ ).

Die Faktoren, die auf die Verdunstung einwirken, sind teils innere, teils äußere:

Innere Faktoren sind solche, die an den Boden selbst gebunden sind, also der $\mathrm{Bau}$ des Bodens, die Form der Bodenoberfläche (rauh oder glatt) usw. Aus losem Boden verdunstet weniger Wasser als aus festem, weil sein Vermögen, Wasser zu heben, kleiner ist; Krümelbildung setzt die Verdunstung herab. Boden mit mittelgroßen Körnern läßt am meisten Wasser verdunsten, großkörniger Boden wenig. Die Durchlässigkeit der leichten Böden, besonders der Sandböden, verhindert das Festhalten oder die Ansammlung größerer Wassermengen in den Oberflächenschichten, befördert also große Schwankungen und schnelles Austrocknen.

Auch Farbe und Art des Bodens spielen eine Rolle, Aus dunklerem Boden verdunstet mehr als aus hellerem; die Stufenfolge ist schwarz, grau, braun, gelb, rot, weiß. Aus Quarzsand und Humusboden ist die Verdunstung am schnellsten, aus Kalksand und Tonboden am langsamsten; Masure konnte Sand und Humus in 3 Tagen soweit wie möglich austrocknen, Tonboden und Kalk in 7 Tagen. Aber die Menge des in einer gegebenen Zeit verdunsteten Wassers ist desto größer, je größer die Wasserkapazität des Bodens ist; hier steht Humus obenan und Quarzsand zu unterst. In einem Versuche von Masure hielt Humus $41 \%$, Sand nur 2,1\% zurück. Die Verdunstung ist aus einem mit Wasser gesättigten Boden größer als einer gleichgroßen Wasserfläche.

$\mathrm{Zu}$ den äußeren Faktoren, die auf die Verdunstung aus dem Boden einwirken, müssen gerechnet werden: Das Sättigungsdefizit der Luft (vergl. S. 49), der Neigungsgrad und die Neigungsrichtung (Exposition) der Oberfläche, die Stärke und die Trockenheit der Winde (S. 66), sowie die Vegetation der Oberfläche.

Eine Pflanzendecke vermehrt die Größe der Oberfläche und verbraucht ununterbrochen Bodenwasser, das durch Verdunstung aus den Blättern und anderen oberirdischen Teilen entweicht. Ein bewachsenes Feld trocknet schneller aus als ein Brachfeld (natürlich unter gleichen

1907. 
übrigen Umständen). Die Pflanzendecke trocknet in ihrer Vegetationszeit den Boden aus, aber in verschiedenem Grade je nach den Wärmeverhältnissen und der Art der Pflanzen (Kräuter trocknen stärker als Bäume aus, Gräser trocknen besonders stark aus); aus Versuchen von Colding geht hervor, daß kurzes Gras bei Kopenhagen im April bis September viel mehr Wasser verbraucht, als die Niederschläge betragen. Feilberg ${ }^{1}$ ) hat diese für die Monate Mai, Juni, Juli und August auf 0,55 Hektar Land und auf einen Tag ungefähr zu 400, 500, 350 und 300 Kubikfuß berechnet; diese Zahlen sind natürlich nur annähernd und ändern sich nach den Verhältnissen. Der Wassergehalt des Bodens nimmt also vom Frühjahre zum Herbste ab; in dieser Jahreszeit ist er am kleinsten und kann 5 bis $7 \%$ weniger betragen als im Frühjahre, worauf er im Winter zunimmt, bis das Pflanzenleben aufs neue erwacht. Die Unterschiede zwischen den Arten beruhen teils auf der Größe der Summe der Blattflächen und auf dem Blattbau, teils auf der Natur des Wurzelsystems, darauf, ob dieses nahe der Oberfläche oder tief liegt; verschiedene Arten werden in Wäldern dadurch zu Unkräutern, daß sie das Wasser verbrauchen, bevor es die Baumwurzeln erreicht. Hierdurch kann auch erklärt werden, daß eine Art auf demselben Standorte oft weniger geschützt ist als eine andere.

Die Wurzeln können das Bodenwasser übrigens nur bis zu einem gewissen Grade verbrauchen. Je mehr der Wassergehalt eines Bodens abnimmt, desto stärker wird der Rest des Wassers festgehalten, und zuletzt kommt ein Punkt, wo die Pflanze kein Wasser mehr aufnehmen kann, obgleich vielleicht noch große Mengen zurückgeblieben sind. Sachs ${ }^{2}$ ) hat dieses durch Versuche mit Tabakspflanzen nachgewiesen. Eine junge Pflanze begann zu welken, als der Boden (dunkler Humus) noch 12,3\% seines Trockengewichtes Wasser enthielt; die Wasserkapazität des Bodens wurde durch sein Trocknen bei $100^{\circ} \mathrm{zu} 46 \%$ jenes Gewichtes bestimmt; also hat die Pflanze nur 33,7\% aufnehmen können, der Rest war ihr unzugänglich. Unter ähnlichen Verhältnissen welkten die Pflanzen in Lehmboden und in Sandboden, als diese noch 8 und 1,5\% enthielten. Nach Versuchen von Heinrich begannen Pflanzen in grobkörnigem Sandboden erst zu welken, als der Wassergehalt auf 1,5\% gesunken war, aber in Torfboden welkten sie bereits, als der Wassergehalt $47,7 \%$ war. Daß verschiedene Pflanzenarten verschieden leicht welken, ist bekannt; über den Welkungskoeffizienten und seine indirekte Bestimmung haben neuerdings Briggs und Shant ${ }^{3}$ ) umfangreiche Untersuchungen veröffentlicht.

1) Feilberg 1891 .

2) Sachs 1865, S. 173 .

3) Briggs und Shantz 1912. 
Ein Boden, aus dem eine Art nicht mehr fähig ist, Wasser herauszusaugen, kann als für diese Art "physiologisch trocken"1) bezeichnet werden, gleichgültig, welche Wassermenge tatsächlich noch im Boden ist. Die physiologische Trockenheit allein spielt bei der Verteilung der Arten eine Rolle ${ }^{2}$ ).

Solche die Wasseraufnahme der Wurzeln herabsetzenden und damit die "physiologische Trockenheit" befördernden Böden sind in erster Linie die "sauren", während im allgemeinen die alkalischen Böden die Wurzeltätigkeit befördern (milder Waldboden usw.). Auch „kalte“ Böden setzen die Aufnahmefähigkeit der Wurzeln stark herab.

Ein Boden mit beträchtlicher Feuchtigkeit kann unter Umständen die Wirkungen eines feuchten Klimas ersetzen. Auch in tropischen Savannen und Wüsten sind die Ufer der Ströme vom Wald umsäumt (Schweinfurths Galerienwälder). In Steppen und Wüsten wachsen Bäume da, wo sich fließendes Wasser findet oder wo das Grundwasser sich der Oberfläche nähert (Oasen). Viele ausdauernde Kräuter, die in Europa trockene sandige Böden bevorzugen, wachsen in dem heißen trockenen Niederungslande von Madeira nur auf feuchtem Boden in der Nachbarschaft von Quellen und Wasserläufen ${ }^{3}$ ). Hervorgehoben muß aber werden, daß lange nicht in allen Fällen feuchter Boden feuchtes Klima ersetzen kann, so können z. B. manche Erica-Arten mäBig trockenen Boden ertragen, aber nie trockene Luft; auf der anderen Seite findet man Tamarix Gallica sowohl in der Sahara als in Mitteleuropa an den feuchten Niederungsrändern usw. - In Gegenden oder Pflanzenvereinen mit starker Schwankung des Feuchtigkeitsgehaltes in den verschiedenen Jahreszeiten richtet sich der Pflanzenverein nach der trockensten Zeit. 16. Kap.).

Eine tote Decke wirkt auch auf die Verdunstung ein (vergl.

Die Bedeutung des Bodenwassers für die Pflanzenformen. Außer dem Seite 47-48 über die Bedeutung des Wassers überhaupt Angeführten sei hier noch erwähnt, daß die Bildung von Adventivwurzeln aus niederliegenden Sprossen offenbar durch Feuchtigkeit begünstigt wird: man trifft nirgends eine so reiche und häufige Ad-• ventivwurzelbildung wie an feuchten Stellen ${ }^{4}$ ). Dieses wirkt auch auf die Lebensdauer der Individuen ein; einjährige Arten werden an solchen Orten seltener ${ }^{5}$ ).

$\left.{ }^{1}\right)$ Schimper 1898; vergl. auch Kihlman 1890 Hedgcock 1902; Clements 1904; Burgerstein 1904.

2) Vergl. Kapitel 24, 28

3) M. Vahl 1904 b.

4) Warming 1884, 1892.

Ђ) Hildebrand 1882 . 
Ferner verzweigen sich die Wurzeln in feuchtem Boden mehr als in trockenem. Auch auf die Wurzelhaarbildung hat das Wasser Einfluß ${ }^{1}$ ).

Was die Formen der Wurzeln betrifft, so haben bekanntlich viele "Wasserwurzeln" eigentümliche Formen ${ }^{2}$ ), aber die wirkenden Ursachen kennt man nicht näher. Besonders charakteristisch sind die dicken, oft am Ende handförmig verzweigten Wasserwurzeln unserer Kiefer, wie sie in leichten Sandböden senkrecht in die Tiefe gehen. - Über Formen der Wurzeln in Wüsten vergl. Cannon ${ }^{3}$ ).

\section{Kap. Die Wärme des Bodens}

Die Wärme des Bodens ist ein geographischer Faktor von großer Bedeutung. Außer dem Kap. 3 über die Bedeutung der Wärme im ganzen Angeführten sei hier erwähnt, daß die Wurzeltätigkeit von der Bodenwärme abhängt und mit steigender Wärme bis zu einem gewissen Optimum größer wird. Eine Pflanze kann in einem mit Wasser gesättigten Boden welken, wenn dessen Wärme unter einen gewissen Grad sinkt, weil die Wurzeln kein Wasser aufnehmen können (physiologisch trocken), und Pflanzen können wegen zu niedriger Bodenwärme erfrieren, selbst wenn sie weit niedrigere Luftwärme aushalten können; Rotbuche, Eiche und Esche können - $25^{\circ}$ Luftwärme ertragen, aber die feineren Wurzeln erfrieren bei -13 bis $-16^{\circ}$ (Mohl). Manche Stelle in den Hochgebirgen und den Polarländern würde sicher pflanzenlos sein, wenn die Bodenwärme nicht vorhanden wäre; denn diese kann stellenweise die Luftwärme bedeutend übersteigen. Messungen der Wärme der Bodenoberfläche in den genannten Gegenden haben Saussure, die Brüder Schlaginweit, John Ball u. a. angestellt.

Über Temperaturanomalien im Sandboden berichtet Süring ${ }^{4}$ ); er kommt nach seinen Untersuchungen zu folgenden kurz zusammengefaßten Resultaten: Bis zu $1 \mathrm{~m}$ Tiefe gleichen sich auch stärkere Temperaturstörungen, wie z. B. die des Sommers 1911, in kurzer Zeit wieder aus. Für den Betrag der aufgenommenen Wärme ist die Bilanz zwischen Ein- und Ausstrahlung maßgebend; weiter unterhalb richtet sich die aufgespeicherte und abgegebene Wärmemenge in erster Linie nach der Dauer der Temperaturstörung in der Luft. - Eine schnellere Temperaturfortpflanzung infolge von Bodenfeuchtigkeit läßt sich im Sommer nur für die obersten $10 \mathrm{~cm}$ nachweisen. Direkte Bestimmungen des Wassergehaltes des Bodens ergeben ein Maximum in der Schicht von $5-15 \mathrm{~cm}$

1) Fr. Schwarz 1883; Gain $1893,1895$.

2) Sachs 1865; Warming 1897 a.

3) Cannon 1911. - Weitere Aufschlüsse über Einfluß der Bodenfeuchtigkeit vergl. Gain 1893, 1895.

4) Süring 1912. 
Tiefe. - Die Wärmekapazität des Sandbodens bei Potsdam betrug für die Schicht von $5-35 \mathrm{~cm}$ im Winter $0,43 \mathrm{~g}$ Kalorien und liegt in den anderen Jahreszeiten um 0,01-0,02 unter dem Jahresmittel von 0,4. Für klimatologische Betrachtungen spielen daher die Schwankungen der Wärmekapazität eine geringere Rolle als der Wechsel zwischen Einund Ausstrahlung und als die Struktur des Sandbodens. Bis zu mindestens $20 \mathrm{~cm}$ Tiefe ist Temperaturfortpflanzung durch Konvektion zu berücksichtigen; sie bewirkt u. a., daß sich bei warmem, trockenem Wetter die Eintrittszeiten der Temperaturextreme in $20 \mathrm{~cm}$ Tiefe verfrühen.

Über die Beziehungen zwischen dem täglichen Gang der Temperatur an der Bodenoberfläche und den untersten Luftschichten hat neuerdings Kretzer ${ }^{1}$ ) umfangreiche Untersuchungen angestellt und die Werte aus verschiedenen Erdteilen miteinander verglichen. Die Hauptresultate sind etwa folgende: Der tägliche Gang der Temperatur der untersten Luftschichten wird in erster Linie von dem täglichen Gang der Temperatur an der Erdoberfläche bestimmt. Dieser Einfluß ruft eine Verzögerung des Eintritts der Maximaltemperatur in der Luft gegen den Eintritt des Höchstwertes der Temperatur an der Erdoberfläche hervor. Der Boden erwärmt sich stärker als die Luft, die von ihm erst ihre Wärme empfängt. Infolge von intensiver Ausstrahlung nach Sonnenuntergang erkaltet der Boden nachts und besonders im Winter stärker als die Luft. Diese Verhältnisse sind als für Landstationen normal anzusehen. - Seestationen haben in Meeresströmungen und Winden bestimmende Faktoren für die tägliche Temperaturschwankung in der Luft und an der Erdoberfläche. Zu allen Jahreszeiten lassen sich bei diesen Stationen Einflüsse des nahen Meeres nachweisen, welche die Wirkung der täglichen Periode der Temperatur an der Erdoberfläche auf die Lufttemperatur zu verdecken vermögen.

Welch ungeheuren Einfluß die Erwärmung der oberen Bodenschichten und namentlich die geringere Abkühlung des Nachts besonders in den Übergangsjahreszeiten hat, zeigen die Versuche mit „Bodenheizung“"2). - Über die Einflüsse der Bodenwärme auf die Zuckerrübenkultur berichtete Kassner ${ }^{3}$ ).

Die Temperatur des Bodens kann in Wüsten außerordentlich hoch steigen. Bonnet beobachtete im Wüstensande zwischen niedrigen Pflanzen $+59^{\circ}$, während die Lufttemperatur $33^{\circ}$ war, Pechuel-Lösche in Loango $75-82^{\circ}$ (vergl. darüber auch S. 33). Neuerdings sind über diese Dinge zahlreiche Abhandlungen erschienen. - Marloth fand den Steinboden in der Karroo zeitweise so heiß, daß man ihn kaum berühren konnte: ein auf den Boden gelegtes Thermometer stieg schnell auf $60^{\circ}$.

1) Kretzer 1912.

2) Mehner, H. 1906 a. a. 0.

3) Kassner 1896. 
Seine Tabelle zeigt die großen Unterschiede zwischen der Bodenoberflächen- und Lufttemperatur, z. B. im November.

Marloth zitiert die Untersuchungen von Sutton und gibt folgende lehrreiche Tabelle.

Maximaltemperaturen der Luft und des Bodens in Kimberley 1901

(Die Thermometerkugel war $25 \mathrm{~mm}$ tief in den Boden versenkt)

\begin{tabular}{|c|c|c|c|c|c|c|}
\hline & & & \multicolumn{2}{|c|}{$\mathrm{Luft}$} & \multicolumn{2}{|c|}{ Boden } \\
\hline & & & $\begin{array}{l}\text { Mittleres } \\
\text { Maximum }\end{array}$ & $\begin{array}{l}\text { Absolutes } \\
\text { Maximum }\end{array}$ & $\begin{array}{l}\text { Mittleres } \\
\text { Maximum }\end{array}$ & $\begin{array}{l}\text { Absolutes } \\
\text { Maximum }\end{array}$ \\
\hline Januar . & . . &.$\quad$. & 34,0 & 37,5 & 48,9 & 58,7 \\
\hline Februar & . . & . . & 32,8 & 39,7 & 43,5 & 51,2 \\
\hline März & . . & - : : & 28,6 & 34,4 & 35,6 & 43,9 \\
\hline April & . . & . . & 26,4 & 30,0 & 33,2 & 36,2 \\
\hline Mai . . & . & .. & 21,9 & 26,4 & 28,6 & 32,3 \\
\hline Juni . . & . . & . . & 19,5 & 22,2 & 25,6 & 28,3 \\
\hline Juli . . & . . & . . & 19,6 & 25,6 & 26,3 & 28,7 \\
\hline August . & . . & . . & 24,7 & 30,9 & 34,2 & 40,8 \\
\hline September & . . &.$\quad$. & 24,5 & 33,3 & 33,2 & 40,0 \\
\hline Oktober & . . & . . & 28,3 & 34,4 & 38,5 & 49,3 \\
\hline November & . . & . . & 33,0 & 40,0 & 49,4 & 57,4 \\
\hline Dezember & . . & . . & 35,1 & 38,9 & 46,0 & 52,6 \\
\hline & & Tahr & 27,4 & 40,0 & 36,9 & 58,7 \\
\hline
\end{tabular}

Die Bodenwärme ist sicher der Grund für verschiedene pflanzengeographische Merkwürdigkeiten. Der Unterschied in der Bodenwärme soll die Höhenzonen in den Alpen umkehren können und z. B. Gestrüppe von Pinus montana, Picea excelsa und Larix decidua unterhalb stattlichen Hochwaldes hervorbringen (Krasan), was aber von anderer Seite stark bestritten wird.

Die gestaltende Rolle der Bodenwärme ist nur wenig bekannt. Jedoch hat z. B. Vesque ${ }^{1}$ ) durch Versuche nachgewiesen, daß hohe Bodenwärme Saftreichtum hervorruft (kurze und dicke Wurzeln, Stengel und Blätter), vielleicht weil die Wurzeltätigkeit durch die Wärme leidet. Auch Prillieux kam zu dem Ergebnis, daß hohe Bodenwärme direkt Knollen hervorbringt. Dadurch wird es leichter verständlich, weshalb Succulenten oft auf Fels wachsen, zwischen Gestein oder auf Boden, der leicht erwärmt wird.

Zwergwuchs wird die Folge niedriger Bodenwärme sein können, wenn hierdurch die Menge des aufgenommenen Wassers und damit die

1) Vesque 1878. 
der aufgenommenen mineralischen Nahrung vermindert wird; dieser Faktor wirkt wahrscheinlich bei dem in der subglacialen Vegetation allgemeinen Zwergwuchse mit. Schon S. 44 wurde erwähnt, daß heterothermischer (kalter) Boden niederliegende Sprosse und Rosettenbildung hervorruft, während homothermischer (warmer) schlanke und hohe Pflanzen hervorbringt, was Krasan für Pinus, Juniperus, Asperula longiflora u. a. nachgewiesen hat. Der heterothermische Boden soll blaubereifte Sproßteile, Verkürzung der Entwicklungszeit u. a. und dadurch Spaltung von Arten in mehrere neue hervorrufen.

Die Hauptquellen der Bodenwärme sind wesentlich folgende: 1. Die Sonnenwärme; nach Krasan soll 2. die eigene Wärme der Erde eine nicht unwichtige (??) Rolle spielen, wenn der Boden ein guter Wärmeleiter ist. Endlich können auch 3. die Absorption von Wasserdämpfen in den Poren des Bodens und 4. chemische Prozesse im Boden (besonders Fäulnis) einwirken; diese Prozesse erhalten namentlich in kalten Ländern Bedeutung.

Für die Erwärmung des Bodens und dadurch für das Pflanzenleben sind selbstverständlich auch solche Faktoren wichtig, die die Abkühlung fördern oder hindern (Ausstrahlung, Verdunstung, Wärmeleitung usw.), sowie andere Faktoren, die kurz behandelt werden sollen. Davon beziehen sich die unter $1-3$ besprochenen auf die Sonnenwärme, die anderen namentlich auf den Boden selbst.

1. Die Zugänglichkeit der Sonnenwärme. Namentlich in den Polarländern spielt das direkte Sonnenlicht eine hervorragende Rolle, was die Verteilung der Vereine in der Landschaft deutlich zeigt. Die Erwärmung des Bodens spielt hierbei eine größere Rolle als die Luftwärme $\left.{ }^{1}\right)$.

2. Der Einfallswinkel der Sonnenstrahlen. Je senkrechter sie einfallen, desto stärker ist die Erwärmung (proportional dem Kosinus des Einfallswinkels). Die geographische Breite, der Neigungswinkel und die Neigungsrichtung (Exposition) des Geländes greifen hierbei ein. In unseren Breiten sind $\mathrm{SW}$-, S-, SO-Abhänge am wärmsten, NO-, N-, NW-Abhänge am kältesten.

Die unter 1 und 2 angeführten Verhältnisse rufen in der Verteilung der Vereine große Unterschiede und zwar unter allen Breitengraden hervor. Man beobachtet z. B. nicht nur in Grönland, daß die südlichen Seiten einer Bergkette mit einer offenen Xerophytenvegetation wie verbrannt dastehen können, während die nördlichen Seiten gleichzeitig von dichten, frischgrünen Moosteppichen bedeckt sind, in die sich einzelne Blütenpflanzen eingestreut finden und die im Sommer von dem langsam

2) Vergl. Kapitel 3. 
schmelzenden Schnee befeuchtet werden ${ }^{1}$ ); auch in den Mittelmeerländern sieht man z. B. die xerophile mediterrane Vegetation mit ihren eigentümlichen Formen und ihrer frühen Blütezeit auf den südlichen Seiten der Berge herrschen und auf diesen hoch hinaufsteigen, während die mitteleuropäische Vegetation mit ihrer langsameren Entwicklung den nordlichen und kühleren Seiten ihr Gepräge gibt ${ }^{2}$ ). Selbst in der Nähe des Äquators, z. B. in Venezuela (unter 10 Grad n. Br.), beobachtet man zwischen südlichen und nördlichen Abhängen die ausgesprochensten Unterschiede; man trifft bei Caracas im nördlichen Venezuela ostwestlich gerichtete, niedrige Erosionstäler oder Falten im Gelände, die auf den südlichen Abhängen so pflanzenarm sind, daß fast nur der rote Ton der Flur die Farbe gibt, während eine dichtere und höhere Vegetation die nördlichen Abhänge bedeckt.

In niedrigeren Breiten (Südeuropa und Tropen) muß daran erinnert werden, daß Nordwinde mehr Feuchtigkeit den Nord-als den Südabhängen bringen. Dieser Umstand ist vielleicht von größerer Wichtigkeit als ihre Exposition gegenüber dem Einfall der Sonnenstrahlen, weil, wenn die Sonne über einem steilen Südabhang steht, dieser weniger der Insolation ausgesetzt ist, als ein weniger steiler nördlicher. Je tiefer die Sonne steht, desto mehr ist die Intensität der Insolation von der Neigungsrichtung abhängig.

Es sei noch angeführt, daß die Schneegrenze auf der Süd- und der Nordseite eines Gebirges sehr ungleich hoch liegen kann, daß die Höhengrenzen vieler Pflanzen von der Exposition abhängen, z. B. die der Rotbuche in den Alpen; die Höhengrenze der Rotbuche ist in Südbayern nach Sendtner gegen SO am höchsten, gegen NO am niedrigsten. Die Arten steigen auf der nördlichen Halbkugel auf der Südseite der Gebirge gewöhnlich weit höher hinauf, als auf der Nordseite (z. B. in den Pyrenäen nach Bonnier). - Obiges wird hinreichen, um zu zeigen, wie die Wärme, in diesem Falle zunächst die Bodenwärme (aber Luftwärme und Bestrahlung können davon nicht getrennt gehalten werden), von den genannten Verhältnissen abhängt.

3. Die Dauer der Bestrahlung. In dieser Dauer sind die Tropen und die Polarländer sehr verschieden, jedenfalls in der Verteilung des Lichtes nach den Jahreszeiten.

4. Die chemische Beschaffenheit des Bodens. Die Wärmekapazität des Bodens ist nach seiner chemischen Natur verschieden. Am leichtesten wird Quarzsand, am schwierigsten Torfboden erwärmt; zwischen beiden stehen Kalksand, Tonboden usw. Die Wärmekapazität des Quarzsandes beträgt nur 0,2, die des Torfes etwa $0,5($ Wasser $=1$ ).

1) Warming 1887.

2) Flahault 1893. 
Die Humusmenge im Boden ist daher für seine Wärmekapazität von besonderer Wichtigkeit.

5. Die Farbe des Bodens. Dunkler Boden wird leichter und stärker erwärmt als heller, natürlich unter gleichen übrigen Umständen. Humboldt fand, daß schwarzer Basaltsand auf der Insel Graziosa eine Temperatur von 51,2 ${ }^{\circ} \mathrm{C}$, weißer Quarzsand jedoch unter gleichen Umständen nur $40^{\circ}$ erreichte. Bei der Ausstrahlung verhält es sich umgekehrt: dunkler Boden kühlt sich nachts schneller ab als heller Boden, wird aber nicht kühler als dieser.

6. Die Porosität des Bodens. Ein stark poröser, kiesiger Boden (heterothermischer Boden, nach Krasan) wird die Sonnenwärme rasch absorbieren und auf seiner Oberfläche stark erwärmt werden, aber die Wärme geht durch Ausstrahlung ebenso leicht wieder verloren. Luftreicher Boden leitet die Wärme schlecht, desto schlechter, je luftreicher er ist, weil die Luft ein schlechter Wärmeleiter ist; fester Boden leitet gut. In Felsenboden ist die Wärmeleitungsfähigkeit größer und gleichmäßiger (homothermischer Boden, Krasan), und hat nach der Art des Gesteines eine verschiedene Geschwindigkeit. Der Karstkalk z. B. ist wegen seiner gleichförmigen Dichtigkeit und seiner Trockenheit ein vorzüglicher Wärmeleiter. Ferner sind Granit, Basalt und andere kristallinische Gesteine gute Leiter. In heterothermischem Boden gibt es viel größere Extreme in den Wärmegraden; die Sommerwärme dringt zu geringer Tiefe hinab und geht im Winter schneller verloren.

7. Der Wasserreichtum des Bodens spielt bei der Bodenwärme wohl von allen Faktoren die größte Rolle, indem bei der Erwärmung und der Verdunstung des Wassers Wärme verbraucht wird (vergl. auch Clements). Das Wasser hat eine weit größere Wärmekapazität als die Bodenarten. Je wasserreicher, desto kälter ist der Boden; trockener Boden wird leichter erwärmt als nasser; aber wasserreicher Boden hält andererseits die Wärme länger fest als trockener Boden, weshalb er im Herbste wärmer ist als trockener Boden. Sandböden sind „warm", weil sie schnell das Wasser verlieren und erwärmt werden; Tonböden sind „kalt". Wasserreicher Boden leitet auch die Wärme nach dem Untergrunde besser als trockener. Felsboden ist der wärmste von allen, weil eben keine Wärme durch Verdunstung gebunden wird. Die Wärme dringt schnell und tief in den Felsen ein, weil dieser ein guter Wärmeleiter ist. In den tieferen Schichten sind die Temperaturextreme groß, während auf losem Boden nur die oberen Lagen erwärmt werden ${ }^{1}$ ). Alle diese Verhältnisse haben z. B. für die Entwicklung der Vegetation im Frühjahre große Bedeutung.

Der gefrorene Boden, den man in den Polarländern mehr oder weniger tief unter der Oberfläche trifft, spielt natürlich für die Vege-

1) Vergl. Homén 1897. 
tation eine große Rolle, teils dadurch, daß sich die Wurzeln von ihm wie von Felsboden wegbiegen (und vielleicht auch wegen der Thermotropie der Wurzeln), teils dadurch, daß die Kälte die Wurzeltätigkeit herabsetzt.

8. Die Beschaffenheit der Vegetation, namentlich ihre Dichtigkeit, wirkt auf die Bodenwärme ein, indem sie den Boden mehr oder weniger der unmittelbaren Erwärmung entzieht und mehr oder weniger auf die Verdunstung aus dem Boden und seine Ausstrahlung einwirkt ${ }^{1}$ ).

9. Die eigene Wärme der Erde. Besonders erwähnt mag auch Krasans Ansicht werden. Er geht davon aus, daß zum wesentlichsten Teile die eigene Wärme der Erde, nicht die Sonnenwärme, auf die Vegetation einwirke, und meint, daß organische Wesen wie die gegenwärtig lebenden ohne die Erdwärme nicht bestehen könnten. Diese wirkt indessen nicht überall gleichmäßig; ihre Wirkungen hängen von den physikalischen Verhältnissen des Bodens, namentlich von der Wärmeleitung und der Wärmestrahlung, ab. Es besteht hierin ein großer Unterschied z. B. zwischen Kalkfels und losem Sandboden; jener leitet die Wärme gut und strahlt viel aus, dieser verhält sich umgekehrt. Auch das Relief der Oberfläche ist von Bedeutung; spitze und zerklüftete Gebirgsmassen strahlen mehr Wärme aus, als ein flaches Gelände oder als zusammenhängende, kompakte Gebirgsmassen, und die Höhengrenzen der Arten können hiervon wesentlich beeinflußt werden. Das Auftreten der "Bergheide" in den südöstlichen Kalkalpen meint Krasan sogar ganz durch die Verhältnisse der Bodenwärme erklären zu können; sie ist an Dolomitgrus und Sand gebunden. Auch die Mächtigkeit der oberen Bodenschichten spiele natürlich eine Rolle. Die Mehrzahl der neueren Schriftsteller steht diesen Anschaungen zum Teil mehr als skeptisch gegenüber. Nach Tabert kann die Bodentemperatur durch die innere Wärme etwa nur um $0,1^{\circ} \mathrm{C}$. erhöht werden, eine sicher unwirksame Menge.

Im Anschluß hieran sei erwähnt, daß man bei Zwickau wegen der Wärme langsam brennender Steinkohle subtropische Pflanzen im Freien hat ziehen können.

10. Die Abkühlung des Bodens durch Wind ist in vielen Fällen imstande, eine wichtige Rolle bei der Ausbildung der Vegetation zu spielen. So z. B. leiden wie bekannt die Pflanzenvereine an der Nordseeküste sehr stark unter den Nordwestwinden (vergl. Kap. 5); die Tätigkeit der Wurzeln wird dabei sicher durch die Abkühlung des Bodens durch die Winde herabgedrückt.

Über das Verhältnis zwischen der Wärme des Bodens und der Luft ist bereits die tägliche Einwirkung S. 42, 90 besprochen worden. Für die Zeit der Schneebedeckung kehrt sich das dort genannte Ver-

1) Vergl. auch die Kapitel 9 und 16. 
hältnis um, die Oberfläche ist meist kühler als die Luft. Der Boden unter der Schneedecke behält bei sehr starken Schneefällen oft beinahe die Temperatur, welche während des Schneefalls herrschte. In Gebirgen ist die Maximaltemperatur des Bodens nahezu so hoch wie die in den Ebenen am Fuße dieser Gebirge, während die Minima nicht entsprechend niedriger sind, so daß also die Abweichung der Bodentemperatur über die Temperatur der Luft mit der Höhe steigt.

Die Wärmeschwankungen sind in den oberen Bodenschichten größer als in den tieferen; sie hören zuletzt in einer gewissen Tiefe ganz auf, wo eine konstante Temperatur herrscht, die Mitteltemperatur des Landes (in Dänemark $7,4^{\circ} \mathrm{C}$. etwa in $25 \mathrm{~m}$ Tiefe).

Aus alledem folgt, daß die Bodentemperatur größeren Schwankungen unterworfen ist, als die der Luft. In den wärmeren Bodenarten sind die Schwankungen stärker, aber die Pflanzen passen ihre Lebensvorgänge schnell der wechselnden Wärme an. Eine schwankende Temperatur, die sich oft dem Optimum nähert, ist den Pflanzen zuträglicher, als eine tief unter dem Optimum bleibende tiefere.

\section{Kap. Die Mächtigkeit des Bodens. Die oberen Bodenschichten und der Untergrund}

Die Mächtigkeit des Bodens, d. h. die Dicke der losen Bodenschichten über dem festen Fels spielt selbstverständlich für die Pflanzen eine große Rolle, besonders für die Bäume. Große Vegetationsunterschiede zeigen flachgründiger Boden, wo der Fels in sehr geringer Tiefe liegt, und tiefgründiger, wo dieses nicht der Fall ist: die Tiefe wirkt nämlich auf die Erwärmung, die Wasserführung, die Nahrungsmenge, das Wachstum der Wurzeln usw. Auf flachgründigem Boden erträgt die Vegetation mehr die Trockenheit und ist von klimatischen Änderungen abhängiger, als auf tiefgründigem; der flachgründige Boden bringt keine so kräftige Vegetation hervor wie ein ähnlicher tiefgründiger, und diese leidet in trockenen Zeiten leichter. Die Vegetation bietet große Verschiedenheiten, je nachdem ein Felsboden fast nackt oder von einer mehr oder weniger dicken Schicht von Verwitterungserde bedeckt ist, und ob diese durchlässig ist oder nicht. Ein Übergang eines Pflanzenvereins in den andern kann allein durch die Bodentiefe verursacht werden; Rikli $^{1}$ ) z. B. schreibt über Corsica: Wenn der Boden, arm an Humus und nur flach, noch dazu trocken wird, so machen die Macchien und Garigues den typischen Felsenheiden Platz. Die Alvarvegetation auf den schwedischen Ostseeinseln Öland und Gotland ist besonders durch die Flachgründigkeit des Bodens hervorgerufen (Fig. 43).

1) Rikli 1903 

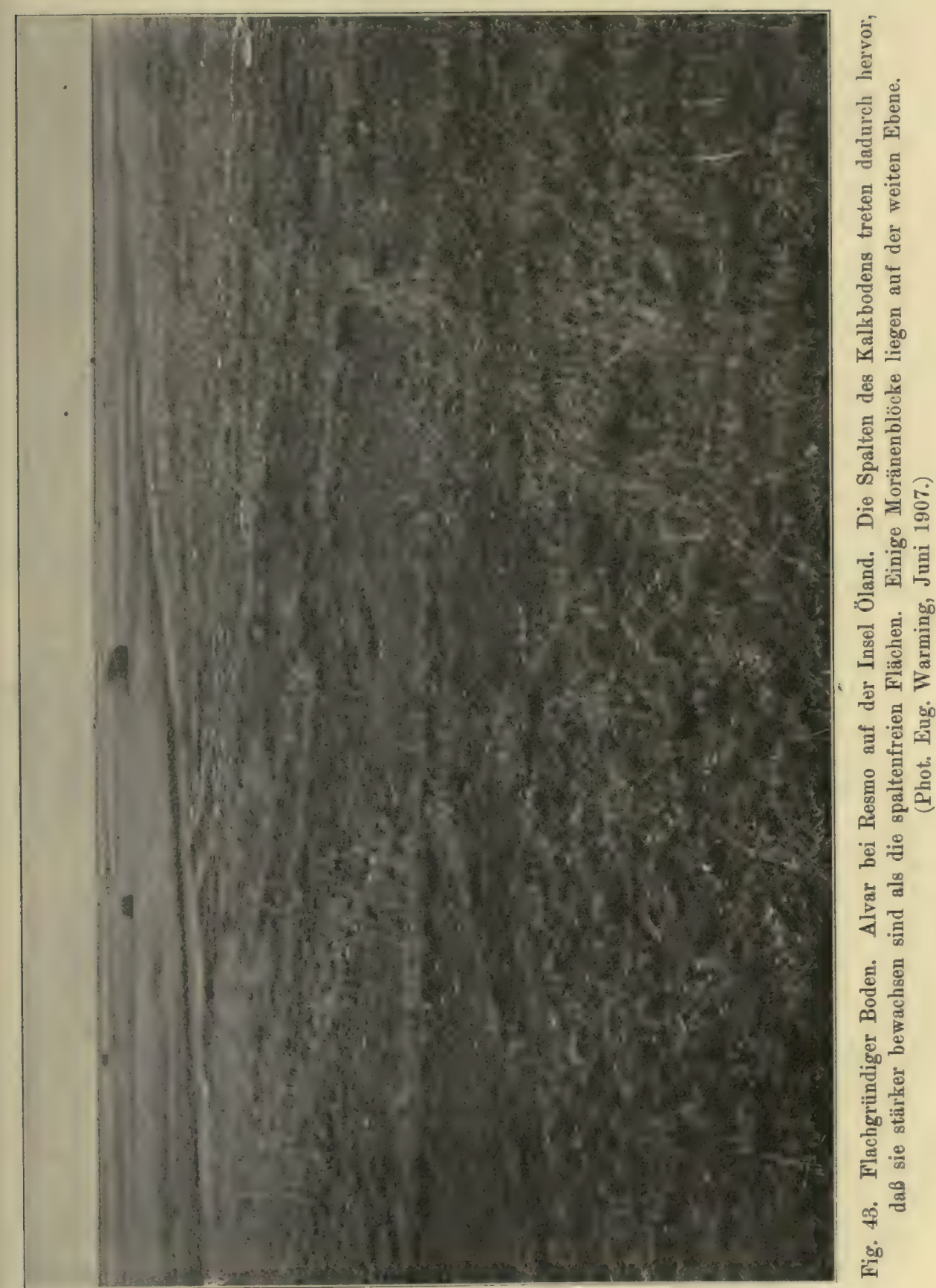
Im Boden unterscheidet man ferner die oberen Bodenschichten von dem Untergrunde. $\mathrm{Zu}$ jenen muß der vollständig verwitterte oberste Teil des Bodens gerechnet werden, der in der Regel mehr oder weniger mit Humus vermischt und von Pflanzen und Tieren bearbeitet worden ist, von Licht, Wärme und Luft mehr beeinflußt wird und an Nahrung, unter anderem wegen des Absorptionsvermögens des Bodens, reicher ist. Unter Absorptionsvermögen versteht man die Eigenschaft des Bodens, daß er, namentlich die Feinerde, teils durch chemische Anziehung, teils durch Oberflächenanziehung (physikalische A.) gewisse, in Wasser lösliche Pflanzennahrungsstoffe, die durch ihn filtriert werden, festzuhalten vermag, so daß sie nicht oder äußerst langsam ausgewaschen werden können; diese Pflanzennahrungsstoffe sind gerade die seltensten und wichtigsten: Phosphorsäure, Kali und Ammoniak, während Salpetersäure, meist auch Kalk und Eisen von Regenwasser leicht ausgewaschen werden. Der Boden hat ein bemerkenswertes Vermögen, die Beschaffenheit des Bodenwassers zu regulieren. Gewöhnlich wird dieses eine sehr schwache Lösung sein, deren Konzentrationsgrad nach den Umständen schwankt. Die verschiedenen Bodenarten haben verschiedenes Absorptionsvermögen. Auch aus der Luft können gewisse Böden, z. B. Tonboden, Nahrungsstoffe aufnehmen, indem sie Ammoniak absorbieren.

Das Verhältnis zwischen den oberen Bodenschichten und dem Untergrunde ist sehr wichtig; sowohl die Mächtigkeit, als der Wassergehalt und andere Eigenschaften der oberen Bodenschichten spielen eine Rolle; im großen und ganzen scheint es, daß das Verhältnis für das Pflanzenleben desto günstiger ist, je entgegengesetzter die Eigenschaften des Untergrundes nach Wasseraufsaugung und Wassergehalt gegenüber denen der oberen Bodenschichten sind. Dehérain stellt folgende Reihe auf:

Leichter Boden mit durchlässigem Untergrunde ist ganz vom Klima abhängig. Ist dieses trocken, so kann er äußerst unfruchtbar sein; an mehreren Stellen Frankreichs wachsen auf solchem Boden Nadelwälder, die ja nur eine geringe Transpiration haben. Sind die Niederschläge reichlich, oder wird der Boden bewässert, so kann er eine stattliche Vegetation tragen, (wenn der Boden aber noch dazu nährstoffarm ist, vorzüglich nur Heide).

Leichter Boden mit undurchlässigem Untergrunde. In einem mittelfeuchten Klima haben solche Böden sehr verschiedenen Wert, je nachdem sie geneigt sind, so daß das Wasser abfließt, oder wagerecht sind; jene Böden tragen oft eine vorzägliche Vegetation, die letzteren können auch sehr sumpfig und zum Ackerbau untauglich sein.

Schwerer Boden mit durchlässigem Untergrunde ist in der Regel fruchtbar, da das überflüssige Wasser in den Untergrund einsickert. 
Schwerer Boden mit undurchlässigem Untergrunde trägt Sumpfregetation und muß entwässert werden, wenn er bebaut werden soll.

Da die Beschaffenheit des Untergrundes oft überaus rasch wechselt, sieht man den Charakter der Vegetation oft auf sehr kurzen Strecken sich gänzlich ändern. Die Neigung des Bodens kann die Bedeutung des Untergrundes wesentlich verändern, wie sie ïberhaupt für die Güte des Bodens von großer Wichtigkeit ist.

\section{Kap. Die Nahrung im Boden}

\section{(chemisches Verhalten)}

Die Pflanze bezieht ihre Nahrungsstoffe teils aus der Luft, teils aus dem Nährboden. Es ist also klar, daß dessen Verschiedenheiten eine hervorragende ökonomische Rolle spielen müssen.

Der Boden bereitet erstens in Verbindung mit der besonderen Tätigkeit der Wurzeln, die bei verschiedenen Arten als verschieden angenommen werden muß, die Nahrung zu, die dreierlei Bestandteile enthält: 1. feste, mineralische Teile, 2. in Wasser aufgelöste Salze, 3. Humusstoffe, d. h. organische Stoffe, die aus Abfällen und zersetzten Teilen von Pflanzen und Tieren stammen. Zweitens sammelt der Boden durch Absorption in den oberen Bodenschichten Nahrung an ${ }^{\mathbf{1}}$ ).

Notwendig nennt man solche Nahrungsstoffe, die die Pflanzen zu ihrer normalen Entwicklung durchaus brauchen. Bei den bisher untersuchten höheren Pflanzen sind es im ganzen nur zehn Elemente: Sauerstoff, Wasserstoff, Kohlenstoff, Stickstoff, Phosphor, Schwefel, Eisen, Kalium, Calcium und Magnesium. Fehlt einer dieser Stoffe im Boden in passenden chemischen Verbindungen, so treten pathologische Zustände ein oder die Pflanze wächst überhaupt nicht. Außerdem nehmen alle Pflanzen verschiedene andere Stoffe auf, deren Nutzen im ganzen zweifelhaft ist, die aber nicht als bedeutungslos angesehen werden diurfen; diese können z. B., wenn sie vorhanden sind, bewirken, daß gewisse notwendige Stoffe in geringerer Menge gebraucht werden, als dann, wenn sie fehlen (Wolff u. a.).

Die Menge der Nahrungsstoffe ist auch wesentlich. Ist ein Stoff unter einem gewissen Minimum vorhanden, so gedeiht die Pflanze nicht; aber die Arten sind sehr verschieden anspruchsvoll; verschiedene Arten nelımen verschiedene Mengen auf (einer der Gründe, weshalb der Landmann Wechselwirtschaft betreibt). Der Praktiker unterscheidet zwischen magerem und kräftigem Boden.

1) Vergl. auch Kapitel 11, S. 98. 
Der Gehalt an löslichen Salzen hängt ab:

1. Von den in löslichem Zustande vorhandenen Mineralien.

2. Von der Absorptionsfähigkeit des Bodens (s. S. 98).

3. Vom Klima.

Wo nur wenig Regen fällt, können die löslichen Salze nicht ausgewaschen werden und können daher bei zunehmender Verwitterung angereichert werden, so daß sie sogar, besonders auf Lehmboden, auskristallisieren können ${ }^{1}$ ).

Ein ungenügender Vorrat an löslichen Salzen ist für den Pflanzenwuchs ungünstig, eine zu große Anreicherung ist aber für die meisten Arten mindestens ebenso schädlich. Eine gleiche Wirkung entsteht durch zu viel Humussäuren. Solche Bodenarten gehören zu denen, die Schimper ${ }^{2}$ ) z. T. als "physiologisch trocken" (s. S. 88), Graebner ${ }^{3}$ ) als "physiologisch arm" bezeichnet hat. Pflanzen auf physiologisch trockenem Boden sind oft identisch mit solchen auf wirklich trockenen (physikalisch trockenen) Böden, oder sind durch dieselben Schutzmittel gegen zu starke Verdunstung geschützt. Auf den Heiden wachsen dieselben Pflanzenarten auf den (chemisch) armen Böden, wie auf den Rohhumuslagen, selbst auf guten (chemisch reichen) Böden, so Calluna, Juniperus, Erica u. v. a.

Bedeutung für die Pflanzenformen haben sowohl die Menge als die Art der Nahrungsstoffe. Nahrungsmangel (d.h. unzureichende Menge eines oder mehrerer Stoffe) kann einer der Gründe für Zwergwuchs und Hungerformen sein; dieses ist durch viele physiologische Versuche und draußen in der Natur, z. B. Zwergsträucher auf Heiden und anderen mageren Böden, nachgewiesen worden. Die Menge eines einzelnen Stoffes kann hier den Ausschlag geben. Es gilt als allgemeines Gesetz, daß die Größe des Ertrages, insoweit er von den Nahrungsstoffen abhängt, von dem Nahrungsstoffe bestimmt wird, der der betreffenden Pflanzenart in verhältnismäßig geringster Menge zur Verfügung steht (Liebigs Gesetz des Minimums).

Wenn ein Nahrungsstoff in so geringer Menge vorhanden ist, daß der Ertrag aus diesem Grunde verringert wird, so wird der betreffende Stoff (nach der Atterbergschen Regel) auch in der Pflanze in verhältnismäßig geringerer Menge vorhanden sein als die Nahrungsstoffe, woran kein Mangel ist; und es liegt dann nahe, anzunehmen, daß auch andere, morphologische Unterschiede hieraus hervorgehen können.

Die Pflanze richtet ihre Wurzelform nach den Eigentümlichkeiten des Bodens ein. Nach Versuchen von Sachs ${ }^{4}$ ) werden die

1) Hilgard 1892 .

2) Schimper 1898 .

3) Graebuer 1904 usw.

4) Sachs 1859, S. 177. 
Wurzeln desto kürzer, je konzentrierter die Nährlösung ist. In magerem Boden werden die Wurzeln meist lang und wenig verzweigt (wofür unsere Sandvegetation, besonders die der Dünen, ausgeprägte Beispiele zeigt; umgekehrt verhält sich die Mehrzahl unserer Heidepflanzen); in kräftiger Erde verzweigen sie sich sehr stark und bilden dichte Massen; treffen sie Bodenschichten mit verschiedener Nahrungsmenge, so ist der Gegensatz zwischen den Wurzelverzweigungen in den verschiedenen Schichten auffällig. „Die Wurzeln suchen die Nahrung, als ob sie Augen hätten" (Liebig).

Die chemische Beschaffenheit des Nährbodens ruft in gewissen Fällen Formenverschiedenheiten hervor. Dieses gilt namentlich für einen Stoff, das Kochsalz. Es ist bekannt, daß sich alle Salzpflanzen durch ein besonderes Äußeres auszeichnen; sie haben namentlich fleischige Blätter, durchscheinende Gewebe u. a. ${ }^{1}$ ) Die Wirkungen des kohlensauren Kalkes und anderer Stoffe sind weniger augenfällig, doch wird ihm, wie in Kap. 14 bemerkt, namentlich von englischen und amerikanischen Forschern floristisch großes Gewicht beigelegt. Die mit dem Vorhandensein und Fehlen des kohlensauren Kalkes meist verbundenen großen chemischen und physikalischen Verschiedenhciten lassen einen ganz anderen Florencharakter entstehen. Neben den a. a. O. genannten Forschern gibt Cowles ${ }^{2}$ ) interessante Bilder von dem Einflusse der darunterliegenden Felsen auf den Charakter der Vegetation.

Unterschiede im Boden haben wahrscheinlich die Scheidung neuer Arten hervorgerufen. Das Galmeiveilchen (Viola calaminaria) ist vermutlich eine durch zinkhaltigen Boden aus $V$. lutea entstandene Form. Auf Serpentin, einem Magnesiasilikat, wachsen zwei Asplenum-Arten, $A$. Serpentini und $A$. adulterinum, die dem $A$. adiantum nigrum und A. viride nahe stehen ${ }^{3}$ ). Über die Beständigkeit dieser Formen müssen z. T. einwandfreie Kulturen Aufschluß geben, früher in die Litteratur gelangte Angaben sind unsicher, z. T. sogar sicher falsch.

Es besteht nach Kerners Studien in den Alpen ein großer Unterschied zwischen den untereinander parallelen Arten, die die kalklosen Schieferalpen oder die Kalkberge bewohnen; solche parallelen Arten (wohl besser Rassen) sind folgende (die kalkliebenden werden in jedem Paare zuletzt genannt): Hutchinsia brevicaulis und alpina, Thlaspi cepaeifolium und rotundifolium, Anemone sulphurea und alpina, Juncus trifidus und monanthos, Primula villosa und auricula, Ranunculus crenatus und alpestris usw.

1) Vergl. auch Abschnitt 4, Salzpflanzen.

2) Cowles 1901

a) Vergl. Schimper 1898; Pfeffer 1897-1904. 
Als Beispiele für die Einwirkung anderer Substrate auf die Form führt Kerner folgende an: Androsace Hausmanni wird als Dolomitform von A. glacialis aufgefaßt; ebenso Asplenum Seelosii und Woodsia glabella als solche von $A$. septentrionale und $W$. hyperborea ${ }^{1}$ ).

Über die Einwirkung bestimmter Magnesium- usw. Verbindungen auf die Pflanzen, ihren Nutzen und Schaden hat neuerdings $\mathrm{Mac} \mathrm{Cool}{ }^{2}$ ) umfangreiche Versuche veröffentlicht.

Da solche Arten, die einander auf verschiedenem Boden ersetzen, sicher von einer gemeinsamen Mutterart abstammen, hat es Interesse, zu untersuchen, worin sie voneinander abweichen, weil sich die Wirkungen des Bodens darin vermutlich offenbaren werden.

Bonnier ${ }^{3}$ ) machte nach Schimper die ersten Versuche, um die Einwirkung des Kalkes auf die äußere Gestalt der Pflanzen sicher zu ergründen. Beobachtungen im Freien sind von mehreren Forschern ausgeführt worden, so von Fliche und Grandeau $)$.

Kerner fand folgendes:

1. Die Kalkpflanzen sind stärker und dichter behaart; oft sind sie weiß- oder graufilzig, während ihre Parallelformen drüsenhaarig sind.

2. Die Kalkpflanzen haben oft blaugrüne Blätter, die anderen grasgrüne Blätter.

3. Die Kalkpflanzen haben Blätter, die mehr und tiefer geteilt sind.

4. Sind die Blätter bei den Kalkpflanzen ganzrandig, so sind sie bei den anderen nicht selten drüsig-sägezähnig.

5. Die Kalkpflanzen haben größere Korollen und

6. meist mattere und hellere Blüten.

Hossaeus ${ }^{5}$ ) hat auf tropischen Karrenfeldern noch an den Kalkpflanzen starkes Verholzen, reduzierte Blattflächen, Knospen mit Schutzblättern, verdickte Wurzeln usw. beobachtet, an Stellen mit Baumwuchs starke Verästelung mit schirmförmigem Wuchs, Sukkulenz usw.

Wenn auch die Eigentümlichkeiten der Kalkflora klar und deutlich sind, hat man doch früher den Einfluß des Kalkes auf die Vegetation überschätzt. Man hat sich nicht damit begnügt, empirisch die vorzugsweise auf Kalk und die vorzugsweise auf Kieselböden wachsenden Pflanzen festzustellen, sondern man unterschied sogar zwischen kalkliebenden und kalkfeindlichen Pflanzen ${ }^{6}$ ). Neuerdings ist nun als zweifel-

$\left.{ }^{1}\right)$ Blytt bezweifelt, daß die norwegische Woodsia glabella die Dolomitform von W. hyperborea sei; sie kommt auch auf Schiefer, nicht nur auf Dolomit vor.

2) Mac Cool 1913.

3) Bonnier 1894.

4) Vergl. Schimper 1898.

s) Hossaeus 1911.

6) Sendtner 1860; Contejean 1881; vergl. auch Magnier 1904; Grafe u. Portheim 1906. 
los festgestellt, daß der Kalkgehalt an sich (soweit er nicht etwa physikalisch wirkt) allein nicht die Ursache der Versehiedenheiten der Flora sein kann, denn es lassen sich nicht nur die meisten Kalkpflanzen in kalkarmem Boden kultivieren, sondern die Kieselpflanzen, sogar die meisten der ganz besonders kalkfeindlichen Sphagna wachsen üppig in reinem Kalkwasser (Kreide usw. ${ }^{1}$ ), wenn das Wasser sonst arm ist an gelösten Salzen.

H. Paul ${ }^{2}$ ) hat neuerdings die Frage der Kalkfeindlichkeit der Torfmoose experimentell gründlich geprüft, und hat dabei gefunden, daß die Sphagna fast alle selbst gegen geringe Mengen von gelöstem kohlensaurem Kalk sehr empfindlich sind, $\mathrm{da} ß$ sie in irgendwie konzentrierten Lösungen abstarben. Er fand die Wald- und Flachmoorarten weniger empfindlich. Ist der Kalk dagegen als schwefelsaures Salz vorhanden, so schadet er nicht, Gips war selbst in gesättigter Lösung absolut unschädlich. Die Torfmoose namentlich der Heidemoore reagieren stark saner und der Verlust der Säure durch den kohlensauren Kalk ist anscheinend die Ursache für das Absterben.

Man hat vielfach übersehen, daß fast alle Kalkböden reich sind an löslichen Mineralstoffen, und dieser Reichtum schließt die Pflanzen nährstoffarmer Böden aus, dazu kommen die wichtigen physikalischen Figenschaften der Kalkböden gegenüber den Kieselböden. Ist das von den Wurzeln aufzusaugende Wasser nährstoffarm (etwa nur 1-3 Teile Salze auf 100000 Teile Wasser) ${ }^{3}$ ), so kann der Boden selbstredend nur eine Vegetation mit geringer jährlicher Stoffproduktion tragen (etwa Heide usw.), auch wenn noch so viel Wasser vorhanden ist. Ist er dagegen nährstoffreich, wird er kräftige Pflanzen tragen: Wälder, wenn stets genug Wasser vorhanden ist, Steppen und Wüsten, wenn das nährstoffreiche Wasser den Pflanzen nur kurze Zeit zur Verfügung steht. Der höhere und geringere Nährstoffgehalt des Bodens ist es, der, günstige klimatische und Feuchtigkeitsverhältnisse vorausgesetzt, in allen Gebieten der Erde die Grundverschiedenheit der Pflanzenvereine ausmacht. Die Heiden der ganzen Welt sind alle, ob sie aus Ericaceen oder anderen Familien gebildet werden, an nährstoffarmen Boden gebunden; mit ihnen zusammen haben wir überall Heidemoore (Hochmoore, im Norden Tundren), die sich nur durch größeren Wasserreichtum unterscheiden. Beide, die häufig eine Menge identischer Pflanzen tragen, zu trennen, weil das eine naß, das andere trocken ist, wäre unnatürlich. Ebenso ist der tropische Wald dem unseren analog, nur modifiziert durch das Klima. Die Steppen der ganzen Welt sind wohl fast alle, wie auch die

$\left.{ }^{1}\right)$ C. A. Weber 1900; Graebner 1901; Kritik bei Clements 1904; H. Paul 1906.

2) Paul 1906 ff.

3) Ramann 1895, 1905. 
Wüsten, nährstoffreiche Gebiete, denen zu großer Stoffproduktion (Wald) nur das Wasser fehlt; erhalten sie Wasser, bewachsen sie üppig (Koopmann), wenn nicht etwa dadurch, daß sie Jahrhunderte lang als Steppe lagen, eine übermäßige Anreicherung von Salzen (besonders Kochsalz) stattgefunden hat. Will man also, wie dies neuerdings vielfach angestrebt, aber wohl unmöglich erreicht wird, ein einheitliches (dabei auch natürliches) System der Pflanzenvereine aufstellen, würde es nach Graebner das Haupteinteilungsprinzip der Nährstoffgehalt des Bodens resp., was auf dasselbe hinausläuft, die tatsächlich in einem bestimmten Zeitraum (Vegetationsperiode) von den Pflanzen aufnehmbare und verwertbare Nährstoffmenge sein zu müssen; vom praktischen Standpunkte muß man aber den Feuchtigkeitsgehalt in den Vordergrund stellen, schon weil er sich im ganzen leichter konstatieren läßt, als der Nährstoffgehalt. Die sich aus den Ernährungsverhältnissen ergebenden Gruppen von Pflanzenvereinen sind natürliche, die meist über die ganze Erde verbreitet, aus einer Reihe ökologisch, tatsächlich nahe verwandter Vereine gebildet werden, die durch das Klima, die geologische Vorgeschichte und lokal durch die physikalischen Eigenschaften des Substrates modifiziert erscheinen. - Graebner ${ }^{1}$ ) hat versucht, ein solches System für Norddeutschland aufzustellen, welches in erweiterter Form im 37. Kapitel des dritten Abschnittes aufgeführt ist. Für Warming sind die Feuchtigkeitsverhältnisse der Luft und des Bodens sowohl zur Pflanzenform als für ein natürliches System der Vereine in erster Linie maßgebend.

Geographische Bedeutung. Die für alle höheren Pflanzen notwendigen Nahrungsstoffe finden sich, wenn man gewisse Böden ausnimmt, (z. B. Quarzsand besonders der Heiden, Heidehumus und Heidetorf, Heidegewässer) fast in den meisten Böden in so großer Menge, daß hierin kein Hindernis dafür bestehen würde, daß jede Art fast überall auf der Erde wachsen könnte. Es muß daran erinnert werden, daß, selbst wenn ein Stoff im Nährboden in sehr geringer Menge vorhanden ist, manche Pflanzen, für die er notwendig ist, doch große Mengen von ihm aufnehmen können; z. B. sammeln die Fucus-Arten sehr viel Jod an, obgleich das Meereswasser nur äußerst wenig davon enthält. Die Pflanze hat ein gewisses quantitatives Wahlvermögen, indem sie die verschiedenen Stoffe in einem anderen Verhältnis aufnimmt als in dem, worin sie im Nährboden vorkommen. Es gibt indessen Stoffe, die bei gewissen Pflanzen wie Gifte wirken und sie von den Standorten ausschließen, wo sie im Boden in größerer Menge auftreten. Dies versteht man leicht, wenn man sich daran erinnert, daß die Pflanzen doch nur bis

2) Graebner 1898, 1901, 1902, 1908, 1910 . 
zu einem gewissen Grade ihre Nahrung wählen können ${ }^{1}$ ). In je größerer Menge sich ein Stoff im Boden findet, desto mehr nehmen die Pflanzen in der Regel von ihm auf; und jedenfalls können Stoffe, die in geringer Menge nützlich oder sogar notwendig wären, in zu großer Menge aufgenommen werden und Gifte werden. Solche Stoffe sind namentlich Kochsalz und Eisenoxydulsalze. Übrigens herrscht hier eine gewisse Freiheit, indem dieselbe Art die verschiedenen Nahrungsstoffe auf verschiedenem Boden in abweichenden Mengeverhältnissen aufnimmt. Individuen derselben Art enthalten auf Granitboden viel Kieselsïure, auf Kalkboden viel Kalk. Endlich sei bemerkt, daß gewisse Stoffe einander teilweise ersetzen können, z. B. Kalk und Magnesia.

Es hat ferner große Bedeutung für das Zusammenleben der Pflanzen, daß jede Art ihre uns fast unbekannten Haushaltungseigentümlichkeiten hat, indem sie, je nach ihrer chemisch-physiologischen Tätigkeit und den Eigentümlichkeiten ihres Wurzelsystemes, die Stoffe in einem anderen Mengenverhältnis aufnimmt als andere Arten. Für das Zusammenleben der Arten ist es auch wichtig, daß die Stoffe nicht mit derselben Geschwindigkeit und zu derselben Zeit oder auf derselben Entwicklungsstufe der Individuen aufgenommen werden (vergl. Liebscher). Dieses ermöglicht es vielen Arten, auf demselben Boden nebeneinander zusammenzuleben, ohne daß ein Nahrungswettbewerb eintritt. Hierauf beruht auch teilweise die Fruchtwechselwirtschaft.

\section{Kap. Die Bodenarten}

Nach der verschiedenen Beschaffenheit des Bodens können folgende Hauptarten des Bodens aufgestellt werden: Felsenboden, Sandboden, Kalkboden, Salzboden, Tonboden, Humusboden, die alle natürlich durch allmähliche Übergänge und zahllose Mittelglieder miteinander verbunden sind, so daß eigentlich eine Unzahl von Bodenformen mit mannigfaltigen Eigenschaften vorkommt ${ }^{2}$ ). Da die genannten Bodenarten äußerst abweichende Eigenschaften haben und daher ökologisch sehr verschiedene Vereine tragen müssen, sollen sie hier kurz gekennzeichnet werden.

1. Felsenboden. Hier ist die Natur des Gesteines dafür bestimmend, welche Vegetation sich auf ihm entwickeln und welchen Grad der Üppigkeit und des Artenreichtums sie erreichen kanu. Worauf es ankommt, sind die Unterschiede in der Härte, der Porosität, der Erwärmungs- und der Wärmeleitungsfähigkeit, dann aber auch der Grad

1) Vergl. auch Hansteen 1909-1912; Treitz b.

2) Ramann 1905; über die Verbreitung, den Ursprung, die Eigenschaften und Anwendung der Mittelschwedischen Böden vergl. G. Andersson u. H. Hesselman 1910. 
der Verwitterungsfähigkeit ${ }^{1}$ ). Die wichtigsten Gesteinsarten sind: Granit, Gneis, Kalkstein, Dolomit, Sandstein, Tonschiefer, Basalt u. a. ${ }^{2}$ ).

Physiologisch ganz ähnlich wie Felsboden wirken die Stämme, Äste und Blätter der Gehölze, auf denen Epiphyten wachsen; auch sie leben neben dem atmosphärischen Staube im wesentlichen von den Verwitterungsprodukten der Rinde usw. - Über die Epiphyten vergl. sonst Kapitel 35.

2. Sandboden. Sand besteht aus mindestens $80 \%$ lose liegenden Körnern verschiedener Minerale, meistens von Quarz, aber auch von Feldspat, Hornblende, Glimmer, bisweilen auch von Kalk, z. B. im Korallensande, von vulkanischen Produkten usw. Der Nährwert des Sandbodens ist nach der chemischen Beschaffenheit der Körner verschieden; reiner Quarzsand ist unfruchtbar, weil die Quarzkörner nicht verwittern und auch nicht als Nahrung dienen können; Sande mit Kalk, Glimmer, Feldspat u. a. Mineralien haben größeren Nährwert. Humus bildet sich in trockenem und losem Sandboden schwierig, weil die organischen Teile in ihm leicht zersetzt und beim Zutritte der Luft oxydiert werden. Ferner hat Sand, namentlich Quarzsand, die häufigste Art von Sand, geringes Absorptionsvermögen und kann nur sehr wenig Wasserdampf aus der Luft absorbieren.

Nach Ramann ${ }^{3}$ ) teilt man die Sande, die gegenüber den gröberen Böden, wie Kies und Grus, zu den Feinerden (mit weniger als $2 \mathrm{~mm}$ Durchmesser der Körner) gerechnet werden, folgendermaßen ein:

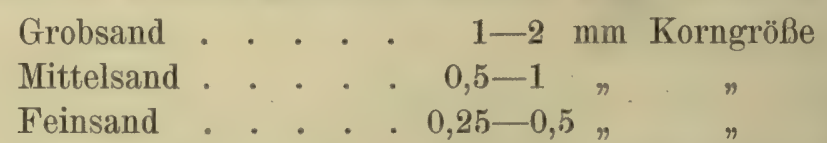

Zum Unterschied von den noch feineren Feinerden (Staub und Schlamm) fällt Sand im Wasser rasch nieder.

Sandboden ist loser Boden, weil die Körner wenig Bindigkeit haben, desto weniger, je größer sie sind. Die Niederschläge sickern in Sand leicht ein, desto leichter, je grobkörniger er ist. Im allgemeinen ist der Wassergehalt des Sandes gering; er hält um so weniger Wasser zurück, je grobkörniger er ist (ca. 3-30\%). Das Vermögen des Sandes, aus dem Untergrunde Wasser aufzusaugen, ist in der Regel sehr gering; das Wasser wird in der Regel höchstens $1 / 3 \mathrm{~m}$ gehoben.

Sand trocknet in der Regel sehr schnell aus und erwärmt sich daher in der Sonne sehr schnell und stark, kühlt sich aber auch nachts sehr schnell und stark ab. Flugsanddünen sind gewöhnlich von einer

1) Vergl. Treitz (a).

2) Vergl. auch Abschnitt 4, die lithophile Vegetation.

a) Ramann 1905, S. 216. 
trockenen und im Sonnenscheine sich stark erwärmenden Sandschicht von nur geringer Mächtigkeit ${ }^{1}$ ) bedeckt; aber diese Schicht hemmt die Verdunstung aus dem darunter liegenden Sande, der sich daher feucht und kühl hält: ein für das Verständnis der Dünenvegetation sehr wichtiges Verhältnis. Nach Livingston ${ }^{2}$ ) scheint in den Wüsten von Arizona eine oberflächlich lagernde, staubförmige Schicht ähnlich zu wirken. Der Unterschied zwischen der Tag- und der Nachttemperatur kann sehr groß sein $\left(40-45^{\circ} \mathrm{C}\right.$.). Sand wird daher nachts leicht und stark betaut, was für seinen Wassergehalt und seine Vegetation sehr wichtig ist. Andererseits leiden Pflanzen auf Sandboden leichter durch Frost. Die Sandflora entwickelt sich früh. - Gewöhnlich auf Sand wachsende Pflanzen werden als Psammophyten oder Psammophile bezeichnet ${ }^{3}$ ).

3. Kalkboden. Kalksand (Sand aus kohlensaurem Kalk) ist minder nahrungsarm als Quarzsand, hat eine etwas größere Wasserkapazität und trocknet weniger leicht aus, ist aber doch trocken und warm. Mergel ist ein inniges Gemisch von kohlensaurem Kalk (ca. 8-45\%, bei Kalkmergel bis ca. $75 \%$ ) mit Ton (ca. 8-60\%) und Quarzsand (unterer Diluvialmergel aus der Mark Brandenburg z. B. enthält 12 bis $18 \%$ kohlensauren Kalk, 25-47\% T'on, 38-62\% Sand); seine Eigenschaften hängen von dem Mengenverhältnis der Teile ab und stehen im allgemeinen zwischen denen von Sand und Ton ${ }^{4}$ ).

4. Tonboden bildet fast einen Gegensatz zu Sandboden. Die für das bloße Auge unsichtbaren, abschlämmbaren Teilchen überwiegen die körnigen. Der Ton besteht hauptsächlich (mindestens $65 \%$ ) aus Kaolin (wasserhaltiges Tonerdesilikat) und kann mehr oder weniger feinen Quarzsand, kohlensauren Kalk, Eisenoxyd usw. enthalten. Kaolin ist keine Nahrung für Pflanzen; aber durch viele andere Stoffe kann der Inhalt des Tones an Nahrungsstoffen sehr groß werden; diese sind jedoch schwer zugänglich. In günstiger Mischung mit Sand, Kalk und Humus ist Tonboden ein fruchtbarer Boden.

Tonboden hat ein großes Absorptionsvermögen und ist zugleich sehr hygroskopisch (kann 5-6\% Wasserdampf aus der Luft absorbieren).

Tonboden ist ein fester oder schwerer Boden, weil die Teile große Bindigkeit haben; die Durchlüftung ist meist schwierig, was für die Vegetation ungünstig ist und zur Säurebildung und zur Versumpfung führt.

1) Meist wenige Centimeter bis höchstens ein Decimeter.

2) Livingston 1906 .

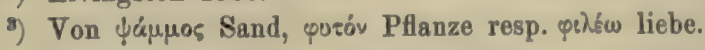

4) Vergl. Kraus 1911; Crampton 1912. 
Tonboden ist ein nasser und kalter Boden, weil er 1. große Kapazität (bis $90 \%$ ) und 2. große Kapillarität besitzt; er saugt aus dem Untergrunde viel Wasser auf und ist für Wasser fast undurchlässig. Übersättigt man ihn mit Wasser, so quillt er, sein Volumen wird größer und die einzelnen Tonteilchen drängen sich auseinander, so daß ein Brei entsteht. Wasserreicher Tonboden ist plastisch. Durch lange Trockenheit wird Tonboden steinhart, zieht sich zusammen und erhält Risse, was auf seine Vegetation einwirkt (vergl. S. 78).

Die ungünstigen Eigenschaften des Tones werden durch Mischen mit Stoffen von entgegengesetzten Eigenschaften, z. B. mit Sand und Kalk, aufgehoben.

Lehm kann dem Ton angereiht werden und ist ein Gemisch von Sand und tonigen Bestandteilen. Er kann aus verschiedenen Felsarten durch Verwitterung hervorgehen. Oft ist er ein Verwitterungsprodukt von Geschiebemergel, dessen kohlensaurer Kalk durch kohlensäurehaltiges Wasser mehr oder weniger vollständig ausgewaschen ist und dessen Eisenoxydulverbindungen in Oxyde und Hydroxyde übergeführt sind; der Boden wird dadurch braun und enthält wesentlich Ton und Quarzsand (Knoblauch).

Laterit ist ein mehr oder. weniger mit Eisenhydroxyd gemischtes Tonerdehydrat, welches in tropischen Gebieten durch Verwitterung und Auslaugung durch vielen und kohlensäurehaltigen Regen zustande kommt. Je nach dem Charakter des Ursprungsgesteines unterscheidet man Gneis-, Granit-, Quarzlaterit u. v. a. Während ursprünglich nur gewisse ostindische Verwitterungserden als Laterit (Buchanan 1807) bezeichnet wurden, ist der Begriff jetzt sehr stark erweitert. Lateritlehm und Lateritton spielt besonders in den tropischen Savannen und Campos eine große Rolle ${ }^{1}$ ).

5. Humus ${ }^{2}$ ) wird von den Resten und Abfällen der Pflanzen und Tiere, oft besonders von tierischen Exkrementen in allen Zersetzungszuständen gebildet, wenn der Sauerstoffzutritt in irgend einer Weise gehemmt wird. Ist genügend Sauerstoff vorhanden, so entsteht kein Humus (lockere Sandböden, viele Böden der Tropen). Humus ist schwarz oder braun und reich an Kohlenstoff, teilweise auch an Stickstoff (Rußlands Tschernosem oder "schwarze Erde" enthält nach Kostytchew sogar 4-6\% Stickstoff). Bei seiner Bildung spielen teils Mikroorganismen (Bakterien, Moneren u. a.), teils größere Tiere, namentlich Regenwürmer, eine große Rolle; reichliche Pilzvegetation verhindert oder hemmt die

1) Vergl. Wohltmann 1892; 0. Lenz.

2) Vergl. C. A. Weber 1903; Früh u. Schröter 1904; über die Humusablagerungen in den Central- und Kalkalpen siehe von Leiningen 1908, 1912. 
Humusbildung (Otto). - Der Humus findet sich in allen Mischungsverhältnissen im Boden (Humuserden).

Humusstoffe gehen mit schwer löslichen Pflanzennahrungsstoffen leicht lösliche Verbindungen ein und rerbessern dadurch den Nährwert des Bodens wesentlich. Sie verändern auch die physikalischen Eigenschaften des Bodens, wenn sie mit mineralischem Boden gemischt sind, erhöhen sein Absorptionsvermögen, seine Wärmekapazität, seine Wasserkapazität u. a. Durch die letztere besonders wird der jeweilige Wassergehalt des Bodens ungeheuer stark beeinflußt. Wie groß dieser Einfluß auf die Bildung der Pflanzenvereine ist, geht am besten daraus hervor, daß oft nur durch Auftragen von Humus (Kompost usw.) baumlose, sonnige Hügel in Wälder, Obstgäirten usw. verwandelt werden können.

Es bestehen große Cnterschiede zwischen den Humusböden je nach dem Grade der Zersetzung und nach den humusbildenden Pflanzen- und Tierarten. Die zalllreichen, z. T. für die praktische Benutzbarkeit außerordentlich verschiedenartigen Humusablagerungen haben im Laufe der Jahrzehnte eine sehr verschiedene und oft irreführende Bezeichnung erfahren. Potonié ${ }^{1}$ ) ist es deshalb als großes Verdienst anzurechnen, daß er eine wissenschaftliche Gliederung angestrebt hat, die auch zu einer einheitlichen Nomenklatur führen soll.

Von den verschiedenen Formen, worunter die Humusbildung vor sich geht, besprechen wir zuerst den an Humus reichsten Boden, nämlich den

A. Torfboden. Kommt sauerstoffhaltiges Wasser mit organischen Stoffen in Berührung, so wird ihm hierdurch sein Sanerstoff entzogen. Wird dann der Zutritt von Sauerstoff verhindert und wird die Arbeit der kleinen Tiere und Pflanzen ausgeschlossen, so geht in vielen Fällen eine unvollständige Zersetzung und Umbildung der organischen Reste vor sich; die Folge wird sein, daß Kohlenstoff angehäuft wird, desto mehr, je mehr die Luft abgeschlossen ist. Überall, wo organische Sul-stanz gezwungen ist, sich unter Luftalschluß zu zersetzen, entstehen freie Säuren, in diesem Falle bilden sich sogenannte Humussäuren (Colloidstoffe von saurem Charakter): es entsteht Torf. Der Wärmegrad des Wassers ist für die Torfbildung von Bedeutung: er darf weder zu hoch noch zu niedrig sein; die Torfbildung findet sich daher besonders in gemäßBigten und kalten Gegenden. Der Torf ist ein an Kohlenstoff reicher, brauner (hell- bis schwarzbrauner) Humus, der viele freie "Humussäuren" und andere Säuren hat, die die im Torfe begrabenen Reste von Organismen erhalten. Durch Entwässerung und Durchlüftung kann Torf in Humus verwandelt werden, der für Pflanzen gut ist. Torf enthält 1 bis 2 (bis 3$)^{\%} \%$ Stickstoff und 0 bis $4 \%$ Kalk

1) Vergl. besonders Potonié 1906, 1908, 1911. 
(gewisse, z. B. gotländische Moore haben angeblich bis $3,21 \%$ Stickstoff und auch viel Kalk), enthält aber sehr wenig Kali und noch weniger Phosphorsäure. Daß sich von diesen wichtigen Pflanzennahrungsstoffen so wenig findet, rührt daher, daß die Säuren des Torfes mit Alkalien lösliche Salze bilden, die ausgewaschen werden $\left.{ }^{1}\right)$. Je nach der Herkunft des Torfes und der Pflanzenzusammensetzung desjenigen Vereines, aus dem er seinen Ursprung nahm, sind die physikalischen und chemischen Eigenschaften sehr verschieden ${ }^{2}$ ).

Torfboden hat folgende Eigenschaften. Er hat von allen Böden die größte Wasserkapazität, so daß er vielmal mehr Wasser aufnehmen kann, als seine festen Teile wiegen; lufttrockner Torf hat nur $15-20 \%$ Wasser. Torf quillt durch Wasserzufuhr zu einem weit größeren Volumen auf, schrumpft aber durch Austrocknen ein und erhält Risse. Wenn er ganz ausgetrocknet ist, wird er öfter außerordentlich lose, fast staubförmig (Torfmull; mit den Mullwehen ist der Flugsand zu vergleichen). Setzt man die Bindigkeit des Tones zu 100, so ist die des Torfes nur 9. Er ist für Wasser fast undurchlässig, und sein Wasserhebungsvermögen ist größer als bei allen anderen Bodenarten. Er ist stark hygroskopisch (nimmt bis zu 10\% Wasserdampf auf). In bezug auf die Wasserleitung verhalten sich die Torfe (z. B. von Heide- und Wiesenmooren) sehr verschieden. Heidetorf, in erster Linie Sphagnumtorf, leitet das Wasser leicht, ist deshalb überall gleichmäßig feucht; Wiesentorf kann oben trocken, unten naß sein.

Wegen seiner dunkeln Farbe wird Torf von der Sonne stark erwärmt, aber umgekehrt nachts stark abgekühlt. Trotz seiner dunkeln Farbe ist Torfboden ein kalter Boden, weil er gewöhnlich wasserreich ist.

Salpeterbildende und viele andere Bakterien des alkalisch reagierenden Bodens können in Torfboden wegen seines Säuregehaltes nicht gedeihen, trotzdem ist die Zahl der Bakterien nach Dachnowsky in den obern Schichten des Torfes sehr groß; sie spielen bei der Bildung des Torfes eine nicht zu unterschätzende Rolle. Jeder Pflanzenverein hat seine eigene Bakterienflora. Näheres über Torfboden im 4. Abschnitte. Genaue Torfuntersuchungen sind neuerdings von Dachnowsky ${ }^{3}$ ) ausgeführt worden.

B. Rohhumus (Trockentorf; dänisch Mor, mit kurzem o) ist "eine Torfbildung auf dem Trocknen"4), eine schwarze oder schwarzbraune, torfartige Masse, die von dicht verfilzten Pflanzenresten, nämlich von Wurzeln, Rhizomen, Blättern, Moosen, Pilzhyphen u. a. gebildet wird.

1) Vergl. auch v. Leiningen 1912.

2) Zailer und Wilk 1907.

3) Dachnowsky 1908, 1909, 1912.

4) P. E. Müller 1878, 1884 . Deutsche Ansgabe 1887 a, S. 45. 
Nach der Hauptmasse der Bestandteile spricht man von Heide (Calluna)rohhumus, Moosrohhumus, Buchenrohhumus, Fichtenrohhumus, Tannenrohhumus, Eichenrohhumus, Kiefernrohhumus ${ }^{1}$ ) usw. P. E. Müller ${ }^{2}$ ) spricht in der deutschen Ausgabe seiner Studien von Heidetorf, Buchentorf, Eichentorf (vergl. auch Grebe) ${ }^{3}$ ). Besonders gewisse Pflanzenarten bilden Rohhumus, weil sie sehr dünne, zahlreiche und stark verzweigte Wurzeln (oder Rhizoiden) ausbilden, die gerade an der Bodenoberfläche liegen und die Pflanzenreste in einen dichten Filz verweben; solche Arten sind z. B. Rotbuche, Calluna, Vaccinium myrtillus, Picea excelsa. Die meisten dieser Pflanzen besitzen Mykorrhizen, die sicher die Verfilzung befördern. Der Rohhumus kann an Pflanzenteilen so reich sein, daß er zur Feuerung gebraucht werden kann (Heidetorf); er kann $50-60 \%$ organische Teile enthalten. Da er über dem Boden einen so dichten, zähen Filz bildet, schließt es einerseits von den darunter liegenden Schichten die Luft (den Sauerstoff) ab und saugt anderseits Wasser begierig wie ein Schwamm ein und hält es mit großer Kraft fest (in unseren regnerischen Klimaten ist er oft einen großen Teil des Jahres naß). Daher werden in ihm wie im Torfe Humussäuren $\mathbf{n}^{\mathbf{4}}$ ) reichlich gebildet. Er reagiert wie Torf sauer. Es finden sich in ihm nur wenige Tiere, meistens Rhizopoden und Anguilluliden, aber keine Regenwürmer. Rohhumus tritt im Walde besonders an den dem Winde ausgesetzten Stellen auf ${ }^{5}$ ), während sich der gewöhnliche Humus mit seinen Regenwürmern und anderen Tieren an die frischen und geschützten Stellen hält; wenn gewöhnlicher Humus in einem Buchenwalde durch ungünstiges Holzfällen und ähnliches in Rohhumus übergegangen ist, so kann sich die Buche nicht weiter verjüngen, sie verschwindet und macht in vielen Fällen der Calluna-Heide Platz ${ }^{6}$ )

Die Entstehung des Rohhumus wird durch niedrige Temperaturen befördert, namentlich, wenn diese zugleich mit feuchter Witterung eintreten ${ }^{7}$ ); daher die Zunahme der Rohhumusbildungen in den feuchten maritimen Klimaten (mit nassen Wintern) und in den arktischen Regionen und Hochgebirgen.

Das Wesen der sogenannten Humussäuren ist noch lange nicht aufgeklärt, die chemische Struktur ist nur bei wenigen einfacher gebauten bekannt, von denen nicht sicher ist, ob sie in dieser Form einen wesentlichen Anteil in der Natur bilden. Die neuere Chemie der

1) Vergl. Möller 1908.

2) P. E. Müller 1887.

3) Grebe 1896; Graebner 1909; Potonié 1906-11.

4) Süchting 1912 .

5) Emeis 1907, 1910; P. E. Müller a. a. O.

8) P. E. Müller 1887; Graebner 1895-1910.

T) Ramann 1886, 1905, 1911. 
Kolloiden scheint die älteren Ansichten über die Natur der Humusstoffe vollständig umzugestalten. Die ungeheuer leichte Zersetzbarkeit derselben erschwert alle Untersuchungen sehr. Selbst die Untersuchung des physikalischen Verhaltens hat vielfach zu keinen zweifellosen Resultaten geführt; so spricht sich Blanck ${ }^{1}$ ) z. B. dahin aus, daß die Diffusionsfähigkeit der Salzlösungen in sauren Böden mindestens sehr stark herabgesetzt ist. Dem widerspricht Minssen ${ }^{2}$ ) sehr energisch. Daß die Aufnahmefähigkeit der Wurzeln in sauren Böden stark herabgesetzt wird, dafür lassen sich zahllose Beobachtungen anbringen ${ }^{3}$ ).

Die Bildung einer Rohhumusschicht führt auch in der Beschaffenheit der darunter liegenden Bodenschichten große Veränderung herbei, die durch P. E. Müllers ${ }^{4}$ ) bahnbrechende Untersuchungen aus Dänemark am besten bekannt geworden und in ihren Hauptzügen folgende sind ${ }^{5}$ ):

Die mit Regenwasser aus dem Rohhumus in den darunterliegenden an löslichen Salzen armen ausgelaugten Sandboden hinabsickernden Humussäuren mit humussauren Verbindungen werden in Berührung mit sauerstoffreichen anorganischen (namentlich Eisenoxyd-) Verbindungen oxydiert, und es entstehen z. B. leicht lösliche Eisenoxydulsalze, die durch kohlensäurehaltiges Wasser aus den oberen Bodenschichten ausgewaschen werden. Dadurch werden diese entfärbt, verlieren fast ganz ihr Absorptionsvermögen, werden sehr nahrungsarm, und unter dem Rohhumus bildet sich hellgrauer oder schwarzer Bleisand ${ }^{6}$ ) (Heidesand, Bleichsand ${ }^{7}$ ). Durch Austrocknen des Rohhumus werden mehrere der ursprünglichen leicht löslichen Humusstoffe schwer löslich und als Humuskohle ausgeschieden.

Die Wasserbewegungen führen ferner Tonteilchen, Eisenoxyd und Humusteile, die nur in salzarmem Wasser löslich sind, weg und führen sie durch den an Salzen armen Bleisand hindurch in die Tiefe, wo sie an der unteren Grenze des ausgelaugten Bleisandes an die noch in Verwitterung begriffene, daher noch lösliche Salze enthaltenden Bodenteilchen kommen. Das Wasser nimmt Salze auf und die Humussäuren werden als gallertige Masse niedergeschlagen, die bei einem bestimmten Grade der Trockenheit wohl durch chemische Veränderung fest und in Wasser unlöslich werden. Die Sandkörner verkleben und es bildet sich

1) Blanck 1903; vergl. auch Ramann 1905, 1911.

2) Minssen 1905, 1907.

8) Süchting 1912.

4) P. E. Müller 1878, 1884, 1887.

$\left.{ }^{3}\right)$ Vergl. auch Ramann 1886, 1905̃; Warming 1896; Früh und Schröter 1904.

ๆ) Müller, Ramann, Graebner a. a. O.; Mayer 1903; Emeis 1908.

₹) Albert 1907; Leiningen 1911. 
die rotbraune oder braune Bodenschicht, die man Ortstein ${ }^{1}$ ) (oder Ahl, in Ostpreußen auch Kraulis, in Westfriesland Knick, englisch: hard-pan, moor-pan, französisch: alios; Fuchserde, Roterde, Branderde, wenn sie noch nicht steinartig hart ist), nennt, die etwa $1 / 2 \mathrm{~m}$ mächtig sein kann und die im fertigen Zustande für Pflanzenwurzeln undurchdringlich ist.

Der Übergang vom gewöhnlichen Humusboden zu Rohhumus wird dadurch hervorgerufen, daß

1. sich Pflanzen mit dicht verfilzten Wurzeln einfinden,

2. die Tiere, insbesondere die Regenwürmer, verschwinden, so daß der Boden nicht durchgearbeitet wird,

3. die Bodenteile, namentlich die Sandkörner, zusammensinken, wodurch der Boden fester und luftärmer wird.

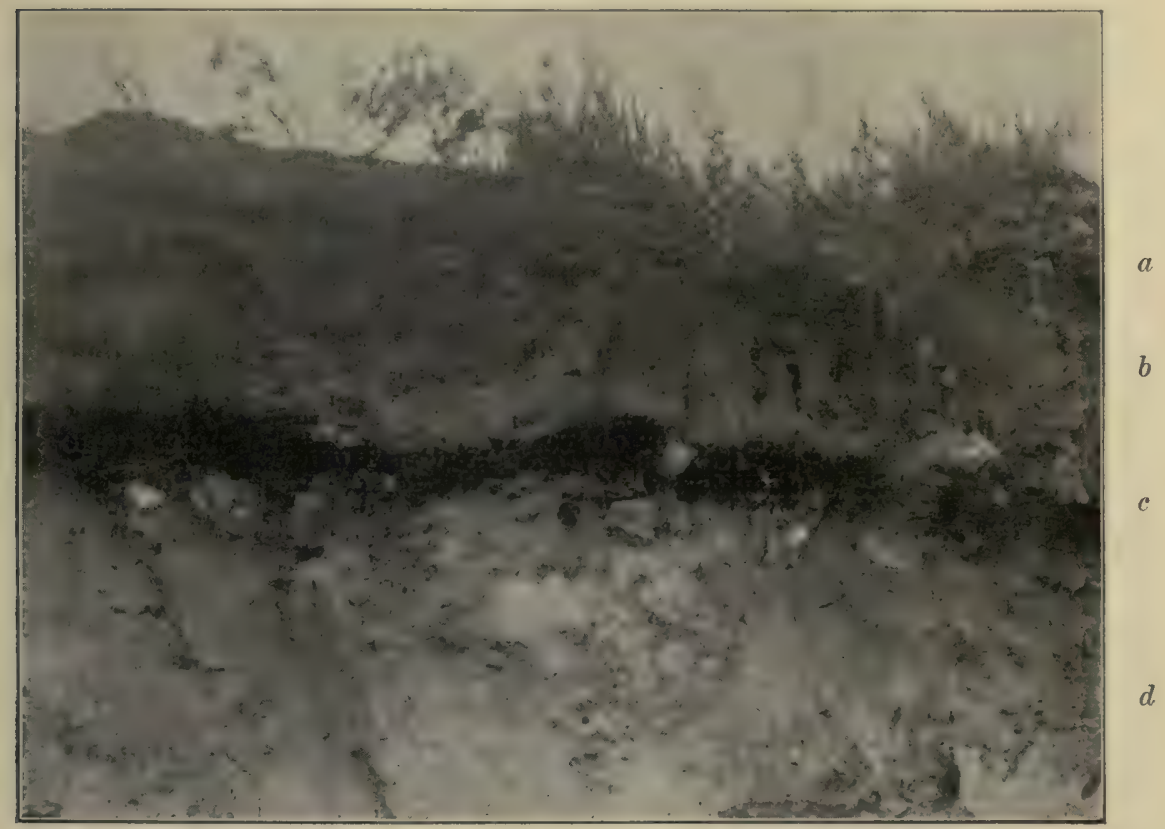

Fig. 44. Typisches Bodenprofil der Ortsteinheide.

$a$ Rohhumus; $b$ Bleisand; $c$ Ortstein; $d$ Gelber und darunter weißer Sand. Lüneburger Heide. (Graebner phot.)

C. Gewöhnlicher Humus (Waldhumus, Gartenhumus, milder Humus usw.; dänisch Muld; deutsch Mull) ist ein inniges Gemisch von Sand und Ton mit Humusstoffen $(8-10 \%)$, ein Gemisch, das größtenteils durch Tiere und Wasser entsteht (vergl. 17. Kap.). Er reagiert

1) Müller, Ramann, Graebner a. a. O.; Warming 1896; Emeis 1900, 1908, 1910; Mayer 1903; Münst; v. Leiningen 1908, 1912. 
fast stets neutral oder alkalisch. Er enthält reichlich Regenwürmer, Insekten, Pilzmyzelien (namentlich solche von Verwesungspilzen) usw. Daß Humusboden ein vorzüglicher Nährboden für Pflanzen ist, wird teils durch seine physikalischen Eigenschaften bewirkt (locker, krümelig, durchlüftet), teils durch seine chemischen, indem er viele Kohlenstoffund Stickstoffverbindungen enthält, teils durch den Umstand, daß die Humusstoffe mit sonst schwer löslichen Nahrungsstoffen leicht lösliche Verbindungen eingehen. Die Humusbildung in den Wäldern vertritt z. T. das Düngen und die Bodenbearbeitung des Ackerbaues.

Faktoren, die die Verwesung der organischen Substanz befördern, hindern die Humusbildung; nach Wollny sind die Wärme und Feuchtigkeit von größter Wichtigkeit. Wie bei allen physiologischen Prozessen gibt es hier ein Minimum, ein Optimum und ein Maximum. Temperaturen über dem Maximum sind kaum von irgendwelcher Wichtigkeit. Das Wasser verdrängt mit seiner Zunahme immer mehr die Luft aus den stärker wasserhaltenden und dichteren Böden wie Lehm und Hunus und wird deshalb eine Zunahme der hemmenden Wirkung auf die Verwesung organischer Substanz, also eine Zunahme der Humusbildung bewirken und zwar selbst dann schon energisch, wenn der Boden noch nicht mit Wasser gesättigt ist.

Sonne und Wind verhindern die Humusbildung, obwohl sie bei einmal vorhandenem Humus seine Verdichtung zu Rohhumus stark befördern können (s. S. 111). Die Humusstoffe verschwinden aus dem Boden durch Wärme, Licht und Sauerstoff; der Kohlenstoff wird zu Kohlensäure, der Stickstoff zu Salpetersäure ${ }^{1}$ ) usw., der Wasserstoff zu Wasser oxydiert.

In niedrigen Breiten geht die Verwesung in den trockenen Jahreszeiten außerordendlich langsam vor sich, zu feuchten Zeiten dagegen ist sie sehr beschleunigt; in den meisten Gebieten ist sie dort so ausgiebig, daß nur ein sehr humusarmer Boden ${ }^{2}$ ) übrig bleibt. In den Tropen und subtropischen Gebieten befindet sich daher eigentlicher Humusboden nur in schattigen Wäldern ${ }^{3}$ ). Torfboden ist sehr selten, aber er kommt dort vor, wo das Klima genügend feucht ist ${ }^{4}$ ); typische Moore fehlen ${ }^{5}$ ).

In Steppen und Wüsten ist der Boden gleichfalls meist arm an Humus, weil die Pflanzen recht spärlich sind, auch wenn der Boden zeitweise feucht genug ist. Nur in dicht bewachsenen Grassteppen ist öfter

1) Utber das Vorkommen und die Bildung von Salpetersäure im Wald und Heideboden vergl. Weiss 1910.

2) Hilgard 1892.

3) Warming 1892; Vahl 1904 b.

4) Ule 1901.

\$) Vergl. Früh und Schröter 1904 S. 143. 
reichlich Humus (Schwarzerde, Tschernosem in Rußland) gebildet, besonders auf den dicht gelagerten LüßBböden ${ }^{1}$ ).

In kühlen gemäßigten Ländern ist Humusboden häufig; nur an offenen der Sonne und dem Winde voll ausgesetzten Stellen, wie z. B. auf Dünen ist der Humus meist nur spärlich. Rohhumus (s. S. 89) ist überall dort häufig, wo durch irgend eine Ursache die Verwesung gehindert wird. Nach Ramann ${ }^{2}$ ) kann es Mangel an Nahrung, Luftabschluß, Überfluß oder Mangel an Wasser oder niedrige Temperatur

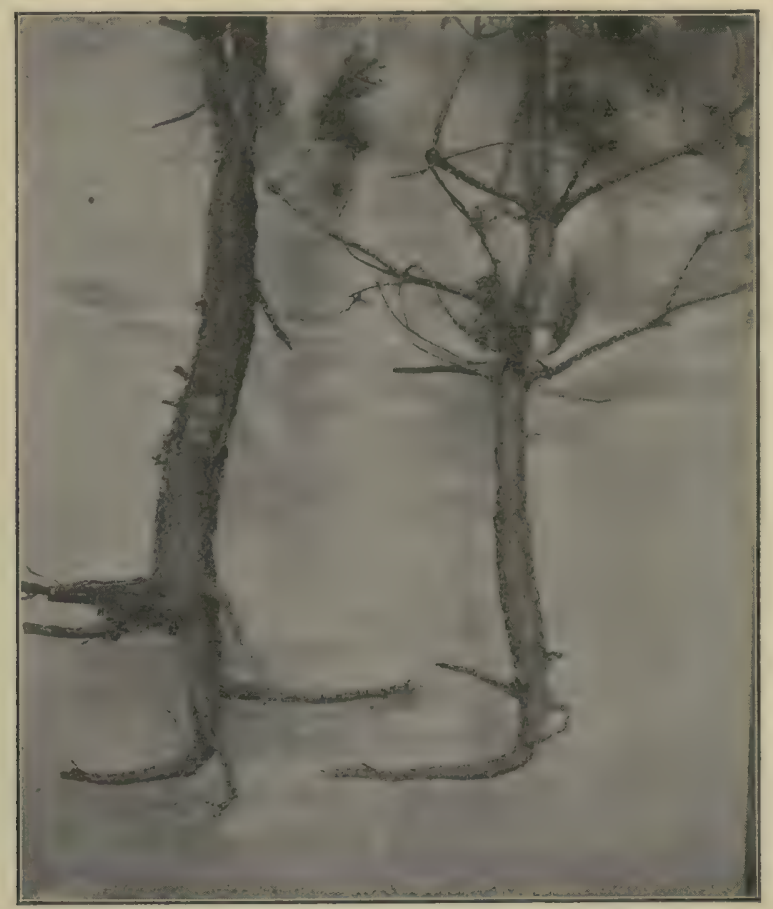

Fig. 45. Anflugkiefern auf Ortsteinboden; die Hauptwurzeln biegen auf den Ortstein wagerecht $a b$ und steigen später schräg auf (Graebner).

sein. Die Rohhumusformationen sind besonders in den Heidegebieten des atlantischen Klimas im westlichen Europa weit verbreitet, wo die Sommer kühl sind, ebenso sind sie sehr häufig in alpinen Lagen oder in arktischen Ländern $\left.{ }^{3}\right)$.

Verschiedene Pflanzenarten verlangen höchst verschiedenen Humusreichtum im Boden. Kerner hat die Pflanzen danach in drei Gruppen eingeteilt. Die erste Gruppe kann den nackten Fels, die ödeste Sand-

1) Albert 1907 .

2) Ramann 1893, 1895.

3) Kerner 1863; Warming 1887; Vahl 1913. 
oder Grusflur usw., wo es keine Spur Humus gibt, besiedeln (hierher z. B. die subglacialen Pflanzen, viele Tundrenpflanzen, Wüstenpflanzen u. a.); ihre Samen oder Sporen werden vorzugsweise vom Winde fortgeführt. Zur zweiten Gruppe gehören Pflanzen, die eine mittlere Menge Humus beanspruchen, wozu Kerner unter anderem einen Teil der Gramineen und Cyperaceen rechnet; und zur dritten Gruppe gehören Pflanzen, die nur in reichem Humus, in den Resten früherer Vegetation, gedeihen, nämlich viele Orchidaceen, Pirola- und Lycopodium-Arten, Azalea procumbens, Vaccinium uliginosum, mehrere andere Moorpflanzen, Halbsaprophyten und schließlich die stark umgebildeten Ganzsaprophyten (Monotropa, Neottia u. v. a.). Daß zwischen den ungewöhnlichen Formen der letzteren und ihrer Ernährungsweise, also zwischen ihren Formen und dem Boden, worauf sie leben, eine Korrelation besteht, dürfen wir als sicher ansehen; aber Näheres wissen wir nicht dårüber ${ }^{1}$ ).

Für Parasiten, die schmarotzend auf anderen lebenden Pflanzen wachsen und aus ihnen ihre Nahrung ziehen, kann der Körper der Wirtspflanze als das Substrat, als der Boden betrachtet werden, an den sie unbedingt gebunden sind (Loranthaceae, Cuscuta, Orobanche, parasitische Pilze usw.). Näheres vergl. Kap. 35.

6. Unter Wasser gebildete Böden (Schlamm). Im Meere werden feine Humusteilchen durch die Tätigkeit der blaugrünen und auch anderen Algen angehäuft und an den ruhigsten Buchten usw. niedergelegt; sie bilden z. B. die Grundlage für die fruchtbaren Marschen der Nord$\mathrm{see}^{2}$ ). Eine andere Art von Schlamm entsteht in Mangrovesümpfen. An vielen Buchten und an den Mündungen vieler Flüsse häufen sich Schlammassen an, die durch Eisensulfide tiefschwarz gefärbt sind; nach Beijerinck und van Delden ${ }^{3}$ ) spielen anaerobe Bakterien bei ihrer Bildung eine Rolle.

Im Süßwasser bilden sich zahlreiche andere Schlammformen. An den Flüssen werden von den herabgebrachten feinen Teilen recht verschiedene Formen abgelagert, je nach der Wasservegetation des betreffenden Flusses, seiner Strömungsgeschwindigkeit und der Zusammensetzung der durchströmten Bodenarten ; namentlich letztere bestimmen den geologischen Charakter des betr. Schlammes. - "Pollenschlamm" entsteht durch die Anhäufung des Pollens windblütiger Bäume, wie der Nadelhölzer, der Buchen usw. - Andere Ablagerungen werden durch chemische Prozesse bewirkt, die mehr oder weniger auf die Tätigkeit niederer Organismen zurückzuführen sind.

1) Für weitere Aufschlüsse über Torf vergleiche das große Werk von Früh und Schröter 1904.

2) Wesenberg-Lund und Warming 1904, Warming 1906, und 4. Abschnitt.

8) Beijerinck 1895; A. v. Delden 1903; Wesenberg-Lund und Warming 1904. 
Kohlensaurer Kalk spielt in der Zusammensetzung des Schlammes namentlich in größeren Teichen und Landseen eine große Rolle. An oder in vielen grünen Pflanzen (Potamogeton, Helodea, Characeae, gewissen Algen usw.) wird durch die Atmung dieser Gewächse kohlensaurer Kalk niedergeschlagen, der sich öfter schon während des Sommers in Krusten ablöst und zu Boden sinkt, sicher aber im Herbst mit dem Absterben dieser Pflanzenteile. Am Grunde des Gewässers reichert sich der kohlensaure Kalk entsprechend der Stärke der Verwesung (in sauerstoffreicherem Wasser) an, so daß der Schlamm mitunter bis über 80 oder gar $90 \%$ Kalk enthält.

Eisenverbindungen sind oft abgelagert und zwar mit oder ohne Tätigkeit von Bakterien, blangrünen Algen usw.

Eine ungemein große Rolle spielen die Schlammablagerungen in ruhigen Seen, in Teichen usw., wo sie namentlich die Verlandung befördern; sie entstehen durch die Überreste von Pflanzen und Tieren, die inı wesentlichen verfaulen (Faulschlamm, Sapropel; Potonié) und bilden sich vorzugsweise in den kühleren gemäßigten Zonen. Einige (in Skandinavien „Gytja“ genannte) sind strukturlose graue oder braune Massen, welche neben den Resten von Pflanzen und kleinen Tieren vielfach die mehr oder weniger gelösten resp. zersetzten Exkremente der Wassertiere enthalten. Nach Potonié enthalten sie eine große Menge fetten Öles. Einen sehr wichtigen Bestandteil für diesen Schlamm liefert das Plankton, besonders in sehr diatomeenreichen Seen. In anderen Fällen sind es vorzugsweise blaugrïne Algen oder die Chitinpanzer kleiner Süßwassertiere, die sich angehäuft finden. Die organischen Verbindungen all dieser Ablagerungen werden, ähnlich wie die des Humus und Torfes überhaupt, reduziert; die Gytja ist eine Art Humusbildung unter Wasser. In größeren bereits stark im Stadium der Verlandung fortgeschrittenen Seen kann die Wellenbewegung des Wassers in der Nähe der Verbindungszonen öfter ganze Bänke dieses Schlammes zusammentreiben (Tessendorff).

Besonders in flachen Gewässern mit vom Humusgehalt braun gefärbten Wasser und lebhaftem Pflanzenwuchs entsteht eine andere Ablagerung, die im nassen Zustande strukturlos, gallertig und braun gefärbt ist, im trockenen Zustande wird sie schwärzlich. An derartigen Orten findet sich gern eine Nymphaeaceen-Vegetation ein ${ }^{1}$ ).

1) Uber die Schlammablagerungen in erster Linie des Süßwassers sind in neuerer Zeit viele Arbeiten erschienen. Von alten Arbeiten ist zu nennen H. v. Post 1862; neuere vergl. Ramann 1895, 1905; Weber 1903; Potonié 190;-1911; Früh und Schröter 1904; Wesenberg-Lund 1901; Ellis 1907; Graebner 1909; Baumann 1911: Dachnowsky 1912. 
7. Salzboden ist ein von einer großen Menge Chlornatrium durchdrungener Boden von verschiedener (sandiger, toniger usw.) Beschaffenheit. Näheres im 4. Abschnitte (Kap. 48-52).

Ist der Boden dauernd feucht, so kann die Konzentration des Salzes ziemlich hoch steigen, ehe der Boden ganz pflanzenfrei wird; sie kann bis $4 \%$ Salzgehalt haben. Schweinfurth beobachtete bei $3 \%$ noch Weizenbau. Sobald aber auch nur kürzere Trockenperioden eintreten, die die Konzentration des im Bodenwasser gelösten Salzes stark steigern, ist der Boden schon bei $1 \%$ Salzgehalt völlig steril.

\section{Kap. Sind die chemischen oder die physikalischen Eigen- schaften des Bodens die wichtigsten?}

Das Vorhergehende hat uns sehr viele Verschiedenheiten in den chemischen und den physikalischen Eigenschaften des Bodens kennen gelehrt, d. h. einerseits in der Menge und in der Art der Bestandteile, anderseits im Bau, in der Wasserkapazität, der Bindigkeit usw.

Kombinationen der verschiedensten Grade all dieser Faktoren rufen die ungeheure Mannigfaltigkeit der Pflanzenvereine eines Gebietes hervor.

Manche Arten sind gegenüber den Bodenarten recht indifferent; sie wachsen auf den verschiedensten derselben. So findet man Phragmites communis z. B. sowohl in süßem Wasser als in sehr salzhaltigem; nach Sickenberger soll Typha latifolia imstande sein, in den Sodaseen Ägyptens gut zu gedeihen. Carex hirta trifft man sowohl im trockenen Dünensande als auf wasserzügigen Wiesenstellen; viele Heidepflanzen wachsen auf der Heide sowohl trocken als naß, z. B. Juniperus, Calluna, Empetrum (Graebner). Carex humilis wächst nach Drude bei Dresden auf recht verschiedenen Bodenarten. Viele weit verbreitete oder kosmopolitische Arten zeigen nur wenig Vorliebe für eine bestimmte Bodenart, andere und zwar die meisten lassen aber deutliche Beziehungen zu bestimmten Bodenarten erkennen. Danach kann man die Pflanzen in bodenvage und bodenstete einteilen.

Von altersher ist man namentlich in Gebirgsländern mit verschiedener geognostischer Cnterlage darauf aufmerksam geworden, daß das Vorkommen der Arten und das Gepräge der ganzen Vegetation mit dem Boden in einer gewissen Verbindung stehen. Beispielsweise kann auf das von Petry ${ }^{1}$ ) behandelte Kyffhäusergebirge hingewiesen werden, wo ein deutlicher Gegensatz zwischen der Vegetation auf dem Rotliegenden und der auf dem Zechstein besteht, nicht nur beim Walde und bei der Waldbodenvegetation, sondern auch z. B. bei der Unkrautflora und

1) Petry 1889. 
namentlich bei der Vegetation der sonnigen, trockenen Höhe und Gebüsche. Das Rotliegende trägt infolge von Nahrstoffarmut eine spärliche und gleichförmige, teilweise mit den Heiden übereinstimmende Vegetation; das Zechsteingebiet hingegen hat Buchenwälder und eine Krautflora mit vielen Arten. Der Gegensatz zwischen den beiden Formationsabteilungen ist so scharf, daß man in Wald und Feld sogleich an der Pflanzendecke merken kann, ob man sich auf der einen oder der anderen befinde; und die Verhältnisse sind derart, daß dieser Gegensatz den Bodenverhältnissen zugeschrieben werden muß.

Ebenso kann man bei Montpellier ${ }^{1}$ ), in der Schweiz ${ }^{2}$ ), Australien (Cambage) und in vielen anderen Gebirgsländern den schärfsten Gegensatz in der Vegetation auf zwei dicht aneinander liegenden Fluren beobachten, ja selbst in Dänemark können solche Beobachtungen gemacht werden. Man kann z. B. in Jütland sehr scharf begrenzte Stellen mit der Weingaertneria-Assoziation (IV. cancscens mit Trifolium arvense, Scleranthus, Hieracium pilosella u. a.) in eine Flur eingestreut sehen, die zwar ebenfalls ein magerer Ackerboden ist, aber doch eine ganz andere Vegetation trägt nnd zahlreiche Maulwurfshaufen hat, während jene Stellen keine Haufen haben (die Vegetation wird gebildet von Leontodon auctumnale, Jasione, Lotus corniculatus, Erigeron acris, Euphrasia officinalis, 'Trifolium pratense, T. repens, Achillea millefolium Chrysanthemum leucanthemum, Equisetum arvense 1. а.).

Die Gründe der allgemein beobachteten Unterschiede in einem klimatisch ganz gleichartigen Gebiet hat man hauptsächlich in zwei verschiedenen Richtungen gesucht. Einige sahen die chemische Beschaffenheit des Bodens als entscheidend an, andere legten das Hauptgewicht auf seine physikalischen Eigenschaften, namentlich auf die Wärme und die Feuchtigkeitsverhältnisse. Die Hauptzüge in diesem noch schwebenden Streite $^{3}$ ) sind folgende.

\section{Die chemische Beschaffenheit des Bodens}

Einer der ersten Vorkämpfer für die chemische Richtung war der Österreicher Unger. Er hob besonders den Gegensatz zwischen Kalkund Kiesel- oder Schieferboden hervor und teilte die Pflanzen in drei Gruppen: Die bodenvagen, d. h. die gleichgültigen (indifferenten), bei denen die chemische Natur der Stoffe keine Rolle spielt, die bodenholden, die zwar einen bestimmten Boden vorziehen, aber an ihn nicht streng gebunden sind, und die bodensteten, die an eine bestimmte

1) Flahault 1893

2) Magnin 1893.

s) Von neueren Arbeiten sei besonders auf G. Gola 1905 mit umfangreicher Litteraturangabe verwiesen. Zailer und Wilk 1907. 
Bodenart gebunden sind. Hiernach kann man zwischen Kalk-, Kiesel-, Schiefer-, Salzpflanzen usw. unterscheiden (vergl. Kap. 12, S. 105 ff.).

Von anderen, die gleichfalls annehmen, daß die chemische Beschaffenheit des Bodens überwiegenden Einfluß habe, können die Deutschen Sendtner, Schnitzlein, Nägeli Kraus, Schimper u. a., die Franzosen Vallot, Fliche, Grandeau, Saint-Lager, Contejean (in späteren Jahren) und Magnin genannt werden; und im ganzen scheinen sich die französischen Forscher in neuerer Zeit hauptsächlich hier anzuschließen.

Es gibt verschiedenes, was für diese Auffassung spricht. Schon S. 100 wurde angeführt, daß gewisse Stoffe im Übermaße für gewisse Pflanzen Gifte werden. Am deutlichsten sieht man dieses beim Kochsalze. Salzpflanzen (Halophyten) haben nicht nur ein höchst eigentümliches morphologisches und anatomisches Gepräge, sondern auch eine ganz bestimmte topogxaphische Verteilung an Küsten, in Salzsteppen und Salzwüsten. Viel Salz im Boden hat eine in hohem Grade ausschließende Kraft; Salz sterilisiert, ruft physiologische Trockenheit hervor und nur verhältnismäßig wenige Arten, meist bestimmter Familien (Chenopodiaceen u. a.) können Chloride in größerer Menge ertragen. Über diese Pflanzen vergl. den 4. Abschnitt.

Bei den anderen Stoffen, z. B. beim Kalk, ist die Sache schon zweifelhafter. Kalk ist für die Pflanzen notwendig. Von gewissen Pflanzen behauptete man (wie S. 81 erwähnt), daß sie den Boden, worin es viel kohlensauren Kalk gibt, fliehen sollten. Solche kalkfliehende Arten sollten sein: Castanea sativa, Pinus maritima, Calluna vulgaris, Erica-Arten, Sarothamnus scoparius, Genista Anglica, Ulex Europaeus, Pteridium aquilinum, Rumex acetosella u. a. Pflanzen, die wir teilweise auf unseren Heiden und auf Rohhumus finden, ferner Gramineen, Cyperaceen, viele Flechten und Laubmoose, besonders Sphagnum ${ }^{1}$ ), und unter den Algen z. B. die Desmidiaceen. Die genannten Blütenpflanzen sollen auf einem Boden, der mehr als 0,02 bis $0,03 \%$ kohlensauren Kalk enthält, nicht gedeihen können. C. A. Webers und Graebners Kulturen haben aber deutlich gezeigt, daß die meisten dieser Pflanzen nicht durch den Kalk als solchen leiden (vergl. darüber S. 102-3).

Andere Pflanzen werden als besonders kalkliebende angeführt, die einen Boden mit vielem kohlensauren Kalk nicht verlassen, z. B. Papilionaceen (Irifolium, Anthyllis vulneraria, Ononis natrix u. a.), Rosaceen, Labiaten, viele Orchidaceen, Tussilago farfarus u. a. Unger führt eine ganze Reihe von Beispielen für Kalkfloren an. In den Alpen wachsen auf Kalk Rhododendron hirsutum, Achillea atrata, Primula auricula usw., 
auf Urgestein dagegen Rhododendron ferrugineum, Achillea moschata, Primula hirsuta usw. Nach Blytt ${ }^{1}$ ) sind Ophrys muscifera und Libanotis montana die einzigen von allen Gefäßpflanzen Norwegens, die sich ausschließlich auf Kalk finden. Adamovié ${ }^{2}$ gibt umfangreiche Listen der Kalk- und Kieselpflanzen der Balkanländer. Die englichen Botaniker, z. B. Moss, Tansley, tun dasselbe für England. Kalkliebende Algen sind z. B. Mesocarpaceae.

Die ,Kieselpflanzen" werden zu den Kalkpflanzen in Gegensatz gebracht. Die vorhin erwähnten "kalkfliehenden“ Arten werden als Kieselpflanzen aufgefaßt. Das Verhältnis ist hier vielleicht das, daß sie durch Konkurrenz vom Kalk vertrieben werden und den Boden wählen müssen, wo der Kalk in sehr geringer Menge auftritt, ohne eine besondere Torliebe für Kieselsäure zu haben, die ein sehr neutraler Stoff ist; so hat z. B. Contejean das Verhältnis aufgefaßt. Zu den Kieselpflanzen gehören die meisten bei uns auf Sandboden und Moorboden wachsenden Pflanzen.

Salpeterpflanzen (nitrophile Pflanzen, Nitrophyten, Ruderalpflanzen) gedeihen am besten da, wo es inı Boden viel Ammoniak- und Salpetersäureverbindungen gibt, daher besonders in der Nähe von menschlichen Wohnungen (Düngerhaufen, stark gedüngter Boden). Sie gehören besonders zu gewissen Familien (Chenopodiaceen, Cruciferen, Solanaceen u. a.) und in ihrem Zellsafte kommen salpetersaure Salze vor. Andere Arten entwickeln sich auf einen solchem Boden kümmerlich, weil sie in ihr Gewebe mehr Salpeter aufnehmen, als sie ertragen können ${ }^{3}$ ). Gewisse Moose (Splachnaceae) und Pilze gedeihen nur auf Mist resp. auf tierischen Exkrementen, Kadavern usw. ${ }^{4}$ ).

Sernander ${ }^{5}$ ) hat eine wichtige Arbeit über nitrophile Flechten publiziert; er unterscheidet ornithokoprophile und saprophile (koniophile) Arten. Sie bilden besondere Associationen auf dem Felsen.

Die Solfataren Javas haben nach Holtermann ${ }^{6}$ ) eine eigentïmliche Flora, die sich von anderen unterscheidet.

Auch andere Stoffe können Gifte werden, wenn sie in großer Menge zugeführt werden; streut man z. B. auf eine Wiese Gips, so sterben gewisse Farne und Gräser, während Klee üppiger wird; desgleichen kann Eisen (Kisensulfat, Eisenoxydul) schädlich wirken, wenn es in

1) Blytt 1893 .

3) Adamović 1909.

5) Schimper $1890-1891$.

4) Uber die Assimilation der Ammoniak- und Nitratverbindungen vergl. Marchal und Carpiaux 1896.

3) Sernander 1912.

o) Holtermann 1907. 
Menge vorhanden ist, obwohl es zu den absolut notwendigen Nahrungsstoffen gehört.

Bei Rothamstedt in England angestellte Versuche haben die Bedeutung der chemischen Beschaffenheit der Nahrung in besonders deutlicher Weise dargelegt; es zeigte sich, daß Stickstoffdündung, besonders mit Salpetersäureverbindungen, die Gräser vorwiegen ließ, so daß diese die Leguminosen verdrängten, während umgekehrt namentlich Kalisalze die Leguminosen förderten. Kulturversuche auf Hochmoor haben nach C. A. Weber zu ganz ähnlichen Resultaten geführt, gewisse Gräser wurden von andern verdrängt ${ }^{1}$ ). Aber im allgemeinen kann man wohl nicht sagen, daß die Versuche der chemischen Richtung eine vorzügliche Stütze geliefert hätten; Kalkpflanzen, Kieselpflanzen, Galmeiveilchen, selbst Salzpflanzen können wohl stets sehr gut auf einem Boden gedeihen, der von den betreffenden Stoffen nicht mehr enthält, als überhaupt jeder Boden, z. B. in botanischen Gärten. Andrerseits spielt der Nährstoffgehalt eine hervorragende Rolle ${ }^{2}$ ).

Aug. Pyr. de Candolle fand auf siebenjährigen Reisen fast alle Arten auf chemisch verschiedenem Boden, und Blytt z. B. ist zu dem Ergebnis gekommen, daß sich die selır wenig bodensteten Arten, die er 1870 in Norwegen gefunden hatte, durch ausgedehntere Untersuchungen an Anzahl vermindert haben.

„Jedes Verbreitungsverhältnis kann durch zweierlei Gründe verursacht werden, entweder durch physikalische oder durch chemische, deren gleichzeitiges Auftreten uns hindert, die Rolle jedes einzelnen deutlich zu erkennen" $\left.{ }^{3}\right)$. Dies ist vollständig richtig, und die Geschichte der Wissenschaft zeigt, daß andere Botaniker den physikalischen Verhältnissen eine größere Bedeutung als den chemischen beilegen.

Die Bedeutung der physikalischen Verhältnisse. Der wichtigste Wortführer für die überwiegende Bedeutung der physikalischen Verhältnisse war der Schweizer Jules Thurmann (1849) in seinen Arbeiten über die Pflanzenwelt des Jura. Man kann seine Lehre kurz so zusammenfassen: Es ist der Bau des Bodens, der die Verteilung der Arten regelt; von diesem Bau hängen namentlich der Wassergehalt und die Wärmeverhältnisse des Bodens ${ }^{4}$ ) $a b$; dieselbe Art kann auf sehr verschiedenen Bodenarten wachsen, wenn sie dieselben Feuchtigkeitsverhältnisse antrifft.

1) Über die Bedeutung des Kalks auf Rohhumus in Buchenwäldern hat P. E. Müller und Müller mit Weis (P. E. Müller und Fr. Weis 1906, 1913) eine Reihe interessante Versuche angestellt. Wird Kalk in hinreichender Menge dem Boden zugeführt, gediehen die Buchen vorzïglich, verglichen mit dem ursprünglichen Zustande.

2) Vergl. auch Sorauer 1909.

3) Vallot 1831.

4) Vergl. Mitscherlich 1898 über die Benetzungswärme des Ackerbodens. 
Thurmann hebt das verschiedene Vermögen der Felsarten hervor, unter der Einwirkung von Luft, Wasser und Wärme (sowohl Frost als Hitze) zu verwittern. Er teilt sie danach in eugeogene und in dysgeogene. Einige Felsarten verwittern leicht und bilden schmell lose Massen (Grus, Sand u. ähnl. „Detritus"); diese „weichen "Felsarten nennt er eugeogen ${ }^{1}$ ) und nach dem Grade der Feinheit der Verwitterungsprodukte pelogen ${ }^{2}$ ) (die Teilchen sind dann sehr fein, staubförmig; vorzugsweise Ton- und Mergelboden) und psammogen ${ }^{3}$ ) (die Teilchen sind gröber, "Sand"). Je nachdem der Boden mehr oder weniger pelogen oder psammogen ist, bildet Thurmann durch die Vorsilben per-, hemi- und oligo-Unterabteilungen oder spricht von pelopsammitischem Boden. Im Gegensatz zu den leicht verwitternden Felsarten nennt er die harten, schwierig angreifbaren dysgeogen ${ }^{3}$ ); sie bilden wenige oder keine Verwitterungsprodukte.

Der feine Boden nimmt, wie S. 85 erwähnt, mehr Wasser in sich auf als der wenig verwitterte Felsboden. Die eugeogenen Felsarten rufen daher einen feuchten und kalten Boden, die dysgeogenen einen trocknen und warmen hervor.

Die Pflanzen, die den feuchten Boden und das eugeogene Gelände suchen, nennt Thurmann hygrophil ${ }^{4}$ ) (Feuchtigkeit liebend), Pflanzen, die den trockneren Boden und die dysgeogenen Felsen suchen, nennt er xerophil ${ }^{5}$ ) (Trockenheit liebend). Seine hygrophilen Arten entsprechen ungefähr den Kieselpflanzen Ungers und anderer, seine xerophilen ungefähr deren Kalkpflanzen, entsprechend Hygrophyten, Pflanzen, die einen hygrophilen Bau resp. hygrophile Anpassungen zeigen, Xerophyten, von xerophilem Bau. Die auf allen Bodenarten vorkommenden Pflanzen nennt Thurmann Cbiquisten. Daß nun ein so offenbarer Untersehied z. B. zwischen der Kalkbodenflora und der Kieselbodenflora besteht, wird nicht durch die Vorliebe der Arten für Kalk oder Kieselsäure verursacht, sondern durch den Umstand, daß die Kalkfelsen schwierig verwittern und das Wasser durch Spalten und Risse in der Regel schnell ablaufen lassen; sie bilden einen trocknen, warmen und wenig tiefen Boden, während Quarz und Feldspatgestein einen losen, tiefen, feuchten und kalten Boden bilden. Wenn Gesteinsarten mit derselben chemischen Zusammensetzung in einigen Fällen hart und fest sind, in anderen stark verwittern, so findet man auf dem ersten Boden „Kalkpflanzen“, selbst wenn er Kieselboden ist, auf dem anderen „Kieselpflanzen", selbst wenn er Kalk ist.

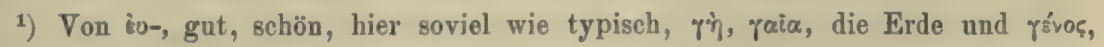
Abstammung, Entstandenes.

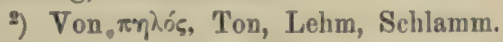

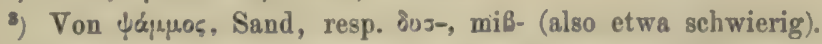

-) Von órpós, feucht, naB und pethím, liebe.

5) Von छทpós, trocken. 
Ferner kann eine Pflanzenart in einem bestimmten Klima einen gewissen Boden wegen seiner physikalischen Eigenschaften verlangen, z. B. in einem feuchten Klima einen warmen und trocknen Boden wie Kalk, aber in anderem Klima einen ganz anderen Boden vorziehen, z. B. in einem warmen und trocknen Klima einen feuchten und kalten Kieselboden. Ein günstiger Boden kann einer Pflanze dazu verhelfen, daß sie in einem weniger günstigen Klima gedeiht; nach Blytt haben z. B. viele Arten in Norwegen ihre Nordgrenzen und Höhengrenzen auf Kalk. Eugeogene und dysgeogene Felsarten können dieselbe Flora tragen. So scheint die Verbreitung der Rotbuche in Südfrankreich erklärt werden zu müssen. Sie gilt bei uns in Nordeuropa für eine kalkliebende Pflanze, aber im mediterranen Gebiete bildet sie nach Flahault ${ }^{1}$ ) nur auf Kieselboden ausgedehnte Wälder und steht auf dem trocknen, warmen Kalkboden vereinzelt, von Quercus sessiliflora bezwungen, nur nicht in den kühlen Tälern mit nördlicher und östlicher Richtung.

Eine und dieselbe Bodenart kann an verschiedenen Stellen sehr verschiedene Verhältnisse in bezug auf Licht, Wärme, Feuchtigkeit und Wind besitzen, so daß verschiedene Pflanzenvereine zur Entwicklung kommen. Daher sieht man auch, daß manche Pflanze in einer Gegend bodenstet, in einer anderen bodenvag ist. Adamović ${ }^{2}$ ) gibt ein schönes Beispiel: Die halkholden Achillea clypeolata und Euphorbia myrsinites kommen in kühleren Gegenden nur auf Kalk, in warmen auch auf feuchteren Standorten, nehmen hier auch mit anderen Standorten vorlieb.

An Thurmann hatte sich z. B. Contejean angeschlossen, der jedoch später zu der anderen Meinung überging; ferner stehen ihm am nächsten Alph. de Candolle, Čelakovský, Krasan (vergl. S. 94), Kerner, H. von Post, Blytt, P. E. Müller, Negri, G. Kraus u. a. ${ }^{3}$ ). Thurmanns Theorie kann jedoch sicher nicht alle Fälle erklären.

In beiden Theorien ist offenbar etwas Wahres enthalten; sowohl chemische als physikalische Verhältnisse machen sich geltend; das Richtige scheint zu sein, daß in einigen Fällen die chemischen Eigenschaften des Bodens, in anderen Fällen die physikalischen (namentlich das Vermögen des Bodens Wasser festzuhalten) die größte Bedeutung haben. Wenn wir Länder wie Dänemark oder das norddeutsche Flachland betrachten, deren Boden aus einem bunten Gemisch der Verwitterungsprodukte der verschiedenen Gesteinsarten besteht, so kann hier verhältnismäßig wenig von hervorstechenden chemischen Charakteren die Rede sein. Der chemische Einfluß tritt am schärfsten nur an den salzhaltigen Böden

1) Flahaut 1893 .

3) Adamovic 1909 .

s) Die hauptsächliche neue Litteratur: vergl. bei Woodhead 1906. - G. Kraus 1911. 
der Küste hervor ${ }^{1}$ ), in den bei weiten häufigsten Fällen spielt der Feuchtigkeitsgehalt die Hauptrolle (vergl. Kap. 9). Temperatur, Beleuchtung, Luft, Niederschläge und Luftfeuchtigkeit, sowie die chemische Natur des Bodens können an bestimmten Stellen ganz gleichartig sein und doch kann die Vegetation völlig verschieden sein, wenn nur der eine Faktor, der Wassergehalt des Bodens, verschieden ist, also den entscheidenden Einfluß ausübt. Wenn wir weiter betrachten, daß die wichtigsten Eigenschaften des Bodens (Temperatur, Durchlüftung, Wassergehalt, Verdunstung usw.) im wesentlichen von seiner Struktur abhängen, dann erscheinen im allgemeinen die physikalischen Eigenschaften des Bodens als die wichtigsten, in erster Linie, weil sie auf den Wassergehalt wirken. Chemische Verschiedenheiten sind stets von physikalischen begleitet und chemische Eigentümlichkeiten können anscheinend physikalische ersetzen, aber die physikalischen dürften doch zunächst stärker entscheidend wirken. Es darf indessen nicht verkannt werden, daß der Nährstoffgehalt des Bodens gleicherweise von großer Wichtigkeit ist, wie besonders von Graebner und Nilsson ${ }^{2}$ ) betont wird. Doch selbst der Nährstoffgehalt resp. seine Verwertbarkeit für die Pflanzen (vergl. S. 103) hängt vom physikalischen Verhalten des Bodens, seiner Wasserkapazität, Absorptionsfähigkeit und vielleicht in erster Linie vom Luftgehalt $a b$.

Für den Artenreichtum einer Vegetation spielen die chemischen Verhältnisse insoweit eine Rolle, als der eine Boden durchweg an Nahrungsstoffen reicher ist, als der andere. Die Unterschiede der physikalischen Eigenschaften sind gleichfalls sehr wichtig. So führt Blytt ${ }^{3}$ ) an, daß die Flora bei Christiania auf dem losen und leicht verwitterten (also reichlich Nahrstoff liefernden) Tonglimmerschiefer besonders reich und abwechselnd, auf den schwierig verwitternden Gneis jedoch immer sehr gleichförmig ist, obgleich diese Gesteinsarten chemisch selır ähnlich sind. Eine Gegend mit großer Abwechslung in den Bodenverhältnissen wird immer einen weit größeren Artenreichtum darbieten, als eine andere mit gleichförmigem Boden.

Nach Kraus bringt besonders ein verschiedener Kalkgehalt eine verschiedenartige Struktur des Bodens und damit abweichende physikalische Verhältnisse mit sich, der Wassergehalt und die Temperatur des Bodens werden wesentlich geändert. Ein höherer Kalkgehalt verursacht auch eine höhere Temperatur und geringeren Wassergehalt, bei geringem Kalkgehalt wird der Boden feuchter und kälter. In Skandinavien spielt der Kalkgehalt des Bodens eine große Rolle für den Verlauf der Humus-

1) Warming 1894 .

2) Graebner 1898, 1901, 1909/10 ff.; Nilsson 1902 b.

5) Blytt 1893 . 
bildung, indem Kalk die Bildung von neutralem Humus begünstigt. Viele mesophile Mullpflanzen konmen deshalb im Norden von Schweden nur auf Kalkboden vor $^{1}$ ).

Aus demselben Fels können je nach der Art der Verwitterung und Ablagerung (aus der Abschlämmung usw.) sehr verschiedene Bodenarten entstehen; die chemischen und physikalischen Eigenschaften werden durch den Ursprungsfels bedingt.

Da die chemischen und physikalischen Faktoren in den einzelnen Böden gleichzeitig wirken und sich ergänzen oder widerstrebcn, so werden wir dadurch gehindert, ein sicheres Urteil über die Bedeutung und die Wirkungsrichtung jedes einzelnen abzugeben.

\section{Kap. Kampf der Arten untereinander}

Ein Faktor, der bei den Fragen nach der Verbreitung der Arten und der Bildung der Vereine nicht immer berücksichtigt worlen ist und den nach Darwin namentlich Naegeli ${ }^{2}$ ) hervorgehoben hat, darf nicht vergessen werden: der Kampf der Arten untereinander. Eine wie kleine Rolle namentlich die chemischen Unterschiede des Bodens spielen, zeigen z. B. die botanischen Gärten mit ihren von den verschiedensten Böden stammenden Pflanzen, die hier in demselben Borlen vorzüglich wachsen. Aber überläßt man sie sich selbst, so werden aus dem dann folgenden Kampfe nur einige wenige (meist einheimische) als Sieger hervorgehen. Die Pflanzen sind offenbar im allgemeinen gegen den Boden ziemlich gleichgültig, wenn man gewisse extreme chenische und physikalische Verhältnisse (z. B. großen Salzgehalt, großen Kalkreichtum, großen Wassergehalt) ausnimmt, - so lange sie keine Mitbewerber haben; nur einige wenige Pflanzen kann man vielleicht als in einer oder in anderer Hinsicht obligat ansehen; die allermeisten sind fakultativ, und ihr Vorkommen hängt von den Mitbewerbern ab. Treten solche auf, so beschränkt einer den andern und die Art geht als Sieger hervor, die die gegebenen Kombinationen von Boden, Licht, Klima usw. am besten ausnutzen kann. So ist die Kiefer (Pinus silvestris) nach Fliche in der ganzen Champagne an Kalkboden gebunden und fehlt auf nicht kalkhaltigem Boden; der Grund ist der, daß die Kiefer in der Champagne eine eingeführte Pflanze ist, für die das Klima, ohne schädlich zu sein, doch auch nicht günstig ist; auf dem nicht kalkhaltigen Boden, worauf sie anderswo vorzüglich gedeiht, unterliegt sie hier anderen Arten, und nur auf Kalkboden wird sie herrschend, ohne sich jedoch schön zu entwickeln. Wollte man sie daher kalkliebend nennen, so würde man

1) Andersson u. Birger 1912.

2) Naegeli $1865,1872$. 
sich irren; sie wächst wie viole andere Wildbiume auf Boden der verschiedensten Art, bei uns am häufigsten auf Sandboden. Wenn wir in Dänemark die Eiche teils auf fouchtom und festem Tonboden, teils auf trockenem und magerem Sandhoden finden, so ist der Grund dafür nicht, daß sie diese Bodenarten vor"zugweise liebt, sondern der, daß sie durch die Buche von den anderen verdrängt wird. Ähnlich gelit es mit dem Heidekrante (Calluna) und vielen anderen Arten, z. B. Anthemis cotula und arvensis, Carlina vulgaris und acaulis, Brunella vulgaris und grandiflora, Veronica teucrium und V. chamaedrys usw. ${ }^{1}$. In den Alpen kïmpfen z. B. nach Na(egeli $\left.{ }^{2}\right)$ Rhododendron ferrugineum und Rh. hirsutum, sowie Achillea moschata und A. atrata (Kiesel- und Kalkpflanzen). Der dänische Forscher P. E. Müller.3) hat mehrere Beispiele dafür beigeliracht, daß die Waldbäume in deu Gebirgen einander in derselben Weise beschränken; stattliche Hochwälder der Weißtanne z. B. grenzen plötzlich an stattliche Wälder einer anderen Art, ohne daß an den Grenzen von schlechtem Gedeihen die Rede ist. Auch Bonnier.4) und andere kamen zu dem Erogebnis, daß die in einer Gegend durchaus an Kalk gebundenen Arten in einer anderen kalkflichend sein und sich anderswo gegen den Boden gleichgültig verhalten können. In der Mitte ihres Verbreitungsgebietes ist eine Art im Nährboden oft nicht wählerisch; aber außerhalb jener Mitte wird sie von anderen Arten gezwungen, einen bestimmten zu wählen ${ }^{5}$ ).

Einige bemerkenswerte Beispiele dafür, daß sich Pflanzen in einer anderen Gegend als in ihrer eigentlichen Heimat mit großer Fülle entwickeln könmen, sind Erigeron Canadensis, Galinsoga parviflora (sogar aus dem tropischen Peru), Oenothera bicnnis und andere jetzt bei uns gemeine amerikanische Unkiäuter; auch Impatiens parviflora, Helodea Canadensis wären hier zu erwähnen. And'rerseits ist Salsola kali, unsere gemeine Strandpflanze, auf den Kornfeldern Nordamerikas das ärgste Unkraut geworden; sie setzt sich stellenweise in den fast ausschließlichen Besitz des Bodens ${ }^{6}$ ).

1) Ludwig 1895 S. 121; Pietsch.

2) Naegeli 1872 .

9) P. E. Müller 1871, 1887.

9) Bonnier 1879 .

5) Vergl. im übrigen Abschnitt 5.

6) Unter der neuen Litteratur über diesen Gegenstand vergl. besonders Cowles 1901 ; St. Lager 1895; Schimper 1898; Gillot 1894; Gain 1895; Ernst 1907; Woodhead 1906; Cambage 1907; Gadeceau 1903; Graebner 1909; 1910 a-c. Die altere Litteratur bei Engler 1899, S. $164-66$. 


\section{Kap. Die Wirkung einer leblosen Decke über der Vegetation}

Die Wirkung einer leblosen Decke hängt unter anderem davon ab, wie lose oder fest sie ist; je loser, desto größer ist die Wirkung in folgenden Hinsichten:

1. Es wird Wasser eingesaugt, die Verdunstung herabgesetzt, die Bodenfeuchtigkeit erhöht.

2. Die Ausstrahlung wird herabgesetzt.

3. Die Schwankungen und die Gegensätze der Temperatur werden im ganzen. vermindert.

Es kommen hier namentlich zwei Arten von Decken in Betracht, der Schnee und das gefallene Laub. Auch eine Stein- oder Kiesbedeckung des Bodens spielt eine große Rolle. Selbst in den trockensten Zeiten bewahrt der Boden in geringer Tiefe eine milde Feuchtigkeit, da durch die Steine die Verdunstung auf einen geringeren Grad herabgedrückt wird und namentlich die Feuchtigkeitsschwankungen stark verringert werden $^{1}$ ).

\section{Der Schnee}

Es ist von alters her anerkannt, daß der Schnee die Vegetation in hohem Grade schützen kann. Daß Schnee das Erfrieren der Wintersaat verhindert, ist wohlbekannt. In den Hochalpen sollen Schneefälle im Sommer bisweilen die Pflanzen davor schützen, der trockenen Kälte und der Verdunstung ausgesetzt zu werden, die nach solchen Schneefällen oft eintreten. Jede Fläche in den Polarländern, von der die Stürme im Winter die Schneedecke wegfegen, hat eine andere Vegetation als die mit Schnee bedeckten Einsenkungen; auf den Tundren Lapplands z. B. siegt namentlich Lecanora Tatarea, während die Strauchflechten auf den mehr geschützten Stellen dicht und hoch wachsen können²). Die Verteilung der Schneedecke ist für die Verteilung ganzer, bestimmter Bestände entscheidend: einige werden auf Kosten anderer geschützt; die im Winter mit Schnee bedeckten Stellen sind im Sommer gewöhnlich an Arten und Individuen am reichsten. Die Schneedecke ist also oekologisch wichtig. Der Schnee umschließt die zahllosen Staubpartikelchen, die in der Atmosphäre schweben, und reinigt diese dadurch, auch sammelt er andere kleine organische oder anorganische Teilchen, die durch den Wind herangeweht werden. Sobald der Schnee schmilzt, werden alle diese Teilchen auf dem Erdboden abgelagert und dadurch wird dort ein äußerst feiner fruchtbarer Boden niedergeschlagen, der sich naturgemäß in den kleinen Furchen, Spalten oder Tälchen sammelt und einer ganz

1) Vergl. Graebner 1909.

2) Kihlman 1890. Vergl. auch Thore E. C. Fries 1913. 
bestimmten charakteristischen Pflanzengesellschaft das Gedeihen ermöglicht. Diese Schneetälchenflora ${ }^{1}$ ) wird auch später erwähnt.

Die Schneedecke hat auch eine gestaltende Bedentung. Einesteils kann hierher der Einfluß gerechnet werden, den große Schneelasten in den Hochalpen auf die Gestalten der Bäume und der Sträucher ausüben (vergl. namentlich die von Pinus montana gebildeten Krummholzoder Legföhrengestrüppe), aber auch auf andere in Gestrüppform auftretende besonders immergrüne Bäume (wie Juniperus, Schneebruchfichten, Alnus viridis, dann auch Fagus silvatica u. a.; Birkengestrüppe in Südgrönland), indem die Stämme zum Boden niedergedrückt werden und auf Abhängen niederliegen ${ }^{2}$ ). Andernteils sei darauf hingewiesen, daß Birke, Juniperus und Picea excelsa in Lappland Gestrüppe bilden ${ }^{3}$ ), die dadurch auftreten, daß alle aus der Schneedecke herausragenden Zweige regelmäßig absterben und daß die Individuen niedrige, tisch- oder schirmförmige Kronen erhalten (Fig. 46 A).

Die Gründe für diese Bedeutung der Schneedecke sind folgende.

Erstens spielen die Wärmeverhältnisse des Schnees eine Rolle, aber kaum die größte. Schnee erscheint weiß, weil die Zwischenräume zwischen den Kristallen mit Luft angefüllt sind, und weil diese Zwischenräume oft einen sehr großen Bruchteil des gefallenen Schnees ausmachen, so ist es gerade der Luftgehalt, der den Schnee zum schlechten Wärmeleiter macht. Ganz gewiß hält der Schnee wegen seiner sehr geringen Wärmeleitungsfähigkeit den Boden wärmer, und je tiefer man im Schnee hinabgeht, desto weniger kalt ist er, so dab der unter tiefem Schnee liegende Boden geringerer Kälte ausgesetzt ist, als der nackte Boden. Aber dieses reicht doch nicht hin, um die vorgefundenen Tatsachen zu erklären ${ }^{4}$ ). Daß die Wärmeschwankungen vermindert werden, da $B$ die Pflanzen nicht dem Wechsel zwischen der Hitze des Tages und der Kälte der Nacht ausgesetzt werden, kann auch nicht so große Bedeutung haben; der Schnee wird namentlich gegen ein zu plötzliches Auftauen schützen, das ja gefährlich werden kann (S. 34). Diesen plötzlichen Wärmeschwankungen dürfte es zuzuschreiben sein, daß oft Pflanzen dicht über der stark reflektierenden Fläche des Schnees auf der Südseite Frostschaden erleiden, während die in dem Schnee steckenden, wie die in die Luft ragenden Teile unversehrt bleiben.

Kihlman hat darauf aufmerksam gemacht, daß die Bäume an der polaren Baumgrenze gewöhnlich erst in einer gewissen, nicht unbedeuten-

1) Vergl. Schröter 1904-1908; Rübel 1912; Vahl 1913.

?) Kerner 1863 S. 512; Rosenvinge 1889; Schröter 1904-1908 S. 663; Szabó 1907.

s) Kihlman 1890; Thore E. C. Fries; vergl. auch Vestergren 1902. Siehe Abbildungen bei Kihlman and Fries.

4) Kjellman 1884 .

Warming-Graebner. 3. Anflage, illustr. 
den Höhe, z. B. 1,5 m über der Schneedecke, sich zu verzweigen beginnen, und er erklärt das dadurch (?), daß die Schneemassen die untere Luft stark abkühlen, und erst in einer gewissen Höhe über ihnen ist die Luftwärme hinreichend für die Bäume, daß sie ihre Zweige entwickeln können. Th. C. E. Fries hat dieses schematisch abgebildet (Fig. 46 B).

Viel wichtiger ist die Bedeutung des Schnees für den Wassergehalt der Pfianzen.

Der Schnee schützt gegen Verdunstung. Hierin muß der Grund für die Erhaltung vieler Arten während des Winters und ferner der für das von Kihlman u. a. erwähnte Absterben von Zweigen, die den Schnee überragen, gesucht werden. Nicht die niedrigen Wärmegrade töten diese Zweige, sondern die in den Polarländern herrschende große Lufttrockenheit und die heftigen Stürme, die die Verdunstung steigern. Zweige und ganze Pflanzen verwelken durch Austrocknung ${ }^{1}$ ).

Als Windschutz spielt der Schnee eine sehr wesentliche Rolle. Einige Arten sind "windhart", d. h. unempfindlich gegen die austrocknende Wirkung der Winde, in den Alpen nach J. Braun z. B. Loiseleuria procumbens, Androsaces Helveticum, Saxifraga caesia und S. retusa; andere dagegen sind sehr empfindlich. Gegen Winderosion schützt der Schnee; sie findet fast nur an im Winter schneefreien Stellen statt.

Durch den Tod vieler Zweige und durch das Auftreten neuer an abnormen Stellen werden die abweichenden, teilweise verbogenen und gekrümmten Gestalten hervorgerufen (vergl. Kap. 5).

Es sind gleichfalls die Wasserverhältnisse, die auf die topographische Verteilung der Arten einwirken, nämlich die durch die ungleiche Verteilung der Schneedecke hervorgerufene ungleiche Verteilung des Wassers im Boden. Die mit Schnee erfüllten Einsenkungen halten sich länger feucht als die höheren und schneefreien Stellen, vielleicht sogar durch die ganze Vegetationszeit.

Die Schneedecke erhält durch ihre Dicke an vielen Orten z. B. in den Steppen von Rußland und Nordamerika, als Wasseransammlung Bedeutung; je nach der reicheren oder der geringeren Versorgung des Bodens wird die Vegetation der folgenden Vegetationszeit reicher oder spärlicher. Der Schnee schützt auch gegen die besonders durch den Barfrost verursachten großen Volumenveränderungen der gefrorenen Erde, wodurch die Pflanzen losgerissen und aus der Erde gehoben werden, so daß die jungen Pflanzen im Frühjahr mit den Wurzeln auf dem Erdboden freiliegen ${ }^{2}$ ).

Wenn eine Schneedecke in gewissen Fällen eine schädliche Wirkung hat, z. B in Einsenkungen der Felder eine solche auf die dichte und

1) Kihlman 1890; Schimper.

2) Sorauer 1909 . 
üppige Wintersaat, so ist der Grund vielleicht der, daß diese erstickt, indem der Luftzutritt erschwert wird.

Ferner erhält die Schneedecke für angrenzende Abhänge dadurch Bedeutung, daß das schmelzende Schneewasser sie benetzt. In Grönland können, wie S. 92 erwähnt, die Nordabhänge einer Gebirgskette im Sommer frisch und üppig grün (namentlich moosreich) sein, während

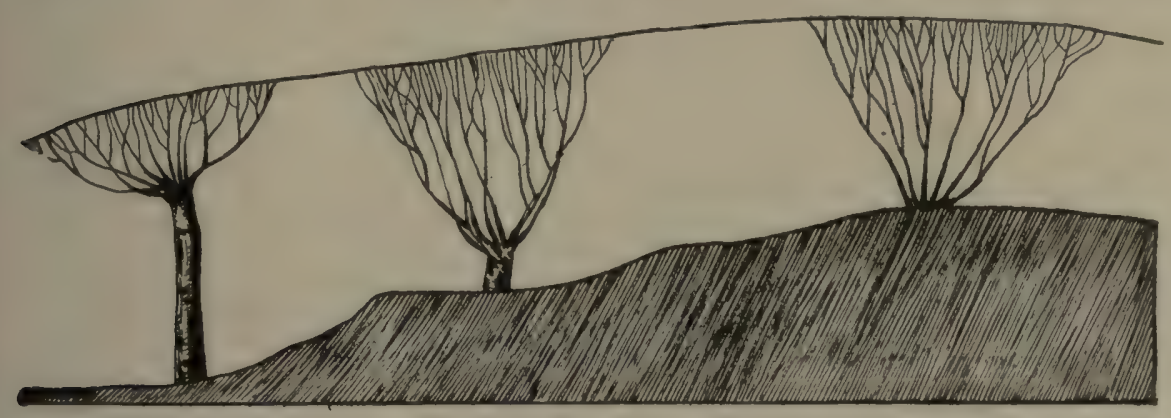

$A$

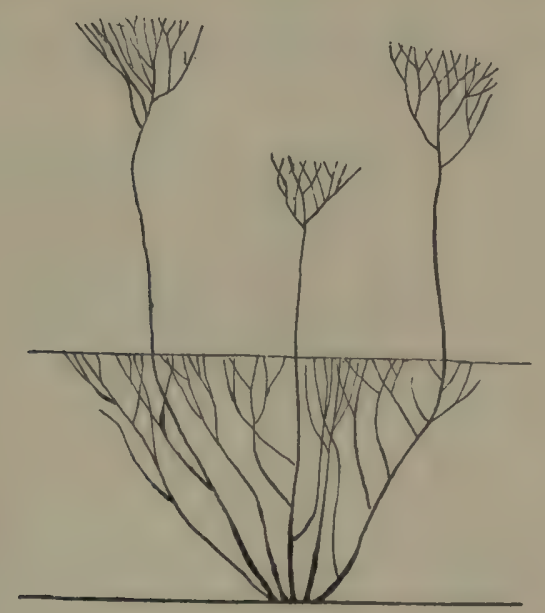

$B$

Fig. 46. Tischbirken; Zusammenhang zwischen Wuchsform und Schneedecke, Bäume an der polaren Baumgrenze. $A$. Uber der Schneedecke absterbend, $B$. sich über der Schneedecke büschelförmig verzweigend. Die Linien bezeichnen die Schneehöhe im Winter. (Nach Fries; vergl. S. 180.)

die Südabhänge gleichzeitig trocken und verbrannt dastehen, weil die Nordabhänge unter anderem von dem langsam schmelzenden Schnee lange benetzt werden, während dieser von den Südabhängen schnell verschwindet ${ }^{1}$ ).

Eine Schneedecke verkürzt die Vegetationszeit, indem sie den Boden abkühlt und die Pflanzen hindert, so früh zum Leben zu

1). Warming 1887 . 
erwachen, wie auf den schneefreien Stellen. Auch dieses greift in die Haushaltung und die Verteilung der Arten tief ein; gewisse Arten erhalten an den Stellen, wo sich der Schnee zu lagern pflegt, eine zu kurze Vegetationszeit oder einen zu kalten Boden und werden von diesen Stellen ausgeschlossen; andere Arten werden hierdurch gerade begünstigt. Blytt teilt z. B. mit, daB rings um die Schneeansammlungen der norwegischen Gebirge, die zwar jeden Sommer etwas einschmelzen, aber kaum jemals ganz schwinden, die Flora wegen der kurzen Vegetationszeit hochalpin ist und eigentlich zu einer größeren Höhe über dem Meere paßt, als jene Stellen sie haben. Selbst an Orten, wo der Schnee nur in besonders warmen Sommern schmilzt, kann man Vegetation finden. Diese muß mehrere Jahre unter dem Schnee geruht haben, bevor sie wieder erwachte. Selbstverständlich gibt es viele Stellen, wo der Schnee so lange liegen bleibt, daß jede Vegetation überhaupt unmöglich gemacht wird.

Man sieht leicht, daß die orographischen und die anderen Verhältnisse, die auf das Schmelzen der Schneedecke einwirken (die Neigung und die Neigungsrichtung des Bodens, die Beschaffenheit der Winde, die Wärmekapazität des Bodens selbst usw.) dadurch pflanzengeographische Bedeutung erhalten.

Der Verlauf der Baumgrenze kann sehr verschiedene Ursachen haben, so z. B. die Tätigkeit des Menschen, der Eintritt strenger Kälte die den betreffenden Bäumen das Reifen der Samen nicht mehr gestattet, besonders aber die Wirkung der kalten austrocknenden und damit tötenden Winterwinde bei gefrorenem Boden, schließlich kann die Baumgrenze aber auch von der Verteilung der Schneedecke abhängen ${ }^{1}$ ).

\section{Tote Pflanzendecken}

Die andere Art Decke ist das alte zu Boden gefallene Laub oder die alte verwelkte Grasdecke. Gefallenes Laub treffen wir besonders in den Wäldern (nicht nur in den das Laub jährlich gänzlich wechselnden, sondern auch in den immergrünen), eine verwelkte Grasdecke auf vielen dichten Weiden, Wiesen, Steppen und Savannen.

Diese Decken müssen eine ähnliche physikalische Wirkung wie der Schnee haben, den Boden wärmer machen, die Wärmeextreme vermindern, den Boden feuchter halten usw.; manche Pflanze hält auf dem Waldboden ohne eine solchen Schutz gegen Austrocknung kaum aus (von Schutz gegen Kälte ist hier oft noch weniger die Rede als beim Schnee ${ }^{2}$ ).

$\left.{ }^{1}\right)$ Utber die physiologische Bedeutung des Schnees vergl. weiter Wöeikoff 1887, 1889.

2) Wegen der Eigenschaften der verschiedenen Waldbodendecken sei hier z. B. auf Ramann 1890, 1893, 1905, 1911 verwiesen. 
Die Laubdecke wirkt auf die Humusbildung im Boden in hohem Grade ein, verbessert diesen dadurch und erhält auch für das Tierleben im Waldboden eine große Bedeutung: sie bewahrt die Feuchtigkeit und verschafft den Tieren des Waldbodens, unter denen die Regenwürmer die wichtigsten zu sein scheinen, Nahrung (vergl. 32. Kap.). Eines wie das andere hindert den Waldboden, aus Humus in Rohhumus überzugehen, und verhindert alle Veränderungen in der Bodendecke, die hiermit gleichzeitig einhergehen und in die Haushaltung des ganzen Waldes mächtig eingreifen würden ${ }^{1}$ ).

In diesem Zusammenhange sei der Nutzen erwähnt, den gewisse andere Pflanzen, namentlich Polar- und Hochgebirgspflanzen, von ihren alten, abgestorbenen Teilen haben.

Es ist eine längst wohlbekannte, schon auf S.37f. erwähnte Sache, daß die alten toten Blätter oft auf den Zweigen der subglacialen Pflanzen in großer Menge sitzen bleiben, sie dadurch in dichte Decken einhüllen, deren Dichtigkeit ferner durch die Bildung gedrängter, kurzer Zweige vermehrt wird. Dieses ist offenbar eine Folge davon, daß die Auflösungs- und die Verwesungsprozesse in dem polaren Klima äußerst langsam vor sich gehen (Bakterien und besonders Pilze gedeihen schlecht), und hat für die Pflanzen den Nutzen, daß ihre Transpiration erschwert wird. Die Natur hüllt die Pflanzen ein, wie der Gärtner seine empfindlichen Gewächse.

Gewisse auf trockenem Felsboden und an ähnlichen trockenen Orten wachsende Arten werden ebenso von alten Zweig- und Blattresten eingehüllt; hier verhindert der Mangel an Feuchtigkeit, nicht der an Wärme, die Auflösungsprozesse durch Pilze und Bakterien. Ob jene Pflanzen davon einen Nutzen haben, läßt sich noch nicht im allgemeinen sagen, ist aber wahrscheinlich. Teils kann man meinen, daß diese alten Pflanzenteile gegen Verdunstung schützen, $d a ß$ sie als Wasser saugende und festhaltende Organe dienen. Hierbei sei auf die Tunikagräser ${ }^{2}$ ), auf die Blattscheidenhüllen von Velloziaceae sowie auf die Wurzelhüllen von Dicksonia und einzelner anderen Farne hingewiesen ${ }^{3}$ ).

\section{Kap. Die Wirkungen einer Iebenden Pflanzendecke auf den Boden.}

Jede Pflanzendecke wirkt auf die physikalischen Verhältnisse des Bodens ein, desto mehr, je dichter und höher sie ist, je länger sie lebt. Am meisten wirken daher die Wälder ein; deshalb ist die Waldboden$1909-10$.

1) Vergl. P. E. Müller 1878, 1894; Ramann a. a. O.; Graebner 1895, 1904,

2) Hackel 1890; Warming 1892.

) Warming 1893; vergl. anch Kapitel 25. 
vegetation ganz anderen physikalischen Verhältnissen unterworfen als die Pflanzen des Hochwaldes selbst.

Die Wirkungen gehen teilweise in derselben Richtung wie die der toten Decken.

\section{Die Wärmeverhältnisse im Boden werden verändert.}

Die Pflanzendecke verringert die Ausstrahlung und ferner die Wirkung der Sonnenwärme. Die Wärmeschwankungen werden daher weniger stark, sowohl die täglichen als die jährlichen. Nackter Boden ist am Tage wärmer, nachts kälter als bewachsener; nackter Boden ist im Sommer gleichfalls wärmer, im Winter kälter als bewachsener. Aber die Mitteltemperatur des bewachsenen Bodens kann niedriger werden, als beim nackten Boden, im Walde jedenfalls $1-2^{\circ}$. Nach Ebermayer ist die Wärme in der Oberfläche des Waldbodens selten höher als $25^{\circ} \mathrm{C}$. Die Amplituden des Jahres nehmen in folgender Reihenfolge ab: bei Luft, nacktem Boden, Moosdecken, Buchenwäldern, Fichtenwäldern. In den Wäldern trägt natürlich die tote Decke zur Erhöhung der Wirkungen bei.

\section{Der Wassergehalt des Bodens wird beeinflußt.}

Ein Teil der Niederschläge geht dem Boden verloren, indem er sich auf den Pflanzen absetzt und verdunstet; besonders gilt dieses von den schwächeren Niederschlägen. In Wäldern gehen etwa $15 \%$ der Niederschläge verloren, in Nadelwäldern mehr als in Laubwäldern. Es wird jedoch das Vermögen des Bodens, die Feuchtigkeit festzuhalten, erhöht, er ist gegen Verdunstung besser geschützt, der Schnee schmilzt langsamer, und das Schneewasser wird vom Boden in höherem Grade aufgenommen.

Anderseits wirkt die Pflanzendecke auf die Schichten des Bodens, in denen die Wurzeln sich ausbreiten, austrocknend ein, desto stärker, je dichter sie ist, weil die Pflanzen aus dem Boden Wasser aufnehmen und durch Transpiration entweichen lassen. Im Walde werden die tieferen Bodenschichten von der Austrocknung durch die Bäume selbst beeinflußt, während auf der Oberfläche die Baumdecke schïtzend wirkt.

\section{als nackter.}

3. Der bewachsene Boden wird im allgemeinen weniger fest

Weil der Regen nicht zu starker mechanischer Einwirkung kommen kann; auch die Tiere (Regenwürmer) spielen hierbei mehr mittelbar eine Rolle.

\section{Boden gedåmpft.}

4. Die Beleuchtung wird auf dem von Pflanzen bedeckten

5. Endlich kann angeführt werden, daß die Luft unter der Pflanzendecke, besonders im Walde, verändert wird; sie wird kühler und feuchter. Der Wind kann selbstverständlich viel weniger wirken. 
6. Auch die Luft über bewachsenem Boden, besonders über Wäldern, wird kühler, was eine stärkere Taubildung, reichlicheren Nebel und Regen veranlaßt. Der Einfluß des Waldes auf das Klima ist oft behandelt worden; er geht in zwei Richtungen, teils vermehrt er die Niederschläge in gewissen Gegenden (in Ebenen jedoch gewiß nicht oder sehr unbedeutend; Untersuchungen in Dänemark und desgleichen in Schweden und Norwegen haben keine nennenswerte Vermehrung nachgewiesen), teils hindert er das gefallene Wasser, schnell wegzufließen, den Pflanzen verloren zu gehen und Überschwemmungen zu verursachen.

7. Die Moosdecke muß besonders erwähnt werden, weil sie namentlich auf den Wassergehalt des Bodens etwas anders als eine andere Pflanzendecke wirkt.

Es besteht ein Unterschied nach der Art der Moosdecke: Einige Moose (Hypnum und Verwandte) bilden 5-6 cm dicke, dichte, auf dem Boden lose liegende Polster; die Stengel anderer Moose sind in einen Filz von Rhizoiden eingehüllt, ihre Vorkeime und Rhizoiden durchweben den Boden mit einem sehr dichten Filz und befördern das Entstehen von Rohhumus (Polytrichum, Dicranum). Die Moose müssen daher auf den Boden verschieden einwirken. Aber im ganzen gilt nach Oltmanns ${ }^{1}$ ) folgendes:

a) Der Moosteppich wirkt wie ein Schwamm. Die dichten, niedrigen Teppiche mit den zahllosen Kapillarräumen zwischen Blättern und Rhizoiden nehmen kapillar und durch die Oberfläche Wasser auf, aber durch Aufsaugen aus dem Boden und durch inneren Transport gar nicht oder sehr wenig (der anatomische Bau ist der Ausdruck hiervon) ${ }^{2}$ ). Daher schlucken und verdunsten die lebenden und die toten Moosteppiche ungefähr gleichviel Wasser.

Die oft als Wurzeln angesprochenen Rhizoiden der Moose dienen im wesentlichen als Fixierungsorgane. Dort, wo sie am stärksten in Anspruch genommen werden, sind sie auch am kräftigsten entwickelt ${ }^{3}$ ).

b) Moosteppiche trocknen den Boden nicht aus. Da die Moose, besonders die lose liegenden Polster, aus dem Boden nicht viel Wasser aufnehmen, trocknen sie den Boden weniger aus, als eine andere Vegetation und schützen den trocknen, sich leicht erwärmenden Boden gegen Austrocknung. Die Verdunstung geht zwar aus einer Moosdecke rascher vor sich als aus einer toten Decke, aber die Moosdecken halten den Boden im ganzen feucht und kalt, und auf nassem und beschattetem Boden rufen sie leicht Versumpfung hervor.

1) Oltmanns 1885 .

2) Haberlandt 1904: Abschnitt 7.

?) Uber die Biologie der Rhizoiden vergl. besonders Paul 1902. 
8. Auch auf die chemischen Verhältnisse des Bodens wird eine Pflanzendecke einwirken können, indem verschiedene Vegetationen in den Nahrungsinhalt des Bodens und das Absorptionsvermögen in verschiedener Weise eingreifen, ihm verschiedene anorganische Stoffe wegnehmen und ihn mit organischen bereichern. Fruchtwechsel und Düngung werden für den Landwirt eine Notwendigkeit, weil er bei jeder Ernte beständig gewisse Mengen der Nahrungsstoffe des Bodens wegführt. Der Forstwirt tut dieses gleichfalls, wenn auch wohl in geringerem Grade, Düngung im Walde wird meist nicht angewandt, dürfte aber, je länger die Forstkultur dauert, immer notwendiger werden. Der Wind führt jedoch aus vielen Wäldern Laub fort und ruft dadurch große Boden- und Vegetationsveränderungen hervor. Wenn man den Grund zu dem bekannten Wechsel der Waldvegetation, der in Dänemark in Jahrtausenden vor sich gegangen ist, in einer Art Wechselwirtschaft der Natur hat suchen wollen, indem jede Waldbaumart den Boden aussaugen und dadurch einerseits zu fortgesetztem Wachstum für sich selbst weniger passend machen sollte, andrerseits ihn für andere Arten zubereiten sollte, so scheint dieses nur bis zu einem gewissen Grade richtig zu sein. Sicher ist, daß neben der alljährlichen Auslaugung durch die Niederschläge durch das Abfahren des Holzes dem Boden einige der nötigsten Pflanzennährstoffe (z. B. Kali) entzogen werden, daß daher eine allmähliche Verarmung des Bodens an diesen Stoffen eintritt. Daher werden öfter anspruchslosere Arten (Kiefern) den anspruchsvolleren mit stärkerer Stoffproduktion (Buche, Eiche) folgen ${ }^{1}$ ). Bei der Einwanderung der Baumarten nach der Eiszeit ist dagegen entsprechend der allmählichen Veränderung des Klimas und der Wanderfähigkeit der einzelnen Arten meist eine umgekehrte Folge zu beobachten ${ }^{2}$ ).

\section{Kap. Die Tätigkeit der Tiere und der Pflanzen im Boden}

Zwischen dem Pflanzen- und dem Tierleben eines Standortes besteht ein inniges und verwickeltes Wechselverhältnis, das sich in verschiedener Weise ausdrückt und für spätere Studien die interessantesten biologischen Ergebnisse verspricht. Hier sollen nur zwei Seiten hervorgehoben werden.

\section{Tätigkeit der Tiere}

Der Boden wird von vielen Tierarten durchwühlt, der Landboden besonders von Regenwürmern, Insekten und Insektenlarven, Tausendfüßen, Kellerasseln, Ameisen ${ }^{3}$ ) u. a., auch von Tieren, die jenen nach-

1) Hausrath 1900; Graebner 1901; 1912.

2) Vergl. Andersson 1903; Graebner 1912.

s) Vergl. anch Ule 1900. 
stellen, z. B. von Maulwürfen, der Meeresboden von kleinen Krustaceen, Röhrenwürmern (Sedentaria oder Tubicolae) u. a.

Erdboden. Die oberste Schicht von Wald- und Ackerboden besteht gewöhnlich aus einem innigen Gemische von mineralischen Teilen, von Tierresten und von Resten der früheren Vegetationen, wie Blättern, Zweigstückchen, Fruchtresten, Samen usw., die sich in verschiedenen Graden der Zersetzung und der Bearbeitung durch die Tiere befinden.

Der Landboden, der an Tieren reich ist, ist auch für Vegetation günstig, gerade weil er an Humusstoffen reich ist (vergl. S. 113 ff.); und fehlt das Tierleben, so ist die Vegetation gewöhnlich niedrig und gedrückt. Die Tiere wirken auf den Boden und dadurch auf die Vegetation besonders auf viererlei Art ein:

1. Sie zerkleinern die Pflanzenreste mit ihren Mundteilen oder, wie die Regenwürmer, in ihrem Magen mit Hilfe der verschluckten Steinchen,

2. sie vermischen in ihren Eingeweiden ihre Nahrung mit mineralischen Teilen des Bodens, d. h. sie befördern die Humusbildung, indem sie einen fein gemischten Boden bilden,

3. sie vergraben im Boden Pflanzenteile,

4. sie machen den Boden durch die von ihnen gebildeten Röhren und Gänge poröser und mehr durchlüftet (der Boden wird "mürbe" oder "gar") ${ }^{1}$ ), und die abgelagerten Exkremente dienen auch dazu, den Boden krümelig und porös zu machen; die Tiere sorgen dadurch für Drainage.

Namentlich spielen die Regenwürmer im Landboden eine Rolle. In Dänemark sind namentlich die beiden großen Arten Lumbricus terrester und rubellus, außerdem L. purpureus, Allolobophora turgida und Euchytreus-Arten bedeutungsvoll. Sie bilden Gänge, die senkrecht, bis $2 \mathrm{~m}$ und tiefer in den Boden hinabgehen und wodurch die Wurzeln tief in die Erde hinabgelangen können. Die Gänge werden mit Pflanzennahrungsstoffen (Blattresten und Exkrementen) ausgefüllt. Fünf andere Arten leben in der Ackerkrume. Bisweilen sind sie in so großen Mengen vorhanden, daß 400000 Individuen auf einem Hektar Land vorkommen.

Nachts und bei feuchtem, dunklem Wetter kommen sie aus ihren Gängen hervor und lagern ihre Exkremente in krümeligen Häufchen oben auf dem Boden ab. Sie zerkleinern die Pflanzenreste, bearbeiten sie mechanisch nnd vermischen sie innig mit den mineralischen Teilen, die sie auch verschluckten. Dazu kommt, daß ihre alkalischen Verdauungsflüssigkeiten die Humussäuren des Bodens neutralisieren. Schatten,

1) Der Begriff der "Bodengare" darf nicht auf einen künstlich gelockerten Boden, dem die die Lockerheit danernd erhaltende Tätigkeit der Tiere fehlt, übertragen werden. 
Schutz vor dem Winde und feuchte Luft befördern das reiche Tierleben des Bodens; Schatten und Schutz vor dem Winde sind daher auch für die Vegetation mittelbar von Bedeutung. Wenn ein Waldboden der Sonne ausgesetzt wird und der Wind das Laub wegfegt, so verschwinden die Regenwürmer, der Boden wird trocken und hart, die Vegetation gehemmt. In saurem Boden, in Sümpfen, auf Heiden und Dünen fehlen die Regenwürmer. Von ihrer Anwesenheit oder ihrem Mangel hängt das Vorkommen von Humus- und Rohhumusboden in unseren Wäldern und Heiden ab, oder umgekehrt verschwinden sie bei Bildung von Rohhumus und Bodensäuren. Selbst auf den Wuchs der Rhizompflanzen in den Wäldern wirken sie ein ${ }^{1}$ ); ihr Auftreten oder ihr Mangel ruft eine Reihe Variationen in der Art des Bodens hervor, denen eine Reihe Variationen in der Pflanzendecke entsprechen ${ }^{2}$ ).

Als ein anderes Beispiel dafür, wie die Tiere auf die Vegetation einwirken können, sei darauf hingewiesen, daß Maulwurfshaufen und Ameisenhaufen sehr oft eine etwas andere Vegetation tragen als der umgebende Boden ${ }^{3}$ ).

Meeresboden. Eine ähnliche, jedoch offenbar durchaus nicht so bedeutende Rolle, wie sie die Regenwürmer in dem Pflanzenleben des Landbodens spielen, haben die Arenicola-Arten und Corophium crassicorne teils in der Zostera-Vegetation an nordeuropäischen Küsten, teils außerhalb dieser ${ }^{4}$ ).

\section{Tätigkeit der Pflanzen}

Eine weit wichtigere Rolle als die Tiere spielen jedoch sicher die saprophilen Pflanzen des Bodens, nämlich Pilze und Bakterien.

Pilze im Boden. Gewiß in jedem humusreichen Boden leben Pilzmycelien; der Waldboden legt im Herbste durch seinen Reichtum an Basidiomyceten dafür Zeugnis $a b$, in welchem Grade er von jenen durchwebt ist. Aber selbst wenn keine oder nur wenige Pilze zur oberirdischen Entwicklung kommen, kann die mikroskopische Untersuchung sie gewiß in jedem humusreichen Boden nachweisen, selbst in saurem Heidetorf; Fäden von Cladosporium humifaciens u. a. treten hier auf, wie auch die Wurzeln von Calluna u. a. ebenso wie die meisten Waldbäume und ein Teil der auf Humus lebenden mehrjährigen Kräuter Mykorrhizen haben ${ }^{5}$ ). Saccharomyceten überwintern im Boden ${ }^{6}$ ).

1) P. E. Müller 1894.

2) Über die Naturgeschichte der Regenwürmer vergl. bes. C. Darwin 1881, P. E. Müller 1878, V. Hensen, Wollny; über die tropischen C. Keller 1887.

э) Buchenau 1876; Warming 1894, 1906; P. E. Müller 1894.

4) Rosenvinge 1889-90; vergl. Warming 1906; betr. Corophium vergl. Warming und Wesenberg-Lund 1904; Warming 1906.

5) Vergl. auch Kapitel 32.

-) E. C. Hansen 1881 und später. 
Noch wichtiger sind die Bakterien ${ }^{1}$ ). Sie finden sich sozusagen in jedem Boden und in jedem Wasser, in den Landböden, in den verschiedensten Schlammbildungen, in Salz- wie in Süßwasser. In den obersten Bodenschichten, besonders rings um bewohnte Stellen, sind sie in Millionen und aber Millionen vorhanden; ihre Anzahl nimmt in dem bewachsenen Boden ungefähr bis $1 / 2{ }^{3} / 4 \mathrm{~m}$ Tiefe $\mathrm{zu}$, sinkt darauf sehr rasch, und etwa von 5-6 m Tiefe an finden sich in der Regel keine mehr: der Boden hat sie aus dem hinabsickernden Wasser abfiltriert. Versuche von Adametz ergaben ${ }^{2}$ ) folgende Zahlen. Es fanden sich:

in $1 \mathrm{~g}$ Sandboden an der Oberfläche . . . 380000 Individuen

"1 g $\Rightarrow \quad$ in $20-25 \mathrm{~cm}$ Tiefe . 460000 \%

" $1 \mathrm{~g}$ Tonboden an der Oberfläche . . 500000 ,

" $1 \mathrm{~g} \quad$ in $20-25 \mathrm{~cm}$ Tiefe . . 464000 "

Andere haben in $1 \mathrm{~g}$ Boden etwa bis eine Million Bakterien gefunden. Die Menge muß natürlich von verschiedenen Verhältnissen abhängen.

Die Artenanzahl ist wahrscheinlich außerordentlich groß, und von einigen Bakterien weiß man sicher, daß sie in der Naturgeschichte des Bodens eine bedeutende Rolle spielen. Einige sind aërob, andere anaërob. Es kommen nicht nur gewöhnliche Fäulnisbakterien vor, wovon viele für die Zusammensetzung der Bodenluft von größter Bedeutung sind, sondern auch Krankheiten erregende Bakterien (z. B. Bacillus tetani, der den Starrkrampf hervorruft) und Arten, namentlich Salpeterbakterien, die im Boden wichtige chemische Verbindungen bilden. Schlösing und Müntz haben zuerst nachgewiesen, daß die Salpeterbildung im Boden durch Mikroorganismen verursacht wird, weil stickstoffhaltiger Boden, worin dieser Prozeß vor sich gehen kann, die Fähigkeit dazu verliert, wenn er auf $110^{\circ}$ erwärmt wird, sie aber wiedererhält, wenn nicht sterilisierter Boden ihm beigemischt wird, und weil Chloroform dem Prozeß augenblicklich Einhalt tut.

Winogradsky war der erste, der diese Organismen, deren es mehrere Arten zu geben scheint, isolierte. Sie lieben einen durchlüfteten, mäßig feuchten, stickstoffhaltigen alkalischen Boden von $10-45^{\circ} \mathrm{C}$. Nach Müntz spielen die Salpeterbakterien bei der Verwitterung der Gesteinsarten eine wichtige Rolle, indem sie in die feinsten Poren hinabdringen und ihre chemische Wirksamkeit ausüben ${ }^{3}$ )

Niklewski ${ }^{4}$ ) fand in verschiedenen Bodenarten, im Teich-oder Schleusenschlamm, Gartenerde, Heideerde, Lauberde usw. aus verschie-

1) Über Bodenbakterien vergl. auch Kolkwitz 1899; E. Heine 1910.

2) Nach Sacchse 1888.

3) Vergl. auch Schröter 1904-8, S. 558.

4) Niklewski 1907. 
denen Teilen Europas ein Stäbchenbakterium (Bacterium oligocarbophitum), welches die Eigenschaft besitzt, Wasserstoff $\mathrm{zu}$ oxydieren. Im besten Falle wurden 0,13 ccm Knallgas in 1 Stunde pro $1 \mathrm{qcm}$ in der von dem Bakterium gebildeten Kahmhant kondensiert. Dieses Bakterium spielt danach sicher bei der Sauerstoffabnahme in manchen Böden eine Rolle.

Manche Bakterien haben die Fähigkeit, den freien Stickstoff der Luft zu speichern und dadurch den Boden an diesem wertvollen Stoff anzureichern, so z. B. die Knöllchenbakterien der Leguminosenwurzeln ${ }^{1}$ ). Ob auch Mykorrhizenpflanzen, wie z. B. Pinus montana ${ }^{2}$ ), diese Fähigkeit besitzen, ist nicht sicher erwiesen.

Einen Boden mit freien Säuren (Humussäuren) lieben die meisten Bakterien nicht; daher gibt es in Torf und ähnlichem Boden meist wenige. Dachnowski hat doch gefunden, daß viele Bakterien in Sumpfmooren vorkommen, welche Toxine produzieren, die für die Pflanzen giftig sind; die Wurzeln werden dann schwieriger Wasser aufnehmen, und die Transpiration muß durch xeromorphe Einrichtungen vermindert werden.

\section{Kap. Einige orographische und andere Faktoren}

Die verschiedenen Faktoren, die im vorhergehenden behandelt sind, finden sich in der Natur auf so verschiedene Weise und in einer solchen Menge von Abstufungen vereinigt, daß in der Beschaffenheit der Standorte und in den Verschiedenheiten der Vegetation die reichste Mannigfaltigkeit entsteht. Aber Mannigfaltigkeit und Abwechselung werden ferner durch die Modifikationen vermehrt, die durch gewisse geographische, zunächst durch orographische Faktoren bewirkt werden. Zu ihnen gehören namentlich die Richtung der Gebirgsketten und der Täler, die Höhe der Gebirgsketten, die Steilheit und die Neigungsrichtung der Abhänge usw.

Die Richtung und die Höhe der Gebirgsketten haben die allergrößte klimatische Bedeutung: sie lenken die Winde in bestimmten Richtungen ab, rufen Föhne hervor (vergl. 5. Kap.), fangen die Feuchtigkeit der Winde auf bestimmten Seiten auf und verdichten die Wasserdämpfe in den höheren Stufen zu Wolken und Regen, weshalb es auf gewissen Seiten oder von einer gewissen Höhe über dem Meere ab in der Nebelregion üppige Wälder geben kann, während es auf anderen Seiten oder darunter sowohl wie darüber äußerst trocken sein kann. Auf hohen Gebirgen stehen die Stufen in wechselseitiger Beziehung mit der Verteilung der Regenmenge. Oft kann man drei Höhenstufen beobachten: eine niedrigere mit spärlichem Regenfall; eine mittlere, die

1) Utber die Stickstoffbakterien vergl. auch Bredemann 1908; Pfeiffer 1902. Über die Biologie der Leguminosenbakterien vergl. auch K. Fuhrmann 1907.

?) Vergl. P. E. Müller 1903. 
Nebel- oder Wolkenregion, mit viel Nebel und Regen, und daher mit Wald bedeckt; eine obere trockene, die sich über die Nebel erhebt (so z. B. im Tianschan, auf Madera, Teneriffa).

Der III. Internationale Botan. Kongre $1910^{1}$ ) hat für die Verbreitungsangaben folgende einheitlichen Bezeichnungen vorgeschlagen:

Zonen, die großen Wärmegürtel der Erde.

Stufe (Höhenstufe, Tiefenstufe [vergl. Engler]), die Gliederung der Vegetation in Gebirgen und in Gewässern, soweit sie gürtelförmig abgestuft ist. An den Ufern an Gewässern, nach der Höhe ïber dem Grundwasserstande (franz.: Etage; engl.: Belt).

Gürtel, die ringförmige Anordnung einer Formation.

Region, das allmähliche horizontale Aufsteigen (s. oben).

Die Küstengebirge Brasiliens sind regnerisch und bewaldet; aber das Innere ist trocken (die "Campos", Steppe, Savanne), weil die Feuchtigkeit des Passates verdichtet und abgesetzt ist, bevor sie dahin gelangt. Ebenso ist in Südafrika die Küste feucht, die Karroo trocken; und die niedrigeren westindischen Inseln sind trocken und regenarm, während die höheren große Niederschläge und üppigere Vegetation haben. Selbst im kleinen können sich die Oberflächenverhältnisse geltend machen; z. B. führt Blytt ${ }^{2}$ ) an, daß steile, nach Süden gewandte Felsenwände der betreffenden Vegetation andere Wärmeverhältnisse darbieten. Unter den hohen Felsenwänden findet sich bei Christiania eine Vegetation, die reich und abwechselnd ist und namentlich mehrere südliche Arten enthält, weil hier an Sonnentagen eine brennende Hitze herrscht. Gunnar Andersson und Selim Birger haben eingehend die floristischen Eigentümlichkeiten der südexponierten Bergseiten im nördlichen Schweden besprochen; Relikte von der wärmeren postglacialen Zeit finden sich hier ${ }^{3}$ ).

Von der Steilheit der Abhänge (von dem Neigungswinkel gegen den Horizont) hängt es ab, ob die Produkte der Verwitterung und der Humusbildung liegen bleiben können oder hinabgespült werden, wie schnell das Wasser von der Oberfläche wegströmt, wie sehr also diese durchnäßt wird, wie dicht und wie hoch eine Vegetation wird, und endlich wie stark die Sonnenstrahlen den Boden erwärmen können (vergl. Kap. 10).

Von der Neigungsrichtung (Exposition) der Abhänge hängt es wesentlich $a b$, welche Vereine zur Entwicklung kommen. Die von Sonne, Regen und Wind getroffenen Abhänge tragen eine ganz andere

1) Vergl. dort I., S. 138. - Flahault 1900, 1901 b. Mit dem Namen "Region“ bezeichnete A. P. De Candolle (1815, 1820), Schouw (1822) und später Grisebach und andere die großen horizontalen Gebiete der Erde, in welchen dasselbe Klima und dieselbe Vegetation herrschte. Wahlenberg u. a. benutzten das Wort als Bezeichnung für vertikale Gebiete, Höhenstufen und Stockwerke (ètages).

2) Blytt 1893 .

3) G. Andersson u. S. Birger 1912. 
Vegetation, als die weniger sonnigen oder weniger dem Regen und dem Winde ausgesetzten. Außer dem S. 92 angeführten sei erwähnt, daß die südwestlichen Abhänge in den russischen Ostseeprovinzen eine mehr hydrophile, die Nordostabhänge eine mehr xerophile Vegetation tragen, weil die südwestlichen Winde Feuchtigkeit, die nordöstlichen Trockenheit bringen ${ }^{1}$ ). Selbst in sehr kleinen Verhältnissen kann die Neigungsrichtung für die Vegetation eine Rolle spielen, z. B. in den Dünen; Giltay $^{2}$ ) hat einige Beobachtungen über den Unterschied in Wärme und Luftfeuchtigkeit gemacht, der auf nur wenige Schritte voneinander entfernten Nord- und Südabhängen der Dünen Hollands herrschen kann ${ }^{3}$ ). In gleicher Weise kann die Vegetation auf den beiden Seiten eines Einschnittes oder eines Dammes an der Eisenbahn oder Landstraße äußerst verschieden sein $\left.{ }^{4}\right)$. Auf der Südseite der Abhänge im östlichen Norddeutschland ist vorzugsweise die Flora der sonnigen (pontischen oder pannonischen) Hügel mit Pflanzen kontinentaler Klimate entwickelt.

Auch der verschiedene geognostische Bau, z. B. die verschiedene Neigung der Schichten, ruft Vegetationsunterschiede hervor ${ }^{5}$ ). Diese Neigung wirkt auf den Lauf des Wassers, auf das Hervortreteten von Quellen und dadurch auf die Vegetation ein. Außerdem kann die Beschaffenheit der Oberfläche selbst ganz verschieden sein, je nachdem diese mit der Fall-Linie der Schichten einen Winkel bildet oder mit ihr ungefähr parallel geht; im ersten Falle kann die Oberfläche steil und kiesig sowie trocken sein, so daß sich nur eine zerstreute und krüppelige Vegetation entwickeln kann, während sie sich in dem anderen Falle allmählich neigt, an Wasser reicher ist und infolgedessen eine dichte und üppige Vegetation trägt. Beispiele hierfür wird man in vielen Gegenden mit Schiefergebirgen finden ${ }^{6}$ ).

1) Klinge 1890 .

2) Giltay 1886.

3) Vergl. auch Warming 1904, 1909.

4) Stenström 1905 .

5) Vergl. Kraus, Boden und Klima, 1911.

-) Das Studium der Ökologie wird sehr befördert durch die Anfertigung von Karten, in denen die typische Vegetation mit einer besonderen Farbe eingetragen ist, und die Vergleichung dieser Karten mit geologischen. Ausgezeichnete Einzelstudien dieser Art haben gemacht Woodhead 1906, R. Smith, W. G. Smith 1903-5. Moss 1913, F'lahault 1894, 1897, 1901 und Drude 1902, 1908 haben Vegetationskarten von größeren Gebieten veröffentlicht. Vergl. auch Clements 1905. 


\title{
III. Das Wasser als Standort
}

\section{Kap. Die ökologischen Faktoren im Wasser}

\author{
(Luft, Licht, Wärme, Nahrungsstoffe, Bewegungen, Farbe \\ des Wassers)
}

Im AnschluB an die Besprechung der Eigentümlichkeiten der festen Böden als Pflanzenträger mögen jetzt die allgeneinen Eigenschaften des Wassers behandelt werden, insoweit sie als Standort der Pflanzen Bedeutung haben ${ }^{1}$ ).

Luft findet sich in verschiedener Menge im Wasser aufgelöst. In der Luft (vergl. 1. Kap.) und im Wasser kommen dieselben Gase vor, aber

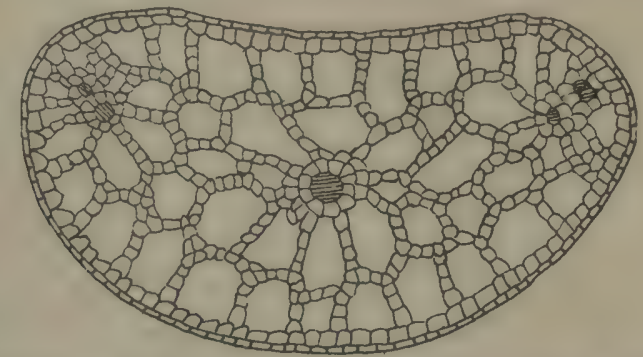

Fig. 47. Querschnitt eines untergetauchten Blattes von Potamogeton natans mit den großen Lufträumen. (Nach Raunkiär.)

in verschiedenen Verhältnissen; in den Gasen des Wassers ist der Sauerstoff in größerer, die Kohlensäure in viel größerer Menge vorhanden, als in der Luft. Wie für die Landpflanzen sind diese zwei Luftarten die allein wichtigen Gase, jener für die Atmung, diese für die Kohlensäureassimilation. Nur gewisse Bakterien können den Sauerstoff entbehren. Die Luft kann indes zu den in Wasser untergetauchten Teilen viel schwieriger zutreten, als zu den in Luft oder in gewöhnlicher Erde befindlichen. Stehendes Wasser kann so arm an Sauerstoff werden, daß höhere Pflanzen und Tiere in ihm fast nicht leben können. Gewisse Arten finden sich vermutlich deshalb an solchen Orten, wo Brandung und Strömung stark sind und wo stetig frisches, d. h. sauerstoffreiches Wasser zugeführt wird; deshalb werden auch viele untergetauchte Pflanzenteile oder ganze Pflanzen (Blätter, Algen usw.) in viele haarfeine Zipfel geteilt (vergl. den Bau der Kiemen), wodurch die mit dem

1) Vergl. Oltmanns 1905 . 
Wasser in Berührung kommende Oberfläche größer wird, als wenn das Organ eine einfache Fläche wäre; und vermutlich aus demselben Grunde tragen viele Algen und Podostemaceen lange Haare, die als Atmungsorgane dienen oder die assimilierende Oberfläche vermehren. Der schwierige Luftzutritt ist ferner ein Grund und vermutlich der wichtigste für die großen Lufträume, die sich bei sehr vielen Wasserpflanzen finden (bei einigen über $70 \%$ des Volumens der Pflanze einnehmend) und wodurch.z. B. die über Wasser befindlichen Teile den untergetauchten oder in schlammigem Boden wachsenden Teilen Luft (namentlich Sauerstoff) zuführen können. Besondere, später zu erwähnende Atmungsorgane haben gewisse Sumpfpflanzen namentlich in den Mangrovesümpfen.

Bei behindertem Luftzutritt und sauerstoffarmem Wasser werden im Boden Humussäuren gebildet, die für Moor- und Torferde bezeichnend sind (S. 109), und die wahrscheinlich verursachen, daß der Boden "physiologisch trocken" wird (siehe Kap. 13).

$\mathrm{Daß}$ das Absorptionsvermögen für Gase beim Wasser mit steigender Temperatur abnimmt, ist vielleicht der wesentlichste Grund, weshalb gewisse Wasserpflanzen im Sommer beim Steigen der Wärme und der Lichtstärke verschwinden, weshalb viele Algen im Winter im kalten Wasser des arktischen Gebietes fruktifizieren (vergl. S. 32) und wir im Winter am Grunde unserer Gewässer oft eine lebhaft grüne Vegetation treffen.

Licht. Auch für alle Wasserpflanzen muß man gewisse Minima, Optima und Maxima der Lichtstärke annehmen. Die Beleuchtung ist für die Verteilung der Algen sehr wichtig ${ }^{1}$ ), wahrscheinlich, auch für die Häufigkeit der Arten zu verschiedenen Jahreszeiten, worüber man jedoch nichts Sicheres weiß. Je weiter Minimum und Maximum voneinander entfernt ist, desto größer wird das Verbreitungsgebiet der Art sein können.

Das Licht spielt für die Assimilation dieselbe Rolle wie bei den Landpflanzen; es kommen jedoch eigentümliche Verhältnisse hinzu. Es wird geschwächt, teils durch Reflexion auf dem Wasser, teils durch Absorption im Wasser, teils durch die hier schwebenden Teilchen, und zwar desto mehr, je unreiner das Wasser ist. Untergetauchte Wasserpflanzen erhalten deshalb, und weil Verdunstung fehlt, im ganzen das Gepräge von Schattenblättern; sie werden langgestreckt gleichwie etiolierte Pflanzen und dünn, das Assimilations-Gewebe wird wenig ausgebildet, dorsiventrale Entwicklung findet sich nur bei Schwimmblättern, das Palisadengewebe verschwindet oder wird niedrig, die Epidermis wird dünn, hat auf den untergetauchten Teilen keine oder eine schwache Kutikula und enthält oft Chlorophyllkörner; denn die Rolle der Epidermis als

$\left.{ }^{1}\right)$ Oltmanns 1905 u. a. Vergl. auch die Hydrophyten-Vegetation in Abschnitt 4. 
Wassergewebe ist hier überflüssig, und Transpiration fehlt bei den untergetauchten Teilen; die äußerste Zellschicht ist bei den Algen gerade die für die Kohlensäureassimilation beste.

Das Licht dringt nur bis zu einer gewissen Tiefe hinab und wird sukzessiv abgeschwächt mit wachsender Tiefe, so daß die Assimilationsenergie mit verschiedenen Tiefen sehr variiert ${ }^{1}$ ); daher kann das Pflanzenleben, Bakterien ausgenommen, nicht $\mathrm{zu}$ großen Tiefen hinabgehen. Vertikale Verschiedenheiten in der Verteilung der Pflanzen werden die Folge sein. Man hat unterschieden:

1. Euphotische Vegetation, welche reichliches Licht empfängt;

2. Dyphotische Vegetation, welche in abgeschwächtem Lichte lebt;

3. Aphotische Vegetation, welche in sehr schwachem Lichte oder völliger Dunkelheit lebt.

Blütenpflanzen gehen höchstens $30 \mathrm{~m}$ hinab (Zostera in den dänischen Gewässern bis zu 12-14 m), Algen etwa bis $40 \mathrm{~m}$, aber noch in 120 bis $150 \mathrm{~m}$ und größerer Tiefe hat man lebende Algen gefunden ${ }^{2}$ ); im Mittelmeer sollen Algen noch in 100-200 m Tiefe leben können. In den klaren Schweizer Seen steigen Characeen bis 25 und $30 \mathrm{~m}$ herab, in den Seen an der Ostseeküste aber nur bis 6 oder $8 \mathrm{~m}$; im Genfer See hat man nach Forel noch in $60 \mathrm{~m}$ Tiefe ein Moos, 1 hamnium alopecurum var. Lemani, gefunden, und 4-500 m Tiefe sind vermutlich die äußerste Grenze, bis zu der das Licht hinabdringt. Daß die Protococcacee Halosphaera viridis in $2200 \mathrm{~m}$ Meerestiefe gefunden wurde, ist gewiß als eine Folge von Meeresströmungen oder als ein periodisches Sinken zu erklären.

Die verschiedenen Farben werden ungleich stark absorbiert und dringen daher zu verschiedener Tiefe hinab. Die roten Strahlen werden in den oberen Wasserschichten absorbiert, die grünen, die blauen und die ultravioletten erst in tieferen. Ultraviolette Farben hat man noch in $400 \mathrm{~m}$ Tiefe durch photographische Platten nachweisen können. Hiermit steht die Verteilung der Algen nach der Tiefe in Verbindung: im roten Licht assimilieren die grünen Algen am besten, im gelben die Braunalgen, während auf die Rotalgen grünes und blaues Licht am besten einwirken; daher trifft man jene nur in den oberen Wasserschichten, diese vorzugsweise in den tieferen. Gegen diese namentlich von Engelmann aufrecht erhaltene Lehre hat Oltmanns eingewandt, daß es bei den Algen nur auf die Lichtstärke ankomme; „die Farbe des Meeres ist nur eine Schattendecke, weiter nichts". - Gaidukow ${ }^{3}$ ) hat

1) B. Jönsson 1903.

2) Sie können oft von der Strömung mitgerissen und in größere Tiefen geführt worden, wo sie sich eine Zeitlang lebend erhalten können (vergl. auch Chun).

3) Gaidukow 1903.

Warming-Graebner. 3. Anflage, illustr. 
neuerdings gezeigt, daß, wenn man Oscillatorieae in gefärbtem Lichte kultiviert, diese ihre Farbe wechseln und die Komplementärfarbe der auf sie einwirkenden annehmen, dadurch sind sie imstande lebhafter zu assimilieren.

Wärme. Untergetauchte Wasserpflanzen sind weit weniger extremen Wärmegraden und weit geringeren Wärmeänderungen, sowohl täglichen als jährlichen, ausgesetzt, als Landpflanzen, weil Wasser eine große spezifische Wärme hat und ein schlechter Wärmeleiter ist; die Wärmeänderungen des Jahres dringen in verhältnismäßig geringe Tiefen hinab, àusgenommen in seichten Gewässern. Viele Wasserpflanzen überwintern grün, weil größere Kälte sie nicht erreicht, und die meisten sind mehrjährig. Das Optimum ihres Wachstums liegt im ganzen tief; gewisse Arten, z. B. Hydrurus (eine Alge aus der Klasse der Phaeoflagellatae), gedeihen nur in sehr kaltem Wasser. Daß viele Algen im Sommer verschwinden, wird vieleicht dadurch hervorgerufen, daß das Optimum der Wärme überschritten wird (vergl. jedoch Kap. 3). Die Algen sind gegen schnelle Veränderung der Wärme oft sehr empfindlich ${ }^{1}$ ), wie überhaupt gegen plötzliche Veränderungen, auch im Salzgehalte des Wassers. Jede Art hat ihre Eigentümlichkeiten.

Hohe Temperaturen finden sich nur in warmen Quellen, und hier wachsen fast ausschließlich Bakterien, Oscillarien und andere blaugrüne Algen (Cyanophyceae), die vielleicht Vertreter der zuerst auf der Erde erschienenen Vegetation sind.

Die Temperatur nimmt mit der Tiefe ab, aber anders in süßem als in salzigem Wasser. In stehendem Süßwasser wird sie auf dem Boden tiefer Seen ca. $4^{0}$ sein, weil süßes Wasser bei dieser Temperatur seine größte Dichte besitzt. Höher liegende Wasserschichten können also viel kälter sein. In den Schweizer Seen beträgt die Bodentemperatur das ganze Jahr ca. $5^{0}$. In den Meeren hingegen werden die Schichten desto kälter sein, je tiefer sie liegen, es sei denn, daß sich warme oder kalte und salzige Strömungen zwischen sie schieben.

Die Einwirkung der Temperatur auf die Verteilung der WasserPhanerogamen wurde von Magnin ${ }^{2}$ ) nachgewiesen, indem er fand, daß sie zu $11 \mathrm{~m}$ Tiefe in den wärmeren Jura-Seen hinabsteigen, aber nur bis $6 \mathrm{~m}$ Tiefe in kalten Seen.

Die Temperatur wirkt auf den Gehalt des Wassers an aufgelöster Luft ein; je kälter, desto reicher ist es an Sauerstoff und an Kohlensäure und desto günstigere Ernährungsbedingungen kann es also dem Pflanzenwachstum bieten. Dieses ist vermutlich wie Kap. 3 bemerkt

1) Oltmanns 1892 .

2) Magnin 1895. 
der wichtigste Grund für die mächtige Entwicklung der Algenvegetation in den Polarmeeren.

Sehr wichtig für das Verständnis der Fauna und Flora der Landgewässer sind die Temperaturbeobachtungen, die neuerdings WesenbergLund ${ }^{1}$ ) in Dänemark angestellt hat. Er fand, daß schon früh im Frühjahr, wenn der größte Teil der Oberfläche der Seen noch mit Lis bedeckt ist, an den von der Sonne bestrahlten Rändern ein erheblicher Teil der Sonnenstrahlen in Wärme umgesetzt wird, so daß sich das Wasser an den bestrahlten Ufern sehr stark erwärmt. Die Temperatur steigt oft an sonnigen Nachmittagen an der Oberfläche unweit des Eisrandes auf ca. $15^{\circ}$. Dadurch erwacht dort das Tier- und Pflanzenleben namentlich niederer Lebewesen, also besonders des Planktons sehr schnell und früh. Das ist sicher der Grund, weshalb man an den Ufern unserer Landseen oft schon große Massen von Algen bemerkt, zu einer Zeit, wo die festgewurzelte Uferflora eben erst zu erwachen beginnt.

Pflanzennahrungsstoffe und andere Stoffe im Wasser. Das Wasser enthält viele Stoffe aufgelöst, die je nach den Gesteinsarten und den Erdschichten, womit es in Wechselwirkung getreten war, verschieden sind. Kohlensaurer Kalk ist ein sehr gemeiner, durch Kohlensäure aufgelöster Stoff (hartes Wasser). Indem sich viele Wasserpflanzen der Kohlensäure des doppelt kohlensauren Kalkes bemächtigen, wird Kalk als einfach kohlensaurer Kalk auf ihrer Oberfläche abgeschieden (Characeen, Arten von Cyanophyceen, Potamogeton-Arten, gewisse Moose usw). Dieser Kalk kann nachher Kalkablagerungen (vergl. S. 117 und Abschnitt 4) auf dem Boden der Seen hervorrufen ${ }^{2}$ ).

Brand $\mathrm{t}^{3}$ ) bestätigte, daß das Meer an Stickstoffverbindungen reich ist, welche bei denitrifizierenden Bakterien reduziert werden. Dieser Prozeß ist wirksamer in tropischen und subtropischen Meeren als in temperierten und kalten, und auch deshalb werden die ersteren relativ arm an Organismen, während die letzteren reich sind (Vahl).

Viele Gewässer enthalten organische Verbindungen aufgelöst, die dadurch, daß sie den Sauerstoff verbranchen, das Wasser zum Aufenthalte für Autophyten ungeeignet machen.

Die wichtigsten Pflanzennahrungsstoffe, wie Kali, Phosphorsäure, Ammoniak, Schwefel usw., finden sich in geringer Menge und in stark verdünntem Zustande gewiß in jedem Wasser, aber man weiß von keinem, da $B$ er deutlich auf die Verteilung der Wasserpflanzen einwirkt. Nur Kalk bildet vielleicht eine Ausnahme, weshalb englische Botaniker (z. B. Tansley, Moss) „Formationen“ von kalkreichen Gewässern von kieselreichen

1) Wesenberg-Lund 1912.

2) Wesenberg-Lund 1904.

8) Brandt 1904. 
trennen. Gewisse Desmidiaceen und Diatomeen sollen Kalk vorziehen, andere Kieselsäure; ähnliche kleine Unterschiede werden sich wohl bei anderen Pflanzen finden. Bedeutung, und zwar eine sehr große Bedeutung, hat in dieser Hinsicht nur das Kochsalz (Chlornatrium). Von den vielen Salzen des Meerwassers: Chlornatrium, Chlormagnesium, schwefelsaure Magnesia, Gips, Chlorkalium u. a., ist das erste das allerwichtigste (ca. $78 \%$ ). Der Salzgehalt der Meere ist bekanntlich sehr verschieden, sowohl auf verschiedenen Stellen als auch oft auf derselben Stelle zu verschiedenen Zeiten. Ungefähre Angaben sind folgende: Das rote Meer 4\%, Mittelmeer 3,5-3,9, die großen Ozeane 3,5, Skagerak 3, Kattegat 1,5-3, der große Belt 1,27, Sund 0,92 (in diesen beiden nach den Strömungen sehr veränderlich), der bottnische Meerbusen $0,1-0,5$, der finnische $0,3-0,7$. Diese Zahlen gelten für das Oberflächenwasser; in den dänischen Meeresteilen findet sich in größerer Tiefe eine salzige Unterströmung aus der Nordsee.

In den Salzseen des Binnenlandes ist der Salzgehalt weit größer, z. B. bis zu einigen zwanzig Prozent im Toten Meere, in welchem er auch an den verschiedenen Stellen sehr verschieden ist, z. B. beim Ausflusse des Jordan viel weniger.

Die große Verschiedenheit der Flora in Salz- und in Süßwasser sowie im brackischen wird später behandelt werden (4. Abschnitt).

Obgleich sich nicht wenige Süßwasseralgen, besonders niedrig stehende, an Kochsalz anpassen können, wobei eine Vergrößerung der Zellen und andere Formenveränderungeu eintreten (Ad. Richter), sind doch fast keine anderen Pflanzen als gewisse Diatomeen dem süßen und dem weniger salzigen Wasser gemeinsam; in dem Brackwasser der Ostsee leben jedoch z. B. einige Characeen, Enteromorpha intestinalis und Potamogeton pectinatus, die sich auch in süßem Wasser finden. Bacillus . (Clostridium) Pasteurianum und Azotobacter kommen sowohl in der Landerde, als im süßen Wasser und im Meere vor.

In den nahrstoffarmen Gewässern der Heiden findet sich eine ganz eigentümliche Flora. Die größte Mehrzahl der Sumpf- und Wasserpflanzen der Landseen und Teiche ist wegen Nahrungsmangels ausgeschlossen.

Die an besonderen Orten auftretenden Schizophyceenvereine werden später besprochen werden.

Das spezifische Gewicht von Salzwasser und von Süßwasser ist sehr verschieden und daraus folgt eine verschiedene Tragfähigkeit, die bei den Planktonorganismen eine große Rolle spielt; Süßwasser hat bekanntlich einen geringeren Auftrieb als Salzwasser. Der regelmäßige den Jahreszeiten folgende Temperaturwechsel im Süßwasser bringt in ihrer Folge auch entsprechende Veränderungen im spezifischen Gewichte 
und damit der Tragfähigkeit mit sich. Viele Planktonorganismen unterliegen periodischen Veränderungen ihrer Gestalt, welche alle darauf hinaus zu laufen scheinen, die Reibungsoberfläche zu vergrößern, und die zeitlich mit den Schwankungen der Temperatur zusammenfallen. Es scheint deshalb höchst wahrscheinlich, daß diese Gestaltsveränderungen in den einzelnen Jahreszeiten als Reaktionen anzusehen sind auf die periodischen Veränderungen in der Tragfähigkeit des Wassers ${ }^{1}$ ).

Die Farbe des Wassers ist im reinen Zustande blau. Eine andere Farbe kann durch Organismen (vergl. später) oder durch beigemengte Tonteilchen u. ähnl. oder, besonders im Süßwasser, durch Humussäuren verursacht werden; gelbes oder braunes Wasser enthält oft viele Humussäuren und reagiert sauer, während alkalisches (hartes) Wasser klar (blau) ist $^{2}$ ).

Die Bewegungen des Wassers sind für die Vegetation von großer Bedeutung. Sie sind entweder Wellenschlag (Brandung) oder Strömungen und wirken zunächst durch Zufuhr von frischem Sau erst of f. In strömendem Wasser ist die Assimilation fast stets sehr lebhaft; das still stehende Wasser ist der Vegetation sehr schädlich, und viele Arten fehlen gewiß aus diesem Grunde in größeren, ruhigen Tiefen oder in eingeschlossenen stillen Buchten. Ferner führt das Wasser neue Nahrung zu; Meerwasser enthält z. B. nur wenig Jod und Kalk, und doch speichern viele Algen davon viel auf. Die Wasserbewegungen sind für die Ernährung um so notwendiger, als viele festsitzende Wasserpflanzen, nämlich Algen, in der Regel keine weitreichenden Wurzeln (im physiologischen Sinne) haben. Die großen Verschiedenheiten zwischen den Algenassoziationen der offenen Küsten und den innerhalb der Schären in ruhigerem Wasser vorkommenden müssen besonders auf diese beiden Faktoren zurückgeführt werden.

Schließlich wirken die Wasserbewegungen mechanisch, indem sie die Pflanzenteile nach der Stärke der Bewegung mit verschiedener Kraft strecken und biegen. Bei den größeren Pflanzen wird mechanisches Gewebe entwickelt ${ }^{3}$ ); auch Kalkinkrustation wird zur Festigung der Meeresalgen dienen können; jedoch wachsen Kalkalgen und viele krustenförmige Algen merkwürdigerweise besonders in tiefem oder in anderem stillen Wasser. Die Gestalt wird in verschiedener Art den Umgebungen angepaßt; so finden sich namentlich in stark strömendem Wasser sehr lang gestreckte Pflanzenteile (das bandförmige Blatt, die langen fadenförmigen Gestalten gewisser Algen).

1) Ostwald 1903a; Wesenberg-Lund, 1900, 1908.

2) Kolkwitz 1910 .

8) Wille 1885 . 
Man muß übrigens zwischen Strömungen und Wellenbewegungen unterscheiden; viele Arten vertragen jene, aber nicht diese. Sehr viele Arten ziehen ruhiges Wasser vor.

Die Bewegungen des Wassers begünstigen unter anderem die Verbreitung der Vermehrungsorgane (losgerissene vegetative Teile, Sporen, Samen $)^{1}$ ). Besonders Wasserpflanzen haben im allgemeinen eine sehr weite geographische Verbreitung. Die Ursachen dafür liegen zum Teil darin, daß auf weite Gebiete hin die Lebensbedingungen der Wasserpflanzen gleichartig oder doch annähernd gleichartig sind; klimatische Unterschiede werden ausgeglichen. Zum Teil liegt es auch daran, daß die Verschleppung der Meerespflanzen über große Entfernungen sehr leicht ist, und daß manche Arten durch Wasservögel oder Insekten oder auch durch Luftströmungen weit fort getragen werden. Das letztere ist natürlich besonders bei den mikroskopisch kleinen Arten der Fall, doch sei daran erinnert, daß z. B. Hegelmaier eine Pflanze von Wolffia arrhiza in einem Hagelkorn fand. $\mathrm{Zu}$ vergleichen ist auch die Wasser- und Landflora der Eiszeit (s. S. 147).

Verschiedenheiten in der Wasserflora, die zugleich sich in der geographischen Lage ausprägen, zeigen, daß diese in mancher Hinsicht stärker bei den Meeresbewohnern ausgeprägt sind, als bei denen anderer Gewässer. Dies mag wohl seine Ursache in den großen physikalischen Verschiedenheiten der Meereswässer untereinander auf der einen Seite und in der größeren Konstanz im Salzgehalt, in der Temperatur und anderen Eigentümlichkeiten des einzelnen Meeresteiles auf der anderen Seite haben (vgl. bes. Aschersons Arbeiten über die Verbreitung der Seegräser).

$\left.{ }^{1}\right)$ Hemsley 1885; Sernander 1901; Schimper 1891; Rosenvinge 1905; Kjellman 1906. 


\section{Zweiter Abschnitt}

\section{Die Lebensformen}

\section{Kap. Die Lebensformen und ihre Grundformen}

Humboldt ${ }^{1}$ ) war der erste, der die Bedeutung der "PflanzenPhysiognomie" namentlich für die Landschaft hervorhob: „Sechszehn Pflanzenformen bestimmen hauptsächlich die Physiognomie der Natur". Er behandelt folgende 19 Formen näher: die der Palmen, Bananen, Malvaceen und Bombaceen, Mimosen, Ericaceen, die Kaktusform, die Orchideenform, die Casuarinen, Nadelhölzer, Pothosgewächse (Araceen), Lianen, Aloegewächse, die Grasform, die Form der Farne, die Liliengewächse, die Weidenform, die Myrtengewächse, die Melastomen- und die Lorbeerform. - Dieses ist natürlich nur eine oberflächliche Unterscheidung systematischer und physiognomischer Typen; jede dieser "Formen" umfaßt in Wirklichkeit große Lebensverschiedenheiten. Ein rein physiognomisches System hat keine wissenschaftliche Bedeutung: erst wenn die Physiognomie physiologisch und ökologisch begründet wird, erhält sie eine solche.

Den nächsten wichtigen Versuch machte Grisebach ${ }^{2}$ ). Er stellte 54, später 60 "Vegetationsformen" auf, die in ein physiognomisches "System" geordnet sind, und suchte nachzuweisen, daß es eine Verbindung zwischen der äußeren Form und den Lebensbedingungen, namentlich den klimatischen Bedingungen gäbe; ein physiognomischer Typus ist für ihn zugleich großenteils ein ökologischer. Indessen bleibt er meistens an dem Physiognomischen hängen und kommt zu solchen morphologischen Kleinlichkeiten, wie, die Lorbeerform mit starrem, immergrünem, ungeteiltem, breitem Blatte von der Olivenform mit starrem, immergrünem, ungeteiltem schmalem Blatte, oder die Lianenform mit netznervigen Blättern von der Rotangform mit parallelnervigen zu

1) Humboldt 1805 .

2) Grisebach 1872. 
trennen; anderseits hat er mit diesen 60 Formen selbstverständlich keineswegs alle Lebensformen gekennzeichnet, sondern, wie er selbst sagt, nur die, die zur Kennzeichnung von Ländern und Klimaten dienen können, weil sie gesellig auftreten. Ferner zog er den anatomischen Bau gar nicht in Betracht und hatte für das wirklich Epharmotische wohl nicht Blick genug ${ }^{1}$ ).

Später veröffentlichte Hildebrand ${ }^{2}$ ) eine vergleichend ökologische Studie über Lebensdauer und Vegetationsweise, und Beobachtungen über Witterungseinfluß auf die Lebensdauer und Lebensweise der Pflanzen, welche von großem Interesse sind. Ein "System" der Formen stellte er doch nicht auf, ebensowenig wie Vesque ${ }^{3}$ ) in seiner bedeutsamen $A b-$ handlung über die Epharmonie.

1884 gab Warming eine Übersicht über die Lebensformen der nordeuropäischen Gefäßpflanzen, die er nach morphologischen und biologischen Charakteren in 14 Hauptgruppen mit vielen Untergruppen ordnete; das Wanderungsvermögen spielte dabei eine große Rolle. Drude bemerkte mit Recht, daß er zu wenig Rücksicht auf die geographischen Verhältnisse genommen hätte ${ }^{4}$ ).

Reiter ${ }^{5}$ ) ist der nächste, der den Gegenstand eingehend behandelt hat. Mit gesundem Blick betont er den inneren Bau, die besondere Betrachtung der wirklichen Anpassungsmerkmale und die Berücksichtigung aller bei einem eigentümlichen Leben und einer besonderen Ausstattung auftretenden Typen, nicht nur die Berücksichtigung der in Menge auftretenden. Aber auch sein physiognomisches „System“ muß verbessert werden: die Anpassungs- und Vererbungsmerkmale werden nicht auseinander gehalten, was übrigens auch sehr schwer, ja oft fast unmöglich ist.

Weiter befaßte sich Drude ${ }^{6}$ ) mit der Frage; er nimmt den biologisch-geographischen Standpunkt ein, der sich auf die Antworten auf die folgenden beiden Fragen stützt: "Was leistet eine betreffende Pflanzenart im Vegetationsteppich eines bestimmten Landes, und wie vollzieht sie unter den Bedingungen ihres Standortes die Gesamtheit ihres periodischen Cyklus". Als Grundzüge von größerer Wichtigkeit betrachtet er die Dauer der Organe und die Schutzeinrichtungen gegen Unbilden der Witterung während ungünstigen Zeiten, und dann auch die Stellung des Erneuerungssprosses an der Hauptachse in ihrer Beziehung

1) Vergl. im übrigen Reiter 1885; Warming 1908.

2) Hildebrand 1883,1884 .

3) Vesque 1882.

4) Drude 1895.

5) Reiter 1885 .

9) Drude $1887,1890,1896,1903$. 
zur Überwinterung ${ }^{1}$ ). 1896 teilte er die Pflanzen in 35 Klassen von Lebensformen, 1913 in $\mathbf{5 5}$.

Krause $^{2}$ ) und später Pound und Clements gaben die Hauptrichtlinien eines System. Das von Pound und Clements $^{3}$ ) nähert sich im allgemeinen dem von Drude. Es ordnet die Pflanzen nach den folgenden Hauptgruppen: Holzpflanzen, Halbsträucher, pleiocyklische Kräuter, hapaxanthische Kräuter, Wasserpflanzen, Hysterophyten und Thallophyten; diese Gruppen zerfallen in 34 Untergruppen.

Raunkiär ${ }^{4}$ ) zeichnete gleichfalls die Grundlinien eines Systems, in dem er, ähnlich wie Drude, das Hauptgewicht auf die Anpassung der Pflanzen legt, die diese in den Stand setzt, die ungünstigen Jahreszeiten zu überstehen, wie sie sich besonders zeigen an dem Grade und der Art des Schutzes, wie wir ihn an den ruhenden Knospen und Triebspitzen finden. Hauptgruppen (mit vielen Unterpruppen) sind Phanerophyten, Chamaephyten, Hemikryptophyten, Kryptophyten und Therophyten ${ }^{5}$ ). Unter Phanerophyten versteht er Pflanzen, deren Verjüngungsknospen wenigstens 1/4 $\mathrm{m}$ über dem Erdboden erhoben sind; bei Chamaephyten sind sie auch über dem Erdboden, aber unter $1 / 4$ m Höhe; Hemikryptophyten sind ausdauernde Kräuter, deren Überwinterungsknospen an oder in der Nähe der Erdoberfläche sitzen. Kryptophyten sind ausdauernde Kräuter mit tiefer im Boden steckenden Überwinterungsknospen, und Therophyten sind einjährige Kräuter. Raunkiärs System wird besonders für das Verständnis des "Pflanzenklimas" Interesse haben. Unter "Pflanzenklima" versteht er: das Klima als Bedingung für eine bestimmte Vegetation und bestimmt durch das statistische Verhältnis zwischen den Lebensformen sämtlicher Arten, durch die Anpassung zum Überleben der ungünstigen Jahreszeit. Er selbst setzt die Formationslehre in Gegensatz zum "Pflanzenklima".

Eine neuere Behandlung des Stoffes stammt von Warming, der seit 1884 eine Reihe von Arbeiten über die Einteilung der Wuchsformen und über die Rolle, die sie in den Pflanzenvereinen spielen, veröffentlichte. 1908 und 1909 suchte er die Grundlinien eines Systems festzulegen, die auch im folgenden mit verschiedenen Änderungen wiedergegeben sind.

Wie die Arten die Einheiten sind, womit die systematische Botanik rechnet, so sind die Lebensformen die Einheiten, die in der ökologischen Pflanzengeographie die größte Rolle spielen. Es hat daher eine gewisse praktische Bedeutung, ob man eine begrenzte Anzahl leicht aufstellen und benennen könne, wobei die leitenden Grundsätze zunächst ökologische

1) Drude 1890, S. 69 ; 1896, S. 46, 1913, Erster Abschnitt.

2) Krause 1891 .

s) Roscoe Pound u. Clements 1898.

*) Raunkiär 1903, 1905, 1907, 1909.

s) Vergl. auch Vahl 1914 . 
Rücksichten sein müssen. Die rein systematisch-morphologischen und anatomischen Charaktere, solche wie Sproßfolge, monopodiale oder sympodiale Verzweigung und viele Formen sowie Nervatur der Blätter, spielen keine Rolle: Aber welche biologischen Grundsätze die wichtigsten seien und daher die erste Grundlage für ein ökologisches System der Lebensformen bilden müßten, ist eine schwierige, durchaus nicht hinreichend durchgearbeitete Frage.

Es kann nicht genug hervorgehoben werden, daß der größte Fortschritt nicht nur für die Biologie im weiteren Sinne, sondern auch für die ökologische Geographie der sein wird, die verschiedenen Lebensformen ökologisch zu erklären: ein Ziel, wovon man noch weit entfernt ist.

Was die Sache ungemein schwierig macht ist auch das, daß alle die verschiedenen Lebensformen durch die allmählichsten Übergänge und zahlreichen Zwischenformen verbunden sind. Eine andere Schwierigkeit liegt in der Auffindung kurzer und bezeichnender Namen, am besten sind natürlich solche, mit welchen jedermann vertraut ist.

Um sich in dem unendlichen Reichtum von Lebensformen zu orientieren, wird es praktisch sein, gewisse "Grundformen des Lebens" hervorzuheben, welche wohl zum größten Teile Vererbungsformen sind, die aber vielfach den Charakter von Anpassungserscheinungen zeigen, zum Teil aber auch nichterbliche Abänderungen darstellen.

Der "Wipfel(Kronen-)baum" ist z. B. eine solche Grundform des Lebens, aber die verschiedenen Arten, welche diese Form bilden können, zeigen eine unendliche Fülle von Anpassungscharakteren. Ob diese erblich fest oder nach der Lebenslage veränderlich sind, muß in den einzelnen Fällen untersucht werden.

Die Grundformen werden im Kap. 22 besprochen, die Anpassungsrichtungen in den folgenden.

\section{Kap. 22. Übersicht der Grundformen des Lebens ${ }^{1}$ )}

I. Heterotrophe chlorophyllose Pflanzen . . . (1) Holoparasiten (Schmarotzer)

Holosaprophyten.

II. Autotrophe chlorophyllhaltige Pflanzen.

A. Durch Symbiose mit Algen chlorophyllhaltig, autotroph

(2) Lichenen (Flechten).

1) Es muß bemerkt werden, daß diese 22 Gruppen nicht alle ganz gleichwertig sind, indem einige mehr umfassend sind als andere und in einer größeren Darstellung abgeteilt werden müssen, z. B. Wasserpflanzen, Lianen, Kriechpflanzen. Der Kürze und Utbersichtlichkeit wegen ist dieses hier unterlassen worden. 
B. Keine Symbiose mit Algen; echt autotrophe Pflanzen.

1. Untergetauchte oder schwimmende Pflanzen

(3) Wasserpflanzen.

2. Landpflanzen und Sumpfpflanzen.

$\times$ Wasseraufnahme durch die ganze Oberfläche . . . . . . . .

(4) Muscoide Typen.

$\times \times$ Wasseraufnahme durch Wurzeln aus der Erde.

a) Nicht selbständige Pflanzen

b) Selbständige.

a. Hapaxanthe (einmal blühende) Kräuter . . . .

$\beta$. Pollakanthe (mehrmals blü-

(5) Lianen. hende) Pflanzen.

$\triangle$ Pflanzen mit vertikaler Grundachse. Orthotrope Assimilationssprosse.

a) Kräuter.

† Laubsprosse mit nicht grasartigen Blättern (Pollakanthe Stauden, ausdauernde Kråuter).

- Orthotrope Langsprosse . .

oo Orthotrope Blattstauden (Standen mit einzelnen, am Erdboden stehenden Blättern) . . . . (11)

$\bigcirc 0$ Orthotrope Rosettenstauden . (12)

+ Grasartige Blätter, orthotroper Grastypus (grasartige Pflanzen) . (13)

b) Halbsträucher . . . . . . . . (14)

c) Polsterpflanzen . . . . . . . (15)

d) Weichstämme . . . . . . . (16)

e) Stammsukkulente . . . . . . (17)

f) Echte Gehölze.

Dikotyle Sträucher . . . . . (18)

Monokotyle Sträucher . . . . (19) 


$$
\begin{aligned}
& \text { Wipfel-(Kronen-)bäume · · · . } \\
& \text { Schopfbäume • • • . . }
\end{aligned}
$$

$\triangle \triangle$ Kriechende Pflanzen (mit oberirdischer horizontaler Grundachse).

1. Heterotrophe Lebensformen. Nicht chlorophyllführende Pflanzen, welche sich von organischen Stoffen nähren (Holosaprophyten und Holoparasiten). Sie sind sehr verschieden im Bau und in der Lebensweise, finden sich sowohl unter Kryptogamen wie unter Phanerogamen, und es gibt sowohl einjährige wie mehrjährige Typen. Die Hemisaprophyten und Hemiparasiten dagegen besitzen Chlorophyll und haben meist die gewöhnlichen Bauverhältnisse der chlorophyllführenden verwandten Pflanzen, die Phanerogamen also grïne Laubblätter, welche, vom Lichte abhängig, den Standortsbedingungen angepaßt sind. Die große Gruppe der Heterotrophen muß in biologische Unterabteilungen eingeteilt werden, diese können aber hier nicht spezieller besprochen werden ${ }^{1}$ ).

2. Die zweite große Gruppe umfaßt die Flechten (Lichenes): höchst eigentümliche Lebensformen, die wie bekannt einer Form von Symbiose ihr Dasein verdanken, einer eigenartigen Verbindung zwischen Pilzen und Algen, welche letzteren die Kohlensäureassimilation besorgen. Die Flechten sind daher vom Lichte abhängig. Ihre Körperformen sind sehr verschiedenartig. Ökologisch sehr wichtig ist ferner ihre Fähigkeit, vollständig austrocknen zu können, bei Wiederbewässerung schnell durch ihre ganze Oberfläche Wasser wieder aufnehmen zu können, und zwar sowohl in tropfbarflüssiger als in Dampfform. Dagegen entziehen sie dem Substrate nichts oder doch höchstens sehr wenig. Daher können sie z. B. schroffe, nackte, von der Sonne durchheizte Felsen bewohnen und auch vielfach als Epiphyten leben. Nach Fitting können einige ephylle Lichenen tief in das Blattgewebe eindringen ${ }^{2}$ ).

3. Wasserpflanzen (Hydrophyten). Hierher gehören die im salzigen oder süßen Wasser ganz untergetaucht oder schwimmend lebenden, selbstassimilierenden Pflanzen. Sie vermögen meist, soweit sie ganz untergetaucht sind, Wasser durch ihre ganze Oberfläche (Algentypus) aufzunehmen; im übrigen vergl. Kap. 31; Transpiration ist bei ihnen ganz ausgeschlossen. Ihre physiologischen und anatomischen sowie morphologischen Verhältnisse sind daher von denen der Landpflanzen ganz verschieden. Abweichungen bieten die auf der Oberfläche des Wassers schwimmenden oder mit Schwimmblättern ausgerüsteten Arten. Thre Körperform ist übrigens äußerst verschieden, worüber Näheres

1) Im übrigen vergl. Kap. 35.

2) Im übrigen vergl. Kap. 35 . 


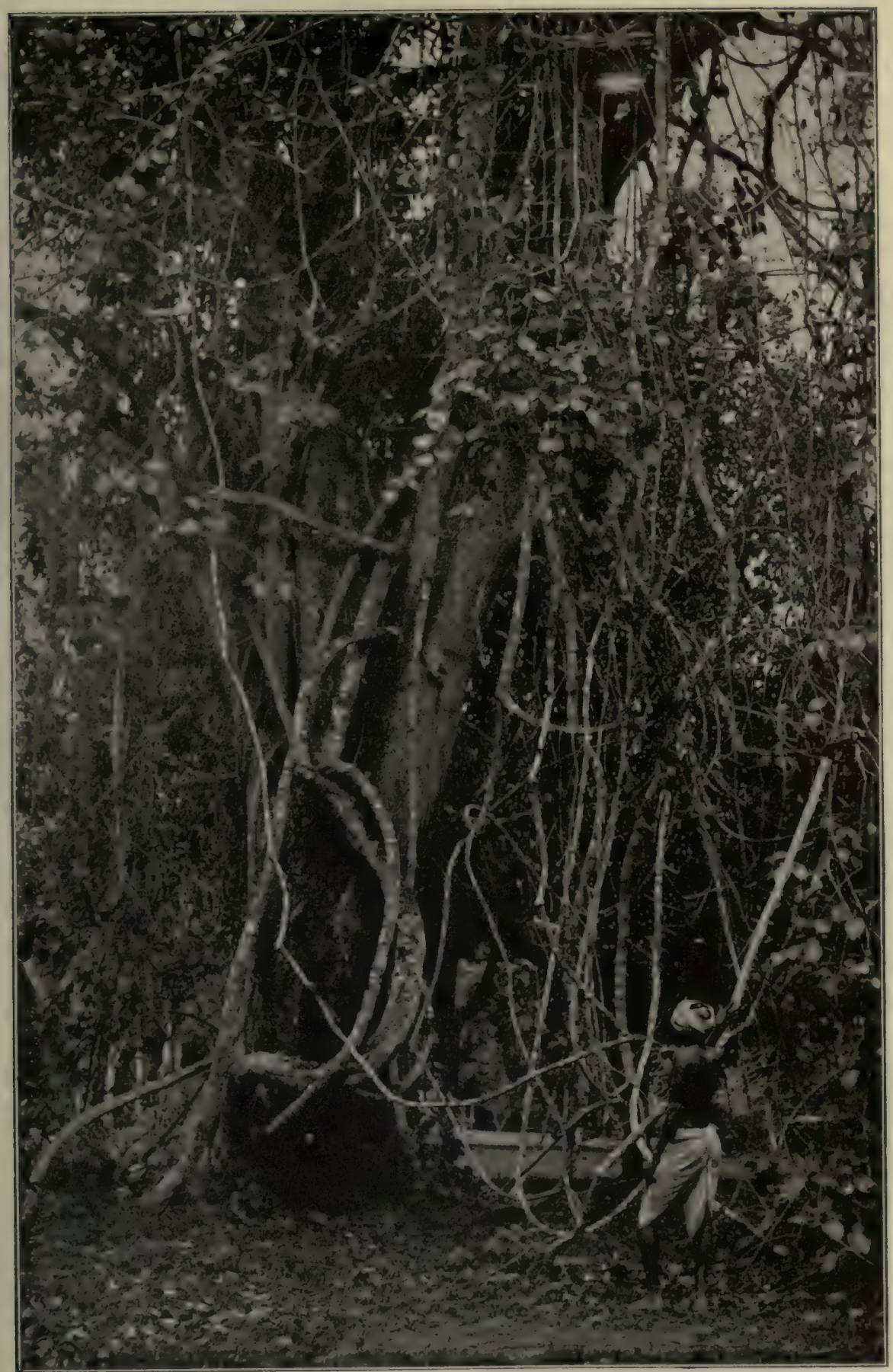

Fig. 48. Urwaldlianen in Trinidad. (Photograph unbekannt.) 
später (Kap. 31 und Abschnitt 4). Die Wasserpflanzen können in mehrere Lebensformen getrennt werden.

Einige Luftalgen (aerophytische Algen) vermögen periodische Austrocknung zu ertragen und können daher senkrechte Felsen und Baumstämme bewohnen.

4. Die muscoide Lebensform. Autotrophe (sich selbst ernährende), auf Chlorophyllassimilation angewiesene Pflanzen, zum größten Teil Landpflanzen aus der Klasse der Moose. Sie trocknen leicht aus, haben gewöhnlich keinen Verdunstungsschutz und können atmosphärisches Nieder-

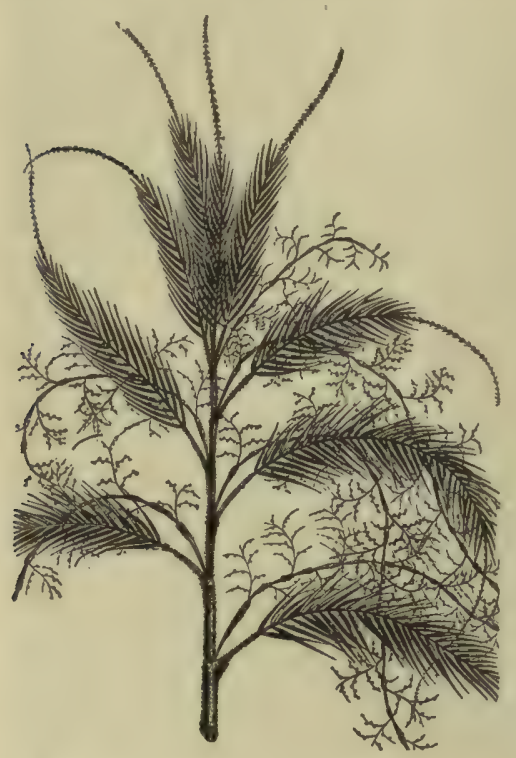

Fig. 49. Spitze eines Triebes der Rotangpalme (Calamus) mit den verlängerten, widerhakigen Mittelstreifen der Blätter.

(Nach Warming - Johannsen.) schlagswasser durch ihre ganze Oberfläche aufnehmen, dagegen nichts oder sehr wenig ans dem Boden (vergl. S. $135 \mathrm{ff}$.), so daß die in oder an demselben lebenden Rhizoiden und ähnlichen Organe (Haarwurzeln) im wesentlichen Haftorgane darstellen.

Pflanzen dieser Lebensform gedeihen überall auf der Erde, anf Felsen und an andern Orten, auch epiphytisch; besonders zahlreich und üppig sind sie in regen- oder nebelreichen Gegenden, dort sogar auf offenem Gelände, sowie in der dampfreichen Luft von tropischen $\mathrm{u}$. $a$. Wäldern. Auch diese Gruppe zerfällt in Unterabteilungen. An diese Gruppe schließen sich unter den Gefäßpflanzen die Hymophyllaceen an, welche zum Teil biologisch und auch in gewissem Sinne anatomisch (vergl. S. 26) den Moosen sehr ähnlich sind. Eine merkwürdige Form der Moose ist Sphagnum ${ }^{1}$ ). Ebenso wird die epiphytische Bromeliacee Tillandsia usneoides sich ohne Zwang hier anschließen lassen.

5. Lianen sind solche Pflanzen, die die mechanische Säulenfestigkeit anderer hochstrebender Pflanzen (in erster Linie die von Bäumen oder Felsen) benutzen, um ohne großen Aufwand an plastischem Material im Streben nach Licht möglichst schnell eine große Höhe zu erreichen; deshalb wachsen sie besonders an kräftigeren Pflanzen in die Höhe. Die Stämme sind lang, dünn und langgliederig, aufstrebend, entweder

1) Vergl. darüber Paul (s. S. 82), Oltmanns n. a. - Abschnitt 4. 
schlingend oder kletternd. (Schmarotzende Lianen sind hier nicht mit eingeschlossen.)

Diese große Gruppe zerfällt in mehrere Unterabteilungen. Die einfachsten sind:

a) Die Halblianen ${ }^{1}$ ) oder Spreizklimmer ${ }^{2}$ ). Zumeist niedrigere Formen, welche an Waldrändern und in Gebüschen klettern; sie benutzen hierzu z. B. Dornen, Haken, spreizende (brachiate) Zweige, welche auf den Verzweigungen anderer Pflanzen ruhen. Auch hoch in die Bäume aufsteigende Typen, wie die CalamusPalmen, erheben sich in ähnlicher Weise (Fig. 49); auch manche Philadelphus klettern hoch.

b) Wurzelkletterer. Die Stengel drücken sich Bäumen oder Felsen an und heften sich dort durch Haftwurzeln fest (Fig. 50-52).

c) Schlingpflanzen. Die Stengel legen sich in losen Windungen um Stämme und Zweige der Bäume und Sträucher (Fig. 53).

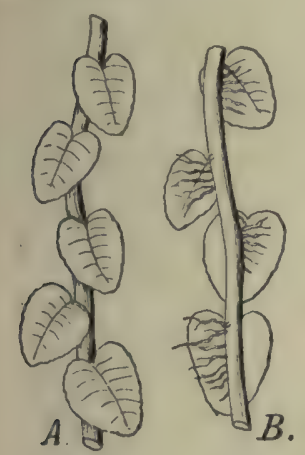

Fig. 50. Marcgravia Schimperiana.

$A$. Kletternder dorsiventraler Sproß von oben,

$B$. derselbe von unten; $C$. aufrechter nichtkletternder SproB. (Nach H. Schenck.)

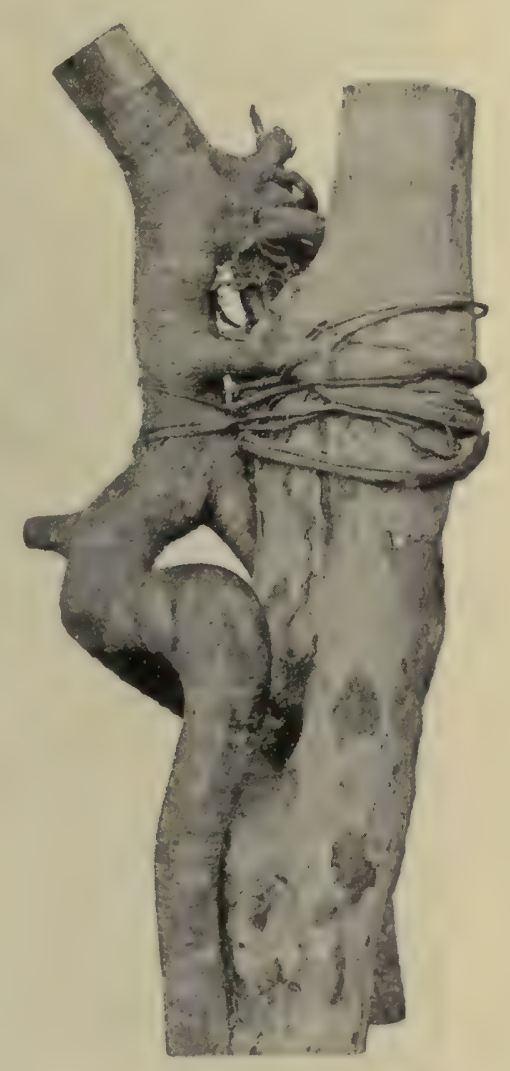

Fig. 51. Westindische Clusia, einen Baumstamm umfassend durch Winden.

(Photogr. Börgesen.)

d) Rankenpflanzen. Sie sind durch besondere reizbare Greiforgane (Ranken) verschiedener morphologischer Herkunft, welche dünne Organe umfassen, oder sich durch Saugscheiben (manche ParthenocissusArten usw.), Krallenhaken (Cobaea usw.) an dicken Bäumen mit Borke, an Mauern usw. festhalten, befähigt, in die Höhe zu steigen (Fig. 54-56).

1) Warming 1892 .

2) Schenck 1892, 1893. 
Einige Arten können sowohl lianenartig als wenigstens zeitweise als Epiphyten auftreten, z. B. Ficus-Arten.

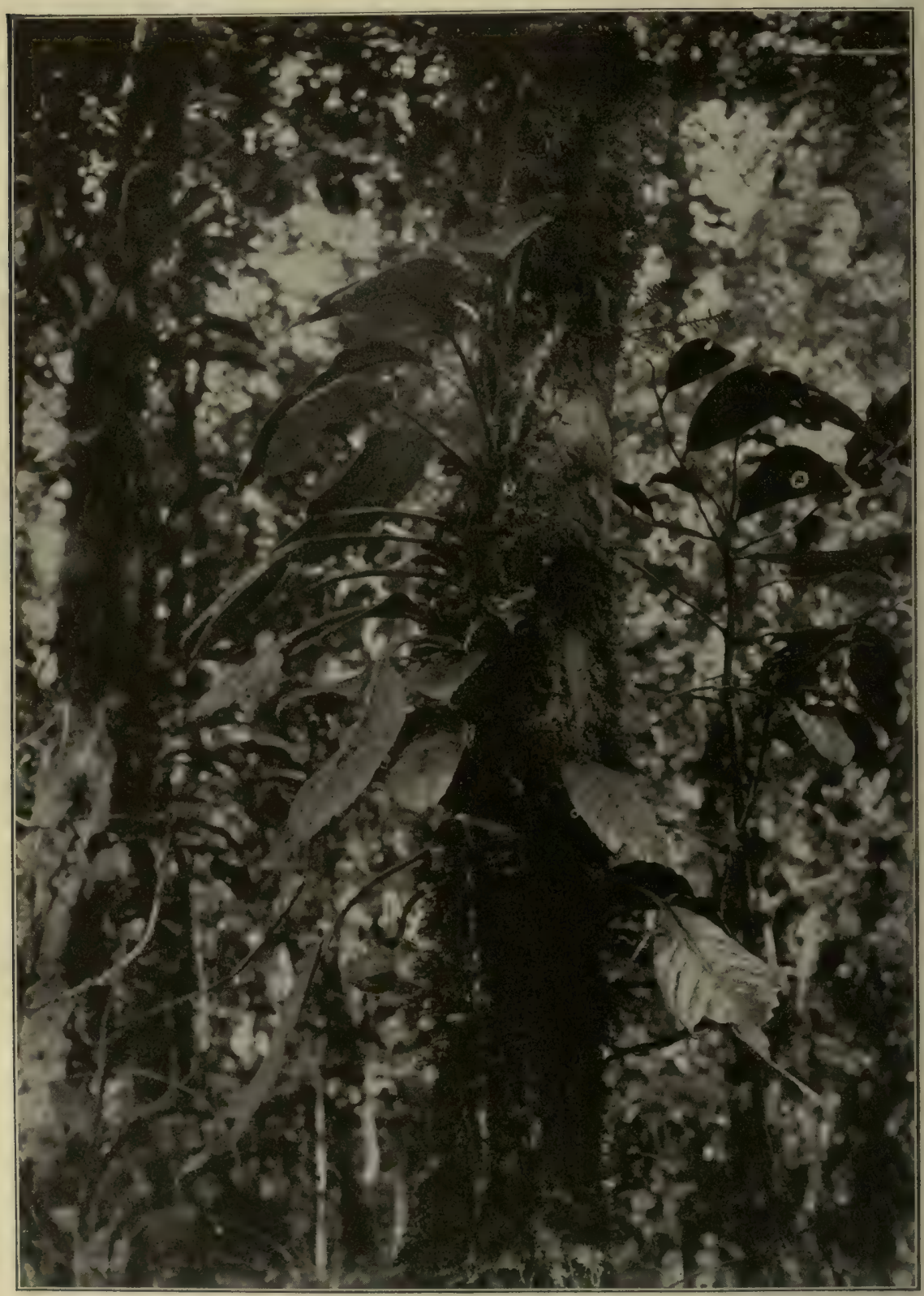

Fig. 52. Mit den Wurzeln am Stamme aufkletternde Aracee. (Nach F. Börgesen.)

Die Lianen sind übrigens im Blatt- und Sproßbau, und was Grundform des Lebens anbetrifft, sehr verschieden; es gibt ein- und mehrjährige, 
Kräuter, Halbsträucher und Gehölze, also Grundformen, welche sich im folgenden ebenso bei den aufrechten, selbständigen Typen wiederfinden, und nach denen man bei den Lianen weitere Unterabteilungen unterscheiden kann. Die Blätter sind bei den meisten mesomorph (mittleren Feuchtigkeitverhältnissen angepaßt, nicht selten auch hygromorph, also feuchtigkeitsliebend) bei anderen xeromorph (trockenheitertragend). Fs scheint das ganz natürlich, weil die Lianen zumeist einem stürkeren Wasserverlust durch Transpiration ausgesetzt sind, weil also die Wasser-

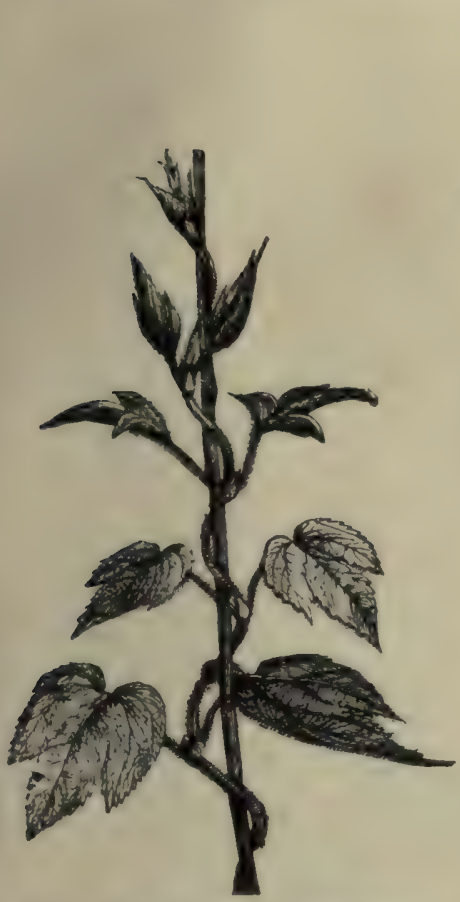

Fig. 53. Hopfen (Humulus), windend. (Nach Baillon.)

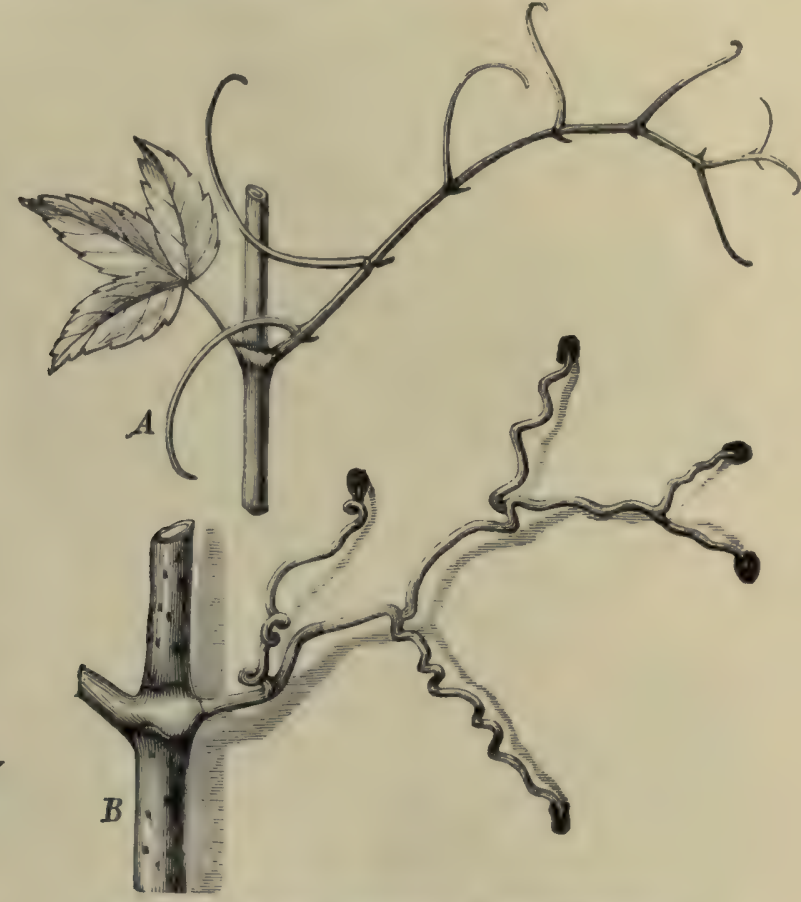

Fig. 54. Selbstkletternder Parthenocissus. $A$. vor, $B$. nach der Anheftung. (Nach Darwin.)

versorgung durch die langen und dünnen Stengel ohne besondere Vorrichtungen nicht reguliert werden kann.

Eine eigentümliche, noch nicht ganz erklärte Konvergenzerscheinung ist die bei sehr vielen Arten wiederkehrende breite, herzförmige Blattspreite, welche auf langen Stielen unter rechten Winkeln vom Stengel ansgeht ${ }^{1}$ ) (Fig. 57).

6. Sommerannuelle (einjåhrige) Kräuter (Monocyklische: Warming 1864. Therophyten: Raunkiär). Selbstassimilierende, nur einmal blühende und fruchtende krautartige Gefäßpflanzen. Der ganze Lebenscyklus von

1) Über Lianen vergl.: Darwin 1875, Schenck 1892, $1893 \%$, Warming 1892, 1901, Lindman 1899 und Neger 1913, wo auch weitere Litteratur $\%$ finden ist. 
der Keimung bis zur Fruchtreife wird ununterbrochen im Laufe von wenigen Wochen („ephemere ${ }^{\prime}$ Arten) bis zu einigen Monaten vollendet.

Die ungünstige Jahreszeit wird durch die gut geschützten Samen überstanden. Die Laubsprosse sind meist aufrecht und gestrecktgliederig,

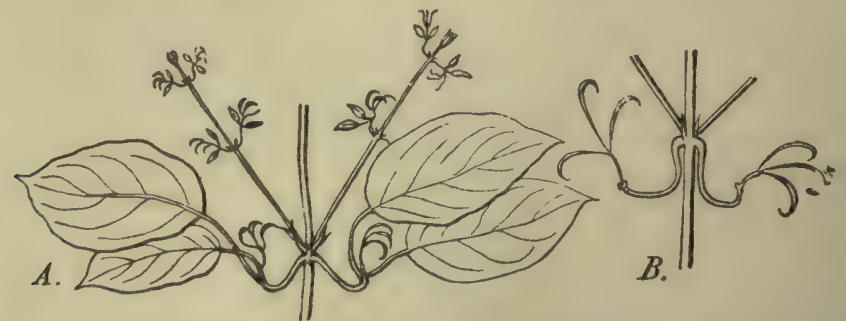

Fig. 55. Bignonia mit Kletterkrallen, B. ohne Blätter. (Nach Schenck.)

oft auch niederliegend, bisweilen findet vor ihrer Anlage eine Rosettenbildung statt. Die Laubblätter sind meist dünn, mesomorph. Auch sukkulente Salzbodenpflanzen sind in dieser Lebensform eingeschlossen. Besonders häufig treten die Einjährigen in periodisch sehr trockenen Klimaten oder an trockenen Standorten auf, sehr zahlreich auch auf

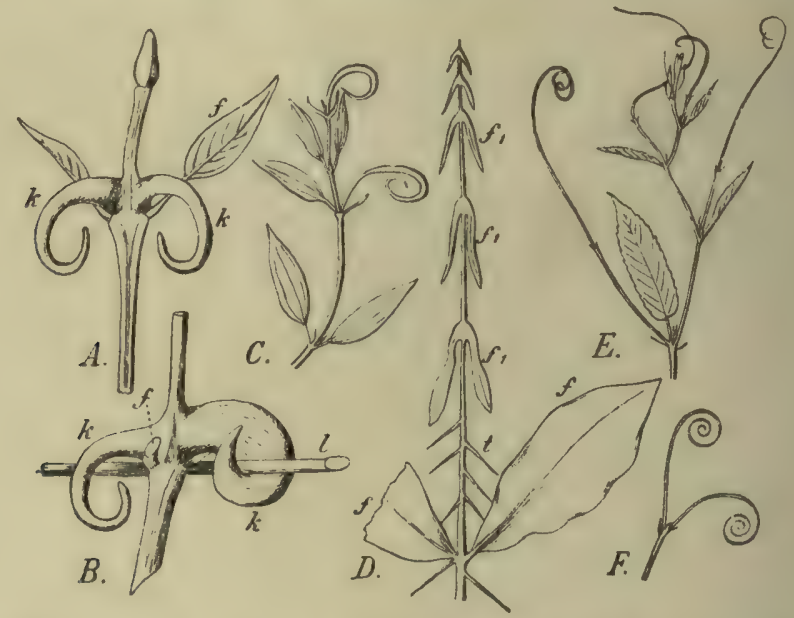

Fig. 56. Kletterhaken. A. und B. Uncaria ( $f$ Tragblätter für die Kletterhaken $k$ );

C. Strychnos; D. Blattende von Desmoncus; E. Reisseckia; F. Serjania.

(Nach Treub und Schenck.)

häufig an der Oberfläche verletztem oder natürlich offenem Boden (z. B. Kulturböden, Dünen, am Meeresufer).

\%. Winterannuelle (einjährig überwinternde) Kräuter (Dicyklische). Selbstassimilierende Kräuter, welche ihren Lebenscyklus gewöhnlich mit einer Unterbrechung der Entwickelung (Winter) in wenigen Monaten vollenden, indem die Keimung im Herbste, Weiterentwickelung, 
Blühen und Fruchtbildung im nächsten Frühling oder Frühsommer erfolgt. Die ersten Laubhlätter, im Herbst gebildet, sind rosettenförmig am Boden genähert. Im folgenden Jahre entspringen aus der Rosette Langtriebe mit Blüten entweder ohne Laubblätter (Schaftbildung) oder

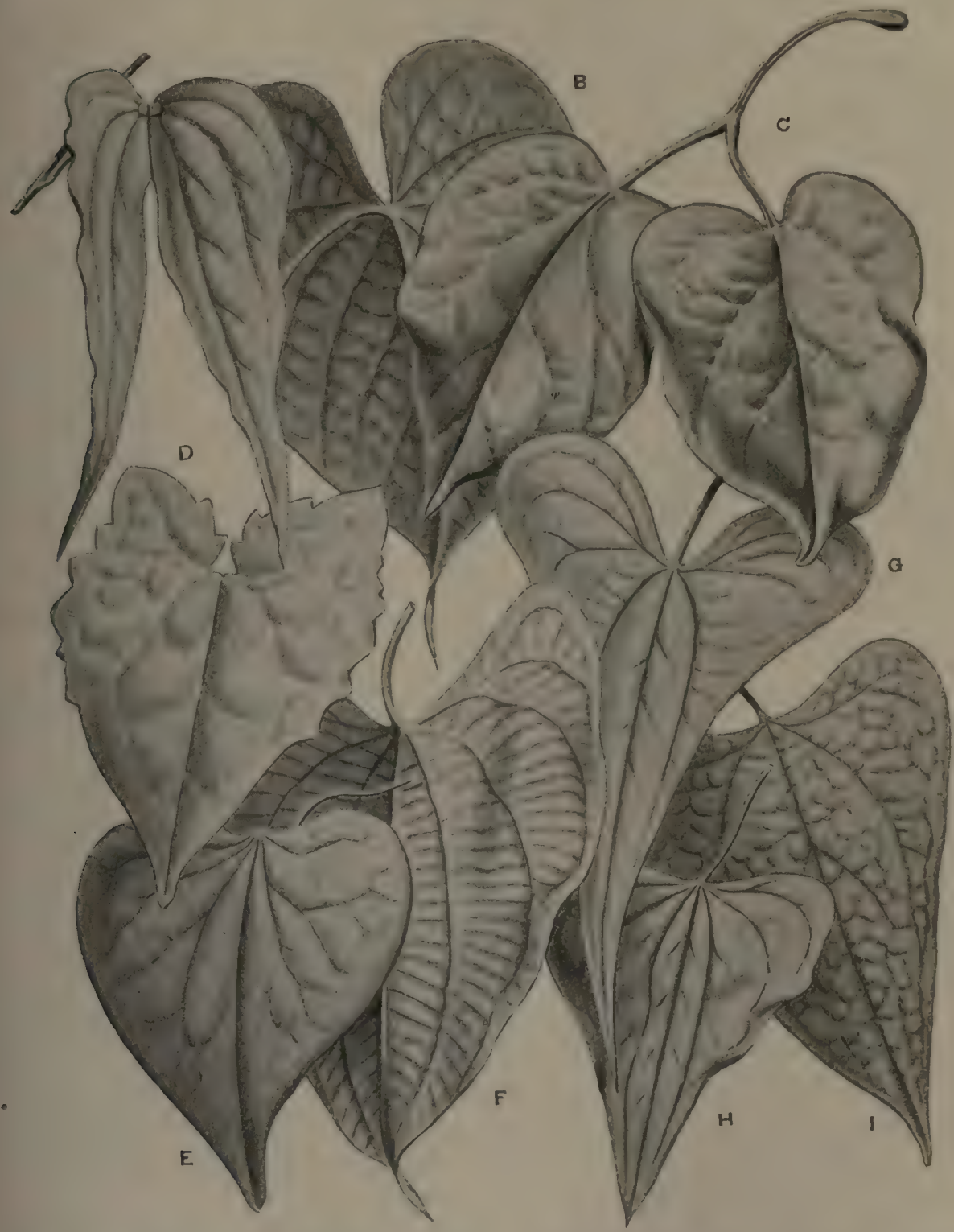

Fig. 57. Blätter von brasilianischen Lianen. A. Bauhinia sp.; B. Ipomoea bona nox; C. Amphilophium sp.; D. Mitania cordifolia; E. Cissampelos sp.; F. Dioscoren dodecaneura; G. D. Lagoasantae; H. D. sinuata; I. Aristolochia triangularis. 
mit solchen; der erstere Typus ist häufiger. Ausgesprochene Speicherorgane werden nicht ausgebildet.

Diese Lebensform ist an Klimate mit deutlich ausgeprägten Wintern angepaßt. Beispiele: Erophila (Draba) verna, Capsella bursa pastoris, Teesdalea nudicaulis (vergl. Fig. 18, S. 35).

8. Zweijährige (bienne) Kräuter (Dicyklische). Selbstassimilierende, Rosetten bildende Kräuter. Im ersten Jahre wird eine Bodenrosette aus Laubblättern gebildet, von welchen gewöhnlich die jüngsten überwintern, ohne daß echte Winterknospen mit Knospenschuppen gebildet werden. Der kurze Stengel wird durch Wurzelkontraktion oft tiefer in den Boden hineingezogen. Reservestoffe werden in der Wurzel und

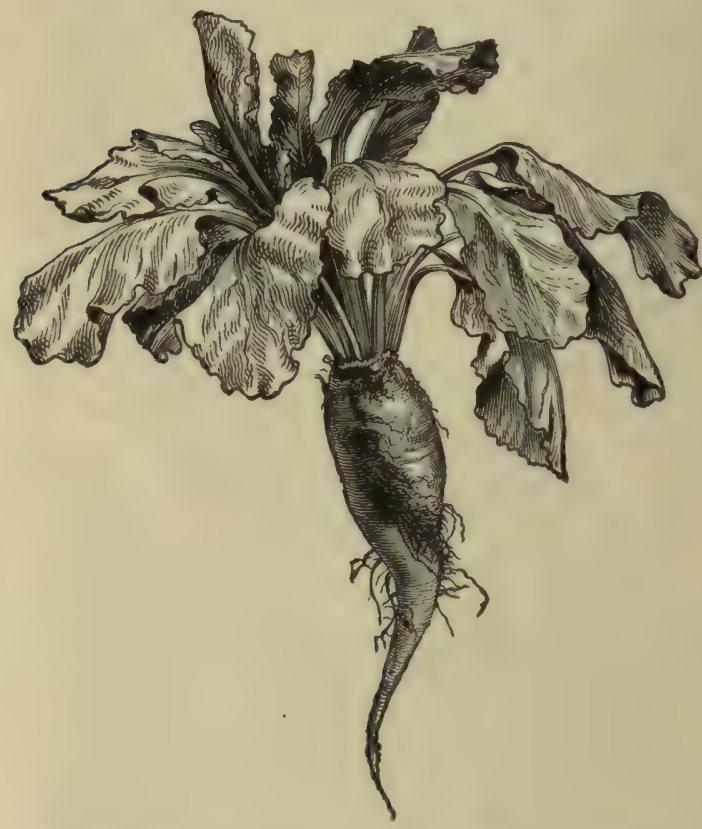

Fig. 58. Herbstzustand eines zweijährigen Krautes (Beta). (Nach Warming-Johannsen.) in dem kurzen Hauptstengel der Rosette gespeichert. In nächsten Jahre entwickelt sich ein hoher, aufrechter, meist laubblattragender, oft verzweigter und blühender Stengel. Der Kreislauf der Entwickelung, also die Lebensdauer der Pflanze, dauert über 12 Monate. Nach der Fruchtbildung stirbt die ganze Pflanze ab.

Dieser Typus kommt besonders in kalttemperierten Klimaten und auf offenen Gelände vor. Hierher gehören viele Kulturpflanzen (Beta vulgaris, Daucus carota, Apium graveolens, Brassica oleracea und and.) Fig. 58.

9. Pleiocyklische (mehrjährige, einmal blühende) Pflanzen (Warming 1884). Weichen dadurch von den echten zweijährigen ab, daß die Rosettenbildung am Boden mehr als ein Jahr ohne Blütenbildung fortgesetzt wird, bis schließlich das Leben nach Bildung des aufrechten blüten- und fruchtbildenden Längssprosses beendet wird; auch hier stirbt nach der Fruchtreife die ganze Pflanze ab.

Viele zweijährige können unter Umständen pleiocyklisch werden, besonders wenn an mageren oder trockenen Orten die Ausbildung der blühfähigen Rosette verzögert wird. An ungünstigen Standorten, so z. B. bei der Kübelkultur der Agave Americana im nördlichen Europa, können 
die Pflanzen sehr alt werden, ehe sie blühen (die sogenannte „hundertjährige Agave").

Diese Lebensform kommt in ähnlichen Klimaten vor wie die zweijährigen, auch z. B. in den zentralasiatischen Hochländern (einige Rheum-Arten) und Tropen (viele Agaven, einige Bananen usw.); im allgemeinen bevorzugt sie aber großßere Wärme.

\section{Pollak-anth ${ }^{1}$ ) Landpflanzen.}

Wenn wir zu den von Kjellman pollak-anthe, von De Candolle polykarpisch genannten Arten übergehen, müssen wir zuerst die Charaktere betrachten, nach welchen diese sehr große Gruppe von selbstassimilierenden Pflanzen der Übersicht wegen in kleinere natürliche Abteilungen gegliedert werden kann. Die Charaktere (A-G) sind nach ihrer allmählich abnehmenden ökologischen Bedeutung geordnet.

A. Dauer der vegetativen Sprosse. Einige sind nur einjährig, sterben also im Herbst fast bis auf die Wurzel ab, andere bleiben durch mehrere bis sehr viele Jahre lebend. Letztere sind meist verholzt, erstere krautartig.

B. Form der Sprosse, ob kurz und kurzgliederig (Rosettensprosse) oder lang, dann gewöhnlich mit längeren bis langgestreckten Stengelgliedern (Langsprosse).

C. Richtung der Sprosse, ob aufrecht (orthotrop) ${ }^{2}$ ), kriechend oder niederliegend (plagiotrop ${ }^{2}$ ) $=$ Kriechpflanzen).

D. Stellung der Verjüngerungsknospen während der ungünstigen Jahreszeit, ob mehr oder weniger hoch in der Luft (Raunkiärs Phanerophyten und Chamaephyten), an der Bodenoberfläche (Hemikryptophyten) oder tiefer in der Erde verborgen (Geophyten Areschougs ${ }^{3}$ ), Kryptophyten Raunkiärs $\left.{ }^{4}\right)$ ). Mit „diageisch" bezeichnet Vahl ${ }^{5}$ ) Pflanzen, welche ihre Sprosse durch die Erde vorzuschieben vermögen, im Gegensatze zu dem oberirdischen oder "epigeischen" Sprosse.

E. Bau der Knospen. Alle Stengelspitzen mit den allerjüngsten Blätteranlagen sind immer von älteren Blättern oder deren Resten umgeben und geschützt. Bei krautartigen Sprossen und bei verschiedenen anderen, z. B. Palmen, Blattsukkulenten, den meisten Rosettenpflanzen, geschieht dieses nur durch ältere Laubblätter (offene oder nackte Knospen); bei vielen Gehölzen, besonders denen der kalten und kühleren gemäßigten Zonen sind sie von besonderen Schutzorganen, meist um-

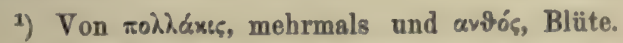

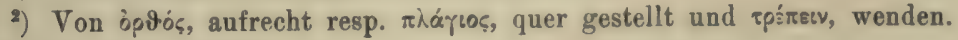

3) Areschoug 1895 .

4) Raunkiär 1903, 1905, 1907, 1908.

s) Vahl 1911. 
gebildeten Laubblättern, „Knospenschuppen“, bedeckt, oder auch durch Teile von Laubblättern geschủtzt ${ }^{1}$ ).

F. Dauer der Laubblätter. Sie ist von geringerer Bedeutung für die Abgrenzung der Lebensformen. Manche Blätter leben wenige Monate, andere mehrere Jahre. In allen Klimaten und in allen Lebensformen, bei krautartigen Pflanzen sowohl als Holzpflanzen, finden sich sommergrüne und auch immergrüne Arten. Doch sind gewisse Klimate und Pflanzenvereine durch das Vorherrschen von immergrünen Arten ausgezeichnet, so z. B. tropische Regenwälder, ozeanisches Klima; gewisse edaphische Eigentümlichkeiten, namentlich Feuchtigkeit im Boden, sind für die Ausbildung immergrüner Formen günstig. Bei Aufstellung von Lebensformen hat man auch oft großes Gewicht darauf gelegt, ob die Arten "rediviv" oder „perenn" (d. h. immergrün) sind.

Schimper") hat das Wort "Tropophyten" gebildet; hiermit soll eine Lebensform bezeichnet werden, die Pflanzen umfaßt, die im Gegensatze zu Hygrophyten uud Xerophyten, je nach der Eigenart der Jahreszeit, abwechselnd Hygrophyten und Xerophyten sind. Es scheint etwa gleichbedeutend mit sommergrüne Pflanzen zu sein, ist deshalb unklar und überflüssig. Es gibt sowohl mesophile, als hydrophile und xerophile "Tropophyten".

Ob die Rhytmik der Pflanzen zu äußeren Faktoren (Klima) in Beziehung steht oder von inneren Ursachen bedingt wird, ist eine noch streitige Frage, von Klebs, Volkens, Dingler, Schimper, Wright diskutiert.

G. Die Verzweigung und vegetative Vermehrung. Ob die Verzweigung der Pflanze reichlich ist oder nicht, ist für die Physiognomie der Pflanze von großer Bedeutung (man denke an Schopfbäume und Wipfel[Kronen-]bäume). Es wird auch im Kampfe ums Dasein zwischen den Arten von großer Bedeutung sein, ob eine Art sich durch Verzweigung weit seitlich ausdehnen kann oder nicht. Vorzugsweise ist die Verzweigung ein phylogenetischer Charakter, weniger ein epharmonischer.

Die vegetative Vermehrung ist von großer Bedeutung für die Lebensfähigkeit der Arten, für ihr Besiedelungsvermögen und ihre Kämpfe - unter einander, scheint aber für ihre Charakteristik als Grundform des Lebens unwesentlich zu sein (ausgenommen bei den Kriechpflanzen). Viele Kräuter haben oberirdische, gewöhnlich wurzelbildende Ausläufer z. B. Fragaria, Ranunculus repens, Mentha-Arten. Andere haben unterirdisch kriechende Grundachsen („Stolon-Rhizome“ Joh. Erikson), z. B. Urtica dioeca, Solanum tuberosum, Phragmites communis, Scirpus lacustris, Typha u. v. a. (Fig. 40).

Wieder andere vermehren sich sehr reichlich durch Wurzelsprosse (z. B. Cirsium arvense, Sonchus oleraceus, Rumex acetosella, Reseda lutea, Fig. 62, 73).

1) Uber dieses Thema existiert eine umfangreiche ältere Literatur, unter der neueren vergl. besonders die Arbeiten von P. Groom 1892 und Raunkiär 1907.

2) Schimper 1898. 
In allen solchen Fällen werden die Arten „sozial“, sie vermögen von größeren Flächen Besitz zu ergreifen und dadurch andere Arten zu unterdrücken.

Die Lebensform wird aber dadurch nicht geändert; eine Rosettenpflanze wie Ranunculus repens bleiht deshalb doch Rosettenpflanze, aber für die sozialen Verhältnisse ist dieses Wanderungsvermögen von größter Bedeutung. Dasselbe Ausbreitungsvermögen kann bei anderen durch reiche Samenbildung erworben werden, meist aber nur, falls die Konkurrenz der ausdauernden besonders der rasenbildenden Kräuter fehlt.

Die ober- und unterirdische Ausläuferbildung läßt sich bisweilen schwierig oder gar nicht von unterirdisch wandernden, länger dauernden, Nährstoff speichernden Grundachsen trennen.

Die Ausläuferbildung, sowohl über als unter der Bodenfläche, ist gewöhnlich an wasserreiche und lose Bodenarten gebunden, da die Feuchtigkeit der Erde die Wurzelbildung fördert, und die Länge und Verzweigung der Wandersprosse durch die Lockerheit der Erde befördert wird.

Die Grundformen des Lebens werden vielfach durch Anpassung der Laubsprosse an der Lebenslage der Pflanze an dem betreffenden Standorte aufgezwungene Lebensführung, namentlich an die Stärke der Verdunstung, ausgebildet. Solche Anpassungen und die dadurch vielfach hervorgerufenen physiognomischen Änderungen sind alle durch die edaphischen und klimatischen Verhältnisse bedingt und erfordern daher eine spezielle, längere Darstellung (vergl. Kap. 23-30).

Die Grundformen werden dadurch aber nicht beeinflußt; es gibt z. B. sowohl Kräuter als Gehölze, sowohl Rosettenpflanzen als Pflanzen mit Langtrieben, welche Blattsukkulenten sind.

Nach dem im Vorhergehenden, unter A-G Entwickelten werden wir die mehrjährigen, mehrere Male fruchtenden, selbstassimilierenden Pflanzen in folgende Abteilungen unterbringen:

I. Aufrechte und mehr oder weniger gerade (orthotrope) Laubsprosse.

A. Kräuter.

a) Stauden (ohne Grasform).

1. Die Assimilationsorgane (Blätter) sitzen an Langtrieben. Die meisten Arten ausdauernd. Pollakanthe Langstauden . . . . . . . . .

2. Die Assimilationsorgane sind einzelne Blätter. Blattstauden . . . . . . . . . .

3. Die Assimilationsorgane (Blätter) sind zu typischen Rosetten gedrängt. Rosettenstauden. . . 
b) Grasform.

4. Die Assimilationsorgane (Blätter) sind schmal, bandartig bis sehr schmal, nach dem Typus der Gräser gestaltet. Grastypus . . . . . . .

B. Halbsträucher. Niedrigere, meist sommergrüne, aber auch oft immergrüne Pflanzen, deren jüngste Sprosse mehr oder weniger krautartig und daher einjährig sind Hier anschließend die meisten Polsterpflanzen . .

C. Weichståmme. Dicke, grüne, weiche Stämme, meist immergrün; offene oder nur durch Scheiden des jüngsten Blattes geschützte Knospen. Gewöhnlich große Blätter

D. Stammsukkulenten. Blattlose grüne sukkulente Stämme mit sehr kleinen, oft eingesenkten Knospen . . . .

E. Echte Gehölze. Aufrechte, verholzte, mehr oder weniger langlebige Sprosse, die in einem Jahre oder länger (immergrüne) die Assimilationsorgane (Blätter) tragen.

a) Sträucher und $\mathrm{Zwergsträucher} \mathrm{...} \mathrm{.} \mathrm{.} \mathrm{.} 18$

b) Typus der Bambusgräser und Rohrpalmen . . 19

c) Wipfel(Kronen-)bäume . . . . . . . 20

d) Schopfbäume mit unverzweigtem nur eine Blattrosette tragendem Gipfel . . . . . . . . .

II. Kriechpflanzen. Sprosse plagiotrop, wurzelschlagend oder dem Substrate eng angedrückt . . . . . . . . .

Wieder einzuteilen in:
A. Kräuter.
B. Halbsträucher.
C. Gehölze (Spaliersträucher).

10. Pollak-anthe Langstauden. Die meisten Arten sind sommergrün. Zu einer bestimmten Jahreszeit entwickeln sich die gewöhnlich langgliederigen Assimilationssprosse aus entweder oberirdischen, aber dicht an der Bodenoberfläche stehenden, oder aus unterirdischen, mehr oder weniger tief in der Erde liegenden Grundachsen. Die Erneuerungsknospen sind gewöhnlich von Knospenschuppen oder doch von Niederblättern geschützt. Die unterirdisch ausdauernden Grundachsenteile sind kurzgliederig und liegen in einer für jede Art einigermaßen bestimmten Tiefe in der Erde (Royers "Loi de niveau"). Es hat dies die ökologische Bedeutung, daß mehrere Arten in einem Pflanzenvereine friedlich nebeneinander leben können, ohne sich den Platz in allzu hohem Grade streitig zu machen ${ }^{1}$ ). Dachnowski ${ }^{2}$ ) z. B. erwähnt, daß in nord-

1) Vergl. z. B. Woodhead, seine Fig. vergl. unten unter Wälder.

2) Dachnowski 1912. 
amerikanischen Sphagnummooren einige Arten ihre unterirdischen Organe in 8-10 Zoll Tiefe, andere in 5-7 Zoll Tiefe erhalten, während sie bei noch anderen hoher liegen ${ }^{1}$ ).

Zur Durchbrechung der Frde sind die Sprosse resp. deren vorgeschobene Spitzen in verschiedener Weise angepaßt ${ }^{2}$ ). Vergl. Fig. 40, S. 74.

Die Laubsprosse sind meist gestrecktgliederig, und selbst wenn sie am Boden etwas kurzgliedriger sind, kommt es doch nicht zu einer eigentlichen Rosettenbildung. Die unteren Blätter sind oft langgestielt, die oberen werden aber successiv kleiner und kurzgestielt oder zuletzt sitzend. Die Sprosse sind fast immer einjährig und haben dünne, mesomorphe (an mäßige Verdunstung angepaßte) Blätter. Die im Boden liegenden überwinternden Grundachsenteile haben mehr oder weniger große Mengen von Reservesubstanz aufgespeichert (Fig. 59-67).

Eine unübersehbar große Mannigfaltigkeit von Typen findet sich hier, die übersichtlich folgendermaßen zusammengestellt werden können.

a) Ohne Wandersprosse und ohne als Knollen oder Zwiebeln ausgebildete Speicherorgane.

b) Wie a aber mit oberirdischen Ausläufern.

c) Wie a aber mit unterirdischen Ausläufern (Stolon-Rhizomen).

d) Wandernde, dauerhaftere, Nahrung speichernde daher dickere Grundachsen (Rhizome).

e) Zwiebel- und Knollenpflanzen. Gewöhnlich ohne Wandersprosse.

a) Die hierher gehörigen Pflanzen sind an den Ort gebunden, können nicht erheblich seitlich wandern. - Die in der Erde liegenden Grundachsen verholzen bei vielen (Drudes Holzkopfstauden); im trockenen lehmigen Boden der tropischen Savannen und Wüsten werden sie bisweilen sehr dick und hart (Xylopodium Lindman 1900; Warming 1892) ${ }^{3}$ ).

Im Frühlinge entwickeln sich ein bis mehrere aufrechte, krautartige Laubsprosse und blütentragende Stengel, deren unterste Teile lebend bleiben und seitlich Verjüngungsknospen für die nächstjährigen Triebe tragen; der größte obere Teil stirbt nach der Fruchtbildung ab. Wenn sich viele Sprosse entwickeln, wird der Wuchs dadurch „rhizoma multiceps" ( "Sproßbasis-komplex" und "Pseudorhizom" von Hj. Nilsson; Crown-formers Hitchcock; Clements 1898; Drude 1890).

In trockenem Boden dauert die Hauptwurzel gewöhnlich lange aus. Oft sind die beblätterten Stengel hoch (Hochstauden). Beispiele: Silene venosa, Cynanchum vincetoxicum.

1) Vergl. hierzu Royer 1881; P. E. Mü̈ller 1894; Rimbach; Raunkiär 1895-1908; Woodhead 1906.

2) Vergl. Areschoug 1895; Massart 1903, 1910. Vergl. Fig. 120 in WarmingJohannsens Lehrbuch, oben Fig. 40.

s) Vergl. S. 78 . 
b) Die Assimilationssprosse sind wie bei a entwickelt, aber es werden oberirdische, dünne, Laubblätter tragende und wurzelbildende Ausläufer gebildet. Damit in Verbindung steht gewöhnlich eine kürzere Dauer der primären Grundachsen und damit natürlich auch die Erscheinung, daß die Hauptwurzel bald verschwindet. Beispiele: auf feuchtem Boden am Ufer der Seen Mentha-Arten, Scutellaria galericulata.

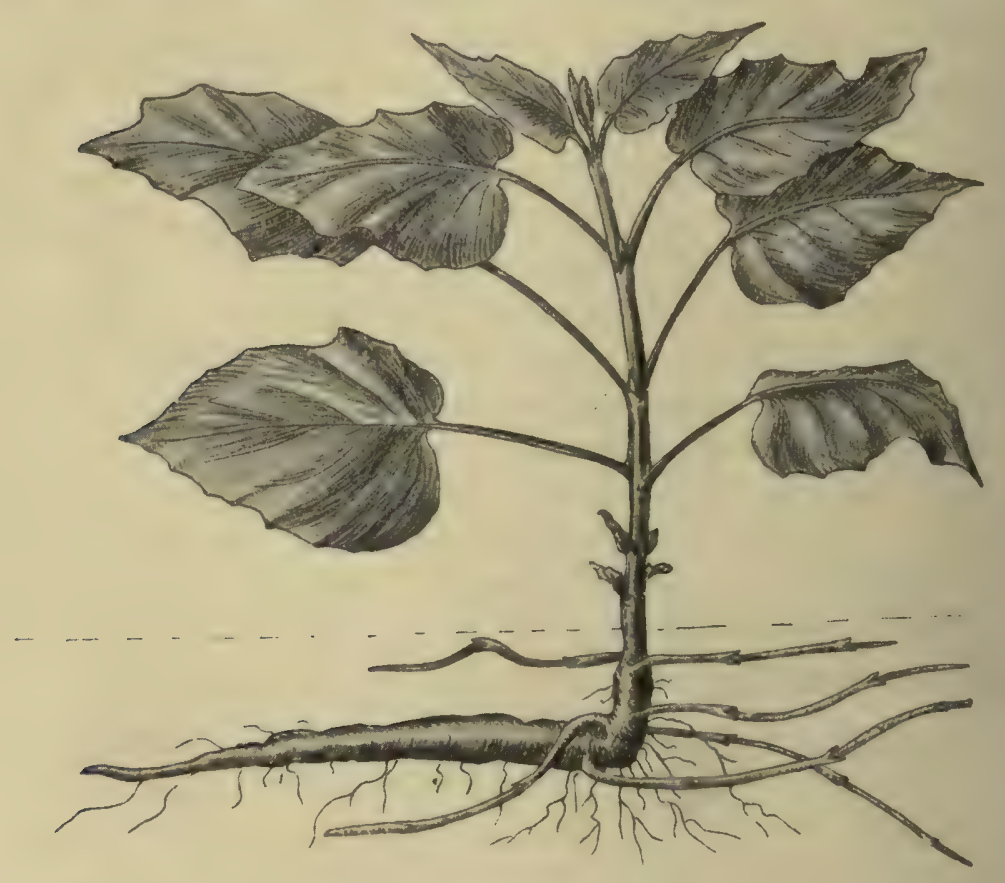

Fig. 59. Circaea intermedia mit schwach speichernden Grundachsen.

(E. Graebner. Nach der Natur.)

c) Im ganzen gleich b, aber die Ausläufer sind unterirdische, gestrecktgliedrige Niederblattsprosse von kurzer Lebensdauer, die nicht oder doch nur schwach als Reservestoffe speichernde Organe ausgebildet sind („Stolon-Rhizomen“ von Joh. Erikson).

Dieser Typus findet sich vorzugsweise im lockeren Humusboden der Wälder, z. B. Asperula odorata, Circaea Lutetiana, Stachys silvaticus, oder im Schlamm der Seen und an den nassen Ufern, z. B. Phragmites communis, Equisetum limosum (s. Fig. 59).

Einige Arten entwickeln am Ende der Ausläufer knollenförmig verdickte Speicherorgane von kurzer Lebensdauer („Kartoffel-Typus“). Auch die Ausläufer selbst leben kürzer als bei den zuerst genannten, z. B. Solanum tuberosum (Fig. 60), Stachys tuberiferus, Trientalis europaea. Hier auch die etwas abweichende Adoxa moschatellina (Fig. 61). 
Fig. 60.

Solanum tuberosum, Kartoffel mit

Knollen; verkleinert. (WarmingJohanusen.)
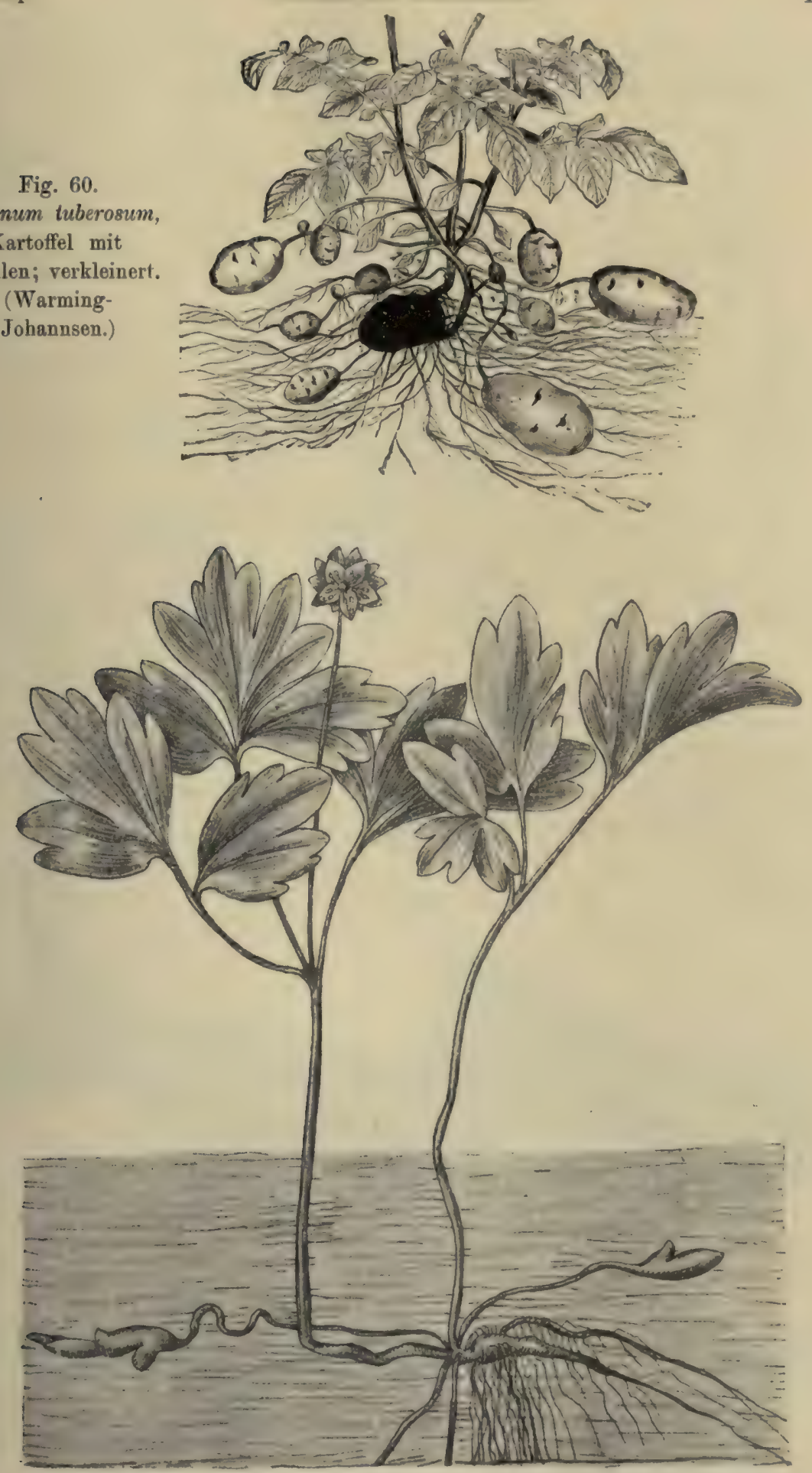

Fig. 61. Adoxa moschatellina mit den knollenförmigen Speicherorganen. (E. Graebner; nach der Natur.) 
Hier schließen sich auch Arten mit reicher Wurzelsproßbildung (z. B. Linaria vulgaris) an (vergl. Fig. 62 und Fig. 73, S. 180).

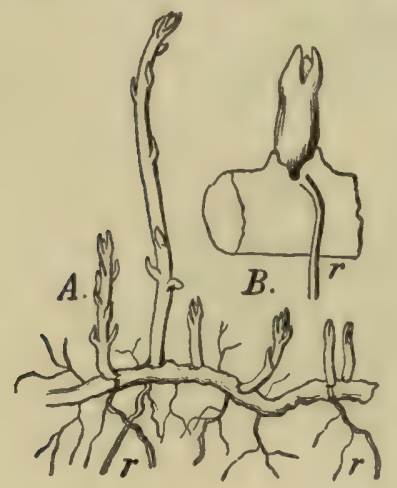

Fig. 62. Turzelsprosse von Linaria vulgaris.

r Seitenwurzeln, A natürliche Größe, $B$ vergrößert. (Warming.) nur eine oder einige sich entwickeln, treiben nach der Ruheperiode einen unverzweigten oder wenig verästelten, kurzlebigen Assimilationssproß. Mitunter gehen dabei die Speicherorgane vollständig zugrunde, an anderen Arten dauern sie d. h. horizontal wachsende, unterirdische, gewöhnlich kurzgliedrige Niederblattachsen, an welchen sich alljährlich gestrecktgliedrige Assimilationssprosse entwickeln. Die Grundachsen sind reich an Reservenahrung, daher oft dick und dauerhafter als die unter $\mathbf{e}$ erwähnten.

Beispiele: Polygonatum multiflorum (P. Japonicum Fig. 63).

e) Zwiebel- und Knollenpflanzen. Viele, besonders monokotyle Pflanzen haben in der Erde knollen- oder zwiebelartige Organe, welche zur Zeit der Ruhe mit Revervenahrung (Stärke u. a.) dicht gefïllt sind. Die Erneuerungsknospen, 'deren gewöhnlich

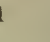


ersteren durch die Sommertrocknis, bei den Wäldern durch die Wurzelkonkurrenz der in Sommer stark verdunstenden Bäume gegeben.

Verschiedene morphologische Unterabteilungen lassen sich unterscheiden :

1. Stammknollen: Arten von Corydallis (Fig. 64).

2. Wurzelknollen: Ophrydeen, Dahlia variabilis (Fig. 65).

3. Zwiebel: Viele Liliaceen und Amaryllidaceen ${ }^{1}$ ) (Fig. 66).

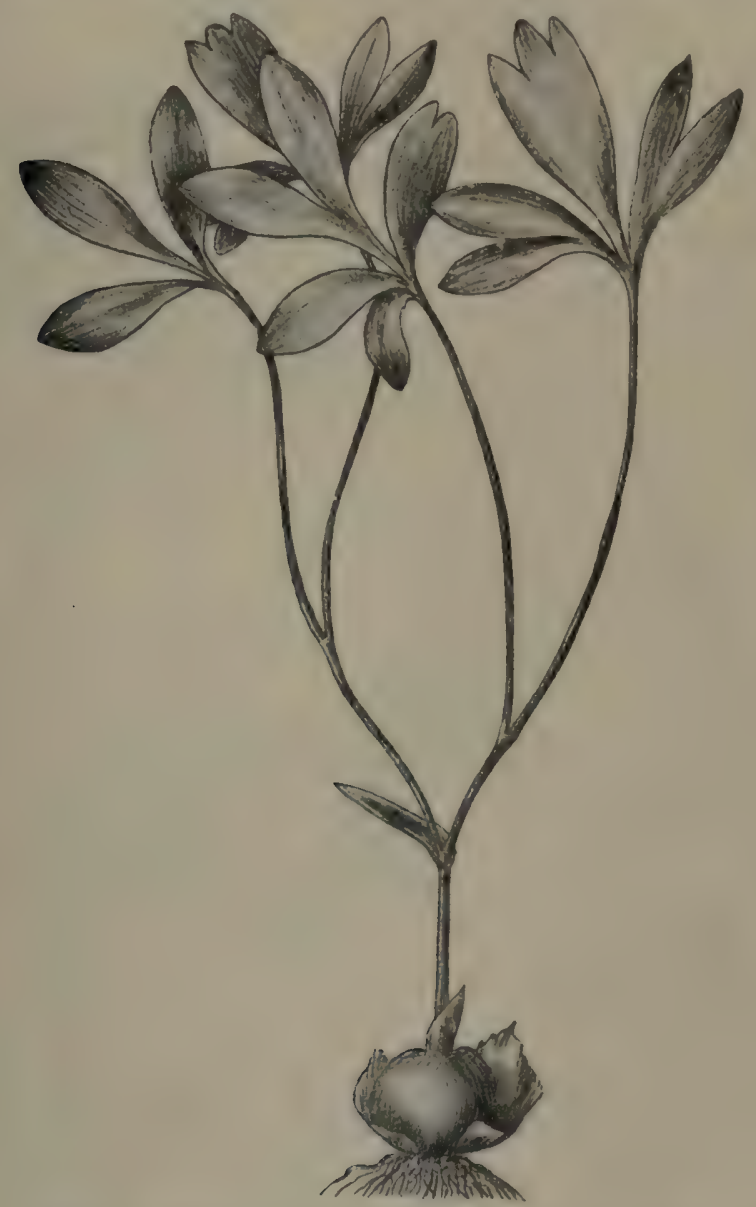

Fig. 64. Corydallis solida mit Stammknolle. (E. Graebner; nach der Natur.)

11. Blattstauden. Die Assimilationsorgane sind vereinzelte Laubblätter, welche von unterirdischen, rerzweigten Wandersprossen entwickelt werden. Beispiele: Pteridium aquilinum, Aspidium (Phegopteris) dryopteris, (Anemone nemorosa, mit laubblatttragenden Blütensprossen), Aspidistra lurida. Hierzu gehören, wie es scheint, hauptsächlich Waldpflanzen (Fig. 67).

1) Über die Lebensgeschichte von Stengelbulbillen vergl. Nakano 1910. 
12. Rosettenstauden (mit nicht grasartigen Blättern). Kryptogame, dikotyle und seltener monokotyle, mehrmals fruchtende Kräuter, deren beblätterte Assimilationssprosse sehr kurz („stammlos“) und kurzgliederig sind. Einige oder meist viele Laubblätter sind rosettenförmig angeordnet (Kap. 10, 11, 18, 23, 25). Viele hierher gehörige Arten sind immergrün.
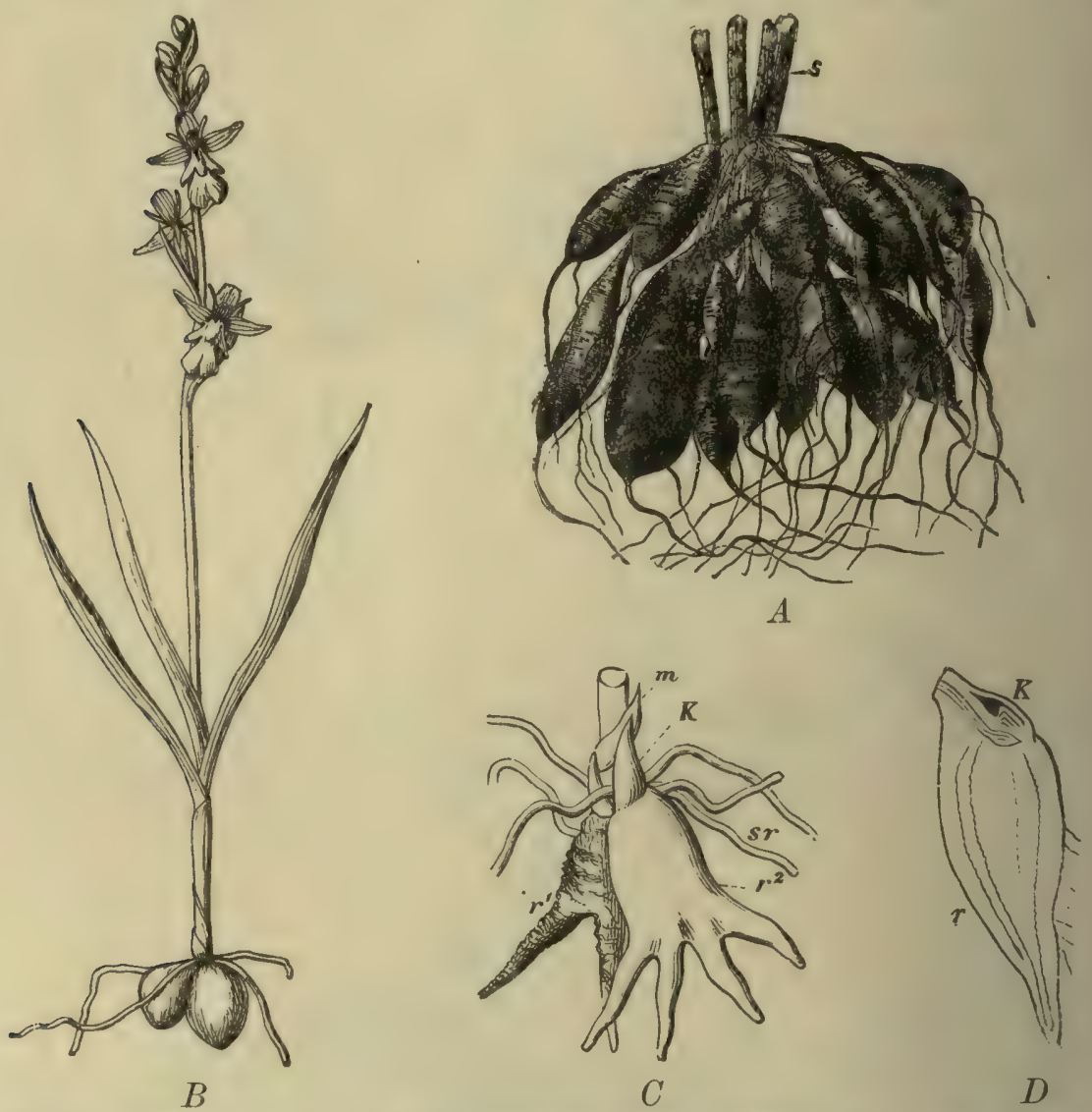

Fig. 65. Wurzelknollen. A. von Dahlia variabilis, Georgine (nach Straßburger). B. Ophrys. - C. Orchis maculatus im Juni, mit $r^{\ell}$ der alten ("Teufelshand") und $r^{2}$ der neuen Knolle („Christushand“), letztere bei $K$ mit der Verjüngungsknospe, $s r$ Saugwurzeln $(1: 1)$. - D. Platanthera, $K$ Knospe $(1: 1)$. - (Nach Irmisch u. a.)

Die Laubblätter lassen sich in zwei Typen teilen:

a) Kurzgestielte Langblätter (Taraxacum, Draba, Primula, Plantago lanceolata u. a. Dikotylen (Fig. 68); unter den Monokotylen z. B. Agave, Bromeliaceen). (Die Gräser werden in eine besondere Gruppe gestellt, die Farnkräuter dagegen hierher.)

b) Langgestielte, breitere Blätter mit länglicher, kreisförmiger oder herzförmiger Spreite (Soldanella, Verbascum phoeniceum, Adenostyles, Drosera rotundifolia, Cyclamen). 
22. Kap.

Ubersicht der Grundformen

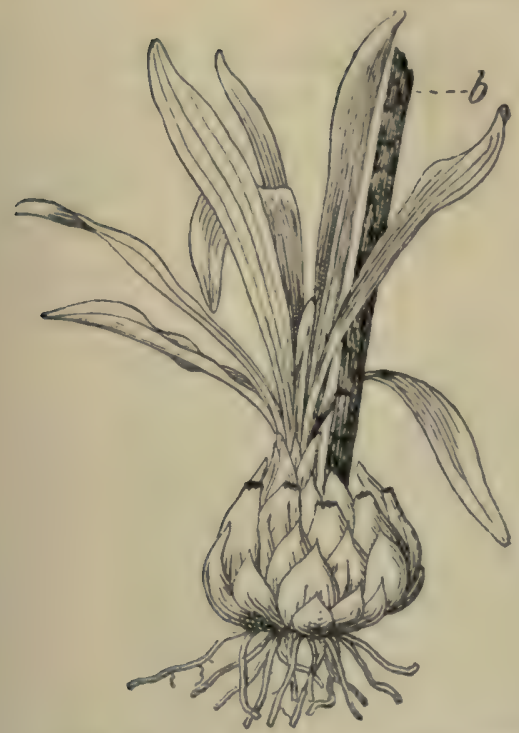

Fig. 66. Zwiebelbildung bei Lilium. (Gezeichnet von Warming.)
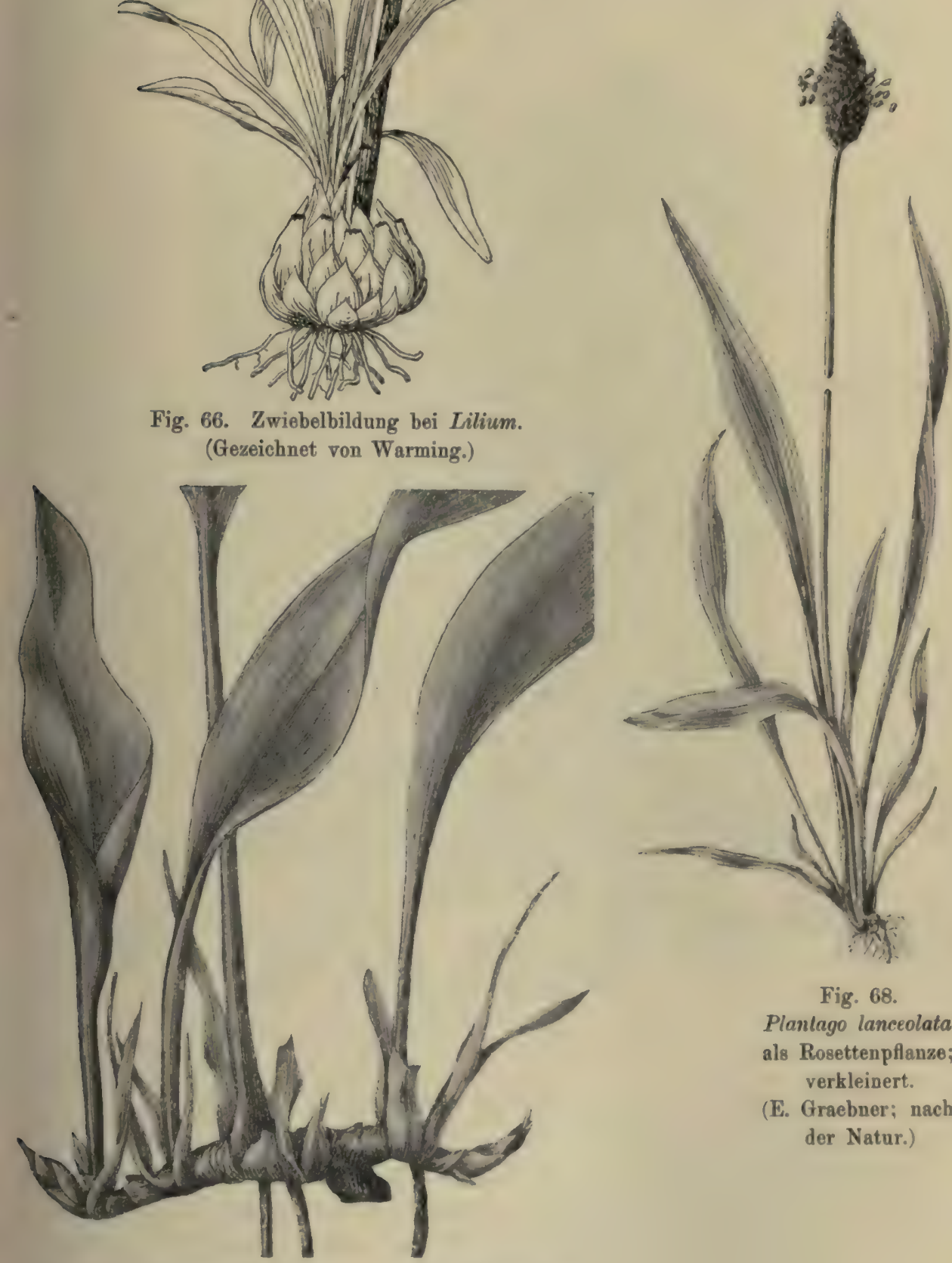

Fig. 68.

Plantago lanceolata als Rosettenpflanze; verkleinert.

(E. Graebner; nach der Natur.)

Fig. 67. Aspidistra. Einzelstehende Laubblatter an Wandersprossen; verkleinert.

(E. Graebner; nach der Natur.) 
Stets sind nackte Knospen ausgebildet, selbst wenn die Laubblätter in der ungünstigen Jahreszeit absterben. In vielen Fällen sterben im Winter die alten Blätter ab, und in der Mitte der Rosette findet sich eine dicht geschlossene Knospe von jüngeren. Die Rosettensprosse haben

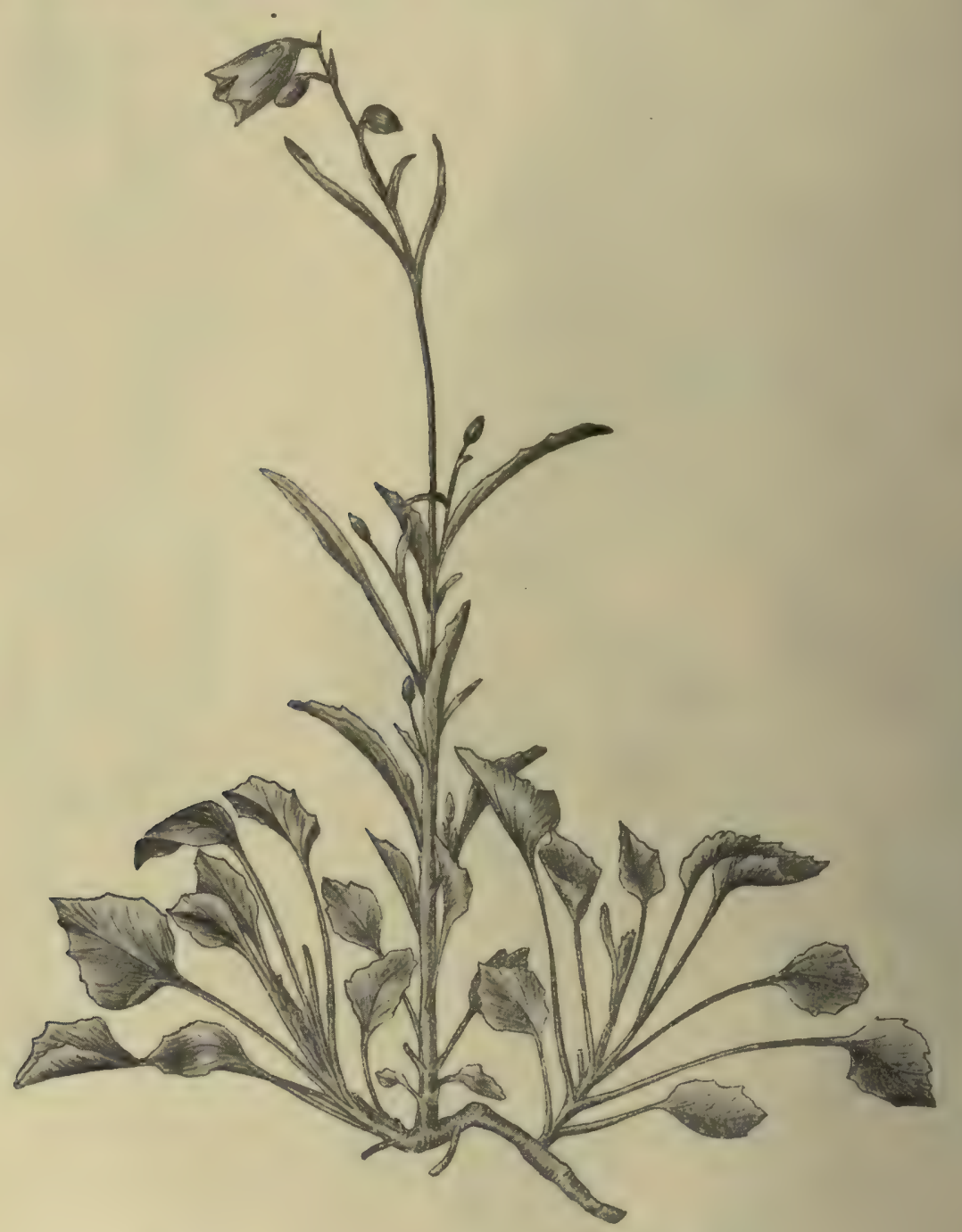

Fig. 69. Campanula Carpatica als Halbrosettenpflanze; verkleinert.

(E. Graebner; nach der Natur.)

dicyklische bis pleiocyklische Entwicklung, d. h. sie bleiben ein bis mehrere Jahre in dem vegetativen Stadium erhalten, ehe sie blühen, fruchten und danach absterben; nur der allerunterste Teil des Sprosses bleibt lebendig. Nahe verwandt sind die dicyklischen und pleiocyklischen Hapaxanthen (Gruppe 8, 9). Bei einigen bleibt die Hauptwurzel erhalten, bei 
anderen wird sie durch Nebenwurzeln ersetzt. Bei den am besten ausgeprägten Typen ist der blühende Stengel ganz ohne Laubblätter und bleibt stets unverzweigt (Blütenschaft); z. B. Taraxacum, PlantagoArten, Armeria vulgaris, Soldanella, Primula-Arten, Papaver nudicaule, Drosera rotundifolia u. a. ("Helrosetplanter" s. „Ganzrosettenpflanzen" bei Raunkiär). Fig. $65 B, 68,72$.

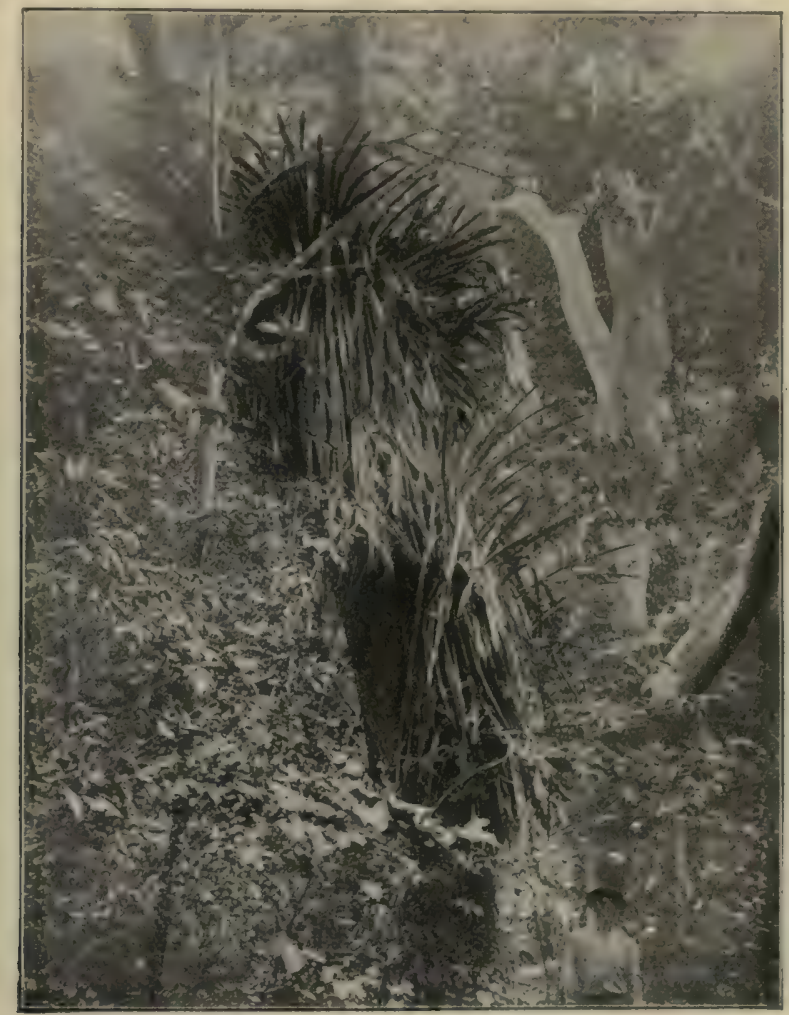

Fig. 70. Hochwald auf St. Jan, Dänisch-W' estindien.

Chevalieria lingulata auf einem Stamme von Spondias lutea; die anderen Bäume sind Hymenaeu courbaril, Andira inermis, Cupania (fulva?), Melicocea bijuga, dazwischen Peperomia. (Phot. Börgesen.)

Die rosettenbildenden Farnkräuter stellen eine etwas abweichende Gruppe dar.

Bei anderen Arten wächst die Rosette, sobald sie blühfähig wird, in einen laubblatttragenden, verlängerten Stengel aus, welcher nicht selten verzweigt ist. Die Laubblätter werden meist nach oben allmählich kleiner; die Größe der Spreite und die Länge des Stieles nimmt ab. Viele von den hierher gehörigen Pflanzen sind Hochstauden, welche eine Mittelstellung (als "Halbrosettenpflanzen") zwischen den "Ganzrosettenpflanzen" und den gewöhnlichen Stauden einnehmen, z. B. Campanula-Arten (Fig. 69). 
Die Rosettenpflanzen finden sich gewöhnlich auf einem der Lichteinstrahlung voll offenen Gelände, und es finden sich sowohl solche von mesomorphem als von xeromorphem Bau, also solche mit geringem und solche mit starkem Verdunstungsschutz. Sie leben sowohl in den Polarländern und Hochgebirgen (Arten von Saxifraga, Papaver, Draba u. a.), als auf nährstoffreichem, lockerem Grasboden wie an anderen Orten der temperierten Länder (Taraxacum, Arten von Plantago, Leontodon, Hypochaeris) und ebenso auch in Hochmooren (Drosera, Pingiicula, Sarracenia, Dionaea), dann weiter sieht man sie in tropischen Wüsten (Typus

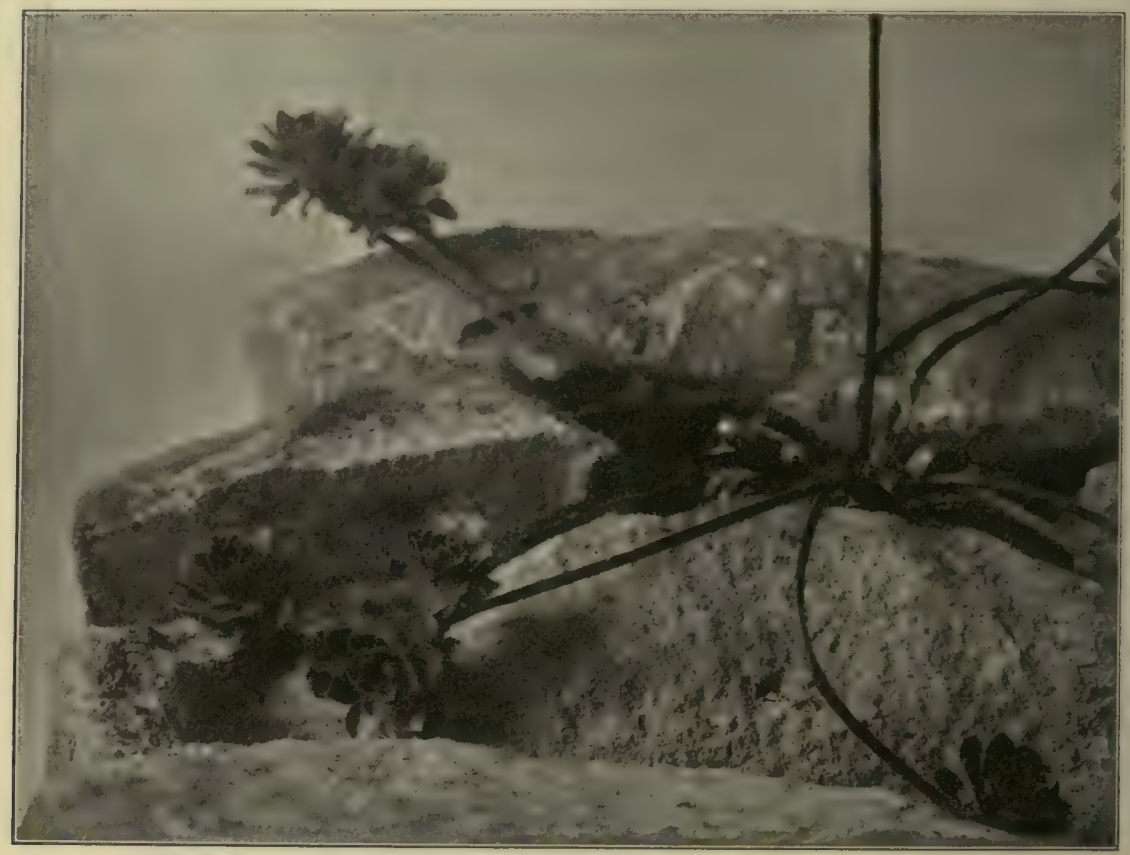

Fig. 71. Saxifraga Brunonis, typische Rosettenstaude mit oberirdischen, wieder Rosetten tragenden wurzelnden Auslåufern. (P. Graebner phot.)

der Agaven, Aloë) und an heißen Felsen in subtropischen und tropischen Gebieten (z. B. Echeveria, Sempervivum). Auch epiphytisch leben einige zu dieser Lebensform gehörige Arten in den Tropenwäldern (Bromeliaceen, Astelia) (Fig. 70), Rosetten vergl. Fig. 10, 11 S. 25, Fig. 23, 24 S. 45 und Fig. 68 S. 175.

Wie die Gruppe der pollakanthen Langstauden kann auch diese folgendermaßen eingeteilt werden:

a) Ohne Wandersprosse, oft mit bleibender Hauptwurzel (Taraxacum, Arten von Draba, Papaver, Plantago). Ein eigentümlicher Typus mit mehrjähriger Stammknolle wird repräsentiert z. B. durch Cyclamen, 
Eranthis; ein anderer mit kurzlebender z. B. durch Crocus, Arum, Amorphophallus.

b) Mit oberirdischen Ausläufern, z. B. Fragaria, Saxifraga flagellifera, Hieracium pilosella, Arten von Sempervivum (Fig. 71).

c) Mit unterirdischen Ausläufern (Stolon-Rhizomen), z. B. Pirola rotundifolia (Fig. 72).

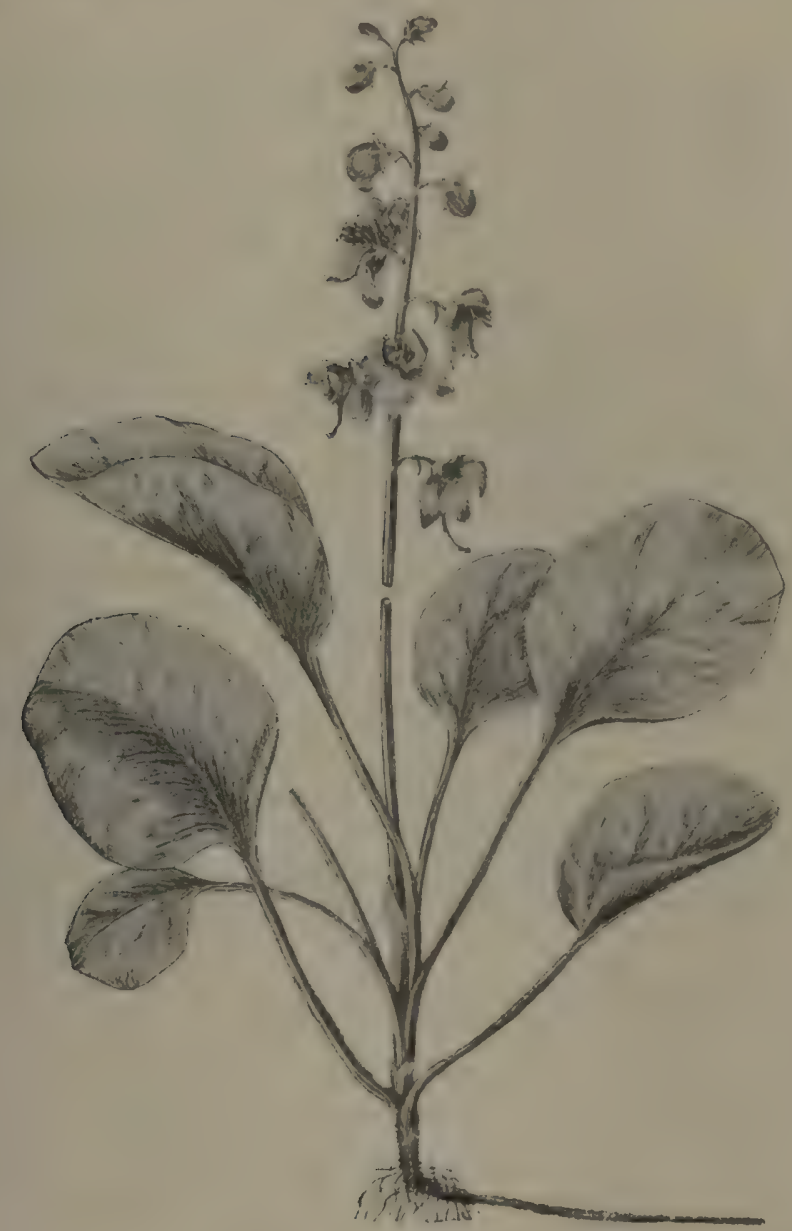

Fig. 72. Pirola rotundifolia mit unterirdischen Ausläufern. (E. Graebner; nach der Natur.)

d) Hieran schließen sich Arten mit reicher Wurzelsproßbildung (Sonchus arvensis, Cirsium arvense, Rumex acetosella, Hig. 73).

e) Rosettenkräuter mit wandernden Grundachsen (Rhizomen), d. h. horizontalen, lang- bis kurzgliedrigen, unterirdischen, nahrstoffspeichernden Grundachsen, von welchen die assimilierenden Sproßteile ausgehen, z. B. Iris pseudacorus, Struthiopteris Germanica. Hierher muß anch der 
Musa-Typus gerechnet werden, riesige, tropische Kräuter mit mehrjährigen, oberirdischen, aus zusammengerollten Blattscheiden gebildeten „falschen Stämmen“.

Von den krautartigen, stammlosen Typen von Rosettenkräutern gibt es alle Übergänge zu den Rosettenbäumen (Schopfbäımen).

13. Pollak-anthe Kräuter der Grasform. Diese Pflanzen verdienen besonders hervorgehoben zu werden ${ }^{1}$ ), weil sie physiognomisch

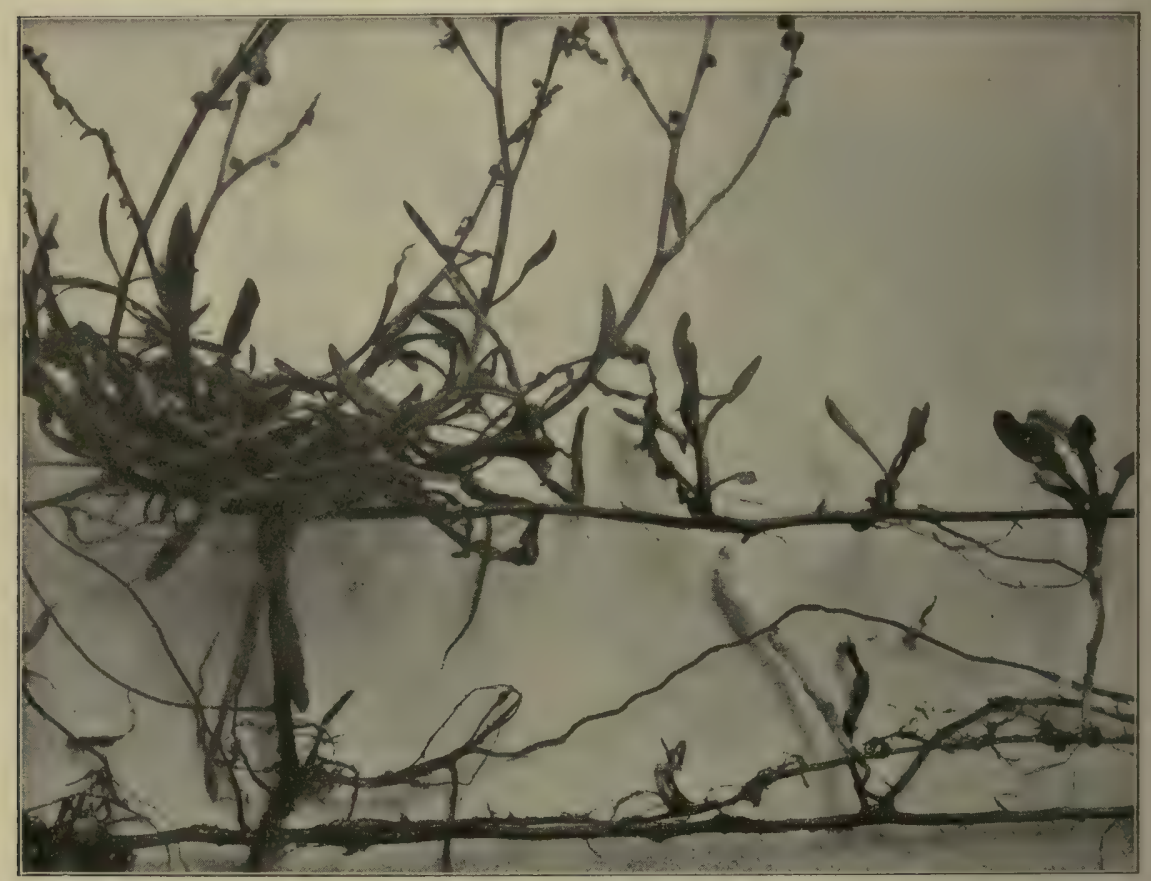

Fig. 73. Rumex acetosella, Bitterling, mit zahlreichen Laubsprossen auf den wagerechten Wurzeln. (P. Graebner phot.)

so eigentümlich sind und weil ihre Rosetten so abweichend im Bau von denen der übrigen Stauden sind. Außerdem spielen die Gräser landschaftlich und geographisch eine sehr bedeutende Rolle. Der rasenförmige Wuchs wird durch die Kurzgliedrigkeit der Halme am Grunde bedingt, deren sich zahlreiche in den Achseln der Grundblätter entwickeln und die sich dann wieder nach demselben Schema (öfter mehrmals in einem Jahre) verzweigen können.

Die eigentümliche Physiognomie des Gramineentypus wird namentlich durch die bandförmigen bis ganz schmal linealischen Blätter hervorgerufen.

1) Vergl. Engler 1913, S. 173. 
Die Sprosse sind sehr oft immergriin, da in diesem Falle nur die ältesten Blätter jedes Sprosses bei Annäherung der ungünstigen Jahreszeit (bei uns der Winter) gänzlich absterben. Die Knospen sind fast immer offen.

$\mathrm{Zu}$ diesem Typus gehören die allermeisten Gramineen, Cyperaceen und Juncaceen; etwas abweichend sind die Eriocaulaceen und Restionaceen.

Unterabteilungen lassen sich ähnlich wie bei 10 und 12 a, b, c, d, e unterscheiden.

a) Ohne Wandersprosse, z. B. Aera caespitosa, Anthoxanthum odoratum, Luzula multiflora, Eriophorum vaginatum.

b) Mit oberirdischen Ausläufern: Festuca thalassica (Glyceria maritima).

c) Mit unterirdischen Ausläufern (Stolon-Rhizomen): Psamma (Ammophila) arenaria, Carex arenaria, Triticum repens, Eriophorum angustifolium.

d) Mit kurzgliedrigen, wandernden, dauerhaften Grundachsen (Rhizomen), z. B. Stipa tenacissima, Nardus stricta (s. Fig. 118).

14. Halbstråncher (Holzstauden Drude; Suffrutices). Ziemlich niedrige (ca. $1 / 3-1 \mathrm{~m}$ hohe) aufrechte Pflanzen mit Langsprossen, welche oft immergrün sind. Die Stengel bleiben krautartig oder verholzen, besitzen aber auch dann meist mehr oder weniger krautartige und, wenigstens im Winter, auf größere oder geringere Strecken ahsterbende Spitzen. Der Typus umfaßt also Mitteldinge zwischen Kräutern und ' Gehölzen. Die Knospen sind offen, die Jahressprosse oft verzweigt.

Die Halbsträucher bilden eine mannigfaltige Gruppe mit sehr verschiedenen Anpassungserscheinungen der Sprosse an die durch die Verhältnisse des Standortes gebotene Lebenslage. In den Tropen, sowie in subtropischen Gebieten, leben viele niedrige, immergrüne Kräuter, z. B. Commelinaceen, die dieser Lebensform zuzurechnen sind, oder in den Wäldern höhere, dünnstengelige, in den älteren Stengelteilen mehr oder weniger verholzende Pflanzen mit mesomorphen Blättern, z. B. Acanthaceen, Rubiaceen, Verbenaceen, Piperaceen, Melastomataceen, Fuchsia usw.

In gemäBigten Klimaten gehören zu dieser Lebensform z. B. auch manche Dianthus-Arten (D. caesius usw.), deren reichrerzweigte untere Stengelteile oft auf lange Strecken verholzen. (Linnaea borealis, Kriechpflanze, vergl. Fig. 74.)

In Steppen, Wüsten und Ländern mit Winterregen finden sich z. B. viele Labiaten (Salvia, Lavandula, Thymus u. a.) von diesem Typus. Dann weiter Kompositen (Artemisia-Arten), Verbenaceen, Euphorbiaceen, Gesneraceen, Leguminosen, Arten von Genista u. a. 
Einen eigentümlichen Typus bilden die Schößlingssträucher ${ }^{1}$ ). Aus einem kleinen dem Boden anliegenden oder unterirdischen, verholzten Sproßverbande entspringen alljährlich aufrechte, verholzende Stengel, die im ersten Jahre nur Blätter tragen und erst im zweiten Jahre kurze, blühende Seitensprosse entwickeln. Nach der Fruchtreife stirbt das ganze Sproßsystem ab, ausgenommen kurze Knospen tragende Stücke im Boden oder an der Bodenoberfläche, von denen dann im nächsten Jahre die Verjüngerung ausgeht. Typus: Rubus Idaeus.

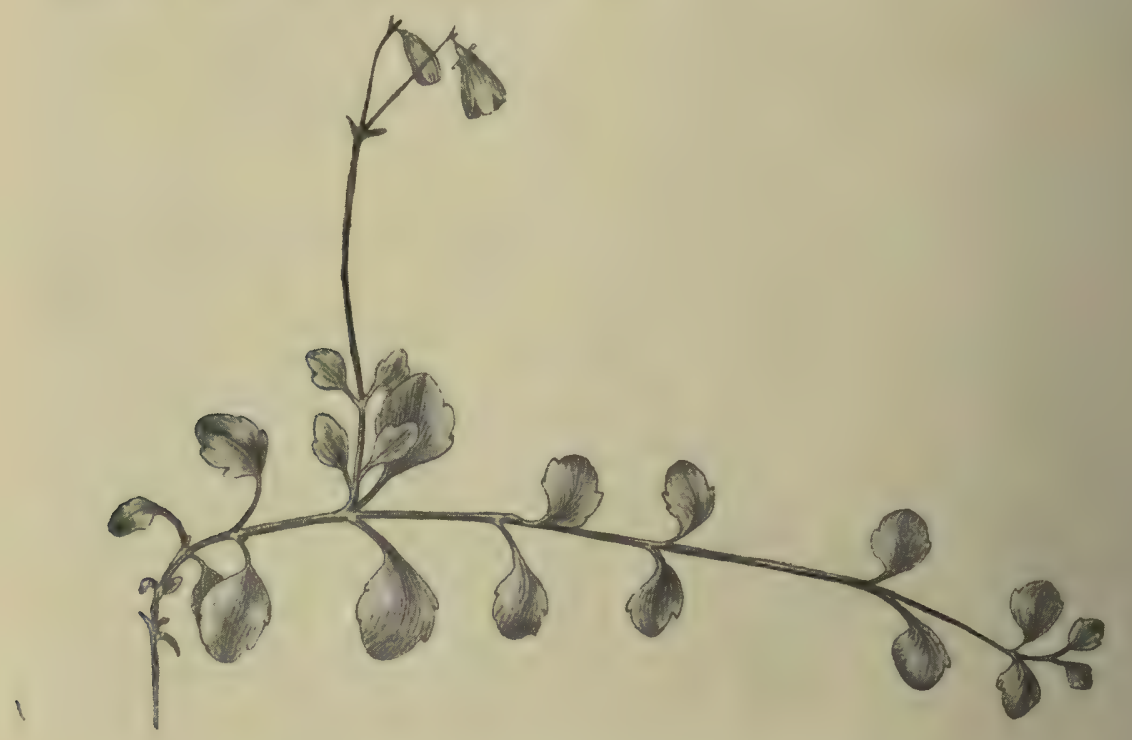

Fig. 74. Linnaea borealis in natürl. Größe. (Nach der Natur.)

15. Polsterpflanzen. Selbstassimilierende Landpflanzen mit oberirdischen, verzweigten, krautartigen oder mehr oder weniger verholzten, recht kurzgliedrigen, langsam wachsenden aber lange lebenden Langsprossen, welche mit kleinen, bei einigen sich dachziegelartig deckenden Laubblättern besetzt sind. Bei einigen hierher zu rechnenden Formen sind die Blätter an der Spitze der Stengel etwas rosettenförmig angeordnet. Sie bilden eine eigentümliche Form der Halbsträucher. Die Sprosse sind, wie bemerkt, verzweigt, und die einer Pflanze etwa von gleicher Länge, oder die seitlichen überragen die mittleren (aufrechten) allmählich an Länge. Dadurch, daß so viele fast an derselben Stelle aus dem Wurzelkopfe der bleibenden Hauptwurzel entspringen und nach allen Seiten ausstrahlen, werden halbkugelige oder mehr oder weniger flache, rundliche Polster gebildet, welche aus den lockeren oder dicht zusammengedrängten Sprossen gebildet sind. Die Zwischenräume

1) Drude 1896 . 
zwischen den einzelnen Sprossen eines solchen Polsters werden von den langsam welkenden und vermodernden Blättern ausgefüllt - „eine Füllmasse mit Schwammwirkung" (Hauri). Die Knospen sind offen. Die Polster können lose und weich sein, sind aber bei einigen auch fest bis sehr hart.

Es gibt eine vollkommene Reihe von Übergangsformen von den kleinen, lockeren Polstern, welche sich z. B. bei Saxifragen und Cruciferen der Polarländer und Hochgelirge finden, bis zu den großen und harten Polstern der Azorellen, Aretiastrum usw., überleiten (Fig. 75). I)ie Azorellen können mehrere Meter im Durchmesser und 0,5-0,8 m Höhe erreichen.

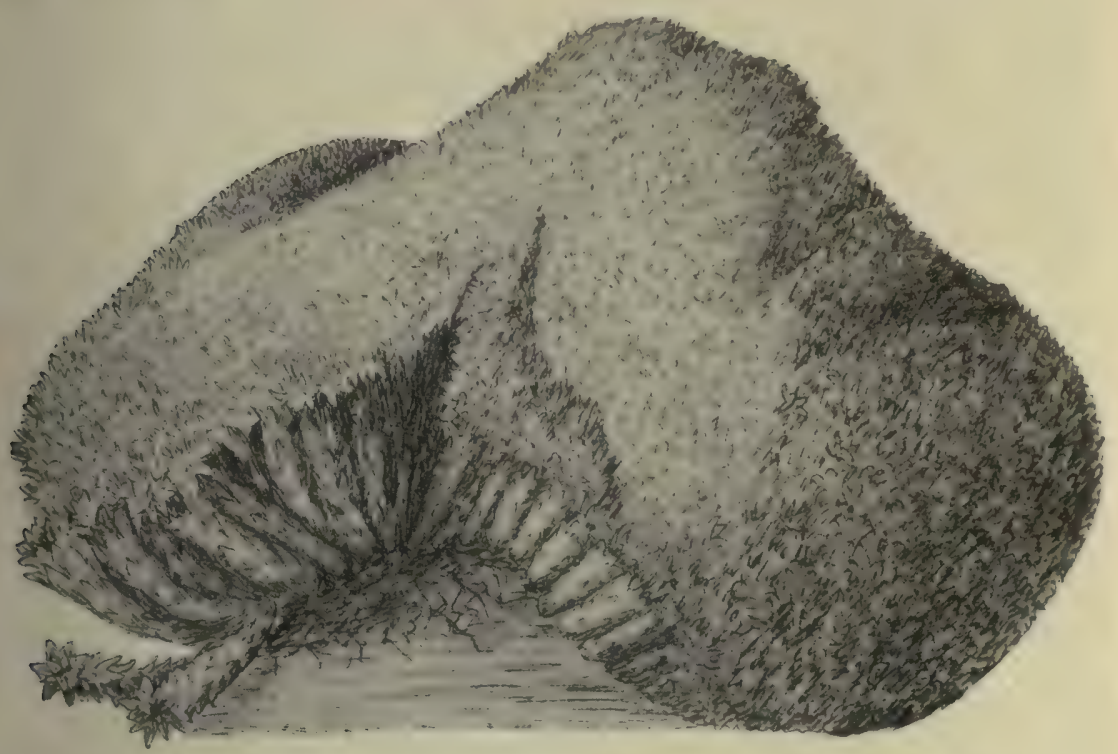

Fig. 75. Aretiastrum Aschersonii (Valerianacee) von den Peruanischen Hochanden; sehr hartes und dichtes Polster; natürl. Größe. (Nach Weberbauer.)

Einige der hierher zu rechnenden Lebensformen sind Modifikationen von Halbsträuchern, die noch nicht erblich fixiert sind, andere kommen überall in derselben Tracht vor.

Die Arten gehören zu den verschiedensten Familien. Die Polsterform findet sich in Polargegenden (Cruciferen, Saxifragen, Silene acaulis, Diapensia Lapponica), Moose Fig. 76, in den Hochgebirgen der Alpen (Caryophyllaceen, Saxifragen, Primula u. a.), des Himalaya, und besonders reichlich in den balkanischen und vorderasiatischen Gebirgen (Primulaceen, wie Dionysia und Aretia, Saxifragen, Caryophyllaceen u. a.); ebenso lebt sie reichlich in den neuseeländischen Alpen (die Kompositen Haastia und Raoulia, Arten von Veronica, von Aciphyllen [Umbellifere] u. a.), 
in den Anden ${ }^{1}$ ) und antarktischen Inseln (Umbelliferen wie Azorella, Arten von Verbena, Juncaceen wie Distichia muscoides).

Aber auch in Wüsten, Steppen und anderen heißen Gegenden mit stark erwärmtem Boden findet sich dieser Typus (Anabasis aretioides in der Sahara, Centaurea spinosa auf Tenedos, Fig. 77), holzige Polster in Südafrikas Wüsten; dann bildet er sich regelmäßig an stark windigen

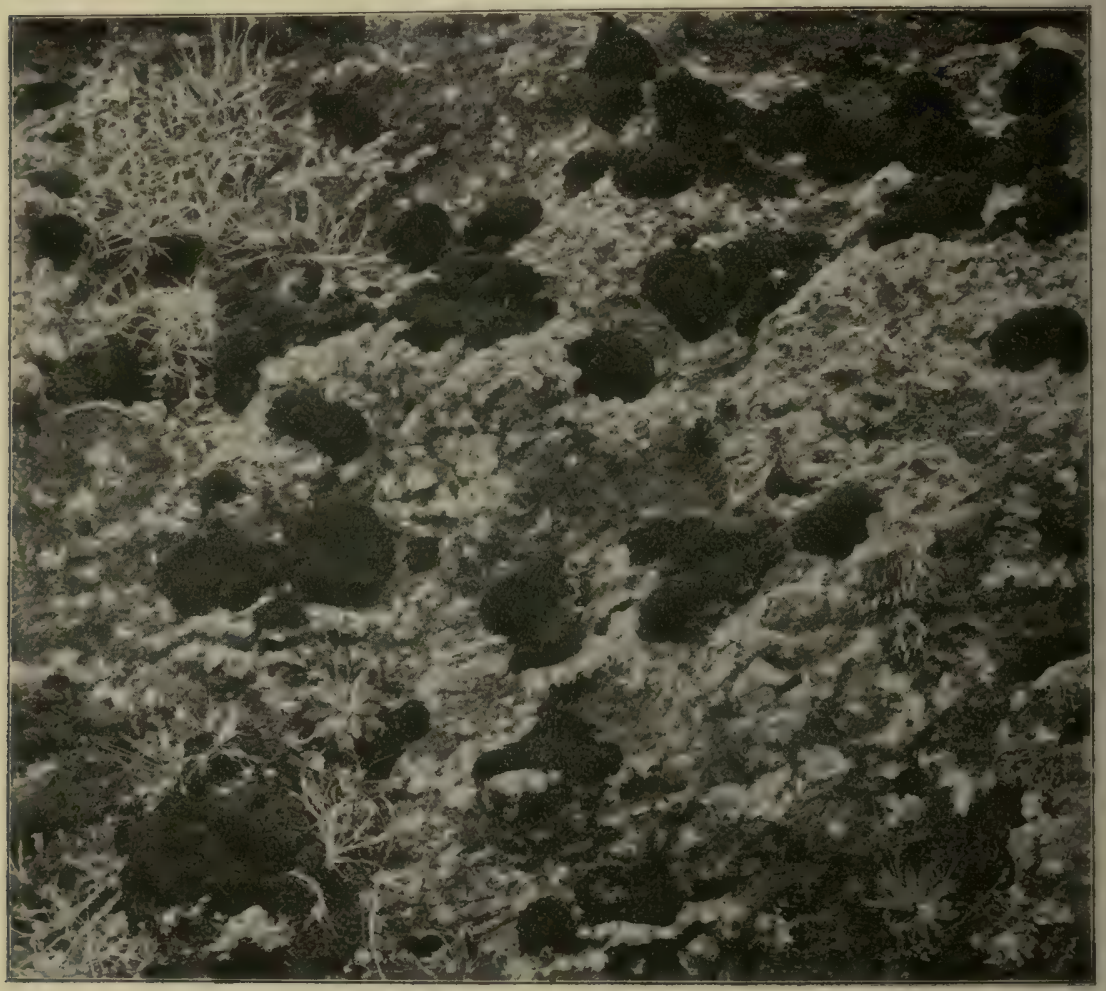

Fig. 76. Grimmia maritima; Strandfelsen auf Bornholm. (Warming phot.)

Standorten in der Nähe der felsigen Meeresküsten (Südwest-England, Bornholm, Fig. 76) und in Hochgebirgen oft aus an geschützten Orten mit nicht polsterartigen Gewächsen.

Über die verschiedenen Typen von "Polstern" und von „Kissen" siehe Hauri u. Schröter ${ }^{2}$ ) Die Aufgabe der Polster ist wohl meistens, die Verdunstung zu reduzieren und Wasser zu speichern.

2) Vergl. Weberbauer 1911.

2) Über Polsterpflanzen vergl. Goebel 1891; Lazniewski 1896; Diels 1896, 1905; Skottsberg 1906; Schröter 1904-8; Schenck 1908; Cockayne 1910, 1912; Hauri 1912 (dort weitere Litteratur); Hauri u. Schröter 1914. 
16. Pflanzen mit Weichstämmen. Tropische Formen mit dicken, weichen, krautartigen oder wenig verholzten, wenigstens anfangs grünen, ausdauernden Stämmen. Die Knospen sind bei dieser Lebensform offen oder nur von dem F'ußteile des zuletzt entfalteten Blattes umschlossen; gewöhnlich ist nur eine geringe Verzweigung bemerkbar. Die Blätter sind oft groß und meist mehr oder weniger mesomorph gebaut. In tropischen Wäldern und Sümpfen, auch epiphytisch. Namentlich Araceen.

Die epiphytischen Orchideen mit oder ohne Knollenstämme schließen sich hier an (Fig. 78).

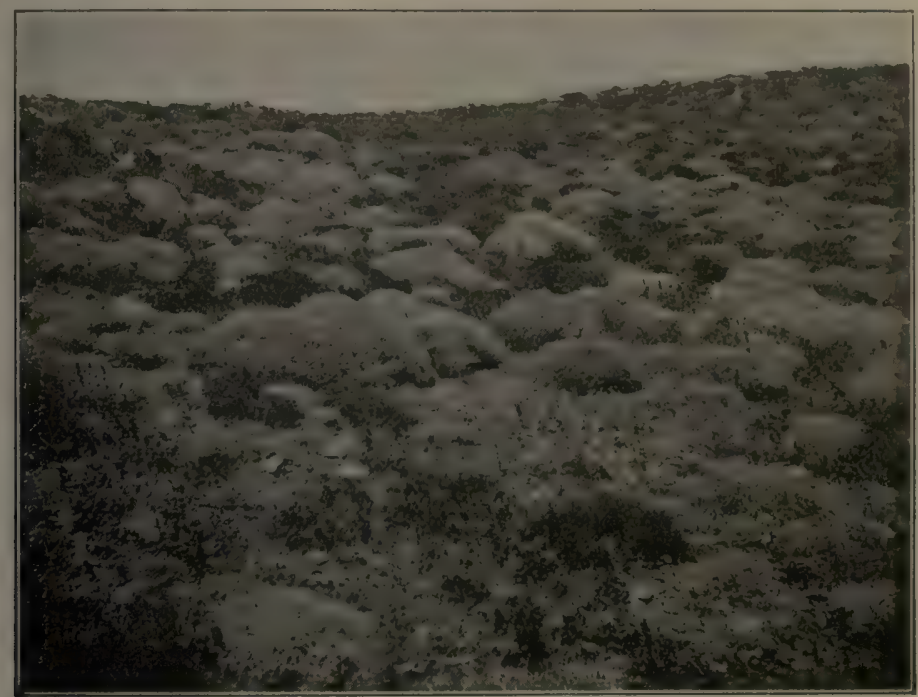

Fig. 77. Aus Tenedos. Die grauen Polster sind von Centaurea spinosa gebildet; die dunklen Flecken sind Poterium spinosum. (Phot. S. Palitzsch.)

17. Stamm-Sukkulenten (Kaktusform). Die Stengel sind krautartig oder mehr oder weniger verholzt, meist grïn, saft- und fast stets schleimreich, unverzweigt oder mit wenigen dicken Ästen, ohne oder doch mit sehr reduzierten Laubblättern, öfter dornig (Fig. 79, 81).

Die Knospen sind sehr klein, gewöhnlich eingesenkt und durch Haare oder haarartige Stacheln (Glochiden) geschützt.

Viele verschiedene Formen der Tracht und Größen lassen sich iunerhalb dieser Lebensform unterscheiden: süulenförmige bis kugelförmige, solche mit flachen Stengeln oder langen zylindrischen; einige haben sogar kletternde oder schlingende Stengel.

Die Stammsukkulenten sind an heiße Klimate mit langer Trockenzeit und wasserarmen Standorten (Steppen, Wüsten, Felsen, Bäume) angepaßt. Besonders: Cactaceae, Stapetia, Arten von Euphorbia ${ }^{1}$ ) Fig. 79.

1) Goebel 1891 . 
Echte Gehölze; die oberirdischen Stengel verholzen stark und sind mehr- bis vieljährig. Es gibt sowohl immergrüne, wie sommergrüne. Bei weitem die meisten haben Langsprosse und sind mehr oder weniger stark verzweigt, sie haben eine große Zahl von oft kleinen bis mittel-

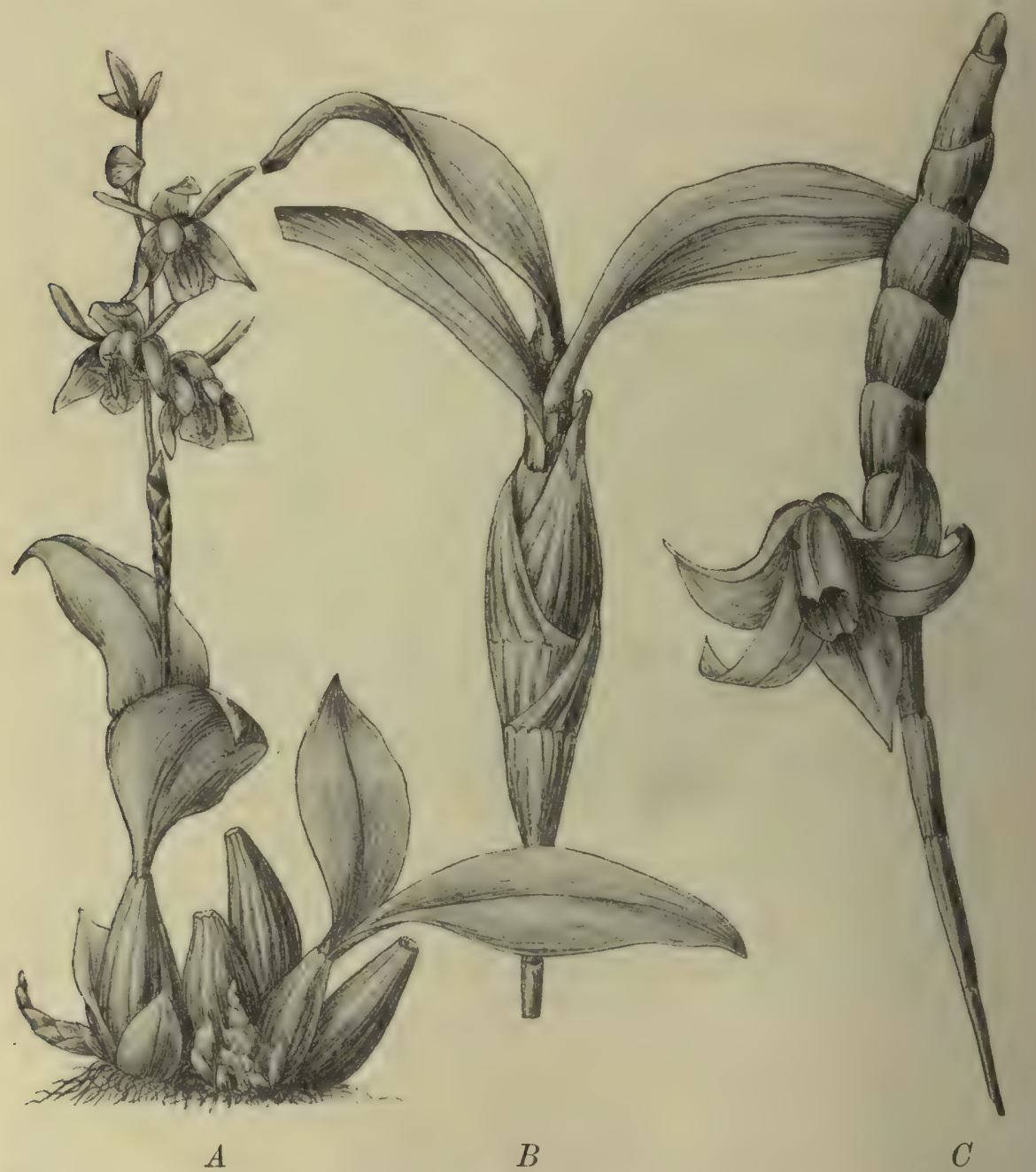

Fig. 78. Orehideen mit Knollenstämmen. A. Coelogyne Sanderae, B. u. C. Dendrobium inaequale. Natürl. Größe. (Nach Kränzlin.)

großen Blättern (Sträucher, Wipfel[Kronen-]bäume). Andere haben kurzgliederige Sprosse; ihre Blätter sind meist groß und gewöhnlich mehr oder weniger rosettenförmig angeordnet (Schopfbäume). Die Verholzung dient wohl besonders dazu, Widerstand gegen Austrocknung zu leisten. Hierzu muß auch der eigentümliche Typus der Bambusen gerechnet werden. 
18. Dikotyle Sträucher und Zwergstrüucher. Niedrige gymnosperme und dikotyle Typen mit aufrechten, vom Grunde ab und gewöhnlich reich verzweigten, verholzten, vieljährigen Stengeln. Viele verschiedene Sproß- und Blattanpassungen kommen hier vor: die Sprosse sind mesomorph, pinoïd, ericoïd, equisetoïd, salicornioïd, usw., die Blätter mesomorph, sukkulent, nadelförmig, schuppenförmig usw. Speziell hervorzuheben wäre noch die Lebensform der Dornstrïucher.

In allen Gegenden der Erde und allen Klimaten ist diese Lebensform verbreitet. Hier schließen sich an:

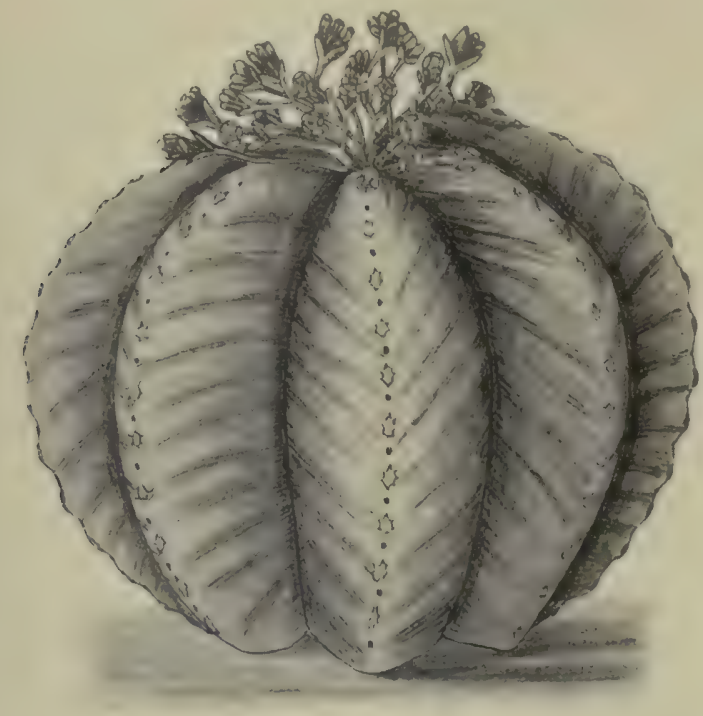

Fig. 79. Euphorbia meloformis, typischer Stammsukkulent der Kaktusform.

(Nach Goebel.)

Zwergsträucher (Fruticuli) sind Holzpflanzen von sehr niedrigem Wuchs, gewöhnlich werden sie nur $20-50 \mathrm{~cm}$ hoch. Die Stengel sind oft unregelmäßig gekrümmt. Sproßbau und Knospenschutz sind je nach den Standorten sehr verschieden. Die meisten haben keine Wandersprosse: Calluna vulgaris; dabei gewöhnlich eine starke bleibende Hauptwurzel; andere bilden unterirdische Wandersprosse aus, z. B. Vaccinium myrtillus (laubwechselnd), V. vitis Idaea (immergrün). (Empetrum gehört. zu den Kriechpflanzen.)

Eine eigentümliche Strauchform ist der Loranthaceentypus (Drudes Holzparasiten), das sind immergrüne Sträucher, die auf Holzpflanzen schmarotzen. Knospenschuppen sind meist nicht vorhanden (Ausnahme Loranthus Europaeus, Viscum album). Hierzu gehören Loranthaceen und Myzodendron. 
19. Monokotyle Sträucher. Hier lassen sich zwei Haupttypen unterscheiden: Die Grasform (Bambusform) und die Rohrpalmenform.

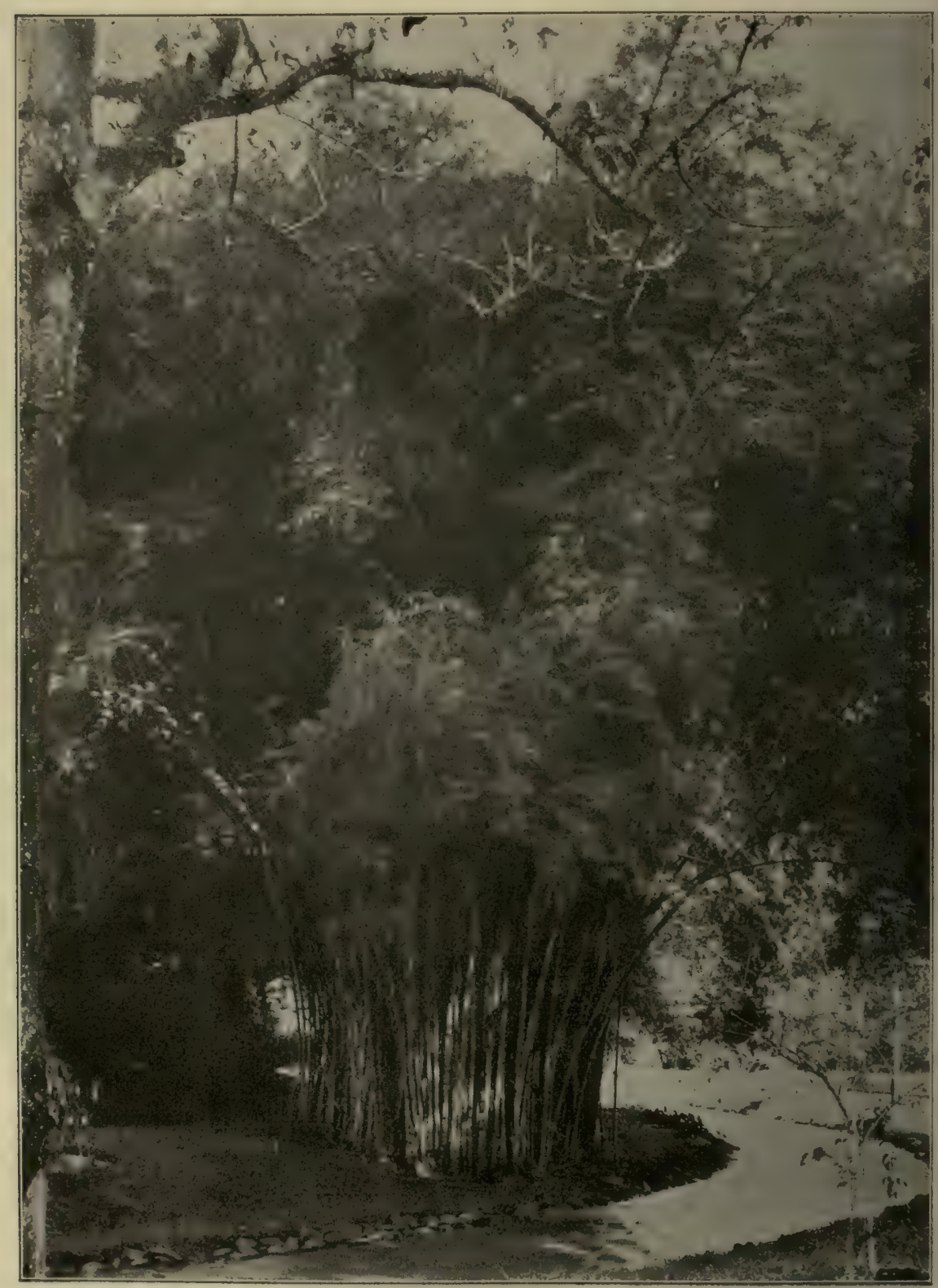

Fig. 80. Bambusengruppe im Botanischen Garten zu Buitenzorg. (Phot. Hj. Jensen.)

a) Die Bambusform. Aus einer horizontalen unterirdischen Grundachse entspringen oft in großer Menge verholzende, mehrjährige, 


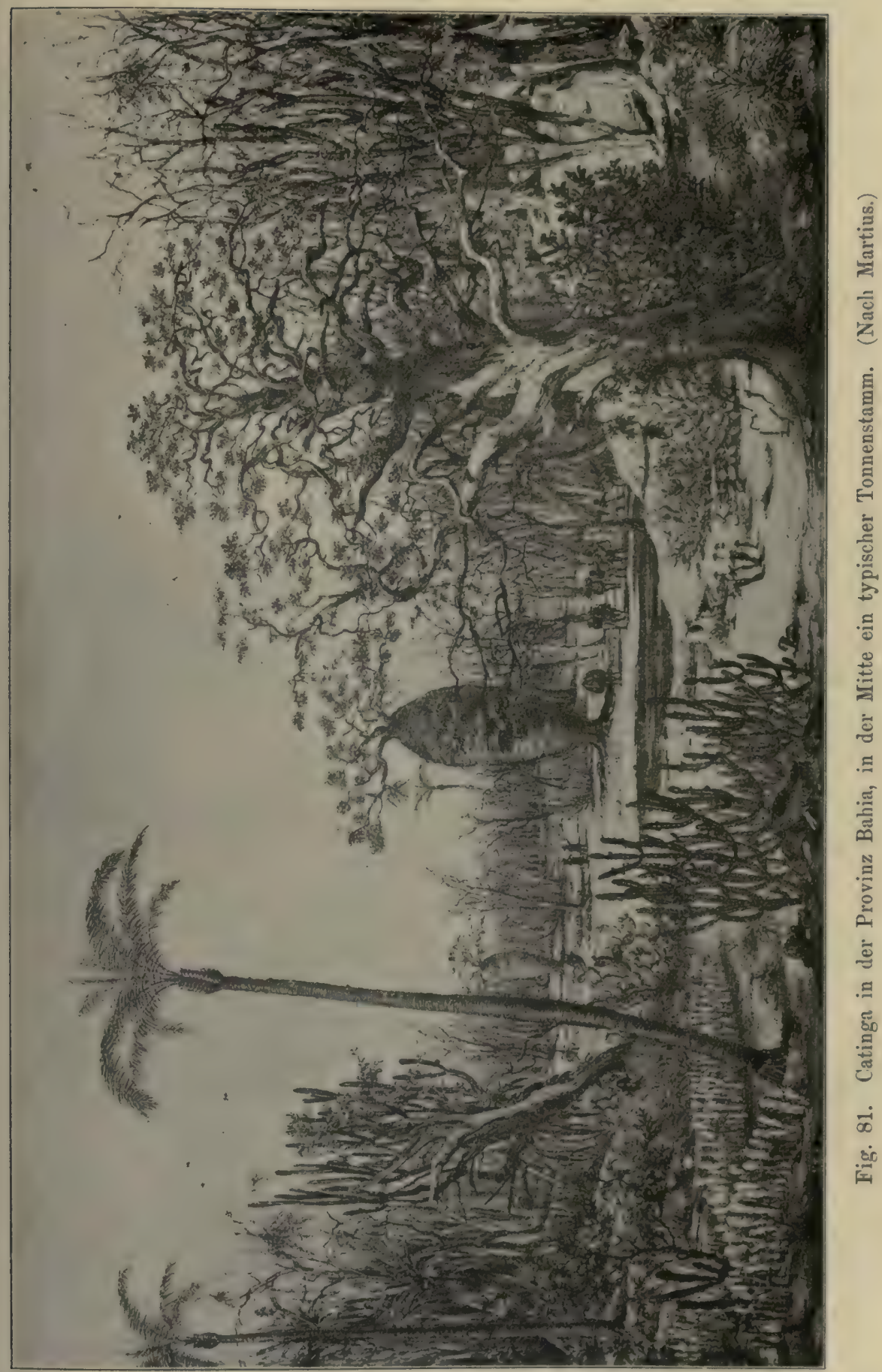


oft mächtige Stengel mit vielen in den Blattachseln stehenden Seitensprossen (Bambuseen, ähnlich Arundo donax). Für viele Arten gilt es, daß die Gebüsche, wenn sie nach einer Anzahl von Jahren zum ersten Male geblüht haben, gänzlich absterben (viele Bambuseen usw.). Vorzugsweise tropische Arten gehören hierher, welche mächtige Gebüsche bilden können; vergl. z. B. Fig. 80 .

Etwas abweichend sind andere Grastypen wie Saccharum officinarum, Phragmites communis u. a. mit kurzer, bis einjähriger Stengeldauer der oberirdischen Sprosse. Phragmites könnte deshalb auch zu den Kräutern mit Langsprossen und unterirdischen Wandersprossen gestellt werden.

b) Typus der Rohrpalmen (Drude); hierzu gehören viele niedrige und dünnstengelige dabei ziemlich gestrecktgliederige Palmen, die an einer unterirdischen Wandergrundachse entspringen. Durch sie werden kleine Gebüsche gebildet (Raphis, Chamaedorea).

20. Wipfel(Kronen-)bäume. Koniferen und Dikotyledonen. Gehölze mit reich verzweigter aus Langsprossen gebildeter Krone, die sich alljährlich vergrößert. Hand in Hand mit der Ausbildung dieser Tracht geht bei fast allen ein regelmäßiges Dickenwachstum des Stammes, welches dem Stamme eine der zunehmenden Last der Krone entsprechende Festigkeit verleiht. Sowohl immergrüne als laubwerfende Arten gehören zu dieser Lebensform. Knospenschutz, Sproßform und Blattform sind äußerst verschieden und zwar teils aus phylogenetischen, teils aus ökologischen Ursachen (wie bei den Sträuchern können die Blätter z. B. sukkulent, pinoid, ericoid, sklerotisch usw. sein; siehe weiteres später; vergl. Kap. 25).

Die Baumformen d. h. ihre Tracht ist übrigens nach den ökologischen Verhältnissen, unter denen die einzelnen Arten leben, sehr verschieden (Krummholzform u. a.).

Eine eigentümliche Form sind die Tonnenstämme. Bäume mit unverhältnismäßig dicken, mehr oder weniger tonnenförmig angeschwollenen Stämmen und geringer Verzweigung der Krone. Das Holz ist sehr weich und wasserreich. Der Typus stellt eine Anpassung an sehr trockene Klimate dar (Bombacaceen in den trockenen Catingas von Brasilien, Adansonia in den Savannen Afrikas, Dendrosicyos; Fig. 81).

Eine andere eigentümliche Form ist die Mangrovenform mit vielen Luftwurzeln, welche bogenförmig nach abwärts wachsen und sich oft auch strahlenförmig verzweigen, um dadurch den Stamm in den Schlamm befestigen. Abbildungen siehe in Kap. 47.

Zwergbäume finden sich namentlich in der Nähe der Baumgrenze im arktischen Gebiete und den Hochgebirgen. Meist werden sie durch die klimatischen Verhältnisse niedrig gehalten und sind dann nicht 


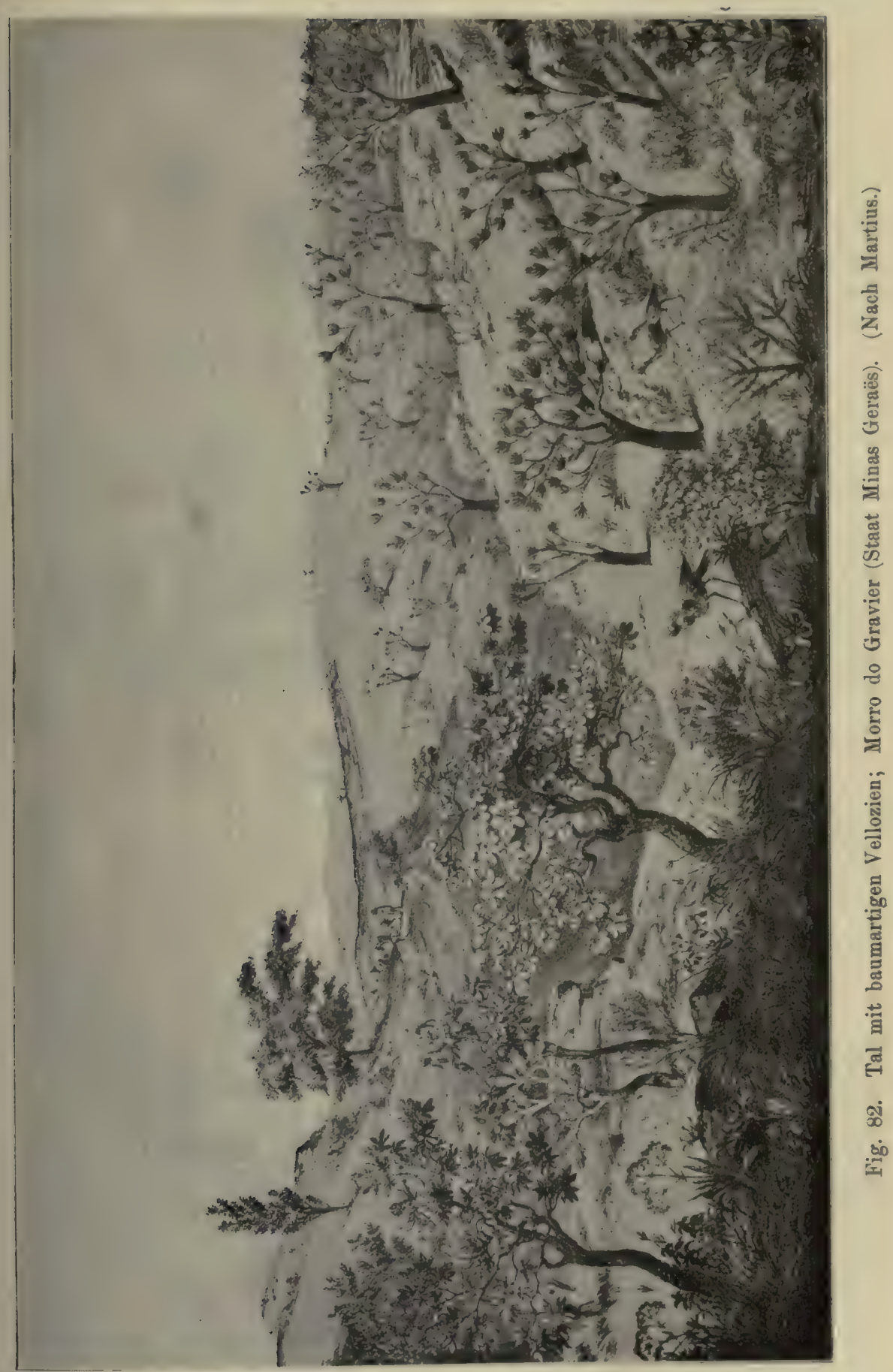


erblich fixiert. Auch in den Halbwüsten und Steppen sind solche Formen nicht selten.

21. Schopfbäume. Immergrüne Bäume mit kurzgliedrigem, unverzweigtem oder doch nur wenig verästeltem Stamme. Die Blätter sind am Ende der Stämme und Äste meist dicht rosettenartig gedrängt, und zwar gewöhnlich zu wenigen, an Zahl aber öfer besonders groß und kräftig. Ihre Anzahl bleibt annäherungsweise die gleiche; wenn neue Blätter sich entwickeln, werden etwa in derselben Anzahl alte abgeworfen. Die Knospen sind offen. Es lassen sich drei Haupttypen unterscheiden.

a) Palmenform. Stämme sehr selten verzweigt, ohne oder mit schwachem sekundärem Dickenwachstum. Blätter sehr groß und geteilt. Farnbäume, Cycadeen, Palmen (Bewohner besonders der Tropen, Fig. 81). Merkwürdige Ausnahmen sind die hapaxanthen Palmen, so Corypha umbraculifera.

b) Liliaceenbäume. Stämme mehr oder weniger verzweigt nit dicken, plumpen, wenig verästelten Zweigen. Einige sekundäres Dickenwachstum von ungewöhnlicher Art. Die Blätter sind wie bei den gewöhnlichen Liliifloren linealisch und ungeteilt, meist von xeromorphem Bau (daher sukkulent oder lederartig). Bewohner. besonders ron tropischen und subtropischen Steppen und Halbwüsten (Aloe, Yucca, Dracaena, Cordyline, Xanthorrhoea, Vellozia Fig. 82, Pandanus).

c) Strelitzia-Form. Der Stamm ist stets unverzweigt und trägt einen zweizeiligen Blattschopf, von Scitamineen-Blättern (Ravenala, Fig. 83; Strelitzia).

Von allen den genannten baumförmigen Typen kommen niedrige, bis fast stammlose Formen vor (Zwergbäume).

22. Kriechpflanzen. Die Assimilationssprosse sind plagiotrop, horizontal auf der Erde niederliegend, oder den Bäumen und Felsen dicht angedrückt. Die Blätter stehen sehr oft zweizeilig mit zur Anheftungsfläche horizontalen Spreiten. Die Stengelglieder sind gewöhnlich gestreckt, bei einigen aber auch kurz. In einigen Fällen sind die Blüten oder Blütenstände blattachselständig und kurz, in anderen entstehen sie auf kurzen aufrechten Laubsprossen von oft kurzer Lebensdauer.

Recht viele verschiedene Typen sind hier zu unterscheiden. Es gibt niederliegende, nicht wurzelnde Formen (formae procumbentes), und solche, die durch Wurzeln an den Boden angeheftet sind (f. repentes). Die letzteren finden sich besonders auf feuchtem Boden, und durch Absterben der ältesten Sproßteile werden die Seitenzweige frei, und neue Individuen werden dadurch selbständig. 
Viele hierhergehörige Arten sind Kräuter (Lycopodium clavatum; Lysimachia nummularia; Hydrocotyle vulyaris; Mcnyanthes trifoliata: Ipomoea pes caprae). Andere sind holzig (Spaliersträucher) z. B.

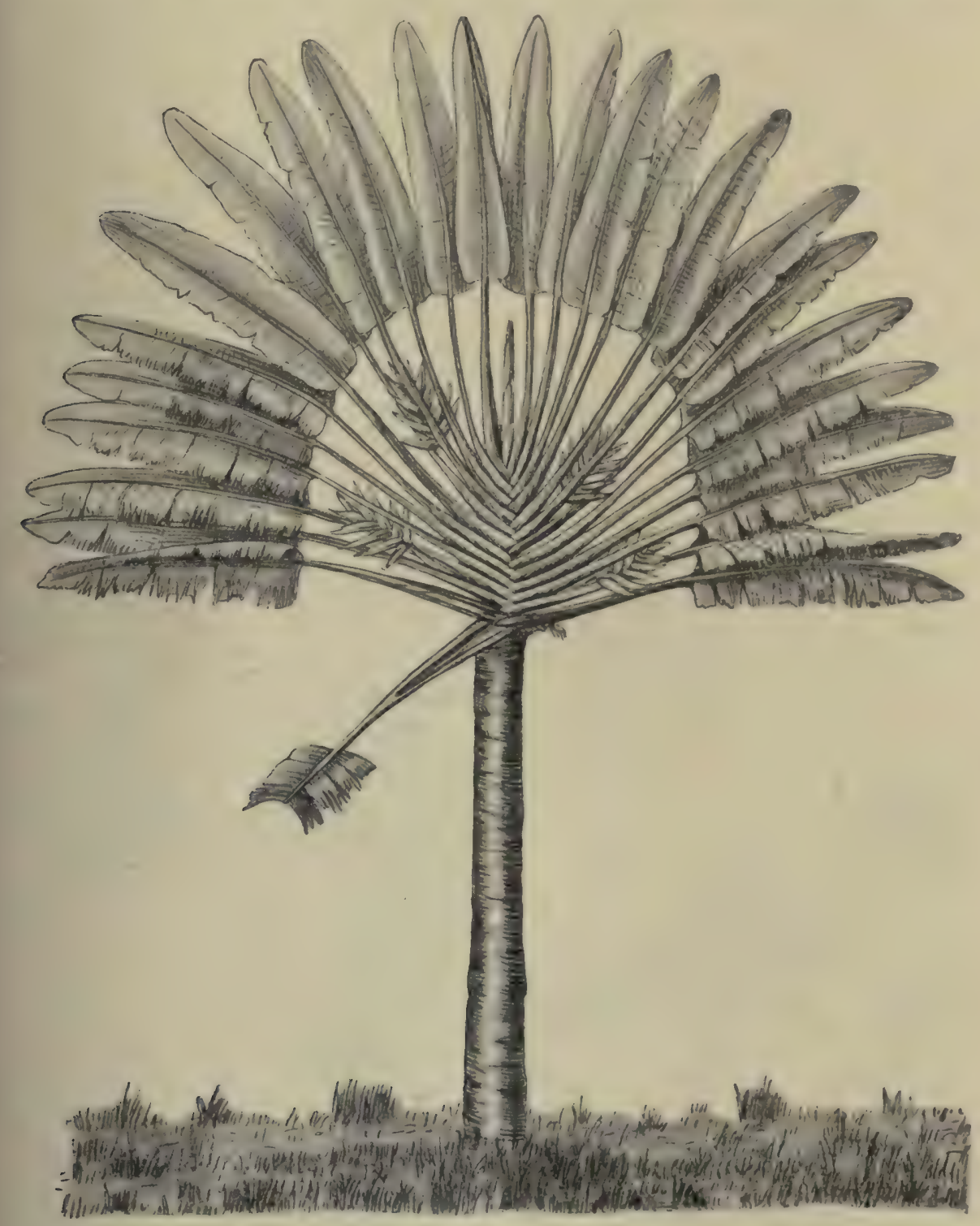

Fig. 83. Ravenala Madagascariensis, Baum der Reisenden. (Nach K. Schumann.)

Arctostaphylos uva ursi (immergrün), A. alpina (sommergrün), Empetrum, Vaccinium oxycoccus; Linnaea borealis Fig. 74, Dryas. Die üherwinternden Knospen sind nackt oder mit Knospenschuppen bedeckt. Vergl. Fig. 22. 
Die Blätter gehören hauptsächlich drei Formen an.

1. Die Nummularia-Form. Die Blätter sind kreisrund, sitzend oder sehr kurz gestielt (Lysimachia nummularia Fig. 84, Marcgravia Fig. 50 S. 159, Epiphytische Araceen u. a., Jungermannia unter den Moosen).

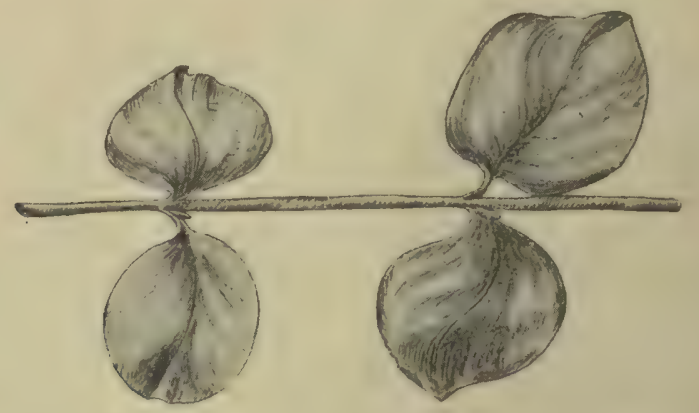

Fig. 84. Lysimachia nummularia. (E. Graebner; nach der Natur.)

2. Langgestielte Rundblätter. Typus: Hydrocotyle vulgaris (Fig. 85; Stengel auch unterirdisch), Menyanthes, Calla palustris ${ }^{1}$ ).

3. Die Lycopodlien-Form. Die Blätter sind linienförmig, aus breitem Grunde langsam verschmälert, allseitig, in vielen Parastichen (Fig. 86).

Vergl. übrigens S. $42-47$.

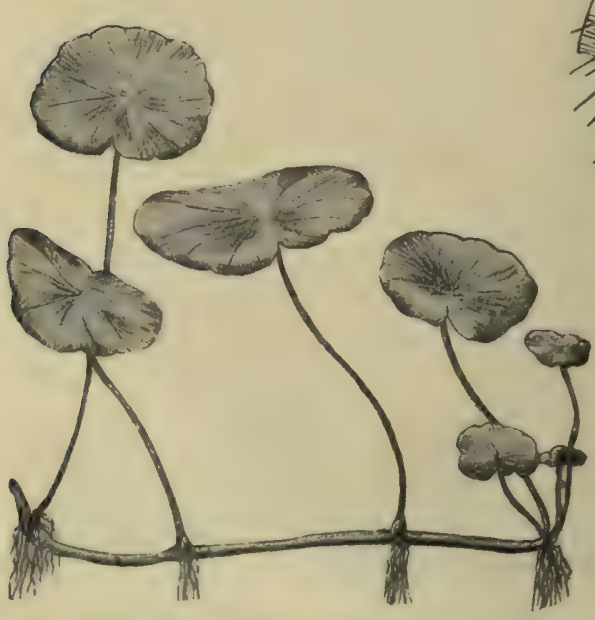

Fig. 85. Hydrocotyle vulgaris.

(E. Graebner; nach der Natur.)

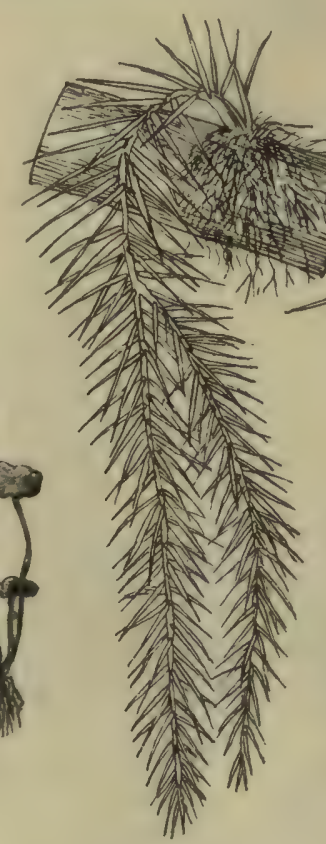

1) Über die Blattformen der Ranunculaceen und Umbelliferen, die vielfachen Lebensformen angehören und einander oft sehr ähnlich sind vergl. R. Bitter 1897. 


\section{Kap. 23. Ökologische Anpassung (Epharmonie) der Lebensformen}

In den vorhergehenden Kapiteln wurden die Grundformen des Lebens besprochen. Wir müssen jetzt die einzelnen Anpassungen derselben an die ihnen gebotene Lebenslage betrachten.

In der Übersicht über die Grundformen des Lebens spielt das Wasser eine hervorragende Rolle. Wir müssen hier nun näher auf diese seine Bedeutung sowohl für die äußere Form als für den inneren Bau der Pflanzen eingehen. Zunächst sei auf das in Kap. 4, 9 und 20 über das Wasser als ökologiseher Faktor Gesagte hingewiesen (vergl. S. 156).

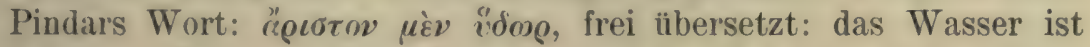
der wichtigste Faktor, gilt vollständig für das Leben und die Formverhältnisse der Pflanzen. Daß das Wasser ebenso nebst dem Nährstoffgehalt des Bodens eine Ausschlag gebende Rolle für die Bildung der Pflanzenvereine und ihre Verteilung auf der Erde spielt, wird später besprochen werden (Abschnitt 4).

Das Wasser hat auch in der Abstammungsgeschichte des ganzen Pflanzenreichs eine entscheidende Rolle gespielt ${ }^{1}$ ).

Hier kann auch an die Rolle erinnert werden, die das Wasser in dem Haushalte der ganzen Natur spielt, indem die Prozesse der Fäulnis und der Humusbildung durch Feuchtigkeit befördert werden; die Mikroorganismen, die diese Prozesse bewirken, brauchen Wasser, und dort wo es besonders in dichten Böden zu viel ist, wo es die Poren verstopft, entzieht es die Luft und verhindert dadurch oft z. B. Verwesungspilze am Herrschen ${ }^{2}$ ).

Auch im Menschenleben zeigt sich die Bedeutung des Wassers für die Pflanzen. Die Geschichte zeigt, in welchem Grade die Wohlfahrt der Länder (Dichtigkeit und Reichtum der Bevölkerung) ans Wasser gebunden ist. In Asien z. B. war die Zivilisation von jeher auf die Gegenden beschränkt, wo ein stark bewässerter Boden das Leben von Menschen sicherte; der Rückgang an Bevölkerung und Fruchtbarkeit in den ältesten Kulturländern steht mit einem Rückgang an Wasserreichtum in Verbindung, mit dem Austrocknen von Quellen, Flüssen und Seen. In Algier geht die Bevölkerungsdichtigkeit fast parallel mit der Menge der Niederschläge (Dehérain). Wassermangel ist der Faktor im Pflanzenlehen, dem der Mensch am meisten hilflos gegenüber steht. Koopmann hat in Turkestan nur durch Bewässerung aus öden Steppen üppige Gärten geschaffen (Ausnahme: Heidegebiete mit großer Feuchtigkeit und geringer Vegetation; vgl. unten).

1) Vergl. Bower, Origin of a landflora; traebner 1909.

2) Vergl. Graebner 1898-1910. 
Zeichnet sich ein Klima durch Periodizität mit großen Extremen in den Niederschlägen aus, so wird nicht die Regenzeit für den Charakter der Vegetation entscheidend, sondern die trockene Zeit, selbst wenn sie von kurzer Dauer ist. Sogar in den Alpen gibt die kurze Zeit starker Verdunstung der Vegetation ihr Gepräge, selbst wenn der ganze übrige Teil des Jahres triefend naß ist (Kerner).

Es ist sicher richtig, daß die besonderen Eigentümlichkeiten eines Standortes durch das Zusammenwirken der verschiedensten Faktoren hervorgebracht werden, durch solche des Bodens wie des Klimas. Man darf keinen derselben vernachlässigen, will man die gesamte Eigenart des Standortes und damit des Pflanzenvereins verstehen; meist wird die Änderung eines einzigen Faktors eine völlige Veränderung der Pflanzenzusammensetzung in der Folge haben. Namentlich der Nährstoffgehalt des Bodenwassers oder was formationsbiologisch oft fast auf dasselbe hinausläuft, die Menge von Nährstoffen, die die Pflanzen an dem Standorte in für sie verbrauchbarer Form während der klimatisch für sie günstigen Vegetationszeit entnehmen und verarbeiten können (vergl. Heide), spielen für die Verteilung der Vereine eine große Rolle ${ }^{1}$ ). Der Wassergehalt ist aber auch von ausschlaggebender Bedeutung für die Ausbildung der Lebensformen, der anatomischen und physiognomischen Anpassungen der Pflanzen usw. - Als Grundsatz kann daher aufgestellt werden:

Der Wasservorrat, der den Pflanzen zur Verfügung steht, die Wasserzufuhr und damitzusammenhängend die Regulierung der Verdunstung sind die Faktoren, welche die größten Verschiedenheiten in der Form und überhaupt im ganzen Leben der Pflanzen hervorrufen.

Wie wir in Kap. 20 sahen, gibt es eine große Gruppe von Pflanzen, die untergetaucht im Wasser leben oder höchstens Schwimmblïtter an der Luft hervorbringen. Dies sind die Wasserpflanzen oder Hydrophyten; sie werden in dem folgenden Kap. 31 und im 4. Abschnitt besprochen.

Im Gegensatze zu ihnen können die anderen Luftpflanzen (Aerophyten) oder Landpflanzen genannt worden. Sie sind alle der Verdunstung ausgesetzt. Zunächst lassen sich unter ihnen zwei Gruppen unterscheiden, die eine mit meist niedrig organisierten Pflanzen, welche stark eintrocknen können, aber Wasser und bisweilen vielleicht auch Wasserdampf durch ihre ganze Oberfläche einzunehmen vermögen (vergl. S. 52 und Gruppe 2 und 4, S. 156 und 158). Das sind die moosartigen (muscoïden) Pflanzen und die Flechten (Lichenen), dazu auch die Luftalgen.

Die zweite Gruppe wird repräsentiert durch die höher organisierten Landpflanzen, Gefäßpflanzen, welche das Wasser durch Wurzeln aus

$\left.{ }^{1}\right)$ Vergl. Graebner 1898-1910. 
dem Boden aufnehmen und nur ausnahmsweise durch die oberirdischen Organe (vergl. S. 156 und Kap. 28).

Der Boden kann, um S(himpers ${ }^{1}$ ) Ausdrücke zu gehrauchen, physikalisch oder physiologisch trocken sein:

Physikalische Trockenheit. Der Boden ist physikalisch trocken, wenn er nur sehr wenig oder gar kein freies Wasser (also nicht chemisch, kristallinisch usw. gebundenes) enthält. Dies ist der Fall:

1. An der Oberfläche von Felsen oder Steinen, die mit Pflanzen hesetzt sind: diese bilden den Verein der Felsbewohner (lithophilen Pflanzen).

2. Auf sandigen Böden, die so hoch über dem dauernden Grundwasserstande liegen, daß dieses auf den Pflanzenwuchs keinen Einfluß ausühen kann, und die wegen ihres starken Filtrations- (s. S. 83, 106) und Austrocknungsvermögens in den trockenen Jahreszeiten sehr stark ausdïrren. Auf diesen Böden wachsen Sandpflanzen-Vereine (psammophile (rewächse). Durch die grobsandigen und kiesigen Standorte führen diese zu denen auf steinigem Boden über.

Hierher müssen auch die Epiphyten gerechnet werden, welche fast alle bestimmte Anpassungen für ihre Wasserversorgung zeigen (vergl. Kap. 35).

Physiologische Trockenheit. Der Boden ist physiologisch trocken, wenn er zwar einen großen Wassergehalt besitzt, der aber den Pflanzen nur zum geringen Teile zur Verfügung steht, oder der nur mit Schwierigkeiten von den Wurzeln aufgenommen werden kann. Fntweder kann es daran liegen, daß der Boden das Wasser sehr fest hält (vergl. Torf, S. 109), oder auch, daß die osmotische Kraft der Wurzeln herabgedrückt wird, wie es z. 13. durch stärker konzentrierte Lösungen mancher Stoffe in Boden geschieht. - Dies kann z. B. der Fall sein, wenn:

1. Der Boden reich an freien Humussäuren ist, oder sonst andere Lösungen von solchen chemischen Stoffen vorhanden sind, die eine ähnliche spezifische Wirkung auf die Pflanzen ausüben ${ }^{2}$ ).

2. Der Boden reich ist an wasserlöslichen Salzen, am häufigsten Kochsalz, welches durch seine Anwesenheit die eigentümliche Lebensform, welche man Salzpflanze (Halophyt) ${ }^{3}$ ) nennt, hervorbringt.

3. Endlich kann langsame Durchlüftung des Bodens, also Mangel an Sauerstoff oder Überschuß an Kohlensäure, die Wrurzeln an der kräf-

1) Schimper 1898 .

2) Vergl. Livingston 1904 und die Arbeiten von Dachnowski.

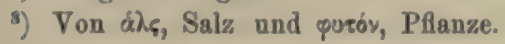


tigen Wasseraufnahme hindern. Dieses ist in den meisten sauren Böden der Fall und muß als Hauptursache der physiologischen Trockenheit derselben angesehen werden.

Xerophyten oder xerophile, trockenheitliebende Pflanzen werden diejenigen Pflanzen genannt, welche an ein Leben auf einem Boden und in einer Luft angepaßt sind, die äußerst troken sein kann

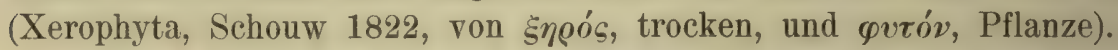

Die Xerophyten bilden den stärksten Gegensatz zu den Wasserpflanzen, den Hydrophyten. Es werden hierher alle Pflanzen gerechnet, die morphologisch oder anatomisch xeromorph ausgestaltet sind, oder auch nur durch Beschaffenheit des Protoplasmas oder eines anderen Zellinhalts besonders befähigt sind, eine mehr oder weniger lange dauernde Trockenheit zu ertragen. Eine kurze, aber periodisch eintretende starke Verdunstung prägt die Vegetation xeromorph aus, selbst wenn sie den ganzen übrigen Teil des Jahres triefend naß ist ${ }^{1}$ ).

Auch die Salz-Landpflanzen (Halophyten) sind eine Form von Xerophyten, wie Wiesner, Schimper und Clements ${ }^{2}$ ) hervorheben.

Die Xerophyten sind auf sehr verschiedene Weise ausgerüstet, um eine starke Trockenheit auszuhalten. Einige, wie die Flechten, die meisten Moose und Algen haben gar keinen anatomisch ausgeprägten Trockenschutz. Die Anpassung dieser Pflanzen an extreme Trockenheit muß in gewissen Eigenschaften des Zellinhaltes gesucht werden, teils in denen des Protoplasmas selbst, teils in der Gegenwart anderer Inhaltsstoffe (z. B. fettes Öl bei Selaginella lepidophylla).

In der Regel ertragen die Pflanzen und Pflanzenteile, Samen und Sporen ausgenommen, jedoch eine so starke Austrocknung nicht, weshalb einjährige, kurzlebige Pflanzen in eine Wüstennatur gut hineinpassen, wo die Regenzeit kurz, die trockene Zeit lang ist.

Diejenigen Landpflanzen aber, welche eine minder starke Trockenheit lieben, die Boden und Luft von mittlerer Feuchtigkeit bewohnen, dabei einen Boden, der sich auch nicht durch starken Salzgehalt auszeichnet, können Mesophyten genannt werden (Mesophyten, Warming 1895, von

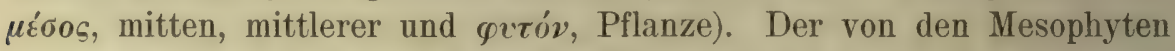
bewohnte Boden darf auch nicht im höheren Maße sauer oder kalt sein; meist ist er gut durchlüftet und dann auch reich an Nahrung, gewöhnlich enthält die Oberkrume auch alkalisch reagierenden Humus oder andere organische Bestandteile. Die Mesophyten leben in sehr verschiedenen Klimaten, sowohl nahe den Polen, als nahe dem Äquator, nur dürfen sie nie der Gefahr einer länger dauernden Trockenperiode ausgesetzt sein. Die solchen Verhältnissen angepaßten Arten sind

1) Kerner 1869

$\left.{ }^{2}\right)$ Wiesner 1889; Schimper 1891, 1898; Clements 1904-1907. 
meist schlank gebaut, haben ziemlich dünne Blätter, kurz, zeigen nicht diese ausgeprägten Einrichtungen zur Regulierung der Verdunstung, wie sie für die Xerophyten beschrieben werden, sie stehen also in ihrem anatomischen Bau usw. zwischen den Hydrophyten und Xerophyten ${ }^{1}$ ); sie sind meist (Ausnahme z. B. Coniferen) mesomorph gebaut.

Selbstverstïndlich gibt es unzählige Mittelformen zwischen diesen Gruppen, und es wird in vielen Fällen äußerst schwierig sein, einen bestimmten P'flanzenverein zu einer bestimmten Gruppe zu stellen, so daß dieses oft von der individuellen Meinung abhängen muß. Aber dieses gilt für jede andere Einteilung und ist unvermeidlich, besonders solange die Ökologie der Vegetationen wissenschaftlich so wenig, wie es jetzt der Fall, untersucht ist.

Wollen wir einen tieferen Einblick in den Haushalt einer Pflanze haben, so müssen wir das Verhältnis zwischen der Wasserversorgung und dem Wasserverbrauche zu den verschiedenen Jahreszeiten kennen; aber man ist weit entfernt, hierüber etwas Näheres zu wissen, und hat nur für einzelne Arten, namentlich für Kulturpflanzen und Waldbäume, einige sichere Daten gewonnen. Neuerdings haben sich besonders amerikanische Forscher mit diesen Fragen beschäftigt.

\section{Kap. Anpassungen der Landpflanzen}

Die Landpflanzen unterscheiden sich sehr wesentlich von allen Wasserpflanzen sowohl in der äußeren Tracht als im inneren Aufbau. Durch die unmittelhare Berührung mit der atmosphärischen Luft sind namentlich die Assimilationsorgane der Verdunstung ausgesetzt und müssen deshalb in eigenartiger Weise an diese Verhältnisse angepaßt werden.

Die Regulierung der Transpiration der Pflanzen scheint der Faktor zu sein, der in die Pflanzenformen und das Pflanzenleben mit am tiefsten eingreift und ihnen neben der relativen Menge der vorhandenen Nährstoffe das stärkste Gepräge aufdrückt. Ist die Verdunstung stärker als die Wasserzufuhr, so welkt die Pflanze, und dieses wirkt auf die allerwichtigsten Lebensprozesse ein, selbst wenn es nicht so weit geht, daß die Pflanze getötet wird (vergl. auch Kap. 4).

Die Transpiration ist ein physiologischer Prozeß (Abgabe von Wasserdampf an die Luft), der von zweierlei Faktoren abhängt: 1. von inneren, d. h. solchen, die in dem besonderen Bau und dem augenblicklichen

1) Zu den angewandten Ausdrücken Hydrophyten, hydrophil, Xerophyten, xerophil, Halophyten, halophil, Mesophyten, mesophil sei bemerkt, daß durch die Endung phyt hier die Pflanze selbst, durch die Endung phil eine Eigenschaft bezeichnet wird, aber nicht ein geringerer Grad der betreffenden Eigenschaft (die Halophilen z. B. sind nicht weniger ausschlieBlich Salzpflauzen als die Halophyten). 
Zustande der Pflanze liegen, und 2. von äußeren Faktoren oder den umgebenden Naturverhältnissen.

Was die inneren Faktoren betrifft, so hängt die Transpiration natürlich von der Größe der verdunstenden Fläche $a b$, und da es bei den Pflanzen besonders die Laubblätter sind, wodurch die Verdunstung vor sich geht, so sind es vor allen Dingen die Größe und die Dicke der Blätter wie auch die Entwicklung des ganzen Lichtsprosses, wovon die Größe der Transpiration abhängt; ferner wird sie von der Beschaffenheit der Epidermis beeinflußt (Cuticula, Wachs, Kork, Haare, Spaltöffnungen). Der Laubsproß gibt, wenn er richtig verstanden wird, die deutlichsten Zeugnisse über die Naturverhältnisse, unter denen die Pflanze aufgewachsen ist (2. Kap., S. 21 ff.). Und am vegetativen Sproß sind es besonders die Laubblätter, welche die größte Mannigfaltigkeit zeigen und am deutlichsten die Epharmonie der Pflanze abspiegeln. Ferner ist die Natur der Wurzeln ein Faktor; je größer die aufsaugende Fläche ist, desto mehr Wasser wird in derselben Zeit aufgenommen werden können; je tiefer die Wurzeln hinabdringen, desto mehr Sicherheit gibt es dafür, daß die Wasserversorgung zur Trockenzeit nicht unterbrochen werde.

Die äußeren Faktoren wurden schon im ersten Abschnitte behandelt; es sind namentlich das Licht (2. Kap.), das Sättigungsdefizit der Luft (4. Kap.), die Luftbewegungen (5. Kap.), die Beschaffenheit, namentlich die Wassermenge des Nährbodens (9. Kap.) und die Konzentration; eine zu starke Lösung der Nährsalze setzt die Verdunstung herab. Häufig werden durch auf weite Strecken wirkende klimatische Faktoren die Bodenverhältnisse wesentlich beeinflußt ${ }^{1}$ ) (z. B. Humusbildungen in den Heidegebieten).

Die Anpassung der Landpflanzen schreitet zur Ermöglichung des Lebens in der unmittelbaren Berührung mit der Luft etwa in folgender Weise fort:

1. Einschränkung des Wasserverlustes, d. h. Regulierung der Verdunstung.

2. Vermehrung resp. Erleichterung der Wasseraufnahme, d. h. Entwicklung besonderer Organe zur Wasserabsorption.

3. Einrichtungen zur Wasserspeicherung, d. h. Entwicklung besonderer Wasserspeicherapparate.

In den folgenden drei Kapiteln sollen diese Anpassungen besprochen werden und in einem folgenden eine Darstellung von einigen bestimmten Charakterzügen im anatomischen Aufbau und besonderen Lebensformen der Landpflanzen gegeben werden, deren Nützlichkeit für die Pflanzen

1) Vergl. anch Clements 1905. 
nicht immer physiologisch klar ist, obgleich die Tatsache ihrer unmittelbaren Beziehungen zu einem trockenen Standorte außer Zweifel ist.

$\mathrm{Zu}$ Beginn sei bemerkt, daß der Grad der Anpassungen der Landpflanzen an das Leben an der Luft ungeheuer verschieden sein kann, je nachdem die äußeren Lebensbedingungen mehr oder weniger extrem sind, wie soeben erwähnt (Kap. 23).

\section{Kap. Regulierung der Verdunstung}

In der neueren Zeit wurden vielfach Versuche gemacht, um die Stärke der Transpiration der Pflanzen im Freien genauer zu bestimmen, z. B. von Livingston, Gleason und Gates, Hesselman, Yapp, Fuller, Dachnowski.

Die Höhe der Verdunstung wird in hohem Grade von der vorschiedenen Natur der Pflanzenvereine bedingt. In den verschiedenen Schichten desselben Pflanzenvereins (z. B. über und unter den Baumkronen) kann sie sehr verschieden sein. Für das Verständnis des Baues der einzelnen Pflanze und des gesamten Vereins sind solche Untersuchungen von der allergrößten Bedeutung.

Die Regulierung der Transpiration resp. Beleuchtung (in diesem und den beiden folgenden Kapiteln) und ihre Einschränkung in trockenen kritischen Zeiten wird besonders bei den Xerophyten durch folgende Mittel besorgt:

Kap. 25:

A. Der anatomische Bau reguliert die Verdunstung.

B. Die Verminderung der verdunstenden Oberfläche, entweder durch Bewegungen (Faltungen usw.) oder durch Verkleinerung der Oberfläche der Blätter oder Stengel, welche stets in der charakteristischsten Weise den herrschenden Verhältnissen des Standorts angepaßt sind.

I. Periodische Oberflächenverminderung (S. 214).

II. Bewegungen der Blätter und Stengel. (S. 217).

III. Dauernde Verkleinerung von Laubblatt und Laubsproß. Eigentümliche Blatt- und Sproßformen (S. 218).

C. Bekleidung mit besonderen Schutzorganen, wie z. B. Haaren, bedeckenden oft dachziegelartig gelagerten Blattorganen oder ähnlichen Einrichtungen, welche das Licht schwächen und auch direkt die Verdunstung herabsetzen (S. 231).

Kap. 26: Regulierung der Beleuchtung der assimilierenden Organe, entweder durch ihre zeitweise Profilstellung, die durch photometrische, von der jeweiligen Lichtintensität abhängende resp. beeinflußte Bewegungen hervorgebracht wird, oder durch dauernde Profilstellung senkrecht zum Einfall der Mittagssonnenstrahlen (Kompaßpflanzen s. S. 24, Fig. 9).

Kap. 27: Entfernung des Regenwassers von den Blättern. 


\section{A. Anatomische Regulierungsmittel}

Der durchgreifende Unterschied zwischen Land- und Wasserpflanzen tritt sehr scharf hervor. Namentlich in folgender Weise finden sich diese Pflanzen verschieden ausgebildet:

I. Verdunstunng durch die Cuticula, Hautgewebe, S. 202-207.

II. Das Durchlüftungssystem, nämlich a) die Spaltöffnungen und b) das Intercellularsystem, S. 207.

III. Hydathoden, S. 211.

IV. Das Chlorophyllgewebe, S. 213.

V. Andere anatomische Mittel, um die Transpiration zu regulieren.

Es ist einleuchtend, daß zwischen einem Hautgewebe, das dauernd von Wasser oder von feuchter Luft umgeben ist, und einem solchen, das von sehr trockener Luft umgeben und starker Transpiration ausgesetzt ist, ein großer Unterschied bestehen muß.

I. Verdunstung dureh die Cuticula (Cuticulare Transpiration). Die Transpiration ist entweder cuticular oder stomatal, d. h. letztere geschieht durch die Spaltöffnungen, jedenfalls durch das Hautgewebe.

Zuerst betrachten wir die cuticulare Transpiration, welche durch die äußersten Zellwände der Pflanze stattfindet, das heißt, durch die Epidermis.

Epidermis. Die Cuticula ist der erste wichtige Transpirationsregulator; ihre Dicke richtet sich nach dem Bedürfnis der Pflanze, die Verdunstung einzuschränken. Doch auch andere Verhältnisse spielen mit ein, denn Bergen ${ }^{1}$ ) fand, daß die Cuticula von jüngeren Blättern für Wasser schwerer durchdringbar ist als die der älteren Blätter. Die Cuticula, bei den Hydrophyten in der Regel sehr dünn, ist bei den Xerophyten meist dick. Die Außenwände der Epidermiszellen werden stark verdickt und cuticularisiert; in einzelnen Fällen werden sogar Kristalle von oxalsaurem Kalk oder Kieselsäure eingelagert. Die Epidermiszellen selbst werden polygonal und erhalten gerade Wände. Die Blätter werden wegen der Beschaffenheit der Epidermis lederartig und glänzend, was besonders ein allgemeines und auffallendes Merkmal tropischer Bäume ist, aber auch bei Pflanzen gemäßigter Klimate mit lange lebenden Blättern vorkommt (z. B. bei Ilex aquifolium, mehreren Koniferen, Vinca u. a.). Dieser Glanz gibt an, daß ein Teil des Lichtes von den Blättern reflektiert wird, was diesen vielleicht von Nutzen ist $^{2}$ ). Hin und wieder haben allerdings auch Schattenpflanzen mattglänzende Blätter (z. B. Arten von Pirola u. a.). Oft ist die Cuticula mit feinen Leisten versehen, besonders wenn die Zellwand nach außen

1) Bergen $1904 \mathrm{~b}$.

\%) Wiesner 1876. 
gewïlbt ist. Vesque ${ }^{1}$ ) und Henslow ${ }^{2}$ ) stellten hierüber die Hypothese auf, daß es zu der Zerstreuung und der Dämpfung der einfallenden Lichtstrahlen diene.

Wachs, das auf der Oberfläche ausgeschieden ist, setzt die Ver(lunstung herah, was Tsehireh ${ }^{3}$ ) und Haberlandt ${ }^{4}$ ) durch Versuche bewiesen haben. Bei Capparis spinosa in der ägyptischen Wüste z. B. bildet sich am Anfange der regenlosen Periode eine dicke Wachsschicht auf den Blättern, so daß die Transpiration gewiß fast vollständig unterdrïrkt wird ${ }^{5}$ ). Die Wachsschichten können sehr dick, z. B. bei Sarcocaulon (Südafrika) über $1 \mathrm{~mm}$ dick sein ${ }^{6}$ ) und bei der Wachspalme his $5 \mathrm{~mm}$. Wachsüherzüge rufen einen bläulichen Reif oder eine graue Decke hervor.

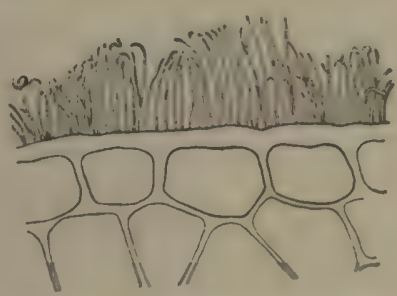

Fig. 87. Wachsauscheidungen auf Zuckerrohr.

(Nach Straßburger.)

Bereifte Blätter haben gewöhulich keine scharfen Zähne am Blattrande, höchstens abgerundete und solche, die mit einem Wasserausscheidungsapparat versehen sind (Fig. 87).

Wachsausscheidungen verhindern, daß Regenwasser die Blätter benetzt, und schützen somit ombrophobe Blätter (s. א. 56) gegen Regen ${ }^{7}$ ).

I)ie Epidermis führt bei Wasserpflanzen und Hygrophyten oft Chlorophyll, die der iibrigen Landpflanzen ist dagegen meist farblos. Sie ist nach Westermaier ${ }^{8}$ ) ein Wassergewebe.

Durch verschiedene Inhaltsstoffe kann die Fpidermis angeblich für Wasserdampf minder durchdringlich werden (s. weiter unten). Ob Gerbstoff, der sich oft besonders in der Epidermis findet, namentlich im Winter hei überwinternden Laubblïttern ${ }^{9}$ ), und der anch bei Steppenund Wïstenpflanzen, z. B. bei Alhagi, Monsonia, Astragalus, Tamarix, mit dem Wissergewehe in Verbindung zu stehen scheint ${ }^{10}$ ), eine Rolle spielt, weiß man nicht. Hingegen spielt Anthocyan, der rote in vielen Pflanzen, besonders in der Epidermis, auftretende Farbstoff, vielleicht dadur(h eine Rolle ${ }^{11}$ ), daß 's Wärme absorbiert und dadurch die Transpiration strigert: andere Forscher deuten den Nutzen dieses Farbstoffes

1) Vesque 1882 a.

ร) Henslow 1894.

3) Tschirch 1882.

4) Haberlandt 1904, 1905.

8) Volkens 1887.

) Vergl. Marloth 1908.

ร) Burgerstein 1904.

8) Westermaier 1882.

) Warming 1884 .

10) Volkens 1887; Henslow 1894.

11) Engelmann 1887; Stahl 1880-94. 
in ganz anderer, z. T. fast entgegengesetzter Weise (vergl. S. 27). Tatsache ist, daß es sich häufig bei jungen Pflanzenteilen und bei Keimpflanzen findet, die Schutz gegen starkes Licht und gegen damit einhergehende starke Verdunstung bedürfen (besonders in den Tropen; bei der Entwicklung des Laubes sind sehr viele junge Sprosse rotbraun) ${ }^{1}$ ).
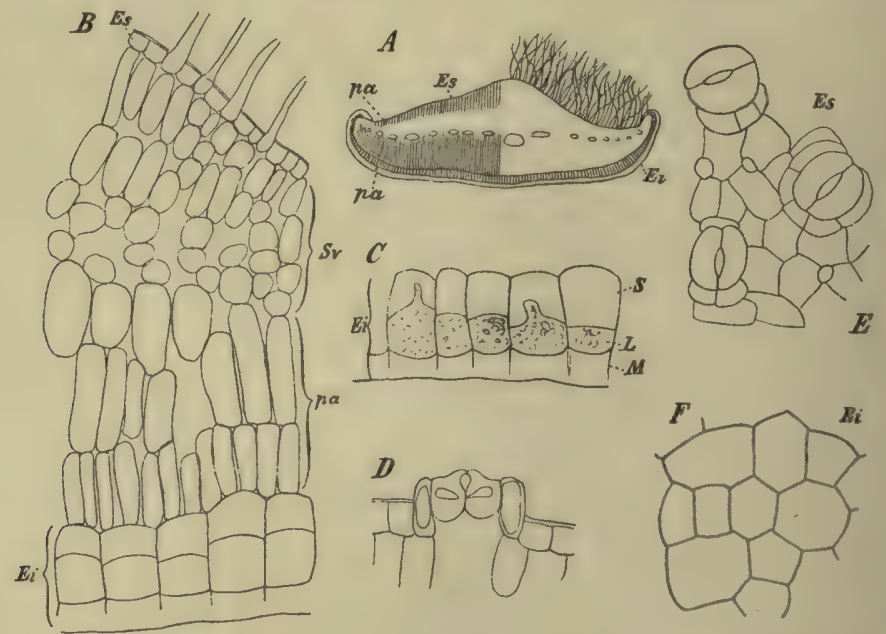

Fig. 88. Thymelaea hirsuta. A. Querschnitt durch das ganze Blatt. B. Ein Stück desselben, stärker vergrößert. $C$. Oberhaut mit verschleimten Innenwänden. D. Spaltöffnung, unter dem Schutze der Haarkleidung. $E, F$. Oberhaut der Ober- und Unterseite.

(Nach F. Börgesen.)
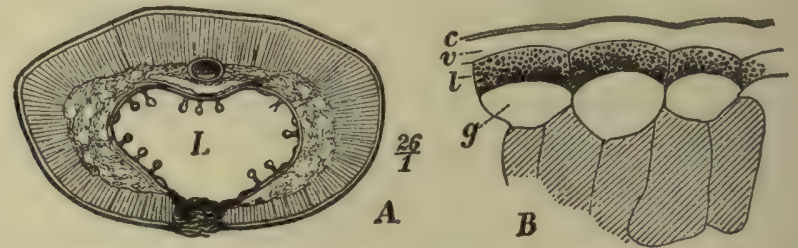

Fig. 89. Querschnitt durch das Blatt von Empetrum nigrum. A. $L$ der große Luftraum mit Drüsenhaaren und vorragenden Spaltöffnungen. $B$. Ein Stück von $A$, stärker vergrößert, $c$ Cuticula, $v$ Außenwand der Epidermiszellen, $l$ Zelllumen, $g$ verschleimte Innenwand. (E. Warming.)

Die Verschleimung der Innenwände der Epidermis muß dann erwähnt werden ${ }^{2}$ ). Bei vielen Xerophyten, besonders bei Holzpflanzen, quellen diese gallertartig auf (Beispiele Empetrum, Arbutus unedo u. a. Ericaceen, Haloxylon, Calligonum u. a.). Vielleicht dient dieses zur Herabsetzung der Transpiration ${ }^{3}$ ), vielleicht wird dadurch ein Wasser-

1) Pick 1882; Kny.

2) Vergl. auch S. 27 und die Fig. 88 und 89.

3) Volkens 1887. 
behïlter gelildet $\left.{ }^{1}\right)$. Hieran schließt sich wohl am nächsten der Schleimkork, welcher bei Haloxylon, Halimodendron, Calligonum u. a. Wüstenpflanzen mit gewöhnlichem Schutzkork abwechselt; er ist quellungsfähig, nimmt begierig Wasser auf und wird dann bloßgelegt nach Sprengung des außerhalh liegenden Schutzkorkes. Bei Halimodendron dient die sekundäre, mit den Jahren mächtige Rinde als Wasserspeicher, sowie auch als schutzmittel gegen extreme Temperaturen (B. Jönsson).

schleim wird in gewissen Fällen von Haaren gebildet (Hansteins Kollateren), z. B. in den Kuospen von Polygonaceen; er dient vielleicht zur Wasseraufnahme, hemmt möglicherweise auch die Verdunstung. I)a Schleim außerordentlich schwer ganz austrocknet, erhält er in kritisehen Zeiten das Leben der Zellen, in denen er sich befindet.

"Lackierte" Blätter. Harz oder ähnliche Stoffe werden von Haar'n auf der Oberfläche vieler Xerophyten, besonders solcher der südlichen Halbkugel ausgeschieden. Die Blätter werden dadurch klebrig und erscheinen wie "lackiert"; sie erhalten eine glänzende, glasartige Decke: die Wände der Epidermis sind dünn und schwach cuticularisiert ${ }^{2}$ ). Der Kreosotstrauch in Nordamerikas Wüsten hat Blätter, welche in der Jugend dünn sind, aber allmählich mit Lack überzogen werden ${ }^{3}$ ). Ebenso Euryops-Arten (Harpixsträucher) in Südafrika ${ }^{4}$ ). In den Peruanischen Anden in 1800-3200 m Höhe haben viele Arten klebrige, harzähnliche Stoffe (Weberbauer).

Salzkrusten werden auf der Oberflïche gewisser Wüstenpflanzen gebildet, die dadurch am Tage ein graues Aussehen erhalten und gegen Transpiration geschützt werden; nachts zerfließen diese Krusten, indem sie aus der Luft Feuchtigkeit aufnehmen (Kap. 28). Die Kalk absondernden Driisen bei Plumbaginaceen, bei gewissen Tamarix- und Saxifraga-Arten sollen wohl gleichfalls der Hemmung der Verdunstung dienen, aber ihre Hauptfunktion liegt vielleicht doch darin, schädliche Salze zu entfernen ${ }^{5}$ ).

Eine Tatsache, die vielleicht von allergrößter Bedeutung ist und möglicherweise den eigentlichen Grund für viele der erwähnten Verhältnisse darstellt, namentlich soweit sie die Epidermis selbst betreffen, ist folgende: Pflanzenteile von Meso- und Xerophyten, die sich von Wasser benetzen lissen, welken weit leichter als solche, die nicht benetzt werden können. Den Grund für diese vermehrte Transpiration sucht Wiesner

$\left.{ }^{1}\right)$ Pfitzer, Westermaier; Tschirch; siehe auch Walliczeck, Vesque, Radlkof'r; B. Jönsson 1902.

g) Volkens 1890; Marloth 1902; Diels 1906.

3) Coville 1893.

4) Marloth $1908 \mathrm{usw}$.

s) Marloth $1897 \mathrm{a}$. 
in einer durch das Wasser hervorgerufenen eigentümlichen Quellung der Zellwände, wodurch der Verdunstungswiderstand vermindert werde. Die vielen erwähnten Mittel, die Transpiration herabzusetzen, werden z. T. die Pflanzenteile auch gegen Benetzung schützen und auf diese Weise starke Transpiration verhindern.

Kork. Daß dieser durch seine mit Luft erfüllten Hohlräume und seine anderen Eigenschaften die Transpiration einschränkt, ist durch Erfahrung und Versuche klar bewiesen. Seine Mächtigkeit steht bisweilen mit der Trockenheit des Klimas offenbar in direkter Verbindung, was z. B. aus dem Unterschiede zwischen den Bäumen der brasilianischen Campos und der diesen direkt angrenzenden Wälder hervorgeht. Der austrocknende Einfluß der Camposbrände scheint den Kork zu weiterem Wachstum anzuregen - eine Selbstregulierung der Natur ${ }^{1}$ ). Sehr dicke Korkmäntel finden sich bei mehreren Wüstenpflanzen, z. B. bei Dioscorea (Testudinaria) elephantipes in Südafrika, Cocculus leaeba in Ägypten.

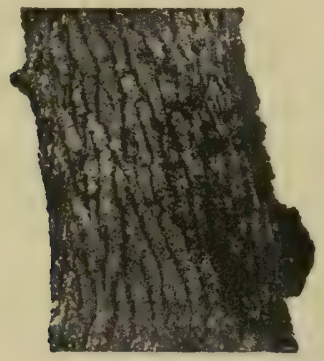

A

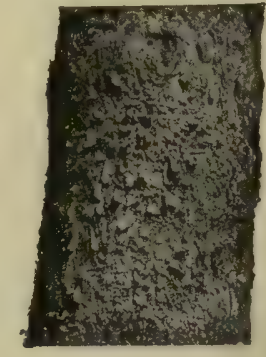

B

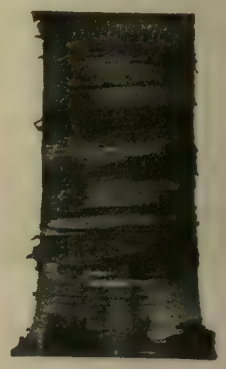

C

Fig. 90. A. Rissige Borke der Eiche; $B$. Schuppenborke der Fichte; $C$. Birke.

(E. Warming.)

In den Luftwurzeln von einigen Orchideen und Araceen ist ein eigentümliches, mechanisch wirkendes Gewebe als Velamen ausgebildet, welches die Wurzel mit einer Schicht von meist mehreren Lagen von Zellen umgibt und den Zweck hat, Wasser zu absorbieren (vergl. Fig. 27). Die Zellen sind denen von Sphagnum, die gleichfalls Wasser absorbieren, ähnlich; sie sind dünnwandig, mit ringförmigen, netzigen oder spiraligen Verdickungen. Wenn die Zellen mit Luft gefüllt sind, erscheint das Velamen weiß, sobald sie aber Wasser aufgenommen haben, scheint das darunter liegende grüne Gewebe der Wurzel mehr oder weniger stark durch. Tropfbar flüssiges Wasser wird plötzlich von dem Velamen aufgesogen und kann von ihm in Berührung mit dem Leitungsgewebe gebracht werden. Möglicherweise kann auch Wasser in Dampfform von dem Velamen aufgenommen werden, doch erscheint das recht unsicher.

1) Warming 1892, mit Abbildungen. 
Wehmer deutet aber den Zweck des Velamens ganz anders, er faßt es als eine Schutzeinrichtung gegen Verdunstung auf ${ }^{1}$ ).

Hier mag auch noch erwähnt werden, daß die Wurzeln vieler xerophytischer Landpflanzen eine sehr dicke Endodermis entwickeln, welche wahrscheinlich auch als Verdunstungsschutz dient.

II. Das Durchlüftungssystem (Stomatäre Transpiration). Die Intercellularräume sind die Orte, an denen hauptsächlich die Verdunstung stattfindet; die transpirierende Oberfläche einer Pflanze darf nicht nur nach duth die Atmosphäre unmittelbar grenzenden Oberfläche, sondern muß auch nach der Wandoherfläche aller Intercellularräume bemessen werden. Man kann dann von vornherein sagen, daß die Luft führenden Intercellularräume bei den Xerophyten viel enger sein und hierin im

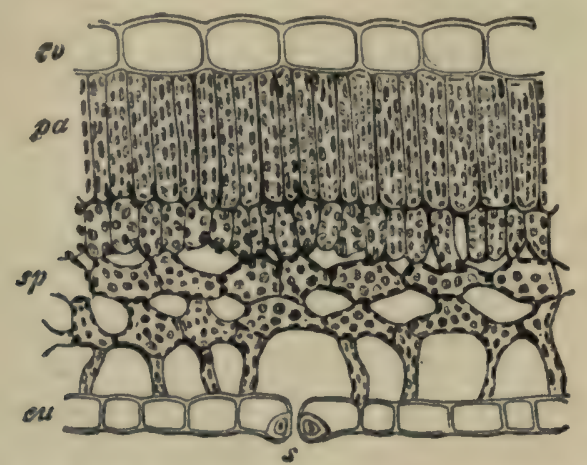

Fig. 91. Querschnitt durch ein Buchenblatt (350:1). eo Epidermis der Oberseite; pa Palisadenparenchym; $8 p$ Schwammparenchym; eu Epidermis der Blattunterseite; 8 Spaltöffnung. (Nach Prantl) - Zum Vergleich s. die Ausbildung des Durchlüftungssystems bei Wasserpflanzen Fig. 47 S. 143 und Fig. 92 S. 208.

größten Gegensatze zu denen der Wasserpflanzen stehen müssen, wo sie, wie S. 143 angeführt, sehr groß sind (ausgenommen die lithophilen Hydrophyten). Desgleichen ist der Unterschied in der Anzahl und der Verteilung der Spaltöffnungen zwischen beiden Gruppen von Pflanzen außerordentlich groß.

a) Die Spaltöffnungen sind, wie Schwendener nachgewiesen hat, durch ihren Bau zu der Regulierung der Verdunstung eingerichtet: sie schließen sich, wenn die Gefahr starker Transpiration eintritt, z. B. wenn die Blätter wegen ungenügende Wasserzufuhr zu welken anfangen; auch viele überwinternde Blätter halten während der Ruhezeit die Spaltöfnungen geschlossen; sie öffnen sich erst wieder, wenn die ungünstige Jahreszeit ihr Ende erreicht hat. Die Schließzellen gewisser Wüstenpflanzen sind nur bei jungen Blättern beweglich, bei den alten aber

7) Burgerstein 1904, S. 69. 
wegen starker Wandverdickungen unbeweglich, und der Spalt kann mit Wachs und Harz verstopft sein ${ }^{1}$ ).

Lloyd fand doch durch Versuche mit nordamerikanischen Wüstenpflanzen (Fouquiera splendens, Verbena ciliaris), daß man aus dem augenblicklichen Zustande des Schließmechanismus auf die Intensität der Verdunstung schließen kann.

Die Anzahl der Spaltöffnungen hängt von der Natur der Umgebung $\mathrm{ab}$; für die in der Luft befindlichen oberirdischen Pflanzenteile gilt im

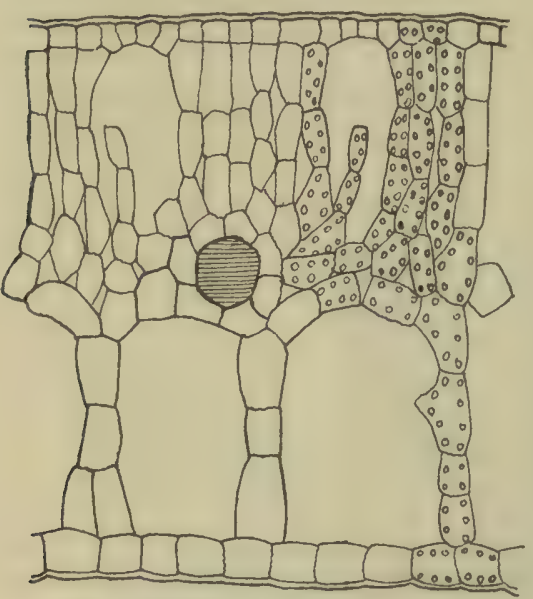

Fig. 92. Potamogeton natans.

Querschnitt durch ein Schwimmblatt

(150: 1) mit großen Luftkanälen.

(Nach Raunkiär.)

Vergl, auch Fig. 47 S. 143.

im großen und ganzen als Kegel, daß je trockener der Standort ist, desto weniger Spaltöffnungen auftreten, was man am besten sieht, wenn man nahe verwandte Arten vergleicht ${ }^{2}$ ).

Die Verteilung der Spaltöfnungen steht mit der Transpiration und den Feuchtigkeitsverhältnissen in engstem Zusammenhange. Wiesengräser haben in der Regel auf beiden Blattseiten Spaltöffnungen, Steppengräser in der Regel nur auf der gefurchten Oberseite ${ }^{3}$ ); andere Xerophyten haben gewöhnlich nur auf der Unterseite Spaltöffnungen, wo sie oft unter Verdunstungshindernissen verborgen sind.

Die Spaltöffnungen werden bei Xerophyten auf verschiedene Weise unter das Niveau der Oberfläche eingesenkt: in Gruben, Furchen usw.. die oft mit Haaren bekleidet sind, wodurch erreicht wird, daß die Luft aus ihnen schwierig heraustreten kann, d. h. daß die Transpiration herabgesetzt wird. Folgende Mittel werden angewandt:

Der einfachste Fall ist der, daß außerhalb der einzelnen Spaltöffnung eine schalen-, krug- oder trichterförmige Höhle gebildet wird, entweder dadurch, daß die Cuticula leistenförmig hervorragt (Vorhof), oder dadurch, daß sich die Nachbarzellen über die unter das Niveau der Oberfläche eingesenkte Spaltöffnung emporwölben (äußere Atemhöhle) ${ }^{4}$ ), z. B. bei Pinus silvestris. Bei Euphorbia paralias wird die

1) Wilhelm 1883; Volkens 1890; Gilg 1891.

2) Pfitzer 1870-72; Zingeler 1873; Czech 1869; Tschirch 1881; Volkens 1881; Altenkirch 1894.

3) Pfitzer $1870-72$.

4) Vergl. Tschirch $1882 \mathrm{a}$. 
Spaltöffnung von niedrigen Papillen umgeben ${ }^{1}$ ), ebenso bei verschiedenen Gräsern und Carices $^{2}$ ).

Gruppenweise in Gruben eingesenkt, die auf der Unterseite der Blätter liegen, deren Eingänge verengert und mehr oder weniger durch Haare verschlossen sind, finden sich die Spaltöffnungen bei Nerium Fig. 93, Banksia u. a. In Längsfurchen eingesenkt treten sie bei seln vielen Pflanzen auf und kommen dann gewöhnlich nur in diesen Furchen vor, deren Ränder oft mehr oder weniger mit Haaren besetzt sind. Viele Stengel, namentlich solche der Rutensproßformen, haben tiefe Furchen, wo allein sich die Spaltöffnungen befinden (Casuarina, Ephedra, Acanthosicyos horrida, GenistaArten usw.). Auf der Oberseite der Blätter finden sich die Furchen bei vielen Steppengräsern, und hier ko̊nnen die Furchen obendrein oft verengert und die Spaltoffnungen durch Zusammenrollen der Blätter mehr eingeschlossen werden (Weingaertneria canescens, Festuca ovina, Calamagrostis [Ammophila], Aristida, Stupa, Sporobolus spicatus, Cynodon dactylon u.a.); vergl. anch S. 217. Auf der Unterseite der Blätter finden sich bei vielen Xero-

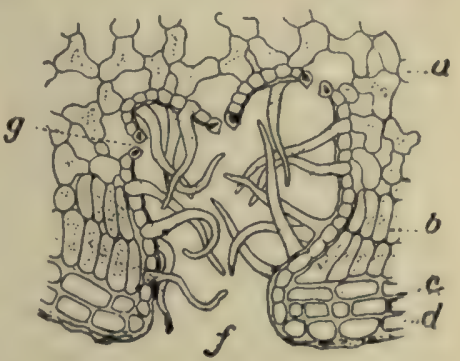

Fig. 93. Nerium oleander, Teil eines Blattquerschnittes.

$g$ Schwammparenchym; $b$ Palisadenparenchym der Unterseite des isolateralen Blattes; $c$ Wassergewebe; $d$ Epidermis; $f$ Eingang in die mit Haaren bekleidete Grube, in welcher die Spaltöffnungen $(g)$ liegen. (Nach Belzung.)

phyten mit Haaren bekleidete Furchen oder breitere Rinnen, z. B. bei Empetrum (s. Fig. 89), Phyllodoce, Calluna, Erica-Arten, Loiseleuria procumbens, Ledum palustre, Cassiope tetragona ${ }^{3}$ ), Dilleniaceen ${ }^{4}$ ), bei siidafrikanischen Arten der Gattungen Rhus, Grubbia, Phylica usw. ${ }^{5}$ ). Auch andere Blätter, deren Ränder weniger zurückgerollt sind und deren Spaltöffnungen auf der behaarten Unterseite liegen, können hierher gerechnet werden, z. B. die von Dryas octopetala.

sind die Blätter dauernd stark aufwärts gerichtet, so daß die Rückseite die sonnenreichste ist, so kann diese so ausgebildet werden wie sonst die Oberseite und Palisadengewebe erhalten; die Furche mit den spaltioffnungen findet sich dann auf der Oberseite (z. B. bei Passerina filiformis, Ozothamnus, Lepidophyllum $)^{6}$ ). Der Wasserdampf wird also bei diesen Pflanzen auf mehr als eine Art gehindert, leicht herauszutreten. Vergl. Fig. 88, S. 204, Thymelaea hirsuta.

2) Giltay 1886 .

2) Volkens 1890; Kihlman 1890; Raunkiär 1895-99.

s) Warming 1887, 1908; H. E. Petersen 1908.

*) Vergl. Steppuhn 1895.

s) Marloth 1908.

5) Lazniewski 1896; Goebel 1891.

Warming-Graebner. 3. Anflage, illuetr. 
Daß diese Verhältnisse zu der Trockenheit des Klimas in direkter Beziehung stehen, sieht man an Arten wie Ledum palustre und Andromeda polifolia; je mehr dem Winde und der Trockenheit ausgesetzt, desto kleiner sind die Blätter und desto mehr zurückgerollt ihre Ränder ${ }^{1}$ ).

Die zuletzt genannten Fälle bilden den Übergang zu den flachen und breiten Blättern, wo eine dichte Decke von Filz- oder Schildhaaren (wie bei Olea, Rhododendron und Elaeagnaceen) oder anderer Haarbekleidung auf der Blattunterseite die einzige Bedeckung oder Schutzwehr der Spaltöffnungen ist (vergl. auch Fig. 19, 20). Solche Blätter haben bisweilen auf der Unterseite stark hervorspringende Nerven, und die Spaltöffnungen liegen dann in den Nervenmaschen, also doch ein wenig eingesenkt (z. B. bei Lantana involucrata in Westindien, nach Warming).

Auf der Oberseite des Blattes findet sich ein dichtes Haarkleid als Decke über die in solchen Fällen hervorragenden Spaltöffnungen bei einigen aufrecht angedrückten Blättern, während die Unterseite nach außen gekehrt, dunkelgrün und glänzend ist, z. B. Thymelaea hirsuta, Fig. 88.

Spaltöffnungen, die in „windstillen", mit Wasserdampf erfüllten Räumen oder durch eine dichte Haardecke eingeschlossen sind, findet man meist über die Blattoberfläche gehoben, gleichwie bei Blättern von Pflanzen, die im ganzen in feuchter Luft leben. Die dicke Haardecke schließt ebenso, wie es durch feste Einrollung der Blätter usw. geschieht, die vor der Spaltöffnung lagernde Luft von der unmittelbaren Berührung mit der bewegten und meist auch trockenen Luft ab.

b) Die Intercellularräume. Schon der Bau der Atemhöhlen kann zu der Regulierung der Transpiration dienen, z. B. dadurch, daß sie cuticularisierte Wände erhalten, daß sie von besonderen Zellen umgeben werden (Restionaceae), oder dadurch, daß sie sehr klein werden. In manchen Fällen erstreckt sich die Cuticula von der Außenfläche der Epidermis durch die Spaltöffnung hinab über die Wände der Atemhöhle ${ }^{2}$ ).

Im allgemeinen gilt, daß die Luft führenden Intercellularräume bei den Xerophyten aus den vorhin angeführten Gründen sehr eng sind ${ }^{3}$ ). Jedoch können Ausnahmen hiervon vorkommen, z. B. bei den Restionaceen, wo außer sehr engen Gürtelkanälen auch große Lufträume vorkommen, die vielleicht bei der Kohlensäureassimilation eine Rolle spielen.

Die erwähnten Gürtelkanäle finden sich auch bei Hakea suaveolens (australische Wüstenpflanze), Olea Europaea, Kingia ${ }^{4}$ ), auch bei einigen Sandgräsern, wie Festuca rubra und Triticum acutum ${ }^{5}$ ), und anderen

ז) Warming 1887.

?) De Bary 1877, S. 79; Pfitzer 1870-72; Gilg 1891.

3) Vergl. z. B. Altenkirch 1894, Messungen von Atemhöhlen.

4) Tschirch 1881, 1882.

5) Nach Giltay 1886 . 
Pflanzen und sind enge Intercellularräume, die in Gürtelform quer um die Palisadenzellen gehen; durch diese Umwege muß das Entweichen des Wasserdampfes erschwert werden. Gewisse Wüstenpflanzen, wie Cynodon dactylon und Sporobolus spicatus, haben einen Wirrwarr von ïußerst feinen, verschlungenen intercellularen Kanälen ${ }^{1}$ ); es ist aber nicht sicher, daß diese verschiedenen Formen von Intercellularen die Aufgabe haben, die Transpiration herabzusetzen.

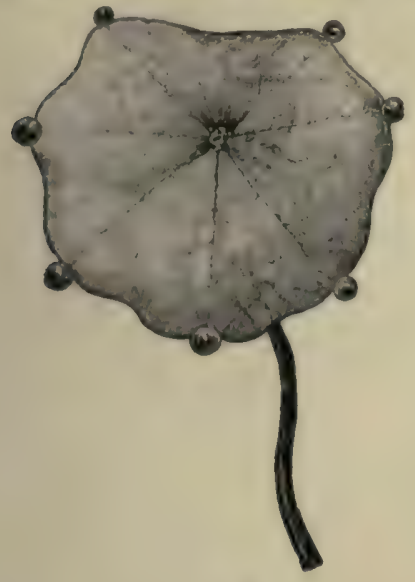

$A$

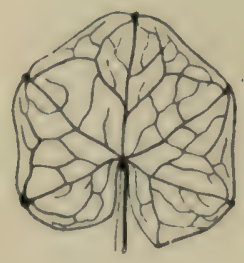

$B$

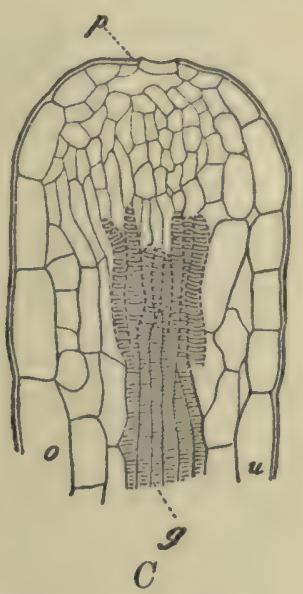

$C$

Fig. 94. Hydathoden. A. Blatt von Tropaeolum mit ausgeschiedenen Wassertropfen (nach Noll); B. Blatt von Caltha palustris (E. Warming); C. Längsschnitt durch einen Blattzahn von Primula Sinensis, o Epidermis der Oberseite, $u$ Epidermis der Unterseite, $p$ Wasserspalte, $g$ im Epithem endigende Tracheiden. (Nach De Bary.)

III. Hydathoden. Die Regulierung der Wassermenge innerhalb der Pflanze wird auch durch Organe ausgeführt, welchen Haberlandt ${ }^{2}$ ) den Namen Hydathoden (d. h. Wasserwege $)^{3}$ ) gegeben hat. Das Wasser wird von ihnen in Tropfenform ausgeschieden. Sie finden sich auch bei einigen Landpflanzen, und zwar sowohl in gemäßigten Klimaten, wie in den Tropen, bei Bäumen sowohl wie bei Kräutern. Wenn die Transpiration durch die zunehmende Sättigung der Luft an Wasserdampf vermindert wird (das Sättigungsdefizit S. 49 also zu schwinden beginnt), und daher die Intercellularräume vielleicht mit Wasser gefüllt werden, wird die Gefahr der Erstickung durch die „Guttation", die Tropfenausscheidung, aufgehoben (Fig. 94). Die einer solchen Wasserabsonderung dienenden Organe sind hauptsächlich folgende:

1. Epidermiszellen von einem bisweilen merkwürdigen Bau, oder eigentümliche Haare (einzellige oder mehrzellige; diese oft in der Form

1) Volkens 1887 .

2) Haberlandt 1894, 1895, 1904.

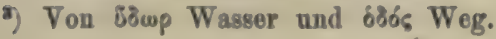


der Drüsenhaare); da diese Organe auf beiden Seiten der Blattspreite, besonders unterseits, auftreten, so erscheinen die ausgeschiedenen Wassermengen auf den Blättern wie Tautropfen.

2. Bei einem Teile der Farne sind die Hydathoden eigentümliche Drüsenflecke auf der Blattspreite.

3. Die bekannten, wie große Spaltöffnungen gebauten Wasserporen, die sich häufig auf der Oberseite der Blattzähne über einem kleinzelligen, dünnwandigen, gewöhnlich farblosen Gewebe (Epithem) vorfinden, in welchem Nerven endigen (Fig. 94, $B, C$ ).

Weiter kann Wasser auch ohne Mitwirkung von Hydathoden durch eine Epidermis ausgeschieden werden, die nach außen gerichtete Poren
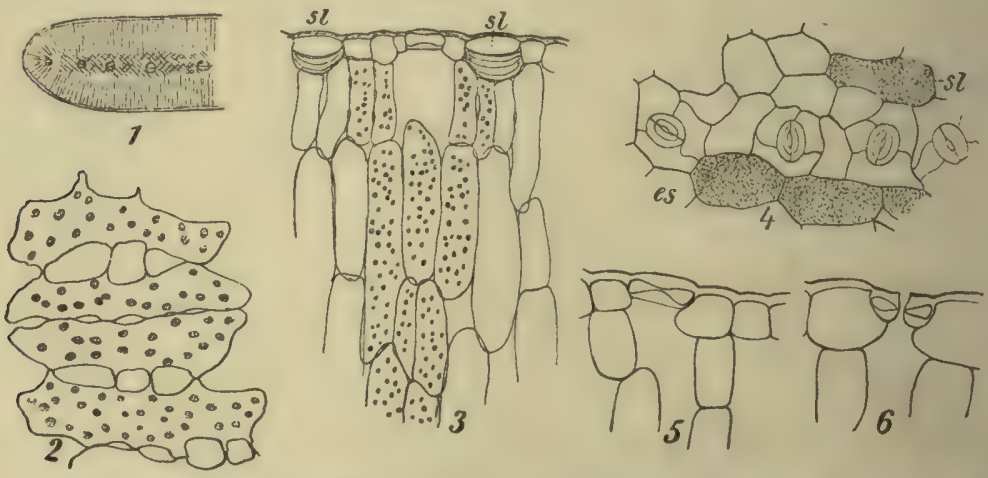

Fig. 95. Cakile aequalis, aus Westindien. Isolaterales Blatt mit etwa drei Schichten Palisadenzellen an jeder Seite. 2. Eine Zwischensehicht von lose liegenden chlorophyllhaltigen Zellen, kein Wassergewebe. Die Epidermis ist an jeder Seite gleich gebaut; einige Zellen haben verschleimte Innerwände ( $8 l$ in 3 und 4). Die Spaltöffnungen im Niveau der Epidermiszellen (5, 6). (E. Warming, 1897.)

besitzt. Schließlich wird Wasser ohne die Tätigkeit lebender Zellen, z. B. bei den Gräsern, ausgeschieden, im Gegensatze zu den vorhergehenden Fällen, in denen lebende Zellen notwendige und aktive Organe sind.

IV. Das Chlorophyllgewebe. Es ist eine Eigentümlichkeit der allermeisten Landpflanzen, $\mathrm{da} B$ sie ein Palisadengewebe haben, und zwar entweder nur auf der Oberseite der dann dorsiventralen Blätter, oder an den isolateralen Blättern auf beiden oder allen Seiten. Bei Wasserpflanzen besteht dagegen das Assimilationsgewebe gewöhnlich aus gleichförmigen, rundlichen Zellen (Fig.47). Bezeichnend für die Xerophyten ist bedeutende Entwicklung des Palisadengewebes, indem entweder die Zahl der Zellschichten vermehrt, oder die Höhe der Schichten (die Länge der Zellen) vergrößert wird, oder auch beides vorkommit ${ }^{1}$ ); vergl. Fig. 95.

1) Vergl. Heinricher 1884; Haberlandt 1894, 1904; E. S. Clements 1905. 
Kap. 4 S. 50 wurde die Meinungsverschiedenheit, die in der Erklärung dieses Bauverhältnisses herrscht, erwähnt und die Vermutung ausgesprochen, daß dieses mit der Trockenheit der Luft und mit der Transpiration in nächster Verbindung stehe.

Das Licht spielt sicherlich auch eine Rolle, denn die hier und da vorkommende schiefe Orientierung der Palisadenzellen zu der Epidermis muB durch die Beleuchtung hervorgebracht sein ${ }^{1}$ ). Vergl. Fig. 15, 16, S. 29.

\section{Andere anatomische Mittel, um die Transpiration zu regu-}

lieren. Ätherische Öle kommen besonders bei Xerophyten vor; die Garigues und die Macchie der Mittelmeerländer ${ }^{2}$ ), die Campos Brasiliens u. a. Vegetationen duften von Cistus, Labiaten, Verbenaceen, Kompositen, Myrtaceen u. a., wie unsere Sandfelder von Thymian, oder die Steppen Asiens von Artemisien. Die ursächliche Verbindung zwischen der Trockenheit des Klimas und des Bodens und dem Vorkommen des Öles ist nicht aufgeklärt, der Nutzen auch nicht. Ätherische Öle verdunsten leichter als Wasser und umgeben die Pflanze mit einer wohlriechenden Luft. Nach Tyndall ist die an ätherischen Ölen reiche Luft weit weniger diatherman, d.h. weit weniger imstande, strahlende Wärme durchgehen zu lassen, als reine Luft; die ätherischen Öle werden demnach die Bestrahlung und dadurch die Transpiration vermindern können ${ }^{3}$ ). Marloth stellt sich zweifelnd dieser Deutung gegenüber, weil die Drüsen bei Hitze nicht entleert werden.

Daß ätherische Öle außerdem anderen Nutzen schaffen können, z. B. den besonders von Stahl ${ }^{4}$ ) hervorgehobenen, gegen pflanzenfressende Tiere zu schützen, ist möglich.

Der Nutzen des Milchsaftes ist nicht sicher erkannt; nach einigen sind die Milchröhren Leitungsbahnen ${ }^{5}$ ), nach anderen (z. B. Kerner) ein Schutz gegen Tiere (Cichorioideen $)^{6}$ ). Vielleicht hat die "Milch ${ }^{6}$ mehr als eine Aufgabe, die eine dürfte die sein, die Pflanze gegen Austrocknung zu schützen. Dafür spricht, daß solche Milch enthaltenden Organe in den Tropen und besonders in heißen und trockenen Gegenden häufig auftreten, und zwar oft bei Pflanzen, die groß- und dünnblättrig sind und anscheinend kein anderes Mittel haben, um das durch Transpiration verlorene Wasser zu ersetzen (Warming).

Durch die verschiedenen oben beschriebenen Einrichtungen ist die Verdunstung der Laubblätter in Einklang gebracht mit den verschieden-

2) Pick 1882; Warming 1897; Raunkiär 1905, 1908.

2) Vergl. Beck 1901 und andere.

9) Volkens 1887 und andere.

4) Kniep 1894; Stahl 1904a usw.; Burgerstein 1904, S. 133, 214; vergl. auch Detto 1908.

5) Haberlandt; Schullerus; Pirotta u. a.

9 Vergl. auch Zander 1896. 
sten Eigenschaften der Umgebung. Man darf deshalb aber doch nicht schließen, daß ein xerophytischer Blattbau unvereinbar sei mit der Fähigkeit, stark zu verdunsten. So fand z. B. Bergen ${ }^{1}$ ), daß die absolute Menge des verdunsteten Wassers, also der Wasserbedarf der Pflanzen in der gleichen Zeit, kaum niedriger war in den typischen Sonnenblättern (Heliophyllen) gewisser immergrüner Gehölze, zu denen auch Olea Europaea und Quercus ilex gehören, als in den dünnblättrigen Ulmus campestris und Pisum sativum.

\section{B. Verminderung der verdunstenden Oberfläche}

Die Ausdehnung der verdunstenden Oberfläche spielt für die Höhe der Verdunstung, für die Menge des verlorenen Wassers eine wichtige Rolle: alle anderen Verhältnisse als gleich vorausgesetzt, wird die Verdunstung desto größer sein, je größer die verdunstende Oberfläche ist, und zwar wird die Verdunstung im wesentlichen im Verhältnis der Oberflächenvergrößerung steigen. Dort wo Laubblätter im wesentlichen die Organe sind, aus denen die Verdunstung stattfindet, sind es ihre Größe und ihre Zahl, welche diese Funktion regulieren und welche deshalb an den verschiedenen Arten im Einklange mit den klimatischen Verhältnissen verschieden gebaut sind, ja öfter an derselben Art je nach der Verschiedenheit des Standorts abändern. In den folgenden Paragraphen werden verschiedene Einrichtungen besprochen werden, die der Herabdrückung der Verdunstung dienen. Vergl. auch Kap. 4.

\section{Periodische Oberflåchenverminderung}

Immergrüne Pflanzen finden sich dort, wo die ökologischen Verhältnisse das ganze Jahr hindurch annäherungsweise gleich sind (z. B. in den tropischen Regengebieten). Wo eine solche Gleichheit nicht vorhanden ist, werden die Pflanzen sommergrün; vergl. indessen die arktischen.

Die gründlichste Art, wie die Pflanze ihre verdunstende Oberfläche vermindern kann, ist, alle stark verdunstenden Teile bei Beginn der trockenen Zeit abzuwerfen. Dieses geschieht erstens bei allen einjährigen Pflanzen, die nach der Samenreife absterben: die Samen solcher Pflanzen sind nämlich gegen Austrocknung sehr widerstandsfähig. Im Einklange hiermit ist der Prozentsatz ephemerer Arten in Wüsten und ähnlichen Gebieten sehr groß; in der kurzen, bisweilen nur wenige Wochen dauernden Regenzeit vollenden sie ihren ganzen Lebenslauf, keimen, blühen, reifen Samen und sterben, so daß sie die trockene Zeit in der Form der in den Samen eingeschlossenen Keime überdauern (z. B. Odontospermum [Asteriscus] pygmaeum) ${ }^{2}$ ) Fig. 96, Anastatica Fig. 26.

1) Bergen 1904 a.

?) Volkens 1878. 
Eine ganz ähnliche Form der Oberflächenverkleinerung findet sich auch bei allen den Zwiebel- und Knollenpflanzen u. a. Arten, deren unterirdische, bisweilen viele Jahre ausdauernde Sprosse in der trockenen Zeit Nahrungs- und Wasserbehälter sind; die oberirdischen Sprosse mit den großen, transpirierenden Flächen sind während der Trockenheit abgeworfen, und das Leben ruht in jenen meist unterirdischen Sprossen latent. In Eile entwickeln diese Arten neue Lichtsprosse und Blüten, wenn wieder Fenchtigkeit eintritt (redivive Pflanzen). Die schnelle Ankunft des Frühlings nach den ersten Regengüssen in den Wüsten,
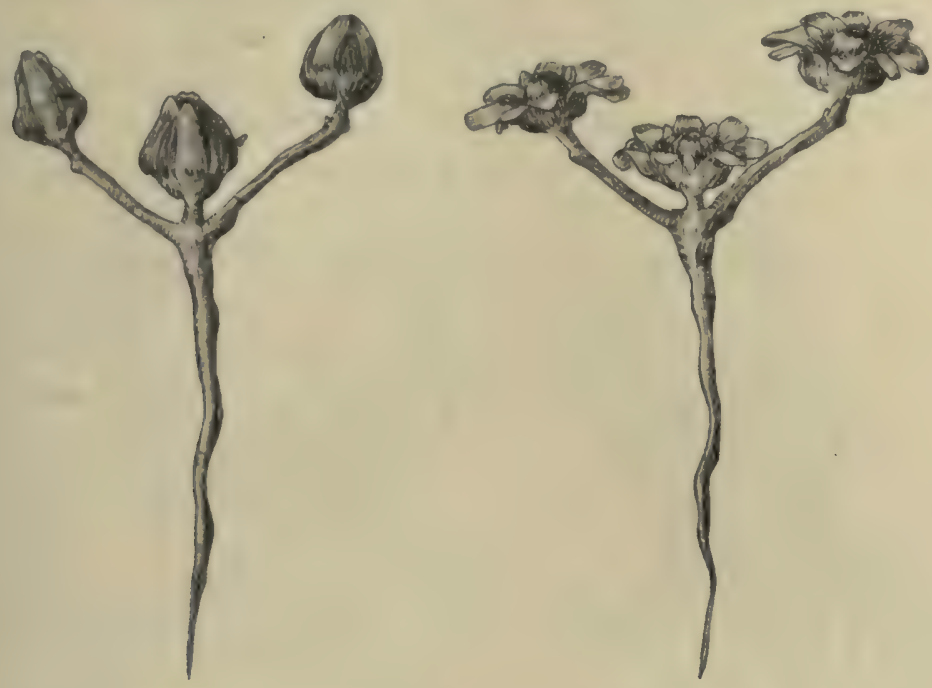

Fig. 96. Odontospermum pygmaeum, Fruchtköpfe, links im trockenen, rechts im befenchteten Zustande. (E. Graebner; nach der Natur.)

Steppen und ähnlichen Gegenden ist von den Reisenden oft mit Bewunderung erwähnt worden. Vergl. Fig. 64, 65. 66, S. 173-175 und Fig. 97.

Ähnlich liegt die Sache bei denjenigen Gehölzen, die vor oder in der trockenen Zeit oder dem Winter das Laub abwerfen (Laubfall). Bei diesen (laubwerfenden) sind alle oberirdischen Teile während der ungünstigen Zeit durch Kork und Knospenschuppen, die mit Kork oder anderen die Verdunstung hemmenden Teilen bedeckt sind, gegen starke Transpiration geschützt.

Bei Pflanzen der gemäßigten und kalten Klimate kann die Ruheperiode mehrere Monate dauern; ebenso bei den tropischen laubwerfenden Gehölzen, wo die Trockenzeit lang und regenlos ist; wo dagegen die Trockenzeit nicht ohne Regen ist, ist die Ruhe kurz oder der Laubfall findet gleichzeitig mit der Neuerzeugung des Laubes statt ${ }^{1}$ ).

3) Vergl. x. B. Warming 1892; Volkens 1912. 


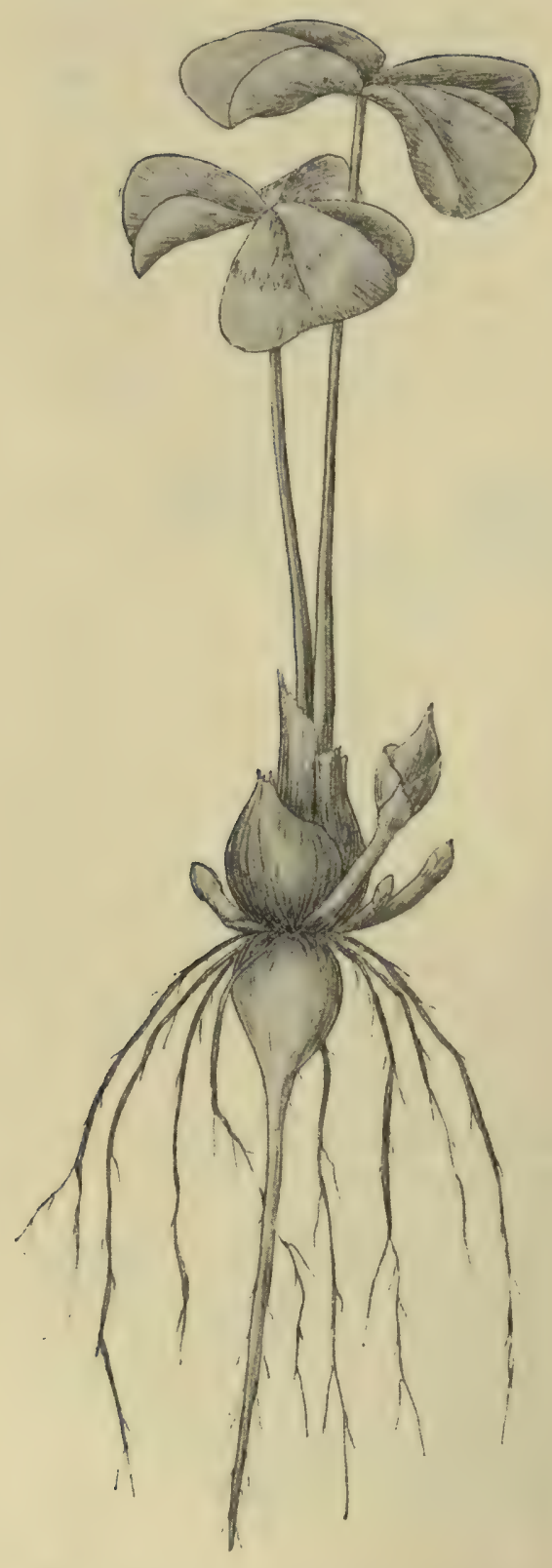

Fig. 97. Oxalis tetraphylla, Zwiebelpflanze, mit Ersatzsprossen und Saftwurzel.

(E. Graebner; nach der Natur.)
Die nur im Sommer belaubten Pflanzen nennt Drude ${ }^{1}$ ) therophyll, die, deren Blätter eine ganze, volle Jahresperiode durchmachen, bei Erzeugung der neuen Blätter im Frühjahr aber absterben (viele Rubus usw. bei uns), sind wintergrün oder holocyklisch. Die, welche ihre Blätter wenigstens für eine zweite Vegetationsperiode bewahren: immergrün oder pleocyklisch.

Ob die Jahresperiodizität ein rein erblicher, also in der Natur der Pflanze liegender Vorgang ist, oder ob sie von den äußeren Verhältnissen abhängt, darüber gehen die Ansichten sehr auseinander. Das Richtigste ist wohl anzunehmen, daß sie eine Anpassung an die Lebenslage ist, welche bei vielen Arten erblich fixiert ist und jedenfalls nur durch vieljährige abweichende Einflüsse aufgehoben werden kann $^{2}$ ).

Bei den sommergruinen Pflanzen ist der Bau der Laubblätter gewöhnlich überhaupt nicht oder doch nur schwach xerophytisch, sondern ist in der Mehrzahl der Fälle mesophytisch, weil eben meist die Vegetationszeit genügend feucht ist, In Ägypten ${ }^{3}$ ) und dem Niederungslande von Madeira ${ }^{4}$ ), wo die Luftfeuchtigkeit und die Niederschläge selbst im Winter gering sind, zeigen die einjährigen Kräuter an den unkultivierten Flächen Schutzeinrichtungen gegen die Trockenheit, welche den Pflanzen auf den bewässerten Feldern und Äckern fehlen. Der Schutz

1) Drude 1913.

2) Vergl. übrigens S. 166, Volkens 1887, 1912; Drude 1913, S. 162.

3) Volkens 1887.

) Vahl $1904 \mathrm{~b}$. 
gegen Verdunstung ist bei den einzelnen Arten um so mehr ausgeprägt, je mehr diese ihre Vegetationszeit über das Finsetzen der Trockenzeit hinaus ausdelmen. Nach Kerner ${ }^{1}$ ) sind die Blätter der laubwechselnden Gehölze an den österreichischen Küsten deshalb so oft unterseits stark behaart, weil die Sommer so trocken sind.

\section{Bewegungen der Blätter und Stengel}

Ganz anders wird die verdunstende Oberfläche bei anderen Pflanzen verkleinert, z. B. bei einem Teile der Gräser, die bei trockenem Wetter ihre Blätter zusammenrollen, so daß selbst breite Blätter dadurch röhren- oder fadenförmig werden. Dieses findet sich z. B. beim Helm (Calamagrostis [Ammophila] arenaria), bei Weingaertneria (Corynephorus) canescens, Festuca-Arten, Anthoxanthum odoratum und vielen anderen Heide-, Dünen- und Steppengräsern; in den Mittelmeerländern z. B. bei
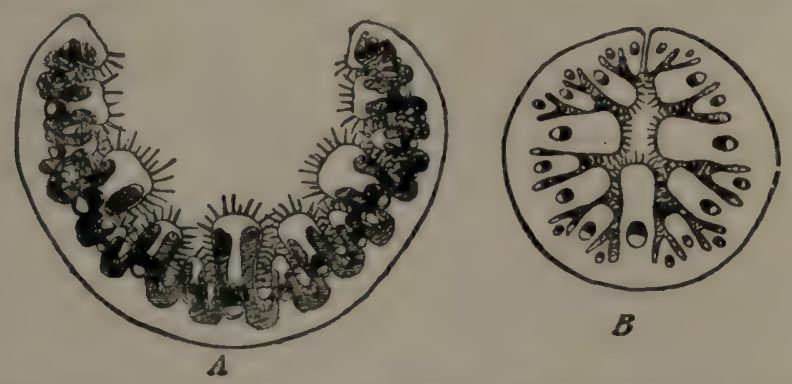

Fig. 98. Calamagrostis (Ammophila, Psamma). Blattquerschnitt $A$ bei feuchtem, $B$ bei trockenem Wetter. (E. Warming.)

Arten von Stupa, Lygeum, Aristida ${ }^{2}$ ). Auch bei Gräsern des Salzbodens, wie Triticum junceum, kommt es vor. Je nachdem die Trockenheit der Luft wächst, rollen sich die Blätter ein, und dadurch wird die transpirierende Oberfläche, auf der die Spaltöffnungen ausschlieBlich oder vorzugsweise liegen, der Verdunstung entzogen; die Spaltöffnungen werden mehr oder weniger in „windstille“ Räume eingeschlossen. Bei feuchtem Wetter breiten sich die Blätter wieder aus. Auch bei den Cyperaceen kommen ähnliche, obgleich weniger starke Bewegungen vor. Bei den Grïsern spielen die Gelenkzellen (cellules bulbiformes, Duval-Jouve), die in den Furchen der Blattoberseite liegen, eine Rolle; sie sind höher als die anderen Epidermiszellen, und ihre aus Cellulose bestehenden Wände falten sich beim Einrollen des Blattes leicht ein. Die bewegende Kraft scheint am ehesten in dem Bastgewebe zu liegen, das sich gewöhnlich auf der Unterseite der Blätter findet und das nach den Umständen entweder Wasser aufnimmt oder abgibt und dadurch quillt oder einschrumpft.

2) Kerner 1886 .

2) Duval-Jouve 1875; Tschirch 1882; Warming 1891 и. a. 
Der Turgor des Mesophylls scheint jedoch, jedenfalls in gewissen Fällen, eine wichtige Rolle $\mathrm{zu}$ spielen ${ }^{1}$ ).

Einige Dikotylen zeigen ähnliche Bewegungserscheinungen, z. B. Hieracium pilosella, Antennaria dioeca, Crepis tectorum (nach Wille), westindische Croton-Arten, Euphorbia paralias (west- und südeuropäische Dünenpflanze; nach Giltay). Die Blätter von Erica tetralix sind auf feuchtem Boden weniger eingerollt als auf trockenem Boden ${ }^{2}$ ); ebenso die Blätter von Ledum palustre.

Selbst bei so xerophytisch gebauten Pflanzen, wie es die Hauslauchpflanzen sind, kann man oft beobachten wie sie in Trockenperioden ihre Rosetten zusammenziehen, so daß die inneren Blätter in den äußeren vollständig versteckt werden; stellt sich nun wieder Regen ein, breiten sich die Rosetten sternförmig aus.

Von Kryptogamen können Farne (Wittrock u. Briosi) und einige Moose, namentlich Rhacomitrium- und Polytrichum-Arten genannt werden; bei trockenem Wetter sind die Blätter von $R h$. canescens, ähnlich auch von Polytrichum piliferum, zusammengebogen, und die Sprosse durch die dicht vereinigten, langen Haare ganz grau; wenn Feuchtigkeit (auch feuchter Boden) vorhanden ist, sind sie sternförmig ausgebreitet. Polytrichum kann die Blattränder über die assimilierenden und dünnwandigen Zellen der Blattmitte legen.

Sehr bekannt ist Selaginella lepidophylla aus den nordamerikanischen Wüsten; in Trockenheit rollt sie sich dicht zusammen, bei Wasserzufuhr breitet sie sich aus. Selaginella lepidophylla (Fig. 99) vermag monatelang anhaltender Trockenheit zu widerstehen. Nach Wittrock kann sie sogar über 10 Jahre in trockenem Zustande leben. Regen und Tau wird besonders durch Haare auf den Enden der Blätter sitzen (Stahl). Auch unter den Farnen finden sich mehrere aus den Gattungen Pelloa, Cheilanthes und Notochlaena, die sich bei zunehmendem Wasserverlust einwärts rollen, so daß nur noch die mit zahlreichen Schülfern bedeckte meist rostfarbene Unterseite sichtbar ist.

\section{Dauernde Verkleinerung von Laubblatt und Luftsproß}

Bei den meisten Pflanzen unserer gemäßigten Klimate ist eine verhältnismäßig geringe Körpermasse von einer großen Oberfläche überzogen; bei vielen Xerophyten ist es umgekehrt; dies wird sehr zweckmäßig sein, denn hier hat die größtmögliche Pflanzenmasse die möglichst kleinste verdunstende Oberfläche.

Bei sehr vielen Xerophyten sind die verdunstenden Organe, d. h. namentlich die Laubblätter, außerordentlich an Größe und Ober-

1) Duval-Jouve 1875; Tschirch 1882.

2) Graebner 1895 . 
flächenausdehnung reduziert, also klein, und damit treten auch Abweichungen in der gewöhnlichen Physiognomie des ganzen Sprosses auf, besondere xerophile Sproßformen in einer Reihe verschiedener Abänderungen. Wassermangel wirkt verkleinernd (Kap. 4); an trockenen, sandigen Standorten werden viele Arten zu Zwergformen. Dieselbe Art kann auf trockenem Boden kleinblättrig, auf feuchtem großblättrig sein, z. B. I'rtica diocca, Viola canina, Erodium cicutarium; mehrere Wüstenpflanzen entwickeln bei Beginn der Regenzeit große Blätter, aber später viel kleinere nder fast gar keine, z. B. Zilla, Alhagi u. a. Die Kleinheit

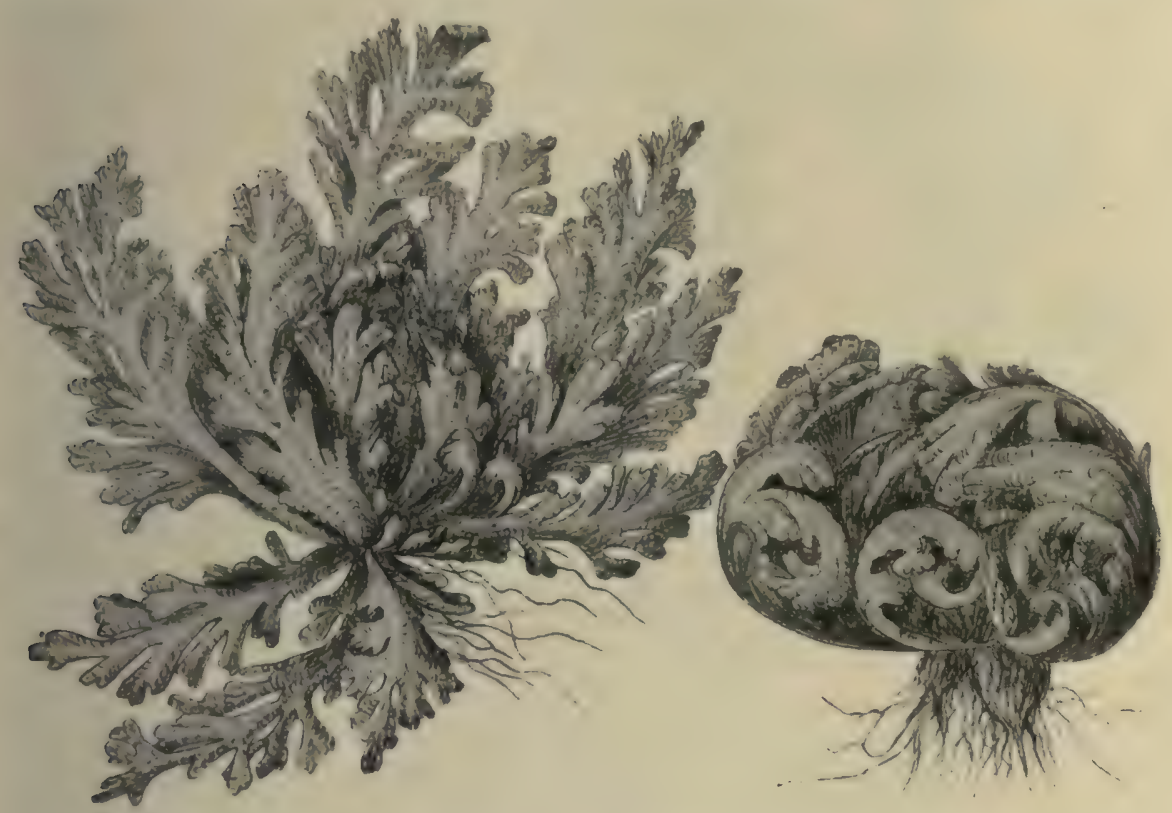

Fig. 99. Selaginella lepidophylla, links bei feuchtem, rechts bei trockenem Wetter. (Nach Hieronymus.)

des Blattes ist hier direkt eine Folge der Trockenheit ${ }^{1}$ ). Aber Wassermangel hat vermutlich auch beigetragen, eine Reihe erblich konstanter Typen zu schaffen, namentlich folgende, die sich durchgehends dadurch auszeichnen, daß sie eine verhältnismäßig unbedeutende Assimilationsarbeit verrichten, weshalb das Waehstum langsam ist.

Blattformen. Die Blätter der Xerophyten sind gewöhnlich steif und lederartig, was besonders durch die dicken, stark cutinisierten Wände der Oberhautzellen hervorgerufen wird („Sklerophyll“ $\left.)^{2}\right)$. Dazu kommt,

1) Vergl. Henslow 1894; Scott Elliot 1905; Pcrey Groom 1892 u. a.

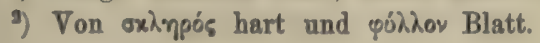


daß sie gewöhnlich ganzrandig sind und auch meist ungeteilt. Die meisten Arten sind immergrün. Die wichtigsten Blattformen sind folgende:

1. Das Nadelblatt oder pinoide Blatt (bei Koniferen, Proteaceen, Ulex Europaeus u. a.). Es ist lang, linealisch, spitz, steif und hat häufig ein mehr oder weniger centrisches Chlorophyllgewebe. Die Beziehung dieses Blattes zur Transpiration geht daraus hervor, daß die Blattoberfläche im Verhältnis zu dem Volumen viel kleiner als bei dem flachen Blatt mit demselben Volumen, die Verdunstungsoberfäche also relativ geringer ist. Dasselbe gilt von den folgenden Blattformen.

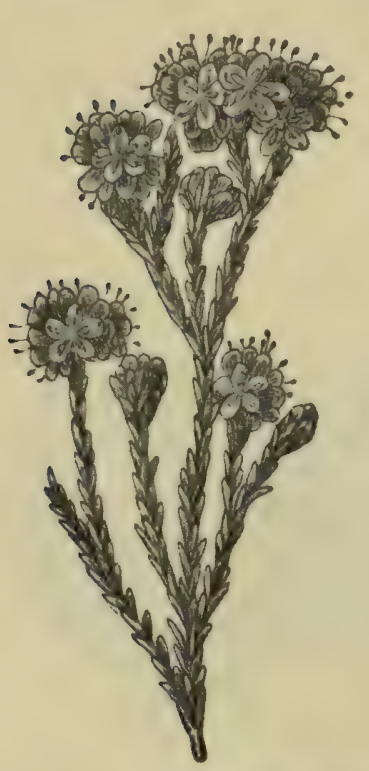

Fig. 100. Agalhosma erectum, typisches Rollblatt. (Nach Engler.)

2. Das ericoïde Blatt ist ein Rollblatt, d.h. die Ränder erscheinen umgerollt, entweder nach unten oder auch (viel seltener, z. B. bei Passerina) nach oben gerollt; dadurch wird es besonders gut abgesteift und außerdem entsteht so eine windstille Furche, worin die Spaltöffnungen verborgen sind. Ericoide Blätter sind häufig kurz oder auch linealisch und finden sich bei Erica, Calluna, Cassiope n. a. Ericaceen, Empetrum, Epacridaceen, Proteaceen, Myrtaceen, Berberis empetrifolia (Chile), bei sủdafrikanischen Thymelaeaceen, Kompositen, Rhamnaceen, Rubiaceen, und bei Arten anderer Familien, die an Stellen mit starker Transpiration oder auf dem sauren Boden der Heiden wachsen (Fig. 100).

Die ericoiden Blätter sind gewöhnlich sehr klein, an den ericoiden Sprossen stehen sie aber sehr zahlreich und dicht als Ersatz für die Kleinheit.

3. Das schuppenähnliche Blatt ist breit und kurz, angedrückt, aufwärts gerichtet, bisweilen herablaufend. Die Spaltöffnungen sind an der Oberseite angebracht, also nicht an der nach außen gekehrten organischen Unterseite (Fig.88). Es findet sich bei vielen Cupressoideen und Pflanzen der verschiedensten anderen Familien, z. B. bei Scrophulariaceen (Veronica thuyoides und $V$. cupressoides auf den Gebirgen Neuseelands) ${ }^{1}$ ), Santalaceen, Tamaricaceen, Kompositen, Umbelliferen (Beisp. Azorella auf den Hochgebirgen von Südamerika und in antarktischen Gegenden), in den Macchien des Kaplandes ${ }^{2}$ ) bei Kompositen, Bruniaceen, Chenopodiaceen, Valerianaceen der Anden u. a. (Fig. 101).

1) Cockayne, Diels.

ఇ) Marloth 1908. 
Der mit solchen schuppenförmigen Blättern besetzte Sproß kann cupressoild oder lepidophyll ${ }^{1}$ ) genannt werden.

4. Das borsten-oder fadenförmige Blatt bei sehr vielen grasähnlichen Monokotyledonen ausgebildet; es ist meist auf der Oberseite gefurcht oder rinnenförmig, und die Spaltöffnungen sind in den behaarten Furchen verborgen. Bewegungen je nach den Feuchtigkeitsverhältnissen kommen vor, z. B. bei Festuca ovina, Weingaertneria (Corynephorus) canescens, vielen Wüsten- und Steppengräsern, Gräsern in den Hochgebirgen (S. 217, Fig. 98). Geteilte Blätter haben oft sehr ähnliche, kleine und stielrunde Abschnitte (z. B. bei Artemisia campestris).

5. Das juncoïde Blatt (Binsenblatt) schließt sich hier an; es ist lang, stielrund, nicht gefurcht (Juncus-Arten, mehrere Cyperaceen

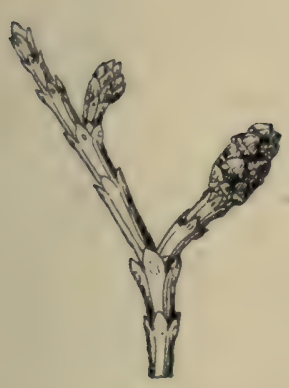

A

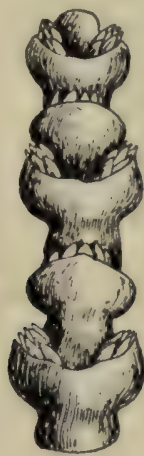

$B$

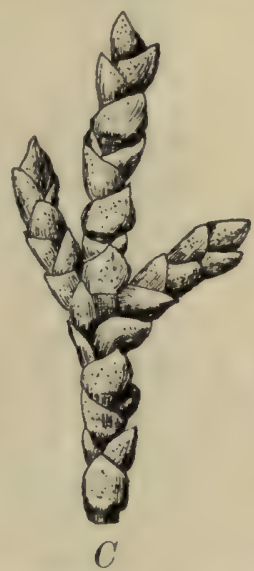

Fig. 101. Pflanzen mit Schuppenblättern. A. Callitris quadrivalvis. B. Anabasis articulata. C. Tamarix pauciovulata. (Alle nach Engler.)

[Scirpus usw.], einige Umbelliferen in den Hochgebirgen von Südamerika) ${ }^{1}$ ). Diese Form trifft man meist auf nassem, kaltem, den Winden ausgesetztem Boden (S. 229).

6. Das myrtoïde Blatt. Ohne zu einem bestimmten der vorhin angeführten Typen zu gehören, kommen sehr viele andere an starke Verdunstung angepaßte Blattformen vor; manche sind schmal und steif und mehr oder weniger zurückgerollt (z. B. bei Lavandula, Hyssopus und anderen Arten der Mittelmeerländer); andere sind breiter und flach (Dryas, Rhododendron Lapponicum, viele Campospflanzen aus Brasiliens Campos u. a.; Fig. 102).

"Myrtoild" können solche Blätter genannt werden, welche wie beri Myrtus communis, Nerium, Olea, Rhododendron-Arten verkehrt-eiförmig, länglich, elliptisch sind, oder doch sonst ganz ungeteilt erscheinen, die

1) Goebel $1891-92$. 

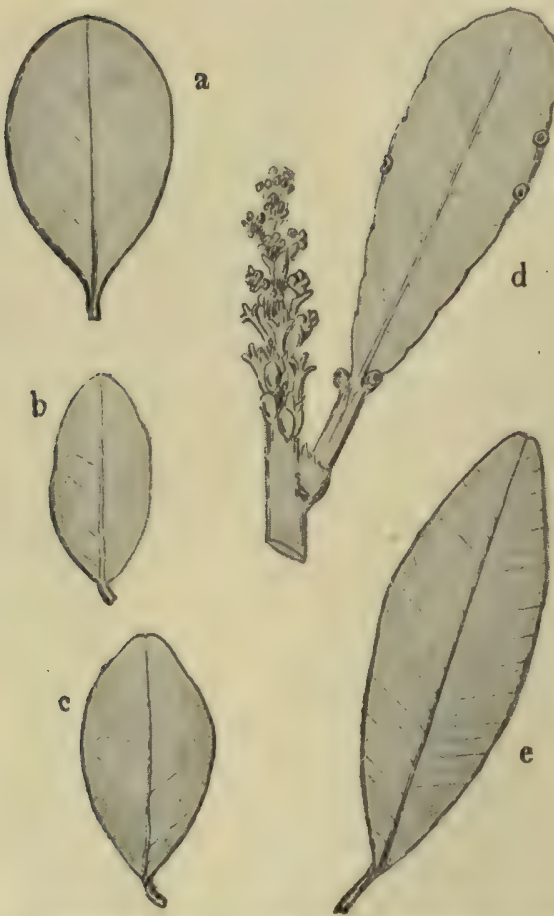

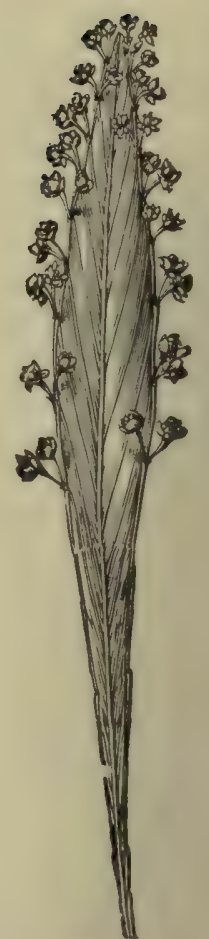

Fig. 103.

Blütentragender

FlachsproB von Xylophylla.

(Nach Baillon.)

Myrcia palustris. b Campomanesia aurea. \& Anisomeris obtusa. d Excoecaria (Sapium) biglandulosa var.

Sellowiana. e Chrysophyllum marginatum.

(Gezeichnet von Lindman.)

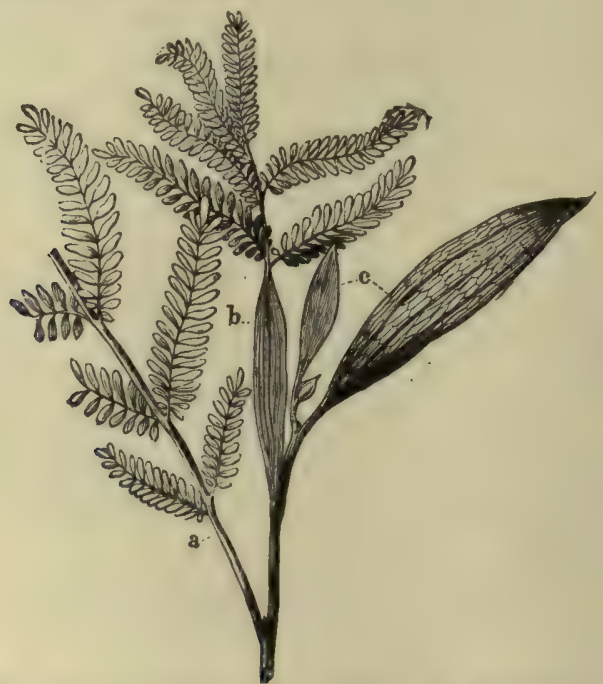

Fig. 104. Zweig einer heterophyllen Acacia. a Doppelt gefiedertes Blatt; $b$ desgleichen mit beginnender Phyllodienbildung; $c$ völlig ausgebildetes Phyllodium. (Nach Warming-Johannsen.) 
keinerlei Zähnung, Lappung oder ähnliches zeigen. Es mögen hier auch die blattähnlichen Kurzsprosse (Kladodien) von Ruscus aculeatus (Fig. 112) und anderen Arten, von Semele androgyna, Xylophylla (Fig. 103) usw. angeschlossen werden. Ferner die Phyllodien der Acacien, Fig. 104, 105. Diese Gebilde sind immergrün, flach, lederartig, steif und im wesentlichen durch die dickwandige Epidermis geschützt.
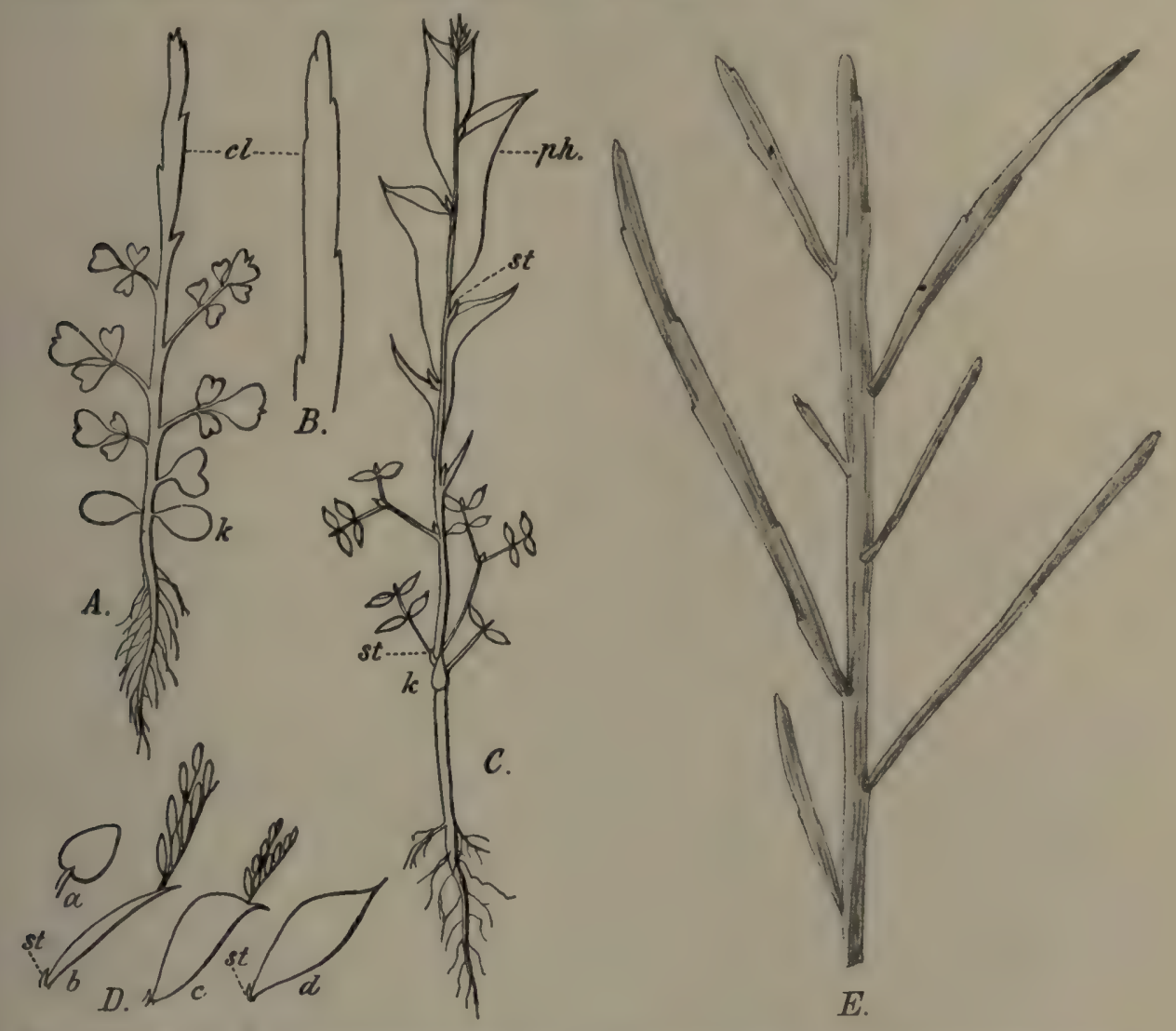

Fig. 105. A, B, E. Carmichaelia australis. $A$. Keimpflanze; $B$. verflachte Sporenspitze vergröBert; $E$. Sproß der ausgewachsenen Pflanze; $C$. Keimpflanze von Acacia alata; D. Blätter von Acacia conspicua, $a$ Kotyledon, $b-d$ zeigen den Übergang zu den Phyllodien. - Bei $A-D$ ist $k$ Kotyledon, $c l$ Kladodium, ph Phyllodinm, st Achselblatt. $(A, D$ nach $F$. Hildebrand, $C$ nach der Natur.)

Dieser Typus läßt sich vielleicht zweckmäßig in mehrere zerlegen, z. B. den Typus des Nerium (Oleander-Typus), des Olivenbaumes, der Sapotaceen usw. Derartige Blattgestalten finden sich besonders bei Holzpflanzen der tropischen, subtropischen und warm temperierten Länder, und sind besonders in Ländern mit Winterregen häufig; auch in so kalten und feuchten Klimaten wie auf den südlichen Inseln Neuseelands kommen nach Cockayne solche Sklerophyllwälder vor. 
Xerophyten haben noch andere, im folgenden erwähnte Schutzeinrichtungen gegen starke Transpiration. (Hierher gehörige Litteratur besonders bei Vesque, Volkens, Goebel, Warming, Henslow, Schimper.)

Die Sprosse der mit den genannten Blattformen (besonders 1, 2,3) ausgestatteten Pflanzen sind gewöhnlich überaus blattreich. Die Anzahl der Blätter ersetzt ihre geringe Größe teilweise; ferner wird vermutlich auch das Zusammendrängen der Blätter auf den kurzgliedrigen Sprossen die Transpiration weniger stark machen.
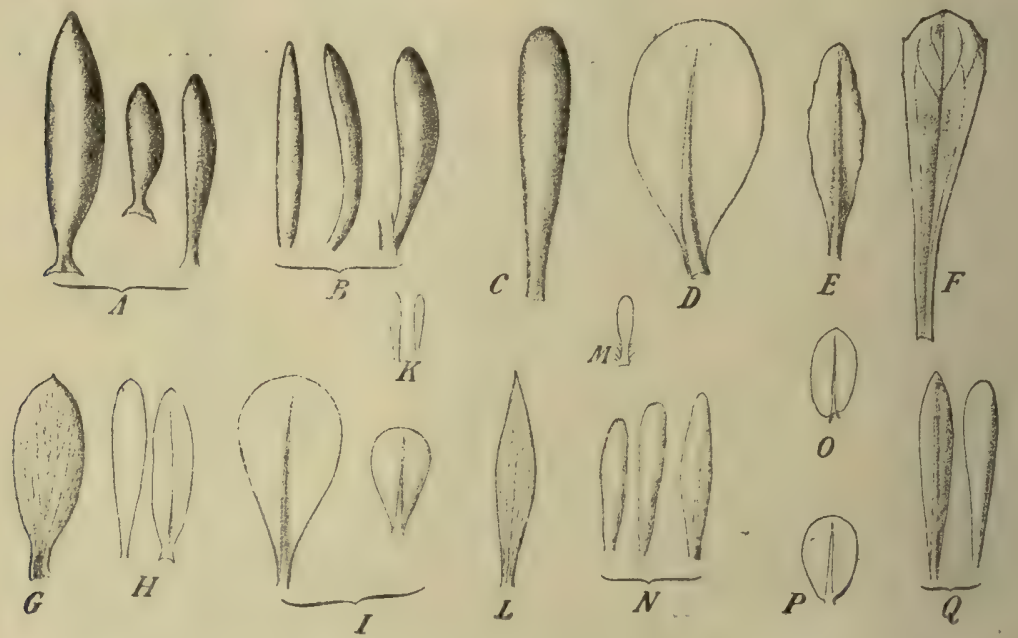

Fig. 106. Blätter tropisch-amerikanischer Halophyten. A. Aizoaceae (Sesuvium portulacastrum, Fig. 107, S.225); B. Batidaceae (Batis maritima); C. Borraginaceae (Tournefortia gnaphalodes); D. Goodeniaceae (Scaevola Plumieri); E. Cruciferae (Cakile aequalis, s. Fig. 95); F. Calyceraceae (Acicarpha spathulata); G. Compositae (Borrichia arborescens); H. Amarantaceae (Philoxerus vermiculatus); I. Compositae (Baccharis dioeca); K. Amarantaceae (Alternanthera [Lithophila] muscoides); L. Rubiaceae (Ernodea liloralis); M. Compositae (Pectis humifusa); N. Borraginaceae (Heliotropium curassavicum); O. Euphorbiaceae (Euphorbia buxifolia); P. Portulacaceae (Portulaca oleracea); Q. Phytolacaceae (Suriana maritima). (Eug. Warming, 1897.)

Von den unter $1-6$ erwähnten steifen oder meist lederartigen und trockenen Blättern (Sklerophyllen) weicht besonders ab:

Die Blattform der Saftpflanzen (Blattsucculenten). Dieses Blatt ist nicht wie die vorigen mechanisch versteift durch verdickte Epidermiswände, Sklerenchym und dergleichen, sondern es erhält seine Steifheit durch die Dicke und den Saftreichtum. Es ist mehr oder weniger stielrund, linealisch, länglich oder spatelförmig úsw., es hat meist keine Zähne oder andere Einschnitte (Beisp. Sedum acre, Sempervivum tcctorum, Mesembrianthemum-Arten, Chenopodiaceen, Batis maritima, Orchidaceen). Diese Form hat eine relativ kleinere Verdunstungsfläche, als wenn dieselbe Masse flach ausgebreitet wäre. Henslows Meinung, 
25. Kap.

daß die Sukkulenz eine direkte Wirkung der umgebenden Naturverhältnisse sei, ist wahrscheinlich richtig. Indessen sind doch nicht

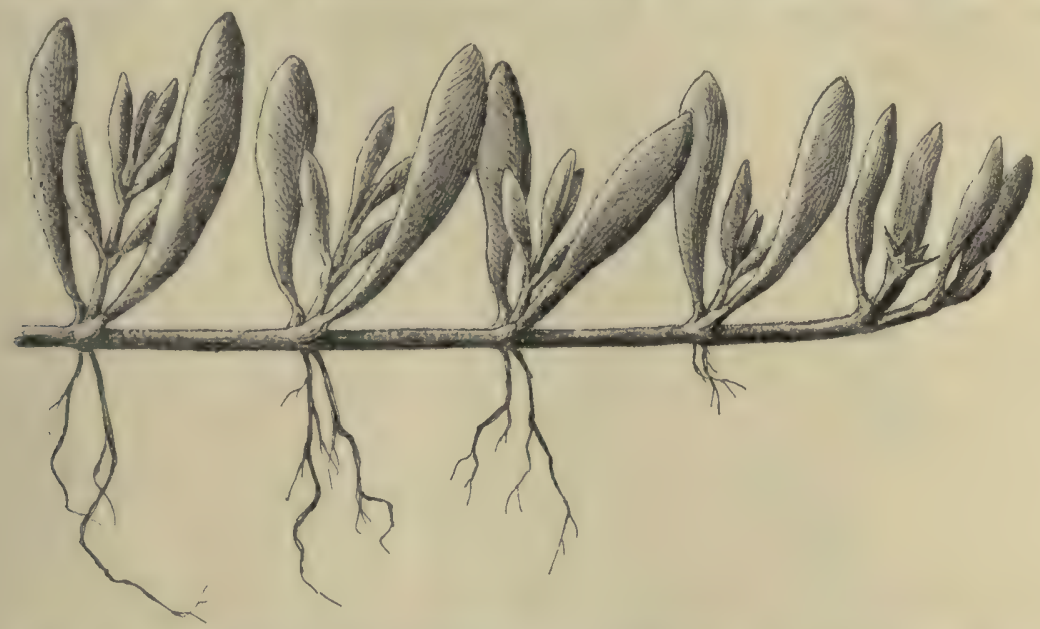

Fig. 107. Sesuvium portulacastrum ans Westindien. (F. Börgesen 1909.)

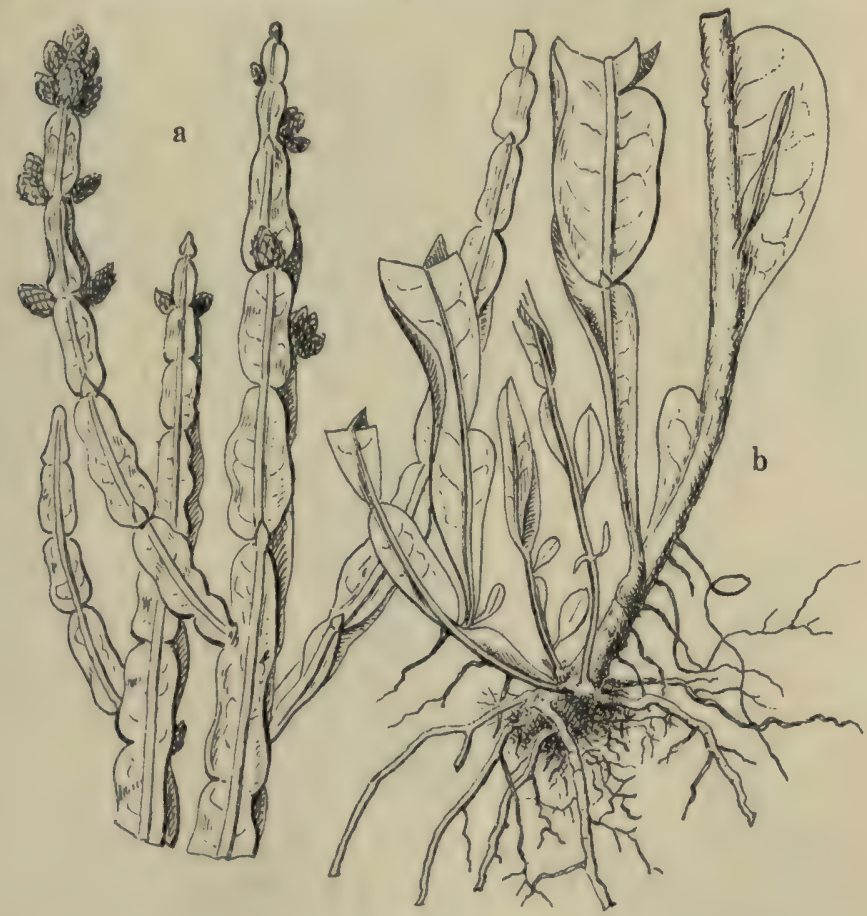

Fig. 108. Baccharis genistelloides, a. f. crispa, Südbrasilien. (Gezeichnet von C. A. M. Lindman 1900.)

alle Sukkulenten Xerophyten, wir finden unter ihnen nicht nur Schatten-, sondern sogar Sumpf- und Wasserpflanzen (z. B. SedumArten, Bulliarda u. a.). Vergl. Fig. 23, 24, sowie Fig. 106 und 107. 
Sprofformen. In Verbindung mit den im vorhergehenden erwähnten, vom breiten, dünnen, weichen, mesophytisch gebauten Blatte abweichenden eigentümlichen Blattformen steht eine entsprechende Reihe

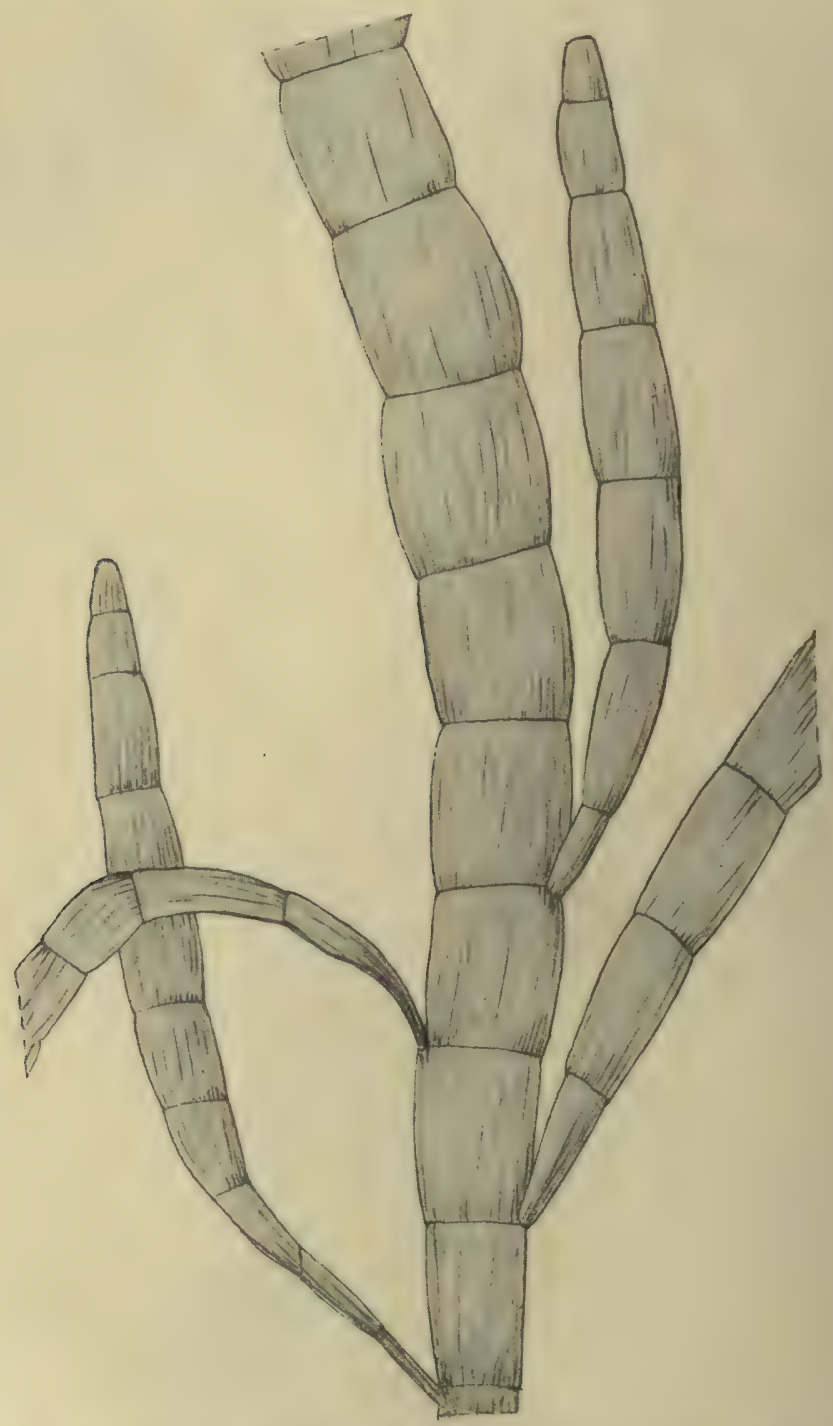

Fig. 109. Muehlenbeckia platyclada. Typischer, bandförmiger, blattloser Stengel. (E. Graebner; nach der Natur.)

von SproBformen, welche den Blattformen analog pinoïd, ericoïd, cupressoïd resp. lepidophyll, oder myrtoïd genannt werden können.

Außerdem gibt es eine Reihe Sproßformen, welche speziell erwähnt werden müssen, weil sie blattlos sind. 
"Blattlose" Sprosse, das sind mit sehr reduzierten oder bald ahfallenden Blättern versehene; das Laubblatt ist verschwunden, der Stamm hat dessen Funktion übernommen und hat Palisadengewebe ausgebildet. Die Epidermis solcher Sprosse funktioniert naturgemäß eine Reihe von Jahren. - Blattlose Sprosse sind folgende.

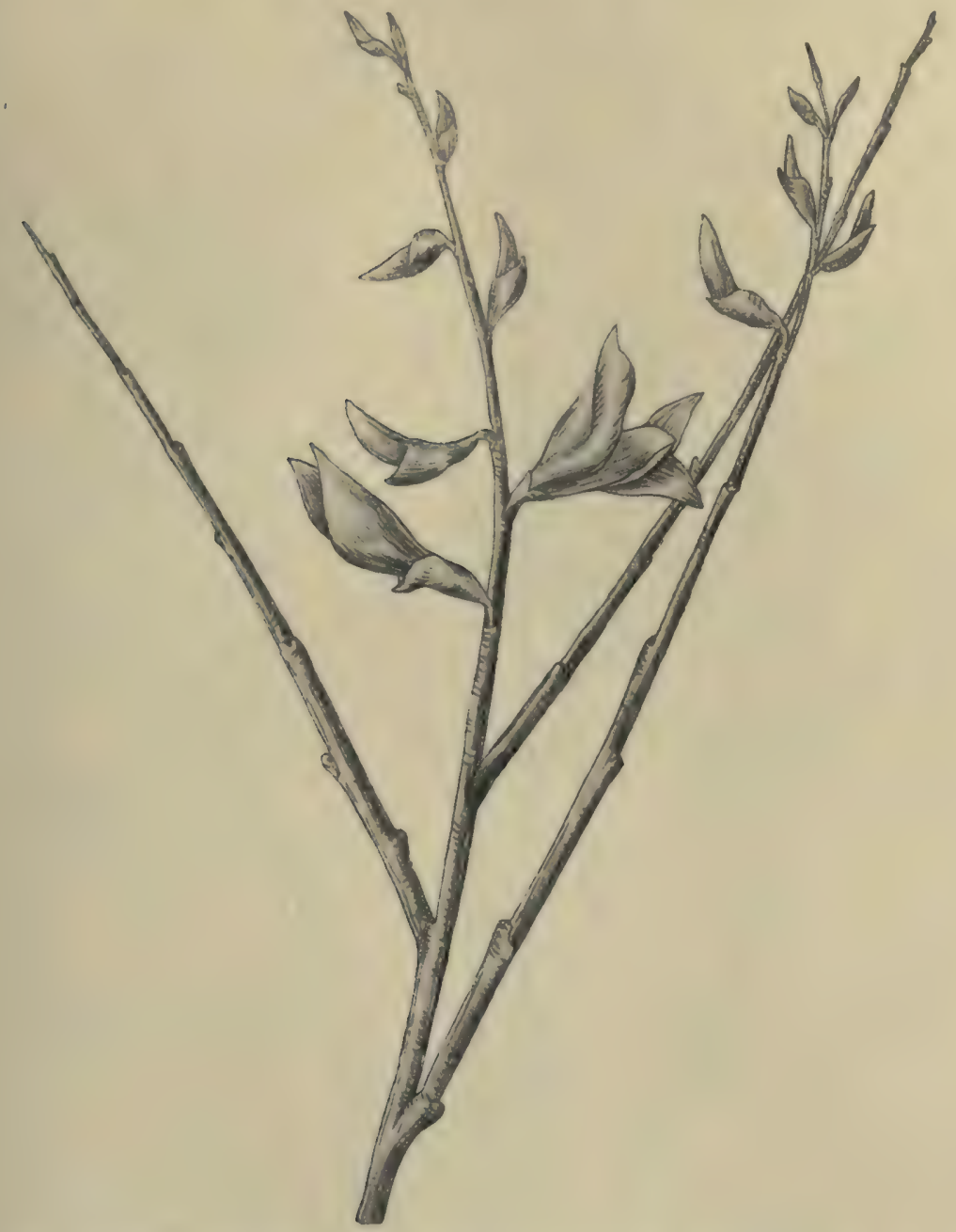

Fig. 110. Spartium junceum, blühender RutensproB. (E. Graebner; nach der Natur.)

1. Die geflügelten, oft blattlosen, oft blattähnlichen schon erwähnten Stengel. Sehr viele Pflanzen mit flachen oder geflügelten stengeln oder herablaufenden Blättern, z. B. Baccharis triptera in Brasilien (Fig. 108), Genista sagittalis, Muehlenbeckia platyclada (Fig. 109), Carmichaelia australis (Fig. 105), Colletia-Arten (Fig. 113) u. a. 
Diese Sproßformen sind gewöhnlich blattlos; der Stengel tritt an die Stelle der Laubblätter.

2. Der Rutensproß (die Spartiumform). Die Sprosse sind rutenförmig, aufrecht, schlank und oft sehr verzweigt; die Blätter sind bei

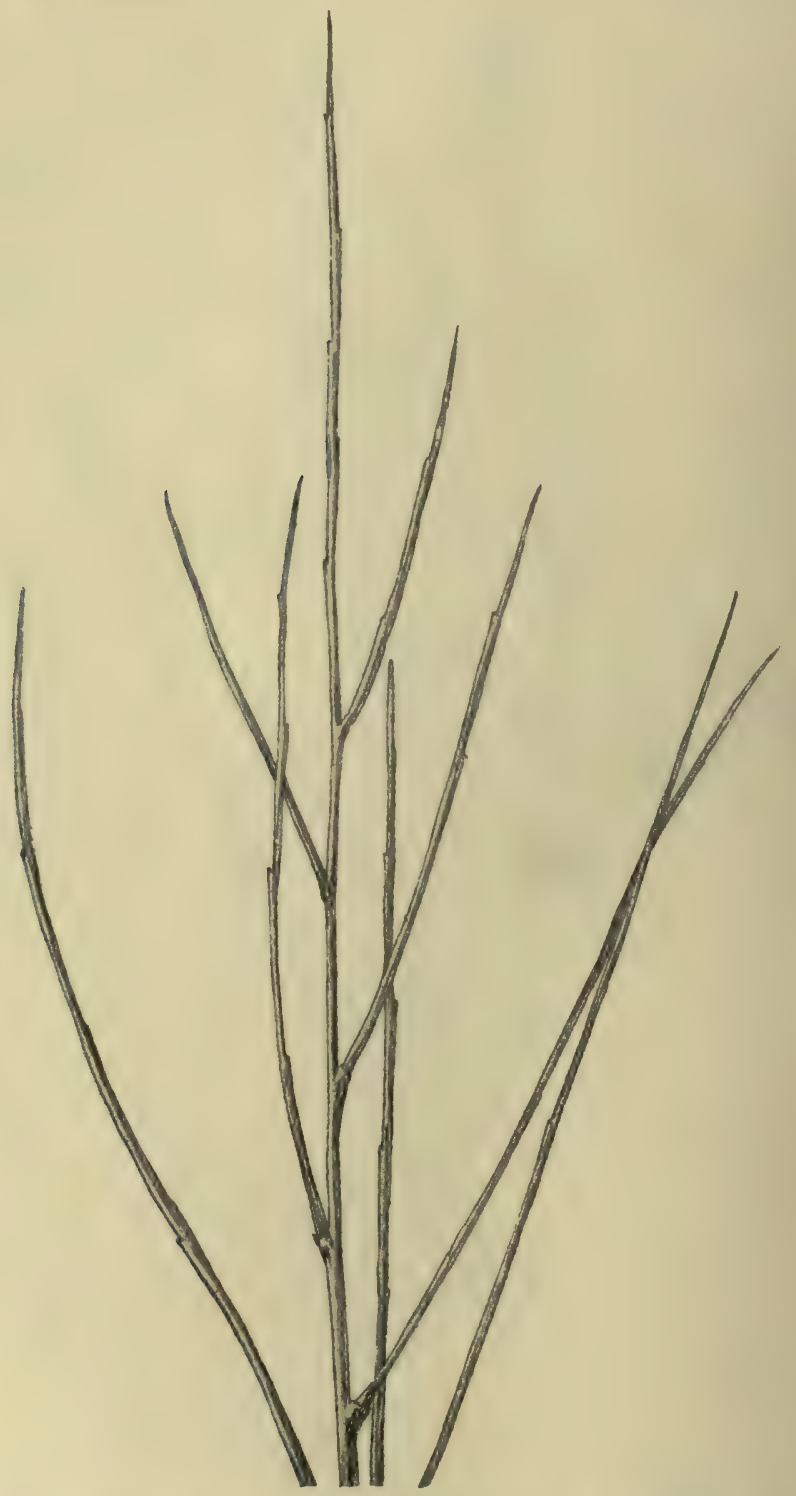

Fig. 111. Sproß von Sphaerolobium, typischer RutensproB. (E. Graebner; nach der Natur.) einigen Arten noch recht groß (z. B. bei Genista tinctoria, Spartium junceum), fallen aber meist bald ab, bei anderen haben sie von Anfang an eine sehr reduzierte Form und keine Funktion. Die Stengel sind 
durch viele Jahre grün, sind stielrund oder tief gefurcht mit Spaltöffnungen und Palisadengewebe in den Furchen, während die Rippen mechanisches Gewebe enthalten. Diese Form ist bei einem Teile der Legıminosen der Mittelmeerländer sehr verbreitet (besonders bei Genisteen; Arten von Genista, Retama, Cytisus), bei Casuarina, Ephedra, mehreren Chenopodiaceen, z. B. bei Anabasis (die jedoch zunächst zu den Halophyten gehört), bei Capparis aphylla, Periploca aphylla, Polygonum equisetiforme usw. ${ }^{1}$ ). Abbildungen vergl. Fig. 110, 111.

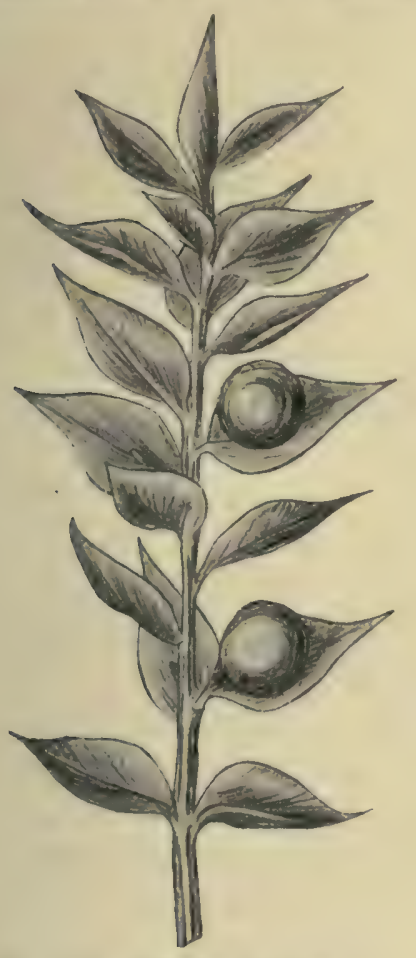

Fig. 112. Ruscus aculeatus, blattartiger Flachsproß.

(E. Graebner; nach der Natur.)

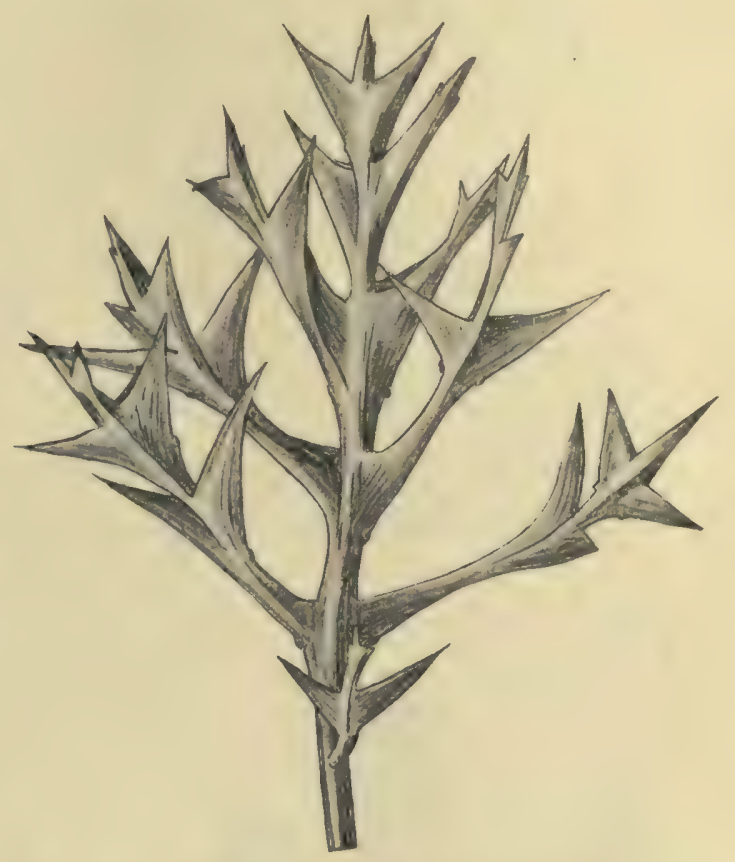

Fig. 113. Colletia, typischer Dornensproß. (E. Graebner; nach der Natur.)

- 3. Der juncoïde Sproß. Die bei vielen Juncus-Arten und Cyperaceen vorkommenden hohen, stielrunden, blattlosen und unverzweigten Sprosse (in der Form den Blättern eines Teiles derselben Arten ähnlich). Über das Verhältnis des Volumens zur Oberfläche gilt das oben Angeführte. Diese Sproßform findet sich auch bei sehr vielen Sumpfpflanzen derselben beiden Familien (Scirpus lacustris, Sc. palustris, bei den Junci genuini usw., wie früher angeführt). Hierher gehören z. B. auch Restionaceen, Irideen (Bobartia spathacea) und andere Pflanzen Südafrikas ${ }^{2}$ ).

$\left.{ }^{1}\right)$ Pick 1881; Volkens 1887; Schube 1885; Ross 1887; Nilsson 1887; Briquet; Schimper 1898.

9) Marloth 1908. 
4. Das nadelförmige Kladodium bei Asparagus steht der pinoïden Form am nächsten.

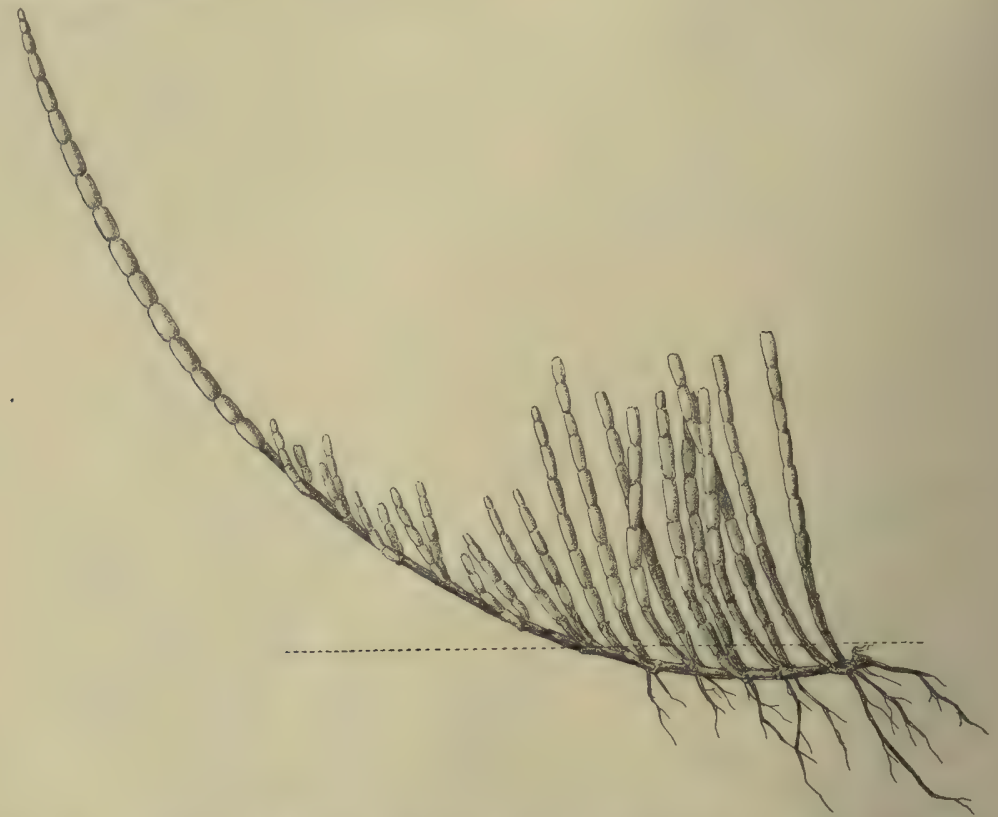

Fig. 114. Salicornia ambigua; Westindien. (Warming gez.; Börgesen 1909.)

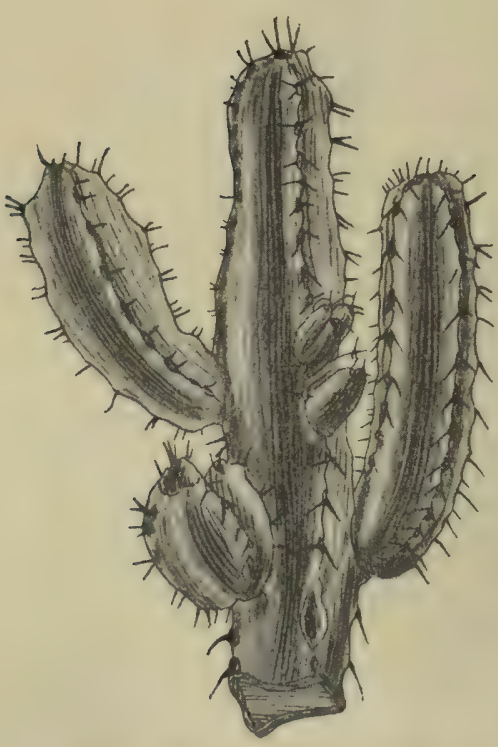

Fig. 115. Euphorbia resinifera. (Nach Engler.)
5. Der Flachsproß, eine blattlose, sehr flache Sproßform, die gewöhnlich senkrecht oder kantenständig ist, findet sich bei Muchlenbeckia platyclada (Coccoloba), Ruscus, Semele, Phyllocladus, Carmichaelia australis u.a. und wird wohl teilweise am besten mit dem sklerophyllen myrtoïden Typus vereinigt werden können (siehe S. 221; Fig. 102, S.222, Fig.103, S.222, Fig.105, S. 223, Fig.108, S.225, Fig.109, S. 226 f., Fig. 112, S. 229).

6. Der Dornensproß, wie er z.B. bei Colletia, Ulex u. a. ausgebildet ist (Fig. 113).

7. Der salicornoïde Sproß ist stielrund, fleischig, langgliederig, mit schuppenförmigen Blättern oder blattlos (Salicornia, Arthrocnemum und andere Chenopodiaceen, Fig. 114). 
8. Die Cacteenform, mit verschiedenen Unterformen, ist bei Cactaccen, Euphorbia, Stapelia usw. zu finden (vergl. S. 185). Sie wird unter den Saftpflanzen nochmals erwähnt werden. Vergl. Fig. 79, S. 187 and Fig. 115.

\section{Hemmung der Transpiration durch bedeckende Organe}

Fs ist klar, daß, wenn lufthaltige Teile, in und zwischen denen die Iuft sehr festgehalten wird, eine transpirierende Fläche bedecken, die 'Transpiration dadurch sehr wesentlich herabgesetzt werden kann. Dieses Mittel findet sich bei vielen Xerophyten auf mehrfache Art angewandt.

Haarbekleidung. Der Gegensatz zwischen Hydrophyten und Xerophyten tritt hier besonders deutlich hervor: jene sind sozusagen kahl, diese oft stark grau- oder weißfilzig und wollhaarig, oft silberglänzend (daher häufige Artnamen wie argentea, canescens, sericea, tomentosa u. a.); diese Farben werden durch die in und zwischen den Haaren eingeschlossene Luft hervorgerufen. Nur tote, mit Luft erfüllte Haare sind zu diesem Zwecke geeignet. Man weiß seit sehr langer Zeit, daß sonst kahle Arten auf trockenen Stellen behaart und behaarte hier stärker behaart werden, als auf feuchten (Ranunculus bulbosus, Polygonum persicaria, Mentha arvensis, Stachys palustris u. a.); die etiolierten Kartoffelsprosse sind in feuchter Luft fast kahl, in trockener behaart ${ }^{1}$ ). Marloth hat festgestellt,

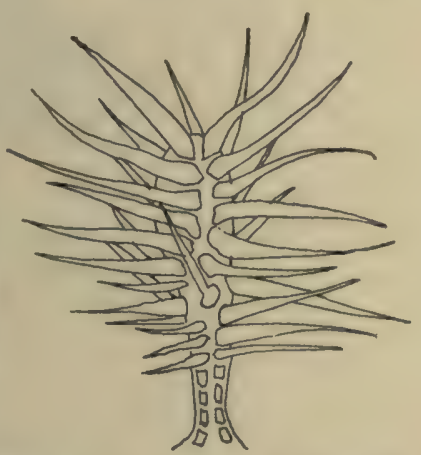

Fig. 116. Stachys Aegyptiaca, ein Haar der Blattfläche, $140: 1$.

(Nach Volkens.) daß viele Charaktere der südafrikanischen Wüstenpflanzen veränderliche Anpassungen sind, welche sich in der Kultur oder in einem minder sonnenreichen Kilima ändern. Von Abbildungen rgl. Fig. 20, 21, S. 38, 39; Fig. 116.

Zilhlreiche Pflanzen auf den Felsen des Mittelmeeres ${ }^{2}$ ) oder in den trockenen Gebüschen Westindiens, mannigfaltige Wüsten-, Steppen- und Hochgebirgspflanzen ${ }^{3}$ ) sind mit Wollhaaren bekleidet. Am stärksten filzig ist vielleicht die Komposite Espeletia auf den Hochgebirgen von Südamerika, bei der mehrere Filzschichten übereinander lagern ${ }^{4}$ ). Die Wolle ist ein Sonnenschirm, sie gleicht plötzliche T'emperaturschwankungen aus und setzt wie ein Stück Filz die Verdunstung herab. Eine besondere Form ist das s'childhaar, das den damit dicht bekleideten Pflanzen einen eigentümlichen silberglanz verleiht: bei Elaeagnaceen, Croton-Arten u. a.

1) Vesque u. Viet 1881.

7) Fur Corsica vergl. Rikli 1903.

э) Vergl. Lazniewski 1896; Goebel 1889-98, II.

4) Goobel 1889-98, II; vergl. die Abbildungen 20, 21, S. 38, 39. 
Die Haarbekleidung befindet sich fast immer auf der Unterseite, dort, wo die Spaltöffnungen liegen, ist sie am dichtesten. Junge Stengel und Blätter sind oft besonders dicht behaart, dichter als die älteren, im Einklange mit ihrem größeren Bedürfnis nach Schutz gegen starke Transpiration. Bisweilen sind die in den trockenen Gegenden der Tropenländer nach der trockenen Zeit zuerst entwickelten Blätter viel filziger und sehen ganz anders aus, als die später erscheinenden, größeren und mehr grünen ${ }^{1}$ ).

Nach Marloth ${ }^{2}$ ) sind die Haare des "Silberbaumes“ (Leucadendron) im Kaplande beweglich; bei genügender Wasserzufuhr stehen sie in einem Winkel von etwa $30^{\circ}$ von der Blattfläche $a b$, so daß die Luft leicht zu den Spaltöffnungen dringen kann, bei Wassermangel aber legen sie sich dicht übereinander und bilden dann einen äußerst wirksamen Verschluß.

Eine besondere Gruppe von Xerophyten, nämlich die Succulenten, haben aber keine Haarbekleidung, sie sind im allgemeinen ganz kahl (die meisten Cacteen, Aloe- und Agave-Arten u. a.).

Die Haarbildung ist wohl, wie alle anderen Mittel der Selbstregulierung der Pflanzen, eine direkte Anpassung ans Klima. Über die wirkenden Ursachen äußert Henslow ${ }^{3}$ ) im Anschluß an einen Gedanken von Mer die Meinung, daß Haare durch lokale Ernährung in Korrelation mit der Unterdrückung des Parenchyms erschienen; in demselben Verhältnis wie das Parenchym gehemmt werde, würden Haare zu dessen Kompensation ausgebildet. Hiermit sind wir jedoch im Verständnis der Korrelation zwischen Behaarung und Trockenheit nicht viel weiter gekommen, selbst wenn die Hypothese richtig sein sollte.

\section{Bedeckende Blätter.}

Alle jungen Sproßteile sind auf irgend eine Weise gegen starke Transpiration und starkes Licht geschützt, namentlich durch ältere Blätter, Nebenblätter, Knospenschuppen usw. $\left.{ }^{4}\right)$.

Zuerst mögen behandelt werden die Knospenschuppen, die wir typisch bei den laubwechselnden Bäumen der gemäßigten und der kalten Gegenden finden, die aber auch in den Tropen auftreten. Durch Verkorkung, Haarbildung, Harzbildung u. ähnl. werden sie für ihre Aufgabe ausgebildet, die noch in der Knospe ruhenden jungen Blätter gegen Transpiration, desgleichen die Knospen bei der Belaubung gegen Temperaturwechsel zu schützen ${ }^{5}$ ) (Fig. 117).

\footnotetext{
1) Schinz 1893 .

2) Marloth 1909 .

3) Henslow 1894, 1895.

7) Vergl. Percy Groom 1893; Raunkiär 1895-99.

5) Grüß 1892; Feist 1884; Cadura u. a.
} 
In manchen Klimaten sind Knospenschuppen selten oder jedenfalls äußerst klein, wie auch die Verjüngungsknospen selbst. Bei den Bäumen der tropischen Regenwälder und bei anderen Tropenbäumen sind äußerst selten schuppenbedeckte Knospen zu finden ${ }^{\mathbf{1}}$ ).

Selbst in Wüstengegenden, wie es z. B. "The Death Valley" in Nordanerika ist, sind Knospenschuppen selten. Coville ${ }^{2}$ ) schreibt: "Schuppige Knospen sind fast unbekannt bei den Wüstensträuchern". Dasselbe ist der Fall bei vielen Gehölzen in den Mittelmeerländern mit Winterregen und in tropischen Regenwäldern ${ }^{3}$ ).

Die jungen Knospenteile vieler xerophytischer Moose sind durch weiße Haare an den Spitzen der alten Blätter geschützt (Polytrichum piliferum u. a.).

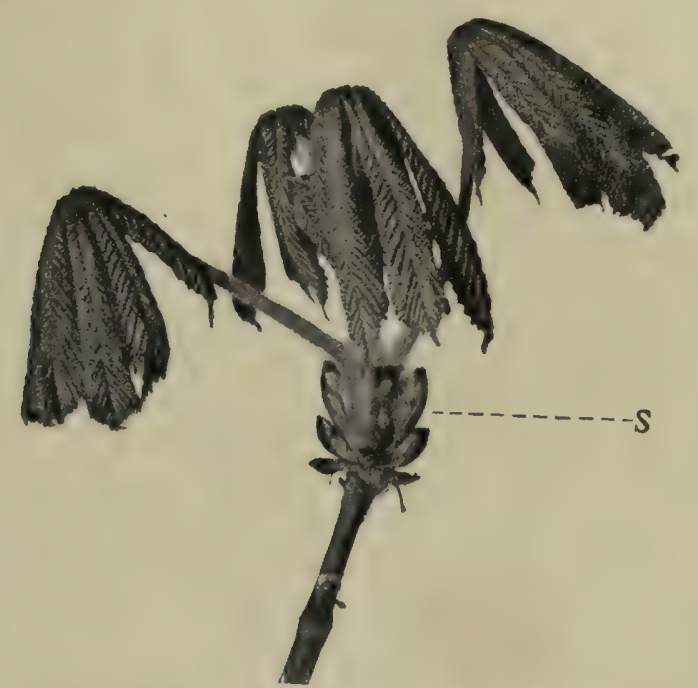

Fig. 117. Aesculus hippocastanum, Roßkastanie, junger SproB, am Grunde $(S)$ noch die bald abfallenden Knospenschuppen. (E. Warming phot.)

Nebenblätter, Blattscheiden (z. B. bei gewissen Dünengräsern) können denselben Dienst leisten, ohne Knospenschuppen im engeren Sinne genannt werden zu können ${ }^{4}$ ), desgleichen die häutigen Nebenblätter von Paronychia-Arten, Herniaria u. a., die die jungen Sproßteile mit einer dichten, silberglänzenden Decke bekleiden.

Alte Blätter und Blattreste leisten in vielen Fällen dieselben Dienste. Tunicagräser nennt Hackel solche Gräser, deren untere Blatteile nach dem Absterben der oberen sehr lange stehen bleiben,

1) Warming 1892, mit Abbildungen.

2) Coville 1893, S. 53.

\%) Schimper 1898, S. 329-351.

4) Vergl. Warming 1907-1909, Figuren. 
entweder als dicht und fest schließende Scheiden oder in ausgefaserter Form. Sie finden sich bei Dünen-, Steppen- und Wüstengräsern (z. B. bei

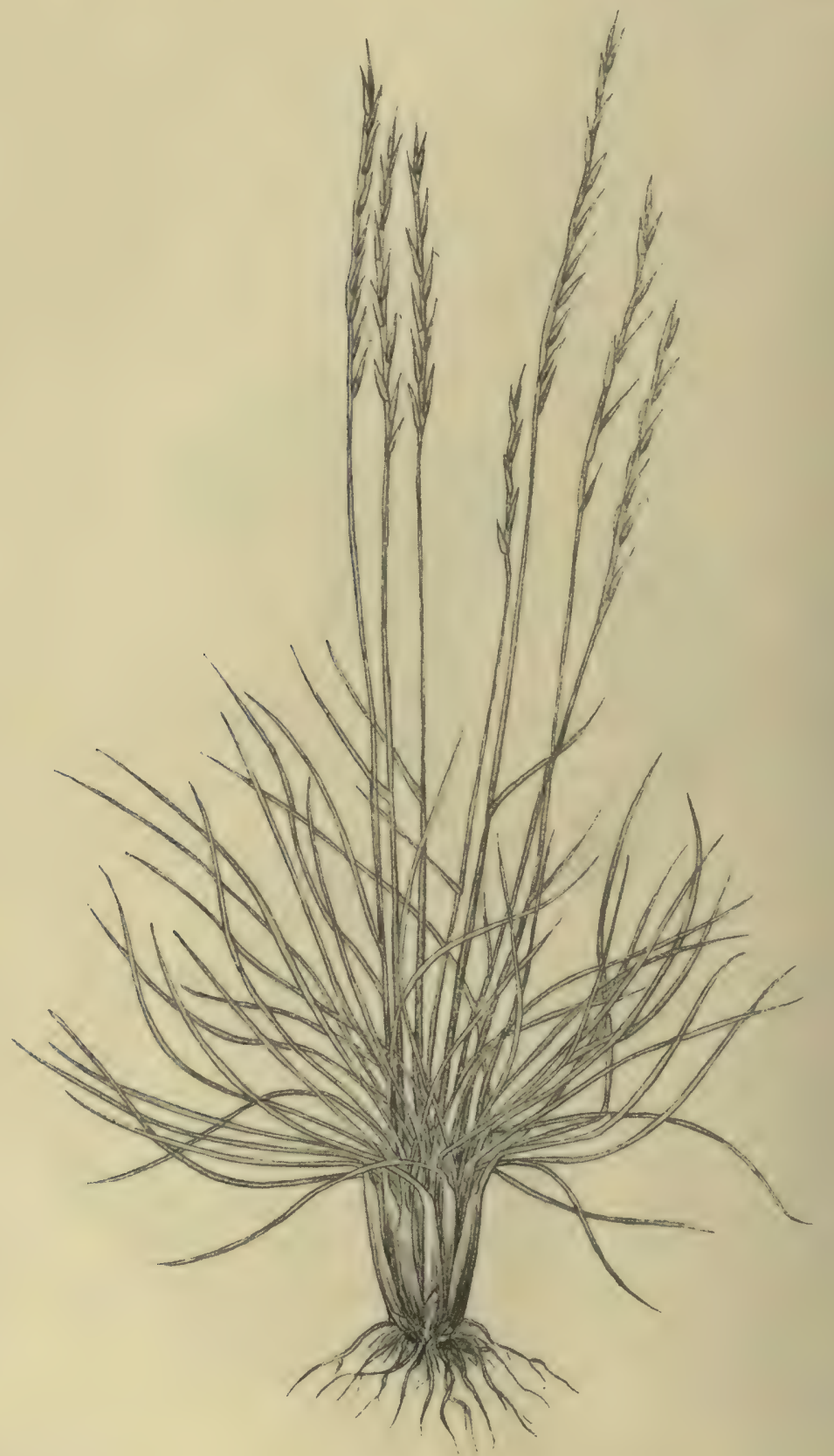

Fig. 118. Nardus stricta, ein Tunicagras; am Grunde die einhüllenden toten Blattscheiden. (E. Graebner; nach der Natur.) 
Nardus stricta, Andropogon villosus, Scirpus paradoxus, S. Warmingii, Aristida-Arten), setzen die Verdunstung herab und sammeln Wasser ${ }^{1}$ ). Dieselben Schutzeinrichtungen zeigen auch Velloziaceen der Berggipfel und der Hochebenen Brasiliens ${ }^{2}$ ). Vergl. die Fig. 82, S. 191 und 118 und 119.

Bei gewissen, besonders bei südafrikanischen Oxalis-Arten finden sich eigentümlich ausgebildete bedeckende Blätter um die Zwiebeln ${ }^{3}$ ); die abgestorbenen Zwiebelschuppen von Tulipa praecox tragen innen einen dichten Filz. Hier müssen auch die kompakten Rasen mit dicht zusammengedrängten Sprossen und Sproßresten der S. 182 erwähnten Polsterpflanzen genannt werden, die sich in der subglazialen, besonders in der südamerikanischen Vegetation allgemein finden, und die oft so hart sind, daß man sie kaum entzweischneiden oder -schlagen kann; hier schützt ein Sproß den anderen, die alten Teile schützen die jungen ${ }^{4}$ ). Vergl. Fig. 75, S. 183.

Die Wurzeln mancher Epiphyten werden gegen zu starke Verdunstung durch die Blätter geschützt, die sich dicht über sie hinlegen und die feuchte Luft um sie festhalten, z. B. bei Conchophyllum imbricatum $^{5}$ ). Die Wurzeln eines Teiles der ägyptischen Wüstengräser (der Gattungen Aristida, Andropogon, Elionurus,

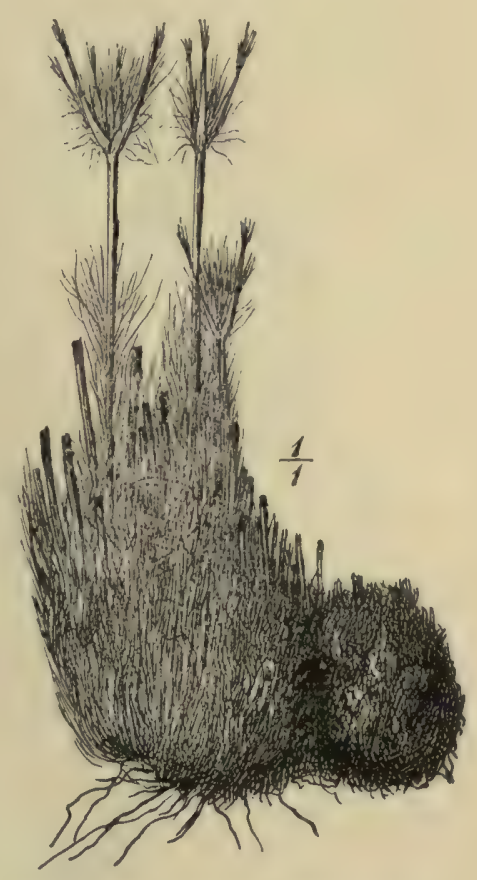

Fig. 119. Scirpus Warmingii von. einem kürzlich abgebrannten Campo bei Lagoa Santa in Brasilien; 1. Juni. Nene Blütenstände sprossen hervor. (Warming 1892.) Panicum, Sporobolus) sind in ihrer ganzen Länge mit Sandhüllen umgeben, die dadurch entstanden sind, daß die Sandkörner durch einen von den Wurzelhaaren ausgeschiedenen Klebstoff verkittet wurden ${ }^{6}$ ). Volkens faßt dieses als Verdunstungsschutz auf ${ }^{7}$ ).

1) Hackel 1890; vergl. auch Warming 1892, Figuren; Henslow 1894.

2) Warming 1893 .

3) Hildebrand 1884 .

4) Vergl. auch Lubbock 1899.

5) Goebel 1899.

6) Über ähnliche Vorkommnisse bei Dünengräsern vergl. Warming 1907-1909.

.7) Volkens 1887. 


\section{Kap. Regulierung der Beleuchtung}

Licht wirkt erwärmend auf die Pflanze und ruft dadurch Verdunstung hervor; wenn es zu stark wird, kann es das Chlorophyll zerstören. Viele Landpflanzen haben daher Einrichtungen, durch welche sie sich vor zu starker Beleuchtung schützen können (vergl. auch Kap. 2). Die Einrichtungen sind vorübergehend oder dauerhaft.

\section{A. Bewegungen, wodurch die Beleuchtung reguliert wird}

Viele Pflanzen haben eine äußerst feine Empfindung für die Stärke des Lichtes und können mit ihren Blättern oder Blättchen Bewegungen ausführen, durch die sie die Beleuchtung regulieren, indem sie für jeden
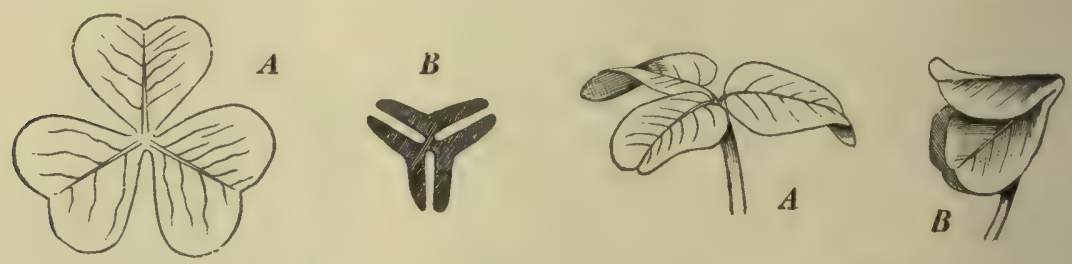

I

II

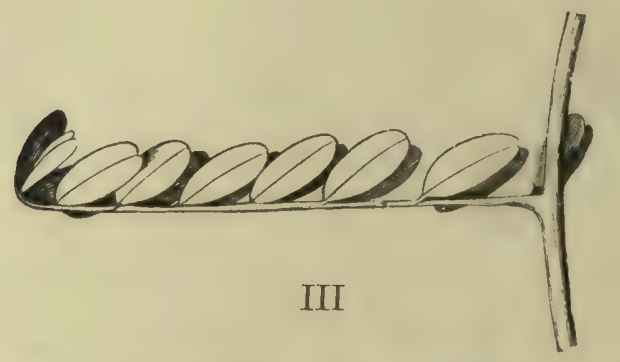

Fig. 120. I. Blätter von Oxalis acetosella, $A$ in Tagstellung bei mattem Lichte, von oben gesehen, $B$ Nachtstellung, ebenfalls von oben; II. Blätter von Trifolium repens, $A$ in Tag-, $B$ in Nachtstellung, das mittlere Blättchen schließt sich zur Deckung der Seitenblätter über diesen zusammen; III. Blatt von Coronilla rosea in Nachtstellung, die Fiederblättchen nach oben gerichtet. (Nach Darwin.)

Lichtgrad einen bestimmten Winkel der Blattspreite mit den einfallenden Strahlen bilden; bei matter Beleuchtung (z. B. in den Morgenstunden, bei bedecktem Himmel oder im Innern eines Waldes) werden die Spreiten möglichst dem Lichte voll ausgesetzt, so daß sie von den Lichtstrahlen unter rechten Winkeln getroffen werden (Flächenstellung); aber je nachdem das Licht stärker wird, stellen sich die Spreiten so, daß sie unter immer spitzeren Winkeln getroffen werden (Profilstellung). Dadurch werden sie relativ weniger beleuchtet und erwärmt, und die Transpiration wird dadurch auch herabgesetzt. Hier- 
her gehören sehr viele Pflanzen mit zusammengesetzten Blättern, besonders aus den tropischen, trockenen Gebüschen, z. B. viele Acacia-Arten

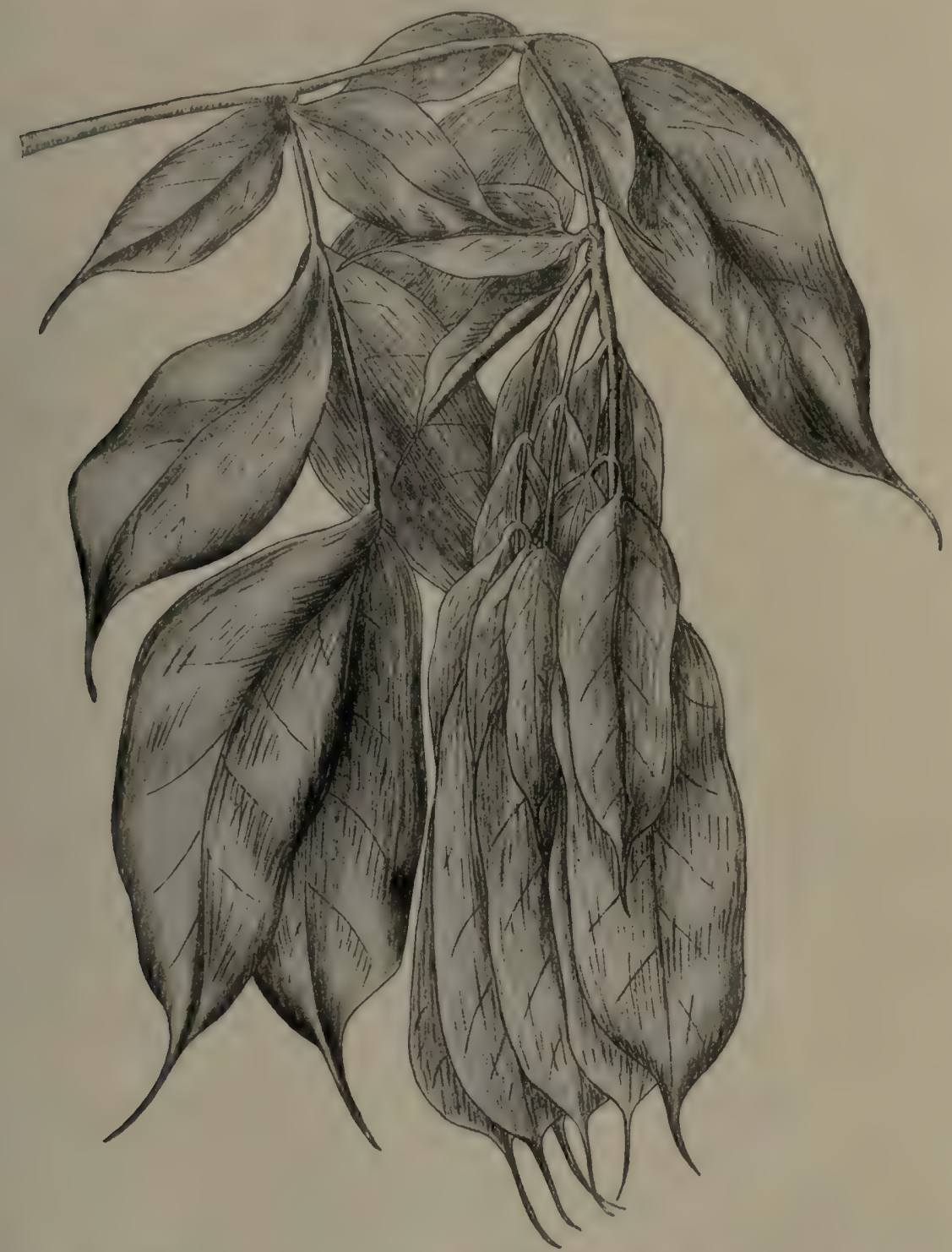

Fig. 121. Junger Trieb von Brownea coccinea; die Blätter hängen wie der Stengel schlaff senkrecht abwärts und decken sich gegenseitig. Die jungen wie auch die älteren haben sehr ausgeprägte Träufelspitzen (vergl. S. 57, Fig. 32); verkleinert.

(E. Graebner; nach der Natur.)

und andere Mimosoideen, viele Papilionaceen, Oxalidaceen (unter anderem Oxalis acetosella), Zygophyllaceen; auch bei Pflanzen mit einfachen Blättern, z. B. bei Hura crepitans, finden sich von der Lichtstärke 
abhängige Bewegungserscheinungen ${ }^{1}$ ). Bei den erwähnten Pflanzen pflegen die Blätter ebenfalls nicht xeromorph gebaut zu sein. Die Blätter z. B. von westindischen Leguminosen mit der Fähigkeit, sich nach der Lichtstärke $\mathrm{zu}$ bewegen, sind oft (immer?) dünn und haben eine kahle und dünne Epidermis ${ }^{2}$ ). Abbildungen vergl. Fig. 120.

Die sich eben aus der Knospe entwickelnden Blätter sind oft senkrecht gestellt, oder bei einigen tropischen Pflanzen hängen sie senkrecht herab; Fig. 121. (Vergl. auch bei Wirkung der Platzregen usw. Kap. 4, S. 53).

\section{B. Fixierte Lichtstellung}

Bei der Entfaltung aus der Knospenlage usw. führen alle Blätter zunächst Bewegungen aus (durch das Wachstum bedingt) und nehmen zuletzt, wenn ihre Wachstumsfähigkeit aufhört, eine für sie günstige feste Lage an; Wiesner ${ }^{3}$ ) hat während vieler Jahre umfangreiche Untersuchungen über diese Dinge angestellt. Die meisten Blüten stellen schließlich ihre Blätter senkrecht zum stärksten zerstreuten Licht; sobald aber das intensive direkte Licht, welches zu stark ist, wirkt, nehmen sie möglichst Profilstellung ein. - Eine Verminderung der Wirkung des Sonnenlichtes und damit zugleich eine verminderte Transpiration werden auch durch dauernde Profilstellung oder ähnliche Stellungen der assimilierenden Flächen hervorgerufen, so daß das starke Licht (besonders der Mittagssonne) sie mitten am Tage unter spitzen Winkeln trifft. Dies ist z. B. der Fall bei den sogenannten Kompaßpflanzen, zu welchen in unserer nordeuropäischen Flora Lactuca scariola gehört, dessen Blätter sich an stark von der Sonne beleuchteten Orten streng nordsüdlich aufrecht stellen ${ }^{4}$ ), werden sie dagegen seitlich durch Bäume, Mauern usw. morgens oder abends beschattet, weicht ihre feste Lage je nach der Stärke der Beschattung von der Mittagslinie ab. Von anderen Kompaßpflanzen sei namentlich Silphium laciniatum (Nordamerika) genannt. Vergl. Fig. 8, 9.

Nach Marloth ${ }^{5}$ ) sind solche in die Mittagslinie eingestellte Blätter in der Kapflora häufig; es gibt kaum eine Familie, von der nicht der eine oder andere Vertreter diese Einrichtung besäße, soweit die Blätter groß genug sind, selbst Crassula falcata zeigt diese Einrichtung. Durch Versuche fand er, daß diese Pflanze immer ihre Blätter in die Meridianlinie stellt.

1) Vergl. C. Darwin 1880.

๖) Warming $1899 \mathrm{~b}$.

s) Wiesner 1876 usw.; vergl. S. 12, Fußnote und 1908, 1909.

4) Stahl 1880, 1881 .

5) Marloth 1908 
Kantenständige Blätter haben viele andere Arten, wie mehrere australischen Eucalyptus-Arten, Acacia-Arten und Proteaceen, Laguncularia racemosa u. a. in Westindien, Bupleurum verticale (Spanien), südafrikanische Statice-Arten usw.

Senkrecht oder steil und steif aufwärts gerichtete Blattspreiten sind bei Xerophyten häufig, die in starkem Sonnenlichte wachsen, z. B. bei Coccoloba uvifera ${ }^{1}$ ) (Westindien), Fig. 8, S. 23, vielen Gräsern (Brachypodium ramosum, Festuca ovina u. a.), Calluna, Peucedanum cervaria ${ }^{2}$ ), Helichrysum arenarium u. a. Seltener sind senkrecht hinabhängende Blattspreiten. Die Flachsprosse, Rutensprosse usw. (S. 227-229) schließen sich hier eng an.

Runzeln und Falten der Blattspreiten wirken vielleicht ähnlich und sind desto häufiger, je trockener das Klima ist, z. B. bei der neuseeländischen Myrtus bullata, in Westindien bei Lippia involucrata,

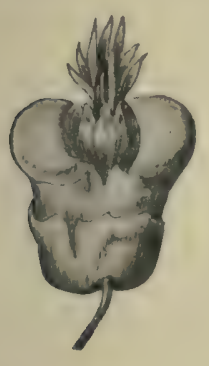

A.

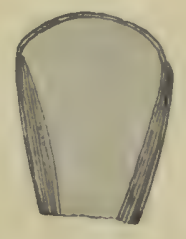

B.

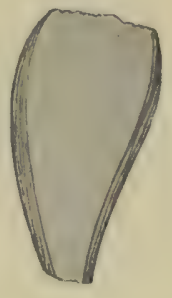

D.

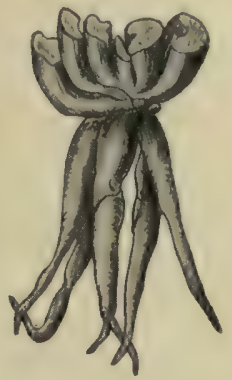

C.

Fig. 122. Fensterblätter. A. Mesembrianthemum opticum, blühend, $1 / 1$; B. Längsschnitt durch ein Blatt. C. Haworthia truncata, D. Längssehnitt durch ein Blatt.

(Nach Marloth.)

Plumeria alba u. a. ${ }^{3}$ ), in der ägyptischen Wüste bei Salvia und Stachys Aegyptiaca, Pulicaria und Urginea undulata u. a. ${ }^{4}$ ), bei uns z. B. bei Vicia cracea $^{5}$ ).

Da diese Stellungsverhältnisse in der Regel erst während der Entwicklung des Individuums durch Drehungen, Krümmungen usw. erreicht werden, so werden sich die Blätter gewiß bei allen Arten der genannten Pflanzenformen nach der Natur des Standortes verschieden stellen. Der Sonne, der Trockenheit und dem Winde ausgesetzt, sind die Blätter weit mehr aufwärts gerichtet, kantenständig oder gekräuselt usw., als im Schatten und in feuchter Umgebung, namentlich in feuchter Luft; dieses zeigen z. B. Calluna, Juniperus communis, Lycopodium selago und $L$.

1) Abbildungen bei Börgesen und O. Paulsen 1900.

2) Nach Altenkirch 1894.

5) Johow 1884.

4) Volkens 1887.

5) Warming. 
alpinum $^{1}$ ). Bei Tilia argentea stehen die der heißen Sonne ausgesetzten Blätter in Profilstellung, die übrigen in Flächenstellung ${ }^{2}$ ).

In der Anlage angeborene Profilstellung haben weiter folgende Pflanzen: die mit Phyllodien (blattförmigen, aber senkrecht gestellten Blattstielen ohne Blattspreite) ausgestatteten australischen Acacien. Hierher gehört ferner das schwertförmige Blatt bei Iridaceen, Tofieldia und Narthecium. Vergl. Fig. 104, S. 223.

Hier müssen auch die Fensterblätter Marloths ${ }^{3}$ ) erwähnt werden; dies sind Blätter von Mesembrianthemum-Arten usw., wie sie in Südafrika vorkommen; sie sind mehr oder weniger zylindrisch oder kreiselförmig, sind in der Erde versteckt, so daß nur ihr stumpfes oder ganz flaches oberes Ende sichtbar ist. In diesem der Sonne ausgesetzten Teile fehlt das Chlorophyll; hier tritt das Licht in das Blatt ein und beleuchtet das an den im Boden versteckten Seiten des Blattes angebrachte Chlorophyllgewebe (Fig. 122).

\section{Kap. Ableitung von Regen}

Oft ist es von Wichtigkeit für die Landpflanzen, daß ihre Blätter nicht zu lange von Regenwasser benetzt bleiben; besonders an feuchten Orten; in regnerischen Gebieten ist es notwendig; daß die Oberflächen schnell abtrocknen, damit die Verdunstung nicht gehemmt wird. (Über ombrophobe und ombrophile Pflanzen vergl. S. 56.)

Besonders in den tropischen Regenwäldern kann es gefährlich werden, wenn die Blätter zu lange zu naß und dadurch auch schwer sind. Es wird nicht nur die Verdunstung eingeschränkt, sondern epiphytische Algen, Flechten, Pilze, Lebermoose, ja sogar (nach Haberlandt) Bakterien siedeln sich auf den Blättern an und hindern die Kohlensäureassimilation (Fig. 123). In der Tat findet man oft die älteren Blätter vieler immergrünen Bäume in den feuchten tropischen Wäldern mit einer Masse epiphyller Arten überdeckt (Kap. 35). Es wird also sicher für die Pflanzen im Regenwalde von Vorteil sein, wenn ihre Blätter schnell trocknen können. Nach Jungner und Stahl ${ }^{4}$ ), die in der Hauptsache gleichzeitig zu denselben Ergebnissen gekommen sind, der erste in Kamerun, der andere auf Java, wird dieses durch verschiedene Mittel erreicht, namentlich durch folgende:

1. Eine glatte Cuticula, die sich nicht benetzen läßt; dieses Mittel ist sehr verbreitet.

$\left.{ }^{1}\right)$ Figuren bei Warming 1887.

2) Kerner 1887-1891.

3) Marloth 1909.

4) Jungner 1891 (Kamerun); Stahl 1893 (Java). 
2. Träufelspitzen. So nennt Stahl die langen, oft von plötzlich verschmälerten Spreiten ausgehenden Spitzen, die typisch bei Ficus religiosa u. a. vorkommen, aber auch bei den verschiedensten Pflanzen (Farnen, Monokotylen und Dikotylen) und sowohl bei einfachen als auch bei zusammengesetzten Blättern auftreten und dazu dienen, den Regen von solchen Blättern, die sich leicht benetzen lassen, schnell abzuleiten. Sie sind natïrlich abwärts gewandt; je länger und je schärfer die Spitze ist, desto schneller trocknet das Blatt. Die säbelförmige Spitze leitet das Wasser am besten ab, bisweilen in einem fast zusammenhängenden Strahle. Träufelspitzen findet man nie bei Blättern, deren Oberfläche

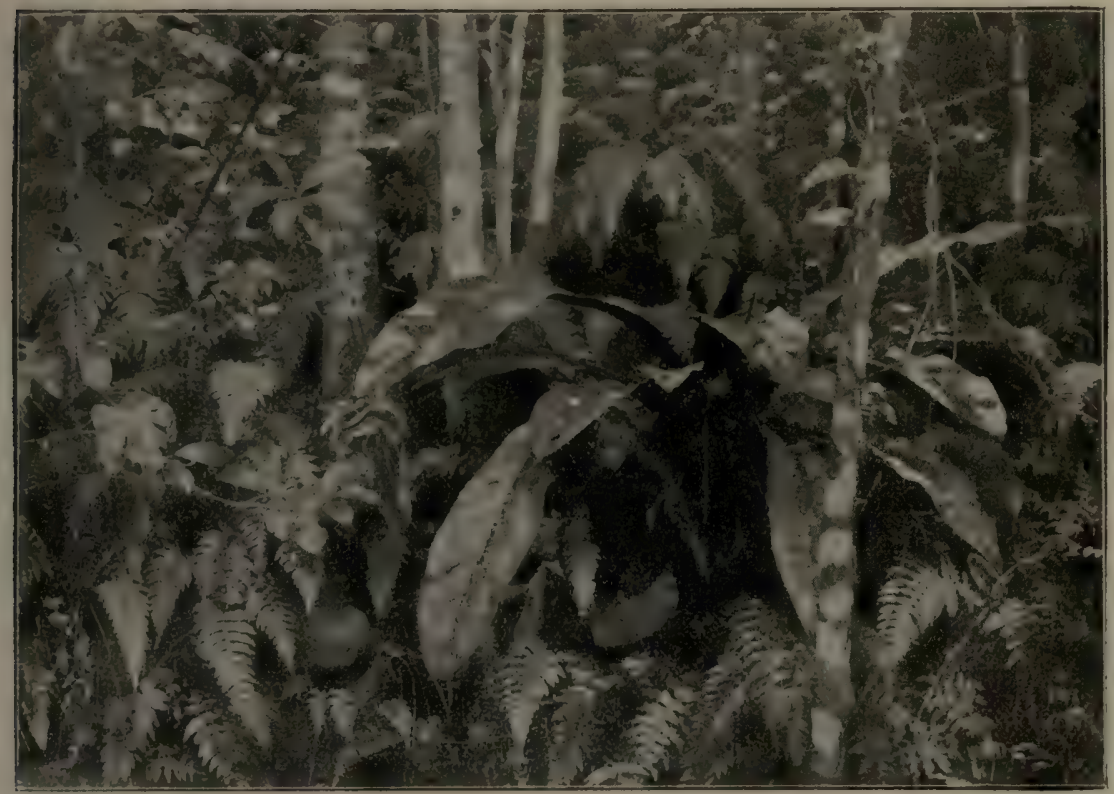

Fig. 123. Anthurium Huegelii mit epiphyllen Flechten, und Blechnum occidentale als Bodenvegetation in Gebüschwäldern. St. Thomas, Dänisch-Westindien.

(Phot. Börgesen.)

nicht oder schwer benetzt werden kann, und gar nicht bei Xerophyten. Vergl. Fig. 32, S. 57; Fig. 57, S. 163; Fig. 121, S. 237.

3. Ferner kommen oft vertiefte Nerven vor, die das Wasser gegen die Blattspitze hinleiten. Der bogenförmige Verlauf der Nerven bei den Melastomataceen u. a. ist gleichfalls für die Wasserableitung vorteilhaft.

4. Sammetblätter beobachtet man namentlich bei krautartigen Pflanzen des Waldbodens und bei Arten der unteren Stockwerke des Waldes, wo es am meisten Schatten und Feuchtigkeit gibt. Die Zellen der Epidermis erheben sich in der Form zahlloser, niedriger Papillen, die dem Blatte einen besonderen Sammetglanz verleihen und zwischen 
denen sich das Wasser infolge der Kapillarität schnell über die ganze Blattspreite zu einer sehr dünnen Schicht ausbreitet; dadurch wird erreicht, daß das Wasser schneller verdunsten kann, als wenn es nicht so ausgebreitet worden wäre. Übrigens ist über diese Papillen auch die Meinung aufgestellt worden, daß sie dazu dienten, dem Blatte mehr Licht zukommen zu lassen ${ }^{1}$ ). Viele Sammetblätter, vielleicht die sehr überwiegende Zahl derselben, sind nicht benetzbar und lassen das Regenwasser in Tropfen abrollen.

\section{Kap. Wasseraufnahme bei Landpflanzen}

Untergetauchte Wasserpflanzen haben in ihrer überwiegenden Mehrheit keine Organe, die dazu eingerichtet wären, Wasser zu absorbieren; das Gegenteil ist der Fall bei den Landpflanzen, deren Einrichtungen in den folgenden Abschnitten besprochen werden sollen.

\section{Unterirdische Organe, die Wasser aufnehmen}

Unterirdische Organe, wie Wurzeln, Rhizoiden, Mycelien usw., sind zur Wasseraufnahme bestimmt; ebenso haben einige Grundachsen wasseraufsaugende Haare, so z. B. die von Coralliorrhiza, Epipogon, Equisetum, Psilotum und von Hymenophyllaceen. Bei xerophilen Pflanzen finden sich nur wenige Abweichungen von der typischen Wurzelausbildung ${ }^{2}$ ).

Zunächst sei erwähnt, daß viele Xerophyten sehr tiefgehende Wurzeln haben, die sie in trockenen Zeiten bei dem Heranschaffen des Wassers aus großen Tiefen unterstïtzen werden. Man hat dieses in den Wüsten von Afghanistan (bei Astragalus-Arten) ${ }^{3}$ ) beobachtet, ferner in der ägyptischen Wüste (z. B. bei Koloquinte, Calligonum comosum, Monsonia nivea); Volkens ${ }^{4}$ ) fand hier Wurzeln, die 20 mal länger als die oberirdischen Organe waren. Aristida pungens hat bis $20 \mathrm{~m}$ lange, verholzende Wurzeln ${ }^{5}$ ). Ähnliches ist von unseren Dünen bekannt, z. B. bei Eryngium maritimum (Blytt) und bei Carex arenaria; diese hat zwei Arten von Wurzeln: sehr feine, verzweigte, oberflächlich liegende und sehr tiefgehende, weniger verzweigte ${ }^{6}$ ). Eben dasselbe ist bei Mesembrianthemum-Arten in Südafrika beobachtet worden ${ }^{7}$ ). Prosopis juliflorus in den nordamerikanischen Wüsten hat bis $15,8 \mathrm{~m}$ lange

1) Vergl. Haberlandt 1905, und Fig. 14, S. 27.

$\left.{ }^{2}\right)$ Uber die Wasserversorgung der Landpflanzen vergl. auch die neueren Arbeiten von Kearney, Shantz und Briggs 1911-1913.

э) Aitchison 1887.

4) Volkens 1887.

s) Price.

-) Buchenau; Warming 1891, 1907-1909, mit Figuren.

7) Marloth 1908. 
Wurzeln ${ }^{1}$ ); Welwitschia muß ungehener lange Wurzeln haben. Ein besonders kräftiges Wurzelsystem haben einige Pflanzen des HereroLandes, die das Wasser aus dem tief liegenden Grundwasser emporheben müssen; Beispiel Acanthosicyos ${ }^{2}$ ). Die hohen Stauden der ungarischen steppen wurzeln ungeheuer tief, und selbst auf den sonnigen Hügeln Mitteldeutschlands und des norddeutschen Flachlandes kann man bis üher $3 \mathrm{~m}$ in die Tiefe gehende Pfahlwurzeln beobachten, die bis zu dieser Tiefe wenig Verzweigung zeigen (Astragalus exscapus, Falcaria sioides).

Eine eigentümliche Einrichtung zur Wasseraufnahme findet sich hei dem nordafrikanischen Halfagrase (Stupa tenacissima); dieses hat auf dem Rhizom eigentümlich gebaute Epidermiszellen, deren Aufgabe es ist, Wasser aufzusaugen ${ }^{3}$ ).

Diplotaxis harra und Euphorbia cornuta in Nordafrika haben horizontale, recht oberflächlich liegende Wurzeln, welche die nächtliche Taubildung ausnützen können.

\section{Oberirdische Mittel zur Wasseraufnahme}

Selbstverständlich muß es für viele in extremer Trockenheit lebende Xerophyten von großer Wichtigkeit sein, den Augenblick ausnutzen zu können, an dem sich Wasser vielleicht nur für kurze Zeit darbietet, und man kann von vornherein erwarten, daß besondere Mittel, die einer schnellen Wasseraufnahme dienen sollen, vorkommen. Dieses ist auch an verschiedenen oberirdischen Teilen der Fall. Es kommt hierbei teils auf die Fähigkeiten der Zellwände, teils auf solche des Zellinhaltes, Wasser aufzunehmen, an. Zunächst sei erwähnt, daß Pflanzen wie Flechten und Moose ${ }^{4}$ ) und viele Algen langes Austrocknen vertragen können (vergl. S. 48, 156, 158). Sie können, wie vielleicht gewisse andere Pflanzen, aus dem Wasserdampfe der Luft Feuchtigkeit aufnehmen; außerdem ist ihre ganze Oberfläche noch imstande, tropfbares Wasser augenblicklich aufzusaugen. Wenn die Pflanzen pulvertrocken und spröde sind, können sie in wenigen Augenblicken weich und wasserreich werden (s. die soeben genannten Seiten).

Die Wassermengen, welche die gewöhnlichen phanerogamen Landpflanzen durch ihre oberirdischen Organe aufzunehmen vermögen, sind im allgemeinen unzureichend, um den Transpirationsverlust zu decken ${ }^{5}$ ). Ausnahmen kommen besonders bei gewissen Xerophyten vor; bei ihnen sind besondere Organe zur Aufnahme von Regen und Tau bekannt.

1) Coville 1893.

2) Schinz 1893.

3rabut 1888 .

4) Utber die Sphagnum-Arten vergl. Hochmoore (4. Abschnitt, 85. Kap.).

7) Ganong 1894; Wille 1887; Kny 1895, vergl. auch Kap. 4. 
Schon das Zuckerrohr z. B. hat nach Janse eine außerordentliche Fähigkeit, durch die Blätter, welche „komplizierte Regenwasserbehälter“ bilden, Wasser aufzunehmen.

Andere Einrichtungen sind folgende:

Wasseraufsaugende Haare haben Volkens und Marloth ${ }^{\mathbf{1}}$ ) bei gewissen Wüstenpflanzen nachgewiesen: bei Diplotaxis harra, Stachys Aegyptiaca, Convolvulus lanatus, Mesembrianthemum, Crassula usw. Schimper ${ }^{2}$ ) sah ähnliche bei gewissen Epiphyten: bei Tillandsia usneoides, Vriesea und anderen Bromeliaceen. Diese Haare sind tot, ohne Turgeszenz, nur am Grunde enthalten sie Protoplasma, hier sind sie auch nicht cuticularisiert, und an dieser Stelle findet die Wasseraufnahme statt (vergl. S. 52, 55; Fig. 28, 29, 30, 31).

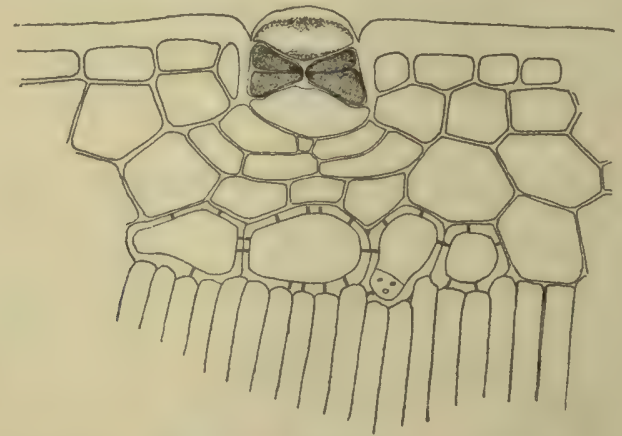

Fig. 124. Salzausscheidende Drüse von Aegiceras corniculata (Siam). Das Hypoderm hat 2-3 Zellschichten; darunter folgt das Palisadengewebe. Die Drüse ist hauptsächlich von einem Kranze von schmalen Zellen gebildet. (Johs. Schmidt, 1905.)

Auch $\mathrm{Mez}^{3}$ ) fand, daß einige Bromeliaceen darauf angepaßt sind, Regen, andere (z. B. Tillandsia usneoides) besonders Tau aufzunehmen. Die vielen feinen Haare der Cacteen sollen gleichfalls hierzu dienen ${ }^{4}$ ). (Über angeblich Wasser saugende Haare in unseren Klimaten vergl. Lundström, Wille, Henslow) ${ }^{4}$ ).

Haberlandt fand durch Versuche, daß mehrere der Seite 211 genannten Hydathoden imstande waren, Farbstofflösungen aufzunehmen, und schloß daraus, daß sie auch dazu dienen, Wasser aufzunehmen und der Pflanze zuzuführen. Dieses wird in den Tropen wohl nur an einem bestimmten Zeitpunkte des Tages stattfinden können, nämlich wenn die ersten Regengüsse fallen, einige Stunden nach 12 Uhr mittags; wenn die

3) Volkens 1887; Marloth, Tr. R. S. South. Afr. 1910.

2) Schimper 1884.

3) Mez 1904 a.

*) Utber Haarbildungen, die als wasseraufsaugende Organe besonders an Pflanz'n der gemäßigten Zonen gedeutet sind, vergl. bes. Lundström 1884; Wille 1887; Henslow 1894. Uber Hydathoden siehe Haberlandt 1904 und S. 211. 
Pflanze zu stark transpiriert hat, werden sie ihr dann helfen können, schnell ihren Torgor wiederzuerhalten. Die Hydathoden würden hiernach als Regulatoren für die Wasserversorgung der Pflanzen sein, das überfluissige Wasser entfernen und Wasser aufnehmen, wenn ein dringendes Bedürfnis hiernach vorliegt.

Als ein anderes Mittel werden Salzdrüsen angeführt, eigentümliche von Volkens ${ }^{1}$ ) entdeckte Drüsenhaare auf den Blättern mehrerer Wüstenpflanzen (z. B. bei Reaumuria hirtella, Tamarix, Cressa Cretica, Frankenia pulverulenta, Statice aphylla u. a.). Diese Drüsen scheiden Lösungen hygroskopischer Salze aus (Chloride von Natrium, Calcium

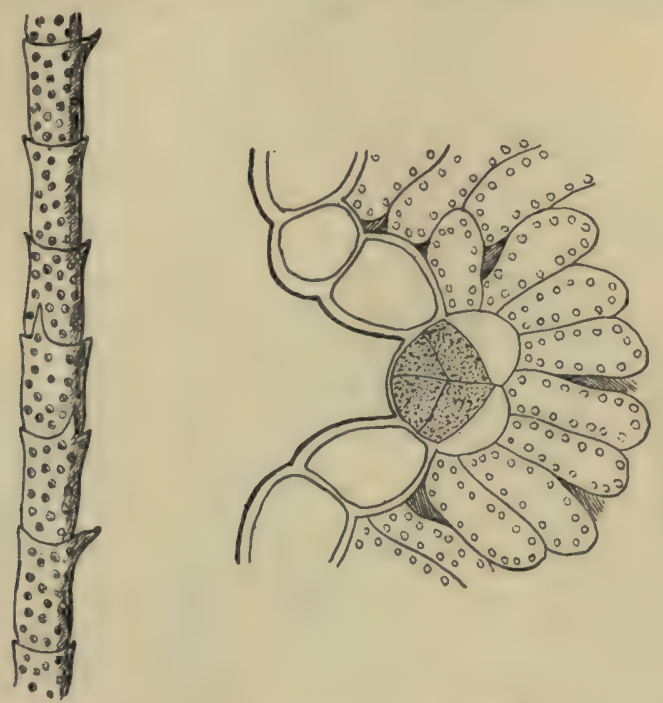

Fig. 125. Tamarix mannifera, links $\mathrm{Zweigstïck}$ mit Salz, rechts Salzdrüse mit angelagerten Palisaden. (Nach Volkens.)

und Magnesium), die am Tage erstarren und den Pflanzenteilen dann eine weiße oder graue Farbe verleihen; nachts zerfließt das Salz, weil es Luftfeuchtigkeit aufnimmt, und dann sind jene Teile grün und mit zahlreichen Wassertropfen bedeckt, selbst wenn kein Tau fällt. Volkens meint, daß die Pflanzen hierbei Wasser aufnehmen. Marloth ${ }^{2}$ ) sieht dagegen diese Salzschicht jedoch nur als eine die Transpiration vermindernde Decke an und meint sogar, daß die Pflanzen sich dabei von einem Teile des aufgenommenen Salzes befreien (S. 205, Fig. 124, 125). Diese Meinung wird auch von Haberlandt ${ }^{3}$ ) geteilt.

Die Luftwurzeln einiger Orchidaceen und Bromeliaceen sind dadurch zur Wasseraufnahme eingerichtet, daß sie mit einem Velamen

1) Volkens 1887

3arloth $1887 \mathrm{a}$.

s) Haberlandt 1903; vergl. auch Joh. Schmidt 1903. 
überzogen sind, d. h. mit einer mehrschichtigen Hülle von Zellen derselben Beschaffenheit wie die Wasser aufsaugenden Zellen von Sphagnum: die Zellen sind nämlich dünnwandig und mit ring-, schrauben- oder netzförmigen Verdickungsleisten versehen. Wenn die Zellen mit Luft gefüllt sind, ist die Hülle weiß; sind sie mit Wasser erfüllt, so wird das Chlorophyllgewebe der Wurzel mehr oder weniger erkennbar. Tropfbares Wasser wird von diesen Hüllen mit Leichtigkeit aufgesaugt und kann von da zum Leitungsgewebe weitergeführt werden. Auch Wasser in Dampfform soll von ihnen aufgenommen werden können (vergl. Fig. 27, S. 53). Sind die Zellen des Velamen lufterfüllt, so müssen sie die Verdunstung herabsetzen und damit das Austrocknen der Luftwurzeln verhindern.

Anders verhalten sich die Luftwurzeln bei gewissen epiphytischen Farnen und Araceen, die kurz sind, mehr oder weniger senkrecht aufwärts wachsen, Humus und dadurch Wasser zwischeneinander sammeln ${ }^{1}$ ).

Faserige Hüllen von Wurzeln oder Blattscheidenresten, oder auch beiden, finden sich bei einigen Farnen (Dicksonia antarctica u. a. Arten, Alsophila-Arten), Velloziaceen, Palmen usw. Ein Teil dieser Pflanzen sind ausgeprägte Xerophyten, und jene Decke dient sicher nicht nur zum Schutze gegen zu starke Verdunstung, sondern gewiß auch besonders zu Wasseransammlung durch Kapillarität und zur Wasserspeicherung ${ }^{2}$ ). Dasselbe gilt nach Buchenau ${ }^{3}$ ) für das Palmietschilf, die Juncacee Prionium serratum (P. palmita), in den periodisch trockenen Flußbetten Südafrikas. Auch die von Hackel ${ }^{4}$ ) als Tunicagräser bezeichneten Gräser sind hierher zu rechnen; sie halten zwischen ihren ausgefaserten oder schuppigen Blattscheiden Wasser zurück (vergl. Fig. 118, 119, S. 234, 235).

In diese Gruppe von Vorrichtungen zur Wasseraufnahme kann auch der Rhizoiden-Filz vieler Moose gerechnet werden. Viele sandliebende Xerophyten, wohl besonders sandliebende Gräser, wachsen in dichten Rasen oder Polstern; auch diese Wuchsform kommt ihnen sicher als ein Mittel, Wasser anzusammeln und festzuhalten, zu gute. Auch die eigentlichen Polsterpflanzen (S. 182) müssen hier erwähnt werden.

Ferner muß angeführt werden, daß auch andere Organe, z. B. die Blätter, zu dem Aufsaugen von Regen und Tau wie auch zur längeren Speicherung des Wassers eingerichtet werden können. Diese sind dann gewöhnlich mehr oder weniger rinnenförmig; als besonders ausgeprägt können die meisten Bromeliaceen, Pandanaceen, das Zuckerrohr u. a. genannt werden; namentlich die trichterförmigen Blattrosetten der

1) Goebel 1891-92; Karsten 1894.

2) Warming 1893.

3) Buchenau 1893.

4) Hackel 1890; vergl. auch Warming 1892, Figuren. 
Bromeliaceen sind dazu vorzüglich eingerichtet, Wasser aufzufangen und einzusaugen; eine besonders merkwürdige Form besitzt Tillandsia bulbosa, deren schmal rinnenförmige Blätter sehr leicht Wasser aufsaugen und zu den Höhlungen zwischen den aufgeblasenen Blattscheiden leiten ${ }^{1}$ ) (Fig. 126).

Besondere Blattformen, die für die Aufnahme und das Festhalten von Wasser eingerichtet sind, haben die Lebermoose. Goebel ${ }^{2}$ ) unterscheidet drei Typen, je nachdem der Unterlappen zusammen mit dem

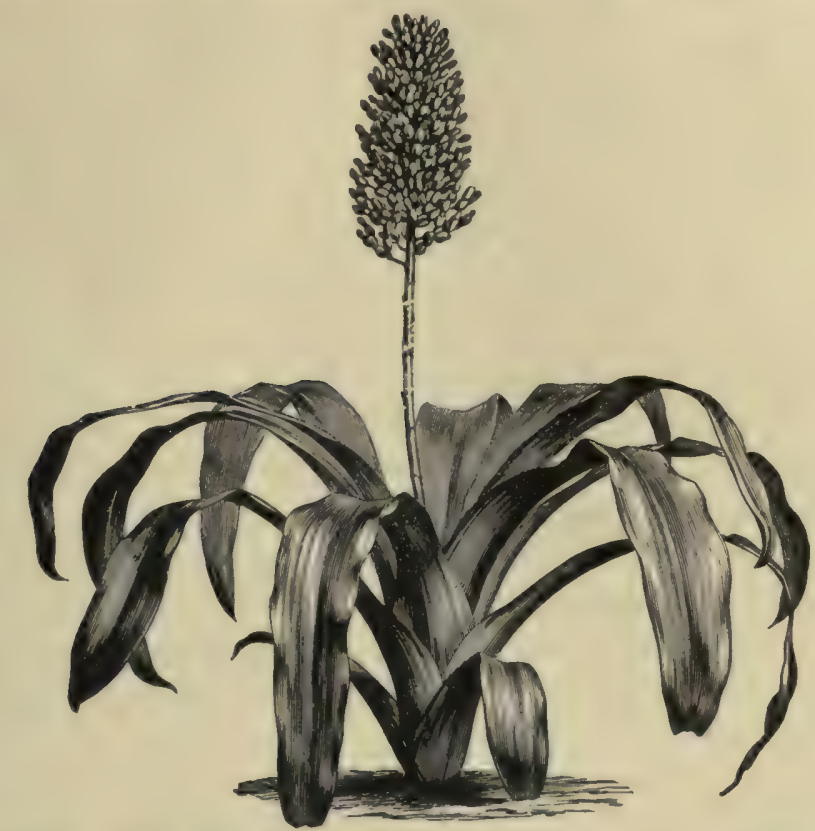

Fig. 126. Rosette einer Bromeliacee; in dem Trichter, den die auseinander weichenden Blätter bilden, sammelt sich Wasser, welches oft eine charakteristische Flora und Fauna beherbergt. (Nach Warming-Moebius.)

Oberlappen, oder für sich allein den Wasserbehälter bildet, oder ob eigentümliche becherförmige "Wassersäcke" (diese bei Frullania cornigera, Physiotium) ausgebildet sind.

\section{Kap. Wasserbehälter}

Eine sehr wichtige und weit verbreitete Einrichtung, durch die Landpflanzen befähigt sind, Trockenperioden zu überstehen, und zwar sowohl Boden- als Lufttrockenheit, ist die Ausbildung von Organen oder doch Gewebeteilen, die befähigt sind, während der feuchten Zeiten

1) Schimper 1884, 1888 a.

2) Goobel 1898-1901, II, S. 58. 
Wasser zu speichern, damit es in den Durstperioden für die Fortsetzung der Assimilation und andere Lebensfunktionen verwandt werden kann. Solche Wasserbehälter finden sich besonders bei Xerophyten. Man kann unterscheiden:

\section{Zellinhalt}

Es gibt Pflanzen oder auch Pflanzenteile, wie z. B. auch eine Anzahl niederer Pflanzen und Sporen von Kryptogamen, welche durch Trockenheit nur sehr schwer getötet werden können, obgleich man an ihnen keine morphologischen Einrichtungen beobachten kann, die einen so energischen Schutz andeuten. Diese Fähigkeiten des Ertragens extremer Trockenheit hängt deutlich mit der Natur des Standortes zusammen ${ }^{1}$ ) (vergl. 4. Kap.). In den folgenden Abschnitten mögen die am meisten ins Auge springenden Einrichtungen besprochen werden.

Schleim, der in verschleimten Zellwänden oder im Zellsafte häufig ist, nimmt Wasser auf und gibt es sehr langsam ab; er wird daher bei den Xerophyten in den verschiedensten Organen gebildet: in Haaren, Laubblättern (S. 204), Stengeln, unterirdischen Knollen und Zwiebeln. Es besteht ein Wechselverhältnis zwischen der Bildung von Schleimzellen im Inneren und der Entwicklung des Hautgewebes. Solche Cacteen z. B., die wie Echinocactus, ein mächtiges Hypoderm haben, führen keine Schleimzellen. Häufig liegen die Schleimzellen der Cacteen in den Kanten, den Warzen und in ähnlichen hervorragenden Teilen, die dem Eintrocknen besonders ausgesetzt $\operatorname{sind}^{2}$ ). Andere Stoffe können vielleicht ähnlich wirken, namentlich

Säuren (z. B. Apfelsäure bei Crassulaceen) ${ }^{3}$ ),

Gerbstoff, der bei gewissen Wüstenpflanzen sehr reichlich auftritt ${ }^{4}$.

Salze, bei Halophyten.

Milchsaft (vergl. S. 213). In röhrenförmigen Organen (meist in Gefäßen oder in Zellen) ist eine gewöhnlich weiße "Milch" enthalten, die wahrscheinlich eine ähnliche Rolle spielt wie die eben genannten Stoffe. Wozu sie dient, weiß man noch keineswegs sicher; wahrscheinlich hat sie mehr als eine Aufgabe, und eine dürfte eben die sein, die Pflanzen gegen Austrocknung zu schützen. Dafür spricht, daß solche Milch enthaltenden Organe in den Tropen und besonders in heißen und trockenen Gegenden häufig auftreten, und zwar oft bei Pflanzen, die dünnblättrig sind und anscheinend kein anderes Mittel haben, um das durch Transpiration

\footnotetext{
1) Vergl. Schröder 1886; V. B. Wittrock 1891.

2) Lauterbach 1889.

3) G. Kraus $1906 \mathrm{a}$.

4) Jönsson 1902; Henslow 1894.
} 
verlorene Wasser zu ersetzen ${ }^{\mathbf{1}}$ ). Wenn man in unterirdischen Zwiebeln (z. B. bei Crinum pratense) ${ }^{2}$ ) Milchsaft findet, so kann dieses gut hiermit übereinstimmen, wenn solche Zwiebeln in einem festen Tonboden wachsen, der in der trockenen Zeit Risse enthält ${ }^{3}$ ).

\section{Wassergewebe}

Landpflanzen, besonders solche, die wenigstens zeitweise starker Trockenheit ausgesetzt sind, entwickeln in der verschiedensten Form und an den verschiedensten Orten Wassergewebe. Echte Wassergewebe sind dünnwandig, farblos (führen kein Chlorophyll, sondern Wasser) und haben keine Intercellularräume (ein Luftwechsel geht hier nicht vor sich). Es gibt äußere Wassergewebe (Epidermis und hypodermale Gewebe) oder innere. Die Zellen sind im allgemeinen sehr groß und meist abgerundet. Das Wassergewebe hat die Fähigkeit, zusammenzufallen, wenn ihm Wasser entzogen wird, bei Wiederaufnahme der Flüssigkeit sich aber wieder auszudehnen und dann wieder völlig turgescent zu werden (Fig. 127). Wasser- oder Saftwurzeln vergl. S. 216, Fig. 97 (Oxalis).

Änfere Wassergewebe. Hier bildet schon die Epidermis selbst ein Wassergewebe (Wasser- und Schattenpflanzen ausgenommen); es ist als solches zuerst von Pfitzer ${ }^{4}$ ), später von Vesque ${ }^{5}$ ), Westermaier ${ }^{6}$ ) u. a. gedeutet worden. Für die Richtigkeit dieser Anschauung sprechen die Farblosigkeit der Epidermis und der Umstand, daß sie eine zusammenhängende Schicht bildet, die in gewissen Fällen mit dem inneren Wassergewebe verbunden ist (vergl. z. B. Velloziaceen ${ }^{7}$ ). Besonders ausgebildet ist die Epidermis bei den Gramineen, Cyperaceen, Velloziaceen u. a., die die auf S. 217 erwähnten Gelenkzellen in bestimmten Streifen der Blattoberseite, besonders über dem Mittelnerv, besitzen; es sind dies Zellen, die größer, namentlich viel höher als die anderen Epidermiszellen sind und die entweder beim Schließen und Öffnen der Blätter eine Rolle spielen ${ }^{8}$ ), oder vielleicht auch als besondere Wasserbehälter dienen ${ }^{9}$ ).

Schleim in den Epidermiszellen haben nicht wenige Wüstenpflanzen, z. B. in der ägyptischen Wüste Cassia obovata, Malva parvi-

1) Warming 1892 .

ๆ) Nach Lagerheim 1892.

3) Uber die Milchsafthaare der Cichorioideen vergl. Zander.

) Pfitzer 1872 .

g) Vesque u. Viet 1881.

ๆ Westermaier 1884 .

7 Warming 1893 , mit Figuren.

5) Tschirch $1882 \mathrm{~b}$.

9) Duval-Jouve 1875; Volkens 1887. 
flora, Peganum harmala, Zizyphus spina Christi u. a. ${ }^{1}$ ); bei manchen Arten sind alle Epidermiszellen verschleimt, bei anderen nur ein Teil. Die Entstehung des Schleimes ist nicht überall bekannt; häufig gehört er den Innenwänden der Epidermis an (S. 204). Bei vielen Xerophyten quellen diese so bedeutend, daß der Zellraum nicht mehr als etwa halb so groß wie das Volumen der Wand oder nicht einmal so groß erscheint, z. B. bei Empetrum, mehreren Ericaceen, Loiseleuria procumbens ${ }^{2}$ ), ägyptischen Acacia- und Reseda-Arten, gewisse Rosa-Arten ${ }^{3}$ ) u. a. Vergl. Fig. 88, 89, S. 204.

Wasser führende Haare. Haare, die als Wasserbehälter dienen, finden sich z. B. bei mehreren afrikanischen Wüstenpflanzen (Mesembrianthemum crystallinum, Malcolmia Aegyptiaca, Heliotropium arboreum, Hyoscyamus muticus, Aizoon, einigen Resedaceen usw. ${ }^{4}$ ), bei vielen Chenopodiaceen, z. B. bei Atriplex coriaceum, A. halimus ${ }^{5}$ ), A. (Halimus) pedunculatum und $A$. portulacoides ${ }^{6}$ ), als "Mehlhaare" bei anderen Chenopodiaceen (in dem "Mehl" genannten Überzuge) und vielleicht auch bei Tetragonia expans ${ }^{7}$ ), Rochea falcata ${ }^{8}$ ) u. a. Sie sind in ihren typischen Formen große, wasserhelle Blasen, die sich über die Epidermis erheben, und die im Sonnenlichte funkeln. Indem ihr Inhalt allmählich verbraucht wird, trocknen sie ein; bei mehreren Chenopodiaceen, z. B. bei Atriplex (Halimus) portulacoides und bei Oxalis carnosa ${ }^{9}$ ) bilden die eingeschrumpften Haare eine luftführende Decke über der Blattspreite. $\mathrm{Ob}$ alle genannten Haare in gleichem Grade als Wasserhaare dienen, muß näher untersucht werden (Fig. 130).

Eine höchst merkwürdige Haarform kommt nach Haberlandt ${ }^{10}$ ) auf den Wurzeln eines epiphytischen javanischen Farnes, Drymoglossum nummularifolium, vor. Die Haare schrumpfen in der trockenen Zeit ein; das Protoplasma zieht sich auf den Grund des Haares zurück und grenzt sich von dem trockenen Teile durch eine Wand ab; wenn Regen eintritt, wachsen die Haare in wenigen Stunden aus und sind wieder mit Wasser erfüllt.

Mächtige peripherische Wassergewebe können entweder durch tangentiale Teilung der Epidermiszellen oder durch Bildung von

1) Pfitzer 1870, 1872; Volkens 1887.

2) Gruber 1882; Henning E. Petersen 1908.

3) Vesque $1882 \mathrm{a}, \mathrm{b}, 1889-1892$.

4) Volkens 1887; Henslow 1894; Schinz 1893.

5) Volkens 1887.

6) Warming 1881, 1906, mit Figuren.

7) W. Benecke 1901.

\$) F. Areschoug 1878.

9) Meigen 1894 .

10) Haberlandt 1893. 
hypodermalem Gewebe entstehen. Sie liegen vorzugsweise auf der Oberseite der Blitter, und wenn sie sich auch auf der Unterseite finden, sind sie hier meist weniger mächtig. Sie hindern kaum das Licht, wohl aber die Wïrmestrahlen am Hindurchtritt, schwächen also dadurch die Verdunstung und sind zugleich Wasserspeicher.

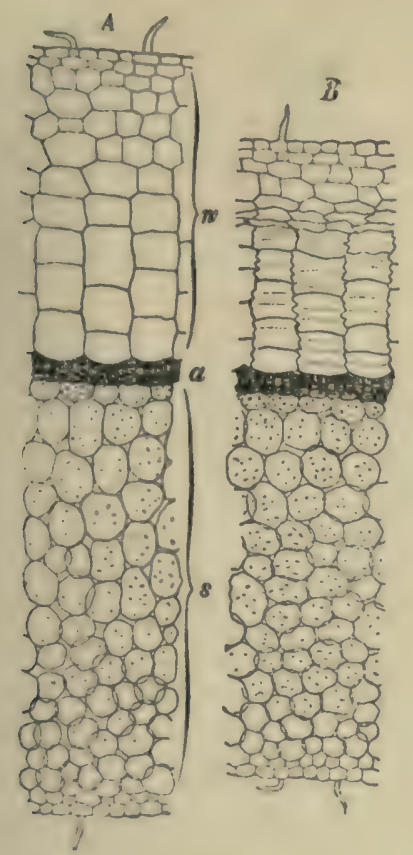

Fig. 127. Querschnitt durch ein Blatt von Peperomia. A von einem frischen Blatte, $B$ von einem abgeschnittenen Blatt, welches 4 Tage bei $18-20^{\circ} \mathrm{C}$. transpiriert hatte; das Wassergewebe ist geschrumpft. w Wassergewebe, a Assimilationsgewebe, \& Schwammparenchym.

(Nach Haberlandt.)

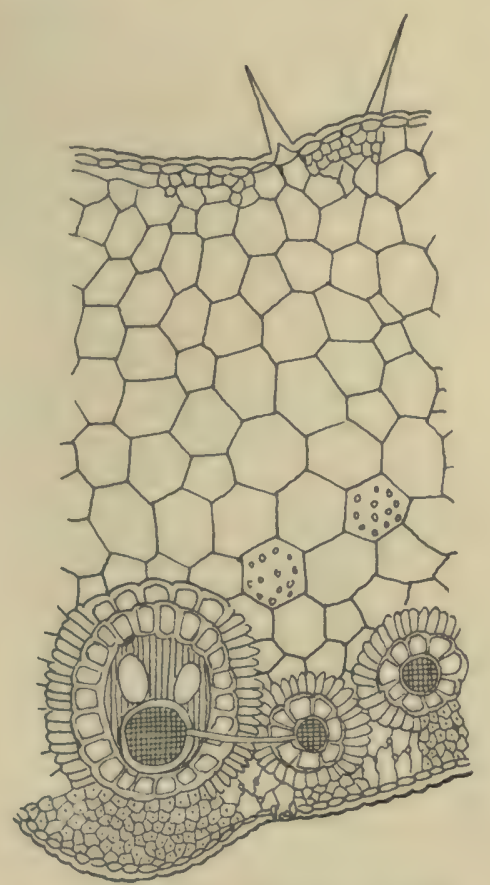

Fig. 128. Andropogon hirtus. Stück eines Blattquerschnittes (140:1); stark entwickeltes Wasserspeichergewebe.

(Nach Volkens.)

Eine mehrschichtige Epidermis ist bei Xerophyten häufig, namentlich bei Felsen bewohnenden und bei epiphytischen Arten; es können mächtige Gewebe entstehen, deren Dicke die des Chlorophyllgewebes übertrifft, z. B. bei Arten von Peperomia (Fig. 127), Begonia, Ficus, Gesneriaceen ${ }^{1}$ ).

Hypodermales Wassergewebe kommt bei anderen Xerophyten vor. In einigen Fällen bildet es nur eine Zellschicht, z. B. bei gewissen

1) Vesque $1882 \mathrm{a}, \mathrm{b}, 1889$-92; Pfitzer 1870, 1872. 


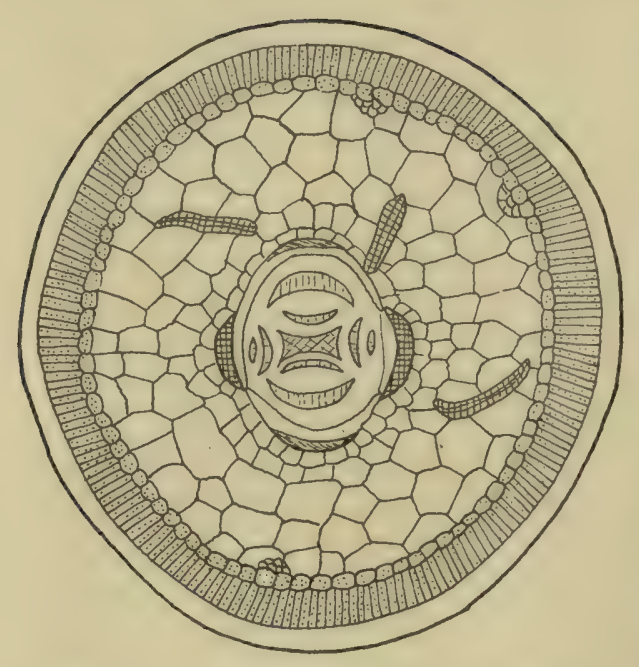

Fig. 129. Haloxylon Schweinfurthii. Querschnitt durch einen jungen Stengel

(30: 1), Wasserspeichergewebe. (Nach Volkens.)

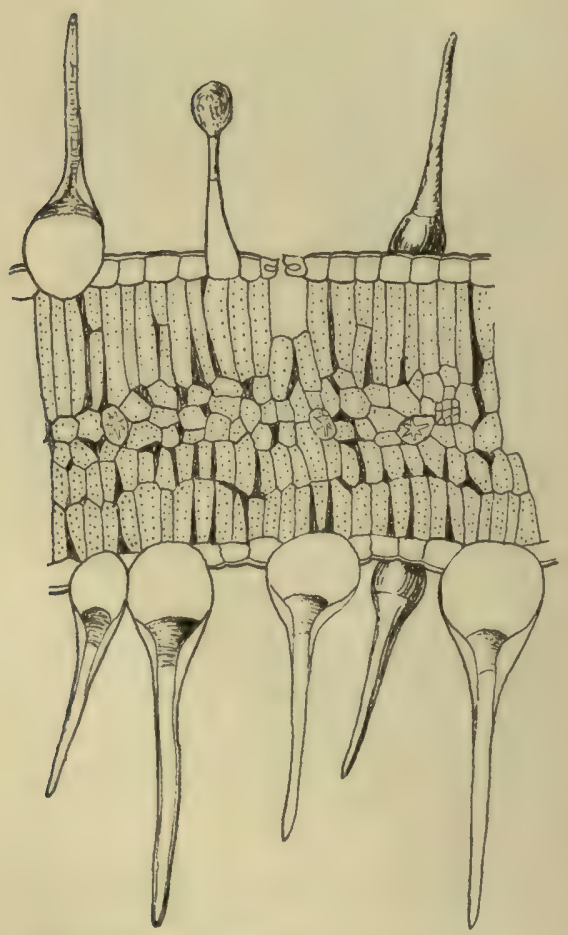

Fig. 130. Heliotropium Arbainense. Blattquerschnitt (140:1), mit Wasserspeichergewebe. (Nach Volkens.)
Genisteen ${ }^{1}$ ), Velloziaceen ${ }^{2}$ ), Orchidaceen $^{3}$ ) usw.; oder es sind 2 bis 3 Schichten (z. B. bei Nerium, Aegiceras, Fig. 124), bei anderen ist es sehr mächtig, wie bei Commelinaceen, Scitamineen, Bromeliaceen und Rhizophoraceen ${ }^{4}$ ). Vergl. Fig. 128. Ein kollenchymatisches hypodermales Wassergewebe findet sich z. B. bei mehreren Cacteen; enge, vom Chlorophyllgewebe zu den Spaltöffnungen führende Intercellularräume durchsetzen es.

Schleimiger Kork mag auch hier erwähnt werden als ein merkwürdiges Korkgewebe, wie es Jönsson ${ }^{5}$ ) bei einer Anzahl asiatischer.Wüstenpflanzen beobachtete (vergl. S. 205).

\section{Tiefor liegende Wasser-} gewebe. Auf verschiedenerlei andere Art kann bei den Xerophyten Wassergewebe auftreten. Folgende Fälle seien hervorgehoben :

a) Wassergewebe, das in der Form von Längsbändern. durch die ganze Dicke des Blattes, von der Epidermis der Oberseite bis zu der der Unterseite reicht, findet sich z. B. bei einigen Wüstengräsern ${ }^{6}$ ), bei Phormium tenax, gewissen Velloziaceen ${ }^{7}$ ).

1) Schube 1885 .

2) Warming 1893.

a) Krüger 1883 .

4) Warming 1883; 0. G. Petersen 1893; Areschoug 1902.

5) Jönsson 1902; vergl. auch Haberlandt 1904, S. 363.

9) Volkens 1887.

7) Warming 1893, mit viel. Figuren. 
Streifen von Chlorophyllgewebe, worin die Nerven liegen, wechseln mit den Wassergewebestreifen ab. Ähnliche Längsbänder verbinden bei Velloziaceen namentlich die Epidermis der Oberseite mit den Wasser führenden Gefäßbündelscheiden ${ }^{1}$ ).

b) Centrales Wassergewebe, das in der Mitte des Blattes liegt und ganz von einer dünnen Schicht Chlorophyllgewebe umgeben wird, tritt hei sehr vielen Xerophyten auf, die zugleich Saftpflanzen sind, außerdem bei vielen Halophyten. Es kommt vor bei Aloë, Agave, Bulbine, Mesembrianthemum, Salsola ${ }^{2}$ ), Atriplex, Halogeton, Zygophyllum usw. In blattlosen Stämmen kann Wassergewebe wie in Blïttern enthalten sein; Beispiele Salicornia und Haloxylon ${ }^{3}$ ). Vergl. die Fig. 129 bis 132.

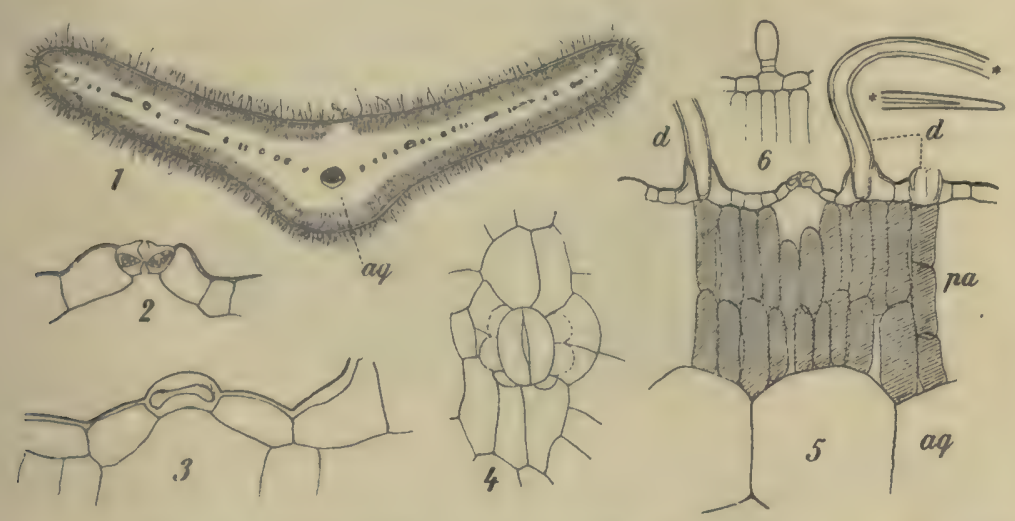

Fig. 131. Tournefortia gnaphalodes (westindischer Strandstrauch). Die Blätter sind isolateral mit gleichartiger Epidermis und etwa zwei Schichten Palisadenzellen auf jeder Seite (5). Die Mittelschicht ist ein echtes Wassergewebe ohne Interzellularräume. Die Spaltüffnungen sind von dem Haarkleide gedeckt und sind in Harmonie hiermit über das Niveau der Epidermis erhoben (2, 3). (Gez. v. Warming, 1897.)

Wasser- und Chlorophyllgewebe können entweder scharf gegeneinander abgegrenzt sein (Fig. 128, 129, 131) oder ineinander allmählich übergehen, indem die Zellen nach dem Innern des Blattes zu weniger ('hlorophlyll führen (viele Crassulaceen, Cacteen u. a.). Wasserspeichernde Idiohlasten finden sich im grünen Gewebe verschiedener Wüsten- und Salzpflanzen ${ }^{4}$ ).

Das Wassergewebe kann unter Umständen während des Lebens der Pflanze in die Dicke wachsen ${ }^{5}$ ).

1) Warming 1893 , mit vielen Figuren.

2) Areschoug 1878, Figur.

3) Volkens 1887; Warming $189 ; \mathrm{b}$.

4) Volkens 1887.

8) Haberlandt 1904 . 
Saftpflanzen (Succulenten, auch "Fettpflanzen" genannt). Pflanzen mit Wassergewebe und reichlich Schleim führendem Parenchym sind dick und „fleischig“, werden Saftpflanzen genannt und sind meist Xerophyten, die ein besonders ausgeprägtes Wassergewebe haben. Sie sind gewöhnlich plump gestaltet, meist ausdauernd, oft vieljährig und gleichen den Kräutern dahin, daß sie grüne Stämme haben, die in der Regel eine geringe Korkbildung w of eine schwache Verholzung aufweisen. Viele der hierher gehörigen Pflanzen haben wie die Bäume eine sehr lange Lebensdauer. Ihr Zellsaft ist reich an Schleim, oft ist ihre Epidermis stark cuticularisiert und die Spaltöffnungen sind eingesenkt. Die Succulenten können viel Wasser aufspeichern, geben es aber äußerst langsam ab (trocknen daher sehr schwierig). Abgetrennte Stücke können oft Monate, ja Jahre (manche Opuntia-Arten) lang frisch bleiben, Wurzel schlagen usw., ohne daß ihnen ein T'Tropfen Wasser oder auch nur feuchte Luft zur Verfügung stände. Die heißesten und trockensten Gegenden sind zumeist ihre Heimat ${ }^{1}$ ).

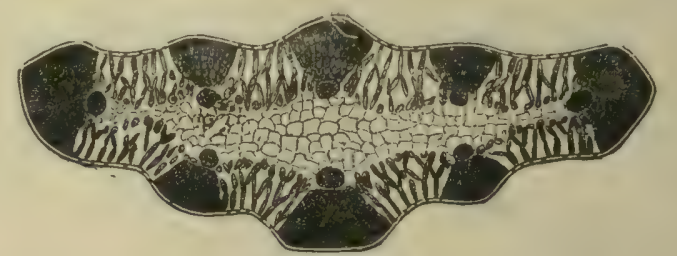

Fig. 132. Querschnitt durch ein Blatt von Asphodelus luteus. p Palisadenzellen, $s$ Schwammparenchym, $o$ die morphologische Oberseite, $u$ die Unterseite.

(Nach Frank.)

Man kann zweierlei Succulenten unterscheiden: Stammsaftpflanzen und Blattsaftpflanzen ${ }^{2}$ ).

Blattsaftpflanzen. Viele Pflanzen zeigen eine Neigung, fleischige Blätter zu bilden, sobald sie an dürren, besonders sandigen Standorten wachsen, während sie an anderen dünnblättrig sind (Fig. 23, 24). Andere Arten haben dagegen eine erblich fixierte Fleischigkeit der Blätter und bekommen auch dann keine dünnen Blätter, wenn sie an feuchtere Standorte gebracht werden. Bei den Blattsaftpflanzen sind die Stengel meist kurzgliedrig, dadurch werden die Blätter sehr oft rosettenständig, haben aber sonst die gewöhnlichen Formen. Die Blätter sind dick, plump, meist ungestielt, in der Regel lang und schmal, bei vielen zylindrisch (die Oberfläche von Prismen und Zylindern ist nächst der von Kugeln die kleinste, die es bei gleichem Volumen geben kann, S. 224); sie laufen oft am Rande und an der Spitze in Dornen aus, sind aber im übrigen

1) In bezug auf ihre Anpassungen vergl. Burgerstein 1904, S. 44, 205.

2) Goebel 1889-93. 
gewöhnlich ungeteilt und ganzrandig (vergl. übrigens Fig. 23, 24, 106). Solche Blattrosetten haben z. B. Agave, Aloë, Sempervivum, Echeveria, mehrere Mesembrianthemum-Arten, epiphytische Orchidaceen u. a.; gestreckte Internodien haben melirere Arten von Sedum, Bryophyllum, Portulaca, Senecio (Kleinia) u. a. ${ }^{1}$.

Stammsaftpflanzen (vergl. auch S. 185 und S. 230). Einen Übergang von den Blattsaftpflanzen zu dieser Gruppe bilden solche Blattsaftpflanzen, welche einen dicken und fleischigen Stengel haben, z. B. verschiedene Crassulaceen, Peireskia.

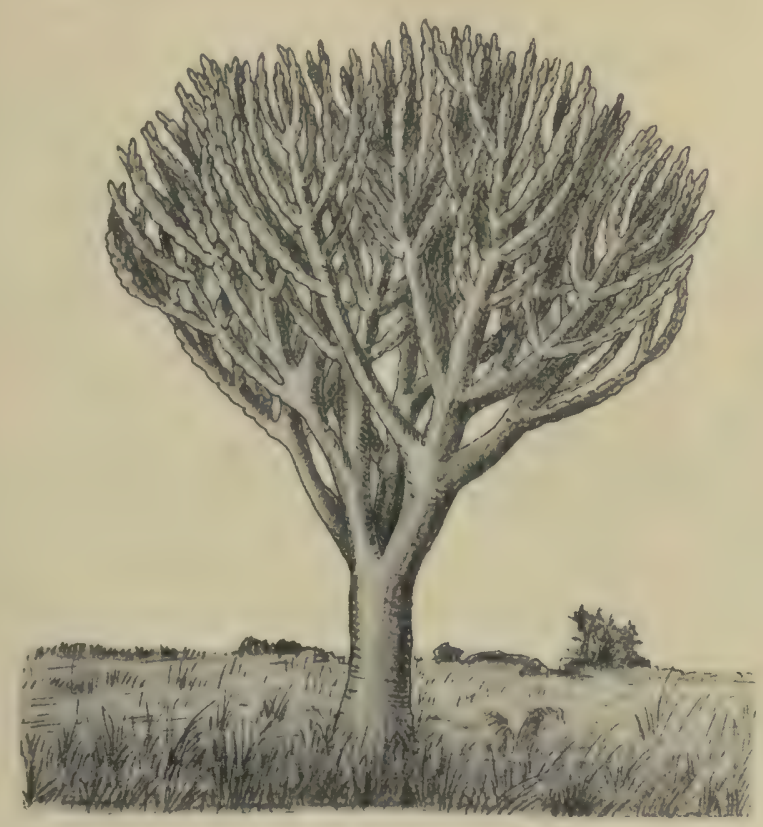

Fig. 133. Euphorbia Reinwardtii, Kandelabereuphorbie. (Nach Schmeil.)

Bei den Stammsaftpflanzen ist der Stamm fleischig und saftig. Bei den ausgeprägten von ihnen sind die Blätter unterdrückt oder zu Schuppen oder Dornen umgebildet; der Stamm hat dann die Funktion der Blätter als Assimilationsorgan übernommen, und die transpirierenden Flächen der Pflanze sind dadurch sehr verringert worden.

Die ausgeprägtesten Saftpflanzen sind Cactaceae (Amerika, Fig.115), Stapelia (Südafrika), Euphorbia-Arten (meist afrikanisch, Fig. 133). Hieran schließen sich Sarcocaulon (Geraniacee; Südafrika), einige Arten von Cotyledon und der Kompositengattung Kleinia. In den verschiedenen Gattungen kommen eine Reihe Körperformen vor, deren Zweckmäßigkeit

1) Vergl. besonders Marloth 1908, S. 221, 311. 
Goebel, Noll u. a. ${ }^{1}$ ) nachgewiesen haben: es treten häufig solche Formen auf, die mit einem gewissen Volumen eine sehr kleine Oberfläche verbinden, nämlich Kugeln, Prismen, Zylinder. Ein Schritt zu der Vergrößerung der Oberfläche findet sich in der Form von Leisten, Kämmen, Warzen usw. bei Mammillaria, Echinopsis u. a. ${ }^{2}$ ). Die Leisten und Kämme sind meist senkrecht gestellt, so $\mathrm{da} ß$ sie $\nabla$ on der Sonne nicht so stark erhitzt werden können.

Einige Cacteen sind äußerst wasserreich, z. B. Echinocactus Emoryi der Sonora-Wüste.

Sowohl Stamm- als auch Blattsaftpflanzen sind unter den Halophyten vertreten.

Die Succulenten weichen von anderen Chlorophyll führenden Pflanzen in der Atmung und der Assimilation ab. Die verschiedenen Bauverhältnisse, die der Verdunstung entgegenwirken, verursachen zugleich eine Hemmung der Kohlensäure-Assimilation; bei der Atmung wird nachts nur wenig Kohlensäure, wohl aber werden viel Apfelsäure und andere organische Säuren gebildet, und diese werden am folgenden Tage zu Kohlehydraten verarbeitet ${ }^{3}$ ).

Der Ursprung der Succulenten soll nach Vesque ${ }^{4}$ ) folgendem zuzuschreiben sein :

1. der Erwärmung des Bodens, die die osmotische Kraft der Wurzeln vergrößert; die Saftpflanzen können sehr hohe Wärmegrade ohne Schaden ertragen und wachsen besonders auf warmen Felsen;

2. dem Umstande, daß die Nahrung abwechselnd in starken und in schwachen Lösungen zugeführt wird.

Zwischen den Saftpflanzen und den S. 221 ff. genannten wasserarmen lederblättrigen Xerophyten gibt es, außer den Unterschieden in der Dicke usw., gewöhnlich physiognomische Verschiedenheiten. Jene sind nämlich in der Regel frischer grün (weil kahl), diese lingegen weiß- oder graufilzig. Es gibt jedoch einzelne behaarte Saftpflanzen, z. B. Sedum villosum. Infolge von Wachsbildung blaugrüne Arten kommen in beiden Gruppen der Xerophyten vor.

$\mathrm{Zu}$ den oberirdischen Knollen gehören auch die knollenförmigen oder doch angeschwollenen Stämme bei gewissen südamerikanischen Bäumen, welche besonders in der Catingavegetation vorkommen (Fig. 81), z. B. bei Chorisia crispiflora (Bombacacee), Jaracatia dodecaphylla (Caricacee), Jatropha podagrica (Euphorbiacee), Adansonia und Adenizun in Afrika u. a. - (Hier sei erwähnt, daß die von Rob. Hartig ausgesprochene

1) Goebel 1889-93; Noll 1893.

2) Über die Morphologie der Cacteen vergl. Vöchting 1874, 1894; Goebel 1892; Schumann 1899 a, b.

2) Aubert 1892; Jost 1903 (Vorles. 15).

4) Vesque 1883. 
Meinung, das wasserreiche $\mathrm{Holz}$ diene bei gewissen Splintbäumen mit flach streichenden Wurzeln, z. B. bei der Birke, als Wasserspeicher, sehr wahrscheinlich zutreffend ist.)

Hier können auch die Luftknollen (Pseudobulbi), die meist bei epiphytischen Orchidaceen vorkommen, genannt werden; sie sind knollenförmige, grüne Stengel, ein- oder mehrgliedrig und tragen ein oder mehrere Laubblätter; noch lange Zeit nach dem Abfallen der Blätter dienen sie als Wasserspeicher; oft enthalten sie einen schleimigen Saft (Fig. 78, S. 186).

\section{Die Zwiebel- und die Knollenpflanzen}

Diese Lebensformen sind schon S. 172 erwähnt, müssen aber hier ihrer Anpassungen wegen nochmals behandelt werden. Sie sind auf verschiedene Weise angepaßt, lange trockene Zeiten auszuhalten. In vielen Fällen sind es nicht nur plastische Vorratsnahrungsstoffe, wie Stärke usw., sondern auch besonders Schleimzellen oder Schleimgewebe, die zu ihrer Fleischigkeit beitragen und teils Baustoffe für die neuen Sprosse ${ }^{1}$ ) sind, teils durch die Wasserspeicherung gegen Eintrocknen schützen. Die Zwiebel- und die Knollenpflanzen wachsen daher besonders in trockenen Gegenden, z. B. in Südafrika und auf den Steppen Asiens (Liliaceae, Iridaceae, Amaryllidaceae u. a.). Poa bulbosa ist nach Aitchison ${ }^{2}$ ) "das gemeinste Gras auf den großen Ebenen von Beludchistan “ und wird sicher durch die dicken Blattscheiden, die eine Art Zwiebel bilden, in stand gesetzt, dort zu leben (Henslow). Marloth ${ }^{3}$ ) gibt für die südafrikanischen Zwiebelpflanzen an, daß sie gegen den gewaltigen Druck, den der austrocknende Boden auf sie ausübt, gut ausgerüstet sind, indem sie (z. B. die kapensischen Oxalis-Arten) entweder durch eine harte Schale geschützt werden, oder durch zahlreiche, übereinander sitzende, weiche, feinfaserige Schichten, deren Baststränge außen als steife Borsten zurückbleiben. Einige Knollen sind Stamm-, andere Wurzelknollen. Es gibt in Südafrika viele merkwürdige, teilweise oberirdische Knollen (sicher Stammknollen), die in blattlosem Zustande von den Steinen, zwischen denen sie wachsen, schwierig zu unterscheiden sind; ein Beispiel ist Dioscorea (Testudinaria) elephantipes, die durch riesige Korkbildungen gegen Austrocknen geschützt wird (vergl. Fig. 134).

Viele Knollen entstehen sicher durch die vereinigte Beteiligung von Stengeln und Wurzeln und bilden eine Art Übergang zu denen,

1) Derartige Knollen kommen auch bei Wasserpflanzen vor, z. B. bei Sagittaria sagittifolia.

3) Aitchison 1887 .

9) Marloth 1887; vergl. auch Hildebrand 1884.

Warming-Graebner. 3. Auflsge, illustr. 
die nur Wurzeln sind; so die verholzten Knollen (Xylopodium) ${ }^{1}$ ) bei vielen Kräutern und kleinen Sträuchern der südamerikanischen Savannen (vergl. anch S. 78, 169) ${ }^{2}$ ).

Wurzelknollen. Bei Crocus und anderen Iridaceen beobachtet man bisweilen helle, spindelförmige, von den Knollen ausgehende Saftwurzeln ${ }^{3}$ ); solche findet man auch an den Zwiebeln gewisser OxalisArten $\left.^{4}\right)$ Fig. 97, S. 216 und unter den Cacteen z. B. bei Cereus tuberosus, jedenfalls bei Pflanzen, deren Sprosse nicht viel Wasser halten können und deren Wurzeln daher knollenförmige, oft von einer Korkhülle umgebene Saftwurzeln sind.

Verschiedene südafrikanische Xerophyten haben auf langen Wurzeln viele spindel- oder kugelförmige Knollen sitzen, die durch Kork geschützte Wasserbehälter sind; Elephantorrhiza hat dicht unter der Erdoberfläche einen solchen Wasserbehälter, der bis $10 \mathrm{~kg}$ wiegen kann, während der Stengel kaum fußhoch ist; eine Bauhinia-Art bildet Knollen von $50 \mathrm{~kg}$ Gewicht ${ }^{5}$ ). In Ägypten gibt es Erodium-Arten mit Wurzelknollen, die nach Volkens ${ }^{6}$ ) als Wasserbehälter dienen. Spondias venulosa hat riesige unterirdische Knollen. Sedum maximum hat bei uns dickfleischige Wurzeln.

Über solche wasserspeichernde Wurzeln vergleiche auch Marloth ${ }^{7}$ ). Die bei vielen südafrikanischen Wüstenpflanzen vorkommenden mächtigen Wurzeln nützen besonders oder ausschließlich durch ihren Inhalt an Wasser; es können zwei oder noch mehr Jahre ohne Regen verstreichen, ohne daß die betreffenden Pflanzen durch Eintrocknen absterben.

Die Größe der Wasserbehälter ist nach ihrer Rolle in dem Leben der Arten sehr verschieden; bei einigen müssen sie ohne Unterbrechung monate- oder jahrelang funktionieren, bei anderen nur wenige Stunden des Tages (z. B. bei den Bäumen der tropischen Regenwälder); einige geben ihr Wasser schnell $a b$, andere äußerst langsam. Damit müssen naturgemäß die Bauverhältnisse im Einklange stehen.

An einigen Pflanzen hat man Zwergwurzeln gefunden, die von manchen Schriftstellern (ob mit Recht?) als Wasserspeicher gedeutet werden, so z. B. bei Aesculus und Verwandten ${ }^{8}$ ), bei einigen australischen Koniferen ${ }^{9}$ ), bei Sedum ${ }^{10}$ ) usw.).

1) Lindman 1900 .

\% Warming 1892, Figur.

3) Raunkiär 1895 (1905, 1907; Figuren).

4) Hildebrand 1884 .

s) Schinz 1893.

9) Volkens 1887 .

7) Marloth 1908, S. 314.

8) J. Klein 1880 .

9) Berggren 1887.

10) Warming 1891; 1907-1909 (dort Figuren). 
Vereinigungen xerophiler Eigenschaften, z. B. morphologischer und anatomischer, kommen sicher überall vor; einige Eigenschaften setzen geradezu das Vorhandensein anderer voraus, um zustande kommen zu können.

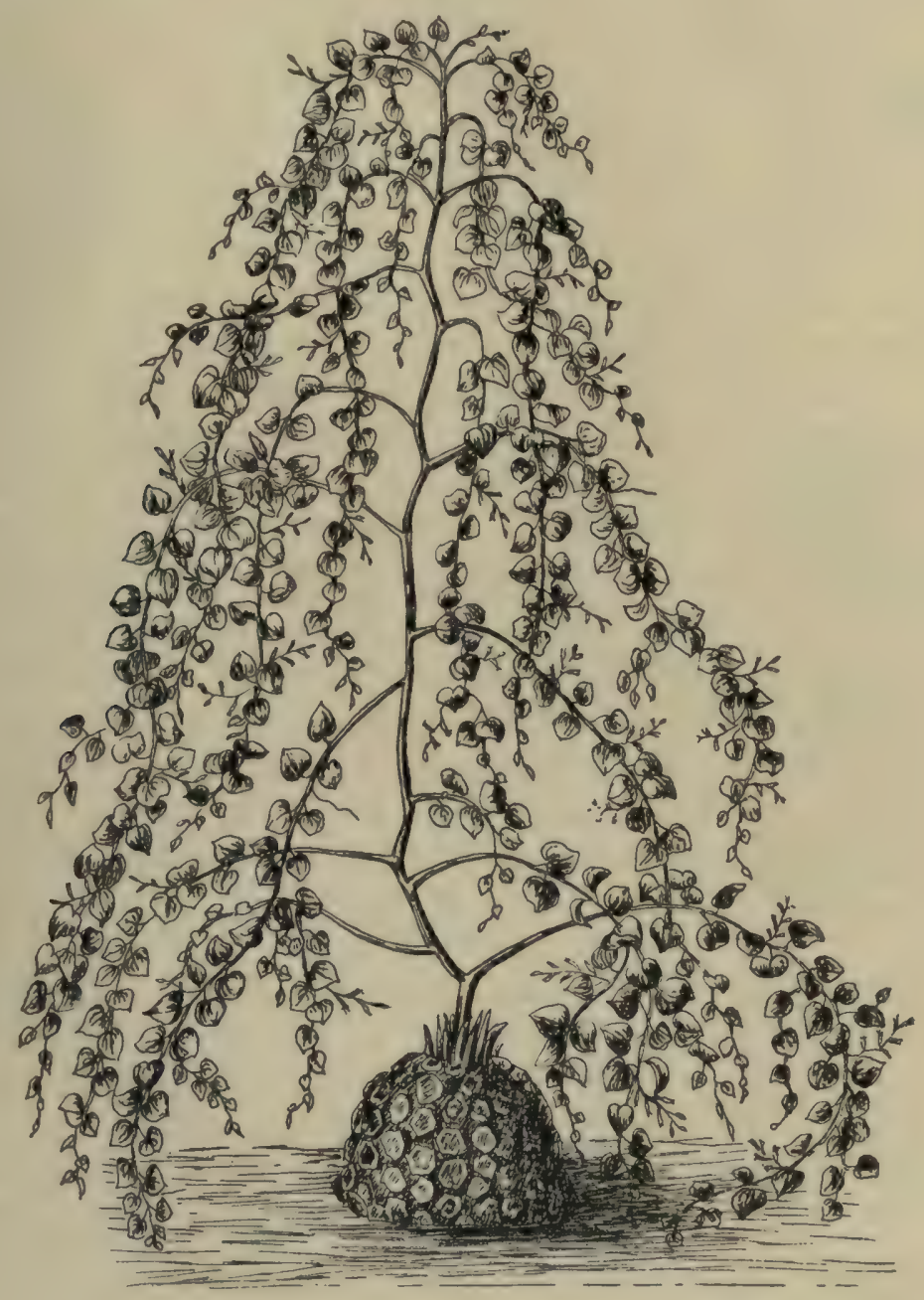

Fig. 134. Dioscorea (Testudinaria) elephantipes. (Nach Pax.)

Ferner seien Korrelationen erwähnt. Die eine Eigenschaft führt bisweilen die andere mit sich. Mit Sukkulenz treten oft zugleich Nebenzellen der Spaltöffnungen auf, die diese schützen, wenn der Pflanzenteil durch Austrocknen einschrumpft ${ }^{1}$ ).

1) W. Benecke 1892. 
Isolierte Wasserzellen; Nervenenden. Die vorhin besprochenen Sukkulenten haben zusammenhängende Wassergewebe, was das Zweckmäßigste zu sein scheint; die Milchsaft führenden Pflanzen (s. S. 213) haben lange, röhrenförmige, verzweigte Behälter. Es gibt jedoch noch andere Wasserbehälter. Zunächst sei erwähnt, daß gewisse Pflanzen

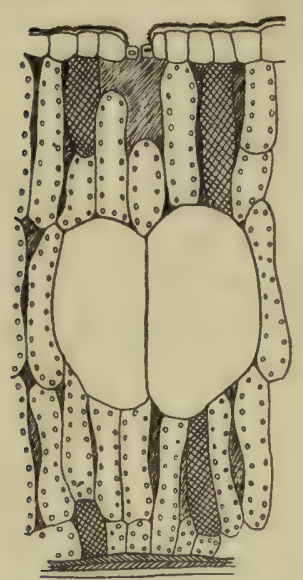

Fig. 135.

Isolierte Wasserspeichelzellen von Nitraria retusa. Von Palisadenzellen umgeben. Die schraffierten Stellen sind mit Gerbstoff erfüllt.

(Nach Volkens.) Zellen haben, die, einzeln oder in Gruppen in das allgemeine Chlorophyllgewebe eingestreut, größer als die anderen Zellen dieses Gewebes, dünnwandig und hell sind; Beispiele sind Nitraria retusa (Fig. 135), Salsola longifolia, Halogeton, Zygophyllum u. a. in der arabischen Wüste $\left.{ }^{1}\right), B a r$ bacenia auf den Bergen Brasiliens ${ }^{2}$ ), dann auch einige parasitische Loranthaceen ${ }^{3}$ ).

Es ist für einige Arten nachgewiesen, daB, wenn man einen Schnitt durch das Blatt eintrocknen läßt, jene Zellen zusammenfallen; setzt man dann Wasser zu, so quellen sie sogleich.

Tracheïde $\left.\mathbf{n}^{4}\right)$. Meist verholzte Idioblasten mit gefäßartigen (schrauben-, seltener netzförmigen) Verdickungen kommen bei vielen anderen Arten auf ähnliche Weise eingestreut vor; sie gleichen den Wasserzellen bei den Velamina der Luftwurzeln (S. 52) und bei Sphagnum, sind kurz, ziemlich dickwandig, porös, aber nicht durchlöchert und füllen sich mit Luft, wenn das Wasser ausgetreten ist. Sie kommen in zweifacher Form vor: entweder an den Nervenenden, oder ohne Verbindung mit den Nerven. Dieses ist der Fall in den Blättern vieler tropischen Orchidaceen ${ }^{5}$ ), bei Crinum-Arten ${ }^{6}$ ), Nepenthes ${ }^{7}$ ), Sanseviera, Capparis und Reaumuria ${ }^{8}$ ), Salicornia ${ }^{9}$ ), Centaurea ${ }^{10}$ ). An den Nervenenden finden sie sich bei anderen Xerophyten (und Halophyten); sie liegen hier, besonders bei Wüstenpflanzen, als riesige, unregel-

1) Volkens 1887.

2) Warming 1893.

3) Marktanner-Turneretscher 1885 .

4) "Reservoirs vasiformes" bei Vesque 1882, 1886; "Spiralzellen und Speichertracheïden" bei Heinricher 1885 .

5) Trécul 1855; Krüger 1883.

8) Trécul 1855; Lagerheim 1892.

7) Kny und Zimmermann 1885.

8) Vesque $1882 \mathrm{a}, \mathrm{b}$.

9) Duval-Jouve 1868.

10) Heinricher 1885. 
mäßige Gefäßzellen mit spaltenförmigen oder länglichen Poren über den feinen, blind endigenden Nervenenden in den Laubblättern und sind oft schwierig von den zu den Gefäßbündeln gehörigen Gefäßzellen zu unterscheiden, z. B. bei Capparis-Arten, Caryophyllaceen ${ }^{1}$ ). Die Rolle, die die Gefäße in den Gefäßbündeln spielen, indem sie sich mit Wasser füllen und es wieder abgeben, ohne zusammenzufallen, scheinen auch diese Wasserzellen zu haben.

Parenchymscheiden um Gefäßbündel dienen z. B. einigen ägyptischen Wüstenpflanzen ${ }^{2}$ ) und bei Restionaceen ${ }^{3}$ ) als Wassergewebe.

Umlagerung von Wasser. Meschajeff ${ }^{4}$ ) scheint der erste gewesen zu sein, der darauf aufmerksam machte, daß bei sukkulenten oder halbsukkulenten Pflanzen in den Zeiten starker und langandauernder Trockenheit das in den älteren Blättern gespeicherte Wasser aus diesen heraus in die jüngeren zu deren Erhaltung, und zwar Turgeszenterhaltung, geleitet wird. Die jungen Blätter bleiben lebend und wachsen womöglich weiter, während die älteren verschrumpfen und absterben. Besonders gut läßt sich dieser Vorgang bei Sukkulenten beobachten, die lange Zeit trocken transportiert sind (vergl. auch Tradescantia Fluminensis u. a.).

Schließlich mag daran erinnert werden, daß die S. 233 besprochenen Tunikabildungen usw. auch dazu dienen können, Wasserbehälter zu sein.

\section{Kap. Andere anatomische und morphologische Eigentümlichkeiten der Landpflanzen}

Bei einem Teile der Bauverhältnisse der Landpflanzen kann niemand an dem Zusammenhange mit der trockenen Umgebung zweifeln, während ihr Nutzen für das Leben der Pflanzen teilweise noch sehr ungewiß ist. Schon früher wurden einige Verhältnisse erwähnt, die vermutlich durch starke Transpiration (starkes Licht, trockene Luft) hervorgerufen werden, so der anatomische Bau des Sonnenblattes (S. 26), namentlich die größere Höhe und die zahlreicheren Schichten des Palisadengewebes in den Sonnenblättern im Vergleiche zu den Schattenblättern, in trockener Luft im Gegensatze zu feuchter Luft ${ }^{5}$ ), die größere Höhe und die engeren Intercellularräume des Schwammparenchyms, die

1) Vergl. Vesque 1882 a, b; Heinricher 1885; Kohl 1886; Volkens 1888; Schimper 1898; Haberlandt 1904.

2) Volkens 1887 .

8) Gilg 1891.

4) Meschajeff 1883; vergl. Burgerstein 1904, S. 228.

5) Lothelier 1893 u. a. 
weniger buchtigen Wände der Epidermiszellen und anderes, dessen sicher bedeutenden Nutzen für das Pflanzenleben man noch nicht klar einsieht. Andere Verhältnisse müssen vielleicht als direkt durch die klimatischen Verhältnisse (Stärke der Transpiration) hervorgerufen aufgefaßt werden, ohne daß sie eine besondere Rolle als Schutzmittel oder ähnliches spielen. Hierher gehört unter anderem die bei Landpflanzen so häufige Verholzung, welche bei Wasserpflanzen äußerst gering ist.

Verholzung ist in erster Linie für die Pflanzen von Nutzen, weil sie deren mechanische Festigkeit erhöht. Bei vielen Pflanzen, auch bei Bäumen, steht sie aber auch in inniger Beziehung zur Wasserspeicherung.

Es ist wichtig, zu bemerken, daß die Verholzung in direkter Beziehung zur Umgebung steht; je trockener der Standort ist, desto stärker ist (mit Ausnahme der Sukkulenten) die Holzbildung. Familien wie die Umbelliferen, Caryophyllaceen, Geraniaceen, Linaceen, Labiaten, Rubiaceen, Dipsacaceen u. a. sind in den gemäßigten Klimaten vorwiegend durch Krautgewächse vertreten, in den wärmeren gemäßigten Gebieten, im Mittelmeergebiete und in den Tropen dagegen sind sie sehr viel reicher an Gehölzen.

Die Verholzung ist besonders bei solchen Xerophyten stark ausgebildet, die im Gegensatz zu den Sukkulenten nur wenig Wasser zu speichern vermögen; sie sind äußerst hart und starr.

Das $\mathrm{Holz}$ der saftarmen Xerophyten ist dicht und hart, oft zugleich spröde und leicht zerbrechlich. Es ist dem Sommerholze ähnlich, indem die Gefäße und die Zellräume eng sind, und der Grund der Ähnlichkeit ist vermutlich, daß die Entwicklungsbedingungen dieselben sind; die geringe Weite steht in Korrelation mit der schwachen Transpiration, die durch die starke Unterdrückung der Blätter und die ungünstigen Wachstumsverhältnisse hervorgerufen wird ${ }^{1}$ ).

Nach Cannon ${ }^{2}$ ) sind die Zweige bewässerter Pflanzen in der Wüste von Tucson ärmer an Leitungsgewebe, als Zweige von demselben Durchmesser von nicht bewässerten Pflanzen. Die Erklärung dafür muß in der Verschiedenheit der Länge und des Charakters der Vegetationszeit der beiden Pflanzen gesucht werden. Welchen Nutzen die Wüstenpflanzen aus der Struktur des Holzes ziehen, ist nicht klar; groß scheint er nicht zu sein, da man kaum annehmen darf, daß die Zellwände als Wasserbehälter dienen können. Jedoch sei daran erinnert, daß verholzte Teile extreme Temperaturen besser aushalten, als wasserreiche und dünnwandige, und daß Bäume starke Feuchtigkeitsschwankungen besser aushalten als Kräuter.

1) Besondere Eigentümlichkeiten der Wüstenpflanzen erwähnt Henslow 1894.

3) Cannon 1905. 
Das mechanische Gewebe wird als Baststränge entwickelt, die unter und über den Nerven in den Blättern, unter oder in der Epidermis, an den Blatträndern verlaufen und desto mächtiger sind, je trockener der Standort ist. Teile des Grundgewebes werden bisweilen in den Stengeln, z. B. bei den Restionaceen ${ }^{1}$ ), als mechanisches Gewebe entwickelt. Steinzellen und Stützzellen werden oft ausgebildet, mehr oder weniger als Idioblasten, in den Chlorophyllgeweben und unter verschiedenen Formen, wonach Vesque ${ }^{2}$ ) die Arten "proteoide", "oleoide" usw. nennt, z. B. in den Blättern von Proteaceen ${ }^{3}$ ), bei Rhizophor ${ }^{4}$ ), Restionaceen, Olea Europaea (lange, wagerecht und senkrecht verlaufende Sklerenchymzellen), Thea u. v. a. In mehreren Fällen ist ein Nutzen dieser verdickten und verholzten Zellen, sowie der starken Epidermis bei den Hartlaubgewächsen, augenfällig, nämlich der, daß sie das Zusammenschrumpfen, das Zusammenfallen oder das Verschieben des für das Leben wichtigen Chlorophyllgewebes verhindern, wenn die Pflanzenteile durch Austrocknen einschrumpfen.

Dornbildungen sind eine andere Form, worin sich die Tendenz der Xerophyten zur Verholzung zeigt. Es ist von alters her bekannt, daß Wüstenpflanzen u. ähnl. oft sehr dornig sind, steife und dornige oder stechende Blätter, dornige Stengel usw. haben. Solche Pflanzen sind äußerst bezeichnend z. B. für den Scrub Australiens, die Felsensteppen und die Hochebenen Asiens (Theophrasts Phrygana-Vegetation), die Kalahari, Ägypten usw. - Die Dornen können morphologisch bekanntlich von sehr verschiedener Bildung sein (ganze Blätter und Blatteile, Haare und Stacheln, verholzende Sprosse, sowohl vegetative Sprosse als auch Blütenstiele); man hat zum Teil hiernach verschiedene Lebensformen aufgestellt (Grisebach die der „Dornsträucher“, Reiter die "Distelform").

Dornen werden nach Lotheliers und Cockaynes ${ }^{5}$ ) Versuchen durch Trockenheit der Luft hervorgerufen; in feuchter Luft wird dieselbe Art dornenlos, die in trockener Luft an Dornen reich ist, z. B. Berberis und Crataegus. Daß dornige Pflanzen in der Kultur (auf besserem Boden usw.) oft die Dornen verlieren, ist eine alte Erfahrung $\left.{ }^{6}\right)$.

Fast von allen, die sich mit den Dornbildungen befaßt haben, ist die Meinung ausgesprochen worden, daß, da die Dornen für die Assimilation direkt keine Rolle spielen und doch kaum als ganz unnütze

1) Gilg 1891.

7) Vesque 1882.

3) Jönsson 1880 .

4) Warming 1883 .

5) Lothelier 1890; Cockayne $1905 \mathrm{~b}$.

F) Vergl. Henslow 1894, S. 223; Vesque und Viet 1881 u. a. 
Organe angesehen werden können, sie vermutlich zum Schutze der Pflanzen gegen Tiere dienen ${ }^{1}$ ). Wallace ${ }^{2}$ ) weist darauf hin, daß dornige Sträucher besonders in den Gegenden von Afrika, Arabien und Centralasien vorkommen, die an großen Pflanzenfressern sehr reich sind. Es erscheint ganz gewiß, daß sie in vielen Fällen auf diese Weise Nutzen bringen, z. B. die langen Dornen von Acacia horrida, A. giraffae u. a. Arten in den trockenen Gegenden Südafrikas gegen die zahlreichen, umherstreifenden Huftierherden; Marloth ${ }^{3}$ ) macht sogar darauf aufmerksam, daß gewisse Arten sich in besonderer Weise dadurch angepaßt haben, daß die längsten und die kräftigsten Dornen auf den jüngsten Exemplaren oder den Wurzelsprossen vorkommen, die von den Tieren am leichtesten erreicht werden können, während die späteren Zweige auf hohen Bäumen ganz dornenlos sind. Übrigens beobachtet man Ähnliches auch bei Ilex aquifolium, deren obere Blätter gewöhnlich dornenlos bleiben, wenn die Pflanze ein hoher Baum geworden ist ${ }^{4}$ ).

Es ist auch klar, daß dornige Pflanzen wegen ihrer Unangreifbarkeit dornenlose besiegen und größere Ausbreitung erlangen können; aber aus allem diesem darf man doch nicht schließen, weder daß die Dornen stets direkte Anpassung an Tiere seien, noch daß sie durch natürliche Selektion in einem an Pflanzenfressern reichen Lande aufgetreten seien. Gegen welche Tiere sollen sich z. B. die Cacteen und die Agaven Mexikos und Westindiens jetzt zu wehren haben? Und sollte sich die Erblichkeit dieser nutzlosen Teile durch die unendlichen Zeiträume erhalten haben, seit die Huftiere hier in größerer Menge vorkamen? Kerner ${ }^{5}$ ) nimmt an, das mediterrane Gebiet sei an dornigen Pflanzen deshalb so reich, weil es auch an Tieren reich ist, und die Hochgebirge wiesen im Einklange mit ihrer größeren Armut an Tieren keine Dorngewächse auf. Aber die arktischen Länder z. B. werden von vielen Pflanzenfressern, darunter von so großen Formen wie Renntier und Moschusochse, überdies in großen Herden durchzogen, und gleichwohl finden sich hier keine Dornen, offenbar weil die Feuchtigkeitsverhältnisse, hier wie in den Hochgebirgen, die Dornbildung nicht begünstigen $^{6}$ ).

Daß andere Dornbildungen bestimmt nachweisbaren Nutzen bringen, ist hingegen sicher, z. B. bei gewissen kletternden Lianen (vergl. S. 158).

Auch in unserem nordischen, feuchten Klima gibt es viele Dornbildungen, deren Nutzen vorläufig unklar ist. Dasselbe gilt von den

1) Delbrouck 1875; Marloth 1887 u. a.

2) Wallace 1891.

g) Marloth 1887.

4) Wallace 1891; Loesener 1901 u. a.

5) Kerner 1869 .

9) Vergl. unter and. Warming 1892; Henslow 1894; Cockayne 1905; Marloth 1908. 
kräftigen Dornen vieler in den Wäldern des Amazonenstromes lebenden Palmen (Astrocaryum, Bactris u. a.), die Wallace ${ }^{1}$ ) erwähnt.

Die physiologischen Gründe, weshalb die verholzten Elemente so kräftig werden, sind noch ziemlich unklar. Doch scheinen starkes Licht und starke Transpiration die Ursachen zu sein. Vesque, Viet, Kohl und Lothelier ${ }^{2}$ ) fanden durch Versuche, daß das mechanische Gewebe mächtiger wird, wenn die Transpiration stärker wird. Cockayne ${ }^{3}$ ) beobachtete, daß bei der Rhamnacee Discaria toumatou die Dornbildung in feuchter Luft nicht stattfand. Stahl, Dufour und Lothelier ${ }^{4}$ ) stellten fest, daß sie im Lichte stärker als im Dunkeln ist (auch etiolierte Pflanzen werden sehr schwachstengelig). Umgekehrt zeigen Versuche, daß durch vermehrte Wasserzufuhr die Holzbildung bei Eiche und Robinia vermindert wird, ebenso wird dadurch besonders bei Monokotyledonen die Ausbildung der mechanischen Elemente schwächer ${ }^{5}$ ).

Zwergwuchs. Gestrüppe und Polsterpflanzen. Schon S. 48 und 219 ff. wurde erwähnt, daß Wassermangel und starke Transpiration Zwergwuchs hervorrufen können. Wind, Wassermangel und andere ungünstige Wachstumsbedingungen erzeugen auch die Krummholzgestrüppe, die Gestrüppe auf unseren Heiden, die krummästigen Sträucher der Ericaceen, die in Nordostdeutschland als Kusselkiefer bekannte krüppelige Form von Pinus silvestris, u. ähnl. Trockener Boden und starke Verdunstung geben den Pflanzen ihr Gepräge, indem sie kurze und kurzgliedrige, gekrümmte Sprosse und Stämme mit spärlicher und unregelmäßiger Knospenbildung hervorrufen; reichliche Feuchtigkeit nebst Wärme bringt lange und gestrecktgliedrige Sprosse hervor. Im Mittelmeergebiete und anderen subtropischen Gegenden mit Winterregen nehmen viele Arten die Gestalt von Sträuchern von mittlerer Höhe an. Beim Gestrüpp und den Wüstensträuchern sind die Zweige und Blätter oft zusammengedrängt, die Verzweigung wird außerordentlich dicht, und die Pflanze im ganzen abgerundet und dicht; Beispiele in der nordafrikanischen Wüste Achillea fragrantissima, Artemisia herba alba, Cleome Arabica u. v. a. ${ }^{6}$, die kugeligen Sträucher von Astragalus und Genista auf Corsica $^{7}$ ), und unter ganz anderen klimatischen Bedingungen die S. 182 erwähnten Polsterformen der kalten, windigen, nassen arktischen

7) Wallace 1891.

2) Vesque und Viet 1881; Kohl 1886; Lothelier 1890.

3) Cockayne 1905 .

4) Stahl 1883; Dufour 1887; Lothelier 1890.

5) Graebner 1895 .

9) Volkens 1887.

7) Rikli 1903; Massart 1898. 
Gegenden, z. B. Draba alpina ${ }^{1}$ ), Silene acaulis ${ }^{2}$ ) Fig. 136, Arten von Saxifraga, viele Moose $^{3}$ ), in den Alpen Androsace Helvetica ${ }^{4}$ ) u. a. Die siidamerikanischen, neuseeländischen und alle anderen Hochgebirge zeigen viele Beispiele für diese wie abgebissen dicht geschorenen, abgerundeten, festen, ja fast harten, aus Sträuchern und aus Stauden bestehenden Polster, in denen zahlreiche Zweige, Blätter und Blattreste zusammengedrängt sind (in Südamerika die beiden Umbelliferen Azorella und Laretia, Oxalis-Arten, Valerianaceen: Aretiastrum Fig. 75 usw. ${ }^{5}$ ), Cacteen u. a.).

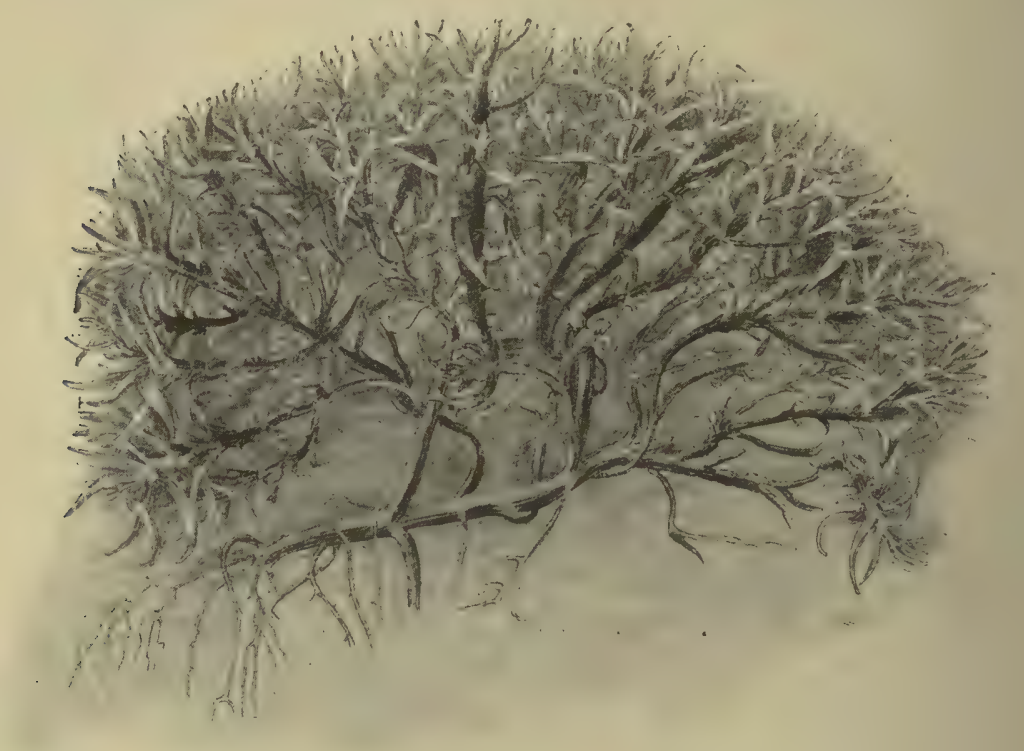

Fig. 136. Aufbau einer Polsterpflanze (Silene acaulis!.

Original von F. G. Meyer.

Eine der merkwürdigsten Polsterpflanzen ist Raoulia mammillaria auf Neuseeland. Überall ist der Grund derselbe: Trockenheit, durch einen oder den anderen Faktor hervorgerufen; Henslow hat jedoch mit Recht darauf aufmerksam gemacht, daß Zwergwuchs auch durch kleinen und schlechten Samen erzeugt werden kann. Jene dichte Verzweigung und die Rasenbildung werden für das Individuum dadurch nützlich, daß die jungen Sprosse besseren Schutz gegen die Verdunstung finden; sie

1) Kjellman 1884, S. 474, Figur.

?) Vergl. The Botany of the Färöes (Copenhagen 1901-8), S. 993 (F. Börgesen).

3) Andersson und Hesselman 1900. - Grimmia maritima Fig. 76, S. 184.

4) Schröter 1904-8.

§) Graebner 1906. 
schützen einander und werden von den alten Sprossen geschützt, in den subglazialen Gegenden gegen das Austrocknen durch die Winde (S. 68), in den tropischen Wüstengegenden gegen Sonnenlicht und Wind.

Die Polsterpflanzen sind in neuester Zeit von C. Schröter und Hauri ${ }^{1}$ ) behandelt worden.

Rosettenpflanzen. Viele Landpflanzen, besonders Xerophyten, haben rosettenblättrige Sprosse, die den erstjährigen Laubsprossen zweijähriger Dikotylen ähnlich sind; man trifft sie in Polarländern, Hochgebirgen, Steppen und Wüsten, bei Epiphyten und tropischen Felsenbewohnern, wie auf S. 45 erwähnt wurde. Die Kurzgliedrigkeit und die daraus folgenden Blattstellungsverhältnisse können sicher nicht in allen Fällen gleichartig erklärt werden, und der Nutzen ist wohl auch nicht immer derselbe. Bei vielen Bromeliaceen dient die Rosette zum Aufsammeln und Aufbewahren von Wasser. Bei Polar- und Gebirgspflanzen hat der niedrige Rosettensproß wohl zunächst den Vorteil, daß die auf der Erdoberfläche ausgebreiteten Blätter den austrocknenden Winden nicht so sehr ausgesetzt sind, daß sie eine größere Luftwärme genießen und zugleich die Wärme des Bodens besser benutzen können. Daß sie in Wüsten den Tau der Nacht besonders vorteilhaft benutzen können, ist wahrscheinlich. Meigen ${ }^{2}$ ) hebt ferner hervor, daß bei vielen Rosettenpflanzen die einander bedeckenden Blätter "windstille Räume“ bilden, die ja die Verdunstung herabsetzen. Rosettenpflanzen passen gut zu einer offenen und niedrigen Vegetation; die nord- und die mitteleuropäischen Grasfluren, die Alpenmatten und ähnliche Vegetationen sind in der Tat an niedrigen rosettenblättrigen Stauden sehr reich (Formen wie Plantago major, Taraxacum officinale, Achillea millefolium, Pimpinella saxifraga). Dagegen sind sie in den Wäldern viel seltener (Warming). Rosettenpflanzen vergl. S. 25, Fig. 11; S. 45, Fig. 23; S. 175, Fig. 68 ; S. 176, Fig. 69 ; S. 247, Fig. 126.

Bonnier ${ }^{3}$ ) zeigte, daß gewisse Arten, welche in den Ebenen langgliedrige Sprosse erzeugen, in den Hochgebirgen Rosetten bilden.

Niederliegende Sprosse. Viele Arten, die auf trockenem und warmem, namentlich auf sandigem Boden wachsen, haben niederliegende Zweige, jedenfalls soweit als diese vegetativ sind. Nach S. 33 ist dieses sicher, wenigstens zum Teil, den Wärmeverhältnissen und der Feuchtigkeit des Bodens zuzuschreiben.

1) Schröter und Hauri 1914; Hauri 1912.

2) Meigen 1894.

s) Bonnier $1890,1894$. 


\section{Kap. Morphologische und anatomische Anpassung der Wasserpflanzen}

Infolge der Ernährungsverhältnisse, die von denen der Luftpflanzen sehr abweichen, haben die Wasserpflanzen sehr viele Eigentümlichkeiten des Baues, die im vorigen Kapitel nur teilweise berührt worden sind. Für die höheren Arten (namentlich Gefäßpflanzen) seien folgende Eigentümlichkeiten des Baues hervorgehoben:

1. Wurzeln und analoge Organe. Da die Nahrung von den untergetauchten Teilen oft vermutlich durch die ganze Oberfläche aufgenommen wird (Algentypus) ${ }^{1}$ ), jedenfalls aber nicht durch die Wurzeln,

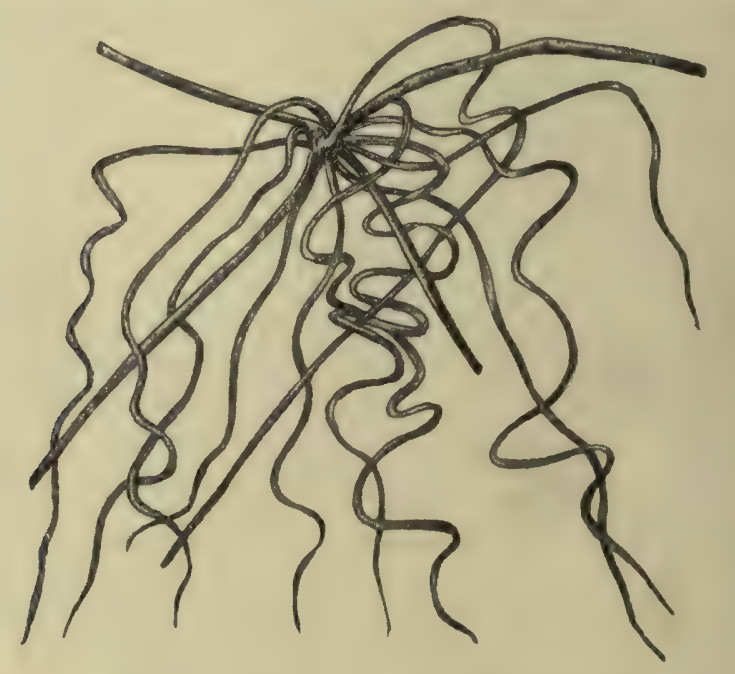

Fig. 137. "Windende" Wurzeln von Hydrilla verticillata; zur besseren Befestigung im Schlamm hin- und hergebogen (Graebner).

werden bei untergetauchten Pflanzen die Organe reduziert, die sonst aus der Erde mineralische Nahrung aufnehmen: die Wurzeln bei den Phanerogamen und die analogen Organe der Kryptogamen. Mehrere Gefäßpflanzen sind ganz wurzellos (Salvinia, Wolffia, Ceratophyllum, Utricularia vulgaris, Aldrovandia, Genlisea); bei anderen hält das Wachstum der Wurzeln bald inne, sie verzweigen sich nicht, und es kann sogar die Wurzelhaube abgeworfen werden (Azolla, Lemna, Hydrocharis, Pontederia, Pistia). Wurzelhaare fehlen bei Lemna minor, L. trisulca, Myriophyllum, Butomus umbellatus, Caltha palustris, Hippuris vulgaris (von

1). Vergl. Graebner 1895, 1906. 
dem Wurzelhalse abgesehen), Nymphaea alba u. a. ${ }^{1}$ ). Die Wurzeln sind zunächst Festheftungsorgane.

Bei einer Reihe von Wasserpflanzen, die in losem Boden haften, sind die Wurzeln entweder mit sehr langen Wurzelhaaren versehen, die eine größere Bodenmenge durchziehen, oder sie sind unregelmäßig hin und her oder spiralig gebogen, wodurch auch das Herausziehen aus dem Schlamm erschwert wird ${ }^{2}$ ) (Fig. 137).

Die steinebewohnenden Algen, Moose und unter den Samenpflanzen die Podostemaceen sind mit besonderen Haftorganen (Hapteren) versehen (Fig. 138).

2. Die Assimilationsorgane. Äußerst mannigfaltig sind die Formen der Algen, worüber die besonderen Werke verglichen werden müssen (und in Kap. 44, 45, 46).

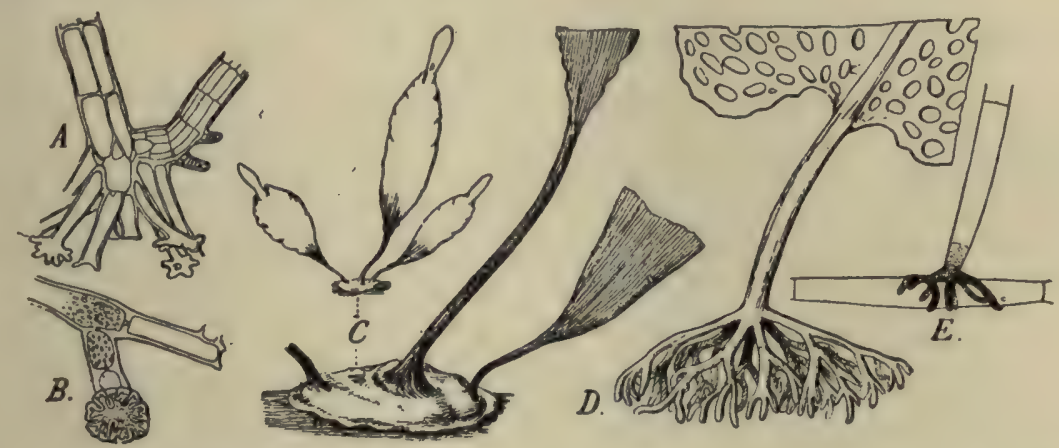

Fig. 138. Haftorgane verschiedener Algen. A. Polysiphonia nigrescens. B. Spermothamnion Turneri. C. Laminaria solidungula. (Die größte Figur ca. 1/8.) Die Haftscheibe ist durch Verschmelzen der "radices scutatae" dreier Exemplare entstanden. D. Agarum Turneri. E. Pithepora Roettleri. (A., $B$ nach Rosenvinge, $C$ nach J. Agardh, $D$ nach Harvey und $E$ nach Wittrock.)

Auch die Formen der GefäBpflanzen sind ziemlich mannigfaltig. Es gibt Arten mit Langsprossen und solche mit Rosettensprossen, Arten ohne und mit Ausläufern; oberirdisch oder unterirdisch kriechende Pflanzen. Weiter gibt es ganz untergetauchte Arten und solche mit Schwimmblättern, andere sind frei schwimmende oder flutende. Aber alle Arten sind krautartig.

Die Blattformen sind auch sehr verschieden, worüber in späteren Kapiteln berichtet wird. Hervorzuheben ist, daß Heterophyllie bei einigen Arten vorkommt, indem die untergetauchten Blätter von den Schwimmblättern verschieden sind.

1) F. Schwarz 1888.

2) Vergl. Graebner 1906. 
3. Lebensdauer. Die allermeisten Wasserpflanzen sind, jedenfalls unter den Gefäßpflanzen mit Ausnahme von einer Anzahl niederer Pflanzen, wie Salvinia, Naias, Subularia, Podostemaceen und wenigen anderen, mehrjährig, was mit den günstigen, von dem Wechsel des Jahres wenig beeinflußten Lebensverhältnissen im Einklange steht. Die vegetative Vermehrung vieler Wasserpflanzen übertrifft weit die geschlechtliche; dieses geht so weit, daß der Fruchtansatz durch das Wasser ganz vierhindert werden kann. Gewisse Pflanzen, wie Helodea Canadensis (in Europa jedenfalls), viele Lemna-Arten u. a. vermehren sich ausschließlich auf vegetativem Wege, und manche in so ungeheuren Mengen, daß sie sehr lästig werden können, z. B. Helodea, Azolla, Eichhornia usw. Bei Hydrilla sind in Europa alle Blüten deformiert, so daß keine Früchte ausgebildet werden können ${ }^{1}$ ). - Im allgemeinen tritt in der Feuchtigkeit und Nässe die geschlechtliche Vermehrung zurück, während diese durch Trockenheit befördert wird.

4. Anatomische Eigentümlichkeiten. Das grüne Gewebe (Chlorophyllgewebe) von Wasserpflanzen ist sehr wenig differenziert; es gibt sehr geringe oder gar keine Differenzierung in den submersen Laubblättern, und keine Differenz zwischen Palisadengewebe und Schwammparenchym. Die Blätter sind daher isolateral.

Die Schwimmblätter haben dorsiventralen Bau.

Die Epidermis ist dünn und führt oft Chlorophyll, was mit der geringen Lichtstärke in Verbindung stehen muß. Haare fehlen bei den allermeisten Blütenpflanzen und sind, wo sie vorkommen, entweder schleimbildend (vergl. S. 205), oder dienen zur Verstärkung der Assimilation oder zur Atmung (die heiden letzten Fälle bei Algen und $\mathrm{P}_{0}$ dostemaceen). Die Cuticula fehlt oder ist sehr dünn, ebenso fehlen Überzïge von Wachs und Kork, daher vertrocknen Wasserpflanzen an der Luft so leicht.

Sehr oft erscheint die Epidermis größerer, untergetauchter Wasserpflanzen (Potamogeton usw.) für Wasser nicht oder sehr schwer benetzbar, beim Herausziehen aus dem Wasser läuft dieses sofort ab und die Oberfläche der Blätter usw. erscheint fettglänzend und trocken. Lundström ${ }^{2}$ ) hat gefunden, daß sich bei den betreffenden Arten in den Epidermiszellen Öltropfen befinden, die an kleine farblose Stäbchen gebunden sind; Lundström nennt sie "farblose Ölplastiden". Sie sind in allen Oberhautzellen zu finden, nur in den an die Hauptnerven und an den Wasserporus grenzenden Stellen fehlen sie, und diese Stellen bleiben denn auch vom Wasser benetzt. Der Zweck dieser Ölzellen ist nicht

1) Caspary 1860.

?) Lundström 1888; Graebner 1906, S. 412. 
ganz klar; sie werden als Schutz gegen Tierfraß oder gegen die Ansiedelung epiphytischer Algen gedeutet, vielleicht sollen sie aber auch (sie finden sich schon in ganz jungen Zellen) die Diffusion zuckeriger Lösungen aus den Blättern in das umgebende Wasser verhindern.

Die Ausscheidung von Wasser ist bei untergetauchten Wasserpflanzen nicht ausgeschlossen, sie geschieht in tropfbarflüssiger Form und wird durch innere Kräfte verursacht. Die Blattspitzen mancher Arten haben Wasserporen, oder die Blattspitzen zerfallen und die Spitzen der GefäBbündel sind daher offen und treten in direkte Berührung mit dem Wasser ${ }^{1}$ ).
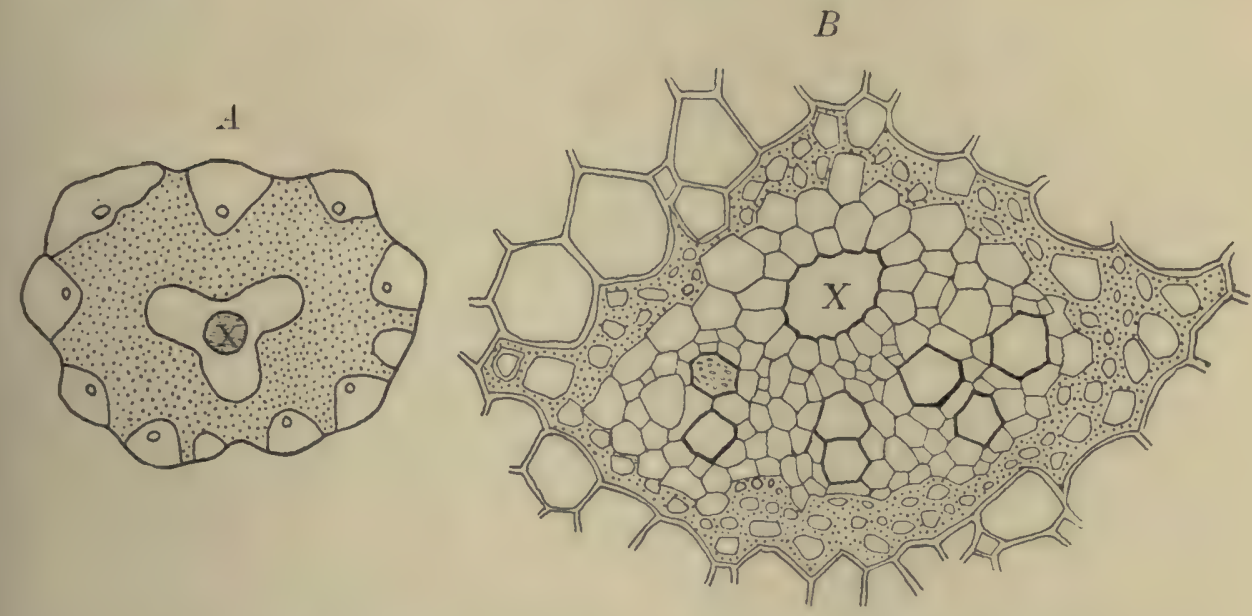

Fig. 139. Potamogeton perfoliatus. A Querschnitt durch den Stengel, $B$ ein GefäBbündel, stärker vergrößert. Bei beiden $X$ der Xylemgang.

(Nach Schenck.)

Verdunstung im strengen Sinne ist natürlich ausgeschlossen, daher fehlen Spaltöffnungen an den allermeisten untergetauchten Teilen und sind bei den wenigen, wo sie vorkommen, vermutlich entweder Wasserporen oder ganz ohne Funktion.

Die Schwimmblätter haben Spaltöffnungen auf der Oberseite ${ }^{2}$ ).

Wasser leitende Röhren werden aus demselben Grunde weniger notwendig; die Gefäße und der ganze Holzteil werden bei den Gefäßpflanzen reduziert. Der Siebteil als eiweißleitendes Gewebe erfährt keine Reduktion. Die leitenden Gewebe werden immer mehr in der Mitte des

1) Vergl. die Arbeiten von Schenck 1886 a; Sauvageau 1889, 1890, 1891, 1894; Wieler 1892; Weinrowsky 1898; Minden 1899; Burgerstein 1904; Graebner 1906.

3) Haberlandt 1904. 
Organes vereinigt, so daß sie zuletzt einen zentralen Strang bilden. (Van Tieghem stellt vier Typen degradierter Wurzeln auf) ${ }^{1}$ ).

Die Menge und Verzweigung der Nerven in den Blättern ist geringer als in Landpflanzen. - Sehr bemerkenswert sind die bei größeren Wasserpflanzen nicht seltenen Xylemgänge ${ }^{2}$ ), die durch .Resorbierung der ursprünglich im Xylem angelegten Gefäßgruppen entstehen und in großen Gefäßbündeln (Potamogeton lucens usw.) eine erhebliche Größe erreichen können (Fig. 139). Diese mit Wasser gefüllten Xylemgänge durchlaufen die Gefäßbündel, von dort aus die Blätter und stehen in Verbindung mit den Wasserporen (s. S. 212) an der Spitze. Es scheint, als ob bei diesen nicht nach dem Algentypus (s. S. 268) lebenden Pflanzen, deren Epidermis durch Schleim oder Öl (s. S. 270) geschützt ist, also wohl kaum dort Nahrungsaufnahme zuläßt, eine Art innerer Ernährung vorhanden ist $^{3}$ ).

Das mechanische Gewebe wird reduziert oder gar nicht entwickelt, weil die Tragfähigkeit des Wassers größer ist als die der Luft. Namentlich werden biegungsfeste Konstruktionen nicht entwickelt. Gegen die Streckung durch Wasserbewegungen wird möglichst im Zentrum des Stengels zusammengedrängtes mechanisches Gewebe mit zugfesten Konstruktionen angewandt ${ }^{4}$ ); gewisse Algen z. B. haben Verstärkungsrhizoiden in den unteren Teilen des Thallus, was Wille ${ }^{5}$ ) eingehend nachgewiesen hat. Verholzung findet sich nicht oder nur sparsam (bei den Gefäßen). Dazu kommt:

Lufträume bei den Wasser- (und Sumpf-) Pflanzen sind sehr häufig und sehr groß. Diese Lufthöhlen dienen zur Verminderung des spezifischen Gewichtes (Schwimmapparate), außerdem zum Luftwechsel (Atmung); Fig. 47, S. 143; Fig. 92, S. 208. Ein eigentümliches Luftgewebe ist das Aërenchym ${ }^{6}$ ) Fig. 140. Bei einer Anzahl großer Algen, z. B. Fucus vesiculosus, Ascophyllum nodosum, Halidrys siliquosus, Sargassum (Fig. 141), Macrocystis u. a. Laminariaceen, kommen luftführende Schwimmblasen vor.

Ohne Lufträume sind die Algen, Moose, kleinere dikotyle Blütenpflanzen, speziell die Podostemaceen. Vergleiche oben die ohne Durchlüftungseinrichtungen und ohne Xylemgänge lebenden Wasserpflanzen, den "Algentypus" ${ }^{7}$ ).

1) Van Tieghem $1870-71$.

2) Schenck 1886 a.

3) Graebner 1906.

4) Schwendener 1874. Warming über Podostemaceen 1871-1901.

5) Wille 1885.

o) Schenck 1889 a; Goebel 1891-92, II.

") Graebner 1895; 1902 u. a. 
Dickenwachstum findet sich bei den Achsenorganen der Wasserpflanzen nur ausnahmsweise, was mit den unter 2 und 3 genannten Umständen zusammenhängt.

Im Gegenteil sind die untergetauchten Stämme von Samenpflanzen viel länger und dünner als bei Landpflanzen und machen oft den Eindruck von etiolierten Stengeln.

Schleim. Bei den verschiedensten Familien der Wasserpflanzen beobachtet man, daß die jungen Pflanzenteile mit Schleim überzogen sind. Während Stahl auch diese Einrichtung als Schutz gegen Tierfraß deutete, kam Schilling durch Versuche zu dem Schluß, daß die

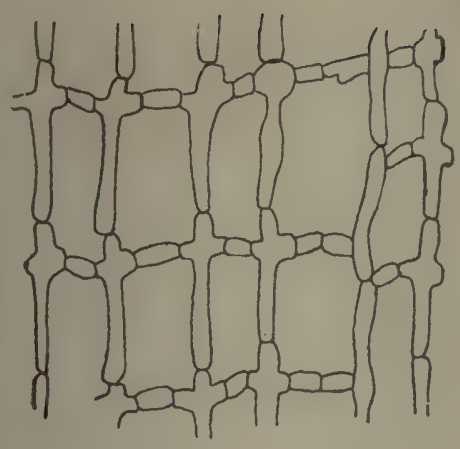

Fig. 140.

Aërenchym. (Nach Schenck.)

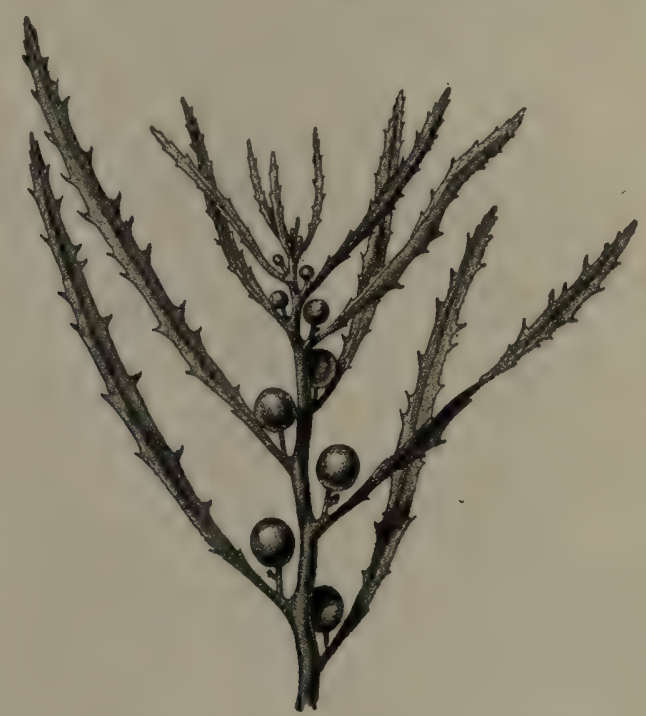

Fig. 141. Sargassum sp.; mit Schwimmblasen; etwa $1 / 8$ vergröBert. (Nach Börgesen.)

Schleimschicht für die Lösungen mancher Salze und Farbstoffe völlig undurchlässig ist; er hält den Schleimmantel also für eine Schutzschicht gegen die direkte Berührung der zarten Zellen mit dem Wasser, um das unerwünschte Aus- und Eintreten von Lösungen bis zu der Zeit zu verhindern, wo die Epidermis ausgebildet ist und selbst schützend wirkt ${ }^{1}$ ). - Der Schleim wird teils von Haaren, teils von inneren Schleimgängen sowie auf Samenschalen gebildet. Der Schleim, der sich oft an Algen, die am Strande oder in stark bewegtem Wasser wachsen, findet, z. B. bei Nemalion multifidum, mag sie gegen die Gewalt der Wasserbewegungen schützen ${ }^{2}$ ). Algen an der Küste, die zur Zeit der Ebbe

1) Stahl 1888; Goebel 1891-92; Schilling 1894 .

) Wille 1885.

Warming - Graebnex; 3. Anflage, illustr. 
trocken liegen, haben ebenso wie andere, zeitweise der Trockenheit ausgesetzten Algen einen Schleimüberzug, der die inneren Teile vor dem Vertrocknen schützt ${ }^{1}$ ).

Die Eigentümlichkeiten der Wasserpflanzen, die hier besprochen sind, sind im allgemeinen als Beispiele einer Degeneration und vom morphologischen wie vom anatomischen Standpunkte als Rückbildungen aufzufassen, sobald man die Wasser- mit den Landpflanzen vergleicht. Dieser Rückschritt mag mit Henslow ${ }^{2}$ ) als eine Anpassung aufgefaßt werden. $\mathrm{Daß}$ auch einige fortschreitende nützliche Anpassungen vorhanden sind, zeigt das Vorkommen des Öles in der Epidermis, der Schleimbildung, des Xylemganges usw.

$\left.{ }^{1}\right)$ Uber die Schleimerzeugung bei Pflanzen vergl. die Arbeiten von Hunger 1899; Schilling 1894; Goebel 1898-1901; B. Schröder 1903.

2) Henslow 1895 . 
Dritter Abschnitt

\section{Das Zusammenleben der Organismen. Sociale Anpassungen. Die Pflanzenvereine}

\section{Kap. Das Zusammenleben der lebenden Wesen}

Die leblosen, physikalischen, chemischen und anderen Faktoren, die im ersten Abschnitte behandelt wurden, reichen durchaus nicht zum vollen Verständnis der Vereinsbildung im Pflanzenreiche hin. Schon Kap. 15 wurde ein anderer Faktor, nämlich der Wettbewerb zwischen den Pflanzenarten untereinander, als von so großer Bedeutung hervorgehoben, daß viele Arten von großen Gebieten der Erdoberfläche nicht durch den unmittelbaren Eingriff der leblosen Faktoren, sondern durch ihren mittelbaren Eingriff, durch den Nahrungswettbewerb mit anderen, stärkeren Pflanzenarten, ausgeschlossen bleiben.

Auch ein anderer Faktor, das Tierleben, hat für die Art und die Haushaltung der Vegetation große Bedeutung. Die Rolle der Regenwürmer, der Insekten und anderer kleiner Tiere bei den physikalischen oder den chemischen Änderungen des Bodens wurde schon behandelt. Das Tierleben greift jedoch auch auf vielerlei andere Weise in das Leben der Pflanzen ein, und unter allen lebenden Geschöpfen steht der Mensch als der voran, der die größten Veränderungen in den Pflanzenvereinen und auch Kämpfe zwischen diesen hervorruft.

Die mannigfaltigen, verwickelten Wechselverhältnisse der lebenden Wesen sind Umstände von allergrößter Bedeutung für das Pflanzenleben und die Pflanzenvereine, so daß sie in einem besonderen Abschnitte behandelt zu werden verdienen (vergl. 5. Abschnitt).

\section{Kap. Die Eingriffe des Menschen}

Auf vielfache Art stehen der Mensch und die Pflanzenwelt in Wechselwirkung. Obwohl die Pflanzenwelt auf den Menschen einwirkt, ist dieser doch bei weitem der stärkere, und die Vegetation wird in dem 
Grade sein Werk, daß es bald nur wenige Gegenden der Erde geben wird, wo er nicht umbildend und zerstörend eingegriffen hat, indem er die Vegetation nach seinem Gebrauch einrichtete oder indirekt auf sie einwirkte. Hier sei nur angedeutet, wie der Mensch, teils direkt, teils indirekt, durch seine Bearbeitung des Bodens, durch seine Kulturpflanzen und seine Haustiere, in den Zustand und in die ökonomische Stellung der ursprünglichen Pflanzenvereine eingreift, und wie er in der Form neuer Kulturpflanzen (z. B. Waldbäume) und neuer Unkräuter den wilden Pflanzen absichtlich oder unabsichtlich neue Mitbewerber zuführt ${ }^{1}$ ). Alte Vereine werden vom Menschen ausgerottet und neue Vereinsformen hervorgebracht; wenn wir z. B. in den Tropen verlassenen Plantagenboden mit Gebüschen von Unkrautpflanzen bedeckt sehen, so ist dieses ein neuer Verein, der natürlich nicht als solcher vorhanden war, bevor der Boden in den Dienst des Menschen genommen wurde, und die betreffenden, nun in riesigen Massen und als ein Verein mit einem besonderen Gepräge und einer besonderen Haushaltung auftretenden Arten müssen vor jener Zeit einzeln am Waldrande und an anderen offenen Stellen zerstreut gewesen $\operatorname{sein}^{2}$ ).

Die Bedeutung des Eingreifens der Menschen ist sehr stark von Crampton ${ }^{3}$ ) hervorgehoben worden. Er teilt die Standorte in künstliche und natürliche; die ersteren finden wir in Pflanzungen, Gärten, Hecken, Feldern usw. Zu ihnen gehören auch solche, die durch Drainierung, Rauch, Haustiere usw. verändert worden sind (Graebners ${ }^{4}$ ) Kultur- und Halbkulturformationen). Näheres über die Eingriffe des Menschen folgt im letzten Abschnitte ${ }^{5}$ ).

\section{Kap. Das Zusammenleben mit den Tieren}

Durch die biologischen Forschungen der Gegenwart, zu denen Darwins Arbeiten den Anstoß gegeben haben, sind wir über mannigfaltige und verwickelte Verhältnisse des Zusammenlebens zwischen Tieren und Pflanzen und über Anpassungen der Pflanzen an Tiere und umgekehrt aufgeklärt worden.

In floristisch-geographischer Hinsicht kann an den Zusammenhang zwischen dem Verbreitungsgebiete gewisser Pflanzen und Tiere, z. B. zwischen Aconitum und Bombus erinnert werden ${ }^{6}$ ), oder daran, daß die

1) K. Fritsch 1902 .

2) Warming 1892.

3) Crampton 1913.

4) Graebner 1909.

5) Über die Veränderungen an Kulturpflanzen, verminderte Fruchtbarkeit usw. vergl. Zacharias 1911; über ihre Disposition für parasitische Krankheiten, Sorauer 1902.

) Kronfeld 1890 . 
Vanille auf Mauritius, wohin sie am Anfange dieses Jahrhunderts eingeführt wurde, nur nach künstlicher Bestäubung Frucht bringt, weil die zur Bestäubung passenden Insekten dort fehlen, oder an die Beziehung, die nach Aurivillius zwischen der Insektenfauna des hohen Nordens und den biologischen Blumentypen der hochnordischen Flora besteht. Weiter seien erwähnt: Angraecum sesquipedale, welches unzweifelhaft an einen Nachtfalter mit enorm langem Rüssel angepaßt ist, oder Yucca filamentosa, die von der Motte Pronuba yuccasella abhängig ist ${ }^{1}$ ).

Es sei ferner auf die ganz verschiedene Rolle hingewiesen, die mit Hilfe von Wind oder von Insekten bestäubte Bliiten in der Physiognomie des ganzen Pflanzenvereines und der Landschaft spielen. Die Bäume der nordischen Wälder sind zumeist an Windbestäubung angepaßt (wenigstens die bestandbildenden), die der tropischen größtenteils an Insektenbestäubung, und hiermit gehen Unterschiede in der Blütenpracht einher, die dem Walde ein ganz verschiedenes Gepräge geben.

Viele ozeanische Inseln, z. B. die Galapagosinseln, sind arm an Blütenpflanzen mit schön gefärbten Blüten, aber reich an Farnen oder an Pflanzen mit kleinen und unansehnlichen Blüten; und dieses muß vermutlich mit der Dürftigkeit der Insektenfauna in Verbindung gebracht werden ${ }^{2}$ ).

Utber Bestäubungsverhältnisse existiert eine ungeheuer große Litteratur; auBer Darwin und Chr. C. Sprengel mögen genannt werden: Axell, Beccari, Briquet, Burkill, Delpino, Scot-Elliot, Fritsch, Hildebrand, Keller, Kirchner, Kuhn, Knuth, Lindman, Loew, Ludwig, MacLeod, Marloth 1908, H. Müller, A. F. W. Schimper, Schumann, Skottsberg, Warming, Willis und viele andere.

Daß gewisse Pflanzenvereine in unserer nordischen Natur einen besonderen Charakter haben können, der durch die Formen der Blütenstände und durch die Stellung der Blüten im Einklange mit dem Niveau, das die Blütenstände in der Vegetation einnehmen, und mit den Insektenbesuchen ausgedrückt wird, hat Grevillius ${ }^{3}$ ) nachzuweisen gesucht.

Ferner sind zu berücksichtigen: die gegenseitige Anpassung, die sich zwischen Insekten und Blüten findet, die Bauverhältnisse, die die Pflanzen instand setzen, ihre Früchte oder ihre Samen oder sogar Knospen und Sproßteile mit Hilfe der Tiere zu verbreiten (saftige und gefärbte Früchte, oder Früchte und Samen mit Hakenvorrichtungen oder Drüsenhaaren usw.). Dieses Thema hat in neuerer Zeit besonders Sernander ${ }^{4}$ ) bearbeitet.

I) Riley 1873 , 1891; Knuth 1904, III, S. 180 .

g) Wallace 1880; siehe M. G. Thomson 1880.

3) Grevillius 1894.

4) Sernander 1901, 1906. 
Besonders betont muß ferner werden das Zusammenleben zu gegenseitigem Nutzen, das zwischen Ameisen und Pflanzen stattfindet (Myrmecodia, Cecropia, Acacia, Triplaris u. a. $\left.{ }^{1}\right)$.

Großes Interesse bieten die neuen Studien Sernanders ${ }^{2}$ ) über die Myrmekochorie. Viele Pflanzenarten besitzen an ihren Früchten oder Samen fleischige Anhängsel, die meist fettes Öl enthalten (Elaiosome Sernanders) und von den Ameisen begierig gefressen werden. Diese Pflanzen entstammen den verschiedensten Familien. Die Stärke der Myrmekochorie ist verschieden, manche Früchte oder Samen werden sofort in den Bau geschleppt und später wieder fort, andere bleiben

1.
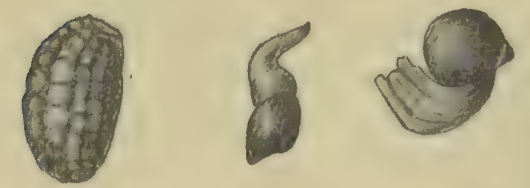

2.
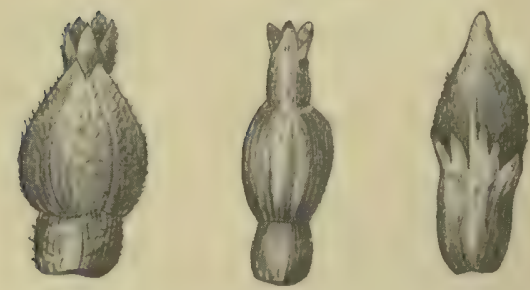

Fig. 142. Myrmekochoren-Früchte und -Samen. 1. Puschkinia scilloides, Luzula pilosa, Corydallis cava. 2. Aremonia agrimonioides, Thesium alpinum, Carex mon-

tana. Nach Sernander u. Ulbrich. längere Zeit liegen. Je nach der Lage der Elaiosomen unterscheidet Sernander eine Anzahl (15) Typen. Besonders stark ist die Myrmekochorie ausgeprägt bei Scilla Sibirica, Corydallis cava, Viola odorata, Veronica agrestis $\mathbf{u}$. a. (Fig. 142).

Weiter das Zusammenleben, das sich zwischen Milben und Pflanzen findet, auf denen Domatien zur Wohnung für jene ausgebildet sind ${ }^{3}$ ), und das Zusammenleben, das nach Cienkowski, Entz, Brandt und Geddes zwischen grün oder gelb gefärbten Algen (Zoochlorella, Zooxanthella) und Tieren (Radiolarien, Infusorien, Flagellaten, Spongilla, Hydra viridis u. a.) herrscht und das als mutualistisch aufgefaßt werden muß, da die Alge kohlenstoffhaltige Nahrung und Sauerstoff herbeischafft, während das Tier ihr Obdach gibt und für die beständige Zuführung von frischem kohlensäurehaltigem Wasser sorgt.

Ferner sind z. B. die Bauverhältnisse zu beachten, die für die Pflanzen nützliche Schutzeinrichtungen besonders gegen die weidenden Tiere bilden: Gifte, Bitterstoffe, Gerbstoffe, ätherische Öle, Raphiden, Dornen, Brennhaare, stechende Borsten u. a.4).

Auch sei hier an die Anpassungen der insektenfressenden Pflanzen an ihre eigentümliche Ernährungsart erinnert; ferner daran, daß gewisse

1) Vergl. Belt 1874; Delpino, siehe Schimper 1898; Raciborski 1898; Warming 1898. Vergl. auch Fiebrig 1909; Ule 1900, 1906.

2) Sernander 1906; Birger 1907; Ulbrich 1907.

•) Lundström 1887. Penzig u. Chiabrera 1903.

*) Stahl 1904. 
Tiere in ökologisch-geographischer Hinsicht dadurch eine große Rolle spielen, daß sie gewisse Pflanzen suchen und zur Nahrung benutzen; so Hirsche, Hasen, Mäuse und ähnliche in den Wäldern, die großen Wiederkäuer auf den Savannen und Steppen Afrikas usw. Hierdurch werden gewisse Pflanzenarten auf Kosten anderer begünstigt, und das ganze Gepräge des Vereines wird ein anderes; über die dabei erfolgende Bevorzugung von giftigen, schlechtriechenden und -schmeckenden Pflanzen vergl. Graebner ${ }^{1}$ ).

Die Veränderung der Pflanzenformen durch die weidenden Tiere sind besonders besprochen und illustriert worden durch L. Klein, Adamovicz ${ }^{2}$ ) usw.

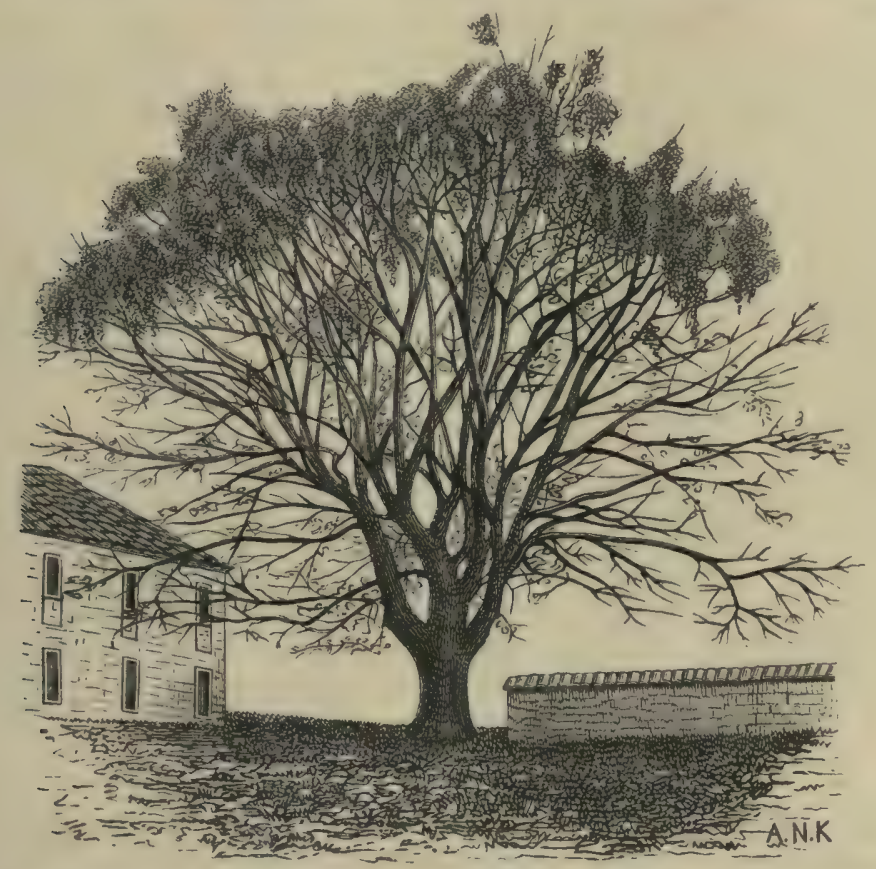

Fig. 143. Ficus-Baum (Urostigma doliarium) in Brasilien, in der Trockenzeit. Der Baum ist blattlos, alles Grüne rührt von Loranthaceen (Struthanthus) her.

(Nach Phot. von Warming 1865 in "Lagoa Santa" [1892]).

\section{Kap. Das Zusammenleben der Pflanzen untereinander}

Verschiedenerlei Bande von sehr verschiedener Stärke können die Pflanzen miteinander verknüpfen; in einigen Fällen greift das Zusammenleben in das Leben der betreffenden Arten tief ein, in anderen Fällen

1) Graebner 1909.

2) Klein 1899; Adamovicz 1909. Utber das in diesem Kapitel besprochene vergl. übrigens Ludwig 1895: C. Schröter 1904-08; F. W. Neger, Biologie der Pflanzen 1913; Jos. Braun 1913, S. 147. 
ist es weit loser, sogar rein zufällig. Indem wir im folgenden mit solchen Formen des Zusammenlebens beginnen, wo die Arten am innigsten und am festesten verknüpft, nämlich organisch verbunden sind (eigentliche Symbiose) ${ }^{1}$ ), gehen wir allmählich zu den loseren Formen über und schließen mit den großen Pflanzenvereinen, die viele Arten des Zusammenlebens umfassen und demnächst der Gegenstand unserer Betrachtung sein werden. Die Formen des Zusammenlebens sind gegeneinander nicht scharf abgegrenzt.

Der Parasitismus ist eine Form des Zusammenlebens, in der die beiden zusammenlebenden Arten am engsten verbunden sein können. Die eine Art versieht die andere mit Nahrung, der Schmarotzer lebt auf oder in seinem "Wirte", von dessen lebendem Gewebe oder doch. seinem plastischen Material. Der Grad, wie weit der Schmarotzer an

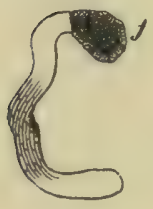

$A$

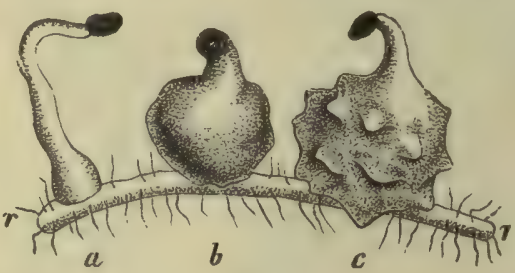

$B$

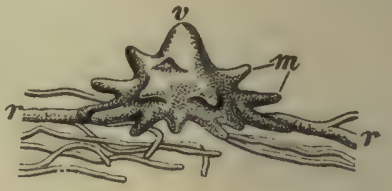

C

Fig. 144. Keimpflanzen von Orobanche (Phelipaea) ramosa, auf der Wurzel $r-r^{\prime}$ sitzend. A. Ganz junge Keimpflanze, oben noch die Samenschale. - B. a das Wurzelende des Keimlings ist etwas angeschwollen, doch hat die Wurzel die Rinde erst zur Hälfte durchbrochen; $b$ das hypokotyle Glied ist stark angeschwollen und mit der Wirtswurzel verwachsen; c Adventivwurzeln treten in Gestalt schwacher Auswïchse hervor. $16: 1 .-$

C. Ältere Keimpflanze, die Adventivwurzeln andere Wurzeln ergreifend. 4: 1 .

(Nach Caspary.)

seinen Wirt gebunden ist und seine Nahrung aus ihm ziehen muß, kann jedoch äußerst verschieden sein und stuft sich bei den verschiedenen Arten ab: Am abhängigsten sind viele Rostpilze oder die Flachsseide (Cuscuta epilinum) oder Orobanche-Arten usw., die nicht nur Ganzparasiten, d. h. außerstande sind, anorganische Nahrung zu benutzen, sondern auch nur auf einer ganz bestimmten Art leben können (Fig. 143, 144, 145).

Weniger abhängig sind die Arten, die auf mehrfache oder auf vielerlei verschiedene Weise gleich gut gedeihen können, entweder auf Arten derselben oder sogar innerhalb verschiedener Familien; Cuscuta epithymum ist eine solche (ganzparasitische) Art, die auf Calluna, Labiaten, Papilionaceen, ja auf Monocotylen und Equisetum u. a. leben kann, und Viscum album ist eine andere (halbparasitische) Art, von der die

1) Schimper 1898 . 
eine Rasse etwa auf einem halben Hundert Arten von Laubbäumen, die andere auf mehreren Nadelbäumen, die dritte nur auf Abies alba schmarotzen kann ${ }^{1}$ ). Von Laub- auf Nadelhölzer und umgekehrt gehen sie nicht über. Sie sind physiologische Varietäten („Gewohnheitsrassen“, Magnus; spezialisierte Formen, Eriksson; biologische Rassen, Rostrup). In den Tropen leben zahlreiche Loranthaceen, die auf Bäumen schmarotzen (Fig. 143); einige von ihnen haben prachtvolle Blüten.

H. Winkler betont neuerdings ${ }^{2}$ ), daß nach seinen Versuchen die Mistel wohl im wesentlichen Wasser entzieht und einen Teil ihres

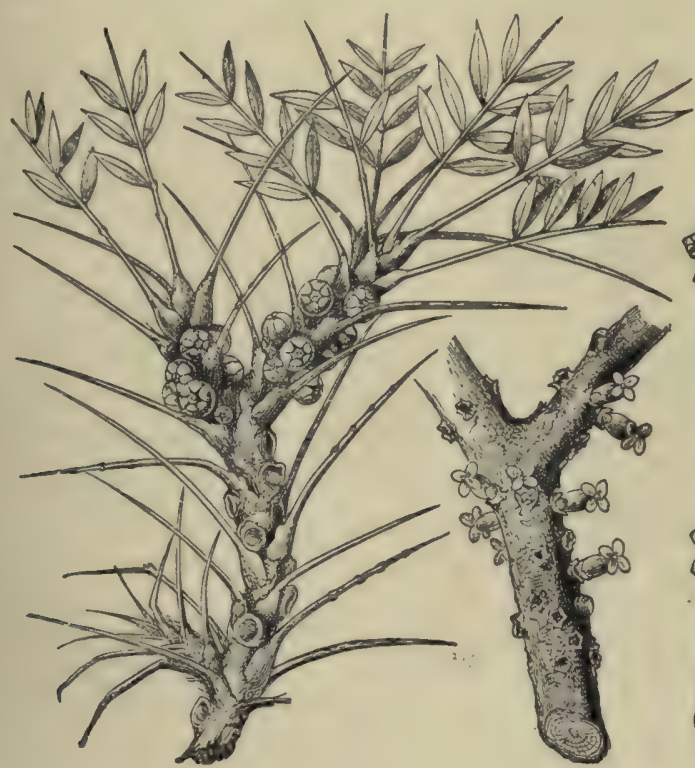

1.

2.

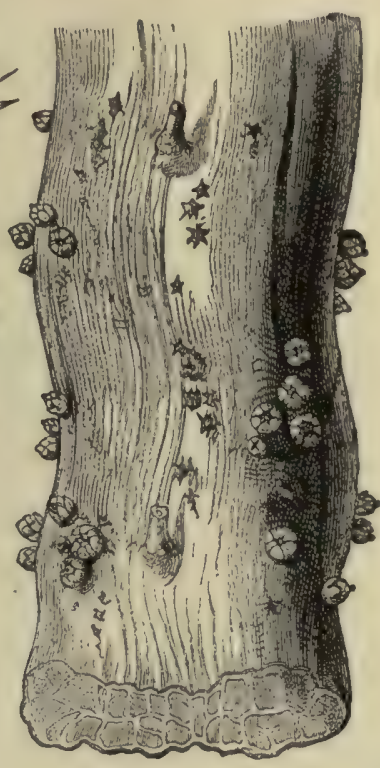

3.

Fig. 145. Rafflesiaceen auf Zweigen von Bäumen und Sträuchern schmarotzend;

1. u. 3. Pilostyles, 2. Apodanthes. Die vegetativen Teile sind vollständig im Wirtskörper eingeschlossen, nur die Blïten treten nach außen heraus. (Nach Kerner.)

Bedarfes an plastischen Stoffen durch Assimilation selbst deckt, daß sie aber auch wesentlich auf die organische Substanz des Wirtes angewiesen ist.

Während gewisse Arten Zwangsschmarotzer (obligatorische Schmarotzer) sind, die nur als Schmarotzer leben können, sind andere weniger gebunden und können gelegentlich vortrefflich als Saprophyten (Verwesungspflanzen) leben, z. B. der Hallimasch (Armillaria mellea). Nectria cinnabarina u. a. Pilze sind wohl stets zuerst Saprophyten,

1) Tubeuf 1912-14.

2) H. Winkler 1913. 
dringen dann aber auch vom toten Gewebe (Astzapfen usw.) in das lebende.

Die Euphrasiaceen, die mit ihren Wurzeln die benachbarter Pflanzen aussaugen (Fig. 146), können zum großen Teil, wenn auch schwächlich

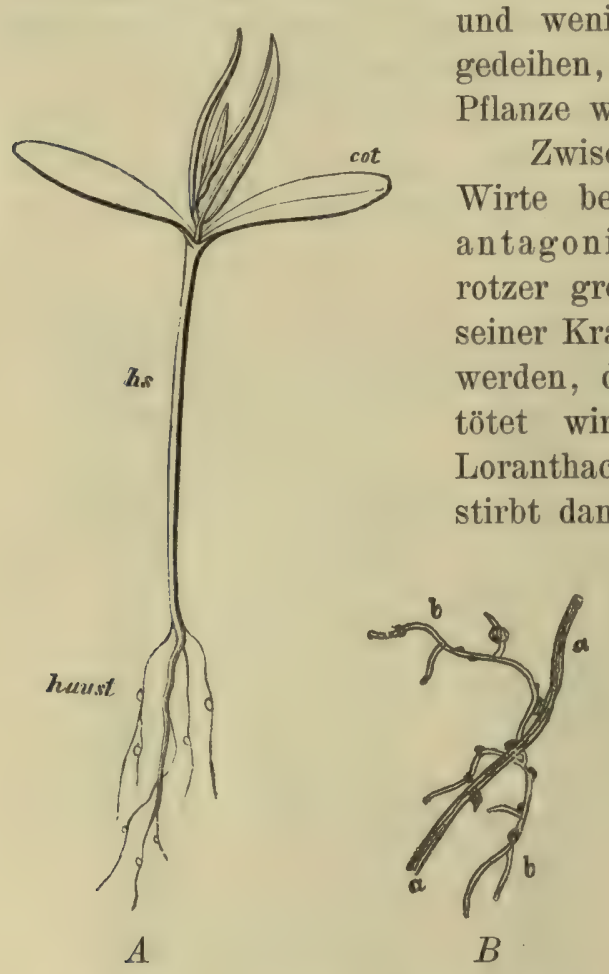

Fig. 146. A. Melampyrum pratense, Keimpflanze. hs Hypokotyles Glied; haust Saugwarzen; cot Cotyledonen; 1:1 (E. Warming). B. $b-b$ Wurzel von Euphrasia officinalis (Augentrost) mit ihren Haustorien, von welchen eins sich auf der Wurzel $a-a$ festgeheftet hat. 1: 1 .

(Nach Warming-Johannsen.) wächst.

wischen dem Schmarotzer und seinem irte besteht ein feindliches (einseitig seiner Kraft. Der Wirt kann so geschwächt , daß er durch den Schmarotzer gewird (Orangenbäume können durch Loranthaceen getötet werden); natürlich der Schmarotzer.

Der Kampf zwischen einer Art und ihren Parasiten ist für die Zusammensetzung der Vereine von besonders großer Bedeutung. Viele Waldbäume unterliegen dem Angriffe von Pilzen (z. B. Pinus silvestris den Angriffen von Lophodermium pinastri, von Polyporus annosus u. a.), und die Natur der Waldvegetation ganzer Länder wird hierdurch beeinflußt. Kulturwälder (meist aus einer Art mit gleichaltrigen Stämmen; „Forsten“) sind dem Angriffe von Schmarotzern mehr ausgesetzt als Naturwälder, weil sich die Schmarotzer in einem gleichförmigen Bestande leichter ausbreiten als in einem ungleichförmigen. Der Parasitenangriff ist neben klimatischen Verhältnissen oft der Grund, weshalb eine Art einer anderen unterliegt.

Helotismus ${ }^{1}$ ). Das Zusammenleben zwischen den Flechtenpilzen und den Algen muß man offenbar am richtigsten als Helotismus auffassen. Eine Flechte ist ein Doppelorganismus, von einem Pilz und

1) Vergl. Reinke, weiter Warming, Den almindelige Botanik, Kjöbenhavn 1895,

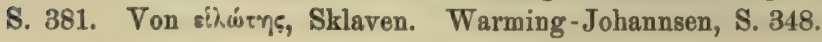


einer Alge gebildet, welch letzere von Hyphen des Pilzes umsponnen und in den Pilzkörper aufgenommen ist. Das Verhältnis wird gewöhnlich als mutualistisch bezeichnet, $d$. $h$. die beiden Organismen sollen einander gegenseitig Dienste leisten, und dieses ist ja wohl auch richtig, indem die Alge offenbar durch ihr Chlorophyll für kohlenstoffhaltige Nahrung und für die Verarbeitung der Nahrung zum gemeinsamen Besten sorgen und der Flechtenpilz das übrige herbeischaffen muß; aber die Gegenseitigkeit ist nicht gleich groß, denn der Pilz muß sich mit der Alge verbinden, um sich zu seiner vollkommensten Form entwickeln zu können, aber die Alge braucht den Pilz keineswegs und zieht es sicher vor, frei, von ihm geschieden, zu leben. Der Ausdruck "Konsortium" ist daher auch nicht zutreffend. Daß die Alge kräftig

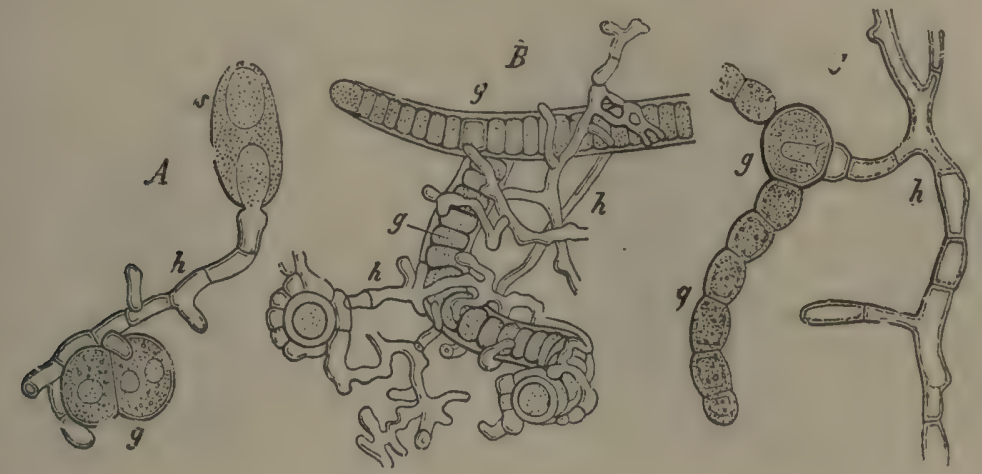

Fig. 147. Gonidientypen von Flechten. $g$ Gonidien, $h$ Hyphen.

A. Keimende Spore von Xanthoria parietina, deren Keimfaden sich auf Cystococeus festsetzt. - B. Ein Scytonema-Faden, der von den Hyphen von Stereocaulon ramulosum umsponnen wird. - C. Eine Hyphe von Physma chalazanum dringt in eine Zelle von Nostoc ein. (Nach Bornet.)

wächst und sich rasch vermehrt, vielleicht sogar größere Zellen als im freien Zustande erhält, braucht nichts anderes als ein Hypertrophismus, ein Krankheitszustand, zu sein. Man hat gemeint, daß die Alge in dem Pilzkörper Schutz gegen Austrocknen fände; aber erstens scheint dieses kaum notwendig zu sein, da die betreffenden Algen gewiß alle ein Austrocknen vorzüglich ertragen, zweitens ist es nicht einmal der Fall, daß sie wirklich Schutz gegen Austrocknen finden, denn die Flechte trocknet unter gegebenen Verhältnissen so ein, daß sie spröde wird. Außerdem ist die Alge daran verhindert, sich auf die für ihre Art vollkommenste Weise zu vermehren, z. B. bilden viele derselben im freien Zustande Schwärmsporen, in der Flechte aber nicht. Die Alge ist in dem Pilze offenbar in Sklaverei, und dieser ist eine Art Parasit, der von gewöhnlichen Parasiten namentlich dadurch abweicht, daß er den Wirt in seinen Körper aufnimmt und daß er selbst für einen Teil der 
im Haushalte des Wirtes verbrauchten Nahrung sorgt. Es besteht also eine gewisse Ähnlichkeit mit den grünen Halbparasiten; aber, während man annehmen muß, daß diese die kohlenstoffhaltige Nahrung wenigstens z. T. selbst erzeugen, braucht der Flechtenpilz nur für die nicht kohlenstoffhaltige Nahrung zu sorgen (Fig. 147).

Auch hier kann das Band zwischen den beiden Organismen recht eng sein, indem der Pilz bestimmte Algenarten wählt (vergl. Schwendener). - Ganz abweichenden Anschauungen über das Verhältnis zwischen Pilz und Alge hat früher Minks und neuerdings Elfving ${ }^{1}$ ) Ausdruck gegeben.

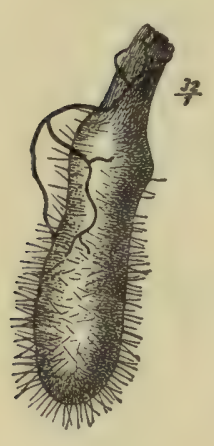

A

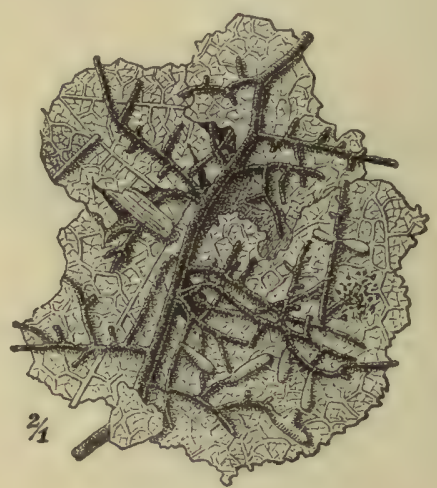

$B$

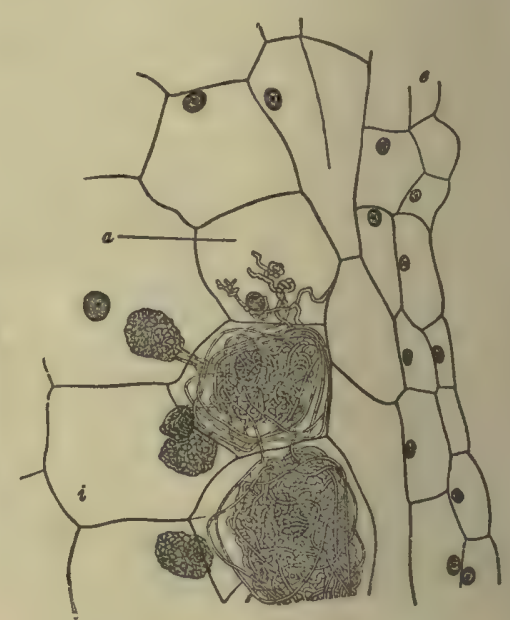

C

Fig. 148. Mykorrhizen. $A, B$ der Buche aus Waldboden. $A$. Eine zur Mykorrhiza umgebildete Wurzel. B. Die Wurzelzweige breiten sich (oft fast rechtwinkelig verzweigt) zwischen den teilweise verwesten Blattresten aus und sind an der Spitze deutlich angeschwollen. - C. Aus einem Längsschnitt durch eine Wurzel von Neottia nidus avis, in der Nähe der Wurzelspitze; e Epidermis, unten in der Rinde 2 mit Pilzhyphen gefüllte Zellen; in den oberen fehlen die Pilzhyphen, doch sind solche eben im Begriffe in die Zellen $a$ und $i$ einzuwandern. ( $A, B$ nach P. E. Müller; $C$ nach Frank.)

$\mathrm{Ob}$ es einen Mutualismus mit vollkommener Gegenseitigkeit, einem für beide Teile gleich vorteilhaften Zusammenleben, gibt, ist zweifelhaft. Die meisten bekannten Verhältnisse des Zusammenlebens zwischen Organismen sind nicht so gut bekannt, daß wir den Zusammenhang vollständig klar durchschauen können. Dieses gilt z. B. von der Mykorrhiza, wobei Wurzeln einer höheren Pflanze mit immer sterilen Pilzhyphen eine enge, entweder ektotrophische oder endotrophische Verbindung eingehen, d. h. entweder mit Hyphen, die vorzugsweise eine Kappe auf der Oberfläche der Wurzelspitzen bilden,

1) Elfving 1914 . 
oder mit Hyphen, die in den Rindenzellen der Wurzeln leben. Mykorrhizen sind bei den meisten Kätzchenträgern, Nadelbäumen, Ericaceen und vielen anderen gefunden worden, besonders bei vielen mehrjährigen Kräutern, die auf Rohhumus-, Torf- und Humusboden, also auf humusreichem Boden leben. Die Mycelien haben sicher von der Blütenpflanze Vorteil, aber es ist sehr wahrscheinlich, daß sie dieser von Nutzen sind; sie ersetzen, jedenfalls in gewissen Fällen, die Wurzelhaare und dienen vermutlich dazu, organische, namentlich stickstoffhaltige Nahrung aus dem an Humus reichen Boden herbeizuschaffen ${ }^{1}$ ) (Fig. 148).

P. E. Müller ${ }^{2}$ ) fand, daß die meisten unserer Waldbäume ektotrophische Mykorrhizen haben, wenige endotrophische. Bei der Bergkiefer fand er zwei Formen, gabelige und traubige, die auf derselben Wurzel vorkommen können. Er ist auch der Meinung, daß diese dazu dienen, den Pflanzen stickstoffhaltige Nahrung zuzuführen. Da er durch ausgedehnte Kultur und Versuche fand, daß die Bergkiefer in Jütland auf ganz humusfreiem Boden der Heidegegenden gut gedeiht, die Fichte aber nicht, daß dagegen die Fichte, wenn sie mit Bergkiefern zusammen gepflanzt wird, gut gedeiht, so glaubt er, daß es die Kiefer ist, die durch ihre Mykorrhizen den Stickstoffhunger der Fichte befriedigt.

Ist dieses, was zunächst für die ektotrophischen Mykorrhizen gilt, richtig, so hat man hier ein bemerkenswertes Beispiel dafür, daß die eine Pflanzenart der anderen hilft, Standorte zu besiedeln, und sich in einem Boden Nahrung zu verschaffen, von dem sie sonst vielleicht ausgeschlossen bliebe; die Calluna-Heide, der Fichtenwald usw. würden dann bis zu einem gewissen Grade diesem Zusammenleben ihr Dasein verdanken.

Die Frage nach der Bedeutung der Mykorrhizen ist aber bei weitem nicht gelöst; verschiedene Hypothesen sind neuerdings darüber aufgestellt worden. Wichtig ist besonders die von Stahl ${ }^{3}$ ), nach welcher die Pilze der ektotrophen Mykorrhizen hauptsächlich Nährsalze für die von ihnen bewohnten Pflanzen herbeischaffen sollen; dadurch würden diese besser imstande sein, den Wettkampf mit anderen Pflanzen aufnehmen zu können. Er fand, daß besonders solche Pflanzen mit Mykorrhizen versehen sind, welche eine schwache Wasseraufnahme haben und deshalb davon bedroht würden, an Nährsalz Not zu leiden.

Percy Groom ${ }^{4}$ ) beobachtete den endophytischen Mykorrhizenpilz bei Thismia und kommt zu dem Schlusse, daß er einen Austausch von Nährstoffen mit der Wurzel bewirkt und namentlich die Erzeugung von

1) Frank 1885; Alfred Moeller 1908 und später.

3) P. E. Müller 1902, 1903.

8) Stahl 1900 .

4) Percy Groom 1905. 
Proteïnkörpern befördert. Der Pilz entzieht der Wurzel gewisse Stoffe und liefert dafür andere wieder; schließlich wird er selbst zu einem gewissen Teile verzehrt. An der ektotrophischen Form sind die Verhältnisse zwischen Pilz und Wurzel anders geartet ${ }^{1}$ ).

Einigermaßen ähnlich, namentlich mit der endotrophischen Mykorrhiza, scheint das Zusammenleben zu sein, das zwischen Leguminosen und Bakterien stattfindet. Daß gewisse frei in der Erde lebende Bakterien (z. B. Clostridium Pasteurianum, Azolobacter chroococcum) Stickstoff aus der Luft assimilieren können, ist sicher. Dasselbe muß auch mit denjenigen Bakterien der Fall sein, welche in den

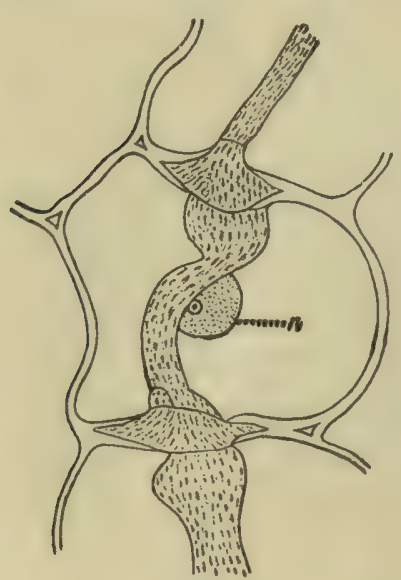

A

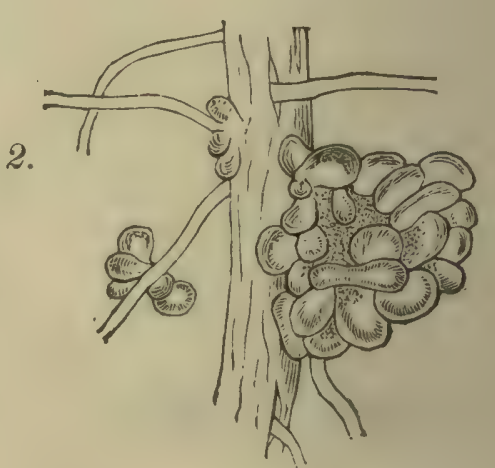

$B$

Fig. 149. Strangförmige Bakterienkolonie aus einem in Bildung begriffenen Knöllchen an der Wurzel der Erbse; ca. 650:1; $n$ Zellkern. Das Cytoplasma ist in der Figur nicht wiedergegeben (nach Prazmowsky). $-B$. Wurzelknöllchen an Leguminosenwurzeln, 1. Seitenwurzeln des roten Klees, 2. Stück einer Wurzel der Saubohne, schwach vergrößert (nach E. Rostrup).

kleinen Wurzelknollen der Leguminosen zu finden sind. Sie sind von außen eingewandert und scheinen in der Pflanze stickstoffhaltige Nahrung aus der Luft $\mathrm{zu}$ assimilieren, schließlich zugrunde $\mathrm{zu}$ gehen, $\mathrm{zu}$ "Bakteroiden" umgebildet $\mathrm{zu}$ werden und durch ihren Stickstoffgehalt den Leguminosen zur Nahrung zu dienen. Man nimmt an, daß die Bakterien von dem Zusammenleben einen Nutzen haben (sie erhalten wohl Kohlenstoffverbindungen von dem Wirte); anderseits würde es bemerkenswert sein, daß sie, wie die endotrophischen Pilze, in

1) Weiter haben über Mykorrhizen u. a. gearbeitet: Bernard 1910; Kamiensky 1881; P. E. Müller 1886, 1902, 1903; Frank 1887; Sorauer 1893; Percy Groom 1895; W. Magnus; Stahl; Mazé 1900; Weyland; Sorauer 1903-4 (dort Litteraturübersicht) und viele andere. Weitere Litteratur bei Neger, Biologie der Pflanzen. 
die Wurzeln eindringen, wenn jenes nicht der Fall wäre ${ }^{1}$ ). Vergl. Fig. 149, 150.

Auch bei Elaeagnaceae, Myrica und Ceanothus finden sich ähnliche Wurzelknollen, die aber nicht durch Bakterien, sondern durch Hyphen eines Pilzes hervorgerufen werden. Auch für diese ist jetzt nachgewiesen worden, daß sie Stickstoff aus der Luft aufnehmen und speichern können.

Gehen wir einen Schritt weiter, so kommen wir zu Pflanzen (Algen), die in anderen Pflanzen Wohnung nehmen, ohne, soweit wir wissen, einen Gegendienst zu leisten. Sie leben nicht auf Kosten des Wirtes, nehmen vielleicht überhaupt nichts von ihm, aber wohnen gewissermaßen frei. Hierher ist wohl die Cyanophycee (Anabaena) zu
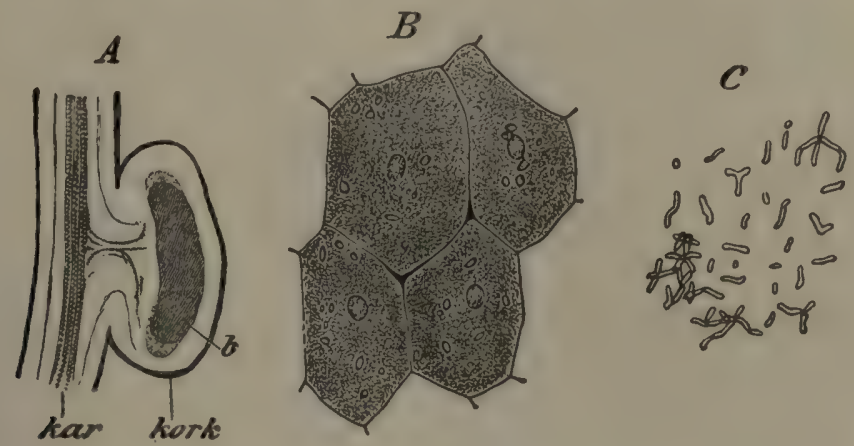

Fig. 150. A. Längsschnitt aus einem jüngeren Wurzelknöllchen der Lupine, schwach vergrößert; kar die Gefäßbündel der Wurzel; kork das Korkgewebe; $b$ die mittlere Partie des Knöllchens (nach Tschirch). - B. Vier Zellen aus der mittleren Partie, ca. $250: 1$. Neben dem Zellkern und einigen Stärkekörnern erscheint der ganze Zellraum von Cytoplasma mit "Bakteroiden" ausgefüllt. - C. Bakteroiden, ca. 1100:1 (nach Frank).

stellen, die in besonderen Löchern auf der Unterseite der Blätter von Azolla lebt, in Löchern, die nur ihretwegen da zu sein scheinen, die sich bei allen vier Azolla-Arten konstant finden und nie frei von Anabaena sind. Die Alge kann ebenso gut frei, von Azolla getrennt, leben.

Ähnlich leben andere Algen endophytisch, $d . h$. in anderen Pflanzen: in Sphagnum-Blättern, in die Nostoc durch die Löcher der farblosen Zellen hineingerät, in gewissen Lebermoosen oder in anderen Algen, z. B. Entoderma viride in der Zellwand von Derbesia Lamourouxii. Vielleicht liegt aber in dem zuletzt genannten Falle Parasitismus vor.

1) Uber die Knöllchen- und Stickstoffbakterien vergl. neuerdings K. Fuhrmann 1908; Bredemann 1908. 


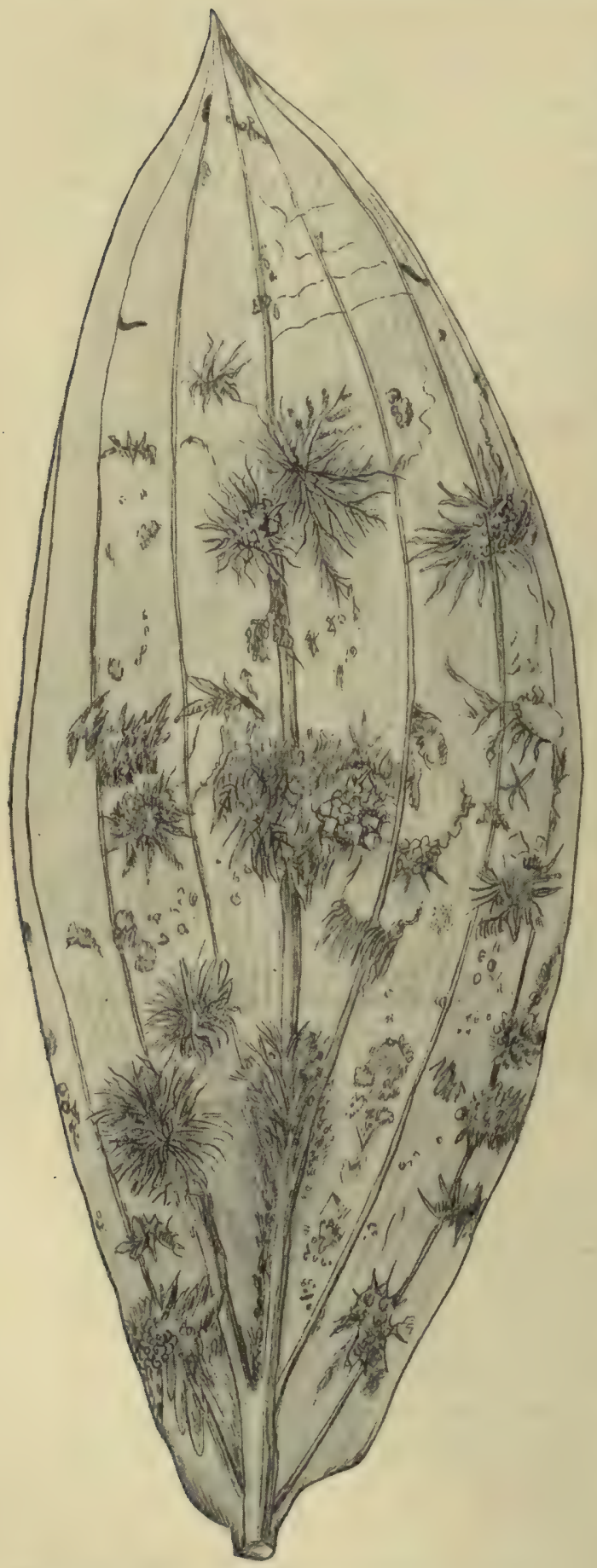

Fig. 151. Blatt von Kibessia azurea mit zahlreichen epiphyllen Flechten. (Nach Stahl.)
Teilweise muß dieses wohl auch mit den Cyanophyceen der Fall sein, die in die aufrechten, gabelzweigigen Wurzeln der Cycadeae eindringen und eine bestimmte Parenchymschicht anregen, auf eine besondere Art zu wachsen und ihnen Platz zu schaffen, und namentlich mit den Algen (Nostoc), die in die Stämme von Gunnera eindringen und die auch frei außerhalb der Wurzeln oder der Stämme leben können ${ }^{1}$ ). Unsere gegenwärtigen Kenntnisse lassen noch nicht $\mathrm{zu}$, überall klar die Natur des Zusammenlebens zu deuten.

Epiphyten. Von den Endophyten, die in anderen Pflanzen nur Wohnung suchen, führt ein kleiner Schritt zu den epiphytisch, d. h. a uf anderen Pflanzen ihr ganzes Leben zubringenden Arten, die aus den lebenden Teilen ihres Wirtes durchaus keine Nahrung nehmen, höchstens von dessen totem Gewebe leben.

Doch hat Fitting ${ }^{2}$ ) nachgewiesen, daß die auf Blättern lebenden („epiphyllen") Flechten auch teilweise Parasiten sind. Einige zerstören jedenfalls die Blätter dadurch, daß sie tief in das Blattgewebe eindringen. Andere, und zwar der größere Teil, dringen nur unter die Cuticula ein und verursachen so im allgemeinen

1) Jönsson 1894.

?) Fitting 1909 . 
nur geringen Schaden. Eine dritte Gruppe wächst über die Cuticula hinweg, indem sie sich auf deren Oberseite anheftet, und dies sind dann typische "Epiphyllen". Die epiphyllen Flechten finden sich vorzugsweise auf glatten Blättern (Fig. 151; Fig. 123).

Auch sonst ist es nicht immer zulässig zu sagen, daß Epiphyten nicht auf Kosten ihrer Wirtspflanze leben, denn Epiphyten können auf anderen Pflanzen in solcher Menge auftreten, daß man annehmen muß, daß sie ihnen durch ihre Masse schaden oder zu große Feuchtigkeit hervorrufen oder die Atmung vermindern, z. B. Flechten auf Bäumen ${ }^{1}$ ).

Das Band zwischen dem Epiphyten und der Art, worauf er sich niederläßt, ist in der Regel weniger innig als in den vorigen Fällen; die meisten Epiphyten können auf vielerlei Pflanzen wachsen, einige sogar außerdem auf Fels. Andere sind jedoch an bestimmte Arten gebunden, weil die Beschaffenheit der Rinde oder der Blattfläche für sie wichtig ist. Es gibt Epiphyten sowohl auf Wasser- als auf Landpflanzen. Mannigfaltige Algen leben auf anderen Algen oder auf Blütenpflanzen, und einige Algen nur auf ganz bestimmten Arten, z. B. Elachista fucicola auf Fucus, E. scutulata auf Himanthalia lorea usw. ${ }^{2}$ ).

Epiphyten auf Landpflanzen gedeihen am besten da, wo es reichlich Luftfeuchtigkeit und Niederschläge gibt. Hierauf hat schon Meyen ${ }^{3}$ ) aufmerksam gemacht, und Schimper hat den Gegenstand später in seinen Arbeiten über die Epiphyten ${ }^{4}$ ) näher behandelt. Trockene Klimate oder Klimate mit lange dauernden Trockenzeiten sind den Epiphyten nicht günstig.

In kalten und in gemäßigten Gegenden sind die Epiphyten meist Algen ( "ärophytische" Algen), Flechten und Moose, in warmen Ländern kommen außerdem eine Menge Farne und Blütenpflanzen aus mehreren Familien hinzu (Orchidaceae, Araceae, Bromeliaceae, Piperaceae usw.), und in den feuchten Tropenwäldern finden sich viele epiphylle, d. $\mathrm{h}$. auf den mehrjährigen Blättern lebende Arten ${ }^{5}$ ). Vergl. Fig. 123, S. 241.

Eigentümlichkeiten des Standortes haben mehrere biologische Anpassungen, die zuerst Schimper bei den Blütenpflanzen aufgeklärt hat, zur Folge, deren wichtigste ${ }^{6}$ ) in den folgenden Seiten behandelt werden sollen:

Verbreitung. Die Samen und Sporen sind auf zweierlei Art eingerichtet, um verbreitet und auf der Unterlage befestigt zu werden.

1) Sorauer 1886; Lindan 1895.

2) Uber die von Fritsch gewählte Bezeichnung "Konsortium" vergl. Fritsch 1906.

3) Meyen 1836.

4) Schimper 1884, 1888; vergl. auch $\mathrm{Mez} 1904$.

5) Goebel 1889-92; Raciborski 1898; Mez 1904; G. Karsten 1894; Treub 1888; G. Jennings.

-) AuBer den eben genannten Forschern vergl. noch Beccari.

Warming.Grabner. 3. Auflage, illustr. 
Entweder werden sie durch den Wind verbreitet, dann sind sie so klein, staubfein und sehr leicht oder sie sind mit langen Haaren versehen, so daß sie leicht vom Winde auf Stämme und Zweige geführt werden können. Dort finden sie eine Spalte oder eine andere Vertiefung, worin sie sich festsetzen können. Andere Samen sind in fleischigen Früchten enthalten, die von den Vögeln gefressen und mit deren Exkrementen die Samen verbreitet

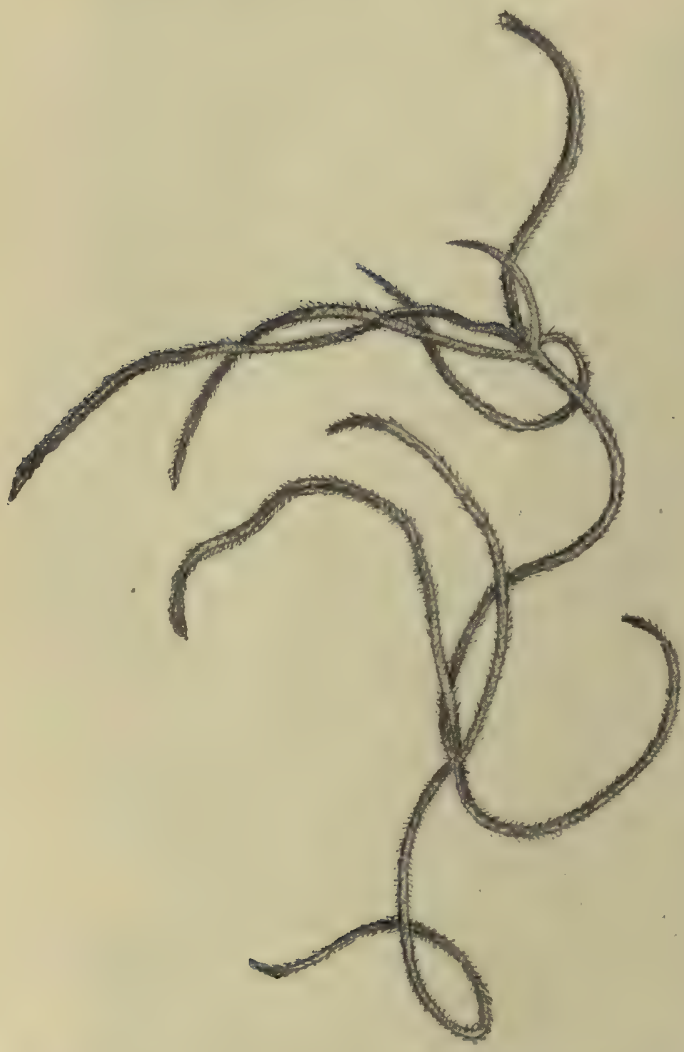

Fig. 152. Zweigstück der gänzlich wurzellosen Tillandsia usneoides. $1: 1$. (Nach Schimper.) und auf Zweigen festgeheftet werden (Araceae, Bromeliaceae, Cactaceae). Eine ganz ungewöhnliche Vermehrungsart hat die wurzellose Tillandsia usneoides; losgerissene Stücke ihrer langen, dünnen Sprosse wickeln sich leicht um die Zweige der Bäume (Fig. 152). Die Festheftung der Epiphyten an die Pflanzenteile geschieht entweder durch Rhizoiden, die in die Spalten der Unterlage (die toten Rindenteile) etwas eindringen (Moose, Flechten usw.), oder durch Haftwurzeln, die reizbar sind und sich teilweise mit Hafthaaren der Unterlage fest andrücken. Oft besteht eine Arbeitsteilung zwischen Haftwurzeln und Saugwurzeln (Fig. 158, 159); Fig. 153; Fig. 51; Fig. 52, S. 160; Fig. 70, S. 177; Fig. 86, S. 194. Die Wasserversorgung

ist für die Epiphyten eine schwierige Aufgabe, da das Regenwasser schnell abfließt. Sie entnehmen sicher das notwendige Wasser mehr dem Tau und Nebeln, als dem Regen. Viele sind eingerichtet, den passenden Augenblick zu ergreifen, und können im trockenen Zustande die Feuchtigkeit augenblicklich mit ihrer ganzen Oberfläche aufsaugen (Algen, Moose, Flechten und Tillandsia usneoides, die wie andere Bromeliaceen eigentümliche Saughaare hat) ${ }^{1}$ ). Auf S. 55, Fig. 28 bis 30 sind die charakteristischen Haare abgebildet, Fig. 30 zeigt eine solche in Tätigkeit.

1) Schimper 1884, $1888 \mathrm{a}$; Mez $1904 \mathrm{a}$. 
Bei den Flechten ist es nach Sievers ${ }^{1}$ ) die Oberseite, welche vorzugsweise das Wasser aufnimmt. Außerdem kommt den Flechten eine starke Hyproskopizität zugute; er fand z. B., daß Usnea barbata 27,7\%, Gyrophora hirsuta $37,5 \%$ und Cladonia rangiferina $50 \%$ ihres Gewichtes an Wasser in Dampfform aufzunehmen vermögen. Hierbei muß aber vielleicht bemerkt werden, daß sich die Wasserdämpfe wohl in tropfflüssiger Form auf den Flechten niedergeschlagen haben.

An dere Epiphyten (Orchidaceae, Araceae) haben Luftwurzeln, die mit einer besonderen, zur Wasseraufnahme eingerichteten Wurzelhülle,

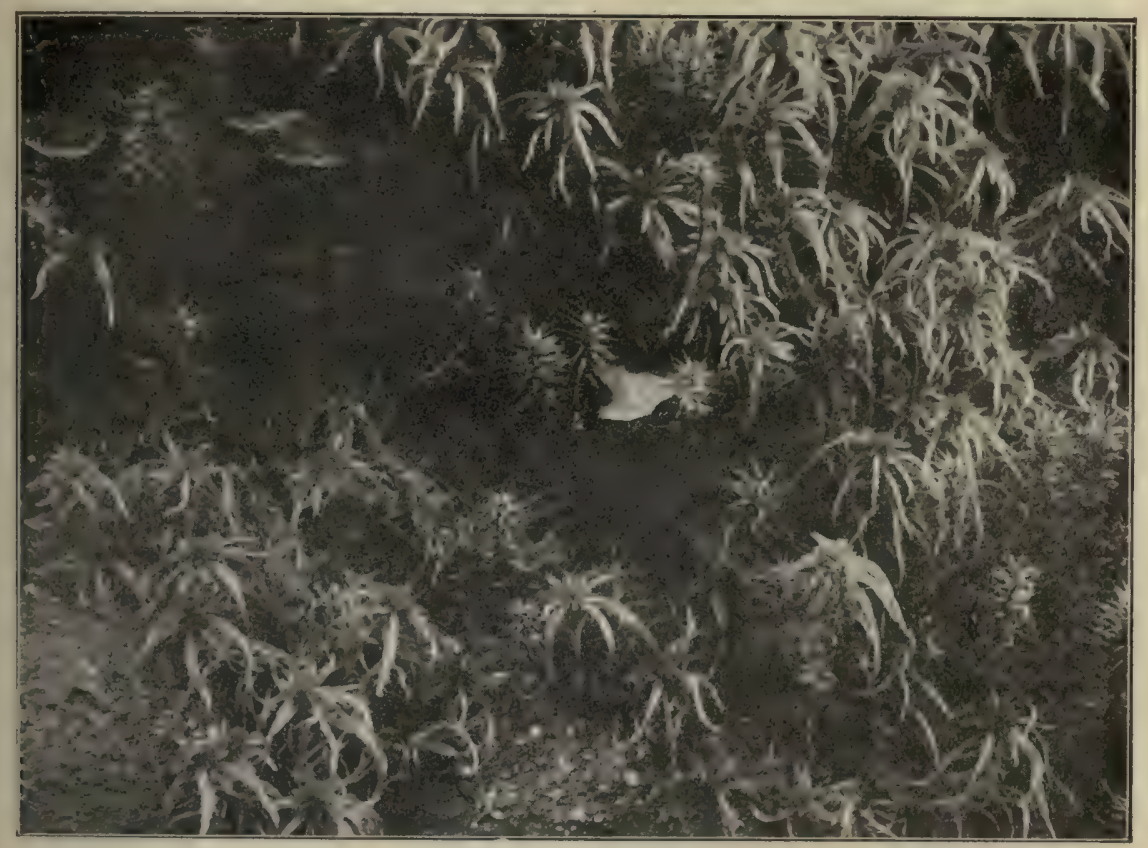

Fig. 153. Sphagnum epiphytisch an senkrechten Felsen der Sächsisch-Böhmischen Schweiz. (P. Graebner phot.)

Velamen, versehen sind (vergl. Fig. 27, S. 53). Wie schon oben bemerkt, dient die Hülle in trockenem, und weil lufterfüllten, weißem Zustande wahrscheinlich auch als Transpirationsschutz.

Noch andere, z. B. Tillandsia bulbosa, haben einen Blattbau, der die Wasseransammlung zwischen den Blättern begünstigt, Fig. 154, und wieder andere haben z. B. zweierlei Blätter, wovon einige dem Substrat ganz angedrückt sind, so daß sie zwischen sich und dem Stamme Wasser kapillar festhalten können, vielleicht auch aufnehmen können

1) Sievers 1909 . 
(Beisp. der Farn Teratophyllum aculeatum nach G. Karsten). Vergl. auch Fig. 126, S. 247.

Dem Austrocknen werden die Epiphyten leicht ausgesetzt sein. Hiergegen haben gewisse Arten (Algen, Flechten, Moose) keinen sicht-

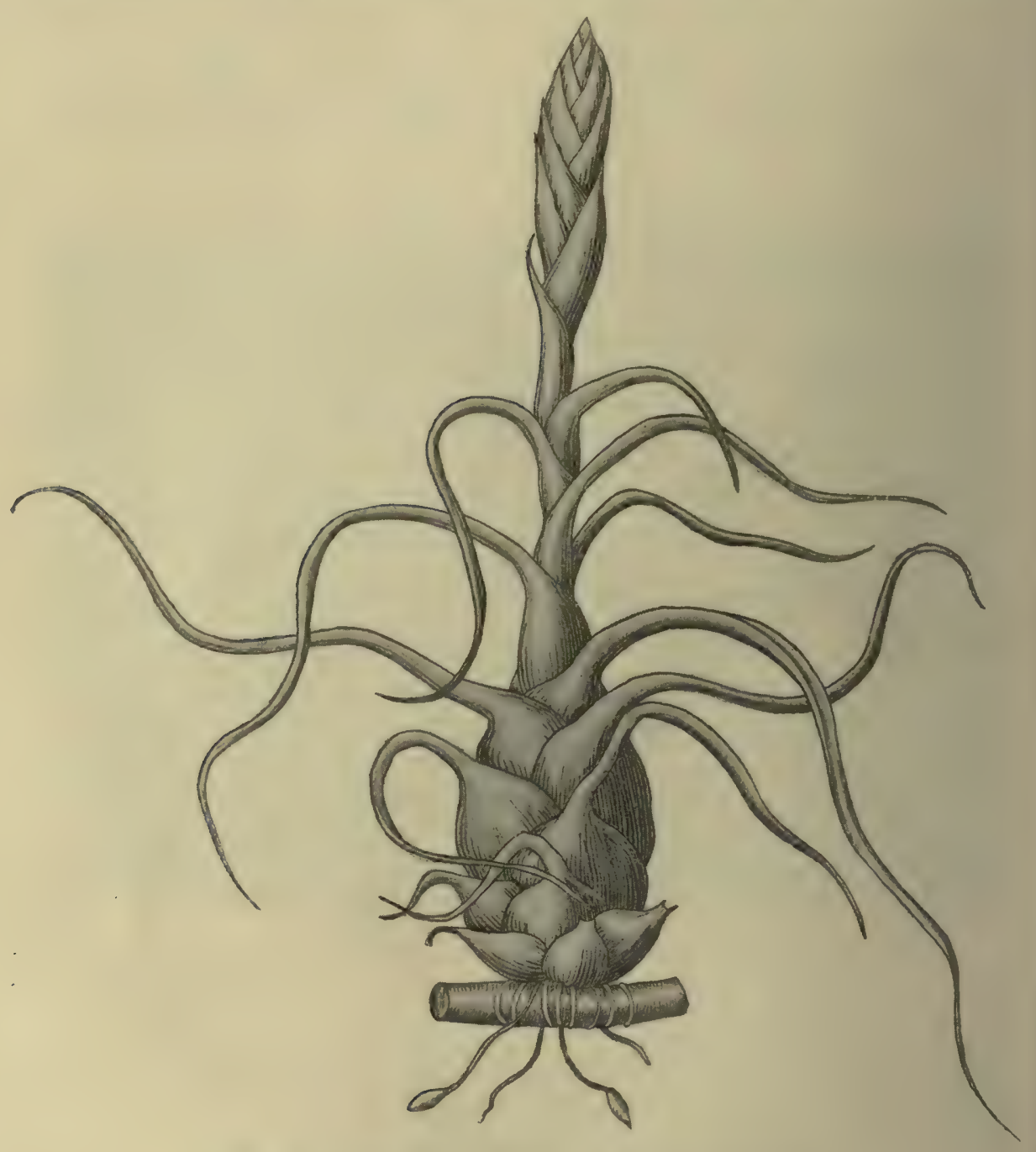

Fig. 154. Tillandsia bulbosa, 1:1. (Nach Schimper.)

baren Schutz; sie können langes Eintrocknen aushalten, ohne zu leiden und erwachen beim ersten Regen oder Taufalle wieder zum Leben. Andere haben sich Wasserbehälter der verschiedensten Art eingerichtet: Wassergewebe in Blättern und Stengeln, welche daher succulent werden (Orchidaceen, Cacteen, Peperomien u. a.), Wasserzellen in den Blättern 
(Orchidaceen u. a.), krugförmige oder anders geformte Höhlungen, Cisternen (epiphytische Lebermoose ${ }^{1}$ ), Dischidia [Taschenblätter, Fig. 155], Araceen u. a.).

Im übrigen sind die Epiphyten recht verschieden ausgebildet, ie nachdem sie hoch oben in den Baumkronen sitzen oder ob sie tief

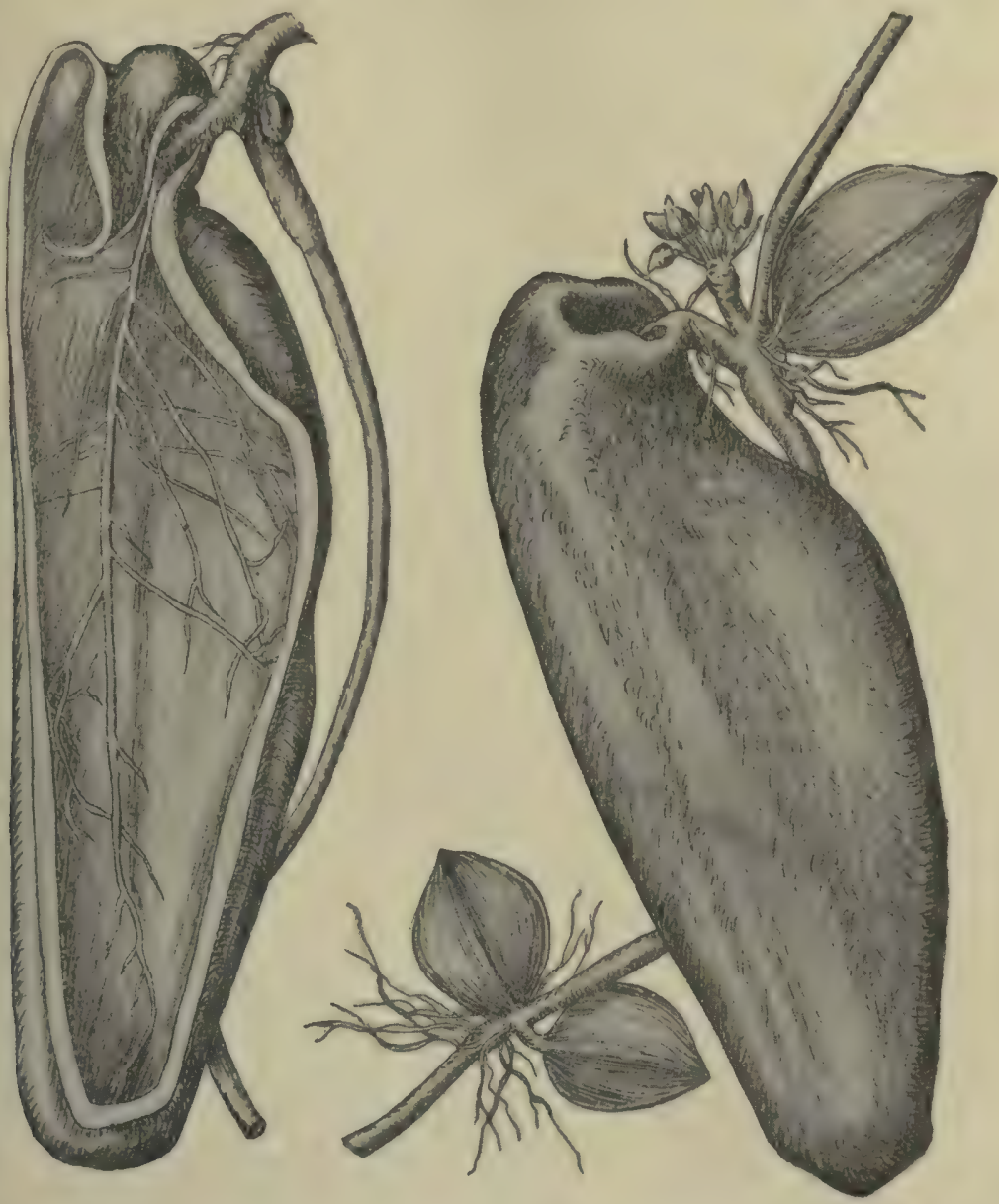

Fig. 155. Dischidia Rafflesiana mit normalen und Taschenblättern; links ein Taschenblatt geöffnet mit den darin befindlichen Wurzeln. (Nach Wettstein.)

unten im Schatten des Waldes leben. Die ersteren sind in weit höherem Grade der Sonne und dem Winde und dadurch der Verdunstung ausgesetzt; sie sind dann oft recht ausgesprochen xeromorph ausgebildet. Die letzteren befinden sich in weit größerer Luftfeuchtigkeit, und sind daher breitblättriger und mehr mesomorph ausgebildet.

1) Goebel 1889-93, 1898-1901. 
Die Nahrung verschaffen sich die Epiphyten auf folgende Weise: den Kohlenstoff aus der Luft, da sie alle lichtliebende und immergrüne Pflanzen sind; einige sammeln außerdem zwischen ihren Wurzeln,

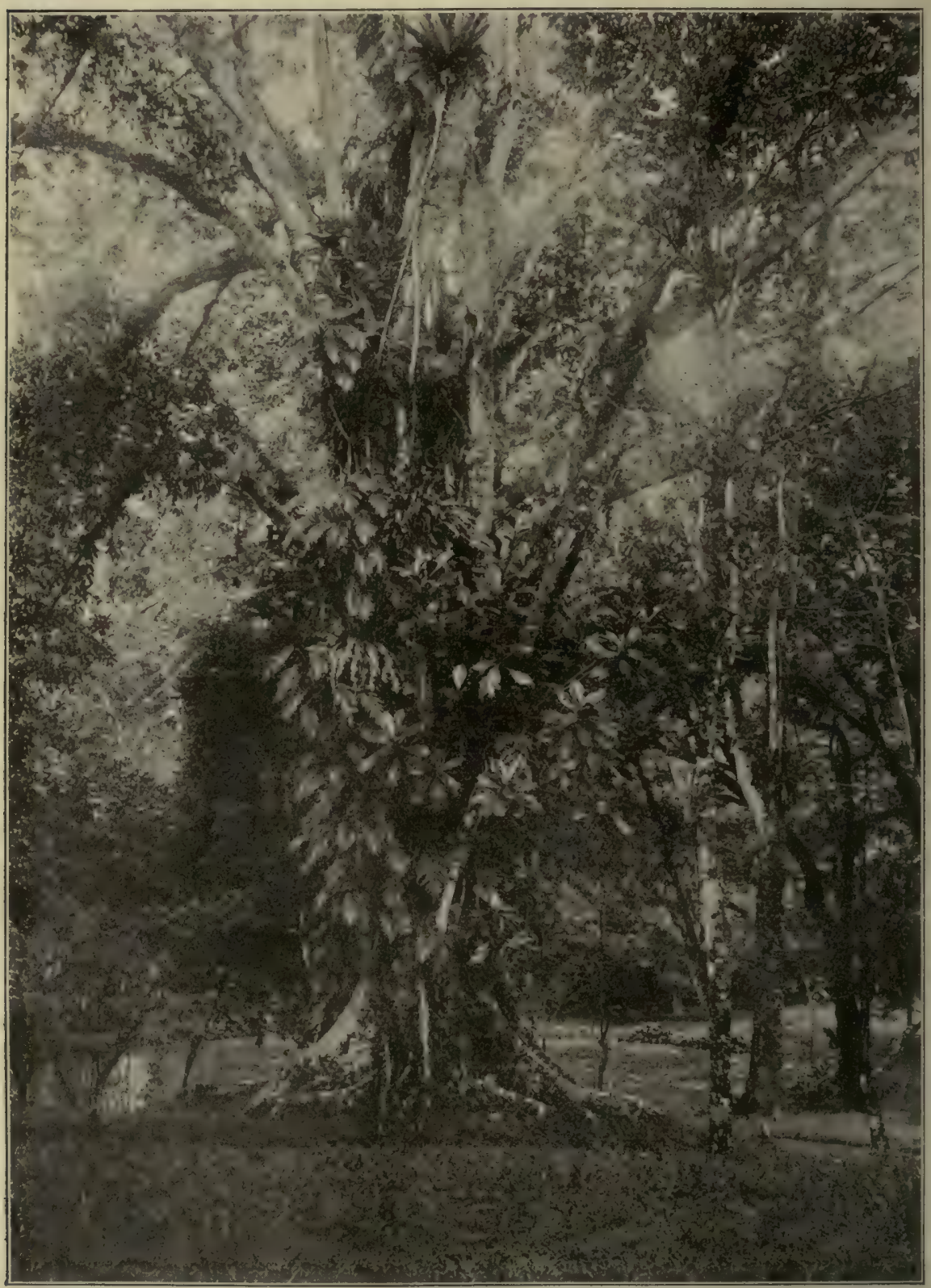

Fig. 156. Ficusbaum mit Fagraea, Asplenum nidus und anderen Epiphyten. Buitenzorg (Java). (Phot. Hjalmar Jensen.) 
zwischen den Blättern ihrer Rosetten oder mit Hilfe besonderer Blätter (Nischenblätter, Mantelblätter), wie z. B. mehrere Farne (Asplenum nidus, Fig. 156, Polypodium quercifolium, Platycerium alcicorne) $)^{1}$ ), humose und mineralische Teile, welche namentlich vom Winde herbeigeführt werden. Andere Arten fangen als echte Epiphyten an, indem sie auf den Bäumen keimen und dort eine Zeit so ihres Lebens zubringen, dann aber Luftwurzeln entwickeln, welche frei abwärts wachsen und schließlich in die Erde eindringen, um dann als straffgespannte Seile die Pflanze mit der Erde zu verbinden und aus der Erde Nahrung und Wasser dem "Hemiepiphyten" zuzuführen. Man hat Wurzeln von solchen hemiepiphytischen Ficus-Arten beobachtet, welche mehr als $30 \mathrm{~m}$ lang waren.

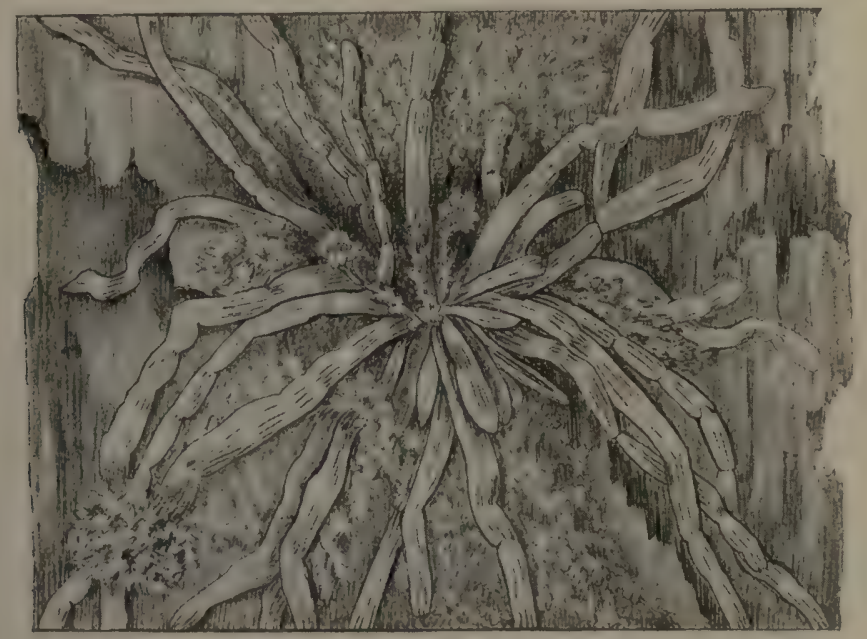

Fig. 157. Taeniophyllum Zollingeri, blühend, mit seinen grünen, Kohlensäure assimilierenden Wurzeln auf der Rinde eines Baumes. 1:1.

(Nach Wiesner.)

Der Sproßbau und die ganze Ausstattung der Epiphyten sind sehr verschieden. Ess gibt ganz wurzellose Arten (Tillandsia usneoides, Fig. 152) und es gibt Arten, deren Vegetationsorgane fast allein die grün en Wurzeln sind, z. B. Polyrrhiza funalis; Aeranthus funalis; Taeniophyllum Zollingeri Fig. 157 (Orchidaceen). Es gibt krautartige und verholzende Arten, sogar typische Sträucher; Rosettenpflanzen und gestrecktgliedrige kommen nebeneinander vor; Arten mit knollenförmigen Stengeln, die als Wasserspeicher dienen (Fig. 78), und solche mit succulenten blattlosen Stengeln (Cacteen) finden sich gleichfalls unter ihnen.

Die Epiphyten können in lichtliebende und schattenliebende eingeteilt werden. Die ersteren sind die an den höheren, dem Lichte

1) Goebel $1889-93$. 
exponierten Stellen lebenden, die anderen wachsen im Innern dichter Gehölze, im Schutze einer feuchten Atmosphäre und einer schwachen Beleuchtung (Gaßner 1913).

Die lichtliebenden Epiphyten haben mit den auf dem Boden wachsenden Xerophyten meist viele Bauverhältnisse gemeinsam, denn sie müssen wie diese daran angepaßt sein, lange dauernde Trockenheit auszuhalten; sie sind eigentlich eine Gruppe von xerophytischen Bodenpflanzen. Hiernach versteht man leicht, weshalb gewisse Arten sowohl auf Bäumen als auf Felsen leben können (z. B. Bromeliaceen, Rhipsalis cassytha und andere Cacteen). Die Epiphyten dürften im allgemeinen aus Bodenpflanzen hervorgegangen sein, dadurch daß solche gelegentlich auf anderen Pflanzen, und zwar wohl immer Holzpflanzen, keimten. Wir

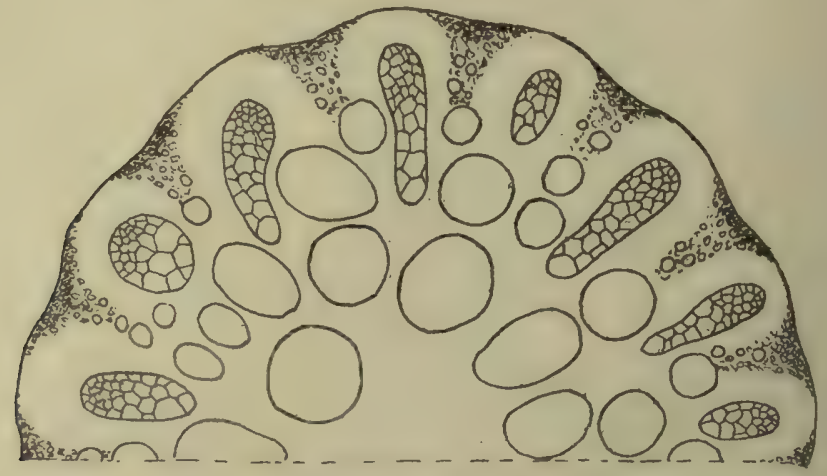

Fig. 158. Querschnitt des zentralen Teiles einer Nährwurzel von Anthurium (aus

Dominica), dick, mit stark entwickelten Gefäßbündeln. (Nach Schimper.)

finden z. B. hier in Nordeuropa eine Menge Arten gewöhnlicher Bodenpflanzen, welche als Gelegenheitsepiphyten in Baumkronen und auf Baumstämmen wachsend gefunden werden (Überpflanzen ${ }^{2}$ ), die sich aber noch nicht an ein epiphytisches Leben angepaßt haben).

Man wird danach die Epiphyten mit Schimper ${ }^{1}$ ) in folgende Gruppen einteilen können:

1. Fakultative Epiphyten, dies sind die zuletzt besprochenen, gelegentlich auf anderen Pflanzen wachsenden Überpflanzen.

2. Hemiepiphyten, d. h. solche Arten, welche sowohl durch Haftwurzeln auf anderen Pflanzen befestigt sind, als auch lange Nährwurzeln in die Erde hinabsenden.

3. Nestepiphyten, welche sowohl Haft- als Nährwurzeln haben, aber diese letzteren wachsen mehr oder weniger aufrecht und da sie sehr zahlreich sind, sammeln sie Humus zwischen sich auf (Fig. 158, 159).

1). Loew 1893; R. Beyer 1895; Stäger 1908; Wittrock 1894.

2) Schimper 1884, 1888, 1898. 
4. Aërophyten nennt er diejenigen, welche nur Haftwurzeln haben; die Nahrung muß von und zwischen den Blättern gesammelt werden. Hierher gehören viele Araceen, z. B. Tillandsia bulbosa, zwischen deren Blattscheiden ${ }^{1}$ ) nicht nur Wasser, sondern auch Humus und stickstoffhaltige Nahrung aus den Exkrementen und den Leichen der dort lebenden Ameisen aufgesammelt werden ${ }^{2}$ ), Fig. 154.

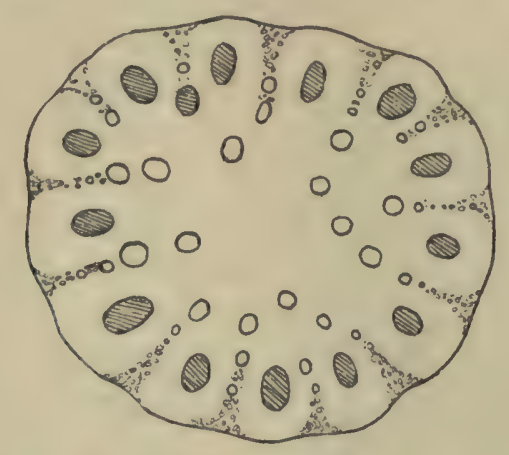

Fig. 159. Querschnitt des zentralen Teiles einer Haftwurzel von Anthurium (aus Dominica), dünn, mit schwach entwickelten aber mechanisch festen Gefäb-

biindeln. (Nach Schimper.)

Saprophyten (Verwesungspflanzen). Bei vielen Epiphyten müssen wir annehmen, daß sie aus den toten Pflanzenteilen (der Rinde), auf denen sie wachsen, Nahrung aufnehmen; sie nähren sich also von toten organischen Stoffen, d. h. saprophytisch.

Größere Mengen von Saprophyten und ausgeprägtere Formen solcher trifft man jedoch nur auf dem Erdboden, besonders in Wäldern, wo Abfall aller Art (verwelkte Blätter, Zweige, Blüten und Früchte) Jahr für Jahr angehäuft werden und reichlichen Humus bilden. Die Saprophyten sind also auch an andere Pflanzen gebunden, aber das Band ist anders geartet als bei den Schmarotzern; es ist der Abfall, der Überfluß selbständiger Pflanzen, den sie für sich benutzen. Einige Saprophyten wählen eine bestimmte Art Abfall, sind also an bestimmte Pflanzenarten gebunden; andere sind freier gestellt. Clavaria abietina, Lactarius deliciosus und andere Pilze trifft man nur in Nadelwäldern, andere wählen Laubwälder und wieder andere wachsen nur auf Dünger (von Pilzen z. B. Poronia, Coprinus, Pilobolus, Sordaria; von Moosen Splachnum); Fig. 160.

1) Vergl. Karsten 1894.

2) Über Epiphyten vergl. übrigens Schimper 1884, 1888, 1898; Treub 1888; Goebel 1888, in Ann. Jard. Buitenzorg, VII, 1889-92, 1898-1901; Went 1893; G. Karsten 1894; Raciborski 1898; Mez 1904 a; Rechinger 1908; Gallemarts 1909; Wittrock 1894; Willis and Burkill 1904; Ule 1904; Cockayne 1901; Massart 1898; Gaßner 1913; Domin 1913. 


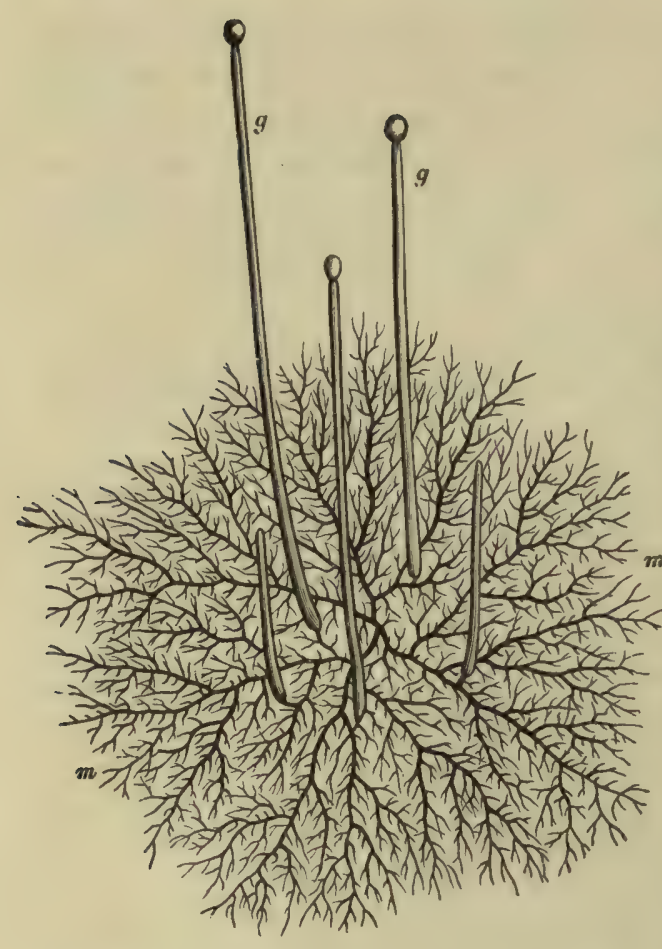

Fig. 160. Phycomyces nilens als typischer Saprophyt; $m$ das Mycel auf oder in der organischen Substanz ausgebreitet; $g$ Sporangienträger. (Nach Sachs.)

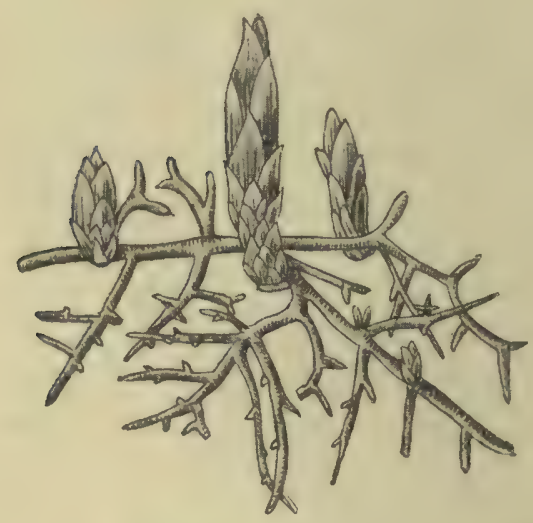

Fig. 161. Junge Pflanze von Monotropa hypopitys als typischer Saprophyt. (Nach Schimper.)
Die Saprophyten sind sowohl Sporen- als Blütenpflanzen und stehen auf einer sehr verschiedenen Stufe der Anpassung an die saprophytische Lebensweise, wie schon oben angedeutet wurde. Jeder milde Humus wimmelt von Pilzmycelien und Bakterien. Blütenpflanzen, die an das saprophytische Leben am stärksten angepaßt sind (Ganz- oder Holosaprophyten), zeichnen sich durch folgende Eigenschaften aus: sie haben kein (oder doch nur wenig) Chlorophyll, sind daher gelblich, rötlich oder bräunlich; ihre Laubblätter sind zu aufwärts gerichteten, mehr oder weniger angedrückten Schuppen reduziert; Spaltöffnungen fehlen meist; anch die Gefäßbündel sind reduziert; ebenso mehr oder weniger auch das Wurzelsystem; die Wurzeln sind kurz, dick und wenig verzweigt, und die vieler sind $\mathbf{M y -}$ korrhizen. Beispiele: Neottia, Coralliorrhiza, Epipogon, Pogonopsis und and. Orchidaceen; Monotropa (Fig. 161); Sarcodes (Pirolaceen); Voyria (Gentianacee); Burmanniaceae; Triuridaceae ${ }^{1}$ ).

Die grünen Saprophyten (Halb-oder Hemisaprophyten) haben das Äußere und den Bau der gewöhnlichen, Kohlensäure assimilierenden Pflanzen. Sie bedürfen in äußerst verschiedenem Grade der organischen Nahrung, und während einige außerhalb eines humusreichen Bodens, z. B. eines Waldbodens, gar nicht

1) Vergl. Johow 1885, 1889; Percy Groom 1885 a, b; Bernard 1910. 
gedeihen können, sind andere vermutlich als fakultative Saprophyten anzusehen (viele Orchidaceen, Pirola-Arten usw.) ${ }^{1}$ ).

Lianen (vergl. auch unter Lebensformen S. 158) ${ }^{2}$ ). Während das Bedürfnis nach kohlenstoffhaltiger Nahrung das Band ist, das die Saprophyten an andere Pflanzen knüpft, werden die Lianen mit anderen Pflanzen durch das Bedürfnis nach einer Stütze für den schwachen Stengel verbunden. Der Ausdruck Liane wird hier im weitesten Sinne gebraucht und umfaßt sowohl die windenden Pflanzen, als die verschiedenen Formen der Kletterpflanzen. Die Lianen sind echte Kinder des Vereinslebens der Pflanzen, namentlich von Wald und Gebüsch; das Dunkel der dichten Vegetation hat sie ursprünglich dazu gebracht, sich emporzustrecken, lange Stengelglieder zu bilden und sich im Laufe der Zeit auf verschiedene Weise anzupassen, um sich festzuhalten, sowie um im inneren Bau Aufgaben der Stoffwanderung und andere neue Aufgaben zu lösen, die die langen und dünnen Stengel stellen ${ }^{3}$ ) (Fig. 48, S. 157).

Die Lianenform ist gerade durch das Vereinsleben hervorgerufen worden, aber die Lianen sind im übrigen insoweit von anderen Pflanzen unabhängig, als tote Stützen in gewissen Fällen ebenso gut wie lebende dienen können. Die Lianen gehören besonders gewissen Familien an: Vitaceae, Asclepiadaceae, Apocynaceae, Bignoniaceae, Cucurbitaceae, Papilionaceae, Sapindaceae, Dioscoreaceae und anderen.

Sehr viele Lianen haben eine sehr charakteristische Blattform: Das Blatt ist lang gestielt, breit und oft mehr oder weniger herzförmig; die Spitze ist abwärts gerichtet, bisweilen fast als Träufelspitze ausgebildet (S. 163, Fig. 57).

\section{Kap. Der Kommensalismus. Die Pflanzenvereine}

Im vorigen Kapitel wurden die verschiedenen Bande behandelt, die die Pflanzen miteinander verbinden können, zunächst ein Individuum mit einem anderen: den Schmarotzer mit dem Wirte, den Herrn mit dem Sklaven (Helotismus der Flechten); ferner wurden die Mutualisten, die Epiphyten, dann die Arten, die sich an ganze Pflanzenvereine anschließen, besprochen. Wir haben nun noch die großen, sehr zusammengesetzten Pflanzenvereine zu betrachten, die der eigentliche Gegenstand der ökologischen Pflanzengeographie (der "Synoekologie“) sind.

1) Vergl. Heinricher 1896, 1897, 1901-3; Wettstein 1902.

2) Aus der neuesten Litteratur vergl. Rothert 1913.

s) Näheres bei Darwin 1875; Schenck 1892, 1893 und Warming 1892, Schimper 1898. 
Der Begriff Verein setzt eine Mannigfaltigkeit, aber zugleich eine gewisse Einheit von Einern voraus. Die Einer sind die vielen Pflanzenindividuen, die sich in jedem Vereine finden, z. B. in einem Buchenwalde, anf einer Wiese, auf einer Heide. Die Einheit tritt dadurch ein, daß eine gewisse, bestimmte Ökonomie dem Vereine im großen und ganzen sein Gepräge gibt, oder daß eine gewisse Menge verschiedener ökologischer Lebensformen zu einer Einheit mit einem gewissen, konstanten Gepräge vereinigt wird, wenn gewisse der im ersten Abschnitte behandelten atmosphärischen, terrestrischen u. a. Faktoren zusammenwirken.

Die Analyse eines Pflanzenvereins wird uns meist eine oder mehrere der vorhin besprochenen Formen des Zusammenlebens zwischen Individuen, z. B. Parasiten, Saprophyten, Epiphyten usw. bemerken lassen. Es gibt kaum einen Wald oder ein Gebüsch, wo Beispiele dieser Formen des Zusammenlebens fehlen, und betrachten wir z. B. den tropischen Regenwald, so werden wir sicher alle denkbaren Formen des Zusammenlebens finden. Aber die Hauptmasse der Individuen eines Vereines wird durch andere Bande als die erwähnten verknüpft: durch Bande, die am besten als kommensalistische bezeichnet werden können. Unter dem von van Beneden ${ }^{1}$ ) gebildeten Begriffe Kommensalismus verstehen wir hier, von dem Sinne des Autors etwas abweichend, ein Verhältnis zwischen Arten, die den Nahrungsvorrat in Luft und Boden miteinander teilen, an demselben Tische speisen; "le commensal est simplement un compagnon de table" (van Beneden).

Es gibt aber bei näherer Analyse der Pflanzenvereine offenbar recht große Unterschiede in den Kommensalen. Man wird folgende Verhältnisse finden:

1. Gleichartige Kommensalen. Wenn ein Pflanzenverein allein von Individuen derselben Art, z. B. von Rotbuchenbäumen und nichts anderem, oder nur vom Heidekraute, oder nur von Aera flexuosa, gebildet werden könnte, so würden wir nur gleichartige Kommensalen haben; denn alle Individuen in jedem von diesen Vereinen würden dann alle dieselben Anforderungen an Nahrung, Licht und andere Lebensbedingungen stellen; da jedes Individuum einen gewissen Raum sowohl für seine oberirdischen als unterirdischen Organe verlangt und da fast nie für alle Nachkommen Nahrung genug vorhanden ist, muß ein Nahrungswettbewerb zwischen den Pflanzen entstehen, sobald der Raum von der bestimmten Anzahl von Individuen eingenommen ist, die je nach der Natur der Art sich zu entwickeln vermag. Die ungünstig gestellten und von Anfang an schwächeren Individuen werden verdrängt und getötet. Ein nur aus gleichartigen herrschenden Kommensalen zusammen-

1) Van Beneden $1869-70$. 
gesetzter Pflanzenverein ist unser Kunstwald (Forst), der nur aus einer Art gebildet wird, dessen Individuen noch dazu gleichaltrig und fast gleich stark sind (vergl. später). Einen solchen Wettbewerb trifft man in allen Vereinen, vielleicht nur nicht in den subglacialen und den Wüstenvereinen; denn in diesen wird der Boden sehr oft oder immer so offen und so ungleichmäßig bedeckt sein, daß dort für viel mehr Induviduen als die schon vorhandenen Platz ist; der Grund ist offenbar darin $\mathrm{zu}$ suchen, daß die ungünstigen klimatischen Lebensbedingungen entweder die Pflanzen verhindern, Samen oder andere Vermehrungsmittel in hinreichender Menge zu bilden, um den Boden zu bekleiden oder die Entwicklung der Keimpflanzen verhindern. Auf einem solchen Boden ist kaum von einem Nahrungswettbewerb die Rede; Kämpfe finden hier besonders zwischen den Pflanzen und der leblosen Natur statt, zwischen den Pflanzen untereinander nicht oder in sehr geringem Grade.

Daß in dem Zusammenschluß von Individuen derselben Art zu einem sagen wir "reinen" Vereine etwas für die Art im ganzen Vorteilhaftes liegen kann, ist einleuchtend; sie wird offenbar auf mehrfache Weise imstande sein, ihr Dasein zu erhalten, z. B. durch die vermehrte Möglichkeit einer reichlichen und sicheren Bestäubung (namentlich bei Anemophilen) und Samenreife, und wahrscheinlich können andere, noch wenig bekannte Vorteile aus dem Vereinsleben hervorgehen. Aber anderseits werden die Parasiten größere Verheerungen und Zerstörungen anrichten können.

Die Bande, die gleichartige Individuen auf demselben gleichartigen Standorte verbinden, sind, wie angeführt, natürlich zunächst dieselben Lebensanforderungen, die gerade auf diesem Standorte und zwar so gut befriedigt werden, daß die Art dessen Besitz gegen andere behaupten kann. Die natürlichen reinen Bestände von Waldbäumen sind immer das Ergebnis von Kämpfen mit anderen Arten. Aber es besteht ein Unterschied in der Leichtigkeit, womit der Verein entsteht und sich ergänzt. Einige Arten sind mehr gesellig (social) als andere, d. h. tauglicher, Vereine zu bilden. Die Gründe hierfür sind biologische, indem sich die Arten sehr leicht durch Ausläufer vermehren (z. B. Phragmites, Scirpus lacustris, Calamagrostis [Ammophila] arenaria, T'ussilago farfara, Asperula odorata), oder daß sie viel Wurzelknospen bilden (z. B. (irsium arvense, Sonchus arvensis), oder auch viele Samen ansetzen, die leicht verbreitet werden und vielleicht auch lange keimfähig bleiben (Calluna, Picea excelsa, Pinus u. a.), oder schließlich kommt auch die Fähigkeit der Arten, Schatten zu ertragen oder selbst andere Arten durch ihren Schatten zu unterdrücken (z. B. Rotbuche, Fichte; S. 19) in Betracht. Eine Anzahl geselliger Arten, die zugleich sehr weit verbreitet sind, vermehrt sich fast nur vegetativ; diese erzeugen selten oder nie Früchte (Pteridium, Acorus calamus in Europa, Hypnum Schreberi, 
Helodea Canadensis in Europa usw.) $\left.{ }^{1}\right)$. Andere Arten stehen fast immer einzeln, z. B. viele Orchidaceen und Umbelliferen.

Bei manchen Arten haben gewiß erdgeschichtliche Verhältnisse das Auftreten in reinen Beständen befördert. Wenn die Waldvegetation in Nordeuropa von wenigen Arten gebildet wird und hier nicht von solchen gemischten Wäldern die Rede ist, wie in den Tropen, in Nordamerika oder selbst in Österreich und anderen südlicheren Teilen von Europa, so könnte ein wesentlicher Grund sein, daß der Boden geologisch sehr jung ist; die Zeit, die verflossen ist, seit die Eiszeit tabula rasa gemacht hat, ist zu kurz, als daß viele mitbewerbende Arten haben einwandern können ${ }^{2}$ ).

2. Ungleichartige Kommensalen. Den Fall, daß ein Verein von Individuen derselben Art gebildet werde, trifft man, streng genommen, kaum irgendwo an; wohl aber können die vorherrschenden Individuen eines Vereines, z. B. in einem Walde, zu einer Art gehören (Buchenwald, Fichtenwald, Calluna-Heide u. a.). Im allgemeinen wachsen jedoch

- viele Arten zusammen, es finden sich viele verschiedene Lebensformen und Formen des Zusammenlebens in einem Vereine vereinigt. Denn selbst wenn eine Art den Platz so vollständig ausgefüllt hat, als es die Natar des Bodens zuläßt, werden andere Arten doch Raum finden und zwischen ihren Individuen wachsen können; ja, soll der Boden ganz bedeckt werden, so muß die Vegetation sicher immer ungleichartig sein; der Landwirt sät daher Samenmischungen auf seine Wiesen. Die größte Mannigfaltigkeit in der Vegetation entsteht dort, wo die größte Mannigfaltigkeit der Lebensbedingungen vorkommt (Darwin).

Die Art des Zusammenlebens wird indessen davon abhängen, welche Forderungen die Arten an die Lebensbedingungen stellen. Wie in den Menschenvereinen ist hier der Kampf zwischen den Gleichartigen am heftigsten, in diesem Fall also zwischen den Arten, die dieselben oder ungefähr dieselben Forderungen stellen und an dem gemeinsamen Tische dieselben Gerichte suchen. Wenn wir in dem tropischen gemischten Walde Hunderte von Arten in einem so bunten Gemische zusammen wachsen sehen, daß das Auge selten zwei Exemplare derselben Art gleichzeitig entdecken $\operatorname{kann}^{3}$ ), so müssen diese Arten sicher ziemlich übereinstimmende Lebensforderungen stellen und insoweit gleichartig sein. Ein starker Nahrungswettbewerb muß zwischen ihnen herrschen. Wenn gewisse Arten, was den Floristen wohl bekannt ist, gern in Gesellschaft voneinander wachsen, wenn man z. B. gewöhnlich Pilularia,

1) Vergl. Graebner 1909, 1910.

2) Warming $1892,1899 \mathrm{~b}$.

3) Warming 1892. 
Isoëtes, Lobelia Dortmannia und Litorella lacustris zusammen findet, so sind die gemeinsamen Forderungen an die äußeren Lebensbedingungen offenbar das Band, das sie verbiudet. Zwischen solchen Arten muß ein Nahrungswettbewerb stattfinden. Welche Art mit der größten Anzahl von Exemplaren auftritt, wird gewiß oft von zufälligen Verhältnissen abhängen, ein kleines Mehr oder Weniger wird sicher oft eine große Rolle spielen, ebenso oft die Zufälligkeit, welche Art sich zuerst anfand; aber im übrigen scheint es, daß morphologische und biologische Verhältnisse (z. B. Entwicklung zu verschiedener Zeit) die Natur des Wettbewerbes åndern können.

In jedem Vereine gibt es jedoch mannigfaltige Arten, die in den Anforderungen an Licht, Wärme, Nahrung usw. höchst verschieden sind. Zwischen solchen Arten wird das Zusammenleben desto freier von Wettbewerb sein, je verschiedener die Anforderungen sind; es läßt sich sogar der Fall denken, daß die eine Art gerade das braucht, was die andere verschmäht; die beiden Arten ergänzen dann einander zur Ausfüllung und zur Benutzung desselben Bodens.

Vielfach sehen wir auch, daß Arten einander Hilfe leisten, wenn z. B. viele Kräuter durch Dorngebüsch gegen die Angriffe des weidenden Viehes geschützt werden, oder wenn die Moosdecke des Fichtenwaldes den Boden gegen Austrocknung schützt und dadurch ein geeignetes Keimbett für die Fichtensamen bereitet; auf der anderen Seite zieht das Moos selbst von dem Schatten der Fichte Nutzen.

In der Regel werden gewiß einige Arten die mächtigsten sein, die Fürsten, die imstande sind, das Gebiet vollständig zu beherrschen, während andere von ihnen abhängen, indem sie z. B. nur in ihrem Schatten oder auf ihrem Abfalle die ihnen am meisten zusagenden Standorte finden. So ist offenbar das Verhältnis zwischen den Bäumen des Hochwaldes und vielen Pflanzen des Waldbodens: Moosen, Pilzen und anderen Saprophyten (S. 297), Farnen, Oxalis acetosella und anderen Begleitpflanzen verschiedener Waldbäume ${ }^{1}$ ). Hier ist dann ein Kommensalismus vorhanden, bei dem die Individuen zwar an demselben Tische, aber von verschiedenen Gerichten speisen.

Anpassungen kommen vor, welche das Zusammenleben der verschiedenen Arten erleichtern, und zwar räumliche sowohl wie zeitliche. $\mathrm{Zu}$ den räumlichen Anpassungen gehört z. B., daß die unterirdischen Organe in verschiedener Tiefe liegen, daß die Nahrungsforderungen verschieden sind, daß die Luftsprosse verschiedenen Lebensformen angehören und auch in verschiedenen Stockwerken sich befinden usw.

Es ist, wie schon früher berührt, von Wichtigkeit für jede Art, daß sie eine bestimmte Tiefe für ihre unterirdischen Organe hat; wir

^) P. E. Müller 1887; Höck 1892-96. 
sehen deshalb auch, daß die Geophyten dieses auf verschiedene Weise anstreben und erreichen. Schon längst hat Royer ${ }^{1}$ ) von der „loi de niveau" gesprochen und viele Untersuchungen liegen vor, welche die Art und Weise illustrieren, auf welche die Sprosse ihre bestimmte unterirdische Tiefenlage aufsuchen ${ }^{2}$ ). Namentlich geschieht dieses durch $\mathrm{Zu}$ sammenziehen der Wurzeln und Einsenkung der Achse in die Erde,

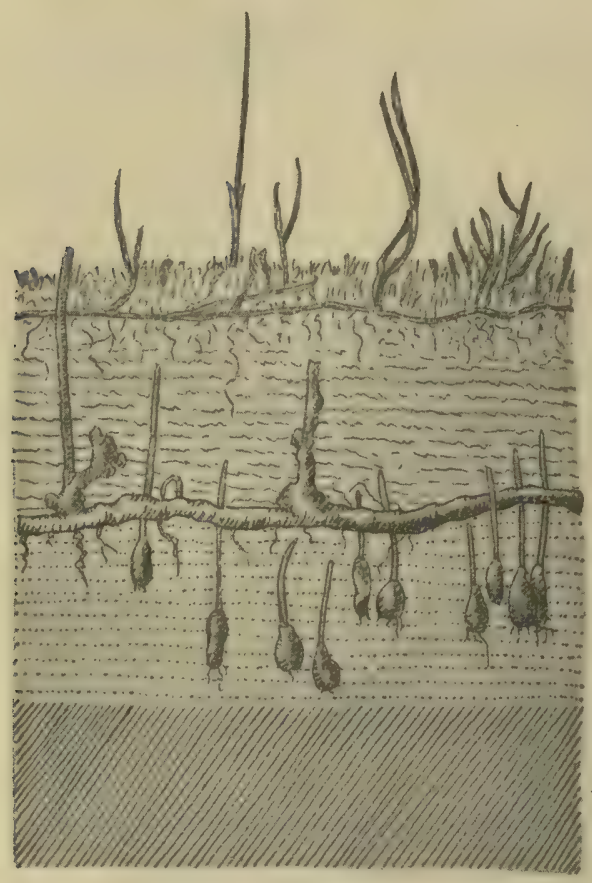

Fig. 162. Oben die Vegetation von Holcus mollis, tiefer die Grundachsen von Pteridium aquilinum, am tiefsten die Zwiebeln von Scilla festalis. (Nach Woodhead.) durch positiv geotropische resp. negativ heliotropische Bewegungen der Sprosse oder durch andere physiologisch interessante, offenbar oft recht verwickelte Erscheinungen.

Woodhead ${ }^{3}$ ) hat den Ausdruck "Komplementär-Assoziation" vorgeschlagen für eine Pflanzengemeinschaft, welche friedlich zusammen lebt, weil ihre Grundachsen in verschiedenen Bodentiefen leben; z. B. beschreibt er eine "Assoziation", in der Holcus mollis die Oberflächenpflanze („surface plant") ist, Pteridium aquilinum tiefer liegende Grundachsen hat und Scilla festalis ihre Zwiebeln am tiefsten entwickelt (Fig. 162). Die lichtliebenden Teile dieser Pflanzen sind säsonkomplementär („seasonable complementary"). Das Entgegengesetzte wäre eine „kompetitive Assoziation", die zusammengesetzt ist aus Arten, die sich gegenseitig bekämpfen, also zur selben Zeit denselben Raum für sich in Anspruch nehmen.

Die Einteilung und Benennung der Pflanzenvereine wird später besprochen werden.

Zeitliche Anpassungen sind z. B. wenn die Luftsprosse sich zu verschiedener Zeit entwickeln, oder wenn die Nahrungsaufnahme zu

1) Royer 1870 .

2) Vergl. Tittmann, Irmisch, Winkler, C. Schimper, Haberlandt, Hildebrand, Rimbach, Seignette, Raunkiär 1905, 1907, Massart 1903, Sherff (Botan. Gazette LIII, 1912); P. E. Müller 1894; Graebner 1902, 1909 a; Woodhead 1906 и. a.

3) Woodhead 1906, S. 345; vergl. auch Massart u. Sherff. 
verschiedenen Jahreszeiten erfolgt, was nach Ramann ${ }^{1}$ ) bei unseren Waldbäumen der Fall sein soll. Viele Frühlingspflanzen (Galanthus nivalis, Corydallis solida, C. cava u. v. a.) sind bereits abgestorben, wenn die Sommerpflanzen sich erst recht zu entwickeln beginnen.

Je besser der Raum und die Zeit verteilt werden kann, desto besser ist es für das Zusammenleben, desto artenreicher und ausgeprägter kann der Verein werden. Es werden sich für die Zukunft unzweifelhaft eine Menge von interessanten Untersuchungen ergeben, die sich zur Aufgabe machen, die gegenseitigen Verhältnisse zwischen den verschiedenen Arten der Vereine zu studieren.

Zwischen den Pflanzenvereinen, den Staaten der Menschen und den Tiervereinen gibt es gewisse Ähnlichkeiten, z. B. den Nahrungswettbewerb, der beiderseits zwischen den gleichartigen Individuen stattfindet und die Unterdrückung oder den Untergang der schwächeren verursacht. Weit größer sind jedoch die Unterschiede. Die Pflanzenvereine stellen die niedrigste Vereinsform dar, zunächst nur eine Anhäufung von Einern, zwischen denen es kein Zusammenwirken zum gemeinsamen Vorteile, eher einen beständigen Kampf aller gegen alle gibt. Nur im uneigentlichen Sinne kann man sagen, daß gewisse Individuen einander beschützen, wenn z. B. die äußersten und am meisten ausgesetzten Individuen in den Kap. 5 erwähnten Gestrüppen als Schutz gegen den Wind für die anderen dienen, die dadurch höher und stattlicher werden; denn sie besorgen diesen Schutz nicht aus besonderem Antriebe, wofür wir in den Tiervereinen Beispiele finden, und sind in keiner Weise besonders angepaßt, als Wache gegen gemeinsame Feinde aufzutreten. In den Pflanzenvereinen herrscht nur die Selbstsucht. Sie haben auch keine höheren Einheiten oder Individualitäten in dem Sinne, wie z. B. die Menschenvereine, die eine innere Organisation mit einem Mittelpunkt und einer Reihe Mitglieder haben, welche in gegenseitiger, gesetzmäßig geregelter Wechselwirkung jedes für das Wohl des Ganzen arbeiten. Es gibt in den Pflanzenvereinen ganz gewiß oft (oder immer) eine gewisse natürliche Abhängigkeit und eine gegenseitige Rücksicht der vielen Glieder eines Vereins von und aufeinander; sie bilden bestimmt organisierte Einheiten höherer Ordnung ${ }^{2}$ ); aber es gibt keine solche Arbeitsteilung, wie in den Menschen- und in gewissen Tiervereinen, daß gewisse Individuen oder Individuengruppen als Organe im weiteren Sinne zum Vorteile des ganzen Vereines dienen.

1) Ramann 1911.

2) Vergl. z. B. Grevillius 1894. 


\section{Kap. Der Standort als Basis für die Klassifikation der Vereine (Pflanzengesellschaften)}

Schon in der Einleitung (S. 2) wurden die durch eine bestimmte Physiognomie, einen bestimmten Inhalt an Lebensformen und eine bestimmte Ökonomie gekennzeichneten Pflanzenvereine behandelt, die eine Folge davon sind, daß sich die Arten, welche an die Beschaffenheit der Standorte ungefähr dieselben Anforderungen stellen oder aus anderen Gründen aneinander geknüpft sind, auf natürliche Weise zu einer Art Einheit zusammenschließen. Es existiert nun aber in der Natur eine ganz ungeheure, unübersehbare Menge von Pflanzenvereinen, und um einigermaßen eine Übersicht über sie zu gewinnen, müssen wir versuchen, sie in Gruppen zu verteilen, ganz wie wir die systematischen Sippen in ein natürliches System zu fügen bestrebt sind.

In der O̊kologie unterscheiden wir drei Haupteinheiten, deren Abstufung jetzt fast allgemein anerkannt ist, in absteigender Ordnung: Standort, Formation und Assoziation. In den Berichten und Vorschlägen zu einer Phytogeographischen Nomenklatur, welche Flahault und Schröter ${ }^{1}$ ) im Auftrage des 2. Internationalen Botaniker-Kongresses in Wien 1905 ausgearbeitet hatten und dem 3. Kongreß 1910 in Brüssel vorgelegt haben, werden diese Einheiten folgendermaßen bestimmt:

Unter Standort (station, habitat) versteht man die Gesamtheit der an einer geographisch bestimmten Lokalität wirkenden Faktoren, soweit sie die Pflanzenwelt beeinflussen.

Eine Assoziation (= Bestandestypus) ist eine Pflanzengesellschaft von bestimmter floristischer Zusammensetzung, einheitlichen Standortsbedingungen und einheitlicher Physiognomie. Sie ist die grundlegende Einheit der Synökologie.

Eine Vegetations-Formation ist der gegenwärtige Ausdruck bestimmter Lebensbedingungen. Sie besteht aus Assoziationen, welche in ihrer floristischen Zusammensetzung verschieden sind, aber in erster Linie in den Standortsbedingungen, in zweiter in ihren Lebensformen übereinstimmen ${ }^{2}$ ).

Die beiden ersten Definitionen sind einstimmig von den KomitéMitgliedern angenommen worden, die letzte mit 8 Stimmen von 11. Man muß wünschen, daß diese Begriffsbestimmungen, welche im ganzen mit dem 1909 von Warming in Oecology of plants gegebenen übereinstimmen, und welche auch diesem Buche zugrunde gelegt werden, auch von den

1) Flahault und Schröter 1910.

2) Siehe auch die Einleitung. 
wenigen angenommen werden möchten, welche ihnen noch nicht zugestimmt haben.

Der Standort wird also die Grundlage für die Gruppierung der Pflanzengesellschaften sein, umfaßt also alle die an einer geographisch bestimmten Lokalität wirkenden klimatischen, edaphischen und anderen (biotischen) Faktoren, welche im 1. Abschnitte erwähnt worden sind.

Diese Faktoren sind in der Natur selbstredend in der verschiedensten Weise kombiniert, daher die ungeheure und unübersehbare Menge solcher Kombinationen, welche obendrein vielfach durch die unmerklichsten Übergänge miteinander verbunden sind. Die erste Aufgabe der ökologischen Pflanzengeographie wird die sein, sie in natürliche Gruppen übersichtlich zusammen zu stellen. Es ist noch nicht möglich, dies mit Sicherheit zu tun, denn es stellen sich verschiedene große und vorläufig nicht zu beseitigende Schwierigkeiten dabei heraus.

Eine erste Schwierigkeit ist, daß die ökologischen Faktoren der einzelnen Lokalitäten und Formationen so ungenau bekannt sind. Die meisten Aufschlüsse, die man in der Litteratur findet, sind höchst unvollkommen und unvollständig. Im allgemeinen drehen sie sich nur um die Flora der Lokalität, höchstens ihre landschaftliche Physiognomie und um die am meisten hervortretenden Lebensformen. Man findet dicke pflanzengeographische Werke, in denen hauptsächlich nur Pflanzenlisten angeführt werden, wo aber keine oder doch nur äußerst unbefriedigende, oberflächliche und zerstreute Aufschlüsse über Klima, Wassergehalt des Bodens, Humus, Anpassungen der Lebensformen usw. zu finden sind. In neuester Zeit haben aber doch verschiedene Forscher angefangen, die ökologischen Faktoren der Lokalitäten durch physiologische Messungen und Wägungen wissenschaftlich exakt zu studieren; besonders in England und Nordamerika ist dieses der Fall (Clements, Cowles, G. D. Fuller, Crampton, Livingston, Dachnowsky, Tansley, Moss, Yapp u. a.), aber auch aus anderen Ländern kommen wertvolle Beiträge (z. B. P. E. Müller, Hesselman, Graebner, Ramann). Nach dem Druck des ersten Abschnittes ist das Werk von Glinka erschienen.

Dazu kommt noch die Errichtung von ökologischen Versuchsstationen, wie das Carnegie-Laboratorium in Arizona, Massarts Versuchsflächen in Belgien usw.

Der Grund für diesen Zustand ist hauptsächlich darin zu suchen, daß die Ökologie eine so junge Wissenschaft ist, und daß nur wenige Botaniker die nötige Vorbildung für diese schwierigen und vor allem vielseitigen Studien haben. Es kommt dazu, daß die Untersuchungen viel Zeit fordern, so daß es namentlich für Reisende, die schnell ein Land durcheilen müssen, ohne längere Zeit an jeder wichtigen Lokalität verweilen zu können, unmöglich ist, sie durchzuführen. Viele Tatsachen 
können aber doch auch von solchen aufgezeichnet werden, so z. B. ob der Boden lehmig oder sandig ist, von Rohhumus oder mildem Humus bedeckt ist, ob er wasserreich oder mittelfeucht oder gar trocken ist usw. Für eine wirkliche Förderung der wissenschaftlichen Ökologie sind eingehende Untersuchungen über chemische und physikalische Natur des Bodens in der Zukunft nötig. Wenn im folgenden die Natur des Standortes für die Haupteinteilung zugrunde gelegt wird, ist es somit ein etwas unsicherer Boden, der betreten wird, und man muß vielfach nach einem gewissen Taktgefühl vorgehen.

Eine zweite Schwierigkeit liegt in der natürlichen Begrenzung der Standorte. Jede Lokalität ist, man könnte fast sagen: immer, so wenig einheitlich, daß man sie fast als ein Mosaik bezeichnen kann. G. Kraus ${ }^{1}$ ) hat durch seine langjährigen, mühsamen Untersuchungen gezeigt, daß selbst auf „kleinstem Raume" so viele Divergenzen, so viele verschiedene Bodenstrukturen und so viele verschiedene kleine Klimaverschiedenheiten vorkommen können, daß ein Standort ganz verwickelte Bilder darbieten kann und es schwierig wird, eine Einheitlichkeit festzustellen.

Dazu kommt, daß die verschiedenen Standorte miteinander durch die allmählichsten Übergänge verknüpft sein können, und daß viele Standorte in fortwährender Entwicklung sind.

Es ist unumgänglich nötig, die Einteilung der Standorte auf der vorläufig unsicheren Grundlage vorzunehmen, um dadurch dann später zu einer tieferen Erkenntnis der Ursachen für die Vegetationsverschiedenheiten zu gelangen, und es muß der Zukunft überlassen werden, eine sichere Grundlage zu schaffen.

Wenn wir dann zur Einteilung der Standorte schreiten, so tritt uns gleich die Frage entgegen: welche Faktoren sind für die Pflanzengesellschaften die wichtigsten, die klimatischen oder die edaphischen oder etwa die biologischen (S. 3). Die Antwort wird wohl die sein, daß jeder Standort immer ein Produkt sowohl von klimatischen wie von edaphischen Faktoren ist, daß es aber Pflanzenformationen gibt, welche man unbedingt überwiegend als edaphische bezeichnen muß (z. B. die Wasserformationen), andere gibt es, die ebenso deutlich klimatisch bedingt sind, z. B. Wüsten und Halbwüsten.

Über andere Grundlagen werden die Meinungen wohl auseinander gehen.

Die Natur des Bodens wird immer ungeheuer von den klimatischen Faktoren beherrscht werden. Die Gesamtwassermenge, die den Pflanzen zur Verfügung steht, namentlich die des Bodens, wird vom Klima abhängig sein; wogegen edaphische Verhältnisse weit weniger auf das

1) G. Kraus 1908. 
Klima Einfluß ausüben können. Derselbe Boden kann in einem trocknen und in einem feuchten Klima ganz verschieden sein und eine ganz verschiedene Vegetation tragen.

Die Wichtigkeit des Bodens bei der Bestimmung für die definitive Entwickelung von Pflanzengemeinschaften verrät sich deutlich durch deren Verbreitung. Da ist keine einzige Pflanzengemeinschaft, die sich ohne Unterbrechung über größere Strecken Landes hinzieht. Alle sind unterbrochen, und zwar entsprechend der Bodenbeschaffenheit durch andere dort besser gedeihende Pflanzengemeinschaften, wie einheitlich das Klima an den benachbarten Stellen auch sein mag. Auf der anderen Seite ist nicht $\mathrm{zu}$ verkennen, daß ein und dieselbe Vegetationsformation in ganz ähnlicher Ausbildung sich in sehr verschiedenen Klimaten vorfindet, und zwar ist dies sowohl bei Wasser- wie bei Landpflanzen zu beobachten.

Es gibt auch Standorte, an welchen die klimatischen und die edaphischen Faktoren in derselben Richtung wirken und dadurch ihre Wirkungen verstärken, wie z. B. sandiger oder steinerner Boden in einem heißen, trockenen Klima; die Folge wird eine ausgeprägte Wüstenvegetation sein.

In 1. und 2. Abschnitte ist auf die große direkte und indirekte Bedeutung des Wassers für das Pflanzenleben aufmerksam gemacht worden. Es ist deutlich, daß die Unterschiede zwischen Wasserpflanzen (Hydrophyten) und Landpflanzen (Aërophyten) die allergrößten sind, was Morphologie, Anatomie und Physiologie betrifft. Das Wasser soll deshalb die Hauptgrundlage für die Klassifikation der Pflanzengesellschaften sein.

Zunächst mögen daher die Pflanzengemeinschaften in Wasserund Landpflanzen gegliedert werden, zwischen denen allerdings keine scharfe Grenze besteht, denn die Sumpfpflanzen (Helophyten) hilden ein Verbindungsglied: ähnlich den Wasserpflanzen haben sie im Wasser oder in dem nassen Boden ihre unterirdischen Organe, die Wurzeln und Grundachsen, nicht selten auch einen Teil ihrer unteren Blätter im Wasser oder im nassen Schlamme ausgebildet; ihre hauptsächlichsten Assimilationsorgane aber ragen in die Luft und sind deshalb, da sie verdunsten usw., dem Luftleben angepaßt und stehen dadurch den Landpflanzen nahe. Die Helophyten bilden ganz bestimmte und ausgeprägte Pflanzenvereine. Pflanzen, wie z. B. die Nymphaeaceen, die Schwimmhlätter besitzen und dadurch mit der Luft in Berührung kommen und verdunsten, sonst aber ans Wasser gebunden sind, müssen den Wasserpflanzen zugerechnet werden.

Die Bedeutung der Wasserversorgung für die Pflanzengesellschaften zeigen z. B. pflanzengeographische Karten wie die Drudes, welche die geographische Verteilung der Ozeane und der großen Binnenseen, 
daneben die der tropischen Regenwälder, Savannen, Wüsten usw. zeigen. Aber auch auf kleinsten Gebieten kommen dieselben Gegensätze vor.

Die Formationen der Wasserpflanzen müssen ferner nach der Beschaffenheit des Wassers, ob salzig oder süß, eingeteilt werden und von den Formationen der typischen Wasserpflanzen leiten natürlich auf beiden Linien die Sumpfpflanzen ganz allmählich zu den typischen Landpflanzen über, also von den Formationen des Salzwassers gehen die Vereine durch die der Salzsümpfe zu den Formationen des trockneren salzhaltigen Bodens über; ebenso werden die Formationen des süßen Wassers durch die der Süßwassersümpfe mit dessen Sumpfvegetation auf Böden, die von süßem Wasser durchtränkt werden, verbunden. In beiden Formationsreihen erscheint es dann natürlich, die Landpflanzen von den wasserreicheren Böden zu den stetig wasserärmeren fortschreitend anzuordnen, so weit dies möglich ist.

Oben ist schon bemerkt worden (vergl. Kap. 22 ff.), daß die Landpflanzen mannigfache Grade der Anpassung an das Luftleben zeigen und daß diejenigen, die die größte Schwierigkeit bezüglich der Wasserversorgung haben, Xerophyten ${ }^{1}$ ) genannt werden; die, die gewissermaßen zwischen den beiden Extremen stehen, wurden als Mesophyten ${ }^{2}$ ) bezeichnet; sie sind also weder Xerophyten noch Helo- oder Hydrophyten. Die verschiedenartige Ausbildung der Landpflanzen nach der einen oder anderen Richtung wird entschieden durch das Zusammenwirken der ökologischen Faktoren, der edaphischen wie der klimatischen, wie sie gerade am Standorte herrschen.

Mit Schimper ${ }^{3}$ ) können wir die Böden in physikalisch trockene und physiologisch trockene (vergl. auch Kap. 23, S. 197) teilen:

Physikalische Trockenheit. Ein Boden ist physikalisch trocken, wenn er nur sehr wenig freies Wasser enthält. Dies ist der Fall:

1. An der Oberfläche von Felsen oder Steinen, die mit Pflanzen der steinliebenden (lithophilen) Formationen besetzt sind.

2. Im Sandboden, der so hoch über dem konstanten Grundwasser liegt, daß dieses auf ihn keine Wirkung ausüben kann, und der während trockener Jahreszeiten durch seine geringe wasserhaltende Kraft und die starke Verdunstung fast alles Wasser verliert. Auf ihm leben die sandliebenden Formationen (psammophile). Thnen schließen sich die Geröllformationen an, deren Boden aus Steinen und Kies gebildet wird.

1) Schouw 1822.

2) Warming 1895 .

3) Schimper 1898. 
Hier können auch, wie schon erwähnt, die Epiphyten genannt werden, die ihr Wasser sich schwierig verschaffen können (Kap. 35).

Physiologische Trockenheit. Ein Boden ist physiologisch trocken, wenn er zwar beträchtliche Wassermengen enthält, wenn diese aber nur in geringem Maße den Wurzeln zugänglich sind, oder wenn das Wasser nur mit Schwierigkeiten absorbiert werden kann, entweder dadurch, daß der Boden das Wasser sehr festhält oder daß die osmotische Kraft der Wurzeln deshalb nicht recht zur Wirkung kommen kann, weil das Wasser stark konzentrierte Lösungen enthält. Dies kann der Fall der sein:

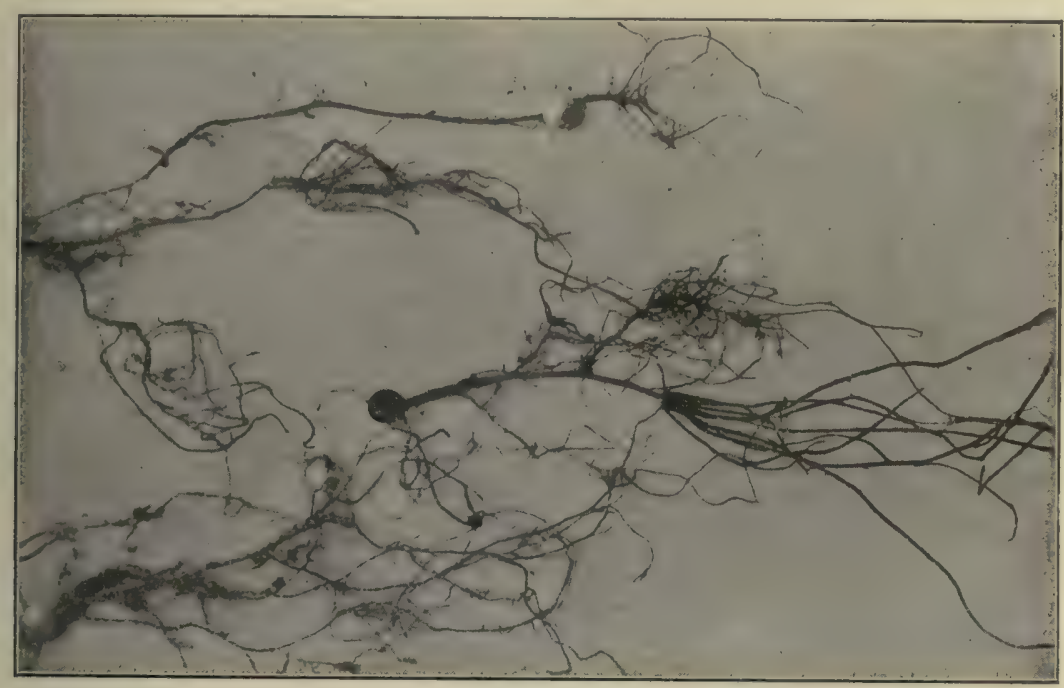

Fig. 163. Fichtenwurzeln im sauren Rohhumus der Lüneburger Heide; durch die physiologische Trockenheit sterben die Wurzelspitzen ab und müssen bei wiedereintretender Feuchtigkeit durch Seitenwurzeln ersetzt werden, dadurch starke Hemmung der Stoffproduktion und Schwäche der Pflanzen gegen Parasiten. (P. Graebner phot.)

1. Wenn der Boden reich an freien Humussäuren ist oder an anderen chemischen Stoffen, die durch ihre spezifische Wirkung auf die Pflanzen diese zur Annahme eines xerophilen ${ }^{1}$ ) Baues veranlassen. Es entstehen die Formationen der sauren Böden (Fig. 163).

2. Wenn der Boden reich an löslichen Salzen ist, meist an gewöhnlichem Kochsalz, welches jenen eigentümlichen xeromorphen Bau der Pflanzen mit sich bringt, wie wir ihn bei den halophilen Formationen, den Salzbodenbewohnern kennen lernen. Ein Halophyt ist in der Tat eine besondere Form der Xerophyten, wie schon

1) Vergl. Livingston 1904 . 
Wiesner ${ }^{1}$ ) und Schimper ${ }^{2}$ ) hervorhoben und wie es neuerdings auch Clements betont.

Diesen xerophytischen Formationen, die nach dem Charakter des Bodens gruppiert sind, der trocken ist oder doch oft oder schnell selbst in feuchten Klimaten austrocknet, kann eine andere Reihe von Formationen angeschlossen werden, bei denen die physikalischen und chemischen Eigenschaften des Bodens deshalb von untergeordneter Bedeutung sind, weil das extreme Klima für die Ausbildung den Ausschlag gibt. Der Boden ist weder zu sauer, noch zu salzig oder zu arm an Nährstoffen, ja er kann sogar genügend feucht sein, um eine üppige Vegetation zu tragen, aber das Klima ist so extrem, d. h. der Boden ist entweder so kalt, wie z. B. in den kalten Klimaten, oder periodisch für längere Zeit so trocken, daß nur xerophile Formationen auf ihm gedeihen können, ausgenommen in Lagen wie in Sümpfen oder an Flußufern, wo der Boden das ganze Jahr über genügend feucht ist; in diesen Fällen spielen dann also die topographischen Faktoren eine Rolle. Die Vegetation der Savannen (Campos) im Innern von Brasilien ist eine durch eine trockene Jahreszeit bedingte Formation; sie ist indessen stets an den höhergelegenen Boden, an hügeliges Gelände gebunden; längs der Wasserläufe und auf den Gebirgen, wo der Boden eine große Feuchtigkeit erhält, wächst Wald (in Afrika "Galeriewälder" Schweinfurths). Es kann hier keinem Zweifel unterliegen, daß, wenn das Klima das ganze Jahr über feucht wäre, dann trügen die Campos Wald $\left.^{3}\right)$. Zu diesem Typus von Steppen und Savannen müssen auch gewisse Hartlaubformationen gerechnet werden.

In den "ariden Gebieten" gesellen extreme Trockenheit des Klimas sich zu extrem trockenen Böden und erzeugen Wüsten und Halbw üsten.

Mesophyten wachsen auf einem Boden mit etwa intermediärem Charakter, er ist weder besonders sauer, kalt oder salzig, dagegen mäßig feucht, meist gut durchlüftet, auch reich an Nährstoffen und oft auch an alkalisch reagierendem Humus. Mesophytische Pflanzengemeinschaften wachsen in sehr verschiedenen Klimaten, nahe den Polen sowohl wie am Äquator, nur dürfen sie nicht der Gefahr einer länger dauernden starken Trockenperiode ausgesetzt sein. An solche Verhältnisse angepaßte Pflanzen zeigen meist eine ziemlich schwache Ausbildung der oben als der Regulierung der Verdunstung dienend genannten Einrichtungen; in diesen Dingen stehen sie etwa in der Mitte zwischen Xerophyten und Hydrophyten. Die Blätter sind meist

I) Wiesner 1889.

2) Schimper 1891, 1898.

3) Warming 1892, 1899. 


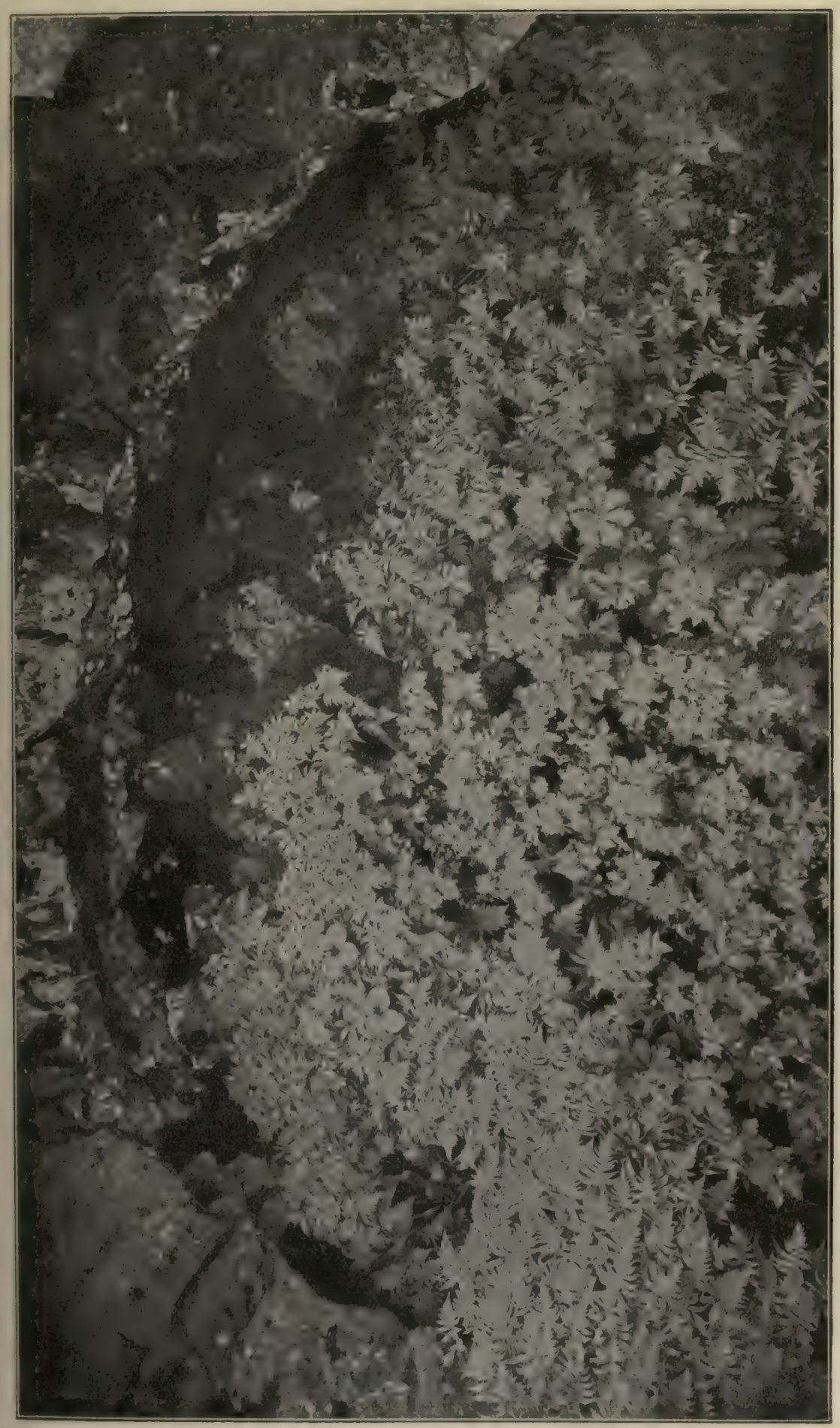

离

들

คी

\%

80 용

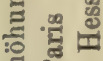

ज्ञ

흘 융

늘

\& 2

+웅.

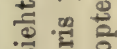

क ث艹

: 츨 잌

통 일

동

동

톨

․ㅡ

$\because$

.

छิ $\ddot{g}$

क

후 힐

흠류

볼 क

효ㅇㅛㅛ

$\forall$

맸 焉

तै कै

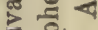

땍응

트 훙 둥

․․

등 클

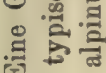

-

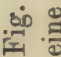


groß und in der Gestalt sehr viel stärker veränderlich als die der Xerophyten. Zähne oder andere Einschnitte am Rande sind häufig, ebenso zusammengesetzte oder reich geteilte Blätter (Fig. 164). Hydathoden scheinen häufig zu sein. Die vegetativen Organe zeigen meist eine frisch grüne Farbe; sie haben keine dicken Bekleidungen von Haaren oder Wachsausscheidungen, die eine graue oder bläuliche Farbe verleihen würden. Die Blätter sind meist dorsiventral gebaut. Spaltöffnungen sind häufig und finden sich oft auch auf der Oberseite der Blätter. Anatomische Eigentümlichkeiten, wie z. B. Wassergewebe, sind sehr selten und wenn sie vorhanden sind, nicht stark entwickelt.

Die größten Verschiedenheiten der mesophyten Pflanzen untereinander hängen davon $a b$, ob die Blätter nur wenige Monate lebend oder ob sie ein Jahr oder länger ausdauern. Ilex aquifolium als Unterholz in den Wäldern des nördlichen Europa ist zweifellos ein Mesophyt, aber ihre Blätter bleiben bis zu 2 Jahren lebend und sind daher ähnlich den Hartlaubgewächsen von xerophilem Bau, denn im Winter sind sie ungünstigen Lebensbedingungen ausgesetzt. In jener Zeit ist der Boden zu kalt (physiologisch trocken), und wenn trockene kalte Winde herrschen, kann die Verdunstung an den Blättern ziemlich stark sein. Ebenso liegt die Sache natürlich bei der Fichte (Picea excelsa) und anderen immergrünen Gehölzen in den kühleren gemäßigten Zonen. Bei den laubabwerfenden Gehölzen in denselben Ländern sind die Blätter dünner, heller grün und biegsamer; die Cuticula ist dünner usw., kurz sie sind typisch mesomorph gebaut.

Im tropischen Regenwalde, der gleichfalls als eine mesophytische Pflanzengemeinschaft aufgefaßt werden muß, gibt es viele Arten, deren Blätter recht xeromorph gebaut sind; weil sie länger als ein Jahr leben, müssen sie so angepaßt sein, daß sie sämtliche Schwankungen, die während des Jahres einzutreten pflegen, ertragen können. Es ist daher schwierig, auch alle Nadelhölzer als Xerophyten zu betrachten, selbst wenn ihre Blätter immergrün sind.

Bei den Nadelhölzern kommen Beispiele vor, daß dieselbe Art ganz verschiedene Standorte bewohnen kann. Schröter ${ }^{1}$ ) sagt z. B. von Pinus montana: "Sie zeichnet sich durch weitestgehende Anpassungsfähigkeit an extreme Standortsbedingungen aus und ist der genügsamste und abgehärtetste von allen unseren Nadelhölzern," „sie bewohnt das schwankende Hochmoor, das trockenste Dolomitgeröll und die sonnigsten Felshänge des Hochgebirges, gedeiht aber andererseits in Kulturen trefflich, auch auf dem losen Flugsand der Dünen und dem mageren Boden der Heide." "Die Bodenansprüche der Bergkiefer sind außerordentlich gering; sie gedeiht auf trockenen und nassen Verwitterungsböden von Granit,

1) Schröter 1907 S. 202 ff.; vergl. auch P. E. Müller 1871, 1887. 
Gneis, Glimmer- und Tonschiefer, Serpentin, Porphyr, Kalk, Dolomit, Mergel, Sandstein." - „Eine Eigenschaft allerdings, das muß hervorgehoben werden, haben alle Wuchsorte der Bergkiefer gemeinsam, nämlich die Armut an assimilierbarem Stickstoff.

Auch Pinus silvestris kann sehr versehiedene Standorte bewohnen: trockenen Sandboden, fruchtbaren reichen Mullboden, dann auch sauren Rohhumusboden usw.

Es muß auch daran erinnert werden, daß ein Standort bisweilen nur scheinbar sehr trocken ist, da die Pflanzen in der Tiefe reichlich Wasser finden. Pinus silvestris wächst bisweilen auf oberflächlich äußerst trockenen Dünen, aber mittels ihrer tief gehenden Wurzeln wird sie aus der Tiefe das nötige Wasser holen können (Fig. 165). An solchen Orten ist in normalen oder trockenen Jahren die Ansiedelung der Gehölze unmöglich; die nur flach wurzelnden Sämlinge vertrocknen in der Sommerhitze; nur in besonders feuchten Jahren bleiben sie erhalten und erreichen die feuchte Tiefe (Graebner). Percy Groom (1914 S. 288) hat eine ähnliche Bemerkung, $P i$ nus Jeffreyi betreffend, gemacht.

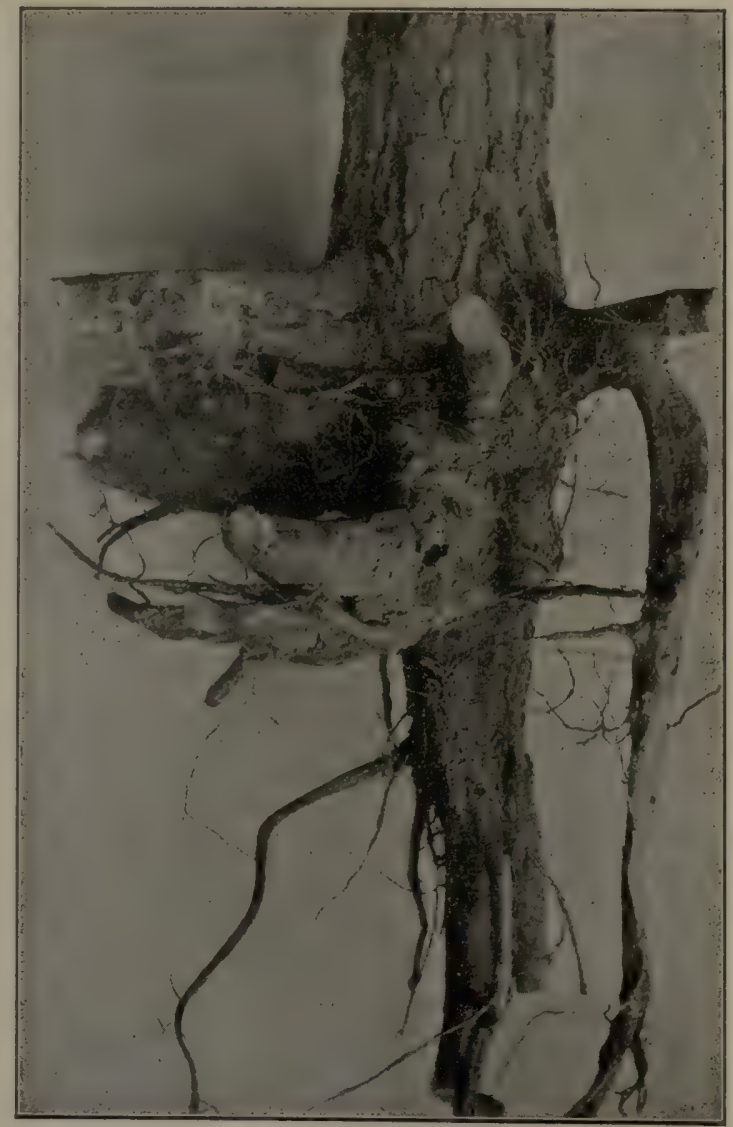

Fig. 165. Pinus silvestris, die Kiefer, auf gut durchlüftetem Boden als typischer Tiefwurzler.

(P. Graebner phot.)

Die Xeromorphie der Coniferen ist, wie Marie C. Stopes ${ }^{1}$ ) auseinandersetzt, ein erblicher Charakter, der in ihrer Entwicklungsgeschichte begründet ist. Ihrer Auffassung nach ist der xerophytische Bau der Nadelhölzer verursacht durch die unvollkommene Ausbildung des Leitungsgewebes. Die Xeromorphie der Gymnospermen ist nach ihr

1) Marie C. Stopes 1907. 
nicht das Resultat direkter Anpassung an trockene Böden, ist keine ökologische Anpassung im gewöhnlichen Sinne, sondern ist im histologischen Aufbau der Pflanzen begründet, der sie unfähig macht, schnell Wasser durch das Holz strömen zu lassen, denn ihr Holz besteht nur aus Tracheiden, die durch die gehöften Tüpfel verbunden sind. Der Durchmesser der Tracheiden ist kleiner als der der höheren Blütenpflanzen; die ganze Struktur des Holzes ist einfacher und einheitlicher als bei den letzteren. - Die Nadelhölzer sind eine sehr alte und noch primitiv gebaute Gruppe, da das holzige Leitungssystem nicht die Mannigfaltigkeit und Veränderungsfähigkeit erreicht hat, wie bei den jüngeren Angiospermen. Marie Stopes kommt etwa zu dem folgenden Schluß: Es scheint, daß die xeromorphen Charaktere der Coniferales in sehr vielen Fällen keine Anpassungen an xerophytische Bedingungen in ihrer eigenen Lebensführung darstellen, sie sind nicht durch in der Jetztzeit erzwungene Notwendigseiten erzeugt und erst dadurch vererbt, sondern sie sind das Resultat der physiologisch begrenzten Leistungsfähigkeit des Holzes in dieser alten und noch unvollkommen entwickelten Pflanzengruppe. Mit andern Worten ist ihr "Xerophytismus" nicht ökologisch, sondern phylogenetisch.

Es kann anscheinend keinem Zweifel unterliegen, daß die Xeromorphie der Coniferen ebenso wie das überwiegende Immergrünsein phylogenetische Charaktere sind, die vom Urtypus her überkommen sind, und daß der xeromorphe Bau der Blätter mit der primitiven Gestaltung des Leitungsgewebes zusammenhängen. Stopes irrt doch wohl darin, daß sie annimmt, daß die jetztzeitigen Nadelhölzer nicht zum größten Teile unter trockenen Lebensverhältnissen wachsen. Wie schon bemerkt, müssen in den kühleren Klimaten mit ausgeprägten Wintern alle immergrünen Pflanzen xerophytisch gebaut sein, weil diese Jahreszeit physiologisch trocken wirkt. Diejenigen, die auf Torf oder Rohhumus leben, leiden auch deshalb an Wassermangel, da der Boden physiologisch trocken ist.

Der primitive Bau des Coniferenholzes mag für die äußere xeromorphe Form der Nadelhölzer ausschlaggebend sein und mag auch die phylogenetische Ursache sein, aber er kann nicht allein für den jetzt überwiegenden Xerophytismus verantwortlich gemacht werden, da die meisten Nadelwälder jetzt auf physikalisch oder physiologisch trockenem Boden leben.

Die Coniferen bieten überhaupt ungemeine Schwierigkeiten, was ihre Verteilung nach Standorten betrifft, weil sie einen ausgesprochen xeromorphen Bau haben, aber auf den verschiedenen Standorten vorkommen, sowohl auf ganz trockenen, z. B. auf magerem sandigen oder steinigen Boden in den Mittelmeerländern (Pinus maritima, P. Halepensis; Juniperus oxycedrus u. a.), als auch in Wäldern, die oft von 
Feuchtigkeit triefen, z. B. Fichtenwälder in feuchten Gebirgen. Weiter wachsen sie sowohl auf mildem Humus mit einem mittleren Wassergehalt als auf sehr nassem und saurem Rohhumus. Wenn irgendwo, so ist es hier sehr schwierig, einen Einblick in die Epharmonie der Pflanzen zu bekommen ${ }^{1}$ ).

Als Beispiel mag erwähnt werden, daß Cowles und Whitford ${ }^{2}$ ) den Nadelwald der östlichen Vereinigten Staaten als eine edaphisch xerophytische Formation erklären, die in den Gegenden vorkommt, wo laubwechselnder Wald überwiegt. In dem gänzlich abweichenden Klima der pacifischen Küste der Vereinigten Staaten überwiegt dagegen der Nadelwald, während die laubwechselnden Gehölze sich zu edaphisch mesophilen Wäldern vereinigen, die den Wasserläufen folgen.

Diese Deutung der Xeromorphie der Coniferen zeigt deutlich, daß wir noch weit davon entfernt sind, die Epharmonie derselben und deren Beziehungen zu den ökologischen Verhältnissen ihrer Standorte zu verstehen. Percy Groom $^{3}$ ) ist der Meinung, daß wir unsere Schlüsse über die Xerophilie einer Pflanze nicht aus dem Blattbau derselben herleiten dürfen, sondern von der Größe der gesamten Laubfläche („leafarea") der betreffenden Arten.

Graebner hat hervorgehoben ${ }^{4}$ ), daß neben dem Wasser auch der Nährstoffgehalt des Bodens oder des Wassers resp. die den Pflanzen während der Vegetationszeit zur Verfügung stehende Nährstoffmenge von größter Bedeutung ist, und hat von diesem Gesichtspunkte aus eine Einteilung der Vereinsklassen gegeben, auf welche in dem folgenden System auch Rücksicht genommen wird; er teilt (im wesentlichen für Mitteleuropa) folgendermaßen ein:

A. Vegetationsformationen mit mineralstoffreichen Wässern, d. h. Formationen, in denen zur günstigen Jahreszeit, also während der Vegetationsperiode, den Pflanzen reichliche Mengen von Nährstoffen in geeigneter Form zur Verfügung stehen; daher für die am Standort herrschende Länge (oder Kürze) der Vegetationszeit verhältnismä日ig starker Jahreszuwachs.

I. Übermäßige Ansammlung von Nährstoffen (auch tierischer, organischer Stoffe); saprophile Flagellatenvereine, Ruderalstellen.

II. Ohne übermäBige Anreicherung von Nährstoffen.

1. Trockener Boden:

Wüsten, Steppen, xerophile Gras- und Staudenvegetation, sonnige (pontische)

Hügel, xerophile Wälder usw.,

1) In Warming, Oecology of plants, 1909, sind die Coniferen in einer selbständigen Sektion untergebracht worden. Richtiger wird es sein, sie nach ihren verschiedenen Standorten zu verteilen, was in diesem Buche versucht worden ist.

2) Cowles $1901 \mathrm{a}$; Whitford 1905.

•) Vergl. Percy Groom 1910; Compton 1911.

4) Graebner 1898, 1902, 1909 \&, 1910 \&. 
2. Mäßig feuchter Boden; kaltes Klima: arktische und alpine Gras- und Krautmatten; wärmere Klima: Waldbildung und zwar:

a) auf Mergelboden Buchenwälder (an sandigeren Stellen oft die Weißbuche vorwiegend),

b) auf Sand- oder doch weniger mergelhaltigem Boden:

a) trockenerer Boden Eichen-, Birkenwälder (hier allmähliche Übergänge zu B 2 b),

B) feuchterer Boden (in einigen Teilen Europas): Fichtenwälder.

3. Nasser Boden:

a) ohne übermäßige Anreicherung von Nährstoffen, meist an fließendem Wasser

a) ohne Utberschwemmung und Eisgang: Erlenbrücher,

ß) mit Übersehwemmung ohne Eisgang: Auenwälder,

$\gamma)$ mit Überschwemmung und Eisgang: natürliche Wiesen,

b) mit übermäßiger Anreicherung [auch (meist pflanzlicher) organischer Stoffe]: Wiesen- oder Grünlandmoore, "saure Wiesen", Sumpfgebüsche und Brücher.

4. Im Wasser, Landseen, Teiche, Flüsse, Bäche (Rohrsümpfe, Plankton, Vereinsklasse der Nereiden).

B. Vegetationsformationen mit mineralstoffarmen Wässern, d. h. Formationen, in denen entweder die zur Verfügung stehende Nährlösung im Boden absolut arm an verwendbaren Salzen ist, oder in denen durch Herabsetzung der Aufnahmefähigkeit der Wurzeln (infolge von Humussäuren, Luftarmut im Boden usw.) die Pflanzen auch in der günstigen Jahreszeit nur wenig verwendbare Nährstoffe aus dem Boden herausziehen können (physiologisch arm); daher für die Länge der Vegetationszeit verhältnismäßig geringe Jahresproduktion.

1. sehr trockener Boden: Sandfelder, Flechtenheiden usw.

2. trockener bis mäßig feuchter Boden:

a) mit Rohhumus, Ortstein oder dicken Bleisandschichten: Moosheiden, Calluna-Heiden,

b) ohne stärkere Rohhumusschichten, Ortstein oder dicke Bleisandschichten:

Kiefernwälder (hier Utbergang zu A 2 b).

3. nasser Boden: Heidemoore, Sphagnumtundren.

4. im Wasser: Heideseen, -tïmpel.

C. Vegetationsformationen mit salzhaltigen Wässern.

1. trockener Boden: Dünen,

2. feuchter Boden: Strandwiesen,

3. nasser Boden: Salzsümpfe,

4. im Wasser: Seegrasvegetation, Mangrovesümpfe.

In Übereinstimmung mit den jetzt dargelegten Grundanschauungen wird die folgende

\section{Einteilung der Standorte}

in 13 Klassen vorgenommen.

I. Serie der Salzwasser- und Salzboden-Formationen (Halophyten-Vegetation)

Klasse 1. Submerse Pflanzen-Vereine des salzigen oder brakischen Wassers der Meere und Binnenlandgewässer. 
Klasse 2. Sumpfregetation an den Ufern der Meere und salzigen Binnenlandseen, sowie Salinensümpfe.

Klasse 3. Landvegetation auf salzhaltigen Böden mit mittlerem oder geringerem Wassergehalt. Vegetation von Land-Halophyten. Klima gewöhnlich heiß und trocken (Salzwüsten).

Die folgenden Klassen sind an süßes Wasser geknüpft.

II. Serie des süßen Wassers und der sumpfigen SüBwasser-Böden

Klasse 4. Submerse Vegetation in Süßwasser-Seen, Tümpeln und Wasserläufen. Wasser nährstoffreich oder nährstoffarm, öfter auch sauer. (Parallel mit I, 1.)

Klasse 5. Sumpfregetation an den Ufern der Wasserbassins oder Flüsse mit süßem Wasser. (Parallel mit I, 2.)

Die Landvegetation, die von dem süßen Wasser abhängig ist (parallel mit Klasse 3), ist so umfassend, daß sie alle folgenden Serien in Anspruch nimmt.

III. Serie der mesophilen und hygrophilen Formationen

Der Boden ist nährstoffreich und wasserreich oder auch mäßig feucht, kann in einigen Fällen periodisch überschwemmt sein. Die Wurzeln erreichen oft das Grundwasser. Milder (neutraler oder alkalischer) Humus wird in den meisten Fällen gebildet. Klima feucht, regenreich. Geschlossene Landpflanzenvegetation mit überwiegend mesomorphen Arten.

Klasse 6. Mikrotherme (kalttemperierte) Formationen.

Klasse 7. Megatherme und mesotherme, tropische und subtropische Formationen.

IV. Serie der torfhaltigen, meist sauren Böden

Klasse 8. Klima feucht und kalt oder kalttemperiert. Der Boden ist aus Torf gebildet, mehr oder weniger wasserreich, aber entweder arm an Nahrung oder doch physiologisch nährstoffarm (vergl. S. 109) und physiologisch trocken, weil er sauer ist (Vegetation von Oxylophyten; Heideformationen im weitesten Sinne), oder verhältnismäßig reich an Mineralsalzen und neutral oder alkalisch in Reaktion (bisweilen die Flachmoore). Landpflanzenvegetation, gewöhnlich geschlossen, aus mehr oder weniger xeromorphen Arten gebildet.

\section{Serie der Kältewüsten}

Klasse 9. Klima kalt und windig, feucht oder trocken. Der Boden ist physiologisch trocken, weil er jedenfalls durch längere Zeit (im Winter, bisweilen auch im Sommer) so kalt ist, daß die Wurzeln der Pflanzen kein Wasser aufnehmen können. Landpflanzenvegetation 
in polaren und Hochgebirgsgegenden, offen, mehr oder weniger xeromorph (Psychrophyten-Vegetation).

\section{Serie der Stein- und Sandböden}

Boden physikalisch trocken, weil er nicht imstande ist, selbst in regenreichen Klimaten, hinlänglich Wasser für die Vegetation aufzunehmen und festzuhalten. Klima verschieden, von untergeordneter Bedeutung.

Klasse 10. Fels- und Steinformationen (Lithophyten-Formationen). Steinboden oder sehr flachgründiger Boden. Die Vegetation in den extremen Fällen nur von gefäßlosen Kryptogamen (Flechten, Moosen, Algen) gebildet.

AnschluB. Spaltenvegetation (Chasmophyten-Vegetation).

Klasse 11. Trockene Sandvegetation. Landvegetation auf trockenem Sandboden, aus gefäßlosen Kryptogamen und vorzugsweise xeromorphen Gefäßpflanzen gebildet. Das Grundwasser liegt zu tief, um von den Pflanzenwurzeln erreicht werden zu können. Keine oder geringe Humusbildung.

Sandpflanzen-Formationen (Psammophyten-Formationen).

VII. Hartlaubformationen der Gebiete mit Winterregen

Klasse 12. Subtropische Vegetation mit Winterregen und Trockenruhe im Sommer. Klima mesotherm (Köppen). Boden verschieden. Hartlaubformationen (Sklerophyll-Formationen), meist aus immergrünen Holzpflanzen zusammengesetzt.

VIII. Serie der subxerophilen Formationen mit Grasboden

Klasse 13. Grassteppen. Mikrotherme und mesotherme Formationen mit kalten Wintern, Schnee und Frost. Grasvegetation. Kein Baumwuchs. Bisweilen Humus. Der regenreichste Monat hat 6 bis 10 Regentage.

Klasse 14. Savannen, subtropische und tropische Formationsbildung. Trockenzeit im Winter (2-4 Monate). Regen im Sommer weniger als $2 \mathrm{~m}$. Boden gewöhnlich lehmig (Lateritboden) oder sandig; geringe oder keine Humusbildung. Vegetation mehr oder weniger offen aus verschiedenen, doch xeromorphen oder subxeromorphen Lebensformen gebildet, darunter Bäume.

IX. Serie der ariden Gebiete, extrem-xeromorphe Lebensformen

Regenarm bis regenlos; der regenreichste Monat hat weniger denn 6 Regentage (Köppen). Lange Ruhezeit der Vegetation. Boden verschieden. Keine Humusbildung. Offene bis sehr offene Formationen aus stark xeromorph gebauten Pflanzen gebildet. (Eremophyten-Formationen.) 
Klasse 15. Halbwüsten (Strauch-, Succulenten- und andere Steppen, nur nicht Grassteppen).

Klasse 16. Wüsten (Hitzewüsten).

Zwei andere Versuche, die Pflanzenformationen übersichtlich zu gruppieren, verdienen hier genannt zu werden, namentlich die von Engler und von Drude, beide 1913.

Engler $\left.{ }^{1}\right)$ gibt eine Einteilung der Pflanzenvereine, von deren grundlegender Idee der folgende Auszug ein Bild geben wird:

I. Formationen der tropischen und subtropischen Zonen.

A. Halophile Formationen.

$A^{1}$. Meeresformationen oder Enalidenformationen:

1. stark salzhaltige.

a) Plankton.

b) Benthos (mit 7 Unterabteilungen).

2. Brackwasser.

$A^{2}$. Litorale:

a) Mangrove (2 Abteilungen).

b) Strandgehölz.

c) Krautformation des sandigen Strandes.

d) Strandfelsen.

e) Überschwemmungsland der Küste.

A $^{3}$. Im Binnenlande:

a) Salzsteppe oder Salzwiiste.

b) Salzsumpf.

c) Salzsee.

B. Hydatophile (Hydrophile) Formationen.

$B^{1}$. Die Pflanzen gröbtenteils unter Wasser oder schwimmend.

a) Hydrocharitenformation (2 Unterabteilungen).

b) Plankton (3 Unterabteilungen).

c) Formation heißer Quellen (mit Schizophyten).

d) Abwässerformation (niedere Saprophyten).

e) Limnaeenformation (4 Unterabteilungen).

$B^{2}$. Die Pflanzen unter Wasser wurzelnd, aber mehr oder weniger über dasselbe hervorragend (Helophyten). Sumpf (9 Unterabteilungen nach Regionen usw.).

$B^{3}$. Die Pflanzen mit den Wurzeln das Grundwasser erreichend, aber mit dem unteren Teile des Stammes und dem oberen der Wurzeln in trockener Erde.

a) Baumloses Alluvialland (3 Unterabteilungen).

b) Alluvialwald oder Galeriewald (5 Unterabteilungen).

C. Hygrophile megatherme Formationen.

a) Unterster immergrüner Laubwald (3 Unterabteilungen).

b) Mittlerer immergrüner Regenwald, in den äquatorialen Gegenden meist um 6-700 m über Meer beginnend (3 Unterabteilungen).

c) Oberer immergrüner Regenwald, in den äquatorialen Gegenden oberhalb $1000-1100 \mathrm{~m}$ (4 Unterabteilungen).

1) Engler 1913 (1914).

Warming-Graebner. 3. Auflage, illustr. 
D. Hygrophile mesotherme Formationen.

a) Oberer Bambuswald.

b) Höhenwald oder Nebelwald.

c) Hochgebirgsbachufer zwischen und über den Höhenwäldern.

d) Feuchtes Hochweide- und Bergwiesenland.

E. Subxerophile Formationen.

$E^{1}$. Baumformationen der Ebene und des Hügellandes.

a) Parkartige Gehölze in den unteren Regionen.

b) Mehr oder weniger dichte Macchia mit hartlaubigem Gehölz.

c) Trockenwald, in welchem neben laubwerfenden Gehölzen auch solche mit immergrünem Laub vorkommen.

d) Trockenes Buschgehölz der Ebene.

e) Palmenhaine.

$E^{2}$. Grasformationen der Ebene.

a) Offene subxerophile Grassteppe (3 Unterabteilungen).

b) Formation winterfeuchter, blumenreicher Ebenen, subtropisch.

$E^{3}$. Buschformationen der Gebirgsländer.

a) Buschformation des roterdigen Vorlandes.

b) Buschgehölze des schwarzerdigen Vorlandes.

c) Gebirgsbusch (3 Unterabteilungen).

d) Bergheide.

e) Gebirgsbuschsteppe.

f) Gebirgsbaumsteppe.

g) Truckener Höhenwald.

$E^{4}$. Pteridium-Formation.

a) Primäre.

b) Sekundäre.

$E^{8}$. Steinige und felsige Formationen nebst anderen Formationen des oberen Gebirgslandes. - Verf. unterscheidet hier Formationen a bis $\mathrm{m}$.

F. Xerophile Formationen.

Von a) Sandwüste unterscheidet Verf. Formationen bis s) Busch- und Baumgrassteppe.

II. Formationen der gemäBigten und kalten Zonen.

Auch die Formationen dieser zweiten Hauptabteilung werden im wesentlichen nach dem Muster der ersten Abteilung, natürlich modifiziert durch die klimatischen Eigentümlichkeiten, eingeteilt.

Drude ${ }^{1}$ ) gibt folgende Darstellung der Formationstionseinteilung:

I. Vegetationstypus der immergrünen Tropenwaldungen. (Äquatoriale Regenwälder; Klimagruppe $\mathrm{I}^{2}$ ) der Iso-Megathermen Hygrophyten.)

1) Drude 1913

$\left.{ }^{2}\right)$ Drude unterscheidet folgende Klimagruppen auf der Erde: A. Die „Iso"-Klimagruppen: I. Iso-Megatherme Hygrophyten, II. Iso-Mesotherme Hygrophyten, III. IsoMesotherme Xerophyten, IV. Iso-Mikrothermen, V. Iso-Niphothere-Hekistothermen. B. Die "Tropo"-Klimagruppen: VI. Tropo-Brachychimene Megathermen, VII. TropoBrachythere Megathermen, VIII. Tropo-Megatherme Xerophyten, IX. Tropo-Mesotherme Xerophyten. - C. Die "Etesial"-Klimagrup pen: X. Etesial-Xerothere Hygrochimenen, XI. Etesial-Hygromesothermen, XII. Etesial-Poikilotherme Psychrochimenen. - D. Die „Helio"-Klimagruppen (mit durch Frostwirkung gesteigerter Verkürzung der Vege- 
II. Vegetationstypus der tropisch-regengrünen Waldungen. (Tropenwälder mit ausgesprochener Trockenperiode; Savannenwälder, Monsunwälder; Klimagruppe VI der Tropo-Brachychimenen-Megathermen bis gegen Klimagruppe VII hin.)

III. Vegetationstypus der subtropisch-immergrünen Hartlaubwaldungen. (Klimagruppe II der Iso-Mesothermen und XI der Etesial-Hygromesothermen.)

IV. Vegetationstypus der etesial-borealen sommergrünen Laub-und frostharten Nadelwaldungen. (Wälder höherer Breiten, streng periodisch; von Klimagruppe X an mit Hygrochimenen einsetzend, typisch in XII mit heißem Sommer und kaltem Winter [Poikilothermen], auslaufend in den mannigfachen Nuancen von Klimagruppe XIV mit Psychrochimenen bis zur nördlichen Baumgrenze, welche erst in XVI erreicht wird.)

V. Vegetationstypus der immergrünen und periodisch belaubten Niederholzformationen aus Gebüsch und Gesträuch. (Scrub, Heiden, Krummholzgebüsche, Retamgebüsche; Klimagruppe IV der Iso-Mikrothermen, X der EtesialXerotheren und von da in sehr verschiedenen Gattungen bis zur Klimagruppe XV der Thero-Mikrothermen.

VI. Vegetationstypus der Hochgrassteppen, Baumsteppen und Savannen. (Mehr oder weniger geschlossene Grasflurformationen des Iso- und TropoMegathermenklimas bis zur Klimagruppe VI.)

VII. Vegetationstypus der (immergrünen) Graswiesen und Grasmoore. (Grasfluren der Iso-, Meso- und Mikrothermen; Klimagruppe II, IV, der Etesialgruppen XI und XII, der Helio-Hygrothermen XIV bis XVI mit winterlicher Schneedecke.)

VIII. Vegetationstypus der Xerophytensteppen und Wüstensteppen. (Dornbuschbestände, Strauchsteppen, Sand-, Lehm-, Salz- und Geröllsteppen mit offener, zerstrenter Vegetation einschließlich zerstreuter Steppengräser. Klimagruppen aller als Xerophyten bezeichneten Nummern III, VII bis IX, XIII, bis zu dem auch im Sommer mikrothermen Klima der Gruppe XVII.)

IX. Vegetationstypus der Chamaephyten, Moose und Flechten auf saurem Boden. (Stauden- und Halbstrauchmatten, Tundren, Moosmoore, Torfmoore; dazu die "Mikrothermen-Chomophyten", d. h. Grat- und Geröllbestände im mikrothermen und hekistothermen Klima, Gruppe $\nabla, X V$ und XVIII.)

$X$. Vegetationstypus der $S \ddot{B} B$ wasserbestände und limnischen Uferformationen. (Amphibische Lebensformen und phanerogame Hydrophyten.)

XI. Vegetationstypus der halophytischen Küstenformationen. Die Lebenslage dieser Bestände wird durch den Salzgehalt und die Wirkung von Ebbe und Flut bestimmt, deren Wechsel besonders die Mangrove-Formation der tropischen Küsten zu einer so ausgezeichneten machen. Die vom Salzwasser bespülten Horizonte gehen nach oben in gesetzmäBiger Folge in xerophytische Kies- und Sandfluren (Dünen) über.

XII. Vegetationstypus der submersen Halophytenformationen. Die Lebenslage dieser Bestände wird von ihrer Besiedelung zwischen Ebbe- und Flutmark, oder unterhalb derselben, beziehentlich von der Tiefe des Wassers an felsigen oder sandigen Küsten bestimmt. Außer ganz wenigen Arten von "Seegräsern" bestehen sie nur aus Algen. Eben dieselben bilden zwischen Küstenformationen und fern von den-

tationsperiode; Raheperiode lichtarm): XIII. Helio-Xerothere Psychrochimenen, XIV.HelioHygrothere Psychrochimenen, XV. Helio-Thero-Mikrotherme Niphochimenen, XVI. HelioBrachythere Niphochimenen, XVII. Helio-Mikrotherme Xerophyten, XVIII. HelioNiphothere Hekistothermen. 
selben im hohen Ozean die mikroskopische, meist aus anderen Arten als unter $\mathrm{X}$ bestehende Schwebeflora, das Plankton der Hochsee.

Die meisten
abteilungen geteilt.

\section{Kap. Physiognomie der Vereine}

Die großen ökologischen Klassen, die im vorigen Kapitel genannt sind, umfassen jede viele verschiedene Typen von Pflanzengemeinschaften. Seit langer Zeit gibt es populäre Begriffe bezüglich dieser Typen, für die allgemein bekannte Namen vorhanden sind, wie Wald, Busch, Wiese, Moor, Heide, Steppe, Savanne, Macchie usw., alle diese sind auch in die wissenschaftliche Terminologie aufgenommen. Die leitenden Gesichtspunkte für diese Unterscheidungen sind physiognomische und als solche abhängig auch von physiologischer Verwandtschaft. Die Physiognomie der Vegetation ist daher nicht nur ästhetisch, sondern auch wissenschaftlich zu betrachten: Die Vegetation bestimmt oft wesentlich die Physiognomie der Landschaft und in dieser Beziehung spielt sie eine ganz andere Rolle, wie die Tiere es $\operatorname{tun}^{1}$ ). Deshalb muß die Physiognomie auch wissenschaftlich behandelt werden.

Die Physiognomie der Pflanzen und dadurch auch der Pflanzenvereine wird durch zwei verschiedene Ursachen bedingt. Die Palmen, der Baumfarn, die Grasform, viele Blatttypen usw., eine ungeheuere Menge von Formen haben eine Physiognomie, welche von den jetzt in der Natur herrschenden Verhältnissen ganz unabhängig zu sein scheint. Wie sie vor undenklichen Zeiten hervorgebracht worden sind, ob durch Selektion, ob durch direkte Anpassung an längst verschwundene ökologische Verhältnisse oder ob orthogenetisch, darüber wissen wir absolut nichts. Ihre Physiognomie ist phylogenetisch oder systematisch und erblich.

Die andere Art von Physiognomie ist die epharmonische, sie steht in offenbarem Zusammenhange mit der jetzigen Lebenslage. Daß ähnliche Lebensbedingungen ähnliche Organisation und ein ähnliches Äußeres hervorrufen, ist durch Tausende von Erfahrungen und Beobachtungen belegt.

Ob diese epharmonischen Lebensformen erblich sind oder nicht, ist eine Frage für sich, die in jedem einzelnen Falle durch Versuche entschieden werden müßte. Manche dieser Lebensformen sind erfahrungsgemäß nicht erblich fixiert; man denke z. B. an die Versuche Kerners oder Bonniers mit Pflanzen aus der Ebene, welche, in den Hochgebirgen

1) Darwin schreibt: "A traveller should be a botanist, for in all views plants form the chief embellishment". - Uber die Physiognomie der Vegetation vom ästhetischen Standpunkte vergl. neuerdings W. Lange 1909, 1912. 
kultiviert, ihre Form änderten, daß sie z. B. Rosettenformen und andere unter den veränderten Verhältnissen ganz abweichende Formen annahmen, welche wieder nur vergängliche Modifikationen waren, die wieder verschwanden, sobald die Pflanzen wieder in die alte Lebenslage zurückgebracht wurden. Es gibt z. B. Polsterformen, welche vorübergehende Modifikationen sind, andere aber, die wahrscheinlich vollkommen erblich sind, und unter allen, auch veränderten, Verhältnissen erhalten bleiben, wie z. B. Azorella, Raoulia u. a.; auch Formen wie die Cacteen, die Agavenform, die Aloeform usw. sind ja erblich fixierte epharmonische Formen.

Die im 2. Abschnitte, 21. und 22. Kap., besprochenen Grundformen des Lebens werden im großen und ganzen phylogenetische sein, die im

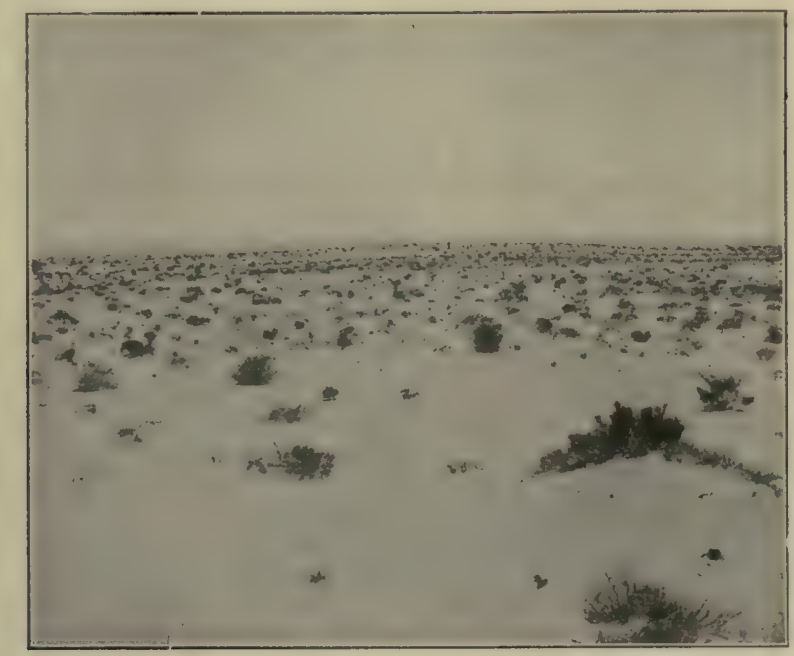

Fig. 166. Sandwüste in Tunesien. (Phot. Dr. V. v. Madsen.)

25. ff. Kap. behandelten Anpassungen derselben dagegen hauptsächlich wieder epharmonische und vielleicht nichterbliche. Eine scharfe Trennung zwischen diesen Formen ist natürlich durch umfassende Versuche möglich.

Deutlich ist aber, daß die Physiognomie der Pflanzen und der Pflanzenvereine von den Lebensformen bedingt wird. Die erste Einteilung der Vereine innerhalb der verschiedenen Klassen der Standorte muß daher nach den Lebensformen geschehen. Durch sie wird in erster Linie die Physiognomie der Vegetation bedingt, und die Physiognomie der Vegetation wird immer eine ungeheuere Rolle spielen, nicht nur für die allgemeine ästhetische, sondern auch für die wissenschaftliche Betrachtung der Landschaft. Die Physiognomie muß somit als Ausdruck der verschiedenen Haushaltung der Gesellschaften aufgefaßt werden. 
Die Umstände, von denen die Physiognomie der Vegetation am wesentlichsten abhängt, sind folgende:

1. Die vorherrschenden Lebensformen: Bäume, Sträucher und Kräuter mit verschiedener Physiognomie, Blattform und Blattgröße, ferner Moose, Flechten usw. - Hiernach werden Formationen gebildet wie: Wald, Gebüsch, Heide, Wiese, Steppe und andere Formen der Krautvegetation, Tundra usw.; Lebensformen wie Lianen und Epiphyten greifen modifizierend ein. Mit "vorherrschend" ist diejenige Lebensform gemeint, welche der Vegetation ihre Physiognomie gibt. Es würde ganz irreleitend sein, hier Gewicht auf statistische Methoden zu legen und die verhältnismäßige Anzahl der verschiedenen Arten als Basis zu

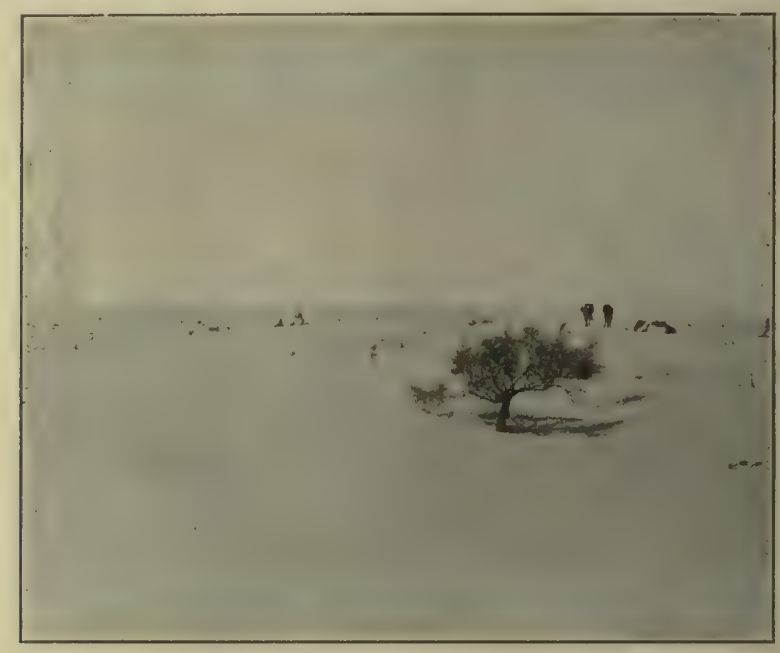

Fig. 167. Sandwüste in Tunesien mit Tamarix.

(Phot. Dr. V. Madsen.)

nehmen. Ein Buchenwald ist ein "Wald" und gehört zu dem Vegetationstypus „Wälder", selbst wenn er nur von einer Baumart gebildet wird, während viele Arten von Stauden, Moosen usw. den Boden bedecken.

In vielen Fällen ist es eine einzelne dominierende Art, welche die Physiognomie bestimmt, z. B. in einem Buchen- oder Fichtenwalde; in anderen mehrere oder viele Arten mit derselben oder ähnlichen Lebensform, z. B. eine Wiese durch die Grasform bestimmt.

2. Die Dichtigkeit (Menge der Individuen). Diese hängt von dem Kampfe der Pflanzen mit der leblosen Natur und von den biologischen Eigentümlichkeiten der Arten ab. In einigen Vereinen wird der Boden dicht bedeckt (z. B. auf Wiesen), in anderen ist die Decke so offen, daß die Farbe des Bodens der Landschaft die Farbe gibt (z. B. auf den 


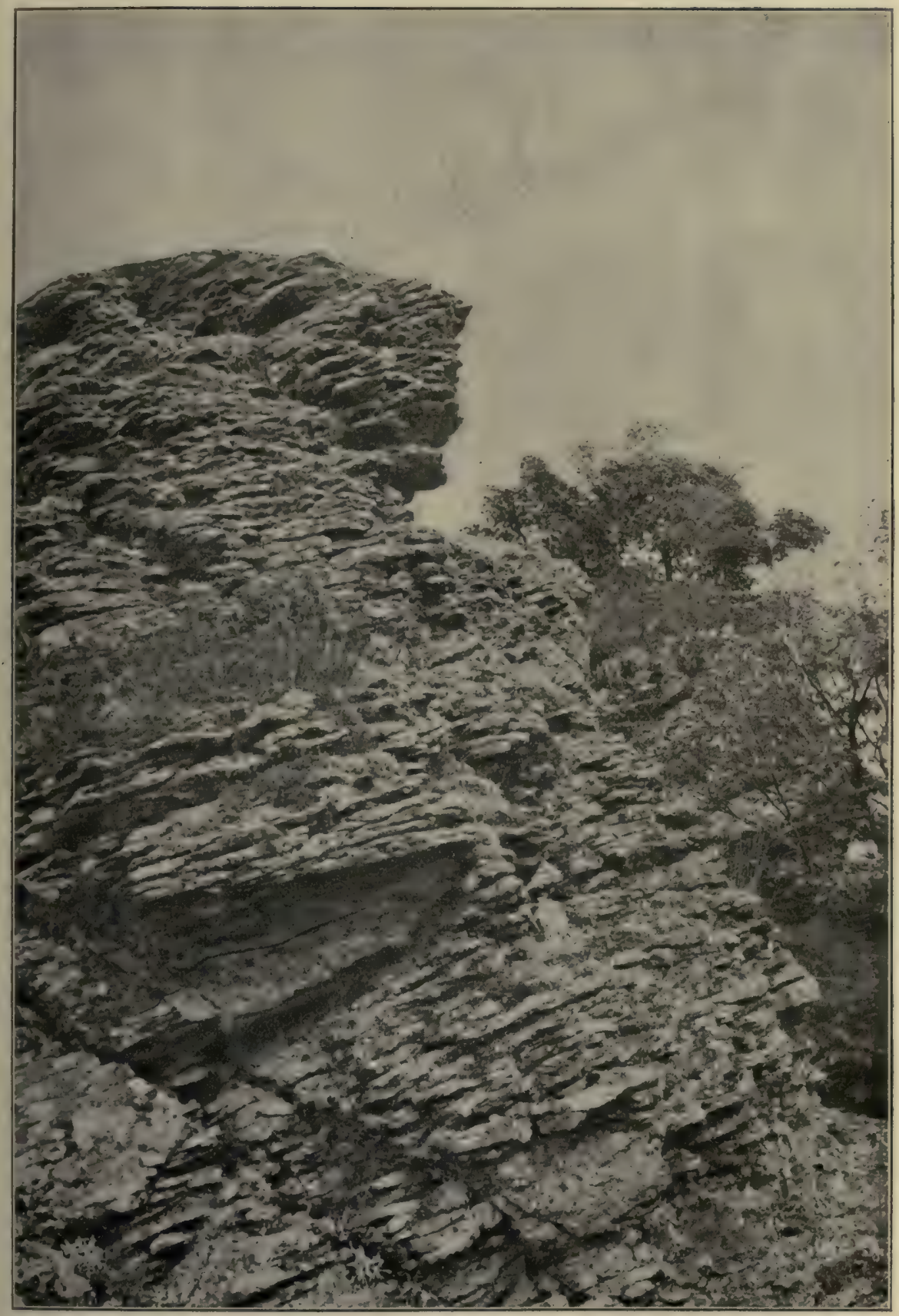

Fig. 168. Steile Tuffwand in den Ungarischen Karpathen (Opálheger Berg) als Beispiel für lockere Besiedlung steiler Hänge. (Phot. Hans Bath $†$, 
Felsenfluren, Wüsten; Fig. 166, 167, 168). Die Formationen werden danach in "offene" und "geschlossene" getrennt.

Offene Formationen kommen z. B. dort zur Entwickelung, wo der Boden unruhig ist (z. B. an Ufern, wo der Wellenschlag herrscht; in Sandgegenden, wo der Wind den Boden in Bewegung setzt) oder wo lebensfeindliche Faktoren herrschen, z. B. Kälte, oder dort, wo der Boden sehr ungünstig ist (z. B. an senkrechten Felsen (Fig. 168), auf stark salzhaltigem Boden usw.). In offenen Formationen wird eine Konkurrenz zwischen den Pflanzen sehr gering sein oder ganz fehlen. Sehr oft ist denn auch die Mischung der Arten recht groß. Für Einwanderung anderer Arten sind sie günstig, und sofern die ökologischen Faktoren sonst günstig sind, wird die offene Formation leicht in eine geschlossene übergehen können. Einige Formationen sind dauernd offen (z. B. Wüsten), andere vorübergehend. Dieses beobachtet man sehr oft auf Kulturböden, die durch die Bodenbehandlung entblößt worden sind.

Die geschlossenen Formationen werden oft von Arten gebildet, welche aus irgend einem Grunde sozial sind, beispielsweise entweder dadurch, daß eine Art leicht alle anderen derselben oder anderer Lebensform zu unterdrücken vermag (etwa die Buche durch ihren Schatten, oder Phragmites an den Ufern unserer Gewässer, welches durch eine überaus reichliche vegetative Vermehrung den Boden zu erobern vermag) oder dadurch, daß sie eine große Samenmenge produziert, vorausgesetzt natürlich, daß der Standort sonst günstig ist.

In den geschlossenen Vereinen ist der Kampf zwischen den Arten weit heftiger als in den offenen. Die Geschlossenheit ist ein Besiedelungshindernis, und eine geschlossene Assoziation wird sich schwerer zu einer anderen weiter entwickeln, wenn sie nicht selbst die Vegetationsverhältnisse am Standort ändert, z. B. wenn ein Kiefern-, Fichtenoder auch Buchenwald durch Rohhumusbildung den Boden verändert und dadurch für eine Callunaheide vorbereitet. Viele geschlossene Pflanzenvereine sind deshalb stabile oder Climax-Vereine, welche vielleicht durch Jahrtausende wesentlich unverändert bleiben ${ }^{1}$ ).

In den geschlossenen Formationen kommen viefach Anpassungen an das gesellige Zusammenleben der herrschenden Pflanzen vor, z. B. Entwickelung von Lianen und Saprophyten. An ihrer Peripherie lösen die geschlossenen Formationen sich oft auf und gehen in lichtere über, weil die ökologischen Faktoren sich ändern.

3. Die Höhe der Vegetation. Man vergleiche den Unterschied zwischen Wald, Gebüsch und Calluna-Heide, die alle wesentlich von Holzpflanzen gebildet werden, zwischen dem hohen Grase der Wiese und dem niedrigen Rasen der Alpenmatte, oder zwischen Wald und Tundra usw.

1) Vergl. Crampton 1912; dagegen Graebner 1912 b. 
Viele, namentlich geschlossene, Formationen haben mehrere Stockwerke von Lebensformen; die größte Anzahl findet sich in den Wäldern, besonders den tropischen Regenwäldern, wo jedoch die Schichten stark ineinander fließen. In unseren kühl temperierten Wäldern treten die Schichten oft deutlicher hervor, so daß man deren folgende unterscheiden kann: 1. Oberste Baumkronenschicht. 2. Niedere Baumschicht. 3. Strauchschicht. 4. Hochstaudenschicht. 5. Kleinstaudenschicht. 6. Bodendecke von Moosen und Flechten. 7. Im Boden lebende Schicht von heterotrophen Pflanzen (Saprophyten). Dazu kommen noch Lianen und Epiphyten.

Finnische und schwedisehe Botaniker unterscheiden nach Hults Vorgang ${ }^{1}$ ) folgende Schichten :

I. Baumschicht.

II. Busch-(Strauch-) Schicht $9 \mathrm{dm}$ bis 4 oder $5 \mathrm{~m}$.

III. Höchste Boden-(Kraut-)Schicht 4,5 bis 8 oder $9 \mathrm{dm}$.

VI. Mittlere Boden-(Kräuter-) Schicht 1 bis $4,5 \mathrm{dm}$.

V. Untere Boden-(Kräuter-) schicht 0,5 bis $1 \mathrm{dm}$.

VI. Schicht der Bodenoberfläche unter $5 \mathrm{~cm}$ hoch (meist Moose, Flechten, Algen).

Eine an diese sich anschließende Darstellung hat neuerdings Kupfer publiziert. Er unterscheidet in einer Formation folgende 7 Schichten: A. Höhere Waldschicht, bis $15 \mathrm{~m}$; B. Niedere Waldschicht, bis $6 \mathrm{~m}$; C. Gebüschschicht, bis $2 \mathrm{~m}$; D. Obere Feldschicht, bis $8 \mathrm{dm}$; E. Mittlere Feldschicht, bis $3 \mathrm{dm}$; F. Niedere Feldschicht, bis $1 \mathrm{dm}$; G. Bodenschicht, bis $3 \mathrm{~cm}$; H. Die eigentliche Boden- bezw. Wasserschicht. (Nach Bot. Centralbl. 1914, 25, S. 516.)

Es dürfte jedoch im allgemeinen genïgen 4 Schichten $\mathrm{zu}$ unterscheiden:

I. Schicht der Bodenoberfläche: unmittelbar dem Boden anliegende Pflanzen, meist Moose, Flechten, Algen).

II. Kräuter-Schicht: von Gräsern und Kräutern gebildet, dazu auch niedrige Sträucher von ähnlicher Höhe.

III. Busch- und Strauch-Schicht: von größeren Sträuchern gebildet.

IV. Baumschicht ${ }^{2}$.

Ökologische Verschiedenheiten in den Schichten. In dem hohen und geschlossenen Pflanzenvereine werden die ökologischen Faktoren in den verschiedenen Schichten naturgemäß recht verschieden sein können. Yapp ${ }^{3}$ ) z. B. hat durch gründliche Untersuchungen mittels Evaporationsmessers gefunden, daß die Verdunstung der Pflanzenteile recht verschieden ist schon in den verschiedenen Höhen einer britischen Moorwiese. In einer Höhe von 1,35 m, 0,65 m und $0,13 \mathrm{~m}$ über dem Boden verhielten die Prozente der Verdunstung sich wie $100: 32: 6,6$. Auch der Bau einer Pflanze kann sich in einer dichten Vegetation in verschiedener Höhe abweichend gestalten; Filipendula ulmaria z. B. hat im ersten Jahre als Keimpflanze nur grundständige Blätter, die unbehaart

j) Hult 1881.

2) Vergl. A. Nilsson 1902 a.

') Yapp 1909. 
sind und Schattenblattstruktur haben. Bei älteren Pflanzen sind die ersten im Frühjahr und die letzten im Herbste gebildeten Rosettenblätter unbehaart, die im Sommer gebildeten mehr oder weniger haarig. Die Blätter des gestreckten Stengels werden desto mehr behaart und haben desto mehr Sonnenblattstruktur, je höher sie stehen - alles in Übereinstimmung mit den mittleren physikalischen Bedingungen der betreffenden Schichten; namentlich wirksam sind die austrocknenden Winde ${ }^{1}$ ).

$\mathrm{Daß}$ die ökologischen Faktoren in den verschiedenen Schichten eines Waldes sehr ungleich sind, was z. B. Licht, Feuchtigkeit der Luft, Windwirkungen usw. betrifft, ist allgemein bekannt, aber im einzelnen wissenschaftlich noch wenig festgestellt ${ }^{2}$ ).

4. Die Farbe der Vegetation. Man erinnere sich z. B. an die braune (immergrüne) Heide und an die grüne (sommergrüne) Wiese. Hier sind auch die Farben der Blüten und ihre größere oder geringere Sichtbarkeit zu erwähnen (Gegensatz zwischen Wind- und Insektenbestäubung).

5. Die Periodizität der Jahreszeiten: Länge der Ruhezeit und andere Phasen der Vegetation (Belaubung, Blütezeit, Laubfall), Verteilung der Niederschläge; vergl. die im Winter oder in der trockenen Zeit das Laub abwerfenden Wälder und die immergrünen; die Steppe, die wenige Monate lang grün und viel länger graubraun und nackt ist; die Vegetation bei uns im Winter und im Sommer usw. Nach den periodischen Änderungen der Vegetation kann man mit Clements einen Aspectus vernalis, aestivalis und auctumnalis (natürlich auch hiemalis) unterscheiden.

Die Lebensdauer der Arten muß gleichfalls in Betracht gezogen werden, namentlich die Dauer der oberirdischen Teile, und die Rolle, die die einjährigen Arten und die Holzpflanzen in der Physiognomie einer Pflanzendecke spielen. Pflanzenvereine werden sehr selten allein von einjährigen Pflanzen gebildet (Beispiele Salicornia herbacea, Frühjahrsflora in Wüsten und gewisse Unkräuter auf kleinen Gebieten).

6. Endlich $m u ß$ die Artenmenge erwähnt werden, die teilweise ein Ergebnis des Kampfes der Arten untereinander um den Platz ist; dieser Kampf kann in hohem Grade gestört werden und wird vom Menschen in der Tat gestört. In einigen Vereinen herrscht immer eine bestimmte einzelne Art vor (Fichtenwälder, Rotbuchenwälder, nordische Zwergstrauchheiden usw.); in anderen ist die Mischung außerordentlich groß. Reich an Arten ist die Vegetation warmer Länder, z. B. die Macchien des Kaplandes, dürftig z. B. die nordeuropäischen Pflanzen-

\footnotetext{
1) Yapp 1912. Vergl. auch G. Kraus 1911; Fuller 1911.

2) Hier mag noch hingewiesen werden auf Ebermayer; Dachnowsky 1911; Scherff 1912.
} 
vereine. Daß günstigere Lebensbedingungen eine mannigfaltigere Flora hervorrufen, ist deutlich; oft spielen gewiß auch geologische Gründe mit ${ }^{1}$ ).

Mit wachsender Artenmenge steigt in der Regel gewiß die Menge verschiedener Lebensformen; obenan steht der feuchtwarme Tropenwald, der seinen unendlichen Reichtum wohl namentlich dem Umstande verdankt, daß er sich in langen Erdperioden in ungestörter Ruhe entwickeln konnte ${ }^{2}$ ).

Daß die Artenmenge unter anderem von den Kampfmitteln der einzelnen Arten abhängt, ist schon Kap. 36 angedeutet worden. Einige Arten treten leicht in dichten, an Individuen reichen Massen auf, andere findet man überall nur in zerstreuten Individuen. Viele Arten können in verschiedenen Vereinen auftreten, weil ihre Lebensansprüche innerhalb weiter Grenzen liegen, und weil sie desto mehr Standorte bewohnen können, je weiter die Grenzen sind. Viele der abgehärtetsten und genügsamsten Arten könnten die meisten Standorte erobern, finden sich aber oft gleichwohl nur auf wenigen, weil sie von den besseren Standorten verdrängt werden. Je eigentümlicher und ungewöhnlicher ein Standort ist, desto gleichartiger wird seine Vegetation im allgemeinen sein, weil in der Regel nur wenige Arten so besonders angepaßt sind, daß sie auf ihm wachsen können.

Beim Studium der Vegetation eines bestimmten Gebietes in floristisch-geographischer Hinsicht ist es notwendig, die relative Menge der verschiedenen Arten zu bezeichnen. Drude ${ }^{3}$ ) gebraucht folgende Ausdrücke: soc. (sociales), den Girundton in der Vegetation angebend; gr. (gregariae), Arten, die in kleinen Herden auftreten, so daß sie gewissermaßen eigene, kleine Bestände in der Hauptvegetation bilden; cop. (copiosae, mit verschiedenen Graden: cop. ${ }^{3}$, cop. ${ }^{8}$ und cop. ${ }^{1}$, nach der abnehmenden Häufigkeit), Pflanzen, die zwischen die vorhingenannten mit geringerer Häufigkeit eingestreut sind; $8 p$. (sparsae), Pflanzen, die hier und da vereinzelt auftreten; sol. (solitariae), ganz einzeln auftretende Pflanzen. Endlich können diese Bezeichnungen vereinigt werden, z. B. sol. gr. (solitarie gregariae) für eine einzelne Herde einer Art.

Die relative Zahl der Arten in einem Vereine muß bei genaueren wissenschaftlichen Untersuchungen zahlenmäßig angegeben werden.

1) Um Lagoa Santa in Brasilien wachsen auf etwa 3 Quadratmeilen ca. 3000 Arten von Gefäßpflanzen (über 2600 sind bestimmt worden, mindestens 400 müssen als nicht gesammelt angesehen werden). Hiervon finden sich in den Wäldern ca. 1600 Arten, auf den Campos ca. 800, wovon 400 resp. 90 Bäume sind, und doch ist das Waldgebiet viel kleiner als das Camposgebiet und wesentlich auf die Täler beschränkt, wo es allen Wasserläufen als Einfassung folgt. Der Grund dieses Reichtums muß wohl in den physikalischen Verhältnissen (größere Feuchtigkeit, reichere Nahrung, namentlich Humus usw.) gesucht werden; aber vielleicht spielen auch hier geologische Gründe eine Rolle, indem die Waldflora wahrscheinlich die älteste ist, und die Camposflora später erst allmählich entstand, als sich Südamerika immer mehr über das Meer hob, und Brasilien daher ein mehr kontinentales und trockneres Klima erhielt (Warming 1892, 1899).

2) Warming 1899.

s) Drude 1889, 1890, 1896, 1913. 
Verschiedene Vorschläge zur Berechnung der relativen Artenzahl und Individuenmenge der Vegetation sind gemacht worden ${ }^{1}$ ). Vergl. auch S. 300, 302 ff., Fig. 162.

Die leichteste statistische Methode zur Bezeichnung der relativen Häufigkeit der Arten hat Raunkiär ${ }^{2}$ ) angegeben. Auf einem quadratischen oder kreisrunden Feld von 0,1 qm zählt man alle vorkommenden Arten und teilt jeder einen Punkt zu. Nach Untersuchung von 50 Feldern summiert man die Punkte, die jede Art erhalten hat, und man hat dann Häufigkeitszahlen von 1-50 für jede Art. Raunkiär hat durch diese Methode eine große Menge von Assoziationen in Dänemark und den Mittelmeerländern studiert ${ }^{3}$ ). Vahl ${ }^{4}$ ) hat dieselbe Methode zu Studien

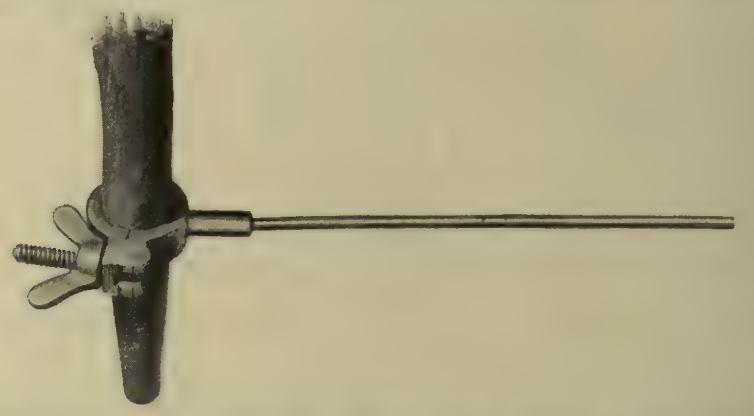

Fig. 169. Meßapparat von Raunkiär; besteht aus einem Ringe, von zwei Hälften gebildet, welche miteinander durch Gelenk vereinigt sind und durch eine Schraube an einem hölzernen Spazierstock in jeder beliebigen Höhe befestigt werden können. Auf der einen Seite des Ringes ist eine Metallstange festgemacht; die Länge desselben ist so groß, daß der Abstand von der Medianlinie des Stockes zum Ende der Stange einem Radius gleich ist, mit welchem ein Kreis geschlagen werden kann, der $1 / 10$ Quadratmeter Fläche umfaßt. (Raunkiär 1912.)

verschiedener Assoziationen in Schweden benutzt, auch die Häufigkeitszahlen für die verschiedenen Lebensformen einer Assoziation festgestellt, um dadurch die Assoziationen genau charakterisieren zu können. Ebenso hat Hanna Resvoll-Holmsen in Norwegen viele statistische Aufnahmen nach dieser Methode gemacht.

Durch solche sorgfältige statistische Untersuchungen entdeckt man bisweilen kleine Arten, welche sich unter höherer Vegetation verbergen

1) Vergl. Stebler und Schröter 1892; Clements 1905, 1907; Oliver and Tansley 1904; W. G. Smith in Journ. of Ecology I: 22; Jaccard 1902, 1907 und viele andere Arbeiten (vergl. Bot. Centralbl. 107, 284 und IIIe Congrès internat. 1910 Bruxelles). Jaccard hat u. a. die Größe des generischen Koeffizienten in den verschiedenen Vereinen sorgfältig untersucht.

2) Raunkiär 1912 (vergl, auch 1908, 1909 a).

3) Raunkiär 1909, 1910, 1913, 1914.

4) Vahl 1911, 1912, 1913. 
und oft numerisch weit zahlreicher als diese sind. Es zeigt dies, daß die Zahlenverhältnisse nicht die Physiognomie zu bestimmen brauchen und daß sie nie eine absolut dominierende Rolle spielen dürfen.

\section{Kap. Formationen}

Die großen Klassen der Standorte sind in Kap. 37 so gut wie möglich abgegrenzt. Innerhalb jeder Klasse gibt es nun eine ungeheure Menge von Pflanzenvereinen, welche physiognomisch wie floristisch voneinander verschieden sind und durch gewisse Standortseigentümlichkeiten hervorgerufen werden. Im vorigen Kapitel wurde erwähnt, durch welche Umstände diese physiognomischen Verschiedenheiten hervorgerufen werden. Den allerwichtigsten Faktor bilden die Lebensformen der Arten (S. 5, 154), da von diesen nicht nur die Physiognomie an und für sich, sondern auch mehr oder weniger die Dichtigkeit der Vereine, die Höhe der Vegetation und die periodischen Erscheinungen derselben abhängen.

In dem Bestreben, diese Menge von Vereinen der Übersichtlichkeit halber zu gruppieren und die Gruppen zu benennen, dürfte es als das Natürlichste erscheinen, die Physiognomie der Lebensformen, wissenschaftlich genommen, d. h. als Ausdruck bestimmter Lebensbedingungen, als Grundlage $\mathrm{zu}$ benutzen, und die Vereine nach den Lebensformen zu benennen: Vereine (Formationen) von Bäumen, Sträuchern, Zwergsträuchern, Halbsträuchern, Hochstauden, Kleinstauden, Moosen, Flechten, Algen usw. Bei der Benennung werden überall, soweit möglich, die volkstümlichen Bezeichnungen benutzt werden.

Diese Aufgabe ist mit sehr großen Schwierigkeiten verknüpft, die eben in der Natur der Sache liegen, weil es nirgends scharfe Grenzen gibt. Daher werden denn auch die subjektiven Auffassungen der einzelnen Beobachter eine ungeheuer große Rolle spielen. Es sind diese Wahrheiten wohl auch allgemein anerkannt ${ }^{1}$ ).

Oben (S. 307) wurde erwähnt, daß die Botaniker jetzt, mit sehr wenigen Ausnahmen, darüber einig sind: die Formation als den ökologischen Ausdruck bestimmter, klimatischer und edaphischer Lebensbedingungen zu betrachten, welcher nichts mit floristischen Verschiedenheiten zu tun hat; daß jede Formation aber aus Assoziationen besteht, welche in ihrer floristischen Zusammensetzung verschieden sein können.

1) Z. B. schreibt Tansley: "A short and easy road to natural classification of vegetation units can no more be found than a short and easy road to a natural classification of species." 
Formation. Der Ausdruck "Formation" oder "Vegetationsformation" wurde von Grisebach 1838 eingeführt. Er schreibt: „Ich möchte eine Gruppe von Pflanzen, die einen abgeschlossenen physiognomischen Charakter trägt, wie eine Wiese, ein Wald usw., eine pflanzengeographische Formation nennen. Sie wird bald durch eine einzige gesellige Art, bald durch einen Komplex von vorherrschenden Arten derselben Familie charakterisiert, bald zeigt sie ein Aggregat von Arten, die, mannigfaltig in ihrer Organisation, doch eine gemeinsame Eigentümlichkeit haben, wie die Alpentriften fast nur aus perennierenden Kräntern bestehen."

Es kann kein Zweifel darüber sein, daß Grisebach den physiognomischen Charakter, zustande gebracht durch ökologische Anpassung, als entscheidend hervorhebt (siehe „perennierende Kräuter", „gemeinsame Eigentümlichkeiten"). Der Begriff "Formation" in diesem Buche schließt sich am nächsten an den Grisebachs.

Eine andere, viel engere Begriffsbestimmung von "Formation" ist die von Hult ${ }^{1}$ ); er stellte etwa ein halbes Hundert "Formationen" für das nördliche Finnland auf; er hat z. B. eine Empetrum-Formation, eine Phyllodoce-F., eine Azalea-F., eine Betula nana-F., eine Juncus trifidus-F., eine Carex rupestris-F., eine Nardus-F., eine Scirpus caespitosus-F. usw. - also kleine, floristisch bezeichnete Gesellschaften ohne ökologische Rücksichten, dem modernen Begriff der "Assoziation" entsprechend.

Dies führt zu einer Zerspaltung der Vegetation nach lokal herrschenden Arten, wodurch die Übersicht und das Gesamtbild leicht verloren gehen, und wobei Vereine mit derselben Haushaltung, also natürlich zusammengehörige, nicht als solche erkannt werden können. Diese Begriffsbestimmung von „Formation“ wird jetzt auch allgemein verlassen. Vergl. auch später unter ${ }_{n}$ Assoziation".

Eine etwas abweichende Begrenzung des Begriffes "Formation" wird namentlich von englischen Botanikern gegeben ${ }^{2}$ ). Auch sie begründen den Begriff „Formation" auf dem Wesen des Standortes. Aber sie legen Gewicht darauf, daß man auf ganz demselben Boden und unter ganz demselben Klima sehr verschiedene Typen von Pflanzenvereinen vorfinden kann, z. B. eine Waldassoziation, eine Gebüschassoziation, eine Wiesenassoziation usw. (für welche Assoziationen also die Lebensformen die Grundlage bieten), und diese Assoziationen bestreben sich räumlich und zeitlich eine bestimmte Entwickelung durchzuführen, so daß sie zuletzt alle in den höchsten Typus, in einen Hauptverein, welcher unter den gegebenen Bedingungen möglich ist, zusammenfließen. Es werden also alle Vereinstypen, welche genetisch verbunden werden können, als Phasen einer einzigen Formation aufgefaßt. Die genannten Forscher scheiden denn auch zwischen progressiven und regressiven Formationen.

1) Hult 1881, 1887.

2) Moss 1906, 1907, 1910, 1913; Tansley 1909, 1911; cfr. Flahault und Schröter 1910. 
Es liegt dieser Auffassung der richtige Gesichtspunkt zugrunde, daß man vielfach in der Natur eine Entwickelung von dem einen Verein zu einem anderen beobachten kann, bis die Entwickelung mit einer "Climax"-Formation zu Ende gebracht wird („Successions" der amerikanischen Botaniker).

Abgesehen davon, daß solche Wandlungen wohl vorzugsweise dort vorkommen, wo der Mensch die ursprünglichen Naturverhältnisse geändert hat, durch Umhauen der Wälder, durch Bildung von Kulturoder Halbkulturvereinen, welche verschwänden, wenn die menschliche Hand zurückgezogen würde, wird es praktisch sehr schwierig sein und oft weitläufige Studien erfordern die genetischen Verbindungen der einzelnen Vereine zu ermitteln und sie als Grundlage für FormationsBestimmungen zu benutzen. Solche entwickelungsgeschichtlichen Studien der Vegetation werden wohl in vielen Fällen in einem gegebenen Gebiete durchgeführt werden können, aber wenn man einen Überblick über die Formationen der ganzen Welt erhalten will, wird die Sache sich wohl unmöglich durchführen lassen. Die Begriffsbestimmung wird sehr oft hypothetischen und subjektiven Meinungen Raum lassen. Wenn eine Vegetation sich von einem Typus zu einem anderen entwickelt, so wird dieses oft, ja wahrscheinlich gewöhnlich, mit durchgreifenden Änderungen der ökologischen Faktoren verknüpft sein, namentlich der Bodenverhältnisse: der Standort bleibt nicht konstant. Wo soll man dabei die Grenzen der Formation feststellen? wo hört die eine auf, und wo beginnt die andere? Wenn z. B. am Meeresstrande eine Marschwiese sich bildet, indem die Entwickelung mit einem Zosteretum anfängt, durch Salicornietum, Glycerietum usw. ganz allmählich weiter führtt ${ }^{1}$ ), so ist eben dadurch die Grundiage für den Begriff der Formation - Einheit des Standortes - verloren gegangen. Auf ganz dieselbe Weise kann man an unzähligen anderen Lokalitäten einen fortschreitenden Wechsel beobachten. Siegrist $\left.{ }^{2}\right)$ schreibt über die Uferwälder der Aare in der Schweiz, daß rom versumpftesten Bruchwald bis zur trockenen, steppenähnlichen, nur mit spärlichen Sträuchern bedeckten Schotterfläche alle Übergangsstadien des durch edaphische Faktoren bedingten Waldes sich aufweisen lassen. Eine rückschreitende Formationsfolge (regressive Succession) haben wir z. B., wenn einem Buchenwalde durch Rohhumusbildung die Selbstverjüngung unmöglich gemacht ist und er zuletzt der Calluna-Heide den Platz einräumen muß.

Das genetische Studium der Pflanzenvereine ist längst als ein sehr verlockendes und anregendes anerkannt worden ${ }^{3}$ ); aber als Grundlage

1) Vergl. Warming 1906, und Kap. 51 (in diesem Buche).

2) Siegrist 1913, 1914.

3) Siehe auch Warming 1895, Abschnitt 7, oder die Ausgabe bei Graebner 1902. 
für Formationsaufstellungen kann es entschieden nicht angewendet werden ${ }^{1}$ ).

Es wird das sicherste sein, die Formationen auf der Natur des Standorts und nach den die Vereine bildenden Lebensformen zu begründen. Die Physiognomie, wissenschaftlich vertieft, muß vom praktischen Standpunkte in erster Linie maßgebend sein für das, was als Formation aufzufassen ist. Danach erst kann man den genetischen Zusammenhang der verschiedenen Formationen nachweisen, - eine Aufgabe von größter wissenschaftlicher Bedeutung.

\section{Typen von Formationen}

Die Mehrzahl der vorher erwähnten Grundformen des Lebens sind imstande selbständige Formationen zu bilden, indem sie als herrschende Glieder der Vereine auftreten. Nach der vorherrschenden Lebensform (vergl. Kap. 22) wird die Formation benannt, und wenn mehrere Stockwerke vorkommen, wird es wohl immer der oberste sein, welches den Charakter der Formation bezeichnet. In einem Walde kann eine Menge von verschiedenen Lebensformen vereint sein - Algen, Moose, Flechten und Gefäßpflanzen mit epiphytischer Lebensweise, auf dem Boden Moose, Lichenen, Pilze, Kräuter, Kleinsträucher, Großsträucher, Lianen usw. aber der Baumbestand ist das Tongebende, er gibt der Formation ihren Namen.

Die Haupttypen der Formationen sind nach den vorherrschenden Lebensformen folgende:

1. Mikrophytenformationen, namentlich im Wasser und in der Erde (hypogäische Pflanzen). Vergl. Kap. 18.

2. Wasserpflanzenformationen, vorzugsweise aus krautartigen Blütenpflanzen und größeren Algen gebildet.

3. Moosformationen. Schon hier kann von mehr als einem Stockwerke die Rede sein (Moosheiden usw.).

4. Flechtenformationen (Lichenenheiden, Tundren).

5. Krautformationen (Wiesen, Prärieen, Steppen usw.). Hier kann es zwei oder mehrere Stockwerke geben, nämlich eine niedrigere Vegetation. von Thallophyten oder Moosen unter der höheren Kräutervegetation; und die Kräuter können sich wiederum in Stockwerke von verschiedener Höhe gruppieren (Hochstauden, Kleinstauden). Man kann passend zwischen Kräutern und Gräsern unterscheiden (Gekräut, Gestäude, Gehälm, Geblätt und Geäß bei Höck²)).

1) Vergl. auch Flahault und Schröter 1910.

2) Höck 1896. 
6. Zwergstrauch - und Halbstrauchformationen, mit Kräutern gemischt, die bisweilen sogar höher wachsen als die Zwerg- und die Halbsträucher. Die länger dauernden holzigen Elemente sind jedoch in der Überzahl, und unter ihnen können mehrere, von den zuerst genannten Formationen, als Stockwerke auftreten. Die Vereine der Zwergsträucher und der Halbsträucher nennt man auch Gesträuche; sie können die Erde dicht bedecken (Callunetum, Vaccinietum, Garrigue, Cistetum usw.).

7. Gebüsche orler dichte Vereine von Sträuchern, d. h. von höheren, verholzenden, vielstämmigen Pflanzen. Hier können schon Epiphyten und Lianen auftreten, und unter dem höchsten Stockwerke können die vorher genannten Vegetationsformen vorkommen. Die Bodenvegretation ist oft sehr dürftig, weil der Schatten der Sträucher zu dicht ist. Tiele Gebüsche sind eigentlich nur degenerierte Wälder und lassen überhaupt schlechte Lebensbedingungen erkennen.

8. Wälder. Die vorherrschende Lebensform ist der Baum. Die Wälder stellen die höchste Stufe der Formationsbildung dar; es sind geschlossene Formationen, welche in vielen Fällen Schlußbildungen (Climax-Formationen) sind. Sie zeigen die größte Mannigfaltigkeit der Lehensformen und die meisten Stockwerke. Die Zahl der Schichten hängt von der Stärke des Lichtes und dem Grade der Feuchtigkeit $a b^{1}$ ).

Im Walde finden sich Lichtpflanzen und Schattenpflanzen bisweilen init großem Bauunterschiede (vergl. Kap. 2, 26). Die Vegetation des Waldbodens hängt von der Beleuchtung, die durch die Baumkronen mehr oder weniger geschwächt wird, von der Luftfeuchtigkeit, von der Bodenfeuchtigkeit, vom Humus u. a. ab. Die stark Schatten gebenden, dicht wachsenden Arten (wie Rotbuche, Fichte, Weißtanne usw.; vergl. S. 19) haben nur eine sehr spärliche untere Vegetation, die Lichtbäume eine reichere, ganz nach ihrem Lichtbedarf. Die Waldränder können von dem Waldinneren floristisch nicht wenig abweichen, weil die Lichtverhältnisse dort die Entwicklung vieler Arten zulassen, die hier nicht gedeihen künnen. Grevillius ${ }^{2}$ ) hat gefunden, daß die hohen Kräuter in lichten skandinavischen Wäldern auf verschiedene Typen zurückgeführt werden können, die voneinander durch die Anordnung des floralen Systemes, die Form und die Stellung der assimilierenden Organe, die Innovation, die Blütezeit, die Verteilung in verschiedene Niveaus des gemeinsamen Pflanzenvereines abweichen.

Ein Wald wird somit gewissermaßen aus verschiedenen Formationen zusammengesetzt, welche ökologisch und floristisch von den obersten schichten beeinflußt werden, aber bisweilen mit großer Deutlichkeit hervortreten. In vielen Wäldern ist der Boden mit Teppichen von

1) Vergl. u. a. Clements 1907.

7) Grevillius 1894.

Wasming - Grabber. a. Anflage, illustr. 
Moosen oder Flechten oder auch Kräutern und Gräsern usw. bedeckt, welche in Übereinstimmung mit kleineren Verschiedenheiten des Bodens, namentlich der Feuchtigkeit desselben, kleinere Verschiedenheiten (Varietäten und „Facies") zeigen.

In dem einen Kiefernwalde (Pinetum silvestris) z. B. findet sich eine Bodendecke von Moosen, in einem anderen von Flechten, in einem dritten von Stauden, in einem vierten von Zwergsträuchern (Calluna vulgaris u. a.) oder von Sträuchern (z. B. Juniperus communis), und der Wald kann danach durch eine Hinzufügung zur Assoziationsbezeichnung näher charakterisiert werden (Pinetum silvestris muscosum oder hylocomiosum, P. s. lichenosum oder cladinosum, P. s. herbosum oder graminosum (z. B. von Aera flexuosa oder Carex arenaria), resp. P. s. suffruticosum, fruticosum usw.

Cajander ${ }^{1}$ ) hat die Meinung ausgesprochen, daß die ökologischen Verhältnisse der Wälder schärfer durch ihre Bodenvegetation bezeichnet werden können als durch die Art des Baumes. Er unterscheidet z. B. in Finnland drei Waldtypen durch eine geringe Zahl von immer vorhandenen Leitpflanzen, nämlich, mit aufsteigender Bonität: den CallunaTypus, den Myrtillus-Typus und den Oxalis-Typus.

Indem die Vereinsformen jetzt hier in dieser Reihenfolge (1-8) angeführt werden, ungefähr in der umgekehrten wie bei Grisebach ${ }^{2}$ ) und Drude $^{3}$ ), wird (vielleicht) der eigene, fortschreitende Entwicklungsgang der Natur von niedrigeren zu höheren, von offeneren zu geschlosseneren Vereinen, von dürftigeren zu günstigeren Verhältnissen angegeben; jedenfalls müssen die Wälder als Schlußglieder gesetzt werden, weil die Vegetation eines Bodens tatsächlich mit ihnen endigen würde, wo die Bedingungen für das Pflanzenleben überhaupt günstig sind (vergl. Kap. 67 den 4. Abschn.). Die Wälder sind auch die Pflanzenvereine, die in die umgebende Natur am stärksten eingreifen; dadurch, daß sie Schutz geben und die Feuchtigkeitsverhältnisse verändern, fördern sie die eine Art von Vegetation und hemmen die andere, nach der verschiedenen Art und der Dichtigkeit des Waldes selbst in verschiedener Weise.

Innerhalb der in Kap. 37 (S. 319) und Abschnitt 4 angeführten Standortsklassen werden ${ }^{4}$ ) die Formationen denn auch, soweit möglich, in derselben Reihenfolge angeführt. Dieses geschieht in der Überlegung, daß vielleicht die genetische Folge innerhalb der Standortsklasse, wenn "Successions" stattfinden, dadurch angegeben werden kann.

Weiter muß noch die Schwierigkeit erwähnt werden, welche darin besteht, daß es sehr oft sehr zweifelhaft ist, wie weit man die Trennung

1) Cajander $1909 \mathrm{~b}$.

2) Grisebach 1872 .

8) Drude 1888, 1890.

4) Wie 1909 in Warmings Oecology. 
der Vereine führen soll. Auf demselben oder auf einem ganz entsprechenden Boden kann man in verschiedenen Gegenden, was die auftretenden Lebensformen betrifft, kleine Verschiedenheiten beobachten. Es finden sich an den schlammigen oder sonnigen Küsten von Nordeuropa z. B. Vereine von Salicornien. An den östlichen Küsten der Nordsee ist es nur die einjährige Salicornia herbacea, welche im Überflutungsgebiete Pflanzenvereine bildet (Fig. 170); an den „salzigen Ästuarienlibenen Südenglands und Nordfrankreichs" kommt nach den Worten von Tansley und Moss ${ }^{1}$ ) ein Verein von Halbsträuchern (Salicornia radicans

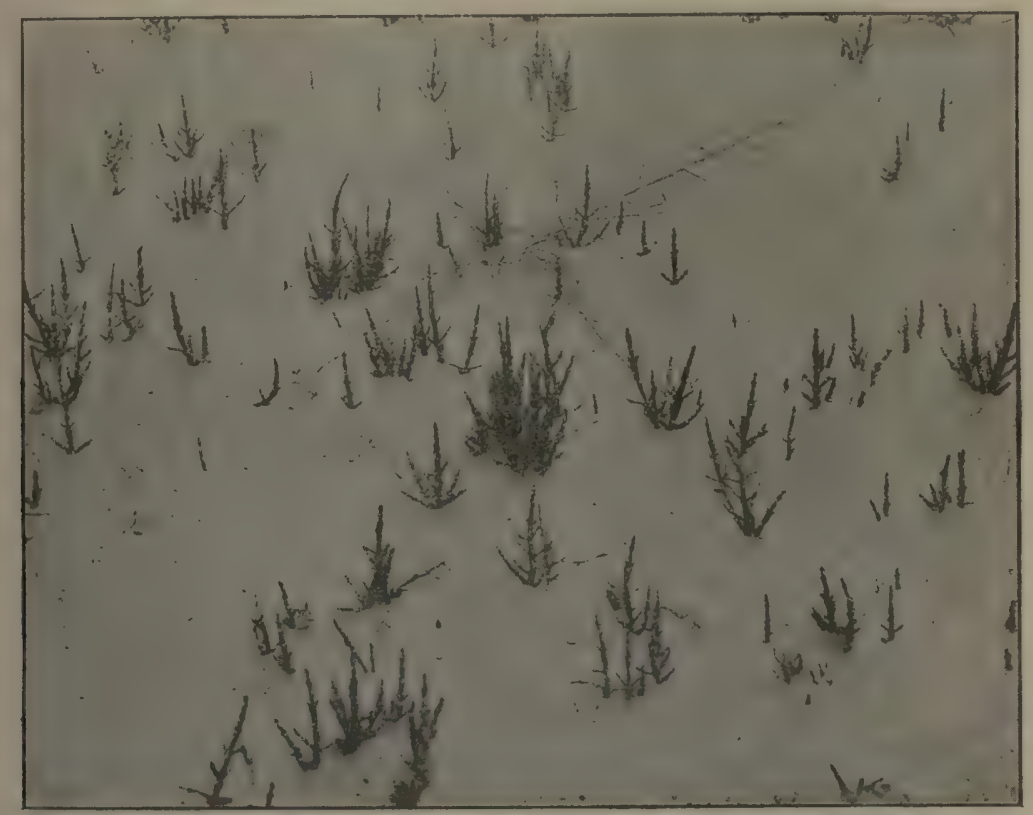

Fig. 170. Salicornia herbacea (hier auf Sandboden) und ein Exemplar von Glyceria maritima. Fanö. (Phot. Warming; 1906.)

und S. lignosa), weiter ein anderer von einjährigen Salicornia-Arten und ein dritter mit einer Mischung dieser beiden Lebensformen vor. In den ganz entsprechenden Standorten der mediterranen und der westindischen Küsten ${ }^{2}$ ) kommt dieselbe Halbstrauchformation ans teilweise anderen Salicornia-Arten vor (Fig. 171). Die edaphischen Verhältnisse scheinen ganz dieselben zu sein, die klimatischen sind aber sehr verschieden; wahrscheinlich sind es unter anderem die Eisverhältnisse, welche im Winter in den Üherflutungsgebieten der Nordseeküsten die Entwickelung der halbstrauchartigen wie überhaupt der ausdauernden Salicornia-Assoziationen

x) Vergl. Flahanlt und Schröter 1910.

$\left.{ }^{2}\right)$ Vergl. Bilder und Text bei Börgesen 1909; Raunkiär 1909a, 1914. 
verhindern, wogegen die einjährigen, welche ihre Samen im schlammigen Boden durch Hakenbürsten befestigen, den Platz behaupten können. Man muß es unbedingt vorziehen, die aus einjährigen Arten gebildeten Vereine von den aus halbstrauchartigen gebildeten als zwei besondere, aber allerdings nahe verwandte, Formationen aufzufassen: die Standorte sind verschieden, die Lebensformen ebenso. Daß Mischungen derselben

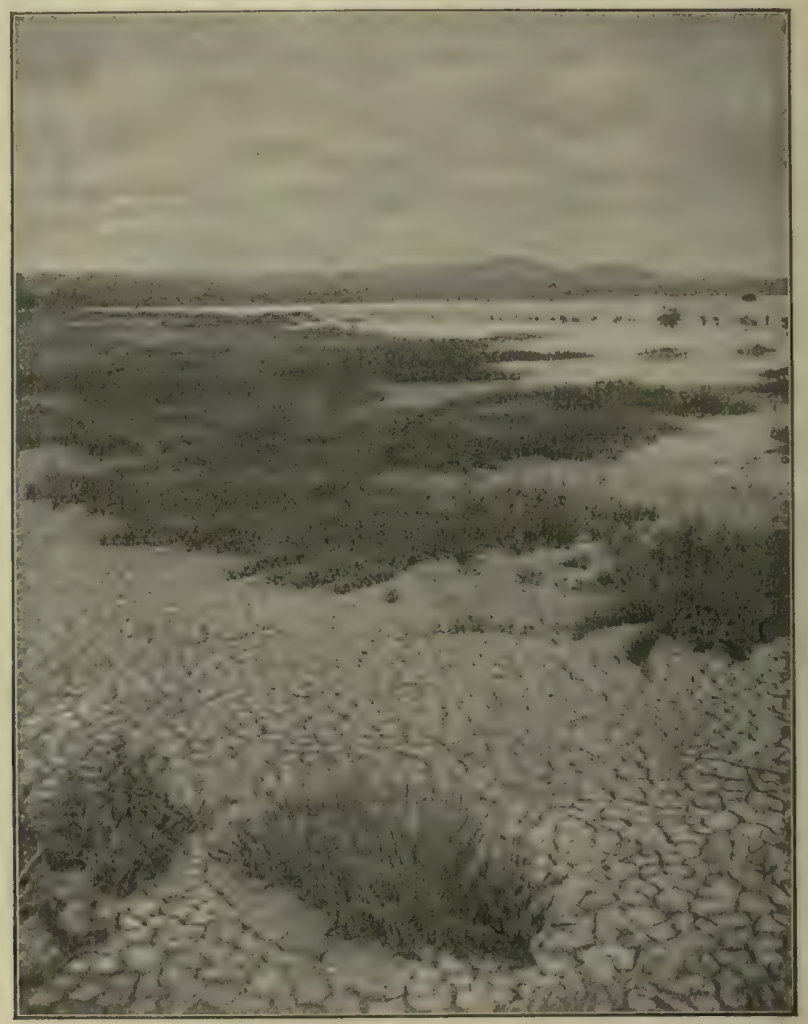

Fig. 171. Ansicht der Mitte von Krausses Lagune (St. Croix, Dänisch-Westindien). Die das Wasser umfassende Vegetation besteht aus Salicornia, Sesuvium usw. Im Wasser sind aufsprossende Mangrove-Pflanzen sichtbar. (Phot. F. Börgesen; 1909.)

in den Grenzgebieten vorkommen, ist zu erwarten ${ }^{1}$ ). Auf denselben oder nahe verwandten Standorten der Nordseeküsten kommen noch andere einjährige Chenopodiaceenvereine vor ${ }^{2}$ ), während die subtropischen und tropischen Küsten wahrscheinlich keine solche haben.

1) Tansley und Moss sagen über diesen Fall: „Dieses Beispiel beweist schlagend die Künstlichkeit der Einteilung nach Wuchsformen auf identischen oder nahe verwandten Standorten." (Vergl. Flahault und Schröter 1910).

3) Warming 1906. 
Übrigens wird es für die Zukunft gerade eine wichtige ökologische Aufgabe sein, die identischen Standorte der Erde genau vergleichend zu studieren. Was die hier erwähnten Standorte der Überflutungsgebiete (Ästuarien-Standorte) betrifft, so wird es z. B. von großem Interesse sein, die wahrscheinlich fast identischen nordeuropäischen mit denen von Spartina stricta u. a. Arten der Küsten von NewYersey zu vergleichen.

Während hier die Formationen zuerst nach Standorten vereinigt werden, danach innerhalb dieser nach Lebensformen getrennt, haben Brockmann-Jerosch und Rübel ${ }^{1}$ ) neuerdings versucht, ein System der Pflanzenformationen aufzustellen, und zwar stellen sie dabei die Forderung auf, daß das System sich ohne eingehendes Studium anwenden läßt, seine Methode soll „induktiv" sein $^{2}$ ). Sie kritisieren die von uns (Warming und Graebner) zugrunde gelegten Ideen und schlagen folgende Einteilung vor, die unserer Meinung nach sich mindestens ebensoviel von einer natürlichen entfernt, wie die übrigen Systeme und dem Studierenden kein klares Bild der Verhältnisse geben kann (vergl. bes. den II. Vegetationstypus).

I. Vegetationstypus: Lignosa, Gehölze.

Die Formationsklassen der Lignosa:

$\begin{array}{lll}\text { 1. Formationsklasse: } & \begin{array}{l}\text { Pluviilignosa, Regengehölze. } \\ \text { 2. }\end{array} \text { " } \\ \text { 3. } & n & \text { Durilignosa, Lorbeergehölze. } \\ \text { 4. } & " & \text { Ericilignosa, Hartlaubgehölze. Heidegehölze. } \\ \text { 5. } & n & \text { Deciduitignosa, Falllaubgehölze. } \\ \text { 6. } & n & \text { Conilignosa, Nadelgehölze. }\end{array}$

Die Formationsgruppen der Lignosa:

1. Formationsgruppe: Pluvisilvae, Regenwälder.

2

3.

4.

5.

6.

7.

8.

9.

10.

11.

12.

$n$
$n$
$n$
$n$
$n$
$n$
$n$
$n$

Pluvirfruticeta, Regengebüsche.

Laurisilvae, Lorbeerwälder.

Laurifruticeta, Lorbeergebüsche.

Durisilvae, Hartlaubwälder.

Durifruticeta, Hartlaubgebüsche.

Ericifruticeta, Heiden.

Aestatisilvae, Sommerwälder.

Aestatifruticeta, Sommergebüsche.

Hemisilvae, Monsunwälder.

Conisilvae, Nadelwälder.

Conifruticeta, Nadelholzgebüsche.

II. Vegetationstypus: Prata, Wiesen.

Die Formationsklassen der Prata:
1. Formationsklasse:
2.
Terriprata, Bodenwiesen.
Aquiprata, Sumpfwiesen.
3. ท
Sphagniprata, Hochmoor.

1) Brockmann-Jerosch und Rübel 1912; Nachträge Rübel 1915.

?) Gradmann 1909. 
Die Formationsgruppen der Prata:

1. Formationsgruppe: Duriprata, Hartwiesen.

2.

Sempervirentiprata, immergrüne Wiesen.

3. "

4.

Altoherbiprata, Hochstaudenwiesen.

5. $\quad$ "

Emersiprata, emerse Sumpfwiesen.

Submersiprata, submerse Sumpfwiesen.

III. Vegetationstypus: Deserta, Einöden.

1. Formationsklasse:

2.

Siccideserta, Steppen.

$n$

Siccissimideserta, Wüsten.

$n$

Frigorideserta, Kälteeinöden.

4.

Litorideserta, Strandsteppen.

$5 . \quad n$

Mobilideserta, Wandereinöden.

IV. Vegetationstypus: Phytoplankton.

Eine ähnliche Einteilung nach Lebensformen hat übrigens längst Kabsch versucht. Gewissermaßen hat auch Kerner 1891, S. 821, dieselben Prinzipien für Aufstellung von neuen Pflanzenvereinen durchgeführt. In der "Ecology of plants" 1909 hat Warming dieselbe Art der Einteilung besprochen. Er schrieb: Weshalb nicht die Lebensformen benutzen als Grundlage für die Klassen? Man könnte dann folgende Klassen aufstellen: Waldformationen, Strauchformationen, Z wergstrauchformationen, Staudenformationen, Moosformationen, Algenformationen. Innerhalb jeder von diesen Klassen könnte man dann ferner scheiden zwischen hygrophilen, mesophilen und xerophilen Formationen. Von einem morphologischen Standpunkte meint er, würde dieses ein gewisses Interesse haben, aber von einem pflanzengeographischen $\mathrm{mu}$ B es verworfen werden, weil ökologisch nahe verwandte Formationen voneinander gerissen werden. Auf natürlich verwandten Stand. orten können verschiedene Assoziationen von Lebensformen zur Ausbildung kommen, und die müssen in dieseibe Klasse vereinigt werden. Ein System wie das von Brockmann-Jerosch und Rübel wird von einer genetischen Ökologie gar keine Vorstellung geben können.

Zur genauen Bezeichnung einer Formation, um sogleich über den Rang der betreffenden Pflanzengesellschaft orientiert zu sein, hat Moss vorgeschlagen, das Suffix —ion dem Namen derselben anzufügen; also sollte z. B. eine Sandpflanzenformation: Arenarion benannt werden ${ }^{1}$ ). Diels ${ }^{2}$ ) hat das Suffix -ium zu griechischen Namen gefügt (z. B. Thalassium = Meeresvegetation, Hygrodrymium $=$ Regenwald usw.). Es ist wohl zweifelhaft, ob solche fremde Namen notwendig sind; für viele Menschen werden sie jedenfalls recht unverständlich sein.

Je nachdem bestimmte Lebensformen in einer Formation allein oder in verschiedenen Kombinationen vorkommen, haben wir zwischen einfachen und zusammengesetzten Formationen zu unterscheiden.

Zusammengesetzte und gemischte Formationen müssen wohl auseinandergehalten werden.

Von den zusammengesetzten Formationen war soeben beim Walde die Rede; bei ihm zeigt sich oft mit besonderer Deutlichkeit, wie ver-

1) Moss 1910 .

2) Diels 1908. 
schiedene Lebensformen und Formationen, letztere sogar mitunter in einiger Ausdehnung, zu einem einheitlichen Ganzen vereinigt erscheinen. Ein anderes Beispiel liefern etwa die Rohrgrasbestände, die aus verschiedenen fast durchweg monokotylischen Kräutern gebildet werden, die ausdauernd sind und gesellig leben; ihre Tracht kann mitunter recht verschiedenartig sein. Zwischen diesen wachsen nun am Grunde oder gar im freien Wasser ganz andere Lebensformen, die man als untergeorduete Pflanzengemeinschaften (subordinate communities) bezeichnen kann. Diese Gemeinschaften können zusammengesetzt sein aus Schizophyceen, Plaukton, Pleuston und am Boden wurzelnden Wasser-

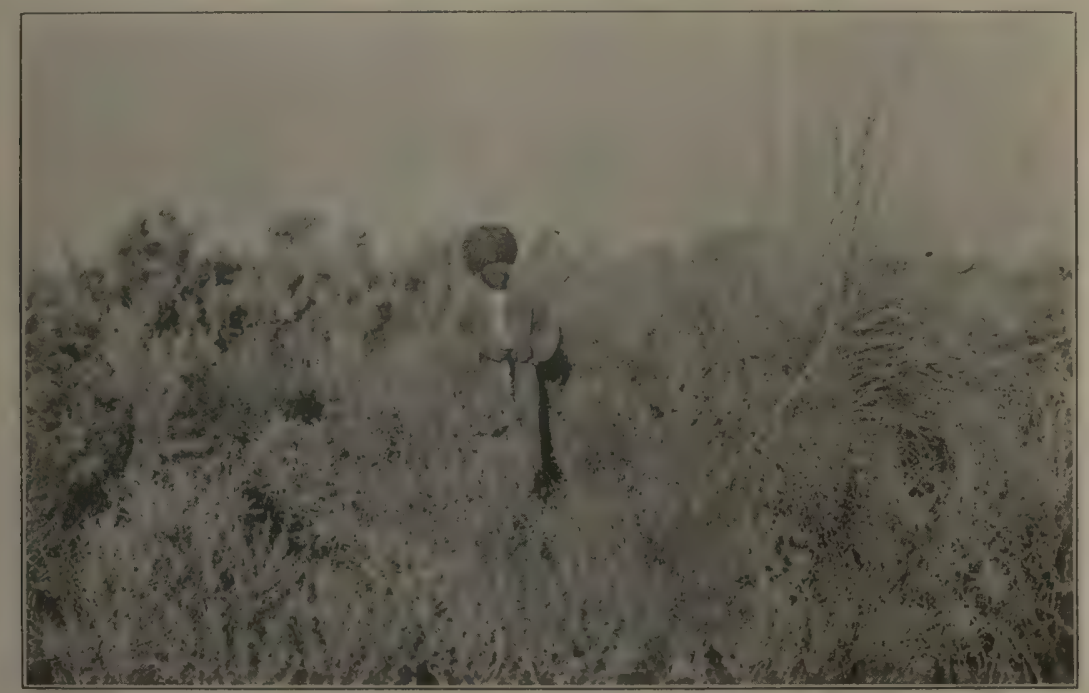

Fig. 172. Gebüsch am Ufer von Amu Daria in der transkaspischen Wüste. Im Hintergrunde Tamarix und Erianthus Ravennae (rechts); im Vordergrunde Alhagi canelorum, Lycium Ruthenicum und Halostachys Caspica. (Ove Paulsen; 1911.)

pflanzen (s. Limnaeen-Vereinklasse) und sind in ihrer Zusammensetzung mehr oder weniger durch die herrschende Vegetation beeinflußt. Im WValde sind ebenso die verschiedenen niedrigeren Stockwerke von solchen Lebensformen zusammengesetzt, welche in den meisten Fällen imstande sind, selbständige und charakteristische Formationen zu bilden, so z. B. Gebüsche, Heide, Grasland, Moosformationen und andere, aber in beiden Fällen würden die dann vorkommenden Arten meist etwas verschieden sein. Für die im Waldesschatten oder unter anderen großen Pflanzen wachsenden Arten sind wirksam nicht nur die Faktoren der Beleuchtung, sondern auch die größere oder geringere Feuchtigkeit des Bodens und der Lufttemperatnr usw. gegenüber einer entsprechenden offenen Formation. Als Beispiel für eine Pflanze, die sowohl untergeordnete als offene herrschende Vereine bilden kann, sei Calluna genannt. Diese Art 
herrscht auf den weiten mit ihren Zwergsträuchern dicht bedeckten Flächen, den Heiden, kann aber auch in den Kiefernwäldern als Untervegetation große Bestände bilden (in den kontinentalen Klimaten nur so).

Eine aus mehreren Stockwerken zusammengesetzte Formation kann auch aus verschiedenen Typen, etwa Xerophyten und Mesophyten, gebildet werden; z. B. gibt es Wälder aus Hartlaubbäumen mit ausgeprägten xeromorphen Arten des oberen Stockwerks und mesomorphen Arten als Unterwuchs. Dieser Wald stellt also eine zusammengesetzte Formation dar.

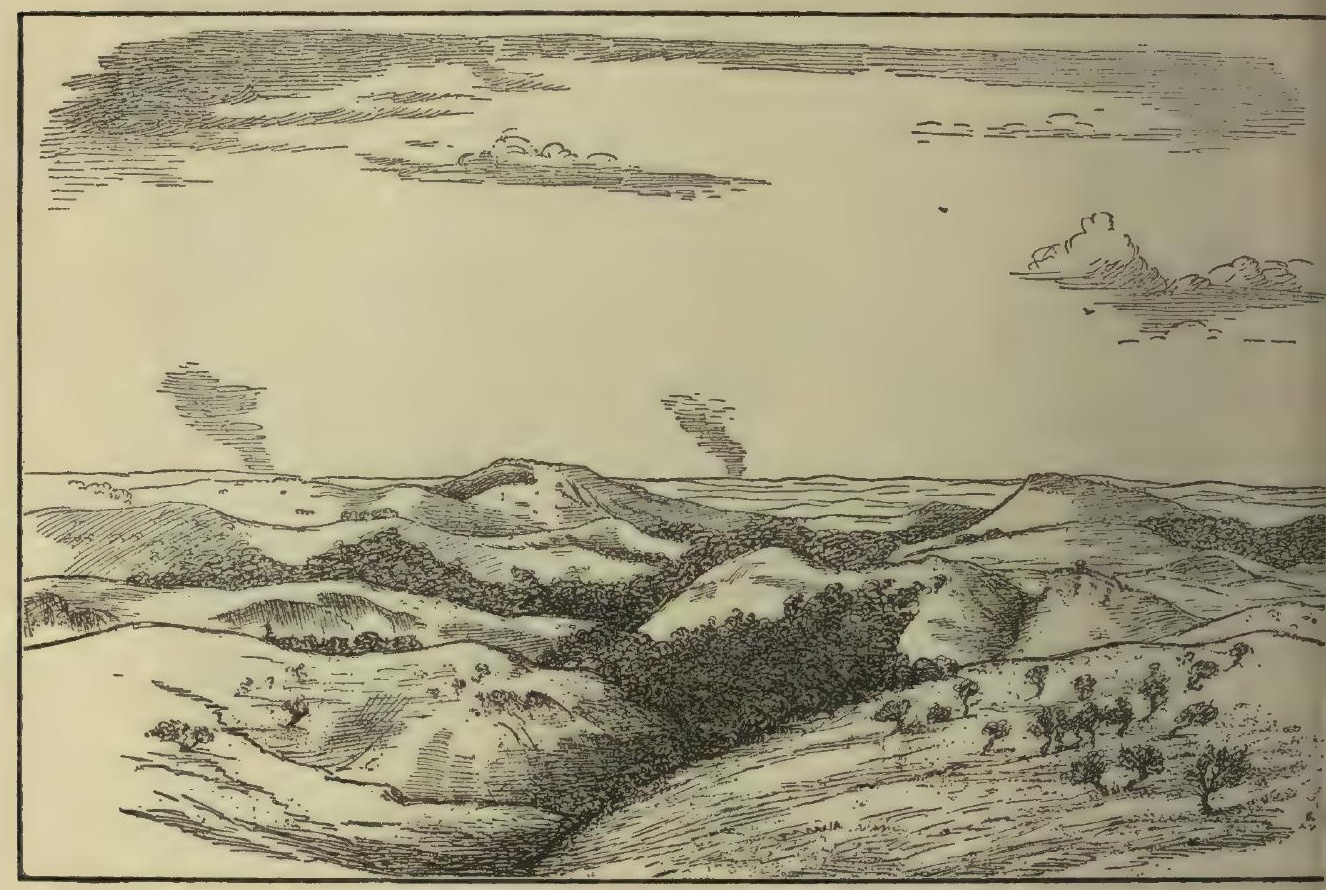

Fig. 172. Gegend in der Nähe von Lagoa Santa im Staate Minas geraes, Brasilien. Aussicht gegen Norden, gegen das Tal des Rio das Velhas. Die Niederungen sind mit Wald erfüllt; alle Anhöhen sind mit Campos bekleidet, teils offene Grascampos ohne Bäume, teils solche mit zerstreuten, gekrümmten Bäumen. In der Ferne Campos- oder Waldbrände. (Gez. von Eug. Warming.)

\section{Gemischte Standorte}

Überall in der Welt finden wir stark kontrastierende Formationen nebeneinander, z. B. Oasen oder Gebüsch und Wälder mitten in den Wüsten, dort wo das Grundwasser erreicbt werden kann. In den transkaspischen Wüsten findet sich solche z. B. längs dem Amudaria ${ }^{1}$ ) Fig. 172.

1) O. Paulsen 1912. 
In den hügeligen Camposgegenden des inneren Brasiliens, etwa um Lagoa Santa, finden sich die Wälder überall in den Tälern und längs der Wasserläufe, weil hier die Bodenfeuchtigkeit größer ist und anscheinend das Grundwasser erreicht werden kann; Fig. 172. Was hier im großen der Fall ist, finden wir vielfach auf kleinem, ja auf kleinstem Raume. Man sieht oft sehr kleine Stücke oder Ausschnitte einer Formation in einer anderen größeren eingestreuet, wenn z. B. Gletscherblöcke mit Flechten und Moosen bewachsen mitten im Walde oder am

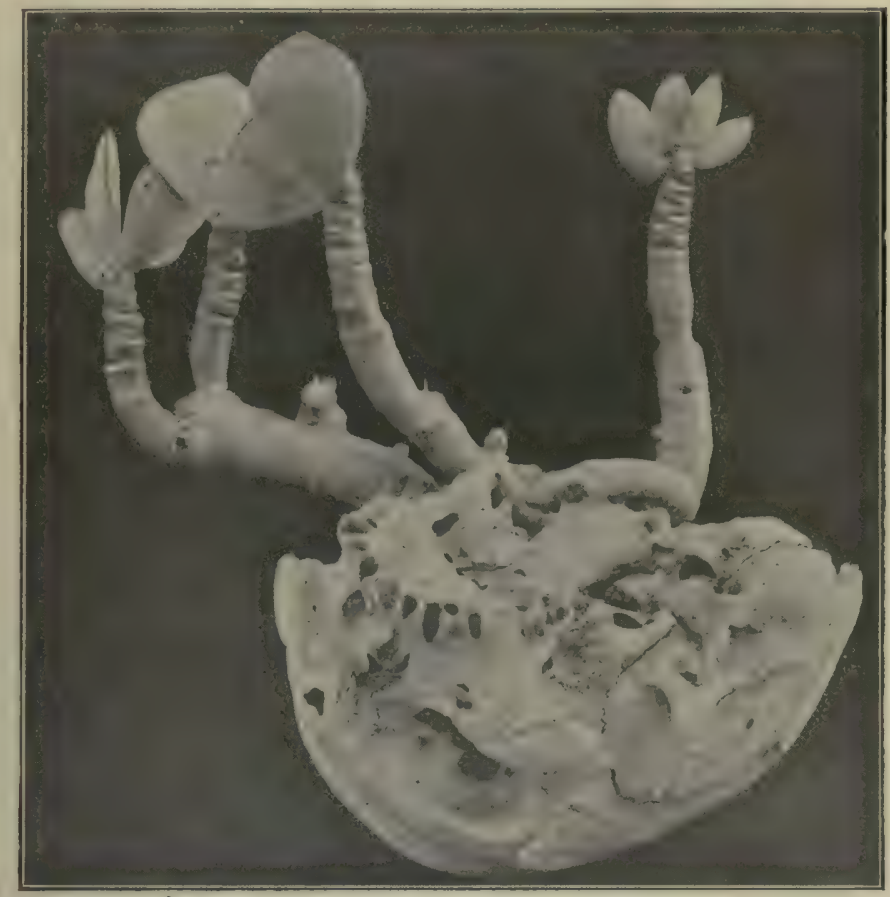

Fig. 174. Hottentottenschädel mit einem darin wachsenden Cotyledon; so in der fast vegetationslosen Wüste von Deutsch-Südwestafrika gefunden, als Beispiel für Veränderung "im kleinsten Raume" durch das im Schädel gesammelte Wasser. Original noch im Botanischen Garten Dahlem. (Nach Ledien.)

Meeresufer zwischen der Salzvegetation vorkommen, oder wenn ganz kleine Wassertümpel mit Algen in einem Grasfelde liegen. Besonders mosaikartig wird die Vegetation dort, wo im seichten Wasser an unseren Küsten große Massen von Steinen, die aus den ehemaligen Gletschern herrühren, sich angesammelt haben; während die Steine mit Algen bewachsen sind oder vielleicht so hoch hervorragen, daß sie oben auch Flechten als Repräsentanten der Felsvegetation tragen können, ist der Sandboden des Wassers mit den Mitgliedern der Seegrasformation bedeckt (Fig. 175, 176). 


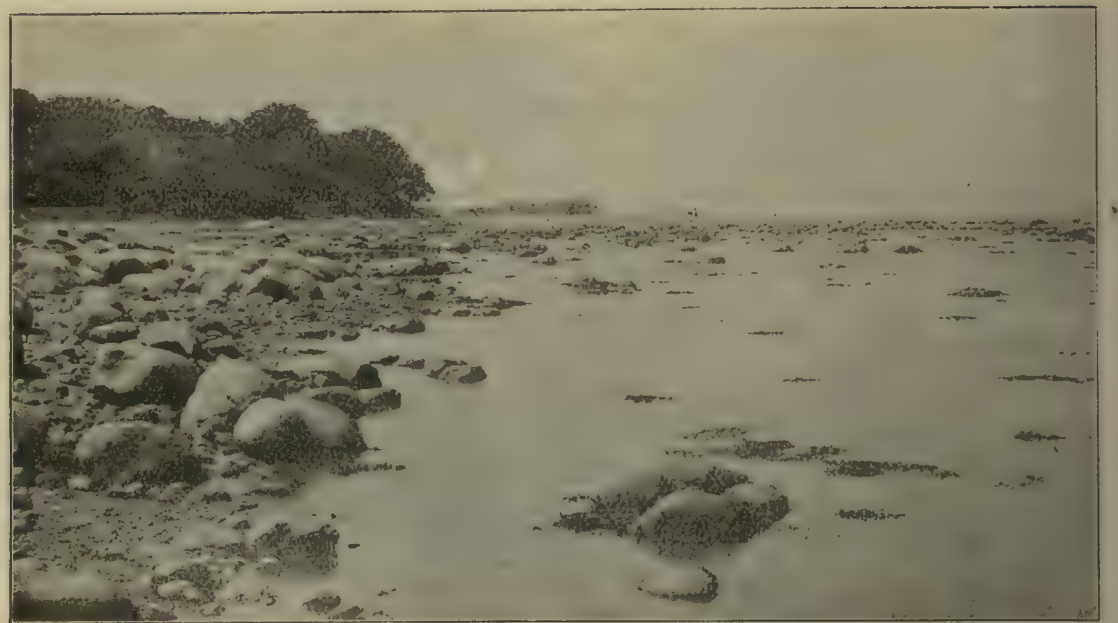

Fig. 175. Am Strande liegen teils auf dem Lande, teils im Wasser ungeheure Mlengen von Steinen, die im Laufe der Zeit aus den alten Moränen der Eiszeit durch Bespülung der Küste freigelegt worden sind. Die im Wasser liegenden tragen unten Algen, oben teilweise krustenförmige Flechten, während der Sandboden zwischen ihnen mit Characeen, Zostera, Ruppia und Zannichellia bewachsen ist. Auch sieht man im Wasser dunkle Flecken von Fucus vesiculosus, der auf untergetauchten Steinen befestigt ist. Südküste von Seeland. (Phot. Eug. Warming.)

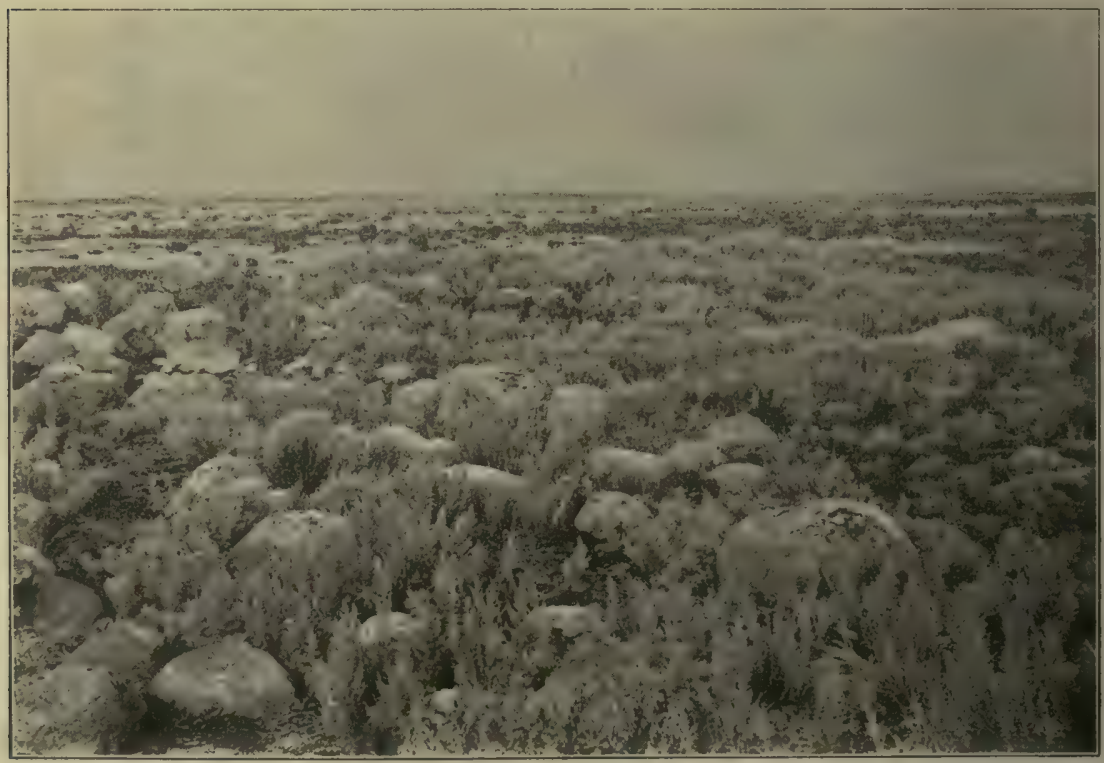

Fig. 176. Strand auf der Insel Samsö im Kattegat. Gemischte Formationen von einer Felsformation (Flechten und Moose auf den Steinen) und einer Halbstrauchformation von Artemisia maritima (bis $0,5 \mathrm{~m}$ hoch) mit eingestreuten Kräutern und Gräsern (Phot. Eug. Warming.) 
Derartige "gemischte Formationen" finden sich vielfach in gebirgigen Gegenden oder auch in hügeligen Dünenlandschaften, wo das Terrain plötzlich und stark wechselt; dadurch ergibt sich ein ebenso

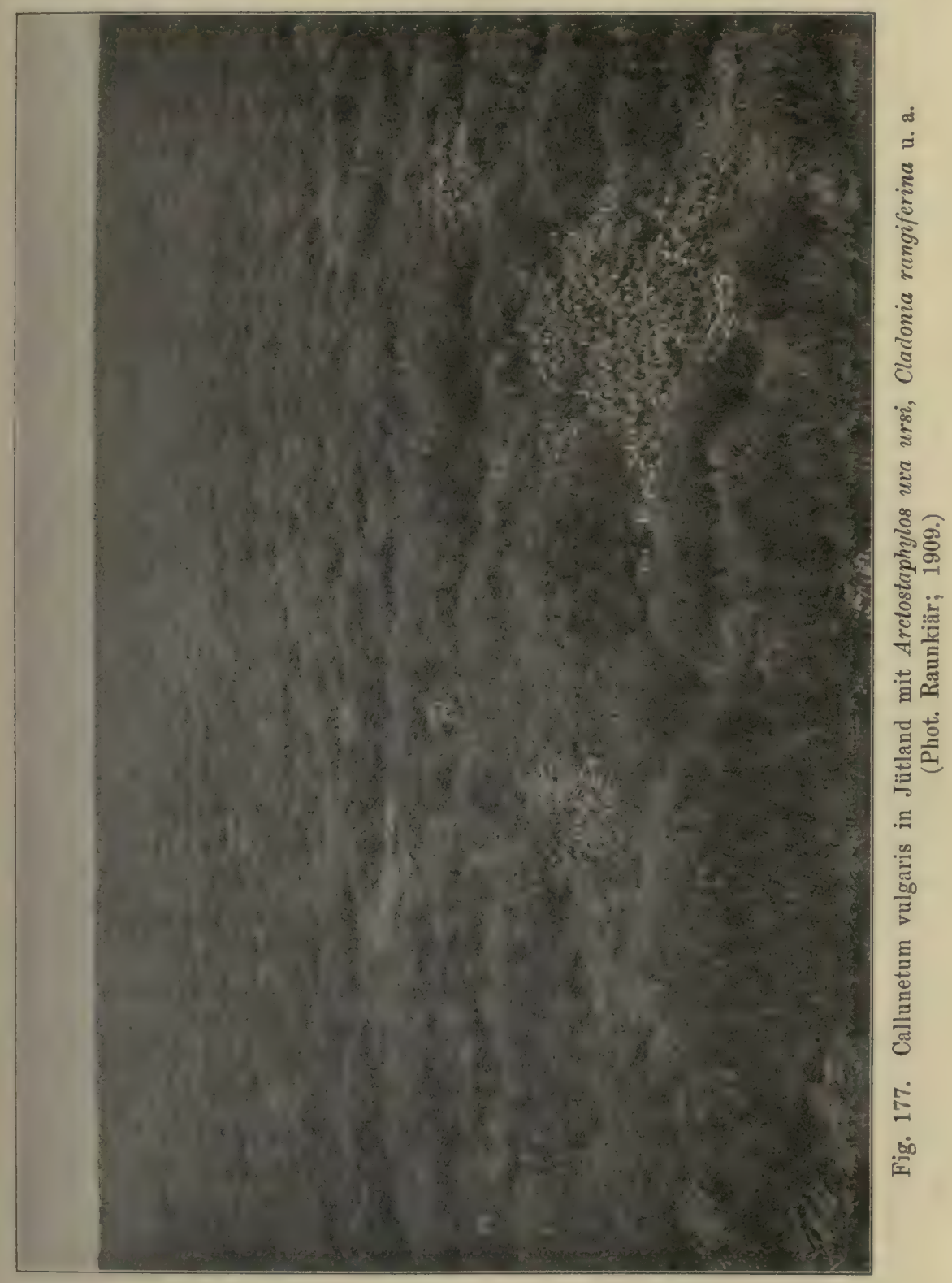

starker und plötzlicher Wechsel der edaphischen Verhältnisse. Man erinnere sich auch an G. Kraus' Untersuchungen über „Boden und K'lima auf kleinstem Raume“. In den Dünen z. B. sind die Senkungen 
zwischen den Sandhügeln oft von Flächen mit saftigen Wiesen erfüllt, da die Wurzeln der Pflanzen hier das Grundwasser erreichen können, oder es finden sich hier auch viele kleine Wassertümpel. Die Anhöhen dagegen sind mit offenen Formationen von grauer oder fahlgrüner Dünenvegetation oder mit bräunlichem Heidekraut bedeckt.

Je ebener und einförmiger der Boden über weite Strecken ist, desto deutlicher wird die Natur einer Formation zum Ausdruck kommen. Deshalb ist z. B. Westjütland mit seinen weiten Ebenen ein vorzügliches Studienobjekt (Fig. 177). Je kleiner die Stücke einer gemischten Formation sind, desto leichter verlieren sie ihren reinen Charakter und nehmen Elemente der fremden Formationen in sich auf. Ein Faktor ist besonders für Änderung und Mischung der Vegetation verantwortlich zu machen, nämlich der Mensch.

Es kann nebenbei bemerkt werden, daß je reicher eine Gegend an verschiedenen Standorten ist, desto reicher wird sie in floristischer Hinsicht werden.

Sekundäre Formationen. Unter den Begriff der sekundären Formationen können wir solche zusammenfassen, die durch menschliche Einflüsse entstanden $\operatorname{sind}^{1}$ ). Verschiedene dieser Vereine sind nur in ihrer Flora verändert worden; diese bezeichnet man als "Halbkulturformationen"; hierher zu rechnen ist auch ein Teil der norwestdeutschen Heideflächen, die durch weidende Tiere beeinflußt sind ${ }^{2}$ ). Andere Formationen entstehen dadurch, daß der Mensch den Wald zerstörte, um ihn in irgend einer Weise nutzbar zu machen. In dieser Weise soll z. B. der "Sibljak" in Serbien ${ }^{3}$ ) entstanden sein, oder auch die Eichenkratts in Jütland, die Tristegia glutinosa-Grasländer in Brasilien ${ }^{4}$ ). Diese Formationen können nur durch die Kultur in ihrer Existenz erhalten werden und sind echte sekundäre Formationen.

Subformationen. Eine Anzahl verschiedener Formationen besitzen eine so große Ausdehnung, zeigen dabei verschiedene geringere ökologische, $d . h$. edaphische und klimatische Verschiedenheiten, so daß es passend erscheint, sie weiter in Subformationen einzuteilen, resp. als solche zu scheiden; genannt seien Plankton-Formation, dikotyler Wald usw., die so geteilt werden können ${ }^{5}$ ).

Für die Einteilung der Wälder würde es maßgebend sein, ob die Bodenvegetation an einer oder zu verschiedenen Lebensformen gehört.

1) Warming 1892; Graebner 1909; hierher auch die „Substitute Association“ von W. G. Smith 1905 , S. 62 .

2) E. H. L. Krause 1892, vergl. dagegen Graebner 1895 und später.

3) Nach Adamović 1902.

) Warming 1892 .

s) Vergl. auch Drude 1902. 
Die Verschiedenheiten der Lebensformen in einem Walde können so groß sein, daß sie ein völlig anderes Bild ergeben können und daher einer Subformation entsprechen werden. Die Subformation als solche $\mathrm{muß}$ aber stets gerechtfertigt erscheinen durch ökologische Ursachen, als da etwa sind: die Tiefe, der Wassergehalt, die Art des Bodens oder auch andere Faktoren. Unsere zunehmende Kenntnis der ökologischen Dinge wird auf alle diese Fragen allmählich Licht werfen. Wie eine Unterscheidung von Subformationen geschehen soll, läBt sich im allgemeinen nicht sagen; es wird wohl vielfach von subjektivem Empfinden abhängen. Von „Association" werden sie wohl schwer zu trennen sein ${ }^{1}$ ).

\section{Kap. Assoziationen}

Eine Assoziation ist „eine Pflanzengesellschaft von bestimmter floristischer Zusammensetzung, welche dem Begriffe der Formation unterzuordnen ist" ${ }^{2}$ ). Eine Formation kann also nach den floristischen Verschiedenheiten in eine Reihe von Assoziationen A, B, C . ., geteilt werden, und sie ist eben die Summe aller dieser. Die Formation der Zwergstrauchheiden ist in Europa und in den Polarländern aus denselben Lebensformen zusammengesetzt (Zwergsträuchern, Kräutern, Gräsern, Moosen, Algen, Flechten) und hat dieselbe Physiognomie (Fig. 177, 178); aber die Arten in Nordwest-Europa und in Grönland werden zum größten Teile ganz verschieden sein. Die grönländische und die nordwesteuropäische Heide sind "Assoziationen" derselben Formation. Auf ganz dieselbe Weise kann man die Hochmoore, die Süßwassersümpfe, die Dünen, die laubwerfenden (sommergrünen) Wälder usw. behandeln. Die Alpenwiesen in der Schweiz entfalten nach Jaccard nicht auf einem Platze ihre gesamte Artenzahl; die Artenliste der Formation muß also aus den an mehreren verschiedenen Stellen wachsenden Pflanzen zusammengesetzt werden. Ein Kornfeld ist eine Kulturformation mit einjährigen oder einjährig überwinternden Arten, aber es lassen sich eine Reihe von verschiedenen Assoziationen unterscheiden, je nach den bestandbildenden Arten (Roggen, Weizen, Mais, Buchweizen usw.).

Zur Charakteristik einer Assoziation gehört notwendig eine Artenliste - eine alle Arten umfassende scheint allerdings überflüssig, wohl

1) Es ist sehr schwierig, für die verschiedenen Arten der Formationen angemessene Namen zu finden. Einige von den vielen Worten im allgemeinen Sprachgebrauch, also die Vulgärnamen, werden auch als wissenschaftliche Ausdrücke gebraucht, so z. B. Steppe, Prairie, Tundra, Caa Tinga, Alang Alang, Savanne und andere (vergl. Warburg 1900), aber viele Vulgärnamen sind unbrauchbar. Andere wissenschaftliche Namen sind neueren Datums, so z. B. Plankton (Hensen) und Garide (Chodat).

9) Flahault und Schröter 1910. Vergl. jedoch z. B. Th. Fries 1913. 
aber ist eine der vorherrschenden oder der leitenden Pflanzen notwendig, der so viel wie möglich die anderen Arten beigefügt werden. Nicht nur Gefäßpflanzen sollen hier erwähnt werden, sondern auch Moose und Thallophyten. $\mathrm{Zu}$ einer genauen floristischen Charakteristik gehört dann weiter eine zahlenmäßige statistische Angabe der relativen Menge der Arten, nach irgend einer der statistischen Methoden ausgeführt (Clements, Oliver n. a.; vergl. S. 332). Die einfachste und leichteste Art der Messung scheint die von Raunkiär angewandte zu sein, welcher selbst eine sehr große Menge von Assoziationen (von ihm leider „Formationen" benannt) aufgenommen hat. Für die Dichtigkeit der Vegetation gibt diese Methode indessen doch nicht die gewünschte Genauigkeit.

Es ist einleuchtend, daß die Assoziationen einer Formation zu Gruppen zusammengestellt werden können, je nach ihrer größeren oder geringeren floristischen Ähnlichkeit; dies berührt aber nicht den Charaktion der Formation, so lange die Lebensformen dieselben bleiben.

Das Studium einer Assoziation umfaßt somit folgende Momente:

1. Bestimmung des Charakters des Standortes, d. h. der dort herrschenden ökologischen Faktoren.

2. Die Aufstellung einer Artenliste, für die ganze Vegetationsperiode, mit einer Statistik der relativen Anzahl derselben und, wenn möglich, der Masse der Individuen.

3. Feststellung ihrer Physiognomie durch wissenschaftliche Bestimmung der Lebensformen und ihrer Anpassungen: darunter auch die geselligen Verhältnisse („komplementäre“ Vorkommnisse). Eine Assoziation wird ev. von einer einzigen (sozialen) Art oder von mehreren sozialen Arten von derselben oder ähnlicher Physiognomie gebildet.

4. Feststellung der Veränderungen der Vegetation im Anschluß an den Fortschritt der Jahreszeiten („seasonal aspects" Clements).

Das Studium der Vegetation eines Ortes muß mit dem Studium der einzelnen Assoziationen anfangen, um dann induktiv weiterzuschreiten, ganz wie die systematischen Studien mit den einzelnen Arten beginnen und von diesen dann zur Bildung der Gattungen und Feststellung der höheren Einheiten fortschreiten. Die Assoziationen sind die Einheiten (die "Individuen“), aus denen man die Formationen bildet.

Der Name „Assoziation“ stammt von Humboldt ${ }^{1}$ ), der — allerdings recht unbestimmt - von „plantes associées“ sprach $^{2}$ ). Später wurde der Name von A. P. De Candolle, Meyen u. a. benutzt.

1) Humboldt 1807 .

2) Die Pflanzengeographie wird von ihm folgendermaßen definiert: "C'est cette science qui considère les végétaux sous les rapports de leur association locale dans les différents climats." 


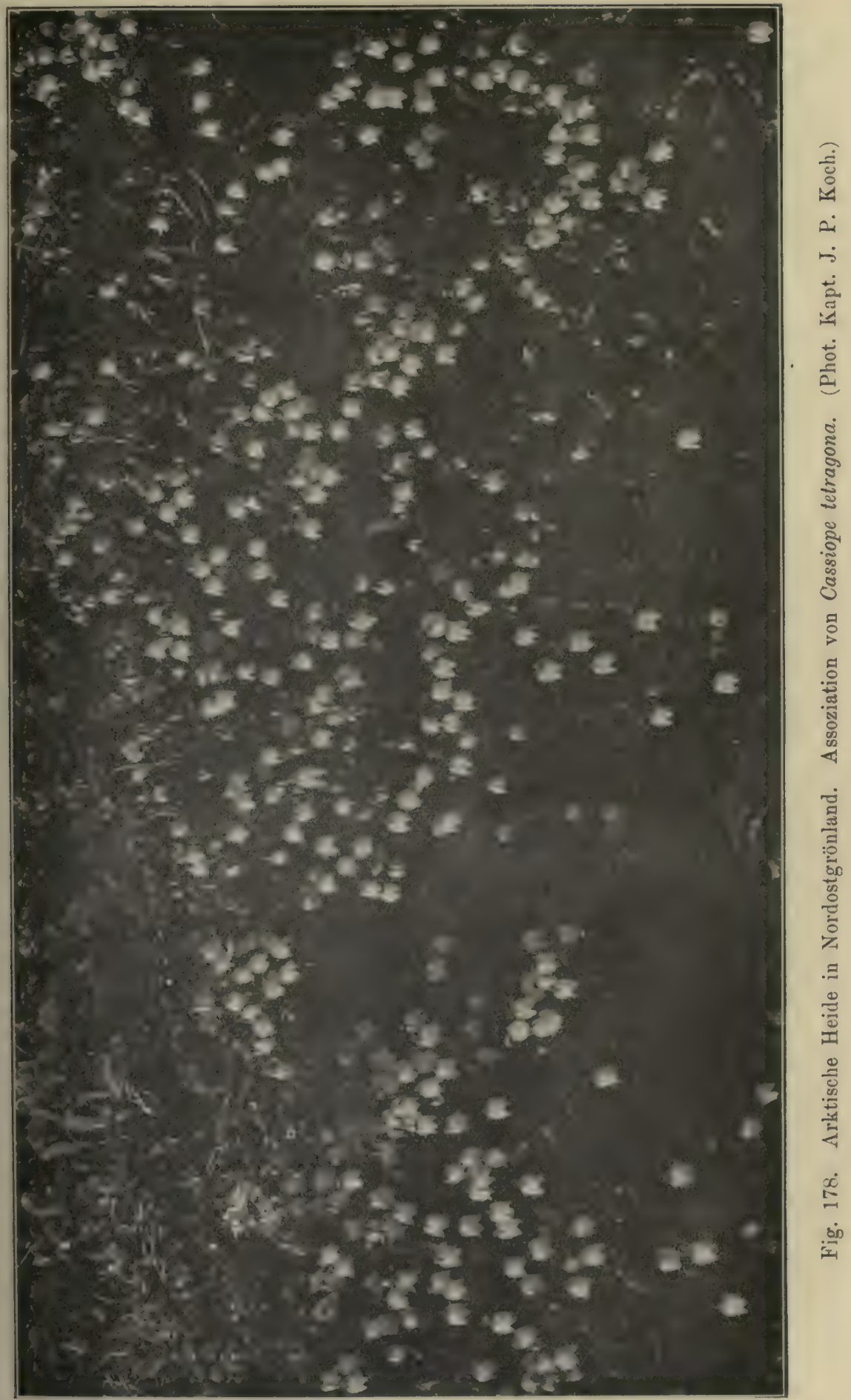


Schouw ${ }^{1}$ ) führte zur schnellen Bezeichnung einer "Assoziation" die Methode ein, das Suffix - etum einem Gattungsnamen beizufügen, indem er von: Ericeta, Rhododendreta, Arundineta, Pineta, Querceta, Fageta usw. sprach, um damit Assoziationen von Erica, Rhododendron usw. zu bezeichnen. Ihm folgte später Meyen und in neuester Zeit werden die Assoziationen vielfach auf diese kurze und klare Weise bezeichnet, wenn sie aus einer einzelnen vorherrschenden Art gebildet werden. Also z. B. Phragmitetum, Scirpetum, Typhetum usw. zur Bezeichnung von Assoziationen der Süßwassersümpfe.

Zur genaueren Bezeichnung der Assoziationen kann man nach dem Vorgange des finnischen Botanikers Cajander ${ }^{2}$ ) den Speziesnamen im Genetiv hinzufügen, als z. B. Scirpetum lacustris (d. h. von Scirpus lacustris gebildet), Typhetum angustifoliae (d. h. von Typha augustifolia gebildet), Pinetum silvestris usw. Diese Bezeichnungsweise entspricht dem volkstümlichen Gebrauche, wenn die Namen der Assoziationen von zwei Namen gebildet werden, von denen der eine die Formation, der andere die dominierende Art angibt. Er entspricht den Bezeichnungen wie Buchenwald, Birkenwald, Federgras-Wiese usw.

In vielen Fällen wird eine Assoziation nicht von einer einzelnen herrschenden, („dominierenden") oder sie physiognomisch charakterisierenden Art gebildet, sondern mehrere Arten haben sich in etwa gleichem Verhältnisse vereinigt, wohl deshalb weil sie unter den gegebenen äußeren Bedingungen gleich stark im Konkurrenzkampf sind. In diesem Falle wird die Assoziation durch Kombination von etwa zwei bis drei Namen zu bezeichnen sein, z. B. Scirpo-Typhetum, wenn Arten von Scirpus und Typha in annäherungsweise gleich großer Zahl die Vegetation bilden, oder man wird z. B. den Namen "mixtum" hinzufügen können (Coniferetum mixtum bei Brockm.-Jerosch u. Rübel).

Wie oben (S. 334) bemerkt wurde, wird die Bezeichnung "Formation" noch hie und da statt "Assoziation" für sehr kleine floristische Gesellschaften verwendet; gewöhnlich geschieht dies wohl aus alter Gewohnheit, insofern aber der Gedanke zugrunde liegt, daß floristische Verschiedenheiten fast stets mit Standortsverschiedenheiten verknüpft sind, weil die Pflanzen oft ein sehr feines Reagens auf edaphische Unterschiede sind, wird dieses eine Schwierigkeit in der ökologischen Systematik offenbaren; wenn aber die Lebensformen in solchen kleinen Vereinen dieselben sind und die Physiognomie im großen und ganzen dieselbe ist, dürfen solche floristische Differenzen nicht Veranlassung zur Benutzung der Bezeichnung "Formation" geben; solche kleine Vereine sind nur Assoziationen von einer sie alle umfassenden Formation oder Abänderungen von einer Assoziation.

1) De Candolle 1820; Schouw 1822; Meyen 1836.

3) Cajander 1903. 
Abänderungen der Assoziationen. Die Assoziationen sind bei weitem nicht immer ganz gleich zusammengesetzt und auch physiognomisch oft nicht ganz gleichartig. Es kommen kleinere Verschiedenheiten vor. "Innerhalb derselben Assoziation", sagen Flahault und Schröter ${ }^{1}$ ), „können lokale floristische Differenzen edaphischen oder genetischen oder selbst zufälligen Charakters zu Unterabteilungen Veranlassung geben (Subassoziationen, "patches", „communities", "societés"), die man mit aller gewünschten Sorgfalt beschreiben muß. Sie sind aber der Assoziation untergeordnet".

Diese Verschiedenheiten sind nun zweierlei Art, man kann sie vielleicht als Varietäten und Facies bezeichnen.

Varietäten. Edaphische Varietäten. Es gibt z. B. von den nordeuropäischen Buchenwäldern, welche als eine Assoziation (Fagetum) innerhalb der Formation: Sommergrüne Laubwälder des kalttemperierten Klimas betrachtet werden müssen, zwei Varietäten, die eine mit mildem, neutralem Humusboden und einer reichen Bodenvegetation von Anemone nemorosa u. a. Arten, Asperula odorata, Arten von Corydallis, Primula, Dentaria, Mercurialis, Stellaria nemorum usw. Die andere hat sauren Rohhumus und trägt eine ganz andere Flora (Aera flexuosa, Melampyrum pratense, Vaccinium myrtillus usw.).

Diese zwei Varietäten, die als Fageta asperulosa und F. myrtillosa bezeichnet werden mögen, können sich dicht nebeneinander finden, ohne daß von klimatischen Verschiedenheiten die Rede sein kann; nur Bodendifferenzen geben zu ihrer Bildung Veranlassung, und durch geeignete Behandlung des Bodens, unter anderem durch Kalkbeimischung, kann Rohhumus wieder in andere, mildere Humusformen übergeführt werden und dadurch die Flora gänzlich geändert werden. Es wird am besten sein, solche Differenzierungen als Assoziations-Varietäten zu bezeichnen.

In ganz entsprechender Weise kann man Varietäten von anderen Baumassoziationen feststellen, z. B. von den Pinus silvestris-Wäldern, was früher erwähnt wurde, von den nordischen Birkenwäldern, die als Betuleta hylocomiosa, B. cladinosa usw. ausgebildet sind, von den Eichenwäldern usw. Moss ${ }^{2}$ ) spricht z. B. von vier verschiedenen "ground societies" in den britischen Eichenwäldern. Solche Varietäten sind in diesen Fällen wohl allein durch Bodenverschiedenheiten bedingt. Einige Arten sind wenig wählerisch und können auf sehr verschiedener Unterlage vorkommen, z. B. Calluna vulgaris auf trockenem Sande und auf nassen Hochmooren, Pinus montana auf Hochmooren und auf Kalkboden usw.

1) Flahault und Schröter 1910.

2) Moss 1913.

Warming-Graebner. 8. Auflage, illustr. 
Graebner ${ }^{1}$ ) unterscheidet unter der Heideformation verschiedene Assoziationen, nämlich: echte Heide (Callunetum) mit verschiedenen Varietäten, wie z. B. solche mit Pulsatilla, Genista, Solidago oder anderen vorherrschenden ausdauernden Kräutern. Woodhead ${ }^{2}$ ) hat dasselbe für die Bestände von Pteridium aquilinum gezeigt, er beschreibt ein Mesopteridetum, d. h. eine Assoziation von Pteridium mit Holcus lanatus und Scilla festalis, und ein Xeropteridetum, eine Assoziation von Pteridium mit Calluna, Vaccinium myrtillus, Aera flexuosa u. a.

Alle diese Fälle zeigen, daß eine Einteilung der Formationen nach Standorten ihre Übelstände haben kann, aber jede andere Einteilungsweise wird denselben Schwierigkeiten begegnen.

Geographische Varietäten. Die genannten Beispiele waren durch Bodenverschiedenheiten bedingt. Aber auch durch geographische und historische Ursachen werden Varietäten hervorgerufen werden, ohne daß von edaphischen Verschiedenheiten die Rede zu sein scheint. Z. B. schreibt Beck von Mannagetta ${ }^{3}$ ), daß Pinus laricio als Hochwaldbaum über ein so großes Gebiet verbreitet ist, daß die Bodenvegetation drei verschiedenen Florenbezirken angehört und zwar dem Pontischen, dem Baltischen und dem Mediterranen. Hier haben wir also drei geographische Varietäten. Höck hat eine Reihe von Untersuchungen über „Begleitpflanzen" unserer nordeuropäischen Waldbäume veröffentlicht ${ }^{4}$ ). Selbst wenn die Arealgrenzen der Bäume und ihrer Bodenpflanzen oft einigermaßen zusammenfallen, ist dieses doch sehr oft gar nicht der Fall, wodurch floristische Verschiedenheiten, die wohl meist historisch (geologisch) begründet sind, in den verschiedenen Assoziationen hervorgerufen werden. Oft kann man ihnen wohl den Wert von geographischen Varietäten zuerteilen.

Facies. Wohl in allen Assoziationen und Varietäten von solchen kommen ganz kleine Standortsverschiedenheiten vor, die so klein sind, daß sie nicht den Gesamtcharakter der Assoziationen ändern können. Hieran knüpfen sich dann kleine floristische Verschiedenheiten, besonders durch soziale Arten hervorgerufen, und diese können wohl auch durch reinen Zufall hervorgerufen werden, z. B. dadurch, daß3 die eine Art leichter einwandern kann, weil sie zufällig in größerer Nähe ist. Solche kleinere Verschiedenheiten können fleckenweise oder gürtelförmig verteilt sein.

In den erwähnten Fageten mit mildem Bodenhumus werden durch kleine Verschiedenheiten der Beleuchtung, der Bodenfeuchtigkeit oder

1) Graebner 1895 usw.

2) Woodhead 1906 .

s) Beck 1902 .

4) Höck 1892, 1893, 1894, 1895, 1896, 1900. 
durch zufällige Finwanderungsmöglichkeiten fleckenweise verteilte Floraverschiedenheiten vorkommen. An einer Stelle trifft man z. B. Anemone nemorosa ganz überwiegend, an andren Flecken oder Strecken bilden Asperula odorata oder Stellaria nemorum, Mercurialis perennis oder Stellaria holostea u. a. ausgedehnte Bestände, die aber den Gesamtcharakter der Vegetation nicht ändern.

Solche kleine Verschiedenheiten können Facies genannt werden ${ }^{1}$ ). Auch in den Wiesen, Grasfluren, Heiden und wohl in allen anderen Assoziationen wird sich diese fleckenweise Verteilung der Arten, namentlich der geselligen Formen, finden. Sie ist wohl oft edaphischer Art, aber auch winzige klimatische Verschiedenheiten, z. B. durch die größere oder geringere Exposition nach der Sonne usw. hervorgerufen. So z. B. kann derselbe Eisenbahndamm auf der Nord- und der Südseite eine recht verschiedene Flora haben, aber die Lebensformen, d. h. die Formation, ist dieselbe. Die alpine Wiese in der Schweiz hat verschiedene Floren in Übereinstimmung mit den verschieden exponierten Abhängen, auf denen sie vorkommt, oder auch ob sie von einem Walde oder einer Bergkuppe längere Zeit des Tages beschattet wird ${ }^{2}$ ). Eine scharfe (rrenze zwischen solchen Faciesflecken und Assoziationen zu ziehen, ist unmöglich.

Gürtelförmige Anordnung der Pflanzenvereine findet sich überall längs den Ufern von Seen und Wasserläufen und entsteht dadurch, Laß das Grundwasser selbst bei sanfter Erhöhung des Terrains desto tiefer liegt, je ferner die Stelle von dem offenen Wasserspiegel entfernt ist, und daß die verschiedenen Arten verschiedene Forderungen an den Wassergehalt des Bodens stellen. Es ist merkwürdig, für wie kleine Differenzen im Wassergehalt der Pflanzenbestand oft empfindlich ist.

So lange die Arten der verschiedenen Gürtel im großen denselben Lebensformen gehören, so lange z.B. alle ausdauernde mesomorphe Kräuter und Gräser sind, wird man die verschiedenen Gürtel als Assoziationen oder vielleicht als Facies einer Assoziation auffassen können. Werden aber andere Lebensformen eingemischt, z. B. Zwergsträucher oder Sträu(her, und werden diese nach und nach herrschend, so daß Zwerggesträuch oder Gebüsch (z. B. von Myrica gale oder Ledum palustre oder von Salices) entsteht, und wenn nach diesen z. B. Bäume auftreten, also ein Wald entsteht, so müssen diese Gürtel als Assoziationen von

1) Der Name wird übrigens von den verschiedenen Verfassern verschieden gebraucht. Der Ausdruck "Facies" scheint zuerst von Lorenz 1863 gebraucht zu sein, um kleine lokale Verschiedenheiten in einer Formation zu bezeichnen. Von andern ist der Auslluck aber gleichbedeutend mit Assoziation gebraucht worden. - Bei englischen Schriftstellern ist unter "facies" oft "the general aspect or appearence" verstanden.

a) Vergl. Stebler und Schröter 1889, 1892; Stenström 1905; Gadeceau 1903, 1909; Warming 1909; Jaccard u. a. 
anderen Formationen betrachtet werden - eine Reihenfolge, die gerade oft an den Ufern von nordeuropäischen Seen zu beobachten ist.

Die gürtelförmigen Assoziationen sind oft genetische Entwickelungsglieder von Formationen, indem die verschiedenen Vegetationsgürtel mit der Zeit sukzessive vorrücken und nach dem Wasser zu verschoben werden, während die höheren ihre Stelle einnehmen, in Übereinstimmung mit der sukzessive fortschreitenden Erhöhung des Bodens (mit der Verlandung).

Nirgends gibt es in der Natur scharfe Grenzen, und so wie es unmöglich ist, die Lebensformen scharf in Gruppen zu verteilen, so ist es ebenso unmöglich, die Pflanzenvereine scharf voneinander abzugrenzen. Treffend sagen Flahault und Schröter ${ }^{1}$ ): „Es ist unmöglich, eine exakte Diagnose der pflanzengeographischen Einheiten zu geben; “ es wird sich deshalb auch zeigen, daß vielfach Meinungsverschiedenheiten darüber herrschen werden, ob dieser oder jener Pflanzenverein als Facies einer Assoziation betrachtet werden soll oder als selbständige Assoziation, und ob eine Assoziation dieser oder jener Formation zugeteilt werden soll ${ }^{2}$ ).

\section{Kap. Succession. Sekundäre Veränderungen der Formationen und Assoziationen}

Es ist schon davon die Rede gewesen, daß wenige Assoziationen als in sich abgeschlossene, unveränderliche Pflanzenvereine betrachtet werden können. In kürzeren oder längeren Zeiträumen können sie unverändert erscheinen; wenige bleiben durch Jahrhunderte unverändert, andere werden schnell mehr oder weniger stark verändert, je nachdem der Standort langsam oder schnell seinen Charakter ändert. Sehr allmählich waren jene Veränderungen, durch welche im Laufe der postglazialen Zeit die Wälder Nordeuropas ihren Charakter änderten und von den Birkenwäldern in Kiefernwälder sich umwandelten und diese wieder in Eichenwälder übergingen, welche endlich jetzt mehr oder weniger oft von den Buchenwäldern verdrängt worden sind ${ }^{3}$ ).

An anderen Stellen geht die Entwicklung schnell vor sich, z. B. bei vielen Verlandungen unserer Seen und Weiher, wenn Reste der an Ort und Stelle lebenden Vegetation und vom Winde hinzugewehte oder durch Wasser hinzugeschwemmte organische und anorganische Körper nach und nach die Wasserflächen ausfüllen, den Boden erhöhen und die

1) Flahault und Schröter 1910.

2) Hierher gehörige Litteratur vergl. ferner Tansley 1911; Moss, Rankin und Tansley 1910; Drude 1913, Th. C. E. Fries 1913 u. a.

3) Nach Beobachtungen zuerst von Steenstrup (1841), später von Gunnar Andersson, C. A. Weber, Graebner (Bodenmüidigkeit), Harz, Sernander u. a. 
eine Assoziation deswegen die andere verdrängen muß. Solche relativ schnellen Veränderungen werden besonders vom Menschen hervorgerufen.

Eine Succession wird bisweilen mit einem z. B. von Waldbrand entblößten Standorte beginnen und, nach einer Reihe von Zwischengliedern, mit einer permanenten Formation (einer Climax-Formation), z. B. einem Walde, einem Callunetum, enden können.

Diese in der Natur stattfindende Entwickelung, von welcher im letzten Abschnitte viele Beispiele gegeben werden, ist in neuerer Zeit, nach dem Vorgange von Cowles und Clements in Nordamerika, vielfach in Amerika, England und anderswo studiert worden ${ }^{1}$ ).

Dachnowski urteilt: „Die Succession von Assoziationen ist eine Form von edaphischer Selektion, hervorgebracht durch das Eindringen gewisser Arten und Verdrängung von anderen." "Jede Assoziation, sagen Flahault und Schröter, ist Glied einer Succession, d. h. einer gesetzmäßigen Aufeinanderfolge von Vegetationen bei Besiedelung eines Standortes", und Cockayne schreibt: Die Assoziationen sind nicht unabhängige Bildungen, jede hat ihre Lebensgeschichte, ihre Jugend, ihre Kraftperiode, und ihr Ende. Dieselbe Climax-Formation kann von verschiedenen Ausgangspunkten erreicht werden, und kann das Resultat nicht von Progression sondern von Reversion sein.

Solche Beobachtungen sind auch die Grundlage für die Begriffsbestimmung der „Formation“, welche Moss, Tansley und andere englische Botaniker vorgeschlagen haben, was oben (S. 334) besprochen wurde.

Im folgenden ist eine Klassifikation der Pflanzenvereine nach den hier dargestellten Prinzipien versucht worden, wesentlich in Übereinstimmung mit der, welche Warming 1909 nach Besprechungen mit Vahl in der Ecology of plants gab. Innerhalb jeder Standorts-Klasse sind die Formationen, so weit möglich, wie schon oben gesagt, in einer Progression von den einfacheren zu den stetig mehr komplizierten und zusammengesetzten geordnet unter der hypothetischen Voraussetzung, daß die Successionen in der Natur oft demselben Wege folgen werden, daß die Reihenfolge daher oft zugleich eine genetische ist. In der Serie der ariden Gebiete ist die Ordnung jedoch abweichend, indem die reicheren und mehr zusammengesetzten Formationen den Anfang machen, und die extremsten Wüsten abschließen.

1) Die Successionen und hierher gehörende Fragen werden besonders besprochen von Clements, Cowles 1899, 1901, 1911 usw.; Chrysler 1905; Cockayne 1911; Cooper 1913; Crampton 1911, 1912; Dachnowski 1912; Drude 1913; Engler 1913; Moss 1907, 1910; Flahault 1900, 1905; Flahault und Schröter 1910; Fuller 1911; Gadeceau 1909; Gleason 1910; Rübel 1911-12; Schröter 1902, 1910; Tansley 1911; Warming 1895, 1909; Th. Fries 1913; Josias Braun 1913 u. a. 


\section{Vierter Abschnitt \\ I. Serie der Halophyten}

\section{Kap. Salzwasservereine und Salzbodenvegetation}

Von den im ersten Abschnitte besprochenen ökologischen Faktoren, welche den Standort bedingen, wurde das Wasser als der allerwichtigste bezeichnet. Das Wasser kommt vor teils als Bodenwasser (9. Kap.), teils bildet es an und für sich Standorte (20. Kap.). Das Wasser kann süß oder durch Kochsalzzusatz salzhaltig sein. Der Unterschied zwischen beiden Wässern ist so groß, daß die Pflanzenvereine in zwei große Gruppen geteilt werden müssen, je nachdem sie an salziges Wasser resp. an salzigen Boden gebunden sind, oder an süßem Wasser und auf Böden, welche von süßem Wasser durchtränkt werden, leben. Es kann noch bemerkt werden, daß es außer den obligaten Halophyten auch fakultative Salzpflanzen gibt. Die Halophyten-Vegetation wird zuerst besprochen.

Salziges und brackisches Wasser kommt an vielen Teilen der Erde vor, erstens in den großen Ozeanen mit ihren sehr verschieden beschaffenen Küsten (felsigen, sandigen, sumpfigen), zweitens in den vielen Salzseen im Innern der Kontinente, in den trockenen Gebieten. Weiter gibt es in der Nähe der Küsten eine Reihe von kleineren Standorten, die mit salzigem Wasser gefüllt sind, z. B. seichte Vertiefungen in den Meeresfelsen am Strande oder seichte Tümpel auf dem Sandstrande, die mehr oder weniger stark vom Regenwasser beeinflußt werden. Ferner sind die Lagunen zu erwähnen, die mehr oder weniger vom Meere getrennt sind, und deren Wasser mehr oder weniger brackisch ist. Noch sind die letzteren Standorte sehr wenig studiert ${ }^{1}$ ). Der Salzgehalt des Wassers ist sehr verschieden, in den Ozeanen gewöhnlich $3-3^{3 / 4} \%$, in der Nordsee z. B. $3,3 \%$, dagegen in der inneren Ostsee $1 \%$ bis $0,1 \%$. Im Toten Meer in Palästina kann man einen Salzgehalt von 20 und

1) Die Vegetation der Felsenvertiefungen an den Küsten Finnlands studierten Levander und Hayrén 1914, die der Färöer F. Börgesen 1905. 
mehr Prozent antreffen. Solche Konzentration scheint alles Pflanzenleben auszuschließen. Vergl. übrigens S. 148.

In den zunächst folgenden Kapiteln werden die Vereine erwähnt, für welche Salz und salziges Wasser maßgebend sind; es sind also überwiegend edaphische Vereine. Sie können in übersichtlicher Weise nach den anderen Eigentümlichkeiten des Standortes, welche in Kap. 20 besprochen wurden, geordnet werden. Diese Figentümlichkeiten bestehen namentlich darin, ob die Pflanzen untergetaucht sind oder aerophil und in welchem Grade, ob der Boden fest oder lose ist, die Gezeiten, Tiefe des Wassers, Bewegung des Wassers usw. Das Klima spielt dagegen für die Salzwasser-Formationen eine unbedeutende Rolle.

\section{Übersicht der an salziges Wasser oder salzigen Boden gebundenen Formationen}

A. Vereine von Wasserpflanzen, d. h. ganz untergetauchten oder frei schwimmend oder schwebend lebenden Pflanzen gebildete, in den Ozeanen ("marine" Vegetation) oder Salzseen im Binnenlande.

a) Frei schwebende oder frei schwimmende, also an keinen festen Boden gebundene Vereine (Plankton) (43. Kap.).

1. Formation des Salzwasserplankton (Halo-Mikroplankton).

2. Formation des Sapro-Plankton.

3. Formation der frei schwimmenden, größeren, untergetauchten Wasserpflanzen (Halo-Megaplankton).

b) Die Bodenvegetation (Benthos), d.h. auf dem Boden liegende oder befestigte, jedenfalls festsitzende, untergetauchte oder mit Schwimmblättern versehene Salzwasservereine (litorale und abyssale Halo-Benthos); wird nach der Natur des Bodens eingeteilt in:

* Die an steinigen oder doch festen Boden gebundenen (lithophilen) submersen Vereine.

4. Formation der Halonereiden (44. Kap.).

** Die untergetauchten, an losen Boden (Sand, Schlamm, Ton) gebundenen Vereine (45. Kap.).

5. Formation von saprophytischen Mikrophyten.

6. Formation von höheren autophyten Algen.

7. Formation der Seegräser (Enaliden).

B. Salzwasser-Sümpfe und ihre Vegetation. Der Boden naß oder wasserreich. Litorale Vereine, an Ufern mit oder ohne Gezeiten (Ästuarien) (Kap. 46).

1. Formation von Algen und Bakterien.

2. Formation von einjährigen Kräutern.

3. Formation der Stauden und Gräser. 
4. Formation der Halbsträucher.

5. Formation der echten Holzpflanzen (Sträucher und Bäume). Mangrovevegetation.

C. Die halophile Landvegetation kann nach dem Boden in lithophile, psammophile und pelophile ${ }^{1}$ ) eingeteilt werden, je nachdem sie an Felsen und Steine, oder an Sand, oder an Ton gebunden sind. Es kommen Vereine vor, die nur aus Kräutern bestehen, ferner solche mit Bäumen, reine Wälder. Flechten und Moose sind auf Salzboden sehr selten, aber es kommen doch einige ausgesprochen halophile Arten vor (Kap. 47).

Halophile Landvegetation findet sich teils an den Küsten der salzigen Gewässer (litoral) oberhalb der Gezeitenzone, teils im Binnenlande von den Meeren entfernt.

Es können wohl folgende Vereinsklassen nach den Standorten aufgestellt werden.

1. Felsenformationen (Kap. 48).

2. Formationen des Strandgerölls (Kap. 49).

3. Formationen auf feuchtem Sandboden in der Gezeitenzone. Formation der Sandalgen usw. (Kap. 50).

4. Formationen auf tonigem, feuchtem, oft periodisch überschwemmtem Boden. Formation der Strandwiesen u. ä. (Kap. 51).

5. Formationen auf trockenem Salzboden. Salzsteppen und Salzwüsten (Kap. 52).

Zwischen vielen von den hier aufgestellten Formationen wird sich in vielen Fällen eine genetische Reihenfolge nachweisen lassen, weshalb sie ganz natürlich eine Serie bilden. Allgemein sei hinzugefügt, daß von Eigentümlichkeiten, wodurch sich die festsitzenden Wasserpflanzen von denen des Planktons auszeichnen, die Entwicklung mechanischen Gewebes hervorgehoben werden muß, das je nach den Anforderungen entweder zug- oder biegungsfest ist. Die in stark strömendem Wasser entwickelten Pflanzen müssen zugfest sein.

Was die festsitzenden Wasserpflanzen betrifft, so ist $\mathrm{zu}$ betonen, daß auf jedem von höheren Pflanzen bewachsenen Boden, sowohl in Süß- als in Salzwasser, sich die Vegetation in Gürtel- und Höhenresp. Tiefenstufen verteilt; die Gründe hierfür sind in den einzelnen Fällen bei weitem nicht sicher nachgewiesen, müssen aber natürlich auf den Kap. 20 besprochenen ökologischen Faktoren (Licht, Wärme usw.) beruhen. Dieselbe gürtelförmige Anordnung findet sich auch bei den Sumpf- und Landpflanzen, welche vom Salzwassser abhängig sind ${ }^{2}$ ). Je weiter vom Meere oder von dem Salzsee entfernt, desto kleiner wird

1) Vergl. Kap. 13, 14.

2) Vergl. S. 355 . 
der Einfluß des Salzes, also im vorliegenden Falle des salzigen Grundwassers und des vom Winde herbeigeführten salzigen Staubes sein; die Pflanzen werden in Übereinstimmung hiermit gürtelförmig angeordnet sein und entsprechend mehr oder weniger vom Salze beeinflußt werden.

Da Halophyten und Xerophyten der Landvegetation vielfach übereinstimmen, so ist es nicht auffällig, daß die Lebensformen der einen Vegetation in die von der anderen Vegetation gebildeten Vereine eingemischt sein können. Man kann z. B. in Venezuela und auf den westindischen Inseln Arten der eigentlich nicht salzliebenden Cacteen und Bromeliaceen in der Strandvegetation zwischen Batis, Sesuvium und anderen echten Strandpflanzen beobachten. Nach Schimper kommen auf Java alpine Pflanzen an salzreichen, feuchten Stellen vor, und Battandier hat zwischen der Strand- und Hochgebirgsflora Algiers eine floristische Ähnlichkeit gefunden. Cochlearia anglica wächst auf den Gipfeln der Schottischen Gebirge und im Überschwemmungsgebiete der Fjorde.

\section{Kap. 43. Das Salzwasserplankton (Haloplankton)}

Der Ausdruck Plankton ist 1887 von Hensen eingeführt worden, um das passiv, durch Wind und Strömungen umbertreibende, in dem Wasser schwebende oder auf ihm schwimmende, sowohl Totes als Lebendes, sowohl Tiere als Pflanzen zu bezeichnen ${ }^{1}$ ).

Lohmann ${ }^{2}$ ) gab folgende Definition vom Plankton: „Das Plankton ist eine in sich geschlossene Lebensgemeinschaft, die das größte Lebensgebiet unserer Erde erfüllt und vermöge ihres Pflanzenreichtums die überragende Nahrungsquelle für das gesamte übrige Leben der Hydrosphäre darstellt, zugleich aber eine Welt von frei im Medium schwebenden Organismen bildet, wie sie nur der Hydrosphäre eigen ist und der Atmosphäre vollständig fehlt." Alle Planktonorganismen müssen dauernd im Wasser schweben können und ihre Körper sind alle in verschiedener Weise daran angepaßt (vergl. Kap. 20).

In diesem Zusammenhang ist natürlich nur die Rede von Phytoplankton und speziell dem mikrophytischen Haloplankton, das ist die im Salzwasser lebende Flora von sehr kleinen Pflanzen (Mikrophyten und Nanophyten). Sie sind niedrig stehende Organismen, die teils wie autophyte Pflanzen aus anorganischem Material organische Stoffe hervorbringen können, teils Saprophyten, die gewiß weit weniger zahlreichen unter ihnen und von ihren Abfallstoffen lebenden Bakterien, sowie einige Peridineen.

Wir unterscheiden zwischen Mikroplankton und Megaplankton.

1) Der dänische Naturforscher O. F. Müller war wohl der erste, der (1786) zuerst auf diese mikroskopische Welt aufmerksam machte, was das Süßwasser betrifft.

?) Lohmann 1912 . 


\section{Formation des Mikroplankton}

Diese Planktonorganismen gehören zu mehreren systematisch niedrig stehenden Gruppen, die namentlich folgende sind:

1. Blaugrüne Algen (Cyanophyceen), als "Wasserblüte" bekannt, wenn sie in Menge vorkommen und das Wasser bläulichgrün, spangrün, graugrün oder rot färben. In den offenen Meeren kommen hauptsächlich Trichodesmium-Arten vor, z. B. Tr. erythraeum (im "roten“ Meer [und in anderen Meeren meist in der Nähe der Küsten], färbt das Wasser rot). Im Brackwasser finden sich Nodularia spumigena (in der Ostsee gemein und in riesigen Mengen, färbt grünlichgrau, wenn tot), Aphanizomenon flos aquae (in der Ostsee), Anabaena baltica (desgl.). Sie sind echte Planktonorganismen, die bei ruhigem Wetter auf der Oberfläche schwimmen wie Rahm auf Milch, aber bei der geringsten Bewegung des Wassers unter der Oberfläche tauchen und dort sich schwebend halten können. Klebahn und Strodtmann haben gefunden, daß diese Arten kleine, unregelmäßige, mit Luft erfüllte Räume im Protoplasma der Zellen haben und daß diese Luftvakuolen ihre Steigfähigkeit verursachen. Nach Molisch und Fischer ${ }^{1}$ ) sind diese Körper nicht Luftvakuolen, und Fischer und Brand ${ }^{2}$ ) kamen zu dem Schlusse, daß sie nichts mit der Schwebefähigkeit zu tun haben.

2. Die Bakterien seien den Cyanophyceen angeschlossen. B. Fischer hat auf der deutschen Plankton-Expedition Bakterien im Ozeane nachgewiesen, selbst weit vom Lande weg und in 800 bis $1100 \mathrm{~m}$ Tiefe, von 200 bis $400 \mathrm{~m}$ Tiefe sogar in recht großer Anzahl. Dieselbe Art zeigt in Form und in Größe große Verschiedenheiten. Viele Bakterien sind selbstbeweglich und besonders schraubig gewunden; einige sind leuchtend.

Unter den Schizomyceten sind nitrifizierende und denitrifizierende Organismen in ihrer Wirkung auf die Veränderung der Zusammensetzung des Wassers von großer Wichtigkeit, je nachdem sie Ammoniak zu Salpetersäure oxydieren oder ob sie Abkömmlinge der letzteren zu Stickstoff reduzieren. Brandt ${ }^{3}$ ) hat danach die Theorie aufgestellt, daß die stärkere Tätigkeit der denitrifizierenden Bakterien in warmem Wasser die Ursache dafür ist, daß das Plankton hier ärmer als in kühleren Meeren ist. Nathansohn ${ }^{4}$ ) und andere bestreiten dies aber.

3. Chlorophyceen finden sich nur wenige im Meere. Die Protococcacee Halosphaera viridis, die die Gestalt einer Kugel besitzt, die

1) Molisch 1904; Fischer 1905. Vergl. anch Wille 1908.

2) Fischer und Brand 1905.

3) K. Brandt 1904.

4) Nathansohn 1908 
bis $0,5 \mathrm{~mm}$ Durchmesser aufweist, kommt gewöhnlich in den gemäßigten und wärmeren Teilen des Atlantischen Ozeans an der Oberfläche oder bis zu einer Tiefe von $200 \mathrm{~m}$ vor. In beträchtlichen Tiefen, nämlich in 100 bis $300 \mathrm{~m}$, hat man in den tropischen Ozeanen Halosphaera, einige besondere Formen von Diatomeen, sowie Planktoniella gefunden, die als eine besondere Form der Schattenflora gelten können.

4. Diatomeen (Fig. 179) bilden eine der wichtigsten Gruppen. Sie färben das Wasser bräunlich oder grünlich, besonders in den kälteren Meeren, wo sie in ungeheuren Mengen mit großem Reichtum an Individuen,
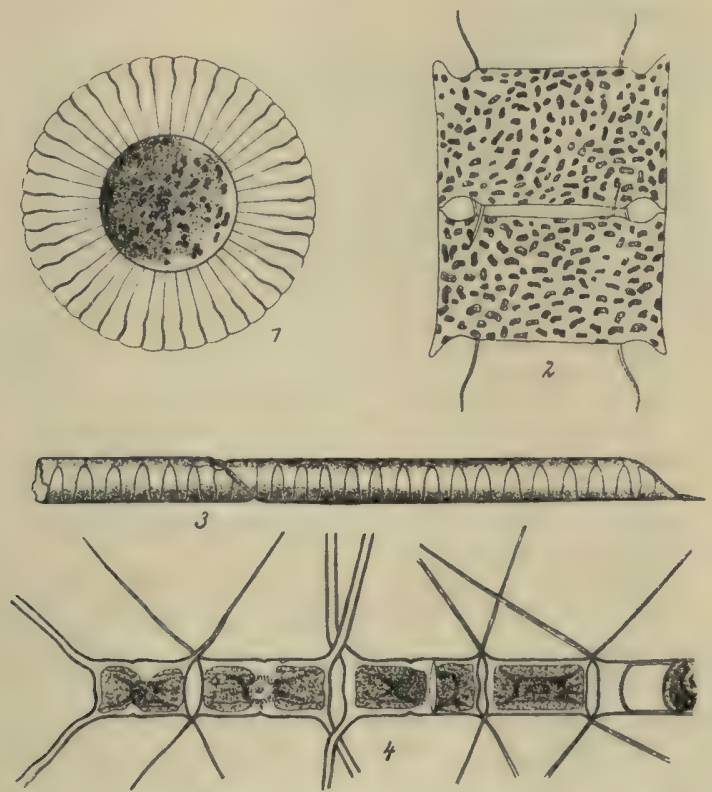

Fig. 179. Planktondiatomeen. 1. Plantionella sol. 2. Biddulphia Mobiliensis (2 Zellen). 3. Rhizosolenia styliformis (1 $1 / 2$ Zellen). 4. Chaetoceras paradoxum (41/2 Zellen). (1, 8, 4 nach Schütt, 2 nach Gran.)

aber mit wenigen Arten auftreten, besonders solchen der Gattungen Thalassiosira, Chactoceras, Rhizosolenia, Coscinodiscus, Thalassiothrix ${ }^{1}$ ) u.a. (über grünliches Wasser im nördlichen Atlantischen Ozean vergl. K. J. V. Steenstrup $)^{2}$ ). Einige leben einzeln, viele sind in Ketten von verschiedener Form vereinigt. Sie sind alle echte Planktonorganismen, die sich nicht auf der Wasseroberfläche schwimmend ansammeln können. Einige sind von Schleim umgeben. Die Diatomeen vermehren sich bekanntlich besonders durch schnelle Zweiteilung, es kommen aber auch verschiedenartige Formen der Sporenbildung vor.

1) Gran 1905.

\%) Steenstrup 1877 . 
5. Peridineen (Dinoflagellata) sind besonders im Salzwasser verbreitet. Man findet sie in größeren Mengen, aber in kleinerer Artenzahl in den gemäBigten Meeren; in den tropischen dagegen ist die Zahl der Individuen geringer, aber es sind zahlreichere und gut unterschiedene Arten vorhanden ${ }^{1}$ ). Die Gattungen Ceratium und Peridinium sind besonders häufig. Die zahl-reichen Formen (geographische Rassen)

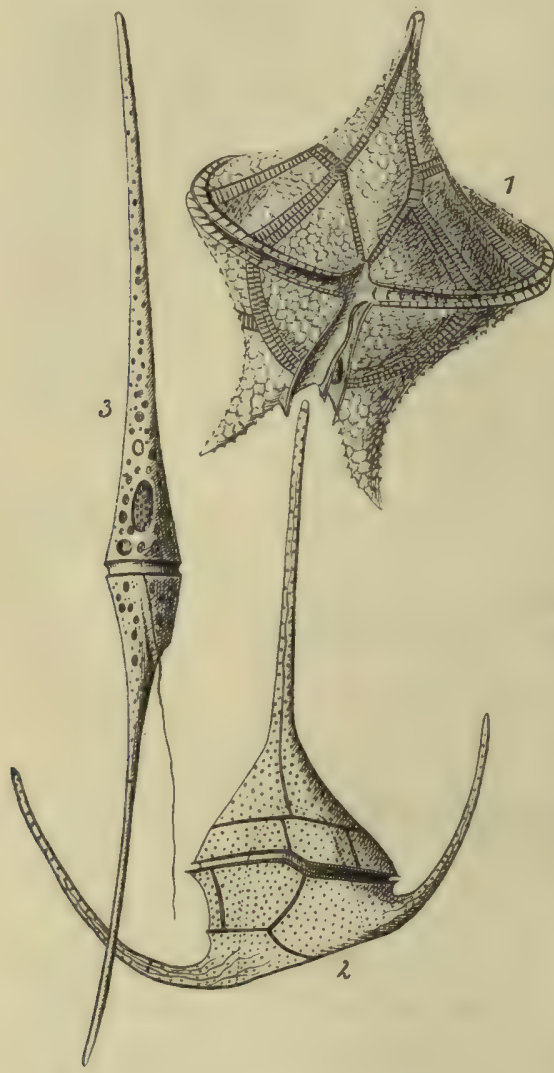

Fig. 180. Planktonperidineen.

1. Peridinium divergens. 2. Ceratium tripos. 3. Ceratium fusus. (Nach Stein.) von Ceratium tripos spielen im Meere die größte Rolle. Die Peridineen sind mit zwei Flagellen ausgerüstet und besitzen Eigenbewegung. Einige Arten sind leuchtend und verursachen im Herbste, wenn sie besonders zahlreich sind, im Mittelmeer, in der Nordsee, im Skagerrak, der westlichen Ostsee usw. das bekannte "Meeresleuchten" ${ }^{2}$ ).

6. Phytoflagellaten (Fig. 181) kommen in großer Menge im Meere vor. $\mathrm{Zu}$ ihnen gehören die Silicoflagellaten und Chrysomonadinen. Von den letzteren sind besonders die Coccolithophoridae wichtig, welche einen Hauptbestandteil des von Lohmann ${ }^{3}$ ) $\mathbf{u}$. a. studierten Nanoplankton ausmachen; zu ihnen gehören die allerkleinsten Planktonorganismen (ca. $1-20 \mu$ ), welche im allgemeinen nicht in den gewöhnlichen Netzen gefangen werden können. Sie sind von einer Schale von kleinen Kalkplatten, Coccolithen, umgeben, welche verschiedene Form haben können. Von den Coccolithophorideen sind in den temperierten Meeren besonders Pontosphaera Huxleyi und Coccolithophora pelagica wichtig; von der ersten können unter günstigen Umständen 5-6 Millionen Zellen in einem Liter Meerwasser vorkommen ${ }^{4}$ ). In den warmen Meeren leben große Mengen von Coccolithophorideen, welche überhaupt überall in den offenen Meeren und oft in großer Menge

1) Schütt 1893 .

2) Ove Paulsen 1904, 1908.

\%) Lohmann 1908, 1911, 1912.

4) Gran 1912. 
vorzukommen scheinen, während sie in der Nähe der Küsten und in den kalten Meeren von geringerer Bedeutung sind. Auch Phaeocystis und Dinobryon sind wichtige Chrysomonadinen; die erstere ist eine arktische Küstenform, deren Zellen viele in Gallerte eingebettet zusammenleben.

Als Pseudoplankton oder tychopelagisches resp. fycholimnetisches Plankton hat man Organismen unterschieden, welche zuerst an einem

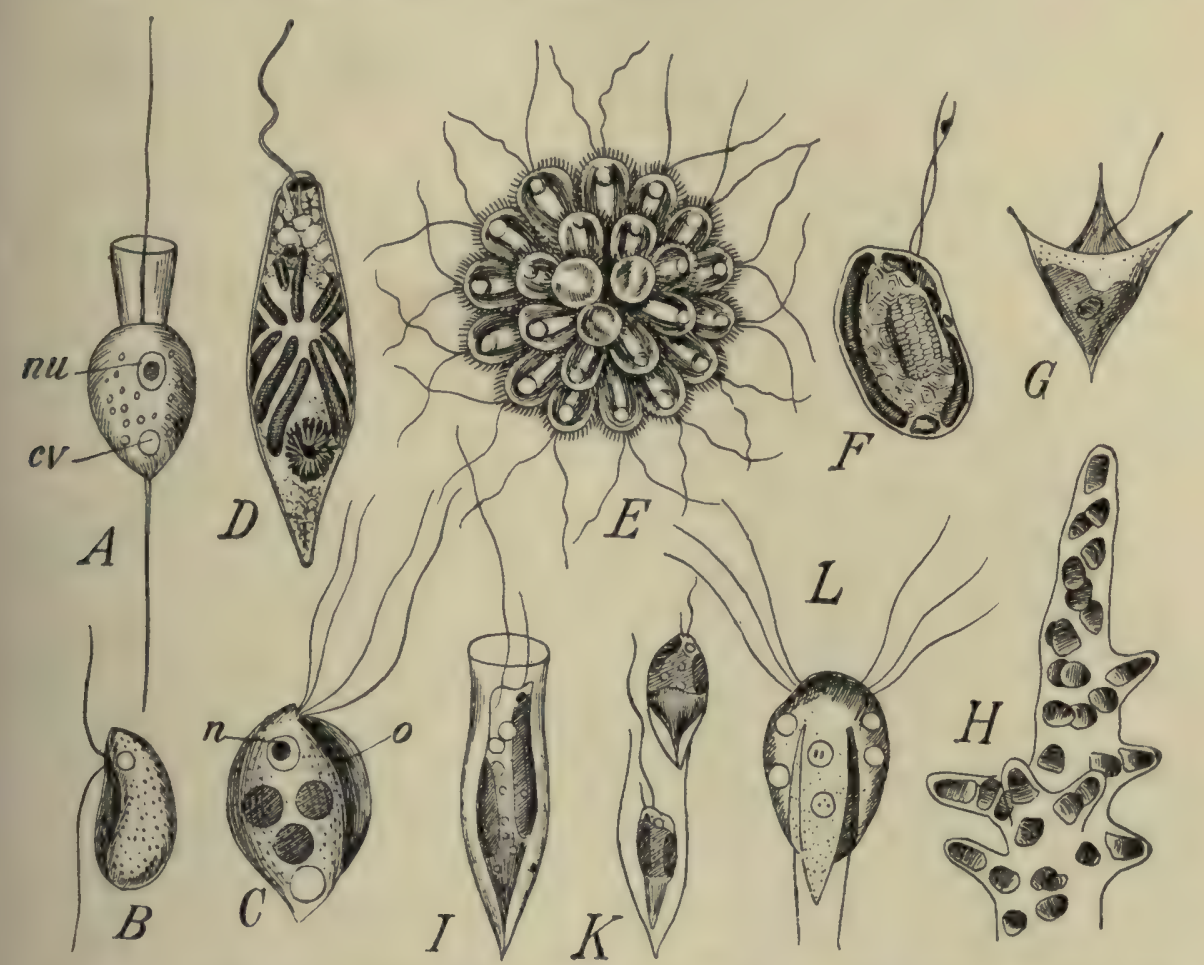

Fig. 181. Flagellaten. Sphaeroeca volvox, einzelne Zelle aus einer Kolonie (nach Lauterborn). B. Bodo edax (nach Klebs), C. Tetramitus sulcatus (nach Klebs). D. Euglaena viridis (nach Senn). E. Synura uvella, Kolonie (nach Stein). F. Cryptomonas erosa (nach Senn). G, H. Hydrurus foetidus: $G$ Schwärmzelle (nach Klebs); H Zweigende einer Kolonie (nach Berthold). $I, K$. Dinobryon sertularia: $I$ einzelne Zelle; $K$ nach der Teilung (nach Klebs). $L$. Hexamitus crassus (nach Klebs). $n$ und $n u$ Kern, $c v$ kontraktile Vakuole, o Mundstelle.

Substrat befestigt sind (Benthos-Organismen), nacher sich aber loslösen und auf der Oberfläche oder im Wasser schweben. So verhalten sich z. B. verschiedene Fadenalgen.

In den Flüssen und wohl auch an vielen Küsten werden feine Schlammteile, organische Detrituspartikeln, selbst feiner Sand im Wasser für eine Zeit schwebend gehalten werden können. Kolkwitz hat den Namen Seston für alles, was im Wasser schweben und durch fein- 
maschige Netze zurückgehalten werden kann, seien es leblose Teilchen wie die genannten oder lebende Plankton-Organismen.

Die Anpassung der Planktonorganismen an die Verhältnisse. Das Vermögen der Planktonorganismen, im Wasser schweben zu können, hängt von drei Faktoren $a b$; es sind dies: 1. Das spezifische Gewicht, d. h. der Unterschied zwischen dem Gewicht des Organismus und dem des Wassers, das durch ihn verdrängt wird; 2. die Form des Organismus; 3. die Viskosität des Wassers, d. h. die Kraft, mit welcher die Teile des Wassers zusammenhängen und Widerstand gegen das Sinken leisten.

Das spezifische Gewicht muß selbstverständlich ungefähr dem des Wassers und nach der Tiefe abgepaßt sein. Es wird natürlich vom Inhalte der Zellen beeinflußt (die Produkte des Stoffwechsels z. B. Fett und Gase, spielen eine Rolle, auch die Dicke der Zellwände: äußerst dünn); es muß bei Arten des Salz- und des Süßwassers verschieden sein. Planktondiatomeen sind saftreicher, aber dünnschaliger als Grunddiatomeen.

Die Fähigkeit zu schweben ist neuerdings durch Wolfgang Ostwald ${ }^{1}$ ) untersucht worden. Die Tatsache, daß die Pflanzen schweben, stellt den Hauptunterschied dar zwischen der Pflanzengemeinschaft des Plankton und allen übrigen Pflanzenvereinen. Das Schweben beruht im wesentlichen darauf, daß das Sinken im Wasser möglichst verlangsamt wird, so daß Strömungen meist einen Auftrieb bedeuten. Jeder Körper, der in einer Flüssigkeit sinkt, muß ein Quantum der betr. Flüssigkeit von gleichem Rauminhalt verdrängen. Die Schnelligkeit des Untersinkens hängt z. T. von der Größe seiner Oberfläche und von seiner Gestalt ab; je stärker durch beide, namentlich durch die bestimmte Form, die Reibung gegen das Wasser erhöht wird, desto langsamer sinkt der Körper. Z. T. wird das Sinken natürlich auch durch das spezifische Gewicht und die größere oder geringere Leichtflüssigkeit der Lösung gegeben. - Oswald schließt:

Der Grad des Sinkens =

$$
\begin{aligned}
& \text { Überschuß des Gewichts (des Organismus } \\
& \text { über ein gleiches Volumen Wasser) } \\
& \text { durch die Gestalt gegebener Widerstand } \\
& \times \text { gröBerer oder geringerer Leichtflüssigkeit. }
\end{aligned}
$$

Wenn daher ein Körper schweben kann, d. h. wenn die Geschwindigkeit des Untersinkens auf ein Minimum beschränkt ist, so muß der Zähler dieses Bruches möglichst klein, der Nenner aber ziemlich groß sein, so daß der Bruch selbst sich möglichst dem Nullpunkt nähert. Bei

3) Vergl. Wesenberg-Lund 1900 a, 1908 usw. 
den Planktonorganismen bemerkt man deshalb in erster Linie das Bestreben, den Gewichtsüberschuß über das Wasser zu verringern; das geschieht zunächst, wie schon oben bemerkt, durch den Zellinhalt (Fette und Gase spielen sicher eine Rolle) ebenso wie durch die Dünnheit der Zellwände. Natürlich ist der Bau entsprechend dem verschiedenen Auftriebe im Salz- und Süßwasser verschieden. Besonders mag bemerkt werden, daß fette Öle den Auftrieb stark befördern und daß sich solche z. B. bei Planktondiatomeen finden; daher spielen sie wohl auch solche allgemeine und bedeutende Rolle im Plankton ${ }^{1}$ ). Auch andere Planktonorganismen, wie Flagellaten, erzeugen Fett.

Einige Planktonorganismen sind selbstbeweglich, z. B. Peridineen und andere Flagellaten. Andere sind nicht selbstheweglich. Die meisten sowohl von den selbstbeweglichen wie von den nicht selbstheweglichen Planktonwesen haben Schwebeeinrichtungen verschiedener Art.

Schwebeeinrichtungen. Der durch die äußere Form gegebene Widerstand gegen schnelles Sinken wird im wesentlichen bedingt durch eine Vergrößerung der Oberfläche im Verhältnis zur Masse, d. h. also eine möglichst starke Abweichung von der kompakten Kugelform. Die Schwebeeinrichtungen sind naturgemäß, um den Wasserwiderstand beim Sinken zu erhöhen, möglichst horizontal angebracht, also im rechten Winkel zur Richtung des Untersinkens. Schütt ${ }^{2}$ ) hat mehrere Verhältnisse nachgewiesen, die dazu dienen, um die Oberfläche der mikroskopischen Organismen des Planktons größer zu machen, wodurch die Schwebfähigkeit wächst wie auch die Fähigkeit, einem zu plötzlichen Steigen oder Sinken zu entgehen. Solche plötzlichen Bewegungen können durch Änderungen des physikalischen Charakters des Seewassers veranlaßt werden und können das Leben der Organismen gefährden. Die Körper der Planktonorganismen sind fast alle (besonders die der Diatomeen und Peridineen) außerordentlich ausgedehnt; bei einigren ist die ()berfläche durch lange Fäden, Borsten und Stacheln (Diatomeen, Peridineen) vergrößert, oder der Körper selbst ist inı ganzen fadenförmig, hisweilen gekrümmt oder schraubig gewunden (Diatomeen); andere sind münzen- oder fallschirmförmig oder haben segel- oder ringförmige Verlängerungen; wieder andere sind zu Ketten oder in gelatinösen Massen usw. vereinigt. Einige Coccolithophoriden baben Strahlen oder Bürsten oder besondere "Schwebebecher" auf ihren Schalen, Verhältnisse, die unverständlich bleiben, wenn sie nicht gerade die angeführte Aufgabe haben (in gewissen Fällen sind z. B. die Stacheln vielleicht zugleich ein sichutz gegen Feinde). Nach Kofoid ${ }^{3}$ ) können einige Ceratium-Arten

1) Beijerinck 1895 .

2) Schütt 1893.

3) Kofoid 1908. 
ihre Hörner abschnüren und regenerieren, was er als Anpassungen an veränderte Umgebungen betrachtet.

Dieses wird durch den Unterschied zwischen den Planktondiatomeen und den Grunddiatomeen bestärkt. Diese sitzen fest oder kriechen umher, haben auf den Schälen Nähte, wodurch das Protoplasma austritt, so $d a ß$ sie sich bewegen, die günstigste Beleuchtung aufsuchen und sich festhalten können. Die Mehrzahl der Planktondiatomeen hat keine Nähte. Die Grunddiatomeen haben die erwähnten Körperverlängerungen usw. nicht.

Die Menge des Planktons. Die starke Teilungsfähigkeit der Planktonorganismen ist der Grund für ihre oft ungeheure Vermehrung und Menge. Eine Vermehrungsbeteiligung von über $50 \%$ ist bei Ceratium konstatiert ${ }^{1}$ ), und unter günstigen Bedingungen sind $25-35 \%$ normale Zahlen. Die Menge ist jedoch nach Zeit und Ort sehr verschieden. Wenn sie in großer Menge vorhanden sind, färben sie die Gewässer: „Das reine Blau ist die Wüstenfarbe der Hochsee. Dem Grün der Wiesen vergleichbar ist die Vegetationsfarbe der arktischen Fluten; doch die Farbe üppigster Vegetation, des größten pflanzlichen Reichtums, ist das schmutzig grünliche Gelb der seichten Ostsee" (Schütt). Hensen hat Methoden erfunden und angewandt, um die Quantität des Planktons zu berechnen. Seine Methoden sind verbessert nnd erweitert worden durch Lohmann ${ }^{2}$ ) und nach ihm Gran ${ }^{3}$ ), die Methoden angewandt haben, durch welche man ein vollständiges Bild von der Zusammensetzung und Menge des Planktons erhalten kann. So teilt Lohmann mit, daß in der Ostsee, in dem offenen nördlichen Meere, von der Küste beeinflußt, und in der tropischen Hochsee sich die Dichtigkeit der Individuen in den oberen $15 \mathrm{~m}$ wie $500: 10: 1$ verhalte (Sommer 1911). Alle Gruppen von Planktonorganismen traten, soweit sie überhaupt in kühlen Gebieten vorkamen, stets zahlreicher auf als in den Tropen; es mußten daher ganz allgemein die Existenzbedingungungen im kalten Wasser günstiger sein als im warmen. Die Absicht solcher Untersuchungen ist $u$. a. die Menge organischer Sub$\operatorname{stanz} z u$ bestimmen, die in einer gewissen Zeit an einem Orte erzeugt wird. Diese Bestimmung ist von höchster Wichtigkeit, weil alle Lebewesen des Meeres, gleichgültig ob hoch oder niedrig organisiert, in ihrer Existenz abhängig sind von den zum Pflanzenreiche gehörigen Planktonorganismen, die Kohlehydrate erzeugen können: Plankton ist die letzte Nahrungsquelle. Die Erzeugung von Fett, wie wir sie bei den Diatomeen, Peridineen usw. beobachteten, unterstützt

1) Gough 1905 .

2) Lohmann 1908 .

3) Gran 1912. 
vielleicht die großen Ansammlungen dieses Stoffes bei den Meerestieren, wie z. B. bei den Heringen, Möwen, Walen und bei allem tierischen Plankton. Es ist nicht ohne Interesse, noch besonders hervorzuheben, daß das Hauptassimilationsprodukt nicht wie bei den Landpflanzen Stärke ist, die spezifisch schwerer ist als Wasser, sondern eben Öl.

Der dänische Botaniker A. S. Oersted war der erste, der die Wichtigkeit der mikroskopischen Pflanzenwelt des Meeres als letzte Nahrungsquelle für die Tiere würdigte. Auf seiner zentralamerikanischen Reise $1845-48 \mathrm{kam}$ er zu diesem Schluß ${ }^{1}$ ).

Zeitliche Verschiedenheiten. Die Menge des Planktons ist zu verschiedenen Jahreszeiten nach Zusammensetzung und Menge verschieden, ganz wie die Landvegetation, weil die Entwickelung der einzelnen Arten hier wie dort von der Temperatur, Beleuchtung und von den Nahrungsstoffen des Wassers abhängig ist.

Es gilt für viele, wahrscheinlich für alle Arten, daß sie zu gewissen Jahreszeiten in der Oberflächenschicht zum Vorscheine kommen, ein Maximum der Menge erreichen und verschwinden (Meroplankton), um anderen Platz zu machen (Holoplankton werden diejenigen genannt, welche immer im Plankton vorhanden sind).

In den nordischen und temperierten Meeren gibt es hauptsächlich zwei Maxima, nämlich eins im Frühjahr und eins im Herbste, während der Sommer und Winter ärmer sind. Jedenfalls gilt dieses für viele Diatomeenarten. Im Skagerrak - Kattegat z. B. kommt im Februar und März ein reiches Diatomeenplankton zum Vorschein, das aus Arten zusammengesetzt ist, welche später (April und Mai) an den Küsten Islands und Grönlands auftauchen. Im April und Mai taucht am ersteren Orte eine andersgeartete reiche Diatomeenflora auf, die etwas höhere Wärme bedarf. Im Juni und Juli trifft man ein weniger reiches und viel einförmigeres Diatomeenplankton (mit Rhizosolenia alata). Vom August bis November, in der wärmsten Jahreszeit ist ein reichliches Plankton von Peridineen zu finden, oft gemischt mit Diatomeen, im ganzen artenreich. Ein ganz ähnliches Plankton findet sich an der Südküste der Nordsee. Endlich im Dezember und Januar ist das Plankton ärmer und zusammengesetzt aus den Arten früherer Monate ${ }^{2}$ ).

Eine Erklärung für diese Veränderungen, spez. für die geringe Menge in den Sommermonaten ist noch nicht sicher gegeben. Brandt meint, sie ständen damit in Verbindung, daß die denitrifizierenden Bakterien in den wärmeren Monaten eine Stickstoffverminderung herbeiführen und dadurch eine Verminderung der Nahrung und Zahl der Individuen. Nathansohn sucht die Erklärung in aufsteigenden Wasser-

1) Siehe Wille $1904 \mathrm{~b}$.

$\Rightarrow$ Cleve: Ostenfeld 1913.

Warming-Graebner. 3. Auflage, illustr. 
strömungen, welche größere Nährstoffmengen herbeiführen; er meint aber, daß auch verschiedene andere Faktoren wirksam sind. Die geringe Menge im Winter ist selbstverständlich von dem geringen Lichte während dieser Zeit abhängig; die Lichtmenge an der Oberfläche ist z. B. bei Kiel ${ }^{1}$ ) im Sommer 40 mal so groß als im Winter.

Die meisten Forscher stellen fest, daß die Küstenformen zum größten Teil am Schlusse ihrer lebhaften Vegetationsperiode reichlich Sporen bilden, die untersinken und bis zum Wiederbeginne der günstigen Jahreszeit auf dem Grunde ruhen.

Die Beschaffenheit des Planktons. Man kann zwischen gleich- und ungleichartigem Plankton unterscheiden. Bisweilen ist es außerordentlich reich an Arten, bisweilen, namentlich wenn die Menge so groß ist, daß das Wasser gefärbt wird, sehr artenarm (Diatomeengebiete in arktischen Meeren). Es sind besonders Diatomeen, Peridineen und Schizophyceen, die das Wasser färben.

Das Plankton bevölkert die ganze freie Wassersmasse bis zu einer gewissen Tiefe, welche verschieden ist. Wahrscheinlich spielt die Lichtstärke dabei eine wesentliche Rolle. Das Wasser der Ozeane ist weit durchsichtiger als z. B. das Wasser in den seichten nordeuropäischen Meeren, und die Lichtstärke hängt natürlich auch von der Jahreszeit ab.

In nördlichen Meeren liegt die Tiefengrenze für das Phytoplankton ungefähr bei $100 \mathrm{~m}$ oder höher. In den Weltmeeren findet sich nach Karsten die Hauptmasse des Planktons in den oberen 150 (200) m, während sich tiefer, bis ca. $400 \mathrm{~m}$, nur eine arme "Schattenflora“ findet. Nach Ostenfeld kommt im allgemeinen die größte Masse der Individuen und Arten in den obersten $100-150 \mathrm{~m}$ vor, in dem Küstenplankton noch mehr oberflächlich.

Die Pflanzengeographie des Meeres ist nur teilweise bekannt. Im großen und ganzen scheinen die Diatomeen in den kalten, die Cyanophyceen in den tropischen, die Peridineen, Coccolithophorideen u. a. in den warmen und temperierten Meeren am zahlreichsten zu sein. Die Arten haben als Wasserpflanzen eine sehr weite Verbreitung, weil die äußeren Verhältnisse über ungeheure Strecken gleichartig sind und mit den Meeresströmungen werden sie weit herumgeführt. So wird eine Menge von Warmwasser-Planktonorganismen längs der Westküste Europas nordwärts geführt, und geht schließlich zugrunde, auf dieselbe Weise werden eine Menge „kalter" Arten längs der Ostküste Nordamerikas șüdwärts geführt. Obg]eich so weit wandernd, haben die meisten Arten doch eine gewisse Ortsansässigkeit, d. h. es gibt gewisse Meeresgebiete, wo sie immer oder periodisch hervorgebracht werden, und nach diesen

1) Pütter 1909. 
Gebieten kann man unterscheiden einerseits ozeanische und neritische, andererseits arktische, temperierte und tropische Arten usw. (Cleve).

Auf diese Weise lassen sich verschiedene Plankton-Elemente unterscheiden ${ }^{1}$ ), z. B. in dem norwegischen Nordmeere sechs verschiedene, nämlich: arktisch-neritisch, boreal-neritisch, temperiert atlantisch-neritisch, arktisch-ozeanisch, boreal-ozeanisch, temperiert-atlantisch-ozeanisch, jedes Gebiet mit seinen Charakterformen.

In den letzten Jahren haben einige Forscher ${ }^{2}$ ) versucht, eine Einteilung des pflanzlichen Planktons in Assoziationen zu geben, die durch verschiedene Temperaturen und verschiedenen Salzgehalt des Wassers bedingt sind; aber ihre Ökologie ist noch wenig bekannt. Cleve hat denselben je nach den herrschenden Gattungen und Arten Namen gegeben, wie: Tricho-Plankton (nach Thalassiothrix), Styli-Plankton (nach Rhizosolenia styliformis), Chaeto-Plankton (nach Chaetoceras), SiraPlankton (nach Thalassiosira), Tripos-Plankton (nach Ceratium tripos) ${ }^{3}$ ).

Die Verbreitung der Arten in den nordischen Gewässern ist durch die internationalen Meeresuntersuchungen (Conseil permanent pour l'exploration de la mer, Résumé planktonique, 1910-1914) gut bekannt geworden.

Die Grenzen zwischen den Gebieten des Meeres, welche dasselbe Plankton haben, sind teils natürliche geographische, z. B. die Ostsee, das Kattegat, das Schwarze Meer, welche ein ganz anderes Plankton haben als die Meere, mit welchen sie in Verbindung stehen. Teils können die Verbreitungsgrenzen von den Meeresströmungen sowie von den Änderungen des Salzgehalts und der Temperatur abhängig sein, indem die verschiedenen Rotationssysteme (Stromwirbel) verschiedenes Plankton haben, z. B. der Irmingerstrom, das nördliche Atlantische Meer, das norwegische Nordmeer, die Nordsee (Gran, Ostenfeld, O. Paulsen)4).

Die nordischen Meere sind viel reicher an Plankton als die wärmeren, offenen Ozeane, welche im allgeneinen arm an Individuen, aber reich an Arten sind.

Das Salzwasser-Plankton pflegt man in folgende Floren einzuteilen:

1. Das Küstenplankton (neritisches P.) und

2. Das Hochseeplankton (ozeanisches P.).

Küstenplankton ist an die Küsten gebunden; in den Tropen besteht es aus Diatomeen, Cyanophyceen und Peridineen, ist aber noch

1) Gran 1902.

2) Cleve 1897, 1901; Gran 1900, 1902; Ostenfeld 1898-1900.

3) Neuere Litteratur siehe namentlich C. Hansen Ostenfeld 1909, 1913; H. Lohmann 1912 a, b, c; Pavillard 1905.

c) Paulsen 1909. 
nicht gut bekannt. In den gemäßigten Zonen sind in der kalten Jahreszeit die Assoziationen identisch mit denen, die während des Sommers in der arktischen Region leben, nur in der warmen Zeit sind sie verschieden. Diatomaceae herrschen in den gemäßigten Zonen außer im Spätsommer und Herbst, wo das Wasser mit einer Temperatur von etwa $20^{\circ} \mathrm{C}$. am wärmsten ist. In dieser Zeit sind Peridineen oder, in brackischem Wasser, Cyanophyceae (Nodularia) und andere die charakteristischen Arten. Vom arktischen Küstenplankton ist bekannt, daß während des Frühlings zahlreiche Diatomeen an der Unterseite des Eises leben ${ }^{1}$, $\mathrm{da} B$ aber, wenn das Eis verschwindet, pelagische Diatomeen und gelbe Flagellaten herrschen.

Das Küstenplankton ist oft sehr reich an Individuen. Nathansohn meint, daß dies eine Wirkung der vertikalen Meeresströmungen ist, welche Nahrungsstoffe von der Tiefe des Meeres emportreiben. Durch den ständigen Verbrauch von Nahrung an der Oberfläche und durch Niedersinken von toten Organismen wird das Oberflächenwasser nahrungsarm; er meint nachweisen zu können, daß dort, wo vertikale Strömungen vorkommen, wo also Wasser, in welchem lange kein Plankton gelebt hat, zur Oberfläche kommt, Planktonmaxima entstehen, selbst wenn es nicht an der Küste ist ${ }^{2}$ ).

Hochseeplankton, d. h. das Plankton des offenen Meeres, besteht aus Peridineen und Coccolithophorideen, aber auch Cyanophyceen, Diatomeen in verhältnismäßig wenigen Arten, und Halosphaera finden sich. Es enthält in den Tropen Trichodesmium, eine große Zahl von Arten der Peridineen und Coccolithophoriden, in gemäßigten und kalten Meeren Peridineen und Diatomeen.

Die meisten Arten, die zum Küstenplankton gehören, verbringen nur einen Teil ihres Lebens pelagisch, während der übrigen Zeit liegen sie, glaubt man, als Sporen usw. auf dem Boden; Hochseeplankton dagegen lebt stets freischwebend im Wasser; Dauersporen sind bei ihm unbekannt. Einige Arten, z. B. Rhizosolenia styliformis, erzeugen Mikrosporen, wie sie indessen auch bei Küstenformen bekannt sind ${ }^{3}$ ).

Die. Tiefe, bis zu der das pflanzliche Plankton in der See herabgeht, ändert sich je nach der größeren und geringeren Durchsichtigkeit des Wassers usw. (vergl. S. 144) ${ }^{4}$ ).

1) Vanhöffen 1897.

2) Nathansohn 1906, 1908.

s) Gran 1902; G. Karsten 1905-7; P. Bergon 1907. II, 123 .

4) Utbersicht über neuere Plankton-Untersuchungen vergl. Journ. of Ecology. 


\section{Formation des Halo-Saproplankton}

Es scheint wahrscheinlich, daß es ein Plankton gibt, welches in ruhigen Stellen im Innern von Buchten, in Lagunen, in salzigen und brackischen Wassertümpeln zu finden ist, und welches gleich dem in nahrungsreichen, besonders stickstoffreichen süßen Gewässern lebenden, überwiegend aus saprophytischen Kleinwesen besteht. Hierüber scheint indessen noch sehr wenig bekannt zu sein, das meiste dreht sich um die Vereine von roten Bakterien, die an vielen Küsten, jedenfalls nordeuropäischen, vorkommen, worüber Warming $u$. a. publiziert haben ${ }^{1}$ ). Bemerkt kann ferner werden, daß das gewöhnliche Phytoplankton der Meere außer Bakterien auch verschiedene andere saprophytische Formen enthält, z. B. einige farblose Peridineen.

\section{Formation des Halo-Megaplankton (die Sargassumassoziation)}

Seit Columbus wissen wir, daß es ein großes Gebiet im Atlantischen Ozean zwischen etwa $22-35^{\circ}$ nördl. Br. und $40-75^{\circ}$ westl. L. ${ }^{2}$ ) gibt, wo große Massen von schwimmenden Algen vorkommen, zu denen wenigstens zwei Arten von Sargassum gehören: S. natans (S. bacciferum), welche die häufigste ist, und Sargassum fuitans ${ }^{3}$ ). Sie kommen gemischt vor. Diese Algen sind gelbbraun bis olivengrün und liegen gewöhnlich in langen Streifen parallel dem Winde. Sie sind immer steril. Einige Botaniker haben gemeint, daß sie alle losgerissene Stücke seien von Pflanzen, welche an den Küsten des tropischen Amerikas festsitzen und von dort durch die Meeresströmungen in die Hochsee hinausgetrieben werden, hier eine Zeitlang herumtreiben und dann nach kurzer Zeit zugrunde gehen. Nach anderen Forschern und nach der neueren Behandlung der Frage ${ }^{4}$ ) setzen die Algen hier indessen ihr Wachstum fort und vermehren sich durch Freiwerden der Seitensprossen, indem sie von hinten absterben. Sie sind hier also echt pelagische Oberflächenalgen (Makroplankton). Von welcher Spezies das Sargassum natans (S. 273, Fig. 141) abstammt, ist vorläufig unsicher, und ob die Arten an Amerikas Küsten festsitzen, ist auch unbekannt. Bekannt ist, daß eine ganz eigentümliche Tierwelt diesen schwimmenden Algenmassen vergesellschaftet ist.

Ein analoges Vorkommen in der Ostsee ist das Auftreten von losen, auf dem Boden freiliegenden, abnorm ausgebildeten Exemplaren von Ascophyllum nodosum, das auch im nördlichen Atlantischen Ozean als

2) Warming 1875 ; verg!. übrigens $K a p .46$.

2) Nach Krümmel. Winge (Botan. Tidsskr. 33, 1913) setzt die Grenzen ctwas anders.

3) Börgesen 1909, mit Hinzufügung 1914.

4) Sauvageau 1907, Winge (1913) und F. Börgesen (1914), wo weitere Litteratur. 
Schwebealge vorkommt. Im Indischen und Stillen Ozean kommen einzelne treibende Pflanzen oder unbedeutende Anhäufungen vor, aber so große Ansammlungen wie im Atlantischen Ozean sind nicht bekannt (Reinbold).

\section{Kap. Halonereïden (steinliebende Hydrophyten des Salzwassers)}

Die Halonereïden bilden eine untergetauchte, an Felsen, lose Steine, Schneckenschalen u. ähnl. feste und harte Unterlagen an den Küsten gebundene Vegetation. Viele der Arten, die sich auf dieser Unterlage finden, wachsen auch epiphytisch, z. B. auch an Pfählen im Wasser. Die Salzwasservereine werden nur von Algen gebildet, die hier ihre höchste und reichste Entwicklung erreichen, in vier Farben (blaugrün, rein grün, braun und rot) und mit einem außerordentlichen Formenreichtum auftreten.

Die chemische Natur des Bodens spielt eine gewisse Rolle, soweit man weiß nur eine geringe, und es handelt sich gewiß nur um das Vorkommen von Kalk; einzelne Algen gedeihen nur in Kalk, den sie mit hyphenähnlichen Fäden durchbohren, oder worauf sie Erosionsfurchen bilden ${ }^{1}$ ); die meisten anderen wachsen gleich gut auf Steinen wie z. B. auf Pfählen, Tierschalen oder auf anderen Algen. Nach Wille sind die Tierschalen durch besondere Assoziationen ausgezeichnet, z. B. Tilopteridaceae. Klimatische Einflüsse sind ökologisch von geringer Bedeutung.

Anpassungen zeigen sich namentlich in folgendem:

Die Festigkeit des Bodens macht Haftorgane (Hapteren, Hafthaare, „crampons" französischer Autoren) notwendig, die bei den Algen bisweilen "Wurzeln" genannt werden. Sie treten wesentlich in zwei Typen auf: als kreisrunde Scheiben (z. B. bei Fucus vesiculosus, Laminaria-Arten; Fig. 183), oder sie sind finger-bis fast korallenförmig verzweigt (Laminaria saccharina u. a. A.; Agarum Turneri; Fig. 182); diese letzteren bestehen bisweilen nur aus einzelnen Zellen oder Rhizoiden. Die Anpassungsmittel zum Festhalten hat namentlich Wille ${ }^{2}$ ) behandelt.

Anatomisch betrachtet haben die Haftorgane in einigen Fällen den Bau von Wurzelhaaren, in anderen Fällen sind sie solide, vielzellige Körper. Die festeste Anheftung haben krustenartige Algen, wie Lithothamnium, Lithophyllum, Hildenbrandia, Lithoderma u. a., die den

1) Chodat 1902; Huber 1906; Lagerheim 1892; Cohn 1893; Nadson 1900; M. le Roux 1907; P. Boysen-Jensen 1909.

3) Wille 1885; Warming 1881 (Podostemaceen). Siehe auch Fig. 138. 
Stein in Krusten überziehen. Eine besondere Stellung nehmen Diatomeen und Desnidiaceen ein, die mit Schleim auf anderen Körpern sitzen. Ebenso die kalkbohrenden Algen ${ }^{1}$ ). Kriechende (wandernde) Steinalgen sind selten, finden sich aber unter den Florideen und bei Caulerpa-Arten.

Intercellular-Räume fehlen ganz oder sind jedenfalls sehr klein und kaum lufthaltig (Ausnahmen sind die Schwimmapparate gewisser in

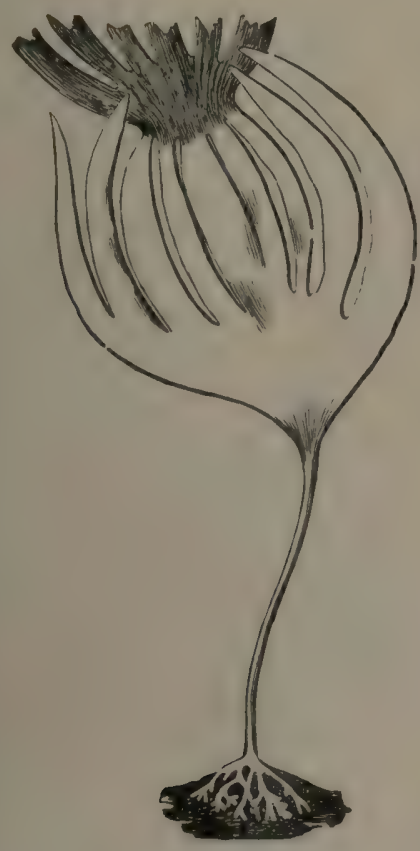

Fig. 182. Laminaria digitata, sehr verkleinert (nach Farlow).

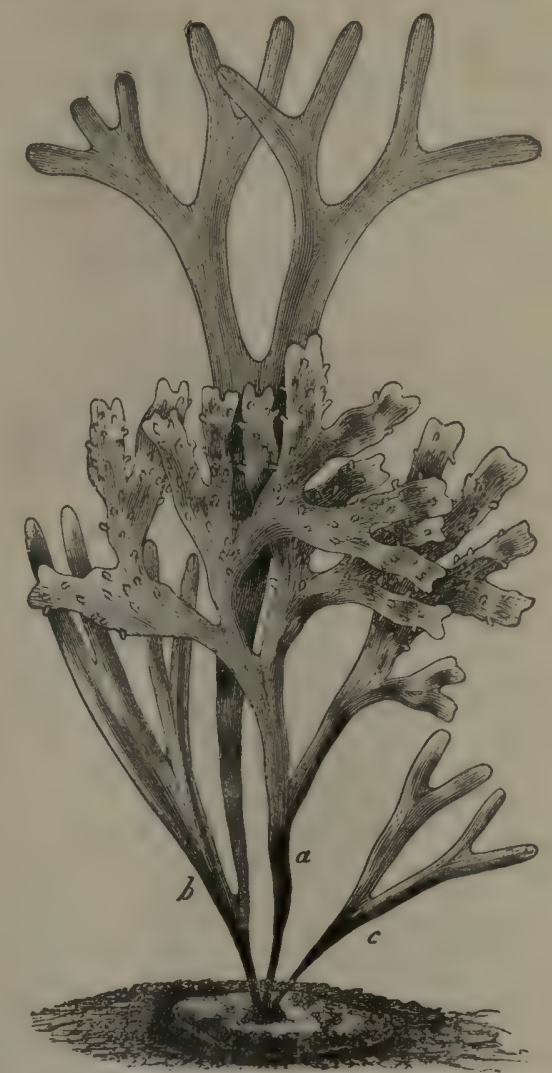

Fig. 183. Die Rotalge (Rhodophycee) Gigartina mamillosa in natürlicher Größe. a fruktifizierend (nach Luerssen).

der litoralen Region oder in niedrigem Wasser lebenden Algen, z. B. von Fucus vesiculosus, Halidrys siliquosus, Ascophyllum nodosum, Sargassum, Cystoseira, Scytosiphon lomentaria). Durch dieses Merkmal tritt die lithophile Vegetation in scharfen Gegensatz zu jeder anderen Wasservegetation. Der Grund ist vermutlich der, daß alle Pflanzen

1) Bornet und Flahault 1889 . 
jener Vegetation in bewegtem Wasser leben, wo ihnen reichlich Luft zugeführt wird.

Für die vielen lithophilen Algen, welche in stark bewegtem Wasser, in der Brandung an der Felsenküste leben, ist es notwendig, daß sie Widerstand gegen Zerreißung leisten können. Zugfeste Konstruktionen entstehen durch mechanisches Gewebe, meist durch kollenchymatisches, auf verschiedene Weise ${ }^{1}$ ).

Ausscheidung von kohlensaurem Kalk in den Zellwänden kommt bei einem Teile der Algen vor. Sie spielt jedenfalls bei einigen eine mechanische Rolle und scheint in anderen Fällen zur Verlängerung des Lebens zu dienen; gewisse inkrustierte Algen sind mehrjährig, während ihre nicht inkrustierten Verwandten einjährig sind (Wille).

Starke Schleimbildung findet sich bei vielen Arten, besonders solchen, die in der litoralen Region wachsen, und dient vielleicht als Schutz gegen Verdunstung während der Ebbe, und wird unzweifelhaft auch den starken Anprall der Brandung, die die Pflanzen gegeneinander und gegen die Felsen schleudert, vermindern.

Weiter sind als Anpassungen zum Leben im Wasser zu erwähnen: Der Mangel an Spaltöffnungen, der verholzten Elemente und der Gefäße, die Bildung von assimilierenden Chromatophoren in der äußersten Zellschicht usw. sind allgemeine, auch hier vorkommende Hydrophytenmerkmale. Das Assimilationsgewebe reicht bis zur Oberfläche; viele Algen haben überdies (nach Wille) ein inneres Assimilationsgewebe, das die durch Atmung in den inneren Geweben gebildete Kohlensäure verarbeitet.

Die Pflanzenformen der steinliebenden Meeresalgen sind überaus verschieden und können bei weitem nicht alle mit den Umgebungen in Anpassungseinklang gebracht werden ${ }^{2}$ ). Ein ökologisches Verständnis ist wohl in sehr wenigen Fällen und nur teilweise erreicht worden. Es gibt einerseits krustenförmige, die für den Aufenthalt in stark bewegtem Wasser besonders geeignet sind; aber viele krustenförmige Algen wachsen, wie angeführt, in tiefem und daher wenig bewegtem Wasser. Es gibt Arten, die den Kiemen analog gebaut, d. h. in haarfeine Zipfel aufgelöst sind, wodurch die Oberfläche viel größer und die Assimilationstätigkeit gesteigert wird; es gibt Arten mit fadenförmigen, unverzweigten Körpern, die sich in dem Wasser wellenförmig bewegen, z. B. Chorda filum; ferner Arten mit blattförmigen Körpern, z. B. Laminaria, Ulva, Monostroma, und namentlich viele Florideen, z. B. Delesseria ${ }^{3}$ ). Vergl. Fig. 182-187, 188.

1) Wille 1885 .

2) Oltmanns 1905.

$\left.{ }^{3}\right)$ Vergleiche hierüber die speziellen algologischen Werke und Engler und Prantl, Die natürlichen Pflanzenfamilien Bd. 1, Abt. 2. Auch z. B. Reinke. 


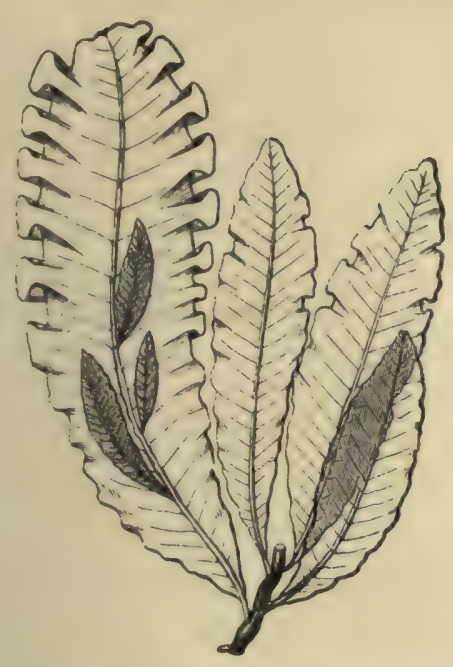

Fig. 184. Delesseria sanguinea; etwa $1 / 8$ der natürlichen Größe. (Nach Warming-Möbius.)

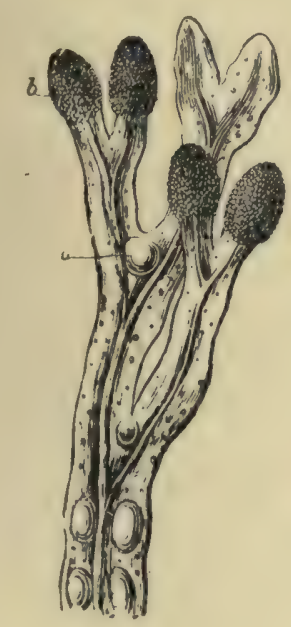

Fig. 186. Fucus vesiculosus, Blasentang mit luftführenden Schwimmblasen (a) und - den Anschwellungen der die Geschlechtsorgane enthaltenden Zweigspitzen.

(Nach Warming-Möbius.)

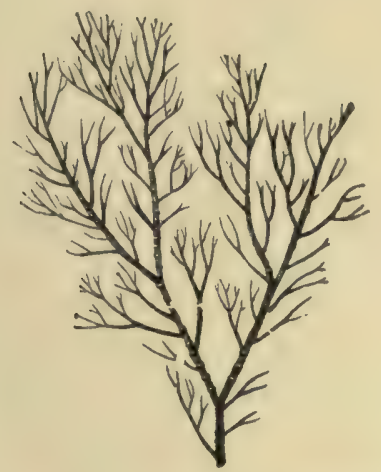

Fig. 185. Ceramium diaphanum; natiirliche Größe.

(Nach Warming-Möbius.)

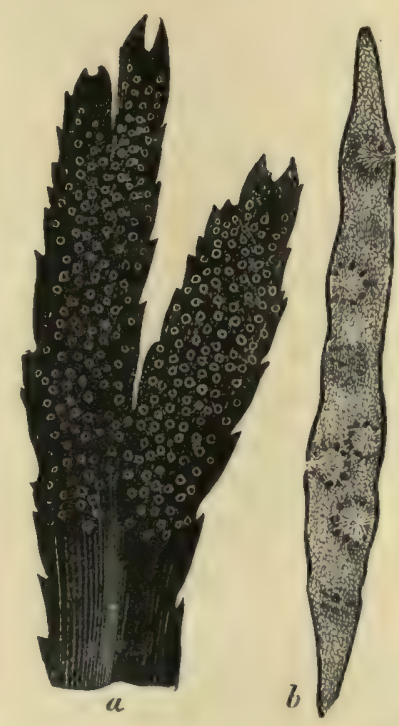

Fig. 187. Fucus serratus, Sägetang; ohne Luftblasen.

a Zweigspitze einer männlichen Pflanze in natürlicher Größe; $b$ Querschnitt durch ein Zweigstück einer weiblichen Pflanze mit den Oogonienbehältern. $1: 4$. (Nach Warming-Möbius.) 
Die Meeresalgenvereine. Floristisch bestehen zwischen den verschiedenen Meeren große Unterschiede; aber auch an den einzelnen Küsten gibt es geographische Verhältnisse, die auf dem abweichenden Haushalte der verschiedenen Arten an den äußerst verschiedenen Standorten beruhen, was hier auch besprochen werden muß.

Die ökologischen Unterschiede hängen besonders von Verschiedenheiten in der Wärme, dem Salzgehalte, der Bewegung und der Beleuchtung des Wassers wie auch vom Schwanken dieser Verhältnisse ab, weiter von der Neigung des Bodens, der Art des Gesteins usw.; besonders wichtig ist aber das Vorkommen oder Fehlen von Ebbe und Flut $^{1}$ ) (Kap. 20).

Der Wärmegrad des Meerwassers ist wichtig. Die kräftigsten "Tangwälder" werden in den kältesten Meeren entwickelt (Eismeer, nördlicher Atlantischer Ozean, Küsten des Feuerlandes, Südspitze von Afrika), wahrscheinlich, weil das kalte Wasser reicher an Sauerstoff und Kohlensäure ist, daher kräftigere Assimilation und Atmung möglich ist. In den südlichen Meeren (Chile usw.) finden sich Individuen von ganz enormer Länge (Macrocystis pyriferu nach Skottsberg wohl $60 \mathrm{~m}$ lang, Durvillea, Lessonia); in den nördlichen erreichen Laminaria-Arten eine sehr bedeutende Größe, z. B. L. longicruris im grönländischen Meere $25 \mathrm{~m}$, Nerencystis im Pazifischen Ozean $100 \mathrm{~m}$. In den tropischen Meeren sind die Arten durchgehends kleiner. Im nördlichen Eismeer kann die Temperatur des Wassers in der Tiefe, wo die reichste Vegetation auftritt, zu keiner Jahreszeit über $0^{\circ} \mathrm{C}$ betragen ${ }^{2}$ ).

Auch die Entwicklungsphasen der Arten werden (nach Rosenvinge u. a.) ${ }^{3}$ ) von den Jahreszeiten stark beeinflußt, und mehrere Arten sehen zu verschiedener Zeit höchst abweichend aus. Einige sind einjährig (z. B. Chorda, Nereocystis u. a. Laminariaceen); von anderen überwintern größere oder kleinere Teile, z. B. die Haftorgane oder die unteren Teile des Thallus; Rhodomela subfusca trägt in der Ostsee im April bis Mai ein reich verzweigtes Sproßsystem mit Fortpflanzungsorganen, die später abgeworfen werden. Desmarestia aculeata sieht gleichfalls zu verschiedenen Jahreszeiten sehr abweichend aus. Einige (z. B. Delesseria sanguinea) fruktifizieren nur im Winter. Kjellmans bemerkenswerte Aufklärungen über das Algenleben in hochnordischen Meeren wurden S. 32 erwähnt.

Der Salzgehalt des Wassers ist der zweite äußerst wichtige Faktor, der in die Zusammensetzung und das Gepräge der Vegetation eingreift. Je weiter wir von der Nordsee zur Ostsee vordringen, desto

1) Börgesen 1905; Beobachtungen von den Färöern.

2) Kjellman 1875 für Spitzbergen, Rosenvinge für Scoresby Sound.

8) Rosenvinge 1898; vergl. Oltmanns 1905. 
süßer wird das Wasser (S. 358), und desto ärmer und verkrüppelter wird im ganzen die Vegetation ${ }^{1}$ ). Das sibirische Eismeer ist gleichfalls artenarm, teils weil der Boden grofenteils Sand oder Ton ist, teils wohl auch wegen des vielen, aus Sibirien kommenden Süßwassers.

Gegen Schwankungen in dem Salzgehalt und der Wärme sind viele Arten sehr empfindlich. Einige Arten können eine geringe Verminderung des Salzgehaltes nicht ertragen, andere können sich nach den Verhältnissen einrichten.

Die Bewegung des Wassers (Brandung, Strömung) und demzufolge die größere Frische (Sauerstoffreichtum) und die größere Nahrungszufuhr greifen ebenfalls in die Verteilung ein (vergl. S. 149). Die Algenflora der stark exponierten Vorberge und der besser geschützten Felsen im Inneren der Fjords ist gewöhnlich sehr verschieden; vergl. z. B. Hansteens Untersuchungen über die Flora außerhalb und innerhalb der norwegischen Schären und Börgesens an den färöischen Küsten (1905).

Hedvig Lovén untersuchte die Luft in den Luftblasen der Algen und die Atmung der Algen und kam unter anderem zu folgenden Ergebnissen: Die Luft in den Fucaceenblasen hat eine andere Zusammensetzung als die Luft im Wasser; die Sauerstoffmenge ist mittags am größten, nachts am kleinsten. Die Algen können jede Spur Sauerstoff des Wassers absorbieren, aber ziemlich lange in ganz sauerstoffreiem Wasser leben und in diesem bedeutende Mengen von Kohlensäure ausscheiden. Fehlt im Wasser Sauerstoff, so können sie den Sauerstoff in den Blasen vollständig verbrauchen.

Das Licht ist der fünfte sehr wichtige Faktor (vergl. S. 144-146). Erstens hat die Lichtstärke Bedeutung; die Grünalgen sind die am meisten lichtliebenden Algen, und dieses ist nach Kjellman vielleicht ein Grund, weshalb sie im nördlichen Eismeere verkrüppelt und in geringer Zahl vorkommen (an den Felsenküsten Grönlands sind sie jedoch üppig entwickelt); bemerkt kann doch werden, daß die oberste Algenvegetation dort vielfach durch die Bewegungen des Eises leidet; dadurch werden die Felsen kahl. - Je weiter man in die Tiefe hinabdringt, desto mehr Licht wird absorbiert, desto weniger Arten sind vorhanden, und zuletzt hören sie ganz auf. Nach Berthold ${ }^{2}$ ) sind die Florideen im allgemeinen schattenliebende Pflanzen. Derselbe fand bei Neapel eine üppige Algenvegetation in einer Tiefe von 120 bis $130 \mathrm{~m}$, während in den arktischen wie im Nordatlantischen Ozean selbst in einer Tiefe von nur 50 bis $60 \mathrm{~m}$ eine ärmliche Vegetation lebt ${ }^{3}$ ). Der verschiedene Lichtbedarf der Algen verteilt sie nach Tiefenzonen.

1) Svedelins 1901.

3) Berthold 1882; vergl. Oltmanns 1905.

s) Rosenvinge 1898; Börgesen 1905. 
Eine Tiefwasserflora kann man bisweilen im Meeresniveau in Höhlen der Felsen finden, z. B. auf den Färöer ${ }^{1}$ ). Falkenberg schreibt von einer Grotte bei Neapel, daß sich „trotz des niedrigen Wasserstandes hier an den dunkelsten Stellen Algen finden, die sonst als charakteristische Pflanzen in einer Tiefe von 50-60 m im Golfe leben".

Auch die Lichtfarbe beeinflußt höchst wahrscheinlich die Verteilung der Algen in Stufen auf den Felsen der Küsten; jedenfalls verändert sich die Farbe mit der Tiefe, die Zusammensetzung des Lichtes wird geändert (die langwelligen, roten und gelben Strahlen gehen am schnellsten verloren) und die Farbe der Algen steht in einem gewissen Verhältnis hierzu. Engelmann hatte 1883 den Satz aufgestellt, daß die Farben der Algen komplementär sind zu der in Wasser dominierenden Lichtfarbe, und Gaidukow schloß sich 1902 dem an. Damit sollte die Erklärung dafür gegeben werden, daß die Rotalgen am tiefsten hinabsteigen, weil sie in dem dort herrschenden blauen Lichte am besten assimilieren. Nach anderen aber (wie W. Magnus, Schindler u. a.) solle eine solche "chromatische Adaptation" nicht existieren (?); die Rotalgen seien vorzugsweise "Schattenpflanzen". Die Blaufärbung vieler Waldschattenpflanzen (Asarum, Galium silvaticum usw.) spricht anch für die erstere Ansicht, da ja bekanntlich im Walde zunächst die kurzwelligen Strahlen vernichtet werden (vergl. Kissling u. a.).

Tatsache ist nun jedenfalls, daß die Algen der Küstenfelsen in verschiedene Tiefenstufen verteilt sind. Agardh ${ }^{2}$ ) benannte sie „Reiche“ (Regnum Zoospermarum, Olivacearum, Floridearum); Lyngbye ${ }^{3}$ ) "Regionen". Örsted ${ }^{4}$ ) war der erste, der die Verbindung zwischen Lichtfarbe und Tiefenstufen feststellte; im Öresund fand er drei „Regionen", die der Grünalgen, Braunalgen und Rotalgen.

Kjellman ${ }^{5}$ ) hat folgende Gürtel oder Stufen ("Regionen“) aufgestellt, welche der Küste parallel verlaufen, und deren jede in eine große Menge von kleinen "Formationen" geteilt, je nachdem die Wasserbewegung stärker oder geringer ist oder ob andere Faktoren einen Finfluß ausüben. "Ebbe und Flut" sind es, welche die wichtigste topographische und biologische Scheidung bestimmen; während der Zeit der Ebbe werden viele Algen trocken gelegt, der Verdunstung und einem stärkeren Lichte ausgesetzt.

1. Der litorale Gürtel, zwischen der höchsten Flut und der niedrigsten Ebbe, mit vielen Grünalgen, Braunalgen und einzelnen Rotalgen; zur Zeit der Ebbe liegen sie bloß; viele können fast amphibisch genannt

1) Vergl. Börgesen 1905.

2) Agardh 1836.

3) Lyngbye 1836.

-) Orrsted 1844.

5) Kjellman $1877,1878$. 
44. Kap. Halonereïden (steinliebende Hydrophyten des Salawassers)

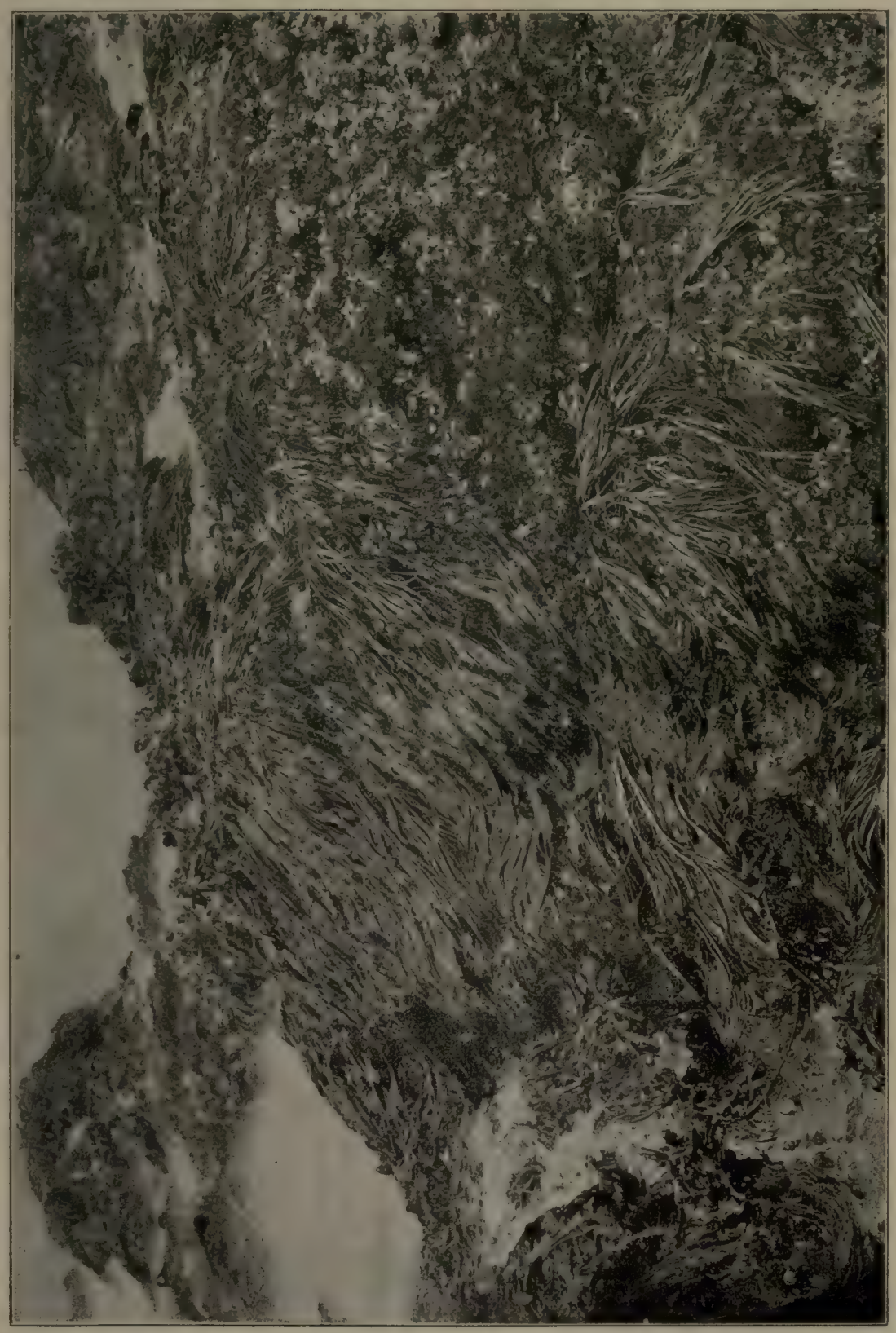

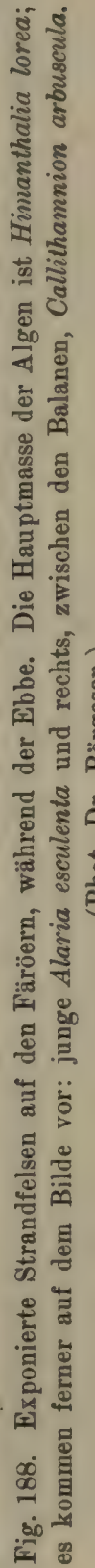




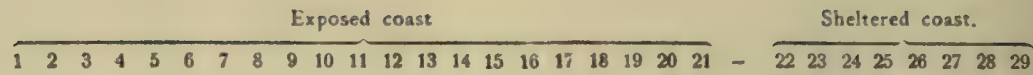

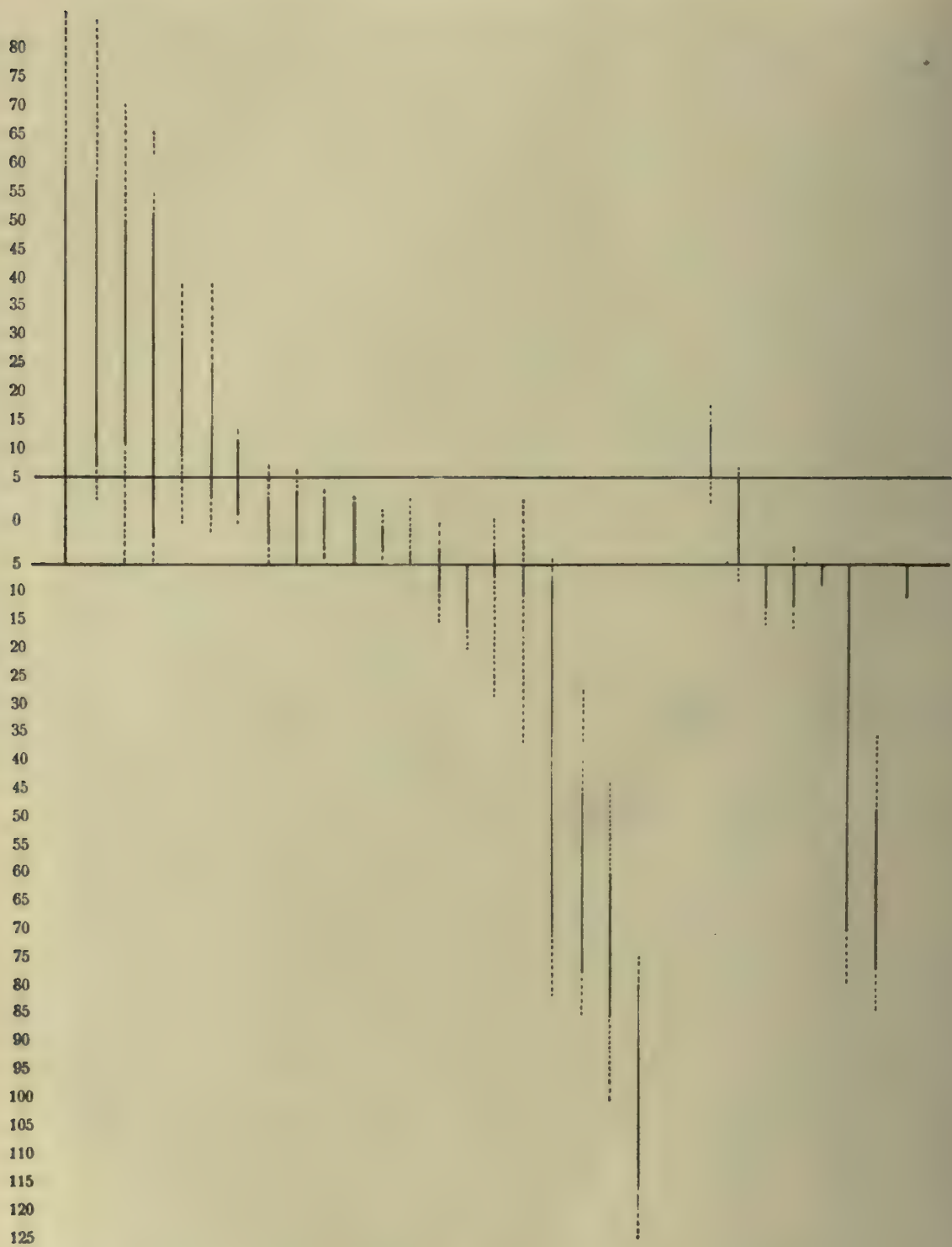

Fig. 189. Schematische Darstellung der Algen-Verteilung nach der Höhe auf den Felsen an den Küsten der Färöer nach Börgesen (1905)。

Die linke Zahlenreihe gibt (in FuB) die Höhe über oder unter dem mittleren Wasserstande (0) an. Zwischen den beiden starken horizontalen Linien liegt das Ufer. Die horizontale Zahlenreihe bezeichnet die in der nebenstehenden Liste (S. 383) angegebenen Arten. 


\section{Liste zu Figur 189.}

1. Hildenbrandia mit Flechten.

2. Chlorophyceen an exponierten Küsten, Prasiola crispa, Rhizoclonium, Enteromorpha, Prasiola stipitata.

8. Porphyra.

4. Rhodochorton.

5. Bangia, Urospora.

6. Fucaceae an exponierten Küsten, Fucus spiralis, Fucus inflatus.

7. Callithamnion.

8. Rhodymenia.

9. Küsten-Corallina.

10. Monostroma

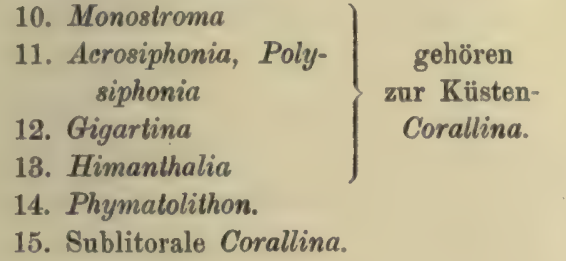

16. Laminaria digitata Laminariaceen 17. Alaria an exponierten

18. Laminaria hyperborea Küsten

19. Desmarestia an exponierten Küsten. 20. Lithoderma.

21. Sublitorale Florideen.

22. Chlorophyceae an geschützten Küsten, Enteromorpha.

23. Fucaceae an steinigen Küsten, Pelvetia, Fucus vesiculosus, Ascophyllum, Fucus inflatus.

24. Sticlyosiphon.

25. Monostroma, Enteromorpha.

26. Halidrys.

27. Laminariaceen an steinigen Küsten, Laminaria faeroensis, Laminaria hyperborea.

28. Desmarestia an steinigen Küsten.

(29. Zostera.)

werden und an sonnigen schattenlosen Tagen stark eintrocknen. Dieser Gürtel kann bedeutend sein; der Gezeitenunterschied kann bis viele Meter betragen.

2. Der sublitorale Gürtel unterhalb der niedrigsten Ebbe bis 20 Faden $(40 \mathrm{~m})$ Tiefe und tiefer; alle Farben sind vertreten. aber die Grünalgen hören auf, und die Rotalgen werden nach der Tiefe relativ zahlreicher.

3. Der elitorale Gürtel geht unterhalb des vorigen soweit wie das Licht hinab und ist sowohl an Arten als an Individuen ärmer; diese werden kleiner und verkrüppelt, was schon Lyngbye bekannt war.

Diese Einteilung ist jetzt allgemein angenommen, mit kleineren Abweichungen bei den verschiedenen Forschern (z. B. Hansteen, Gran, Schiller, Börgesen, Helgi Jónsson, Reinke, Cotton, Davis, Kylin u. a.).

Rosenvinge und Börgesen ${ }^{1}$ ) z. B. fanden, daß die litorale Stufe dort gesetzt werden muß, wo die Algenvegetation anfängt, auf den Färöer hoch oberhalb der höchsten Flutgrenze, an einigen Stellen bis 25-30 m Höhe, was von der Steilheit der Felsen und der ungeheuer starken Brandung abhängt, welche das Wasser hoch hinaufschleudert. In ihn sind an den Felsen auch Flechten eingemischt, wie Verrucaria maura u. a. Arten, Lichina, Ephebe. Diese Arten sind jedenfalls teilweise als aerobiotische zu betrachten, denn sie müssen längere Trockenperioden aushalten können. Eine elitorale Stufe erkennen sie nicht an.

1) Rosenvinge 1898; Börgesen 1905. 
Helgi Jónsson ${ }^{1}$ ) schiebt für Island einen semilitoralen Gürtel ein, zwischen dem Fucus- und dem Laminariagürtel, welcher in dem sublitoralen oberhalb des Bereiches der Rhodophyceen tonangebend ist.

Von den Haarbildungen der Algen sind einige assimilierend (z. B. bei Desmarestia aculeata, Chorda tomentosa), andere farblos (besonders bei den Braun- und Rotalgen). Diese werden stärker entwickelt, wenn das Licht stärker ist, und Berthold hat die kaum richtige Meinung ausgesprochen, daß sie die Aufgabe hätten, die Beleuchtung zu regulieren; sie sind wohl nach Rosenvinge ${ }^{2}$ ) am ehesten Absorptions- oder Atmungsorgane.

Die genannten Faktoren beeinflussen die Vegetation sowohl im großen als im kleinen und tragen, vermutlich mit anderen Faktoren (z. B. mit der Art des Bodens), dazu bei, auch im kleinen eine Menge standortliche Unterschiede, eine Menge von oft sehr kleinen Assoziationen hervorzurufen, deren Gepräge hauptsächlich einer Art oder einigen wenigen Arten, die die Hauptmasse bilden, sein Dasein verdankt. Hayrén ${ }^{3}$ ) z. B. zeigte, welche ungeheuer große Menge von kleinsten Standorten am Meeresstrande Finlands vorkommen, jeder mit seiner speziellen Flora.

Kjellman und andere haben diese kleinen Vereine "Formationen" benannt. Börgesen, Cotton ${ }^{4}$ ), Davis u. a. nennen sie richtiger „Associationen". Die steinliebenden Algen scheinen, trotz der großen, aber keineswegs fundamentalen Formverschiedenheiten, nur eine einzige, allerdings sehr große und formenreiche Formation bilden zu können, welche vielleicht je nach örtlichen Verschiedenheiten in Gruppen (Subformationen) geteilt werden kann. Die Zahl der Assoziationen wird jedenfalls ungeheuer groß werden.

In den großen Gesellschaften mächtiger Algen, z. B. zwischen den Laminaria-Stielen, finden viele schwächere Formen einen günstigen Platz, ganz wie die Kräuter der Bodenvegetation in sen Wäldern. Auch eine Menge von Epiphyten kommen in den Algenwäldern vor ${ }^{5}$ ).

Verschiedenheiten der Jahreszeiten. Da die angeführten Faktoren zu verschiedenen Jahreszeiten mit ungleicher Stärke wirken, entstehen auch zeitliche Unterschiede in der Entwicklung der Ernährungs- und der Fortpflanzungsorgane. Jede Art der Meeresalgen scheint ihre bestimmte Entwicklungszeit zu haben, die z. B. unter verschiedenen Breitengraden verschieden sein kann: Arten, die bei uns mit dem Beginne des Sommers verschwinden, können im Eismeere den

1) Helgi Jonsson 1911.

2) Rosenvinge 1912 .

3) Hayrén' 1914.

4) Cotton 1912.

s) Börgesen 1905, Fig. 161. Tobler, Epiphyten der Laminarien (Englers Jahrb. XLIV, 1910). 
ganzen Sommer fortdauern (Rosenvinge). In unseren Meeren weicht die sommerliche Algenvegetation von der winterlichen stark ab (Kjellman, Rosenvinge), und selbst unter der südlichen Breite Neapels beobachtet man dasselbe (Berthold), Hier sind vielleicht Beleuchtung und Wellenschlag entscheidend, aber unter höheren Breiten spielt wohl die Wärme die größere Rolle.

Die eigentümliche Pflanzengruppe der Diatomeen verdient besonders hervorgehoben zu werden, weil ihre Formverhältnisse von allen anderen abweichen; zu ihnen gehören die Grunddiatomeen und biologisch verschiedene Typen: es gibt frei bewegliche, die auf der Unterlage (Steinen, anderen Algen) umherkriechen, und gestielte, unbewegliche Formen, die besonders die Randzonen der Salzgewässer bewohnen, sich leicht losreißen und dann mit dem Plankton vermischen können (Schütt); vergl. S. 365.

Feuchte Felsen können eine Vegetation von Luftalgen (aërobiotischen Algen) tragen, die eine Übergangsform zwischen der untergetauchten Felsenvegetation und der Landvegetation bildet. Eine supralitorale Stufe tritt hier vermittelnd auf. An Felsenküsten kann, wie oben erwähnt, der Gischt der Brandung bisweilen besonders hoch hinauf reichen, und an solchen Orten können Meeresalgen (Ulothrix, Enteromorpha u. a.) weit über dem höchsten Wasserstande vorkommen (Rosenvinge, Börgesen u. a.). Der Haushalt dieser Vereine ist jedoch kaum wesentlich von dem der im Wasser lebenden verschieden, obgleich die betreffenden Arten besonders ausgerüstet sein müssen, um größere Trockenheit als die untergetauchten auszuhalten.

\section{Kap. Vereine der submersen Salz-Wasserpflanzen auf losem Boden}

Der Bau des Bodens ist der S. 74-76 erwähnte, aber die Poren sind mit Wasser erfüllt, und die Luft ist sicher in äußerst geringer Menge vorhanden, wenn sie überhaupt vorkommt.

Die Beschaffenheit des Bodens kann zwischen reinem Sande, der meist Quarzsand, in den Tropen auch Korallensand ist, und je nach der Stärke der Wellenbewegung mehr oder weniger kleine Steine oder Schalen von Meerestieren beigemischt enthalten kann, Ton und Schlamm (S. 116) wechseln. Diese Unterschiede spielen sicher eine gewisse floristische und ökologische Rolle; nach Wille ist Schalenboden durch besondere Algengesellschaften, z. B. durch Tilopteridaceen, ausgezeichnet. Hierüber weiß man im übrigen noch nicht viel Sicheres. Eine besondere Rolle spielt der Schlamm, der aus toten, organischen Resten gebildet ist. 
Die Bewegung des Wassers hat eine große gestaltende und floristische Bedeutung; sie hängt von topographischen Verhältnissen sowie von den Gezeiten, den Winden u. a. m. ab. Stark bewegter Meeresboden ist sicher ganz pflanzenlos, z. B. große Gebiete des Bodens der Nordsee. Helgoland liegt wie eine Oase in einer Sandwüste, weil der Sand ununterbrochen durch Wellenschlag und Ebbe und Flut in Bewegung gesetzt wird (Reinke).

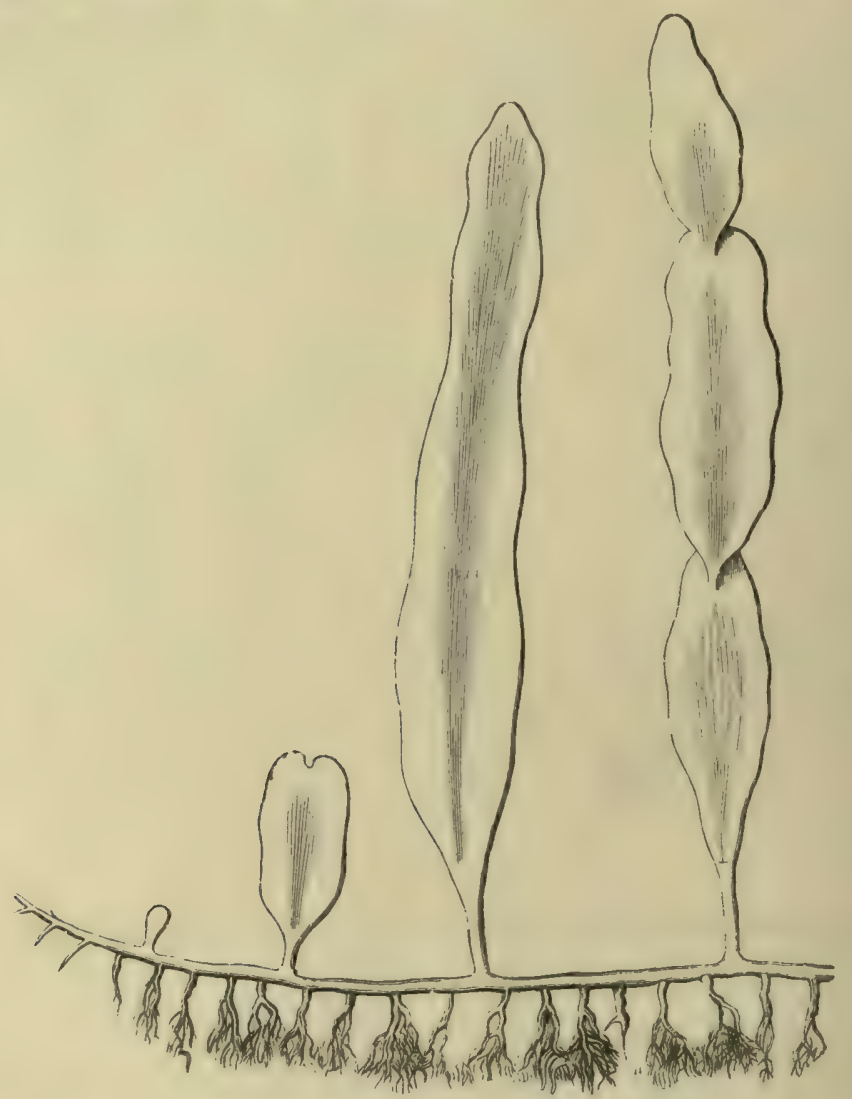

Fig. 190. Caulerpa prolifera; nach Reinke. (Aus Warming-Johannsen.)

Eine große Rolle spielt auch der Salzgehalt des Wassers (vergl. S. 148,358$)$.

Die Flora des losen Bodens besteht aus weit weniger und auch einfacheren und einförmigeren Algen als die des Felsbodens, dagegen sind hier vorzugsweise die Blütenpflanzen zu finden. Hieraus ergeben sich mehrere bedeutende Abweichungen von der lithophilen Vegetation, namentlich folgende:

1. Wurzeln oder andere Organe, die sich wurzelartig im Boden verzweigen, dienen zur Befestigung der Pflanzen und zur Nahrungs- 
aufnahme; andere besondere Haftorgane fehlen. Die Wurzeln erreichen jedoch, wie bei den Wasserpflanzen im allgemeinen, nicht die Ausdehnung und die Verzweigung wie bei den Landpflanzen. Verschiedene tropische Algen, wie Udotea, Halimeda, Penicillus, welche auf losem, sandigen oder schlammigen Boden wachsen, werden dort befestigt und nehmen vielleicht auch (?) Nahrung auf durch die hyphenähnlichen Haare, welche von dem unteren Teile des Thallus ausgehen und in den Boden eindringen (Fig. 190, 191). Dasselbe gilt für die Characeen.

2. Wagerechte auf oder meist in dem Boden wachsende Rhizome oder solchen analoge Teile (z. B. bei der Alge Caulerpa) sind sehr verbreitet, woraus eine gesellige, dichte, an Individuen reiche Vegetation

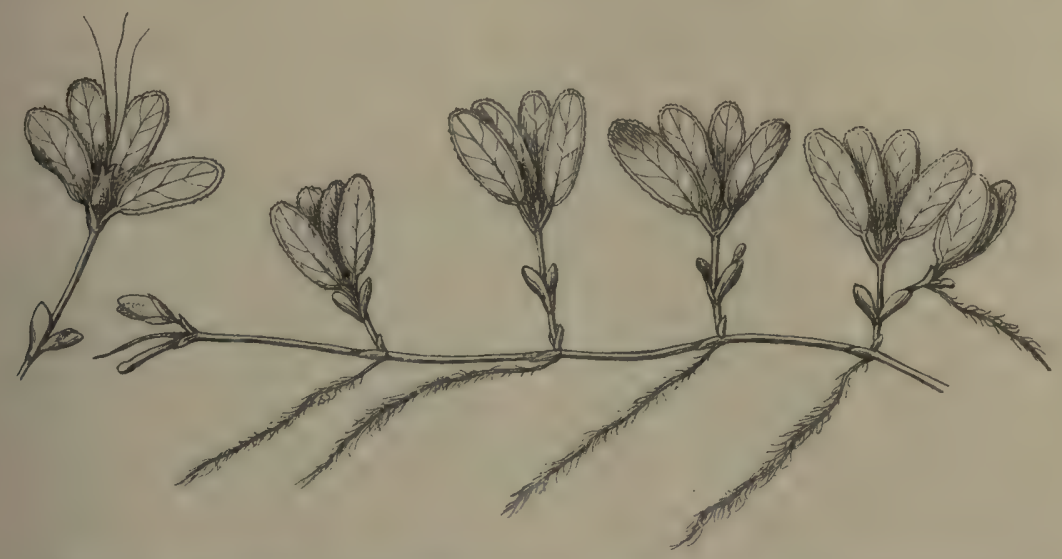

Fig. 191. Halophila Aschersonii (natürl. Größe) von Dänisch-Westindien.

(C. H. Ostenfeld, 1902.)

hervorgeht (z. B. "Wiesen" von "Seegräsern", wie Zostera). Dieser Wuchs steht in deutlichem Einklange mit der losen Bodenbeschaffenheit (S. 78).

3. Die den Wasserpflanzen eigentümlichen großen, mit Luft erfüllten Interzellularräume (S. 206) unterstützen alle im Wasser untergetauchten Organe der Gefäßpflanzen bei der Atmung. Außerdem werden diese Lufträume für die Atmung der Wurzeln und der Rhizome, die im Boden leben, notwendig sein, weil jeder unter Wasser liegende Boden ungefähr die möglichst dichte Lagerung seiner Teilchen hat und weil die Wurzeln und die Rhizome gewiß in einem an Sauerstoff sehr armen Boden leben, da dessen Poren ganz mit Wasser erfüllt sein werden, das nicht leicht erneuert wird.

Nach der Beschaffenheit des Bodens müssen diese Wasserpflanzen in mehrere Formationen geteilt werden. 
1. Die der saprophytischen Mikrophyten auf Schlammböden, die reich an organischen Stoffen sind,

2. Die Vereine der autophyten Pflanzen, Algen und Blütenpflanzen, auf Sand- und Lehmböden.

\section{Formation. Saprophytische Schlammboden-Vereine}

Organischer Schlick, d. h. ein von faulenden und verwesenden organischen Teilen erfüllter schwarzer Schlamm, wimmelt von gewissen niederen Tieren, läßt aber kein höheres, autophytes Pflanzenleben gedeihen, wohl aber eine reiche Flora von Bakterien und anderen Sapro-

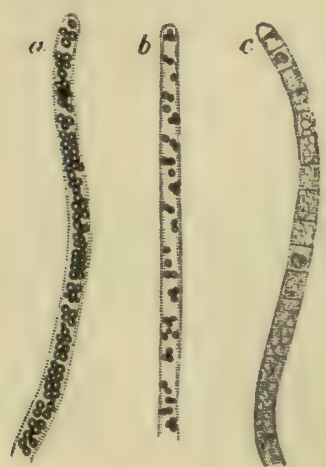

Fig. 192. Schwefelbakterien

(Beggiatoa alba).

$a$ mit reichlichem Inbalt an Schwefelkörnern;

$b$ und $c$ nach eintägigem und dreitägigem Aufenthalte in schwefelwasserstofffreier Flüssigkeit; die Schwefelkörner verschwinden zuletzt ganz (Winogradsky). phyten, welche lose auf oder in dem Schlammboden liegen oder nur durch Schleimhüllen an dem Schlamme befestigt sind. In solchem an Fäulnisstoffen reichem Boden wird sich wohl immer sehr wenig oder gar kein Sauerstoff vorfinden, so daß die dort lebenden Organismen vorzugsweise anaërob sein müssen.

A. Solcher Boden befindet sich besonders in ruhigen Buchten und in seichten Strandtümpeln mit Brackwasser. Hier sieht man oft Anhäufungen von Tangen und anderen Algen, die einen an Individuen und an Arten reichen Verein bilden (litorale Vereine $\left.{ }^{1}\right)$. Die Schwefelbakterien (Beggiatoen, die Purpurbakterien) scheiden hier wie in den heißen Quellen in ihrem Inneren Schwefel ab (was Cohn zuerst nachgewiesen hat), indem sie den bei der Wechselwirkung zwischen den toten organischen Teilen und den Schwefelverbindungen des Wassers gebildeten Schwefelwasserstoff aufnehmen und diesen dann zu Schwefel und Wasserstoff oxydieren. Nach der Beobachtung von Sickenberger spielen die roten Schwefelbakterien auch bei der Sodabildung in den ägyptischen Salzseen eine wesentliche Rolle (Fig. 192, 193).

Was die Purpurbakterien betrifft, so hat Molisch gefunden, daß einige freie Schwefelkörnchen in ihren Körpern ablagern, andere dagegen nicht; sie können keine Kohlensäure assimilieren und scheiden keinen Sauerstoff aus, wie man früher glaubte. Sie sind mehr oder weniger sauerstoffempfindlich. Organische Substanzen sind für ihre Ernährung unbedingt notwendig; sie assimilieren solche durch die Hilfe des Lichtes.

1) Warming 1875; Engler 1883. 
In gleicher Weise gibt es in den nordeuropäischen Meeren und Fjorden schlammige Stellen, an denen sich eine saprophytische Vegetation finden dürfte. Ein schwarzer Schlamm ist sehr häufig in den Seen, an den Meeresufern und ebenso im Grunde der Meere; er ist meist sehr reich an Schwefeleisen. Nach Beijerinck ${ }^{1}$ ) und van Delden ${ }^{2}$ ) ist die Reduktion des Sulphates im Wasser auf eisenhaltigem Boden von bestimmten anaëroben Bakterien, wie Microspira desulfuricans und $\boldsymbol{M}$. aestuarii begleitet.

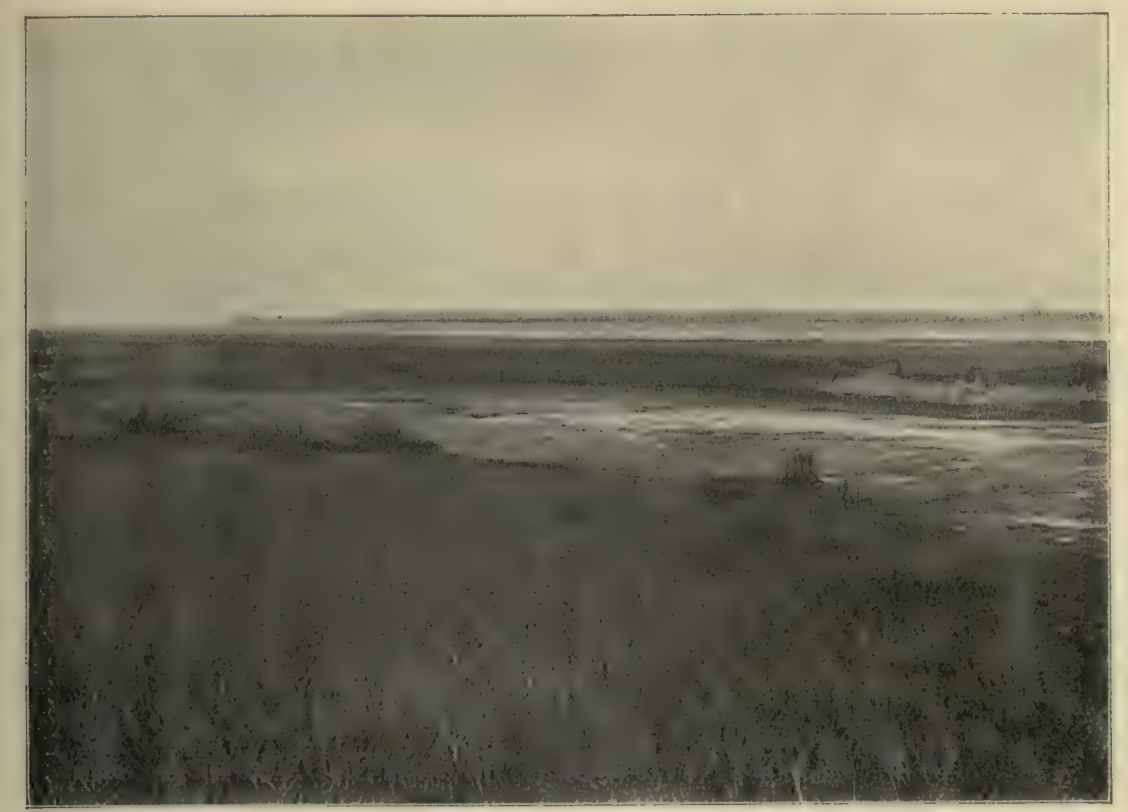

Fig. 193. Strandsumpf von roten Schwefelbakterien; rot gefärbt ist der hellé Teil; auch andere Farben treten hervor, z. B. weiß durch Beggiatoa. Bei Prästö auf Seeland. (Phot. Eug. Warming.)

Die Vegetation auf solchen toten organischen Massen, die meist auf dem Grunde von Wasser aufgehäuft sind, wird teils von Oscillarien, teils von Bakterien usw. gebildet, bisweilen auch von einzelnen anderen Algen, die aber hier kaum ihre rechte Heimat haben. Jene Massen liegen gewöhnlich lose auf dem moderigen Boden, Beggiatoa z. B. in kreideweißen, flockigen Massen, Clathrocystis rosei-persicina, ferner Bacterium sulphuratum, B. Okeni u. a. Purpurbakterien in roten Massen, die weite Strecken an Meeresküsten bedecken und von weitem sicht-

1) Beijerinck 1895 .

9) Van Delden 1903. 
bar sind ${ }^{1}$ ). Sie bilden weiße oder, wo Purpurbakterien vorherrschen, rote Überzüge auf den faulenden Massen.

Schon 1818 hat Hofman Bang in Dänemark eine kleine Abhandlung über die landbildende Tätigkeit der "Conferven" an den Küsten Dänemarks veröffentlicht. "Conferva chthonoplastes", wie er die Alge nannte, welche jetzt Microcoleus chthonoplastes (Hofman Bang) Thuret heißt, erhöht alljährlich den Boden der Küste, indem sie durch ihre schleimigen Fäden die sandigen und tonigen Partikel festhält, welche vom Wasser zugeführt werden. Die Spitzen der Fäden wachsen immer weiter und erheben sich so über die zuletzt abgelagerte Schicht. Auf diese Weise hat sich bei Fühnen eine Schlamm- und Sandbank gebildet, welche im Sommer durch die schleimigen Algenfäden so schlüpferig ist, daß es recht schwierig ist, dort zu gehen ohne zu fallen.

Dieser Boden wird dann ein geeignetes Keimbett für Salzphanerogamen. Microcoleus ist aber nicht die einzige Art, welche hier eine Rolle spielt. Örsted untersuchte später diese Formation und fand verschiedene andere Schizophyceen samt Purpurbakterien. Ganz entsprechende Landbildungen beobachteten Vaupell, Warming $u$. a. auf den Watten der Nordseeküste ${ }^{2}$ ) und später ist dieselbe Formation von W. G. Smith, Fritsch u. a. besprochen worden ${ }^{3}$ ).

Die S. 362 ff. erwähnten Algenvereine können wohl auch in Sümpfen und auf periodisch trocken liegenden Böden vorkommen. Näher studiert sind sie kaum.

Eine höchst eigentümliche Verlandung von Salzseen durch Cyanophyceen kommt nach Handel-Mazzetti ${ }^{4}$ ) in Mesopotamien vor. Er schreibt z. B.: Das größte und konstanteste brackische Wasser ist der mehrere Stunden im Umfange messende See El Chattunije. Er verlandet anscheinend rasch, denn die Algen an seinen Ufern, Cyanophyceen, in erster Linie Dichothrix gypsophila (Kütz.) Born. u. Flahault scheiden reichlich Kalk aus. Dadurch entsteht ein weißklumpiges, anfangs weiches Gestein, das sich später setzt und erhärtet und den See überall einfaßt. Es bildet einen günstigen Boden für höhere Pflanzen, vor allem für Juncus acutus.

B. Eine ähnliche saprophytische Schlammvegetation ist die abyssale. Sie tritt in größeren Tiefen der Meere auf, wo das Wasser ruhig ist, wo wenig oder kein Licht, wenig Wärme, geringe Temperaturschwankungen, aber öfter ein reiches Tierleben vorhanden ist. Wahrscheinlich wird sie nur von Bakterien und ähnlichen Saprophyten gebildet und schließt sich

1) Vergl. Warming 1875, 1906.

2) Warming 1906.

3) Fritsch $1907 \mathrm{~b}$.

4) Handel-Mazzetti 1912. 
daher gewiß naturgemäß hier an. Man weiß indessen so gut wie nichts von dieser Vegetation. Als Beispiel einer Stelle, wo wahrscheinlich ein reiches Bakterienleben gedeiht, sei auf das Schwarze Meer hingewiesen. Nach Andrussow trifft man hier in 100-600 und mehr Faden Tiefe große Mengen von Schlamm mit subfossilen Resten von Brackwasserschaltieren, die aus der nicht fernen Zeit stammen, als das Schwarze Meer ein Brackwassersee war, und die ausstarben, als das Mittelmeer hineinbrach. Die Strömungsverhältnisse rufen in der Tiefe eine mangelhafte Ventilation hervor, und das Wasser wird hier unten sauerstoffarm, aber sehr reich an Schwefelwasserstoff. Es lebt hier kein Tier, die organischen T'eile des Schlammes werden von Tieren nicht verzehrt; es ist jedoch sehr wahrscheinlich, daß sich hier ein reiches, anaërobes Bakterienleben findet.

C. Aestuarien. Sehr nahe diesen aus Bakterien gebildeten Assoziationen stehen diejenigen, die auf schlammigem Boden, aber unter stärkerer Anwesenheit von Sauerstoff auch auf dem Boden seichter Gewässer vorkommen und zwar ebenso auf Böden, die periodisch trocken gelegt, vom Meere dauernd überflutet werden (Aestuarien). An unseren nordeuropäischen Küsten finden sich viele solcher meist aus Schizophyceen gebildete vor, z. B. Assoziationen von Lyngbya, von Rivularia, von Microcoleus chthonoplastes u. a.

Auf schlammigem Boden hart am Rande der Gewässer und mehr oder weniger als Luftalgen lebend, treten viele verschiedene Assoziationen von anderen Algen auf, z. B. Enteromorpha, Monostroma, Ulothrix, Vaucheria u. a. in dunkelgrünen dichten sammetartigen und oft polsterförmigen Massen. Sie nehmen teil an der Bildung der Marschwiesen (vergl. Kap. 46, 47; Die Salzsỉmpfe).

\section{Formation von höheren, autophyten Algen}

Die letztgenannten Algen-Assoziationen in seichtem Wasser und auf den schlickigen Küsten selbst sind wohl wesentlich von autophyten Pflanzen gebildet, worüber wir indessen wohl nichts Sicheres wissen. Vielleicht nehmen sie biologisch zwischen den echt saprophytischen Vereinen und den ausgeprägt autophytischen eine Mittelbildung ein und so würde ihr Boden auch ein Mittelding sein - ein lehmiger oder sandig-schlammiger Boden, der reich ist an organischen Substanzen. Dasselbe gilt wahrscheinlich auch von den tropischen Lagunen mit ruhigem oder doch keinem starken Wellenschlag ausgesetztem Wasser, auf welchem höhere Algen wachsen. Als Beispiel können die von Börgesen ${ }^{1}$ ) besprochenen Assoziationen der westindischen Lagunen

3) Börgesen 1900 und 1911 . 
genannt werden; es wachsen hier z. B. Arten von Caulerpa ${ }^{1}$ ), Halimeda, Penicillus und Udotea, die alle durch haarförmige, wurzelähnliche Organe in dem Boden befestigt sind (Fig. 194).

Characeta. In unseren nordischen, brackischen Gewässern kommen ähnliche Assoziationen von Characeen vor, bisweilen ausgedehnte wiesenähnliche Vereine bildend, die einen eigentümlichen, strengen Geruch haben.

\section{Formation der Seegräser (Enaliden)}

Die Blütenpflanzen, welche diese Formation bilden, gehören nur 2 Familien an: Potamogetonaceen (Zostera, Phyllospadix, Posidonia, Cymodocea, Halodule, Althenia, ferner, besonders in Brackwasser, Ruppia und Zannichellia) und Hydrocharitaceen (Halophila, Enalus, Thalassia). Epiphytische Algen kommen an den Blättern usw. oft vor.

Formverhältnisse. Obwohl zu zwei verschiedenen Familien gehörig, sind die Seegrasarten einander im Äußeren so ähnlich, daß man sterile Individuen oft verwechselt hat.

Die typische Form wird durch Zostera (Z. marina, Z. nana) gut dargestellt; alle sind wie diese untergetaucht; echte Schwimmblätter fehlen, was wohl damit im Einklange steht, daß die Wellenbewegung stark ist; die Blätter sind bandförmig, an der Spitze abgerundet, ganzrandig. Diese Blattform (das Bandblatt oder zosteroïde Blatt) steht mit den Strömungen und der Tiefe des Wasses im Einklange und kommt unter ähnlichen Verhältnissen bei Arten des süßen Wassers vor. Die Breite des bandförmigen Blattes richtet sich bei $Z$. marina deutlich nach der Wassertiefe: je seichter das Wasser ist, desto schmaler ist das Blatt (forma angustifolia); in tieferem Wasser werden die Pflanzen kräftiger und breitblätteriger.

Infolge der weit wandernden Rhizome treten geselliger Wuchs und die weit, oft meilenweit ausgedehnten, dichten, grasgrünen, „unterseeischen Wiesen" auf.

Die Blüten sind sehr reduziert und unansehnlich ${ }^{2}$ ); das Blühen geht auf oder unter Wasser und mit dessen Hilfe vor sich; daher sind die Pollenkörner bei einigen unter Wasser blühenden Arten fadenförmig (Zostera, Cymodocea) oder in lange Ketten vereinigt (Halophila ${ }^{3}$, vergl. z. B. Holm, 1885), offenbar, um von der langen Narbe leichter aufgefangen

1) Svedelius 1906; Börgesen 1907.

2) Schenck 1886 b.

s) Vergl. z. B. Ascherson 1871, 1875 ff., Balfour 1878, Ascherson u. Gürke im Engl.-Prantl, Nat. Pflafam. II. 
werden zu können, wenn sie das spezifische Gewicht des Wassers haben und von der Wasserströmung umhergeführt werden. Die Stiele der weiblichen Blüten sind bei Enalus und Ruppia spiralis lang und ziehen sich nach der Bestäubung schraubenförmig zusammen ${ }^{1}$ ).

Assoziationen. Zosteretum marinae ist in den nordeuropäischen Meeren die häufigste und mächtigste Assoziation. Das Seegras oder Aalgras bildet längs der Küsten auf sandigem oder seltener schlammigem Boden in geringer Tiefe einen Gürtel; in unseren Meeren ist die

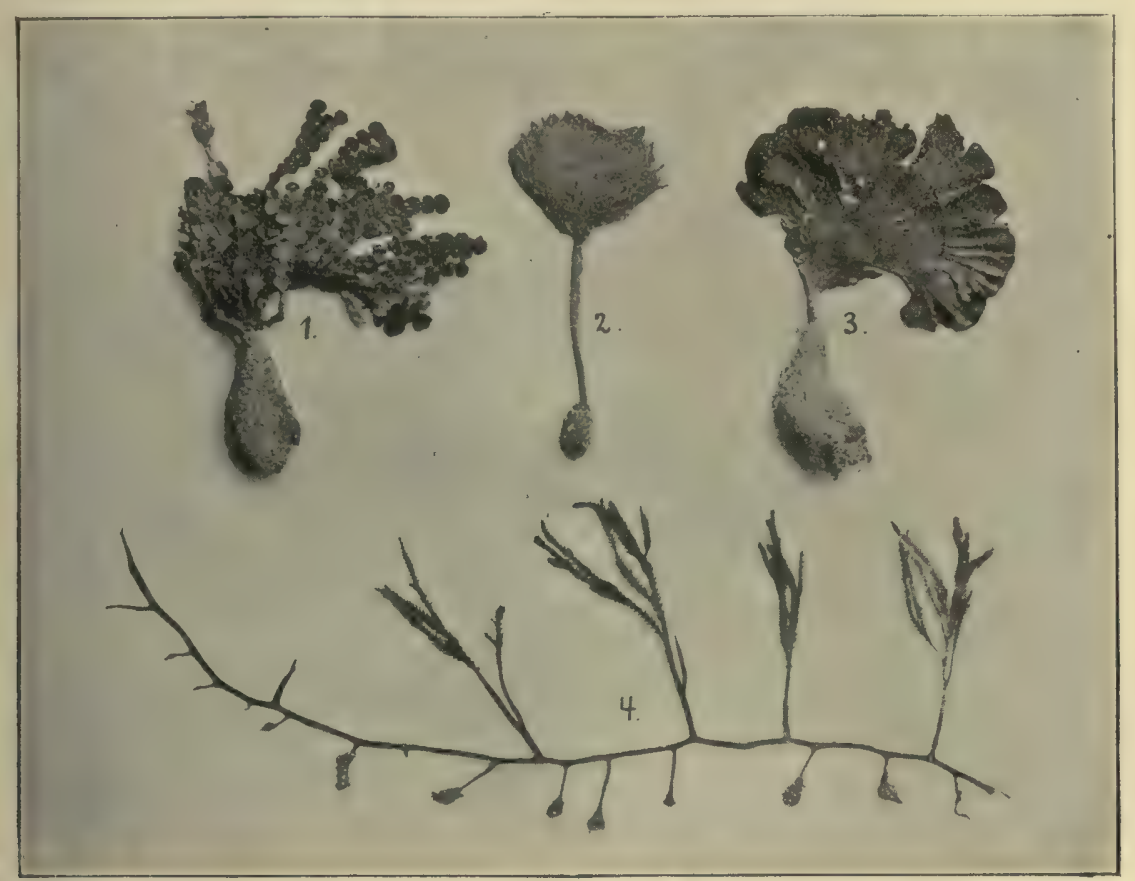

Fig. 194. Meeresalgen von losem und weichem Boden (Dänisch-Westindien). 1. Halimeda. 2. Penicillus. 3. Udotea. 4. Caulerpa. (Verkleinert.)

(F. Börgesen.)

untere Grenze etwa bei $14 \mathrm{~m}$; sie hängt natürlich von der Lichtstärke, also von der Klarheit des Wassers ab. Es fordert einen in gewissem Grade geschützten Boden. Die wagerechten Grundachsen durchweben den Meeresboden nach allen Richtungen; sie sind durch büschelig gestellte Wurzeln befestigt und endigen mit bogenförmig aufsteigenden Spitzen; sie müssen sich durch den Boden vorwärts pflügen. Die an der Grundachse entspringenden bandförmigen bis 1 oder $1,5 \mathrm{~m}$ langen und bis $1 \mathrm{~cm}$ breiten Blätter fluten im wogenden oder strömenden Wasser hin und her. Auf seichterem Boden werden die Blätter kürzer und schmaler,

1) Vergl. Svedelins 1904. 
auf den Watten der Nordsee z. B. finden sich ganz schmalblättrige Formen. Die Art ist wintergrün, blüht im Hochsommer unter dem Wasser.

Epiphytisch wachsen auf den Zostereen verschiedene Algen (Diatomeen, Desmotrichum undulatum, Arten von Ectocarpus, Ceramium, Polysiphonia, Melobesia u. a.), ebenso Bryozoen u. a. kleine Tiere. Auf dem Boden, zwischen den Grundachsen kommen, z. B. auf den periodisch (zur Ebbezeit) trocken gelegten Watten der Nordsee, ebenso an den Küsten von Nordamerika (nach Davis) Assoziationen von Cyanophyceen und Chlorophyceen vor (Anabaenae, Lyngbyae usw.); ihnen beigemischt sind bisweilen auch vereinzelte Exemplare von Grün- und Braunalgen, welche auf Steinen oder Kalkschalen befestigt sind, z. B. Phyllophora Brodiaei, Cladophora gracilis, Furcellaria fastigiata, Fucus u. a. nach Rosenvinge. C. G. Joh. Petersen hat durch eigene Methoden und neue Apparate weitläufige Untersuchungen über die Tier-Vereine auf dem Meeresboden in Skagerak, dem Kristianiafjord und den dänischen Gewässern gemacht. Sie sind in den Berichten von der dänischen Biolog. Station veröffentlicht, die letzte 1915. Durch diese seine Bonitierungsuntersuchungen hat er gefunden, daß sich in ganz Dänemark im Sommer ein Quantum von 24 Millionen Tons Zostera findet, und daß die Jahresproduktion doppelt so groB $^{\text {ist }}{ }^{1}$ ).

Zostereta nanae sind in nördlichen Meeren seltener; finden sich entweder innerhalb der Zostereta marinae auf seichterem (ca. 20-50 cm tiefem) Wasser oder auch wie z. B. im Mittelmeere auf größere Strecken allein herrschend. Oft wächst Zostera nana in Gesellschaft von RuppiaArten und Zannichellia, welche auch selbständige Assoziationen bilden können. Auch die einjährige Najas marina ist mitunter assoziationsbildend.

Eine Anzahl von mehr oder weniger veränderten Formen von verschiedenen Algenarten, welche die Strömungen herbeigeführt haben und welche zwischen den Blättern und Sprossen der genannten Assoziationen, namentlich den Zostereten, zurückgehalten wurden, verbleiben hier, ohne zu fruktifizieren, wachsen aber und vermehren sich, erleiden dabei verschiedene Formveränderungen; solche Formen sind z. B. Ascophyllum nodosum var. scorpioides, Phyllophora Bangii, Formen von Ph. Brodiaei, Ahnfeltia plicata, Cladostephus verticillata u. a. (Rosenvinge).

Im brackischen Wasser der nordeuropäischen Fjorde und Buchten finden sich ausgedehnte Potamogetoneta pectinati, bis zu $3-6 \mathrm{~m}$ Tiefe, und in noch weniger salzigem Wasser, besonders in Strandwassertümpeln kommen Batrachium-Arten (B. marinum usw.) vor sowie Myriophyllum.

1) Über Biologie von Zostera marina vergl. Ostenfeld 1908 a; C. G. Joh. Petersen 1914, 1915. 
Viele Salinengewässer (Solquellen, -gräben usw.) haben eine eigene Algenvegetation, oft gemischt mit Ruppia und Zannichellia.

In den Eismeeren scheint diese Vegetation fast $z u$ fehlen, vielleicht weil das Eis ihre Entwicklung nicht zuläßt. Dagegen finden sich velschiedene Assoziationen von Arten der beiden Familien in subtropischen und tropischen Meeren, z. B. im Mittelmeere Cymodocea nodosa und Posidonia oceanica.

In den westindischen Lagunen hat Börgesen ${ }^{1}$ ) fünf Meeres-Plınerogamen gefunden: Cymodocea manatorum, Halodule Wrightii, Tha-

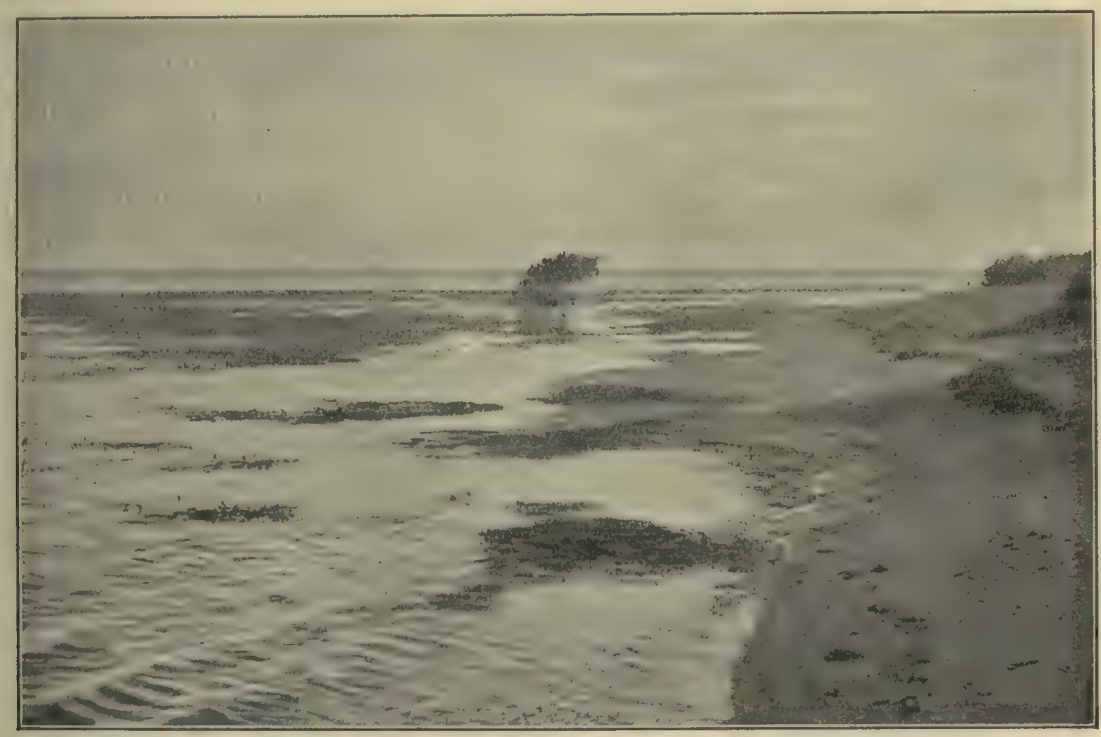

Fig. 195. Assoziation von Thalassia testudinum und anderen Seegräsern. St. Croix, Westindien. (F. Börgesen.)

lassia testudinum, Halophila Baillonis und H. Aschersonii. Zwischen diesen können Algen aus der oben erwähnten Formation (Penicillus usw.) vorkommen. Eine solche Seegrasassoziation, Thalassietum testudini von St. Croix, welche bei niedrigem Wasserstande teilweise zum Vorschein gekommen war, hat Börgesen abgebildet (Fig. 195).

Seegras spielt in der Biologie des Meeres eine bedeutende Rolle (Eierlegen der Fische; Thalassia testudinum dient Schildkröten zur Nahrung); die Zostereta der Meere sind von großer Bedeutung für die Entwicklung des Aales („Aalgras") und andere Tiere ${ }^{2}$ ).

1) Börgesen 1909 .

a) C. G. Joh. Petersen 191 o. 


\section{Kap. Formationen der Salz-Sümpfe}

Zu den Wasserpflanzen werden hier alle Pflanzen gerechnet, deren Assimilationsorgane im Wasser untergetaucht sind oder höchstens auf dem Wasser schwimmen, zu den Sumpfpflanzen (Helophyten, helophilen Pflanzen) alle Pflanzen, die unter Wasser festgewurzelt oder an wasserreichen Boden gebunden sind, deren Laubsprosse sich aber jedenfalls wesentlich über die Wasserfläche emporheben. Daß es keine scharfe Grenze teils zwischen Wasser- und Sumpfpflanzen, teils zwischen Sumpfund Landpflanzen gibt, ist schon erwähnt worden. Die S. 362 ff. genannten Schizophyceenvereine schließen sich nahe hier an.

Der Boden ist mehr oder weniger reich an organischem Schlamm, das Wasser seicht und verhältnismäßig ruhig.

Sümpfe kommen hauptsächlich in kleinen Buchten und an vor Wellenschlag und starkem Winde ziemlich geschützten Lokalitäten vor, wo die feinen schlammigen und tonigen Teilchen sich ansammeln können. Viele Sümpfe sind den Gezeiten ausgesetzt, und andere werden zeitweise sehr durch zuströmendes süßes Wasser, so z. B. in den Mündungen der Flüsse, beeinflußt.

Folgende Formationen können nach den Lebensformen unterschieden werden:

1. Formation der Sand-Algen und Bakterien,

2. $\quad$ " einjährigen Kräuter,

3. " " Stauden und Gräser,

4. $"$ Halbsträucher,

5. $"$ Holzpflanzen.

1. Die Formation der Sand-Algen und Bakterien ist schon besprochen worden; vergl. im wesentlichen S. 388-391.

\section{Formation der einjährigen Kräuter}

In Nordeuropa gibt es in in den Strandsümpfen hauptsächlich nur Vereine von krautartigen Pflanzen und zwar folgende einjährige:

Salicornieta herbaceae. Salicornia herbacea tritt auf zwei verschiedenen Standorten auf; zunächst auf Sandboden an den Küsten der Nordsee, welcher von der Flut täglich oder jedenfalls oft überschwemmt wird. In dem Sandboden können hier die Sandalgen-Vereine angesiedelt sein (vergl. Fig. 170, S. 339).

Eine solche Vegetation bildet oft den Anfang einer Sandmarsch, indem der Boden durch zugewehten Sand allmählich erhöht wird und andere Blütenpflanzen einwandern; der Anfang kann z. B. durch Festuca thalassica (Glyceria maritima) gemacht werden. Dieser Verein kann 


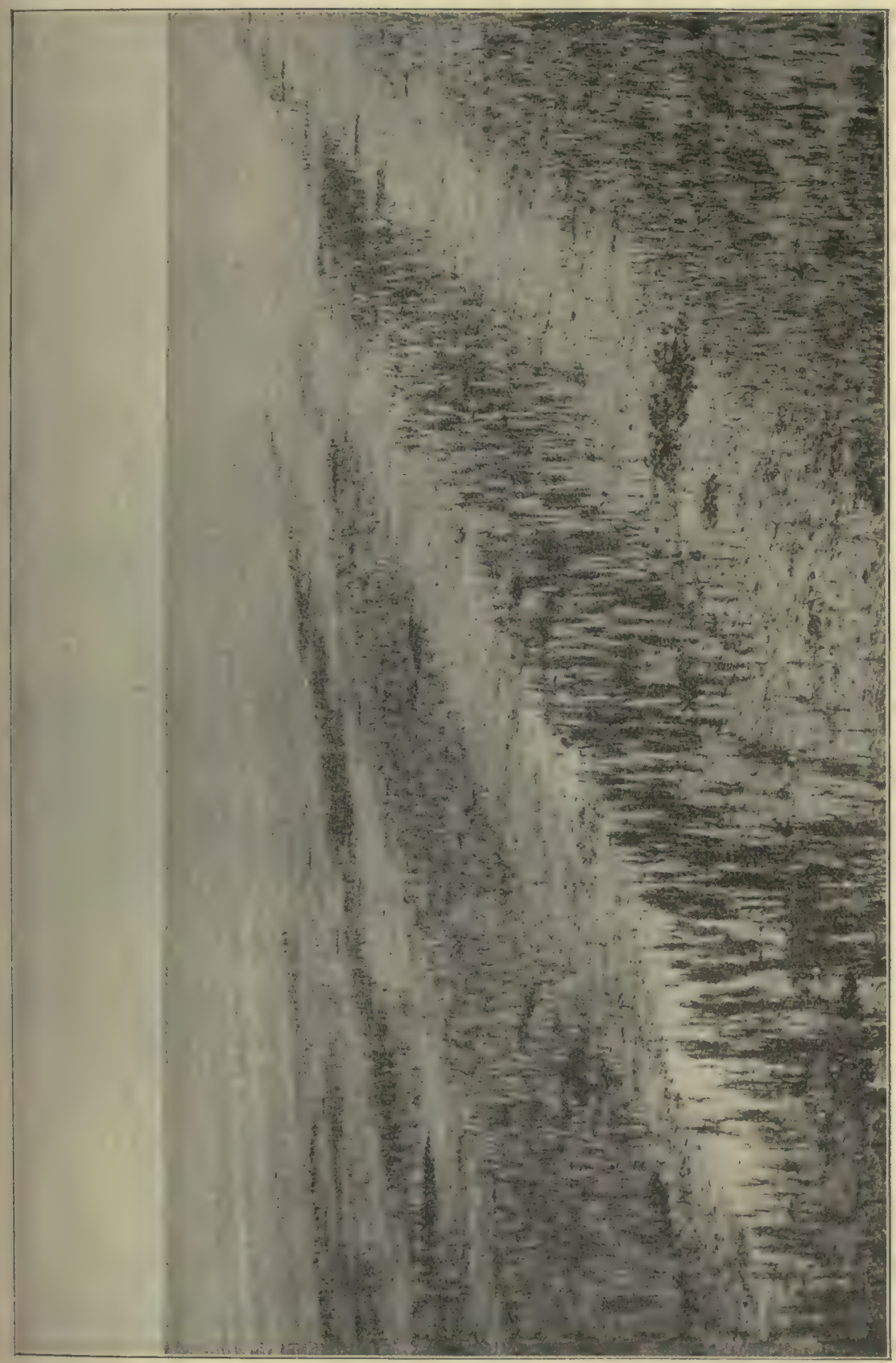

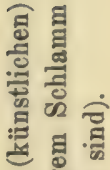

홍

$\Xi \Xi$

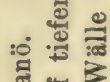

纯

उ.

递

总

合

동. 행

है

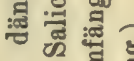

它嵒青

品

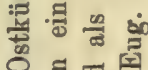

0 혀의

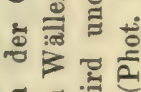

도로 일

苋 嵌

ฐิ

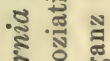

ㅎำ

¿ 4

के

क :

동

茯

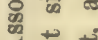

य晋

ळं

$\rightarrow$ 휴

si : 
nicht zu den Sümpfen gerechnet werden, bildet aber eine den Sandalgen folgende Formation.

Zweitens findet man Salicornia herbacea auf tiefem, weichem, wasserreichem Schlammboden, wo diese einjährige, aber merkwürdigerweise succulente Pflanze während der Flut tief im Wasser steht.

Oft sieht man das Salicornietum im Vordergrunde; weiter hinaus kommit ein Zosteretum; beide kommen während der Ebbe an die Luft und werden dann deutlich sichtbar. Beide Assoziationen sammeln Schlick auf und bereiten dadurch den Boden einer Salzwiese vor. Vorzüglich sieht man dieses an Küsten der Nordsee in den Marschgegenden, wo die Flut eine Menge äußerst feiner, organischer und anorganischer, meist toniger Bestandteile herbeiführt, die sich während des Hochwassers niedersenken. Festgehalten und abgeseiht werden diese Bestandteile zunächst vom Seegrase (Zostera), das große, Schlick sammelnde Bänke bildet (S. 393), in niedrigerem Wasser demnächst von Algen; besonders aber dient Salicornia herbacea als Schlammfänger, wodurch der Boden allmählich erhöht wird. Eine Verstärkung der Verlandung wird von den Anwohnern angestrebt und dadurch befördert, daß sie niedrige Wälle ins Meer hinausführen, auf welchen sich die Salicornia schneller einfindet (Fig. 196).

Salicornia herbacea bildet in reinen, aber sehr offenen Assoziationen die äußerste Zone der eigentlichen Landvegetation; sie iiberzieht große Strecken der während der Ebbe trocken gelegten Watten und steht während der Flut unter Wasser, obwohl sie eine kaktusähnliche Stammsaftpflanze und anscheinend wie ein sehr ausgeprägter Xerophyt ausgestattet ist: mit Blattlosigkeit und einem fleischigen Stengel, der die Assimilation übernommen hat, ein von dem inneren Wassergewebe scharf abgesetztes, zweischichtiges Palissadengewebe ${ }^{1}$ ) und obendrein tracheïdenförmige Wasserzellen (S. 260) besitzt (Fig. 170, 197).

Schon an Englands südlichen Küsten treten halbstrauchartige Salicornien, meist südlichere Arten ${ }^{2}$ ), auf; vielleicht wirkt das Eis im Winter nicht so zerstörend für diese Salicornien, wie es in Dänemark sein würde, weshalb sie dort gedeihen, während an den nördlicheren Küsten nur die einjährigen Schutz finden (S. 339).

\section{Stauden- und Gras-Formationen}

Scirpeta. Eine andere ganz verschiedene Sumpf-Vegetation von krautartigen Pflanzen findet sich auch an den nordeuropäischen Küsten mit verschiedenen Assoziationen, nämlich Scirpeta maritimae und

1) Duval Jouve; Hultberg; Warming 1890, Fig. 1, 1906.

2) Vergl. Tansley u. Moss 1910. 
Scirpeta Tabernaemontani. Auch Phragmiteta communis kommen in brackischen Gewässern vor.

Alle drei Arten sind vieljährige Hochstauden mit starken ausläuferartigen Grundachsen, die die Fähigkeit besitzen, in einer gewissen Boden- und Wassertiefe zu kriechen. Die Vereine können daher sehr groß und sehr dicht werden, sie erreichen eine Höhe von ca. $1-1,5 \mathrm{~m}$ oder was Phragmites betrifft, noch darüber (Fig. 198).

In anderen Gegenden treten natürlich andere Arten assoziationsbildend auf, meist Cyperaceen (Carex-Arten in Nordrußland) ${ }^{1}$ ) usw. Auf

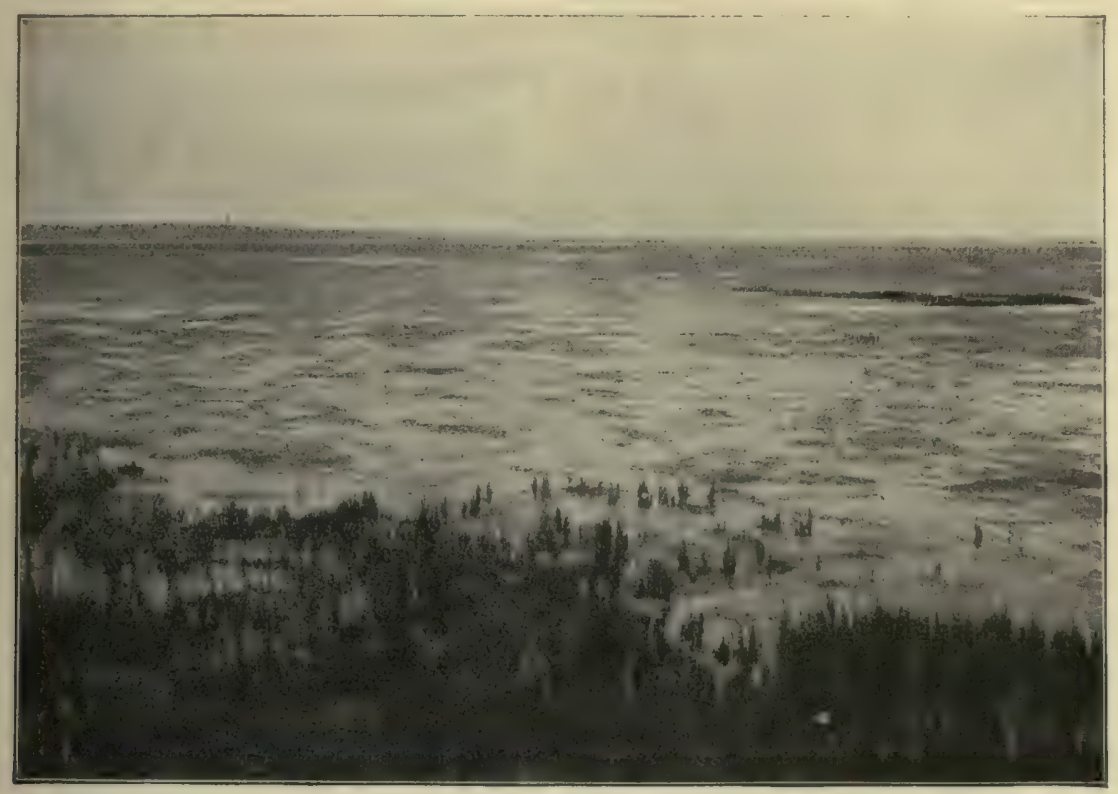

Fig. 197. Salicornietum herbaceae an der Westküste von Jütland, im Vordergrunde und weiter hinaus im Meere (der schwarze Fleck rechts). Im Meere sonst Zosteretum und zwischen den Zostera-Pflanzen ist der Boden mit Mierocoleus chtonoplastes, Lyngbya a. a. Schizophyceen gedeckt. (Eug. Warming.)

Samoa bildet nach Rechinger ${ }^{2}$ ) der Farn Acrostichum aureum auf Boden, der mit Brackwasser getränkt ist, dichte Bestände, welche keine anderen Pflanzen aufkommen lassen. Die starren blechartigen Blätter dieses Riesenfarns erreichen oft eine Länge von über $3 \mathrm{~m}$. Die jungen Pflanzen wachsen im zähen, schwarzen Schlamm.

Ähnliche Salzsümpfe finden sich auch im Binnenlande weit von den Meeren, z. B. in Asien im Anschlusse an die Steppen und Wüsten, wo Wasser vorhanden ist. Nach Martjanow werden die in Zentralasien am

1) Pohle 1907.

2) Rechinger 1908. 
Altai vorkommenden von einer dichten Einfassung aus Phragmites communis umgeben, die mehrere Meter hoch wird, und außerhalb deren man auf trocknerem Boden folgende Arten findet: Salicornia herbacea, Suaeda maritima, Taraxacum collinum, Lactuca Sibirica, Triglochin maritimum, Plantago maritima, Glaux maritima, Atriplex litoralis, Aster tripolium u. a., also großenteils Arten, die aus der nordischen Flora wohlbekannt sind.

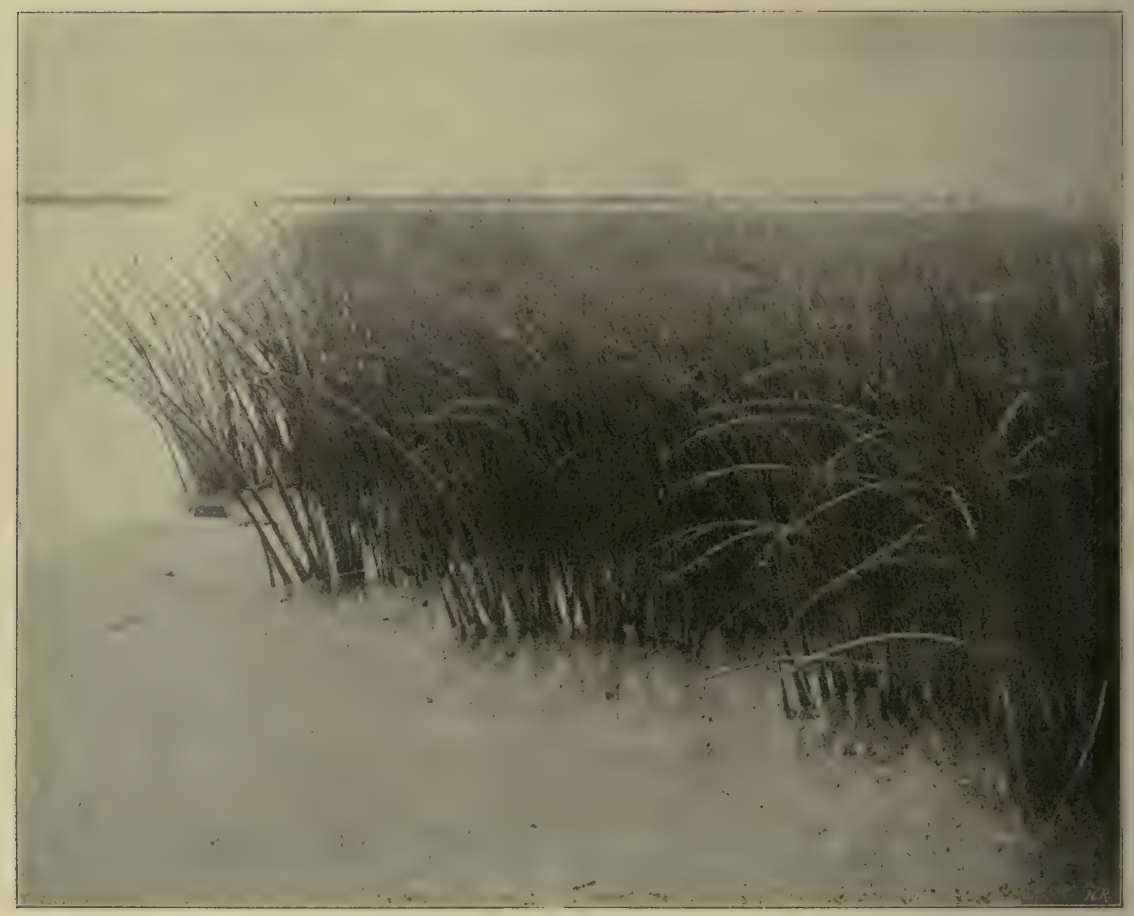

Fig. 198. Strandsumpf mit Scirpus Taüernaemontani, zurzeit trockengelegt wegen niedrigen Wasserstandes. Der horizontale Wuchs der unterirdischen Rhizome tritt deutlich hervor. (Phot. Eug. Warming.)

Hierher gehören auch die Spartina-Bestände an Englands und Nordamerikas Küsten.

Diese Hochstauden-Sümpfe sind den Rohrsümpfen der süßen Gewässer ganz parallel, aber floristisch sind sie verschieden, wenn man von einigen Bestandbildnern, namentlich von Phragmites absehen will.

\section{Formation der Halbsträucher}

Es ist längst bekannt, daß die Gehölzbildung nach den Tropen hin häufiger wird, so daß viele Gattungen, die in gemäßigten Gegenden nur krautartig sind, in den subtropischen und tropischen Gebieten immer 
mehr durch verholzende (Halbsträucher, Sträucher oder Bäume) vertreten werden. Dies gilt auch von der Sumpfvegetation der Küsten. Es kommen z. B. mehrere halbstrauchartige bis strauchartige Salicornien, succulente Halbsträucher wie Batis maritima и. a. in den tropischen Sümpfen vor $(\mathrm{S} .340)^{1}$ ). Da sie jedoch melur zur Vegetation des trockengelegten Landes gehören, werden sie unter dieser besprochen werden. An den Küsten des Mittelmeeres findet man sie nicht selten als typische Uferflora.

\section{Formation der von größeren Holzpflanzen (Sträuchern, Bäumen) gebildeten Salzsümpfe}

Von solchen gibt es wahrscheinlich mehrere Assoziationen, jedenfalls sind mindestens zwei, die Mangrovevegetation und das $\mathrm{Ni}$ petum, zu unterscheiden.

1. Die Mangrovensümpfe. Von allen an Sümpfe in salzigem oder brackischem Wasser gebundenen Pflanzenvereinen sind die Mangrovensümpfe die größten, interessantesten und am besten bekannten. Sie treten an allen tropischen Meeren, besonders an flachen, sumpfigen Küsten auf, wo das Wasser verhältnismäßig ruhig ist (Lagunen, Buchten, Flußmïndungen), aber selten, wo Sandboden, Felsenboden und Brandung vorkommen; Ebbe und Flut verhindern ihr Auftreten nicht. An vielen Stellen erstreckt sich die Mangrovenvegetation längs der großen Flüsse weit in das Land hinein. Das Wasser ist gewöhnlich mehr oder weniger brackisch, bisweilen sogar fast süß.

Die Mangrovenvegetation ist meist eine niedrige immergrüne Wald- oder Gebüschvegetation und stellt sich, vom Meere aus gesehen, als eine dunkelgrïne, dichte, oft undurchdringliche Masse niedriger Bäume mit einer Unzahl bogenförmiger Luftwurzeln dar. Rhizophora mangle erhelt sich jedoch auf gïnstigen Stellen zu einem stattlichen Hochwalde, z. B. an den Flußmündungen Venezuelas (Johow), ebenso $R$. mucronata in Ostasien. Gewöhnlich sind die Kronen unten in einer geringen Höhe über dem Wasser scharf abgeschnitten, und unter ihnen sieht man, wo Rhizophora-Arten den äußersten Rand der Vegetation bilden, den Wirrwarr jener zahllosen braunen Wurzeln. Der während der Ebbe stellenweise bloBgelegte Boden ist ein weicher, tiefer, schwarzer Schlamm, der mit organischen, verwesenden, stinkenden, offenbar bakterienreichen Massen erfïllt ist. Das Wasser zwischen den Bäumen kann mit einer schmutzigen Haut bedeckt sein, und Luftblasen steigen vom Grunde herauf und platzen auf der Oberfläche.

Die Mangrovevegetation kommt auch auf Boden vor, der jedenfalls naß, aber niemals eigentlich vom Wasser bedeckt ist.

1) Börgesen u. Paulsen 1900; Raunkiår 1909; Börgesen 1909. 
Viele Crustaceen verschiedener Gattungen leben hier, durchwühlen den Boden, begraben welke Blätter und entfalten eine ähnliche Tätigkeit wie die Regenwürmer in dem salzfreien Humusboden (C. Keller); vergl. Kap. 18.

Die Flora ist artenarm (etwa 26 Arten aus 9 Familien) und auf den ausgedehnten Gebieten der alten Welt von Ostafrika bis Australien ziemlich gleichförmig; die amerikanische Flora ist noch ärmer. Die Mangrove der afrikanischen Westküste ist näher verwandt mit der ostamerikanischen als mit der von Ostafrika, was sicher durch die Meeresströmungen bedingt ist. Wir haben also zwei große, floristisch ziemlich verschiedene Mangrovengebiete, das indische und das atlantische; doch schließt die westamerikanische sich derjenigen der Ostküste an. Der Grund liegt wohl darin, daß in älterer Zeit eine Wasserverbindung zwischen den beiden Ozeanen vorhanden war. Die Arten verteilen sich folgendermaßen:

Nur in der östlichen Mangrove finden sich:

2 Meliaceen (Carapa Moluccensis, C. obovata),

4 Lythraceen (Sonneratia acida, S. alba, S. caseolaris, S. apetala),

1 Rubiacee (Scyphiphora hydrophyllacea),

1 Myrsinacee (Aegiceras majus [corniculatum]),

1 Acanthacee (Acanthus ilicifolius).

Sowohl in der östlichen (asiatischen) wie in der westlichen (atlantischen) Mangrove finden sich:

Rhizophoraceen (9 im Osten: Brugiera caryophylloides, B. eriopetala, B. gymnorrhiza, B. parviflora; Ceriops Candolleana, C. Roxburghiana; Kandelia Rheedii, Rhizophora conjugata, $R$. mucronata; im Westen nur Rhizophora mangle).

Combretaceen (2 im Osten: Lumnitzera coccinea, L. racemosa; 1 im Westen: Laguncularia racemosa).

Verbenaceen (1 im Osten: Avicennia officinalis var. alba; $2 \mathrm{im}$ Westen: Avicennia nitida, A. tomentosa).

In Afrika allein findet sich Heritiera litoralis.

Von den genannten Arten ist nur eine krautartig: Acanthus ilicifolius, die übrigen sind Sträucher oder Bäume. Auch ein Farn, Acrostichum aureum, kommt vor (siehe S. 399).

Die Wurzeln sind oft dicht mit Florideen und anderen Algen bewachsen, welche während der Ebbe periodisch trocken gelegt werden.

Anpassungsverhältnisse.

1. Befestigung. Die verschiedene Weichheit des Bodens und die Tiefe des Wassers machen sich geltend und rufen zunächst eine Verteilung der Arten in gürtelförmige Assoziationen hervor; zu äußerst 
wachsen solche, die sich in dem tieferen Wasser am besten befestigen können, die Rhizophora-Arten; innerhalb dieser, in niedrigerem Wasser oder trocknerem Boden, solche Arten, die dieses in geringerem Grade zu tun vermögen (Avicennia, Bruguiera, Aegiceras, Carapa u. a.).

Wahrscheinlich machen sich in den verschiedenen Gürteln auch Unterschiede im Salzgehalte geltend.

Die Rhizophora-Arten befestigen sich durch Stützwurzeln, d. h. durch Luftwurzeln, die vom Stamme entspringen und, indem sie sich gewöhnlich strahlenförmig verzweigen, unter einem großen Bogen in den

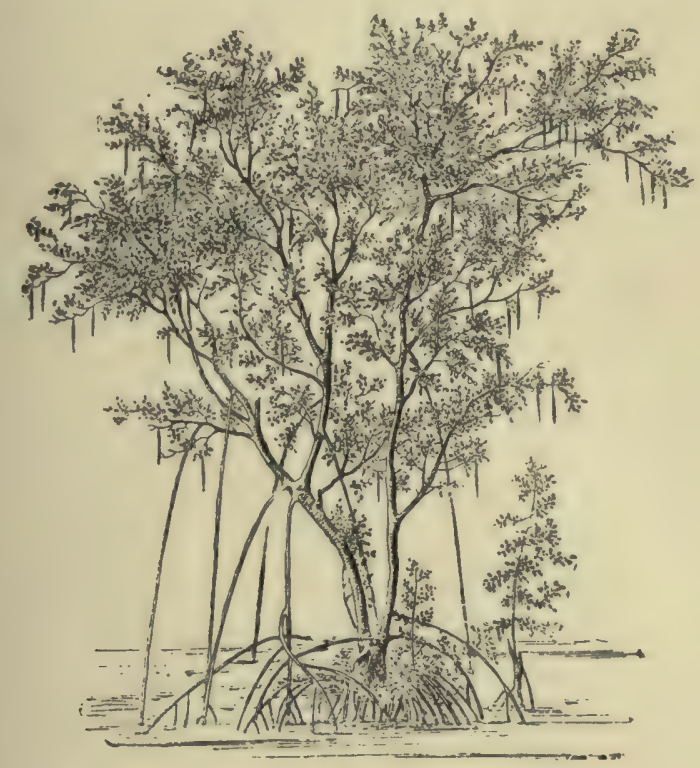

$A$

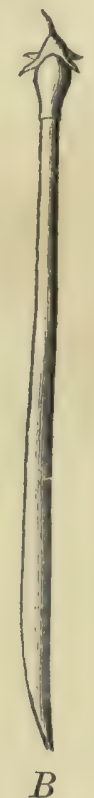

Fig. 199. Rhizophora mangle (Westindien). Die aus der Krone herabhängenden, langen, dünnen Körper sind die bereits in der Frucht sich entwickelnden Keimpflanzen, von welchen eine (auch sehr verkleinert) in $B$ abgebildet ist (A. S. Örsted).

Boden hinabwachsen (Fig. 199, 200) ${ }^{1}$ ). Diese strahlenförmige Verzweigung soll dadurch hervorgerufen werden, daß die Wurzelspitzen durch einen kleinen Käfer angefressen werden (van Leeuwen). So werden die Bögen, worauf ein Baum ruht, sehr zahlreich; die Basis und der Widerstand gegen die Biegungen, welche die Wasserbewegung und die Winde veranlassen könnten, werden größer, als wenn der Stamm nur auf sich allein stände. Der anatomische Bau der Wurzeln stimmt mit den ungewöhnlichen Anforderungen, die an sie als Stützwurzeln gestellt werden, überein und weicht von dem der meisten anderen Wurzeln dadurch ab, daß das

1) Warming 1883; Börgesen u. Paulsen 1898, 1900; Börgesen 1909. 
mechanische Gewebe um ein großes Mark in Röhrenform angebracht ist, die Wurzeln also säulen- oder biegungsfest (Schwendener) gebaut sind ${ }^{1}$ ). Ähnliche Stützwurzeln haben namentlich auch Ceriops und Acanthus iticifolius.

Indem die Rhizophoren als äußerste Vorposten der Mangrove zwischen ihren Wurzeln Schlamm sammeln, befördern sie die Landbildung.

2. Atemwurzeln. Die Atmung ist in dem wasserreichen, mit organischen Teilen erfüllten, sauerstoffarmen Boden schwierig. Daher haben alle Mangrovenpflanzen ein stark entwickeltes System von Lufträumen; die untergetauchten Teile haben einen sehr schwammigen und weichen Bau; Spaltöffnungen und ungewöhnlich große Lenticellen auf den über Wasser befindlichen Teilen verbinden die Intercellularräume mit der Atmosphäre. Gegen Druck sind strahlig angeordnete Zellen dieses Schwammgewebes mit radiären Versteifungslisten versehen; auch die unten unter $5 \mathrm{~h}$ erwähnten bastähnlichen Zellen dienen wahrscheinlich dem selben Zwecke (Figuren bei Warming 1883). Die Luftwurzeln von Rhizophora dienen zugleich als Atemwurzeln. Andere Arten haben ganz besondere, ungewöhnliche Atemwurzeln, deren Form verschieden ist $\left.^{2}\right)$. Avicennia hat aufwärts wachsende, unverzweigte, fußlange Wurzeln ("Spargelwurzeln"); diese stehen in sehr langen Reihen, die von den Bäumen ausstrahlen und die Lage der wagerechten Wurzeln bezeichnen, von welchen sie entspringen ${ }^{3}$ ) (Fig. 201, 202). Ähnliche Atemwurzeln haben Sonneratia acida ${ }^{4}$ ) und Laguncularia (diese gehört jedoch nicht zu der eigentlichen Mangrovenvegetation). Knieförmig gebogene Wurzeln, deren Knie das Wasser überragt, kommen bei Bruguiera und in geringerem Grade bei Lumnitzera vor; kammförmige Verlängerungen, die mit der Wurzel wachsen, hat Carapa. Versuche bekräftigen die Auffassung, daß diese eigentümlichen Bildungen Atemwurzeln sind. Der anatomische Bau ist mit dem Zwecke im Einklange ${ }^{5}$ ).

3. Keimung; Viviparie. Mehrere Arten der Mangroven zeigen die seltene Erscheinung, „lebendig 'gebärend (vivipar)" zu sein, indem der Keim schon auf der Mutterpflanze, ohne Ruhezustand und beständig von ihr ernährt, zu einer mehr oder weniger entwickelten Pflanze auswächst; dieses bei anderen Pflanzen abnorme Verhalten ist hier normal. Man findet folgende Stufenreihe.

1) Warming 1883; Tansley u. Fritsch 1905 .

5) Vergl. Taf. 37-40 bei Johs. Schmidt 1906.

8) Göbel 1886. Vergl. Warming in Börgesen u. Paulsen 1898, 1900; Börgesen 1909.

4) Karsten 1891.

5) Ähnliche Atemwurzeln von Pflanzen von Süßwassersümpfen vergl. weiter unten, dann Kearney 1901, Koorders 1907. 


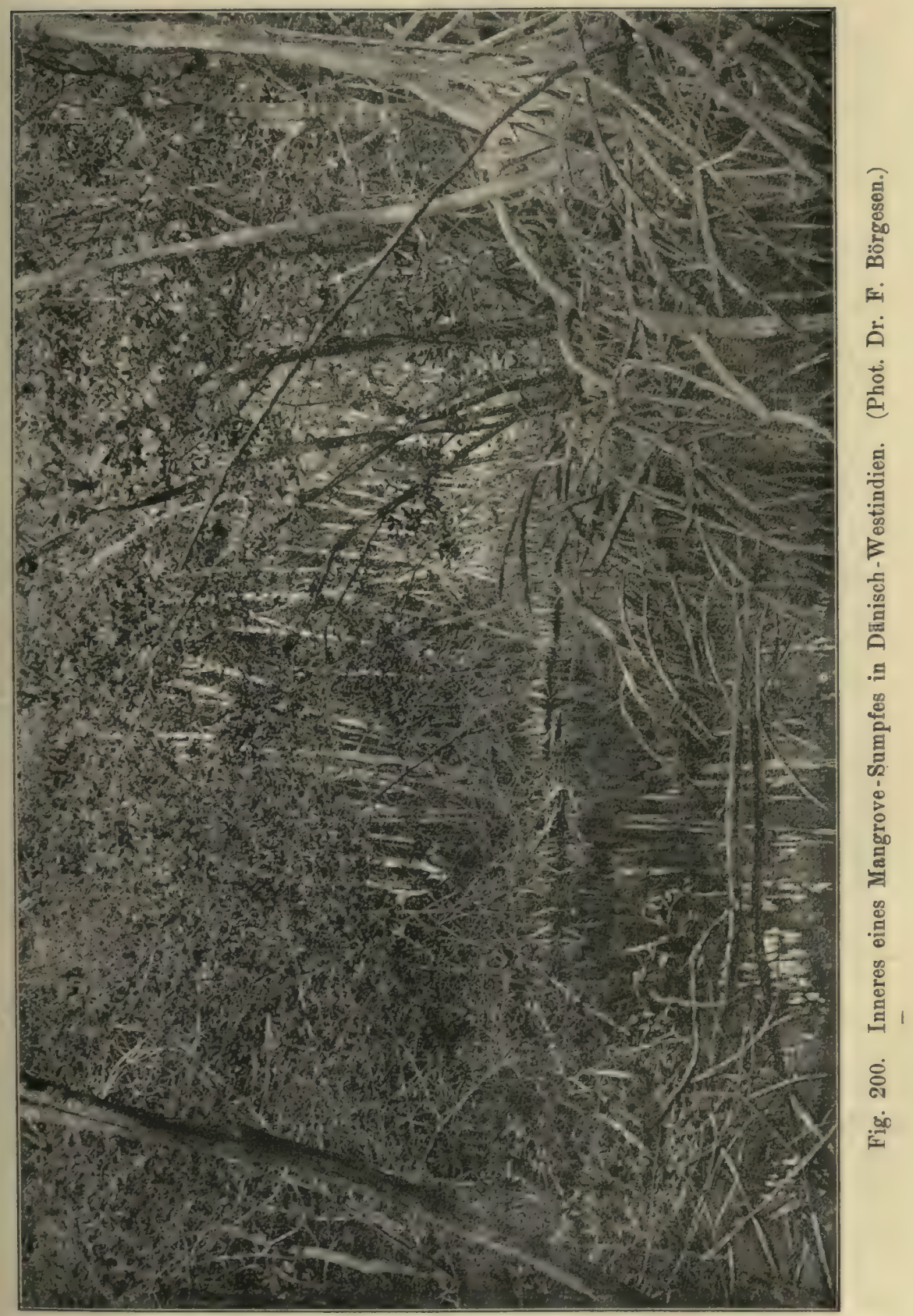


1. Bei Aegiceras tritt der Keim aus dem Samen heraus, bleibt aber von der Frucht umschlossen; er hat einen großen Keimstengel und ist grün.

2. Bei Avicennia treten das Endosperm und später der Keim aus dem Samen heraus und liegen frei in dem Fruchtfache; der Keim ist grün und wird von der Mutterpflanze durch eine lange, vielfach verzweigte hyphenähnliche Saugzelle, welche die Placenta durchwächst, ernährt.

3. Bei Rhizophora und nahestehenden Gattungen (Bruguiera, Ceriops) wächst der Keim nicht nur aus dem Samen, sondern auch aus

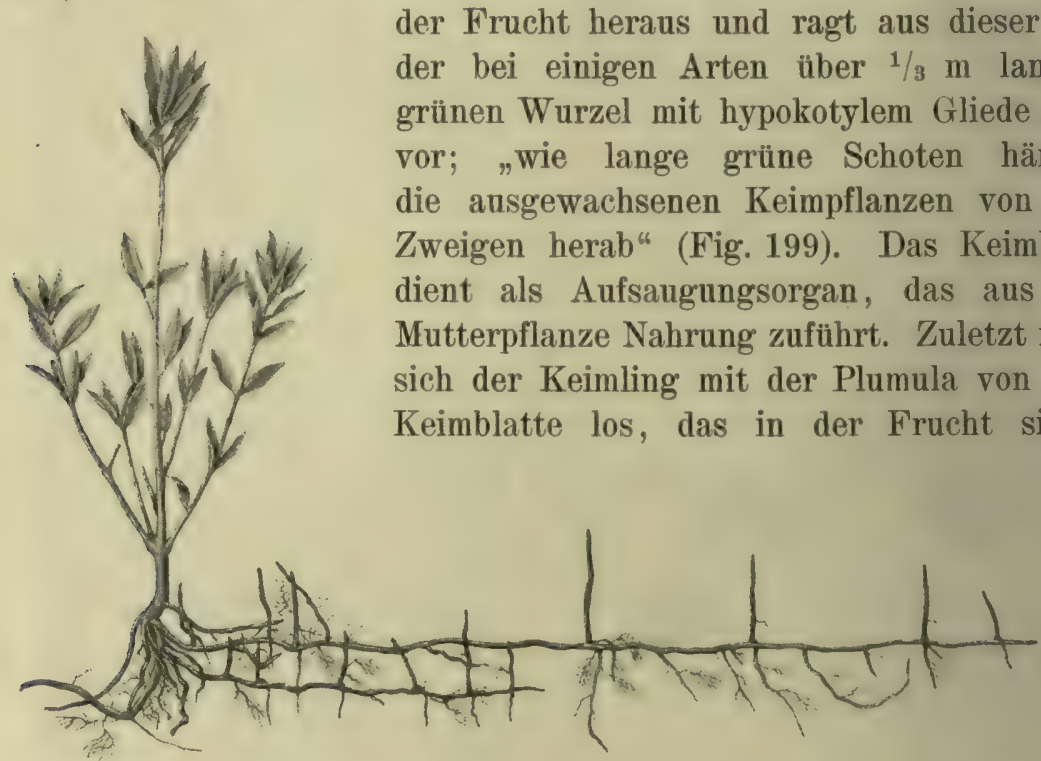

Fig. 201. Avicennia nitida; junge Pflanze, ca. 1/8 der natürlichen Größe. Westindien. (F. Börgesen, 1909.)

bleibt und mit ihr verwelkt. Der Keimling fällt in das Wasser oder den Schlamm hinab und ist durch seine ganze Form (er ist etwas keulenförmig und hat ein spitzes Keimwurzelende) an dieses Fallen und an das Einbohren in den Schlamm angepaßt; hier entwickeln sich die schon angelegten Seitenwurzeln schnell ${ }^{1}$ ). Gelingt es dem Keimling nicht, sich zu befestigen, so schwimmt er und wird sich sogar an einem ganz anderen Strande anheften können, so daß er mit Hilfe des Wassers zugleich die Wanderung der Art besorgt. Die Viviparie ist bei den in sehr tiefem Wasser und sehr weichem Boden wachsenden Rhizophoraceen am stärksten und für sie offenbar eine günstige Eigenschaft.

1) Warming 1883; Karsten 1891. 
Als eine Anpassung an die Verhältnisse muß auch die Eigentümlichkeit angesehen werden, daß der Keim grün ist, und daß Verankerungsorgane vorkommen, teils aufwärts gerichtete steife Haare (Widerhaken) auf dem Keimling, teils Seitenwurzeln, die im Inneren fertig angelegt sind (bei Avicennia, Aegiceras, Sonneratia, Rhizophora n. a.) und in kurzer Zeit hervorbrechen können.

4. Wanderungsmittel. Alle Strandpflanzen haben sehr weite Verbreitungsgebiete. Die Mangrove enthält ziemlich dieselben Arten

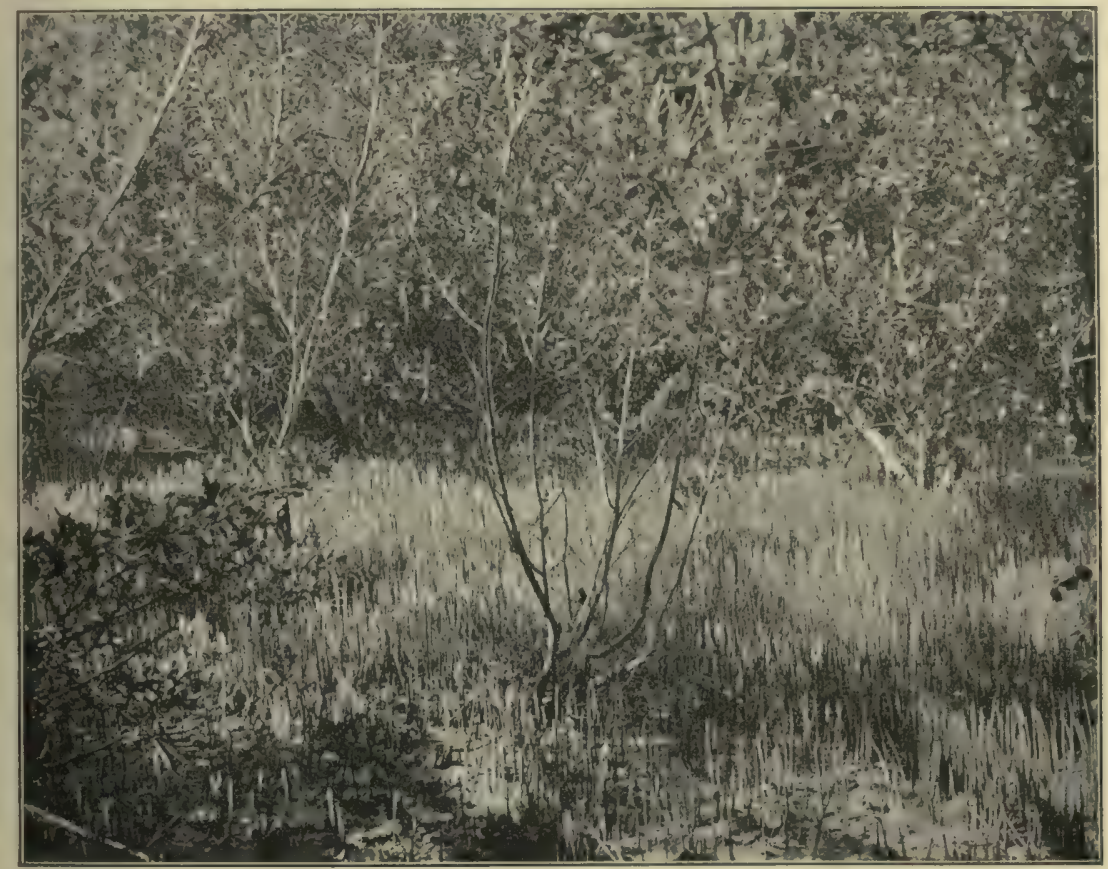

Fig. 202. Avicennia nitida-Assoziation anf St. Croix. Grobe Mengen der Atemwurzeln erheben sich aus dem Schlamme. (F. Börgesen, 1909.)

längs allen tropischen Küsten von Australien bis Ostafrika (ausgenommen die sehr regenarmen, trockenen Küsten Arabiens). Die Gründe hierfür sind teils, daß Medium und Temperatur überall gleichförmig sind, teils die vorzüglichen Wanderungsmittel. Die Früchte, Samen oder Keimpflanzen der Mangrovenarten können wegen der Lufträume der Schale oder anderer Teile, die das spezifische Gewicht vermindern, sehr lange schwimmen und verlieren dabei die Keimfähigkeit nicht ${ }^{1}$ ).

5. Xerophiler Bau. Die Mangrovenarten sind bis auf eine Ausnahme (Acanthus ilicifolius) Bäume und Sträucher. Thre Laubsprosse

1) Hemsley 1885; Schimper 1891; Guppy 1906. 
zeigen, obgleich die Pflanzen in Wasser oder auf einem sehr wasserreichen und schlammigen Boden wachsen, merkwürdigerweise mehrere Bauverhältnisse, die auch bei den an Trockenheit angepaßten Pflanzen vorkommen ${ }^{1}$ ). Es sind namentlich folgende:

a) Die Blätter sind dick, lederartig oder etwas fleischig (besonders bei Sonneratia, Lumnitzera, Carapa, Rhizophora, Avicennia).

b) Die Epidermis ist dickwandig und stark kutikularisiert; die Blätter sind oft sehr glänzend (z. B. bei Rhizophora mangle).

c) Hydathoden. Verschiedene Organe an Blättern der MangrovePflanzen sind von Areschoug ${ }^{2}$ ) als Hydathoden angesprochen worden. In der Mangrove der Küste von Siam fand Schmidt ${ }^{3}$ ), daß bei Aegiceras cornieulatum Drüsen anf der Oberseite der Blätter Salz abscheiden. Während der Nacht nehmen die Salzkristalle Wasser aus der Luft auf und schmelzen; am Morgen verdunstet das Wasser wieder und das Salz kristallisiert wieder aus. Es ist dies eine ganz gleichartige Erscheinung, wie sie Volkens (vergl. S. 245) bei gewissen Wüstenpflanzen als Verdunstungsschutz fand. Schmidt fand diese Einrichtung in der Mangrove nur an der genannten Pflanze (s. Fig. 124, S. 244).

d) Die Spaltöffnungen sind unter das Niveau der Oberfläche eingesenkt; krugförmige Vorhöfe sind allgemein.

e) Wassergewebe ist immer vorhanden, oft sehr mächtig. Bei Rhizophora mucronata werden die älteren Blätter, die nicht weiter assimilieren, dicker als sie in der Jugend waren; dieses rührt von der Vergrößerung ihres Wassergewebes her; das Blatt ändert die Funktion (Haberlandt). Das Blatt ist daher von einem "Regenblatt" sehr verschieden.

f) Das Mesophyll liat fast keine Intercellularräume, und das Palissadengewebe ist das einzige oder das überwiegende Chlorophyllgewebe (Sonneratia, Lumnitzera u. a.).

g) Die Nervenenden breiten sich in kurze Speichertracheïden aus (Bruguiera, Avicennia, Ceriops usw.; vergl. S. 260).

h) Lange Steinzellen oder bastähnliche mechanische Zellen liegen bei einigen Arten zwischen den Palissadenzellen oder sogar im Wassergewebe, besonders bei Rhizophora, Sonneratia, Carapa (vergl. S. 263) und in dem Marke der Rhizophora ${ }^{4}$ ).

i) Schleimzellen findet man bei mehreren Arten (Sonneratia, Rhizophora u. a.).

k) Einige Blätter sind stark und dicht behaart (Avicennia).

$\left.{ }^{1}\right)$ Uber den morphologischen Aufbau vergl. Johs. Schmidt 1903.

2) Areschong 1902.

8) Schmidt 1903.

4) Warming 1883 . 
1) Profilstellung ${ }^{1}$ ) der Blätter und damit einhergehende Isolateralität kommen bei Sonneratia, Lumnitzera, Ceriops vor (auch bei Laguncularia).

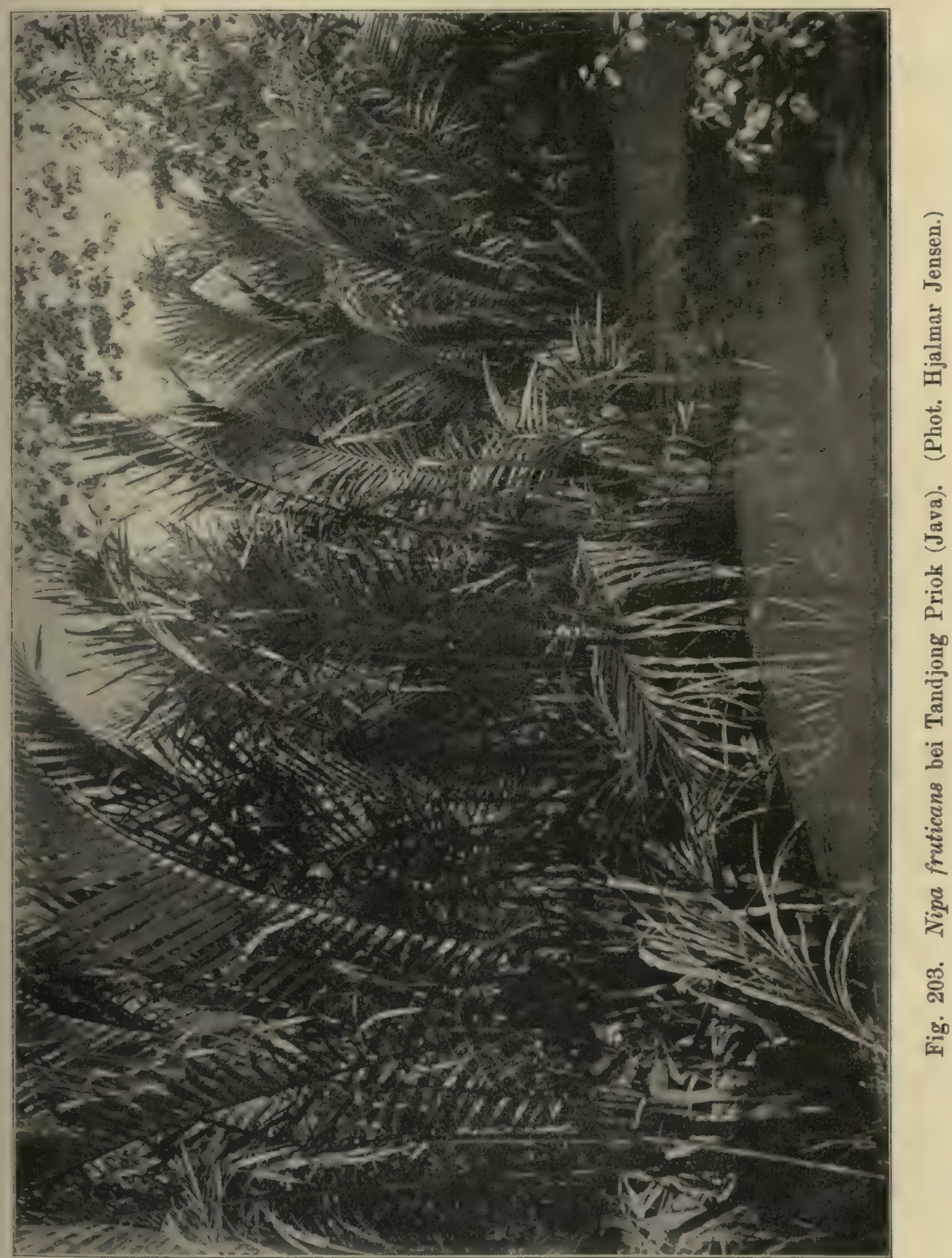

Der Grund dieses xerophilen Baues ist, wie früher dargelegt wurde, etwas rätselhaft. Es sei daran erinnert, daß auch viele Sumpfpflanzen

I) Vergl. J. Schmidt 1903. 
des Süßwassers und viele Moorpflanzen Bauverhältnisse zeigen, die jedenfalls scheinbar Anpassungen an Trockenheit sind (vergl. Kap. 80).

Nach Faber ${ }^{1}$ ) ist die Transpiration bei den Mangroven bei mehreren Arten sogar recht beträchtlich. Das transpirierte Wasser wird dadurch ersetzt, daß sie hohe, einige sogar gewaltige Druckkräfte in ihrem Gewebe haben; sie vermögen diese Druckkräfte nach der Konzentration des Wassers zu regulieren, in dem sie wachsen.

Es kann bemerkt werden, daß die Rinde der Rhizophoraarten sehr reich an Gerbstoff ist. Die vegetativen Knospen sind alle, doch auf verschiedene Weise, geschützt. Hierüber, sowie über den Sproßbau, hat Schmidt (1903) eine Menge Beobachtungen.

Assoziationen. Durch die ungeheure Menge von Wurzeln und Pflanzen in einem Mangrovenwalde wird die Anhäufung von Schlamm und organischen Resten begünstigt, die Verlandung wird eingeleitet. Nach und nach wird der Boden höher, das Wasser seichter, und zuletzt wird der Boden so stark aufgehöht, daß die tägliche Flut ihn nicht mehr überschmemmen kann; nach und nach werden die Regengüsse das Salz auswaschen, und gleichzeitig mit diesen Veränderungen des Standortes tritt eine Veränderung des Bestandes, der Assoziationen, ein. Von diesen gibt es mehrere: Rhizophoreta in tiefsten Wasser, in seichterem Wasser folgen Avicennieta, Laguncularieta, Sonneratieta u. a. selbst Acrosticheta aurei, und zuletzt treten Assoziationen auf, welche nicht mehr zu den halophilen Wäldern oder Gesträuchen gerechnet werden können, also fast salzfrei sind. Nach Raunkiär (1909) und Börgesen (1909) findet sich z. B. in Westindien eine Conocarpus-Assoziation (C. erecta) mit Anona palustris, Bucida buceras und den succulenten Halbsträuchern Batis, Salicornia ambigua und Sesuvium, auf höherem und trockenem Lagunenboden innerhalb der Mangroveformation. Vergl. Fig. 114 und 107. Dieser schließen sich an: eine Halbstrauchformation, Lagunengebüsche aus Batis, Salicornia u. a.

Wo die Mangroven in den Deltas der großen tropischen Flüsse vorkommen, z. B. im Amazonas, können sie direkt in die Regenwälder des flachen Alluviallandes übergehen ${ }^{2}$ ).

Litteratur über die Mangrovenvegetation: Warming 1883; Goebel 1886; Johow 1884; Schimper 1891; Schenck 1889; G. Karsten 1891; Haberlandt 1893; Börgesen und O. Paulsen 1898,1900; Areschoug 1902; Schmidt 1903; Karsten 1904, Vegetationsbilder II, 2; Tansley u. Fritsch 1905; Holtermann 1907; Raunkiär 1909 a; Börgesen 1909; Engler 1910.

Assoziation von Nipa fruticans. Die Nipa- "Formation" nennt Schimper ${ }^{3}$ ) die von der Palme Nipa fruticans in Ostasien und Australien

1) Faber 1913.

2) Siehe z. B. C. W. Anderson, Journ. of Ecology, I.

$\left.{ }^{3}\right)$ Schimper 1891. Siehe auch Karsten u. Schenck, Vegetationsbilder I. 
gebildete Vegetation, die sich an die Landseite der Mangrovensümpfe anschließt und also an Lagunen und Sümpfen, aber meist auf trocknerem und minder salzhaltigem Boden vorkommt; jedoch kann sie auch unmittelbar aus dem Wasser emporwachsen. Die Palme ist fast stammlos, hat aber mächtige, $3-6 \mathrm{~m}$ lange, gefiederte Blätter und kann so dicht wachsen, daß man sich nur mit der Axt einen Weg durch die Vegetation bahnen kann, worin auch andere Arten, darunter solche der Mangrove, als untergeordnete Bestandteile auftreten können (Fig. 203). Analog mit dieser Vegetation ist die Bactris-Vegetation Südamerikas.

Schimper erwähnt Nipa zuerst mit den Arten der Mangrovenvegetation, kurz darauf sagt er, daß sie besser als eine eigene „Formation" aufgestellt wird, zu der er auch Acrostichum aureum rechnet. Schmidt ${ }^{1}$ ) trennt sie ebenfalls von der Mangrovenvegetation, rechnet sie aber zu den Sumpfgebüschen des süßen Wassers, obwohl sie auch gelegentlich in den inneren Teilen der Mangrovenvegetation auftreten kann. Auch Acanthus ilicifolius gehört nach ihm nicht zur Mangrove.

\section{Kap. Halophytische Landvegetation}

Nachdem im Vorhergehenden die Vereine von in Salzwasser untergetauchten Pflanzen und die Vereine der Salzsümpfe besprochen worden sind, kommen wir jetzt zu der Vegetation, die auf Böden wachsen, wo Land und Meer sich begegnen, also zu den auf salzhaltigem Boden des trockneren Landes, auch des Binnenlandes, vorkommenden Pflanzenvereinen, welche ständig oder doch meist dem Luftleben ausgesetzt sind und höchstens in kurzen Zeiträumen von salzigem Wasser bedeckt sind (Terrestrische Vegetation).

Salzreicher Boden kommt auf der Erde an mannigfaltigen Stellen vor, nämlich: längs den Küsten aller Ozeane und den Ufern salziger Binnenseen, an Salzquellen, die aus der Erde hervorbrechen (z. B. an vielen Stellen Mitteldeutschlands) ${ }^{2}$ ) und in den inneren, regenarmen Teilen namentlich der großen Kontinente vermutlich z. T. auf altem, trocken gelegtem Meeresboden, der vom Regen nicht ausgewaschen werden konnte. Nach Bunge gibt es 9 solcher großen Salzgebiete, wovon jedes einzelne seine floristischen Eigentümlichkeiten hat: das Tiefland Australiens, die Pampas, innere Teile von Nordamerika, westliches Mittelmeergebiet, östliches Mittelmeergebiet, Südafrika, Gebiet des roten Meeres, Gebiet des kaspischen Meeres, Zentralasien. Die Salze, um die es sich hier handelt, sind besonders Kochsalz, Gips und Magnesiasalze.

1) Schmidt 1903.

2) Vergl. Ascherson 1859 und später; Petry 1889. 
Die Einwirkungen des Salzes sind nicht nur auf die in nächster Nähe der Meere liegenden Areale der Küsten beschränkt, wo Brandung und Hochwasser den Boden mit Salz durchtränken können, oder wo das Grundwasser in geringer Tiefe salzig ist; sondern Salzpartikel werden auch von den Stürmen recht weit in das Land hineingeführt. So hat z. B. Frödin gefunden, daß an der schwedischen Westküste bei dem Gebirge Kullen Salz in einer Höhe von $95 \mathrm{~m}$ und in einem Abstande von $500 \mathrm{~m}$ vom Meere nachweisbar war, daß weiter nördlich, dem Skagerak gegenüber, der Einfluß zu wenigstens $3 \mathrm{~km}$ vom Strande reichte ${ }^{1}$ ). Innerhalb dieses Gürtels hatten viele Pflanzen einen ungewöhnlich großen Gehalt an Chlor, und dieser reichte hin, um den Pflanzen eine deutlich xerophytische Ausbildung zu geben; der Boden wurde in höherem Grade physiologisch trocken. Auch an der Westküste Jütlands nimmt man in starken landeinwärts wehenden Stürmen die Salzpartikel in der Luft viele hundert Meter vom Meere wahr, der Nebel ist salzig und die Pflanzen können salzig schmecken.

Die Menge des Salzes ist recht verschieden. Nach Kearney finden sich typische Salzpflanzen auf Sandstrand mit 0,003-0,15\% Salz, aber an Salzwiesen kann $0,29-2,6 \%$ vorkommen und in den Salzwüsten im Innern von Nordamerika $3-3,5 \%$.

Überall, wo der Boden salzreich ist, erscheint eine ganz besondere Vegetation, die nur von einigen wenigen, bestimmten Familien zusammengesetzt wird und deren Formen in morphologischer und in anatomischer Hinsicht eigentümlich sind.

Eine bestimmte Anreicherung von löslichen Salzen muß stattgefunden haben, ehe eine halophytische Vegetation in die Erscheinung tritt; die Natur des Salzes erscheint dabei einigermaßen indifferent; die Vegetation stimmt in allen wesentlichen Teilen, z. B. unter folgenden Standortsbedingungen überein ${ }^{2}$ ): Die Salzstellen von Ungarn werden durch kohlensaures Natron beeinflußt, die von Siebenbürgen durch Soda-Chlorid; bei Budapest an den Bittersalzquellen sind die Salze Sodaund Magnesia-Sulphate. Die schädliche Wirkung der einzelnen Salze unterscheidet sich sehr stark $^{3}$ ).

Die Salzpflanzenvegetation ist gegen klimatische Einwirkungen in hohem Grade unempfindlich, z. B. gegen die Höhe über dem Meere; überall, in allen Weltteilen und Klimaten und in allen Höhen, die sie erreichen kann, hat sie dasselbe Gepräge. Gewisse Arten haben sogar eine sehr weite Verbreitung, z. B. Salsola kali (in vielen Gegenden wie meist in Mitteleuropa kein Halophyt, sondern ausgeprägter Sandbewohner)

1) Frödin 1912.

2) Bernátsky 1905.

3) Kearney u. Cameron 1902. 
und Gilaux maritima, die nicht nur an den Küsten von Nordwesteuropa, selbst an der regnerischen Küste Norwegens, sonder'n auch auf den Salzsteppen von Tibet vorkommen: Salsola ist in Nordamerika auf Getreidefeldern ein lästiges Unkraut geworden.

Fïr die Vegetation auf Salzboden ist ferner gemeinsam, daß die Flora sehr dürftig und der Bestand meist sehr offen ist. Die ausschließende, für viele Pflanzen giftige Wirkung des Salzes wurde schon S. 98 behandelt. Es sei noch hinzugefügt, daß die Austrocknungsfähigkeit des Bodens eine Rolle spielt, indem eine geringe (angeblich $1 \%$ ) Salzmenge alle anderen Pflanzen außer den Halophyten vertreiben kann, wenn er leicht ausgetrocknet ist, während, wenn dieses nicht der Fall ist, 2-3\% Salz erforderlich sind. Schweinfurth beobachtete noch Weizenbau auf Boden, dessen Wasser $3 \%$ Salz enthielt, wenn der Boden dauernd feucht blieb.

Folgende Familien sind salzliebend: Chenopodiaceae, Aizoaceae, Plumbaginaceae, Portulacaceae, Tamaricaceae, Frankeniaceae, Rhizophoraceae und Zygophyllaceae. Außerden sind folgende oft auf Salzboden vertreten: Cruciferae, Caryophyllaceae, Fuphorbiaceae, Cyperaceae, Gramina, Malvaceae, Primulaceae, Asparagoideae, Compositae u. a. m.

Ausgeprägt salzfliehend sind z. B. Betulaceae, Fagaceae, Piperaceae, Urticaceae, Rosaceae, Ericaceae, Araceae usw. Auch Moose und Flechten gedeihen auf Salzboden nicht.

\section{Lebensformen und deren Anpassungen ${ }^{1}$ )}

Biologische Eigentümlichkeiten. In der Salzvegetation treten sowohl ein- als auch mehrjährige Kräuter, ebenso Halbsträucher, Sträucher und Bäume auf. Die Anzahl der einjährigen Arten scheint groß zu sein: so sind nach Masclef ${ }^{2}$ ) von den 35 an Salzboden gebundenen Arten Nordfrankreichs 20 Arten mehrjährige, halb verholzende Kräuter, die übrigen, also fast die Hälfte, einnal blühende Arten. Der Grund für die verhältnismäßig große Menge dieser Arten ist nicht ganz klar; wahrscheinlich wird sie nur mittelbar dadurch hervorgerufen, daß die Salzbodenvegetation gewöhnlich sehr offen ist und also solchen Arten Platz bietet.

Eigentümlichkeiten des Baues. Schon früher (Kap. 37, S. 312) wurde auf eine gewisse Übereinstimmung in dem äußeren und dem inneren Bau der Halophyten und Xerophyten hingewiesen. Im folgenden genannte, bei den Xerophyten auftretende, morphologische und

1) Hierzu kann verglichen werden: Areschvug 1902; Börgesen u. Paulsen 1900; Diels 1898; Harshberger 1908, 1909; Warming 1897, 1906; Börgesen 1909; Chermezon 1910; Miss B. D. Cross 1910.

2) Masclef 1888 . 
anatomische Eigentümlichkeiten kommen auch hier vor ${ }^{1}$ ). Der Grund hierzu ist vermutlich, daß Salz den Boden physiologisch trocken macht.

Das augenfälligste Kennzeichen der Salzpflanzen ist, daß die allermeisten Succulenten sind: Die meisten Arten sind Blattsaftpflanzen (Grisebachs Chenopodeenform), einige sind Stammsaftpflanzen, z. B. Salicornia und Caralluma-Arten (Asclepiadacee). Die Blätter sind dick, fleischig und hell, ganzrandig, mehr oder weniger durchscheinend. Vergl. Fig. 14, 16. Blatttypen tropisch amerikanischer Halophyten sind Fig. 106, S. 224 abgebildet. Dies wird teils durch den großen Saftreichtum der Zellen und deren geringeren Reichtum an Chlorophyll, teils durch die kleineren Intercellularräume verursacht. Es ist eine alte Erfahrung, daß gewisse Arten sowohl in einer saftreichen, dickblättrigen Strand- oder Salzvarietät, als auch in einer dünnblättrigen Landform auftreten (Beispiele Lotus corniculatus, Geranium Robertianum, Convolvulus arvensis, Matricaria inodora, Hieracium umbellatum, Solanum dulcamara и. а.). Kulturversuche ${ }^{2}$, wie man sie auch vielfach in den botanischen Gärten beobachten kann, zeigen gleichfalls, daß gewisse Salzpflanzen auf einem gewöhnlichen, salzarmen Boden dünnere Blätter erhalten und auch andere Kennzeichen verlieren (Cakile maritima, Cochlearia officinalis, Salicornia herbacea, Spergularia media, Salsola soda u. a.), während sich andere Arten nicht oder doch weniger verändern, und daß umgekehrt gewisse Arten der Landpflanzen bei Kultur auf Salzboden (Begießen mit Chlornatrium-Lösung) dickblättriger werden (z. B. Lotus corniculatus, Plantago major, Convolvulus arvensis u. a.). Diese Dickblättrigkeit wird besonders durch eine Vergrößerung der Zellen des Mesophylls bewirkt; diese werden groß und rundlich; namentlich die inneren sind arm an Chlorophyll, werden sehr hell und bilden bei einigen ein echtes Wassergewebe (Fig. 95, 131, 129). In einigen Fällen tritt bei zylindrischen Organen ein typisches Wassergewebe auf und wird von einem Palissadengewebe umgeben, z. B. bei Salsola kali ${ }^{3}$ ), Batis maritima ${ }^{4}$ ) und in dem Stengel von Salicornia ${ }^{5}$ ); in anderen Fällen findet es sich auf der Unterseite. Schleimzellen kommen auch, wie bei den Xerophyten, zur Entwicklung. Bei einigen Arten schließen sich an die Nervenenden Speichertracheïden mit Spiralfasern oder dieselben sind im Mesophyll isoliert, ohne Verbindung mit den Nerven (bei Salicornia-Arten, Frankenia, Statice, Limoniastrum u. a. Nach Duval-Jouve führen sie bei Salicornia bald Wasser, bald Luft $^{5}$ ). Die Wanddicke und die Kutiku-

1) Warming 1897, 1906; Schimper 1891; Kearney 1900.

3) Batalin 1884; Lesage 1890; Boodle 1904.

2) Areschoug 1878 .

4) Figur bei Warming 1890,1897 .

5) Duval-Jouve 1868; Volkens 1887; Warming 1906 (Fig. 77-84); Hultberg; Chermeson 1910. 
larisierung der Epidermis sind bei den Succulenten nicht bedeutend; dies ist bemerkenswert und könnte darauf hindeuten; daß die Luft des Standortes selten sehr trocken sei, hängt aber wahrscheinlich damit zusammen, daß der Schutz gegen Verdunstung auf andere Weise erreicht wird. Ausnahmen zeigen jedoch der Saxaulbaum u. a. Wüstenpflanzen. Miß Ann C. Halket ${ }^{1}$ ) hat durch Experimente gefunden, daß die Oberhaut bei Salicornia und Suaeda einen so großen osmotischen Druck hat, daß sie nicht nur süßes Wasser, sondern auch salziges hindurchläßt und daß dieses während der Zeit der Flut die Pflanze mit Wasser versorgen muß; das Wurzelsystem ist nur unbedeutend.

Die Spaltöffnungen liegen auf beiden Seiten und, nach den vorhandenen, nicht zahlreichen Untersuchungen der eigentlichen, succulenten Salzpflanzen aus der Strandvegetation, gewöhnlich in dem oder ungefähr in dem Niveau der Oberfläche, nicht eingesenkt.

Ferner ist das Palissadengewebe der Salzpflanzen mächtig. Lesage $^{2}$ ) hat durch Versuche gezeigt, daß die einzelnen Zellen höher werden, daß oft auch Querteilungen stattfinden; das Salz wirkt morphologisch ungefähr ebenso wie Sonnenlicht. Die Blätter sind häufig isolateral (über die Anatomie siehe Warming, Chermezon, Harshberger 1909).

Die Intercellularräume werden klein (Lesage).

Die succulenten Salzpflanzen haben in der Regel eine dunkelgrüne Farbe, die später oft in Gelbgrün oder Rot übergeht; wenn alles andere durch die Sonne verdorrt worden ist, bilden sie auf salzhaltigem Boden, z. B. in gewissen Steppen um das kaspische Meer, das einzige Grün, dem das Auge begegnet. Lesage hat durch Versuche nachgewiesen, daß der Chlorophyllgehalt durch vermehrten Salzgehalt bisweilen abnimmt, indem die Chlorophyllkörper kleiner oder weniger zahlreich werden. Damit scheint die von Griffon ${ }^{3}$ ) gefundene Tatsache, übereinzustimmen, daß bei derselben Art die assimilatorische Tätigkeit geringer ist bei der an salzhaltigen Stellen lebenden Form als bei der gewöhnlichen.

Wachsüberzüge findet man bei recht vielen Arten, die dadurch eine bläuliche und matte Farbe erhalten (Eryngium maritimum, Triticum junceum, Elymus arenarius, Crambe maritima, Mertensia maritima, Glaucium flavum, Spinifex squarrosus u. a.).

Die meisten Salzpflanzen sind kahl. Einige Arten sind jedoch behaart, aber seltener weichhaarig oder grauhaarig (Kochia hirsuta, Senecio candicans). Die behaarten Salzpflanzen sind gewiß besonders Sand- oder Felsenpflanzen; oft haben sie besondere Wasser-

\footnotetext{
1) Halket 1911 .

2) Lesage 1890

3) Griffon 1898
} 
haare (S. 250), deren große, kugelige, dünnwandige, perlenähnliche, mit Saft erfüllte Endzellen („Mehl“) abfallen oder die zu einer mattgrauen Decke einschrumpfen (Atriplex-Arten, Obione portulacoides, Mesembrianthemum $)^{1}$ ).

Die Verholzung ist im ganzen gering, namentlich bei den succulenten, und hierin besteht eine Abweichung gegen die Xerophyten. Es gibt zwar mehrere dornige Arten, meist mit Blattdornen (Salsola kali, Eryngium maritimum, Echinophora spinosa, Carthamus lanatus u. a.); diese Arten sind jedoch vielleicht an Sandboden gebunden, dem dann das Auftreten der Dornen zugeschrieben werden müßte. Steinzellen kommen bei einigen im Mesophyll vor, doch wohl besonders bei Holzpflanzen der Salzwüsten und sandigen Strandgebüschen, welche weniger halophil sind.

Die äubere Form der Halophyten. Hier sei zunächst erwähnt, daß die Höhe der Pflanzen nach Versuchen von Lesage bei gewissen Arten, z. B. bei Lepidium sativum, auf Salzboden abnimmt. Die Halophyten erreichen in der Regel ebenfalls weder eine große Höhe noch einen großen Umfang. Auch aus Versuchen Stanges ${ }^{2}$ ) und anderer geht hervor, daß konzentrierte Nährlösungen (nicht nur von Kochsalz, solldern auch von Salpeter und Glycerin) das Längenwachstum hemmen, während das Dickenwachstum nicht immer größer wird. Auffällig ist, daß manche einjährige Ackerpflanzen auf dem salzigen Srhlick der Nordseeküste in Zwergformen auftreten, die nur wenige Blätter und oft nur eine Blüte resp. Frucht erzeugen; am auffälligsten war dies an Sinapis alba, deren fruchtende Pflänzchen z. T. noch die Keimblätter besaßen.

Die Blätter. Weiter findet man bei den Halophyten dasselbe Bestreben nach Oberflächenverminderung wie bei den Xerophyten; es zeigt sich namentlich darin, daß die Blätter klein bleiben (s. Fig. 106, S. 224). Versuche von Lesage zeigen, daß viel Salz im Boden die Blätter kleiner und gleichzeitig dicker macht. Oft sind sie linealisch und hall)stielrund (Suaeda, Portulaca, Salsola usw.); die spatelförmige und die längliche Form sind sehr häufig $\left.{ }^{3}\right)$. Die Blätter sind selten eingeschnitten, sondern gewöhnlich ungeteilt und ganzrandig. Einige Pflanzen sind schuppenblättrig, z. B. Tamarix (s. Fig. 101 C, 125): andere werden fastblattlose Stammsaftpflanzen, z. B. Salicornia, Halocnemum, Arthrocnemum, Haloxylon: oder sie bleiben saftarm, wie Ephedra und Casuarina.

1) Anderen Blattbau vergl. Warming 1897, 1906, Harshberger 1909, Chermezon 1910, Miss Cross 1910.

2) Stange 1892.

3) 16 Abbildungen vergl. bei Warming 1897 (trop.-amerikan. Typen). 
Die ericoide Blattform (S. 220), auf der Blattunterseite mit einer behaarten Furche, worin die Spaltöffnungen liegen, haben Niederleinia juniperoides (eine Frankeniacee der argentinischen Salzsteppen), Frankenia-Arten u. a. Bei einer Lippia-Art (L. [Acantholippia] Riojana, einer Verbenacee) liegen die Blätter dem Stengel aufwärts an; zwischen dem Blatte und dem Stengel treten Haare auf, und auf der assimilierenden Außenseite findet man tiefe, behaarte Furchen.

Sehr häufig nehmen die Blätter eine ähnliche aufrechte Stellung ein wie bei vielen Xerophyten, so daß die Lichtstrahlen sie bei dem höchsten Stande der Sonne unter spitzen Winkeln treffen, und hiermit geht dann ein isolateraler Blattbau einher; Beispiele sind Atriplex (Obione) portulacoides, Suaeda maritima, Sesuvium portulacastrum, ein Teil der Arten der Mangrovenvegetation ${ }^{1}$ ). Vergl. Fig. 107, S. 225.

Die Stengel der Halophyten sind oft niederliegend, von einem gemeinsamen Ausgangspunkte, dem Grunde der Hauptachse, nach allen Seiten ausgebreitet; auch die Hauptachse ist niederliegend. Dieses beobachtet man bei Atriplex-, Suaeda-, Salsola- und anderen Chenopodiaceen-Arten, ferner bei Polygonum persicaria, P. Raji und Verwandten, Senecio vulgaris und anderen Pflanzen unserer Küsten. Es wird nicht durch den Wind verursacht, weil keine bestimmte Richtung der Stengel vorherrscht; die große Unregelmäßigkeit deutet auf lokale Verhältnisse hin, die gewiß in der verschiedenen Erwärmung des oft steinigen Bodens bestehen.

Die meisten behandelten Eigentümlichkeiten des Baues findet man auch bei den Xerophyten. Es besteht also eine bemerkenswerte Übereinstimmung zwischen Halophyten und Xerophyten; in der Tat trocknen beide langsam ein, wenn sie starker Verdunstung und Trockenheit ausgesetzt werden; wer succulente Arten getrocknet hat, weiß dieses aus Erfahrung. Bei dem langsamen Trocknen sind jedoch nicht nur die besprochenen Schutzeinrichtungen gegen starke Transpiration wirksam, sondern bei den Halophyten wohl auch in hervorragendem Maße der salzige Zellsaft, da dieser langsamer verdunstet als reines Wasser. Auch in floristischer Hinsicht ist Gemeinsames nachgewiesen worden, z. B. das Vorkommen derselben Arten in der Strand- und der Gebirgsvegetation; besonders auffällig ist in dieser Beziehung das gleichzeitige Vorkommen der Cochlearia-Arten auf den Spitzen des Schottischen Hochlandes oder in arktischen Gebirgen und im Flutgebiet der Fjorde.

Was ist nun der Grund für diese merkwürdige Übereinstimmung zwischen Pflanzen, die auf sehr trocknem Boden und in sehr trockner Luft wachsen, und solchen Pflanzen, von denen sich viele ganz gewiß unter ähnlichen Verhältnissen entwickeln (Vegetation der kontinentalen

$\left.{ }^{1}\right)$ Vergl. darüber Johow 1884; Karsten 1891; Warming 1897 b; Schmidt 1899, 1903. 
Salzsteppen), andere hingegen an Küsten wachsen, wo die Luft durchaus nicht trocken ist und der Boden wasserreich sein kann, zeitweise sogar vom Meere überspült wird (z. B. die Salicornia-Vegetation an den Küsten der Nordsee während der Flut, Cochlearia und Ligusticum [Haloscias] Scoticum in den norwegischen Fjorden), oder beständig in Wasser wachsen, wie die Mangrovenpflanzen? Die Antwort hat Schimper ${ }^{1}$ ) zu geben versucht.

Er weist zunächst auf den schädlichen Einfluß hin, den das Salz im Zellsafte auf die Assimilation und auf das Leben im ganzen ausübt; Salz wird ein Gift für die Pflanze, da es leicht in zu großer Menge aufgenommen wird und dann tödlich wirkt. Um zu vermeiden, daß zu viel Salz durch die Transpiration emporgehoben und in den Zellen aufgespeichert werde, müßten sich die Pflanzen, nach seiner Erklärung, gegen zu starke Transpiration schützen, und daher würden die vielen genannten Schutzeinrichtungen ausgebildet. Es muß zweifelhaft erscheinen, ob diese Erklärung richtig ist.

Nach experimentellen Untersuchungen von Delf ${ }^{2}$ ) transpirieren Salicornia annua und Suaeda maritima ebenso stark oder noch stärker als ein typischer Mesophyt wie Vicia faba. In nicht turgeszentem $\mathrm{Zu}$ stande können sie Wasser durch die ganze Oberfläche aufnehmen. Dies stimmt mit dem obenerwähnten Baue der Epidermis.

Stahl ${ }^{3}$ ) hatte gefunden, daß die Spaltöffnungen bei Halophyten immer offen sind und somit nicht imstande sind, die Transpiration zu regulieren. Nach anderen ${ }^{4}$ ) ist das aber nicht der Fall. Die Spaltöffnungen von Salicornia und Aster tripolium sind nach Delf oberflächlich gelegen, öffnen und schließen sich wie bei Mesophyten und sind empfindlich gegen Licht und gegen Änderungen der Luftfeuchtigkeit. Die echten Xerophyten Sedum acre und S. album verhalten sich ganz ähnlich, auch sie zeigen eine starke Transpiration. Die Spaltöffnungen von Suaeda und Atriplex portulacoides fand Delf niemals offen.

Über den Stoffwechsel der Halophyten vergl. Diels ${ }^{5}$ ), nach dessen Untersuchungen es wenig wahrscheinlich erscheint, daß die Xerophytenstruktur die Anhäufung der Chloride dauernd hindern kann, zumal da in allen Halophyten eine dauernde Zersetzung der Chloride stattfindet.

Viel wahrscheinlicher als Schimpers erste Erklärung ist eine andere, von ihm angedeutete Ansicht, daß die Schutzeinrichtungen gegen starke

1) Schimper 1890, 1891, 1898.

2) Delf 1911.

8) Stahl 1894.

4) Rosenberg 1897; Diels 1898 b; Benecke 1901.

s) Diels 1898 b. 
Transpiration vielleicht dadurch bedingt seien, daß die Wasseraufnahme aus einer Salzlösung für die Pflanzen schwierig ist (was Sachs 1859 nachgewiesen hat) ${ }^{1}$ ).

Die Frage über die Anpassungen der Halophyten, namentlich der succulenten auf feuchtem Boden wachsenden, ist noch gar nicht gelöst. Es wird notwendig werden, die succulenten von den auf andere Weise xerophytisch ausgebildeten Arten zu trennen und zu studieren, um die Ökologie der ersteren besser verstehen zu können.

Die Vegetation der Land-Halophyten läßt sich in folgende Formationen gliedern:

1. Formationen der Strandfelsen und des Strandgerölles (Litophile Halophytformationen); (48., 49. Kap.).

2. Litorale Formationen des salzigen Sandbodens (Psammophile Halophytformationen); (50. Kap.).

a) Formation der Sandalgen.

b) $\quad$, Sandkräuter.

c) $\quad, \quad$ Gebüsche auf Sandstrand.

d) $\quad \pi$ Wälder auf Sandstrand.

3. Litorale Formationen auf salzhaltigem, tonigem Boden (Pelophile Halophytformationen) 51. Kap.

4. Salzvegetation des Binnenlandes; Salzsteppen; Salzwüsten (52. und 116. Kap.).

\section{Kap. Formationen der Strandfelsen}

Felsenliebende Vereine. Auf Felsen am Meere können die Pflanzen aus zwei Gründen einen xerophilen Bau erhalten; ein Grund ist die Felsennatur im allgemeinen (S. 197 und Kap. 92), der andere die Nähe des Meeres. Der Gischt der Brandung und die vom Wellenschaume und vom Winde auf den Pflanzen abgesetzten Salzteilchen rufen eine rein halophytische Vegetation oder jedenfalls eine floristische Modifikation der Felsenvegetation hervor, indem ihr Halophyten beigemischt werden.

Schon oben (S.382-383) wurde erwähnt, daß solche der Einwirkung salzigen $T$ assers ausgesetzten Felsen salzliebende Algen in bedeutender Höhe über dem höchsten Punkt der Flut und selbst höher als der Wellenschlag zu tragen vermögen (aërophile oder aërobiotische Algen).

Es bildet sich an solchen Strandfelsen eine eigentümliche Vegetation aus, welche in Übereinstimmung mit dem verschiedenen Abstande vom Meere gürtelartig entwickelt ist und sowohl aus Algen und Flechten, als aus Blütenpflanzen gebildet ist ${ }^{2}$ ).

1) Vergl. auch Hedgecock 1902.

2) Vergl. Warming 1906; Gallöe 1908; Sernander 1912; Hayrén 1914. 
Zu unterst kann ein Brandungsgürtel (Wellengürtel) unterschieden werden, welcher an der gewöhnlichen Hochwasserlinie anfängt und unter Umständen viele Meter hoch werden kann, z. B. auf den Fåröern ${ }^{1}$ ).

Über diesem kommen andere Gürtel zur Ausbildung, die von der Schroffheit der Felsen, der Tiefe des Meeres, dem Salzgehalt des Wassers und von der Heftigkeit der Stürme abhängig sind; zu unterst ein „Spritzgürtel“ bis zur Höhe, bis zu der das Wasser spritzt. Höher, resp. mehr oder weniger weit landwärts werden noch Salzpartikel vom Winde geführt, durch welche der Boden salzhaltig werden kann und daher auch der Pflanzenwuchs beeinflußt wird ${ }^{2}$ ).

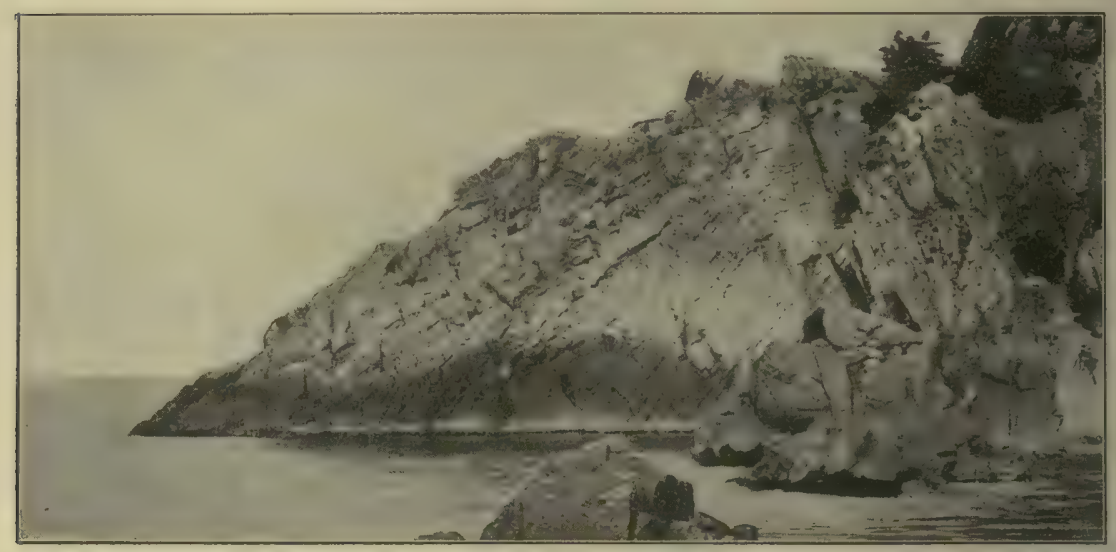

Fig. 204. Strandfelsen vom Gebirge Kullen (Westküste von Schweden).

Die unteren schwarzgefärbten Teile der Felsen bilden die Brandungsgürtel mit der Assoziation: Verrucarietum Maurae. (Photograph unbekannt.)

Als solche Gürtel lassen sich nach Sernander und Hayrén unterscheiden, z. B. der Grenzgürtel auf sanft geneigten Flächen an der Spritzwassergrenze (Hayrén), der supramarine Meeresgürtel und der supramarine Binnenlandsgürtel; sehr eingehend sind die Assoziationen aller Gürtel von Hayrén besprochen worden.

Auf den Küstenfelsen von Bornholm in der Ostsee, auf dem Kullen an Schwedens Westküste, sowie an anderen schwedischen Küsten finden sich nach Warming ${ }^{3}$ ):

1. Unterst Assoziationen von Algen und Krustenflechten (Lichina, Ephebe, Vervucaria).

1) Börgesen 1905 .

2) Frödin 1912.

3) Warming 1906 . 
2. Über dieser ein Verrucarietum Maurae, welches ein kohlschwarzes Band auf dem Felsen in einer geringen Höhe über dem Meere bildet; es entspricht dem Brandungsgürtel. Diese Assoziation verlangt offenbar, ab und zu vom Wellenschlage benetzt zu werden; Trockenheit erträgt sie nicht; starkes Licht scheint sie auch nicht nötig zu haben. Ihre Höhe hängt ab von der Exposition gegen die Sonne, von der Stärke des Windes und der Brandung. Sie ist an der Nordseite der Felsen am schönsten entwickelt; an der Südseite namentlich dort, wo sie gegen starkes Sonnenlicht geschützt ist (Fig. 204).

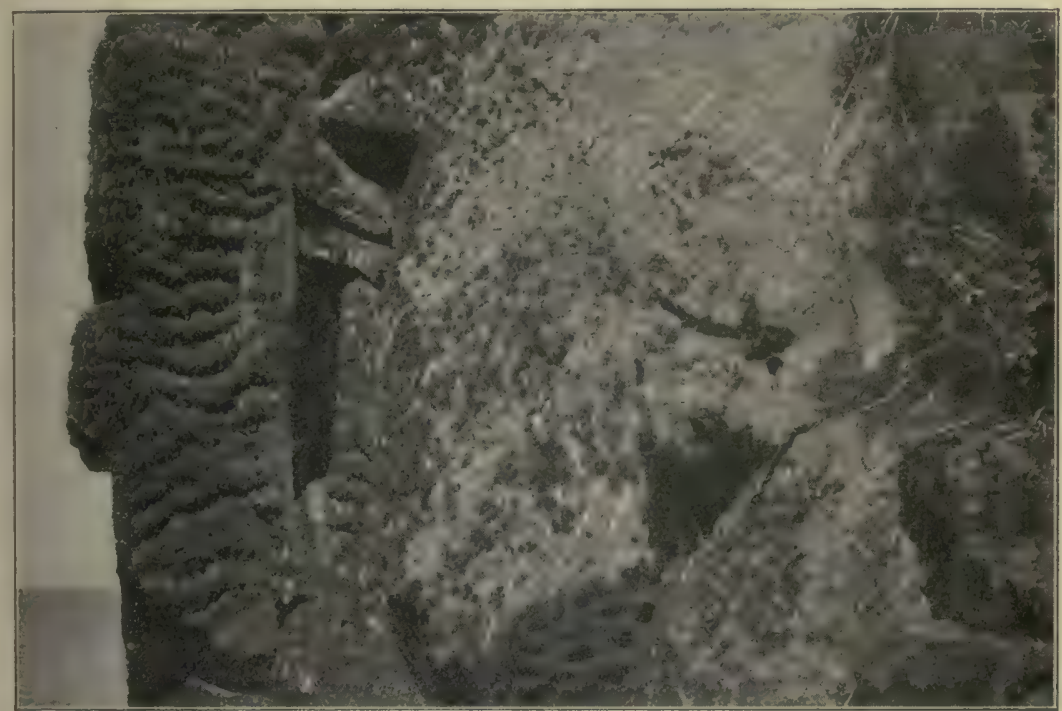

Fig. 205. Senkrechte Felsen auf Bornholm (Ostsee). Links das Meer. Assoziationen von Ramalina scopulorum (links) und Krusten und Blattflechten; rechts vor diesen: Xanthoria parietina, Parmelia saxatilis, $P$. omphalodes, P. olivacea, Physcia aquila, Rubus plicatus u. a. (Phot. Eug. Warming.)

3. Über dieser Assoziation folgt wieder eine von krustenförmigen Flechten, nämlich eine braungelbliche von Placodium murale gebildete, der Spritzgürtel. Hier ist mehr oder weniger die Blattflechte Xanthoria parietina eingemischt. Hayrén hat hier mehrere Assoziationen beobachtet.

4. Noch höher folgt eine Assoziation aus strauchförmigen Flechten, nämlich ein Ramalinetum, aus Ramalina scopulorum gebildet (Fig. 205). Die Wirkung des salzigen Wassers ist hier weit geringer, aber doch noch merklich. Auch eine Reihe anderer Flechten findet sich hier, welche nicht zu den Halophyten gerechnet werden können. Die Zahl der Blattflechten wird allmählich größer. Es lassen sich nach Frödin dünne Überziige von Salz noch in einem Abstande von mehreren hundert Metern vom Meere nachweisen. Frödin hat gefunden, daß $R$. scopulorum eine Leit- 
pflanze ist für das Windsalzgebiet. Der Salzgehalt, die Größe und Fruchtbarkeit dieser Pflanze nimmt deutlich mit dem Abstande vom Meere ab.

In den ersten beiden Flechtengürteln wachsen in den Felsspalten salzliebende Blütenpflanzen, wie Matricaria maritima, Aster tripolium, Statice, Silene maritima, Arten von Atriplex. u. a. Etwas höher erlischt die Wirkung des Salzes und die Vegetation der Küstenfelsen wird denen des Binnenlandes gleich ${ }^{1}$.

Unter den salzliebenden Pflanzen an der Küste von Bornholm kann ein Moos genannt werden, Grimmia maritima, welches in kleinen Polstern auf den Strandfelsen im supramarinen Meeresgürtel auftritt.

Vergl. Fig. 76, S. 184; zwischen Grimmia maritima sind dort zu bemerken Plantago coronopus, Festuca rubra (links oben) und auf den Steinen Lecanora atra, Aspicilia cinerea, Xanthoria parietina, Physcia aquila, Parmelia omphalodes, Ramalina scopulorum u. a.

Über die finnländischen Strandfelsen vergl. die schöne Arbeit von Hayrén 1914.

Hayrén hat auch die aufeinander folgenden Assoziationen in der Vegetation der finnischen Strandfelsen studiert. "Der Landhebung zufolge werden die Felsen immer höher über den Meeresspiegel emporgehoben, d. h. auf einem bestimmten Flecke wird die Wirkung des Meereswassers im Laufe der Zeit abgeschwächt und die Bedeutung der atmosphärischen Agentien vergrößert. Der anfangs glatte Felsen wird rauh. Durch Verwittern und die Arbeit der Pflanzen wird immer mehr Bodenmaterial herbeigebracht, das vom Winde in den Spalten und Vertiefungen der Felsen angehäuft wird. Die Vegetationsbedingungen verändern sich stetig, und dies gibt Anlaß zum Einwandern neuer Pflanzenarten, die vielleicht einst wieder von anderen Arten verdrängt werden." „Gemäß der Verteilung der Standorte und ihrer verschiedenartigen physikalischen Bedingungen läßt sich diese Entwicklung der Vegetation nach drei Hauptreihen verfolgen: die Serien der Felsenflächen, diejenigen der Spalten und die der Vertiefungen. In jeder Serie folgen mehrere Assoziationen regelmäßig aufeinander, und die Reihenfolge sowie der Gang der Entwicklung werden hauptsächlich durch drei Faktoren bestimmt: 1. den nach oben geringer werdenden Wirkungsgrad des Salzwassers, 2. die wachsende Menge des losen Bodenmaterials und 3. den Feuchtigkeitsgrad der Oberfläche." „Bei fortschreitender Entwicklung bemerkt man eine Tendenz zu demselben Ziele, und zwar zum Überziehen des Felsens mit der Vegetation der trocknen Felsenheide (Cladina und Calluna), die in der Tat auf bedeutenden Arealen der waldtragenden Schären zu finden ist."

Koprophile Assoziationen (Vegetation der Vogelsitzplätze). Als eine eigene Formation sind vielleicht anzusehen die von Sernander und

1) Warming 1906. 
Hayrén besprochenen Assoziationen von nitrophilen Lichenen, welche besonders auf Küstenfelsen vorkommen, auf Vogelbergen und Vogelklippen, wo die Seevögel sich niederzulassen pflegen und wo sie mit ihren Exkrementen düngen. Der Standort muß ja hier wesentlich durch den Dünger der Vögel und die Überreste ihrer Mahlzeiten geändert sein. Sernander unterscheidet dabei zwischen ornithokoprophilen Vereinen und koniophilen, welche letztere den vom Winde hergeführten Staub als Stickstoffquelle benutzen. Solche Vereine sind aber nicht ausgesprochen litorale, auch im Binnenlande, weit vom Meere entfernt, kommen sie vor.

Über die Vegetation an den Strandfelsen Schwedens vergl. Sernander 1912, über die Finlands Hayrén 1914.

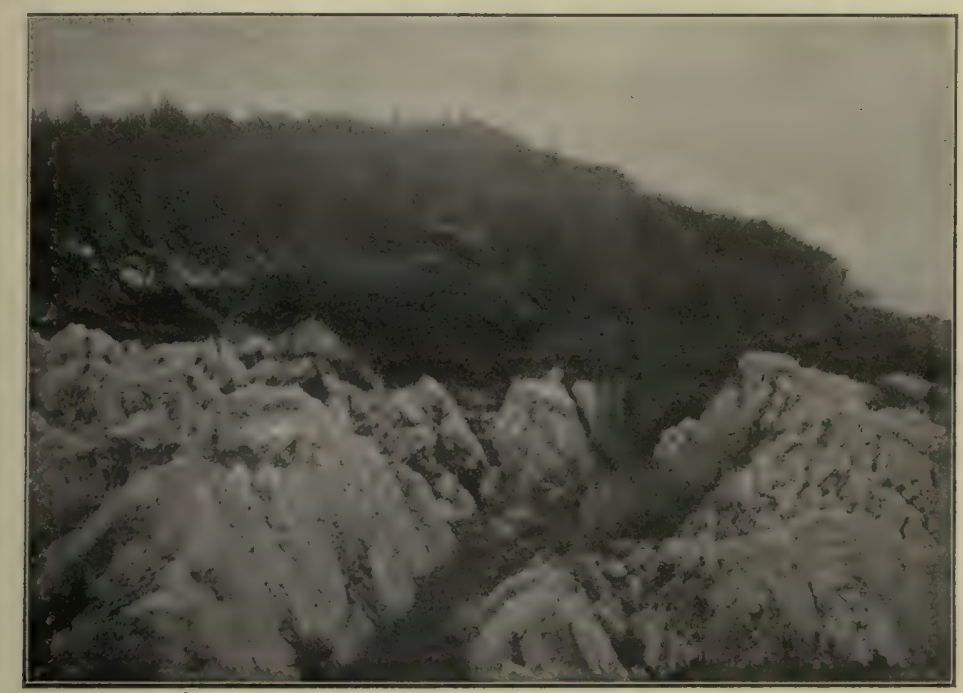

Fig. 206. Ein Exemplar von Pinus Halepensis, durch die Stürme ein dichtes, nur wenige Meter hohes Gestrüpp bildend; Felsen des Cap Martin an der Französischen Riviera. (P. Graebner phot.)

Im besonderen kann erwähnt werden, daß Porsild auf Disko in Grönland eine wesentliche Änderung der Flechtenvegetation an denjenigen Strandfelsen beobachtete, auf welche die Eskimos ihre gefangenen Fische zum Trocknen hinlegen (Fig. 17 in 1902).

Die maritimen und marinen Flechten an den Küsten von Dublin hat Matilda Knowles studiert und abgebildet 1913. Sie unterscheidet folgende Gürtel der "siliceous rocks" von oben nach unten gerechnet: 1. Der Ramalina-Gürtel, mit einer oberen und einer unteren Abteilung und verschiedenen untergeordneten Arten; 2. der Orange-Gürtel, mit verschiedener Breite der Küste ringsherum, gebildet namentlich von Physcia parietina und Arten von Placodium; 3. der Lichina-Gürtel 
mit der semimarinen Lichina confinis und der marinen L. pygmaea; 4. der Verrucaria-Maura-Gürtel, welcher normal über Pelvetia canaliculata und zwischen höchster Ebbe und höchster Flutmarke liegt; 5. der Gürtel der marinen Verrucaria-Arten, der jeden Tag für längere oder kürzere Zeit vom Flutwasser bedeckt ist. Die herrschenden Arten sind Verrucaria microspora, V. striatula und V. mucosa, auch Arthopyrenia halodytes u. a. Auf Kalkfelsen verhielt diese Lichenenformation sich anders.

In Nordamerika hat Cannon ähnliche aus Flechten an Strandfelsen gebildete Assoziationen erwähnt, zu unterst eine Lichina-pygmaea-Assoziation, als höhere Stufe Lichina confinis.

Eine gleichfalls ähnliche Vegetation bewohnt die Adriatischen Küsten; auch hier bekleidet Verrucaria Maura mit ihren oft "pechschwarzen Krusten" die Felsen und in den Spalten der Klippen leben fleischige Halophyten, Kräuter und Sträucher, wie Crithmum maritimum, Statice cancellata, Inula crithmoides, Athrocnemum glaucum u. a. ${ }^{1}$ ).

In Madeira leben an dem Salzwasser ausgesetzten Felsen wenige succulente Arten. Hier und da heben sich einzelne Individuen ab von Mesembrianthemum nodiflorum, Portulaca oleracea, Beta maritima oder Crithmum maritimum ${ }^{2}$ ). Auf den Kanarischen Inseln wachsen an unzugänglichen Felsen, die dauernd durch die Salzwasserspritzer der Brandung naß sind, zahlreiche Arten von Statice, welche hellgrüne Blattrosetten besitzen und blau, rot oder weiß blühen; ihre Blütenstände sind etwa $0,5 \mathrm{~m} \mathrm{hoch}^{3}$ ). Oft tragen die Küstenfelsen eine ausgesprochen halophytische Vegetation von Spermophyten, die an keinem anderen Standorte vorkommen. Dies ist der Fall am Mittelmeere, in Westindien und in den meisten ähnlich gearteten Orten der Erde.

Küstenfelsen der brasilianischen Küste, welche von der Brandung bespritzt werden, beherbergen nach Schenck auch starrblättrige Felsenbromeliaceen.

Schimper 11. a. ${ }^{4}$ ) machen darauf aufmerksam, daß man hier, wie natürlich auch bei anderen felsenbewohnenden Formationen unterscheiden muß zwischen den Arten, welche wirklich dem Felsen angeheftet sind, und solchen (Chasmophyten), welche im Erdboden wurzeln, der sich in den Felsspalten angesiedelt hat.

Die Vegetation der Felsspalten (Chasmophyten). Mit dem von Schimper ${ }^{4}$ ) gebildeten Namen Chasmophyten bezeichnet man die Pflanzen, welche in den Spalten der Felsen Fuß gefaßt haben. Hier sind die

1) Beck 1901 .

2) Vahl $1904 \mathrm{~b}$.

s) Christ 1885 ; C. Schröter 1908. ton 1911.

4) Schimper 1898; Cockayne 1901; Oettli 1903; Chermezon 1910; Cramp- 


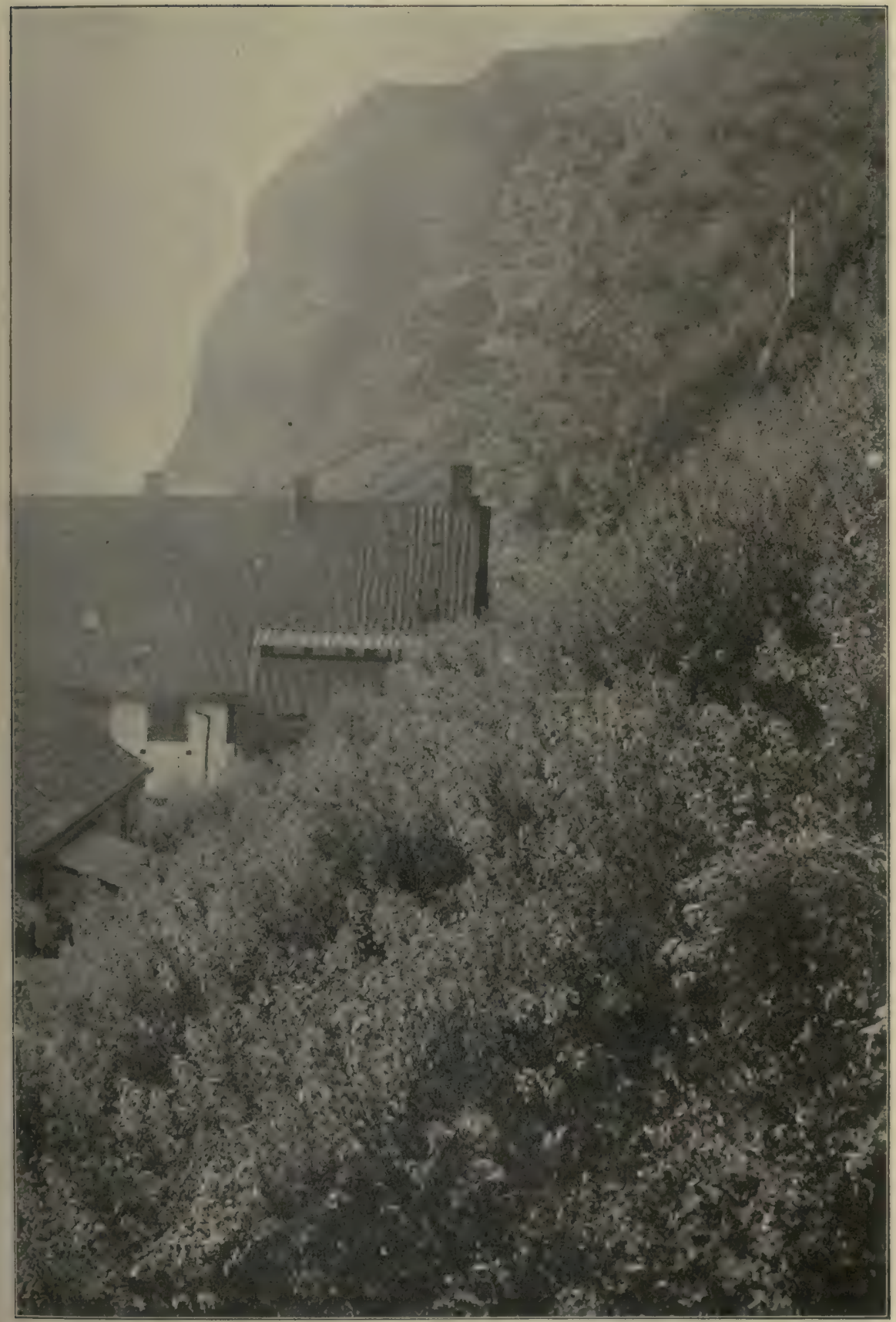

Fig. 207. Massen-Vegetation des wilden Kohls (Brassica oleracea) an den Sandsteinfelsen von Helgoland. (Mit Genehmigung der Königl. Biologischen Anstalt.) 
ökologischen Verhältnisse ganz verschieden von den auf dem festen harten Fels herrschenden, weil Detritus, Erde und auch Humus sich hier anhäufen kann, und eine mehr oder weniger große Feuchtigkeit hier dauernd bewahrt werden wird, da der die Spalten einschließende Fels die Verdunstung verhindert. Fig. 206 bis 209.

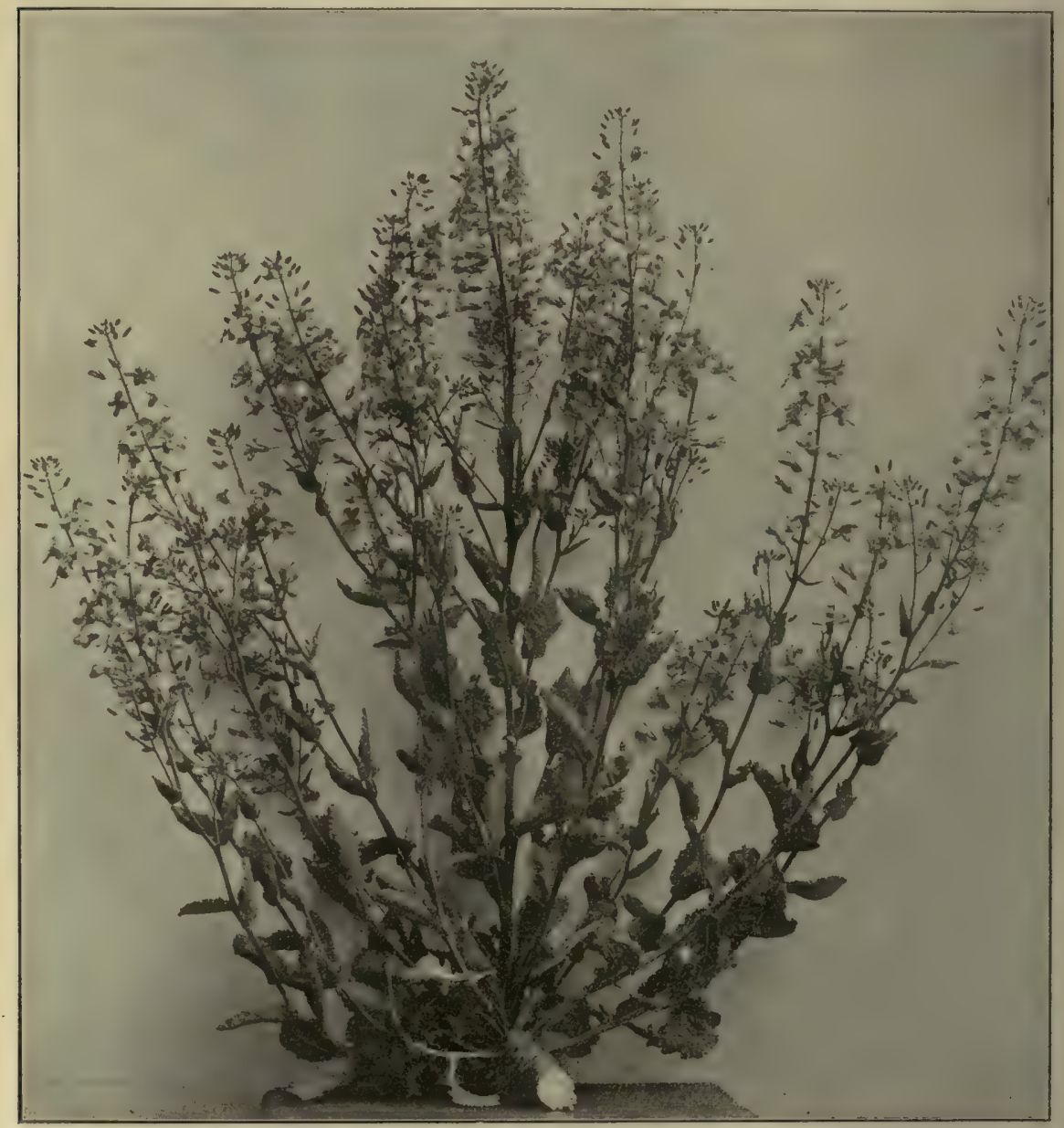

Fig. 208. Einzelne blühende Pflanze des wilden Kohls (Brassica oleracea) auf Helgoland.

(Mit Genehmigung der Königl. Biologischen Anstalt.)

Die Arten, welche die Spalten der Strandfelsen bewohnen, sind mehr oder weniger halophil; man kann hier oft ein Gemisch finden von deutlichen Halophyten und Pflanzen des Binnenlandes, welche gar nicht halophytisch sind, aber doch Salzstaub des Meeres und salzige Nebel vertragen können. 
$\mathrm{Zu}$ den deutlichen Halophyten der Felsspalten müssen in Nordeuropa z. B. folgende Blütenpflanzen gerechnet werden: Aster tripolium, Silene maritima, Triglochin maritimum, Spergularia marina, Festuca thalassica (Glyceria maritima) und $F$. distans. Es sind dies also Arten, die gar nicht für die Strandfelsen besonders charakteristisch sind, sondern auf anderen Formationen am Strande vorkommen, wie z. B. in den Strandwiesen. Brassica (Fig. 207, 208) nur an Felsen.

Sehr eingehend werden die Formationen und Assoziationen der verschiedenen Gürtel der Strandfelsen Finlands von Hayrén 1914 behandelt.

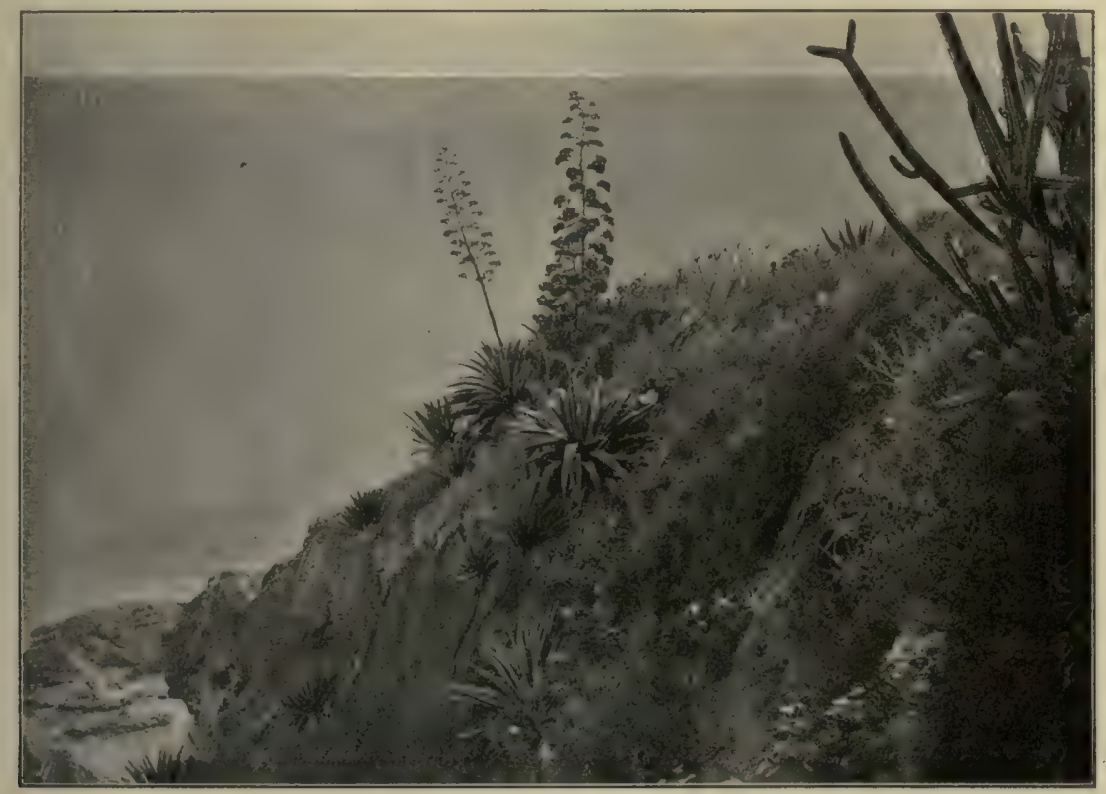

Fig. 209. Felsenküste auf St. Croix (Dänisch-Westindien) mit Agave, Cereus. Plumieria u. a. (Phot. Dr. F. Börgesen.)

Im übrigen mag auf das über die Felsenvegetation des Binnenlandes Gesagte verwiesen werden (Kap. 92 ff.).

Formation der am Strande liegenden Felsenblöcke und großen abgerundeten Steine (Fig. 175, 176, S. 346). An den nordeuropäischen Küsten trifft man hier und da große Anhäufungen von abgerundeten Moränen-Blöcken, wie z. B. auf Bornholm, an der deutschen Ostseeküste usw. An anderen sind es eckige, von den Felsenküsten herabgestürzte Steine, welche den Strand bedecken. Auch an vielen anderen Felsenküsten ist dieses der Fall, so z. B. auf den dänischen westindischen Inseln. Zwischen den Blöcken sammeln sich oft Sand und Pflanzenreste, namentlich solche von Algen an. Auf einem derartigen Boden entwickelt 
sich eine Vegetation, die eigentlich mehreren Formationen angehört, und zwar einerseits der typischen Felsenformation, andererseits den Formationen des losen Bodens. Kräuter, Sträucher und selbst Bäume, welche wohl größtenteils halophil sind, bilden das Gemisch ${ }^{1}{ }^{1}$.

\section{Kap. Formationen des Strandgerölles}

Geröll-Formationen (Strandwälle). Wo der Wellenschlag stark ist, wird der Sand weggespült und der Strand wird dann oft nur aus stark gerollten und abgerundeten, größeren oder kleineren Steinen bestehen, welche, wenn sie kleiner sind, durch jeden starken Wellenschlag rasselnd und lärmend hin und her bewegt werden. Oft werden gerade ausgestreckte und recht hohe Standwälle aus Sand und kleinen bis etwa faustgroßen Steinen aufgeworfen. An tropischen Küsten sind oft größere und kleinere Korallenblöcke eingemischt, oder die Wälle bestehen überwiegend aus Kalkresten der Seetiere. Auch in Nordeuropa werden solche Wälle aus den Kalkschalen von Muscheln und Konchylien gebildet. Auf solchen Wällen werden bisweilen große Massen von Überresten der Seetiere und von Algen ausgeworfen und können dadurch die Natur des Geröllbodens verändern (Fig. 210, 211).

In England haben Oliver, später Salisbury, Hill und Hanley ${ }^{2}$ ) sehr gründliche Studien über die allgemeine Morphologie und Wachstumsweise der Strandwälle publiziert. Die beiden letzteren haben namentlich den Wassergehalt bestimmt, das Wasserniveau, die Verschiedenheiten in der Verteilung des süßen und salzigen Wassers usw. Das süße Wasser ist ein "lokales Produkt", d. h. ist ohne Verbindung mit dem süßen Wasser des Inlandes. Der Winterregen und der Schnee scheint den größten Beitrag zur Menge des süßen Wassers zu liefern, aber auch der Tau scheint ein sehr wichtiger Faktor zu sein. Zwischen den vielen kleinen Steinen wird das Wasser lange aufgespeichert und ruft eine mesophytische Vegetation hervor, z. B. von Silene maritima und Lathyrus maritimus, welche die Schafe in den heißesten Trockenzeiten aufsuchen.

An der Küste der Nordsee haben die englischen Forscher verschiedene Typen von Strandwällen (Shinglebanks) und die gürtelförmige Anordnung der Assoziationen nachgewiesen, namentlich in Norfolk bei Weybourne-Blakeney, wo ein solcher Wall von ca. $13 \mathrm{~km}$ Ausdehnung längs der Küste vorkommt. Die Flora ist verschieden je nach der Höhe des Walles. Die niederen Teile desselben, welche vom Hochwasser überflutet werden, tragen eine halophytische Vegetation, während die

1) Vergl. Börgesen 1909, Raunkiär 1909 a.

2) Oliver 1912, 1913, in Tansley 1911, Oliver und Salisbury 1914, Hill und Hanley 1914. 


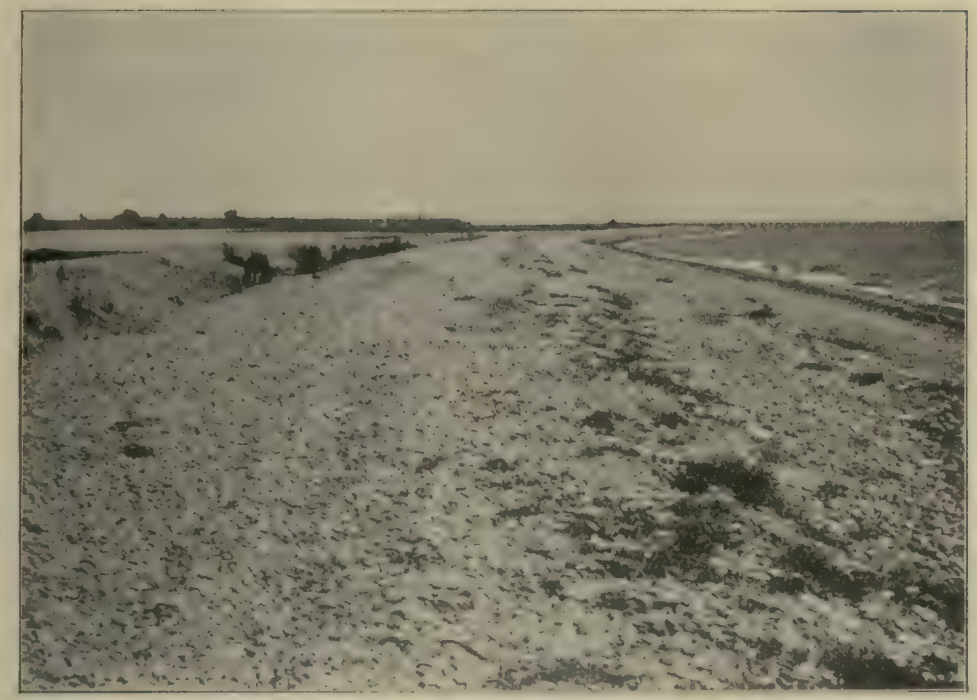

Fig. 210. Strandwall auf der dänischen Insel Langeland. (Phot. P. Harder, Juli 1904. Aus Warming 1906.)

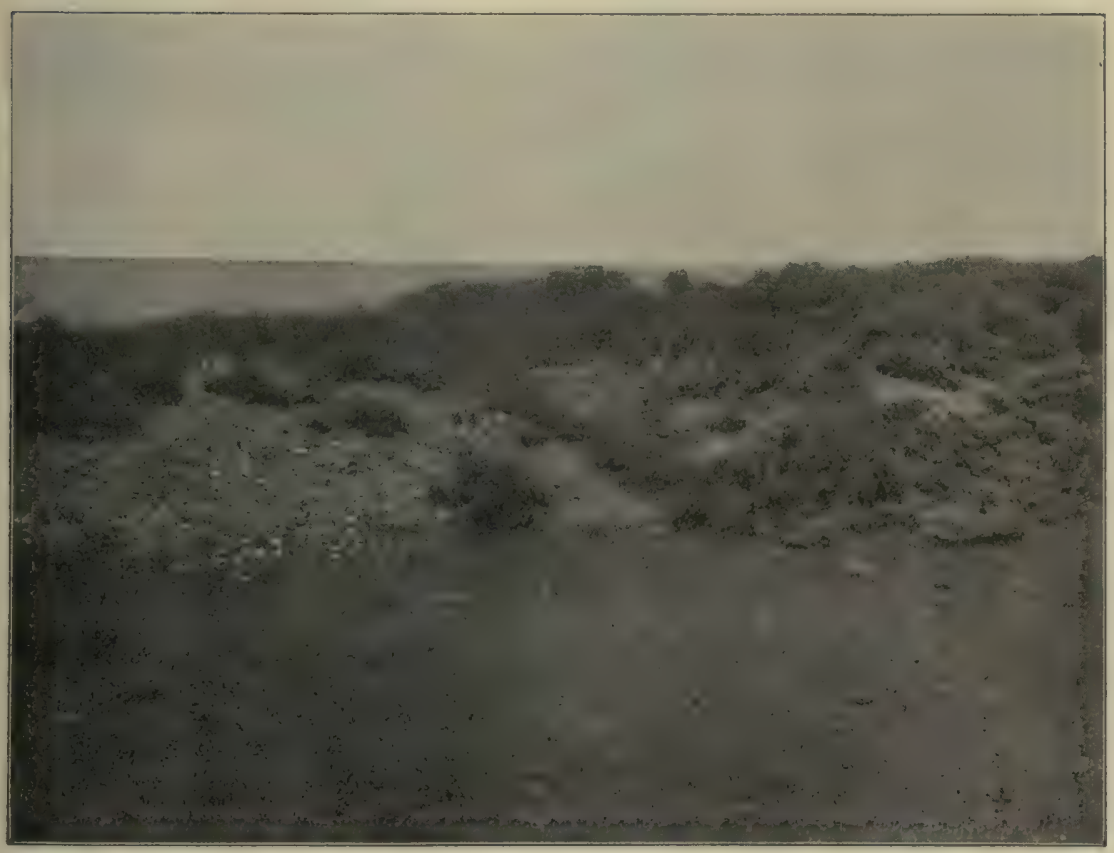

Fig. 211. Strandwall aus kleinen Steinen gebildet im nördlichen Jütland; bewachsen mit Hippophaës rhamnoides, Glaucium luteum. Im Vordergrunde eine Strandwiese. (Phot. Eug. Warming, August 1902.) 
höheren und außerhalb des Bereiches des Seewassers liegenden von Nicht-Halophyten bewachsen sind, die sogar teilweise vom Salzstaub in stürmischem Wetter getötet werden, so z. B. Rumex crispus var. trigranulatus. Unter den Halophyten muß Suaeda fruticosa hervorgehoben werden, welche oft Gebüsche von $0,6 \mathrm{~m}$ Höhe bildet und ein starkes Verjüngungsvermögung besitzt. Auch Honckenya (Arenaria) peploides kann recht dichte Assoziationen bilden, sonst ist die Vegetation sehr offen, die Pflanzen wachsen sehr zerstreut, von nackten Geröllsteinen getrennt.

Bis jetzt liegen nur wenige ökologische Studien über solche Strandwälle vor; vorausgesehen werden kann, daß die Lebensformen recht verschieden sein werden, und ihre Anpassungen recht verschieden seien. Zwischen den Steinen wird bedeutende Feuchtigkeit zurückgehalten werden können.

An den dänischen Küsten finden sich derartige Wälle, die hauptsächlich nur mit krautartigen Pflanzen bewachsen sind, andere aber auch, wahrscheinlich ältere, auf welchen sich ein Gebüsch aus niedrigen Sträuchern gebildet hat, z. B. aus Hippophae rhamnoides ${ }^{1}$ ). Diese Art zeigt übrigens durch ihre Verbreitung, daß sie salzhaltiges Grundwasser vertragen kann, aber trotzdem von Salz ganz unabhängig ist ${ }^{2}$ ).

\section{Kap. Vegetation des losen salzigen Bodens}

Wir gehen jetzt zu den aus losen Materialien gebildeten Böden mit halophiler Vegetation über, zu den alluvialen Strandbildungen, von denen einige periodisch vom Salzwasser überflutet werden (Aestuaria). Andere etwas höher gelegene werden zwar nicht auf diese Weise vom Salzwasser beeinflußt werden, die sie bewohnenden Pflanzen erreichen aber mit ihren Wurzeln das salzige Grundwasser oder die oberirdischen Teile werden vom Schaume der Wogen und von salziger Luft, die vom Winde herbeigetragen wird oder von salzigen Nebeln beeinflußt. Im Innern der Kontinente gibt es vielfach seichte Salzseen und Salztümpel, die im Sommer ganz oder fast ganz austrocknen, und deren ausgetrocknete Böden von Salz imprägniert sind.

Der Boden kann aus Sand (Kieselsand, Korallensand) gebildet sein, oder auch aus Schlamm, Ton, Lehm, schließlich kann er auch ein unbestimmbares Gemisch von allen sein.

Es zeigt sich, daß verschiedene Arten sowohl auf Sand, wie auf Schlamm oder auf toniger Erde gut gedeihen; z. B. Salicornia herbacea oder an der französischen Mittelmeerküste Salicornia glauca; es finden

1) Warming 1906, Fig. 29; 1909, Fig. 99-102.

2) Vergl. z. B. Palmgren. 
sich Salicornieta von dieser Art an einigen Stellen auf reinem Sande, der fest ist, weil er feucht ist, an anderen auf lehmigem Boden. Für solche Pflanzen scheint die Feuchtigkeit des Bodens maßgebend zu sein. Vergl. Fig. 170, S. 339.

Es ist unmöglich, eine scharfe Grenze zu ziehen zwischen den verschiedenen losen Böden, welche salzliebende Pflanzen tragen; an geschützten Stellen findet man sehr feinkörnige Böden aus Schlamm und Lehm oder Ton gebildet, auf Stellen, welche dem Wellenschlage und den Winden mehr ausgesetzt sind, wird der Boden vorzugsweise

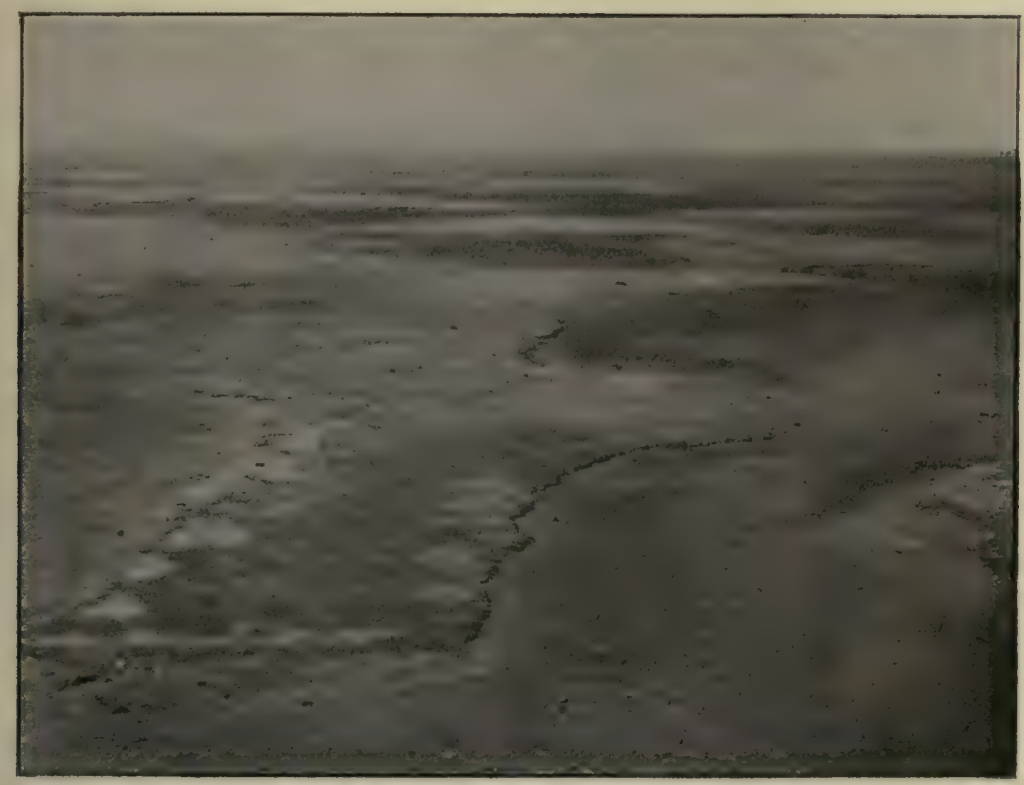

Fig. 212. Sandwatte auf Manö, dänischer Nordseeinsel. Die blangrünen Algen haben Krusten auf dem Sande gebildet, welche teils durch ihre Farbe hervortreten, teils dadurch, daB sie vom Wellenschlag bei Hochwasser teilweise zerstört worden sind.

(Phot. Eug. Warming.)

aus Sand und Grus oder kleinen Steinen bestehen; und endlich gibt es, wie in Kap. 49 erwähnt, Strandwälle, die hauptsächlich aus kleinen Steinen, Schalen von Seetieren und Sand gebildet und von der Brandung aufgeworfen sind.

Zwischen diesen Bodenformen gibt es alle Übergänge und die Pflanzenvereine werden danach mehr oder weniger verschieden sein.

Ebenso finden sich im Binnenlande alle Zwischenformen. Es wird hier zweckmäßig sein, folgende salzigen Standorte getrennt zu besprechen. 1. Sandboden, 2. Ton- und Schlammboden. 


\section{Formationen des feuchten, salzigen Sandbodens}

Der Sandboden und seine Eigenschaften wurden S. 106 behandelt. Die Vegetation, die sich auf dem losen Boden entwickelt, ist überall eigentümlich und verdankt ihm und den übrigen physikalischen Bedingungen, namentlich den Wärme- und den Feuchtigkeitsverhältnissen, ihre Kennzeichen. Sandboden kommt zwar auch im Binnenlande, aber besonders an den Küsten vor, und seine Vegetation ist hier am anziehendsten ausgebildet.

Der Ursprung der meisten Sandböden ist gewiß dem Wasser zuzuschreiben, namentlich der zermahlenden und schlämmenden Tätigkeit des Wellenschlages, in geringerem Grade anderen Kräften (der schleifenden Wirkung des windbewegten Sandes, der spaltenden Wirksamkeit der Pflanzenwurzeln, der Kraft der Sonnenhitze, Steine zu zerbröckeln, vergl. auch die "Schattenverwitterung“ Schweinfurths in Ägypten); daher trifft man Sandbildungen an sehr vielen Küsten an, hier oft als Dünen. Auch in vielen Binnenlandsgebieten findet man sie, oft gleichfalls als Dünen.

In der chemischen Natur des Bodens besteht, wie S. 106 angeführt wurde, nicht nur ein Unterschied nach der chemischen Art der Körner, sondern auch nach dem Salzgehalte; hierin besonders unterscheiden sich die Sandbildungen des Strandes von denen des Binnenlandes. Die Vegetation des Sandstrandes ist eine Halophytenvegetation, weil der Sand am Meere salzhaltig ist und das salzige Grundwasser meist bereits dicht unter der Oberfläche liegt. Der Sand kann Quarz-, Kalksand ( Korallensand") usw. sein.

An den nordeuropäischen Küsten, dort, wo starke Differenzen zwischen Flut und Ebbe vorhanden sind, z. B. an den Nordseeküsten, kommen die sogenannten Sandwatten vor, d. h. große Sandflächen, welche während der Ebbe trocken liegen. Die niedrigsten von ihnen sind pflanzenleer. Höher liegende, welche nur kürzere Zeit oder nur während der Hochfluten überschwemmt werden, tragen die Formation der im Sande begrabenen oder auf dem Sande liegenden Sandalgen, die Cyanophyceen- und Chlorophyceenvereine, welche auf S. 390 erwähnt wurden.

A. Formation der Sandalgen an Küsten mit Gezeiten (Fig. 212). An sandigen Meeresküsten des nördlichen Europa leben Algen und Schizophyten, welche eine dünne Schicht auf oder unter der Oberfläche des Sandes bilden und diesem, wenn sie reichlich vertreten sind, eine charakteristische Farbe verleihen. An den Küsten Dänemarks gibt es verschiedene derartiger Assoziationen: Chlam y do mon a deta, zusammengesetzt aus Arten von Chlamydomonas und Diatomaceae, welche lose 
auf dem nicht verklebten Sande liegen. Schizophyceta, gebildet aus blaugrünen Algen und Diatomeen; diese verkleben vermittels ihrer Schleimhüllen oder -scheiden die Sandkörner miteinander und bilden dadurch eine dünne, aber ziemlich derbe, mehr oder weniger krustenartige Lage, welche meist dicht unter der augenblicklichen Oberfläche des Sandes sichtbar wird ${ }^{1}$ ). Mit dieser Pflanzengemeinschaft treten in auffälliger Weise bestimmte Tiergesellschaften auf. Die Assoziation hat eine riesig weite Ausdehnung längs der Nordseeküsten, wo die Sandwatten sich oft meilenweit ausdehnen.

Dieser Subformation nahe verwandt ist eine Gemeinschaft von Cyanophyceen und Diatomeen, die gleichfalls ihren Wohnplatz innerhalb des Gezeitengebietes hat und die Schlickflächen bewohnt, welche vom Seewasser während der Flut abgelagert worden $\operatorname{sind}^{2}$ ).

Auf etwa derselben Höhenstufe wie die Assoziationen der Sandalgen trifft man auch Areale, wo der feuchte und salzige Sand bis zu einiger Tiefe bläulichschwarz oder graulichschwarz gefärbt ist. Es rührt dies von Schwefeleisen-Bakterien her, welche die Salze des Meeres zersetzen und Schwefeleisen hervorbringen ${ }^{3}$ ). Nach Beijerinck ${ }^{4}$ ) und van Delden ${ }^{5}$ ) spielen anaërobe Spirillen (Microspira desulfuricans und andere) eine wesentliche Rolle dabei. Die Formation trifft man nicht nur an den Meeresküsten, sondern sie ist auch noch allgemein verbreitet im Schlamme des süßen Wassers, in Pfuhlgründen usw. Nicht nur Sulfate reduzierende Bakterien, sondern z. B. auch Bacillus subtilis finden und betätigen sich hier.

Die Formation der Sandalgen bildet eine bestimmte Stufe, und zwar die äußerste der Ästuarien, d. h. der periodisch überfluteten und trockengelegten Gebiete an den Küsten.

Auf etwas höher gelegenem Boden kommen andere Assoziationen resp. Formationen zur Entwicklung, die oft in genetischer Verbindung miteinander stehen. Sie entsprechen also der litoralen Stufe der steinliebenden Algen- und Flechtenassoziationen (Kap. 49).

B. Kraut-Formation. Die Assoziationen in nördlich gemäßigten Gebieten, welche auf die Sandalgen folgen, sind krautartige, und dasselbe gilt wahrscheinlich auch in den meisten Fällen in subtropischen und tropischen Ländern.

1) Eine ganz ähnliche Assoziation findet sich in den feuchteren Sandheiden (Graebner).

3) Vergl. Warming u. Wesenberg-Lund 1904, Warming 1906.

3) Warming $\mathrm{a}$. Wesenberg-Lund 1904.

3) Beijerinck 1895 .

g) van Delden 1903.

Warming - Graebner. 3. Auflage, illustr. 
Diese ans Meer grenzende Fläche, die oft vom Meere überspült wird und die mehr oder weniger steinig, bisweilen sogar eine Grus- oder eine Geschiebefläche sein kann, hat in geringer Tiefe unter der Oberfläche salzreiches Grundwasser. Die Vegetation ist sehr offen und sehr dtirftig; eine Pflanze steht hier, eine andere dort, von anderen entfernt; es wird das wohl zunächst durch Wind und Wasser (Hochwasser) verursacht.

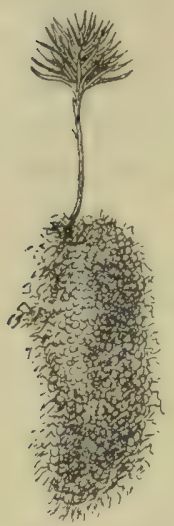

Fig. 213.

Stämmchen von Polytrichum, im Sande der Dünen durch die Rhizoiden verankert.

(Nach Warming.)

Als die äußerste Assoziation findet man vielfach am flachen Sandstrande, besonders an der Nordsee, eine von Triticum (Agropyrum) junceum gebildete; es ist ein ausdauerndes, niedriges Gras mit weitlaufenden, unterirdischen Grundachsen, es ist daher sehr befähigt, Flugsand zu sammeln und Embryondünen, seltener höhere, zu bilden ${ }^{1}$ ).

Meist sind die äußersten Assoziationen von größtenteils einjähỉigen Arten gebildet (Salicornieta herbaceae, Atripliceta mit vielen Arten von Atriplex, Suaeda maritima u. a., Cakileta maritimae mit Cakile maritima, Salsola kali u. a., Fig. 216).

Schon oben wurden die Assoziationen von der einjährigen Salicornia herbacea besprochen, welche sich oft auf feuchtem Sandboden findet, und zwar oft mit den Sandalgen vergesellschaftet (Kap. 39, S. 339, Fig. 170).

Die einjährigen Arten (Cakile maritima, Salsola

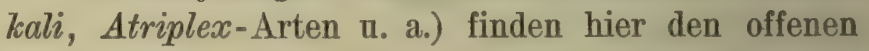
Platz, den sie fordern; sie werden in ihrer Entwicklung von der Wandelbarkeit des Bodens nicht gehindert.

Die aus Chenopodiaceen gebildeten Vereine finden sich besonders dort, wo Überreste von Zostera oder Meeresalgen sich aufgesammelt haben; sie wachsen zwischen und auf diesen. An gewissen Küsten können so große Massen von Seegräsern (in Nordeuropa von Zostera, an den mediterranen Küsten von Posidonia und Caulina, in Westindien von Thalassia und Cymodocea) oder Tangen aufgeworfen werden, daß sich Schichten von $1 / 2-1 \mathrm{~m}$ Höhe und mehr bilden, welche mit der Zeit einen eigentümlichen, ganz neuen Boden und Standort zustande bringen ${ }^{2}$ ) (Fig. 214).

Wird den aufgeworfenen Seegras- oder Tangmassen Sand durch Aufwehung oder Auswurf beigemengt, so bildet sich ein eigentümlicher dunkler Sandboden, der die Chenopodiaceen dort oft als grünes Band

1) Reinke 1909; Warming 1907-1909.

2) Warming 1906, Fig. 53; Skottsberg 1907. 
am sonst kahlen Strande trägt; im Innern enthält die verfaulende organische Substanz viele Bakterien.

Mehr landwärts auf dem sanft ansteigenden Boden, wo das Meer noch seltener Unruhe bringt, treten Assoziationen von mehrjährigen

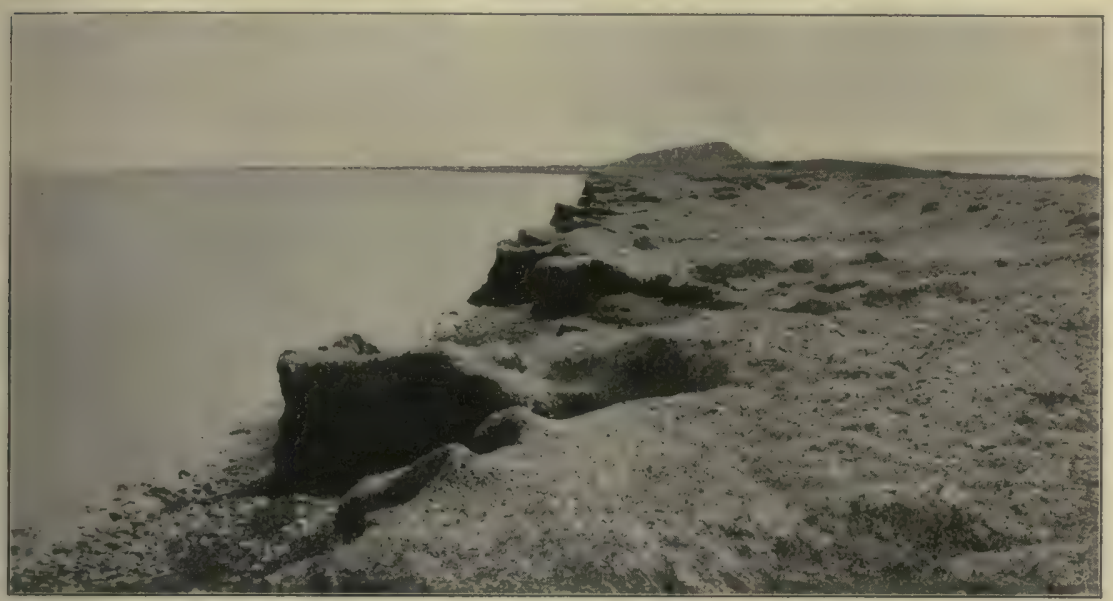

Fig. 214. Boden aus reiner vermodernder Zostera marina gebildet, an der Küste von Samsö (dänischen Kattegat-Insel). (Phot. Eug. Warming, August 1900.)

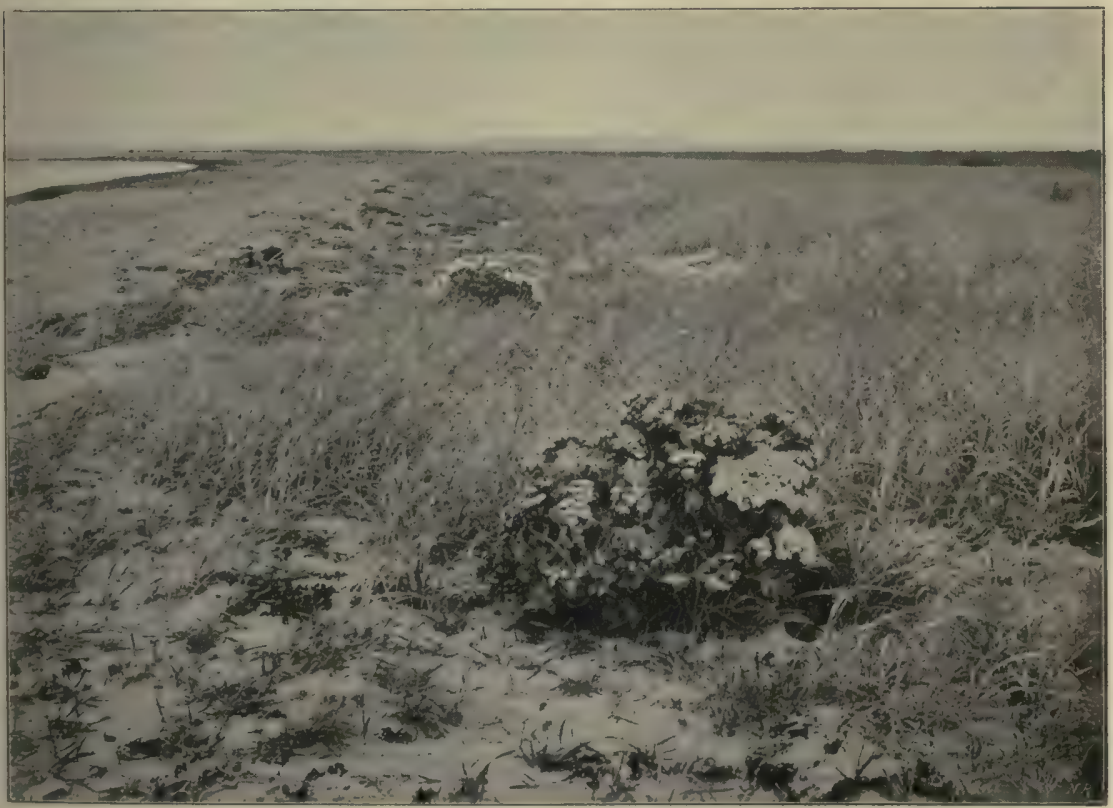

Fig. 215. Sandstrand an der Nordküste von Seeland mit Hordeum (Elymus) maritimum; blühende Exemplare von Crambe maritima, Rumex crispus u. a. sind eingestreut. (Phot. Eug. Warming.) 
Kräutern mit meist kriechenden Grundachsen auf, weil auch sie mit dem losen Boden im Einklange stehen und sich leicht erhalten, wenn sie einmal Fuß gefaßt haben: Honckenya peploides, Triticum junceum.

Nur auf ruhigerem, besonders steinigem Boden, der über die Meeresfläche wenig gehoben ist, trifft man meist mehrjährige Arten mit vielköpfiger, tief gehender primärer Wurzel an, wie Mertensia maritima, Eryngium maritimum (Fig. 219), Crambe maritima, Ligusticum (Haloscias) scoticum, Silene maritima, Matricaria inodora usw. An vielen Stellen

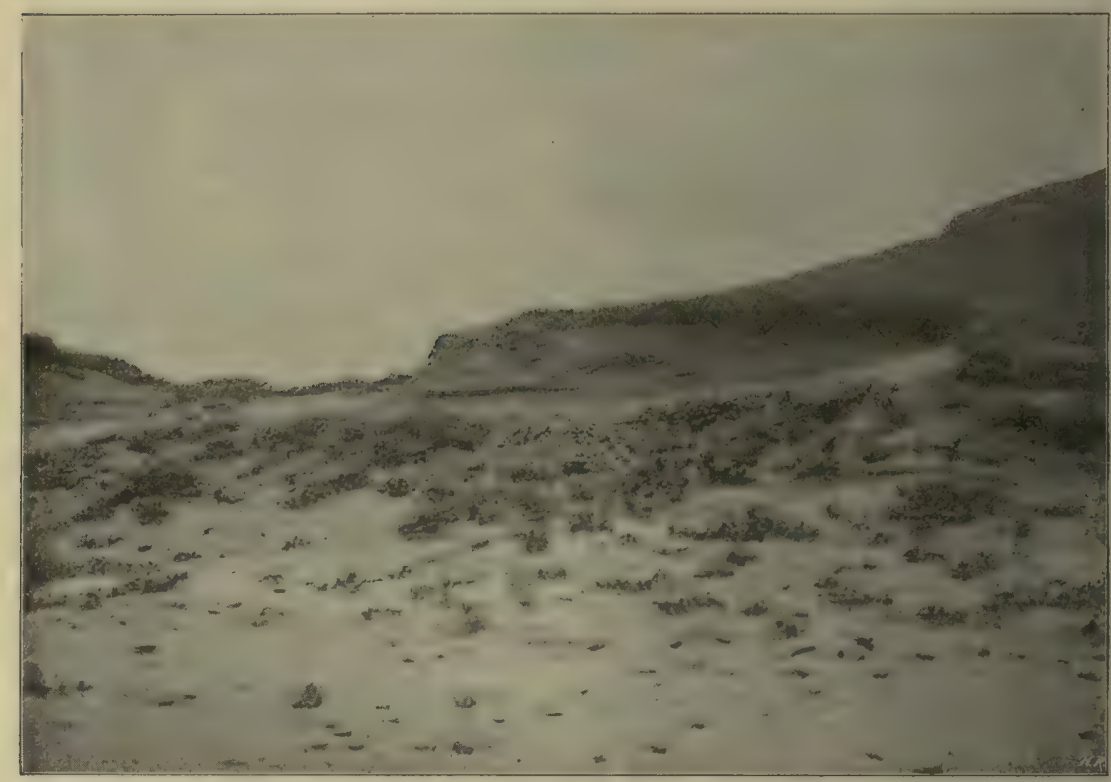

Fig. 216. Sandstrand auf den Färöern mit Assoziation von Cakile maritima. AuBerdem kommen Honckenya (Arenaria) peploides, Arten von Atriplex, Potentilla anserina, Carex incurva und Hordeum (Elymus) arenarium vor.

(Phot. Eug. Warming.)

treten auch Assoziationen von Hordeum (Elymus) arenarium auf, große Flächen deckend, in welche die genannten Pflanzen und andere eingestreut sein können (Fig. 215).

Die Halophyten-Natur dieser Kräuter zeigt sich in mehreren Kennzeichen der Vegetation. Fleischige Blätter haben die meisten, eine blau bereifte Epidermis einige Arten (Triticum, Eryngium, Crambe, Mertensia, Glaucium flavum). Behaart sind Kochia hirsuta und Senecio viscosus; dornig ist Salsola kali. An gewissen Orten kann hier auch die blattlose, kaktusähnliche Salicornia herbacea vorkommen, die sonst besonders an Salinen heimisch ist. Alle diese Pflanzen sind Lichtpflanzen, die 


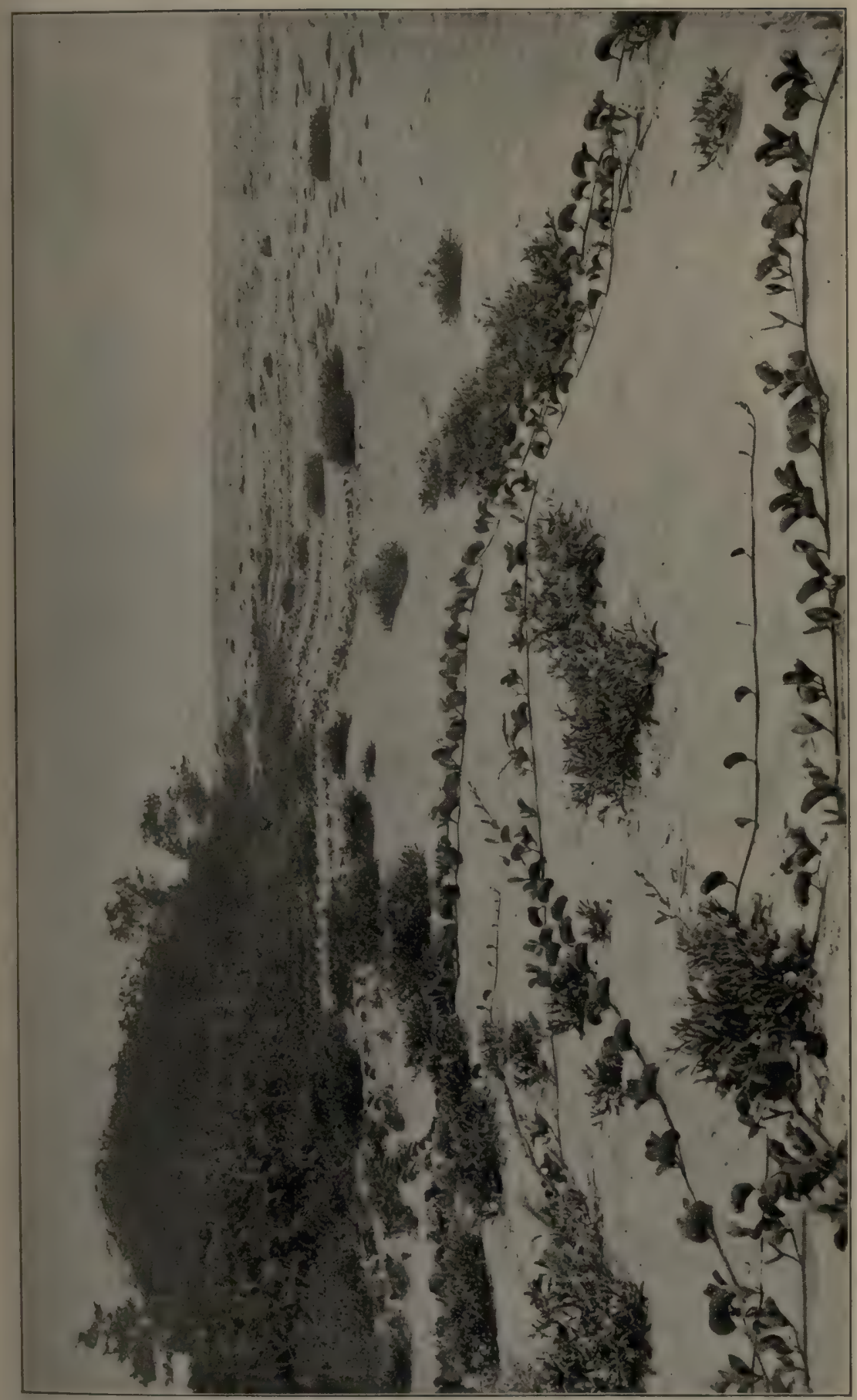

สํํㄹ

卷 क

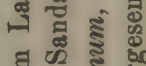

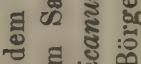

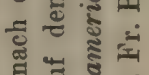

के है है

है है है

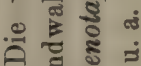

๘ँّ

造

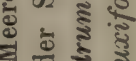

1

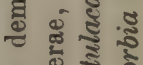

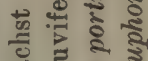

: है है

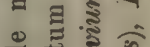

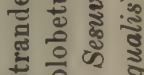

कू :

ซึ๊ :

घ क हू हु है

芩志

कำ

:

.

3 ह ह

드 은

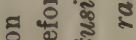

용

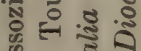

प-

密.

휴 ๘

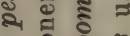

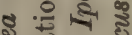

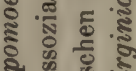

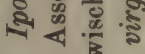

듀용

$\therefore$ so 
keinen Schatten vertragen (Buchenau). Außer dem Abstande vom Meere und den dadurch bedingten Verschiedenheiten in der Ruhe spielt die Höhe über dem Grundwasser eine Rolle für die Vegetationsverschiedenheiten.

Das jetzt angeführte galt Nordeuropa. Auch auf dem Strande der Färöer trifft man eine der dem südlicheren Europa ganz ähnliche Vegetation $^{1}$ ) (Fig. 216) und ebenso weit nördlicher, z. B. noch in Grönland ${ }^{2}$ ).

Weiter nach Süden, z. B. schon an den Küsten Hollands, findet man mehrere andere Arten, z. B. Convolvulus soldanella, die zu den Pflanzen mit unterirdischen Ausläufern gehört, und Euphorbia paralias. Noch weiter südlich, an den Küsten Frankreichs, Dalmatiens usw. treten noch andere Arten auf: Matthiola sinuata usw.; aber die Lebensformen bleiben dieselben ${ }^{3}$ ).

Eine ganz ähnliche Sandstrand-Vegetation kommt in Nordamerika und wohl überall in der Welt vor. Chrysler z. B. erwähnt eine ganz ähnliche, aber floristisch natürlich etwas verschiedene Sandformation von Maryland. In Nordamerika kommen übrigens verschiedene europäische Strandpflanzen vor oder doch nahestehende, vikariierende Arten.

In den Tropen treten andere Arten auf, die der Vegetation ein ganz abweichendes Gepräge geben können; diese Vereine dürfen jedoch gewiß nicht als besondere Formationen aufgefaßt werden.

Unter dem Namen Pescaprae-"Formation"4) hat Schimper die tropische Sandstrand-Vegetation behandelt, worin die Convolvulacee Ipomoea pes caprae eine hervorragende Rolle spielt; Fig. 217. Die großblättrigen, fleischigen, dunkelgrünen und mehrere Meter langen, bisweilen mit großen, roten Blüten geschmückten Sprosse dieser Art kriechen auf dem Sande hin, schlagen in ihm Wurzeln und bilden oft ein dichtes Netzwerk. Zwischen der Ipomoea wachsen z. B. in Westindien die Gräser Sporobolus Virginicus und Cenchrus echinatus, Euphorbia buxifolia, Canavalia obtusifolia usw. Überdies kommen mehrere andere Arten vor, die gleichfalls großenteils a uf dem Sande wachsen und nicht, wie bei uns Carex arenaria, weit kriechende, im Sande begrabene Rhizome haben; dieses Verhalten steht vielleicht damit in Verbindung, daß fliegender Sand hier seltener ist, teilweise weil der Sand oft ein schwerer und grobkörniger Kalksand (Korallensand) ist, und auch weil die Winde nicht mit der Stärke wie an unseren nordischen Küsten wehen.

1) Ostenfeld $1908 \mathrm{~b}$.

2) Porsild 1902.

3) Flahault 1893; Flahault et Combres 1894; Raunkiär 1914.

4) Vergl. Warming 1897; Fr. Börgesen; Raunkiär; H. Schenck 1903; vergl. auch Tansley und Fritsch 1905. 
Von den tropischen Küsten werden verschiedene andere Assoziationen erwähnt. Im Wachstum sind der Ipomoea mehr oder weniger ähnlich Canavalia-Arten (Warburg erwähnt eine Canavalia-„Formation" von den Molukken, Raunkiär ein Canavalietum obtusifoliae von Westindien), das fleischige Sesuvium portulacastrum u. a. (Fig. 218); daran schließen sich Amarantaceen (Alternanthera, Achyranthes, Iresine oder Philoxerus vermicularis), Rubiaceen (Spermacoce, Hydrophylax) und selbst Gräser (Sporobolus Virginicus, Cynodon dactylon) und Cyperaceen (Remirea maritima, Fimbristylis sericea $)^{1}$ ). Verschiedene Assoziationen werden

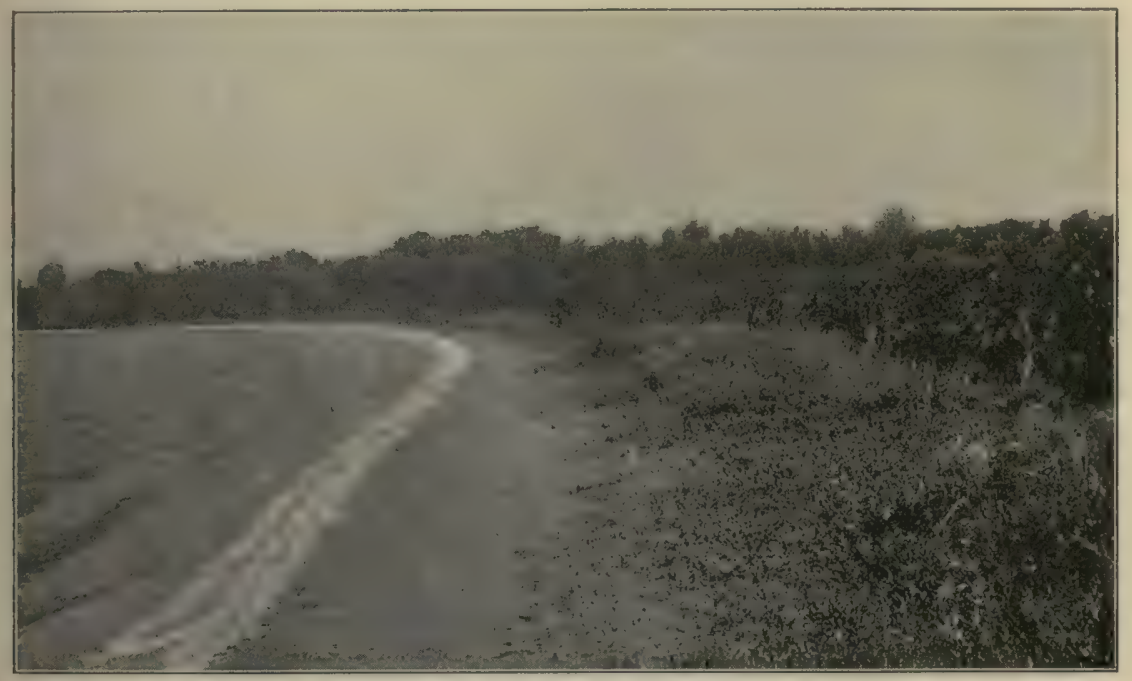

Fig. 218. Sandstrand bei Salt Pond auf der Südseite von St. Croix.

Von links nach rechts: Das Meer - Schaumstreifen - schmaler Sandstrand ohne Vegetation - Sesuvium portulacastrum - Sesuvium, Philoxerus und Batis - Sporoboletum virginici - Laguncularia racemosa, Conocarpus erecta - Coccolobetum uvuviferae.

(C. Raunkiär.)

erwähnt, z. B. Sporeboletum virginici, Sesuvietum portulacastri. Am asiatischen Strande spielt der blaugrüne Spinifex squarrosus eine ähnliche Rolle und hat ähnliche unterirdische Grundachsen wie der Helm bei uns; die Mächtigkeit seines Wassergewebes steht wohl damit in Verbindung, daß er auf salzigem Boden wächst. Der Gegensatz zwischen der Vegetation der europäischen Quarzsanddünen und der tropischen Sandstrandvegetation zeigt sich darin, daß Convolvulus soldanella, die europäische Verwandte der Ipomoea pes caprae unterirdisch wandert ${ }^{2}$ ).

1) Die Anatomie der einzelnen Arten ist abgebildet bei Warming 1897.

2) Raunkiär 1909 a; Börgesen 1909; über die Formationen des Strandes sieht ferner Engler 1910. 
Es ist sehr natürlich, đaß auch diese Pflanzen in gürtelförmige Assoziationen angeordnet sind. Vergl. auch Fig. 221.

Der tropische Sandstrand zeigt wie der unserige Beispiele von Rosettenbildung und von Sprossen, die niederliegend und nach allen Seiten ohne Wurzeln zu schlagen, lose auf dem Sand ausgebreitet sind,

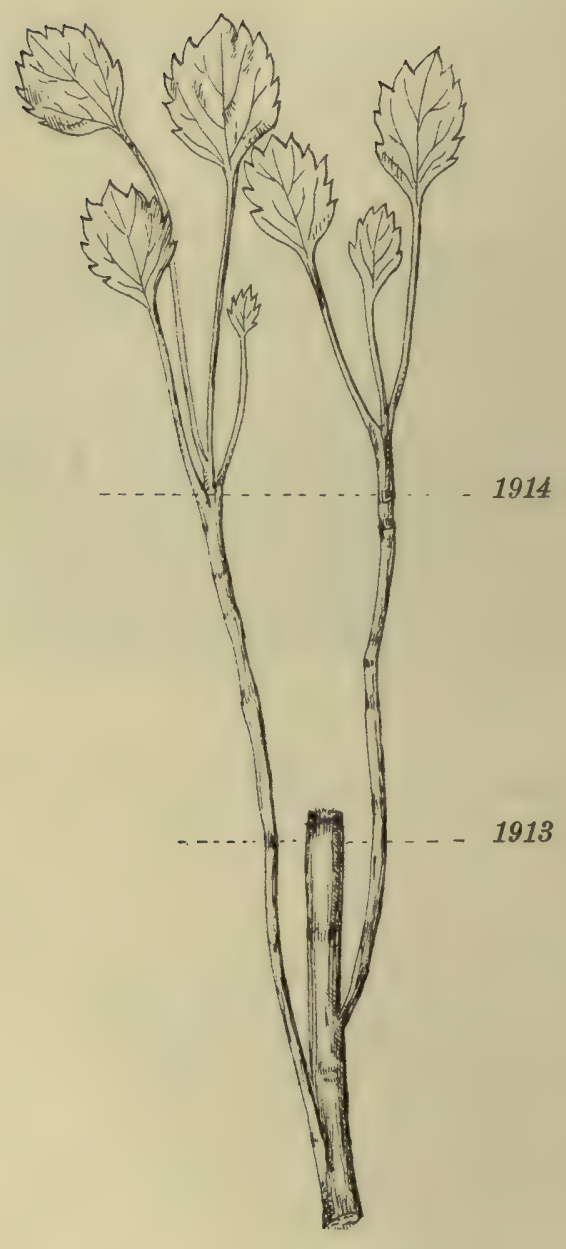

Fig. 219. Eryngium maritimum; mit dem Wachstum der Düne durch den alljährlich neu aufgewehten Sand sich erhebend; hatte im Vorjahre geblüht. (Nach Warming.)

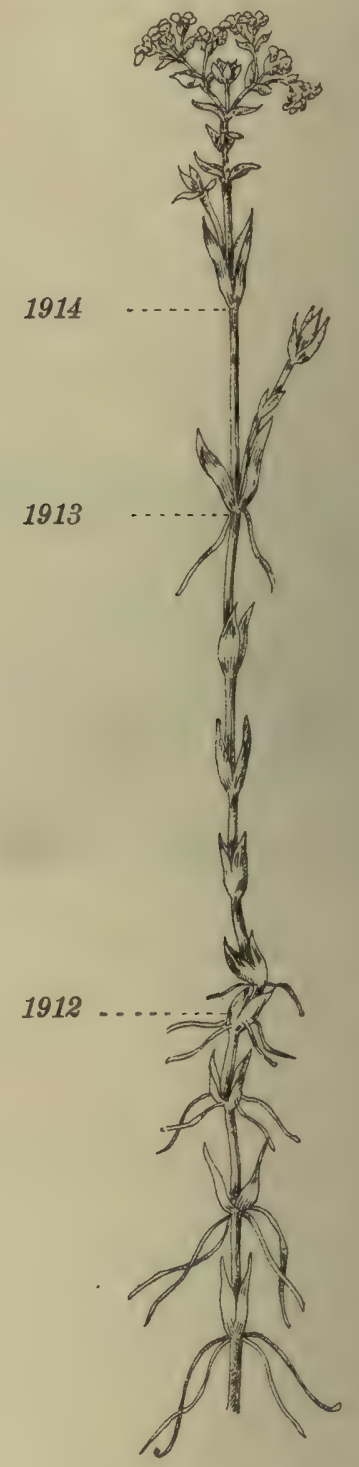

Fig. 220. Honckenya peploides, wie Fig. 219 (Nach Warming.) 
der ostindische Strand, z. B. bei Euphorbia thymifolia, E. pilulifera, Sida-Arten, Indigofera enneaphylla ${ }^{1}$ ), der amerikanische bei Euphorbia buxifolia, Heliotropium inundatum, Cakile aequalis, Portulaca pilosa u.v.a. Alle diese Pflanzen sind kleinblättrig und mehr oder weniger saftreich.

Weiter landwärts trifft man dann gewöhnliche $\mathrm{D}$ ü $\mathrm{n}$ en oder Strandwälle. Von beiden gilt, daß ihre Vegetation mehr der xerophytischen des Landes, welche vom Regenwasser beeinflußt ist, angehört, als der halophytischen.

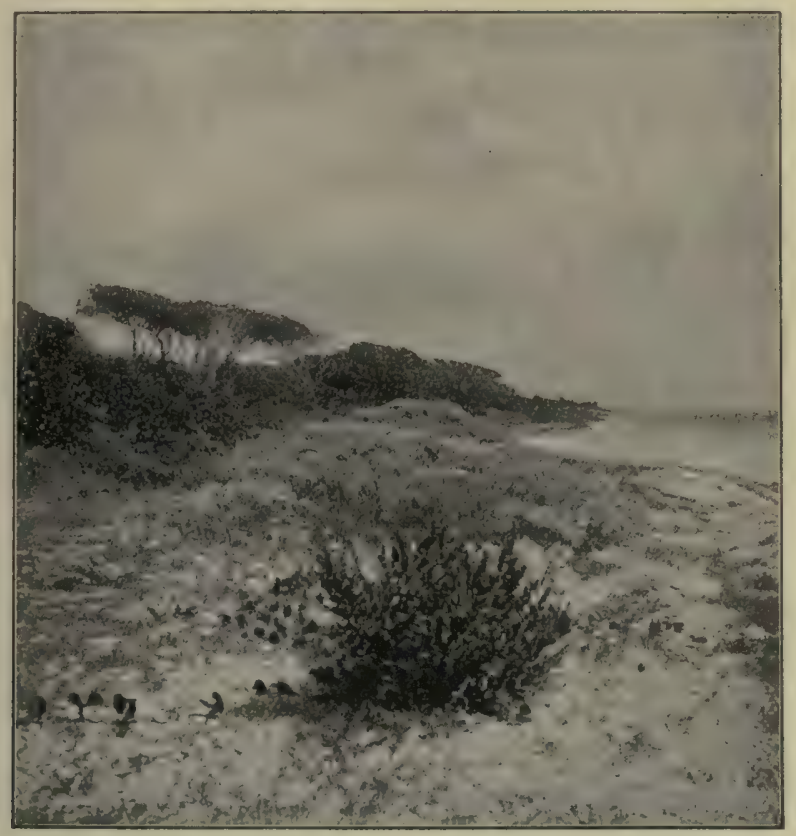

Fig. 221. Sandstrand auf St. Croix. In der Mitte graue dichte Büsche von Tournefortia gnaphalodes; im Vordergrunde Suriana maritima von Sporobolus Virginicus umgeben und einigen Ipomoea. Im Hintergrunde Strandwälder von Coccoloba mit Manchinel. (Phot. Dr. F. Börgesen.)

C. Die Dünen. Die Dünen und ihre Vegetation werden am besten in einer eigenen Standortsklasse besprochen (Kap. 99-100); denn selbst wenn die Dünenbildung am häufigsten an den Küsten der Meere stattfindet, kommt sie ja auch in großer Ausdehnung im Binnenlande vor, besonders in den Sandwüsten von Afrika und Asien. Selbst wenn viele Arten für die Küstendünen eigentümlich sind und als halophil bezeichnet werden können (Fig. 219-225), ist die Formation doch überall dieselbe, und zwar eine ausgesprochen xerophile. Die Frage, ob die Vegetation

1) Schimper 1891 . 
der Dünen als halophil oder rein xerophil zu betrachten sei, ist besprochen worden namentlich von Kearney ${ }^{1}$ ).

Hier sei nur bemerkt, daß die erwähnten Strandkräuter in Gegenden mit Flugsand Sand auffangen und sammeln können und so Dünenembryonen bilden, welche eventuell später zu höheren Dünen emporwachsen können (Fig. 213, 219, 220). Die gröBte Bedeutung haben natürlich die ausdauernden Arten, und unter diesen an der Nordsee besonders Triticum junceum ${ }^{2}$ ).

D. Formation der Gebüsche auf Sandstrand. Auf der Landseite der erwähnten halophilen Krautformation kann oft ein Gebüsch von

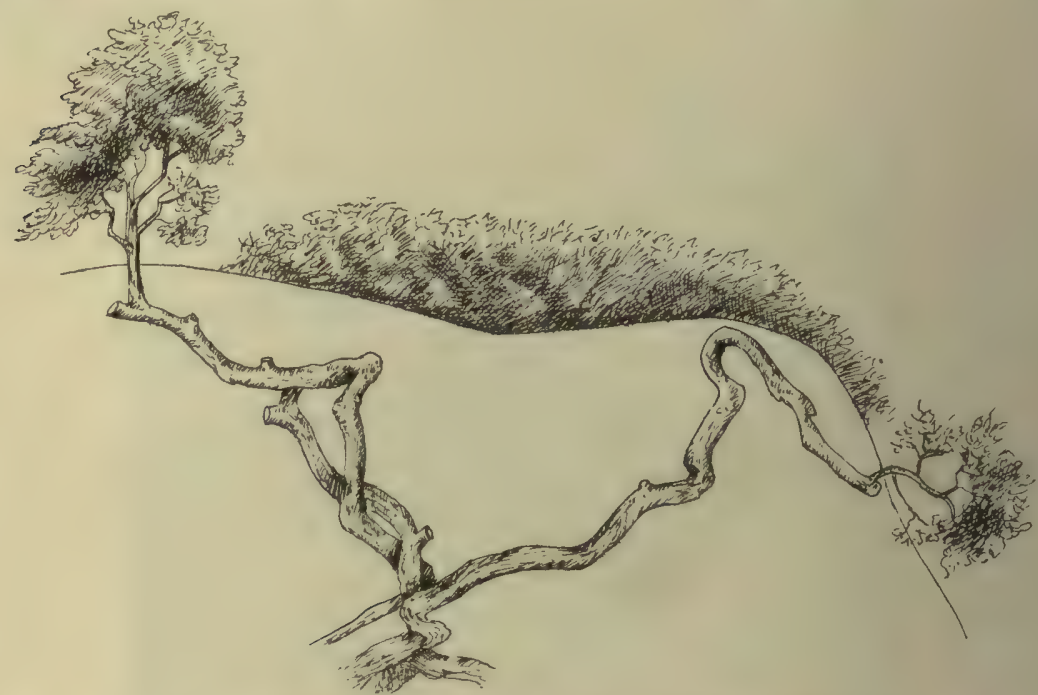

Fig. 222. Alte Eichenpflanze, dauernd in den Dünensand eingeweht, nur die obersten Zweige ragen in die Luft. (Nach Roepstorff bei Warming 1909.)

Sträuchern folgen. In Westindien z. B. ist eine Tournefortia gnaphalodes-Assoziation (Fig. 221) nicht selten; diese Art ist ein Strauch oder Halbstrauch von ca. $1 \mathrm{~m}$ Höhe mit dicken, graufilzigen Blättern. Mit ihm können natürlich andere Sträucher, sowie Kräuter und krautartige Lianen assoziiert sein.

An der Nord- und Ostsee bildet namentlich der Sanddorn, Hippophaës rhamnoides ${ }^{3}$ ), charakteristische Bestände, er und seine Begleiter, wie an der Ostsee Salix Pomeranica, werden zu Zeiten der Stürme oft

1) Kearney 1904 .

2) Reinke 1909; Warming 1909.

3) Über die Vegetationsverhältnisse und die Begleitpflanzen des Hippophaës rhamnoides vergl. besonders A. Palmgren 1912. Warming 1907-09, Fig. 99-102. 
von großen Mengen Salzwassers überschüttet (Fig. 224, 225) und die Krautflora ist daher auch zum großen Teile halophil.

In den asiatischen und afrikanischen Küsten sind nicht selten kleine T'amariskengebuische auf mehr oder weniger salzigem Sandboden zu treffen; sie können eine recht bedeutende Höhe erreichen und sehen matt, bläulich, glanzlos aus; in der Blütezeit bedeckeu sich die schuppigen, dünnen Zweige mit zahllosen kleinen, hellroten Blüten.

Die Conocarpus-Assoziation. Am inneren Rande der westindischen Mangrove, auf höherem und trockenerem Boden findet sich

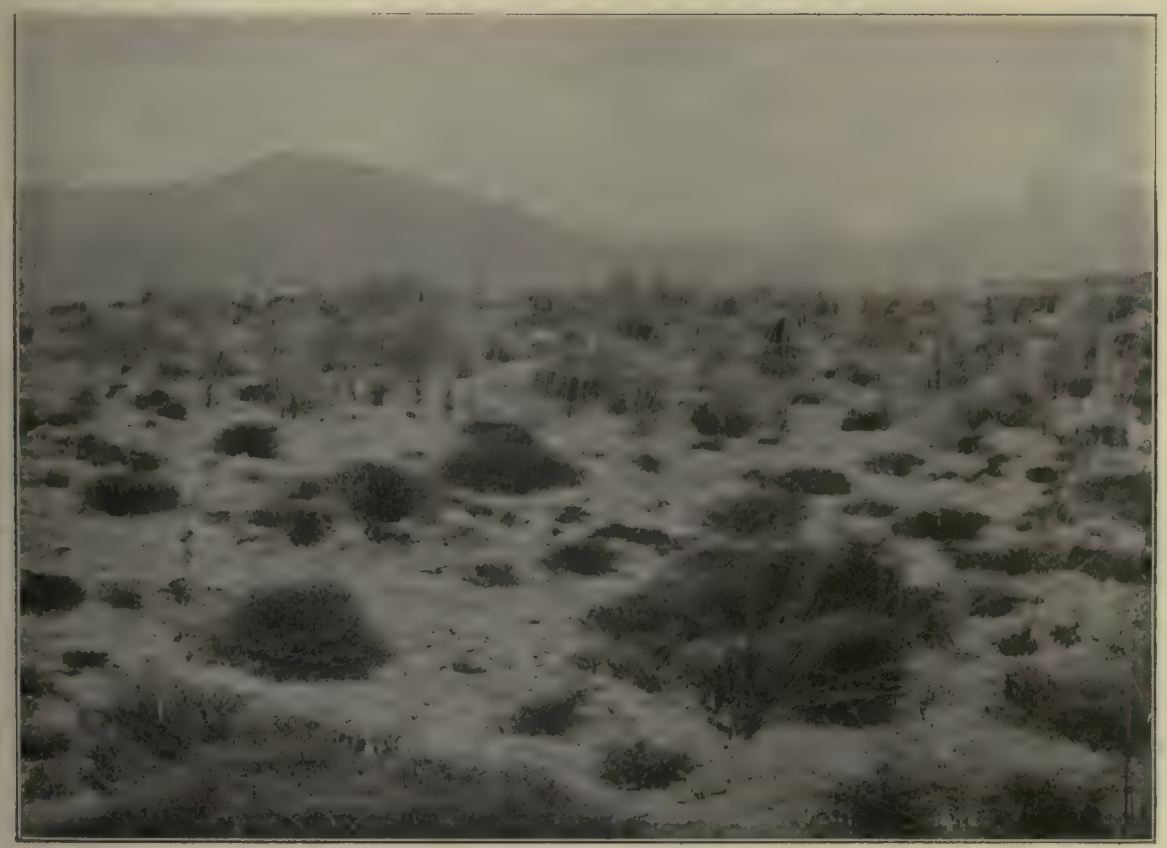

Fig. 223. Sandstrand bei Ajaccio auf Corsika, mit Scrophularia ramosissima u. a. (Phot. F. Börgesen.)

oft eine aus Conocarpus erectus als dominierende Art gebildete Vegetation (S. 410). Der Boden scheint bisweilen tonig, bisweilen recht sandig zu sein; so soll als Bodenvegetation auf den dänischen westindischen Inseln z. B. vorkommen ${ }^{1}$ ): Sporobolus Virginicus, Heliotropium Curassavicum, Acacia Farnesiana usw. (vergl. Fig. 221).

E. Formation der Wälder auf Sandstrand. Um solche zu finden, muß man sich am besten in die Tropen begeben.

1) Raunkiär 1909 . 
Tropische Strandwälder. Psammophyten und Halophyten vermischen sich am Sandstrande in der Nähe des Meeres. Nach dem Lande hinein wird die Vegetation allmählich rein psammophil, in dem Grade, wie das Salz aus dem Sande ausgewaschen worden ist; und hier treten in den Tropen niedrige Strandwälder oder Buschwälder auf, die insoweit doch halophil sind, als sie nur an den Meeresküsten vorkommen und als die Wurzeln wahrscheinlich bis zu dem salzhaltigen Grundwasser hinabreichen. Die Bäume sind niedrig und haben gekrümmte Stämme und Zweige mit lederartigen, fleischigen oder auf andere Weise xerophil ausgestatteten, oft großen Blättern. Zwischen den Bäımen treten

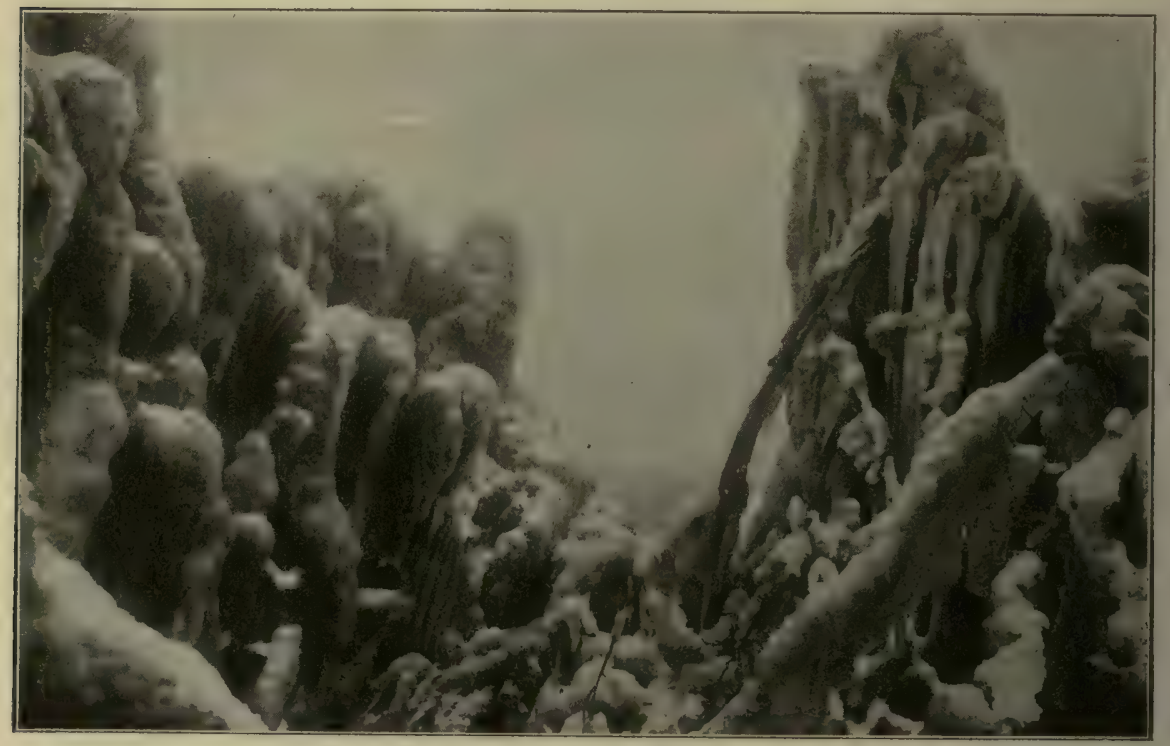

Fig. 224. Strandgebüsche auf den Dünen von Kolberg nach einer Sturmflut im Winter, zum Teil zusammengebrochen; zeigt, welche großen Mengen von Salzwasser bei Sturm in die Dünen gelangen, und welche Belastung die Gehölze ertragen müssen; vergl. Wetterbäume der Hochgebirge. (Phot. Käthe Meier-Kolberg.)

Sträucher auf, die oft dornig sind; Lianen und Epiphyten fehlen auch nicht, und das Ganze kann sehr dicht und unwegsam sein.

Als solche Assoziationen der Strandwälder auf Sandboden mögen folgende genannt werden:

Das Barringtonietum oder die von Schimper behandelte ostasiatische (indische und australische) Barringtonia-„Formation“, wo die großblättrigen und großblütigen Myrtaceen Barringtonia racemosa u. a. Arten, ferner Hibiscus tiliaceus, Casuarina, Thespesia populnea, Terminalia catappa, Heritiera litoralis u. v. a. eine Rolle spielen ${ }^{1}$.

2) Schimper 1891 . 
Diese Vegetation kann durch Caesalpinia bonducella, Canavalia-Arten und andere Lianen fast undurchdringlich gemacht werden. In den ostasiatischen Strandwäldern treten Kokospalmen und eigentümliche Typen wie Pandanus, z. B. P. labyrinthicus, auf, die den Rhizophoren im Wuchs ähnlich sind, weil auch sie sich in einem losen Boden befestigen müssen ${ }^{1}$ ).

Von den Philippinen erwähnt Whitford Sandstränder mit Arten von Pandanus, Barringtonia, Casuarina equisetifolia.

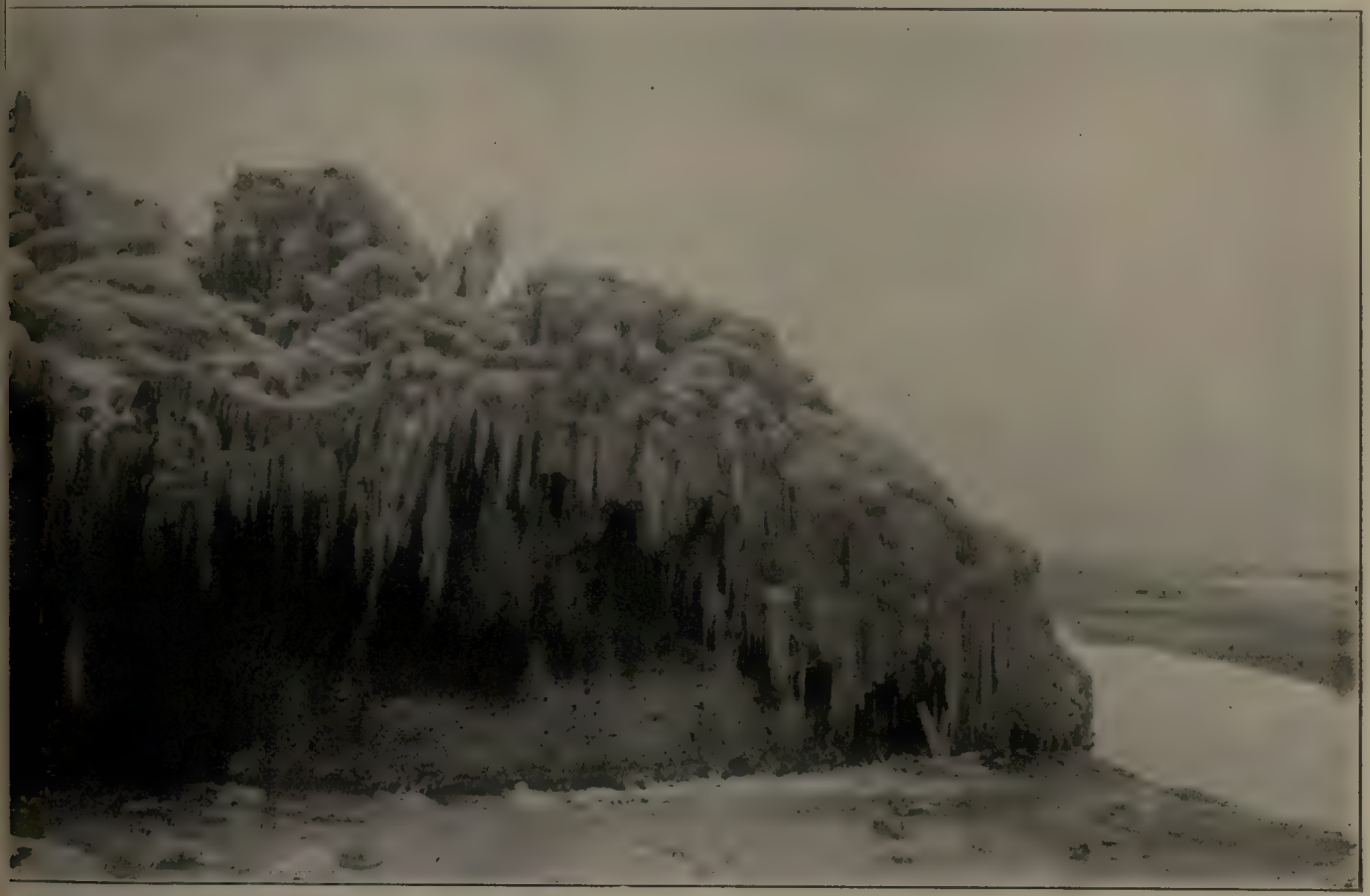

Fig. 225. Wie Fig. 224. Eisanhang auf den Gehölzen der Dünen an der Ostseeküste nach einer Sturmflut (1913). (Phot. Käthe Meier-Kolberg.)

Das Coccolobetum uviferae, die westindische CoccolobaAssoziation, wo C. uvifera vorherrscht, ein kleiner Baum oder Strauch mit großen, sehr steifen, steil aufwärts gerichteten Blättern² ${ }^{2}$; er bildet am Strande Gebüsche und kann mit wurzelschlagenden, kriechenden Zweigen auftreten (Fig. 217, 218). Mit ihm findet man viele andere Arten, auch Holzpflanzen, auch einige in Asien auftretende Arten oder Gattungen.

Diese niedrigen Wälder oder Gebüsche sind oft durch dornige Sträucher und Lianen aus den Leguminosengattungen Caesalpinia, Canavallia und Dalbergia undurchdringlich.

1) Uber die singalesischen Küsten vergl. Tansley und Fritsch 1905.

2) Abgebildet von Warming in Börgesen und Paulsen 1900. S. 23, Fig. 8. 
Von Strandsträuchern, die hier vorkommen, können genannt werden Ernodea littoralis, Chrysobalanus icaco, Arten von Lantana, Cordia ${ }^{1}$.

Hier schließen sich weiterhin die brasilianischen Restingawälder an, die in vielem an die Kap. 107 behandelten Campos cerrados des Inneren Brasiliens erinnern. Typische Beispiele finden sich z. B. am Strande bei Rio de Janeiro auf feinem Quarzsande. Die Bestände sind immergrün, xerophytisch, aus kleinen Bäumen (bis $7 \mathrm{~m}$ Höhe) und Sträuchern $(0,5-3 \mathrm{~m})$ gebildet; sie stellen eine mehr oder weniger offene Assoziation dar, wo der weiße Sandboden überall zutage tritt. Sandbewohnende Kakteen, Zwergpalmen, Bromeliaceen, Zwergsträucher, oft von niederliegendem Wuchs, Gräser und Kräuter kommen auch vor. Schlingpflanzen, sowie epiphytische Bromeliaceen und Strauchflechten finden sich mehr oder weniger reichlich; sie werden durch die feuchte Luft und die feuchten Winde der Küste begünstigt. Im Schatten der Holzpflanzen kommen mehrere Kräuter vor.

Diese Strandwälder bilden den Übergang zu den gewöhnlichen Xerophytenwäldern; die in einigen dieser Wälder häufigen, gekrümmten Stamm- und Zweigformen kommen auch hier vor; die Blätter sind bei einigen Arten lederartig, steif, dick und behaart, ohne fleischig zu sein, bei anderen fleischig und kahl. Die Restingawälder Brasiliens erscheinen nicht streng an den Strand gebunden, weil sie nach Schenck oft tief im Lande auftreten können, wo es keinen Salzboden gibt. Sie sind nach ihm eher eine Sand-Assoziation ${ }^{2}$ ).

Der Strandwald auf Koh Chang in Siam, oberhalb des Gezeitengebietes, wird nach Joh. Schmidt ${ }^{3}$ ) auch von vielen periodisch laubwechselnden Arten gebildet. Casuariana equisetifolia kommt auch vor hier wie an den Küsten Australiens usw.

Halophyten-Wälder auf Sandboden im Binnenlande. Als Beispiel von solchen mögen die von der Chenopodiacee Haloxylon ammodendron auf dem salzhaltigen Sandboden Centralasiens gebildeten Wälder genannt werden. Der Saxaulbaum erreicht eine Höhe von $5-6 \mathrm{~m}$ und eine Stammdicke etwa von $20 \mathrm{~cm}$; die grauen Stämme sind gekrümmt und gedreht und sehen mit ihren zahlreichen, schuppigen, dünnen, Salicornia-ähnlichen Zweigen wie ein „grün gefärbtes Bündel von Reisern" aus"). Der Baum bildet einen Wald ohne Nadeln und Blätter, der aber doch grün ist und blüht und an die Casuarinen-Wälder Australiens erinnert. (Das Holz ist hart, sehr spröde und ohne Jahresringe). An ihn schließen sich wenige andere Pflanzen: Calligonum

1) Näheres bei Börgesen und C. Paulsen 1900; Raunkiär 1909 a; Börgesen 1909.

2) Über diese Wälder vergl. Schenck $1903 \mathrm{a}$, auch Hemmendorff 1912.

ร) Joh. Schmidt 1906.

4) Basiner 1848 . 
Persicum, Pteropyrum Aucherii u. a. an; an solchen Stellen beobachtet man auch den Wurzelschmarotzer Cistanche tubulosa mit seinen schmutzig violetten Blüten.

Der Salzgehalt im Stamme ist bedeutend, der in der Rinde beträgt etwa $6,25 \%$; sogar die Epidermiswände sind durchsetzt mit Kristallen und ähnlichen Ablagerungen. Ausgeschiedene Mengen von hygroskopischen Salzen nehmen des Nachts Tau auf. Der Kork ist so gebaut, daß gewisse schleimige Schwellpolster Wasser aufnehmen. Wenn die Wasserzufuhr aufhört, wird die Schleimerzeugung eingestellt und bedeckender Kork erzeugt. Weiter erscheinen zahlreiche Tannin enthaltende Idioblasten. Die assimilatorische Tätigkeit wird erhalten durch die Ausbildung von Chlorophyll in der sekundären Rinde ${ }^{1}$ ).

\section{Kap. Formationen des salzigen Tonbodens}

\section{A. Krautformation}

Nordeuropäische Strandwiesen. An der Küste der Nordsee finden sich Marsch- oder Strandwiesen, die auf zwei verschiedene Weisen entstehen können und danach Sandmarsch und Schlickmarsch genannt werden. Für die erstere Form bildet eine sandige Strandebene die Grundlage, für die andere Schlick, d. h. sehr feine Partikel von Ton und organischen Stoffen. Auf derselben Wiese können beide Bodenarten vorkommen, ebenso alle möglichen Mischungen derselben.

Die Sandmarschen liegen den störenden Einflüssen des bewegten Meeres am nächsten; die eigentlichen Marschwiesen oder Schlickmarschen bilden sich unter ruhigeren Verhältnissen, wo, gegen die starken Wellenbewegungen geschützt, die sehr feinen, tonigen und organischen Teile, welche von der Flut zugeführt werden, abgelagert werden können.

Die Sandmarsch fängt ihre Entwicklung auf einer Sandfläche an, auf welcher man namentlich die Formation der Sandalgen (S.431) und die Formation der halophytischen Kräuter auf Sandboden erwarten kann, z. B. Salicornietum herbaceae. Nach Salicornia wandern nämlich an: Festuca thalassica (Glyceria maritima), Triticum junceum, Agrostis alba, Festuca rubra, Glaux maritima u. a.; an den Küsten Englands findet man mehrere Arten von Salicornia und Statice an solchen Plätzen. Nach und nach fangen diese Pflanzen die vom Meere aufgeworfenen und vom Winde landeinwärts getragenen Sandmassen ${ }^{2}$ ) auf; der Boden wird für andere Kräuter bewohnbar, und nach und nach wird die Sandfläche von einer zuletzt ganz geschlossenen Krautdecke mit wenigen beigemischten

1) Über die merkwürdigen Anpassungserscheinungen am Saxaulbaum vergl. B. Jönssen 1902.

2) Vergl. Abbildungen bei Warming 1906. 
Halbsträuchern und Moosen gebildet. Auf dem Sande entwickelt sich ein aus verflochtenen Wurzeln und Grundachsen gebildeter, zäher, von organischen Resten grau oder schwarz gefärbter Bodenteppich ${ }^{1}$ ).

Die Schlickmarsch dagegen hat einen weit fruchtbareren Boden, der aus einem in feuchtem Zustand zähen Ton gebildet ist.

Hierher gehören die großen Strecken von Marschwiesen, welche an geschützten Stellen der Nordseeküste in Dänemark, Deutschland, Holland und England vorkommen.

Bei der Ausbildung derselben spielen zwei Assoziationen eine sehr bedeutende Rolle, 1. die Zostereta auf den Schlickbänken der Watten (S. 393 und Fig. 196) und die diesen folgenden 2. Salicornieta herbaceae, welche S. 396 und Fig. 197 erwähnt wurden.

In England tritt auch an einigen Küsten ein Spartinetum auf; es wird dies von drei Spartina-Arten gebildet, büschelförmigen Gräsern mit steifen Blättern, welche dieselben Stellen wie Salicornia einnehmen und auch ebenso stark schlickfangend sind ${ }^{2}$ ).

Diese Vereine fangen während der Flut, wenn das Wasser ruhig ist, die feinen tonigen und anderen Partikel auf. Dadurch, daß diese niedersinken, erhöht sich der. Boden langsam und wird dadurch wieder für andere Arten günstig.

Die dritte gürtelförmige Assoziation ist das Festucetum thalassicae (Glycerietum maritimae), Fig. 226. Wenn der Boden höher und trockner geworden ist, nachdem sich der Schlick im Laufe der Jahre zwischen den einjährigen Salicornien niedergeschlagen hat, so findet sich diese Assoziation ein. Festuca thalassica (Glyceria maritima) bildet mit ihren schmalblättrigen, bläulichgrünen Sprossen ${ }^{3}$ ) einen niedrigen, zusammenhängenden und dichten, oder nach dem Meere zu unterbrochenen, saftigen Grasteppich; mit ihr finden sich andere ausgeprägte Halophyten ein: Triglochin maritimum, Spergularia marina, Suaeda maritima, Plantago maritima, Aster tripolium, Glaux maritima, Statice limoniam, Arten von Atriplex, Cochlearia u. a.; alle sind auf eine oder die andere Art deutlich halophytisch gebaut. Schizophyceen, Rhizoclonium- und Vaucheria-Arten sind auf Tonboden häufig. Raunkiär ${ }^{4}$ ) hat durch statistische Aufstellungen verschiedene Facies gefunden. 1. Glyceria Salicornia; 2. Glyceria - Suaeda maritima und Salicornia; 3. Glyceria und Triglochin; 4. Glyceria-Aster tripolium; 5. Glyceria-Plantago maritima.

1) Vergl. Reinke 1909.

2) Uber die Marschwiesen Englands vergl. Tansley und Rankin in Tansley 1911.

3) Warming 1890, Fig. 3.

4) Raunkiär 1909. Vergl. auch Warming 1906. 


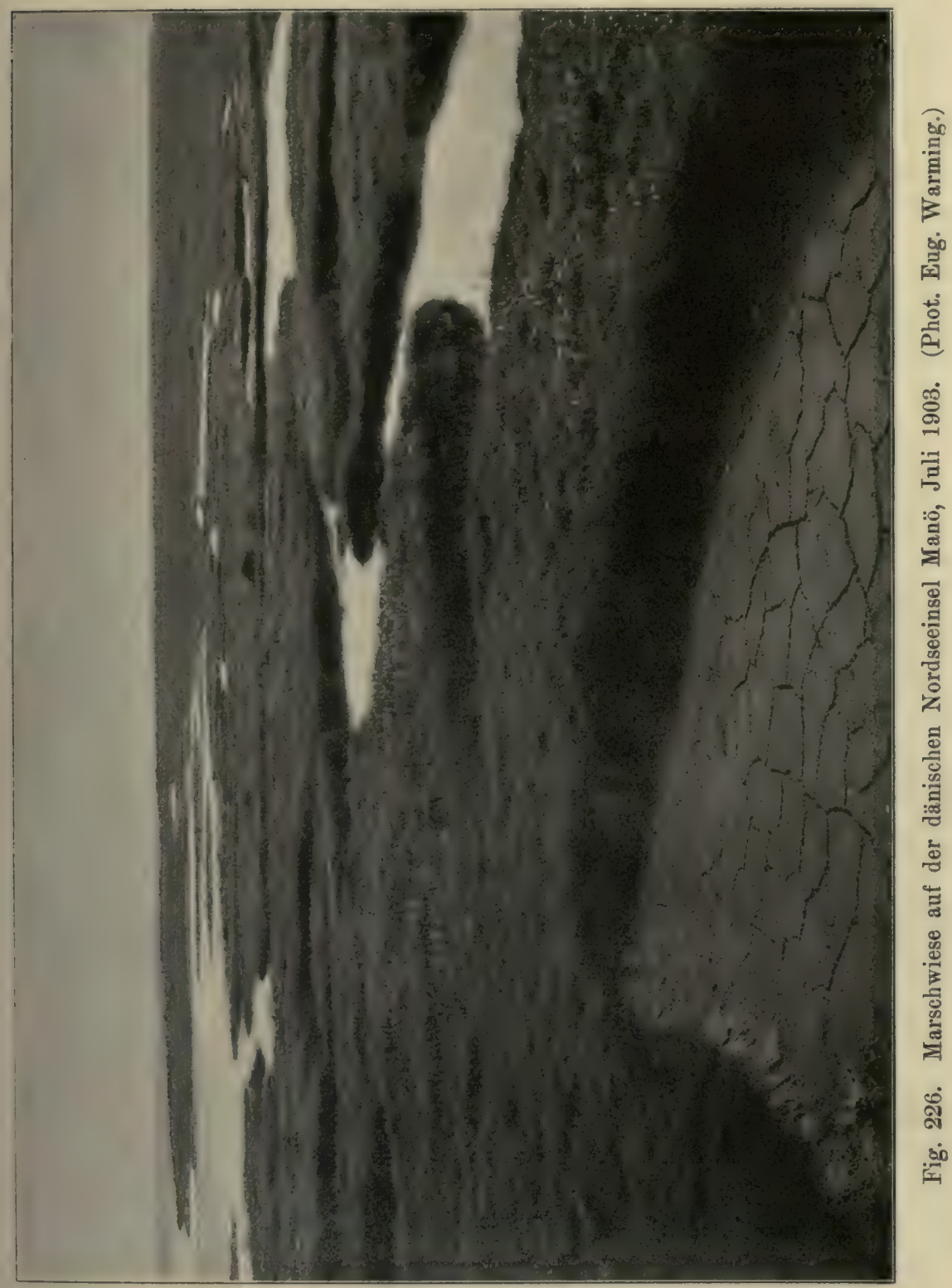

Erklärung zu Fig. 226. Die Flut dringt eben ein und hat die vielen Löcher und Vertiefungen, welche sich immer in alten Marschwiesen finden, bedeckt. Im Vordergrunde eine solche, in welcher sich der der Hitze und Trockenheit ausgesetzte Schlick in polygonale Felder zusammengezogen hat. Die Hauptmasse wird von Festuca thalassica (Glyceria maritima) gebildet; in dem weichen, saftigen Teppiche derselben sieht man die Blüten von Spergularia marina; ebenso eingestreut Exemplare von Suaeda maritima, Aster tripolium, Triglochin maritimum $\mathrm{u}$. a. 
Merkwürdig ist, daß auch verschiedene höhere Algen sich einfinden und mit den Marsch-Blütenpflanzen assoziieren können, was dafür zeugt, daß diese ersten Assoziationen noch sehr naß und salzig sind. Zwischen Armeria, Statice, Aster usw. wandern z. B. in England Fucus vesiculosus und $F$. spiralis, Pelvetia canaliculata, Catenella opuntia, Bostrichia scorpioides, viele Grünalgen wie Rhizoclonium, Chaetomorpha, Enteromorpha und andere Algen ein; sie werden teilweise mit ihren unteren Teilen im Schlicke begraben und dadurch wie mit Wurzeln befestigt, ohne daß sie Haftorgane bilden, oder sie liegen auch lose zwischen den Blütenpflanzen. Viele nehmen auf diesem ungewöhnlichen Standorte auch ungewöhnliche Formen an. Einige leben sogar epiphytisch auf den Blütenpflanzen ${ }^{1}$ ).

Sarah Baker fand in England eine Pelvetia-Salicornia-Assoziation und eine Fucus -Aster-Assoziation. Cotton unterscheidet in Nordamerika nach den Algenvereinen vier verschiedene Assoziationen der Marschwiesen.

Die Erklärung dieses Auftretens von Algen liegt darin, daß das Festucetum thalassicae (Glycerietum maritimae) täglich einige Stunden während der Flut überschwemmt wird.

Der Boden wird fortwährend, Jahr für Jahr, während der Flut mit Schlick bedeckt, und langsam schreitet die Erhöhung des Bodens fort. Daraus folgt aber zuletzt die Unterdrückung der Festuca thalassica, and die Vegetation geht in die der höheren Strandwiesen über, die wesentlich eine aus mehrjährigen Kräutern (darunter auch Gräser) bestehende, sehr niedrige und dichte Vegetation ist, welche jedoch wegen ihres Anschlusses an einem ausgeprägten Salzboden nicht zu den mesophilen Wiesen gerechnet werden darf. Ihre verschiedenen Gürtel sind stufenweise folgende: Junceta Gerardi, Festuceta rubrae, Armeria-Festucetum rubrae usw. ${ }^{2}$ ). Hier treten unter anderen folgende Arten auf: Juncus Gerardi, Plantago maritima, Glaux, Armeria maritima, Trifolium fragiferum, Spergularia, Artemisia maritima, ron Gräsern z. B. Arten von Hordeum, Festuca, Poa usw. Von einjährigen Arten findet man Lepturus filiformis, Erythraea-Arten und den Hallschmarotzer Odontites. Die Wurzeln dieser Pflanzen durchziehen eine oft bis $20 \mathrm{~cm}$ dicke Rohhumusschicht. Die genannten Assoziationen entsprechen verschiedenen Höhen des Bodens und werden nach der Höhe in verschiedenen Zeiträumen überschwemmt, die höchsten vielleicht nur ein paarmal im Jahre.

Durch Eindeichen der Strandwiesen, dadurch hervorgerufenes Aus. waschen des Salzes und durch Kultur erhält man die künst. lichen, äußerst fruchtbaren Marschwiesen (Fig. 226).

1) Sauvagean 1908; Sarah Baker 1912; Cotton 1912.

2) Warming 1890, 1906; Raunkiär 1909. 
An einigen Stellen an der Nord-und Ostsee kommt eine dem Glycerietum etwa parallel stehende Assoziation vor, das Juncetum maritimi, mit Juncus maritimus als dominierende Art, eine steife, graulichgrüne bis etwa halbmeterhohe Pflanze ${ }^{1}$ ).

Fine ganz entsprechende Vegetation, zum Teil mit ganz denselben Assoziationen, kommt an Englands Ostküste vor. Über den Salzgehalt der verschiedenen Gürtel wird folgendes angegeben: im Salicornietum $0,21 \%$, im Festucetum thalassicae $0,09 \%$, im Festucetum rubrae $0,03 \%$. In den Kultur-Marschwiesen ist schließlich der Salzgehalt sehr gering ${ }^{2}$ ).

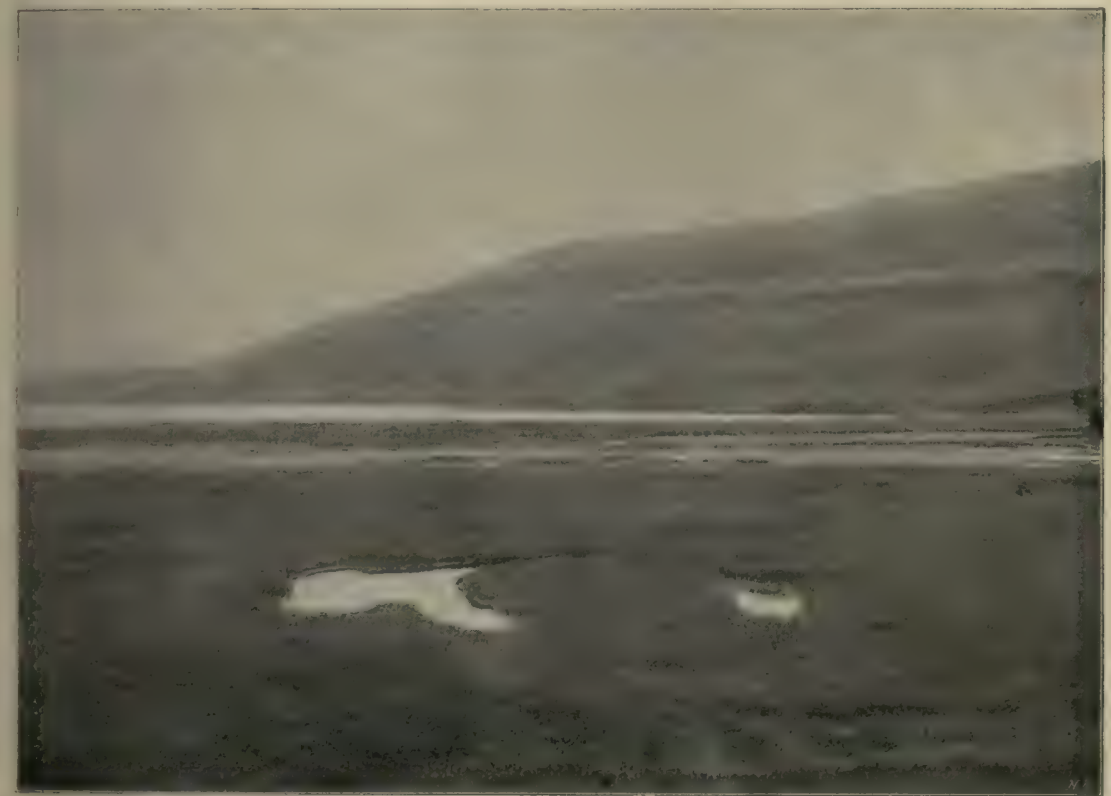

Fig. 227. Murschwiese auf den Färöern mit ebensolchen Wasserlöchern wie an den Nordseemarschen. Die Grasdecke ist von Fesluca thalassica gebildet, auch kommt eine Assoziation von Plantago maritima vor. (Phot. Eug. Warming.)

Auch auf den Färöern kommen solche Strandwiesen vor, welche vorzugsweise aus Festuca thalassica gebildet werden, daneben Plantago maritima, Triglochin maritimum, Armeria vulgaris, Festuca rubra, Agrostis alba f. stolonifera, und zerstreut Cochlearia, Festuca distans, Scirpus pauciflorus, Leontodon auctumnalis usw.

Fleckenweise tritt auch eine Carex salina-Assoziation auf, welche ans höheren Stauden und Halbgräsern gebildet ist: Carex salina, C. Iyngbyei, Heleocharis palustris usw. ${ }^{3}$ ).

2) Fig. bei Warming 1906; Tansley 1911.

2) Pristley in Journ. Ecol. I, 54. Vergl, auch Chermezon und Mascleff.

) Ostenfeld $1908 \mathrm{~b}$. 
In Ostgrönland finden sich wohl kaum ausgedehnte Strandwiesen, aber doch Anfänge von solchen, wo Glyceria vilfoidea und Stellaria humifusa auf Schlickboden eine dünne aber dichte Schicht bilden; im höheren Niveau kommen viele andere Kräuter hinzu ${ }^{1}$ ).

Eine ganz ähnliche zonale Strandwiesen-Vegetation wird von den Küsten des weißen Meeres erwähnt („üppige Salzwiesen“ mit Alopecurus ventricosus u. a.: Pohle) und aus Nordamerika, z. B. von Chrysler, Bray (Texas), Ganong, Transeau. Nach Harshberger ${ }^{2}$ ) findet man z. B. folgende Gürtel: 1. Spartina stricta maritima im Ebbe- und Flutgebiet auf schlammigem Boden, entsprechend Salicornia herbacea an der Nordsee; 2. Spartinetum patentis, nur vom hohen Wasser erreicht; 3. Scirpetum pungentis; 4. Assoziation von Hochstauden mit Sträuchern ${ }^{3}$ ).

Nach Ganong ${ }^{4}$ ) ist an der Fundy-Bay die äußerste Zone ein Spartinetum, gebildet von Spartina stricta; ihr folgt auf der Landseite ein Gürtel von Salicornia und Suaeda, der wieder in eine Wiese (Staticetum) von Statice und Spartina juncea übergeht. Die Salzwiesen von Nebraska sind in der Hauptsache aus Distichlis spicata stricta gebildet $^{5}$ ).

Hierher muß wahrscheinlich auch die Salicornia-Assoziation der Oberen Anden, die R. Fries ${ }^{6}$ ) beschrieben hat, gestellt werden.

Strandwiesen sind in Südafrika ${ }^{7}$ ) nur wenig verbreitet, und zwar meist an den Flußmündungen. Im wesentlichen werden sie gebildet aus Eragrostis glabrata, welches mit seinen Grundachsen dichte Gewirre bildet. Dazwischen kriecht die Convolvulacee Falkia repens und ebenso häufig Frankenia capitata; beigemischt sind oft Plantago carnosa und Statice scabra, an besonders salzigen Stellen Salicornia fruticosa und Chenolea diffusa. An erhöhten Stellen übezieht das Gras Stenotaphrum glabrum den Boden mit einem grünen Teppich, in dem hie und da Samolus campanuloides, S. Valerandi und Polypogon Monspeliensis wachsen.

Die Vegetation in der Umgebung der Salzquellen (Soolequellen) oder in salzigen Niederungen im Innern eines Kontinents, wie z. B. Europas, unterscheidet sich nicht wesentlich von der Strandwiese; einen besonders guten Vergleich gestatten die stellenweise bis in die Nähe des Meeres reichenden Soolquellen von Kolberg in Pommern. In Sibirien

1) Chr. Krunse 1912.

2) Harshberger 1909, siehe auch 1911.

s) Über die den Strandwiesen entsprechenden Assoziationen Grönlands, Islands und der Färöer vergl.: Warming 1887; Porsild 1902; Ostenfeld 1908 b; H. Jonsson 1914.

c) Ganong 1903.

5) Pounds and Clements 1898 (1900). Utber die nordamerikanischen Strandwiesen vergl. auch: Harshberger 1900, 1909; Hitchcock 1898; Kearney 1900.

C) R. Fries 1904 .

? Vergl. Marloth 1908. 
werden nach Cajander in der Nähe von Salzquellen Wiesen gebildet von Potentilla anserina, Glaux maritima, Salicornia herbacea und Festuca (Glyceria) distans. Auf ungarischen Steppen wachsen vielfach dieselben Arten wie an den Küsten des nördlichen Europa ${ }^{1}$ ). In Polen finden sich salzige Niederungen mit Aster tripolium und etwa 10 anderen Arten des Salzbodens der Meeresküsten.

Viele Arten und Gattungen der Salzwiesen haben eine merkwürdig weite Verbreitung; z. B. stimmt nicht nur die Halophytenflora Nordamerikas in vielen Punkten durchaus mit der Europas überein, sondern sogar in Neuseeland findet sich eine Anzahl von Gattungen, die auch auf europäischen Salzwiesen in derselben oder in anderen Arten vorkommen. Von diesen Gattungen sind zu nennen: Apium, Atriplex (A. patula), Carex, Chenopodium (C. glaucum), Eryngium, Festuca, Lepidium, Samolus (S. litoralis), Scirpus und Triglochin.

\section{B. Halbstrauchformation}

Längs den subtropischen und tropischen Küsten, z. B. in Westindien, auch in den warm temperierten Mittelmeerländern, kommen an vielen Stellen Vereine von niedrigen succulenten Halbsträuchern vor. Es ist schwierig zu sagen, ob sie am besten den Salzsümpfen oder der halophyten Landvegetation zugerechnet sein sollen. Die Standorte sind Mittelbildungen zwischen dem Sumpfe und dem Landboden, so wie auch die Pflanzen selbst zwischen krautartigen und Holzpflanzen in der Mitte stehen. Ebenso ist der Boden verschieden; bald ist er vorzugsweise tonig, bald sandig, bald stellt er Zwischenbildungen zwischen Sand und Ton resp. Gemische derselben dar. Bisweilen wird das Gelände wohl überflutet, wenn Hochwasser eintritt. Es gilt vielleicht für die dort wohnenden Pflanzen, namentlich Salicornia-Arten, dasselbe, was Hill $^{2}$ ) für die Wurzelhaare von Salicornia (herbacea) gezeigt hat, nämlich, daß sie ihr osmotisches Vermögen nach dem umgebenden Medium ändern können.

Diese Assoziationen sind entschieden mit der von Salicornia herbacea in Nordeuropa nahe verwandt. Sie repräsentieren dieselbe Stufe am Strande, zeugen aber von einem verschiedenen, nämlich subtropischen oder tropischen Klima. Es sind ebenso succulente Arten, blattlos (Salicornia) oder mit zylindrisch-spindelförmigen, succulenten Blättern versehen (Sesuvium, Batis). Vergl. Fig. 106, 107, 170.

Verschiedene Assoziationen kommen vor, z. B. folgende:

Salicornietum fruticosae. Auf Tonboden der Küsten des Mittelmeeres, z. B. bei Montepellier ${ }^{3}$ ), tritt eine ungefähr $1 / 3-1 / 2 \mathrm{~m} \mathrm{hohe,}$

1) Bernatsky 1905. - Die böhmischen Salzwiesen hat T. Domin (1905 a) beschrieben.

2) Hill 1908.

ग) Flahault et Combres 1894; Raunkiär 1914. 
dichte, dunkelgrüne Halophytenvegetation auf, die besonders aus der halbstrauchigen Salicornia fruticosa oder Arthrocnemum glaucum besteht ${ }^{1}$ ), der besonders Atriplex portulacoides, Statice limonium, St. bellidifolia u. a. Arten, Scirpus holoschoenus usw. beigemischt sind. Die genannten Salicornieen wurden schon als Pflanzen der Felsküsten, besonders der Adria, genannt. Im Schatten der Sträucher wächst oft eine

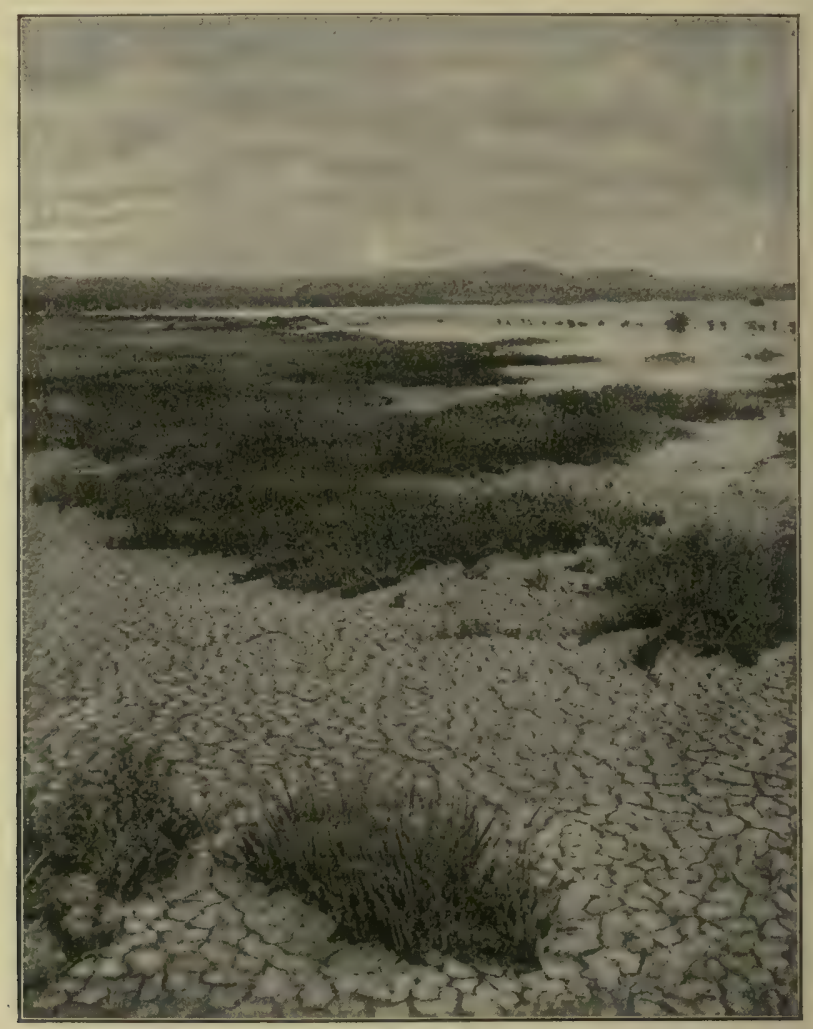

Fig. 228. Halbstrauchformation an der Südküste von St. Croix. Salicornia ambigua (vergl. Fig. 114), Sesuvium portulacastrum und Batis maritima. Im Wasser junge Mangrovenbäume. (F. Börgesen.) S. dasselbe auch Fig. 171, S. 340.

Schizophycee, Lyngbya aestuarii, in verfilzten Massen (vergl. S. 391). Dieser Verein weicht von unseren, vorhin behandelten Tonstrandvereinen durch die strauchartigen Arten ab und muß von ihnen als Formation der Lagunengebüsche geschieden werden, die zunächst mit der Salzsteppe auf Tonboden zu vergleichen ist (Batis, Sesuvium). Vergl. Fig. 171, S. 340.

1) Duval-Jouve 1868 . 
Salicornietum ambiguae. An den Küsten des karibischen Meeres findet man an den Lagunen flache und tonige Strecken, die mit einer, dieser südeuropäischen ökologisch offenbar nahe verwandten Vegetation bewachsen sind. Von halbstrauchartigen Arten kommen hier folgende vor: Batis maritima (gewöhnlich $1 / 2 \mathrm{~m}$ hoch), Salicornia ambigua, Sesuvium portulacastrum (kann gesellig auftreten und weite Strecken mit einer häufig niedrigen, saftreichen, blaugrünen Decke überziehen), ferner Arten von Portulaca und Heliotropium (H. Curassavicum) u. a. ${ }^{4}$ ).

An der Südküste von St. Croix findet sich eine dichte Vegetation von Salicornia ambigua und anderen der genannten Halbsträucher. Der aus Schlamm gebildete Boden hat sich an vielen Stellen, ähnlich wie es auch in kühlen Gebieten geschieht, der tropischen Hitze ausgesetzt, in polygonale Felder zusammengezogen.

Sehr interessant ist eine Formation von Halbsträuchern und Sträuchern, wie sie sich stellenweise in Wiesenform übergehend in der Nähe des Mittelmeeres findet ${ }^{1}$ ). Mit Ruscus aculeatus und Cotoneaster pyracantha wuchsen dort auf engem Raume an der ostitalienischen Küste, einen lockeren Bestand bildend, u. a. Thalictrum angustifolium, Althaea officinalis, Linum maritimum, Oenanthe Lachenalii, Aster tripolium, Inula crithmoides, Artemisia Gallica, Sonchus maritimus, Erythraea tenuiftora, E. spicata, Samolus Valerandi, Statice serotina, Plantago coronopus, Suaeda maritima, Juncus acutus, J. maritimus, Schoenus nigricans, Scirpus litoralis, S. holoschoenus, Carex extensa, Crypsis aculeatus, also ein eigenartiges und interessantes Gemisch der verschiedenen Typen.

\section{Kap. Salzvegetation des Binnenlandes. Salzsteppen. Salzwüsten}

An den tiefsten Stellen des nordafrikanischen Wüstenlandes, wie Tunesien und Algerien, liegt eine Reihe von zum Teil großen, seichten Salzseen, die sogenannten Chotts (Fig. 229). Sie finden sich in einem abflußlosen Gebiete. Zur Regenzeit sind weite Strecken überschwemmt, da ihnen die Flüsse von den Gebirgen Wasser zuführen, in der langen Trockenzeit verdunstet das Wasser mehr oder weniger, und blendend weiße Salzkrusten, die wie Eis aussehen, bezeichnen ihre Lage. „Über der erhitzten Hochebene ist die Luft nun in zitternder Bewegung, und die Fata morgana zaubert dem erschöpften Wanderer allerlei verlockende Trugbilder vor" (Rikli und Schröter).

Auf dem trockengelegten Boden ist die Vegetation äußerst arm; doch kann man hier und da einige Pflanzen treffen, aber sowie man

4) Börgesen u. Poulsen 1900.

1) Ascherson u. Graebner 1895. 
sich von diesen Salzseen und Salzwüsten entfernt, wird sie immer reicher, und man kann von "Salzsteppen" sprechen, denn der Unterschied zwischen Steppe und Wüste beruht in den trocknen Gebieten nur auf einem mehr oder weniger dichten Pflanzenbestande: wo mehr Boden unbedeckt, als von der Vegetation bedeckt ist, hat man Wü ste, wo das Umgekehrte der Fall ist, Halbwüste und Steppe.

Die Vegetation in den Salzsteppen wird hauptsächlich von succulenten Chenopodiaceen gebildet, von denen nur wenige einjährig sind, die meisten sind knorrige, kleine Halbsträucher. Aus anderen Familien sind auch Statice, Frankenia u. a. reichlich vertreten.

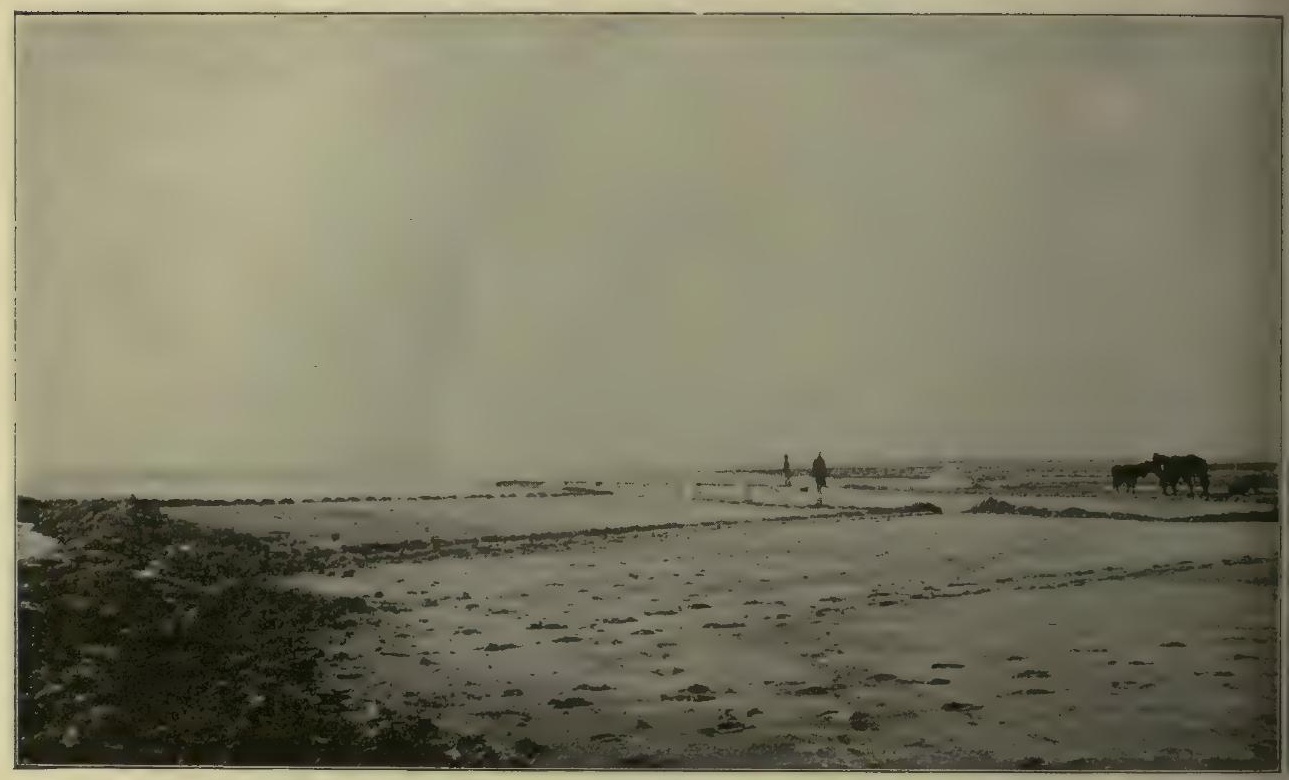

Fig. 229. An den Ufern des Salzsees Chott el Djerid in Südtunesien. 'Das Ufer ist morastig; man sieht die Fubstapfen. (Phot. Eug. Warming.)

Salzsteppe und Salzw üste kommen besonders in Afrika und Asien vor.

Die Lebensformen sind vorzugsweise succulente Kräuter und Halbsträucher mit fleischigen, gewöhnlich stielrunden Blättern, oder fleischigen, aber blattlosen Stengeln.

Auf den Salzsteppen kommen sowohl ausdauernde, namentlich Stauden und Halbsträucher, als einjährige Arten vor; die ausdauernden sind oft in der Minderzahl, besonders Artemisia-Arten und Chenopodiaceen. Die einjährigen können sehr reich an Individuen sein. Die klimatischen und edaphischen Faktoren sind baumfeindlich; Bäume kommen daher nur selten vor. 
Salzsteppen gibt es an vielen Stellen der inneren, kontinentalen Teile der Länder (Spanien, Ungarn, Südost-Rußland, Nordafrika, Ostafrika, Asien, Nordamerika, Pampas Argentiniens, Australien usw.; vergl. neunte Serie).

Der Boden ist mehr oder weniger tonig und undurchlässig. Humus wird nicht oder äußerst wenig gebildet. In der Regel liegen sie in abflußlosen Senkungen, nach welchen Wasser von den höher liegenden Stellen abfließen kann. In der Mitte derselben liegt oft ein kleinerer oder größerer Salzsee oder ein Salzsumpf, der im Sommer austrocknet und sich mit weißen Salzkrusten bedeckt, wie früher erwähnt wurde.

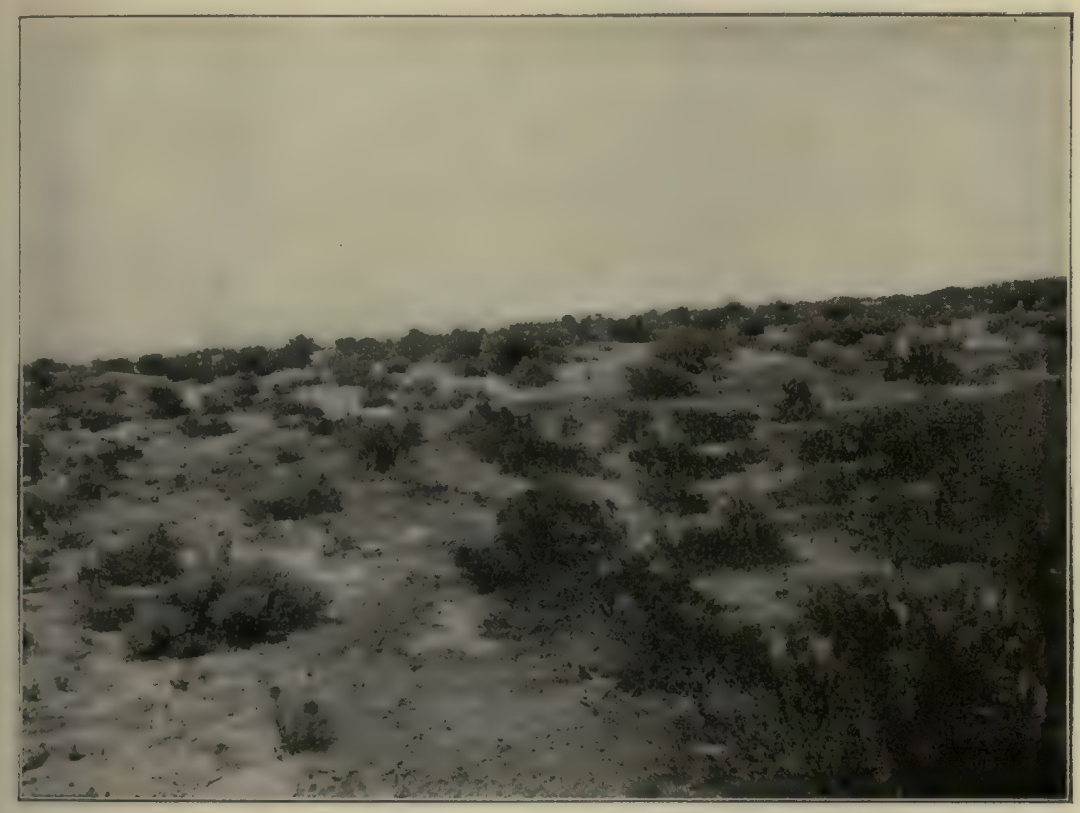

Fig. 230. Salzsteppe in der Nähe von Tooele in Utah.

Die Pflanzen sind Arten von Salicornia und Spirostachys nebst Atriplex confertifolia und einigen Exemplaren von Suaeda. (Phot. O. Paulsen.)

Die Salzsteppen sind mit den äußersten Zonen des Tonstrandes, namentlich mit der Salicornia- und der Festuca-Zone, ökologisch nahe verwandt, aber doch besonders mit der besprochenen halophilen Strauchregetation an den Küsten des Mittelmeeres und Amerikas. Der Boden ist sehr unvollständig bewachsen; die Arten sind wenig zahlreich, sie bilden auf dem oft grauen oder weißlichen Boden zerstreute Rasen, die als dunkle Flecken erscheinen, und sind meist entweder dunkelgrün und kahl, oder mit einer grauen (mehligen, schuppigen, filzigen) Haarschicht bedeckt, z. B. Artemisia herba alba in Nordafrika, Chenopodiaceen usw., oder durch Wachs blaugrün. Die Salzsteppe bleibt grün, wenn alle andere 
Vegetation ringsum welk geworden ist. Viele Arten sind mehr oder weniger strauchartig und haben schmale, linealische oder spatelförmige Blätter oder sind blattlos.

Die Arten gehören zum großen Teile der Familie der Chenopodiaceen an und sind succulent.

In Algerien fanden Rikli und Schröter ${ }^{1}$ ) z. B. folgende Reihenfolge der Arten. Zuerst 1. eine Salzwiese, ein Juncetum acuti. Auf schwach salzhaltigem Boden bildete Juncus acutus stachelige Horste; daneben Arten von Atriplex, dann Schismus und andere Gräser (Hordeum maritimum, Lepturus incurvatus, Sphenopus divaricatus), ferner Arten von Spergularia, Frankenia usw. Auch vereinzelte Sträucher kamen vor. 2. Ein Staticetum. Je näher das Ufer des Salzsees, desto einförmiger die Flora. In größter Mannigfaltigkeit trat Statice Sebkarum auf, neben ihr zwei andere Staticen, ferner einige Blattsucculenten, wie Spergularia marina, Suaeda fruticosa, Inula crithmoides usw. 3. Ein Salicornietum, fast nur von (vier) Arten von Salicornia gebildet, wuchs in nächster Nähe des Salzsees, da wo der Boden den größten Salzgehalt aufweist. Ihnen gesellen sich Arten von anderen Chenopodiaceen. Auf Wurzeln der Salicornien und AtriplexArten schmarotzt die einzige Balanophoracee der Mittelmeerländer, Cynomorium coccineum. 4. Der Salzsee selbst; dort wachsen nach Flahault und Doumergue verschiedene Blütenpflanzen (Althenia filiformis, zwei Ruppia-Arten) und Characeen nebst dem Lebermoose Riella helicophylla.

Über die „Salzsteppen" des südlichen Algeriens schrieben Rikli und Schröter, daß mit Ausnahme von Halogeton sativus und Salicornia herbacea, welche einjährig sind, die übrigen zahlreichen Arten knorrige, zuweilen bedornte Kleinsträucher sind, mit linealischen bis pfriemlichen oder gebüschelten Blättern, die mehr oder weniger succulent sind. Zwischen dem Gewirr der dem Boden angedrückten Äste sammelt sich Sand, und es entstehen höckerartige Miniaturdünen. Die Chenopodiaceen wachsen in einem Boden, der bald völlig von Salzwasser durchtränkt ist, bald aber so ausgetrocknet ist, daß er von Trockenrissen durchzogen wird. Die genannten Forscher geben ein Verzeichnis von etwa 30 Begleitpflanzen.

Auf den europäisch-asiatischen Salzsteppen findet man Arten der Gattungen Anabasis, Halimocnemis, Salicornia, Atriplex, Haloxylon, Brachylepis (Asclepiadacee), Frankenia, Nitraria usw.

In Nordamerika kommen z. B. folgende Chenopodiaceen vor: Sarcobatus Maximiliani (S. vermiculatus, "Pulpy-thorn", Saftdornstrauch),

1) Rikli u. Schröter 1912. 
Atriplex confertifolia, Spirostachys occidentalis, Salicornia herbacea, Suaeda u. a.; sie sind teilweise Sträucher. Die von ihnen gebildeten Salzsteppen liegen auf den großen Hochebenen westlich der Rocky Mountains, z. B. in der Gegend des Salzsees von Utah.

Die Salzsteppen Argentiniens (los Salitrales) sind in die Pampas eingemischt und gehen in sie über. Pflanzen, die nur auf Salzboden wachsen, sind Suaeda divaricata, Spirostachys Patagonica und S. vaginata, Halopeplis Gilliesii, Niederleinia juniperoides, Statice Brasiliensis u. a. (F. Kurtz).

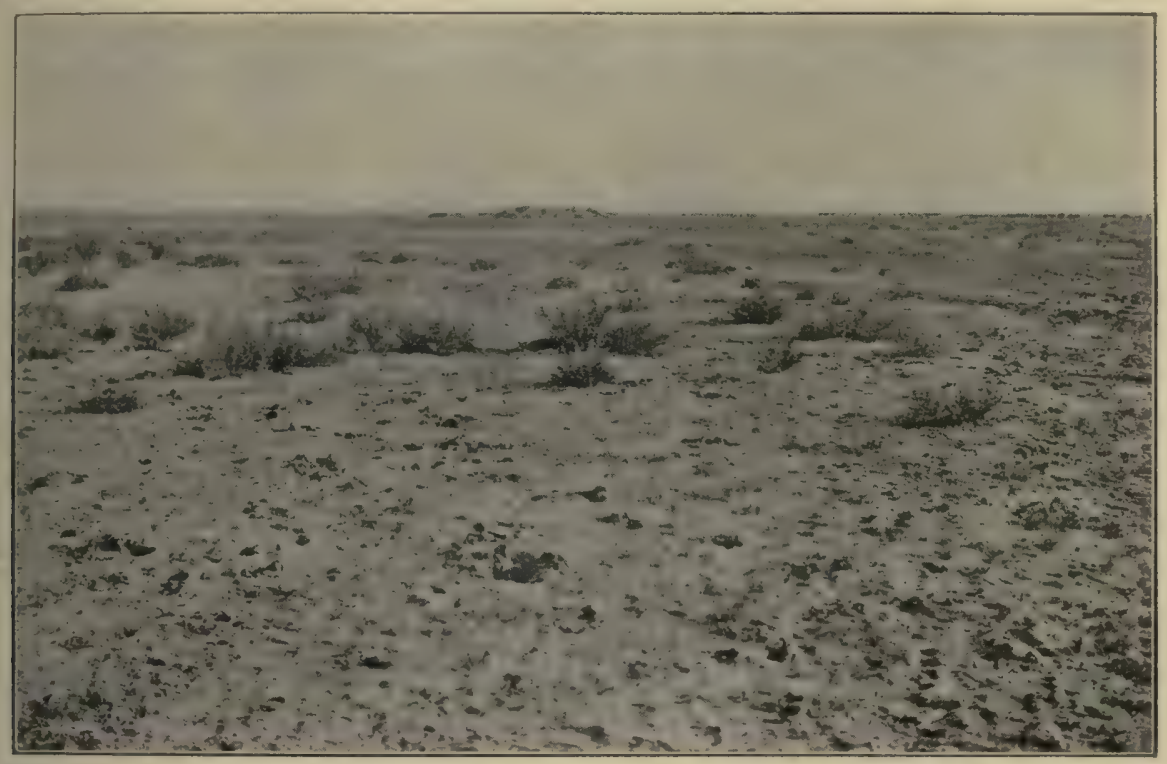

Fig. 231. "Szor" (Salzwiiste) in der Nähe von Buchara.

Der Boden ist weib von Salz und von zerstreuten Exemplaren von Aeluropus littoralis und Halostachys caspica (den Sträuchern) bewachsen. Im Monat Mai.

(Nach 0. Paulsen 1912.)

Salzsteppen und andere Steppen sind natürlich häufig durch sehr allmähliche Übergänge miteinander verbunden, weil der Boden der Steppen oft etwas salzhaltig ist. Sie gehen auch in reine, ganz vegetationslose Wüsten über.

Salzwüsten. Als typisch kann die nach Buhses ${ }^{1}$ ) Beschreibung große persische Salzwüste genannt werden, die noch unfruchtbarer als die Sahara ist und $1 / 30$ des persischen Reiches umfaßt. Der tonige, in der Tiefe schlammige Boden hält das Salz zurück, das stellenweise

2) Buhse 1850 . 
auskristallisiert und bis fußdicke, weiße, glänzende Schichten bildet. Auf dieser gelblichgrauen, 115 geographische Meilen weit ausgedehnten Fläche, deren Hauptmasse Sand ist, welchem Kalk, Eisenoxyd, Kochsalz, schwefelsaures Natron, sowie andere Salze und Ton beigemischt sind, gedeiht gar keine Pflanze, kein Grashalm, kein Moos, auch keine noch niedrigere Pflanze: sie ist die Wüste der Wüsten.

Die Salzwüsten Argentiniens sind nach Brackebusch ${ }^{1}$ ) oft riesigen Schnee- und Eisfeldern und in der Regenzeit Salzseen ähnlich; einige sind ganz pflanzenlos. Von den Chenopodiaceen werden folgende genannt: Arten von Atriplex, Spirostachys, Halopeplis, Suaeda, von Gräsern Munroa, Muehlenbergia, Pappophorum, Chloris usw. Außerdem gibt es Papilionaceen, Portulacaceen, Apocynaceen, Cactaceen usw.

Über die Ökologie der Salzsteppen, Salzwüsten und Salzwiesen wissen wir noch wenig. Das meiste und beste ist bei 0 . Paulsen zu finden, der die transkaspischen Gebiete durchforschte ${ }^{2}$ ). Die meisten Arten der Wüsten sind sommer-annuelle (z. B. Salicornia herbacea, Arten von Statice, Frankenia u. a.) oder mehrjährige krautartige Halophyten. Ephemere Frühlingspflanzen gibt es nicht. Holzpflanzen kommen dagegen zerstreut vor. Durch große Entfernungen getrennt wachsen kleine Sträucher von der blattlosen Halostachys Caspica. Andere Sträucher sind Halocnemum strobilaceum und Lycium Ruthenicum (Fig. 231).

Die meisten Arten sind Halophyten, und besonders succulente Chenopodiaceen. Daß die Nacktheit der Salzwüste nur dem Mangel an süßem Wasser zuzuschreiben ist, zeigte sich nahe Buchara, als eine Bewässerung eines Areals stattfand; es bildete sich eine Decke von Aeluropus litoralis so dicht, daß fast alle anderen Halophyten unterdrückt wurden (O. Paulsen).

Die Salzvegetation wird übrigens am Ende des vierten Abschnitts unter Halbwüsten und Wüsten wieder erwähnt werden.

1) Brackebusch 1893.

$\left.{ }^{2}\right)$ O. Paulsen 1912. 


\section{Serie. An süßes Wasser gebundene Vereine}

\section{Kap. Süßwasservereine}

Über die ökologischen Faktoren im Wasser im allgemeinen vergl. Kap. 20, sowie auch Kap. 31.

Nach den Verschiedenheiten der Standorte und der Lebensformen werden die obengenannten Vereine in eine mit der Einteilung der Salzwasservereine und Salzwassersümpfe gleichartige Form eingeteilt werden können. Eine Einteilung der Standorte nach den chemischen Verschiedenheiten der Gewässer (Reichtum an Kalk, Humussäuren, organischen Zersetzungsprodukten usw.) wird sich vielleicht in der Zukunft durchführen lassen, namentlich für die Planktonorganismen, aber vorläufig scheint es unmöglich. Analysen des Wassers der süßen Seen als Beiträge zur Lösung dieser Aufgabe finden sich in verschiedenen Werken, z. B. bei Brönsted und Wesenberg-Lund (Dänemark), bei Guyer (Schweiz). Am meisten abweichend scheinen das braune, humussaure und wahrscheinlich meist nährstoffarme Wasser der Moorteiche und das von vielen organischen Stoffen und Salzen verunreinigte Wasser der Dorfteiche, Abwässer usw. Vorläufig werden die ersten indessen nur teilweise als spezielle Standorte abgetrennt.

I. Vereine von Wasserpflanzen (ganz submerse oder nur mit aerophilen Laubblättern versehene).

A. Schwebe- und Schwimmregetation. Ganz frei schwebende, untergetauchte und schwimmende Pflanzen.

1. Schwebepflanzen-Formation von autophyten Arten. (Plankton-Formation; Limnoplankton) ${ }^{1}$ ). Kap. 54.

2. Formation des Saproplankton Kap. 55.

3. Schwimmpflanzen-Formation (Pleuston- oder MegaplanktonFormation) Kap. 56.

B. Bodenvegetation (Limno-Benthos) von auf dem Boden liegenden oder befestigten Pflanzen, welche entweder ganz untergetaucht sind oder höchstens Schwimmblätter haben. Nach der Beschaffenheit des Bodens, ob Sand oder Schlamm, ob Steine oder Felsen, ist sie weiter einzuteilen.

1. Der Boden ist steinig, lithophile Vereine: Kap. 57.

2. Der Boden ist lose und oft weich (Sand, Schlamm, Ton).

1) Von גíum, See, Teich. 
a) Vereine von Fäulnisbewohnern auf losem Boden: Kap. 59.

b) Vereine von selbständigen (autophytischen) Limnäen (Algen, Moose, Gefäßpflanzen) auf losem, weichen Boden: Kap. 60.

II. Ufervegetation (Helophyten-Formationen) ${ }^{1}$ ). Pflanzenvereine auf wasserreichen Böden, die entweder periodisch trockengelegt werden, oder auf denen die Pflanzen immer die unteren Teile im Wasser haben, die höheren assimilierenden Teile in die Luft ragen lassen. Semiaërische Vegetation.

Nach den Bodenverhältnissen und der Tiefe des Wassers in mehrere Formationen einzuteilen (siehe Kap. 61).

III. Die von süßem Wasser abhängige Landvegetation (Aërische Vegetation) ist so mannigfaltig, daß eine Einteilung an dieser Stelle nur angedeutet werden kann. Sie kann nach folgenden Standorten geteilt werden, und wird in besonderen Serien besprochen werden.

a) Böden mit mittlerem Wassergehalt, naß oder feucht; Wasser nährstoffreich und sauerstoffreich. (Mesophyt-Vereine; Serie III).

b) Boden physiologisch trocken (Vegetation des Rohhumus- und Torfbodens; Kältewüsten). Serie IV und V.

c) Boden physikalisch trocken (Vegetation des Steinbodens und des Sandbodens). Serie VI.

d) Boden klimatisch trocken (Vegetation der Hartlaubgewächse, der Grassteppen, Savannen und der Trockengebiete). Serie VII, VIII und IX.

Über die Vereine von Wasserpflanzen und an den Ufern wachsenden Pflanzen (Sumpfpflanzen usw.) kann weiter folgendes bemerkt werden:

Die ökologischen Faktoren werden mehr oder weniger beeinflußt von der Größe und der Tiefe der Gewässer; von der Beschaffenheit der Ufer (ob schroff oder sanft verlaufend). In kleinen Wassertümpeln und am flachen Ufer mit seichtem Wasser wird die Temperatur ${ }^{2}$ ) des Wassers leicht erhöht und es kommen andere Arten zur Entwicklung als in tieferem Wasser. Die kalten Bergbäche haben andere und ärmere Assoziationen als wärmere Gewässer. Die Wasserbassins der Polarländer sind arm an Vegetation.

Große Unterschiede werden durch die Bewegungen des Wassers hervorgerufen, ob es stehend, schwach fließend oder stark strömend ist $^{3}$ ). Besonders der Sauerstoffgehalt und die alkalische Reaktion

1) Èoఢ̧, Sumpf.

2) Über Temperaturverhältnisse in der Litoralregion vergl. Wesenberg-Lund 1912.

8) Über speziellere Standorte der Algenvegetation vergl. Comère 1914. 
des Wassers werden dadurch beeinflußt. Flüsse, Bäche, Quellwasser und anderes strömendes Wasser, ja selbst die dem Winde zugänglichen Waldseen werden weniger erwärmt und sind daher reich an Sauerstoff; in stillen Tümpeln und Weihern wird der Sauerstoffgehalt dagegen sehr vermindert, besonders wenn starke Humusstoffbildung stattfindet (Heidegewässer, Moortümpel). Auch die Unterschiede in der Bewegung des Wassers sind von großer Bedeutung; die Flußvegetation (potamophile Vegetation) ${ }^{1}$ ) ist von der der Seen mehr oder weniger verschieden.

Die Klarheit des Wassers ist von Bedeutung und zum Teil von der chemischen Zusammensetzung desselben abhängig. Huitfeld Kaas z. B. hat die norwegischen Seen in vier Gruppen mit verschiedener Durchsichtigkeit des Wassers geteilt: 1. Seen, welche durch den Schlamm des Gletschers getrübt sind; 2. Seen mit braunem Wasser, reich an Humussäuren; 3. Seen, reich an Plankton, mit langsamer Strömung; 4. tiefe Seen, arm an Plankton und nicht getrübt durch suspendierte Teile.

Gewässer, welche reich an Stickstoffnahrung und an faulenden organischen Teilen sind (Exkremente von Tieren usw.) und solche, welche sehr kalkreich oder sehr eisenhaltig sind, rufen Verschiedenheiten der Assoziationen hervor, die besondere Standortklassen bilden miissen.

Periodische Erscheinungen. Ganz wie im Meere werden auch in süßen Gewässern in Abhängigkeit vom Klima periodische Erscheinungen vielfach beobachtet, sowohl was die Gefäßpflanzen betrifft, als die Thallophyten. Noch sind sie wohl wenig studiert. Beispielsweise kann auf die Untersuchungen von Fritsch (1906, 1907), Fritsch mit Miß Rich (1909, 1913), Kolkwitz, Rabanus verwiesen werden. Die erst genannten unterscheiden in England vier jährliche Perioden in der Algenvegetation: 1. Winterphase, von Mitte Dezember bis Ende Februar; viele freie Diatomeen (Diatomé-Phase). 2. Frühlingsphase, von Anfang März bis Ende Mai oder Mitte Juni; "Spirogyra-Phase" mit vielen Arten von Spirogyra, dazu Cladophora fracta. 3. Sommerphase von Anfang Juni bis Mitte September; Cladophora-Phase, mit vielen epiphytischen Diatomeen. 4. Herbstphase, von Mitte September bis Mitte Dezember; eine nicht scharf charakterisierte Übergangsphase, oft mit vielen Spirogyra, Oedogonium. Diese Veränderungen hängen nach innen ab von Veränderungen in der Stoffkonzentration und von der Temperatur des Wassers, von der Menge aufgelöster Luft, von dem Gehalt an organischer Substanz und von der Beleuchtung ${ }^{2}$ ).

Gürtelbildungen. Wie in den salzigen Gewässern und an den Ufern derselben, wird die Vegetation in den süßen Gewässern sich überall nach der Tiefe des Wassers und nach den damit in Verbindung

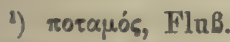

$\left.{ }^{2}\right)$ Uber diese noch wenig studierten Erscheinungen siehe auch Comère. 
stehenden Verschiedenheiten in Beleuchtung und anderer ökologischer Faktoren, gürtelförmig oder stufenförmig anordnen. Ganz dasselbe findet man an allen Ufern, da die verschiedenen Arten der Sumpf- und Landpflanzen nach der verschiedenen Tiefenlage des Grundwassers verschiedene Abstände von dem offenen Wasser einnehmen. Die Breite der Gürtel hängt von der geringeren oder größeren Neigung des Bodens ab. Wenn die Tiefe des Wassers oder der Abstand vom Grundwasser nach und nach verändert wird, die Tiefe verringert oder der Abstand vergrößert wird dadurch, daß organische Überreste und anorganisches Material hinzugeführt werden (vergl. 9. Kap.), wird der Wohnplatz der Assoziationen in Übereinstimmung hiermit verändert, und zwar wird eine Verschiebung derselben immer in der Richtung a uf die Mitte des Wasserbassins zu stattfinden. Durch diese "Verlandung " werden die Gewässer zuletzt ganz verschwinden können, wie es ja auch vielfach auf weiten Strecken geschehen ist.

Ganz wie am Meere werden sich auch hier in den süßen Gewässern ein Brandungsgürtel, ein Spritzgürtel, ein supralakustriner Gürtel und wohl hier und da noch andere Gürtel unterscheiden lassen $^{1}$ ).

Die Flora der süßen Gewässer ist im ganzen sehr verschieden von der der salzigen; im Brackischen können doch einige Süßwasserarten vorkommen, und nach Comère können bisweilen Süßwasseralgen sich dem salzigen Wasser anpassen, selten umgekehrt; so findet man nicht selten Enteromorpha intestinalis in süßem und salzigem Wasser.

\section{Kap. Formation der mikrophytischen Schwebepflanzen (Limnoplankton)}

Über den Namen "Plankton" und über das Salzwasserplankton vergl. 43. Kap. (S. 274).

Die Flora des Süßwasserplankton (Limnoplankton) besteht hauptsächlich aus denselben systematischen Gruppen wie die des Meeres, und zwar namentlich aus folgenden:

1. Cyanophyceae. Eine nicht geringe Zahl von besonders fadenförmigen, blaugrünen Algen; in unseren europäischen Gewässern besonders: Anabaena circinalis, A. flos aquae, Aphanizomenon flos aquae, Clathrocystis aeruginosa, Polycystis aeruginosa, P. prasina, Gloeotrichia echinulata, Nostoc, Oscillatoria, Lyngbya, Microcystis u. a., die das Wasser gewöhnlich grünspanartig oder bläulichgrün färben und einen

1) Über die Vegetationsgürtel an den Rändern und Ufern der Gewässer vergl. Magnin 1893; Macmillan 1897; Warming 1897 a; Gadecean 1909; Graebner 1909; Massart 1910; Baumann 1911; Dachnowski 1912; Comère 1914. 
eigentümlichen Geruch verbreiten. Über Arten, die auf der Oberfläche des Wassers als "Wasserblüte" schwimmen, vergl. S. 362.

2. Schizomyceten (Bakterien) sind sehr verbreitet, aber ihre Menge ist recht verschieden und wechselt von wenigen bis $\mathrm{zu}$ vielen tausend Individuen im Kubikcentimeter. Die pelagische Region der meisten Seen enthält die wenigsten $\left.{ }^{1}\right)$. Im Züricher See waren in einer Tiefe von $80 \mathrm{~m} \mathrm{28-30} \mathrm{im} \mathrm{Kubikcentimeter,} \mathrm{im} \mathrm{Konstanzer} \mathrm{See} \mathrm{in} \mathrm{einer}$ Tiefe von $60-65 \mathrm{~m}$ deren $31-146$. Die Zahl ist am kleinsten an der Oberfläche und größer in etwas tieferen Lagen. Nach der Ansicht einiger Forscher werden die Bakterien an der Oberfläche durch Licht getötet, andere vertreten die Meinung, daßs die Zahl in der Tiefe vermehrt wird durch die dort vorhandene größere Menge sich zersetzender organischer Substanz, die meist ihren Ursprung in den abgestorbenen Plankton-Organismen habe.

3. Diatomeen. In frischem Wasser kommen vor Melosira (besonders in Niederungsseen), Cyclotella (besonders in alpinen Seen), Fragilaria, Asterionella, Tabellaria und andere ${ }^{2}$ ). Die Gattungen Rhizosolenia und Attheya sind im süBen Wasser nur durch wenige resp. die letztere durch eine Art vertreten, welche aber weit verbreitet sind; die übrigen Arten dieser Gattungen sind Meeresbewohner. Einige von ihnen leben einzeln, viele aber leben zu Ketten verschiedener Art in Kolonien verbunden. Alle sind sie echte Planktonorganismen, welche nicht imstande sind, auf der Wasseroberfläche schwimmende Massen zu erzeugen. Sie sind in Schleim eingehüllt.

Außer den echt limnetischen (pelagischen) Arten kommen nach Wesenberg-Lund u. a. noch zwei andere Gruppen vor: die eine „tycholimnetische ${ }^{\text {3 }}$ ) Arten umfassend, die andere eigentlich Bodenorganismen, welche gelegentlich zum Schweben gebracht werden.

4. Peridineen (Dinoflagellaten) finden sich besonders in Salzwasser und färben, wenn sie in großen Mengen auftreten, die Gewässer braun, z. B. das kosmopolitische Ceratium hirundinella; vergl. Kap. 43.

5. Euflagellaten, meist einzellige, nackte, selbstbewegliche Organismen, welche bisweilen in großen Mengen, namentlich in kleinen Wassertümpeln auftreten und die Gewässer färben können, z. B. Euglena sunguinea rot, E. viridis (S. 365, Fig. 181) grün.

6. Chlorophyceen sind sehr zahlreiche, besonders in Teichen und in kleineren Seen. Durch eine große Anzahl von Gattungen werden sowohl selbstbewegliche (Volvocaceen) als nicht selbstbewegliche (besonders Desmidiaceen, Pediastrum und Scenedesmus) vertreten. Einige

2) Forel 1878, 1901; Schröter 1897.

2) (Schröter u.) Kirchner 1896.

3) Zufällige Planktonten; เúxฑ, Zufall, Glück.

Warming-Graebnero 3. Auflage, illustr. 
müssen als echte Plankton-Organismen betrachtet werden, z. B. Sphaerocystis Schroeteri, Dictyosphaerium, Oocystis, Botryococcus und Golenkinia radiata ${ }^{1}$ ). Die allermeisten aber sind gelegentlich limnetisch.

7. Durch Lohmanns Untersuchungen im Meer veranlaßt, hat man in den letzten Jahren das Nanoplankton des Süßwassers studiert. Es hat sich gezeigt, daß viele äußerst kleine Mikroorganismen die feinsten Garnnetze passieren; sie werden jetzt durch Zentrifugen ausgeschieden (daher auch der Name Zentrifugenplankton) und dann weiter studiert.

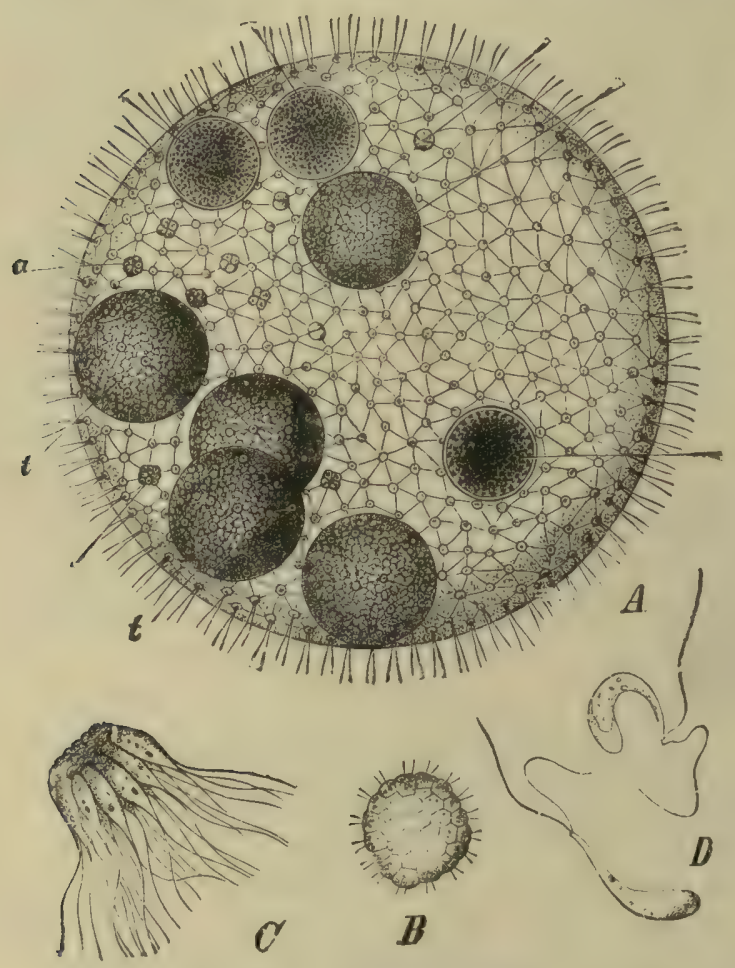

Fig. 232. Volvox globator.

Es scheint vorläufig; als ob besonders die Chromulinen von Bedeutung sind. Man meint, daß das Nanoplankton als Hauptnahrung für die Zooplanktonten eine große Rolle spielt und die Wanderungen derselben reguliert; bisher ist unsere Kenntnis hiervon nur sehr gering ${ }^{2}$ ).

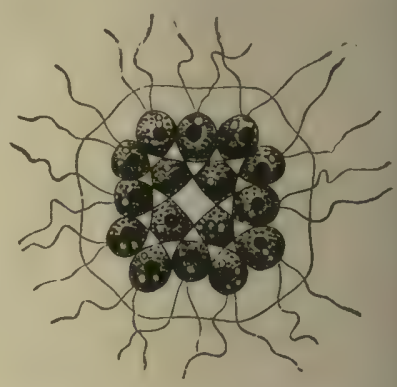

Fig. 233. Gonium pectorale.

Von den genannten Planktonten sind einige selbstbewegliche (z. B. Bakterien, Flagellaten, Volvocaceen), andere nicht, und von diesen haben einige Einrichtungen, durch welche sie leichter schweben können (über Schwebevermögen s. 43. Kap.). Wesenberg-Lund ${ }^{3}$ ) ist übrigens zu dem Resultate gekommen, daß die größte Menge des Planktons in unseren Gewässern Boden- und Litoral-Formen sind, welche sich einem mehr

1) Lantzsch 1914, Colditz 1914.

2) Vgl. Chodat 1898; (Schröter u.) Kirchner 1896.

ə) Wesenberg-Lund 1908. 
oder weniger pelagischen Leben angepaßt haben. Nur von solchen Arten, welche schweben können, wird natürlich hier die Rede sein können.

Gelegentliches Plankton (tycholimnetisches Plankton). Zum Plankton im eigentlichen Sinne dürfen die Pflanzen nicht gerechnet werden, die wie viele Süßwasseralgen (Oedogonium, Cladophora u. a.) anfangs festsitzen, später in ruhigem Wasser emporsteigen und sich mit Hilfe von Luftblasen (vermutlich Sauerstoff- oder Kohlensäureblasen), die zwischen ihren verfilzten Fäden ausgeschieden werden, schwimmend erhalten. Sie werden deshalb als gelegentliches oder auch falsches Plankton zu bezeichnen sein, im Gegensatze zu dem "eulimnetischen", welches seine ganze Entwickelung im offenen Wasser durchführt (ausgenommen die Ruhestadien auf dem Boden des Gewässers).

Die Verteilung des Planktons nach den verschiedenen kleinen Standorten der Gewässer ist noch wenig studiert. Es gibt in den größeren Seen pelagische Assoziationen im offenen Wasser, welche von den neritischen in der Nähe der Ufer verschieden sind. An den Ufern und in seichten Gewässern sind sie am reichsten, besonders Volvocaceen spielen eine Rolle.

Weiter kann zwischen Potamoplankton (Plankton der Flüsse), Heleoplankton (Pl. der Sümpfe), Sphagnoplankton (Pl. der Torfsümpfe) geschieden werden ${ }^{1}$ ).

Auch in vertikaler Richtung finden sich Verschiedenheiten; Apstein $^{2}$ ) unterscheidet in einem See bei Kiel folgende 3 Zonen: Oberflächenschicht bis $2 \mathrm{~m}$ Tiefe, Mittelschicht 2-10 m Tiefe, Tiefenschicht unter $10 \mathrm{~m}$. Nach Comère ist das Plankton unter $5 \mathrm{~m}$ spärlich.

Die Menge des Plankton ist bisweilen sehr groß, ganz wie beim Haloplankton, sie wechselt aber auch hier mit den Jahreszeiten. Die Diatomeen haben Maxima im Herbste und Frühjahr, doch für verhältnismäßig kurze Zeit. Im Sommer treten Arten von Peridineen, von Anabaena, Aphanizomenon u. a. auf. Cyanophyceen steigen bisweilen in ungeheurer Menge zur Oberfläche und bilden "Wasserblüte".

Die vorliegenden Untersuchungen von Wesenberg-Lund und anderen zeigen, daß die verschiedenen Planktonarten in verschiedenen Seen große Unterschiede zeigen in bezug auf das Eintreten der Maxima. Als ein Beispiel von der Periodizität in einem bestimmten See kann auf die Untersuchungen Guyers in dem Greifensee in der Schweiz verwiesen werden. „In den Wintermonaten, von November bis April dominieren die Diatomeen, im Sommer sind die Individuenzahlen jeder anderen Familie überlegen, und in erster Linie muß hier Ceratium hirundinella genannt werden." Vergl, auch Rabanus.

1) H. Bachmann 1911.

ๆ) Apstein 1896. 
Eine Tabelle zeigt, wie das Vegetationsmaximum von Melosira crenulata in den Dezember fällt, das von Asterionella in den Februar und März, das von Synedra in den April und Mai, das von Ceratium hirundinella in den Juli usw. Guyer meint, daß die Temperatur nicht der entscheidende Faktor ist, sondern die mehr oder weniger günstigen Ernährungsbedingungen des Wassers und zweitens die Konkurrenzfähigkeit ${ }^{1}$ ).

Die Farbe der Baltischen Seen wird im allgemeinen bestimmt durch die der Chromatophoren der herrschenden Plankton-Organismen. In Übereinstimmung mit der Periodizität des Süßwasser-Plankton unterliegt der Farbenwechsel der Seen bestimmten Perioden. Die Zeit, in der die Planktonorganismen die Farbe nur in geringem Maße beeinflussen, liegt meist zu Anfang Juni, zu einer Zeit, wo die Diatomeen verschwunden sind und die Cyanophyceen noch nicht aufgetreten sind. Die Farbe der alpinen Seen in arktischen Regionen wird nur wenig durch Plankton verändert, weil dies dort eben nur in geringer Menge vorhanden ist ${ }^{2}$ ).

Über die Periodizität siehe übrigens oben und ferner West, sowie Fritsch und Miß Rich ${ }^{3}$ ). Ähnliche Perioden hat Comère unterschieden: in der Frühjahrsperiode üppige Vegetation und Bildung von Reproduktionsorganen, in der Sommerperiode schwache Vegetation bis die biologische Tätigkeit in der Herbstperiode wieder aufgenommen wird.

Die Veränderungen der Planktonorganismen nach den Jahreszeiten (die Temporalvariationen) hat besonders Wesenberg-Lund studiert ${ }^{4}$ ): auch andere haben Beiträge geliefert, z. B. Guyer.

Die Planktonorganismen sind ziemlich kosmopolitisch; ihre Verbreitung durch Vögel muß ungemein leicht sein. W. u. G. S. West unterscheiden drei verschiedene Florengebiete: Das britisch-skandinavische, das des Viktoria-Njánsa und das von Viktoria. Im britischen Plankton dominieren die Desmidiaceen $(40 \%)$.

Die Planktonvegetation scheint die erste zu sein, die nach der Eiszeit die süßen Gewässer bevölkerte ${ }^{5}$ ).

1) Vgl. Whipple 1894, 1896.

?) Die quantitative Menge des Plankton zu bestimmen hat Apstein versucht; vergl. Zacharias 1891; Lohmann.

$\left.{ }^{8}\right)$ West 1912; Fritsch u. Miß Rich 1909.

4) Wesenberg-Lund 1904-1908, 1910.

5) In den letzten Jahren ist eine riesige Literatur über das Plankton erschienen; unter den Forschern seien genannt: Gran und Wille in Norwegen, Cleve in Schweden, Ostenfeld, Ove Paulsen und C. Wesenberg-Lund in Dänemark, Apstein, Hensen, Brand, Zacharias, Chun, Haeckel, G. Karsten, Lohmann, Schütt, Marsson und Kolkwitz (1902, 1907 - 8, 1910), Volk (1903) in Deutschland, G. S. West (in Tansley 1911), W. u. G. S. West (1908) und John Murray in England, G. Huber und Schröter in der Schweiz, Schröter u. Kirchner 1896-1902, Kofoid in Nordamerika. Über die Litteratur vergl, auch Oltmanns 1905. 


\section{Kryoplankton ${ }^{1}$ ). Die glaziale Vegetation des Eises und des Schnees}

Diese Vegetation, aus Mikrophyten zusammengesetzt, welche dauernd eiskaltem Wasser und äußerst niedriger Temperatur ausgesetzt ist, schließt sich der des Limnoplanktons aufs engste an, und darf wohl nur als eine Assoziation desselben betrachtet werden.

Schon lange weiß man, daß Tiere und Pflanzen auf den ausgedehnten „ewigen" Schnee- und Gletscherfeldern der Polarländer (der Arktis und Antarktis) ${ }^{2}$ ) und der Hochgebirge (Alpen, Pyrenäen, Anden) leben; es sind meist mikroskopische, aber sie können wie das Plankton in so ungeheuren Mengen auftreten, daß sie Schnee und Eis färben. Die Tiere sind besonders Poduriden (Desoria saltans, der blaue Achorutes viaticus), Tardigraden, Rädertiere, Rundwürmer. Die Vegetation, womit uns besonders Wittrock und Lagerheim ${ }^{3}$ ) bekannt gemacht haben, wird meist von Wasserpflanzen, nämlich von Algen (Diatomeen, Grünalgen, Cyanophyceen, Bakterien), und von Moosen (im Vorkeimzustande) gebildet; 1892 schätzte Lagerheim ihre Artenzahl auf 72. Nach den Farben unterscheidet man roten, braunen, grünen und gelben Schnee.

Roter Schnee ist der gewöhnlichste und am längsten bekannte; seine Farbe wechselt von blutrot bis rosenrot, ziegelrot und purpurbraun. Er wird besonders durch die Schneealge Chlamydomonas (Sphaerella) nivalis, und durch ihre Var. lateritia verursacht. Diese einzellige, kugel- oder eiförmige Alge hat einen roten Inhalt und färbt die obersten Schneeschichten bis zu wenigen $\mathrm{cm}$ Tiefe; sie vermehrt sich im geschmolzenen Schneewasser durch Schwärmsporen. Außerdem kommen Gloeocapsa sanguinea, Diatomeen u. a., in Ecuador besonders Chlamydomonas-Arten vor.

Brauner Schnee wird unter anderem durch eine Desmidiacee, Ancylonema Nordenskiöldii, hervorgebracht, die einen violetten Zellsaft hat und zusammen mit anderen Algen und dem „Kryokonit" (sehr feinen mineralischen Teilen) auf dem grönländischen Inlandeise eine wichtigere Rolle spielt, indem sie die Sonnenwärme stärker aufsaugt als das Eis und in dieses tiefe Löcher schmilzt. Mit ihr leben z. B. Pleurococcus vulgaris, Scytonema gracile, Diatomeen u. a. zusammen.

Grüner Schnee wird durch Grünalgen verursacht, z. B. durch Desmidiaceen, ferner durch Raphidium nivale ${ }^{4}$, Cyanophyceen und Moosvorkeime und grüne Individuen von Chlamydomonas (Sphaerella) nivalis. Hellgelber und grüngelber Schnee werden durch eine

1) Schröter $1904-8$, S. 623 . xpúọ, Frost, Eis.

2) Wille in Gain 1908-10.

ॠ) Wittrock 1883 . Lagerheim 1892.

4) Chodat 1896. 
andere Alge, vielleicht durch den von den Schneefeldern der Karpathen bekannten Chlamydomonas flavivirens hervorgerufen.

Diese Pflanzenvereine sind deutliche Beispiele für die außerordentliche Abhärtung der Pflanzenzellen; einen anderen Schutz, um starke Kälte auszuhalten, als die eigentümlichen Eigenschaften des Protoplasmas scheinen sie nicht zu haben; allerdings wird die rote Farbe ihnen vielleicht möglich machen, Wärme zu absorbieren ${ }^{1}$ ). Den größten Teil des Jahres liegen sie in Eis und Schnee eingefroren und im Dunkel der Polarnacht; wenn die Sommersonne Eis und Schnee schmilzt, erwachen sie zum Leben, und führen in Wasser, dessen Temperatur nur wenig über $0^{0}$ beträgt, ihre Ernährung und Fortpflanzung aus. Jede Nacht friert an manchen Orten das am Tage geschmolzene Wasser, und so vergeht ihr Leben in Eis und Eiswasser (vergl. S. 34). Auch in einer anderen Hinsicht ist die Schneealge merkwürdig abgehärtet: sie kann trocken aufbewahrt und viele Monate relativ hoher Temperatur ausgesetzt werden, ohne zu sterben ${ }^{2}$ ). Dasselbe gilt von gewissen Schneetieren.

\section{Kap. Die Formation des Saproplanktons}

Als eine besondere Formation können neben den Vereinen des in reinem Süßwasser lebenden Planktons die saprophilen Flagellatenvereine erwähnt werden. Es wird darunter die von Flagellaten wie Euglena viridis und $E$. sanguinea, von Arten wie die farblose Polytoma uvella, von verschiedenen Cyanophyceen und Bakterien gebildete Vegetation verstanden, die allgemein in stehendem Wasser vorkommt, das besonders reich an organischen Stoffen und gewiß sehr sauerstoffarm ist, z. B. in Wasser bei menschlichen Wohnungen (Mistjauche, Straßenpfützen usw.), wo Wasservögel und andere Tiere ihre Exkremente ablegen usw. Das Wasser kann von den Organismen gefärbt sein und zwar gewöhnlich stark grün. Die grünen Organismen können vermutlich Kohlensäure assimilieren, während sie Stickstoffverbindungen und andere Nahrung aus den organischen Teilen des Wassers aufnehmen; sie sind also wohl Halbsaprophyten. Euglena sanguinea u. a. färben rot. Diese Organismen sind außerdem dadurch von den Lebensformen des Planktons unterschieden, daß die am häufigsten auftretenden selbstbeweglich sind. Echte Planktonorganismen sind hier durch die Beschaffenheit des Wassers ausgeschlossen ${ }^{3}$ ). Euglaena viridis vergl. S. 365, Fig. 181.

1) Wulff 1902 .

2) Wittrock 1883 .

3) Über die Vegetation der Hanflöcher mit fauligem Wasser vergl. A. Rabanus 1915. 
Die saprophilen Organismen (die Saprobien) werden jetzt von Kolkwitz und Marsson ${ }^{1}$ ) in drei Gruppen verteilt: Poly-, Meso- und Oligosaprobien. In der Polysaprobienzone findet die stärkste organische Verschmutzung statt und deshalb herrscht dort der größte Reichtum an Spaltpilzen. In den folgenden Zonen sind die Selbstreinigungsprozesse geringer, und in der Zone der Oligosaprobien überwiegen die Diatomeen, die Zahl der Spaltpilze ist geringer und auch höhere Blütenpflanzen können hier gedeihen.

Unter den saprophilen Organismen eines solchen Gewässers finden sich auch viele Infusorien. Sobald die Reinigung weiter fortgeschritten ist, treten Chlorophyll führende Pflanzen auf, wie Scenedesmus, Rhaphidium, Diatomeen und andere, mit der fortschreitenden Reinigung vermehren sie $\left.\operatorname{sich}^{2}\right)$.

Die Selbstreinigung der Flüsse $^{3}$ ), die beim Durchfließen großer Ortschaften verunreinigt sind, beruht im wesentlichen auf der Tätigkeit von Bakterien und anderen Mikrophyten. Der Prozeß kann bis zur völligen Reinigung des Wassers von organischen Substanzen weiter gehen. Mitunter nimmt das Endprodukt die Form von Schwefeleisenverbindungen an, welches dann ein Bestandteil der schwarzen Schlammes ist. Schenck ${ }^{4}$ ) studierte den Rhein zwischen Bonn und Köln und kam zu dem Schlusse, daß grüne Algen keine große Rolle bei diesem Prozeß spielen, sondern daß fadenförmige und stabförmige Schizomyceten die organische Substanz zersetzen ${ }^{5}$ ).

\section{Kap. Formation des Megaplankton oder Makroplankton ${ }^{6}$ )}

An den Ufern von Süßwasser, an Stellen mit Schutz gegen Wellenschlag, z. B. zwischen Sumpfpflanzen, in kleineren Gewässern (Gräben, Teichen usw.) lebt eine Vegetation, die zwar schwimmend und zum Teil schwebend wie das eigentliche Plankton (also jedenfalls nicht festgeheftet) ist und zwischen deren Arten Planktonorganismen zwar oft eingemengt sind, die aber doch so wesentlich von dem Plankton abweicht, daß sie zu einer besonderen Formation gestellt werden muß. Sie unterscheidet sich von ihm in zwei Punkten: 1. in dem Vorkommen von größeren Pflanzen, namentlich Blütenpflanzen, Wasserfarnen und

1) Kolkwitz und Marsson 1908. - Kolkwitz 1911, 1914.

2) Vergl. Kolkwitz u. Marsson 1902; Volk. 1903; Marsson 1907, 1908.

2) Schorler 1898.

4) Schenck 1893 .

s) Nach 1814 erschien: Lauterborn, Die Sapropelische Lebewelt. Heidelberg 1915.

-) Der Name Hydrochariten-Vereine muß diesem allgemeineren weichen. Siehe anch S. 373 . 
Moosen, also von ganz anderen Lebensformen, und 2. von Algen aus ganz anderen Gruppen als im Plankton.

Die Lebensformen der ersten Gruppe sind doch nie scharf voneinander verschieden; es gibt Arten, deren Assimilationsorgane ganz frei auf der Oberfläche des Wassers schwimmen oder herumtreiben und andere, bei welchen sie völlig untergetaucht bleiben, so daß höchstens die Blütensprosse in die Luft erhoben werden. Die ersten sind die eigentlichen Schwimmpflanzen.

Kirchner wandte 1896 den Ausdruck "Pleuston" an, um die wirklich typischen Vertreter der Hydrochariten-Formation zu bezeichnen ${ }^{1}$ ), indem er das Hauptgewicht auf deren Eigenschaft legte, daß sie frei schwimmen, so daß sie also von Wind und Wellen umhergetrieben werden können. Thre Atmungsorgane usw. sind in direkter Berührung mit der atmosphärischen Luft. 1902 hat Schröter den Ausdruck in dem Umfange angewandt, wie er auch in diesem Buche angenommen ist. Er schloß auch solche Samenpflanzen der Hydrocharitenformation ein, die zwar auch wurzellos und freischwimmend sind, die aber untergetaucht bleiben wie z. B. Ceratophyllum, Utricularia vulgaris und andere. Außerdem unterscheidet Schröter mit vollem Recht zwischen der konstant und der nur zeitweise flutenden Flora. $\mathrm{Zu}$ den zeitweise flutenden Pflanzen rechnet er die im Frühjahr schwimmenden Algen, weiter gehören hierher Lemna trisulca, die nur zur Blütezeit auf der Oberfläche schwimmt, sonst stets untergetaucht bleibt; Stratiotes aloides schwimmt im Sommer oben, in den kalten Jahreszeiten lebt sie auf dem Gewässergrunde ${ }^{2}$ ).

A. Schwimmpflanzen (plantae fluitantes); Pleuston von Schröter und Kirchner.

Die konstanten und meist typischen, also schwimmenden Repräsentanten des Pleuston oder Megaplankton sind folgende Gruppen:

1. Moose, nämlich Arten von Riccia.

2. Wasserfarne Azolla und Salvinia (beide sind schwimmend; Fig. 234). Von anderen Farnen Ceratopteris thalictroides.

3. Blütenpflanzen.

a) Mit Schwimmblättern oder Schwimmsprossen versehene: Hydrocharis, Hydromystria stolonifera (Trianea Bogotensis), Lemna minor (Fig. 235), L. polyrrhiza, L. gibba, Wolffia arrhiza, Phyllanthus fluitans, Pistia und Eichhornia crassipes.

1) Der Name Pleuston von dem griechischen: $\pi \lambda \hat{\varepsilon}^{\omega} \omega$, segeln. Schröter u. Kirchner 1896-1902.

2) Graebner 1906 . 
56. Kap.

b) Übergangsformen zu der durch Wurzeln befestigten Limnäenvegetation: Hottonia palustris, Jussieua repens, Desmanthus natans 'u. a.

Viele Blütenpflanzenarten können die Gewässer in außerordentlicher Menge erfüllen, z. B. Lemna, Pistia, Eichhornia crassipes.

B. Untergetauchte (also schwebende) Arten finden sich bei folgenden:

1. Moose: Arten von Sphagnum, Hypnum, Amblystegium.

2. Farne: Arten von Riccia.

3. B lüt e $\mathrm{n} p \mathrm{fl}$ anzen: Ceratophyllum, Utricularia, Aldrovandia (Fig. 236) und zeitweise schwimmend Lemna trisulca (Fig. 235), Stratiotes aloides.

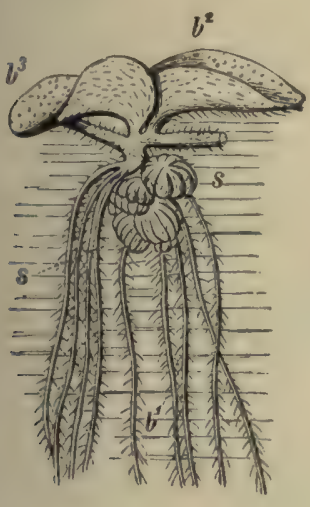

$A$

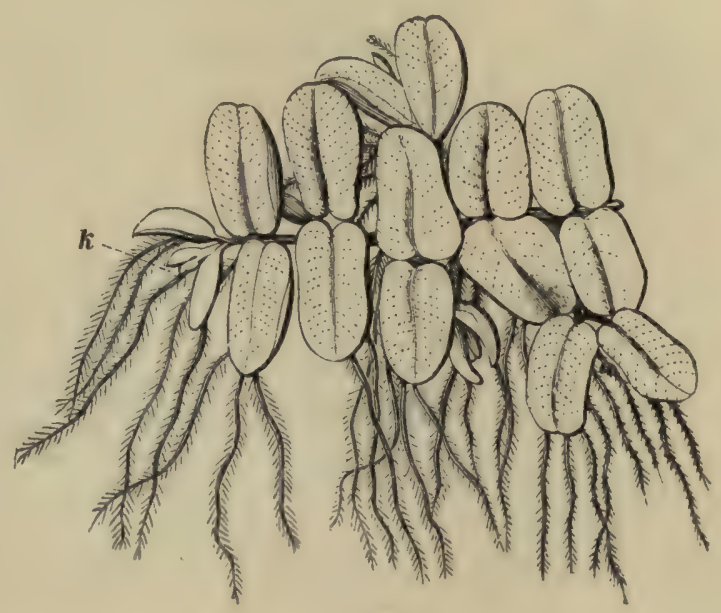

$B$

Fig. 234. Salvinia natans. A Stück der schwimmenden Pflanze von der Seite gesehen, die beiden oberen Blätter als Schwimmblätter ausgebildet, das dritte des Quirls zum wurzel- und kiemenartigen Wasserblatt ausgebildet. $B$ Pflanze von oben gesehen.

(Nach Bischoff.)

Anpassungen. . Die untergetauchten Arten müssen, wie die Planktonorganismen, etwa das spezifische Gewicht des Wassers haben; die normal schwimmenden Arten halten sich besonders durch Schwimmblätter, die alle stark mit Luft erfüllt sind, auf der Oberfläche. Dieser Umstand erhält z. B. bei Lemna gibba und bei Hydromystria in der Dicke der Sprosse und in der stark gewölbten Unterseite der Blätter seinen Ausdruck. Besondere Schwimmorgane finden sich entwickelt bei Eichhornia crassipes, Neptunia und Jussieua repens.

Der Sproßbau ist verschieden. Bei den meisten untergetauchten Blütenpflanzen haben die Sprosse sehr gestreckte Internodien und sehr dünne Stengel; die gewöhnlich sitzenden oder kurzgestielten Blätter sind 
in fadenförmige Zipfel geteilt (Utricularia, Ceratophyllum, Hottonia u. a.) Bei den schwimmenden sind die Sprosse meist kurzgliedrig und kurz, und die Spreiten haben oft die für Schwimmblätter typische Form, d. h. sie sind sehr breit, schildförmig herzförmig, oder eiförmig mit herzförmigem Grunde (Riccia natans, Salvinia, Hydrocharis, Hydromystria; auch Azolla kann hier genannt werden); etwas anders geformt, aber doch breit, sind die Sprosse von Lemna und die Blätter von Pistia. Die Aufgabe des Schwimmblattes ist unter anderem, die Gleichgewichtsstellung der Pflanze auf dem Wasser zu sichern; in Übereinstimmung hiermit werden Schwimmblätter oder ähnliche Gleichgewichtsorgane bei einigen Keimpflanzen frühe gebildet (Salvinia, Lemna usw.) ${ }^{1}$ ). Vergl. Fig. 234 bis 237.

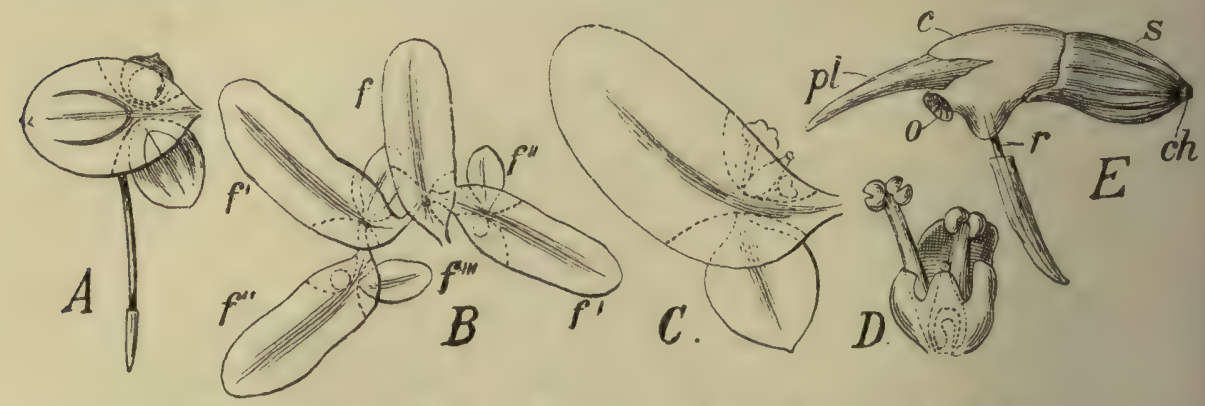

Fig. 235. A Lemna minor, Sproß mit Tochtersproß und Frucht. B-E Lemna trisulca, $B$ steriles Sproßsystem, $C$ Teil einer blühenden Pflanze, $D$ Blütenstand in der Spatha eingeschlossen: in der Mitte die $\$$, nur aus einem durchsichtigen Fruchtknoten bestehende Blüte, rechts und links je eine $\sigma^{\top}$, auf ein Staubblatt reduzierte Blüte, $E$ Keimpflänzchen, ${ }_{8}$ Samen mit Chalaza $(c h), o$ Operculum, $r$ Würzelchen, $c$ Cotyledon, $p l$ PlumularsproB. ( $B, C$ nach Eichler; $\boldsymbol{A}, \boldsymbol{D}, \boldsymbol{E}$ nach Hegelmaier.)

Daß dieser Unterschied zwischen untergetauchten und schwimmenden Blättern eine enge Anpassung an die Umgebungen ist, sieht man besonders deutlich bei Salvinia und bei Wasserpflanzen, die mit Wurzeln befestigt sind, z. B. bei Ranunculus (Batrachium), Trapa, Cabomba u. a., die sowohl untergetauchte als schwimmende Blätter haben (Fig. 234, 237).

Bei den frei im Wasser schwebenden Pflanzen wird die Nahrung von der ganzen Oberfläche aufgenommen, und bei den Gefäßpflanzen fehlt daher entweder die Wurzel (Wolffia, Aldrovandia, Ceratophyllum, Utricularia vulgaris u. a.) oder ist stark reduziert (vergl. 31. Kap.); die wichtigste Rolle der Wurzel bei Pflanzen wie Lemna, Hydrocharis u. a. ist gewiß, der Pflanze eine bestimmte Stellung im Wasser zu sichern, sie gegen Umwerfen zu schützen (dieselbe Funktion haben die Wasserblätter von Salvinia).

1) Goebel 1891 . 
Fortpflanzung. Die Teilung der vegetativen Organe spielt bei allen eine große Rolle; nicht nur die Algen, sondern auch Farne wie Azolla, Blütenpflanzen wie Lemna, Hydrocharis, Stratiotes, Eichhornia azurea. Daher können viele Arten in ungeheurer Menge auftreten und reine Assoziationen bilden (Lemneta, Hydrocharideta, Azolleta usw.) und oft so dicht werden, daß sie den Verkehr stark hindern können (Eichhornia azurea).

Da die hervorragendsten Vertreter dieser Formation auf der Wasseroberfläche schwimmen, werden sie durch den Wind leicht segelnd fortgetrieben oder durch die Strömungen mitgerissen, bis sie in ruhige Buchten gelangen, wo sie sich oft in großer Zahl ansammeln können, man vergleiche Lemna in unseren Gewässem. Huber ${ }^{1}$ ) gibt einige Aufklärung über die flutenden Inseln in den ruhigen Buchten des Amazonas. Diese sind oft sehr ausgedehnt und werden z. T. durch Pleuston gebildet,

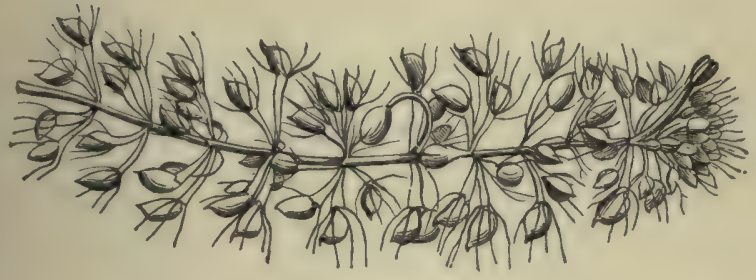

$A$

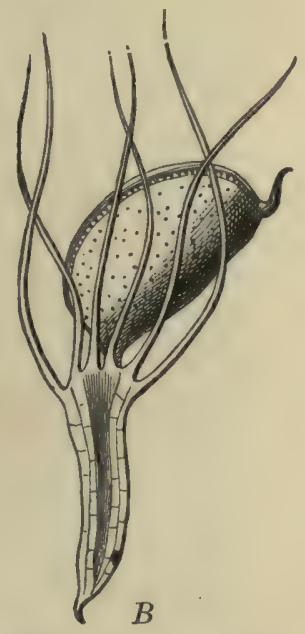

Fig. 236. Aldrocandia vesiculosa. A Habitus. $B$ Blatt mit Fangschlauch und den borstenförmigen Gipfeln. (Nach Schnizlein.)

z. B. durch Eichhornia azurea, aber auch aus halbflutenden Gräsern, die nicht zu dieser Formation gehören; ebenso finden sich andere Sumpfpflanzen, die losgerissen sind. In gleicher Weise kommen im südlichen Nordamerika große Massen von Eichhornia crassipes vor (vergl. Fig. 238). In Norddeutschland bilden unzählige Exemplare von Stratiotes aloides ähnliche, oft sehr ausgedehnte schwimmende Inseln oder Wiesen.

Als Verbreitungsmittel dienen vorzugsweise die vegetativen Teile, z. B. bei Lemna; die kleinen Sprosse von Wolffa Brasiliensis u. a. werden durch Wasservögel verbreitet. Im Einklange hiermit ist Sporenoder Samenbildung bei mehreren fast unbekannt oder sehr selten (z. B. bei Lemna).

Die Befruchtung ist bei den Kryptogamen ans Wasser gebunden, und einige wenige Blütenpflanzen blühen unter Wasser (Ceratophyllum);

1) Huber 1906 . 
die Blüten anderer werden in der Luft entwickelt, sind sogar meist Insektenblüten (Utricularia, Hottonia, Hydrocharis usw.). Die Fruchtreife geht in den meisten Fällen unter Wasser vor sich.

Lebensdauer. Die allermeisten sind mehrjährig, wie die Wasserpflanzen im ganzen. Einjährig sind z. B. Salvinia natans (S. auriculata ist ausdauernd) und Ceratopteris. Die Blütenpflanzen bilden oft besondere, knospenähnliche Wintersprosse (hibernacula), die im Herbste zu Boden sinken, weil sie keine lufterfüllten Interzellularräume entwickelt haben (Hydrocharis, Utricularia, Aldrovandia, Ceratophyllum, Stratiotes $^{1}$ ), viele Potamogeton-Arten usw.), oder die mit Vorratsnahrung erfüllten, jüngeren, noch nicht stark lufthaltigen Sprosse überwintern

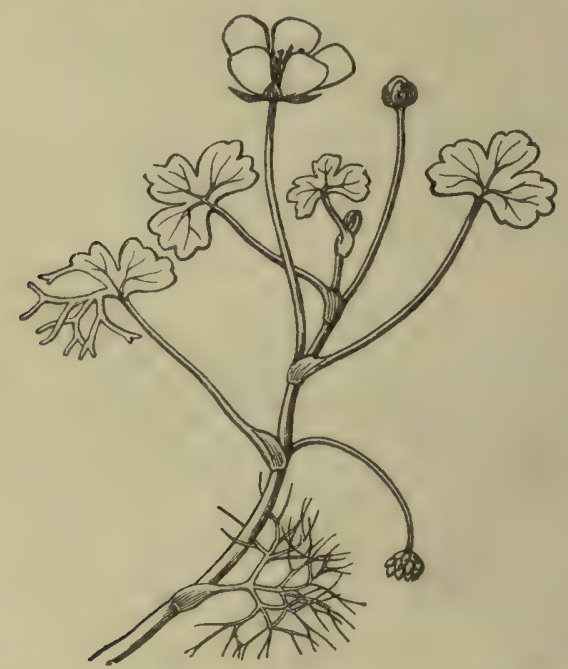

Fig. 237. Ranunculus (Batrachium) aquatilis, die untergetauchten Blüten kiemenartig zerspalten, die oberen flache Schwimmblätter. (Nach Warming-Meinecke.)

ohne irgend eine Umbildung, nachdem die entwickelten Teile abgestorben sind (Lemna). (Auch gewisse Algen, z. B. Cladophora fracta, zeigen eine ähnliche Entwicklung, indem sie im Herbste zu Boden sinken, und durch dicke, inhaltreiche Zellen überwintern, die im Frühjahre zu neuen Individuen auswachsen; Wille).

Assoziationen. Verschiedene Assoziationen lassen sich, wie erwähnt, leicht unterscheiden (Lemneta, Hydrocharideta, Stratioteta, Pontederieta, Pistieta usw.), und werden aus allen Teilen der Welt erwähnt - von Neu-Seeland (Cockayne), Amerika, Europa usw. Auch solche von submersen Arten sind bekannt (Ceratophylleta z. B.). Für ihr Vorkommen spielt der Reichtum des Wassers an Nährstoff und chemischen

1) Wesenberg-Lund 1912. 
Eigenschaften eine wesentliche Rolle. Einige Vereine sind an $n$ ährstoffarme, andere an nährstoffreiche Wässer geknüpft. In Heidetümpeln oder Torflöchern in Sphagnum (Heidemooren) findet sich oft

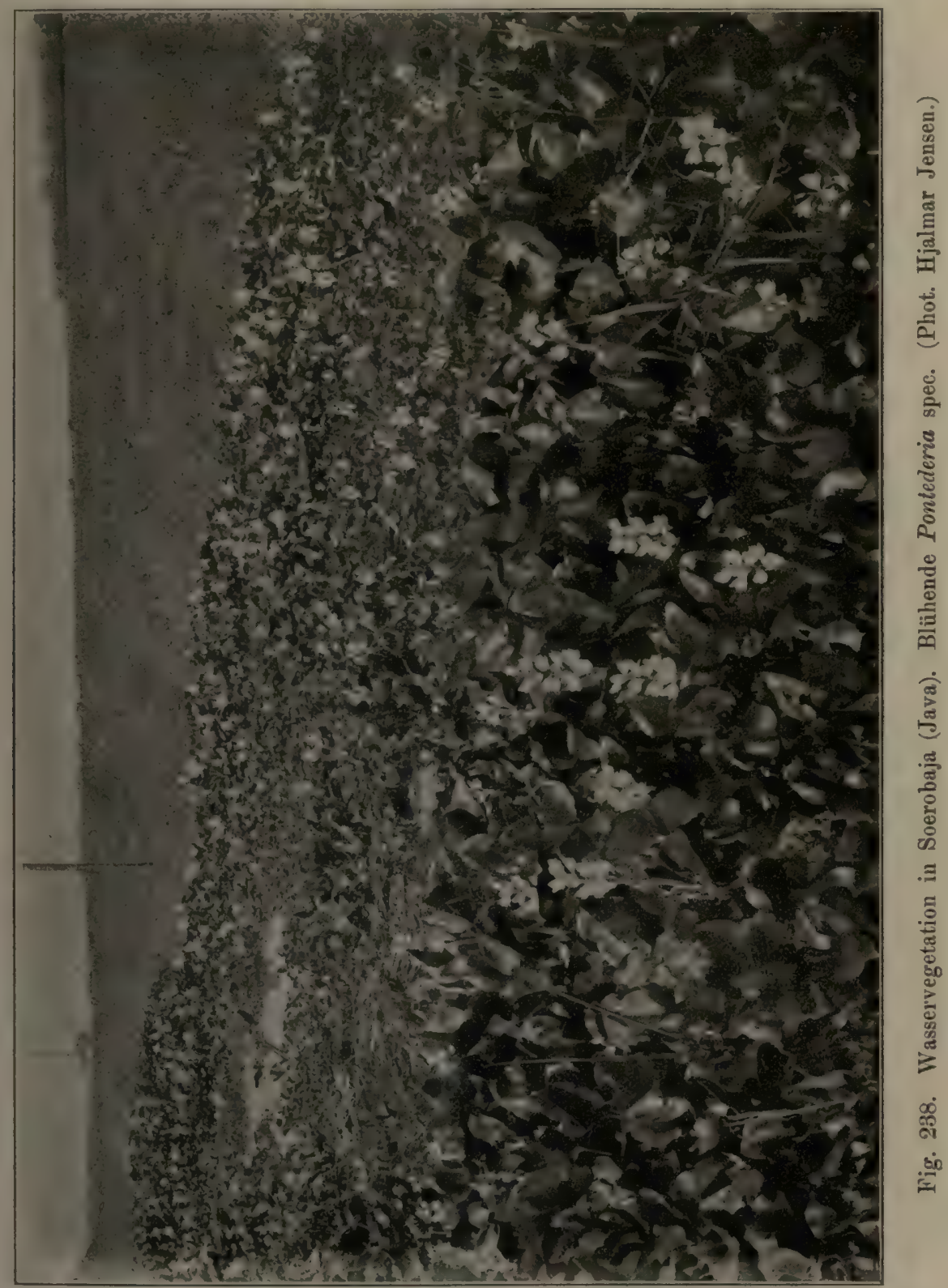

eine entsprechende sehr artenarme Vegetation, sehr oft ist es nur flutendes Sphagnum, welches die Gewässer vollständig erfüllt. Das Tierleben ist in solchen Gewässern äußerst arm, wie überhaupt in den echten Heidewässern. 
Uber diese Formation vergl.:

Kirchner in Schröter u. Kirchner 1896-1902.

Schenck 1886 b.

Gadeceau 1909. Baumann 1911.

Dachnowski 1912.

Schließlich mag erwähnt werden, daß temporär erscheinendes Pleuston vorkommt, d. h. Pflanzen oder Pflanzenteile, die von der Ufervegetation oder von der Bodenvegetation losgerissen worden sind und nun für kürzere oder längere Zeit auf der freien Wasserfläche herumtreiben. Thm schließen sich auch die Kap. 54 besprochenen tycholimnetischen grüngelben Algenmassen an (Zygnemeta, Conferveta usw.), welche sich im Frühjahr und Frühsommer auf ruhigen Gewässern ansammeln.

\section{Kap. Vereine von steinliebenden (epilithischen) Süßwasser- pflanzen (Limno-Nereiden)}

Die Sü $B w$ asservereine steinliebender Pflanzen sind viel ärmer als die der halophilen und bestehen teils aus Algen (fast allein Chlorophyceen, Schizophyceen und Diatomeen), teils aus Moosen (Fontinalis, Dichelyma, Cinclidotus u. a.), oder auch aus Blütenpflanzen, nämlich aus Podostemaceen und Hydrostachydaceen. Sie sind viel ärmer sowohl an Arten, Formen und Individuen, als auch an Kräftigkeit und Größe.

Die Algen. Von den Grünalgen sind namentlich Cladophoraceen und andere Fadenalgen repräsentiert (Oedogoniaceen, Zygnemaceen, Ulothrix, Chaetophora, Stigeoclonium u. a.); von Braunalgen kommen sehr wenige vor (Pleurocladia lacustris); ebenso Rotalgen (z. B. Lemanea, Batrachospermum, Hildenbrandtia) ${ }^{1}$ ). Die blaugrünen Algen (Cyanophyceen) sind repräsentiert wie im Salzwasser, besonders durch Rivularia u. a.

Furchensteine. Eine eigentümliche Assoziation findet sich am Rande vieler Seen, wo Calothrix, Plectonema und andere Cyanophyceen sich mit kohlensaurem Kalk inkrustieren und "Furchensteine" bilden, d. h. Algenkrusten, welche jahrringartig in die Höhe wachsen, so daß die Algen sich nur in der äußersten Schicht lebend finden ${ }^{2}$ ). Schröter und Le Roux nennen sie Schizothricetum.

Nach Wesenberg-Lund werden die Kalkkrusten erzeugt außer durch die Cyanophyceae (Schizothrix, Rivularia) auch durch Diatomeen, Chlorophyceae (Cladophora) und die Phaeophycee Pleurocladia lacustris. Diese Krusten finden sich besonders an Steinen, wo das Ufer flach ist, nur selten reichen sie bis zu einer Wassertiefe von $1 \mathrm{~m}$. Im Sommer,

1) Vergl. Comère.

2) Baumann, Schenck u. Karsten, Vegetationsbilder IX, 3, Taf. 13; Baumann 1911. Boysen Jeysen 1909. Ljungquist 1914. 
wenn der Wasserstand sinkt und viele Steine vom Wasser entblößt werden, reißen die Krusten auf und fallen $a b$; während des Winters werden sie vom Eise abgekratzt. Auf diese Weise können die Algen zur Kalkablagerung in den Seen beitragen ${ }^{1}$ ).

Ähnliche Bildungen finden sich auch bisweilen am salzigen Wasser und in der Heidevegetation auf Rohhumus, wo sich in länger stehenden Pfützen eine Schicht blaugrüner Algen in jeder Regenperiode auf der vorhergehenden bildet, so daß allmählich dicke Krusten entstehen.

Die Diatomeenflora kann recht reich sein; oft sieht man dichte, schleimige, braune Überzüge über den Steinen, die von Diatomeen gebildet sind. Auch treten eine große Menge epiphytisch an anderen Pflanzen auf.

Moose. Besonders die Gattung Fontinalis liefert häufig dichte und große Bestände.

Blütenpflanzen. Die beiden Familien Podostemaceae, welche vorzugsweise über die tropischen Gegenden von Amerika, Afrika und Asien in einer Anzahl von etwa 100 Arten verbreitet sind, und die Hydrostachydaceen, die auf Afrika und Madagaskar beschränkt sind, sind hier als Repräsentanten zu nennen. An stark fließendes Wasser sind besonders die Podostemaceen gebunden.

Die Anpassungen sind in der Hauptsache dieselben wie bei den Salzwasserpflanzen, nur einfacher, der geringeren Mächtigkeit und dem einfacheren Bau der Pflanzen entsprechend. Haftorgane (Hapteren) sind bei allen notwendig; finden sich namentlich in größerer Mannigfaltigkeit bei den Podostemaceen entwickelt (Fig. 239). Bei diesen kommen oft kriechende oder thalloide Wurzeln vor, welche den Felsen durch zahlreiche Hapteren angeheftet sind. Interzellularräume fehlen auch hier, und zwar selbst (was recht bemerkenswert ist) in den Vegetationsorganen dieser Blütenpflanzen, welche hierin eine ganz algenähnliche Anpassung an stark bewegtes, sauerstoffreiches Wasser (Wasserfälle) zeigen (vergl. Algentypus Graebners S. 203). Nur in den in die Luft emporragenden Blütenstandsachsen kommen Interzellularräume vor. Ausscheidung von Kalk in den Zellwänden ist hier selten; dagegen finden sich bei den Podostemaceen gewöhnlich Kieselkörper in den Zellen, wodurch ihre Körper zweifellos ein größeres Widerstandsvermögen gegen die zerreißende Macht der Wasserströme sowie gegen das Eintrocknen während niedrigen Wasserstandes erhalten. Auch Schleimbildungen kommen seltener vor, sie dürften auch hier die Bedeutung haben, Widerstand gegen Austrocknung zu leisten.

Der Mangel an Spaltöffnungen, an verholzten Elementen und Gefäßen (oder diese sind doch sehr stark reduziert), die Bildung von

1) Chodat 1902; Forel 1901; Schröter u. Kirchner 1896. 
assimilierenden Chromatophoren in der äußersten Zellschicht usw. sind allgemeine, auch hier vorkommende Hydrophyteneigentümlichkeiten.

Die Formen der Algen sind gewöhnlich sehr einfach; unverzweigte oder verzweigte Fäden sind die häufigste Form. Bei den Podostemaceen ist die Formmannigfaltigkeit die größte; es kommen sowohl thalloide, krustenförmige Vegetationsorgane vor (Erythrolichen, Lawia, Hydrobryum u. a.), als kiemenförmige, d. h. in haarförmige Zipfel aufgelöste, wodurch die Assimilationsfähigkeit vergrößert wird; es kommen moosähnliche Formen vor (Tristicha hypnoides, Arten von Mniopsis und Podostemon, Fig. 239)), unverzweigte fadenförmige (z. B. Wurzeln bei

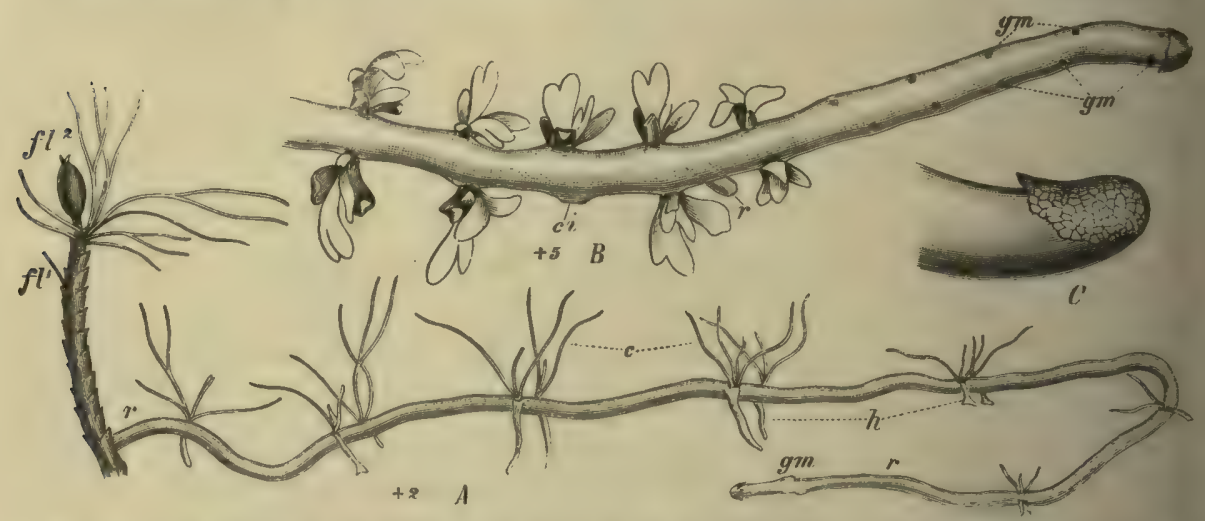

Fig. 239. Podostemon ceratophyllum, von einem Sprosse entspringt eine lange, kriechende Wurzel $(r-r)$, mit Hapteren $(h)$ versehen; verschiedene kiemenartig feine Sprosse $(c)$ sind auf ihr teils schon zur Entwicklung gekommen, teils (bei $\mathrm{gm}$ ) noch eingeschlossen; auf dem Muttersprosse bedeutet $f l^{1}$ die Blüte 1. Ordnung, $f l^{2}$ die 2. Ordnung. $B, C$ Mniopsis Weddelliana; $B$ die stark abgeflachte thalloide Wurzel trägt 5 schon zur Entwicklung gelangte Sproßpaare (ein Sproß bei ci abgebrochen), und 5 in die Knospe eingeschlossene Knospenpaare $(\mathrm{gm}) ; C$ Wurzelspitze mit einseitiger Haube. Nach Warming. - Bei anderen Podostemaceen sind Haftorgane ausgebildet, die denen der steinbewohnenden Meeresalgen (vergl. Fig. 138, S. 269) ähnlich sind.

Dicraea elongata, welche sich in dem Wasser wellenförmig bewegen), und auch ganz blattförmige Vegetationsorgane (Marathrum, Oenone, Mourera). Dieser Parallelismus zwischen den Formen der Meeresalgen und der Podostemaceen muß besonders hervorgehoben werden, weil er darauf hindeutet, daß diese Formen Anpassungsformen $\operatorname{sind}^{1}$ ).

Nach den Verschiedenheiten der Lebensformen köunen hier zwei oder drei Formationen aufgestellt werden, selbst wenn die ökologischen Verschiedenheiten zwischen ihnen geringer sind als bei entsprechenden Landpflanzen, der einförmigen Lebenslage entsprechend.

${ }^{1}$ ) Vergl. Warming, Familien Podostemaceae (dänisch mit französ. Résumés; in Kgl. Danske Videnskab. Selsk. Skrifter. VI R. 2 (1881, 1882), 4 (1888), 7 (1891), g (1899), 11 (1901).) 


\section{Formationen der Algen}

Viele Assoziationen (oder möglicherweise Subformationen) miissen in Übereinstimmung mit der großen in der Umgebung entfalteten Variation unterschieden werden. So z. B. ist die Flora des strömenden Wassers mehr oder weniger von der des ruhigeren verschieden. $\mathrm{Zu}$ denen des fließenden Wassers (potamophilen Arten) gehören nach Comère hesonders Lemanea, Chantransia, Batrachospermum, Cladophora, Ulothrix, viele Diatomeen usw. - Die Wärme des Wassers ruft Verschiedenheiten hervor und wirkt hervorragend bei dem periodischen Auftreten, der Schnelligkeit der Entwickelung und beim Verschwinden einzelner Arten in den verschiedenen Jahreszeiten ${ }^{1}$ ).

Eiskalte Gebirgsströme haben eine sehr eigenartige Flora, in ihnen finden sich Hydrurus, Prasiola fluviatilis, Tetraspora cylindrica u. a. ${ }^{2}$ ).

Auf Steinen in flachem Wasser längs der Seeufer lebt eine völlig verschiedene Flora mit Arten von Cladophora, Rivularia, mit Diatomeen usw.

Verschiedene Moose sind mitunter den Algen beigemischt, so unter anderen Fontinalis.

Schröter und Kirchner ${ }^{3}$ ) unterscheiden im Bodensee ein Encyonemetum mit verschiedenen Untergruppen, nämlich Spirogyretum, Tolypotrichetum und Schizotrichetum.

C̈ber Verschiedenheiten der Assoziationen vergl. z. B. Fritsch und Miß Rich. Die Verbindungsglieder der verschiedenen Assoziationen an Verschiedenheiten der Standorte (Nährstoffmenge, Kalkgehalt des Wassers, Bewegungen und Wärme der Gewässer usw.) sind noch nicht erläutert worden.

\section{Formation der Moose}

Scheint selten zu sein und wird wohl wesentlich durch Assoziationen von Fontinalis repräsentiert.

\section{Formation der Samenpflanzen}

Wird nur durch die schon besprochenen Podostemaceen und Hydrostachydaceen repräsentiert. Sie kommen besonders in stark strömenden Flïssen vor, besonders in Stromschnellfelsen und Wasserfällen, welchen standorten sie denn auch auf merkwürdige Weisen angepaßt sind. Sie scheinen nur bei niedrigem Wasserstande zu blühen, wenn sie auf einige Zeit trocken gelegt werden ${ }^{4}$ ).

1) Rabanus 1915 .

2) Lagerheim 1892.

3) Schröter u. Kirchner 1896, 1902.

4) Vergl. außer Warmings 6 Abhandlungen neuere Untersuchungen von Willis, Went, W. Magnns. 
Die Arten wachsen gewöhnlich gesellig; von Assoziationen muß es daher eine recht große Menge geben.

\section{Formation der aerobiotischen oder aërophilen Algen}

Im Anschluß an die Vereine der steinliebenden Wasserpflanzen wird ein etwas verschiedener Standort besprochen werden können, nämlich die von Algen bewohnten, periodisch trockenen und periodisch vom Regen oder herabrieselndem Wasser benetzten Felsen. Solche Vereine von aërobiotischen („subaërischen" oder "semiaquatischen") entwickeln sich reichlich an Wasserfällen, deren Schaum und Gischt beständig die Felsen benetzt, und in Gegenden mit großen und über das ganze Jahr verteilten Niederschlägen (z. B. auf Java) oder in Gebieten mit großer Luftfeuchtigkeit. Auf Felsen, die von Süßwasser benetzt werden, Stromfelsen, welche über das Wasser emporragen, kann sich ein schwammiger, filziger Teppich von Algen (Trentepohlia, Rhodocorton islandicum, Rh. purpureum, Vaucheria, Diatomeen, Desmidiaceen, blaugrünen Algen), Moosen, Farnen und anderen Kräutern bilden, ja sogar kleine Sträucher, die beständig sehr naß sind oder von Wasser triefen, können sich einfinden. Assoziationen von dieser Formation kommen aber auf vielen anderen Standorten vor, z. B. Baumstämmen, an Mauern u. a., wo sie von Regen, Nebel und Tau benetzt werden ${ }^{1}$ ). Die senkrechten schwarzen Streifen an den kahlen Steilhängen der Gebirge werden von Algen gebildet an den Stellen, wo bei Regenwetter Wasser herunterrieselt, die aber sonst trocken sind.

Auch hier am Süßwasser finden sich Vogelsitzplätze (vergl. S. 422), wo die Düngung der Wasservögel und Sickerwasser eigentümliche Vegetation hervorrufen kann.

\section{Kap. Vereine von Süßwasserpflanzen auf losen Böden}

Der Bau des Bodens ist der im 7. und 13. Kap. erwähnte, aber die Poren sind mit Wasser erfüllt, und die atmosphärische Luft ist sicher in äußerst geringer Menge vorhanden, wenn sie überhaupt vorkommt. Hieraus ergeben sich mehrere Abweichungen von der lithophilen Vegetation, namentlich folgende, die schon S. 386 ff. besprochen worden sind, und ebensowohl für die Arten des süßen als des salzigen Wassers gelten. Dazu gehört für die größeren Arten Ausbildung von Wurzeln oder wurzelartigen Organen zur Befestigung im Boden, jedoch nicht in der Ausdehnung wie bei Landpflanzen. Bei einigen fehlen sogar die Wurzelhaare, z. B. bei Hippuris, abgesehen vom Wurzelhalse bei Hottonia und

1) Vergl. Comère, Cotton. Nach 1914 erschien Boye Petersen 1916. 
Elodea. Oft sind die Wurzeln zur besseren Befestigung im Boden hinund hergebogen oder gewunden (vergl. darüber Kap. 31, S. 268). Das Vorkommen von wagerecht wachsenden Grundachsen (Rhizomen und ähnlichen Bildungen) ist im losen Boden recht häufig. Die Ausbildung von großen Interzellularräumen, um die untergetauchten Teile mit Luft zu versehen, ist sehr allgemein verbreitet, damit Hand in Hand geht oft die Reduktion der Gefäße (über die Xylemgänge vergl. Kap. 31, S. 271), des mechanischen Gewebes u. a. m.

Abweichend hiervon sind namentlich die Thallophyten.

Die meisten Arten und die eigentlichen Wasserpflanzen sind ganz untergetaucht; ausgenommen bei einigen die Befruchtungsorgane, die Blüten oder Blütenstände; es kommen hier aber auch Arten vor, welche Schwimmblätter haben (semiaërische Arten), und die dadurch einen Übergang bilden zu den in der Luft lebenden Pflanzen.

Nach der spezielleren Beschaffenheit des Bodens und anderer ökologischen Faktoren kommen viele verschiedene Assoziationen vor, welche im ganzen zu vier Formationen gerechnet werden können:

1. Formation der Saprobien. 59. Kap.

2. Formation der autophyten Thallophyten.

3. Formation der Moose.

4. Formation der Gefäßpflanzen.

60. Kap.

Im folgenden werden sie aber nur in zwei Kapiteln behandelt und zwar im 59. Kap. die aus Saprophyten gebildete Formation und im 60. Kap. die Autophyten.

\section{Kap. Formation der Saprobien auf losem Boden}

Auf toten organischen Substanzen auf dem Boden der Seen, oder wo Schlamm abgelagert ist, der an solchem reich ist, kommt eine Vegetation von saprophytischen Algen und Bakterien vor, die bisweilen sehr reich sein kann. Sie liegt mehr oder weniger lose auf der Oberfläche des Bodens, und findet sich natürlich nur dort, wo der Boden nicht vom Strom oder von den Wellen in Bewegung gesetzt wird, also entweder in den größeren Tiefen der Gewässer oder an anderen Stellen, wo Ruhe herrscht. Diese Vegetation ist noch wenig studiert, aber man weiß, daß sie existiert. Nach Forel gibt es im Genfer See bis $100 \mathrm{~m}$ Tiefe eine bräunliche Schicht niederer Algen (meist Schizophyceae und Diatomeae), einen organischen Filz.

Auch weit höher hinauf trifft man eine solche Vegetation, auf einem Boden, in welchem viele niedere Tiere: Würmer, Wasserregenwürmer, Larven u. a. gedeihen, und wo auch der Aal wühlt und sich an diesen Tieren fett frißt. 
Auch in den süßen Gewässern kommen Assoziationen aus Purpurbakterien mit Beggiatoen und anderen, allerdings grünen, aber wahrscheinlich saprophytischen Cyanophyceen (Oscillatoria, Spirulina, Lyngbya u. a.) vor (vergl. Kap. 45).

Da die Flüsse, die große Städte durchlaufen, z. B. die Themse und die Seine, sehr viele organische Abfälle aufnehmen, da ihr Wasser aber nur wenige Meilen weiter unterhalb wieder klar und bakterienarm wird, hat man die Anschauung ausgesprochen, daß diese „Selbstreinigung“ der Flüsse Pflanzen, besonders Schizophyceen zuzuschreiben sei. Schenck (1893) untersuchte den Rhein zwischen Bonn und Köln und kam zu dem Ergebnis, daß grüne Algen hierbei keine große Rolle spielen und daß Faden- und Stabbakterien die organischen Stoffe aufnehmen ${ }^{1}$ ).

Auch in den nährstoffarmen Wässern der Heiden finden wir mitunter einen entsprechenden Verein. In flachem, ganz durch Humusstoffe braun gefärbtem Wasser ist oft nur eine einzige blaugrüne Alge (Oscillariacee) in großen Massen vertreten.

Kolkwitz und Marsson ${ }^{2}$ ) haben die Saprobien in drei Gruppen geteilt, je nachdem sie in stark, schwächer oder wenig verunreinigtem Wasser leben: Polysaprobien, Mesosaprobien und Oligosaprobien.

Eigene Assoziationen bilden die Eisenbakterien, welche in ihren gallertartigen Hüllen Eisenoxydverbindungen in mehr oder weniger großen Massen ablagern. Dadurch bekommen sie eine braunrote Farbe. Der "Brunnenfaden“, Crenothrix polyspora und Clamydothrix ochracea, sind die gewöhnlichen, die neben einigen anderen oft große Assoziationen in stillem stehendem oder langsam fließendem Wasser bilden. Übrigens können sie auch ohne Eisen sehr gut wachsen (Molisch) ${ }^{3}$ ).

\section{Warme Quellen}

Andere Assoziationen von Cyanophyceen und Bakterien kommen auf einem anderen, durch die Wärme des Wassers etwas abweichendem Standort vor, das sind die der warmen Quellen oder Thermen, die sich in den verschiedensten Teilen der Erde finden. Der Wärmegrad ist natïrlich höchst verschieden; bei niedrigeren Temperaturen gedeihen noch Blütenpflanzen in ihnen, aber unter höheren Temperaturen bleiben nur Cyanophyceen mit Beggiatoa zurück (Beggiatoa, Lyngbya, Oscillaria, Hypheothrix, Phormidium, Spirulina, Nodularia u. a.). Die Arten sind über die ganze Erde ungefähr dieselben. Sie bilden grüne, gelbe, weiße, rote oder braune, schleimige oder fadenförmige Massen oft von mehreren cm Dicke, die bisweilen anscheinend fast strukturlose Gallerte sind.

1) Uber die Selbstreinigung der Elbe unterhalb Dresden vergl. Schorler 1898

2) Kolkwitz und Marsson 1908; Kolkwitz 1911, 1914.

3) Molisch 1910. 
Aus europäischen Thermen kennt man z. B. Anabaena thermalis (in Wasser mit Temperaturen bis $57^{\circ} \mathrm{C}$.), Arten von Leptothrix (in Kirlsbad: $55,7^{\circ}$ C.), Beggiatoa, Oscillaria $\left(44-51^{\circ}\right.$ C. $)$, Hypheothrix (Island), Tolypothrix lanata (Grönland) u. a. Lyngbya thermalis kennt man von Island, von den Schlammvulkanen Italiens und von den warmen Quellen Unartok in Grönland $\left(40^{\circ} \mathrm{C}\right.$.).

Mit den Cyanophyceen kommen Eisenbakterien, Schwefelbakterien und andere vor, auch Diatomeen und höher organisierte Algen.

Die höchsten Temperaturen, die man angegeben findet, sind folgende: $81-85^{\circ} \mathrm{C}$. von Ischia (Ehrenberg), bis $90^{\circ} \mathrm{C}$. von den Azoren (.Moseley) und sogar $93^{\circ}\left(200^{\circ}\right.$ F.) von Kalifornien (Brewer). Bei Las Trincheras in Venezuela kommt eine warme Quelle vor, die bei ihrem Ursprung eine Wärme von $85-93^{\circ} \mathrm{C}$. hat; die Algen wachsen hier in Wasser ron mehr als $80^{\circ} \mathrm{C}$. (Warming).

Das Wasser vieler heißer Quellen, die sich ja meist in vulkanischen Gegenden vorfinden, enthält Schwefel, Kalk oder andere mineralische Stoffe, ohne daß die Zusammensetzung der Vegetation dadurch wesentlich geändert wird.

Eine besondere Rolle spielen gewisse dieser Algen, indem sie kristallinische Massen von kohlensaurem Kalk oder von Kieselsinter ausscheiden; im Arno wird von Schizophyceen Travertin gebildet; in den Thermen von Karlsbad werden gleichfalls mächtige Kalksinter ausgeschieden. In Nordamerika finden sich zahlreiche heiße Quellen und Geiser im Yellowstoneparke; Weed ${ }^{1}$ ) hat die merkwürdige, gesteinsbildende Wirksamkeit, die die Algen hier ausüben, geschildert; sie wachsen hier besonders in Wasser, das etwa $30-85^{\circ}$ warm ist und variieren in bunten Regenbogenfarben zwischen rot, orange, weiß und grün je nach der Temperatur des Wassers. Cohn meint, daß sich eine besondere Fähigkeit, kohlensauren Kalk aufzuspeichern, bei diesen Algen finde.

Sollten diese von den am niedrigsten organisierten Algen gebildeten Vereine heißer Quellen uns nicht ein Bild von der ältesten Vegetation der Erde geben?! $\left.{ }^{2}\right)$

Auf den feuchten Felsen in der nächsten Umgebung der Quellen kïnnen viele von denselben thermophilen Algen subaërisch vorkommen.

1) Weed 1887-88; vergl. die von ihm angeführte reiche Literatur.

$\left.{ }^{2}\right)$ Hierzu vergl. auch Comère; Podpera, 1904, in Englers, Jahrb. XXXIV Harshberger 1897; Josephine Tilden 1898; Istvanffi 1905; über Japan: Miyoshi 1897. 


\section{Kap. Die autophyten Limnäen. Formationen auf losem Sïßwasserboden}

Hierher gehören alle auf losem (sandigem, tonigem, schlammigem) Boden, in Süßwasser, besonders in ruhigem, wachsenden Vereine aus autophyten Pflanzen, deren Individuen entweder ganz untergetaucht sind oder höchstens Schwimmblätter haben (die Blüten werden fast immer über das Wasser gehoben).

Die Flora wird gebildet:

1. von Grünalgen, namentlich von Characeen, die sich besonders auf Mergelboden finden, den sie oft mit einem dichten, eigentümlich unangenehm riechenden Teppich überziehen (Characeta).

2. von Moosen (Fontinalis, Arten von Hypnum und Sphagnum).

3. von Pteridophyten: Wasserfarnen (Marsilia, Pilularia) und Isoëtes (Fig. 240, 241).

4. von Blütenpflanzen: Wie im Meere kommen Potamogetonaceae, aber in größerer Artenzahl, vor, ferner teilweise Hydrocharitaceae (Elodea, Vallisneria, Hydrilla), Sparganium simplex, S. affine und S.minimum, Elisma natans, außerdem viele Dikotyledonen: Nymphaeaceae, Cabombaceae, Ranunculaceae (Ranunculus: die Mehrzahl der BatrachiumArten), Arten von Callitriche, Subularia, Elatine, Helosciadium inundatum, Limosella, Myriophyllum, Montia, Limnanthemum, Lobelia Dortmanna u. a.

Epiphyten; als solche treten viele Diatomeen und Cyanophyceen auf und sind oft in Schleim eingehüllt.

Ganz neuerdings hat Rabanus ${ }^{1}$ ) auf die Periodizität (vergl. bereits S. 369, 468) der Algenvegetation in Baden ausführlich hingewiesen und durch zahlreiche tabellarische und graphische Darstellungen erläutert. Gewisse Algen (z. B. Spirogyra) gehen mit Beginn der Wärme stark zurück, andere (die Mehrzahl) zeigen dann stärkeres Wachstum.

Anpassungen. Die Formenmannigfaltigkeit ist im Gegensatze zu der entsprechenden Salzwasservegetation außerordentlich groß, was sicher durch den größeren Wechsel in den Lebensbedingungen erklärt werden kann, namentlich dadurch, daß es sowohl stark strömendes als sehr oft ganz ruhiges Wasser gibt, während das Meer keine so große Ruhe darbietet und seine Wasserbewegungen vorzugsweise die eigentümliche Form des Wellenschlages haben. Ein Hauptunterschied ist demnach der, daß nicht nur ganz untergetauchte Typen, sondern auch Arten mit Schwimmblättern oder mit Sprossen, die auf dem Wasser schwimmen, vorkommen.

1) Rabanus 1915 . 
Alle Arten sind krautartig und fast alle ausdauernd (einjährig sind z. B. Subularia aquatica, Najas, Trapa, welche nur dann gesellig wachsen küunen, wenn zahlreiche Samen über den Boden ausgesät werden).

Der Sproßbau ist sehr verschieden. Die allermeisten haben im Einklange mit dem losen Boden kriechende Grundachsen (Fig. 240) und zeigen daher geselligen W uchs (z. B. Potamogeton, Hippuris, Nymphaea und Nuphar mit unterirdischen, Myriophyllum, Ranunculus, Callitriche u.a. mit oberirdischen wagerechten Stengeln). Die Characeen gehören mutatis mutandis auch hierher. Bei anderen wurzeln die rosettenblättrigen Sprosse an langen Ausläufern in gewissen Abständen von der Mutter-

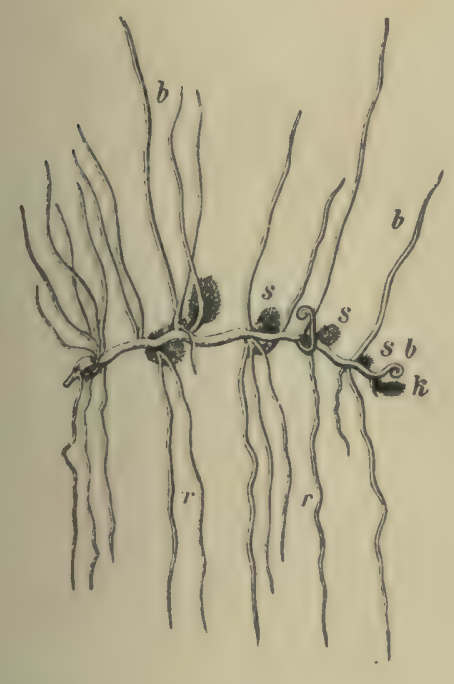

Fig. 240. Pilularia globulifera.

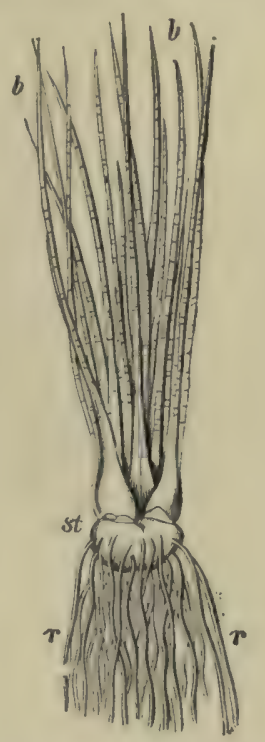

Fig. 241. Troëtes lacustris.

(Warming-Johannsen.)

pflanze fest (z. B. Litorella, Vallisneria, Fig. 246). Alle solche mit wandernden Sprossen versehenen Arten können auf dem Seeboden dichte Bestände bilden, die reich an Individuen, aber arm an Arten sind.

Eine kleinere Zahl von Arten hat senkrechte, kurzgliedrige Grundachsen mit Laubblattrosetten, ohne solche Wanderungsmittel; ihre Individuen stehen dann mehr einzeln (Isoëtes, Lobelia Dortmanna).

Es gibt folgende drei wesentlich verschiedene Formen von Assimilationsprossen.

A. Der völlig untergetauchte Rosettentypus. Die Sprosse sind senkrecht, unverzweigt und kurzgliedrig, die Blätter rosettenständig, sitzend und meist untergetaucht (Vallisneria mit bandförmigen Blättern, Isoëtes, Lobelia Dortmanna, Subularia aquatica und Litorella uniflora mit mehr stielrunden). (Fig. 241.) 
B. Der völlig submerse gestrecktgliedrige Langsproßtypus. Die Sprosse sind aufrecht, gestrecktgliedrig, dünnstengelig und verzweigt; Haupt- und Seitensprosse haben in der Regel gleiche Dicke (kein Dickenwachstum), ganz wie bei gewissen im 56. Kap. behandelten Pflanzen. Die oft sehr langen und dünnen Sprosse sind sehr biegsam und fähig, der Wasserbewegang nachzugeben. Die Länge hängt von der Tiefe und der Strömung des Wassers ab. Die Landformen derselben Arten haben kürzere Internodien. Hierher gehören z. B. Myriophyllum, Najus, Hippuris, Potamogeton pectinatus, P. perfoliatus u. a. Arten, Ranunculus Baudotii, Zannichellia, Callitriche autumnalis, Elodea. Die Blätter sind linealisch oder länglich (selten breit) und bei einigen sehr fein geteilt. Vergl. auch Chara, Fig. 248.

Die anatomischen Verhältnisse der meisten Wasserpflanzen sind gleichfalls sehr eigenartig, sie wurden bereits auf S. 268-274 erörtert (Ölgehalt, Xylemgänge, Schleimgehalt der jungen Teile usw.).

C. Die Schwimmblattform. Außer untergetauchten Blätterı von verschiedener Form kommen Schwimmblätter vor. Die Sprosse sind entweder wie bei A oder wagerechte Grundachsen (Nuphar luteum, Nymphaea alba u. a. Nymphaeaceen, Fig. 243); in beiden Fällen sind die Schwimmblätter äußerst langgestielt, um die Oberfläche des Wassers erreichen zu können. Bei anderen sind die Sprosse gestrecktgliedrig und die Stiele der gewöhnlich auf dem kurzgliedrigen Stengelende rosettenförmig vereinigten Schwimmblätter kürzer; z. B. Ranunculus (die meisten $B a$ trachium-Arten), Trapa natans, Potamogeton natans, Elisma natans, Callitriche verna, Fig. 237, 244.

D. Eine etwas abweichende Form ist Nelumbium, die sich am nächsten an die Nymphaeaceen mit wagerechten Grundachsen anschließt. und auch zuerst Schwimmblätter entwickelt, nachher aber schildförmige Luftblätter auf eleganten Stielen hoch über den Wasserspiegel erhebt ${ }^{1}$ ), Fig. 242.

Die Blattformen. Die Abhängigkeit der Blattform (und teilweise die des Sprosses) von dem Medium tritt hier besonders augenfällig hervor. Es gibt fünf Hauptformen von Blättern: 1. das Schwimmblatt und vier untergetauchte Formen, die man in zwei Gruppen vereinigen könnte, einerseits die hauptsächlich bei Dikotylen vorkommenden sehr fein zerteilten (2. myriophylloïden) Blätter, anderseits die wesentlich langen und linealischen ungeteilten (3. zosteroïden, 4. die elodeoïden und 5. die isoëtoïden) Blätter (Literatur: vergl. Schenck $1886 \mathrm{~b}$ ).

1. Das Schwimmblatt begegnete uns schon bei dem Pleuston (55. Kap.). Es tritt auch hier bei Nymphaea, Nuphar, Cabomba, Brasenia u. a. Nymphaeaceen, Limnanthemum, Hydrocleis, Elisma, Ranun-

1) Hj. Jensen 1905. 
culus, Trapa, Callitriche, Potamogeton (natans u. a.), Polygonum (amphi(inum) u. a. Gattungen mit derselben allgemeinen Form auf: es ist breit (kreis-, ei-, herz-, nierenförmig, rhombisch oder elliptisch, selten lanzett-

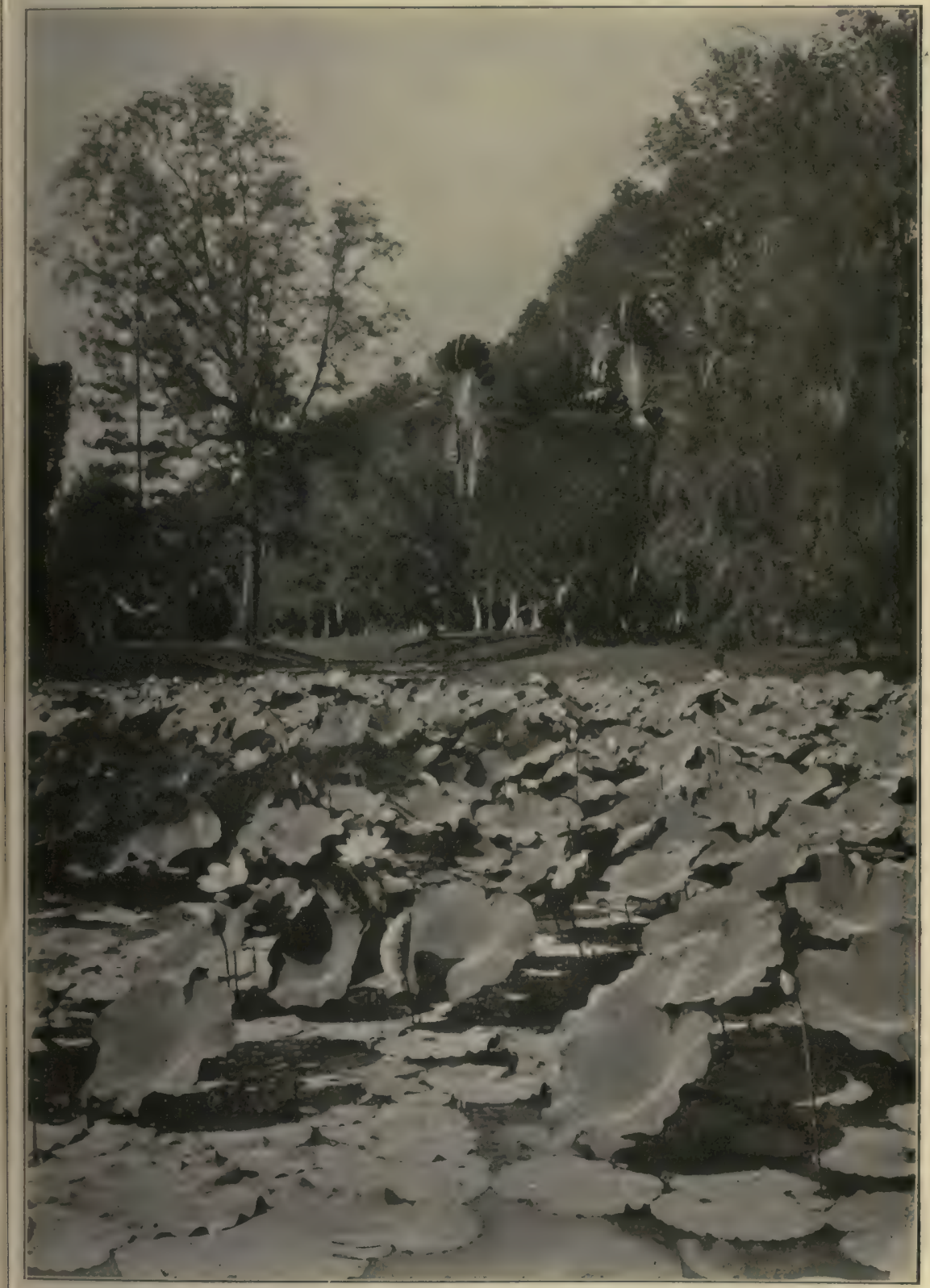

Fig. 242. Wasservegetation mit Nelumbium im Botan. Garten in Buitenzorg. (Phot. Hjalmar Jensen.) 
lich), ungeteilt und ganzrandig, selten gekerbt oder eingeschnitten (z. B. bei Trapa (Fig. 244), Ranunculus [Batrachium] und $R$. sceleratus), ferner recht dick und fest (lederartig), hat bisweilen einen mechanisch verstärkten oder nach oben gebogenen Rand und ist vorzüglich geeignet, auf dem Wasser zu schwimmen und den Wasserbewegungen zu widerstehen; die riesigen Schwimmblätter von Victoria regia, Euryale ferox und ähnlichen werden außerdem durch mächtige Rippen auf der Blattunterseite gekräftigt. Linealische Spreite findet sich z. B. bei Glyceria fuitans, den Sparganium-Arten usw. Die Spreite des Laubblattes ist dorsiventral gebaut und hat das Palisadengewebe anf der Oberseite. Die Unterseite

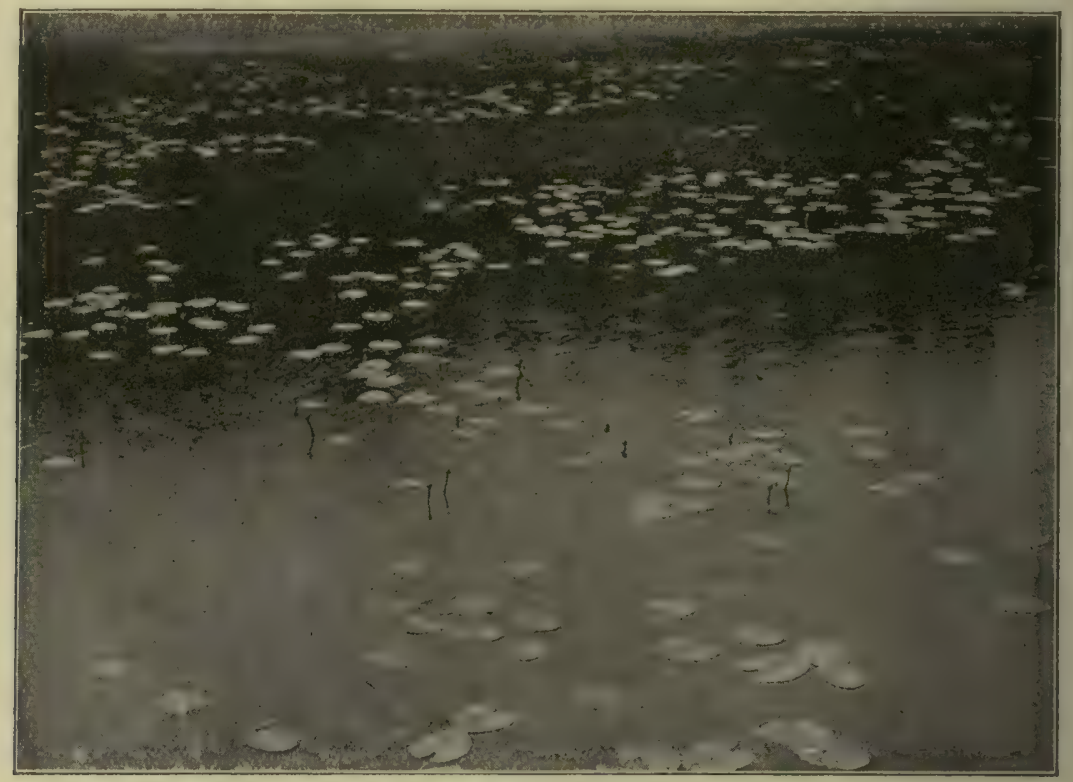

Fig. 243. Teich mit blühendem Nuphar pumilum. Eine kleine Assoziation von Myriophyllum erhebt ihre Infloreszenzen. (Phot. Eug. Warming.)

ist oft durch Anthocyan dunkelrot, dessen Nutzen nicht mit Sicherheit bekannt ist. Stacheln auf der Unterseite der Spreite und auf dem Stiele haben Victoria und Euryale. Sie ist zum Leben in der Luft angepaßt. Vergl. Fig. 242-244 und Fig. 237, S. 476.

Spaltöffnungen werden ausgebildet, doch nur oder überwiegend auf der Oberseite, deren Epidermis kein Chlorophyll enthält, und werden gegen die Verstopfung mit Wasser dadurch geschützt, daß die Blattoberseite das Wasser nicht annimmt (wegen der sehr fethaltigen Kutikula oder wegen Wachs). Hiermit geht einher, daß die Oberseite oft stark glänzend oder weißlich ist ${ }^{1}$ ).

1) Jahn 1886 . 
Die Länge des Stieles richtet sich nach der Wassertiefe; wenn die Spreite mit der Luft in Berührung gelangt, wird sein Wachstum gehemmt. Bei den gestrecktgliedrigen Sprossen werden zugleich die Internodien gehemmt, z. B. bei Trapa, Callitriche; das Längenverhältnis zwischen den Stielen der Schwimmblätter und die Stellung der Schwimm-

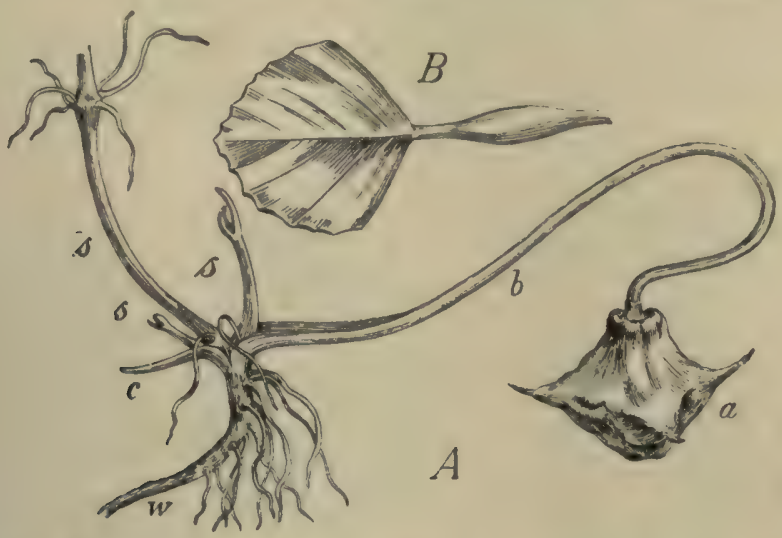

Fig. 244. Trapa natans. A Keimende Pflanze, $a$ Frucht, $b$ Stiel des in der Frucht bleibenden Keimblattes, $e$ das andere Keimblatt, $s$ Stempel, $w$ Wurzeln; links oben die kiemenblattartigen Wasserwurzeln. $B$ Schwimmblatt.
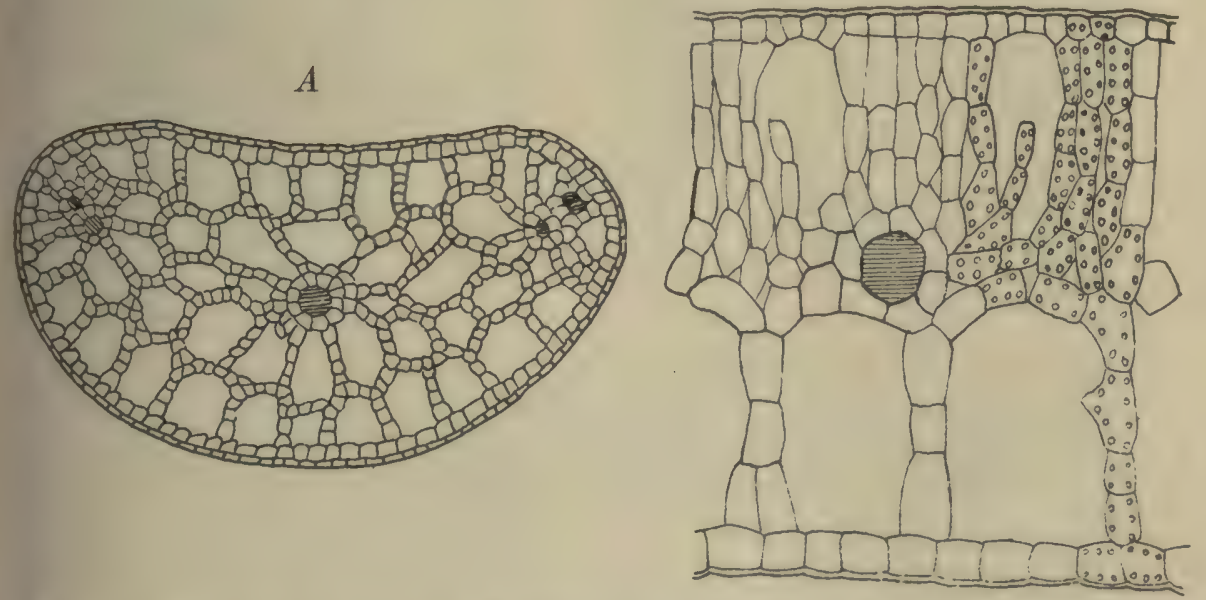

Fig. 245. Potamogeton natans. $A$ Untergetauchtes Blatt, binsenförmig. $B$ Schwimmblatt, flach und völlig anders gebaut (vergl. dieselben Fig. 47, S. 143, Fig. 92, S. 208).

blätter sind bei solchen Arten so, daß alle Spreiten auf dem Wasser Platz finden. Frank hat die Meinung geäußert, daß der Druck der höher liegenden Wassersäule das Wachstum des Stieles befördere; Versuche anderer haben ergeben, daß die Berührung mit der Luft und die größere Lichtmenge die Form des Schwimmblattes hervorrufen. 
Eine Anzahl von Arten sind heterophyll (Fig. 245), sie haben nicht nur flutende, sondern auch untergetauchte Blätter. Nach Askenasy ${ }^{1}$ ) und anderen erscheinen die Schwimmblätter bei Batrachium und Cabomba nicht eher, als die Pflanze blühen will, so daß sie besonders dazu dienen die Blüten über Wasser zu heben.

Die untergetauchten Blätter weichen von den Schwimmblättern anatomisch bedeutend ab (besonders in der Epidermis und dem Chlorophyllgewebe). Sie haben folgende Formen:
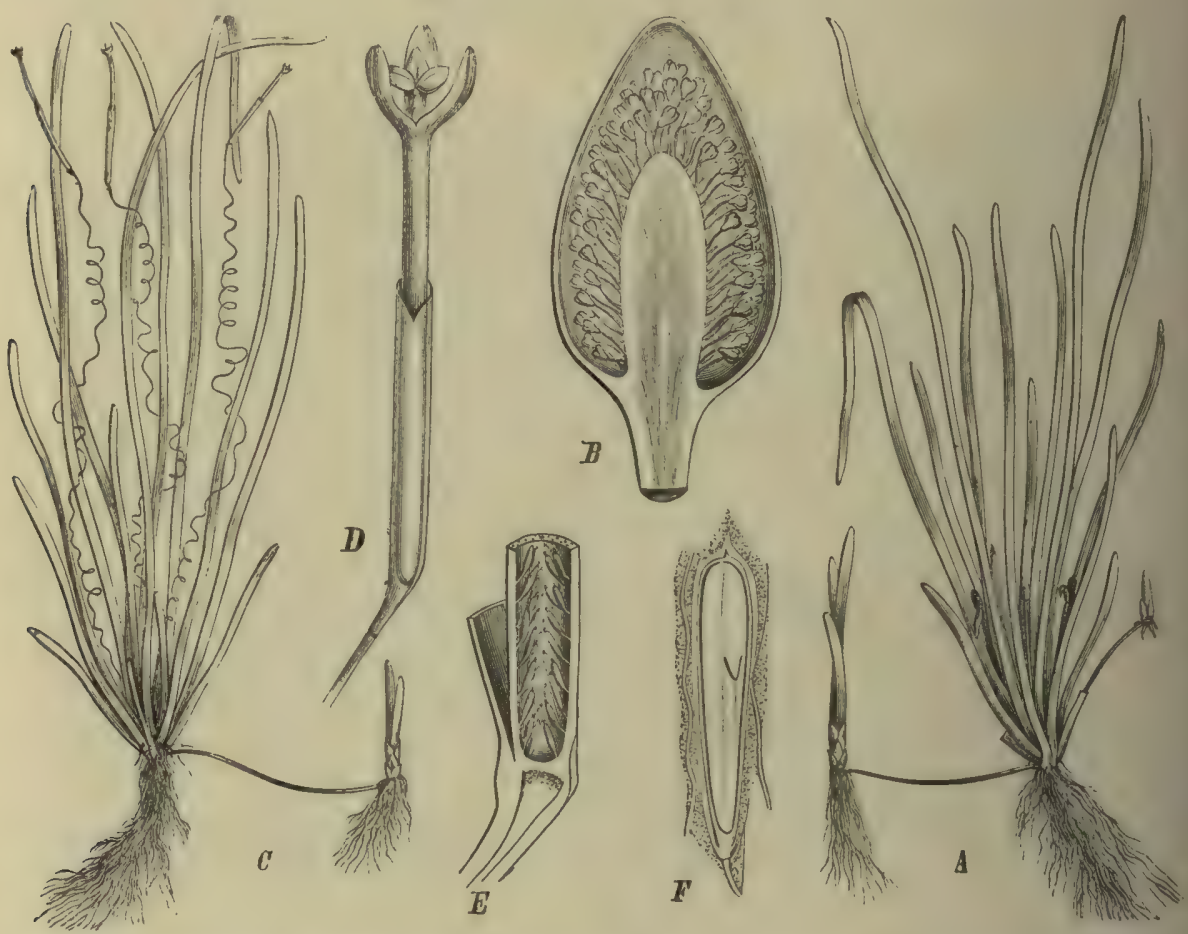

Fig. 246. Vallisneria spiralis als Beispiel für das Bandblatt. $A$ männliche Pflanze; $B$ Spatha derselben, vergröBert; $C$ weibliche Pflanze (wie $A$ verkleinert); $D$ weibliche Blüte mit Spatha, vergrößert; $E$ untere Hälfte des Fruchtknotens, vergrößert; $F$ Samen, der Länge nach durchschnitten, stark vergrößert. (Nach Schnizlein.)

2. Das Bandblatt oder "zosteroïde" Blatt, das bei den Seegräsern allgemein vorkommt, ist hier seltener (Vallisneria, Fig. 246, Sparganium, Potamogeton-Arten u. a.). Daß es an tiefere oder an strömende Gewässer (beide scheinen auf dieselbe Weise zu wirken) angepaßt ist und durch sie hervorgerufen wird, sieht man z. B. bei gewissen Sumpfpflanzen wie Alisma plantago, Sagittaria sagittifolia, Echinodorus ranunculoides, wenn sie gezwungen werden, sich in solchem Wasser zu entwickeln.

Askenasy 1870. 
Ähnliche Blattformen trifft man unter denselben Verhältnissen bei Potamogeton natans ( $1 / 2 \mathrm{~m}$ lange Stromblätter) und Scirpus lacustris.

3. Das helodeoïde Blatt, d. h. das längliche oder schmal linealische, kurze, flache, sitzende, ungeteilte Blatt findet sich häufig bei Helodea, Fig. 247, Potamogeton densus, obtusifolius, pusillus u. a. Arten, Hippuris, Zannichellia, Callitriche autumnalis u. a. Arten, Najas. Hierher gehören auch die Wassermoose. Breitere Blattformen finden sich bei anderen Potamogeton-Arten; etwas abweichende zeigt besonders P.lucens.

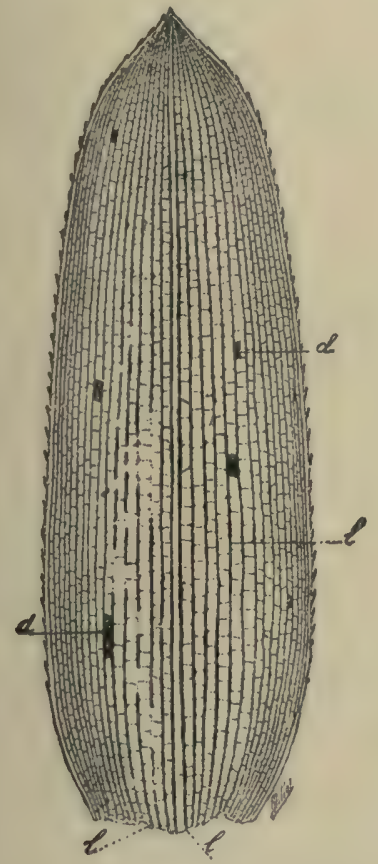

Fig. 247. Helodea Canadensis. Blatt, schwach vergröBert; dunkele Streifen Luftkanăle $(l) ; d$ abgestorbene Partien im Blatte.

(Nach Devaux.)

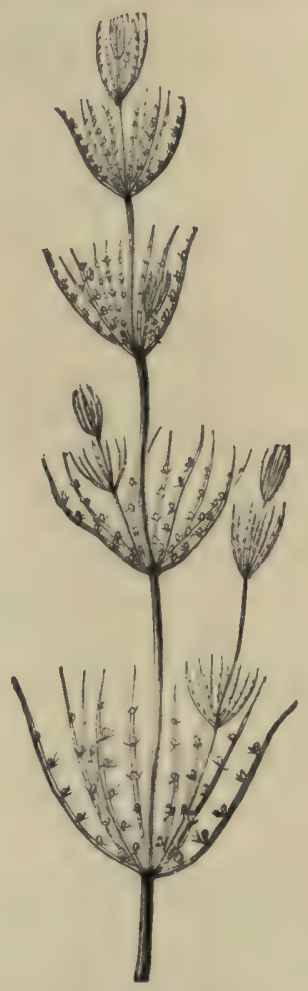

Fig. 248. Chara fragilis mit den an myriophylloide Blätter erinnernden, seitlichen, röhrenförmigen Kurzsprossen. (Nach Strasburger.)

4. Das linealische, ungeteilte, ganzrandige, sitzende, stielrunde Röhrenblatt kommt bei Pilularia, Isoëtes, Fig. 241, Potamogeton natans, Lobelia Dortmanna, Litorella lacustris vor, die meist kurzstengelige Pflanzen sind. Subularia, Scirpus fluitans und die Characeen können hier am nächsten angeschlossen werden, Fig. 248.

$\mathrm{Da}$ ß diese beiden ziemlich übereinstimmenden Blattformen gleichfalls, jedenfalls teilweise, durch die Einwirkung des Wassers hervor- 
gerufen werden, beobachtet man bei Arten, die sowohl Land- als Wasserformen haben, z. B. bei Hippuris vulgaris, Elatine alsinastrum, Isoëtes lacustris, Pilularia (Fig. 240, 241) u. a.; die Wasserblätter sind viel länger und schlaffer als die Luftblätter.

5. Das myriophylloïde oder in fadenförmige oder linealische Abschnitte geteilte Blatt (analog den Kiemen der Fische) ist sehr verbreitet (Myriophyllum, Helosciadium inundatum, Ranunculus [Batrachium, Fig. 237, 249], Cabomba) und findet sich auch bei mehreren Sumpfpflanzen, wenn sie in tieferem Wasser wachsen, z. B. bei Oenanthe phellandrium, Oen. fistulosa, Sium latifolium. In seine Nähe kann das ungewöhnliche, durchlöcherte Blatt von Ouvirandra fenestralis gestellt werden. Daß die Tiefe der Einschnitte und die Feinheit der Abschnitte durch den Einfluß des Mediums hervorgerufen werden (Tiefe des Wassers, Stärke der Strömung u. a.), geht aus vielen Beobachtungen hervor; wenn

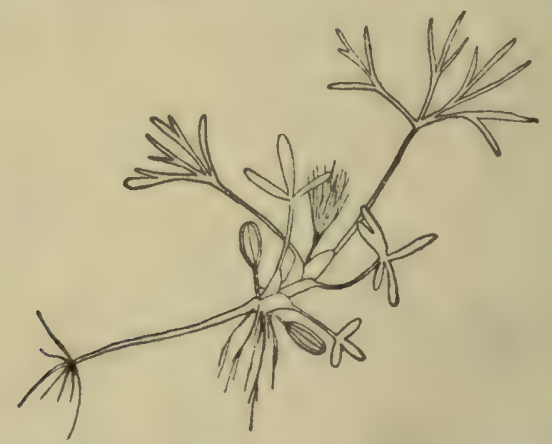

Fig. 249. Keimpflanze einer Ranunculus sect. Batrachium mit myriophylloiden Blättern oberhalb der Keimblätter. (Nach 0. Gelert.)

die Sprosse die Wasseroberfläche erreichen, erscheinen Schwimmblätter (Beisp. Ranunculus [Batrachium] aquatile, Fig. 237), oder Blätter mit kürzeren, breiteren, dickeren Abschnitten, besonders wenn die Sprosse das Wasser überragen (Beisp. Myriophyllum). Der physiologische Grund für diese Verschiedenheit liegt vermutlich besonders in der durch das gedämpfte Licht veranlaßten größeren Streckung und in dem Ausschlusse der Transpiration. Die fein geteilten Blätter passen gut zu dem Medium, indem ihre Oberfläche größer geworden und dadurch die Nahrungsaufnahme, vermutlich auch die Lichtwirkung begünstigt worden ist. Die Wasserbewegungen lassen kaum größere Flächen $\mathrm{zu}^{1}$ ).

1) Über die Formverschiedenheiten der Wasser- und Sumpfgewächse und über ihre Abhängigkeit von den ökologischen Standortsfaktoren hat in neuerer Zejt H. Glück (1905, 1906, 1911 ff.) ausgedehnte gründliche Untersuchungen veröffentlicht. - Über die Verschiedenheiten der Wasser- und Landformen von Polygonum amphibium siehe Massart 1902. - Siehe auch: Bau der Wasserpflanzen, Chatin 1856; H. Schenck 1886 a, b. 
Die Fortpflanzung. Die Fortpflanzung der Kryptogamen geht bekanntlich im Wasser vor sich. Von den Blütenpflanzen hingegen heben fast alle ihre Blüten über das Wasser empor; einige suchen die Hilfe von Insekten zur Bestäubung (Hottonia, Utricularia-Arten, Nymphaceaeae usw.), andere die des Windes oder des Wassers oder haben Selbstbestäubung (Hippuris, Myriophyllum, Potamogeton u. a.). Mit Hiffe des Wassers wird der Pollen z. B. bei Zannichellia, Ruppia ${ }^{1}$ ), Callitriche und Najas übergeführt; kleistogam können unter Wasser blühen Subularia aquatica, Limosella aquatica, Euryale ferox, Elisma natans, Ranunculus (selten). Ein besonderes Verhältnis (parallel mit dem von Ruppia) zeigt Vallisneria (die kleinen männlichen Blüten reißen sich los, schwimmen auf der Wasseroberfläche umher und bestäuben hier die Narben der auf dem Wasser ruhenden weiblichen Blüten); ihr steht Helodea am nächsten. Bei Ruppia schwimmt der Pollen an die an die Wasseroberfläche gelangenden Narben.

Nach der Bestäubung werden viele Früchte unter das Wasser gezogen oder gebogen und reifen hier (Beisp. Potamogeton, Trapa, Ranunculus). Die Samenverbreitung findet oft durch besondere, zu dem Medium passende Mittel statt: die Samen oder die Früchte vieler Arten sind wegen eines eigentümlichen Baues leichter als das Wasser, werden von diesem getragen und nach anderen Standorten fortgeführt (Ravn, Ohlendorff), viele andere aber, wie die vieler Potamogeton, von Helosciadium inundatum u. a., sind schwerer als Wasser und sinken unter, die von der erstgenannten Gattung können oft lange liegen, ehe sie keimen ${ }^{2}$ ).

Vegetative Vermehrung ist wie bei den meisten Wasserpflanzen sehr verbreitet, sie geht leicht durch einfaches Losreißen von Sproßteilen vor sich und hat eine große biologische Bedeutung; einige Arten werden sogar fast apogam. Calla palustris, viele Potamogeton-Arten und Stratiotes ${ }^{3}$ ) haben besondere sich leicht losreißende Knospen. Die schnelle Ausbreitung von Elodea und ihre ungeheure Menge von Individuen in Europa ist allein durch vegetative Teilung bewirkt worden, da sie keine Samen bringt, weil hier nur ein Geschlecht (die weibliche Pflanze) vorkommt, auch von Stratiotes kommt meist auf weite Strecken nur ein Geschlecht vor. Die starke vegetative Vermehrung ist der Brutknospenbildung, der Verzweigung, den wagerechten gestrecktgliedrigen Grundachsen und der leichten Beiwurzelbildung zuzuschreiben.

Die allermeisten Arten überwintern grün auf dem Grunde des Wassers, wo die Wärmeverhältnisse nicht so extrem wie in der Luft

1) Vergl. Graebner 1906.

3) Sauvageau 1890, 1891; Graebner 1906.

3) Wesenberg-Lund 1912. 
sind (Callitriche, Zannichellia, Nymphaeaceae, Stratiotes, Vallisneria u. a.). Besondere Überwinterungsorgane, die im Herbste von dem abfaulenden Muttersprosse frei werden, sind die knorpeligen Wintersprosse von Potamogeton crispus u. a. Arten (vergl. Sauvageau), die kugeligen, dicht gedrängte Blätter enthaltenden Knospen von Utricularia, Myriophyllum, Brutknospen von Stratiotes, Hydrilla, Helodea ${ }^{1}$ ) u. a.

\section{Assoziationen}

Nach den ökologischen Standortsfaktoren und dem für jede Art geeignetsten Optimum ordnen die Limnäen sich, wie S. 355 und 380 erwähnt wurde, in mit dem Ufer mehr oder weniger parallelen Gürteln. Daß die Größe des Wasserbassins, die Tiefe und Bewegung des Wassers, Art des Bodens u. a.m. für die Bildung der Assoziationen eine große Rolle spielen, ist auch erwähnt. Auch der größere oder geringere Gehalt des Wassers an Nährstoff, also an löslichen Salzen, Sauerstoff und an Humussäuren spielt floristisch eine bedeutende Rolle. In den nährstoffreichen Gewässern, wie Flüssen, Landseen und Landteichen, kommen andere Arten vor als in den nährstoffarmen der Heideseen und Heidetümpel. In den ersteren kommen viele Grünalgen, namentlich Characeen, von Moosen Fontinalis und Hypnum-Arten, von Blütenpflanzen viele Batrachium-Arten, Sparganium simplex, S. ramosum u. a. vor. In den nährstoffarmen von Moosen namentlich Sphagnum, von Blütenpflanzen Sparganium affine, S. minimum, S. diversifolium, S. Friesei u. a. Auch der verschiedene Reichtum an Kalk wird vielfach eine floristische Rolle spielen, worauf namentlich englische Botaniker großes Gewicht legen.

Die Assoziationen zeigen über ungeheure Strecken der temperierten Weltgegenden große Übereinstimmungen, selbst wenn die Arten recht verschieden sind; aus Europa und Nordamerika liegen viele Angaben vor, auch aus Japan.

Die periodischen Erscheinungen in eiuem Teiche sind von Fritsch und Miß Rich auch rücksichtlich der Blütenpflanzen studiert worden ${ }^{2}$ ).

Assoziationen von Algen. In den tiefsten Teilen von Seen in Europa, gewöhnlich 8-12 m, befinden sich Assoziationen von autophyten Grundalgen, hauptsächlich bestehend aus einem Filz ron Cladophoraceen mit Chotophoraceen, Palmellaceen, Cyanophyceen und Diatomeen, wo auch Fontinalis antipyretica eingemischt sein kann. Brand fand einen Gürtel von dieser Art in einer Tiefe von $20 \mathrm{~m}$ an. Hier trifft man auch große kugelige Gebilde von Cladophora Sauteri ${ }^{3}$ ).

1) Ascherson-Graebner Synopsis.

2) Vergl. Journ. of Ecology, 1913, 1, 295; vergl. auch Rabanus 1915.

s) Fleroff 1907. 
Assoziationen von Characeen bilden gewöhnlich den äußersten, tiefsten Gürtel in sehr verschiedener Tiefe. Die Characeen gehen im Genfer See bis $20-25 \mathrm{~m}$ (Forel), im Bodensee bis zu $30 \mathrm{~m}$ nach Schröter und Kirchner, aber meist gewiß nur 6-17 m tief hinab; bei $60 \mathrm{~m}$ Tiefe fand man im Genfer See merkwürdigerweise noch ein Moos, Thamnium alopecurum var. Lemani.

Die Characeen werden aber auch in sehr seichtem Wasser gefunden und bilden oft ausgedehnte, dichte Teppiche, „Wiesen“, eigentümlich streng riechende, kalkreiche. Bisweilen wachsen sie in so seichtem Wasser, daß sie in Trockenzeiten trockengelegt werden und als weißliche Massen erscheinen. Auch im braunen, sauren Wasser der Moorgräben können sie sich finden.

Assoziationen von Moosen. Es ist namentlich Fontinalis antipyretica, die in Europa Teppiche in einigen Metern Tiefe bilden (3-4 m), welche nach Wesenberg-Lund für das Tierleben im Winter große Bedeutung haben.

Assoziationen von Blütenpflanzen. Helodeeta. Assoziationen von Helodea canadensis kommen hie und da vor und gehen höchstens bis zu $6 \mathrm{~m}$ Tiefe herab.

Myriophylleta und untergetauchte Potamogetoneta bilden oft den nächsten Gürtel, der bis 4-6 m hinabsteigen kann. Von PotamogetonArten können hier z. B. P.lucens, P. pectinatus, $P$. perfoliatus und $P$. pusillus genannt werden; ersterer geht wohl am tiefsten und erreicht die größte Mächtigkeit, aber auch die anderen finden sich öfter tief und massenhaft. Die kleineren Arten behaupten meist die untiefen Stellen, die mächtigeren gehen am weitesten hinaus. Die untergetauchten können besser stark bewegtes, strömendes Wasser ertragen als die mit Schwimmblättern versehenen, sie finden sich daher auch weiter vom Ufer entfernt. Mit ihnen vergesellschaftet findet sich Ceratophyllum.

Von anderen untergetauchten Assoziationen im seichteren Wasser nahe den Ufern können erwähnt werden: Isoëteta lacustris, Lobelieta Dortmanna, Littorelletae lacustris. Diese Arten in Gesellschaft miteinander und im Norden oft mit Subularia aquatica bilden bisweilen eine eigentümliche niedrige Vegetation aus ähnlich geformten Rosettenpflanzen mit Röhrenblättern auf Sandboden. Es ist Littorella, welche gewöhnlich vorherrschend ist, weil sie durch ihre reichliche Ausläuferbildung leicht die Überhand über die drei anderen, an den Platz gebundenen Arten bekommt. Letztere finden sich daher meist nur spärlich eingestreut, aber Litorella bleibt, solange sie untergetaucht ist, steril, nur auf dem trockengelegten Ufer können die windbestäubten Blüten sich entwickeln. In demselben Vereine finden sich auch mitunter Elatine triandra, Bulliarda aquatica, Scirpus acicularis u. a. Die 
Schwimmblatt-Assoziationen gehen gewöhnlich nicht zu so großen Tiefen hinab wie die untergetauchten Arten, suchen auch mehr die ruhigeren, gegen Wind und Wellenschlag geschützten Stellen der Gewässer auf. Folgende Assoziationen kommen vor: Nuphareta lutei; Nymphaeeta albae u.a., bisweilen in reinen, bisweilen in gemischten Vereinen; maximale Tiefe wohl $3-5 \mathrm{~m}$, gewöhnlich gehen sie nur bis 2-3 m oder sogar noch weniger tief ${ }^{1}$ ).

Polygoneta amphibii leben in etwas geringerer Tiefe. Ebenso die Assoziationen von Batrachium, Trapa natans, Elisma natans.

In Nordamerika kommen Gürtel vor, welche den europäischen ganz ähnlich sind nach Erläuterungen von Coulter, Cowles, Transeau, Pieters. Überhaupt hat die Flora Nordamerikas mit der europäischen große Ähnlichkeit; in Nebraska z. B. finden sich folgende europäische Gattungen: Batrachium, Myriophyllum, Ceratophyllum, Potamogeton, Lemna u. v. a.

In Maryland finden sich nach Chrysler folgende Gürtel: 1. Potamogeton-Assoziation, 5-10 Fuß, in welcher Brasenia purpurea u. a. eingemischt sein können; 2. Nymphaea-Assoziation, 2-5 Fuß; 3. Pontederietum cordatae, 1-2 Fuß, in welchem Sagittaria u. a. Danach kommen die Rohrsümpfe mit folgenden Gürteln: 4. Zizania aquatica; 5. Typha latifolia; 6. Alnus rugosa u. a. ${ }^{2}$ ). Berühmt sind: Victorieta regiae im Amazonas, wie auch Pontederieta cordatae u. a. vorkommen.

In Japan nach Nakano um die in der Mitte der Seen lebenden untergetauchten Arten von Potamogeton, Vallisneria, Hydrilla u. a. kommen 4 andere Gürtel vor von 1. Zizania aquatica, 2. Typha angustifolia, 3. Phragmites communis und 4. Sagittaria sagittifolia.

In den erwähnten Assoziationen können verschiedene andere Arten eingestreut sein, in den Potamogeta z. B. Myriophyllum, Ceratophyllum u. a., vom Plankton abgesehen.

Die Limnäenvegetation steht dem Megaplankton nahe (55. Kap.). Die Grenze zwischen ihnen ist nicht scharf; sie finden sich oft vermischt, und in beiden treten dieselben Gattungen, aber mit verschiedenen Arten auf. Gewisse gewöhnlich schwimmende Arten können gelegentlich festwurzeln (Pontederia crassipes, Hydrocharis, Stratiotes, Pistia); umgekehrt können normal festgewurzelte Arten gelegentlich schwimmen, z. B. Ceratopteris $^{3}$ ).

1) Über die europäischen Gewässer vergl. Schröter u. Kirchner 1896-1902; Baumann 1911; Gadeceau 1909; Magnin 1893, 1894; Chatin 1856; Fleroff 1907; Bachmann 1911; Glück 1905, 1906, 1911; Kurz 1912; Groß 1912. - Über die Wasservegetation in England vergl. Marietta Pallis in Tansley 1911.

2) Die nordamerikanischen Assoziationen sind besprochen worden von Pieters; Mac Millan; Jennings 1909; Dachnowski 1912; Pool 1913, Harshberger u. a.

\%) Goebel 1889-91, Il. Teil. 
Natürlich gibt es auch keine scharfe Grenze zwischen der Vegetation der festgewurzelten Wasserpflanzen und der der Sumpfpflanzen; es gibt viele "amphibische“ Arten, die sowohl in besonderen Wasserals in Landformen auftreten, z. B. Polygonum amphibium, mehrere Sparganium-Arten, Glyceria fluitans u. a. Die Quellenpflanzen sind auch eine Art Übergangsform zwischen Land- und Wasserpflanzen; sie ziehen das stark strömende, sauerstoff- und kohlensäurereiche Wasser vor; Beisp. Montia rivularis.

\section{Kap. Ufervegetation}

Am Rande der Gewässer ist eine Grenzvegetation entwickelt, die gleichsam zwischen Wasserpflanzen und Landpflanzen in der Mitte steht. Wie die Wasserpflanzen sind diese Pflanzen an offenes Wasser oder doch jedenfalls an sehr wasserreichen und oft überschwemmten Boden gebunden und haben ihre Wurzeln in diesem Boden, oder auch frei im Wasser, wie die Landpflanzen aber erheben sie ihre Assimilationsorgane frei in die Luft. Sie werden Sumpfpflanzen genannt (Helophyten, helophile Pflanzen, von ${ }^{2} \lambda o_{\xi}$, Sumpf), besonders wenn sie in tieferem Wasser leben und mächtiger sind. Sie sind den Schwankungen des Wasserstandes unterworfen und können bisweilen trockengelegt werden. So gibt es Assoziationen, die an periodisch trockengelegte Böden gebunden sind und gewöhnlich niedrige Kräuter enthalten.

Daß es keine scharfen Grenzen zwischen den Wasser- und Sumpfpflanzen oder anderen Uferpflanzen, sowie auch zwischen diesen und den Landpflanzen gibt, ist schon oben erwähnt.

Die Ufervegetation eines und desselben Sees oder Wasserlaufes kann an den verschiedenen Stellen sehr verschieden sein; die Verschiedenheit hängt wohl meist auch von der Verschiedenheit der Standorte ab. So gibt es oft große Verschiedenheiten zwischen den Seiten eines Sees, welche den herrschenden Winden und dem Wellenschlage ausgesetzt sind, und denjenigen, welche an der Windseite liegen, geschützt gegen den Anprall des Windes, ebenso ist die Vegetation in eingeengten, ruhigen Buchten geschützt. Daß die Verlandung der Seen an der ruhigen Windseite vorzugsweise gefördert sind, hat schon längst Forchhammer beobachtet, ist auch in neuerer Zeit ausführlich besprochen worden ${ }^{1}$ ).

An dieser Seite bilden sich oft echte Sümpfe mit hohen Stauden und Holzpflanzen, und eine lebhafte Torfbildung findet statt; oft ist das Wasser mehr oder weniger kaffeebraun, d. h. durch Humusstoffe verunreinigt. An den den Winden und dem Wellenschlage ausgesetzten Seiten ist das Ufer oft niedrig (wenn nicht aus Felsen gebildet) und

1) Klinge 1890; Warming $1897 \mathrm{a}$. 
sandig oder auch von vielen kleinen rundlichen Steinen oder Geröll bedeckt. Das Wasser ist klar und die Vegetation besteht gewöhnlich nur aus niedrigen Kräutern.

Es gibt ferner Verschiedenheiten zwischen den Nord- und Südseiten der Seen; jene Ufer, welche der Sonnenwärme am meisten ausgesetzt sind, zeigen eine frühere Entwicklung der Vegetation, was Wesenberg-Lund ${ }^{1}$ ) besonders hervorgehoben hat.

Es gibt natürlich auch Vegetationsunterschiede nach der Größe des Wasserbassins; ein großer See wird in dieser Hinsicht von einem kleinen Tümpel verschieden sein.

Ein besonders wichtiger Faktor ist die Periodizität des Wasserstandes (vergl. 20. Kap.). Für die in tieferem Wasser wachsenden Pflanzen spielt sie gewöhnlich keine Rolle; aber an den flachen Ufern gibt es ein Grenzgebiet, das auf eine größere oder geringere Breite für kürzere oder längere Zeit trockengelegt werden kann; hier kommen alsdann ganz andere Assoziationen zur Entwicklung als anderswo. Die Schwankungen des Wasserstandes können durch verschiedene Ursachen hervorgerufen werden, das Anschwellen z. B. durch die Schneeschmelze im Frühjahr, oder durch gewöhnliches Hochwasser im Frühjahr durch lange andauernden Regen, die Senkung durch Verdunstung des Wassers in langen Trockenzeiten.

Dieses Überschwemmungsgebiet oder die sandigen Ebenen der Tropen, die in der Regenzeit überschwemmt werden, mit ihren mehr oder weniger amphibischen Pflanzen haben ihre eigenen Assoziationen, die sowohl von der eigentlichen Sumpfvegetation als auch von der an dem starken Wellenschlag exponierten Standorten vorkommenden verschieden sind.

Die Formationen der Ufervegetation sind verschieden, man kann mindestens folgende unterscheiden.

1. Die Rohrsümpfe aus vielen verschiedenen Assoziationen von ausdauernden Kräutern, namentlich Hochstauden gebildet Kap. 63.

2. Die Sumpfgebüsche und Sumpfwälder Kap. 64.

3. Die amphiphytische ${ }^{2}$ ) Ufervegetation aus niedrigeren, oft periodisch trocken gelegten Kräutern. Die Formation der Quellfluren Kap. 65.

Hieran schließen sich noch andere Formen von Süßwasservegetation, z. B.

4. Vegetation des Alluviallandes der Flüsse. Uferwaldungen Kap. 66.

1) Wesenberg-Lund 1912 .

2) Schröter u. Kirchner 1902, S. 42. 


\section{Kap. Formationen der Sumpfpflanzen}

Die Sumpf- und Moorpflanzen sind an seichtes und ruhiges Wasser gebunden, oder an Boden, der jedenfalls während eines längeren Zeitraumes eine bedeutende Wassermenge (vermutlich über $80 \%$ ) enthält. Der Boden ist lose, oft sogar sehr lose und weich, ferner meist reich an Humus (Torferde, Schlamm; vergl. 13. Kap.). Es gibt unzweifelhaft Unterschiede zwischen der Vegetation, welche an nährstoffreiches, besonders an kalkreiches Wasser gebunden ist ("swamps" der Engländer) und derjenigen, die in nährstoffarmem oder in säurereichem Wasser wachsen. Es ist aber noch nicht möglich, einen allgemeinen scharfen Unterschied zu fixieren, im allgemeinen weisen die ersteren einen starken, die letzteren einen schwachen Jahreszuwachs auf.

Die Anpassungen an die Standorte werden im allgemeinen folgende sein.

1. Die Sumpfpflanzen sind (wie die Wasserpflanzen) vorzugsweise mehrjährig (S. 270).

2. Viele Sumpfpflanzen bilden leicht Beiwurzeln und haben kriechende Grundachsen oder Ausläufer. Unterirdisch sind diese bei Equisetum limosum, Phragmites, Typha, Acorus, Butomus, Scirpus lacustris, S. (Heleocharis) palustris, Eriophorum angustifolium und E. alpinum, Sparganium, Carex limosa, C. chordorrhiza, C. acutiformis u. a. Arten, Epipactis palustris, Scheuchzeria palustris u. a. Monokotylen, Myrica gale, Rubus chamaemorus, Andromeda polifolia, Vaccinium uliginosum, Lysimachia vulgaris und L. thyrsiflora, Ranunculus lingua, Sium latifolium (knospenbildende Wurzeln) u. a. Oberirdische Wandersprosse finden sich besonders in Mooren: bei Vaccinium oxycoccus, Narthecium ossifragum, Hydrocotyle vulgaris, Lycopodium inundatum n. a.

Rasenbildende Pflanzen mit einer geringen vegetativen Wanderfähigkeit oder ohne solche kommen jedoch auch vor, z. B. Lythrum salicaria, Cicuta virosa, Alisma plantago, Rumex hydrolapathum u. a. Oft wachsen sie teilweise in ihrem eigenen Abfalle und erheben sich auf ihren eigenen Resten immer höher; ein Grund hierfür ist offenbar der, daB das Wasser in diesen schwammigen Rasen, wo Stengel- und Blattreste nebst Wurzeln miteinander verfilzt sind, kapillar gehoben wird. Hierher gehören Eriophorum vaginatum, Scirpus caespitosus, Carex stricta, paniculata, Aera discolor (A. uliginosa) u. a.

Außerdem kommen Pflanzen mit anderem Wuchs vor; z. B. müssen solche, die auf Sphagnum vorkommen, die Fähigkeit haben, mit dem wachsenden Boden emporzuwachsen (P. E. Müller). 
3. Als Anpassung an die geringe, in gewissen Fällen durch bebesondere Verhältnisse (Aufhäufen organischer Reste, Torfbildung, 13. und 16. Kap.), Verweben von Wurzeln und anderem, was eine Luft abschließende Decke bildet) verringerte Luftmenge des feuchten Bodens finden sich hier innere Lufträume in Stengeln, Blättern und Wurzeln, wie bei den Wasserpflanzen. Besondere Einrichtungen sind:

a) Das Aerenchym ${ }^{1}$ ), d. h. ein Gewebe von dünnwandigen, nicht verkorkten Zellen, das wie Kork sein eigenes Kambium hat und große, Luft führende Intercellularen bildet (Fig. 140, S. 273). Äußerlich tritt es als weiße, schwammige Hülle auf (bei Epilobium hirsutum u. a. Arten, Lythrum salicaria, Lycopus Europaeus, der Mimosacee Neptunia oleracea u. a.).

b) Atemwurzeln (Pneumatophoren). Bei einigen Bäumen und Sträuchern werden wie in den Mangrovesümpfen (S. 404) senkrecht a ufwärts wachsende Wurzeln gebildet, deren Spitzen über das Wasser hervortreten und die durch ihre Pneumathoden, d. h. durch die Lenticellen oder durch andere Verbindungen mit der Atmosphäre, dem Intercellularsystem der im Schlamme wachsenden Teile Luft zuführen (Goebel, Wilson, Schenck, Schimper, G. Karsten). Sie finden sich bei gewissen Palmen, Taxodium distichum u. a., vielleicht auch bei Jussieua repens (Goebel). An vielen Standorten wird das Wasser wahrscheinlich auch arm an Sauerstoff sein. Abbildung eines Taxodium-Sumpfes siehe im nächsten Kapitel.

4. Die Assimilationsorgare der eigentlichen Sumpfpflanzen sind gewöhnlich mesomorph, aber bei einer beträchtlichen Anzahl kommt auch Xeromorphie vor. Diese wird Kap. 80 ff. näher besprochen werden.

Viele Sumpfpflanzen sind heteroblastisch; ihre aufeinander folgenden Blätter sind voneinander wesentlich verschieden. Die Anpassungsfähigkeit an die äußeren Verhältnisse des Standorts sind sehr groß, und eine Menge Blattformen werden in Epharmonie mit dem Leben im Wasser oder in der Luft entwickelt ${ }^{2}$ ).

Als Beispiel kann Sium latifolium erwähnt werden. Die untersten untergetauchten Blätter haben doppelt fiederteilige Blättchen mit linealischen Zipfeln, während die der Luftblätter schief lanzettlich, ungeteilt und scharf gesägt sind.

5. Die Samen und die Früchte vieler Sumpfpflanzen sind mit Lufträumen und anderen Einrichtungen versehen, die sie bei der Verbreitung durch Wasser unterstützen ${ }^{3}$ ), sind also ganz wie bei den Wasserpflanzen eingerichtet.

1) Schenck 1889.

2) Vergl. Costantin 1886; Schenck 1886; Glück 1905-11; Baumann 1911.

s) Vergl. Ravn. 


\section{Kap. Rohrsümpfe}

Diese namentlich von hohen monokotylen Stauden gebildete, in mehr oder weniger tiefem, meist stillem oder langsam fließendem Wasser wachsende Vegetation scheint sich den nährstoffreichen Vereinen der Süßwasserpflanzen am nächsten anzuschließen; zwischen den einzelnen Sprossen oder Blättern sieht man im allgemeinen überall das klare Wasser, das gerade hier oft Vertretern des Megaplanktons Platz gibt. Die Assoziationen bilden oft lange ununterbrochene Gürtel an den Ufern von Seen und Flüssen und spielen eine landschaftlich wichtige, physiognomische Rolle. Bei der Verlandung der Gewässer sind sie von größter Bedeutung; als Pioniere der Landvegetation und als Wellenbrecher schreiten sie vor und erobern Land (Näheres im 5. Abschnitte).

Flora in nordeuropäischen Gewässern. Von den verschiedenen Gattungen oder Arten, die sich hier finden, seien angeführt Phragmites communis, Scirpus lacustris, S. Tabernaemontani, Typha, Butomus umbellatus, Glyceria spectabilis u. a. Arten, Phalaris arundinacea, Iris pseudacoms, Cladium mariscus, Carex paniculata, C. gracilis, C. filiformis, C. acutiformis, C. stricta, C. riparia, C. vesicaria u. a. Arten, Alisma plantago, Sagittaria, Sparganium ramosum, S. simplex, Acorus calamus und Calla palustris, die die wichtigsten bei uns vorkommenden monokotylen Vertreter dieser Vereinsklasse sind; daran schließen sich Equisetum heleocharis und von den Dikotylen Senecio paludosus, Sonchus paluster, Menyanthes trifoliata, Lythrum salicaria, Epilobium hirsutum, Rumex hydrolapathum, Lysimachia vulgaris und L. thyrsiflora, Ranunculus lingua, Oenanthe aquatica, Sium latifolium, Cicuta virosa und viele andere. Wo diese Sumpfformation sehr offen ist, wird man vielfach eine Mischassoziation von Sumpfpflanzen finden, namentlich in den Scirpeten mit Nymphaeeten, und natürlich auch mit Plankton.

Die großen und herrschenden Arten dieser Formation lassen oft eine eigentümliche Verbreitung erkennen. Manche Teiche und sogar mittelgroße Seen sind von nur einer herrschenden Art der "Hochgräser" eingefaßt, so z. B. öfter von Phragmites communis oder von Typha angustifolia. An anderen, besonders an den großen Seen, an den Ausbuchtungen großer Flußläufe sieht man die einzelnen herrschenden Arten zwar größere Bestände bilden, aber nach kürzerer oder längerer Strecke werden sie von einer anderen Art abgelöst, häufig, ohne daß auch an den Rändern eine Mischung eintritt. Der Grund für diese eigenartige Ablösung ist nicht leicht anzugeben und auch nicht ganz klar. Es scheint, als ob die erste besiedelnde und sich kräftigende Art wenigstens für lange Zeit die Oberhand an der betreffenden Stelle behält und der Konkurrenz der anderen erfolgreich Widerstand leistet. 
Ordnung der gürtelförmigen Assoziationen. Nach der Tiefe des Wassers und vielleicht nach anderen davon abhängigen Verhältnissen (Licht, Wärme, Wasserbewegung) ordnen sie sich in Gürteln, die in einem großen Teile von Europa ungefähr dieselben sind und fast reine Bestände sein können ${ }^{1}$ ). $\mathrm{Zu}$ bemerken ist doch, daß die Arten nicht immer in derselben Reihenfolge vorkommen.

Folgende Assoziationen kommen vor, hier soweit möglich in der Reihenfolge vom tieferen zum seichteren Wasser angeführt.

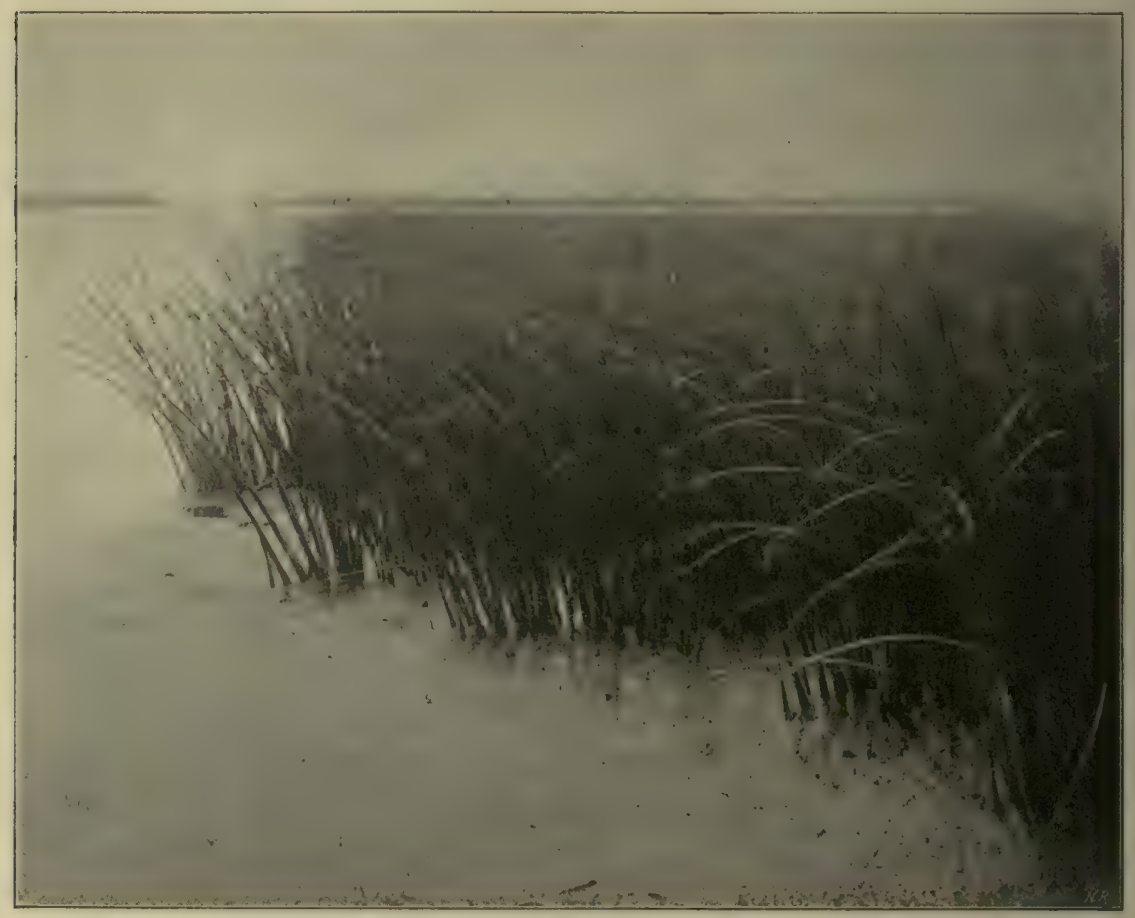

Fig. 250. Scirpetum Tabernaemontani, bei niedrigem Wasserstande trockengelegt. (Phot. Eug. Warming.)

Scirpeta von Scirpus lacustris oder S. Tabernaemontani gebildet. Die blattlosen, von nur einem einzigen gestreckten Stengelglied gebildeten Stengel mit dem Blütenstande an der Spitze werden 2-3,5 m lang; gewöhnlich und am üppigsten finden die Assoziationen sich bei $1-2 \mathrm{~m}$ Wassertiefe. Diese Art geht nicht in die Landvegetation hinein; kann aber Wasserblätter bilden.

Phragmiteta von Ph. communis, dem Rohr oder Schilfrohr. Diese Art hat eine außerordentlich weite Verbreitung; sie bildet in

1) Vergl. Magnin in Jura: 1893, 1894; Kirchner u. Schröter 1896-1902; Warming 1897 a; Gadecean 1909. 
einer Ausdehnung von vielen Quadratmeilen undurchdringliche Bestände (Phragmiteta) und schwimmende Rohrdecken im Donaudelta, in den Deltas im kaspischen Meer und im Aralsee, ja selbst in Australien; sie

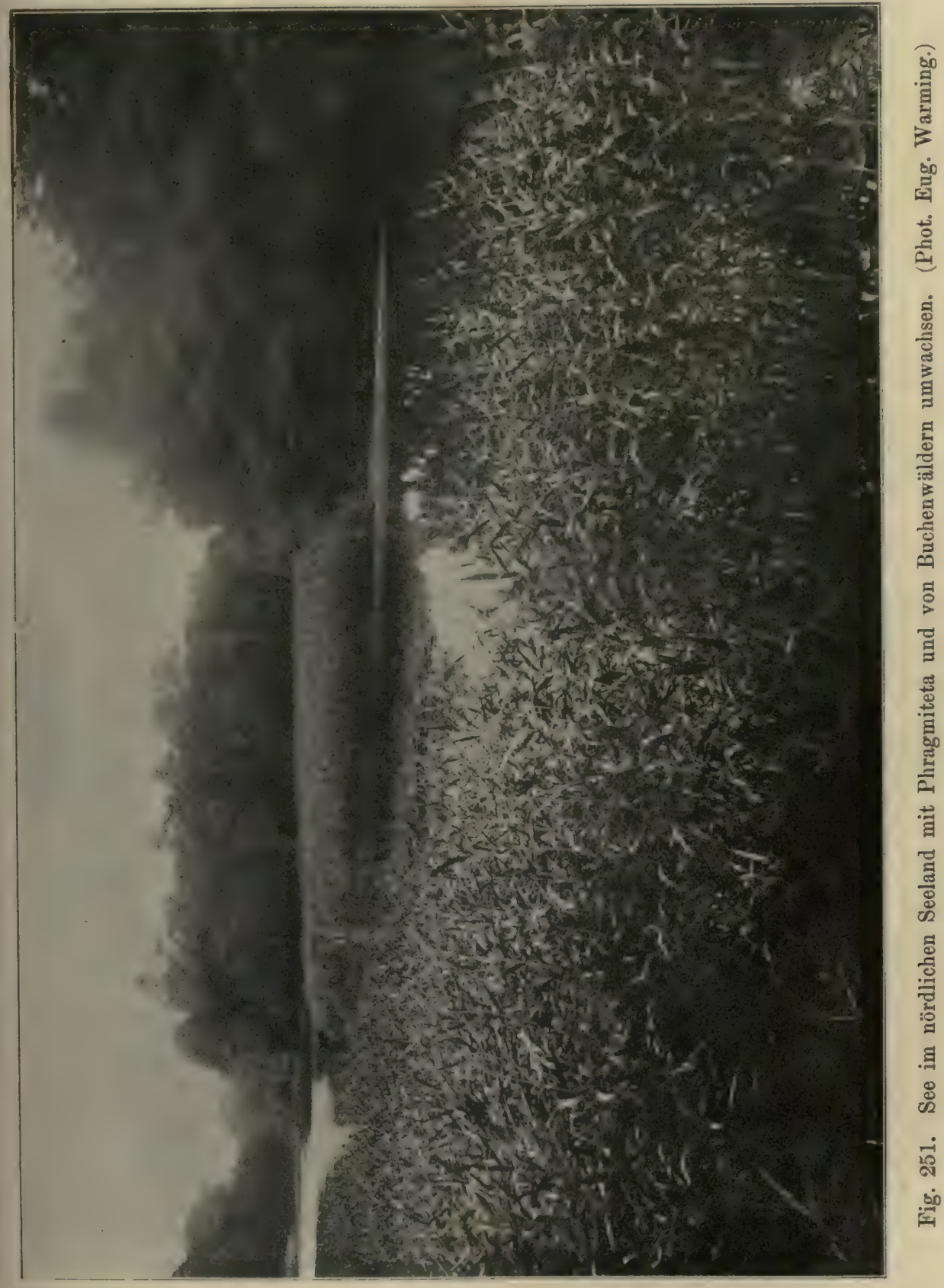


erreicht am Syr Darja eine Höhe von $6 \mathrm{~m}$. In Deutschland in der Lausitz wächst die Rasse pseudodonax, die sogar fast $10 \mathrm{~m}$ hoch wird und wohl identisch ist mit dem aus manchen Tropenseen erwähnten Riesenrohr; wie es auch in Westindien ("Canna indica" nach Urban) eingebürgert ist ${ }^{1}$ ). Sie erträgt Salzwasser gut und kann in einer Wassertiefe von $3 \mathrm{~m}$ wachsen. In den Mittelmeerländern bildet es bisweilen mit den oft mehrere Meter hohen Gräsern Arundo donax und Erianthus Ravennae Vंereine. Als Beispiele für seine Fähigkeit, sich nach den Verhältnissen zu richten, sei noch angeführt, daß es an vielen Stellen der Nordsee und anderwärts auf die Dünen hinaufgeht und oberirdische Ausläufer bis zu 6 und mehr Meter Länge bildet (Inseln Manö, Fanö usw.). Sie vermag noch auf wenig wasserreichem Boden, z.B. in einem Niederungsmoor, zu gedeihen, wenn auch kümmerlich; ist aber auch fast gar nicht hydrophytisch angepaßt. Die Phragmiteta sind oft so dicht, daß die Sonne nicht zum Wasser hinab dringen kann, was wohl meistens in den Scirpeta lacustris der Fall ist.

Wie starke Trockenheit Phragmites zu ertragen vermag, zeigen die Beobachtungen von Schweinfurth in Ägypten, wo die Art bis an die Wüstenränder wächst, ganz niedrig bleibt und die eingerollten Blätter und kurzen Triebe fast stachelartig abstehen. Ganz ähnliche Erscheinungen zeigten sich an den Ufern des Schlachtensee bei Berlin, in den Jahren als das Wasser des Sees etwa $3 \mathrm{~m}$ abgesunken war und die Phragmiteten dadurch an dem Rand der sonnbestrahlten sandigen Böschung zu stehen kamen.

Typheta, T. angustifoliae und T.latifoliae, sind auch gemein, besonders auf schlammigem Boden. Sie erreichen Höhen von meist 3 bis $4 \mathrm{~m}$, werden aber noch höher; die südeuropäische T. Schuttleworthii wird sogar bis $15 \mathrm{~m}$ hoch.

Glycerieta G. aquaticae (G. spectabilis) und andere Arten, können auch sehr ausgedehnt sein; auf dem salzhaltigen Boden am - Neusiedlersee bildet diese Art "wahre Graswälder" fast von 2 m Höhe, auch an den Havelufern (Havelmielitz, Schilf) bildet sie ausgedehnte Bestände, oft neben Phragmites und Scirpus lacustris.

Phalaris arundinacea kann auch reine Assoziationen bilden, die doch niedriger und weniger dicht sind; gewöhnlich sind Nebenbestände in den anderen Assoziationen.

Eine ähnliche Rolle spielt Butomus umbellatus, der stellenweise (so öfter im norddeutschen Flachlande) an durch die Schiffahrt usw. bewegten und verschmutzten Buchten die Herrschaft auf große Stellen erreicht hat.

1) Ascherson-Graebner Synopsis II etc.; Graebner in Aus der Natur X. 
63. Kap.

In seichterem Wasser finden sich folgende Assoziationen:

Equiseteta E. limosi; fast reine, graugrüne, eigentümliche Assoziationen.
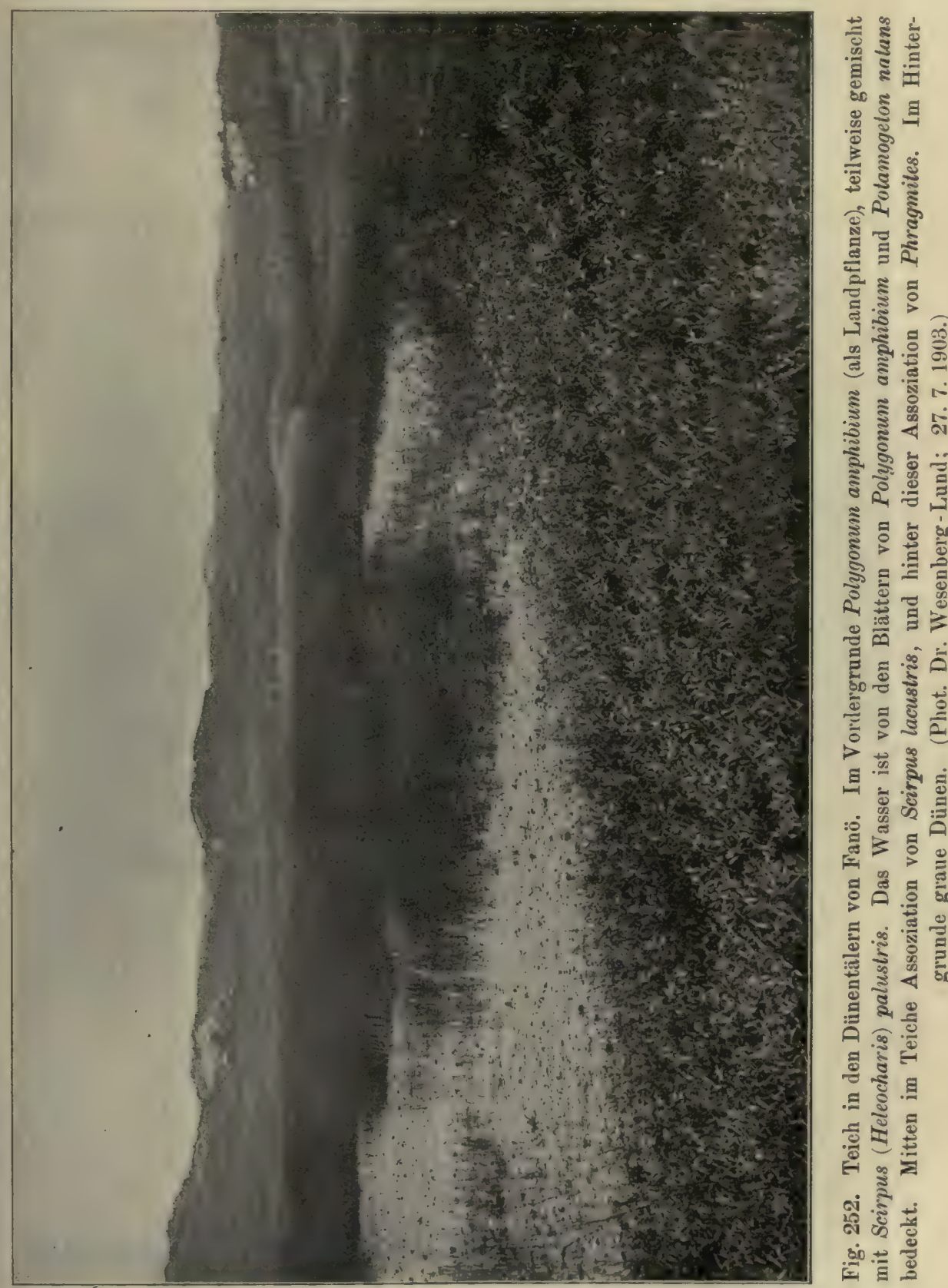
Heleochareta lacustris; dunkelgrün, auch auf den nassen Landboden einwandernd (Fig. 253).

Ebenso in seichtem Wasser und an der Grenze von Land und Wasser treten auf die:

Magnocariceta aus größeren, vorzugsweise geselligen, kriechenden Arten gebildet (wie Carex acutiformis, C. vesicaria, C. rostrata, C. riparia), oft aber auch aus mächtigen Bülten zusammengesetzt (so namentlich durch Carex stricta, C. disticha, C. paradoxa, C. paniculata usw.), Fig. 256.

Die großen Bülten von Carex stricta stehen mehr oder weniger isoliert im Wasser, und zwischen ihnen gedeihen oft Wasserpflanzen

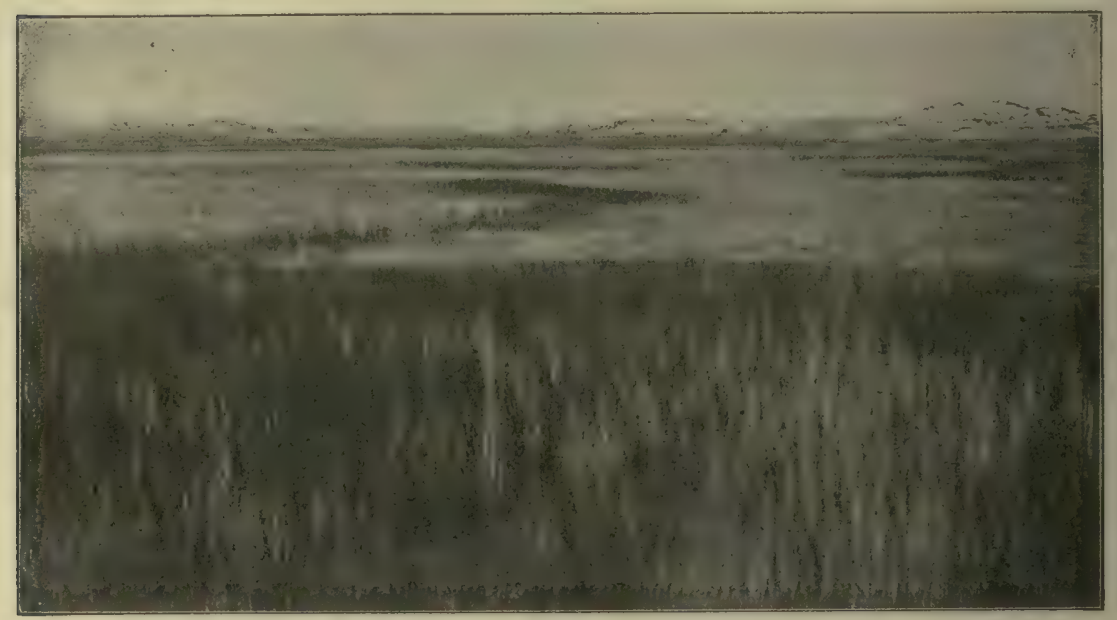

Fig. 253. Assoziation von Scirpus (Heleocharis) palustris in einer sandigen Dünengegend in Jütland. Zwischen den zahlreichen Sprossen von Heleocharis finden sich zerstreut: Juncus lamprocarpus, Polygonum amphibium, Lobelia Dortmanna, Lysimachia thyrsiflora u. a. Viele Algen sind an die Heleocharis-Sprosse geheftet oder vegetieren zwischen ihnen. (Phot. Eug. Warming.)

wie Wassermoose, Characeen, Potamogetonen u. a. Diese Magnocariceta spielen eine wichtige Rolle bei der Verlandung. Sie kommen nur in nährstoffreichen Gewässern vor (die Distrophophyten von Gadeceau).

Zwischen ihnen und am inneren Rande der Assoziationen der großen Monokotyledonen und geschützt von ihnen gegen die Gewalt der Wellen treten eine Menge schwächere Arten auf, z. B. Alisma plantago aquatica, Iris pseudacorus, Rumex hydrolapathum, Caltha palustris, Ranunculus lingua, Epilobium hirsutum, Lythrum salicaria, Oenanthe fistulosa, Cicuta virosa und viele andere. Auch von diesen können einige ziemlich reime Assoziationen bilden, z. B. Iris pseudacorus (Fig. 255) und Sium latifolium, dessen Individuen sich besonders blühend durch die weißen 
Blütenstände bemerkbar machen. Als Unterwuchs in den Rohrsünıfen können verschiedene Moose usw. auftreten ${ }^{1}$ ).

Genau dieselben gürtelförmigen Assoziationen wie in Nordeuropa kommen in Nordamerika wieder. Nach Transeau ${ }^{2}$ ) folgt in den Michigan-Seen nach der Wasservegetation, die aus Potamogeton und Nymphaea besteht, die "cat-tail-Dulichium-Assoziation" mit Typha, Phragmites und Dulichium. Weiter binnenländisch folgen die "CassandraSociety", Strauch- und Jungbaum-Assoziation und Wald. Cowles ${ }^{3}$ ) findet

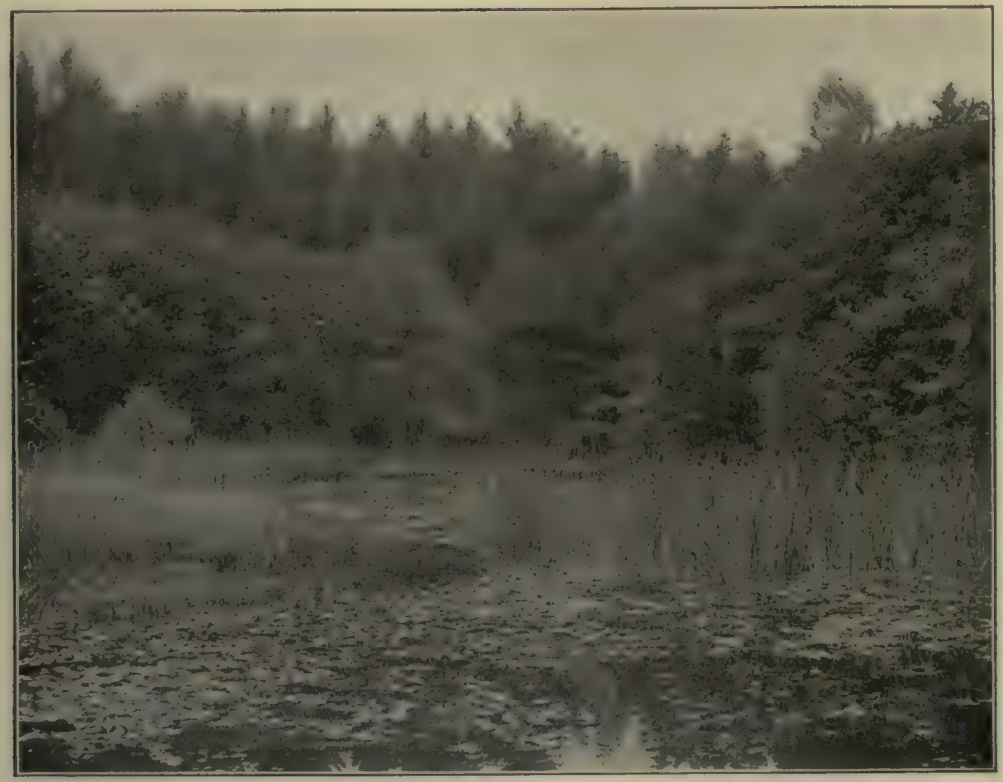

Fig. 254. Ein Teich in Nord-Seeland, Mitte Juli. Die Wasserfläche ist von Potamogeton natans gedeckt. Rechts streckt sich eine Assoziation von Scirpus lacustris weit hinein, links ebenso ein Caricetum rostratae. Im Hintergrunde links Typhetum latifoliae und Scirpetum lacustris. Der Teich ist links von einem Alnetum incanae umgeben; rechts Buchenwald; im Hintergrunde Fichtenwald (Piceetum excelsae).

(Phot. Mag. Ö. Winge, 1907.)

in der Umgebung von Chicago folgende Zonen: 1. Chara, 2. Nymphaea, 3. Carex und Scirpus, 4. Cassandra calyculata und andere Sträucher, 5. Wald. An anderen Stellen folgt auf die Cariceta die Graswiese ${ }^{4}$ ).

1) Über die Rohrsümpfe usw. in Europa vergl. Kerner, Warming 1897 a; Schröter ฉ. Kirchner, Gadeceau 1909; Marietta Pallis bei Tansley 1911.

3) Transean 1903, 1905.

ग) Cowles 1901.

4) Vergl. auch Pieters 1894, 1901; Hitchcock 1898; V. Borbás (Bernátsky) 1907;

Früh u. Schröter 1904. 
In Virginia kommen nach Kearney ${ }^{1}$ ) ähnliche Rohrsümpfe vor, in denen er Assoziationen von Typha-Sagittaria längs der Flüsse und von Scirpus-Erianthus am Rande der Waldsümpfe unterscheidet. Hier kommt auch die Arundinaria macrosperma-Assoziation vor, welche große Flächen der Dismal-Sümpfe überzieht. Längs der Flüsse wachsen nach Harshberger ${ }^{2}$ ) in Pennsylvanien ausgedehnte Rohrsümpfe, in welchen er verschiedene Assoziationen unterscheidet, darunter die von Zizania, von Typha, von Sagittaria latifolia und Ambrosia trifida. In Sümpfen mit langsam fließendem Wasser findet man andere Assoziationen, dar-

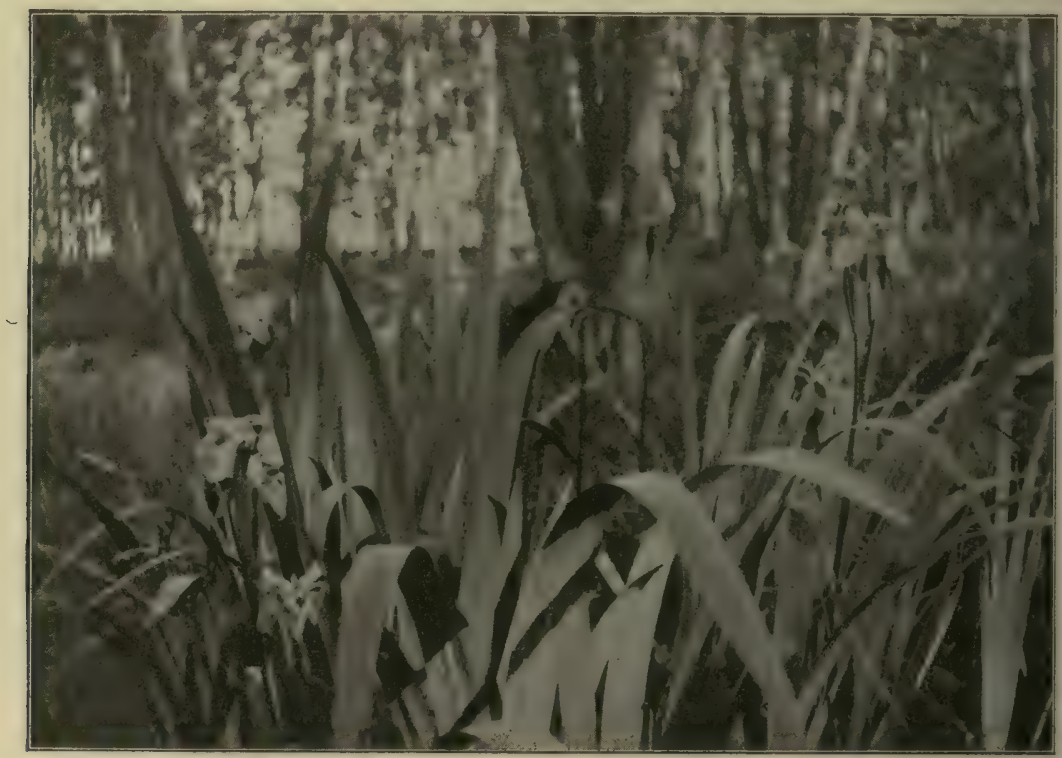

Fig. 255. Bestand von Iris pseudacorus am Erlenbruchrande. (Phot. R. GroB.)

unter die von Symplocarpus (mit Spathynema foetida und Arten von Osmunda), von Iris - Typha - Acorus und von Heracleum - Veratrum Eupatorium. Überall ist die Physiognomie und bis zum gewissen Grade sind auch die Gattungen dieselben wie in Europa.

In arktischen Gegenden kommen solche Assoziationen von Hochstauden nicht vor; aber es können sich noch solche von kleineren Arten finden, wie z. B. von Hippuris vulgaris (Fig. 257), von Menyanthes trifoliata, von Eriophorum Scheuchzeri oder nordischen Sparganien. Sumpfpflanzen fehlen auch in den Hochalpen nach Jos. Braun; sind aber in anderen Gegenden in hohen Gebirgslagen vorhanden.

1) Kearney 1901. Utber Nordamerika vergl. ferner Pool 1913.

2) Harshberger 1904. 
In Südeuropa tritt schon Cyperus Syriacus auf, "Graswälder" bildend, und besonders weit ausgedehnte und mächtige Assoziationen bildet Cyperus papyrus im inneren Afrika, z. B. am oberen Nil, "Sadd" genannt ${ }^{1}$ ). In lagunenartigen Altwässern nehmen sie ihren Ursprung, Hochwasser hebt die Pflanzendecke empor, bis sie schließlich losreißt und als schwimmende Insel weiterlebt. Stellenweise werden sie zu gewaltigen Barren zusammengeschoben, welche der Schiffahrt fast unüberwindliche Hindernisse entgegenstellen. Mit zur Bildung des "Sadds" helfen auch andere, so namentlich Arten von Aeschynomene (Deuerling).

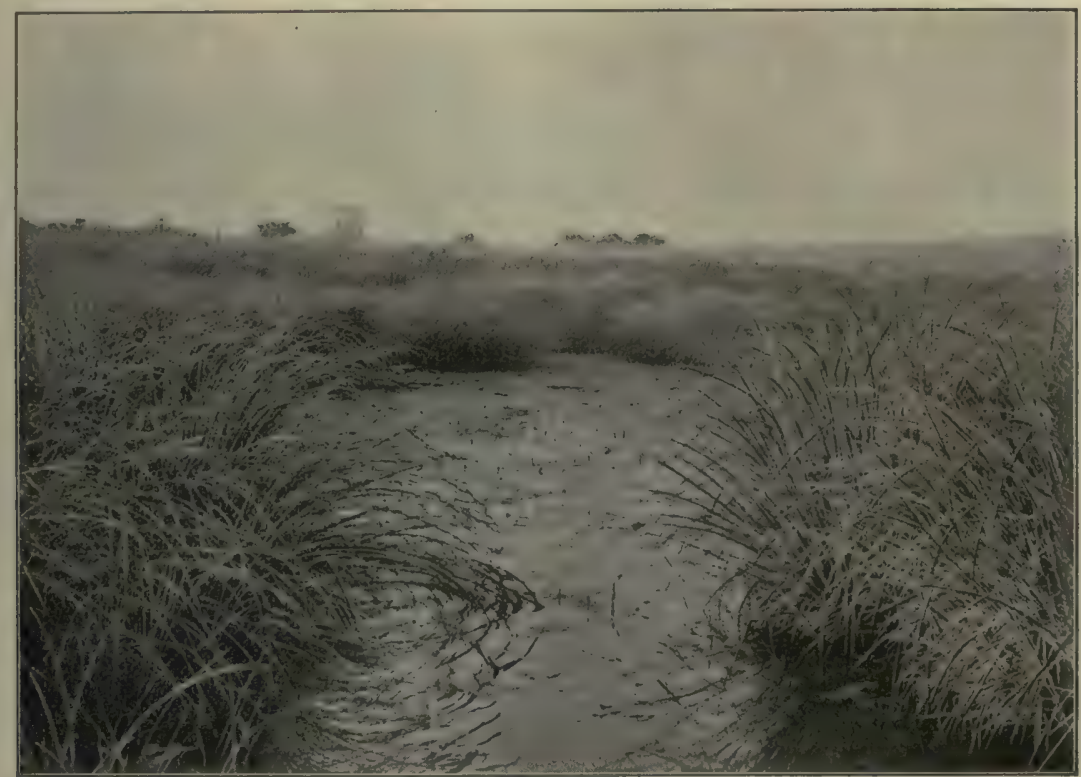

Fig. 256. Moortümpel von Assoziationen der Rohrsümpfe umgeben und mit Potamogeton natans auf der freien Wasserfläche. Das Wasser ist am nächsten begrenzt von einem Magnocaricetum, bestehend namentlich aus Caricetum strictae. Weiter nach außen auf weniger wasserreichem Boden eine Assoziation von Calamagrostis lanceolata.

(Phot. C. Raunkiär.)

Andere Typen von Sümpfen von krautartigen Pflanzen in Afrika werden von Marloth und Engler ${ }^{2}$ ) erwähnt, nicht nur Phragmiteta, Typheta und Cypereta papyri, sondern auch Scitamineta, Zantedeschieta u. a. und gemischte Assoziationen von diesen Arten und vielen anderen. Eine besondere Assoziation ist die vom Palmietto (der Juncacee Prionium palmito) in Südafrika gebildete. "Zu Tausenden“, sagt Marloth, ,stehen die dicht gedrängten Stämme in dem sumpfigen Gelände der Flußläufe. Sie hindern den Lauf des Wassers in solchem Maße, daß

3) Vergl. Hope 1902 in Ann. of Botany XVI.

2) Marloth 1908; Engler, Die Pflanzenwelt Afrikas. 
an einer Lokalität das Gebirgswasser vier Tage gebraucht hat, um eine Strecke von sieben Stunden zurückzulegen". Buchenau ${ }^{1}$ ) hat den Bau der Stämme untersucht; „als Wasserspeicher dient vor allem das reich entwickelte Schwammparenchym, welches durch die dicke, wohl die Hälfte der Stammasse bildende Faserhülle wirksam gegen Wasserverlust nach außen geschützt ist".

Im warmen Amerika finden sich andere, teils aus europäischen Gattungen, teils aus ganz anderen gebildete ähnliche Sümpfe; die Ufer des Valencia-Sees in Venezuela sind von dichten Rohrsümpfen aus Typha

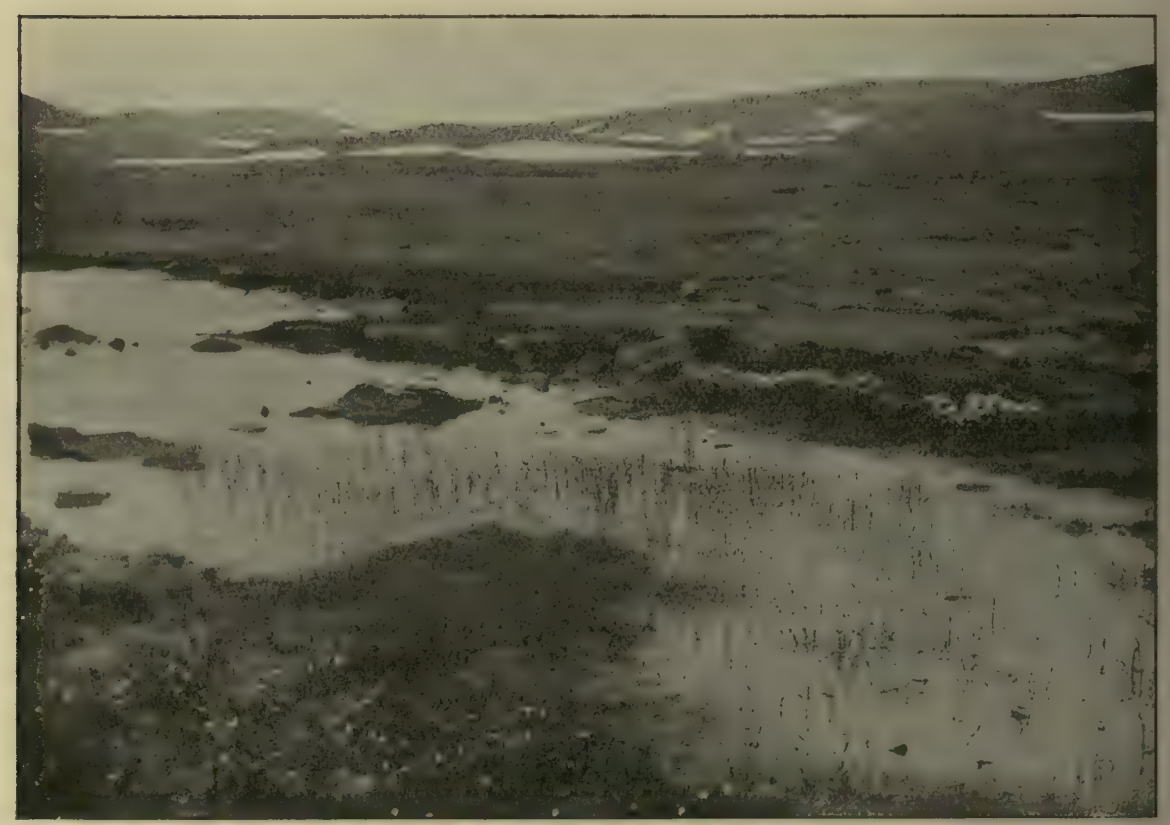

Fig. 257. Assoziation von Hippuris vulgaris in Nordost-Grönland. (A. Lundager 1912 in "Danmark-Expeditionen".)

Domingensis umgeben, die höher als mannshoch werden, die U'fer des Titicaca desgleichen von der Cyperacee Malacochaete tatora usw.

Von den Araceen sind viele Arten Sumpfpflanzen, wie gewöhnlich mit pfeil- oder herzförmigen Blättern; dichte, oft mehrere Meter hohe Bestände werden von ihnen gebildet, z. B. von Montrichardia arborescens auf Trinidad und den angrenzenden Teilen Südamerikas, von Caladium u. a. (vergl. Martius). Von Scitamineen treten HeliconiaArten ähnlich im tropischen Amerika auf, ja selbst riesige Amaryllidaceen (Crinum) begleiten die Flüsse von Guayana. Selbstverständlich

1) Buchenau 1893. 
sind diese Vegetationen nie absolut rein; andere, vielleicht sogar viele andere Arten sind den hier genannten tonangebenden Arten beigemischt.

Dickichte von Gunnera Chilensis begleiten die Fluß-und Bachufer im südchilenischen Urwalde ${ }^{1}$ ). In den tropischen Ländern treten Holzpflanzen in größerer Anzahl auf und beeinflussen das Gepräge der Rohrsümpfe. Die Physiognomie dieser tropischen Staudensümpfe ist

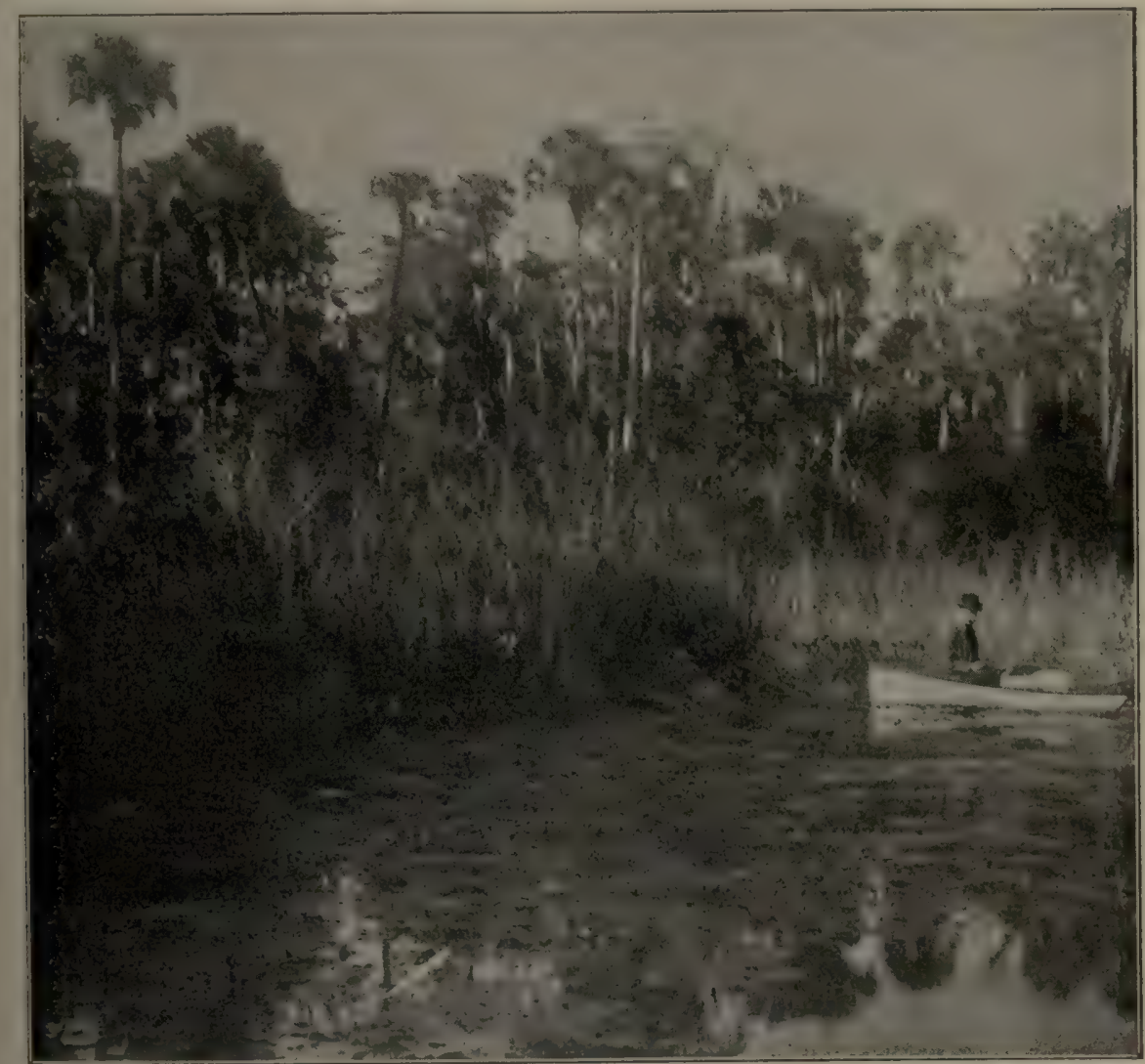

Fig. 258. Sumpfregetation in Lake County, Florida, mit Arundinaria, Taxodium und Sabal palmetto. Febr. 1893. Dedit Th. Holn.

durch diese abweichenden Formen von der der europäischen sehr verschieden.

In extratropischen Südamerika, z. B. in Uruguay, kommen nach Gassner tỵpische Rohrsümpfe vor, zusammengesetzt aus dichten Horsten hoher Gräser (Panicum, Paspalum, Andropogon oder Phragmites communis). In die Zwischenräume eingestreut finden sich Sträucher und Halbsträucher.

2) Dusén u. Neger 1908.

Warming - Graebner. 3. Anflage, illustr. 


\section{Anpassungen}

Nur die Krautsümpfe der nördlich temperierten Länder sind, was Lebensformen und Anpassungen betrifft, einigermaßen gut bekannt.

Fast alle Arten sind mehrjährige Kräuter, zweijährig z. B. Ranunculus sceleratus. Besondere, knollenförmige Überwinterungs- und Vermehrungsorgane (Stengelknollen auf Ausläufern) hat Sagittaria. Eine und die andere Holzpflanze kann sich auch einfinden (Salix cinerea, Alnus glutinosa u. a.).

Kräftige kriechende Grundachsen bringen bei gewissen Arten geselliges Wachstum und dichte, reine Bestände hervor (Phragmites, Seirpus lacustris, Equisetum heleocharis, Typha usw., im Nil z. B. Cyperus papyrus). Die Bildung von Wurzelsprossen, die besonders an trocknen Orten auftritt, ist in der Vegetation der Rohrsümpfe selten (Sium latifolium); desgleichen sind rasenbildende Arten selten.

Die Laubsprosse sind verschieden gebaut, hauptsächlich nach 3 Typen: 1. Der oben erwähnte Typus von Scirpus lacustris, S. Tabernaemontani usw. mit den langen, blattlosen Stengeln; 2. neben langen, linealischen Blättern, die vom Rhizom oder von dem Grunde des blühenden Stengels ausgehen, finden sich hohe Schäfte, die den Blütenstand tragen (Typha, Acorus, Butomus usw.); 3. hohe Halme mit langen, in zwei Reihen abstehenden Blättern bei den Gräsern u.a. - Gemeinsam ist, daß die vorherrschenden, meist monokotylen Pflanzen, die das Gepräge der Vegetation hervorrufen, hoch, schlank und unverzweigt sind. Selbst bei einer Ranunculacee wie Ranunculus lingua findet sich derselbe Habitus wieder, so daß sich auch in diesem vermutlich eine Anpassung ausdrückt, deren Natur noch unklar ist. Jedoch kann hervorgehoben werden, daß diese hohen, schlanken Sprosse Winden, Wellen und Strömungen leicht und elastisch ausweichen und sich wieder aufrichten; besonders gilt dieses für die in sehr tiefem Wasser wachsenden Sprosse und Blätter (von Scirpus lacustris, Sparganium, Typha, Phragmites u. a.).

Die Rohrsümpfe und die an ihrem äußeren (dem Lande näheren) Rande auftretenden Assoziationen (Magnocariceta usw.) bilden oft ein Entwicklungsglied in einer Reihe, die mit den folgenden, aus Holzpflanzen gebildeten Assoziationen abschließt. Diese letzteren werden deshalb hier angeschlossen, obgleich sie gewöhnlich namentlich durch Säurebildung in Wasser abweichen. Während die Rohrsümpfe besonders in strömendem Wasser Kalk und Sauerstoff haben („swamps"), wird das Wasser in ihren äußeren Teilen oft sauer und sauerstoffarm („bogs“ der Engländer).

Zu diesem Kapitel vergl. ferner Worth, 1914, in Beihefte z. Bot. Centralbl. 32. 


\section{Kap. Formationen der Sumpfgebüsche und Brücher in Süßwasser}

In Rohrsümpfen und Wiesenmooren kommen oft einige Holzpflanzen vor, aber an anderen Orten werden diese so zahlreich, daß sie Gebüsche und Wälder (Brücher) bilden. In Nordeuropa findet sich ein geringer Anfang zu solchen in den Beständen der Erlen, Birken und Weiden in den Rohrsümpfen an den Ufern süßer Gewässer; als eigene Assoziationen treten namentlich die Erlenbrücher auf.

Die Erlenbrücher Nordeuropas sind von vielen Botanikern besprochen worden ${ }^{1}$ ). Sie können auf einem Schlammboden auftreten, wo zu gewissen Jahreszeiten und vielleicht das ganze Jahr das klare Wasser zwischen den Bäumen steht. Wenn die Erlen in größerer Zahl in einer flachen, offenen Wasserfläche aufsprossen, so geschieht dies oft so, daß sich bei der bekannten Form der Verlandung in dem Wasser zahlreiche Bülten der Magnocariceta (vergl. S. 508) gebildet haben, die bei zunehmendem Alter in ihrer Mitte locker werden und verkahlen (beginnende Hexenringbildung), auf dieser lichten Stelle im Carex-Rasen keimen die Erlen gern, wachsen mit ihren Wurzeln durch die Bülten hinab und wenn sich die Erle ausbreitet, beschattet sie den Carex, auf dem sie Fuß faßte, dieser stirbt allmählich ab und zerfällt. Dadurch wird der obere Teil der Erlenwurzeln, der über das Wasser ragt, frei und die Erlen stehen in der charakteristischen Weise auf "Stelzen". Im Wasser können Assoziationen von Lemma minor, Calla palustris, Stratiotes aloides und anderen Wasserpflanzen auftreten. In älteren Erlenbrüchern wird der Boden von torfbildenden Pflanzenresten aufgefüllt und nach und nach trockener. Viele Landpflanzen wandern dann allmählich ein, z. B. Farne, Moose, Oxalis, Lythrum, Valeriana, Filipendula ulmaria (Spiraea ulmaria), Cicuta virosa, Menyanthes, Carex-Arten u. a., die sich besonders an die trockneren Stellen um den Fuß der Erlen anschließen. Auch Salix-Arten, Viburnum opulus, Rhamnus frangula, Rubus idaeus u. a. können den Erlen beigemischt sein. An andern Orten bilden Humulus lupulus und Urtica dioeca undurchdringliche Dickichte.

Zuletzt kann sich ein Wald bilden, wo der Boden von Assoziationen gewöhnlicher Waldpflanzen bedeckt wird, z. B. von Mercurialis perennis, Stellaria holostea u. a., und die Bodenvegetation kann sehr mannigfaltig werden.

Saliceta bilden anderswo in Europa die Ufervegetation an Seen und Flüssen; sie sind meist aus Arten von Salix zusammengesetzt, und

1) z. B. Abromeit 1912; Fleroff 1907: Graebner 1909; Marietta Pallis bei Tansley 1911. 
Zwar meist aus S. alba, die besonders an norddeutschen Fluß- und Seeufern die charakteristischen hohen Bäume erzeugt, S. fragilis, S. cinerea, S. pentandra und anderen; an diesen Orten beobachtet man besonders häufig Weiden-Bastarde. Zwischen den Weiden wachsen ausdauernde dikotyle Kräuter, wie Lysimachia vulgaris, Epilobium hirsutum, Arten von Valeriana, Filipendula ulmaria, ebenso auch Gräser, wie Calamagrostis lanceolata und Phragmites. Schlinggewächse in diesen Sumpfgebüschen sind Solanum dulcamara, Convolvulus sepium und Humulus lupulus.

Betuleta und Pineta kommen nach Fleroff ${ }^{1}$ ) auf Sumpfland in Rußland vor; beide findet man auch in Norddeutschland, die letzteren sind aber meist niedrig und kränklich. Diese Assoziationen kommen aber meist nicht auf so nassem Boden vor wie die vorigen, insbesondere die Erlenbrüche.

Ausgedehntere Sumpfgebüsche und Sumpfwälder kommen im südlichen Teil der Vereinigten Staaten vor, wo sie sich als ausgedehnte Wälder auf nassem, torfigem Boden erheben. In Virginia sind zwei ähnliche Assoziationen: Wachholder-Sumpf und der "Black-gum-swamp“ mit verschiedenen untergeordneten Assoziationen ${ }^{2}$ ).

Wachholder-Sumpf (Juniper-swamp) wird, mitunter ausschließlich, aus Chamaecyparis gebildet. Der Boden besteht aus sehr saurem Torf, der im Sommer mit 3-6 dm Wasser bedeckt ist.

Black-gum-swamp ist aus Nyssa biflora und Taxodium distichum (Fig. 258) zusammengesetzt. Auf den horizontalen Wurzeln des letzteren entspringen keilförmige Wurzeln, die die Höhe eines Meters erreichen; sie sind denen von Bruguiera der Mangrovesümpfe ähnlich und dlenen gleichfalls als Atemorgane (vergl. S. 404). In dem Schlamm bieten sie die festen Stellen, auf die man treten kann. Viele Epiphyten leben an den Stämmen ${ }^{3}$ ). Im Wasser zwischen den Stämmen wachsen Azolla, Wolffiella und andere. Der Boden ist sauer, aber nicht so torfig und trocken wie bei den Wachholder-Sümpfen. Das Wasser bedeckt in der Regel den Boden 3 bis $10 \mathrm{dm}$ hoch. Nyssa und Taxodium sind laubwechselnd, und ebenso verhalten sich in Virginien im wesentlichen die niedrigeren Pflanzen. Weiter südlich treten dann eine Anzahl immergrüner Sträucher auf, dazu verschiedene kurze Palmen mit Sabal und Chamaerops. In der Nähe der Tropen erscheinen Tillandsia usneoides und andere Epiphyten in den Baumkronen. Nahezu alle in den amerikanischen Sumpfwäldern wachsenden Gehölze sind gegen schnelle Verdunstung geschützt. Spaltöffnungen kommen bei fast allen Arten lediglich auf der Unterseite vor, bei einigen

1) Fleroff 1907.

2) Kearney 1901.

3) Theodor Holm brieflich an Warming. 
sind sie eingesenkt. Im wesentlichen trefen folgende Bildungen auf: Haar- oder Wachsbekleidung, dicke Kutikula und dicke Außenwände der Epidermis, Verschleimung der äußeren Epidermiszellen, Hypoderm, Mehrschichtigkeit des Palisadengewebes. Die starke Entwicklung der Schutzorgane gegen das Vertrocknen ist eine Folge der Bodensäure, die sich in organischen Ablagerungen anhäuft.

Hierher gehören auch Harpers Cypress-Ponds von Taxodium imbricatum gebildet; in nassem Wetter steht das Wasser 2-3 Fuß hoch, aber sie trocknen oft aus und der Boden ist nur von einer dünnen Humusschicht bedeckt.

Auch andere Assoziationen von Sumpfbäumen kommen im atlantischen Nordamerika vor, z. B. Tamarack-Swamps mit Larix Americana und Abies balsamea; Cedar-Swamps von Thuja occidentalis gebildet; Sumpf-Kiefernwald von Pinus Elliottii u. a. m. ${ }^{1}$ ).

In den Tropen kommen mehrere, noch sehr wenig untersuchte Formen von Sumpfwäldern und Sumpfgebüschen vor. Eine kleine Fächerpalme, eine Bactris, bedeckt z. B. auf Trinidad große, sumpfige Gebiete im Tieflande am Caroni-Fluß. Eine andere Palme, Phoenix paludosa, lebt in ostasiatischen Sümpfen. Nach Kurz gibt es in Burma Sumpfwälder, die während der Regenzeit blattlos sind. Koorders ${ }^{2}$ ) gibt eine interessante Schilderung eines Waldsumpfes im Inneren von Sumatra, in dem Atemwurzeln (bei Calophyllum, Eugenia u. a.), Stützwurzeln, Brettwurzeln und merkwürdige besenartige Luftwurzeln vorkommen; letztere sind 1-1,5 m lang. Die physiologische Trockenheit und diese Eigentümlichkeiten des Baues sind eine Folge des Sauerstoffmangels im Boden.

Bambuswald (Bambusetum). Tropische Bambuswälder müssen offenbar als ein Assoziationstypus betrachtet werden, der zu den Sumpfwäldern gehört. Tropische Flüsse sind oft umgeben von Bambusgebüschen, welche meist undurchdringliche Dickichte bilden. Humboldt erwähnt, daß längs des Magdalenenflusses ununterbrochene Wälder von Bambus und bananenblättrigen Heliconia-Arten stehen.

An das Nipetum von Nipa fruticans kann auch hier erinnert werden. Ist unter den salzigen Sümpfen erwähnt (S. 410, Fig. 203).

In diesen Sumpfgebüschen wird wie erwähnt das Wasser, wenn es stagnierend ist, oft braun und säurehaltig, sobald Torfbildung im Boden beginnt. Diese Vereine schließen sich dadurch den Sauerbodenpflanzen (Oxylophyten) an und hätten auch bei diesen untergebracht werden können; anderseits schließen sie sich durch den Wasserreichtum des

1) Vergl. Harper 1906; Bray 1906.

2) Koorders 1907. 
Bodens den eigentlichen Wasserpflanzenvereinen an. Es gibt ja auch Wassertümpel und Gräben in Mooren, wo das Wasser braun, reich an Humussäuren und arm an Nährstoff ist, welche sich doch durch ihre Lebensformen sehr eng an die Wasserformationen schließen. Die Sumpfgebüsche und Sumpfwälder sind eben Zwischenformen zwischen verschiedenen Formationen und wahrscheinlich immer Übergangsglieder in einer Entwicklungsreihe. Eine scharfe Grenze zwischen den Assoziationen des sauren Bodens und des nicht sauren $\mathrm{zu}$ machen ist unmöglich.

Ebenso ist es unmöglich, eine scharfe Grenze zu ziehen zwischen Sumpfwald und dem mesophilen und hygrophilen Walde auf trocknerem, nur feuchtem Lande; es zeigt uns dieses z. B. die semi-aquatischen Urwälder, welche den Amazonas begrenzen, gewöhnlich als "Igapo"1) bekannt, und welche alljährlich überschwemmt werden ${ }^{2}$ ).

\section{Kap. Vegetation der flachen, sandigen und kiesigen Ufer. Periodisch wechselnder Wasserstand}

Von den Rohrsümpfen abweichende Assoziationen kommen auf flachen, sandigen oder kiesigen Ufern vor, wo der seichte Wasserstand periodisch wechselt. Die Ursachen können verschieden sein, und danach werden die Assoziationen verschieden werden. Man kann unterscheiden zwischen :

1. Flachen kleinen Tümpeln, wo in trockenen Zeiten das Wasser verschwunden ist. Hierher zu rechnen ist auch die Vegetation vieler Gräben und anderer zeitweise überschwemmter und überfluteter Stellen resp. solche mit dauernd niedrigem Wasser.

2. Überschwemmungsgebiete am Rande der Flüsse oder überhaupt weite flache Mulden, die in der Regenzeit überschwemmt sind, in der Trockenzeit aber ausgetrocknet daliegen. Engler ${ }^{3}$ ) z. B. erwähnt vom Kapland weite baumlose Ebenen, von tiefem beweglichem Sande bedeckt, welche im Winter und Frühjahr überschwemmt, im Herbste fast gänzlich ausgedörrt sind. Diese Sandfelder sind durch das reichliche Vorkommen von Restionaceen charakterisiert, denen sich halbstrauchige Proteaceen, Ericaceen, Bruniaceen, Thymelaeaceen, Penaeaceen, Verbenaceen hinzugesellen. Mannigfache Assoziationen kommen hier vor; zahlreiche Zwiebel- und Knollengewächse, z. B. Oxalidaceen und manche andere Pflanzen mit wasserspeichernden Knollen. Auch blattsucculente

1) Eine gute Abbildung vergl. Huber Bull. Herb. Boiss. n. s. VI t. 10 (1906).

3) J. Huber 1906.

8) Engler 1910. 
Dikotylen, insbesondere Mesembrianthemum-Arten. In Usambara kommt ebenso nach Engler Grasland der Creeks vor, große Sandfelder, die sich oft stundenlang landeinwärts dehnen und in der Regenzeit größtenteils unter Wasser stehen. Hier wachsen Cyperaceen, Eriocaulaceen, Ipomoea pes caprae u. a. Aus ähnlichen periodischen Teichen erwähnt Marloth Aponogeton distachyum, welches bisweilen Hunderte von Quadratmetern der Wasserfläche mit seinen ovalen Blättern und duftenden weißen Blüten bedeckt. Seine unterirdischen Rhizome sind so stärkereich, daß sie gleich Kartoffeln verwendet werden.

Aus Brasilien erwähnt Ule von den Ufern des Rio São Francisco blumenreiche Flächen von meist kriechenden, niederliegenden Kräutern aus verschiedenen Familien (Heliotropium, Iresine, Evolvulus, Zornia, Cassia, Mimosa u. a.), wogegen Gramineen und Cyperaceen nur spärlich auftreten.

In temperierten Ländern, z. B. Nordeuropa und Nordamerika, kommen ähnliche trockengelegte Mulden und baumloses Alluvialland vor. Nach Hitcheock ${ }^{1}$ ) finden sich z. B. solche im westlichen Kansas, wo doch hapaxanthe Arten allgemein sind. Ähnliches auf Sandflächen in Nordeuropas Dünengebieten (Juncus ranarius, Juncus Balticus, Sagina nodosa, im westlichen Europa Anagallis tenella u. a.).

Eine andere Reihe von hierher gehörigen Lokalitäten findet sich im Grenzgebiete des Landes und der flachen Teiche, wo der Boden sandig und kiesig ist, welches Grenzgebiet ebenfalls dem Wechsel des Wasserstandes ausgesetzt ist. Die hier lebenden Pflanzen, welche also periodisch vom Hochwasser bedeckt werden und bei Niederwasser mehr oder weniger trocken gelegt sind, sind dadurch ausgezeichnet, daß sie oft in auffallender Weise diesem Wechsel des Wasserstandes angepaßt sind, namphibisch" geworden sind ${ }^{2}$ ).

Dieser Gürtel gehört halb zum See und halb zum Lande; es kommen sowohl eigentliche Wasserpflanzen als eigentliche Landpflanzen vor. Gadeceau nennt diesen Gürtel „Heterophylletum“, Schröter und Kirchner haben den Namen "Amphiphyten " für die hierher gehörigen Arten. Sie schreiben ${ }^{3}$ ) etwa: Jeder Teil an der Grenzzone wird jährlich für längere oder kürzere Zeit überschwemmt, welche um so länger ist, je näher er dem See liegt.... So stellt diese Zone einen allmählichen Übergang dar von den Lebensbedingungen vom Lande zum See. Daher sind die bedeckenden Pflanzen in Zonen angeordnet, je nach dem Grade der Anpassung an das Wasserleben. Die geographische "Grenzzone" muß in drei Unterabteilungen geteilt werden: a) Sumpf-

1) Hitchcock 1898.

2) Vergl. namentlich Glück.

3) Schröter (und Kirchner) 1902. 
wiese, die dem trockenen Lande am nächsten liegt und meist nicht überschwemmt ist; b) die Verlandungszone; c) kiesige oder sandige Streifen, die arm an Vegetation sind. - Nur die beiden letzteren kommen hier in Betracht. In ihnen wachsen sowohl Landformen von Wasserpflanzen, typische Vertreter der Grenzzone, als auch solche, die den Sumpfwiesen oder Gräben angehören und bis hierher vorgedrungen sind. Die genannten Botaniker unterscheiden am Bodensee zwei Assoziationen: Heleocharetum (mit Scirpus [Heleocharis] acicularis, Litorella, $R a-$ nunculus reptans, Myosotis palustris var. caespititia, Agrostis alba und anderen), und ein Polygonetum. - Weiter unterscheiden sie eine vierte Formation, nämlich die von Alluvialpflanzen, einschließlich einer Tamaricetum-Assoziation (mit Myricaria [Tamarix] Germanica, Hippophaёs und anderen), welche die "Grenzzone" bedeckt, wo sie die Form der sandigen oder kiesigen Küste angenommen hat und Pflanzen der Ufer-Alluvionen wie auch alpine Pflanzen umfaßt.

$\mathrm{Zu}$ diesen amphibischen Formationen, die namentlich am Vierwaldstätter See usw. große Flächen bedecken, gehören auch die in der Schweiz „Streurieder“ genannten Pflanzengesellschaften, in denen meist Phragmites vorwiegt, welche aber ein buntes Gemisch von Sumpf-, Wiesen- usw. Pflanzen darstellen.

Als eine der häufigsten im nördlichen Europa vorkommenden Assoziationen kann genannt werden: Das Litorelletum, aus den kleinen Rosetten von Litorella lacustris gebildet, welche nur trockengelegt blühen kann. Mit ihr kommen viele kleine krautartige Pflanzen vor, z. B. Ranunculus reptans und $R$. flammula, Scirpus [Heleocharis] acicularis, Juncus bufonius, J. lamprocarpus, Arten von Callitriche, Elatine, Bulliarda, Isoëtes und andere; auch einige Wasserpflanzen, wie Arten von Potamogeton, welche sich nach Baumann ${ }^{1}$ ) hier wie einjährige Arten verhalten.

Auch größere Stauden können hier auftreten und gemischte oder reine Assoziationen bilden, z. B. Scirpus [Heleocharis] palustris, Hippuris vulgaris, Polygonum amphibium, Agrostis alba, Alisma ranunculoides, A. plantago aquatica, Myosotis palustris ${ }^{2}$ ).

H. Baumann hat auch ein Agrostidetum erwähnt, gebildet von Agrostis alba, Juncus lamprocarpus, J. alpinus, Scirpus [Heleocharis] palustris u. a.

In dieser Formation finden sich eine Menge Arten, welche beim Wachstum im Wasser sich verändern, entweder eine Reduktion aller vegetativen Teile erleiden, oder umgekehrt eine Vergrößerung; auch kommen bei ihnen verschiedene Blattformen vor (heteroblastische Arten),

1) Bäumann 1911.

2) Vergl. Baumann in Karsten u. Schenck, Vegetationsbilder IX, 3. 
wie sie durch die verschiedenen äußeren Faktoren hervorgerufen werden, Phänomene, die Glück in großer Fülle und Vollständigkeit studiert hat.

Dieselbe Formation kommt natürlich auch in anderen Ländern vor, z. B. in Nordamerika. Hierher scheint die von Pool besprochene Assoziation von Nebraska zu gehören, welche auf niedrigem Wasser mit Sandboden vorkam und einen breiten Gürtel einnahm. Hier fanden sich Arten von Chara, Najas flexilis, Zannichellia palustris, Ruppia, Heleocharis acicularis und Algen; wahrscheinlich war das Wasser etwas salzig.

Noch muß erwähnt werden, daß es eine Reihe von verschiedenen Standorten der strömenden Gewässer gibt, z. B. Quellfluren, deren Vegetation von der Temperatur des Wassers abhängig ist; bei sehr niedriger Temperatur und bei sehr hoher kommen hauptsächlich nur Cyanophyceen vor. In anderen gibt es reichlich Moosteppiche, z. B. von Philonotis fontana, Paludella squarrosa, Arten von Aulacomnium, Hypnum u. a., meist dicht und strotzend, welchen verschiedene wasserliebende Gefäßpflanzen angehören; in Grönland z. B. Ranunculus Lapponicus, R. nivalis, R. hyperboreus, Saxifraga rivularis, S. stellaris f. comosa u. a.

In nordeuropäischen, moorreichen Quellfluren ist besonders Montia rivularis häufig, aber auch Epilobium, Cardamine kommen vor, und in alpinen Quellfluren der Alpen und in Norwegen ist z. B. Saxifraga aizoides, S. stellaris, S. saxatilis, Viola biflora u. a. nicht selten.

Andere Assoziationen kommen auf reicherem Boden und bei höheren Temperaturen vor, z. B. die Vegetation von Hochstauden, welche von Filipendula ulmaria (U. pentapetalı), Equisetum maximum (E. telmateia), Geranium palustre, Impatiens noli tangere, Cardamine amara u. a. Arten gebildet wird. Selbst wenn eine Reihe von Florenlisten zusammengestellt wird, so wird dadurch nur wenig erreicht, weil die ökologischen Verhältnisse aller dieser, oft nur wenig umfangreichen und wenig hervortretenden Assoziationen nicht genauer studiert sind.

\section{Kap. Alluvialland der Flüsse, Uferwaldungen}

Das Alluvialland an den Flüssen ist sehr verschieden, was die edaphischen Verhältnisse anbetrifft. Es gibt nasse und es gibt trockene Flußbänke, es gibt sandige und schotterreiche Ufer und es gibt mehr oder weniger lehmige Ufer; es gibt solche, die periodisch überschwemmt werden und andere, deren Vegetation sich nur mit dem Grundwasser begnügen muß.

Nach allen diesen Verschiedenheiten wird auch die hier entwickelte, edaphisch gebundene Vegetation verschieden sein; zugleich 
bieten die Flußufer vielfach Beispiele von Entwicklung einer Formation zu einer anderen.

Ein Standort, der wohl auch verschiedene besondere Eigentümlichkeiten hat, sind die Flußbetten, deren Sand, wie auch oft unendliche Mengen von gerollten Steinen, periodisch trockengelegt werden, und mitunter am Ende dauernd trocken bleiben, so daß dann eine Entwicklung beginnt, welche mit der Waldbildung enden kann ${ }^{1}$ ). In Norwegen finden sich hier oft Bergpflanzen, welche von den Höhen mit dem Wasser herabgeführt worden sind.

Das Schwemmland der großen Flüsse weist vielfach interessante Folgeformationen auf, welche noch wenig bekannt sind. Es gibt sandige und tonig-schlammige Standorte, wo die Erde wasserdurchtränkt ist, und von welchen die Entwicklung ihren Ursprung nimmt ${ }^{2}$ ).

Interessante Verhältnisse der Auenwälder an der Aare in der Schweiz erwähnt Siegrist ${ }^{1}$ ). Sie scheinen eine einförmige Waldformation zu sein, zeigen aber in der Tat äußerst komplizierte Verhältnisse. „Weisen sie doch vom versumpftesten Bruchwald bis zur trockenen steppenähnlichen, nur mit spärlichen Sträuchern bedeckten Schotterfläche alle Übergangsstadien des edaphisch bedingten Waldes auf." Ausschlaggebend sind zwei edaphische Faktoren: 1. Die Zusammensetzung des Bodens, ganz besonders die Mächtigkeit der dem Schotter aufgelagerten Sand- und Humusdecke, und 2. der Wassergehalt des Bodens. Es finden sich Böden, die das höchste $\mathrm{Maß}$ von Nässe aufweisen, welches Laubbäume ertragen können, Bruchwald; Böden, welche zeitweise überschwemmt oder doch naß sind, Auenwald; mäßig feuchte Böden, welche einen durch das Klima bedingten mesophytischen Mischwald tragen, eine Übergangsformation zu dem Föhrenwald und den Sanddornbeständen, welche auf Böden wachsen, welche meist über dem Bereich der heutigen Hochwasser, und daher auf verhältnismäßig trockenen Schotterbänken wachsen. In allen diesen Gehölzformationen kann man eine Formationsfolge beobachten, da alle in einem ganz bestimmten Abhängigkeitverhältnis zu einander stehen. An ein und derselben Stelle folgen die verschiedenen Pflanzengesellschaften aufeinander, je nachdem der Lauf des Flusses und damit die edaphischen Verhältnisse sich ändern. „Bruchwald und Auenwald sind nicht stabile unveränderliche Formationen, sondern nur Phasen einer langen Entwicklungsreihe, die ihren Abschluß findet in einem mesophytischen Mischwald."

Ganz so wie an der Aare Gebüsche von Hippophaës rhamnoides auf den Schotterbänken des Flusses zur Entwicklung kommen, findet man an vielen anderen Flüssen nur Sand- und Kieselalluvionen mit

1) Vergl. Hanna Resvoll-Holmsen 1914; Drude, Auenwälder; Siegrist 1913, 1914.

2) Vergl. z. B. Flahault et Comḅres 1894; Raunkiär 1914. 
Sträuchern oder Halbsträuchern bewachsen (Fig. 172, S. 343), in der Schweiz z. B. von Myricaria Germanica ${ }^{1}$ ).

Viel bedeutender als in den Alpenländern sind in ihrer Ausdehnung die meist aus Eichen bestehenden Auenwälder in den ebenen Gebieten, wie sie aus Norddeutschland zuerst Drude beschrieben und behandelt hat. Sie bilden sich in den weiten Überschwemmungsgebieten der großen Ströme außerhalb der Strömungs-(Eisgang-)Zone. Ihre Flora ist vor allen andern Laubwäldern schon physiognomisch durch den kraftvollen

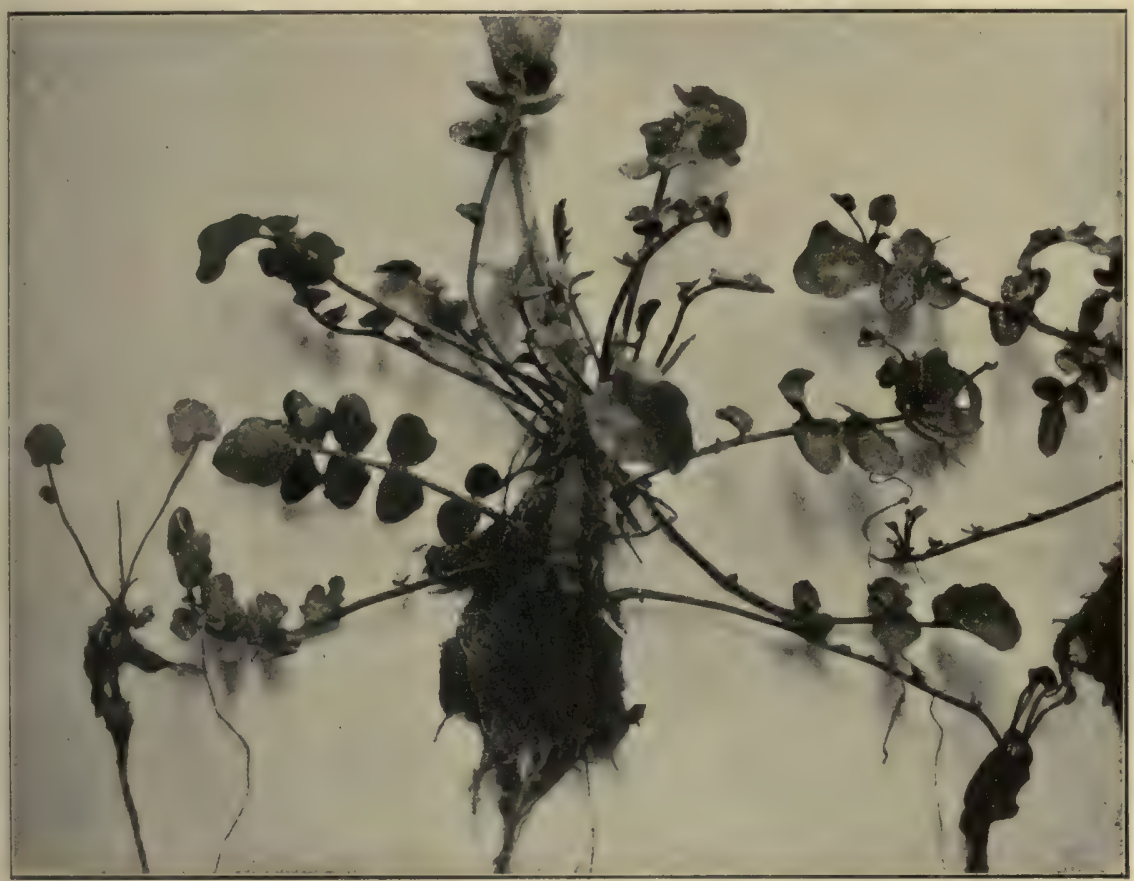

Fig. 259. Vegetative Vermehrung von Cardamine palustris auf Schwemm- und Schlammboden. Auf den Mittelstreifen der Blätter entstehen junge Pflanzen, die einwurzeln und (links) selbständig werden. Wächst besonders in Formationen wie S. 509, Fig. 254. (Phot. Graebner.)

Unterwuchs an Sträuchern und namentlich an hohen Stauden (oft fast undurchdringlich) ausgezeichnet. Oft auch nähert sich ihr Unterwuchs sehr dem der übrigen Laub-, besonders Buchenwälder, namentlich bez. der Frühlingsflora, Anemone nemorosa, A. ranunculoides, Corydallis cava u. a. bedecken weite Flächen. An den tiefliegenden Stellen geht die Flora in die der Waldbrücher, besonders Erlenbrïcher, über; Brennnessel und Hopfen sind oft in großen Massen vorhanden.

1) Vergl. z. B. Schröter u. Kirchner. 
Was für die Auenwälder gilt, gilt ganz sicher auch für zahlreiche andere Uferwälder und Wälder, die im Überschwemmungsbereich der Flüsse vorkommen, was in den Tropen von Schweinfurth "Galeriewald " genannt wird. Es sind dies Wälder, die an das Grundwasser gebunden sind und daher in der trockensten Wüste vorkommen können, die Ufer der Flüsse begleitend. Man denke z. B. an die Dattelwälder in den Oasen Nordafrikas ,mit den Füßen im Wasser, mit dem Kopf in der Hölle". In den transkaspischen Wüsten kommen auch höhere Wälder von Pappeln vor.

Es könnten hier auch die Igapos, die S. 518 erwähnt wurden, wieder genannt werden.

Die verschiedenen Reisenden erwähnen aus allen Ländern Uferwaldungen und Galeriewälder, die natürlich nach den Ländern und den Klima starke floristische und auch physiognomische Verschiedenheiten aufweisen, so daß sie zu verschiedenen Typen oder Subformationen gerechnet werden können ${ }^{1}$ ).

Von diesen Uferwäldern gehören viele den im folgenden erwähnten mesophilen und hygrophilen Assoziationen an, nämlich denjenigen, die nur an feuchten Boden gebunden sind.

Diese jetzt besprochenen Sumpf- und Flußufer-Formationen setzen sich unmittelbar in einer Kette der verschiedenen Landpflanzen-Formationen fort: Zuerst begegnen wir sandigen Ufern, wie beim Meere, mit offener Vegetation oder feuchten Standorten mit einer geschlossenen Grasdecke (Wiesen, Wiesenmoore und ähnliches). Danach folgen dann allmählich immer trockenere Assoziationen, in welchen die Wurzeln das Grundwasser nicht mehr erreichen können. Diese werden im folgenden besprochen.

Über den Sandstrand der Süßwasserseen liegen z. B. von Cowles Beobachtungen vor.

An den Ufern der großen Süßwasserseen ist die gürtelförmige Anordnung der Vegetation oft ähnlich der der Meeresküsten (vergl. 50. Kap.). Auch hier haben wir oft Lebensformen, die von dem losen, feinkörnigen Sande abhängig sind, je nachdem der Sand noch flüchtig oder schon fester gelagert ist. Im allgemeinen liegen aber über diese Uferbildungen nur wenige Beobachtungen vor. Nach Cowles ${ }^{2}$ ) ist der untere Teil des Ufers durch Sandalgen charakterisiert (vergl. S. 432), der mittlere, der zwischen der Hochwassergrenze der Winter- und der Sommerstürme liegt, wird von einjährigen Kräutern bewohnt, unter denen viele fleischige Arten

1) Vergl. z. B. Gassner 1913; Dusén u. Neger 1908; Adamoviez 1909; Engler, Afr. I, 942.

2) Cowles 1900. 
sich befinden, wie sie auch an den salzigen Küsten wachsen. Als Beispiele seien genannt Cakile Americana, Corispermum hyssopifolium und Euphorbia polygonifolia. Über der Hochwassergrenze des Winters beginnt dann ein Sandfeld, auf dem namentlich Arten mit kriechenden Grundachsen gedeihen, unter ihnen Triticum (Agropyrum) dasystachyum und Lathyrus maritimus. Zwischen ihnen findet man dann auch ein- und zweijährige Kräuter und einige in ihrem Wachstum zurückgebliebene Sträucher.

Auf Presque Isle hat Jennings ganz entsprechende Gürtel beobachtet: 1. "The lower beach" mit der "Chlamydomonas-Formation", 2. "The Drift-Beach" mit der „Cakile-Xanthium-Formation", entsprechend Mac Millans „Midstrand" und Cowles „Middle-Beach“, auf losem Sand mit vielem Treibholz; das Grundwasser liegt hoch. Nach dieser Formation kommen noch trockenere und mehr xerophytische. Sie werden unter Sandvegetation besprochen ${ }^{1}$ ).

\section{Serie der mesophilen und hygrophilen Formationen}

\section{Kap. Allgemeine Bemerkungen}

Schon oben (S. 198) wurde der Begriff der Mesophyten besprochen. Unter Mesophyten sind solche Pflanzen zu verstehen, welche in mittleren edaphischen Verhältnissen leben; extreme Faktoren werden gemieden. Der Boden muls feucht und frisch sein, weder sehr wasserreich noch besonders wasserarm sein. Die Mesophyten meiden Böden mir stagnierendem, sauerstoffarmem Wasser und ebenso solche mit salzigem (kochsalzhaltigem) Wasser.

Der Boden muß gut drainiert und, jedenfalls zu gewissen Jahreszeiten, gut durchlüftet sein. Er muß durchlässig und unter günstigen Verhältnissen tiefgründig sein.

Die Mesophyten lieben reichliche Niederschläge, die über die Jahreszeiten gleichmäßiger verteilt sind, als dort, wo Xerophyten ihre Heimat haben; ebenso ziehen sie eine Luft vor, die reich an Wasserdampf ist („Hygrophyten“). Die Bodendecke der hierher gehörigen Formationen speichert gewöhnlich leicht große Mengen der Niederschläge auf.

Die Mesophyten lieben Schutz vor austrocknenden Winden.

1) Jennings 1909. Hierher gehörige Beobachtungen finden sich weiter bei Holmboe (1914) für Cypern. 
Der Boden ist reich an Nährstoff, oft kalkhaltig und auch gewöhnlich reich an mildem, also nicht sanrem Humus, besonders in den schattenreichen Wäldern. In alten Humuserden kommt oft viel assimilierbarer Stickstoff vor. Die Mesophytenvereine haben daher eine hohe Stoffproduktion und zeigen oft eine sehr große Fülle und einen Reichtum an Lebensformen und Arten.

Die Vegetation ist dicht geschlossen; kein mesophiler Verein ist so offen und pflanzenarm, wie gewisse xerophile und halophile Vereine, was durch die günstigen Lebensbedingungen zu erklären ist. In den niedrigsten und einfachsten Vereinen spielen Gräser und andere Kräuter die wichtigste Rolle; solche Vereine sind die Wiesen, Weiden, Krautfluren u. a.; reicher sind die Vegetationen der hohen Stauden und die mesophilen Gebüsche, wo mehrere Stockwerke der Pflanzen vorkommen; am reichsten ist der tropische Regenwald. Oft sind die mesophilen Vereine Schlußformationen einer Entwicklungsreihe. Nach Cowles neigen extreme Vereine immer mehr zur Entwicklung in mesophile.

Das Tierleben im Boden ist gewöhnlich sehr reich (Regenwürmer, Insekten u. a.). Ebenso wimmelt der Humusboden wohl immer von Bakterien und Pilzen, darunter auch Saccharomyceten.

Der morphologische und der anatomische Bau der Mesophyten ist verschieden; bei den meisten mesomorph, bei anderen xeromorph. Im allgemeinen ist er mesomorph, d. h. von so mittlerer Beschaffenheit und für die Botaniker der gemäßigten Gegenden, wo die wissenschaftliche Forschung ihre Heimat hat, ein so alltäglicher, daß man Schwierigkeiten gehabt hat, die hier vorkommenden Anpassungen zu verstehen. Der La usproß ist verschieden, aber die Laubblätter sind, der feuchten Luft entsprechend, gewöhnlich relativ groß, flach und dünn; ihre Formen sind mannigfaltig, aber bei den dikotylen Arten der gemäßigten Klimate sind sie oft eingeschnitten und im Rande gezähnt oder gesägt. Der Reichtum an Blattformen ist im ganzen größer als in den anderen Serien. Die Spreiten der Laubblätter sind gewöhnlich dorsiventral, die Haut dünn, ohne starke Kutinisierung, die Wände der Hautzellen sind wellenförmig. Haare von verschiedenen Formen kommen vor, aber das Haarkleid ist dünn und meist nicht dichtfilzig. Viele Arten sind recht plastisch, z. B. die Buche (vergl. Fig. 15) und jedenfalls sehr viele andere unserer gemeinen Pflanzen. Die Fähigkeit, sich nach den Verschiedenheiten der Umgebungen zu richten, ist bei Mesophyten vielleicht sogar stärker als bei anderen Pflanzen; aber hierüber weiß man noch zu wenig. Es besteht jedoch kein Hindernis, daß einzelne xeromorphe Bauverhältnisse vorkommen, weil, wie der tropische Regenwald zeigt, kurz dauernde, aber stark trockene Zeiten eintreten können, welche solche notwendig machen. Auch werden die Blätter der immergrünen Baum- und Strauch-Arten oft mehr oder weniger lederartig: 
sowie ganzrandig, aber doch nicht hartlaubig. Dieses hängt damit zusammen, daß die Wasseraufnahme in kalten Klimaten im Winter unmöglich ist.

Eine ganz eigentümliche Stellung nehmen dabei die Coniferen ein; nach ihrem äußeren und inneren Bau sind sie xeromorph, aber sie kommen auf sehr verschiedenen Böden, besonders der nördlichen kalt temperierten Zone, sowohl trockenen, als mäßig feuchten bis sehr feuchten, vor - sogar Sumpfwälder werden von Coniferen gebildet, wie Kap. 64 erwähnt wurde. Sie nehmen aber im großen und ganzen ähnliche Lokalitäten ein, wie die mesophyten Wälder der nördlichen mesothermen Gegenden. Näheres Kap. 74-76.

Die mesophilen Formationen sind gewöhnlich sehr artenreich, was wohl sicher eine Folge der günstigen Lebensbedingungen ist ${ }^{1}$ ). Es wird ja allgemein angenommen, daß günstige Lebensbedingungen und ein relativ leichtes Leben neue Abänderungen hervorrufen oder begünstigen, also zur Bildung neuer Arten beitragen.

Die mesophilen Vereine sind vorzugsweise in den gemäBigten Gegenden heimisch, namentlich innerhalb des nördlichen Waldgebietes, wo der Regen meist Sommer- und Herbstregen ist, also in der immergrünen Nadelholzzone und der Zone der laubwechselnden Laubwälder, kommen aber auch in den Polarländern und den Tropen vor. Sie sind ferner, besonders in gemäßigten Gegenden, oft an Kulturland gebunden; ihr Boden und ihr Klima passen zu den Kulturpflanzen der Menschen vortrefflich. Durch die Eingriffe der Kultur sind die ursprünglich gewiß sehr wenigen Vereine in eine Menge neuer Vereine, besonders Kulturvereine, aufgelöst und gespalten worden, die miteinander beständig kämpfen und ebenso schwierig zu kennzeichnen wie zu benennen sind. Die Kulturpflanzenvereine bestehen größtenteils aus ein- oder zweijährigen Arten, sind ebenfalls mesophile Vereine, werden aber in diesem Werke nicht näher behandelt.

Die vielen Formationen und Assoziationen von dieser großen Serie werden am besten in drei Gruppen geteilt:

A. Mesophile Formationen der kalten und kalttemperierten Gegenden (der nördlichen Polarzone und der nördlichen kalten Gürtel Koeppens).

a) Mesomorphe Gråser- und Kråutervereine.

Arktische und alpine Gras- und Krautmatten. 68. Kap.

Wiesen. 69. Kap.

Hochstaudenfluren. 70. Kap.

Weiden auf Kulturland. 71. Kap.

(Kulturformationen werden in diesem Buche nicht besprochen.)

${ }^{1}$ Vergl. über das Verhältnis zwischen den Wäldern und den Campos bei Lagoa Santa in Brasilien Kap. 38, S. 250. 
b) Formationen von breitblättrigen, meistens dikotylen, laubwerfenden, mesomorphen Holzpflanzen.

Mesomorphe Gebüsche. 72. Kap.

Mesomorphe Wälder. 73. Kap.

c) Vereine von, meist immergrünen und xeromorphen, Coniferen.

Allgemeine Bemerkungen. 74. Kap.

Laubwechselnde Nadelholzwälder (Lärchenwälder). 75. Kap.

Immergrüne Nadelholzwälder. 76. Kap.

B. Subtropische mesophile Vegetation.

Grasfluren, Wiesen (auch tropische). 77. Kap.

Immergrüne Wälder. 78. Kap.

Kanarische Lauraceenwälder.

Subtropische Regenwälder.

C. Tropische mesophile Vegetation. 79. Kap. (Grasfluren, siehe 77. Kap.).

Monsunwälder (laubwechselnde tropische Wälder).

Regenwälder von breitblättrigen Bäumen.

Palmen-, Bambus- und Farnwälder.

\section{Kap. Mikrotherme (arktische und alpine) Gras- und Krautmatten}

In den Polarländern und oberhalb der Baumgrenze vieler Hochgebirge kommen ausgedehnte grüne Fluren monokotyler und dikotyler Kräuter vor: eine Vegetation, die floristisch mit den angrenzenden Felsenfluren verwandt sein kann, jedoch immer eine Menge anderer Arten enthält, weil die Lebensbedingungen günstiger sind. Man kann zwei Vegetationsschichten unterscheiden, nämlich eine Bodenschicht aus Moosen und vielleicht Algen, und eine Feldschicht aus Gräsern und Kräutern; letztere kann bisweilen in zwei zerlegt werden, und zwar eine höhere aus höheren Arten und eine niedrigere. Holzpflanzen sowie Zwerg- und Halbsträucher fehlen oder die letzteren sind selten und sehr klein.

Diese Vegetation tritt als eine frisch grüne, geschlossene, dichte und, wenn sie typisch ist, niedrige und weiche Decke auf, was durch den Ausdruck Matte bezeichnet wird. Wurzeln und die kurzen senkrechten oder wandernden Rhizome sind meist dicht verfilzt, so daß ein Humusboden entsteht, ungefähr wie auf unseren Strandwiesen, mit denen die Vegetation die größte physiognomische Übereinstimmung hat. Rosettensprosse sind bei den Dikotylen, vermutlich im Einklange mit der geringen Höhe der Vegetation und dem reichlichen Lichtzutritte, wie in den subglazialen Vereinen allgemein; mit diesen haben die Matten auch anderes gemeinsam, z. B. die tiefen, reinen Blütenfarben und 
gewisse xerophile Merkmale. Die meisten Arten sind mehrjährig, Gräser und Stauden. Typische Holzpflanzen fehlen (jedenfalls höhere), aber Halbsträucher können eingemischt sein. Moose findet man oft in größerer oder kleinerer Menge eingemischt; aber Flechten fehlen, oder sind selten und spärlich.

Die Matten der Polarländer und der mitteleuropäischen u. a. Hochgebirge scheinen ökologisch so übereinzustimmen, daß sie nicht getrennt werden dürfen; aber vielleicht muß eine Einteilung in Grasfluren und Krautfluren stattfinden, die beide aus Kräutern bestehen, jene hauptsächlich aus Gramineen, diese besonders aus dikotylen Stauden. Man würde vielleicht verschiedene Subformationen nach den vorherrschenden Lebensformen unterscheiden können, ob Gräser, Kleinstauden oder Hochstauden. Von Assoziationen gibt es eine chaotische Menge, was teils durch die geographische Lage, teils durch edaphische Verhältnisse (Bewässerung, Nährstoffmenge usw.) bedingt wird. Ein Faktor, der hier von spezieller Bedeutung sein wird, ist die Zeit, bis zu der die Schneedecke im Frühling liegen bleibt.

Als ein erster Schritt zur Bildung einer Matte werden vielleicht zwei Formationen betrachtet werden können, welche übrigens am nächsten der Kältevegetation zugerechnet werden können.

Eine Lebermoosformation kommt nach Th. E. C. Fries ${ }^{1}$ ) in der alpinen Höhenstufe der lappländischen Gebirge bei Überrieselung mit Schmelzwasser vor; besonders findet sich eine Anthelia nivalis-Assoziati on welche einen dichten, schwärzlich-graublauen, dünnen Überzug über dem mehr oder weniger feuchten Schneeboden bildet. Innerhalb der höheren Teile dieser Höhenstufe ist sie dominierend, sie kommt aber auch niedriger vor $^{2}$ ).

Eine andere sehr charakteristische Formation sind die von Oettli und Schröter ${ }^{3}$ ) erwähnten Schneetälchen in den Alpen sowohl wie in den nordeuropäischen Gebirgen (Schottland usw.). Dies sind nach Schröter meist sanft geneigte, flache oder konkave Stellen, die in den Gebirgen ebenso wie in den Polarländern vorkommen und vom Wasser des schmelzenden Schnees benetzt werden. Wo sie Mulden darstellen, in denen der Schnee lange liegen bleibt, da ist in ihnen meist eine mehr oder weniger dicke schwarze Humusschicht abgelagert, die ihren Ursprung dem Schnee verdankt. Der letztere bringt jedesmal einen kleinen Teil organischen Staubes aus der Luft mit herab, anderer wird durch den Wind zugeführt; auf diese Weise wird der Schnee "gedüngt".

1) Th. E. C. Fries 1913.

2) Vergl. auch W. G. Smith 1912; Hanna Resvoll Holmsen 1914 b; Josias Braun 1913; Furrer 1914.

3) Oeltli 1903; Schröter 1904-1908.

Warming - Graebner. B. Auflage, illustr. 
Diese Standorte sind scharf charakterisiert durch die niedrige 'Temperatur, durch den Reichtum an Humus und die danernde Sättigung des Bodens mit Wasser. In der Schweiz ist die Pflanzengesellschaft, die sich hier ansiedelt, sehr konstant und nur aus wenigen Arten zusammengesetzt; in erster Linie wächst hier Salix herbacea, mit ihr Alchimilla pentaphylla, Gnaphalium supinum, Ligusticum mutellina, Plantago alpina, Soldanella-Arten, Sibbaldia procumbens und andere. Erwähnt oder beschrieben sind die Schneetälchen auch von Rübel 1912; Vahl 1913; Jos. Braun 1913.

Diese beiden Formationen könnten, vielleicht auch besser, unter den Kältewüsten (V. Serie) besprochen werden.

Arktische und subarktische Grasmatten. In vielen arktischen Matten überwiegen die Gräser die andern monokotylen oder dikotylen Pflanzen. Von Kola erwähnt Brotherus üppige Grasmatten, die aus Poa pratensis und Festuca rubra bestehen, neben denen sehr viele Stauden vorkommen: Arten der Gattungen Trollius, Ranunculus, Cochlearia, Geranium, Melandryum, Cerastium, Rubus ( $R$. chamaemorus, $R$. arcticus), Chamaepericlymenum (Cornus) Suecicum, Archangelica, Matricaria, Solidago, Rhinanthus usw. Den genannten Matten ähnliche Grasmatten werden von Novaia Semlja angegeben, kommen in Grönland besonders bei Eskimowohnungen und auch auf Island vor. Auf dieser Insel greift die Kultur gewiß oft bedeutend ein, indem namentlich Dünger ein Faktor von großer Bedeutung wird; „auf das Gras wird des Landes Wohlfahrt gebaut" (Thoroddsen). Die gemeinsten Arten sind hier Anthoxanthum odoratum, Alopecurus geniculatus, Aera caespitosa, Poa trivialis, P. pratensis, Agrostis alba usw.; andere mono- und dikotyle Stauden sind natürlicherweise eingemischt.

Die Reisenden unterscheiden übrigens die vorzugsweise mit Gräsern bewachsenen Fluren nicht scharf von den besonders mit dikotylen Kräutern bedeckten Fluren; als "Weide" wird offenbar meist jede Flur bezeichnet, die eine frisch grüne, dichte und niedrige Decke hat und sich zum Abweiden eignet.

Krautfluren. Den arktischen Grasmatten ist wohl immer eine größere oder geringere Menge monokotyler und dikotyler Stauden beigemischt. Wo diese das Übergewicht über die Gräser erhalten, tritt eine andere Vegetation auf, die man Krautflur oder (mit Rosenvinge) „Urteli“ d.h. Krauthalde nennen kann, weil sie meist auf Abhängen vorkommt. Sie ist in den Polarländern sicherlich weit verbreiteter als die typische Grasflur; man kann sogar Vereine finden, wo sich Gräser kaum entwickeln. Solche blütenreichen, frischgrünen Fluren kommen in Grönland an geschützten Stellen allgemein vor, wo der Boden gleichmäßig feucht bleibt, und nicht nur im Tieflande, sondern bisweilen auch 
in recht großer Höhe. Sie sind niedrig, dicht, weich, ihre Stauden besonders rosettenblättrig. Außer mehrjährigen Kräutern sind den Gräsern oft Zwergsträucher wie Salix herbacea, S. polaris und Cassiope hypnoides beigemischt. Auch frischgrüne Moose (Hypnum, Aulacomnium usw.) spielen eine Rolle ${ }^{1}$ ). Dieselbe Vereinsform findet man auf Island, auf den Färöern $\left.{ }^{2}\right)$, in England, in Skandinavien und in Finnland.

Was Island betrifft, so schildert sie Thoroddsen 1914 folgendermaßen: Es gibt vier Varianten von Grasland. Grasige Abhänge finden sich oft auf den Bergen, besonders wo die Felsen von Tuff oder Breceia gebildet sind. Die Gräser sind besonders Agrostis vulgaris, A. canina, Anthoxanthum odoratum, Festuca ovina, Poa alpina, P. nemoralis; diesen schließen sich Kräuter wie Geranium silvaticum, Trifolium repens, Brunella vulgaris, Leontodon autumnalis u. a. an. Die Vegetation ist reich an Arten und sehr gemischt, doch die Gräser herrschen vor. Von den anderen Varianten kann erwähnt werden: das trockene unkultivierte Grasland auf grobem, steinigem Sande mit einer dünnen Humusschicht und einer niedrigen, ziemlich offenen Vegetation aus Arten von Festuca, Aera, Poa, Agrostis, untermischt von Juncus, Luzula und Elyna. Rings um die Höfe findet man den "Tun", d. h. Haus-Feld, etwa entsprechend den alpinen „Lägern"; es ist gedüngtes Grasland, oft sehr holperig und stark bultig. Eine Reihe von Gräsern herrschen hier mit Ranunculus acer, Taraxacum officinale, Rumex acetosa, Polygonum viviparum u. a. untermischt.

Die Blumenmatten auf Kolgujew am Weißen Meere werden von Poble ${ }^{3}$ ) geschildert als „liebliche Oasen“ in der subarktischen Pflanzenwelt. An geneigten Hängen der Ufer, unter dem Einflusse günstiger Verhältnisse des Luft- und Bodenklimas vereinigt sich eine ganze Reihe von Pflanzen zu geschlossener Vegetationsdecke auf nicht zu schwerem, frischem, sandig-tonigem Bodenmaterial. Alles überschüssige Wasser fließt schnellstens ab. Die schützende Schneedecke verschwindet schnell im Frühjahr. Der wichtigste Faktor für die Entwicklung dieser Oasen ist nicht die Exposition, sondern Schutz vor den Winden. Diese subarktische Matte trägt einen dichten Bestand von Stauden und Gräsern. Der Boden ist humusreich; Moose finden sich in geringer Zahl, es fehlen diejenigen, die zur Bildung von Rohhumus Veranlassung geben. Auch Hochstauden kommen vor, und von den Insekten sind besonders die Bombus-Arten auffällig.

Wie reich die arktischen und subarktischen Krautfluren sein können, geht daraus hervor, daß Heuglin von Novaia Semlja Stellen erwähnt,

1) Warming 1887 , S. $37-39$.

\%) Vergl. Ostenfeld 1908 b.

3) Pohle 1907, Taf. 30. 
wo etwa 50 Arten Blütenpflanzen auf einem Gebiete von wenigen Quadratellen wachsen. Stefánsson berichtet von einer Krautflur im Vatn-Tale des nördlichen Islands, wo auf einer Quadratelle 24 Arten vorkommen.

Auf den Krautfluren können die Blätter der Kräuter bisweilen recht groß und üppig werden, z. B. bei Alchimilla vulgaris, Ranunkeln, Potentillen usw., und zwar wegen der großen Luftfeuchtigkeit, der lange dauernden aber schwachen Beleuchtung und des geschützten, gewöhnlich sonnigen und humusreichen Bodens. Die Arten sind mehrjährig, gewisse Gentiana-Arten ausgenommen, und nur in der Vegetationszeit grün. Über den Sproßbau ist zu bemerken, daß die Rasenform mit bleibender primärer Wurzel oder mit senkrechter mehrköpfiger Grundachse (vergl. besonders Pohle) zu überwiegen scheint, daß aber auch wandernde. Sprosse vorkommen; diese Verhältnisse sind jedoch noch zu wenig untersucht. Rosettensprosse sind sehr allgemein ${ }^{1}$ ).

Die alpinen Matten. An ähnlichen Standorten wie in den arktischen und subarktischen Ländern kommen Matten vielfach in den Hochgebirgen der Schweiz und anderer Teile der Alpen und anderer Hochgebirge vor, und werden von dort von vielen Forschern besprochen. Sie finden sich besonders auf humusreichen, sanften Abhängen ohne Rücksicht auf die Exposition, wo aber die Bewässerung dem Boden eine gewisse Frische und Feuchtigkeit gibt. Vielfach gehen sie in Wiesen über. Der Unterschied zwischen den Matten und den Wiesen ist nicht groß und muß namentlich darin gesucht werden, daß die Matten eine niedrigere Vegetation sind, so daß sie wesentlich zum Abweiden dienen, wogegen die Wiesen gemäht werden können.

Als typisches Beispiel kann man wohl Kerners Carex ferruginea"Formation" bezeichnen, welche Pflanzen enthält wie Soldanella alpina, Gentiana acaulis, Alpenaurikeln, Alpenanemonen, Nigritella, Globularia nudicaulis, Phaca frigida, Lotus corniculatus u. v. a. Kräuter, von Gräsern Sesleria caerulea, Festuca violacea, F. pulchella u. a.; auch einen und den anderen Zwergstrauch oder niederliegenden Strauch kann man finden: Erica carnea, Salix reticulata, S. retusa, Dryas usw.

Es gibt eine sehr große Zahl von floristischen Varianten und Assoziationen, vergl. z. B. Stebler 1897 und 1899, Stebler und Schröter, Stebler und Volkart, Schröter 1904-08; Brockmann-Jerosch 1907; Rübel 1911-12, 1913; und was S. 349 nach Jaccard angeführt wurde; Braun und Furrer u.a. Furrer scheidet zwischen Mähwiesen und mahdfreien Wiesen (Nardeta, Curvuleta, Cariceta, Elyneta usw.) ${ }^{2}$ ) (Fig. 260, 261).

1) Utber arktische Matten vergl. Middendorff, v. Baer, Nathorst, Kjellman (1884), Warming (1887), Rosenvinge, Pohle u. a.

2) Furrer 1914. 
$\mathrm{Zu}$ den Matten scheint auch folgende Assoziation gerechnet werden zu können: Steblers und Schröters Leontodon-Matte oder „Milchkrautweide"; diese ist zusammengesetzt aus Leontodon hispidus, $L$. autumnalis, L. Pyrenaicus, Crepis aurea, Homogyne alpina, Meum mutellina, Arten von Potentilla, Geum, Sibbaldia, Plantago, Soldanella (S. alpina), Veronica (V.alpina), Polygonum viviparum usw., außerdem aus Gräsern. In anderen Vereinen herrschen Meum mutellina oder Plantago alpina oder Salix herbacea oder Gnaphalium supinum oder Alchimilla pentaphylla vor; diese fünf Arten sind für die "Schneetälchen-

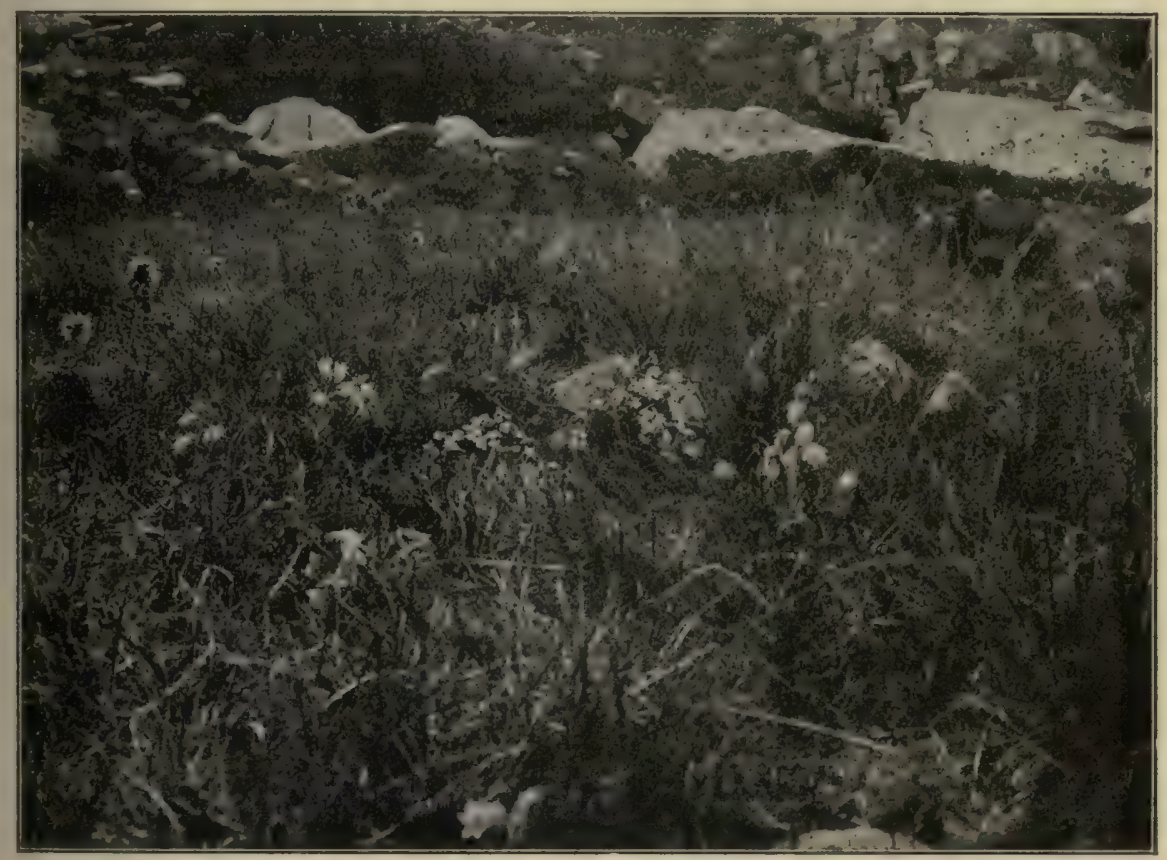

Fig. 260. Alpenmatte auf der Mussalaspitze des Rilagebirges in Bulgarien, etwa 2400 m. Pedicularis orthantha, Dianthus microlepis, Sesleria comosa, Campanula Orbelica, Alopecurus brachystachys. (Phot. Adamovié.)

Rasen" (vergl. S. 529) kennzeichnend, deren niedrige, dichte Matten meistens Schafen und Ziegen als Weide dienen. Die Matten der Alpen haben bekanntlich einen Teil der Arten mit den Polarländern gemeinsam.

Die "Fettmatten" von Rübel gehören alle der subalpinen Stufe an, sie sind gebunden an flachen Boden und schwach geneigte Hänge. Von 1700-2080 m gehören im Bernina-Gebiet alle Fettmatten zur Assoziation des Trisetum flavescens und seiner "Subassoziationen". Die geringste Erhöhung und Feuchtigkeitsverringerung bringt Festuca rubra fallax zum Vorherrschen. Auch Agrostis tenuis kann solche „Sub- 
assoziationen" bilden. Die obersten Fettmatten bei 2100 m Höhe gehören besonders der Poa alpina-Assoziation an.

Als "Matten" werden von manchen Botanikern viele Assoziationen bezeichnet, die teilweise ein sehr verschiedenes ökologisches Gepräge zu haben scheinen und wahrscheinlich zu anderen, besonderen Vereinsklassen gestellt werden müssen. Stebler und Schröter behandeln unter anderen folgende Vereine: 1. Die Nardus stricta-Assoziation, die auf magerem und trockenem Boden (Trockenwiesen anderer) auftritt und oft mit Zwerggebüsch der Alpenrosen oder mit Zwergstrauchheiden abwechselt. In den Bestand sind folgende Pflanzen eingestreut: Potentilla aurea, $P$. silvestris, Calluna vulgaris, Leontodon Pyrenaicus, Trifolium alpinum, Geum montanum, Arnica montana, Homogyne alpina, Lycopodium alpinum, ferner Gräser (Aera [Deschampsia], Anthoxanthum odoratum, Festuca rubra u. a.), Luzula albida und spicata, Massen von Flechten (Cladonia, Cetraria) und außerdem Vaccinium-Arten. Ein in vielen Beziehungen der Heide nahestehender Verein. Ein anderer Verein ist 2. die Carex firma-Assoziation, die in den Kalkgebirgen auf trockneren Stellen in $2000-2900 \mathrm{~m}$ Höhe den letzten zusammenhängenden Teppich dichter, niedriger Rasen mit kurzen, steifen Blättern bildet und als Begleiter der Carex firma folgende Arten enthält: Elyna spicata, die feinblättrige Rasen bildende Festuca pumila, Carex nigra u. a. grasartige Pflanzen und "wie in den grünen Rasen eingestreute Perlen" eine Reihe Saxifraga- und Gentiana-Arten, Alsine verna, Campanula Scheuchzeri, Primula integrifolia usw. Diese beiden Vereine haben offenbar ein ziemlich xerophiles Gepräge, und namentlich der erste kann wohl am richtigsten zu den xerophilen, nämlich zu den subglazialen Vereinen gerechnet werden. Daß die Matten in gewisse subglaziale Vereine übergehen, ist ganz natürlich, da sie oft zwischen ihnen vorkommen und auf den Gebirgen deren Fortsetzung nach unten bilden, also unter günstigeren Wachstumsverhältnissen auftreten.

Die Schwierigkeit, diese vielen verschiedenen alpinen Assoziationen richtig beurteilen $\mathrm{zu}$ können und danach $\mathrm{zu}$ verteilen, rührt wohl teilweise daher, daß der Charakter der Standorte oft ungenügend angegeben wird, teilweise auch daher, daß eine Art an mehreren Standorten und in mehreren Assoziationen vorherrschen kann; nicht nur, nach Braun und Furrer, z. B. Pinus montana auf Hochmooren und Kalk, sondern auch Gräser wie Sesleria coerulea als xerophile Pflanze auf trockenem sonnenreichem Boden in den Alpen und auf nassem Boden auf der Insel Oeland in der Ostsee, oder die Caresc curvula-Assoziation (das "Curvuletum") in den Hochalpen.

Wenn das prozentuale Vorkommen der verschiedenen Lebensformen in den verschiedenen Assoziationen statistisch aufgeführt würde, die Anpassungen der Laubsprosse angegeben wären und die Boden- 
beschaffenheit genan studiert wäre, würde man mit größerer Sicherheit urteilen können.

In unserer nordeuropäischen Natur scheint die Kap. 51 besprochene Strandwiese der Verein zu sein, der mit den arktischen und den alpinen Grasmatten und Krautfluren physiognomisch am nächsten verwandt ist. Die Strandwiese ist eine dichte, niedrige, oft weiche Vegetation mit dicht verfilzten Sprossen und Wurzeln in einem Rohhumusboden, wie viele, aber durchaus nicht alle jener Matten. Als den Strandwiesen ähnlich erscheinen z. B. gewisse Grasmatten der Hochalpen,

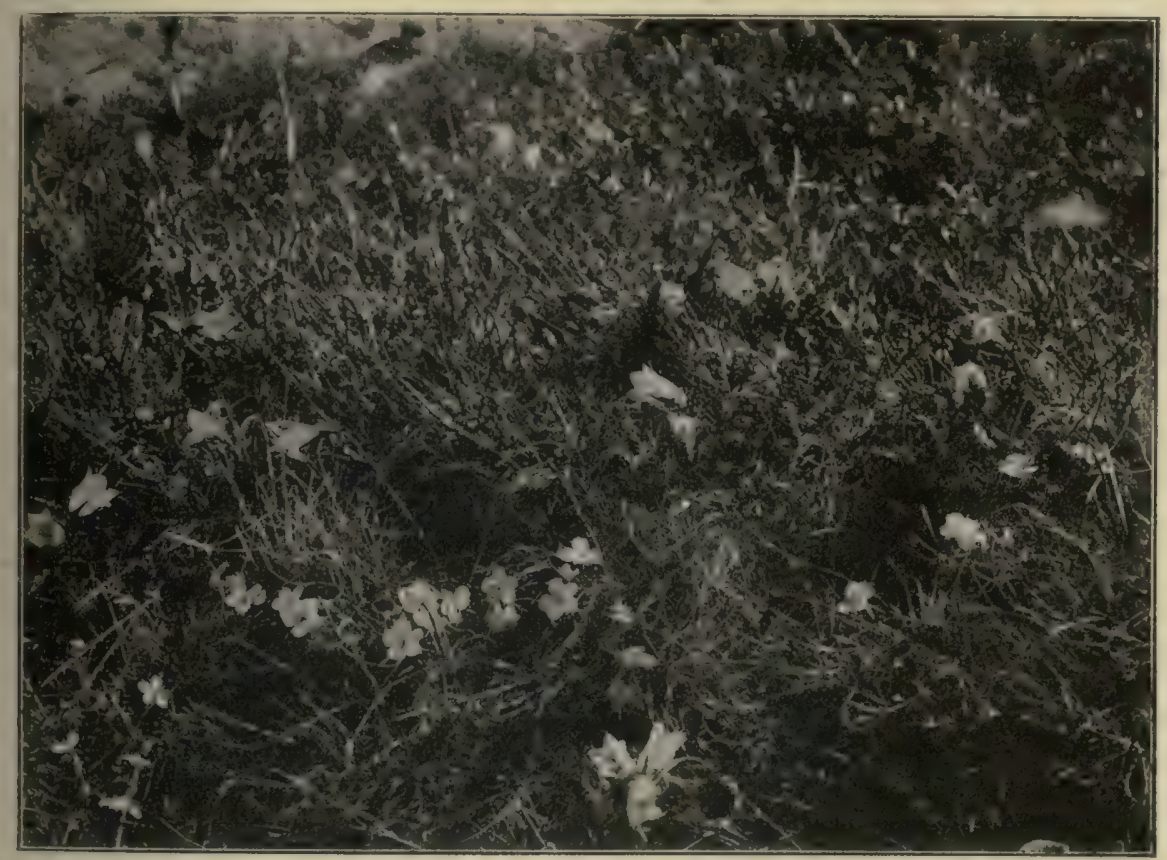

Fig. 261. Alpenmatte am Vitošgebirge in Bulgarien, mit Dianthus microlepis, Campanula Steveni und C. Orbelica, Sesleria marginata.

(Phot. Adamovice.)

die viele xerophile Merkmale haben, indem dieselben Kennzeichen auch an Salzboden gebunden auftreten; schmale, fast stielrunde Blätter, schwache Dickblättrigkeit $\mathbf{n}$. a.

Alle hohen Gebirge haben sicher solche Gras- und Krautmatten an der Waldgrenze. Boris Keller ${ }^{1}$ ) scheidet im Altaigebirge zwischen Pratum subalpinum, P. subpaludosum, P. humidum und vielen anderen Assoziationen. In den Anden treten nach Brackebusch "Alpenwiesen" auf: vorzügliche Weiden, auf denen sich wegen der reichlichen Nieder-

2) Boris Keller 1914. 
schläge ein vortrefflicher Graswuchs einfindet und die auf einem fruchtbaren, oft von Felsenmassen durchbrochenen Boden vorkommen. Die Flora ist nach der Breite und nach der Höhe über dem Meere sehr verschieden. Außer sehr vielen Grasarten gibt es eine Menge von Stauden, einjährigen Arten (?) und kleinen Sträuchern, die sich alle durch einen prächtigen Blütenschmuck auszeichnen und zu den Familien der Ranunculaceen, Malvaceen, Cruciferen, Polygalaceen, Geraniaceen, Caryophyllaceen, Rosaceen, Passifloraceen u. a. gehören. Doch kommen auch viele niedrige Cacteen, Farne, Moose und Flechten eingestreut vor, so daß diese Vegetation den typischen Matten und Wiesen der Alpen nicht ganz entspricht. Sie steht wohl einen Teile der xerophilen Matten der Alpen ökologisch am nächsten. R. Fries ${ }^{1}$ ) erwähnt als weit verbreitet in den Argentinischen Anden immergriine Hypsela-Wiesen, in welchen die Vegetationsorgane, Blatt- und Blütenstiele, sehr kurz sind und bei den Sprossen der Rosettentypus überwiegt.

"Alpenmatten" im Kaukasus werden von Rikli und Rübel ${ }^{2}$ ) erwähnt: Die Gräser treten stark zurück; vorherrschend sind saftige Kräuter, daneben treten aber auch Zwergsträucher und einige Therophyten auf. Nach der Höhe der Vegetation (vergl. Taf. 6-7) scheinen diese Matten eher zu den Hochstaudenfluren oder Wiesen zu gehören.

\section{Kap. Wiesen}

Alle im vorhergehenden behandelten, in den Polarländern und den Hochgebirgen vorkommenden Mesophytenvereine müssen wir insoweit als natürliche Vereine betrachten, als der Mensch in ihre Natur gar nicht eingegriffen hat oder ihnen doch nur in geringem Grade seinen Stempel aufzudrücken vermocht hat, meistens dadurch, daß er sie zu Weiden für Rindvieh, Schafe und Ziegen benutzte. Es gibt ganz sicher Ländereien, die von der Natur selbst mit mesophilen Gras- und Krautvereinen bedeckt worden sind. Von welchen Faktoren ihr Auftreten abhängt, muß näher untersucht werden; doch kann man so viel sagen, daß es besonders die niedrigen Wärmegrade, die kühlen regnerischen Sommer, die kurze Vegetationszeit oder die heftigen Winde und unzureichenden Niederschläge, in den Hochgebirgen auch häufig das Abgleiten des Schnees oder Lawinenbildung sind, welche die kräftigeren Lebensformen, besonders die Bäume, daran hindern, jenen Boden zu erobern, so z. B. in Island, auf den Färöern, in Schottland usw. Mayr führt an, daß es in Nordamerika Stellen gebe, wo die relative Lufteuchtigkeit während der Vegetationszeit so tief (unter $50 \%$ ) herabsinke, daß Wälder unmöglich

1) R. Fries 1905 .

2) Rikli u. Rübel 1913. 
seien und nur die im Bereiche des Taues liegende Vegetation bestehen könnte.

Aber in allen Ländern mit Klima von mittlerer Wärme und Feuchtigkeit, wo der Mensch, namentlich der Kulturmensch, hinreichend lange seinen Einfluß hat geltend machen können, wo Niederschläge und Luftfeuchtigkeit über das ganze $\mathrm{Jahr}$ gleichmäBig verteilt sind, kommen kïnstliche Gras- und Krautvereine (Halbkultur-Assoziationen) ${ }^{1}$ ) vor, nämlich Wiesen und Weiden, die ihre Entstehung und ihre Zusammensetzung gänzlich dem Menschen verdanken (Düngung, Drainage, Mahd, Abweiden). Die allermeisten dieser Vereine wachsen auf einem früher bewaldeten Boden; der Wald hat dem Eingriffe der Menschen weichen müssen. Flahaults ${ }^{2}$ ) "prairies pseudo-alpines“ in den Pyrenäen sind solche Wiesen, die sich auf entwaldetem Boden entwickelt haben. Überließe man solche Vereine sich selbst, so würden sie sicherlich im Laufe der Zeit in Wälder übergehen. Andere Wiesen hingegen sind, z. B. an Strömen, wo der Baumwuchs durch Überschwemmungen, Eisgang u. a. unmöglich gemacht wird, gewiß keine Kulturprodukte ${ }^{3}$ ).

Im folgenden legen wir namentlich nordeuropäische Wiesen und Weiden zugrunde; zwei Formationen, die an einen ziemlich feuchten oder einen ziemlich trocknen Boden gebunden sind. Die Wiesen kommen häufiger in natürlicher Form vor, die Weiden jedoch ganz gewiß nur selten.

Als Typus der Wiesen können zunächst die der nordeuropäischen Tiefländer genannt werden.

Die Wiesen stehen auf der Grenze zwischen den mesophilen und den hydrophilen Vereinen; einige Wiesentypen schließen sich diesen am nüchsten an; anderé gehören bestimmt zu den mesophilen Vereinen. Der Boden hat eine gewisse Feuchtigkeit $(60-80 \%$ Wasser im Sättigungszustande). Sein Grundwasser liegt indessen nicht so hoch wie in den Sümpfen, hat einen Stand, der nach den Jahreszeiten mehr als in diesen wechselt, und strömt zugleich mehr, wodurch der Boden periodisch durchlüftet wird. Dieser ist oft ein reicher, tiefer Humus, kann aber auch

2) Graebner 1909.

2) Flahault 1901 .

$\left.{ }^{3}\right)$ E. H. L. Krause gibt an: "Das Wort Wiese bezeichnet anscheinend ursprünglich ein von der Kultur nicht beeinfluBtes, nasses Gelände". Die gegenwärtigen Wiesen Norddeutschlands sind nach ihm „Kulturprodukte". Graebner (1909 und früher) führt hierzu Ausnahmen an. Der Begriff „Wiese" wird übrigens in verschiedenem Umfange angewandt, in weiterem Umfange von Stebler und Schröter, welche 21 Typen der Wiesen aufstellen. Nach ihnen ist eine "Wiese" eine Pflanzengesellschaft von zahlreichen, vorzugsweise mehrjährigen und krautartigen Landpflanzen oder auftauchenden Sumpf- und Wasserpflanzen gebildet, welche die Erde mit einer mehr oder weniger geschlossenen Narbe decken; verholzende und hapaxanthische Arten können als Nebenbestandteile auftreten. 
Sandboden sein, so besonders auf neuen Wiesen. Es gibt auch Wiesen, die sich auf Torfboden entwickelt haben.

Die Wiesen sind wie die Matten Assoziationen von mehrjährigen und krautartigen Pflanzen, besonders von Gräsern, und die Pflanzendecke ist ebenso sehr dicht geschlossen und zusammengedrängt, aber die Wiese hat eine höhere Vegetation, weshalb die krautartigen Hauptbestandteile mehr als eine Schicht bilden können.

Die Pflanzendecke hat wie die Matte einen dichten, zähen Filz von Wurzeln und Rhizomen, und da die Pflanzen so hoch (fußhoch und höher) sind und eine geschlossene Decke bilden, so sieht man den Boden nicht. $\mathrm{Zu}$ der Dichtigkeit der Decke trägt nicht wenig bei, daß die Wiese gemäht oder (seltener) abgeweidet wird. Mitten in der Vegetationszeit werden alle Pflanzen ihrer vegetativen Teile beraubt. Das Mähen greift in die Naturvervältnisse der Wiese bedeutend ein, indem es die Samenreife verhindert, die Verzweigung befördert und die floristische Zusammensetzung verändert. In der Natur wird der durch die Mahd hervorgerufene Einfluß durch die bei vielen Flüssen regelmäßigen Sommerüberschwemmungen hervorgebracht.

Die Pflanzendecke ist im Sommer frisch grün und besteht sowohl nach den Individuen als auch oft nach den Arten größtenteils aus Gramineen: Aera (Deschampsia), Avena, Dactylis, Festuca, Poa, Holcus, Anthoxanthum, Alopecurus, Phleum, Briza, Agrostis usw. Oft sind 20-30 Arten auf derselben Wiese ziemlich gleichmäßig gemischt. Außer diesen wird die Pflanzendecke noch von vielen monokotylen und dikotylen Stauden gebildet (Ranunculaceen, Papilionaceen, Compositen usw.). Bäume, Sträucher (z. B. Salix repens) und einjährige Arten (letztere fast nur auf Maulwurfshaufen, z. B. Saxifraga tridactylites) sind fast ausgeschlossen. Die Wiesen zeichnen sich durch ihren Blütenreichtum aus, weshalb ein reiches Insektenleben an sie gebunden ist, weiterhin durch ihre frisch grüne Farbe, wodurch sie zu den ebenfalls grünen und sehr ähnlichen, aber blütenarmen Wiesenmooren einen Gegensatz bilden. Zwischen den Kräutern findet man, an ihrem Grunde, besonders wenn sie niedriger sind, oft viele Moose: Hypnum, Aulacomnium, Mnium, Bryum usw.

Die Ruhezeit der Vegetation wird nur durch Frost herbeigeführt; aber die Wiese steht, obgleich im Winter gelbgrau und verwelkt, doch einer immergrünen Vegetation ökologisch sehr nahe, weil unter den alten Blättern frisch grüne vorkommen und weil viele gelbgewordene Blätter bei mildem Wetter schnell wieder grün werden. Das Wachstum der Gräser beginnt erst bei $11-15^{\circ} \mathrm{C}$.

Die Anpassung der Vegetation zeigt sich in folgendem.

1. Die Arten sind überwiegend mehrjährig; für einmal blühende ist offenbar nicht Licht und Platz genug vorhanden (von den halb- 
parasitischen Rhinantheen muß, wie bei anderen Pflanzenvereinen, abgesehen werden); von einjährigen kommt (außer der eben erwähnten Saxifraga) Linum catharticum vor, von zweijährigen z. B. Cirsium palustre.

2. Einige Arten haben vorzugsweise kriechende Rhizome und sind auf diese Weise ausgeprägt teppichbildend (von Gräsern Poa pratensis, Festuca rubra, Agrostis alba, ferner einige Carices usw.). Andere Stauden mit kriechenden Rhizomen sind Lathyrus pratensis, Valeriana dioeca, Epilobium palustre, Mentha, Lycopus, Equisetum palustre usw.).

Die meisten Gräser sind jedoch rasenbildend, z. B. Aera caespitosa, Avena pubescens, Dactylis glomerata, Alopecurus pratensis, Anthoxanthum, Festuca elatior, Poa trivialis, Briza media, Holcus lanatus u. a.; überhaupt haben die meisten Stauden nur eine schwache oder gar keine vegetative Wanderungsfähigkeit (Myosotis palustris, Rumex acetosa, Succisa pratensis, Geranium pratense, Polygonum bistorta, Coronaria (Lychnis) flos cuculi, Parnassia, Arten von Ranunculus, Caltha, Trollius, Primula u. a.). Der Grund hierfür ist wahrscheinlich der Widerstand, den die zahlreichen, zähen und verflochtenen Graswurzeln und Grasrhizome für Arten mit wandernden Sprossen bilden. Zwiebel- und Knollenpflanzen sind seltener (Orchis, Colchicum autumnale).

3. Die Blätter sind mesomorph, d. h. dünn, flach, breit, biegsam und kahl, haben weder eine dicke Epidermis noch einen anderen besonderen Verdunstungsschutz. Die Grasblätter führen auf beiden Seiten Spaltöffnungen und können sich nicht einrollen. Mechanisches Gewebe ist schwach oder gar nicht entwickelt. Turgeszenz macht viele Sprosse und Blätter steif.

Assoziationen. Die Flora ist auf den verschiedenen Wiesen natürlicherweise sehr ungleichartig, namentlich im Einklange mit den Unterschieden in der Feuchtigkeit des Bodens und je nach den Florengebieten, ferner nach dem Eingriffe der Kultur (Weiden, Mähen, Grabenziehen, Bewässerung; vergl. auch Wittmack). So führt C. A. Weber ${ }^{1}$ ) mehrere Assoziationen (die er als "Subformationen" bezeichnet) des natürlichen Graslandes an, wovon folgende $\mathrm{zu}$ den mesophilen Wiesen gerechnet werden müssen: 1. Im Graslande der hohen Geest die Assoziation der Poa pratensis (etwa 2-3 m über dem mittleren Grundwasserstande), 2. die der Poa trivialis $(1-1,5 \mathrm{~m}$ über diesem Stande), 3. die der Acra caespitosa (im Juni und Juli 0,4-0,7 m über dem Wasser der Gräben). Die "Assoziationen" der Carex panicea, der C.gracilis und der Molinia caerulea hingegen dürften eher zu den Mooren gehören oder dem Übergangsgebiete von der Geest zur Marsch ist die "Assoziation" der Festuca elatior, und aus dem Graslande der eingedeichten, eigent-

2) C. A. Weber 1892; vergl. auch 1909. 
lichen Marsch sind die "Subformationen“ der Agrostis alba, der Poa pratensis und des Lolium perenne zu mesophilen Wiesen oder Weiden zu rechnen.

Es mag hier auch an die S. 82,83 erwähnten Untersuchungen Feilbergs erinnert werden.

In Norwegen hat Hanna Resvoll-Holmsen ${ }^{1}$ ) die Häufigkeit der Arten in einigen Wiesen statistisch gemessen; am meisten hervortretend waren Agrostis borealis und A. vulgaris, Festuca rubra, Poa alpina und $P$. pratensis; Carex alpicola in einigen Wiesen, andere Arten in anderen Typen von Grasland.

Das Grasland in England wird von Will. G. Smith und Crampton ${ }^{2}$ ) besprochen. Die Entwicklung derselben wird durch die kalttemperierten, feuchten Sommer, durch den vielen Regen und Nebel begünstigt. Von der Höhe über dem Meere ist sie nicht abhängig. Aber dieses Klima führt sauren Boden und Bildung von Rohhumus und Torf mit sich, welche Bodenarten nach Norden und Westen an Häufigkeit zunehmen und für das Grasland ungünstig sind.

Das natürliche Grasland muß in zwei Gruppen geteilt werden: der stabile Typus findet sich an Orten, welche durch lange Zeiträume nur langsamen geologischen Änderungen ausgesetzt gewesen sind; er findet sich z. B. auf Kreideboden und auf exponierten kalkreichen Hügeln und Felsanhöhen, z. B. den Dolerithügeln im mittleren Schottland. Die andere Gruppe wird gebildet aus den veränderlichen („migratory“) Typen an Arten, deren Oberflächen Änderungen verschiedener Art ausgesetzt sind. Darunter werden fünf Typen von Grasland unterschieden: 1. Die eine Grasnarbe bildenden Typen ("turfforming Types“), sowohl mit konstanten als mit veränderlichen Untertypen. 2. Die Wiesen-Typen mit höheren Gräsern und Kräutern. 3. Die Rasen-Typen („Tussock Types“) mit groben, harten oder zähen Gräsern und dichter Rasenform, besonders auf veränderlichen Lokalitäten, z. B. Nardus stricta. 4. „The stooled meadow Types", hauptsächlich aus Aera caespitosa und Molinia coerulea, auch bültenbildenden Carices (z. B. Carex paniculata) gebildet. 5. „Lairgrasslands and the Camp-follower Types", eine heterogene Gruppe, eine Halbkulturformation durch Tiere hervorgerufen, welcher sich andere durch die Kultur mehr unmittelbar hervorgerufene Varianten von Grasland anschließen.

Wiesen wie unsere nordischen findet man noch in den Ebenen Südeuropas; in den Tropen scheinen sie zu fehlen oder jedenfalls sehr selten zu sein (Deutsch-Ostafrika, Matto grosso in Brasilien); häufiger sind sie wohl nur auf den Gebirgen.

1) Hanna Resvoll-Holmsen 1914.

2) Will. G. Smith u. Crampton 1914 . 
In Gebirgsgegenden treten echte Wiesen an vielen Stellen auf, z. B. in einer Menge von Assoziationen in Norwegen, in der Schweiz, in Serbien usw. Adamovie ${ }^{1}$ ) hat eine Reihe von Typen erwähnt: Waldwiesen, Bergwiesen, Talwiesen usw. Günther Becks "Talwiesen " sind solche; sie werden meist zweimal gemäht und enthalten 12 Grasarten und viele andere Kräuter. Es gibt allein in der Schweiz eine Menge verschiedener Wiesenbestände ${ }^{2}$ ). Schröter teilt sie in trockene, nasse und frische Wiesen.

Gewisse Pflanzengesellschaften von den östlichen Prärien Nordamerikas scheinen sich Wiesen zu nähern. Zum Beispiel schreiben Roscoe Pound und Clements ${ }^{3}$ ) über die Prärien Nebraskas: sie müssen im allgemeinen als mesophytisch betrachtet werden; man kann zwei Formen unterscheiden, die hohen und die niedrigen Prärien; die letzteren haben mehr mit Wiesen und Weiden gemein; die erstere besitzt in mancher Hinsicht keine geringe Ähnlichkeit mit den Sandhügeln. Die hauptsächlichsten Gräser der ersteren sind Rasenbildner, die der letzteren Bültenbildner ${ }^{4}$ ).

\section{Kap. Hochstaudenfluren}

Die Hochstaudenfluren können von den Wiesen unterschieden werden sowohl durch das Zurücktreten der Gräser, als auch durch die größere Zahl von hohen Stauden, dann auch durch ihren weniger dichten Wuchs, so daß man den dunkeln, humusreichen und feuchten Boden zwischen den Pflanzen oft leicht sehen kann.

Sie kommen sowohl in den Polargegenden als auch in südlicheren Gegenden der kalt temperierten nördlichen Halbkugel und in hohen Gebirgen der wärmeren Lånder vor.

Ganz ähnliche Hochstaudenfluren erwähnt Thekla Resvoll ${ }^{5}$ ) aus Norwegen und Pohl von den Ufern des weißen Meeres (Kolgujew).

Als ein erstes Beispiel können die "Oasen der Tundren" genannt werden, die blütenreiche Hochstaudenfluren darstellen. Sie werden von Middendorff geschildert und für Sibirien angegeben, z. B. für die Abhänge am Taimyr-Flusse, wo sie gegen die rauhen Winde geschützt sind und wo der Boden ein schwarzer Humus ist. Caltha palustris, Geum glaciale, Arten von Potentilla, Ranunculus, Polemonium, Eritrichium, Oxytropis, Pedicularis, Saxifraga, Papaver (P. nudicaule),

1) Adamovié 1909 .

2) Stebler u. Schröter 1892; Schröter 1904; Rübel 1911-1913; BrockmannJerosch; Furrer 1914.

₹) Roscoe Pound u. Clements 1900.

4) Utber die Wiesen Nebraskas vergl. Pool 1913.

s) Th. Resvoll 1913; Pohle 1907, Taf. 30. 
Delphinium und viele andere hohe Stauden dieser Oasen beleben die trostlose Umgebung mit ihren zahlreichen Blüten und lebhaften Farben. Eine ähnliche Vegetation Novaia Semljas schildern v. Baer und Heuglin. Nathorsts "Sluttningar" (d.h. Abhänge) auf Spitzbergen und Kjellmans "Blomstermark" (d. h. Blumenflur) in Sibirien sind jedenfalls ökologiseh nahe verwandte Vegetationen. Ebenso sind die S. 531 erwähnter Blumenmatten Pohles diesen Vegetationen nahe verwandt, kaum von ihnen zu trennen.

Von Grönland werden sie von verschiedenen dänischen Forscherr erwähnt $^{1}$ ). Sie finden sich in Tälern, feuchten Schluchten, an Abhängen wo Wasser niederrieselt.

Eine ähnliche Vegetation, die weder zu den Matten noch zu der typischen Wiesen gerechnet werden kann, findet sich an vielen süd. licheren Stellen. Hayek ${ }^{2}$ ), Domin ${ }^{3}$ ) und C. Schröter (a. a. O.) erwähner solche. Der letztere beschreibt die reichbeblätterten Stengel, dereI breite, horizontal abstehende Blätter in ihrem Schatten auf dem Boder nichts aufkommen lassen.

Sehr bekannt sind dann auch die oft schwer durchdringlichen, hoher Bestände südosteuropäischer und asiatischer Gebirge, namentlich des Kaukasus, des Himalaja u. a. In Deutschland finden sie sich schor an den Hängen des Altvatergebirges. Die Eigenart der Vegetations bedingungen beruht bei diesen Hochstaudenfluren darin, daß währenı der kalten Monate Verhältnisse dort herrschen, wie sie zur Entstehun Ł der Matten und Alpenwiesen führen, daß aber die reichliche Erwärmun! im Sommer einer üppig wachsenden Mesophytenvegetation günstig ist so daß der dichte Krautbestand mehrere Meter hoch werden kann.

„Hochstaudenwiese“. Brockmann-Jerosch erwähnt von dem Puschla eine "sehr charakteristische Formation" von Hochstauden. "Da, wo ei guter, milder und humoser Boden mit genügender Feuchtigkeit sich ver bindet, entsteht an sonnigen Lagen oft eine unvergleichlich üppig Vegetation, die sich vornehmlich aus hochstengeligen Kräutern zusammeı setzt und Hochstaudenwiese oder Karflur benannt wird." Dieselb erwähnt Roth vom Murgtal, wo sie gebildet wird von Arten von Aconi tum, Adenostyles, Mulgedium usw.

Viele andere ähnliche Vereine sind erwähnt, z. B. die Auwiesen it Nordural von Pohle ${ }^{4}$ ).

Ostasiens Wiesen zeichnen sich durch die größere Höhe de Gräser aus; auch die dikotylen Kräuter werden viel höher, stellenweis

1) Warming 1887; Kruuse 1912.

2) Hayek 1907 .

3) Domin 1904, 1905 a.

4) Pohle 1907. 
mehrere Fuß hoch. Das Gepräge der Wiesen geht hierdurch verloren: es entstehen Hochstaudenvereine, von denen Asien in mehreren Gegenden Beispiele aufweist und die Kittlitz abgehildet hat, gemischte Bestände stattlicher, hoher Stauden, namentlich riesiger HeracleumArten, welche sich über einen üppigen Wiesenboden erheben, und ferner die .Parklandschaften" (Ostasiens, deren Grasfluren Bïume und Strüucher in sich aufgenommen haben und dadurch an die Savannen ('rinn('In ${ }^{1}$ ). C̈ber diese verschiedenen Vereine liegen noch so wenige

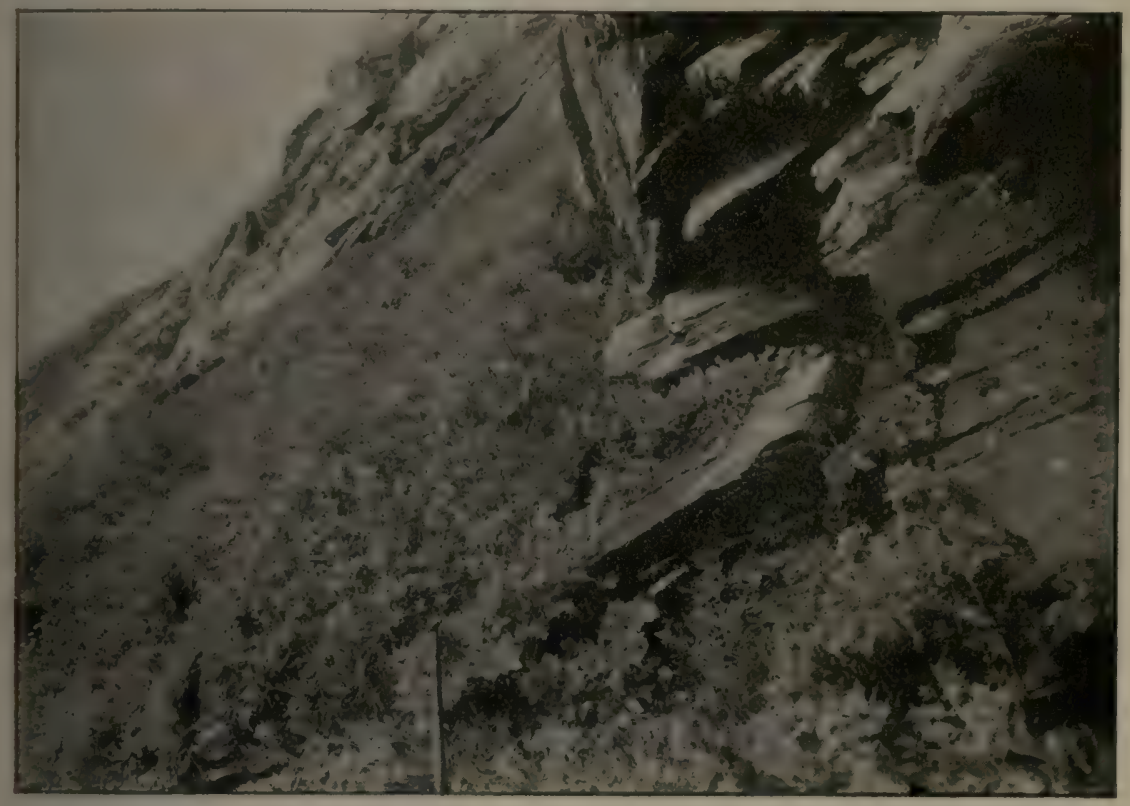

Fig. 262. Kräuterhalde, von Wasser überrieselt, auf der Ostküste von Grönland, $600 \mathrm{~m}$ iib. M. Die Vegetation ist vorzugsweise gebildet von Alchimilla glomerulans, A. filicaulis f. vestita und Taraxacum croceum, dazu eine Menge andere dikotyle Stauden, einige Gräser, Farne und Moose, welche eine Schicht von $30-35 \mathrm{~cm}$ Höhe bilden; dazu Salix und Archangelica officinalis, welche letztere bedeutende GröBe $(1 \mathrm{~m})$ erreicht.

(Phot. Chr. Kruuse; vergl. 1912: 127.)

und unvollst:ändige Mitteilungen vor, daß es unmöglich ist, ihnen ihren rechten Platz anzuweisen.

Im allgemeinen scheint das häufige Vorkommen der Hochstaudenfluren eine charakteristische Erscheinung des kurasischen Südostens zu sein. Für den Wanderer ist es ein eigenartiges Gefühl, innerhalb der meist ül)er mannshohen Stauden zu wandern, die scheinbar unendlich sich ausdehnend, ihm jede Möglichkeit der Orientierung nehmen. Der (irund ihrer Ausbildung liegt augenscheinlich in den großen Kontrasten

2) Grisebach 1872 . 
des Sommer- und Winterklimas in den betreffenden Gebirgen. Die Winter sind ausgezeichnet durch die starken und trockenen, absolut waldfeindlichen, kalten Winde (vergl. Schimper); in den Sommermonaten, die infolge der südlichen Lage bezw. der günstigen Einstrahlung der Sonne gegenüber den nördlicheren Gebirgen eine verhältnismäßig lange Vegetationszeit haben, herrschen an denselben Orten bei günstigen Bodenverhältnissen die denkbar besten Lebensbedingungen für Pflanzen der gemäßigten Zone. In der Folge entwickelt sich eine so üppige Sommerflora, wie sie ähnlich in ihrer Massenvegetation wohl nur bei den zeitweise feuchten, zeitweise sehr trockenen Steppengebieten mancher Tropenländer (vergl. Kap. 106) vorkommt.

\section{Kap. Weiden auf Kulturland (Kultur- und Halbkultur- assoziationen)}

Von der Wiese zur Weide ist kein großer Sprung. Der Unterschied beruht besonders auf der Feuchtigkeit des Bodens. Die Weiden sind gewöhnlich höher gelegen und trockener; sie werden keiner größeren Feuchtigkeit ausgesetzt, als der, welche die allgemeinen Niederschläge ihnen bringen. Die Vegetation der Weiden ist niedriger und offener als die der Wiesen; sie können oft nicht gemäht, sondern nur abgeweidet werden. Viele Grasfelder in den dicht bevölkerten temperierten Gegenden der nördlichen Halbkugel zeigen eine trostlose Einförmigkeit und Öde, weil sie immer und immer von Schafen und anderen Haustieren abgenagt werden; der Boden wird ganz wie bei den Matten, die oben besprochen wurden, nur von einem sehr kurzen aber dichten Grasrasen mit eingestreuten Kräutern, besonders dikotylen Stauden, bedeckt. Nur solche Pflanzen, welche die Tiere meiden, erreichen einen höheren Wuchs, z. B. Disteln, Aera caespitosa, Sträucher von Juniperus communis usw.

Die Färöer sind zum größten Teile von einer solchen Grasnarbe bedeckt, welche die Schafe geformt haben ${ }^{1}$ ).

Die isländischen, durch die Kultur verhältnismäßig weniger beeinflußten Weiden haben Feilberg und Stefánsson ${ }^{2}$ ) behandelt. Ihre wichtigsten Gräser sind Festuca rubra, Poa alpina, P. pratensis und Aera caespitosa; auf gedüngten Stellen und an Quellen treten viele andere auf. (Vergl. auch Thoroddsen, S. 400).

Die Weiden sind in den nordeuropäischen Ebenen und in anderen Gegenden, die ursprünglich bewaldet waren, fast ohne Ausnahme Kunstprodukte, die, falls die Menschen untergingen, verschwänden, und dann vom Walde ersetzt würden, wie auch ihr Boden ursprünglich vom Walde

1) Ostenfeld $1908 \mathrm{~b}$.

2) Stefánsson 1894 . 
erobert worden war. Ausnahmen hiervon bilden nur kleinere Weidelichtungen innerhalb alter Wälder, die durch das Wild regelmäßig abgeweidet werden und von ihm auch eine Düngung erhalten. Stellenweise ist Spiranthes spiralis in Norddeutschland für solche Orte charakteristisch. Die Weiden bestehen sicher meist hauptsächlich aus Gräsern; es sind über große Teile Europas dieselben Arten: Festuca rubra, Lolium perenne, Nardus stricta, Anthoxanthum, Poa pratensis, Agrostis vulgaris, Bromus-Arten, Triticum repens, Holcus mollis u. a. (selbst auf den „pascoli“ Italiens findet man viele dieser Arten); aber auch dikotyle Kräuter, namentlich dikotyle wie Chrysanthemum leucanthemum, Achillea millefolium, Campanula rotundifolia, Arten von Plantago, Taraxacum, Leontodon, Bellis, Ranunculus, Cerastium, Trifolium, Daucus, Pimpinella, Carum usw. spielen eine wesentliche Rolle. Viele Moose (Hypnum) können beigemischt sein.

Assoziationen. Die floristische Zusammensetzung hat hier ein geringeres Interesse, weil die Weiden durch die Kultur, nach dem Gebrauche, den der Landwirt von ihnen macht, umgebildet und verändert werden. Jedoch sei bemerkt, daß man bei den Weiden mehr Erfahrungen darüber hat, eine wie eingreifende Bedeutung das Wasser hat und wie empfindlich die Pflanzen sind. Schon S. 83 wurde nach Feilberg erwähnt, wie sich die Vegetation auf den Ebenen bei Skagen in Jütland mit dem Grundwasserstande verändert; nach demselben ausgezeichneten Beobachter besteht ein Unterschied zwischen dem Gräserwuchs in Jütland und auf Seeland, der dem Umstande zuzuschreiben ist, daß in Jütland im Frühjahr etwas mehr Niederschläge fallen, als auf Seeland. Ferner zeigen die auf S. 539 angeführten Beobachtungen Webers, wie die Vegetation von dem Abstande vom Grundwasser abhängt ${ }^{1}$ ).

Auch die mineralische Zusammensetzung des Bodens spielt eine Rolle; so unterscheidet R. Smith ${ }^{2}$ ) z. B. in Schottland Weiden auf Basalthügeln, solche auf Silurischen Hügeln und solche des „Pentland“. Auch andere edaphische und geographische Faktoren spielen eine Rolle. Eine große Menge von Assoziationen kommt in Übereinstimmung mit klimatischen, edaphischen, biotischen und historischen Faktoren vor ${ }^{3}$ ).

So wie die Matten und Wiesen sich nicht durch scharfe Charaktere voneinander und von den Weiden trennen lassen, gibt es auch keinen scharfen Unterschied zwischen den letzteren und den trockeneren, hügeligen, mehr oder weniger offenen Triften im mittleren Europa, welche mit Namen wie Grastriften, Hügeltriften ${ }^{4}$ ) usw. belegt worden

7) Vergl. auch Wittmack; Graebner 1898 a, b; 1909.

2) R. Smith $1900 \mathrm{a}$.

3) Florenlisten z. B. bei Tansley 1911.

) Drude 1905.

Warming - Graebner. 3. Auflage, illustr. 
sind, und welche mehr oder weniger stark xerophil ausgeprägte Vereine sind, welche in die Grassteppen übergehen.

Hierher scheint eine Anzahl von Assoziationen zu gehören, welche Warming früher ${ }^{1}$ ) unter dem Kapitel „Chersophyten“" angebracht hatte ${ }^{2}$. Einige von ihnen werden wohl hier unter die mesophilen Formationer gestellt werden können, andere schließen sich den Steppen enger an Eine detaillierte ökologische Bearbeitung derselben ist dringend nötig

In den Assoziationen der trockenen Wiesen in Deutschland finder sich nicht selten auch Arten, die für die steppenartigen Vereine charakte. ristisch sind und die ebenso wie die oben beschriebenen Prärienverein Übergangsglieder zwischen diesen Vereinsgruppen darstellen. In Nord deutschland ist es besonders die Formation der sonnigen (pontischen Hügel, die die steppenartigen Pflanzenvereine vertritt und zu der danı die trockenen Wiesen überleiten. Unter anderen findet man hier of Helianthemum chamaecistus, Phleum Boehmeri, Avena pratensis usw. auch Ausläufer der sonst wenig dicht bewachsenen, sonnigen Hügel sowie flache oder gemuldete Kuppen, in denen die Gräser dicht zu sammenrücken, nehmen öfter die Physiognomie einer Wiese an.

\section{Kap. Formation der mesophilen Gebüsche kalter und kalttemperierter Klimate}

In mikrothermen Ländern oder in gęwissen Höhenstufen der Berg kommen an vielen Stellen Gebüsche vor, welche zu den mesophilen un. hygrophilen gerechnet werden müssen. Ein Teil derselben findet sic] in den Polarländern und in alpinen und subalpinen Höhen, ein andere Teil in den Tiefländern; letztere sind zum größten Teile oder stet Kulturprodukte. Sie schließen sich den in dem vorigen Kapitel be sprochenen Krautvereinen nahe an, und solche besonders aus Hoch stauden gebildeten finden sich oft unter ihnen.

Arktische und subarktische Gebüsche sind gewöhnlich Saliceta: man findet sie im Grunde der Täler an geschützten, sonnigen Stelleı besonders wo fließendes oder von den Felsen herabsickernde Wasser eine gleichmäßige Feuchtigkeit schafft, wo sich dunkler, feuchtes neutraler Humus angesammelt hat, den Regenwürmer bewohnen. I Grönland ${ }^{3}$ ) sind sie besonders von Salix glauca (Fig. 263-265) gebilde die jedenfalls zum 72.-73. Breitegrade hinaufgeht. In Südgrönland bild sie ausgedehnte, oft fast undurchdringliche Gebüsche von einigen (1Metern Höhe, mit Stämmen von 5-6 und mehr cm Dicke, jedoch weit

1) Warming 1909 .

2) Der Name stammt von Clements 1905; von छ́soos, trocken, öde.

3) Warming 1887; Rosenvinge 1898; Porsild 1902, 1912; C. Kruuse 1912. 


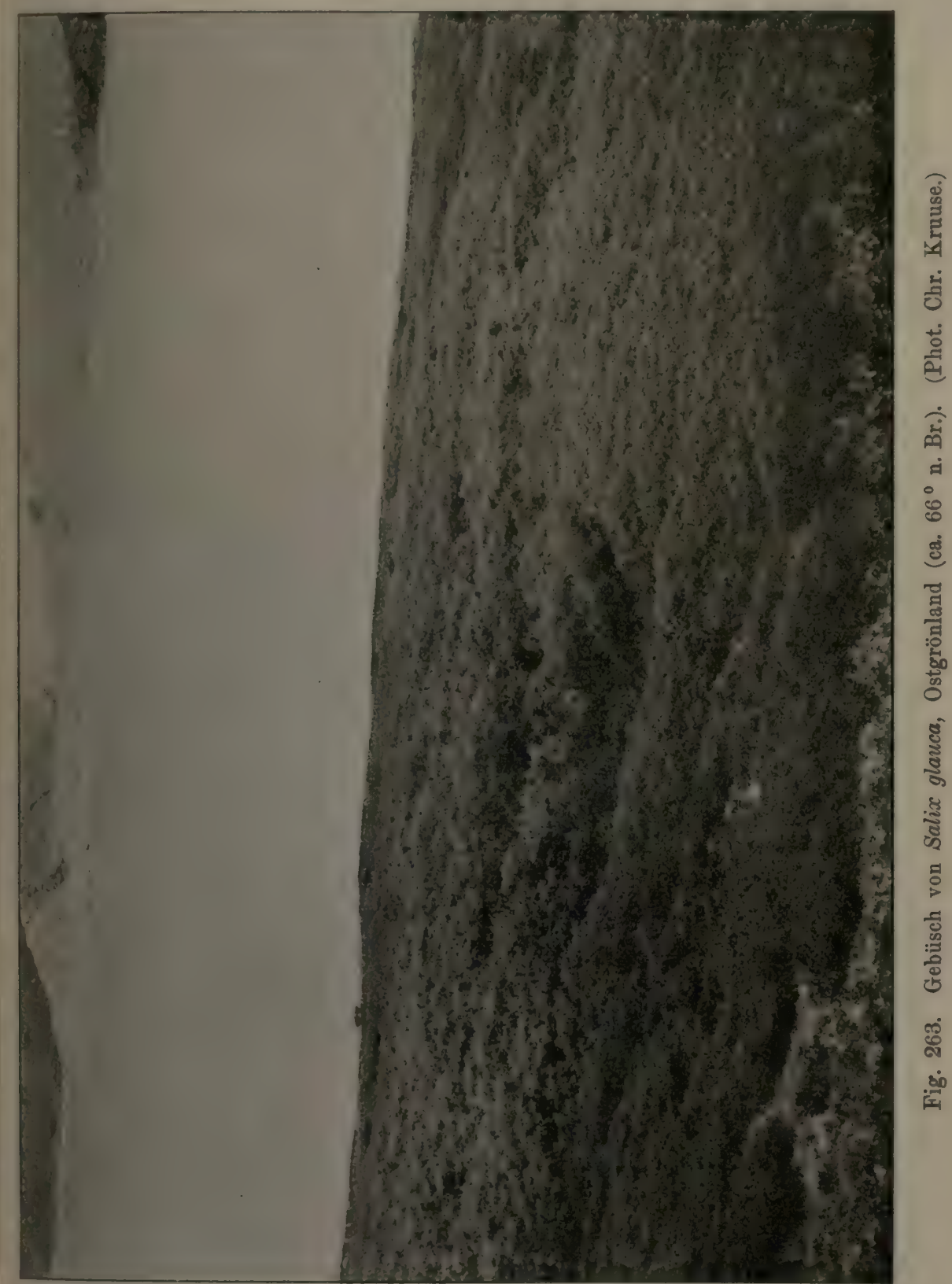

Erklärung zu Fig. 263. Die Sträucher erreichen über $1 \mathrm{~m}$ Höhe und die Stämme, welche dem Buden aufliegen, werden über $3 \mathrm{~m}$ lang und $3 \mathrm{~cm}$ im Durchmesser. Selten fand Kruuse mehr als 40-60 Jahresringe. Jedes Individuum hat 3-6 Stämme. Der Borlen hat eine Laubdecke von 2-5 cm, darunter $5-10 \mathrm{~cm}$ poröse Mullerde und darunter r. $10 \mathrm{~cm}$ feste Mullerde. Die Bodenvegetation ist aus Arten von Potentilla, Saxifraga, Stellaria, Cerastium, Arabis, Pirola, Taraxacum, Gräsern u. a. gebildet, und viele von diesen hatten merkwürdige Höhe. Näheres bei Kruuse 1912: 134 . 
nördlich erreichen sie kaum $1 \mathrm{~m}$ Höhe und haben mehr oder weniger niederliegende Zweige. Unter den Weiden gedeihen große und breitblättrige, frisch grüne, mehrjährige Kräuter wie Archangelica offcinalis, Oxyria, Taraxacum officinale, Alchimilla vulgaris, PotentillaArten, Epilobium angustifolium, Arabis alpina, ferner Poa alpina und andere breitblättrige, grasartige Pflanzen, Farne und große, lockere Moose (Hylocomium, Hypnum, Dicranum usw.).

Noch bei $72^{\circ} 30^{\prime} \mathrm{n}$. Br. fand Porsild bei Orpik eine Bodenvegetation von Gräsern (Poa pratensis, Trisetum, Hierochloë) und Stauden wie Stellaria longipes, Pirola grandiflora (Fig. 265), Arten von Saxifraga, Campanula u. a., oder an schattigeren Stellen aus gewöhnlichen Waldmoosen.

Ebenso ist Island reich an Saliceten ${ }^{1}$ ), z. B. von Salix lanata (Fig. 266), S. phylicifolia, S. glauca von 1-2 m Höhe.

Oberhalb der Waldgrenze auf Europas Bergen kommen vielfach Gebüsche vor, z. B. in Norwegen. Hier treten oberhalb (und auch in) der Birkenstufe (der „Birkenregion“) Saliceta mixta auf, besonders längs den Bachufern und an den Flüssen und auf feuchtem, abschüssigem Terrain. Sie weichen von den grönländischen dadurch $a b$, daß viele verschiedene Arten (Salix Lapponum, S. lanata, S. arbuscula, S. glauca, S. phylicifolia, S. nigricans u. a.) die Gebüsche bilden und daß eine noch reichere Kräuterflora auf ihrem Boden gedeiht. Einige derselben werden 2-3 m hoch, andere bleiben niedriger. Salix myrsinites kann 2-5 dm hohe Gebüsche bildend gefunden werden. Die Bodenvegetation hat am meisten Ähnlichkeit mit der der Birkenwälder ${ }^{2}$ ). Bonnier und Flahault nennen sie "Weiden-Prärien" und heben diese ausgedehnten Weidengebüsche als einen Unterschied gegen die Alpen hervor, wo die meisten jener Weidenarten zwar auch vorkommen, aber weniger vorherrschen. Dieselben Gebüsche findet man in Lappland und Sibirien.

Diese Weidengebüsche haben verschiedene xerophytische Anpassungen, sind aber doch laubwechselnd. Sie sind überhaupt in dem gemäßigten Europa allgemeine Begleiter von Flußufern außerhalb der Sumpfgebiete. Andere Gebüsche werden oberhalb der Waldgrenze von Birken oder von Birken und Weiden gebildet, die von Erle, anderen Sträuchern und von hohen Stauden begleitet sind, z. B. von Arten von Aconitum, Ranunculus, Digitalis, Geranium silvaticum, Vicia, Lathyrus, Epilobium, Thalictrum, Polemonium, Equisetum, im Inneren Lapplands von Veratrum, Senecio nemorensis u. a. Diese Birkengebüsche gehen natürlicherweise hier und da in Birkenwälder über.

Von alpinen Mesophytengebüschen in der Schweiz und Balkan mögen die Grünerlengebüsche genannt werden. Alnus viridis bildet

1) Thoroddsen 1914.

2) Statistische Aufzeichnungen hat Vahl gegeben, 1913. 
in den Alpen in 1200-2000 m Höhe auf überrieselten Stellen dichte Gebüsche mit einer Grundvegetation von Hochstauden.

In den Alpen kommen oberhalb der Waldgrenze andere Gebüsche von niederen Sträuchern vor, z. B. Pineta montanae und Rhododendreta; da der Boden aber in diesen wohl meist mit Rohhumus bedeckt zu sein scheint, müssen sie unter den Assoziationen des saueren Bodens besprochen werden. Sie sind offenbar auch weit mehr xeromorph, als die jetzt erwähnten Gebüsche bildenden Sträucher, da sie immergrün sind.

Die Tiefländer gemäßigter Gegenden sind an den Weidengebüschen ähnlichen Gebüschen reich. Immergrüne Ilex-Gebüsche treten an den

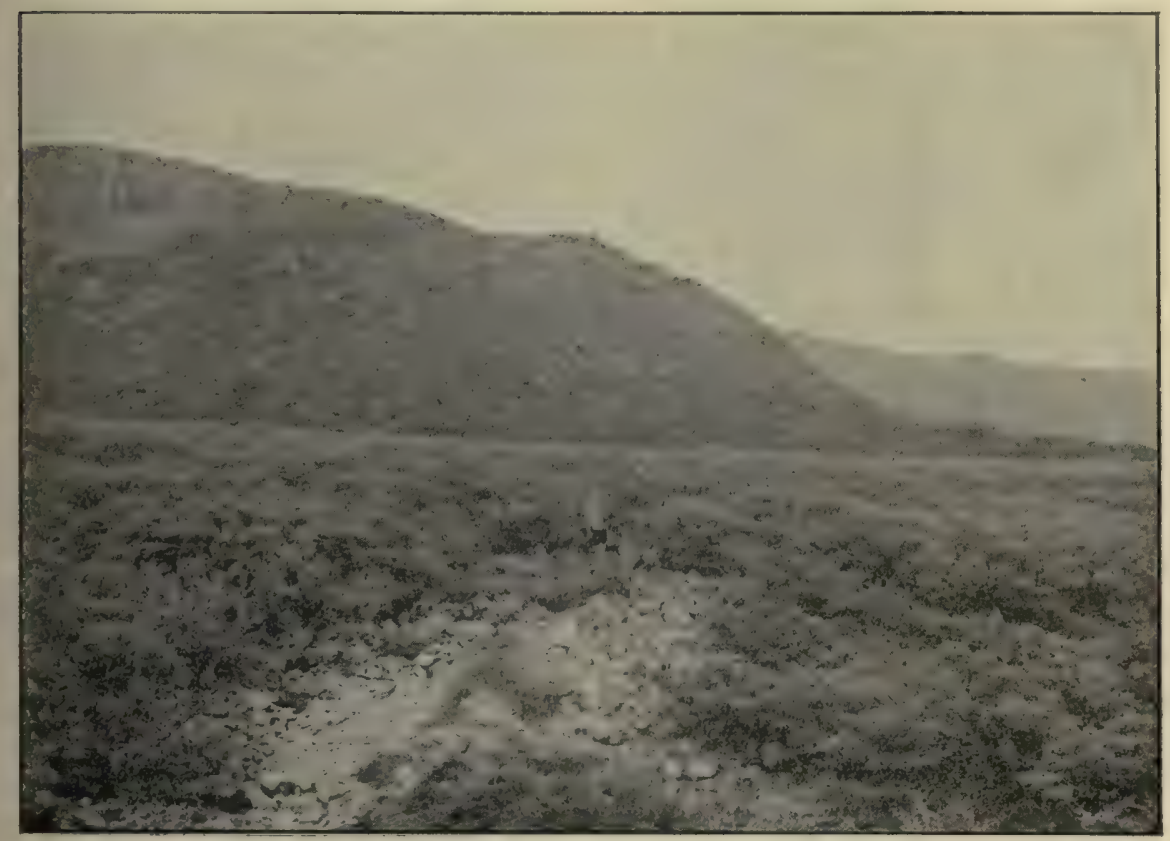

Fig. 264. Gebüsch von Salix glauca, auf $72^{\circ} 30^{\prime} \mathrm{n}$. Br. in Westgrönland (wahrscheinlich das nördlichste in Westgrönland). (Phot. M. Porsild.)

südwestlichen Kiisten von Norwegen wie auch im nordwestdeutschen Flachlande wie überhaupt im westlichen Europa auf, und diese sind, offenbar ganz natürlich, von der großen Lufteuchtigkeit und Regenmenge des ozeanischen Klimas bedingt.

Gebüsche der Mesophyten verdanken gewiß verschiedenen Ursachen ihr Dasein. Die vorhin aus den Polarländern und den Hochgebirgen erwähnten sind natürliche Gebüsche; sie treten an Stellen auf, wo die Wachstumsbedingungen (Wärmeverhältnisse, Winde usw.) für die Wälder ungünstig, aber für die Gras - und Krautmatten zu gut sind. Andere Gebüsche sind Kulturprodukte (Halbkulturformationen), indem sie 
Reste der durch Menschenhand gefällten Wälder darstellen und nun fortdauernd durch ungünstige Verhältnisse niedergehalten werden, die direkt oder indirekt durch den Eingriff des Menschen hervorgerufen worden sind; Beispiele hierfür sind Eichengebüsche in Jütland ${ }^{1}$ ), auf der Balkanhalbinsel, zusammengesetzt an einer Stelle aus Cotinus, an anderen aus Quercus, Crataegus oder Paliurus ${ }^{2}$ ), und die von Focke ${ }^{3}$ ) erwähnten Weißbuchengestrüppe auf der Geest der deutschen Nordseeküste.

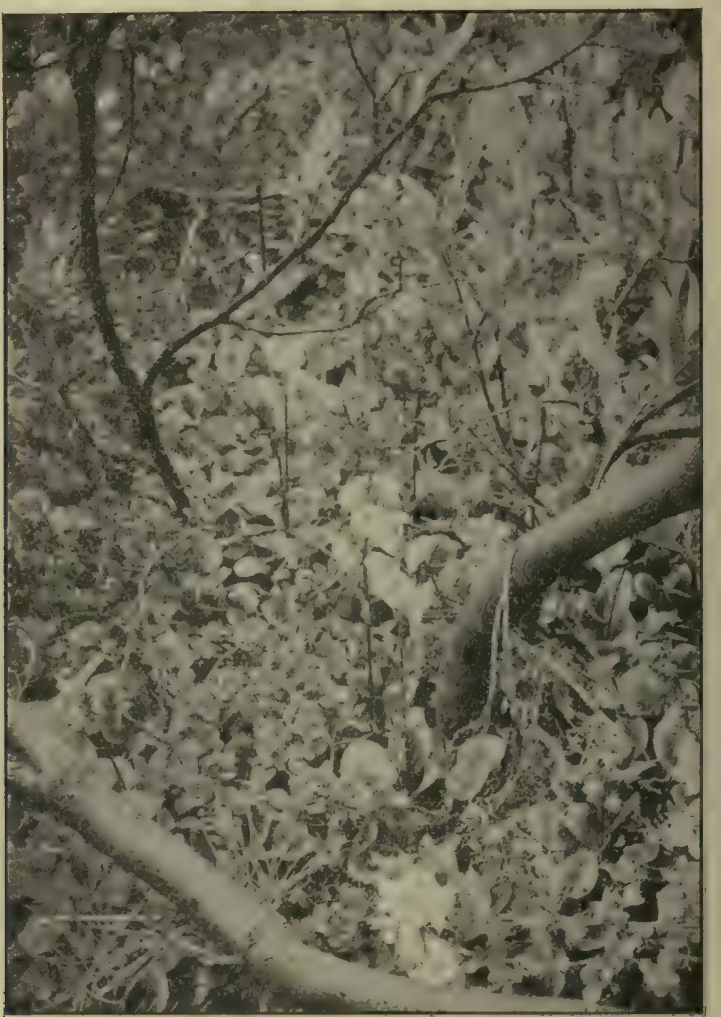

Fig. 265. Pirola grandiflora als Bodenvegetation in dem Gebüsch von Salix glauca. (Phot. M. Porsild.)

Hierher gehört z. B. auch die Haselstrauch-„Formation“ am Puschlav, die ohne die Holzgewinnung und das Beweiden in einen Wald übergehen würde, und andere "zoogene" Gebüsche in der Schweiz ${ }^{4}$ ).

Hierher wird wohl auch Adamoviés ${ }^{5}$ ) „Sibljak“ zu stellen sein, obgleich er mehr xerophil ist, mit Anklängen an die Steppe. Es ist

1) Vaupell 1863; Warming 1907.

2) Adamovié 1898; Vahl 1907.

3) Abh. naturw. Ver. Bremen, Bd. XIII, S. 261.

4) Brockmann-Jerosch 1907.

5) Adamović 1902. 
ein aus sommergrünen Sträuchern zusammengesetztes, wärmeliebendes Buschwerk, welches, der vollen Sonne ausgesetzt, einen Grenzverein zwischen Wald und Steppe darstellt. Die Sibljak-Sträucher sind Arten von Cytisus, Prunus chamaecerasus, Paliurus, Juniperus und anderen, die nie in Wäldern wachsen. Zwischen diesen wachsen als untergeordnete Bestandteile eine Anzahl von Steppenpflanzen. Die Sibljak-Formation ist streng vom Walde geschieden und zeigt auch keine Übergänge $\mathrm{zu}$ der an die Luftfeuchtigkeit der Meeresufer gebundenen Macchia; diese letztere ist immergrün, der Sibljak vorwiegend laubwechselnd. Sibljak

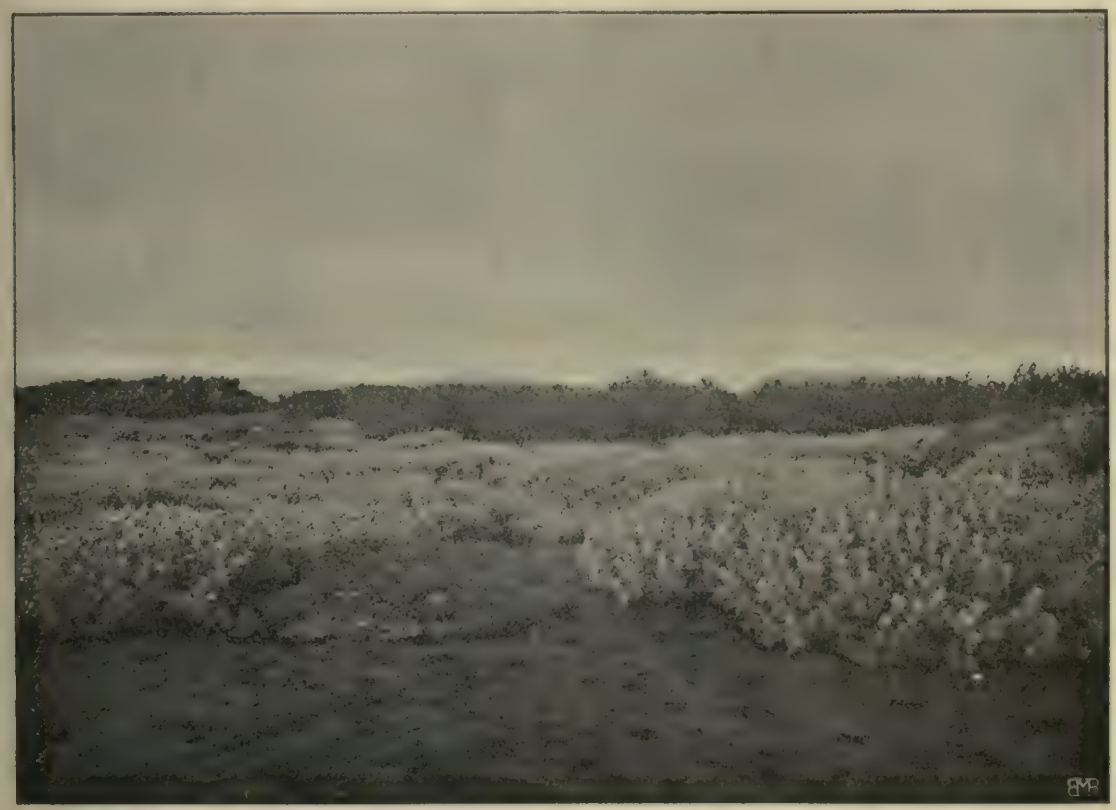

Fig. 266. Gebüsche von Salix lanata in Island. Im Hintergrunde Betula odorata auf schwarzem Flußsande (vulkanischer Asche) wachsend. Aus Thoroddsen 1914.

(Phot. A. Hesselbo.)

ist wohl auch als natürliche Formation zu betrachten, obgleich er sicher jetzt viele früher bewaldete Flächen bewohnt, die durch Waldverwüstung kahl geworden sind und die jetzt oft allen mühseligen Versuchen der Wiederbewaldung widerstanden haben. Typisch ausgebildet ist die Formation in den niederen Gebirgslagen der Balkanhalbinsel.

Ähnliches Buschland kommt in Rumänien im Süden der Dobrudscha ${ }^{1}$ ) vor und ganz nahe schließen sich ihm auch oft ausgedehnte Gebüschassoziationen in den übrigen Teilen des Mittelmeergebietes an, so die Ostrya-carpinifolia-Gebüsche im südlichen Istrien, die selbst nach der

i) Grecescu 1898; Vahl 1907. 
größten Sommerhitze noch lebhaft grün sind, die Bestände von Ficus Carica an den trockenen Hängen selbst noch an den südlichen Ausläufern der Alpen. Letztere werden oft als Brennholz abgeschlagen und dadurch werden dann auch andere Arten, wie Castanea usw., an der Baumbildung gehindert und in Buschform erhalten. - Auch in warmen Lagen anderer Länder finden sich ähnliche Gebüschformationen, so in Ungarn ${ }^{1}$ ) und selbst noch so weit westlich wie in Böhmen ${ }^{2}$ ) und bei Wien ${ }^{3}$ ), ja auch die charakteristischen Buschbestände Süd- und Mitteldeutschlands sind hierher zu rechnen, so z. B. die Sauerkirschen(Prunus acida)-Bestände des Saaletales.

Im Kaukasus ist nach Radde ${ }^{4}$ ) Buschland aus Paliurus aculeatus in beträchtlicher Ausdehnung vorhanden; in diesem wachsen Pflanzen der Steppe und des Waldes bunt durcheinander. Buschland aus Arten von Glycyrrhiza, wie es in Transkaukasien vorkommt, muß gleichfalls zu diesen Typen gerechnet werden, ebenso wie das von laubwechselnden Sträuchern in Aragonien ${ }^{5}$ ) usw.

Mesomorphe und xeromorphe Gebüsche gehen natürlicherweise ineinander über. Als eine solche Mittelform kann man auch die von Günther Beck ${ }^{6}$ ) behandelten, auch vielfach in anderen Teilen Europas vorkommenden Gebüsche von Prunus spinosa, Crataegus, Rosa, Cornus, Berberis, Brombeere, Himbeere u. a. betrachten, die sich im Frühjahre meist mit einem schneeweißen Blütenschmucke bekleiden und im Herbste glänzende Beeren oder Steinfrüchte tragen. Unzählige Stauden bedecken den Grund der Gebüsche; was im Hochwalde Licht braucht, sammelt sich in solchen lichtreichen Gebüschen. Auf vielen Stellen treten diese gebüschbildenden Arten als Unterholz unter Lichtbäumen wie Fraxinus, Populus tremula und Prunus padus auf.

\section{Kap. Formation der sommergrinen Laubwälder}

Unter sommergrünen Wäldern versteht man solche Laubwälder, die laubwechselnd sind, deren Bäume eine kürzere oder längere Zeit des Jahres, im Winter, blattlos stehen und also nur einige (meist 5-8) Monate belaubt sind ${ }^{7}$ ). Dieses Verhältnis steht in enger Verbindung mit

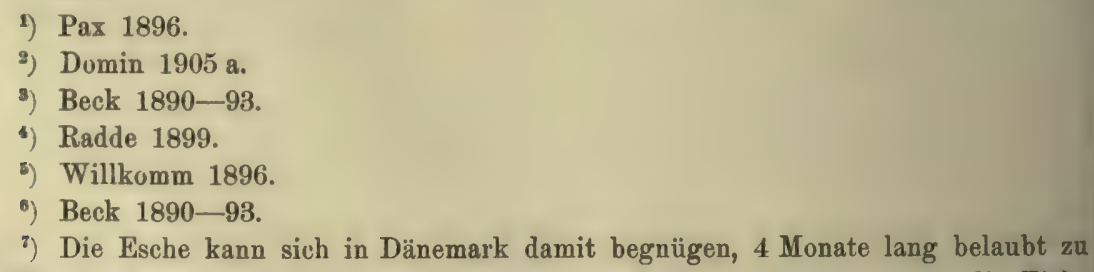
sein. Die Buche soll auf Madeira 8 Monate (etwa 250 Tage) Laub tragen, die Eiche aber 9-10 Monate. Gewisse Wälder innerhalb der Wendekreise sind offenbar noch länger belaubt. 
dem Klima und kommt am häufigsten in den gemäßigten und den kalten Gegenden mit einem ausgeprägten Winter vor, überdies auch innerhalb der Tropen auf trocknem Boden. Die Blätter in den mesophilen laubwechselnden Wäldern sind dünn und biegsam, durchscheinend, haben eine schwache Epidermis, sind dorsiventral gebaut und verhalten sich gegen äußere Einflüsse oft plastisch (z. B. bei Fagus). Sie stellen sich senkrecht zu der Richtung der stärksten diffusen Beleuchtung. Ihre Formen sind recht mannigfaltig. Es kommen ungeteilte, geteilte und zusammengesetzte Blätter vor; aber sie sind doch nicht so stark und in so viele Blättchen geteilt, wie es bei Arten des tropischen Regenwaldes oft vorkommt.

Es gibt also eine Zeit der Belaubung und eine des Laubfalles. In jener Zeit sieht man nur die jungen, gewöhnlich frischgrünen Sprosse; jedoch können bisweilen (z. B. bei Quercus und Acer-Arten) auch rötliche Farben vorkommen, die durch Anthocyan verursacht werden. Das Laub wird im Laufe des Sommers allmählich dunkler grün; vor dem Laubfalle treten gelbliche und rötliche Farben auf, indem teils das Chlorophyll entfärbt wird (bei den gelblichen Blättern), teils Anthocyan auftritt (bei den rötlichen Blättern, die bei nordamerikanischen Bäumen besonders prächtig gefärbt sind).

Der La ubfall steht gewöhnlich in Verbindung mit dem Eintritte der kalten Zeit des Jahres; dieselbe Art kann ihre Vegetationszeit ganz nach den klimatischen Verhältnissen verlängern oder verkürzen. Einige Arten können ihre Vegetationszeit in hohem Grade verkürzen. Im Tieflande Madeiras wird das neue Laub schon im Dezember oder Januar sichtbar. Die Gelbfärbung der Blätter fängt im September oder Oktober an. Andere Arten besitzen diese Fähigkeit in weit geringerem Grade. Die Buche, Vitis vinifera und V. labrusca, Aesculus, Platanus orientalis belauben sich alle im März. Die Blätter der Buchen entfärben sich im November, die anderen Arten schon im September oder Oktober (Menezes; Heer, Botan. Zeitung 1853). In Dijon belaubt sich die Eiche früher als die Buche, in Nordeuropa umgekehrt (Vaupell 1858). Wahrscheinlich muß der tiefere Grund zu diesen Verschiedenheiten in der mit der Kälte (dem kalten Boden) einhergehenden Austrocknung gesucht werden; die Ursachen des Laubfalles sind, soweit sie in klimatischen Schwankungen zu suchen sind, gewiß dieselben, sowohl wo Kälte als auch wo Hitze und Trockenheit sie hervorrufen. Volkens ${ }^{1}$ ) hat neuerdings darauf hingewiesen, daß namentlich in den Tropen auch andere Dinge, wie z. B. Stoffwechselverhältnisse, den Laubfall veranlassen können; davon soll ausführlicher im 79. Kapitel die Rede sein. - Auch bei uns kann man beobachten, daß eine Anzahl von Bäumen (sehr deutlich

1) Volkens 1912 
z. B. die Roßkastanie, Aesculus hippocastanum) eine so weitgehende Anpassung an die Notwendigkeit des Laubwechsels zeigen, daß sie im Herbst ihr Laub verfärben und abwerfen, auch wenn in anomalen Jahren noch keine irgendwie stärkere Herabdrückung der Temperatur erfolgt ist.

Während der Ruhezeit sind die jüngsten Sproßteile gegen zu starke Transpiration durch Knospenschuppen (Fig. 117), die älteren durch Kork geschützt. Ein hervortretender Unterschied zwischen den Knospen der Tropenbäume und der mesomorphen Bäume der temperierten Klimate ist die Größe; bei jenen sind sie gewöhnlich sehr klein, bisweilen ganz unscheinbar und haben keine großen mit starkem Kork bekleideten Knospenschuppen; bei letzteren sind sie weit größer, bisweilen sogar sehr groß und mit großen, stark xeromorph ausgestatteten Knospenschuppen versehen, wenn auch die Schuppen wie bei Pterocarya, Viburnum lantana u. a. deutlich aus zurückgebildeten Laubblättern bestehen. Die Unterschiede müssen mit dem verschiedenen Klima in Zusammenhang stehen; die Größe der Knospen muß damit in Verbindung stehen, daß der junge Sproß weit entwickelt sein muß, weil die Vegetationszeit so kurz ist; es müssen eine Menge von Blättern, sowie oft auch die Blütenstände schon in dem Jahre vor der Vegetationszeit angelegt werden; das erfordert Platz, und deshalb müssen die überwinternden Knospen groß sein und daher auch viele und große Knospenschuppen ausgebildet werden; diese müssen dann auch besonders als Schutzorgane für die jungen Blatt- und Blütenteile teils im Winter, teils während der Laubentfaltung im Frühjahr dienen, deshalb sind sie melır oder weniger xeromorph gebaut. Neben dem Schutz gegen Austrocknen (vergl. die Waldfeindlichkeit der trockenen Winterwinde 5. Kap.), liegt sicher ihre Hauptaufgabe auch in der Verlangsamung der Temperaturschwankungen durch schlechte Wärmeleiter (vergl. 16. Kap.). Bei den tropischen Bäumen kommt solches nicht in Frage $(\text { Warming })^{1}$ ).

Vorratsnahrung ist notwendig und wird im Parenchym der Stämme, in den Knospen und den Wurzeln abgelagert.

Die mesomorphen laubwechselnden Bäume haben oft eine reiche Verzweigung, sie sind mit vielen kleinen Zweigen versehen; fast alle Knospen, die unten auf dem Jahressprosse sitzenden ausgenommen, werden zu Zweigen entwickelt, worin die Beleuchtungsverhältnisse jedoch Störungen hervorrufen können. Dadurch entsteht ein mehr zusammenhängendes Laubdach, als man es bei tropischen Bäumen gewöhnlich findet.

Die laubwechselnden Bäume haben keine so günstigen Vegetationsbedingungen wie die immergrünen, da ein großer Teil ihres Lebens in Untätigkeit vergeht; sie erreichen auch selten die riesigen Größen der immergrünen Bäume des tropischen Regenwaldes.

1) Vergl. auch Warming 1892. 
Die Familien, die in den mesophilen Wäldern des gemäßigten Europas eine Rolle spielen, sind besonders die Familien der Kätzchenträger, ferner die Gattungen Fraxinus, Acer, Tilia und Ulmus, denen sich in wärmeren Gegenden allmählich viele andere anschließen. In den

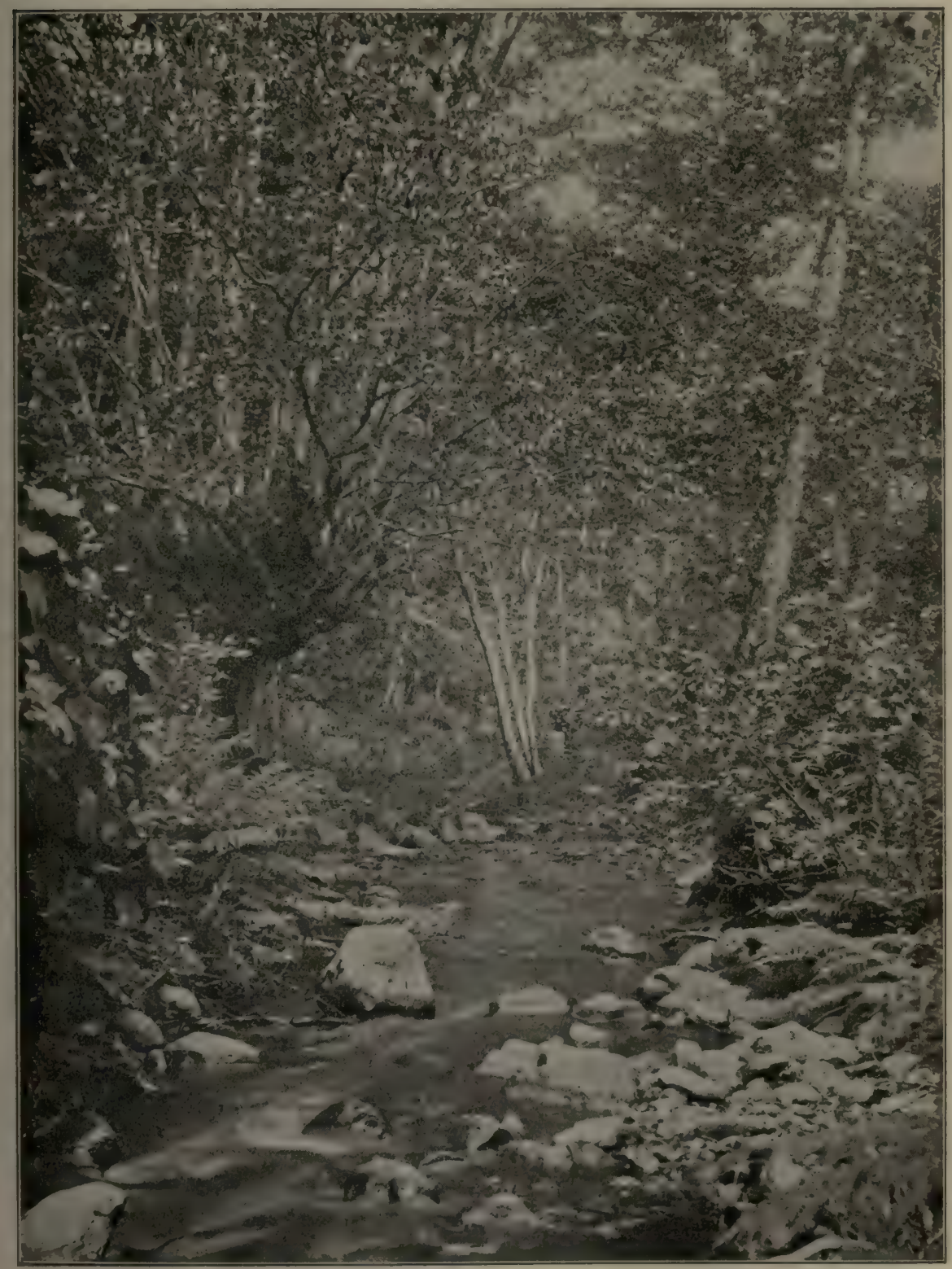

Fig. 267. Dichter Laubwald mit dichtem Unterholz und Bodenwuchs in den Ungarischen Karpathen. (Phot. Hans Bath †, 
nordamerikanischen und den ostasiatischen Wäldern kommen viele andere Gattungen vor.

In den nordeuropäischen Laubwäldern, die wir hier hauptsächlich zugrunde legen müssen, sind die Bäume meist Windbestäuber und blühen gewöhnlich sehr früh, vor oder während der Belaubung; die Blüten überwintern in den Knospen oder nackt. Von den südlichen Formen blühen mehrere bei uns erst im Sommer und sind Insektenbestäuber; Beispiele hierfür sind die Linden.

In den Laubwäldern gibt es mindestens ein, oft mehrere Vegetationsstockwerke unter dem Hochwalde, nämlich eine Strauchschicht (diese kann in feuchtem Klima sogar doppelt sein), eine Hochstaudenschicht, eine Kleinstaudenschicht und eine Bodenschicht, an die sich oft noch die hypogäische Vegetation anschließt ${ }^{1}$ ). Die "Schichten " sind natürlich nicht als scharf abgegrenzte Stockwerke aufzufassen (Fig. 267, 268). Sie entsprechen den in den vorigen Kapiteln erwähnten Formationen von Sträuchern und Kräutern. Die ökologische Ausstattung der Pflanzen, die sich bestimmten Bäumen anschließen, ist nach dem Schatten, den diese geben, sowie auch nach der Bodenfeuchtigkeit u. a. verschieden. Die Kräuter des Waldbodens sind meist hoch und gestrecktgliedrig (keine oder sehr wenige Rosettenpflanzen kommen vor, was mit der schwachen Beleuchtung des Waldbodens in Verbindung gebracht werden muß $)^{2}$ ). Die Blätter der Pflanzen des Unterholzes und des Waldbodens sind denen des Hochwaldes ähnlich, aber noch dünner und noch mehr meso- oder hygrophil gebaut; einige sind ausgeprägte Schattenblätter, die sich im Bau den Blättern der Hydrophyten nähern. Dieses wird zunächst durch den Schatten und die feuchtere Luft verursacht, aber wohl auch durch den feuchten Humusboden (S. 113 ff.). Die Blätter sind demgemäß durchgehends groß, breit, flach, dünn, matt und kahl, z. B. bei Oxalis acetosella, Anemone nemorosa, Impatiens noli tangere, Lactuca muralis, Arten von Corydallis, Circaea, Paris, Adoxa, Mercurialis, Convallaria usw. Die Waldgräser haben breite, biegsame, meist bogenförmige Blätter ohne Einrollungsvorrichtung, und tragen die Spaltöffnungen ungeschützt auf beiden Seiten oder besonders auf der nach oben gekehrten Unterseite (Milium effusum, Poa nemoralis, Melia uniflora, M. nutans, Dactylis Aschersoniana, Festuca gigantea, Bromus erectus, Brachypodium silvaticum u. a.). - Die häufig vorkommende bläuliche Färbung der Blätter der Waldbodenarten hängt sicher mit der Regulierung der Lichtzusammensetzung (Lichtfilter) zusammen (vergl. S. 21). S. 516).

1) Vergl. S. 329, 337; ferner Kupffer 1914 (Ref. im Botan. Centralbl. 125.

3) Warming 1901. Über Lichtgenuß im Walde siehe 2. Kap. 
Viele Pflanzen in feuchten und schattigen Wäldern sind nach Wiesner ombrophob („regenscheu“), d. h. ihre Blätter lassen sich nicht benetzen; aber einige, wie Sanicula Europaea, sind ombrophil (S. 56).

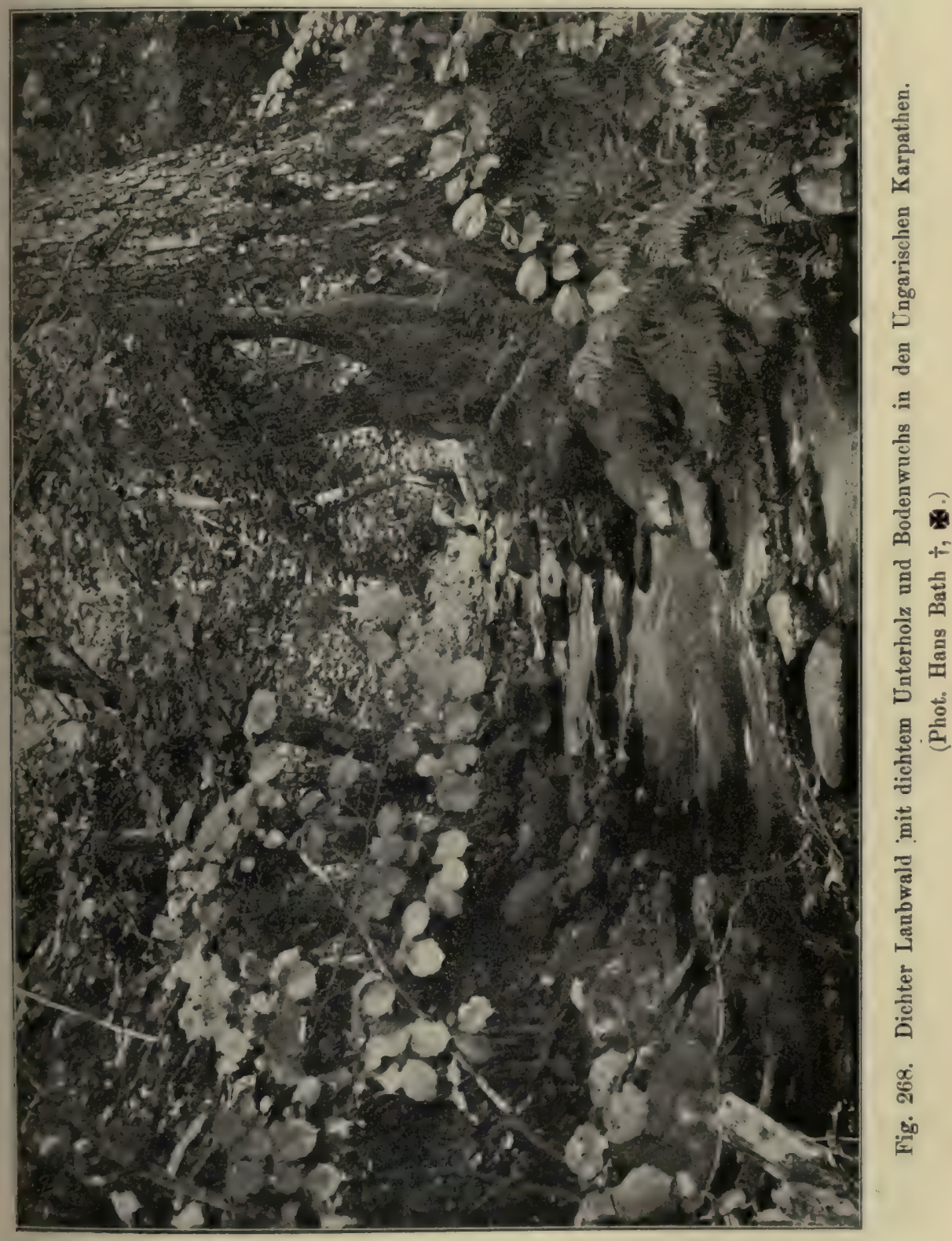

In den sommergrünen Wäldern der temperierten Klimate gibt es eine merkwürdig große Zahl von Geophyten; dieses wird man nicht als eine Anpassung an besonders ungünstige Verhältnisse auffassen können, 
denn gerade in Wäldern werden alle extremen Verhältnisse, was Kälte und Hitze, Wind und Feuchtigkeit betrifft, wesentlich gemildert; eher steht es damit in Verbindung, daß sie Jahr für Jahr von dem fallenden Laube bedeckt werden und durch Jahrtausende sich diesem Zustande angepaßt haben (Warming).

Die Bodenschicht wird oft im wesentlichen aus Gräsern, Kleinstauden und Moosen gebildet; die von ihnen und von dem gefallenen Laube gebildete Decke wirkt in hohem Grade wassersammelnd und Feuchtigkeit bewahrend. Ist sie besonders dicht geschlossen, so kann sie auch die Verjüngung der Bäume hindern, indem die Bodenvegetation die Keimlinge derselben erstickt.

Von Epiphyten gibt es wesentlich nur Moose und Flechten, in England usw. oft noch massenhaft Polypodium u. a. Farne, aber selten Blütenpflanzen, und von Lianen kommen sehr wenige vor: Lonicera periclymenum, Hedera, Humulus, Clematis.

Der reiche humose Waldboden trägt viele Saprophyten, im Herbste feuchter Jahre besonders Pilze. Unter den Blütenpflanzen gibt es wenige Holosaprophyten (Monotropa, Neottia, Epipogon, Coralliorrhiza), aber wahrscheinlich sind auch viele Hemisaprophyten, z. B. Orchidaceen und Pirola-Arten., Mykorrhizen findet man bei vielen Baumarten und bei Saprophyten.

Die Bodenvegetation der Wälder ist oft nicht für dieselbe Baumart dieselbe; sie kann sogar recht verschieden sein, was mit edaphischen Verhältnissen und allen anderen Standortfaktoren in Verbindung steht (Nährstoffreichtum und Feuchtigkeit, auch Beleuchtung u. a.). Wie auf S. 339 erwähnt wurde, will Cajander sogar danach drei Typen der Wälder besonders nach seinen Untersuchungen in Deutschland aufstellen; sie sind mit aufsteigender Bonität: der Calluna-Typus, der Myrtillus-Typus und der Oxalis-Typus.

Nach diesen Verschiedenheiten kann man Subassoziationen aufstellen. Besonders muß die Bildung von saurem Rohhumus in vielen Wäldern hervorgehoben werden; solche gehören dann streng genommen der Klasse der saueren Standorte an (IV. Serie).

Vahl hat in Buchen-, Eichen-, Erlen- und Birkenwäldern und in gemischten Laubwäldern in Südschweden folgende Typen von Bodenvegetation gefunden. Auf Mullboden sind Kräuter mit unterirdischer Wanderung an Zahl herrschend. Nur in wenig schattigen Birken- und Eichenwäldern, die von Menschen gelichtet sind und von Haustieren beweidet werden, sind Kräuter mit oberirdischer Wanderung und ohne Wanderungsvermögen herrschend. Auf Rohhumus sind Moose zahlreich und die Bodenvegetation besteht aus unterirdisch wandernden Zwergsträuchern, wozu auch viele unterirdisch wandernde Kräuter sich gesellen. Auch im Buchenwald kommt der harte Rohhumus vor, in 
welchem Pflanzen ohne Wanderungsvermögen, besonders Aera flexuosa, herrschen ${ }^{1}$ ).

Es gibt eine große Menge von Assoziationen von sommergrünen Wäldern der temperierten Klimate, und zwar sowohl reine Assoziationen, z. B. Buchenwälder, Birkenwälder, Eichenwälder u. a., als auch Mischwälder. In den seit Jahrhunderten kultivierten Ländern, z. B. hier in Europa, werden sehr wenige "Urwälder" sein, die meisten sind auf verschiedene Weise von den Menschen geändert. Thr Vorkommen hängt von klimatischen, historischen und edaphischen Verhältnissen ab (namentlich von der Bodenfeuchtigkeit, der Nährstoffmenge u. a.). Der Kalkreichtum des Bodens spielt sicher eine große Rolle; kalkhaltiger Boden ist bei weitem der reichste an Arten, mit Kieselboden (Sandboden) verglichen, und oft sind die Bestände verschiedener Bodenarten floristisch sehr verschieden. Die englischen Botaniker legen besonders großes Gewicht auf diese Bodenunterschiede, wie S. 334 erwähnt wurde ${ }^{2}$ ). Sie ordnen die Wälder Englands in drei Reihen nach den edaphischen Verhältnissen: 1. Wälder mit sehr feuchtem Boden, die Alnus-Salix-Reihe (hier im 64. Kap. besprochen). 2. Die Quercus-Betula-Reihe auf kalkarmem Boden und mit mehreren Assoziationen nach Feuchtigkeit des Bodens usw. 3. Die Fagus-Fraxinus-Reihe auf kalkreichem, das heißt auch nährstoffreichem Boden; ebenso mit mehreren Assoziationen.

Viele Wälder der nördlichen gemäßigten Länder sind vom Menschen vernichtet worden und haben dem Kulturboden weichen müssen ${ }^{3}$ ); viele Gramineta (Wiesen, Grasheiden, z. B. Nardeta strictae ${ }^{4}$ ), Aereta flexuosae, Festuceta ovinae) stehen auf altem Waldboden und würden dem Walde wieder Platz machen, wenn sie von der Kultur verlassen würden.

Auf viele andere Weise greift der Mensch in die Zusammensetzung und Ökologie der Wälder ein, weil die Bäume von so großer ökonomischer Bedeutung für ihn sind; es kann dies hier aber nur angedeutet werden.

Von Bedeutung für die Physiognomie und Flora der Wälder sind ïbrigens auch die Feuersbrünste, die in vielen Ländern vorkommen. Was die Laubwälder betrifft, werden sie wohl nur durch den Menschen angelegt werden, wenn er z. B. in den Tropen einen Wald umhaut und in der trockneren Jahreszeit abbrennt, um den Boden für wenige Jahre für Kulturzwecke nutzbar zu machen, wonach er den Boden sich wieder selbst überläßt. Der Wald wächst dann wieder auf, aber mehr oder weniger verändert und verschlechtert.

$\left.{ }^{1}\right)$ Vahl 1911, 1912. Uber die schwedischen Laubwälder siehe ferner Birger 1908; Andersson u. Hesselman 1907.

2) Vergl. Moss 1907, 1913; Moss, Rankin und Tansley 1910; Tansley 1911.

3) Graebner 1909.

4) Siehe Tansley 1911. 
Was die Nadelwälder betrifft, so wird nicht nur der Mensch sie durch Abbrennen für Kulturzwecke vernichten, um ebenso nach einigen Jahren den Boden sich selbst zu überlassen, z. B. in Finnland und Schweden, sondern vielfach werden sie auch durch Blitzschläge angezündet und brennen so nieder.

Über die Nadelwälder von Nordamerika schreibt z. B. Roland Harper ${ }^{1}$ ), daß man ruhig versichern kann, daß es keinen Wald von Pinus palustris gibt und nimmer gegeben hat, welcher nicht Zeichen von Feuersbrünsten aufwiese. Weiter meint er, daß wenn es möglich wäre die Feuersbrünste zu verhindern, dann würde diese Art bald aussterben; denn wo das Gras nicht abgebrannt wird, werden die meisten Samen von der Grasdecke des Bodens am Auskeimen verhindert werden, und andere Bäume würden auch den Wuchs der Kiefer hindern.

Es ist auch leicht zu verstehen, daß, selbst wenn ein Wald nach einer Feuersbrunst den selben Boden wieder mit der Zeit zurückerobert, die sozialen und ökologischen Verhältnisse vielfach verändert sein werden.

Im folgenden werden einige besonders nordeuropäische Waldtypen als Beispiele von laubwechselnden Wäldern des kalttemperierten Gürtels hervorgehoben; es muß aber bemerkt werden, daß es eine ungeheuere Menge von Varianten gibt, Mischwälder, Schluchtwälder, Bergwälder u. a., welche floristisch und teilweise auch ökologisch voneinander abweichen. Die unendliche Variation der klimatischen und edaphischen Faktoren bedingt diese Unmenge von Varianten.

Von den Assoziationen in Nordeuropa sollen hier folgende als Beispiele ausführlicher besprochen werden: Die Buchenwälder, die Eichenwälder, die Birkenwälder ${ }^{2}$ ).

Die Buchenwälder (Fageta silvaticae) sind in Dänemark, in dem westlichen Deutschland usw. auf mildem, kalkhaltigem Humusboden am schönsten entwickelt. Die Buche (Fagus silvatica) ist ein ausgeprägter Schattenbaum, dessen hoher, schlanker, glatter und hellgraueı Stamm eine Krone trägt, welche durch ihre zweizeilige Blattstellung. ihre vielen Kurztriebe, ihre Blattmosaik und die Fähigkeit der Blätter selbst in schwachem Lichte zu assimilieren, dicht und schattenspendenc wird. Nur ein sehr gedämpftes Licht erreicht den Waldboden, weshall dieser kein Unterholz aufweist und in vielen Wäldern sogar äußers? pflanzenarm ist, wozu auch die dichte Decke des herabgefallenen Laube: beiträgt (Fig. 269).

1) Roland Harper 1913.

2) Von wichtigeren, hier nicht in Einzelheiten referierten Werken vergl. Druci 1902; Graebner 1909; Tansley 1911; Thekla Resvoll 1913-1914; Hanna Resvol Holmsen 1914; Cajander 1909 a und b; Thore Fries 1913. 
Dadurch, daß die weit ausladenden Äste benachbarter Bäume sich ineinander schieben, fällt auch zwischen den einzelnen Baumkronen wenig Licht hindurch.

I)ie Art des Bodens ist übrigens sehr verschieden, und die Bodenvegetation hiermit in Übereinstimmung; die Hauptunterschiede liegen darin, ob der Boden milder Humus oder saurer Rohhumus ist ${ }^{1}$ ). Im ganzen bevorzugt die Buche einen guten tiefgründigen Mergelboden. Es lassen sich dann zwei Sulasssoziationen unterscheiden, von denen der Buchenwald auf Rohhumus eine riickschreitende Entwicklung zeigt und oft sich nicht verjüngen kann. Die meisten unserer Buchenwälder

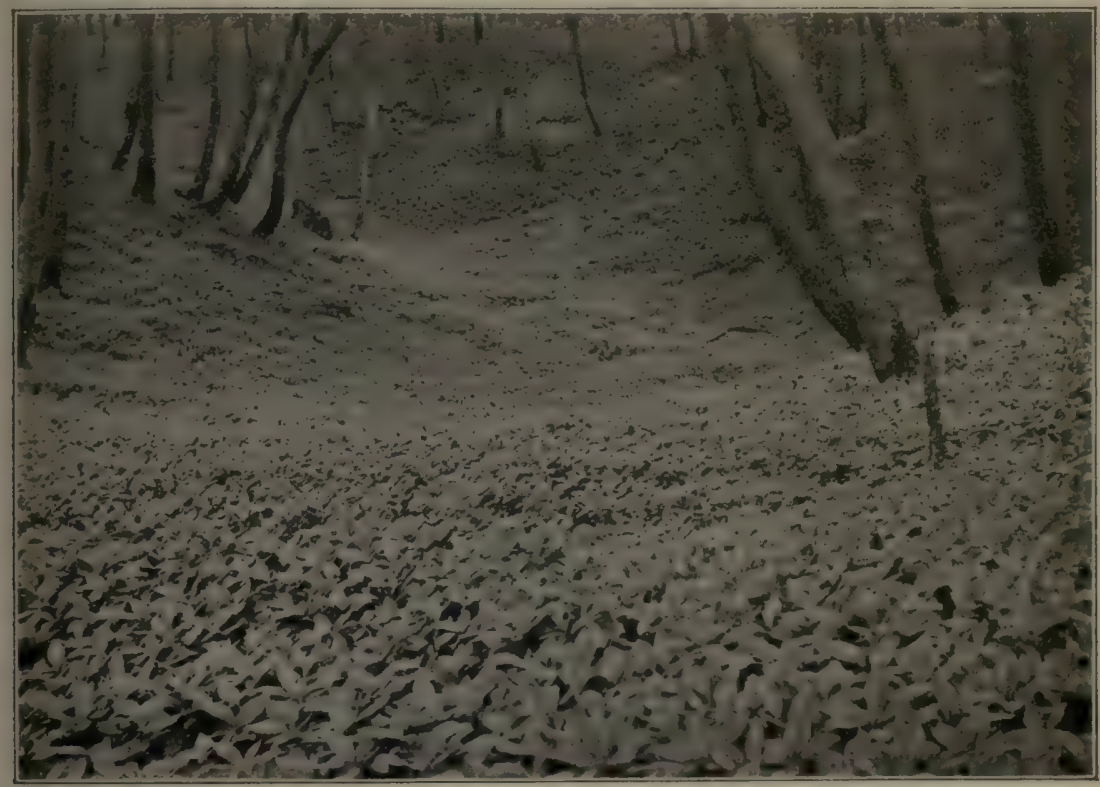

Fig. 269. Eine Assoziation von Mercurialis perennis deckt dicht den Boden in einem Buchenwalde der Insel Möen (Dänemark). (Phot. K. Yendo.)

sind, wie überhaupt unsere "Forsten", Kunstbestände, in denen die Bäume etwa gleichaltrig nebeneinander stehen, statt daß wie im Lrwalde alle Altersklassen gemischt sind. Dadurch sind die Ansprüche der einzelnen Individuen an den Boden sehr gleichartig, eine bestimmte Bodenschicht ist gleichmäßig von den Wurzeln durchzogen, so daß die Wurzelkonkurrenz den höchsten Grad erreicht und deshalb das Unterholz auch oft so gut wie ganz fehlt, ebenso wie eine natïrliche Verjüngung.

1. Subassoziation. Der humusreiche Buchenwaldboden ist krïmelig und porös, von Regenwürmern und anderen kleinen T'ieren

1) P. E. Müller 1878, 1884, 1894, 1899; auch Höck 1895; Graebner 1901, 1909. Warming-Graebner. 8. Auflage, illustr. 
durchwühlt und durchlüftet. Das Volumen seiner Poren beträgt an der Oberfläche $50-60 \%$, seine Teile verschieben sich leicht. Im Hochsommer wird er oft fast nur von dem braunen, welken Buchenlaube bedeckt, das samt den herabgefallenen Zweigen, Früchten usw. eine dichte Decke bildet, welche gegen die zersetzte Unterlage scharf begrenzt ist. Nur hier und da, wo mehr Licht hinabdringt, findet man einige Blütenpflanzen wie Asperula odorata, Oxalis acetosella, Anemone nemorosa, A. ranunculoides, Hepatica, Viola silvatica, Mercurialis perennis, Melica uniflora, Milium effusum, Dactylis Aschersoniana, Stellaria nemorum, Corydallis-Arten, Hedera helix u. a. Moose sind fast nicht vertreten; solche, die bisweilen vorkommen, bilden auf dem Boden einen sehr niedrigen Überzug (z. B. Bryum argenteum).

Die Vegetation des Buchenwaldbodens ist dadurch ausgezeichnet, daß sie vorwiegend eine Frühjahrsvegetation mit sehr kurzer Vegetationszeit ist; sie muß das Licht benutzen, bevor sich der Hochwald belaubt, oder während er noch ganz junges Laub trägt ${ }^{1}$ ). Blühen, Assimilieren und Fruchtreifen finden eilig statt, und im Hochsommer sind von mehreren Arten nur wenige Spuren über dem Boden zurückgeblieben. So verhalten sich solche unserer Pflanzen, die den Buchenwaldboden am meisten kennzeichnen: Arten von Anemone, Corydallis, Gagea, teilweise auch Primula usw.

Andere Pflanzen bleiben längere Zeit grün: Mercurialis perennis (Fig. 269), Oxalis acetosella, Stellaria holostea, S. nemorum, Pulmonaria officinalis, Luzula pilosa, Carex digitata, C. remota und die Gräser (Milium, Melica uniflora, Dactylis Aschersoniana, Poa nemoralis u. a.).

Einigen früh blühenden Arten ist es eigentümlich, daß der Keim bei dem Abfallen der Samen äußerst wenig entwickelt ist; bisweilen ist er sogar nur einzellig (bei Ficaria und Corydallis cava, denen Eranthis hiemalis angeschlossen werden kann). Auch dieses steht vermutlich auch damit in Verbindung, daß diese Frühjahrspflanzen eine kurze Vegetationszeit haben; die Samen erhalten von der Mutterpflanze Nährgewebe mit, aber die sonst auf der Mutterpflanze vor sich gehende Entwicklung findet erst als eine Nachreife des frei gewordenen Samens statt.

Im Einklange mit der kurzen Vegetationszeit und dem frühen Blühen steht ferner, daß fast alle Arten mehrjährige Kräuter sind (einjährig sind Impatiens noli tangere, Cardamine impatiens u. a.).

Ferner begünstigt die lose Beschaffenheit des Bodens die Entwicklung wagerecht unterirdisch wandernder Sprosse. Daher findet man viele Arten mit solchen, z. B. Aspidium (Phegopteris) dryopteris, Anemone nemorosa, A. ranunculoides, Asperula odorata, Mercurialis

1) Vergl. Graebner 1909. 
perennis, Dentaria bulbifera, Stellaria nemorum, St. holostea, Oxalis acetosella, Adoxa, Stachys silvaticus, Convallaria majalis, Arten von Polygonatum, Cephalanthera, Circaea, Paris, Epipactis, Listera ovata, Melica uniflora, Dactilis Aschersoniana usw., von Saprophyten Neottia, Coralliorrhiza, Epipogon, Limodorum und Monotropa (diese hat knospenhildende Wurzeln). Oberirdisch wandern Glechoma hederacea, Lysi-

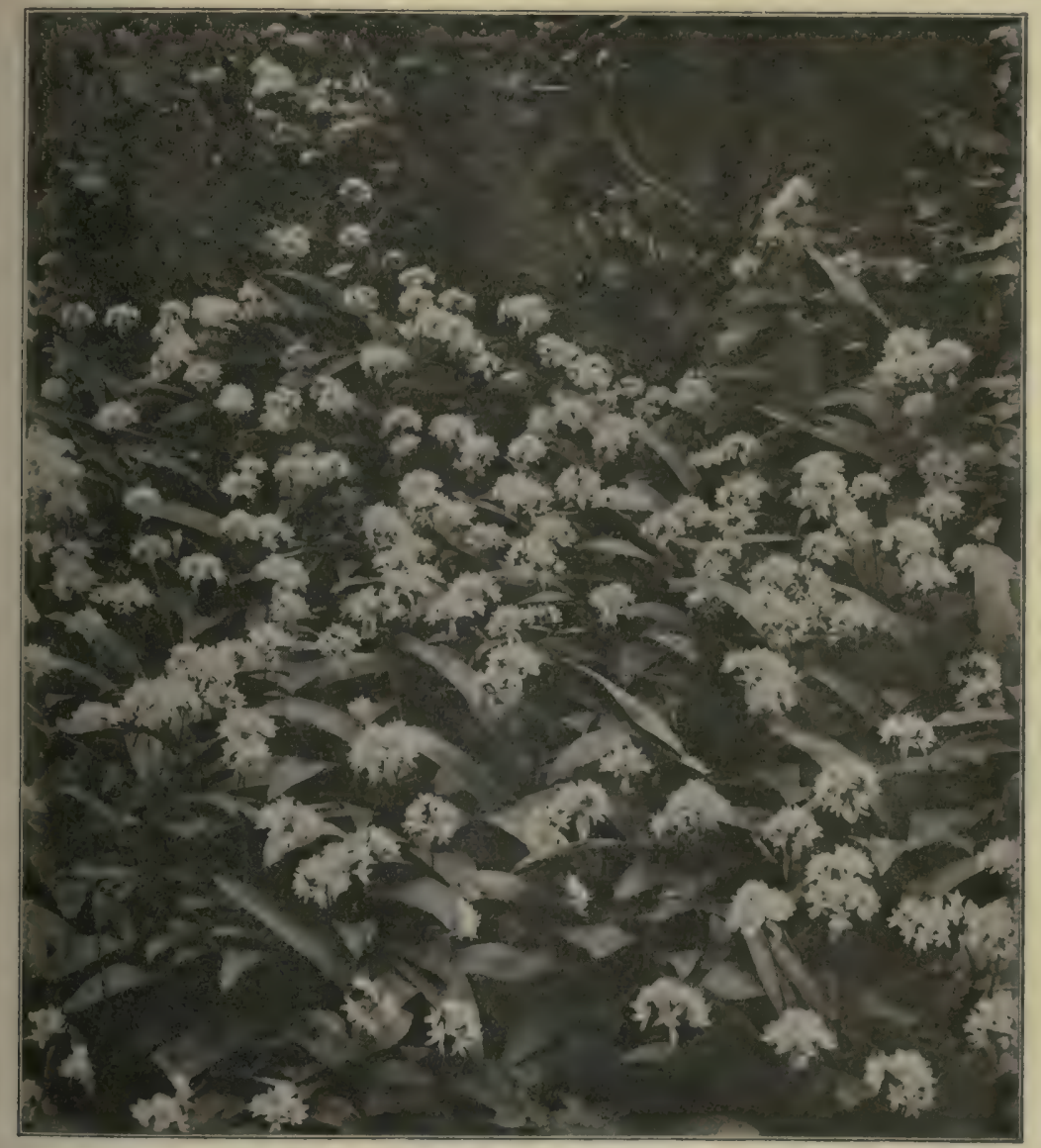

Fig. 270. Bodenvegetation eines Laubwaldes anf Bornholm. Assoziation von Allium ursinum. (Phot. Eng. Warming.)

machia nemorum, Lamium galeobdolon und Lycopodium annotinum. In ganz ähnlicher Weise wie die oberirdisch wandernden Kräuter vermehren sich eine größere Anzahl von Sträuchern, wie z. B. Ribes grossularia, R. alpinum (Fig. 271), R. nigrum, Cornus sanguinea und die amerikanische C. alba. Ihre schlaffen Zweige senken sich mit der Spitze zu Boden, diese wird im Laub usw. eingeschüttet, wurzelt und bildet einen neuen Strauch. so können die genannten und andere Arten durch vegetative Vermehrung 
allmählich große Strecken überziehen. - Keimung im losen Laubschutt ist stets schwierig. Von den Arten mit starkem Wanderungsvermögen werden oft reine Assoziationen gebildet, z. B. Mercurialieta.

An den Standpunkt gebunden sind z. B. Campanula trachelium, Epilobium montanum, Sanicula Europaea, Hieracium murorum, Pulmonaria officinalis, Primula-Arten, Actaea spicata, Brachypodium silvaticum, Festuca gigantea u. a. Gräser, Luzula pilosa, Aspidium filix mas, A. spinulosum, Athyrium filix femina. Hierher gehören auch knollen- und zwiebeltragende Arten: Knollen haben Corydallis-Arten, Arum maculatum, Cyclamen (z. B. in den Buchenwäldern der Alpen), Phyteuma spicatum, Orchis-Arten u. a. Ophrydeen; Zwiebeln haben Gagea, Allium ursinum (Fig. 270), Lilium martagon, Galanthus, Scilla bifolia u. a. Allium ursinum kann dichte Assoziationen bilden, welche durch die große Samenmenge hervorgebracht werden.

Von Moosen gibt es einige, besonders am Fuße der Bäume; Flechten kommen aber auf dem Boden nicht vor.

Dieser Typus von Buchenwald entspricht dem „Fagetum silvaticae calcareum" von Tansley.

2. Subassoziation. Der Buchenwald auf Rohhumusboden hat eine ganz andere Bodendecke („Siebenstern-Vegetation“ P. E. Müllers), er findet sich glücklicherweise fast nur in geringer Ausdehnung, ausgenommen, wo er der Verheidung entgegengeht (s. unten). Auf dem festen, von Wurzeln und Pilzmycelien durchwebten Boden, dessen Porenvolumen verringert worden ist, der nicht von Regenwürmern durchwühlt und nicht durchlüftet wird, der deshalb Humussäuren bildet (S. 110), der von der Sonne ausgetrocknet wird und von dem die Laubdecke oft bald fortgeweht wird, gedeiht meist eine dichte Vegetation der Aera flexuosa, eines fadenblättrigen und xerophil gebauten Grases, das weiche, dichte Rasen bildet, ferner der Siebenstern (Trientalis Europaea), Majanthemum bifolium, der Halbparasit Melampyrum pratense (die beiden letzten Arten kommen auch auf losem Humus vor) und eine sehr reiche Moos vegetation. Die dichten und weichen Moosteppiche bestehen aus Polytrichum (P. formosum), Hypnum Schreberi, H. cupressiforme, H. purum u. ґ. Arten, Hylocomium triquetrum, H. splendens u. a. Arten, Dicranum scoparium, Leucobryum glaucum, Mnium-Arten; selbst Sphagna können sich auf dem oft nassen, etwas versumpften Boden einfinden. Calluna und Vaccinium myrtillus finden sich auch oft ein, und dann nähert sich der Boden dem der Calluna-Heide. Ist dieser der Weg gebahnt, und kann die natürliche Verjüngung der Buche nicht mehr vor sich gehen, so verschwindet der Buchenwald schließlich an vielen Stellen und macht der Calluna-Heide Platz ${ }^{1}$ ).

1) P. E. Müller 1899; Graebner 1895, 1901, 1904, 1909. 
Die Nordgrenze der Buchenwälder geht von Südnorwegen, über Westschweden durch Ostpreußen bis zum Kaukasus (die hier vorkommende Buche wird mit Recht als eigene Art [Fagus orientalis?] betrachtet). Natürlich sind die Begleitpflanzen der Buche je nach den ()rten sehr verschieden. Von den Facies der kaukasischen Buchenwälder hebt Rübel hervor ein Fagetum asiaticae laurocerasorum ${ }^{1}$ ).

Über Buchenwälder vergl. ferner Ascherson 1883; Hoeck 1892, 1895, 1896; Hub. Winkler 1907; Moss, Rankin u. Tansley 1910; Tansley 1911; Macgregor 1913; Skene in Journ. of Ecology I, 94.

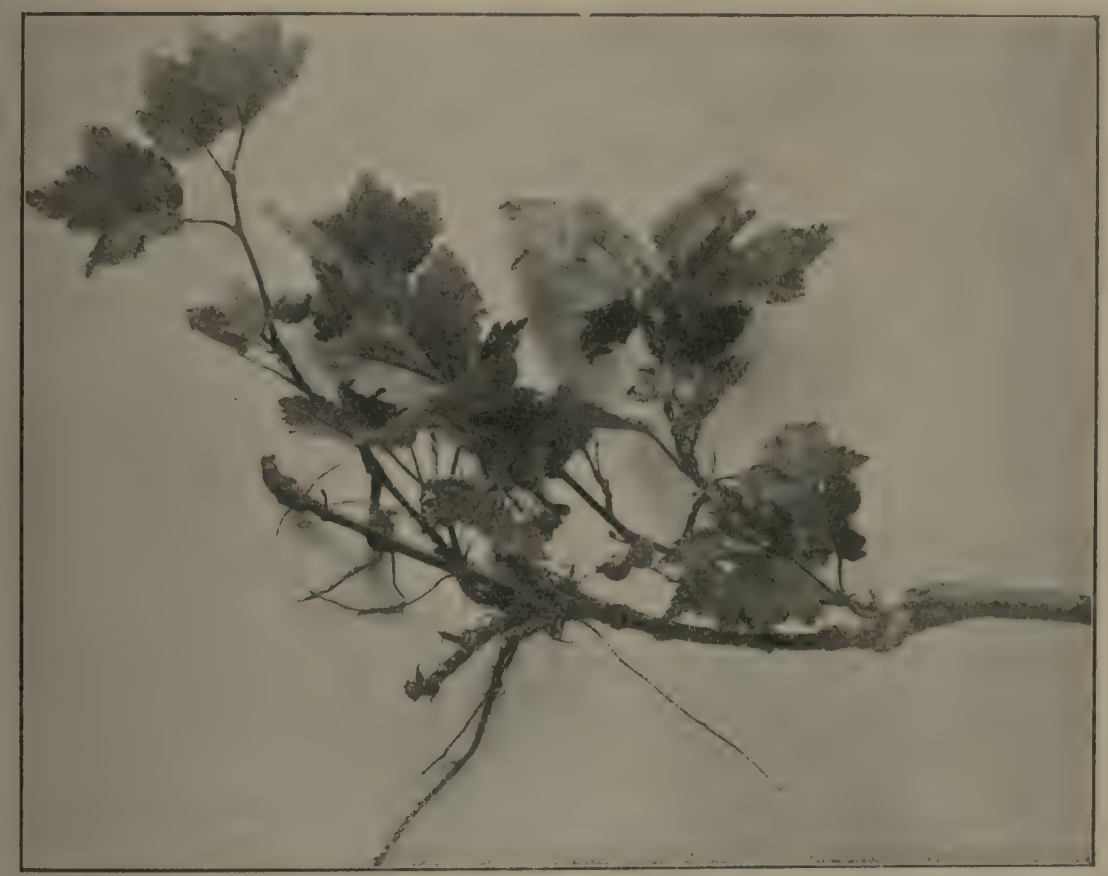

Fig. 271. Zweig von Ribes alpinum, mit der Spitze niederliegend und wurzelnd, so eine neue Pflanze erzeugend. (Phot. P. Graebner.)

Die Eichenwälder (Querceta). Die Eiche (Quercus pedunculata und Q. sessilis [Q. sessiliflora]) ist ein Baum von mittlerem Lichtbedürfnis, mit $2 / 5$-Blattstellung und ziemlich unregelmäßiger Verzweigung. Ihre gekrümmten Zweige bilden eine Krone, die nicht so dicht und schattig ist wie die der Buche, bei der auch die Äste benachbarter Bäume nicht so ineinanderfahren, so daß erheblich viel mehr Licht zwischen ihnen auf den Boden fällt. In Dänemark wird die Eiche bekanntlich von der Burhe verdrängt, unter anderem deshalb, weil diese ein Schattenbaum

1) Rübel 1914. 
ist, dessen Belaubung einige Wochen vor der der Eiche eintritt. Nur an den feuchten Stellen, z. B. auf dem niedrigen Tonboden von Laaland und auf dem mageren Sandboden von Westjütland kann sie den Wettbewerb der Buche aushalten. In Norddeutschland läßt sich wenig von der Konkurrenz beider Baumarten bemerken.

Der Hochwald ist sehr gemischt, gerade weil das Lichtbedürfnis der Eiche ein mittleres ist. In deutschen und österreichischen Wäldern sind Tilia, Acer, Populus tremula, Ulmus, Fraxinus, Carpinus u. a. oft in Eichenwälder eingemischt; in Frankreich bilden Fagus und Castanea oft Nebenbestandteile der Eichenwälder. In Westeuropa spielt Ilex aquifolium oft eine große Rolle.

Im Gegensatze zur Buche und gerade weil der Eichenwald viel mehr lichtoffen ist, hat er ein reiches Unterholz und steht oft in einem dichten Gebüsche von Corylus, Crataegus, Acer campestre, Prunus spinosa, Carpinus, Rhamnus frangula, Euonymus Europaea, Salix, Viburnum opulus, Rubus Idaeus, Lonicera xylosteum u. a.; diese Straucharten wechseln nach den Verhältnissen des Standortes. In gewissen Fällen können sich Juniperus, Pteridium und sogar Calluna einfinden, namentlich wo der Wald auf magerem Sandboden steht. In österreichischen Wäldern kommen außerdem Viburnum lantana, Ligustrum vulgare, Staphylea pinnata, Daphne mezereum usw. vor. Wenn auch nicht in dem Maße wie beim Buchenwald, so läßt sich doch auch hier das Zurücktreten des Unterholzes in den gleichalterigen Kunstbeständen (Forsten) bemerken.

Der Waldboden des Eichenwaldes kann ein guter, schwarzer oder graubrauner, krümeliger, mürber und von Regenwürmern bewohnter, humushaltiger, feuchter Lehm sein; unter und zwischen den Sträuchern des Gebüsches gedeihen dann eine Menge Gräser und Kräuter, ohne indessen eine zusammenhängende Decke zu bilden: Arten von Anemone und Viola, Vicia cracca, Hypericum perforatum, H. quadrangulum, Potentilla silvestris, Campanula rotundifolia, Achillea millefolium usw. Außerdem spielt besonders bei Anwesenheit von etwas Lehm Pteridium aquilinum eine hervorragende Rolle. Die meisten Waldbodenpflanzen blühen im Frühjahre; vergl. S. 562.

Der Boden kann aber auch sandig sein, und dann wird er weniger reich an Humus und die Flora des Unterholzes und der Bodenkräuter wird verschieden sein. In solchen Eichenwäldern wird z. B. Juniperus communis häufig sein können. In England, wie auch schon in Nordwestdeutschland und nach Vahl in Schweden, kommt eine Subassoziation vor mit vorherrschenden Calluna vulgaris und Vaccinium myrtillus auf dem Boden. Der Boden kann auch, obgleich seltener, ein Rohhumusboden sein ${ }^{1}$ ); aber der Rohhumus der Eichenwälder ist von dem der

1) Vergl. P. E. Müller 1899; Moss, Rankin u. Tansley 1910. 
Buchenwälder sehr verschieden (P. E. Müller). Hin und wieder wächst der Eichenwald auch auf sumpfigem, luftarmem oder auf feinsandigem, dichtem Boden oder im Überschwemmungsgebiet der Flüsse an ruhigen Stellen (Drudes "Auenwälder") ${ }^{1}$ ).

Die Birkenwälder (Betuleta). Die Birke (Betula pubescens [oder odorata] und $B$. verrucosa) ist ein ausgeprägter Lichtbaum, was schon ihre offene Krone zeigt; sie kann auf sehr verschiedenem Boden wachsen: in Felsspalten, auf trockenem, nährstoffarmem Grus- oder Sandboden, auf feuchtem Humus, sogar oft auf nassem Torfboden, in Hochmooren, und zwar bevorzugt die Hängebirke (B. verrucosa) die trockenen, die Besenbirke (B. pubescens) die feuchten Böden. Die Birkenwälder werden denn auch unter verschiedenen Standortsklassen zu erwähnen sein.

Die Bodenflora der Birkenwälder kann nach der Beschaffenheit des Bodens und auch nach dem Klima sehr verschieden sein; oft ist sie sehr reich, weil viel Licht zu ihr hinabgelangt.

1. Der Boden ist mäßig feucht. Die Bodenvegetation gleicht der der Wiesen, die von Gräsern und vielen Stauden gebildet wird. In einigen Fällen hat man Betuleta graminosa, Gräser vorherrschend, z. B. Milium effusum, in anderen Fällen Betuleta herbosa mit vielen und großblättrigen, schönblühenden Hochstauden unterschieden, in Nordskandinavien bisweilen in südländischer Üppigkeit und 1-1,5 m hoch. Hier wachsen z. B. Geranium silvaticum, Cirsium-Arten, Polemonium campanulatum, Solidago virga aurea, Trollius Europaeus, Equisetum silvaticum, Geum rivale, Filipendula ulmaria, Anthriscus vilvestris, Angelica officinalis, Paris quadrifolia, Aspidium-Arten. Ein solcher Wald könnte "Birkenwiese" genannt werden. Eine Bodenschicht von Waldmoosen ist bisweilen reichlich entwickelt, so daß von Betuleta muscosa gesprochen werden kann. In anderen Fällen bildet Equisetum silvaticum Bodenassoziationen (Facies), Betuleta equisetosa ${ }^{2}$ ).

2. Der Boden ist trocken, oft sandig. Die Bodenvegetation ist eine Art Heide mit einer dichten Vegetation von Cladonia rangiferina, Polytrichum juniperinum u. a. Moosen, Molinia coerulea, Salix repens, Calluna, Carex-Arten usw., Betula nana, Empetrum, Juniperus communis: Betuleta cladinosa.

3. Betuleta callunosa (Graebner: Birkenheide). Der Boden ist mit mehr oder weniger mächtigem, trockenem oder feuchtem, sauerem Torf oder Rohhumus bedeckt. Die Bodenvegetation wird besonders von

1) Uber die Eichenwälder Englands siehe auch Tansley 1911; Moss 1913; Adamson 1912.

2) Beispiele von Birkenwald mit Wiesenvegetation und Angaben des Häufigkeitsgrades der Arten siehe Hanna Resvoll-Holmsen 1914. 
Gräsern (Molinia coerulea, Aera flexuosa) und Zwergsträuchern wie Calluna vulgaris, Vaccinium myrtillus, V. uliginosum und anderen Hochmoorpflanzen oder Nadelwaldpflanzen gebildet.

4. Betuleta fruticosa. Viele Sträucher wie Rhamnus frangula, Juniperus communis kommen hier vor. Betuleta juniperosa werden erwähnt (Sylvén).

Die Schwierigkeit einer scharfen Abgrenzung der Vereine in Xerophyten-, Mesophytenvereine usw. zeigt sich hier wie in manchen anderen Fällen; die immergrüne, xeromorph angepaßte Form und die mesomorphe Form können nebeneinander wachsen.

Die Birkenwälder sind oft oder gewöhnlich nicht reine Assoziationen, weil sie so lichtoffen sind. Bäume wie Sorbus aucuparia, Populus tremula, Salix-Arten, oder auch Nadelhölzer, namentlich Pinus silvestris, können beigemischt $\operatorname{sein}^{1}$ ).

Birkenwälder finden sich besonders in den nördlichen Gegenden von Europa, von Asien und Nordamerika. In Island und Südgrönland ist es die Birke, besonders $B$. odorata, welche am nördlichsten geht, welche die ärmlichen und offenen Wälder bildet ${ }^{2}$. Es ist auch die Birke, welche auf der skandinavischen Halbinsel die oberste Waldassoziation bildet (in der subalpinen Höhenstufe oder „Region“).

Nach Thoroddsen ${ }^{3}$ ) besteht der größte Teil der Birkenwälder von Island aus krïppeligen Kleinbäumen oder Sträuchern, 1-3 m hoch, was unzweifelhaft besonders den Zerstörungen der Schafe zuzuschreiben ist. Wohlgewachsene Birken kommen hie und da vor; am meisten bekannt ist der Hallormstada-Wald in Ost-Island und zwei andere; in diesen erreichen die Birken eine Höhe von 8-9 m mit einem Umfange von $70-80 \mathrm{~cm}$, und viele haben eine Höhe von 5-7 m. Mit den Birken findet man auch Sorbus aucuparia, Salix phylicifolia, S. lanata, S. glauca, Betula nana, Juniperus communis. Die Bodenvegetation ist of heidemoor-ähnlich, und dieselben Arten werden denn sowohl im Walde wie auf den Heidemooren gefunden; in anderen Fällen dominieren dagegen Gräser oder Moose (Hylocomien) auf dem Waldboden und auch Hochstauden kommen vor (Filipendula ulmaria, Angelica silvestris, Geranium silvaticum, Alchimilla vulgaris u. a.).

Auf ähnliche Weise können mehrere andere unserer wildwachsenden Bäume reine oder gemischte Bestände mit einem mehr oder weniger

1) Vergl. Resvoll-Holmsen 1914.

2) Über die Birkenwälder vergl. namentlich schwedische und norwegische Forscher: Gunnar Andersson und Selim Birger, Hesselman, Sylvén, Simmons, Thekla Resvoll, A. Blytt, Hanna Resvoll-Holmsen 1914; Vahl 1911, 1913. Ein Bild der Birkenlandschaft in Südgrönland siehe Rikli in Karsten u. Schenck, Vegetationsbilder J. R., 8. Heft.

8) Thoroddsen 1914. 
rerschiedenen Charakter je nach den Unterschieden in der Feuchtigkeit des Bodens und in den Lichtverhältnissen des Waldes bilden.
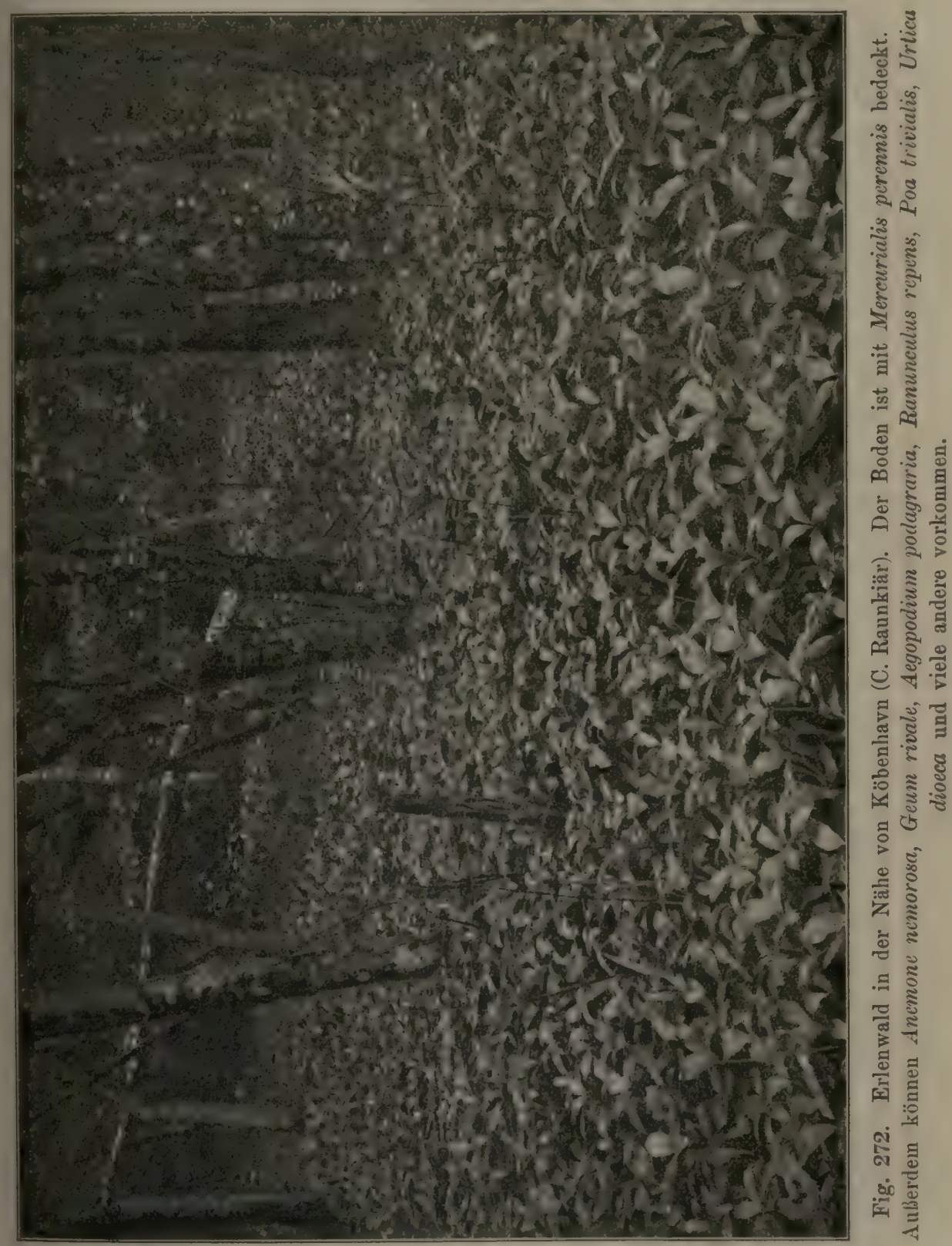

Die Esche (Fraxinus excelsior) bildet in Dänemark und anderwïrts, z. B. in Norddeutschland, Niederösterreich usw. auf losem, feuchtem, reichem Boden, eigene Wialder mit einer dichten Waldboden- 
vegetation von Hochstauden, die sonst gewöhnlich auf offenen, feuchten Fluren oder Wiesen vorkommen. Übrigens sind wohl die meisten Eschenwälder künstliche Pflanzungen in den feuchten Niederungen in den Wäldern, wo die Buche nicht gedeihen kann; an manchen geeigneten Orten schlägt die Esche aber auch selbständig auf und macht allen andern Bäumen erfolgreich Konkurrenz. In England kommen offenbar öfter größere natürliche, wertvolle Eschenwälder vor, welche von den Botanikern der Cambridge Schule zu der auf kalkhaltigem Boden wachsenden "Ash-beech"-Series gerechnet werden und deren Flora scharf von der der Eichen-Birken-Series auf Kieselboden geschieden wird ${ }^{1}$ ). Auch in den englischen Eschenwäldern finden sich verschiedene Facies in der Bodenvegetation, je nachdem der Boden feuchter oder trockener ist. Tansley sagt, daß die Esche nur auf nicht kalkhaltigem Boden herrschen wird, wenn der Boden feucht oder naß ist.

Die Grauerle (Alnus incana) bildet im nördlichen Schweden Wälder mit einer Bodenvegetation von Hochstauden wie Filipendula ulmaria, Geranium silvaticum, Geum rivale, Aera caespitosa, Milium effusum, Urtica dioeca, Moosen usw. ${ }^{2}$ ). Sie ist wenig anspruchsvoll bezüglich der Boden- und Feuchtigkeitsverhältnisse, gedeiht sie doch auf den nordostdeutschen Stranddünen ebensogut wie auf dem Kalkschutt der Rüderdorfer Kalkberge usw.

Die Schwarz- oder Roterle (Alnus glutinosa) wurde schon unter den Sumpfwäldern besprochen. Es kommen aber auch Erlenwälder auf einem tief humosen, weichen aber nur feuchten Boden vor, deren Bodenvegetation von der der fenchteren Eschenwälder wenig abweicht, und in welchen z. B. Mercurialis perennis reine und große Assoziationen bilden kann (Fig. 272).

\section{Andere laubwechselnde Wälder.}

In gleicher Weise bilden andere europäische Bäume reine oder gemischte Bestände, deren Charakter mit der Feuchtigkeit und Belichtung des Bodens wechselt.

In Schweden gibt es einen Mischwald, "Gehölz-Wiese", welcher aus laubwechselnden Gehölzen wie Eiche, Rüster, Linde und Weißbuche, unter denen ein Unterwuchs von Sträuchern und großen Kräutern, der sehr reich an Arten und üppig ist. Der Bestand ist offen, gut belichtet und parkartig, hat einen reichen Humusboden; möglicher' weise ist er mehr oder weniger durch die Kultur verändert worden.

1) Vergl. Adamson; Moss, Rankin u. Tansley 1910; Tansley 1911; Moss, Tansley a. a.

2) Grevillius 1894 . 
Hesselman ${ }^{1}$ ) hat den Wald in seinen Einzelheiten studiert, namentlich die Belichtungsverhältnisse, die assimilatorische Tätigkeit und die Verdunstung der ausdauernden Kräuter, also die wesentlichen Lebensfunktionen derselben.

Die Kap. 66 erwähnten „Auenwälder“ Drudes zeigen gewöhnlich einen ähnlich üppigen oft fast undurchdringlichen Unterwuchs von Sträuchern und Kräutern.

Die Auenwälder in Nordkurland werden von Pohle ${ }^{2}$ ) besprochen. Sie scheinen solche Bodenverhältnisse zu haben, daß sie am besten den mesophilen Wäldern angeschlossen werden müssen. Sie sind natürliche Parklandschaften, deren Schönheit zum Teil durch die Mannigfaltigkeit der biologischen Wuchsformen bedingt wird. Es finden sich in ihnen Sträucher wie Arten von Ribes, Spiraea, Lonicera und die Liane Atragene Sibirica, mit Hochstauden wie Paeonia anomala.

Jenseits der Waldgrenze nimmt der Wald nur kleinere Teile des Landes ein, die besten, entwässerten Böden und windgeschützten Orte, gewissermaßen Inseln in dem offenen Gelände.

Im Gebiete der Donau, namentlich in ihrem Mittellaufe, sind die Wälder in auffallendem Grade gemischte Wälder von Fagus, Carpinus, Quercus sessiliflora, Acer, Betula, Prunus cerasus, Pirus communis, Populus, Tilia und Coniferen „in reichster Abwechselung"; das Unterholz besteht aus Berberis, Cornus sanguinea, C. mas, Evonymus Europaea, E. verrucosa, Prunus-Arten, Juniperus communis usw. Auch Zwergsträucher von Ericaceen, Polygala chamaebuxus usw. kommen vor ${ }^{3}$ ). Diese Mannigfaltigkeit weist auf die größere Nähe der Tropen hin und hat wahrscheinlich zugleich einen geologischen Grund: das Land war nach der Eiszeit länger eisfrei als z. B. Skandinavien, und die Einwanderung der Arten ist leichter gewesen als hier. Übrigens kommen auch reine Assoziationen vor z. B. von Aesculus auf den Balkangebirgen usw.

Ein ähnlicher urwaldartiger Mischwald ist der von Rikli und Rübel $^{4}$ ) besprochene „kolchische Niederungswald", ein außerordentlich reicher, feuchter Wald, in welchem Coniferen mit verschiedenen Laubbäumen zusammenwachsen und dessen Unterholz teilweise aus immergrünen Arten besteht (Buxus, Ilex aquifolium, Prunus laurocerasus, Ruscus hypoglossum); dieser Wald enthält eine große Menge von Kletter- und Schlingpflanzen, macht den Eindruck von "fabelhafter Üppigkeit" und „erinnert einigermaßen an subtropische Regenwälder".

1) Hesselman 1904. Er nennt ihn "Laubwiese".

8) Pohle 1901.

$\left.{ }^{8}\right)$ Kerner 1863; Günther Beck 1890-93; Vierhapper und Handel-Mazetti 1905; Adamoviẻ 1909.

4) Rikli 1913. 
In den Mittelmeerländern kommen in den Bergen auch andere Wälder vor, solche von Castanea sativa (diese nähern sich den xernphilen Wäldern), Platanus orientalis usw. In den Kastanienwälderu Portugals kann eine schöne Bodenvegetation von Hochstauden v01kommen z. B. Paeoniae, Iris, Lupinus u. a. ${ }^{1}$ ). Populus nigra und $P$. alba bilden den Klein-Poppelwald in Serbien²), und namentlich auf der ungarischen Puszta, wo ihn schon Alexander von Petöfi besang (Bernatzký).

Nordamerika hat einen dem europäischen entsprechenden Waldgürtel mit sommergrünen Bäumen. Auch für die nordamerikanischen Wälder ist die starke Mischung der Arten kennzeichnend. Ferner ist das Unterholz dichter und höher; viele europäische Gattungen lieferı Beiträge zu diesen, in Nebraska z. B. Arten von Sambucus, Cornus. Ribes, dazu kommen amerikanische wie Symphoricarpus usw. Lianell treten häufiger auf. Die Physiognomie der Wälder ist jedoch ungefähr dieselbe wie bei uns. Von Epiphyten gibt es, wenn die südlichen Gegenden ausgenommen werden, jedenfalls keine anderen als Moose und Flechten. Die Herbstfarben (rot, gelb) sind ungewöhnlich tief, besonders bei Arten von Quercus, Crataegus usw. Die Flora ist verschieden. Viele Gattungen sind gerade in der gemäßigten Zone heinisch und kommen hier in zahlreichen Arten vor: Quercus, Juglans, Carya, Betula, Alnus, Ulmus, Celtis, Fagus (F. ferruginea), Castanea, Carpinus, Ostrya, Populus, Salix, Acer, Fraxinus u. a. Aber überdies gehen viele subtropische oder an die Tropen erinnernde Typen bis hierhin, namentlich in den südlichen und den östlichen Gegenden, weil die Verbindung des Landes mit südlichen Gegenden nach der Eiszeit eine leichte Einwanderung zuließ; von solchen für unsere nordeuropäische Natur fremden Gattungen können genannt werden: Magnolia, Liriodendron, Robinia, Gleditschia, Gymnocladus, Catalpa, Morus, Liquidambar, Sassafras, Platanus, Aesculus u. a. (Näheres bei Mayr).

Nach Fuller ist die am meisten verbreitete Assoziation in den vereinigten Staaten der mesophytische "Klimax"-Wald, charakterisiert namentlich entweder durch Acer saccharinum oder Fagus grandifolia oder beide. In ihnen kommen viele verschiedene Assoziationen vor. Nach Livingston ${ }^{3}$ ) bilden in Michigan die Buchen-Ahorn-Wälder die höchsten Bestände, die auch auf den besseren Boden wachsen; ihnen folgt die Ahorn-Rüster-Assoziation, die Eichen-Hikory(Carya)-Assoziation, die Eichen-Hasel-Assoziation und die Eichen-Kiefern-Assoziation; diese Stufen zeigen nacheinander die allmähliche Verschlechterung des Bodens an ${ }^{4}$ ).

1) Chodat 1909 .

9) Adamovié 1898.

3) Livingston 1903.

4) Weitere Einzelheiten vergleiche bei Mayr 1890; Cowles 1901; Whitford 1901, 1905. 
Sommergrüner Wald kommt auch im Feuerlande vor, reiner Urwald von Nothofagus pumilio und $N$. antarctica. Eine hohe Schneedecke findet sich hier im Winter. Die Regenmenge beträgt hier nur etwa die Hälfte von der in dem westlichen und nördlicheren Regenwalde. Die Junkelheit im Inneren ist nicht so groß wie in diesem, und der Boden ist entweder nur mit Stämmen, Zweigen und Blättern bedeckt, oder auch mit Moospolstern und Grasteppichen samt schönblühenden Waldkräutern. Zahlreichere immergrüne Sträucher als in unseren nordeuropäischen Buchenwäldern kommen vor, z. B. Berberis ilicifolia. Auf den Bäumen schmarotzen Myzodendron punctulatum und $M$. oblongifolium $^{1}$ ). Bemerkenswert ist das Vorkommen von immergrünen Wäldern von anderen Nothofagus-Arten in westlicheren Teilen des Feuerlandes (siehe später) ${ }^{2}$ ).

Japanische Wälder. Bei seiner großen nord-südlichen Ausdehnung und den sehr verschiedenen Höhenlagen muß Japan äußerst verschiedene Waldtypen besitzen; Japan hat eine tropische Zone mit Ficus Wightiana u. a., eine subtropische, in der auch immergrüne Laubwälder vorkommen (besonders wichtig ist der Kampferbaum); weiter eine temperierte Zone unter anderen mit Buchenwäldern (Fagus Japonica) und eingemischten Nadelbäumen, und schließlich eine kalte Zone, wo reine Nadelwälder vorkommen, mit ihnen auch Birkenwälder. Man sieht in Japan und China $^{3}$ ), daß im Walde Arten von denselben Gattungen nebeneinander wachsen, einige immergrüne, andere laubwerfend. Hier ist der Sommerwald "in statu nascendi“. Geht man weiter nördlich, so wird er immer typischer, aber er verarmt und wird gleichmäßiger.

Übrigens ist auch der japanische Wald im ganzen sehr reich an Arten und steht dadurch im Gegensatze zu den gewöhnlichen europäischen Wäldern; man kann im Monate Juni in einem üppigen Gebirgswalde etwa 100 Baum- und Straucharten mindestens aus 76 Gattungen blühen sehen. Hier sind die Gründe für die Mannigfaltigkeit sicherlich ebenfalls geologische. Die Waldregion auf dem Fuji-no-yama enthält nach Rein ${ }^{4}$ ) wesentlich Laubwälder, aber hier und da bilden Nadelhölzer geschlossene Bestände. Die Laubwälder bestehen besonders aus laubwechselnden Eichen, Buchen und Ahornen, denen sich Arten von Zelkova, Juglans, Pterocarya, Betula, Tilia, Fraxinus, Magnolia, Cercidophyllum, Acanthopanax und Aesculus anschließen. Die Flora hat bekanntlich eine große Verwandtschaft mit der des östlichen Nordamerika.

1) Skottsberg 1906.

9) Vergl. Neger 1897, 1901; Dusén 1905; Reiche 1907.

a) Diels 1908 .

4) Rein in Petermanns Mitteil. 1879. 
Es gibt eine Menge Lianen der Gattungen Actinidia, Celastrus, Vitis, Rhus, Wistaria (W.polystachya $=W$. Chinensis), Akebia, Clematis usw. Das Unterholz ist sehr reich. Dieser Wald erinnert offenbar vielfach an die tropischen Wälder.

\section{Kap. Nadelwälder (Conifereta)}

Die Coniferen haben eine schon im Äußeren stark ausgesprägte Xèromorphie. Kennzeichnend ist daš nadelförmige Blatt, dessen geringe Oberfläche zusammen mit der starken Cuticularisierung der Epidermis, der häufigen Einsenkung der Spaltöffnungen und anderen xeromorphen Eigentümlichkeiten die Transpiration herabsetzt. Die immergrünen Nadelbäume verdunsten nach Versuchen viel weniger Wasser als die Laubbäume; im übrigen ist die Verdunstungsfähigkeit je nach den Arten verschieden. Die Lärche verdunstet aus den weichen und einjährigen Nadeln natürlich stark $^{1}$ ). Die Nadelbäume haben in Übereinstimmung mit dem xeromorphen Bau nur wenige oder unbedeutende Wurzelhaare.

Es wurde oben (S. 315) erwähnt, daß diese xerophytischen Charaktere der Coniferen in ihrer Morphologie, Anatomie und Physiologie in der Tat nicht leicht zu erklären sind. Nach Marie Stopes sollen sie mit dem phylogenetisch hohen Alter der Coniferen zusammenhängen, und mit dem unvollkommenen Wasserleitungsvermögen ihres trachealen Systems. Percy Groom nennt sie "architectural xeroophytes". Er macht doch darauf aufmerksam, daß von den amerikanischen Pinus-Arten diejenigen, welche die engsten Tracheïden besitzen, in ihrer Verbreitung mehr xerophil sind als diejenigen, welche die weitesten Tracheïden haben ${ }^{2}$ ); er meint, daß die große Fläche sämtlicher Blätter eines Baumes es notwendig macht, daß3 das einzelne Blatt xeromorph gebaut wird ${ }^{3}$ ).

M. Vahl legt besonders darauf Gewicht, daß die Xeromorphie für die immergrünen Nadelbäume ein Schutzmittel gegen die Verdunstung im Winter sein muß. Viele Arten, wohl besonders der südlicheren Gegenden, aber auch z. B. Pinus silvestris sind auch an trockenen Boden gebunden oder oft an Humus- oder Torfboden, die im Frühjahr erst auftauen, wenn die Temperatur der Luft schon sehr hoch sein kann.

Compton legt bei den Coniferen besonders Gewicht auf den Mangel an Plastizität, sie können ihre Blätter nicht den ökologischen Verhältnissen des Standorts anpassen ${ }^{3}$ ).

In der Tat wachsen Nadelhölzer, mit, soweit wir sehen können, im wesentlichen denselben anatomischen Eigentümlichkeiten, auf äußerst verschiedenen Standorten, doch zum allergrößten Teil in den gemäßigten

1) Vergl. Percy Groom 1910.

2) Percy Groom 1914.

3) Percy Groom 1910. Vergl. anch Compton 1911. 
Ländern der nördlichen Halbkugel, wo auch die sommergrünen Wälder vorzugsweise zu Hause sind.

Sie bilden einen mächtigen Gürtel um die ganze nördliche kalte und temperierte Zone, der polaren Baumgrenze folgend, also in denselben Regionen wie viele der sommergrünen Laubhölzer, und vielfach in Konkurrenz mit diesen tretend. Die Fichte (Picea excelsa) z. B. ist von Nordosten in die skandinavische Halbinsel eingedrungen, während die Buche von Südwesten ankam; im südlichen Schweden sind sie sich begegnet und kämpfen hier um den Platz (Hult). Bisweilen scheinen die Nadel- und die Laubwälder sich nach klimatischen Verschiedenheiten zu verteilen; z. B. herrscht nach Hayata Laubholz auf der Südseite des Berges Fuji in Japan, Nadelwald dagegen auf der Nordseite. Unter denselben klimatischen Verhältnissen finden wir die verschiedenen Arten an sehr verschiedenen Standorten, ohne daß sich diese Verschiedenheiten im Äußeren oder Inneren kundgeben. Am Lena findet man nach Cajander, daß Pinus silvestris auf den trockensten Stellen, Larix Sibirica auf mittelfeuchten und Picea obovata auf den nassesten, fast sumpfartigen Standorten wachsen.

Noch schroffer tritt der Gegensatz zwischen den Standorten hervor, wenn man z. B. die Kiefernwälder des kalttemperierten und regnerischen Norwegens oder Schottlands aus Pinus silvestris gebildet mit den mediterranen Wäldern von Pinus pinea oder der auf noch trocknerem und heißerem Boden wachsenden $P$. Halepensis vergleicht. Sie zeigen uns, daß Physiognomie und Ökologie nicht immer übereinzustimmen brauchen.

Die Coniferen Nordamerikas wachsen gleichfalls an den verschiedensten Standorten; in der Sierra Nevada in Kalifornien ist die Regenmenge sehr verschieden je nach den Höhenstufen der Berge; wo die Regenmenge $62-90 \mathrm{~cm}$ beträgt, wachsen Sequoia gigantea, Abies concolor, Arten von Pinus und Libocedrus; wo sie $80-180 \mathrm{~cm}$ hoch ist, gedeiht Sequoia sempervirens, Picea, Tsuga. In größeren Höhen (1500-2150 m), wo eine Niederschlagsmenge von $100-125 \mathrm{~cm}$ fällt, wachsen andere Arten von Pinus und Abies.

Ein Beispiel eines gemischten Waldes in Connecticut gibt Nichols ${ }^{1}$ ); es ist ein "Urwald", welcher hauptsächlich von Tsuga Canadensis und Fagus grandifolia gebildet wird, die beide im ganzen etwa gleich zahlreich sind und wenigstens $55 \%$ des gesamten Bestandes ausmachen; außerdem kommen ca. 10 andere Baumarten vor, den Gattungen Acer, Quercus, Betula, Castanea, Fraxinus, Tilia, Prunus und Pinus angehörend, welche zerstreut vorkommen. Der Boden ist mit mesophytischen Kräutern und Moosen bedeckt.

Noch rätselhafter wird die xerophytische Natur bei denjenigen Arten, welche an ganz verschiedenen Standorten wachsen können.

1) Nichols 1913. 
Pinus silvestris kommt sowohl an sehr trockenen Standorten vor, z. B. auf Sanddünen oder auf den norddeutschen mageren Sandfeldern als auch anf sehr nassem Torf- und auf mittelfeuchtem Boden, ganz ähnlich der Calluna vulgaris, Juniperus communis oder anderen Heidepflanzen, ohne daß sich ihr Bau, soweit wir wissen, nach den verschiedenen Bedingungen wesentlich ändert. In vielen Fällen wird wohl Sauerstoffmangel im Boden ein den verschiedenen Standorten gemeinsamer Faktor sein. Pinus silvestris ist vielleicht eigentlich besser von den mesophyten Formationen zu trennen.

Die Unterbringung der Nadelhölzer in einer einzigen Standortsklasse ist eine Unmöglichkeit; anderseits sind die Standortsfaktoren, welche für die verschiedenen Arten die günstigsten sind, noch nicht so genau studiert, daß man darnach alle mit Sicherheit in bestimmte Klassen verteilen könnte.

Die Bodenvegetation ist nach den herrschenden Arten und der Verschiedenheit der Standorte sehr verschieden.

In solchen Nadelwäldern, die aus stark schattenspendenden Bäumen bestehen, z. B. aus Picea excelsa, ist die Bodendecke oft sehr dürftig. weil die Wälder dunkel sind, infolge der vielen blatttragenden Sprosse: deren Blätter kein Licht durchgehen lassen und das ganze Jahr sitzen bleiben. Die Dunkelheit dauert also das ganze Jahr. In anderen. mehr lichtoffenen Wäldern, besonders den hellen Lärchenwäldern, kanr sie äußerst reich sein.

Roh humus wird in vielen, vielleicht den meisten reinen Nadelwälderr gebildet, und zwar besonders in denjenigen, welche in kühlen und sehs regenreichen und nebeligen Gegenden vorkommen. Auch hierüber sinc die Untersuchungen wohl noch unvollständig ${ }^{1}$ ).

Bodenvegetation der immergrünen nordeuropäischen Nadel. wälder. Die Waldbodenpflanzen sind alle mehrjährig, aber im Sproß bau und anderen Lebensverhältnissen z. T. sehr verschieden. Zwergsträ u. cher und Halbsträucher sind zahlreich, namentlich Vaccinium-Arten Ledum, Calluna, Empetrum, Juniperus; hierher können auch die meister Pirola-Arten gerechnet werden. Die meisten dieser Sträucher sind wi viele Kräuter immergrün. Die Gräser sind in gewissen Wäldern seh spärlich, in anderen wieder zahlreich. Stauden, besonders Kleinstaudes sind gleichfalls vertreten. Kryptogamen kommen häufig vor.

Kriechende Grundachsen oder knospenbildende Wurzeln habe: nicht wenige Arten (Arten von Pirola, Monotropa, Vaccinium, Majanth mum, Goodyera repens, Oxalis acetosella, Trientalis Europaea, Pteridiu: aquilinum, Aspidium [Phegopteris] dryopteris u. a.), was vermutlich m der losen Beschaffenheit des Bodens zusammenhängt (mit der dicke

1) Vergl. indessen namentlich von Bentheim bei Graebner 1904; Erdmann 19 
Decke der abgefallenen Nadeln und des Mooses). Oberirdisch wandern Linnaea, Lycopodium clavatum, L. annotinum, Veronica officinalis $u_{.} a_{.}$; aber die meisten sind doch an den Standort gebunden und besitzen eine vielköpfige primäre Wurzel oder eine senkrechte, vielstengelige Grundachse.

Die Kräuter haben meist keinen xerophilen Bau; sie sind Mesoplıyten, die zu dem Schatten und der feuchten Luft des Waldes passen; unter den Zwergsträuchern dagegen sind die immergrünen deutlich xerophil angepaßt.

Eine Eigentümlichkeit, welche die nordischen Nadelwälder zu den Laubwäldern in einen gewissen Gegensatz stellt, ist die Menge von Zwergsträuchern mit fleischigen Früchten (Vaccinium-Arten, Arctostaphylus uva ursi, Empetrum, Juniperus communis u. a.) Dies hängt wahrscheinlich mit dem Aufenthalte zahlreicher Vögel in den Nadelwäldern zusammen, die die gefressenen und ihrem Körper anhängenden Samen oder Früchte von Ort zu Ort tragen; sie haben z. B. in Dänemark, Schleswig-Holstein usw. Linnaea, Pirola-Arten und Goodyera in die oft nur etwa hundert Jahre alten Kieferpflanzungen wahrscheinlich aus Norwegen und Schweden eingeführt ${ }^{1}$ ).

Die Bodenvegetation der laubwerfenden Nadelwälder (der Lärchenwälder) ist ökologisch deutlich von der immergrünen verschieden.

Die Nadelwälder sind teils A. laubwechselnd (Lärchenwälder), 75. Kap., teils B. immergrün, 76. Kap.

\section{Kap. Laubwechselnde Nadelwälder (Lärchenwälder)}

Die laubwechselnden Nadelhölzer, die Lärchenwälder, erscheinen in den Lebensverhältnissen von den andern Nadelwäldern sehr verschieden.

Die Lärchen (Larix-Arten in Europa L. decidua $=L$. Europaea) sind die frosthärtesten aller Nadelbäume, indem sie die Nadelform ihrer Blätter mit dem Laubfalle vereinigen. Sie bilden noch rings um den Kältepol Sibiriens Wälder (L. Sibirica), ertragen eine größere Trockenheit als die Fichte und können eine sehr kurze Vegetationszeit benutzen, vielleicht weil ihre sehr stark verdunstenden $\mathrm{Nadeln}^{2}$ ) weit rascher assimilieren können, als die der immergrünen Arten, sie sind in dieser Hinsicht den sommergrünen Laubbäumen ähnlich. Die Lärchen sind daher von der Winterkälte weniger abhängig als von der Wärme des Sommers; sie sind kontinentale Bäume. Ferner sind sie ausgeprägte

1) Warming 1904 .

2) Siehe Percy Groom 1910.

Warming-Graebner. 3. Anflage, illustr. 
Lichtbäume; daher ist es in ihren Wäldern hell, und der Boden ist deshalb mit zahlreichen krautartigen Blütenpflanzen nebst Farnen und Moosen bedeckt; in den Lärchenwäldern der Alpen ( $L$. decidua) z. B. findet man Arnica montana, Solidago alpestris, Campanula barbata, viele Orchidaceen usw.

Rübel $^{1}$ ) setzt den mittleren Lichtgenuß im Berninagebiet auf $1 / 5$. Bei dieser Helligkeit gedeiht ein Wiesenunterwuchs, der als Weide dienen kann. Die Wiesentypen, die hier zur Entwickelung kommen, sind: das Nardetum strictae, das Trifolietum alpini und das Trifolietum repentis. Die Assoziation nennt er daher Laricetum pratosum; Boris Keller erwähnt von Altai ein Laricetum herbosum, welches wohl ähnlich ist.

Rübel macht auf eine merkwürdige Assoziationsfolge aufmerksam, die hier vorkommt, da die alten Lärchen nicht mehr genügend Licht für die jungen Lärchen durchlassen. Zugleich hat sich am Boden genug Humus angesammelt, so daß junge Arven gedeihen können; für diese Art ist noch hinreichend Licht (Lichtgenuß 1/25) vorhanden; so verwandelt sich dann der Lärchenwald in einen Arvenwald um.

Im Altai scheinen die Lärchenwälder ebenso verdrängt zu werden, und zwar durch die mesophile Kraut- und Grasvegetation des Waldbodens. Nach Krassnoff ${ }^{2}$ ) stehen hier hundertjährige riesige Lärchen, einzeln oder gruppenweise, weit voneinander in den Wäldern, und auf dem von den feinen Nadeln gebideten alten Humusboden ist eine so hohe und üppige Hochstaudenvegetation aufgewachsen, daß man sich leicht darin verbergen kann. Diese besteht aus Arten von Aconitum, Delphinium, Paeonia, Clematis (Atragene) u. a. Jedes Jahr fallen Millionen von Lärchensamen in dieses Krautmeer hinab; aber nur wenige finden Platz, um zu keimen: der Wald wird hier anscheinend verschwinden.

Rohhumus wird nach Pohle ${ }^{3}$ ) in Nordrußland in den Wäldern von Larix Sibirica von Astmoosen gebildet. Dasselbe gilt vielleicht auch von anderen Lärchenwäldern.

\section{Kap. Die immergrinen Nadelwälder}

Von den vielen Nadelwaldformen sind die europäischen Nadelwälder am besten untersucht worden. Folgende verdienen hier beispielsweise behandelt zu werden.

Kiefernwälder (Pineta). Die Kiefer (Pinus silvestris) kann auf sehr verschiedenen (an natürlichen Standorten meist ziemilich nährstoffarmen) Böden wachsen, von trockenem und warmem Sandboden oder

1) Rübel 1913.

2) Krassnoff 1888.

3) Pohle 1907. 
Felsenboden mit einer dünnen Schicht losen Bodens bis zu feuchtem (mitunter nassem) und weichem Moorboden (S. 315). Sie ist ein außerordentlich genügsamer Baum und darin dem Heidekraute ähnlich; sie ist ein Lichtbaum, dessen innere Zweige daber bald absterben, so daß der Stamm nackt wird; die Nadeln sitzen meist nur 3-4 Jahre und zwar allein an den Zweigenden und auf dem Wipfel, in schlechteren Beständen oft nur 1 oder 2 Jahre. Der Waldboden ist im Einklange hiermit oft recht dicht bewachsen, bald mit dieser, bald mit jener Pflanzengemeinschaft, aber doch mit einer im ganzen xerophilen Vegetation ${ }^{1}$ ). Folgende Varianten (Subassoziationen) können unterschieden werden:

Pineta silvestris cladinosa ("Kiefernflechtenheiden“). Die Bodendecke ist im wesentlichen eine Flechtenheide. Renntierflechten Cladonia rangiferina, C. alpestris, C. silvatica, Cetraria Islandica und andere Strauchflechten breiten ihren weißgrauen Teppich, in den oft niedriges, verkrüppeltes Heidekraut und andere Heidepflanzen (Linnaea, Arctostaphylos uva ursi, Pirola-Arten, Lycopodium annotinum, L. clavatum, Potentilla silvestris, Viola canina, Majanthemum bifolium usw.) eingesprengt sind, über den Boden aus, so besonders dort, wo der nährstoffarme Boden trocken und warm ist.

Pineta silvestris hylocomiosa. Der Bodenteppich ist dicht von Waldmoosen (Hylocomium, Hypnum), aber auch anderen Gattungen, wie Polytrichum und Dicranum, gebildet. Diese Assoziation ist mitunter ebenso charakteristisch für lichtere Fichtenwälder als für Kiefernwälder. Vergl. auch die Abbildungen bei der Heideformation Kap. 88.

Pineta silvestris graminosa und herbida (oder herbosa [Boris Keller]). Die weiche und dichte Bodendecke aus Gräsern und Stauden gebildet. Von Gräsern finden sich namentlich Aera (Deschampsia) Hexuosa und Festuca ovina, dann auch z. B. Carex arenaria, oft steril mit langen Blättern, C. Ligerica, Luzula pilosa und dikotyle Stauden wie Oxalis acetosella, Fragaria vesca, Epilobium angustifolium, Potentilla arenaria, Hieracium murorum u. v. a., dazwischen oft viele Moose.

Pineta silvestris fruticosa (Kiefernheide). Die Bodendecke ist im wesentlichen eine Zwergstrauchheide, gebildet aus Calluna, Vaccinium myrtillus, V. uliginosum, V. vitis Idaea, Populus tremula, und Empetrum, zwischen ihnen als höherer Strauch Juniperus comminis, mitunter zahlreich (ein kleiner „Wald im Walde"); auch die Fichte (Picea excelsa) kann als Unterholzstrauch auftreten. Es gibt nordische Kiefernwälder, deren Boden eine außerordentlich trockene Decke ist, die aus Arctostaphylos uva ursi, Juniperus, Calluna, Betula nana, Antennaria dioeca u. a., ferner aus Massen von Flechten (Cladonia) und Moosen (Grimmia usw.) besteht.

2) Gute Bilder bei Hanna Resvoll-Holmsen 1914. 
Eine Liste der Kiefernwaldpflanzen in Norddeutschland hat Höck ${ }^{1}$ ) aufgestellt.

Vahl und Hanna Resvoll-Holmsen ${ }^{2}$ ) haben die Zusammensetzung der Bodenvegetation in Pineten statistisch studiert.

Vahl ${ }^{3}$ ) hat folgendes gefunden: In Skandinavien ist der flechtenreiche Kiefernwald auf trockenem Sandboden besonders verbreitet. Unter den Zwergsträuchern der Bodenvegetation sind solche, welche oberirdisch wandern oder ohne Wanderungsvermögen sind, an Zahl der Individuen überwiegend. Auf weniger trockenem Boden ist der Kiefernwald reich an Moosen. In der Bodenvegetation sind unterirdisch wandernde Zwergsträucher, besonders Vaccinien herrschend. Selten ist schattiger Kiefernwald, wo die Bodenvegetation aus Moosen mit wenigen Gefäßpflanzen besteht.

Die Bodenvegetation des nordischen Kiefernwaldes besteht also namentlich aus Xerophyten; denn der Boden ist mager und trocken, Licht und Wind können gewöhnlich leicht herabdringen und auf die Vegetation austrocknend wirken. Einer und der andere Mesophyt kann jedoch auch hier Fuß fassen. Im ganzen passen diese Kiefernwälder also eigentlich nicht gut in die Serie der Mesophyten, aber des $\mathrm{Zu}$ sammenhanges wegen werden sie hier besprochen. Die südrussischen Kiefernwälder z. B. sind dagegen von den skandinavischen offenbar nicht wenig verschieden, weil auf ihrem Waldboden viele stattliche Stauden wachsen (Tanfiljew); die berühmten ostpreußischen Kiefernwälder mit ihren erstklassigen Bäumen, die außerhalb des Verbreitungsgebietes der Buche oft auf besseren Böden wachsen, haben eine ganz entschiedene Mesophytenvegetation, der der Mischwälder entsprechend und gehören deshalb hierher.

Die auf Heidemooren mitunter Bestände bildende Form ist meist eine eigene Rasse (turfosa).

Birken und Populus tremula sind bisweilen in den Kiefernwald eingemischt; sie sind ja alle Lichtbäume ungefähr mit demselben Lichtbedürfnis $\left.{ }^{4}\right)$.

Die Arvenwälder (Cembreta oder Pineta cembrae) der Schweiz sind in einem großen Werke von Rikli ${ }^{5}$ ) behandelt worden, dann auch

1) Höck 1893.

$\left.{ }^{2}\right)$ Vahl 1911, 1914; Resvoll-Holmsen 1913.

8) Vahl 1911.

4) Über die Pineta silvestris vergl. z. B. Domin $1905 \mathrm{~b}$; G. Andersson u. Hesselman 1907; Nielsson 1896, 1897 a, b, 1902; Hesselman 1906; Birger 1904; Tansley 1911; Vahl 1911; Rübel 1913; Boris Keller; Graebner 1895, 1901, 1904, 1909, 1912; Hanna Resvoll-Holmsen 1914.

s) Rikli 1909. 
von Schröter, Rübel ${ }^{1}$ ) u. a. Nach Rikli sind sie jetzt von vielen Punkten der Schweiz verdrängt worden.

Der Arvenwald ist dunkler als der Lärchenwald (Kap. 75) und besiedelt im Berninagebiete alten humosen Boden. Der Unterwuchs ist besonders aus Kleinsträuchern und Zwergsträuchern gebildet (Cembretum fruticosum); verschiedene Facies kommen vor, so z. B. Vaccinieta myrtilli, Rhodoreta, Junipereta, Aretostaphyleta uvae ursi, Calamagrostideta villosae.

Von anderen europäischen Pineten könne noch hier die Pineta montanae genannt werden, obgleich sie sicher zum größten Teile einen sauren Rohhumusboden haben.

Die Krummholakiefer (Pinus montana) ${ }^{2}$ ) bildet in den Pyrenäen und den französischen Alpen stattliche Wälder, sinkt aber weiter östlich zu Gestrüpp (Krummholz, Legföhren-Gebüsch, Latschen) herab und muß sich hier, von anderen Arten von den besseren Standorten verdrängt, mit den dürftigsten Standorten begnügen. Sie ist ein schattenspendender Baum, obgleich nicht in so hohem Grade wie die Fichte (vergl. P. E. Müller 1887), und der Boden ihrer Wälder bleibt daher pflanzenarm.

Merkwürdig ist, daß sie sowohl auf den trockensten und unfruchtbarsten Gebirgsabhängen als auch auf nassem Moorboden vorkommt, indem sie an beiden Stellen Gestrüppe oder Buschwälder bildet (S. 314). Unter ilır wachsen auf den Mooren teils Sträucher wie Ledum palustre, Andromeda polifolia, Calluna, Vaccinium uliginosum, V. myrtillus, V. vitis Idaea, V. oxycoccus, teils niedrige Kräuter wie Eriophorum und Carex, Moose wie Hylocomium, Dicranum und Sphagnum, ferner Flechten. Es ist dieses ein Calluna-Moor (Kap. 86) mit Baumwuchs. Viele dieser Pflanzen sind xerophil gebaut (vergl. Kap. 80). Auch die Kiefer (Pinus silvestris) geht, wie bemerkt, in ähnlicher Weise auf die Moore hinaus. Es sind die genügsamsten, am meisten abgehärteten Pflanzen, sowohl baum- als auch strauchartige, die auf so extremen Böden wachsen können ${ }^{3}$ ). Vergl. übrigens Kap. 88.

Die südlicheren Pinus-Wälder haben wohl im allgemeinen trockene Standorte mit einer xerophilen Bodenvegetation, namentlich die großen Wälder der Pinus Halepensis in Südeuropa, welche die Hülseneiche (Quercus ilex) auf Stellen, wo der Felsen ziemlich verwittert ist, verdrängen ${ }^{4}$ ). Mitunter sind die Bestände der Aleppokiefer sehr dicht (Lussin), so daß nur eine dürftige Grasvegetation gedeiht. Wo sie lichter sind, dringen verschiedene Formationen in sie ein, so am Kap

1) Rübel 1913.

2) Vergl. P. E. Müller 1887; Ascherson u. Graebner Synops. 1. u. 2. Aut.

э) Vergl. Graebner 1895, 1898 ff.

t) Elahault 1893. 
Martin an der französischen Riviera die Cistus-Macchị usw., dort gehen die Bestände auch bis ans offene Meer, und völlig niedergedrückt sind sie mit Strandpflanzen aller Art gemischt.

Die Pineten von Pinus pinea im Mittelmeergebiet mit einer sehr interessanten, teils sehr xerophilen, teils sumpfigen und sogar halophilen Flora ${ }^{1}$ ) (Ascherson-Graebner, 1893) zeigen oft ein buntes Gemisch von laubwechselnden und immergrünen Sträuchern und Halbsträuchern, sowie ausdauernden und einjährigen Kräutern.

Die Pinares der kanarischen Inseln (Christ, 1885). Diese Wälder bestehen aus Pinus Canariensis und kommen etwa von 1600 bis zu $2000 \mathrm{~m}$ Höhe besonders auf den trockneren, windigen und sonnigen Abhängen vor (der Lorbeerwald wählt den feuchteren Boden). P. Canariensis (der Pinar) hat einen kegelförmigen, bis zur Erde Zweige tragenden Stamm, $15 \mathrm{~cm}$ lange Nadeln, die in eleganten Bogen herabhängen. Man hört keinen Vogelgesang in diesen Pinares, nur das Sausen des Windes. Die Bodenvegetation weicht wie der Hochwald selbst von unserer nordischen Natur stark ab; sie besteht besonders aus Cistus- und GenistaArten, denselben xerophilen Gattungen, die in den mediterranen Macchien eine hervorragende Rolle spielen, und ist ein Abglanz dieser Macchien und der Garigues, gleichwie sie in den nordischen Wäldern wesentlich mit der Flechten- und der Zwergstrauchheide oder der Felsenflur übereinstimmt. Außer den genannten Sträuchern sind Daphne gnidium, Asphodelus ramosus, der Farn Notochlaena Marantae, zwei AdenocarpusArten (Leguminosen) u. v. a. häufig. Die Cedernwälder des Libanon, Cyperns ${ }^{2}$ ) und Nordafrikas gehören auch hierher. Diese auf sehr trockenem Boden wachsenden Nadelwälder können jedoch kaum zu der Serie der mesophilen Formationen gerechnet werden, eher zu der der Hartlaubformationen (XIII, § 104).

Auch weiter südlich in Afrika finden sich Nadelwälder. Nach Engler kommen in vielen Teilen von Ostafrika in der obersten Waldregion eine baumartige Juniperus-Art vor, J. procera, dessen Stämme 30 bis $50 \mathrm{~m}$ Höhe und unten nicht selten über $1 \mathrm{~m}$ Dicke erreichen; sie bilden zusammenhängende Bestände oder werden wenigstens in den Waldbeständen herrschend. Die Art scheint eine geringe Feuchtigkeit zu beanspruchen. In Natal kommen nach Bews Podocarpus-Wälder vor, diese gehören wohl, wie auch in Brasilien, den megathermen (iebieten an.

Fichtenwälder (Piceeta). Die Fichte oder Rottanne (Picea excelsa) gedeiht wie die Kiefer auf Boden von verschiedener Beschaffenheit, ist aber bezüglich der Grundfeuchtigkeit doch anspruchsvoller.

1) Ascherson-Graebner 1893; Holmboe 1914.

?) Holmboe 1914. 
Brockmann-Jerosch schreibt sogar von der Fichte an Puschlav, daß sie ganze Hänge beherrscht unbekümmert um die Änderungen der ökologischen Bedingungen. Im allgemeinen muß man sie doch weit mehr als die Kiefer den mesophilen laubwechselnden Bäumen gleichstellen.

Die Fichte ist ein stark schattenspendender Baum, dessen Zweige und Nadeln im Einklange hiermit viel länger sitzen bleiben als bei der Kiefer (die Nadeln 8-13 Jahre) und dessen Krone die bekannte, dicht geschlossene Kegelform erhält. Die Vegetation des Waldbodens stimmt hiermit überein: Unterholz fehlt, der Boden ist in den dunkelsten Fichtenwäldern oft ganz nackt; nur einige spärlich entwickelte Moose gedeihen auf der dichten, meist mehrere Zentimeter (ja mitunter mehrere Dezimeter) dicken Nadeldecke, aus der sich jedoch im Herbste Scharen von Hutpilzen entwickeln. Übrigens ist auch bei ihr die Bodenvegetation nach den Standorten und den Alterszuständen der Bäume sehr verschieden. Es finden sich z. B. folgende Subassoziationen:

Piceeta excelsae hylocomiosa. Wo das Licht reichlicher ist, werden die Moose üppiger; die Bodenvegetation kann in guten Wäldern eine zusammenhängende, dichte, gleichförmige, grüne, weiche Moos matte werden (meist Hylocomium-Arten, deren Polster lose auf dem Boden liegen und einen von Regenwürmern bewohnten Humus verhüllen, ferner Polytrichum, Dicranum usw.; diese beiden Gattungen können jedoch auch Moosrohhumus bilden). In die Moosdecke und den losen Boden sind oft viele Blütenpflanzen eingestreut, viele mit kriechenden Grundachsen (Oxalis acetosella, Trientalis Europaea, Circaea, Vaccinium myrtillus, V. vitis Idaea, Anemone-Arten, Viola silvatica, Listera cordata, Linnaea, Pirola-Arten, Farne, Bärlappe usw.). Diese Pflanzen sind teilweise ausgeprägte Schattenpflanzen, einige zugleich Saprophyten (Monotropa, Goodyera u. a.).

Ein Piceetum sphagnosum wird von Boris Keller von Altai angeführt; es ist vielleicht ein zugrundegehender versumpfender Wald, wie solche von Nordschweden bekannt sind und auch im Gebiete der Lüneburger Heide beobachtet sind. Piceeta excelsae herbida mit vielen Kräutern, z. B. Matten von Oxalis acetosella oder Piceeta excelsae graminosa mit dichten, weichen Grasteppichen namentlich aus Aera flexuosa sind besonders in jüngeren Beständen oder in lichteren Gebirgswäldern zu beobachten (letztere nit zahlreichen Übergängen der Flora zu der der Misch- und Laubwälder). Für die Flechten ist der Fichtenwald meist zu dunkel, weder Boden noch Stämme sind mit ihnen bekleidet; eine Ausnahme bilden jedoch Wälder mit magerem Boden und höhere Gebirgswälder, wo besonders Usnea in langen Bärten von den Zweigen herabhängt und dem Walde ein eigentümliches Gepräge verleiht (Blytt). 
Piceeta excelsae fruticosa. Im nördlichsten Europa sind die Verhältnisse oft anders: der Boden wird mehr von den xerophilen Zwergsträuchern des Kiefernwaldes bedeckt, es kann sich ein Unterholz von Salix, Betula, Alnus, Sambucus nigra.usw. entwickeln, und Flechten sind vorhanden, obgleich spärlich.

Piceeta excelsae vacciniosa mit reichlichen Moosen sind in Skandinavien sehr verbreitet ${ }^{1}$ ).

Die dichten Fichtenwälder halten natürlich die Feuchtigkeit weit besser fest als die Kiefernwälder, und sind von den Niederschlägen weniger abhängig als diese. Rohhumus kommt auch nicht selten in Fichtenwäldern vor; die Bodendecke der Fichtennadeln kann von den feinen Fichtenwurzeln durchwebt sein und einen Torf bilden, unter welchem Bleisand und Ortstein auftreten, ganz wie in der CallunaHeide oder im Buchenwalde. Der Fichtenrohhumus ist heller und anfangs weniger fest als der Calluna- oder der Buchenrohhumus ${ }^{2}$ ), später kann er sich zu sehr festem Torf verdichten. In den feuchten Klimaten bringt es in den Beständen der Ebenen die Rohbumusbildung und die damit Hand in Hand gehende Bodenverdichtung also der Luftabschluß mit sich, daß jede folgende Fichtengeneration immer flacher wurzelt als die vorhergehende. An Orten, wo die alten Bäume bis weit über $1 \mathrm{~m}$ tief wurzelten, dringt die zweite Generation kaum mehrere Dezimeter ein, die dritte streicht mit ihren Wurzeln ganz flach ${ }^{3}$ ).

Die Fichte bildet aus den niederliegenden Zweigen, die oft weit umher liegen, öfter Beiwurzeln und neue Gipfelsprosse. Daher kann sie vielstämmig werden und Gestrüppe bilden (J. M. Norman). Sie hat hierin vor der Kiefer etwas voraus; während diese die Bauform behält, bis die Verhältnisse ihrem Wachstum eine Grenze stecken, geht die Fichte in Lappland in der Gestalt von verkrüppelten und niederliegenden Formen über die Waldgrenze hinaus (Kihlman); sie tritt in diesen Formen auch an dem norwegischen Meeresufer auf (Blytt).

Die Omorica-Wälder von Picea omorica in entlegenen Tälern der Balkanhalbinsel sind besonders von Beck ${ }^{4}$ ) und Adamovićs ${ }^{5}$ besprochen und abgebildet.

Tannenwälder. Abieta. Abies alba (A.pectinata), die Edeltanne bildet im mittleren und südlichen Europa in den Gebirgen oft ausgedehnte hohe Bestände, deren Boden mitunter sehr feucht ist. In

1) Statistik bei Vahl 1911.

$\left.{ }^{2}\right)$ Über Fichtenrohhumus siehe P. E. Müller $1887 \mathrm{a}$; Grebe 1896; v. Bentheim bei Graebner 1904; Erdmann 1904.

3) Graebner in Zeitschr. f. Forst- u. Jagdwes. und 1909.

4) Beck 1901 .

5) Adamović $1909 \mathrm{a}, \mathrm{b}$. 
vielen Gebirgen, wie in dem sächsisch-böhmischen Sandsteingebirge, im Riesengebirge, im Harz, in Thüringen usw. ist die Tanne meist mit der Fichte gemischt, in anderen Gebirgen wiegt die Tanne auf weite Strecken vor (Schwarzwald). Beide scheinen nicht an besondere Bodenarten gebunden $\mathrm{zu}$ sein und treten oft miteinander in Konkurrenz.

Taxus baceata ist in England oft häufig in Buchenwäldern, bildet doch auch an einigen Stellen kleine eigene Assoziationen auf ähnlichen Verhältnissen wie die Buchenwälder (Tansley). Auch in Deutschland gab es ausgedehntere Bestände von Taxus, meist mit Laubholz gemischt, die aber meist der Axt zum Opfer gefallen sind. Noch jetzt enthält der Zießbusch in Westpreußen einige 1000 Stämme und auch in den Mittelgebirgen (Fränkischer Jura usw.) findet man Eibenbestände ${ }^{1}$ ).

Die ausgedehnten sibirischen Nadelwälder müssen hier übergangen werden. Einige Worte wurden bereits von ihnen gesagt. Nach Cajander sind die Wälder an der Lenamündung sehr feucht und reich an Epiphyten.

Gemischte Wälder. In vielen Nadelwäldern sind mehrere Arten miteinander gemischt, besonders, wie es scheint, je weiter man in Europa nach Osten geht (vielleicht weil das Land hier länger als in den nordwestlichen Gegenden bewachsen gewesen und weil die Artenwanderung großenteils von Osten nach Westen vor sich gegangen ist). In dem russischen Gouvernement Perm z. B. sind unter anderem Larix Sibirica, Pinus cembra, Abies Sibirica nebst Laubbäumen den von der Fichte (Picea excelsa und $P$. obovata) gebildeten Wäldern beigemischt. Das Gepräge der Bodenvegetation hängt wie sonst von den Lichtverhältnissen und dem Alter des Waldes ab; man findet dieselben Moosteppiche mit eingestreuten Blütenpflanzen, sogar dieselben Arten, wie bei uns.

Auch die nordamerikanischen ungeheuren Nadelwälder müssen hier unberücksichtigt bleiben. Über die Abies- und Pinus-Wälder Nordamerikas, deren nördlichste auf Eisboden wachsen und deren Physiognomie teilweise von der der europäischen Nadelwälder abweicht, vergl. Mayr und viele nordamerikanische Verfasser.

Viele amerikanische Pinus-Arten und andere Nadelhölzer kommen an edaphisch und klimatisch sehr verschiedenen Lokalitäten vor, was in der Zukunft näher zu studieren sein wird.

Bilder von den versehiedenen Arten finden sich an vielen Stellen, z. B. in Karsten u. Schenck, Vegetationsbilder IX 1-2; Purpus 1907; Sargent; Cowles; Harshberger 1914 u. a.

1) Vergl. Conwentz 1912; Ascherson-Graebner Synopsis I (1. u. 2. Auf.). 
Von anderen Nadelwäldern, welche den mesothermen Klimaten zugerechnet werden müssen, aber des Zusammenhanges wegen hier angefügt werden können, kann an folgende erinnert werden:

Araucarienwälder. In Brasilien kommen ungefähr vom Wendekreise ab und weiter südlich in Rio grande große, fast reine Pinheiros, Wälder der Araucaria Brasiliensis, vor. Dieser breitnadelige Baum hat eine dunkelgrüne, pinienförmige Krone (vergl. Martius). Lianen fehlen. Daß sich die tropische Natur hier geltend macht, z. B. durch das Auftreten epiphytischer Blütenpflanzen, ist natürlich; auch in anderer Weise, z. B. durch Sproß- und Knospenbau, weichen sie von den Nadelhölzern der gemäßigten und kalten Klimate ab. Der Waldboden kann von niedrigem Gesträuch mit Gräsern und Stauden oder von hohen Sträuchern und kleinen Bäumen bedeckt sein ${ }^{1}$ ).

Die Araucarienwälder in Chile werden von $A$. imbricata gebildet. Diese Art wird $60 \mathrm{~m}$ hoch mit Stämmen von 2-2,5 m Durchmesser. In geschlossenem Bestande und dem Winde ausgesetzt, reinigt sie sich frühzeitig; die Krone auf dem langen kahlen Schaft, wird schirmförmig und ist oft völlig flach. Die Wälder bilden die obere Baumgrenze, von $1000-2000 \mathrm{~m}$; in tieferen Lagen nehmen sie krüppelhaften Wuchs an. Nach dem anatomischen Baue der Blätter muB A. imbricata als eine ausgesprochen xerophile Pflanze betrachtet werden. Im Inneren des Waldes herrscht ein lichter Schatten; die große Trockenheit der Luft bedingt den fast vollkommenen Mangel einer Lianen- und Epiphytenvegetation. Die Bodenvegetation wird teils von Holzpflanzen (Arten von Nothofagus, Embothrium, Colletia, Ribes, Escallonia, Berberis u. a.) gebildet, teils von einer ziemlich reichen krautartigen Vegetation.

Podocarpus-Wälder kommen nach Fiebrig ${ }^{2}$ ) in Bolivien in dem unteren Teil der alpinen Höhenstufe vor. Stattliche Wälder, bis $10 \mathrm{~m}$ hoch, fassen auf den steilen Wänden der Abhänge Fuß; wo sie gedeihen, da ist Feuchtigkeit vorhanden, da ist der meist felsige Boden reichlich mit Wasser durchtränkt, und der Wald selbst vermehrt durch seinen Schatten und durch das Zurückhalten des Regens die Feuchtigkeit und schafft dadurch auch eine feuchte Atmosphäre. Eine große Anzahl von Lianen aus den Familien der Vitaceen, Cucurbitaceen, Asclepiadaceen, Convolvulaceen, Leguminosen, Dioscoreaceen verflicht die Bäume; auf dem Boden gedeihen eine große Anzahl von Kräutern, darunter dem Feuchtigkeitsgehalt entsprechend auch viele Farne. Es ist dieses also ein Nadelbergwald, der auch etwas von dem Charakter des tropischen Regenwaldes in sich birgt. In dem tropischen Tieflande kommen wohl keine Nadelwälder vor.

1) Schenck 1903 a; Dusén und Neger 1908.

3) Fibrig 1910 . 


\section{Kap. Subtropische und tropische Grasfluren und Wiesen}

In den warmtemperierten und tropischen Tiefländern sind natürliche Grasfluren sicher sehr selten. Der Wald hat wohl immer die für ihn geeigneten Standorte eingenommen, und wo jetzt Wiesen vorkommen, sind sie gewiß meist Kulturprodukte, ausgenommen vielleicht in manchen Überschwemmungsgebieten der Flüsse, in denen die starke Strömung den Baumwuchs ähnlich wie in den gemäßigten Klimaten hindert.

In Brasilien kommen sehr oft Grasfelder vor, die einen äußerst dichten Bestand der klebrigen Melinis minutiflora (Tristegia glutinosa, "Capim gordura") aufweisen. Einige wenige andere Pflanzen, darunter auch strauchartige, können eingestreut auftreten; aber jenes Gras herrscht vor und verleiht der Landschaft zur Blütezeit eine rotbraune Farbe. Es sind diese „Capim gordura“-Felder immer Kennzeichen eines alten, jetzt entblößten Waldbodens $)^{1}$.

In Westindien kommen ebenfalls Grasfluren vor, die teils aus wilden Arten, teils aus eingeführten Panicum- und Paspalum-Arten, ferner aus Avena (Arrhenatherum) Domingensis, Pennisetum setosum, Sporobolus u. a. bestehen; den Gramineen sind einige Cyperaceen beigemischt, z. B. Arten von Kyllingia und Fimbristylis. Zwischen dem Grase wachsen Cassia-Arten, Sida-Arten, Cipura und andere Kräuter und kleine Sträucher. Die Sträucher würden die krautartige Vegetation bald verdrängen, wenn man sie nicht regelmäßig abschnitte. Diese Weiden findet man auch auf altem Waldboden; sie waren auf den Inseln ursprünglich nicht vorhanden.

Im Kaplande kommen Wiesen vor, welche nach Marloth den europäischen sehr ähnlich sind; auf den tonigen, feuchten Flächen hat sich eine Vegetation entwickelt, welche meist aus Süßgräsern und Cyperaceen besteht, zwischen welchen sich zahlreiche andere Kräuter, darunter auch Zwiebel- und Knollengewächse entwickelt haben. Viele schöne Monokotylen in ungeheurer Zahl, Tausende des prächtigen Ornithogalum thyrsoides, Drosera-Arten usw. wachsen dazwischen.

Die Sandwichinseln weisen ungewöhnlich ausgedehnte Grasfluren auf, die nach Hillebrand von Paspalum, Panicum und außerdem besonders von dem vor wenigen Jahrzehnten eingeführten Cynodon dactylon gebildet werden; sie sind also jedenfalls vom Menschen bedeutend verändert worden und verdanken ihr Dasein wohl ganz der Kultur. Sie werden als "dichte Matten" beschrieben.

In Australien scheinen von der jungfräulichen, unberührten Natur gebildete Grasfluren vorzukommen, die teils aus Gräsern, wie Poa, Glyceria, Briza, Festuca und Panicum, teils aus Liliaceen и. а.

2) Warming 1892 . 
zusammengesetzt sind. Besonders häufig ist das Känguruhgras (Anthistiria ciliata und $A$. imberbis), das im Blattbau an unsere Wiesengräser erinnert. Jedoch zeigen diese Grasfluren teilweise die Beschaffenheit der Steppen.

\section{Kap. Subtropische immergrüne Laubwälder}

Immergrüne Laubwälder kommen besonders in den regenreichen, warmen Tiefländern der Tropen vor („tropische Regenwälder"), ferner an mehreren Orten in gewissen Höhen der Gebirge und an den südwestlichen feuchten und regnerischen Küsten Südamerikas sowie den entsprechenden Gegenden von Neuseeland. Zwar treten in vielen dieser Wälder Arten auf, die eine kürzere oder längere Zeit ganz entlaubt sind; aber bei den meisten Bäumen bleiben die Blätter bis nach der nächsten Belaubung oder jedenfalls länger als 12 Monate sitzen (s. S. 606).

Da trockenere Zeiten in den meisten Gegenden zu einer oder der anderen Zeit des Jahres eintreten können, und da die Blätter länger als ein Jahr ausdauern, es selbst in dem Gebiete des tropischen Regenwaldes, z. B. auf Java, Tageszeiten geben kann (vormittags, bis der Regen etwa um 2 oder 3 Uhr nachmittags einsetzt), an denen die Luft relativ trocken ist und die Transpiration gefährlich werden könnte (Haberlandt), so sind die allermeisten Blätter des immergrünen Laubwaldes auf eine oder die andere Art gegen zu starke Transpiration geschützt. Das Blatt ist daher keineswegs so gleichförmig gebaut, wie in den Laubwäldern der gemäßigten Gegenden. Es ist von derber, mehr oder weniger lederartiger Konsistenz und nähert sich auf verschiedene Weise dem eigentlichen Hartlaube. Es ist gewöhnlich ganzrandig und oft ganz ungeteilt von elliptischer, lanzettlicher oder ähnlicher Form. Es wendet wohl immer die Fläche dem zerstreuten Lichte zu. Gewöhnlich ist es unbehaart, doch finden sich auch Blätter, die an der Unterseite mit einem dichten Haarkleide bedeckt sind (z. B. Sapotaceen).

In den immergrünen, subtropischen und tropischen Laubwäldern finden Laubfall und Belaubung nicht so allgemein und gleichzeitig statt, wie in den gemäßigten Gegenden; der damit einhergehende Wechsel in der Blattfarbe fehlt. Indem das Laub älter wird, fällt es allmählich ab, jedoch vorzugsweise in gewissen Monaten, in dem mittleren Brasilien z. B. in den Monaten Juli, August und September. Der Wald hat das ganze Jahr eine dunkler grüne Farbe, als unsere Wälder sie in der Regel zeigen; obgleich einzelne Arten zu der Zeit ihrer Belaubung eine besonders auffallende Farbe aufweisen (gewöhnlich sind die jungen Blätter rotbraun), verlieren sie sich in der Menge der übrigen Arten. Knospenschuppen fehlen gewöhnlich, jedenfalls in dem tropischen Regenwalde ${ }^{1}$ ).

1) Vergl. Warming 1892. 
Da die Laubblätter vermutlich das ganze Jahr tätig sein können (einige Arten bilden fast während des ganzen Jahres neues Laub), ist es leicht verständlich, daß es der Pflanze möglich wird, viel mehr plastisches Material hervorzubringen, als unsere laubwechselnden Bäume es tun können; darauf beruhen das rasche Wachstum und die riesige Größe vieler tropischen Bäume.

Typen der mesophilen oder hygrophilen immergrünen Laubwälder sind folgende: die subtropischen immergrünen Laubwälder, z. B. der kanarische Lauraceen-Wald (der jedoch vielleicht zu den xerophilen Wäldern zu rechnen ist) und die tropischen Regenwälder, außerdem einige besondere, von bestimmten tropischen Pflanzenformen gebildete Wälder, z. B. Palmenwälder, Farnwälder.

Wie es auf der einen Seite unmöglich ist die mesophilen Laubwälder von den echten Hartlaubwäldern zu trennen, so ist es auf der anderen Seite auch nicht möglich, eine scharfe Grenze zu ziehen nach der Seite der auch Feuchtigkeit liebenden mikrothermen Wälder, in denen der Boden Rohhumus oder Humustorf bildet. Die antarktischen Wälder Südamerikas und Neuseelands werden unzweifelhaft, jedenfalls teilweise, am richtigsten $\mathrm{zu}$ den letzteren gerechnet.

Subtropische hygrophile immergrüne Laubwälder. Die Lauraceen-Wälder der Kanarischen Inseln hat Christ $^{1}$ ) geschildert. In der Wolkenregion, wo sogar im Sommer täglich dicke Nebel lagern, entwickeln sich die Lorbeerwälder besonders in Tälern und Klüften. Der Boden bedeckt sich mit einem dichten grünen Teppiche von Farnen und Moosen. Die Wälder bestehen aus Bäumen der Lorbeerfamilie (Persea Indica, Laurus Canariensis, Ocotea foetens, Phoebe Barbusana), denen Ilex Canariensis, Erica arborea, Myrica faya usw. reichlich beigemischt sind. Das Unterholz wird von großblättrigen Sträuchern wie Arten von Ilex, Rhamnus glandulosa, Viburnum rugosum u. a. gebildet von Lianen treten z. B. Smilax-Arten auf. Die Blätter gehören besonders zur Lorbeerform, d. h. sie sind ungeteilt, unbehaart, ganzrandig, fest und lederartig; aber auch andere, rein xerophile Typen beobachtet man. Die Knospen haben gewöhnlich Knospenschuppen. Nur wenig Licht dringt zum Boden hindurch. Ein eigentümlicher, tief grüner Schatten herrscht in dem Walde unter dem Dache der Lauraceen-Bäume. Man findet hier eine Frische und Luftfeuchtigkeit, die zu der glühenden Hitze der offenen Abhänge in starkem Gegensatze steht, welcher durch den vom Waldboden ausgehenden Erd-, Moos- und Veilchengeruch verstärkt wird. Der Waldboden ist fast allein von einer überwältigenden Farnmenge bedeckt und erinnert dadurch an die Wälder auf Neu-Guinea

1) Christ 1885, S. 481. 
und anderen Inseln des stillen Ozeans; im übrigen ist er an Kräutern arm. Durch allmähliche Übergänge sind diese Wälder mit den xerophilen Macchien verbunden.

Derselbe Waldtypus findet sich auf Madeira ${ }^{1}$ ) und verschiedenen tropischen Hochländern, z. B. Ceylon. Marloth gibt eine meisterliche Schilderung des Knysnawaldes im Kaplande ${ }^{2}$ ).

Es schließen sich hieran verschiedene Coniferenwälder, z. B. die Araucariaceen-Wälder, die jedoch nicht nur physiognomisch sondern auch in anderen Hinsichten bedeutend abweichen (erwähnt S. 586).

Auch die in den regenreichen Gegenden von Südchile, Patagonien und Neuseeland vorkommenden an Farnen, Moosen und anderen Kryptogamen reichen immergrünen Wälder schließen sich nahe an, sind aber entschieden oxylophytische Wälder mit torfigem Boden, was bisher nicht von den Lorbeerwäldern und Araucarien-Wäldern angegeben wird, und für die ersteren, soweit sie von uns selbst beobachtet werden konnten, auch sicher nicht zutrifft.

$\mathrm{Zu}$ den subtropischen Regenwäldern gehören Wälder in Florida, wo Schimper den Wald vorzugsweise ans einer immergrünen Eiche, Quercus virens, zusammengesetzt fand, neben welcher Arten von Magnolia, Palmen u. a. auftraten. Nach Harper ${ }^{3}$ ) sind die dortigen immergrünen Wälder von Arten von Persea, Magnolia, Quercus, Ilex u. a. gebildet mit einer Untervegetation von immergrünen Sträuchern und Kräutern. Hieran schließen sich ähnliche Wälder in Mexiko.

Ähnliche Wälder finden sich weiter in den Bergen tropischer Gebiete im Wolkengürtel derselben. Hierzu wären die Farnwälder auf Jamaika und anderen westindischen Inseln zu rechnen.

Das ozeanische Klima begünstigt immergrüne Baumvegetation. Wir finden daher solche z. B. an den Küsten von Chile und auf den Juan Fernandez Inseln. Hauman Merck schildert die Flora der regenwaldähnlichen Wälder in den Bergen von Valdivia $\left(40^{\circ} \mathrm{s}\right.$. B. $)$, die sich durch großen Reichtum an Pflanzen auszeichnen, darunter Lianen, Epiphyten und viele Hymenophyllaceen, mit ihren durchscheinenden Blättern, die stets von Wasser triefen; auch Basidiomyceten finden sich reichlich.

Der antarktische Wald in Patagonien geht weiter nördlich in die subtropischen Regenwälder über und wird dabei artenreicher. Lianen, Epiphyten und Bambus wachsen hier in Menge und so zeigt der antarktische Wald schon die Übergänge zum tropischen Regenwalde. Der chilenische Regenwald zeigt noch Arten von Nothofagus, aber mit ihnen

2) Vahl 1904 b; vergl. auch Engler, Afrika I: 863; Svedelius 1907.

2) Marloth 1908.

8) Harper 1911. 
wachsen zahlreiche andere Arten, wie z. B. Laurelia sempcrvirenz, Drimys Chilensis, Persea lingue und Podocarpus nubigena. Unterholz ist reichlich. Unter den Epiphyten sind neben Moosen und Farnen zwei Gesneraceen, Sarmienta repens und Mitraria coccinea und auch zwei Arten von Luzuriaga gemein. Im Gegensatz zum tropischen Regenwalde sind die Blätter der meisten Bäume aufwärts gerichtet und lederartig, während Träufelspitzen selten sind ${ }^{1}$ ).

Im Regenwalde von Juan Fernandez haben nach Johow ${ }^{2}$ ) die Stämme lederartige oder häutige Blätter ohne Träufelspitzen; Lianen sind selten; epiphytische Farne sind häufig und im Unterholz leben viele Farne. Ähnliche Schilderung von diesen bergigen Inseln im indischen Ozean an den Küsten Chiles geben Skottsberg sowie Dusén und Neger ${ }^{3}$ ). Besonders wird der große Reichtum an Farnen hervorgehoben, Farnbäume von Dicksonia Berteroana von 6-8 m Höhe und einem Stammdurchmesser von fast $1 \mathrm{~m}$. Skottsberg bezeichnet diesen Regenwald jedoch nicht als subtropisch, sondern als warmtentperiert, von ausgesprochen xeromorphem Bau, dabei stellt er aber keinen Hartlaubwald dar. Alle echten höheren Epiphyten und Lianen fehlen. Der Boden ist nach Skottsberg von tiefem, feuchtem und reichem Humus bedeckt, und Moosdecken bekleiden die Baumstämme.

Diesen chilenischen Wäldern schließen sich dann die echten tropischen Regenwälder an. Bis nähere Untersuchungen namentlich über die Beschaffenheit des Humus vorliegen und bis wir über die Ökologie der Pflanzen in den patagonischen, südchilenischen und tropischen Regenwäldern genauer unterrichtet sind, wird es unmöglich sein, sie richtig ökologisch voneinander zu scheiden.

Im äußersten Norden von Neuseeland kommen noch Regenwälder vor, wie sie sonst die Nordinsel überwiegend bedeckten, und zwar in mehreren Assoziationen, den lokalen ökologischen Verhältnissen entsprechend. Die Kauri (Agathis australis), Beilschmidia, Lauraceen u. a. bilden diese fast subtropischen ${ }^{4}$ ) Wälder.

Farnwålder. Baumfarne sind abhängig von feuchter Luft; sie sind die Anzeiger dafür, daß die Luft dauernd mit Wasserdampf gefüllt ist und daß das Klima gleichmäßig ist. Jie Wälder in Neuseeland, Australien und Tasmanien sind reich an Baumfarnen; dort bilden sie stellenweise mit anderen Farnen und dünnblättrigen Kräutern die Hauptmasse der Vegetation. Auf einigen der höheren westindischen Inseln, z. B. auf Jamaika, welches außerordentlich reich an Farnen ist, findet

3) Philippi 1858; Neger 1897 a, b, 1901.

2) Johow 1896.

3) Skottsberg 1914; Dusén und Neger 1908.

4) Cockayne 1908. 
man in einer gewissen Höhe der Gebirge, besonders in der Nebelregion, eine Pflanzenformation, die man Farnwald nennen kann, in denen Gattungen wie Cyathea und Alsophila vorkommen. Im südwestlichsten Zipfel Englands (Lizard) hat man in Waldlichtungen zwischen Eichen vor langen Jahren Baumfarne angepflanzt, die sich selbständig vermehrend, dort sich völlig einzubürgern scheinen. - Vielleicht geben die Farnwälder ein Bild eines der ältesten Typen der Waldvegetation ${ }^{1}$ ).

Baumfarne sind oft sehr reichlich in subtropischen Regenwäldern, die in einer gewissen Höhe tropischer Gebirge vorkommen, und wo sie dann die tropischen Regenwälder ersetzen.

Subtropische Regenwälder kommen nicht nur an den schon erwähnten subtropischen Orten vor, wo der Regen das ganze Jahr über fällt, sondern man begegnet ihnen auch auf Gebirgen innerhalb der tropischen Zone, wo in einer gewissen Höhe der Niederschlag durch alle Monate sehr stark ist und in Regionen, wo der Winter mehr oder weniger regenlos ist, trotzdem im wesentlichen der ganze Regenfall groß ist. Diese letzteren Regionen findet man an den Ostseiten aller Kontinente, so z. B. in den Vereinigten Staaten, in Südbrasilien, im östlichen Afrika, in Ostaustralien bis Tasmania, in Südchina und Südjapan. In diesen Regionen überwiegt, wie Schimper ${ }^{2}$ ) auseinandersetzte, der subtropische Regenwald dort, wo die jährliche Regenhöhe groß ist, während Savannenwald und Savanne trocknere Länder bewohnen. An solchen Orten kann der Regenwald sich dem tropischen an Üppigkeit nähern ${ }^{3}$ ).

\section{Kap. Tropische Wälder}

Es gibt verschiedene Typen von tropischen Wäldern, die hier in einem Kapitel vereinigt werden mögen.

LaubwechseInde Wälder kommen in den Tropen, obwohl seltener vor, nähern sich jedoch gewiß stets den xerophilen Laubwäldern. Mar findet z. B. im Inneren von Brasilien auf Kalkfelsen Wälder, derer vorherrschende Arten (Mimoseen) das Laub in der trockenen Zeit ver. lieren, so daß die Lichtverhältnisse im Walde ganz anders als in des Regenzeit werden; aber viele andere Bäume bleiben belaubt, abgesehes von den oft dornigen und brennenden Sträuchern und Kräutern des Unterholzes und des Waldbodens ${ }^{4}$ ). Es ist dieses ein edaphisch be. dingter Trockenwald.

1) Vergl. Hochstetter 1863; Tennison-Woods in Nature XXI; Cockayne; Die 1896, 1905.

2) Schimper 1898.

8) Rein 1881; Mayr 1890.

4) Warming 1892 . 
Anders verhalten sich z. B. die Monsunwälder der Tropen, regengrüne, durch lange Trockenheit laubwechselnde Wälder, welche viel weniger reich als die tropischen Regenwälder sind. Hierher gehören

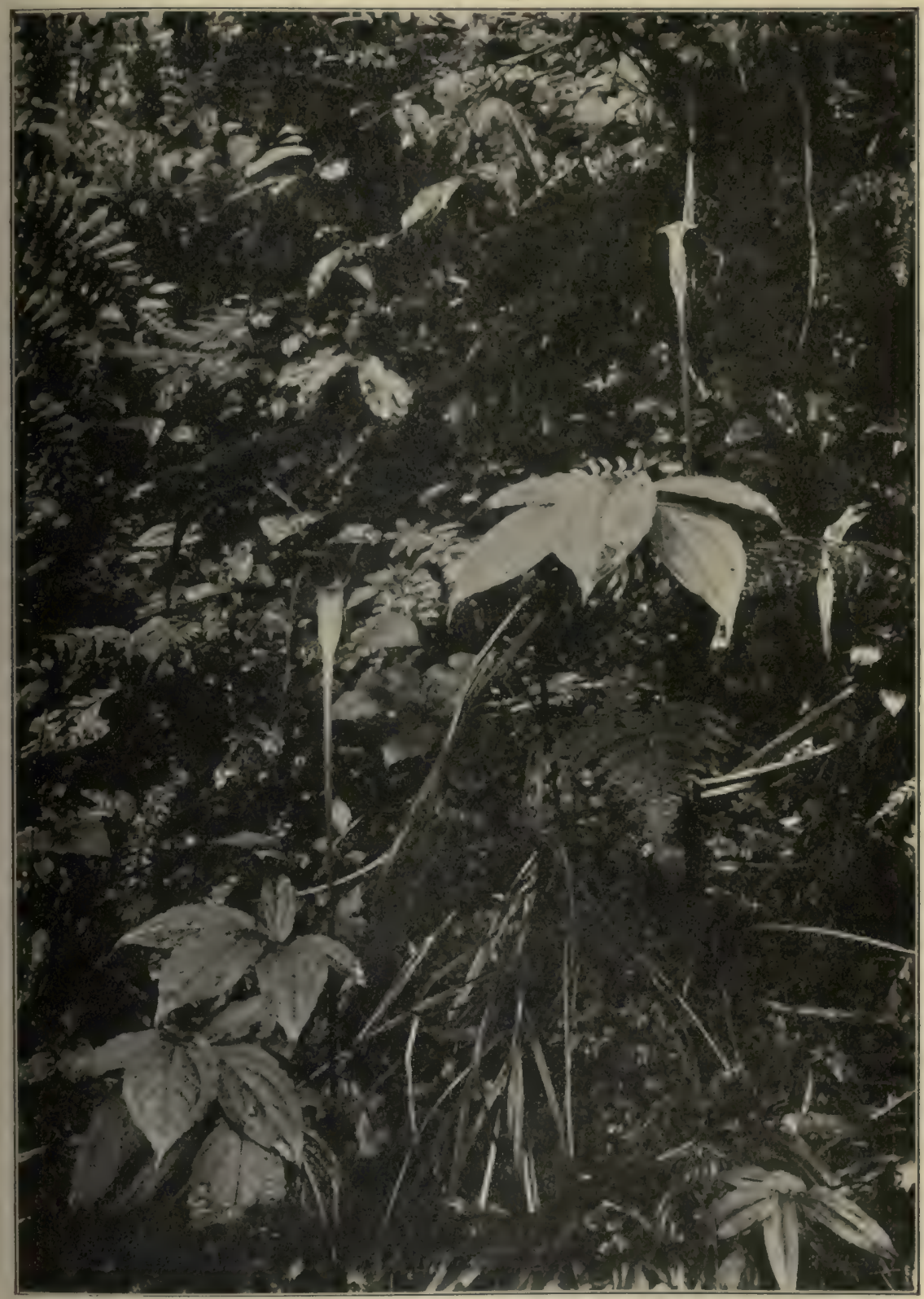

Fig. 273. Boden des Urwaldes zwischen Tjibodas und Kandangbadog auf Java, ca. 6500' über dem Meere. (Phot. Hjalmar Jensen.)

Warming-Graebner. 3. Auflage, illustr. 
z. B. die indischen und ostasiatischen Teakwälder ${ }^{1}$ ). Büsgen ${ }^{2}$ ) schildert und bildet ab den javanischen Teakwald; ein Drittel der Wälder Javas sind reine Bestände des Teakbaumes, Telktona grandis. Er bevorzugt die Gegenden, in denen ein ausgesprochener Wechsel zwischen trockenem Ostmonsun und sehr regenreichem Westmonsun vorhanden ist. Die heißen Ebenen und niederen Hügel sind auf weite Strecken mit einförmigem Teakwalde bedeckt. In der Trockenzeit stehen die Wälder ganz kahl. Sie gedeihen sowohl auf tonigen als kalkhaltigen, sandigen und anderen Böden und werden $30-40 \mathrm{~m}$ hoch. Das Unterholz und die Bodenflora ist recht arm; ebenso sind die Epiphyten recht spärlich. In anderen Teilen von Ostasien tritt die tropische Natur mehr hervor durch die große Menge epiphytischer Farne und Blütenpflanzen und durch die Loranthaceen, die auf den entblätterten Zweigen ähnlich wie bei uns die Misteln im Winter aussehen.

Die tropischen immergrünen Regenwälder. Rings um die Erde findet man in den äquatorialen Ländern eine Waldzone, an die man gewöhnlich denkt, wenn der Ausdruck "Urwald" genannt wird. Ein Urwald ist natürlich jeder jungfräuliche Wald, dessen ursprüngliche Beschaffenheit dadurch bewahrt ist, daß ein Eingriff des Menschen gar nicht oder nur in unmerklichem Grade stattgefunden hat. Die Bäume bleiben stehen, bis ihr Leben von selbst oder im Kampfe mit dem Nachbarn aufhört, bis der tote Körper zu Boden sinkt, verwest und eine Stelle offen läßt, welche ein Kampfplatz für andere Arten wird. Es gibt noch jetzt Urwälder sowohl auf dem "von Stürmen umbrausten Felsenboden" Lapplands und Norwegens, als auch in Deutschland und Böhmen und auf den feuchtwarmen Ebenen des Amazonenstromes.

Die tropischen Regenwälder sind an die Gegenden gebunden, in denen die Passatwinde wehen, eine hohe, das ganze Jahr hindurch ziemlich gleichmäßige Wärme herrscht, wo von der hoch am Himmel stehenden Sonne ein Lichtmeer herabflutet, und wo die senkrecht aufsteigenden, mit Wasserdampf gesättigten Luftmassen bei ihrer Ausdehnung und Abkühlung in den höheren Luftschichten täglich die heftigsten Niederschläge hervorrufen ${ }^{3}$ ). Hier steigen zwischen den Kronen der Bäume häufig warme Nebel auf, Wassertropfen triefen wenigstens zu gewissen Jahreszeiten während des größten Teils des Tages von den Blättern, und die Luft kann fast mit Wasserdampf gesättigt sein (in Buitenzorg auf Java ist die Luftfeuchtigkeit etwa von 2-3 Uhr nach-

1) Vergl. Kurz 1875; Schimper 1898; Brandis 1898; Karsten 1908 b. bilder III 3.

9) Büsgen, Jensen und Busse, 1905, in Karsten und Schencks Vegetations-

s) Über physiologische Beobachtungen über Feuchtigkeit, Transpiration usw. in dem Regenwalde Jamaikas siehe Forrest Shreve 1914. 
mittags bis nächsten Vormittag ungefähr $95 \%$ ); wochenlang sinkt sie nach Giesenhagen nicht unter $90 \%$. Die somit über das ganze Jahr regelmäßig verteilte Regenmenge kann auf mindestens $200-400 \mathrm{~cm}$

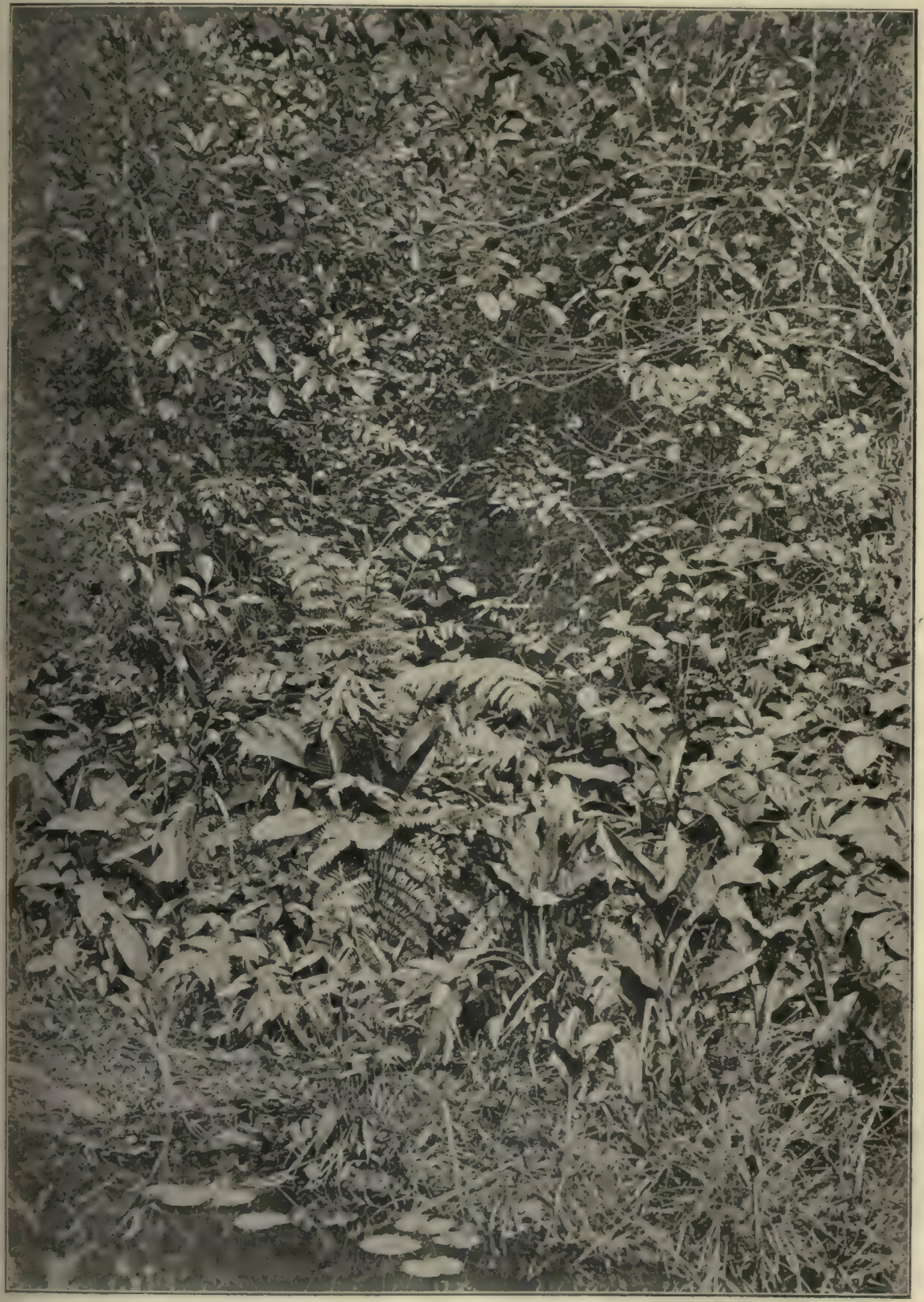

Fig. 274. Vegetation an dem Ufer einer Igarapé in der Nähe von Braganza (Amazonas). (Phot. J. Huber.) 
angenommen werden. Die jährliche Regenmenge wird angegeben: für Buitenzorg zu $499 \mathrm{~cm}$, für Kamerun $388 \mathrm{~cm}$, für Ceylon $240-384 \mathrm{~cm}$. Für Mitteleuropa ist sie ungefähr 50-100 cm. Eine Trockenzeit kommt auf großen Strecken überhaupt nicht vor, und dauert, wo sie eintritt, höchstens wenige Monate. Wo dies der Fall ist, wird immergrüner Wald an die feuchten Flußufer gebunden sein (als "Galeriewald" Schweinfurths).

Der Waldboden dieser Regenwälder ist sicher immer ein milder, nährstoffreicher Humus, schwarz und porös, mit verwesenden Resten der Zweige, Blätter und Früchte erfüllt und wird vermutlich von Tieren durchwühlt. Jedoch ist die Humusschicht nicht so dick, wie man es oft annimmt; viele Meter dicke Humusschichten sind nicht die Regel (vergl. Reinhardt u. a.). Während einige den Boden als immer durch und durch naß ansehen, sagen andere und sicherlich mit mehr Recht, daß der Regen in ihm wegen der Porosität bald hinabsickert. Auf Samoa gibt es nach Rechinger Regenwald mit humusarmem Boden.

Unter solchen Verhältnissen muß sich die Pflanzenwelt mit einer Fülle und Mannigfaltigkeit wie nirgends sonst entwickeln. Die Assimilation der Laubblätter kann durch das ganze Jahr vor sich gehen. Der tropische Regenwald ist der Höhepunkt der Entwicklung der Vegetation auf der Erde. Er hat namentlich folgende Eigentümlichkeiten:

Die Ausnutzung des Raumes. Es gibt Vereine, deren Raum sehr stark besetzt ist. Man findet gewöhnlich so viele Stockwerke derPflanzen, daß das Ganze beinahe ein zusammenhängendes Wirrwarr ist (s. Fig. 273, 274). Die Unordnung ist für den tropischen Regenwald äußerst charakteristisch. Es gibt einen "Wald über dem Walde" sagt Humboldt treffend. Unter dem höchsten Stockwerke der Bäume, daß sich mit schlanken, dicken, zweiglosen Stämmen vielleicht bis zu 40-50 m Höhe und höher erhebt; wachsen andere Bäume von mittlerer Größe, welche die Zweige jenes Stockwerkes erreichen; unter ihnen wieder andere: schlanke, dünnstämmige, niedrige Palmen, Baumfarne usw., und zwischen diesen Sträucher und Halbsträucher der Urticaceen, Piperaceen, Myrsinaceen, Rubiaceen, Acanthaceen, Melastomataceen u. a: Mächtige, 4-5 m hohe Kräuter von den Typen der Scitamineen und der Araceen sind eingestreut; in afrikanischen Wäldern kommen auch hohe Gräser und Cyperaceen vor: ist noch eine Stelle auf dem Waldboden übrig, wohin Licht herabdringen kann, so wird sie von dunkelgrünen Farnen, Selaginellen, Moosen und ähnlichen Schattenpflanzen eingenommen. Der Raum wird ausgefüllt und zwar vorzugsweise von hohen „Phanerophyten" (Fig. 273, 274). Auf dem javanischen Vulkane Gedeh, sagt Domin ${ }^{1}$ ), ist die jährliche Regenmenge fast $500 \mathrm{~cm}$; es ist hier schwer, Etagen des Waldes zu unterscheiden:

1) Domin 1913. 


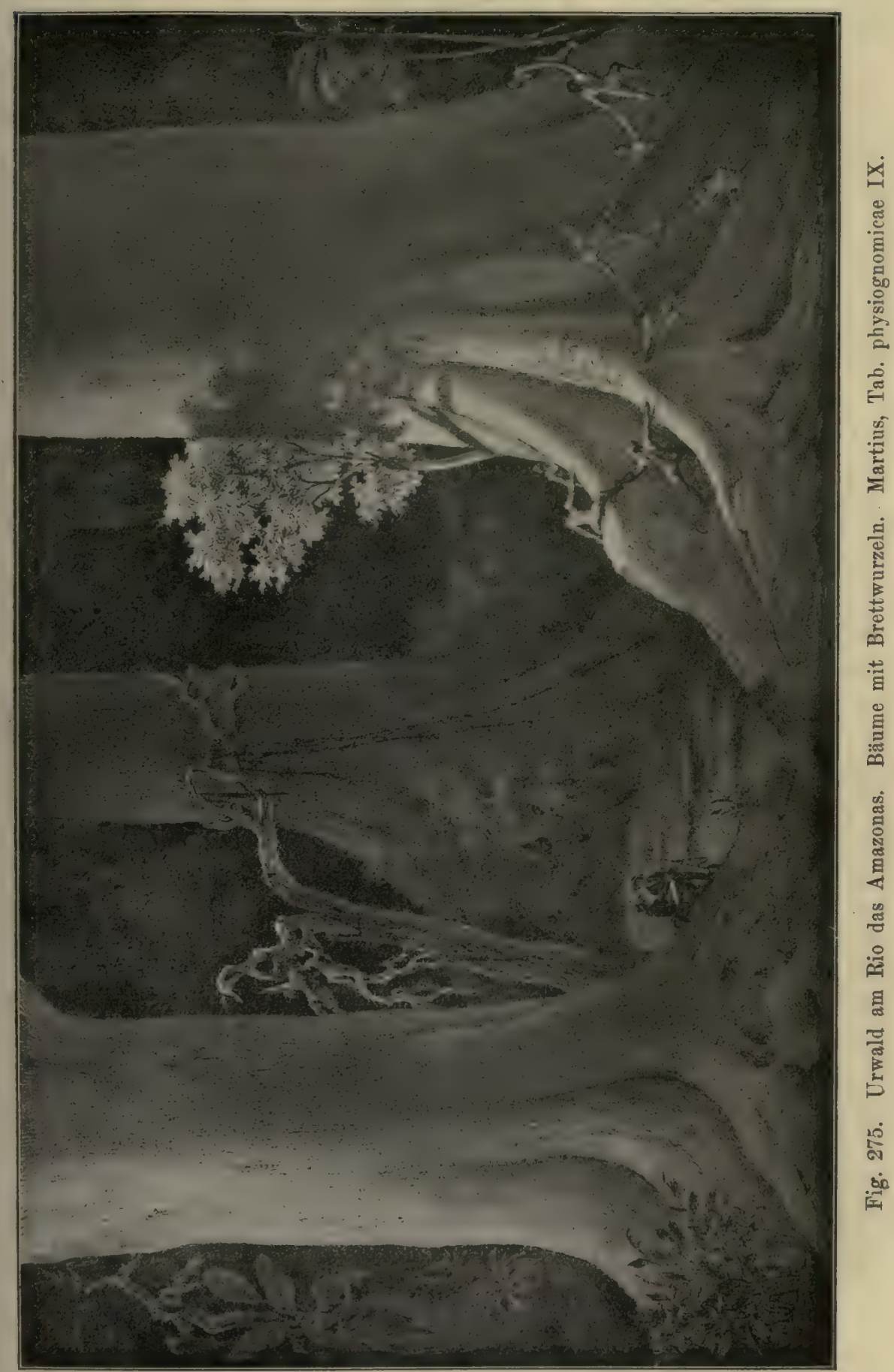


der Raum wird vom Boden bis zu den Gipfeln des Waldriesen mehr oder minder erfüllt, es herrscht hier tatsächlich ein wahrer "horror vacui", wie Junghun treffend gesagt hat. In anderen Wäldern hat man aber bestimmte Etagen gefunden; z. B. fand Burkill im Ost-Himalaya in den Regenwäldern drei Stockwerke, einen obersten von Baumriesen mit relativ kleinen Blättern und Windverbreitung der Samen, einen mittleren von großblättrigen kleineren Bäumen und zur Verschleppung durch Tiere angepaßten Früchten resp. Samen, und eine Bodenvegetation, in welcher die Pflanzen nicht so großblättrig waren, ausgenommen die längs der Waldwege. Die Lichtstärke in einem von diesen Wäldern fand er bis auf $0,005-0,002$ des vollen Sonnenlichts reduziert.

Es gibt jedoch auch Urwälder, in denen der Boden fast ganz nackt ist; Martius hat ein ausgezeichnetes Beispiel aus dem Tieflande der Amazonas in seinen "Tabulae physiognomicae" abgebildet (Fig. 275). In solchen, wie in den anderen Regenwäldern, wird der schwarze Humus des Bodens von abgefallenen, verwesenden und feuchten Blättern, Zweigen, Fruchtresten $u$. ähnl. bedeckt, zwischen denen nur noch Saprophyten der bizarrsten Gestalten (Burmanniaceen, Pirolaceen, Gentianaceen usw., vergl. S. 297) oder Wurzelparasiten (Rafflesiaceen, Balanophoraceen) Platz finden. Große Hutpilze sind indessen selten.

In den tropischen Regenwäldern kommen nicht nur eine große Anzahl von systematischen Typen vor, wie Palmen, Scitamineen, Bambusen, welche an die Tropen gebunden sind, sondern auch eine Menge eigentümlicher epharmonischer Lebensformen.

Äußerst charakteristisch und zahlreich wegen der großen Luftfeuchtigkeit in allen Regenwäldern sind die Scharen der Epiphyten ${ }^{1}$ ) (S. 288), welche Stämme und Zweige, jedenfalls in den Kronen der Bäume, wo die Lichtmenge hinreichend ist, bedecken Orchidaceen, Araceen, Bromeliaceen (Fig. 276), Piperaceen u. a. Blütenpflanzen, in Amerika und Afrika auch Cactaceen (Rhipsalis), ferner Farne, Moose usw. Die Bäume in den Wäldern der javanischen und der molukkanischen Nebelregion sind in einen durchnäßten Moosfilz, bisweilen hoch oben bis in die Kronen, eingehüllt, der selbst dicker als die Stämme sein kann und ihnen ein sonderbares, dunkles Aussehen verleiht (Fig. 278). Von Farnen sind hier namentlich die moosähnlichen Hymenophyllaceen heimisch, die nach ihrem anatomischen Bau "wahre Nebelpflanzen" darstellen (Fig. 277). In den beständig von Regenwolken umhüllten Farnwäldern auf Samoas Bergen gibt es nach Rechinger ${ }^{2}$ ) buchstäblich nicht einen Baum oder Strauch,

1) Vergl. die Fig. 52, S. 160, bei dieser ist die Unterschrift folgendermaßen zu berichtigen: Urwald in Tjibodas (Java) mit am Stamm aufkletternder Aracee. (Phot. Hj. Jensen.)

2) Rechinger 1908. 


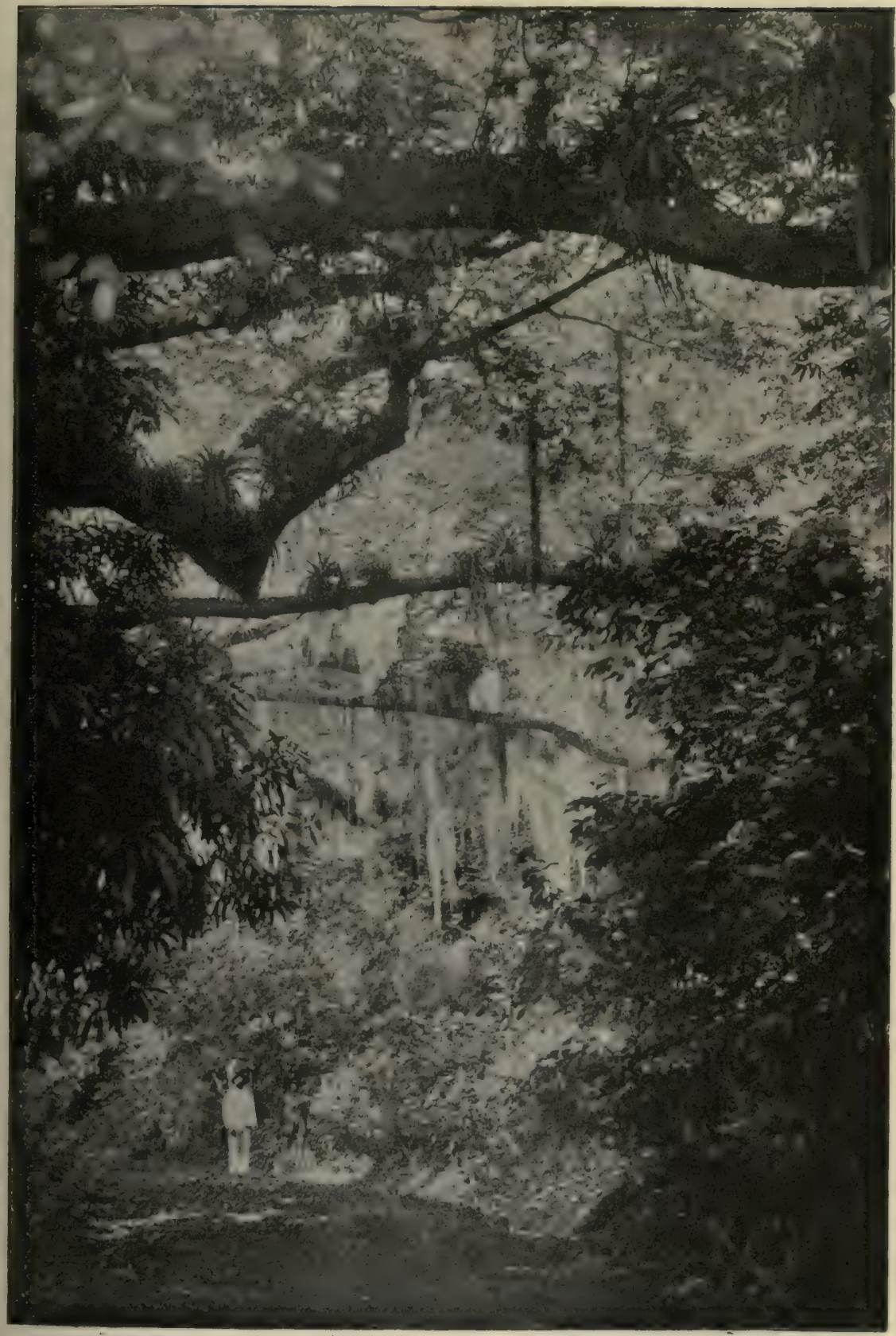

Fig. 276. Wald auf St. Jan (Dänisch-Westindien). Auf den Zweigen eines links stehenden Seidenwollenbaumes sieht man Girlanden von der epiphytischen Tillandsia usneoides; ebenso andere Epiphyten (Tillandsia utriculata u. a. m.). (Phot. Dr. Börgesen.) 
der nicht epiphytische Farnkräuter trägt, z. B. Polypodium subauriculatum, dessen Blätter eine Länge von 2-3 m erreichen können. Selbst die Blätter von immergrünen Arten können dicht von epiphyllen Algen, Lebermoosen und kleinen Flechten bedeckt sein (Fig. 151). Die Moosformen der Regenwälder hat Giesenhagen ${ }^{1}$ ) bearbeitet; er unterscheidet verschiedene Typen derselben, welche in unserer heimischer Flora unbekannt sind. Die Moose können nach ihm zuletzt so zahlreich und schwer werden, daß die Zweige der Bäume brechen. Zu den Epiphyten, die der Niederschläge am allermeisten bedürfen, gehören nach Schimper die holzigen, wovon sich in den regnerischen Urwäldern viele entwickeln: das feuerrote Rhododendron Javanicum schmückt die Baumkronen in den Gebirgswäldern Javas, und zusammen mit ihm beobachtet man Arten von Ficus, Medinilla (Melastomacee), Fagraea (Loganiacee), Sciadophyllum (Araliacee) usw. In den javanischen Gebirgswäldern findet man die gemeinen, mächtigen epiphytischen Farne Asplenum nidus und Platycerium alcicorne, ferner große Pflanzen von Lycopodium phlegmaria u. a. L.-Arten und Psilotum (P. flaccidum), die wie meterlange Pferdeschwänze von den Bäumen schlaff herabhängen. Endlich gibt es eine große Menge Lianen (S. 152 und Fig. 48), deren Blätter und Blüten man selten sieht, deren oft wunderlich geformte, lange Stämme jedoch zwischen dem Boden und den Baumwipfeln ausgespannt sind oder in Bogen von diesen herabhängen oder teilweise auf dem Boden liegen. Die vielen anderen Pflanzen geben den Lianen unzählige Stützpunkte - bisweilen dienen als solche sogar die Luftwurzeln der Araceen - und helfen ihnen, in die Wipfel emporzugelangen und dadurch die für ihre Assimilation nötige Lichtstärke zu finden, die auf dem Waldboden nicht vorhanden ist.

Die Anzahl der Arten des tropischen Regenwaldes ist außerordentlich groß. Der Mangel an geselligem Zusammenleben der Individuen einer Art, den man hier beobachtet, ist oft erwähnt worden; er steht zu der Gleichförmigkeit unserer nordeuropäischen Wälder im größten Gegensatze und wird z. B. dadurch erläutert, daß in Brasilien auf 3 Quadratmeilen um Lagoa Santa etwa 400 Baumarten in den Wäldern wachsen (Warming). Whitford ${ }^{2}$ ) erwähnt, daß auf den Philippinen auf einer Fläche von 1200 Quadratmetern 896 Stämme über 3 m Höhe wuchsen, die zu 120 Arten gehörten. - Diese Mannigfaltigkeit hat sicherlich zum Teil einen geologischen Grund, nämlich das hohe Alter und den nie unterbrochenen Entwicklungsgang der Tropennatur ${ }^{3}$ ), dann aber auch einen physikalischen, nämlich die günstigen Lebensbedingungen; denn es gibt Beispiele dafür, daß ein feuchter und reicher Boden eine größere Artenmenge als benachbarter trockner und dürftiger Boden hervorruft.

1) Giesenhagen 1910.

2) Whitford 1911.

3) Wallace; Warming 1892, 1899 b; vergl. auch S. $612 \mathrm{f}$. 
Es mag z. B. erwähnt werden, daß die Wälder um Lagoa Santa, welche alle Täler und alle feuchten humusreichen Niederungen längs

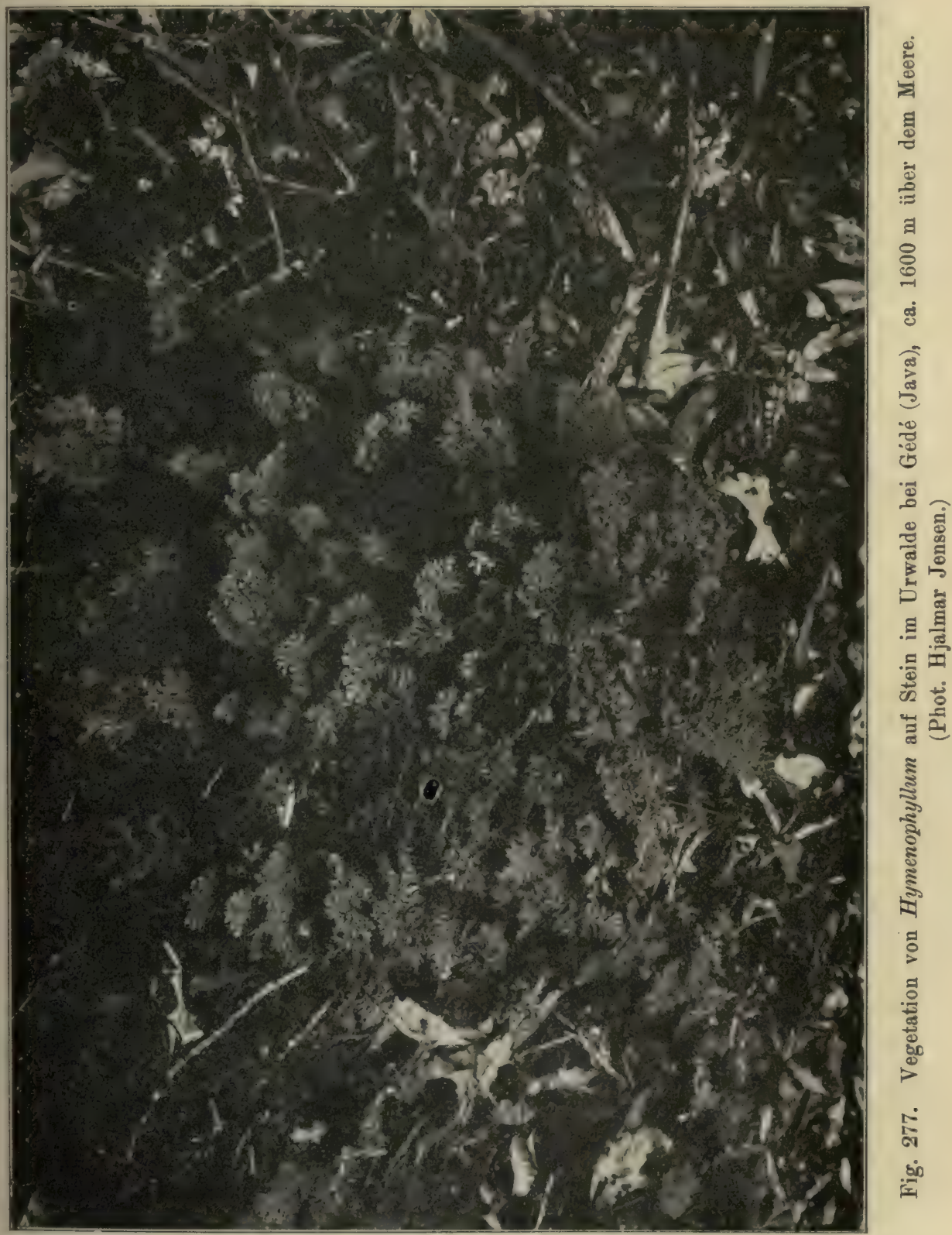

den kleinen Wasserläufen erfüllen, eine Flora von 400 Bäumen und ca. 1000 anderen Lebensformen haben. Die Campos, welche die Anhöhen einnehmen und deren Boden ein roter, steifer in der Trockenzeit harter, 
in der Regenzeit schlüpferiger Lateritboden ganz ohne Humus ist, hat nur ca. 730 Arten, wovon 80 Arten Bäume sind. Das Klima ist natürlich ganz dasselbe, nur die Feuchtigkeit, die Lockerheit und der Humusreichtum des Bodens sind gegeneinander abgegrenzt. Wälder und Campos stehen mit äußerst scharfen Grenzen einander gegenüber.

Die Formen der Bäume. Die meisten Formen bieten nichts Auffallendes dar, aber einige sind bemerkenswert. Haberlandt ${ }^{1}$ ) hat einige erwähnt und abgebildet: die Schirmform, die Kandelaberform, die Etagenbäume, und mehrere andere könnten außer der Palmenform und anderen bekannten Formen genannt werden. Die Verzweigung ist weit mannigfaltiger, anscheinend viel unregelmäßiger als bei unseren Bäumen; besonders häufig ist es, daß die Zweige nur an der Spitze ein Büschel von großen Blättern tragen, und daß jeder Sproß nur sehr wenige Seitenzweige hat. Gerade in den unteren Stockwerken des Waldes kommen kleine dikotyle, oft unverzweigte Bäume vor mit sehr großen Blättern an der Spitze. Sehr auffällig sind auch die oft fast zwiebelartigen Verdickungen des Stammgrundes einiger Bäume (Palmen usw.), die zweifellos der stärkeren Windfestigkeit dient.

Brettwurzeln kommen bei mehreren Arten vor. Hierunter versteht man Wurzeln, die vielmal höher als dick sind und als große, oft gekrümmte Platten von dem unteren Teile des Stammes bisweilen bis zu einer Höhe von 2-3 m ausgehen; der Querschnitt des Stammes erhält am Boden die Form eines vielstrahligen Sternes, und der Raum um den Fuß des Baumes wird in eine Menge Kammern geteilt (Fig. 279, 275). Diese Wurzeln dienen jedenfalls wesentlich dazu, Bäumen mit riesigem Stamm und sehr großer Krone einen festen und breiten Grund zu geben. Brettwurzeln findet man besonders bei gewissen Arten von Bombacaceen und Ficus, ferner bei Myristica, Carallia, Sterculia, Canarium u. a. Nach Schimper sind sie ein besonderes Merkmal regenreicher Wälder und fehlen in regenarmen ${ }^{2}$ ). Zum Vergleich sei erwähnt, daß in unseren Wäldern senkrecht stehende flach brettartige Wurzeln namentlich an Kiefern und Fichten vorkommen, wenn der Boden stark humos und sauer ist und dadurch die Wurzeln gezwungen werden flach oberflächlich zu streichen; das Dickenwachstum erfolgt dann im wesentlichen auf der Oberseite der Wurzeln ${ }^{3}$ ).

Stützwurzeln (vergl. Fig. 199, 200), ähnlich der bei Rhizophora vorkommenden Form (S. 403), zeigen einige Palmen (Iriartea, Chamaedorea u. a.); ferner Pandanus. Sie treten als stielrunde Stützen auf, die vom Stamme in einer gewissen Höhe entspringen und unter einem spitzen

1) Haberlandt 1893, $1899 \mathrm{~b}$.

2) Vergl. anch Whitford 1906.

- Graebner in Zeitschr. f. Forst- u. Jagdwes. und 1909. 
Winkel in den Boden hinabdringen: sie haben bisweilen dieselbe strahlenförmige Verzweigung wie bei Rhizophora; die Anzahl der Stiitzen, die ein einzelner Baum erhält, ist mitunter sehr bedentend (oft viel über 20).

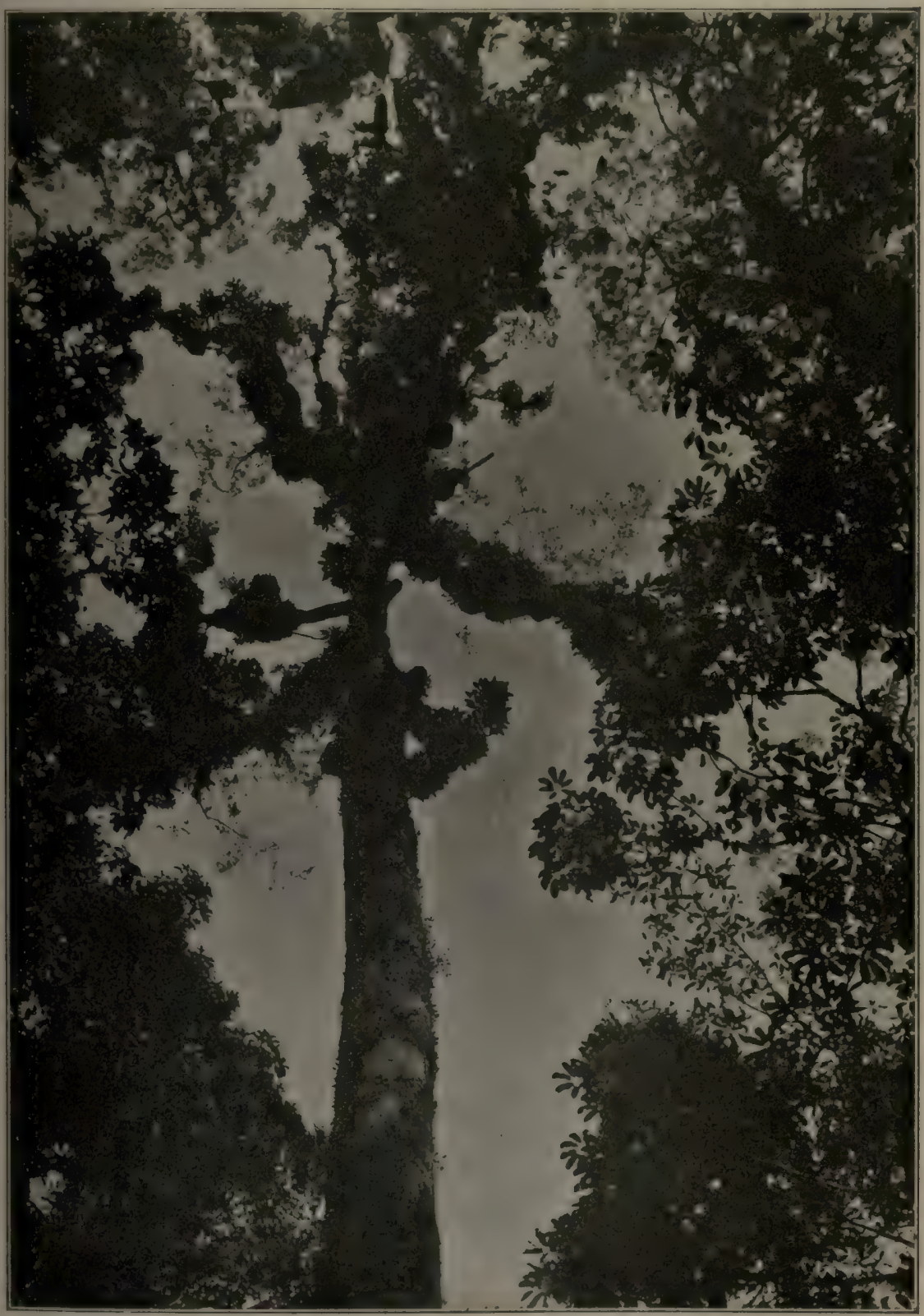

Fig. 278. Podocarpus-Baum mit dicken Moospolstern bewachsen. (Die Pbotographie ist fast senkrecht gegen den Himmel genommen.) Im Urwalde von Tjibodas (Java).

(Phot. Hjalmar Jensen.) 
Unter einer anderen Form treten sie bei Ficus religiosa u. a. auf, wo sie von den Zweigen entspringen und es einem einzelnen Baume ermöglichen, sich über eine riesige Fläche auszubreiten und einen ganzen Wald mit einer außerordentlich dicken Laubdecke und einem tiefen Schatten $\mathrm{zu}$ bilden; der Schatten ist wohl einer der Gründe dafür, daß die Wurzeln so gut gedeihen.

Noch andere eigentümliche Wurzeln kommen hier vor, so z. B. die am Stamme entspringenden in harte Dornen umgewandelten, bei der Palme Acanthorrhiza usw.

Die Rinde. Die Borke ist meist dünn, tritt aber in sehr verschiedenen Formen auf. In dieser Beziehung tritt zum Beispiel ein großer Gegensatz hervor zwischen den Bäumen der brasilianischen Campos, die eine sehr dicke Kork- und Borkenbekleidung an den Stämmen zeigen, obwohl sie oft nur wenige Meter von den Waldbäumen entfernt wachsen ${ }^{1}$ ).

Dornige Stämme sind nicht selten $\left(H u r a^{2}\right)$, Erythrina, Flacourtia usw.), am häufigsten bei Palmen. Ferner findet man Bäume mit merkwürdigen geschichteten Korkkegeln auf den Stämmen (Xanthoxylum a. a.).

Die Knospen haben nicht (oder doch selten und wohl meistens in trockeneren Wäldern) solche trocknen Knospenschuppen wie die meisten unserer Bäume ${ }^{3}$ ); aber krautige Nebenblätter, Blattscheiden und Blattauswüchse schützen die Knospen, und oft tritt ausgeschiedenes Wasser, Harz oder eine gallertartige Flüssigkeit zwischen der Knospe und ihrer Hülle auf ${ }^{4}$ ); vergl. S. 232.

Blüten sieht man nicht viele, sogar auffallend wenige, obgleich der Tropenwald immer reich an Blüten ist; sie kommen in der Regel allzuhoch oben in den Baumkronen vor. Aber wenn man von einem hoch gelegenen Punkte den Wald überschauen kann, so sieht man oft große gelbe, weiße, violette oder rote Flecken in ihn eingestreut; das sind blühende Bäume oder Lianen. In vielen Fällen sind die Blüten sehr klein (z. B. bei den Lauraceen und den meisten Papilionaceen), aber ihre große Menge macht sie den Insekten leicht sichtbar.

Stammblütige (Cauliflore) Arten. Bei einigen Arten sitzen die Blüten merkwürdigerweise auf den dicken Stämmen und den Zweigen (oder mitunter sogar nur an dem Grunde des Stammes); Jahr für Jahr entwickeln sie sich aus denselben "schlafenden Augen". Das bekannteste

1) Warming 1892 Fig. auf S. 225.

2) Anatomie und Entwickelungsgeschichte bei Didrichsen, Botanisk Tidsskr. 19 (Köbenhavn 1897).

${ }^{8}$ ) Warming 1892 . Figuren anf S. 409-411.

4) Percy Groom 1892; Schimper 1898; Raunkiär 1905, 1907. 
Beispiel solcher Arten ist der Kakaobaum (Theobroma Cacao) Fig. 280; andere Beispiele bieten Myrtaceen, Sapotaceen, Leguminosen, Ficus Roxburghii u.a.Arten, Crescentia cujete, Swartzia-Arten u.a. ${ }^{1}$ ). Wallace meint, daß die Blüten dieser stammblütigen Arten an Bestäubung durch Schmetterlinge angepaßt seien, die in dem stillen Walde oft umherschweben. Ob dieses richtig sei, ist unentschieden. Nach dem Blütenbau erscheint es z. B. für Theobroma nicht richtig; hier sind eher andere Insekten wirksam oder es findet Selbstbestäubung statt. Vergl. Fig. 280.

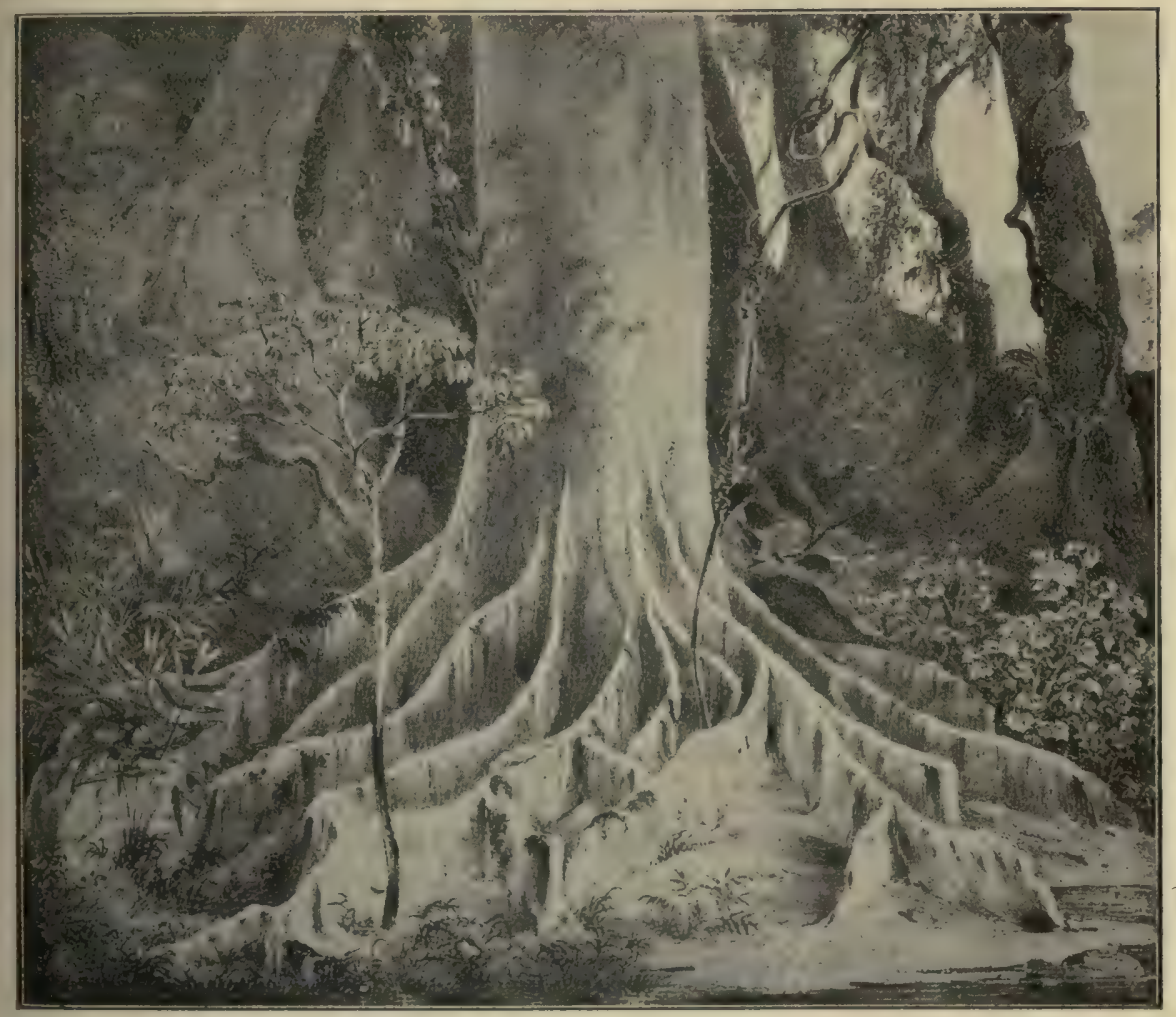

Fig. 279. Ficus-Baum mit Brettwurzeln im Staate Rio de Janeiro.

(Martius, Tab. physiognomicae XVI.)

Daß diese Stammblütigkeit, die sich bei den Bäumen gemäßigter Zonen ziemlich selten findet (Cercis, Gymnocladus, Gleditschia usw.), eine eigenartige Anpassung an das Tropenklima darstellt, deutet die entsprechende Caulicarpie in den Urwäldern der Steinkohlenperiode $a^{2}{ }^{2}$.

1) Wallace 1891; Haberlandt 1893; Whitford 1906; Esser in Verh. naturh. Ver. Rheinl. Westf. 1887; Huth in Verh. bot. Ver. Brand. 1888.

2) Gothan 1887 . 
Periodizität. In dem tropischen Regenwalde gibt es weder Sommer noch Winter, weder Frühjahr noch Herbst; die in anderen Pflanzenvereinen deutliche periodische Entwicklung ist hier verschwindend klein oder fehlt. Der Regenwald ist immer grün. Einige Arten erhalten während des ganzen Jahres neues Laub; zeigen einzelne Arten auch eine deutliche Ruhezeit, oder sind sie eine kurze Zeit sogar ganz blattlos, so verschwinden sie doch unter den vielen anderen, denen eine solche Ruhezeit fehlt oder deren Ruhezeit in eine andere Zeit des Jahres fällt. Es haben zwar vermutlich die allermeisten Arten eine bestimmte Zeit des Blühens; diese ist jedoch keineswegs für alle Arten dieselbe. Der Wald ist daher (wie auch die Savannen Südamerikas) das ganze Jahr blütenreich. Im Leben des Waldes als Ganzes gibt es also keine Periodizität. Bei Lagoa Santa in den Camposgegenden Brasiliens ist das Verhältnis folgendes: Die Blätter der Waldbäume dauern gewöhnlich nicht viel über ein Jahr; eine kürzere oder längere Zeit stehen verschiedene Arten ganz kahl, namentlich Bombacaceen, Arten von Ficus, Erythrina, Jaracatia, Cedrela u. a. ${ }^{1}$ ). Doch muß bemerkt werden, daß diese Wälder nicht typische Regenwälder sind²).

Volkens $^{3}$ ) hat der Periodizität des Laubfalles neuerdings ein eigenes Werk gewidmet. Viele Botaniker, vielleicht die meisten, sind derselben Meinung wie Volkens, daß die Periodizität eine erblich fixierte Eigenschaft ist, welche sich unveränderlich zeigt, selbst wenn die äußeren Lebensbedingungen geändert werden. Im Gegensatze hierzu steht G. Klebs, der in mehreren Abhandlungen durch vieljährige Untersuchungen zu zeigen bestrebt ist, daß die periodischen Erscheinungen alle von der Umwelt abhängig sind; die Ruheperiode sei somit keine erblich fixierte, sondern lasse sich durch geeignete Mittel aufheben, so daß es ihm sogar gelungen ist, Arten das ganze Jahr hindurch zum Wachsen zu bringen ${ }^{4}$ ). Das wahrscheinlichste ist wohl, daß es Periodizität gibt, die in Epharmonie mit den äußeren Verhältnissen erblich fixiert ist und sich deshalb regelmäßig, aber von den gleichmäßigen klimatischen Verhältnissen in den Tropen gänzlich unbeeinflußt, äußert, und solche, die noch nicht erblich geworden ist.

Volkens tritt nach seinen Beobachtungen dagegen dafür ein, daß ebenso wie in den laubwechselnden Wäldern in den Gegenden mit deutlichen Wintern auch in den Tropen eine deutliche Periodizität im Laubwechsel sich bemerkbar macht, die mit den äußeren Verhältnissen nicht in direktem Zusammenhange steht. Die Ursachen dafür müssen

1) Näheres über die Periodizität und Abbildungen bei Warming 1892.

$\left.{ }^{2}\right)$ Utber die Periodizität im Regenwalde von Jamaika hat Forrest Shreve 1914 hübsche Beobachtungen publiziert.

s) Volkens 1912.

*) Vergl. hierzu Klebs 1911, 1912, 1914. 
innere sein, die z. T. physiologisch noch nicht völlig aufgreklärt sind. Er schreibt a. a. $\left.0 .{ }^{1}\right)$.: Es ist eine weitverbreitete Meinung, daß in regenreichen Tropenländern die Natur nie zur Ruhe komme, daß Werden und Vergehen sich ohne Pause aneinander schließen. Mit Bezug auf den Laubwechsel hieße dies: Die Bäume treiben fortwährend, lassen an der Spitze aller Zweige unaufhörlich neue Blätter hervorsprießen, während früher gebildete in der Reihenfolge ihrer Entwicklung zum Abfall gelangen. Ein solches Verhalten kommt im westjavanischen Regenwalde zwar vor, ist aber äußerst selten. Volkens nennt nur zwei Bäume, die sich derartig verhalten, nämlich die Leguminose Albizzia Moluccana und die Sapindacee Felicium decipiens, beides Arten, die auch sonst bio-

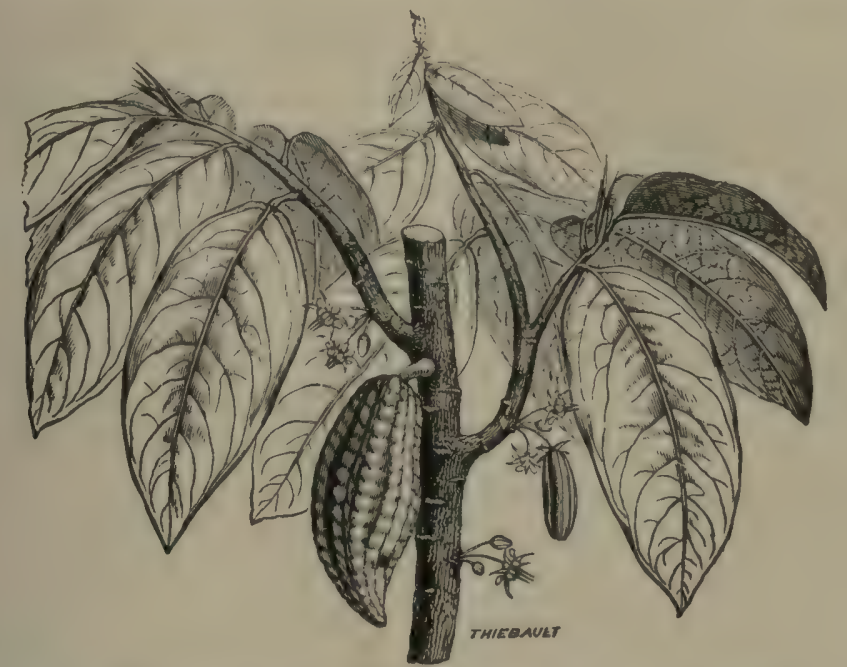

Fig. 280. Kakao (Theobroma cacao) als Beispiel für Cauliflorie, Blüten und Frucht am Stamme. (Aus Warming, System. Bot.)

logisch von der Mehrzahl der Baumarten recht abweichende Eigentümlichkeiten haben. So entwickelt sich die Albizzia z. B. ganz außerordentlich rasch in 18 bis 20 Jahren zu einem großen Baume von $30 \mathrm{~m}$ Höhe mit einem Stammumfange von 2 bis $3 \mathrm{~m}$, stirbt dann aber schon wieder $a b$, in einem Alter also, in dem die meisten Bäume erst mit ihrer vollen Blüten- und Fruchtentwicklung beginnen.

Die bei weitem überwiegende Mehrzahl der Bäume verhält sich ganz anders; es lassen sich nach Volkens zwei Gruppen von Bäumen unterscheiden, und zwar solche mit weichen Blättern, ähnlich unseren Linden, Erlen usw. und solche mit derben, lederartigen Blättern, wie sie die sogenannten immergrünen Gehölze, Ilex, Efeu usw., besitzen.

1) Vergl. auch Neger 1913, S. 75 ff. 
A. Bäume, die zweimal im Jahre, im Frühjahr und Herbst (zu den Monsunzeiten) oder noch öfter das Laub werfen: so verhalten sich $\mathrm{z}$. B. Ficus hirta, Sterculia laevis und andere Arten, tropische Acer-Arten usw. Ficus hirta wirft die Blätter in Fristen von etwa $4 \frac{1}{2}$ bis 5 Monateu ab; jedesmal dauert die Zeit des Abwerfens 8 bis 10 Tage und die Bäume stehen dann 3 bis 5 Tage kahl, dann öffnen sich die Knospen wieder und nach $1^{1 / 2}$ bis $2^{1 / 2}$ Wochen ist die völlige Wiederbelaubung vollendet. Fast alle Zustände kann man bei verschiedenen Individuen nebeneinander beobachten, da die einzelnen Bäume in ihrem Laubwechsel nicht an eine bestimmte Jahreszeit gebunden sind. Anders verhält sich z. B. die Leguminose Pongamia glabra; diese wirft im Januar und Juli, also zweimal im Jahre, das gesamte Laub, steht etwa 5 Wochen kahl und belaubt sich dann wieder. Bei noch anderen Arten bleibt das Laub noch länger als ein halbes Jahr am Baume, nämlich etwa 8 bis 10 Monate. So kann man beobachten, daß ein Exemplar etwa im August das Laul abwirft, dann wieder im Juli und im darauf folgenden April. Dadurch entsteht naturgemäß das Bild eines scheinbar völlig regellosen Torganges, wenn man nicht die einzelnen Individuen betrachtet. Ebenso ist die Zeitdauer, wie lange der Baum kahl steht, äußerst wechselnd, wie schon oben bemerkt, bei einigen nur einige Tage, bei anderen Wochen, ja bei wieder anderen (z. B. Albizzia lebbek) bis zu 6 Monaten. Durch alle diese Vorgänge wird das von den Reisenden oft erwähnte Bild des immergrünen Tropenwaldes hervorgerufen. Mitunter beginnt der Laubfall am Grunde der Krone, bei anderen an der Spitze und schreitet nach unten fort.

B. Einen gewissen Übergang zu den immergrünen Bäumen bilden diejenigen, bei denen alljährlich auch nur einmal ein Schub neuer Blätter erscheint, bei deren Erscheinen dann erst die alten Blätter abfallen. Hier können sogar die ivdividuellen Eigentümlichkeiten soweit gehen, daß ein Individuum kurze Zeit kahl bleibt, das andere derselben Art die letzten alten Blätter erst nach dem Erscheinen der neuen abwirft. Bei manchen Arten erscheinen die jungen Blätter zu derselben Zeit, wenn die alten fallen, so daß zugleich junge und abfallende vorhanden sind, bei anderen werden die alten Blätter erst abgeworfen, wenn die neuerschienenen bereits ausgebildet sind, so daß nicht einmal eine Lichtung der Krone erfolgt. Der dritte vorkommende Fall ist, daß sich die einzelnen Äste eines Baumes unabhängig voneinander ent- und belauben, so daß also einzelne oder mehrere Äste ihr Laub wechseln zu einer Zeit, wo die andern noch belaubt bleiben (z. B. Strychnos nux vomica). Als bei diesem Baum im April einige Äste ihr Laub geworfen hatten und schon junge rötliche Blätter hatten, hatten andere noch das alte dunkelgrüne Laub; diese letzteren warfen aber nach zwei Wochen auch das Laub, um nach einer weiteren Woche wieder junge Blätter zu haben. 
C. Auch bei den Pflanzen mit lederartigen Blättern lassen sich gewisse Typen unterscheiden. Die Mehrzahl der tropischen Gehölze ist immergrün, d. h. sie werden nie kahl und werfen zu den bestimmten Perioden nur einen Teil ihres Laubes ab. Am verbreitetsten ist die Erscheinung, daß etwa so viel Laub zu derselben Zeit fällt, als der Neuaustrieb erzeugt. - Bei den meisten immergrünen Gehölzen kann man beobachten, daß zwei Schübe im Jahre vorhanden sind, von denen der älteste der beiden vorhandenen vergeht, wenn ein neuer hinzutritt. Bezüglich der Gleichzeitigkeit ist folgendes $\mathrm{zu}$ bemerken:

1. Alle Knospen treiben gleichzeitig aus und zwar, wie oben bemerkt, zumeist in zwei Schüben, so daß also stets die ältere Hälfte des vorhandenen Laubes abfällt, wenn ein neuer Schub erscheint. Es sind also stets zwei Schïbe lebend am Baume vorhanden.

2. Nur ein Teil der Knospen treibt zu gleicher Zeit aus; infolgedessen fällt auch nur ein Teil des Laubes am ganzen Baum. Sehr häufig ist bei diesem Typus Fallen und Treiben zeitlich nicht aneinander geknüpft.

Die Laubblätter sitzen in dem tropischen Regenwalde fast immer lïnger als ein Jahr auf dem Baume (also etwa 13-14 Monate) ${ }^{1}$ ) und manche sind wahrscheinlich oft viele Monate tätig, vielleicht länger als ein Jahr, was für die Pflanzen von grundlegender ökonomischer Bedeutung ist und ihr riesiges Wachstum und die Produktion der großen Masse organischer Substanz erklärt. Die alten Blätter krümmen sich nach Haberlandt bisweilen durch aktive Bewegungen, um den jungen Blättern Platz zu schaffen. Über die Farbe des Waldes vergl. das S. 588 Angeführte.

Es ist eine für mehrere tropische Bäume charakteristische Erscheinung, daß die jungen Blätter schlaff herabhängen, oft selbst, nachłem sie schon ihre volle Größe erreicht haben (Fig. 121).

Die Zahl der Blattformen des tropischen Regenwaldes ist außerordentlich groß. Wir finden nicht nur die auch bei uns vorkommenden eiförmigen, elliptischen und ähnlichen, einfachen oder einmal zusammengesetzten Blätter, sondern es gibt auch viele andere neue Formen, z. B. das fiederförmige oder das fächerförmige Laub der Palmen, die großen, ungeteilten, eine eigentümliche Nervatur aufweisenden Blätter der Scitamineen, die gefiederten Blätter der Leguminosen, namentlich das mehrmals zusammengesetzte Mimosenblatt, dessen zahllose Blättchen ron der Lichtstärke abhängige Bewegungen ausführen, das gefingerte Blatt bei Bombacaceen und Panax (Araliacee), das fingerförmig geteilte,

1) Vergl. Warming 1892; Holtermann 1902; Volkens 1903.

Warming-Graebner. 3. Anflage, illustr. 
schilaförmige Blatt der Cecropia u. a., die langgestielten, großen, herzoder herzeiförmigen Blätter der Araceen, ferner die (sich an der Spitze der Zweige fingerförmig stellenden) Blätter der Bambusgräser usw. Die häufigste Blattform bei den Bäumen ist jedoch wohl das "Lorbeerblatt", d. h. das große, kahle, glänzende, elliptische oder lanzettliche, mehr oder weniger lederartige und ganzrandige Blatt, wofür Ficus elastica ein Beispiel bietet. Glänzende und lederartige Blätter sind überhaupt ein auffallender Charakterzug der Tropenwälder („Glanzlichter des Tropenläubes"), während die Blätter unserer Wälder matt und durchscheinend sind $^{1}$ ). Ganzrandige Blätter sind weit häufiger als bei uns (vergl. S. 314); die gezähnten und zerschlitzten Blätter der Mesophyten kommen kaum oder sehr selten vor. Im allgemeinen kann man wahrnehmen, daß die Blatter oft riesig groß sind, z. B. in den feuchten Küstenwäldern Brasiliens und in den Wäldern am Amazonenstrome, überdies viel dunkler grün als in den gemäßigten Gegenden, weil die Blätter und besonders wohl das Palisadengewebe dicker als bei uns sind. Andere Blätter hingegen sind, besonders bei den Stauden und Sträuchern in den unteren Stockwerken der Wälder, infolge des schwachen Lichtes und der feuchten Luft, welche hier herrschen, sehr dünn. Sie finden sich bei Pflanzen, welche weder direktes Sonnenlicht lieben noch starke Luftbewegungen.

Die Regulierung des Wassergehaltes der Pflanzen. Nach den Untersuchungen Haberlandts und anderer sind die Pflanzen in dem javanischen Regenwalde und wohl überhaupt in den höheren Stockwerken der tropischen Regenwälder Verhältnissen ausgesetzt, die weit extremer sind, als sie z. B. unsere europäische Natur irgendwo aufweisen kann. Ungefähr von 6-7 Uhr morgens ab steigt die Wärme bis um 1-2 Uhr, und die Lufttrockenheit nimmt unter der direkten Beleuchtung durch die Sonne andauernd und allmählich zu. Die Luft hat zuletzt oft ein Sättigungsdefizit von $30 \%$. Die andere Periode beginnt mit den Gewittern und den heftigen Regengüssen etwa um 2-3 Uhr; die Luft ist im übrigen Teile des Tages so mit Feuchtigkeit gesättigt $(93-95 \%)$, daß fast alle Transpiration unterdrückt wird. Zwei Drittel des Tages ist die Luft demgemäß ungefähr mit Wasserdampf gesättigt. Gegen die Gefahren, die also im Laufe des Tages von zwei ganz verschiedenen Seiten die Pflanzen, besonders ihren Assimilationsprozeß bedrohen, schützen sie sich auf verschiedene Art, wie aus dem Folgenden hervorgeht.

Wenn durch die erwähnte Sättigung der Luft mit Wasserdampf die Transpiration herabgesetzt wird, so entsteht die Gefahr, daß die Pflanzen wegen des fortdauernden starken Wurzeldruckes aus der

1) Über die „lackierten" Blätter vergl. Volkens 1890. 
nassen Erde zu große Wassermengen aufnehmen, so daß „ein Zustand höchster Turgeszenz" eintråte, wodurch die Luft aus den Intercellularräumen ausgetrieben und diese vollständig mit Wasser erfüllt werden könnten. Diese Gefahr wird durch wasserausscheidende Organe, "Hydathoden", abgewandt, deren verschiedene Formen schon im Kap. 25 (S. 211) erwähnt wurden. Nach Faber sind nicht allein die Hydathoden, sondern auch die gewöhnlichen Spaltöffnungen imstande, flüssiges Wasser austreten zu lassen.

Eine andere Gefahr entsteht durch die große Lufttrockenheit und die damit Hand in Hand gehende starke Transpiration am Vormittage. Zwar ist die gesamte Transpiration sehr gering (nach Haberlandt sogar zwei bis dreimal geringer als bei Pflanzen des mitteleuropäischen Klimas, was jedoch Stahl $^{1}$ ) als teilweise unzutreffend ansieht), aber vormittags ist sie stark und führt die Gefahr des Welkens oder jedenfalls einer so starken Verminderung des Turgors in den Pflanzen herbei, daß die Kohlensäureassimilation đarunter leiden könnte. Dadurch erklärt sich das merkwürdige Verhältnis, daß viele Pflanzen des tropischen Regenwaldes ähnliche Schutzeinrichtungen gegen starke Verdunstung besitzen, wie wir sie bei den Xerophyten kennen gelernt haben: man trifft oft dicke, stark cuticularisierte Epidermen, eingesenkte Spaltöffnungen, Schleimzellen, Speichertracheïden, Wassergewebe u. a. Das Wassergewebe von Ficus elastica ist wohlbekannt. Man weiß auch ange, daß mehrere Palmenblätter und die großen und dünnen Blätter der Scitamineen Wassergewebe auf der Oberseite oder bisweilen auf beiden Seiten führen; es kann ebenso mächtig wie das Assimilationsgewebe sein $\left(\right.$ Pfitzer $\left.^{2}\right)$ : nun wird dieses Wassergewebe verständlich. Mehrere Arten des javanischen Regenwaldes (z. B. Gonocaryum piriforme, Anamirta cocculus) haben nach Haberlandt im Chlorophyllgewebe, ganz wie mehrere auf S. 263 erwähnte Xerophyten, mechanische Zellen; diese haben offenbar eine ähnliche Bestimmung, nämlich die, das Chlorophyllgewebe gegen Schrumpfung bei Trockenheit zu schützen.

Das Angeführte gilt selbstverständlich zunächst für die Pflanzen der oberen Stockwerke, deren Blätter sich an der Oberfläche des Waldes befinden und von den Sonnenstrahlen getroffen werden. Bei den unteren Pflanzen hingegen, die sich im Waldinneren in dem Schatten der anderen verbergen, muß man andere Verhältnisse erwarten. Hier findet man in der Tat Pflanzen, die stark an Schatten und feuchte Luft angepaßt sind, wie die Hymenophyllaceen, deren papierartig dünne Blattspreiten nur eine oder wenige Zellschichten ohne eine eigentliche

1) Stahl 1894.

2) Figuren bei O. G. Petersen 1893. 
Epidermis und ohne Intercellularräume haben, deren Stengel Wurzelhaare tragen usw. ${ }^{1}$ ).

Andere Bauverhältnisse scheinen mit den Regengüssen der Tropen in nächster Verbindung zu stehen, teils mit deren Heftigkeit, wofür es in unseren Klimaten nichts Ähnliches gibt, teils mit deren Häufigkeit.

Anpassung an mechanische Einwirkungen ${ }^{2}$ ). Das in große! Entfernung hörbare Geräusch des auf die Wälder herabstürzenden Regens zeigt dessen Heftigkeit an; aber die Bäume sind daran angepaßt diese zu ertragen. Viele einfache Blätter sind fest und lederartig, j; die Epidermis kann so stark verkieselt sein, daß die ganze Spreite stei und zerbrechlich wird (Medinilla magnifica); sie sieht wie "grün lackier tes Blech" aus. Die Blätter anderer Arten, namentlich die von Mi mosen, Akazien und anderen Leguminosen und von Palmen, sind in viel Blättchen oder Abschnitte geteilt, so daß sie dem Regen wenig Wider stand leisten; sehr oft können sie obendrein Bewegungen ausführell wodurch sie die Blattspreiten zusammenfalten, so daß sie den Wasser tropfen eine geringere Oberfläche oder sogar nur eine Kante darbieter: Bei anderen Pflanzen sind die Blätter in Falten gelegt oder rinnenförmị was sie gleichfalls aus mechanischen Gründen widerstandsfähiger macht dieses ist am deutlichsten bei den Palmenblättern der Fall, deren fieder oder fächerförmig angeordnete Abschnitte der Spreite in Falten geleg sind, indem der Winkel zwischen den Seitenteilen entweder aufwärt oder abwärts gewandt ist. Die Blattstiele sind oft a ufwärts gerichte hier also vermutlich aus einem anderen Grunde als in den Xerophytel vereinen, nämlich um dem Schlage der Regentropfen einen größere Widerstand entgegenzusetzen. In vielen anderen Fällen sind die Blat spreiten oder die Zweige jedoch hängend, namentlich solange sie jun sind, was denselben Nutzen schafft (vergl. S. 609 und Fig. 121); vie große Blätter der Araceen verbleiben in dieser Stellung, anderichten sich später aufwärts. Die riesigen Blätter der Palmen, Scit: mineen u. a. haben große, stengelumfassende Blattscheiden, die daz beitragen, dem Stamme und den Blättern eine bedeutend größe Festigkeit zu verleihen.

Die Häufigkeit der Regengỉsse kann gleichfalls auf die Pfla zen wirken, nämlich dadurch, daß die Blattspreiten zu naß und schwer werden. Hierdurch wird die Transpiration gehemmt $\left.{ }^{3}\right)$. Den d durch hervorgerufenen Übelständen wird auf verschiedene Weise begegn

1) Warming-Johannsen. - Weitere Einzelheiten über die Verdunstung in feuch tropischen Klimaten vergl. Haberlandt 1892, 1897; Stahl 1894; Burgerstein 1904; tay 1897, 1898; Holtermann 1902, 1907.

2) Wiesner $1895 \mathrm{a}, 1897$.

8) Uber ombrophile und ombrophobe Arten siehe S. 56; vergl. auch Wiesner 189: 
namentlich durch glatte Cuticula, Träufelspitzen, rinnenförmig vertiefte Nerven und Sammetblätter, was im 27. Kap. näher erörtert ist.

Assoziationen der tropischen Regenwälder ${ }^{1}$ ). Die Flora der tropischen Regenwälder ist so mannigfaltig, daß es zu weit führen wïrde, über sie Näheres mitzuteilen. Die vorherrschenden Bäume gehören hesonders zu den Leguminosen, Lauraceen, Myrtaceen, Moraceen usw.

Von einzelnen Arten gebildete Bestände gehören in der tropischen Traldvegetation zu den größten Seltenheiten. Die Wälder auf den Philippinen sind besonders von Dipterocarpaceen gebildet, vom Meere bis zu einer Höhe von $2500 \mathrm{Fuß}$. Merkwürdig ist, daß sie fast reine Bestïnde von wenigen Arten bilden (Brown and Mathews). Die tropischen Regenwälder bilden wegen der starken Mischung ihrer Arten auf der ganzen Erde offenbar nur eine einzige Vereinsklasse. Die Regenwälder sind im höchsten Grade Mischwälder. Es ist schon angeführt worden, daß die Wälder auf ca. drei Quadratmeilen um Lagoa Santa in Brasilien (a. 400 Baumarten aufweisen ${ }^{2}$ ). Wenn in Brasilien in der Trockenzeit ein Waldkomplex umgehauen wird („Derrubada“ der Brasilianer), um unmittelhar vor dem Beginn der Regenzeit abgebrannt zu werden, damit der Boden für Kulturpflanzen vorbereitet werden kann, gibt es für den Botaniker eine vorzügliche Gelegenheit, die Zusammensetzung der Wäldeı zu studieren. Beim Studium von sechs solcher Derrubaden erhielt Warming ${ }^{3}$ ) folgende Resultate:

Unter 62 Individuen . . 32 Arten.

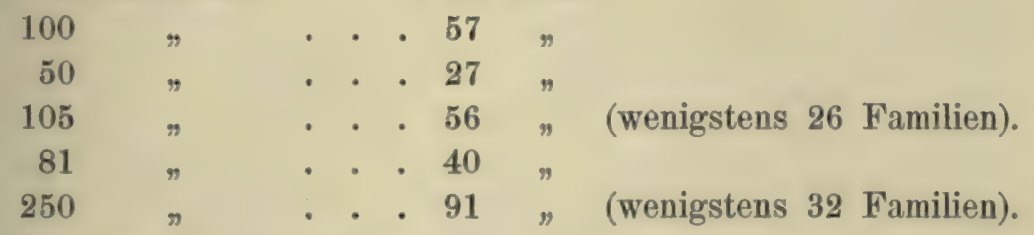

In den fünf ersten aufgeführten Beispielen war jede Art ungefähr durch zwei Individuen vertreten, bei dem letzten etwa durch deren drei.

Es kann vorausgesetzt werden, daß es eine große Menge von Varianten (Assoziationen) der tropischen Regenwälder geben muB. Die Flıra ist ja äußerst verschieden in den verschiedenen ungeheuer ausgedehnten tropischen Ländern, und innerhalb jedes einzelnen von diesen

1) Außer den schon genannten Autoren über tropische Wålder vergl. Haberlandt 1893 ; Schimper 1898; Koorders 1907.

9) Die zahlreichsten Familien sind: Papilionaceae 30 Arten, Myrtaceae 27, Rubiaceae 23, Lauraceae 23, Artocarpaceae 18, Caesalpiniareae 17, Euphorbiaceae 17, Meliacene 15, Mimosaceae 12, Anonaceae 11 (Warming 1892).

3) Warming 1892 . 
gibt es wieder verschiedene Typen, je nach den unzähligen Verschiedenheiten der ökologischen Faktoren: der Höhe über dem Meere, dem: Klima, der Exposition, der Bodenfeuchtigkeit usw. ${ }^{1}$ ). So unterscheider z. B. Whitford ${ }^{2}$ ) zwischen zehn Waldtypen auf den Philippinen. Hubes hat ebenso am Amazonas verschiedene Assoziationen und "Facies" unterscheiden können ${ }^{3}$ ). Der vom Flusse entferntere Wald ist von den der Flußufer selbst floristisch verschieden.

Der Wald, der auf den wieder verlassenen Kulturböden in Brasilies aufwächst, ist zunächst floristisch recht verschieden von dem jungfräu lichen Walde (mato virgem), und zwar in jeder Hinsicht viel ärmer Ganz ähnlich geht es anderswo mit den sekundären Formationen. Treu erwähnt, daß ein kleiner Wald auf Java, der 40 Jahre alt war, seh verschieden von dem Urwalde war; nur 140 Arten von Gefäßpflanze wuchsen dort, und kaum eine Spur von Lianen und Epiphyten ${ }^{4}$ ).

Auch ist der Charakter des Regenwaldes verschieden in den ver schiedenen Weltteilen; von Afrika wird z. B. angegeben, daß er a Lianen und Epiphyten weniger reichhaltig ist.

Im Vorhergehenden hatten wir den tropischen Regenwald vc Augen, dessen Physiognomie von dikotylen Bäumen beherrscht wir selbst wenn Palmen, Bambusen und Farnbäume vielfach eingemiscl sind. Es kommen aber kleinere Assoziationen von diesen Typen vo welche dann eine gänzlich abweichende Physiognomie haben und ves dienen speziell hervorgehoben zu werden.

Besondere Typen tropischer Wälder sind die Palmenwälder, d: Bambuswälder und die Farnwälder.

\section{Palmenwälder}

In die tropischen Regenwälder sind oft Palmen eingemisch namentlich kleine und dünnstämmige Arten in den unteren Stockwerkt der Wälder. Im tropischen Südamerika findet man jedoch einzeln überwiegend aus Palmen bestehende Wälder, namentlich längs der FluJ ufer oder auf noch feuchterem Boden. So gibt es in Brasilien „Burit: sales", d. h. Wälder der Buritypalmen (Mauritia vinifera und M. Alexcuosa Lund $^{5}$ ) schreibt über diese Wälder: „Die Täler sind mit einem frische lebhaften Grasteppiche überzogen und in dem Grunde, wo immer e Bach fließt, mit Gruppen der unvergleichlich schönen Burity geschmückt

1) Vergl. z. B. Forrest Shreve über den Regenwald in Jamaika 1914.

2) Whitford 1906; vergl. z. B. auch Engler 1910; Dusén 1910.

8) Huber 1906.

4) Treub 1908.

s) Lund vergl. Warming 1892. 


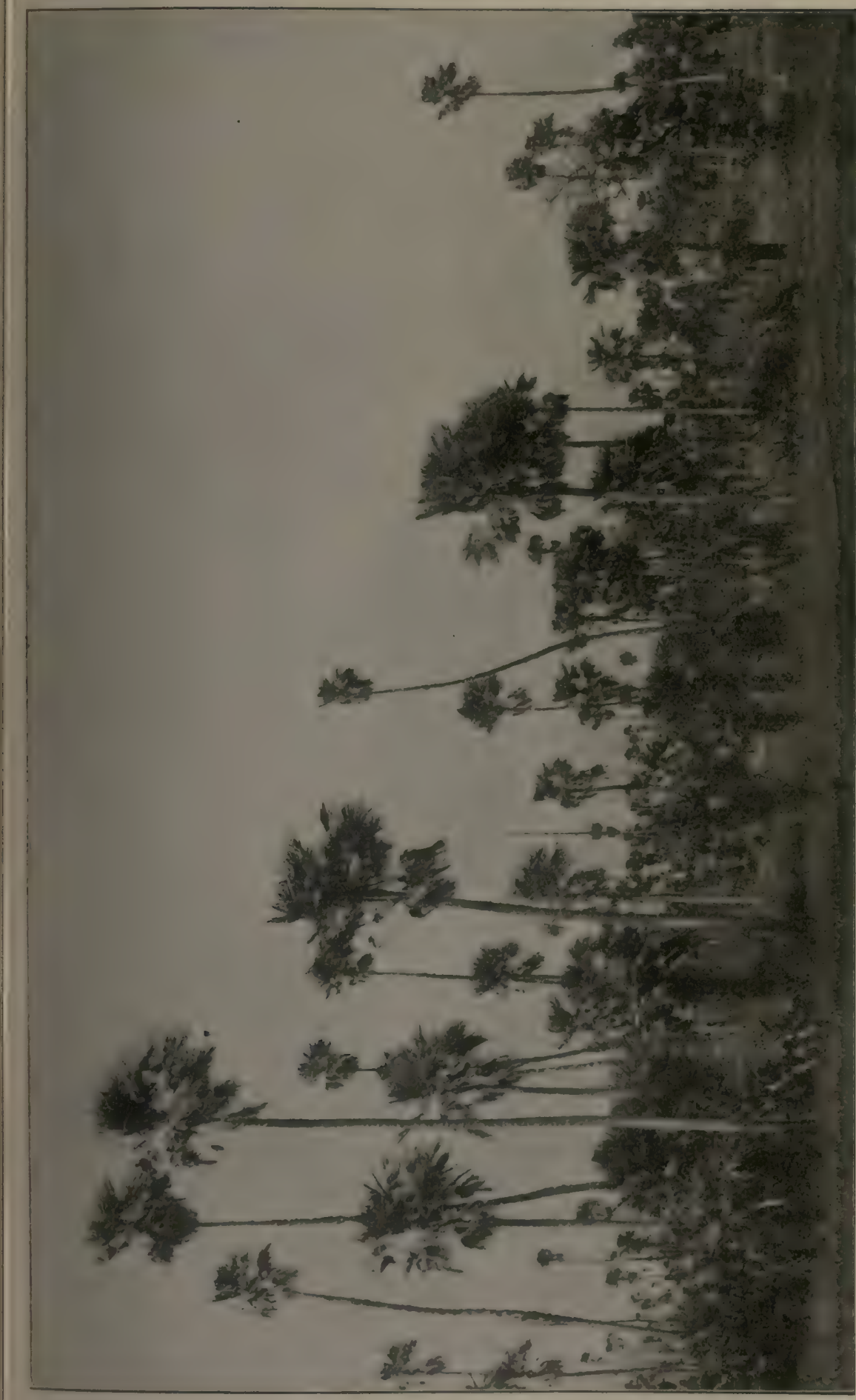

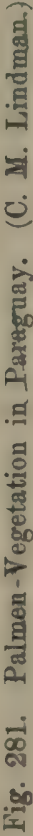




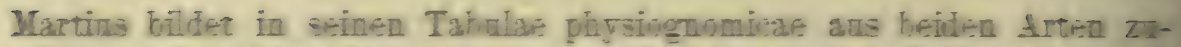
sammengesetzte Walder ah. Ferner besitat Gran chavo in dem nowiwestlichen Argentinien anf seinen gruben Elwenen amscedtehnte Palmon-

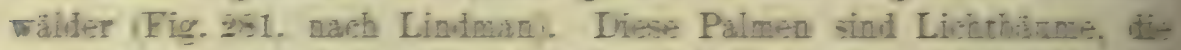
nur offene and schattenluse Bestände bilden konnen; der Wald wiri hell and hat vermutheh eine pflanzenreiche Bodenvegetariva.

Gaber ${ }^{2}$ bespricht ähnliche _Palmares in Cruguay. Weite Flatber werden von Cowa yatai helferkt, einem Palmenwalde mit wissenarterer Cntervegetation, deters sarannenimig. Ins einem dichten Tepoich nit-

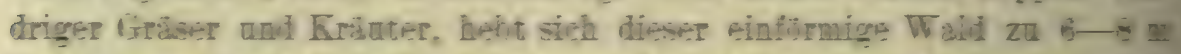

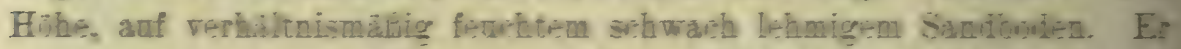
prophezeit jedneb den Tntergang dieser lieblimben Whater, weil iweidenden Ferden alle anfwahtwenden jongen Pflanzen verzebren, sie

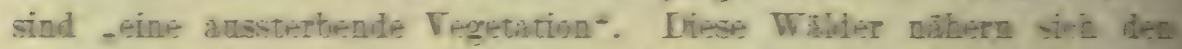
Savanneo und werden ron Lindman swir anshanlieh ahgetiadet.

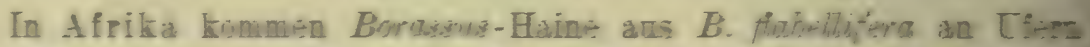
und in Niederngen vor, welche zur Regenzeit start bewassert werden"

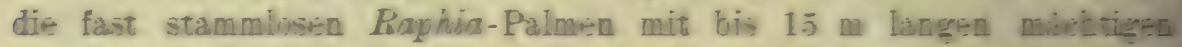
Wedeln bilden an den Flubafern and in versumpiten Barktalem undurchdringliche Irickichte\%. Uiese letzten Palmenwaluep gehoren aiw eher zu den in Kap. 54 besprechenen Waldern. Therhanpt sokeirtu die reinen Paimenwalder starke Bodenfeuchtigheit zu lieten, sit sicd shygrophin".

\section{Bambuswalder}

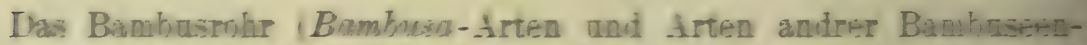
gattungen bildet in Ostasien. seltner in Afrika, fast undurthidringlite Wälder. Im âquatorialen Afrika oberhalb 1 sou m werden z. B. Asior ziationen von der his $10 \mathrm{~m}$ hohen Arumdinaria alpinats ceabilitet. In ustliehen Himalaga fand Burkill gigantisebe Bambusbestande auf striltu Abhängen. Busse erwähnt den Bambuswald auf Java: zwistenn dea eigentliven Regenwald und dem Castarinenwald in der . Wolkenregiveliegt eine Zine ron Bambuswald in 1200-16000 m Höbe und zu der - Regenregion- gehorend ivergl. Fig. 8\%. Eingestrent finden sith Arten won Querewas. Aeer. Mneropanax, Fiens u. a. der Boden wird ron eintr Strauch- und Krantflora bedecht. Welche mit der des Recenwalles act der gleichen Hïhenstufe am näehsten verwanit ist. Cnter den Epiphyten wird eine Freyeinetia genannt. Hamboldt erwahnt. dab lang-

7) Gafiner 1913.

3) Engler 1910

* Busse 1908.

5) Eingler 1910 
dem Magdalenenstrome ununterbrochene Wälder aus Bambus und pisangblättrigen Heliconia-Arten vorkommen. Die tropischen Ströme sind oft von einer Bambuseinfassung umgeben.

\section{Farnwälder}

Während Palmen- und Bambuswälder z. T. einen ziemlich nassen Boden zu fordern scheinen, sind die Baumfarne namentlich an Luftfeuchtigkeit gebunden; sie sind ein sicheres Kennzeichen für eine andauernd mit Wasserdampf gesättigte Luft und für ein gleichmäßiges Klima $\left.{ }^{1}\right)$. Baumfarne sind oft sehr häufig in tropischen und subtropischen Regenwäldern in einer gewissen Höhe der Berge. Die Wälder Australiens und Tasmaniens sind reich an Baumfarnen (Fig. 283). Oft können diese zusammen mit anderen Farnen und dünnblättrigen Kräutern die Hauptmasse der Vegetation bilden. Chamberlain fand einen schönen Farnbaum, Dicksonia Youngii, so häufig in gewissen Gegenden von Südost-Australien, daß er fast undurchdringliche Wälder bildet. Auf mehreren der höheren westindischen Inseln, z. B. auf der an Farnen außerordentlich reichen Insel Jamaika (Fig. 282), findet man auf den Gebirgen in einer gewissen Höhe eine Vegetation, die als Farnwald bezeichnet werden kann (Cyathea, Alsophila).

1) Vergl. über die Farnwälder auch Kap. 78. 


\section{Serie. Formationen der Torfböden}

\section{Kap. Eigentümlichkeiten der Vegetation auf torfhaltigen Böden}

Wenn wir von den Verlandungszonen (Kap. 53) an den Süßwassersümpfen unseren Weg weiter landeinwärts nehmen, werden wir sehr oft, indem die Vegetation immer dichter wird, als eine weitere Stufe der Entwicklung eine Landregetation auf torfhaltigem Boden treffen, der von dem der milden Humusböden der Wiesen, Gebüsche und Wälder, welche in der dritten Serie besprochen wurden, bedeutend abweichen.

Der Boden hat in den extremen Fällen den Charakter von saurem Torf und Rohhumus (vergl. Kap. 13). Schon in den Sümpfen fing eine solche Torfbildung an, und in verschiedenen Sumpfwäldern ist das Wasser zwischen den Bäumen braun und sauer (siehe Kap. 9, 13 und 64); solche Wälder könnten auch in diese Serie gebracht werden.

Eine Übergangsformation zwischen den in der dritten Serie besprochenen Humusböden und den sauren Torfböden bilden diejenigen, welche von neutralem oder alkalischem Torf gebildet werden (vergl. besonders die Flachmoore).

Der torfhaltige Boden wurde Kap. 13 besprochen. Hier muß folgendes ausgeführt werden:

Der saure Torfboden ist nährstoffarm, besonders arm an leicht assimilablem Stickstoff; die Assoziationen sind "oligotrophisch" (Weber) oder "dystrophisch" (Gadeceau) ${ }^{1}$ ).

Der Boden ist ferner sauer, namentlich wo Sphagnum auftritt (daher werden die Sauerbodenvereine Oxylophyten genannt) ${ }^{2}$ ). Die meisten Arten dieser Vereine sind nicht kalkliebend. Oft wandern sie zuerst auf sterilen Sandboden ein, auf welchem sie dann selbst Rohhumus hervorbringen und dichte, weit ausgedehnte eigentümliche Vereine bilden. $\mathrm{Ob}$ diese Säuren als Humussäuren im alten Sinne betrachtet werden müssen oder ob eher kolloïde Substanzen vorliegen, durch welche Säuren frei gelassen werden, die als wirksam betrachtet werden müssen, ist für die Pflanze ganz gleichgültig. Nach Baumann und Gully ist von freien Humussäuren in den Sphagneten keine Rede; die Säurewirkungen rühren

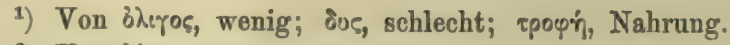

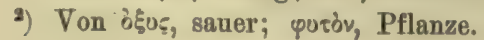




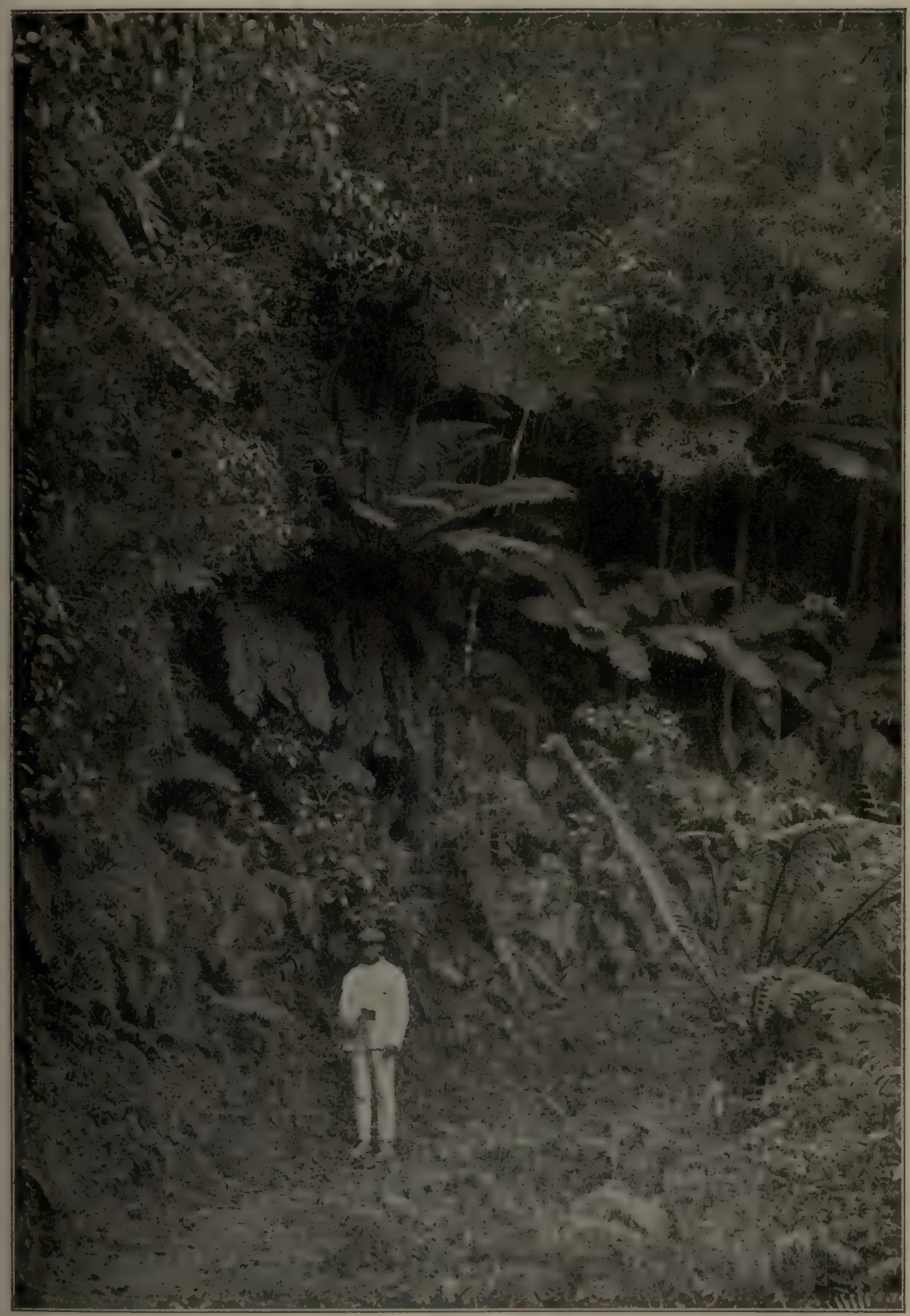

Fig. 282. In "The blue mountains" auf Jamaica. Urwald mit reicher Farnvegetation. (Phot. Dr. F. Börgesen.) 
nicht von solchen her, sondern von quellbaren Kolloïden der Zellmembranen des Sphagnum ${ }^{1}$ ).

Dachnowski, der vorzügliche Arbeiten über die Torfbildung in Nordamerika geliefert hat ${ }^{2}$ ), ist der Meinung, daß für die Pflanze schädliche Stoffe durch die Wirksamkeit von Bakterien und anderen niederen Organismen produziert werden; jede Assoziation hat ihre besondere Bakterienflora und die chemische Zusammensetzung des Wassers im Boden wird dadurch jedenfalls geändert. Auch Livingston spricht von "Sumpf-Giftstoffen" („bog toxins").

Der Boden ist schlecht durchlüftet und mehr oder weniger arm an Sauerstoff. Hesselman ${ }^{3}$ ) z. B. hat gezeigt, daß die Sphagnummoore in Schweden äußerst arm an Sauerstoff sind; die Fichtenwälder auf Sphagnummoorboden mit stagnierendem Wasser leiden an großem Sauerstoffmangel; wenn das Wasser sehr reich an Humusstoffen ist, kann es völlig frei von Sauerstoff sein. In den dichten Sphagnumpolstern fehlt der Sauerstoff vollständig. Fine Humusschicht von $10 \mathrm{~cm}$ Höhe kann langsam hindurchfließendem Wasser $36 \%$ des Sauerstoffes entziehen. In versumpften Fichtenwäldern zeigte sich das Wasser in $20 \mathrm{~cm}$ Tiefe so gut wie sauerstofffrei.

Das Wasser kann in größerer oder geringerer Menge im Boden vorhanden sein, aber zu den Vereinen mit ständig freiem oberflächlichem Wasser gehören die im nachfolgenden angeführten nicht ${ }^{4}$ ).

Torfbildung wird oft durch das Klima bedingt. Wo dieses feucht, kalt oder kalt temperiert ist, wird Torfbildung leicht vorkommen; reichlich Regen und dichte Nebel begünstigen Torfbildung in kalten Klimaten. Denn unter diesen Verhältnissen verwesen die Pflanzenreste langsam oder gar nicht, es werden durch Fäulnis vegetabilische Stoffe als Rohhumus angehäuft, in welchen, wie überall da, wo organische Stoffe unter Luftabschluß oder unter mangelhafter Sauerstoffzufuhr sich zu zersetzen gezwungen sind, Säuren u. a. gebildet werden. Wir finden daher die im folgenden besprochenen Formationen z. B. im nordwestlichen Europa (Fig. 284), dann auch in subarktischen, weniger in arktischen Gegenden, und klimatisch entsprechenden Teilen von Nordamerika, und auf den höheren Bergen Europas in der alpinen und subalpinen Region; weiter sind sie entwickelt an den südwestlichen Küsten von Südamerika, in Patagonien und im Feuerlande; auch auf den antarktischen Inseln südlich von Neuseeland finden sich mächtige Torfbildungen; bis $10 \mathrm{~m}$ Tiefe kann alles ein sehr saurer Torf sein, der als nahrungsreich angegeben wird ${ }^{5}$ ).

1) Baumann u. Gully 1910.

2) Vergl. namentlich 1912, 1909.

3) Hesselman 1910.

4) Über das Grundwasser siehe Kap. 9.

s) Chilton 1909; Cockayne 1904 u. a. a. Stellen. 
Brockmann-Jerosch und Rübel ${ }^{1}$ ) betonen gleichfalls die Abhängigkeit der Heidebildung usw. von den feuchten Klimaten in ihrer Kritik gegen die Verwertung ökologischer Grundprinzipien zur Einteilung der

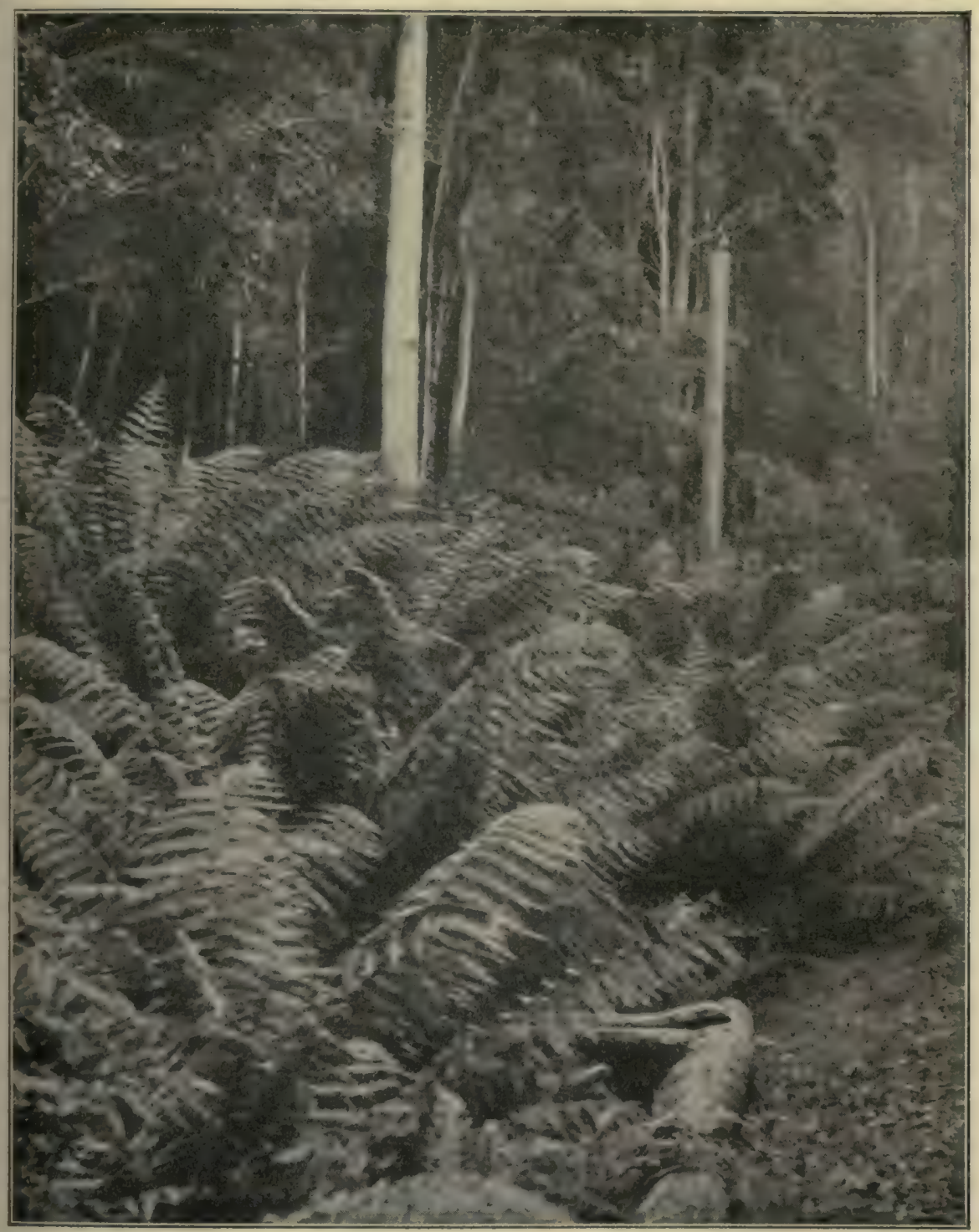

Fig. 283. Urwald in Australien (Neu Süd Wales). Eucalyptusbäume und Farne.

Pflanzenformationen; indem sie hervorheben, daß ja Heiden, die zu den typischen Formationen der "sauren" Böden gehören, auch auf reinem

1) Brockmann-Jerosch u. Rübel 1912. 
Sande in den geeigneten Klimaten vorkommen können ${ }^{1}$ ). Es ist dies zweifellos zutreffend, aber gegenüber der ungeheuren Ausdehnung der Heideflächen auf Rohhumus sprechen die kleinen Flächen mit abweichenden Verhältnissen kaum mit und man würde sicher gegen jedes Einteilungsprinzip genau dasselbe einwenden können, denn es wird, welches man auch wählen mag, stets Ausnahmen resp. Übergänge zu anderen Gruppen geben, weil wir es ja mit lebenden und z. T. wandlungs- und anpassungsfähigen Dingen zu tun haben.

Torfbildung findet in tropischen Ländern fast nur auf Bergen statt, teils weil die Sphagneta hohe Temperaturen fliehen und viel Luftfeuchtigkeit brauchen, teils weil die Wärme die Zersetzung der organischen Teile in hohem Grade begünstigt. In den Polarländern ist sie sparsam und gering, meist jedoch wohl deshalb, weil die Masse der Vegetation gering ist; Torfbildung findet auf Grönland z. B. durch Webera nutans und Hypnum stramineum statt.

Auf Böden mit Eigenschaften wie die geschilderten entwickeln sich Vereine, die aus sehr verschiedenen Lebensformen zusammengesetzt aber doch nahe verwandt sind und oft genetisch verbunden sein können.

Die niedrigsten stark hervortretenden Lebensformen sind Moose und Flechten, welche dem erwähnten feuchten und kühlen Klima vorzüglich entsprechen. Die Gefäßpflanzen, welche sich hier entwickeln und sowohl Stauden als Zwergsträucher, Sträucher und Bäume sein können, zeigen merkwürdigerweise viele xerophytische Charaktere, d. h. sie sind auf verschiedene Weise vor starker Transpiration geschützt, was in einem sonderbaren Gegensatze zum Klima zu stehen scheint. Der Boden ist aber physiologisch trocken.

Die wichtigsten von diesen xerophytischen Charakteren sind folgende:

1. Starke Haarbekleidung. Haare anf der Blattunterseite, z. B. der Haarfilz bei Ledum, Salix repens, S. lanata und S. glauca, und die Schildhaare bei Lyonia (Andromeda) calcyculata, ebenso in Nordamerika z. B. Nyssa uniflora, Persea pubescens und Magnolia Virginiana, welche in Sümpfen wachsen ${ }^{2}$ ). Die Haare haben möglicherweise wesentlich die Aufgabe, zu verhindern, daß das Wasser die Spaltöffnungen verschließe, die nur auf der Unterseite vorkommen, setzen aber auch die Transpiration herab.

2. Im Anschluß hieran sei erwähnt, daß bei Salix myrsinites, di€ in Lappland besonders auf Sumpfwiesen wächst, die Blätter nach dem Verwelken sitzen bleiben und die Jahressprosse bedecken (Kihlman).

1) Grillbach 1884; Graebner 1901 ff.

2) Kearney 1901. 


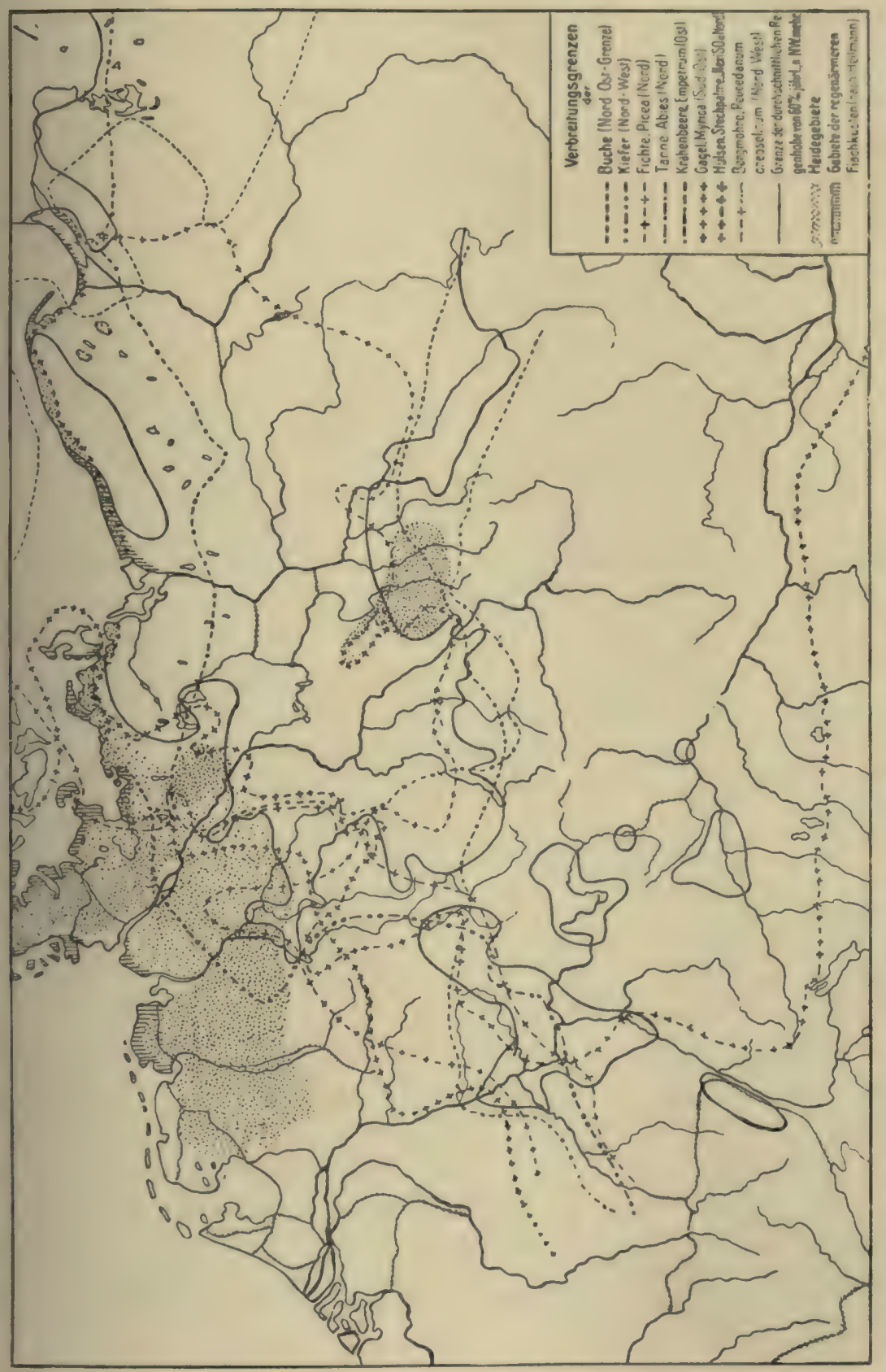

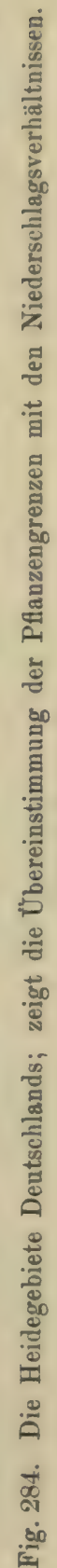


3. Papillen, die vielfach die Spaltöffnungen überdecken (mehrere Gramineen und Cyperaceen, z. B. Carex limosa, C.panicea, C. rariflora u. a., Lysimachia thyrsiflora, Polygonum amphibium). Sie sollen vielleicht zunächst die Spaltöffnungen davor schützen, durch Wasser verstopft zu werden ${ }^{\mathbf{1}}$ ).

4. Wachsüberzüge auf dem ganzen Blatte (Vaccinium uliginosum) oder nur auf der mit Spaltöffnungen versehenen Unterseite (Andromeda polifolia, Vaccinium oxycoccus, Primula farinosa, Salix Groenlandica, Carex panicea usw.) und in Nordamerika z. B. Acer rubrum, Persea pubescens u. a. ${ }^{2}$ ).

5. Starke Cuticularisierung (verschiedene Blätter, die Stengel von Scirpus caespitosus u. a.).

6. Lederartige Blätter. Diese Eigenschaft wird namentlich durch eine dicke Oberhaut hervorgerufen (Andromeda polifolia, Vaccinium oxycoccus, V. vitis Idaea, Ledum palustre ${ }^{3}$ ) und steht vielleicht damit in Verbindung, daß solche Blätter grün überwintern.

7. Schleim bildet sich z. B. in den Oberhautzellen von Berchemia scandens, und eine kontinuierliche hypodermale Schicht findet sich unter der Epidermis der Oberseite von Pieris nitida ${ }^{4}$ ).

8. Ericoïde Blätter. Es finden sich Arten mit schmalen, linealischen oder fadenförmigen Blättern, deren Spaltöffnungen in tiefe, „windstille", von Haaren usw. beschützte Räume eingeschlossen sind, so daß der Wasserdampf schwierig heraustreten kann (Erica tetralix, Empetrum, Calluna vulgaris; andere Beispiele sind Arten der nächsten Gruppe).

9. Die Assimilationsorgane sind bei vielen Arten senkrechte, stielrunde Blätter oder blattlose, assimilierende Stengel, z. B. bei Equisetum limosum, Arten der Junci genuini, in geringerem Grade bei anderen Juncus-Arten, Scirpus caespitosus u. a. Arten, Eriophorum vaginatum, Carex microglochin, C. dioeca, C. chordorrhiza, C. pauciflora usw.

10. Kantenständige Blätter (Profilstellung) bei Narthecium, Tofieldia, Xyris wie in den Sümpfen bei Iris und Acorus. Das Licht trifft die Blätter unter spitzen Winkeln.

11. Es kann hier auch an Sumpfpflanzen erinnert werden, bei denen die Blätter flach, breit, aber gleichfalls senkrecht oder aufwärts gerichtet, lang und ungeteilt sind, z. B. bei Alisma plantago, Sagittaria, u. a. Alismataceen, Butomus, Typha, Sparganium, Ranunculus lingua, Lathyrus nissolia.

1) Kihlman 1890; Volkens 1890; Raunkiär 1895-9, 1901.

2) Kearney 1901; Dachnowski 1912.

8) Anatomie bei H. E. Petersen 1908.

4) Kearney 1901. 
12. Breitblättrige Cyperaceen können ihre Blätter schließen (immer?), deutlich bei Carex vulgaris (C. Goodenoughii); die Spaltöffnungen sind jedoch nicht auf die Oberseite beschränkt.

13. Polsterpflanzen. Cockayne ${ }^{1}$ ) nennt eine Anzahl von neuseeländischen Arten in Torfsümpfen, z. B. die Caryophyllacee Colobanthus muscoides, die Polsterbildung zeigen.

14. Krummholz- und $Z$ wergbildungen finden sich allgemein bei den Holzpflanzen.

Daß hier ein ursächlicher Zusammenhang zwischen dem in allen Fällen sehr nassen Standorte und den erwähnten Bauverhältnissen besteht, an deren Stelle man zunächst ganz andere erwarten sollte, ist offenbar. Bei Gattungen, die sowohl Sumpf- als auch solche Landarten enthalten, die nicht an sehr trocknen Orten wachsen (Mesophyten), wird man oft finden, $\mathrm{da} \beta$ diese letzten die breitblättrigsten sind, während man eher das Umgekehrte erwarten sollte. Die Sumpfarten Epilobium palustre und Lysimachia thyrsiflora sind unsere schmalblättrigsten Arten ihrer Gattungen; Galium palustre und G. elongatum sind gleichfalls schmalblättriger als die mesophilen Arten, usw.

Der Boden muß physiologisch trocken sein, wenn nicht immerwährend, so doch periodisch. Die Wurzeln können nur mit Schwierigkeit Wasser aus dem feuchten oder sogar wasserreichen Boden aufnehmen und müssen deswegen durch Xeromorphie gegen Austrocknung geschützt werden (Kap. 13). Es ist aber eine noch ungeklärte Frage, welche von den ökologischen Faktoren maßgebend sind.

Hier muß auch hervorgehoben werden, daß viele Arten, besonders Heidepflanzen ${ }^{2}$ ) merkwürdigerweise sowohl auf trocknem und warmem Boden als auf äußerst feuchtem und kaltem Boden wachsen können, z. B. Calluna, Empetrum, mehrere Pinus-Arten, Juniperus communis, Betula nana, Saxifraga hirculus, Ledum palustre, Vaccinium myrtillus u. a. in Europa, Pinus taeda in den Dismal Swamps in Nordamerika ${ }^{3}$ ) oder Phormium tenax und Phyllachne Colensoi in Neuseeland ${ }^{4}$ ). Man sollte also meinen, $d a ß$ es zwischen beiden Bodenarten wesentliche Übereinstimmungen gäbe und $\mathrm{da} \beta$ unter den Lebensbedingungen der Sumpfpflanzen einige seien, die sie zwängen, mit dem Wasser ökonomisch zu verfahren. Die Sache ist noch unklar; für die Heidepflanzen ist sicher, daß sie oft an nährstoffarme Substrate gebunden sind.

2) Cockayne 1904 .

2) Vergl. Graebner 1895, 1901.

3) Kearney 1901.

4) Cockayne 1904, 1910.

Warming-Graebner. 3. Auflage, illustr. 
Folgende Frklärungen sind gegeben worden:

1. Johow und Kihlman ${ }^{1}$ ) haben auf die Beobachtung von Tschaplowitz hingewiesen, daß es ein Transpirationsoptimum gibt und daß deshalb selbst die Sumpfpflanzen gezwungen sein können, die Transpiration herabzusetzen.

2. Nasse Erde ist kalte Erde (Kap. 10); daher entwickelt sich die Vegetation im Frühjahr auf Mooren und in Sümpfen spät, und das Blühen findet spät statt (gewisse Arten ausgenommen). Kihlman und Goebel $^{2}$ ) weisen darauf hin, daß viele Pflanzen, obgleich sie auf recht nassen Stellen wachsen, doch mit Wollhaaren bedeckt sind (wie die Espeletia-Arten von Venezuela, S. 37, Fig. 20, 21) oder auf andere Weise gegen Transpiration geschützt sind, weil die starken Winde die Vegetation austrocknen, wenn die Wurzeltätigkeit durch den kalten Boden gehemmt ist. Dieses erklärt den xerophilen Bau bei Pflanzen des hohen Nordens und der Hochgebirge gut und spielt sicher eine große Rolle; aber da z. B. die Rohrsümpfe ihre Physiognomie sogar in den Tropen unter Verhältnissen bewahren, wo es weder austrocknende Winde noch kalten Boden gibt, so kann diese Erklärung nicht alle Fälle umfassen.

In jedem Frühjahr kann man sich davon überzeugen, daß noch zu einer Zeit, wo die Lufttemperatur und damit die Verdunstung durch die Sonnenwärme schon recht hoch sind, in geringer Tiefe Eis im Boden im Moore steckt.

Dachnowski ${ }^{3}$ ), der auf die biologischen Prozesse im Boden besonderes Gewicht legt, hat jedoch die Hochmoore auf Cranberry Island nicht besonders kalt oder kälter als andere Substrate gefunden, auch ist die Evaporation daselbst nicht besonders stark. Auch weist er darauf hin, daß Torf sich in tropischen Ländern bilden kann, wo niedrige Temperaturen nicht vorkommen.

3. Ein anderer Umstand, dem auch eine Rolle zugeteilt wird, ist, daß die Wurzeltätigkeit in dem sehr nassen und sauerstoffarmen Boden durch die schwierigere Atmung erschwert wird. Die Wurzeln der Sumpfpflanzen verbrauchen nach Freyberg in einer gewissen Zeit weniger Sauerstoff als die der Landpflanzen, und damit ihre Arbeit mit der der oberirdischen Organe im Gleichgewichte bleiben kann, muß auch die Tätigkeit dieser Organe herabgesetzt werden. Daß viele auf Heiden und anderen trocknen und warmen Böden wachsende Pflanzen auch auf Mooren wachsen können, bleibt hiernach nicht unverständlich, wenn man berücksichtigt, daß der Heideboden, wo die Pflanzen (z. B. Calluna, Pinus-Arten u. a.) wachsen können, oft ein äußerst schlecht durch-

1) Johow 1884; Kihlman 1890.

2) Kihlman 1890; Goebel 1889-1891.

8) Dachnowski 1911. 
lïfteter, zeitweise sehr nasser Rohhumusboden, „eine Torfbildung auf dem Trocknen" (P. E. Müller) ist, immer ist dies aber keineswegs der Fall, z. B. Dünenheiden. Im übrigen darf man auch nicht vergessen, daß der Heidetorf periodisch ziemlich stark ausgetrocknet sein kann.

Der Luftmangel in den wachsenden Hochmooren zeigt sich besonders darin, daß Gehölze (bes. Pinus silvestris) ihre neuen Wurzeln schräg aufwärts, also nach den besser durchlüfteten jüngeren oberen Teilen des Moores schicken (Graebner).

4. Ferner muß als ein für die Torfbodenpflanzen vielleicht wichtiges Agens hervorgehoben werden, daß Torfboden ein starkes Wasserbindungsvermögen hat (S. 85 und 109). Nach Crump ${ }^{1}$ ) ist $1 / 3$ des Wassergehalts nicht aufnehmbar für Erica tetralix, Molinia coerulea und Pteridium; $1 / 4$ nicht für Deschampsia und Nardus; $1 / 5$ nicht für Calluna vulgaris in reinem Torf; $1 / 6$ nicht für Vaccinium myrtillus und Agrostis; $1 / 7$ nicht für Eriophorum sp., Calluna vulgaris in sandigem Torf; $1 / 9$ nicht für Vaccinium vitis Idaea. Es scheinen nach diesen Angaben diesen Arten doch recht große Quantitäten von Wasser zur Verfügung zu stehen.

5. Es kann auch daran erinnert werden, daß viele Moore im Sommer in den oberen Schichten stark austrocknen können. Durch ein aus Scheuchzeria, Rhynchospora alba, Carex limosa u. ähnl. Sumpfpflanzen bestehendes Moor kann man oft nicht nur mit trocknen Schuhen hindurchgehen, sondern die Sphagna können so trocken sein, daß sie bei jedem Schritte knistern. Auch viele arktische Sümpfe oder Moorgebiete trocknen oft ganz aus. Dieser wechselnde Wasserstand muß anch von großer Bedeutung für die Wasserversorgung der Hochmoorpflanzen $\operatorname{sein}^{2}$ ).

6. Ferner sei darauf hingewiesen, daß die Spaltöffnungen der an feuchten Orten (in Sümpfen, feuchten Wäldern) wachsenden Pflanzen die Transpiration nicht ebenso wie andere Pflanzen regulieren können. Sie behalten offene Spaltöffnungen und transpirieren ununterbrochen gleich stark, bis sie welken ${ }^{3}$ ). Dieses ist vielleicht auch ein Grund für die erwähnten xerophilen Bauverhältnisse.

7. Der bedeutendste Faktor muß doch gewiß in den chemischen Eigenschaften des Wassers in den Böden gesucht werden; in diesen erblicken auch viele Forscher die Erklärung der Tatsachen.

Dachnowski und Livingston ${ }^{4}$ ) suchen die Ursache in chemischen Substanzen, vorläufig unbekannter Art, vielleicht Wurzelsekrete bei

1) Vergl. Journ. of Ecology I.

2) Burns 1911.

8) Stahl 1894 .

4) Livingston 1904; Dachnowski 1908, 1909, 1911, 1912. 
Sauerstoffmangel gebildet oder Toxine durch die Wirkung von Bakterien und Pilzen hervorgebracht, welche die Xeromorphie direkt oder indirekt hervorrufen sollen. Dachnowski hat im Gegensatz zu früheren Untersuchungen gefunden, daß Torfboden sehr reich ist an Bakterien, welche große chemische Stoffumwandlungen verursachen. Sowohl aërobe als anaërobe Bakterien kommen vor.

Andere suchen die Ursache der physiologischen Trockenheit des Bodens in den Säuren, welche man gewöhnlich in Torfböden findet ${ }^{1}$ ); doch nicht immer sind sie vorhanden. Tansley ${ }^{2}$ ) gibt an, das gewisse Typen von Flachmooren neutrale Reaktion geben; Moss und Crampton sagen sogar auch, daß gewisse 'Torfgewässer alkalisch und nicht sauer sind.

Die Frage nach allen Ursachen der Xeromorphie muß also vorläufig unbeantwortet bleiben. In der Tat ist es wohl auch nicht eine einzelne Ursache, sondern mehrere, die mitwirken. In dieser Hinsicht sind z. B. die Untersuchungen von Yapp über Xeromorphose bei Sumpfpflanzen, besonders Filipendula ulmaria, interessant. Er fand, daß bei dieser Pflanze die Keimlinge und Blätter des ersten Jahres kahl sind, aber an den blühenden Pflanzen werden die Sproßteile regelmäßig desto mehr behaart, je höher sie sitzen, sind also oben stärker xeromorph; die Menge der Haare und die Größe der Palisadenzellen werden in den oberen T'eilen im allgemeinen in desto höherem Grade entwickelt, je stärker die Transpiration und die Lichtstärke steigen; die Blätter der unteren Blattrosetten haben noch keine Haare. An den alten Pflanzen sind die unteren Teile hygrophil und mesomorph, die oberen mehr xeromorph. Auch die Periodizität des Jahres macht sich geltend; von Juni oder Juli nimmt die Stärke der Behaarung ab. Mehr oder weniger zeigen andere Arten denselben Wechsel.

Schließlich sei noch hervorgehoben, daß es andere Bauverhältnisse und andere Formen der Blätter als die angeführten gibt, die anscheinend kein xerophiles Gepräge haben oder noch in keinen nachweisbaren Einklang mit den Standorten gebracht werden konnten, z. B. breite, rundliche oder nierenförmige Blätter bei Rubus chamaemorus, Caltha palustris, Comarum palustre, Viola palustris, Hydrocotyle. Hier machen phylogenetische Verhältnisse sich wahrscheinlich geltend; die meisten sind indessen auch xeromorph gebaut. Andere Charaktere entsprechen einem wasserreichen Boden, z. B. die Luftkanäle bei Eriophorum, Cladium u. a.

$\left.{ }^{1}\right)$ Siehe Weber 1902, 1903; Schimper 1898; Cowles 1901; Bruncken 1902 a; Früh und Schröter 1904.

2) Tansley 1909. 
Über die große Variabilität der anatomischen Charaktere bes. bei monokotylen Sumpfpflanzen vergl. Graebner ${ }^{1}$ ). Diese Veränderlichkeit läßt die jetzt von vielen Schriftstellern beliebte Verwendung der Anatomie für die Systematik von Sumpfpflanzenfamilien nur mit größter Vorsicht anwendbar erscheinen.

Die Formationen, welche anf Torf- und Rohhumus vorkommen, können folgendermaßen geordnet werden:

A. Gras- und Krautformationen.

1. Wiesenmoore (Niederungsmoore) bilden oft die erste Entwicklungsstufe und sind den hydrophytischen Formationen am nächsten verwandt (81. Kap.).

2. Die Tussock-Vegetation der antarktischen Gegenden (82. Kap.).

B. Moos- und Flechten-Formationen.

3. Moos-Tundren und Moos-Heiden (83. Kap.).

4. Flechten-Tundren und Flechten-Heiden (84. Kap.).

5. Sphagnum-Moore (Hochmoore) (85. Kap.).

C. Formationen von Holzpflanzen.

6. Zwergstrauch-Moore and -Heiden (86. Kap.).

7. Formation der Kleinstrauchgebüsche (87. Kap.).

8. Wälder auf torfhaltigen Böden (88. Kap.).

Die Reihenfolge dieser Formationen entspricht mehr oder weniger einer Entwicklungsreihe, indem Gras- und Krautformationen wie die Formationen der Thallophyten sich oft in solche von Holzpflanzen entwickeln und dann niedrigere Stockwerke in den Strauch- und Waldformationen bilden. Die Tussock-Vegetation steht etwas fremdartig zwischen den anderen.

Über die Vegetation auf Torf- und Rohhumusböden siehe namentlich das große Werk von Früh u. Schröter 1904. Vergl. auch ferner Weber 1902, 1903. Ramann 1895, 1906; Pound and Clements 1900; Clements 1904; Mac Millan 1893, 1896, 1897; Livingston 1904 usw.; Dachnowski 1912 n. früher; Tansley 1911; Graebner 1895 usw.; Yapp 1909, 1912; Wheldon and Wilson 1907; W. G. Smith and Moss 1903; Moss 1913; Potonié 1908, 1911 (vergl. auch unter Wiesenmoore); P. E. Müller 1887, 1906; Mentz 1912; Carsten Olsen 1914; Hanna Resvoll-Holmsen 1913; Pammel; Roland Harper 1913; Cajander 1913; PreuB 1910; Ljungquist 1914 und viele andere.

1) Graebner 1895 . 


\section{Kap. Wiesenmoore}

Die Wiesenmoore bilden sich oft außen um die Rohrsümpfe herum am Rande stehender oder fließender Gewässer, deren Umfang sie gewöhnlich immer mehr einschränken, indem die Rohrvegetation allmählich fortrückt. Sie stehen in genetischer Verbindung mit der Sumpfvegetation mit offenem Wasser und sind oft durch Übergänge mit dieser verbunden. Sie sind gewöhnlich Schlußglieder der Verlandung und können dann lange Zeit auf großen Strecken die herrschende Vegetation bilden. Sie werden auch mit vielen anderen Namen bezeichnet, z. B. Sumpfwiesen, Seewiesen, Riedwiesen, Sumpfmoore, saure Wiesen, Grünmoore, Grünlandsmoore, Grasmoore, Flachmoore, Niederungsmoore. Der Name Wiesenmoor dürfte der zweckmäßigste sein, da er am wenigsten zu Verwechslungen Veranlassung gibt und die vorherrschende Vegetation am schärfsten kennzeichnet. "Infraaquatische Moore" sind sie auch genannt worden, weil die Torfbildung unter dem Wasser stattfindet ${ }^{1}$ ).

Diese Vegetation braucht eine geringere Wassermenge, als die der Rohrsümpfe. Namentlich tritt weniger offenes Wasser auf; man sieht das Wasser weniger als in den Rohrsümpfen, oft nur periodisch. Das Grundwasser jedoch steht immer hoch. Die Vegetation ist dichter, und ihre Laubsprosse ragen fast ganz in die Luft empor. Das Wasser steht oder fließt langsam; das Gelände ist flach und wagerecht, in arktischen Ländern, in Gebirgen usw. aber auch schwach geneigt.

Im Boden bilden die verflochtenen Wurzeln und Grundachsen einen dichten zähen Torf. Der Boden wird durch die aufgehäuften Pflanzenteile zuletzt (vergl. Kap. 13) moorartig; mächtige Torfschichten können besonders von gewissen Arten gebildet werden, denen sich bisweilen auch Arten der Rohrsumpfregetation, besonders Phragmites, anschließen. Die Pflanzenreste bilden schwarzen, amorphen Torf und sind so zersetzt, đaß sie kaum wiedererkannt werden können; in den jüngeren Hochmooren sind sie besser erhalten. Der Torf ist gewöhnlich dicht, daher naß, meist schmierig, leitet das Wasser schwer, daher kann er oben ganz trocken und in geringerer Tiefe schmierig naß sein (für gärtnerische Kulturen fast unbrauchbar). Torf der Hochmoore ist dagegen fast ganz gleichmäßig feucht oder trocken, weil er das Wasser gut leitet und luft-

1) Der englische Name ist fen; der schwedische kärr, flackmossa; der dä nische Kär, Kärmose. Derselbe Name wird offenbar oft in verschiedenem Sinne ge braucht. Unter Myr versteht man in Norwegen und auf Island im allgemeinen Moor bildungen. Man unterscheidet in Norwegen zwischen Gräsmyr (auch kurz Myr genannt, Sumpfmoore) und Mosmyr (dies sind die Heidemoore). Nach v. Post sind Myr Moore mit Sphagnum und vielen Flechten (also Heidemoore); "die Flechten konkurrieren mit den Moosen". 
reich ist (für gärtnerische Kulturen sehr gesucht). In jüngeren Mooren kann die eigentliche Torfbildung noch recht unbedeutend sein.

Die Wiesenmoore werden mehr oder weniger von mineralreichem (tellurischem) Wasser gespeist im Gegensatze zu den Hochmooren, für welche die atmosphärischen Niederschläge am wichtigsten sind.

Das Wasser ist gewöhnlich neutral oder alkalisch, oft kalkreich, wird aber auch als mitunter stark säurehaltig angegeben. In Hochmooren dagegen ist es immer sehr sauer und kalkfrei resp. kalkarm.

Der Torf der Wiesenmoore ist schwer und sehr reich an Pflanzennahrung (10-30\% Asche), der der Hochmoore sehr arm an Nahrung, unter anderem an Stickstoff, der jedoch der Vegetation nicht immer leicht zugänglich ist. Wahrscheinlich steht hiermit in ursächlichem Zusammenhange, daß hier Pflanzen, die sich durch ihre Blätter Stickstoff verschaffen können, vorkommen: die insektenfressenden Pflanzen. Diese werden bei uns und anderwärts besonders auf Hochmoorboden gefunden; Beispiele: Drosera, Dionaea, Sarracenia, Darlingtonia, Cephalotus.

Flora in Nordeuropa. Die Wiesenmoore werden besonders von grasartigen Pflanzen gebildet, denen viele Dikotylen beigemischt sind. Folgende Familien und Gattungen sind vertreten: vor allem Cyperaceen, namentlich Carex-Arten in großer Anzahl (daher die Namen Grasmoore), Cariceta -; oft bilden die Cyperaceen Rasen („Bulten“ oder "Bülten"), besonders in den dem offenen Wasser nächsten und wasserreichsten Gürteln („Sumpfmoore“), oder auch eine verfilzte Decke; ferner sind Arten von Eriophorum, Rhynchospora, Scirpus, Schoenus u. a.; von Gramineen Aera caespitosa, Agrostis vulgaris, Molinia coerulea; weiterhin Schachtelhalme (Equisetum limosum und E. palustre); von Farnen namentlich Aspidium (Lastraea) thelypteris; Juncaceae, Juncaginaceae (Triglochin palustre), Orchidaceae (Epipactis palustris, OrchisArten u. a.), Umbelliferae (Peucedanum palustre, Angelica und Archangelica), Ranunculaceae (Caltha, Trollius, Ranunculus), Rosaceae (Comarum palustre, Geum rivale u. a.), ferner Menyanthes, Galium palustre, Epilobium palustre, E. parviflorum, Parnassia palustris u.v. a.

Lebensformen. Die krautartigen Pflanzen sind fast alle mehrjährig; einzelne sind zweijährig, aber von einjährigen finden sich nur wenige (meist schmarotzende Rhinanthaceen) außerhalb des aufgewühlten Bodens der Maulwurfhaufen usw. (Saxifraga tridactylites usw.). Oft sind Sträucher eingemischt, namentlich von Salices, Betula nana u. a. Arten, Alnus, Rhamnus frangula, Empetrum, Ericeen u. a., besonders auf den Rasen und den trockeneren Stellen. Unsere Sumpfpflanzen sind vielleicht teilweise Reste aus der Eiszeit, z. B. Saxifraga hirculus und Carex chordorrhiza (vergl. 5. Abschn.). 
Unter und zwischen den höheren Pflanzen gibt es in den Sumpfmooren meist zwei Stockwerke: außer den vielleicht einzeln auftretenden niedrigeren Stauden eine Bodenvegetation von Moosen (Arten von Amblystegium, Hypnum cuspidatum, cordifolium u. a. Arten, Mnium- und Polytrichum-Arten, Paludella squarrosa u. a., aber jedenfalls in den jüngeren Mooren keine oder spärliche Sphagna, später finden sich solche ein, und Übergänge zu den Sphagneta werden gebildet). Die Moose sollen ein untrügliches Kennzeichen dafür sein, daß keine Luftzirkulation in der Erde stattfinde. Sie spielen lange nicht die Rolle wie in den Sphagnummooren. Für Flechten ist es bei uns im allgemeinen zu warm; in arktischen Mooren hingegen finden sie sich bisweilen oft an ganz nassen Stellen (mitunter bestandbildend) beigemischt.

Der Sproßbau der Gräser und Stauden ist in der reichen Flora. sehr verschieden. Eine allgemeine Anpassung kann kaum nachgewiesen werden. Von den tonangebenden Monokotylen bilden einige dichte, hohe Rasen, z. B. Carex stricta, die bisweilen eine Zone außerhalb. der Rohrsümpfe (d. h. näher nach dem Lande zu als diese) bildet und zwischen deren Rasen oft offenes Wasser vorkommt, bis eine andere Vegetation dessen Platz einnimmt ${ }^{1}$ ). Rasenbildende Arten sind, in starkem Gegensatze zur Rohrsumpfvegetation, hier ziemlich häufig, z. B. Carices und einige Gräser.

Arten mit Ausläufern und mit Wanderrhizomen finden sich sehr reichlich (Equisetum palustre, Carex Goodenoughii, C. panicea, C. gracilis, C. acutiformis, Menyanthes etc.). Aus statistischen Untersuchungen Vahls nach der Methode Raunkiärs geht hervor, daß das Wiesenmoor eine Formation ist, in welcher unterirdisch wandernde Kråuter überwiegen ${ }^{2}$ ).

Die Wiesenmoore sind also eine geschlossene Formation, überwiegend aus grasartigen Pflanzen, namentlich Cyperaceen mit spärlichen eingestreuten Stauden und Klein- oder Zwergsträuchern. Physiognomisch werden sie also durch die grasartigen Pflanzen gekennzeichmet. (Von den österreichischen "Sumpfwiesen“ führt Günther Beck an: 34 Cyperaceen, 12 Gramineen, 3 Juncaceen, ferner eine Menge Stauden und Kräuter, wovon 18 Monokotylen sind.) Sie enthalten zur Winterszeit graue, verwelkte Blätter und Sprosse. Der Frühling beginnt wegen des sehr spät in dem schlecht wärmeleitenden Humus auftauenden Bodeneises, wegen der durch vieles Wasser und dnrch Verdunstung hervorgerufenen Kälte des Bodens und wegen der kalten Luft über den Bodeneinsenkungen spät, einige früh blühende Arten z. B. Eriophorum vaginatum ausgenommen, ruht die Vegetation sehr lange.

1) Kerners „Zsombék-Formation"; vergl. Verh. zool.-bot. Ver. Wien, VIII.

2) Raunkiär 1909; Resvoll-Holmsen 1912; Vahl 1911. 


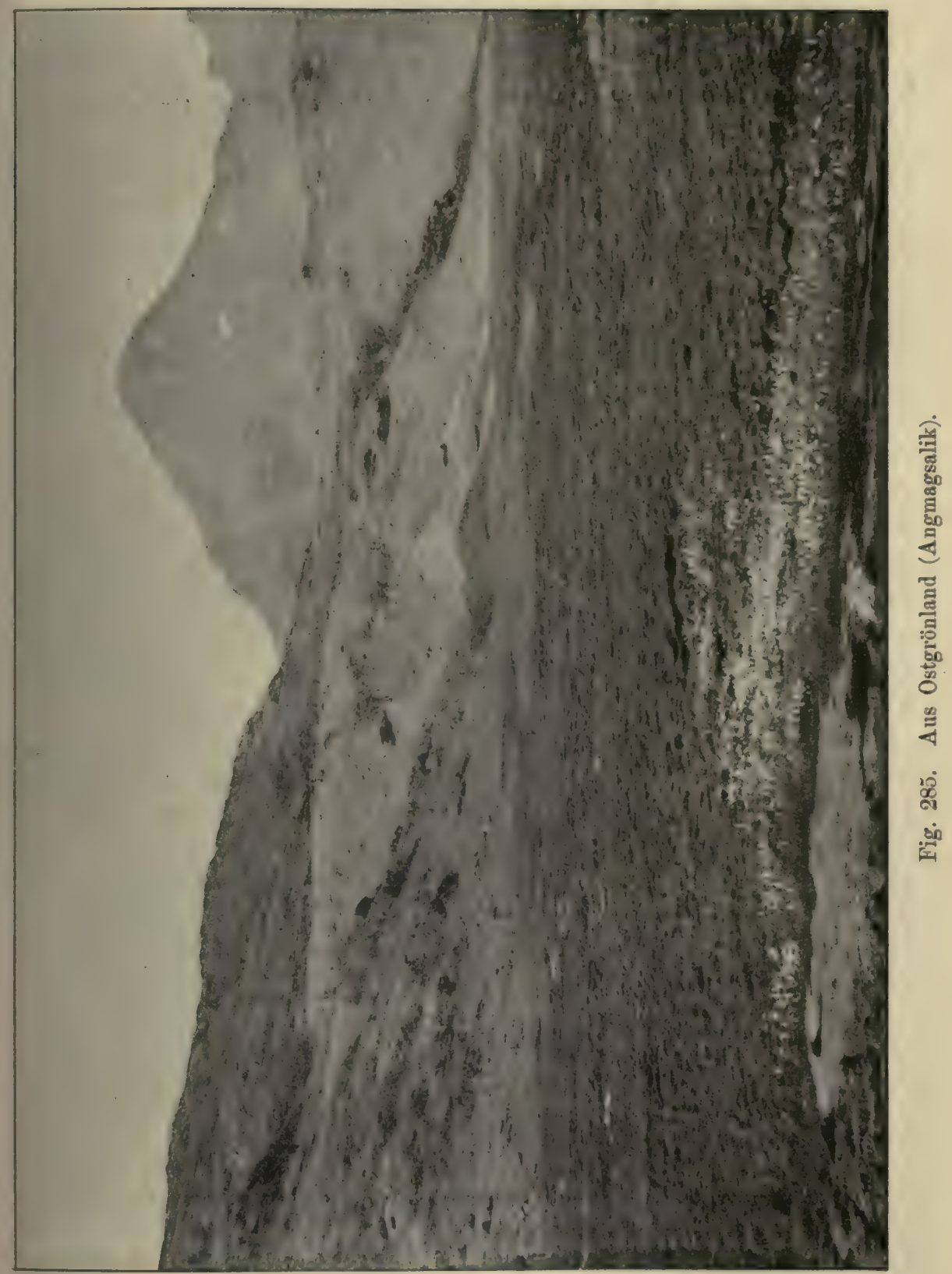

Erklärung zu Fig. 285. Im Vordergrunde ein Wassertümpel von einer Assozintion von Eriophorum Scheuchzeri umgeben. Danach folgt ein Flachmoor mit Horsten von Carex rigida, ferner mit Carex rariflora, Eriophorum Scheuchzeri und Moosen (Amblystegium, Polytrichum, Grimmia, Dicranum u. a.). Zerstreut finden sich Potentilla palustris, Cerastium trigynum, Polygonum viviparum und Salix herbacea. Hinter dem Moor sandige Abhänge, deren Sand durch die Föhnstürme hergeweht ist. (Näheres bei Krunse 1912, 103.) 
Die Assoziationen sind sehr verschieden in den verschiedenen, namentlich in den kalttemperierten und kalten Ländern, wo Wiesenmoore vorkommen, selbst in demselben Lande und an demselben See. Der Sauerstoffgehalt und Wasserreichtum (Tiefe des Grundwassers), Nahrungsgehalt des Bodens wie andere edaphische Faktoren sind hier von Bedeutung. Viele Wiesenmoore sind Halbkulturformationen und werden durch Düngung, Kanalisierung usw. vielfach verändert. Nach den an den einzelnen Orten vorherrschenden Gattungen können die Sümpfe Cariceta, Eriophoreta, Hypneta, Junceta, Scirpeta, Molinieta usw. genannt werden ${ }^{1}$ ), ferner nach den Arten Carex stricta, C. rostrata usw., Cariceta strictae, rostratae usw., Junceta obtusiflori, effusi, compressi, conglomerati, Scirpeta caespitosi usw., Eriophoreta polystachii usw.

Statistische Untersuchungen von Hanna Resvoll-Holmsen ${ }^{2}$ ) zeigen, daß die Torfmoore Norwegens große Unterschiede darbieten, daß in einigen die Cyperaceen die Physiognomie bestimmen, in anderen Zwergsträucher, wie Andromeda polifolia; diese müssen dann zu einer anderen Formation gehören. In Grönland finden sich bis zu den höchsten Breiten hier und da Junceta besonders solche von Juncus arcticus (Hartz 1895) und Eriphoreta Scheuchzeri ${ }^{3}$ ). Auch in den Hochalpen finden sich bisweilen Eriophoreta von derselben Art ${ }^{4}$ ).

Potonié $^{5}$ ) hat sich sehr eingehend mit der Klassifikation namentlich der Torf- resp. Humusablagerungen beschäftigt und deren Nomenklatur durch eine allgemeine Sachverständigenkonferenz besonders für die geologische Kartierung Deutschlands festzulegen sich bemüht. Seiner Einteilung der Torfe und Humusablagerungen (der „rezenten Kaustobiolithe") legt er eine solche der lebenden Humusformationen zugxunde; die Moore teilt er, außer den Hochmooren, folgendermaßen ein:

1. Flachmoore:

A. Verlandung durch Organismen (Sapropel[Faulschlamm]bildung: Seen,

Weiher (Teiche), Meeresküsten, Gezeitenzone.

B. Flachmoorwiesen:

Sumpfflachmoorwiesen,

Strandflachmoorwiesen,

Schwingflachmoorwiesen; Schwingmoore und schwimmende Moorinseln.

1) Stebler u. Schröter 1889-92; Hult 1881, 1887.

2) H. Resvoll-Holmsen 1914, S. 32.

3) Kruuse 1911/1912; Lundager 1912.

4) Rübel 1913.

8) Potonié 1906, 1908, 1911. 
C. Flachmoorwälder:

Sumpfflachmoorwälder,

Strandflachmoorwälder,

Schwingflachmoorwålder.

2. Zwischenmoore:

Birkenmoore,

Birken-Kiefernmoore,

Zwischenmoornadelwälder.

Eine besondere Form der Wiesenmoore sind die Schwingmoore, deren Boden "schwingend" ist, weil er auf dem Wasser schwimmt. Außer einer Anzahl von Moosen (Hypnum-Arten, Aulacomnium palustre, Mnium-Arten, Paludella squarrosa usw.) findet man hier besonders Aspidium (Polystichum) thelypteris, Carex limosa, C. lasiocarpa, C. chordorrhiza u. a., Scirpus trichophorum (Eriophorum alpinum), E. gracile u. a., Malaxis paludosa, Menyanthes trifoliata u. a. Blütenpflanzen ${ }^{1}$ ).

Moossümpfe. Bisweilen überwiegen die Moose (Aulacomnium, Hypnum cuspidatum u. a. Arten, Polytrichum) die Blütenpflanzen. Es entstehen dann dichte, weiche Moosteppiche mit sparsam eingestreuten Blütenpflanzen, Lycopodien und Flechten. Solche Moossümpfe finden sich in arktischen Ländern ${ }^{2}$ ), müssen vielleicht als eine eigene Vereinsklasse aufgestellt werden, die den Moostundren nahe stände, und gehen jedenfalls in diese wie besonders in die Sphagnummoore über, d. h. sowohl in Polytrichum- als in Sphagnum-Tundren.

Hieran lassen sich wohl die Quellmoore anschließen. In Nordeuropa trifft man oft am Fuß von Anhöhen oder in den Tälern Areale, wo Wasser hervorquillt, ohne daß von einer eigentlich strömenden Quelle die Rede sein kann. Langsam tritt das Wasser aus den wasserführenden Erdschichten. Die Oberfläche ist oft schwach uhrglasförmig gewölbt oder auch deutlich an der Berglehne ansteigend.

Diese "Quellmoore" sind sowohl von Geologen (Wahnschaffe, Potonié) als Botanikern (in Dänemark A. Mentz) ${ }^{3}$ ) besprochen worden. Sie haben eine eigentümliche Flora, sowohl von Moosen als von Gefäßpflanzen. Von den Moosen ist in Dänemark und auch anderwärts am meisten charakteristisch Paludella squarrosa; mit ihr kommen vor: Philonotis fontana, Acrocladium cuspidatum, Climacium dendroides, Gymnocybe palustris, Arten von Hypnum, verschiedene Sphagnum-Arten. Von den Gefäßpflanzen besonders Arten von Carex (C. limosa, C. Goode-

1) Die Floren der Moore Ostpreußens siehe H. Groß 1.912.

2) „Wiesenmoore" bei Brotherus; Warming 1887; Porsild 1902; Dusén 1905; Rikli 1910.

A. Mentz 1912 . 
noughii, C. diandra, C. canescens, u. a.), Eriophorum, Agrostis, Caltha, Comarum, Menyanthes, Pedicularis silvatica, Viola palustris usw.) ${ }^{1}$ ).

Allmählich, wenn man weiter landeinwärts geht, verändert sich die Vegetation mit der größeren Tiefe des Grundwassers; es kommen Übergänge zu den Süßwiesen vor (Kap. 69) ${ }^{2}$ ) (vergl. Abromeit). Andererseits gehen die Moorwiesen auch in Hochmoore über, indem die Sphagna nach und nach zahlreicher werden und zuletzt den Boden beherrschen. Früh spricht von "Mischmooren", als sehr allgemein in der Schweiz vorkommend, wo das Flachmoor von Hochmoor überlagert ist und einen flachen durchtränkten Saum um die gewölbten Hochmoore bildet.

In einigen Mooren können sich recht dichte Saliceta entwickeln, aber diese sind wohl dann eigentlich alte Moore.

Wiesenmoore finden sich in den meisten Teilen der Erdoberfläche, selbst in arktischen Ländern, z. B. am Weißen Meere ${ }^{3}$ ). Oft findet man Übergänge zwischen ihnen und den Sumpfgebüschen oder Sumpfwäldern. Als Beispiel sei eine Form der Sumpfwiese erwähnt, die Adamovie ${ }^{4}$ ) aus Serbien beschreibt: Hier werden Assoziationen gebildet von Salix pentandra und Betula pubescens, welche vom Grunde an reichlich verzweigt sind und niemals Mannshöhe erreichen. Zwischen diesen Sträuchern erscheinen kleinere Gruppen von Phragmites und Typha latifolia und unter den den Boden bedeckenden Pflanzen befinden sich Calamagrostis lanceolata, Avena mufescens, Cirsium palustre, Succisa praemorsa (S. pratensis), Caltha palustris, Trollius Europaeus, Polemonium coemuleum und andere.

Wiesenmoore kommen z. B. auch im östlichen Paraguay vor, wo der Grundwasserstand hoch ist. Die dichten Horste der Gräser finden sich nur vereinzelt, in mehr oder weniger weiten Abständen voneinander; gewöhnlich sind die Gräser und Cyperaceen klein; ihnen schließen sich krautige Arten aus anderen Familien an, z. B. Eriocaulaceen, Drosera. auch Sphagna ${ }^{5}$.

Übrigens ist noch wenig über ihr Vorkommen und ihre Ökologie in anderen Weltteilen bekannt ${ }^{6}$ ).

1) Die Quellmoore Ostpreußens siehe H. Groß 1912. Siehe auch oben S. 390.

2) Die Wiesen aus Gramineen schließen sich eng an die Cariceten an. Die ihnen zuträglichste Wassermenge ist vermutlich $60-80 \%$, während sich Saatfelder mit 40 bis $60 \%$ begnügen. Die Cariceten haben eine größere Wassermenge als $80 \%$. Der Wasserspiegel der Wiesen steht im Sommer in 15-30 cm Tiefe.

3) Pohle 1903, 1907.

4) Adamović 1898 .

b) Gaßner 1913.

6) Bews erwähnt aus Natal „March"-bildungen, welche vielleicht Wiesenmoore sind. - Litteratur über Wiesenmoore: Mentz 1910, 1912; Vahl 1911; Eriksson 1912; Rübel 1911-12; GroB 1912; Alb. Kurtz 1912; Hanna Resvoll-Holmsen 1914. Nach 1914: Wangerin. 


\section{Kap. Tussock-Vegetation}

"Tussock" bedeutet im allgemeinen eine Vegetation von dichten, hohen Horsten von Gräsern und Halbgräsern. Der Name wird besonders verwendet für eine Assoziation der antarktischen Inseln und anderer Gebiete. Gräser verschiedener Arten bilden mächtige Bulten, Rasen oder Horste von $1-2 \mathrm{~m}$ Höhe. Der Sockel wird von den abgestorbenen Stengel- und Blattmassen gebildet, ganz wie bei Carex stricta in Europa; dieser kompakte Sockel wird von zahlreichen Grundachsenzweigen und Wurzeln durchzogen, und alte Sockel werden auch von anderen Pflanzen besiedelt.

Die Arten sind namentlich folgende: Auf den subantarktischen Inseln südlich von Neuseeland ist an vielen Stellen die bis $11 / 2 \mathrm{~m}$ hohe Poa litorosa die leitende Tussockpflanze, an anderen Poa foliosa, P. fabellata oder $P$. anceps. In Neuseeland kommen in dem östlichen Steppenklima "Steppen" von Tussockgräsern vor (Danthonia, Triodia) und sind hier Schlußassoziationen. Auf Südgeorgien tritt Poa flabellata auf und bildet auf weite Strecken reine Assoziationen, in denen die Horste so dicht stehen, daß nur wenige Pflanzen zwischen ihnen wachsen können. Eine

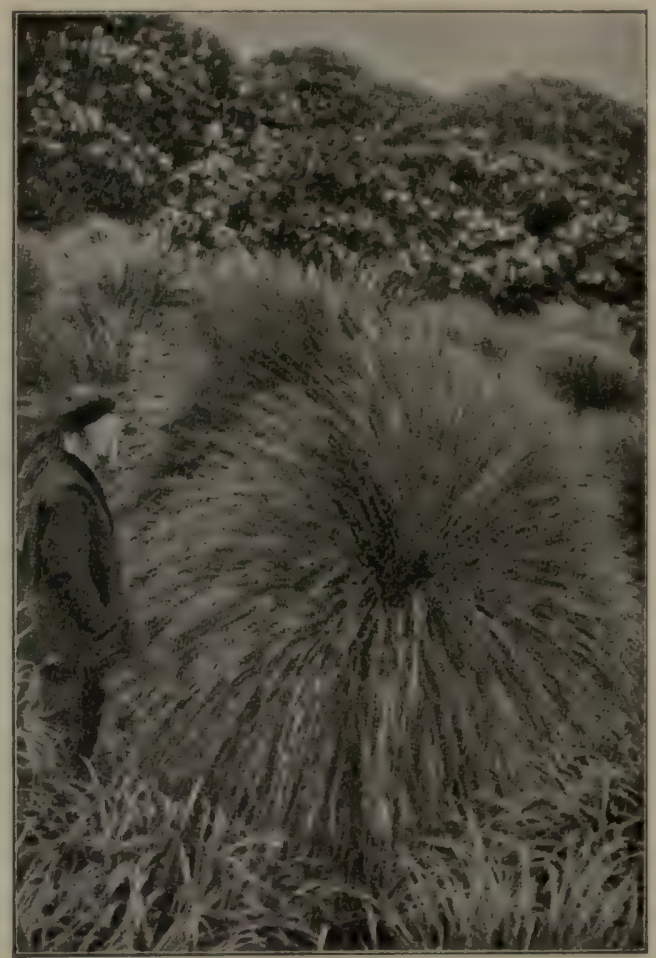

Fig. 286. Tussock-Formation in Neu-Seeland; Bestand von Poa litorosa, ganz vorn Carex ternaria, im Hintergrunde Olearia Lyallii (Cockayne). ähnliche Schilderung der Tussock-Vegetation auf dem Graham-Lande gibt skottsberg ${ }^{1}$ ), der Poa flabellata als eine halophile Art betrachtet, da sie auf die Nähe des Neeres beschränkt ist und gegen die binnenländische (iras-Tundra scharf abgegrenzt ist. Er erwähnt, daß, wenn ein TussockHorst stirht und dekomponiert wird, Moose, Acaena und andere Pflanzen einwandern, welche für eine Zeit den Platz aufnehmen, bis ein anderer Horst das Loch ausfüllt.

1) Skottsberg 1912. 
Die Tussockassoziationen sind offenbar sehr verschieden und müssen vielleicht später anderen Formationen zugeteilt werden; einige scheinen den halophytischen Formationen nahe zu kommen, und wachsen z. B. auf Strandfelsen, andere haben einen ausgeprägten Torfboden, wieder andere schließen sich den alpinen Heiden an und finden sich auf Abhängen des Binnenlandes. Skottsberg schreibt, daß Poa flabellata und Festuca erecta auf Graham-Land „eine Art Moorformation bilden".

Cockayne nennt die Poa foliosa-Assoziation „a meadow", eine Wiese; diese Formation muß indessen von unseren europäischen Wiesen sehr verschieden sein, wie das Folgende zeigt. Cockayne beschreibt die Tussock-Formation von Neuseeland etwa folgendermaßen: Die Oberfläche des Bodens ist ein sehr nasser Torf, der an vielen Orten einen echten Sumpf bildet. Die Tussock-Wiese ist keineswegs eine einheitliche Formation, sondern ändert so sehr in der Zusammensetzung und in der Physiognomie $a b$, daß sie in verschiedene Subformationen geteilt werden muß. Eine von diesen ist

(a) Der Tussock-Abhang am Meere. Vom steilen Abhang des Ufers aus weichem, nassem und schwammigem Torf erhebt sich eine dichte Masse von Tussocks in etwa $15 \mathrm{~m}$ Höhe, welche auf dicken Sockeln so dicht nebeneinander wachsen, daß es schwer ist, zwischen ihnen zu gehen. Diese Tussocks bestehen hauptsächlich aus Grasarten, wahrscheinlich Poa anceps. Gemischt mit diesen Tussocks sind andere von Poa foliosa und Carex trifida.

(b) Flache Tussock-Wiese, würde vielleicht besser unter den Heiden angebracht werden". Der schlecht drainierte Boden, arm an Nährstoffen, das reichliche Vorkommen von Flechten und Bärlappen, die verkümmerten Büsche von Coprosma und die halbxerophytischen Farne sprechen sicher für ihre Zugehörigkeit zu den Heiden. Auf der anderen Seite scheint die Anwesenheit eines Grases als vorherrschende Pflanze sie in die Gesellschaft der Wiesen zu verweisen. Die Oberfläche der Wiese besteht im wesentlichen aus lockerem braunem Torf. $\mathrm{Zu}$ den häufigsten Pflanzen hier gehören Blatt- und Strauchflechten, verschiedene Arten von Moosen und Lebermoosen.

Diese Ausführungen Cockaynes genügen, um zu zeigen, daß es sich dabei um eine Formation mit saurem Torf handelt. Sie steht aber den von der nördlichen Halbkugel beschriebenen Formationen so fern, daß sie nicht mit einer derselben zusammen in eine Gruppe gebracht werden kann.

Auf anderen Neuseeland benachbarten Inseln wird die TussockFormation im allgemeinen von Poa foliosa, Danthonia bromoides und Carex trifida gebildet.

Die Assoziation von Poa litorosa von der "Antipoden-Insel" be. schreibt Cockayne als so dicht, daß es kaum möglich ist auf dem nassen 
torfigen Boden sich zwischen den Horsten hindurchzudrängen; es ist viel leichter über sie hinweg zu wandern, indem man von dem einen zu dem anderen springt. Die Vegetation der ganzen Insel erhält ihr Gepräge durch die Tussocks. - Ein Farnkraut (Aspidium [Polystichum] vestitum) kann reichlich mit den Tussocks auftreten, und unter diesen beiden Arten wachsen viele niedrige Pflanzen. Der Boden kann aus einem so weichen, losen, braunen Torf bestehen, daß ein Stock tief hineingesteckt werden kann.

In Patagonien, Süd-Georgia, ebenso auf den Falkland-Inseln und anderen subarktischen Inseln kommt die Tussock-Formation vor. S. Birger hat die Tussock-Formation der Falkland-Inseln beschrieben. Sie kann hier ausgedehnte Strecken überziehen; die Tussocks erreichen eine Höhe und einen Durchmesser von mehr als $2 \mathrm{~m}$. Die einzelnen Horste sind voneinander durch so weite Zwischenräume getrennt, daß ein Mann sie durchschreiten kann. Diese Zwischenräume werden durch Seelöwen erzeugt und im Inneren eines "Tussock-Waldes" („tussockforest") findet man ein reiches Tierleben. Wo die Tussocks zusammenschließen, herrscht Poa flabellata vor. Das Tussock-Gras von Süd-Georgia ist ebenfalls Poa flabellata; es erreicht eine Höhe von 1,5 m; der große Horst zeigt grangrüne Blätter, welche, obwohl 1 bis $2 \mathrm{~m}$ lang, sehr stark dem Winde widerstehen; sie erheben sich auf dicken, torfigen Polstern, welche 5 bis 6 Dezimeter hoch sind und von der faulenden Masse der Grundachsen, Wurzeln und Blätter gebildet werden. Auf dieser Insel beginnt die Tussock-Formation an der Küste an der oberen Grenze der Gezeitenzone und zieht sich ununterbrochen hin bis zu einer Höhe von annähernd $300 \mathrm{~m}$, und an den geschützten Nordabhängen bedeckt sie weite Flächen ohne Unterbrechung. Die einzelnen Polster sind voneinander durch Zwischenräume getrennt, welche durch die bogenförmig darüberragenden Blätter des Tussock völlig zugedeckt $\operatorname{sind}^{1}$ ).

Was in unserer nordischen Natur wohl der Tussock-Vegetation am nächsten kommt, sind die Moore, in welchen rasenförmige Cyperaceen die Hauptmasse bilden. Ein Bild von solcher Vegetation gibt die von Ostgrönland von Kruuse abgebildete (Fig. 285). Im Vordergrunde sieht man eine Wasserlache, ungeben von einem Eriophoretum Scheuchzeri, und zwischen diesem und den sandigen Halden am Fuße der Berge auf dem flachen Boden liegt ein solches Rasenmoor ("Tue-Kär" bei Kruuse), hauptsächlich bewachsen mit Carex rigida, C. rariflora, Eriophorum Scheuchzeri, Moosen (Amblystegium-, Polytrichum-, Grimmia-, Dicranum-

1) Uber Tussock-Assoziationen anf Neuseeland und den umliegenden Inseln vergl. Cockayne 1904, 1909, 1910. Über Süd-Georgien und die Falklandinseln siehe S. Birger 1906; Skottsberg 1909 b, 1912. 
Arten und in den Rinnen Anthelia pilacea). Von Gefäßpflanzen können ferner genannt werden: Potentilla palustris, Cerastium trigynum, Polygonum viviparum und Salix herbacea. Ähnliche Rasenmoore sind gemein in Grönland; die Rasen sind $10-30 \mathrm{~cm}$ hoch, durch ca. $10 \mathrm{~cm}$ breite Furchen getrennt, in welchen das Wasser im Frühling und Herbste stagniert. Im Winter sind sie mit Schnee bedeckt, der erst im Frühling verschwindet; das Schmelzwasser hält sich lange zwischen den Bulten und friert jede Nacht zu Eis. Die Rinnen sind im Sommer schwarz ron den Amblystegien und Hypnen, selten von Sphagnum (teres und riparium) angefüllt. Viele andere Blütenpflanzen als die genannten können eingestreut sein ${ }^{1}$ ).

In der Tracht der Tussock-Vegetation recht ähnliche Bestände, nur niedriger, bilden in Deutschland usw. die Schoenus-Arten; auch die ökologischen Verhältnisse scheinen ähnlich zu sein.

\section{Kap. Moostundren, Moosheiden}

Tundren werden die großen, flachen oder schwach welligen, waldlosen Gebiete in Sibirien und Nordrußland genannt; jedoch nennen die Finnen jede waldlose, offene Strecke, z. B. von Wald entblößte Berggipfel, eine Tundra. Auch die "barren grounds“ in Nordamerika sind wahrscheinlich teilweise jedenfalls "Tundren" im finnischen Sinne des Wortes. In der Phytogeographie bezeichnet der Ausdruck lediglich baumlose moorähnliche Pflanzengenossenschaften im polaren Klima. Die Tundra erhebt sich vom arktischen "Fell-field“, wenn die Moose oder die Flechten die Oberhand über alle anderen Pflanzen bekommen und eine ununterbrochene weiche Decke bilden. Übergangsstadien zwischen "Fell-fields" und Tundra hat Porsild ${ }^{2}$ ) aus Grönland beschrieben.

Boris Keller ${ }^{3}$ ) erwähnt viele Varianten von Tundren; z. B. Tundra lapidoso-lichenosa, T. herboso-lichenosa, T. fruticoso-hylocomiosa usw.

Während der Eiszeit waren die mittleren, unvereisten Teile von Europa wohl echte Tundren ${ }^{4}$ ).

Nach Middendorf ${ }^{5}$ ) ist die Tundra stets von nassem Boden und feuchter Luft begleitet; das ausschließliche Überwiegen von Sumpfboden ist charakteristisch für die Polargebiete. Als erste Ursache hierfür müssen wir die kurze Dauer der schneelosen Jahreszeit ansehen, verbunden mit niedriger Temperatur im Sommer und häufigem Nebel. Der

1) Kruuse 1912 .

2) Porsild 1902. Utber den Begriff Tundra siehe Sernander 1898, Pohle 1907.

3) B. Keller 1914.

4) Vergl. auch C. A. Weber 1903 usw.: Graebner 1912.

5) Middendorf 1867. 
arktische Sommer ist dem Frühling der gemäßigten Zonen ähnlich; im Winter überwiegt dagegen große Lufttrockenheit. Die Verdunstung ist gering, der Boden ist naß und in den Polarländern gibt es keine warme Jahreszeit, während der der Boden trocknen könnte. $\mathrm{Zu}$ diesen klimatischen Faktoren kommen edaphische hinzu, besonders das Bodeneis, welches das Versickern des Wassers verhindert. Bodeneis ist nicht die Hauptursache der Versumpfung, wie schon durch die Tatsache gezeigt wird, daß der größere Teil des nordrussischen Waldgebietes sumpfig ist, trotzdem dort kein Bodeneis ist. Hier ist aber auch während des kurzen Sommers die Zeit zu kurz für den Abfluß des Wassers. An

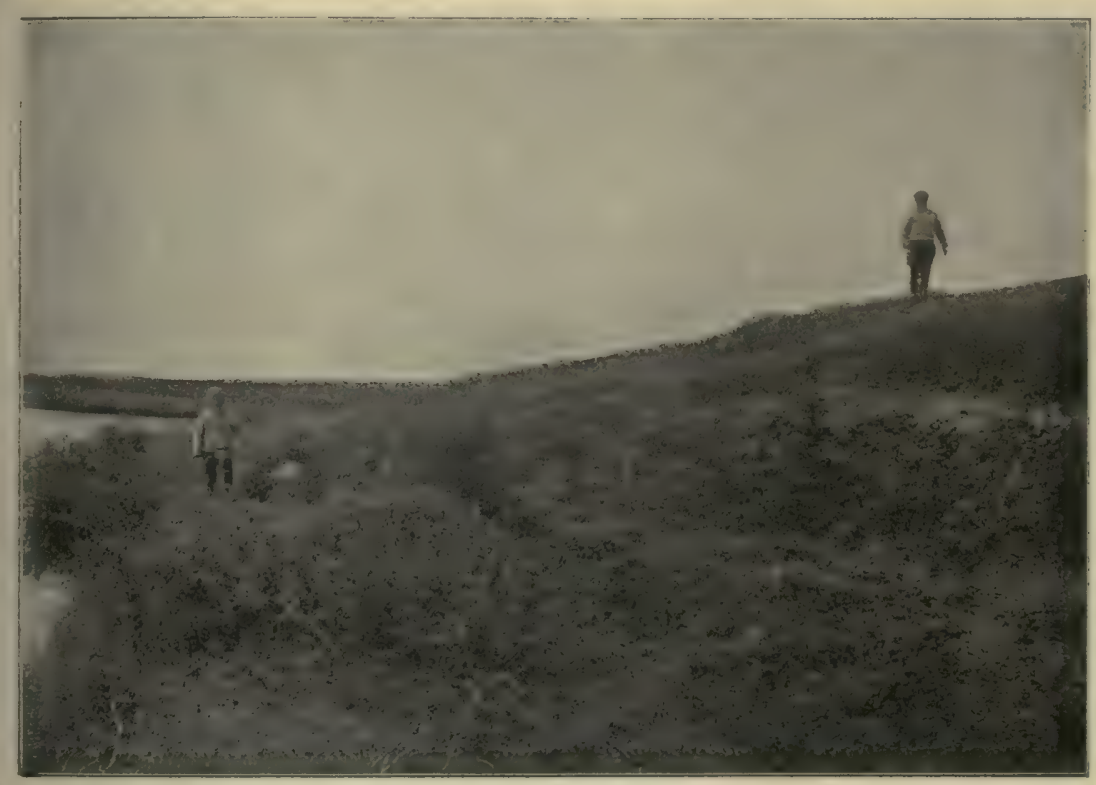

Fig. 287. Torfhügel in der Tundra am Ufer eines Sees.

Die höckerige Tundra besteht ganz aus solchen Hügeln oder Höckern, die eine Höhe von 2-3 m erreichen. (Phot. Tanfiljew.)

steil geneigten Abhängen ist das Abfließen des Wassers erleichtert und die Moorbildung ist daher auch gehemmt. Dies erklärt auch, weshalb in Gebirgsländern wie Grönland die Tundren nur ein kleines Gebiet bedecken, während sie sich in Sibirien nahezu über das ganze Land erstrecken. Nach Porsild ${ }^{1}$ ) kommt in Grönland die Moostundra auf Felsen in Senkungen im Terrain vor, auf horizontalen, nicht-drainierten Terrassen der Basaltklippen, auf den flachen Vorgebirgen unter den Basaltklippen und auf den flachen feuchten Moränen. Der Boden ist kalt, besonders wenn das Bodeneis in der Nähe der Oberfläche liegt.

1) Porsild 1902.

Warming-Graebner. 3. Auflage, illustr. 
Pohle, der so vorzügliche Schilderungen der arktischen russischen Vegetation gegeben hat ${ }^{1}$ ), schreibt von den Tundramooren auf Kanin, daß sie sich unter dem Einflusse häufiger Nebel, überhaupt großer Luftfeuchtigkeit bilden. Rohhumus oder Torf entsteht unter diesen Verhältnissen und wird von Moosen, namentlich Polytrichum- und Dicranum-Arten, Flechten, verschiedenen Zwergsträuchern (Salices, Arctostaphylos alpina, Halmgewächsen u. a.) gebildet, besonders aber von Rubus chamaemorus, der viele Buckel vollständig bedeckt und andere Gewächse mit seinem üppigen Geblätt unterdrückt.

Nach Pohle spielen die Sphagna nicht die führende Rolle nördlich der Waldgrenze, wie etwa in den südlicheren Breiten der Nadelwaldzone. Sie sind den klimatischen Einflüssen nicht mehr gewachsen und werden von anderen Pflanzen überflügelt. Es sind namentlich Polytrichum und Dicranum, welche assoziationsbildend sind; in ihren geschlossenen Rasen leben auch verschiedene Gefäßpflanzen (Stauden, Gräser, Zwergsträucher), ganz wie in den Sphagneten in südlicheren Breiten.

Die Moostundra der Halbinsel Kola ist von Kihlman beschrieben; in diesem Distrikt ist die Tundra ebenso wie die im vorigen Abschnitt beschriebene von Tanin aus zwei Formationen, Torfhügelchen und Lachen, zusammengesetzt.

In den Tundramooren tritt nach Pohle durch Ungleichheiten im Boden eine Differenzierung ein, indem die schwerer verwesenden organischen Reste Erhöhungen schaffen; unter Mitwirkung von Winden und Schmelzwassern, welche hier Material abtragen, und es dort wiederum anfügen, schließen sich Hügel zu Torfrücken aneinander, erweitern sich die Vertiefungen zu Lachen und Teichen. Die Torfhügel sind isolierte hügelige Gebilde von kalottenförmiger Gestalt, oft mehrere Meter hoch, welche einen ewig gefrorenen Kern haben und wie alle Erhöhungen in der Tundra der austrocknenden Wirkung der Winde in erhöhtem Maße ausgesetzt sind und deshalb nur xeromorph organisierte Gewächse tragen können (Fig. 287).

Die Torfhügel erheben sich bis zu Höhen von 2 bis $3 \mathrm{~m}$ über die Oberfläche der Umgebung. Pohle ${ }^{2}$ ) ist der Meinung, daß Torfhügel ganz normale Bülten von Moos sind, die im Laufe. von Jahrhunderten oder Jahrtausenden sich durch allmähliches stufenweises Wachstum erhoben haben ${ }^{2}$ ). Die Torfhügel sind während des Winters von Schnee entblößt, während die umgebenden niedrigeren Teile davon erfüllt sind. Infolgedessen zeigen sich dort Verschiedenheiten im Boden. Wo der Schnee tief liegt, kann die während des Winters vorherrschende niedrige

1) Pohle 1907.

2) Pohle 1903. 
Temperatur nicht tief in den Boden eindringen; dieser bleibt dadurch verhältnismäßig warm und taut schnell auf, nachdem der Schnee geschmolzen ist, so daß sich also an solchen Orten kein Bodeneis findet. Auf der anderen Seite wird an den Stellen, wo die Schneedecke dünn ist oder ganz fehlt, der Frost tief in den Boden eindringen und es bildet sich Bodeneis, welches in dem kühlen Sommer in tieferen Lagen nicht auftauen kann. Das Bodeneis schmilzt im Torfboden mit der größten Schwierigkeit (wie ja auch bei uns im Frühjahr in den Hochmooren) und deshalb bleibt es in den kalten Klimaten während des ganzen Sommers oft in einer Tiefe von wenigen Zentimetern erhalten.

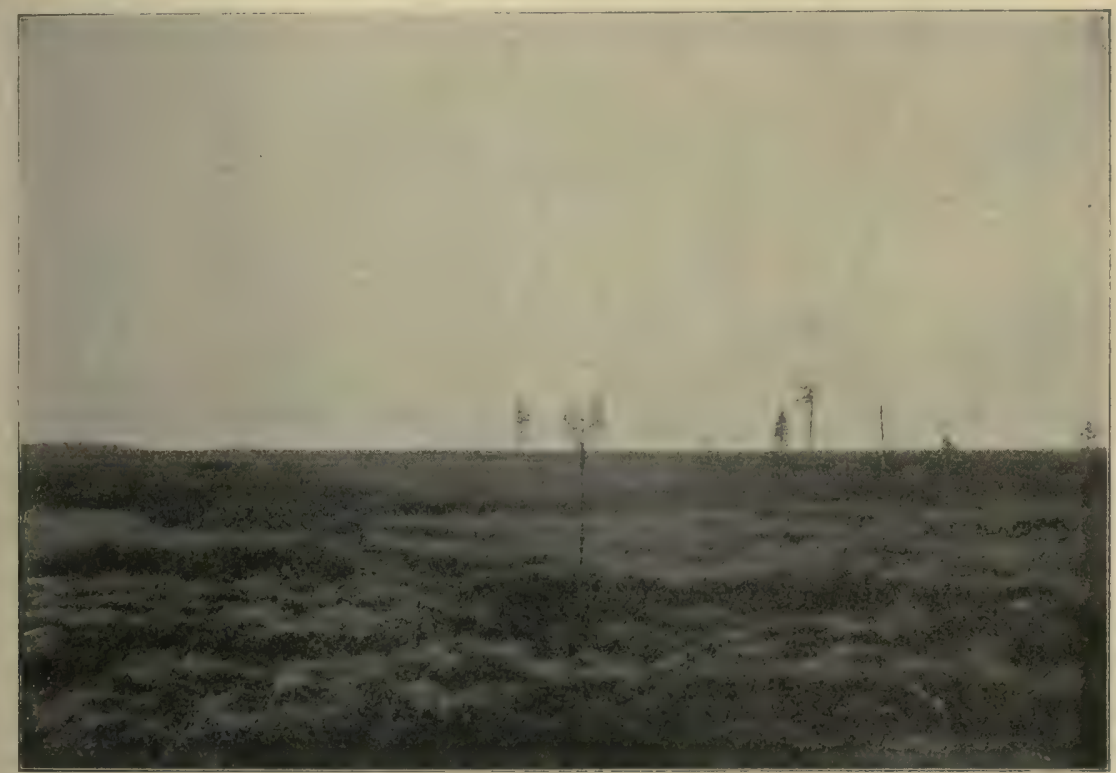

Fig. 288. Ein Sphagnummoor im Waldgebiet an der Grenze der Tundra.

Bewachsen mit Sphagnum, Betula nana, Rubus chamaemorus (blühend; die weißen Punkte im Vordergrund sind Blüten von $\boldsymbol{R}$. ch.). Anf dem Moor einige Kiefern. (Phot. Tanfiljew.)

Die Vegetation der Torfhügel ist ausgesprochen xerophil. Arten von Sphagnum kommen nur spärlich vor, während Arten von Polytrichum. reichlich vorhanden sind in der Gestalt großer Moose, deren aufrechte Stämme dicht gedrängt stehen und so einen weichen flachen Teppich bilden. Selbst wenn der Boden, auf welchem sie wachsen, von schmelzendem Schnee unter der Oberfläche sehr naß ist, kann er durch die Sommersonne oberflächlich ausgetrocknet sein und dadurch hart werden. Während des Winters, wenn die größte Lufttrockenheit über der nordischen Tundra herrscht, werden die Pflanzen durch die Winde ausgetrocknet. Die Polytricha können in ihren dichten Polstern Wasser 
festhalten, aber trotzdem zeigen sie eine xeromorphe Struktur; einige Arten haben Blätter, die, wenn sie trocken sind, ihren Rand umrollen können, so daß derselbe sich über das Assimilationsgewebe legt. Mit den Polytrichen bilden Dicranum elongatum, D. tenuinerve und andere Dicranum-Arten dichte feste Polster; eingemischt in diesen luftabschließenden Teppich von Rohhumus erzeugenden Moosen sind Arten von Hylocomium, Hypnum, Rhacomitrium, Jungermannia und andere Bryophyten, Flechten, Zwergsträucher, so Empetrum, Betula nana und Vaccinium myrtillus, dazu auch Kräuter, die zu den Arten der Felsenfluren („Fell-fields“) gehören.

Moose sind befähigt das unwirtliche Gebiet $\mathrm{zu}$ besiedeln, nicht allein durch ihre Fähigkeit auszutrocknen und bei Wiederbefeuchtung weiter zu leben, sondern auch durch ihre Unempfindlichkeit, die sie befähigt schon bei niedrigen Temperaturen $\mathrm{zu}$ assimilieren; darin sind sie den meisten Blütenpflanzen überlegen.

Die Senkungen führen kein Bodeneis; der Boden ist, wie schon oben betont, nicht so kalt wie der in den Torfhügeln, und in der trockenen Jahreszeit sammelt sich hier das Wasser. Hier kann die Formation des Sphagnum-Moores, wie es eigentlich der gemäßigten Waldregion eigentümlich ist, in die Tundra einwandern. Diese Sphagnum-Moore dehnen sich aber nicht weit über die Waldgrenze aus. In den TimanBergen und in asiatischen Tundren sind sie nur spärlich zu finden, weiter nördlich fehlen sie ganz.

Die Torferzeugung in der Tundra ist sehr verschieden. Pohle ${ }^{1}$ ) sah in Nordrußland Lagen von mehr als 6 m Dicke. Nach Kihlman ${ }^{2}$ ) überwiegt auf der Halbinsel Kola nicht so sehr die Bildung von Moostorf, als die von Rohhumus, der von lebenden Pflanzenteilen durchsetzt ist. Im allgemeinen scheint die Bildung neuen Torfs in der Tundra nicht groß zu sein; im Gegenteil scheint die Tendenz oft rückschreitend zu sein, wie es im folgenden Abschnitt besprochen wird. Der Boden enthält stets reichlich Humussäuren, und diese Eigentümlichkeit trägt sehr wesentlich zur Xeromorphie der darin wachsenden Pflanzen bei.

Rückschreitende Entwicklung der Moostundren. Nach Cajander ${ }^{3}$ ) erleiden die Moore des nördlichen Europa eine rückschreitende Entwicklung; z. B. am Weißen Meere sind sie in ein hügeliges Gelände verwandelt, welches mitunter sehr große Torfhügel aufweist. Cajander ist der Meinung, daß mit zunehmender Ausdehnung oder auch mit wachsender Meereshöhe (in den Alpen) diese rückschreitende Entwicklung deutlicher wird.

\footnotetext{
1) Pohle 1903.

2) Kihlman 1890 .

s) Cajander 1905.
} 
Öfter wird jedoch sicher als rückschreitende Entwicklung seitens der Pflanzengeographen der Zustand angesprochen, der durch einen "Moorbruch" veranlaßt wird. Wenn das wachsende Moor eine gewisse Höhe über seiner Umgebung erreicht hat, kommt es vor, daß die Vegetationsdecke an einem Rande aufreißt und dann die ganze innere Moormasse als zähe schwarze Flüssigkeit reichlich austritt und sich über das niedrigere Gelände wälzt oder talwärts abfließt. Die zurückbleibenden Teile des Moores, namentlich die durch die seitliche Bewegung zerreißende Vegetationsdecke, trocknen natürlich in der Folge stark aus, es bilden sich Vegetationsinseln und zwischen ihnen Taleinsenkungen mit nacktem Torf, der in der Sonne und im Winde zu fliegen anfängt ${ }^{1}$ ).

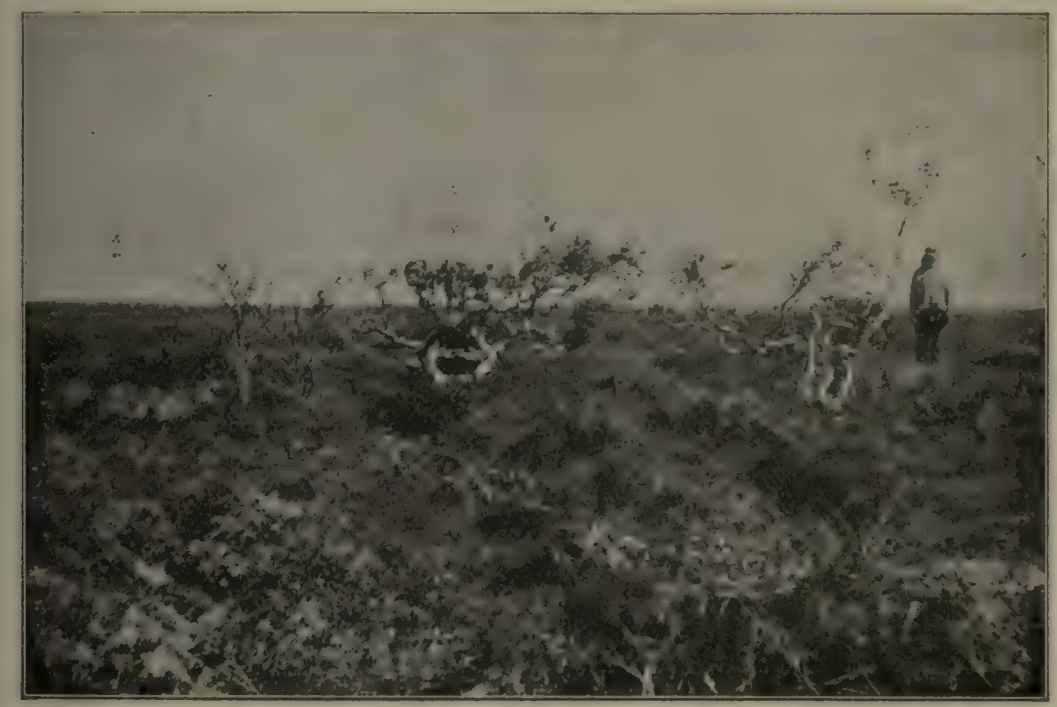

Fig. 289. Tundra mit Birkengestrüpp. (Phot. Tanfljew.)

Auch Simmons ${ }^{2}$ ) spricht von den Moorhügeln in Lappland, welche wesentlich aus Sphagnen und anderen Mooren aufgebaut sind und 0,5 bis $1 \mathrm{~m}$ hoch werden. Auf ihnen sind viele von den arktischen Stauden und Zwergsträuchern zur Entwicklung gekommen. Zwischen den Hügein kommt bisweilen das Grundwasser zum Vorschein, und hier wachsen andere Arten. Diese Hügel werden oft von den heftigen Winden zerstört ${ }^{3}$ ).

Die rückschreitende Entwicklung der Torfhügel, die schon beruihrt wurde, geht nach Pohle auf folgende Weise vor sich. Spalten,

$\left.{ }^{1}\right)$ Vergl. C. A. Weber $1894 \mathrm{a}, \mathrm{b}$; Graebner in Tansley 1913; Tansley 1914.

2) Simmons in Engl. Jahrb. XLIII.

8) Cajander 1910 and Pohle. 
welche durch Frostwirkung entstanden sind, werden durch Regen und Schmelzwasser erweitert; Winde führen dann die gelockerten Torfteilchen hinweg und es können sich durch die Erosion Mulden bilden. Unter günstigen Umständen kann jedoch die Neubildung des Torfes sogleich wieder beginnen.

Eine ähnliche Rückbildung von Torfböden kennt man aus Schottland. Crampton und Macgregor ${ }^{1}$ ) erwähnen, daß Ben Armine mit Torf bedeckt gewesen ist; jetzt sind die Gipfel nackt, Regen und Wind hat den Torf entfernt. Stellenweise spielen in Schottland und Nord-England nach Graebner sicher auch die oben erwähnte Moorbrücke eine Rolle.

Assoziationen. Die physiognomische und die botanische Beschaffenheit der Tundren sind nach den besprochenen sehr wechselnd; namentlich geben Unterschiede in der Bodenfeuchtigkeit innen ein verschiedenes Gepräge. Die trockenste Moostundra, die Polytrichum-Tundra, die im Sommer Austrocknung ertragen kann, gehört zu den ausgesprochen xerophilen Vereinen. Die Dicranum-Tundra schließt sich hier an. Die Sphagnum-Tundra hingegen ist eine mit Wasser beladene denen der Heidemoore sehr verwandte, durch die mangelnde Wärme modifizierte Vegetationsformation (Middendorffs "schwappende Tundra") und findet sich auf den großen, wellenförmigen Flächen, wo das Wasser schwer abfließt. Mit diesen Moosassoziationen wechseln dann seichte, fast pflanzenlose Seen ab.

In der nordischen und der mitteleuropäischen Natur sind es die Moore, die das beste biologische und floristische Bild von den Tundren geben; ein Teil unserer Moorpflanzen sind, wie bereits früher angeführt, vielleicht Relikte der Tundren, die nach der Eiszeit auftraten und den jetzigen Tundren ähnlich gewesen sein müssen ${ }^{2}$ ).

Auf den hohen Bergen von Schweden und Norwegen, auf den Färöern, und so weit man sehen kann auch in anderen kalten und feuchten Gegenden der nördlichen Halbkugel kommen in größerer oder geringerer Ausdehnung Moosassoziationen vor (Moosheiden), die sich besonders auf trocknerem, of felsigem Boden entwickeln. Die Fähigkeit der Moose, einzutrocknen und wieder aufzuleben, wenı Feuchtigkeit eintritt, ihre große Genügsamkeit und ihre Fähigkeit, anscheinend bei sehr niedrigen Temperaturen, eher als die Blütenpflanzen, zu assimilieren, ist schon oben besprochen. Die Moosheiden sind nur eine trocknere Form der Moostundra.

1) Crampton u. Macgregor 1913.

2) Die Tundren Nordeuropas und Sibiriens sind besonders von Middendorff 1867 ; Heuglin 1874; Kjellman 1882; Kihlman 1890; Sernander 1898, 1900; Cajander 19(03; 1905; Pohle 1907; Hanna Resvoll-Holmsen 1913 und Thore C. E. Fries 1913 besprochen worden. Kjellmans „Kärrmark" d. h. Sumpffeld steht offenbar einer Moostundra am nächsten. 
Moosheiden kommen anscheinend am häufigsten nur auf der nördlichen Halbkugel, besonders in Sibirien und Lappland, vor. Heuglin schildert sie von Jugor Shar; auch in Nordamerika und Grönland sind sie bekannt. Sie schließen sich den später zu besprechenden Felsenfluren am nächsten an. Die subglazialen Felsenfluren gehören zu den Tundren im weitesten Sinne und sind eine Abteilung derselben. Moose und Flechten, alles sehr genügsame, mit nährstoffarmem Substrate vorliebnehmende und abgehärtete Pflanzen, sind auf ihnen fast immer in großen Mengen heimisch. Als Moosheiden kann man solche Felsenfluren

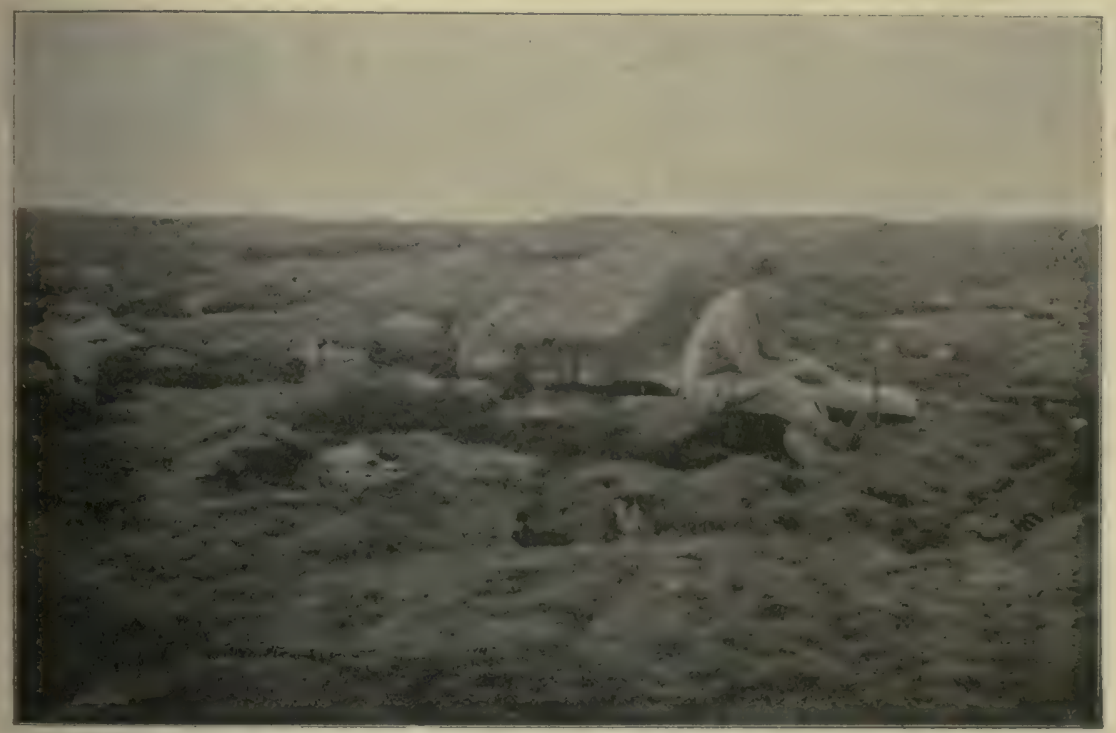

Fig. 290. Grimmia-Heide auf den Färöern, in $768 \mathrm{~m}$ über dem Meere.

Die Oberfläche ist mit einer nur von Steinen durchbrochenen Matte von Grimmia ericoides bedeckt. Diese Formation wird nie unter $400 \mathrm{~m}$ getroffen; sie liebt horizontalen oder schwach abschüssigen Boden, der nicht besonders naß und nicht zu starken Stürmen ausgesetzt ist. In der Matte finden sich andere Moose, Flechten und wenige

Blütenpflanzen. (Der Bryologe C. Jensen sitzend.) (Phot. C. H. Ostenfeld.)

bezeichnen, wo die Moose über alle anderen Pflanzen die Oberhand gewinnen und den Boden ganz mit einer zuammenhängenden, weichen Matte bedecken. Oben wurden die Sphagnum-Tundren erwähnt, die eine sehr nasse Vegetation sind. Die Moosheiden hingegen kommen auf trocknerem Boden vor, besonders da, wo Verwitterungsboden und Moränengrus vorhanden ist. Verschiedene Assoziationen kommen vor.

Die Grimmia-Assoziation ${ }^{1}$ ). Diese Vegetation ist sehr monoton und stellt eine weiche, graulich-grüne Decke von Grimmia hypnoides, seltener von $G$. ericoides, dar, in welche wenige Blütenpflanzen, Flechten

1) Vergl. Ostenfeld $1908 \mathrm{~b}$. 
und andere Moose eingestreut sind (Fig. 290). Diese Assoziation findet sich auf den höchsten sturmgepeitschten Gipfeln, nie unter $400 \mathrm{~m}$ Höhe über dem Meere, auf flachem oder wenig geneigtem Boden. Ähnliche Grimmieta hypnoidis finden sich auf den Lavafeldern Islands ${ }^{1}$ ) (Fig. 291).

Andere Assoziationen sind Dicraneta (elongati, tenuinervi; "Dicranum-tundra"), welche dichte feste Rasen darstellen ${ }^{2}$ ).

Die Polytrichum-Arten bilden auch oft Assoziationen; ihre hohen, aufrechten Stengel schließen dicht aneinander und bilden eine niedrige, weiche Decke. Selbst wenn der Boden, worauf sie wachsen, im Frühjahre durch den schmelzenden Schnee sehr wasserreich ist, wird die Sommersonne ihn doch oberflächlich trocknen können, so daß er hart wird; und im Winter, wenn über den nordischen Tundren große Lufttrockenheit herrscht, sind es die Winde, welche die Pflanzen austrocknen. Die Polytrichum-Moose können, wie auch bereits oben hervorgehoben wurde, in ihren dichten, verfilzten Rasen Wasser festhalten, haben aber trotzdem einen xerophilen Bau.

Diesen Decken von Luft abschließenden, Rohhumus bildenden Moosen sind ähnlich wie bei den Torfhügeln beigemischt: Arten von Hypnum, Grimmia, Jungermannia u. a. Moose, Flechten, Zwergsträucher (Empetrum, Betula nana, Vaccinium myrtillus u. a.) und ebenso Kräuter derselben Arten wie auf den Felsenfluren.

Diese Moosassoziationen schließen sich solchen an, welche auf sehr trockenem Boden, sogar Sandboden wachsen, z. B. in Kieferwäldern, in Dünen; wahrscheinlich ist es die Luftfeuchtigkeit, die ihnen in Verbindung mit ihrer großen Genügsamkeit das Leben auf solchen Standorten erlaubten. In den Alpen soll Polytrichum septentrionale auf verlassenem Gletscherboden Moosteppiche bilden, und z. B. im Ötztal kann man aus Sand und Grus (die von den Bergen herabgespült wurden) bestehende große Flächen sehen, die mit einer weichen Grimmia-Matte nebst eingestreuten kleinen Fichten, Juniperus und Kräutern bedeckt sind.

In den gemäßigten Zonen finden sich seltener entsprechende Vereine auf trocknerem, nährstoffarmem Sandboden ${ }^{3}$ ). Auf solchem Boden kommen in den Heidegegenden Dänemarks Assoziationen vor, welche eine Mittelstellung zwischen Heide und Moor einnehmen; dänische Botaniker nennen sie "Moskär" und scheiden zwischen Sphagnum-Kär, Polytrichum-Kär, Dicranum-Kär und Grimmia-Kär). Ähnliche finden sich in Irland ${ }^{5}$ ) und auf den Faröer ${ }^{6}$ ).

1) Thoroddsen 1914.

2) Sernander 1898.

$\left.{ }^{8}\right)$ Graebner 1895, 1901.

4) Vergl. Börgesen und C. Jensen 1904; Mentz 1902.

3) Pethybridge und Praeger 1905.

6) Ostenfeld 1908 . 
Selbst so südlich wie auf Madeira kommen Grimmia-Assoziationen auf den hohen Bergen auf periodisch überschwemmtem Boden vor, anscheinend ohne daß Rohhumus gebildet wird ${ }^{1}$ ).

Auf der südlichen Halbkugel scheinen auch ähnliche Moosheiden wenigstens sehr lokal vorzukommen. Skottsberg erwähnt mehr oder weniger reine Moosmatten in Graham Land, welche von Brachythecium antarcticum oft mit Hypnum-Arten gemischt auf gut exponierten Abhängen mit reichlicher Wasserzufuhr vorkommen.

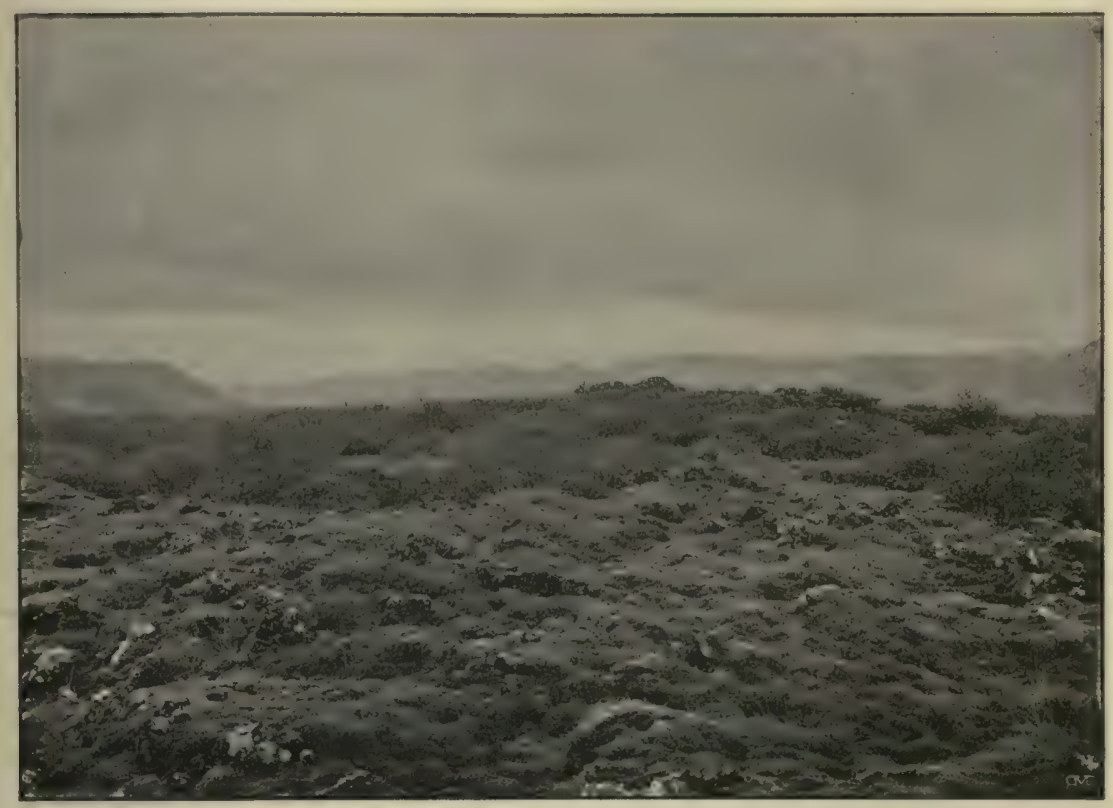

Fig. 291. Lava-fjeld in Nordrárdal im Distrikt des Borgarfjord.

Die Lava ist bis zu einer Dicke von $3 \mathrm{dm}$ mit Decken von Grimmia hypnoides belegt; die herausragenden Teile sind mit Krustenflechten bedeckt; zerstreut Polster von Fesluca ovina; im Hintergrunde Birkengebüsch. (Phot. A. Hesselbo; in Thoroddsen 1914.)

\section{Kap. Flechtenheiden, Flechtentundren}

In der alpinen und subalpinen Region der Gebirge der nördlichen Halbkugel und im Tieflande der arktischen und subarktischen, seltener in kleineren Flächen in den Heidegebieten der gemäßigten Zone, auf den öden Flächen im hohen Norden, in Lappland, Sibirien, Spitzbergen, Island, Grönland und Nordamerika, sowie auch in den südlichsten Gegenden von Südamerika trifft man reine Flechtenassoziationen mit

1) Vahl 1904 b. AuBer den schon genannten Arbeiten vergl. Ramann, Bodenkunde 1895 und 1911; Sernander 1898 und Dusén 1905. 
sparsamer Einmischung von Moosen, grasartigen Pflanzen, Kräutern und Halbsträuchern - Flechtenheiden und Flechtentundren.

Die Flechtenheide ist noch trockner als die Moosheide. Hult ${ }^{1}$ ) gibt für seine Cladina-Formation eine Bodenfeuchtigkeit an, die vermutlich nicht über $40 \%$ betrage ${ }^{2}$, wächst wie die vorige auf nährstoffarmem Boden und kommt besonders in hügeligem, bergigem Gelände vor, wo in geringerer Tiefe Felsenboden auftritt. Eine schwache Schicht von Humus, zunächst von Rohhumus, bedeckt diesen oft und trägt die Flechtenheide. Der Boden ist zwar trocken, aber Luftfeuchtigkeit können die Flechten nicht entbehren; selbst wenn sie es ertragen können, periodisch durch Verdunstung stark auszutrocknen, werden sie doch nur da gut gedeihen können, wo es häufig Nebel, Regen und Tau gibt. Die Abhärtung der Arten ist im übrigen verschieden. Nach Kihlman ${ }^{3}$ ) gibt es mehrere Formen (Assoziationen) der Flechtenheide, welche verschiedene Stufen der Empfindlichkeit bezeichnen, und zwar besonders gegen trockene Winde.

Strauchförmige Flechten gedeihen am besten dort, wo die Luft still und feucht ist, und sind daher seltener im äußersten Norden. Die Cladina-Heide (gebildet von Cladonia rangiferina, $\mathrm{Cl}$. alpestris $\mathrm{u}$. a. mit beigemischtem Sphaerophoron corallioides) ist am empfindlichsten: sie liebt lange Schneebedeckung, erträgt keinen trocknen Wind und sucht daher besonders Einsenkungen im Gelände auf; sie ist übrigens auf allen ausgedehnten, im Binnenlande liegenden alpinen Hochebenen Nordeuropas und des arktischen Amerika gemein. Die Arten der PlatysmaHeide (Platysma cucullatum, Pl. nivale u. a., Cetraria crispa, C. Islandica u. a.) sind mehr abgehärtet. Die besonders aus Alectoria ochroleuca, $A$. divergens und $A$. nigricans bestehende und an Zwergsträuchern reichere Alectoria-Heide ist am meisten abgehärtet. In Übereinstimmung mit diesen Unterschieden in der Abhärtung sind die Standorte, wo die Flechtenheiden vorkommen, verschieden.

Die Heiden dicht wachsender, hoher Strauchflechten sind weiche, dicke Matten, die der Landschaft einen eigentümlichen gelbgrauen Ton verleihen, der selbst von weitem in die Augen fällt. Man findet sie in typischen Formen auf den Fjelden (Hochebenen) Norwegens (z. B. zwischen Gudbrandsdalen und Österdalen), in Lappmark und in Sibirien. In Grönland z. B. sind sie jedoch spärlich und schwach entwickelt (Rosenvinge, Hartz), typisch nur in dem Inneren des südlichsten Teiles, wo sie große Gebiete bedecken können und besonders aus Stereocaulon alpinum und Cladonia rangiferina bestehen. Letztere Art,

1) Hult 1881, 1887.

2) Utber die Lebensform der Flechten vergl. S. 156, 282.

s) Kihlman 1890; vergl. auch Hult a. a. O.; Th. C. E. Fries 1913. 
von der Bevölkerung "Hungermoos" genannt, bildet auch in der Lüneburger Heide usw. Bestände.

Zwischen den Flechten findet man auf der nördlichen Halbkugel Empetrum und Betula nana, Loiseleuria procumbens und andere Ericaceen, Juniperus communis sowie andere kriechende niedrige Strïucher und Zwergsträucher. Verschiedene Kräuter sind in diese Decke spärlich eingestreut (Arten von Lycopodium, Carex, Aera [Deschampsia] Hexuosa, Nardus stricta, Juncus, z. B. J.trifidus, Hieracium, und viele andere Arten), ganz wie in der Moosheide; natürlich sind auch Moose beigemischt. Sowohl die Zwergsträucher als auch die Kräuter sind oft xeromorph, und die Arten dieselben wie in den angrenzenden Felsenfluren; sie bleiben gewöhnlich niedrig und in der Flechtenmatte mehr oder weniger verborgen. Die Ursachen der Xeromorphie werden dieselben sein wie in der Moosheide, d. h. Säure und Kälte des Bodens ebenso wie Wind.

In den antarktischen Ländern scheint die Flechtenheide, hauptsächlich aus Neuropogon Taylori gebildet, auf den höheren Bergen der Kerguelen vorzukommen: sie wächst auch in Südgeorgien mit Sphaerophorus, Stereocaulon Magellanicum, Neuropogon melaxanthus und Sticta Freycinetii ${ }^{1}$ ).

Auf den wagerechten oder welligen Tundrenflächen Nordeuropas, die im Winter durch die Stürme von Schnee rein gefegt werden, gedeihen Strauchflechten schlecht; hier bekommen Krustenflechten das Übergewicht, und namentlich erreicht Lecanora Tartarea eine riesige Aushreitung, z. B. auf den lappländischen Heiden. Hier überwächst sie mit ihren spröden, weißlichen Krusten den dichten Filz der Flechtenheiden, den die trocknen Winde getötet haben ${ }^{2}$ ); ferner kommt sie an mehreren Stellen in Grönland vor, obgleich in weniger großem Maßstabe. Auch in den gemäßigten Zonen sind Flechtenheiden vertreten, allerdings nicht in großer Ausdehnung ${ }^{3}$ ).

Die Formationen nährstoffarmer Substrate, also die Felsenfluren, die Moosheiden, die Flechtenheiden (übergehend in die Zwergstrauchheiden) und von nassen Vegetationen die Sphagnum-Moore teilen sich in die meisten öden Gegenden des hohen Nordens, namentlich von Lappland, Sibirien, Nordamerika („barren grounds"), Grönland, Spitzbergen und Island, ferner in die höheren Gebiete der Hochgebirge und in den antarktischen Ländern an der Magellan-Straße usw. Sie geben uns gewiß ein Bild von der ersten Vegetation, die im Norden nach der Eiszeit

1) Vergl. Schenck $1905 \mathrm{~b}$; Skottsberg 1905.

2) Kihlman 1890 .

3) Graebner 1895; Warming 1907-09. 
herrschte. Thnen schließen sich unter etwas günstigeren Vegetations bedingungen die Zwergstrauchheiden an.

Wenn die Zwergsträucher, namentlich Betula nana, Calluna vu garis, Vaccinium myrtillus, V. uliginosum und einzelne Weiden höhe werden, so erhalten wir eine Vegetation mit zwei Stockwerken, un wenn die Zwergsträncher zahlreicher werden, so geht die Flechtenheid in die Zwergstrauchheide über (86. Kap.).

\section{Kap. Sphagnummoore (Sphagneta, Heidemoore, Moosmoort Hochmoore)}

Diese Moore werden vorzugsweise von Torfmoos (Sphagnum) gi bildet und entstehen auf verschiedene Weise - als lakustrische (1.) ur extralacustrische (2.) Moore.

1. In Waldsümpfen und Torflachen sieht man in Nordeuror oft ausgedehnte schwimmende Sphagnum-Teppiche, von denen nur odi kaum die allerobersten Sproßteile über die Wasserfläche emporrage Verschiedene Arten können solche Teppiche bilden, z. B. Sphagnu acutifolium und Verwandte, seltener S. cymbifolium und Verwandt Mit der Zeit werden die Teppiche dichter und fester, indem auch Sumr pflanzen sich einfinden, wie Calla palustris, Menyanthes trifoliata, $C$ marum palustre, Carex limosa, C. filiformis u. a. Es bilden si schwimmende Inseln, "Schwingmoore", "Schaukelmoore". Fleroff schildert solche aus Rußland, auf welchen wuchsen Ledum palust, Andromeda polifolia, Vaccinium oxycoccus (Ox. palustris), Drosera rotu difolia, Eriophorum-Arten, Scheuchzeria palustris u. a. Wenn die Dec. fester geworden ist, wandern auch Sträucher und Bäume ein, vorwiegel Birken, Kiefern (Pinus silvestris) und Salices. Auch Erlen können av wachsen und ein Erlenbruch entstehen, dann müssen aber (durch sei liche Wasserzufuhr usw.) die ursprünglichen Verhältnisse völlig ve ändert worden sein.

2. Auch auf feuchtem, wenig durchlässigem Boden, über dem se feuchte Luft lagert, der aber nicht offenes Wasser zu haben braucl können Sphagnum-Moore entstehen. Feuchte Luft und Tau sind die Leben bedingungen für jedes Sphagnum-Moor; die meisten derselben erhalt ihre gesamte Feuchtigkeit aus den atmosphärischen Niede schlägen ${ }^{2}$ ). Sehr oft bilden sie sich oben auf alten Flachmoore auch können sie auf nassem Sandboden entstehen, ja sogar a Felsen, die oft von Wasser benetzt werden, z. B. an der Westküs

1) Fleroff 1907.

2) Vergl. Graebner 1898. 
von Schweden und Norwegen. Die Torfmoose lieben reichliche Niederschläge, aber weder hohe Temperatur, noch große Lufttrockenheit. I)as milde feuchte Klima, z. B. von Nordwesteuropa, begünstigt die Bildung von Sphagneten. In trockenen und heißen Klimaten kommen sie nicht zur Entwicklung. Ein gewisser Gleichgewichtszustand zwischen Verdunstungsgröße und Menge der Niederschläge muß vorhanden sein. Die (Oberfläche des Grundwassers steht oft hoch und verhindert das zu schnelle Niedersickern des Regenwassers. Für die Ernährung der Moorpflanzen hat es dagegen geringe oder gar keine Bedeutung.

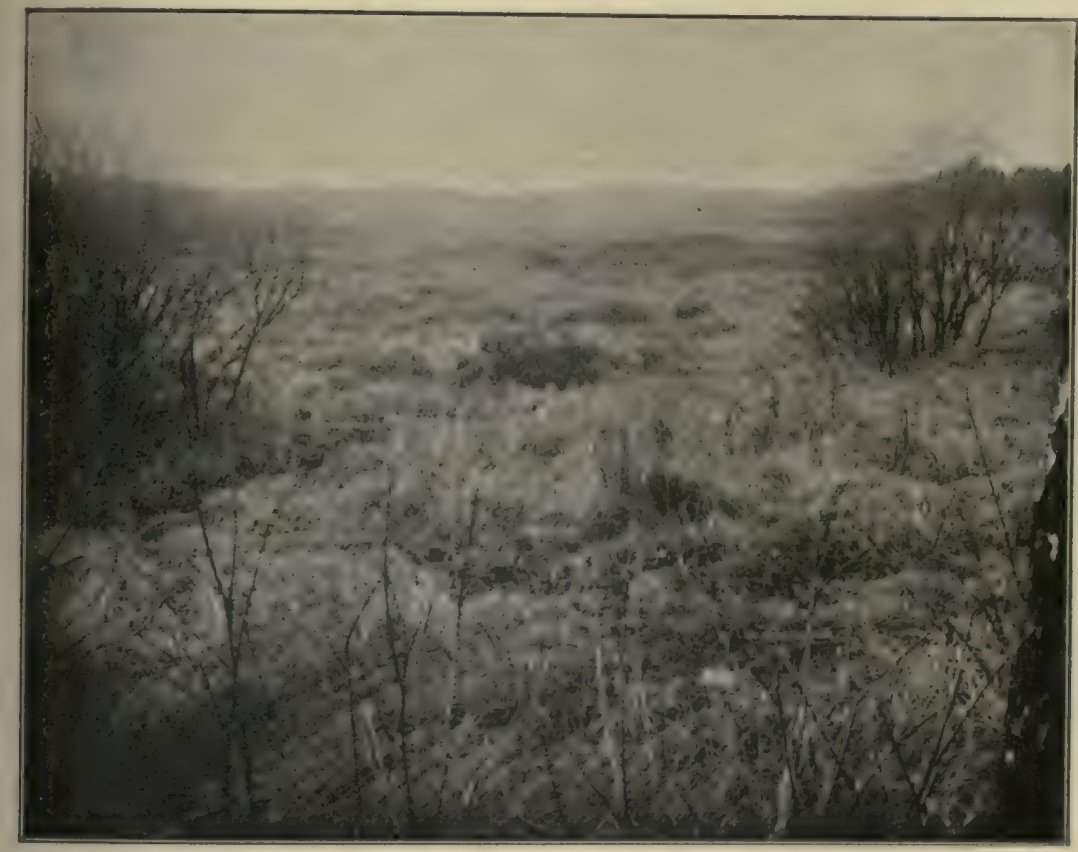

Fig. 292. Beginnende Hochmoorbildung. Zwischen den Sträuchern (Salix) bilden Molinia und Eriophorum vaginatum Bulten, zwischen denen wieder Sphagnum aufwächst. Lüneburger Heide. (Phot. P. Graebner.)

Der Bau, die Lebensbedingungen und der Wuchs der SphagnumArten rufen die eigentümliche Vegetation dieser Moore hervor. Die mit Blättern dicht besetzten, kahlen Stengel tragen neben jedem vierten Blatte einen Zweig; die Zweige hängen bei vielen Arten herab und legen sich dem Stengel mehr oder weniger dicht an. Der Úmfang der stengel enthält in 1-5 Zellschichten große, dünnwandige Kapillarzellen, deren Wände oft durch ring- und schraubenförmige Verdickungsleisten abgesteift und zugleich von Löchern durchbrochen sind. Hierdurch und durch den dichten Wuchs der Moose werden Kapillaren 
gebildet, die das Wasser stark ansaugen und festhalten (Fig. 294). DaB die Sphagna das Wasser aus dem Boden heraufsaugen, ist irrtümlich, sie heben das Wasser nur auf eine ganz geringe Höhe; ihr Gedeihen hängt ganz vom atmosphärischen Wasser ab („aerisches" Wasser, im Gegensatz zu "tellurischen"). Die Wasserbewegung im Heidemoor ist im wesentlichen absteigend ${ }^{1}$ ). Wurzeln oder wurzelähnliche Organe werden nicht gebildet. Die Blätter bestehen aus einer Zellschicht: teils aus schmalen, langen, grünen Zellen, die ein Netz bilden, teils aus Zellen, die den Kapillarzellen des Stengels ähnlich sind, nämlich aus farblosen, durchlöcherten Zellen, welche größer als die grünen Zellen sind, die Maschen zwischen ihnen ausfüllen und gleichfalls kapillar wirken. Die Folge ist, daß die Sphagnum-Pflanzen durch Kapillarität von unten bis oben mit Wasser beladen werden, wenn dieses vorhanden ist. Während die älteren Teile allmählich absterben und ir Torf übergehen (über dessen Wasseraufsaugungsvermögen vergl. S. 110) wachsen die Spitzen stets mit großer Energie weiter; eine Generatior wird auf der anderen aufgebaut. Dadurch wächst das Sphagnum-Moo] andauernd an Höhe, außerdem an Umfang, also auch an Ausdehnung solange die atmosphärischen Niederschläge (bes. Regen, Tau) ausreichenc vorhanden sind (austrocknender Wind ist ein wesentlicher Feind de: Vegetation); es entstehen dicke, weiche Moosmassen, die sich bedeuten über den Stand-des Grundwassers erheben können ("supraaquatische" Moore), und die sich oft in der Mitte höher emporwölben als an des Rändern, weil das Wasser in der Mitte am längsten Zutritt gehabt hat Daher stammt der Name "Hochmoore", der aber sehr wenig zweckmäßi६ erscheint, da er von vielen Schriftstellern, selbst namhaften Botanikerı und Pflanzengeographen, irrtümlich für hochliegende Moore gebrauch wurde und noch wird. Man wird diese Mißverständnisse in der Littera tur bei Beibehaltung des Namens stets erneuern. Der Name Heidemoo: (oder auch Sphagnum-Moor) scheint hier bei weitem besser, da er diesel eine echte Heidevegetation tragenden Verein sofort kennzeichnet un Mißverständnisse ausschließt. Wenn dagegen eingewendet wird, daß de Name auch von Nichtbotanikern für ein verheidetes Moor gebraucht ist so kann man erstens Fehler von Nichtfachmännern doch nicht vermeides und zweitens wird jedes verheidete Moor tatsächlich einen diesem Ver ein sehr nahe verwandten darstellen, ja in den meisten Fällen ihm zu geordnet werden müssen.

Von den Sphagnum-Arten seien hervorgehoben: S. cymbifolium S. fuscum, S. Austini, S. rubellum, S. teres, S. recurvum, S. medium u. Sie bilden verschiedene Assoziationen von Sphagneten und sind gürtelförmig angeordnet.

1) C. A. Weber 1902. 
Warnstorff $^{1}$ ) teilt die Sphagnen nach ihren Verhältnis zum Wasser in folgende Gruppen: 1. hydrophile; 2. helodeophile; 3. hygrophile.

Die hydrophilen sind ganz in Wasser untergetaucht oder ragen nur mit den obersten Sproßspitzen über das Wasser heraus (die Gruppen Cuspidata und Subsecunda).

Die helodeophilen stehen gleichfalls mit ihren unteren Teilen im Wasser (Gruppe Cymbifolia), und die hygrophilen treten nur in sehr nassen Jahren mit tellurischem Wasser in Verbindung (Gruppe Acutifolia).

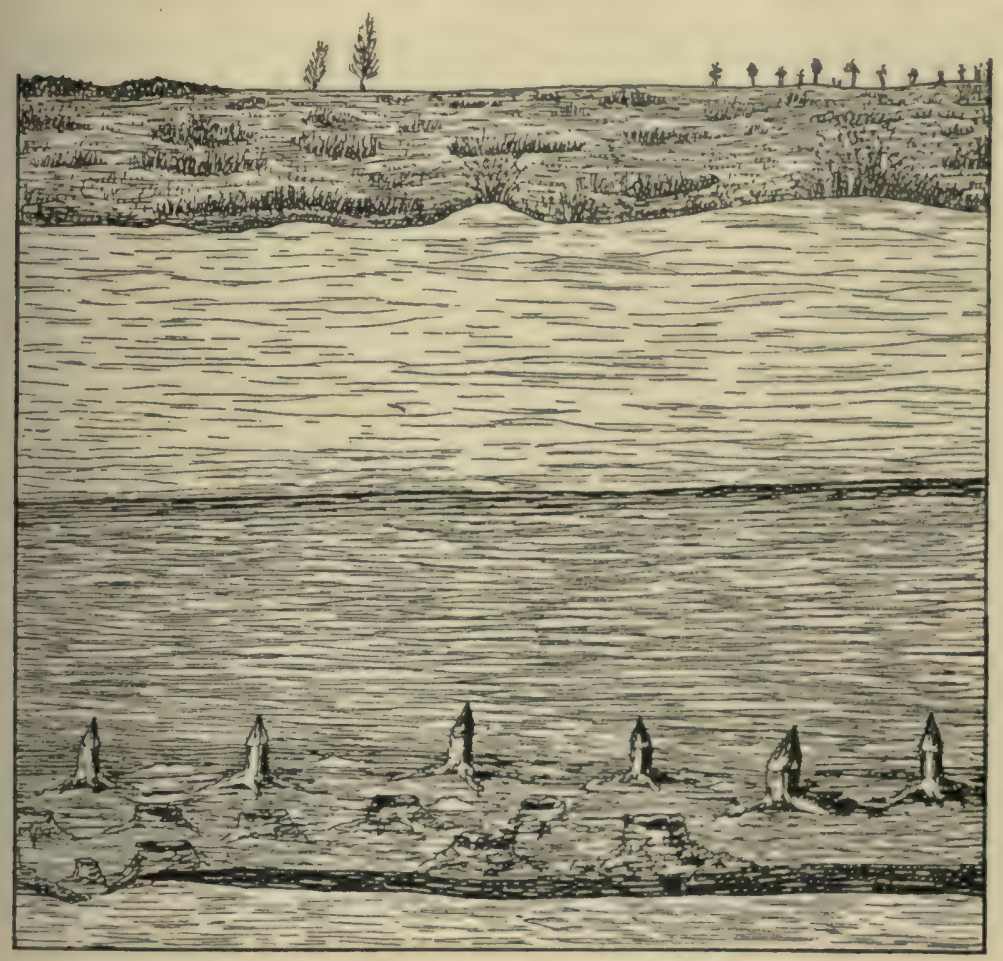

Fig. 293. Profil eines alten Hochmoores, am Grunde die kegelförmig zugespitzten Stämme des ehemaligen Waldes, darüber der (dunkle) untere und der (hellere) obere Sphagnum-Torf. (Nach C. A. Weber.)

Das Wasser im Hochmoor unterscheidet sich von dem im Niederungsmoor unter anderm anch dadurch, daß es kalkarm ist. Der Torf ist arm an assimilierbarem Stickstoff, Kali, Phosphorsäure und damit natürlich auch an den meisten wichtigen Nährstoffen, er ist im allgemeinen sehr nährstoffarm. Nach den meisten Schriftstellern verhindert die Anwesenheit von Kalk die Entstehung der Hochmoore, weil Sphagnum als kalkfeindlich angesprochen wird. Graebner ${ }^{2}$ ) hat nach

1) Warnstorff 1911

2) Graebner $1895 \mathrm{ff}$. 
den Beobachtungen von Ramann ${ }^{1}$ ) und den Versuchen von C. A. Weber, dem es gelang, gewisse Sphagnum-Arten in reiner Kreide gut zu kultivieren, die Ansicht ausgesprochen, daß nicht der Kalk, sondern die Anwesenheit größerer Mengen löslicher Salze das Wachstum des Sphagnum verhindern; nur in ganz schwachen Lösungen vermögen die Hochmoorsphagnen zu leben, jede Düngung tötet sie sofort ab. Weber ${ }^{2}$ ) und Transeau ${ }^{3}$ ) wollen der Anwesenheit gewisser Mengen von löslichen Salzen kein so entscheidendes Gewicht zusprechen. Paul*) hat neuerdings nachgewiesen, daß die Sphagnen zu ihrer Ernährung unbedingt Säuren gebrauchen, die sie z. T. selbst ausscheiden. Die meisten Kalkverbindungen neutralisieren diese Säuren und machen damit den Sphag-

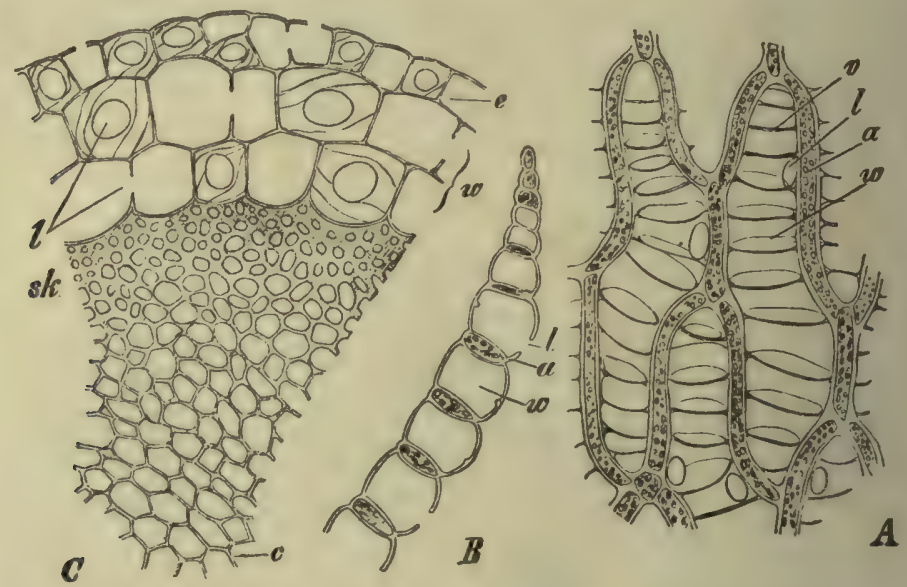

Fig. 294. Sphagnum (Torfmoos). A Flächenansicht des Blattes von Sphagnum cymbifolium, $a$ chlorophyllführende Zellen, $w$ Wasserzellen mit ringförmigen Verdickungsleisten, $l$ Löcher; $B$ Querschnitt durch das Blatt von Sphagnum fimbrialum; $C$ Teil eines Stengelquerschnittes von Sphagnum cymbifolium, $c$ Mark, $8 k$ Zellen mit verdickten

Wänden, $w$ Wasserzellen mit Löchern und Verdickungsleisten, $e$ Epidermis.

(Nach Strasburger.)

nen das Leben unmöglich. Die verschiedenen Arten der Sphagnen verhalten sich den Kalkverbindungen gegenüber verschieden; im allgemeinen sind die Formen der Hochmoore viel empfindlicher als die der Wälder usw.

Nach Bertsch kann die Nährstoffmenge in der Mitte ausgedehnter Hochmoore auf $1 / 11$ derjenigen der Wiesenmoore herabsinken. Vergl. auch Früh und Schröter (1904) über die Vegetation der Hochmoore ${ }^{5}$ ).

1) Ramann 1895 .

2) C. A. Weber 1900.

8) Transeau 1905 a.

4) Paul 1908.

5) Uber den Torf der Wiesenmoore vergl. S. 630. 
Nach Paul (vergl. oben) führen die verschiedenen Arten verschiedene Säuremenge. Die Hyalinzellen sollen nach Baumann und Gullis ${ }^{1}$ ) die Säurewirkungen hervorrufen.

Die Sphagnum-Moore sind sehr arm an Sauerstoff und sehr sïurehaltig. Wo Sphagnum in die nordschwedischen Fichtenwälder oder in Kiefern-, seltener Laubholzwaldungen Norddeutschlands hineindringt, versumpfen und leiden diese durch den großen Sauerstoffmangel im Boden; gegen Nässe ist die Fichte weniger empfindlich, wohl aber gegen

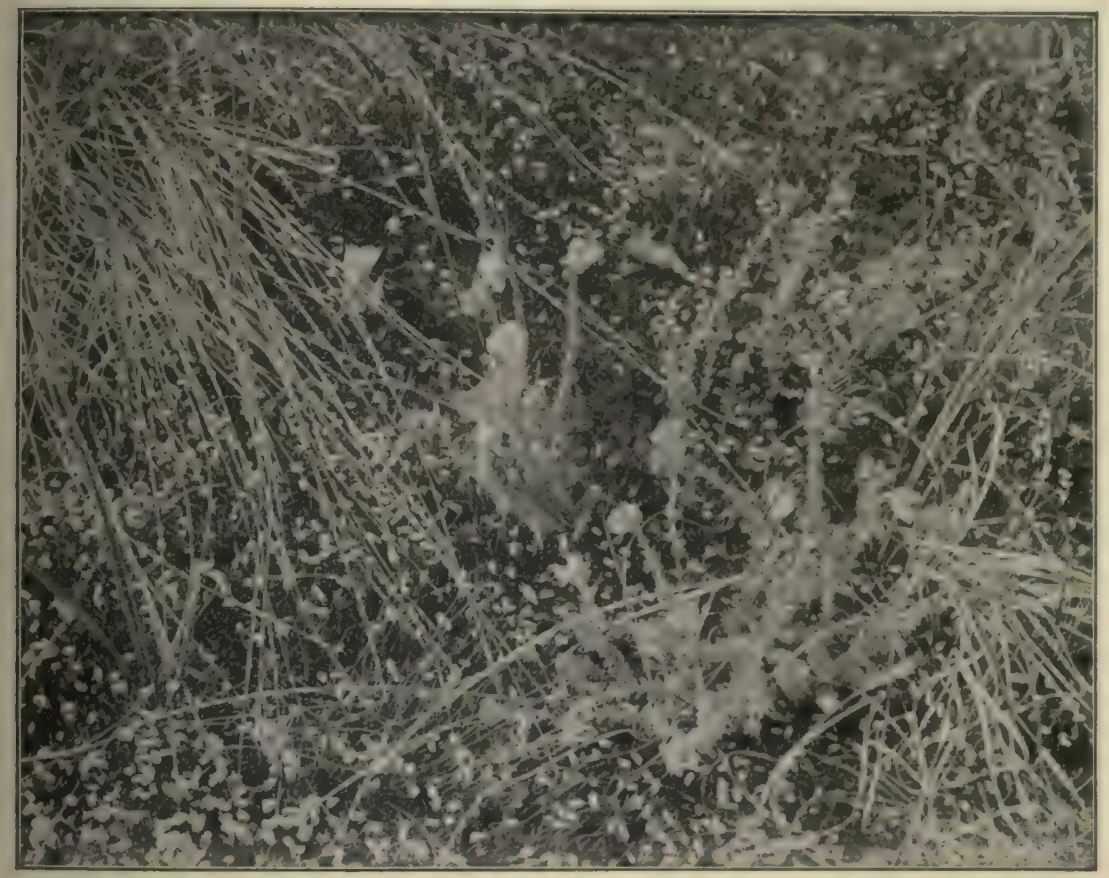

Fig. 295. Schwimmendes Polster von (fruchtendem) Polytrichum in einem Heidekolk. Junge Pflanzen von Erica tetralix und Scirpus caespitosus wachsen auf.

(Phot. P. Graebner.)

Sauerstoffmangel des Substrates. „Die Versumpfung des Fichtenwaldes ist nicht so sehr eine Wasser-, sondern eine Sauerstofffrage" "2).

Flora und Lebensformen. Auf diesem weichen, losen, von Sphagnum gebildeten Boden finden sich natürlich auch andere Pflanzen ein, unter anderem einige Arten der Wiesenmoore; aber die Flora wird nicht so reich wie in diesen, wahrscheinlich weil der Boden viel ärmer an Nährstoff ist als in den Wiesenmooren. Die Pflanzen müssen ja alle hauptsächlich als Saprophyten leben.

2) Baumann u. Gullis 1910 .

5) Hesselman $1910 \mathrm{~b}$.

Warming-Graebuer. 3. Auflage, illustr. 
Folgende Pflanzengruppen sind in den nordeuropäischen Mooren vorhanden:

Moose. Von anderen Laubmoosen finden sich z. B. Arten von Polytrichum, Aulacomnium, Bryum, Paludella, Dicranum u. a. Gattungen ein; von Lebermoosen z. B. Aneura, Cephalozia, Jungermannia. Flechten sind in den nassen Mooren nur noch sparsam. Arten vom Grastypus sind zahlreich; von Cyperaceen, z. B. Rhynchospora alba, mehrere Carex- und Eriophorum-Arten (besonders E. vaginatum), Scirpus caespitosus; von Gräsern z. B. Molinia coerulea, Agrostis canina, Nardus stricta, Aera flexuosa, Sieglingia (Triodia) decumbens. Von Juncaceen z. B. Juncus filiformis.

Stauden. Von Farnen: Aspidium (Lastraea) thelypteris. Von Monokotylen z. B. Narthecium ossifragum, Scheuchzeria palustris, Triglochin palustre; von Dikotylen: Viola palustris, Pedicularis palustris und P. silvatica, Drosera-Arten, Pinguicula vulgaris, Menyanthes trifoliata, Rubus chamaemorus, Chamaepericlymenum (Cornus) Suecicum, Saxifraga hirculus, Malaxis paludosa, Lycopodium inundatum. Halbsträucher: Comarum palustre. Zwergsträucher, besonders die Bicornes, sind häufig: Vaccinium uliginosum, V. oxycoccus und V. vitis Idaea, Andromeda polifolia, Ledum palustre, Erica tetralix, auch Calluna vulgaris, ferner Empetrum nigrum, Myrica gale, Betula nana, Salix repens und besonders S. rosmarinifolia. Höhere Sträucher: Arten von Salix und Betula. - Bäume. Auf älteren, höheren und trockneren Mooren finden sich Kiefernarten ein (Pinus silvestris bes. die var. turfosa, P. pumilio u. a.); sie sind hier verkrüppelt, sind dem Krummholz- oder Legföhrengestrüppe der Hochalpen ähnlich. Auf österreichischen Mooren bilden $P$. uliginosa und $P$. pumilio physiognomisch und botanisch verschiedene Bestände ${ }^{1}$ ).

In anderen Ländern trifft man natürlich ganz andere Gattungen und Arten, in Nordamerika z. B. Kalmia, Sarracenia, Darlingtonia usw., von denen sich z. B. Kalmia angustifolia in Deutschland (Hannover) völlig eingebürgert hat. In allen ökologischen Dingen scheinen die nordamerikanischen Hochmoore den nordeuropäischen gleich zu sein ${ }^{2}$ ).

Ökologisches. Lebensdauer der Arten. Fast alle sind mehrjährig. Außer den etwa vorhandenen Schmarotzern (Rhinantheen) kommen noch Cicendia filiformis, Montia lamprosperma und andere einjährige Arten vor.

Über den Sproßbau läßt sich kaum etwas Allgemeines sagen. Vahl hat durch statistische Untersuchungen nach der Methode Raunkiärs

1) G. Beck in Ann. naturhist. Hofmus. Wien, III.

2) Vergl. Ganong 1897; Transeau 1903, 1905, 1906; Mac Millan 1893, 1896 Harshberger 1911. 
gefunden, daß unterirdisch wandernde Arten wenig zahlreich sind, wogegen oberirdisch wandernde Arten und solche ohne Wanderungsvermögen vorherrschen ${ }^{1}$ ).

So lange das Moor noch sehr naß ist, wird es als Sphagnum-Moor bezeichnet werden können; die Sphagnum-Arten dominieren, die anderen. Arten sind in das Sphagnum-Moor eingestreut. Groß²) schreibt ibber dieostpreußischen Moore, daß die Vegetation eines Hochmoores stets relativ sehr gleichförmig ist, und nur folgende, mehr topographisch als floristisch differente Facies sind zu unterscheiden: 1. Die Vegetation der Randgehänge und 2. die Vegetation der Hochfläche; wozu denn noch

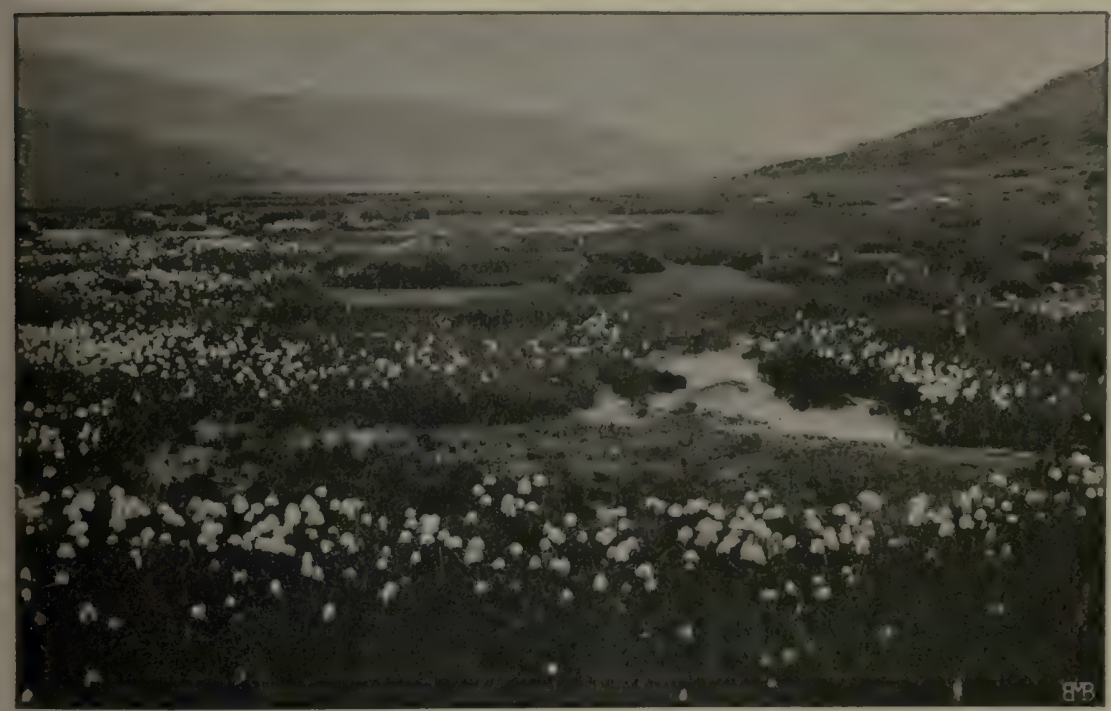

Fig. 296. Geitabergsvatn in Island. Moorvegetation mit Eriophorum angustifolium, Scirpus caespitosus, Carex chordorhiza u. a. Carex-Arten, Menyanthes trifoliata, Equisetum limosum u. a. (Phot. A. Hesselbo, in Thoroddsen 1914.)

hinzuzufügen sind 3. die Vegetation der Hochmoorteiche, und 4. die der Rüllenbäche. „Die Vegetation der Hochmoore ist ein mehr oder weniger bultiges, braungrünes, braunes oder purpurrotes Sphagnetum, in dem Bliitenpflanzen eine untergeordnetere Rolle spielen, wenn sie auch gewöhnlich reichlich vorkommen: Eriophorum vaginatum, Scirpus caespitosus und Calluna vulgaris sind die herrschenden Arten."

Natürlich kommen verschiedene Assoziationen vor, nicht nur solche, die von den verschiedenen Sphagnum-Arten gebildet werden,

1) Vahl 1911, 1912.

$\left.{ }^{8}\right)$ Grob 1912; über denselben Gegenstand vergl. ausführlicher die grundlegenden Arbeiten von C. A. Weber (bes. 1902). 
die eigentlichen Sphagneta, sondern auch solche aus Stauden zr sammengesetzt, letztere allerdings nur so, daß der Charakter als Spha! num-Moor nicht verloren geht; es sind dies namentlich Eriophoret vaginati, E.Scheuchzeri, Scirpeta caespitosi, Molinieta coerule

Wenn das Moor aus irgend einem Grunde auszutrocknen beginn ändern sich die Verhältnisse, floristisch sowohl wie auch physiognomisc] und verschiedene andere Pflanzen nehmen überhand, womit schließlic andere Formationen in die Erscheinung treten. $\mathrm{Zu}$ diesen gehöre in Nordeuropa namentlich Calluna vulgaris; es entstehen auf dem Tor boden Zwergstrauchheiden, Calluneta vulgaris, an deren Bildur auch andere Zwergsträucher wie Empetrum nigrum, Vaccinium ulig nosum, $V$. vitis Idaea, Andromeda polifolia u. a. teilnehmen; auc Flechten, besonders Cladonien, werden zahlreicher ${ }^{1}$ ).

Auch die Hochsträucher, wie Salix aurita u. a. können an ander Orten an Anzahl zunehmen und können Gebüsche bilden (Salicet Betuleta nanae).

Auch die Bäume, die bisher nur einzeln vorkamen, können zal reicher werden, so zahlreich, daß Wälder, „Moorwälder“ entstehen. A dem sauren Boden können z. B. die Buche, die Esche und viele ande nicht gedeihen; aber Arten wie Pinus montana, $P$. pumilio, $P$. silvest var. turfosa, Betula odorata und B. verrucosa können Assoziationen au bilden, niedrige Wälder, die dem Krummholz- und Legföhrengestrüp! der Hochalpen ähnlich sind. Auf dem trocknenden Moorboden gedeih auch niedrige Zwergsträucher und Stauden, welche in dem feucht Sphagnum-Teppiche nicht leben können, z. B. Vaccinium myrtill Trientalis Europaea, Juncus squarrosus, Molinia coerudea, Aera flexuos Nardus stricta, Erica tetralix, ein Zeichen, daß der Boden torfigt saurer Rohhumus ist.

Die Entwicklung führt also zu mehreren verschiedenen ander Formationen, welche eine mehr oder weniger geänderte Moosmoorveg tation mit ihrer Bodenschicht aus Moosen und Feldschichten aus krau artigen Pflanzen und Zwergsträuchern als Bodenvegetation hat, welc in den folgenden Kapiteln spezieller besprochen werden. Das a sterbende Hochmoor zeigt alle Übergånge zu diesem. Diese Form tionen sind gewöhnlich nur als Altersstadien in der Entwicklung betrachten, welche auf demselben Moore nacheinander und nebeneinand zum Vorschein kommen können. Gewöhnlich sind sie gürtelförmig das Wasserbassin herum angeordnet; oft findet sich nächst dem Was: z. B. ein Caricetum, nach diesem folgt ein Eriophoretum, n diesem wieder ein Callunetum oder Vaccinietum uliginosi usw., die Serie z. B. mit einem Cladinetum oder etwas Ähnlichem auf d

2) Vergl. z. B. Tansley 1911; Moss 1913. 
trockensten Boden abschließt, vielleicht ist auch zum Schluß ein Pinetum silvestris mit Heideboden vorhanden. Es ist der Wassergehalt und die Humusmenge des Bodens, welche entscheidend sind.

In England ist die Gürtelbildung in den südlichen Pennines nach der Höhe folgende: Vaccinietum myrtilli ca. 520-635 m, Eriophoretum vaginati ca. $365-610 \mathrm{~m}$, Calluni-Eriophoretum ca. $380-540 \mathrm{~m}$, Callunetum vulgaris ca. $230-470 \mathrm{~m}^{1}$ ).

Nach Dachnowski existiert eine genaue Übereinstimmung zwischen dem Bau und der Farbe des Torfes und der rezenten Vegetation; licht-

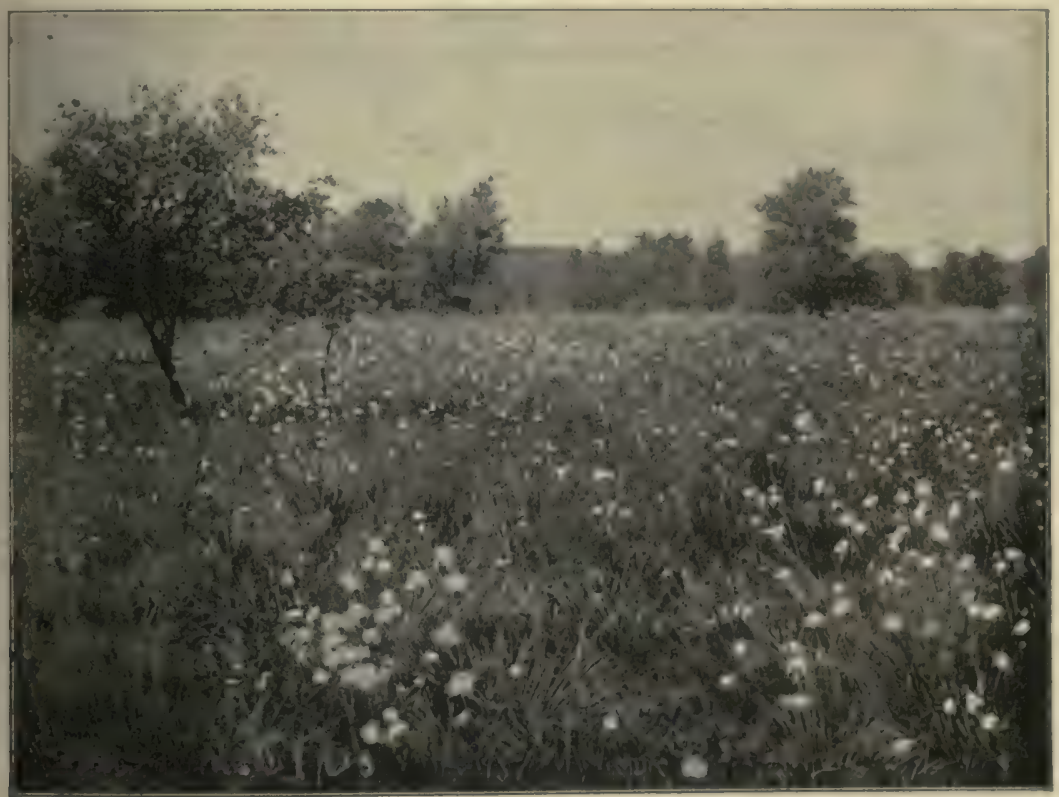

Fig. 297. Ein Hochmoor auf Seeland im Frühsommer.

Die Vegetation hauptsächlich Calluna, Vaccinium oxycocens und Eriophorum vaginalum, welche letztere gerade in Fruchtbildung steht. (Phot. C. Raunkiär.)

grefärbter Torf z. B. trägt eine wiesenähnliche Vegetation, dunkler homogrener, dekomponierter Torf Bäume, Sträucher usw. In den Wäldern gibt es vielfach strukturlosen Torf. Auch der Wassergehalt in den verschiedenen Torfarten ist verschieden ${ }^{2}$ ).

Nur solche Arten können auf Sphagnum-Mooren wachsen, die den Moosen im Höhenwachstum zu folgen vermögen, wie nur solche Arten auf heweglichem Dünensande gedeihen, die den zufliegenden Sand durchwachsen kőnnen.

1) Tansley 1911, wo auch andere Angaben; ebenso Moss 1913.

ग) Näheres bei Dachnowski 1912. 
Indem die älteren T'eile der Pflanzen allmählich vom Sphagnum überwachsen werden und in Torf übergehen, werden anch die Reste jener Pflanzen im Torfe begraben. Der Torf kann 3-4 m, in Ostpreußen auch 6-10 m Mächtigkeit erreichen. Besonders torfbildend sind, außer Sphagnum-Arten, Polytrichum juniperinum, Scirpus caespitosus, Eriophorum vaginatum, Erica und Calluna. Auch Tierreste. Kulturgegenstände $u$. a. können in Torf eingeschlossen und aufbewahrt werden. Die Säuren schützen organische Teile gegen Fäulnis vorzüg. lich; Moorwasser ist bakterienfrei oder doch bakterienarm. Die in Moorwasser begrabenen Pflanzenteile (Blätter, Früchte, selbst mensch. liche und tierische Körper usw.) können Jahrtausende lang erhalter werden. Auf diese Weise wird man die Ontogenese eines Moores vor dem Zeitpunkte ab verfolgen können, wo nur eine Wasserfläche mi Plankton und anderen Wasserpflanzen existierte, durch den Zeitraum wo die Verlandung und Ausfüllung des Gewässers mit Resten v01 Wasser- und Sumpfpflanzen vollendet wurde, bis zu dem Zeitpunkte wo die Bildung eines Sphagnum-Moores durch die fortschreitend Trockenheit des Moores mit Bildung von Strauch- und Waldformatione: abgeschlossen wurde. Während die Wiesenmoore flach sind (daher de Name „Flachmoore"), werden die Hochmoore mit der Zeit in der Mitt uhrglasförmig gewölbt erscheinen.

Nordeuropas Waldmoore, die vor Jahrtausenden in kleinen See und Teichen in Wäldern gebildet wurden und die von Bäumen um wachsen und teilweise oder zeitweise mit Bäumen bestanden wares schließen sehr viele Pflanzenreste ein, die uns den Entwicklungsgan der Vegetation und der Flora des Landes zeigen. Die Unterlage de Moore ist oft ein feiner, von den umgebenden Höhen bald nach der Eis zeit herabgeschlämmter Ton mit Resten von Betula nana, Dryas, Sali polaris, S. reticulata u. a. Pflanzen aus den Tundren, die nach der Eis zeit die erste Vegetation des vom Eise verlassenen Moränenboder bildeten (Nathorst hat 1870 jene Reste zuerst gefunden). Die weites Entwicklung hat Steenstrup dreißig Jahre früher (1841) in seiner bi merkenswerten Arbeit über die Waldmoore Vidnesdam- und Lillemoo: auf Seeland nachgewiesen ${ }^{1}$ ). Der erste Baumwuchs nach der Tundre periode wurde nach Steenstrup von Populus tremula gebildet, die vi Moosen (Hypna, Sphagna) begleitet wurde; hiermit begann die Moo bildung. Auch Betula trat früh auf und begleitete die folgenden Schic ten. Allmählich wurden die Moore von einer Waldvegetation umgebs deren Bäume in das Moor stürzten und nebst ihren Blättern, Frücht usw., die der Wind wegführte, begraben wurden. Die erste Hochwal.

3) In erster Linie vergl. über alle diese Fragen die äußerst gewissenhaften kritischen Arbeiten von C. A. Weber. 
vegetation war die der Kiefer (Pinus silvestris); sie wurde von der Eiche (Quercus sessiliflora und Qu. pedunculata) abgelöst, und diese zuletzt von der Buche, die in den obersten Schichten der Moore nur sehr sparsam angetroffen wird. In Norwegen meint Blytt einen Wechsel von Torf- und Waldschichten (Baumstämmen) gefunden zu haben, der einem Wechsel feuchter und trockner Perioden entspreche; Sernander teilt dieselbe Ansicht. Die Waldmoore sind an Baumresten reicher als die Sumpfmoore, und haben mehr Wassermoose als diese (vergl. A. Schulz).

Geographische Verteilung der Sphagnum-Moore

Viel mehr als die Niederungsmoore wird das Hochmoor durch die klimatischen Verhältnitse beeinflußt, da es einzig und allein von den atmosphärischen Niederschlägen, nicht aber vom Bodenwasser abhängt. Deshalb ist seine Verbreitung auch beschränkter als die der Moore in allgemeinen.

In den Tropen ist die Torferzeugung meist auf die Gebirge beschränkt, weil die hohe Temperatur sehr stark die Verwesung der organischen Substanzen befördert. An Teilen der Ostküste von Brasilien, wo der Regenwald überwiegt, kommen an feuchten Stellen SphagnumPolster vor, wahrscheinlich wird aber kein Torf gebildet. Die Torfbildung ist am stärksten in Ländern mit mäßig hoher Temperatur und großer Feuchtigkeit. In sonnigen Gebieten ist sie spärlich und schwach, in subtropischen Ländern mit Winterregen ist das Hochmoor ausgeschlossen. Ebenso ist die Formation in arktischen Ländern nur schwach entwickelt, weil überhaupt der Vegetationszuwachs gering ist. In Grönland wird Torf von Webera nutans und Hypnum stramineum ${ }^{1}$ ) gebildet; er wird beschrieben aus Sibirien (obgleich nicht in solcher Menge wie in der Nïhe der Ostsee) ${ }^{2}$ ), in Spitzbergen ${ }^{3}$ ), in Waigatsch und auf der Tierra del Fuego.

Die eigentliche Heimat der Hochmoore ist die kalttemperierte Zone der Nadelhölzer und die westlichen Teile der Laubwaldzone, wo das Klima ozeanisch ist. Die Laubwaldzone der östlichen Teile der Kontinente (Asien, Amerika) ist für Hochmoore ungünstig wegen der hohen Sommertemperatur und der geringen relativen Lufteuchtigkeit. Hochmoore sind in den östlichen Vereinigten Staaten selten. In den Russischen Steppengebieten kommt Hochmoor hier und da in Gruppen von Kiefernwäldern $\operatorname{vor}^{4}$ ).

In kalttemperierten Teilen der südlichen Halbkugel, z. B. in Patagonien und Tierra del Fuego, wird das Hochmoor aus Sphagnum, Azorella,

1) Warming 1887 .

3) Middendorff 1867; Pohle 1907.

s) Nathorst 1883.

4) Kuznezow 1898. 
Carex, Empetrum rubrum und anderen Pflanzen zusammengesetzt. In den nördlichen Teilen der Westküste von Patagonien wird es selten mit der Abnahme der atmosphärischen Niederschläge im Sommer ${ }^{1}$ ). Neuseeland hat alpine Moore, die durch eine Reihe antarktischer Gattungen charakterisiert sind ${ }^{2}$ ).

\section{Gramineta auf Torfböden}

Nach W. G. Smith ${ }^{3}$ ) gibt es große Areale von Glazialbildungen in Südschottland und dem westlichen englischen Hochlande, welche mit Grasformationen bedeckt sind. Die Pflanzen sind im wesentlichen Gräser, Juncaceen und Cyperaceen. Molinia coerulea forma depauperata, Sieglingia und Nardus stricta sind die am meisten charakteristischen Arten, welche häufig auf weite Strecken herrschen. Der Boden ist saurer Torf, der gewöhnlich während des größten Teiles des Jahres naß ist. Ähnliche, aber kleine Areale kommen in der Umgebung von vielen Torfmooren Dänemarks, Norddeutschlands usw. vor.

\section{Kap. Formation der Zwergsträucher auf torfhaltigem Boden}

Wie bereits auf S. 658 erwähnt wurde, können die Sphagnum-Moore reichlich mit Zwergsträuchern bewachsen sein; nach und nach kann diese Decke so dicht werden, besonders wenn die Kultur nicht eingreift, daß die Physiognomie des Moores ganz verändert wird; es entsteht eine neue Formation, eine Zwergstrauchformation, deren Boden noch lange von Sphagnum beherrscht wird, nach und nach aber, je nachdem die Trockenheit größer wird, sich wesentlich ändert. Er bleibt immer ein sehr nährstoffarmer und saurer Torfboden. - Auf solche Weise haben z. B. im nördlichen Jütland, in Nordwestdeutschland (Fig. 284) usw. kilometerweite Flächen sich mit einem einförmigen, braunem Teppiche von Calluna vulgaris bedeckt, z. B. „das große Wildmoor in Jütland“, das mehrere Kilometer in jeder Richtung mißt ${ }^{4}$ ).

Auch auf ganz anderem, nährstoffarmem und ursprünglich gar nicht torfhaltigem Boden können sich solche Zwergstrauch-Assoziationen entwickeln, die in Nordeuropa "Heiden" genannt werden. So nennt man in Nordeuropa die baumlosen Gebiete, die überwiegend mit immer-

${ }^{2}$ ) Dusén 1905 .

${ }^{2}$ ) Diels 1896; Cockayne. Neuere Litteratur über Hochmoore vergl. bei Früh u. Schröter, Weber, Graebner und C. W. G. Smith.

s) In Tansley 1911.

4) Solche Zwergstrauch-Assoziationen werden in Dänemark "Lyngmoser" (CallunaMoore) genannt, in Schweden "Rismyrar" (Ris bezeichnet Zwergsträucher). 


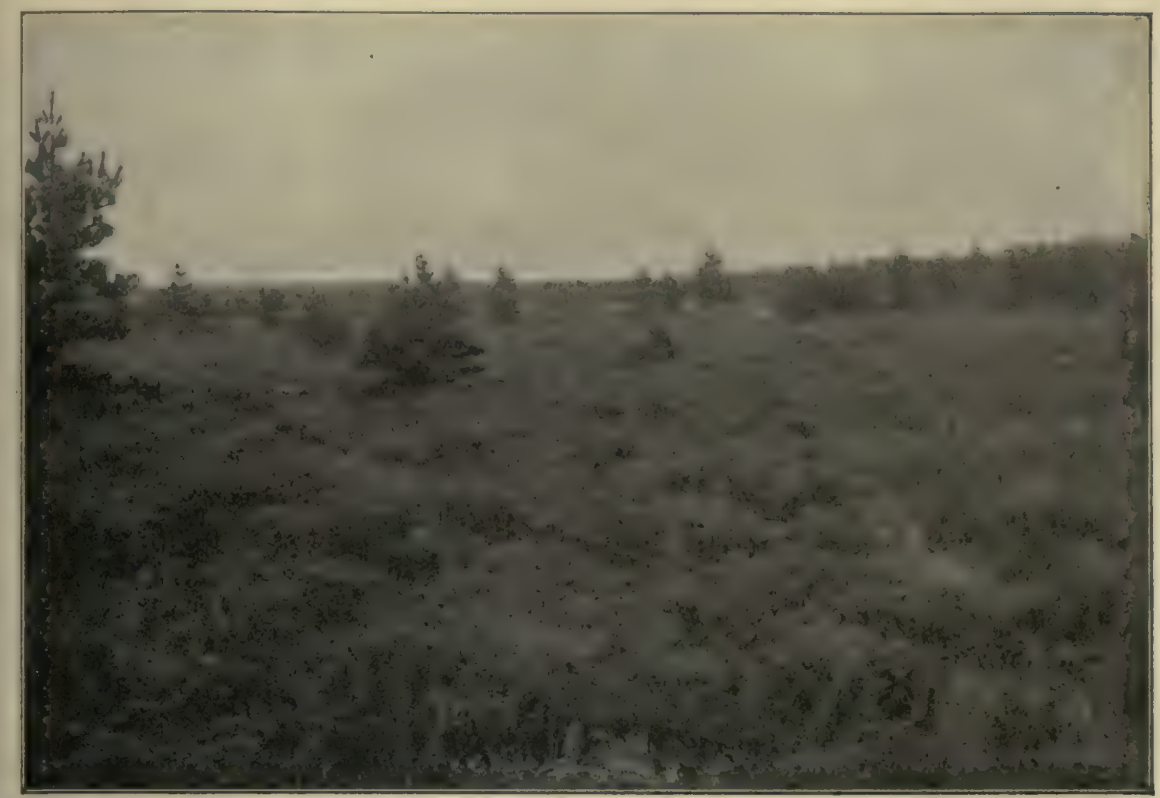

Fig. 298. Lüneburger Heide bei Munster. Auf alter unbeweideter (fiskalischer) Ortstein-Heide stehen Anflugkiefern, von denen aber mindestens ebensoviele absterben als neu aufwachsen. (Phot. P. Graebner.)

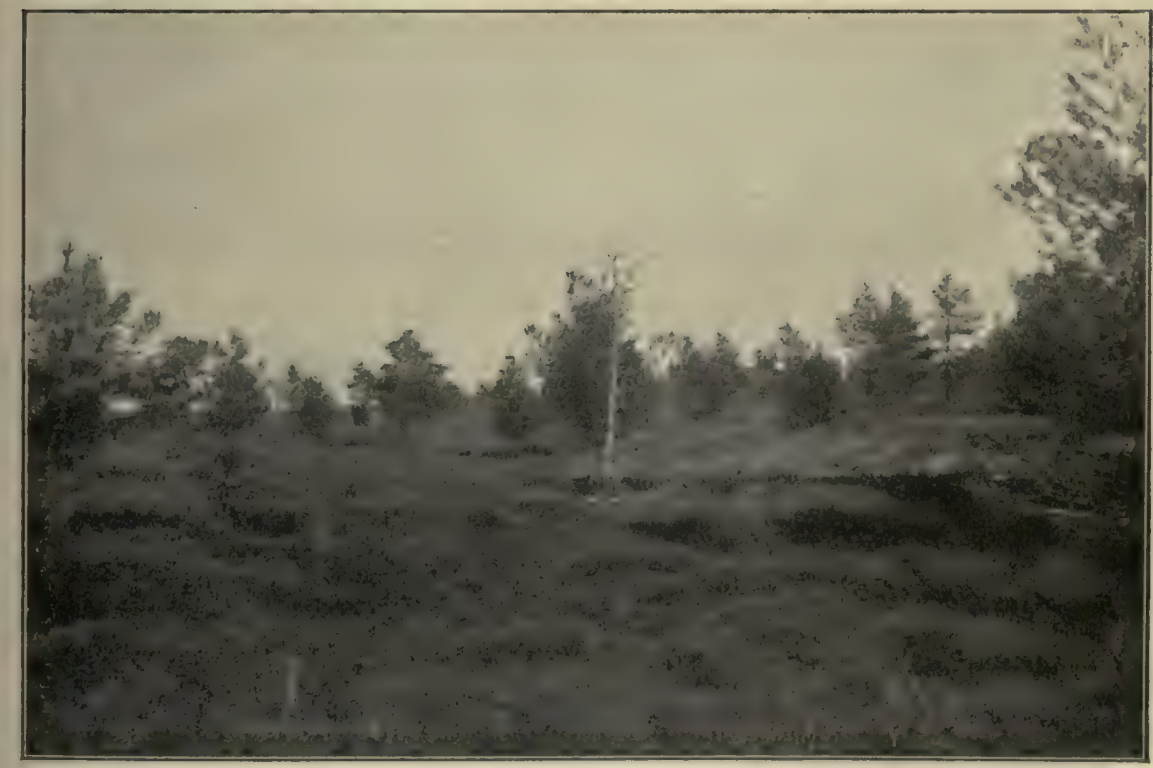

Fig. 299. Lüneburger Heide bei Mnnster. Anderer Teil derselben Heide, in der einzelne Bäume viel älter geworden sind, aber (z. B. in der Mitte) ohne ersichtlichen Grund absterben. (Phot. P. Graebner.) 
grünen, kleinblättrigen Zwergsträuchern bewachsen sind, besonders mit Ericaceen (Ericaceen-Heiden $)^{1}$ ). Die Pflanzendecke ist nach den herrschenden Feuchtigkeits- und Beleuchtungsverhältnissen verschieden hoch, oft etwa $1 / 3 \mathrm{~m}$ hoch und noch höher, oft aber auch nur einen oder zwei Dezimeter; 'sie kann einerseits so dicht sein, daß der Boden nicht zu sehen ist, anderseits so offen, $\mathrm{da} B$ er stark entblößt erscheint und zwischen den Sträuchern anderen Pflanzen Platz bietet. In vielen Fällen haben die Zwergsträucher die Spalierform angenommen (in den arktischen Heiden z. B. Betula nana, Salix, Juniperus; vergl. frühere Kap.), und einige haben normal diese Form (ArctostaphylosArten, Empetrum usw.). Ein Callunetum kann sich auch auf magerem, trockenem Dünensande entwickeln (vergl. Kap. 97), und die großen, aus ausgewaschenem Gletschersande in der Eiszeit gebildeten Ebenen Norddeutschlands und Dänemarks waren ursprünglich sicher zum großen Teile von meilenweiten Heiden gedeckt, welche vielfach dem Ackerlande haben weichen müssen. Sobald aber ein früher bebauter Boden innerhalb der Heidegebiete für längere Zeit unbearbeitet liegt, rückt Calluna sofort ein: man sieht die kleinen aus Keimpflanzen entstandenen Polster auf dem Boden erscheinen, zuerst bilden sie eine offene Vegetation, bald aber eine geschlossene Decke. Auf Sandflächen der diluvialen Gletscherflüsse bildet sich dann später eine Schicht von saurem Rohhumus, der mitunter auch als Brennmaterial (Heidetorf) benutzt werden kann, meist aber zu viel Sand enthält. Unter der Humusdecke differenziert der Boden sich in Bleisand und Ortstein (vergl. S. 111 ff.; Fig. 44, 45). In den Meeresdünen scheint diese Ausbildung nicht Platz zu greifen ${ }^{2}$ ).

Zwergstrauchheiden bilden sich auch auf Felsenfluren in nördlichen kalten, auch arktischen, sowohl wie entsprechenden antarktischen Gegenden.

Die Zwergstrauchheiden sowohl wie die Heidemoore sind Formationen mit wenigstens zwei Stockwerken von Pflanzen: das oberste aus den herrschenden, tonangebenden Zwergsträuchern; Kräuter, Gräser, Moose und Flechten, namentlich Moose und Flechten füllen als zweites Stockwerk die Zwischenräume unter und zwischen den Zwergsträuchern aus.

Lebensformen. Die Zwergsträucher (siehe S. 187) haben gebogene, gekrümmte, oft zerbrechliche Zweige. Die meisten, namentlich die tonangebenden Arten sind immergrün (Calluna, Empetrum, Juniperus, Arctostaphylos usw.); aber die Farbe ist immer dunkel und bräunlichgrün, im Winter noch mehr als im Sommer. Die Blätter

2) Über den Ausdruck Heide vergl. Focke (Abh. naturw. Ver. Bremen, XIII, S. 254); E. H. L. Krause $1892 a$; Graebner 1895, 1901; Rübel 1914 a.

?) Warming 1907-09. 
sitzen dicht, sind sehr zahlreich, klein, meist linealisch und häufig ericoïd (S. 220).

Die Arten sind in Nordeuropa, dessen Heiden wir zuerst im folgenden vor Augen haben, vorzugsweise folgende immergrüne Zwergsträucher: von dem ericoïden Typus Calluna vulgaris und Empetrum nigrum, an feuchteren Stellen auch Erica tetralix; mit breiteren, lederartigen, flachen, ganzrandigen Blättern Arctostaphylos uva ursi (besonders an den offeneren Stellen der Vegetation), Vaccinium vitis Idaca, Thymus serpyllum, von dem pinoïden Typus Juniperus communis. Dünne Blätter, die im Herbste abfallen oder jedenfalls welken, haben

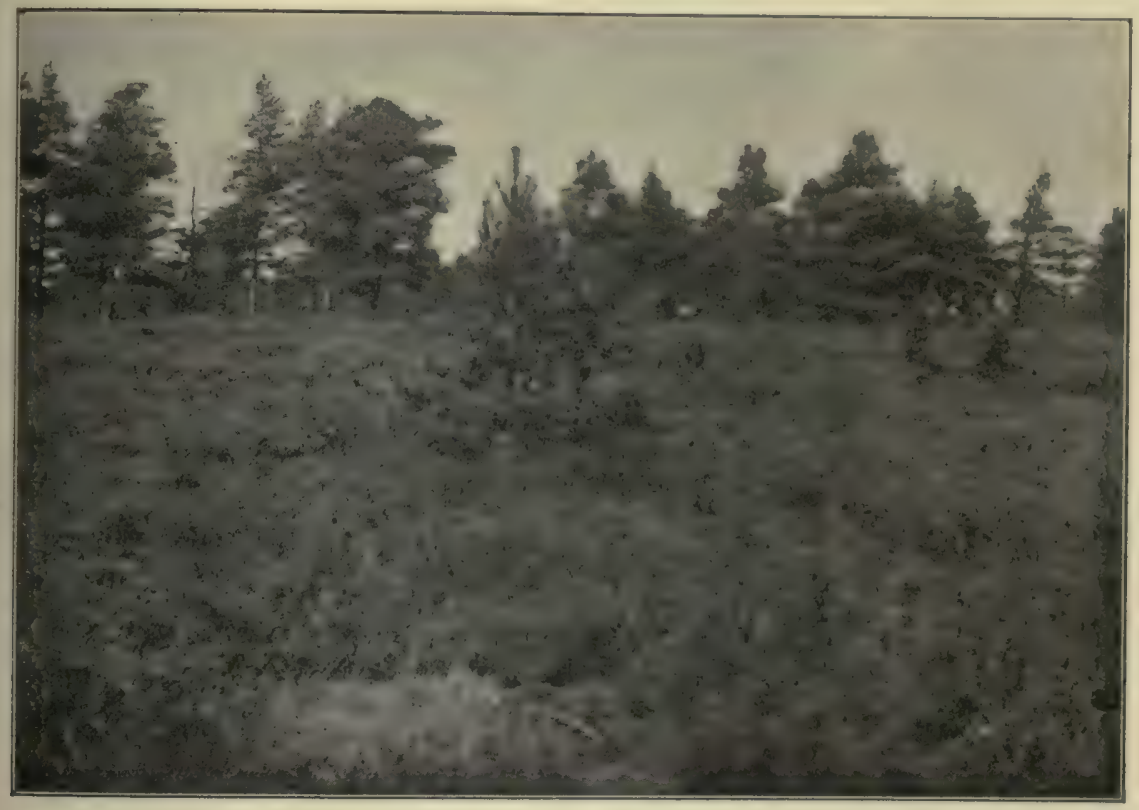

Fig. 300. Teil derselben Heidefläche wie Fig. 298, 299.

Salix repens, Vaccinium myrtillus, das jedoch mehr auf Waldboden vorkommt, ferner in den nördlichsten Gegenden Arctostaphylos alpina, Betula nana, Salix herbacea, S. polaris und S. reticulata und mehrere andere, darunter in südlicheren Gegenden Vertreter der Rutensproßform (Sarothamnus, Genista-Arten; S. 228). Mehrere dieser laubwechselnden oder wenigstens nicht wintergrünen Pflanzen baben einen Verdunstungsschutz in der Form von grauen oder silberweißen Deckhaaren oder von Wachs. Dornig sind einige Genista-Arten und Ulex.

Die in Nordeuropa vorherrschenden Zwergsträucher, Calluna, Erica und Empetrum sind rasenbildend, haben lange ausdauernde primäre Wurzeln. Empetrum hat niederliegende, wurzelnde Sprosse. 
Viele Sträucher haben fleischige Früchte, die von Vögeln gefressen werden (Empetrum, Vaccinium, Arctostaphylos).

Unter und zwischen den Zwergsträuchern wachsen einige Moose und Flechten, die mit ihren Rhizoiden den Boden durchweben, von Flechten besonders Cladonia rangiferina, Cetraria Islandica, Sphaerophoron coralloides usw., von Moosen namentlich Arten von Polytrichum, Rhacomitrium, Hypnum und Hylocomium.

Ferner treten Gräser und Kräuter auf, vorzugsweise mehriährige; die ein- und zweijährigen Arten halten sich in dem dichten Gesträuche schwierig und kommen höchstens auf seinen nackten Stellen vor (z. B. Aera praecox, A. caryophyllea; von den schmarotzenden Rhinantheen muß auch hier abgesehen werden). Die Kräuter und die Gräser sind meistens an den Standort gebundene, mehr oder weniger stark ausgeprägte Rasenbildner (z. B. Arnica montana, Solidago virga aurea, Campanula rotundifolia usw.), die zu dem dichten Boden besser als die Arten mit unterirdisch wandernden Sprossen passen.

Deutlich xerophil gebaut sind besonders die immergrünen Zwergsträucher, aber auch viele Kräuter. Über diese sei hier nur erwähnt, daß breite, dünne, kahle Blattspreiten kaum vorkommen, daß z. B. die Gräser meist borsten- oder fadenförmige Blätter mit Spaltöffnungen in solchen Furchen haben, die sich nach den Verhältnissen öffnen und schließen können: bei Weingaertneria canescens, Nardus stricta (einem Tunicagrase), Festuca ovina u. a.; vergl. S. 221 (vergl. Fig. 118). Sehr klein-oder schmalblättrig sind viele nur hin und wieder beigemischte Arten, z. B. Rumex acetosella, Campanula rotundifolia, Scleranthus, Artemisia campestris, im Vergleiche mit ihren nächsten Verwandten anderer Standorte; wollhaarig sind andere, z. B. Antennaria und Gnaphalium; von Succulenten findet man nur Sedum acre vor.

Die Zwergstrauchheide kommt in mehreren Ländern der gemäßigten und kalten Gegenden der nördlichen Halbkugel vor und entwickelt sich typisch auf ausgedehnten Flächen, z. B. in Jütland und besonders in Nordwestdeutschland. (Vergl. Karte S. 623.)

Assoziationen. Diese sind oft gemischt, aber viele Arten bilden reine Assoziationen, d.h. solche, die vorzugsweise aus einer Art von Zwergsträuchern gebildet sind. Diejenige, welche die größte Ausdehnung hat und viele Quadratmeilen von Land bedeckt oder doch bedeckt hat, ist das Callunetum vulgaris. Das Heidekraut, Calluna vulgaris, die tonangebende, Bestand bildende Art, ist eine merkwürdige Pflanze. Es ist genügsam und zählebig, weder im Boden noch im Klima wählerisch. Es kann, wie gesagt, ebenso gut auf dem unfruchtbarsten mitunter (wenigstens oberwärts) ziemlich trockenen Sandboden wie auf sehr nassem Moorboden (der mitunter periodisch trocken ist) wachsen und gedeiht 


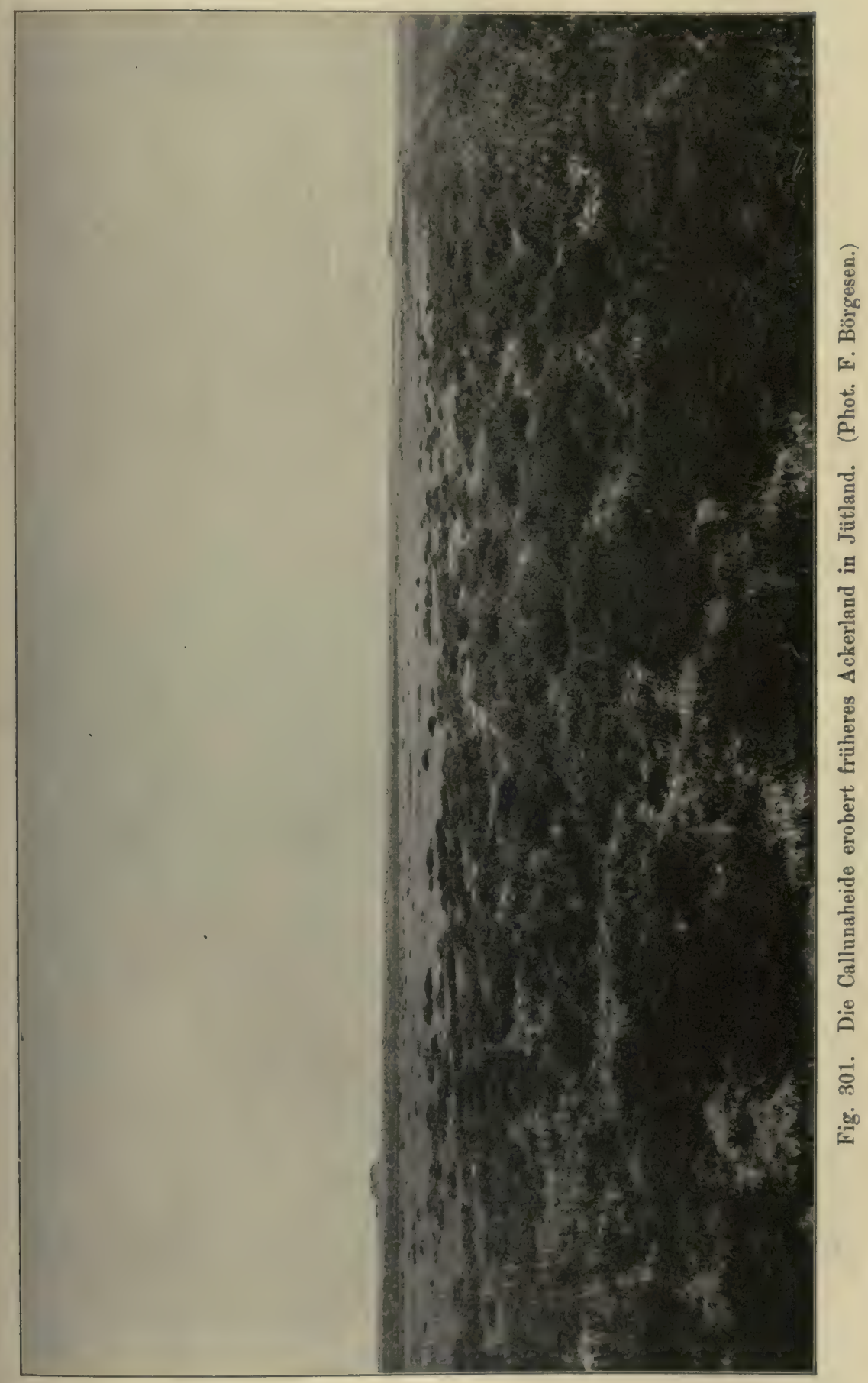


besonders auf humusreichem Boden gut. Es kann noch auf mäßig gutem Boden wachsen, was ihm jedoch selten erlaubt wird, weil es durch andere Arten von dort verdrängt wird. Diese Arten, welche größere Lebensanforderungen stellen und besonders eine höhere Stoffproduktion zeigen, verschmähen den mageren oder sauren und luftarmen Boden der Heide und überlassen ihn dem Heidekraute. Hier wird es eine gesellige Art und ist dann auf meilenweiten Gebieten fast allein herrschend. An vielen Stellen, z. B. in Dänemark, bedeckt das Heidekraut alte Waldgebiete, namentlich von Buchen- und Eichenwäldern, welche durch Rohhumusbildung die Fähigkeit der Selbstverjüngung verloren haben, und hierdurch oder auch durch den Wind zugrunde gegangen sind. Es gibt viele Fälle, die zeigen, daß das Heidekraut in die Wälder eindringen kann und schließlich den ganzen Waldboden erobert; es gibt auch einige Beispiele, die zeigen, daß Waldbäume in die Heide einwandern können und schließlich die Heide verdrängen. Dann muß der Heideboden aber sicher immer reich an Nährstoff sein und die Heidevegetation war mehr oder weniger künstlich (Schafweide).

Auf Kalk und Mergel wächst es wegen der herrschenden Konkurrenz auf dem guten Boden selten; auf armem Kalkboden (besonders Muschelkalk) tritt es mitunter auf (De Candolle, Graebner, Rayner, Jones and Tayleur ${ }^{1}$ ), fordert in Klimaten mit größerer Luftfeuchtigkeit Sonnenlicht und offenen Boden (in kontinentaleren Gebieten wächst es in der Ebene nur in Wäldern) und erträgt große, mit Trockenheit verbundene Winterkälte gewiß nicht, wie es eben gegen große Trockenheit überhaupt empfindlich ist. Aber im übrigen sieht man es sowohl an den niederschlagsarmen Küsten des Mittelmeeres als auch im regenreichen Norwegen gut gedeihen. Die Lebensdauer des Heidekrautes wird mit 20-30 Jahren als Durchschnitt gewiß schon sehr hoch angegeben; bisweilen sieht man die Calluna-Vegetation plötzlich auf großen Strecken ausgehen, wahrscheinlich weil die betreffenden Pflanzen jenes Alter erreicht haben, junge Pflanzen treten dann meist in Menge an ihre Stelle.

Rayner fand durch seine Versuche, daß Pilze schon am Samen vorhanden sind und ihn infizieren; die Mykorrhiza wird sehr früh gebildet.

Statistische Artsauszählungen im Callunetum vulgaris in Jütland finden sich bei Raunkiär ${ }^{2}$ ).

Die Gründe für den niedergedrückten Wuchs und die xerophile Natur der Heidevegetation Nordwesteuropas müssen teils im Klima, teils im Boden, namentlich in letzterem gesucht werden.

Die Vegetationszeit ist gewöhnlich trocken und die Transpiration kann dann stark sein, wenngleich eine herrschende Heidevegetation

1) Rayner 1911.

2) Raunkiår 1909 b. 
wenigstens stets eine gewisse Luftfeuchtigkeit voraussetzt. (Vergl. Karte S. 623.) Im Frühjahre (Mai, Juni) ist die Luftfeuchtigkeit, jedenfalls in Dänemark, am geringsten. Im Winter spielen in den nördlichsten Gegenden die Winterkälte und die Trockenheit samt den Stürmen für die immergrünen Pflanzen eine wichtige Rolle. Die Winde wehen über die trockenen Flächen, auf denen Zwergstrauchheide besonders vorkommt, mit großer Stärke, und sind wohl der wichtigste klimatische Faktor, der stellenweise den Wald verhindert, den Boden zu erobern.

Im Norddeutschen Flachlande mit seinem ziemlich monotonen geologischen Aufbau macht sich die Abhängigkeit der Verbreitung der Heide-

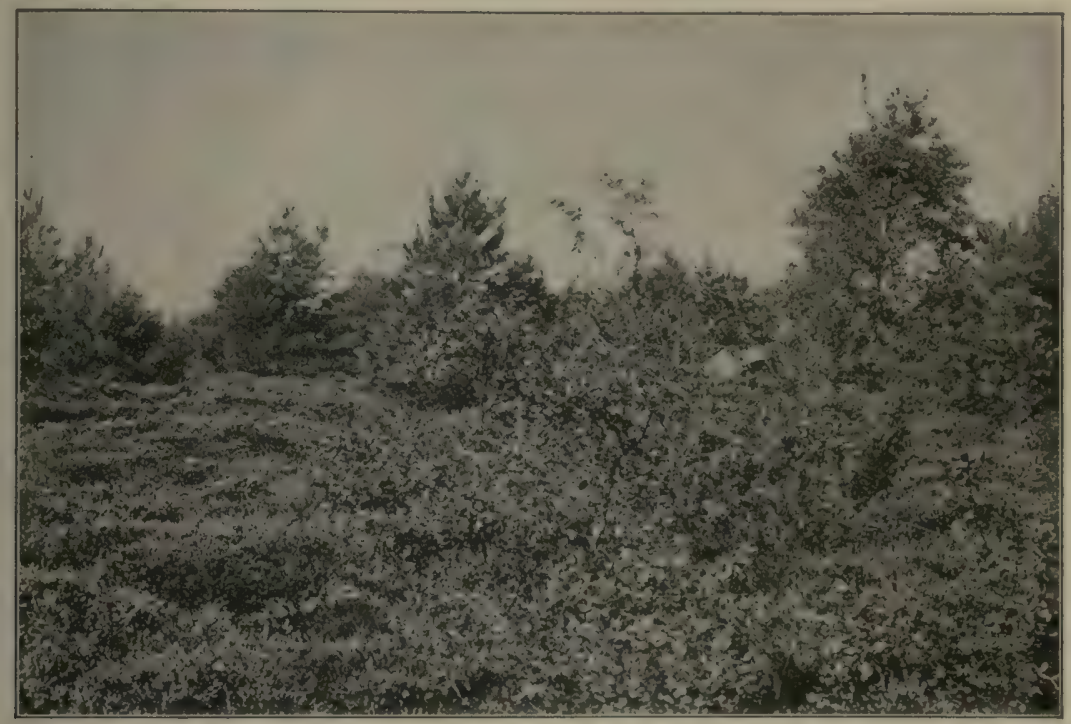

Fig. 302. Der Wald wandert in die Heide ein (vergl. Fig. 298-300).

(Die dänische Ostseeinsel Bornholm.) (Phot. Eng. Warming.)

formation von den Niederschlagsverhältnissen sehr deutlich bemerkbar. In den niederschlagreichen Teilen des Nordwestens dehnen sich die Riesenflächen der ostfriesischen bis Lüneburger Heiden und in SchleswigHolstein schließen sie sich an die dänischen an. Fin schmaler Heidestreifen folgt der Ostseeküste, ist aber an den Trockengebieten an den Strommü̈ndungen unterbrochen. Losgelöst von dem Hauptkomplex der Heidegebiete tritt die Formation wieder in den feuchteren Landesteilen der Priegnitz, besonders aber in der Lausitz auf. Als charakteristischer Begleiter ist etwa Myrica gale zu nennen, dessen Verbreitungsgrenze fast genau der Niederschlagsgrenze von jährlich $60 \mathrm{~cm}$ Regen folgt. Andere Charakterpflanzen der Heide (Erica tetralix, Empetrum usw.) folgen in ihren Grenzen in mehr oder weniger großen Abständen dieser 
Grenze fast parallel, wodurch der ausschlaggebende Einfluß der Niederschlagshöhe sich erweist. Dem entsprechend meiden viele südöstliche pontische (kontinentale) Arten in gleichfalls parallelen Verbreitungsgrenzen tie Heidegebiete ${ }^{1}$ ).

Die Beschaffenheit des Bodens ist jedoch offenbar weit wesentlicher als das Klima. Der Boden ist meist ein äußerst nahrungsarmer, nach der Eiszeit vom Wasser stark ausgewaschener und ausgeschlämmter Quarzsandboden (S. 106), auf welchem sich, wie gesagt, eine oft nur dünne Rohhumusschicht gebildet hat. Besonders Calluna und Vaccinium myrtillus gehören zu den im Rohhumus üppig wachsenden Pflanzen, die dadurch, daß sie ihn mit ihren Wurzeln verfilzen, den Heidetorf (Trockentorf) hervorbringen, wobei sie von Moos-Rhizoiden, Cladosporium-Hyphen usw. unterstützt werden. Die Rohhumusschicht nimmt begierig Feuchtigkeit auf, hält sie lange fest, hindert die Verdunstung aus dem Boden und erschwert den Zutritt der Luft, weshalb Humussäuren entstehen. In trockenen Zeiten jedoch kann die Schicht wegen ihrer dunkeln Farbe leicht erwärmt und stark ausgetrocknet werden. Bei starker Austrocknung verschwindet jedoch das Heidekraut und macht dann gewöhnlich der Flechtenheide Platz (so in Norddeutschland). In den nicht seltenen Fällen, wo unter echten Calluna-Heiden ein mehr oder weniger nährstoffreicher Boden liegt, ist es die dicke und dichte Rohhumuslage, die den Wald fernhält und ihn meist vorher schon vernichtet hat. In den feuchteren atlantischen Klimaten bildet sich, wie schon früher auseinander gesetzt, sehr leicht früher oder später, sicher wenigstens in den reinen Nadelholzbeständen ${ }^{2}$ ), eine Rohhumusschicht, die durch ihre ungünstigen Wirkungen (vergl. S. 90) die Wiederverjüngung des Waldes hindert und keiner anderen Vegetation die Lebensmöglichkeit läßt als der Heide.

Zwischen Calluna-Heide auf trockenem Boden und Calluna-Moor läßt sich keine scharfe Grenze ziehen; im letzteren ist der Boden nasser und der Torf kann viel dicker werden, bis meterdick und mehr; auf der ersteren ist der Trockentorf gewöhnlich nur wenige Zentimeter bis einige Dezimeter dick und weit trockener. Erhebliche floristische Unterschiede gehen hiermit Hand in Hand.

Ericeta tetralicis. Auf den feuchteren Stellen der Zwergstrauchheiden finden wir mit Calluna gemischt oft Erica tetralix in Menge, gewöhnlich auf kleineren, seltener größeren Strecken. Nicht selten wird sie bestandbildend und mit ihr treten dann oft die Mehrzahl derjenigen Pflanzen auf, die wir als für Heide-(Sphagnum)-moore charakteristisch kennen. Ist das Klima feucht genug, so daß Sphagnum üppig

1) Graebner $1895 \mathrm{ff}$.

2) Vergl. v. Bentheim bei Graebner usw. 
wachsen kann, so verwandelt sich solcher Verein leicht in Heidemoor. Umgekehrt wird stets, wenn ein Heide-(Sphagnum)-moor aus irgend

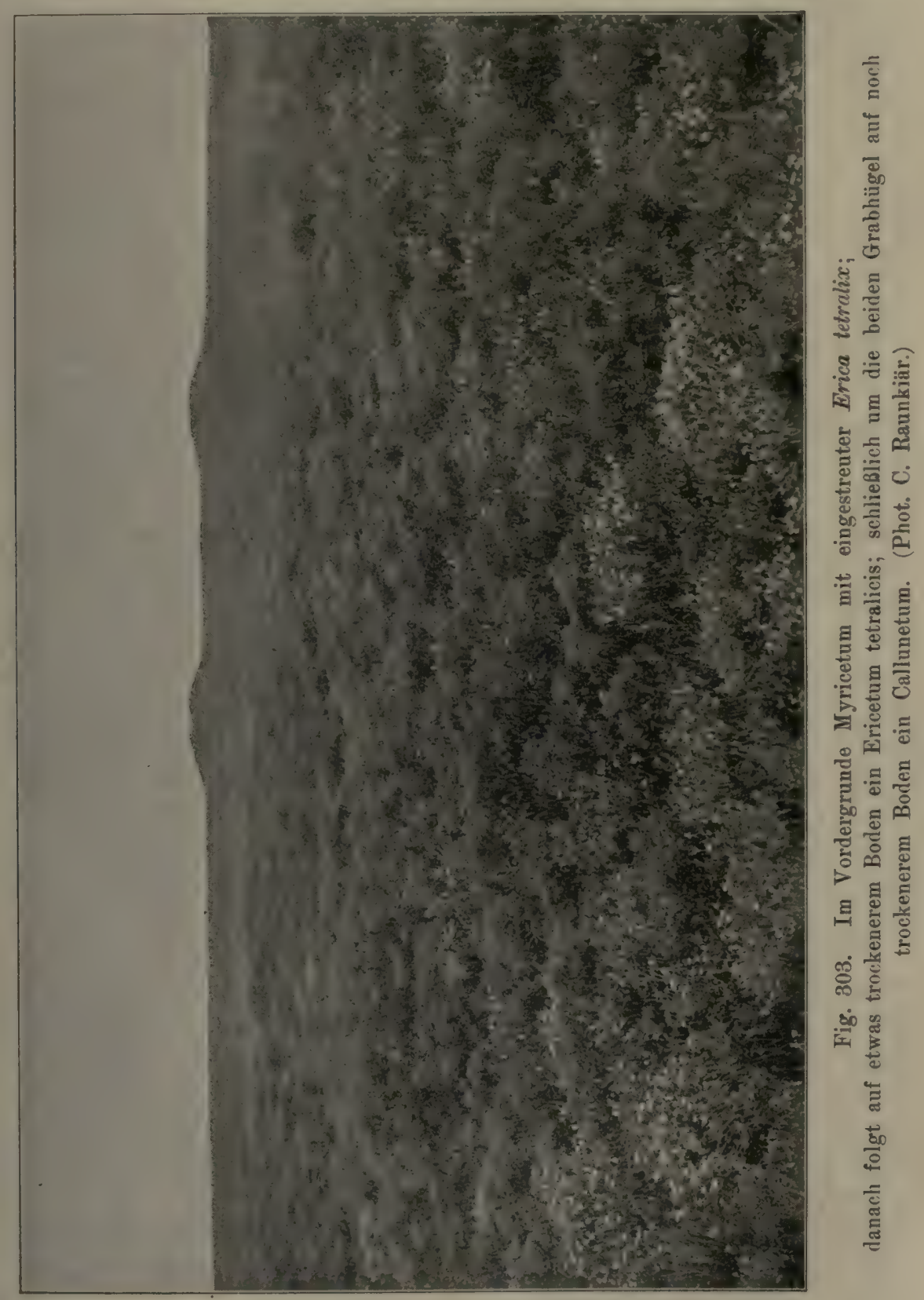

einen Grunde trockener wird, Calluna die Oberhand erhalten (Fig. 303). Wenn die Trockenheit zu groß wird, alsdann verschwindet auch das 
Heidekraut und nur wenige anspruchslose Moose, Flechten und Blattpflanzen finden sich zerstreut auf dem kahlen Boden.

Myriceta, aus Myricae gale gebildet, finden sich an vielen Stellen in Nordeuropa auf nassem Boden, oft gürtelförmig im Umkreise um Seen und Wiesen oder um Sphagnum-Moore. Oft sieht man gemischte Assoziationen von Myrica, Erica tetralix und Calluna valgaris, an welchen alle drei fast gleich großen Teil nehmen.

Vaccinieta myrtilli (oder Myrtilleta) finden sich auf trocknerem Boden und als reine Assoziationen vorzugsweise als Bodenschicht in Wäldern aus Nadelholz (Pineta silvestris, Piceeta excelsae und in Buchenwäldern mit Rohhumusboden). Wo die Art sich außerhalb des Waldes findet, wird man gewiß immer den Schluß ziehen können, daß dort früher Wald gestanden hat. Sie ist eine echte Rohhumuspflanze.

Gräser überwiegen die Calluna in zwei Fällen (Grasheiden); entweder ist der Boden verhältnismäßig nährstoffreich, dann bildet der Verein einen Übergang zu Wiesen oder Weiden, oder der Boden trocknet zeitweise zu stark aus (bezw. die Lufttrockenheit wird zu groß), auch dann treten oft trockenheitliebende Gräser (Weingaertneria) in den Vordergrund. Die allertrockensten oft nur Cladonia rangiferina tragenden Flächen sind heidekrautlose Sandfelder.

In den Heiden Englands unterscheidet W. G. Smith (in Tansley 1911) fünf Facies (d. s. Assoziationen): I. Die trockene Reihe: a) typisches Callunetum; b) Calluna-Vaccinium-Heide; c) Calluna-Pteris-Heide. II. Nasse Reihe: a) Calluna-Nardus-Heide; b) Calluna-Tetralix-Heide. Vergl. auch Elgee.

Über die Zwergstranchheiden Nord- und Mitteleuropas vergl. Graebner $1895 \mathrm{ff}$.; C. A. Weber 1900; Koernicke und Roth 1907. Die Heiden Englands siehe Tansley 1911; Moss 1913; Elgee 1912, 1914. Die Heiden Dänemarks: Mentz 1900, 1902; Raunkiär 1889 a, 1909 b; Warming $1907-9$.

Im nördlichsten Europa findet man noch Calluneta in den westlicheren Teilen, aber gegen Osten hin treten sie mehr zurück, ganz so, wie sie auch in Norddeutschland an die westlichen Gegenden gebunden sind, wo das Klima mehr ozeanisch ist.

Aus den Untersuchungen von Vahl und Frau Resvoll-Holmsen ${ }^{1}$ ) scheint hervorzugehen, daß die Hochgebirgsheiden an trockeneren Orten reich an Flechten sind, und daß Zwergsträucher ohne unterirdisches Wanderungsvermögen, z. B. Empetrum, Arctostaphylos-Arten, Betula nana, an Zahl den unterirdisch wandernden Vaccinien überlegen sind. Auf feuchterem Boden ist die Heide moosreicher, wogegen dort die Flechten eine untergeordnete Rolle spielen. Hier sind die Vaccinien sehr zahlreich.

2) Vahl 1913; Resvoll-Holmsen 1912. 
Im nördlichen Europa treten andere Arten auf, namentlich Betula nana, Arctostaphylos alpina, Ledum palustre (schon in Nordostdeutschland öfter an trockeneren Orten, in Kiefernwäldern usw.), Loiseleuria procumbens, Phyllodoce coerulea, Rhododendron Lapponicum u. a., die gemischte und teilweise auch reine Assoziationen bilden, namentlich aus Betula und Ledum.

Betuleta nanae gehören zu den höheren ( $1 / 3-1 \mathrm{~m}$ hohen) Assoziationen. Nach Pohle ${ }^{1}$ ) ist die "Zwergbirkentundra" im Osten des Samojedenlandes geradezu eine herrschende Assoziation. Hier kommen weite vom sparrigen Gesträuch der Zwergbirke eingenommene, gewöhnlich etwa kniehohe Gefilde vor. Der bindige Boden ist tonig mit Beimischung von Sand und kleineren Gesteinsbrocken, und mäßig feucht. Die Birke selbst ist xeromorph mit kleinen, harzüberzogenen, glänzenden Blättern. Unter dem dichten Gesträuche findet sich eine kurze Decke von Moosen mit wenigen Flechten (Cladonien, Stereocaulon, Nephroma arcticum u. a.), Salix reticulata, Arten von Pedicularis, Sagina, Stellaria, Juncus, Luzula und dichte Horste von Gräsern, Eriophorum Scheuchzeri u. a.; die Holzgewächse machen stets die größte Masse aus (Ledum, Empetrum, Vaccinium vitis Idaea, V. uliginosum, Salices u. a.). Obgleich Rohhumus nicht erwähnt wird, scheint es kaum zweifelhaft, daß der Boden sauer sein muß; jedenfalls kommen die erwähnten Sträucher an anderen Stellen vielfach auf Rohhumus vor. Daß hier im östlichen Teile der subarktischen Zone vielleicht wenig Rohhumus gebildet wird, mag daher herrühren, daß nach Pohle eine relativ große Trockenheit der Luft herrscht und die Menge von Niederschlägen gering ist.

Allmählich leitet besonders in den Hochgebirgen und in den kalten Zonen diese Formation in die der Hochsträucher (vergl. dieselbe S. 516) über. Im hohen Norden, z. B. auf den Tundren Lapplands, treten Betula nana (die Zwergbirke) und andere Birken als Sträucher auf, welche niedrige, flach gedrückte Gebüsche bilden, oft zusammen mit grauhaarigen Weiden (Salix glauca, S. lanata u. a. Arten). Gleich oberhalb der Baumgrenze tritt in den Gebirgen Skandinaviens eine Grauweiden-Zone mit Salix lanata, S. glauca u. a. auf, deren Blätter gegen starke Transpiration im ganzen durch Haarfilz, aber auch durch dicke Haut, Wachsbildungen usw. geschützt sind. In Grönland findet man noch um den $72 .^{\circ} \mathrm{n}$. Br. ähnliche Weidengebüsche, die bis $1 \mathrm{~m}$ hoch werden, deren Stämme und Zweige dicht verflochten sind und die aus Salix glauca und Betula nana bestehen. Diese Gebüsche müssen jedoch vielleicht am ehesten zu den mesophilen Vereinen gerechnet werden (vergl. Kap. 72). Desgleichen bilden Zwergbirke, Weiden und Wacholder gemeinsam auf den Gebirgen Norwegens ausgedehnte, niedrige $\left(1 /{ }_{2}-2 / 3 \mathrm{~m}\right.$

1) Pohle 1907. 
hohe) Gebüsche, die am meisten den Alpenrosengebüschen der Alpen entsprechen.

Empetreta nigri. Eine Assoziation von Empetrum nigrum, eine „Empetrumtundra“ kommt nach Pohle auch am Weißen Meere vor. Die Früchte werden in Menge gefressen und zerstreut durch Larus argentatus. Zugleich mit Arctostaphylos uva ursi und A. alpina bildet Empetrum dem Boden fest aufliegende, schwellende Teppiche, welche ein für die windoffene Tundra wichtiges, bodenschaffendes Element als Hnmussammler sind. Mit einer Reihe anderer niederliegender Holzpflanzen schaffen sie mit der Zeit ein neues Substrat, einen braunschwarzen, torfartigen Rohhumus, der ein deutliches Zeichen für die Eigenschaften des Klimas ist, d. h. er zeigt beständig feuchte Luft und beständig trocknende Winde an, sowie niedrige Temperaturen. Dieselben Faktoren erklären denn auch die xeromorphe Organisation der oberirdischen Teile der Pflanzen: Verkürzung der Zweige, Verkleinerung der Blattflächen, Einrollung der Blattränder, oder daß die Blätter dicht übereinander gelegt werden usw.

In den norddeutschen Heidegebieten finden sich auch hier und da, wie auf den Bergheiden der Mittelgebiete Bestände von Empetrum, wenn auch meist von geringerer Ausdehnung. Auch mehrere andere Arten können Bestände bilden; in Finnland gibt es z. B. LoiseleuriaBestände, Phyllodoce-Bestände usw. (bei Hult „Formationen“), die stellenweise auch auf den Felsenfluren vorkommen können.

Zwischenformen zwischen Heide und Hochmoor kommen im nördlichsten Europa ${ }^{1}$ ) (Finnland, Schweden, Norwegen, Schottland ${ }^{2}$ ), Norddeutschland usw.) vielfach vor. So erwähnt $\mathrm{Hult}^{3}$ ) eine eigentümliche Assoziation, die "ein vollständiges Mittelding zwischen Heide und Moor" ist und deren Vegetation hauptsächlich aus kleinen Weiden (Salix reticulata, S. herbacea und S. polaris), überdies aus zahlreichen Stauden und Zwergsträuchern besteht (von diesen sind z. B. Dryas, Arctostaphylos alpina, Loiseleuria, Phyllodoce zu nennen). Alle diese Vorkommnisse beweisen, daß Heiden und Heidemoore eine natürliche Gruppe bilden. Ähnliche Übergangsformen kann man auch auf den Gebirgen Mitteleuropas beobachten, so auch auf dem Heide- und Moorgelände des Brockenmassivs im Harz usw.

In der arktischen Zwergstrauchheide spielen Calluna und Erica fast keine oder gar keine Rolle, sondern namentlich Empetrum und eine Reihe Ericaceen: Cassiope tetragona (Fig. 178), Vaccinium uliginosum var. microphyllum, V. vitis Idaea, Ledum palustre f. decumbens,

1) Über die Heiden des subarktischen Europa vergl. weiter Simmons 1912.

2) Crampton 1911.

8) Hult 1887; Graebner 1895 ff. 
Phyllodoce caerulea, Loiseleuria procumbens, Arctostaphylos alpina, A. uva ursi, Rhododendron Lapponicum, ferner Diapensia Lapponica, Dryas

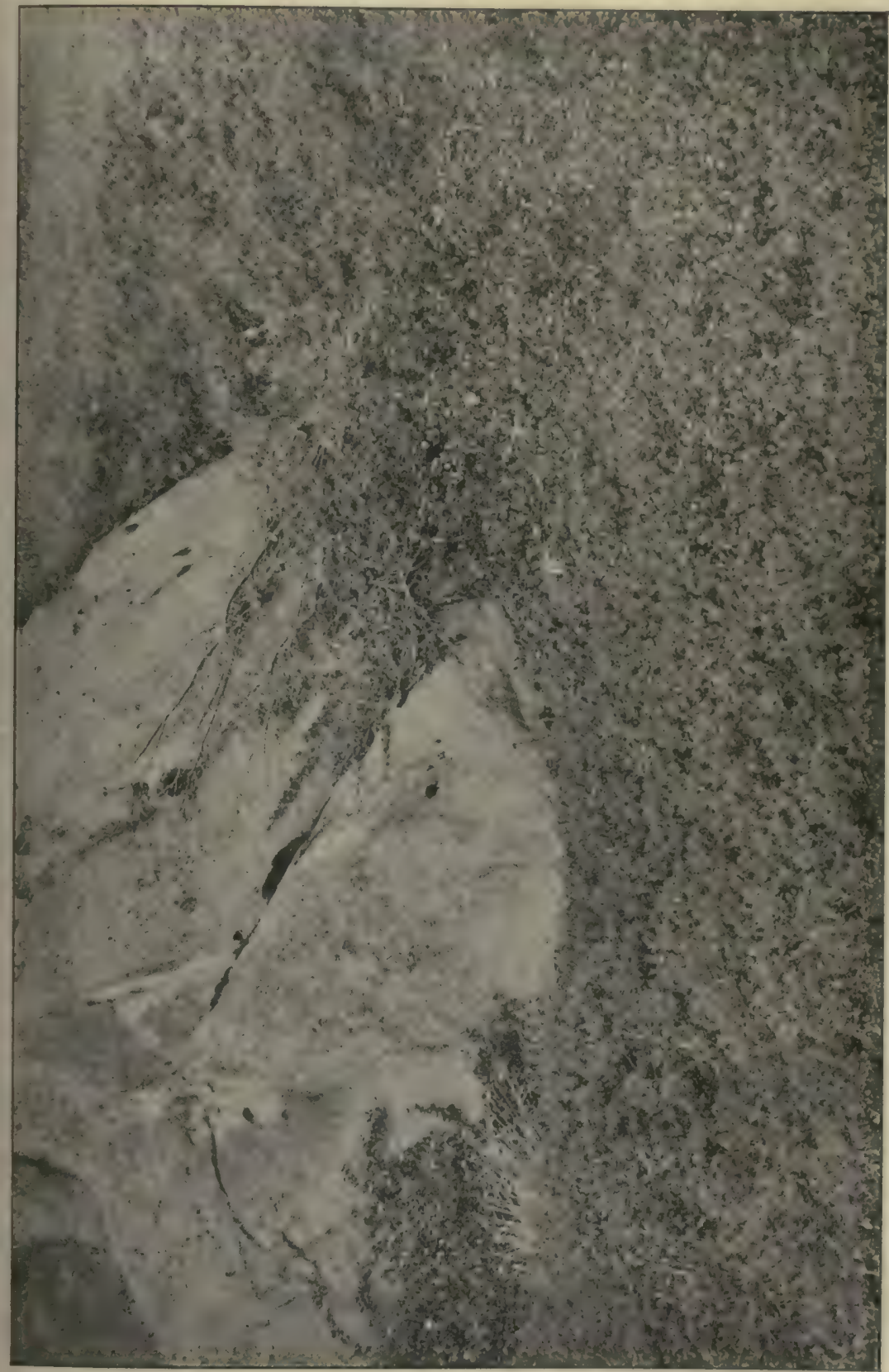

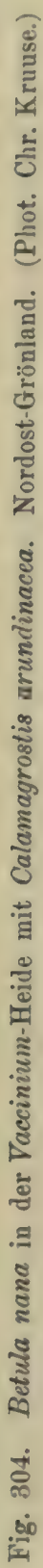

octopetala, Betula nana und glandulosa, Juniperus communis, Salix glauca, herbacea und polaris u. a., um nur die Zwergsträucher zu nennen. 
Auf Island kann Dryas octopetala in einer solchen Menge von Individuen (zusammen mit Silene acaulis, Armeria maritima, Thymus serpyllum u. a.) auftreten, daß sie eigene Assoziationen bildet, die "Dryas-Heide" 1 ).

Die Zwergstrauchheiden bedecken weite Gebiete Grönlands, Nordamerikas und des nordöstlichen Asiens; sie haben viele Polarreisende mit Feuerung versehen, reichen jedoch kaum bis zu den nördlichsten Gegenden und bis zu großen Gebirgshöhen; da treten die dürftigeren und genügsameren Felsenfluren an ihre Stelle. Der Boden ist wie in Europa ein Rohhumusboden.

Die grönländischen Heiden sind an vielen Stellen in den „Meddelelser om Grönland" von den vielen dänischen Botanikern, die West- und Ostgrönland bereist haben, eingehend besprochen und abgebildet ${ }^{2}$ ).

Sehr ausgebreitet sind Assoziationen von der etwa $15-30 \mathrm{~cm}$ hohen Cassiope tetragona, deren Blüten denen von Convallaria majalis in Form, Farbe und Duft ähnlich sind.

Auch andere Arten bilden reine Assoziationen, z. B. Vaccinium uliginosum, Empetrum nigrum, Dryas octopetala und D. integrifolia.

Kräuter (darunter viele immergrüne), Gräser, Moose und Flechten sind wie sonst in größerer oder geringerer Menge beigemischt, und an vielen Stellen findet man sehr allmähliche Übergänge von der geschlossenen Formation der Zwergstrauchheide zu den Felsenfluren, sowie zu den Moos- und den Flechtenheiden; die Arten sind teilweise dieselben, aber ihre Menge ist eine andere. Über die Arten vergleiche die zitierte Litteratur.

Floristische Mittelformen zwischen der arktischen und der norddeutschen Heide kommen auf Island, in Lappland und dem nördlichen Skandinavien vor (Grönlund, Hult, Brotherus п. a.).

Südeuropäische Gebirge. In den Alpen finden sich ausgedehnte Zwergstrauchheiden mit verschiedenen Assoziationen. Nach Brockmann-Jerosch z. B. in der Puschlaw Assoziationen von Vaccinium myrtillus, V. uliginosum, Rhododendron ferrugineum, Calluna vulgaris, Juniperus communis var. nana und Arctostaphylos uva ursi. Einige ziehen schneefreie Stellen vor, andere meiden sie. Man kann dieselben Assoziationen auch als Bodenvegetation in lichten Wäldern finden. "Die Bergheide" der südöstlichsten Kalkalpen hat nach Krasan durchaus dieselben xerophilen Lebensformen, aber teilweise andere Arten, z. B. Erica carnea, Rhododendron hirsutum, Polygala chamaebuxus, Globularia u. v. a. Ericaceen.

1) Stefansson, S. 189.

2) Warming 1887; Porsild 1902; Hartz und Kruuse 1911; Kruuse 1912; Lundager 1912. Alle in "Meddel. om Grönland“, Köbenhavn, gewöhnlich englisch geschrieben oder mit französischen Resumées. 
Erica carnea kommt sowohl in als über dem Waldgürtel vor; in der subalpinen Region der östlichen Kalkalpen findet man Heide, die aus Daphne striata gebildet wird, mit Polygala chamaebuxus und Globularia nudicaulis. In größeren Höhen bildet Loiseleuria (Azalea) procumbens Heiden; in der Azalea-Heide kann der Rohhumus eine Dicke von einem halben Meter erreichen ${ }^{1}$ ).

Im südöstlichen Europa erscheint an Stelle der fehlenden Calluna an gewissen Stellen Bruckenthalia spiculifolia²).

Die Antarktische Heide wird auf den Kerguelen von Acaena adscendens gebildet. Auf den nördlichen und östlichen Abhängen, wo die atmosphärische Feuchtigkeit groß ist, herrscht Acaena meist allein auf dem sehr humosen Boden. Die kriechenden Hauptachsen bedecken den Boden mit einem engmaschigen Netze, von welchem sich die beblätterten Triebe senkrecht bis zu einem halben Meter Höhe erheben. An Orten, wo die Luft weniger feucht ist, ist das Aussehen der Formation verschieden, denn Acaena legt sich dort dicht auf den Boden und die einzigen aufrechten Teile derselben sind die Triebspitzen und die zahlreichen Blütensprosse. Derartige Plätze sind durch die groBe Zahl der Begleitpflanzen ausgezeichnet, wie z. B. Lomaria alpina, Azorella, Pringlea, Galium antarcticum und Ranunculus biternatus. Die Heide der Kerguelen ist diejenige Formation, die die für den Pflanzenwuchs günstigen Stellen bedeckt, besonders die vor dem Winde geschützten ${ }^{3}$ ). Auch in Südgeorgia bildet Acaena adscendens Heiden $\left.{ }^{4}\right)$.

Die „ozeanische" Heide auf den Falklandsinseln bespricht Skottsberg ${ }^{5}$ ). Assoziationen von Cortaderia, Empetrum rubrum und Poa flabellata kommen vor. Die Heide von Empetrum ist "die klimatische Normalformation des Gebietes", welche er als Seitenstück zu der nordatlantischen Heide betrachtet. Von anderen Zwergsträuchern kommen Pernettya pumila, Gaultheria microphylla, Daphne muscosa, Vaccinium oxycoceus und Myrtus nummularia vor.

In Neuseeland scheint die Myrtacee Leptospermum scoparium mit ihren steifen Stämmen und schmalen Blättern Heiden zu bilden, bisweilen allein, auf trockenem oder feuchtem, aber immer armem Boden. In Sümpfen, in sauren Sphagnum-Mooren, auf sturmumwehten Sand-

1) Utber die Zwergstrauchheiden der südeuropäischen Berge vergl. Kerner 1863; Christ 1877; Krasan 1883; Hayek 1907; Brockmann Jerosch 1907, S. 278; Schröter 1904-08; Engler 1901; Furrer 1914.

2) Adamovié 1898 .

3) Schenck 1905 .

4) Will 1890; Skottsberg $1912 \mathrm{a}$.

3) Skottsberg 1913. 
hügeln, auf trockenen Felsen, ja selbst nahe bei heißen Quellen und Vulkanen, überall gedeiht sie, ein Seitenstück zu unserer Calluna ${ }^{1}$ ).

Die Zwergstrauchheiden gehen einerseits in die tropischen Strauchsteppen über, andererseits in die subglaziale Vegetation, und endlich drittens in die Moore, nämlich durch die nasse Heide, worin bei uns im Norden von Zwergsträuchern Erica tetralix, Andromeda polifolia und Myrica gale vorherrschen, von Kräutern Narthecium, Gentiana pneumonanthe, Pedicularis silvatica, Drosera-Arten, Pinguicula, einige Cyperaceen (Rhynchospora alba und Rh. fusca, Scirpus caespitosus, Eriophorumund Carex-Arten), von Gräsern besonders Molinia caerulea; ferner treten Moose, darunter Sphagnum-Arten, auf, aber Flechten fehlen am Boden.

\section{Kap. Formation der Sträucher auf Torfboden}

Schon oben (Kap. 86) wurde erwähnt, daß nicht nur die Zwergsträucher, aufrechte oder spalierförmig niederliegende wie Empetrum, den Moorboden bedecken, sondern daß auch etwas höhere Sträucher, wie Salix-Arten, einwandern können. Man sieht hier und da in Nordeuropa, daß Gebüsche auf trocknerem Moorboden, der hauptsächlich aus Moosen gebildet wurde, entstanden sind, namentlich Saliceta von Salix cinerea, S. aurita und anderen Salices, zum Teil auch mit eingestreuten Büschen von Alnus glutinosa, Myrica gale, Betula-Arten (B. humilis, B. verrucosa u. a.). Die Bodenvegetation kann verschieden sein und gehört wohl im allgemeinen der Wiesenmoor-Formation an, aber auch Calluneta können auftreten.

Junipereta. Eine andere Art, die in gewissen Gegenden eine große Rolle spielt, ist Juniperus communis, besonders in den trockneren Heidegegenden. Die Lüneburger Heide ist reich an Sträuchern dieser Art, z. B. im Totengrunde bei Wilsede; in der Eifel ist ein großes Wachholdergebiet geschützt. Verschiedene Wuchsformen dieser Art kommen vor: aufrechte säulenförmige bis buschige und niederliegende oder gar große baumartige. Oft findet man alle diese Formen dicht beieinander.

Saliceta ${ }^{2}$ ). Im subarktischen und arktischen Europa sowie in Island und Grönland kommen oft Gebüsche vor, welche aus Salices (vergl. Fig. 263-266), z. B. Salix glauca, S. Lapponum, S. hastata, S. myrsinites, S. arbuscula u. a., strauchartiger Betula odorata und auch höheren Exemplaren von Betula nana gebildet sind. Auf den Bergen Norwegens und Schwedens findet sich ein Gürtel von grauen Weiden, welche durch dicke und behaarte Blätter, dicke Oberhaut oder Wachsüberzüge mehr oder weniger xeromorph sind. Sie sind gewöhnlich etwa meterhoch und

1) Cockayne 1910.

2) Vergl. z. B. Thore C. E. Fries 1913. 
höher. Ebenso bildet Betula nana und Juniperus communis niedrige $(1 / 2 \ldots 2 / 3 \mathrm{~m}$ hohe $)$ weitausgedehnte Strauchbestände. Diese Gebüsche haben offenbar nicht immer einen aus Rohhumus gebildeten Boden (vergl. unter den mesophilen Formationen Kap. 72). Dieses hängt von der Wasserzufuhr ab; auf Boden mit frischem und daher sauerstoffhaltigem Wasser wird sichmilder Humus mit reicher Bodenvegetation bilden können, auf moosigem Boden mit stagnierendem sauerstoffarmem Wasser entsteht Rohhumus mit einer anderen Vegetation. Die Bodenvegetation kann z. B. folgende sein: Die Bodenschicht ist ein Moosmoor aus Sphagnum, Amblystegia, Paludella squarrosa und anderen Moosen gebildet; die "Feldschicht" ist aus Arten von Juncus, Eriophorum, Carex, Caltha, Comarum palustre u. a. Gefäßpflanzen zusammengesetzt. Wenn aber der Schatten sehr dicht wird, kann der Boden fast nackt werden ${ }^{1}$ ).

Subalpine Gebüsche auf Rohhumus. Wo wie in Mitteleuropa die Gipfel der höchsten Gebirge bereits in der Wolkenregion liegen, wird die Rohhumusbildung sehr durch die feuchte nebelige Atmosphäre und die niedrige Temperatur befördert, und dort erheben sich auf dem sauren Boden Gebüsche, die über der Waldgrenze beträchtliche Strecken bedecken.

Die Alpenrosengebüsche in den Alpen, den Pyrenäen und unter höheren, waldähnlicheren Formen im Himalaya werden von RhododendronArten gebildet, bisweilen in Gesellschaft mit Juniperus communis (dem Wacholder); der Verdunstungsschutz sind hier Schildhaare und Harzüberzug. Diese Gebüsche schließen sich den Zwergstrauchheiden an. Auf den Kalkalpen bildet Rhododendron hirsutum diese Gebüsche, während in den Zentralalpen $R$. ferrugineum an seine Stelle tritt. In den Rhododendron-Beständen wächst eine Anzahl von Zwergsträuchern der Heide, z. B. Vaccinium oder Calluna ${ }^{2}$ ).

Andere subalpine Assoziationen - z. B. in Serbien ${ }^{3}$ ) - werden aus Juniperus communis oder aus Vaccinium-Arten bezw. aus Mischungen aus beiden gebildet.

Gestrüppe der Zwergbäume. Auf hohen, windigen Stellen der Gebirge und an windigen Orten der hohen nördlichen Breiten treten Gebüsche oder Zwergwälder solcher Baumarten auf, die anderwärts Hochwälder bilden. Die Fichte (Picea excelsa) z. B. tritt in Lappland als kriechender und wurzelschlagender Strauch auf; sie nimmt eigentümliche, abgerundete, äußerst dicht verzweigte, niedrige Gestrüppformen

1) Sylvén 1904 .

2) Einzelheiten vergl. bei Kerner 1863; Hayek 1907; weiter Christ 1870; Schröter $1904-08$.

?) Adamoviẻ 1898 . 
an und kommt so teils einzeln, teils in ausgedehnten Matten oder Gebüschen vor, indem sie ihre dünnen Zweige in der Flechtenheide teilweise verbirgt ${ }^{1}$ ). Ihr Verdunstungsschutz beruht im Bau der Blätter. -

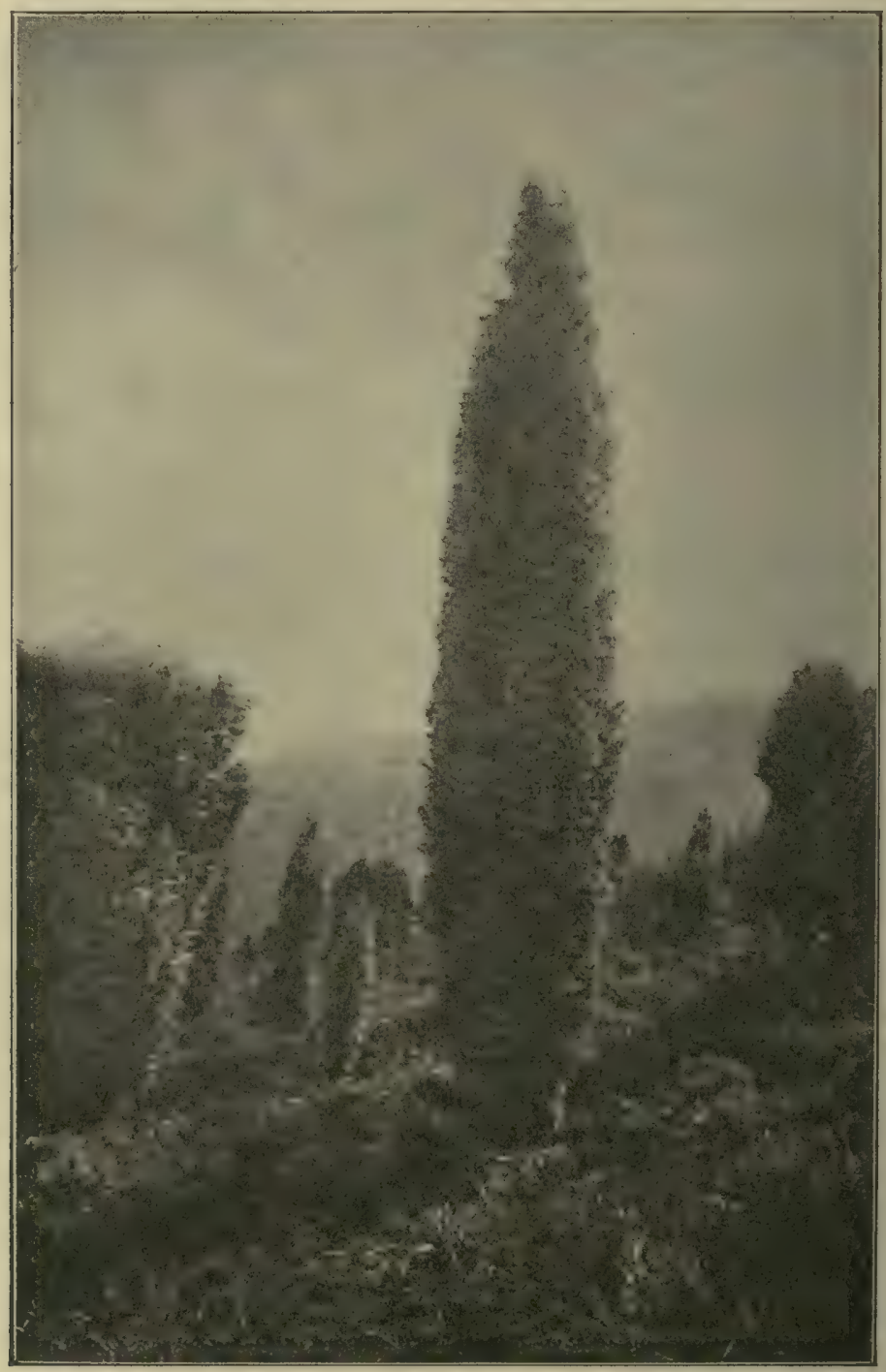

Fig. 305. Wacholderschutzpark am Wibbelsberg bei Niederheckenbach, Kreis Ahrweiler in der Eifel. Nach einer käuflichen Karte des Eifelvereins.

Anch die Kiefer (Pinus silvestris) und, in Sibirien z. B., die Arve (P. cembra) bilden auf ähnliche Art Gestrüppe. - Die Birke (Betula pubescens) wächst auf den Flechtenheiden Lapplands (wohl in der Unterart

1) Figuren bei Kihlman 1890. 
B. Carpatica) zum Teil in zerstreuten Exemplaren; diese drücken sich verkrüppelt dem Boden an und brauchen bisweilen 50 bis 60 Jahre, um einen $2 \mathrm{~m}$ langen und $4 \mathrm{~cm}$ dicken Stamm $\mathrm{zu}$ bilden, dessen Zweige

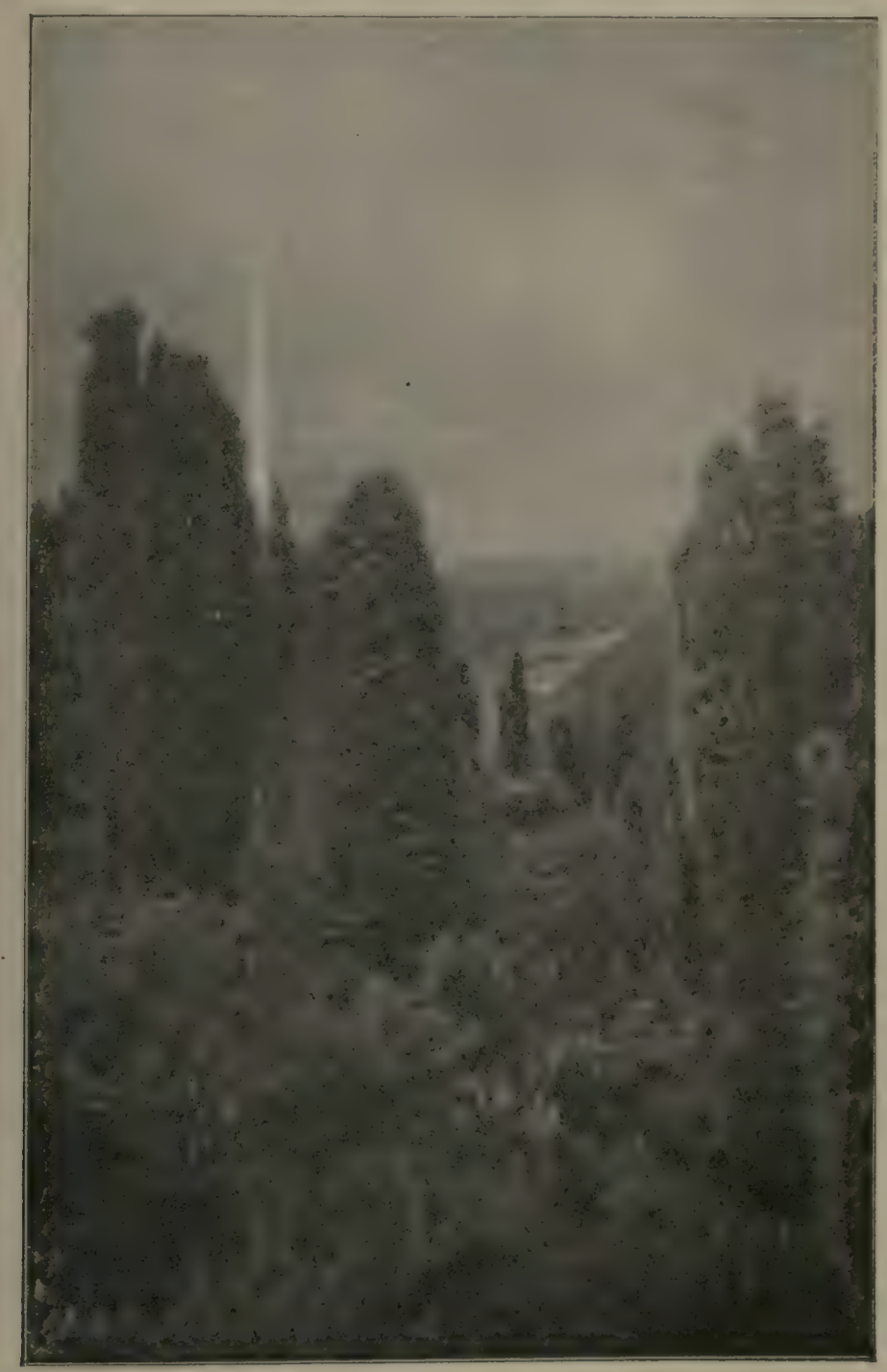

Fig. 306. Wacholderschutzpark am Wibbelsberg bei Niederheckenbach, Kreis Ahrweiler in der Eifel. Nach einer käuflichen Karte des Eifelvereins.

sich nicht über die Flechtenheide erheben. Aber an günstigeren Stellen wird sie höher und bildet Gestrüppe, die etwa 1-2 m Höhe erreichen und worin großblättrige (mesophile) Stauden auftreten können. Die Birke nähert sich in der Ökologie den xerophil gebauten Arten; sie 
heftet sich z. B., ebenso wie die Nadelbäume, auf den nackten, von der Sonne erwärmten Sandsteinfelsen der sächsischen Schweiz fest und bildet im nördlichen Europa oberhalb der Zone der Nadelbäume Gebüsche und Wälder. Als Verdunstungsschutz dienen ihr offenbar namentlich die „lackierten" Blätter. Es ist kaum zweifelhaft, daß der Boden in diesen Gestrüppen torfig ist.

In den Hochgebirgen hört der Wald nicht plötzlich auf; er sinkt zu einem Gestrüppe von niedrigen Bäumen und Sträuchern herab, bevor die offenen Matten und Felsenfluren beginnen, die aus Kräutern, Flechten, Moosen und Zwergsträuchern bestehen. Diese Gestrüppe werden je nach den Gegenden der Erde von verschiedenen Arten gebildet. In den Hochalpen sind die Krummholz- oder Legföhrengestrüppe die bekanntesten Xerophytengebüsche ${ }^{1}$ ). Sie werden von Varietäten der Krummholzkiefer (Pinus montana f. pumilio, f. uncinata, f. mughus) gebildet, die sich in westlicheren Gegenden (Westalpen, Pyrenäen) zu stattlichen Bäumen $(10-20 \mathrm{~m})$ erheben, und treten zwischen der Waldgrenze und den alpinen Matten auf. Ein aufrechter Stamm wird nicht entwickelt; die Stämme kriechen über den Boden hin, an Abhängen hinab, werden von Moosen und anderen Pflanzen bewachsen, schlagen Wurzeln, senden bogenförmige, kräftige Seitenzweige aufwärts, die mehr als mannshoch werden, und schließen sich oft dicht und fest beinahe zu Polstern zusammen, welche die schwersten Schneelasten tragen können. Ganze Gebirgsabhänge und -kämme können von den dunkelgrünen, verfilzten Massen des Krummholzes so dicht bewachsen sein, daß sie ganz undurchdringlich werden; man kann oft eher auf ihnen, als in ihnen gehen. Der weiche, humusreiche, oft ganz torfartige Boden saugt viel Wasser auf. Durch die Kronen des Krummholzes gegen den Wind geschützt, entwickeln sich hier, je nach den Lichtverhältnissen und der Menge abgefallener Nadeln usw., mehr oder weniger viele andere Pflanzen, die früher zur Blüte kommen als auf den nahen Felsen oder Matten. In jüngeren Beständen treten besonders Alpenrosen, Wacholder, Rosen, Daphne, Polygala chamaebuxus, Empetrum, Vaccinium-Arten, Erica carnea, Calluna und andere niedrige xerophile Zwergsträucher auf, aber außer ihnen Arten von Brunella, Digitalis, Campanula usw., ferner viele Gräser und Cyperaceen, überdies Moose und Flechten ${ }^{2}$ ). Diese Krummholzgestrüppe sind eine echte xerophile Vegetation, die gut im stande ist, einerseits die starke Verdunstung, das starke Sonnenlicht und die schneidend kalten Winde, anderseits die große Feuchtigkeit des wasserreichen Bodens, die häufigen und dichten Nebel, Regengüsse und Schneefälle auszuhalten. Das Krummholz und das Heidekraut sind zwei

1) Vergl. z. B. Kerner 1863a, 1869; Schröter 1904; Kirchner, Loew, Schröter 1904.

$\left.{ }^{2}\right)$ Näheres bei Kerner $1863 \mathrm{a}$. 
parallele, in ihren Forderungen genügsame Arten, die von anderen leicht nach den schlechtesten Lebensbedingungen hin verdrängt werden. Überhaupt sind diese alpinen Legföhrengestrüppe auf torfigem Boden der Zwergstrauchheide verwandte Vereine.

Gestrüppe findet man sicher auch auf allen anderen hohen Gebirgen oberhalb der eigentlichen Waldgrenze. Beispielsweise kann angeführt werden, daß es auf den hohen Gebirgen Japans eine solche Region in 2200-2500 m Höhe gibt, die aus Pinus parviflora (mit der Arve verwandt) nebst Birke, Alnus viridis u. a. besteht.

\section{Kap. Wälder auf Torfboden}

Auf die Wiesenmoore, Sphagnum-Moore und Heidemoore in Nordeuropa wandern auch Bäume ein, wie schon vorne berührt wurde. Die häufigsten sind Betula pubescens (resp. B. odorata) und B. verrucosa, Pinus silvestris, seltener Picea excelsa, Alnus glutinosa. In sehr vielen Fällen werden die Moore sich in einen Wald verwandeln können, namentlich Erlen- und Birkenwälder. (Die Erlensümpfe sind schon S. 515 besprochen worden.)

In südlicheren Gegenden ist es namentlich Pinus montana, welche die Hochmoore mit einem niedrigen, offenen Wald aus krüppelhaften Kiefern bedecken kann ${ }^{1}$ ). Der hohe Stand des Grundwassers ist wahrscheinlich Ursache des Krüppelwuchses von Bäumen auf Mooren.

Die Bodenvegetation kann recht verschieden sein, entweder treten Pflanzen der Zwergstrauchheiden oder der Wiesenmoore auf mit Eriophoreta, Cariceta usw. Worauf die Verschiedenheiten beruhen, ist noch nicht ganz deutlich, wahrscheinlich auf dem Trockenheitszustande des Bodens, indem die Zwergstrauchheide den trockeneren Boden vorzieht.

Dieselben Verschiedenheiten finden sich auch in den schwedischen und norwegischen Wäldern. Die Nadelwälder in Schweden und Norwegen sind in großer Ausdehnung Rohhumuswälder; namentlich gilt dieses von den Fichtenwäldern; auch in den künstlichen Fichtenbeständen des nordwestdeutschen Flachlandes kann der Rohhumus bis $\mathrm{zu}^{1 / 2} \mathrm{~m}$ dick werden (Fig. 311). Diese Wälder sind entweder ganz künstlich oder an den natürlichen Standorten der Fichte waren sie, nach den Untersuchungen von v. Bentheim und Graebner Eichenmischwälder.

In altem Wald auf gutem Boden besteht die Bodenvegetation aus Moosen mit wenigen Gefäßpflanzen. In weniger schattigen Wäldern ist der Boden zwar reich an Moosen, aber dazu gesellen sich zahlreiche Zwergsträucher, besonders unterirdisch wandernde Arten. Nur wo der

1) Vergl. hierzu Groß 1912: Die Zwischenmoore. 
Boden durch Quellwasser berieselt wird, findet man Mullboden, und der Unterwuchs ist dann reich an unterirdisch wandernden, mesophilen Kräutern. Die gepflanzten Fichtenwälder von Dänemark sind viel dunkler als die natürlichen norwegischen und schwedischen Wälder, und der Boden ist oft ohne grüne Pflanzen. Nur wo der Wald gelichtet wird, finden sich grüne Pflanzen ein und bilden eine zusammenhängende Bodenvegetation. Zwei verschiedene Fazies sind hier häufig, eine Fazies mit Oxalis acetosella und eine mit Aera flexuosa als herrschende Art ${ }^{1}$ ). Über die Wurzelbildung in den Heidewäldern vergl. S.686, Fig. 307 und 308 .

Die natürlichen Kiefernwälder Englands sind in der Jetztzeit auf Schottland beschränkt und von Pinus silvestris var. Scotica gebildet. Sie kommen auf demselben Boden vor wie die Calluneta, werden daher von englischen Botanikern der "Heideformation" angeschlossen (vergl. Kap. 76). Der Boden kann Rohhumus von mehreren Zentimetern Dicke sein, und die Bodenvegetation wird hauptsächlich von Calluna gebildet, wenn der Wald offen ist, dagegen von Vaccinium myrtillus mit Aera flexuosa, wenn er geschlossen und der Schatten stärker ist ${ }^{2}$ ).

Die Birkenwälder Lapplands wachsen auch auf verschiedenen Böden, wonach die Bodenvegetation entsprechend verschieden ist. Sie sind schon S. 567 unter den mesophilen Formationen erwähnt worden. Hier muß noch hinzugefügt werden, daß z. B. nach Simmons ${ }^{3}$ ) die trockensten heideartiges Gestrüpp tragen, aus Zwergsträuchern („Reisern“) bestehend, wie Betula nana, Vaccinium-Arten, Empetrum, Juniperus communis und anderen, ferner Linnaea borealis, Lycopodium alpinum usw.; andere haben eine Bodenschicht von Moosen, sie sind Betuleta muscosa, mit eingestreuten Stauden wie Trientalis Europaea, Pedicularis Lapponica u. a. Andere haben eine flechtenreiche Bodenvegetation. In wieder anderen, wo der Boden feuchter ist, findet sich eine deutliche Strauchschicht von größerer Betula nana mit anderen Kleinsträuchern oder Zwergsträuchern, mehreren Gräsern und Stauden an. Auch eine Bodenvegetation von Hochstauden kann vorkommen, sowie ganz sumpfige Stellen und beinahe humusfreie Stèllen.

Birkenwälder von Betula tortuosa umsäumen nach Pohle ${ }^{4}$ ) vielfach die Ufer des Weißen Meeres in Gegenden, wo die Fichte gegen dit Unbilden des Klimas nicht mehr aufkommen kann; sie sind sehr niedrig;

1) Vahl 1911; Raunkiär 1909. Über die schwedischen Nadelwälder vergl. ferner Birger 1908; Anderson und Hesselman 1907; J. V. Eriksson 1912.

2) Tansley 1911; die genannte schottische Form der Kiefer ist selır eigenartig und gehört augenscheinlich der „altenglischen“ Flora an (vergl. Graebner, ebend.).

\%) Simmons 1912.

4) Pohle 1907. Ưber die Birkenwälder Nordeuropas vergl. auch Resvoll-Holmsen 1914 und Th. C. E. Fries. 


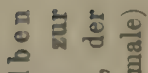

욘

밿ㅇ

范 苛

है

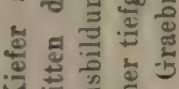

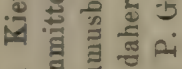

됼. 氠

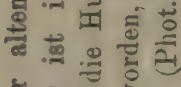

능

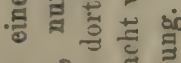

능

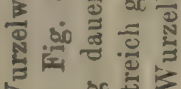

\$. 일

₹

की

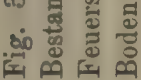

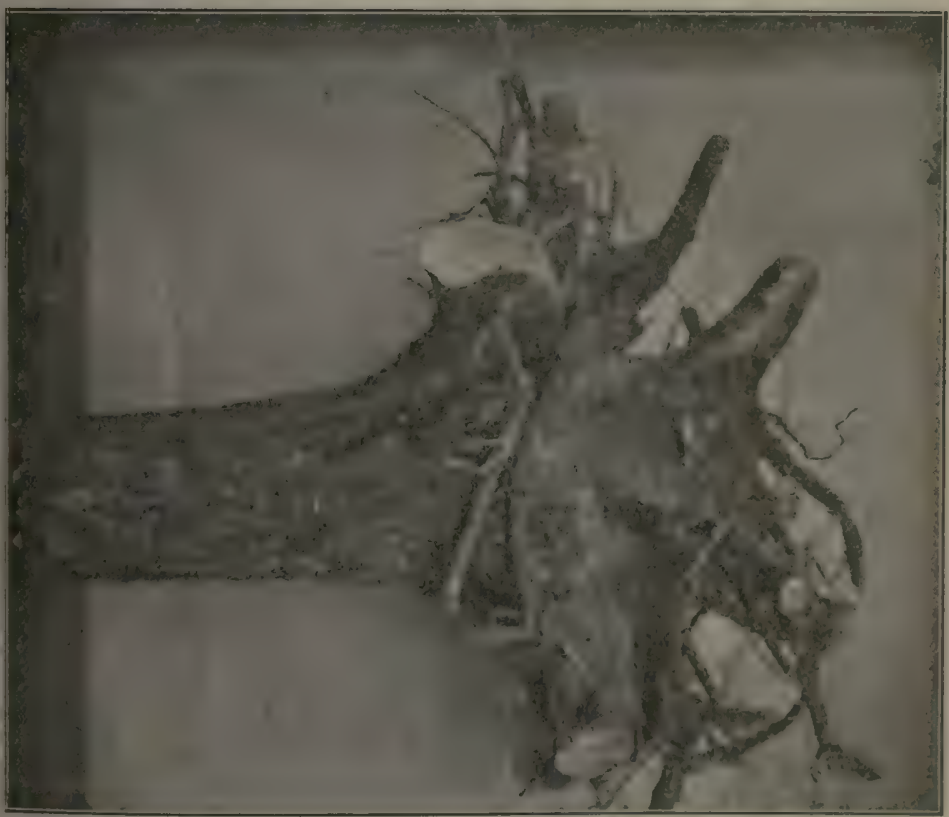

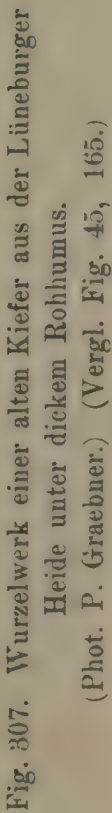


die Stämme und Zweige sind gekrümmt und knorrig, unregelmäßig aufwärts gebogen; aus niederliegendem Grunde steigen sie allmählich im Zickzack auf. Die Blätter sind lederartig hart. Am Boden findet sich unter relativem Windschutz und Halbschatten, wobei es an Feuchtigkeit nicht mangelt, eine dicke Rohhumusschicht mit einer geschlossenen Vegetationsdecke von Moosen (Hylocomium- und Dicranum-Arten), dazu große Lagen der fahlgrünen Flechte Nephroma arcticum, sowie dichte Gestrüppe von Vaccinium myrtillus mit Chamaepericlymenum (Cornus) Suecicum, Aera flexuosa.

Ganz ähnliche Birkenwälder wie die in Nordeuropa finden sich, obgleich sparsam in der Jetztzeit, in Island ${ }^{1}$ ).

Auch im südlichsten Grönland ${ }^{2}$ ), im Innern der Fjorde, kommen Birkengestrüpp oder niedrige Birkenwälder aus Betula qdorata var. tortuosa und var. alpestris vor. Die Stämme sind, wie in den von Pohle geschilderten, niederliegend, werden aber recht dick und bis $6 \mathrm{~m}$ hoch, meist aber erheben sie sich sowie auch die Zweige bis zu Manneshöhe und etwas höher. Der Boden ist vielleicht nicht Rohhumus; in den sehr dichten Birkenvereinen ist der Boden fast nackt, sonst ist die Bodenvegetation überwiegend eine trockene Grasvegetation (besonders aus Aera flexuosa und Anthoxanthum odoratum), doch können Flechten eingestreut sein, und Flechtenheide kommt auch vor. Sie gehören vielleicht eher zu Serie III $^{3}$ ).

Afrikanische Wälder auf Torfboden. Über die auf Ruwenzori vorkommende Heideformation schreibt Engler ${ }^{4}$ ): Sehr eigenartig ist die um $3000 \mathrm{~m}$ beginnende Heideformation von baumartiger, $3-8 \mathrm{~m}$ hoher Philippia Johnstonii (Ericacee) gebildet, welche so wie die unterhalb vorkommende Erica arborea mit Usnea, Sticta und Anaptychia behangen ist; abgestorbene Stämme sind im Ericaceenurwald massenhaft vorhanden und dicht von Moosen bedeckt. Der Boden ist hier mit 1-1,5 m (?) dicker Schicht von Sphagnum Pappeanum überzogen; es finden sich aber auch Polytrichum, Peltigera und Sphaerophorus. Außer Ericaceen wachsen hier noch Arten von Gymnosporia, Cornus, Olinia, Rapanea, der bis zu $3 \mathrm{~m}$ hohe Rubus Runsorensis, Ranunculus, Peucedanum; eine Orchidee, kleine Farne und Impatiens zieren den Moosteppich. Zwischell

1) Vergl. Thoroddsen 1914 und hier S. 690, Fig. 310.

2) Sie sind von den dänischen und anderen Grönlandsforschern in "Meddelelser om Grönland“ besprochen worden, besonders von Rosenvinge 1898 .

${ }^{3}$ ) Es bestätigt dieses und andere Beispiele in dieser Serie die Richtigkeit der Anschauung von Th. C. E. Fries (1913), daß eine Assoziation nur durch die Vegetation angegeben werden $\mathrm{muB}$, daB dagegen die Beschaffenheit des Standortes von geringerer Bedentung sein kann. „Eine Assoziation ist ein Pflanzenverein von bestimmter floristiscl.er Zusammensetzung und gleichförmiger Physiognomie".

4) Engler 1910, S. 678. 
3100 und $3400 \mathrm{~m}$ tritt dann $1-1,5 \mathrm{~m}$ hohes Vaccinium Stanleyi auf. Noch viele andere Arten von derselben Zone werden genannt. Es ist also ein echtes Hochmoor im tropischen Afrika als Bodenschicht für einen ${ }_{n}$ Heidewald".

Die nordamerikanischen Wälder auf Torfboden sind von verschiedenen Forschern erwähnt. Namentlich muß auf Dachnowski ${ }^{1}$ ) verwiesen werden. Auf den Mooren sind folgende amerikanische Typen sehr charakteristisch: Larix pendula mit eingestreuten Tsuga Canadensis, Betula lutea und Thuja occidentalis.

Eir stellt folgende Formationsfolge auf: 1. Planktonformation; 2. Randvegetation von submersen Arten, Nymphaeaceen, Sium, Bidens u. a.;

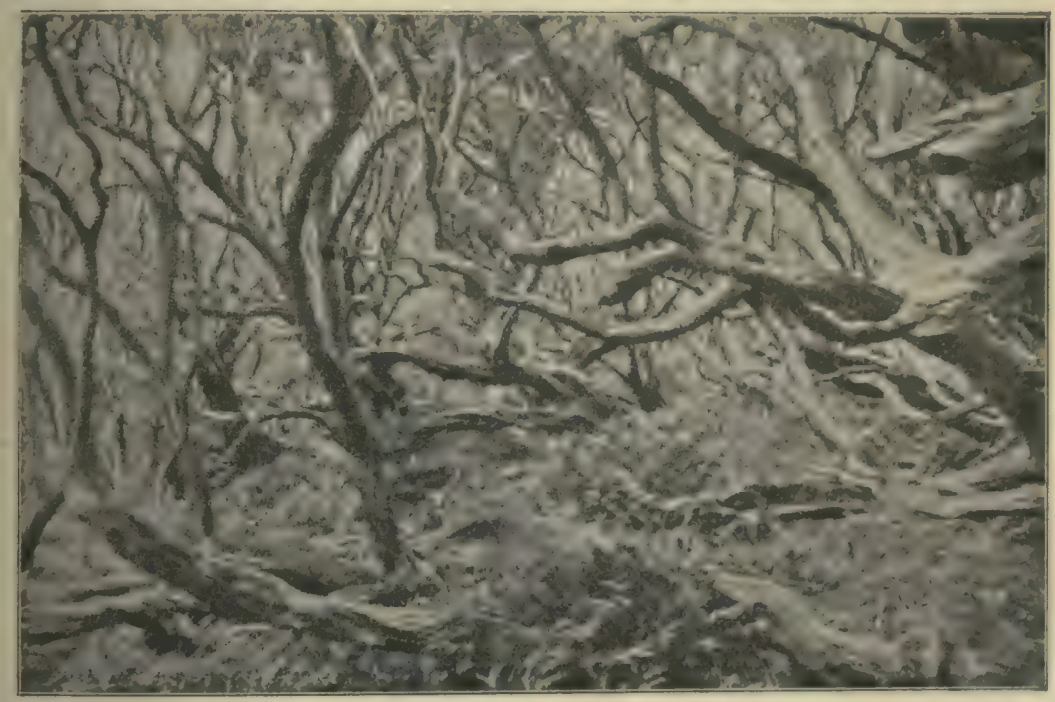

Fig. 309. Rata-Skov auf den Aucklandinseln; das charakteristische Geliölz ist Meterosideros lucida. (Nach Cockayne.)

3. Ufervegetation (Rohrsümpfe usw.), "Bog-Succession" oder Torfbodenvegetation mit 4. Torfwiese (bog meadow) mit Carex, Juncus, Vaccinium macrocarpum, Sphagnum-Arten, Menyanthes; 5. Torfheide mit den Zwergsträuchern Chamaedaphne, Andromeda, Vaccinium-Arten, Potentilla fruticosa usw.; 6. Moorgebüsch (Alnus, Rhus, Aronia, Ilex verticillata, Salix-Arten, Populus tremuloides, Cephalanthus, Cornus usw.; 7. Nadelwald mit Larix pendula (L. laricina), Thuja, Viburnum usw.; 8. Mesophytischer Laubwald, in welchem die Larix-Assoziation durch Assoziation von Acer-Fraxinus-Ulmus ersetzt wird, welche die Schlußregetation bildet.

1) Dachnowski 1912; vergl, auch Journ. Ecology I, S. 286-292.

Warming-Graebner. 3. Auflage, illnotr. 
Die antarktischen Wälder. Die antarktischen Wälder Südamerikas sind durch die Schilderungen von Darwin, Hooker und Dusén bekannt geworden. Man findet sie von dem südlichen Chile, von dem 36. ${ }^{\circ}$ südlicher Breite bis zum Feuerlande, wo sie das Land vom Meere bis zu 1700-2000 m Höhe auf der westlichen Seite der Gebirgskette bedecken. Das Klima zeigt eine geringe jährliche mittlere

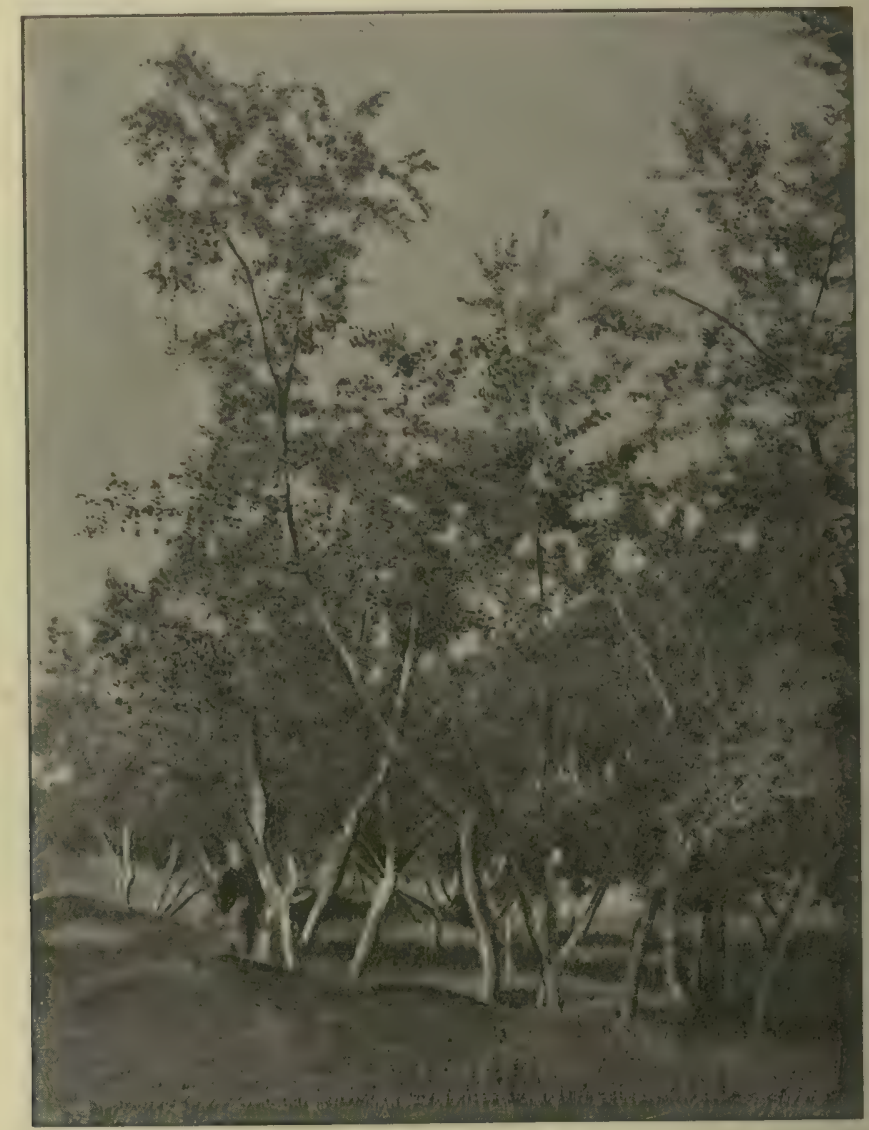

Fig. 310. Birkenwald bei Hallormstad, Island. (Th. Thoroddsen.)

Wärme $\left(5-7^{\circ} \mathrm{C}\right.$.) und nur etwa $9^{\circ}$ Unterschied zwischen der mittleren Wärme des Winters und der des Sommers, aber eine sehr große, fast über alle Monate des Jahres verteilte Regenmenge. Unter diesen Verhältnissen entwickelt sich ein äußerst üppiger Wald, der in den nördlichen Gegenden durch die große Menge Lianen und Epiphyton, ferner durch das Unterholz, worin Baumfarne und Bambus eine Rolle spielen, ein tropisches Gepräge erhält. Diese Wälder müssen 
sicher als den immergrünen Regenwäldern der Tropen am nächsten stehend betrachtet werden und wurden auch bei diesen berührt. Südwärts verliert sich dieses; aber die Wälder stehen doch infolge des feurhten Klimas das ganze Jahr dunkelgrün da. Buchen aus der ('rattung Nothofugus sind hier die gewöhnlichsten Bäume. Immergrün sind $N$. brtuloides, $N$. Dombeyi, $N$. alpina, $N$. nitida u. a. Arten; laubwechselnd und im Winter kahl sind $N$. antarctica, N. pumila, N. obliqua, N. procera. Die Blätter dieser Buchen sind klein $(1-2 \mathrm{~cm})$ und myrtenähnlich aher zahlreich, lederartig mit glïnzender, dunkelgrüner Oberseite; die

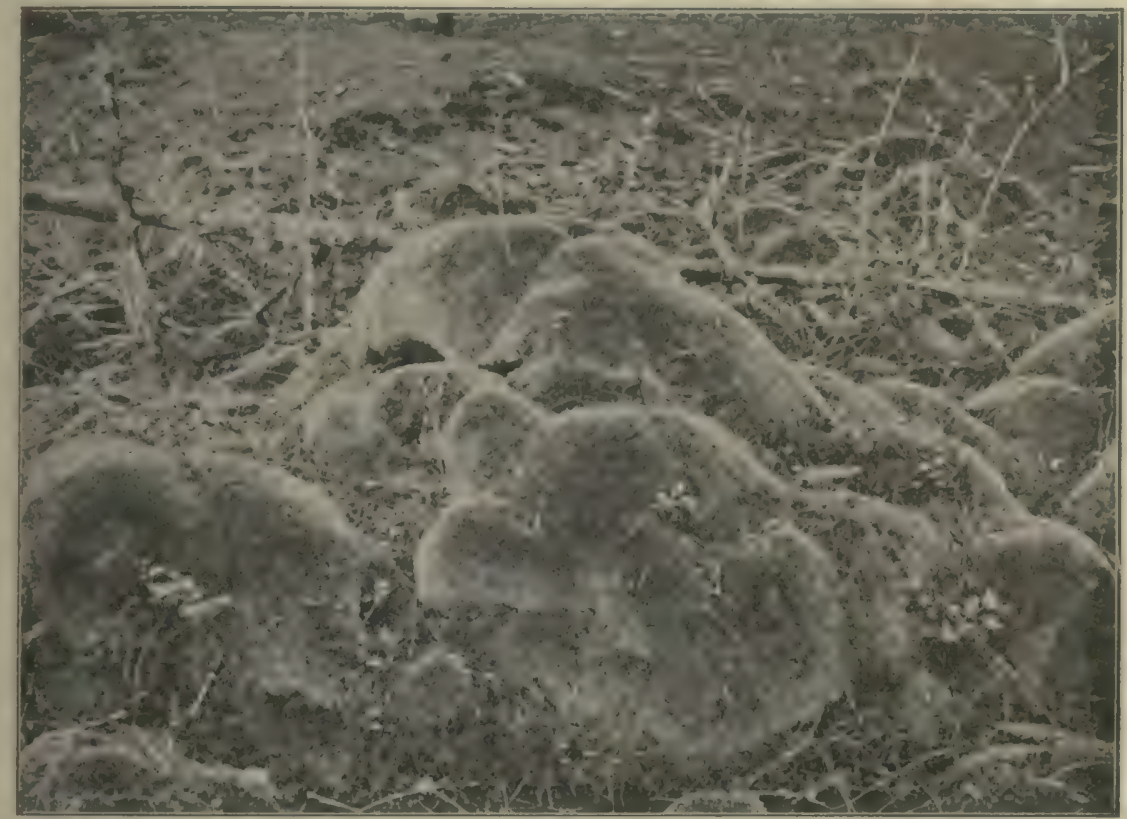

Fig. 311. Polster von Leucobryum glaucum im künstlichen Kiefernwald. Unterlüss in der Lüneburger Heide. (Phot. P. Graebner.) Vergl. S. 685.

Physiognomie ist daher eine ganz andere als die unserer Rotbuche. Die Knospen sind durch Schuppen geschützt.

Finige Arten ( $N$. antarctica, $N$. pumila u. a.) bilden fast reine Assoziationen; im allgemeinen sind sie mit anderen gemischt.

Floristisch bemerkenswert ist, daß die mit Fagus nahe verwandte (iattung Nothofagus hier mit Proteaceen, Myrtaceen, Podocarpus, Libocedrus, Fitzroya Patagonica (der Alerze, einem riesigen Nadelbaume) und anderen tropischen und australischen Typen gesellig auftritt und daß auf den Buchen das schmarotzende Myzodendron wächst. Namentlich mit Neuseeland ist die Äbnlichkeit groß. In den südlichen Wäldern, 
auf dem Feuerlande, wo der Wald fast nur aus einer Buchenart $(N$. betuloides) gebildet wird, sind Drimys Winteri und Maytenus Magellanica fast die einzigen baumförmigen Begleiter.

Der immergrüne Wald von Nothofagus Dombeyi hat eine dunkelgrüne, fast schwarze Laubmasse und bleiche Stämme. Im Inneren herrscht nach Skottsberg eine chaotische Wildnis von unbeschreiblicher Dichtigkeit.

Die nördiicheren Wälder sind nach Darwins Schilderungen so undurchdringlich, daß niemand, der es nicht gesehen hat, sich von diesem Gewirr absterbender und toter Stämme eine Vorstellung machen kann. "Wir befanden uns häufig 10-15 Fuß über dem Boden, so daß die Matrosen zum Scherz wie beim Loten ihre Messungen ausrufen." Lianen und Epiphyten, bambusartige Gräser usw. rufen mit vielen anderen eine undurchdringliche Wildnis hervor.

Die südlichsten Wälder sind weit ärmer und einförmiger und haben wenig Unterholz. Als Epiphyten kommen Hymenophyllaceen und andere Farne vor, aber Flechten sind spärlich. Der Waldboden ist bedeckt mit einem dichten, ununterbrochenen Teppich von mit Wasser gesättigten Moosen und Lebermoosen, zwischen denen Hymenophyllaceen wachsen. Der immergrüne Charakter der Laubmasse muß als Folge der Kürze der warmen Jahreszeit angesehen werden.

Die Stellung aller dieser Wälder ist nicht ganz klar. Doch scheint es deutlich, daß die südlichen durch ihre wasserdurchtränkten Moosteppiche einen sauren Rohhumusboden haben müssen und sich dahes den in diesem Kapitel besprochenen Formationen am nächsten anschließen. Die nördlichen dagegen haben kaum einen sauren Boden und gehören daher wohl zu den subtropischen immergrünen Regenwäldern (Kap. 79).

Offenbar ganz ähnlich den magellanischen sind die neuseeländischen Wälder, welche in mehreren Publikationen von Cockayne so vorzüglich geschildert werden. Von den Wäldern des nassen Stewart Island sagt er, daß die Moose in größter Üppigkeit wuchern. Der Waldboden ist von Moosen und Hymenophyllaceen bedeckt. Gewisse Moosarten wachsen in großen Kugelpolstern von 50-60 cm Durchmesser, innen vertorfend, außen fortwachsend, also ähnlich wie die großen LeucobryumPolster in manchen nordwestdeutschen Heidewäldern (Fig. 311).

Dasselbe gilt für die Auckland-Inseln, für die feuchten Mischwälder der Nebelregion auf Kermadec Island.

Der Wald, den Cockayne den "Rata Forest" (Fig. 309) nennt, ist besonders von der Myrtacee Meterosideros lucida gebildet, an geschützten Stellen ca. 5-12 m hoch, an windigen mehr strauchförmig, immergrün. Die Stämme sind oft in mehr als ihrer halben Länge auf dem Boden niederliegend, die Zweige sonderbar gekrümmt. In dem dichten Walde ist 
die Luftfeuchtigkeit groß und das Licht schwach; vicle gefallene, tote stämme liegen umher; große Mengen von Monsen, Lebermoosen, großhlittrigen Flechten und Hymenophyllaceen bedecken den Boden und die Bïume im ruhigen Inneren des Waldes. Die Moose bilden große Polster. Zwei Faktoren, welche Xeromorphie besonders hervorrufen, sind die Bäume ausgesetzt, nänlich den fürchterlichen Stürmen und dem schlecht Irainierten, oft tief torfigen Boden. Der Boden kann uneben scin durch den wïhrend vieler Generationen gebildeten Torf. Die Blätter von Meterosideros lucida sind daher dick und lederartig, dabei gliinzend grün. Im Inneren des Waldes herrschen dagegen Ruhe und hygrophytische Verhïltnisse, was die vielen Moose und Hymenophyllaceen zeigen ${ }^{1}$ ).

1) Über die letzten in diesem Kapitel besprochenen Wälder vergl. C. Darwin 1845; J. D. Hooker 1847; Dusén 1898-1905; Reiche 1907; Neger 1897 a, b, 1901; Aboff 1902; Cockayne 1904, 1908 a , b, 1909, 1910; Diels 1905; auch HaumannMerck 1913. 


\section{Serie. Kältewüsten •}

(Vergl. Kap. 3 und S. 319)

\section{Kap. Die subglazialen Formationen}

Gleich unterhalb der Schneegrenze, in den Polarländern bis zum Meeresniveau, und in den Hochgebirgen auf der höchsten alpinen Stufe, auf welcher ein Pflanzenleben sich entfalten kann, entwickelt sich eine Vegetation, die man wegen vieles Übereinstimmenden als subglaziale oder nivale Vereine zusammenfassen kann; auch Kältewüsten können diese Gebiete genannt werden, weil sie eine äußerst ärmliche und niedrige, dazu sehr offene, teilweise xeromorphe Vegetation tragen („Fjäldmarker"). Sie schließen sich den Tundren am nächsten an, sind verarmte und degenerierte Tundren; die Wüstennatur zeigt sich in der Offenheit der Vegetation, fast überall zeigt sich der nackte, humusarme Boden.

Die maBgebenden Faktoren in diesen Gebieten sind namentlich klimatische ${ }^{1}$ ).

1. Die Lufttemperatur ist im ganzen niedrig und nimmt in den Gebirgen je auf $100 \mathrm{~m}$ Steigung um ca. $0,6^{\circ}$ ab. Die Mitteltemperatur des wärmsten Monats ist niedrig und erhebt sich nur wenige Grade über den Nullpunkt. Hauptsächlich die Wintertemperaturen sind oft sehr niedrig (namentlich in den Polarländern), besonders für die nicht vol Schnee bedeckten Pflanzen. Die bestimmte Abnahme der Wärme ruft gewisse Höhen- und Breitengrenzen der Arten und gewisse Schneegrenzen hervor (örtliche Verhältnisse, wie Neigungsrichtung usw. greifen in hohem Grade ändernd ein; vergl. Kap. 19). In der Vegetationszeit können starke Temperaturschwankungen vorkommen, auch Fröste und Schneefälle, welche die Entwicklung hemmen und auf die Pflanzenformen einwirken.

Die Schwankung der Tagestemperatur in hohen Gebirgslagen ist von der der Ebenen wesentlich verschieden; sie ist in den geschlosseuen Tälern und auf Hochebenen größer als in den Tiefländern unter der gleichen Breite; während durch die starke Insolation die Tagestemperatur ziemlich hoch steigen kann, sinkt die Temperatur während der Nächte oft

1) Vergl. z. B. Kerner 1869; Schröter 1904-1908. 
erheblich unter $0^{\circ}$. Anders auf den Berghängen und in offenen und geneigten Tälern; hier sind die täglichen Temperaturschwankungen klein. Der jährliche Gang der Temperatur ist in den Gebirgen, namentlich in den Tropen, von dem des Tieflandes nicht wesentlich vers(hieden ${ }^{1}$ ). Auf dem Antisana in Ecuador ist der Unterschied zwischen dem heißesten und dem kältesten Monat nur $3,2^{\circ}$. Je mehr man sich den Polen nähert, desto schärfer sind natürlich die Jahreszeiten auch in den Gehirgen ausgeprägt. Auf Hochebenen sind die Jahresschwankungen der Temperatur in der Regel größer als in den umgebenden 'Tiefländern, auf den Berghängen und Gipfeln dagegen kleiner. DaB die Kälte allein die Waldbildung nicht ausschließt, wurde bereits S. 30 betont, da ja die kältesten

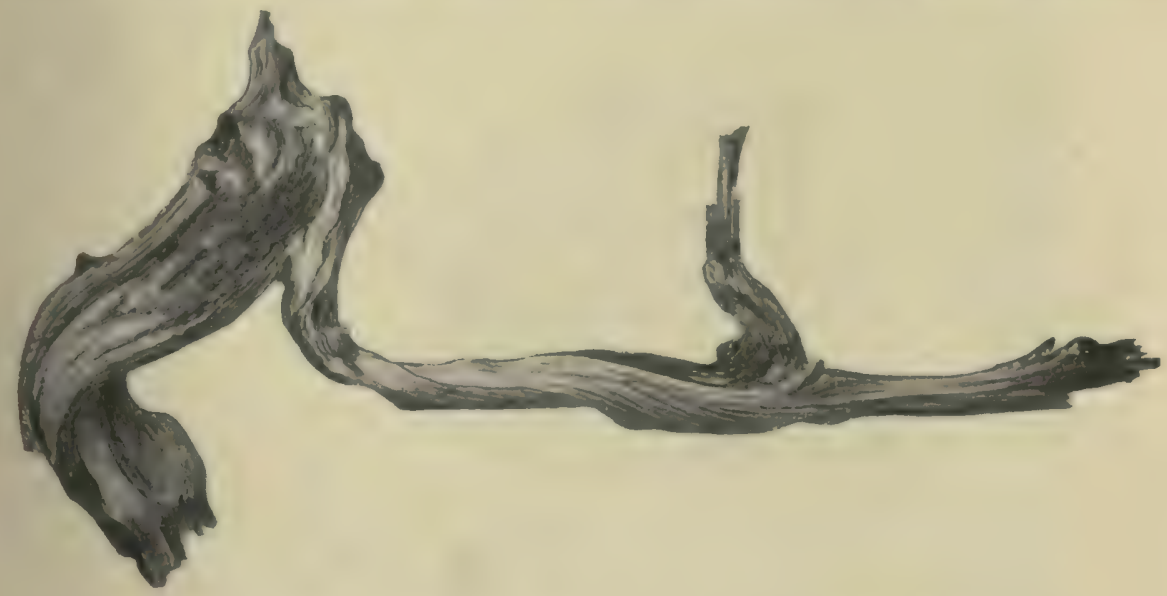

Fig. 312. Stammstück von Juniperus, von den Stülmen kantig geschliffen.

(Nach Josias Braun.) Vergl. auch Fig. 35-38.

Teile der Erde noch Wälder tragen. Dagegen findet sich nirgends Wald, wo die Mitteltemperatur des wärmsten Monats unter $10^{\circ}$ beträgt.

2. Die Bodentemperatur ist niedriger als in den umgebenden Tiefländern, jedoch nimmt sie mit der Höhe viel langsamer ab als die Lufttemperatur. Beobachtungen auf dem Pic du Midi zeigen, daß die Maxinıa der Bodentemperatur jenen der tieferen Lagen ungefähr gleichkommen, während die Minima bedeutend tiefer sind. Die Temperatur des Bodens ist in der Sonne viel größer als die der Luft, z. B. kann in den argentinischen Punas die Luft $24^{\circ}$ warm sein, der Boden gleichzeitig $65^{\circ}\left({ }^{2}{ }^{2}\right)$, und der Unterschied zwischen der Bodentemperatur am Tage

2) Hann, Klimatologie, 8. Aufl, 1908-11, Bd. II.

2) Seckt in Petermanns Mitteilungen 1914. Obgleich die Vegetation der Puna kaum als Kältewüste, sondern als Hochgebirgssteppe zu betrachten sein wird, ist es doch das ZweckmäBigste, sogleich hier die Lebenslage derselben zu besprechen. 
und in der Nacht ist viel größer als in tiefer gelegenen Gegenden. An vielen Stellen findet sich Bodeneis in geringer Tiefe.

3. Die Bewegungen der höheren Luftschichten sind stärker als jene der tieferen, was besonders für isolierte Gipfel Bedeutung hat. Die Berghänge sind oft der Trockenheit herabsinkender Luftmassen ausgesetzt, und die Luft kann plötzlich sehr trocken werden, wenn ein solcher Fallwind einsetzt, aber eben so plötzlich wieder gesättigt werden. Der Wind ist wohl der wichtigste ökologische Faktor; er trocknet die Pflanzen aus, und selbst wenn dieselben im Wasser wachsen, wird seine Kälte die Wassererneuerung in den in die Luft ragenden Teilen hemmen; die Pflanzen müssen sich gegen das Austrocknen schützen. Die Winde kühlen auch den Boden ab (vergl. Kap. 10). Fig. 312, 313.

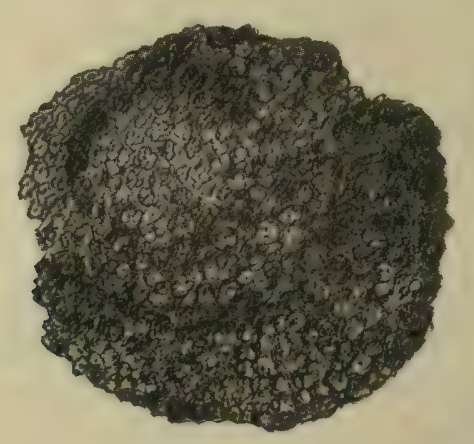

Fig. 313. Androsaces Helveticum, das dichte Polster ist in der Mitte von den Stürmen abgetötet. (Nach Josias Braun.)

4. Feuchtigkeit ist in der Vegetationsperiode zeitweise groß, sowohl in der Luft als auch im Boden. Es kann Überfluß an Regen und Nebel herrschen und viel Schnee fallen; die aufsteigende Bewegung der Luft kann eine Abkühlung und Verdichtung des Wasserdampfes verursachen. In den Polarländern ist die relative Feuchtigkeit der Luft während des Sommers an den meisten Orten hoch; die Zahl der Tage, an welchen atmosphärische Niederschläge fallen, ist sehr gering, aber die Nebel sind häufig. Auf der Polaris-Expedition fand man, daß die relative Feuchtigkeit während des Sommers etwa $75 \%$ betrug, aber dieser Betrag ist wohl außerordentlich niedrig; an der Lady Franklin Bay maß man $81 \%$.

In den Gebirgen wächst die Regenmenge mit der Höhenlage bis zu einer gewissen Höhe und fällt darüber hinaus wieder ab; diese fragliche Maximalhöhe ändert sich je nach der Gegend und der Jahreszeit. Die Zone der größten Regenmenge ist die untere Grenze der Wolkenregion. In größeren Höhen sinkt die Regenmenge, weil bei der abnehmenden Temperatur die für jeden Grad Temperaturerniederung aus- 
geschiedene Wassermenge kleiner wird. In vielen Gegenden befindet sich über der Wolkenregion eine trockene Zone, in der die Luft sehr

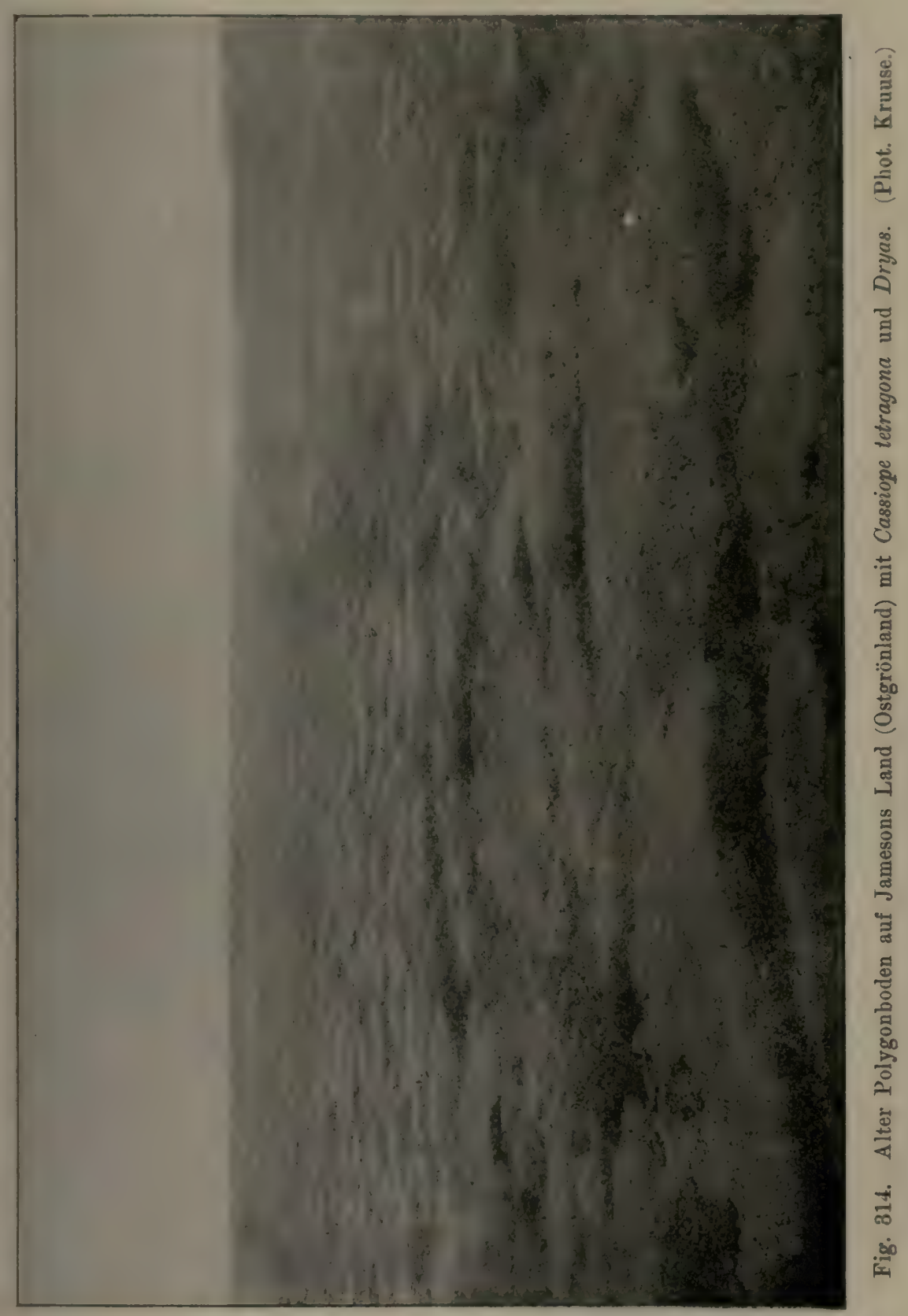

trocken ist und wo nur selten Regen fällt, z. B. auf dem Teyde-Peak (Teneriffa) und in Centralasien. Nach Meyen ist auf den Anden der Wind 
mitunter so trocken, daß die Haut aufreißt, Blut austritt und man nur in wollenen Kleidern reisen kann; in der Puna hat die Luft mitunter nur $20 \%$ Feuchtigkeit. Die Verdunstung ist in den Gebirgen wegen des niedrigeren Luftdruckes größer als in den Ebenen unter gleicher Temperatur und Luftfeuchtigkeit. Vertikale Luftströmungen zwischen den Bergen sind stets von großer Wichtigkeit. Jeder aufsteigende Luftstrom bringt große Lufteuchtigkeit mit sich, daher Nebel oder Regen, jeder absteigende große Lufttrockenheit. Danach kann Trockenheit und Feuchtigkeit sich sehr plötzlich ändern. Periodisch kann also in der Luft und im Boden große Trockenheit herrschen, weshalb die Vegetation xerophil werden $m u B$, selbst wenn die trockenen Zeiten nur wenige Stunden dauern. Die Vegetation der Hochalpen kann nach Kerner bisweilen triefend naß stehen, so daß sich das Wasser aus den Moosrasen auspressen läßt, aber wenige Stunden später, nachdem trockener Ost- oder Südwind geweht hatte, kann sie so trocken sein, daß sie unter den Füßen knistert. Ähnliches gilt für gewisse Stellen in den Polarländern; in Grönland, besonders in Nordostgrönland, wird große Lufttrockenheit und Wärme mit starker Verdunstung durch die starken Föhnwinde hervorgerufen ${ }^{1}$ ).

5. Das Licht. Das Licht in den Hochgebirgen ist reicher an blauen, violetten und ultravioletten Strahlen. Die Intensität der Sonnenstrahlen wächst mit der Höhe über dem Meere und ist in den Hochgebirgen wegen der dünneren und staubloseren Luft und der schwächeren Luftschicht, welche die Sonnenstrahlen zu durchlaufen haben, sehr groß. Die Sonnenwärme weckt die Sprosse zu Leben und Wachstum zu einer Zeit, wo der Boden noch sehr kalt ist. In den Polarländern ist die Intensität der Sonnenstrahlen geringer, wirkt dafür aber mit geringeren Unterbrechungen; der Unterschied zwischen Tag - und Nachttemperatur wird verwischt. Der große Unterschied zwischen den Polarländern und den tropischen Hochgebirgen ist namentlich die monatelange Dunkelheit in jenen und die Gleichförmigkeit in diesen. Das starke Licht am Tage und die Kälte in der Nacht arbeiten in den Hochgebirgen dem Wachstum entgegen; das andauernde, obgleich bedeutend schwächere Licht und die im ganzen niedrigen Temperaturen der Polarländer haben dieselbe Wirkung. Diese Umstände bringen Zwergwuchs hervor.

6. Die Vegetationszeit. Bezüglich der Vegetationszeit kann man zwei Extreme unterscheiden: die arktisch-temperierte und die tropische.

Der arktisch-temperierte Typus. In der aktischen Zone, wie auch auf hohen Gebirgen innerhalb der gemäßigten Zonen ist die Vege-

1) Vergl. Hartz und Kruuse. 
tationszeit kurz; in der Regel dauert sie nur wenige Wochen. In Franz-Josefsland haben nur 1 oder 2 Monate eine Mitteltemperatur, die über $0^{0}$ steigt. In den östlichen Alpen dauert in den größten Höhen, die noch von Samenpflanzen bewohnt werden (etwa $3300 \mathrm{~m}$ ), ebenso wie an ungünstigen Stellen (Schneelöchern usw.), die Vegetationszeit nur einen Monat. Bezüglich der Feuchtigkeit und der Beleuchtung sind größere Differenzen vorhanden in den arktischen Flachländern, als in den Hochgebirgen der gemäßigten Zonen. . Nichtsdestoweniger ist der allgemeine Charakter der Vegetation derselbe an beiden Orten, die auch viele Arten gemeinsam haben. Beiden gemeinsam sind die heftigen

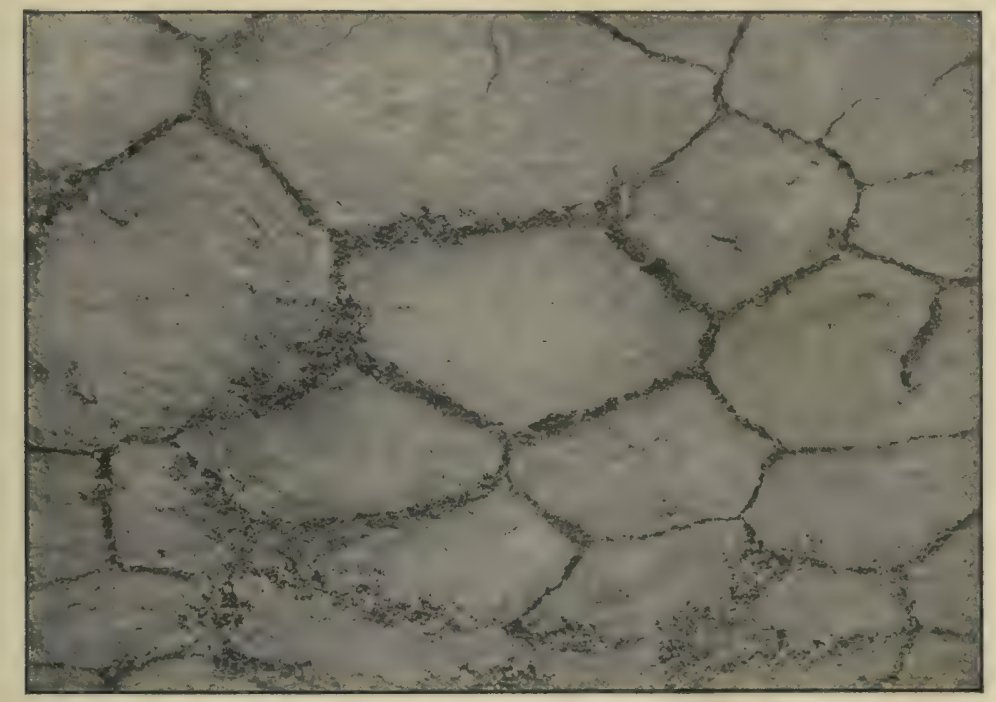

Fig. 315. Junges Polygonfeld mit Stellaria humifusa. Nordostgrönland. (Hartz und Kruuse.)

Winde, die sehr kurze Vegetationszeit und vor allem die Häufigkeit der Fröste während der Vegetationszeit.

Der tropische Typus unterscheidet sich von dem vorigen dadurch, daß die Vegetationszeit während des ganzen Jahres andauert.

Der subtropische Typus mit einer langen Vegetationsdauer steht zwischen beiden Extremen.

Auf tropischen Gebirgen ist die Insolation stärker als in höheren Breiten, und folglich sind auch die Maxima der Bodentemperatur viel höher. Dies gibt der Vegetation einen gänzlich verschiedenen Charakter.

7. Die edaphischen Verhältnisse sind recht verschieden und spielen für die Entwicklung verschiedener Formationen eine gewisse Rolle. Humus wird wohl oft nicht gebildet, jedenfalls nur Rohhumus, 
aber die Winderosion wird ihn wohl immer entfernen. In vielen Fällen, z. B. in den Alpen, in der Puna, hat der Wechsel von Frost und Sonnenhitze das Gestein in Trümmer zersprengt, so daß große "Geröllhalden * und "Geröllfluren" von scharfkantigen Steinen entstanden sind, die reine Steinwüsten darstellen.

Im allgemeinen kann der Boden in den Polarländern und in vielen Hochgebirgen sicher als älterer oder jüngerer Moränengrus bezeichnet werden, und selbstverständlich nähert sich die Vegetation auf Boden, der an Steinen reich ist (die "Schuttfluren"), der Felsenvegetation (92. Kap.).

In anderen Fällen ist der Boden lehmig oder tonig und mit nur wenigen Steinfragmenten bedeckt. An diesen Arten wird man recht häufig ein Phänomen wahrnehmen können, das längst von Scoresby, v. Baer, Heuglin, Middendorff u. a. erwähnt, und von Kjellman näher besprochen wurde, nachher von Kruuse und Hartz in Grönland und von Thoroddsen in Island, von Th. Wulff und Hanna Resvoll-Holmsen auf Spitzbergen beobachtet und abgebildet wurde ${ }^{1}$ ). Es entsteht das, was Kjellman „Rutemark", Polygonboden, nannte; der Tonboden ist durch Austrocknung steinhart geworden und bildet unregelmäßige Polygone, getrennt durch Spalten, die etwa $6 \mathrm{~cm}$ breit und $10-20 \mathrm{~cm}$ tief sein können. In solchen Spalten sammeln sich oft Steine, wie Thoroddsen gezeigt hat, und es wandern zuerst Moose und Flechten ein. Nach und nach finden sich auch Blütenpflanzen an, und zuletzt kann der ganze Boden mit einer Tundravegetation bedeckt sein. Die Folgeformationen, die hier stattfinden, sind z. B. von Wulff geschildert.

Die von keiner losen Erde bedeckten Felsen mit ihren Chasmophyten (vergl. Kap. 94) werden in Kap. 92 besprochen werden.

Im allgemeinen gilt, daß der Boden als $\mathrm{kalt}$ bezeichnet werden muß, selbst wenn er an günstig exponierten Stellen zur Mittagszeit bisweilen stark erwärmt werden kann. Besondere Bedeutung für die Entwicklung und Verbreitung der Vegetation hat die Schneedecke (vergl. S. 128); je nach den Unebenheiten des Terrains und der Exposition für Schnee und Wind wird die Schneedecke verschieden hoch sein und längere oder kürzere Zeit im Jahre liegen bleiben, und dadurch die Entwicklung der Vegetation mehr oder weniger verzögert werden. Die Dauer der Schneedecke ist von größter Wichtigkeit; auf ausgedehnten Strecken wird der Schnee von den Winden weggeführt. Auch wo der Schnee vielleicht verhältnismäßig früh schmilzt, aber der Boden vielleicht in der ganzen Vegetationszeit von geschmolzenem Schneewasser befeuchtet wird, wird er kalt werden, und die Wurzeltätigkeit wird dadurch herabgesetzt. Es rufen Verschiedenheiten von dieser Art eine Unzahl von

1) Kjellman 1882; Hartz 1895; Hartz und Kruuse 1911; Thoroddsen 1914; Hanna Resvoll-Holmsen 1909, 1913; Thorild Wulff 1902. 
kleinen und großen Standorten, auch mit entsprechenden floristischen und Vegetations-Verschiedenheiten hervor. Es kann hier an die S. 128 bis 129 und 529 erwähnte "Schneetälchen"-Vegetation erinnert werden, welche durch den Schnee gedüngt wird.

Wahrscheinlich in den allermeisten Fällen mag der lose Boden in der Tat reich an Nährstoff sein; es bekommt diese Tatsache aber geringe Bedeutung den erwähnten klimatischen Faktoren, namentlich der Kälte und den Winden, gegenüber.

Unter „Kältewüsten" hätten auch die Firn- und Eisfelder (die glaziale Natur, "die Schneeflur") besprochen werden können. Es mag genügen, auf das S. 469 besprochene Kryoplankton zu verweisen.

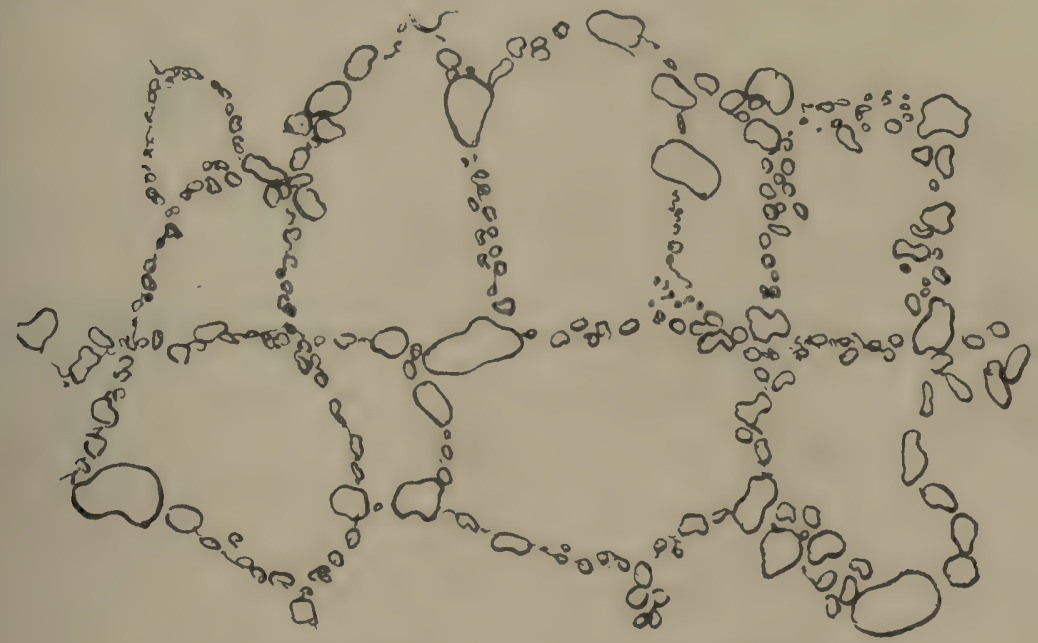

Fig. 316. Polygonfeld mit Steinen in den Furchen. Island.

(Von Thoroddsen gezeichnet.)

Eine wichtige Arbeit über die Natur und die Pflanzenwelt der "alpinen Schneestufe" ist neuerdings (1913) erschienen: Jos. Braun, Die Vegetationsverhältnisse der Schneestufe in den Rätisch-Lepontischen Alpen.

\section{Kap. Anpassungen der Pflanzen in den Kältewüsten}

Die Kälte, die starken Winde und die übrigen jetzt besprochenen ökologischen Faktoren drücken den Pflanzen ihren Stempel auf ${ }^{1}$ ). Der Boden muß als „physiologisch trocken" bezeichnet werden (vergl. S. 197), und eine Reihe von xeromorphen Pflanzenformen wird hervorgerufen, namentlich unter den Geröllpflanzen.

1) Daher der Name Psychrophyten, d. h. Pflanzen der kalten Orte; von Yuxpós, kalt. 
Im folgenden müssen zuerst die arktischen und europäischen Kältewüsten vorzugsweise berücksichtigt werden.

1. Die Lebensformen. Moose und Flechten sind zahlreich. Diese Pflanzen können große Kälte ertragen; der Erfrierpunkt der Blätter vieler Moose kann unter $-20^{\circ} \mathrm{C}$. sein (Irmscher) ${ }^{1}$ ). Auch Algen kommen wahrscheinlich vor.

Von den Gefäßpflanzen sind die allermeisten mehrjährig: Kräuter, Halmträger oder Zwergsträucher. Bäume und höhere Sträucher fehlen; das feuchte Klima ist für die Verholzung nicht günstig, und dieses ist einer der wesentlichsten Punkte, in welchen die Kältewüsten von den Hitzewüsten abweichen. Der Mangel an Wärme und die starken Winde begrenzen das Vorkommen der größeren Holzgewächse nach aufwärts auf den Bergen und gegen die Pole hin. Dagegen sind kleine Holzgewächse (Zwergsträucher, Spaliersträucher) allgemein (Dryas, Loiseleuria, Diapensia u. a.).

Einjährige und einjährig überwinternde Arten sind selten. In den nördlichen Polarländern sind einjährig Koenigia Islandica (Polygonacee), wahrscheinlich auch Gentiana-Arten (G. nivalis, serrata u. a.) und Pleurogyne (Gentianacee); einige wenige andere (Draba crassifolia usw.) jedoch sind wahrscheinlich zweijährig. In den Alpen kommen mehrere Gentiana-Arten vor, die jedenfalls nur einmal blühen (als ein¡ährig werden z. B. auch Euphrasia-Arten aufgeführt; aber diese und ähnliche Halbparasiten sind nicht zu berücksichtigen, weil ihre Lebensbedingungen ganz andere sind). Bonnier und Flahault ${ }^{2}$ ) geben für die Westalpen folgende Stufenfolge an, womit sich die Dauer ändert: Die Anzahl der einjährigen Arten ist zwischen 200 und $600 \mathrm{~m}$ über dem Meeresspiegel $60 \%$, bei $600-1800 \mathrm{~m} 33 \%$ und über $1800 \mathrm{~m}$ nur $6 \%$. Kerner gibt für Tirol übereinstimmend $4 \%$ an, während in den Tälern ungefähr gleich viel ein- und mehrjährige Arten vorkommen. Für verschiedene Breiten geben Bonnier und Flahault an: $45 \%$ bei Paris $\left(49^{\circ} \mathrm{n} . \mathrm{Br}\right.$.), $30 \%$ bei Christiania (fast $60^{\circ} \mathrm{n}$. Br.), $26 \%$ bei Listad in Norwegen $\left(61^{\circ} 40^{\prime} \mathrm{n}\right.$. Br.). In entsprechender Weise gibt Vahl $\left.{ }^{3}\right)$ für verschiedene Breiten folgende Zahlen an: Portugal 34\%; Dänemark $20 \%$; Island $11 \%$; Grönland $8 \%$. - Nach Warming ${ }^{4}$ ) gibt es in Grönland nördlich von $73^{\circ} \mathrm{n}$. Br. keine einjährige Pflanze, abgesehen von den vielleicht durch Menschen eingeführten; zwischen $73-71^{0}$ finden sich $1 \%$, zwischen $71-67^{0}: 2 \%$, zwischen $67-64^{0}: 3 \%$, zwischen $64-62^{\circ}: 4,1^{\%}$ und zwischen $62-60^{\circ}$ n. Br. $5 \%$. Einige

1) Vergl. S. 156, 158.

2) Bonnier und Flahault 1878; Kerner 1869.

3) Vahl 1904 b.

4) Warming 1887. 
Arten sind im Tieflande einjährig, im Gebirge mehrjährig, z. B. Arenaria serpyllifolia, Роа апnиа ${ }^{1}$ ), oder einjährige Tieflandarten werden im Hochgebirge durch mehrjährige Arten vertreten, in den Alpen z. B. Draba verna durch D. laevigata, Viola tricolor durch $V$. lutea usw. Zweijährig sind Arten von Cochlearia, Arabis, Hutchinsia (Kjellman, Josias Braun).

Die Gründe für diese Verhältnisse sind in der kurzen Vegetationszeit und der geringen Wärme zu suchen. Die einjährigen Arten blühen, wenn die Wärme am größten ist; ihre Samen müssen bei abnehmender Wärme, unter ungünstigen Verhältnissen, reifen und werden daher leicht unfruchtbar. Möglicherweise sind mehrere einjährige Arten dadurch in mehrjährige verwandelt worden, $d a ß$ der Samenansatz verhindert wurde und die Vegetationsorgane in Korrelation hiermit kräftiger wurden oder länger dauerten.

Raunkiär ${ }^{2}$ ) hat das arktische Klima als Chamaephyten-Klima bezeichnet, während das kalttemperierte ein Hemikryptophyten-Klima ist (über diese Namen vergl. S. 153); er sieht die Ursache für diese Verschiedenheiten darin, daß je weiter gegen Norden, desto mehr muß die Pflanze kämpfen, nicht nur gegen die Kälte von oben, sondern auch gegen die Kälte von unten, d. $h$. gegen die Kälte des ständig in der Tiefe gefrorenen Bodens. Die Pflanze muß daher eine passende Stellung diesen beiden Gefahren gegenüber einnehmen, und diese Mittelstellung gibt, meint er, eben den Chamaephyten-Typus. Er glaubt auch, daß man eine Grenzlinie, welche er "Biochor" nennt (indem er Köppens Namen in einem anderen Sinne benutzt), zwischen dem nordischen und dem arktischen Klima ziehen kann, und er zieht sie dort, wo die Prozentzahl der Chamaephyten $20 \%$ ist, welche Linie etwa mit der JuniIsotherme von $4,5^{\circ}$ zusammenfällt. Ähnliche Resultate findet er in den Hochgebirgen (Alpen) ${ }^{3}$ ).

Da hohe Pflanzen fehlen, entwickeln sich keine kletternden und windenden Arten.

2. Die Entwicklung beginnt zwar spät, geht aber in der Vegetationszeit sehr schnell vor sich. Der Frühling bricht namentlich in den Polarländern eilig herein. Pflanzen, die in der Ebene zu den spät blühenden gehören, blühen in den Alpen früher, obgleich sie sich weit später entwickeln. Die Entwicklungszeit mancher Arten ist (sicher unter der Einwirkung der Winterkälte) im ganzen viel kürzer als anderswo von der Natur ausgewählt.

1) Kerner 1869; Bonnier 1884.

2) Raunkiär 1907, 1908, 1911.

$\left.{ }^{8}\right) \mathrm{Zu}$ demselben Resultat ist Drude (Deutschlands Pflanzengeographie, 1896, S. 405) für die Pflanzen des Hochgebirges gekommen: „Die Triebknospen liegen meistens in oder an der bestehenden Blattrosette zu Tage". 
3. Die subglazialen Arten sind im ganzen Frühlingspflanzen, d. h. sie blühen sehr früh, bevor die Laubblätter ganz entwickelt sind; einige blühen sogar schon unter dem Schnee (Soldanella, Primula acaulis, Crocus vernus u. a.); dieses beruht darauf, daß die Blüten in dem Jahre vor dem Blühen angelegt werden, und daß den Blütenknospen eine reichliche Nahrung in den angrenzenden Sproßteilen zur Verfügung gestellt ist. Es scheint in der Tat, daß sehr viele, vielleicht die allermeisten der arktischen Blütenpflanzen ihre Blüten im Jahre vorher anlegen ${ }^{1}$ ).

Dadurch wird erreicht, daß die kurze Vegetationszeit zu dem Reifen der Samen ausgenutzt werden kann, das wohl sonst aus Wärmemangel kaum hätte stattfinden können. Ausnahmen bilden z. B. Compositen, die in wenigen Wochen ihre Früchte reifen können, oder solche Arten, die wie die nordischen Cochlearia-Formen das Blühen wie die Fortsetzung der Fruchtreife selbst nach den strengsten und längsten Frostperioden unbeschädigt fortsetzen (S. 35).

4. Vermehrung auf vegetativem Wege (bes. durch Brutknospenbildung) spielt in dem Leben gewisser Arten sicher eine große Rolle, vielleicht als Ersatz für den fehlenden Samenansatz oder den Verlust der Blütenbildung (Saxifraga cernua, S. stellaris f. comosa, S. flagellaris, Polygonum viviparum, vivipare Gräser (Fig. 317). An vielen Standorten sind die Lebensbedingungen jedoch so schlecht, daß der Boden von Pflanzen durchaus nicht bedeckt wird und daß diese einzeln zerstreut, mit großen Abständen voneinander, stehen.

Sproßverhältnisse. Besondere Schutzmittel gegen Kälte gibt es nicht; was man als solche gedeutet hat, sind Schutzmittel gegen Austrocknung durch zu starke Verdunstung (vergl. S. 37) oder gegen zu starke plötzliche Wärmeschwankungen. Aber auf verschiedene Weise drücken die klimatischen Verhältnisse der Pflanzenwelt ein eigenes Gepräge auf.

1. Die meisten Sprosse sind oberirdisch: es geht dann weder Zeit noch Nahrung mit dem Durchbrechen des Bodens verloren. Die Sprosse leben gewöhnlich länger als ein Jahr und entwickeln zuerst eine Reihe von vegetativen Jahressprossen, bevor sie blühen; eine lange Ernährungsarbeit muß dem Blühen vorausgehen, dem das letzte Jahr gewidmet wird.

2. Die Sprosse sind ferner bei einem Teile der Arten, bei Kräutern und Zwergsträuchern, immergrün; dieses hat den Nutzen, daß günstige Temperatur und Beleuchtung während des ganzen Jahres ausgenutzt

1) Einzelheiten z. B. bei Warming 1908, 1909; K. Jessen 1911, 1914; Mentz 1909, in "Structure and Biology of Arctic Flowering Plants", in Meddelelser om Grönland, Bd. 36, 37, Kopenhagen. 
werden können (S. 40). Die überwinternden Lauhblätter sind jedenfalls bei einigen Arten reich an Nahrung, die im Frühjahre verhraucht wird, wonach sie verwelken. Kerner vergleicht die kurzen, rosettenblättrigen Sprosse von Saxifraga-Arten und ähnlichen recht treffend mit olserirdischen Zwiebeln. Die verwelkten Blätter bleiben lange sitzen. Im Herbste nehmen die Blïtter von vielen Arten stark rote Farben an (Anthokyan).

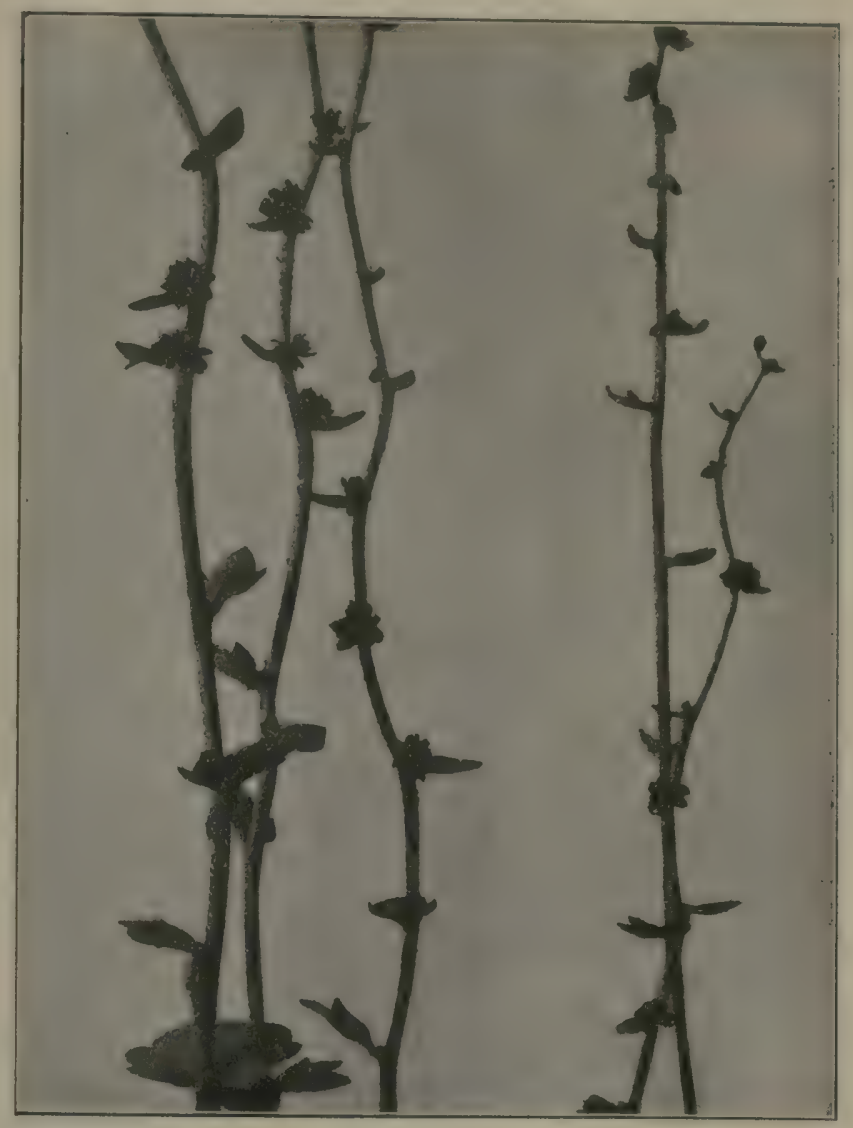

Fig. 317. Saxifraga cernua mit Brutknospen in den Blütenständen an Stelle des Fruchtansatzes. (Phot. P. Graebner.)

Echte Zwiebel- und Knollenpflanzen sind sehr selten (in den Alpen z. B. Lloydia serotina, Chamaeorchis alpina), vielleicht weil mit umstïndlicher Sproßentwicklung keine Zeit verloren gehen darf. In den andinen Felsenfluren (Punas) sollen jedoch viele Pflanzen mit unterirdischen Reserveorganen vorkommen. Die allermeisten Dikotylen haben eine vielküpfige, kräftige primäre Wurzel und bilden keine oder 
wenige Beiwurzeln (Typen sind Silene acaulis, Arten von Arenaria, Draba, Dryas, Saxifraga oppositifolia u. a.).

Kräuter mit wagerecht wachsenden, wurzelschlagenden, oberoder unterirdischen Sprossen und Zwergsträucher mit unterirdischen Sprossen sind seltener. Die kleinen polaren Weiden, Salix herbacea und S. polaris, gehören zu den letzteren. Sie entwickeln ihre dünnen, verholzenden und verzweigten, wurzelschlagenden Stämme in der Erde, und nur ganz kurze Zweige mit etwa 2-3 rundlichen Blättern ragen in die Luft hervor.

3. Äußerst bezeichnend ist der Zwergwuchs, der durch die auf S. 694 ff. unter 1-5 erwähnten, das Wachstum hemmenden Verhältnisse verursacht wird (vergl. auch Kap. 3, 5, 10), und der sich namentlich im folgenden zeigt.

Folgende Formtypen sind häufig:

a. Rosettenstauden (S. 45, 174). Die vegetativen Sprosse sind kurz und kurzgliedrig, oft Rosettensprosse, während die blütentragenden mehr oder weniger schaftartig entwickelt sind und kleine, hochblattartige Blätter tragen (z. B. Papaver nudicaule, Saxifraga). Alpine Arten weichen daher von den verwandten oder den parallelen Tieflandarten in der Tracht oft bedeutend ab (z. B. Artemisia nana von A. campestris, Aster alpinus von $A$. amellus) $\left.{ }^{1}\right)$. In der Puna der Anden kommen "kryptokaule" Zwergsträucher vor, deren unterirdischer Stammteil holzig ist und, ohne eigentlich knollenartig zu sein, oft das mehrhundertfache Volumen einnimmt von dem die Erdoberfläche überragenden rosettenblättrigen Teile der Pflanze ${ }^{2}$ ).

b. Niederliegende (prostrate) Pflanzen (S.42, 192). Bei anderen, besonders Zwergsträuchern, sind die Sprosse jedoch lang, aber niederliegend und dem Boden dicht angedrückt, indem sie die wärmsten Luftschichten und den besten Windschutz aufsuchen, sich oft zwischen Flechten und Moosen verbergend. Die verbogenen, gekrümmten und gedrehten Sprosse liegen oft spalierförmig über dem Boden (Betula nana, Juniperus, Empetrum, Salix retusa, S. reticulata, S. glauca, Dryas octopetala, Loiseleuria procumbens u. a.) $\left.{ }^{3}\right)$. Diese spielen in der Zusammensetzung der arktischen und alpinen Vegetation eine hervorragende Rolle. Die knorrigen Äste von Salix retusa in den Alpen liegen flach, ohne Adventivwurzeln dem Boden auf, oder überkleiden auch die Felsblöcke mit einem grünen Teppich ${ }^{4}$ ). Diese Kriechsträucher haben einen äußerst langsamen Wuchs. Die Jahresringe sind oft nur $0,1-0,2 \mathrm{~mm}$ breit. Bisweilen bekommen

2) Bonnier 1890.

2) Fiebrig 1910; Weberbauer 1911. - Vergl. S. $265 \mathrm{ff}$.

8) Vergl. S. 193 und Hayrén 1914.

4) H. Schenck 1908. 
sie in Ostgrönland durch die schleifende Kraft der Sand- und Steingeblïse merkwürdig abgeschliffene und zugeschärfte Stänme, was Hartz u. Kruuse und J. Braun (vergl. Fig. 312) durch viele Bilder illustriert haben. Juniperus nana bildet in der alpinen Höhenstufe dicht der Erde angeschmiegte, teppichartige Rasen, die oft nur 5-10 cm hoch sind, und je höher sie auf den Bergen wachsen, desto unansehnlicher werden $\left.\operatorname{sie}^{1}\right)$.

c. Polsterpflanzen (vergl. S. 182, 265). Übergänge zu den echten Polsterpflanzen kommen in den Polargegenden und Hochalpen bei vielen Arten von Saxifraga, Caryophyllaceen, z. B. Silene acaulis, Cruciferen

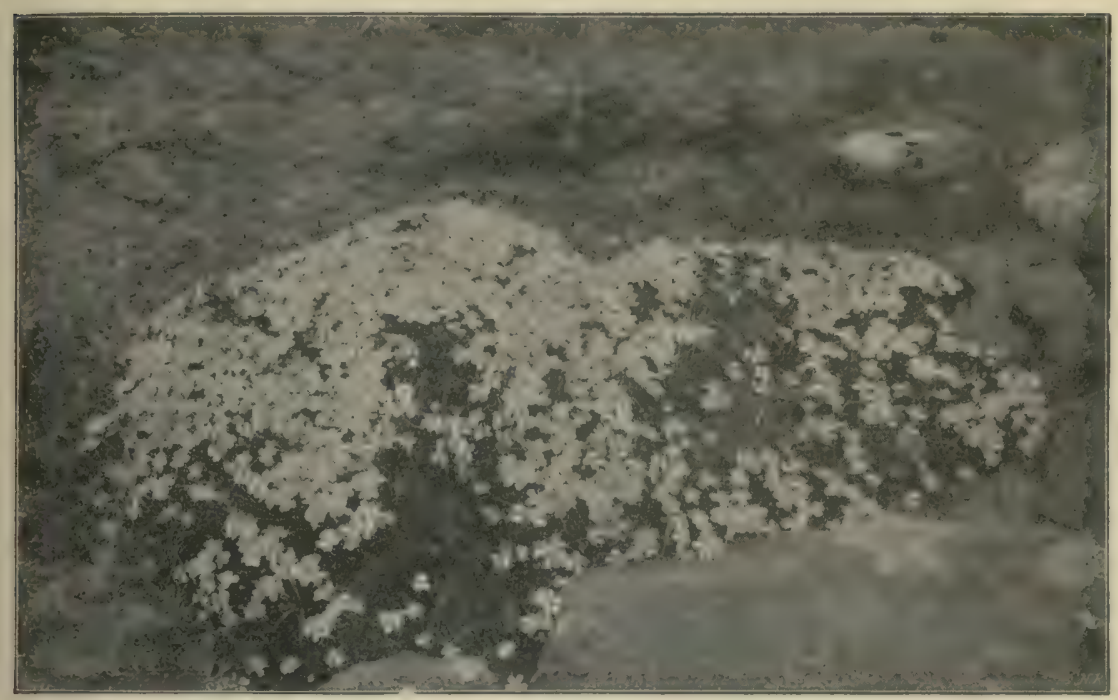

Fig. 318. Silene acaulis, Polster von den Färöern.

(Phot. Börgesen.)

(Draba), Diapensia Lapponica u. a. vor; die oberirdischen Sprosse sind dicht gedrängt, bilden aber doch im ganzen keine so dicht und fest geschlossene Halbkugel wie die ausgeprägten Polsterpflanzen ${ }^{2}$ ). Ebensolche Lebensformen bilden in den Hochanden verschiedene Compositen, Azorella, Adesmia, ja selbst eine Ephedra und Cacteen ${ }^{3}$ ).

Solche und auch feste Polsterpflanzen sind in den subglazialen Gegenden sehr allgemein verbreitet. Die Verzweigung ist oft sehr dicht; dadurch erhalten viele Arten eine sehr niedrige und dichte,

1) Adamovié 1909.

2) Vergl. Warming 1909, Fig. 12; Henning E. Petersen 1908 b (Diapensia, Fig. 1, 2); Thoroddsen 1914, Dryas Fig. 38; Ostenfeld 1908 b; Hauri 1914, 1916.

*) Fiebrig 1910. 
gewölbte, oft halbkugelförmige Rasen- oder Polsterform, die nicht nur für Blütenpflanzen, sondern auch für Moose bezeichnend und die sehr augenfällig ist, wenn man die subglazialen Arten mit den parallelen oder den verwandten Tieflandarten vergleicht. Die Dichtigkeit der Rasen wird dadurch vergrößert, daß die alten, toten Pflanzenteile (Blätter usw.) lange sitzen bleiben, ohne zu verwesen. Diese dichten Polster, die z. B. in den Hochgebirgen Südamerikas in typischen Formen (bei Azorella, Aretiastrum u. a.) auftreten, können sich gegen Austrocknen unter anderem dadurch schützen, daß ihre alten und dichten Massen sehr begierig Wasser aufsaugen und festhalten, daher wohl auch wegen der hohen spezifischen Wärme des Wassers länger warm bleiben, wenn sich die Umgebung abkühlt ${ }^{1}$ ).

Wie schon erwähnt, sind es in Südamerika und den subantarktischen Inseln besondere Arten von Azorella und Bolax (Azorella selago, A. lypopodioides, Bolax Bovei, B. glebarii) ${ }^{2}$ ), auf Neuseeland und den anliegenden subantarktischen Inseln, z. B. auf der Stewart-Insel dagegen auf allen weniger geschützten Stellen Polster von Dracophyllum politum (Epacridacee), Donatia, Raoulia Haastii u. a., welche eine Rolle spielen ${ }^{3}$ ). Selbst die Gräser müssen sich in den subglazialen Gegenden den Verhältnissen, namentlich den Winden, anpassen; die Blätter werden nicht nur trocken, hart, spitz und steif, sondern auch, z. B. bei Festuca. orthophylla, steil aufgerichtet, so daß die Pflanze einen dicht geschlossenen Horst bildet ${ }^{4}$.

Die Laubblätter. Die Laubblätter sind klein, und viele Arten haben abgerundete, mehr oder weniger ganzrandige Formen; selbst bei den Moosen werden sie bei derselben Art kürzer und relativ breiter, als an anderen Standorten; die Laubblätter anderer Pflanzen hingegen sind linealisch, so daß diese (z. B. Saxifraga- und Sagina-Arten) moosähnlich werden, oder sie sind auch schuppenartig oder ericoüd.

Die Richtung der Blätter kann anders sein, als an anderen Standorten derselben Pflanzenart; sie werden mehr aufrecht, angedrückt und konkav (vergl. z. B. die Figuren von Juniperus und Lycopodium bei Warming $)^{5}$ ) und sind bei einigen Arten immer aufwärts bis vertikal gerichtet (bei Arten mit Juncus-ähnlichen Blättern, nämlich bei Ottoa oenanthoides und Crantzia linearis, nach Goebel).

Blattbau. Der xerophile, namentlich durch die unter 3 und 4 (S. 696 ff.) genannten Verhältnisse hervorgerufene Bau offenbart sich

2) Goebel 1889-91; Meigen 1894 .

2) Weberbauer 1911; Skottsberg 1906.

3) Cockayne; Diels 1896, 1905.

4) Fiebrig 1910.

s) Warming 1887 . 
zunächst bei den mehrjährigen, imm ergr ü nen Laubsprossen in folgendem: Die Blätter sind oft lederartig, steif und stark glïnzend (cuticularisiert), z. B. bei Loiseleuria procumbens, Globularia cordifolia, oder sie sind dick und saftig (Arten von Saxifraga, Sempervivum u. a.), oder sie haben eine mehr oder weniger dichte $\mathrm{Haarbekleidung}$, besonder's auf der Lnterseite (Rhododendron, Draba-Arten, Cerastium alpinum, Espletia, Culcitium usw.). Die Spaltöffnungen sind oft in Furchen, oder unter zurückgerollten Blatträndern, oder unter Deckhaaren verborgen

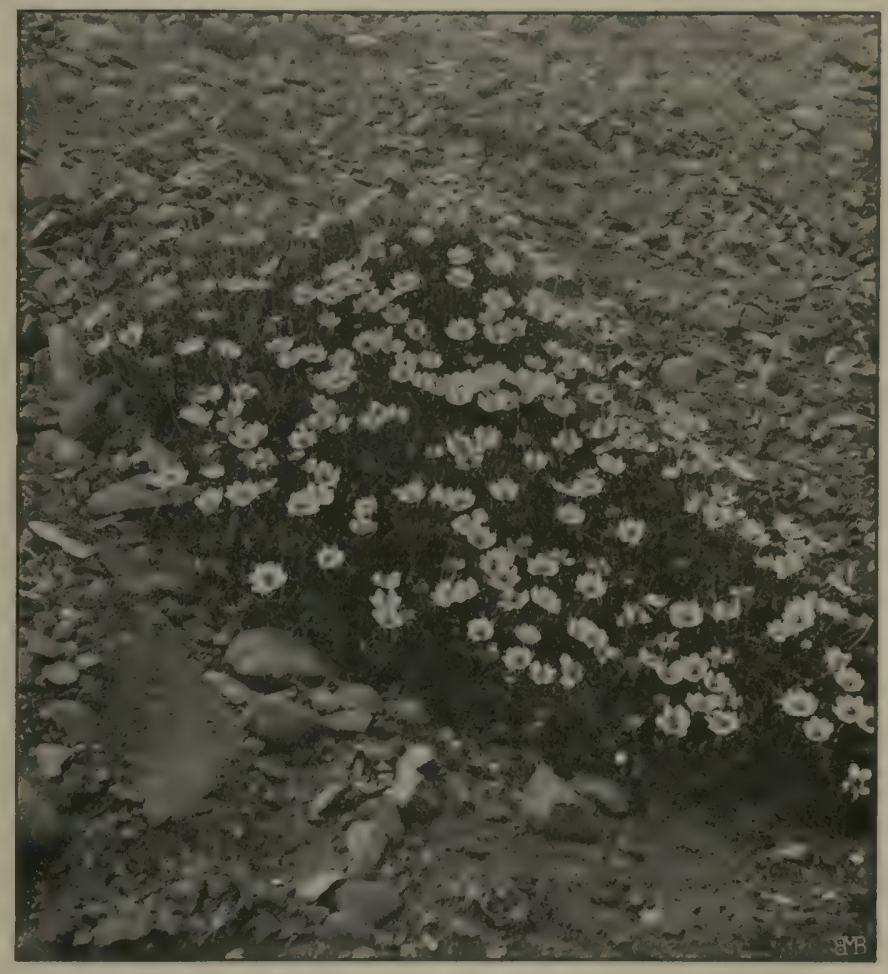

Fig. 319. Dryas octopetala auf Island. (Phot. A. Hesselbo in Thoroddsen 1914.)

(Cassiope tetragona, Ledum palustre f. decumbens u. a. Ericaceen, Eimpetrum, Dryas usw.). Die Haardecke wird namentlich gegen zu starke Transpiration, zu starkes Licht und zu schnelle Temperaturwechsel schützen. Die nur im Sommer grïnen Blätter haben diesen xerophilen Bau nicht oder in geringem Grade.

Der Blattbau der alpinen Pflanzen ist von Lazniewski, Leist, Wagner und Bonnier untersucht worden. Die beiden letzten Forscher stimmen in ihren Ergebnissen im ganzen überein; diese sind folgende, wenn man die alpinen Blätter mit denen entsprechender 'Tieflandpflanzen 
vergleicht: Die alpinen Blätter sind durch ein mehr entwickeltes Palisadengewebe an eine stärkere Assimilation angepaßt, weshalb ihre Blätter durchgehends (um $1 / 6-1 / 5$, bisweilen sogar um $1 / 3$ ) dicker als die der Tieflandpflanzen sind, und zwar im Verhältnis zu der Größe der Fläche, oft auch absolut. Sie sind stets dorsiventral und wegen größerer Intercellularen lockerer gebaut. Sie haben auf beiden Seiten viele Spaltöffnungen, aber besonders auf der Oberseite, bisweilen hier viel mehr als auf der Unterseite. Die Schließzellen liegen in dem Niveau der Epidermis-Oberfläche, die vorhin besprochenen überwinternden Blätter ausgenommen. Wagner meint, daß die Alpenpflanzen eine größere Assimilationsenergie brauchen, weil der Kohlensäuregehalt der Luft geringer sei (vergl. jedoch S. 10 und den sogleich $\mathrm{zu}$ besprechenden arktischen Blattbau) und die Vegetationszeit kürzer sei; dazu komme, dal3 die Lichtstärke, der die Alpenpflanzen ausgesetzt sind, größer sei und die stärker brechbaren Strahlen zahlreicher seien.

Bonnier ${ }^{1}$ ) verglich bei 19 Arten Blätter von Spitzbergen und Jan Mayen mit solchen aus den Alpen und kam zu den folgenden, gewiß $\mathrm{zu}$ allgemein ausgedrückten Ergebnissen. Das arktische Blatt ist dicker und fleischiger, hat ein lockereres, an großen Lufträumen reicheres Mesophyll, dessen Palisadengewebe schwächer ausgebildet ist und abgerundete Zellen aufweist, und eine dünne Cuticula (bei den immergrünen Arten jedoch kaum dünner: Börgesen). Dieser Bau wird nach ihm dadurch verursacht, daß die Luftfeuchtigkeit in den Polarländern mit der Breite zunimmt, während sie in den Hochgebirgen von einer gewissen Höhe über dem Meere an abnimmt, und daß die Alpenpflanzen in einer gewöhnlich nebelfreien Luft mit oft wechselnder, am Tage sehr starker Beleuchtung, die Polarpflanzen hingegen fast beständig in Nebel oder in einem wenig starken Lichte leben. Diese Erklärung steht im Einklange mit Versuchen, die Lothelier ${ }^{2}$ ) und Bonnier mit Pflanzen in feuchter und trockener Luft anstellten, und mit Versuchen Bonniers an Pflanzen in dauernder (elektrischer) Beleuchtung. Das wenig starke Licht scheint jedoch von größerer Bedeutung zu sein als die Nebel, die, bei hinlänglicher Entfernung von den Küsten, in den Polarländern kaum häufiger sind als in den Alpen. Diese Ergebnisse Bonniers stimmen mit den älteren Untersuchungen von Th. Holm ${ }^{3}$ ) und den neueren von Börgesen überein ${ }^{4}$ ).

1) Bonnier 1894 .

2) Lothelier 1890, 1893.

s) Holm 1887.

4) Viele Abbildungen vom Blattbau arktischer Pflanzen finden sich in „Meddelelser om Grönland", Bd. 36 u. 37. Kjöbenhavn. 
Farbe. Die Laubblätter werden nach Bonnier mit wachsender Höhe (und Breite?) oft tiefer grün; sie bilden mehr Chlorophyll, wodurch sie eine größere Assimilationsenergie erhalten und ihre geringe Größe ersetzen. Bonnier ${ }^{1}$ ) bemerkt, daß es ein Optimum der Höhe gebe, in welchem die Blätter den tiefsten Ton des Grünes erreichen. Roten Zellsaft (Anthocyan) findet man in den Hochgelirgen und Polarländern oft; er wird von einigen als ein Schutz gegen das intensive Sonnenlicht angesehen, und nach Tischler sind rote Rassen von Pflanzen widerstandsfähiger gegen Kälte als grüne. Lidforss fand indessen, daß eine rote Varietät von Veronica hederifolia in kaltem Wetter zugrunde ging, während eine grüne dieses überlebte; die rote war aber früher zum Leben geweckt worden und ging dann durch die Spätfröste zugrunde. Die Wirkung von Anthocyan ist vielleicht nicht immer dieselbe ${ }^{2}$ ).

Die Blüten. Zwergwuchs kommt nur beim Ernährungssprosse vor, während Blüte und Frucht im Hochgebirge dieselbe Größe wie im Tieflande haben ${ }^{3}$ ). Wenn angegeben wird, daß die Blüten dort sogar größer würden, so ist dieses sicher meist nur eine subjektive, nicht auf Messungen gestützte Auffassung, die vielleicht gerade durch die Kleinheit der Vegetationsorgane veranlaßt wird.

Die Farben der Blüten werden in größerer Höhe über dem Meere und unter höheren Breiten tiefer und reiner. Die gesättigten, reinen Farben namentlich von Enzianen, Glockenblumen, Potentillen usw. in den Alpen, von Mimulus, Lupinus, Sida u. a. in den Anden sind bekannt. Besonders findet man viele weißblütige Arten in den subglazialen Gegenden stärker rot, als in tiefer liegenden; nach Blytt sind z. B. die Blüten von Achillea millefolium, Trientalis, Carum carvi und die Hüllblätter von Chamaepericlymenum (Cornus) Suecicum in den Gebirgen Norwegens oft stärker rot als im Tieflande. Der subjektive Eindruck spielt gewiß auch eine Rolle: die Blütenfarben erscheinen an den niedrigen Pflanzen, die oft in einer unfruchtbaren Umgebung wachsen, stärker; aber Bonnier und Flahault haben durch Vergleiche mit Farbenskalen gefunden, daß die Farben wirklich tiefer sind. Dieses muß dem in den Gebirgen starken, in den Polarländern lange andauernden Sonnenlichte zugeschrieben werden.

Die am höchsten in den Hochgebirgen aufsteigenden und am weitesten gegen die Pole vordringenden Arten sind alle frühblühend und schnell fruchtend, besonders aus den Gattungen Saxifraga, Draba,

1) Bonnier 1890 .

2) Vergl.S. 27, 203. Stahl; Tischler 1905; Lidforss 1909; Hanna Resvoll-Holmsen 1918; Th. Wulft 1902.

7) Vergl. z. B. B. Bonnier 1890. 
Silene, Gentiana, Ranunculus usw. Viele Arten können unter tiefem Schnee im Winter schon blühend angetroffen werden (Saxifraga oppositifolia, Soldanella u. a.).

Was die Blütezeit betrifft, kann übrigens bemerkt werden, daß man dieselbe Art zu sehr verschiedener Zeit in Blüte finden kann, je nachdem sie früher oder später von der Schneedecke entblößt wird.

Weniger ausgebildet sind Dornen und Stacheln; sie fehlen bei den subglazialen Pflanzen fast ganz; die Rosa- und Rubus-Arten haben meist weniger oder keine Stacheln. Dieses muß wohl der großen Feuchtigkeit, die in der Entwicklungszeit herrscht, zugeschrieben werden.

Aromatische, wie auch bittere und harzartige Stoffe werden in den Polarländern nur in geringer Menge entwickelt, in den Hochgebirgen aber jedenfalls häufiger. In den Anden z. B. sind kleine Compositen mit solchen Stoffen (nach Meyen) viel häufiger als in der verwandten Flora des Tieflandes. Es wird dies vermutlich durch das stärkere Licht verursacht. Die Blüten der Hochgebirge sind sicher durchgehends weit wohlriechender als die der Polarländer.

\section{Kap. Die Formationen der Kältewiisten (subglaziale Felsenfluren)}

Das besonders Charakteristische für die Vegetation ist, daß sie offen ist. Es ist eine oft besprochene Tatsache, daß die Wälder an ihrer Polargrenze oder an der Grenze der alpinen Höhenstufe offener und niedriger werden als weiter unten; die Bäume werden in ihren Kämpfen mit den Unbilden der Natur mehr und mehr voneinander entfernt gestellt und dabei allmählich krüppelhafter; es wird ihnen stets schwieriger, ihre Samen auszureifen und Jungwuchs hervorzubringen. Auch mit den Moos- und Flechtenheiden und den Tundren geht es so, je weiter sie gegen die Pole vorrücken oder je höher sie in die Hochgebirge hinaufsteigen. Schließlich wird keine zusammenhängende Pflanzendecke mehr gebildet, und wir haben die Kältewüste erreicht. Nur hier und da an besonders günstigen Stellen findet sich etwas, was man mit Middendorff eine "Oase" nennen kann ${ }^{1}$ ), ein Stück der Flechtenheiden oder Zwergstrauchheiden usw.

Für die Felsenfluren (dänisch „Fjældmarker“) oder die Kältewüsten ist am meisten bezeichnend, daß die Pflanzen niedrig sind (Zwergwuchs zeigen), und daß der Boden durchaus nicht von Pflanzen bedeckt

1) Vergl. S. 531, 541. 
ist. Ein Individuum steht hier, ein anderes da; zwischen ihnen sieht man den nackten, kiesigen, steinigen, sandigen oder tonigen Boden, der demgemäß die Farbe der Landschaft bestimmt. Pansch, Hartz und andere Polarforscher sahen in Ostgrönland Gegenden, die so nackt waren, daß sie kaum ein Moos oder eine Flechte fanden. Der (irund für diese Armut an Individuen liegt in dem Mangel an Wärme und Schutz gegen Wind. Zwischen dem Klima und der Dichtigkeit der Vegetation mul3 offenbar ein gewisses konstantes Verhältnis bestehen, so daß nicht mehr Samen oder andere Vermehrungsorgane sich bilden oder sich zu Pflanzen entwickeln können, als gerade für die nun einmal vorhandene Vegetation hinreichen. Humus entsteht kaum, dazu ist der Pflanzenwuchs zu dürftig und die Zersetzungsprozesse sind zu schwierig. Die sulgglazialen Arten (und die Felsenpflanzen) können als Pioniere der Pflanzenwelt betrachtet werden, weil sie von andern Pflanzen oder Tieren am wenigsten abhängen. Auf dem Übergange zur Zwergstrauchheide treten unter den zahlreicheren Zwergsträuchern Rohhumusbildungen auf. Auf Nowaja Semlja vermissen wir nach Pohle ${ }^{1}$ ) eine Torftundra und eine Zwergstrauchheide; nur die Kältewüste herrscht dort. Die Kältewüsten sind verarmte Tundren.

Als ein anderes Merkmal können die vielen Sporenpflanzen hervorgehohen werden. Es sind besonders Flechten und Moose, namentlich in nordischen und arktischen Kältewüsten; dieses erklärt sich dadurch, daß diese Pflanzen bei den niedrigen Temperaturen gedeihen können. Ihre Menge ist jedoch je nach den Standorten verschieden, teilweise sicher nach der Natur des Bodens; auf Schiefer soll im Norden die Anzahl der Blütenpflanzen größer, als die der Moose und Flechten, und die Vegetation mannigfaltiger sein; umgekehrt auf Urgebirge, wo die Vegetation in Flechten- und Moosheiden übergeht. Aber außer diesen Sporenpflanzen trifft man höhere Pflanzen an, sowohl Kräuter als auch Zwergsträucher, wie schon erwähnt wurde.

Die Kältewüsten müssen sicher nach dem Klima und dem Boden in mehrere Formationen geteilt werden, wenn sie näher ökologisch studiert werden, namentlich Flecken von Zwergstrauchheide, von Moostundra, von Flechtentundra, von Schneetälchenvegetation, die auch hier angebracht werden könnte (vergl. S. 529), Grassteppe (z. B. auf den Falklandsinseln). Von Assoziationen gibt es jedenfalls eine große Menge. Denn die Flora ist je nach den Erdteilen äußerst verschieden. Wenn Formationen unterschieden werden können, würden sie wohl vorzugsweise durch die oben besprochenen Bodenverhältnisse hervorgerufen werden, je nachdem ob der Boden flach und lehmig, oder felsenartig mit nacktem Steinboden („Felsentundra“), wo vielleicht blaugrïne Algen und Flechten

2) Pohle 1907. 
die einzige Vegetation bilden, oder von Schutt oder Felsentrümmern gebildet ist. Eine solche Kältewüste schildert Pohle: auf der Hochfläche an der Ostküste des Weißen Meeres liegen Felstrümmer überall umher, wie von Riesenhand ausgestreut, von kleinen Gesteinsbrocken bis zu riesenhaften Granitblöcken ${ }^{1}$ ). Hier ist das Reich der Flechten, deren Krusten alles Gestein bedecken, - eine furchtbare Öde ${ }^{2}$ ).

In den Kältewüsten spielt der Schnee eine äußerst wichtige Rolle, indem er je nach den Windverhältnissen und Unebenheiten des Terrains in dickeren oder dünneren Schichten abgelagert wird oder auch ganz weggeweht wird, so daß die Pflanzen im Winter den eisigen Winden ausgesetzt sind. Die dünneren Schneeschichten schmelzen im Frühling und Sommer natürlich weit schneller als die dicken, von welchen viele sogar Jahre lang liegen bleiben können. Die Folge ist, daß für die Pflanzen der Frühling zu sehr verschiedener Zeit eintritt, selbst auf ganz kleinen Flächen. Derselbe Schneefleck zeigt in zonenförmiger Anordnung sehr verschiedene Jahreszeiten um sich herum. Über das Abschmelzen der Schneelager und das damit Hand in Hand gehende Erwachen der Vegetation haben Rübel im Berninagebiet und Thekla Resvoll $^{3}$ ) in Norwegen sorgfältige Beobachtungen angestellt. Diese Verhältnisse der Schneelager tragen ungeheuer mit zu dem kaleidoskopischen Äußeren in vielen arktischen Kältewüsten bei.

Die arktische Felsenflur trifft man rings um den Nordpol, in dem nördlichsten Nordamerika, in Sibirien, Nordeuropa, Grönland, auf Island (wo sie wohl im allgemeinen Melur, im Plural Melar, genannt wird) ${ }^{4}$ ). Ihre wichtigsten Sträucher und Zwerg-Kriechsträucher sind Juniperus communis, viele Salices, Betula nana, Empetrum, Diapensia Lapponica, die Ericaceen Cassiope tetragona, Arctostaphylos alpina, Loiseleuria procumbens, Rhododendron Lapponicum, Phyllodoce caerulea, Vaccinium, Ledum, Kalmia und die Rosaceen Dryas octopetala und D. integrifolia. Die wichtigsten Kräutergattungen sind von Gräsern Poa, Festuca, Trisetum, Hiërochloe, Nardus u. a.; von Cyperaceen Carex, Elyna (E. Bellardi), Kobresia (K. bipartita); von Juncaceen Luzula, Juncus; von Liliaceen Tofieldia. Ferner kommen viele Caryophyllaceen vor,

1) Vergl. hierzu Kap. 95.

2) Litteratur der arktischen und europäischen Kältewüste: Kihlman 1890; Hult 1887; Warming 1887; Hartz 1895; Th. Holm 1887; Nathorst 1883; Kjellman 1882, 1884; G. Andersson 1900, 1902; Porsild 1902; A. Cleve 1901; Sernander 1898; Pohle 1903; C. Hansen-Ostenfeld 1908; Hartz u. Kruuse 1911; Kruuse 1912; Hanna Resvoll-Holmsen 1913, 1914; Th. C. E. Fries 1913.

3) Sie werden in den Berichten der 16. Skandinavischen Naturforscher-Versammlung in Kristiania 1916 veröffentlicht.

7) Vergl. Stefansson; Thoroddsen. 
namentlich Cerastium alpinum, Silene acaulis, Viscaria alpina, ferner Compositen, Cruciferen (Draba, Cochlearia, Vesicaria, Braya usw.), Campanula uniflora, Papaver nudicaule, Polygonum viviparum, Pirola rotundifolia, Rhodiola rosea, Arten von Ranunculus, Potentilla, Saxifiaga, Pedicularis usw. Außerdem gibt es immer viele Moose und Flechten verschiedener Form, auch Strauchflechten (Cetraria, Cornicularia, Sphaerophoron, Cladonia usw.), und diese Sporenpflanzen spielen an vielen Orten die größte Rolle oder sind fast allein vorhanden.

Assoziationen. An den verschiedenen kleinen Standorten treten bisweilen gewisse Arten in größerer Menge auf (je nachdem der Boden mehr steinig, felsig, kiesig, tonig oder sandig, mehr warm oder kalt ist, lüngere oder kürzere Zeit von Schnee bedeckt ist, mehr oder weniger vor den Winden geschützt ist, vom Schmelzwasser gewïssert wird usw.) und geben der Vegetation ein besonderes Gepräge, wonach man verschiedene Assoziationen unterscheiden $\operatorname{kann}^{1}$ ), z. B. von Juncus trifidus, ErdLecidea, Diapensia, Carex rupestris, Dryas, Silene acaulis, Ranunculus glacialis usw., oder gemischte, z. B. von Dryas, Potentilla nivea. Ebenso gibt es reine Flechtenassoziationen, besonders auf den Berggipfeln (Parmelieta centrifugae, Gyrophoreta).

Übergänge zu der Bergheide finden sich natïrlich auch, offene Assoziationen, wo Zwerg- und Spaliersträucher in größerer Menge auftreten.

An den tonigen Polygonboden (Kap. 89) muß hier erinnert werden. Mit der Zeit können die Spalten eine recht dichte Vegetation darbieten, während die Tonflächen sonst nur in großen Zwischenräumen mit Polstern und Büscheln bekleidet sind; es wachsen hier Arenaria, Silene acaulis, Armeria, Taraxacum, - alle mit tiefen Pfahlwurzeln, mit zerstreuten Flechten und in der Sommerzeit, wenn feucht genug, mit blaugrünen Algen bedeckt.

Äußerst sparsam bewachsen sind nach Kruuse namentlich die Grusflächen, deren Körner zu mehr als $50 \%$ über $5 \mathrm{~mm}$ Durchmesser haben. Die Pflanzen sind im höchsten Maße von dem Winde und der Erosion durch die Gruskörner beeinflußt.

Nordeuropäische Gebirge. Eine ähnliche Vegetation wie die soeben beschriebene findet sich auf den höchsten Bergen von Norwegen und Schweden, ebenso in Schottland, von welcher W. G. Smith eine eingehende, vorzïgliche Darstellung gegeben hat ${ }^{2}$ ), und auf den Färöern ${ }^{3}$ ).

1) Vergl. z. B. Hult 1887; er nennt sie „Formationen“.

2) Tansley 1911.

3) Ostenfeld $1908 \mathrm{~b}$. Uber Island vergl. Thoroddsen 1914. 
In den Hochalpen ${ }^{1}$ ) kommen Felsenfluren mit derselben Physiognomie vor, bis zu den Feldern des "ewigen" Schnees und Eises und zwischen diesen, wo die Sonne und die Neigung des Bodens zur Sommerzeit nackte Stellen hervorbringen; aber die Arten sind neben vielen gemeinsamen teilweise von denen der Polarländer abweichend. Hier findet man besonders in den Kalkgegenden der Alpen Geröllanhäufungen (Geröllhalden, pierriers) mit einer bestimmten Krautvegetation; in weit voneinander getrennten, aber von einem Punkte aus nach allen Seiten entwickelten rundlichen Rasen liegen die Pflanzen auf dem nackten, zeitweise sehr trockenen Gerölle. Der Boden trägt hier mehr als in den Polarländern dazu bei, Xerophyten hervorzurufen ${ }^{2}$ ). In den Tiroler Hochalpen werden die Geröllhalden nach Kerner (1864) zuerst von einer zerstreuten Vegetation aus einigen Cruciferen (Arabis alpina, Hutchinsia alpina usw.), SaxifragaArten, Linaria alpina, Salix retusa und S. herbacea besiedelt, zwischen denen sich Gräser und Riedgräser, dann Zwergsträucher, Dryas, später Loiseleuria procumbens, die beiden Arctostaphylos-Arten usw. einfinden. Namentlich Loiseleuria kann stellenweise schließlich die Herrschaft erhalten und Assoziationen bilden, die den Anfang einer Zwergstrauchheide darstellen ${ }^{3}$ ). Moose und Flechten sind weniger wesentlich, als in Nordeuropa und in den Polarländern; jedoch spielt Polytrichum septentrionale auf allen unlängst von Moränengrus bedeckten Stellen eine große Rolle.

Schenck ${ }^{4}$ ) bespricht die Vegetation der alpinen Höhenstufe in den Alpen, die hochalpine Fels- und Steinwüste, die Schuttformation, und zu oberst die Felsblockhalden mit ihren Flechten und Moosen, sowie die anderen durch verschiedene Bodenbeschaffenheit hervorgerufenen Assoziationen.

Merkwürdigerweise findet sich nach Rübel im Berninagebiete in der nivalen Stufe, sogar noch in $3120 \mathrm{~m}$ Höhe, ein wohl entwickeltes Curviletum (oder Caricetum curvulae) mit eingestreuten Stauden u. a. Auch J. Braun spricht von diesem Curvuletum als "kleinste und allerkleinste, oft noch hoch über den letzten Beständen in sonnigen, windgeschützten Felsnischen geborgenen Krummseggenteppichen". Unter den "Pionierrasen" der Schneestufe der Rätisch-Lepontischen Alpen bespricht er ferner das Elynetum, von 1800-3000 m, welches windoffene, frühzeitig schneefreie und trockene Kämme und Vorsprünge bevorzugt, das Semperviretum, aus Carex sempervirens gebildet, das

3) Litteratur: Christ 1879; Kerner 1869, 1886; Günther Beck 1901; Stebler und Schröter 1889, 1892; Schröter 1904-08; Rübel 1911-12, 1913; Oettli 1903; BrockmannJerosch 1907. Eine eingehende Darstellung der Vegetation der Schneestufe siehe Jos. Braun 1913.

2) Vergl. auch Kap. 95 und 96 in Serie VI.

3) Vergl. auch Rübel 1913.

4) Schenck 1908. 
Festucetum pumilae und Seslerietum coeruleae. Die hochalpine Blumenmatte dringt in wenig blütenreicher Gestalt mit vorherrschenden Glumifloren in die Nivalstufe hinein. Jedoch schildert Jos. Braun auch "Dikotylenteppiche" meist von ausdauernden Dikotylen auf ruhigem Feinschuttboden gebildet, mit buntem Farbenschmuck, als Oasen im dunkeln Schieferschutt. Zu der Schuttflora gehören eine Reihe rerschiedener Assoziationen, welche die von Verwitterungsprodukten des umgebenden Gesteins gebildeten Bodenflächen in Besitz genommen haben, darunter z. B. Flechten- und Moospolster, die Geröllflora, und die Saliceten, welche aus Salix serpyllifolia gebildet werden, der einzigen Holzpflanze, welche noch in der "Schneestufe" bei 2640 his $3000 \mathrm{~m}$ Höhe häufig vorkommt. Ihre abgefallenen Blätter können mit der Zeit eine Humusschicht bilden, in welcher verschiedene Stauden einen passenden Standort finden.

Als ein besonderer Vegetationstypus wird die Felsfl u r besprochen: der nackte Fels, der keine Rasenflecken wie die erwähnten trägt, und wo ein großer floristischer Unterschied zwischen Kalk- und Kieselboden beobachtet wird (vergl. Kap. 92).

Die Schneefelder in den Hochgebirgen der Herzegowina haben nach Günther Beck im Sommer sehr viele Frühjahrspflanzen, die merkwürdigerweise zum Teil Zwiebel- und Knollenpflanzen sind (Scilla bifolia, Muscari botryoides, Corydallis tuberosa, Anemone nemorosa, Crocus Heuffelianus, Saxifraga, Viola u. a.); hierin zeigt sich eine deutliche Abweichung von den Felsenfluren der Polarländer, die der größeren Trockenheit und der stärkeren Hitze des Sommers zugeschrieben werden muß.

Sehr viele Gattungen sind den nördlichen Polarländern, den Hochgebirgen der nördlichen Halbkugel und denen Javas gemeinsam ${ }^{1}$ ).

Antarktische Kältewüsten. Das antarktische Festland ist überall unter Schnee begraben. Nur an wenigen schneefreien Orten mit günstigen Verwitterungsverhältnissen kommen Pflanzen vor. Die Vegetation besteht aus Moosen und Flechten, die bald vereinzelt wachsen, bald kleine Flecken von Moos- oder Flechtentundren bilden. In den Moospolstern können vereinzelte Exemplare von Aera antarctica vorkommen ${ }^{2}$ ).

Physiognomisch und floristisch schließen sich die Felsenfluren und Kältewüsten des Feuerlandes, der Falklandsinseln, sowie der antarktischen Inseln (Kerguelen) an die der Anden an. Doch wird die Feuchtigkeit größer als in den Punas sein und die Ähnlichkeit mit den polaren Kältewüsten ist größer. Das Klima der antarktischen Inseln zeigt eine große Ähnlichkeit mit dem der tropischen Hochgebirge,

1) Vergl. Meyen 1836 .

2) Skottsberg 1912 b. 
weil die T'emperaturunterschiede in den verschiedenen Jahreszeiten gering sind. In einer langen Jahreszeit steigt die Temperatur wenige Grade über $0^{\circ}$. Auf den Kerguelen hat der Winter eine Mitteltemperatur von $1^{0}$, der Sommer eine solche von $6^{\circ} \mathrm{C}$. In Süd-Georgia haben nur die drei kältesten Monate Mitteltemperaturen unter $0^{\circ} \mathrm{C}$., die Mitteltemperatur des wärmsten Monats ist aber nur $5,3^{\circ} \mathrm{C}$. Hierdurch erhellt die Ähnlichkeit zwischen tropischen und antarktischen Hochflächen. Auf dem antarktischen Kontinent ist die Mitteltemperatur des wärmsten Monats $0^{\circ}$ und noch tiefer. Südlich von $70^{\circ}$ südl. Br. herrscht lange Zeit ein kalter Antizyklon, wie er sicher zur Eiszeit bei uns als vegetationfeindlichstes Moment gewütet hat.

In Süd-Georgia wird die Vegetation der Gesteinsfelder im wesentlichen durch zerstreute Rasen von Poa caespitosa (Tussock-Gras) gebildet $^{1}{ }^{1}$. Z Zwischen den Tussocks wachsen nur wenige andere Arten. Auf den Falklandsinseln ist das Tussock-Gras gleichfalls gemein. Schon oben (Kap. 82) wurde bei der Besprechung dieser Grashorste darauf aufmerksam gemacht, daß ihre ökologische Stellung noch recht unsicher ist. Auf den Falklandsinseln ist die Gesteinswüste in der Form viel reicher als in Süd-Georgia; es kommen immergrüne Zwergsträucher vor, so Chiliotrichum amelloideum, Pernettia empetrifolia, welche sich oft zu einer wirklichen Heide erheben. Weiter findet man hier besonders die polsterförmige Umbellifere Azorella caespitosa ${ }^{2}$ ), welche schmutzig grüne, halbkreisförmige, oft mehr als ein Meter hohe und sehr harte Polster bildet; der Umkreis wird gebildet durch zahlreiche kleine Schosse, die alle gleich groß sind und dicht mit schuppenähnlichen Blättern bedeckt sind. Diese Schosse hängen so dicht und fest an den dazwischen liegenden alten Blättern und Schossen, daß man selbst mit dem Messer schwer ein Stück der Pflanze loslösen kann.

Dusén beschreibt eine "Bolax-Heide“, gebildet aus Bolax glebaria, d. h. Azorella caespitosa, in den südlichen Landstrichen von Rio Grande; die Polster dieser Pflanze fließen fast überall zusammen und bilden so eine meist ununterbrochene, weite Fläche, die dicht und hart ist ${ }^{3}$ ). Flechten, Moose, wie z. B. Rhacomitrium, und andere Pflanzen können über diese Polster zerstrent wachsen.

Nach Skottsberg gibt es in Süd-Georgien alle möglichen Übergänge zwischen grasreichen Tundren und Moos- und Flechtenteppichen ${ }^{4}$ ).

1) Skottsberg 1912.

2) Vergl. Groebel 1891; Schenck 1905 b.

3) Dusén 1905.

4) In Raport of The Voyage of S. Y. "Scotia" (Edinburgh) finden sich in Bd. III Abhandlungen über die Botanik von Rudmose Brown, Cardot u. a. - (mir unbekannt. W.). 
Dieser Vegetation steht die der Gesteinsfelder auf den Hochgebirgen von Neuseeland nahe. Hier sind die Mehrzahl der Arten xerophytische Polsterpflanzen, die über die Felsen zerstreut sind. Besonders bemerkenswert sind die "Vegetabilischen Schaf"-Pflanzen, Arten von Raoulia und Haastia. Dichte Polster werden anch von Celmisia viscosa, Arten von Veronica, Hectorella und anderen gebildet $^{1}$ ).

Tropische Hochgebirgsformationen. Auf den Hochgebirgen Südamerikas (in Venezuela, Bolivien, Peru, Chile) findet man in den subglazialen Höhenstufen ausgedehnte Felsenfluren mit der typischen offenen Vegetation der Kältewüsten, deren Individuen auf dem felsigen, schotterigen Boden in kleinen Rasen zerstreut sind, und in ähnlichen Lebensformen wie die auf den erwähnten nördlichen Felsenfluren auftreten. Doch kommen auch verschiedene abweichende Typen vor, und in mehreren Richtungen sind die klimatischen Verhältnisse hier unter den Tropen oder nahe denselben bedeutend abweichend. Besonders gilt dieses von den sehr trockenen Hochgebirgen, z. B. den Punas in Peru und anderen, welche daher wahrscheinlich am besten als Hochgebirgssteppe bezeichnet werden können.

Die Paramos von Venezuela bis Ecuador sind nach Goebel ${ }^{2}$ ) feuchter als die Punas von Peru, deren starke Winde tote Tiere schnell austrocknen und ihre Verwesung hindern sollen. Die Paramos sind pflanzenreicher; aber Cacteen, die auf den Punas gemein sind, kommen hier selten vor. Trotz der großen Feuchtigkeit, der vielen Regen und Nebel, die den Sonnenschein plötzlich ablösen können, ist die Vegetation doch xeromorph. Viele Arten haben pinoïde, cupressoïde, juncoïde oder wollhaarige Sprosse. Unter den hier vorkommenden Typen erwähnt Goebel besonders die Compositen Espeletia und Culcitium (Frailejon genannt, die er auch abbildet), wovon namentlich $E$. grandiflora ein sonderbares Gewächs ist, ein Schopfbaum, der $2 \mathrm{~m}$ hoch wird, unverzweigt bleibt, durch die zahlreichen alten Blattreste so dick wie ein menschlicher Körper wird und oben eine Menge in sehr dichte Wolle gehüllte Blätter und Blütenstände trägt. In den höchsten Regionen bilden sie zusammen mit niedrigen Alpenkräutern, Gräsern und Farnen die einzige Vegetation.

Afrika. Die Vegetation anf den hohen afrikanischen Bergen hat gewisse Ähnlichkeit mit der hochandinen, aber auch hervortretende Unterschiede. Aus der Ferne betrachtet scheint es ein ununterbrochener, grasiger Rasen zu sein, bei näherem Zusehen sieht man aber, daß die

1) Diels 1896, 1905. Vergl, auch Cockayne.

2) Goebel 1889. 
Grasbulten getrennt sind. Gräser und Seggen bilden Polster, die zwischen Faustgröße und Tellergröße schwanken; ihre Halme, etwa $7 \mathrm{~cm}$ hoch, erheben sich aus den Achseln von aufrechten oder umgefallenen Blättern. In der trockenen Jahreszeit ist der Boden kahl oder mit Moosen und Flechten bedeckt; sobald der Regen einsetzt, sprossen zahlreiche Kräuter hervor. Zuerst erscheinen monokotyle Knollen- und Zwiebelgewächse, wie Hypoxis angustifolia, Hesperantha Volkensii und andere; ihnen folgen dikotyle Kräuter und Halbsträucher, wie Wahlenbergia Olivieri, Tolpis Abyssinica, Helichrysum Meyeri-Johannis und viele andere. Schließlich wachsen dort kleine Bäume, welche eine Höhe von 5-8 m erreichen und vom Winde nach Südwest übergebogen sind. Es sind nur wenige Arten, unter ihnen Agauria salicifolia, Erica arborea und Ericinella Mannii. Thre Äste sind mit Flechten behangen. In größerer Höhe werden die Grasbulten kleiner, während schwächliche Sträucher, besonders von Ericinella Mannii und Senecio Jonstonii überwiegen. Die letztgenannte Art repräsentiert hier dieselben Lebensformen wie Espeletia in Südamerika. In Abessinien wird sie durch die Lobelioidee Rhynchopetalum montanum ersetzt ${ }^{1}$ ).

Charakteristisch für tropische Hochgebirgsvegetation ist das Vorkommen von Zwergbäumen, welche sie von anderen in diese Klasse gehörigen Formationen unterscheiden. Die tropische Hochgebirgsvegetation nähert sich dadurch der der Savannen und Steppen an.

1) Volkens 1897; Rosen 1909. 


\section{Serie der Stein- und Sandböden}

\section{Kap. Allgemeines. Die eigentlichen Felsformationen (Lithophyten-Formationen)}

Seite 320 ist diese Serie kurz charakterisiert worden; sie umfaßt Formationen, deren Böden meist physikalisch trocken sind, weil sie nicht imstande sind, selbst in regenreichen Klimaten Wasser in größerer Menge für die Vegetation aufzunehmen und für längere Zeit festzuhalten. Solche Standorte, die entweder aus dem festen Felsboden (vergl. S. 105) gebildet sind, oder aus Trümmern der Felsen in den verschiedensten Größen, von großen Steinen bis herab zum feinen Sande bestehen, finden sich über die ganze Erde verbreitet und werden natürlich auch vom Klima stark beeinflußt. Der Charakter des Bodens ist jedoch für die Art der Vegetation maßgebend. Humus kommt nicht oder in sehr geringen Mengen vor, wenn es sich um die typischen, ausgeprägten Formationen handelt. Die Standorte können folgendermaßen geordnet werden :

Klasse 10. Fels- und Steinformationen.

1. Die eigentliche Felsformation (Lithophyten-Formation) ${ }^{1}$ ). 92. Kap.

2. Flachgründiger Boden. 93. Kap.

3. Spaltenvegetation (Chasmophytenvegetation) ${ }^{2}$ ). 94. Kap.

Hierzu als Anhang: Vegetation der Bergklüfte und Höhlen.

4. Vegetation der Trümmerfelder von großen, ruhenden Steinen (Blockmeere; Felsenmeere). 95. Kap.

5. Geröll- oder Schutthalden. Grusböden. 96. Kap.

Klasse 11. Trockene Sandvegetation (Psammophile Vegetation) ${ }^{3}$ ).

1. Eigenschaften des Standortes (Sandboden; vergl. S. 106). Dünen. 97. Kap.

2. Lebensformen und Anpassungen. 98. Kap.

3. Europäische Formationen und Assoziationen. 99. Kap.

4. Außereuropäische Länder. 100. Kap.

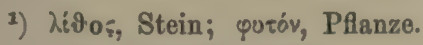

2) $\chi \dot{\alpha} \sigma \mu \mu$, Spalte, Kluft.

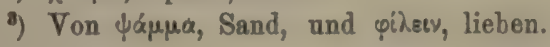

Warming-Graebner. 3. Auflage, illustro 
Die Tegetation auf der Oberflïche ron schroffen Felsen und großen Steinen, welche Schimper lithophytisch nannte, soll zuerst in diesem Kapitel besprochen werden. $\mathrm{Zn}$ bemerken ist jedoch, daß diejenige Felsenvegetation, welche den Spritzgürtel der am Meere oder an Salzseen liegenden Felsen bekleidet (vergl. Fig. 204), sowie die, welche überhaupt rom Salzwasser beeinflußt wird, schon Kap. 48 besprochen wurde, und daß ebenso die Felsregetation, welche den Spritzgürtel der süßen Gewässer bilden, in Zusammenhang mit der Hydrophytenformation behandelt wurde. Es ist hier also nur die Rede ron solchem Steinboden, der das Wasser nur in Form von den atmosphärischen Niederschlägen in ihren verschiedenen Formen empfüngt (vergl. 4. Kap.). Die lithophytische Vegetation der Kältewüsten ist auch hier eingeschlossen.

Die Pflanzen, welche senkrechte oder doch sehr schroffe (etwa bis zu einer Neigung ron etwa $40^{\circ}$ ) Felsen allein zu bekleiden rermögen, sind ausschließlich Kryptogamen. In wenigen Fällen können auch überhängende Flächen von solchen bewohut werden. Diese Kryptogamen sind: Algen, Flechten und Moose.

Die Algen können selbst den senkrechten Fels auf große Strecken färben; sowohl im hohen Norden, als auch in Skandinavien und in den Alpen sieht man schwarze Streifen an den Felsen herablaufen und eine Vegetation von Schizophyceen (Stigonema-Arten) anzeigen, die dem gelegentlich, zu Regenzeiten, herabsickernden Wasser folgt. Die „schwarzen Felsen" in Angola sind so nach Algen (Scytonema, nach Welwitsch) benannt, und die kegelförmigen Granitgipfel um Rio de Janeiro werden durch eine kleine Alge braun gefärbt. Die Algen Trentepohlia iolithus und $T$. aurea färben die Felsen rot und gelb. Die Algen heften sich in den meisten Fällen einfach mit Hilfe der Schleimschichten ihrer Zellwände fest. Sie werden "Luftalgen * oder aërophytische Algen genannt. Einige Algen leben nur oberfliichlich (sind „epilithisch“), andere im Innern des Gesteins (sind „endolithisch“). In Felsenhöhlen Islands kommt $150 \mathrm{~m}$ über dem Meere Rhodocorton Islandicum vor ${ }^{-1}$ ) und auf den Lavafeldern Trentepohlia-Arten und andere Algen ${ }^{\%}$.

Die Flechten sind besonders Krustenflechten (Lecanora, Lecidea, Biatora u. a.) und Blattflechten (Parmelia, Xanthoria, die schwarzen Gyrophora-Arten u. a.). Auf weniger schroffen Flächen, wo die Vegetation älter ist, finden sich auch Strauchflechten ein. An den Kalkfelsen kommen auch endolithische Flechten vor, d. h. solche, deren Hyphen den Stein durchwachsen, wogegen die Apothecien immer an den Tag treten, z. B. Verrucaria calciseda ${ }^{3}$ ). Die Farben sind oft lebhaft: bei Buellia geographica und Xanthoria elegans grüngelb und gelbrot.

1) Helgi Jonsson.

2) Vergl. weiter Schade, Schorler 1914, Diels 1914.

3) Darbishire 1914; Bachmann 1904 und in Pringsh. Jahrb. $190 \%$. 
Die Moose sind z. B. Hypnum-Arten, graue Grimmia-Arten, oder Andreaea-Arten, schwarzbraune Moose, die auf dem Gesteine dichte Polster bilden und deren Vorkeime zu flachen Krusten auswachsen. Die Farben sind also oft dunkel, schwarz oder grau.

\section{Anpassungen}

Anheftung. An den steilsten Felsen können die losen Verwitterungsmassen nicht liegen bleiben; hier können sich nur solche Pflanzen niederlassen, welche Mittel haben, sich auf dem Gesteine selbst

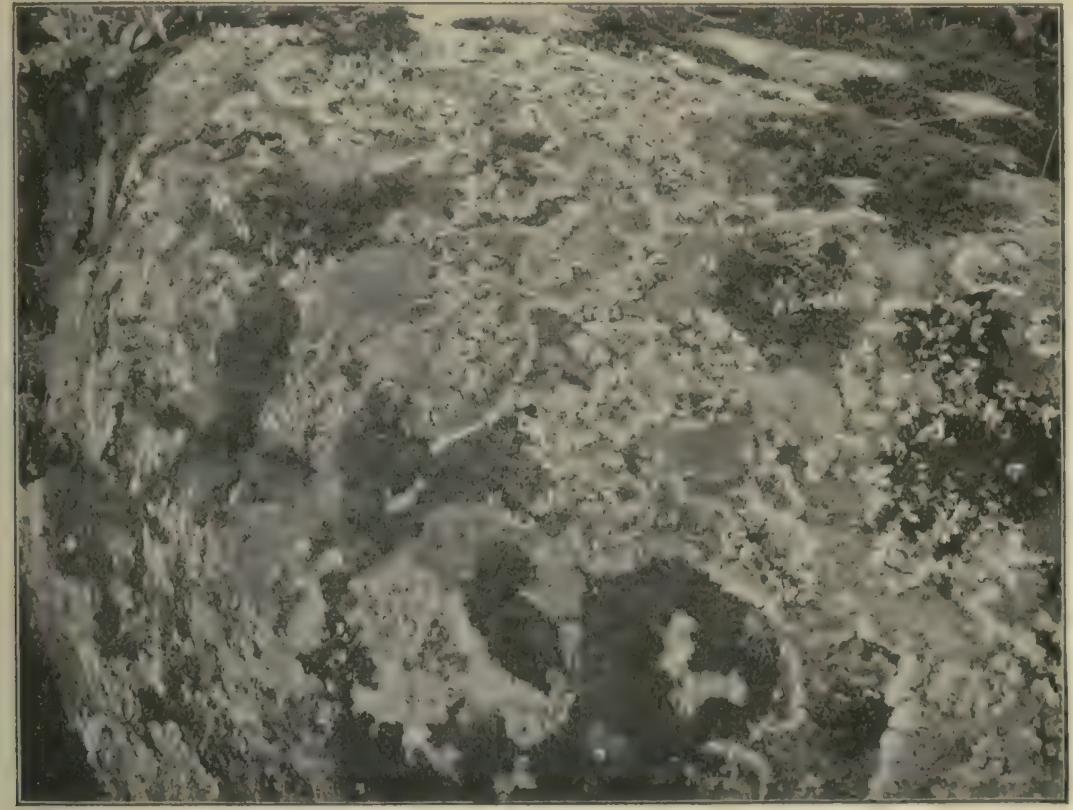

Fig. 320. Bornholm 1903. Eine reiche Flechtenvegetation auf senkrechten Felsen. Die Hauptmasse ist Parmelia saxatilis; ferner findet sich Parmelia omphalodes und P. olivacea, Lecanora atra und pallida, Anaplychia ciliaris, Physcia aquila, eine einzelne Ramalina scopulorum. Auch einige Moose finden sich (Orthotrichum, Leucodon sciuroides usw.). (Phot. E. Warming.)

anzuheften, und die wenigen Pflanzen, die in etwaigen Rissen und Spalten des Gesteines festen Fuß fassen können. Die genannten Lithophyten haben denn auch alle Hapteren, durch welche sie sich (älnnlich den Nereiden, Kap. 44) den festen, selbst glatten Steinen anheften können, wenu der Thallus nicht selbst, wie bei aerophytischen Algen, dem Fels sich eng ankleben kann. Merkwürdigerweise wird berichtet, daß in Ostafrika eine Blütenpflanze (Barbacenia) massenhaft auf glatten Felsen wächst, indem sie diese mit zahlreichen oberirdischen Wurzeln überzieht. Eine andere merkwürdige Blütenpflanze ist nach .Johs. 
Schmidt ${ }^{1}$ ) die kleine Orchidee Eria semiconnata. Das Bild in Karsten und Schencks Vegetationsbilder zeigt eine fast senkrechte Felswand im Urwalde von Koh Chang (Siam) mit den Knollen dieser Pflanze bedeckt; sie sind "dem Fels dicht angeschmiegt" und jetzt, in der trockenen Zeit, ganz blattlos. Sie sind ca. $1 \mathrm{~cm}$ breit und gleichen fast kreisrunden Knöpfen.

Die Art des Gesteins (ob eugeogen oder dysgeogen [S. 123]) spielt für solche Pflanzen eine sehr wichtige Rolle; je härter und freier von Spalten es ist, desto schwieriger heften sich die Pflanzen an. Auf dem Ätna fand Schouw $^{2}$ ) prähistorische Lavaströme, die noch keine Vegetation hatten; im übrigen wird eine Flechte, Pterocaulon Vesuvianum, als die erste Pflanze, die sich auf der Lava niederläßt, genannt. Andererseits werden weiche Gesteine, wie viele Kalkfelsen, leicht bewachsen; die Rhizoiden der Moose und der Flechten, die Fäden der Algen durchbohren und zernagen sie; bei gewissen endolithischen Kalkflechten liegt der ganze Thallus sogar mehrere Millimeter tief in dem Gesteine, nur die Apothecien kommen zuletzt außen zum Vorschein.

Der Kalk wird durch ausgeschiedene Säuren und Enzyme schwammartig durchlöchert, er kann dann größere Mengen von Feuchtigkeit aufnehmen und festhalten. Selbst die Gonidien (Chroolepus) können selbständig eindringen. Die Luftalgen, vorzugsweise Chrooccaceen, sind bessere Kalklöser als die Flechten ${ }^{3}$ ).

Das Gestein ist für die meisten, wie für die Meeresalgen, wesentlich nur eine Unterlage, aber für andere, namentlich für die Flechten, zugleich ein Nährboden, in den sie mehr oder weniger tief hinabdringen. Großenteils müssen die Felsenpflanzen jedoch ihre mineralische Nahrung aus den Niederschlägen und den vom Winde auf ihnen abgesetzten Staubmassen entnehmen.

Für Saprophyten erscheint der Boden nicht günstig, und doch sollen sich solche einfinden, sobald eine geringe organische Grundlage vorhanden ist. Im Berner Oberlande soll ein Salpeterbacterium an gewissen Standorten (z. B. auf dem Faulhorn) die Felsen durchsetzen und mürbe machen.

Wasseraufnahme. Da der Standort absolut physikalisch trocken ist, weil die Unterlage kein Wasser enthält und das Regenwasser schnell abläuft, müssen die genannten echten Lithophyten imstande sein, Wasser durch ihre ganze Oberfläche aufnehmen zu können. Das ist eben bei den drei Lebensformen der Fall, wie S. 156-158 erwähnt wurde. Regenwasser, Schneeschmelzwasser, auf den Felsen

1) Johs. Schmidt 1906.

2) Schouw 1821.

3) Bachmann 1914; Darbishire 1914; Nadson 1900. 
niedersickerndes Wasser, Nebel und Tau spielen daher für die an einen solchen Boden gebundene Vegetation eine weit größere Rolle, als sonst. Es sind zunächst die Feuchtigkeitsverhältnisse und die Wärme der Luft sowie die Menge der Niederschläge dafür bestimmend, wie relativ üppig die Vegetation wird und welche Lebensformen zur Entwicklung kommen; der Boden spielt in dieser Hinsicht keine oder eine äußerst geringe Rolle. Nur einige Moose und Lebermoose haben Einrichtungen, durch welche Wasser aufbewahrt werden kann, z. B. Rhizoidenfilze, hohle Blattteile, Wassersäcke usw. ${ }^{1}$ ).

Vermögen, Austrocknung zu ertragen. Selbst wenn die Luftfeuchtigkeit groß ist, gibt es kaum eine Gegend, wo sie das ganze Jahr gleichartig ist und nicht periodisch, obwohl für kurze Zeit, auf ein Minimum sinkt; aber die kurze Zeit könnte die Vegetation töten, wenn diese nicht an Trockenheit angepaßt wäre. Die Vegetation kann auf den Felsen, denen sie angeheftet ist, durch die Sonne zu Temperaturen erhitzt werden, die den gewöhnlichen Grenzen des Lebens nahe sind $\left(50-60^{\circ}\right.$; z. B. bei den Pflanzen auf den Kalkbergen Dalmatiens: Kerner); umgekehrt wird die Temperatur nachts sehr tief sinken können, tiefer als bei Pflanzen, die auf anderem Boden wachsen. Die Felsenpflanzen sind mit den Epiphyten ökologisch nahe verwandt und oft identisch. Der Felsboden ist der wärmste von allen Böden; in Übereinstimmung hiermit wachsen gewisse Arten auf hohen Bergen nur auf Felsen, aber in der Ebene auch auf losem Boden.

Es ist schon S. 156 und 158 erwähnt worden, daß es für die Lebensformen der Flechten und Moose eigentümlich ist, daß sie zum T'eil völlig austrocknen können, und bei Wiederbewässerung schnell Wasser aufnehmen. Zugleich sind sie gegen hohe Kältegrade wenig empfindlich ${ }^{2}$ ). Dasselbe gilt für gewisse aërophytische Pflanzen.

Kein Wunder, daß die Kryptogamen in den Polarländern und den höchsten Stufen der Hochgebirge eine so große Rolle spielen.

Es gibt große floristische Unterschiede zwischen Kalk- und Kieselfelsen, Sandstein- und Schieferfelsen, und als besondere Standorte können Hausmauern und Hausdächer erwähnt werden ${ }^{3}$ ). An dieser Stelle können auch die nitrophilen Assoziationen von Flechten erwähnt werden, welchc auf Felsen zum Vorschein kommen, die von den Exkrementen der Vögel gedüngt werden. Sernander hat hierüber eine bemerkenswerte Arbeit geschrieben ${ }^{4}$ ). Auf gewissen Gipfeln von Felsen und Steinen, wo Krähen, Möwen und andere Vögel ihre Aussichts- und Ruheplätze

1) Goebel $1889-91$.

2) Für die Moose vergl Irmscher 1912.

ग) Vergl. z. B. Adamovié 1913.

4) Sernander 1912. 
haben, und wo diese Vögel ihre Exkremente hinterlassen, welche vom Regen in Streifen an den Stein- und Felsenseiten hinuntergespült werden, fehlen die gewöhnlichen Flechten und werden von koprophilen Arten ersetzt. Eine ausgeprägt koprophile Assoziation, welche sowohl auf der südlichen als auf der nördlichen Halbkugel besonders an Küstenfelsen gebunden ist, ist die Prasiola-Assoziation, eigentlich also eine AlgenAssoziation, aber oft mit eingestreuten Flechten. Auf den Felsen Schwedens treten viele Verschiedenheiten in der Flechtenvegetation hervor, je nachdem stickstoffreiches Wasser von den Exkrementen herabsickert oder nicht; nitrophile Assoziationen sind z. B. Physcietum caesiae, Physcietum obscurae. Hult ist der Meinung, daß die vielen verschiedenen Assoziationen sogar zu einer Formation vereinigt werden können, „die Formation der nitrophilen Lichenen“. Einige Assoziationen sind schwach koprophil, z. B. das Lecanoretum saxicolae; stark koprophil sind z. B. Ramalinetum polymorphae, Xanthorietum lychneae usw.

Andere Faktoren, welche Verschiedenheiten des Standortes und dadurch Verschiedenheiten der Vegetation hervorrufen, sind die Exposition und der Neigungsgrad der Felsen.

Die Exposition kann höchst verschieden und daher von äußerstem Einfluß auf die Vegetation sein; benachbarte Felsen können sich daher in allen Teilen gänzlich verschieden verhalten und ebenso können auch die Seiten eines Berges in ihrer Zugänglichkeit für Wind, Regen und Sonne gänzlich verschieden beeinflußt sein und daher eine völlig abweichende Flora tragen.

Der Neigungsgrad ändert in gleicher Weise $a b$ und ist von nicht geringerer Bedeutung. Je steiler der Abhang ist, an desto größeren Stellen wird der kahle Fels zum Vorschein kommen; je flacher er dagegen ist, desto mehr wird die Ablagerung von Detritus aller Art, abgewitterte Felsteile, Pflanzenreste usw. begünstigt, und je mehr lose Bodenteile abgelagert oder von den Pflanzen festgehalten werden, desto dichter kann sich das Ganze mit Vegetation bedecken.

In seinen gründlichen Untersuchungen über die Flechtenvegetation scheidet Sernander zwischen Zenitflächen, senkrechten Wänden und überhängenden Wänden. Es ist namentlich die Wasserzufuhr und die Stärke der Beleuchtung, von welchen die Verschiedenheiten der Assoziationen abhängen. Auch die Verteilung des Schnees, die Exposition für Nebel und Tau u. a. m. hat Bedeutung.

Eine wichtige, auf exakten Messungen des Lichtgenusses, der Lufttemperatur, der Felstemperatur, der Temperatur im Innern der Moosrasen usw. fußende Untersuchung über die Differenzen an den Felswänden der Sächsischen Schweiz hat Schade ${ }^{1}$ ) veröffentlicht. Er hat

1) Schade 1912. 
drei Haupttypen von Standorten: feuchte, überrieselte und trockene. Die „bergfeuchten", welche feucht sind, ohne daß Wasser herabtropft, sind von zahlreichen Moosen und teilweise von Feuchtigkeit liebenden Flechten bedeckt. Eine ganze Reihe von Assoziationen kommen hier vor. Auf den überrieselten Felsen zeichnet das Sickerwasser seinen Weg in scharf begrenzten Streifen durch drei Assoziationen: ron Diatomeen, Grünalgen und Sphaerocarpa. Die trockenen Felsen haben vorwiegend südliche Exposition und sind hauptsächlich von Flechten bedeckt. Später hat Schorler ${ }^{1}$ ) die "Elementar-Assoziationen" der Algen an denselben Felsen geschildert, und zwar folgende: 1. Assoziationen der nassen Felsen: das Stephanosphaeretum, das Cladophoretum, das Bacillariacetum, das Chromulinetum, das Gloeocapsetum, das Gloeocystetnm. 2. Assoziationen der bergfeuchten Felsen: das Mesotaenietum, das Pleurococcetum.

Kihlmans ${ }^{2}$ ) Untersuchungen beweisen, daß verschiedene Arten von Flechten eine verschiedene Widerstandskraft gegen die Wirkungen der kalten Winde haben. Nach Zukal ${ }^{3}$ ) brauchen Arten von Parmelia mehr Feuchtigkeit als die krustenartigen von Lecanora; die letzteren sind weniger befähigt, Wasserdampf der Luft aufzunehmen, als die ersteren.

Geographische und klimatische Unterschiede. Zu den Faktoren, welche große floristische Unterschiede der senkrechten und stark schroffen Felswände hervorrufen müssen, gehören auch die geographischen Unterschiede in der Breite und der Höhe über dem Meere. Die Vereine der tropischen Tiefländer müssen ungeheuer von denen der kalt temperierten oder der polaren abweichen. In den Kältewüsten begegneten wir schon den Felsformationen mit ihren Flechten und Moosen.

Folgeformationen. Die ersten Ansiedler auf kahlen Felsen, namentlich Algen und Flechten, erzeugen allmählich ein Substrat für höher entwickelte Arten, deren nächste Moose und Strauchflechten sind. Während die ersten Ansiedler horizontal ausgebreitete vegetative Teile haben und dem Felsen angedrückt sind oder ihn sogar krustenförmig überziehen, erheben sich ihre Nachfolger als kleine Rasen oder strauchartig (so Arten von Ramalina, Cladonia u. a.), welche sowohl die Algen, als die Krusten- und Blattflechten überwuchern, mehr Wasser als diese festhalten können und mehr organische Substanz erzeugen. In solchen Beständen von Moosen und Strauchflechten kann auch Platz für Algen als Untervegetation bleiben.

1) Schorler 1914.

2) Kihlman 1890 .

3) Zukal 1895 . 
Selbst bei den Felsbewohnern findet man eine deutliche Konkurrenz, einen Kampf um den Platz und die Unterdrückung einer Art durch die andere. In Nordamerika haben Cooper und Bruce Fink ${ }^{1}$ ) wertvolle Beiträge geliefert; sie untersuchten verschiedene Flechtenassoziationen einschließlich der Lecanora-Assoziationen exponierter "Boulder", Lecanora calcarea-contorta-Assoziationen von exponierten, wagerechten Kalkflächen und andere. In Schweden ist der Wettbewerb zwischen den Arten von A. Nilsson, Malme und Sernander studiert ${ }^{2}$ ). Man sieht zuerst Krustenflechten sich als getrennte Flecke ansiedeln; die Flecke dehnen sich allmählich aus, bis sie zusammenfließen, indem jeder seinen scharf umgrenzten Rand bewahrt, oder indem sie ineinanderfließen, eine Art unterdrückt eventuell die andere.

Die ersten Ansiedler auf entblößten Steinflächen in Schweden sind nach Sernander Krustenflechten und aürophytische Algen. Später treten Blattflechten hinzu und überwachsen die Krustenflechten. Wenn die Flechten ein wenig Humus gebildet haben, siedeln sich Moose an, besonders Grimmia lanuginosa, zuerst als vereinzelte Moospolster, die zusammenwachsen und sich über die Flechten ausbreiten. Im Monsrasen wachsen vereinzelte Blütenpflanzen. Inden die lose Erdschicht durch Humusbildung and angeflogenen Sand tiefer geworden ist, wird die Moosformation durch eine von xerophilen Gräsern gebildete Formation ersetzt. Die häufigsten Gräser sind Agrostis vulgaris, Festuca ouina, Aera flexuosa usw. Grimmia stirbt aus, wogegen andere Arten von Moosen zwischen den Gråsern auftreten. Eine ähnliche Entwicklung beobachtete Hayrén in Finnland (1914). In Dänemark hat Gallöe in zwei großen Abhandlungen mit mehreren hundert Abhildungen die Ökologie uud Anatomie der Flechten bearbeitet und auch die Folgeassoziationen besprochen ${ }^{y}$ ).

Die erste Notwendigkeit für die sich ansiedelnden Arten sind Mittel, sich fest anzuheften, und gerade die ersten Ansiedler, Thallophyten und Moose, bereiten einen günstigren Ansiedlungsboden für die größßeren Arten vor, als da sind Farne und Blütenpflanzen. In den Moospolstern säen sich aus ferner Samen von Sedum acre und anderen Blütenpflanzen, die dort dann keimen und sich entwickeln; in den Tropen kommen \%. B. Peperomia-Arten u. a. vor. In den Polstern von Sedum usw. finden dann die Wurzeln anderer Pflanzen Platz zur Anheftung.

Andere Beispiele von Folgeformationen auf Felshoden siehe G. F. Nichols 1914, und besonders gründliche Aufschlüsse über die ökologischen Verhältnisse und die Folge der Assoziationen finden sich bei Diels (1914).

Litteratur. Diels 1914, dort andere Litteratur; Ostenfeld 1908 b; Schorler 1914.

2) Fink 1902; Cooper 1913.

2) A. Nilsson 1899 b; Malme 1901; Sernander 1908 und 1912.

5) Gallöe 1908, 1913. 


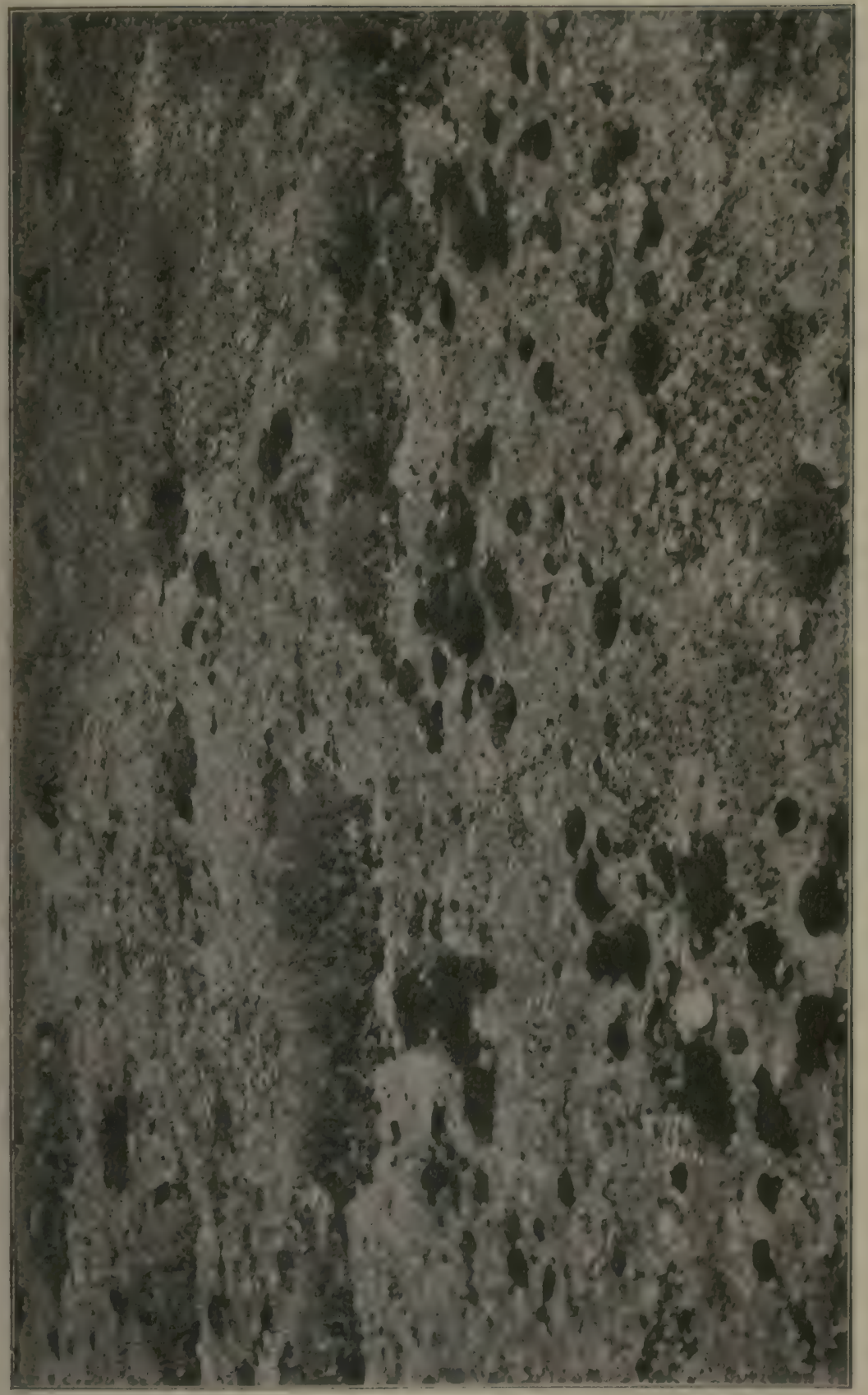

ह

लें

in 


\section{Kap. Flachgrïndiger Boden}

Je weniger geneigt der Hang eines Felsens ist, desto leichter können sich die am Schluß des vorigen Kapitels erwähnten Folgeformationen entwickeln. Allmählich wird auf diese Weise ein Felsblock oder ein ganzer Abhang sich mit Samenpflanzen und Moosen bekleiden, und im Laufe von Jahren, wie sich Humus anbäuft und Erde durch Wind oder Wasser herangeführt ist, können Gebüsche oder Wald entstehen. Solche oberflächliche Vegetation ist natürlich ökologisch im höchsten Maße beeinflußt durch die Dicke des Substrates. Die dünne Erdschicht wird leicht erhitzt und trocknet daher auch leicht aus; infolgedessen müssen die angesiedelten Pflanzen xeromorphen Bau besitzen.

In diese flachwurzelnde Vegetation müssen auch all die Pflanzen eingerechnet werden, die sich auf allen kleinen Blöcken ansiedeln, die sich über die Oberfläche eines Felslandes erheben. Auf vielen Felsen sieht man nur ganz geringfügige Siedelungen, in denen Gräser oder andere Kräuter aufsprossen, in denen in Nordeuropa auch öfter Calluna wächst oder, wenn die Bodenlage dicht genug ist, auch Sträucher.

Als ein Beispiel von sehr flachgründigem Boden mögen die Alvaren Schwedens genannt werden (Fig. 43, 321). So nennt man von einem harten Silurkalkstein gebildete Ebenen, welche weitausgedehnte horizontale Plateaus auf den Ostseeinseln Gotland und Öland bilden und auch in Westergötland vorkommen. Sie sind höchstens von einer dünnen Erdschicht, einer Verwitterungsschicht des Gesteins gebildet, oft ganz nackt. Die Vegetation ist oft sehr offen, jedenfalls ist sie, wenn auch streckenweise geschlossen, eine sehr niedrige felsensteppenartige. Wo die Erdkrume etwas dicker wird und drainiert ist, kann man eine geschlossene Grasnarbe finden. Die Lebensformen der Pflanzen sind Kräuter, Moose, Flechten und einige Zwergsträucher. Von höheren Sträuchern kommt nur Juniperus communis und Prunus spinosa vor, von Bäumen kein einziger. Die krautartigen Pflanzen sind teils Gräser, teils Stauden, aber auch nicht wenige hapaxanthe Kräuter finden sich. Die Vegetation ist ausgesprochen xeromorph; bemerkenswert ist das Vorkommen von vielen Zwergformen, alle Arten sind hier kleiner als an allen anderen Standorten; die Reduktion des oberirdischen und starke Ausbildung des unterirdischen Achsensystems; die Reduktion der transpirierenden Flächen, Einrollung der Blätter, z. B. bei Festuca ovina und F. Oelandica, Potentilla fruticosa u. a., Plantago lanceolata var. dubia, P. maritima var. gentilis, Medicago lupulina; Wachsüberzüge (z. B. Festuca ovina var. glauca); niederliegende Sprosse, starke Behaarung usw. Die Blätter sind gewöhnlich aufrecht gerichtet und mehr oder weniger isolateral; 
ihre Oberhaut ist dickwandig und die Intercellularräume klein. Mehrere schwedische Botaniker haben diese eigentümliche Vegetation besprochen ${ }^{1}$ ).

An vielen Stellen wird der Kalk von in verschiedene Richtungen gehenden Spalten durchsetzt. In diesen entwickelt sich eine höhere und oft ganz mesomorphe Vegetation. Selbst die Kiefer kann sich hier einfinden und eine Höhe von 3-4 m erreichen. Hesselman erwähnt, daß dort, wo der Verwitterungsboden dicker ist und ein fruchtbarer Boden

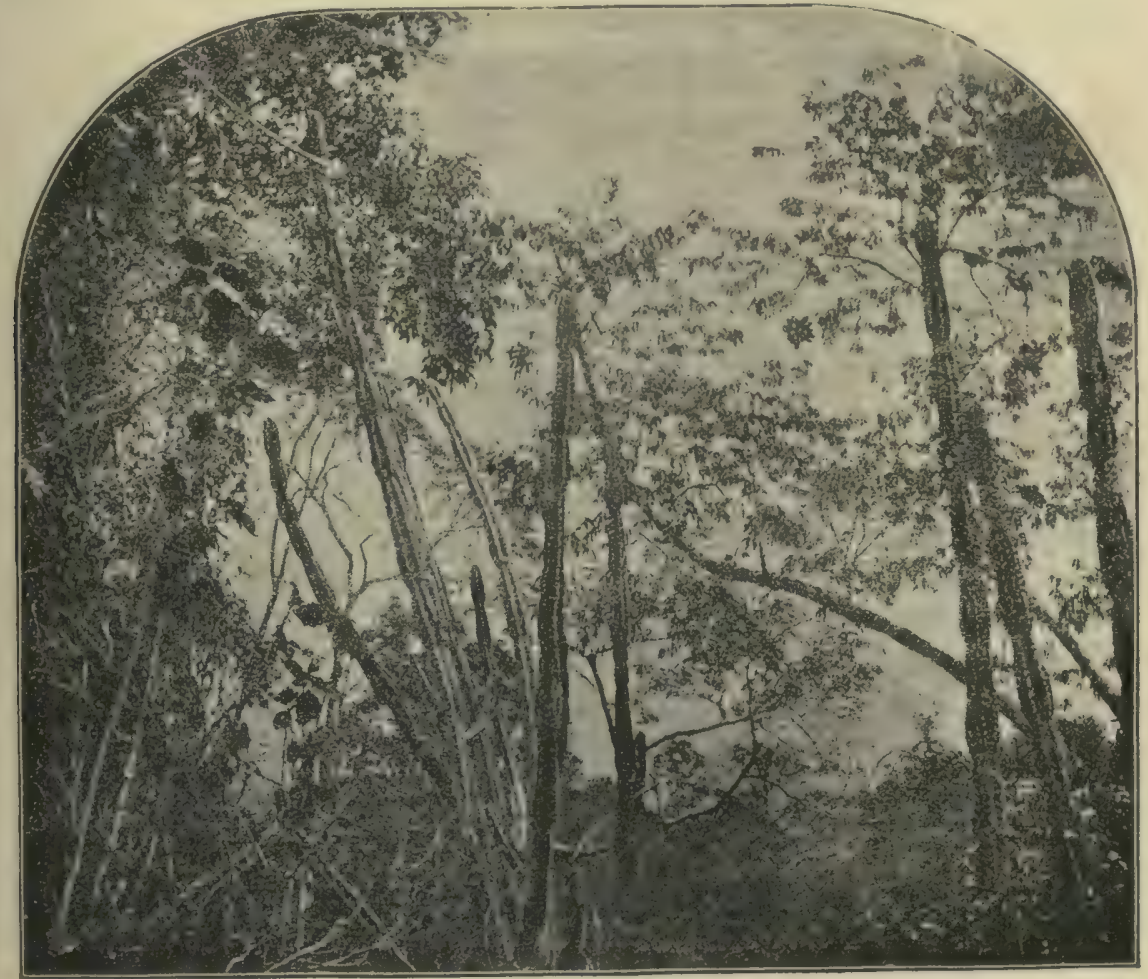

Fig. 322. Vegetation auf den Felsen von Lapa vermelhae in der Nähe von Lagoa Santa. Das Bild ist von dem Rande eines Felsens genommen, die Zweige von Bäumen, die gesehen werden, sind von hohen Waldbäumen am Fuße der senkrechten Felsen (z. B. sieht man rechts oben Zweige von der Anonacee Uvaria macrocarpa mit einer aus Teilfrüchten, die 10-12 cm lang sind, gebildeten Frucht). Der Cereus ist wahrscheinlich coerulescens.

(Phot. Eug. Warming 1864; vergl. 1892.)

von Mullhumus mit bis $20 \%$ Kalk zuoberst, und Mullhumus mit bis $34 \%$ darunter gebildet worden ist, sich ein höherer Kiefernwald entwickeln kann; bisweilen kann auch ein Fichtenwald entstehen; seine Höhe hängt von der Tiefe des Mulls ab. Der Boden dieses Waldes

1) J. Erikson 1895; Grevillius 1896; Hemmendorff 1897; Witte 1906; Sernander 1908; Hesselman 1908 b; Falck 1913 (Sv. Bot. Tidskr. VII). 
ist mit Gräsern und Kräutern bedeckt, auch Spaliersträncher, wie Arctostaphylos uva ursi, können vorkommen. Liegt dagegen undurchlässiger Boden unter der Erdkrume, so ist Baumwuchs ausgeschlossen, und die Vegetationsverhältnisse sind ungünstig.

Flachgründiger Boden spielt sicher auch eine bedeutende Rolle an vielen anderen Standorten, z. B. bei der Garigue, Garide usw.

Ein anderes Beispiel ist folgendes. In der Nähe von Lagoa Santa, im Inneren Brasiliens, finden sich Kalkfelsen aus einem sehr harten, kristallinischen Gesteine bestehend. Sie liegen von typischen Campos umgeben, sind aber selbst mit Wald bedeckt. Der Wald ist hier offen und sehr xerophytisch, mit den anderen, in den Talniederungen der Gegend wachsenden Wäldern verglichen. Während diese immergrün sind, verlieren die Mimusoideen und anderen Bäume auf den Kalkfelsen früh in der Trockenzeit ihre Blätter. Außer den Bäumen sind diese Felsen reich an brennenden und dornigen Pflanzen; es ist eine Plage, in der Hitze dort zwischen all diesen menschenfeindlichen Pflanzen zu wandern. Auch Cacteen kommen dort vor, während sie in den Campos der Umgegend unbekannt sind ${ }^{1}$ ). Die Flachgründigkeit des Bodens und der schnelle Ablauf des Wassers müssen die Ursachen dieser xerophytischen Vegetation sein.

$\mathrm{Zu}$ den "flachgründigen Böden" müssen auch die meisten wagerechten oder schwach geneigten vorspringenden Absätze oder Gesimse gerechnet werden, die sich, oft von sehr geringer Größe, auf Felsen vorfinden (in den Alpen „Bänder“ genannt). Erde und Pflanzenreste sammeln sich hier und eine recht verschiedene Vegetation entwickelt sich hier, gewöhnlich aus hingeführten Arten von Formationen der Umgegend bestehend. Ein Beispiel der Vegetation von Ostgrönland findet sich bei Kruuse ${ }^{2}$ ). Die Bändervegetation in den Alpen mit Eryngium alpinum, oft auch Gentiana lutea und anderen auffälligen Pflanzen ist oft erwähnt.

\section{Kap. Spaltenvegetation (Chasmophytische Vegetation)}

Durch die Vegetation der Alvaren werden wir zu einem von dem harten Fels abweichenden Standorte, zur Vegetation der Spalten, zu den Chasmophyten, hinübergeführt. Chasmophyten nennt Schimper diejenigen Pflanzen, welche in den oft vielen Spalten der Felsen wurzeln, die mit Detritus ausgefüllt sind. In diese Spalten werden durch Wind und Regen feine Erdteile usw. hinein gebracht und Wasser wird angesammelt. Die Größe der Ansammlung hängt von der Weite und der

1) Warming 1892.

2) Kruuse 1912 . 
Lage der Spalten ab. In den Ablagerungen finden sich Pflanzen ein, und deren tote Reste vermehren die Menge des Substrates; es bildet sich ein Mullboden. Bald erscheinen, falls es die exponierte Lage nicht verhindert, auch Regenwürmer, und wie andere Bodentiere durchwühlen und durchlüften sie den Boden. Je nachdem eine solche Spalte nun weit oder eng ist, je nach der geographischen und lokalen Lage, und nach Oettli auch je nachdem Schnee liegt oder nicht, ist die Vegetation der Spalten verschieden (Fig. 323).

Wenn ein Felsen sehr steil ist und keine Spalten hat, können sich nur echte Steinbewohner anfinden, wenn anderseits die Felsen viele Spalten und Klüfte aufweisen, so siedeln sich zahlreiche Chasmophyten

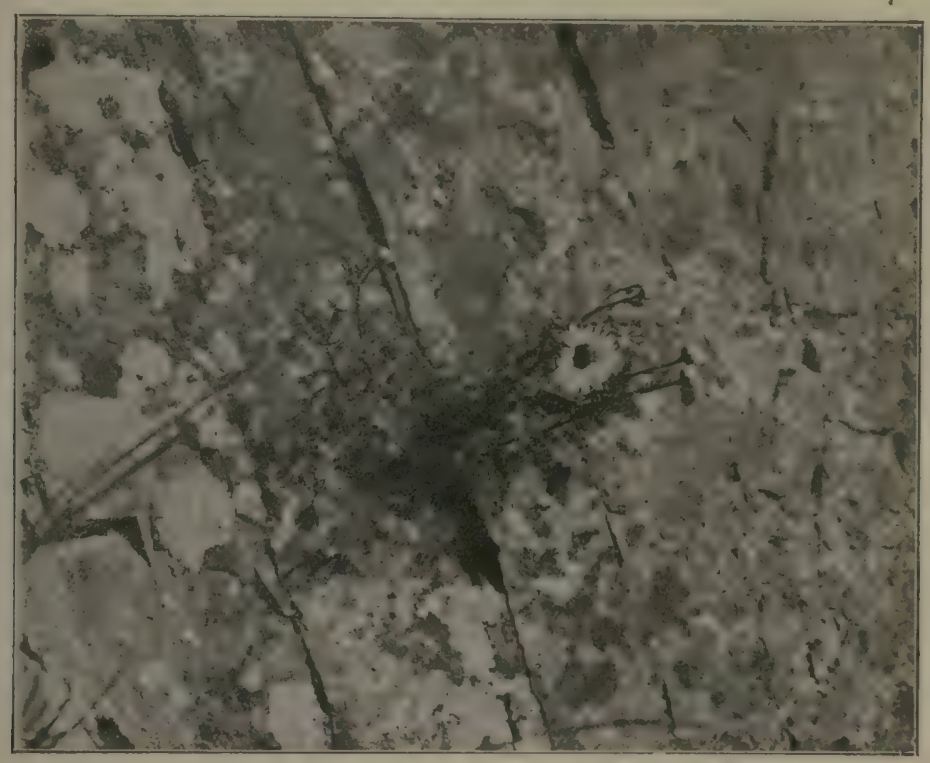

Fig. 323. Matricaria maritima in den Spalten auf Strandfelsen auf Bornholm.

(Phot. Eug. Warming.)

an, die meist wurzeltragende, oft sehr tief wurzelnde Pflanzen sind. Viele der charakteristischen Spalten- wie auch die Geröllpflanzen haben die Eigentümlichkeit, daß ihre tiefgehenden Wurzeln, die im Grunde der Spalte oder im Gerölle keine erheblichen Feuchtigkeitsschwankungen, jedenfalls keine Trockenheit gewohnt sind, ein Eintrocknen des Bodens um ihre Wurzeln herum nicht ertragen können; sie sind deshalb in der Kultur auf unbedecktem Boden zum Teil äußerst heikel.

Mitunter sind die Spaltenpflanzen nur Arten von anderen und sehr verschiedenen Standorten (Wiesen, Waldboden, Äcker u. a.), welche hier einen gemeinsamen Standort gefunden haben; floristisch sind die Spalten deshalb wenig von der Umgegend verschieden; aber einige Arten sind 
doch für die Spalten mehr geeignet als andere, und das richtigste wird es sein, die Spalten-Vegetation als eine eigene Formation zu betrachten, denn die Spalten bilden ja einen recht abweichenden Standort. Die Vegetation eines steilen Felsabhanges wird auf diese Weise aus zwei Formationen gebildet, die mit Lithophyten bekleideten harten, unzerklüfteten Partien nnd die mit Chasmophyten bewachsenen, humuserfüllten Ritzen. Die Lebensformen der beiden Formationen sind auch ganz verschieden. Die Lithophyten sind mit wie es scheint äußerst wenigen Ausnahmen nur niedrige Kryptogamen mit Hapteren, die Chasmophyten nicht nur solche, sondern auch höhere, wurzeltragende Kryptogamen und Phanerogamen, darunter sogar Sträucher und Bäume.

Die chasmophytische Vegetation der

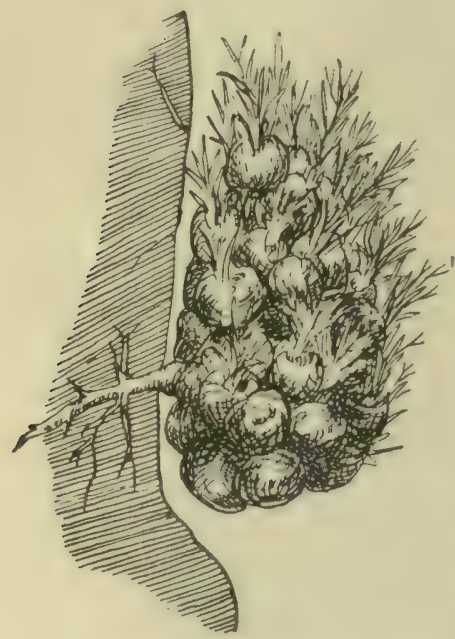

Fig. 324. Adenia Pechuellus mit seiner in den Felsritz eindringenden Pfahlwurzel. Schweiz ist von Oettli behandelt worden ${ }^{1}$, weiter finden sich nur hier und da zerstreute Beobachtungen bei anderen Autoren ${ }^{2}$ ).

Die Rhizoiden und Wurzeln sind oft in enge Spalten eingeengt und dann fast. wie Papier flachgedrückt; die Wurzeln von Gräsern z. B. bilden oft ganz flache Büschel, die die Spalte ausfüllen. Die Pfahlwurzeln anderer Pflanzen sind oft in gleicher Weise flach, wenn die Spalten eng sind. Die Wurzeln, die dem Wasser in die Spalte folgen, gehen oft sehr tief (Fig. 324). Die Fähigkeit der Hauptwurzel, sich später zu verkürzen, scheint sehr verbreitet und für die betreffenden Arten von Wichtigkeit zu sein.

Die in Betracht kommenden Arten haben meist einen büschelförmigen Wuchs und entfernen sich nicht weit von ihrem Hauptwurzelsystem.

Die Lebensformen sind sehr verschieden.

Einjährige Pflanzen sind an Felsen selten, weil sie nur wenige für ihre Keimung günstigen Stellen finden. In Ländern mit einer langen trockenen Jahreszeit können sie nichtsdestoweniger eine hervorragende Rolle spielen. An den Felsen von Madeira sind sehr häufig Gnaphalium lutei-album, Campanula erinus, Gymnogramme leptophylla, zwei einjährige Arten von Aichryson und Sinapidendron rupestre; in den Tiefländern sind gerade die einjährigen Kräuter an Individuen

2). Oettli 1903 .

2) Z. B. Christ 1885; Marloth 1908; Schenck 1908; Warming 1906, 1914. 
reicher als die ausdauernden und werden in dieser Hinsicht nur von den Halbsträuchern übertroffen ${ }^{1}$ ).

Ausdauernde Rosettenpflanzen sind häufig; die Rosettensprosse sind ja im ganzen charakteristisch für dem Licht stark ausgesetzte Stellen. Von Rosettenpflanzen können genannt werden in der nördlichen kalttemperierten Zone: Arten von Saxifraga ( $S$. aïzoon, S. cotyledon usw.), von Sempervivum, Draba, Primula, Androsaces, Papaver und viele Farne vom Rosettentypus (Arten von Aspidium [Lonchitis], Cystopteris, Asplenum, Woodsia usw.); in den wärmeren, subtropischen und tropischen Gegenden: Arten von Bromeliaceen, Agaven, Aloë, Cotyledon, Echeveria und anderen Crassulaceen.

Polsterpflanzen sind auch nicht selten. Auf den Felsen Kleinasiens wächst z. B. Draba Cappadocica; die oft $20 \mathrm{~cm}$ im Durchmesser großen, an die Felsen angeschmiegten, äußerst dichten Polster setzen sich aus dicht beblätterten Zweigen zusammen. Die Blätter sind klein und dicht wollig behaart. Diese Polster vermögen in hohem Grade Wasser festzuhalten, was sehr vorteilhaft ist. Vom Ural nennt Pohle mächtige Polster von Gypsophila Uralensis.

Viele andere Stauden mit verschiedenem Wuchs kommen vor, auf den Tuffelsen auf Disko in Grönland z. B. Viscaria alpina, PotentillaArten, Sedum villosum u. a. ${ }^{2}$ ), in den Alpen Arten von Cerastium, Arenaria, Veronica, Sedum u. a.

Auch Orchideen, Liliaceen und Amaryllidaceen, Umbelliferen usw. können beteiligt sein.

Die Dikotylen haben eine ausdauernde primäre Wurzel, die in Felsenspalten eindringen kann, und gewöhnlich keine Beiwurzeln; auch die Monokotylen sind an eine einzelne Stelle (eine Felsenspalte) gebunden und können auf vegetativem Wege nicht wandern.

Zwergsträucher finden sich auch ein, z. B. Calluna vulgaris, deren Samen vom Winde herbeigeführt werden. Von den Spaliersträuchern der Kalkfelsen in den Alpen kann Rhamnus pumila besonders genannt werden; er wurzelt in den Spalten von oft senkrechten Kalkwänden, und die Äste legen sich dicht den Felsen an, ohne Haftwurzeln zu bilden; wahrscheinlich ist es die Hitze des von der Sonne erwärmten Gesteins, welche diese enge Anschließung verursacht. Im Ural z. B. Cotoneaster ${ }^{3}$ ).

Auch größere Sträucher können vorkommen, z. B. auf den Kalkfelsen im Ural Juniperus nana mit armdicken Stämmen, niedrige Büsche

1) Vahl $1904 \mathrm{~b}$; für Cypern vergl. Holmboe 1914.

?) Porsild 1902.

3) Pohle 1907. 
von Betula tortuosa ${ }^{1}$ ). Ebenso sind Bäume nicht selten; auf den Felsen von Bornholm (in der Ostsee) wachsen z. B. Birken, Weiden, Eichen u. a. In Brasilien z. B. baumartige, 2-4 m hohe Velloziaceen, und auch Pflanzen der Lebensform der Cacteen sind allgemein.

Je nach den Umständen sind die Pflanzen xeromorph oder mesomorph. An Örtlichkeiten der Tropen, wo die Luft feucht ist, also z. B. auf Felsen in Wäldern und in den feuchten Gebirgstälern, wo der Nebel oft über dem Boden schwebt, kann man ebenso wie in gemäßigten, feuchten Gegenden eine Vegetation antreffen, die von der trockener Felsen durch ihre dichten, grünen Moospolster abweicht, zwischen denen sich auch kleine Farne und Blütenpflanzen von mehr oder weniger xerophilem Bau ansiedeln können.

Rikli schreibt von den Felsfluren auf dem Montserrat in der Nähe von Barcelona, daß aus allen Spalten und Ritzen der Felsmauern und Felsritzen in schattigen Lagen Pflanzen hervorwachsen; an den feuchten Nordlagen sind die Felsen stellenweise mit einem zusammenhängenden, saftiggrünen Teppiche förmlich bekleidet von Hedera und schwellenden Moospolstern; aus den mit dunkler humoser Erde ausgefüllten Ritzen wachsen Mengen großer, dünner Blattflächen hervor. Ähnliche Bilder kann man an luftfeuchten Lagen mediterraner Inseln, z. B. an der dalmatinischen Küste und sicher auch anderwärts beobachten.

Unterschiede in der Exposition verursachen große Vegetationsunterschiede, weil die Feuchtigkeitsmenge, die zur Verfügung steht, sehr verschieden sein kann.

Mesophyten sind oft ein nicht unbeträchtlicher Teil der anwesenden Pflanzen. Einige der Spalten bekommen Wasser von höher gelegenen Teilen des Berges und halten während langer Trockenperioden Wasser fest; andere Spalten erhalten Wasser nur gerade durch den Regen, der sie trifft. Einige enthalten reichlich Detritus und haben deshalb eine größere wasserhaltende Kraft, andere sind arm daran und lassen das Wasser daher schnell abfließen. Auch die chemische Zusammensetzung des Detritus spielt eine Rollle; reichlicher Humus, womöglich mit Regenwürmern gibt andere Lebensbedingungen als humusarmer Detritus. Felsspalten können eben endlos verschiedene Standorte darbieten ${ }^{2}$ ).

Aber xerophytische Arten sind im ganzen gemein, besonders auf der Mittagssonne exponierten Seiten der Berge.

Die Felsen können schon in kalten und gemäBigten Klimaten in Spalten und zwischen den Moosrasen auch Succulenten tragen (besonders Crassulaceen wie Sempervivum, Rhodiola rosea und Sedum-Arten,

1) Pohle 1907.

2) Oettli 1903. 
und sueculente Saxifragen), oder Pflanzen mit kleinen, dicken, dachziegeligen Blättern wie Saxifraga oppositifolia oder Silene acaulis, oder Pflanzen mit trockenen, lederartigen Blättern wie Diapensia u. a. Je wärmer und trockener das Klima wird, desto mehr werden Moose, Flechten und Algen zurückgedrängt, während die Zahl der Blïtenpflanzen, die sich in den Spalten der Felsen und auf ihren kleinen Vorsprïngen anheften, zunimnıt; ganz andere Familien treten auf als in den kühleren Gegenden. Auf den Felsen der Kalkalpen, zwischen dem Gesteine ihrer "steinernen Meere", in den Gebirgen der Herzegowina usw. findet man häufig weißwollige Cerastium-Arten, steife Rasen von Arenaria-Arten, ferner Arten von Veronica, Alchimilla, Saxifraga usw., Arten, die niedrige, dichte Rasen, kleine, steife Blätter, kräftige Epidermen, Behaarung, dicke Korkschichten ${ }^{1}$ ) und viele andere Anzeichen einer xerophilen Natur besitzen. Schon in den niedrigeren Zonen der Alpen werden Succulenten wie Sempervivum- und Sedum-Arten zahlreicher, und gehen wir zu den echten tropischen, von der Sonne beschienenen und durchwärmten Felsen, so sehen wir zwar z. B. noch einige Krustenflechten gedeihen, aber die Menge der Saftpflanzen und der anderen xerophilen Blütenpflanzen wird größer: wir finden sowohl xeromorphe, immergrüne Rosettenpflanzen, z. B. Agaven, Bromeliaceen, Velloziaceen und Yucca-Arten in Amerika, Aloë, Dracaena, Mesembrianthemum, Rochea, Echeveria, Aizoon, Sempervivum, Cotyledon und andere Crassulaceen oder Senecio (Kleinia) in Afrika ${ }^{2}$ ), unter anderem auf den Kanaren (Christ), als auch Stammsaftpflanzen wie die Euphorbien in der alten Welt, und die Cacteen in der neuen. Neben diesen Pflanzen findet man grauhaarige, kleine Sträucher, nämlich Croton-Arten, wohlriechende Lippia-Arten (Verbenaceen), Halbsträucher oder Zwergsträucher mit linealen, zum Teil ericoïden Blättern (Erica, Coleonema u. a.), kleine Kräuter mit fleischigen Blättern wie Peperomia, Pilea und Pedilanthus, ferner knollentragende Orchidaceen und knollen- und zwiebeltragende Liliifloren.

Viele dieser Pflanzen scheinen fast darauf angewiesen $z u$ sein, von der Luft zu leben, und doch erreichen sie eine bedeutende Größe; die "saftstrotzenden Prachtpflanzen" hängen von den scharfkantigen, festen Felsen der Canaren, Madeiras usw. anscheinend rein oberflächlich herab; aber in Wirklichkeit senden sie ihre Wurzeln in die Spalten und holen aus diesen das kapillar festgehaltene Wasser; „ihre strickähnlichen Wurzeln laufen unglaublich tief in das feuchte Innere des Felsens hinein" ${ }^{3}$ ). Zu gewissen Zeiten, besonders in dem kurzen Früh-

1) Vergl. Holmboe 1914: 263.

2) Vergl. Christ 1885; Marloth 1908.

3) Christ 1885.

Warming-Graebner. 3. Auflage, illustr. 
jahre, schmücken sie die braunen oder grauen Felsen meist mit bunten Blüten. Auch die Saftpflanzen sind bisweilen von der Luftfeuchtigkeit abhängig, z. B. nach Marloth Rochea coccinea von den "sommerlichsn Wolken".

Über die Felsvegetation im Urwalde von Koh Chang (Siam) schreibt Johs. Schmidt ${ }^{1}$ ), daß der nackte Fels, wo er hervortritt, eine äußerst charakteristische Vegetation trägt, nämlich kaktusähnliche Euphorbien, verschiedene Knollen- und Zwiebelgewächse, einjährige während der Trockenperiode abgestorbene Kräuter, xeromorphe Orchideen und Farnkräuter, xeromorphe Moose und aërophytische Algen. Die Mehrzahl zeigt die Eigentümlichkeit, daß sie im Gegensatze zu den gewöhnlichen Pflanzen des Urwaldes ihre Vegetationsperiode auf die Regenzeit (im Sommer) beschränken, während sie in der Trockenzeit gewöhnlich ganz blattlos, oft aber mit Blüten stehen.

Es hängt also von der Luftfeuchtigkeit, der Exposition, dem Wasserreichtum und der Wasserzufuhr der Spalten usw. ab, wie die Anpassungen der Assimilationsorgane sich gestalten. Xeromorphe und mesomorphe Arten sind oft beisammen. So ist nach Vahl ${ }^{2}$ ) die Vegetation an den senkrechten Felsen von Madeira eine verschiedenartige Mischung von Xerophyten und Mesophyten; an der Seite weißwollig behaarter Zwergsträucher wachsen Farne und Lebermoose. In den heißen, trockenen Niederungen Madeiras aber trocknen alle Triebe im Sommer ab; die Felsspalten haben nicht genügend Feuchtigkeit, um den Mesophyten den Ersatz des verdunsteten Wassers zu gestatten. Die senkrecht gespaltenen Basaltfelsen sind oft fast frei von Pflanzen, weil sie nicht imstande sind, Wasser festzuhalten; an schattigen Plätzen und in feuchten Klimaten sind aber auch die Basaltspalten pflanzenreich. Unregelmäßig gespaltene Basaltfelsen sind meist von wenigen streng xerophytisch gebauten Halbsträuchern und einigen Kräutern bewohnt. Wo sich Basalt- und Tufflagen abwechseln, wird ihre große Verschiedenheit bezüglich ihrer wasserhaltenden Kraft sehr deutlich. Der Tuff, der ein guter Wasserleiter ist, ist bedeckt mit Adiantum capillus Veneris u. a., oder in der Nähe von Kulturland mit Parietaria Judaica und hebt sich meist in Form wagerechter Bänder ab. Während des Sommers trocknen diese Mesophyten zum Teil ein. Felsen, die ganz aus Tuff bestehen, haben meist eine ebenso ärmliche Vegetation wie die aus Basalt, weil sie nicht von undurchlässigen Lagen durchsetzt sind oder keine solche unter ihnen liegt ${ }^{3}$ ).

1) Schmidt 1906 .

9) Vahl $1904 \mathrm{~b}$.

${ }^{3}$ ) Uber Spaltenvegetation finden sich ferner Beobachtungen z. B. bei Holmboe 1914 (Cypern). 
Bergklüfte. Als Anhang zur Spaltenvegetation der Felsen mag hier ein eigentümlicher, abweichender Standort erwähnt werden, nämlich die großen, tiefen, schattigen Klüfte, die in vielen Gebirgen vorkommen. In diesen kann sich eine üppige mesophytische und hygrophile Vegetation entwickeln, weil sie hier feuchte Luft und Schatten vorfindet, ebenso Schutz vor den Winden. Besonders viele Farne kommen hier vor.

Bisweilen ist die Vegetation auf den verschiedenen Seiten verschieden, was von der Exposition abhängen kann und auch von der Neigung der Schichten im Gesteine. Wenn diese in einer bestimmten Richtung geneigt sind, und diese Richtung schräg zu der Kluft steht, wird man z. B. auf der einen Seite eine stetige Bewässerung durch niedersickerndes Wasser sehen, während die andere Seite trocken ist; dies ruft natürlich einen bedeutenden Unterschied in der Vegetation hervor. Auf den Färöern sind solche Klüfte im Basalt häufig ${ }^{1}$ ), ebenso in manchen Gegenden der Alpen („Kamine“), auf dem Karst usw. In West-Irland wächst in solchen Spalten im Kalk viel Adiantum und oben auf der Fläche Dryas so dicht beieinander, daß man mitunter beide mit einer Hand greifen kann.

Auch Verschiedenheiten der Windexposition rufen Unterschiede hervor $\left.^{2}\right)$. Auf dem Boden, wo Humus sich vielleicht zwischen großen Steinblöcken gesammelt hat und wo Wasserrinnen fließen, wird die Vegetation noch üppiger. In Island findet sich vielfach ähnliches.

Höhlen im Fels. Eine eigene, aber seltene Variation der Felsenvegetation findet sich in Höhlen, die nicht so tief und dunkel sind, daß doch Pflanzen sich in ihnen entwickeln können. Oben wurde schon die hoch über dem Meere auf den Westmaninseln gelegene Höhle erwähnt, wo H. Jónsson eine rote Meeresalge (Rhodochorton) entdeckte. Ganz verschiedene Höhlen sah Holmboe ${ }^{3}$ ) auf Cypern; wo die Wände feucht sind, trift man gewöhnlich Selaginella denticulata in Menge, hier und da mit Adiantum capillus Veneris, und am tiefsten Schattenformen von Parietaria officinalis. An einer Stelle sah er eine Höhle, von deren Wänden das kalte, klare Wasser in Menge herausrieselte; die Wände waren mit Moosen bedeckt und Adiantum capillus Veneris wuchs hier in großer Üppigkeit; außerdem fand sich hier Samolus Valerandi.

In den durch elektrisches Licht künstlich erleuchteten Höhlen, z. B. in den Tropfsteinhöhlen des Harzes, des Fränkischen Jura usw., haben sich sehr bald an den Felsen um die Lampen herum Moose angesiedelt und zum Teil dichte Polster erzeugt. In ganz dunklen Höhlen finden sich nur Pilze als Verwesungspflanzen auf hineingeratener

1) Ostenfeld $1908 \mathrm{~b}$.

2) Für Schottland siehe W. G. Smith bei Tansley 1911.

a) Holmboe 1914 . 
organischer Substanz, auf Hölzern usw. (z. B. Paxillus acheruntius). Blütenpflanzen gehen zum Teil, wenn auch nie blühend und nur mit großen, schlaffen Blättern vegetierend, so weit in die Höhleneingänge hinein, daß man an ihren Standorten an hellen, sonnigen Tagen kaum eine Zeitung mehr zu lesen imstande ist.

\section{Kap. Vegetation der Trümmerfelder von größeren Fels- blöcken (Felsenmeere, Blockmeere)}

Der Formation der Felsen schließen sich sehr nahe die oft weit ausgedehnten Felder oder Abhänge von größeren oder kleineren Steinen an, oft gemischt mit großen Blöcken, wie sie durch das Abwittern von steilen Felswänden (durch Hitze und Frost) oder in noch größerer Ausdehnung durch Bergstürze entstehen. Meist bestehen sie aus scharfkantigen Steinen, die meist am Grunde steiler Felsen oder großer Massive aufgeschichtet sind (Fig. 325).

Ist die Lage großer Blöcke und Steine sehr dick, so können Jahrhunderte vergehen, bis sich außer Algen, Flechten und Moosen an den Blöcken zwischen ihnen eine nennenswerte Vegetation höherer Pflanzen anfindet. Je zahlreicher die kleinen Steine zwischen den großen liegen, oder je dünner die Blockschicht ist, desto schneller und reichlicher sammelt sich Erde, Humus usw. an Stellen an, an denen Pflanzen gedeihen können. Dann findet man im Schutze der Steine und Blöcke oft eine sehr üppige mesophile Vegetation mit Farnen und Blütenpflanzen. An günstigen Stellen wachsen auch Wälder an solchen Orten und beschatten das Felsenmeer völlig, so daß eine Waldvegetation einzieht. An lichten Orten wird die Krautvegetation oft sehr ïppig und hoch. Wo Luftfeuchtigkeit genügend vorhanden ist, wachsen im Baumschutz oft mächtige Moospolster, in denen höhere Pflanzen, von Bäumen besonders Fichten, keimen und später mit ihren Wurzeln die Blöcke umspannen.

An solchen Geröllflächen findet man besonders zwei Formationen:

1. Lithophyten auf den Steinen.

2. Die übrige Vegetation zwischen und anf den Steinen.

Je nach der Stärke der Ansammlung von Erde werden die Steine früher oder später überwachsen und schließlich von Erde eingehüllt. Es verschwinden die Lithophyten alsdann. Die Vegetation ändert sich demgemäß mit dem Alter, geht in andere Formationen über, es kommt eine deutliche Succession zur Entwicklung bis eine Climax-Vegetation, wohl immer der Wald, den Abschluß bringt.

Solche Steinanhäufungen finden sich in allen bergreichen Ländern mit leichter zerklüftenden Felsen. Fig. 326 zeigt ein Bild von einem 
Trümmerfeld an den Küsten des Kattegat; es gehört allerdings der halophytischen Serie an, weil die Pflanzen wesentlich Halophyten sind, mag aber hier als Darstellung von einem Trümmerfeld im ersten Stadium dienen.

Je nach den klimatischen Verhältnissen werden sich solche steinigen Ahhänge verschieden entwickeln. Es tritt ein großer Unterschied hervor zwischen den trockenen und den feuchten Klimaten. In dem kalttemperierten, regenreichen Norwegen z. B. werden die Zwischenräume

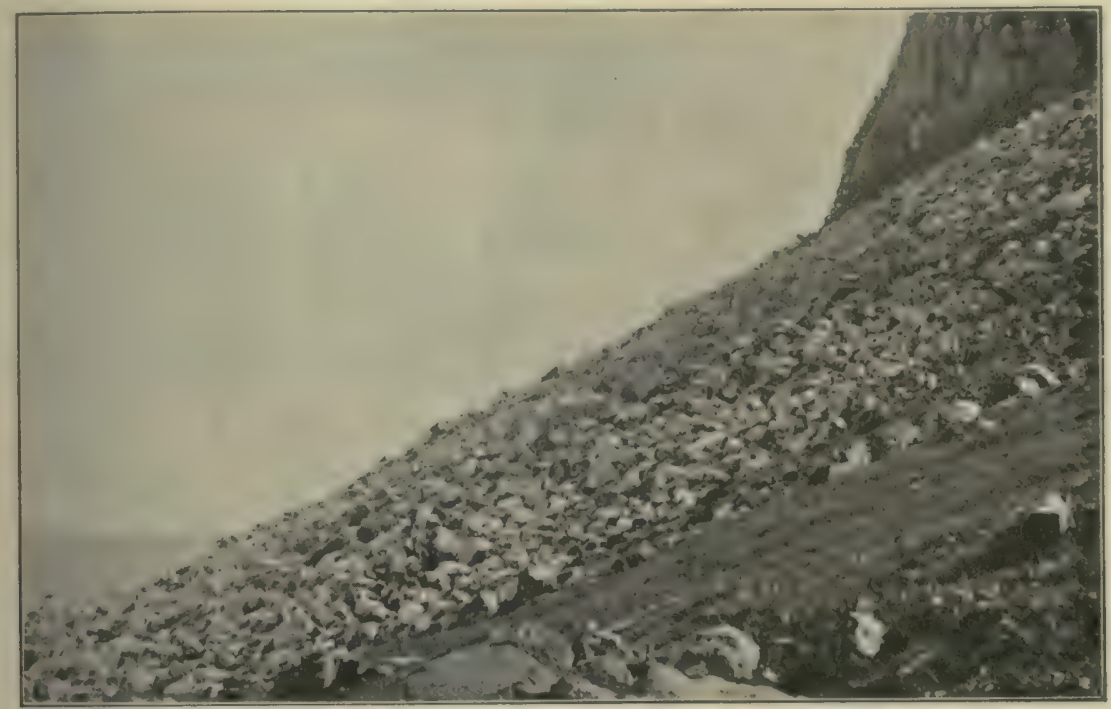

Fig. 325. Färöer; 2-300 $\mathrm{m}$ ůber dem Meere.

Die erste Vegetation auf und zwischen den Steinen ist eine Moosvegetation, welche zuletzt reiche Teppiche bilden kann. In diesen finden sich ein z. B. Oxyria digyna, Rumex acetosa, Festuca rubra u. a. Ferner, wenn durch die Moosvegetation eine dickere Humusschicht gebildet worden ist, können andere, kräftigere Blütenpflanzen einwandern. Unter den eingewanderten kann sich auch das kleine Hymenophyllum Tunbrigense vorfinden. Weitere Steine stürzen immer herab. (Phot. Eug. Warming.)

zwischen den Felsblöcken nach und nach mit so vielen Resten der örtlichen Vegetation und so vieler vom Winde hingeführter Erde und Detritus ausgefüllt werden, daß eine reiche Vegetation aus Bäumen, Sträuchern mit allerlei Gräsern und Kräutern, besonders Hochstauden, sich auf dem gebildeten Humus entwickeln kann. Solche Standorte sind dort unter dem Namen "Ur " bekannt ${ }^{1}$ ). Sie tragen zuletzt Gebüsche oder niedrige lichte, seltener hohe dichte Wälder von Corylus, Ulmus, Tilia, Fraxinus, Acer, Sorbus, Quercus, Rosa, Crataegus u. a. (die von Blytt

1) „Urd" im Isländischen; vergl. Stefansson S. 236. 
behandelt wurden), in deren Schutz sich eine reiche Flora südlicher Pflanzenformen ansiedelt: stark duftende Labiaten, Geranien, Hypericum, Dentaria bulbifera, Lathyrus silvester, L. (Orobus) vernus, L. niger, verschiedene Gräser usw. Wenn eine solche Geröllhalde sehr reich an Arten ist und kräftig entwickelte Pflanzen trägt, so wird dieses nicht nur darauf beruhen, daß der Wind anorganische Teile und Humus zwischen den Steinen anhäuft, sondern auch darauf, daß sich unter diesen Feuchtigkeit sammelt, die dann sehr schwer verdunstet, daß ferner der Gesteinsboden leicht durchwärmt wird, und daß solche Halden fast immer auf geneigten Stellen am Fuße der Felsenwände vorkommen, wo sie, wenn die Neigungsrichtung der Abhänge nicht allzu ungünstig ist, leicht erwärmt werden. Diese Vegetation ist überwiegend oder ganz aus mesomorphen Arten zusammengesetzt. Daß auch in anderen Weltgegenden ein Wald den steinblockreichen Boden zuletzt bekleiden kann, wenn sich hinreichender Humus gesammelt hat, sieht man z. B. bei Cockayne (1911).

Als Gegensatz hierzu kann man Bilder von Socotra betrachten, welche in Karsten und Schencks Vegetationsbilder III, 5 veröffentlicht worden sind. Zwischen den großen kahlen Felsblöcken wachsen in der glühenden Sonne merkwürdige xeromorphe Lebensformen, wie Adenium Socotranum, Dendrosicyos Socotrana, Euphorbia arbuscula, Dracaena cinnabari, Boswellia Socotrana, Stammsucculenten und Holzpflanzen von auffälligem Habitus. Die ganze Vegetation ist sehr offen und wüstenartig.

Ähnliche Standorte mit anderen Arten sind die Blocklavaströme in Kleinasien, die Zederbauer erwähnt ${ }^{1}$ ), wild zerklüftete Felsen, zwischen welchen z. B. Paeonia corallina gern wächst in Gesellschaft von Amelanchier vulgaris und Cotoneaster nummulifolia. Ihre Wurzeln sind etwas rübenförmig verdickt, die Blätter sind groß und unzweifelhaft mesomorph.

Hierher können wir auch die von Karsten und Stahl $\left.{ }^{2}\right)$ besprochenen Kalksteintrümmer Mexikos ziehen, obgleich die Steine kleiner sind und feinkörnige Erde häufiger ist. Es hat sich hier eine außerordentlich reiche und mannigfaltige, aber höchst interessante, extrem xeromorphe Vegetation auf dem von kahlen weißen Steinen übersäeten Boden entwickelt: Agaven, Yucca, Peireskia, eine Euphorbiacee von ephedraähnlichem Aussehen, Pedilanthus, Bromeliaceen, Cacteen, z. B. Echinocactus-Rasen, durch seitliche Sprossungen aus wenigen Exemplaren hervorgegangen, Mamillarien, blattsucculente Tradescantien; ferner blattlose oder dornige Sträucher mit lederigen, weißbehaarten, am Rande

1) Zederbauer 1906 a.

2) Veg. Bilder I, 8, Taf. 44. 


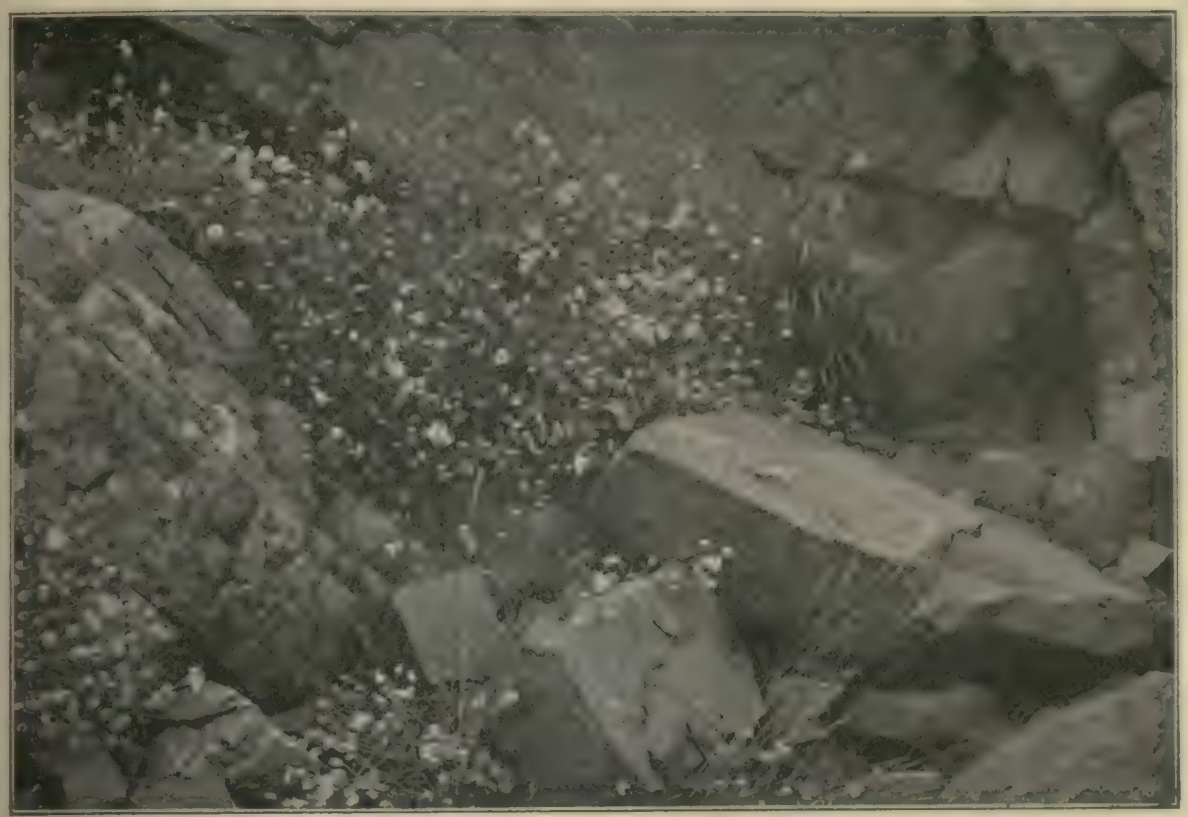

Fig. 326. Felspartie auf Kullen (Schonen in Südwest-Schweden). 10. Juli 1907. In der Mitte zwischen den Steinen Silene maritima, Festuca rubra, Aster tripolium; auf den Steinen Ramalina scopulorum und andere graue, weiße und schwarze Flechten. (Phot. Eug. Warming.)

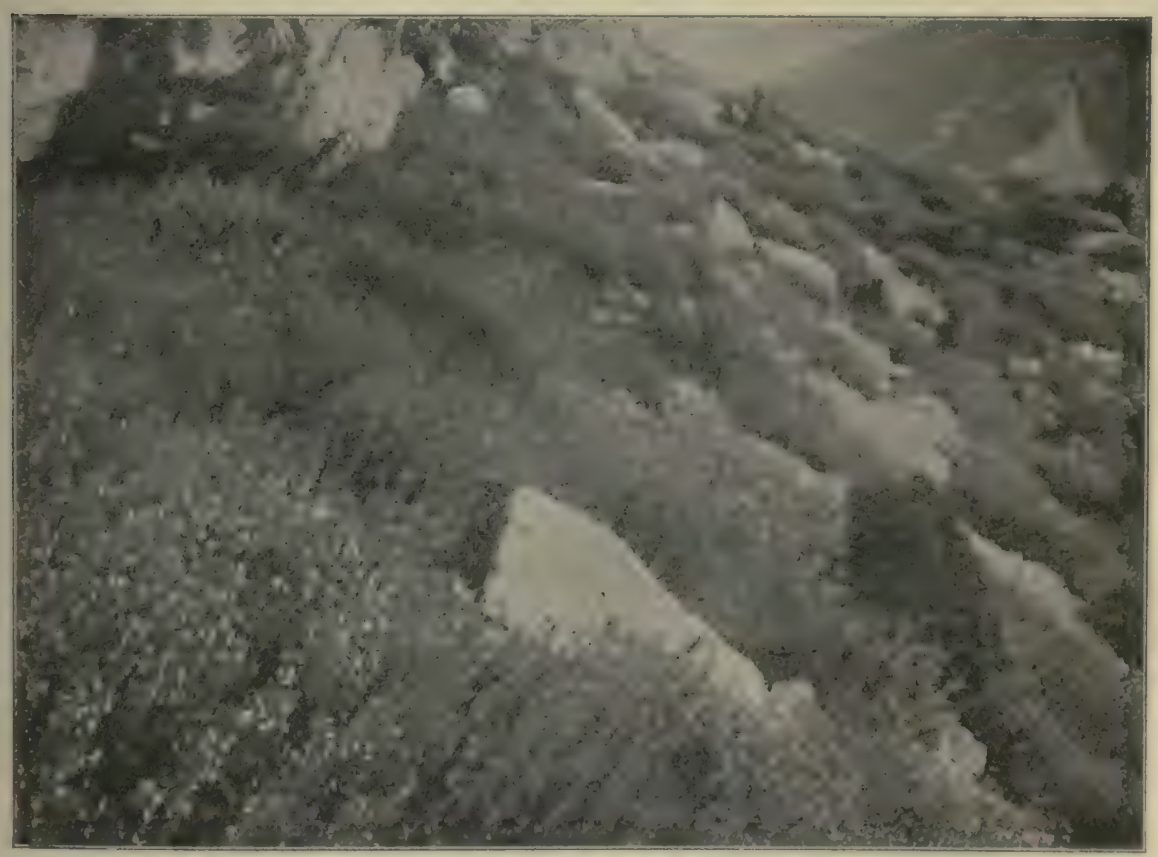

Fig. 327. Felsentrift in Serbien in der submontanen Region. Salvia-officinalis-Assoziation. (Phot. Adamović.) 
umgerollten Blättern (Compositen), Leguminosen, Ipomoea usw. In diesem ausgesprochen trockenen Klima hat sich auf dem sehr trockenen Boden eine ausgesprochen xeromorphe Vegetation entwickelt - eine SteinHalbwüste.

Während die oben erwähnte mesophytische Vegetation auf Norwegens Geröllhalden („Urer“) sehr wohl den mesophilen Wäldern angeschlossen werden kann, hat man da eine weit typischere Felsenvegetation, wo die Spalten im Gesteine von den Zwischenräumen zwischen den Felsblöcken ersetzt worden sind. Diese Formationen bilden auch einen Übergang zu den „Felsensteppen“" und könnten so benannt werden, resp. zu den Steinwüsten.

Ähnliche Standorte finden sich in vielen heißen tropischen oder subtropischen und warmtemperierten Ländern, z. B. die von Adamovié ${ }^{1}$ ) beschriebenen „Felsentriften" Dalmatiens, wo große und kleine Steine den Boden bilden und die Pflanzen zwischen sich aufnehmen, so daß hier eine offene Vegetation von Hochstauden gebildet wird, ähnlich der S. 741 abgebildeten von den dänischen Küsten. Felsentriften sieht man in ganz Dalmatien in jeder Höhenstufe und auf jedem Substrat (Fig. 327). Sie können reicher und ärmer sein. Eine reiche Vegetation und eine kompaktere Pflanzenmenge tritt an jenen Stellen auf, die nicht zu steil sind und wo zwischen den Felsblöcken noch ziemlich viel Feinerde sich ansammeln kann. Grasige Felsentriften kommen da hervor, wo die Steine in gewissem Abstande voneinander liegen. Alle Pflanzen sind xeromorph und an solche Standorte ganz besonders angepaßt (Adamovié). Selbst die anspruchslose Seestrandföhre, Pinus Halepensis, wird auf den unwirtlichsten Steinfluren einwandern und kann prächtige Wälder bilden ${ }^{2}$ ).

Handel-Mazzetti ${ }^{3}$ ) hat uns ein Bild von der verbreitetsten Vegetationsformation der Hochgebirgsstufe in Kleinasien gegeben - Schuttund Gesteinsfluren mit reichlichem, wenn auch mehr oder weniger zerstreutem Pflanzenwuchs ${ }^{4}$ ). Hier muß auch an die Garigues der Mittelmeerländer (Ser. VII) und die Felsenheide der Canaren (Christ) erinnert werden.

Ein Bild einer üppigeren tropischen Vegetation an einer Felsenküste in Westindien hat Börgesen gegeben; sie wurde oben bei der Vegetation der Strandfelsen erwähnt, obgleich sie vielleicht äußerst wenig vom Salzwasser beeinflußt wird (Fig. 209).

1) Adamovié 1909.

2) Adamović 1913, Taf. 45.

3) Handel-Mazzetti 1912 b, Taf. 35.

4) Über Blockfelder vergl. ferner Hess 1909. 


\section{Kap. Geröllhalden, Schutthalden (Gerölffluren)}

Ein abweichender Standort bildet sich dort, wo durch Verwitterung am Fuße der Berge große, etwa unter $45^{\circ}$ geneigte Abhänge von kleinen eckigen Felsstücken gebildet werden, welche eine leicht bewegliche, unstete, rutschende Masse darstellt, und dessen Geröll bei jedem Schritt in Bewegung kommt. Auch feinkörnige Massen, mit der Zeit auch eine geringe Menge von Humus werden sich hier einfinden. In Tirol werden diese Abhänge Muren, sonst auch Schurren usw. genannt.

Auf solch losem Boden müssen die Pflanzen oft einen harten Kampf um ihre Existenz mit dem stetig rutschenden Trümmerschutt führen; ihre Existenz muß dann auf verschiedene Weise gesichert werden, z. B. durch sehr kräftige, tiefgehende Wurzeln, welche die oberirdischen Organe oft an Größe bedeutend übertreffen; durch kriechende Grundachsen u. a. Viele Pflanzen wurzeln indessen auch sehr flach, so daß sie stets mit den rutschenden Steinen mitgleiten, soweit sie nicht verschüttet werden. Schröter hat eine Menge von ökologischen Typen aufgestellt, und auch von Hess und von Cockayne ${ }^{1}$ ) werden die Wuchsformen eingehend besprochen (ortsfeste Rasentriebe und Polster, wandernde Schuttüberkriecher und Schuttwanderer, Ausläufer von zweierlei Formen usw.). Die Formen hängen von der Ruhe oder Bewegung des Gerölls ab.

So lange ein Geröllabhang noch jung. ist, macht auch ein anderer Faktor sich geltend: das Regenwasser läuft zwischen den Steinen schnell fort, aber die Feuchtigkeit hält sich lange Zeit unter den Steinen, so daß sogar ausgeprägt mesomorphe Arten zur Entwicklung kommen können; der Boden ist eine edaphische Einöde mit floristischen Unterschieden je nach den Bodenverschiedenheiten (Unterschiede namentlich zwischen Kalk- und Kieselboden). Die Vegetation ist sehr offen und oft mehr oder weniger wüstenartig („Geröllwüsten“) und xeromorph; vergl. z. B. Cockayne ${ }^{2}$ ), nach welchem auch die großen Polsterpflanzen, welche "vegetable sheeps" genannt werden, auf solchem Boden zur Entwicklung kommen können.

Wenn viele Feinerde da ist, wird die Vegetation dichter und reicher werden, denn die Erde gibt einen größeren Nahrungsvorrat und unter den Schottern hält sich die Feuchtigkeit besonders lange ${ }^{3}$ ).

Auf solchem ruhenden Geröllboden werden mit der Zeit verschiedene Formationen sich entwickeln können, je nachdem der Standort in feuchten

1) Schröter 1904-08; Adamović 1909 a; Hess 1909; Cockayne 1910, 1912.

2) Cockayne $1908 \mathrm{~b}, 1910,1912 \mathrm{~b}$.

8) Vergl. auch S. $76-77$. 
oder trockenen Regionen liegt; in den Alpen z. B. Geröllheiden, welche von dichten Teppichen von Erica herbacea (E. carnea) mit vielen anderen Pflanzen gebildet sind. In Neuseeland sind nach Cockayne viele Alpenwiesen auf solchem Boden erwachsen, und auch Gebüsche und $\mathrm{W}$ älder werden hier einen passenden Boden finden können. Geröllhalden (oder Geröllfluren) werden somit vielfach in unbewegliche, ruhende Fluren übergehen, Schuttfluren, welche sich mit der Zeit mit einer geschlossenen Decke von Kräutern, Gräsern u. a. Lebensformen bedecken.

Es versteht sich von selbst, daß zwischen den Geröllwüsten auf den aus Felsenblöcken oder aus Schutt gebildeten Fluren der Bergabhänge und den flachen Steinwüsten oder Steinsteppen in der Sahara und ähnlichen subtropischen Wüsten kein wesentlicher Unterschied bestehen kann; die Lebensformen müssen vorzugsweise xeromorph werden, und die Vegetation ist sehr offen, die Pflanzen stehen äußerst zerstreut. Diese Steinsteppen und Steinwüsten werden aber ganz besonders von dem trockenen und heißen Ḱlima ein Gepräge bekommen und werden am besten unter den trockenen Klimaten besprochen werden (Serie IX). Aber auch in den Polarländern und z. B. in Neuseeland, sowie in den Hochgebirgen kommen horizontale oder wenig geneigte Geröll- und Steinwüsten vor, die aber in diesem Buche, des abweichenden Klimas wegen, unter „Kältewüsten" besprochen worden sind.

Mit dieser Geröllvegetation kann verglichen werden die parallele Vegetation der Salzbodenvereine (Kap. 48, 49).

Eine eigentümliche Form von Steinwüsten entsteht z. B. in Island, indem die Stürme alle kleinkörnigen Teile wegführen, und nur grobe Körner und kleine und große Steine zurückbleiben; Thoroddsen bespricht und bildet diese Steinwüsten $a b^{1}$ ).

Selbst in Jütland kommen in kleinerem Stile solche Steinwüsten vor, indem der Wind die Sandkörner der alten fluvio-glazialen Ebenen entfernt hat, zurückgeblieben sind nur die rund abgeschliffenen Steine; in diesen horizontalen Einöden finden sich nur kleine, xeromorphe, vom Winde geprägte Arten sehr zerstreut vor; namentlich Koeleria glauca, Weingaertneria canescens, Armeria maritima, Festuca rubra ${ }^{2}$ ) fristen hier ein ärmliches Leben in Gesellschaft mit einigen kleinen Krustenflechten und kümmerlichen Cladonien ${ }^{3}$ ).

1) Thoroddsen 1914.

2) Warming 19(07-) 09 .

3) Uber die in den vorhergehenden Kapiteln besprochene Vegetation vergl. Hitchcock 1898; Oettli 1903; Pohle 1903; Rikli 1903; Adamovié 1898; Ostenfeld 1908 b; Brockmann-Jerosch 1907; Schröter 1904-08; C. Flahault 1906 b; Warming 19(07-)09; Diels 1896; Chodat 1909; Rübel 1911-12, 1913. - Rikli 1915, Kreta und Sizilien in Karsten u. Sckencks Vegetationsbilder, 13. R., H. 1-2. G. Kraus hat in Württemberg die Vegetation verschiedener Steinböden sorgfältig studiert (1906 a, 1910). Josias Braun 1913. 


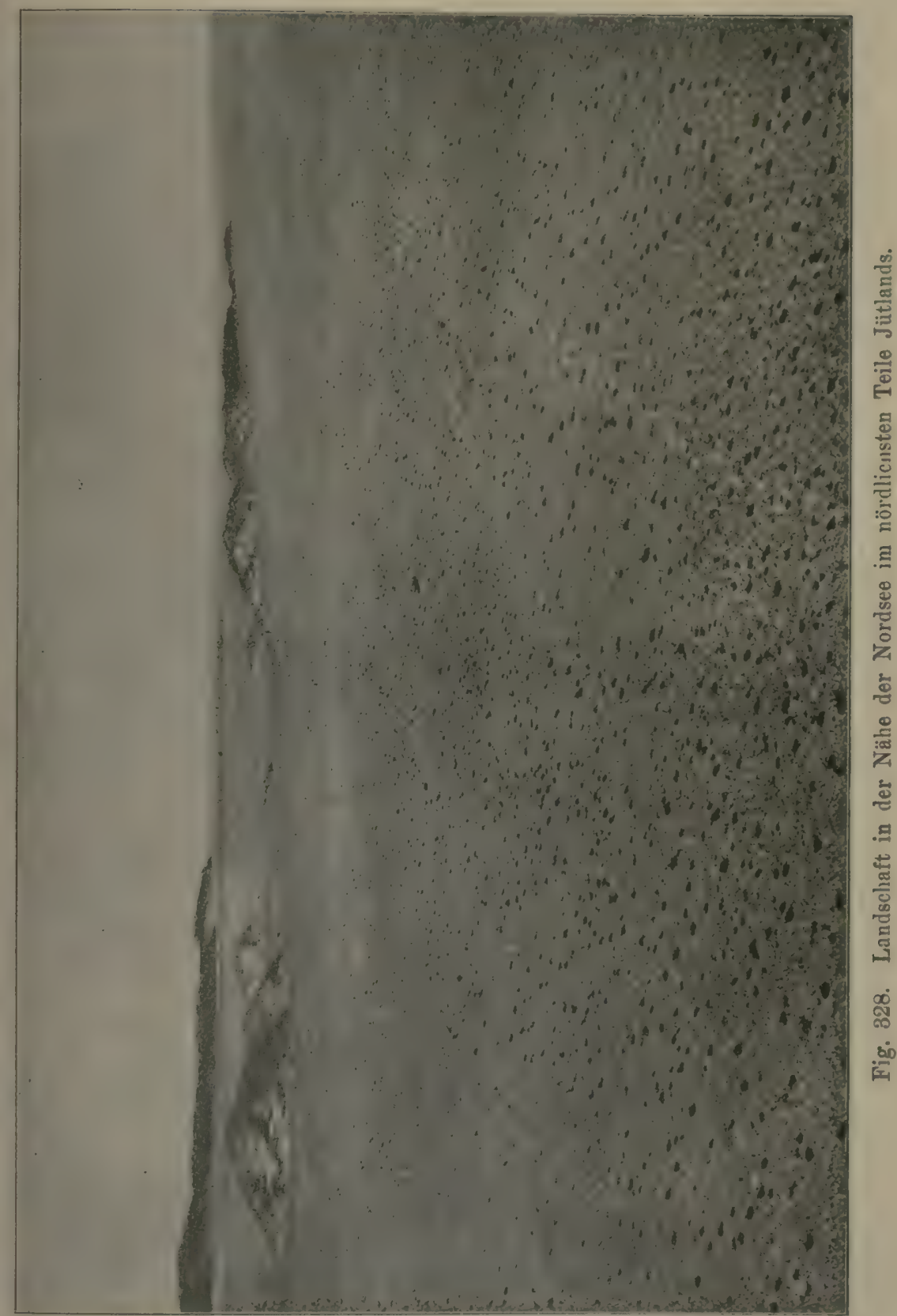

Erklärung zu Fig. 328. Der Wind hat zum Teil den Sand weggeweht. Die Ebene ist ein gelbbrauner, von kleinen Kieselsteinen (die meisten weniger als j) cm Durchmesser) bedeckter Sandboden. Die Steine sind schwarzgefleckt von Krustenflechten. Einige selır zerstreute krüppelige Phanerogamen finden sich auch (vorzugsweise Weingaertneria canescens und Koeleria glauca; auch einige Exemplare von Fiestuca rubra, Armeria vulgaris, einige schwarze Moose und die Flechte Cladonia foliacea var. alcirornis). Auf der Ebene liegen einige Dünen. Das Meer fern im Westen. (Phot. Eug. Warming.) 


\section{Kap. Sandvegetation (Psammophile Formationen)}

Die im folgenden besprochene Vegetation auf Sandboden ist diejenige, die so hoch über dem Grundwasser liegt, daß die Wirkungen desselben ausgeschlossen sind; also nur die Vegetation, in welcher die Eigenschaften des trockenen oder höchstens feuchten Sandes zum Ausdruck kommen, und deren Vegetation eine ausgesprochen xeromorphe werden muß, weil ein solcher Sandboden physikalisch trocken ist. Die Formationen des Sandbodens sind überwiegend edaphisch bedingt.

Oft bilden solche Standorte die unmittelbare Fortsetzung von wasserdurchtränkten Standorten, oder Standorten, auf welchen das Grundwasser so hoch liegt, daß es leicht von den Pflanzenwurzeln erreicht wird, und daß der Sand fest gebunden wird, welche daher eher den Salz- oder Süßwasserformationen (Kap. 50, Kap. 65) zugerechnet werden müssen. Solche Standorte finden sich am Sandstrande von Meeren und von Binnenlandseen; Cowles und Jennings haben in Nordamerika solche eingehend besprochen. Jennings z. B. fand auf der Presque Isle im Erie See in Pennsylvanien folgende Reihe ${ }^{1}$ ):

1. Der niedere Strand mit einer Chlamydomonas-Assoziation, reichend vom Wasser bis zu der höchsten Grenze, bis zu welcher die Wellen von den Sommerstürmen getrieben werden.

2. Der "Drift"-Strand mit der Cakile-Xanthium-Formation reicht von der vorigen Grenze bis zu der oberen Grenze der Winterstürme. Auch dieser Gürtel ist von losem Sand gebildet; zuzeiten wird die Oberfläche sehr heiß und trocken, aber das Grundwasser ist der Oberfläche sehr nahe. Die Vegetation besteht aus einjährigen Arten und die Pflanzen sind jedenfalls in ihren oberen Teilen xerophytisch. Dieser Gürtel entspricht ganz dem Gürtel der einjährigen Halophyten auf sandigem Meeresstrande, z. B. in Nordeuropa. Danach folgen die trockenen Assoziationen (hier "Formationen" genannt).

3. Die Sandebene mit der Artemisia-Panicum-Assoziation, ohne bestimmte Abgrenzung gegen den zweiten Gürtel. Sie entspricht nach dem Verfasser Cowles' "Upper beach", Mac-Millans "Backstrand" usw. Hier reichen die Wellen nicht hinauf, weshalb zweijährige und ausdauernde Arten hier gedeihen können. Sie ist auch etwas besser gegen den Wind geschützt. Mit der Zeit kann sich hier Humus bilden und der Boden an Pflanzennährstoffen reicher werden. Die Vegetation ist offen, indem die Pflanzen im allgemeinen nur etwa $20 \%$ der Fläche

1) Jennings 1909. 
bedecken. Die herrschenden Arten sind Artemisia Canadensis, A. caudata und Panicum virgatum; verschiedene Assoziationen und Facies kommen indessen vor, selbst eine Cladonia-Assoziation.

4. Ferner entwickelt sich eine Arctostaphylos.JuniperusHeide, also eine immergrüne $Z$ wergstrauchheide von xerophytischem Charakter, und eine geschlossene Vegetation.

Ferner entwickelt sich auf dem sandigen Boden eine Reihe von anderen Formationen, über welche der Verfasser berichtet: Eine Pinusstrobus-Assoziation, eine Quercus-velutina-Assoziation, die vielleicht nicht die Schlußvegetation sind, es scheint aber, daß sie als solche lange Zeit existieren können. Ferner wird eine andere Reihe von "Formationen" unterschieden, welche reich an Teichen und Lagunen ist, und wo z. B. Myrica-Gebüsch, Wald von Prunus serotina, Dünen mit verschiedener Vegetation, nämlich Populus-Dünen, Ammophila-(Psamma) arenariaDünen, Andropogon-Dünen, Prunus-Dünen und gemischte PrunusSmilax-Dünen vorkommen.

Der Sandboden und seine Eigenschaften wurden S. 106 besprochen. Es wurde hervorgehoben, daß Sandböden

1. aus sehr kleinen, lose liegenden Körnern bestehen (Größe gewöhnlich im Durchschnitt 0,25-0,1 mm);

2. ein sehr geringes Absorptionsvermögen besitzen, besonders wenn sie aus Quarzsand bestehen;

3. einen geringen Wassergehalt haben, wenn sie über dem Grundwasser liegen, weil das Wasserhebungsvermögen in der Regel sehr gering ist;

4. in der Regel oberflächlich schnell austrocknen und sich daher in der Sonne schnell und stark erwärmen, aber sich nachts auch schnell und stark abkühlen.

5. Sandböden sind sehr durchlässig, werden daher auch leicht ausgelaugt und sind deshalb unfruchtbar.

6. In allen nackten Sandböden wird die oberste, oft nur wenige Zentimeter bis einige Dezimeter dicke Schicht völlig ausgetrocknet, so daß die Sandkörner ganz lose liegen. Diese Schicht schützt dann die tiefer liegende Sandmasse gegen Verdunstung, und in nackten Sandböden wird man daher gewöhnlich in geringer Tiefe unter der Oberfläche feuchten und kühlen Sand treffen, der sich mit den Händen zu Klumpen formen läßt.

Die oberste lose Schicht wird, wenn die Körner sehr klein sind, leicht vom Winde weggeführt und anderswo abgelagert. Dadurch können "Dünen", d. h. Sandhügel, gebildet werden. Dünen sind immer äolische Bildungen, nur von feinem Sande gebildet, und können sehr verschiedene 
Höhen, bis 100 oder gar bis $300 \mathrm{~m}$ erreichen. Sie entstehen nicht nur an den Küsten, wo die Meereswellen das Material liefern, sondern auch im Binnenlande an den Ufern von großen Seen und durch Ausblasen von Sand aus trockenen Flußbetten, besonders in trockenen kontinentalen Klimaten, in den Sandwüsten usw. In den subtropischen Wüsten in Afrika, Asien und anderswo stellt die Form solcher nackter Sandhügel gewöhnlich die eines Halbmondes dar, welcher die konkave Seite vom Winde abwendet. Sie sind unter dem Namen "Bogendünen" („Barkhanen“) bekannt.

In regenreichen (humiden) Gegenden können sich Dünen schwieriger bilden, oder einmal gebildete Dünen werden für lange Zeiten festliegen, weil die oberste Sandschicht oft feucht wird und weniger leicht austrocknet; aber wenn dieses letztere in trockenen Zeiten dennoch geschieht, werden sich auch hier Sandhügel bilden. Dünen finden sich daher über die ganze Erde verbreitet, von den Polargegenden bis zum Äquator, wenn nur die zwei Faktoren vorhanden sind: Wind und trockener Sand. An der Ostküste Grönlands ${ }^{1}$ ) finden sich typische Dünen, von Salix und Festuca rubra bewachsen (Fig. 329). Dünen kommen denn auch sowohl in feuchten als in trockenen Klimaten vor; sie sind Standorte überwiegend edaphischer Art.

Dünen können sich bilden auf Flächen wo keine deutlichen Hindernisse des Bodens die Anhäufung des Sandes fördern; wenn eine ganz nackte Düne sich bildet, wird der windwärts gewendete Abhang eine Neigung von nur $5-10^{\circ}$ haben, die Leeseite des Hügels dagegen eine Neigung von ca. $30^{\circ}$. An dieser Seite gleitet der Sand herab und bleibt je nach seiner Korngröße, Kohäsionskraft usw. in mehr oder weniger steiler Böschung, deren Neigungswinkel vom Winde gänzlich unabhängig ist, liegen. Beim Vorherrschen einer bestimmten Windrichtung geschieht die Dünenbildung meist sehr regelmäßig, wenn die Vegetation spärlich ist oder fehlt, wie überhaupt die Form der Dünen sehr von der Vegetation beeinflußt wird $^{2}$ ).

Diese Form der nackten Düne kommt in unseren kalttemperierten Gegenden seltener, und vorzugsweise nur bei jungen und kleinen Dünen vor. In der Regel wird die Anhäufung des Sandes durch Pflanzen veranlaßt, indem diese den fliegenden Sand zwischen ihren Sprossen auffangen oder seine Ablagerung an der Leeseite veranlassen. Weiße Dünen werden solche Dünen genannt, bei denen die Vegetation so spärlich ist, daß die Farbe des Sandes das Gesamtbild der Düne bestimmt; mitunter sind solche Dünen äußerst arm an Pflanzen oder diese

1) Vergl. Hartz u. Kruuse 1911 Figur 9, 15, 19, 24.

2) Vergl. Sokolow 1894; Gerhardt 1900; Cowles 1899; Cornish 1897; Wessely 1873; Warming 1891, 1907-09; Massart 1893, 1898 a, 1908; Wery 1906. 
fehlen so gut wie ganz. Ganz kahle weißse Dünen werden häufig vom Winde in ihrer Form verïndert, werden in der Windrichtung verschoben und heißen dann "Wanderdünen" (vergl. unten).

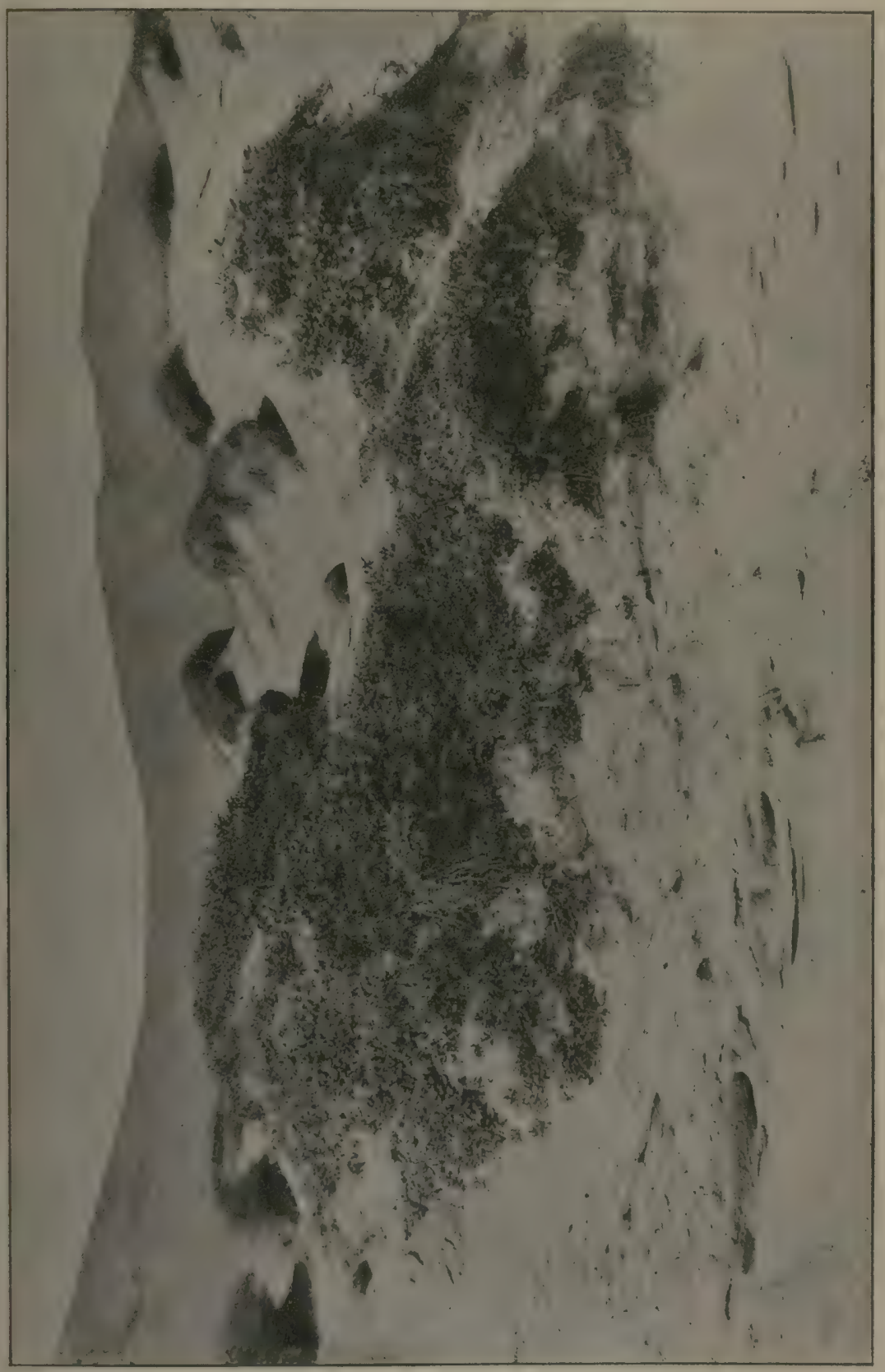

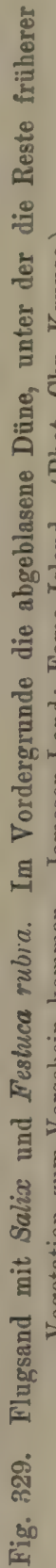


An unseren sandigen Küsten ist die Dünenbildung eine allgemeine Erscheinung. Die Wellen und die Flut werfen Sand, dessen durchschnittliche Größe der Körner in der Regel weniger als $1 / 3 \mathrm{~mm}$ beträgt, auf den Vorstrand, und die Flut kann ihn nicht höher hinaufschaffen. Die Sonne trocknet ihn aus, und der Wind führt ihn darauf fort. Der fliegende Sand lagert sich, wie der vor dem Winde einherfliegende Schnee, überall ab, wo es Ruhe und Schutz vor dem Winde gibt, hinter Steinen, Schneckenschalen, Holzstücken usw., auch um die Pflanzen: es bilden sich kleine Dünen („Dünen-Embryonen“).

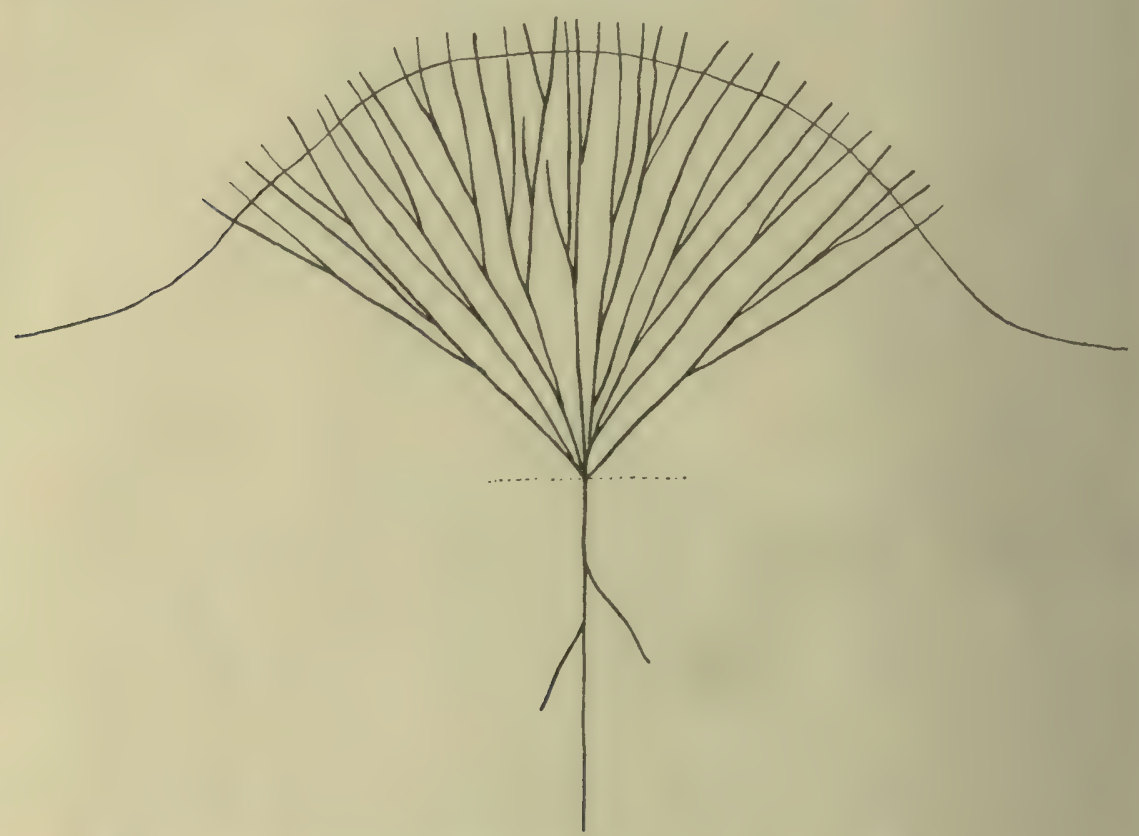

Fig. 330. Schematischer Längsschnitt durch eine kleine Düne auf Cypern, von Medicago marina gebildet. Die punktierte Linie gibt den gemeinsamen Ursprung aller Sprosse an, d. h. die Oberfläche des Sandbodens zur Zeit der Keimung. Die Höhe der Dünen war ca. $1 \mathrm{~m}$, der Durchmesser einige Meter. Die Wurzel wurde in drei Fällen zu einer Tiefe von 44,64 und $71 \mathrm{~cm}$ verfolgt.

(J. Holmboe 1914.)

Die Pflanzen befördern das Höherwerden der Düne, indem der Sand zwischen ihnen zur Ruhe kommt (Fig. 330). Namentlich gilt dieses von gewissen "sandbindenden" Arten, die mit der Natur des Dünenbodens in besonderem Einklange stehen und eigentümliche Lebensformen besitzen, welche man auf allen anderen wandernden Dünen über die ganze Erde antrifft, und welche die Veranlassung sind, daß die Dünenvegetation als besondere Formationen aufgestellt werden muß. Die typischen Dünenpflanzen haben die Fähigkeit, eine Bedeckung durch den zufliegenden 
Sand ertragen zu können und danach wieder durch den Sand zu wachsen; es ist einleuchtend, daß dadurch, daß die neuen Sprosse wieder Sand ansammeln, die Düne immer höher werden muß (Fig. 330). In dem von feinem Sande gebildeten Inneren der Düne wird man eine große Zahl von alten Rhizomteilen, Wurzeln und überirdischen Sprossen finden; reißt der Wind eine alte Düne nieder, so kommen diese Eingeweide der Düne zum Vorschein. In Nordeuropa haben Calamagrostis (Psamma, Ammophila) arenaria und Elymus arenarius besonders ein solches Vermögen, in anderen Gegenden andere, z. B. Medicago marina

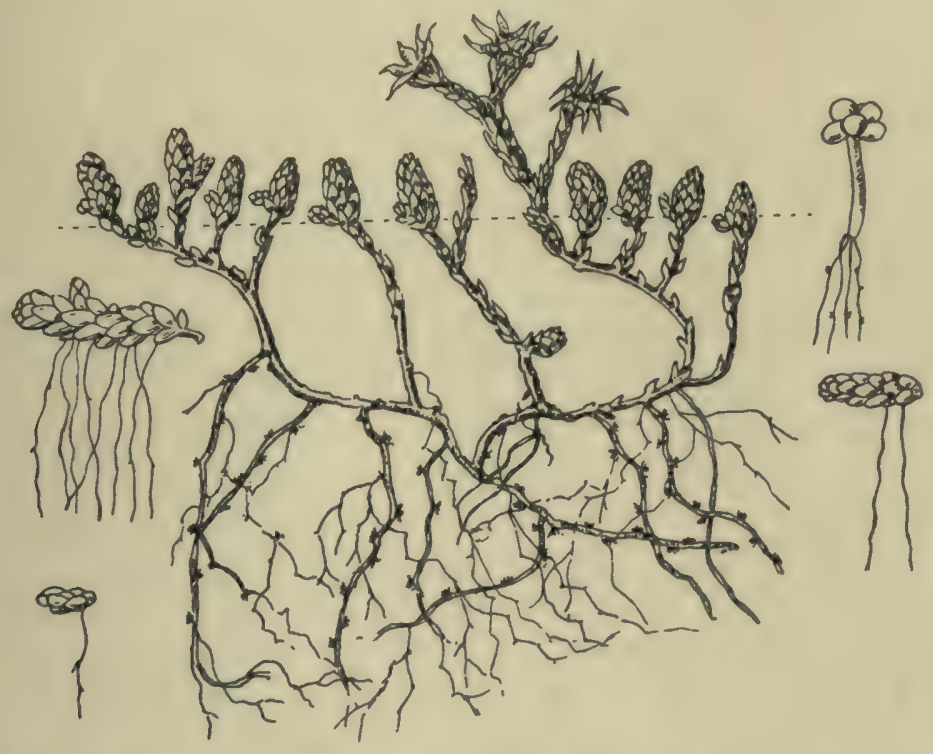

Fig. 331. Sedum aere auf Dünensand. In der Mitte die durch den aufgewehten Dünensand wachsende Pflanze, daneben verschiedene losgelöste Sproßstücke, die einwurzeln. Daneben eine Keimpflanze. (Warming gez.)

auf Cypern nach Holmboe, Aristida pungens und andere in Nordafrika und Asien, Myrica cordifolia und Rhus erenata im Kaplande nach Marloth, usw. Vergl. auch Fig. 219, 220 (S. 440).

Die Düne ist fast durch und durch eine sehr lose Masse, die von den Pflanzenwurzeln und den Rhizomen der auf ihr lebenden Vegetation durchwachsen wird. Solange die Düne noch in dem beweglichen Stadium ist, werden Arten, die an die Stelle gebunden sind, schwerlich existieren können; die Folge ist denn auch, daß die herrschenden Pflanzen auf den flüchtigen Dünen der ganzen Welt solche ausdauernden Arten sind, die mit reich verzweigten Grundachsen kriechen, welch letztere ebenso wie die aus ihnen hervorsprossenden Wurzeln lang 
und strähnig sind. Daß die Pflanzen xerophytisch gebaut sein müssen, leuchtet ein.

Die Pflanzen müssen ständig einen Kampf mit dem Winde führen, der fortwährend bestrebt ist, den Sand weiter zu treiben, wodurch wieder die Pflanzen losgerissen werden. Oft gelingt es dem Winde, in Dünen, die schon mit einer Pflanzendecke versehen sind, große Teile zu zerstören, die Pflanzen loszureißen, große Löcher oder kesselförmige Vertiefungen in den Sandhügeln zu bilden, an deren Wänden die Rhizome und Wurzeln, die "Eingeweide" der Dünen, lang herabhängen und vom Winde in Bewegung gesetzt werden (Windmollen, „blow-outs" der Engländer).

Die Dünen können auf diese Weise in der Windrichtung weiter wandern, sie werden "Wanderdünen", und die Richtung der Hügelketten wird z. B. im nördlichsten Jütland die Richtung der herrschenden Winde auf schöne instruktive Weise angeben, was K. J. V. Steenstrup gezeigt hat ${ }^{1}$ ). Für West- und Ostpreußen vergl. Gerhardt und Abromeit.

In diesen Windmollen beginnt der Kampf zwischen dem Winde und den Pflanzen von neuem, indem von der umgebenden Vegetation ständig Pioniere vorgeschickt werden, um den neuen Boden zu besiedeln; aber diese Pioniere sind wohl meist andere Arten als die, welche die ganz neuen weißen Dünen zu bevölkern beginnen.

In anderen Fällen gelingt es den Pflanzen, welche die Düne mit Hilfe des Windes und des Sandes bildeten, sich stärker zu vermehren und eine immer dichtere Decke zu bilden; in den Zwischenräumen zwischen ihnen finden dann andere Arten ein gutes Unterkommen, kleinere und andere Lebensformen, welche hier Windschutz haben. Die "weiße" und „bewegliche" Düne wird zur "grauen" oder "befestigten". Nach und nach wird die Düne mit einer dichten Vegetation bedeckt, welche den ferneren Angriffen der Winde Trotz zu bieten vermag. Es wird sich dann eine Entwicklungsreihe (Succession) von verschiedenen Formationen ergeben, z. B. Gras- und Krautflur, Zwergstrauchheide, Gebüsch, Wald.

Ein Dünengelände kann ein ungeheuer chaotisches Gemenge von Sandhügeln und dazwischenliegenden Tälern sein, und die Vegetation wird danach meist außerordentlich verschieden sein, je nach dem Alter der Dünen, nach der Exposition (da die der Mittags- und Nachmittagssonne ausgesetzten Seiten viel trockener sind als die entgegengesetzten,

1) Steenstrup 1894 in Meddel. Dansk Geolog. Forening. I. Vergl. Warming 1906-09, wo einige seiner Karten reproduziert sind und wo viele Bilder von solchen Aushöhlungen gegeben sind. Siehe auch: Cowles; Gerhardt 1900 mit vielen Abbildungen; Graebner 1910 mit vielen Abbildungen. 


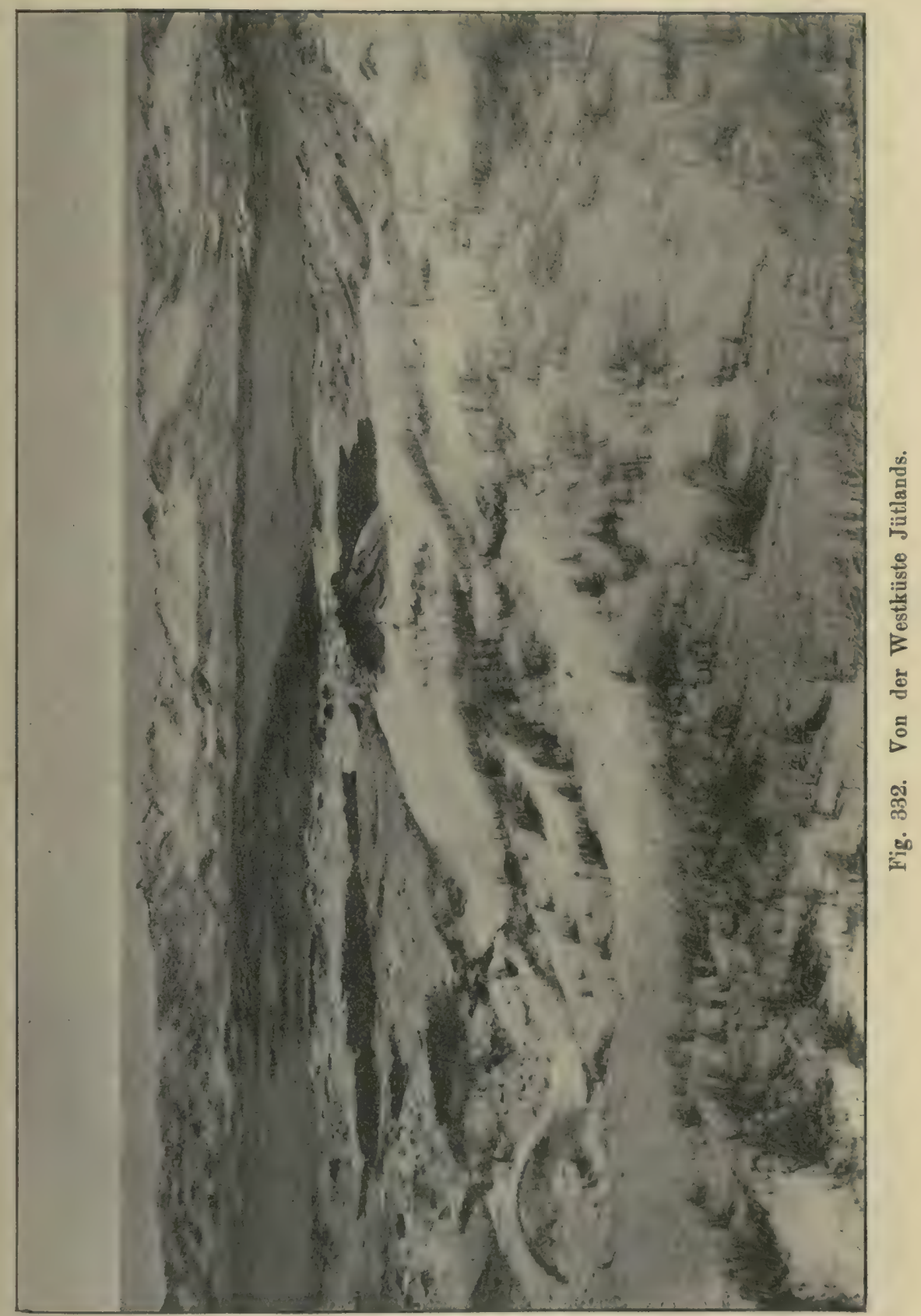

Erklärung zu Fig. 332. Im Hintergrunde die Nordsee. Zwischen der äußeren Dünenkette und einer zweiten inneren liegt eine grüne mit Gräsern und lieblich blühenden Kräutern bedeckte Ebene. Die Dünen im Vordergrunde sind recht offen, nur spärlich mit Calamagrostis (Psamma) arenaria und anderen Pflanzen bewachsen. (Phot. Eug. Warming.) 
viel „grauer", während diese oft frisch grün sind) und je nach dem Abstande der Vegetation vom Grundwasser.

Die Oberfläche der eigentlichen Dünenhügel wird im allgemeinen so hoch über dem Grundwasser liegen, daß die Vegetation von diesem ganz unbeeinflußt ist; viele von den Dünentälern liegen gleichfalls noch hoch über dem Grundwasser, so daß dies auch hier keine Wirkung haben kann; andere von ihnen aber können so tief sein, daß die Pflanzen vom Grundwasser Vorteil ziehen können. Oft finden sich größere, flache Ebenen zwischen den Dünenketten, deren Vegetation dann völlig verschieden ist von der der Sandhügel; während jene grau oder grünlichgelb sind, hier und da vom Winde zerrissen, so daß der gelblich-weiße Sand zum Vorschein kommt, sind diese Dünentäler und Ebenen, wo der feuchte Sand mehr oder weniger humos ist, von einer lieblichen, frisch grünen und blumenreichen, dichten Narbe bedeckt (Fig. 332). In poetischen Worten hat z. B. Buchenau von der bezaubernden Schönheit der Dünentäler an der Nordseeküste gesprochen. Bisweilen liegen diese Ebenen so tief, daß offene Wasserlachen und Teiche mit den Formationen des Süßwassers entwickelt sind (vergl. Fig. 252).

Es ergibt sich von selbst, daß diese Standorte, wo das Grundwasser so hoch liegt, daß Wiesen und mesophile Blumenteppiche sich entwickeln können, oder wo es sogar ans Licht tritt und Teiche und Wassertümpel bildet, nicht zu der hier besprochenen trockenen Sandvegetation gerechnet werden können; der Standort ist $\mathrm{zu}$ verschieden (vergl. Serie II und III).

Dagegen müssen hier solche Sandebenen angeführt werden, wie wir sie z. B. in Jütland und Norddeutschland auf dem alten sandigen Gletscherboden gebildet sehen. Auf diesen mageren, trockenen Sandflächen finden sich ganz dieselben Formationen, welche auf den grauen Dünen hintereinander hervortreten.

Sehr eng schließen sich hieran die Sandsteppen und Sandpußten, z. B. in Südosteuropa, welche so vorzüglich von Adamovié ${ }^{1}$ ) geschildert sind, und welche sich auf trockengelegten Becken des pannonischen Meeres gebildet haben.

Was für die Entwicklung der Vegetation auf einer weißen Düne von großer Bedeutung ist, sowohl inbetreff der Schnelligkeit der Entwicklung, als der Höhe, Dichtigkeit und des Reichtums der Vegetation, ist der Gehalt des Bodens an Nährstoff, besonders an Kalk. Die Dünen Belgiens und Hollands sind weit reicher au Kalk, der von Schalen der Seetiere herrührt, als die nur aus ausgewaschenem, armem Gletschersande bestehenden Dünen der Westküste der jütländischen Halbinsel.

1) Abromeit (1900); Adamovié 1909. 
Es ergibt sich von selbst, daß auch Einmischungen von Humus oder Lehm in den reinen Kieselsand die Vegetation beeinflussen miissen ${ }^{1}$ ).

\section{Kap. Lebensformen und Anpassungen}

Die Lebensformen sind äußerst verschieden, was mit dem Alter des Standortes in Verbindung steht; man trifft jedenfalls in den Dünen der Nordseeküste nicht nur Algen, Flechten und Moose, sondern auch Gräser und Kräuter von den verschiedensten Typen, ebenso Zwergsträucher, Sträucher und Bäume. Dies wird dann verschiedene Formationen nacheinander zur Ausbildung bringen.

Die Pflanzen werden sich überall auf Sandboden, wo das Grundwasser nicht in erreichbarer Tiefe liegt, xeromorph ausbilden. Die Ursachen sind folgende:

1. Es herrschen meist starke Winde, wo es Sandboden und namentlich Dünen gibt; der Wind hat zwei Wirkungen: er trocknet aus (Kap. 5), und die Sandkörner, die er fortführt, wirken mechanisch. Sie können Steine glatt schleifen und bei solchen Pflanzen, die in diese Vereine nicht hinein passen, z. B. bei Pappeln, die auf Flugsandgebieten gepflanzt sind, die dünnen, breiten Blätter durchlöchern ${ }^{2}$ ).

2. Der Nahrungsmangel ist sehr groß; nur in den dem Meere am nächsten liegenden Dünen findet man etwas kohlensauren Kalk, der aus den Schalen der Meerestiere stammit; aber in den weiter entfernten Dünen ist er von dem kohlensäurehaltigen Regenwasser aufgelöst worden. Von Stickstoff und Humus ist äußerst wenig vorhanden; die gebildeten Humusstoffe werden schnell zu Kohlensäure und Wasser oxydiert und verschwinden.

3. Die von der Sonne beschienene Düne erwärmt sich stark und schnell: die Wärme kann in der Oberfläche zur Mittagszeit im Monat Juli bis zu $50-80^{\circ} \mathrm{C}$. steigen (vergl. Giltay 1886); warme Luftströmungen gehen vom Boden aus und treffen die Pflanzen.

4. Das Licht wird vom nackten Sandboden reflektiert und trifft die Blattunterseiten. Die Beleuchtung ist im ganzen stark. Die Sonnenwärme trocknet die obersten Schichten oft ganz aus, so daß die Sandkörner lose liegen, aber in geringer Tiefe ist der Sand doch feucht. Der Temperaturwechsel kann in 24 Stunden sehr stark sein.

1) Utber Dünenbildung in Nordeuropa vergl. Gerhardt 1900; Warming $1909 \mathrm{~b}$; Ostenfeld 1908 b; Reinke 1903 a, b, c, 1909, 1911, 1915; Graebner 1910 b, ff.; Tansley 1911.

9) Uber die furchtbaren Wirkungen der Föhnwinde in Nordostgrünland vergl. Hartz u. Kruuse 1911, mit vielen Abbildungen. Vergl. ferner Massart 1904. 
5. Dazu kommt noch der in den Eigenschaften des Sandes liegende Wassermangel (S. 106 und oben, S. 749).

Das alles trägt dazu bei, der Vegetation des trockenen Sandbodens mehr oder weniger den Charakter einer Wüstenvegetation aufzudrücken; aber, wie Harper bemerkt, die Trockenheit der Dünen liegt im Boden und nicht in der Luft wie in den meisten Dünenregionen; Ascherson verglich oft die physiognomische Ähnlichkeit der Wüstendünen der Sahara mit großen weißen Dünengebieten an der Ostsee oder im norddeutschen Binnenlande.

Die Sandvegetation der an den Meeresküsten oder Salzseen liegenden Dünen wird allerdings etwas von der Nähe des salzigen Wassers beeinflußt; Marloth erwähnt, daß die Sanddünen in Süd-Nanib noch bis gegen $30 \mathrm{~km}$ binnenwärts chloridhaltig sind, aber im allgemeinen läßt sich die Wirkung nicht so weit spüren und wird jedenfalls wohl nur sehr klein sein. Die Sandvegetation ist im ganzen genommen eine xerophile, nicht halophile, enthält deshalb auch keine oder sehr wenig Succulenten. Jedoch ist die Grenze unmöglich scharf zu ziehen, und es gibt ja Assoziationen, wie z. B. die S. 444 erwähnten Strandwälder auf Sandboden, deren Arten nur in der nächsten Nähe des Meeres vorkommen ${ }^{1}$ ).

6. Die biotischen Faktoren auf Sandboden, also solche, welche die Vegetation selbst hervorruft, sind nur wenige: Windschutz und Schatten in den Dünen mit hohen Pflanzen, eine geringe Humusbildung auf altem, mit Vegetation bedecktem Sandboden.

Von der Sandvegetation der verschiedenen Gegenden der Welt muß die nordeuropäische zum Ausgangspunkt genommen werden, weil sie bisher am besten studiert ist. Auch die nordamerikanischen sind vorzüglich studiert (Cowles a. a.). Weiter kann bemerkt werden, daß viele Arten von Dünenpflanzen eine sehr weite geographische Verbreitung haben. Verschiedene europäische Arten finden sich auch in Nordamerika, z. B. Calamagrostis (Ammophila, Psamma) arenaria, Lathyrus maritimus, oder es kommen vikariierende Arten vor, so z. B. von der Gattung Cakile. Maximovicz nennt nicht weniger als sechs Arten, welche sowohl in Nordeuropa, als im Amurlande vorkommen. Aristida pungens spielt eine wichtige Rolle sowohl in der Sahara, als in den Sandwüsten Asiens ${ }^{2}$ ).

1) Vergl. Kearny 1904; Chermeson 1910.

$\left.{ }^{2}\right)$ Anatomie von Sandpflanzen findet sich besprochen z. B. bei: Börgesen und Paulsen 1900; Abromeit bei Gerhardt 1900; Warming 1906-09; Harshberger 1908; Chermeson 1910; A. M. Starr 1912; O. Paulsen 1912. 


\section{Kap. Assoziationen der Sandvegetation in Europa}

Sandboden und Dünenbildung finden sich sowohl im Binnenlande, als an den Küsten, an den letzteren am stärksten hervortretend.

Der Sandboden und seine Vegetation wurde, soweit sie vom Salzwasser des Meeres beeinflußt werden, schon Kap. 50 unter der Halophytenvegetation erwähnt. Es finden sich, wie gesagt, eine Reihe von Formationen mit gürtelförmiger Anordnung längs der Küsten; namentlich folgende:

1. Die Sandalgenformation in dem feuchten Sande der Aestuarien (S. 432).

2. Die Formation der Schwefeleisen-Bakterien; ebendort.

3. Die Formation der einjährigen Halophyten (S. 434).

4. Die Formation der mehrjährigen Halophyten; ebendort.

Als Fortsetzung dieser Formationen folgen dann eine Reihe von anderen, die auch oft gürtelförmig angeordnet sind; es sind etwa folgende;

1. Die weißen oder beweglichen Dünen.

2. Die befestigten, grauen Dünen mit verschiedenen Formationen.

3. Dünenheide.

4. Dünengebuische.

5. Dünenwälder.

Ferner finden sich auf dem flachen oder welligen Sandboden, ohne stets an Dünenbildung gebunden zu sein:

6. Sandfluren des Binnenlandes.

7. Calluneta des Binnenlandes (vergl. Kap. 86).

Die beweglichen oder, weißen" Dünen. Es wurde schon erwähnt, daß verschiedene Halophyten, wie Triticum junceum und Honckenya peploides, beides ausdauernde Arten mit unterirdischen Ausläufern, und auch andere Arten oft den Anfang der Dünen bilden; „Dünen-Embryonen “ entstehen durch sie, auf welchen die hohen eigentlichen Dünengräser sich dann einfinden. Die beiden wichtigsten derselben sind Hordeum (Elymus) arenarium und Calamagrostis (Ammophila, Psamma) arenaria. Alle beide, besonders Psamma, sind Horstgräser mit mächtigen unterirdischen Ausläufern. Elymus hat breite, blaubereifte Blätter, Psamma weit schmälere und rinnenförmige, welche die Fähigkeit haben, sich einzurollen, wenn die Verdunstung zu groß wird (vergl. S. 217), und im Winde sich so zu drehen, daß sie dem Winde den Rücken zuwenden, an dem ein starkes Hypodermalgewebe angebracht ist, so daß die Blätter von der schleifenden Wirkung des fliegenden Sandes nichts zu fürchten haben ${ }^{1}$ ).

1) Morphologie und Anatomie dieser Gräser vergl. Warming 1907-09. 
Alle beide bilden reine Assoziationen. Die Elymeta finden sich gewöhnlich in dem äußersten Gürtel, dem Meere am nächsten. Die Sprosse dieses hohen, stattlichen Grases stehen gewöhnlich zerstreut, so daß die Assoziation recht offen erscheint (rergl. Fig. 41).

Die Psammeta arenariae sind die wichtigsten Dünenbildner an Nordeuropas Küsten, und die Art wird gewöhnlich zur Bepflanzung und Fixierung der Dünen rerwendet (Fig. 333). Die Sprosse sind zu dichteren

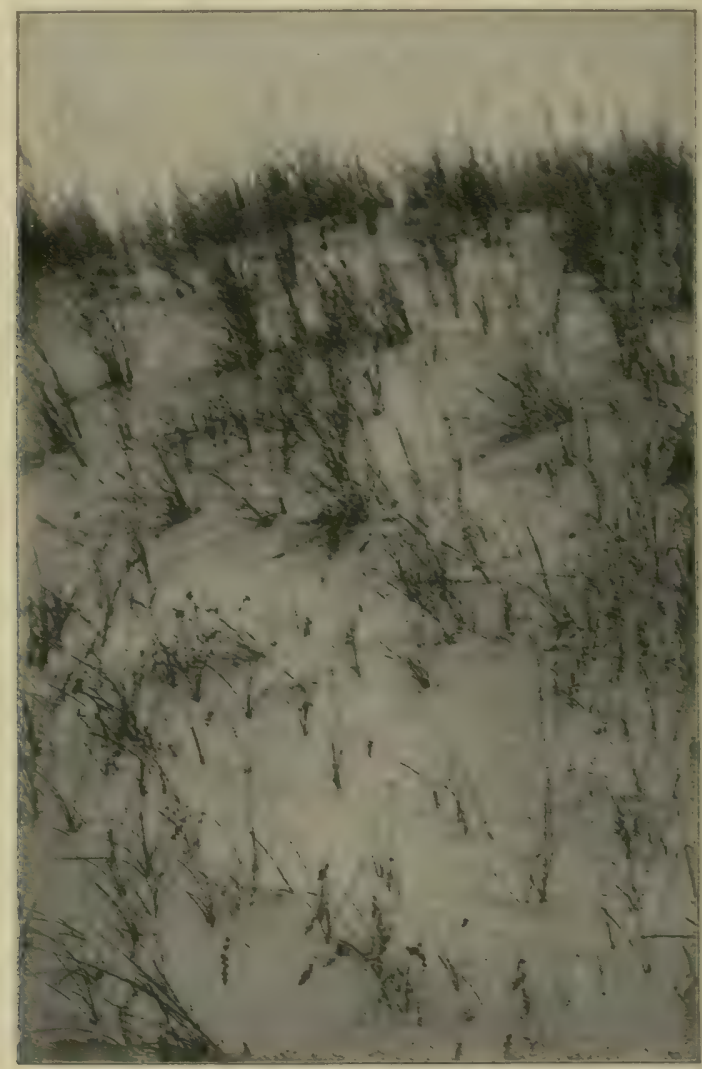

Fig. 333. Dünenpartie im Inneren Jütlands. Calamagrostis (Psamma) arenaria und Carex arenaria. (Phot. F. Börgesen,)

Horsten vereinigt und können eine weit mehr geschlossene Assoziation bilden als die von Elymus. Dasselbe gilt für die weit seltenere Culamagrastis (Psamma) Bultica, die aber jetzt an der Ostseeküste für die künstliche Festigung von Dünen besonders beliebt ist. Die beiden Arten Elymus arenarius und Calamagrostis (Psamma) arenaria können auch auf flachem Sandboden Assoziationen bilden, z. B. auf dem Sandstrande. Durch beide, $0,7-1 \mathrm{~m}$ hohen Gräser banen die Dünen sich höher und höher, wenn sand rom Winde hinzugetragen wird; zwisehen ihren Sprossen 
und Horsten wandern andere Arten ein, und es entstehen nach und nach „die grauen Dünen“.

Verschiedene andere, aber kleinere Arten vom Grastypus können wegen unterirdischer Ausläufer reine Assoziationen bilden, z. 13. Festuca rubra var. arenaria und Carex arenaria; ebenso einige Dikotvlen wie Lathyrus maritimus.

Die Eigentümlichkeiten der Lebensformen, welche besonders durch die Lockerheit des Bodens veranlaßt sind, sind schon früher erwähnt

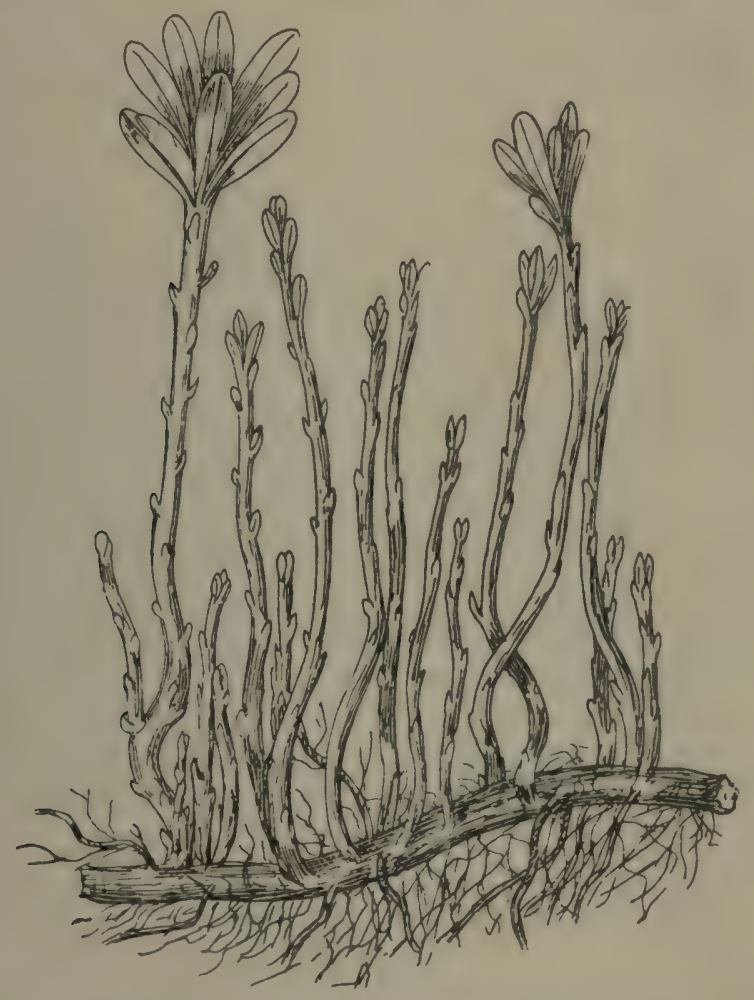

Fig. 334. Hippophaës rhamnoides. Eine flachstreichende Wurzel mit zahlreichen aufsteigenden Adventivsprossen. (Nach Warming.)

worden: es sind besonders Bildung von mächtigen, unterirdischen Ausläufern und die Fähigkeit, vom Sande begraben zu werden und durch den Sand wieder in die Höhe zu wachsen. Die Arten sind in den verschiedenen Gegenden der Welt natürlich sehr verschieden, aber was für die nordeuropäischen Arten gilt, wird in der Hauptsache auch in anderen Weltteilen zu finden sein.

Da der Dünenboden wandelbar ist, weil Meer und Wind ununterbrochen neue Sandmassen zuführen und dieser die I)ünenform unaufhörlich verändert, so werden sich an den Standort gebundene Pflanzen 
nicht in den beweglichen „weißen“ Dünen erhalten können. Die unterirdischen Teile in typisch ausgeprägten Dünen sind daher weit ausgedehnte (viele Meter lange), reich verzweigte Grundachsen; so beim Helm (Calamagrostis [Ammophila] arenaria), der wichtigsten Dünenpflanze Nordeuropas, welcher durch die dichte rasenförmige Stellung seiner Blätter und durch seine Fähigkeit, den Sand anzusammeln und durch ihn hinaufzuwachsen, die anderen weit übertrifft; ferner bei Hordeum (Elymus) arenarium, Triticum junceum, Carex arenaria, Calamagrostis (Psamma) Baltica, Lathyrus maritimus u. a. Hierher kann weiter Hippophaës rhamnoides mit weit kriechenden Wurzeln, welche zahlreiche Wurzelsprosse bilden, gerechnet werden (Fig. 334) ${ }^{1}$ ).

Triticum junceum ist eine von den Sandpflanzen, deren Assoziationen an der Nordseeküste die Dünenbildung auf dem salzigen Sande am Dünenfuße beginnen ${ }^{2}$ ), desgleichen Honckenya peploides, welche an den baltischen Küsten häufiger ist als Triticum junceum, aber sie können nur niedrige Dünen bilden. Calamagrostis arenaria und Hordeum arenarium verdrängen sie und bilden die hohen Dünen. Viele andere Dünenpflanzen haben die Fähigkeit durch über sie gehäuften Sand emporwachsen zu können.

Die feststehenden oder grauen Dünen. In den grauen, befestigten Dünen Nordeuropas werden die erwähnten Eigentümlichkeiten zurückgedrängt, sie stehen eben mit der Reweglichkeit des Bodens in den weißen Dünen in Verbindung (vergl. S. 78). Zwischen den Sprossen von Calamagrostis (Ammophila) arenaria und Hordeum (Elymus) arenarium können sich andere Pflanzen niederlassen, wenn der Wind die Düne in Ruhe läßt; je mehr jene beiden Pflanzen den Sand zur Ruhe bringen, desto mehr bereiten sie anderen Arten einen festen Boden und sich selbst den Untergang vor. Niedrigere Pflanzen mit weniger kräftigen unterirdischen Organen, an den Standort gebundene, ein- oder mehrjährige Pflanzen, wie Erophila verna, Teesdalia nudicaulis u. a., welche eiu Begraben durch den Sand nicht ertragen, finden sich ein; die Vegetation wird immer dichter, auch Moose (Polytrichum, Ceratodon purpureus, Rhacomitrium u. a.), Flechten und einzelne Cyanophyceen siedeln sich an, und ihre Rhizoiden oder Thalli durchwehen und verkitten den Sand: der Boden wird fester und dichter bewachsen (Fig. 338) ${ }^{3}$ ). Auch Arten mit Rasenform oder mit Rosetten und vielköpfiger primärer Wurzel können nun hier gedeihen, z. B. Leontodon auctumnalis, Hypochaeris radicata, Weingaertneria canescens, und zuletzt ist der Boden beinahe

1) Warming 1907-09, Fig. 99-102.

2) Reinke 1909 usw.; Warming a. a. 0. - Vergl oben S. 434.

8) Graebner $1897 \mathrm{ff}$ 
mit einem ganz niedrigen, aber dichten, graugrünen Teppiche bedeckt die "grane Düne" ist gebildet (Fig. 336) ${ }^{1}$ ).

Die Entwicklung geht nicht an allen Seiten der Dünen und Dünentäler auf ganz dieselbe Weise vor sich; floristische Verschiedenheiten und Verschiedenheiten der Lebensformen kommen je nach den ökologischen Verschiedenheiten zum Vorschein.

Die Assoziationen der beweglichen Düne waren alle sehr offen; die Entwicklung geht in der Richtung, den Boden mit immer dichterer

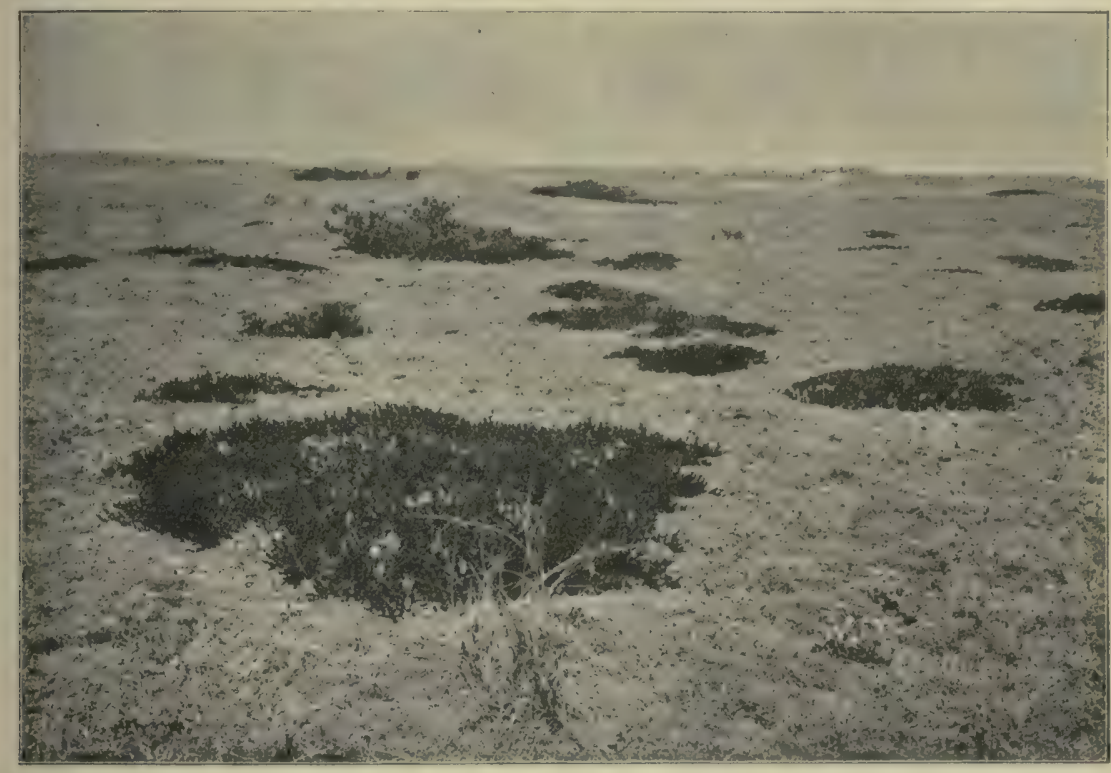

Fig. 335. Ebene in Nord-Seeland. Der Sandboden ist mit einem Teppiche von Cladonia rangiferina bedeckt, in welchen sich eingestreut finden niedrige Polster von Empetrum nigrum (in welchen wieder andere Blütenpflanzen Standorte finden, z. B. Armeria vulgaris, Pulsatilla nigricans, Hieracium pilosella u. a.). Auf dem Bilde sieht man auch ein paar kleine angeflogene Kiefern (Pinus silvestris) und einen Horst von Calamagrostis

(Psamma) arenaria. (Phot. Eug. Warming.)

Vegetation zu bedecken. Jenen beiden Gräsern wird es schließlich zu eng; lange kämpfen ihre unfruchtbaren Sprosse, besonders die des Helms, ums Leben, aber dann unterliegen auch sie; die dichte Narbe, welche jetzt die Sandoberfläche deckt, hindert wahrscheinlich die Atmung ihrer unterirdischen Organe, sie kränkeln deutlich und sterben ab. In den Binnendünen, wo Calamagrostis epigeios eine ähnliche Rolle spielt wie Elymus am Strande, hält sich das genannte Gras viel länger, es

$\left.{ }^{1}\right)$ Utber die Flora vergl. z. B. Warming 1909; Buchenau 1890; Graebner 1910. 
bildet schließlich Bestände, die nur wenige kräftige Arten zwischen sich dulden.

Auf dieser Entwicklungsstufe der Düne, wenn noch die oberflächliche Kruste auf dem Sande dünn und spröde ist, ereignet es sich oft, daß der Wind Löcher in sie reißt, besonders auf den der Sonne am stärksten ausgesetzten Süd-und Südwestseiten, und es entsteht eine Windmolle, wie oben erwähnt.

Die Arten, welche diese entblößte Stelle zu decken sich bestreben, sind durchschnittlich andere als die hohen Dünengräser, welche die weißen Dünen aufbauen; es sieht aus, als ob diese alten Sandmassen, die schon früher Pflanzen ernährt haben und wahrscheinlich mehr oder weniger vom Regen ausgelaugt worden sind, jetzt keine passende Standorte mehr für sie sind; es sind jetzt z. B. Festuca rubra arenaria: Carex arenaria, Lathyrus maritimus, alle mit unterirdischen Ausläufern. weiter auch hapaxanthische Pflanzen, wie Jasione montana, Viola tri. color, Erophila verna, oder büschelförmige Gräser, wie Koeleria glauca Weingaertneria canescens, Festuca ovina u. a., welche die nackte Fläch kolonisieren. Reine Assoziationen können von einigen von dieser Arten gebildet werden, z. B. Weingaertnerieta, Festucetar ubrae, Lathy. reta maritimi.

Unter den anderen krautartigen Pflanzen, welche reine Assozia. tionen bilden können, müssen ganz besonders die Flechten und Moos hervorgehoben werden. Auch Flechtenassoziationen werden sich au altem Sandboden entwickeln können und eine kärgliche Humusbildun hervorrufen.

Verschiedene Arten von diesen Lebensformen wandern mit deI Blütenpflanzen ein, und einige spielen keine geringe Rolle bei der Be festigung des Sandes. Von den Moosen können Polytrichum piliferun (vergl. Fig. 213) und andere Arten genannt werden, ferner Tortula m ralis, Dicranumscoparium, Grimmia ericoides, Ceratodon purpureus später Arten von Hypnum usw. Oft macht Tortula ruralis var. arenicoli den Anfang; sie kann große Assoziationen bilden, in welchen man di kleinen Stengelenden eben aus der Sandfläche hervorragen sieht. Au älterem Dünenboden, besonders in den feuchteren Niederungen, kommes die viel kräftigeren Polytrichum-Arten zur Entwicklung, und durcl ihre reichen Rhizoiden binden sie die Sandkörner zu zusammenhängen den Krusten.

Flechten gedeihen nur, wo kein oder nur wènig flüchtiger San mehr vorkommt; sie wachsen meist zu langsam, um sich auf erheblich Strecken durch Sandüberlagerungen heraufarbeiten zu können. Von de Arten, die sich zuerst einfinden, kann Cornicularia aculeata hervol gehoben werden; später kommen Cladonia rangiferina, $C l$. fimbriat Cl. gracilis, $\mathrm{Cl}$. coccifera und andere Arten, Cetraria nivalis, Stereocaulo: 
paschale u. a. hinzu, und auf älterem Sandboden kann namentlich Cludoniu rangiferina weite, graue Cladonieta bilden - Bild der Flechtentundra (Fig. 337, 336).

Durch das Zusammenwirken von Moosen, Flechten und Blïtenpflanzen kann der Boden zuletzt mit einem dicht geschlossenen Teppiche bedeckt werden ${ }^{1}$ ). Hier und da überwiegen die Blütenpflanzen, sonst die

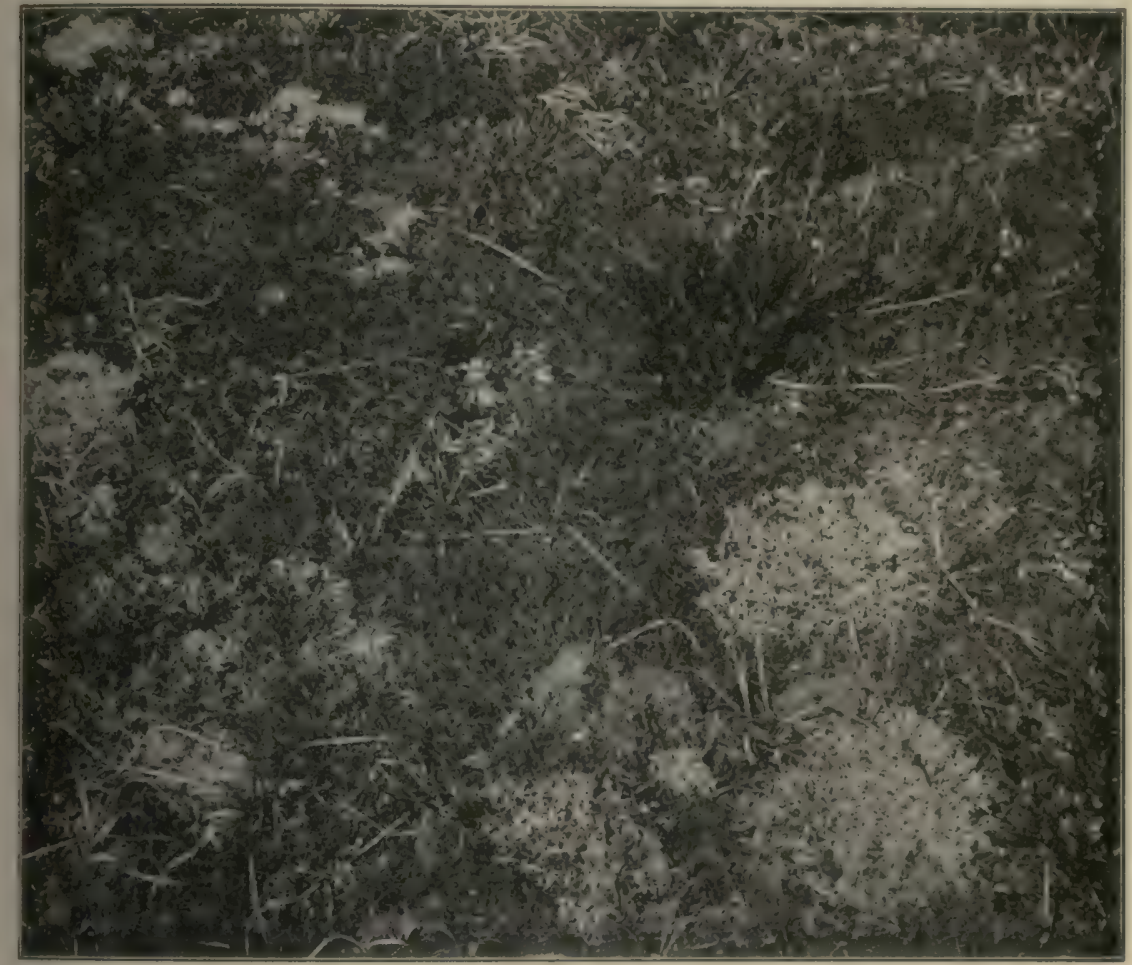

Fig. 336. Oberfläche einer Düne auf der Ostseeinsel Bornholm; 4. Juni. Die Vegetation ist geschlossen, hauptsächlich aus Flechten und Moosen gebildet. Die Hauptuasse ist Cladonia coccifera, $\mathrm{Cl}$. gracilis und $\mathrm{Cl}$. fimbriata. Auch kommt hie und da Cladonia rangiferina vor (z. B. rechts unten), sowie Cornicularia aculeata und Parmelia physodes. Von Blütenpflanzen sieht man hier z. B. Calluna, Blätter von Carex arenaria, Artemisia campestris. (Phot. Eug. Warming.)

Mnose oder die Flechten und bilden kleine, selbständige, eigene Formationen dieser Lebensformen. Durch alle diese Pflanzen wird auch Humusbildung eingeleitet und damit eine weitere bedeutende Veränderung des Bodens: die Luftzirkulation in der obersten Schicht des Sandes wird wesentlich herabgemindert, die Pflanzen können daher ihre

2) Tafel bei Graebner 1910 . 
Wurzeln nicht so tief senden; der Boden wird trockener werden, weil die Verdunstung durch die Pflanzendecke stark vergrößert wird, und damit folgt denn auch eine stärkere Xeromorphie der Pflanzen. Andere Arten werden nach und nach die zuerst eingewanderten verdrängen.

Von den Varianten der Krautdüne muß noch besonders die Hochstaudendüne genannt werden, welche an den baltischen Küsten in weniger windigen Lagen vorkommt und durch ihren Reichtum an hohen Kräutern ausgezeichnet ist (z. B. Hieracium umbellatum [oft alles beherrschend], Epilobium angustifolium, Silene viscosa, Chrysanthemum [Tanacetum] vulgare und andere Stauden von $0,5-0,7$ oder selbst 1 m Höhe).

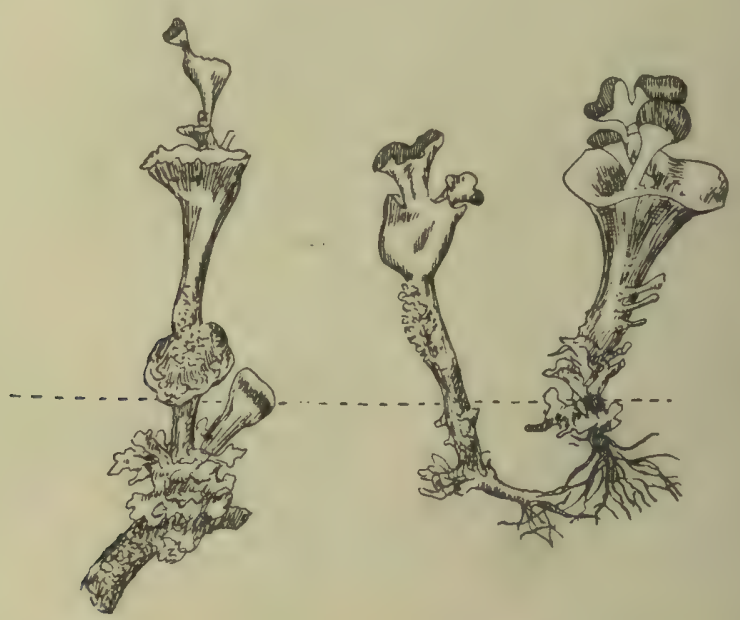

Fig. 337. Cladonia. Allmählich sich erhöhender Boden der grauen Düne, dem die Flechte folgt. (Nach O. Gallöe bei Warming 1909.)

Die trockene Sandflur auf Stellen des Binnenlandes ist großenteils ein Kulturprodukt, das auf altem Heideboden entsteht und öfter wieder zu Heide wird, wenn der Mensch dieses nicht verhindert. Die Sandflur hat wesentlich dieselben Arten wie die graue Düne und mehrere Arten mit der Zwergstrauchheide gemeinsam; die Arten sind genügsam und im ganzen zum Ertragen langer Trockenheit besser ausgerüstet als das Heidekraut usw. Da der Boden meist ein sehr nährstoffarmer ist und sich von dem der Zwergstrauchheide lediglich durch größere Trockenheit unterscheidet, ist diese Vereinsklasse von Graebner $^{1}$ ) als heidekrautloses Sandfeld der Heide angegliedert (verg]. Fig. 335).

1) Graebner $1895 \mathrm{ff}$. 
Zwergstrauch-Vegetation. Die graue Düne behält vielleicht nicht immer diese niedrige Krautvegetation, sondern geht oft in Zwergstrauch-Formation, namentlich in Calluneta vulgaris, die Dünenheide, über: die gewöhnliche Schlußvegetation dieser Entwicklung. Aber auch Salix repens argentea und Empetrum nigrum können öfter eine recht bedeutende Rolle spielen; man findet Dünenseiten und Dünentäler, welche über große Strecken von Saliceta argenteae bedeckt sind, in welche liebliche, schön blühende Kräuter eingestreut sein können.

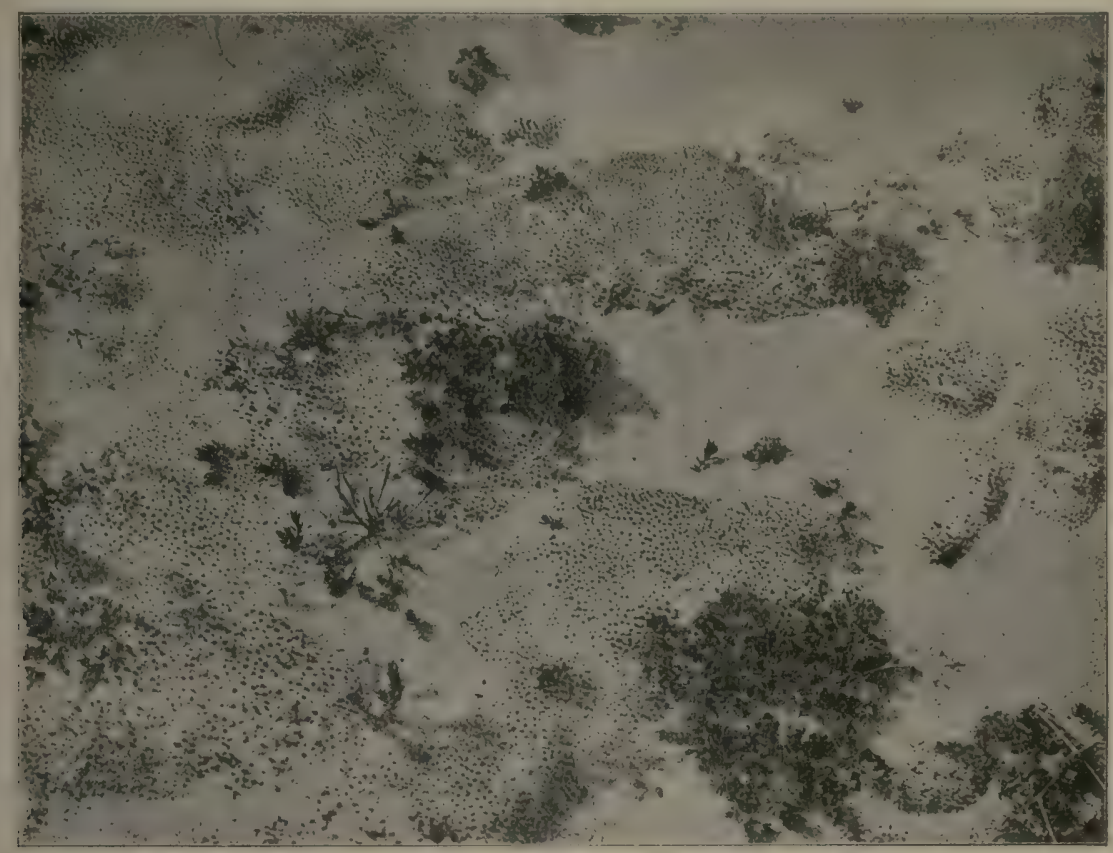

Fig. 338. Düne auf der Nordküste von Seeland.

Der Sand wird zuerst von einer Moosvegetation (Tortula ruralis) befestigt; auf dem Bilde sind auch Exemplare von Cerastium semidecandrum und Thalictrum minus u. a. m. zu sehen. (Phot. Eug. Warming.)

Auch andere Zwergsträucher finden sich ein, z. B. die schöne, weißgelbblühende Rosa pimpinellifolia dunalis ${ }^{1}$ ) und Genista Anglica..

Calluneta vulgaris. Die bedeutendste Rolle spielt jedoch Calluna vulgaris; in einem Abstande vom Meere oft bis zu vielen Kilometern kann sie in den regnerischen Teilen Nordeuropas das ganze Dünenareal erobert haben, Hügel und Täler mit einem niedrigen, braunen Kleide überdeckend. Ganz dasselbe gilt von den alten Binnenlanddünen

1) Graebner 1910, S. 230. 
auf dem Gletschersande, z. B. im Inneren von Jütland. Einen Unterschied gibt es indessen doch im Standorte, insofern als der Sandboden in den Stranddünen sich meist nie in Rohhumus, Bleichsand und Ortstein zu differenzieren scheint, wie es im eisenhaltigen Gletschersande der Fall ist. Das Callunetum mit seiner xeromorphen Vegetation und seiner Rohhumusbildung ist schon unter den Formationen des Torfbodens besprochen worden (Kap. 86).

Ganz wie der Wind große Löcher in den Dünen verursachen oder sie durchbrechen kann, ist er auch imstande, die Heide aufzubrechen, wohl besonders, öfter nur dann, wenn Feuer die Heidevegetation zerstört hat und selbst die Schicht von Rohhumus (Torf) verzehrt hat, oder noch häufiger, wenn auf regelmäßigen Pfaden des Menschen oder der Schafe der Sand unter dem Humus freigelegt ist (vergl. S. 112); der unterliegende Bleisand kann dann ein Spiel seiner Launen werden; Dünen werden gebildet, und solche, die vielleicht spätglazialen Ursprungs oder auch ganz modern sind, finden sich an vielen Stellen der jütländischen Halbinsel, wie in der Lüneburger Heide und anderswo.

Die von der Vegetation befreiten Sandflächen verhalten sich im übrigen wie die Windmollen, da die Pflanzen wie dort so auch hier von neuem bestrebt sind, diese Narbe zu heilen und die sandigen Flächen wieder mit Vegetation zu decken. Auch hier werden es andere Pflanzen als Calluna sein, welche den Anfang bilden, wie z. B. Polytrichum piliferum, das durch seine Rhizoiden die Sandkörner zu festen Decken verkitten kann, ferner Empetrum nigrum u. a.

Gebüsch-Formationen. Hippophä̈ta. Weiter führt die Entwicklung an verschiedenen Stellen in Nordeuropa, namentlich an der Küste, zur Bildung von granen Gebüschen von Hippophaës rhamnoides, welche eine Höhe von mehreren Metern erreichen können und wegen der unheimlichen, langen Zweigdorne undurchdringlich werden können, besonders in abgestorbenem Zustande. Sie haben durch ihre schmalen Blätter, ihre dichte Schildhaardecke und ihre Dornbildung eine ganz xerophile Natur ${ }^{1}$ ). Auf den Dünen der pommerschen Ostseeküste, öfter auch ziemlich binnenländisch, gesellt sich meist ziemlich regelmäßig Salix (daphnoides) Pomeranica als Charakterstrauch bei.

Gebüsche von anderen Salix-Arten und Rosen oder von Populus tremula kommen auch vor, sind aber meist unbedeutend, sehr häufig werden sie als Kunstbestände zur Festigung älterer Dünen angewandt. Auch Kleinwälder von Populus tremula finden sich, obwohl seltener, ebenso (künstlich) von $P$. nigra.

1) Näheres bei Warming 1891, 1907-09, dort 195 Bilder von Dünen und Dünenpflanzen; Buchenau 1895-96; Palmgren 1912; Graebner 1910 usw. 
Bewaldete Dünen. Auf Sandboden, selbst auf Dünen haben Wälder sich hier und da entwickelt, wo die Windverhältnisse es erlauben. Die Westküste Jütlands ist von Natur baumlos, aber in neueren Zeiten sind verschiedene Dünen mit Nadelwald bekleidet worden, namentlich haben Pinus montana und Picea Canadensis ( $P$. alba) Verwendung gefunden; dann, wenn diese den Weg gebahnt haben, auch Picea excelsa, Pinus silvestris, Picea Sitchensis u. a. Auf vielen deutschen Binnendïnen bildet die Kiefer große Bestände je nach der Feuchtigkeit des Bodens mit reicherer bis sehr armer Unterflora.

An den baltischen Küsten, wo die Windverhältnisse günstiger sind, kommt natürlicher Baumwuchs auf den Dünen vor, z. B. auch dort

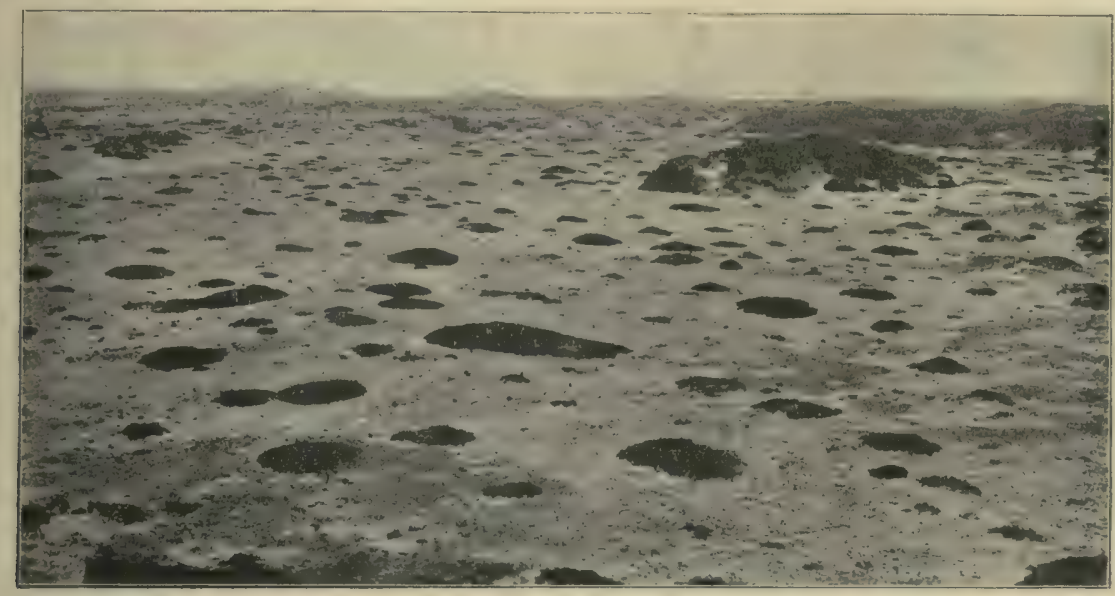

Fig. 339. Kies-Sandflora im Inneren von Jütland.

Der Sand wird zuerst von Polytrichum piliferum befestigt (die grauen punktierten Areale). Auf diesem Boden findet sich Empetrum nigrum ein (die schwarzen Polster). Auch Calluna vulgaris findet sich (mehr halbkugelig als Empetrum), aber noch sparsam. Die Empetrum-Polster sind am höchsten auf der Westseite wegen eingewehten Sandes. (Phot. Eug. Warming.)

natürliche Pineta silvestris, ebenso auf den schwedischen Ostseeinseln usw.

Die Dünenlandschaft um Riga reicht stellenweise bis über $30 \mathrm{~km}$ landeinwärts und ist mit Kiefernwald bedeckt (Pineta silvestris hylocomiosa, cladinosa, vacciniosa, callunosa) nach Kuppfer, also äußerst ähnlich den deutschen Binnendünen. In neuerer Zeit legt man auf vielen Dünen der Küsten wie des Binnenlandes Baumpflanzungen an; auf der kurischen Nehrung Pinus silvestris und $P$. montana, an den Küsten Frankreichs Pinus maritima u. a.

Querceta. Noch kann erwähnt werden, daß krummholz-ähnliche Gebüsche von Quercus pedunculata und Qu. sessiliflora, durch Menschen 
und Wind degenerierte Überreste der früheren Wälder, in Jütland gefunden werden, selbst auf Dünen (vergl. Fig. 222). An einigen Stellen sind sie eigentlich die Gipfel von alten, im Flugsande begrabenen Eichenwäldern, welche sich alljährlich erneuern ${ }^{1}$ ). Eine mesomorphe Bodenvegetation findet sich hier, und wie in allen geschlossenen Wäldern kann Humus entstehen.

Anpassungen der Vegetation auf den, granen Dünen“6. Es ist schon erwähnt worden, daß die Assoziationen der hohen Dünengräser in den nackten oder weißen Dünen anderen Lebensformen angehören, als die Arten der grauen Dünen; je beweglicher der Boden ist, desto mehr wird er von Arten mit weit streichenden unterirdischen Organen (Rhizomen, Wurzeln) und mit lebhafter Bildung von Sprossen und Beiwurzeln bewohnt, den Arten, welche ein Begraben ertragen können und durch die Sanddecke hinaufwachsen; je fester und ruhiger der Boden ist, desto mehr fällt er den anderen Lebensformen zu. In der grauen Düne und auf den trockenen Sandfluren, sowie den trockenen Zwergstrauchheiden kann man Lebensformen mit folgenden Merkmalen unterscheiden:

1. Weit kriechende Rhizome oder Sprosse bildende Wurzeln haben Carex arenaria, Galium verum, Sonchus arvensis, Festuca rubra, Lathyrus maritimus, Sedum acre, Rumex acetosella u. a. Hierher stellt man am natürlichsten auch die Moose und von strauchartigen Pflanzen Hippophaës, Salix repens, Rosa pimpinellifolia u. a.

2. Eine ortsfeste Rasenform haben andere, z. B. von Gräsern Weingaertneria canescens, Festuca ovina, Nardus stricta; von Dikotylen Ononis repens, Anthyllis vulneraria, Eryngium maritimum, Dianthus deltoides, Artemisia campestris, Armeria vulgaris u. a., die fast alle sehr tief gehende Wurzeln besitzen. Einige sind gestrecktgliedrig, andere haben Rosettensprosse. Hier schließen sich Zwergsträucher wie Calluna und Empetrum, wie auch der Halbstrauch Thymus serpyllum an.

3. Viele Arten haben Sprosse, die auf dem Sande niederliegen, ihm angedrückt sind (ohne Wurzeln zu schlagen), und Blätter, die von dem gemeinsamen Ausgangspunkte, dem oberen Ende der primären Wurzel ausstrahlen (Beispiele Artemisia campestris, Ononis).

4. Einige wenige haben oberirdisch kriechende Sprosse: $A n$ tennaria dioeca, Hieracium pilosella, Polypodium vulgare, Thymus serpyllum, Sedum acre, von den Zwergsträuchern Empetrum nigrum.

5. Endlich findet man sehr viele einjährige und einjährig überwinternde Arten (vergl. Fig. 338), die darauf hinweisen, daß die Düne viel von der Natur der Steppe besitzt; sie keimen im Herbste

$\left.{ }^{1}\right)$ Warming 1909; Fig. vorne auf S. 442. 
oder im Frühjahre, entwickeln sich und blühen in dem zeitigen Frühjahre, schließen aber vor dem Beginne der Sommerhitze ihr Leben ab, weil der warme Boden die Entwicklung befördert (Trifolium arvense, Filago minima, Aera praccox, Bromus mollis, Phleum arenarium usw. Von den einjährig-überwinternden Arten können Jasione montana, Erophila verna, Cerastium semidecandrum, C. tetrandrum und Teesdalea nudicaulis genannt werden). Hiernach würde auch das angeblich nur einmal blühende (oft allerdings vieljährige) Eryngium maritimum gehören. Diese hapaxanthen Arten fangen übrigens an, sich schon in den beweglichen Dünen zwischen den hohen Dünengräsern einzufinden (vergl. Fig. 41).

Was weiter die Anpassungen der krantartigen Pflanzen betrifft, sind sie im ganzen genommen niedrig und haben kleine oder schmale Blätter, meist mit ausgeprägter Xeromorphie in enger Übereinstimmung mit den ökologischen Faktoren, die oben genannt wurden. Im Einklange mit der Trockenheit, der Sonnenhitze und dem Nahrungsmangel steht das zahlreiche Auftreten der kleineren, einjährigen, schnell blühenden Pflanzen.

Die mehrjährigen Kräuter, die Gräser und die Sträucher sind im ganzen kleinblättrig, schmalblättrig; die wesentlichste Ausnahme hiervon bilden Hordeum (Elymus), Calamagrostis (incl. Ammophila) und einige andere auf den weißen Dünen wachsende Pflanzen, die hoch und kräftig sind, was dadurch verursacht sein wird, daß die Wanderdünen wasserreicher und wohl auch nahrungsreicher sind als die bewachsenen und feststehenden Dünen. Die meisten Gräser haben tief gefurchte Blätter, die sich einrollen können (Calamagrostis [Ammophila], Triticum junceum, Nardus, Festuca ovina u. a.); kein Gras hat breite, saftige und hellgrüne Blätter. Hordeum arenarium hat zwar breite Blätter, die jedoch wie bei Triticum junceum durch eine Wachsschicht blaugrün sind. Mit Wachs bedeckt sind auch die Blätter von Lathyrus maritimus, Eryngium maritimum, Mertensia maritima, Glaucium flavum, Crambe maritima u. a. Wollhaarig sind z. B. Salix repens argentea, Gnaphalium und Antennaria; schildhaarig ist Hippophaës; auch stark drtisenhaarige Pflanzen findet man, deren Oberfläche von Sandkörnern dicht bedeckt wird (Senecio viscosus, Ononis repens, Cerastium semidecandrum u. a.). $\mathrm{Zu}$ den Tunicagräsern gehören Nardus und Koeleria glauca (s. S. 234, Fig. 118).

Nicht wenige Arten setzen die Transpiration dadurch herab, daß sie ihre Blatter senkrecht stellen (Salix repens) oder stark kräuseln (Eryngium). Vesque und Giltay haben darauf aufmerksam gemacht, daß der bei einem Teile der Sandpflanzen vorkommende dorsiventrale Bau mit Palisadengewebe auf der Blattunterseite, obgleich die Blattspreiten wagerecht sind, dem vom Sandboden reflektierten, starken Lichte zugeschrieben werden muß. 
Dornbildungen kommen bei Hippophaës vor und machen dessen Gebüsche fast undurchdringlich, ferner bei Eryngium, Genista Anglica, G. Germanica und Ononis (S. 263).

Gleichfalls kann angeführt werden, daß die Blätter vieler Pflanzen, namentlich von Rosettenstauden, oft dem Boden fest angedrückt sind (z. B. Sonchus arvensis, Leontodon auctumnalis, Hypochaeris radicata, Taraxacum), und daß viele Arten ihre Sprosse im ganzen wagerecht über dem Sande ausbreiten, vermutlich wegen der Wärmeverhältnisse ${ }^{1}$ ).

Von Succulenten gibt es nur einige Arten (Sedum acre).

Als Schutz gegen die mechanische Wirkung des Windes dienen die oben erwähnte bemerkenswerte Fähigkeit des Helms, seine Blätter in großem Bogen mit der Rückenseite gegen den Wind zu wenden, und diese festen, kahlen und glänzenden Blattrückenseiten selbst, die mit hypodermalem Sklerenchym versehen sind. Ferner sind die großen Blattscheiden, welche die Blütenstände des Helms, von Hordeum arenarium, Weingaertneria u. a. lange umschließen, offenbar ein guter Schutz gegen jene Wirkung.

Tief gehende und wenig verzweigte Wurzeln, die teils das Losreißen verhindern können, teils Wasser aus großen Tiefen heraufschaffen können, wenn die Oberfläche ausgetrocknet ist, haben viele Arten, z. B. Calamagrostis arenaria, Hordeum (Elymus) arenarium, Carex arenaria (zweierlei Wurzeln; vergl. Buchenau, Warming) und Eryngium. Die Wurzelhaare der grasartigen Pflanzen funktionieren lange; die Sandkörner haften an den Wurzeln mehrerer Arten, z. B. beim Helm, Koeleria glauca und beim Strandhafer mit besonderer Kraft fest, und bilden Sandröhren um sie, welche gegen Vertrocknung schützen können, falls sie losgerissen werden sollten. Es ist dieses ein spezifischer Wüstencharakter $^{2}$ ).

Unserer nordischen Vegetation am ähnlichsten ist natürlich die an anderen Küsten Nordeuropas vorkommende; aber es kommen andere Arten hinzu, z. B. Euphorbia paralias und Convolvulus soldanella in Nordwestdeutschland, Holland und weiter südlich. Eine große Reihe von Forschern haben sich mit der englischen, holländischen, belgischen Sandvegetation, besonders den Dünen, beschäftigt ${ }^{3}$ ).

Im Innern von Norddeutschland kommt, wie bereits oben erwähnt, Sandboden (Gletschersand) mit Sandvegetation und hier und da mit oft mächtigen Dünenbildungen vielfach vor. Bis auf die allerdürrsten, wie

1) Warming $1907-09$, S. 259. Fig. 46, 154, 155.

") Vergl. Volkens 1887; R. Price 1911; oben S. 235.

$\left.{ }^{8}\right)$ Litteratur über nordeuropäische Dünen. Abromeit 1900; Buchenau 1889; Gerhardt 1900; Giltay 1886; Graebner 1895 a, 1901, 1910; Hesselman 1908 a; Massart 1893, 1908, 1912; Preuß 1910; Raunkiär 1889, 1909 b, 1913; Reinke 1903 b, 1909, 1911, 1912, 1915; Warming 1891, 1907 (1909); Thekla Resvoll 1906. 
sie besonders im östlichen Teile verbreitet sind, sind die meisten mit Kiefern und Birken bewachsen. Ihre charakteristische Flora zeigt oft viele Vertreter der Pflanzen der sonnigen Diluvialhügel (Steppen) und daneben die typischen Sandbewohner, wie z. B. Dianthus arenarius, Astragalus arenarius, Heliotropium arenarium, Antennaria dioeca, Helichrysum arenarium, Euphorbia cyparissias, Potentilla arenaria und Verwandte, Sedum-Arten, Calamintha acinos, Verbascum-Arten, Galium verum und G. mollugo, Hieracium pilosella und viele andere, dazu die Pulsatilla-Arten, besonders $P$. pratensis. Mit Ausnahme der heißesten

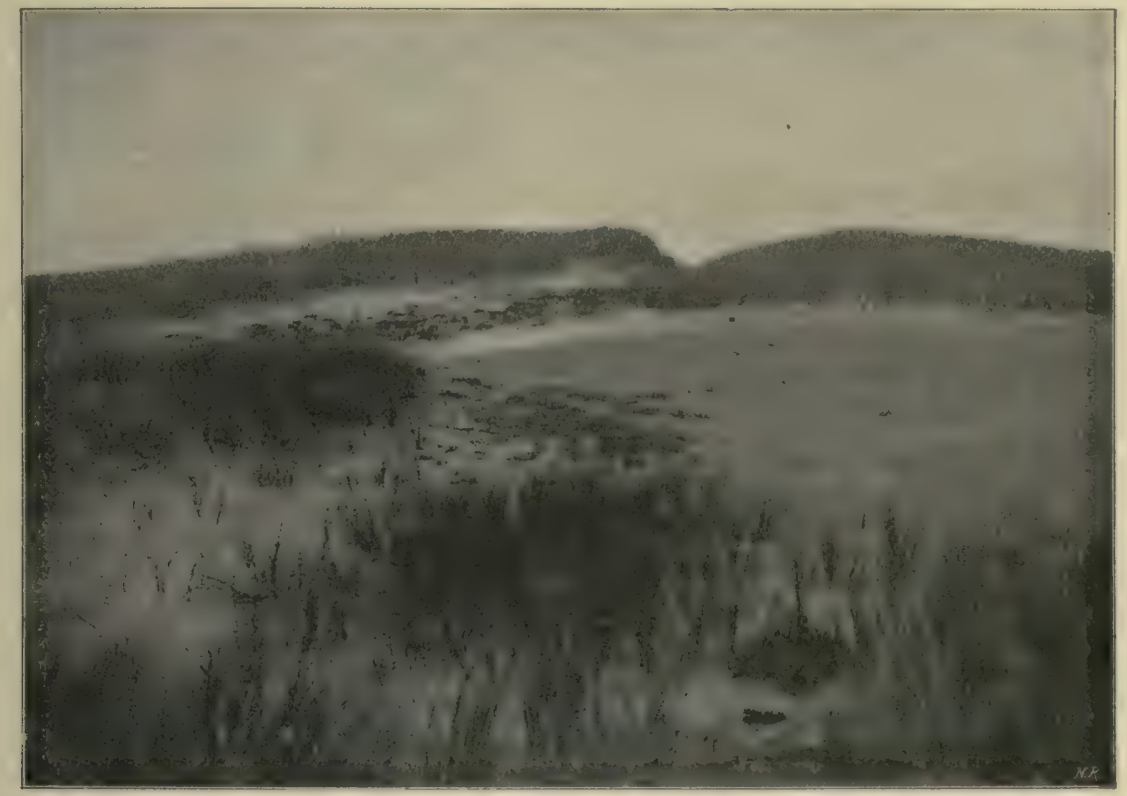

Fig. 340. Düne auf den Färöern.

Die Vegetation besteht hauptsächlich aus Calamagrostis (Psamma) arenaria und Honckenya peploides. (Phot. Eug. Warming.)

Zeit zeigt die Vegetation fast das ganze Jahr Blütenschmuck. Von grasartigen Pflanzen sind meist in großen Mengen, oft größere Bestände bildend, zu finden: Calamagrostis epigeios, Carex arenaria, Festuca ovina, F. rubra, Weingaertneria canescens usw., anch Rumex acetosella überzieht oft große Strecken durch ihre zahlreichen Wurzelsprosse (Fig. 73). Von Gehölzen bildet besonders Sarothamnus scoparius oft große Bestände, die die Landschaft im Frühjahr oft weithin gelb färben. Des Vorkommens vieler einjährig überwinternder Arten wurde schon oben gedacht ${ }^{1}$ ).

1) Graebner 1909, 1910 b. 
Auch im Süden Europas treten ähnliche Sandvegetationen auf, z. B. auf dem alten Meeresboden der ungarischen Ebenen; Borbas und Kerner ${ }^{1}$ ) haben dessen Vegetation geschildert. Hier findet man im Einklange mit dem losen Boden dieselben meterlangen Wurzeln und Rhizome (z. B. bei Festuca vaginata, die hier die Rolle des Helms zu spielen scheint) und denselben Schutz gegen Transpiration; von hier werden auch knollenförmige unterirdische Organe angeführt.

Adamovié $^{2}$ ) hat die Dünen Serbiens geschildert. Hier sind die ersten Ansiedler das einjährige Polygonum arenarium und Veronica triphyllos; ihnen folgen Medicago minima, Bromus-Arten, Viola tricolor u. a. Später kommen dann auch zweijährige und ausdauernde Kräuter vor. Vom zweiten Jahre an erscheinen die ausdauernden Pflanzen, und es bilden sich verschiedene Assoziationen, wie die Festuca-Assoziation, die Euphorbia-Assoziation u. a. Sanddünen können in die Sand-Pußta bezw. die Sandsteppe übergehen.

Der Dünensand ist übrigens verschieden; teilweise ist er aus verwittertem Nummulithenkalk gebildet, und auf diesem kommen eine Menge kalkliebender Pflanzen vor. Die Sandmassen werden teils von kriechenden Stengeln, teils von starken, langen Wurzeln durchzogen. Dünen, Sandsteppen, samt Wäldern auf Sandboden in Südrußland siehe Novopokrovskij in Englers Jahrb. Bd. 50.

Die Dünen der Färöer (Fig. 340) vergl. bei Ostenfeld 1908, die von Island bei Jonsson 1905 und Thoroddsen 1914. Nach Thoroddsen ist Hordeum (Elymus) arenarium das am meisten charakteristische Gras. oft mit Festuca rubra arenaria und, wenn der Sand ruhiger geworden ist: mit anderen Arten gemischt. Ausgedehnte Strecken werden von SalixArten bedeckt, und auch Betuleta können auftreten. Der Flugsand is1 oft schwarz, vulkanischer Herkunft; die Neubesiedelung der Windmoller wird auch von ihm besprochen. Wenn in diesen und anderen Fälle Gesträuche und selbst Wälder sich auf den Dünen oder jedenfall: auf Flugsand entwickeln können, so mag der Grund dazu wohl darir zu suchen sein, daß tiefgehende Wurzeln ihnen das nötige Wasse: verschaffen.

Was die Polargegenden betrifft, so sind z. B. die grönländisches von Rosenvinge, Porsild und Hartz und Kruuse ${ }^{3}$ ) besprochen worden die des Weißen Meeres von Pohle ${ }^{4}$ ); hier fehlt Calamagrostis (Psamma arundinaria und wird durch Hordeum (Elymus) arenarium, Juncacee! und andere Spezies ersetzt.

1) Kerner 1863 .

2) Adamović 1904, 1909 a.

2) Rosenvinge 1896; Porsild 1902; Hartz und Kruuse 1911.

4) Pohle 1903. 
Chodat ${ }^{1}$ ) schilderte die Dünen am siidufer des Genfer sees, und in Verbindung damit die Assoziationen der strandvegetation und der Flußufer. Er führt ein neues Wort, "Garide", in die Wissenschaft ein, um eine Vegetation zu bezeichnen, welche mit den französischen Garigues Ähnlichkeit hat und auf "aridem", also sehr trockenem Boden vorkommt; er vergleicht sie mit der deutschen ,Steppenheide“, sie hat aber floristisch und morphologisch große Ähnlichkeit mit der 1)ünenvegetation. Sie kommt im Rhonetal und in den Jurabergen vor, auf offenen, besonnten und auch mehr oder weniger steinigen Lokalitäten; daher sind die Pflanzen xeromorph, kleinblattrig, behaart, niedrig, gekrümmt usw.; sie haben oft unterirdische Wasserbehälter und ein großes Wurzelsystem. I)ie Vegetation ist besonders zusammengesetzt aus Sträucheru wie Juniperus communis, Berberis vulgaris, Ligustrum vulgare, Arten von Rosa u. a., ferner aus einer Reihe von Halbsträuchern und Krïutern, darunter auch psammophile Arten, die sich zum Teil auch in der Landvegetation an der mediterranen Küste wiederfinden. Es scheinen die Gariden zwischen die Sandfluren und die Steinfluren der Garigues gestellt werden zu müssen.

Die Dünen an der Mittelmeerküste sind niedrig und unbedeutend; die Flora ist von der unserer nordeuropäischen Dünen recht verschieden, namentlich viel reicher an Arten, und es scheinen viel mehr Arten graufilzig zu sein. Die sandbindenden Gräser sind Calamagrostis (Psamma) arenaria, Cynodon dactylon u. a. Selbst so weit gegen Osten, wie auf Cypern, gehören Triticum junceum und Calamagrostis (Psamma) arenaria zu den wichtigsten sandbindenden Arten, aber neben ihnen ist z. B. Imperata cylindrica zu nennen ${ }^{2}$ ).

Im Rhonedelta sind die Dünen mit fast undurchdringlichen aromatischen Macchien bewachsen, deren Gebüsch aus Juniperus Phoenicea (die 6-8 $\mathrm{m}$ hoch wird), Pistacia lentiscus, Plillyrea angustifolia, Tamurix Gallica, Ruscus aculeatus u. v. a. besteht. Auf alten Dünen bilden sich oft Wälder von Pinus pinea oder P. Halepensis mit Macchia- oder Gariguepflanzen als Unterholz.

Sandvegetation wie die behandelte mit ähnlichem oder anderem Schutz gegen Transpiration, mit vielen bei uns in Europa unbekannten Lelensformen findet man auch sonst auf der Erde, sind aber (Nordamerika ausgenommen) bisher ökologisch wenig untersucht worden. Wir müssen uns mit zerstreuten Notizen begnïgen.

2) Chodat 1902 .

$\left.{ }^{2}\right)$ Flahault 1893; Flahault und Combres 1894; Raunkiär 1909 b, 1914; Holmboe 1914. 


\section{Kap. Dünen außereuropäischer Länder}

Die Ökologie der Sandpflanzen anderer Länder ist im ganzen weniger bekannt. Doch sind einige Züge hier und da erwähnt, welche zeigen, daß die wichtigsten obengenannten Eigentümlichkeiten auch dort zu finden sind; z. B. hat der dänische Botaniker $\mathrm{Hj}$. Jensen ${ }^{1}$ ) Spinifex squarrosus in Java erwähnt und abgebildet; er sagt ausdrücklich, daß diese Pflanze die Rolle von Elymus und Psamma in Nordeuropa übernimmt; sie hat ebenso lange Ausläufer, aber sie sind oberirdisch wi€ bei verschiedenen anderen tropischen Dünenpflanzen ${ }^{2}$ ).

Afrika. In Afrika werden die Faktoren der Sandböden mit der Faktoren eines Wüstenklimas kombiniert, und die Vegetation wird dahes noch extremer xeromorph als in Nordeuropa; wir kommen hier zu deI Sandwüsten mit ihren Dünen, im Osten von Nordafrika Areg und Igidi im Westen Erg genannt.

Die ungeheuren Gebiete mit Sandboden finden sich teils an des Küsten, teils im Inneren (Sahara usw.). Echte Flugsanddünen finde man in der Sahara (Fig. bei Schirmer und Massart 1908) und ron da bi nach Syrien, Turkestan usw.; sie erreichen eine Höhe von 100-300 m un sind oft fast ganz pflanzenleer. Die Dünen entstehen oft um Sträuches welche den Sand aufsammeln (Astragalus-Arten, Genisten, Tamarisker Calligonum comosum u. a.), und welche auch befähigt sind, mit der sich ständig anhäufenden Sande im oberen Teile weiter zu wachsen. Vo Charakterpflanzen, die sonst noch hier vorkommen, können genannt wer den: Aristida pungens, Genista Saharae, Retama monosperma, Euphorbi Guyoniana, Scorzonera, Scrophularia Saharae, Reaumuria vermiculat, Saccocalyx satureoides, Ephedra alata u. a., die man teilweise in de Sandwüsten Asiens wiederfindet.

Die Vegetation ist am Tage der brennendsten Hitze und nacht einer bedeutenden Kälte ausgesetzt; hier gibt es eine sehr lange trocken Zeit und eine kurze Vegetationszeit; oft fällt jahrelang kein Regen. Di Pflanzen müssen dazu eingerichtet sein, teils sich gegen jene zu schützel teils diese auszunutzen (vergl. Kap. 114, Wüstenvegetation).

In den Dünentälern ist die Vegetation anders als auf den Düne! hier kann eine halbstrauchartige Artemisia, die bis $0,6 \mathrm{~m}$ hohe A. mon sperma, oft weithin die Täler überziehen. Es kann dabei bemerkt werde. daß der Sand den Regen aufnimmt, und auch hier wie im allgemeint unter der Oberfläche (S. 106 f.) feucht ist, daher die Sandwüsten für d:

i) Hj. Jensen 1905.

2) Vergl. auch Ipomoea pes caprae, Canavalia u. a., Kap. 50. 
Pflanzenleben weit ginstiger sind als Felsen und Felshlock- oder Steinwüsten. Vergl. im übrigen Kap. 114-116: Die Wüsten ${ }^{1}$ ).

C̈ber Socotra schreibt Engler, daß die trockene, von Flugsand bederkte Ebene im Süden eine extrem xeromorphe Wüstenflora beherbergt. Fast alle Pflanzen zeigen das den Wustenpflanzen eigene (iraugrün der Sprosse und Blätter, manche auch dichte Behaarung. Hahituell sind es dornige Halbstrïucher mit sparrigen Ästen und kleinen oder ganz reduzierten Blättern, ferner Stauden mit tiefgehenden Grundachsen, Succulenten und Einjährige.

Auch Deutsch-Südwestafrika hat dichte, hier und da undurchdringliche Gebüsche, die die Dünenhügel des Strandes mit Lebensformen bedecken, welche entweder zu der Eriken-, der Myrten- nnd der Oleanderform, aber zu sehr verschiedenen Familien gehören, oder welche durch eine stark wollige Behaarung oder auf andere Weise gegen starke Transpiration geschützt sind. Ein sehr merkwürdiger Strauch der afrikanischen I)ünen ist die Naras, die Cucurbitacee Acanthosicyos horrida, welche die Höhe eines Mannes erreicht. Ihr fehlen Blätter; aher Dornen sitzen auf den verfilzten Zweigen, in welchen die Spaltöffnungen in tiefen Furchen versteckt sind, paarweise so dicht und in solcher Menge, dalß undurchdringliche Gebüsche, wie unsere Hippophä̈s-Gebüsche, entstehen. Die Wurzeln können $15 \mathrm{~m}$ lang und länger werden und die I)icke eines Armes erreichen; sie dringen bis zum Grundwasser hinab. I)ie Winde häufen den Sand um die Pflanzen auf, aber die Sprosse wathisen mit den Sandmassen und kommen wieder nach oben, ganz wie der Helm in unseren Dünen. Marloth erwähnt auch andere Pflanzen der Sandfluren ${ }^{8}$ ).

I)ie Vegetation Südafrikas weicht offenbar, weil das Klima ganz anders ist, von der Sandvegetation Nordafrikas bedeutend ab. Narloth ${ }^{3}$ ) schildert die Dünenvegetation des Kaplandes. Als wichtiger Strauch wird Myrica cordifolia mit zahlreichen unterirdischen Zweigen erwähnt. Chymocorea empetroides scheint an die Nähe des Meeres gebunden zu sein. Die meisten Dünensträucher gehören zu Familien, welche in der afrikanischen Flora weit verbreitet sind (Anacardiaceen, Celastraceen, Ellenaceen, Santalaceen u. a.). Auf den Dünen werden auch australische Acacien angepflanzt, welche ebenso gut wie in Australien gedeihen (z. B. A. suligna, A. cyclops). Nach Ėngler kann man unterscheiden: 1. tiefen, lockeren, trockenen Steppensand, welcher ausgelangt ist und nur wenig Nährstoffe enthält; er trägt oft hochstämmigen, meist unter-

1) Utber die afrikanischen Dünen vergl. Flahault; Rikli und Schröter 1912; Brorkman-Jerosch und Heim 1908; Massart 1898 a.

$\left.{ }^{2}\right)$ Marloth 1888 .

3) Marloth 1908. 
holzlosen, lichten Trockenwald von laubabwerfenden Bäumen, welche jedoch infolge des in ihren Wurzeln und Stämmen aufgespeicherten Wassers noch grünes Laub während des größten Teiles der Trockenzeit besitzen und sogar während derselben blühen und Früchte bilden; 2. nicht tiefen Sand über steinigem Boden, mit armem Buschgehölz besetzt, welches sich stellenweise zu undurchdringlichem Gestrüpp verdichtet; 3. humosen, lehmigen Sand mit größerer Grundfeuchtigkeit, auf welchem sich Ufer-oder Niederungswald entwickelt.

Auf den Hochebenen des Kaplandes kommen stellenweise Sandebenen vor, welche ganz vegetationslos sind. Es kommen auch andere Ebenen mit tiefem, beweglichem Sande vor, welche zu gewissen Jahreszeiten ganz überschwemmt sind. Hier entwickelt sich eine sehr verschiedene, eigentümliche Vegetation, hauptsächlich durch Restionaceen charakterisiert, Restionaceen-Heiden ${ }^{1}$ ).

Es ist offenbar, daß sich hier Sandböden vorfinden, deren Vegetation nach den edaphischen und klimatischen Faktoren sowohl unter sich recht verschieden ist, als auch von derjenigen der nordafrikanischen Wüsten bedeutend abweicht. Es muß der Zukunft überlassen sein, das Nähere hierüber aufzuklären.

Asien. Nach den klimatischen Verhältnissen ist die Vegetation der Sandfelder und Sanddünen sehr verschieden. Es kann z. B. angeführt werden, daß auf den Sanddünen der Kirgisensteppen Pinus, Betula, Populus, Salix und Ulmus zusammen wachsen. Die meisten Sandgegenden scheinen sonst typische Sandwüsten zu sein. Kotschy schildert das unendliche, isabellgelbe Sandmeer östlich von Suez; Dünenbildung veranlaßt hier z. B. Nitraria tridentata. Die besten sandbindenden Pflanzen der transkaspischen Steppen sind Carex physodes und Aristida pungens. Auf Sandboden treten außerdem die teilweise blaugrünen und blattlosen Arten von Calligonum, Pteropyrum, Ephedra und Ammodendron (Papilionacee) auf, auch die merkwürdigen, bis $3-8 \mathrm{~m}$ hohen und bis über $1 \mathrm{~m}$ dicken (gewöhnlich doch nur $15-30 \mathrm{~cm}$ starken) Saxaul-Bäume (Haloxylon ammodendron), die beinahe Wälder bilden (vergl. Halophytenvegetation), aber nach Bessey einen Unterboden von Ton oder Kalk verlangen.

Eine eingehende, durch morphologische und anatomische Darstellung der betreffenden Arten gründliche ökologische Schilderung der transkaspischen Sandvegetation gibt der dänische Botaniker O. Paulsen $\left.{ }^{2}\right)$. In Transkaspien ist Aristida pennata der erste Pionier auf dem Flugsand.

1) Marloth 1908.

2) 0. Paulsen 1912 a, b. Mit 79 Figuren. 
Wenn der Sandflug durch die Wirksamkeit der Aristida etwas weniger lehendig geworden ist, siedeln sich verschiedene Rutensträucher an, z. B. Ammodendron Conollyi und A. Karelini, Calligonum- und Salsola-Arten, Haloxylon ammodendron usw. Zwischen den Strüuchern können auch Kräuter vorkommen. In den beweglichen (weißen) Dünen sind $62 \%$ der Kräuter einjährig. Wenn der Sandflug aufhürt und die Vegetation dichter wird, werden die Ammodendron-Arten selten, Salsola arbuscula und Calligonum-Arten dominieren. Kräuter werden häufiger, besonders die mehrjährigen, die hier $56 \%$ der krautartigen Arten ausmachen. Am besten ist die Vegetation der Sandebenen dort ausgeprägt, wo zwar auch die Rutensträucher dominieren, wo aber viele Stauden und einjührige Pflanzen wachsen. Die Mehrzahl der Kräuter gehören der Frühlingsflora an. $25 \%$ der Kräuter sind einjährig. Mit Ausnahme der Aristida-pennata-Assoziation sind die Sandsteppen demnach den Strauchsteppen (Kap. 111) nahe verwandt ${ }^{1}$ ).

Ton den Sandpflanzen der Küsten des indischen Ozeans ist, nach Cleghorn und Goebel, besonders Spinifex squarrosus hervorzuheben, ein blaugrünes, steifes Gras mit weit kriechenden, unterirdischen Ausläufern und schmalen Blättern. Seine fast kopfgroßen Blütenstände sind kugelförmig, federleicht und haben steife, elastische, lange Ährenstiele, die nach allen Seiten auseinander spreizen; sie werden, in großen Sprüngen hüpfend, vom Winde über den Sand hin gerollt und streuen bei dieser Bewegung ihre Samen aus (Steppenläufer). Oben (S. 439) wurde Spinifex von den Dünen Javas nach Hj. Jensen erwähnt. Er erwähnt auch, daß z. B. Pandanus und Calotropis gigantea auf den Dünen wachsen, und selbst eine Zwiebelpflanze, Gloriosa superba, deren Zwiebeln oft metertief im Sande zu suchen sind.

Nordamerika. Die nordamerikanischen Botaniker Cowles, Coville, Rydberg, Kearney, Pound and Clements, Hitchcock, Harshberger, Fuller, Harper, Pool u. a. haben in den letzten Jahren eine lange Reihe von ausgezeichneten Bearbeitungen ihrer Sandvegetation veröffentlicht. Nur wenige Worte können hier darüber gesagt werden. Eine besonders große Rolle für die genannten Schriftsteller spielt das Studium der Entwicklungsserien („Successions") der verschiedenen Formationen; dazu kommt, daß man mit Instrumenten, wie Athmometer, die Entwicklung in Verbindung mit der Verdunstung und dem Bodenwassergehalt bringt und erklärt ${ }^{2}$ ). Auch die "Blowouts" sind gründlich floristisch besprochen worden.

$\left.{ }^{1}\right)$ Über Centralasiens Dünen vergl. auch Bessey 1905 in Karsten u. Schencks Vegetationsbilder, III, 2.

2) Vergl. z. B. Fuller 1914. 
Auf den Dünen der Ufer des Michigan-Sees, die besonders von Cowles studiert sind, spielt als Dünenbildner die Hauptrolle Calamagrostis (Psamma) arenaria, in zweiter Linie sind $\mathrm{zu}$ nennen Triticum (Agropyrum) dasystachyum, Elymus Canadensis, Calamagrostis longifolia, Salix adenophylla, S. glaucophylla, Prunus pumila und Populus monilifera. Sobald einer der Weidenbüsche vom Sande begraben ist, treiben die bedeckten Zweige Wurzeln. Ebenso wachsen Populus monilifera und $P$. balsamifera am Ufer auf und bilden Gebüsch- und Baumgruppen, die die Ursache zur Sandansiedlung werden können. Genau wie bei den nordeuropäischen Dünen werden allmählich die Lebensbedingungen für die dünenbildenden Pflanzen ungünstig. Die Düne wird hoch und trocken und die Pflanzen sterben allmählich ab, die Fläche wird wieder kahl und der Sand wird wieder in Bewegung gesetzt. Manche Arten, wie die Calamagrostis, können durch ihre verwebten Grundachsen noch nach dem Absterben sandbindend wirken, andere, wie die Pappeln, können dies nicht. Auf der Leeseite wachsen Weiden, Pappeln, Vitis cordifotia, Gräser und auch andere Dünempflanzen, auf der Windseite fehlen sie naturgemäß, da sie bei der Schnelligkeit der Oberflächenveränderung nicht $\mathrm{Fuß}$ fassen können. Je weiter die Düne vom Ufer entfernt ist, je schwächer die Windwirkung ist und je mehr sie etwa durch vorgelagerte Dünen geschützt ist, desto schneller bewächst sie. Die erste Pflanze, die auf der Leeseite der sich nur noch langsam bewegenden Wanderdüne erscheint, ist Calamagrostis (Psamma) arenaria, dann erscheinen Asclepias Cornuti, Equisetum hiemale und Calamagrostis longifolia. Innerhalb weniger Jahre ist die Leeseite von Sträuchern und Bäumen bedeckt, z. B. von Cornus alba (C. stolonifera), Salix adenophylla, S. glaucophylla, Vitis cordifolia, Prunus Virginiana und Tilia Americana. Die Sträucher unterdrücken die Kräuter; Bäume wachsen auf und bilden einen Wald, in dem Pappeln, Eichen, Eschen, Walnüsse, Sassafras und andere Bäume wachsen; an ihnen klimmen zahlreiche Lianen: Celastrus scandens, Vitis cordifolia, Rhus toxicodendron, Parthenocissus quinquefolia und Smilax hispida. An offenen Stellen und am Waldrande sind die Sträucher zahlreich; zu den ursprünglichen Arten gesellen sich viele andere. Die Mehrzahl der Arten in den Dünenwäldern, wie wir sie ganz ähnlich auch an der Ostseekïste in Europa finden, sind ausgesprochene Mesophyten. An der Windseite sind es einjährige und zweijährige Kräuter, die sich zuerst ansiedeln; unter ihnen spielt Corispermum hyssopifolium, ebenso wie nach seiner Einschleppung in Europa an ähnlichen Orten, die Hauptrolle. Auch hier erheben sich in Laufe der Zeit Sträucher und bilden eine Formation ${ }^{1}$ ), die zusammen. gesetzt ist aus Arctostaphylos uva ursi mit Juniperus sabina uni

1) Cowles nennt diese Formation "Heide". 
J. communis. Im Schutze der Strauchformation keimen Baumgehölze und es bildet sich ein Nadelwald von Pinus strobus, P. Banksiana, P. resinosa, Thuja occidentalis, Abies balsamea und Juniperus Virginiana. Unter den Bäumen wachsen Dünensträucher, im Schatten siedeln sich Moose an. An den Ufern des Michigan-Sees ersetzt Buschland von Quercus coccinea teilweise die Nadelholzwälder.

In Virginia und Nord-Carolina sind nach Kearney ${ }^{1}$ ) Calamagrostis (Psamma) arenaria, Uniola paniculata, Panicum amarum und Iva imbricata die ersten sandbindenden Arten. Später werden vom Ufer her

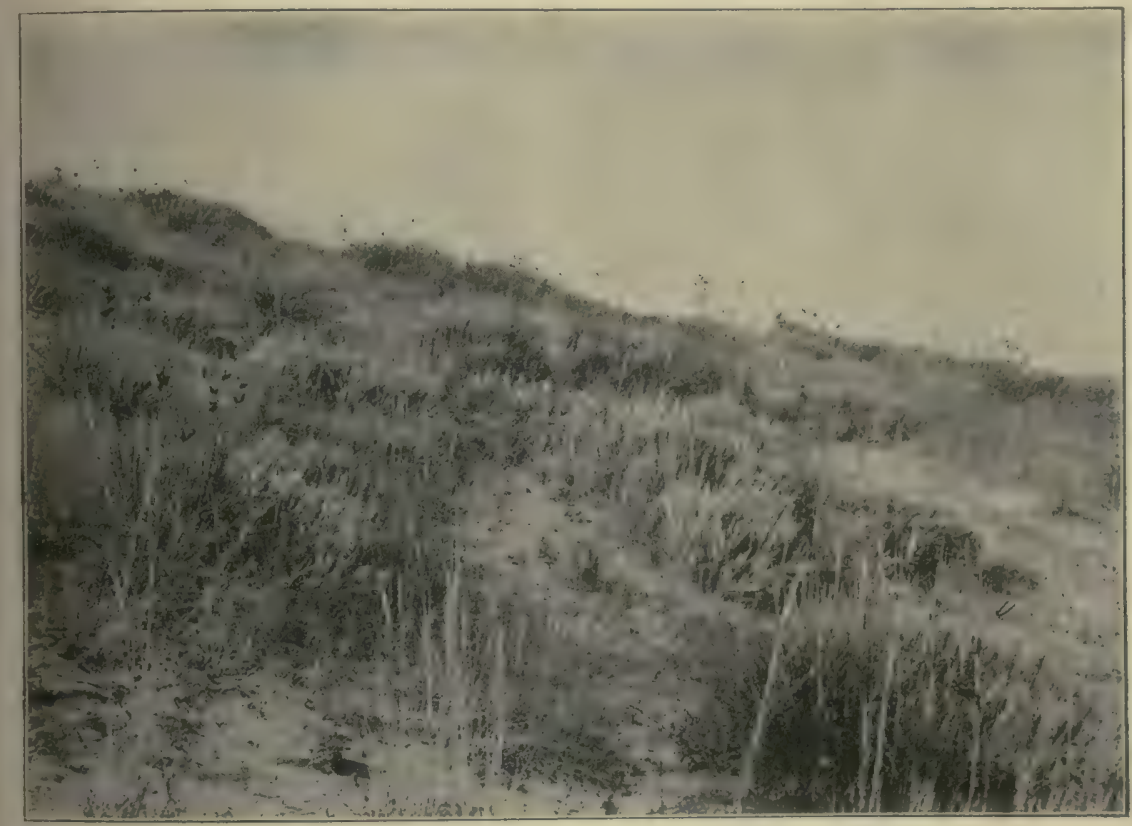

Fig. 341. Sandhügel östlich von Yuma (Colorado, Nordamerika) mit Yurca glauca, Artemisia flifolia, Menzelia nuda (vorne links), Andropogon scoparius (oder A. Hallii). 10. August 1913. (Phot. G. E. Nichols, New Haven ct.)

die Dünen mit Grasland aus Psamma und Panicum besiedelt, in dem Sträucher von Myrica Carolinensis, Quercus Virginiana und Rhus copallina wachsen. Die ältesten Dünen sind mit Kiefernwald bedeckt.

Die Dünen von Nebraska sind mit folgenden sandbindenden Gräsern bewachsen: Calamovilfa longifolia, Redfieldia flexuosa, Eragrostis tenuis, ferner mit Muehlenbergia pungens und vielen anderen.

Die Sandhügel in Georgia sind nach den Darstellungen Harpers von vielen Bäumen und Sträuchern bedeckt (Arten von Quercus, Pinus),

1) Kearney 1901 . 
dazu Lianen und viele ausdauernde Kräuter, aber die einjährigen sind auch sehr zahlreich. Eine Anzahl Arten sind immergrün. Man bemerkt dadurch schon die Nähe der Tropen ${ }^{1}$ ).

In den sandigen Gebieten des nördlichen Mexiko (in der TularosaWüste) bilden sich Dünen, in denen Yucca radiosa die wichtigste sandbindende Pflanze ist; ihre Wurzeln streichen wagerecht auf eine Entfernung von über $10 \mathrm{~m}$; ihr Stamm kann ohne zu leiden vom Sande eingedeckt werden; man hat bis zu $10 \mathrm{~m}$ lange eingeschüttete Stämme beobachtet. Zwei Gräser (Andropogon und Sporobolus), wenige Sträucher und Halbsträucher mit vielen einjährigen Arten vervollständigen die Vegetation ${ }^{2}$ ). Der Triebsand in der Tularosa-Wüste wird von Gips, nicht von Kiesel gebildet.

In Südamerika kommt Sandvegetation an den Küsten vor, aber auch im Innern von Chile $^{3}$ ) und der Argentinischen Republik gibt es ungeheure Sandgebiete und mächtige Dünen ${ }^{4}$ ). Außer mehreren Grasarten (Cenchrus, Diachyrium, Bouteloua) wachsen hier andere, meistens scheinbar blattlose Pflanzen: die Zygophyllee Bulnesia retamo, eine echte Sandpflanze, die dem Vordringen des Sandes oft eine Grenze steckt, Ephedra- und Cassia-Arten, Mimosa ephedroides, die Borraginacee Cortesia cuneata u. a.

In den Argentinischen Anden unterscheidet Rob. Fries eine Lampaya-Assoziation und eine Palaegonium arenicola-Assoziation. Die Sand- und Dünenvegetation in Uruguay wird von Gaßner besprochen ${ }^{5}$ ).

In Australien spielt nach Diels ${ }^{6}$ ) in den Dünen ein Gras, Triraphis rigidissima, dieselbe Rolle wie Aristida pungens in der alten Welt. Von Holzpflanzen finden sich zwerghafte Exemplare von Casuarina und Exocarpus, ferner die Gattungen Frenela, Eucalyptus, Fusanus, Codonocarpus. Casuarina scheint eine charakteristische Dünenpflanze zu sein.

Neuseeland. Nach Cockayne finden sich Dünen auf dem Vulkanplateau mit Podocarpus nivalis, Dacrydium laxifolium, Dracophyllum recurvum, Olearia nummularifolia u. a.

1) Litteratur: Coville 1893; Cowles 1899; Fuller 1911, 1914; Gleason 1910; Harper 1906; Harshberger 1900, 1902, 1911 a; Hitchcock 1904; Kearney 1904; Gates 1912; Pound and Clements 1898; Rydberg 1895; Mac Dougal 1903, 1912; Anna Starr 1912; Pool 1913. Die "Sand plains succession“ wurde auch von Nichols in Connecticut studiert (1914).

2) Vergl. Coville und Mac Dougal 1903.

3) Albert 1900.

4) Brackebusch 1893; Hauman Merck 1913 b.

8) Rob. E. Fries 1905; Gassner 1913.

-) Diels 1906, mit Abb. von Pritzel. Vergl. auch Ostenfeld 1915 b. 
Später hat Cockayne andere Veröffentlichungen über die Sandvegetation Neuseelands herausgegeben. Eine verholzte Lupine, Lupinus arboreus, wird als Sandbinder benutzt; andere ebenso benutzte Arten sind Scirpus frondosus und Spinifex hirsutus; die niederliegenden Sprosse dieser letzteren werden viele Fuß lang; zuerst liegen sie oberflächlich auf dem Sande, sich durch viele Nebenwurzeln befestigend, aber zuletzt bohren sie sich in den Sand hinein, und nur Horste von langen, mit silberweißen Haaren bedeckten Blättern sind über dem Sande zu sehen. Nach dem Gürtel der weißen Dünen mit den sandbindenden Arten folgt ein Strauchgürtel mit Coprosma, Cassinia, Pimelea u. a., und ein dritter Gürtel mit Leptospermum scoparium, Arundo, Phormium u. a. ${ }^{1}$ ).

Aus der eben gegebenen Darstellung der Vegetation der Dünen und des trockenen Sandbodens geht erstens hervor, daß solche Standorte in allen Gegenden der Welt, in allen Klimaten vorkommen, von den Polargegenden bis zum Äquator, von den regenreichen Küsten Nordeuropas bis in die trockenheißen Binnenländer der großen Kontinente. Es folgt daraus, daß die Flora des trockenen Sandbodens äußerst verschieden sein muß.

Zweitens ist es einleuchtend, daß es gerade hier mehr als sonst sehr schwierig sein muß, scharfe Grenzen zwischen den Formationen ziehen zu können; die große Unbeständigkeit und Veränderlichkeit der Dünen, jedenfalls in ihrer ersten Lebenszeit, tritt hier hindernd in den Weg. In älteren Dünen, die schon festgelegt sind, oder in den trockenen Sandebenen ist eine Abgrenzung schon leichter. In einer typischen Dünengegend wird ferner eine scharfe Abgrenzung, auch wegen der chaotischen Vermengung von Hügeln und Tälern, mit der verschiedenartigsten Exposition und Höhe über dem Grundwasserstande zu den Unmöglichkeiten gehören. Kleine Stücke vieler verschiedener Formationen werden miteinander bunt gemischt erscheinen.

Im allgemeinen kann man wohl sagen, daß die beweglichen Dünen vorzugsweise mit größeren Gräsern, die tiefliegende Auslạ̈ufer haben, bewachsen sind. Mit der Zeit, wenn die Düne ruhig wird, siedeln sich andere und kleinere, krautartige Pflanzen in den großen Zwischenräumen zwischen ihren Sprossen an, darunter sowohl einjährige (sommerannuelle und winterannuelle) wie pollakanthe Kräuter und Gräser, Algen, Moose und Flechten; die Vegetation wird immer dichter und dichter, bis zuletzt der Boden zum Schluß ganz bedeckt ist. Später kommen dann andere Lebensformen wie Halbsträucher, Kriechsträucher, Zwergsträucher, Hochsträucher und schließlich Bäume hinzu. Die Entwicklungsfolge kann aber anch in anderer Weise vor sich gehen.

2) Diels 1896; Cockayne 1904, 1908, 1909a, 1910, 1911. 
Die eine Formation geht somit allmählich in eine andere über. Die Vegetation der festliegenden Dünen stimmt floristisch vielfach mit der Vegetation der Sandfelder und Sandfluren desselben floristischen Gebietes, selbst mit den ganz ebenen, wenn nur das Grundwasser tief liegt, überein.

Die Pflanzen der offenen, weißen Dünen, sowie die der festliegenden Dünen in ihren ersten Entwicklungsphasen, sind im großen und ganzen xeromorph. Mit der Zeit, wenn andere und höhere Formationen sich entwickeln, ändert sich dies, da gleichzeitig auch die Bodenverhältnisse sich verändern, denn nach und nach bildet sich eine humöse Schicht auf dem Sande; neue Standorte entwickeln sich somit mit der Zeit, und im Schatten der Gebüsche und Wälder kommen auch mesomorphe Arten zur Entwicklung. Die Transpirationsverhältnisse in dem ganzen Vereine ändern sich auch, wie Fuller in Nordamerika durch exakte Messungen gefunden hat; am Ende steht schließlich ein mesophiler Wald auf dem alten Dünenboden. 


\section{Serie. Hartlaubvegetation der Gebiete mit Winterregen}

(12. Klasse; vergl. S. 320)

\section{Kap. Hartlaubvegetation. Hartlaubformationen}

Der Ausdruck Hartlaub (Sklerophyll) ${ }^{1}$ ) stammt von Schimper ${ }^{2}$ ); er bezeichnet damit xerophytisches Buschgelände und Buschwald in subtropischen Gebieten mit Winterregen, weil das schmale, dicke, ganzrandige, immergrüne Blatt in diesen Gebieten so außerordentlich häufig ist, im Gegensatz zu dem breiten, weichen Blatte der Mesophyten in den temperierten Gegenden.

Solche Gebiete mit Winterregen sind die Mittelmeerländer, Kalifornien, der südwestliche Teil der Kapkolonie, die Küstenstriche von Süd- und Westaustralien und Chile zwischen 30 und $38^{\circ}$ südl. Br. Das Klima ist nach Köppen mesotherm. Theobald Fischer hat ${ }^{3}$ ) die mittlere jährliche Regenmenge der Mittelmeerländer zu 759,4 mm berechnet, also mehr als für Deutschland $(708,9 \mathrm{~mm})$, aber die Verteilung der Regen ist der ausschlaggebende Faktor: der Regen fehlt, wenn die Wärme am größten ist; der Sommer ist fast regenlos, der Niederschlag weniger als $50 \mathrm{~mm}$. - In den genannten Gebieten sind die Winter mild, selbst wenn leichter Frost vorkommt. Der Regen fällt in wenigen aber heftigen Schauern; der Winter erfreut sich vielen Sonnenscheins. Der Sommer ist trocken; die leichten Regenfälle sind wenig häufig; es herrscht längere Zeit eine Trockenruhe der Vegetation. Mehr im Innern großer Kontinente ist der Winter oft sehr regenarm, wie z. B. in dem südlichen Kalifornien, im Innern Chiles, Spaniens, Kleinasiens usw. In solchen Gebieten überwiegt die Halbwüste. Wo indessen die Winterregen reichlicher sind, ist das Land mit niedriger Halbstrauch- und Buschvegetation bedeckt. Wohl entwickelter Wald ist indessen selten.

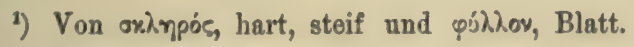

2) Schimper 1898.

3) Nach Rikli u. Schröter 1912. Vergl. die Hydrothermfigur S. 61.

Warming-Graebner. 3. Auflage, illustr. 
Eine Verlängerung der Sommertrockenheit ist der Vegetation feindlich, daher die Seltenheit großer Bäume. Diese sind klein, mit knorrigen Stämmen und Ästen, meist bleiben sie strauch-oder halbstrauchartig. Die Blätter der Bäume oder Sträucher sind in der Regel immergrün und in verschiedener Art gegen Austrocknung geschützt, doch ist ihr Bau nicht so ausgeprägt wie der der Wüstenpflanzen. Der Name Hartlaub ist insofern nicht gut, als es auch andere Vegetationsformationen gibt, deren Blätter überwiegend hart und steif sind, z. B. die Buchenwälder in Patagonien, die Ratawälder in Neuseeland. Deshalb wird es auch das Natürlichste sein, hier auch Formationen anzuführen, deren Blätter vom typischen Hartlaub etwas abweichen, aber ebenfalls stark xeromorph sind. Die häufigste Anpassung ist die Reduktion der Blattspreite und deren charakteristische Form; die Blätter sind klein und ungeteilt, Blätter von mittlerer Größe sind selten und finden sich nur an besonders begünstigten Stellen. Unter den verschiedenen Blattformen sind zu erwähnen: das breite elliptische Blatt, das harte schuppenförmige Blatt, das ericoide, wie das von Erica, Elytropappus Rhinocerotis, Cliffortia falcata u. a., das pinoide Blatt an verschiedenen Capensischen Familien, das linealische eingerollte Blatt verschiedener Labiaten; dreizählige und gefiederte Blätter kommen vor bei Leguminosen, bei Pistacia und Cunonia Capensis.

Die meisten Blätter sind steif, dick, stark cuticularisiert, vielfach durch Wachsausscheidungen bläulich bereift und reich an Skleroderm; die Intercellularräume sind reduziert. Nach Guttenberg ${ }^{1}$ ) haben fast alle immergrünen hartlaubigen Blätter des Mittelmeergebietes einen charakteristischen Mechanismus zur Verhinderung des Zusammenfallens des Assimilationsgewebes in Gestalt von Hilfszellen oder Zellgruppen. Die Blattunterseite ist mitunter behaart; selten sind beide Seiten wollhaarig. Knospenschuppen sind nicht häufig.

Winter und Frühling sind die Hauptzeiten des Zuwachses der Hartlaubvegetation, wenn auch kurze Kälteperioden im Winter den Zuwachs unterbrechen. In den Mittelmeerländern beginnt vom Januar ab die Blütezeit vieler ausdauernder Frühlingskräuter und im Januar fangen die Sträucher an zu treiben ${ }^{2}$ ). Im Sommer blühen nur wenige extrem xerophytisch gebaute ausdauernde Kräuter; die zahlreichen Zwiebel- und Knollengewächse ruhen zu dieser Zeit im Boden, die einjährigen Kräuter tragen Früchte und Samen. Im Spätsommer und Herbst treten bereits mannigfache, jenen des Frühlings in den kühleren Klimaten entsprechende Lebenserscheinuugen auf.

1) Guttenberg 1907 .

2) Vaupell 1858. 
Die Lebensformen sind verschieden. Nach Raunkiïr haben die Mittelmeerländer Therophytklima, d. h. sie sind reich an sommerannuellen Pflanzen ${ }^{1}$ ). Übrigens kommen sowohl Kräuter als Halbsträucher und echte Gehölze vor.

Danach unterscheiden wir zwischen

Formation der Halbsträucher und Kräuter (Garigues, Tomillares);

Formation der Zwergsträucher und "Landes";

Formation der Hochsträucher (Maquis);

Formation der Wälder.

\section{Kap. Formationen von Halbsträuchern und Kleinsträuchern (Felsentriften, Felsensteppen, Halbstrauchsteppen)}

Auf Steppen und Savannen sind die Gräser vorherrschend, Stauden, Halbstrïucher und Sträucher in der Minderzahl; es gibt indessen andere xerophile Vegetation, bei der das Umgekehrte der Fall ist, die aber im übrigen je nach den Gegenden ein sehr verschiedenes Aussehen hat. Im allgemeinen kann sie "Felsensteppe“ ${ }^{2}$ ) genannt werden. Der Felsenboden liegt der Oberfläche nahe und tritt oft zutage, wodurch die ganze Vegetation sehr mannigfaltig wird; sonst ist der Boden gewiß gewöhnlich ein fester Ton. Beispiele für diese Art Vegetation sind folgende:

Die Garigue. Von den trockenen, hügeligen und bergigen Gegenden Südfrankreichs, in den Südalpen und bis zu den Felsen Griechenlands und Syriens findet man eine sehr verbreitete, in Frankreich „la garigue" genannte Vegetation. Flahault hat sie wiederholt behandelt; später namentlich Rikli, Schröter und Tansley, Chodat ${ }^{3}$ ).

Der Boden hat keinen Humus, ist flachgrïndig und steinig und meist sehr kalkreich; die Felsen liegen oft nackt. Kleine Sträucher, Halbsträucher und Kräuter bemächtigen sich bald des Bodens und der Felsenspalten und schmücken sie trotz der scheinbaren Dürftigkeit mit einer bunten Mannigfaltigkeit; nirgends kommen sie jedoch zu einer geschlossenen Decke zusammen; die Vegetation ist offen und der starken Insolation ausgesetzt. Die Farbe der Landschaft wird oft mehr durch den Boden als durch die Vegetation hervorgerufen. Hier entwickelt

1) Raunkiär 1914 .

$\left.{ }^{2}\right)$ Mit einer Heide hat dieser Verein, ausgenommen vielleicht die Luftfeuchtigkeit, ükologisch nichts gemein, sein Boden ist nährstoffreich, der Steppe entsprechend trocken (Gr.).

3) Flahault $1888,1893,1901 \mathrm{~b}, 1906 \mathrm{~b}$; Chodat 1909; Rikli u. Schröter 1912. Vergl. auch Tansley, Journ. of Ecol., I. 
sich die echte mediterrane Flora. Der Winter hemmt deren Entwicklung kaum; gewisse Arten wachsen das ganze Jahr hindurch, z. B. Ruscus aculeatus, und mitten im Winter kann man viele Pflanzen blühend finden. Das Frühjahr (April, Mai) ist die schönste Zeit der Vegetation. Der Sommer hingegen mit seiner Regenlosigkeit und Hitze bringt eine Ruhezeit hervor; dazu kommt, daß der Boden sehr trocken ist; "das wenige Wasser sickert sofort in die Tiefe, so daß bei der täglichen intensiven Insolation der Boden oberflächlich steinhart ausgetrocknet wird". Die Pflanzen müssen sich, um dort aushalten zu können, gegen die starke Transpiration wappnen, was sie auf sehr verschiedene Weise besorgen, z. B. indem sie die Transpirationsflächen einschränken, sich mit Wollhaaren bekleiden, ätherische Öle ausscheiden, oder unterirdische Zwiebeln und Knollen usw. bilden.

Die Vegetation besteht meist aus immergrünen Kleinsträuchern und Halbsträuchern und ist gewöhnlich etwa fuß-bis kniehoch, seltener bis zu 1-1,5 m. (Die "Garide“ dagegen ist nicht immergrün.) Viele der Pflanzen sind dornig, andere Hartlaubpflanzen, andere wieder Rutenoder Filzpflanzen. Hier findet man z. B. Dornsträucher wie Calycotome intermedia, die bisweilen Halbkugelform annimmt, Ulex Africanus, Asparagus horridus, die dornige Genista scorpius, Halbsträucher wie die aromatischen Labiaten Lavandula spica, Thymus vulgaris und Rosmarinus officinalis, ferner die drüsenhaarigen, aromatischen und großblütigen Cistus-Arten, Pistacia terebinthus und lentiscus, Phillyrea angustifolia Daphne gnidium, Quercus coccifera, Juniperus Phoenicea, Chamaerops humilis, Euphorbia dendroides u. a., auch verholzende Umbelliferen (Bupleurum fruticosum), Plantago-Arten (P. cynops), Borraginaceen (Lithospermum fruticosum) u. a. treten auf; „je heißer und trockener die Natur ist, desto mehr verholzende Arten" sind vorhanden.

Zwischen diesen Dornsträuchern, Kleinsträuchern und Halbsträuchern wachsen zahlreiche Stauden, teils Kleinstauden, teils Hochstauden. Auch die Anzahl der Zwiebel- und der Knollenpflanzen ist groß; Arten von Narcissus, Iris, Asphodelus, Muscari, Tulipa, Orchidaceen u. a. schmücken die Felsen im Frühjahre. Einjährige Pflanzen sind verhältnismäßig zahlreich, da das Klima heiß ist und es genug offenen Boden für sie gibt. Die krautartigen Pflanzen gehören meistens zu den Gramineen, Kompositen, Papilionaceen und Labiaten und sind so zahlreich, daß sie die Physiognomie der Vegetation bestimmen. Von den Gräsern kann namentlich das gesellig wachsende, borstenblättrige Brachypodium ramosum genannt werden. Die aromatischen Pflanzen sind außerordentlich zahlreich; überall bemerkt man das starke Aroma der Labiaten, CistusArten, Terebinthen (Ruta u. a.), der Leguminose Psoralea bituminosa, der Kompositen u. a. 
Die Flora ist außerordentlich reich. Rikli und Schröter ${ }^{1}$ ) besprechen artenreiche Garigues im nördlichen Algerien. Die etwas feuchteren Stellen tragen eine Garigue, die meist nur Kniehöhe, ausnahmsweise auch halbe Mannshöhe erreichen. Mit zunehmender Trockenheit kann man alle Übergänge bis zur typischen Felsensteppe verfolgen. Wo der Boden trockener oder steiniger ist, rücken die Gebüsche auseinander, und es entsteht Raum für eine mannigfache Begleitflora, teils aus Arten zusammengesetzt, welche das ganze Jahr über zu grünen vermögen, z. B. xerophytische Gräser (Brachypodium ramosum, Ampelodermus tenax u. a.), teils aus mehr oder weniger ephemeren Arten. "Der steinharte Boden ist ein wahres Reservoir von Keimen der verschiedensten Art: Zwiebeln, Rhizome, Wurzel- und Stengelknollen, Samen: alle erwarten sie nur den befruchtenden Regen, um dann wie durch Zauberschlag dem sonst steinigdürren Boden zu entsprossen. Zum Teil besitzen diese Arten farbenprächtige Blüten, saftige Triebe, die in einem auffallenden Kontrast zu ihrer Umgebung stehen. Bleibt der Regen aus, so ist die Flora kaum zu erkennen, viele Arten erscheinen dann nur in dürftigen Kümmergestalten, andere fehlen ganz." Die Zahl der Therophyten (Sommer-Annuellen), die im ersten Frühjahr eine sehr bedeutungsvolle Rolle spielen, ist 117.

Die Garigue schließt sich einerseits an die Felsen, anderseits an die Macchie und andere Xerophytengebüsche an. Auch geht sie in "Garide" über. Sie wird von verschiedenen Forschern, z. B. Flahault, Adamovié, L. Blane, als durch Waldzerstörung entstanden bezeichnet. Nach Rikli sind ihre Komponenten einerseits dürftig entwickelte Pflanzen der Macchien, anderseits Bestandteile der „Felsenheide“. Hierher gehören offenbar auch die "steinigen Hügeltriften" Adamoviés.

Die Garigue ist natürlich nicht überall gleichartig; es gibt offenbar eine Reihe von verschiedenen Assoziationen, z. B. Cistus-Bestände in Spanien, "Jarales" genannt ${ }^{2}$ ). Asphodelus - und Acanthus-Arten scheinen z. B. der Garigue von Attika ein besonderes Gepräge zu verleihen.

$\mathrm{Zu}$ den Gariguen muß auch die Zwergpalmen-Assoziation (Chamaerops humilis) gerechnet werden, aus den stammlosen oder kurzstämmigen (gelegentlich mit bis $6 \mathrm{~m}$ hohen Stämmen), meist büscheligen, $1 / 3-1 \mathrm{~m}$ hohen Pflanzen dieser Art mit ihren sparrigen Blättern gebildet. Über weite Strecken hat sie sich gesellig ausgebreitet, indem sie fast jede andere Vegetation verdrängt hat (Palmensteppe könnte man sie nennen). Mit ihr finden sich z. B. Myrtus communis, Pistacia lentiscus,

1) Rikli u. Schröter 1912.

2) Vergl. Chordat 1909. 
Olea Europaea var. oleaster, Arten von Asparagus, Asphodelus u. a. ${ }^{1}$ ) kleinen Kräutern.

Die Palmito-Assoziationen sind nach Rikli und Schröter Mitteldinge zwischen Garigue und Felsenheide. Durch ihre tiefsitzenden Wurzelstöcke ist die Zwergpalme ein gefürchteter Feind der Urbarmachung des Bodens.

Ob andere Gesträuche von Palmen, z. B. folgende, hierher zu führen sind, muß vorläufig unentschieden bleiben. Mayr schildert die Gebüsche von Serenaea serrulata; diese Sabalee streckt sich über die Erde hin und bedeckt den mageren Sandboden, wo früher Wälder von Pinus australis und $P$. Cubensis standen, nachdem diese Wälder niedergebrannt oder gefällt worden waren. Die Palme hat schon viele Quadratmeilen mit Beschlag belegt. Fährt das Feuer über sie hin, so verbrennen oder verwelken zwar die fächerförmigen Blätter, aber aus den im Boden verborgenen Stämmen sprießen neue Blätter hervor.

Ferner müssen hierher gerechnet werden die Tomillares; dies sind Formationen von Halbsträuchern, besonders Labiaten, wie sie in den Mittelmeerländern häufig sind und besonders auf den trockenen spanischen Plateaus vorkommen ${ }^{2}$ ). Der Name kommt vom spanischen Namen für Thymus, "tomillo“. Man kann verschiedene Assoziationen unterscheiden je nach den vorherrschenden Pflanzenarten, namentlich Thymus-Tomillares, Lavandula-Tomillares und Salvia-Tomillares. Trotz der weiten Verbreitung dieser Formation ist meist nichts über ihre Ökologie bekannt ${ }^{3}$ ).

Adamovié ${ }^{4}$ ) schreibt von ihnen: In mediterranen Ländern (im besonderen spricht er von den Balkanländern) begegnet man oft mehr oder weniger ausgedehnten Gruppen von Halbsträuchern, welche meist ein maulwurfshügelartiges Aussehen besitzen und durchgehend stark duften, infolge des außerordentlichen Reichtums an ätherischen Ölen. Es sind xerophile, immergrüne Labiaten-Assoziationen mit Stauden.

Den Namen Theophrasts „Phrygana" verwendet er für eine meist xerophile mediterrane Vegetation, bestehend aus laubabwerfenden Halbsträuchern und Stauden, die in der Regel stark dornig und stachelig sind; sie findet sich oft in derselben Gegend wie die Tomillares, erstere weisen auf nährstoff- und humusreicheren Boden mit nördlicher und östlicher Exposition hin, letztere auf sehr mageren, schotterig-sandigen, stark besonnten Boden. Alle beide stehen auf altem Waldboden und sind von großer Bedentung für die Physiognomie der Landschaft. Die

1) Vergl. z. B. Rikli u. Schröter 1912, 73.

2) Willkomm 1896; Chodat 1905; Rikli 1907.

3) Utber Tomillares der Balkanhalbinsel vergl. Adamovié 1909 a, b.

4) Adamovié 1909. 
Phrygana haben eine außerordentlich weite Verbreitung in den südlichen Balkanländern und zeigen fast durchgehend Poterium spinosum und Astragalus Thracicus als Hauptleitpflanzen. Verschiedene andere Assoziationen kommen vor.

"Les Landes". Die "Heiden" in der Gascogne, welche unter dem Namen "Les Landes" bekannt sind, und die ähnliche in Nordspanien vorkommende Vegetation, die aus oft gegen meterhohen Sträuchern und Kleinsträuchern gebildet werden, haben nichts mit den nordischen Zwergstrauchheiden zu tun. Der Boden ist verschieden. Sie sind eine immergrüne Vegetation. In neuerer Zeit hat sie A. Mentz ${ }^{1}$ ) besprochen. Er hebt hervor, daß die nordischen Ericaceen hier fehlen, dagegen sind andere Arten vertreten (Erica scoparia, E. ciliaris, E. vagans und andere Sträucher von $0,7-2 \mathrm{~m}$ Höhe). Von den nordeuropäischen "Heiden" weichen sie durch den Mangel an Rohhumus ab. Gräser und Cyperaceen, sowie Flechten und Moose haben hier eine geringere Bedeutung als in den nordischen Heiden. Sie bilden den Übergang zu den von Erica arborea gebildeten Gestrüppen und Wäldern und zu den steppenartigen Macchien.

Halbstrauchsteppen. Obgleich es unmöglich ist, eine scharfe Grenze zwischen Sträuchern und Halbsträuchern zu ziehen (Kap. 22), scheint es doch natürlich, als eine von den trockenheitliebenden Hochsträuchern und Dornsträuchern recht verschiedene Formation die der Halbstrauchsteppen zu trennen. Sie werden vorzugsweise von Artemisia-Arten gebildet, sowohl in der alten Welt als in Nordamerika.

Die Artemisia-Steppen in Südosteuropa, an den Ufern des Schwarzen Meeres, sowie im centralen Asien, z. B. im nördlichen Turan, sind bewachsen mit niedrigen, auf dem braunen, besonders lehmigen Boden zerstreut stehenden Kräutern und Halbsträuchern, die hauptsächlich graugrüne, behaarte, aromatische Achillea-Arten und gegen Ende des Sommers Artemisia-(Wermut-)Arten (A.maritima, A. frigida u.a.) sind, außer vielen anderen Arten, die gewöhnlich in folgender Reihenfolge auftreten: im Anfange des Frühjahres zarte, saftreiche, grüne Kräuter (Ranunculaceen, Cruciferen, Papaveraceen, Liliaceen und einjährige Arten), später mit zunehmender Hitze und Verdunstung andere, teilweise sehr dornige Kräuter (Xanthium spinosum, Alhagi Camelorum, Eryngium campestre, Ceratocarpus arenarius usw.) und zuletzt die grauweißen Artemisia-Arten mit Salzkräutern, deren Wurzeln sehr tief hinabdringen (Krassnoff).

1) Mentz 1911. 
Die Sommervegetation der transkaspischen Lehmsteppen wird oft nur gebildet von Artemisia herba alba und anderen Artemisien. An anderen Orten ist Salsola rigida die Hauptart. Andere Halbsträucher und Sträucher werden gebildet von Salsola-, Ephedra-, Calligonum- und Astragalus-Arten. Im Frühling wachsen zwischen den Sträuchern Poa bulbosa und Hordeum secalinum, die einzigen mehrjährigen Gräser, und verschiedene Stauden, z. B. Arten von Tulipa, Geranium, Ferula, Rheum usw. Diese verschwinden im Sommer wie die zahlreichen einjährigen Kräuter. Die Steinwüsten gehören ebenso zur Formation der Strauchsteppen ${ }^{1}$ ).

Weiter gegen Nord und West, wo der Regenfall größer ist, sind diese Halbstrauchsteppen von den Grassteppen begrenzt. Grassteppe, Halbstrauchsteppe und Wüste bilden drei Stufen der Abnahme der Regenmenge. In den Wermutsteppen wird der Boden oft etwas salzig sein. Bisweilen kommen Grassteppen und Wermutsteppen in derselben Gegend gemischt vor; die ersteren bewohnen dann die Anhöhen, von welchen das Salz ausgewaschen ist, die letzteren die etwas salzigen Niederungen. Auf ähnliche Weise bilden die Wermutsteppen einen Gürtel rings um die Salzwüsten und Salzseen. Wo Wermutsteppe herrscht, ist Kultur des Erdbodens nur durch künstliche Bewässerung möglich; doch ist diese Vegetation nicht nutzlos, insofern als sie den nomadisierenden Völkern Futter für ihre Schafe und Kamele gibt.

Die Wermutsteppen haben unzweifelhaft ihre nächsten Verwandten in den Tomillares in Spanien und den Garigues. Sie sind wie diese eine Halbstrauchformation aus durch ätherische Öle stark aromatischen Pflanzen. Durch die dornigen Phrygana des Adamovié sind sie mit den trockenen Dornstrauchsteppen verwandt.

In Nordafrika kommen auch Wermutsteppen vor aus Artemisia herba alba und A. campestris mit einer Anzahl von anderen xerophytischen Gewächsen; hierzu gehören xeromorphe Gräser, wie Lygeum spartum, Stipa tenacissima, Aristida pungens, Koeleria pubescens, oder auch Chenopodiaceen-Halbsträucher, wie Halocnemum strobilaceum, Atriplex halimus oder Anabasis articulata, weiter können auch andere Arten wie Plantago albicans, Peganum harmala usw. beteiligt sein (Listen bei Flahault); die Artemisien können aber auch recht reine, offene Assoziationen bilden.

Artemisia-Steppen Nordamerikas. Als ein anderes Beispiel einer Vegetation, wo wie bei den eben geschilderten zerstreut wachsende Sträucher und Halbsträucher mit Kräutern gemischt die Hauptrolle spielen, sei das trockene und öde Land zwischen den Rocky Mountains

3) Paulsen 1912 a u. b. 
und der Sierra Nevada genannt. Es herrschen nach Asa Gray besonders Artemisia-Arten, verholzende Kompositen mit kleinen Köpfen und Chenopodiaceen vor. Nach Watson ist keine Stelle, selbst in der trockensten Jahreszeit, ohne Vegetation. Bäume fehlen; Grasteppiche findet man auch nicht, wohl aber einige vorherrschende Arten strauch-oder halbstrauchartiger Pflanzen, die anscheinend alle andere Vegetation ausschließen. Kennzeichnend sind auch die gleichförmig gefärbten, vorzugsweise grauen oder dunkel olivenfarbigen Kräuter. Am häufigsten ist Artemisia tridentata ("everlasting sage-brush"), ein Strauch, der so weite Gebiete bedeckt, daß das Auge sie nicht überschauen kann. Auch andere Arten bilden dort große Assoziationen, wie z. B. Artemisia filifolia $\left.{ }^{1}\right)$.

Südafrikanische Garigues. Auch in Südafrika kommen Gegenden mit Winterregen vor. Nach Schimper finden sich typische Garigues im Kaplande, besonders von Ericaceen und ericoïden Kleinsträuchern gebildet. Was Marloth als "Hügelheide" bespricht, ist eine Garigue mit Arten von Zwergsträuchern (Arten von Evica, Blaeria cricoides, Thymelaea, Passerina, Rutaceen u. a.). Viele andere Lebensformen kommen auch vor (vergl. die kapländischen Macchien, S. 798)²).

\section{Kap. Hartlaubgebüsche (Macchien)}

Einige von den im vorigen Kapitel behandelten Halbstrauch-Assoziationen werden bisweilen "Macchie" genannt, z. B. Macchie von Cistus und Rosmarinus. Der Name muß aber für ein höheres, aus wirklichen Sträuchern und Kleinbäumen gebildetes Gehölz reserviert bleiben. Die Gehölze können eine Höhe von $1-2-3 \mathrm{~m}$ erreichen und einen „fast undurchdringlichen, durch dornige Schlingpflanzen verfilzten Wirrwarr" bilden (Petit). Einige sind sogar dichte, dunkle Gebüsche. Nach Brockmann-Jerosch kommen sie auch auf Silikatgestein vor, und da dieses wasserreicher ist, werden sie hier höher. Adamović beschreibt sie als immergrüne Buschwerke, welche teils undurchdringliche Dickichte bilden, teils von Karren und Schratten zerstïckelt und gelockert sind, und die uns überall in mediterranen Küstengegenden begegnen. Nach Flahault, Chodat und anderen Forschern sind sie jedenfalls teilweise Halbkulturformationen, aus zerstörten und degenerierten Wäldern hervorgegangen. Briquet betrachtet sie als eine selbständige Vegetation.

Die mediterranen Macchien werden in Italien Macchie (im Singular Macchia), in Spanien Monte baxo, in Griechenland Xerovuni,

1) Pool; Pound and Clements; O. Paulsen 1915 a; Rübel 1915.

2) Vergl. Engler 1910; Marloth 1908. 
in der Litteratur nach dem korsischen Ausdrucke auch Maquis benannt. Sie sind an einen stellenweise 4-6 Monate lang regenlosen Sommer und einen milden Winter mit etwas Regen und feuchter Luft gebunden. Die Sträucher sind daher meist immergrün, wenige laubwechselnd. Bei einigen immergrünen Arten sind die Blätter lederartig und glänzend oder grauhaarig, gewöhnlich elliptisch oder eiförmig, ganzrandig; zu diesem Typus gehören z. B. Myrtus, Buxus, Nerium, Olea Europaea var. oleaster, Laurus, Quercus ilex, Pistacia lentiscus, Juniperus oxycedrus und andere Arten, Viburnum tinus, Phillyrea, Arbutus unedo, Ilex aquifolium u. a. $\mathrm{Zu}$ den verbreitetsten im östlichen Mediterraneum gehören Phillyrea media und Juniperus oxycedrus. Erikoïde Typen sind Erica arborea, E. Corsica und andere Arten. Zur Rutensproßform gehören sehr viele Arten, z. B. Spartium junceum, dessen große, gelbe Blüten sich gegen Ende des Frühjahres von dem Gebüsche abheben, Genista-Arten, auf Corsica z. B. die steifdornige G. Corsica usw. Von Formen mit Kladodien kommen Ruscus und Asparagus, dieser teilweise in Lianenform wie auch Smilax aspera vor. Gemein sind CistusArten, die in Spanien stellenweise ganze Quadratmeilen bedecken $(C$. ladaniferus). Sie gehören zu den aromatischen Pflanzen, die in den trockenen Gegenden der westlichen Mittelmeerländer überall eine außerordentliche Rolle spielen und von denen noch audere $\mathrm{zu}$ nennen sind, namentlich Halbsträucher, z. B. Labiaten (Thymus vulgaris, Arten der Gattungen Lavandula, Calamintha, Rosmarinus, Stachys, Teucrium usw.), ferner Myrtus communis, Terebinthinen usw. Behaarte Blätter, eingerollte Blätter, schmale Blätter und andere früher erwähnte Bauverhältnisse zeigen die trockene Natur an. Dornige Pflanzen gibt es nicht wenige, z. B. wilde Olivenbäume, Ilex aquifolium, Calycotome spinosa, Prunus spinosa. Schließlich sei angeführt, daß hier eine Menge Zwiebelpflanzen vorkommen, die in dem zeitigen Frühjahre blühen: Crocus, Romulea, Hyacinthus usw. Adamovié hat eine Übersicht über die Flora der Küsten des Adriatischen Meeres geliefert ${ }^{1}$ ).

Die Macchien sind in den Mittelmeerländern von Spanien bis nach Palästina, an Europas wie Afrikas Küsten, sehr verbreitet, bedecken besonders auf den warmen Kalkfelsen weite Gebiete und sind floristisch sehr übereinstimmend. Sie sind eine öde, unfruchtbare, nicht nutzbare Vegetation, die mit den S. 787 behandelten Garigues ökologisch und floristisch nahe verwandt ist. Auch auf den Dünen im Rhonedelta (Camargue) kommt Gebüsch vor, welches von Flahault zu den Macchien gestellt wird. Es ist in ihnen heiß; sie sind reich an Blüten (jedenfalls im Frühjahre, d. h. im Februar und März) und an Aroma. Was

1) Adamović 1909 
wesentlich dazu beiträgt, sie undurchdringlich zu machen, ist die Menge windender und kletternder Pflanzen, die hier auftreten: teils Rubus-Arten, teils Formen wie Smilax aspera, Rosa sempervirens, Rubia peregrina, Asparagus acutifolius, mehrere Clematis-Arten usw.

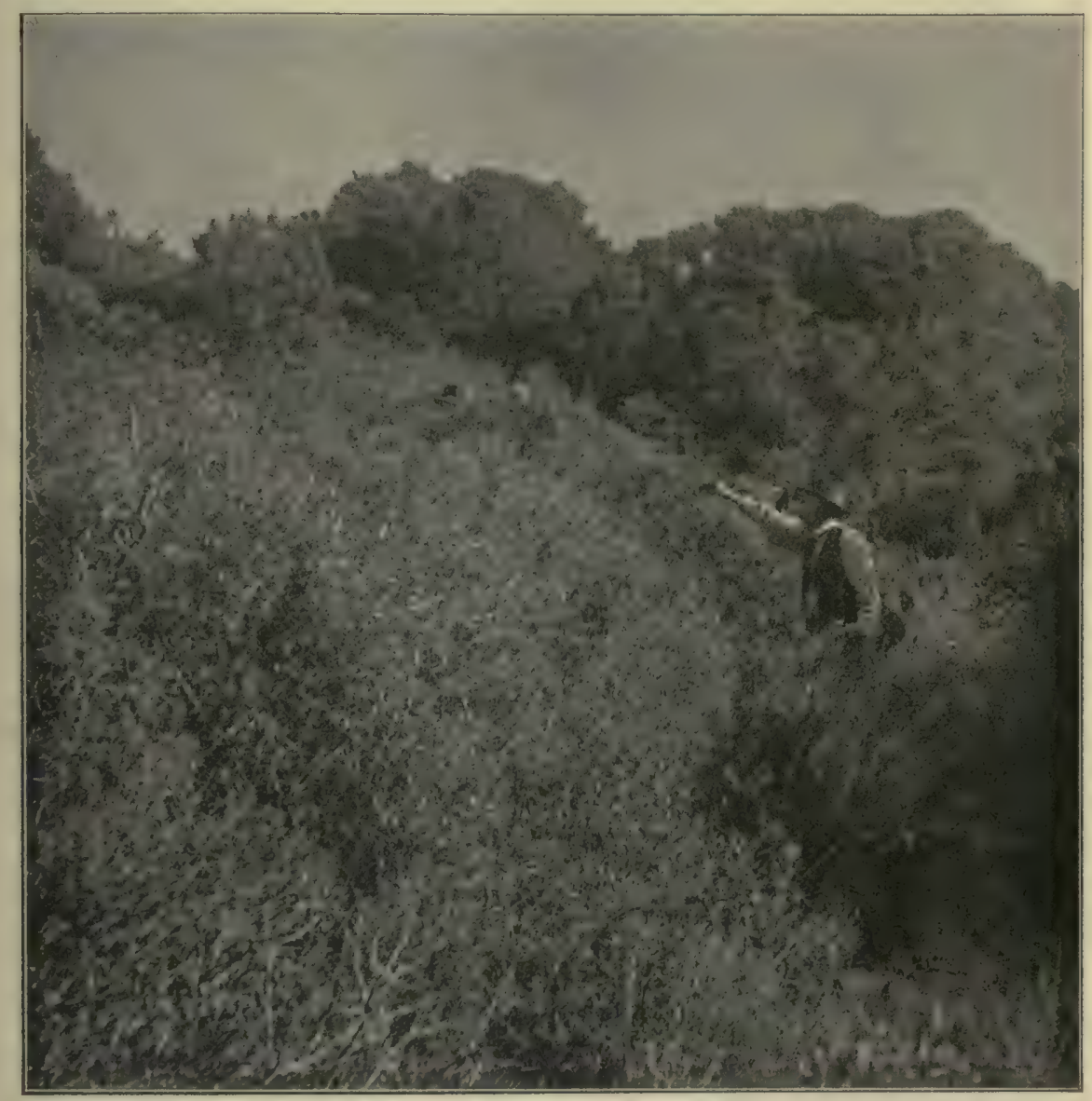

Fig. 342. Macchie an der Rhonemündung (Camargue, Juni)

mit Pinus pinea, Juniperus Phönicea, Phillyrea angustifolia, Pistacia lentiscus, Juncus acutus, Erianthus Ravennae u. a.; fast undurchdringlich. (Von Flahault zur Verfügung gestellt.)

Die Macchien können auch als Untervegetation in lichten Wäldern auftreten, z. B. in von der Korkeiche, Pinus Halepensis, usw. gebildeten.

Einige Macchien sind sehr artenreich und die Arten in fast gleicher Menge gemischt, andere werden von wenigeren aber sozial in größerer Menge auftretenden gebildet. Verschiedene Assoziationen 
kommen vor. Von solchen, welche vorzugsweise aus einer Art gebildet werden, kann genannt werden:

Das blattlose Retama-Buschland im südlichen Spanien, wohl nahe mit der echten Strauchsteppe verwandt.

Die Zwergpalmen-Assoziation kann gleichfalls hier aufgeführt werden ${ }^{1}$ ).

Rikli und Schröter besprechen eine Callitris-Macchie in Algerien, in welcher als Holzpflanzen eingemischt waren: Olea Europaea var. oleaster, Pistacia lentiscus, Ceratonia siliqua, Calycotome spinosa, Arbutus unedo, Phyllyrea media, Arten von Cistus, und als Liane Ephedra altissima genannt sind. Zwischen den Büschen breitet sich ein blumenreicher Rasen aus ${ }^{2}$ ).

Pseudomacchien. Pseudomacchien nennt Adamović ${ }^{3}$ ) eine mit den echten Macchien nahe verwandte xerophile Vegetation aus immergrünen Sträuchern, welche die montanen und submontanen Höhen der Berge im östlichen Mittelmeergebiete bedecken und daselbst die Böschungen von Hügeln und Bergen bekleiden. Sie köunen einen strengeren Winter aushalten. Die höchsten Arten sind aus den Gattungen Juniperus (J. oxycedrus, J. excelsa), Quercus, Buxus (B. sempervirens) und von Prunus lauracerasus gebildet. Die echten Macchien sind an das Küstenklima mit milderen Wintern und einer längeren Vegetationsperiode gebunden.

Der Sibljak, den Adamovié ${ }^{4}$ ) ebenso ausführlich besprochen hat, ist eine verschiedene, namentlich laubabwerfeude Formation, wie auch die sonst ähnlichen von Ficus Carica, Ostrya carpinifolia usw.

Außer von den schon genannten werden die mediterranen Macchien besprochen von Raunkiär 1914.

Makaronesische Macchie. Auf den Azoren, auf Madera und den Kanarischen Inseln ist der Winter so milde, daß selbst höhere Teile der Gebirge innerhalb der subtropischen Klimazone liegen. Der Sommer ist im allgemeinen regenlos, aber regelmäßige Winde bewirken in einer bestimmten Zone eine Nebelregion, in der die atmosphärische Feuchtigkeit steigt, dadurch der Vegetation Feuchtigkeit zuführt und die Wirkungen der Insolation herabmindert. In dieser feuchten Region wird die Macchie durch Sträucher gebildet, die etwa 3-5 m hoch sind; unter ihnen sind einige mediterrane Arten, wie Erica arborea und $E$. scoparia; in der Hauptsache aber sind die Arten von denen des Mittelmeergebietes verschieden, besonders durch die Blattgröße. Die Blätter

1) Vergl. S. 789; Börgesen 1897.

2) Litteratur: Flahault; Adamovié; Rikli und Schröter; Chodat.

3) Adamovié 1909

4)Adamovié 1901. 
sind meist mittelgroß, gehören aber sonst zum Hartlaubtypus. Die häufigsten Arten sind Laurus Canariensis, Ilex Canariensis, Heberdenia
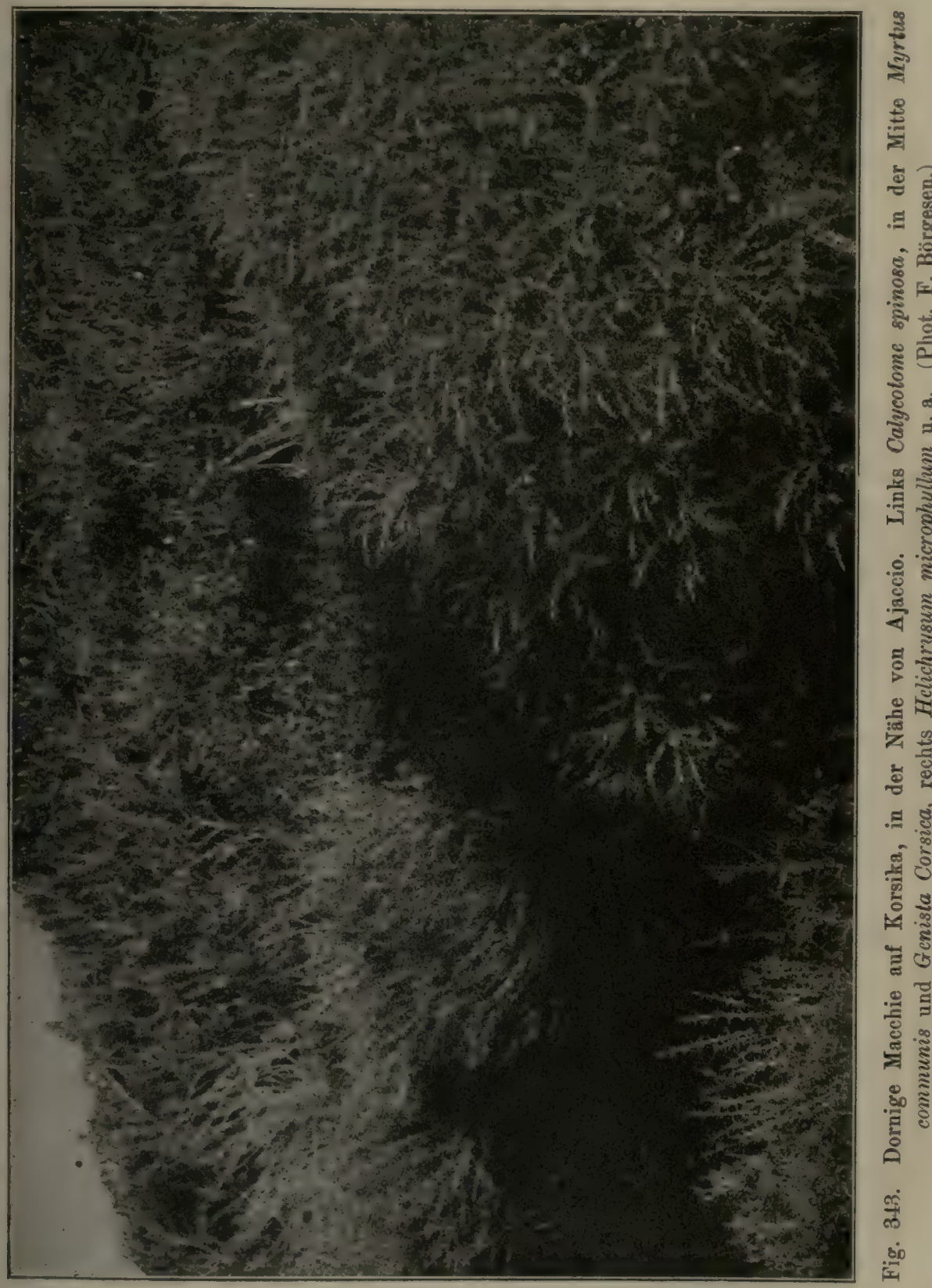

excelsa und Myrica faya. Lianen sind spärlich vorhanden, zwiebel- und knollentragende Pflanzen fehlen meist ganz. An den Südabhängen der 
Kanarischen Inseln, wie auf Madera und den Azoren wird die Macchie oberhalb der Nebelregion von kleinblättrigen Sträuchern gebildet.

Kapländische Macchien. Die eigentliche Kapflora ist nach Marloth keine Hartlaubflora, denn sie erträgt keine extreme Lufttrockenheit, fordert Grundwasser und ein bestimmtes Regenminimum; aber an den Bergseiten und Abhängen bei Kapstadt und anderswo im Kaplande finden sich $4 \mathrm{~m}$ hohe Formationen, welche sich den Garigues und den Macchien der Mittelmeerländer anschließen. Auch sie werden von niedrigen (bis $3 \mathrm{~m}$ hohen), immergrünen Sträuchern mit kleinen, oft ericoïden oder pinoïden, steifen, nicht selten bräunlichgrünen oder grauen Blättern gebildet. Zur Winterszeit (Mai bis Oktober) wird der Boden häufig vom Regen durchnäßt, und die Sträucher triefen bisweilen von Wasser; dies ist die Zeit ihres Wachstums. Danach kommt die lange trockene Sommerzeit, die es auszuhalten gilt. Die Laubentfaltung fängt an, wenn im Mai der Regen beginnt, und unmittelbar nach dem ersten Winterregen fangen auch die Pflanzen an zu blühen, zuerst (nach Bolus) viele Oxalis-Arten, danach Liliifloren und andere mit Zwiebeln oder Knollen versehene Gewächse; schließlich folgen die Mesembrianthemen, Kompositen u. a. Niemals fehlen Blüten ganz, selbst in den trockensten Monaten (März, April). Übrigens ist die Verteilung des Regens in der Kapvegetation nach Marloth nicht überall dieselbe, und der Winter ist nicht allgemein die regenreichere Jahreszeit.

Die Sträucher und Halbsträucher sind immergrün, weil die Temperatur der Monate so gleich ist; ihre Blätter sind klein, weil sie sich in den Wintermonaten entwickeln müssen, auch die Blüten sind aus demselben Grunde klein. Die Flora ist besonders durch die zahlreichen Proteaceen charakterisiert (Protea, Leucadendron, Faurea u. a.).

Sehr viele Arten haben genau dieselbe, namentlich erikoïde und pinolde Tracht, so daß es sehr schwierig ist, sie in blütenlosem Zustande zu unterscheiden, obgleich sie äußerst verschiedenen Familien angehören: Ericaceen (etwa mit 400 Erica-Arten), Proteaceen, Rhamnaceen, Santalaceen, Polygalaceen, Rutaceen (Diosmeen) usw. Cyperaceen und Gramineen spielen hier eine untergeordnete Rolle; hingegen herrscht ein Reichtum an Zwiebel- und Knollenpflanzen (Iridaceen, Liliaceeli; Oxalis-Arten usw.), denen sich Pelargonium-Arten, Crassulaceen u. a. beigesellen (Rehmann). Die Restionaceen sind auch zahlreich, vielleicht jedoch mehr an feuchten sandigen Standorten. Früher waren ansehnliche Bäume recht häufig, jetzt sind sie șelten.

Diese Macchien sind vielleicht darin von den mediterranen verschieden, daß sie eine etwas größere Feuchtigkeit verlangen (Marloth). Auch in anderen Teilen des Kaplandes kommen typische Macchien vo: mit verschiedenen Assoziationen. 
"Das Rhenosterveld" ist nach Marloth eine besondere, eigenartig ausgeprägte Modifikation der Macchia, eine Halbkulturformation, die hauptsächlich von Elytropappus Rhinocerotis gebildet wird, einer ericoïden Komposite, die nur etwa $0,7 \mathrm{~m}$ hoch wird und weite Strecken gesellig bedecken kann, indem sie spärlich von Mesembrianthemum-Arten, Zygophyllaceen, Zwiebelpflanzen $\mathrm{u}$. a. begleitet wird.

Wo Gelände von der Kultur verlassen und sich selbst überlassen bleibt, kommen nach Marloth schöne Folgeformationen vor. Es gibt Strecken, welche vor 15 Jahren typische Hügelsteppe (Garigue) trugen, und welche jetzt von dicht geschlossenen Beständen von Protea incompta oder Leucadendron plumosum eingenommen sind. Es ist dann selbstverständlich, daß es allmählich Übergänge zwischen garigue- oder macchienartigen Formationen geben muß. Die Arten der Hügelsteppe treten in den niederen Stockwerken der Macchien auf.

Die Vegetation des südlichsten Afrika ist in verschiedenen Publikationen von Marloth vorzüglich geschildert worden ${ }^{1}$ ).

Eine Übergangsform zu den Strauchsteppen scheint die von ihm Dornmacchia genannte Formation zu sein, ein fast lückenloses Gebüsch von 3-4 m Höhe, von giftigen Euphorbien, scharfdornigen Celastraceen und Apocynaceen, buschigen zwergbaumartigen Caesalpiniaceen und der Salvadoracee Azima tetracantha gebildet, und überragt von den schlanken Kronen der Aloe pluridens. Auch Brunnthaler ${ }^{2}$ ) bespricht und bildet diese Dornmacchia ab; vegetationslose Flecken in der Masse von dornigen Sträuchern mit Baumeuphorbien und den anderen merkwürdigen Lebensformen kommen zwar vor, sie sind jedoch zum Durchschreiten des Ganzen zu klein.

Nahe verwandt mit diesen Dornmacchien erscheinen folgende Formationen:

Chile hat Espinales oder "Espinarwaldungen", wo Colletia (Rhamnacee) mit immergrünen, gegenständigen Dornzweigen eine wichtige Rolle spielt, und auch Cacteen und Bromeliaceen nicht fehlen. Meigen schildert die trockenen Gebüsche um Santiago, wo Cereus quisco und die Bromeliacee Puya Chilensis besonders hervortreten. Hier und da erhebt sich ein Baum über die Sträucher. Schlinggewächse sind häufig, ebenso Knollen- und Zwiebelpflanzen aus den Familien der Liliaceen, Amaryllidaceen, Iridaceen und Oxalidaceen.

In Kalifornien werden die Macchien oder macchienähnlichen Assoziationen Chaparals genannt; diese werden vielleicht besser unter den Steppen angebracht. Von den vielen vorläufig noch mit Zweifel unterzubringenden Vegetationsformen können hier noch genannt werden

1) Vergl. besonders Marloth 1908.

?) Brunnthaler 1911. 
die argentinische „Monte“, die Haumann Merck von Rio negro erwähnt, und die ostandinen Hartlaubhölzer (Weberbauer).

Die australische Gebüschvegetation, die Scrub genannt wird, scheint indessen besser der Macchie angeschlossen werden $\mathrm{zu}$ können; doch muß bemerkt werden, daß dieser Name "Scrub" verschieden benutzt wird, sogar selbst für Hochwald. Der Scrub Australiens kommt namentlich im Inneren und in den westlichen und südwestlichen Gegenden vor, welche trocken sind, weil der über sie hinwehende Passat seine Feuchtigkeit längst auf den östlichen Küstenbergen abgegeben hat. Diese Gebüsche werden etwa 3-4 $\mathrm{m}$ hoch und bestehen aus verfilzten, sehr oft undurchdringlichen Sträuchern, die immergrün sind, aber schmutzig grüne und braungrüne Töne haben. Eigentliche Dornsträucher sind hier seltener, aber die Blätter sind oft sehr schmal oder in viele linealische und steife Abschnitte geteilt, die in stechende Spitzen auslaufen. Pflanzen der ericoïden und der pinoïden Form sind allgemein, besonders Proteaceen; andere haben Phyllodien oder kantenständige Blätter (Akazien, Eucalypten); aber auch breite, steife, rasselnde Blätter kommen vor. Der Boden zwischen den Sträuchern ist oft nackt, da es dort äußerst wenig Gras und Kräuter gibt, in anderen Fällen aber ist er von einem dichten Untergebüsche bedeckt. Viele Arten, die je nach den Teilen des Landes verschieden sind, setzen diese trostlose und nicht nutzbare Vegetation zusammen. Die bemerkenswertesten Familien sind Proteaceen, Myrtaceen (Gattungen Eucalyptus, Melaleuca, Leptospermum u. a.), Epacridaceen, Mimosoideen (Acacia), Myoporaceen usw.

Unter ihnen sind verschiedene Assoziationen zu unterscheiden, welche von den Einwohnern, zum Teil mit besonderen Namen, belegt worden sind, z. B. folgende:

Mallee-Scrub ist im wesentlichen aus Eucalyptus (E. dumosa u.a.) gebildet, deren Büsche etwa Mannshöhe besitzen. In schrecklicher Eintönigkeit erinnern diese weiten Strecken an ein unendliches Meer von Sträuchern, welches sich über das tischförmig flache, trockene Land mit dem kahlen, gelben oder rostfarbigen Boden erstreckt, der überall zwischen dem Gewirr verflochtener Zweige hervorsieht. Mit den Eucalypten wachsen auch Melaleuca, Casuarina und andere Holzgewächse.

Mulga-Scrub ist im wesentlichen aus dornigen Acacia-Arten zusammengesetzt, welche an den Stellen, wo sie dicht stehen, ein undurchdringliches Dickicht bilden.

Brigalow-Scrub, der sich besonders in Queensland findet, wird vorzugsweise von Acacia harpophylla gebildet ${ }^{1}$ ).

1) Michaelsen und Hartmeyer 1907. Über Südwest-Australien vergl. in erster Linie Diels 1906. Ostenfeld 1915 b. Tschirch 1881. 


\section{Kap. Hartlaubwälder}

Die Grenze zwischen Gebüsch und Wald ist natürlicherweise nirgend scharf. Das sieht man z. B. auf den Zwergstrauchheiden Jütlands und Schleswig-Holsteins, deren Eichengestrüpp gegen Osten oft unmittelbar in Wald übergeht. Bei allen diesen Gebüschen dürfte man Gelegenheit haben, zu sehen, wie sie sich auf der Seite, wo sie von

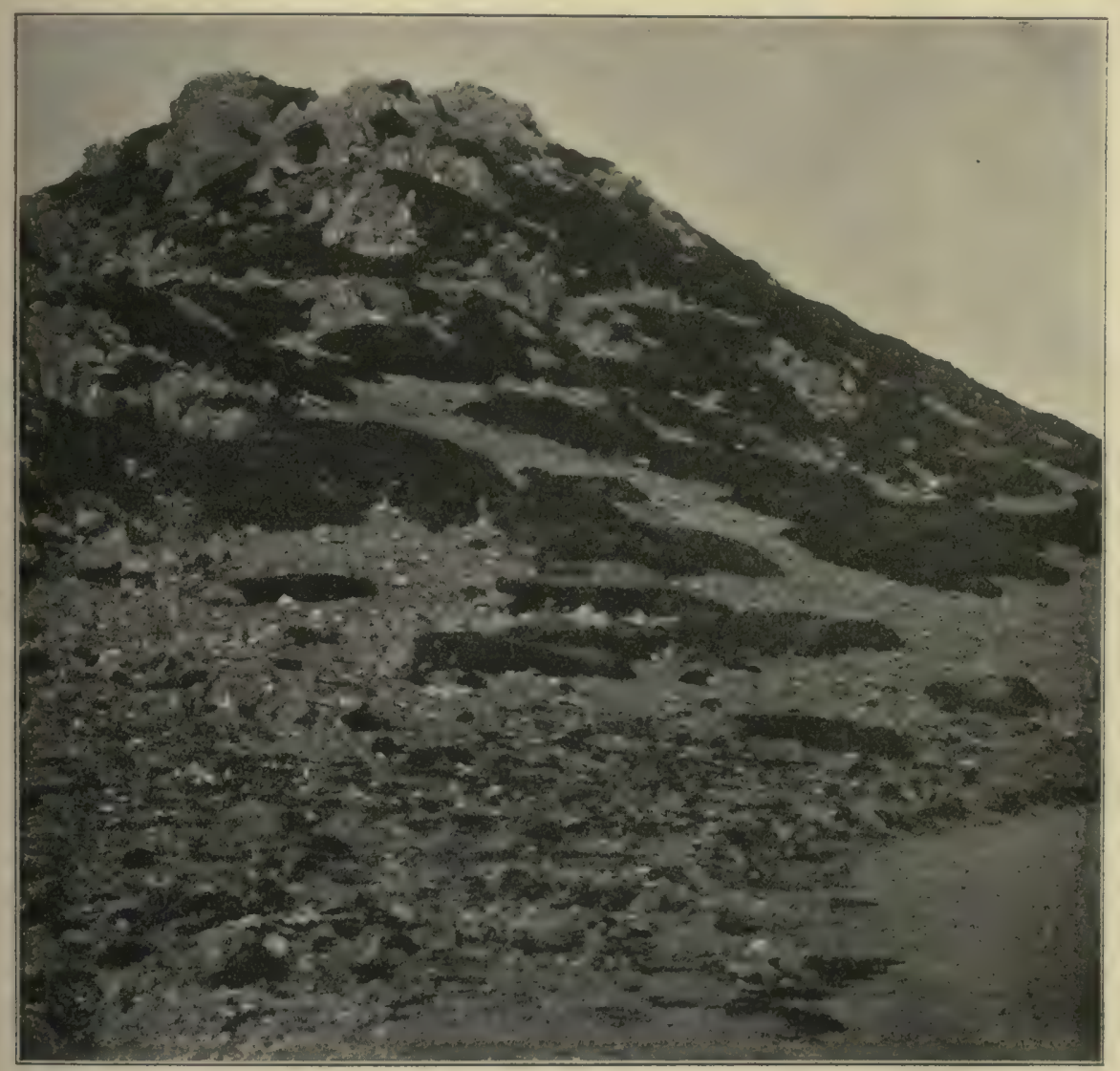

Fig. 344. Niedrige, vom Winde geprägte dicke Gesträuche von Pistacia lentiscus bei Ajaccio in Corsica. (Phot. Dr. F. Börgesen.)

den schädlichen Faktoren besonders angegriffen werden, allmählich in einsam stehende, haufenförmige Individuen auflösen. Die Eichengebüsche Jütlands sinken vor dem Ungestüm der Winde gegen Westen oft zu solchen vereinzelt stehenden, immer niedriger werdenden, flachen und breiten Haufen herab; dasselbe beobachtet man in den Hochalpen auf der Grenze der Krummholzgestrüppe und der Alpenmatten; das Krumm- 
holz sieht man zuletzt wie riesige Heidekrautsträucher in die Alpenmatte eingestreut. Ebenso ist es mit den Gariguen, Macchien und den Hartlaubwäldern.

Die Klasse der Hartlaubformationen hätte eigentlich mit den Wäldern beginnen sollen und mit den Macchien und Felsentriften schließen, weil jedenfalls sehr oft die Entwicklung in dieser Reihenfolge vor sich gegangen ist; die Felsentriften sind oft degenerierte Macchien, die Macchien degenerierte Wälder, und eine scharfe Grenze zwischen diesen Formationen zu ziehen ist unmöglich; spricht doch z. B. Chodat von einer "Maquis arborescente".

In Niederungen, wo der Boden für längere Zeit feuchter ist, werden die Sträucher der Macchien höher, und auf solchen Stellen gehen die Macchien oft in Wälder über. An besonders günstigen Lokalitäten findet man echte Wälder, in welchen nicht nur Holzpflanzen, welche den Macchien angehören, vorkommen, sondern auch echte Waldbäume, und der Boden wird von schattenliebenden, mesophilen Kräutern und Moosen bedeckt.

Die typischen Hartlaubwälder treffen wir, wie die Macchien und Felsentriften, in den subtropischen Gegenden mit Winterregen; schon die Mittelmeerländer zeigen uns typische Beispiele. Die Blätter der immergrünen Arten sind gewöhnlich ungefähr lanzettlich oder elliptisch und ungeteilt, ferner ganzrandig, steif und lederartig (Grisebachs Oleander-, Lorbeer-, Oliven-, Eucalyptus-Form u. a.), oder sie sind zusammengesetzt (meist einfach oder doppelt gefiedert).

Eigentliche Knospenschuppen fehlen z. B. bei Olea Europaea und wohl bei den meisten anderen, oder es kommen wenige Niederblätter an der unteren Grenze der Jahressprosse vor, wie bei Laurus nobilis und anderen Lorbeergehölzen.

Von den Assoziationen müssen folgende genannt werden, von denen die zwei ersten ganz typisch sind.

Die mediterranen Eichenwälder. In den Mittelmeerländern kommen niedrige Wälder immergrüner Arten vor, z. B. aus Eichen, namentlich aus Quercus ilex bestehende ${ }^{1}$ ). Diese Art hat lanzettliche, dornige, wollhaarige Blätter und ist ein echter Xerophyt, der auf trockenem und steinigem Boden, teilweise sogar auf Felsenboden wächst. Ihr schließen sich eine Menge anderer baum- oder strauchartiger Pflanzen, auch Halbsträucher und Stauden an, welche alle xerophil gebaut sind und welche man teilweise draußen in den sonnigen Garigues oder in den Macchien wiederfinden kann. "Die Garigue ist eine Waldboden-Vegetation, aber

1) Über die Steineichenwälder (Quercus ilex und ballola) siehe ferner Rikli und Schröter 1912. 
ohne Bäume“ (Flahault), Von diesen Pflanzen kann Qucrcus coccifera genannt werden, die niedrige und strauchförmige Eiche, welche durch ihre Wurzelsprosse von ganzen Strecken der Garigues Besitz ergreift und niedrige, nicht nutzbare Gebüsche bildet; ferner Juniperus oxycedrus, Cistus-Arten, Arbutus unedo, Viburnum tinus, Paliurus australis, Ilex aquifolium usw. Kleine Lianen findet man dort auch: Lonicera implexa, Smilax aspera, Rosa sempervirens u. a.

In größeren Höhen, auf nassem, kaltem, tonigem Boden treten die laubwechselnden Quercus pubescens, Qu. Apennina und andere zum Teil systematisch sehr kritische Arten an die Stelle der immergrünen, ebenfalls wegen ihrer steifen, meist behaarten Blaitter deutlich xerophile Formen ${ }^{1}$ ).

In Algier bildet nach Trabut $^{2}$ ) und anderen Quercus suber auf kalkarmem Boden Wälder an Orten, wo die jährliche Regenhöhe $60 \mathrm{~cm}$ überschreitet. In diesen Waldgebieten ist Ackerbau ohne künstliche Bewässerung möglich. Dort, wo der Wald zwischen den immergrünen Bäumen auch laubwechselnde, wie Castanea, Populus tremula, Alnus glutinosa, Fraxinus und Ulmus enthält, erinnert seine Flora mehr an die mesophyten Wälder Mitteleuropas als an die der Macchien. Auf den Atlasgebirgen wird Wald von Quercus ballota gebildet.

Auch in den nördlicheren Teilen des Mittelmeergehietes finden sich nicht selten ähnliche immergrüne und besonders gemischte, zum mehr oder weniger großen Teil laubwechselnde Eichenwälder, so namentlich auf den dalmatinischen Küstengebirgen und den vorgelagerten Inseln $\left.(\text { Graebner })^{3}\right)$.

In den Mittelmeerländern findet man ferner Olivenwälder oder vielmehr Olivenpflanzungen, die von der ausgeprägt xerophil gebauten Olea Europaea (S. 263) gebildet werden; sie ist eine ausgeprägt immergrüne Holzpflanze, deren Blätter $2-3$ Jahre sitzen bleiben, lanzettlich und graubehaart sind.

Die Lorbeerwälder. Wälder aus Laurus nobilis kommen z. B. an der österreichischen und kroatischen Küste vor, wo sie hier und da mehr oder weniger ausgedehnte, ziemlich reine Assoziationen bilden. In diesen Wäldern bilden die Macchienelemente nach Adamovié das Unterholz und den Niederwuchs, mitunter sind sie aber auch so dicht, daß sie nur einen höchst dürftigen Unterwuchs aufkommen lassen (Graebner). Von Lianen sind z. B. Smilax aspera, Ephedra campylopoda,

1) Flahault 1898; Ascherson u. Graebner Syn. IV.

$\left.{ }^{2}\right)$ Trabut 1888; Rikli u. Schröter 1912. Vergl. auch Chodat 1909, der die Niederwaldvegetation bespricht.

3) Vergl. Adamovié 1909; über die Insel Arbe besonders Morton 1912. 
Lonicera implexa, Asparagus acutifolius, Tamus communis und Arten von Clematis eingestreut. An den südistrischen Küstengebirgen folgen über dem Lorbeerwalde oft charakteristische dichte Bestände von Ostrya carpinifolia, die selbst nach langen Trockenperioden im August und September noch frisch grün sind. Zwischen ihnen finden sich Castanea und andere; ihr Unterwuchs ist im wesentlichen mesomorph.

Die lederartigen Blätter sind für ein Hartlaubgewächs ziemlich groß, sie sind unbehaart und frisch dunkelgrün. Sie sind wohl auch an feuchtere Standorte gebunden, wovon die Lorbeerwälder zeugen, welche auf den Kanarischen Inseln vorkommen; sie bewohnen hier die feuchteste von den Höhenstufen der Berge, die jedoch im Sommer gelegentlich mehrwöchentlich sehr wolkenarmen Trockenperioden ausgesetzt sein können (Burchard) ${ }^{1}$ ).

Christ ${ }^{2}$ ) hat eine anziehende Beschreibung von ihnen gegeben; sie entwickeln sich in der Nebelregion und besonders in den Tälern und Schluchten, in denen selbst im Sommer täglich oder fast täglich dichter Nebel sich erhebt. Der Boden ist mit einem dichten Teppich von Farnen und Moosen bedeckt. Der Wald besteht aus Lauraceen-Bäumen mit Persea Indica, Laurus Canariensis, Ocotea foetens und Phoebe Barbusana; reichlich untermischt sind Ilex Canariensis, Erica arborea, Myrica faya und andere. Das Unterholz ist zusammengesetzt aus Rhamnus glandulosa, Viburnum rigidum u. a., als Lianen sind Smilax-Arten vorhanden. Die Blätter gehören dem Lauraceen-Typus an, d.h. also sie sind ungeteilt und lederartig, aber auch andere rein xerophytische Typen kommen vor. Ein eigener, tiefer Schatten herrscht in diesem Walde. Die erfrischende Feuchtigkeit kontrastiert scharf mit der glühenden Hitze an den offenen Hängen und wird erhöht durch den Geruch der Veilchen, Moose und Erde. Zahllose Farne bekleiden den Waldboden, und das erinnert an Wälder in Neuguinea und anderen pacifischen Inseln; abweichend von diesen sind Kräuter selten.

Den selben Waldtypus trifft man in Madera.

Diese Lorbeerwälder nähern sich den mesophytischen Wäldern, besonders den tropischen Regenwäldern, aber Laurus nobilis kommt auch in den waldähnlichen Macchien vor in Gesellschaft mit solchen Arten wie Olea Europaea, Myrica faya, Ilex perada, Rhododendron Ponticum (Chodat).

Viele andere Hartlaubwälder kommen in anderen Gegenden der Erde vor, wo der Regen im Winter fällt, z. B. Australien, Chile, Kalifornien. Noch vermissen wir genaue ökologische Studien über diese

1) Burchard, Englers Jahrb. XLIX, Beibl. 109.

2) Christ 1885 . 


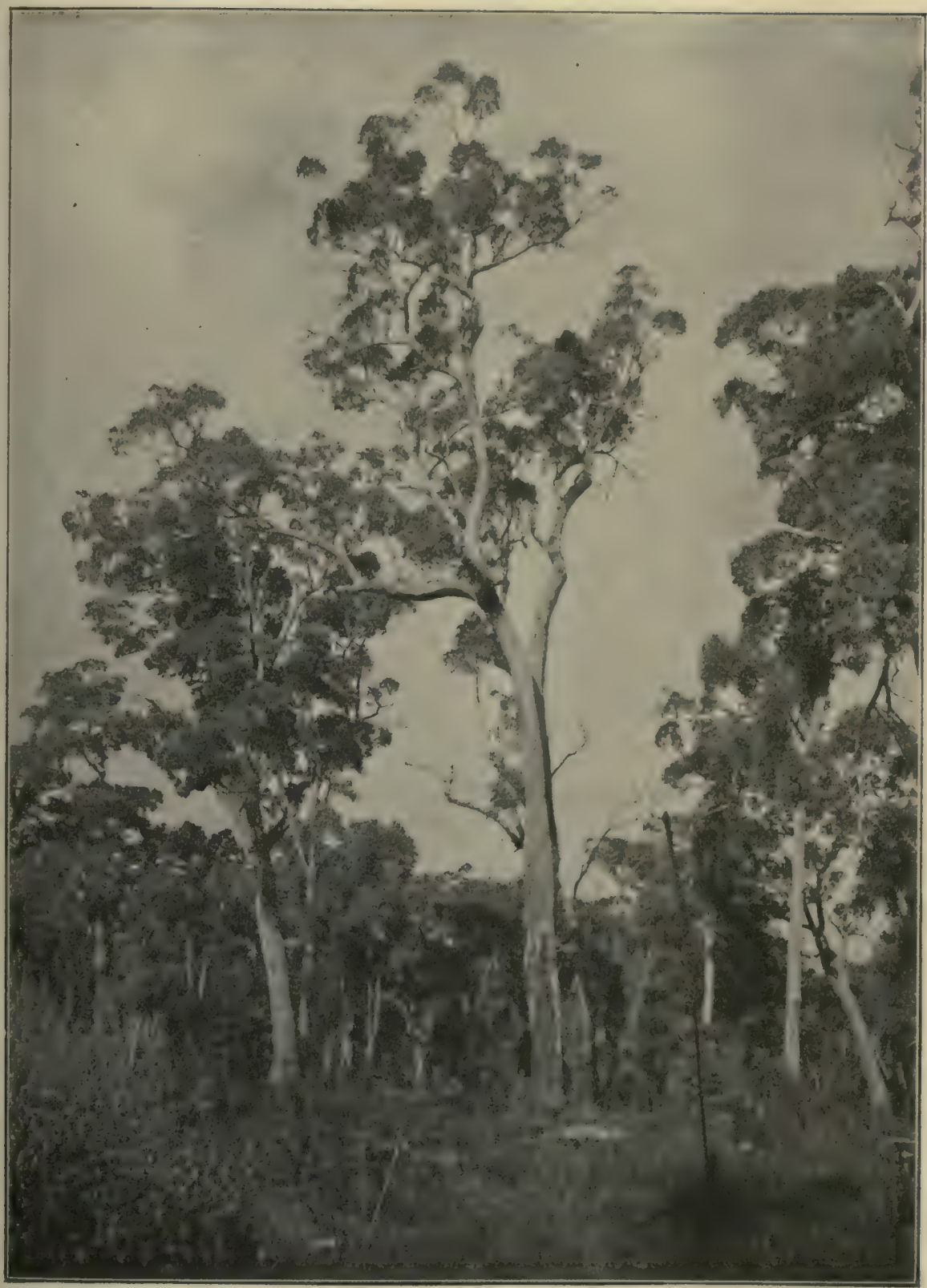

Fig. 345. Westaustralien: Hochwald von Eucalyptus marginata Sm. im Hügellande. Am Boden Hartlaubgebüsche, rechts ein niedriger Grasbaum (Xantorrhoea Preissii). (Phot. E. Pritzel.) 
Wälder, um ihre Stellung zu den vorhergehenden und zueinander richtig beurteilen zu können.

Die in Australien so häufigen Wälder von Eucalyptus-Arten scheinen jedenfalls teilweise hierher gerechnet werden zu können. Andere wachsen in den Gegenden, wo der Regen im Sommer fällt und werden wahrscheinlich ökologisch verschieden sein und gehören wohl zu den Savannen ${ }^{1}$ ) (Fig. 345).

In Kalifornien werden die Wälder aus Arten von Quercus $(Q$. macrocarpa) und Sequoia sempervirens gebildet.

Von den Coniferenwäldern scheinen einige nach ihrem Vorkommen in den warm temperierten Gegenden mit Winterregen und trockenen Sommern zu der "Hartlaub"-Klasse zu gehören, z. B. die Wälder von Pinus Halepensis und P. maritima in Südfrankreich und anderswo im Mittelmeergebiete. Rikli und Schröter ${ }^{2}$ ) besprechen ein Pinetum Halepensis im nördlichen Algerien. Macchien- und Gariguespflanzen bilden ein ziemlich reichhaltiges Unterholz, wo z. B. folgende Arten vorkommen: Chamaerops humilis, Pistacia lentiscus, Arten von Cistus, Helianthemum fumana, Genista, Calycotome, Lavandula, Rosmarinus, Zollikoferia, von Gramineen z. B. Iygeum spartum, Stupa parviflora, Ampelodesmus tenax, Andropogon hirtus, Poa bulbosa und einigen annuellen, sowie eine große Anzahl von Kleinsträuchern und Stauden. Die Zahl der Sommer-Annuellen ist sehr groß.

1) Vergl. Diels 1906; Ostenfeld 1915 b.

2) Rikli u. Schröter 1912. 


\section{Serie der subxerophilen Formationen mit Grasboden}

(Klasse 13 und 14, S. 320)

\section{Kap. Subxerophile Gras- und Staudenvegetation (Steppen und Prärien)}

Indem wir zu den subxerophilen Vereinen fortschreiten, die an Individuen reicher sind, kommen wir zuerst zu den mehr oder wenig geschlossenen, stauden- und grasreichen Vereinen, die als Steppen und Savannen bekannt sind, und zu den sich ihnen anschließenden Abänderungen. Diese Vereine sind alle an Gegenden gebunden, die im Binnenlande der großen Kontinente liegen und von den Meeren gewöhnlich durch Gebirge und Wälder geschieden werden, welche die Feuchtigkeit der von den Meeren kommenden Winde abfangen. Die Regenmenge in der Vegetationszeit ist im Verhältnis zur Verdunstung gering, wenn auch die Jahressummen der Niederschläge oft nicht sehr klein sind, im Präriengebiete von Nordamerika z. B. 50-70 cm, in den russischen Grassteppen $40-50 \mathrm{~cm}$. In anderen Gegenden ist die Regenmenge weit geringer und beträgt nur etwa $30-40 \mathrm{~cm}$.

Der Boden in den Steppen und Savannen hat oft keinen Humus, oder ist doch humusarm, oft viel reicher an löslichen Salzen als der Boden der Waldgegenden. In den besseren Grassteppen hat jedoch humusreicher Boden (Tschernosem) große Verbreitung, besonders in Südrußland, Marokko und den Prårien Amerikas.

Der Ausdruck "Steppe" stammt aus Rußland und bezeichnet dort die baumlosen oder baumarmen Gegenden Südrußlands, obgleich sie in vieler Hinsicht untereinander abweichen. In der Botanik gibt es mehrere Vegetationsformationen, welche "Steppen“" genannt werden; man spricht von Grassteppen, Strauchsteppen, Salzsteppen, Ton- oder Lehmsteppen, ja selbst von Sandsteppen und Wüstensteppen, neben den nach gewissen vorherrschenden Pflanzengattungen benannten Steppen (Artemisia-Steppe, Stupa-Steppe usw.). Humboldt rechnet mit Unrecht zu den Steppen im weitesten Sinne sogar die niedereuropäischen Zwergstrauchheiden, und Middendorf nennt die Tundren "Eissteppen". Heiden und Steppen sind sehr streng zu unterscheiden; bei der Steppe finden wir stets nährstoffreichen Boden, der eine viel höhere Stoffproduktion 
erreichen würde, wenn nicht durch die langen Trockenperioden die Vegetation gehemmt und Waldwuchs gehindert würde; die Steppenpflanzen erzeugen meist in der kurzen Vegetationszeit ganz unverhältnismäßig kräftige Sprosse. Der Zwergwuchs der Heide stammt von der Nährstoffarmut (resp. der physikalischen oder chemischen Unmöglichkeit für die Pflanzen, reichlich Nahrung aufzunehmen), sehr trocken darf sie nicht werden, sonst wird sie eine Sandflur. Rohhumus wird in der Heide gebildet.

Die typischen Steppen in engerem Sinne sind die Grassteppen, z. B. die baumlosen, meist mit Gräsern und anderen Stauden bewachsenen ausgedehnten Ebenen in Südrußland, Ungarn, Centralasien, Nordamerika (Prärien) und Argentinien (Pampas). Die Pflanzendecke ist ein mehr oder weniger geschlossener Teppich und hat ein xerophiles oder subxerophiles Gepräge. Durch diese beiden Verhältnisse unterscheiden sich die Steppen von den Wiesen mit ihrer dichten Vegetation und ihren hellgrünen, weich- und breitblättrigen Gräsern und Stauden; aber anderseits ist die Pflanzendecke bei den Grassteppen dichter und höher als in den subtropischen und tropischen Steppen und in den Wüsten. Sie stehen jedenfalls an der Grenze von ariden Steppen und Wiesen; die südrussischen werden auch bisweilen Wiesensteppen genannt.

Diese baumlosen Grassteppen sind im wesentlichen extratropisch, in den kalttemperierten Gegenden und in subtropischen Gegenden verbreitet. Sie bilden die 13. Klasse in dieser Serie (Kap. 106).

Am engsten an diese schließen sich die baumtragenden Grassteppen, die gewöhnlich Savannen (in Brasilien Campos) und Baumsteppen genannt werden; sie werden als subxerophile Vegetationsform mit zu dieser VIII. Serie gerechnet und als Klasse 14 besprochen (Kap. 107).

Im Gegensatz zu dieser Vegetationsform stehen dann die weit mehr xerophilen Formationen, die als Strauchsteppen, Dornbuschsteppen, Catinga, Succulentsteppen, Halbwüsten und Wüsten bezeichnet werden. Sie gehören der "ariden Serie" an und sind in tropischen sowie in subtropischen und kalttemperierten Gegenden, die durch ein Minimum von Niederschlag ausgezeichnet sind, verbreitet (z. B. dem tropischen Afrika, dem mexikanischen Hochlande, dem inneren Australien). Auch die Halbstrauchsteppen könnten vielleicht den Anfang dieser VIII. Serie bilden; sie werden aber wohl am besten der ariden Serie angeschlossen werden $^{1}$ ).

1) Uber Formen von Steppen und Wüsten vergl. oben O. Paulsen 1912, 1915; Rübel 1914 a, c, 1915 a, c. 


\section{Kap. Die baumlosen Grassteppen}

Der Charakter der Grassteppen wird vom Klima erzeugt, namentlich durch die Verteilung der Niederschläge. Es gibt gewöhnlich zwei Ruhezeiten, eine von der Sommerdürre (Sommerruhe) und eine von der Kälte hervorgerufene Winterruhe. Die Steppen haben meist kein stehendes Grundwasser, und ihre Vegetation hängt von den Niederschlägen stark ab. Jedoch ist die Bodenbedeckung den ganzen Sommer über sichtbar und kann während dieser ganzen Zeit beweidet werden. Die Grassteppen stehen etwa in der Mitte zwischen den Wiesen der kühltemperierten Gegenden und den ariden Steppen, nähern sich jedoch am meisten den ersteren.

Europa. Die Grassteppen Südlosteuropas. Ökologisch und floristisch betrachtet sind die Steppen Südrußlands und die Pußten Ungarns dieselbe Vegetation (Békétow u. a.) ${ }^{1}$ ).

Die Frage nach der Vorgeschichte der Steppen hat in Rußland eine reiche Litteratur veranlaßt; einige (Baer, Dokutschajew, Ruprecht, Tanfiljew u. a.) meinen, daß sie immer Steppen gewesen seien, andere (Pallas, Palimpsestow), daß sie nach Waldverwüstungen anfgetreten seien.

Die Steppen des südlichen Rußlands bedecken zum größten Teil einen trocken gelegten alten Meeresboden. Der Boden ist verschieden. In den nördlichsten Steppengegenden gibt es viel Lößboden, in südlicheren ist Sediment (eines aralo-kaspischen Quartärmeeres) vorherrschend, und im nördlichen Kaukasien geben Glazialbildungen den Untergrund. Ein großer Teil des Steppengebietes wächst auf dem schwarzen, humusreichen Tschernosem („Schwarzerde“); südlicher kommt der chokoladefarbige Boden vor, und in Südosten gehen die Grassteppen in die Wermutsteppen über. Das Tschernosem bedingt die große Fruchtbarkeit des südlichen Rußland; der Boden kann 3-5 m tief sein und bis $13-16 \%$ Humus enthalten.

Es ist unentschieden, ob die Verteilung von Wald und Steppe vom Klima oder vom Boden abhängt - wahrscheinlich von beiden. Baer meinte, daß die lange Trockenheit die Baumlosigkeit der Steppen erzeuge; Middendorff war der Ansicht, daß die heißen und trockenen Winde des Sommers dieses täten; Békétow, der Geologe Dokutschajew und der Pflanzengeograph Tanfiljew sehen den Salzgehalt des Bodens als einen Grund an, weshalb sich die Wälder nicht des Steppenbodens bemächtigt haben. Tanfiljew macht darauf aufmerksam, daß der Wald mit dem all-

1) Nach Rübel (1914) bedeutet der russische Name „Steppe" unbebaute Ebene; PuBte in Ungarn ist ein slavischer Name, der bezeichnet: öde, leer, wüst. Weit verschiedene Formationen werden somit als "Steppe" bezeichnet, wie oben hervorgehoben. 
mählichen Auswaschen des Bodens vorrückt. Die Wälder findet man nach ihm in den Steppengegenden unter anderem besonders auf den Höhen der Wasserscheiden, weil diese Höhen am meisten ausgewaschen sind. Ramann (1911) schreibt dagegen, daß die Schwarzerden als echt klimatische Böden auf den verschiedensten Gesteinen und Ablagerungen entstehen. Man kennt Schwarzerden auf Löß, Tonen, Kalkgestein, Gneiß usw. Ihre Humusstoffe sind aus der Zersetzung der abgestorbenen Steppenpflanzen, besonders der Wurzeln der Steppengräser, hervorgegangen. Leicht lösliche Salze sind in den Schwarzerden nur selten in solcher Menge vorhanden, daß sie sich als kristallinische Lagen abscheiden; dann gehören die Böden zu den Salzböden. Der größere Salzgehalt ist eine Folge des Klimas.

Die Klimatologen ${ }^{1}$ ) stimmen indessen alle darin überein, daß das Klima der Steppengebiete trockener ist als das der Wälder; im besonderen fällt der Regen selten. Die einzelnen Regenfälle sind oft heftig, so daß die Hauptmenge des Wassers oberflächlich abläuft, ohne in den Boden einzudringen. In den Regionen, in denen die Grassteppe überwiegt, scheint der Baumwuchs keineswegs absolut ausgeschlossen zu sein; er wird nur durch klimatische Ursachen erschwert. Im Kaukasus schildert Radde ${ }^{2}$, wie an den Flüssen, die die Steppe durchfließen, Bäume des Uferwaldes im Wachstum gehindert werden und daß viele ihrer Blätter im Sommer vertrocknen. In diesen Gebieten ist der Wald auf die edaphisch günstigen Stellen beschränkt; er kommt hier in den Flußtälern vor, ebenso bewohnt er die weniger salzhaltigen Hügel ${ }^{3}$ ) und den groben Sand oder Kies, in den das Wasser leichter als in den schweren Lehmboden eindringen kann ${ }^{4}$ ).

Die südrussissischen Steppen sind große Ebenen, unbehindert können die starken östlichen Winde über sie hinstreichen und die Verdunstung steigern. Die Vegetation ist mehr oder weniger geschlossen, ist aber selbst im Sommer sichtbar und dadurch von der der Wüsten zu trennen.

Das Klima der Steppe ist kontinental. Im Winter haben 3 bis 5 Monate Mitteltemperaturen unter $0^{\circ}$. Der Niederschlag ist im Winter nicht groß, und überdies gestatten die heftigen Stürme keine Ansammlungen einer dickeren Schneelage, weshalb auch die Schneeschmelze im Frühling nur eine Bodenschicht von mäßiger Tiefe zu durchtränken vermag. Das Frühjahr fängt im April an. Dann sprießen die Pflanzen schnell aus dem Boden hervor, frisch grün und blütenreich. Im Frühling

1) Woeikof, Hann und Köppen. Siehe Rikli 1907 b.

9) Radde 1899.

3) Middendorf 1867; Tanfiljew 1898, 1903, 1905.

4) Kostytscheff 1890 . 
und Frühsommer ist die Regenmenge nicht gerade klein. Der Juni ist der regenreichste Monat $(5-7 \mathrm{~cm})$, aber der Regen kommt in Form von wenigen, heftigen Gewittern, daher fließt der größte Teil des Wassers oberflächlich ab. Im Juli hat die mittlere Temperatur eine Höhe von $19-23^{\circ}$ erreicht. Die Luftfeuchtigkeit ist während des Sommers $60-70 \%$, also nicht extrem klein. $\mathrm{Zu}$ dieser Zeit ist jedoch der Boden ausgetrocknet; die Steppe nimmt einen graugelben und welken Ton an, der Boden birst und wird staubig (vergl. S. 61). Doch verschwindet die Vegetation nie ganz, kann auch im Sommer beweidet werden, wodurch die Grassteppen sich gerade von den Wüsten unter-

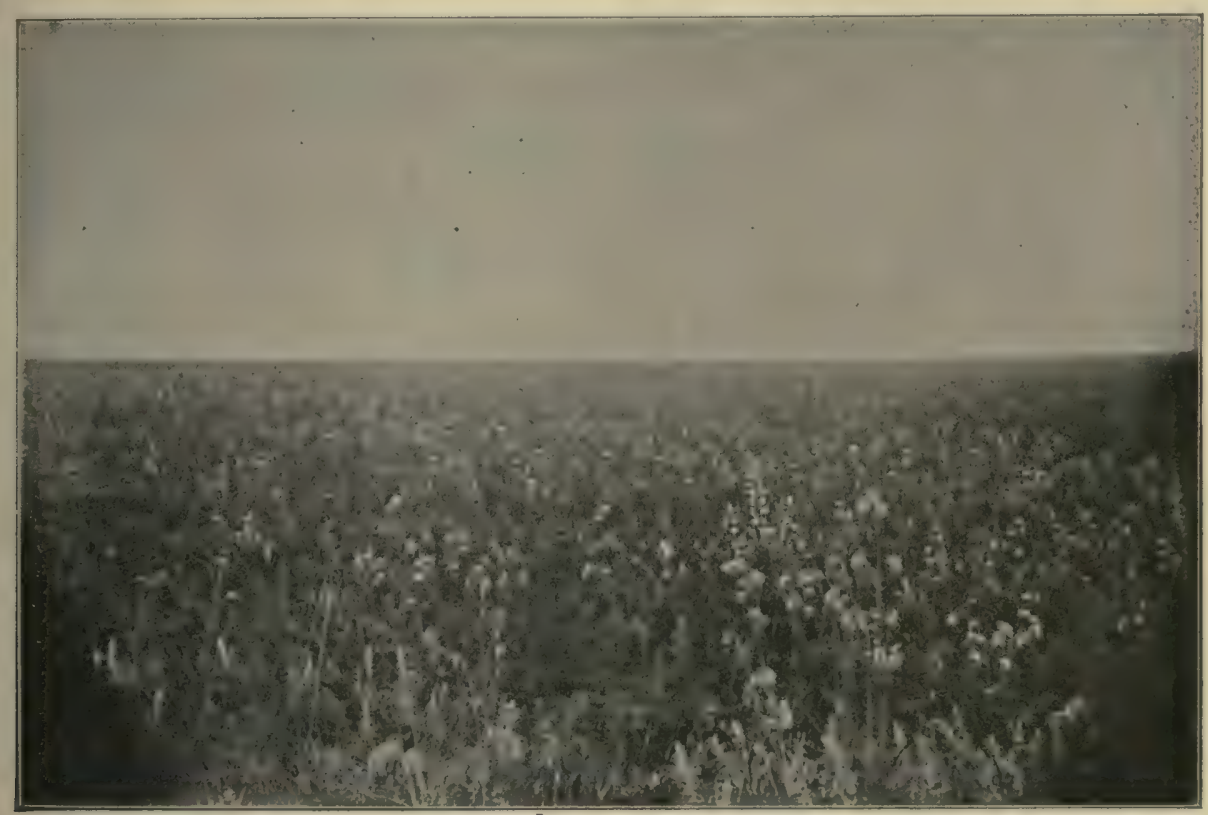

Fig. 346. Steppe mit Salvia nutans (und Silene viscosa, ein Exemplar). Stupa ist hier von Salvia überdeckt. Gouv. Charkow; Juni 1893. (Phot. Tanfiljew.)

scheiden, wo die krautartigen Pflanzen im Sommer ganz verschwinden, so daß nur die mehr oder weniger verholzten Halbsträucher und Kleinsträucher übrig bleiben. Im August und September ist die Regenmenge bedeutend kleiner als im Frühsommer. Im Herbst, wo die sinkende Temperatur die Verdunstung herabsetzt, wird dann durch die Feuchtigkeit auf der Steppe wieder etwas Grün hervorgerufen; es ist dann, abgesehen von gewissen Artemisia- und anderen Arten, besonders die Zeit einjähriger Chenopodiaceen und ähnlicher Salzkräuter. Der Winter folgt dem Sommer oft unmittelbar. Im November, Dezember fängt der Winter mit seinen Schneestürmen an; die Schneefälle sind für die Vegetation eine wichtige Wasserquelle. Der Winter ist lang und außerordentlich streng. 
Der Wechsel der Witterung drückt natürlich der Vegetation das Gepräge auf. Im Frühling erscheint eine reiche Vegetation von Zwiebelund Knollenpflanzen, Tulpen, Fritillarien, Hyazinthen, Iris und anderen Pflanzen mit schönen und großen Blüten. Im Sommer herrschen zahlreiche Hochgräser, wie Stupa-Arten, Salvien und andere reich blühende Pflanzen. Im Herbste endlich entwickeln sich besonders viele Kompositen, namentlich Artemisien, weiter Staticen u. a.

Lebensformen. Daß die angeführten Lebensbedingungen eine xerophile Vegetation hervorrufen müssen, ist leicht einzusehen. Die mehrjährigen Kräuter erhalten ihr Leben wesentlich durch die unterirdischen Teile, die im Boden gegen vollständiges Austrocknen geschützt sind. Die Pflanzen sind teils Frühjahrspflanzen mit Zwiebeln und Knollen, in der Gegend von Orenburg z. B. ein bunter Schmuck von Liliaceen (Fritillaria, Allium, Scilla, Gagea, Tulipa), Iris, Corydallis, Adonis vernalis u. a., teils sich später entwickelnde Stauden mit tiefer gehenden Pfahlwurzeln und oft graufilzigen Sprossen (besonders weiter nach Asien hin), z. B. Labiaten, Cruciferen, Artemisia-Arten, Caryophyllaceen, Malvaceen, Papilionaceen und viele Gräser. Die Gräser sind mehrjährige Rasengräser; die höchsten Rasen bestehen aus Stupa-Arten; die Blätter sind schmal, steif, oft stechend; sie bleiben, obgleich in verwelktem Zustande, viele Monate erhalten. Die Gräser bilden die Hauptmasse der Vegetation, geben die Physiognomie an; ihre Wurzeln gehen tief und sind oft stark verzweigt; die Gräser verbranchen viel Wasser und wirken daher austrocknend auf den Boden. Deshalb könneu andere Pflanzen oft nur schwierig den Kampf mit ihnen bestehen. Die echten Steppengräser sind hoch und steif und können den Stürmen Trotz bieten.

Viele einjährige, kurzlebige Arten findet man eingestreut als Folge der Kürze der Vegetationszeit und der Offenheit der Vegetation. Dies bildet einen großen Unterschied sowohl gegen die subglazialen Fluren, als auch gegen unsere mesophilen Wiesen und Weiden. Halbsträucher kommen vor, Bäume und Sträucher dagegen fehlen. Ein genaueres Studium der Samenverbreitung wird wahrscheinlich zeigen, daß teils der Wind, teils die Tiere den Transport der Samen besorgen. $\mathrm{Zu}$ den Erscheinungen der Steppen gehören auch die "Steppenläufer", als welche z. B. Gypsophila paniculata, Ceratocephalus arenarius, Rapistrum perenne u. a. vorkommen; wenn diese Pflanzen abgestorben sind, werden sie vom Winde losgerissen und zu kugeligen, oft riesigen Klumpen verfilzt, die von den Stürmen mit meterlangen Sprüngen über die Ebenen fortgeführt werden („Steppenhexen") ${ }^{1}$ ).

1) Vergl. Ascherson 1892. 
Üppigkeit und Reichtum der Steppe sind je nach den Gegenden sehr verschieden und hängen größtenteils vom Boden ab. Auf der besten südrussischen Steppe, deren Boden die erwähnte "schwarze Erde" ist, herrschen Festuca ovina, Koeleria cristata mit Medicago falcata, Thymus serpyllum u. a. vor; auf der weniger guten Steppe ist das Thyrsagras (Stupa pennata, S. Lessingiana und S. capillata) zahlreicher vorhanden, während weniger Stauden auftreten; die schlechteste Steppe ist fast allein mit den hohen Rasen der xerophilen Thyrsagräser, besonders mit denen von Stupa pennata, bewachsen. Wie offen der Boden ist, zeigen die interessanten Tafeln von Cornies, auf denen die sorgfältig abgesteckten und abgemessenen Areale einzelner Arten dargestellt sind.

Nach Krasnoff ist die Flora der eigentlichen Schwarzerdesteppen vorzugsweise aus lebhaft gefärbten Stauden gebildet, während mit zunehmender Trockenheit die Gräser die Oberhand gewinnen und die große Einförmigkeit der Steppe hervorrufen. Er ist auch der Meinung, daß die Steppenflora von einer alten Flora abstammt, die bereits vor der Glazialzeit das ganze Gebiet bedeckte.

Die russischen Grassteppen gehen gegen Osten in die des südwestlichen Sibirien über; dagegen grenzen sie gegen Südosten an andere Formationen, nämlich an die Strauchsteppen mit oft salzigem Boden und an die Einöden der transkaspischen Länder ${ }^{1}$ ).

Die Steppen Asiens bieten offenbar eine höchst verschiedene Physiognomie dar. Am Altai gibt es Krautsteppen und Grassteppen, die mit ihren wogenden Thyrsagräsern und ihren Gypsophila-Arten den Steppen der südrussischen "schwarzen Erde" ähnlich sind (Krasnoff, Martjanow). Es gibt ferner Strauchsteppen, in welchen Kleinsträucher und Halbsträucher vorherrschen; sie entwickeln sich auch in Rußland, z. B. von Spiraea erenifolia usw. gebildet ${ }^{2}$ ).

Rumänien und Serbien. Im Tieflande von Rumänien wächst eine Steppe, die der russischen nahe verwandt ist ${ }^{3}$ ). Auf sandigem Boden in Serbien leben Steppen, deren Vegetation aus xerophilen Gräsern, ausdauernden Kräutern, Knollen- und Zwiebelgewächsen, Sträuchern und einjährigen Kräutern zusammengesetzt ist. Die Blätter stehen mehr oder weniger aufrecht oder aufwärts gekrümmt; viele von ihnen sind imstande sich einzurollen oder sie schützen sich durch photometrische Bewegungen vor der Insolation, andere haben reduzierte Blätter. Die Wurzeln sind lang und dringen oft sehr tief in den Boden. Adamovic gibt eine ausgezeichnete Schilderung von der Vegetation, die er "Wüstensteppe" nennt ${ }^{4}$ ).

1) Vergl. O. Paulsen 1912.

3) Über Persiens Steppen und Wüsten siehe Stapf 1888.

8) Grecescu 1898.

4) Grassteppen anf Cypern, vergl. Holmboe 1914. 
Ungarns Sandpußten sind den Steppen Südrußlands im großen und ganzen sehr ähnlich; die ökologischen Verhältnisse, die Entwicklung, die Lebensformen, teilweise auch die Arten sind dieselben. Kerner unterscheidet verschiedene Assoziationen, z. B. die Federgras-Assoziation (Stipetum), die Goldbart-Assoziation, die aus den hohen, dicht aneinander schließenden Rasen des Andropogon gryllus besteht und insoweit von der typischen Steppe abweicht, ferner eine Assoziation aus einjährigen Bromus-Arten. Die Vegetation ist nicht geschlossen, der sandige Boden tritt zwischen den Pflanzen hervor ${ }^{1}$ ).

In den Sandpußten trifft man viele xerophytische Charaktere, z. B. senkrechte Stellung der Laubblätter (Lactuca scariola, L. saligna, Lythrum virgatum, Linaria vulgaris und andere Arten, welche in Nordeuropa nicht diesen Charakter haben).

Von den Sandpußten ganz verschieden sind die Salzpußten, welche auf undurchlässigem Boden auftreten, wo das Regenwasser sehr schwer versickert; es kommt hier eine mehr oder weniger hygrophile Vegetation mit Halophyten gemischt zum Vorschein. Diese Assoziationen gehören zu den Halophytrereinen ${ }^{2}$ ).

"Die pontische Heide" in Niederösterreich oder die niederösterreichische „Federgrasflur" auf trockenem, sandigem oder schotterigem Boden sind nach der Darstellung von G. Beck den Ungarischen Pußten sehr ähnlich. Es kommt offenbar eine recht große Anzahl von Varianten der Grassteppe vor, die je nach den Assoziationen verschieden sind ${ }^{3}$ ).

Ein gleichfalls hierher gehöriger Verein ist der besonders im östlichen Deutschland, Ungarn und im westlichen Rußland verbreitete der sonnigen, pontischen (auch pannonischen) Hügel, der, wo er in Kultur genommen ist, wegen seiner Hitzigkeit mit Vorliebe zur Anlage von Weinbergen, Obstplantagen usw. Verwendung findet. Im Aussehen unterscheidet er sich in nichts von manchen Steppen Südosteuropas. Im Frühjahre zeigen die Abhänge und welligen Flächen oft eine blumenreiche Flora, in der an manchen Orten besonders Adonis vernalis eine führende Rolle spielt. Sonst sind die Peucedanum-Arten, Dianthus Carthusianorum, Tunica prolifera, Scorzonera purpurea und viele andere, besonders aber Stupa pennata und S. capillata, Charakterpflanzen ${ }^{4}$ ).

Ökologisch sehr abweichend, wenn auch in der Physiognomie oft ähnlich ist die Grasheide, die zu den echten Heideformationen gehört und durch die geringe Stoffproduktion aller ihrer Pflanzen auch in den regenreichen Zeiten von den Grassteppen verschieden ist. Von den

$\left.{ }^{1}\right)$ Kerner 1863. Vergl. auch Bernátsky 1904 b.

2) Bernátsky 1905.

3) Vergl. auch Kerner 1863 a, 1886.

4) Vergl. Graebner 1896 b, 1898 a, b, 1901, 1903, 1907, 1909. 
Zwergstrauchheiden abweichend und dadurch zu den Steppenformationen hinneigend sind die trockenen von ihnen dadurch, daß infolge einer alljährlichen stärkeren Austrocknung des Bodens die Herrschaft der Heidesträucher unmöglich ist. Die dürrste Assoziation unter ihnen ist das heidekrautlose Sandfeld, welches im wesentlichen von Weingaertneria, Flechten usw. gebildet wird ${ }^{1}$ ).

Auch in der Schweiz und anderen Teilen der Alpen kommt eine Menge von Assoziationen vor, welche vielleicht am besten den Grassteppen angeschlossen werden, z. B. folgende.

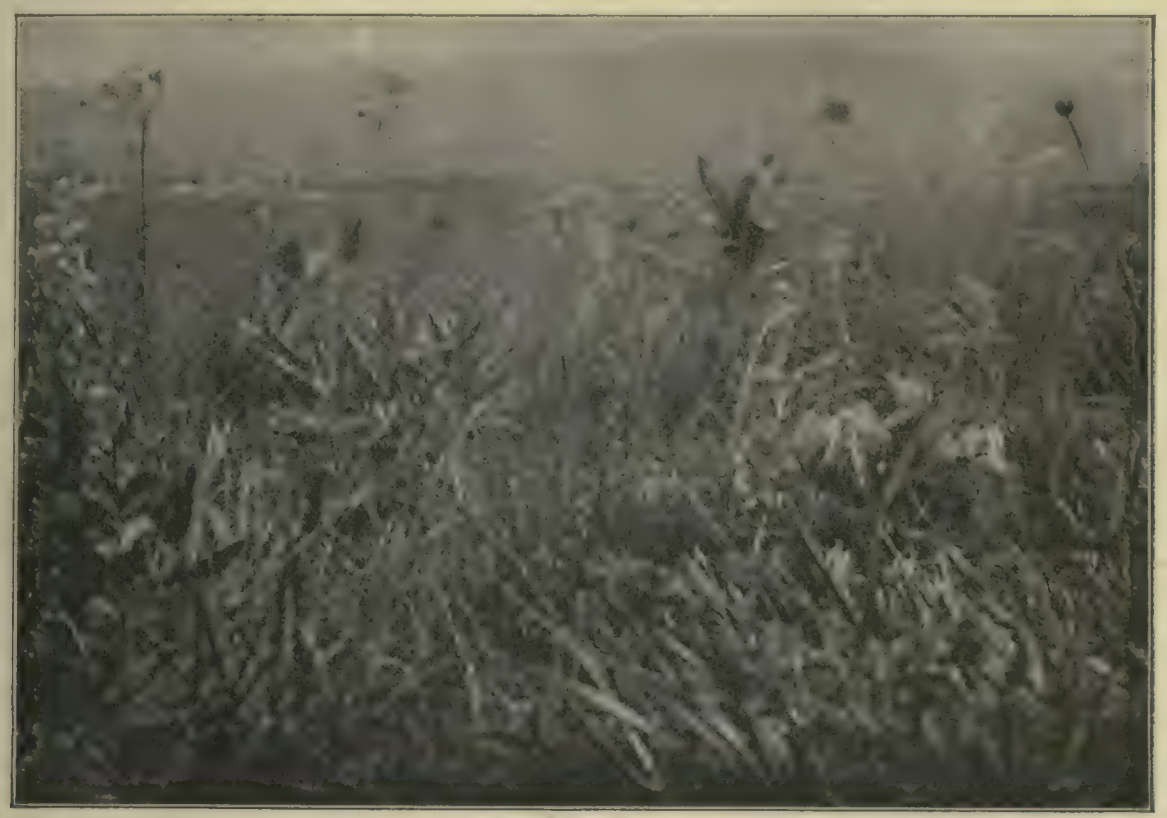

Fig. 347. Bergsteppe in Serbien, 1300-1500', mit Vegetation von Stupa Grafiana, Centaurea chrysolepis, Ferulago monticola, Achillea clypeolata, Bromus fibrosa, Salvia amplexicaulis, Veratrum nigrum, Anchusa Barrelieri, Dianthus.

(Phot. Adamovié.)

Die Assoziation der Festuca Valesiaca, die sich an sonnigen, trockenen Stellen mit flachgründigem Boden in Wallis entwickelt. Die herrschende Art bildet kleine Polster, die aus zahlreichen dichtstehenden Schossen gebildet sind, die viele graugrüne, gefaltete Grundblätter erzeugen, zwischen denen die steifen, 2 bis $3 \mathrm{dm}$ hohen Halme stehen. Zwischen den Gräsern wachsen verschiedene ausdauernde Kräuter, unter denen sich auch Zwiebelgewächse, wie Gagea saxatilis und Muscari

1) Graebner 1895 a, 1901, 1904. 
comosum befinden. Bei den Gräsern sind eingerollte Blätter häufig, so bei Festuca Valesiaca, Kocleria Valesiaca und Stupa pennata; andere Gräser, wie Poa bulbosa und P. concinna, haben Knollen als Wasseroder Nährstoffspeicher. Der häufigste Verdunstungsschutz sind Haare, so bei Oxytropis Halleri und Artemisia Valesiaca, oder Succulenz bei Sempervivum arachnoideum, oder auch eine Oberflächenverminderung der Assimilationsorgane, bei Onobrychis arenaria und Plantago serpentina.

Weniger xerophytisch ist die Bromus-Wiese, in der $B$. erectus vorwiegt; sie kommt im wesentlichen an den trockenen, sonnigen Lehnen der Kalkgebirge vor (auch auf der Balkanhalbinsel usw.). Als Begleitpflanzen sind zu nennen Galium mollugo, Festuca rubra, F. ovina, $F$. pratensis, Arrhenatherum elatius, Carex montana, C. verna, Brunella vulgaris, Salvia pratensis und andere. (Vergl. übrigens Kap. 68.)

Die iberischen Steppen. Die trockene Natur Spaniens hat an mebreren Stellen echte Steppen hervorgebracht, die Willkomm geschildert und durch folgende Verhältniszahlen gekennzeichnet hat: $3 / 5$ Kräuter, $1 / 4$ Halbsträucher, $1 / 9$ Gräser, über $1 / 20$ Sträucher, $1 / 27$ Flechten und Algen. Etwa $1 / 6$ aller Arten haben eine frische grüne Farbe, $5 / 6$ sind anders gefärbt.

Von interessanten Arten der iberischen Steppen sei das Espartogras (Stupa [Macrochloa] tenacissima) genannt, das mit seinen großen, steifen Rasen auf dem spanischen Hochlande weite Flächen gesellig bekleidet und die nahe verwandten russischen Thyrsagräser ersetzt. Andere iberische Steppengräser sind Stupa parviflora und Avena filifolia nach Rikli ${ }^{1}$ ), der die Blattanatomie von dieser Art untersuchte. Diese Steppen erscheinen ökologisch etwas verschieden von den russischen, indem sie trockener sind und sich den Wüstensteppen nähern. Nach Rikli sind namentlich die Küstensteppen im südöstlichen Spanien sehr xerophytisch und kommen Drudes "Wüstensteppen" am nächsten, in denen die Vegetation sehr offen ist. Wenn der Boden durch anhaltende Trockenheit steinhart geworden ist, vermag das Regenwasser nicht einzusickern, es fließt schnell ab und unter dem klaren Himmel mit der gewaltigen Insolation muß sich eine sehr trockene und offene Vegetation entwickeln.

Die Nordafrikanischen Grassteppen gehören ebenso zu den trockneren Typen (Wüstensteppen). Oft erwähnt sind die Halfa-Steppen in Nordafrika ${ }^{2}$ ), welche von Stupa tenacissima gebildet werden. Es ist erwähnt。

1) Rikli 1907 b. Vergl. auch Chodat 1909, der eine „Macrochloa-Assoziation"

2) Flahault $1906 \mathrm{~b}$; Rapport sur les herborisations de 1a Soc. bot. de France pendant la Session d'Oran. Bull. Soc. Bot. France, LIII (in der Litteraturliste ausgefallen). Rikli 1907; Rikli, Schröter und Tansley 1912; Schröter und Rikli 1912. 
ein Büschelgras, dessen Horste zerstreut stehen. „Das heiße, trockene Klima gestattet nur die Entwicklung einer mehr oder wenig offenen Pflanzendecke fast ausschließlich aus graugrünen Xerophyten". Es ist ein stark xeromorphes Steppengras mit mehrjährigen, harten, zähen Rollblättern, die nur in der Regenzeit nicht eingerollt sind und gewöhnlich 5-8 dm, bisweilen bis 1,4 m lang werden. Die Art bevorzugt Grusboden, fehlt aber auch auf Löß- und Sandboden nicht. Oft sind Hunderte von Quadratkilometern von Stupa und Artemisia herba alba bedeckt; in den Niederungen wird die letztere gewöhnlich allein herrschend, so wie Halfa in den höheren Lagen. Die Begleitpflanzen sind sehr verschieden. Listen der Arten vergl. besonders bei Flahault.

Die Drinn-Steppe. Nach Rikli und Schröter ist Aristida pungens die Leitpflanze. Dieser Typus ist bezeichnend für Sandböden und Dünengebiete, erreicht aber seine Hauptverbreitung in der Wüste, wo er unter anderm durch sein weitauslaufendes Wurzelwerk den beweglichen Sand festlegt.

Die Sennah-Steppe ist ein dritter Typus Nordafrikas, durch das Spartogras, Lygeum spartum, charakterisiert. Sie nimmt die Standorte in Besitz, welche Übergangsgebiete zwischen Sand- und Lehmboden sind.

Ein vierter Typus ist die Schih-Steppe, die von Artemisia herba alba gebildet wird.

Die beiden letzten Typen bewohnen besonders die mehr zentralen Teile des inneralgerischen Hochlandes. "Wie wasserlose Flüsse durchziehen sie die Halfasteppe oder umsäumen sie gegen die zentrale Depression des Hochlandes in einer Breite von mehreren Kilometern".

Auch in Südafrika kommen Grassteppen in großer Ausdehnung vor, zu verschiedenen Typen gehörend, welche noch ein gründliches ökologisches Studium bedürfen. Die Regenzeit ist gewöhnlich kurz, die Trockenperioden sind lang. Engler ${ }^{1}$ ) nennt verschiedene Typen.

a) Die Niedergrassteppe. Niedrige Gräser bedecken meist in Abständen den steinigen oder sandigen Boden.

b) Die Hochgrassteppe hat Gräser von 1-2 m Höhe, meist Büschel bildende Andropogoneen. Zwischen ihnen wachsen krautartige Pflanzen, teils einjährige, teils Zwiebel- und Rhizomgewächse mit einzelnen blühenden Sprossen oder auch Stauden, welche aus einem kurzen, niedrigen Grundstock einen Büschel von blühenden Sprossen emporsenden. Amarantaceen kommen ganz besonders gern in den baumlosen Grassteppen vor, meist graugrünliche, oft sehr hohe Stauden. Eigentliche Grassteppen ohne oder mit sehr vereinzelten Bäumen und Sträucheru finden sich besonders in Ostafrika unter $1200 \mathrm{~m}$.

1) Engler 1910 (1908b-1915).

Warming-Graebner. 3. Auflage, illustr. 
c) Hochgrassteppe des höheren Gebirgslandes. Über $1200 \mathrm{~m}$ an Abhängen, wo sie den Steppenwinden, aber nicht den Seewinden zugänglich sind, lebt diese eigenartige Vegetation.

In Rhodesia kommen nach R. Fries Grassteppen aus 2-4 m hohen Gräsern vor, welche im September und Oktober vollständig trocken sind. Aus Natal hat Bews gute Schilderungen der Grasvegetation mit ihren verschiedenen Varianten gegeben. Auf dem Hochlande ist Antistiria imberbis das wichtigste Gras, welches auf losem, gut durchlüftetem Boden reine Assoziationen bilden kann. Wenn Unterschiede des Bodens zum Ausdruck kommen, treten andere Arten hinzu, z. B. Andropogon cerisiiformis; diese kann auch herrschend werden. Die Einwirkung der Menschen kann man an vielen Stellen bemerken. - Die Grasvegetation bekleidet ungeheure Strecken in Natal. Die Gräser sind fast alle ausdauernd, einige wenige nur sind einjährig. Die ausdauernden haben Büschelform mit vielen intravaginalen Verjüngungssprossen, welche Ausläufer bilden (?). Die Stengel und Blätter sind oft mit groben Haaren bekleidet, auch die Ährchen sind oft behaart.

Bews unterscheidet zwei Haupttypen, der eine ist das Hochbodenfeld mit gut durchlüftetem Boden, größerer Regenmenge und weniger Frost im Winter. Die Gräser sind hoch; meist herrschen Antistiria imberbis und Arten von Andropogon. Es findet sich hier eine endlose Menge von Variationen. Aristida junciformis bildet über weite Strecken Assoziationen, besonders längs der zahlreichen Wege, welche durch das Land führen. Der andere Typus auf niedrigem Niveau und auf hartgetrocknetem Boden hat andere Grasarten und dornige Holzpflanzen.

Auch in Ostafrika kommen nach Engler ${ }^{1}$ ) Hochgrassteppen vor; zahlreiche Arten von Andropogon, Chloris, Pennisetum, Eragrostis, Aristida u. a. bilden hohe, Getreidefeldern ähnliche Bestände, sehr häufig aber mit Vorherrschen einer einzigen Art. Zwischen den Gräsern treten besonders Convolvulaceen, Malvaceen, Leguminosen, Amarantaceen und Cucurbitaceen auf.

Diese Hochgrassteppen entfernen sich unzweifelhaft recht bedeutend von den fruchtbaren, russischen Schwarzerdesteppen; sie sind offenbar mit dem Grasboden in den Savannen und Campos der tropischen Gegenden sehr nahe verwandt, wo die klimatischen Verhältnisse von denen Südeuropas sehr abweichen, indem eine ausgeprägte Regenzeit den Sommer charakterisiert, wogegen die kalte aber frostfreie Zeit den Winter bezeichnet. Anderseits finden sich in Asien Steppen, welche den Schwarzerdesteppen Südrußlands sehr ähnlich sind. Nach

1) Engler, A., 1910. Die Pflanzenwelt Afrikas. Grundzüge der Pflanzenverbreitung in Afrika und die Charakterpflanzen Afrikas. Die Vegetation der Erde. IX. Bisher erschienen Bd. I, II, 1, 2, III. 
Krassnoff ${ }^{1}$ ) wachsen im Altai solche Steppen mit wogenden Thyrsa grïsern, Arten von Gypsophila u. a. Die Abekansche Steppe in der Nähe des Altai wird von Martjanoff erwähnt.

Nordamerikanische Prärien und „Great plains“. Die Prärien Nordamerikas sind teilweise echte Steppen und durch dieselben physikalischen Faktoren hervorgerufen: durch kontinentales Klima, lange und strenge, trockene Winter mit trockenen Winden, Schnee und Ninimaltemperaturen von -20 bis $-50^{\circ}$, heiße und trockene, von Mitte Juli ab oft regenlose Sommer mit kalten Nächten. Sie haben

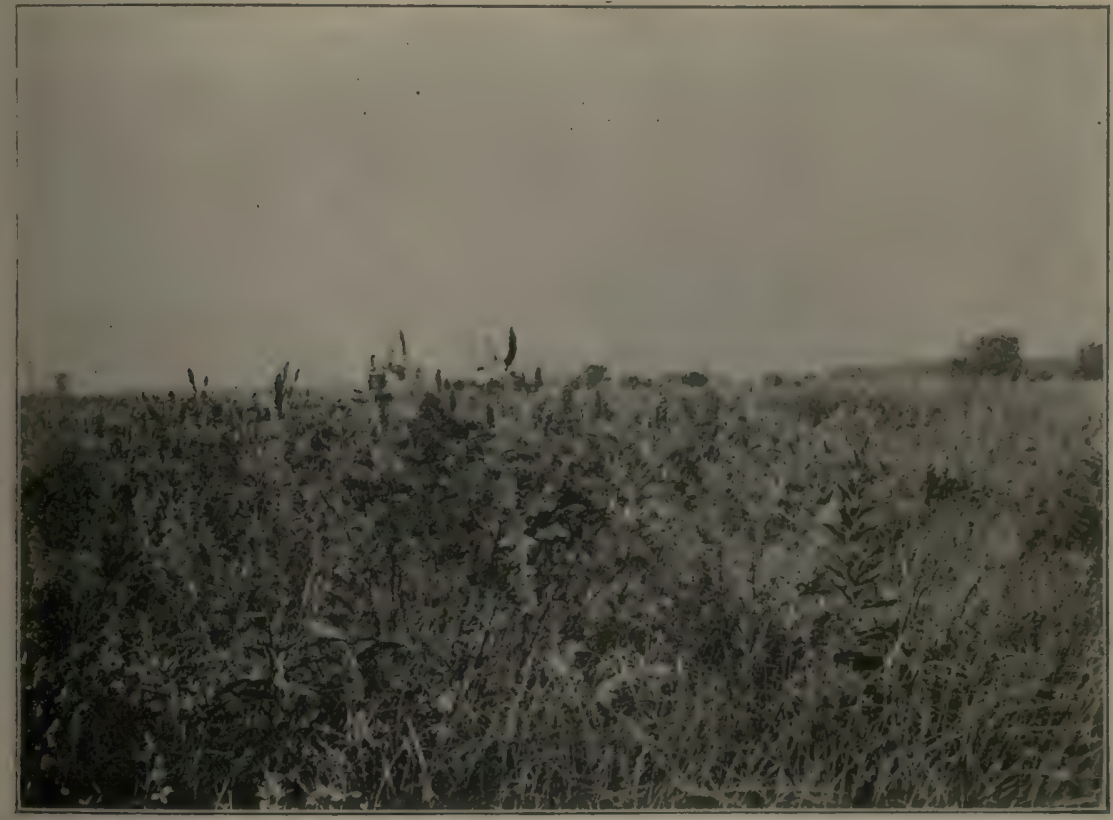

Fig. 348. "Low Prairie" bei Lincoln, Nebraska. Vorne Glycorrhiza lepidota (?) und Asclepias purpurea. August. (Phot. Brockmann-Jerosich.)

eine kurze Vegetationszeit, die durch vorübergehende Niederschläge eingeleitet wird. Auch hier kommen jedenfalls in gewissen Gegenden zwei Ruhezeiten vor.

Das Klima kann kurz dadurch charakterisiert werden, daß es gegen Süden langsam wärmer wird, gegen Westen zu trockener und im Sommer zugleich heißer. So ist die durchschnittliche jährliche Regenmenge für Kansas, Nebraska und Colorado beziehungsweise 73, 65 und $40 \mathrm{~cm}$ (abgerundete Zahlen, berechnet nach Briggs und Belz). In Über-

$\left.{ }^{1}\right)$ Siehe 1888, Martyanow, und Referat in Englers Jahrb. 1882, IX. 
einstimmung hiermit findet man im östlichen Teile üppige Grasfluren, die eigentlichen Prärien, die kulturfähig sind und jetzt auch stark genutzt werden, wogegen der westliche Teil, "the great plains" genannt, eine arme Vegetation von kurzen und kurzwurzeligen Gräsern trägt und nur teilweise feucht genug ist, um lohnende Erträge geben zu können; das Gedeihen der Kulturgewächse ist hier wie westlich von den Rocky Mountains von speziellen Kulturmethoden (dry farming) abhängig.

Die Regenzeit fällt in den Sommer, Mai bis Juni, die trockenste Zeit ist überall der Winter; North Platte (Nebraska) hat z. B. in den Monaten November bis einschließlich März nur ungefähr $7 \mathrm{~cm}$ Regen. Im Januar geht die $0^{0}$-Isotherme, im Juli die $28^{\circ}$-Isotherme durch das Präriegebiet. Die Temperaturschwankungen, tägliche sowie längere, sollen groß sein.

Die Prärien sind riesige Ebenen, an deren Horizont die Krümmung der Erde erkennbar sein kann; heftige Stürme können über sie hinweg wehen; ihr Boden soll im Osten fast ebenso wie der in SüdruBland sein, nämlich ein schwarzer, mit Sand vermischter Ton, der wenigstens stellenweise tiefen, aus den Resten zahlloser vorausgegangener Vegetationen bestehenden Humus enthält und hierin einen unendlichen Reichtum für kommende Zeiten besitzt.

Die Prärien sind baumlos, nur längs der Wasserläufe findet sich Wald. Der Ursprung und die Entwicklungsgeschichte der Prärien sind eine vielumstrittene Frage. Nach einer Hypothese von Lesquereux ist der Prärieboden ein alter, langsam ausgetrockneter Seeboden, der Boden von Seen, denen durch die Aufwölbung der Anden in der Tertiärperiode die Wasserzufuhr entzogen wurde. Auch nach Harvey ${ }^{1}$ ) sind die Prärien präglazialen Ursprungs, die von den Prärien der Tertiärzeit stammen, welche dadurch entstanden sein sollen, daß der Niederschlag durch Frhebung der Rocky Mountains vermindert wurde.

Bezüglich der Wasserversorgung sind die Prärien günstiger gestellt als die Steppen Asiens; sie werden vom Regen mehr ausgewaschen, und mächtige Flüsse, denen sich eine Baumvegetation anschließt, durchströmen sie. Die gewöhnlichste Erklärung ihrer Baumlosigkeit ist, daß das Feuer, durch die Indianer oder durch Blitz hervorgerufen, die wichtigste Rolle gespielt hat. Andere suchen die Ursache in den starken, baumfeindlichen, südwestlichen Winden, in chemischen Eigentümlichkeiten des Bodens oder auch im Charakter des Klimas. Harshberger ${ }^{2}$ ) ist der wohl kaum haltbaren Meinung, daß Boden und Klima für Baumvegetation günstig sind, daß aber die Entwicklung des Landes für die Besiedlung mit Gräsern günstiger war als für jede andere Vegetation,

1) Harvey 1908.

2) Harshberger 1911. 
und daß die Grasvegetation, nachdem sie einmal das Land erobert hatte, muächtig genug war, den Wald fernzuhalten, jedenfalls eine schnelle Eroberung durch denselben zu verhindern.

Harshberger schreibt: Eine Prärie ist ein dicht mit Gräsern bewachsenes, geschlossenes Areal ohne Wald, aber mitten in einer bewaldeten Region liegend, wo das Klima für Baumwuchs günstig ist, aber wo die Grasvegetation exklusiv genug war, um in Verbindung mit ökologischen, physiographischen, edaphischen und historischen Faktoren,

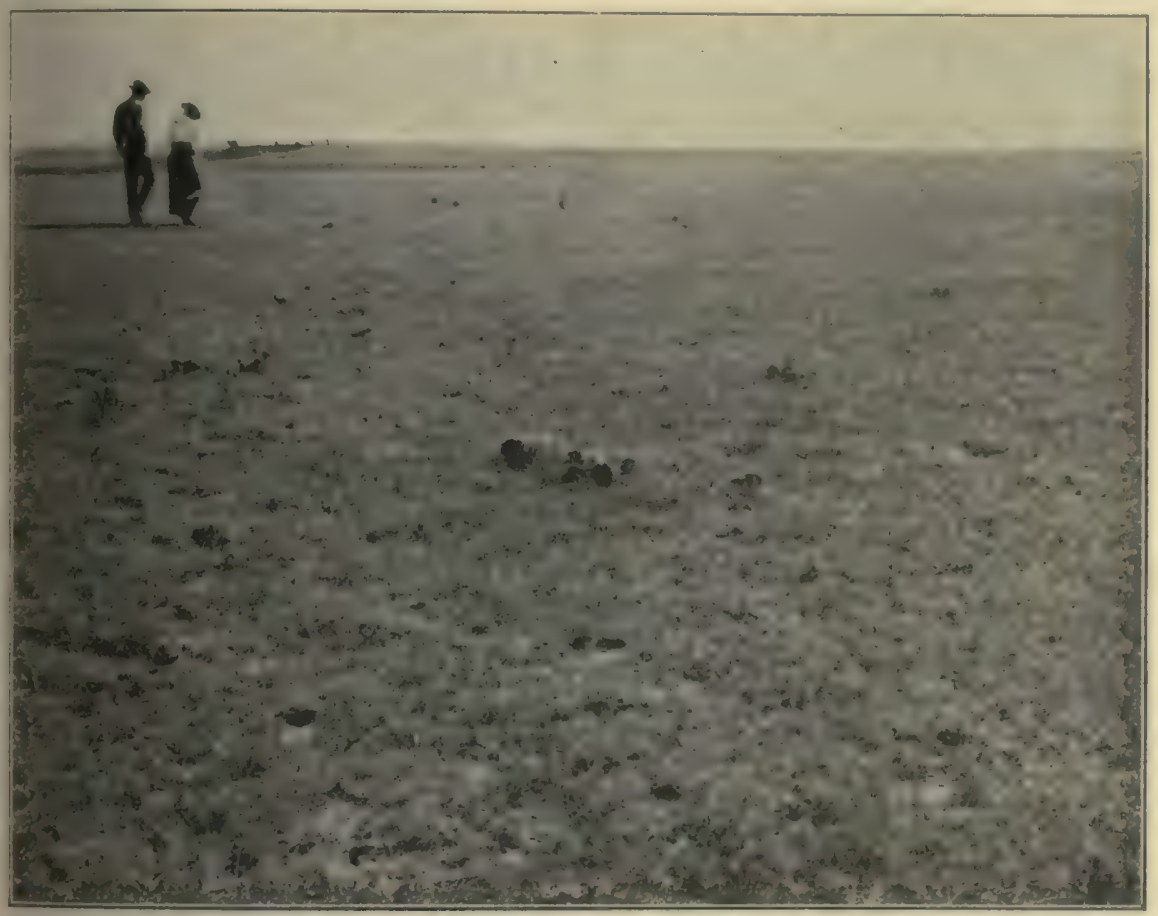

Fig. 349. „Short-grass"-Prärie mit Opuntia und Buchloë dactyloides bei Akron (Colorado, Nordamerika). (Phot. G. E. Nichols.)

viel mehr als durch Wassermangel und Bodenbedingungen, die Einwanderung der Waldbäume zu verhindern. Daß die Prärien sehr lange haumlos gewesen sind, ist daraus ersichtlich, daß die östlichen und westlichen Wälder keine einzige Baumart gemeinsam haben.

Mayr gibt an, die Feuchtigkeit sei stellenweise hinreichend groß, daß die Prärie hier einen Wald tragen könnte, und meint, daß die ïstlichen Teile ursprünglich einen Wald besessen hätten, der durch Präriebrände zerstört worden sei; gerade zu der Zeit der großen Präriebrände (September und Oktober) herrschen die erwähnten trockenen 
Westwinde vor. Harvey glaubt, daß die Bodenpilze fehlen, durch welche die Waldbäume ernährt werden sollen, daß die Schwierigkeit der Keimung der Samen in der dichten Grasmatte und schließlich auch Präriebrände weitere Gründe sind, weshalb die Krautvegetation den Sieg davon getragen hat. Dazu kommen noch die ungeheuren Herden von Büffeln (Bisons), welche zu Millionen die Prärien beweidet haben. Durch die Beweidung wurde die Grasnarbe dichter, und die Bisons sind wie die Indianer hin und her gezogen, welche das Gras, der Jagd wegen, anzündeten.

Die hauptsächlichsten Präriegebiete finden sich mitten in Nordamerika in den Staaten Nebraska, Jowa, Kansas und den beiden Dakotas. Von diesem Zentrum ab nehmen die typischen Prärien sowohl nach Süden als Norden langsam ab. Nach Harshberger zerfällt dieses große Areal in vier natürliche Abteilungen mit nord-südlicher Ausdehnung, die durch die Unterschiede der Regenmenge hervorgerufen sind. Im Osten liegt ein Übergangsgebiet, das mit den baumtragenden Prärien beginnt, dann folgen nach Westen zuerst der Präriedistrikt, der Sandhügeldistrikt und schließlich nach den Rocky Mountains hin der „Foothill Distrikt", durch welchen der Übergang zu den Hochgebirgen eingeleitet wird und wo die Flora bereits montane Einmischungen erhält.

Eine große Menge von Assoziationen, welche wohl teilweise Subformationen genannt werden können, kommen auf dieser ungeheuren Strecke vor, selbst wenn wir nur die typische Grasformation vor Augen haben; die Wälder, Sümpfe, Felsen usw. gehören ja anderen Formationen und zum Teil sogar anderen Formationsklassen an.

1. Im östlichen Übergangsgebiet, wo der Wald mit den Prärien konkurriert, kann man in Illinois und Wisconsin zwischen trockenen und nassen Prärien unterscheiden. In den trockenen herrschen von Gräsern „Bunch-grasses", das heißt hohe Gräser ( $1 / 2$ bis $1 \mathrm{~m} \mathrm{hoch)}$ von dichtem büschel- oder horstförmigem Wuchs vor, besonders Chrysopogon nutans, Andropogon furcatus, A. scoparius, Koeleria cristata, Eatonia obtusata, Stupa spartea u. a. Mit ihnen gemischt kommen eine Menge von Kräutern vor, welche zu verschiedenen Jahreszeiten ihre Blüten entfalten und dadurch der Prärie ein zeitweilig sehr verschiedenes Aussehen geben könne.

2. Das Zentrum der echten Prärie ist wesentlich gleichförmiger in der Vegetation. Es tritt an vielen Orten ein deutlicher Unterschied zwischen der Vegetation in den Niederungen und der auf den höheren Prärien hervor; die erstere ist mehr geschlossen, die letztere offener. Zwei Hauptassoziationen kommen vor: a) Die "Prairie-grass"-Assoziation auf leichterem Boden, und b) die „Buffalo-grass“-Assoziation auf mehr lehmigem Boden. 
a) Die Prairie-gras-Assoziation wird hauptsächlich von Gräsern gebildet, welche Ausläufer haben und daher den Boden mit einer geschlossenen Narbe decken. Die Arten sind hauptsächlich Sporobolus asperifolius, Koeleria cristata, Eatonia obtusata und Panicum Scribnerianum; auch Bouteloua curtipendula und B. oligostachya sind sehr häufig. Dagegen sind die "Bunch-gräser" Andropogon scoparius und $A$. furcatus, welche anderswo charakteristisch sind, hier von geringer Bedeutung. Das verschiedene Aussehen in den einzelnen Jahreszeiten („Aspects") wird von Pound und Clements und von Harvey beschrieben.

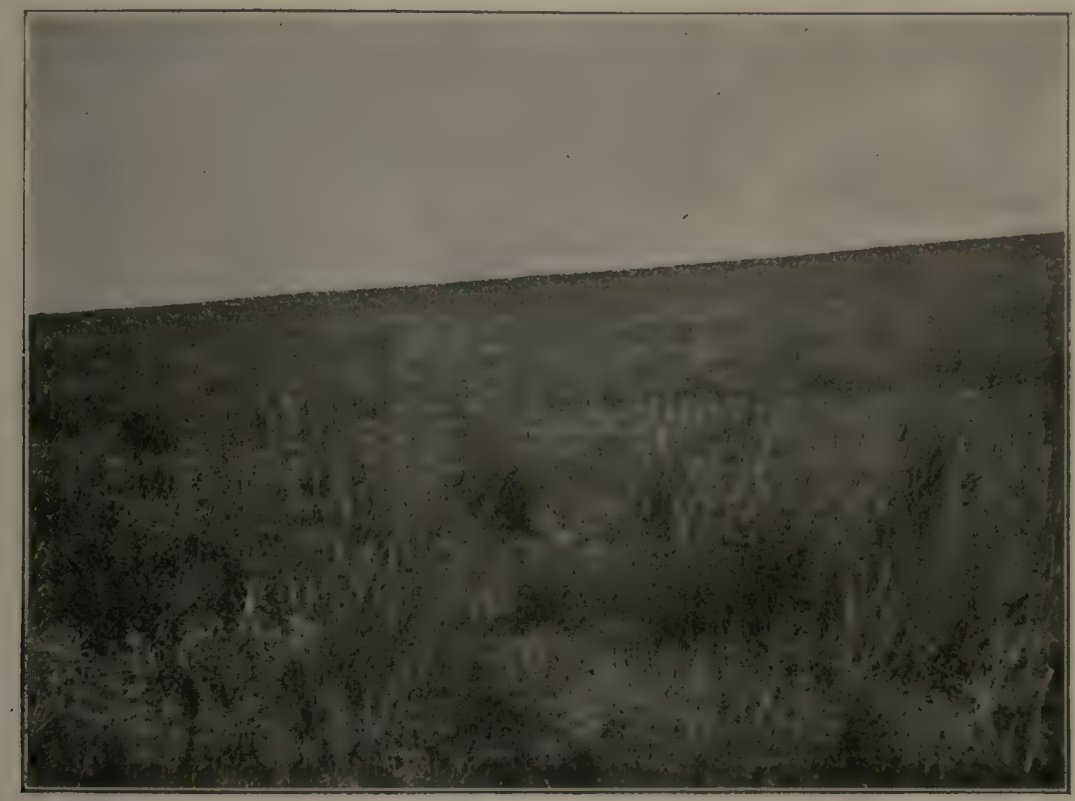

Fig. 350. "Great plains" bei Yuma, Colorado. "Bunch grass"-Assoziation mit Andropogon scoparius, Eriogonum annuum (die weißen) u. a. (Phot. Ove Paulsen.)

b) Die Buffalo-gras-Assoziation („short-grass-Assoziation“) wird vom Büffelgras (Buffalo-gras, Buchloë [Bulbilis] dactyloides) und dem Grama gras (Bouteloua oligostachya) gebildet; ersteres wächst namentlich auf lehmigen Plateaus, letzteres auf sandigen Strecken. Namentlich die letztere Art bildet fast reine, dichte Teppiche. Andere Gräser sind dort nie in Menge zu finden, nur hier und da leben sie zwischen dem Büffelgras. Dieses "Kurz-Grass" ist von zwergigem Wuchse, und die Wurzeln sind auch sehr kurz. In Übereinstimmung hiermit findet es sich auf lehmigem Boden, wo das Wasser nicht schnell den tieferen Bodenschichten zugeleitet werden kann. Es ist zugleich die Haupt- 
vegetation der westlichen "plains". Verschiedene dikotyle Stauden kommen hier vor (Fig. 349).

Auch Asa Gray hat diese östlichen und nördlichen Prärien geschildert; sie sind reines Grasland, wo zahlreiche Compositen (besonders Heliantheen und Astereen), Leguminosen (besonders Galegeen) und andere Stauden den Gräsern beigemischt sind, die der Landschaft ihr Gepräge geben. Das „Büffelgras" besteht nach Asa Gray namentlich aus Munroa squarrosa, den Chlorideen Buchloë dactyloides und Bouteloua, ferner aus vielen anderen Gattungen (Stupa, Aristida, Hordeum, auch mit Sect. Elymus u. a.). Man nennt dieses Gebiet das Land des Büffelgrases; es ist eine niedrige, sammetartige Grasdecke, die, wenn auch keine Rasen, so doch etwas Ähnliches bildet, und die nur in der ersten Frühlingszeit grün, sonst grau ist. Aber es hat selbst im Winter Nahrungswert. Hier ist, oder richtiger war, die Heimat der großen Bison- und Antilopen-Herden (Asa Gray).

Diese Prärien reichen im Süden bis nach Texas, welches ein Klima hat, das passend "Grassplains"-Klima genannt werden kann, denn die Gräser bilden das Grundelement der Vegetation. Doch selbst wo die Regenmenge am größten ist, ruft das Klima in Verbindung mit anderen Faktoren doch eine ausgeprägt xerophytische Vegetation hervor.

3. Der Sandhügeldistrikt gehört zu den sogenannten "great plains"; er reicht von Nebraska gegen Norden bis Dakota, gegen Süden bis Kansas, Oklahoma, Indianer-Territorium und Texas, sowie bis nach Nordost-Colorado hinein. Dieses Areal ist die Region des "Bunchgrases", welches auch weiter östlich vorkommt, sowie der Dünen und der Windmollen (, , blowouts").

Die Bunchgras-Vegetation wird gebildet aus Andropogon scoparius, Stupa comata, Calamagrostis (Calamovilfa), Andropogon Hallii und einer Anzahl von untergeordneten Arten von Gräsern usw. Die „beardgrass"Assoziation dagegen von Aristida purpurea und A. basiramea, Sporobolus cuspidatus und Stupa spartea.

Wire Gras-Assoziation wird von Pool und Shantz eine namentlich aus Aristida longiseta gebildete Assoziation genannt (Fig. 351). Die Wurzeln dieses Grases gehen 2-3 Fuß tief in den Boden.

Neben dieser Art kommen andere Gräser (z. B. Grama-Gras) vor, deren Wurzeln nicht so tief eindringen, dazu verschiedene Dikotylen, z. B. Ipomoea leptophylla mit ihren riesigen unterirdischen Knollen.

Bunch gras und Wire gras, die beide leichtere, vom Wasser leicht durchdringliche Böden bevorzugen, können nach Shantz als Anzeiger für kultivierbares Land gelten, wogegen Kurzgras einen Boden anzeigt, der das Wasser in den obersten Schichten festhält, so daß es schnell wieder verdunstet. Wenn Kurzgrasland gepflügt wird, kommen langwurzelige 
Arten und besiedeln es (z. B. Wire gras), weil der Boden jetzt für Wasser leichter durchdringlich ist. Die Vegetation kehrt aber langsam zu der des Kurzgrases zurück.

Die Flugsandgebiete und deren Windmollen $($ „Blowouts" $)$ in den Sandhügeln haben eine abweichende Vegetation; Yucca glauca findet sich hier; Gräser kommen nicht zur Herrschaft. Redfieldia flexussa dominiert in den Windmollen der vom Winde zerrissenen Dünen, sie gleicht biologisch der europäischen Calamagrostis (Psamma) arenaria. Rydberg und Bessey haben nähere Aufschlüsse über sie gegeben ${ }^{1}$ ), aber

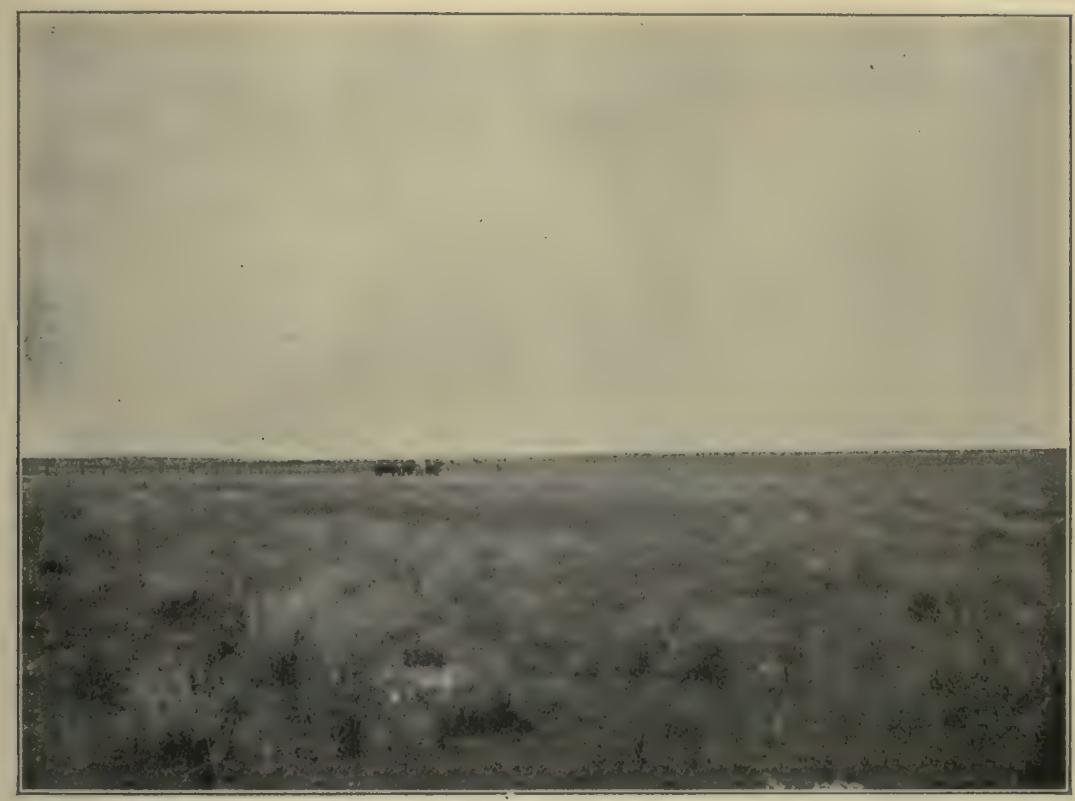

Fig. 351. „Wire-grass"-Prärie mit Aristida longiseta, Eriogonum, Grindelia squarrosa, Artemisia Canadensis. (Phot. Ove Paulsen.)

die Lebensformen scheinen noch nicht eingehend genug studiert zu sein. Im übrigen gehören sie auch zu den eigentlichen Sandformationen und nicht zu den Grassteppen.

4. Der „Foothill Distrikt" erstreckt sich nordwärts durch Dakota, Montana, Assinibora und Alberta, erreicht seine Nordgrenze in Athabasca; südwärts ist er verbreitet durch Colorado und New-Mexico. Er ist ein hohes Tafelland von zahlreichen Canions durchbrochen. Von den drei von Harshberger hier aufgestellten „Formationen" interessieren uns hier nur die Gras-Assoziationen. In der Ferne sehen sie typischen

2) Harshberger 1911, S. 532. 
Prärien ähnlich. Zwei Gräser beherrschen die Vegetation und geben der Landschaft ihre Physiognomie, nämlich Stupa comata und Triticum (Agropyrum) spicatum. Die Stupa-Assoziation entwickelt sich auf den höher gelegenen Prärien, eine Grasnarbe bildend mit vielen eingemischten Kräutern, so Arten von Lupinus, Astragalus, Oxytropis, Psoralea, Tradescantia Virginica, alle mit blauen Blüten; andere haben gelbe Blüten usw. Auch die Bouteloua (Grama-Gras)-Assoziation kommt hier vor. Auf den niedrigen, sandigen und den "Gumbo-Plains" herrscht die Agropyrum-Assoziation; die herrschende Art ist Triticum (A.) spicatum.

Zwischen den Rocky Mountains und der Sierra Nevada ist die Natur sehr abweichend (nach Mayr sinkt die Luftfeuchtigkeit in der Vegetationszeit bis auf $40-50 \%$, und die Niederschläge des ganzen Jahres betragen nur ca. $100 \mathrm{~mm}$ ). Es entsteht daher im wesentlichen eine niedrige Strauch- und Halbstrauch-Vegetation; stellenweise, ganz wie im inneren Asien, kommen Halbwüsten und Wüsten mit salzhaltigem Boden oder ohne solchen vor.

Südwärts verändert sich die Natur gleichfalls; hier werden Cacteen, Agave- und Yucca-Arten und ähnliche Saftpflanzen oder anders gebaute Xerophyten allmählich zahlreicher; einerseits geht die Natur in die Wüsten der Hochebenen von Texas und Mexiko, anderseits in trockene Gebüsche über.

Die Lebensformen und Anpassungen der Prärien sind noch selır unvollständig bekannt. Gute Aufschlüsse gibt z. B. Bray ${ }^{1}$ ) über die Prärien von Texas. Er schildert vier "Aspects" im Jahre. Der Frühling wird von einjährigen Kräutern beherrscht. Nach dieser "Welle" kommt der Sommer mit einer Grasvegetation, die so dicht ist, daß sie keine Spur der vorhergehenden Phase übrigläßt; die Grasdecke ist so dicht, als wäre es ein wohlkultiviertes Timothyfeld, also eine Kunstwiese. Wenn die Gräser abwelken, kommt die Herbstflora, wieder mit einjährigen Kräutern, jedoch nicht mit so zahlreichen, daß sie die Gräser verdecken können. Schließlich das Winterbild, in welchem die Gräser ein nahrungsreiches Futter bieten; diese Jahreszeit ist so milde, daß sie dem Graslande erlaubt, grün zu bleiben bis in den Februar, wo der Fruihling wiederkommt:

Bray unterscheidet zwischen mehreren Typen von Grasland; humide, semihumide, semiaride und aride Typen. Die Prärien besitzen viele Typen mesophytischer Vegetation (mit Ausläuferbildung, üppigen Wuchs usw., vergl. S. 541). Die Gräser der Kurzgrasvegetation, der Great Plains, sind stark xerophytisch gebaut, zwergartig, mit Blättern,

1) Bray 1901, 1906. 
die kurz und schmal sind und im Sommer schnell verwelken. - In einigen Prärien sind Pflanzen mit unterirdischen Knollen häufig ${ }^{1}$ ).

Trockenkultur ("Dry farming ") wird in den trockeneren Gegenden Nordamerikas allgemein betrieben. Sie besteht in einer Behandlung des Bodens, bei der namentlich die Oberfläche locker gehalten wird, so daß das Regenwasser schnell aufgesogen wird und nicht abläuft. Nach dem Regen muß die Oberfläche wieder gelockert werden, damit eine trockene und rauhe Kruste zustande kommt, die die Feuchtigkeit im Lntergrunde schützen kann. In den „Great plains", wo der Niederschlag $37-50 \mathrm{~cm}$

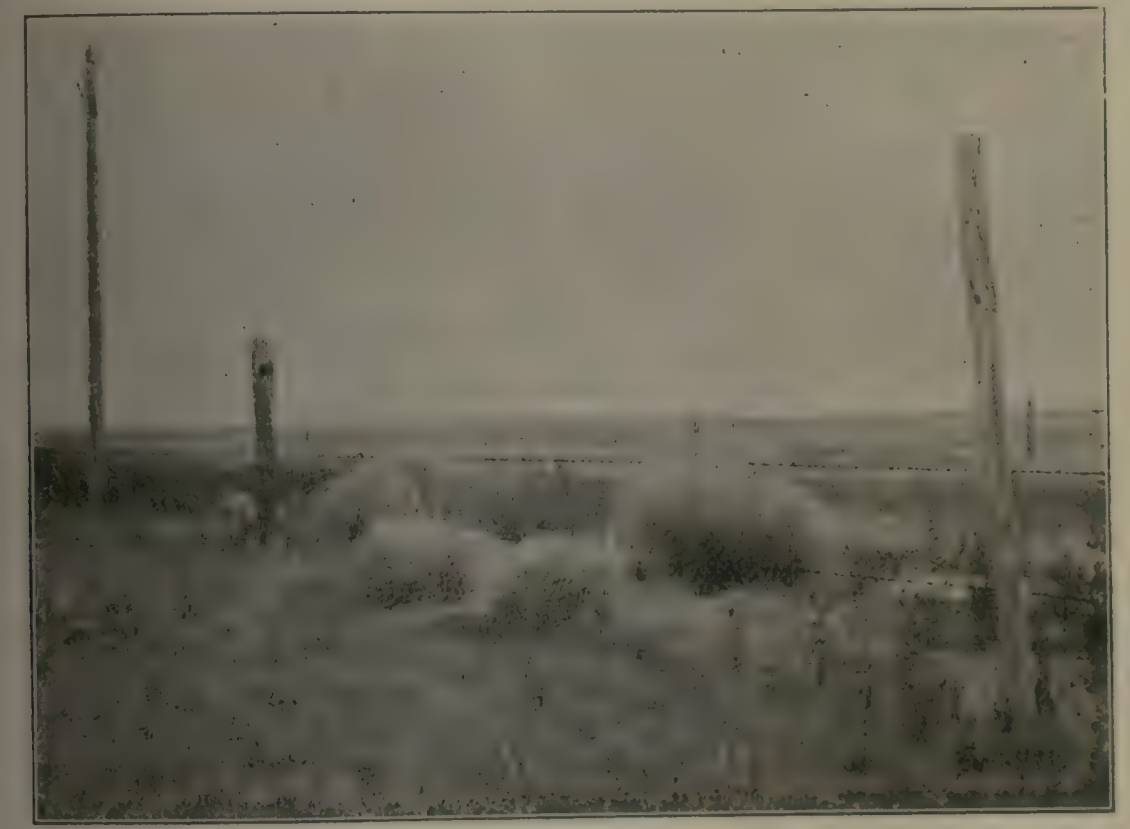

Fig. 352. Steppenläufer von Salsola pestifer in der Prärie bei Akron, August 1913. (Phot. Brockmann-Jerosch.)

beträgt, kann auf besseren Stellen jedes Jahr eine Ernte gewonnen werden, aber in dem "Great basin" (zwischen den Rocky Mountains und den Küstengebirgen), wo der Niederschlag unter $85 \mathrm{~cm}$ bleibt, müssen die Felder jedes zweite Jahr unter ständiger Bearbeitung brach liegen bleiben, damit sie sich für das nächste Jahr mit Wasser füllen können. Über ökologische Untersuchungen, die mit „Dry farming“ in Verbindung stehen, siehe Briggs und Belz, Briggs und Shantz und Shant\%. Wie in Südeuropa, hören Steppenlüufer auch mit zu den Eigentümlichkeiten der Prärien, z. B. von Salsola pestifer (Fig. 352).

1) Bray und Thornberg 1901. 
Neuere Litteratur über die Prärien: Bray 1901; Harshberger 1911; Harvey 1908; Shantz 1911; Briggs und Belz 1911; Briggs und Shantz 1912, 1913; Pool 1913; Ove Paulsen 1915; Rübel 1915 c; Journ. Ecol. IV, 45 (fünf Abhandlungen); Iljin 1916.

Die Pampas sind das dritte große Steppengebiet. Der Name stammt von den Quichua-Indianern und bezeichnet "grasbewachsene, völlig baumlose ebene Strecken" (Brackebusch). Sie nehmen die große, steinlose, alluviale Fläche in Südamerika ein, die von dem atlantischen Ozeane bis zu den Anden, von Patagonien bis zu den Wäldern voll Paraguay und Brasilien reicht.

Der Boden ist meist ein sandiger, an manchen Stellen auch toniger und salzhaltiger Löss. Das Klima ist wie in den Steppen und Prärien, jedoch etwas feuchter und weniger extrem. Nach Koeppen ist nicht die absolute Regenhöhe, sondern die Häufigkeit der Niederschläge der ausschlaggebende Faktor. Die Regenmenge in den Pampas ist nicht klein (etwa $4 \mathrm{dm}$ bis $1 \mathrm{~m}$ im Jahre), aber die Zahl der Regentage ist sehr gering, so daß allmonatlich Trockenperioden eintreten. Der regenreichste Monat weist selten mehr als 5 bis 10 Regentage auf. Der Regen kann bisweilen sehr lange ausbleiben; der Boden verwandelt sich dann in eine trockene, für Wasser undurchdringliche Masse, von der die Gewitterregengüsse unwirksam abfließen. Stürme wehen über die Ebenen unbehindert dahin. Die Pampas von Uruguay haben nach Gassner eine Regenmenge von $762 \mathrm{~mm}$ jährlich, die fast gleichmäßig verteilt ist, aber in den einzelnen Jahren große Unregelmäßigkeiten zeigt; vielwöchentliche Trockenperioden können auch hier zu allen Jahreszeiten auftreten.

Es bestehen wesentliche Unterschiede zwischen diesen und dem Klima der russischen Steppen: die strengen Winter und die lange bleibende Schneedecke kommen nicht vor, und Taubildung ist reichlich. Daher bleibt die Grasdecke lange grün, in gewissen Gegenden auch während des Winters.

Gassner ist der Meinung, daß die Baumlosigkeit unzweifelhaft den klimatischen Verhältnissen zuzuschreiben ist, daß diese aber zur Erklärung allein nicht hinreichen, denn gewisse eingeführte Bäume, z. B. Eucalyptus, gedeihen vorzüglich. Daß das Pflanzen von Bäumen selbst da gelingt, wo es kein fließendes Wasser gibt, war auch Darwin bekannt. Er suchte demgemäß auch einen geologischen Grund für Baumlosig. keit; für wahrscheinlich hielt er den, daß das Land in geologischem Sinne so jung ist.

Lebensformen. Ausdauernde Gräser bilden die Hauptmasse der Vegetation; sie sind mehr oder weniger xeromorph, daher braungrün oder graugrün gefärbt. Die unendliche, ebene oder etwas wellige, gleichförmige, baumlose Fläche ist mit mehrjährigen Gräsern und Kräutern bewachsen; die Grasflur ist vorherrschend; „ein uferloses Meer von 
Gräsern, wo das Auge am Horizonte keinen Ruhepunkt findet, außer wo die Sonne aufgeht und niedersinkt" ${ }^{1}$ ). Die hauptsächlich vertretenen Gattungen sind Melica, Stupa, Aristida, Andropogon, Pappophorum, Panicum, Paspalum n. a.

Die Gräser werden in der kalten Jahreszeit in ihrem Wachstum gehemmt, aber einige von den eingeführten, z. B. Poa annua, gedeihen gerade im Winter massenhaft; letzteres fehlt aber dann vom Frühjahr bis Herbst, ist also einjährig-überwinternd. Von den anderen Gräsern entwickeln sich einige im Frühjahr, andere sind eigentliche Sommergräser, und eine dritte Gruppe vermittelt den Übergang zum Winter. Das Bild der Jahreszeiten ist somit recht wechselnd. Unterschiede in der Bodenfeuchtigkeit rufen auch Vegetationsverschiedenheiten hervor.

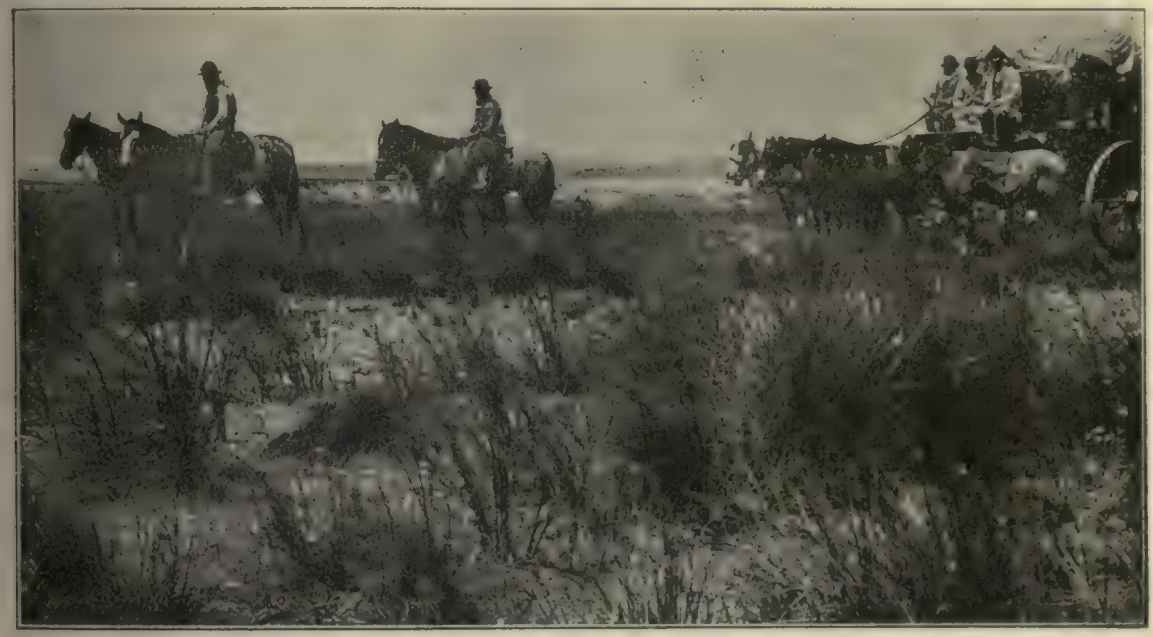

Fig. 358. Pampa im Staate Buenos Aires, mit Postwagen.

Die Gräser gehören zu den Gattungen Erianthus und Eliomurus.

(Phot. Lindman.)

Zwischen den Gräsern wachsen eine Menge Stauden aus vielen Familien, under anderem Verbena, Portulaca, Oxalis, Solanum, Apocynaceen, Compositen, Eryngium u. a., deren Blüten farbige Flecken in der Grasvegetation bilden. Merkwürdigerweise kommen sehr viele europäische Arten vor, die auf meilenweiten Strecken die inländische Vegetation haben verdrängen können; distelartige Compositen wie Cynara cardunculus (die Artischocke), Silybum Marianum, Lappa, ferner Lolium perenne, Hordeum murinum, H. secalinum, Medicago denticulata, Foeniculum capillaceum. In der Flora um Buenos Aires sind nach Otto Kuntze mindestens $3 / 4$ eingewanderte, meist mediterrane Arten.

1) Grisebach 1872. 
Von den Stauden haben viele knollige Grundachsen oder ausdauernde oberirdische Teile; die Zahl der Zwiebelpflanzen scheint geringer zu sein. Im Winter blühen viele Oxalis-Arten.

Die Anzahl der einjährigen Arten ist sicher sehr gering.

Assoziationen. Es bestehen in den Pampas wesentliche floristische Verschiedenheiten, die aber noch wenig studiert sind; nach F. Kurtz kann man von einer Verbena-Pampa, Junquillo-Pampa (mit Sporobolus [Diachyrium] arundinaceus); Tupa-Pampa (mit Panicum Patagonicum), Zamba-Pampa, Chinata-Pampa u. a. je nach den herrschenden Arten reden. Ebenso unterscheidet Gassner eine Anzahl Assoziationen nach den örtlichen und edaphischen Verschiedenheiten. Westlich des Paraná, also in den mehr kontinentalen Gegenden, ist die Ähnlichkeit mit den russischen Steppen offenbar am größten, indem die Gräser höher, steifblättriger werden und wie hier in Rasen wachsen, die zwischen sich nackte Räume lassen. In dieser Hinsicht nähern sich die Pampas dort den Savannen.

Nach Gassner sind die Pampas der Jetztzeit gewiß "nennenswert" anders als zu der Zeit, als die Europäer einwanderten und ihre Haustiere einführten. Die ursprünglichen Pampas hatten mindestens kniehohe, steppengrasartige und im Winde unablässig wiegende Gräser, die jetzigen haben weit kürzere und oft wiesenartige Rasenteppiche ${ }^{1}$ ).

Die Steppen Patagoniens sind von Dusén, Neger und Skottsberg näher besprochen worden ${ }^{2}$ ). Es macht sich deutlich das bösere Klima auf die Vegetation geltend, welche sich der der Hochgebirgssteppen nähert. Eine Eigentümlichkeit ist das Auftreten mehreer Horst- und Polsterpflanzen. Letztere können so hart sein, daß eine Revolverkugel in sie kaum eindringen kann, z. B. Azorella madreporica und Bolax glebaria. Viel lockere Polster bilden andere, z. B. Mulinum spinosum und Stupa humilis. Die Polster dieser letzteren sind ca. $15 \mathrm{~cm}$ hoch und haben schmale, steif aufgerichtete Blätter, deren Spitzen hart und stechend sind; die Polster oder Büschel haben 6-8 $\mathrm{cm}$ Durchmesser und stehen bisweilen in Abständen von 10-20 cm voneinander. Besonders auf den weitgestreckten Treibsandfeldern am Ostfuß der Kordillere scheint diese Stupa zu gedeihen; sie kann hier als einzige Pflanze oder in Gesellschaft weniger anderer spärlich auftretender Arten Strecken von 50-60 km oder mehr Ausdehnung bedecken.

In Australien und Neuseeland kommt auch gleichfalls eine Vegetation vor, welche sich hier am besten anzuschließen scheint, aber noch

1) Utber die Pampas von Argentinien und Uruguay vergl. Brackebusch 189?; Ch. Darwin 1845; Gassner 1913; Grisebach 1872; Koeppen 1900; F. Kurz 1893.

?) Dusén und Neger 1908; Skottsberg 1910. 


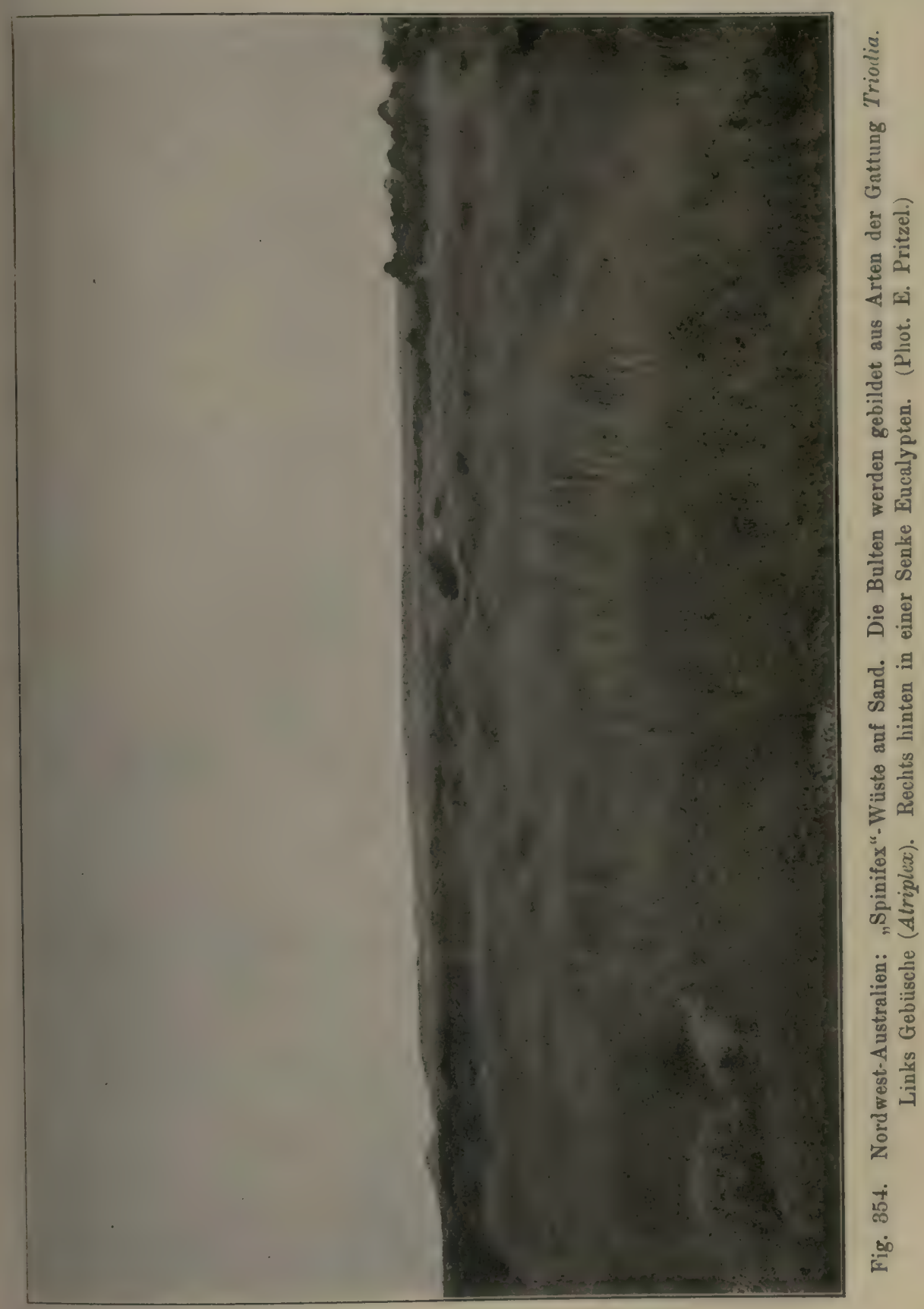


wenig bekannt ist. Domin ${ }^{1}$ ) z. B. spricht von offenen Grasebenen in Queensland mit Vorherrschen vom Mitchell-Grass (Astrebla sp.) und Flinders Grass (Anthistiria membranacea), in südlicheren Gegenden dagegen mehr von "Blue Grass" (Andropogon). Gewöhnlich ist die Vegetation nicht dicht, und zwischen den Grasbulten sprossen nach Regen eine Menge einjähriger Kräuter hervor (Fig. 354).

Aus Neuseeland spricht Cockayne auch von Steppen, die z. B. von Danthonia Raoulii („Red tussock“) gebildet werden.

Grassteppen von geringer Ausdehnung werden von verschiedenen reisenden Botanikern aus verschiedenen und auch aus tropischen Ländern erwähnt, aber so unvollständig beschrieben, daß ihre Natur nicht richtig beurteilt werden kann. Es gibt aber offenbar eine Menge von Varianten. Hier können nur noch folgende tropische Gras-Assoziationen berührt werden:

In Ostasien kommen gewisse gesträuchartige Assoziationen, namentlich Bestände des Alang-Alang-Grases (Imperata arundinacea) vor; es gibt auf Java kein zäheres und lästigeres Unkraut als dieses Gras, das sich solcher Stellen bemächtigt, wo der Wald ausgerodet wurde, und das $1-2 \mathrm{~m}$ hoch wird. Nach Rechinger ${ }^{2}$ ) kommt es im Archipel von Neuguinea namentlich auf jung vulkanischem Boden vor. Die Gräser können so dicht zusammenschließen, daß fast nichts zwischen ihnen aufkommen kann, ausgenommen einige andere Gräser und einige dünnstengelige Dikotylen. Rechinger meint, daß Warburg sie nicht mit Recht als eine ausschließlich sekundäre Vegetation betrachtet. Da auch Bäume eingesprengt vorkommen können, bildet die Assoziation wohl einen Übergang zu den Savannen.

Auf der Insel Koh Chang in Siam finden sich Strecken bekleidet mit Gräsern, die oft eine riesenhafte Größe erreichen, z. B. Arundo Madagascariensis, welche 3-4 $\mathrm{m}$ hoch wird $^{3}$ ).

Auch auf den hohen tropischen Bergen kommen wie es scheint typische Grassteppen (Bergsteppen) vor. In Mexiko ${ }^{4}$ ) z. B. gibt es solche oberhalb der Baumgrenze aus Gräsern mit harten, schmalen Blättern gebildete (Sporobolus, Aera, Festuca, Calamagrostis u. a.); sie stehen in dichten, hohen Büscheln, zwischen welchen Stauden von vielen Gattungen wachsen ${ }^{5}$ ).

Farnsteppen. Schließlich kann hier eine andere Art sekundärer Vegetation erwähnt werden, die allerdings nicht Gras-Steppe genannt

1) Domin 1910.

2) Rechinger 1908 .

3) Johs. Schmidt 1906.

4) Purpus 1907.

5) Ebenso erwähnt Weberbauer (1912) aus Peru in 3000-4200 m Höhe Grassteppen mit eingestreuten Sträuchern. 
werden kann, weil die Komponenten ganz anderen Lebensformen angehören, die aber doch mit den Gräsern den Charakter gemeinsam haben, daß die oberirdischen Organe krautartig sind, und daß das Aussehen der Formation nach der Jahreszeit, ähnlich den Grassteppen, wechselt. Es gibt „Farnsteppen“, die von dem weit verbreiteten Adlerfarn (Pteridium aquilinum) gebildet werden. In den Mittelmeerländern wie auch in Brasilien usw. gehört er zu den Pflanzen, die sich des Bodens bemächtigen, nachdem die Wälder zerstört worden waren; seine großen Blätter können so dicht werden, daß man in sie ohne Buschmesser nicht eindringen kann, und daß fast alle anderen Pflanzen ausgeschlossen werden. Auch in Afrika, z. B. in Usambara, scheinen die Farnsteppen ähnlich auf waldlosen Gebieten, gewöhnlich entwaldeten Flächen aufzutreten. Ganz ähnliche Adlerfarnbestände kann man an den entwaldeten Hängen der schottischen Gebirge beobachten ${ }^{1}$ ).

Auf der chilenischen Insel Juan Fernandez kommt nach Skottsberg ${ }^{2}$ ) eine „Farnsteppe“ vor auf dem stark den Winden ausgesetzten Hochplateau mit hervorragenden Steinen; Hymenophyllen und Moose wachsen auf ihrem Grunde. Ob diese Vegetationsform hierher gebracht werden kann, ist etwas zweifelhaft.

\section{Kap. Baumsteppen (Savannen, Campos)}

Unter diesen Namen fassen wir jene tropischen (megathermen), in Gegenden mit Sommerregen und mit Trockenperiode im Winter vorkommenden Grasfluren zusammen, welche mehr oder weniger mit kleineren Bäumen bewachsen sind. Die Baumvegetation ist im jedem Falle so offen, daß die Sonne den Boden reichlich bescheinen kann, so daß der Baumwuchs keinen wesentlichen Einfluß auf die Bodenvegetation hat. Bisweilen stehen die Bäume so weit voneinander, daß man nur alle 100-200 Schritt einen Baum trifft und kilometerweite Strecken zwischen den Bäumen entlang sehen kann. Der Boden kann verschieden sein, sandig, lehmig, und oft ist er wohl von dem roten Laterit (S. 108) gebildet.

Das abfallende Laub und die verwelkende Bodendecke wird durch die Hitze und Trockenheit zerstört ohne Humus bilden zu können. Die Vegetation hat nur eine Ruhezeit (die trockene und kühlere Zeit), sie steht dann mehr oder weniger welk da, mit gelbgrauen Tönen, ist aber auch dann keineswegs blütenlos. Die mit xerophil gebauten, oberirdischen Organen ausgestatteten Pflanzen halten diese Zeit aus, wo die Savannen oft durch Brände verwüstet werden. Die Regenzeit fällt mit dem

1) Tansley 1911; Graebner 1913 b, S. 68.

2) Skottsberg 1914.

Warming-Graebner. 3. Auflage, illustr. 
Sommer zusammen; bei ihrem Beginne wird alles frisch grün, und die Menge der Blüten wird vielmal größer. Namentlich die abgebrannten Savannen bedecken sich schnell mit einer frisch grünen, blütenreichen Vegetation.

Die Bäume bekommen beim oder vor dem Anfange der Regenzeit neues Laub und etwa gleichzeitig fällt das alte zu Boden.

Die Bodenvegetation ist in den typischen Fällen eine Hochgrassteppe. Die Hauptmasse der Pflanzen sind hohe (ca. ${ }^{1 / 3}-1 \mathrm{~m}$ hohe), grob- und steifblättrige Gräser, die in Rasen wachsen, zwischen denen man jedoch den gewöhnlich tonigen, oft roten Boden allenthalben sehen kann, wenn die Pflanzendecke nicht allzu hoch ist. Aber neben ihnen gibt es besonders auf gewissen Savannen (gewisse Savannen sind einen Teil des Jahres überschwemmt) viele Cyperaceen, z. B. auf denen Guayanas, ferner eine Menge Stauden und Halbsträucher, und im Gegensatze zu den echten Steppen auch Sträucher und Bäume, die wiederum von wenigen Lianen und Epiphyten begleitet werden. In Wirklichkeit besteht ein allmählicher Übergang zwischen der Grassteppe und den Savannen (Campos der Brasilianer). Die mit Bäumen am dichtesten bewachsenen Campos nennen die Brasilianer geschlossene Campos (Campos cerrados), die eine Art niedrige, offene, sonnige Wälder mit gekrümmten und gedrehten Stämmen und Äster und einer reichen, aus Gräsern, Stauden und zerstreuten kleinen Halbsträuchern und Stäuchern bestehenden Bodenvegetation darstellen. Zwischen den offenen Savannen mit sehr zerstreuten Bäumen („Reine Campos“, Campos limpos der Brasilianer) und den lichten Savannenwäldern gibt es ganz allmähliche Übergänge. Um Lagoa Santa im Staate Minas Geraës in Brasilien sind die steileren Seiten der Hügel, wo der Boden durch Auswaschen des Regens mehr steinig ist, oft nur mit Hochgräsern und Stauden bedeckt, während die ebeneren Teile der Campos dort, wo die Erde steinfrei ist, mit Campos cerrados bedeckt sind; an einigen Stellen werden die Bäume höher, zeigen einen geraderen Wuchs, so daß man wirklich von einem Savannenwald sprechen kann.

Die Vegetation ist subxeromorph oder xeromorph, und zwar wegen der in vielen Gegenden monatelang andauernden trockenen Winterzeit, in der oft kein Regen fällt und der Tau die einzige oberirdische Wasserquelle zu sein scheint; außerdem ist das Klima im ganzen trocken und kontinental. Dies zeigt sich in Folgendem, dem wir zunächst die am besten bekannten, südamerikanischen Savannen, die Campos Brasiliens, zugrunde legen ${ }^{1}$ ).

2) Warming 1892. Dänisch mit französischem Résumé. 


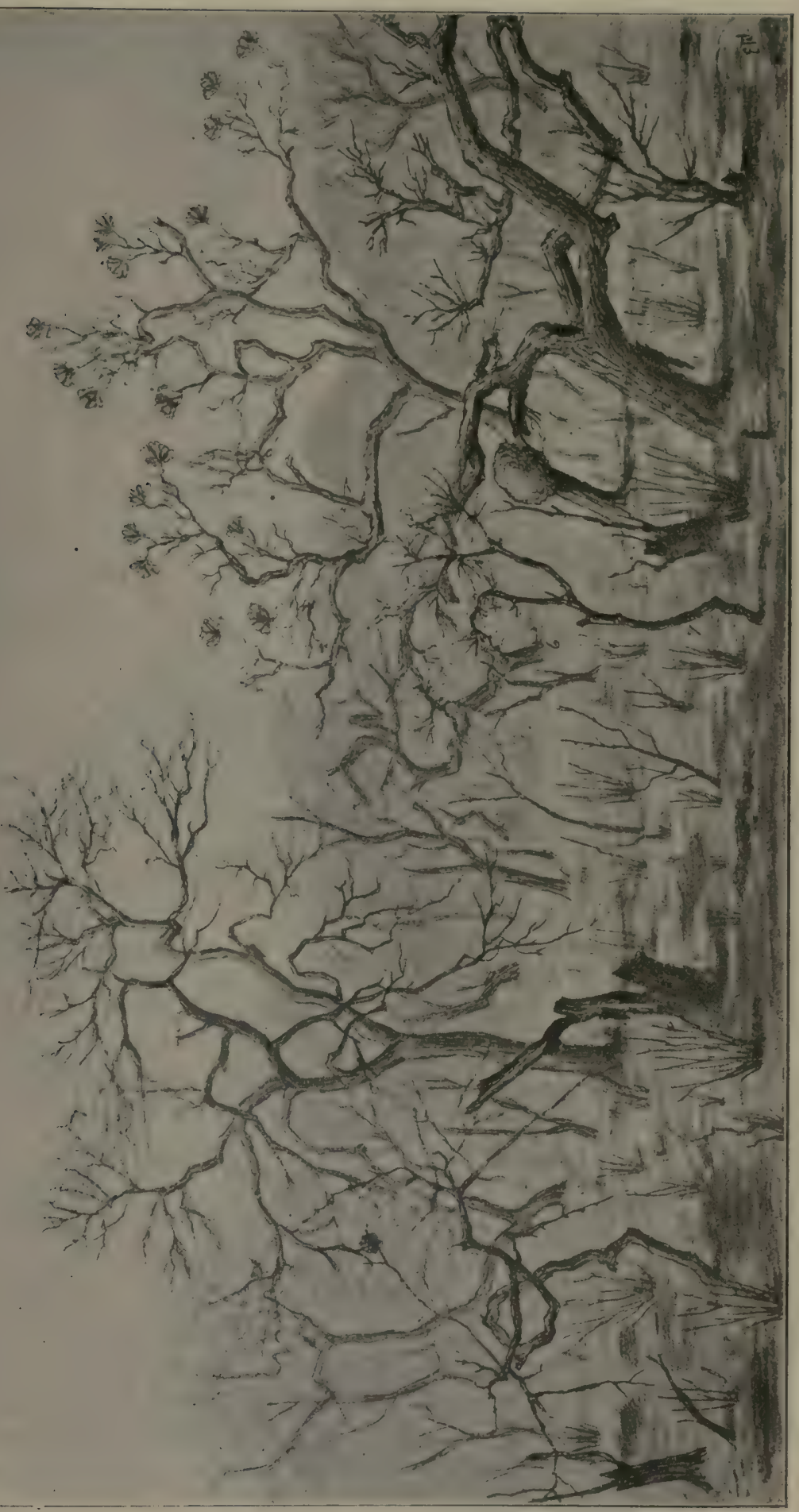

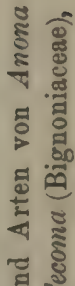

म्न

है

ต

$\therefore$ 밍

ऽ. छ

유. 퓰

ह. 50

है

을

ㅊํ

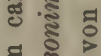

है

हึ है

हू స్ స్

동

ज蛒

.

迹.

苋

क क क

\&

हี จํำ

ॠँ

क.

๘

है

芯要

है

के

$\stackrel{5}{\circ}$

을

国

20

เอิ

욜 
Die Campos Brasiliens. Auf einem etwa dreijährigen Aufenthalte in Lagoa Santa im Staate Minas Geraës in Brasilien fußend, hat Warming die dortige Camposvegetation eingehend geschildert ${ }^{1}$ ). Dieselbe bedeckt weitaus den größten Teil der Oberfläche, namentlich alle Hügel des stark welligen und hügeligen Landes, während die Wälder die Täler einnehmen, in denen die Feuchtigkeit größer ist, und wo sie weiterhin den Ufern der kleinen Wasserläufe oder des Flusses Rio das Velhas folgen. Die Grenze zwischen Wald und Campo ist, wie man sagen könnte, haarscharf; ganz unvermittelt, mit einem Schritte, tritt man aus dem sonnenreichen Campo in den dunklen Wald hinein, dessen Ränder von Sträuchern dicht geschlossen sind, und in welchem die Lianen oft in großen an überaus schönen Blüten reichen Girlanden (namentlich Bignoniaceen) herabhängen. Vergl. Fig. 172, S. 344.

Die Camposvegetation wird aus Gräsern und Stauden gebildet mit eingestreuten Halbsträuchern und Sträuchern, und wie gesagt gewöhnlich findet man auch mehr oder weniger zahlreiche, zerstreute Bäume, welche oft der Landschaft einen parkartigen oder obstgartenähnlichen Charakter geben.

Die Pflanzen sind bis auf wenige Prozente mehrjährig; der Grund hierfür ist gewiß darin zu suchen, daß die einjährigen Pflanzen in dem Wettbewerbe mit den hohen, dichten, mehrjährigen unterliegen, außerdem vielleicht in den Savannenbränden und in anderem. Zwiebel- und Knollengewächse, sowie eigentliche Succulenten sind, jedenfalls in den Campos von Lagoa Santa, sehr selten.

Die Gräser, welche die Hauptmasse bilden, wachsen in wenig dichten Rasen (die Formation gehört nicht zu den "Rasensteppen") und bilden selten Ausläufer; ihre Blätter sind gewöhnlich schmal, steif, rauh, behaart und bisweilen mit Wachs bedeckt. Sie gehören besonders den Gattungen Paspalum, Panicum, Andropogon und Aristida an. In den mehr offenen Campos (Campos limpos) ist die Höhe ca. $0,3-0,5 \mathrm{~m}$, in den dichter und mit Bäumen bewachsenen bis $1 \mathrm{~m}$, ja die blühenden Sprosse einiger Arten erreichen 1,5-2 m. Die Blätter sind derb, grau- oder bläulichgrün und oft langhaarig. Auch die Cyperaceen sind häufig (Arten von Scirpus, Rhynchospora); alle sind steif- und schmalblättrig; die sonderbarste Art ist Scirpus paradoxus ${ }^{1}$ ).

Die mehrjährigen Kräuter, ferner viele Halbsträucher und Sträucher haben einen eigentümlichen Wuchs, indem sie in der Erde knollige, unregelmäßige, verholzende Körper aufweisen, die vermutlich sowohl aus Stengeln als auch aus Wurzelteilen, meist jedoch aus Stengeln bestehen (Xylopodien, S. 169) und aus denen zahlreiche, meist ganz 
unverzweigte oder wenig verzweigte Sprosse emporwachsen ${ }^{1}$ ). Ausläufer fehlen auch bei den Kräutern, desgleichen oberirdisch wandernde Sprosse.

Die Arten gehören vorzugsweise zu folgenden Familien und Gruppen Compositen, Papilionaten, Caesalpinioideen, Mimosoideen, Convolvulaceen, Labiaten, Verbenaceen, Amarantaceen u. a.; viele Orchideen, darunter das prachtvolle Epistephium sclerophyllum, auch Bromeliaceen, im ganzen etwa 550 krautige Arten, sind vertreten.

Von Halbsträuchern und Sträuchern gibt es namentlich an einigen Lokalitäten eine nicht geringe Zahl; die Höhe derselben beträgt etwa $0,5-1 \mathrm{~m}$. Es ist besonders schwierig, hier zwischen echten Sträuchern und Halbsträuchern zu unterscheiden, weil die Camposbrände verändernd eingreifen. Rasenbildung (caespitoser Wuchs) kommt auch bei diesen sehr oft vor, und einzelne Sträucher können sich über mehrere Quadratmeter ausbreiten, da ihre langen Sprosse nur wenig verzweigt sind. Dieser Wuchs ist augenscheinlich auch durch Camposbrände verursacht. Von den ca. 170 Arten gehören die meisten den Myrtaceen (42), Malpighiaceen (27), Melastomataceen (18) und Compositen (12) an; etwa 25 andere Familien sind außerdem vertreten.

Die Bäume sind durchgehends niedrig, die höchsten in den dichtesten Campos ungefähr so hoch wie unsere Obstbäume (3-8 m, andere nur $0,5-3 \mathrm{~m}$ ) und sind diesen in den gekrümmten Stämmen und Zweigen ähnlich; ihre Rinde hat im allgemeinen einen sehr dicken und leichten, kettenförmig aufgerissenen Kork, der oft durch die Brände geschwärzt ist (vergl. Abbildungen bei Warming a. a. O.). Die Rinde der Waldbäume hat diese Eigentümlichkeiten nicht. Die wichtigsten Camposbäume der etwa 80 Arten gehören den Vochysiaceen (8 Arten), Papilionaten (5 Arten) und anderen Leguminosen, Myrtaceen, Guttiferen, Bignoniaceen, Apocynaceen, Proteaceen, Compositen, Rubiaceen, Bombacaceen (4 Arten) usw. an.

Flechten, Moose und Algen fehlen auf dem Boden ganz und kommen höchstens auf Steinen und Bäumen äußerst spärlich vor.

Die Xerophyten-Natur zeigt sich ferner in der Steifheit der Dikotylenblätter (einige sind so steif und trocken, daß sie im Winde rasseln, z. B. die Rubiacee Palicourea strepitans, die Bombacaceen, Curatella u. a.), ferner in ihrer Richtung, oft in ihrer geringen Größe; viele sind lanzettlich oder lanzettlich-verkehrteiförmig; der erikoide und der pinoide Typus fehlen indessen fast ganz. Auch die starke Behaarrung zeigt ihren xeromorphen Bau; einige sind kahl und mit Wachs bedeckt, andere drüsenhaarig oder "lackiert". Ätherische Öle findet man bei einer ganzen Reihe Pflanzen, in Südamerika besonders bei Verbenaceen,

1) Figuren bei Warming, S. 215. 
Labiaten und Myrtaceen. Ein Teil der Gräser und der Cyperaceen hat "Tuniken" (Figuren bei Warming 1892, S. 189, 191, 192, 240).

Viele Bäume verlieren in der trockenen, kälteren Zeit vollständig das Laub und stehen dann längere oder kürzere Zeit blattlos, z. B. die Bignoniaceen (Tecoma-Arten), Anona crassiflora, Eugenia dysenterica.

Camposbrände. In der trockenen Jahreszeit, namentlich gegen Ende derselben, werden die Campos vielfach angezündet und große Strecken brennen ab. Der Zweck ist, das trockene Gras, das den Haustieren schlecht als Futter dient, durch neues zu ersetzen. Wenn ein Campo angezündet ist und die Rauchwolken emporsteigen, eilen die Vögel von allen Seiten herbei, die insektenfressenden, um die aus dem Grase herausgetriebenen Insekten zu fangen, Raubvögel, um andere Vögel und Schlangen zu erbeuten. Unmittelbar nach dem Brande bietet ein Campo ein trauriges Bild; verkohlte Äste und Stämme, alle Kräuter und Gräser bis zum Boden abgebrannt, höchstens die untersten 4-5 cm über der Erde stehenden noch lebendig, sind aber auch schwarz von den verkohlten Blatt- und Astresten. Die Erde ist mit Kohle und Asche dicht bedeckt. In kurzer Zeit findet ein vollständiger Laubfall der Bäume und Sträucher statt; der Eintritt des Frühlings wird aber beschleunigt, schnell sproßt das grüne Gras, und grüne, reichblühende Kräuter kommen bald aus dem schwarzen Boden hervor; je näher der Regenzeit der Brand stattgefunden hat, desto schneller entwickelt sich alles. Wird ein Campo im September abgebrannt, so kann der Boden etwa nach einer oder zwei Wochen mit einer grünen, blütenreichen Decke geschmückt sein, obgleich noch kein Regentropfen gefallen ist. Es folgt von selbst, daß die Formen der Holzpflanzen im höchsten Grade von dem Feuer beeinflußt werden; die unregelmäßige Verzweigung, die gekrümmten Stämme und Zweige sind zum großen Teile eine Folge der Brände, und die Sträucher und Halbsträucher erhalten wohl durch die Brände die so häufigen Formen mit vielen einfachen oder wenig verzweigten, rasenförmig gestellten, aus einem gemeinsamen, unterirdischen, unregelmäßigen, verholzten Stamm- und Wurzelgebilde entspringenden Sprossen. (Viele Bilder bei Warming 1892.)

Das Camposgebiet Brasiliens (os campos geraës) umfaßt ungeheure Gebiete in San Paulo, Minas, Goyaz, Mattogrosso, Bahia und anderen Teilen des Inneren.

Alle Campos Brasiliens sind denen von Lagoa Santa nicht ganz ähnlich. Es gibt bei den großen Verschiedenheiten im Boden, Klima, Meereshöhe usw. viele Abänderungen in der Physiognomie der Savannen, die teils auf der Höhe der Pflanzendecke, teils auf dem Verhältnis zwischen Gräsern und Stauden einerseits, zwischen Sträuchern und Bäumen anderseits beruhen. Es gibt also Campos, wo die Bäume über dem mit 
einer $1 / 2$ bis fast $1 \mathrm{~m}$ hohen Vegetation bedeckten Boden so dicht zusammenschließen, daß eine Art Wald entsteht, der offen, sonnig, schattenlos und heiß ist, worin man frei wandern, oft sogar nach allen Richtungen reiten kann (Campos cerrados). Es gibt andere, wo Bäume außerordentlich spärlich und niedrig sind, oder wo sie ganz fehlen und die Gras- und Staudendecke sehr niedrig und fast dem Boden angedriickt ist. Auf den hohen Bergen kommen Campos vor, welche recht erheblich abweichend sind. Warming ${ }^{1}$ ) hat einen solchen von Serra da Piedade im Staate Minas geschildert. Dieser Berg ist $1783 \mathrm{~m}$ hoch. In jeder Nacht bis oft weit in den Vormittag hinein ruhen die kalten Nebel, welche von den östlichen Waldgegenden hergezogen sind, über dem Gipfel, während solche Nebel in den trockenen eigentlichen Camposgegenden unbekannt sind oder höchstens während des Nachts und Vormittags in den Flußtälern sich sammeln. Die Vegetation auf dem aus Eisenerz gebildeten Gipfel von Serra da Piedade wird natürlich schon von diesem klimatischen Unterschied beeinflußt, der sich zeigt z. B. schon in der Menge der Flechten, unter anderen der hohen Strauchflechten (Cladonien). Die Flora ist von der der nur 35-40 km entfernten Lagoa Santa total verschieden.

Auf dem höchsten Gipfel Brasiliens, der Serra do Itatiaia (fast $3000 \mathrm{~m}$ hoch), kommen andere, mehr oder weniger ähnliche Campos vor. Dusén hat ihren Charakter und die Vegetation geschildert. Eigentümliche Lebensformen kommen in wieder anderen hochliegenden trockenen Campos des inneren Brasiliens vor, nämlich baumförmige Velloziaceen; ihre Stämme sind dichotomisch verzweigt, und die Zweige enden mit einem Blattschopf von xeromorphen, linealischen Blättern, deren bleibende Reste die Zweige und Stämme bedecken. Unzählige Wurzeln brechen aus den Achsen hervor und streben, indem sie diesen Mantel aus Blattresten durchwachsen, parallel zu den Achsen abwärts zur Erde. Die ganze Hülle von Blattresten und Wurzeln scheint ein Wasser (Tau, Nebel, Regen) absorbierender Apparat zu sein ${ }^{2}$ ).

Die Campos der südlichsten brasilianischen Staaten, welche wohl vielfach den Pampas ähneln, hat Lindman geschildert ${ }^{3}$ ).

Palmares. Ein eigentümlicher Campo von Gran Chaco, westlich des Paraguayflusses, ist gleichfalls von Lindman beschrieben worden. Er schildert ihn als trockene, mit Hochgräsern (Andropogon u. a.) bewachsene weite Ebene, wo Billionen von Copernicia australis, der Charakterpflanze für den Gran Chaco, lichte Wälder bilden. Vergl. Fig. 281, S. 615 .

1) Warming 1869.

2) Oben S. 191, Fig. 82. Warming 1893 mit vielen anatomischen Bildern.

?) Lindman 1900 . 
Während diese offenbar mit den echten Campos zusammenzubringen sind, entfernen sich die Pantanaes bedeutend von diesen; sie sind offene, ebene Campos oder Wiesen, welche wenigstens in der Regenzeit überschwemmt sind. Sie haben einen zarten, aber dichten Graswuchs aus kleinen Cyperaceen, Eriocaulonaceen, Xyridaceen u. a. und BuritiGruppen von der Palme Mauritia vinifera. Sie gehören offenbar mehr mesophyten Vereinen an. - Dieselben Buritisales erwähnt P. W. Lund in seinem Reisetagebuche von den inneren brasilianischen Staaten.

Araucarieta Brasiliensis. Die subtropischen Wälder von Araucaria Brasiliensis dagegen würden sich weit besser den Campos anschließen können (vergl. S. 586).

Ganz typische Baumsavannen, denen von Lagoa Santa physiognomisch vollkommen gleich, kommen im nördlichsten Südamerika vor, z. B. auf den trockenen Hügeln in der Nähe von Valencia in Venezuela. Xerophyten, wie Rhopala (Proteacee), Curatella americana, Byrsonima, Plumiera und andere Holzpflanzen, Gräser wie Paspalum und Andropogon usw., ganz wie in Brasiliens Campos, sind hier die Charakterpflanzen (Warming). Auch andere Arten sind mit den letzteren gemeinsam, in welcher Menge ist näher zu untersuchen (Fig. 356).

Dagegen weichen offenbar bedeutend mehr die Savannen ab, welche als Llanos (aus llano, d. h. eben) in Venezuela und angrenzenden Ländern bekannt sind. Die unendlichen Ebenen Venezuelas sind durch Humboldts großartige Schilderungen bekannt geworden. Es gibt hier sehr wenige Bäume; stellenweise fehlen sie sogar ganz, ausgenommen an den feuchtesten Stellen, wo Palmen (Mauritia flexuosa, Corypha inermis) und andere Pflanzen Wälder bilden; an anderen Stellen kommen vereinzelte Bäume von Rhopala (Proteacee) und anderen Arten vor; aber sonst bilden Gräser einen oft mannshohen Bestand, worin Compositen, Leguminosen, Labiaten, Amarantaceen usw. wachsen. Große Teile der Llanos stehen in der Regenzeit infolge der Überschwemmungen des Orinoko unter Wasser; aber offenbar gibt die lange trockene Zeit der ganzen Vegetation doch ein xerophiles Gepräge, worüber indessen keine näheren Untersuchungen vorliegen.

Über die Llanos vergl. Humboldt, C. Sachs, Ernst.

Die Patanas in Ceylon sind nach Pearson ${ }^{1}$ ) xerophytische, grasige Abhänge und Ebenen von beträchtlicher Ausdehnung, welche zum Teil von Arten derselben Grasgattungen (Panicum, Paspalum, Sporobolus, Aristida u. a.) bewohnt sind wie die der Savannen und Pampas. Bäume sind verhältnismäßig spärlich vorhanden, gebildet von 2 Arten (1 Myrtacee und 1 Euphorbiacee). Es gibt trockene und feuchte Patanas.

1) Pearson 1899; Holtermann 1906. 
Die trockenen Patanas, welche Höhen von weniger als $1500 \mathrm{~m}$ bedecken, sind zweifellos den amerikanischen Savannen nahe verwandt; und ebenso wie bei diesen, sind verschiedene Theorien aufgestellt worden über die Gründe des Auftretens dieser ausgedehnten Flächen eigenartiger Vegetation inmitten des üppigen subtropischen Wuchses der Bergregion. Steppenbrände scheinen hier eine wesentliche Rolle zu spielen; in den

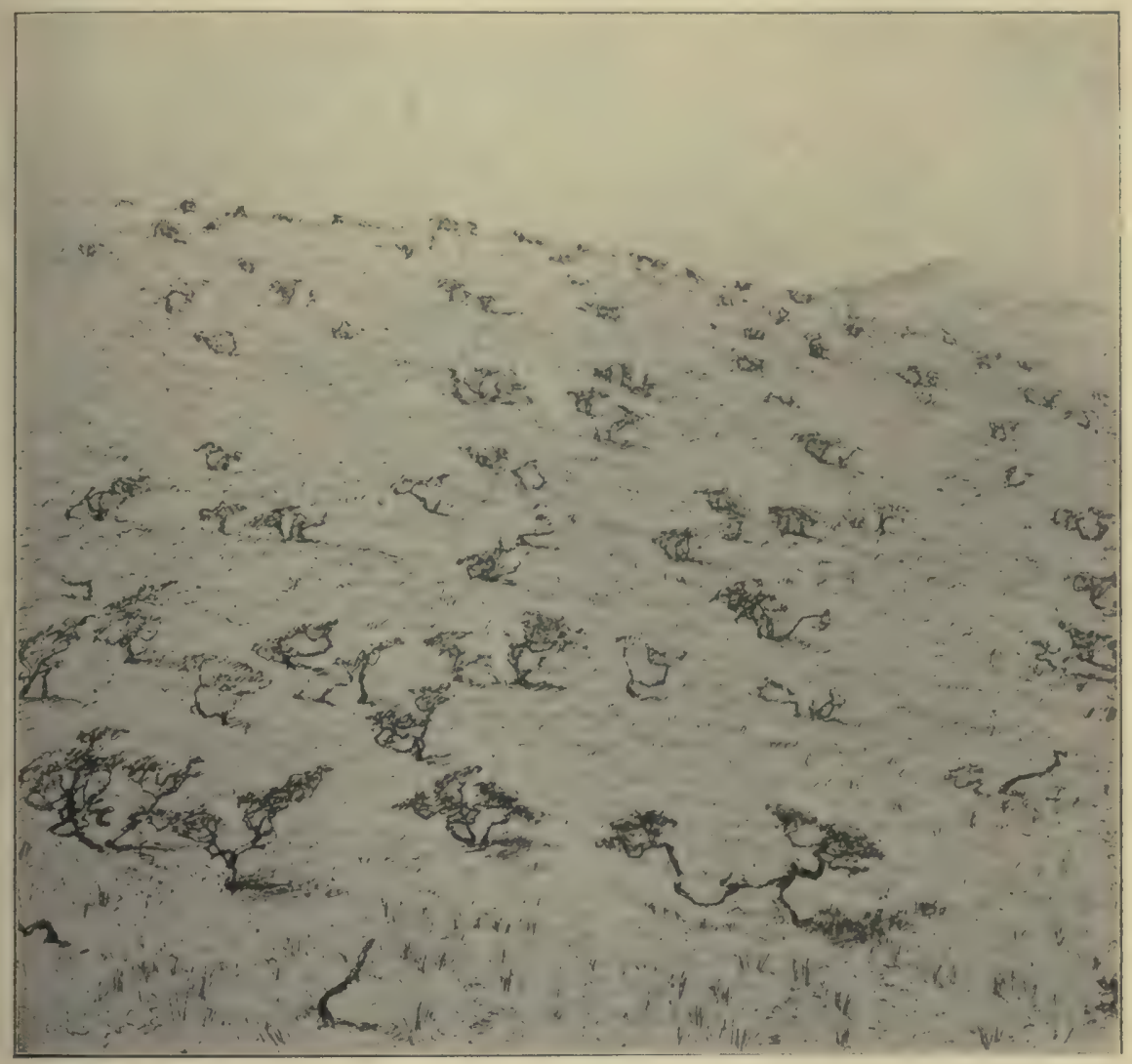

Fig. 356. Savanne in der Nähe von Valencia in Venezuela.

Zerstreute, gekrümmte Bäume auf mit Hochgräsern bewachsenem Boden.

(Gez. von Eug. Warming 1892.)

eigenartigen klimatischen Verhältnissen muß wohl der Grund für den Übergang des Savannenwaldes in die Savanne gesucht werden. Oberhalb $1500 \mathrm{~m}$ erscheinen die feuchteren Patanas, die durch einen sauren Humusboden ausgezeichnet sind, und mit den Formationen auf solchem Boden in den gemäßigten Klimaten verglichen werden können.

Die Savannen oder Baumsteppen Afrikas nehmen große Flächen ein, besonders in den südlichen Teilen. Sie erscheinen vielfach 
denen von Südamerika sehr ähnlich. Sie sind wohl weniger xerophytisch als die Hochgrassteppen im nördlichsten Afrika, welche oben (S. 828 ff.) erwähnt wurden. Der Boden ist verschieden, meist lateritisch mit wechselndem Sandgehalt, ziegelrot bis hellrot, oder sandig. Es spielt eine große Rolle, ob das Grundwasser für die Pflanzen erreichbar ist oder nicht; die Dumpalmen (Hyphaene Bussei und H. plagiocarpa) finden sich in Ugogo nur, wo sie das Grundwasser zu erreichen vermögen.

In Ostafrika unterscheidet Engler ${ }^{1}$ ) verschiedene Assoziationen (oder möglicherweise Formationen), die zu den Savannen gehören:

1. Baumlose Gras-Savanne; hierher gehören:

a) Niedergras-Savannen.

b) Hochgras-Savannen. Nach Passarge ${ }^{2}$ ) kommen im Hinterlande von Kamerun baumlose Savannen nur auf den Plateaus vor.

2. Busch-Savanne mit Gräsern, Sträuchern und kleinen Bäumen.

3. Baum-Savanne mit großen Bäumen, darunter Adansonia digitata, dieser in Afrika so verbreitete Riese. Die Bäume sind laubwechselnd ${ }^{3}$ ).

Pechuel-Lösche ${ }^{4}$ ) schildert Savannen vom Kongo und bezeichnet sie als Campine.

Im Kaplande (in Britisch-Kaffrarien) kommen nach Thode ähnlich aussehende Savannen in Gegenden mit Sommerregen und ausgeprägter trockener Zeit vor; jedoch treten hier, sicher besonders auf mehr bergigem und steinigem Gelände, ein Teil der merkwürdigen südafrikanischen Succulenten auf, wie die mehrere Meter hohe Euphorbia tetragona, Aloë-Arten, Senecio-(Kleinia-)Arten u. a., und außerdem Zwiebelpflanzen. Gräser bilden jedoch die Hauptmasse (Gattungen Danthonia, Panicum, Eragrostis) und stehen dem Vieh das ganze Jahr über zur Verfügung. Zwischen ihnen gibt es eine Menge Stauden und Halbsträucher. „Dieser bunte Blumenteppich, in welchem indessen doch die gelben und die weißen Farben vorherrschen, gewährt, an die Physiognomie der Prärien Nordamerikas erinnernd, einen erfreulichen Anblick, der nur in der trockenen Periode für einige Wochen vermißt wird" (Thode). Im Frühjahre herrschen wie in Steppen und Wüsten Zwiebelpflanzen und Orchideen, im Sommer Asclepiadaceen, Scrophulariaceen, Gnaphalieen u. a. vor. Später treten Malvaceen, Oxalidaceen u. a. auf, und zu allen Zeiten findet man Leguminosen und Compositen. In die Decke sind ferner wie

$\left.{ }^{1}\right)$ Engler 1895, vergl. auch 1906 ff., 1910 (1908-1915).

2) Passarge 1895 .

3) Uber die Baumsteppe ("Veld") in Rhodesia vergl. auch Gibbs 1906.

1) Pechuel-Lösche 1882. 
in ganz Südamerika einzeln oder gruppenweise stehende Holzpflanzen eingestreut, meistens Akazien; Acacia horrida, der Karroodorn, ist besonders bezeichnend; "wohin es sich auch wenden mag, begegnet das
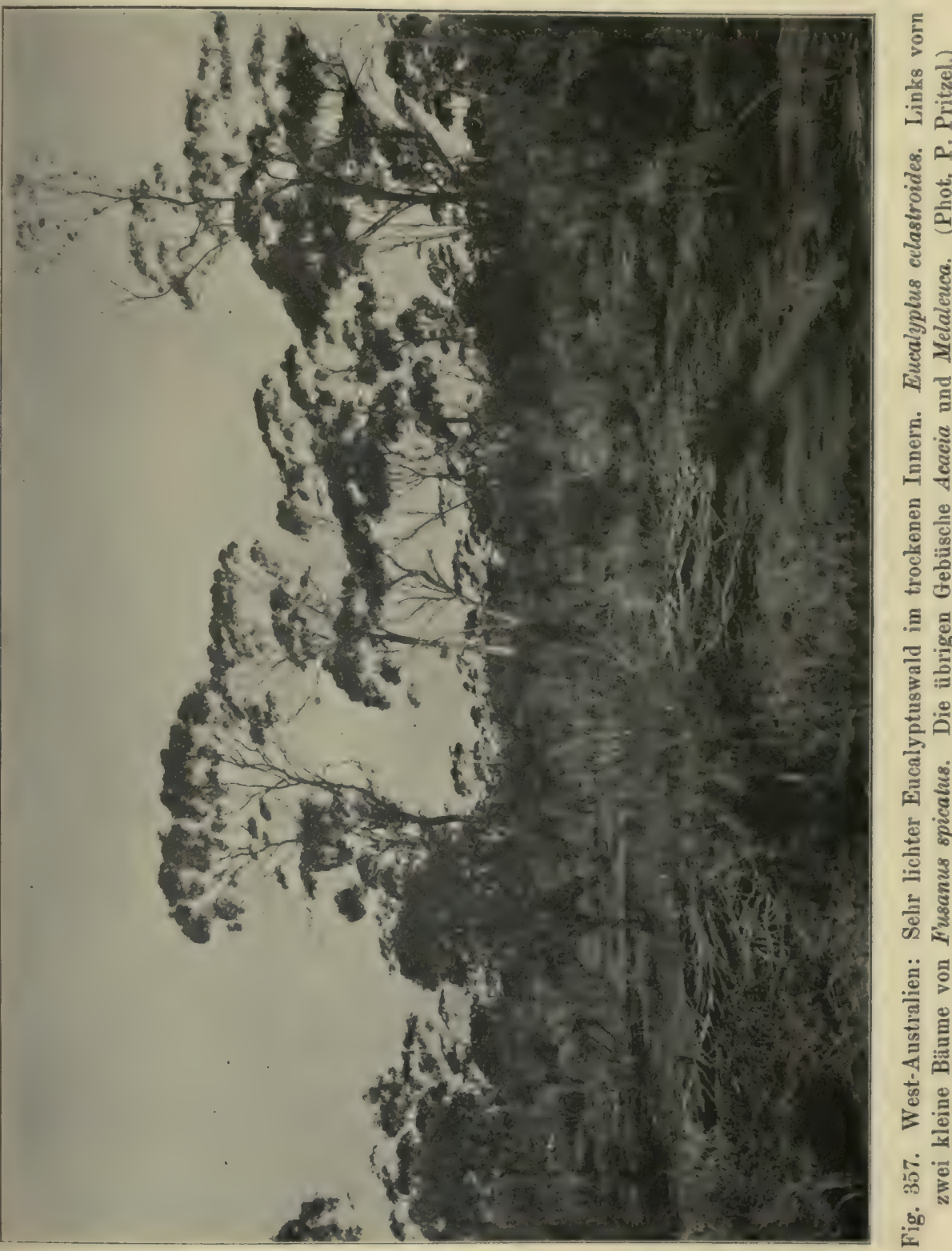

Auge des Wanderers dem feinzerteilten Fiederblatte der Akazien" (Thode). Die Bäume in den Savannen Afrikas sind meist laubwerfend sommergrün. 
Sehr instruktive Bilder von südafrikanischen Savannen gibt Busse ${ }^{1}$ ). Die Baumsteppe in Togo scheint teilweis ganz den brasilianischen Campos cerrados gleich zu sein. Es sind ebenfalls Hochgrassteppen mit Bäumen. In einigen sind die Gräser höher als in Brasilien, z. B. das Elefantengras (Pennisetum Benthami) von über $1 \mathrm{~m}$ Höhe. Es scheint dies aber von größerem Wasserreichtum des Bodens abzuhängen, denn dieses Gras wird als ein nichtxeromorphes bezeichnet, so wie auch die Bäume usw. der Elefantengras-Savannen nicht xerophytisch sind. Sein BorassusHain in der Steppe ist eine Savanne mit hohen Gräsern (AndropogonArten). Borassus flabellifer ist eine anspruchslose Palme, die auf sehr verschiedenen Bodenarten wächst (z. B. auf bindigem Ton, steinigem Bodẹn, Rotlehm, Küstensand usw.); die Stämme bilden eigenartige, bauchige Anschwellungen, das Holz ist leicht und schwammig. Sie kann reine Assoziationen bilden, ist aber, wie auch Hyphaene Thebaica, ein echter Grundwasserbaum, und die Bodenvegetation ist daher wohl weniger xerophytisch als in den trockneren Savannen, welche hoch über dem Grundwasser liegen.

Eine der auffallendsten Erscheinungen der afrikanischen Baumgrassteppen sind die Kigelien und der Affenbrotbaum. Der letztere (Adansonia digitata) hat merkwürdige, fleischig-dicke Stämme, welche sehr wenig verholzt sind und einen ausgezeichneten Wasserspeicher darstellen. Deshalb kann der in der trockenen Zeit 5-6 Monate hindurch laublose Baum seine kolossale Entwicklung auf einem trockenen Boden durchmachen; der Baum wird bis $25 \mathrm{~m}$ hoch und kann einen Stammumfang von $8 \mathrm{~m}$ erreichen. Diese Eigentümlichkeiten sind phylogenetischer Natur; man findet sie z. B. wieder bei amerikanischen Bombacaceen (Chorisia ventricosa u. a.), obwohl nur bei wenigen in so extremer Entwicklung.

Eine Gattung, welche für die afrikanischen Savannen äußerst charakteristisch ist und in einer großen Zahl von Arten auftritt, ist Acacia. Gewöhnlich sind sie durch ihre ausgeprägte Schirmkrone erkennbar, z. B. Acacia spirocarpa, welche von Busse vorzüglich abgebildet worden ist. Er unterscheidet zwischen Schirmkrone und Terrassenkrone. Acacia horrida hat bis $10 \mathrm{~cm}$ lange Stipulardornen, die oft von Ameisen bewohnt sind. Ebenso hat Acacia spirocarpa scharfe und schlanke, bis zu $4 \mathrm{~cm}$ lange Dornen, welche zwischen dem spärlichen, fein gefiederten Laube hervorstechen.

Verschiedene Akazien sind in der Karroe in den oft trockenen Flußbetten an das Grundwasser gebunden.

Viele andere Varianten von Baumsteppen finden sich außerdem noch in Afrika, z. B. in Angola, der südlichen Kalahari und anderen

1) Busse 1906 . 
Gegenden, echte Savannen mit hohen Gräsern, welche Rasen, aber keinen Teppich bilden. Hierher scheinen auch die fruchtbaren Buschsteppen von Usambara (Engler ${ }^{1}{ }^{\text {}}$ zu gehören, wo sich auf losem Boden aus-
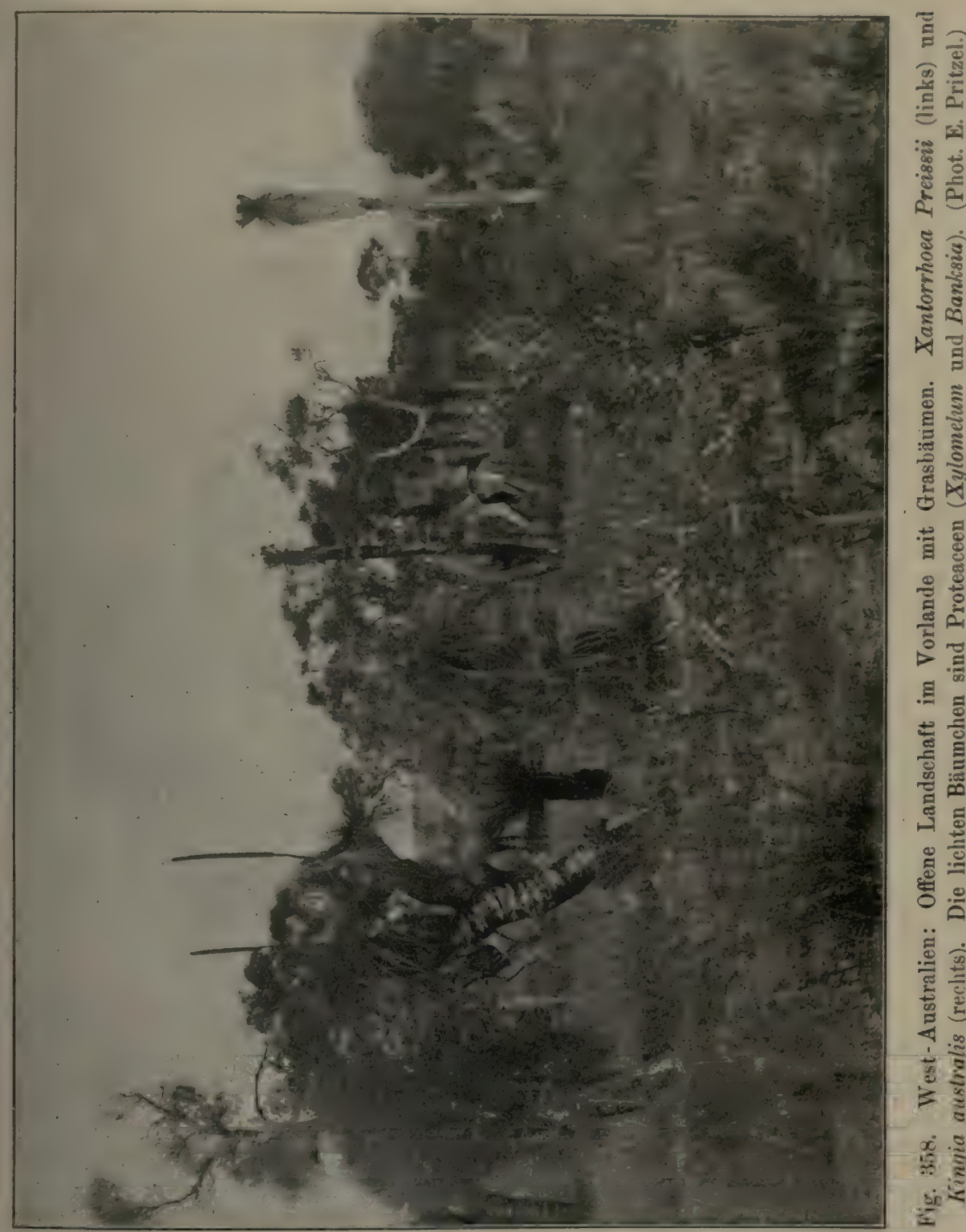

gedehnte Grasflächen von in Büscheln wachsenden ('irïsern mit rereinzelten Sträuchern und zahlreichen Termitenhügeln vorfinden. Zu den

1) Engler 1894, 1910 u. a. Über die Grasflora Südafrikas siehe Stapf 1901. 
Ursachen, welche diese Verschiedenheiten hervorrufen, gehört es auch, ob die Savannen in der Regenzeit überschwemmt werden oder nicht.

Australien. Obwohl in verschiedener Hinsicht, wohl namentlich durch die Höhe und dichtere Stellung der Bäume und die schlanken Stämme, von den typischen Savannen mit ihren niedrigen, obstbaumähnlichen Bäumen abweichend, scheinen einige von den EucalyptusWäldern Australiens doch zu der Formation der Steppenwälder zu gehören. Grisebach spricht auch von den "Waldsavannen" Australiens und sieht „das bewaldete Grasland" als eine Eigentümlichkeit Australiens an.

Auf eigentümliche Weise werden Wald und Grasland vereinigt. In den offenen, hellen Eucalyptus-Wäldern stehen die Bäume so weit entfernt, daß ihre Kronen einander nicht berühren können; der Waldboden ist hier eine zusammenhängende Grasdecke mit beigemischten Stauden, die am Anfange der Regenzeit hervorsprießen und einen frischen, saftigen Rasen bilden. In der trockenen Zeit verschwinden viele Pflanzen; am längsten halten Gräser und Compositen aus, ganz wie in den Campos Brasiliens. Das Land erscheint, von ferne gesehen, dicht bewaldet; aber man kann durch diese Wälder reiten, ja nach allen Richtungen hin fahren. Es besteht offenbar eine große Ähnlichkeit mit den brasilianischen Campos cerrados; nur sind die Bäume viel höher und schlanker, und die Artenzahl ist vermutlich geringer.

Die Eucalyptus-Wälder des subtropischen Australiens, wo der Regen im Sommer fällt, sind immergrün und müssen auch zu den xerophilen Wäldern gerechnet werden. Sie sind hell, nicht schattig, weil die glanzlosen, schmutzig grünen Blätter schmal oder stielrund oder kantenständig sind; steif und lederartig sind sie alle ${ }^{1}$ ). Da die Bäume wenig Schatten geben, bedeckt sich der Boden mit Gras und blütenreichen Kräutern; "das bewaldete Grasland ist eine Eigentümlichkeit des australischen Bodens". "In rascher Folge wechseln die Blumen: zuerst blühen die monokotyledonischen Knollengewächse, von Woche zu Woche folgen andere Formen, bis tief in die Zeit der Dürre erhalten sich zahlreiche Compositen und namentlich Gnaphalieen (die Immortellen)" (Grisebach). Wir haben hier eine Vereinigung von Steppe oder Savanne und Wald. Vergl. Fig. 357, 358, 359.

Domin hat die Ansicht ausgesprochen, daß die Wälder sekundär sind, indem sie durch die Brände der Eingeborenen hervorgerufen sind.

Der Tjemoro-Wald (Casuarina-Wald) auf den ostasiatischen Inseln und die Catinga-Wälder Brasiliens werden wohl besser den ariden Formationen zugerechnet (vergl. Kap. 110).

1) Uber die Anatomie vergl. Tschirch 1881. 
Bei allen Savannen, Prärien und wohl auch bei Grassteppen hat man immer wieder die Frage aufgeworfen: Weshalb fehlen die Bäume, oder weshalb kommen nur wenige und zerstreute Bäume vor? Die
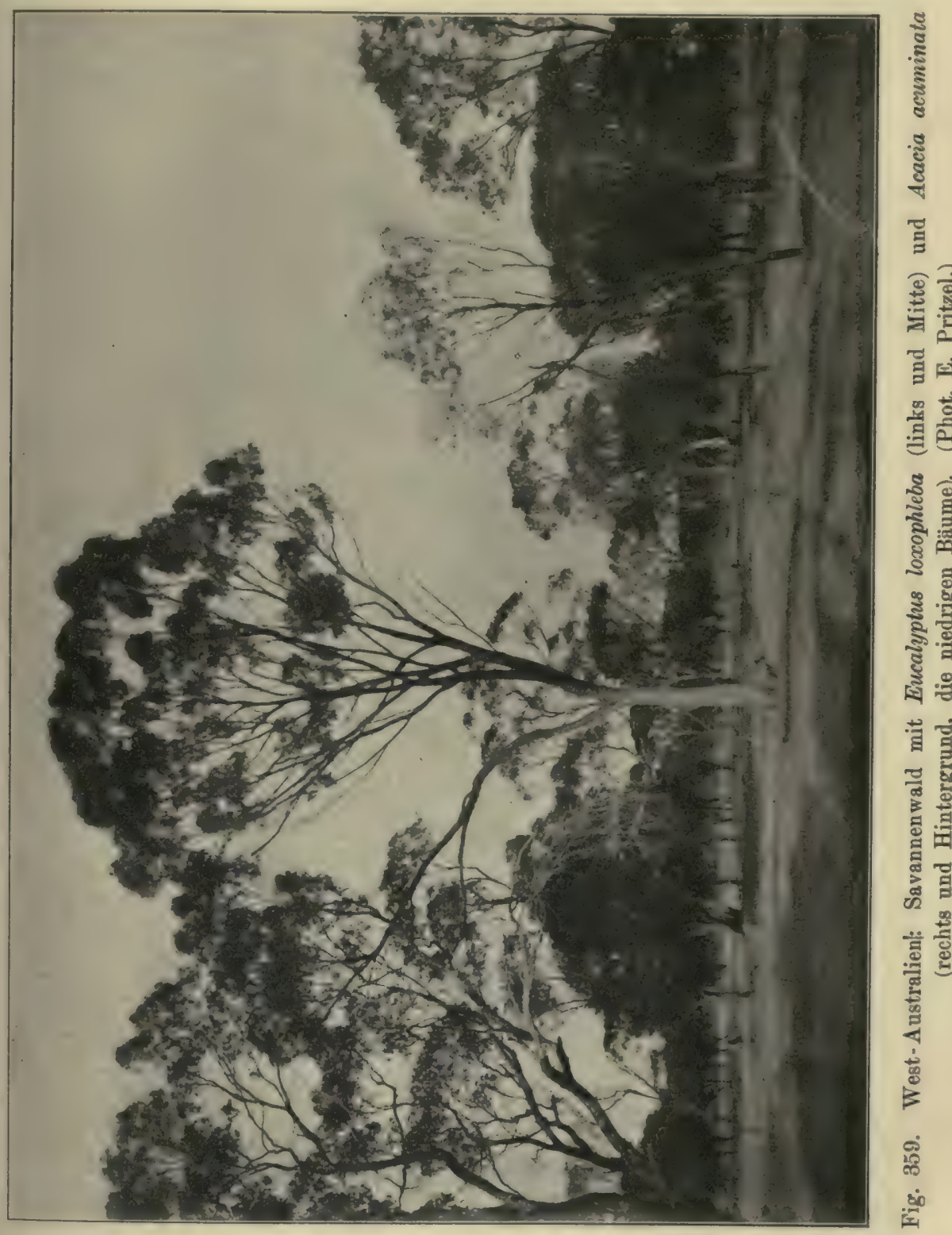

Gründe hierfür sind sicher teils geologische, teils klimatische. Das brasilianische Hochland war vermutlich ursprünglich bewaldet, aber allmählich erhielten die zentralen und ältesten Teile, als sich das Land 
in immer größerer Ausdehnung hob, ein kontinentales und trockneres Klima, und die Waldvegetation wurde in Campos umgewandelt ${ }^{1}$ ). Die eigentümlichen Formen der Bäume und vieler anderen Pflanzen werden hier nicht nur durch das Klima, sondern auch durch die Camposbrände verursacht. Auf Java und Sumatra sind Savannen nach Junghuhn durch Zerstörung von Wäldern entstanden. Die Llanos sind mit einer relativ jungen Vegetation bedeckt, die von den Gebirgen Guayanas und Venezuelas eingewandert ist (Ernst). Zwischen dem Alter einer Vegetation und ihrem Artenreichtum besteht ein bestimmtes Verhältnis. Die Llanos, die Pampas, die Prärien z. B. sind, nach dem, was über sie vorliegt, offenbar jünger und zugleich viel artenärmer als die uralten Hochländer Brasiliens und Guayanas. Auch die Artenarmut Nordeuropas, namentlich in den Wäldern, ist gewiß dem wegen der Eiszeit relativ jungen Alter eines Teiles der Vegetation zuzuschreiben ${ }^{2}$ ).

1) Warming 1892. Oben S. 838.

2) Warming $1899 \mathrm{~b}$. 


\section{Serie. Die ariden Gebiete (Einöden)}

\section{Kap. Aride Gebiete. Halbwïsten und Wüsten}

Die in den vorigen Kapiteln 105-107 besprochenen Gras- und Baum-Steppen (Savannen) haben im großen und ganzen eine subxeromorphe oder xeromorphe Vegetation, und streckenweise, wo Grundwasser hinreichend hoch liegt, kommen auch mesomorphe Formen zum Vorschein, so daß Übergänge zu Wiesen und Alluvialwald gebildet werden. Die Vegetation ist, obwohl der nackte Boden gewöhnlich sichtbar ist, dennoch im wesentlichen geschlossen zu nennen, Gräser bilden zum größten Teile die herrschende Vegetation oder in den Baumsteppen die Bodenvegetation.

Andere Formationen entwickeln sich in den tropischen und subtropischen Regionen dort, wo die jährliche Regenmenge kleiner bis sehr klein wird und wo die Niederschläge selten oder sehr unregelmäßig werden, oder auch wo edaphische Verhältnisse größere T'rockenheit mit sich bringen. Wenn der Regen selten und unregelmäßig fällt, oder die Regenzeiten von kurzer Dauer sind, wo also die heißen und trockenen Zeiten den längsten Teil des Jahres dauern, wird die Vegetation noch ausgesprochener xeromorph, und eine Menge von höchst merkwürdigen Anpassungen der Lebensformen kommen zum Vorschein. Den langen, bisweilen jahrelangen Ruhezeiten der Vegetation und der Regenarmut müssen sie angepaßt sein. Gräser sind spärlich und geben jedenfalls der Vegetation nicht ihr Gepräge.

Es bilden sich Halbwüsten und Wüsten: Besonders wird die Wüstennatur sich geltend machen, wenn der Boden noch dazu extrem physikalisch trocken ist (Sand, Felsen, steifer Lehm, salzig). In vielen Fällen mag er vielleicht sehr reich an Nährstoff sein; dieser nützt aber der Vegetation nichts, weil das allein belebende Wasser fehlt.

Der Übergang zu den Halbwüsten und Wüsten ist allmählich und nicht unvermittelt. Es gibt hier wie überall alle Übergänge und Zwischenstufen zwischen den verschiedenen Formationen; scharfe Grenzen werden sich überhaupt unmöglich ziehen lassen. Die Maquis (Kap. 103) sind den Halbwüsten nahe verwandt; es muß der Zukunft vorbehalten sein, schärfere Grenzen zwischen den im folgenden besprochenen Pflanzenvereinen zu ziehen.

Der Übergang zu den Halbwüsten wurde schon im vorigen Kapitel durch die dort erwähnten Trockenwälder eingeleitet. Dieser Formations- 
typus muß aber hier ausführlicher besprochen werden; seine extremen Formen gehören hierher.

In der folgenden Darstellung wird die Reihenfolge der Formationen folgende sein: Trockenwälder, Succulentenformationen, Trockengebüsch, Halbstrauchformationen mit Polsterformationen, und zuletzt die echten Trocken- und Hitzewüsten. Die Schilderung wird auf diese Weise von höherer, reicherer und weniger offener Vegetation zu der sehr armen und ganz offenen, aus sehr vereinzelten Pflanzen gebildeten fortschreiten, und schließt mit derjenigen ab, in der der Boden wegen der Hitze und Trockenheit ganz oder fast ganz nackt bleibt. Wahrscheinlich geht die Entwicklung jetzt an vielen Stellen gerade in dieser Richtung vor sich; es ist eine recht verbreitete Annahme, daß das Klima in vielen Weltgegenden fortwährend trockener wird. Daß die Formationen vielfach ineinander übergehen, ist selbstverständlich.

Eine interessante Untersuchung hat Engler vorgenommen, indem er sich bemüht hat, herauszufinden, ob alle Xerophyten sich auf hydrophytische oder hygrophile oder subxerophile Typen zurückführen lassen. Schon in der Kreidezeit gab es seiner Meinung nach XerophytenFormationen ${ }^{1}$ ).

\section{Kap. Trockenwälder}

Die afrikanischen Reisenden sprechen oft von "Trockenwäldern". Insoweit hiermit eine von den Baumsteppen abweichende Formation bezeichnet werden soll, muß ein Baumverein gemeint sein, in welchem die Bäume weit dichter stehen als in den Savannen oder Baumsteppen. Solche Wälder mit Grasboden gibt es aber auch. Rob. Fries ${ }^{2}$ ) z. B. spricht von Trockenwald in Rhodesia: er ist „im allgemeinen" immergrün; der Boden ist mit meterhohem, trockenem Grase bedeckt, und von Lianen gibt es keine. Diese Wälder gehen in die sparsam mit Bäumen bewachsenen Baumsteppen über und sind ihnen offenbar nahe verwandt. Ein anderer Waldtypus ist nach Fries reicher an Lianen und wohl auch ein dichterer Trockenwald.

Andere "Trockenwälder" entfernen sich von den Baumsteppen dadurch, daß nicht Gräser auf dem Boden herrschen, dieser dagegen mit Sträuchern, Succulenten und anderen Lebensformen bedeckt ist. Diese Wälder nähern sich offenbar bezüglich der Trockenheit des Klimas oder des Bodens einen Schritt weiter der Wüstennatur. Sie werden den Anfang der Vegetation der "Ariden Gebiete" darstellen.

Als erstes Beispiel von echten Trockenwäldern können die in verschiedenen Gegenden Afrikas vorkommenden erwähnt werden. In Ugogo,

1) Engler $1914 \mathrm{~b}$.

2) Rob. Fries 1913. 
das zu den trockensten Gebieten in Deutschostafrika gehört, gibt es typischen Trockenwald, der vorwiegend aus Brachystegia-Arten gebildet wird ${ }^{\mathbf{1}}$ ).

Die Boswellia-Wälder in Abessiniens Hochland werden von Boswellia papyrifera gebildet und wachsen auf sehr steinigem Boden und an sonnigen dürren Felsabhängen. Schweinfurth ${ }^{2}$ ) beschreibt diese niedrigen und lichtoffenen, sonst aber recht dichten Wälder. Die wollig behaarten Blätter stehen gehäuft an den Spitzen der Zweige. Sie leben nur während der Sommerregen (wenige Wochen), die ganze übrige Zeit des Jahres stehen die Pflanzen mit völlig kahlen Ästen da. Unterholz gibt es in diesen Wäldern fast nicht. In der Trockenzeit scheint jede Spur von vegetativer Tätigkeit erloschen.

Zu den Trockenwäldern müssen auch die Wälder aus Dracaena cinnabari gerechnet werden, welche auf Socotra, meist auf Granitund Kalkboden wachsen, und fast undurchdringliche Buschwälder sind ${ }^{3}$ ). Über Wälder aus Euphorbien vergl. S. 854.

In südlicheren Teilen Afrikas kommen viele andere lichte Wälder vor, die von laubabwerfenden und immergrünen Arten gebildet werden, wie sie Engler ${ }^{4}$ ) näher bespricht. Die Bäume sind meist Leguminosen (Caesalpinioideen). Es gibt wenig Unterholz, so daß man bequem zwischen den Bäumen hindurchgehen kann.

Gehen wir auf Amerika über, so trifft man im inneren Brasilien, wo das Klima selbst für Camposvegetation $\mathrm{zu}$ trocken ist, die merkwürdigen Caatingawälder, die zuerst Martius beschrieben und abgebildet hat (Fig. 81). In mehr zentralen und nördlichen Gegenden Brasiliens findet man diese Wälder besonders auf Kalkboden; die meisten Bäume schützen sich gegen die dauernde Trockenheit und Hitze durch Laubfall, weshalb die Wälder in der trockenen Zeit außerordentlich heiß sind. Merkwürdige Baumformen treten hier auf; am bekanntesten ist Chorisia crispiflora, eine Bombacacee mit einem tonnenförmig angeschwollenen Stamme, dessen lockeres und weiches $\mathrm{Holz}$ als ein riesiger Wasserbehälter aufzufassen ist; Spondias tuberosa hat in ihren Wurzelwülsten vermutlich unterirdische Wasserbehälter. Kleinere Bäume und Gebüsche sind immergrün, haben dann aber in den lederartigen, dicken und steifen oder weißbehaarten Blättern einen Verdunstungsschutz. Die Caatinga-Wälder sind reich an dornigen und brennenden Pflanzen (Jatropha u. a.), an säulenförmigen Cacteen und anderen Succulenten. Sie sind regengrüne Wälder. Kaum wird die trockene Zeit von dem ersten Frühjahrsregen abgelöst, so tritt die Belaubung eilig ein; in ein

3) Busse 1907; Taf. 40-45.

2) Schweinfurth in Karsten und Schencks Veget. Bild. II, 8.

3) Wettstein 1905.

4) Engler 1910 (1908-1915). 
bis zwei Tagen kann alles grün sein. Ganz anders verhalten sich die verwandten westindischen trockenen Gebüsche oder Buschwälder. Die große pflanzengeographische Rolle des Wassers zeigt sich hier auf vielerlei Art; ist in der Nähe der Oberfläche Grundwasser, welches die Wurzeln erreichen können, so sollen die Caatinga-Wälder auch in der trockenen Zeit grün bleiben können.

Die in den nördlicheren Gegenden Brasiliens (im Staate Bahia) vorkommenden Caatinga-Wälder hat $\mathrm{Ule}^{1}$ ) beschrieben und abgebildet. Sie sind von mimosenartigen Bäumen, Capparis yto, Bombacaceen, Manihot u. a. gebildet, mittelhohen Bäumen, zwischen denen auch Sträucher und Kräuter wachsen. Das Klima ist sehr trocken. Von April bis Oktober fällt kein Regen, und in den übrigen Monaten sind die Niederschläge zuweilen sehr spärlich. In der trockenen Jahreszeit verlieren fast alle Gehölze ihr Laub. Wenn im Oktober der Frühling kommt, bedeckt sich der Boden mit vielen Kräutern; eine Amaryllidacee bedeckt große Strecken. Gräser sowie Compositen sind aber selten wodurch eben ein starker Gegensatz zu den Campos und Savannen hervortritt. Einen anderen Unterschied bilden die vielen dornigen Sträucher. Auch hier kommen merkwürdige Baumgestalten vor, z. B. die Bombacacee Cavanillesia arborea mit tonnenförmig verdicktem Stamme, der oft mehrere Meter im Durchmesser erreicht; sie blüht in der trockenen Jahreszeit. Viele Cacteen, Arten von Cereus, Opuntia und Melocactus, sowie auch Euphorbia phosphorea u. a. Letztere ist blattlos und mit kantigem Stengel versehen, dadurch erinnert sie an afrikanische Formen; sie bildet oft mehrere Meter hohe, dicht verzweigte Gebüsche. Viele Bromeliaceen bedecken gruppenweise den Boden. - Übergänge von dieser Formation zu den Campos und zu einer Bergstrauchformation wachsen ebenfalls in Bahia.

Bei Lagoa Santa ${ }^{2}$ ) finden sich Kalkfelsen, die von Wald bedeckt sind; in der Trockenzeit verlieren die Bäume ihre Blätter weit früher als die Camposbäume, die oft nur wenige hundert Meter von ihnen wachsen; weiter leben hier dornige, brennende Sträucher und Cacteen, während solche Lebensformen in den Campos fehlen (vergl. Kap. 107; Fig. 322).

Blattlose Wälder. Von merkwürdigen Waldformen können die von Casuarina-Arten gebildeten Tjemoro-Wälder auf dem trockenen und nackten Boden der Gebirge von Ostjava und den Sunda-Inseln genannt werden, wo die Niederschläge gering sind und von dem porösen Boden nicht zurückgehalten werden. Ihr Verdunstungsschutz besteht in ihrem eigentümlichen Sproßbau: schachtelhalmähnliche, fast blattlose, stielrunde, dunkle, matte und grüne Sprosse, oft mit Spaltöffnungen, die

1) Ule 1908.

) Warming 1892 . 
in tiefen Furchen der Zweige liegen. Schimper ${ }^{1}$ ) schildert diese Wälder von dem javanischen Berge Gunung Ardjuno etwa aus 2500-3000 m Höhe. Der Boden ist von den braunen, toten, nadelähnlichen Zweigen der Casuarinen bedeckt, ganz wie mit Kiefernnadeln in einem europäischen Kiefernwalde; und auf dieser Decke wachsen einige Krüuter, z. B. die schmalblättrige Festuca nubigena und Euphorbia Javanica, die zahlreich vorkommen. Polster kleiner, geruchloser Veilchen (Viola ser. pens u. a.), Plantago Asiatica, kleine, weißblütige Umbelliferen (Pimpinella-Arten), kleine Gnaphalium-Arten, besonders aber Pteridium aquilinum geben der Flora ein europäisches Gepräge. Auf weniger steilen Stellen wird die Vegetation üppiger, und es kommen mehrere Strïucher hinzu, darunter Antennaria-Arten und Rubus pruinosus. Von den Kräutern erinnert Sonchus Javanicus an unseren S. arvensis; Valeriana Javanica ist unserer $V$. officinalis sehr ähnlich; ferner findet man aus europäischen Gattungen z. B. Ranunculus prolifer, Galium Javanicum, Alchimilla villosa, Cynoglossum Javanicum, Thalictrum Javanicum und Agrimonia Javanica. Moose sind hier spärlich.

Hier können auch die Saxaul-Wälder im inneren Asien, aus Haloxylon gebildet, erinnert werden (S. 446); sie finden sich besonders auf salzhaltigem Sandboden.

Auch Coniferen-Wälder können hier angeführt werden. In Arizona in Nordamerika macht der Wüstencharakter sich auch in den Wäldern von Pinus edulis geltend. Sie wachsen besonders auf Kalk, Basalt und Sand und sind licht. Neben dem genannten und anderem Nadelholze finden sich auch Quercus undulata, Juniperus monosperma, Yucca, Agave, Opuntia usw. Während der Trockenperiode ist der Boden kahl oder nur dürftig mit starren Gräsern und Stauden bestanden, sobald aber die Regenzeit eintritt, sprießen zahlreiche ausdauernde und einjährige Kräuter hervor ${ }^{2}$ ).

\section{Kap. Succulenten-Halbwiisten}

In vielen von den erwähnten Trockenwäldern und Trockengebüschen kommen eingestreut mehr oder weniger zahlreiche Repräsentanten der merkwürdigen Lebensformen: Blatt- und Stammsucculenten vor. An anderen Stellen sind es eben die Succulenten, welche der Vegetation ihren Charakter geben und im wesentlichen der Landschaft die Physiognomie aufdrücken. Solche Vegetation bezeichnet noch einen Schritt weiter in die Gebiete der Trockenheit, wahrscheinlich namentlich bezüglich der Trockenheit und Wärme des Bodens. Es ist besonders

1) Schimper 1893.

$\left.{ }^{2}\right)$ Purpus 1907. 
felsiges und steiniges Terrain, aber auch lehmiger Boden, der in der Trockenzeit von der Sonne steinhart gebacken wird. Hat doch Vesque gefunden, daß große Hitze des Bodens gerade succulente Formen hervorruft (S. 256).

Die Pflanzenformen, welche hier erscheinen, haben oft im Verhältnis zu dem trockenen, heißen Boden eine ganz merkwürdige Höhe

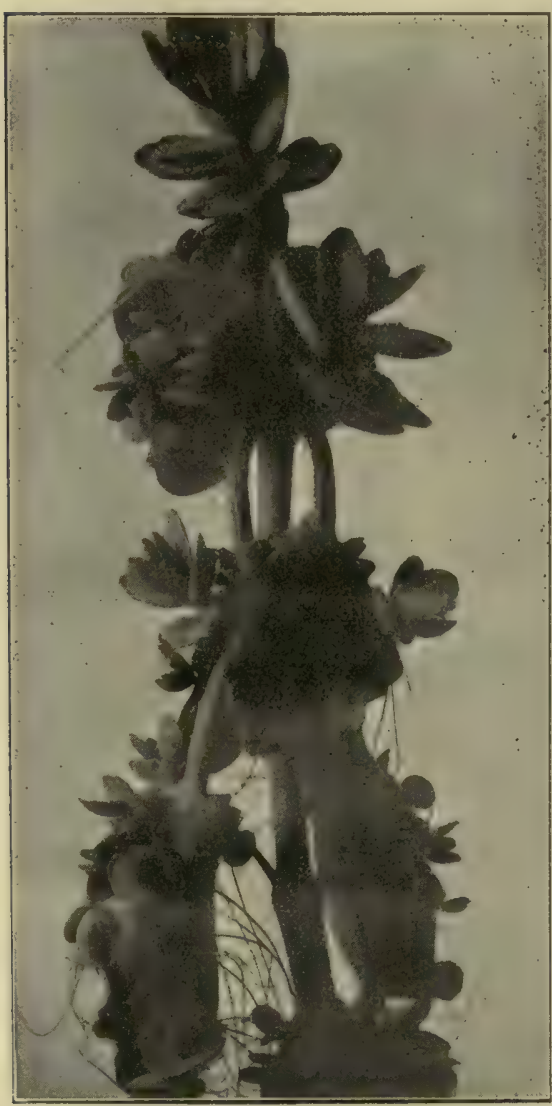

Fig. 360. Bryophyllum calycinum. Starke vegetative Vermehrung durch wurzelnde Adventivsprosse an den Blättern,

Stengeln und in den Blütenständen. Trockene and steinige Plätze in allen Tropenländern. (P. Graebner phot.) und Mächtigkeit, können auch in großer Menge gesellig auftreten. "Wüste" kann eine solche Vegetation nicht genannt werden, wo mächtige Cacteen, Agaven, Aloè; Euphorbien hervorwachsen können, wohl aber eine Halbwüste, denn sie dient dem Menschen zu nichts und anch für die großen Tiere ist sie von keinem Nutzen.

Floristisch ist die Vegetation der Succulenten-Halbwüsten in Afrika und Amerika, wo sich die größten finden, sehr verschieden; aber eine merkwürdige ökologische Kongruenz hat dieselben Formen hervorgerufen. Die Agaven Amerikas entsprechen ganz den AloëArten in Afrika, die Cacteenform Amerikas ganz den stammsucculenten Euphorbien und Stapelien Afrikas (Fig. 115).

Afrika ist besonders reich an merkwürdigen, man könnte sagen abenteuerlichen Gestalten. Die blattlose Säulenform wird besonders durch Euphorbia-Arten vertreten. In Südwestafrika (GroßNamaland, Damaraland), wo die $\mathbf{1}^{1 / 2}-2^{1 / 2} \mathrm{~m}$ hohen, dunkelgrauen Büsche zerstreut auf der weißen, sandigen Fläche stehen, in ihrer Gesamtheit eine dicht gedrängte, oben abgeflachte Gebüschmasse bildend ${ }^{1}$ ). Schinz spricht von einer "Euphorbienzone" innerhalb des wüstenartigen Küstenlandes.

1) Schenck, Veget. Bild. I, Taf. 26. 
Selbst Trockenwälder werden von den Euphorbien gebildet. In Abessinien, in 1500-2000 m Höhe über dem Meere, bildet Euphorbia

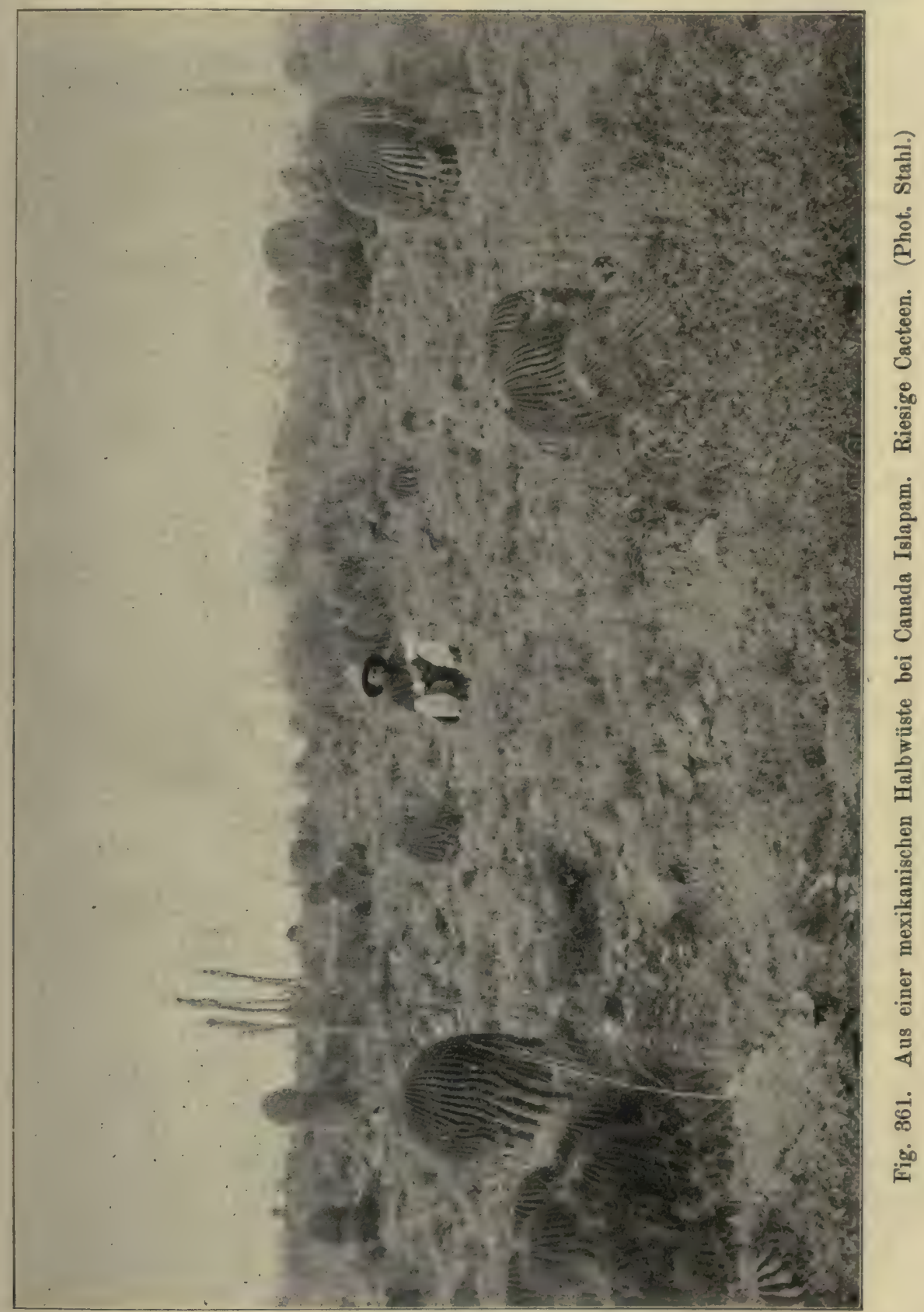

Abyssinica ganze baumartige Assoziationen; soweit das Auge reicht, reihen sich die graugrünen Kandelaberbäume einer an den anderen, auf 
weiten Strecken der Berggehänge allen Raum für sich allein in Anspruch nehmend. An den etwas beschatteten Lücken am Grunde der Stämme haben sich mancherlei strauchförmige Gewächse angesiedelt, welche meist mit hartem Laube versehen sind ${ }^{1}$ ). (Fig. 133.)

Das Unterland der Canarischen Inseln ist ein Bergland, welches von tiefen Schluchten durchzogen ist, deren Abhänge mit einer charakteristischen Steppenvegetation bedeckt sind. Die größten Sträucher bilden die kaktusähnliche Euphorbia Canariensis und die gleichfalls succulente Kleinia neriifolia. Unter den kleineren Sträuchern, welche ungefähr $1 \mathrm{~m}$ hoch sind, befinden sich mehrere Euphorbia-Arten; von diesen ist $E$. aphylla blattlos, die übrigen haben nur im Sommer kein Laub. Untermischt mit den Sträuchern wachsen xerophytische Halbsträucher, und in einer Höhe von etwa $100 \mathrm{~m}$ werden sie von zahlreichen Crassulaceen begleitet; zwischen diesen leben Gräser mit eingerollten Blättern, Zwiebelgewächse (darunter Urginea und Scilla) und einjährige Kräuter ${ }^{2}$ ). Das Hochland der Cap Verdischen Inseln ist gleicherweise Euphorbien-Halbwüste.

Festland von Afrika. Die Succulentensteppe in Ostafrika ist von Volkens ${ }^{3}$ ) beschrieben worden. Sie wird im wesentlichen von kaktusähnlichen Arten von Euphorbia, Stapelia, Sanseviera und Kleinia gebildet. Zwischen ihnen wachsen Sträucher, darunter die dornigen Caralluma codonoides und Adenia globosa. Verschiedene Straucharten haben knollige Stämme, aus denen die Zweige entspringen.

In Marokko gibt es aus Arten von Euphorbia zusammengesetztes Buschland. Die führende Art E. Mauritanica hat im Winter Blätter, ist aber im Sommer entlaubt.

Höchst merkwürdige Lebensformen finden sich auf der Insel Socotra: hohe, säulenförmige, unverzweigte oder nur wenig verzweigte Stämme mit mächtigem Speichergewebe und relativ kleinen Kronen; namentlich Adenium Socotranum, Dendrosicyos Socotrana, Dorstenia gigas $\mathbf{u}$. a. bilden solche Gestalten. Auch in anderen trockneren Gebieten des tropischen Afrika sind diese Arten heimisch ${ }^{4}$ ).

Eine andere dikotyle Pflanze, welche hier erwähnt werden muß, ist Cotyledon fascicularis. Der hellrindige Stamm ist $1-2 \mathrm{~m}$ hoch und fast mannsdick und dient als Wasserspeicher. "Butterbaum" wird er genannt, weil der Stamm so weich ist. Das Wurzelsystem ist so schwach entwickelt, daß ein schwacher Stoß genügt, selbst große Exemplare umzuwerfen. Zur Zeit der Herbstregen bedecken sich die zahlreichen

1) Karsten und Schenck, Veget. Bild. II, 8.

$\left.{ }^{2}\right)$ Christ 1885; Vahl 1904 b; Schröter 1908.

3) Volkens 1897.

4) Wettstein in Karsten und Schenck, Veget. Bild. III, 5. 
dünnen Zweige mit kleinen, fleischigen, kurzlebigen Blättern. Zur Sommerzeit steht die Pflanze kahl da, ist aber dann mit zahlreichen, großen, roten Blüten geschmückt. Diese Art bildet eigene Assoziationen;
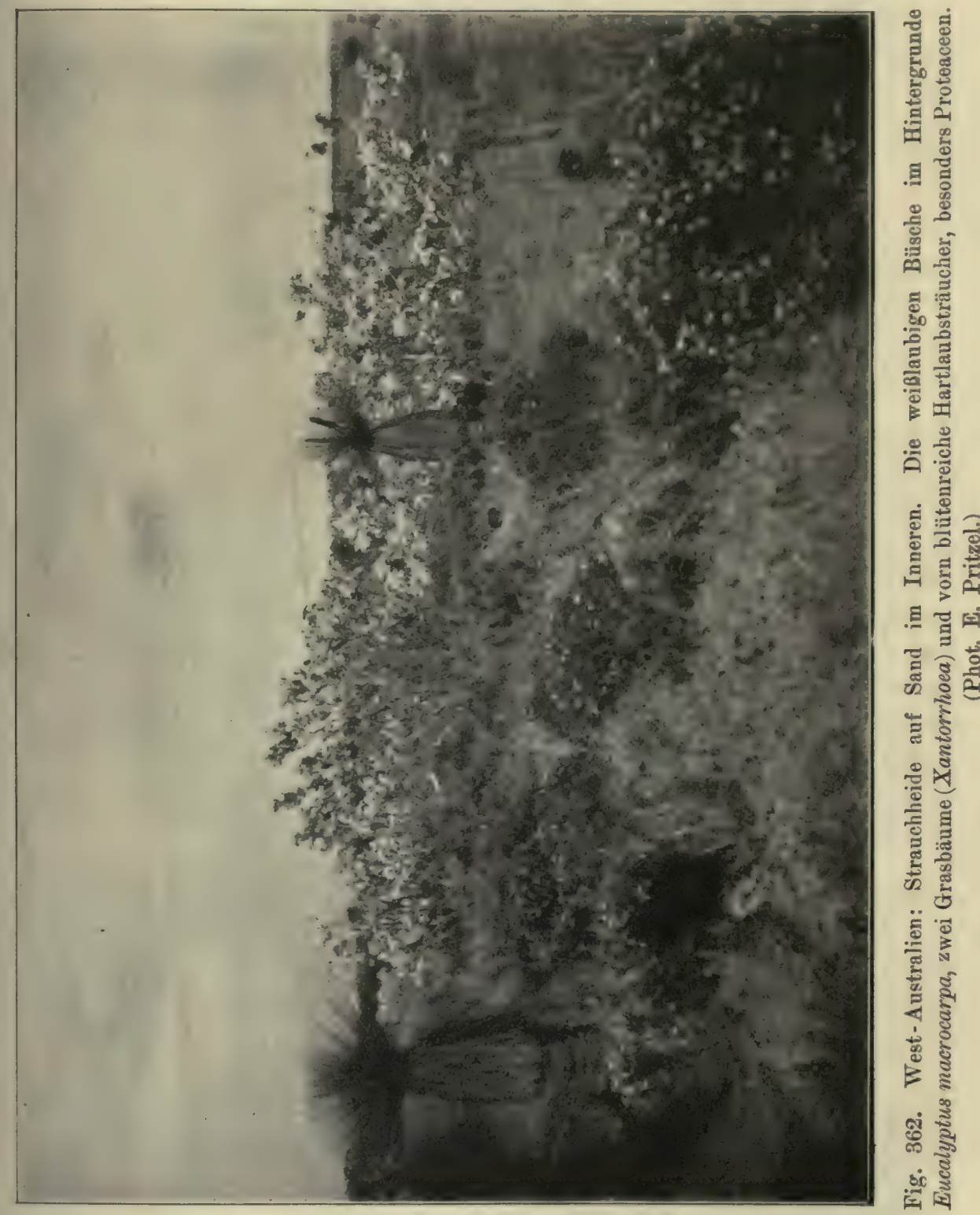

zu Tausenden stehen diese dickstämmigen Gewächse beisammen, meist in Gesellschaft mit anderen Succulenten ${ }^{1}$ ).

2) Brunnthaler 1911. 
Die Karroo ist eine an Succulenten reiche Halbwüste Südafrikas, die Marloth ${ }^{1}$ ) eingehend besprochen hat. In der Karroo ist nach ihm und Brunnthaler die Regenmenge sehr gering (unter $100 \mathrm{~mm}$ ) und fällt sehr unregelmäßig. Der Boden wird mitunter ungeheuer stark erwärmt (z. B. bis $60^{\circ}$, während man in der Luft $45^{\circ}$ mißt); in der Nacht sinkt die Temperatur um $30^{\circ}$ und mehr. Winde sind häufig. Der Boden ist tonig und reich an mineralischen, löslichen Salzen und an Kalk, aber arm an Humus. Wo eine Wasserzufuhr möglich ist, ist er naturgemäß sehr fruchtbar.

Die Grasvegetation ist dort für die Physiognomie ganz unwesentlich; eine Grasnarbe fehlt vollständig. Die herrschende Vegetation wird von Zwergsträuchern und Succulenten (Mesembrianthemum, Crassula, Cotyledon, Euphorbia, Stapelia, Kleinia, Aloë u. a.) gebildet, welche gemischt sind, oder auch in reinen Assoziationen auftreten.

In der Karroo finden sich auch merkwürdige, steinenachahmende Succulenten aus den Gattungen Mesembrianthemum und Crassula; sie werden durch diese Ähnlichkeit dagegen geschützt, von Pavianen und anderen Tieren gefressen $\mathrm{zu}$ werden. Die Mesembrianthemum-Arten haben übrigens einen äußerst verschiedenen Habitus und Ausbildung der Vegetationsorgane. Einige Arten sind über mannshohe Sträucher, welche ein Gebüsch bilden, andere sind nur erbsengroße Gebilde, z. B. M. pygmaeum und andere von den steinähnlichen (vergl. Fig. 122). In der Karroo sind sie in ungeheurer Anzahl von Individuen und Formen vorhanden. Bei einigen sind die Blattpaare bis gegen die Spitze verwachsen, und durch die eingetrockneten Reste der vorjährigen Blätter, welche sie umgeben, erhalten sie ein weißes Aussehen. Sie können schließlich auch den Habitus von Polsterpflanzen annehmen.

Viele stark xeromorphe Bildungen kommen hier vor, Organe zur Wasserspeicherung oder unterirdische Knollen, Zwiebeln und Rhizome als Mittel gegen die Gefahren der Trockenheit. Von den Sträuchern, die meist nur kurze Zeit nach einem Regen belaubt sind, sind viele mit Dornen versehen und bilden die Blüten meist zur Zeit der Trockenheit. Viele Arten sind blattlos.

Nach Marloth bedeutet das Wort "Karroo" "dürr". Er sagt, daß "wo im Osten die Grassteppe beginnt, hört die Karoo auf". Die meistens trockenen Flußbetten werden von Akazien (A. horrida) und Karreebäumen (Rhus viminalis) umsäumt. Im übrigen muß auf das ausgezeichnete Werk von Marloth verwiesen werden.

Von den Monokotylen spielen in den südafrikanischen Halbwüsten und Wüsten die Aloë die größte Rolle; einige Arten derselben sind baum-

2) Marloth 1908. 
förmig, bis $3 \mathrm{~m}$ hoch mit dichotomer Verzweigung, mit fleischigen, zweizeiligen oder spiralig rosettenartig gestellten Blättern. Aloë plicatilis, die zu den baumförmigen mit zweizeiligen Blättern gehört, ist nach Brunnthaler ein uralter Typus, wie eben Südafrika überhaupt ein uraltes Land ist, das seit der Kreidezeit über dem Meere gelegen hat. Eine eigentümliche blattsucculente Gattung ist Sansevieria, deren lange steife

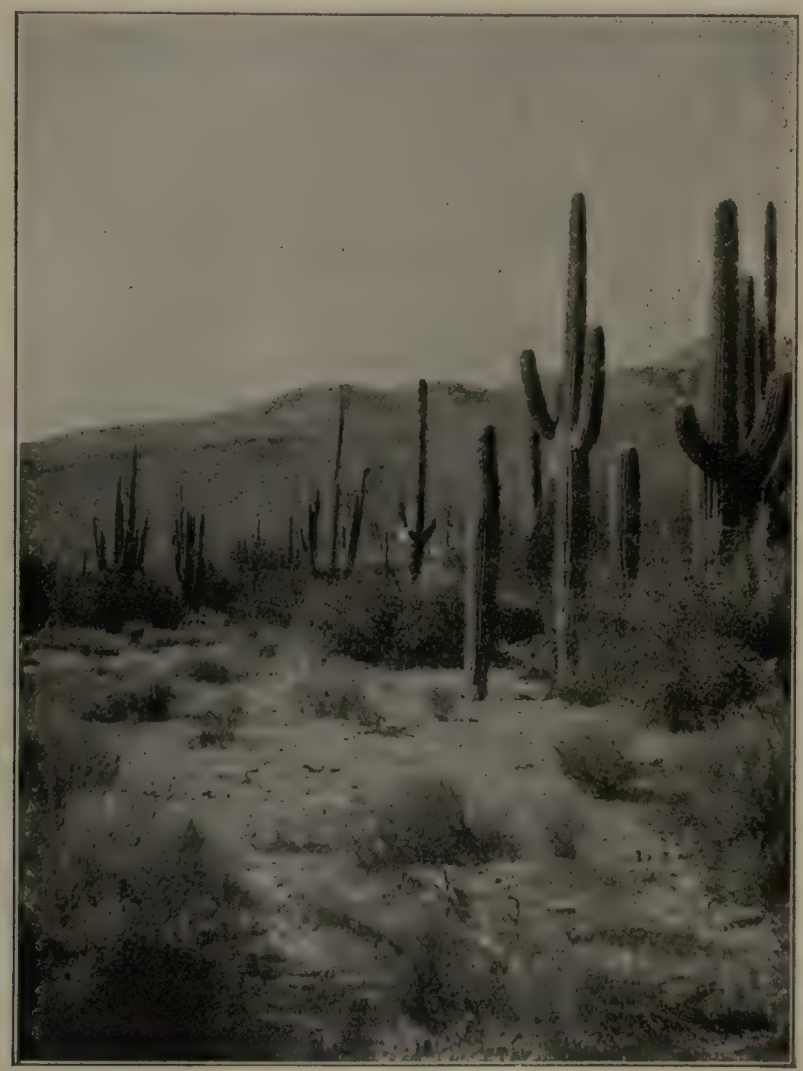

Fig. 363. Halbwüste (bei Base Camp, Tuczon plain, Nordamerika), mit Cereus giganteus, Bigelowia coronopifolia (auf dem Boden) und Prosopis im Hintergrunde. (Phot. Ove Paulsen.)

Blätter bei den am meisten xerophytischen Arten etwa stielrund, 2 bis $3 \mathrm{~cm}$ dick sind und dabei eine Länge bis etwa $2 \mathrm{~m}$ erreichen können. S. longifolia wird von Busse ${ }^{1}$ ) besprochen: die aus den unterirdischen Grundachsen entspringenden Blätter schießen fast senkrecht aus dem Boden auf und ähneln Bajonetten oder zugespitzten Stöcken. Wie andere Arten bilden auch bei dieser die Blätter dichte Gruppen, reine

1) Busse 1907 . 
Assoziationen. An der Ostgrenze von Ugogo wandert man bisweilen stundenlang durch fast ununterbrochene dichte Assoziationen von Sansevieria, die hier und da mit wenigen Exemplaren einer Alö̈-Art oder Euphorbia Reinhardtii (vergl. Fig. 133) vergesellschaftet sind. Die fleischigen Blätter aller Arten sind vortreffliche Wasserbehälter und liefern bekanntlich auch wertvolle Faser.

Amerikas Succulenten-Vereine. Nordamerikas Halbwüsten sind wie die Südafrikas reich an Succulenten. Die Cacteen repräsentieren die blattlosen Stammsucculenten und treten mit einem großen Reichtum von Arten und Formen auf, namentlich auf felsigen und steinigen Bergabhängen. Sie können nach Stahl, der vorzügliche Abbildungen von ihnen geliefert hat, so dichte Assoziationen bilden, daß man kaum in diesen gehen kann. Es gibt flachgedrückte, niederliegende Opuntien, zylindrische oder kugelförmige Melocacteen, hohe zylindrische, höchst sonderbare, baumförmige Gestalten u. a. Cereus giganteus, der mexikanische Riesencactus, streckt seine gigantischen Armleuchtern ähnlichen Zweige bis zu $18 \mathrm{~m}$ Höhe empor und bedeckt die niedrigeren Berge, so daß sie von ferne aussehen, als ob sie mit Nadeln bespickt wären. Andere Cacteen bilden kurze, reich verzweigte, mit weißlichen Stacheln übersäte Stämme, oder liegen zu einem Gebüsche verflochten auf dem Boden. Viele von ihnen werden von den Eingeborenen als giftig angesehen; jedenfalls ist es äußerst schwierig und schmerzhaft, ihre Stacheln aus dem Fleische herauszureißen, wenn sie sich in dieses eingebohrt haben, und oft durch Widerhaken festsitzen. Opuntia-Arten mit roten und gelben Dornen erheben sich längs der Wege und sind stets zerrissen; aber wo ein Stück auf der Erde liegt, da schlägt es Wurzeln und wächst zu einer neuen Pflanze heran (Mayr).

In den nordamerikanischen Halbwüsten sind die Cacteen gewöhnlich mit anderen Lebensformen gemischt, namentlich mit Agaven und Liliaceenbäumen (Arten von Yucca).

Stahl schreibt von den letzteren: Die 5-6 $\mathrm{m}$ hohen, unten bis zu 2 Fuß dicken, grauen Stammsäulen tragen an ihrem Ende einen Schopf von aufrechten, starren, grünen Blättern. Unter den lebenden Blättern trägt der Stamm einen dichten Besatz von abgestorbenen, abwärts gerichteten Blättern, deren älteste gebräunt, die im Absterben begriffenen dagegen lebhaft gefärbt sind.

In diesen Succulenten-Halbwüsten in Nordamerika finden sich auch viele gymnosperme und dikotyle, stark xeromorphe Sträucher, z. B. der Kreosotstrauch (Covillea tridentata), Arten von Ephedra und Acacia, Fouquiera splendens usw.

Einen Schritt weiter zum Wüstencharakter scheint die Pflanzengesellschaft gemacht zu haben, welche Stahl aus Mexiko beschreibt und 
abbildet. Auf einem schwach nach Süden geneigten Abhang ${ }^{1}$ ) war der sonnendurchglühte, äußerst grelle Licht- und Schattenkontraste aufweisende Boden streckenweise ganz pflanzenleer. Zwischen den Steinen wuchsen hier Echinocereus conglomeratus, und wenn Regen gefallen ist, sproßt eine Anzahl von Kräutern hervor.

In Südamerika kommen so ausgedehnte Wüstensteppen wie die Nordamerikas nicht vor. Doch auf den trockenen Höhen der Anden von Peru finden sich Anklänge; Weberbauer spricht von der kräuterarmen Region der Säulencacteen und Wüstensträucher; ein Xerophytengemisch aus Säulencacteen, regengrünen Sträuchern, Halbsträuchern und kurzlebigen Einjährigen ${ }^{2}$ ).

Ausgezeichnete Bilder von derartigen Succulenten-Halbwüsten finden sich in Schenck und Karstens Vegetationsbildern, I, und in vielen nordamerikanischen Werken.

\section{Kap. Formation der Trockengebiische. "Dornstrauchsteppen"}

Die im 109. Kapitel erwähnten Wälder waren im ganzen niedrig, licht und enthielten mehr oder weniger xeromorphes Gesträuch, namentlich Dorngesträuch als Unterholz. Eine andere, gleichfalls recht dichte Formation wird allein von solchem Gesträuch gebildet.

In den Tropen und heißen Gegenden der Erde, besonders in den tropischen und den subtropischen findet man überall Gebüsche xerophil gebauter Sträucher, die gewöhnlich dicht und undurchdringlich, steifblättrig, dornenreich und schmutziggrün sind; sie können oft als Dorngebüsche bezeichnet werden and sind gewöhnlich immergrün, einige sind aber auch laubwechselnd.

Trockengebüsch findet sich an manchen Stellen in Afrika. Sehr verbreitet besonders auf sehr trockenem Boden ist Akaziengebüsch. Engler bespricht es öfters; im Damaralande, Amboland und Kalahari bedeckt es, abwechselnd mit Steppen, die weiten Ebenen ${ }^{3}$ ).

Busse schreibt von dem Dorngebüsch in Ugogo. Grau ist der Grundton der Landschaft, grau der felsige Boden, grau bis silberweiß sind die Rinde und die Zweige der zu undurchdringlichen, $3-5 \mathrm{~m}$ hohen Mauern an beiden Seiten des Weges zusammentretenden Bäume und Sträucher, die durch zahllose Dornen gegen jeglichen Angriff geschützt erscheinen: eine zur Todesruhe erstarrte Umgebung. Ab und $\mathrm{zu}$

1) Karten und Schenck, Veget. Bild. II, Taf. 22.

2) Weberbauer 1912.

8) Vergl. namentlich Engler 1910 (1908-1915). 
Schirmakazien und Armleuchter-Euphorbien, Commiphora-Arten (Burseraceen) mit papierdünner, abblätternder Borke und bläulicher oder grünlicher Rinde - alles in allem bietet der Dornbusch eine Pflanzenvereinigung dar, deren Vertreter ihre Anpassung an lange Trockenperioden aufweisen.

Viele andere merkwürdige Lebensformen kommen in der afrikanischen Buschsteppe vor, z. B. die Apocynacee Strophanthus Eminii, deren Nebenwurzeln zu fleischigen Walzen von 2-5,5 cm Durchmesser anschwellen; in kürzeren oder längeren Abständen sind sie wurstförmig eingeschnürt und an den Einschnürungsstellen entspringen die kleinen, dünnen, normal gebildeten Seitenwurzeln, welche die Nahrung aufnehmen (Fig. 364). Derartige Wurzeln leisten den Pflanzen große Dienste als Wasserspeicher. Der Strauch steht während des größten Teiles des Jahres in trostloser Kahlheit.

An anderen Stellen herrschen Akazien uneingeschränkt, z. B. in der südöstlichen Kalahari, besonders Acacia horrida, A. detinens und $A$. heteracantha, deren Namen ihre Dornen andeuten, und andere Arten, die auch alle dornig sind. Gewöhnlich ist es eine bunte Gesellschaft, in der besonders trockene Xerophyten aus den Familien der Ericaceen, Proteaceen, Compositen u. a., mit Succulenten, wie säulenförmigen Euphorbia-Arten u. a., gemischt hervortreten. Zwischen ihnen kommen viele Zwiebel- und Knollenpflanzen vor. In Usambara findet man trockene "Creek"-Gebüsche, die durchschnittlich 7-8 m hoch werden, sehr licht sind und zahlreiche schmarotzende Loranthaceen aufweisen; sie bestehen namentlich aus Acacia spirocarpa. Der Boden ist mit Stauden und Saftpflanzen bewachsen (Engler).

Die Akazien werden nach Engler von Insekten bestäubt, und die leichten dünnhäutigen Früchte dann durch den Wind verbreitet; die dicken, nährstoffreichen Samen sichern den Keimpflanzen eine rasche Entwicklung. So sehen wir denn die Akazien in großen Teilen Afrikas immer siegreicher auftreten, je mehr anderen Holzgewächsen die Existenz erschwert wird. Arten mit doppelt gefiederten Blättern sind häufig in allen Gegenden mit großer Lufttrockenheit; wahrscheinlich schützen sie sich gegen das zu starke Licht durch Bewegungen der Blättchen ${ }^{1}$ ).

Die Sträucher in den afrikanischen Halbwüstengebüschen verlieren nach Engler fast alle in der Trockenzeit das Laub; mit dem Regen bekommen sie neue Blätter.

In anderen Gegenden Afrikas ist es Iamarix, die die Charakterpflanze der "Wüstensteppen" bildet, indem sie in vereinzelten kleinen Bäumen und Sträuchern auftritt.

$\left.{ }^{1}\right)$ Vergl. Warming 1892, S. 179. 
Amerika. Ähnliche Gebüsche findet man z. B. in Venezuela, und ihnen nahe stehen vermutlich die in dem nördlichen Mexiko, in Texas und Arizona vorkommenden Chaparals, die großenteils aus Mimosoideen und vielen anderen Dornsträuchern bestehen, in Texas besonders aus Prosopis juliflora, P. pubescens, Cercis u. a. Leguminosen, Prunus, Juglans nana, Morus, Rutaceen (Xanthoxylum), Simarubaceen (Castela), der Zygophyllacee Larrea Mexicana usw.

Nach Bray ${ }^{1}$ ) kommen im westlichen Texas zwei Formen des Chaparals vor, die ihre Verschiedenheit klimatischen, geologischen und physiographischen Gründen verdanken. Nach demselben Beobachter ist das Chaparalgebiet trockener als das der Grassteppe. Im Chaparal kommen viele Zwiebel- und Knollengewächse vor. Parish $^{2}$ ) gibt an, daß in der

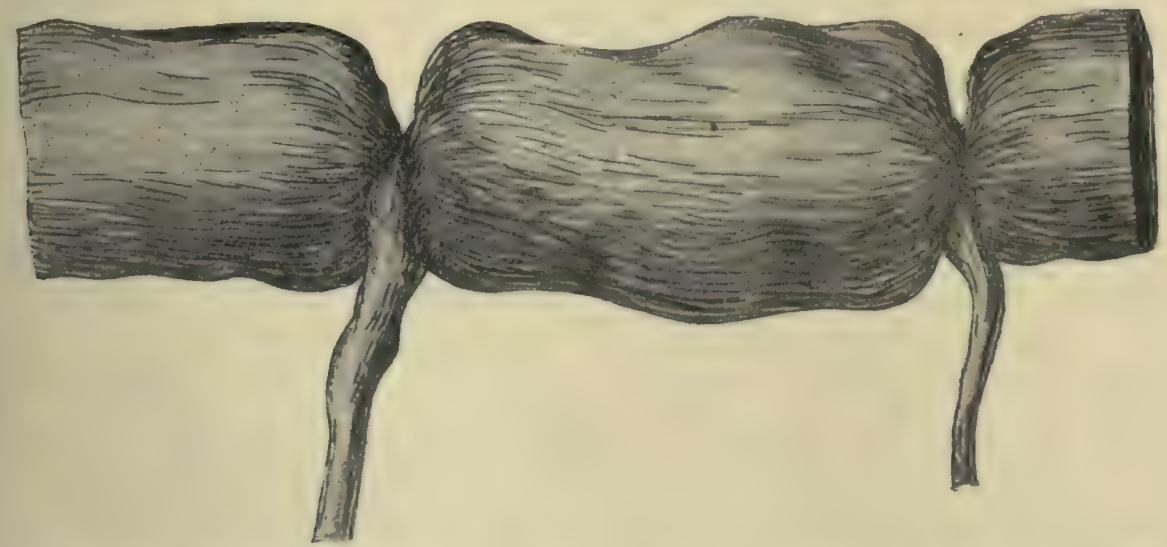

Fig. 364. Strophanthus Emini; Wurzel mit den eigentümlichen Einschnürungen. E. Graebner, nach der Natur.

Strauchsteppe des südlichen Kalifornien die einjährigen Arten 36,5\% der Flora ausmachen. Die Sträucher bleiben hier während des Sommers blattlos. Durch diesen Charakter dürften die Chaparals sich stark von den sonst verwandten mediterranen Macchien, den Dornmacchien und Espinales (vergl. S. 799) entfernen.

Nach Spalding ${ }^{3}$ ) gibt es Mesquite-Wälder und Gebüsche in der unteren Sonora-Zone; "Mesquite" ist der Name für Prosopis glandulosa f. velutina, die teils als Strauch von wenigen Fuß Höhe auftritt, teils baumartig und bis über $10 \mathrm{FuB}$ hoch wird; ihr Stamm erreicht eine Dicke von $3 \mathrm{dm}$ und mehr im Durchmesser. In ihrer allgemeinen Erscheinung

1) Bray 1901.

2) Parish 1903.

s) The Plant world, XIII. 
ist diese Art ein Xerophyt: dornig mit lederartigen Blättern; sie fordert aber eine reichlichere Wasserversorgung als die meisten ihrer Begleiter. Nach Bray ${ }^{1}$ ) wandert die Mesquite an vielen Stellen in die Prärien von Texas ein; sie muß nach ihm als ein Pionier für "The lower Sonoran" Waldland betrachtet werden.

Aus Brasilien (Bahia) werden dornenreiche "Caatinga"-Gebüsche erwähnt.

Argentinien. Reich an trockenen, meist dornigen Gebüschen oder Buschwäldern ist ferner Argentinien. Hierher muß die Vegetation gerechnet werden, welche Grisebach die "Chanar-Steppe", Hieronymus "Espinarwaldungen" nennt, deren Blätter so klein sind, daß die langen braunen, langdornigen Zweige mehr in die Augen fallen als das Laub selbst. Der Name bezieht sich auf den dornigen ChanarStrauch, Gourliea decorticans (Leguminose), der zusammen mit Akazien (Acacia Farnesiana), Zizyphus, immergrünen Compositen (Baccharis, Tessaria u. a.) vorherrscht. Auch Cacteen und Bromeliaceen kommen vor. Die Monte-,Formation" (Lorentz), worin periodisch blattlose Sträucher wie Arten von Prosopis, Lippia, Acacia, Cassia u. a. mit Cacteen und Atriplex-Sträuchern zusammen auftreten, gehört gleichfalls hierher. (Monte bedeutet Gebüsch, Buschwald.)

Diese argentinische Chanar-Steppe und die Monte-Vegetation werden von Brackebusch u. a. zu den Wäldern gerechnet. Der Boden wird von einem geringen, oft verschwindenden Humus bedeckt, weil die Vegetation nur schwachen Schatten gibt, die Niederschläge unbedeutend sind und das Wasser schnell in den Boden sickert. Nach den vorherrschenden Bäumen können mehrere Bestände unterschieden werden. Eine Menge Lianen und auch einige epiphytische Blütenpflanzen treten hier auf: ein Zeichen für die Nähe der. Tropen.

Auf den Inlandsdünen Argentiniens kommen nach Otto Kuntze andere Gebüsche vor, mit Baccharis-Arten, Atriplex pamporum $(1 / 2 \mathrm{~m}$ hoch), dem blattlosen Rutensproßstrauche Heterothalamus spartioides (Composite) und anderen Compositen. Noch armseliger und offener sind die auf Grusboden wachsenden dornigen Gebüsche Patagoniens, meist von Leguminosen, Compositen, Solanaceen u. a. gebildet. Hieran schließt sich ferner die von Gassner ${ }^{2}$ ) beschriebene Sierra-Vegetation Uruguays.

Im tropischen Amerika gibt es andere Xerophytengebüsche, wahrscheinlich sekundären Ursprungs, die hier genannt werden können, obgleich sie nicht vorzugsweise aus Dornsträuchern gebildet sind, z. B. die trockenen Crotongebüsche (Crotoneta) Westindiens. Die „VirginiaIslands" und andere Inseln der regenarmen Antillen sind großenteils

1) Bray 1906.

2) Gassner 1913. 
von einem grauen trostlosen, nicht nutzbaren, brennend heißen Gebüsche bedeckt, zwischen dessen dornigen, verfilzten Sträuchern und niedrigen Bäumen man ohne Axt nicht vordringen kann. Viele Arten sind gra ufilzig, z. B. die Croton-Arteu, die stellenweise in dem Grade vorherrschen, daß sie ausgedehnte, fast reine Gebüsche bilden (z. B. im östlichen Teile von St. Croix nach Eggers), ferner wachsen hier aromatische Verbenaceen (Lantana), Cordia-Arten, Melochia tomentosa usw. Andere hingegen stehen in frisch grünem, glänzendem Laube da, und gewöhnlich sieht man solche Arten als dunkelgrüne Flecken mit dem grauen Buschwerk seltsam kontrastierend eingestreut, was besonders auffällt, wenn man

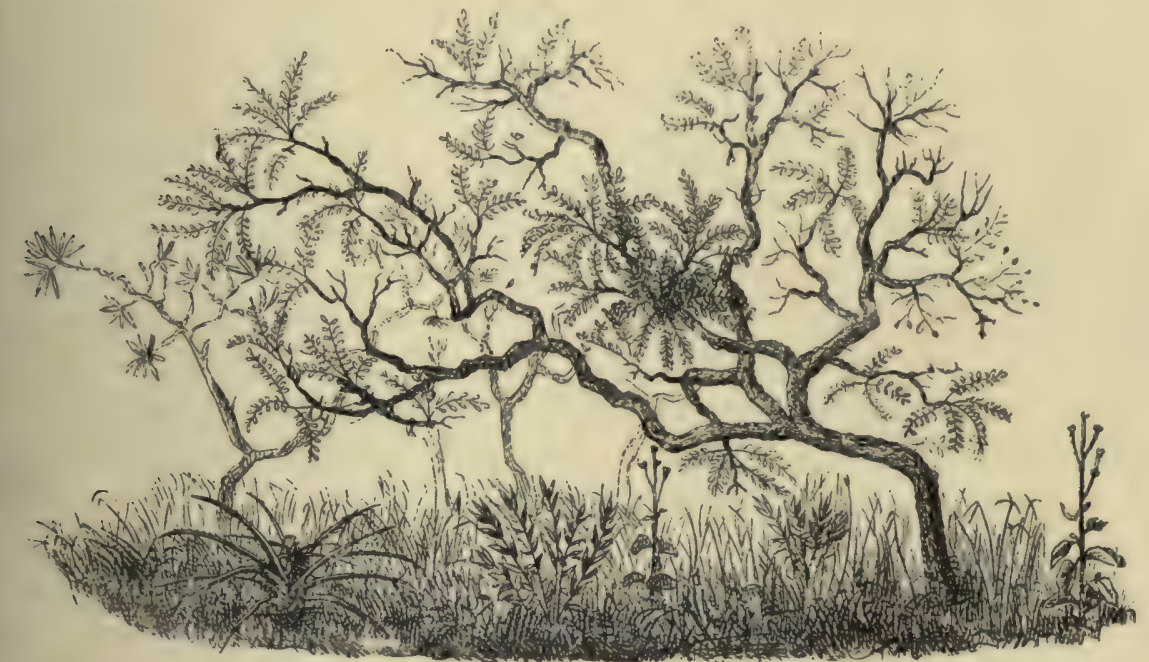

Fig. 365. Offener Campo cerrado bei Lagoa Santa.

Der Baum ist Andira (inermis?), am Boden links Bromelia bracteata, rechts Eremanthus sphaerocephalus, in der Mitte dieselbe und Ipomoea sp. - Die Höhe des Grases ist 0,3 bis $0,5 \mathrm{~m}$. (Aus Warming 1892.) Vergl. Kap. 107.

in einiger Entfernung größere Gebiete überschauen kann. Hier gibt es viele dornige Sträucher, besonders Acacia Farnesiana, A. tortuosa, Parkinsonia aculeata, Randia aculeata usw., außerdem Cacteen (Cereus, Opuntia, Melocactus) und Agave-Arten; nicht wenige Pflanzen mit Milchsaft finden sich, z. B. Plumiera, Rawwolfia, Calotropis, ferner viele Sträucher mit aufwärts gerichteten oder sich nach der Lichtstärke bewegenden Blättern (besonders Akazien) oder anderen Einrichtungen für den Verdunstungsschutz. In diesen tropischen Gebüschen gibt es auch einige Lianen und Epiphyten (Bromeliaceen), obgleich die große Lufttrockenheit deren kräftige und reichliche Entwicklung behindert. Die Blätter werden nicht regelmäßig abgeworfen; nach langer Trockenzeit 
hängen sie schlaff und mehr oder weniger verwelkt hernieder ${ }^{1}$ ). Diese Crotoneten werden auch von Boldingh besprochen.

Asien. In Zentralasien sind die Sandstrecken an gewissen Stellen mit Dornstrauchgebüsch („Dornstrauchsteppen") bewachsen. Man findet sie besonders in Persien, Tibet und anderen Gegenden Zentralasiens. Der Boden ist auch nicht selten tonig und steinig und trocknet leicht aus. In der gleichfalls offenen Vegetation spielen Gräser nicht die Rolle wie sonst in Steppen, sondern es kommen vorzugsweise dornige Sträucher vor, namentlich auf dem mehr steinigen Boden; sie stehen jedoch keineswegs so dicht, daß sie ein zusammenhängendes Gebüsch bilden. Es sind hauptsächlich Papilionaceen (Astragalus-Arten, Alhagi camelorum, Caragana-Arten, Halimodendron halodendron [H. argenteum] u. a.), denen sich viele Compositen anschließen, besonders solche der Gattungen Artemisia, Cnicus, Echinopus, Centaurea u. a., ferner Caryophyllaceen, Staticen, mächtige Umbelliferen (Scorodosma, Narthex, Dorema, Ferula) und Rheum-Arten. Wo die Sträucher in den trockensten Gegenden einzelner werden, geht das Gebüsch in die Wüste über. An anderen Orten wird der Graswuchs reichlicher, und die Strauchsteppe geht in eine Grassteppe über. In Persien und in den armenischen Bergen sind Arten von Astragalus vorherrschend. Auf den Felsen zerstreut wachsen sie zusammen mit Arten von Acantholimon, Silene und anderen sehr xerophilen Pflanzen.

Diese Arten treten häufig in Polsterform oder als "Kugelbüsche auf. Astragalus-Arten aus der Sektion Tragacantha wachsen nicht nur in den Steppen Kleinasiens und in den meisten orientalischen Gebirgen, sondern auch in alpinen Höhen auf den westlichen Bergen, z. B. auf dem Ätna. Auch die Plumbaginacee Acantholimon caryophyllaceum mit nadelförmigen Blättern spielt als dornige Polsterpflanze eine Rolle ${ }^{2}$ ).

Eine ganz ähnliche Vegetation aus zerstreuten, kugeligen Sträuchern kommt an vielen Stellen im Mittelmeergebiete vor, so z. B. in Spanien, auf den Balearischen Inseln usw.; besonders auf hartem, lehmigem Boden beobachtet man diese Lebensform. Viele von den Sträuchern oder Halbsträuchern gehören zu den Labiaten, z. B. zur Gattung Salvia. Eremostachys macrophylla (Labiate) bildet runde, niedrige Gebüsche von 1 bis $2 \mathrm{~m}$ Durchmesser mit rauhbehaarten Blättern. Auch Compositen bilden solche Kugel-Halbsträucher, z. B. Centaurea spinosa auf den kleinasiatischen Inseln (vergl. Fig. 77, S. 185).

1) Börgesen und Paulsen 1900; Boldingh 1909.

2) Vergl. Zederbauer 1906; Handel-Mazzetti 1912 b. 
Die Strauchvegetation, welche in diesem Kapitel besprochen ist, ist auch den Hartlaubformationen nahe verwandt und geht an vielen Stellen in diese über ${ }^{1}$ ).

Das Bambusgebüsch (Fig. 80) ist eine andere Form derartiger Vegetation, die man z. B. in hochliegenden, trockenen Gegenden Ostindiens findet. Niedrige, dornige Bambusgräser wachsen gesellig zusammen, sind miteinander verflochten, bedecken den Boden mit ihren Blattresten und schließen bisweilen alle anderen größeren Pflanzen aus; hier und da sind sie in Gesellschaft von Feronia und Aegle (zwei Aurantioideen), Mimosoideen, Rhamnaceen-Sträuchern, cactusähnlichen Euphorbia-Arten, des Oschur (Asclepiadacee) usw. Auch auf den Anden und anderen Gebirgen Südamerikas kommen Bambusgebüsche vor, z. B. aus Chusquea cristata bestehende, die fast den ewigen Schnee erreichen können.

Der erwähnte Oschur, Calotropis procera, ist ein Strauch mit großen, steifen, rundlichen, blau bereiften Blättern und ist reich an Milchsaft. Er bildet in Asien, auch z. B. auf weiten Gebieten um den Tsad-See, die sogenannte Oschur-Vegetation und wurde in Amerika eingeführt, wo er an vielen Stellen Westindiens und Venezuelas in Menge vorkommt und mitten in der glühendsten Sonnenhitze auf dem trockensten Boden vortrefflich wächst.

Es kann hier auch an die Chamaerops-Bestände in den westlichen Mediterran-Gebieten erinnert werden; diese sowohl wie die Macchien haben viel Ähnlichkeit mit dem soeben erwähnten Trockengebüsch, aber die klimatischen Verhältnisse sind verschieden, der Blattbau usw. soviel bekannt auch.

\section{Kap. Hochgebirgssteppen}

In noch unwirtlicheren Gegenden hört selbst das zusammenhängende Gesträuch auf, und zwar wegen klimatischer Trockenheit, heftiger Winde usw.; die Individuen trennen sich, größere oder kleinere Zwischenräume bilden sich zwischen den einzelnen Büschen, und die Sträucher selbst formen sich gewöhnlich zu Kugelbüschen oder großen halbkugeligen Polsterbüschen von 1 bis $3 \mathrm{~m}$ Durchmesser und bis etwa $1 \mathrm{~m}$ Höhe.

Hierher gehören viele Hochgebirgssteppen, die den im vorhergehenden besprochenen Dornbuschsteppen nahe stehen. Es ist erwähnt worden (S. 696), daß die oberste subnivale Höhenstufe der tropischen und subtropischen Hochgebirge sich durch große Lufttrockenheit, intenses Licht und starke Stürme auszeichnet: Faktoren, die eine stark xeromorphe und offene Vegetation hervorrufen. Die Vegetation, die sich

1) Vergl. Holmboe 1914 . 
hier entwickelt, muß sicher als eine selbständige Formation angesehen werden, ist aber ökologisch lange nicht hinreichend bearbeitet; es ist eine eigenartige Felsenflur, deren Vegetation als Hochgebirgssteppe bezeichnet werden kann und die vielfach in typische Hochgebirgswüste übergeht. Folgende Beispiele seien erwähnt:

Afrika. Auf den Kanarischen Inseln liegt die Peak-Region über den Wolken und stellt eine meist pflanzenleere Wüste dar. Die Luft ist hier sehr trocken, die relative Feuchtigkeit nur $12-35 \%$. Doch kann die kanarische Pinie noch recht ansehnliche Bestände bilden ${ }^{1}$ ).

Auf den hohen Gebirgen Teneriffas treten oberhalb der Kiefernwälder zunächst Gebüsche des weißblütigen Cylisus prolifer auf; aber sobald man die obere Grenze der Wolkenzone erreicht, tritt man in eine vollkommen trockene Region ein, die von der wegen der Höhe brennenden Sonne beschienen wird und wo Spartocytisus supranubius ungefähr die einzige vorherrschende Pflanze ist. Der Boden ist mit Tausenden und Abertausenden von Sträuchern dieser Art wie übersät, die bis $3 \mathrm{~m}$ hoch, dicht, halbkugelförmig, der Erde angedrückt und schwarz sind und sich am Grunde in außerordentlich viele dunkelgrüne Zweige auflösen (Fig. 366). Im Monate Mai erscheinen die kleinen Blätter und die weißen oder rötlichen Blüten, aber schon im Juli sind Blätter, Blüten und Früchte verschwunden; den Rest des Jahres über scheint diese Pflanze beinahe leblos zu sein. Ein zusammenhängendes Gebüsch bilden diese Sträucher jedoch nicht; sie stehen weit eher in dem scharfkantigen Bimssteingeröll inselartig zerstreut. Wenige andere Xerophyten und einjährige Pflanzen wachsen zwischen ihnen (Christ).

Asien. Auf hohen Gebirgen Zentralasiens dehnen sich vielfach über den Wäldern der Wolkenregion alpine Steppen aus, deren Flora ein merkwürdiges Gemisch von Steppenpflanzen und alpinen Typen darstellt. In Tibet fand Rockhill in großer Höhe eine Vegetation von zerstreuten Horsten von Gras, Rhabarber und Allium senescens.

Südamerika. Die Punas der Anden müssen als Gebirgssteppe betrachtet werden. Benrath, Weberbauer ${ }^{2}$ ) und Fiebrig haben sie geschildert. In einer Höhe von $3500-3700 \mathrm{~m}$ trifft man die typische Punavegetation. Die wichtigsten klimatischen Faktoren sind die starken, öfter orkanartigen Luftbewegungen, der Mangel an Niederschlägen, die große Lufttrockenheit und die anßerordentlich starke Intensität der Licht und Wärme liefernden Insolation in Verbindung mit starker Luftverdünnung. Den Boden bilden gewöhnlich Schottermassen. Auf dem Potosi ist die Mitteltemperatur selbst im November $14,2^{\circ}$ C. Nichts-

1) Burchhard in Englers Jahrb. XLIX, Beibl. 109.

2) Weberbauer 1911 . 


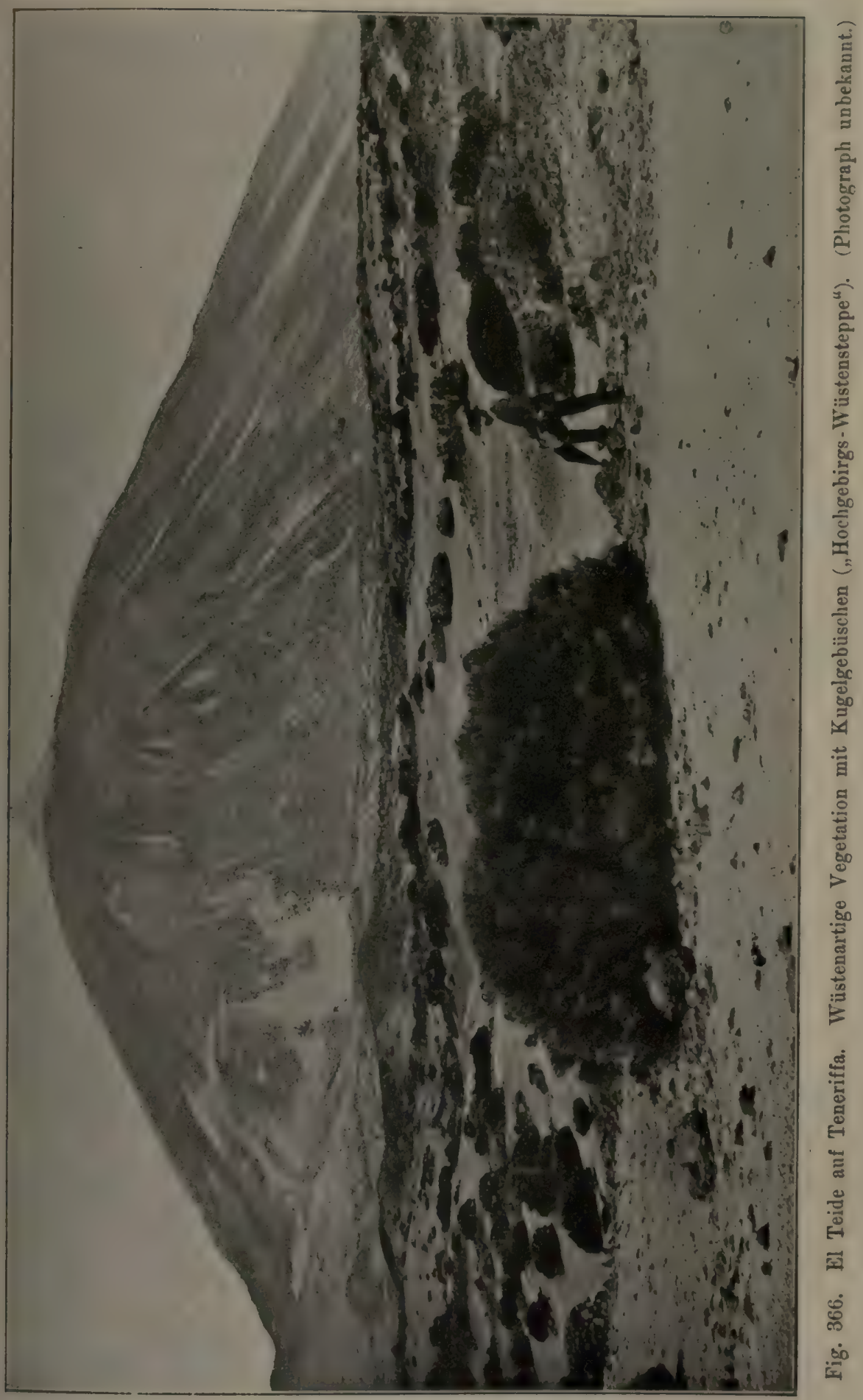


destoweniger kann zu allen Jahreszeiten Frost eintreten. Schnee fällt oft im Sommer, bleibt aber selten länger als einen Tag liegen, selbst wenn er hoch liegt. Starke Winde trocknen alles aus. Tote Tiere bleiben als Mumien liegen; sie gehen nicht in Fäulnis über.

Die Puna ist eine Halbwüste mit ausgesprochener Xeromorphie. Alle Arten sind ausdauernd. Namentlich drei Lebensformen herrschen vor: Die Polsterpflanzen (Fig. 75), die Rosettenpflanzen (besonders Compositen) und die stengellosen Zwergsträucher (Compositen, Amaranten, Astragalus-Arten usw.). Zwergsträucher und Polsterpflanzen bilden die

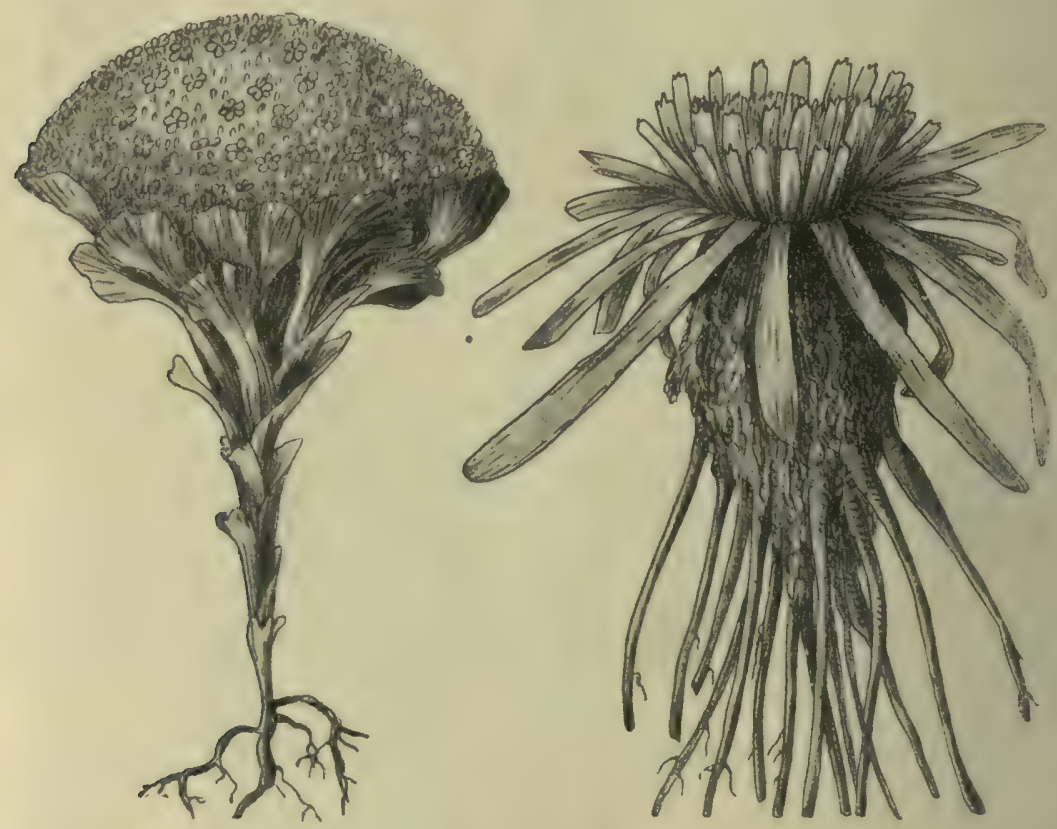

Fig. 367. Stangea Henrici, eigenartige Valerianacee der höchsten Anden; alle Arten der Gattung leben hier über $4000 \mathrm{~m}$. - Rechts die Composite

Werneria nubigena. (Nach Weberbauer.)

charakteristische Höhenvegetation. Von Stauden gibt es nur wenige, jedoch kommen auch Zwiebelgewächse vor.

Die Anpassungen der Sprosse äußern sich namentlich in der starken Reduktion des oberirdischen Wuchses ("kryptokaule" und "akaule“ Pflanzen, Fig. 367-369), dem stark entwickelten Wurzelsystem, der Verholzung der Achsen, den kleinen, meist dicken, stark kutikularisierten und häufig dornigen Blättern, der dichten Behaarung und der Bildung von Harz und ätherischen Ölen.

Die Punas sind ärmer an Pflanzen als die Paramos. Andere Arten und Gattungen als in den arktischen Gegenden und auf Europas Bergen 
geben der hochandinen Vegetation ein abweichendes Gepräge; außer Viola, Anemone, Alchimilla, Draba, Senecio, Gentiana, Poa, Hordeum und vielen anderen europäischen Gattungen gibt es hier z. B. Nassauvia, Chuquiragua, Baccharis - Arten mit wunderlicher Form und andere Compositen, Tropaeolum, Loasa, Blumenbachia, Verbenaceen, Cactaceen, Calceolaria, Mimulus, Melastomataceen, Krameria, Lupinus, Calyceraceen u. v. a. Besonders müssen die Umbelliferen der Gattung Azorella hervorgehoben werden. (Vergl. auch Fig. 75.) A. caespitosa auf den Falklandsinseln bildet mehr als meterhohe, halbkugelige, außerordentlich harte Polster von schmutziggriuner Farbe. Der Umfang wird von zahlreichen kleinen Sprossen gebildet, die alle gleich hoch und mit Schuppenblättern dicht bedeckt sind; sie sind mit den zwischenliegenden alten Blatt- und Sproßteilen so dicht zusammengepackt, daß es mitunter schwierig ist, ein Stück mit dem Messer herauszuschneiden. Flechten und andere Pflanzen können sich auf den Polstern ausbreiten. Die Alpenrosen der Schweiz werden hier durch $E s$ callonia- und Bejaria-Arten ersetzt.

Unter den eigentümlichen Typen der Puna müssen die Cacteen genannt werden. In der Puna Boliviens gibt es Säulencacteen, welche die absolut höchstwüchsigen Pflanzen in allen über $3000 \mathrm{~m}$ gelegenen Höhen sind, gerade auf den den Stürmen am meisten ausgesetzten freien Anhöhen, Bergrücken usw. erreichen sie die stattliche Höhe

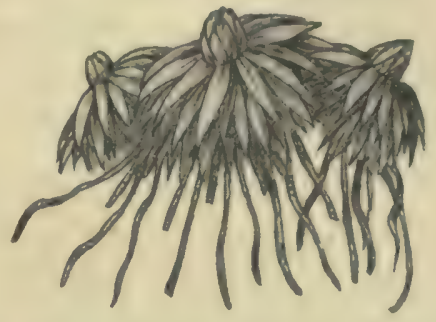

Fig. 368. Lucilia Tunariensis (Composite). (Nach Weberbauer.)

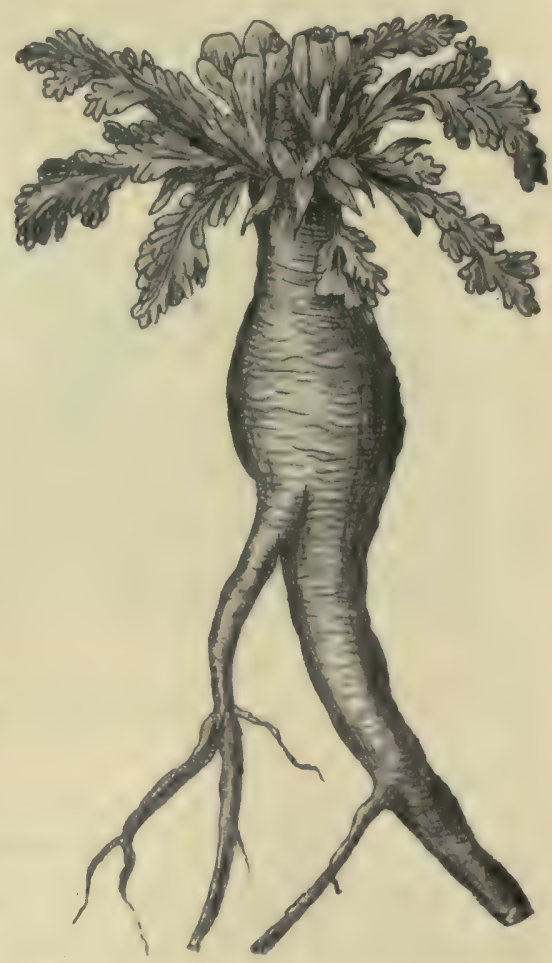

Fig. 369. Nototriche longirostris (Malvacee). (Nach Weberbauer.) von 5 und mehr Metern und einen Stammdurchmesser von $40 \mathrm{~cm}$ und mehr. Andere Cacteen können auch Polster bilden.

Auf den chilenischen Punas treten (nach Meigen) Moose und Flechten sehr zurück. Flechten sind sehr selten und nur auf einzelnen 
Stellen in gröBerer Menge vorhanden; eine Moosdecke oder sogar nur ausgedehnte Moospolster gibt es nirgends. Der Grund hierfür ist die große Trockenheit ${ }^{1}$ ).

In den Argentinischen Anden unterscheidet Rob. Fries drei Typen von Strauchsteppen: Hoffmannseggia-Assoziation, Cactus-Assoziation und Azorella-Assoziation. Die letzte gehört wohl kaum zu den Hochgebirgssteppen.

Eine Vegetation, welche die Mitte zwischen den Hochgebirgssteppen, dem Trockengebüsch und den Macchien bildet, scheint folgende zu sein: Als „Buschsteppe" bezeichnen Rikli und Schröter eine nordafrikanische Vegetation, welche aus sehr dicht verzweigten Büschen gebildet ist, die gewöhnlich nur eine Höhe von 1-3 m erreichen, und die sich fast immer dicht über der steinigen Unterlage in mehrere gleichwertige Stämmchen teilen. Da das dichtbelaubte und ineinander verflochtene Astwerk bis an den Boden reicht, so besitzen sie Kugel- oder Kegelform. Vorherrschend ist der nackte, gelbbraune, einen Ton ins Rötliche zeigende Boden. Über demselben zerstreut sind in gleichmäßiger Verteilung die dunklen, fast schwarzgrünen Flecken der immergrünen Gebüsche. So kommt eine Landschaft zustande, die in ihrem Gesamteindruck ganz an das Fell eines Panthers erinnert; man könnte sie als „Pantherbuschsteppe" bezeichnen.

Die Leitpflanzen sind am Djebel Mekter im Atlas am Nordrand der Sahara: Quercus ilex v. ballota und Juniperus oxycedrus, an dritter Stelle ist J. Phoenicea zu nennen. Die tonangebenden Arten wären somit mediterrane Niederungspflanzen, Vertreter der Macchien und Garigues, die hier eine Gebirgsflora bilden.

Hierher muß wohl auch die Vegetation gerechnet werden, welche Holmboe $^{2}$ ) auf Cyperns höchsten Bergen oberhalb der Waldgrenze fand, welche aus Sträuchern von Berberis, Juniperus, Rosa canina, Sorbus aria und aus knollenbildenden Stauden, sowie einjährigen Kräutern bestand.

\section{Kap. Dornenlose Halbstrauchsteppen}

Schon im Kap. 52 sind diese Steppen erwähnt worden, weil sie gewöhnlich an salzhaltigen Boden gebunden sind. Es muß hier jedoch wieder an sie erinnert werden, weil der Boden doch wohl nie stark salzhaltig ist und oft stark ausgelaugt sein muß, falls er überhaupt überall salzhaltig war. Sie schließen sich den vorigen Formationen recht gut an.

$\left.{ }^{1}\right)$ Meigen 1893. Über die Punas vergl. auch Tschudi, Goebel 1891. Über die Geröllhalden in der alpinen Höhenstufe Mexikos vergl. C. A. Purpus 1907.

$\left.{ }^{2}\right)$ Holmboe 1914. 
Die dornenlosen Halbsträucher treten, wie schon S. 146 erwähnt, in Menge in den Gebieten des Winterregens auf, aber gehen auch in angrenzende Steppen- und Wüstengebiete hinein; jedoch schreibt Engler ${ }^{1}$ ): , an steinigem und sandigem Boden treten in ganz trockenen Gebieten Halbsträucher, wie Pelargonium, Sarcocaulon, Hermannia, Corchorus nur sehr vereinzelt vor". Die meisten Arten gehören zu den Compositen, namentlich zur Gattung Artemisia. Als solche "Wermutsteppen" sind schon die russischen und westasiatischen (S. 791) erwähnt worden. Es kann hier folgendes hinzugefügt werden:

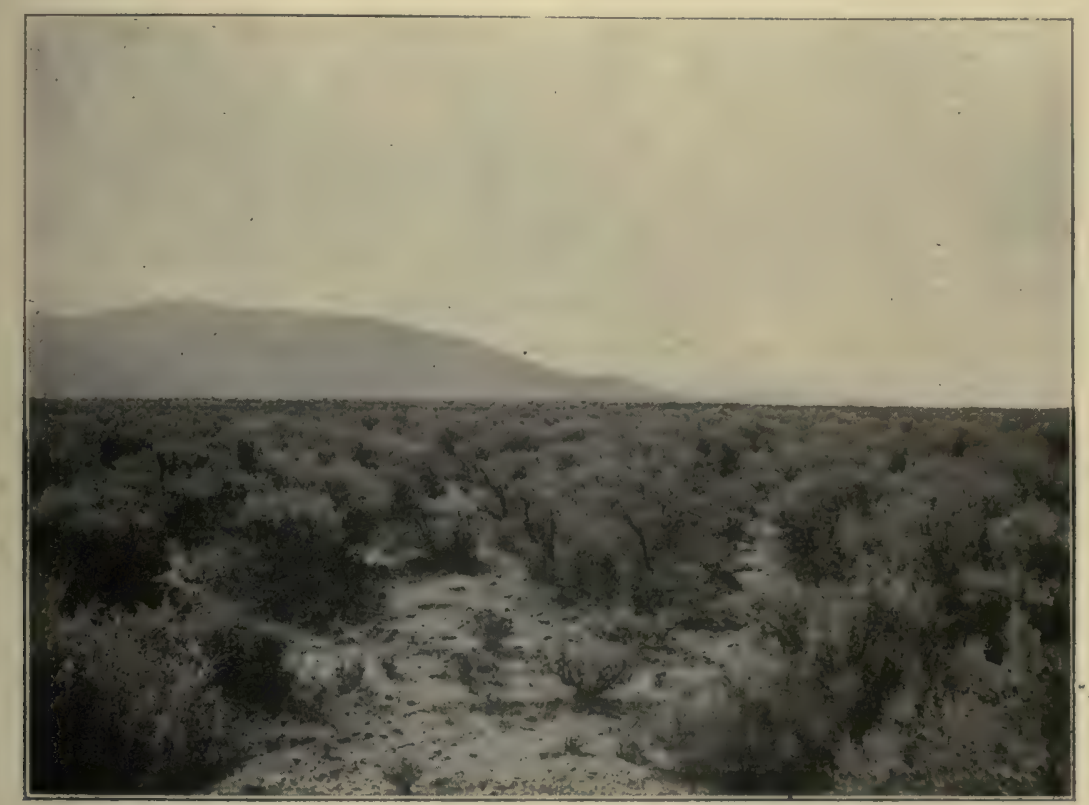

Fig. 370. Assoziation von Artemisia tridentata ("Sage brush") bei Toole in Utah.

Wermutsteppe. Im nördlichen Turan und in Südost-Rußland, wie in den Kalmückensteppen der unteren Wolga, sind unendliche Flächen vorherrschend mit Artemisia-Sträuchern (A. maritima und $A$. frigida) bedeckt. Sie bilden eine Zone um die Wüsten von Turan. Weiter nördlich und westlich, wo die Regenfälle häufiger sind, werden sie von einem Kranze von Grassteppe begrenzt. Grassteppe, Strauchsteppe und Wüste stellen drei Stufen der Abnahme der Häufigkeit der Regenfälle dar. Die Wermutsteppe zeigt eine Vorliebe für den Lehmboden, der meist eine hellbraune Farbe (Rübel) zeigt und keinen Humus enthält; meist ist er in diesen trockenen Gebieten mäßig salzig und daher auch physio-

1) Engler 1910. 
logisch trocken. In den Übergangsteilen zwischen Wermut- und Grassteppe werden die salzigen Senkungen von den Wermutsträuchern bewohnt, während die Abhänge der Hügel, aus denen das Salz ausgelaugt ist, mit Grassteppe bedeckt sind. In gleicher Weise bildet die Wermutsteppe eine Zone um die echten Halophyten der Ufer der Salzseen und -Sümpfe. Wo Wermutsteppe herrscht, ist Kultur nur mit Hilfe künstlicher Bewässerung möglich, das Land liefert nur nomadisierenden Stämmen Unterhalt, da es für die Schafe und Kamele Futter liefert.

Grau und tot erscheinend dehnt sich die Wermutsteppe über unendliche Flächen, die Farbe wird durch die weißbehaarten Blätter der Artemisien hervorgerufen. Die Wurzeln dieser Arten gehen bis zu einer Tiefe von $4 \mathrm{~m}$ in den Boden und ermöglichen so den Pflanzen die Existenz selbst zu einer Zeit, wo die dörrenden Sonnenstrahlen fast alles übrige Leben verschwinden lassen. Zwischen den Artemisia-Büschen wachsen Sträucher und Stauden, wie Alhagi camelorum, Xanthium spinosum und Eryngium campestre, gleichfalls sehr tiefwurzelnde Arten. Im Frühling blühen zahlreiche einjährige Kräuter und Knollenpflanzen, die mit Beginn des Sommers bereits in Frucht stehen ${ }^{1}$ ).

In Nordamerika finden sich ausgedehnte Wermutsteppen in den kontinentalen Gegenden, besonders auf salzhaltigem Boden. Artemisia tridentata und andere Arten dieser Gattung bilden bisweilen weit ausgedehnte Assoziationen.

Ein anderes Beispiel einer Vegetation, in der zerstreute Sträucher und Halbsträucher untermischt mit Kräutern die Hauptrolle spielen, bieten die trockenen Gebiete zwischen den Rocky Mountains und der Sierra Nevada dar (Fig. 370). Auch hier sind nach Asa Gray die herrschenden Pflanzen Arten der Gattung Artemisia, mit ihnen kleinköpfige Compositen und auch Chenopodiaceen. Nach Watson ist dort selbst in der trockensten Jahreszeit kein Fleck ohne Vegetation. Bäume fehlen, ebenso ein Grasteppich; an seine Stelle treten aber strauchige oder halbstrauchige Arten, die scheinbar alle andere Vegetation verdrängen. Charakteristisch sind die einfarbig meist grauen oder dunkel olivfarbigen Kräuter; am häufigsten ist auch hier der "everlasting sage-bush" Artemisia tridentata, dessen Halbsträucher unendliche Flächen bedecken, nirgends aber wächst er so dicht, daß er das Durchwandern hindert; meist erreicht er nicht $1 \mathrm{~m}$ Höhe. Eingemischt sind auf diesem häufig salzigen Boden Atriplex confertifolia, A. canescens, Artemisia spinescens, Kochia prostrata, Eurotia lanata, Graya polygaloides п. a. ${ }^{2}$ ).

Compositensteppe im Caplande in Südafrika. Die Gipfel der Tafelberge nördlich der Karroo sind von einer Steppenvegetation bedeckt,

1) Nazarow 1886; Krasnoff 1886, 1888; Radde 1899; Rübel 1914.

2) Pound und Clements 1898-1900; Rübel 1915 a. 
in der Halbsträucher vorherrschen, die zumeist zur Familie der Compositen gehören. Die wichtigsten Gattungen sind Helichrysum, Senecio, Berkhaya, Euryops, Pentzia und Gazania; auch Leguminosen, Crassulaceen und Scrophulariaceen sind häufig. Zahlreiche Arten von Knollenund Zwiebelgewächsen sind hier heimisch ${ }^{1}$ ).

\section{Kap. Hitzewuisten (Die Trockenwïsten)}

Wenn wir mit den „Wüsten“ unsere Darstellung der Vegetationstypen abschließen, folgen wir wahrscheinlich teilweise dem Gange der Natur. Scheint es doch, daß alle bekannten großen Wüsten ständig zunehmen, alle sind einer vermehrten Austrocknung unterlegen; das Wüstenareal der Erde scheint sich stetig zu vergrößern.

Durch ganz allmähliche Übergänge sind die Halbwüsten mit den Wüsten verbunden; der Unterschied ist nur ein quantitativer; es handelt sich hier stets um eine mehr oder weniger offene Vegetation, um kleinere, ja zwerghafte bis größere Pflanzengestalten. Eine scharfe Grenze kann unmöglich ebensowenig hier wie anderswo gezogen werden. Wenn Diels sagt, daß eine Wüste mehr offenes Land hat als von Vegetation bedecktes, so dürfte er damit eine korrekte Definition der "Wüste" gegeben haben (Fig. 166, 167).

Die Bezeichnung "Wüste" ist nicht streng wissenschaftlich; sie bedeutet im allgemeinen nur ausgedehnte Gebiete, wo kein Leben vorkommt oder wo sich nur ein außerordentlich schwaches Leben zeigt. Das Meer ist trotz seines Reichtumes an Organismen für das Auge des Laien eine ungeheure "Wasserwüste"; man spricht von den "Schneeund Eiswüsten“ der Polarländer (den Kältewüsten), und die fruchtbarsten Lande (wie die Magdeburger Börde) nennt Ascherson sogar mit demselben Rechte eine „Kulturwüste“; aus den weiten grünen Flächen hebt sich nichts ab, auf dem das Auge ruhen kann. Es gibt sowohl in den Hochgebirgen als auch in den tropischen Tiefländern Wüsten, und in Persien kommen Salzwüsten vor, pflanzenlose weißgraue Salzflächen von vielen Quadratmeilen Ausdehnung. Im allgemeinen herrscht in den echten Wüsten immer Armut an irgend etwas, Armut an Nahrung, an Wärme oder an Wasser, oder auch Überfluß an Stoffen, die in zu großer Menge dem Pflanzenleben schädlich werden; die Hauptrolle spielt hier das Kochsalz ${ }^{2}$.

1) Bolus 1886 .

2) Rikli und Schröter (1912, S. 128) stellen eine lange Reihe von Typen auf: Trockenwüsten, Kältewüsten, Dunkelwüsten (die Urtiefen der Ozeane und Binnengewässer), Hitzew üsten (heiße Quellen), Hungerwüsten (nährstoffarme Gewässer und Böden), osmotische Wüsten (zu hoher osmotischer Druck wirkt schädlich), Giftwüsten, mechanisch bedingte Wüsten, anthropogene Wüsten. 
Indessen wird der Name Wüste doch gewöhnlich für solche weit ausgedehnten Gegenden auf beiden Seiten des tropischen Waldgürtels angewandt, die sich durch eine außerordentliche Hitze und durch Mangel an Feuchtigkeit auszeichnen, wo die Niederschlagshöhe bisweilen nur wenige Millimeter jährlich erreicht, und wo die Vegetationsperioden durch den zeitweiligen Mangel an Feuchtigkeit verursacht werden. Solche Trockenw üsten werden in diesem Kapitel behandelt.

Es ist nicht Nahrungsmangel des Bodens, der die Wüstenbildung hervorruft, sondern einzig und allein die Trockenheit. Was das Wasser ausrichten kann, zeigen uns die unterirdisches Wasser führenden Oasen und die Wadis (trockene Flußtäler) der Wüsten.

Die Dattelpalmen-Oasen (vergl. S. 614), welche von allen Seiten von der pflanzenärmsten, brennend heißen und trockenen Wüste umgeben sind, sind zum Teil schattenreiche Wälder, deren feuchter, periodisch bewässerter Boden eine frisch grüne Vegetation von Fruchtbäumen, krautartigen Kulturpflanzen und anderen mesomorphen Kräutern und Gräsern trägt.

Ebenso findet sich längs der Flußläufe Wald oder Gebüsch. Am Amu Darja in Transkaspien gibt es Ufergehölz und selbst Wälder von Populus, Tamarix, daneben hohe Gräser in dichten Vereinen, z. B. von Phragmites und Erianthus, sowie Sträucher und Schlingpflanzen ${ }^{1}$ ). Die Wasserläufe in Nordafrikas Wüsten sind von Tamarisken und Nerium umkränzt, welche beide oft Buschwerk bilden. An ihren Seiten findet man Halophyten, wie Scirpus holoschoenus, Sonchus maritimus, Cyanophyceen usw., ähnlich wie in den Marschsümpfen in Süd- und Nordeuropa ${ }^{2}$ ). Auch die S. 295 besprochenen durch Schwefeleisen schwarz gefärbten Schlammassen, welche durch Bakterien gebildet wurden, kommen z. B. an den Ufern der Flüsse in Südtunesien vor (Warming).

Die Wüstenvegetation gleicht in vielen Punkten der der Felsenfluren, zunächst darin, daß die Pflanzendecke nie zusammenhängend ist; die Pflanzen stehen in vereinzelten, weit voneinander entfernten Individuen, und manche Gebiete sollen absolut pflanzenlos sein. Die Farbe der Pflanzen ist graugrün, aber auch hier bestimmt die Farbe des Bodens die der Landschaft (vergl. Fig. 166, 167). Ferner stimmen beide Vegetationsgruppen darin überein, daß die Pflanzen verkrüppelte $\mathrm{Zwerge} \mathrm{sind.} \mathrm{Rasen-}$ form und Strauchform sind in der Wüste ebenso allgemein, wie in der Felsenvegetation, und weit wandernde, unterirdische Sprosse findet man nur da, wo der Boden sandig wird. Ferner ist die Vegetation ausgeprägt xeromorph, in enger Anpassung an die starke Sonnenhitze der Wüsten,

3) O. Paulsen 1912. Vergl. S. 343, Fig. 172.

2) Flahault 1906. 
an die oft außerordentlich starke Erwärmung des Bodens und die oft viele (bis neun) Monate lange trockene Zeit; was in den Felsenfluren durch Kälte und Wind hervorgerufen wird, verursachen hier neben den Winden Hitze und Regenmangel. Rikli und Schröter definieren, die Wüste" folgendermaßen: "Sie ist ein klimatisch bedingtes Trockengebiet, das entweder ganz vegetationslos oder von vereinzelten xerophytischen Stauden urd Sträuchern besiedelt ist, so daß der nackte Boden weit vorherrscht".

Die Wüsten sind, was die Ärmlichkeit der Vegetation betrifft, einen Schritt weiter entwickelt als die Halbwüsten.

Die Wüste ist nahe verwandt mit den vorangehend besprochenen Halbwüsten und Steppen. Steigt die Feuchtigkeit des Standortes, geht sie in Steppen über. Wüsten- und Steppenpflanzen zeigen dieselben Lebensformen und ökologischen Anpassungen.

Das Klima. Die Hitzewüsten sind in erster Linie klimatisch bedingt und können auf recht verschiedenen Bodenarten entstehen. Als klimatisch wichtige Faktoren können hervorgehoben werden: Mangel der Niederschläge, starke Hitze und Verdunstung am Tage, starke austrocknende Winde ${ }^{1}$ ).

Die Regenmenge ist oft sehr gering, sie bleibt meist unter $25 \mathrm{~cm}$ jährlich, und ist sehr unregelmäBig verteilt; es können in einigen Wüsten Jahre vergehen, in welchen fast kein Regen fällt. Massart schätzt die Regenmenge in der Sahara auf $15 \mathrm{~cm}$ im Jahre. In der Wüste von Atacama in Südamerika fällt fast nie Regen. An der Walfischbay an der Küste von Südafrika ist die jährliche Regenmenge $7 \mathrm{~mm}$, und diese fällt meist in nur sechs Tagen im Jahre. Regelmäßige Beobachtungen über die Regenmenge sind von mehreren Stationen am nördlichen Rande der Sahara veröffentlicht; hier fällt der Regen im Winter, aber auch zu dieser Jahreszeit können Monate vergehen ohne einen einzigen Regentag. Im Wüstengebiet von Arizona ist nach Purpus die Regenmenge 176-298 mm. Köppen rechnet diejenigen Gegenden zu den Wüsten, in denen der regenreichste Monat höchstens sechs Regentage hat.

Vergleichsweise mag angeführt werden, daß in Dänemark die jährliche Regenmenge ca. $614 \mathrm{~mm}$ beträgt, in Norddeutschland 450 bis gegen 700 .

In allen Wüsten gibt es jedoch günstigere Lokalitäten, sei es daß Gebirgsketten vorhanden sind, an denen die Regenmenge bedeutender ist, oder daß nach Regengüssen in trockenen Flußbetten Wasser fließt, und zwar oft in ungeheuren, gewaltsam strömenden Massen, so daß der

1) Einzelheiten, was das Folgende betrifft, siehe Rikli und Schröter 1912, Kap. 9. 
Untergrund für eine längere Zeit feucht bleibt. Der Regen fällt in manchen Wüsten oft in gewaltiger Menge wolkenbruchartig, so daß sich tiefe Erosionstäler bilden und große Felsblöcke herumgewälzt werden können. In der Wüste in Nordafrika z. B. gibt es viele trockene Flußbetten. Die Nebelbildung hat in gewissen Küstengegenden eine große Bedeutung, z. B. an der Walfischbay in Südwestafrika.

Der Tau spielt gewiß in vielen Wüsten eine nicht zu unterschätzende Rolle, namentlich dort, wo Seewinde das Wüstengebiet erreichen. Volkens sagt vom Tau in der ägyptischen Wüste, daß in der langen, trockenen Zeit wegen der starken Erniedrigung der nächtlichen Temperatur eine reichliche Taubildung stattfinden kann, der dann die einzige oberirdische Wasserquelle ist. Hierzu muß jedoch bemerkt werden, daß seine Beobachtungen an der Grenze der Wüste und des fruchtbaren Niltals gemacht sind; nach anderen ist die Menge des Taues in der eigentlichen Wüste fast Null und die Erscheinung ungeheuer selten. Fitting ${ }^{1}$ ) fand in den Monaten März bis April niemals Tau bei Biskra in Algier ${ }^{2}$ ).

Die Temperaturen der tropischen Wüsten sind oft sehr hoch. Im Sommer steigt die Temperatur bisweilen über $50^{\circ} \mathrm{C}$. In der Sahara hat man bis $51,4^{\circ} \mathrm{C}$. beobachtet, und von amerikanischen Wüsten gibt Mac Dougal $53,3^{\circ}$ an.

Starke Temperaturschwankungen gehören zu den Eigentümlichkeiten der Wüsten. In der Nacht findet eine starke Abkühlung statt, bisweilen so stark, daß die Temperatur unter Null sinkt. Ascherson beobachtete in der Libyschen Wüste nach einem Tage von fast $30^{\circ}$ in der Nacht $-4^{\circ}$.

Frost ist im Winter nicht selten. Im Inneren von Arabien sank die Temperatur in der Nacht im Winter auf 1893 bis -5 und $-10^{\circ} \mathrm{C}$., während das Thermometer am Tage mehr als $25^{\circ} \mathrm{C}$. zeigte ${ }^{3}$ ). In Transkaspien sinkt die Temperatur im Winter bis $-40^{\circ}$, steigt im Sommer bis $+48^{\circ}$, und die Mitteltemperatur ist +25 bis $30^{\circ}{ }^{4}$ ). Aus afrikanischen Wüsten wird sogar eine Temperatur von 60 bis $70^{\circ}$ am Tage und $15^{\circ}$ in der Nacht angegeben; also eine Differenz in 24 Stunden von 45 bis $55^{05}$ ).

Die Luftfeuchtigkeit ist äußerst gering. Massart hat einmal sogar nur $2 \%$ gemessen. Eine Anzahl Beobachtungen am Nordrand der Sahara zeigt Zahlen von $51,3 \%$ bis herab zu $3 \%{ }^{6}$ ).

1) Fitting 1911.

2) Vergl. auch Rikli und Schröter 1912, S. 133.

s) Nolde, Meteorol. Zeitschr. 1895.

4) O. Paulsen 1912.

s) Engler, Afr. I.

6) Rikli und Schröter S. 136. 
Licht in der Wüste. Am Nordrand der Sahara hat Rübel, wie schon früher Wiesner in Kairo und Strakosch in Ägypten und dem ägyptischen Sudan, nach Wiesners Methode den Lichteinfall studiert ${ }^{1}$ ). Er bestätigt Wiesners Resultate. Das Charakteristische ist die geringe chemische Lichtintensität, deren Ursache ist, daß die Luft infolge der Suspension von Staubteilen meist sehr trübe ist; besonders die chemisch wirksamen Strahlen werden abgeschwächt. In Aïn-Sefra regnete es am 30. und 31. März, und durch die dadurch gereinigte Luft drang eine Lichtintensität von 1100; am 5. April konnte sich die Lichtintensität trotz voller Sonne und höherem Sonnenstande nicht über 580 erheben. Das Gesamtlicht am Nordrand der Sahara zeigt große Übereinstimmung mit dem Ägyptens.

Die Winde sind ein Faktor, welcher die Austrocknung in hohem Grade befördert, und in den meisten Wüsten herrschen starke Winde.

Die Verdunstung ist daher in allen Wüsten sehr groß ${ }^{2}$ ). Sie überwiegt den Niederschlag sehr erheblich. Nach Trabut betrug die Regenmenge im Jahre 1906 in Bini-Ounif am Nordrande der algerischen Sahara $91,6 \mathrm{~mm}$, aber der Verdunstungsmesser zeigte eine verdunstete Wasserschicht von 4637,7 mm; die Verdunstung war also 50,6 mal größer als der Regenfall.

Es ist leicht zu verstehen, daß die erwähnten Faktoren eine äußerst xeromorphe Vegetation hervorrufen müssen. Thnen schließen sich nun aber in den meisten Fällen die Eigenschaften des Bodens verstärkend an.

Der Boden, namentlich der lehmige, wird wohl in den meisten Fällen reich an Nahrung (Kali, Phosphorsäure, Nitraten) sein. Die Nährsalze, die anderswo vom Regen ausgewaschen werden, werden in dem trockenen Wüstenklima aufgehäuft. Durch Bewässerung, z. B. der Imperial Valley am Südrande der Coloradowïste in Nordamerika, schuf man ebenso wie in Turkestan ein reiches Ackerland, in welches auch viele fremde Unkräuter einwanderten. Die Wasserarmut hindert in den Wüsten aber die Aufnahme der Nahrung und dadurch die Ausbildung einer kräftigeren Vegetation. Das Grundwasser liegt zu tief für die Vegetation oder ist zu salzig.

Die Bodenfeuchtigkeit der oberen Erdschichten in der Wüste kann dagegen auffällig groß sein. In Tucson waren die obersten, nach Spalding und Livingstone, nach einer langen Trockenperiode staubtrocken. In $3 \mathrm{~cm}$ Tiefe enthielten sie jedoch noch $2 \%$ Wasser, in $10-12 \mathrm{~cm}$ $5-10 \%$, in $15 \mathrm{~cm} 13 \%$, bei $35 \mathrm{~cm}$ Tiefe $15 \%$ (berechnet auf das

1) Rikli und Schröter 1912.

`) Uber das Klima der Wüsten vergl. besonders Rikli und Schröter 1912. 
Volumen, welches die untersuchte Bodenprobe beim Absetzen in Wasser einnimmt ${ }^{1}$ ). Vergleiche über die Trockenschicht der Dünen S. 750 und über "Dry farming"s S. 827.

Der Boden ist im allgemeinen genommen ohne Humus, aber salzhaltig, sehr verschieden, wonach die Wüsten zu verschiedenen Typen geführt werden: Felswüsten, Sandwüsten, Tonwüsten, Salzwüsten.

Fels- und Steinwüsten. Es gibt wenige Felsarten, welche den so enorm großen, täglichen Temperaturschwankungen Widerstand leisten können; die meisten werden zersprengt, und oft sieht man Blöcke solcher Felsreste mitten in einem wüsten Trümmer- und Kiesfelde liegen. Dazu gesellen sich die Winde, welche durch ihr Sandgebläse die Felsstücke abschleifen und abrunden. Es gibt Gebiete, in denen die vereinigten Kräfte der Erosion, der Sonne und des Windes die Felsen in eine Unzahl von Steinen und Grus zerteilt haben. Man findet z. B. in Ägypten "Kieswüsten (Serīr)", wo abgerundete, braunschwarze, klingende Kieselgeröllstücke die wesentlich sandigen Flächen weithin bedecken und von ferne über dem rotgelben Wüstensande dunkel erscheinen; Grussteppen ("steppes rocailleux", Trabut, Flahault) kommen ferner in Algier vor, und ausgedehnte, steinige Hochebenen, die „Hammada“ der Eingeborenen, mit scharfkantigen Sand- und Kalksteinen, bilden den größten Teil der Sahara; auch auf der oberen Karroo-Terrasse des Kaplandes trifft man wasserlose Steinwüsten an.

Wird die Zertrümmerung fortgesetzt; so entsteht Sand, und ausgedehnte Sandwüsten kommen in Sahara, Südafrika, Zentralasien, Arabien usw. in allen großen Wüstengebieten vor, ein Spiel der heftigen

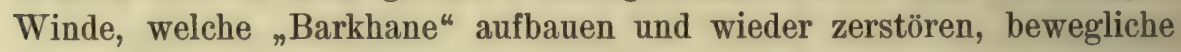
Dünen, die absolut pflanzenleer sind oder höchstens ganz vereinzelte Pflanzen tragen.

Tonwüsten. Endlich gibt es Wüsten, deren Boden aus einem an Steinen reichen, festen, rötlichen Ton besteht, der in der trockenen Zeit fest und steinhart wird, so daß er Risse erhält, und fast als ein Felsenboden zu betrachten ist, z. B. auf den Hochebenen Mexikos.

Diesen schließen sich die Salzwüsten an, welche sich in mehr oder weniger großen, abflußlosen Becken finden, in welchen sich Schlamm, Lehm und namentlich Löß gesammelt haben, und in welche auch öfter salzhaltige Gewässer ihr Wasser ergießen, welches dann in der trockenen Luft verdunstet, so daß die im Wasser gelösten Salze (Kochsalz, Natronsalz, Glaubersalz u. a.) ausgeschieden werden und als weiße Krusten auskristallisieren. Die Vegetation der Salzwüsten ist schon Kap. 52

1) Nach Rikli und Schröter. 
(vergl. S. 459) besprochen worden; sie wird aus höchst eigentümlichen Halophyten gebildet, aber immer nur aus wenigen Arten, welche diesem eigentümlichen Boden angepaßt sind.

Wie die Salzwüsten sind auch die Steinwüsten und Sandwüsten oben (Serje VI) besprochen worden.

$\mathrm{Zu}$ den erwähnten Verschiedenheiten des Wüstenbodens kommt noch eine gemeinsame Eigentümlichkeit: Der Wüstenboden ist heiB; in den afrikanischen und den asiatischen Wüsten erreicht seine Temperatur nicht weniger als $50-60^{\circ} \mathrm{C}$, und an der Loangoküste hat man Temperaturen von $75-80^{\circ} \mathrm{C}$. gemessen, einmal sogar fast $85^{\circ} \mathrm{C}$. (Hann Klimatologie, S. 381). Nachts kühlt er so stark ab, daß die Gesteine mit lautem Knall springen können.

Alle diese edaphischen Faktoren haben eine Wirkung, welche in, derselben Richtung geht wie die des Klimas: eine äußerst xeromorphe Vegetation $\mathrm{zu}$ schaffen. Im allgemeinen wird man wohl darüber einig sein, daß die klimatischen Faktoren die größte Bedeutung haben. Es mag wohl aber auch vorkommen, daß es Lokalitäten gibt, wo die edaphischen überwiegen, wie z. B. in Texas ${ }^{1}$ ).

\section{Kap. Lebensformen der Wïste}

Schnelligkeit der Entwicklung. In allen Wüsten beobachtet man die erstaunliche Schnelligkeit der Entwicklung nach oder gar schon kurz vor ${ }^{2}$ ) den ersten Regenfällen bei Beginn des Frühlings. Frische grüne Triebe erscheinen plötzlieh; zahlreiche und oft schöne Blüten entfalten sich an den dürren Sträuchern oder entsprießen dem eben noch so trockenen Boden.

Diese Flora der Regenzeit wird zum großen Teile von einjährigen Kräutern gebildet, welche bald blühen und Frucht ansetzen, um danach gleich wieder zu verschwinden und in den meist gut geschützten Samen gegen die sengende Hitze Widerstand zu leisten. Viele vollenden ihren Lebenslauf in wenigen Wochen, "bisweilen in wenigen Tagen" (Flahault), "Ephemere", wie sie Volkens nennt, so z. B. Odontospermum pygmaeum. Es ist leicht verständlich, daß sie äußerst zwerghaft werden und oft nur wenige Samen ansetzen. Die Laubsprosse haben mesomorphen Bau; von Xeromorphie ist keine Spur zu bemerken, ausgenommen daß einige Salzpflanzen succulent sind oder in anderer Form Xeromorphie zeigen.

1) Bray 1906. Hierüber vergl, auch namentlich Ove Paulsen 1912; Massart. Über den Bau der Graswurzeln Price 1911.

2) Volkens 1887.

Warming-Graebnex. 3. Auflage, illustr. 
Unter den vielen von 0 . Paulsen sorgfältig studierten und abgebildeten Arten mag beispielsweise der einjährige Ceratocarpus arenarius hervorgehoben werden. Im Frühlinge erscheinen die linealischlanzettlichen Laubblätter, die mit Sternhaaren dicht bedeckt sind; die Mittelrippe ist von einem dicken Sklerenchymring umgeben. Im August gleicht die Pflanze einer dornigen Kugel; die Blätter sind auf die dornig gewordenen Mittelrippen reduziert, das Parenchym der Fläche ist abgestorben und verschwunden; alle Blätter sind jetzt nur noch als Dornen vorhanden, und die Assimilationsarbeit wird allein von den beiden verwachsenen Vorblättern, welche die Frucht umschließen, geleistet.

Die Zahl der einjährigen Arten in den Wüsten ist verhältnismäßig groß (Raunkiärs Therophytenklima). Nach Coville beträgt ihre Zahl auf den Felsen $35 \%$, in der Sandwüste $55 \%$ in Death Valley. Nach Raunkiär ist daselbst die Prozentzahl 42, und ebenso in der Libyschen Wüste. Watson ${ }^{1}$ ) hat beobachtet, daß in Neumexiko die einjährigen und kleinen Stauden keine zeitliche Fixierung für ihre Funktionen zeigen, indem sie grünen, blühen und fruchten, sobald es geregnet hat.

Von Pollakanthen gibt es sowohl Gehölze als Kräuter von verschiedenen Typen: Bäume, Sträucher, Halbsträucher, Stauden (mit Knollen, Zwiebeln, Rhizomen), Gräser. Lianen fehlen; es würde für sie zu schwierig sein, in der so offenen Vegetation Stützen zu finden. Auch Epiphyten sind selten, was in der wasserdampfarmen Luft natürlich erscheint; doch hat G. Karsten Beispiele davon angegeben, daß eine äußerst xerophile Gesträuchvegetation (also eher die einer Halbwüste) einen reichen Behang von Epiphyten tragen kann. Es kann auch bemerkt werden, daß große Wurzelparasiten nicht selten sind; in den Tunesischen Wüsten (und Halbwüsten) kann man mächtige, stark gefärbte Orobanchen finden.

Von den Pollakanthen der Wüsten sind eine Menge regengrün, d. h. die unterirdischen Organe schlummern in der Erde, bis sie vom Regen geweckt werden; dann entfalten sie schnell ihre saftigen, mesomorphen Blätter und Lichtsprosse, welche mit zunehmender Trockenheit wieder verschwinden.

Andere behalten ihre Sprosse über der Erde mit verschiedener xeromorpher Anpassung (vergl. Abschnitt 2); auch von diesen sind einige laubabwerfend, nachdem die Laubblätter mit dem Regen zum Vorschein kamen.

$\mathrm{Daß}$ „Aridität" der bedeutungsvollste Faktor für die Entwicklung dieser Pflanzen ist, hat Mac Dougall besonders betont ${ }^{2}$ ); die Quantität

1) Watson 1912.

2) Plant world XII (1909). 
der organischen Stoffproduktion wird durch die Trockenheit vermindert (Zwergwuchs, Kleinblättrigkeit, blattlose Sprosse sind die Folge); die Bodenfeuchtigkeit wird vermindert und aller Humus verschwindet; die Wurzel- und Sproßsysteme werden alle verändert; die längerdauernden Blätter müssen der großen Trockenheit angepaßt werden, breite, dünne,

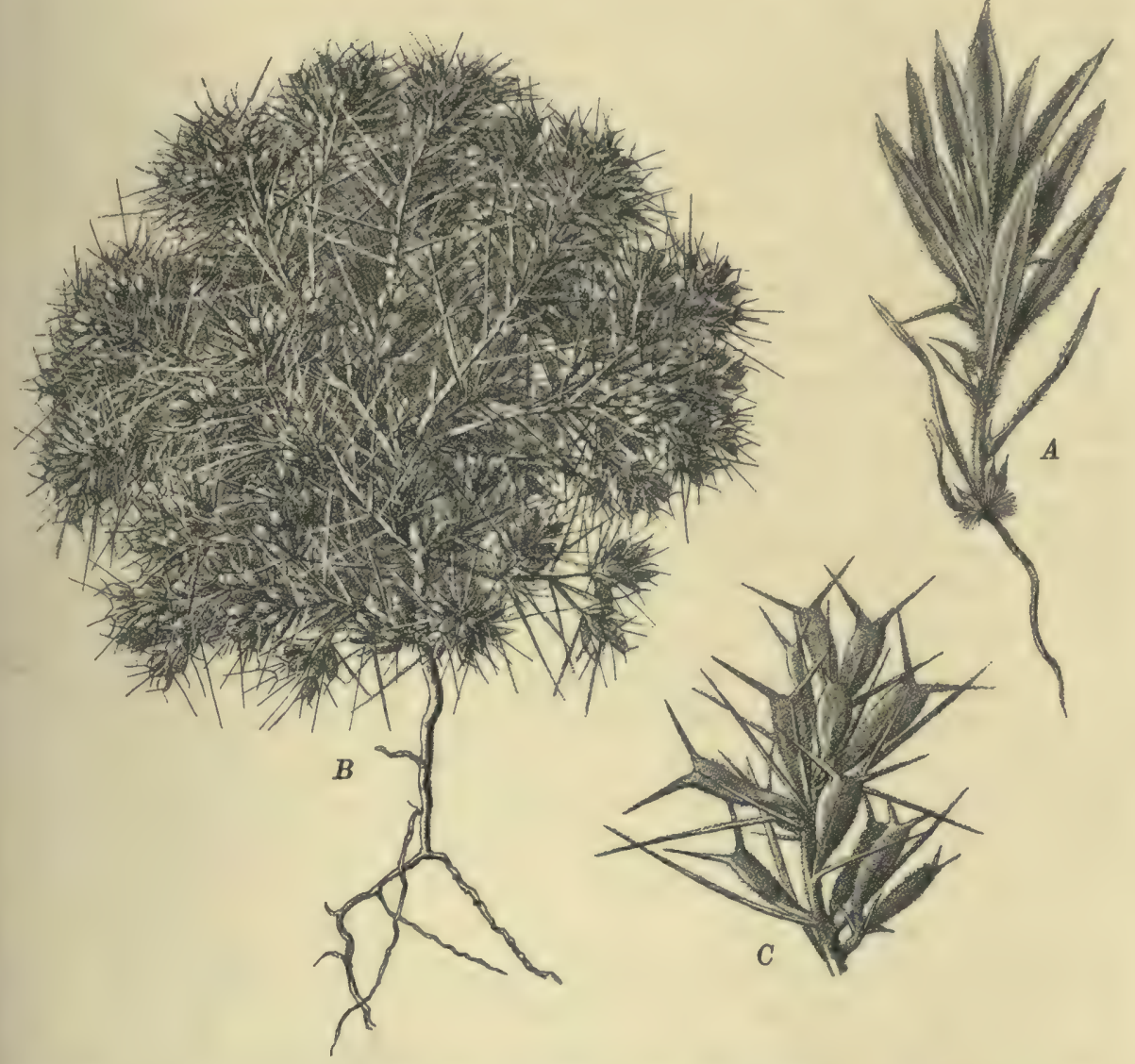

Fig. 371. Ceratocarpus arenarius, sommerannuelle Wüstenpflanze aus Transkaspien. $A$ Junge Pflanze mit grünen Blättern und wenigen Früchten, Mai $(1 / 1)$. $B$ Ältere Pflanze $(1 / 2)$. $C$ Zweig von $B(1 / 1)$; das Parenchym der Blätter ist verschwunden und die Mittelrippen bleiben als Dornen zurück; August. (O. Paulsen.)

mesomorphe Blätter sind unmöglich, jedenfalls wenn sie für längere Zeit assimilationsfähig bleiben sollen. Die Veränderungen gehen namentlich in zwei Richtungen: 1. Reduktion und Schutz der Oberflächen (Blattlosigkeit), 2. Entwicklung von Speicherorganen, namentlich von Wasserspeichern: einige sammeln Wasser „für Dekaden“. Mac Dougall meint ferner, $\mathrm{da} ß$ die Xerophyten im allgemeinen junge Typen sind. $\mathrm{Zu}$ den 
früheren, alten Typen gehören Bennettitales, Cycadeen und Coniferen; einige von diesen bewohnen jetzt Gegenden mit der größten Fülle von Feuchtigkeit, weshalb man nur mit vielem Rückhalt einen ursächlichen Zusammenhang zwischen dem Blattbau einer Pinus- oder Cycadeen-Art und der Trockenheit des Standorts annehmen kann.

Von den im zweiten Abschnitte besprochenen xeromorphen Typen kommen auch viele in den Wüsten vor, namentlich solche, welche der Wasseraufnahme dienen, die Verdunstung regulieren und die Wasserspeicherung besorgen. Bei den oberirdisch lange dauernden Sprossen finden sich solche Anpassungen, wogegen bei den Rhizom-, Knollen- und Zwiebelgewächsen, bei welchen die oberirdischen Teile vergänglich sind, diese ganz mesomorph sind, wie bei den einjährigen. Hier können nur noch einige Punkte von größerer Wichtigkeit berührt werden.

Man hat oft von den Schwierigkeiten der Pflanzen bei der Wasserversorgung gesprochen, und auf die enorm langen, weit streichenden Wurzeln hingewiesen, als ein Mittel zur Aufnahme des nötigen Wassers (man hat z. B. Wurzeln von Tamarix gemessen, welche $50 \mathrm{~cm}$ lang waren; das Gras Aristida pungens soll 20 m lange, tauähnliche Wurzeln haben), oder auf die tiefgehenden Wurzeln, oder die Wasserspeicher, welche sich in Regenzeiten mit Wasser füllen. Verschiedenartige Haare dienen dazu, Wasser aufzunehmen (vergl. S. 250). Ebenso dient diesem Zwecke die lange Dauer der Wurzelhaare ${ }^{1}$ ).

Einen ganz neuen Gesichtspunkt in dieser Frage hat Fitting ${ }^{2}$ ) eingenommen; er meint, daß es hier sicher keine so sehr tief gehenden Wurzeln gibt. In trockenen Wüstengebirgen werden sie nicht in zu große Tiefen vordringen können, gewiß nicht bis zum Grundwasser. Nach Fitting ist es weder der Tau, noch sind es die tief im Boden verborgenen wasserreichen Schichten, welche von den ausdauernden Pflanzen ausgebeutet werden, sondern die meisten von diesen Gewächsen verstehen es, sich die spärliche Feuchtigkeit der obersten, höchstens 1 bis $3 \mathrm{~m}$ mächtigen, scheinbar sehr trockenen Bodenschichten zugänglich zu machen. Dieses stimmt auch mit Livingstons Beobachtungen in Arizona ${ }^{3}$ ): der Feuchtigkeitsgehalt ist hier schon wenige Zentimeter unter der Oberfläche groß genug, um manche Wüstenpflanzen dauernd genügend mit Wasser zu versorgen. Die Wüstengewächse nach Fitting haben besondere Anpassungen und Einrichtungen, um die Feuchtigkeit auch noch aus relativ sehr trockenen Böden heraus zu reißen, und zwar: hohe, ja ungeheuer hohe osmotische Druck-(Saug-)kräfte, die bei einigen bis 100 Atmosphären steigen. Er fand solche hohen Werte in der trockenen

1) Massart; R. Price 1911. Über die Wurzeln vergl. Cannon 1911.

2) Fitting 1911.

3) Livingston $1906,1910$. 
Fels-, Geröll- und Lehmwüste, in der Sandwüste und auf feuchtem Kulturboden sind sie indessen wesentlich niedriger. Es wird dadurch verständlich, daß Kräuter, die gar nicht xeromorph gebaut sind, dennoch in der Wüste gedeihen können.

Diese Höhe des osmotischen Druckes wird nach Fitting bei einigen durch Speicherung von Kochsalz erreicht, bei anderen ohne solche.

Die Wüstenpflanzen haben nach Fitting auch ein ungeheures Regulationsvermögen der Saugkräfte. Die Pflanzen der Salzsümpfe zeigen nicht so hohe Druckkräfte wie die auf trockenem Salzboden, und auch in den Dünen ist der osmotische Druck wesentlich geringer als in der Felsenwüste.

Was die Lebensformen betrifft, so kann zu dem im zweiten Abschnitte Mitgeteilten noch hinzugefügt werden, daß Mac Dougall ${ }^{1}$ ) zwei Typen von Wüstenpflanzen auch physiologisch trennt, nämlich die Sklerophyllen und die Succulenten. Die ersteren haben hohe osmotische Druckwerte im Zellsaft, die Succulenten dagegen verhältnismäßig niedrige, z. B. Echinocactus Wislizeni 3-6, Cereus giganteus (Carnegia) 6-8 (Fig. 363), Opuntia 6-8, Agave wenig höhere; doch wächst der Druck durch Austrocknung. Die Succulenten scheinen, und das ist für die Ökologie von großem Interesse, solche Standorte vorzuziehen, wo der Regen regelmäßig zu bestimmten Jahreszeiten fällt; das Wurzelsystem dieser Pflanzen breitet sich horizontal ganz oberflächlich aus, wodurch das Regenwasser sofort ausgenutzt werden kann. Manche Succulenten vermögen es mit ihren oberirdischen Organen durch aus toten Zellen bestehende Stacheln aufzunehmen. Daß Haare Wasser aufnehmen können, welches dann den lebenden Teilen des Pflanzenkörpers zugute kommt, ist bereits früher beobachtet und erwähnt worden (vergl. Kap. 28).

Losgerissene Pflanzen der Wüsten. Sowohl in vielen Wüsten, als auch in den verwandten Steppen, in welche die Wüsten oft übergehen, findet man gewisse Arten, die vom Boden losgerissen werden und eine Zeit lang im Winde umhertreiben ("Steppenläufer", "Steppenhexen"). (Vergl. S. 813, 827.) Unter diesen wird von alters her die "Rose von Jericho" (Anastatica Hierochuntica) aufgeführt, aber nach Volkens mit Unrecht. Jedoch gehört eine Composite, Odontospermum (Asteriscus) pygmaeum, die nach Michon und Schweinfurth sicher die wahre "Rose von Jericho" ist, hierher, und in Südafrika kommt eine Amaryllidacee, Brunsvigia, vor, deren Fruchtstand nach Bolus ähnlich ein Spiel der Winde ist, wie die Fruchtstände von Spinifex in den Dünen Ostindiens (S. 779). Schließlich kann auch an die der lithophilen Wüstenvegetation

1) Mac Dongal 1912. 
angehörige Krustenflechte Parmelia esculenta erinnert werden, die durch Stürme von den Felsen losgerissen und massenweise als "Manna“ fortgeführt wird und an anderen Stellen niederfällt; sie gehört zu den häufigsten Erscheinungen der Wüsten von Zentralasien bis nach Algier ${ }^{1}$ ).

Die Hygrochasie ${ }^{2}$ ) ist gleichfalls eine meist den Wüstenpflanzen zukommende Eigenschaft; Stengel, Fruchtstiele, Fruchtklappen, Hüllblätter usw. sind in trockenem Zustande eng zusammen gebogen und spreizen, sobald sie feucht werden. Dadurch können z. B. Samen nur in feuchter Zeit ausgestreut werden (z. B. Anastatica Hierochuntica, Lepidium spinosum, Odontospermum pygmaeum, Ammi visnaga, Arten von Mesembrianthemum usw. Viele Pflanzen feuchterer Klimate zeigen umgekehrt Xerochasie (z. B. Daucus carota). Vergl. Kap. 25.

Blüten. Nur wenig untersucht ist die Anpassung der Blüten; nach Flahault ${ }^{3}$ ) ist die Anzahl der Anemophilen verhältnismäßig groß; es gibt jedoch eine Anzahl schöngefärbte Arten. Henslow ${ }^{4}$ ) hat wohl die meisten Blüten untersucht; er fand häufig Selbstbestäubung; die Antheren stehen oft auf derselben Höhe wie die Narbe; Volkens und Massart sind jedoch nicht derselben Meinung.

Die Samenverbreitung ist wenig bekannt (vergl. indessen oben Hygrochasie) ${ }^{5}$ ).

\section{Kap. Die Wïstenregionen der Erde}

Es gibt ungeheure von Wüsten bedeckte Areale in Nord- und Südafrika, Zentralasien, Nordamerika und Australien. Eine kurze Besprechung einiger derselben mit ihrer Flora muß hier gegeben werden.

Nordafrika. Als Typus wählen wir die von Volkens vorzüglich bearbeitete ägyptisch-arabische Wüste. Sie ist ein Gemisch von Felsen-, Grus- und Sandwüsten, wo oft in 8-9 Monaten kein Regentropfen fällt. Es regnet fast nur im Winter (Dezember bis April). Am Nordrand von Sahara fallen ca. 17,5 cm Regen, im Inneren 7-10 $\mathrm{cm}^{6}$ ).

1) Vergl. z. B. Basiner, S. 65.

2) Ascherson 1892.

s) Flahault 1906.

4) Henslow 1894.

s) Die Anatomie und Morphologie der Wüstenpflanzen sind bearbeitet von Volkens 1887; Massart 1898; Coville 1893; Jönsson 1902.

Die Physiologie von Mac Dougal 1903, 1906, 1907; Spalding 1904; Fitting 1911. Feruer: Cannon (1913) in der Publikation des Carnegie-Institutes Nr. 178; vergl. Bot. Centralbl. CXXV, 414; CXXVI, 261.

B) Brockmann-Jerosch 1908 . 
Nirgends hat man die Luft am Tage trockener gefunden als in Nordafrika (2-25\% relative Feuchtigkeit), und nachts kann die Temperatur sehr bedeutend fallen (oft unter $0^{\circ}$ ). Die Luft kann in der trockenen

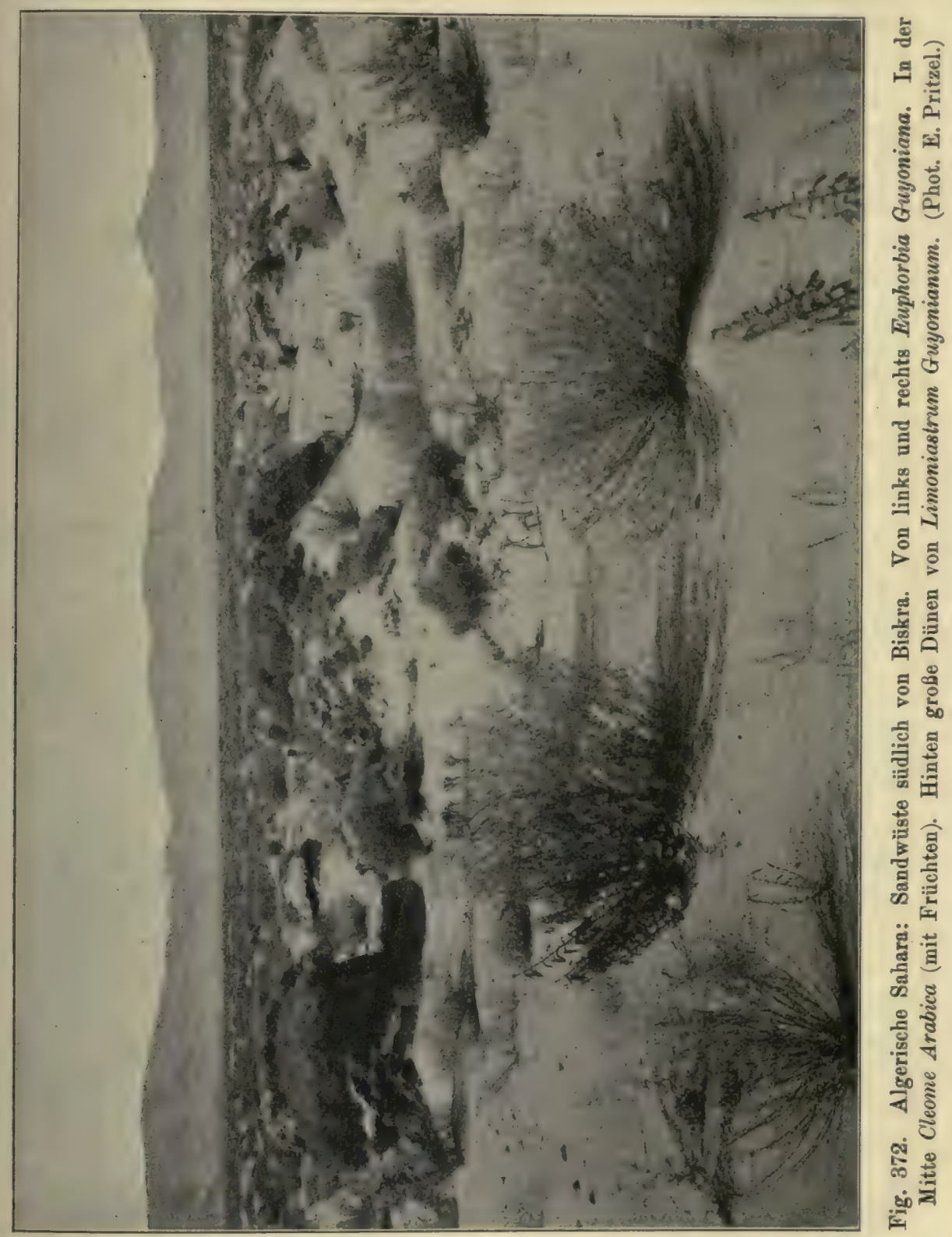

Zeit über $50^{\circ} \mathrm{C}$. erwärmt werden, und der Boden ist am Tage in der Regel noch bedeutend wärmer als die Luft. Im allgemeinen herrscht dann eine vollkommene Windstille, besonders in den Tälern. 
Das Gepräge der Vegetation ist in der trockenen Zeit folgendes: Die meisten Pflanzen sind grauweiße, oder schmutziggrüne, niedrige, bisweilen halbe Mannshöhe erreichende, abgerundete, halbkugelförmige Sträucher, und teilweise niedrige, meist niederliegende, rasenbildende Kräuter; selten treten windende oder mit größeren bleibenden Blättern versehene Kräuter auf.

Kaum sind etwa Anfang Februar die ersten Regengüsse gefallen, so belauben sich die strauchartigen Pflanzen und blühen bald und es keimen sehr viele "ephemere" Arten mit einer Lebenszeit von 1-2 Monaten (z. B. Odontospermum pygmaeum); auch einige wenige saftreiche, daher länger dauernde einjährige Arten entwickeln sich (z.B. Mesembrianthemum; vergl. Kap. 29). Nach der Anzahl der einjährigen Arten besteht also ein außerordentlicher Unterschied zwischen der Wüstenvegetation und der subglazialen Vegetation (S. 702). Demnächst sprießen eine Menge Zwiebelpflanzen hervor, deren Sprosse und Blüten fertig vorgebildet waren und nur auf Regen warteten, um sich voll zu entwickeln. Diese Frühjahrsflora erinnert an die subglaziale Vegetation, wo es jedoch nur wenige Zwiebelpflanzen gibt.

Weiter kommen sehr viele andere, mehrjährige Kräuter mit Erdsprossen und sicher meist mit einer vielköpfigen primären Wurzel vor; viele haben Rosettensprosse und breiten die Blätter flach auf dem Boden aus.

Bei den einjährigen oder „ephemeren" Arten gibt es im Bau natürlicherweise nur wenig, was Anpassung an das trockene Klima zeigt; denn das Leben verläuft ja gerade unter den günstigsten Verhältnissen, und die wesentliche Anpassung ist seine kurze Dauer. Wohl die meisten von ihnen haben indessen eine im Verhältnis zur Kleinheit der oberirdischen Teile ungeheuer lange Wurzel, so z. B. Anastatica Hierochuntica. Bei allen anderen Arten zeigt sich die Anpassung auch im Bau. Die Bauverhältnisse der Succulenten und der Zwiebelpflanzen wurden S. 192 ff., die Wassergewebe und die mit Wasser erfüllten Haare S. 189 ff. behandelt. Die Blätter der Gräser sind kurz, steif, eingerollt, saftarm. Die Hammadas haben fast ausschließlich kleine Sträucher, deren Blätter und Stämme mit filzigen Haaren bedeckt sind. Viele Sträucher haben blattlose Sprosse, oder solche mit schuppenähnlichen Blättern, z. B. Tamarix, Ephedra, Polygonum equisetiforme; viele Blätter werden zu Dornen usw. Häufig ist die Ansammlung von Schleim in den inneren Teilen der Pflanze, besonders in der Rinde, seltener bei Halimodendron im Mark. Das Assimilationsgewebe bleibt lange tätig; nachdem die primären Assimilationszellen verschwunden sind, erscheint das Chlorophyll in der sekundären Rinde und man findet es dort sogar noch in alten Ästen. 
Die Sahara hat dieselbe Natur wie die ägyptisch-arabische Wüste. Schirmer, Flahault, Massart, Hochreutiner, Brockmann-Jerosch, Rikli, Schröter u. a. haben sie besprochen. Es kommen hier die verschiedenen Typen trockener Wüsten vor. Von der Felsen- und Steinwüste (Hammada) sagt Flahault, daß man über ihren floristischen Reichtum erstaunt ist. Hier findet sich z. B. Anabasis articulata, Stupa tenacissima, Limoniastrum, Thymelaea microphylla, Halocnemum strobilaceum, Zollikoferia arborescens, Forskälea tenacissima, Asparagus horridus.

Die Kieswüste (Serir, Reg) hat eine ăußerst arme Vegetation. Nach Brockmann-Jerosch haben viele ausdauernden Pflanzen Polsterwuchs oder sind halbkugelig; Polsterwuchs hat z. B. Anabasis aretioides, welche von Hauri eingehend studiert worden ist. Halbkugelig sind z. B. Zilla macroptera, Arten von Zollikoferia u. a. Er sieht in diesen Wuchsformen in erster Linie einen Schutz gegen die Wirkung des Windes, namentlich der Sandgebläse, sowie auch gegen zu starke Erwärmung, zu starke Verdunstung u. a. m.

In der Steinwüste kommen auch viele einjährige Arten vor, namentlich in den flachen Mulden, wo der Boden etwas feuchter ist; ihnen verdanken wir es, daß der Boden in so kurzer Zeit nach dem Regen grün erscheint; eine ungeheure Menge von Samen muß in der Erde verborgen liegen. Übrigens werden als Pflanzen der Kieswüste z. B. genannt: Arten von Anabasis, Zollikoferia, Ephedra, Pancratium, Stupa, Lygeum, Peganum, Artemisia, Statice usw.

Die Felsensteinwüsten und Kieswüsten sind es, welche den größten Teil der Sahara einnehmen. Neben ihnen kommen auch Sandwüsten mit ihren hohen Dünen („Erg“) vor. Wo der Sand ganz fest liegt, ist Vegetation und Flora reich, was mit der Feuchtigkeit in Verbindung steht, welche im Sande erhalten bleibt (siehe S. 106-107); die beweglichen Dünen können ganz pflanzenleer sein. Die Pflanzen der Dünen sind Kap. 100 erwähnt. Charakterpflanze ist Aristida pungens ${ }^{1}$ ).

Die Lehm-oder Tonwüsten finden sich in den Niederungen und sind mehr oder weniger von Salz imprägniert. In Nordafrika finden sich große Salzseen (Chott) von Salzsümpfen und Lehmwüsten umgeben. Die Pflanzen, die hier wachsen, sind Arten von Frankenia, Statice u. a. (Kap. 52, Fig. 229).

Wo das Grundwasser hoch liegt, in trockenen Flußbetten usw., findet man wilde Dattelpalmen, und hier spielt hie und da Nerium Oleander eine ähnliche Rolle wie die Weiden in Europa.

1) Über die Sandwïsten der Sahara vergl. Massart 1898 \&; Reinke 1915 in Englers Jahrb. LIII; Brockmann-Jerosch und Heim 1908. 
Die südafrikanischen Wüsten. Südafrika hat ähnliche Grus-, Sand- und andere Wüsten wie Nordafrika, die jedoch weniger pflanzenarm sind (die Kalahari, die Karroo, Groß-Namaqua-Land usw.); viele merkwürdige Lebensformen entwickeln sich hier. Von diesen sei hier an Tumboa Bainesü (Welwitschia mirabilis) erinnert, welche Welwitsch und Baines im Damaralande entdeckten; auf einer ganz trockenen Ebene fanden sie außer wenig Gras nur diese Art, die ihre beiden einzigen, riesigen Laubblätter auf dem trockenen Boden ausbreitet, ihre Wurzeln tief hinabsendet und das ganze Jahr ununterbrochen vegetieren kann, ohne durch Kälte oder Trockenheit zum Stillstande gezwungen zu werden ${ }^{1}$ ).

Die Küste von Dentsch-Südwestafrika ist eine fast regenlose Einöde, eine 150 - $200 \mathrm{~km}$ breite Sandwüste mit vielen Dünen, die von den trockenen Südwestwinden aufgeworfen sind. Weiter landeinwärts fällt mehr Regen, und hier geht die Wüste in Steppen über ${ }^{2}$ ).

Weiter nach Osten zu folgen Kies- und Steinwüsten und weiter Steppen, wie die Regenmenge von der Küste nach dem Innern zunimmt.

Die Karroo, welche oben (S. 858) erwähnt wurde, ist teilweise Halbwüste mit tonigem Boden und Vorherrschen von Succulenten und Zwergbüschen, teils aber auch reine Wüste. „Braun ist die Farbe des Karroo", schreibt Marloth ${ }^{3}$ ), "braun sind Gestein und Geröll, gelb oder rötlich der Boden, grau, gelb oder bräunlich die starren Büsche". "Es gibt hier", schreibt er, "weite Flächen ohne jeden Pflanzenwuchs und andere, sandige sowohl wie steinige, welche nur vereinzelt stehende, verkümmerte Gewächse tragen ".

Viele Wüstenpflanzen Südafrikas haben oberirdische Knollen, die den Steinen, zwischen denen sie wachsen, so ähnlich sind, daß es in der trockenen Zeit, wenn sie keine Blätter haben, fast unmöglich ist, sie ohne nähere Betrachtung von den Steinen zu unterscheiden, was Wallace als Mimicry auffaßt (S. 257).

Hier findet man eine Menge Zwiebel- und Knollenpflanzen (Liliaceen, Amaryllidaceen, Iridaceen, Oxalidaceen u. a.), Succulenten in großer Mannigfaltigkeit und Anzahl von Individuen (nach Bolus gehören in gewissen Gegenden der Karroo 30\% der Vegetation zu diesem Typus, z. B. Mesembrianthemum, Euphorbia, Aloë, auch Pelargonien) und saftarme Xerophyten vieler verschiedenen Familien: Proteaceen, Restionaceen ${ }^{4}$ ), Mimosoideen (Acacia-Arten) usw.

1) Uber Welwitschia vergl. J. D. Hooker in Transact. I.inn. Soc. XXIV, 1863; Karsten und Schenck, Veget. Bilder I, Tab. 28.

3) Dinter 1915 .

3) Marloth 1908.

4) Gilg 1891 
In allen diesen Wüsten beobachtet man dieselbe überraschend schnelle Entwicklung der Vegetation, wenn in den Monaten Juni oder Juli die ersten Regengüsse gefallen sind und der Frühling kommt. Grüne, frische Sprosse erscheinen plötzlich, und zahlreiche, oft prächtige Blüten entfalten sich auf den trockenen Sträuchern oder sprießen aus dem bisher trockenen Boden hervor.

Zentralasien. Vorzügliche und gründliche Schilderungen der asiatischen Wüsten verdanken wir russischen Forschern (Basiner, Borszczow, Antonow, Korshinsky, Semenow u. a.) und dem dänischen Botaniker

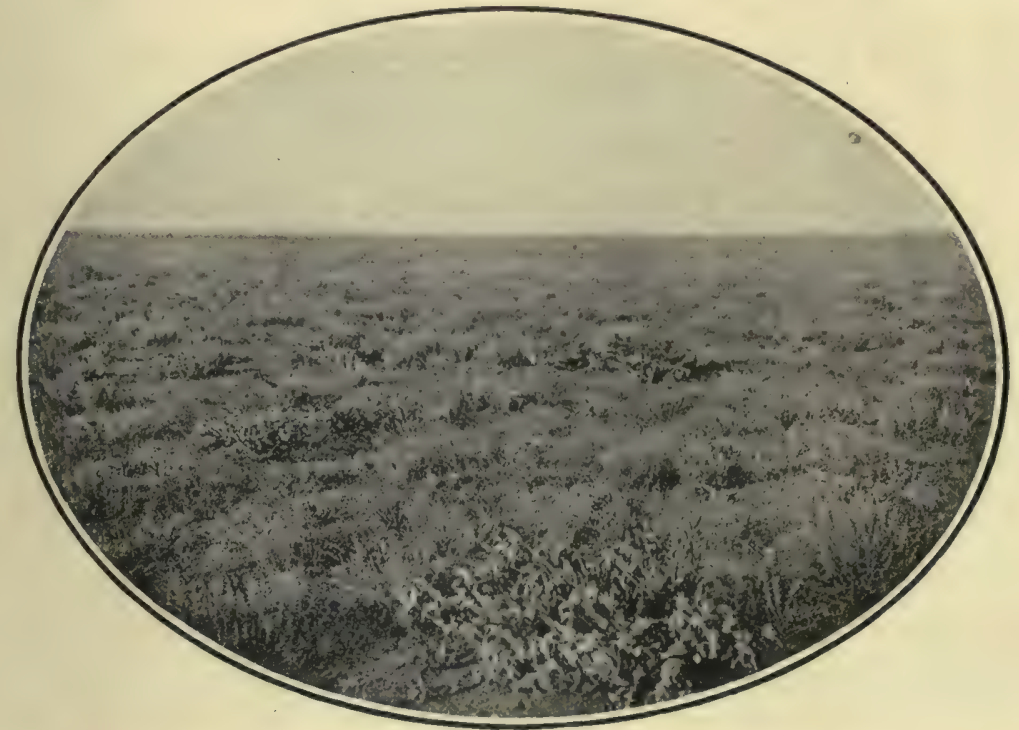

Fig. 373. Frühlingsbild der "Halbwüste" in Samarkand.

Im Vordergrunde halbverwelkte Rosetten von Ferula asa foetida. Eine Artemisia-Art dominiert, dabei Poa bulbosa, Haplophyllum lasianthum, Carum Turkestanicum, Eremostachys labiosa. Mai. (Phot. 0. Paulsen.)

O. Paulsen ${ }^{1}$ ). Der letztere hat die Wüsten ökologisch bearbeitet. Das Klima im Transkaspischen Tieflande ist kontinental mit kaltem Winter und sehr heißem Sommer; in Kasalinsk ist das Winterminimum $-40^{\circ} \mathrm{C}$., das Sommermaximum $+48^{\circ}$. Der Winter ist nicht sehr lang; der Frost dauert nicht lange, ist aber streng. Der Januar ist der kälteste Monat (für zwei Stationen ca. $-28^{\circ}$ als mittleres absolutes Minimum für 10 Jahre). Schnee ist nicht selten. Der Frühling beginnt Ende Februar und ist verhältnismäßig warm. Der Juli ist am heißesten; die absoluten Maxima für zwei Stationen betragen ca. $42-43^{\circ}$. Die Luft ist klar

1) Ove Paulsen 1912. 
und die nächtliche Ausstrahlung groß. Die täglichen TemperaturSchwankungen können daher sehr groß sein. Radde beobachtete in einer Sandwüste eine Schwankung von $36^{\circ}$ in 24 Stunden und Capus fand sogar $40^{\circ}$. Die Niederschläge sind unbedeutend; die meisten fallen im Winter und im Frübling; Juli und August sind äußerst trocken; in Merw hat es in diesen Monaten in vier Jahren nicht geregnet. Die Zahl der Regentage ist klein. Die Lufttrockenheit ist groß (im Mittel 61\% Feuchtigkeit). Hitze und Trockenheit rufen im Sommer eine sehr starke Verdunstung hervor; nach Semenow ist sie an manchen Orten 3-4 mal größer als der Niederschlag, an anderen 24 mal und in Petro Alexandrowsk sogar $270 \mathrm{mal}$. Das Land wird daher immer trockener und trockener; Syr Darya, der Aralsee und andere Seen werden fortwährend verkleinert; nach einigen Schriftstellern sinkt der Aralsee $7 \mathrm{~m}$, nach anderen 4,2 $\mathrm{m}$ im Jahrhundert.

Folgende Wüstensteppen kommen nach $\mathrm{O}$. Paulsen in Transkaspien vor: Salzwüste, Lehmwüste, Stein- und Kieswüste und Sandwüste.

Die Salzwüste ist im 51. und 52. Kapitel besprochen worden ${ }^{1}$ ).

Die Lehmw üste. Der Boden ist nicht so salzreich, daß das Salz oberirdisch zum Vorschein kommt, er ist aber trockener als in der Salzwüste. Wo diese beiden Formationen beisammen vorkommen, nehmen die Salzwüsten die Niederungen ein, wo das salzige Grundwasser die Vegetation beeinflussen kann. Der Boden ist meist aus Löß gebildet; da die obere Schicht des Bodens gewöhnlich sehr dicht ist, fließt das Regenwasser leicht fort, und da Löß ein feinkörniger Boden ist, wird noch prozentualiter viel des Wassers festgehalten, so daß die Pflanzen nur eine verhältnismäßig geringe Menge aufnehmen können. Löß ist dunkel gefärbt und wird in der Sonne stark erhitzt. Middendorf hat an einem sonnigen Tage im Mai eine Temperatur von $62^{\circ} \mathrm{C}$. auf dem Löß, aber nur $45^{\circ} \mathrm{C}$. auf einer weißen Salzinkrustation beobachtet.

Die Vegetation ist reicher als in der Salzwüste; es findet sich hier eine Flora, die den Frühlingsregen ausnutzt, im wesentlichen von kurzlebigen, einjährigen Arten gebildet; außerdem ist eine Sommerund eine Herbstflora zu unterscheiden. Die Frühlingsvegetation ist am reichsten am Fuße der Berge, wo die zusammenfließende Wassermenge größer ist; sie kann so reich sein, daß sie den Namen einer "Halbwüste" verdient (Fig. 373); sie wird wesentlich von Gräsern gebildet (Poa bulbosa, Hordeum secalinum) und einer Reihe anderer einjähriger Arten aus den Familien der Papaveraceen, Cruciferen, Boraginaceen, Umbelliferen u. a. Auch einige Stauden blühen im Frühling, nämlich Arten von Tulipa, Ixiolirion, Allium, Gagea, und Knollenpflanzen wie Geranium tuberosum

1) Vergl. auch Bot. Centralbl. CXXV, 39. 
and Leontice incerta usw. Die Frühlingsvegetation ist niedrig, bis nur etwa $3 \mathrm{dm}$ hoch, und ist nicht xeromorph gebaut. Mitte Mai beginnt diese Vegetation schon zu verwelken, ja viele von den Frühlingspflanzen haben schon im April ihre Samen zerstreut. Im Juni ist schon das typische Bild einer Wüste vorhanden; der Boden ist stellenweise ganz nackt, in der Regel aber trägt er zerstreute Sommerpflanzen. Die Zahl dieser ist äußerst begrenzt; oft bilden die Artemisien die ganze Sommervegetation, an anderen Stellen ist Salsola rigida die häufigste Art; ferner kommen andere Chenopodiaceen, Arten von Ephedra, Calligonum, Reaumuria, Astragalus usw. vor; nahe den Oasen und Flüssen wachsen

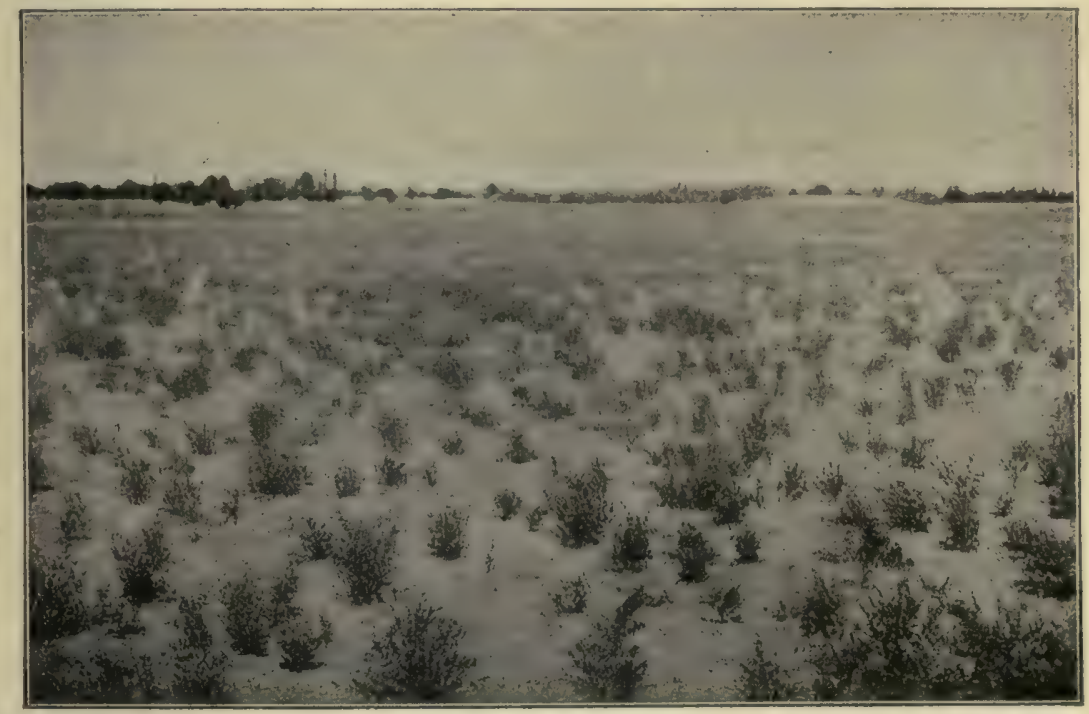

all Fig. 374. Eine Sandebene nahe Buchara; mit Alhagi camelorum, Zygophyllum Eichwaldii, Peganum harmala, Goebelia alopecuroides, einigen Exemplaren von Suaeda pterantha, Salsola sclerantha, Atriplex dimorphostegium, Ceratocarpus arenarius. Mai. (Phot. O. Paulsen.)

Kleinsträucher von Tamarix, Nitraria, Halimodendron, weiter Chenopodiaceen, Prosopis, Lycium, Frankenia, Heliotropium, Statice usw. Einige Halbsträucher der Lehmwüste sind laublos oder dornigbelaubt. Von einjährigen Sommerpflanzen kommt eine Anzahl vor, welche meist zu den Chenopodiaceen gehören, die alle succulent sind. Paulsen hebt drei Typen hervor: Arten mit dornigen Blättern, solche mit dornlosen Blättern und „Bracteol-Succulenten“ mit wasserspeichernden Hochblättern in den Blütenständen. Über Ceratocarpus vergl. S. 882.

Die Steinwüsten. Der Boden ist Felsen oder Kies oder ein Konglomerat, z. B. mit Löß als Bindemittel. Die Vegetation ist äußerst arm, nach Boris Keller ist oft nur $1 / 5$ mit Pflanzen bedeckt; nur in 
Mulden und wo die Zahl der Steine geringer ist, kommen einige niedrige Halbsträucher und Zwergsträucher vor (Arten von Salsola, Artemisia, Capparis, Atraphaxis; Haloxylon Ammodendron, die etwa 0,5 m hoch werden, u. a.).

Die Sandw üsten zeigen verschiedene Typen (Fig. 166, 167, 374). Allen gemeinsam ist das Vorkommen von Sträuchern und Bäumen mit Rutenzweigen; die Halophyten sind hier in der Minderzahl. Auf den beweglichen Dünen (Barkhanen) ist Aristida pennata Pionier; sie bindet den Sand zuerst, und ihre dichten Horste sind die einzigen Stellen, wo die Samen anderer Pflanzen keimen können. Später finden sich auf minder beweglichen Flächen in bestimmter Folge Gehölze ein wie Ammodendron, Calligonum und Salsola, die dann sehr lockere Assoziationen bilden, denen auch einige ausdauernde Kräuter beigemischt sind. Auf den gefestigten Dünenhügeln treten die Holzpflanzen dichter zusammen, und die ausdauernden Kräuter werden zahlreicher, ganz wie auf unseren nordeuropäischen Dünen; ein typisches Beispiel von Folgeformationen in der asiatischen Wüste. Auf den Sandebenen sind die Kräuter zahlreicher, die Bäume aber klein oder sie fehlen ganz.

Es wird angegeben, daß die großen Flugsandwüsten in Asien und Ostrußland von der Vegetation gebunden werden würden, wenn sie sich selbst überlassen und nicht von den Nomaden und ihren Tieren betreten würden.

Nordamerikanische Wüsten. Viele Teile des Südwestens von Nordamerika haben den Charakter echter Wüsten oder nähern sich ihnen doch erheblich in Gestalt der Strauchsteppe. Durch die Einrichtung des Carnegie-Laboratoriums zu Tucson inmitten der Wüsten von Arizona wird durch die gemeinsame Forschertätigkeit mehrerer Botaniker (wie Coville, Mac Dougall, Clements, W. A. Cannon, Spalding, Livingston u. a.) diese Wüste bald zu den am besten bekannten in bezug auf die dort herrschenden biologischen und physiologischen Verhältnisse gehören (vergl. Kap. 110, 113).

Auch Purpus ${ }^{1}$ ) hat amerikanische Wüsten geschildert. Die Hänge der zahlreichen Mesas in Arizonas Wüstengebiet haben meist einen felsigen und geröllreichen Boden. Viele xerophile Dorngehölze, welche nur während einer kurzen Zeit belaubt sind, kommen hier vor. Bei Parkinsonia microphylla hat die grüne Rinde hauptsächlich die Funktion der Blätter übernommen. Fouquiera splendens ist charakteristisch für dieses Gebiet; ferner finden sich Prosopis juliflora, Larrea Mexicana, Acacia, Ephedra, Lycium und zahlreiche Halbsträucher (Compositen, Labiaten, Malvaceen, Papilionaceen u. a.), Cacteen und Yucca-Arten.

1) Purpus 1907. 
Ein reicher Flor von Stauden und Einjährigen schmückt die kahlen Flächen während der Regenperiode ${ }^{1}$ ).

Australien $^{2}$ ). Die xerophilen Savannen und Strauchvereine Australiens lösen sich in vielen Gebieten des Inneren, die nur $20 \mathrm{~cm}$ Regen oder noch weniger Niederschlag erhalten, gänzlich auf und machen Kies-, Lehm- oder Sandwüsten Platz. In der Lehmwüste sind buschige Acacia-Arten mit steifen Ästen und starren Phyllodien, auch schönblütige Eremophila-Sträucher und Chenopodiaceen mit succulenten, oft hellgrau gefärbten Blättern besonders bezeichnend. Namentlich auf chloridreichem Boden sind solche Chenopodiaceen, die "Salt-bushes" der Australier, häufig und charakteristisch. In anderen Gegenden der Wüste herrschen starre, stechende Gräser aus der Gattung Triodia vor und bilden jene "Spinifex"-Einöden, die wegen ihrer Wasserlosigkeit und Unpassierbarkeit bei den Reisenden verrufen sind.

Die sandigen Strecken der Wüsten und ihre Dünen sind sehr spärlich bewachsen, pflegen aber einige dürftige Holzgewächse zu enthalten: so die cupressoide Frenela, blattlose starre Casuarina und Exocarpus, auch ein paar kümmerliche Eucalyptus.

Die unregelmäßig, in oft jahrelangen Pausen niedergehenden Regengüsse der Wüste rufen einen vergänglichen Wuchs von Annuellen hervor, unter denen kleine Compositen weitaus am häufigsten und geselligsten auftreten; viele davon sind mit farbigen scariösen Hüllen versehen („Immortellen") und beleben während der kurzen Zeit ihrer Blüte anmutig das Bild der Wüstenlandschaft.

Es kann noch auf ein Sammelreferat von sieben Arbeiten über Wüsten von Mac Dougal, Shreve usw. in Journ. Ecology III: 42 ff. verwiesen werden. Über Wüsten vergl. übrigens: Bladnell 1910; Handel-Mazetti 1914; B. Jönsson 1902; Spalding 1904, 1909; Rübel 1915; Livingston 1906, 1910; Gleason 1910; Price 1911; Rikli und Schröter 1912; Darbishire 1914; B. A. Keller 1911-12; Cannon 1905, 1908, 1911, 1913.

1) Litteratur über nordamerikanische Wüsten siehe namentlich bei Mac Dougal.

2) Von L. Diels. 
Fünfter Abschnitt

\section{Der Kampf zwischen den Pflanzenvereinen}

\section{Kap. Einleitende Bemerkungen}

Im vorhergehenden wurden die Pflanzenvereine im allgemeinen als fest bestehend, in Ruhe befindlich, in ihrer Entwicklung abgeschlossen und nun friedlich nebeneinander lebend betrachtet. So verhalten sie sich in Wirklichkeit durchaus nicht, wie schon S. 9 bemerkt worden ist: es findet überall und ununterbrochen ein Kampf zwischen ihnen statt, jeder einzelne versucht beständig, in das Gebiet der anderen einzudringen, und jede kleine Veränderung in den Lebensbedingungen verändert sofort das bisher bestehende Gleichgewicht, bringt sogleich eine Verschiebung und eine Veränderung in dem gegenseitigen Verhältnis hervor. Oft rufen anscheinend äußerst kleine Veränderungen in den Lebensbedingungen merkwürdig große Veränderungen in der Vegetation hervor. „Die Hebungen und die Senkungen des Grundwasserstandes sollen nicht erst, wenn sie Fuße, sondern schon, wenn sie Zolle betragen, beachtet werden" sagt der erfahrene Praktiker Feilberg ${ }^{1}$ ). Die Verteilung der Vegetation um kleine Seen und Wasseransammlungen in Zonen, oder die Verteilung von Webers "Subformationen" der Wiesen oder die der einzelnen "Typen und Subtypen" der Heide zeigt dasselbe ${ }^{2}$ ). Ferner gibt P. E. Müller ${ }^{3}$ ) an, wie verschwindend kleine klimatische Veränderungen genügen, damit sich eine Waldvegetation in eine andere verändere. Aus Graebner ${ }^{4}$ ) geht hervor, wie die verhältnismäßig geringen Unterschiede im Klima einzelner Teile des norddeutschen Flachlandes scharfe Florengrenzen hervorgebracht haben. Verschiedene Pflanzenformationen folgen in der Tat nacheinander auf demselben Standorte; jede einzelne ist ein Glied vielleicht in einer langen Reihe.
1) Feilberg 1890 .
2) Weber 1892.
3) P. E. Müller -1887 b.
4) Graebner 1895, 1901. 
Der Kampf zwisehen den Vereinen gründet sich natürlich auf den schon im 15. Kap. und 36. Kap. erwähnten Kampf zwischen den Arten; dieser Kampf entsteht durch das Bestreben der Arten, ihr Verbreitungsgebiet durch die Wanderungsmittel, die jeder einzelnen zur Verfügung stehen, zu erweitern. "Platz wird gesucht" in der Welt der Pflanzen nicht weniger als im Menschenleben. Millionen und aber Millionen von Samen, Sporen und ähnlichen Vermehrungsorganen werden jährlich ausgesandt, um den Arten neue Standorte zu erwerben; Millionen und aber Millionen gehen zugrunde, weil sie an Stellen ausgesät werden, wo die physikalischen Verhältnisse oder die Bodenverhältnisse ihre Entwicklung direkt hindern oder wo andere Arten stärker sind.

Erst in neuerer Zeit ist man auf den ununterbrochenen Kampf in der Natur zwischen den Arten untereinander aufmerksam geworden. Es ist Darwins Verdienst, auf die große biologische Bedeutung dieser Kämpfe hingewiesen zu haben, die bekanntlich ein Glied seiner Hypothese über den Ursprung der Arten bildet. Andere haben den Kampf jedoch schon früher beobachtet, so Augustin Pyramus de Candolle, indem er sagt: "Toutes les plantes d'un pays, toutes celles d'un lieu donné, sont dans un état de guerre les unes relativement aux autres" (Essai élém. géogr. bot. 1820).

Von wesentlicher Bedeutung dafür, daß der Kampf und der Wettbewerb zwischen den Arten sehr hervortreten, sind selbstverständlich die Veränderungen, die auf der Erdoberfläche ununterbrochen in den Bodenverhältnissen, den klimatischen Verhältnissen und den anderen Lebensbedingungen der Pflanzen, kurz in den Veränderungen des Standortes, vor sich gehen. Die Ergebnisse der Kämpfe würden ohne diese Veränderungen nicht so deutlich werden. Diese sind namentlich folgende: 1. Bildung neuen Bodens, 2. Veränderungen des alten Bodens oder seiner Pflanzendecke und der im ersten Abschnitte behandelten Faktoren, besonders durch die Eingriffe des Menschen. Die Eingriffe des Menschen sind teils unmittelbare, wenn er z. B. den Boden für seine Zwecke bearbeitet, Wälder urbar macht, Moore trocken legt, teils mittelbare, indem er z. B. die Haustiere weidet, indem er mäht, düngt usw.

Hier kann auch Clements ${ }^{1}$ ) erwähnt werden; bezüglich der Wanderungen und der Einwanderung von Pflanzen unterscheidet er zwischen Wanderung und „Ecesis" ${ }^{2}$ ). Wanderung (migration) ist die durch Sporen oder Samen usw. bewirkte Einwanderung in ein neues Gebiet, Ecesis bedeutet die Einordnung einer Pflanze am neuen Standort; sie ist natürlich der entscheidende Faktor bei der Einwanderung, weil eben ohne sie eine Wanderung unmöglich ist. Im übrigen behandelt er die Formen

1) Clements 1904.

2) Von oixos (vergl. S. 2, Fußn. 2) abgeleitet.

Warming-Graebner. 3. Auflage, illustr. 
der Einwanderung, Hindernisse, Endemismen usw. wie schon andere Schriftsteller.

Schröter hat die Faktoren der Standortsänderungen folgendermaßen rubriziert als Seiten der genetischen Pflanzengeographie ${ }^{1}$ ). 1. Geogene, Veränderungen der edaphischen Verhältnisse; 2. Klimatogene; 3. Biogene, Veränderungen der lebenden Umwelt; 4. Anthropogene, durch Einwirkung des Menschen hervorgerufene, und 5. Phylogenetische, oder Änderungen in der Pflanze selbst, teils von innen heraus, teils durch den Reiz oder die Auslese durch die äußeren Faktoren. Diese Seite der ökologischen Pflanzengeographie ist übrigens in den späteren Jahren nach dem Vorgange von Cowles und.Clements sehr eifrig von nordamerikanischen Botanikern betrieben worden (vergl. Kap. 15 und 41). Auch von anderen Seiten sind wertvolle Beiträge geliefert worden, z. B. von Ernst Furrer (1914), Siegrist (1913), Cajander (1909 b), Jos. Braun (1913).

Die Kämpfe zwischen den Vereinen werden im folgenden an einigen Beispielen erläutert.

\section{Kap. Geogene Veränderungen; neuer Boden}

Wenn irgendwo ein neuer Boden auftritt, so wird er bald von Pflanzen erobert. Es ist sehr anziehend, die weitere Entwicklung der Vegetation in allen ihren Phasen zu verfolgen. Man wird Zeuge einer langen Reihe von Kämpfen zwischen den nacheinander einwandernden Arten; diese Kämpfe werden bisweilen erst in vielen Jahrzehnten einen relativen Abschluß erreichen.

Neuer Boden wird namentlich an folgenden Stellen gebildet: an den Küsten, wo das Meer neues Material herbeiführt, an den Flußmündungen, in den Flußbetten selbst und in den Gewässern, wo herabgeschwemmte Massen oder die Reste der Pflanzen abgelagert werden, durch die Tätigkeit der Gletscher, durch herabstürzende Gesteinsmassen, durch vulkanische Ausbrüche, durch Feuer, das die alte Vegetation verzehrt, ferner durch verschiedene Eingriffe des Menschen, besonders da, wo bebautes Land sich selbst überlassen wird usw. In den letzten Fällen ist der Boden nicht in demselben Maße neu wie in den ersten; er ist nicht steril, sondern schließt mehr oder weniger Samen, Rhizome und andere Pflanzenteile ein.

Geogene Änderungen können im übrigen sowohl sehr plötzliche, als sehr langsame, vielleicht säkulare sein; im letzten Falle sind sie oft schwer zu beobachten, und die eingreifenden Faktoren treten weniger deutlich hervor. Es mögen Beispiele beider hier angeführt werden.

1) C. Schröter $1913 \mathrm{im} \mathrm{Handwörterbuch} \mathrm{der} \mathrm{Naturwissenschaften.}$ 
Plötzliche Bodenveränderungen. Vulkanische Ausbrüche können pflanzenlose Gebiete hervorbringen. Die Lavafelder hatten selbstverständlich anfangs keine Vegetation. Wo sie pflanzenreich sind, beruht dies auf der Beschaffenheit der Lava; einige sind noch nach langen Zeiträumen äußerst pflanzenarm. Grönlund gibt an, daß auf den großen Lavafeldern bei Myvatn im nordöstlichen Island, die 1724-29 entstanden, oft nur Krustenflechten mit einzelnen Arten von Gyrophora und Stereocaulon wachsen; selbst Moose gibt es nur sehr wenige, besonders Rhacomitrium lanuginosum.

Die Verwüstung der Insel Krakatau bei Java im Jahre 1883 ist ein vorzüglich studiertes Beispiel. Die alte Vegetation wurde durch die gewaltige Eruption vollständig verwüstet, und ein neuer Boden, aus Aschen-, Lapilli- und Lavafeldern bestehend, entstand. Die Pflanzeneinwanderung aus Java und anderen Inseln (Java und Sumatra liegen resp. 35 und $45 \mathrm{~km}$ von Krakatau entfernt) wurde zuerst (1886) von Treub untersucht, der zu dem Ergebnis $\mathrm{kam}^{1}$ ), daß die Asche und der Bimsstein zuerst von einer dünnen Schicht Schizophyceen (besonders Lyngbya Verbeekiana und L. minutissima) bedeckt wurden, die den Boden für die Keimung von Farnsporen, welche sich in Menge einfanden, vorbereiteten. „Drei Jahre nach dem Ausbruche bestand die neue Flora von Krakatau fast allein aus Farnen (12 weit verbreitete Arten). Die Phanerogamen fanden sich nur vereinzelt vor, hier und da an der Küste oder auf dem Berge." Sie waren besonders durch Wasser und Vögel herbeigeführt worden. Später, 1906, wurde die neue Insel von Ernst ${ }^{2}$ ) besucht, der das Problem der Wiederbesiedlung solcher durch vulkanische Ausbrüche vegetationslos gewordenen Böden gründlich studiert hat. Er fand die Differenzierung der Vegetation weiter fortgeschritten, am Strande eine Pes caprae-Assoziation und einen typischen Strandwald, höher hinauf und im Innern waren die Abhänge bis an den oberen Rand dicht bewaldet von mehr oder weniger krummholzartigen Bäumen. Aus allen Untersuchungen geht hervor, daß die Besiedlung gleichzeitig sowohl im Innern wie am Strande vor sich ging. Als Zahl der Blütenpflanzen stellte Treub 1886: 15, 1897: 56 und Ernst 1906: 92 fest (die Gesamtzahl aller Arten 1906: 137). Letzterer ist der Meinung, daß in einem Klima wie dem von Krakatau die Besiedlung neuen Bodens verhältnismäßig rasch vor sich geht. Auf Salak stehen jetzt auf Boden, der vor kaum 240 Jahren verwüstet wurde, dichte "Urwälder", nach seiner Ansicht kann aber noch weit schneller, nach z. B. 60 Jahren, oder selbst nach 12 Jahren, der neue Boden dicht bewachsen sein, wenn die Verhältnisse günstig sind. Beccari fand, daß der Vulkan Tamboro auf Sumbava, der

1) Treub 1888; 1897 mit Penzig (Penzig 1902).

2) Ernst 1907, 1909. 
1815 vollständig urbar gemacht worden war, im Jahre 1874 von oben bis unten mit einem jungfräulichen Walde bedeckt war.

Anderswo sind es Bergstürze, Bergschlipfe, Bergrutsche oder menschliche Arbeiten, die den Felsenboden bloßlegen. In den Alpen und in vielen anderen Gebirgsländern sieht man gewaltige Gesteinsmassen mit einem bestimmten Neigungswinkel den Fuß der Berge umgeben: herabgestürzte Massen (Geröllhalden, Schuttkegel, Muhr, Urer; vergl. 56. Kap.). Der Entwicklungsgang ist in der Regel folgender. Zuerst finden sich Felsenpflanzen ein: Flechten, Algen und Moose (S. 722); ihre Rhizoiden dringen ins Gestein, je nach dessen Härte und Porosität, mehr oder weniger tief ein und machen es mürbe. Ferner führen Regen und Wind auf und zwischen diese Pflanzen Staubteile hin, und schaffen in Verbindung mit den verwesenden Teilen der Pflanzen selbst einen spärlichen Humus, auf dem jedoch höhere Pflanzen Fuß fassen können ${ }^{1}$ ). Es hängt von der Steilheit und der Verwitterungsfähigkeit des Bodens ab, wie reich die Vegetation wird. An den steilen Seiten bleibt die Vegetation offen und niedrig, im wesentlichen eine Thallophyten- und Moosvegetation (Felsenvegetation); auf weniger steilem Boden, wo sich das Gestein bald mit Pflanzen und Humus bedeckt, entsteht oft schließlich ein Wald. Bei Eisenach hatten Regengüsse tiefe Klüfte und ferner Grus-Terrassen gebildet. Auf diesen zeigte die Vegetation nach Senft ${ }^{2}$ ) folgenden Entwicklungsgang. Zuerst wurden die nackten Halden von Flechten und Moosen (Hypnum sericeum, Barbula muralis $u$. a.) bekleidet. Nach einigen Jahren folgten einige xerophile Gramineen (Festuca ovina, Koeleria cristata usw.) und Stauden mit flach streichenden Wurzeln (eine Vegetation trockener Stellen). In diesem Vegetationsteppich fanden sich später andere xerophile Kräuter wie Helianthemum annuum, Ononis spinosa, O. repens, Origanum vulgare, Anthyllis vulneraria u. a. ein, auch einige Sträucher wie Crataegus, Juniperus und Viburnum lantana. Namentlich Juniperus bildete dichte Gebüsche. Als die Pflanzendecke so weit fortgeschritten war, siedelten sich mit Hilfe der Tiere mehrere andere Sträucher mit fleischigen Früchten an und bildeten in 12 Jahren ein undurchdringliches Gebüsch: endlich traten Sorbus, Fagus u. a. Bäume auf, und es entstand ein Wald. Der Boden wurde stets durch den Tod der früheren Bewohner verändert und verbessert; eine Vegetation unterdrückte die andere; zuletzt besiegte

1) Die meisten Geröllhalden können nicht als ganz neuer Boden bezeichnet werden, indem das Herabstürzen langsam vor sich geht und Humus mit Pflanzensamen und ähnlichem mitgeführt wird, oder wenn ein großer Bergsturz einen Abhang auf einmal verwüstet, so bedeckt sich dieser allmählich mit den gemeinen Arten der benachbarten Vereine (Blytt).

2) Senft 1888. 
der Wald das Gebüsch, das sich schließlich nur am Waldsaume als Grenzzone erhalten konnte.

Durch Absturz, Erosion usw. entblößte Abhänge mergelhaltiger Diluvialhügel bedecken sich zuerst meist mit einem im wesentlichen aus Bestandteilen der Segetal- und Ruderalflora bestehenden Vereine vorzugsweise einjähriger Pflanzen und erst allmählich findet sich die für diese sonnigen Abhänge charakteristische Flora überwiegend ausdauernder Pflanzen an.

Flur- und Waldbrände. Neuer Boden ist natürlicherweise nicht immer ganz frei von Pflanzenkeimen. Es kommt wesentlich auf seine Entstehung an. So wird auch Boden, dessen Vegetation von Feuer verwüstet worden ist, hierdurch gewöhnlich nicht ganz sterilisiert worden sein; er wird mit Ausnahme ausgebrannter Moorflächen Samen, lebende Wurzeln und Rhizome in großer Anzahl bewahren und hieraus neue Pflanzen hervorsprießen lassen. Jedoch wird die Pflanzendecke oft derart zerstört, daß eine wesentlich neue Vegetation einwandern kann; auch wird der Nährstoffgehalt des Bodens durch die Asche verändert, ebenso die Beleuchtung und anderes. Über Prärie-, Savannen- und Waldbrände liegen in der Litteratur viele Mitteilungen vor $^{1}$ ).

Tropische und subtropische Grasfluren (Steppen und Savannen) werden in allen Weltteilen von den Bewohnern absichtlich niedergebrannt, in einigen Gegenden wegen der Jagd, in anderen wegen des Viehes, indem man durch Abbrennen der alten, trockenen Gras- und Staudendecke schnell eine neue Grasflur hervorrufen will. Mehrere dieser Vereinsformen, namentlich die Savannen und die Prärien, tragen, wie Kap. 105, 106 erwähnt wurde, zerstreute Bäume. Es liegt der Gedanke nahe, daß dort, wo ein Baum wachsen kann, auch viele Bäume gedeihen und einen Wald bilden können. Wenn nun tatsächlich kein Wald vorhanden ist, so hat man daraus den Schluß gezogen, daß sein Fehlen den Bränden zuzuschreiben sei. Es ist eine alte Frage, ob die Prärien Nordamerikas früher bewaldet oder baumlos waren. Einige, z. B. Miller Christie, Mayr und Redway ${ }^{2}$ ) meinen, die Prärien Nordamerikas seien baumlos, weil die Brände das Aufwachsen der Bäume verhindern, die Brände seien auch die Ursache dafür, daß Schnecken und Regenwürmer fehlen. Andere, z. B. Asher, sind der Meinung, daß sie ursprünglich baumlos waren. Asa Gray hat die Ansicht ausgesprochen, daß es zwischen dem Boden, der genug Regen erhält, um einen Wald hervorzubringen, und dem, der hierzu zu wenig Regen empfängt, ein umstrittenes Gebiet gebe, wo verhältnismäßig schwache Ursachen entscheiden können, ob das Land Wald oder Prärie werden solle; hier

1) Warming 1892; L. S. Gibbs 1906; Pearson 1899; oben S. 820, 838, 847.

3) Christie 1892; Mayr 1890; Redway Geogr. Journ. III (1894). 
hätten die Präriebrände viel zu bedeuten. Dieses scheint unbedingt richtig zu sein.

Über die Campos Brasiliens hat P. W. Lund in Lagoa Santa ${ }^{1}$ ) folgende Ansicht geäußert: sie seien Wald gewesen, den das Feuer in Savannen (Campos) umgewandelt hat. Reinhardt und Warming ${ }^{2}$ ) sind anderer Ansicht, obgleich keiner von ihnen, namentlich nicht Warming, die große gestaltende Bedeutung der Brände leugnet (vergl. Fig. 355, 356, 365); vergl. auch Volkens ${ }^{3}$ ), der gleichfalls diese Anschauung vertritt.

Die selbe Frage ist auch über die Steppen Afrikas erhoben worden. Busse $^{4}$ ) nimmt an, daß das südliche Togo, welches jetzt Steppenland ist, in einer "noch nicht allzu weit zurückliegenden Epoche" von einem typischen Regenwalde bedeckt war. Der Mensch hätte aber diesen durch Axt und Feuer zerstört, und nachher hätte der Wald sich nicht wieder bilden hönnen.

Das Feuer ist eines der Mittel, womit der Mensch in die Naturverhältnisse eingreift; es tritt in allen Tropenländern direkt in den Dienst der Kultur, indem sich der Mensch hier gewöhnlich durch Fällen und Niederbrennen von Wäldern Kulturland verschafft ${ }^{5}$ ). Solange der Boden kultiviert wird, was oft nur wenige Jahre der Fall ist, muß man beständig mit den wilden Pflanzen kämpfen, um die Kulturpflanzen zu schützen, unter anderem mit den Stamm- und Wurzelsprossen der alten Waldbäume. Kaum hat man den Boden sich selbst überlassen, so bedecken ihn die wilden Pflanzen wieder. Zuerst siedeln sich eine Menge einjährige und andere Kräuter, ferner Sträucher an: eine schlichte, plebejische Unkrautvegetation, deren Samen und Früchte von allen Enden herbeifliegen oder durch Vögel herbeigeschafft werden. Es entsteht ein Verein, der allmählich ein Unkrautgebüsch wird (eine „sekundäre Formation"). Bald aber wachsen die Waldpflanzen aufs neue empor; sie sprießen aus Stämmen und Wurzeln hervor, vielleicht auch aus Samen, die im Waldboden verborgen lagen: nach einer Reihe von Jahren steht der Wald wieder da. Oft aber entspricht die neue Formation keineswegs der alten, so stammen nach Pearson ${ }^{6}$ ) die Patanas in Ceylon vom Savannen-Walde ab, dürften aber jetzt wohl dauernd Grasland bleiben, da sie durch die Veränderungen des Bodens nicht wieder Wald werden können.

Auch in manchen Gegenden Nordeuropas ist es noch Gebrauch, Boden durch Abbrennen der Wälder für Kulturzwecke bloß zu legen;

1) Lund 1835 .

2) Reinhardt 1856; Warming 1892 .

3) Volkens 1897.

4) Busse 1906 .

8) Vergl. Warming $1892,1899 \mathrm{~b}$.

-) Pearson 1899. 
diese Brände werden die Pflanzendecke gründlich ändern, selbst wenn der Boden später sich selbst überlassen bleibt. Nach Kihlman ${ }^{1}$ ) hindern Waldbrände in Finnland die Fichte, sich in gewissen Gegenden der nordischen Waldzone auszubreiten. Die Kiefer haben sie erweislich aus Gebieten verdrängt, wo sie vorher reichlich vorhanden war. Je nördlicher die Gebiete liegen, desto größer ist der Einfluß der Waldbrände, weil die Samenreife schwieriger wird. Zwischen Kola und dem ImandraSee entdeckte Kihlman eine $3 \mathrm{~km}$ lange Erhöhung, deren Flora vor mehreren Jahren durch Feuer verwüstet worden war; die hier früher

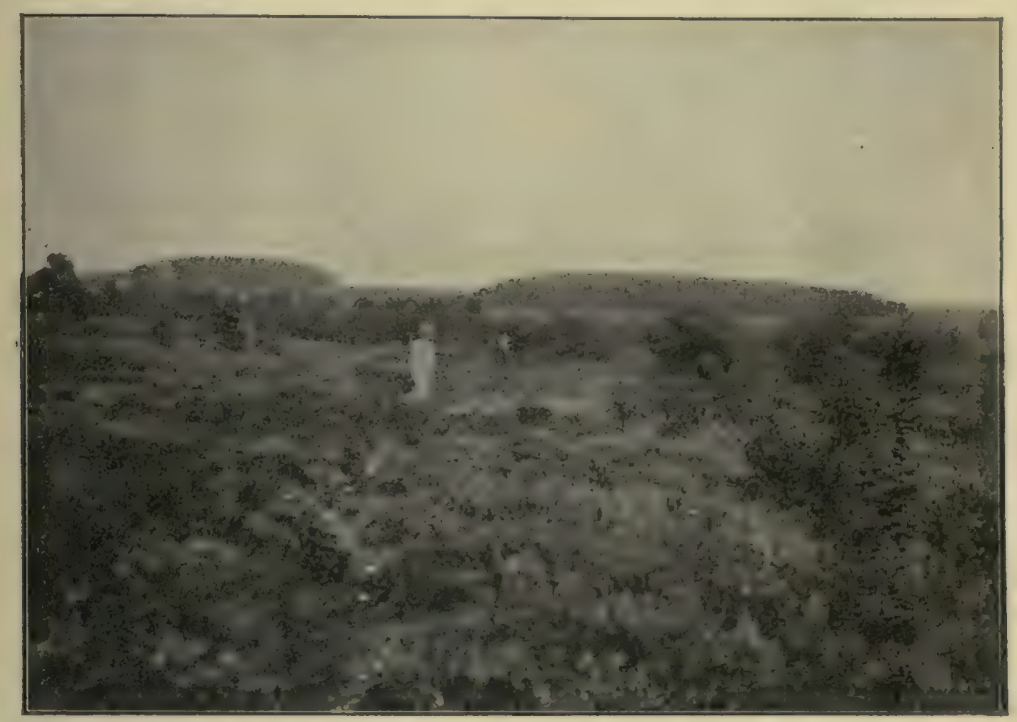

Fig. 375. Links und hinten alte Heide, in der Mitte und rechts verlassenes Ackerland, auf welchem Birken usw. anfwachsen, dazwischen wieder Heidekraut. Die beiden Personen stehen an der Grenze des in die Heide gelegten ehemaligen Ackers. (Phot. P. Graebner.) Vergl. auch Fig. 301.

herrschenden Fichten waren alle tot, standen aber noch da nebst einzelnen Kiefernbäumen, welche die Zerstörung überlebt hatten. Der Boden war im übrigen von einem jungen, schon ziemlich dichten Birkenbestande eingenommen, worin man vergeblich nach Nadelbäumen suchte. Es scheint, daß die Birke hier mit Hilfe des Feuers die Fichte verdrängen wird, weil ihre Samen leichter reifen. Hult ${ }^{2}$ ) schildert, wie mächtig die Waldbrände in Blekinge (Südschweden) in den Kampf der Vegetationen eingreifen. Kihlman sagt wörtlich: „Die Waldbrände waren in NordSkandinavien bisher so häufig, daß man mit ihnen als mit einem

x) Kihlman 1890 .

2) Hult 188 . 
konstanten, die Physiognomie der Landschaft beeinflussenden Faktor rechnen muß".

In Nordamerika, wo man mit großer Rücksichtslosigkeit gegen die Wälder auftrat, hat sich auch die Vegetation und Physiognomie der Landschaften gewaltig geändert ${ }^{1}$ ). Harper ${ }^{2}$ ) hat in Florida einen gewissen Zusammenhang zwischen der Vegetation wasserumschlossener Inseln und Halbinseln und der der übrigen Teile gefunden; Schutz gegen Feuer ist die hauptsächlichste Ursache für einen "Wald-Climax".

Krassnoff $^{3}$ ) berichtet, $\mathrm{daB}$ er in den inneren Tälern des Altai 10-11 km längs abgebrannten Wäldern reiste. Obgleich es lange her war, seit das Feuer hier gewütet hatte, war doch kein neuer Wald entstanden, sondern es wogte hier ein mehrere Fuß hohes Meer von Kräutern, und zwar von solchen, die keinen Rasen bilden: Helleborus, Aconitum, Thalictrum, Ligularia, Paeonia, Pedicularis usw. Der Wald scheint hier durch eine ganz andere Vereinsklasse verdrängt zu werden.

Auch die Heidebrände geben uns Beispiele für die Bildung neuen Bodens (Fig. 375). Oft tritt eine Entwicklung der Vegetation ein, bei der die zuerst auftretende Vegetation von der späteren recht versehieden ist; zuletzt erobert Calluna das verlorene Gebiet zurück, oft aber wird Calluna sofort wieder Bestand bilden, die bis zum Boden abgebrannten Pflanzen schlagen am Grunde wieder aus und zahllose Sämlinge gehen auf. Oft aber dauert es auch Jahrzehnte, bis Calluna wieder herrscht; anfangs wird sie dann von Gräsern (Molinia, Festuca usw.) überwachsen und unterdrückt. Moorbrände geben eine andere Gelegenheit, Kämpfe der Vegetationen zu beobachten; nach ihnen finden sich zunächst Senecio silvaticus und Epilobium angustifolium ein. Die Namen "Ildmärke" und "firewood" dieser Art weisen darauf hin, daß sie sowohl in Dänemark als in Amerika auch zu den Pflanzen gehört, die sich an Brandstellen zuerst ansiedeln.

Hier sei auch an die durch den Plaggenhieb hervorgebrachte Bloßlegung neuen Bodens erinnert. Nachdem die Heidesträucher mit der oberen Bodenschicht abgestochen worden sind, um als Streu oder zur Aufsaugung von Dünger benutzt zu werden, überzieht sich der bloße Boden zunächst meist mit Moosen (Polytrichum) und einjährigen kleinen Kräutern (Radiola, Centunculus, Cicendia), zwischen denen Heidekrautkeimpflanzen, oft auch junge Bäume, besonders Birken und Kiefern, aufgehen. Arnica siedelt sich oft in Massen an solchen Stellen auf den nordwestdeutschen Heiden an ${ }^{4}$ ).

1) Rübel 1915 .

2) Harper 1911.

3) Krassnoff 1888.

4) Focke, Graebner 1895. 
Ähnlich wird an allen anderen Stellen, wo eine alte Vegetationsdecke, oft durch Menschenhand, zerrissen wird, ein neuer und von dem alten verschiedener Verein auftreten, der jedoch in der Regel wieder von dem früheren verdrängt werden wird. Wo der Wind in die alte, lange bewachsene feststehende Düne ein Loch reißt, wächt eine andere Vegetation empor; besonders ist dann wieder für den Helm Platz. Wo das Wasser

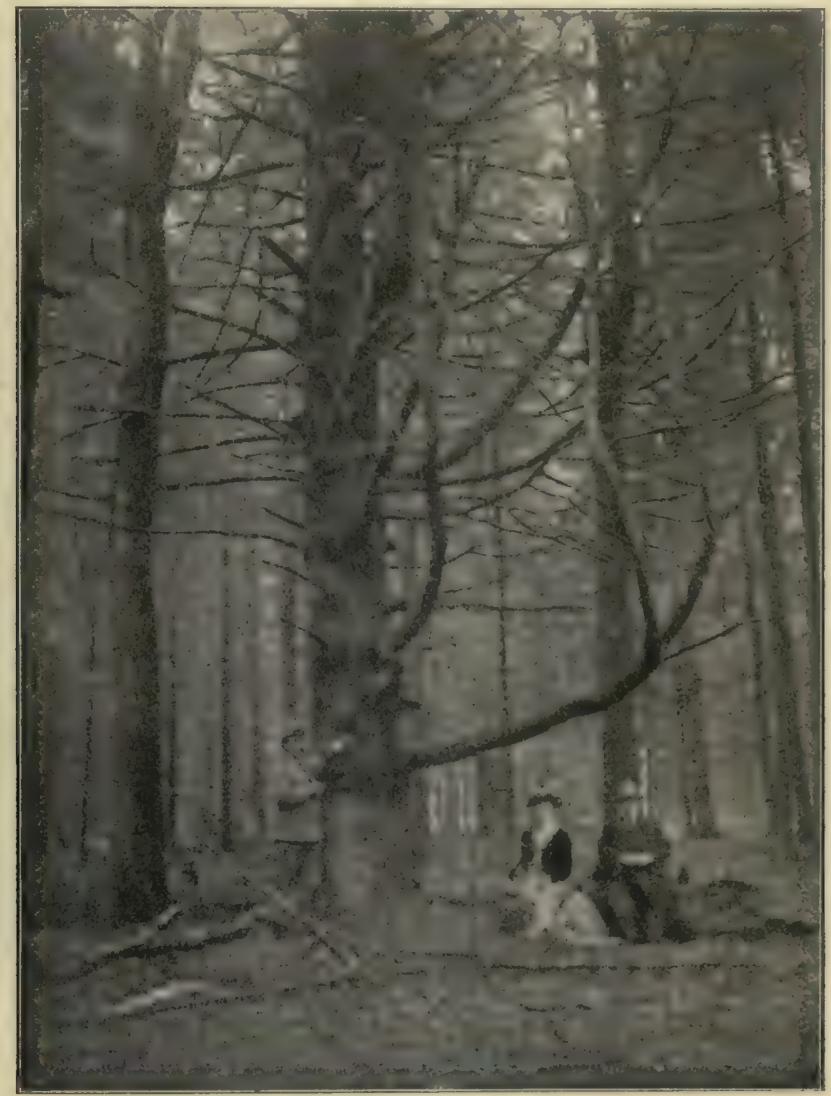

Fig. 376. Alte Fichte im "Urwald" von Lübberstedt in der Lüneburger Heide. Die ehemals im lichten Eichenmischwald aufgewachsene Fichte ist nach Entfernung der Eichen und Bildung einer dicken Rohhumusschicht durch die um sie aufgewachsene jüngere Fichtengeneration eingeengt und hat ihre Äste daher zum Teil aufwärts gerichtet. (Phot. P. Graebner.)

auf den Matten der mehrjährigen Kräuter der Strandwiesen (51. Kap.) offene Stellen bildet, findet sich gleichfalls eine andere, wesentlich aus einjährigen Halophyten (Salicornia, Suaeda maritima u. a.) bestehende Vegetation ein. Wo eine Lawine in einem Walde einen baumlosen Streifen gebildet hat, stellt sich meist eine ganz andere Pflanzendecke ein. 
Durch die Eingriffe des Menschen werden in ausgedehntem Maßstabe die Bodenverhältnisse verändert, Wälder werden umgehauen, Kulturboden bereitet und vielleicht wieder verlassen. Simmons hat erläutert, wie die Flora in Lappland sich durch die Tätigkeit der Menschen gegenwärtig verändert ${ }^{1}$ ).

Ein neuer Boden, der schnell von einer Schar von Pflanzen besiedelt wird, die wesentlich Unkräuter sind, erscheint nicht nur in dem soeben genannten Falle, sondern überhaupt da, wo bisher bebautes Land sich selbst überlassen wird. Man sieht dieses z. B. auf den Feldern Nordwestdeutschlands und Jütlands, wenn der magere Boden, der einen dürftigen Getreideertrag geliefert hat, unbenutzt liegt und allmählich zur Heide wird. Man beobachtet es ferner in Blekinge, wo nach den mustergïltigen Untersuchungen Hults der neue Boden zuerst von Unkräutern und Pflanzen mit leicht fliegenden Samen bedeckt wird; nach einigen Jahren ist das Feld eine ziemlich artenreiche Grasflur geworden (mit 40-60 Arten Blütenpflanzen), und die Unkräuter sind verschwunden. Dann finden sich Bäume und Sträucher ein; es entsteht ein Wald. Auf magerem Boden erobert das Heidekraut die Flur, kann aber, wenn in geringerer Tiefe besserer Boden lagert und kein Ortstein vorhanden ist, vom Walde verdrängt werden.

Man beobachtet allenthalben denselben Kampf; nur ein Beispiel sei noch angeführt. Wenn man auf Korsika einen kultivierten Boden, der früher mit einer Macchia bedeckt war, sich selbst überläßt, so finden sich zuerst Kräuter ein: Papaver hybridum, Helianthemum guttatum, Trifolium agrarium, Galactites tomentosa, Jasione montana u. a. ${ }^{2}$ ). Nach einigen Jahren verdrängt Cistus Monspeliensis diese Krautvegetation; nach und nach kehrt auch die übrige Macchien-Vegetation zurück: zuerst siedelt sich Daphne gnidium an, dann folgen die anderen Arten und Cistus Monspeliensis wird schließlich auf den Platz zurückgedrängt, der ihm in der Macchia zukommt.

Langsamere Bodenveränderungen werden oft durch die eigene Tätigkeit der Vegetation herbeigerufen. Beispielsweise können folgende hervorgehoben werden:

Die Sandvegetation unserer Küsten wurde Kap. 50 und 97 behandelt. Zuerst entsteht auf dem flachen, bisweilen mehrere Hundert Fuß breiten Vorstrande, auf dem das Meer Sand ablagert, eine Vegetation von Sandhalophyten: die Vegetation des Sandstrandes. Darauf wirft der Wind in diesem Gebiete Dünen auf, die von den eigentlichen Dünenpflanzen, wie Helm usw., besiedelt werden (wandernde oder „weiße“ Dünen). Diese Pflanzen bereiten einer neuen Vegetation den Platz vor,

1) Simmons, siehe Journ. of Ecology I, 64 .

2) Vergl. Fliche 1888. 
wenn sie aus dem Kampfe mit dem Winde als Sieger hervorgehen; denn zwischen ihnen und in ihrem Schutze können nun andere Arten gedeihen. Indem diese aufwachsen und eine immer dichtere Decke bilden, wird es den Dünenpflanzen zu eng; sie sterben allmählich ab und an ihre Stelle tritt die Vegetation der "grauen" (feststehenden) Düne oder die Sandflur, in vielen Fällen die Zwergstrauchheide ${ }^{1}$ ).

G. Beck ${ }^{2}$ ) schildert die Vegetationsformationen, die auf den in der Donau durch Hochwasser gebildeten Sandbänken nacheinander auftreten. Zuerst finden sich auf dem nackten feuchten Sande einige Kräuter ein (Polygonum- und Chenopodium-Arten), zwischen denen dann Samen von

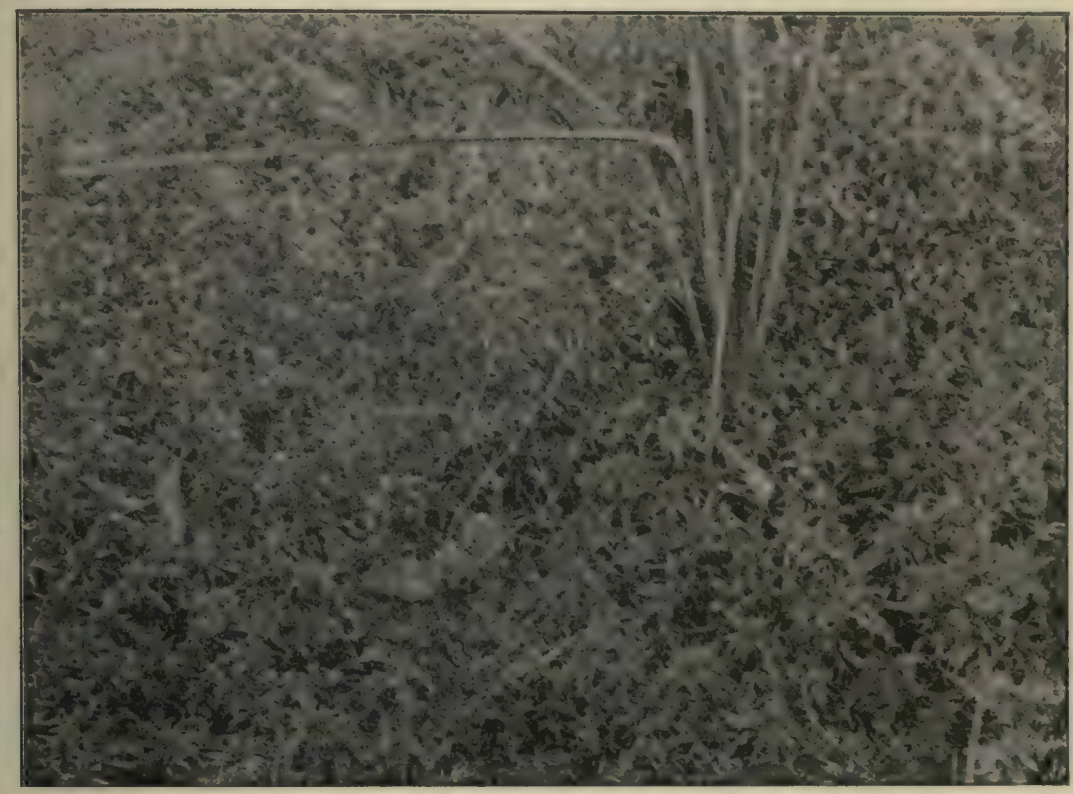

Fig. 377. Schwimmende Sphagnum-Decke in einem Heidetümpel.

In der Mitte hat sich eine Keimpflanze von Carex rostrata als erster phanerogamer Ansiedler eingefunden. (Phot. P. Graebner.)

Salix, Populus, Alnus und Myricaria Germanica keimen. Darauf siedeln sich eine Menge anderer Kräuter an, besonders solche mit kriechenden Achsen, einige an den feuchteren, andere an den trockeneren Stellen, und bilden eine „Wellsandflur". Die Weiden, Pappeln, Erlen und andere Bäume wachsen inzwischen auf und bilden einen Buschwald, die "Weidenau", die durch ihren Schatten die Kräuter unterdrückt. Wo sich aber Humus bilden kann, den das Hochwasser nicht wegführt, da werden

$\left.{ }^{1}\right)$ Näheres bei Warming 1891, 1906, 1907 usw.; Graebner 1895, 1901; Cowles 1899; Gerhardt 1900; Adamović 1904; Pool 1913. Vergl. ferner Ove Paulsen 1912 und Kap. 99.

2) G. Beck 1890 . 
die Weiden und Erlen zurückgedrängt, und es entsteht ein ganz anderer, aus Populus und Ulmus bestehender Wald, die "Pappelau". Ähnlich verhält sich die "Kämpen-Flora" in der Weichselniederung.

Überall auf der Erde kann man an ähnlichen Standorten ähnliche Kämpfe beobachten ${ }^{1}$ ).

Es sei hier noch auf die von Stefánsson ${ }^{2}$ ) behandelte Entwicklung der Vegetation im Vatn-Tale auf Island hingewiesen, wo Schlamm und Sand in dem Flusse kleine Inseln bilden, die allmählich von Eriophorum, Carex und Gräsern besiedelt werden. Diese Pflanzen verdrängen einander nach und nach in einer bestimmten Reihenfolge.

Wie die Heidemoore auf Sandboden entstehen, hat Graebner ${ }^{3}$ ) geschildert: zuerst treten Schizophyceen auf, deren Fäden den Sand bis zu $3 \mathrm{~mm}$ Tiefe durchweben; dann finden sich Polytrichum juniperinum, Radiola millegrana, Juncus capitatus und andere ein- und mehrjährige Pflanzen ein, schließlich Sphagnum, Ledum, Calluna usw. Daß durch Ansiedelung oder Einwanderung von Sphagnum in die Wälder diese vernichtet werden können, wurde mehrfach betont.

Die Marschbildung. An der Küste der Nordsee und an ähnlichen Stellen der Küsten des Kattegats und der Ostsee, werden, wo es meist Ebbe und Flut, ferner Schutz gegen starken Wellenschlag gibt, während der Flut die mitgeführten, äußerst feinen, "Schlick" genannten Ton-, Sand- und Humusteilchen abgelagert (vergl. Kap. 51). Die Vegetation spielt bei dieser Landbildung eine wichtige Rolle, indem in dem tieferen Wasser der Watten zuerst Seegrasbestände (Zostera marina, S. 393), nach diesen in weniger tiefem Wasser Salicornia herbacea (S. 396, 448) sich festsetzen und zwischen ihren Sprossen dem sich niederschlagenden Schlick sowie den sich festsetzenden Schizophyceen (besonders Microcoleus chthonoplastes) Ruhe und Platz gewähren. Langsam wird der Boden höher; endlich ist er so hoch, daß die tägliche Flut ihn nicht überspülen kann. Dann wird die Salicornia-Zone von anderen Pflanzen erobert: nach und nach entwickeln sich Festuca-, Juncus Gerardi- und andere Bestände aus der Klasse der Strandwiesen auf dem allmählich höher und trockener werdenden Boden $\left.{ }^{4}\right)$. In den Strandwiesen leben keine Regenwürmer; wird aber eine solche Wiese eingedämmt und durch den Regen ausgewaschen, so geht ihr Rohhumus- in milden Humusboden über, und die Regenwürmer finden sich ein ${ }^{5}$ ). Im Laufe der Zeit wird der Boden der Strandwiesen sicher immer

1) Vergl. z. B. Siegrist.

2) Stefánsson 1894 .

3) Graebner 1901.

4) Über diese Zonen vergl. Kap. 51 und Warming 1890, 1894, 1906.

s) P. E. Müller 1878. 
ausgewaschen werden, und ihre Vegetation sich dann in Übereinstimmung damit ändern.

Die Entwicklungsgeschichte der Vegetation, die sich auf dem an der Rhonemündung gewonnenen neuen Boden einfindet, haben Flahault und Combre ${ }^{1}$ ) geschildert. Auf dem niedrigen, feuchten, salzreichen Alluviallande von Camargue siedelt sich zunächst Arthrocnemum macrostachyum an. Um diese Pflanze sammeln sich kleine Mengen von Sand und organischem Staube und erhöhen den Boden in sehr geringem Maße. Bald schließen sich Salicornia fruticosa, Atriplex portulacoides und Aeluropus litoralis den ersten Rasen des Arthrocnemum an. Durch neues,

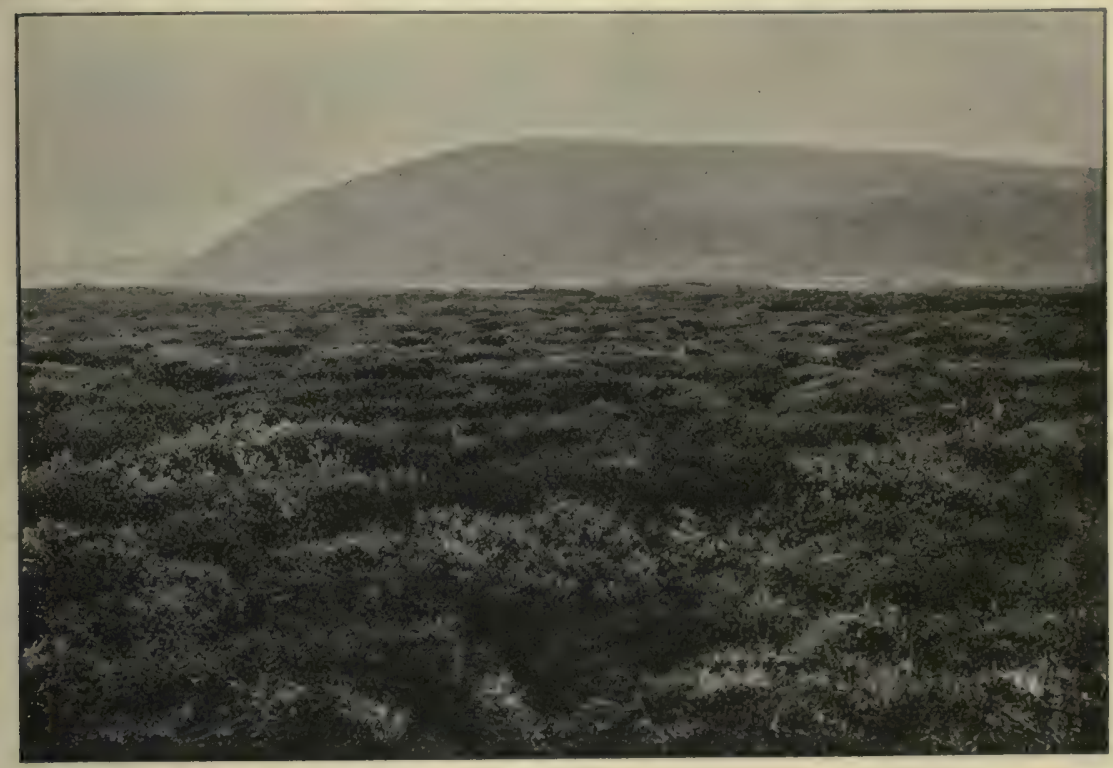

Fig. 378. Arktisches Moor in Island. Betula nana, untermischt mit Salix lanata, S. phylicifolia, darunter Empetrum, Aretostaphylos, Anthoxanthum odoralum und Polygonum viviparum. (Phot. Hesselbo.)

angewehtes Material entstehen zwischen den niederliegenden Stengeln dieser Pflanzen kleine Erhöhungen von 2-3 m Durchmesser und $10 \mathrm{~cm}$ Höhe und es bildet sich etwas Humus. Das Regenwasser wäscht die Erhöhungen aus; es finden sich andere Pflanzen ein, auch einjährige. Die Vegetation kann in eine ganz andere übergehen und sogar Nadelbölzer (Juniperus Phoenicea, Pinus pinea) in sich aufnehmen.

Auf Strandwällen geht auch eine regelmäßige Entwicklung vor sich, die mit Gesträuch enden kann (49. Kap.). Auch in Grönland hat Porsild die Entwicklung geschildert ${ }^{2}$ ).

1) Flahault et Combres 1894 .

2) Porsild 1902. Ferner für Europa Warming 1906; Oliver 1911-13. 
Noch ein anziehendes Beispiel für die Landbildung an den Meeresküsten durch die Arbeit der Vegetation und für die damit einhergehende Ablösung einer Vegetation durch eine andere sei angeführt: nämlich die Arbeit der Mangrovenvegetation (Kap. 46). Die äußerste Zone bilden die Rhizophora-Arten. Tausende ihrer Luftwurzeln schwächen die Macht des Wellenschlages; herbeigeführte organische und andere Teile sammeln sich hier und schlagen sich nieder. Dadurch bereiten die Rhizophoren den Boden für andere Pflanzen der Mangrovenvegetation vor, die nicht so tief in das Meer hinausgehen können. Landeinwärts, auf trocknerem Boden, geht diese endlich in die xerophilen Strandwälder, z. B. in die Barringtonia-Wälder, über. So rückt die Mangrovenvegetation an günstigen Stellen immer weiter in das Meer hinein.

Kämpfe in süßen Gewässern. Außer Salicornia und Zostera wirken viele andere Pflanzen als Schlammfänger. Wassermoose, Algen und andere Süßwasserpflanzen fangen in Flüssen und Seen zwischen einander Sand und Schlamm auf; z. B. Lemanea fluviatilis und Cinclidotus riparius können in Gebirgsbächen durch und durch mit Sand durchsetzt sein; ebenso anderswo Vaucheria.

„Verlandung“ (vergl. auch Fig. 377). In den süßen Gewässern Europas findet ein Entwicklungsgang statt, der in den Grundzügen folgender ist. Die Pflanzen sind hier in Zonen verteilt, die teils von der Wassertiefe, teils von der Art des Bodens abhängen, und die sehr deutlich Glieder einer Folgeformation („Succession“) sind. In tieferem Wasser herrschen neben dem Plankton namentlich die Limnäen-Vereine (Kap. 58); unter dem Wasser breiten sich Myriophyllum, Characeen u. a. aus, auf der Wasseroberfläche in seichterem Wasser die Schwimmblätter von Potamogeton, Nuphar und Ranunculus. Näher nach dem Ufer beginnt in seichterem Wasser die Sumpfregetation; ganz außen herrscht die Rohr-Vegetation, die von den höchsten und kräftigsten Arten, von Scirpus lacustris, Phragmiles u. a., gebildet wird (vergl. Kap. 63). Die Reste aller dieser Formationen werden im Laufe der Zeit nebst anorganischen Teilen, die durch Wasserströmungen und Wind herbeigeführt werden, auf dem Boden des Wassers aufgehäuft, und dieser wird nach und nach höher. Dadurch wird anderen Sumpfpflanzen der Platz bereitet, die nur in seichterem Wasser wachsen können, z. B. Sium latifolium, Sparganium, Carex-Arten, Ranunculus lingua, Menyanthes, Lythrum, Oenanthe aquatica (Oe. phellandrium), Iris, Butomus, Acorus, Equisetum heleocharis (E. limosum). Allmählich gehen die Rohrsümpfe in Wiesenmoore über (Kap. 81); das Wasserbecken wächst durch Carices und andere Wiesenmoorpflanzen zu. Wenn diese so hoch aufgewachsen sind, daß das Wasser bis zum Wasserspiegel oder über diesen hinaus mit Pflanzen und Pflanzenresten erfüllt ist, so finden sich auf dem torfhaltigen Sumpfboden mehrere Gräser, ferner monokotyle und dikotyle Kräuter ein: es 
entsteht eine Wiese, die jedoch gewiß meist mit Gebüsch (z. B. mit Weiden- und Erlengebüsch) und mit Wald bedeckt werden wird, wenn die Natur nicht vom Menschen gestört wird.

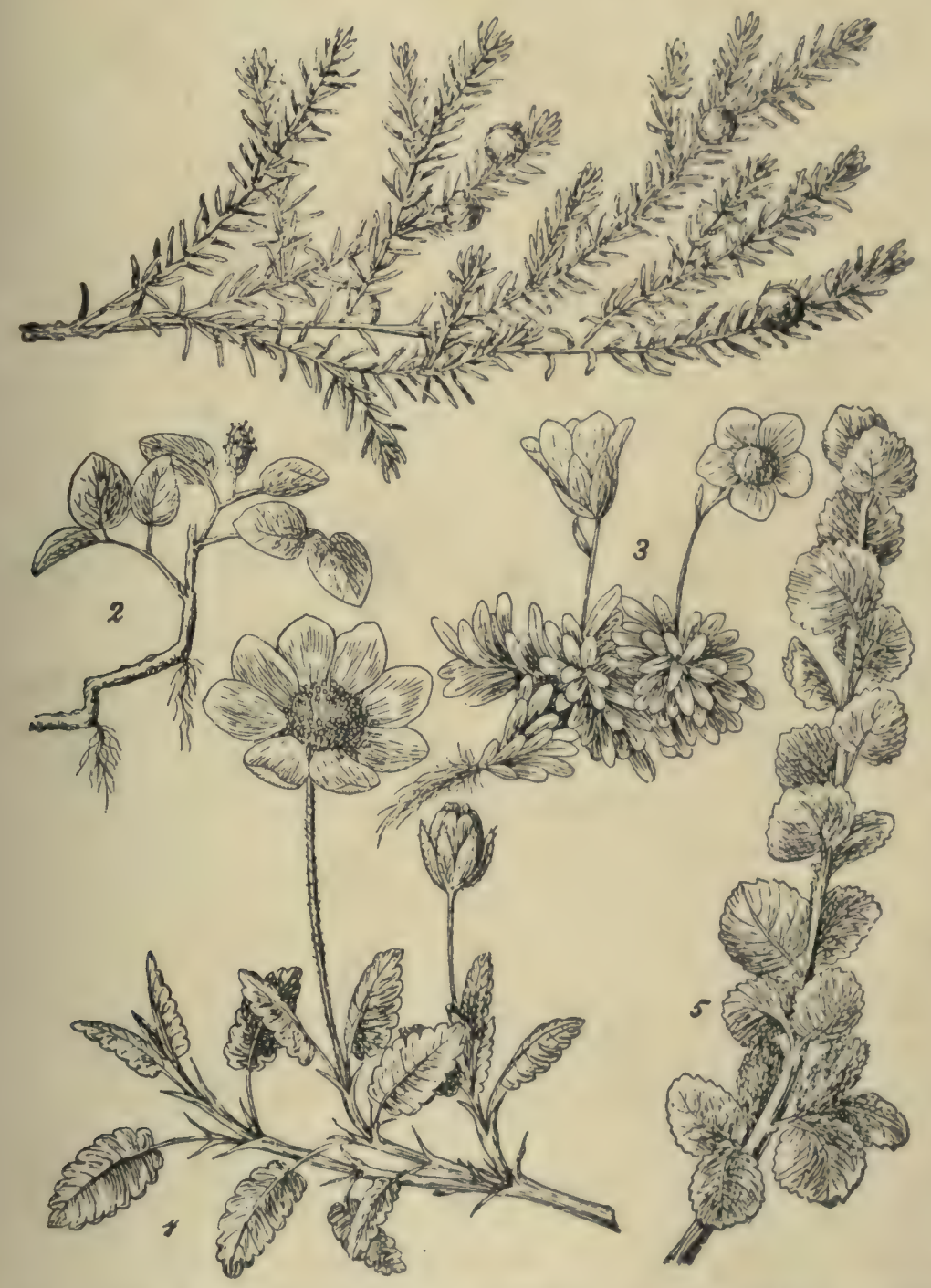

Fig. 379. Pflanzen der Tundravegetation, deren Reste im norddeutschen Moränenboden sich finden. 1. Empetrum nigrum. 2. Salix polaris. 3. Diapensia Lapponica. 4. Dryas oetopetala. 5. Betula nana.

Es ist nicht notwendig, daß die Entwicklung zuletzt gerade so, wie es eben angeführt wurde, vor sich geht. Die Sumpfmoore können auch in Sphagnummoore übergehen, wenn sich verschiedene Sphagna 
ansiedeln und diese die Entwicklung fortsetzen (Kap. 85); das Sphagnummoor baut sich oben auf dem Sumpfmoore auf, immer höher, hoch über dem Stande des Grundwassers (vergl. Fig. 293). Auch dabei braucht die Entwicklung nicht stehen zu bleiben. Der trocknere Boden wird für andere Pflanzen, namentlich für Holzpflanzen, passend; das Sphagnummoor bereitet bei irgendwelcher Austrocknung der Calluna-Heide den Weg, indem Calluna, Vaccinium-Arten und andere Heidepflanzen auf der trockneren Oberfläche einwandern (Kap. 86). Ein solches verheidetes Moor ist das etwa 100 Quadratkilometer große "Wildmoor" in Nordjütland. Zuletzt kann diese Calluna-Heide auch in Wald übergehen, indem sich Betula und Pinus silvestris einfinden (Kap. 87, 88). Wird der Boden trocken gelegt, etwa künstlich, so treten an die Stelle jener Bäume andere, z. B. Picea excelsa und Quercus.

Über diese und ähnliche Entwicklungsvorgänge vergl. Steenstrup 1841; Kerner 1863; Hult 1881; Klinge 1890; Stebler und Schröter 1892; Weber 1894; Magnin 1893; Scott Elliot 1900; Früh und Schröter 1904; C. Mac Millan; Graebner 1907; Tansley 1911; Marietta Pallis 1916 u. a.

Auf dem nordeuropäischen Moränenboden bildeten sich viele Moore in kleinen Seen und Wasseransammlungen, die aus der Eiszeit stammen. Unter dem Moore findet man eine dünne Tonschicht, die durch Ausschlämmen der umgebenden Höhen entstanden ist und worin die subglaziale Tundrenvegetation, die in dem Lande gleich nach der Eiszeit auftrat (die Dryasvegetation: Dryas octopetala, Salix reticulata: S. polaris, Betula nana, Oxyria digyna, Arctostaphylos alpina, Polygonum viviparum u. a.), zahlreiche Reste abgelagert hat (Fig. 379). Diese fossilen Reste wurden 1870 von Nathorst in Schonen, später in Dänemark und vielen anderen Ländern entdeckt. In den Wasserbecken fand folgende Entwicklung statt. Die Limnäen-Vegetation entwickelte sich zuerst, und an ihrem Rande begannen sich Rohrsümpfe oder auch Moorbildungen (Sphagnum, Hypnum) in dem Wasser auszubreiten. Allmählich schritt die Entwicklung vom Rande nach der Mitte des Beckens in der Form eines schwimmenden Sphagnummoores (dänisch: "Hängesäk") vor, auf dem Eriophorum, Carices u. v. a. Pflanzen wuchsen. Die umgebenden Höhen erhielten, da das Klima milder wurde, Baumvegetationen in folgender Reihenfolge: Populus tremula, Betula, Pinus silvestris und Quercus, wie Jap. Steenstrup ${ }^{1}$ ) zuerst zeigte. Stämme dieser Bäume wurden vom Winde umgeworfen und im Moore nebst ihren Blättern, Früchten usw. begraben: es entstanden die namentlich in Nord-Seeland häufigen, baumreichen Waldmoore (Fig. 293). Auf ihrer Oberfläche tragen diese oft ein Wiesenmoor oder Sphagnumvegetation; viele von ihnen sind von Wiesen bedeckt oder in neuerer Zeit, nachdem die Kultur sie mit Beschlag belegt hatte, selbst von Weiden und Getreidefeldern.

1) Steenstrup 1841 . 
Es gibt selbstverständlich noch viele andere Formen des Verwachsens der Wasserbecken, die teils nicht näher untersucht worden sind, teils hier nicht erwähnt werden können. In Torfgruben z. B. sieht man bisweilen Rhizome oder sogar wagerecht liegende Assimilationssprosse des Equisetum heleocharis von den Wänden oder Rändern der Gruben nach der Mitte wachsen und allmählich anderen Pflanzen den Weg bahnen.

Im großen und ganzen ist die Entwicklung der Vegetation in Dänemark und vielen anderen Ländern in den letzten Jahrhunderten und vielleicht in Jahrtausenden in der Richtung der Trockenlegung vor sich gegangen und geht noch in dieser Richtung vor sich. Die Wasservegetation unterliegt, Seen und Teiche verschwinden, die Wasserläufe werden eingeschränkt. Darüber liegen viele historische, archäologische und geologische Zeugnisse vor. Das Verwachsen der dänischen wie überhaupt der baltischen Küstenseen und der in der Nähe der Nordsee hängt von der Windrichtung ab, worauf schon der dänische Geologe Forchhammer vor Jahrzehnten in seinen Universitätsvorlesungen aufmerksam gemacht hat. Klinge ${ }^{1}$ ) hat in den russischen Ostseeprovinzen dieselbe Abhängigkeit beobachtet. Die westlichen Ufer der Seen sind meist seicht, flach und sumpfig, während die östlichen Ufer aus steilen, steinigen Abhängen bestehen. Der Grund hierfür ist der, daß es an den westlichen Ufern der Seen gegen die herrschenden südwestlichen und westlichen Winde mehr Schutz und Ruhe gibt als an den östlichen Ufern, wo der Wellenschlag das Verwachsen hindert. An den westlichen Ufern kann die Sumpfregetation daher vorrücken, sie weichen immer weiter ins Wasser zurück, während sich die östlichen Ufer vielmehr landeinwärts bewegen.

Ein eigentümlicher, durch steigende Trockenheit hervorgerufener Entwicklungsgang ist aus Lappland bekannt ${ }^{2}$ ). Hier unterliegen die Sphagnummoore bei zunehmender Trockenheit folgenden Veränderungen. Die Sphagnum-Moose sterben allmählich ab, indem ihre Rasen von anderen Moosen, die geringere Feuchtigkeit verlangen, und namentlich von Flechten überwachsen werden. Zuerst treten Strauchflechten und einige Zwergsträucher auf (Flechtenheide, Kap. 84). In einem späteren Stadium werden sowohl jene als auch diese kränklich und gehen aus; gleichzeitig kommen die grauweißen Flecken der Lecanora Tartarea zum Vorschein und überdecken nach und nach alles mit ihren spröden, rissigen Krusten, durch welche schwächliche Zweige von Empetrum, Vaccinium myrtillus, Ledum u. a. hervorragen. In verschiedenen Gegenden Lapplands sind die am höchsten liegenden Teile der wellenförmigen Moosdecke mit

1) Klinge 1890 .

2) Kihlman 1890 .

Warming-Graebner. 3. Auflage, illustr. 
diesen Krusten wie mit Leichentüchern überzogen. Übrigens ist die Entwicklung hiermit nicht immer abgeschlossen; dadurch daß die begrabenen Pflanzen allmählich verwesen und erdig werden, verliert die LecanoraKruste ihre sichere Befestigung. Die durch Frost oder Trockenheit gebildeten Risse bieten dem Winde Angriffspunkte; bald wird die Kruste zerrissen. Der schwarze Torf liegt dann für jede Pflanzenansiedelung offen; aber der Zusammenhang seiner Teile ist zu lose, als daß sich eine Vegetation dauernd niederlassen könnte. Die Stürme wühlen unaufhörlich in den losen Massen, graben in ihnen große Löcher ganz wie in den Sanddünen, und es entstehen Mullwehen. Im Grunde und auf den Seiten der Löcher, die oft bis zu dem alten Moränenboden hinabreichen, kann sich dann eine neue Vegetation ansiedeln ${ }^{1}$ ).

Ein etwas anderes Bild bietet die Entwicklung natürlich dort dar, wo sich der Wasserspiegel plötzlich bedeutend senkt. Feilberg ${ }^{2}$ ) führt hierfür ein Beispiel an. Die ursprüngliche Sumpfvegetation im Söborg See auf Seeland mit Menyanthes, Phragmites, Equisetum heleocharis u. a. wurde nach künstlicher Senkung des Wassers zuerst von Carex acutiformis, Agrostis vulgaris, Poa trivialis abgelöst; bei fortgesetzter Abnahme der Feuchtigkeit eroberte Poa pratensis große Gebiete, wurde jedoch allmählich von Festuca rubra verdrängt. Greift dann die Kultur ein, indem der Untergrund gelockert und der Boden mit einer dünnen Schicht sandigen Tones bedeckt wird usw., so wandern die guten Futtergräser (Dactylis glomerata, Festuca elatior, Poa trivialis u. a.) und Trifolium repens ein.

Neuer Boden tritt auch da auf, wo Senkungen des Wasserstandes Felsen bloßlegen, die sich bisher unter Wasser befanden. Ein solcher Fall ist vom Mälar-See bekannt und von Callmé und Grevillius untersucht worden.

Das vorhergehend Gesagte hat schon mehrere Beispiele für die hervorragende Rolle geliefert, welche die Höhe des Grundwassers oder das Niveau, bis zu dem das Wasser steigen kann, spielen. Es kann jedoch nicht genug hervorgehoben werden, daß der Wassergehalt des Bodens von allergrößter Bedeutung ist und daß äußerst geringe, fast unmerkliche Unterschiede dieses Gehaltes oft einen entscheidenden Einfluß ausüben (Kap. 9).

Die besprochenen Beispiele zeigten Übergänge von hydrophilen zu mesophilen oder xerophilen Vereinen. Den umgekehrten Entwicklungsgang kann man finden, wenn der Wasserreichtum des Bodens aus irgend einem Grunde steigt (z. B. durch Aufdämmung eines Flüßchens oder Baches durch Dünen, durch Verstopfung des Ausflusses usw.).

1) Vergl. oben Kap. 85 und auch Cajander 1904 b, 1905 b.

2) Feilberg 1891. 
So beobachtete Graebner ${ }^{1}$ ) in der Nähe der pommersch-westpreußischen Grenze beim Orte Ossecken, daß durch den abgerutschten Sand einer Wanderdüne dem dort mündenden Bache der Ausfluß verstopft war und wie statt des Kiefernwaldes mit Heidevegetation in dem aufgestauten Wasser Typha und andere Sumpf- und Uferpflanzen, am Rande Alnus usw., sich ansiedelten.

Nach Blytts Theorie ${ }^{2}$ ) wechseln trockene und feuchte Zeiträume von großer Länge miteinander $a b$, und in Übereinstimmung hiermit sollen die Moore wechselnde Schichten von Baumstämmen, die auf dem Moore während der trockenen Zeiten wuchsen, und von Moos aufweisen, das aus den feuchten Zeiten stammt, in denen die Waldvegetation zurückgedrängt worden war (Fig. 293). Die gegen die Blyttsche Theorie eingewendeten Tatsachen sind oben schon berührt.

Die großen Moore Norddeutschlands sind angeblich nach einer Versumpfung der ursprünglich mit Wald bedeckten großen Flächen entstanden. - In Nordamerika sollen durch Biberwohnungen hervorgerufene Überschwemmungen vorkommen: ein Beispiel für das Eingreifen der Tiere.

Die Folgeformationen auf Felsen sind wohl bekannt. Zuerst bekleiden sich die nackten Felsen mit Algen und Krustenflechten. Diese bereiten den Untergrund für Strauchflechten (für ein Cladinetum usw.) nder für Moosgesellschaften. In dem mehr oder weniger dicken 'T'eppich der letzteren keimen einige Phanerogamen; schließlich kann sich unter Umständen eine Callunaheide entwickeln und als Schlußformation vielleicht ein Nadelwald (vergl. auch Serie VI und Malme 1901).

Alle anderen Veränderungen, die in den Naturverhältnissen des einen oder des anderen Standortes eintreten, werden dieselben Folgen haben: nämlich Veränderungen in der Vegetation dadurch, daß gewisse Arten nun instand gesetzt werden, die älteren zu verdrängen. Diese Veränderungen können, wie besprochen, von sehr verschiedener Art sein und überaus langsam, für uns fast unmerklich, vor sich gehen. Welche Faktoren in der Entwicklung der Vegetation die wichtigste Rolle spielen, ist sehr oft außerordentlich schwierig zu entscheiden, und gewöhnlich ist es nicht ein einzelner Faktor, sondern es sind eine ganze Reihe Faktoren, die ineinander eingreifen und zusammenwirken.

Die Veränderung in dem Wasserstande und dem Wassergehalte des Bodens ist ein Faktor, wie wir gesehen haben; die Veränderung in der chemischen Natur des Bodens, z. B. die Auswaschung des Kalkes, ist ein anderer. Es wurde Kap. 106 erwähnt, daß Steppe und Wald in Rußland miteinander kämpfen; wenn Tanfiljew recht hat, so ist das

3) Graebner $1895 \mathrm{~b}$.

?) Blytt 1882 . 
langsame, aber beständig fortschreitende Auswaschen des Bodens der Grund für den Sieg des Waldes ${ }^{1}$ ).

Auch in Mitteleuropa gab es nach Nehrings Annahme einmal Steppen, nämlich nach der Tundrenperiode, die der Eiszeit folgte; diese Steppen sollen später zu Wäldern geworden und von den jetzt vorhandenen steppenartigen Vereinen vielleicht durch den Salzgehalt verschieden sein. Die Gründe für diese Veränderung der Vegetation, falls sie wirklich in der angenommenen Weise vor sich gegangen ist, sind wohl noch nicht nachgewiesen, müßten aber gewiß zunächst in klimatischen und physikalisch-geographischen Änderungen oder Einflüssen gesucht werden. In späterer Zeit haben die Wälder auf weiten Gebieten dem Ackerlande weichen müssen.

Graebner führt ${ }^{2}$ ) Beispiele von Veränderung der Vegetation an ohne Klimawechsel. Besonders hat er auf die "Bodenmüdigkeit" hingewiesen, die dadurch hervorgerufen wird, daß eine Art in mehreren Generationen denselben Boden bewohnt, so daß dieser unfähig wird, auch ferner derselben Art günstigen Stand zu bieten. Bodenmüdigkeit tritt desto deutlicher hervor, je weitere Strecken die Art bewohnt hat. Die Kiefer z. B. versagt in der Lüneburger Heide meist gänzlich bereits in der zweiten bis dritten Generation, sie wird kränklich und leicht von Parasiten getötet. Dieses dürfte der Bodenmüdigkeit zuzuschreiben sein; wie auch sicher die meisten bestandbildenden. Arter allmählich anderen weichen. Je langlebiger eine solche Art ist (wie z. B. Eichen, Buchen usw.), desto weniger wird naturgemäß die Bodenmüdigkeit auffällig werden resp. im Zeitraum einiger Menschenleben in die Erscheinung treten. Mischbestände werden in der Theorie unbeschränkt sich wieder erneuern können, weil ja eine Art immer wieder an Stelle der anderen aufwachsen kann, ohne daß die Zusammensetzug des Waldes merklich geändert würde. Graebner konstatierte, daß sämtliche genau dem Standorte nach festgelegten Bestände von Kräutern, z. B. im Kolberger Stadtwalde usw., nach einigen Jahrzehnten weiter gewandert oder verschwunden waren und anderen Platz gemacht haben. Kriechende Arten, wie Anemone nemorosa, A. ranunculoides, Mercurialis perennis, hatten sich meist in der Nachbarschaft angesiedelt, einjährige, wie die Melampyrum-Arten usw., waren zumeist sprungweise gewandert.

Im allgemeinen wird sich die natürliche Regel aufstellen lassen, daß die Bodenmüdigkeit für eine bestimmte Pflanzenart desto eher eintritt, je kurzlebiger sie ist und je dichter sie ohne Beimischung anderer Arten den Boden bedeckt resp. mit ihren Wurzeln durchzieht. Einjährige

1) Tanfiljew 1894, 1905.

2) Graebner 1913. 
Arten werden im wesentlichen schnell bodenmüde werden, Gehölze und namentlich natürlich Bäume verhältnismäßig langsam. Von den letzteren können solche bis über 1000 Jahre alt werdende, wie die Eiche, sehr viel länger ein Terrain bewohnen, als die kurzlebige Kiefer, die ja meist kaum mehrere Jahrhunderte alt wird und deren Generationen im dichten Bestande schnell einander folgen. Als eine anscheinende Ausnahme mag z. B. auf Calluna hingewiesen werden (vergl. unten).

Die Bodenmüdigkeit ist eine den Landwirten in ihrem Vorkommen seit langem wohlbekannte Erscheinung; die allgemeinen Regeln der Fruchtfolge sind überall anerkannt. Die letzten Ursachen für die sicher

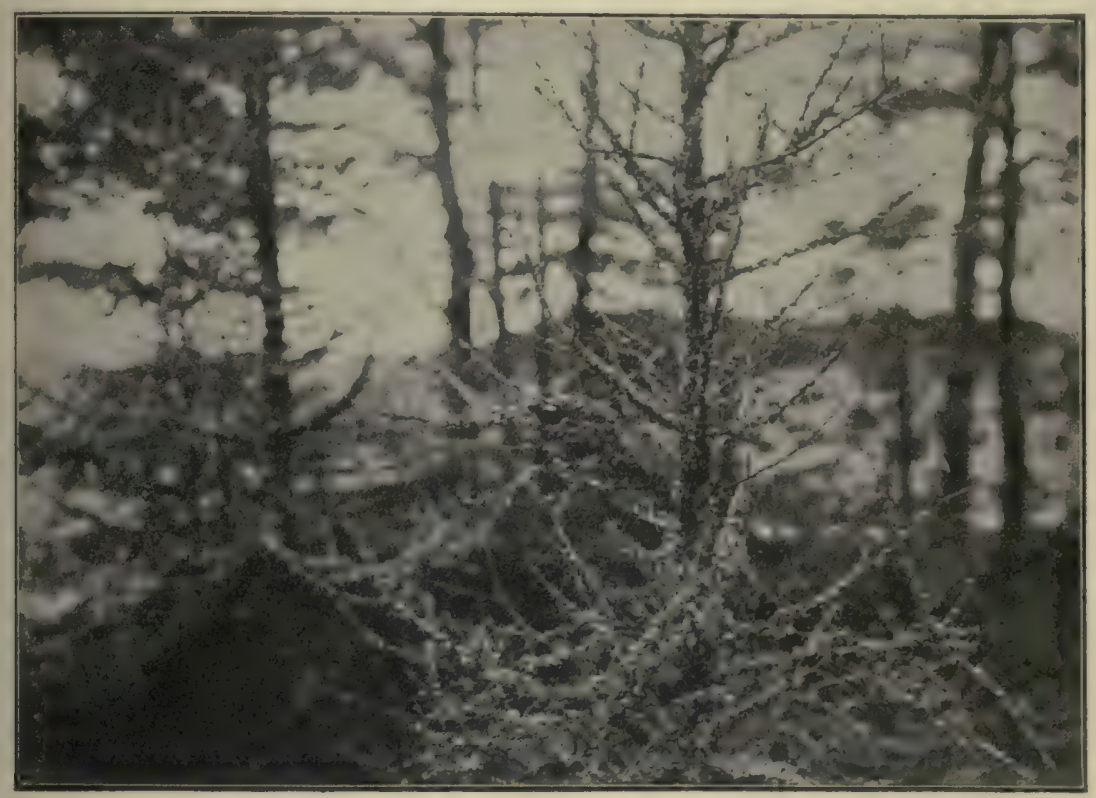

Fig. 380. Lärche in der Lüneburger Heide, unter Rohhumusbildung krankend und durch Flechtenansiedlung völlig erstickt. (Phot. P. Graebner.)

in die ganze Ökologie der Pflanzen tief eingreifende Erscheinung der Bodenmüdigkeit sind noch nicht bekannt. Die ursprüngliche Annahme, daß gewisse Nährstoffe von einer Pflanze zu stark in Anspruch genommen würden, ist sicher irrtümlich; in botanischen Gärten, wo alljährlich vielfach dieselben Pflanzen an derselben Stelle stehen müssen, die wieder alljährlich reichlich gedüngt werden, werden sie trotzdem an ihren alten Standorten kümmerlich und krank, während sie in den Randteilen üppig wachsen. Vielleicht ist die Ursache für die Bodenmüdigkeit eher in der Ansammlung bestimmter Exkretstoffe oder gewisser Bodenbakterien zu suchen. 
Eine gleichfalls auf Bodenmüdigkeit zurückzuführende Erscheinung ist die Bildung der Hexenringe, die zuerst bei den größeren Pilzen beobachtet wurde. Die einzelnen fruchtbildenden Generationen der betreffenden Arten entstehen exzentrisch nacheinander, so daß sie allmählich immer größer werdende Kreise bilden, die schließlich mehrere Meter Durchmesser haben können. Genau dieselbe Bildung kann man auch bei rasenbildenden oder kriechenden Blütenpflanzen beobachten, die Mitte stirbt aus und die Pflanzen wachsen exzentrisch weiter. In den verlassenen Kreis kehrt die betreffende Art nicht oder doch erst nach langen Jahren zurück. Auch bei einjährigen Pflanzen kann man ähnliches finden, am alten Standort verkümmern die Exemplare und verschwinden.

In eigentümlicher Weise entsteht ein neuer Boden da, wo die alte Vegetation von selbst abstirbt. Dieses geschieht bei der Calluna-Heide, da, wie es sowohl aus Jütland als auch (nach Graebner) aus Norddeutschland bekannt ist, Calluna meist nur 10-20 Jahre lebt und dann an Altersschwäche stirbt. Wenn die Calluna-Pflanzen auf großen Gebieten gleichzeitig absterben, weil sie dasselbe Alter erreicht haben, oder aus unbekannten anderen Ursachen, so tritt ein bloßer Boden auf, und die Heide verjüngt sich dann durch Keimpflanzen. Überhaupt scheint Calluna insofern eine bemerkenswerte Ausnahme zu bilden, da es anscheinend viele Generationen hintereinander an demselben Orte leben kann, ohne bodenmüde zu werden. Wenigstens gilt das für die Zentren seiner Wohngebiete; in den Gebieten lockerer Verbreitung scheint das nicht der Fall zu sein. Eine Entwicklung in entgegengesetzter Richtung geht übrigens vor sich, wo die Calluna-Heide von nährstoffreichem Wasser überrieselt wird. Schon ein Jahr nach dem Beginne der Überrieselung geht das Heidekraut aus, und nach Verlauf von 3 Jahren kann die Heide von einem Grasteppich abgelöst und der Boden, nachdem die Bodensäuren vermindert sind, von Regenwürmern bewohnt sein.

\section{Kap. Klimatogene und biogene Änderungen}

Im vorigen Kapitel wurden Beispiele von Vegetationsänderungen gegeben, von denen es einigermaßen deutlich war, daß geogene Faktoren die wirksamsten waren. Sicher haben klimatische und biogene, sowie andere Faktoren in vielen Fällen mit hineingespielt. In vielen anderen Fällen ist es weit schwieriger, die Causae efficientes festzustellen, daß aber biotische wie auch oft klimatische zusammenwirken, dürfte sicher sein. Eine Anzahl Beispiele können dafür angeführt werden.

Oft haben Arten nicht die Grenzen ihres natürlichen Areales erreicht. Es ist durch viele Tatsachen bewiesen worden, daß es viele Arten gibt, die noch wandern und durchaus nicht die Ver- 
breitung erlangt haben, welche Boden, Klima, das eigene Wanderungsvermögen und andere Verhältnisse zulassen. Solche Arten werden in vielen Vereinen siegreich aus dem Kampfe hervorgehen können, ohne daß Veränderungen in den Verhältnissen der leblosen Natur einzutreten brauchen. Im kleinen sieht man oft Beispiele von solchen Veränderungen. Es gibt z. B. auf der dänischen Insel Bornholm (in der Ostsee) wie auch zahlreich in der Lüneburger Heide usw. Zwergstrauchheiden (Calluneta), in welche Samen von den westlich davon liegenden Wäldern hineinfliegen und keimen; verschiedene junge Bäume von der Kiefer, Fichte und Birke sind jetzt in ordnungsloser Mischung und von sehr verschie-

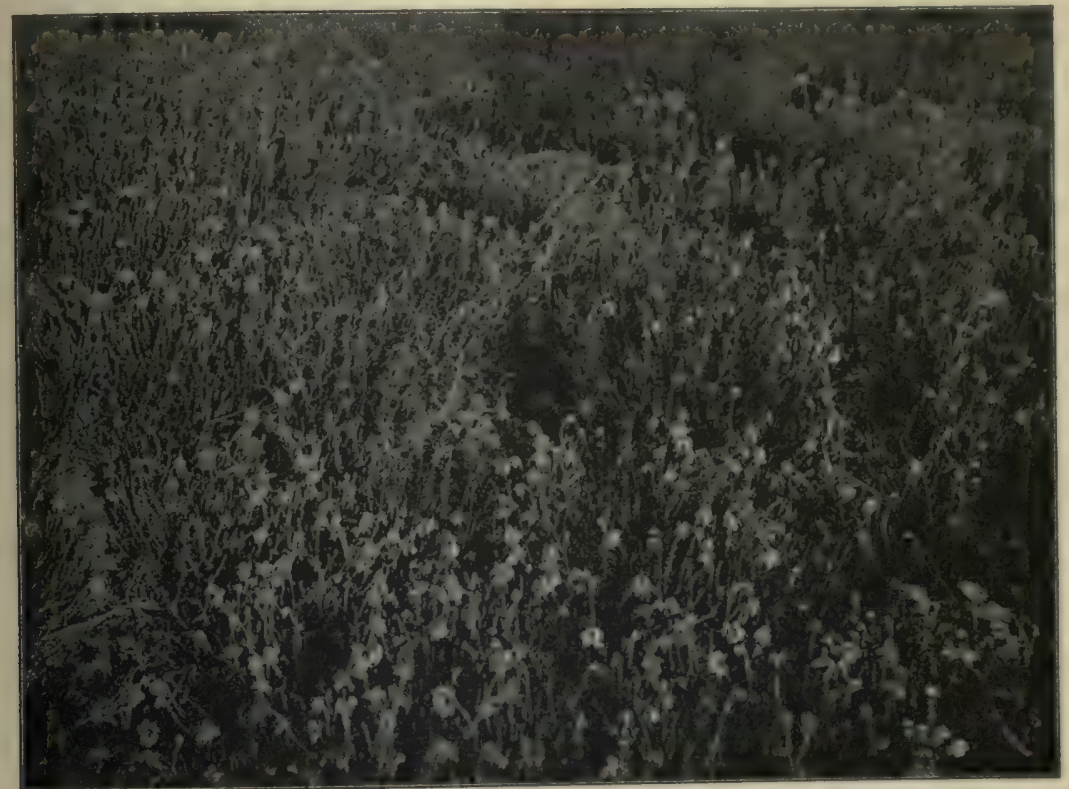

Fig. 381. Erica-Heide in Jütland als SchluBvegetation in Heidegebieten.

(Phot. Börgesen.)

denem Alter emporgewachsen; nach und nach werden die Heiden sich in Wald verwandeln, wenn nicht die bei der Heideformation besprochenen waldfeindlichen Faktoren seinen Zusammenschluß und sein Heranwachsen verhindern (vergl. Kap. 86; Fig. 302).

Viele Unkräuter wandern aus fernen Gegenden in alle Länder ein. Senecio vernalis z. B. hat sich erst seit nicht viel mehr als zwei Menschenaltern in Norddeutschland als bestandbildendes Unkraut nach Westen verbreitet $^{1}$ ). S. 829 wurden die Scharen europäischer Pflanzen erwähnt,

2) Ascherson 1863; Graebner 1907, $1909 \mathrm{~b}$; vergl. dort auch die übrigen in Deutschland eingebürgerten Arten. 
die in Argentinien eingewandert sind und hier stellenweise die ursprüngliche Vegetation verdrängt haben. Anderseits sind Pflanzen von Amerika nach Europa eingewandert und haben stellenweise unsere ursprünglichen Arten verdrängt; nordamerikanische Einwanderer sind Helodea Canadensis in unseren süßen Gewässern, Opuntia und Agave Americana in den Mittelmeerländern, und mehrere Unkräuter (Oenothera biennis, Erigeron Canadensis usw.). Auf ähnliche Weise ist eine ungeheure Menge von Arten in Neuseeland eingewandert (nach Cockayne etwa 555), und einige von ihnen unterdrücken wilde Arten des Landes, ähnlich wie bei uns Impatiens parviflora die $I$. nolitangere. Es ist natürlich notwendig, daß Klima und Boden für die einwandernden Pflanzen passen; sonst gelingt ihnen ihr Eindringen nicht, selbst wenn der Mensch sie beschützt, was z. B. aus mißlungenen Versuchen, Bäume einzuführen, hervorgeht.

In den Wäldern Nordeuropas ist vielfach ein Artenwechsel eingetreten, der noch gegenwärtig fortdauert. Steenstrups Mooruntersuchungen (1841) lehrten uns, daß in Dänemark eine Vegetation der anderen folgte (S. 662, 912). Die älteste Baumvegetation war nach seinen Untersuchungen von Birken und Zitteraspen gebildet; später wanderte die Kiefer (Pinus silvestris) ein und bildete den ersten Hochwald; nach ihr folgte die Eiche und zuletzt die jetzige, in Dänemark und südlicheren Gegenden besonders aus Buchen gebildete Waldvegetation. Diese letzte Phase des Kampfes zwischen Eiche und Buche wurde besonders durch Untersuchungen von Vaupell ${ }^{1}$ ) klargestellt, und 1870 ergänzte Nathorst die Untersuchungen Steenstrups, indem er, wie oben erwähnt, in Schonen bei Malmö die arktische Tundrenvegetation in tonigen Süßwasserablagerungen unter den Mooren und den Überresten der ersten Baumvegetation entdeckte. Hier sei ferner auf P. E. Müllers Studien ${ }^{2}$ ) über den Kampf zwischen Wald und Zwergstrauchheide hingewiesen ${ }^{3}$ ).

Welche Ursachen diese durch Jahrtausende fortgesetzten Veränderungen der Vegetation haben, ist schwierig zu sagen ${ }^{4}$ ). Es haben offenbar mehrere Faktoren zusammengewirkt. Klimatische Veränderungen haben vielleicht die wichtigste Rolle gespielt: das im ganzen milder werdende Klima, dazu das milde und feuchte Klima der Eichenperiode, nach welcher wieder eine kältere Zeit eintrat. Die zuerst eingewanderten Arten sind die im allgemeinen größere Kälte ertragenden nördlichen. $\mathrm{DaB}$ eine säkulare, großartige Wechselwirtschaft stattfinden sollte, daß die eine Art den Boden für die nachfolgende

1) Vaupell 1857, 1863.

$\left.{ }^{2}\right)$ P. E. Müller $(1878,1884), 1887$ a, 1899.

$\left.{ }^{8}\right)$ Eine übersichtliche Darstellung siehe Warming 1904.

4) Siehe auch Adams 1905. 


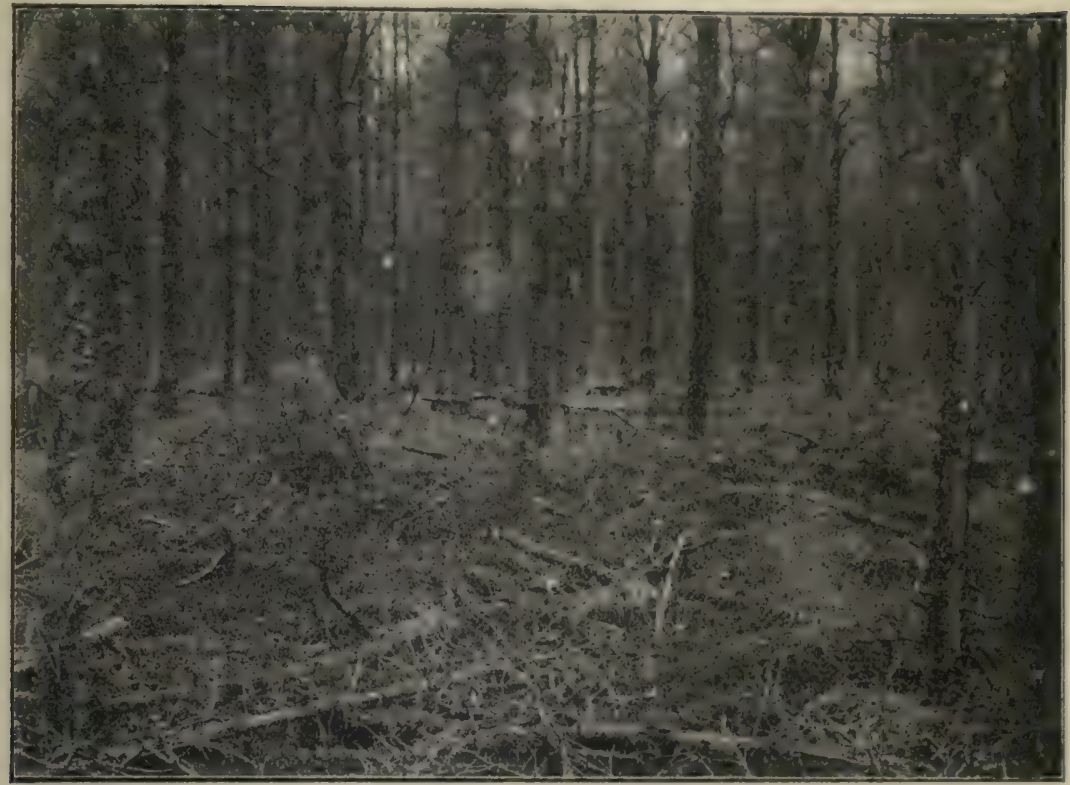

Fig. 382. Zusammenbrechender (künstlicher) Kiefernwald in der Lüneburger Heide. Der Boden ist bereits ganz mit (im Schatten noch nicht blühendem) Heidekraut bedeckt. (Phot. P. Graebner.)

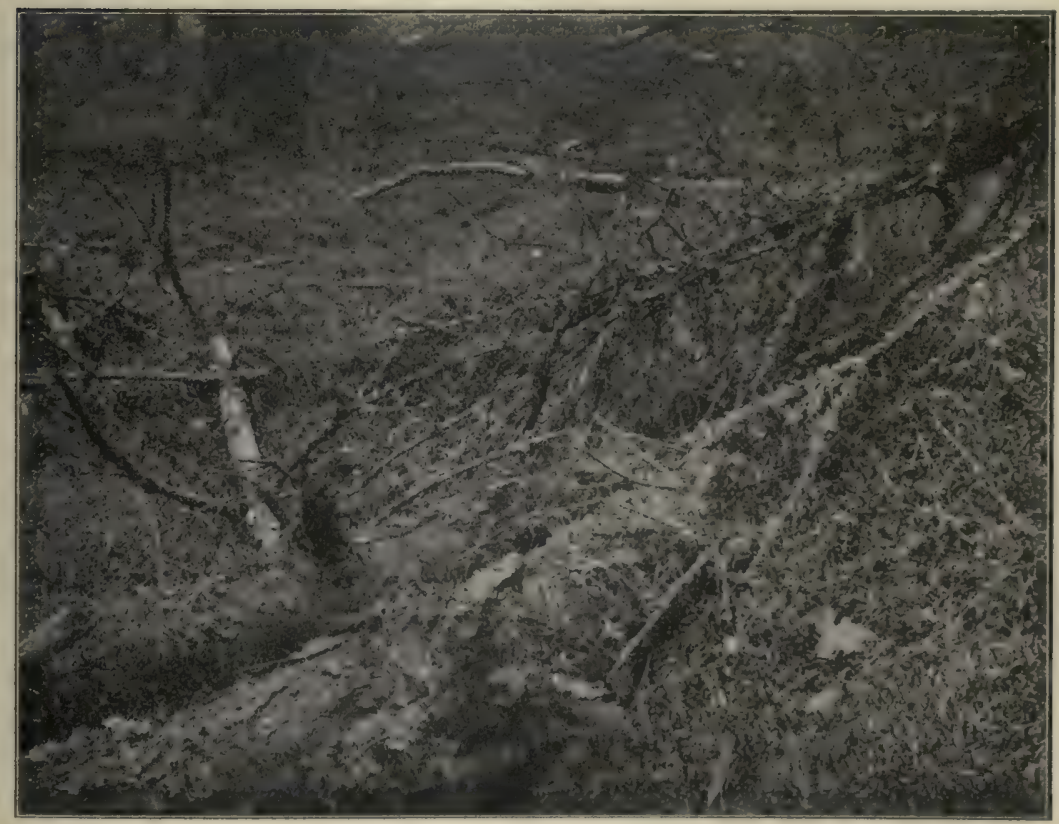

Fig. 383. Die umgestürzten Stämme des Bestandes (Fig. 382) werden von MIoos und Heidekraut überwuchert. (Phot. P. Graebner.) 
passender und für sich selbst weniger passend machen würde („Bodenmüdigkeit"), ebenso wie dieses gewisse niedrige Organismen tun, ist wenigstens bezüglich großer Landstriche recht wahrscheinlich. Es wird unter gewissen Bedingungen eine fortgesetzte Veränderung des Bodens durch Anhäufen von Humus, wenn eine Abfuhr der die Hauptnährstoffe des Bodens enthaltenden Pflanzenteile (in Gestalt von Ernte jeder Art, Heu oder Holz) nicht stattfindet, die anspruchsvolleren Arten auf Kosten der zuerst auftretenden genügsamen Arten begünstigen, oder anderseits durch Bodenverschlechterung (Rohhumus usw.) die anspruchsvolleren Arten vertreiben und den anspruchslosen (Heide usw.) den Platz schaffen. Zu den anspruchsvolleren Waldbäumen gehören Eiche und Rotbuche, während Birke und Kiefer genügsam sind (vergl. auch Fig. 385). Ferner ist die W anderungsfähigkeit der Arten sehr verschieden. Birke, Espe und Kiefer haben leichte, mit Flügeln oder Haaren zum Windtransport eingerichtete Samen, sie wanderten daher zuerst ein; die der Eiche und Buche sind viel schwerer und für Wanderungen weit weniger geeignet. Dazu kommt, daß Birke und auch Espe schon in recht jugendlichem Alter als Sträucher reichlich fruchten können; älter muß schon die Kiefer werden. Die Eiche braucht im allgemeinen mehrere Jahrzehnte, und die Buche muß fast ein halbes Jahrhundert alt werden, ehe sie reichlich zu fruchten vermag ${ }^{1}$ ).

Es kann weiter nicht zweifelhaft sein, daß auch das verschiedene Verhältnis der Bäume zum Lichte (vergl. 2. Kap.) eine wichtige Rolle gespielt hat. Für die Kämpfe zwischen Eiche und Rotbuche in Dänemark ist ferner die Tätigkeit des Menschen (Fällen von Bäumen, Trockenlegen und Grabenziehen) von Bedeutung gewesen und hat der Rotbuche fortgeholfen, so daß sich die Eiche nur an feuchteren Stellen und in mageren Gegenden Jütlands hat halten können. An diesen Stellen gedeiht die Buche nicht gut, sie erreicht eine geringere Höhe und reift die Samen schlecht; dadurch erhält die Eiche das Übergewicht. Auf Sandboden bildet die Buche überdies leicht Rohhumus und wird außer stande, sich zu verjüngen. Noch hat die Buche anscheinend nicht ihr durch das Klima begrenztes Gebiet erobert; sie schreitet noch nordwärts, z. B. im südlichen Norwegen, fort.

In einer Reihe von Jahrhunderten ist die Calluna-Heide in Dänemark und Norddeutschland auf Kosten der Wälder vorgedrungen. Jütland war früher von Eichenwäldern bedeckt, kaum jedoch ein zusammenhängender Wald, die Lüneburger Heide trug Eichen-, Buchenund Mischwälder; jetzt sind die Eichengestrüppe der Heiden fast die einzigen Erinnerungszeichen des Waldes. Die Auslaugung der oberen Schichten des Bodens durch die Niederschläge muß zuerst einen ziemlich hohen Grad erreicht haben, wenn die Erneuerung des Waldes ver-

3) Graebner 1912 a. 
hindert wird und die Calluna-Heide an seine Stelle tritt ${ }^{1}$ ). Dann wirken andere Faktoren oft plötzlich der Heide den Sieg verschaffend ein. Rücksichtsloses und unkundiges Holzfällen, die Benutzung des Holzes zu der in Jütland im Mittelalter in großem Maßstabe betriebenen Gewinnung von Eisen aus Raseneisenstein oder zur Salzgewinnung in Lüneburg und der Westwind haben den Wald ausgerottet. Sobald der Boden austrocknet, entsteht eine Decke von Rohhumus, und die Vegetation verändert sich, wie P. E. Müller nachgewiesen hat ${ }^{2}$ ). Die Regenwürmer verschwinden, die Erde wird fester. In der Rohhumusschicht

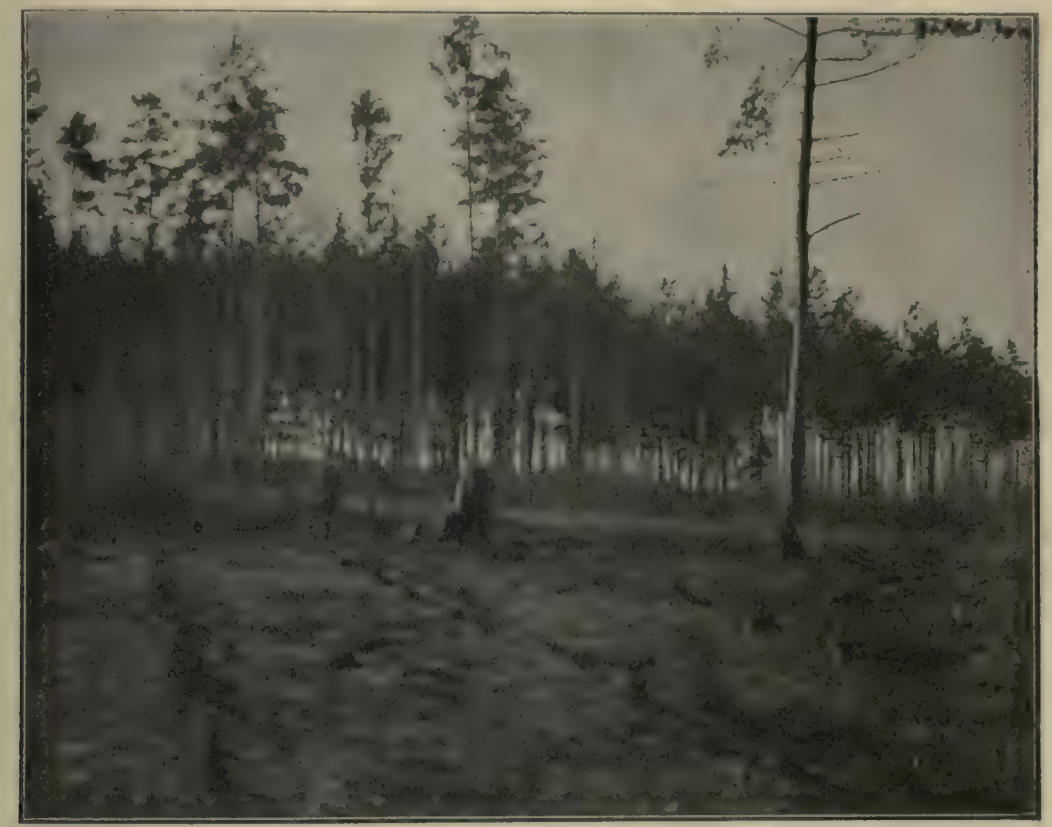

Fig. 384. Infolge von selbstgebildetem Rohhumus absterbender Fichtenwald. Die krankenden (schüttekranken) Fichten haben nur noch oberflächlich tätige W urzeln, werden daher vom Winde umgestürzt. (Phot. P. Graebner.)

entstehen Humussäuren, und in dem Untergrunde infolge der ausschlämmenden Wirkung des Regenwassers die bekannten Schichten des Bleisandes und schließlich vielfach auch des Ortsteines (Kap. 86). Die Bodenvegetation des Waldes wird gleichzeitig eine ganz andere. In dem humusreichen Buchenwalde wächst die S. 561 besprochene Vegetation von Anemone, Corydallis, Asperula odorata usw. Wird der Boden Rohhumus, so wandert die S. 564 erwähnte Vegetation von Aera caespitosa, Trientalis, Majanthemum usw. ein, und der Boden ist für

1) Graebner 1895, 1896, 1901; vergl. auch Kap. 86 .

2) P. E. Müller 1887 a, 1899. 
Calluna vulgaris besonders gut passend. Allmählich wandert diese ein und wandelt, da die natürliche Verjüngung der Buche auf diesem Boden besonders wegen des Luftabschlusses und vielfach auch der Nährstoffarmut der oberen Schichten unmöglich wird, die Vegetation in eine Heide um (Kap. 86). Diese Veränderung geht besonders auf den windigen Hügeln und auf den Westseiten der Wälder vor sich (Fig. 384).

Sowohl der Eichenwald als auch der Buchenwald unterliegen in dem Kampf mit dem Heidekraute, wenn auf dem ausgelaugten Boden das Holzfällen in ihnen dem Winde Spielraum verschafft. Ist der Boden

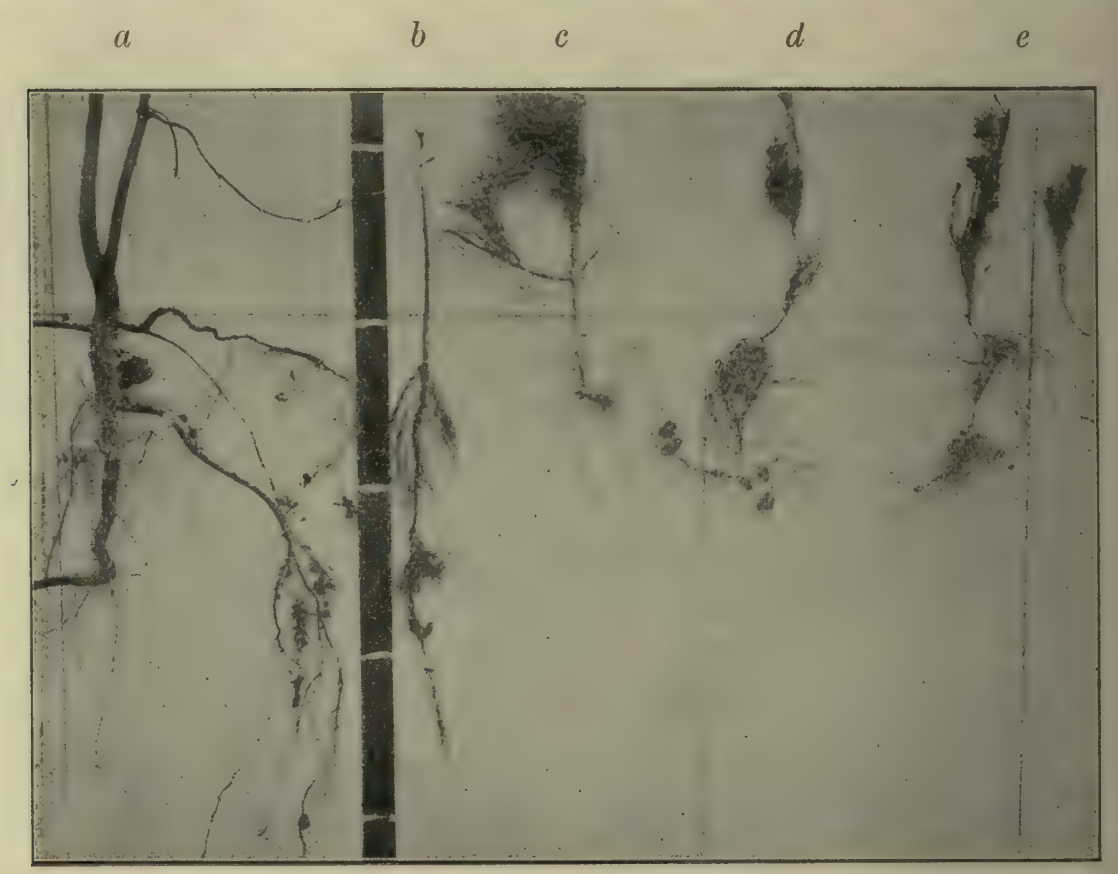

Fig. 385. Gehölzsämlinge auf demselben Rohhumusboden mit sehr verschiedener Wurzeltiefe. $a, b$ Buche, $a$ ältere, durch die verdichteten Schichten beeinfluBt; $c, d$ Kiefer; $e$ Fichte. Der Mabstab in dm. (Phot. P. Graebner.)

nicht ausgelaugt, sondern bis in die oberen Schichten noch ziemlich nährstoffreich, dann veranlaßt auch falsche Waldwirtschaft und Wind keine Heidebildung, sondern wenn durch zu starken Wind oder Trockenheit die Bewaldung gehindert wird, entstehen in Norddeutschland die bekannten vielen südosteuropäischen naheverwandten Busch-, Steppen-, Gestrüpp- oder Staudenvereine unserer sonnigen (pontischen) Hügel.

In reinen Nadelwaldungen geht der Rückgang des Baumbestandes meist viel schneller vor sich; durch die dauernde Schüttung der Nadeln auf dem flachen Gelände der feuchteren nordwesteuropäischen Gebiete bildet sich sehr bald eine so starke luftundurchlässige Rohhumusschicht, 
daß oft schon die zweite Generation so flach wurzeln muß, daß sie dem Winde nicht standhalten kann ${ }^{1}$ ).

Eine andere Art, die stellenweise auch noch nicht ihre natürlichen Grenzen erreicht hat und noch weiter nach Westen wandert, ist die Fichte (Picea excelsa). Sie ist auf der skandinavischen Halbinsel von Osten eingewandert und nach Süden vorgedrungen, hat aber Südwestschweden und Dänemark noch nicht erreicht. An mehreren Stellen ist sie in Norwegen durch die Pässe eingedrungen (Gloersen) und hat die

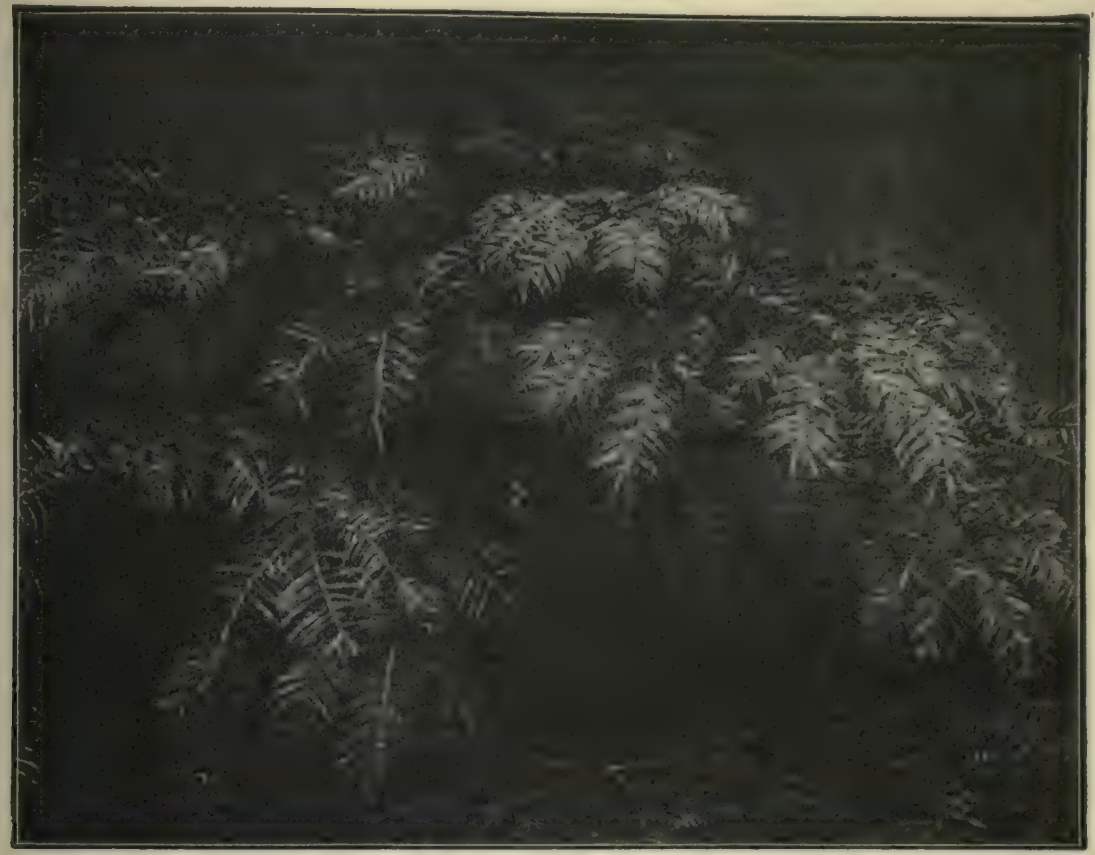

Fig. 386. Fichte im tiefen Schatten erwachsen, breiter als hoch.

Durch die Fähigkeit, Jahrzehnte lang tiefen Schatten zu ertragen, imstande bei späterer Lichtstellung sofort in die Lücke zu wachsen und dadurch den erst als Sämlinge aufwachsenden Lichtpflanzen erfolgreich Konkurrenz zu machen (vergl. S. 20, 30). (Phot. P. Graebner.)

Kiefer verdrängt, hat jedoch nicht überallhin gelangen können, so daß die Verbreitung merkwürdige Lücken zeigt. $\mathrm{DaB}$ sie die Kiefer besiegen kann, beruht besonders auf ihrer größeren Abhärtung und ihrer Fähigkeit, Schatten zu ertragen (näheres bei G. Andersson; Fig. 386), sowie daß sie durch ihren dichten Schatten alles andere erdrücken kann. Im südwestlichen Schweden ist sie der von Südwesten einwandernden

1) Vergl. Bentheim bei Graebner 1904. 
Buche begegnet, und der Kampf zwischen diesen beiden Arten ist hier stehend ${ }^{1}$ ).

Die Entwicklungsgeschichte der Vegetation Europas ist von vielen Botanikern behandelt worden, namentlich Ad. Engler 1879-82, G. Andersson 1896, Clemens Reid, Marie Jerosch 1903, Graebner 1912, A. Blytt 1882, 1893, Sernander 1896 usw.

Von vielen anderen Ländern liegen Beobachtungen über ähnliche Kämpfe zwischen verschiedenen Baumarten vor, und nicht überall ist das Ergebnis dasselbe für dieselben Arten, die miteinander kämpfen. Das hängt von den ökologischen Bedingungen ab. Innerhalb ihres Hauptverbreitungsgebietes, sagt Mayr, sind die meisten Holzarten bodenvag, d. h. können auf sehr verschiedenen Standorten ihr Fortkommen finden, aber außerhalb desselben sind sie an einen Standort von bestimmter Beschaffenheit gebunden. Dasselbe ist für Pflanzen der Heide, der sonnigen Hügel und anderer an bestimmte klimatische oder Bodenverbältnisse gebundenen Formationen konstatiert worden.

SchluBvegetation ("Klimax-Vegetation“). 1895 schrieb Warming in der ersten (dänischen) Auflage dieses Buches folgendes: Auf jedem Gebiete gehen ganz gewiß langsame, für uns vielleicht nur in großen Zeiträumen wahrnehmbare Vegetationsveränderungen vor sich, die durch die Kämpfe zwischen den Arten entstehen, ohne daß gewöhnlich die physikalischen Verhältnisse verändert werden. Keine Assoziation ist ewig unverändert, ist etwas Fertiges. Man muß diese Überzeugung gewinnen, wenn man sieht, wie die verschiedenen Assoziationen in einer langen Reihe aufeinander folgen können, nachdem einmal ein Gebiet neuen Bodens bloßgelegt worden war. Es kann auf das von Hult geschilderte Gebiet von Blekinge in Südschweden hingewiesen werden, dessen meiste "Vegetationsformationen nur Zwischenstadien für einige wenige Schlußglieder sind, deren Verteilung über das Gebiet schließlich vom Boden bestimmt wird". Man muß jedoch annehmen, daß die besprochenen Kämpfe in sehr alten Ländern selten seien, deren Vegetation nicht in nennenswertem Grade von Menschen oder Tieren beeinflußt wird und die in sehr langen Zeiträumen der Einwanderung von Arten aus den Nachbarländern ausgesetzt gewesen sind; hier muß zuletzt ein gewisser Gleichgewichtszustand erreicht werden. Denn die allermeisten Vegetationsveränderungen, die wir eintreten sehen, z. B. die vielen Veränderungen in der Waldvegetation, von denen aus den verschiedensten Gegenden der Erde berichtet wird, wurden sicherlich durch physikalische Veränderungen verursacht, die in neuerer Zeit stattgefunden hatten, namentlich durch Veränderungen, welche die Zerstörung des Waldes durch den Menschen hervorgerufen hatte. Einige Veränderungen in der Natur der Wälder werden wohl einfach durch die Einwanderung neuer

1) Hult 1885 . 


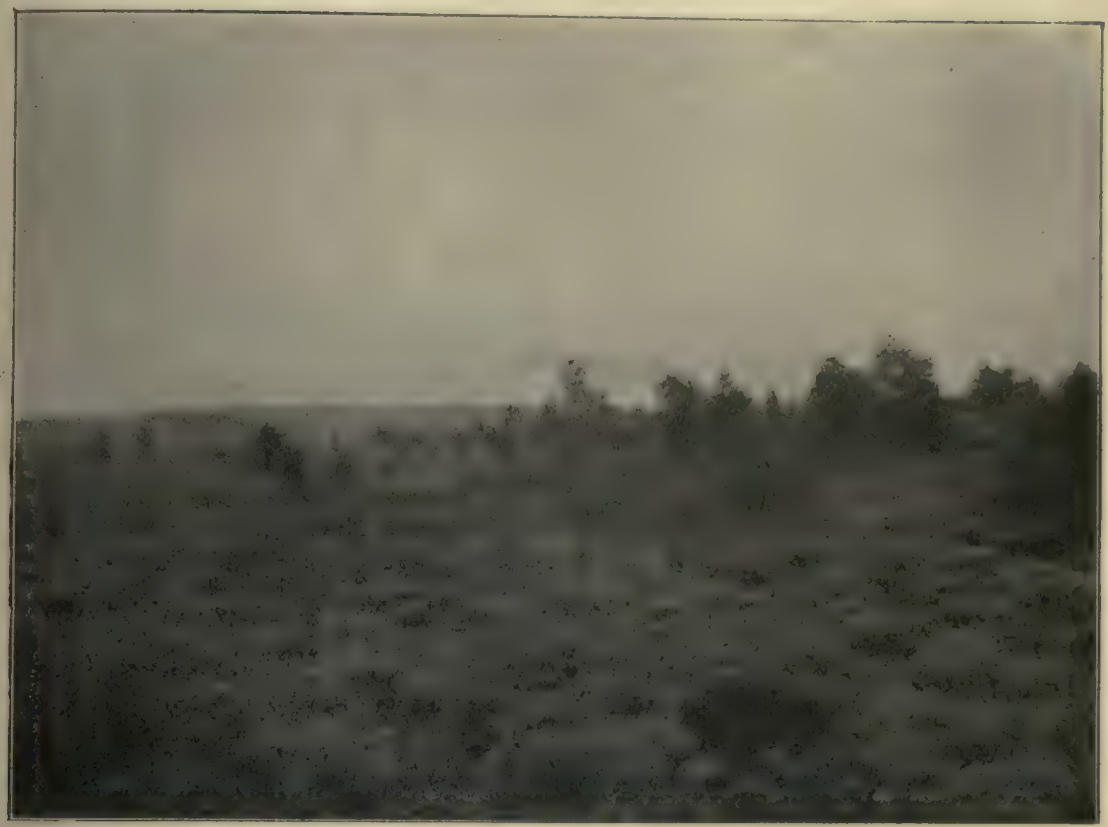

Fig. 387. Rand des Bestandes von Fig. 388 gegen die freie Heide. Munster in der Lüneburger Heide (vergl, auch Fig. 298 ff.). (Phot. P. Graebner.)

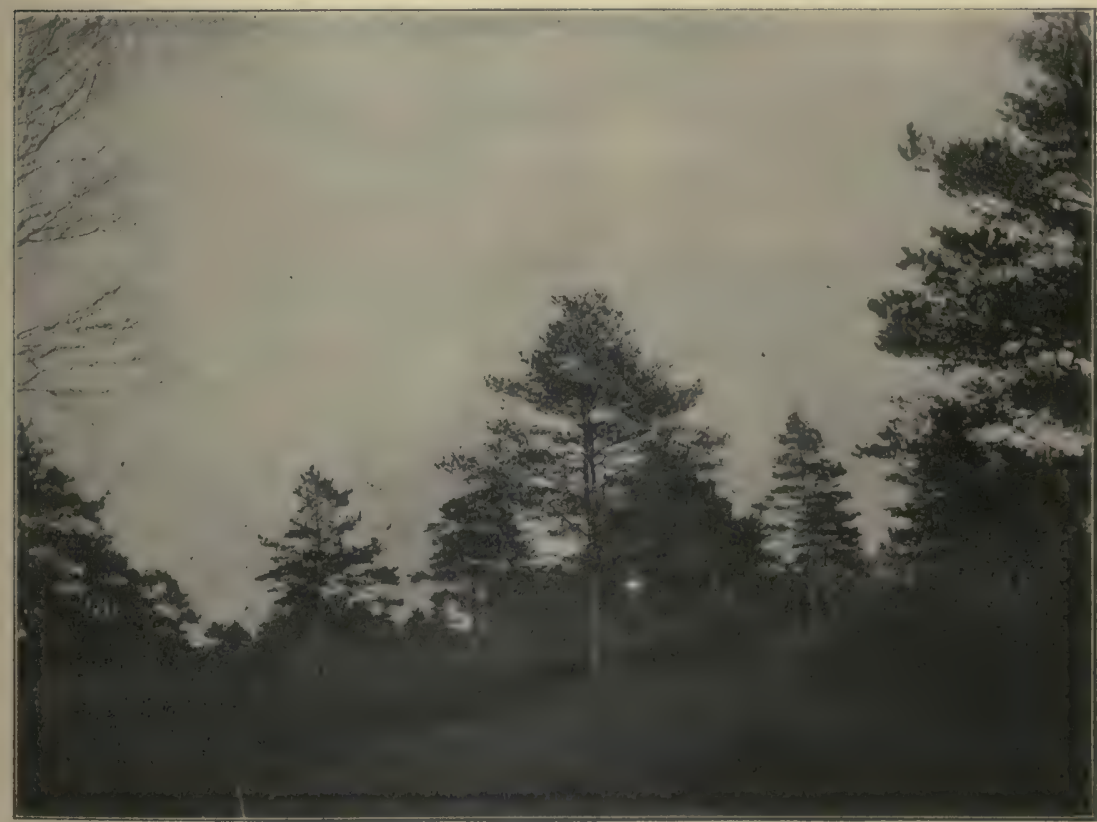

Fig. 388. Kampf zwischen Kiefernwald und Heide. Einige Bäume, besonders der große mittlere, sterben ohne ersichtlichen Grund wieder ab. (Phot. P. Graebner.) 
Arten verursacht; vielleicht sind so die Waldveränderungen aufzufassen, die in Rußland vor sich gehen, wo die Eiche nach Korzchinsky ${ }^{1}$ ) früher oder später von der Rotbuche verdrängt werden wird und wo sogar diese von der Fichte verdrängt werden soll, und ebenso die entsprechenden Veränderungen in Norddeutschland ${ }^{2}$ ).

Überläßt man die Vegetation eines größeren Gebietes ganz sich selbst, so wird zweifellos auf einem gewissen Terrain eine bestimmte Formation zuletzt, nachdem eine hinreichend lange Zeit vergangen war, alle anderen verdrängen und das Schlußglied der Entwicklung bilden.

Auf S. 922 wurde der Sieg der Ericaceen-Heide über den Wald behandelt. Borggreve und E. H. L. Krause ${ }^{3}$ ) haben die Heide als eine "Halbkulturform" bezeichnet, die nur der menschlichen Kultur (Plaggenwirtschaft, Schafweide) ihr Auftreten verdanke; dieses ist jedoch nicht richtig. Die Ericaceen-Heide ist an gewissen Stellen Nordeuropas sicherlich eine natürliche Schlußvegetation, nicht nur auf den Bergabhängen von Blekinge in Schweden, sondern selbst auf dem mageren Sandboden Westjütlands; sie ist gewiß ebenso ursprünglich und natürlich wie der Eichenwald; in Jütland wie in Nordwestdeutschland ist es sicher, daß sie schon im Steinalter existierte ${ }^{4}$ ). Etwas anderes ist es selbstverständlich, daß sie sich gerade durch die Hilfe der Kultur auf Kosten des Waldes bedeutend ausgebreitet hat. Beachtenswert sind die Beobachtungen, daß die (wohl stets künstliche) Ericaceen-Heide stellenweise vom Walde verdrängt wird (vergl. auch oben, S. 670, Fig. 302: Bornholm).

Als andere Schlußglieder in Blekinge führt Hult namentlich folgende Vegetationstypen an: 1. Kiefernwälder auf trockenem Sande, auf Moränenboden mit Geschieben und auf Torfmooren; 2. Fichtenwälder auf wenig mächtigen Strandmooren; 3. Birkenwälder der Betula pubescens auf tieferen Mooren und auf Wiesenmooren; 4. die „Haintälchenformation" an Flüssen und Quellen; 5. Dorngebüsch auf den wärmsten, trockenen Stellen, und 6. Buchenwälder auf jedem anderen Boden. Alle übrigen „Formationen" verwandeln sich allmählich, nicht nur die Grasfluren, sondern auch die Menyanthes- „Formation“, die Sümpfe und die Wiesenmoore; "sogar auf den F'elsen entwickelt sich eine lange Reihe von Übergangsbildungen", ehe sich die abschließende Waldvegetation einfindet (Hult 1885).

1) Korzchinsky 1891 .

2) Vergl. Grisebach 1872 und Göppert; später C. A. Weber, Graebner u. a.

3) Borggreve 1872; E. Krause 1892.

4) Sarauw 1898; unter einigen der „Steinhäuser“ der Lüneburger Heide liegt echter Heideortstein. 
Mit Ausnahme des Dorngebüsches sind alle anderen SchluBglieder dieser Vegetationsformationen Wälder, also Bestände, deren Verteilung im Gelände von der Beschaffenheit des Bodens abhängt. Der Wald ist in allen Gegenden das natürliche SchluBglied in der Entwicklung der Vegetation, ausgenommen da, wo Felsenboden, Nährstoffmangel, Wasser, Kälte oder Trockenheit (Wassermangel, Wind) die Entwicklung der Bäume verhindern. An solchen Stellen werden Felsenflur, Zwergstrauchheide, Tundra, Wiese, Steppe, Wüste, Gestrüpp und andere Vereine die Schlußglieder der Vegetation bilden.

Alle diese Fragen sind in neuester Zeit eifrig studiert worden, namentlich in Dänemark, Mitteleuropa, Großbritannien und Nordamerika; vergl. z. B. Kerner 1863; Whitford 1901; Cowles $1901 \mathrm{~b}$; Clements und andere nordamerikanische Botaniker, sowie auch englische (Moss, Tansley, Crampton). In Großbritannien z.B. von Crampton ${ }^{1}$ ), der zwischen "migratory formations" und "stable formations" unterscheidet; "migratory" sind diejenigen, welche sich leicht verändern, weil sie dem Einflusse von geologischen Änderungen der Oberfläche ausgesetzt sind, "stable“ diejenigen, deren Verbreitungszentrum in einer langen Periode verhältnismäßig unverändert geblieben ist, „from the geological standpoint and under climatic conditions favourable to the type of vegetation"; er hat vier Haupttypen von „stable formations“, nämlich Moorvegetation, Wälder, Heiden und Grasland („Moorland", „Woodland“, „Heathland", „Grassland"). Andere britische Forscher sind Oliver und seine Schüler, Darbishire, Moss, Tansley usw. Es ist in Kap. 30 erwähnt worden, daß Moss u. a. sogar alle Vereinstypen, welche genetisch verbunden werden können, als Phasen einer einzigen Formation betrachten. In der englischen Zeitschrift „Journal of ecology" hat die Ökologie ein vorzügliches Organ gefunden.

Namentlich ist die "dynamische Pflanzengeographie“ in ausgedehntem Maßstabe und von einer großen Anzahl von Botanikern nach dem Vorgange von Cowles und Clements studiert worden, und unter dem, dem deutschen Begriffe der Folgeformationen entsprechenden, Schlagworte "Successions" ein beliebtes Studium geworden. Als erste größere Arbeit von Cowles muß wohl seine Arbeit von 1899 über die "Successions" in der Vegetation der Sanddünen am Michigan-See genannt werden. Er unterscheidet im übrigen zwischen 1. "regional successions", d. h. solchen Vegetationsänderungen, welche durch säkuläre, also wesentlich klimatische Änderungen hervorgerufen werden, z. B. die postglazialen Verschiebungen der Vegetationstypen; 2. "topographic successions", welche viel schneller verlaufen und von topographischen Veränderungen abhängen, also Veränderungen des Bodens, sie sind progressive oder

1) Crampton 1912.

Warming-Graebner. 8. Auflage, illuetr. 
regressive; und 3. "biotic successions", welche durch andere lebende Wesen verursacht werden, also auch alle durch Menschen hervorgerufene.

Vergl. ferner Cowles 1911. Die Moos-Folgevereine studierte ferner Clements ${ }^{2}$, der zwischen "primären“, die auf Neuland anfangen, und "sekundären“, welche durch Störungen einer primären Lokalitït anfangen, scheidet; und von anderen amerikanischen Verfassern z. B. Cooper ${ }^{2}$ ), der die Successionen auf Isle Royale, welche zu einer Klimaxvegetation hinauf führen, in "xerarche" und "hydrarche" teilt, je nachdem sie auf xerophytischem oder hydrophytischem Standorte anfangen, um sich mehr und mehr mesophytisch auszubilden. Ferner Brunckin 1902; Chrysler 1905; Fuller ${ }^{8}$ ), der über die Bedeutung der Verdunstung für die Vegetationsänderungen schrieb und durch geeignete Methoden und Instrumente die Verdunstung in den verschiedenen Assoziationen erlauterte; Harvey 1908; Pool 1913; Livingston (siehe Litteraturliste); Mac Millan (Pop. Sc. Rev. VI); Harper 1905; Transeau 1905 a, 1906; Whitford 1901; Adams 1905 .

Auch von vielen anderen Llindern liegen Untersuchungen vor über Kintwicklungsfolge von Vegetationstypen; außer den schon oben genannten Forschern können genaunt werden z. B.: aus Schweden von Sernander, Malme, J. E. Ljungquist 1914; aus Dünemark von Warming 1890,1891, 1906, 1909; aus Rußland Paczoski 1893, Krassnoff $\left.1888^{4}\right)$.

Siehe ferner: Cockayne (Tongariro National Park) und 1911; A. Nilsson 1899; Raunkiła 1902, 1914; Briggs and Schantz.

\section{Kap. Allgemeine Sätze über Besiedlung von Neuland. Waffen der Arten in ihren Kämpfen. Seltene Arten}

In der ersten (dänischen) Ausgabe (1895) dieses Buches schrieb Warning: Es ist schwierig, schon jetzt etwas Allgemeines über die auf einem neuen Boden auftretende Vegetation zu sagen, weil es darüber wenige eingehende Untersuchungen gibt; noch jetzt ist es schwierig, mehr zu sagen als er damals wagte, nämlich:

1. Die erste Vegetation auf neuem Boden ist offen. Es vergeht immer einige Zeit, bevor sich eine zusammenhängende Vegetationsdecke bildet. Die Individuen stehen anfangs sehr zerstreut, aber allmählich wird ihre Menge größer. Es kann noch hinzugefügt werden, daß sehr oft die niedrigsten, durch Sporen verbreiteten Pflanzen zu den ersten gehören; z. B. auf Krakatau waren es Algen, namentlich blaugrïne; ebensolche sind es an den Sandküsten (S. 389, 433); auf Felsen sind Algen und Flechten die ersten Bewohner.

2. Die Artenzahl ist anfangs gering, wächst jedoch und ist nach Verlauf einer gewissen Zeit größer als später, indem viele Arten anfänglich einen giuustigen Platz finden, aber später verdrängt werden,

2) Clements 1904, 1905, 1907.

3) Cooper 1912, 1913; siehe auch Journ. Ecol. I, 148.

2) Fuller 1911, 1914.

4) Nach Actes du Congrès international de Botanique de Bruxelles 1910. 
wenn sich die Decke schließt und sich tyrannischere Arten eingefunden haben. Verschiedene Teile des neu bewachsenen Geländes werden sich oft sehr ungleichartig mit Pflanzen bedecken. Allmählich wird die Vegetation gleichartiger und artenärmer.

3. Sehr oft werden ein- und zweijährige Arten zuerst viel zahlreicher als später sein, indem sie auf dem offenen Gelände gilnstigere Bedingungen finden als auf dem bedeckten; viele werden der Unkrautflora der Gegend angehören. Darauf werden die mehrjährigen Kräuter und zuletzt vielleicht die Holzpflanzen uberwiegen.

4. Die zuerst einwandernden Arten werden die sein, welche in der Nähe vorkommen und die besten Mittel für die Verbreitung durch Wind oder Vögel haben. Die Geröllhalden der Alpen werden zuerst von Arten mit fliegenden Samen besiedelt ${ }^{1}$ ). Wird in Norwegen ein Nadelwald zersört, so wandern zuerst Birke und Pappel (leichter fliegende Früchte und Samen) nebst Sorbus (Beeren) ein ${ }^{2}$ ).

5. Handelt es sich um die Einwanderung von Bäumen, so werden die Lichtbäume oft vor den Schatten ertragenden erscheinen; das Umgekehrte kann nicht stattfinden. Sträucher werden von Bäumen unterdrickt.

6. Die Ausbildung zu ausgeprägten Formationen geht allmählich vor sich. Die ersten, miteinander gemischten Individuen gehören in Wirklichkeit zu verschiedenen natürlichen Assoziationen, event. Formationen, die sich erst nach und nach auf die passendsten Standorte verteilen. Man kann demnach von Anfangs-, Utbergangs- und Schlußassoziationen (Klimaxvereinen) sprechen.

Clements hat hinzugefügt: „Die Zahl der Arten und Individuen in jedem Stadium (Formation) nimmt konstant $\mathrm{zu}$ bis zu einem Maximum, von da an nimmt sie nach und nach ab vor den Formen des nächsten Stadiums. Das Intervall zwischen zwei Maximis wird von einer gemischten Formation eingenommen. Eine sekundäre Succession beginnt nicht mit dem Anfangsstadium der primären, die sie ersetzt, sondern gewöhnlich mit einer viel späteren ${ }^{\text {" }}$ ).

Von dem Angeführten gibt es natürlich Ausnahmen, wie nachstehendes zeigt.

Einjährige Pflanzen können unter Umstånden später einen günstigeren Standort erlangen als anfangs. Fliche hat eine gedankenreiche

1) Kerner 1868; Vogler 1901 b.

2) Blytt 1882; Hult 1885.

) Rübels Ubersetzung 1913 im Handwörterbuch der Naturwissenschaften. Vergl. unch die Bemerkungen und Darstellung Rübels. Vergl. weiter Clements 1904, 1905, 1907 , in welchem letzten Werke er auch einen Paragraphen mit "The laws of succession" verfaßt hat. (Siehe ferner 1916 am Ende dieses Buches.) 
Schilderung der Veränderung gegeben, die im Laufe der Zeit mit den jungen Waldpflanzungen bei Champfêtu vor sich gingen ${ }^{1}$ ). Zuerst war der junge Wald so hell, daß eine kräftige, dichte Vegetation mehrjähriger, geselliger Arten nebst Moosen auftreten konnte. Nach und nach vermehrte sich die Anzahl der Holzpflanzenarten; Quercus, Carpinus und Fagus überwuchsen die anderen, schwächten oder unterdrückten die Bodenvegetation. Da sich der Boden gleichzeitig veränderte, je nach der Menge des Waldabfalles in verschiedener Weise, so fanden die einjährigen Arten in diesem gemischten Walde immer günstigere Standorte.

Die Kampfwaffen der Arten. In nächster Verbindung mit der hier besprochenen Frage über Besiedlung von Neuland und der Kämpfe zwischen den Pflanzen steht die Frage nach den Mitteln, durch welche eine Art die andere verdrängt. Es gibt kaum eine anziehendere ökologische Aufgabe als diese; aber sie ist noch äußerst wenig studiert worden; der erste Schritt ist, die faktisch vorkommenden und vielfach beobachteten Vegetationsänderungen festzustellen; der nächste und schwierigste ist aber, die causae efficientes klarzulegen. Ein weites und besonders anziehendes Arbeitsfeld liegt hier der Forschung offen. Noch sind wir überaus weit davon entfernt, die Fragen auch nur für eine einzige Art zufriedenstellend gelöst zu haben; z. B. verstehen wir den Kampf der Buche mit der Eiche nicht vollständig. Selbstverständlich kann man nicht bei einem solchen Gerede stehen bleiben, wie bei dem, daß Platzmangel entscheidend wäre, oder daß sich im Pflanzenreiche wie in allen anderen Vereinen um die Nahrungsfrage alles drehe. Denn wissenschaftlich betrachtet lösen sich diese Rendensarten in eine Reihe der schwierigsten Fragen auf, welche die Wissenschaft stellen kann und welche allseitige Untersuchungen erforden werden, bevor sie beantwortet werden können: Ist es der Mangel eines oder des anderen Nahrungsstoffes oder des Wassers im Boden, oder die zu große Menge eines anderen Stoffes, ist es Mangel an Wärme oder an Licht oder an einer passenden Vereinigung beider, oder können Wurzeln und Rhizome so dicht zusammen wachsen, daß sie rein mechanisch anderen Pflanzen den Weg versperren, oder können auch bei den höheren Pflanzen, wie bei gewissen Bakterien und Schimmelpilzen, chemische Stoffe von den Wurzeln ausgeschieden werden, welche für die sie erzeugenden oder für andere Arten giftig sind? usw.

Wir sehen wie die einjährigen Kräuter auf dem vor kurzem bloßgelegten Boden, worauf sie sich niedergelassen hatten, durch mehrjährige verdrängt werden; aber mit welcher Waffe diese siegen, können wir nicht

1) Fliche 1883. 
mit Sicherheit sagen. Wir sehen vielfach die kieselliebende Vegetation der "Sandes" (Ornithopus perpusillus, Teesdalia, Spergula, Rumex acetosella, Pteridium aquilinum u. a.) verschwinden, wenn auf die mageren Fluren Kalk gebracht wird (der entweder selbst Nährstoffe mitführt oder doch die vorhandenen leichter zugänglich macht), und sehen wie sie allmählich wiederkehren, je nachdem das kohlensäurehaltige Wasser den Kalk auflöst oder wegschafft; aber wir kennen den tieferen Grund dafür nicht.

Das Zusammenleben zwischen den lebenden Wesen ist in Wirklichkeit so verwickelt, mannigfaltig und reich, und die vielen Glieder sind so eng verknüpft, daß Veränderungen an einem Punkte weit reichende Veränderungen an anderen herbeiführen können. Hier ist für den Forscher genug zu tun.

Eine interessante Arbeit über den Einfluß des Schattens auf die Verteilung der Kräuter haben Stebler und Volkart ${ }^{1}$ ) publiziert. Aber nicht nur die mannigfaltigen Verbältnisse der Arten zu den im ersten Abschnitte behandelten ökoløgischen Faktoren (Licht, Wasser, Wärme usw.) spielen bei diesen Veränderungen eine Rolle, sondern auch die verschiedenen biologischen Eigentümlichkeiten der Lebensformen, von denen man nicht sagen kann, daß sie eine unmittelbare Folge jener Faktoren seien, z. B. der normalen Lebensdauer der Arten. Wenn der Wald auf einer Reihe von Standorten das Schlußglied der Vegetation werden wird, so beruht dieses unter anderem auf dem langen Lebensalter und der bedeutenden Größe der Waldbäume; diese können sich über die Kräuter und die Sträucher erheben, sie überschatten und Jahr für Jahr viele Samen hervorbringen. Hierdurch siegen die Waldbäume über viele andere Lebensformen leicht, wenn auch langsam, selbst wenn es nur einem einzigen Individuum gelungen war, einzuwandern. Es spielt in den Kämpfen nicht nur eine Rolle, ob die eine Art mehr Licht verlangt oder mehr Schatten erträgt als die andere (Kap. 2), oder feuchten Boden, feuchtere Luft oder stärkeren Wind oder stärkere Verdunstung (vergl. Fuller) besser erträgt als eine andere Art, sondern auch, ob sie schneller oder langsamer wächst, im Frühjahre früher das Laub entfaltet, als die mitbewerbenden Arten, und ob sie sich hierbei als junge und als alte Pflanze anders verhalten kann. Es spielt nicht nur eine Rolle, ob der Nahrungsgehalt des Bodens für eine Art passender ist als für eine andere, sondern auch, ob die eine Art mehr Samen bildet, als die andere, in einem früheren Alter fortpflanzungsfähig wird, ob sie sich vielleicht reichlicher auf vegetativem Wege durch Wurzelsprosse oder Brutknospen vermehrt (vergl. gesellige Arten, Kap. 36, 38), ob ihre Samen die Keimfähigkeit lange bewahren („harte Samen“)

2) Stebler und Volkart 1904. 
oder sie schnell verlieren, ob die Samen leichter keimen, ob die Zweigstellung und die übrige Architektonik die eine oder die andere ist. So sind biologische, physiologische und andere Eigentümlichkeiten neben den vielen im ersten Abschnitte besprochenen Faktoren in dem Kampfe von wesentlichem Einflusse; bisweilen erhält eine Art fast durch unmerkliche Vorteile vor einer anderen Art einen Vorsprung.

Die verschiedene Zeit der Entwicklung im Jahre kann es einer Reihe von Arten ermöglichen, nebeneinander an derselben Stelle zu leben; ebenso die verschiedene Tiefenlage der Wurzeln, Knollen oder sonstigen ausdauernden Organe. Oben S. 304 (Fig. 162) ist bereits der von Woodhead ${ }^{1}$ ) gegebene Bodenquerschnitt besprochen. Holcus mollis wurzelt dort oberflächlich, tiefer liegen die Grundachsen von Pteridium, während Scilla festalis mit ihren Zwiebeln am tiefsten liegt.

Außer den Lebenseigentümlichkeiten der einzelnen Arten können viele andere Verhältnisse in diesen Kämpfen von Bedeutung sein, z. B. der Angriff der Schmarotzerpilze, der Insekten oder anderer Tiere (Mäuse in Wäldern usw.), das Vorkommen und der Mangel wühlender Tiere im Boden (vergl. die Regenwürmer, Kap. 18), kurz die ganze Reihe der Freunde und der Feinde der Pflanzen.

Von besonderer Bedeutung sind noch die Wanderungsmittel, welche den Arten zur Verfügung stehen. Von geringerem Nutzen sind meist die vegetativen Wanderungsmittel, jedoch muß in dieser Hinsicht auf eine tiefere Kenntnis der Lebensformen Gewicht gelegt werden; durch solche können die Pflanzen meist nur in langsamem Tempo vorwärts kommen (vergl. indessen Helodea in Europa) im Vergleich mit den „Siebenmeilenschritten“, welche die Samen machen können. Ein wichtiges Kapitel in der Pflanzenökologie sind daher auch die Wanderungsmittel der Pflanzen. Hier kann nur ganz kurz auf die Hauptfaktoren hingewiesen werden. Es sind folgende:

Der Wind (anemochore Ausrüstungen). Im Anschluß an das S. 899 über Krakatau Gesagte kann erwähnt werden, daß ca. $37 \%$ der Gefäßpflanzenflora dem neuen Boden zugebracht worden sind über Distanzen von 18,5-40,8 km. Nach Warming ${ }^{2}$ ) führte ein Sturm am 12. Februar 1881 zahlreiche Zweigstücke und Früchte von Calluna vulgaris von Schweden nach Jütland über eine Strecke von 110 bis $120 \mathrm{~km}$ hinweg, und zwar in solcher Menge, daß sie auf einer Linie von $4 \mathrm{~km}$ Länge ausgestreut waren. Über glatte Eis- und Schneefelder

3) Woodhead 1906 .

2) Warming 1887 . 
können Pflanzenteile auch leicht und weit durch den Wind transportiert werden ${ }^{1}$ ).

Die Strömungen des Meeres und der süBen Gewässer (hydrochore Verbreitung). Untersuchungen von Hemsley, Darwin, Schimper, Warburg, Sernander, Guppy, Rosenvinge, Warming ${ }^{2}$ ) und vielen anderen haben gezeigt, daß viele Samen und Algen durch die Meeresströmungen verbreitet werden können; man erinnere sich auch, daß Samen aus Westindien vom Golfstrome nach den nordwestlichen Küsten Europas getragen werden und daß die Früchte der Lodoicea Seychellarum eher in der Drift der nordischen Meere bekannt waren, ehe man die Pflanze in ihrer tropischen Heimat kannte. Für die süßen

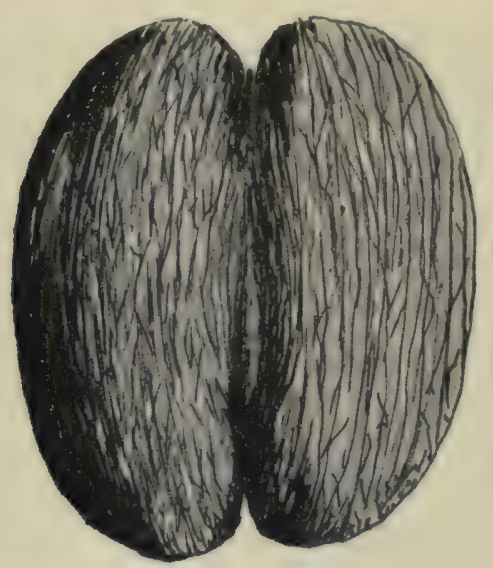

Fig. 389. Frucht von Lodoicea Seychellarum, wurde lange, ehe die Palme bekannt wurde, in der Drift selbst nördlicher Meere gefunden.

(Original P. Graebner jun.)

Gewässer liegen Untersuchungen von Kölpin Ravn u. a. vor. Treibeis, Eisberge, schwimmende Baumstämme u. a. können Träger von Pflanzensamen sowie von Tieren oder Eiern von solchen sein; im Laufe von 25 Jahren wanderten 263 Tierarten in Krakatau ein, darunter ein Regenwurm.

Tiere (zoochore Verbreitung). Bei endozoischer Verbreitung werden die Samen von den Tieren verschluckt und mit den Exkrementen ausgestreut. Es wurde vielfach bezweifelt, ob die Samen wirklich über weitere Strecken unbeschädigt transportiert werden können, obgleich

1) Holmboe 1898. Uber die Wanderungsmittel der Pflanzen vergl. namentlich die zwei Arbeiten von Sernander 1901 und 1906.

2) Warming 1887. 
gewisse Vögel 50-80 km in der Stunde fliegen können. Nach neueren Untersuchungen ist dies sicher möglich und spielt eine große Rolle für die Verbreitung der Arten.

Bei epizoischer Verbreitung heften sich die Samen resp. Früchte den Tieren an, und in vielfacher Weise sind sie zu einem solchen Transporte eingerichtet. In Nadelwäldern Dänemarks, Schleswig-Holsteins usw. wachsen jetzt Linnaea borealis, Goodyera repens und einige seltene Pirola-Arten, und da alle Nadelwälder in den genannten Gebieten im Laufe der letzten 100-150 Jahre angelegt worden sind, kann es kaum zweifelhaft sein, daß die Samen dieser Arten durch die Zugvögel von den Wäldern Norwegens, Schwedens oder Norddeutschlands zugebracht sind.

Bei synzoischer Verbreitung werden die Samen absichtlich von Tieren weggeführt, weil ihnen irgend ein nährstoffhaltiges Organ angehängt ist. Diese Verbreitungsweise hat namentlich Sernander ${ }^{1}$ ) in einem großen Werke studiert und experimentell für die Ameisen nachgewiesen; "Elaiosome" nennt er diejenigen nährstoffreichen, ölreichen Samenanhängsel („Carunculi“, „strophiolae“), welche dem Transport durch Ameisen angepaßt sind (vergl. Fig. 142).

Schleuderfrüchte werfen selbst durch explosive Bewegungen die Samen von der Mutterpflanze weg (Impatiens, Oxalis acetosella, Cyclanthera und andere Cucurbitaceen, Cardamine, Hura crepitans и. a.).

Wir müssen uns hier mit diesen Andeutungen begnügen. Es liegt eine außerordentlich große Litteratur über Pflanzenwanderungen vor; außer den schon genannten Namen können folgende aufgeführt werden: Birger 1907, Clements 1907, Goebel, Heintze, Hesselman, Holmboe 1898; Hult, Hildebrand, Jouan 1865, Kerner, Kjellman, E. Krause, Mac Leod (in Dodonaea), Massart, Ostenfeld 1908, J. Schiller, Vogler, F. E. Weiss.

Sernander hat ${ }^{2}$ ) die skandinavischen Pflanzenarten nach ihren Verbreitungsmitteln eingeteilt, besonders interessant sind dabei seine Untersuchungen über die Drift der Meere und des Süßwassers und über die Verbreitung durch den Wind, sowohl die Verbreitung vegetativer Sprosse als der Samen und Früchte betreffend. Er weist auch nach, daß die verschiedenen Pflanzen auf die Verbreitung in bestimmten Jahreszeiten eingerichtet sind und je nach der Art weit oder weniger weit wandern können.

Weiter kann auch auf den Aufsatz von Schröter, 1913, „Genetische Pflanzengeographie" im Handwörterbuch der Naturwissenschaften verwiesen werden, Bd. IV.

1) Sernander 1906; vergl. Ulbrich 1907.

2) Sernander 1901. 
Die Fähigkeit der Arten, sich auszubreiten, hängt nicht nur von der Beschaffenheit der Verbreitungsmittel, sondern auch von anderen Verhältnissen ab. In der Regel wird man geneigt sein, die Geschwindigkeit, womit die Wanderungen vor sich gehen, zu überschätzen. Der genannte, vortreffliche französische Forstbotaniker Fliche hat bei dem Studium eines besonderen Standortes folgende Ergebnisse über die Geschwindigkeit, womit gewisse Arten wandern, erhalten. Die größte Entfernung, bis wohin die Samen geführt werden, ist für F'agus silvatica 500-600 m, für Castanea sativa 500-550 m, für Pinus silvestris $115 \mathrm{~m}$, für Sorbus aucuparia 1400-2100 m. Diese Entfernungen sind kurz;

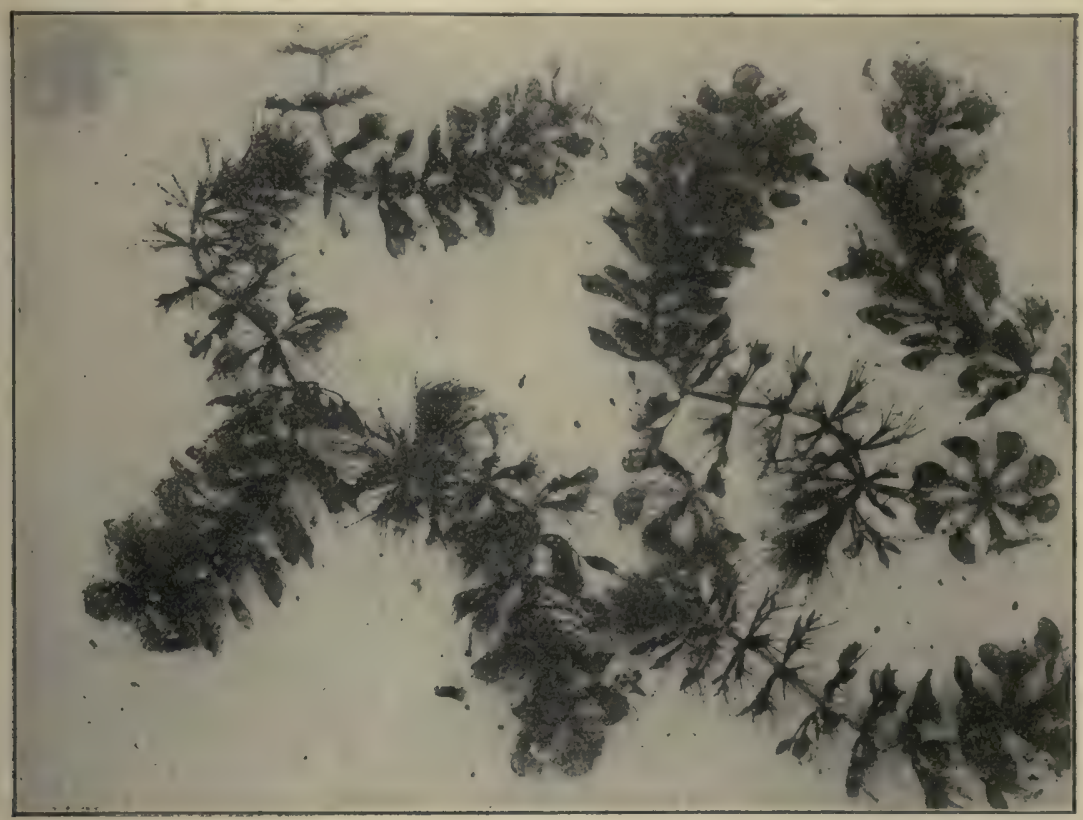

Fig. 390. Aldrorandia vesiculosa; wurzellose, seltene Art. Vergl. auch Fig. 236.

(Phot. P. Graebner.)

die fleischigen Früchte des Sorbus zeigen die größte, die geflügelten Samen der Kiefer die kleinste, obgleich diese für lange Wanderungen am besten ausgestattet zu sein scheinen. Mit Rücksicht auf das Alter, wann jene Bäume Früchte tragen, berechnete Fliche, daß sie für die Wanderung von Nancy nach Paris $(280 \mathrm{~km}) 18640,12925,48680$ und 1330 - 2000 Jahre brauchen würden. Selbstverständlich sind diese Zahlen mit Vorsicht zu benutzen; soviel scheint jedoch aus ihnen hervorzugehen, daß Wanderungen (ohne die Übertragung durch Vögel!) erstaunlich langsam erfolgen; sie sind beachtenswert, zumal da wenige Untersuchungen auf diesem Gebiete vorliegen. 
Die Erfahrungen der Landwirte weisen auf ähnliche Verhältnisse hin. Auf eingedämmten und trocken gelegten Gebieten kann mitunter erst nach einer langen Reihe von Jahren eine zusammenhängende Pflanzendecke entstehen, wenn der Mensch nicht durch Aussaat von Gräsern nachhilft. Gewisse leicht fliegende Arten siedeln sich zuerst an. Nach Mayr ${ }^{1}$ ) ist das Präriengebiet Nordamerikas nur etwa $500 \mathrm{~km}$ breit, und doch gibt es nicht eine einzige Baumart, die der atlantischen und der pazifischen Flora gemeinsam wäre, abgesehen von solchen nordischen Arten, welche die Prärien im Norden umgehen können. Dies zeigt, wie schwierig es für Vögel und Wind sein kann, Samen durch weite Entfernungen, jedenfalls über Land, zu tragen. Hult kam bei dem Studium der Moose Finnlands zu ähnlichen Ergebnissen: die Wanderungen gehen sehr langsam vor sich und werden durch die säkularen klimatischen und die geologischen Veränderungen reguliert.

Alphonse de Candolle hat in Übereinstimmung hiermit nachgewiesen, daß in den Alpen gewisse Gebiete verhältnismäßig weit pflanzenreicher als andere sind, weil jene Gegenden in der Eiszeit nicht mit Eis bedeckt waren oder weil sie früher als die anderen eisfrei wurden. Man kann wohl auch mit Recht annehmen, daß die Armut Nord- und Mitteleuropas an Baumarten in den Wäldern davon herrührt, daß der Boden geologisch sehr jung ist und eine größere Anzahl von Arten, die vor der Eiszeit in Nordeuropa wohnten, den Weg ohne Hilfe des Menschen nicht über die großen ost-westlichen Gebirgszüge der Alpen, Karpathen, Balkangebirge usw. haben zurückfinden können, wie z. B. Aesculus hippocastanum, Picea omorika, Corylus colurna, Juglans usw. In derselben Weise scheinen die uralten Gebiete Südamerikas (namentlich das Hochland Brasiliens und Guayana) weit artenreicher zu sein als die jüngeren (die Pampas und die Savannen). Innerhalb jener Gebiete ist wiederum die Waldvegetation viel artenreicher als die Savannen. Ob dieses darauf beruhe, daß sie älter sei als diese, oder darauf, daß die günstigeren Vegetationsverhältnisse die Artenbildung mehr als auf diesen gefördert hätten, ist noch unentschieden ${ }^{2}$ ).

Über die Meere werden die Vögel Samen in weite Ferne eher forttragen können, als über Land, weil sie dort keine Ruhepunkte finden, wo sie sich niederlassen und die Samen verlieren können.

Noch ein Umstand sei hervorgehoben, der für die Verbreitung der Arten von Bedeutung ist, nämlich: welche Art zufällig zuerst anlangte. Sind die Verhältnisse derart, daß sie für mehrere Arten gleich gut passen, so wird der Ausfall des Kampfes davon abhängen, weleher

1) Mayir 189.

2) Warming $1892,1899 \mathrm{~b}$. 
Art es gelingt, das Gelände zuerst zu besetzen; "beati possidentes" werden daun den Besitz möglicherweise behaupten können. Hierdurch ist vermutlich die Verteilung der Phragmiteta, der Scirpeta und anderer Bestände in unseren Rohrsümpfen oder die Verteilung verschiedener Zwergsträucher auf den Zwergstrauchheiden zu erklären.

Es muß jedoch betont werden, daß für die Übersiedelung einer Art an einen anderen Ort es nicht hinreichend ist, daß sie gute Wanderungsmittel besitzt; es ist selbstverständlich auch notwendig, daß sie einen günstigen Standort trifft, wo sie keimen und sich entwickeln kann.

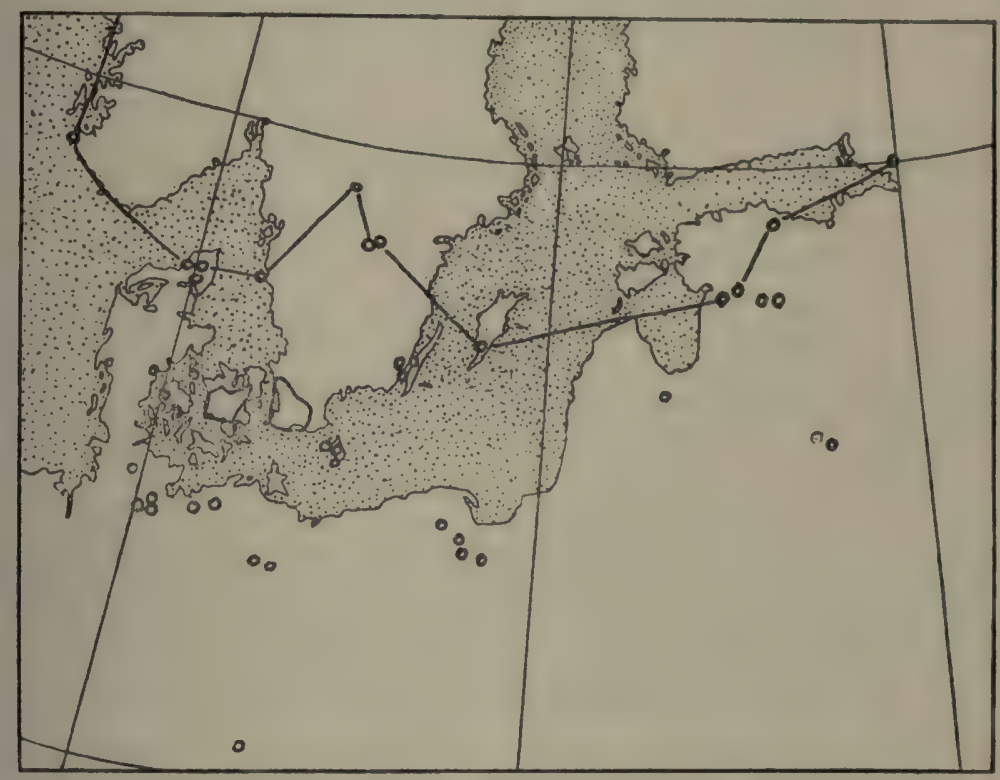

Fig. 391. Verbreitung der Dryasablagerungen in der Umgebung der Ostsee. O Wichtige Fundstellen. (Nach Nathorst und Andersson.)

Clements hat, wie Kap. 117 erwähnt, dafür den Ausdruck „Ecesis“ (oix $\sigma \iota \varsigma)$ geprägt ${ }^{1}$ ).

Im allgemeinen kann man sagen, daß eine Art desto größere Aussicht hat, aus dem Kampfe siegreich hervorzugehen, je mehr sie sich in ihrem optimalen Gebiete befindet, d. h. je mehr für sie am meisten passende ökologische Verhältnisse vorhanden sind; daher hat eine Art die härtesten und aufreibendsten Kämpfe immer an der Grenze ihres Verbreitungsgebietes zu bestehen, insofern sie auf ihrer Wanderung hier an die in klimatischer Hinsicht äußersten Grenzen gekommen ist. Je besser das Klima für eine Art paßt, desto weniger wählerisch ist sie

1) Clements 1904, 1905. 
bezüglich des Bodens und anderer Verhältnisse, und desto besser kann sie den Kampf mit den Mitbewerbern aufnehmen. Ein Beispiel für das Angeführte ist das S. 903 erwähnte Schicksal der Kiefer und der Fichte in Lappland. Wird eine Baumart auf einem Standorte innerhalb ihres Optimums gefällt oder niedergebrannt, so wird sie in der Regel nach der bloßgelegten Stelle zurückkehren, wenn die Natur sich selbst überlassen wird; begegnet ihr dieses Schicksal jedoch außerhalb des Gebietes ihres Wachtums, so kehrt sie nicht mehr zurück, sondern es wandert die Baumart ein, auf deren optimalem Gebiete der Standort liegt (nach Mayr). In den großen Heidegebieten Nordeuropas kann man die Heidepflanzen an allen nur erdenklichen Standorten finden, so auch an Bahndämmen, Ackerrainen usw., ja Erica tetralix fand sich in der Lüneburger Heide in den Ritzen einer Kalksteinmauer, und Empetrum, Rubus chamaemorus usw. wachsen im westlichen Norwegen sogar auf Dächern; außerhalb der Hauptheidegebiete sind alle diese Pflanzen, wie auch Calluna, an bestimmte Standorte gebunden.

Die Ergebnisse der Kämpfe sind also 1. die Verteilung der Arten in natürliche Vereine, 2. Veränderungen in der Zusammensetzung der Vegetation überall auf der ganzen Erde; dazu kommen noch 3. das Auftreten seltener Arten und möglicherweise 4. die Bildung neuer Arten.

Seltene Arten. Der Kampf der Pflanzen untereinander erhält einen floristischen Ausdruck auch in den seltenen Arten, die bei vielen botanischen Sammlern bekanntlich die Hauptrolle, spielen.

Eine Art kann in einem Gebiete aus verschiedenen Gründen selten sein:

1. weil passende Standorte fehlen, z. B. Felsenboden im Flachlande,

2. weil sie ein Ansiedler ist und auf ihrer Wanderung eben erst in das betreffende Gebiet gekommen ist, aber vielleicht Jahr für Jahr häufiger werden wird (Helodea Canadensis in Europa, Senecio vernalis usw.),

3. weil sie eine "Reliktenpflanze“ d.h. ein Rest einer früheren, nun verdrängten Vegetation ist,

4. weil sie eine neu entstandene Art ist (eine endemische Pflanze).

Die S. 912, 922 ff. behandelte, große Pflanzenwanderung, die nach der Eiszeit in Europa stattfand (vergl. Fig. 391), hat ihre Spuren in den vielen Reliktenpflanzen zurückgelassen, die sich hier und da erhalten haben, gegenwärtig stellenweise nur in wenigen Exemplaren vorkommen und immer mehr aussterben. Die Örtlichkeiten, wo sie sich erhalten haben, sind solche, die mit den Naturverhältnissen der Tundrenperiode am besten übereinstimmen: nämlich kalte und nasse Sumpf- und Sphagnummoore. Solche Überbleibsel sind in Dänemark und Norddeutschland vielleicht 
Chamaepericlymenum (Cornus) Suecicum, Betula nana, Rubus chamaemorus, Polygonum viviparum, Saxifraga hirculus, Scheuchzeria palustris, Primula farinosa, Carex chordorrhiza. Diese Arten werden möglicherweise zum Teil allmählich seltener werden oder ganz aus den Floren verschwinden, wie es schon anderen Reliktenpflanzen ergangen ist.

In den Gebirgen (Alpen, Riesengebirge) sind diese Reliktenpflanzen viel ausgeprägter und deutlicher erkennbar ${ }^{1}$ ).

Endemische Pflanzen sind oft sehr selten, weil sie vielfach „neue Arten" sind, die noch nicht Zeit gehabt haben sich weiter zu verbreiten. Die Hochgebirgsflora Ceylons z. B. hat eine große Menge von Endemismen; Willis und Svedelius haben über diese interessante und wichtige Arbeiten veröffentlicht ${ }^{2}$ ).

Willis zieht aus seinen Beobachtungen den Schluß, daß die Arten durch Mutation entstehen. Bastardierung scheint hier jedoch nicht ausgeschlossen zu sein.

\section{Kap. Die Entstehung der Arten}

Durch alles Vorhergehende geht wie ein roter Faden der Gedanke: der Bau und die ganze Entwicklung der Arten stehen in genauestem Einklange (Epharmonie) ${ }^{3}$ ) mit ihren Umgebungen, sie sind an diese angepaßt (zeigen Anpassung, Epharmose). Es wurde schon S. 5 angedeutet, daß sich die Pflanzen verändern und an die n euen Verhältnisse anpassen können, unter denen sie sich entwickeln müssen. Die Arten kommen, wie in den vorhergehenden Kapiteln erwähnt, unter neue Verhältnisse entweder dadurch, daß sich die Naturverhältnisse ihres Standortes ändern, oder dadurch, daß sie nach anderen Standorten wandern, deren Verhältnisse von denen der ursprünglichen verschieden sind. Es wurde ferner angedeutet, daß die Folge dieser Veränderung der Arten wahrscheinlich die Entstehung neuer Arten sein kann.

Eine Veränderung der Individuen, die zur Veränderung der Arten führen kann, ist eine notwendige Voraussetzung für jede Abstammungslehre, sei es die Lamarcks oder Darwins oder aller denkbaren anderen. Über diese Bildung von neuen Arten sei hier einiges bemerkt, ohne daß eine umfassende Betrachtung dieser größten und schwierigsten Frage der Biologie versucht werden soll.

1) Engler $1879-82$.

2) Willis 1903; 1915: The endemic Flora of Ceylon with reference to geographical distribution and evolution in general, in: Philos. Transact. Roy. Soc. of London B. Vol. 206. Svedelius 1907.

5) Vesque $1882 \mathrm{a}$. 
Neue Arten können auf verschiedene Weise entstehen, aber in jedem Falle muß vorausgesetzt werden, daß die genotypischen Anlagen selbst verändert werden müssen, weil nur dadurch neue Eigenschaften auf die neue Generation erblich übertragen werden können.

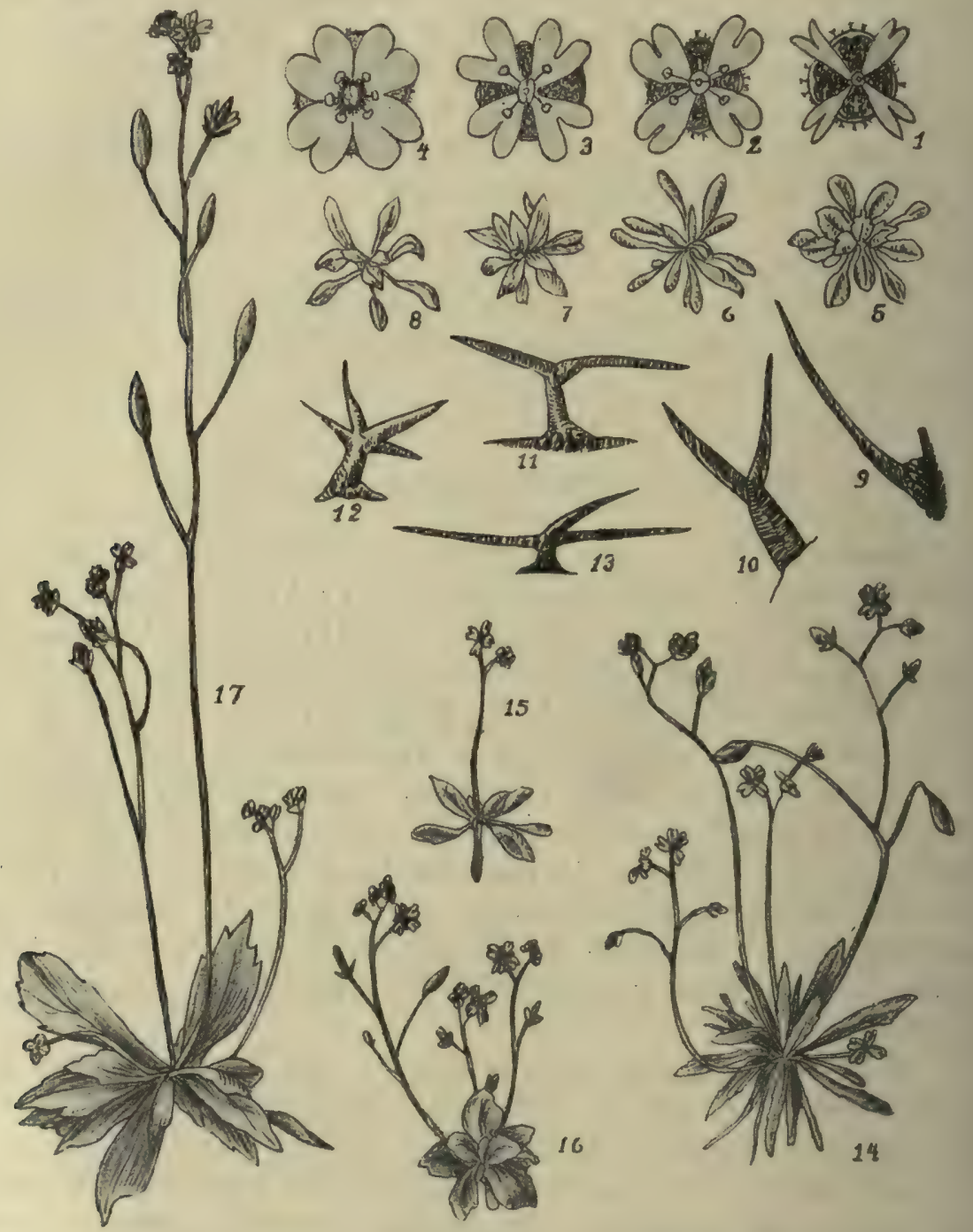

Fig. 392. Veränderlichkeit von Erophila verna in der Tracht, Gröbe und in den einzelnen Teilen. 1-4. Blïten; 5-8. Blattrosetten; 9-13. Haare; 14-17. Tracht.

(Nach de Vries-Klebahn.)

Die sexuellen Zellen können erfahrungsmäßig durch Bastardierung verändert werden, $d . h$. durch Kombination von Anlagen, welche sowohl vom Vater wie von der Mutter herstammen können (z. B. Circaea intermedia). 


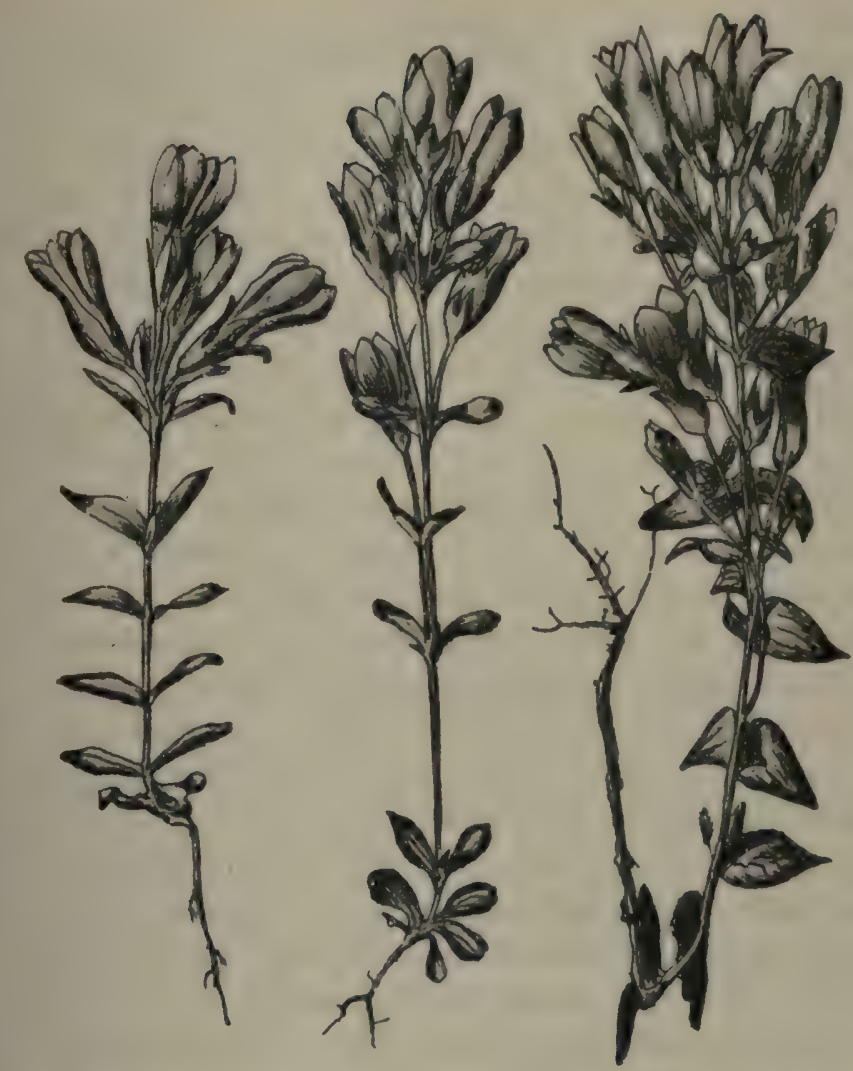

Fig. 393. Saisondimorphismus von Gentiana campestris, links die Frühjahrs-, in der Mitte die Sommer- und rechts die Spätsommerform. Nach Wettstein.

Fig. 394.

Saisondimorphismus bei Euphrasia officinalis, links die Frühjahrs-, rechts die Sommerform. Nach Wettstein.

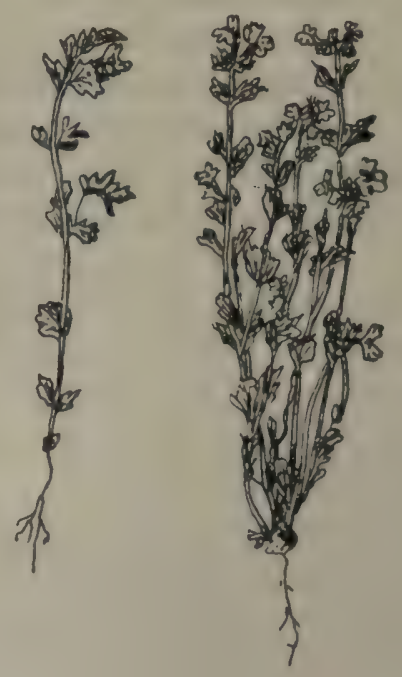


Eine andere Form ist diejenige, welche jetzt gewöhnlich Mutation genannt wird; sie ist eine dauerhafte Veränderung der Anlagen durch für uns noch rätselhafte Ursachen; letztere sind uns gewöhnlich ganz unbekannt, vielleicht oft rein zufällig und jedenfalls in ihrer Wirkungsweise am Ende noch unverständlich; aber überall müssen wir davon ausgehen, daß die Eigenschaften der Organismen die notwendigen Folgen bestimmter Ursachen sind, was Nägeli in seinem großen Werke von 1864 so scharf hervorgehoben hat. Seine "Theorie der bestimmten und direkten Bewirkung" ist ja, allgemein genommen, wenigstens teilweise auch die Lehre Lamarcks, welche er besonders in seinem Buche von 1809: "Philosophie zoologique" entwickelt hat. Der Lamarckismus oder die Annahme von der Vererbung erworbener Eigenschaften, oder besser ausgedrückt: „erworbener Anlagen“, gewinnt in der neuesten Zeit wohl immer mehr Anhänger, obgleich sie bisher nur wenige sichere Stützen gewonnen hat. Wie Darwin und andere Anhänger der Entwicklungstheorie nahm Lamarck die Veränderlichkeit der Formen an und ebenso schenkt er den Haustieren und Kulturpflanzen besondere Beachtung. Nach Lamarck geht die Fortentwicklung der Natur resp. die natürliche Veränderung der Formen unaufhörlich vor sich. Die Zeit und die Natur der Umgebung sind die beiden wichtigsten Faktoren für die natürliche Gestaltung all der verschiedenen zur Entwicklung gelangenden Formen. Die Umgebung wirkt auf die Organismen, so daß, wenn sie sich ändert oder wenn der Organismus wandert und so einer anderen Umgebung ausgesetzt wird, das Tier die "Notwendigkeit" (besoin) fühlt, sich den neuen Bedingungen anzupassen, es macht natürlich einen verschiedenen Gebrauch von seinen Gliedern oder hört auf, sie zu gebrauchen und veranlaßt sie so, sich dem Wechsel zu unterwerfen. Lamarck, aber noch mehr sein Zeitgenosse Geoffroy St. Hilaire, legten Gewicht auf die direkten Einwirkungen des umgebenden Mediums auf den Organismus, aber Lamarck nimmt dies im wesentlichen für die Pflanzen an. Im Neo-Lamarckismus wird der frühere Typus der aktiven Anpassung kaum diskutiert, der passiven Anpassung resp. der Selbstregulierung (Selbstanpassung, Epharmosis) dagegen wird größere Beachtung gezollt. Lamarck versichert ohne Versuche, daß die in dieser Weise entstandenen Formen ihre erworbenen Eigenschaften auf ihre Nachkommen übertragen; dies ist ein sehr schwacher Punkt in seiner Theorie und eine heute viel erörterte Frage. Es versteht sich von selbst, daß Lamarck keine Ahnung von Protoplasma, Idioplasma, Sexualzellen, dem Wesen der Befruchtung usw. hatte; auch ist es ja deutlich, daß seine Lehre im höchsten Grade auf Spekulation begrïndet war; sie experimentell zu begründen, lag ihm fern. Daß aber die Umweltfaktoren, also der Standort im weitesten Sinne, die von ihm als die wichtigsten angesehenen Entwicklungsfaktoren waren, ist deutlich. 
Die erste Bedingung dafür, daß sich eine neue Art durch Anpassung aus einer anderen zu entwickeln vermag, ist, daß diese plastisch ist, d. h. ihren Bau und ihre Lebenstätigkeit in Übereinstimmung mit den neuen Verhältnissen verändern kann. Man muß annehmen, daß alle Arten in allen ihren Organen, in der äußeren Gestalt wie in dem inneren Bau, mehr oder weniger plastisch sind, am wenigsten vielleicht die sehr alten und aussterbenden Arten. Diese Plastizität findet man sogar bei den allerniedrigsten Organismen, z. B. bei den Plasmodien der Schleimpilze; sie muß überall auf Eigenschaften des Protoplasmas zurückgeführt werden.

Daß die meisten Pflanzen nun in der Tat sehr plastisch sind, ist durch eine sehr große Menge von Experimenten und Erfahrungen bestätigt worden; Beobachtungen von einer langen Reihe von Botanikern liegen hierfür vor. Es kann hier noch kurz auf einige von den in den früheren Seiten besprochenen Tatsachen hingewiesen werden.

Die wichtigsten Standortsfaktoren, die hier in Betracht kommen, sind Licht, Wärme, Luftfeuchtigkeit, Wasser und Qualität der Nahrung im Boden. Zur Erläuterung diene das Folgende.

Im 2. Kapitel wurden die Eigentümlichkeiten der Sonnen- und der Schattenpflanzen behandelt. Wie Lichtwechsel Drehungen, Formenveränderungen oder Wanderungen der Chlorophyllkörper in den Pflanzen hervorrufen kann, und wie Lichtwechsel die Stellung der Blattspreiten ändern kann (26. Kap.), so kann eine Veränderung der Beleuchtung auch eine Entwicklung nach dem morphologischen und dem anatomischen Bau hin veranlassen, der für die genannten Pflanzen kennzeichnend ist und als ihnen nützlich angesehen werden muß. Sogar die eigentümlichen Formen der blattförmigen Cacteen sind hauptsächlich dem Lichte zuzuschreiben, was Vöchting und Goebel nachgewiesen haben. Die Etiolierung der Lichtpflanzen im Dunkeln ist vermutlich als eine nützliche Anpassung aufzufassen. $\mathrm{Da} B$ das Licht die Differenzierung der Vegetationsorgane von Marchantia und die Bildung der Archegonien auf der von ihm abgewandten Seite der Farnvorkeime hervorruft, sind andere, wohlbekannte Beispiele für die gestaltende Wirkung des Lichtes.

Bekanntlich gibt es bestimmte und konstante Verschiedenheiten zwischen Erdsprossen und Lichtsprossen im ganzen und bei derselben Art, oder zwischen dem Bau von Wurzeln und Lichtsprossen. Costantin hat denselben Sproß oder dieselbe Wurzel im Boden und in Luft kultiviert und nachgewiesen, daß die mannigfaltigen äußeren Verhältnisse die Organe sowohl anatomisch als auch morphologisch verschieden ausprägen und daß die vorkommenden Unterschiede dieselben sind, welche die unter den entsprechenden Verhältnissen normal lebenden Pflanzenteile auszeichnen.

Warming-Grabbner. 3. Auflage, illustr. 
Man hat auch Versuche über die Einwirkung der Wärme auf die Pflanzenteile angestellt. Die Versuche von Emil Chr. Hansen zeigen, daß Wärme auf verschiedene Weise Gärungspilze erblich ändern kann. Die von Prillieux und Vesque beweisen, daß die Erwärmung des Bodens die osmotische Kraft der Wurzeln steigert, so daß die Pflanzen succulent werden und gerade die Wasserbehälter und den bedeutenden Umfang nebst der geringen Transpirationsfläche erhalten, die sie darin unterstützen, auf dem erwärmten trockenen Felsenboden oder auf ähnlichem Boden auszuhalten. Den Wärmeverhältnissen kann man vielleicht auch die stärkere Entwicklung von Wachs auf den Halmen von Hordeum, Triticum Sect. Secale und anderen Gräsern zuschreiben, welche P. Nielsen und Raunkiär (nach mündlichen Mitteilungen) in warmen Sommern beobachtet haben, wodurch die Transpiration vermutlich auf eine mit den veränderten Verhältnissen übereinstimmende günstige Weise herabgesetzt wird. Bekannt ist in naturhistorischen und landwirtschaftlichen Kreisen, daß auch die Tiere in Anpassung an die Wärmeverhältnisse (Behaarung stärker in kälteren Umgebungen, Änderung der Farben gewisser Polartiere nsw.) abändern können.

Luftfeuchtigkeit; Wasser. Im ersten Abschnitte und später sind in verschiedenen Kapiteln die anatomischen und die morphologischen Eigentümlichkeiten der Hydrophyten und der Xerophyten besprochen worden. Versuche von Costantin, Schenck, Askenasy, Lothelier, Dufour, Volkens u. a. zeigen, daß sich die verschiedenen Organe (Wurzeln, Stamm, Blätter, Haare) bei derselben Art morphologisch und anatomisch verändern, je nachdem sie sich in Luft oder in Wasser, in trockener oder in feuchter Luft entwickeln, und daß dadurch gerade solche Bauverhältnisse erzeugt werden, die für Land- und Wasserpflanzen oder für Xerophyten und Hydrophyten im allgemeinen kennzeichnend sind, oder daß jedenfalls eine Entwicklung in der Richtung nach diesen Bauverhältnissen eintritt. Es ist eine deutliche Selbstregulierung, daß die Intercellularräume kleiner werden, je stärker die die Transpiration hervorrufenden Faktoren wirken, und umgekehrt. Gewisse Arten sind bekanntlich sehr plastisch, z. B. kann man die Landform des Polygonum amphibium in wenigen Wochen in eine Wasserform umwandeln (Hildebrand, Massart); besonders Monokotylen der Heide besitzen eine erstaunliche Wandlungsfähigkeit an trockenen und nassen Standorten, vergl. Juncus supinus usw. (Graebner 1895).

Verschiedene Nahrung ruft, wie den Landwirten wohlbekannt ist, Unterschiede in der Tracht hervor; auch Unterschiede im Blütenbau scheinen hieraus hervorgehen zu können, indem eine stärkere Ernährung eine größere Blütenachse, größere Blüten und mehr Blütenblätter (z. B. mehr Fruchtblätter bei Papaver, bei schlechter Ernährung weniger: 
Warming) hervorbringt. Die S. 415 erwähnten Versuche von Lesage, Pflanzen an Salzboden anzupassen, zeigen dasselbe.

Von Versuchen, bei welchen verschiedene Außenweltfaktoren gleichzeitig zusammenwirken, kann hingewiesen werden z. B. auf die von Kerner und Bonnier, welche Pflanzen der Ebene in den Hochgebirgen kultiviert haben und umgekehrt. Überall bestätigt sich, daß Veränderungen der Faktoren auch mehr oder weniger durchgreifende Veränderungen der betreffenden Pflanzen hervorrufen.

Ferner kann erwähnt werden, daß mechanische Kräfte, z. B. vermehrter Zug oder Druck auf den Bau der Organe abändernd wirken, wie Heglers Versuche nachgewiesen haben: je größere Anforderungen an die Stärke eines Pflanzenteiles gestellt werden, desto stärker wird er (Schwendener).

Es werden also nicht nur die äußeren Bauverhältnisse beeinflußt, sondern auch die inneren: nicht nur die Länge der Wurzel und der Stengelglieder, die Größe und die Dicke oder die Länge der Blätter, die reichlichere oder die spärlichere Entwicklung der Haare usw., sondern auch die relative Dicke von Rinde, Zentralzylinder und Mark in den Achsenorganen, von Palisadengewebe und Schwammparenchym in den Blättern, die Höhe der Epidermis, die Dicke der Cuticula, die Anzahl und die Mächtigkeit der Gefäßbündel, die Verholzung, und namentlich die Mächtigkeit des Holzes, der Gefäße und der Tracheïden, die des mechanischen Gewebes, die Größe der Intercellularräume ${ }^{1}$ ), die Bildung des Chlorophylls, die Entwicklung der Spaltöffnungen, der Endodermis usw.

Die Pflanze hat also eine auf vielfache Art nachweisbare Fähigkeit, auf äußere Einflüsse zu reagieren. Bisweilen kann der eine Teil direkt beeinflußt werden, ohne daß sich andere verändern. Sogar dasselbe Blatt paßt sich bisweilen verschieden an, wenn es unter verschiedenen Bedingungen lebt; z. B. überragen die oberen Teile der Blätter von Stratiotes oft das Wasser, werden dann weniger durchsichtig und überdies dunkler grün, als die untergetauchten Teile, erhalten Spaltöfnungen usw. (Costantin).

Ferner sind nicht nur die Formenverhältnisse, sondern auch bio$\log$ ische Eigenschaften plastisch. Die Gärtner wissen aus Erfahrung, daß verweichlichte Pflanzen durch Frost leichter getötet werden, als andere Individuen derselben Art; einjährige oder zweijährige Arten köunen durch äußere Verhältnisse mehrjährig werden; die Zeiten der Ruhe, der Belaubung und des Laubfalles, die Blütezeit können andere werden; kleistogame Blüten können durch kaltes und dunkles Wetter

1) Vergl. Graebner 1895. 
hervorgerufen werden ${ }^{1}$ ), und alpine oder arktische Blüten erscheinen an Selbstbestäubung mehr angepaßt, als Blüten derselben Arten aus anderen Gegenden (Warming, Lindman). Einen Teil der hierher gehörigen Tatsachen hat Henslow ${ }^{2}$ ) gesammelt. Im ganzen ist der Stoff wechsel der Pflanze sicherlich überall den Gesetzen der Anpassung oder Selbstregulierung unterworfen. Saccharomyces richtet sich nach der Gegenwart oder dem Fehlen des Sauerstoffes, der Turgor der Wurzel nach den Hindernissen, denen sie begegnet, usw.

Natürlich sind nicht alle Pflanzen in gleichem Maße plastisch. Teils werden sich bei den Arten Unterschiede in der von ihrer Verwandtschaft stammenden Disposition geltend machen, teils die Entwicklungsstufe, auf der die Art oder die Gattung als Ganzes steht (gewisse Gattungen, wie Hieracium und Rubus, scheinen bekanntlich in lebhafter Entwicklung zu sein), teils der Grad, in welchem die erworbenen Kennzeichen durch Vererbung befestigt worden sind. Demnächst werden sich einige mehr in der einen, andere mehr in der anderen Richtung verändern. Auch sind nicht alle Individuen derselben Art gleich variabel.

Hinzuzufügen wäre noch ${ }^{3}$ ): Jede Art variiert, und zwar jede in verschiedener Weise. Während Typen, die uns systematisch als "alt " fixierte, "wenig abändernde" bekannt sind, gewöhnlich nur hin und wieder in einem Merkmal (also etwa in Blattform, Blütengestalt, Behaarung usw.) variieren, sehen wir bei den Individuen polymorpherer Formenkreise mehr und mehr Organe und Organteile (bis zu anatomischen Unterschieden herab) abändern. Von den ersteren Typen, also (den „alten", wenig variablen) lassen sich nun erfahrungsgemäß sehr schwer neue irgendwie konstante Formen züchten, trotz der auch bei den Gärtnern selbstredend geübten strengsten Isolierung. Bei den polymorpheren (und schließlich den polymorphsten Gruppen) bilden sich aber graduell immer mehr und mehr konstante Formen, die (natürlich immer unter der Voraussetzung strengster Isolierung) um so konstanter sind, je mehr von den der betreffenden "Art" eigentümlichen Abänderungen verschiedener Organe sich in dem betreffenden Mutterindividuum vereinigt finden. Ob eine einzelne Abänderung dabei über den Rahmen einer bestimmten Variation (Galtonsche Kurve usw.) hinausgeht oder nicht, scheint ziemlich nebensächlich. Bei überhaupt stark variierenden Gruppen (polymorphen Formenkreisen) wird man selbstredend danach eine viel viel größere Tendenz zur Konstanz der einzelnen

1) Voechting 1893; Graebner 1893; Goebel, Einleitung in die experimentelle Morphologie 1908.

2) Henslow 1894, 1895.

2) Graebner in diesem Werke 2. Aufl., 393. 
Abänderungen finden, sobald Bastardierung ausgeschlossen ist, als bei den nur wenig Abänderung zeigenden Arten, bei denen also eine Kombination einer größeren Zahl von abändernden Merkmalen viel viel seltener ist. Bei den Gärtnern, die sich wissenschaftlich mit der Anzucht neuer Formen beschäftigen, ist es eine längst bekannte Tatsache, daß von den Tausenden aus den Aussaaten hervorgehenden jungen Pflanzen (deren Blüten- oder Frucht- usw. Merkmale man noch nicht

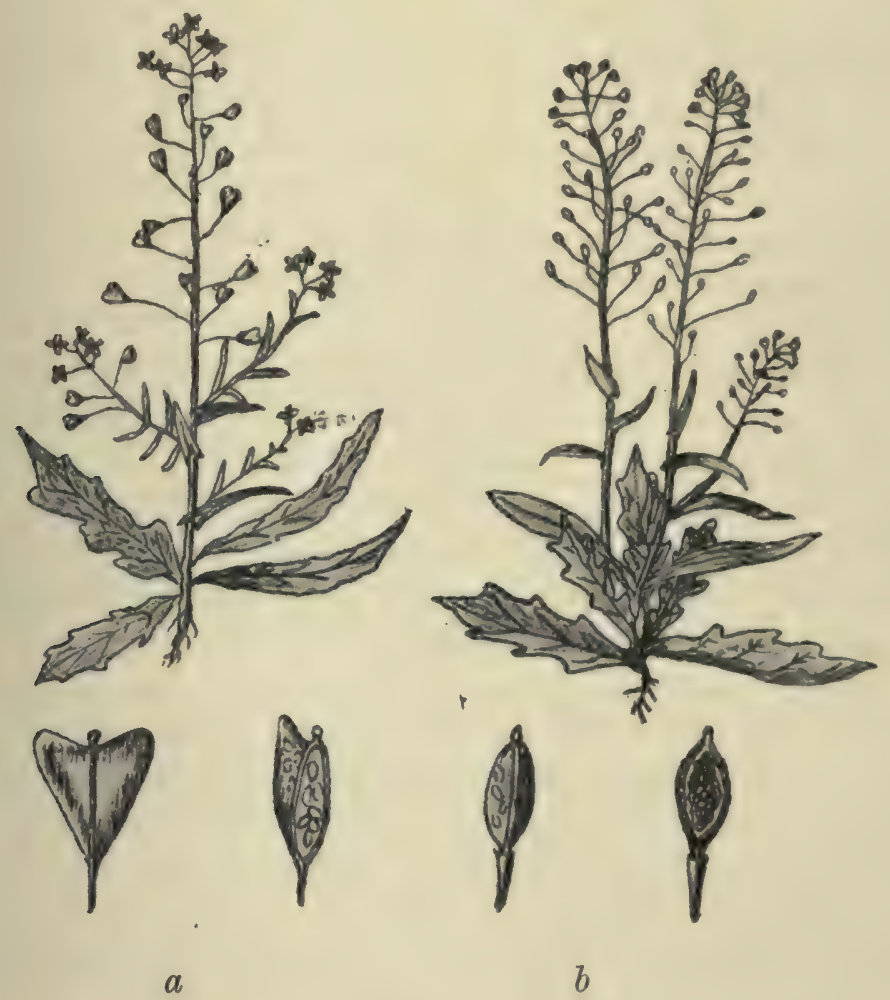

Fig. 395.

a Capsella bursa pastoris mit geflügelter Frucht mit abfallenden Klappen;

b C. Heegeri mit ovaler Frucht und durch Zerfallen der Klappen freiwerdenden

Samen. (P. Graebner jun. gez.)

kennt!) nur von denjenigen Pflanzen die Entstehung einer konstanten Form zu erwarten ist, die schon als junge Pflanzen (also auch in ganz nebensächlichen Merkmalen) sich von dem Gros möglichst abweichend zeigen. Je weniger stark die Abweichung der neuen Form ist, d. h. je weniger zahlreich die Zahl der abändernden Merkmale ist, desto schwieriger ist die Fixierung der Form (also ihrer Merkmale). Je mehr diese Schwierigkeit hervortritt, desto mehr ist die Selektion, die Zuchtwahl 
notwendig. Bei ganz polymorphen Gruppen hat durch die stets eintretende Summierung der Merkmale fast jede Pflanze (wenn sie isoliert wird) ihre konstante Nachkommenschaft (vergl. Oenothera usw.). Je weniger groß die Variationsfähigkeit (vieler Merkmale) ist, desto mehr wird in den Nachkommen des betreffenden abändernden Individuums sich eine Tendenz zum Rückschlag eines verhältnismäßig (etwa procentualiter) großen Teils der Merkmale der Abänderung bemerkbar machen. Es wird also eine verhältnismäßig immer größere Zahl „zurückschlagender" Individuen auftreten, die zur Erzielung einer Konstanz ausgemerzt werden müssen. Je weniger Merkmale bei einer bestimmten erzogenen Abänderung eines einzigen Organs (etwa Blütenform usw.) mit dieser Abänderung zugleich abweichend vom Typus auftreten, desto mehr Generationen mit steter Zuchtwahl gehören dazu, diese Abänderung als solche samenbeständig zu machen. Capsella Hegeri (vergl. Solms-Laubach) scheint auch eine solche in neuester Zeit entstandene Art zu sein, in der sich eine Menge von Merkmalen der verhältnismäßig sehr wenig abändernden $C$. Bursa pastoris vereinigt haben, und die trotz ihrer zweifellos sehr großen Jugend (bei wohl nur zufälliger Isolierung!) eine Konstanz aufweist, die Erstaunen erregen muß (Fig. 395). Für die künstlichen durch Isolierung und Zuchtwahl erzogenen konstanten Rassen liegen eine große Reihe von Beispielen vor, namentlich in unseren bekannten Kulturpflanzenrassen (kurzlebige Nutz- und Zierpflanzen).

Es ist also sicher, daß die Pflanzen sich ändern können und sich in Harmonie mit den Außenweltfaktoren bringen können. Eine weit größere Anzahl von Beobachtungen und Versuchen als die hier angedeuteten lassen sich anführen unter Hinweisung auf Costantin, Volkens, Lothelier, Stahl, Vöchting, Schenck, Lesage, G. Karsten, Frank, Dufour, Vesque, Bonnier, Askenasy, Goebel, Lewakoffski, Graebner und andere über die morphologische und die anatomische Plastizität des einzelnen Individuums oder der einzelnen Art. Das Ergebnis dieser Versuche ist. daß durch die Veränderung der Lebensbedingungen eine Entwicklung. hervorgerufen wird, die eben in der Richtung der Anpassung an die Lebensbedingungen geht, von welcher wir wissen, daß sie die normale und konstante Anpassung der Lebensformen oder der Pflanzenvereine ist, welche unter den betreffenden Standortsbedingungen ihr Leben zubringen.

Es entsteht dann aber die große und schwierige Frage: haben diese Arten (Lebensformen, Pflanzenvereine) nun auch gerade durch solche Epharmose (Selbstanpassung, Selbstregulierung) ihre konstanten Eigentümlichkeiten erhalten, also, un das geläufige Schlagwort zu benutzen, durch Vererbung erworbener 
Anlagen ${ }^{1}$ ). Daß dieses der Fall sein $\mathrm{kann}$, ist die Überzeugung des Verfassers dieses Buches, trotzdem es ebenso eine sichere Erfahrung ist, daß die allermeisten der erwähnten Änderungen ebenso schnell verschwinden können, wie sie gekommen sind, wenn die Pflanzen bald unter die früheren Standortsverhältnisse zurückgebracht werden und überhaupt bald anderen Außenfaktoren ausgesetzt werden. Es ist deshalb wohl verständlich, daß so viele Forscher die Möglichkeit der Erwerbung neuer Anlagen durch Außenweltfaktoren verneinen. Lamarck hob aber außer diesen genannten auch einen anderen Faktor als besonders wichtig hervor, nämlich lange Zeit, aber dieser Faktor fehlt eben in den betreffenden Versuchen; die Pflanzen müssen durch viele Generationen, vielleicht Jahrhunderte lang, den betreffenden Faktoren ausgesetzt sein, damit die Wirkungen von ihnen im Idioplasma der Pflanze fixiert werden können.

Für die Möglichkeit der Vererbung "erworbener" Anlagen kann übrigens erstens auf eine Reihe von Indizienbeweisen in der Pflanzengeographie verwiesen werden, z. B. die vielen Beispiele von Konvergenz, d. h. ähnliche Epharmonie verschiedener systematischer Typen unter ähnlichen Lebensbedingungen, z. B. in den Hochgebirgen und Polargegenden, in den Steppen und Wüsten, am Meeresstrande und auf Salzboden im Binnenlande, wovon der vierte Abschnitt in diesem Buche eine Menge Belege gibt. Auch die Zoologie liefert eine Menge von Beispielen (die Höhlentiere, Wüstentiere, Polartiere usw.).

Vikariierende Arten. Weiter gehört hierher z. B. das so allgemeine Vorkommen von nahe verwandten Arten, Kleinarten, Unterarten oder Rassen, in nahe aneinander grenzenden, aber doch, was Standort betrifft, etwas verschiedenen Gegenden und, was Ausbildung betrifft, in Epharmonie mit diesen Verschiedenheiten, wie z. B. verschiedene von Wettstein nachgewiesene Verhältnisse, oder die Nachweisung von Diels von der fein abgestuften Anpassung südwestaustralischer Arten an die entsprechenden feinen Abstufungen des Klimas. Es kann daran erinnert werden, daß es eben das Vorkommen von vikariierenden Arten auf den Galapagosinseln und auf dem südamerikanischen Festlande war, welches bei Darwin die Überzeugung von erblicher Umbildung der Arten

1) Es muß darauf hingewiesen werden, daß der Ausdruck „erworbene Eigenschaften“ von verschiedenen Schriftstellern verschieden gebraucht wird. Während einige darunter diejenigen Eigenschaften verstehen, die von einem Individuum während seiner Lebensdauer erworben resp. angenommen sind, verstehen andere darunter auch die Eigenschaften, die ein Individuum abweichend von seinen Erzeugern durch die (oder bei der) Geburt nerworben", d. h. mitbekommen hat. Über das letztere (Mutation, Variation) braucht nicht diskutiert zu werden, strittig bleibt die erstere Frage: sind während der Lebensdauer erworbene (durch Anpassung angenommene) Eigenschaften auf die Nachkommenschaft tibertragbar? 
befestigte; viele andere biogeographische Tatsachen müssen zu demselben Schluß führen. Die ozeanischen Inseln spielen ja überhaupt eine große Rolle in den Diskussionen über die Abstammungslehre im allgemeinen, aber viele von diesen „stellvertretenden" Arten sprechen allerdings nicht mit absoluter Deutlichkeit für eine „bestimmte und direkte Bewirkung".

Auch das häufige Vorkommen von geographischen Varietäten und Kleinarten besonders in der Peripherie von Arten mit einem großen Verbreitungsgebiet sprechen für die Einwirkung der Außenweltfaktoren.

Direkte Beweise für erbliche Veränderungen durch Einwirkungen von Umweltsfaktoren gibt es zurzeit noch wenige, aber doch genug um zu zeigen, daß auf diese Weise eine Bildung neuer konstanter Sippen stattfinden kann. Es gibt Versuche, welche beweisen, daß chemische Eingriffe erbliche Umwandlungen hervorrufen können, indem die Erbanlagen der Sexualzellen, männlicher sowohl wie weiblicher, geändert werden können. Der Nordamerikaner Mac Dougal gibt an, daß er Abkömmlinge von Pflanzen, in deren unbefruchtete Fruchtknoten er chemische Auflösungen eingespritzt hatte, erhielt, und von diesen Abkömmlingen zeigten einige erbliche Abweichungen von der Mutterpflanze.

Hier kann auch auf die Erfahrungen hingewiesen werden, welche über Umwandlungen von asexuellen Organismen durch äußere Faktoren hervorgerufen werden können (Hefezellen, Bakterien), Umwandlungen, welche ganz oder für eine Anzahl erblich sind. Am deutlichsten aber sind, was die Erblichkeit anbetrifft, die von Em. Chr. Hansen, Tower, Standfuß, Fischer u. a. ausgeführten Umwandlungen durch physikalische Einwirkung, namentlich durch abweichende Temperatur oder Feuchtigkeit der Umgebung. Besonders sind Insekten Versuchsobjekte gewesen (Schmetterlinge, Käfer); von den erhaltenen Abweichungen zeigte sich eine größere oder geringere Prozentzahl erblich. Besonders deutlich sprechen die Experimente von Tower mit Koloradokäfern (Leptinotarsa undecimlineata), welche erhöhter Wärme und trockenerer Luft ausgesetzt wurden, wenn die Tiere sich in einem bestimmten Entwicklungsstadium befanden; er konnte dann erbliche Farbenabweichungen erhalten.

Überhaupt scheinen physikalische Einwirkungen deutlicheren Erfolg zu geben als chemische. Es kann erinnert werden an die merkwürdigen Resultate, die Em. Chr. Hansen in Kopenhagen mit Hefezellen erhielt; gewissen erhöhten Temperaturen ausgesetzt, wurden sie asporogen, und zwar so konstant, daß sie später nicht in ihren ursprünglichen Zustand zurückgebracht werden konnten, selbst wenn unzählige Generationen anderen Einwirkungen ausgesetzt wurden. Die ursprünglichen erblichen Anlagen waren vollständig verändert worden. $\mathrm{Da} \beta$ die Hefezelle keine sexuelle Fortpflanzung hat, muß als unwesentlich betrachtet werden. 
Diese Resultate Hansens scheinen in der Litteratur wenig beachtet $\left.\mathrm{zu} \operatorname{sein}^{1}\right)$.

Auch Pasteur und andere haben durch Versuche gezeigt, daß virulente Bakterien ihrer giftigen Eigenschaften in manchen Fällen erblich beraubt werden können; es hat sich gezeigt, daß farblose Rassen sich aus farbstoffbildenden Bakterien züchten lassen und für längere Zeit erblich fixiert sind, selbst wenn sie wieder unter normale Verhältnisse gebracht worden waren. „Da man jetzt allgemein“, sagt 0 . Hertwig in seinem neuesten Werke ${ }^{2}$ ), neine dauerhafte idioplasmatische oder genotypische Veränderung der Keimzellen als eine Mutation bezeichnet, ist jeder durch Beobachtung gefundene oder durch Experiment hervorgerufene Fall einer solchen, wenn sie auf die nächste Generation übertragen wird, auch ein $\mathrm{B} e \mathrm{we}$ is für die Vererbung erworbener Eigenschaften". Hertwig selbst hat experimentell nachgewiesen, daß Samenzellen durch radioaktive Bestrahlung in ihrer Konstitution so verändert werden können, mögen sie noch in der Keimdrüse des lebenden Tieres sein oder nach ihrer Entleerung der Einwirkung ausgesetzt werden, so daß die Radiumwirkung auf das Ei übertragen werden kann, und Hertwig hat kein Bedenken, dieses als eine Vererbung einer erworbenen Anlage zu bezeichnen.

Auch scheint er mir recht zu haben, wenn er ferner den Schluß zieht, daß die Umweltsfaktoren „auf den ganzen Lebensprozeß der sich entwickelnden Versuchsobjekte, namentlich auf ihren Stoffwechsel und ihre ganze Konstitution eingewirkt" haben; der ganze Organismus ist verändert worden. Das mag nun richtig sein oder nicht, so viel steht offenbar fest, daß die Umweltsfaktoren Organismen dauerhaft verändern können, so daß ihre Abkömmlinge als "neue" Typen bezeichnet werden müssen. Das ist ja aber eben der Kern im Lamarckismus; viele von den so allgemeinen durch äußere Einwirkung hervorgerufenen Abweichungen, welche schnell verloren gehen, wenn die betreffenden Organismen anderen Einwirkungen ausgesetzt werden, würden nach meiner Auffassung wahrscheinlich mit der Zeit dauerhaft werden - es ist aber lange Zeit erforderlich, vielleicht Jahrtausende - aber Zeit spielt in der Natur keine Rolle, was eben die Ansicht Lamarcks war.

Es gibt also jedenfalls, wie erwähnt, zwei verschiedene Arten der Bildung neuer erblich dauerhafter Arten, nämlich die Bastardierung und die Einwirkung von Außenfaktoren auf die Organismen. Ob es noch eine andere Form gibt muß dahingestellt sein; ich denke an das, was Vesque „variabilité phylétique“ nannte, eine ererbte Variabilität, die von

1) Siehe Gesammelte theoretische Abhandlungen über Gärungsorganismen von Em. Chr. Hansen, herausgegeben von A. Klöcker. Jens 1911.

ə) Hertwig 1916: Das Werden der Organismen. 
der Abstammung der Arten, aber nicht von den Umgebungen abhängt. Es ist diese phylogenetische Entwicklung wohl identisch mit der, welche später von Eimer Orthogenesis genannt worden ist, Nägelis Progressionsprinzip.

Die Darwinsche Selektion hat nach der Auffassung der neueren Zeit nicht ganz die Bedeutung, welche ihr ursprünglich und durch viele Jahre zugeschrieben wurde; aber ganz ohne Bedeutung bleibt sie nicht. Aus dem oben Gesagten geht hervor, daß äußere Einwirkungen bisweilen abnorme Organismen hervorrufen, schwache und wenig lebensfähige Individuen; hier kommt „die Selektion" als regulierender Faktor und entfernt diese Individuen im Kampfe um Existenzmittel mit den befähigteren, der Lebenslage besser angepaßten.

Von den durch die artbildenden Kräfte hervorgerufenen Individuen gibt es drei Kategorien, nämlich erstens diejenigen, die nicht existenzfähig sind, jedenfalls nicht mit anderen Individuen den Kampf aufnehmen können und deshalb früher oder später verschwinden. Zweitens diejenigen, deren Charaktere indifferent sind, weder schädlich noch besonders nützlich; solche werden wohl oft ihren Platz unter den anderen Lebewesen behaupten können und ihre neuen Eigenschaften auf die Abkömmlinge vererben, und ich denke mir solcherart viele von den Baumarten der tropischen Regenwälder entstanden, in welchen, wie im 79. Kapitel erwähnt, die Artenmischung ungeheuer ist, ohne daß eine Art die anderen zu besiegen vermag. Drittens gibt es diejenigen Individuen, welche durch besonders nützliche Eigenschaften ausgestattet sind, sich also in ausgeprägter Weise den Umweltsfaktoren angepaßt zeigen; diese werden vorzugsweise imstande sein, eine Stelle im Kampfe ums Leben zu behaupten und sich in der Welt zu vermehren. Wenn man die Veränderungen beobachtet, welchen die Arten durch veränderte Lebenslage in der wilden Natur gewöhnlich unterworfen sind und von welchen oben Beispiele gegeben wurden, wird man, wie es scheint, finden, daß diese Veränderungen in einer für das Leben nützlichen Richtung vor sich gehen; es haben die Organismen vorzugsweise die Fähigkeit, sich den äußeren Einwirkungen in zweckmäßiger Weise zu adaptieren, und das ist es, was ich direkte Anpassung oder besser Selbstregulierung genannt habe.

Die Selbstregulierung scheint vorzugsweise bei den Vegetationsorganen oder auf dem Gebiete des Stoffwechsels, also auch bei der Ausprägung der Lebensformen und der Formationen, ihr Wirkungsfeld zu haben. Der Blütensproß folgt in seiner Entwicklung offenbar teilweise ganz anderen Gesetzen, als die vegetativen Organe; jedenfalls sind seine Reaktionen, soweit man weiß, gegen die Einwirkungen des Klimas und des Bodens viel geringer. Dies wird wesentlich darauf beruhen, daß der Blütensproß eine kurze Dauer hat, und daß die Prozesse 
des Stoffwechsels im Vergleiche mit denen der vegetativen Organe untergeordnet sind. Daß Eigentümlichkeiten, welche die Lebensformen kennzeichnen, aus direkter Anpassung an die Umgebung, aus einer Selbstregulierung der Natur hervorgegangen sind, die in zahllosen Reihen von Generationen stattfand, während gleichzeitig die Vererbung (welche neuen Anpassungen entgegenarbeitet) die erworbenen Merkmale in stärkerem oder geringerem Grade befestigte, erscheint als unzweifelhaft. Lamarck hat in dieser Hinsicht einen schärferen Blick für die Wahrheit gehabt, als Darwin und andere seiner Nachfolger. Die direkte Anpassung ist sicherlich einer der mächtigsten Entwicklungsfaktoren der organischen Welt. Durch ihr Studium wird das große Lebensgeheimnis uns etwas klarer werden; wir dürfen freilich nicht erwarten, dessen Kern je zu erkennen.

Im allgemeinen haben Werke oder Abhandlungen, welche nach 1914 erschienen sind, nicht ausgenutzt werden können, sind aber doch teilweise in der Litteraturliste angeführt worden. Speziell muß ich aber doch hier am Ende dieses Abschnitts erwähnen, daß ein neues, großes Werk von Frederic E. Clements in Minnesota mir zu spät in die Hände kam, um hier benutzt zu werden; es heißt: „Plant succession. An Analysis of the development of vegetation". Published by the Carnegie Institution of Washington, No. 242, 1916. Es enthält in seinen über 500 Seiten unter anderem: Concept and causes of succession; Initial causes; Ecesic causes; Reaction; Stabilisation and Climax; Structure and Units of Vegetation; Direction of Development; Classification of Series; Climax formations of North America; Past Climates and Climaxes. Es ist durch 61 Tafeln und 51 Textfiguren illustriert. (Warming.) 



\title{
Sach- und Namen-Register
}

\author{
von H. Stange
}

Aalegri̊s 393, 395

Abies 575

- alba 281, 584

- balsamea 517, 781

- concolor 575

- pectinata 584

- Sibirica 585

Absorptionsvermögen 98 , $100,106,109$

Acacia 228, 237, 239, 250 , $278,800,843,860,864$, 894

- acuminata 847

- alata 223

- australische 240

- conspicua 223

- cyclops 777

- detinens 862

- Farnesiana 443, 864

- Giraffae 264

- harpophylla 800

- heteracantha 862

- heterophylla 222

- horrida $264,844,858,862$

-. saligna 777

- spirocarpa 844, 862

- tortuosa 865

Acaena 637

- adscendens 679

Acanthacee 181,402

Acantholimon 866

- caryophyllaceum 866

Acantholippia 417

Acanthorrhiza 604

Acanthopanax 573

Acanthosicyos 243

- horrida 209, 777

Acanthus 789

- ilicifolius 402, 404, 407. 411

Acer $553,555,566,571,572$, $572,575,608,616,741$

- campestre 566

-Fraxinus-Ulmus 689

- pseudoplatanus 20, 36

- rubrum 624

- saccharinum 572

\section{Achillea 791}

- atrata 120,127

- clypeolata $124,814,815$

- fragrantissima 265

- millefolium 119, 267, $545,566,711$

- moschata 121, 127

Achorutes viaticus 469

Achyranthes 439

Acicarpha spathulata 224

Aciphylla 183

Ackérerde 84

Aconitum 276, 542, 548, 578,904

Acorus 501, 510, 514, 910

- calamus 38, 301, 503

Aretia 183

Acrocladium 635

Acrosiphonia 383

Acrostichum anreum 399, 402,411

Actaea spicata 564

Actinidia 574

Acutifolia 655

Adansonia 190, 256

- digitata 842, 844

Adenia 734

- globosa 856

Adenium 256

- Socotranum 742, 856

Adenocarpus 582

Adenostyles 174, 542

Adesmia 707

Adhäsion 85

Adiantum 739

- capillus Veneris 738, 739

Adonis vernalis 812

Adoxa moschatellina 170, $171,556,563$

Adventivwurzeln 88, 280

Aegiceras 252, 403, 406, 407

- corniculatum 244, 408

- majus 402

Aegle 867

Aegopodium podagraria 569

Aeluropus litoralis 459, 460 , 909
Aenderungen, biogene 918

- klimatogene 918

Aera 531, 534, 538, 832

- antarctica 717

- caespitosa 181, 530, 539,

$540,544,570,631,923$

- caryophylles 668

- discolor 501

- flexuosa $309 \mathrm{ff}, \quad 354$, $559 \mathrm{ff}$.

- praecox 668, 771

- uliginosa 501

Aeranthus funalis 295

Aërenchym 272, 273

Aërophyten 196, 297, 309

Aeschynomene 511

Aesculus 258, 553, 571, 572, 573

- hippocastanum 233, 554, 938

Ästuarien 341, 359, 391

Agarum Turneri 269, 374

Agathis anstralis 591

Agathosma erectum 220

Agauria salicifolia 720

Agave 45, 165, 174, 178, $232,258,255,427,826$, $853,865,885$

- Americana 164, 920

- , hundertjährige 165

Agavenform 325

Agrimonia Javanica 853

Agropyrum 74, 826, 8. a. Triticum

- dasystachyum 525, 780

- junceum 434

- spicatum 826

Agrostis 581, 538, 627, 636

- alba $447,451,520,530$, 539,540

- borealis 540

- canina 531, 658

- stolonifera 451

- tenuis 533

- valgaris 531, 540, 545, $631,728,914$ 
Ahl 113

Abnfeltia plicata 394

Aichryson 734

Ailantus 20

Aira s. Aera

Aizoaceae 224, 413

Aizoon 45, 250, 737

- Canariense 44

Akebia 514

Alang Alang 349

Alaria esculenta 381

Albizzia lebbeck 608

- Moluccana 607

Alchimilla 737, 871

- filicaulis 543

- glomerulans 543

- pentaphylla 530,533

- villosa 853

- vulgaris $532,548,568$

Aldrovandia vesiculosa 268 , $473,474,475,476,937$

Alectoria divergens 650

- nigricans 650

- ochroleuca 650

Algen 32, 116, 117, 120, $143,145,149,269,272$, $282,283,320,333,336$, 349,359

- aërobiotische 385,419 , 482

—, aërophile 419,482

- aërophytische 158,289

- auf Strandsteinen 346

- autophyte 359,391

- blaugrüne 146,362 , 431

- Farben 380

- Formation 481

-, krustenförmige 149

--Luftblasen 379

-typus 268, 272

- verteilung, schematische Darstellung 382

Alhagi 203,219

- Camelorum 343, 791, 866, 874,893

Alisma plantago aquatica $492,501,503,508,520$, 624

- ranunculoides 520

Alkalien 110

Alkoholgärung 79

Allium 812, 892

- senescens 868

- ursinum 563, 564

Allobophora turgida 137

Alluvium 73, 521

Alnus $559,572,584,631$, $689,907,908,915$

- glutinosa 514, 570, 680, 685,803

- incana 570

- rugosa 498

- viridis 129, 548, 685
Aloë 178, 192, 232, 253, $255,735,737,842,854$, 858,890

- plicatilis 859

- pluridens 799

Aloëform 325

Aloëgewächse 151

Alopecurus 538

- brachystachys 533

- geniculatus 530

- pratensis 539

- ventricosus 452

Alpenmatte 328

Alpenrosen 684

Alsine verna 534

Alsophila 246, 592, 617

Alternanthera 439

- muscoides 224

Althaen officinalis 455

Althenia 392

- filiformis 458

Aluminium-Silikate $\mathbf{7 4}$

Alvaren 729

Alvarvegetation 96,97

Amarantaceae 224

Amaryllidaceen 173,257

Amblystegium 473, 632, 633 , 639,681

Ambrosia trifida 510

Ameisen 136, 278, 297

Amelanchier vulgaris 742

Ammi visnaga 51, 886

Ammodendron 778

- conollyi 779

- Karelini 779

Ammoniak 98, 121, 147

Ammophila 78, 209, 217 , 301,771 , 8. a. Calamagrostis

- arenaria $181,217,758$, 759,762

--Dünen 749

Amorphophallus 179

Ampelodesmus tenax 789 , 806

Amphilophium 163

Anabaena 287, 394

- Baltica 362

- circinalis 464, 467

- flos aquae 464, 467

- thermalis 485

Anabasis 229, 458

- aretioides 65, 184, 889

- arcticulata 221, 792, 889

Anagallis tenella 519

Anamirta coccculus 611

Anaptychia 688

- ciliaris 723

Anastatica 214

- Hierochuntica 51, 885, 888

Anchusa Barrelieri 814, 815

Ancylonema Nordenskiöldii 469
Andira inermis 177, 865

Andreaea 723

Andromeda 689

- calcyculata 509, 622

- polifolia $210,501,581$, $624,634,652,658,660$, 680

Andropogon 513, 782, 818, $829,832,836,839,840$, 844

- cerisiiformis 818

- Dünen 749

- furcatus 822, 823

- gryllus 814

- Hallii 824

- hirtus 251, 252, 806

- scoparius 781, 822,823 , 824

- villosus 235

Androsace 696, 735

- glacialis 102

- Hausmanni 102

- Helvetica 130, 266

Anemone 562, 566, 583, 871, 923

- alpina 101

- nemorosa 8, 173, 353, $355,523,556,562,569$, 717,916

- ranunculoides 8, 523, 562,916

- salphurea 101

Anemophile 301

Aneura 658

Anflug-Kiefern 115, 665

Angelica 631

- officinalis 567

- silvestris 568

Angiospermen 316

Angraecum sesquipedale 277

Anguillaliden 111

Anisomeris obtusa 222

Anona 835

- crassiflora 838

- palustris 410

Anordnung, gürtelförmige 355

Anpassung, anatomische 196

- biologische 289

- ökologische 316

- physiognomische 196

- räumliche 303

- soziale 275

- zeitliche 304 .

Anpassungsmerkmale 152

Anthelia pilacea 640

Anthemis arvensis 127

- cotula 127

Antennaria 668, 771, 853

- dioeca 218, 579, 770, 773

Anthistiria ciliata 588

- imberbis 588,818

- membranacea 832

Anthocyan 27, 203 
Anthoxanthum 538, 539, 545

Anthoxanthum odoratum

$181,217,530,531,534$, 688,909

Anthriscus silvestris 567

Anthurium 296

- Huegelii 241

- leuconeurum 28

Anthyllis vulneraria 120 , 770,900

Antökologie 5

Anziehung, chemische 98

-- physikalische 98

Apfelsäure 248, 256

A phanizomenon flos aquae $362,464,467$

Aphanothece 496

Apium 453

- graveolens 164

Apocynaceae 299

Apodanthes 281

A ponogeton distachyum 519

Arabis 547, 703

- alpina 548, 716

Araceen 51, 151, 160, 185, $246,290,291,293,413$

- epiphytische 194

Araucaria Brasiliensis 586 , 840

- imbricata 586

Araucarienwälder 586

Arbutus unedo 204, 794, 796,803

Archangelica 530, 631

- officinalis 543,548

Arctostaphylos 666, 674, $675,716,909$

- alpina 193, 642, 667, 668, $676,677,714,912$

- -Juniperus-Heide 749

- uva ursi $193,347,577$, $579,667,668,676,677$, 678,780

Area 1

Aremonia agrimonioides 278

Arenaria 706, 715, 735, 737

- peploides 430,436

- serpyllifolia 703

Arenicola 138

Aretiastrum 183, 266, 708

Argentea-Arten 231

Aride Gebiete 849

A ristida 209, 217, 235, 818, $824,829,836,840$

- basiramea 824

- junciformis 818

- longiseta 824,825

- pennata 778,779

- pungens 242, 753, 758, $776,778,782,792,884$

- purpurea 824

A ristolochia triangularis 163

Armeria 450, 715

- maritima 678,746
Armeria valgaris 176,451 , $747,768,770$

Armillaria mellea 281

Arnica 904

- montana 584, 578, 668

Aronia 689

Aronstab 8

Arrhenatherum 587

- elatius 816

Artemisia 181, 213, 812, $866,873,889,891,894$

- campestris 44, 221, 668, $706,765,770,792$

- Canadensis 749, 825

- caudata 749

- filifolia 781, 793

- frigida 791, 873

- Gallica 455

- herba alba $265,457,792$, 817

- maritima 346, 450, 791, 873

- monosperma $\mathbf{7 7 6}$

- nana 706

- - Panicum-Assoziation 748

- spinescens 874

--Steppe 791, 792, 807, 811

- tridentata 793, 873, 874

- Valesiacs 816

Arthopyrenia halodytes 424

Arthrocnemum 230, 416

- glaucum 424, 454

- macrostachyum 909

Arum 179

- maculatum 8, 564

Aruncus silvester 57

Arundinaria 513

- alpina 616

- macrosperma 510

Arundineta 352

Arundo 783

- donax 190, 506

- Madagascariensis 832

Arvenwälder 580

Asarum 380

Asclepiadaceas 299, 414

Asclepias Cornuti 730

- purpurea 819

Ascophyllum 383

- nodosum 272, 373, 375 , 394

- scorpioides 394

Asparagoideae 413

Asparagus 280, 790, 794

- acutifolius 795,804

- horridus 788, 899

Aspectus aestivalis 380

- auctumnalis 330

- hiemalis 330

- vernalis 330

Asperula longiflora 92
Asperula odorata 170,301 , $358,355,562,928$.

Asphodelus 788, 789, 790

- luteus 254

- ramosns 582

Aspicilia cinerea 422

Aspidistra 175

- lurida 173

Aspidium 567, 785

- dryopteris 178, 562, 576

- filix mas 564

- spinulosum 564

- thelypteris $681,685,668$

- vestitum 639

Asplenum 785

- adiantum nigrum 101

- adulterinum 101

- nidus 294, 295, 600

- Seelosii 102

- septentrionale 102

- Serpentini 101

- trichomanes 21, 22

- viride 101

Assimilation 31, 256

- sgewebe 251

- sorgane 269

Assoziationen 2, 3, 806, 349, 352,410

- A bänderung 353

-, koprophile 422

- Verånderungen, sekundäre 356

- kompetitive 304

Astelia 178

Aster 450

- alpinus 706

- amellus 706

Asterionella 465, 468

Asteriscus pygmaeus 214, 885

Aster tripolium 400, 418 , $422,427,448,449,453$, 455,743

Astragalus 203, 242, 265, $776,792,826,866,893$

- arenarius 773

- exscapus 243

- Thracicus 791

Astrebla 832

Astrocaryum 265

Atemhöhle 208, 210

Atemwurzeln 404

Athyrium filix femina 564

Atmung 48, 256

Atragene 578

- Sibirica 571

Atriplex 42, 44, 253, 416, $434,436,448,458,458$, $460,831,864$

- canescens 874

- confertifolia $457,459,874$

- coriacea 250

- dimorphostegia 893

- halimus 250,792 
Atriplex litoralis 400

- pamporum 864

- patula 453

- pediculata 250

- portulacoides 250,417 , 418, 454, 909

Attheya 465

Auenwälder 318, 522

Aufbau, histologischer 316

Auftanen 38

Aulacomnium 521, 531, 538, 658

Ausläufer 78, 181, 301

Austrocknung 135, 292

Austrocknungsvermögen197

Autophyten 72, 147

Avena 538, 587

- filifolia 816

- pratensis 546

- pubescens 539

- rufescens 636

A vicennia 403, 404, 406, 407, 408

- nitida 402, 406

- officinalis 402

- tomentosa 402

Azalea procumbens 116

Azalea procumbens-Heide 679

Azima tetracantha 799

Azolla 268, 270, 287, 472, 474,516

Azorella 183, 184, 220, 266, $325,663,679,708,871$

- caespitosa 718,871

- lycopodioides 708

- madreporica 830

- selago 708

A zotobacter chroococcum 286

Bacharis 864,871

- crispa 225

- dioeca 224

- genistelloides 225

- triptera 227

Bacillus azotobacter 148

- Pasteurianus 148

- subtilis 433

- tetani 139

Bacterium Okeni 389

- sulphuratum 389

Bactris 265, 411, 517

Bäume, fettspeichernde 35

-Gestalt 64, 190

—, immergrüne 129

-, Kämpfe 19

- mit Brettwurzeln 597

Bakterien, anaerobe 82,116

_, denitrifizierende 147

Bakterienkolonie, strangförmige 286

Bacterium oligocarbophilum 140
Bakteroiden 286, 287

Bambusa 616

Bambusen 186, 190

Bambusform 188

Bambusgräser 168

Bambusgruppe 183

Bambuswald 517, 616

Bananen 151, 165

Bandblatt 392, 492

Bangia 383

Banksia 209, 845

Barbacenia 260, 723

Barbula muralis 900

Barringtonia-Formation 444, 445

- racemosa 444

- Wälder 910

Basalt 94, 106

Basaltsand 94

Basidiomyceten 138

Basis 306

Bastgewe be 217

Baststränge 263

Batidaceae 224

Batis $361,410,414,439,453$, 454

- maritima 224, 401, 454, 455

Batrachium 474, 486, 488, 490, 492, 494, 496, 498

- aquatile 476, 494

- marinum 394

Batrachospermum 478, 481

Bauhínia sp. 163, 258

Baum der Reisenden 193

Baumfarne 324, 617

Baumgrenze 131, 132

Baumkronenschicht, oberste 329

Baumschicht, niedere 329

Baumsteppen 833, 841

Baumwuchs-Formen 64

Bauverhältnisse, ana tomische 70

-, besondere 70

-, morphologische 70

Bau, xeromorpher 311

-, xerophiler 311, 407

Beggiatoa alba 388,389

Beggiatoen 389, 485

Begleitpflanzen 303 , 354

Begonia 251

Beilschmidia 591

Bejaria 871

Bellis 545

- perennis 32

Beleuchtungsdauer 15

Beleuchtung, Regulierung 201, 236

Bennettitales 884

Benthos 359

Berberis 263, 552, 571, 586, 872

- empetrifolia 220
Berberis ilicifolia 573

- vulgaris 775

Berchemia scandens 624

Bergheide 95

Bergkiefer 285, 314

Berkhaya 875

Besiedlung, lockere 327

- von Neuland 930

Beståubung 277, 301

Bestrahlungsdauer 93

Beta 164

- maritima 424

- vulgaris 164

Betula 42, 571, 572, 573, $575,584,778,912$.

- alpestris 688

- Carpatica 683

- glandulosa 677

- humilis 680

- lutea 689

- nana $13,567,568,579$, $625,631,643,644,647$, $658,662,666,667,674$, $675,677,680,681,686$, $706,714,909,911,912$, 941

- odorata $551,567,568$, $660,680,685,686$

- pubescens $567,636,682$, 685,928

- tortuosa $686,688,736$

- verrucosa $567,660,680$, 685

Betulaceae 413

Betuleta cladinosa 353

- hylocomiosa 353

Bewegungen 143

Bewegungserscheinungen 14

Biatora 722

Biddulphia Mobiliensis 363

Bignoniaceae 299

Bignonia(mit Kletterkrallen) 162

Binnenlandgewåsser 318

Binnenlandsgürtel, supramariner 420

Binsenblatt 221

Birke 20, 35

Birkengestriüppe 129

Birkenwälder 8, 318, 352, 356,567

-, nordische 353

Bitterstoffe 278

Blaeria ericoides 793

Blätter, s. auch Blatt

-, aphotometrische 24

-, bedeckende 232

- behaarte 408.

- Bewegungen 217

-, euphotometrische 24

- ganzrandige 416

- herablaufende 227

- kantenständige 239

-, kleinbleibende 416 
Blätter, lackierte 205

- Nervatur 154

-, panphotometrische 25

-, photometrische 24

-, plastische 29

-Profilstellung 409

- Richtung 22

- rinnenförmige 246

Blasentang 377

Blasen, wasserhelle 250

Blattbau, anatomischer 26

Blatt, borstenförmiges 221

-, ericoïdes 220

—, fadenförmiges 221

- formen 219

-, helodeoïdes 493

- im Schatten, in der Sonne 29

-, juncoïdes 221

- mosaik 28, 25

-, myriophylloides 494

—, myrtoüdes 221

-nerven, rinnenförmig vertiefte 57

-, pinoides 220

-rosette der Ananas 45

-rosetten von Sempervivum 45

- - trichterförmige 246

- saftplanzen 254, 414

-scheiden 233

- scheidenhüllen 133

-, schuppenähnliches 220

- spreite, Falten usw. 236, 239

-stauden 167

- -, orthotrope 155

- stiele, rinnenförmig vertiefte 57

- succulenten 45, 224

-typen 324

-, zosteroïdes 492

Blechnum occidentale 241

Bleichsand 112

Bleisand 112, 113

Blitzschläge 71

Blockmeere 740

Blütezeit 40

Blumenbachia 871

Blumenuhren 32

Blumenmatten 531

Blutbuchen 29

Biuten, inneres 49

Bluthaseln 29

Bubartia spathace 229

Boden-Abkühlung 95

- Arten 4, 86, 105

- Austrocknung 85

- Bau 72

-Beleuchtung 134

- Beschaffenheit, chemische 73,93

—, bewachsener 134, 135

- Bindigkeit 76, 77, 78
Boden, chemisches Verhalten $99,100,118,119,136$

-Decke 88, 329

-Durchluiftung 79, 125

- Erwårmung 92

- Farbe 86, 94

- Feinheit 73

- fester 77

--Feuchtigkeit 104, 318

-, flachgrindiger 96,97 , 780

-, flüchtiger 77

-, garer 137

- gefrorener 94

- Gewicht 80

- Heizung 90

-, hetero-, homotermischer

92,94

- Kälte 68

-, kalter 88, 92, 132

- Kapillaritåt 78

-, krümeliger 137

-Lagerung 73

- leichter 98

-, loser 78, 74, 77, 78

-. Luft 79

- Mächtigkeit 96

-, magerer 99

-. milder 77

-, mürber 77, 137

-, nackter 134

-, nährstoffarmer 103

- Nährstoffgehalt, 72, 99, 104,125

-, neuer 898

-, pelopsammitischer 123

-, physikalische Eigenschaften 118, 119, 125

- physikalisch trockener 100,310

-, physiologisch arm 100

-, physiologisch trocken $100,144,310,311$

--Porosität 94, 187

-, salzhaltiger 310

-, saurer 88,311

- schichten 96,98

-, schwerer 77, 98

- sekundärer 72,73

- Skelett 74

-, sterilisierter 139

_, stickstoffhaltiger 139

-, strenger 77

- Teile 74

—, tiefgründiger 96

- Temperatur 91, 125

- torfhaltiger 319,618

-, trockener 100, 317

- Untergruid 96, 98

—veränderungen 899, 906

- Verdunstung. 125

- Volumen 80

- Wärme $89,91,92$, 134
Boden-Wasser 72, 80, 88, $94,125,134$

-, wasserreicher 810

-, zinkhaltiger 101

Bodo edax 365

Bolax 708

- Bovei 708

- glebarii 708, 718, 830

Bombacaceen 151, 190, 256

Bombus 276

Borassus flabellifera 616,844

- -Haine 616, 844

Borke 206

Borraginaceae 224

Borrichia arborescens 224

Borsten 278

Bostrichis scorpioides 450

Boswellia Socotrana 742

Botryococcus 466

Boutelona 782, 826

- curtipendula 823, 824

- oligostachys 823, 824

Brachylepis 458

Brachy podium ramosum 239 , 788,789

- silvaticum 556, 564

Brachystegia 851

Brachythecium antarcticum 649

Branderde 113

Brandung 149

Brandungsguirtel 420

Brasenia purpurea 488, 498

Brassica oleracen 164, 425 , 426,427

Braunalgen 380

Braya 715

Brennhaare 278

Briza 538, 587

- media 539

Brombeere 552

Bromelia bracteata 865 .

Bromeliaceen, epiphytische 56

Bromeliacee, Rosette 247

- Schuppe 55

Bromus 545, 774, 814

- erectus 556, 816

- fibrosus 814,815

- mollis 771

-. Wiese 816

Broussonetia 37

Brownea coccinea 237

Bruchwald 522

Bruckenthalia spiculifolia 679

Brücher 318

Bruguiera 403, 404, 406, 408, 516

- caryophylloides 402

- eriopetala 402

- gymnorrhizs 402

- parviflora 402

Brunella 634 
Brunella grandiflora 127

- vulgaris $127,541,816$

Bruniaceen 220

Brunnenfaden 484

Brunsvigia 885

Bryophyllum 255

- calycinum 854

Bryum 538, 658

- argenteum 562

Buchen 19, 38, 71, 127, 284, 328,553

-blätter 29, 207

- Rohhumus 111

- Wälder $8,134,302,318$, $352,356,560$

Buchloë dactyloides 821,823 , 824

Buchweizen 349

Bucida buceras 410

Buellia geographica 722

Bulbilis dactyloides 823

Bulbine 253

Bulliarda aquatica 225, 497, 520

Bulnesia retamo 782

Bupleurum fruticusum 788

Burmanniaceae 298

Butomus 501, 514, 624, 910

- umbellatus $268,503,506$

Butterbaum 856

Buttersäuregårung 82

Buxus sempervirens 571, 794, 796

Byrsonima 835,840

Caa Tinga 349

Cabomba 474, 488, 492, 494

Cabombaceae 486

Cactaceae 185, 231, 255, 290

Cacteen 232, 253, 256, 292, $325,361,834$

Cacteenform 231

Cactus 872

Caesalpinia bonducella 445

Cakile 525, 758

- aequalis $212,224,437$. 441

- Americana 525

- lanceolata 437

- maritima 414, 434, 436

- Xanthium-Formation 748

Caladium 512

Calamagrostis 209, 217, 771, 824,882

- arundinacea 677,774

- arenaria 217, 301, 753, $755,758,759,760,762$, $763,772,773,775,780$, 781,825 , s. a. Ammophila

- Baltica 760, 762

- epigeios 763, 773

- lanceolata 511, 516, 636

- longifolia 780

Calamintha 794
Calamintha acinos 773

Calamovilfa 824

- longifolia 781

Calamus-Palmen 159

- Triebspitze 158

Calceolaria 871

Calcium 74, 99, 245

Calendula arvensis 32

Calla palustris 194, 495, 515, 652

Calligonum 204, 778, 779, 792,893

- comosum 242, 776

- Persicum 446, 447

Callithamnion 383

- arbuscula 381

Callitriche 486, 487, 489, $491,495,496$

- antumnalis 488,493

- verna 488

Callitris-Macchie 796

- quadrivalvis 221

Calluna-Heide 285, 302, 318, $328,669,670,672,912$

- Moor 672

- Rohhumus 111

- Typus 338

Callunetum 337, 347, 354, 357

Calophyllum 517

Calothrix 478

Calotropis 865

- gigantea 779

- procera 867

Caltha 539, 631, 636, 681

- palustris 211, 268, 503, $508,541,628,636$

Calyceraceae 224

Calycotome 806

- intermedia 788

- spinosa 794, 796, 797

Campanula 177, 548, 684

- barbata 578

- Carpatica 176

- evinus 734

- Orbelica 533, 535

- persicifolia 28

- rotundifolia 545, 566, 668

- Scheuchzeri 534

- Steveni 535

- trachelium 564

- uniflora 715

Campomanesia aurea 222

Campos 141, 213, 344, 345, 833,836

-flora 221, 331

Canarium 602

Canavalia 445

- obtusifolia 437, 438, 439

- Formation 439

Canna indica 506

Capparis 260, 261, 894

- aphylla 229

- spinosa 203
Capparis yto 852

Capsella bursa pastoris 164 , 949,950

- Heegeri 949, 950

Caragana 866

Carallia 602

Caralluma 414

- codonoides 856

Carapa 403, 404, 408

- Molucensis 402

- obovata 402

Cardamine 521, 936

- amara 521

- impatiens 562

- palustris 523

Carex 399

- acutiformis 501, 503,508 , 632,914

- alpicola 540

- arenaria 181, 242, 338, $438,579,760,761,762$,

$764,765,770,772,773$

- canescens 636

- chordorrhiza 501, 624, $631,635,659,941$

- curvula 534

- diandra 636

- digitata 562

- dioeca 624

- distichia 508

- extensa 455

- ferruginea 532

- filiformis = lasiocarpa

- firma 534

- Goodenoughii 625, 632, 635,636

- gracilis $503,539,632$

- hirta 118

- humilis 118

- incurva 436

- lasiocarpa 508, 685, 652

- Ligerica 579

- limosa 501, 624, 627, 635,652

- Lyngbyei 451

- microglochin 624

- montana 278, 816

- nigra 534

- panicea 539, 624, 632

- paniculata 501, 503, 508, 540

- paradoxa 508

- pauciflora 624

- physodes 778

- rariflora 624, 639

- remota 562

- rigida 633,639

- riparia 503, 508

- rostrata 508, 634, 907

- rupestris 715

- salina 451

- sempervirens 716

- stricta 501, 503, 508, $632,634,637$ 
Carex ternaria 637

- trifida 638

- verna 816

- vesicaria 503,508

-- vulgaris 625

Caricacee 256

Carlina acaulis 127

- vulgaris 127

Carmichaelia australis 228 , 227,230

Carnegia 885

Carpinus 71, 566, 572, 982

Carthamus lanatus 416

Carum 545

- carvi 711

- Turkestanicum 891

Carya 572

Caryophyllaceen 183,261 , 262,413

Cassandra calyculata 509, s. a. Andromoda

Casselia-Wurzelknolle 77

Cassia 519, 587, 782, 864

- obovata 249

Cassinia 783

Cassiope 220

-- hypnoides 581

- tetragona 209, 851, 676, $678,697,709,714$

Castanea 552, 566, 572, 575, 803

- sativa 120, 572, 987

Castela 863

Casuarina $151,209,229$, $416,444,446,782,800$, 852,895

- equisetifolia 445, 446

-...Wald 846

Catalpa 572

Catenella opuntia 450

Catinga 189,256

Caulerpa 375, 387, 392, 393

- prolifera 386

Caulina 434

Cavanillesia arborea 852

Ceanothus 287

Cecropia 278, 610

Cedrela 606

Celastrus 574

- scandens 780

Cellules bulliformes 217

Cellulose 217

Celmisia viscosa 719

Celtis 572

Cenchrus 782

- echinatus 438

Centaurea 260, 866

- chrysolepis 815

- chrysolepus 814

- spinosa 184, 185, 866

Centunculas 904

Cephalanthera 563

Cephalanthus 689

Cephalotus 631
Cephalozia 658

Ceraminm 394

- diaphannm 877

Cerastium 580, 545, 547 , 735,737

- alpinum 709, 715

- semidecandrum 767, 771

- tetrandrum 771

- trigynum 638, 640

Ceratium 864, 367, 368

- fusus 364

- hirundinella 465, 467 , 468

- tripos 364, 371

Ceratocarpos arenarius 791, $882,883,893$

Ceratocephalus arenarius 812

Ceratadon purpureus 762 , 764

Ceratonia siliqua 796

Ceratophyllum 39, 268, 472 , $473,474,475,476,497$, 498

Ceratopteris 476,498

- thalictroides 472

Cercidopyllum 573

Cercis 605, 863

Cereus 427, 852, 865

- giganteus $859,860,885$

- quisco 799

- tuberosus 258

Ceriops 406, 408, 409

- Candolleana 402, 404

- Roxburghiana 402, 404

Cetraria 534, 715

- crispa 650

- Islandica 579, 650, 668

- nivalis 764

Chaetoceras 363,371

- paradoxum 363

Chaetomorpha 450

Chaetophora 478

Chamaedaphne 689

Chamaedorea 190, 602

Chamaeorchis alpina 705

Chamaepericlymenum Suecicum $530,658,688,711$, 941 , s. a. Cornus

Chamaephyten 158, 165

Chamaerops 516, 867

- humilis 788, 789, 806

Chantransia 481

Chara 488, 509, 581

Characeen 117, 145, 147, $346,387,392$

Chara fragilis 493

Chasmophyten 78, 320, 424

Chenolea diffusa 452

Chenopodiaceae 120, 121, $220,224,229,230,250$, 413

Chenopodiaceen-Vereine 340

Chenopodium 453, 907
Chenopodinm glancum 458

Chevaliera lingulata 177

Chiliotrichum amelloidenm 718

Chitinpanzer 117

Chlamydomonas 432

- flavivirens 470

- lateritia 469

- nivalis 469

Chloride 245

Choris 460,818

Chorisia crispiffora 256, 851

- ventricosa 844

Chlorkalium 148

Chlormagnesium 148

Chlornatrium 118, 148

Chloroform 139

Chlorophy ceen $362,383,432$, 478

Chlorophyll 298

Chlorophyllgewebe 212, 253, 263,270

Chlorophyll-Zersetzung 22

Chorda 378 ,

- filum 376, 378

- tomentosa 384

Christushand 174

Chroolepus 724

Chrysanthemum leucanthemum 119,545

- vulgare 766

Chrysobalanus icaco 446

Chrysomonadinen 364, 365

Chrysophyllum marginatum 222

Chrysoplenium alternifolium 74

Chrysopogon nutans 822

Chuquiragua 871

Chusquea aristata 867

Chymocorea empetroides 777

Cicendia 904

- filiformis 658

Cichorioideen 213

Cicuta virosa 501, 503, 508, 515

Cinclidotus 478

- scoparius 910

Cipura 587

Circaen 27, 556, 563, 583

- intermedia 170,942

- Lutetiana 74, 170

Cirsium 567

- arvense 166, 179, 301

- palustre 539, 636

Cissampelos sp. 163

Cistanche tubulosa 447

Cistetum 387

Cistus 218, 582, 788, 789, $793,803,806$

- ladaniferus 794

- Monspeliensis 906

Cladina 422,650 
Cladium 628

- mariscus 503

Cladonia 534, 715, 727, 766

- alcicornis 747

- alpestris 579,650

- Assoziation 749

- coccifera 764, 765

- fimbriata 764, 765

- foliacea 747

- gracilis 764, 765

- rangiferina 291, 347 , $567,579,650,668,674$, $763,764,765$

- silvatica 579

Cladophora $478,481,496$

- fracta $463,467,476$

- gracilis 394

- Sauteri 496

Cladosporium 672

- humifaciens 138

Cladostephus verticillata 394

Clamydothrix ochracen 484

Clatrocystis aeruginosa 464

- rosei-persicina 389

Clavaria abietina 297

Clematis 558, 574, 577, 795, 804

Cleome Arabica 265, 887

Cliffortia falcata 786

Climacium dendroides 635

Climax-Formation 323, 335, 357

Clostridium azotobacter 148

- Pasteurianum 148, 286

Clusia 159

Cnicus 866

Cobaea 159

Coccolithophora pelagica 364

Coccolithophoridae 364,367 , 370

Coccolithophorideen 370

Coccoloba 230, 245

- uvifera 23, 239, 445

Coccolobetum uviferae 439

Cocculus leaeba 206

Cochlearia 417, 418, 448, $451,530,703,704,715$

- fenestrata 16,35

- officinalis 414

Cocos yatai 616

Codonocarpus 782

Coelogyne Sanderae 186

Colchicum antumnale 539

Coleonema 737

Coloetriche 520

Colletia 227, 229, 230, 586, 799

Colobanthus muscoides 625

Comarum 636

- palustre $628,631,652$, 658,681
Combretaceen 402

Commelinaceen 181, 252

Commiphora 862

Communities 353

Compositae 224, 413

Conchophyllum imbricatum 235

Conferva chthonoplastes 390

Conferven 390

Coniferen 315

Coniferales 316

Coniteretum 352, 574

Conocarpus - Assoziation 410

- erectus 410, 439, 443

Convallaria 556

- majalis 563, 678

Convolvulus arvensis $\mathbf{4 1 4}$

- lanatus 244

- sepium 516

- soldanella 438, 439, 772

Copernicia australis 839

Coprinus 297

Coprosma 638, 783

Corallina 383

Coralliorrhiza 242, 298, 558, 563

Corchorus 873

Cordia 446, 865

Cordyline 192

Corispermum hyssopifolium 525,780

Cornicularia 715

- aculeata 764, 765

Cornus 552, 572, 688, 689

- alba 563, 780

- mas 571

- sanguinea 563, 571

- Suecica 530, 658, 688, 711,941 , 8. \&. Chamaepericly menum

Coronaria flos cuculi 539

Coronilla rosea 236

Corophium crassicorne 138

Cortaderia 679

Cortesia cuneata 782

Corydallis $173,353,556$, $562,564,812,827,923$

- cava 278, 305, 523, 562

- solida 173,305

- tuberosa 717

Corylus 566, 741

- colurna 938

Corynephorus canescens 217, 221 , s. a. Weingaertneria

Corypha inermis 840

- umbraculifera 192

Coscinodiscus 363

Cotinus 550

Cotoneaster 735

- nummulifolia 742

- pyracantha 455

Cotula cinerea 44

Cotyledon 255, 735, 737, 858
Cotyledon fascicularis 856

- im Hottentottenschädel 345

Covillea tridentata 860

Crambe 436

- maritima 415, 435, 436, 771

Crantzia linearis 708

Crassulaceen 45, 244, 248 , $253, .255,858$

Crassula falcata 238

Crataegus 263, 550, 252,

$566,572,741,900$

Crenothrix polyspora 484

Crepis aurea 533

- tectorum 218

Cressa Cretica 245

Crescentia cujete 605

Crinum 260, 512

- pratense 249

Crithmum maritimum 424

Crocus 8, 179, 258, 794

- Heuffelianus 717

- vernus 704

Croton 218, 231, 737, 865

- flavens 67

Cruciferae 121, 183, 224, 413

Crypsis aculeatus $\mathbf{4 5 5}$

Cryptomonas erosa 365

Cucurbitaceae 299

Culcitium 38, 709, 719

Cunonia Capensis 786

Capania (fulva?) 177

Cupressoideen 220

Curatella 837

- americana 840

Cuscuta 116

- epilinum 280

- epithymum 280

Cuticula 202, 240, 288

Cyanophyceen 146, 147. $287,288,362,370,372$, 390,478

- Vereine 432

Cyathea 592, 617

Cycadeen 192, 288

Cyclamen 174, 178, 564

Cyclanthera 936

Cyclotella 465

Cydonia Japonica 40

Cymbifolia 655

Cymodocea 392, 434

- manatorum 395

- nodosa 395

Cynanchum vincetoxicum 169

Cynara cardunculus 829

Cynodon dactylon 209, 211, $439,587,775$

Cynoglossum Javanicum 853

Cynomorium coccineum 458

Cyperaceen 82, 116, 120 , $181,217,221,229,249$, $399,413,631$ 
Cyperus papyrus 511, 514 - Syriacus 511

Cystopteris 735

- fragilis 313

Cystoseirs 375

Cytisus 229, 551

- prolifer 868

Cytoplasma 287

Dacrydium laxifolium 782

Dactylis 538

- Aschersoniana 556, 562, 563

- glomerata 539, 914

Dahlia variabilis 173,174

Dalbergia $\mathbf{4 5}$

Dampfform 49

Danthonia 637, 842

- bromoides 638

- Raoulii 832

Daphue 684

- gnidium 582, 788, 906

- muscosa 679

- mezereum 566

- striata 679

Darlingtonia 681,658

Daucus 545

- carota 52, 164, 886

Decke, lebende 4

Decke, leblose 4

Delesseria 376

- sanguinea 377,378

Delphinium 542, 578

Dendrobium inaequale 186

- nobile 53

Dendrosicy os 190

- Socotrana 742, 856

Dentaria 353

- bulbifera 563, 742

Derbesia Lamourouxii $\mathbf{2 8 7}$

Deschampsia 534, 538, 627

- flexuosa 579, 651, 8. a. Aera

Desmanthus natans 473

Desmarestia 383

- aculeata 378,384

Desmidiaceen $120,148,375$

Desmoncus 162

Desmotrichum undulatum 394

Desoria saltans 469

Detritus 123

Diachyrium 782

- arundinacens 830

Dianthus 814,815

- arenarius 773

- caresius 181

- Carthusianorum 815

- deltoides 770

- microlepis 533, 585

Diapensia $702, \mathbf{7 1 5}, 737$

- Lapponics 183, 677, $707,714,911$

Diatomacege 872, 432
Diatomeen $148,368,367$, $370,385,483$

Diatomeenplankton 369

Dichelyma 478

Dichothrix gypsophila 390

Dichtigkeit 326

Dickenwachstum 273

Dicksonia 183

- antarctica 246

- Berteroana 591

- Yourgii 617

Dicraea elongata 480

Dicranum 135, 548, 579, $581,583,633,639,642$, $646,648,658,688$

- elongatum 644

- scoparinm 564, 764

- tenuinerve 644

Dictyosphaerium 466

Digitalis 548, 684

Dikotyledonen 190, 218

Dilleniaceen 209

Diluvium 78, 82

Dinobryon 365

- sertularia 365

Dinoflagellata 364

Diodia radicans 437

Dionaea 178, 681

Dionysia 183

Dioscoreaceae 299

Dioscorea 56

- dodecaneura 163

- elephantipes 206, 257, 259

Diphotaxis harra 55, 243

Dipsacaceen 262

Discaria toumatou 265

Dischidia 293

- Rafflesiana 293

Distichia muscoides 184

Distichlis spicata stricts 452

Dolomit 102,106

-geröll 314

- grus 95

-Verwitterangsböden 815

Domatien 278

Donatia 708

Doppelorganismus 282

Dorema 866

Dornbildung 27, 263, 278

DornensproB 229, 280

Dorngebüsch 303

Dornsträucher 187

Dornstrauchsteppen 861

Dorstenia gigas 856

Draba 174, 178, 706, 707, $709,711,715,735,871$

- alpina 266

- Cappadocica 735

- crassifolia 702

- laevigata 703

- verna 164, 703

Dracaena 192, 737
Dracaena cinnabari 742,851

Dracophyllum politum 708

- recurvum 782

Drainage 187

Drainzöpfe 79

Drimys Chilensis 591

- Winteri 692

Drinn-Steppe 817

Drosera 178, 587, 631, 686, 658,680

- rotundifolia 174, 652

Drüsenflecke 212

Drüsenhaare 245,277

Drüse, salzausscheidende 244

Dryas 193, 221，532，662, 676, 697, 702, 706, 709, $715,716,739$

-ablagerungen 939

- Heide 678

- integrifolia 678,714

- octopetala $65,209,677$. $678,706,709,714,911,912$

Drymoglossum nummularifolium 250

Dünen $78,75,318,437,441$, 749

-, auBereuropäische 776

- bewaldete 769

-Bildung 63

--Embryonen 752

- feststehende oder graue 762

--Flugsand 314

- gräser 217

-, graue 762, 763

-heide 767

-, in Afrika 776

-, in Asien 778

_, in Australien 782

- , in Neuseeland 782

- in Nordamerika 779

-, in Südamerika 782

-, weiße, bewegliche 759

Dulichium 509

Durchlüftungssystem 207

Durvillea 378

Eatonia obtusata 822,823

Echeveria 45, 178, 255, 735, 737

Echinocactus 248, 742

- Emoryi 256

- Wislizeni 885

Echinocereus conglomeratus 861

Echinodorus ranunculoides 492

Echinophora spinosa 416

Echinopsis 256

Echinopus 866

Ectocarpus 394

EdelweiB 37

Eiche 20, 38, 71, 89, 127, $265,553,570$ 
Eichenkratt 348

Eichenrohhumus 111

Eichentorf 111

Eichenwälder 318, 353, 356 , 565

Eichhornia 270

- crassipes $472,473,475$

- azurea 475

Eingriffe des Menschen 275

Einöden 849

Eisanhang auf Dünengehölzen $\mathbf{4 4 5}$

Eisen 98, 99, 121

-oxyd 112

-oxydul 121

-oxydulsalze 105

- oxydulverbindungen 108

- sulfat 121

- sulfide 116

--Verbindungen 74

Elachista fucicola 289

- scutulata 289

Elaeagnaceen 210, 231, 287

Elaiosome 278

Elatine 486, 520

- alsinastrum 494

- triandra 497

Elektrizität, Wirkung 71

Elephantorrhiza 258

Elionurus 235, 829

Elisma 488

- natans 486, 488, 495, 498

Elodea 483, 486, 488, 493, 495 , 8. a. Helodea

Elymus 78, 771, 776, 824

- arenarius $75,415,436$, $753,759,762,763,772$, s. a. Hordeum

- Canadensis 780

Elyna 531, 714

- Bellardi (spicata)534,714

Elytropappus Rhinocerotis 786,799

Embothrium 586

Empetrum-Heide 67

Empetrum nigrum s. Heide

- rubrum 664, 666, 679

Empfindlichkeit des Chlorophylls 27

Enaliden 359, 392

Enalus 392, 393

Endemismus 1

Endodermis 207

Endophyten 288, 289

Enteromorpha 383, 385, 391, 450

- intestinalis 148,464

Entoderma viride 287

Entwickelungsglieder, genetische $\mathbf{3 5 6}$

Epacridaceen 220

Epharmonie (Epharmose) 5, 195,317

Ephebe 383, 420
Ephedra 209, 229, 416, 707, $778,782,792,860,888$, 889,894

- alata 776

- altissima 796

- campylopoda 803

Epidermis 26, 202, 249, 270

- Verschleimung 204

- mehrschichtige 251

Epidermiszellen 28, 29, 211

Epilobium 521, 548

- angustifolium 548, 579, 766,904

- hirsutum 502, 508, 508, 516

- montanum 564

- palustre 539, 625, 631

- parviflorum 631

Epipactis 563

- palustris 501, 631

Epiphyllen' 289

Epiphyten 50, 52, 106, 156, $197,288,311,326,329$

-, licht-, schattenliebende 295

Epipogon 242, 298, 558, 563

Epistephium sclerophyllum 837

Epithem 212

Equisetum 242, 280, 548

- arvense 119

- heleocharis $503,514,910$

- hiemale 780

- limosum 170, 501, 631, $624,659,910$

- maximum (telmateia)

221, 521

- palustre 539, 631, 632

- silvaticum 567

Eragrostis 818, 842

- glabrata 452

- tenuis 781

Eranthis 179

- hiemalis 562

Erbse 286

Erdbeerblätter 29

Erdboden 137

-, chemischer Einfluß 4

-, fester 4

-, Måchtigkeit 4

- Nahrung 4

-, physikalischer EinfluB 4

Erde 72

-, schwarze 108

Erdwärme, eigene 95

Erdoberfläche, Relief 62

Erdvolumenveränderungen 130

Eremanthus sphaerocephalus 865

Eremophila-Sträucher 895

Eremophyten - Formationen 320

Eremostachys labiosa 891
Eremostachys macrophylla 866

Eria semiconnata 724

Erianthus 510, 829, 876

- Ravennae 343, 506, 795

Erica 88, 100, 120, 209, 220, 737,786

- arborea 589, 688, 720, $791,794,796,804$

- carner 532, 678, 679, 684,746

- ciliaris 791

- Corsica 794

- Heide 919

- herbacea 746

- scoparia 791, 796

- tetralix 218, 624, 627 $657,658,660,662,667$, $671,672,678,674,676$, 680,940

- vagans 791

Ericaceen 151, 204, 250, 265, 413

Ericeta 352

Ericinella Mannii 720

Erigeron acris 119

- Canadensis 127, 920

Eriocaulaceen 181

Eriogonum annuum 823,825

Eriophorum 581, 627, 628, $631,636,652,680,681$, 908,912

- alpinum 501, 635

- angustifolium 181, 501 659

- gracile 635

- Scheuchzeri 633, 639, 675

- vaginatum 181, 501, 624 , $632,653,658,659,661$, 662

Eritrichum 541

Erlenbrücher 318, 515

Erlenwald 569

Ernodea litoralis 224, 446

Erodium 258

- cicutarium 219

Erophila verna 762, 764, 771,942

Erosion 83

Eryngium 436, 453, 829

- alpinum 732

- campestre 791, 874

- maritimum 242, 415, 416, $436,440,770,771,772$

Erythrolichen 480

Erythraea 450

- spicata 455

- tenuiflora 455

Erythrina 604, 606

Erythrophyll 27

Erythroxylon 835

Escallonia 586, 871

Esche 20, 89, 552, 569 
Espeletia 38, 39, 231, 626, $709,719,720$

- grandiflora 719

Eucalyptus 289, 782, 806, 828,895

- celastroides 843

- dumosa 800

- loxophleba 847

- macrocarpa 857

- marginata 805

Eucalyptusbäume im Urwald 621

—-Wålder 848,846

Euchytreus 137

Eugenia 517

- dysenterica 838

Euglaena sanguinea 465,470

- viridis $365,465,470$

Euonymus 8. Evonymas

Eupatorium 510

Euphorbia 185, 281, 255, $856,858,890$

- Abyssinica 855

- aphylla 856

- arbuscula 742

- Assoziation 774

- buxifolia 224, 487, 438, 441

- Canariensis 856

- cornuta 243

- cyparissias 778

- dendroides 788

- Guyoniana 776, 887

- Javanica 853

- Mauretanica 856

- meloformis 187

- myrsinites 124

- paralias 208, 218, 438, 772

- phosphorea 852

- pilulifera 441

- polygonifolia 525

- Reinhardtii 255, 860

- resinifera 230

- tetragona 842

- thymifolia 441

Euphorbiaceen 181, 224, 256,413

Euphorbien 6

Euphrasia 702

- officinalis 119,943

Eurotia lanata 874

Euryale ferox 490, 495

Euryops 205, 875

Evolvulus 519

Evonymus Europaea 566, 571

- verrucosa 571

Excoscaria biglandulosa var. 222

Exocarpus 782, 895

Facies 358, 354, 355

Facultative Epiphyten 296
Fadenalgen 365

Fagucene 418

Fageta 852,853

- asperulosa 353

- myrtillosa 353

Fagraen 294, 600

Fagonia Cretica 44

Fagus 28, 553, 566, 571, $572,691,900,932$

- ferruginea 572

- Fraxinus-Reihe 559

- grandifolia 572, 575

- Japonica 573

- orientalis 565

- silvatica $129,560,937$

Falcaria sioides 243

Familien, salafliehende usw. 413

Farbe der Vegetation 380

Farben 145

- filter 21

Färbung der Pflanzen 27

Faktoren der Außenwelt $\mathbf{B}$

-, biotische 4

-, chemische 72

-, direkte 80

-, edaphische $3,4,72,310$

-, klimatische $3,4,10,310$

-, mittelbar wirkende 8,4

-, סkologische 310

-, orographische 140

-, physikalische 72

- topographische 312

-, unmittel bar wirkende 3,4

Falkia repens 452

Farnbänme 192

Farnform 151

Farnkräuter, rosettenbildende 177

Farnvegetation, im Urwald 619,621

Farnwålder 591, 617

Fastigiaria furcellata s. Furcellaria

Faurea 798

Fäulnis 92

Fanlschwamm 117

Federgras-Wiese 352

Feinerden 76, 106

Feinsand 106

Feldspat 106

Feldspatgestein 123

Felicium decipiens 607

Felsarten 128, 124

Felsbewohner 197

Felsblöcke am Strande 427

Felsenboden 105

Felsen, fenchte 385

-fluren 328

-, subglaciale 712

- formationen $320,360,721$

-heiden 96

- meere 740

-pflanzen 27, 33,52
Felsen, senkrechte 421

- steppen 787

-triften 787

Fels, fester 72

-, loser 72

- hånge 314

Fensterblätter 239, 240

Feronia 867

Ferula 792, 866

- asa foetida 891

Ferulago monticola 814,815

Festheftung der Epiphyten 290

Festrce 217, 453, 531, 588, 587, 714, 882, 908

- Assoziation 774

- distans 427, 451, 453

- elatior 539, 914

- erecta 638

- gigantea 556, 564

- glauca 730

- nubigena 853

- Oelandica 780

- orthophylla 708

- ovina 209, 289, 531, 579, $649,668,764,773,728$, $730,770,771,813,816$, 900

- pratensis 816

- pulchella 532

- pumila 534

- rubra 8. b. T. ovina 914

- rabra arenaria 761,764 , 773,774

- rubra fallax 583

- thalassica 181, 396, 427. $447,448,449,450,451$

- vaginata 774

- Valesiaca 815

- violacea 532

- Zone 457

Festucetum rubrae 764

Fettpflanzen 254

Fenchtigkeit 62

Ficaria 562

Fichte 20, 71, 285, 301, 314, 337, 575

-, alte im ,Urwald ${ }^{4} 905$

Fichtenblätter, in Schatten u. Sonne 30, 925

Fichtenrohhumus 111

Fichtenwald 285, 302, 303, $317,318,330,582$

- absterbender 923

Ficus 160, 251, 295, 600, $602,606,616$

-baum 279, 294

-baam mit Brettwurzeln 18,605

- Carica 552, 796

- elastica 26, 610, 611

- hirta 608

- religiosa 56, 57, 241, 604

- Roxburghii 605 
Ficus Wightiana 573

Filago minima 771

Filipendula ulmaria 329,515 , $516,521,567,568,570$, 628 , s. a. Ulmaria

Filtrationsvermögen 83,197

Filz 111, 135

Fimbristylis 587

- sericea 439

Fittonia Verschaffeltii 28

Fitzroya Patagonica 691

Fixierungsorgane 135

Flächenstellung 236

Flachsseide 280

Flachsproß 230

- , blattartiger 229

-, bluitentragender 222

Flacourtia 604

Flagellaten 278, 365, 367

-vereine 317

Flechten 120, 154, 156, 196, $282,283,289,290,320$, $326,333,336,349,383,413$

- auf Bäumen 289

-, epiphylle 288, 289

- formationen 336

- heiden 318,649

-, koniophile usw. 121

-pilze 282

-, saprophile 121

- tundren 649

Florideen 375

-, sublitorale 383

Flugsanddünen 106

Flüsse 318

Foeniculum capillaceum 829

Föhn 64, 140

Föhrenwald 522

Fontinalis $478,479,481$, 486,496

- antipyretica 496, 497

Formae procumbentes 192

Formation 333, 334, 352

Formationen, gemischte 342

--, geschlossene 328

-, halophile 311

-, hygrophile 319,525

-, kalttemperierte 319

-, lithophile 310

-, megatherme 319

- mesotherme, mesophile, mikrotherme 319,525

- offene 328

-, progressive 334

-, psammophile 310

-., regressive 334

-, sandliebende 310

—, sekundäre 348

_, steinliebende 310

-, subtropische $\mathbf{3 1 9}$

-, subxerophile 807

-, tropische 319

- Typen 336

-Verănderungen 356
Formationen, zusammengesetzate 342,344

Formationsfolge, ruickschreitende. 335

Furskålea tenacissima 889

Forsten 282, 300

Fouquiera splendens 208 , 860,894

Fragaria 29, 166, 179

- vesca 579

Fragilaria 465

Frailejon 37

Frankenia 42, 414, 417, $456,460,889$

- capitata 452

- pulverulenta 245

Frankeniaceae 413

Fraxinus 552, 555, 566, 572, $573,575,741,803$

- excelsior 569

Frenela 782, 895

Freycinetia 616

Fritillaria 812

Frost 107

-brand 37

-krebs 37

Fruchtwechselwirtschaft 105

Frühjahrsflora 330

Frühlingsptanzen 305

Frullania cornigera 247

Fruticuli 187

Fucaceae 383

Fuchserode 113

Fuchsia 181

Fucus 104, 289, 394

- inflatus 383

- serratus 377

- spiralis 383,450

- vesiculosus 272, 374, 375, $377,383,450$

- - auf submersen Steinen 346

Furcellaria fastigiata 394

Fusanus 782

- spicatus 843

Gagea 562, 564, 812, 892

- saxatilis 815

Galactites tomentosa 906

Galanthus 564

- nivalis 305

Galeriewälder 88, 312

Galinsoga parviflora 33, 127

Galium antarcticum 679

- elongatum 625

- Javanicum 853

- mollugo 773, 816

- palustre 625,631

- silvaticum 380

- verum 773

Galmeiveilchen 101, 122

Ganzparasiten 280

Ganzrosettenpflanzen 176
Ganzsaprophyten 116, 298

Garide 349

Garrigue $96,213,337,787$, 793

Gartenerde 139

- humus 113

Gaultheria microphylla 679

Gazania 875

Gebirgsketten, Höhe und

Richtung 140

Gebüsch 328, 337

Gebüsche, mesophile 546

- auf Sandstrand 442, 444

Gebüsch - Formationen 768

- in der Wiiste 344

Gehölze, immergrüne 214, 314

-, laubwechselnde 215, 217, 314

Gehölzsämlinge 924

Gelenkzellen 217, 249

Genista 181, 209, 229, 265, $354,582,667,806$

- Anglica 120, 767, 772

- Corsica 794, 797

- Germanica 772

- sagittalis 227

- Saharae 776

- scorpius 788

- tinctoria 228

Genisteen 252

Genlisea 268

Gentiana 532, 534, 712, 871

- acaulis 532

- campestris 943

- lutea 732

- nivalis 702

- pneumonanthe 680

- serrata 702

Geogene Veränderungen 898

Geophyten 165, 304

Georgine 174

Geraniaceen 255, 262

Geranium 530, 792

- palustre 521

- pratense 539

- Robertianum 414

- silvaticum $313,531,548$, $567,568,570$

- tuberosum 892

Gerbstoff 203, 248, 260, 278

Geröllformationen 310

-halden 745

Geschiebemergel 108

Gesneraceen 181, 251

Gesteinsarten 106

Gesteine, Erwärmungsfähigkeit 105

-, Härte 105

-, Porosität 105

- Verwitterungsfähigkeit 106

-, Wärmeleitungsfähigkeit 
Gesteinspflanzen 52

Gesträuche 337

Gestrüppbildung 46, 265

Geum 533

- glaciale 541

- montanum 534

- rivale 567, 569, 570, 631

- urbanum 25

Gewebe, eiweiBleitendes 271

-, grüe 270

_-, mechanisches 263, 272

Gewicht, spezifisches 148

Gewohnheitsrassen 281

Gigartina 383

- manillosa 375

Gips 81, 103, 121, 148

Glaucium flavum. 415,436 , 771

- luteum 429

Glaux maritima 400, 413, $447,448,450,453$

Glechoma hederacea 563

Gleditschia 572, 605

Gletscherablagerungen 73

Glimmer 106

- Verwitterungsbo̊den 315

Globularia 678, 709

- nudicaulis 532, 679

Glochiden 185

Gloeotrichia echinulata 464

Gloeocapsa sanguinea 469

Gloriosa superba $\mathbf{7 7 9}$

Glyceria 587

- fluitans 490, 499

- maritima 181, 339, 396, $427,447,448,449$

- spectabilis 503

- vilfoidea 452

Glycerietum 335

Glycyrrhiza 552

- lepidota 819

Gnaphalium 668, 771, 853

- luteo-album 734

- supinum 580, 533

Gneis 106, 125

-. Verwitterungsböden 315

Goebelia alopecuroides $\mathbf{8 9 3}$

Golenkinia radiata 466

Gonidien 283

Gonium pectorale 466

Gonocaryum piriforme 611

Goodeniaceae 224

Goodyera 577, 583

- repens 576, 936

Gourliea decorticans 864

Gramineentypus 180,181

Granit 94, 106

-boden 105

- fels 72

- Verwitterungsböden 314

Grasdecke 132

Grasfluren 587

Grasform 151, 180, 188, 324

Gras-Formationen 398
Grasmatten, alpine 818, 528

-, arktische 318,528

-, mikrotherme 528

Grassteppen 320, 821

-, baumlose 809

- Nordafrikas 816

- Südafrikas 817

- Südosteuropas 809

Grastypus 168

Grasvegetation, subxerophile 807

-, xerophile 317

Grauerde 570

Graya polygaloides 874

Great plains 819

Grenzgürtel 420

Grimmia 579, 633, 639, 647, 648,723

- ericoides 647,764

- Heide 647

- hypnoides 647, 649

- lanuginosa 728

- maritima 184, 422

Grindelia squarrosa 825

Grobsand 76, 106

Großsträucher 336

Grubbia 209

Grubengas 82

Grünalgen 380

Grundachsen 78

- bildung 74

-, kurzgliedrige 181

Grunddiatomeen 368

Grundformen 151

Grundwasser 81

- spiegel 79, 83

-schwanknngen 83

- Stand 81

Grünlandmoore 82, 318

Grus 106, 123

Gunnera 288

- Chilensis 513

Gürtelbildung 141, 380, 383, 384

Gürtelstufen-V egetation 360

Guttation 211

Gymnocladus 572, 695

Gymnocybe palustris 635

Gymnogramme leptophylla 734

Gymnospermen 315

Gymnosporia 688

Gypsophila 819

- paniculata 812

- Uralensis 735

Gyrophora 722, 899

- hirsuta 291

Gytja 117

Haarbekleidung 281

Haare 211, 270

-, wasseraufsaugende 244

-, wasserführende 250

Haarleisten 56
Haastia 183, 719

Habitat, Habitatio 1, 2, 8, 10

Hagel 54

Hafthaare 374

Haftorgane 269,874

Haftscheibe 269

Haftwurzeln 296

Hakes suaveolens 210

Hakenvorrichtungen 277

Halbkulturformationen $\mathbf{8 4 8}$

Halblianen 159

Halbrosettenpflanzen 177

Halbsaprophyten 116, 298

Halbstrăucher 153, 155, 168, $181,383,360,396,787$

Halbstranch formationen 387 , 400,453

Halbstrauchsteppen 787

- dornenlose 872

Halbwüsten $308,321,849$

-, succulente 853

Halfagras 243

Halidrys 383

- siliquosus 272, 375

Halimeda 387, 392, 393

Halimocnemis 458

Halimodendron halodendron (argenteum) 205, 866, 888, 898

Halimus pedunculatum 250

- portulacoides 250

Hallimasch 281

Halo-Benthos 359

Halocnemum 416

- strobilaceum 460, 792, 889

Halodule 392

- Wrightii 395

Halogeton 258, 260

- sativus 458

Halonereïden 359,374

Halopeplis 460

- Gilliesii 459

Halophila 392

- Aschersonii 387, 395

- Baillonis 395

Halophyten 120, 197, 199, 248, 311

-form 416

- - Serie 358

_, tropisch - amerikanische 224

- Vegetation 318

Haloplankton $359,361,373$

Halo-Saproplanktou 373

Haloscias 418

Halosphaera 372

- viridis 145, 362, 363

Halostachys Caspioa 343, 459,460

Haloxylon 204, 253, 416, 458, 853

- ammodendron 446, 778, 894 
Haloxylon Schwoinfurthii 252

Haplophyllum lasianthum 891

Haptere 269

Hapaxanthen 176

hard-pan 113

Harpixsträucher 205

Hartlaubformationen 320,785

Hartlaubgebüsche 793

Hartlaubgewächse 68, 263

Hartlaubvegetation 785

Hartlaubwälder 801

Hauslauch 218

Hautgewebe 248

Haworthia truncata 239

Heberdenia excelsa 796

Hectorella 719

Hedera 558, 736

- helix 562

Heide 41, 314, 324, 326

—, alte 903

-, arktische 351

-, braune(immergrüne)330

-, echte 354

-, freie 927

- erde 139

- gebiete Deutschlands

(Karte) 623

- gewässer 104

- gräser 217

- humus 104

-moore 52, 82, 103, 110, 318,652

- pflanzen 27

-rohhumus 111

- sand 112

- seen 318

-torf $85,86,104,110,111$

_- saurer 138

-tümpel 318

Hekistothermen 63

Heleocharis acicularis 520, 521, 8. a. Scirpus

- palustris 451, 501, 507, 508,520

Helianthemum chamaecistus 546

- fumana 806

- guttatum 906

Helianthus annuus 900

Helichrysum 875

- arenarium 239, 773

- microphyllum 797

Heliconia 512, 517, 617

Heliophyllon 214

Heliotropie 45

Heliotropium 455, 519, 893

- Arbainense 252

- arboreum 250

- arenarium 773

- Curassavicum 224, 443, 455
Heliotropium inundatum 441

Helleborus 904

Helm 217

Helodea s. Elodea 117, 270, 496, 934

- Canadensis 127, 270, 302, 493, 497, 920, 940

Helophyten 309, 310, 396

Helosciadium inundatum $486,494,495$

Helotismus 282

Helrosetplanter 176

Hemikryptophytun 153,165

Hemiparasiten 156

Hemiepiphyten 295, 296

Hemisaprophyten 156, 298

Hepatica 562

Heracleum 510, 643

Heritiera litoralis 402,444

Hermannia 873

Herniaria 233

- glabra 44

Hesperantha Volkensii 720

Heterothalamus spartioides 864

Heterotrophen 156

Hexamitus crassus 365

Hibiscus tiliaceus 444

Hieracium 651, 948

- murorum 564, 379

- pilosella 119, 179, 218, $763,770,773$

- umbellatum 414, 766

Hierochloë 548, 714

Hildenbrandia 374, 383, 478

Himanthalia 383

- lorea 289, 381

Himbeere 552

Hippophaës 520, 770

--Gebüsche 777

- rhamnoides $429,430,442$, $522,761,768,771,772$

Hippuris 482, 487, 488, 493, 495

- vulgaris 268, 494, 510, 512,520

Hitzew üsten 875

Hochgebirgsformationen, tropische 719

Hochgebirgsgegenden 41

Hochgebirgspflanzen 37,133, 231

Hochgebirgssteppen 867

Hochgebirgs - W Wustensteppe 869

Hochgräser 503

Hochmoore 82, 103, 314, 353, 652

Hochmoor, altes 655

-bildung 653

- im Frühsommer 661

Hochseeplankton 871,372

Hochstauden 169, 333, 359
Hochstaudenfluren 541, 542

- schicht 329

- Sümpfe 400

Hochwald 303

-pflanzen 134

Hoffmannseggia 872

Höhenstufen-V egetation 360

Holcus lanatus 354, 589

- mollis 304, 545, 934

Holosaprophyten 154, 156, 298

Holoparasiten 154, 156

Holoplankton 369

Holzparasiten 187

Holzpflanzen 153, 360, 396

Holzstauden 181

Homogyne alpina 533, 534

Honckenya peploides 430 , $436,440,759,762,773$

Hopfen 161

Hordoum 450, 824, 871, 946

- arenarium 436, 759, 762, $771,772,774$ (Elymus)

- maritimum 435, 458

- murinum 829

- secalinum 792, 829, 892

Hornblende 106

Hottonia 482, 495

- palustris $473,474,476$

Hügel, pannonische, pontische 142, 317

-, sonnige 142, 817

Hüllen, faserige 246

Humulus 161, 558

- lupulus 57, 515, 516

Humus 76, 77, 78, 83, 84, $94,108,109$

- brauner 109

- bildung 183

- boden 105

-, gewöhnlicher 118

-kohle 112

-, milder 113

- neutraler 126

- să $79,100,109,111$, $144,149,311$

- - freie 197

- stoffe 74, 99

Hangerformen 100

Hura 604

- crepitans 237, 936

Hutschinsia 703

- alpina 101, 716

- brevicaulis 101

Hyacinthus 8,794

Hydathoden 211, 314, 408

Hydra viridis 278

Hydrilla 270, 496, 498, 486

- verticillata 268

Hydrobryum 480

Hydrocharis 6, 268, 472 , $474,475,476,498$

Hydrocharitaceen 392

Hydrocleis 488 
Hydrocotyle 628

- vulgaris 198, 194, 501

Hydromegathermen 62,68

Hydromystria stolonifera $472,473,474$

Hydrophylax 439

Hydrophyten 123, 156, 196, $199,309,310$

-, lithophile, steinliebende 207, 374

Hydrothermfigur für Süditalien 61

- fuir Sumatra 39

Hydroxyd 108

Hydrurus 146, 481

- foetidus 365

Hygrochasio 51

Hygrophyten 50

Hygroskopizität $83,84,291$

Hylocomium 548, 568, 581, $583,644,668,688$

- splendens 564

- triquetrum 564

Hymenaea courbaril 177

Hymenophyllaceen 26, 27, $50,158,242$

Hymenophyllum 26

- tunbrigense 141

- im Urwalde 601

Hyoscyamus muticus $\mathbf{2 5 0}$

Hypericum 742

- perforatum 566

- qnadrangulum ō66

Hypertrophismus 283

Hyphaene Bussei 842

- plagiocarpa 842

- Thebaica 844

Hyphen 283

Hypheothrix 484, 485

Hурnaceas 82

Hypnum cordifolium 682

- cupressiforme 564

- cuspidatum 632, 635

- purum 564

- Schreberi 301, 564

- sericum 900

- stramineum 622,663

Hypochaeris 178

Hypochaeris radicata $\mathbf{7 6 2}$, 772

Hypoderm 248

Hypoxis angustifolia 720

Hypsela $\mathbf{5 3 6}$

Hysterophyten 153

Hyssopus 221

Jahres-Amplituden 134

Jahresproduktion, geringe 318

Jahreszeiten - Periodizităt 330

-- Verschiedenheiten 384

_, physiologisch trockene 62

Jahreszuwachs 317
Jaracatia 606

- dodecaphylla 256

Jasione 119

- moutana 764, 771, 906

Jasminum nudiflorum. 40

Jatropha 851

- podagriea 256

Idioblasten 260, 283

- wasserspeichernde 253

Ilex 549, 589, 590

- aquifolium 202, 264, 314, $566,571,594,803$

- Canariensis 589, 797, 804

- perada 804

- verticillata 689

Imbibitionswasser 47, 85

Impatiens 688, 936

- noli tangere 521, 556, 562, 920

- parviflora 127, 920

Imperata arundinacea 832

- cylindrica 775

Indigofera enneaphylla 441

Infusorien 278

Insekten 113, 136, 150

-bestäubung 330

-larven 136

Insolationsmaxims 41

Intercellalarräume 207, 210, $375,387,415$

Inula crithmoides 414, 455, 458

Jod 104, 149

Ipomoes 38, 744

- bona nos 163

- leptophylla 824

- pes caprae $193,437,438$ 439, 441, 519

- sphaerocephalus 865

Iresine 439,519

Iriartea 602

Iridaceen 240, 257, 258

Irideen 229

Iris $8,572,624,738,812$, 910

- pseadacorus 179,508, 508, 510

Isoëtes 303, 486, 487, 493

- lacustre 487, 494

Juglans 572, 573, 988

- nana 863

Juncaceen 181, 184

Juncus 82, 221，229, 581, $624,675,681,689,708$, 714

- acutus $390,455,458,795$

- alpinus 520

- arcticns 634

- Balticus 519

- bufonius 520

- capitatus 908

- filiformis 658

- Gerardi 450, 908

- lamprocarpus 508, 520
Juncus maritimus 451,455

- monanthos 101

- ranarius 519

- squarrosus 660

- supinus 946

- trifidus 101, 651, 715

Jungermannia 194, 644, 647, 658

Juniperus 706

- excelsa 796

- monosperma 853

- nana $678,695,707,735$

- oxycedrus $316,794,796$, 803,872

- Phoenicen 775, 788, 795, 872, 909

- procera 582

- sabina 780

- Virginiana 781

Jussiena repens 473,502

Iva imbricata 781

Ixiolirion 892

Kahmhaut 140

Kakteen 6

Kaktus 151

- form 185

Kali $98,110,147$

Kalium 99

Kalk 98, 102, 103, 105, 106, $124,148,149$

- ablagerungen 147

-algen 149

- Ausscheidung 376

- berge 101

- boden 103, 105, 107, 353

- fels 72

-inkrustation 149

-, kohlensaurer 101, 117, 147

-mergel 107

-, oxalsaurer 202

-pfianzen 102, 103, 120 , $122,132,127$

-salze 81

-sand 84, 85, 98, 107

- stein 106

- Verwitterungsböden $\mathbf{8 1 5}$

Kalmia 658, 714

- angustifolia 658

Kälte 66

- schutz 28

-wiisten 319, 694, 712

-, antarktische 717

Kampf zwischen Kieferwald und Heide 927

- zwischen den Pflanzenvereinen 896

- waffen der Arten 930, 932

Kandelabereuphorbie $\mathbf{2 5 5}$

Kandelia Rheedii 402

Kaolin 107

Kapillarität 85

Kapillarråume 76 
Karstkalk 94

Kartoffeln 38

-sprosse, etiolierte 231

-Typus 170

Kätzchenträger 555

Keimpflanzen 280

Keimung 404

Kellerasseln 136

Kibessia azurea 288

Kiefer 126, 315

-rohhumus 111

- wälder $318,356,578$

-wald, zusammenbrechender 921

-Wurzelbildung 687

Kielmeyera 835

Kingia 210

- australis 845

Kies 76, 106

- bedeckung 128

Kieselboden 102, 103

Kieselpflanzen 120, 121, 122, 123,127

Kieselsäure 105, 148, 202

Kissen 184

Kladodien 223

Kladodium, nadelförmiges 230

Klassifikation der Pflanzengesellschaften 306

Klee, roter 286

Kleinia 255, 737, 842, 856, 858

- neriifolia 856

Kleinstauden 333

Kleinsträucher 336,787

Kletterpflauzen 299

Klima 100

-, atlantisches 42

-, extremes 312

-, kaltes 318

- kontinentales 42

-, waldfeindliches 39

-, wärmeres 318

Knallgas 140

Knick 113

Knöllchenbakterien 140, 287

Knollengewächse 49

Knollenpflanzen 169,215,257

Knospenbau 165

Knospenschuppen 39, 165, 232

Kobresia 714

- bipartita 714

Kochia hirsuta 415, 436

- prostrata 874

Kochsalz 101, 104, 105, 120 , 148,311

Koeleria cristata 813,822 , 823,900

- glauca $746,747,764$, 771,772

- pubescens 792

- Valesiaca 816
Koenigia Islandica 702

Kohl, wilder 425, 426

Kohlehydrate 256

Kohlensäure $10,114,148$,

- Assimilation 47

- Bildung 79

Kohlenstoff 99, 114

Kollateren 205

Kolloiden 112

Kolonie-Zweigende 365

Kommensalen, gleichartige 300

-, ungleichartige 7, 302

Kommensalismus 299, 303

Kompaßpflanzen 22, 24, 238

Komplementår-Assoziation 304

Kompost 109

Konglomerate 73

Koniferen 190, 202, 220

-, australische 258

Konvergenz, epharmotische 6

Kork 39, 206

-, schleimiger 252

--Ubberzüge 270

Kornfeld 349

Korallensand 106

Korrelationen 259

Kraft, osmotische 311

Krameria 871

Krankheitszustand 283

Kraulis 113

Kräuter 193, 336, 349

-, bienne 155, 164

-, dicyklische 162

-, dikotyle 174

-, einjährige 161, 359, 396

-, einjährig überwinternde 162

- hapaxanthe 153,155

-, holzige 193

-, kryptogame 174

-, mehrmals fruchtende 174

-, monokotyle 161,174

-, pleiocyklische 153, 155

-, pollak-anthe 180

-, sommerannuelle 155,161

-, winterannuelle 155, 162

-, zweijährige 164

Krautformationen 336,433 , 447

Krautmatten, alpine 318,528

—, arktische $318,528,530$

-, mikrotherme 528

Kreide 103

Kreosotstranch 205

Kriechpflanzen 154, 156 , $165,166,168,181,187$, 192

Kronenbänme 154, 156, 168, 186

Krümel 76

Krummholzgestrüpp 129,265

Krummholzkiefer 581
Krustaceen 137

Kryoplankton 469

Kryptogamen 156, 218, 268

-, gefäblose 320

Kryptophyten 158, 165

Kugeln 256

Kulturwälder 282

Kunstwälder 300

Kusselkiefer 265

Küstenplankton 370,871

Kutikula 52

Kyllingia 587

Labiaten 120, 218, 262, 280

Lactarius deliciosus 297

Lactuea muralis 27, 556

- saligna 814

- scariola 22, 24, 238, 814

- Sibirica 400

Laguncularia $\mathbf{4 0 9}$

- racemosa 239, 402, 404, 439

Laminariaceen 272

Laminaria 376,378

- digitata 375

- faroensis 383

- hyperborea 383

- longicruris 378

- saccharina 374

- solidungula 269

Lamium album 57

- galeobdolon 563

Lampaya-Assoziation 782

Land-Halophyten 319

Landpflanzen $155,158,196$, $309,360,396$

-, Anpassungen 199, 261

-, mesorphe 319

-, pollak-8nthe 165

-, polykarpische 165

Landseen 318

Landvegetation 319

-, halophile 360

- halophytische 411

Langsproße 165

-, orthotrope 155

Langstauden, pollak - anthe 167,167

Lantana 446, 865

- involucrata 210

Lappa 829

- nemorosa 27

Lärche 20, 574, 577, 917

Lärchenwälder 577

Laretia 266

Larix 577

- Americana (pendula)517, 689

- decidua (Europaea) 91, 577,578

- laricina 689

- Sibirica 575, 577, 578, 585

Larrea Mexicana 863, 894 
Lastraea thelypteris 631,658

Lathraea 7

Lathyrus 548

- niger 742

- maritimus $428,525,758$, $761,762,764,770,771$

- nissolia 624

- pratensis 539

- silvester 742

- vernus 742

Laterit 108

Laubblätter 214, 216, 218

- Dauer 166

Laubblatt-Verkleinerung 218

Lauberde 139

Laubfall 39

Laub, gefallenes 128, 132 - sproB 200

- - Anpassung 167

-

Laubmoose 48, 120

Laubwald, dichter 555, 557

Laubwålder, sommergrüne 552

-, subtropische 588

Lanrelia sempervirens 591

Laurus 794

- argentatus 676

- Canariensis 589, 797, 804

- nobilis 802, 803, 804

Lavafelsen - Grube 313

Lava-Fjeld 649

Lavandula 181, 221, 794, 806

- spica 788

- Tomillares 790

Lawia 480

Lebensdauer 57, 270

Lebensformen $3,5,6$ ff. 151,336

-, Anpassung 195, 413,757

-, extrem-xeromorphe 320

-., heterotrophe 156

- mesophile 58

-, muscoide 158

-Physignomie 333

- , vorherrschende 326

- der Wüste 881

Lebens-Grundformen $\mathbf{1 5 4}$

Lebermoose 247, 287

-, epiphytische 293

Lecanora 722, 727, 728

- atra 422, 723

- calcarea-contorta 728

- esculenta 33

- pallida 723

- Tatarea 128, 651, 913

Lecidea 715,722

Ledum 576, 622, 714, 908, 913

- decumbens 676, 709

- palustre 209, 218, 355, $581,624,625,652,658$, $675,676,709$
Leeseite 63

Legföhrengestrīppe 129

Leguminosen 122, 181, 288, 286

-wurzeln 140

Lehm 108

-boden 100

Leisten 256

Leitungsgewebe $\mathbf{3 1 5}$

Lemanea 478, 481

- fluviatilis 910

Lemna 268, 270, 498

- gibba 472, 478

- minor $268,472,473,474$, 475,515

- polyrrhiza $472,473,475$

- trisulca $268,472,478,474$

Leontice incerta 893

Leontodon 178,545

- auctumnale 119,451 , $531,533,762,772$

- hispidus 533

- Pyrenaicus 533, 534

Leontopodium alpinum 37

Lepidium 453

- sativum 416

- spinosum 51, 886

Lepidophyllum 209

Leptinotarsa undecimlineata 952

Leptospermum 800

- scoparium 679, 783

Leptothrix 485

Lepturas filiformis 450

- incurvatus 458

Lerchensporn-Arten 8

Lesquerella arctica 46

Lessonia 378

Leucadendron 232, 798

- plumosum 799

Leucobryum glaucum 564, 691,692

Leucodon sciureides 723

Leuchtmoos 27

Lianen 151, 154, 155, 158, $299,326,328,329,336$

- brasilianische 163

-, kletternde 264

- schmarotzende 159

Libanotis montana 121

Libocedrus 575,691

Lichina 383,420

- confinis 424

-Gürtel 423

- pygmaea 424

Lichenen 154, 156, 196, 836

-, ephylle 156

- auf Strandsteinen 346

Licht 3, 11, 148, 144, 265

-båume 19

- Bedeutung 15

- farbe 380

-intensitäit, stündliche 20 , 21
Lichtpflanzen 15, 887

-mangel 50

-messer 12, 13

-, 8konomische Bedeutung 47

-, vu schwaches 18

- sinnesorgane 28

- stärke 15, 879

- stellung, fixierte 238

-, zerstrentes 288

Ligularia 904

Ligusticum mutellins 580

Ligusticum Scoticum 418, 436

Ligustrum vulgare 566. 775

Liliaceen 173, 257

- båume 192

Liliengewåchse 151

Lilium martagon 564

Lilium (Zwiebelbildung) 175

Limnaeen 486

Limnanthemum $6,486,488$

Limno-Nereiden 478

Limnoplankton 464

Limodorum 563

Limoniastrum 414, 889

- Guyonianum 887

Limosella 486

- aquatica 495

Linaceen 262

Linaria alpina 716

- vulgaris 172,814

- - (Wurzelsprosse) 172

Linde $20,556,570$

Linnaea 577, 579

- borealis $8,181,182,198$, 936

Linum catharticum 539

- maritimum 455

Lippia 737, 864

- involucrata 239

- Riojana 417

Liquidambar 572

Liriodendron 572

Listera cordata 583

- ovata 563

Lithoderma 374, 383

Lithophyllum 374

Lithothamnium 374

Lithophila 224

Lithophyten 78

- Formationen 320, 721

Litorella 487, 497, 520

- lacustris (uniflora) 303, $487,493,520$

Lithospermum fruticosum 788

Lloydia serotina 705

Loasa 871

Lobelia Dortmannia 303, $486,487,493,508$

Lodoices Seychellarum 935

Loiseleuria $676,679,702$ 
Loiseleuria procumbens 130 , $209,250,651,675,677$, 706, 709, 714, 716

Lolium perenne 540, 545, 829

Lomaria alpina 679

Lonchitis 735

Lonicera 571

- implexa 803, 804

- periclymenum 558

- xylosteum 566

Lophodermium pinastri 282

Loranthaceae 116, 187, 260, $279,281,282$

Loranthus Europaeus 187

Lorbeer 37

-form 151

-wälder 803

Lösungen, konzentrierte 311

LöBboden 114

Lathyreta maritimi 764

Lotus corniculatus 119, 414, 532

Lucilia Tunariensis 871

Luft 4, 49, 72, 74, 76, 79, $134,135,143$

-algen 158, 196, 385

-Bewegungen 3, 63

-feuchtigkeit 3, 47, 49, 289

- Verteilung 57

- knollen 257

-, Maximaltemperaturen 91

-pflanzen 196, 268

- räume 272

- Sättigungsdefizit 86

-sprob-Verkleinerung, danernde 218

-strömnngen 72

—wurzeln 245, 260

--Zusammensetzung 3, 10

Lambricas purpureus 137

- rubellus 137

- terrester 137

Lumnitzera coccinea 402, 404,408

- racemosa 402,404,408

Lopinus $572,711,826,871$

- arboreus 783

Lupine, Wurzelknöllchen 287

Luzula 531, 675, 714

- albida 534

- multiflora 181

- spicata 534

- pilosa $278,562,564,579$

Luzuviaga 591

Lychnis flos cuculi 539

Lycium 893

- Ruthenicum 343, 460

Lycopodien-Form 194

Lycopodium 116, 651, 708

- alpinum 239, 240, 534, 686

- annotinum 563, 577, 579
Lycopodium clavatum 198, 577,579

- inundatum 501, 658

- linifolium 194

- phlegmaria 600

- selago 239

Lycopus 539

- Enropaeus 502

Lygeum 217, 889

- spartum 792, 806, 817

Lyngbya 391, 394, 399, 464, 484

- aestuarii 454

- minutissima 899

- thermalis 485

- Verbeekiana 899

Lyonia calcyculata 622

Lysimachia nemorum 563

- nummularia 193,194

- thyrsiflora 74, 501, 503, $508,624,625$

- vulgaris 501, 503, 516

Lythraceen 402

Lythrum 515, 910

- salicaria 501,502,503,508

- virgatum 814

Macchie 96, 213, 324, 330, 793

Macrochloa tenacissima 816

Macrocystis 272

- pyrifera 378

Macropanax 616

Magnesia 105

-, schwefelsaure 148

Magnesiasilikat 101

Magnesium 99

Magnolia 572, 573, 590

- Virginiana 622

Majanthemum 576, 923

- bifolium 21, 564, 579

Mais 349

Makroplankton 373,471

Malacochaete tatora 512

Malaxis paludosa 635,658

Malcolmia Aegyptiaca 250

Malva parviflora 249

Malvaceae $\mathbf{4 1 3}$

Malvaceen 151

Mammillaria 256

Mangifera Indica 23

Mangrovenform 190

Mangrove, östliche 402

-Pflanzen 340

- sümpfe 116, 318, 401, 405

-vegetation 360,401

-, westliche 402

Manihot 852

Mannaflechte 33

Mantelblätter 295

Marathrum 480

Maregravia 194

- Schimperiana 159

Marchantia 945
Marschen 116

Marschwiese 335

Marsilia 486

Matricaria 530

- inodora 42, 414, 436

- maritima 422, 733

Matten, alpine 532

Matthiola sinuata 438

Maulwürfe 137

Maulwurfshaufen 119

Mauritia flexuosa 614,840

- vinifera 614,840

Maytenus Magellanica 692

Medicago denticalata 829

- falcata 813

- Iupulina 730

- marina 752,758

- minima 774

Medinilla 600

- magnifica 612

Meere 318

Meeresalgen 149, 393, 434

- krustenförmige 376

_, steinliebende 376

-vereine 378

Meere, Salzgehalt 148, 149

Meeresboden 138

- stark bewegter 386

Meeresgürtel, supramariner 420,422

Meer, Höhe über dem (Meereshöhe) 62

Meeresleuchten 364

Meeresnähe 62

Meeres - Pflanzengeographie 370

Meerwasser 149

- Wärmegrad 378

Megaplankton 361, 471

Megistothermen 63

Mehlhaare 250

Melaleuca 800,843

Melampyrum 916

- pratense 353,564

Melandryum 530

Melastomaceen 8, 181, 241

Melastomenform 151

Meliaceen 402

Melica 829

Melica nutans 556

- uniflora 556, 562, 563

Melicocca bijuga 177

Melinis minutiflora 587

Melobesia 394

Melocactus 852, 865

Melochia tomentosa 865

Melosira 465

- crenulata 468

Mentha 166, 589

- arvensis 231

Menyanthes 194, 515, 631, $632,636,689,910 \mathrm{ff}$.

- trifoliata 198, 503, 510, $685,652,658,659$ 
Meum mutellina 533

Menzelia nuda 781

Mercurialis 23, 358, 556

- perennis 355, 515, 561, $562,563,569,570,916$

Mergel 76, 107

- boden 123

- Verwitterungsboden 315

Meroplankton 369

Mertensia 436

- maritima 415, 436, 771

Mesembrianthemum 32, 224, $240,242,244,253,416$, $519,737,799,858,886$, 888,890

- crystallinum 250

- opticum 239

- pygmaeum 858

Mesocarpaceae 121

Mesophyll 218, 408

Mesophyten 56, 198, 199, $205,310,312$

Mesopteridetum 354

Mesothermen 63

Mebapparat von Raunkiär 332

Meterosideros lucida 689, 692,693

Microcoleus chthonoplastes $390,391,399,908$

Microcystis 464

Microspira desulfuricans 433

Microspora aestuarii 389

- desulfuricans 389

Mikania cardifolium 163

Mikroorganismen 108, 139

Mikrophyteu 361

- formationen 336

-, saprophytische 359

Mikroplankton 361, 362

Mikrothermen 68

Milben 278

Milch 248

- krautweide 533

- saft 213, 248

Milium effusum 356, 562, 567,570

Mimosa 519

- ephedroides 782

Mimosen 151

Mimosoideen 287

Mimulus 711,871

- Tillingii $\mathbf{4 4}$

Mineralien 100

Mistel 281

Mitraria coccinea 591

Mittelsand 106

Mniopsis 480

- Weddelliana 480

Mnium 538, 564, 632, 685

Molinia 653, 904

- caerulea 539, 540, 567, $568,627,631,658,660$, 664,680
Molinis depanperata 664

Moneren 108

Monokotyledonen 221, 265' 280

Monostroma 376, 383, 391

Monotropa 7, 116, 298, 558, $563,576,583$

- hypopitys 298

Monsonia 208

- nivee 242

Montia 486

- lamprosperma 658

- rivularis 499, 521

Montrichardia arborescens 512

Moor 324

- gotlëndische 110

- pan 113

-pflanzen 116

Moosdecken 134, 135, 803

Moose 183, 266, 269, 289, $290,308,820,326,338$, $336,349,850,413$

- auf Strandsteinen 346

-formationen 336, 481

-heiden 318, 640

-moore 652

-humus 111

-teppiche 92, 135

- tundren 640

Moränenblöcke 97

Mor (dänisch) 110

Morus 572, 868

Mourera 480

Muehlenbeckia platyclada $226,227,230$

Muehlenbergia 460

- pungens 781

Muld 113

Muldegium 542

Mulinum spinosum 830

Mull 113

-boden 315

-pflanzen, mesophile 126

Munroa 460

- squarrosa 824

Musa 180

Muscari 8, 788

- botryoides 717

- comosum 815, 816

Mutualismus 284

Mycel 298, 242, 285

Mykorrhiza 111, 138, 284, 285,298

-pflanzen 140

Myosotis eaespititia 520

- palustris 520, 539

Myrica 287

- cordifolia 758,777

- Caroliuensis 781

- faya $589,796,804$

- gale $355,501,658,671$, 674,680

-Gebuisch 749
Myrioa palustris 222

Myricaria Germanica 520, 528, 907

Myriophyllum 268, 394, 486, $487,488,490,494,495$, $496,498,910$

Myristica 602

Myrmekochorie 278

Myrmecodia 278

Myrsinacee 402

Myrtaceen 218, 220

Myrte 37

-ngewdichse 151

Myrtillus-Typus 388, 558

Myrtus 794

- bullata 22, 29, 289

- communis 221, 789, 794, 797

- nummularia 679

Myzodendon 187, 691

- oblongifolinm 573

- punctulatam 573

Nachtblìten 32

Nachttemperatur 107

Nadelblatt 220

Nadelhölzer 35, 151, 314, 316

Nadelwälder 8,574

_, immergrüne 578

-, laubwechselnde 577

Nährboden, Bau 4, 72

-, chemische Beschaffenheit 101

Nährstoffgehalt 317

Nahrung 47, 149, 294

- aufnahme 47

-mangel 100

- stoff 47,143

-stoff-M enge 99, 103

-stoffe, notwendige 99

-wettbewerb 105, 300, 301, 302

Nährwurzeln 296

Najas 270, 487, 488, 493, 495

- flexilis 521

- marina 394

Nanismus 48

Nanoplankton 364

Narcissus 788

Nardus 627, 714, 771

- stricta 181, 234, 285, $534,540,545,651,658$, $660,664,668,770,771$

Narthecium 240, 624, 680

- ossifragum 501, 658

Narther 866

Nassauvia 871

Natrium 245

Naturwälder 282

Nebel 52, 54

-region 50, 54, 140, 141

Nobenblätter 283 
Nectria cinnabarina 281

Nelumbium 489

Nemalion multifidum 273

Nemophyten 361

Neottia 7, 116, 298, 558, 563

- nidus avis 284

Nepenthes 260

Nephroma arcticum 675,688

Neptunia 473

- oleracea 502

Nereiden 318

Nereocystis 378

Nerium 209, 221, 228, 252, 794

- oleander 209, 889

Nervenenden 260, 408

Nerven, vertiefte 241

Nestepiphyten 296

Neuropogon melaxanthus651

- Taylori 651

Niederschläge $3,47,52,289$

-, Aufnahme 52

- Gröbe 57

-, Schutz gegen 26

-, Verteilung 57, 63

-, Zeit 60

Niederschlagsmenge 59,88

Niederleinia juniperiodes 417,459

Nigritella 532

Nipa fruticans $409,410,517$

Nipetum 401

Nischenblätter 295

Nitraria 898

- retusa 260

- tridentata 778

Nitrophyten 121

Nodularia 372,484

- spumigena 362

Nomenklatur, phytogeographische 306

Nostoc 283, 287, 288, 464

Notochlaena Marantae 582

Nothofagus 573, 586, 590

- alpina 691

- antarctica 573, 691

- betuloides 691, 692

- Dombeyi 691, 692

- nitida 691

- obliqua 691

- procera 691

- pumilio 573, 691

Nototriche longirostris 871

Nummularia-Form 194

Nuphar 487, 488, 910

- luteum 488

- pumilum 490

Nymphaea 487, 488, 498, 509

- alba 269, 488

Nymphaeaceae 6, 117, 309, $486,495,496$

Nyssa biflora 516

- uniflora 622
Oasen 88, 344

Oberflächenalgen 373

Oberfläche, verdunstende 214

Oberflächenverminderung 214, 215

-wasser 83

Obione portulacoides 416

Oceta foetens 589, 804

Odontites 450

Odontospermum pygmaeum $51,214,215,881,885$, 888

Oedogonium 463, 467

Oele, ätherische 213,278

Olplastiden, farblose 270

Ölzellen 270

Oenone 480

Oenanthe aquatica 503,910

- fistulosa 494, 508

- Lachenalii 455

- phellandrium 494, 910

Oenothera 950

- biennis $32,127,920$

Olea 210, 221

- Europaea 210, 214, 263, $790,796,802,803,804$

- oleaster 790, 796

Oleander 37, 223

Olearia Lyallii 637

- nummularifolia 782

Olinia 688

Olivenbaum 223

- form 151

-wälder 803

Onobrychis arenaria 816

Ononis natrix 120

- repens $770,771,772$, 900

- spinosa 900

Oocystis 466

Ophrydeen 173

Ophrys 174

- muscifera 121

Opuntia 254, 821, 852, 853, $860,865,885,920$

Orange-Gürtel 423

Orangenbäume 282

Orchideen 51, 53, 116, 120 , $151,185,224,245,252$, $255,260,289,291,292$, 293, 298, 299, 302

-, Knollenstämme 186

Orchis 539, 564, 631

- maculatus 174

Organismen, Zusammenleben 275

Organe, unterirdische 242

Origanum vulgare 900

Ornithogalum thyrsoides 587

Ornithopus perpusillus 933

Orobanche 116, 280

- ramosa 280
Orobus vernus 742

Orthotrichum 723

Ortstein 113, 318

-boden 115

- Heide 665, 667

-heide, Bodenprofil 113

Oscillaria 484, 485

Oscillarien 146

Oscillatoria 464, 484

Oscillatorieas 146

Osmose 47

Osmunda 510

Ostrya 572

- carpinifolia 551, 796, 804

Ottoa oenanthoides 708

Ouvirandra fenestralis 494

Oxalidaceen 237

Oxalis 235, 257, 258, 266, $515,558,798,829,830$

- acetosella 7, 27, 236, 237, $303,556,562,563,576$, $579,583,686,936$

- carnosa 250

- tetraphylla 216

- Typus 338

Oxycoccus palustris 652

Oxyd 108

Oxylophyten 819

Oxyria 548

- digyna 741, 912

Oxytropis 826

- Halleri 816

Ozothamnus 209

Paconia 572, 578, 904

- anomala 571

- corallina 742

Palaegonium arenicola-Assoziation 782

Palicourea strepitans 837

Paliurus 550, 551

- aculeatus 552

- australis 803

Palisadengewebe 26,212,415

Palisadenparenchym 29

Palisadenzellen 260

Palmen 22, 34, 151, 192, $246,265,324,590$

- form 192

-wälder 614, 615

Palmietschilf 246

Paludella 658

- squarrosa $521,632,635$, 681

Pampas 828

Panax 609

Pancratium 889

Pandanus 22, 192, 445, 602, 779

- labyrinthicus 445

Pandanaceen 246

Panicum 235, 513, 587, 829, $836,840,842$

- amarum 781 
Panicum Patagonicam 83

- Scribnerianum 823

- virgatum 749

Papaver 178, 541, 785

- hybridum 906

- nudicaule 176, 541, 706 , 715

Papillen 209

Pappel 68

Pappophorum 460, 829

Parasiten 56, 71, 116

Parasitismus 280, 287

Parenchymscheiden 261

Parietaria Judaica 738

- officinalis 739

Paris quadrifolia 313, 556, 563,567

Parkinsonia aculeata 865

- microphylla 894

Parmelia 722, 727

- esculenta 846

- olivacea 421, 723

- omphalodes 421, 422, 723

- physodes 765

- saxatilis 421, 723

Parnassia 539

- palustris 631

Paronychia 233

Parthenocissus 159

- quinquefolia 780

- selbstkletternder 161

Paspalum 513, 587, 829, 836,840

Passat 63, 66, 67, 141

Passerina 220, 793

- filiformis 209

Paxillus acheruntius $\mathbf{7 4 0}$

Pectis humifusa 224

Pediastrum 465

Pedicularis 541, 675, 715, 904

- Lapponica 686

- orthantha 533

- palustris 658

- silvatica $636,658,680$

Pedilanthus 737, 742

Peganum 889

- harmala 250, 792, 893

Peireskia 255, 742

Pelargonium 798, 873

Peltigera 688

Pelvetia 383

- caniculata 424,450

Penicillus 387, 392, 393, 395

Pennisetum 818

- Benthami 844

- setosum 587

Pentzia 875

Poperomia 177, 251, 292 , 728,737

Peridineen 361, 364, 367 , 370

Peridininm divergens $\mathbf{3 6 4}$

Perilla Nankinensis 29
Periodizitat 195

Periploce aphylla 229

Pernettya pumila 679

- empetrifolia 718

Persea Indica 589, 590, 804

- lingue 591

- pubescens 622, 624

Pes caprae-Formation $\mathbf{4 8 8}$

Petraea volubilis 28

Pencedanum 688, 815

- cervaria 239

- palustre 681

Pflanzen, autophyte 861

- autotrophe 154, 155, 158

-, Bewegungen 48

- im Boden 4

-, bodenholde, bodenstete 118,119

-, bodenvage 118, 119

- decke 183

- einjährige 214

-, etiolierte 265

- fresser 264

- gemeinschaften, untergeordnete 343

-geographie, floristische, genetische 1, 2

-Gewebe, mechanisches 149

-, giftige 279

-, grasartige 155

- insektenfressende 278

-, helophile 396

-, heterotrophe 154

-, holocyklische 216

- hygrophile 123

-, hypogåische 836

-, immergrüne 166, 214, 216

-, kalkfliehende 120

-, kriechende 156

-, laubwechselnde 60

-, Leben 48

-, lithophile 197

—, moosartige, muscoide 196

_, nitrophile 121

-ökologie, genetische 9

-, ombrophil, ombrophob 56

-Physiognomie 151

- pleiocyklische 164, 216

- perenne 166

-, pollakanthe 155

-, Pontische 52

-, redivive 166

-, regenfreundlich, regenschen 56

-, saprophile 138

-, schlechtschmeckende, schlechtriechende 279

-, scliwimmende 155

-, soziale 167

-, sommergrüne 216

-, Sterben 48
Pflansen, subglaciale 116, 183

-, submerse 818

- Tutigkeit 188

-, therophylle 216

-, trockenheitliebende 198

- , tropische 38

-, untergetanchte 155

-vereine 2, 6, 275, 299, 806

-vereine-Verteilung 64

- -Verzweigung 166

-, windende 299

-, windharte 130

- Wassergehalt 130

- wintergrüune 216

- xerophile 123, 198

-, Zusammenleben 6, 105, 279

Phaca frigida 532

Phaeocystis 365

Phaeoflagellatae 146

Phalaris arundinaces 508, 506

Phanerophyten 158, 165

Phegopteris 562

- dryopteris $173,813,576$

- polypodioides $\mathbf{3 1 3}$

Phelipaea 280

Philippia Johnstonii 688

Phillyrea 794

- angustifolia 775, 788, 795

- media 794, 796

Philonotis fontana 521, 635

Philoxerus 439

- vermicularis 224, 437, 439

Phleum 538

- arenarium 771

- Boehmeri 546

Phoebe Barbusana 589, 804

Phoenix paludosa 517

Phormidium 484

Phormium 783

- tenax 252, 625

Phosphor 99

- shiore 98, 110, 147

Photometrische Bewegungen 23

Phragmites psendodonax 506

Phragmitetum 352, 505

Phycomyces nitens 298

Phylica 209

Phyllachne Colensoi 625

Phyllanthus fluitans $\mathbf{4 7 2}$

Phyllocactus 29

Phyllocladus 230

Phyllodien 222, 240

Phyllodoce 676

- caerulea 209, 675, 677, 714

Phyllophora Bangii 394

- Brodiaei 394

Phyllospadix 392

Phymatolithon 388

62

Warming-Graebner. 3. Auflage, illustr. 
Physcia aquila 421, 422, 723

- parietina 283, 423

Physiognomie, epharmonische 324

- der Pflanzen 40

-, phylogenetische 324

- der Vegetation 2, 5, 324, 326

- der Vereine 324

Physiotium 247

Physma chalazanum 283

Phyteuma spicatum 564

Phytoflagellaten 364

Phytolacaceae 224

Phytoplankton 361, 370

Picen 53, 575

- alba 68, 769

- Canadensis 68, 769

- excelsa $91 \mathrm{ff}$.

- obovata 575,585

- omorica 584, 938

- Sitchensis 769

Pieris nitida 624

Pilea 737

Pilobolus 297

Pilostyles 281

Pilularia 302, 486, 493, 494

- globulifera 487

Pilze 121, 138, 281, 283, 303,336

Pilzhyphen 110, 284

Pilzmyzelien 113, 188, 298

Pilze, parasitische 116

Pilzvegetation 108

Pimelea 783

Pimpinella 545, 853

- saxifraga 267

Pinetum 352, 769

- silvestris u. Assoziationen 338, 352

Pinguicula 178, 680

- vulgaris 658

Pinus 92, 301, 574, 575, 625, $626,778,781,884$

- australis 790

- Banksiana 781

- Canariensis 582

- cembra 585, 682

- Cubensis 790

- edulis 853

- Halepensis 316, 428, 575, $581,744,775,795,806$

- Jeffreyi 315

- laricio 354

- maritima 120, 316, 769, 806

- montana $20,68,91,129$, $140,314,353,534,581$, $584,660,684,685,769$

- mughus 684

- palustris 560

- parviflora 685

- pinea 575, 582, 775, 795, 909

- pumilio $658,660,684$
Pinus resinosa 781

- Scotica 686

- silvestris $18 \mathrm{ff}$.

- - Wälder 353

- strobus 20, 781

- -Assoziation 749

- taeda 625

- turfosa 580, 658, 660

- uliginosa 658

- uncinata 684

Piperaceen 181, 289, 413

Pirola 116, 202, 299, 547, $558,576,577,579,583$

- grandiflora 548, 550

- rotundifolia 179,715

- umbellata 74

Pirolaceen 298

Pirus communis 571

Pistacia 786

- lentiscus $775,788,794$, $789,795,796,801,806$

- terebinthus 788

Pistia 268, 472, 473, 474, 498

Pisum sativum 214

Pithospora Roettleri 269

Placodium 423

- murale 421

Plankton 117, 318, 343, 359, 361, 464

--Beschaffenheit $\mathbf{3 7 0}$

-diatomeen $363,367,368$

- Elemente 371

- Formation 348

Planktoniella 363

Planktonmenge 368

Planktonorganismen 149 , 362

-Anpassung 366

Planktonperidineen 364

Plantae caespitosae 46

Plantago 176, 178, 583, 545

- albicans 792

- alpina 530

- Asiatica 853

- carnosa 452

- coronopus 422, 455

- cynops 788

- dubia 730

- gentilis 730

- lanceolata 174, 175, 730

- major 267,414

- maritima 400, 448, 450, 451,730

- serpentina 816

Plantionella 363

Platanthera 174

Platanus 572

- orientalis 553,572

Platycerium alicicorne 295, 600

Platysma 650

- cucullatum 650

- nivale 650

Platzregen 58
Plectonema 478

Pleurocladia lacustris 478

Pleurococcus vulgaris 469

Pleurogyne 702

Pleuston 343

Plumieria 427, 840, 865

Plumeria alba 239

Plumbaginaceen 205, 413

Poa 450, 531, 538, 587, 714

- alpina 531, 534, 540, 544,548

- anceps 637,638

- annua 703, 829

- bulbosa 257, 792, 806, $816,891,892$

- caespitosa 718

- concinna 816

- flabellata $637,638,639$, 679

- foliosa 637,638

- litorosa 637,638

- nemoralis 531, 556, 562

- pratensis 530, 539, 540, $544,545,548,914$

- trivialis 530, 589, 569, 914

Podocarpus 582, 603, 691

- nivalis 782

- nubigena 591

--Wälder 586

Podostemaceae 144, 269, 270, 272, 479

Podostemon 480

- ceratophyllum 480

Pogonopsis 298

Polarländer 41

Polarpflanzen 37, 133

Polemonium 541, 548

- campanulatom 567

- coeruleum 636

Pollenschlamm 116

Polster 184, 185

-bildung 68

Polster, dichte 246

-formen 325

-pflanzen $68,155,168,182$, $235,246,265,266$

Polycystis aeruginosa 464

- prasina 464

Polygala chamaebuxus 571 , $678,679,684$

Polygonaceen 205

Polygonatum 563

- Japonicum 172

- multiflorum 172

Polygonfeld 699, 701

Polygonum 907

- amphibium 489, 499,507, $508,520,624,946$

- arenarium 774

- aviculare 45

- bistorta 589

- equisetiforme 229, 888

- persicaria 231, 417

- Raji 417 
Polygonum viviparum 17, $531,533,633,640,704$, 715, 909, 912, 941

Polypodium 558

- quercifolium 295

- subauriculatum 600

- vulgare 770

Polypogon Monspeliensis 452

Polyporus annosus 282

Polyrrhizs funalis 295

Polysiphonia 383,394

- nigrescens 269

Polystichum thelypteris 685

- vestitum 639

Polytoma avella 470

Polytrichum 135, 434, 564, $579,583,632,633,639$, $642,643,646,648,658$, $668,688,762,904$

- formosum 564

- juniperinum 567, 662, 908

- piliferum 218, 233, 764, 768,769

--Polster, schwimmendes 657

- septentrionale 647,648 , 716

Pongamia glabra 608

Pontederia 268, 477

- crassipes 498

Pontosphaera Huxleyi $\mathbf{3 6 4}$

Populus 571, 572, 778, 876, 907,908

- alba 572

- balsamifers 780

-Dünen 749

- monilifera 780

- nigra 572, 768

- tremule 552, 566, 568, $579,580,662,768,803$, 912

- tremuloides 689

Porenvolumen 76

Poronis 297

Porphyra 383

Porphyr-Verwitterungsböden 315

Portulaca 416, 455, 829

- oleracea 224, 424

- pilosa 441

Portulaceae 224, 413

Posidonia 392, 434

- oceanica 395

Potamogeton 39, 117, 177, $270,487,492,495,498$, $509,520,910$

- crispus 496

- densus 493

- lucens 272, 498, 497

- natans $143,208,488,489$, $491,493,509,511$

- obtusifolius 493

- pectinatus 148, 497
Potamogeton perfoliatus $271,488,497$

- pusillus 498, 495, 497

Potamogetonaceen 392

Potamogetoneta pectinati 394

Potentilla 588, 541, 547, $548,715,735$

- alba 40

- anserina 436,453

- arenaria $40,579,773$

- aurea 534

- fruticosa 689,730

- nives 715

- palustris 638,640

- silvestris 534, 566, 579

Poterium spinosum 185, 791

Pothosgewăchse 151

Prårien 349, 807, 819

Prasiola 726

- crispa 383

- fluviatilis 481

- stipitata 383

Pringlea 679

Primula 174, 176, 183, 353, $539,562,564,735$

- acaulis 704

- anricula 101, 120

- farinosa 624,941

- hirsuta 121

- integrifolia 534

- Sinensis 211

- villose 101

Primulaceae 413

Prioninm palmito 246, 511

- serratum 246

Profilstellung 236, 240

Pronuba yuccasella 277

Prosopis 859, 864, 893

- glandulosa 863

- juliflorus 242, 863, 894

- pubescens 863

- velutina 863

Protea 798

- incompta 799

Proteaceen 68, 220, 289, 263

Proteïnkörper 286

Protococcaceae 145, 362

Protococcus viridis 283

Prozesse, chemische 92

Prunus 571, 575, 863

- acida 552

- cerasus 571

- chamaecerasus 551

-Dünen 749

- laurocerasus 571, 796

- padus 552

- Pissartii 29

- pumila 780

- serotina 749

--Smilax-Dünen 749

- вpinosa 552, 566, 730,794

- Virginiana 780

Psamma 217, 776, s. a. $\mathbf{A m -}$ mophila, Calamagrostis
Psamma arenaria 181,758 , $755,758,759,760,768$, $778,775,780,781,825$

- Dünen 749

- arundinacea 774

- Baltica 760, 762

Parmmophile Formationen 748

Psammophyten 107

-Formationen 320

Pseudobulbi 257

Pseudoplankton 365

Psendorhizom 169

Psilotum 242, 600

- flaccidum 600

Psoralea 826

- bituminose 788

Psychroclinie 44

Psychrophyten-Vegetation 320

Pteridium 301, 566, 627

- aquilinum 120, 178, 304, $354,566,576,833,853$, 933

Pterocarya 554, 578

Pterocaulon Vesuvianum 724

Pteropyrum $\mathbf{7 7 8}$

- Aucherii 447

Pulicaria 239

Pulmonaria officinalis 562 564

Pulsatilla 354

- nigricans 763

- pratensis 773

Purpurbakterien 388

Puschkinia scilloides 278

Puya Chilensis 799

Qualea 835

Quarz 106, 123

-sand 83, 84, 85, 93, 104, 106,107

Quellen, warme 484

Querceta 352

Quercus 550, 553, 572, 575, $616,741,781,796,912$, 932

- Apennina 803

- ballota 803,872

- Betula 559

- coccifera 788, 803

- coccinea 781

- ilex 214, 581, 794, 802, 872

- macrocarpa 806

- pedunculata $565,663,769$

- pubescens 803

- sessiliflora (sessilis) 124, $565,571,663,769$

- suber 803

- -velutina-Assoziation 749

- undulata 853

- virens 590

- Virginiana 781 
Radiola 904

- millegrana 908

Radiolarien 278

Rafflesiaceen 281

Räume, windstille 267

Ramalina 727

- scopulorum 421, 422 , 723,743

-Gürtel 423

Randia aculeata 865

Rankenpflanzen 159

Ranunculaceae 486

Ranunculus 474, 486, 487, $488,489,490,494,495$, $530,539,541,545,548$, $681,688,712,715,910$

- acer 313, 581

- alpestris 101

- aquatilis 476,494

- Baudotii 488

- biternatus 679

- bulbosus 231

- crenatus 101

- flammula 520

- glacialis 715

- hyperboreus 521

- Lapponicus 521

- lingua 501, 503, 508, 514, 624,910

- nivalis 521

- prolifer 853

- repens 166, 167, 509

- reptans 520

- sceleratus 410,514

Raoulia 183, 325, 719

- Hastii 708

- mammillaria 266

Rapanea 688

Raphia-Palmen 616

Raphiden 278

Raphidium nivale 469,471

Raphis 190

Rapistrum perenne 812

Rasen 235, 246

-bildnng 46, 68

- form 44

- von Dryas octopetala 65

Rassen, biologische 281

Rauhfrost $\mathbf{5 2}$

Ravenala Madagascariensis 192, 193

Rauwolfia 865

Reaumuria 260, 893

- hirtella 245

- vermiculata 776

Redfieldia flexuosa 781 , 825

Regen 52

--Ableitung 56, 57, 240

- blatt 57, 408

-menge 58

-wald, tropischer. 7, 310, $314,591,594$

- - subtropischer 590

-wasser-Entfernung 201
Regenwürmer 108, 111, 113 , 138, 136

Regionen 58, 141

Regulierungsmittel, anatomische 202

Regulierung der Transpiration 31

Reisseckia 162

Remirea maritima 439

Resedaceen 250

Reseda lutea 166

Restionaceae 181, 210, 229, 261, 263

Retama 229

- monosperma 776

Rhacomitrium 644, 668, 718,762

- canescens 218

- lanuginosum 899

Rhamnaceen 220, 265

Rhamnus frangula 515,566 , 568,631

- glandulosa 589, 804

- pumila 735

Rheum 165, 792, 866

Rhinanthus 530

Rhipsalis 598

- cassytha 296

Rhiroclonium $383,448,450$

Rhizoiden 111, 135, 242, 290

- Filz 246

Rhizoma multiceps 169

Rhizome $78,110,169,181$

- , wagerechte 387

Rhizophora 263, 602, 603, 910

- conjugata 402

- mangle 401,402,403,408

- mucronata $401,402,408$

Rhizophoraceen 252, 402, $406,407,408,413$

Rhizopoden 111

Rhizosolenia 363, 465

- alata 369

- styliformis 363, 371, 372

Rhodiola rosea 715,736

Rhodochorton 383

Rhodocorton islandicum 482 , 722

- purpureum 482

Rhododendreta 352

Rhododendron 210,709

- ferrugineum 121, 127 , 678,681

- hirsutum 120, 127, 678, 681

- Javanicum 600

- Lapponicum 221, 675, 677, 714

- Ponticum 804

Rhodomela subfusea 378

Rhodophycee $\mathbf{3 7 5}$

Rhodymenia 383

Rhopala 840

Rhus 209, 574, 689
Rhus copallina 781

- crenata 753

- toxicodendron 780

- viminalis 858

Rhynchopetalum montanum 720

Rhynchospora 836

- alba 627, 631, 658, 680

- fusca 680

Ribes 571, 572, 586

- alpinum 563, 565

- grossularia 563

- nigrum 563

Riccia $472,473,474$

Riella helicophylla 458

Riesenfarn 399

Rivularia 391, 478, 481

Robinia 265, 572

- pseudacacia 21

Rochea 737

- falcata 250

Rodochorton 739

Röhrenblatt, linealisches 493

Röhrenwürmer 187

Roggen 349

Rohhumus 110, 112, 113, $138,135,311,318$

Rohrpalmen 168

Rohrpalmenform 188

Rohrsümpfe 318, 400, 503

Rollblatt 220

Romulea 794

Rosa $250,552,684,712$, 741,775

- canina 872

- pimpinellifolia dunalis 767, 770

- sempervirens 795, 803

Rosaceae 120, 413

Rose von Jericho 51, 885

Rosettenbildung 41, 45

Rosettenbåume 180

Rosettenformen 325

Rosettenkräuter 180

Rosettenpflanze 45, 167, 267

Rosettensprosse 165

Rosettenstauden 167

Rosmarinus 793, 794, 806

- officinalis 788

Rostpilze 280

RoBkastanie 283, 554

Rotangform 15!

Rotangpalme-Triebspitze 158

Rotalgen 375, 380

Rotbuche 7, 20,89, 98, 111, $124,300,301,337$

Rotbuchenwälder 330

Roterde 113

Roterle 570

Rotfärbung 27

Rotliegendes 118

Rottannenwälder 134

Rubia peregrina 795 
Rubiaceen 181, 216, 220, $224,262,402$

Rubus 530, 712, 795, 948

- areticus 530

- chamaemoras 501, 530, $628,642,643,658,940$

- idaens 182, 515, 566

- plicatus 421

- pruinosus 853

- Runsorensis 688

Ruderalpflanzen 121

Ruderalstellen $\mathbf{3 1 7}$

Ruellia Daveauana 28

Ruhezeiten 40

Rumex acetosa 531, 539, $7 \$ 1$

- acetosella $120,166,179$, $180,668,770,773,983$

- crispus 430,435

- hydrolapathum 501, 503, 508

- trigranulatus 430

Rundblätter, langgestielte 194

Ruppia 392, 393, 394, 395, $458,495,521$

- auf Strandboden 346

Ruscus 230

- aculcatus $223,229,455$, 775

- hypoglossum 571

Rüster 570

Ruta 788

Rutensproß 228, 239

- blühender 227

-, typischer 228

Sabal 516

- palmetto 513

Sabularia 493

- aquatica 487, 495, 497

Saccharomyces 948

Saccharomyceten 138

Saccharum officinarum 190

Saccocalix satureoides $\mathbf{7 7 6}$

Sägetang 377

Sättigungsdefizit der Luft 49

Säuren 248

Saftpflanzen 224, 254

Saftreichtum 01

Saftwurzeln 258

Sagina 675,708

- nodosa 519

Sagittaria 498, 503, 510, 514

- latifolia 510

- sagittifolia 257, 492, 498

Salices 355, 642, 714

Salicornia 42, 44, 230, 253, $260,340,414,416,447$, $448,457,458,905,910$

- ambigua $230,410,454$, 455

- annua 416

- fruticosa 452, 454, 909

- glauca 430
Salicornia herbacea 330,339 , 414 bis $416,430,434,486$, $452,453,458,459,460$, 908

- lignosa 339

- radicans 339

- Zone 457

Salicornien, halbstrauchartige 398

Salicornieta herbaceae 396 bis 400

Salicornietum 335

Salinensiimpfe 42

Salix 515, 543, 566, 568, $572,584,631,653,666$, $689,750,751,778,907$

- adenophylla 780

- alba 516

- arbuscula 548, 680, 779

- arctica 43

- aurita 660,680

- cinerea 514, 516, 680

- daphnoides 768

- fragilis 516

- glauca 546 bis 550,568 , $622,675,677,680,706$

- glaucophylla 780

- Groenlandica 624

- hastata 680

- herbacea 530, 531, 533, $633,640,667,676,677$, 706, 716

- lanata 548, 551, 568, 622, 675,909

- Lapponum 548, 680

- myrsinites 548, 622, 680

- nigricans 548

- pentandra 516, 636

- phylicifolia 548, 568, 909

- polaris 531, 662, 667, $676,677,706,911,912$

- Pomeranica 442, 768

- repens 538, 567, 622, $658,667,770,771$

- argentea 767

- reticulata 532, 662, 667 , $675,676,706,912$

- retusa 532, 706, 716

- rosmarinifolia 658

- serpyllifolia 717

Salpeter-Bakterien 139

- bildung 139

-pflanzen 121

-săure 98, 114, 121

Salsola 253, 416, 894

- sclerantha 893

- kali 127, 412, 413, 414, $416,434,436$

- longifolia 260

- pestifer 827

- rigida 792, 893

- soda 414

Salvia 181, 239, 866

- amplexicaulis 814, 815

- nutans 810
Salvia-officinalis-Assoziation 743

- pratensis 816

- Tomillares 790

Salvinia 268, 270, 472, 474

- anriculata $\mathbf{4 7 6}$

- natans 473,476

Salzboden 105, 118

- bewohner 311

-Formation 318, 360

- -Gräser 217

- vegetation 358

Salzdrüisen 245

Salze, gelöste $99,100,103$

-, lösliche 197, 311

-, hygroskopische 51, 245

Salzgehalt 386

Salzkrusten 205

Salzpflanzen 101, 120, 122 , 197,253

- behaarte, kahle 415

Salz, schwefelsaures 103

-see 456

-steppen $360,455,456,457$

- suimpfe 310, 318, 396

Salzwasser 148,310

- Formation 318

-pflanzen, submerse 385

- plankton 359, 361, 371, 464

--Sümpfe 359

-vereine 358

Salzwiese 458

Salzwüsten 319, 360, 455

Sambucus 572

- nigra 584

Samen, lufttrockene 33

-, myrmekochore 278

-reife 301

-verbreitnng 70

Sammetblätter 57, 241

Samolns 453

- campanuloides 452

- litoralis 453

- Valerandi 452, 455, 739

Sand 78, 83, 95, 105, 106 , $123,310,315,320,721$ --Algen 396

-algenformation 360,432

-dorn 522

- ebenen 82

- felder 213

-, feuchter, salziger 432

-flora 107, 318

-flur, trockene 766

- geblåse 64

-, gelber 113

- gräser 210

-hüllen 235

-körner 106

- marschen 447

- Nährwert 107

- pflanzen 197

- - Formationen 320

-puBten Ungarns 814 
Sandstein 73, 106

Sandvegetation 320, 748, 759

Sandstein - Verwitternngsböden 315

Sandwälle 431, 432

Sandwüste 325,326

Sanicula Europaea 557, 564

Sanseviera 260, 856, 859

Santalaceen 220

Sapindaceae 299

Sapinm 222

Sapotaceen 223

Saprobien auf losem Boden 483

Sapropel 117

Saprophyten 7, 281, 297, $298,303,328,329,361$

- fakultative 299

Sapro-Plankton $\mathbf{3 5 9}, \mathbf{4 7 0}$

Sarcobatus Maximiliani 458

- vermiculatus 458

Sarcocaulon 203, 255, 873

Sarcodes 298

Sargassum 272, 373, 375

Sargassum-Assoziation $\mathbf{3 7 8}$

- bacciferum 373

- fluitans 373

- hystrix 373

- natans 373

Sarmienta repens 591

Sarothamnus 667

- scoparius 120, 773

Sarracenia 178, 681, 658

Sassafras 572, 780

Saubohne 286

Sauerstoff $10,79,99,143$, 149

Saughaare 290

Savannen 141, 810, 312, 320, $324,349,833$

- Afrikas 841

Saxaulbaum 415, 446, 447

Saxifraga 178, 183, 205, 266, $534,541,547,548,708$,

$709,711,715,717,737$

- aicoides 521

- aïzoon 735

- Brunonis 178

- caesia 130

- cernua 704, 705

- comosa 521, 704

- cotyledon 735

- flagellaris 704

- flagellifera 179

- hirculus $625,631,658$, 941

_ oppositifolis 706, 712, 737

- retusa 130

- rivularis 521

- saxatilis 521

- stellaris 521, 704

- tridactylites 538,539,631

Scaevola Plumieri 224

Scenedesmus 465, 471
Schachtelhalme 80

Schatten 29, 301

-bäume 19

-blätter 27, 261

-flora 370,380

-pflanzen 15, 337

- pflanzen, Unterschied 21

- auf Waldboden 50

Scheuchzeria 627

- palustris 501, 652, 658, 941

Schiefer 73

-alpen 101

-fels 72

- pflanzen 120

Schih-Steppe 817

Schildhaar 231

Schismus 458

Schistostega 27

Schizomyceten 362

Schizophyceen $148,343,370$, 399,483

Schizothrix 478

Schlamm 78, 106, 116

Schlammablagerungen 117

Schlammboden - Vereine, saprophytische 388

Schlammvegetation $\mathbf{3 9 0}$

Schleim 205, 248, 249, 273

-bildung 376

-kork 205

-zellen 248, 408, 414

Schleusenschlamm 139

Schlickmarsch $\mathbf{4 4 8}$

Schlick, organischer 388

Schlingpflanzen 159

Schmarotzer 154, 280

-, obligatorische 281

Schnee 52, 128

-alge 34

-, brauner 469

-bruchfichten 129

- decke 96, 129, 130, 131

- grenze 42

-, grüner bis roter 469

-tälchenflora 129

一, Wärmeverhältnisse 129

-wasser 131

Schoenus 631

- nigricans 455

Schopfbaum 156

Schopfbänme $168,180,186$, 192

SchöBlingssträucher 182

Schutthalden $\mathbf{7 4 5}$

Schutz gegen extreme Temperaturen 34

- kork 205

-organe 201

Schwärmsporen 283

Schwärmzelle 365

Schwammparenchym 26, 29 , 251,261

Schwammwirkung 183

Schwarzerde 114
Schwarzerle 20, 570

Schwarzrotfärbung 29

Schwebealge 374

Schwebebecher 367

Schwebeeinrichtungen 367

Schwebepflanzen-Formation 461

Schwefel 99, 147

Schwefelbakterien 388, 389

Schwemmlands-Boden 73

Schwimmblasen 272, 273

Schwimmblätter 309

Schwimmblatt-Querschnitt 208

Sehwimmpflanzen - Formation 461

Scilla 812, 856

- bifolia 564, 717

- festalis 304, 354, 934

- Sibirica 278

Sciadophyllum 600

Scirpetum 352

- lacustris 352

- maritimae 398

- Tabernaemontani 399, 504

Scirpo-Typhetum 352

Scirpus 221, 453, 509, 510, 631,836 , s. a. Heleocharis

- acicularis 497, 520

- caespitosus 501, 624, 657, $658,659,662,680$

- fluitans 493

- frondosus 783

- holoschoenus 454, 455, 876

- lacustris 78, 166, 229, 301,493 , 501, 503, 504, $506,507,509,514,910$

- litoralis 455

- palustris 229, 501, 507, 508,520

- paradoxus 235, 831

- pauciflorus 451

- Tabernaemontani 400 , 508,514

- trichophorum 635

- Warmingii 235

Scitamineen 252

- Blätter 192

Scleranthus 119,668

Scorodosma 866

Scorzonera 776

- purpurea 815

Scrophulariaceen 220

Scrophularia ramosissima 443

- Saharae 776

Scutellaria galericulata 170

Scyphiphora hydrophyllaces 402

Scytonema 722

- Faden 283

- gracile 469

Scytosiphon lomentaria 375 
Sedentaria 137

Sedum 225, 258, 736, 787, 773

- acre 224, 418, 668, 728, $753,770,772$

- album 418

- maximum 258

- villosum 256, 735

See, diatomeenreiche 117

-gråser 359, 392, 393

Seegras - Vegetation 318

- Wiesen 387

Selaginella denticulata 739

- lepidophylla 48, 198, 218, 219

Semele 230

- androgyna xylophylla 223

Sempervivum $39,45,178$, $179,255,709,785$ bis 737

- arachnoideum 816

- tectorum 224

Senecio 225, 737, 842, 871, 875

- candicans 415

- Jonstonii $\mathbf{7 2 0}$

- nemorensis 548

- paludosus 503

- silvaticus 904

- vernalis 919,940

- viscosus 436,771

- vulgaris 417

Sennah-Steppe 817

Sequoia gigantea 575

- sempervirens 575, 806

Serenaea serrulata 790

Serjania 162

Serpentin 101

- Verwitterungsböden $\mathbf{3 1 5}$

Sesleria caerulea 532, 534

- comosa 533

- marginata 535

Seston 365

Sesuvium 340, 361, 410, $439,453,454$

- portulacastrum 224, 225, $417,437,439,454,455$

Sibbaldia 533

- procumbens 530

Sibljak 348

Sida 441, 587, 711

Sieglingia decumbens 658

Silberbaum 232

Silene 712, 866

- acaulis 17, $18,68,69,183$, $266,678,706,707,715$, 737

- maritima 422, 427, 428, 436,743

- venosa 169

- viscosa 766, 810

Silybum marianum 829

Silicoflagellaten 364

Silphium laciniatum 238
Sinapidendron supestre 784

Sinapis alba 416

Sium latifolium 494, 501, $502,508,508,514,910$

Smilax 589, 804

- aspera 794, 803

- hispida 780

Sklerenchym 224

-zellen 263

Sklerophyll 219

- Formationen 320

- wälder 223

Sklerophyten - SträucherBlattypen 228

Sodasee 118

Solanaceen 121

Solanum 829

- dulcamare 414, 516

- tuberosum 166, 170, 171

Soldanella $174,176,580$, $533,704,712$

- alpina 532, 533

Solidago 354, 530

- alpestris 578

- virga aurea 567, 668

Solitarie gregariae $\mathbf{8 8 1}$

Sommerholz 262

Sommerpflanzen 305

Sommerregen 60 .

Sonchus arvensis 179,801 , $770,772,853$

- Javanicus 853

- maritimus 455, 876

- oleracens 166

- paluster 503

Sonne 29

Sonnenblätter 27, 261

Sonnenpflanzen 50

-, Unterschied 21

Sonnenstrahlen-Einfalls winkel 92

Sonnenwärme 92

Sonneratia acida 402, 404, 407,408

- alba 402, 407, 408

- spetala $402,407,408$

- caseolaris 402, 407, 408

Sorbus 741, 900, 981

- aria 872

- aucuparia 568, 987.

Sordaria 297

Spalierform 42, 68

Spalierstråucher 168, 193

Spaltöffnungen 207, 271, 408,415

Spaltenvegetation 320, 732

Sparganium 490, 492, 494, $501,514,624,910$

- affine 486,496

- diversifolium 496

- Friesii 496

- minimum 486, 496

- ramosum 496, 503

- simplex 486, 496, 503
Spargelwurzeln 404

Spartina 400, 448

- juncen 452

- stricts 341

- stricta maritima 452

Spartiumform 228

Spartium junceum 227, 228, 794

Spartocytisus supranubius 868

Spathyema foetida 510

Spergula 983

Spergularia 450,458

- marina $427,448,449,458$

- media 414

Spermacoce 439

SpermothamnionTurneri 269

Sphaerella nivalis 34, 469

Sphaerocarpa 727

Sphaerocystis Schroeteri 466

Sphaeroeca volvox $\mathbf{3 6 5}$

Sphaerolobium 228

Sphaerophoron $\mathbf{7 1 5}$

- corallioides 650,668

Sphaerophorus 651, 688

Sphagnum acutifolinm 652

- Austini 654

- cymbifolium $652,654,656$

- fimbriatum 656

- fuscum 654

- medium 654

- Pappeanum 688

- recurvum 654

- riparium 640

- rubellum 654

- teres 640,654

- Blätter 287

- Decke, schwimmende 907

- Moor 643, 644, 652, 672

-torf 110

-tundren 318

Sphenopus divaricatus 458

Spinifex 885

- hirsutus 783

- squarrosus $415,489,776$, 779

Spiraea 571

- crenifolia 813

- ulmaria 515

Spiranthes spiralis 545

Spirogyra 463, 486

Spirostachys 457,460

- occidentalis 459

- Patagonica 459

- vaginata 459

Spirulina 484.

Splachnaceae 121

Splachnum 297

Spondias lutea 177

- tuberosa 851

- venulosa 258

Spongilla 278

Sporangienträger 296

Sporen 150, 289

-, keimende 288 
Sporenpflanzen 298

Sporoboletum virginici 439

Sporobolus 235, 587, 782, 832,840

- arundinaceus 830

- asperifolius 828

- cuspidatus 824

- spicatus 209, 211

- Virginicus 437, 438, 439, 441,443

Spreizklimmer 159

Spritzgürtel 420

Sprosse, blattlose 226, 237

-, cupressoide 221

-, epigeische 165

—, juncoide 229

-, kurzgliedrige 41

-, lepidophylle 221

_, niederliegende 267

-, orthotrope, plagiotrope 165

-, salicornoide 230

SproBbasis-Komplex 169

SproBfolge 154

SproBformen 165, 226

Stäbchenbakterium 139

Stachys 794

- Aegyptiacus231,239,244

- palustris 231

- silvaticus 170, 563

- tuberiferus 170

Stïmme, falsche 180

Stammsaftpflanzen 254, 414

Stammsukkalente 155, 168, 185

Standorte 2, 306, 307, 310, 336

-, Begrenzung 308

-, Beschaffenheit 306

-, Einteilnng 318

-, gemischte 344

Stangea Henrici 870

Stapelia 6, 185, 231, 255, 856,858

- pinnata 566

Statice 239, 414, 422, 447, $450,452,456,460,889$

- aphylla 245

- bellidifolia 454

- Brasiliensis 459

- cancellata 424

- limoniam 448, 454

- scabra 452

- Sebkarum 458

- serotina 455

Stauden-Formationen 398

Staudenvegetation, subxerophile 807

-, xerophile 317

Steenstrups Lichtmesser 13

Steiffrieren 38

Steine, groBe abgerundete 427

Steinalgen, kriechende 375

Steinbedeckung 128
Steinböden 320, 721

Steinformationen 320

Steinzellen 263, 408

Stellaria 547, 675

- holostea 355, 515, 562, 563

- humifusa 452, 699

- longipes 548

- media 56

- nemorum 74, 353, 355, 562,563

Stengel-Bewegungen 217

-, bandförmige 226

- blattlose 226

-, gefluigelte 227

Stenotaphrum Americanum 437

- glabrum 452

Steppen 141, 213, 312, 317, $324,326,349,807$

- Asiens 813

- Australiens usw. 830

- Rumäniens 813

- Serbiens 813, 814

- SüdruBlands 809

-, iberische 816

-, orientalische 8

- suideuropäische 8

- gräser 217, 221

-pflanzen 27, 49, 231

Sterculia 602

- laevis 608

Stereocaulon 43, 675, 899

- alpinum 650

- Magellanicum 651

- paschale 764, 765

- ramulosum 283

Stigeoclonium 478, 496

Stigonema 722

Stickstoff 99, 114

- Armut 315

-bakterien 287.

Sticta 688

- Freycinetii 651

Stictyosiphon 383

Stipa 8. Stupa

Stoffwanderung 47

Stolon-Rhizome 166, 181

Strandfelsen 420

--Formationen 419

Strandgeröllformationen 360,428

Strandpflanzen 42

-, gemeine 127

Strandstrauch, westindischer 253

Strandsumpf $\mathbf{4 0 0}$

Strandwiesen 318

-formation 360

Strandwålder, tropische 444

Strandwalle 428,429

Stratiotes 475, 476, 495, 496, 498,947

- aloides 472, 473, 515

Stråucher, kugelige 265
Sträucher, krummästige 265

-, monokotyle 155,188

- auf Torfboden 680

--Vereine 337

Strauchflechten 128

Strauchschicht 329

--Steppen 321

Strelitzia 192

- Form 192

Strömungen 149

Strophanthus Eminii 862, 863

Struthanthus 279

Struthiopteris Germanica 179

Strychnos 162

- nux vomica 608

Stafe 141

Stapa 209, 217,810,812,824, 829,889

- capillata 815

- comata 824,826

- Grafiana 804

- humilis 830

- parviflora 806, 816

- pennata $813,815,816$

- spartea 822,824

- tenacissima 181, 243, 792, $816,817,889$

--Steppe 807, 812

Stützwurzeln 403

Stützzellen 263

Suaeda 42, 44, 415, 416 $417,418,452,457,459$, 460

- divaricata 459

- fruticosa 430,458

- maritima $400,434,448$ $449,455,905$

- pterantha 893

Subassoziationen 353

Subformationen 348

Subglaziale Formationen 694

Submerse-Vegetation 319

Subularia 270, 481

Subxerophile Formationen 320

Succession 356

-, regressive 335

Succisa praemorsa (pratensis) 539,636

Succulenten 254

- -Steppen 321

- Vereine Amerikas 860

SüBwasser 116, 148

- boden, loser 486

-böden, sumpfige 319

-pflanzen, epilithische 478

_- auf losen Böden 482

-plankton 464

- sümpfe 310, 352

-tiere 117

-vereine 461

Suffrutices 181

Sumpfgebüsche $\mathbf{3 1 8}$ 
Sumpfgebüsche in SüBwasser 515

Sumpfpflanzen 80, 155, 309, 360,396

- Formationen 501

Sumpfregetation 99, 319

Swartzia 605

Symbiose 7, 156, 280

- mit Algen 154, 155

Symphoricarpus 572

Synedra 468

Synökologie 9, 229, 306

Syntrophie 7

Synura uvella 365

System, physiognomisches 151

Szor (Salzwüste) 459

Tabakpflanzen 87

Tabellaria 465

Taeniophyllum Zollingeri 295

Tallophyten 153

Tamaricaceen 220, 413

Tamariskengebuische 443

Tamarix 37, 203, 205, 245, $343,416,862,876,884$, 893

_ Gallica 88, 775

- Germanica (Myricaria) 520

- mannifera 245

- paciovulata 221

Tamus communis 804

Tanacetum vulgare (Chrysanthemum) 766

Tangwålder 378

Tannenrohhumus 111

Tannenwälder 584

Taraxacum 174, 176, 178, $545,547,715,772$

- collinum 400

- croceum 543

- officinale 267, 531, 548

- vulgare 32

Taschenblätter 293

Tau 52, 54, 107

Tausendfüße 136

Taxodium 513

- distichum 502, 516

- imbricatum 517

Taxus baceata 585

Tecoma 835, 838

Teesdalia 933

- nudicaulis 164, 762, 771

Teiche 318

Teichschlamm 139

Tektona grandis 594

Temperaturanomalien 89

Temperaturen, zuträgliche 39

Temperaturfortpflanzung 90

Temperatur-Gang, tåglicher 90,95

Temperaturgrenzen $\mathbf{3 2}, 34$
Temperaturwechsel 34

Teppichform 42

Teratophyllum aculeatum 292

Tessaria 864

Testudinaria 257, 259

- elephantipes 206

Tetragonia expansa 250

Tetramitus sulcatus 365

Teucrium 794

Teufelshand 174

Thalassia 392,484

- testudinum 395

Thalassiosira 368,871

Thalassiothrix 368,871

Thalictrum 548, 904

- alpinum 813

- angustifolium 455

- Javanicum 853

- minor 767

Thallophyten 336,350

Thallus 272

Thamnium alopecurum var. Lemani 145,497

Thea 263

Theobroma cacao 56, 605, 607

Thermotropie 95

Thermotropismus 44

Therophyten 1583, 161

Thesium alpinum 278

Thespesia populnea 444

Thismia 285

Thlaspi cepaeifolium 101

- rotundifolium 101

Thuja occidentalis 517,689 , 781

Thymelaea 793

- hirsuta 204, 209

- microphylla 889

Thymelaeaceen 220

Thymian 213

Thymus 181

- serpyllum $667,678,770$, 813

- Tomillares 790

- vulgaris 788,794

Tiefenstufen- Vegetation 360

Tiefwasserflora 380

Tiefwarzler, typischer $\mathbf{8 1 5}$

Tiere 79,81

- im Boden 4

Tierleben 275

Tiere, Tätigkeit 136

Tilia 555, 566, 571, 573, 575, 741

- Americana 780

- argentea 240

Tilopteridaceen 374,385

Tillandsia bulbosa 247,291 , 292, 297

- usneoides 56, 158, 244, $290,295,516,599$

- - (Schuppen) 55

- utriculata 599
Tjemoro-Wålder 852

Tofieldia 240, 624, 714

Tolpis Abyssinica 720

Tolypothrix lanata 485

Tomentosa-Arten 281

Ton 88

-boden 77, 84, 85, 98, 98, $105,107,123$

- -, salziger 447

- erdehydrat 108

- erdesilikat 107

- glimmerschiefer 125

Tonschiefer 106

- Verwitterungsböden $\mathbf{3 1 5}$

Tonnenståmme 189, 190

Torf 109

Torfboden 84, 85, 98, 109 , 110

- Formationen 618

Torfhuigel in der Tundra 641

Torfmoos 656

Torfmull 110

Tortula ruralis 764,767

Tournefortia gnaphalodes 224, 253, 441, 442

Toxine 140

Tracheiden 260, 316

Tradescantia Fluminensis 261

- Virginica 826

Träufelspitzen 56, 57, 241

Tragacantha 866

Transpiration 14, 31, 39, 265

-, cuticulare 202

- Hemmung 231

-, Regulierung 199

schutz 291

-; stomatäre 207

_, stomatale 202

- Unterschiede 50

Trapa 23, 474, 487, 489, 490, 491,495

- natans $25,488,491,498$

Trapaeolum 871

Trentepohlia 482

- aurea 722

- iolithus 722

Trianea Bogotensis 472

Trifolium 120, 545

- agrarium 906

- alpinum 534

- arvense 119, 771

- fragiferum 450

- pratense 119

- repens $164,236,531,914$

Trichodesmium 372

- erythraeam 362

Trientalis 23, 711, 923

- Europaeв 170, 564, 576, $583,660,686$

Triglochin 453

- maritimum 400,427, 448, 449,451

- palustre 681,658

Triodia 637, 831, 845 
Triodis decumbens 658

Triplaris 278

Triraphis rigidissima 782

Trisetum 548, 714

- flavescens 533

Tristegia glutinosa 587

- glutinosa-Grasländer 348

Tristicha hypnoides 480

Triticum 436, 946

- acutum 210

- dasystachium 525, 780

- junceum 217, 415, 434, $436,442,447,759,762$, 771,775

- repens 181,545

- spicatum 826

Triuridaceae 298

Trockengebüsche 861

Trockenheit, physikalische 197, 310

-, physiologische 88, 197, 311

Trockenheitspflanzen 83

Trockentorf 110

Trockenwälder 850

Trockenwüsten 875

Trollius 530, 539, 631

- Europaeus 567, 636

Tropaeolum 211

- majus 22

Tropenpflanzen 28, 53

Tropenvereine, immergrüne 41

Tropfenbildung 49

Tropophyten 166

Tschernosem 108, 114

Tsuga 575

- Canadensis 575, 689

Tubicolae 137

Tuffwand, steile 327

Tulipa 788, 792, 812, 892

- praecox 235

Tumboa 49

- Bainesii 890

Tundra 103, 326, 328, 349

- mit Birkengestrüpp 645

- flora Lapplands 38

Tundrenpflanzen 116

Tunikabildungen 261

Tunikagräser 133, 233, 234, 246

Tunica prolifera 815

Turgor 218

Tussilago farfara 120, 301

Tussock-Vegetation 637

Typen, muscoide 155

Typha 166, 501, 503, 509, $510,514,624,915$

- angustifolia 498, 503

- Domingensis 512

- latifolia 118, 498, 636

Typhetum angustifoliae 352 , 506

Typheta latifoliae 106
Typheta Schuttleworthii 506 Typhetum 352

Ubiquisten 123

Udotea 387, 392, 393

Uberflutungsgebiete 341

Uberpflanzen 296

Ufer, flache, sandige und kiesige 518

- gebuisch 343

-vegetation 499

- - einer Igarapé 595

-wälder 335 , 521

Ulex 230, 667

- Africanus 788

- Europaeus 120, 220

Ulmaria pentapetala 521 , s. a. Filipendula

Ulme 20

Ulmus 555, 566, 572, 741, 778, 803, 908

- campestris 214

Ulothrix $385,391,478,481$

Ulva 376

Umbelliferen 183, 184, 220 , 221, 262, 302

Uncaria 162

Uniola paniculata 781

Unkräuter, amerikanische 127

Unkrautflora 118

Untergrund 98

Unterholz 20

Urginea 856

- undulata 239

Urospora 383

Ursprungsfels 126

Urostigma doliarium 279

Ursachen, ökologische 349

Urticaceae 413

Urtica dioeca $166,219,515$, 569,570

Urwald am Rio das Amazonas 597

-boden auf Java 598

- lianen 157

Usnea 583, 688

- barbata 291

Uttricularia 495,496

- valgaris $268,472,473$, 474,476

Uvaria macrocarpa 731

Vaccinietum 387

Vaccinium 534, 576, 577, $661,677,684,686,714$, 912

- macrocarpum 689

- microphyllum 676

- myrtillus $111 \mathrm{ff}$.

- oxycoceus $193,501,581$. $624,652,658,679,681$

- nliginosum 116, 501,568, $579,581,624,652,658$, $660,675,676,678$
Vaccinium Stanleyi 689

- vitis Idaea $187,579,583$, $581,624,627,650,660$, $667,668,675,676$

Valeriana 515, 516

- dioeca 539

- Javanica 853

- officinalis 853

Valerianaceae 8

Valerianaceen der Anden 220

Vallisneria 492, 495, 486, 487, 496, 498

- spiralis 492

Vanille 277

Varietäten 353

-, geographische 354

-, physiologische 281

Vaucheria 391, 448, 482, 910

Vegetation, aphotische 145

-, chasmophytische 732

-Decke, leblose 128

-, dyphotische 145

-, euphotische 145

- auf Felsen 731

- der Felsspalten 424

- Formen 6, 151

-formation 306, 309, 334

- gürtel 356

--Höhe 328

一, marine 359

-periode 104

- tage, Anzahl 41

-, terrestrische 411

- der Trümmerfelder 740

-, ungleichartige 302

-, Unterschiede 57

-, Verteilung 70

-zeit, zu kurze 132

Velamen 51, 53, 206, 245, 260, 291

Vellocia 192

Vellozien, baumartige 191

Velloziaceae 133, 285, 246, 249, 252

Verankerungsorgane 407

Veratrum 510, 548

- nigrum 814, 815

Verbascum 773

- phoeniceum 174

Verbena 184829,830

- ciliaris 208

Verbenaceen 181, 218, 408

Verdunstung $48,49,50,66$, $85,86,167$

-, cuticulare 202

- Herabdrüickung 214

-, Regulierung 200, 201

-, Schutz 130, 207

Vereme, felsenliebende 419

-, frei schwebende 359

-, frei schwimmende 359

-, Haushaltung 46

- Kämpfe 46

-, littorale 388

-, Verteilung 46 
Vererbungsmerkmale 152

Verholzte Teile 27

Verholzung 262, 416

Verjüngerungsknospen-Stellung 165

Vermehrung, geschlechtliche 270

-, vegetative 166

Verouica $183,538,719,735$, 737

- agrestis 278

- alpina 533

- chamaedrys 56, 127

- cupressoides 220

- hederifolia 711

- officinalis 577

- teucrium 127

- thuyoides 220

- triphyllos 774

Verrucaria 420

- calciseda 722

- Maura-Gürtel 424

- maura 383

- microspora 424

- mucosa 424

- striatula 424

Verrucarietnm Maurae 420, 421

Verstärkungsrhizoiden 272

Verteilung, topographische 72

Verwesungspflanzen281,297

Verwesungspilze 113

Verwitterungssboden 73, 314

Verzweigung, monopodiale 154

-, sympodiale 154

Vesicaria $\mathbf{7 1 5}$

Viburnum 689

- lantana 554, 566, 900

- opulus 515, 566

- rigidum 804

- rugosum 589

- tinus 794, 803

Vicia 548

- cracca 239, 566

- faba $\$ 18$

- sepium 74

Victoria regia 490

Vinca 202

Viola 566, 717, 871

- biflora 521

- calaminaria 101

- canina 219,579

- lutea 101, 703

- odorata 40, 278

- palustris $628,636,658$

- serpens 853

- silvatica 562,583

- tricolor 703

Viscaria alpina 715,735

Viscum album 187, 280

Vitaceae 299

Vitis 574

- cordifolia 780
Vitis labrusca 553

- vinifera 558

Viviparie 404, 406

Volvox globator $\mathbf{4 6 6}$

Voyria 298

Vriesea 244

Wacholder 684

-schutzpark 682,683

Wachs 203

-ausscheidungen anf Zuckerrohr 203

-palme 203

Wachstum-Hemmung 22

Wachsủberzüge 52, 270,415

Wahlenbergia Olivieri 720

Wälder, blattlose 852

-, edaphische, mesophile 317

-, gemischte 585

-, japanische 578

-, tropische 592

- auf Sandstrand 443

- auf St. Jan 599

- aaf Torfboden 685

- in der Wüste 344

-, xerophile 317

Wald, wandernder 671

Waldboden 298

-pflanzen 28, 27

-Tierleben 133

- vegetation 133, 134

Waldflora 331

Waldhumus 113

Waldsavannen Australiens 846

Waldzonen 57

Wanderdünen 751

Wandersprosse 181

Wanderungsmittel 407

Wärme $3,4,32,62,143,146$

-, ökonomische Bedeutung 47

-erzengung 14

-kapazität 90,93, 109

-leiter, schlechte 37

-schwankungen 129

-summe 41

Warzen 256

Wasser, absorbiertes 81

_, alkalisches 149

-, an den Boden gebnndenes 57

- A usscheidung 271

-, blaues 149

-, braunes 149

-, chemisch gebundenes 81

-, emporgezogenes 81

-, gelbes 149

- geographische Bedeutung 57

- hartes 147, 149

-, mineralstoffarmes, -reiches 317, 318

_, ökonomische Bedeutung 47
Wasser, salzhaltiges 310,818

-, stehendes 82

- sủbes 810, 819

- Umlagerung von 261

Wasser-Absorption 200

-adern 79

- aufnahme bei Landpflanzen 242

- oberirdische 243

- aufstau 83

- behălter 247

- - Größe 258

-bewegung 149, 379

-blüte 362

-dampf 50, 51, 84

- -Absorption 92

- Farbe 148, 149

-formationen 308

- gehalt 81

- gewebe 203, 249, 251, $260,314,408,414$

- -, duBere 249 bis 253

-hebungsvermögen 83,84 , 110

-kapazität 83, 85, 109, 110

-menge 35, 49, 80

-pflanzen 4, 80, 158 bis 156 , 196, 309, 348, 396

- - mehrjährige 270

- -, anatomische Anpassung 268

- - Formationen 336

- - Verbreitung, geographische 150

- morphologische Anpassung 268

- Standort 148

- - Vereine 359

- Phanerogamen 146

-poren 49, 212

- Båcke 247

--Salxgehalt $358,378,379$

-speicherung 200

-stand, periodisch wechselnder 518

- stoff 90, 114, 140

- strömungen 73

-verlust - Einschrainkung 200

-versorgung 48, 290

-vögel 150

- wege 211

-wurzeln 89

-zollen 260, 292

Webera nutans 622, 663 .

Weichstlimme 155, 168, 185

Weide 68

Weidenform 151

Weiden anf Kulturland 543

Weingaertneria 815,8 . a. Corynephoris

-Assoziation 119

- canescens 119, 209, 217. $221,668,674,746,747$, $762,764,770,772,778$ 
Weißbuche 7, 20, 71, 318, 570

Weißtanne 20, 127, 337

Weizen 349

- samen 35

Welkungskoeffizienten 87

Wellengürtel 420

Wellenschlag 149

Welwitschia 49,243

- mirabilis $49,243,890$

Wermutsteppe 792,873

Werneria nubigena 870

Wettbewerb 275

Weymoutskiefer 36

Widerstandskraft 68

Wiese $324,326,536,537$

-, sommergrüne 330

-, saure 318

_, subtropische, tropische 587

-, unterseeische 392

-moore 82, 110, 318, 630

-torf 110

Wind, austrocknend 66

- Feuchtigkeitsgehalt 62

-, Nutzen 70

-bestäubung 330

- erosion 69, 130

-schäden 66

-schattenseite 63

--Schutz 69, 136

--Schutzwehren, topographische 70

-wirknng-Gründe 66

Winterregen 60, 785

Wipfelbäume 154, 156, 168, 180,186

Wirt 280, 281

Wirtspflanze 289

Wirtswurzel 280

Wistaria 574

- Chinensis 574

- polystachaya 574

Wohngebiet 1

Wolffia 268

- arrhiza 150, 472, 474

- Brasiliensis 475

Wolffiella 516

Wolken 52, 54

-region 141

Wolle 231

Woodsia 735

- glabella 102

- hyperborea 102

Wüsten $308,310,817,321$, 849
Wüstenpflanzen $49,51,116$, 205, 231, 253

-, australische 210

-, nordamerikanische 208

Wüstenregionen der Erde 886

Wüstensträucher 233,265

Wüstenzonen 57

Wurzel, windende 268

- form 100

-haare 268

-hals 269

-haube 268

- hüllen 53, 133, 291

-kletterer 159

- knollen 258

- knospen 301

- tätigkeit 89

Xanthium 525

- spinosum 791, 874

Xanthoria 722

- elegans 722

- parietina 421, 422

Xanthorrhoea 192, 857

- Preissii 805, 845

Xanthoxylum 604, 863

Xeromorphie 315, 316

Xerochasie 51

Xerophilen 63

Xerophyten 52, 56, 123, $198,199,205,207,296$, 310,311

- vegetation 92

Xerophytismus 316

Xeropteridetum 354

Xerothermen 62

Xylemgang 271, 272, 274

Xylophylla 222

Xylopodium 169, 258, 836

Xyris 624

Xyromelum 845

Yucea 192, 787, 742, 826, $853,860,894$

- filamentosa 277

- glauca 781, 825

- radiosa 782

Zannichellia 392, 394, 395, $488,493,494,496$

- palustris 521

- auf Strandböden 346

Zechstein 118

Zelle, einzelne 365
Zellinhalt 34, 248

Zellen, lichtreflektierende 27

Zellsaft 27, 47

Zelkova 573

Zilla 219

- macroptera 889

Zitterpappel 20

Zizania 510

- aquatica 498

Zizyphus 864

- spina Christi 250

Zollikoferia 806

- arborescens 889

Zonation 81

Zonen 61, 62, 141

Zoochlorella 278

Zooxanthella 278

Zornia 519

Zostera 145, 383, 392, 399, 434, 910

- marina $392,435,908$

- nana 392

- auf Strandboden 346

- - Vegetation 138

Zosteretum 335, 399

- marinae 393, 397

- nanae 394

Zuckerrohr 244, 246

Zusammenleben der Organismen 275

- mit den Tieren 276

Zwangsschmarotzer 281

Zweige, niederliegende 267

Zwergbäume 190

Zwergformen 41

Zwergsträucher 36, 168, 187, 338,349

- anf torfhaltigem Boden 665

Zwergstrauchformationen 337

Zwergstrauchheiden 330 , 349

Zwergwuchs $48,91,92,110$, 265

Zwergwurzeln 258

Zwiebeln, unterirdische 248

Zwiebelgewächse 49

Zwiebelpflanzen 169,215 , 216, 257

Zygophyllaceae 237, 413

Zygophyllum 253, 260

- Eichwaldii 893

Zylinder 256 


\section{Auswahl der Litteratur}

A bromeit, Joh., 1900. Dünenflora. Gerhardt, Handbuch Deutsch. Dünenbanes. Berlin. - 1912. Die Vegetationsverhältnisse von Ostpreußen. Englers Jahrb., Beibl. $106 \mathrm{ff}$. Adamovič, L., 1898. Die Vegetationsformationen Ostserbiens. Englers Jahrb. XXVI.

- 1901. Die Sibljak-Formation. Ebendort.

- 1904. Die Sàndsteppen Serbiens, Ebendort XXXIII.

- 1905. Uber eine bisher nicht unterschiedene Vegetationsformation der Balkanhalbinsel, die Pseudomacehie, Verh. Zool.-Bot. Ges. Wien, LVI.

- 1909 a. Die Vegetationsverhältnisse der Balkanländer. Engler u. Drude, „Die Vegetation der Erde". XI.

- 1909 b. Vegetationsbilder ans Dalmatien. Karsten a. Schenck, Vegetationsbilder, VII, 4 und 1913, X, 7, 8.

Adam, Helen, siehe Brenchley.

Adams, C. C., 1905. An oecological survey in Northern Michigan. Rep. Univ. Mus. Lansing, Michigan.

Adamson, R. S., 1912. An ecological study of a Cambridgeshire woodland. Journ. Linn. Soc., Bot. XL. (Referat in Journ. of Ecology 1: 55.)

Aderhold, R., 1905. Utber den durch teilweise Zerstörung des Blattwerks der Pflanze zugefügten Schaden. Prakt. Blätter f. Pflanzenschutz, III, $13 \mathrm{ff}$.

Agassiz, L., 1850. Observations on the vegetation in "Lake superior", Boston.

Ahlfvengren, Fr. E., 1902-3. Die Vegetationsverhältnisse der westpreuBischen Moore östlich der Weichsel. Schriften der Naturforsch. Gesellsch. in Danzig. N. F., XI, Danzig 1903-4.

Aitchison, J. E. T., 1887. The Botany of the Afghan Delimitation Commission. Trans. Linn. Soc., II, 3.

Albert, F., 1900. Las dunas del centro de Chile. Act. Soc. Sci. Chili, X.

Albert, R., 1912-14. Bodenuntersuchungen im Gebiete der Lüneburger Heide. Zeitschr. f. Forst- n. Jagdwes. XLIV-XLVI.

Alb off, N., 1902. Essai de Flore raisonuée de la Terre de Feu. Ann. Mus. La Plata, I. Albrecht, G., 1908. Utber die Perzeption der Lichtrichtung in den Laubblättern. Diss. Berlin.

Altenkirch, G., 1894. Studien über die Verdunstungsschutzeinrichtungen in der trocknen Geröllflora Sachsens. Englers Bot. Jahrb., XVIUI.

Andersson, Gunnar, 1895. Växtpalaeontologiska undersökningar af svenska torfmossar II. Bih. k. Sv. Akad. Handl. XVIII.

- 1896. Svenska växtvärldens historig. Stockholm.

- 1900. Om växtlifvet i de arktiska trakterna. Nord. Tidsskr.

- 1902. Für Pflanzengeographie der Arktis. Geogr. Zeitschr.

Warming-Graebner. 8. Anflage 
Andersson, Gunnar, 1906. Entwicklungsgeschichte der skandinav. Flora. Jena.

- und H. Hesselman, 1906. Bidrag till kännedomen om Spetsbergens och Beeren Eilands kärlväxtflora. Bihang K. Sv. Vet. Akad. Handl. 26.

- - 1907. Vegetation och flora i Hamra kronopark. Skogsvårdsföreningens tidskrift. II. Stockholm.

- - 1910. Verbreitung, Ursprung, Eigenschaften und Anwendung der Mittelschwedischen Böden. Mit 4 Karten, 50 Kartenskizzen, Profilen und Figuren. Stockholm.

- und Selim Birger, 1912. Den norrländska florans geografiska fördelning och invandrings-historia. Upsala 1912.

Andrée, A., 1915. Veränderungen in der Flora der Umgebung von Hannover seit Ehrhards Zeiten. 6.-8. Jahresb. Nieders. Bot. Ver. Hannover.

Andrussow, 1893. Tiefuntersuchungen im Schwarzen Meere. Mitteil. Geogr. Ges. Wien, XXXVI.

Apstein, C., 1896. Das Süßwasserplankton. Kiel u. Leipzig. Siehe Zacharias.

Areschoug, F., 1878. Jemförande undersökningar öfver bladets anatomi. Lund. Fysiografiska Sällsk.

- 1880. Om klimatets inflytande p̊̊ vexternas organisation. Det 12 te skandinav. Naturforskaremöte.

- 1882. Der Einfluß des Klimas anf die Organisation der Pflanze, insbesondere auf die anatomische Struktur des Blattes. Englers Bot. Jahrb., II.

- 1895. Beiträge zur Biologie der geophilen Pflanzen. Lunds Univ. Årsskr., XXXI.

- 1902. Untersuchungen über den Blattbau der Mangrovepflanzen. Biblioth. Botan., LVI.

- 1906. Uber die Bedeutung des Palisadenparenchyms für die Transpiration der Blätter. Flora, XCVI.

Armitage, El., 1914. Vegetation of the Wye Gorge at Symons Yat. Journ. Ecol., II, $98-109$.

Ascherson, P., 1859. Die Salzstellen der Mark Brandenburg. Zeitschr. d. deutsch. geolog. Ges., XI.

- 1874. Vorläufiger Bericht über die botanischen Ergebnisse der Rohlfsschen Expedition zur Erforschung der libyschen Wüste. Bot. Zeitg.

- 1863. Verhandl. Bot. Ver. Prov. Brandenbarg, V.

- 1866. Flora der Provinz Brandenburg. Berlin.

- 1877. Laubfall and Wiederbelaubung in Aegypten. Sitzber. Bot. Ver. Brandenbarg, XIX.

- 1881. Subflorale Axen als Flugapparate. Jahrb. Bot. Gart. Berl., I, 318 ff. i. tab.

- 1883. Von der Verbreitung der Pflanzen (Pflanzengeographie). Frank-Leunis Synopsis. 8. Aufl., II, 1.

- 1883 a. Botanische Exkursion in die Reisfelder Oberitaliens. Sitzber. Ges. Naturf. Freunde. Berlin, XXV.

- 1883 b. Alphonse De Candolles physiologische Einteilung. Ebendort.

- 1893. Botanische Reiseeindrücke aus Hinterpommern, West- und Ostpreußen. Ebendort XXXV.

- 1892. Hygrochasie und zwei neue Fälle dieser Erscheinung. Ber. Deutsch. Bot. Ges., X.

- 1912. Verzeichnis der in ihrer Flora bekannten Salzstellen der Provinz Brandenburg. Jahrb. Geolog. Landesanst. 1911, 1, S. 494 ff.

- und Graebner, P., 1895. Die Pineta von Ravenna. Verh. Bot. Ver. Brandenburg, XXXVII.

- $1896 \mathrm{ff}$. Synopsis der Mitteleuropäischen Flora. Leipzig. 
Ascherson, P., und Graebner, P., 1898-99. Flora des nordostdeutsehen Flachlandes. Berlin.

Askenasy, E., 1870. Ober den EinfluB des Wachstumsmediums anf die Gestalt der Pflanzen. Bot. Zeitg., XXVIII.

- 1890. Utber einige Beziehungen zwischen Wachstum und Temperatur. Ber. Deutsch. Bot. Ges., VIII.

Aston, B. C., 1916. The Vegetation of the Tarawera Mountain, New Zealand. Journ. Ecol., IV, 18-26.

Aubert, 1892. Recherches sur la respiration et l'assimilation des plantes grasses. Rev. Gén. de Bot., IV.

A ubagen, 0., 1896. Zur Kenntnis der Marsohwirtschaft. Landw. Jahrb. XXV, 5 Abb.

Bachmann, E., 1904. Die Beziehungen der Kieselflechten $2 u$ ihrem Substrat. Ber. Deutsoh. Bot. Ges., XXI.

- 1914. Kalklösende Algen. Ber. Dentsch. Bot. Ges, XXXIII.

Bachmann, H., 1911. Das Phytoplankton des SüBwassers mit besonderer Berücksichtigung des Vierwaldstättersees. Luzern.

Baker, Sarah M., 1912. On the brown seaweeds of the salt marsh. Journ. Linn. Soc., Bot., XL.

Bakke, A. L., 1914. Studies on the transpiring power of plants as indicated by the method of standardized hygrometric Paper. Journ. Ecol, II, 145-173.

Basiner, 1848, in Baer u. Helmersen, Beiträge zur Kenntnis des Russischen Reiches.

Batalin, A., 1884. Wirkung des Chlornatriums anf die Entwickelung von Salicornia herbacea. Bull. Congrès Internat. St. Pétersbourg.

Battandier, J. A., 1883. Sur quelques cas d'hétẻromorphisme. Bull. Soc. Bot. France, XXX.

- 1887. Quelques mots sur les causes de la localisation des espèces. Ebendort IX.

- und Trabut, L., 1898. L'Algerie. Bibliothèque scientifique contemporaine.

Baumann, E., 1911. Die Vegetation des Untersees (Bodensee). Stuttgart.

Baur, E., 1917 s. Haberlandt.

Beck von Mannagetta, G., 1884. Flora von Bernstein in Niederösterreich und der weiteren Umgebung. In M. A. Becker, Bernstein in Niederösterreich. Wien.

- 1890-3. Flora von Niederösterreich. Wien.

- 1901. Die Vegetationsverhältnisse der illyrischen Länder. Engler u. Drude, Vegetation d. Erde, IV.

- 1902. Uber die Umgrenzung der Pflanzenformationen. Österr. Bot. Zeitschr., LII.

- 1904. Hochgebirgspflanzen in tiefen Lagen. Sitzber. Deutsch. Ver. Böhmens. Lotos.

Benecke, W., 1892. Die Nebenzellen der Spaltöffnungen. Bot. Zeitg., I.

- 1901. Uber die Diels'sche Lehre von der Entchlorung der Halophyten. Pringsh. Jahrb, XXXVI.

Beneden, P. J. van, 1869-70. Le commensalisme dans le règne animal. Bull. Acad. Roy. Belg., $2^{\circ}$ sér., XXVIII, XXIX.

Beketoff, A. De l'influence du climat sur la croissance de quelques arbres résineux. Mém. Soc. Imp. Nat. Cherb., XV.

Benrath, 1904. Eine Reise durch die Cordilleren Mittelperus. Geogr. Zeitschr.

Berg, A. Die Quellmoore beaw. Gehångemoore Norddeutschlands. Die Naturwissenschaften.

Bergen, J. Y., 1903 a. The Macchie of the Neapolitan coast region. Bot. Gazette, XXXY.

- $1903 \mathrm{~b}$. Transpiration of Spartium junceum and other xerophytic shrubs. Ebendort XXXVI. 
Bergen, J. Y., 1904 a. Transpiration of sun leaves and shade leaves of Olea europea and other broad-leaved evergreens. Ebendort XXXVIII.

- 1904 b. Relative transpiration of old and new leaves of the Myrtus type. Ebendort.

- 1905. Tolerance of drought by Neapolitan cliff flora. Ebendort XL.

Bergon, P., 1907. Biologie des Diatomées. Bull. Soc. Bot. France, LIV.

Bernard, N., 1909. L'évolution dans la Symbiose des Orchidées et leurs champignons commensaux. Ann. Sc. Nat., 9 Sér., IX.

Bernátsky, J., 1899. Beiträge zur Kenntnis der endotrophen Mycorrhizen. Termész. Füz., XXII:

- 1901. Pflanzenökologische Beobachtungen auf Süd-Lussin. Ebendort XXIV.

- 1902. UUber die Pflanzenformationen des Lokvagebirges. Növén. Közlem, I, $328 \mathrm{ff.}$

- 1904 a. Anordnung der Formationen nach ihrer Beeinflussung seitens der mensch-

lichen Kultur und der Weidetiere. Englers Jahrb, XXXIV.

- 1904 b. Über die Baumvegetation des ungarischen Tieflandes. Festschr. Aschersons

70. Geburtst., $73 \mathrm{ff}$.

- 1905. Über die Halophytenvegetation des Sodabodens im ungarischen Tieflande.

Ann. Mus. Nation. Hungarici, III.

- 1907. Flora des Plattensees. V. Borbas in Resultate d. wissensch. Erforsch. des

Balatonsees, II. Budapest.

Bernbeck, 0., 1907. Der Wind als pflanzenpathologischer Faktor. Dissertation. Stuttgart. Englers Jahrb., XLV.

- 1911. Der Wind als pflanzengeographischer Faktor. Ebendort XLV, 471.

- 191d. Veränderlichkeit der forstlichen Bodenbonität. Nat. Zeitschr. Forst- u. Landwirtsch., XIV, $20 \mathrm{ff}$.

Bessey, C. E., 1900. Some agricultural possibilities of Western Nebraska. Ann. Rep. Nebraska St. Bd. Agric.

- E. A., 1905. Vegetationsbilder aus Russisch-Turkestan. Karsten u. Schenck, Vegetationsbilder, III, 2.

Bews, J. W., 1912. The Vegetation of Natal. Annals of the Natal Museum, II.

- 1913. An oecological survey of the Midlands of Natal. Annals of the Natal Museum, II, 4.

- 1915. The growth forms of Natal Plants. Roy. Soc. South Africa, V, p. 5.

- 1916. An Account of the chief Types of Vegetation in South Africa, with Notes on the Plant Succession. Journ. Ecol., IV, 129.

Beyer, B., 1895. Ergebnisse der bisherigen Arbeiten bezüglich der Überpflanzen außerhalb der Tropen. Verh. Bot. Ver. Prov. Brandenb., XXXVI, S. 105-129.

Birger, Selim, 1906 a. Die Vegetation einiger 1882-6 entstandenen schwedischen Inseln. Englers Jahrb., XXXVIII.

- 1906 b. Die Vegetation bei Port Stanley auf den Falklandsinseln. Ebendort XXXIX.

- 1907. Tilläg till Pajala sockens flora. Bot. Notiser.

Bitter, R., 1897. Vergleichend-morphologische Untersuchungen über die Blattformen der Ranuneulaceen und Dmbelliferen in Flora LXXXIII.

- 1899. Über das Verhalten der Krustenflechten beim Zusammentreffen ihrer Ränder. Pringsh. Jahrb., XXXIII.

Blackman, F. F. and Tansley, A. G., 1905. Oecology in its physiological and phytotopographical aspects. New Phytologist, IV.

Bladnell, 1910. The Sanddunes of the Libyan Desert. The geogr. Journ., XXXV. Bl a n c, L., 1905. La végétation aux environs de Montpellier. Bull. Soc. Bot. France, LII.

Blanck, Edw., 1903. Uber die Diffusion des Wassers im Humusboden, in Die Landw. Vers.-Stat.

Blankinsh ip, J. W., 1903. The Plant-formations of Eastern Massachusetts. Rhodora, V. 
Blomquist, S., 1912. Till högbuskformationens ekologi. Svensk bot. Tidskr., V.

Blytt, A., 1870. Christiania omegns Phanerog. og Bregner. Christiania.

- 1882. Die Theorie der wechselnden kontinentalen and insularen Klimate. Nebst Nachtrag. Englers Jahrb., II.

- 1893. Zur Geschichte der nordeuropäischen, besonders der norwegischen Flora. Ebendort XVII.

Boerker, R. H., 1916. A historical Study of Forest Ecology; its Development in the Fields of Botany and Forestry. Forestry Quarterly. Sept. 1916.

Börgesen, F., 1894. Bidrag til Kundskaben om arktiske Planters Bladbygning. Bot. Tidsskr., XIX. (Sur l'anatomie des feuilles des plantes arctiques. Journ. de Bot., IX, 1895.)

- 1897. Beretning om et Par Exkursioner i Sydspanien. Bot. Tidsskr., XXI.

- 1900. A contribution to the knowledge of the marine Alga vegetation on the coasts of the Danish West-Indian Islands. Ebendort XXIII.

- 1905. The algo-vegetation of the Faeroese coasts. Botany of the Faeroes, III. Copenhagen.

- 1906. Algenvegetationsbilder von den Küsten der Färöer. Karsten u. Schenck, Vegetationsbilder, IV, 6.

- 1909. Notes on the Shore Vegetation of Danish West-Indian Islands. Bot. Tidsskrift, XXIX.

- 1911. The algal vegetation of the lagoons in the Danish West-Indies. Biologiske Arbejder tilegnede Eug. Warming. Köbenhavn.

- 1914 a. The marine Algae of the Danish West-Indies. 2. Phaeophyceae. Dansk Botan. Arkiv. 1.

- $1914 \mathrm{~b}$. The species of Sargassum found at the shores of the Danish Islands. Mindeskrift for Japetus Steenstrup. Köbenhavn.

- nnd Paulsen, 0., 1900. La végétation des Antilles danoises. Rev. Gén. de Bot, XII.

- und Jensen, C., 1904. Utoft Hedeplantage. Bot. Tidsskr., XXVI, $177 \mathrm{ff}$.

Boldingh, J., 1909. The Flora of the Dutsch West-Indian Islands .St. Eustatius, Saba and St. Martin. Diss. Leiden.

Bolus, 1886. Sketch of the Flora of South Africa. Offic. Handb. Cape of Good Hope. Bommersheim, P., 1909. Untersuchungen über Sumpfgewächse. Beihefte Bot. Centralbl., XXIV, 2.

Bonnier, G., 1879. Quelques observations sur les relations entre la distribution des Phanérogames et la nature chimique du sol. Bull. Soc. Bot. France, XXVI.

- 1884. Sur quelques plantes annuelles ou bisannuelles qui peuvent devenir vivaces aux hautes altitudes. Ebendort XXXI.

- 1890 a. Influence de hautes altitudes sur les fonctions. Comptes Rendus, Paris, CXI.

- 1890 b. Cultures expérimentales dans les Alpes et les Pyrénées. Rev. Gén. de Bot., II.

- 1894 a. Les plantes arctiques comparées aux mêmes espèces des Alpes et des Pyrénées. Ebendort VI.

- 1894 b. Adaptation des plantes au climat alpin. Ann. sc. nat. Bot., 7. sèr., XX.

- 1894 c. Remarques sur les différences que présente l'Ononis natrix cultivé sur un sol calcaire ou sur un sol sans calcaire. Bull. Soc. Bot. France, XLI.

- 1895 a. Recherches expérimentales sur l'adaptation des plantes au climat alpin. Ann. Sc. Nat., 7. sér., XX.

- 1895 b. Influence de la lumière électrique continuée in Rev. gén. Bot., VII.

- et Flahault, C., 1878. Observations sur les modifications des végétaux suivant les conditions physiques du milieu. Ann. Sc. Nat., 6. sér., VIl. 
Boodle, L. A., 1904. Succulent leaves in the Wallflower (Cheiranthus Cheiri). New Phytologist, III.

Borbas, V. Vergl. Bernátsky, 1907.

Borge, 0., 1897. AJgologiska notiser III. Zur Kenntnis der Verbreitungsweise der Algen. Bot. Nat.

Borggreve, 1872. Utber die Einwirkung des Sturmes auf die Baumvegetation. Abh. Naturw. Ver. Bremen, III.

Bornet et Flahault, 1889. Sur quelques plantes vivant dans le test calcaire des mollusques. Bull. Soc. Bot. de France, XXXVI.

Bowman, J., 1911. Physiography of the United States and Principles of Soils in Relation to Forestry.

Boye Petersen, Johannes, 1916. Studier over Danske aërofile Alger. Med 4 Tavler. Résumé en Français. Kgl. Danske Vidensk. Selskabs Skrifter., 7 R., naturw. og mathem. Afdeling XII, 7.

Boysen Jensen, P., 1909. Über Steinkorrosion an den Ufern von Furesö. Intern. Revue d. ges. Hydrobiologie, II.

- - 1914. Studier oves Havbundens organiske Stoffer. Fra Den danske biolog. Station, XXII.

- - 1915. Hydrobiologie, in Kultur der Gegenwart, III, IV, 1.

Brackebusch, 1893. Über die Bodenverhältnisse des nordwestlichen Teiles der Argentinischen Republik mit Bezugnahme auf die Vegetation. Petermanns Mitteil., XXXIX.

Brand, F., 1896. Über die Vegetationsverhältnisse des Würmsees und seine Grundalgen. Bot. Centralbl., LXV.

- 1905. Über die sogenannten Gasvakuolen und die differenten Spitzenzellen der Cyanophyceen, sowie der Schnellfärbung. Hedwigia, XLV.

Brandis, D., 1887. Die Beziehungen zwischen Regen und Wald in Indien. Meteorol. Zeitschr.

- 1889. Address: Specifische Individualität in dem Eintritt und in der Daner der Blüthezeit bei Phanerogamen. Sitzungsber. d. niederrhein. Ges. Bonn.

Brandt, K., 190-. Über die Bedeutung der Stickstoffverbindungen für die Produktion im Meere. Beihefte, Bot. Centralbl, XVI.

Braun, Josias, 1913. Vegetationsverhältnisse der Schneestufe in den Rätisch-lepontischen Alpen. Denkschriften Schweiz. Naturf. Ges., XLVIII.

- 1915. Études sur la végétation méditerranéenne. I. Les Cévennes méridionales. Genève.

- et Furrer, Ernst, 1913. Remarques sur l'étude des groupements de plantes. Bull. de la Soc. Languedocienne de Géographie, XXXVI.

Bray, W. L., 1901. The oecological relations of the vegetation of western Texas. Bot. Gazette, XXXII.

- 1906. Distribution and adaptation of the vegetation of Texas. Bull. Univ. Texas, LXXXII.

Bredemann, G., 1908. Regeneration der Fähigkeit zur Assimilation von freiem Stickstoff des Bacillus amylobacter. Ber. Deutsch. Botan. Gesellsch., XXVI, $362 \mathrm{ff}$.

Brenchley, W. E., and Adam, Helen, 1915. Recolonisation of cultivated Land allowed to revert to natural conditions. Journ. Ecol., III, 192-210.

Brewer, W. H., 1864. Notice of plants found growing in hot springs in Californis. Proc. Calif. Acad., III.

Brick, C., 1888. Beiträge zur Biologie und vergleichenden Anatomie der baltischen Strandpflanzen. Schrift. Naturf. Ges. Danzig, VII. 
Briggs, L. J., 1900-1. Investigations on the physical properties of soils. U.S. Dept. Agric. Field Oper., Div. Soils.

- 1916. Daily transpiration during the normal growth period and its correlation with the weather. Journ. Agricult. Research, VII, No. 4.

Briggs and Belz, 1911. Dry farming in relation to rainfall and evaporation. U.S. Deptm. of Agric. Bureau of plant industry. Bull. No. 188.

Briggs and Shantz, 1912. The wilting coefficient for different plants and its indirect determination. Ebendort No. 230. - Botan. Gazette, LIII.

- $1913 \mathrm{a}, \mathrm{b}$. The water requirement of plants. I. Investigations in the great plains in 1910 and 1911 ; in U. S. Dep. of agricult. Bull. No. 284. - II. A roview of the literature; ebendort Bull. No. 285.

- - 1914. Relative water requirement of plants. Journ. Agric. Res. Wash., III, No. 1.

- 1915. Influence of hybridization and cross-pollination on the water requirement of plants. Ebendort IV, No. 5.

- 1916 a. Hourly transpiration rate on clear days. Ebendort $\nabla$, No. 14.

- 1916 b. Daily transpiration during the normal growth period. Ebendort VII, No. 4.

Brockmann-Jerosch, H., 1907. Die Flora des Puschlav (Kanton Graubünden) und ihre Pflanzengesellschaften. Leipzig.

- - 1913. Der EinfluB des Klimacharakters auf die Verbreitung der Pflanzen und Pflanzengesellschaften. Englers Jahrb., IL. Beiblatt. (Vergl. Journ. Ecol. I.)

- - und Heim, 1908. Vegetationsbilder vom Nordrand der algerischen Sahara. Karsten u. Schenck, Vegetationsbilder, VI, 4.

- - und Rübel, E., 1912. Die Einteilung der Pflanzengesellschaften nach ökologischphysiognomischen Gesichtspunkten. Leipzig. (Vergl. Journ. Ecol. I, 27.)

Brotherus, 1880. Botanische Wanderungen auf der Halbinsel Kola. Bot. Centralbl. XXVI.

Broun, A. F., 1905. Some notes on the "Sadd" Formation of the Upper Nile. Journ. Linn. Soc. Lond., XXXVII.

Brown, F. B. H., 1905. A botanical survey of the Huron River Valley, III. The plant societies of the Bayou at Ypsilanti, Michigan. Bot. Gazette, XL.

Bruncken, Ernest, 1902 a. Stadies in plant distribution. Bull. Wisconsin. Nat. Hist. Soc., II.

- 1902 b. On the succession of forest-types in the vicinity of Wisconsin. Ebendort II.

Brundin, J. A. Z., 1888. Bidrag till kännedomen om de svenska fanerogama örternas skottutveckling och öfvervintring. Akad. afhandl. Upsala.

Brunnthaler, J., 1911. Vegetationsbilder aus Südafrika. Karsten u. Schenck, Vegetationsbilder, IX, 1-5.

Brönsted, J. N., und Wesenberg-Lund, C., 1911-12. Chemisch-physikal. Untersuchungen der dänischen Gewässer. Intern. Revue d. ges. Hvdrobiologie und Hydrographie.

Buchenau, Fr, 1887. Vergleichung der nordfriesischen Inseln mit den ostfriesischen in floristischer Beziehung. Abh. Naturw. Ver. Bremen, IX.

- 1889 a. Über die Vegetationsverhältnisse des Helms (Psamma arenaria, Röm. et Schult.) und der verwandten Dünengräser. Ebendort X.

- 1889 b. Die Pflanzenwelt der ostfriesischen Inseln. Ebendort XI.

- 1893. Uber den Aufbau des Palmiet-Schilfes aus dem Kaplande. Bibliotheca botanica. 27. Heft.

- 1896. Die ostfriesischen Inseln and ihre Flora. Verh. 11. Deutsch. Geographentag, Bremen.

- 1901. Die Flora der Maulwurfshanfen. Abh. Naturw. Ver. Bremen, XV, $297 \mathrm{ff}$. 
Buchenau, Fr., 1903. Der Wind und die Flora der ostfriesischen Inseln. Ebendort XVII.

- 1904. Uber den Reichtum des Kulturlandes unserer Städte an Pflanzensamen. Festschrift Aschersons 70. Geburtst., $27 \mathrm{ff}$.

Buder, Johs., 1915. Zur Kenntnis des Thiospirillum jenense und seiner Reaktionen auf Lichtreize. Pringsheims Jahrb. wiss. Bot.

Buhse, F. A., 1850. Nachrichten über die groBe Salzwüste in Persien. Bull. Soc. Nat. Imp. Moscou, XXIII.

Bunge, Al., 1880. Pflanzengeographische Beobachtungen über die Familie der Cheno. podiaceen. Mém. Acad. d. St. Pétersbourg; 7 sér., XXVII, No. 8.

Burck, W., 1909. Contribution to the knowledge of watersecretion in plants. K. Akad. Wet. Amsterdam.

Burgeff, H., 1909. Die Warzelpilze der Orchideen. Jena.

Burgerstein, A., 1904. Die Transpiration der Pflanzen. Jena.

Burkill, J. H., 1911. The Botany of the Abor Expedition. British Association Reports. Vergl. Journ. of Ecology, I, 141.

Burns, G. P., 1911. A Botanical Survey of the Huron River Valley. Bot. Gazette, LII.

Buscalioni, L., e Pollacci, 1903. Le antocianine ed illoro significato biologico nelle piante. Atti Inst. Bot. Univ. Pavia, 2a ser., VIII.

Büsgen, M., Jensen, Hj., und Busse, W., 1905. Vegetationsbilder aus Mittel- und Ost-Java. Karsten u. Schenck, Vegetationsbilder, III, 3.

Busse, W., 1005. Über das Auftreten epiphyllischer Kryptogamen im Regenwaldgebiet von Kamerun. Ber. Deutsch. Bot. Ges., XXIII.

- 1906 a. Das südliche Togo. Karsten u. Schenck, Vegetationsbilder, IV, 2.

- 1906 b. Westafrikanische Nutzpflanzen. Ebendort IV, 5.

- 1907. Deutsch-Ostafrika. Ebendort V, 7.

Cajander, A. K., 1903. Beiträge zur Kenntnis der Vegetation der Alluvionen des nördlichen Eurasiens. Die Alluvionen des mnteren Lena-Tales. Act. Soc. Sc. Fenn., XXXII.

- 1904. Ein Beitrag zur Entwicklungsgeschichte der nordfinnischen Moore. Fennia, XX.

- 1905 a. Die Alluvionen des Onega-Tales. Act. Soc. Se. Fenn., XXX1II.

- 1905 b. Beiträge zur Kenntnis der Entwicklung der europäischen Moore. Fennia, XXIL.

- 1909 a. Beiträge zur Kenntnis der Vegetation der Alluvionen des nördlichen Eurasiens. III. Die Alluvionen der Tornio- und Kemi-Täler.

- $1909 \mathrm{~b}$. Uber Waldtypen. Helsingfors.

- 1910. Torfmarkernas Växttopografi. Atlas öfver Finland. Text.

- 1913. Studien über die Moore Finnlands. Acta Forestalia Fennica, II. Helsingfors.

Callmé, 1887. Om de nybildade Hjelmaröarnes vegetation. Bihang Sv. Vet. Akad. Handl., XII.

Cannon, W. A., 1905. On the water-conducting systems of some desert plants. Botan. Gazette, XXXIX.

- 1908. The topography of the chlorophyll apparatus in desert plants. Publ. Carnegie Inst. of Washington, No. 98.

- 1911. The Root Habits of Desert Plants. Carnegie Inst. of Washington, No. 131.

- 1913 a. Notes on roots Variation in some Desert plants. The plant world 16.

- 1913 b. Some relations between salt-plants and salt spots. Vergl. Bot. Centralbl., CXXVI, 261.

- 1913 c. Botanical features of the Algerian Sahara. Carnegie Inst. of Washington Publ. 178. Bot. Centralbl., CXXVI, 261. 
Capus, M. G., 1883. Le climat et la végétation du Turkestan. Ann. d. Sciences nat. 6. sér., $\mathrm{XV}$.

Caspary, R., 1860. Uber das Vorkommen von Hydrilla verticillata in Verh. 35. Vers. Deutscher Naturf. $u$. Ärzte, Königsberg.

Cavara, 1901. La vegetazione della Sardegna meridionale. Nuov. Giorn. Bot. Ital., VIII.

Cavers, F., 1914. Golas osmotic Theory on Edaphism. Journ. Ecol., II, 209-231. Chatin, A., 1856. Anatomie comparée des végétaux. Paris.

Cheeseman, F. F., 1882. Trans. Auckl. Inst.

Chermezon, H., 1910. Recherches anatomiques sur les Plantes littorales. Ann. Sc. Nat, Bot., 9. Serie, XII.

Chilton, Ch., 1909. The Subantarctic Islands of New Zealand. II. Wellington.

Chodat, R., 1898. Études de biologie lacustre. Bull. Herb. Boissier, VI.

- Algues vertes de la Suisse.

- 1902. Les dunes lacustres de Sciez et les Garides. Bull. Soc. Bot. Suisse, XII.

- 1905. Une excursion botanique à Majorque. Bull. Trav. Soc. Bot. Genève, XI.

- 1909. Excursions botaniques en Espagne et au Portugal. Bull. Soc. Bot. Genève, I.

- 1916. La végétation du Paraguay. Resultats scientifiques d'une Mission Botanique Suisse au Paraguay. I. Genève.

Christ, H, 1879. Das Pflanzenleben der Schweiz. Basel.

- 1885. Vegetution und Flora der Canarischen Inseln. Englers Jahrb., VI.

- 1897. Die Farnkräuter der Erde. Jena.

- 1910. Geographie der Farne. Jenø.

Chrysler, M. A., 1904. Anatomical notes on certain strand plants. Botan. Gazette, XXXVII.

- 1905. Reforestation at Wood's Hole, Ma. A study in succession. Rhodora, VII.

- The ecological plant geography of Maryland. Maryland Weather service, III.

Chun, C., 1900 -3. Aus den Tiefen des Weltmeeres. Jena.

Cieslar, A., 1904. Die Rolle des Lichtes im Walde. Mitt. Forstl. Versuchsw. Österreichs, XXX.

Cleghorn, H., 1856. Note on the sandbinding plants of the Madras beach. Hooker's Lond. Journ.-Bot, VIII.

Clements, E. S., 1905. The relation of leaf structure to physical factors. Trans. Amer. Microse. Soc.

Clements, F. E., 1897. Vergl. Pound.

- 1902 a. A system of nomenclature for phytogeography. Englers Jahrb., XXXI, Beibl. LXX.

- 1902 b. Greek and Latin in biological nomenclature. University Studies, Univ. Nebraska, III.

- 1904. The development and structure of vegetation. Bot. Surv. of Nebraska. Studies in the Vegetation of the State, III.

- 1905. Research methods in oecology. Lincoln, Nebr.

- 1907. Plant physiology and oecology. London.

- 1916. Plant Succession; an Analysis of the Development of Vegetation. Carnegie Institution of Washington. Auszug bei Tansley in Journ. Ecol., IV, 198.

Cleve, A., 1901. Zum Pflanzenleben in Nordschwedischen Hochgebirgen. Bihang Sv. Vet. Akad. Handl, XXVI.

Cleve, P., 1894. De svenske hydrograf. undersökningar, åren 1893-4. Ebendort XX.

- 1901. The seasonal distribution of Atlantic Plankton organisms. Göteborg. 
Cockayne, L., 1901. A short account of the plant-covering of Chatham Island. of New Zealand Inst., XXXIV.

- 1904. A botanical excursion during midwinter to the Southern Islands of New Zealand. Ebendort, XXXVI.

- 1905 a. Notes on the vegetation of the Open Bay Islands. Ebendort XXXVII.

- $1905 \mathrm{~b}$. On the significance of spines in Discaria Toumaton, Raoul. New Phytologist, IV.

- 1907. Some observations on the coastal vegetation of the South Island of New

Zealand. Trans. New Zealand Inst, XXXIX,

- 1908 a. A botanical Survey to the Tongariro National Park. Dept. of Lands, XI.

- 1908 b. Report on a Botanical Survey of the Waipoua Kauri Forest. New

Zealands Dept. of Lands, XII.

- 1909 a. Report on the Sand-Dunes in New Zealand. Wellington 1909.

- 1909 b. Report on a Botanical Survey of Stewart Island. Wellington.

- 1909 c. The ecological botany of the subantarctic islands of New Zealand. Artic. X

in Chilton, The subantartic islands of New Zealand. Wellington.

- 1910. New Zealand Plants. Wellington.

- 1911 a. The Mount Arrowsmith district. Transact. New Zealand Inst., XLIII.

- 1911 b. Dune Areas of New Zealand. Dept. of Lands New Zealand. Wellington.

- 1912 a. Observations concerning Evolution, derived from ecological studies in

New Zealand. Trans. New Zealand Inst., XLIV.

- 1912 b. The flora of New Zealand. Extract from "New Zealand Yearbook".

Cohn, F., 1892. Über Entstehung von Kalk- und Kieselgetein durch Vermittlung von Algen. Jahresb. Schles. Ges. vat. Cult.

- 1893. Uber Erosion von Kalkgestein dureh Algen. Ebendort.

Comère, J., 1914. De l'action du milieu considérée dans ses rapports avec la distribution générale des Algues d'eau douce. Bull. Soc. Bot. France, LI. (Journ. Ecol., III.)

Comes, 1887. Le lave, il terreno Vesuviano e la loro vegetazione. Übersetzt in Sammlung gemeinverständlicher wissenschaftlicher Vorträge, IV, 80. 1889.

Compton, R. H., 1911. Xerophily in the Coniferae and microphylly. New Phytologist, $\mathbf{X}$.

Congrès IIIme International de Botaniqne. Bruxelles 1910. Vol. I.

Conseil permanent pour l'exploration de la mer: Résumé des observations sur le plankton 1-8. Bull. trimestriel 1910-1913.

Contejean, C., 1881. Géographie botanique. Paris.

Conwentz, H., 1899. Die Eibe in der Vorzeit der skandinavischen Länder. Danzig.

- 1901-2. Die Gefährdung der Flora der Moore. Prometheus.

- 1905. Die Fichte im Norddeutschen Flachland. Ber. Deutsch. Bot. Ges. XXIII, $220 \mathrm{ff}$.

- 1912. Taxus. Englers bot. Jahrb., XLVI, Beibl.

- Beiträge zur Naturdenkmalpflege, I-V, Berlin. Zahlreiche Aufsätze.

- 1916. Uber die Notwendigkeit der Schaffung von Moorschutzgebieten. Berlin.

Cooper, Will. S., 1912. The ecological succession of mosses, as illustrated upon Isle

Royale, Lake Superior. The Plant world, XV, $197 \mathrm{ff}$. Ref. Journ. Ecol., I, 201.

- 1913. The climax forest of Isle Royale, Lake Superior, and its development.

Bot. Gaz, LV; efr. Journ. of Ecol. I.

- 1916. Plant successions in the mount Robson Region, British Columbia. The Plant

World, XIX. (Journ. Ecol., IV, 196.)

Cornies. In Beiträge znr Kenntnis des russischen Reiches, XI.

Cornish, V., 1897. The formation of sand dunes. Geogr. Journ. 
Correns, C., 1892. Über die Abhängigkeit der Reizerscheinungen böherer Pflanzen von der Gegenwart freien Sauerstoffes. Habil.-Schrift Tübingen.

Costantin, J., 1883. Études comparées des tiges aériennes et souterraines des Dicotylédones. Ann. Sc. Nat., 6. sér., XVI.

- 1884. Recherches sur la structure de la tige des plantes aquatiques. Ebendort 6. sér., XIX.

- 1885 a. Recherches sur l'influence qu'exerce le milieu sur la structure des racines. Ebendort 7. ser., I.

- 1885 b. Observations critiques sur l'épiderme des feuilles des végétaux aquatiques.

Bull. Soc. Bot. France, XXXII.

- 1885 c. Recherches sur la Sagittaire. Ebendort.

- $1885 \mathrm{~d}$. Influence du milieu aquatique sur les stomates. Ebendort.

- 1886. Études sur les feuilles des plantes aquatiques. Ann. Sc. Nat., Te sér., III.

- 1887. Observations sur la flore du littoral. Journ. de Bot., I.

- 1897. Accommodation des plantes aux climats froid et chaud. Bull. Sei. France et Belgique, XXXI.

Cotton, A. D., 1912. Marine Algae. Clare Island Survey, part. 15. Proceed. Roy. Irish Academy, XXXI. Ref. in Journ. Ecology I, $209 \mathrm{ff}$.

Coulter, S. M., 1903. An oecological comparison of some typical swamp areas. Rep. Missouri Bot. Gard., XV.

Coville, F. V., 1893. Botany of the Death Valley Expedition. U. S. Dept. Agric. Contrib. U. S. Nat. Herb., IV.

- u. Macdougal, D. T., 1903. Desert Botanical Laboratory of the Carnegie Institution, Washington, DC.

Cowles, H. C., 1899. The oecological relations of the vegetation on the sand dunes of Lake Michigan. Botan. Gazette, XXVII.

- 1901 a. The influence of underlying rocks on the character of vegetation. Ball. Am. Bur. Geogr., II.

- $1901 \mathrm{~b}$. The physiographic oecology of Chicago and vicinity; a study of the origin, development and classification of plant societies. Botan. Gazette, XXXI.

-, Livingston, B. E., Shav, Ch. H., Spalding, V. M., Transeau, E. N., 1909. Present Problems in Plant Ecology. Botanical Society of America. Publication 43. Baltimore, Md. The American Naturalist, XLIII.

- 1911. The causes of vegetative cycles. Botan. Gazette, LI.

Crampton, C. B., 1911. The vegetation of Caithness. Published under the auspices of the committee for the survey and study of British Vegetation. Edinburgh.

- 1912. The geological relations of stable and migratory plant formations. Scott. Bot. Review, I. (Siehe: Journ. Ecol., I, 47 ff.)

- and Macgregor, M., 1913. The plant ecology of Ben Armine, Sutherlandshire. Scottish Geographical Magazine, XXIX. Ref. in Journal of Ecology I, $219 \mathrm{ff}$. Crampton, 1914, siehe W. G. Smith.

Cross, B. D., 1910, Some New Zealand Halophytes. Trans. New Zealand Inst., XLII. Crossland, C., 1903. Note on the dispersal of mangrove seedlings. Ann. of Bot. XVII.

Crump, W. B., 1913 a. Notes on water content and the wilting point. Jorun. of Ecology, I, $96 \mathrm{ff}$.

- $1913 \mathrm{~b}$. The coefficient of humidity: a new methode of expressing the soil moistere New Phytologist, XII.

Czapek, Fr., 1909. Beiträge zur Morphologie und Physiologie der epiphytischen Orchideen Indiens. Sitzungsber. Akad. Wiss. Wien, CXVIII.

- 1917, siehe Haberlandt. 
Dachnowski, A., 1908. The toxic property of bog water and bog soil. Botan. Gazette, XLVI.

- 1909. Bog toxins and their effect upon soil. Botan. Gazette, XLVII.

- 1910. Physiologically arid habitates and drought resistance in plants. Botan. Gazette, IL.

- 1911. The Vegetation of Cranberry Island (Ohio) and its Relation to the Sub. stratum, Temperature and Evaporation. Botan. Gazette, LII.

- 1912. Peat deposits of Ohio, their origin, formation and use. Geolog. Survey of Ohio 4 Ser., Bull. VI. Ref. in Journal of Ecology I, $286 \mathrm{ff}$.

- 1914. The international phytogeographic excursion of 1913 and its significance to ecology in America. Journ. Ecol; II, $273 \mathrm{ff}$.

Dangeard, 1888. Note sur la gaîne foliaire des Salicornieae Benth. \& Hook. Bull. Soc. Bot. de France, XXXV:

Darbishire, O. V., 1914. Some Remarks on the Ecology of Lichens. Jounal of Ecology, II. Pl. X-XIII.

Darwin, C., 1859. Origin of species. London.

- 1881. The formation of vegetable mould through the action of worms. London.

Darwin, F. and Pertz, D. F. M., 1896. On the effect of water-currents on the assimilation of water plants. Proc. Cambr. Phil. Soc., IX.

Davis, B. M., 1913. A biological Survey of the Waters of Woods Hole and Vicinity. Sect. II. Botanical. Bulletin of the Bureau of Fisheries, XXXI. Washington.

De Candolle, A. P., 1820. Essai élémentaire de géographie botanique. Dict. Sc. Nat., XVIII.

- 1832. Physiologie végétale. Paris.

De Candolle, Alphonse, 1856. Géographie botanique raisonnée. Paris et Genève.

- 1874. Constitution dans le règne végétal de groupes physiologiques applicables à la géographie ancienne et moderne. Bibl. Univ., I.

Deherain, P., 1892. Traité de chimie agricole.

Delden, A. van., 1903. Beitrag zur Kenntnis der Sulfatreduktion. Centralbl. f. Bakteriologie und Parasitenkunde, XI.

Delf, E. Marion, 1911. Transpiration and behaviour of stomata in halophytes. Ann. of bot., XXV.

- 1915. The meaning of Xerophily. Journ. Ecol., III, $110 \mathrm{ff}$.

Detto, C., 1903. Über die Bedeutung der ätherischen Öle bei Xerophyten. Flora, XCII.

Deuerling, 0., 1910. Die Pflanzenbarren der amerikanischen Flüsse, mit Berücksichtigung der wichtigsten pflanzlichen Verlandungserscheinungen. Mit Beitrag von G. Schweinfurth, München.

De Vries, H., 1901. Die Mutationstheorie. Leipzig.

Diels, L., 1896. Vegetationsbiologie von Neu-Seeland. Englers Jahrb., XXII,

- 1898 a. Die Epharmose der Vegetationsorgane bei Rhus L. Gerontogeae. Ebendort, XXIV.

- 1898 b. Stoffwechsel und Struktur der Halophyten. Pringsh. Jahrb., XXXII.

- 1904. Die hochalpinen Floren Ostasiens. Festschr. Aschersons 70. Geburtst., $487 \mathrm{ff}$.

- 1905. Uber die Vegetationsverhältnisse Neu-Seelands. Englers Jahrb., XXXIV.

- 1906. Die Pflanzenwelt von West-Australien südlich des Wendekreises. Engler u. Drude, Die Vegetation der Erde, VII.

- 1908. Pflanzengeographie. Leipzig.

- 1909. Formationen und Florenelemente im nordwestlichen Kapland. Englers Jahrb., XLIV. Vergl. Journ. Ecol., III, 182.

- 1914. Die Algenvegetation der Südtiroler Dolomitriffe. Ber. Deutsch. Botan. Ges., XXXII. Ref. Journ. Ecol., III, 182. 
Dingler, H., 1905. Versuche und Gedanken zum herbstlichen Laubfall. Ber. Deutsch. Bot. Ges, XXIII, $463 \mathrm{ff}$.

Dinter, K., 1915. Eine botanische Reise im zentralen Deutsch-Südwestafrika. Nat. Ges. Isis Bautzen.

Dodds, G. S., Ramaley, F. u. Robbins, W. W., 1908. Studies in Mesa and Foothill Vegetation. The University of Colorado Studies, VI.

Dokutschjew, 1893. The russian steppes. Petersburg.

Domin, K., 1904. Die Vegetationsverhältnisse des tertiären Beckens von Veseli, Wittingau und Gratzen in Böhmen. Beiheft Bot. Centralbl., XVI.

- 1905 a. Das böhmische Mittelgebirge. Englers Jahrb., XXXVII.

- 1905 b. Das böhmische Erzgebirge und sein Vorland. Arch. f. d. Naturwiss. Landesdurchf. v. Böhmen, XII.

- 1913. Vegetationsbilder aus Java. Karsten u. Schenck, Vegetationsbilder, XI, 5.

Donner, K., 1894. O. v. Hagen, Die forstlichen Verhältnisse Prenßens. 3. Aufl. Berlin.

Drude, 0., 1876. Über ein gemischtes Auftreten von Heideu- und Wiesenvegetation. Flora, LIX.

- 1884. Die Florenreiche der Erde. Petermanns Mitteil., LXXIV. Ergänzungsheft 74.

- 1886-7. Atlas der Pflanzenverbreitung. Berghaus, Physikal. Atlas. Neue Ausg., 5. Abteil.

- 1887 a. Entwurf einer biologischen Einteilung der Gewächse. A. Schenk, Handbuch der Botanik, III, S. 487.

- 1887 b. Über die Standortsverhältnisse von Carex humilis bei Dresden. Ber. Deutsch. Botan. Ges., V.

- 1888. Pflanzengeographie. In Neumayer, Anleitung. 2. Anfl., II.

- 1889. Uber die Prinzipien in der Unterscheidung von Vegetationsformationen, erläutert an der zentraleuropäischen Flora. Englers Jahrb., XI.

- 1890. Handbuch der Pflanzengeographie. Stuttgart.

- 1896. Deutschlands Pflanzengeographie. Stuttgart.

- 1902. Der Hercynische Florenbezirk. Engler u. Drude, Die Vegetation der Erde, VI.

- 1904. Die Beziehungen der Ökologie zu ihren Nachbargebieten. Address in S. Louis. - Vgl. ${ }_{n} \mathrm{Isis}^{*}$ in Dresden, 1905.

- 1905. Pflanzengeographie. Neumayrs Anleitung za wissenschaftlichen Beobachtungen auf Reisen, 3. Aufl., S. 321-388.

- 1908. Die kartographisehe Darstellung mitteldeutscher Vegetationsformationen. Bericht V. Zusammenkunft d. Freien Vereinigung d. systemat. Botaniker u. Pflanzengeographen. Leipzig.

- 1913. Die Ókologie der Pflanzen. Braunschweig.

- u. Schorler, B., 1916. Beiträge zur Flora Saxonica. Naturw. Gesellsch. Isis. Dresden, 1915.

Dubois, Eug., 1916. Hollands Duin als nataurlijke Zeeweering en de Tijd. Tijdschr. k. Need. Aardrijksk. Gen. 2. ser., XXXIII, $395 \mathrm{ff}$.

Ducellier, L., 1911. Etude phytogéographique des dunes de la baie d'Alger. Rev. gén. Bot., XXIII, 273.

Dufour, L., 1886. Note sur les relations qui existent entre l'orientation des feuilles et leur structure anatomique. Bull. Soc. Bot. France, XXXIII.

- 1887. Influence de la lumière sur la forme et la structure des feuilles. Ann. Se. Nat., 7. sér., V.

Dusén, P., 1898. Uber die Vegetation der feuerländischen Inselgruppe. Englers Jahrb.. XXIV. 
Dusén, P., 1903. The vegetation of Western Patagonia. Rep. Princeton Univ. Exped. Patagonia, VIII.

- 1905. Die Pflanzenvereine der Magellanswälder. Wissensch. Ergeb. d. Schwed. Exped. Magellansländern, 1895-7, III.

- u. Neger, F. W., 1908. Chilenisch-patagonische Charakterpflanzen. Karsten u. Schenck, Vegetationsbilder, VI, 8.

- 1910. Beiträge zur Flora des Itatiaia. Arkiv för Botanik, Stockholm, IX. Duval-Jouve, 1868. Des Salicornia de l'Hérault. Bull. Soc. Bot. France, XV.

- 1875. Histotaxie des feuilles de Graminées. Ann. Sc. Nat., 6. sér., I.

Eberdt, 0., 1887. Beitrag zu der Untersuchung über die Entstehungsweise des Palisadenparenchyms. Diss., Freiburg i. B.

- 1888. Über das Palisadenparenchym. Ber. Deutsch. Botan. Ges., VI.

Eggers, H., 1876. St. Croix's Flora. Vidensk. Meddel. Naturh. Forening. Kjöbenhavn. Elgee, F., 1907. The origin of the Clevelandmoors. Pap. Clevel. Nat. Fj. Cl.

- 1912. The moorlands of north-eastern Yorkshire, London. Vgl. Journ. Ecology, I, 66 .

- 1914. The vegetation of the eastern moorlands of Yorkshire. Journ. Ecology, II.

Ellis, D., 1907. A contribution to our knowledge of the thread-bacteria. I. Centralbl. f. Bakt. u. Parasitenkunde, XIX.

Emeis, E., 1900. Die AufschlieBung des Ortsteins durch Entwässerung, im Landw. Wochenbl. Schlesw.-Holst., L.

- 1907. Ungünstige Einflüsse von Wind und Freilage auf die Bodenkultur, in Allg. Forst- u. Jagd-Ztg.

- 1908. Die Ursachen der Ortsteinbildung und ihr EinfluB auf die Landeskultur, in Schleswig-Holstein. Ebendort.

- 1910. Untersuchungen und Betrachtungen über das Verhalten der Humusarten. Ebendort.

Engelbrecht, 1905. Die Aufgaben des Sonderausschusses für Klima und Wetterkunde. Jahrb. der Deutsch. Landw. Ges., $437 \mathrm{ff}$.

Engelmann, 1887. Die Farben bunter Laubblätter und ihre Bedeutung für die Zerlegung der Kohlensäure im Lichte. Bot. Zeitg., 1887.

Engler, Ad., 1879-82. Versuch einer Entwicklnngsgeschichte der Pflanzenwelt. Leipzig.

- 1883. Über die Pilzvegetation des weißen oder toten Grundes in der Kieler Bucht. 4. Bericht der Kommission zur Untersuchung der deutschen Meere.

- 1891. Über die Hochgebirgsflora des tropischen Afrika. Abh. Berliner Akad.

- 1894. Über die Gliederung der Vegetation von Usambara. Abh. Berliner Akad. S. auch Englers Jahrb., XVII (1893).

- 1899. Entwicklung der Pflanzengeographie in den letzten hundert Jahren. Wiss. Beitr. Gedächtn. 100 jähr. Wiederkehr Antritts A. v. Humboldts Reise nach Amerika am 5. Juni 1799. Berlin.

- 1900. Utber die Vegetationsverhältnisse des Ulugurugebirges in Deutsch-Ostafrik\&. Sitzungber. Berliner Akad.

- 1901. Die Pflanzenformationen und die pflanzengeographische Gliederung der Alpenkette erläutert an der Alpenanlage des neuen königlichen botanischen Gartens zu Dahlem-Steglitz bei Berlin, mit zwei Orientierungskarten. Notizbl. Kgl. Bot. Gart. Berlin, III., App. VII.

- 1902. Die pflanzengeographische Gliederung Nordamerikas. Ebendort, App. IX.

- 1903 a. Die Frühlingsflora des Tafelberges bei Kapstadt. Ebendort, App. XI.

- 1903 b. Über die Vegetationsformationen Ostafrikas. Zeitschr. Erdk. 1902. 
Engler, Ad., 1904. Utber die Vegetationsverhältnisse des Somalilandes. Abh. Berlin. Akad.

- 1906 a. Beiträge zur Kenntnis der Pflanzenformationen von Transvaal und Rhodesia. Sitzungsber. Berliner Akad.

- 1906 b. Vegetationsverhältnisse von Harar und des Gallahochlandes. Ebendort.

- 1908 a. Pflanzengeographische Gliederung von Afrika. Ebendort.

- 1908 b-1915. Die Pflanzenwelt Afrikas, I, 1, 2, 3; II; III, 1. Die Vegetation der Erde, herausgeg. von A. Engler und O. Drude, IX.

- 1908 c. Die Vegetationsformationen tropischer und subtropischer Länder. Englers Jahrb., XXXXI.

- 1914 a. Pflanzengeographie. Kultur der Gegenwart, III, IV, 4.

- $1914 \mathrm{~b}$. Uber Herkunft, Alter und Verbreitung extrem xerothermer Pflanzen. Sitzungsber. Akad. Wien, XX, Math. Nat. Cl. $564 \mathrm{ff}$.

- 1916. Führer zu einem Rundgang durch die Gewächshäuser des königlichen botanischen Gartens. Dahlem-Steglitz bei Berlin.

Engler, Arnold, 1903. Untersuchungen über das Wurzelwachstum .... Holzarten. Mitt. Schweiz. Zentralanst. Forstl. Vers.-Wes., VII.

- 1911, 1913. Einfluß der Provenienz des Samens auf die Eigenschaften der forstlichen Holzgewächse I and II. Zürich in Mitt. Schweiz. Zentralanst. Forstl. Vers.-Wes, VIII n. X.

- 1916. Spektrophotometrische Untersuchungen im Walde. Nat. Zeitschr. Forst- u. Landwirtsch., XIV, $77 \mathrm{ff}$.

Erikson, J., 1895. Studier öfver hydrofiba växter. Bot. Not.

- 1895. Alfvarfloran pä Öland. Bot. Not.

- 1896. Studier öfver Sandfloran i östra Shåne. Meddel. fr. Stockholms Högsk.; Sv. Vet. Akad. Handl., XXII, Bihang.

Eriksson, J. V., 1912. Bälingie mossars utvecklingshistoria och vegetation. Svensk Bot. Tidskr., VI.

Ernst, A., 1907. Die neve Flora der Vulkaninsel Krakataa. Zürich.

- 1908. Beiträge zur Ökologie und Morphologie von Polypodium pteropus Bl. Ann. Jardin bot. de Buitenzorg, XXII (2. Sér., VII); vgl. Bot. Centralbl., CXXII.

Faber, F. C. v., 1913. Utber Transpiration und osmotischen Druck bei den Mangroven. Ber. Deutsch. Bot. Ges., XXXI.

Falck, K., 1913. Alfvarvegetation på Öland. Sv. Bot. Tidskx., VII. Stockholm. Farrow, E. P., 1915, 1916. On the Ecology of the vegetation of Breckland. Journ. Ecol., III, 211; IV, 57.

Fedde, F., 1901. Unsere Teichflora. Allg. Fischerei-Ztg.

Fedschenke, B. und Fler off, A., 1907. RuBlands Vegetationsbilder.

Feilberg, P., 1890. Om Gräskultur paa Klitsletterne ved Gammel Skagen. Søborg. Autographie.

- 1891. Om Enge og vedvarende Gärsmarker. Tidsskr. Landökon.

Ferdinandsen, C. und Winge, Ö., 1912. Kobberdammene i Aldershvile. Skov. Botan. Tidsskr., XXXIII. Köbenhavn.

Feucht, 0., 1909. Der nördliche Schwarzwald. Karsten a. Schenck, Vegetationsbilder, VIII, 3.

Fiebrig, K., 1909. Ceoropia peltata und ihr Verhältnis zu ... Insekten, mit einer Notiz über Ameisendornen. Biolog. Centralbl., XXIX.

- 1910. Ein Beitrag zur Pflanzengeographie Boliviens. Englers Jahrb., XLV.

Fink, B., 1903. Some common types of Lichen formations. Torrey Bulletin, XXX. - 1896-1903. Contributions to a knowledge of the Lichens of Minnesota. Minnesota Botan. Stud., I, II, III. 
Fischer, A., 1891. Beiträge zur Physiologie der Holzgewächse. Pringsh. Jahrb. wiss. Bot. XXII.

Fitting, H., 1909. Uber die Beziehungen zwischen den epiphyllen Flechten und den von ihnen bewohnten Blättern. Ann. du Jardin Bot. de Buitenzorg, 2. Sér. Suppl. 3.

- 1911. Die Wasserversorgung und die osmotischen Druckverhältnisse der Wüstenpflanzen. Zeitschr. f. Botan., III, $209 \mathrm{ff}$.

Flahault, Ch. Nouvelles observations sur les modifications des végétaux suivant les conditions physiques du milieu. Ann. Sc. Nat., 6. sér., IX.

- 1888. Les herborisations aux environs de Montpellier: II. Les Garigues. Journ. de Bot., II.

- 1893. Distribution des végétaux dans un coin de Languedoc. Montpellier.

- 1894. Projet de carte botanique, forestière et agricole de la France. Bull. Soc. Bot. France, XLI.

- 1896. Catalogue raisonné de la Flore des Pyrénées-orientales. Perpignan.

- 1897. Essai d'une carte botanique et forestière de la France. Ann. de Géogr., VI.

- 1899. La naturalisation ot les plantes naturalisées en France. Bull. Soc. Bot. France, XLVI.

- 1900. Projet de nomenclature phytogéographique. Comptes rendus du Congrès Internat. de Botanique à l'Exposition Universelle de 1900, Paris.

- 1901 a. La flore et la végétation de la France, avec une carte de la distribution des végétaux en France. In Coste, Flore de la France.

- 1901 b. Premier essai de nomenclature phytogéographique. Bull. Soc. Languedoc. de Géogr.

- $1901 \mathrm{c}$. Les limites supérieures de la végétation forestière et les prairies pseadoalpines en France. Rev. des Eaux et des Forêts.

- 1904. Rapport . . a au sujet des jardins botaniques de l'Aigoual. Montpellier.

- 1906. Les progrès de la géographie botanique depuis 1884. Progr. Rei Bot., I.

- et Bonnier, 1879. Vgl. Bonnier.

- et Combres, P., 1894. Sur la flore de la Camargue et des alluvions du Rhône. Bull. Soc. Bot. France, XLI.

- u. Schröter, C., 1910. Phytogeographische Nomenklatur. 3. Congrès international de Botanique. Bruxelles. Siehe: Actes du Congrès. I.

Fleroff, A. T., 1907. Wasser- und Bruchvegetation aus Mittelrußland. Karsten u. Schenck, Vegetationsbilder, IV, 8.

Fliche, 1888. Un reboisement. Ann. Sci. Agron., I.

- et Grandeau. Recherches chimiques sur la bruyère commune. Ebendort.

Focke, W. 0., 1871. Uber die Vegetation des nordwestdentschen Tieflandes. Abh. Naturw. Ver. Bremen, II.

- 1890. Die Herkunft der Vertreter der nordischen Flora im niedersächsisehen Tieflande. Ebendort XI.

- 1892. Beiträge zum Verständnis des heimischen Pflanzenlebens. Ebendort XII.

- 1895. Die Heide. Abh. Naturw. Ver. Bremen, XIII.

- 1904 a. Natürliche Standorte für einheimische Wanderpflanzen. Festschrift Aschersons 70. Geburtst., 248 ff.

- 1904 b. Änderungen der Flora an der Nordseeküste. Abh. Naturw. Ver. Bremen, XVIII, 175.

Forel, F. A., 1866. Note sur les galets sculptés des lacs. Bull. Soc. Vaud. Sci. Nat.

- 1878. Faunistische Studien in den SüBwasserseen der Schweiz.

- 1891. Allgemeine Biologie eines Süßwassersees. In Zacharias: Die Tier-und Pflanzenwelt des Süßwassers. 
Forel, F. A., 1892-1901. Le Léman. I-III.

Foxworthy, F. W., 1910. Distribution and utilization of the Mangroveswamps of Malaya. Ann. Jard. bot. Buitenzorg. 3. Suppl., I.

De Fraine, Ethel, 1913. The Anatomy of the genus Salicornia. Linnean Societys Journal, XLI.

Fricke, 1904. Licht- und Schattenbolzarten, ein wissenschaftlich nicht begründetes Dogma. Centralbl. f. d. ges. Forstwes., XIX.

Fries, R. E., 1905. Zur Kenntnis der alpineu Flora im nördlichen Argentinien. Nov. Acta Reg. Soc. Sci. Upsala, Ser. 4, I.

- 1913. Die Vegetation des Bangweolo-Gebietes. Svensk Bot. Tidskr., VII.

Fries, Thore E. C., 1913. Botanische Untersuchungen im nördlichen Schweden. Uppsala a. Stockholm.

Frimmel, Fr. von, 1911. Die untere Cuticula des Taxus-Blattes, ein Lichtreflektor. Österr. Bot. Zeitschr. LXI.

Fritsch, F. E., 1906. Problems in aquatic biology, with special reference to the study of Algal periodicity. New Phytologist, V.

- 1907 a. A general consideration of the subaërial and freshwater Algal Flora of Ceylon. Pt. I. Proc. Roy. Soc. B.. LXXIX.

- $1907 \mathrm{~b}$. The Rôle of Algal growth in the Colonization of New Ground and in the Determination of Scenery. The Geographical Journal. Novbr.

- and Rich, Miss F., 1909. Biology and Ecology of the Algal Flora of Abbots Pool, near Bristol. Bristol Naturalists Societys Proceed. 4. Ser., II.

- - 1913. British Freshwater Algae in Nature. Ann. de biologie lacustre, VI.

Fritsch, K., 1902. Über den EinfluB des Ackerbaues nnd der Wiesenkultur anf die Vegetation; in Mitt. Naturw. Ver. Steiermark.

- 1906. Beobachtungen über blütenbesuchende Insekten in Steiermark. Verh. zoolt. bot. Ges. Wien, LVI, $135 \mathrm{ff}$.

Früh, J., 1901. Die Abbildung der vorherrschenden Winde durch die Pflanzenwelt. Geogr.-Ethnogr. Ges. Zürich.

- und Schröter, C., 1904. Die Moore der Schweiz, mit Berücksichtigung der gesamten Moorfrage. Bern.

Frödin, J., 1912. Tvenne västskandinaviska klimatfaktorer och deras värtgeografiska betydelse. Arkiv f. Botanik. Stockholm, XI.

Fuchs, 'T., 1882. Untersuchungen über den EinfluB des Lichtes auf die bathymetrische Verteilung der Meeresorganismen. Verh. zool.-bot. Ges. Wien, XXXII.

Fuhrmann, K., 1908. Knöllchenbakterien der Leguminosen. Mitt. Nat. Ver. Steiermark, XLIV (1907).

Fuller, G. D., 1911. Evaporation and Plant succession., The Bot. Gazette, LII.

- 1912 a. Evaporation and the stratification of vegetation. Ebendort LIV.

- 1912 b. Soil moisture in the Cottonw ood Dune Association of Lake Alichigan. Ebend. LIII.

- 1914. Evaporation and Soil moisture in Relation to the Succession of Plan. Associations. Ebendort LVIII. (Journ. Ecol. II, 258.)

Furrer, E, 1914. Vegetationsstudien im Bormiesischen. Mitt. aus d. Bot. Museum d. Universität Zürich, LXVIII. (Journ. Ecol. III, 2.)

Gadeceau, E., 1903. Essai de géographie botanique sur Belle-Ile-en Mer. Mémde la Soc. nat. des Sciences nat. et. mathém. de Cherbourg, XXXIII.

- 1909. Le lac de Grand Lieu, Monographie phytogéographique. Nantes.

Gaidukow, N., 1903 a. Die Farbenänderung bei den Prozessen der komplementären chromatischen Adaptation usw. Ber. Deut. Bot. Ges., XXI.

- 1903 b. Uber den EinfluB farbigen Lichts auf die Färbung der Oscillarien. Script. Bot. Hort. Univ. Petropol, XXII. 
Gaidukow, N., 1904. Die Farbe der Algen und des Wassers. Hedwigia, XLIII.

Gain, E., 1893. Contribution à l'étade de l'influence du milieu sur les végétaux. Bull.

Soc. Bot. France, XL.

- 1895 a. Recherches sur le rôle physiologique de l'eau dans la végétation. Ann.

Se. Nat., $7^{e}$ sér., $\mathrm{XX}$.

- 1895 b. Action de l'eau du sol sur la végétation. Rev. gén. de Bot., VII.

Gain, L., 1908-10. La flore algologique des Regions antarctiques et. subantarctiques.

Deuxième expédition antarctique française par J. Charcot. Paris.

Gallemaerts, V., 1909. Sur les phanérogames épiphytes. Recueil de l'Institut botan. Léo Errera. VIII.

Gallöe, O., 1908. Danske Likeners ökologi. Bot. Tidsskr. XXVIII (mit weit über 100 Abbildungen).

- 1913. Forberedende Undersögelser til en Almindelig Likenökologi. 240 Fig.

Dansk Botan. Arkiv, 1. Köbenhavn.

Ganong, W. F., 1894. On the absoprtion of water by the green parts of plants. Botan. Gazette, XIX.

- 1897. Upon raised peat bogs in the province of New Brunswick. Trans. Roy. Soc. Canada, Ser. 2, III.

- 1899. Preliminary outline for a plan for a study of the precise factors determining the features of New Brunswick vegetation. Bull. Nat. Hist. Soc. New Brunswick, XVII.

- 1902. A preliminary synopsis of the grouping of the vegetation (phytogeography) of New Brunswick. Ebendort XXI.

- 1903. The vegetation of the Bay of Fundy salt and diked marshes. Botan. Gazette, XXXVI.

- 1904. The cardinal principles of ecology. Science, XIX.

- 1906. The nascent forest of the Miscon beach plain. Botan. Gazette, XLII.

Gassner, G., 1913. Uruguay. Karsten n. Schenk, Vegetationsbilder. XI. 1-4.

Gates, Fr. C., 1912. The vegetation of the beach area in Northeastern Illinois and Southeastern Wisconsin. Bull. Illin. State Laborat. of Nat. History, IX.

Gauchery, P., 1899. Recherches sur le nanisme végétal. Ann. Sc. Nat., 8 e sér., IX.

Gebbing, J., 1910. Über den Gehalt des Meeres an Stickstoffnährsalzen. Int. Revue d. ges. Hydrobiol u. Hydrogr., III.

Geikie, J., 1898. The Tundras and steppes of prehistoric Europe. Scot. Geogr. Mag. Geilinger, G., 1908. Die Grignagruppe am Comersee. Mitt. bot. Museum Zürich XLI. 304 S. u. Karte. Diss. Zürich.

Gerhard, G., 1902. Beiträge zur Blattanatomie des Knysnawaldes. Hildesheim.

Gerhardt, J., 1900. Handbuch des deutschen Dünenbaues. Berlin. Vgl. A bromeit.

Gerschon, S., 1905. Variationen von Jussieua repens. Abh. K. Leop. Kar. Akad. Naturf., LXXXIV.

Gertz, O.. 1913. Om anthocyan hos alpina växter. Botaniska Notiser.

Gèze, J. B. 1911. Expériences de culture et de selection de plantes de marais. Minist. d'Agricult. Paris.

- 1912. Définitions phytogéographiques de quelques stations hygrophiles. Comptes rend. Paris.

Gibbs, L. S., 1906. A contribution to the botany of Southern Rhodesia. Jour. Linn. Soc. Lond., XXXVII.

Giesenhagen, K., 1910. Die Moostypen der Regenwälder. Ann. Jard. bot. Buitenzorg. 2 Ser., III.

Gilg, E., 1891. Beiträge zur vergleichenden Anatomie der xerophilen Familie der Restiaceae. Engler's Jahrb., XIII. 
Gillot, F., 1894. Influence de la composition minéralogique des roches sur la végétation; colonies végétales hétérotropiques. Bull. Suc. Bot. France, XLI.

Giltay, E., 1886. Anatomische Eigentümlichkeiten in Beziehung auf klimatische Umstände. Neederl. Kraidk. Arch., IV.

- 1897. Vergleichende Studien über die Stärke der Transpiration in den Tropen und in mitteleuropäischen Klima. Pringsh. Jahrb. wiss. Bot, XXX.

- 1898 a. Uber die vegetabilische Stoffbildung in den Tropen und in Mittel-Europa. Ann. Jard. Bot. Buitenzorg, XV.

- 1898 b. Die Transpiration in den Tropen und in Mittel-Europa, II. Pringsh. Jahrb. wiss. Bot., XXXI.

- Die Transpiration in den Tropen und in Mittel-Europa, III. Ebendaort XXXIV. Ginzberger, A. und K. Maly, 1905. Exkursion in die illyrischen Länder, II. Internat. Botan. Kongress, Wien.

Gleason, H. A., 1909 a. Some unsolved problems of. the prairies. Bull. Torrey Bot. Cl. XXX. $205 \mathrm{ff}$.

- $1909 \mathrm{~b}$. The vegetational history of a river dune. Trans. Illin. State Akad. Sc. II. $19 \mathrm{ff}$.

- 1910. The vegetation of the Inland Sand Deposits of Illineris. Bull. Illin State Laboratory of Natural History, IX., 3.

- 1912. An isolated Prairie Grove and its Phytogeographical Significance. Bot. Gaz. LIII.

Glinka, K., 1914. Die Typen der Bodenbildung. Berlin.

Glück, H., 1905, 1906, 1911. Biologische und morphologische Untersuchungen über Wasser- und Sumpfgewåchse. I, II, III. Jena.

- 1909. Utber die Lebensweise der Uferflora. Engler's Jahrb. XLIII.

Goebel, K., 1886. Utber die Luftwurzeln von Sonneratia. Ber. Deutsch. Bot. Ges., IV.

- 1889-93. Pflanzenbiologische Schilderungen, I (1889), II (1892)。

- 1912-15. Organographie der Pflanzen. 2. Auflage. Jena.

Gola, G., 1905. Studi sui rapporti tra la distribuzione delle piante e la costituzione fisico-chimica del suolo. Ann. di Botan., III.

-. siehe Cavers.

Gothan, W., 1913. Entwickelungsgeschichte der Pflanzenwelt. Das Leben der Pflanze, III. Stuttgart, Kosmos.

Gough, L. H., 1905. Report on the plankton of the Englisch Channel in 1903. Internat. investigations. Marine biol. Assoc. Report. 1.

Gradmann, Rob., 1909. Über Begriffsbildnng in der Lehre von den Pflanzenformationen. Engler's botan. Jahrb. XLIII, Beibl. 99.

Graebner, P., 1893. Biologische Notizen. Verh. botan. Ver. Prov. Brandenburg XXXV.

- 1895 a. Studien über die norddeutsche Heide. Engler's Jahrb., XX.

- 1895 b. Zur Flora der Kreise Putzig, Neustadt Wpr. und Lauenburg in Pommern. Schrift. Naturf. Ges. Danzig, IX.

- 1896 a. Das Reifen der Früchte und Samen frühzeitig von der Mutterpflanze getrennter Blütenstände. Naturw. Wochenschr., XI.

- 1896 b. Klima und Heide in Norddeutschland. Naturw. Wochenschr., XI.

- 1898 a. Gliederung der westpreußischen Vegetationsformationen. Ebendort, N. F., IX.

- 1898 b. Über die Bildung natürlicher Vegetationsformen im norddeutschen Flachlande. Arch. d. Brandenburgia, IV. Naturw. Wochenschr, XIII.

- 1901. Die Heide Norddeutschlands. Leipzig.

- 1903. Botanischer Führer durch Norddeutschland. Berlin. 
Graebner, P.. 1904 (mit Bentheim, O. von). Handbuch der Heidekultur. Leipzig.

- 1906 a. Potamogetonaceae u. Hydrocharitaceae im Kirchner, Loew, Schröter Lebensgeschichte, I. 1.

- 1906. b Die Gattungen der natürlichen Familie der Valerianaceen. Engl. bot. Jahrb. XXXVII.

- 1906 c. Die wirtschaftfeindlichen Faktoren der Heide und die sich daraus ergebenden Pflanzenkrankheiten. Jahresb. Ver. angew. Botan.

- 1907. Die Pflanze. Landeskunde Prov. Brandenb. I. $129 \mathrm{ff}$.

- 1909. Pflanzengeographie. Wissensch. u. Bildung. Leipzig.

- 1909. Die Pflanzenwelt Deutschlands. Lehrbuch der Formationsbiologie. Leipzig.

- 1909. Heide und Moor. Stuttgart.

- 1910. Lehrbuch der allgemeinen Pflanzengeographie. Leipzig.

- 1910 a. Uber Veränderungen von Vegetationsformationen in 32 Ber. Westpr. Botan. Zool. Ver. Danzig.

- 1910 b. Pflanzenleben in den Dünen in Solger etc. Dünenbuch. Stuttgart.

- 1910 c. Natürliche Veränderungen von Vegetationsformationen und deren fossile

Reste in Zeitschr. Deutschén Geol. Ges. LXII; Ber. Westpr. Botan. Zool. Ver.

- 1912. Die Entwickelung der Deutschen Flora. Leiprig.

- 1912 b. Vegetationsschilderungen. Leipzig u. Berlin.

- 1913 a. Die Veränderungen natürlicher Vegetationsformationen ohne Klimawechsel.

Bot. Jahrb. IXL, Beibl. 109.

- 1913 b. Pflanzengeographische Eindrücke auf d. Britisch. Inseln, in Tansley 1913 a, $67 \mathrm{ff}$.

- 1914. Dickenwachstum u. Stockfäule. Englers bot. Jahrb. L. (Festband Englers 70. Geburtst.)

Grafe und Porthein, 1906. Untersuchungen über die Rolle des Kalkes in den Pflanzen. Sitzb. Akad. Wien.

Gran, H. H., 1900. Hydrograph. biol. Studies of the North Atlantic Ocean and the coast of Nordland. Rep. Norweg. Fish. and Mar. Investig. I, 5.

-- 1901. Studien über Meeresbakterien. I. Bergens Museums Aarsbok. X.

- 1902. Das Plankton des norwegischen Nordmeeres. Rep. on Norwegian Fish and Marine Investigations, II. Bergen.

- 1905. Diatomeen. Nordisches Plankton hrsg. von K. Brandt, XIX.

- und Nathanson, A., 1908. Beiträge zur Biologie des Planktons. I. A. Nathanson, UUber die allgemeinen Produktionsbedingungen im Meere. - Internat. Revue d. ges. Hydrobiol. u. Hydrygr. I.

- 1909. Fortsättelle. Ebendort II.

- 1912. Pelagic plant life. Murray \& Hjort: The depths of the ocean. London.

- 1914. The plankton production of the north European waters in the spring of 1912. Conseil permanent pour l'expl, de la mer. Bull. planktonique.

- 1915. The Plankton production of the North European waters in the spring of 1912. Bull. planktonique pour l'année 1912 publié par le bureau du conseil permanent international pour l'exploration de la mer. Copenhague.

Gray, Asa, 1884. Characteristics of the North American Flora. Americ. Journ. Sci. and Arts. Ser. III, 28.

Grebe, C., 1896. Aufforstung von Ödländereien III. Heideboden. Zeitschr. Forstu. Jagdwesen. XXVIII.

Grecescu, 1898. Conspectus florei Romaniei. Bucuresti.

Grevillius, A. Y., 1893. Om vegetationens utveckling på de nybildade Hjelmaröane. Sv. Vet. Akad. Handl., Bihang XVIII.

- 1894. Biologisch-physiognomische Untersuchungen einiger schwedischen Haintälchen. Bot. Zeitg., LII. 
Grevillius, A. Y., 1897. Morphologisch-anatomische Studien über die xer.phile Phanerogamenvegetation der Insel Oland. Englers Jahrb., XXIII.

- 1909. Zur Physiognomie der Wasservegetation. Ber. Vers. Bot. u. Zool. Ver. Rheinl.-Westf. 43 ff. t. I, II.

Griggs, R. F., 1913, 1914. Behavious of plant species at the edges of their range. Zwei Abhandl. ref. in Journ. Ecol., III, 253.

Griseba ch, A. R. H., 1838. Linnaea, XII.

- 1872. Die Vegetation der Erde. Leipzig.

- 1875. Pflanzengeographie. In Neumayer, Anleitung. I. Aufl. Berlin.

- 1880. Gesammelte Abhandlungen. Leipzig.

Grönlund, C., 1884-90. Plantevåxten paa Island. Festskr. Naturh. For. Kjobbenhavn. Groom, Percy, 1892. On Bud-protection in Dicutyledons. Trans. Linn. Soc. Lond., Ser. 2, III.

- 1895. Contribution to the knowledge of Monocotyledonous saprophytes. Journ. Linn. Soc. Lond, XXXI.

- 1910. Remarks on tho Oecology of Coniferae. Ann. Botany, XXIV.

Grosglik, 1884. Uber den EinfluB des Lichtes auf die Entwicklung des Assimilationsgewebes. Bot. Centralbl. XX.

Gross, H., 1912. Ostpreußens Moore. Schriften der physik.-ökonom. Gesellsch. zu Königsberg i. Pr., LIII. Jahrg.

Grottewitz, C., 1900. Physiognomie der märkischen Heidemoore. Nat.-Z. 35.

Gruber, 1882. Anatomie und Entwickelung des Blattes von Empetrum. Diss., Kónigsberg.

Gruner, L., 1872. Zur Charakteristik der Boden-und Vegetationsverhältnisse der Steppengebiete und der Dniepr- und Koncha-Niederung. Bull. Soc. Imp. des Naturalistes, Moscon, XLV, 1.

Grüss, J., 1892. Beiträge zar Biologie der Knospe. Pringsh. Jahrb., XXIII.

Gubler, A., 1851. Observations sur quelques plantes naines. Comptes Rendus Soc. Biol. Paris, III.

Güllinger, G., 1909. Die Grignagruppe am Comersee. Beihefte Bot. Centralbl. XXIV, 1. (Vergl. Bot. Centralbl., CXIII, 209.)

Gïnther, Konr., 1914. Physiognomik der Tropenlandschaft. Naturw. Wochenschr. XXIX.

Guppy, H. B., 1893. The river Thames as an agent in plant dispersal. Journ. Linn. Soc. London, XXIX.

- 1906. Observations of a naturalist in the Pacific. II. Plant-Dispersal. London.

Gutten berg, H. v., 1907. Anatomisch-physiologische Untersuchungen über das immergrüne Laubblatt der Mediterranflora. Englers Jahrb., XXXVIII.

- 1917. Siehe Haberlandt.

Guyer, O., 1910. Beiträge zur Biologie des Greifensees. Stuttgart.

Haberlandt, G., 1882. Vergleichende Anatomie des assimilatorischen Gewebesystemes der Pflanzen. Pringsh. Jahrb., XIII.

- 1892 a. Über die Transpiration einiger Tropenpflanzen. Sitzungsber. Wiener Akad., CI.

-- 1892 b. Anatomisch-physiologische Untersuchungen über das tropische Laubblatt. Ebendort.

- 1893. Eine botanische Tropenreise. Leipzig.

- 1895. Über die Ernährung der Keimlinge und die Bedentung des Endosperms bei viviparen Mangrovepflanzen. Ann. Jard. Bot. Buitenzorg, XII.

- 1894-5. Uber wassersecernierende und -absorbierende Organe. Sitzungsber. Wiener Akad., CIII, CIV. 
Haberlandt, G., 1898. Über die GröBe der Transpiration im feuchten Tropenklima.

Pringsh. Jahrb., XXXII.

- 1904. Physiologische Pflanzenanatomie. Leipzig.

- 1905. Die Lichtsinnesorgane der Laabblätter. Leipzig.

- 1917. Physiologie und Ökologie I. Botanischer Teil mit Czapek, Fr.; Guttenberg, H. v. und Baur, E. - Die Kultur der Gegenwart, III, 4, 3.

Hackel, E., 1890. Über einige Eigentümlichkeiten der Gräser trockener Klimate. Verh. Zool.-Bot. Ges., Wien, XI.

Haeckel, E., 1866. Generelle Morphologie. Berlin.

Hann, J., 1901. Lehrbuch der Meteorologie. Leipzig.

Handel-Mazzetti, von, 1912 a. Mesopotamien. Karsten u. Schenck, Vegetationsbilder, $\mathrm{X}$.

- 1912 b. Kurdistan. Ebendort.

- - 1914. Die Vegetationsverbältnisse von Mesopotamien und Kurdistan. Ann. Naturhist. Hofmus. Wien, XXVIII. (Journ. Ecology, III.)

Halket, Ann C., 1911. Absorption by the Aerial Parts of Certain Salt-Marsh Plants. New Phytologist, X.

Hansen, Ad., 1901. Die Vegetation der ostfriesischen Inseln. Ein Beitrag zur Pflanzengeographie, besonders zur Kenntnis der Wirkung des Windes auf die Pflanzenwelt. Darmstadt.

- 1903. Hierzu sich anschließende kritische Aufsätze in Englers Jahrb., XXXII.

- 1904. Experimentelle Untersuchungen über die Beschädigung der Blätter durch Wind. Flora, XCIII.

Hansteen-Cranner, B., 1892. Algeregioner og Algeformationer. Nyt. Mag. f. Naturvid. kaben, XXXII.

- 1909-12. Über das Verhalten der Kulturpflanzen zu den Bodensalzen. Nyt. Mag. f. Naturvidensk., XLVII-L.

Harper, Roland M., 1906. A phytogeographical sketeh of the Altmaha Grit Region

of the coastal Plain of Georgia. Annals N. Y. Acad. Sc., XVII, I, 1-414.

- 1910. Preliminary Report on the Peat Deposits of Florida. Third annual Report Florida State Geological Survey.

- 1911. The relation of climax vegetation to islands and peninsulas. Bull. Torrey Bot. Clab, XXXVIII.

- 1913. A botanical eross-section of northern Mississippi, with notes on the influence of soil on vegetation. Ebendort XL, No. 8 .

- 1913. Economic Botany of Alabama. I. Geographical Reports on Forests. Geological Survey of Alabama.

- 1914. Geography and Vegetation of Northern Florida. Florida State Geological Survey. 6. Ann. Report. (Vergl. Journ. Ecol. III, 249.)

Harshberger, J. W., 1897. The vegetation of the Yellowstone hot springs. Amer. Journ. Phar., LXIX.

- 1900. An oecological study of tke New Jersey strand flora. Proc. Acad. Nat. Sei. Philad., LII.

- 1901. An oecological sketch of the flora of Santo Domingo. Ebendort LIII.

- 1902. Additional observations. Ebendort LIV.

- 1903. An oecological study of the flora of mountainous North Carolina. Bot. Gazette, XXXVI.

- 1904. A phyto-geographic sketch of extreme south-eastern Pennsylvania. Torrey Bull., XXXI.

- 1905. The plant formations of the Bermuda Islands. Proc. Acad. Nat. Sci. Philad., LVII. 
Harshberger, J. W., 1905. The plant formations of the Catskills. Plant World, VIII.

- 1908 a. The comparative leaf structure of the sand dune plant of Bermuda. Proceed.

Americ. Philosoph. Soc., XLVII.

- 1908 b. An water-storing tubers of plants. Bull. Torr. Bot. Club, XXXV, $271 \mathrm{ff}$.

- 1909 a. The vegetation of the Salt Marshes and of the Salt and Fresh Water Ponds

of Northern Coastal New Jersey. Acad. of Nat. Sc. of Philadelphia, Aug.

- $1909 \mathrm{~b}$. The comparative Leaf Structure of the Strand Plants of New Jersey.

Proceed. Amer. Philos. Soc., XLVIII.

- 1909 c. Action of Chemical Solution on Bud Development. Proc. Acad. Nat. Sc. Philadelphia.

- 1911 a. Phytogeographic Survey of North America. Engler u. Drude, Die Vegetation der Erde, XIII.

- $1911 \mathrm{~b}$. An hydrometric investigation of the influence of the sea water... Proc. Amer. Phil. Soc., L.

- 1914 a. The vegetation of South Florida. Transactions of the Wagner Free Institute of Science. VII, Part. 3, Philadelphia.

- 1914 b. The vegetation of Nantucket. Bull. Geogr. Soc. Philadelphia, XII.

- 1916. The vegetation of the New Yersey Pine-Barrens. An ecological investigation. Philadelphia. 329 p., 284 Figg.

H artz, N., 1895. Östgrönlands Vegetationsforhold. Meddel. om Grönland, XVIIII.

- and Kruuse, Chr., 1911. The vegetation of Northeast Greenland. Ebendort XXX.

Harvey, L. H., 1903. A study of the physiographic oecology of Mt. Ktaadn, Maine. Univ. of Maine Stud, V.

- 1908. Floral Succession in the Prairiegrass Formation of South-eastern South Dakota. Botan. Gaz., XLVI.

Haselhoff und Lindau, 1903. Die Beschådigung der Vegetation durch Rauch. Leipzig.

Hauman-Merck, L., 1913 a. La forêt Valdivienne. Recenil de l'Institut Botan. Léo Errera, IX.

- - 1913 b. Etude Phytogéographique de la Region du Rio Negro inférieur. Anales del Museo Nacional de Historia Natural de Buenos Aires, XXIV.

Hauri, H., 1912. Anabasis aretioïdes Moq. et Coss., eine Polsterpflanze der algerischen Sahara. Beih. Bot. Centralbl., XXVIII. (Vergl. Journ. Ecol. I, 1913.)

- 1916. Anatomische Untersuchungen an Polsterpflanzen nebst morphologischen und ökologischen Notizen. Beihefte z. Bot. Centralbl., XXXIII, Abt. 1.

- und Schröter, C., 1914. Versuch einer Übersicht der siphonogamen Polsterpflanzen. Englers Jahrb., L (Festband für A. Engler).

Hausrath, H., 1900. Zum Vordringen der Kiefer und Rückgang der Eiche in den Waldungen der Rheinebene. Verh. Naturw. Ver. Karlsruhe, XIII (1895-1900).

Hayek, A. von, 1905. Exkursion auf den Wiener Sehneeberg II. Internat. Botan. Kongre $B$, Wien.

- 1907. Die Sanntaler Alpen. Steiner Alpen. Abh. Zool.-Bot. Ges. Wien, IV.

Hayrén, E., 1914. Über die Landvegetation und Flora der Meeresfelsen von Tvärminne, Helsingfors. Acta Soc. pro Fauna et Flora Fennica, XXXIX. (Vergl. Bot. Centralbl., CXXVI, 600.)

- 1914. Om Vegetationen på Pyhätun-turi. Terra, XXVI. Helsingfors.

Hedgcock, George G., 1902. The relation of the water content of the soil to certain plants, principally mesophytes. Bot. Surv. of Nebraska, VI. Lincoln, Nebr.

- 1915. Parasitism of Comandra umbellata. Journ. Agric. Res. Wash., V, No. 3. Hegi, G., 1902. Das obere TöBtal und die angrenzenden Gebiete. Diss. Zürich. 434 S. u. 2 Karten. Mitt. Bot. Mus. Zürich, XVI. Bull. Herb. Boiss. 


\section{Auswahl der Litteratur}

Hegi, G., 1905. Beiträge zur Pflanzengeographie der bayerischen Alpenflora. Ber. Bayer. Bot. Ges., X. Habilschr. München.

Heine, E., 1910. Die Bodenbakterien. Gartenflora, LIX.

Heinricher, E., 1884. Über isolateralen Blattban. Pringsh. Jahrb., XV.

- 1885. Über einige im Laube dikotyler Pflanzen trockenen Standortes auftretende

Einrichtungen, welche mutmaßlich eine ausreichende Wasserversorgung des Blattmesophylls bezwecken. Bot. Centralbl., XXIII.

- Die grünen Halbschmarotzer. Pringsh. Jahrb., XXXI, XXXII, XXXVI, XXXVII, XXXVIII.

Hellmann, G., 1899-1902. Regenkarten der PreuBischen Provinzen. Berlin.

- 1904. Die relative Regenarmat der deutschen Flachküsten in Sitzungsber. Preuß. Akad. Wissenseh., LIV.

Hemberg, E., 1904. Tallens degenerationszoner i södra och västra Sverige. SkoggVärdsfören. Tidskr.

Hemmendorff, E., 1897. Om Ölands Vegetation. Upsala.

- 1912. Bilder aus der Resting-Vegetation bei Rio de Janeiro. Svensk. bot. Tidskr.VI.

Hemsley, W. B., 1885. On the dispersal of plants by oceanic currents and birds. Challenger Rep. Botany, I.

Henning, E., 1889. Agronomiskt-växtfysiognomiska studier i Jemtland. Sver. geol. Undersökn. Ser. C. No. 102, 1889.

- 1895. Studier öfver vegetations förhallandena i Jemtland ur forstlig, agronomisk och geologisk synpunkt. Ebendort No. 145, 1895.

Hensen, V., 1887. Über die Bestimmungen des Planktons. Ber. Kommis. Wiss. Unters. Deutsch. Meere, V, VI.

- 1890. Einige Ergebnisse der Plankton-Expedition der Humboldt-Stiftung. Sitzungsber. Berliner Akad.

- 1911. Das Leben im Ozean nach Zählungen seiner Bewohner. Ergebnisse der Plankton-Expedition, $\nabla$.

Henslow, G., 1894. The origin of plant-structures by self-adaptation to the environment, exemplified by desert or xerophilous plants. Jouru. Linn. Soc. Lond., XXX.

- 1895. The origin of plant-structures. London.

Herder, F. v. Die neueren Beiträge zur pflanzengeographischen Kenntnis RuBlands. Englers Jahrb., VIII, IX.

Herzog, Th. Pflanzenformationen aus Ost-Bolivia. Karsten a. Schenck, Vegetationsbilder, R. VII, Heft $6-7$.

Hess, R., 1898. Uber Waldschutz und Schutzwald. Hamburg.

Hess, Eug., 1909. Über Wuchsformon der alpinen Geröllpflanzen. Beih. Bot. Centralblatt, XXVII, und Englers Jahrb., XLV. Diss. Zürich.

Hesselman, H., 1879. Några iaktagelser öfver växternas spridning. Bot. Notis.

- 1900. Om mykorrhizabildningar hos arktiska växter. Medd. Stockh. Högsk. No. 203.

- 1904. Zar Kenntnis des Pflanzenlebens schwedischer Laubwiesen. Beih. Bot. Centralbl., XVII.

- 1905. Stenströms studier öfver Expositionens Inflytande på Vegetation. Arkiv f. Bot., IV.

- 1908 a. Om flygsandsfälten på Fårö. Skogsvårdsföreningens Tidskrift.

- 1908 b. Vegetationen och skogsväxten på Gotlands hällmarker. Ebendort.

- 1910 a. Studier öfver de norrländska tallhedarnas föryngringsvillkor. (Studien über die Verjüngungsbedingungen der nordländischen Kiefernheiden.) Medd. fr. Stat. Skogsförs.-anst., VII.

- $1910 \mathrm{~b} . \quad 0 \mathrm{~m}$ Vattnets syrehalt vch dess inverkan på skogsmarkens försumpning och skogens växtlighed. Meddel. från statens försöksanstalt (mit deutschem Resumee); vergl. Z. f. B., III, 414. 
Heuglin, M. Th. v., 1874. Reisen nach dem Nordpolarmeer 1870-71, III.

Hildebrand, F., 1870. Über die Schwimmblätter von Marsilia und einigen anderen amphibischen Pflanzen. Bot. Ztg.

- 1873. Utber die Verbreitungsmittel der Pflanzen. Leipzig.

- 1882. Die Lebensdauer und Vegetationsweise der Pflanzen, ihre Ursachen und ihre Entwicklung. Englers Jahrb., II.

- 1884. Die Lebensverhältnisse der Oxalis-Arten.

Hilg ard, 1892. Afreport on the relations of soil to climate. S.S. Dept. Agric., Weather Bar., III. Washington.

Hill, E. J., 1900. Flora of the White Lake region, Michigan. Bot. Gazette, XXIX.

Hill, G. R., 1913. Respiration of fruits and growing plant tissues in certain gasses. Bull. Cornell Univ. Agric. exp. Stat, Dep. pl. physiol.

Hill, T. G., 1908. Observations on the osmotic properties of the root hairs of certain saltmarsh plants. The New Phytologist, VII.

- 1909. The Bouche d'Erquy in 1908. New Phytol, VIII.

- and Hanley, J. A., 1914. The structure and Water-content of Shingle Beaches. Journ. of Ecology, II. (Vergl. Bot. Centralbl., CXXVI, 456.)

Hitchcock, A. S., 1898. Oecological plant geography of Kansas. Transact. Acad. Sci. St. Louis, VIII.

- 1899. A brief outline of oecology. Transact Kansas Acad. Sci., XXVII.

- 1904. Methods used for controlling and reclaiming sand dunes. U. S. Dept. Agric. Bull., LVII. (Vergl. Nation. Geogr. Mag.)

Hochreutiner, G., 1899. Dissemination des graines par les poissons. Bull. du Labor. Univ. Genève, III.

- 1904. Le Sud-Oranais. Ann. du Conserv, et du Jard. Bot. Genève, VII-VIII. Höck, F., 1892. Begleitpflanzen der Buche. Bot. Centralbl., LII.

- 1893 a. Nadelwaldflora Norddeutschlands. Forschungen zur Deutschen Landesund Volkskunde, hrsg. von Kirchhoff, VII.

- 1893 b. Begleitpflanzen der Kiefer in Norddeutschland. Ber. Deutsch. Bot. Ges., XI.

- 1895. Brandenburger Buchenbegleiter. Verh. Bot. Ver. Prov. Brandenburg, XXXVI.

- 1896. Laubwaldflora Norddeutschlands. Forschungen zur Deutschen Landes- und Volkskunde, hrsg. von Kirchhoff.

- 1898 a. Eine Genossenschaft feuchtigkeitsmeidender Pflanzen Norddentschlands. Allg. Bot. Zeitschr.

- 1898 b. Allerweltspflanzen in unserer heimischen Phanerogamenflora. Deutsche Bot. Monatsschr.

- 1898 c. Studien über die geographische Verbreitung der Waldpflanzen Brandenburgs. Verh. Bot. Ver. Brandenburg, XL.

- 1899. Zahlenverhältnisse in der Pflanzenweit Norddeutschlands. Ebendort XLI.

- 1900 a. Laubwaldflora Norddeutschlands. Forschungen zur deutschen Landes- und Volkskunde, hrsg. von Kirchhoff.

- 1900 b. Geographiche Verbreitung der Waldpflanzen Brandenburgs. Verh. Bot. Ver. Brandenburg.

- 1906. Verbreitung der Gefäßpflanzen deutscher Binnengewässer. Beih. Bot. Centralblatt, XIX, 2, 3ł3 ff.

Holm, Th., 1887. Novaia Zemlias Vegetation. Dijmphna-Togtets Zool.-Bot. Udbytte. Kjöbenhavn.

- 1891. On the vitality of some annual plants. Americ. Journ. Sci., XLII.

Holm boe, J., 1898. Nogle iakttagelser over fröspredning paa ferskvandis. Bot. Notiser.

- 1899. Strandplanter $\mathrm{i}$ det indre af Norge. Naturen, III.

- 00. Nogle ugräsplanters indvandring i Norge. Nyt. Mag. Naturv. Kristiania, XXXIX. 
Holmboe, J., 1903. Planterester i Norske torvmyrer. Vidensk Selsk. Skr. I Mat.nat. Kl. No. 2 m. Abb. u. 5 T.

- 1904 a. Studien über norwegische Torfmoore. Englers Jahrb., XXXIV, $204 \mathrm{ff.}$

- 1904 b. Hoiere epifytisk planteliv i Norge. Christiania Vid. Selsk. Forh.

- 1914. Studies on the Vegetation of Cyprus. Bergens Museums Skrifter. N. R., I, No. 2.

Holtermann, C., 1902. Anatomisch-physiologische Untersuchangen in den Tropen. Sitzungsber. Berliner Akad.

- 1907. Der Einfluß des Klimas auf den Bau der Pflanzengewebe. Leipzig.

- 1912. In der Tropenwelt. Leipzig.

H omén, 1897. Der tägliche Wärmeumsatz im Boden. Helsingfors.

Hooker, J. D., 1847 a. Botany of the antarctic Voyage of H. M. Discovery Ships Erebus and Terror.

- $1847 \mathrm{~b}$. On the vegetation of the Galapagos Archipelago. Linn. Transact., XX.

- 1896. Lecture on insular floras. London.

- - On the struggle for existence amongst plants. Pop. Sci. Rev., VI.

Hossaeus, C. C., 1911. Edaphische Wirkungen des Kalkes auf die Vegetation tropischer Karren und Karrenfelder. Engl. Bot. Jahrb., XLV, S. $662 \mathrm{ff}$.

Hryniewiecki，B., 1898. Die Flora des Urals. Sitzungsber. d. Naturforsch. Ges. Dorpat, XII, 1.

- 1911. Ostgrenze von Fagus silvatica in Europa. Kosmos. Lwow, XXXV.

Huber, G., 1905. Monographische Studien im Gebiete der Montgglerseen (Südtirol), mit besonderer Berücksichtigung ihrer Biologie. Arch.f. Hydrobiol. u. Planktonk., I.

Huber, J., 1906. La végétation de la vallée de Rio purus (Amazonas). Bull. Herb. Boissier, sér. 2, VI.

Huitfeld-Kaas, K., 1906. Planktonundersögelser i Norske Vande. Christiania.

Hult, R., 1881. Försök till analytisk behandling af växtformationerna. Meddel. Soc. Faun. Flor. Fenn., VIII.

- 1885. Blekinges vegetation. Ebendort XII.

- 1886. Mossfloran i trakterna mellan Aavasaksa och Pallastunturit. Acta Soc. Faun. Flor. Fenn., III.

- 1887. Die alpinen Pflanzenformationen des nördlichsten Finlands. Ebendort XIV.

Hultberg. Anatomiska undersökningar öfver Salicornia. Lunds universitets årsskrift, XVIII.

Humboldt, Alex., 1806. Ideen zu einer Physiognomik der Gewächse. Tübingen 1806. - Wieder abgedruckt z. B. in dem 2. Bande von

- 1805. Ansichten der Natur. 3. Ausgabe, Stuttgart und Tübingen 1849.

- 1805 (1807). Essai sur la géographie des plantes. Paris.

Hunger, W., 1899. Uber die Funktion der oberflächlichen Schleimbildungen im Pflanzenreiche. Leiden.

Huth, E., 1887. Die Klett-Pflanzen, mit besonderer Berücksichtigung ihrer Verbreitung durch Tiere. Biblioth. Botan., IX.

- 1889. Die Verbreitung der Pflanzen durch die Exkremente der Tiere. Samml. Naturw. Vortr., III, Berlin.

- 1892. Steppenläufer, Windhexen und andere Wirbelkräater. Helios, Frankfurt ^.0.

- 1893. Windhexen und Schneeläufer. Ebendort.

Iljin, V. S., 1916. Relation of transpiration to assimilation in steppe plants. Journ. Eeol., IV, 65.

- Nazarova, P. and Ostrovskaja, 1916. Osmotic pressure in roots and in leaves in relation to habitat moisture. Journ. Ecol., IV, 160. 
Irmscher, E., 1912. Über Resistenz der Laubmoose gegen Austrocknung und Kälte. Pringsh. Jahrb. wiss. Bot, L. (Vergl. Journ. Ecol. I.)

Issatchenko, B. L., 1914. Recherches sur les Microbes de l'Océan glacial arctique.

Petrograd. L'expédition seientifique pour l'exploration des pêcheries de la côte mourmane.

Istvanffi, G. von, 1898. Die Kryptogamenflora des Balatonsees. Result. d. wiss. Erforsch. d. Balatonsees. 2. Bd., II.

- 1905. Flore microscopique des thermes de l'île Margitsziget. Budapest.

Ja ap, O. 1897. Auf Bäumen wachsende Gefäßpflanzen in der Umgegend von Hamburg. Verh. naturw. Ver. Hamburg.

Jaccard, P., 1902. Gesetze der Pflanzenverteilung in der alpinen Region. Flora, XC.

- 1908. Nouvelles recherches sur la distribution florale. Bull. Soc. Vaudois. Sc. Nat. XLIV.

- 1912. The distribution of the flora in the alpine zone. New Phytologist, 11. (Hier die Liste der früheren Publikationen.)

- 1914. Distribution florale de quelques formations terrestres et aquatiques. Revue générale de Botanique, XXVI.

Jäggli, M., 1908. Monographia floristica del Monte Camoché (presso Bellinzona). Diss. Zürich. Bull. Soc. Tic. Sc. Nat. Bellinzona, IV. m. Karten u. 5 Taf.

Jahn, E., 1886. Utber Schwimmblätter. Beitr. z. wiss. Bot., X.

Jeffreys, H., 1916. On the Vegetation of four Durham Coal-Measure Fells. I. General Description of the Area and its Vegetation. Journ. Ecol, IV, 174.

Jennings, 0. E., 1909. A botanical survey of Presque Isle, Pennsylvania. Annals of the Carnegie Museum, $\nabla$.

Jensen, Hj., 1905. Vegetationsbilder aus Mittel- u. Ost-Java. Karsten u. Schenck, Vegetationsbilder, III, 3.

Jeros c h, Marie, 1903. Geschichte und Herkunft der schweizerischen Alpenflora. Leipzig.

Jeswiet, Jak., 1913. Die Entwickelung der Flora der holländischen Dünen. Diss. Zürich.

Johow, F., 1884 a. Über die Beziehungen einiger Eigenschaften der Laubblätter zu den Standortsverhältnissen. Pringsh. Jahrb. wiss. B̨ot., XV.

- 1884 b. Die Mangrovensümpfe. Kosmos.

- 1885. Die chlorophyllfreien Humusbewohner Westindiens, biologisch-morphologisch dargestellt. Pringsh. Jahrb. wiss. Bot., XVI.

- 1889. Die chlorophyllfreien Humuspflanzen nach ihren biologischen und anatomischentwicklungsgeschichtlichen Verhältniesen. Ebendort XX.

- 1896. Estudios sobre la flora de las Islas de Juan Fernandez. Santiago.

Jonsson, H., 1895. Optegnelser fra Vaar- og Vinterexkursioner i Øst-Island. Bot. Tidsskr., Kjöbenhavn. XIX.

- 1905. Vegetationen i Syd-Island. Ebendort XXVII.

- 1911. Nogle Bemärkninger om Rhodocorton islandicum. Biologiske Arbejder tilegnede Eug. Warming. Köbenhavn.

- 1912. The marine algal vegetation of Iceland. Botany of Iceland, I. Copenhagen and London.

- 1914. Strandengen i Sydvest-Island. Mindeskrift for Japetus Steenstrup. Köbenhavn. Johansson, K., 1897. Hufvuddragen af Gotlands växttopografi och växtgeografi. K. Sv. Vet. Akad. Handl., XXIX.

- 1899. Studier öfver hapaxantiska vïxter: Ebendort Bih. XXV.

Johnson, N. M., 1912. Ecological terminology as applied to marine Algre. Scottish Bot. Review, I. (Ref. Journ. Ecol., I, 55.) 
Jönsson, B., 1878-9. Bidrag till kännedomen om bladets anatomiska byggnad hos

Proteaceerna. Lunds Univ. Årsskr., XV.

- 1902. Zur Kenntnis des anatomischen Baues der Wüstenpflanzen. Ebendort XXXVIII.

- 1903. Assimilationsversuche bei verschiedenen Meertiefen. Nyt Mag. f. Naturw., XLI.

Jouan, H., 1865. Recherches sur l'origine et la provenance de certains végétaux phanérogames observés dans les îsles du Grand-Océan. Mem. Soc. Sci. Nat, Cherbourg, XI.

Journal of Ecology Cambridge. Zahlreiche Artikel und umfassende Referate.

Junghuhn, 1852-4. Java. Dentsche Ausgabe bei Hasskarl, 2 Bde., Leipzig.

Jungner, J. R., 1891. Anpassungen an das Klima in den Gegenden der regenreichen Kamerungebirge. Bot. Centralbl., XLVII.

- 1894 a. Klima und Blatt in der regio alpina. Flora, LXXIX.

- 1894 b. Studien über die Einwirkang des Klimas hauptsächlich der Niederschläge auf die Gestalt der Früchte. Bot. Centralbl., LIX.

Kästner, M., 1911. Beiträge zur ökologie einiger Waldpflanzen. Frankenberg i.S. I, II.

- 1913. LichtgenuB-Studien an einigen Waldpflanzen. Frankenberg i. S.

Karsten, G., 1891. Uber die Mangrovevegetation im Malayischen Archipel. Bib. Bot., XII.

- 1894. Morphologische und biologische Untersuchungen über einige Epiphytenformen der Molukken. Ann. Jard. Bot. Buitenzorg, XII.

- Das Phytoplankton des Antarktischen Meeres nach dem Material der Deutschen Tiefsee-Expedition, 1898-9. Wiss. Ergeb. Deutsch. Tiefsee-Exped., II.

- 1903 a. Vegetationsbilder aus dem Malayischen Archipel. Karsten u. Schenck. Vegetationsbilder, I, 2.

- 1903 b. Mexikanischer Wald der Tropen und Subtropen. Ebendort I, 4.

- 1903 c. Monokotylenbäume. Ebendort I, 6.

- 1904. Die Mangrovevegetation. Ebendort II, 2.

- 1905-6. Das Phytoplankton des Atlantischen Oceans. Ebendort.

- 1907. Das indische Phytoplankton. Ebendort.

- und Schenck, H., $1903 \mathrm{ff}$. Vegetationsbilder. Jena.

- und Stahl, E., 1903. Mexikanische Cacteen-, Agaven- u. Bromeliaceen-Vegetation. Ebendort I, 8.

Kearney, T. H., 1900. The plant-covering of Oeracoke Island. Contrib. U. S. Nat. Herb., V.

- 1901. Report on a botanical survey of the Dismal Swamp region. Ebendort V.

- 1904. Are plants of sea beaches and dunes true halophytes? Bot. Gazette, XXXVII.

- 1913. The wilting coefficient for plant in alkali soils. Washington.

- and Cameron, F. C., 1902. Some mutual relations between alkali soils and vegetation. Rep. U. S. Dept. Agric., LXXI.

- und Shantz, H. L., 1911. The water economy of dry land crops; in Yearbook of Departm. of Agric.

-, Briggs, Shantz, Me Lane und Piemeisel, 1914. Indicator significance of vegetation in Toocle Valley, Utah. Journ. Agric. Res. Wash., I, No. 5.

Keilhack, K., 1915. Tropische nnd subtropische Torfmoore auf Ceylon und ihre Flora. Vorträge herausgegeben von der Deutsch. Bot. Gesellsch.

Keller, Boris A., 1911-12. Pflanzengeographische Untersuchungen im Kreise Saissan! des Semipalatinskgebietes. Vergl. Bot. Centralbl., CXXV, 39.

- 1914. In Berg und Tal des Altai, I. Kasan. 
Keller, C., 1887. Humusbildang and Bodenkultur unter dem Einfla $B$ tierischer Thätigkeit.

Keller, Rob., 1903. Vegetationsbilder ans dem Val Blenio. Mitteil. d. Naturw. Gresellsch. Winterthur.

- 1904. Vegetationksizzen ans den Grajischen Alpen. Ebendort.

Kerner von Marilaun, A., 1858. Ưber die Zsombek-Moore Ungarns. Abhandl. Zool.-Bot. Ges. Wien, 8.

- 1863. Das Pflanzenleben der Donaulånder. Innsprnck.

- 1869. Die Abhängigkeit der Pflanzengestalt von Klima und Bodeu. Ebend.

- 1886. Österreich-Ungarns Pflanzenwelt. Die österr.-ungar. Monarchie in Wort und Bild. 2. Band, I. Abt., Wien.

- 1887. Pflanzenleben. 2 Bde. Leipzig.

Kiblman, A. O., 1890 a. Pflanzenbiologische Studien aus Russisch-Lappland. Aot. Soc. Faun. Flor. Fenn., VI. Auszug in Flora, 26.

- 1890 b. Bericht einer naturwissenschaftlichen Reise nach Russisch-Lappland im Jahre 1889. Fennia, III.

Kinzel, W., 1915. Frost und Licht als beeinflussende Kräfte der Samenkeimung. Nat. Zeitschr. Forst- u. Landwirtsch, XIII, $433 \mathrm{ff}$.

Kirchner, 0., siehe Schröter und Kirchner.

- Loew and Schröter, 1904 ff. Lebensgeschichte der Blütenpflanzen Mitteleuropas. Stuttgart.

Kissling, P. B., 1895. Beiträge zur Kenntnis des Einflusses der chemischen Lichtintensität auf die Vegetation. Halle a. S.

Kittlitz, 1850-52. Vierundzwanzig Vegetationsansichten von Küstenländern und Inseln des stillen Ozeanes.

Kjellman, F. R., 1878. Über Algenregionen und Algenformationen im östlichen Skager Rack. Sv. Vet. Akad. Handl. Bihang, V.

- 1882. Om vätligheten pa Sibiriens Nordkust. Vega-Expeditionens vetenskapl. iakttagelser, $\mathrm{I}$.

- 1883. Norra Ishafvets Algflora. Ebendort, III.

- 1884. Ur polarväxternas lif. Nordenskiöld, Stadier och Forskningar. Stockholm.

- 1906. Om främmande alger ilanddrifna vid Sveriges vestkust. Arkiv f. Botanik, V. Stockholm.

Klebahn, H., 1895. Gasvakuolen, ein Bestandteil der Zellen` der wasserbliitebildenden Phycochromaceen. Flora, LXXX.

Klebs, G., 1911. Über die Rhythmik in der Entwicklung der Pflanzen. Sitzungsber. Heidelberg. Akad. Wiss. Abhandl., XXIII.

- 1912. Utber die periodisehen Erscheinungen tropischer Pflanzen. Biol. Centralbl, XXXII. Vgl. Journ. Ecology, I, 190.

- 1914. Über das Treiben der einheimischen Bäume, speziell der Buche. Abhandl. Heidelberger Akademie.

Klein, L., 1899. Die Physiognomie der mitteleuropäischen Waldbåume. Karlsruhe. - 1904. Charakterbilder mitteleuropäischer Waldbäume, I. Karsten u. Schenck, Vegetationsbilder, II, 5, 6, 7.

- 1913. Forstbotanik. Tübingen.

- 1914. Ästhetik der Baumgestalt. Festrede Techn. Hochschnle Karlsruhe, viele Tafeln.

Klinge, J., 1890. Über den Einfluß der mittleren Windrichtung auf das Verwachsen der Gewåsser. Englers Jahrb., XI.

Kluyver, A. J., 1913. Ist man berechtigt, die mit dem ultravioletten Lichte der Heraeuslampe erzielten photochemischen Ergebnisse auf die bei der Pflanze im 
Sonnenlichte vor sich gehenden Prozesse ohne weiteres zu übertragen? in Österr. Bot. Zeitschr., LXIII.

Knoblauch, E., 1896. Ökologische Anatomie der Holzpflanzen der südafrikanischen immergrïnen Buschregion. Habilitationsschr.

Knowles. Matilda C., 1913. The maritime and marine Lichens of Howth. Scient. Proceedings of the Roy. Dublin Soc. (N. S.), XIV, No. 6. Vgl. Journ. Ecology, II, 134.

Kny, L., 1878. Methoden zur Messung der Tiefen, bis zu welchen Lichtstrahlen in das Meerwasser eindringen. Bot. Zeitg., XXXVI.

- 1895. Utber die Aufnahme tropfbar flüssigen Wassers durch winterlich entlaubte Zweige von Holzgewächsen. Ber. Deutsch. bot. Ges, XIII.

- 1902. Über den Einfluß des Lichtes anf das Wachstum in Bodenwurzeln. Pringsh. Jahrb. wiss. Bot., XXXVIII, $421 \mathrm{ff.}$

- 1909. Der Turgor der Markstrahlzellen. Landwirtsch. Jahrb., XXXVIII, 375 ff. Kölsch, A. Heide und Moor. Stuttgart.

Köppen, V. Die Wärmezonen der Erde nach der Dauer der heißen, gemäBigten und kalten Zeit und nach der Wirkung der Wärme auf die organische Welt betrachtet. Meteorol. Zeitschr.

- 1900. Versuch einer Klassifikation der Klimate, vorzugsweise nach ihren Beziehungen zur Ozeanenwelt. Geograph. Zeitschr.

Körnicke, M. und Roth, F., 1907. Eifel und Venn. Karsten u. Schenck, Vegetationsbilder, $\nabla, 1,2$.

, foid, Ch. A., 1908. Exuviation, Autotomy and Regeneration in Ceratium. Univ. California publ. Zoology, IV.

Kohl, 1886. Die Transpiration der Pflanzen und ihre Einwirkung auf die Ausbildng pflanalicher Gewebe.

Kolkwitz, R., 1899. Beiträge zur Kenntnis der Erdbakterien in Centralbl. f. Bakteriol., Paras. u. Infektionskrankh., 2. Abt., V.

- 1905. Die Beurteilung der Talsperrenwässer vom biologischen Standpunkt. Journ. f. Gasbel. u. Wasservers. München. Ausführlicher in:

- Zur Biologie der Talsperren. Mitt. a. d. Kgl. Prüfungsanst. f. Wasservers. (jetzt Kgl. Landesanstalt f. Wasserhygiene) 1911, Heft 15. Vergl, ebenda auch 1913, Heft 17.

- 1910. Die Farbe der Seen und Meere. Deutsche Vierteljahrsschrift für öffentliche Gesundheitspflege, XLII. Vergl. auch Pflanzenphysiologie, 1914.

- u. a., 1911. Wasser und Abwasser. Handb. d. Hygiene von Rubner, v. Gruber u. Ficker, Bd. II, Abt. 2. Leipzig.

- 1912 a. Plankton und Seston. Ber. Deutsch. Bot. Ges., XXX. Vgl. Journ. Ecology, I, 77.

- 1912 b. Quantitative Studien über das Plankton des Rheinstroms von seinen Quellen bis zur Mündung I. Mitt. Prüfungsanst. Wasserversorg. usw. Berlin, XVI. Vergl. auch Ber. d. Deutsch. Bot. Ges., XXX. 1912.

- 1914. Pflanzenphysiologie. Jena.

- u. Marsson, 1902. Grundsätze für die biologische Beurteilung des Wassers. Mitt. a. d. Kgl. Prüfungsanst. f. Wasservers., Heft I. Berlin.

- - 1908. Ökologie der pflanzlichen Saprobien. Ber. Deutsch. Bot. Ges., XXVI.

Koorders, S. H., 1895. Beobachtungen über spontane Neubewaldung auf Java. Forstl. Naturw. Zeitschr., IV.

- 1907. Ein von der Holländisch-Indischen Sumatra-Expedition entdecktes TropenMoor. Vgl. Potonié in Naturw. Wochenschr., XLII.

Korshinsky, S., 1891. Utber die Entstehung und das Schicksal der Eichenwälder im mittleren RuBland. Englers Jahrb, XIII. 
Kostytscheff, 1890. Der Zusammenhang zwischen den Bodenarten und einigen Pflanzenformationen. Scripta Bot. Hort. Univ. Petropolitanae, III.

Krasan, F., 1882. Die Erdwärme als pflanzengeographischer Faktor. Englers Jahrb., II.

- 1883. Die Bergheide der südöstlichen Kalkalpen. Ebendort, IV.

- 1884. Über die geothermischen Verhältnisse des Bodens und deren Einfluß auf die geographische Verbreitung der Pflanzen. Verh. Zool.-Bot. Ges. Wien, XXXIII.

Krassnov, A., 1886. Geobotanical Researches in the Kalmuk Steppe. (In Russian.)

Bull. Russ. Geogr. Soc., XXII. Vgl. Herder in Englers Jahrb., X (1889),

Literaturbericht.

- 1888. Bemerkungen über die Vegetation des Altai. Englers Jahrb., IX.

- 1894. Steppes de la Russie méridionale. Ann. de Géographie 1894.

Kraus, G., 1905. Anemometrisches von Krainberg bei Grmbach. Verh. Phys.-Med.

Ges. Würzburg. N. F., XXXVII.

- 1906 a. Über den Nanismus unserer Wellenkalkpflanzen. Ebendort, XXXVIII.

- 1906 b. Die Sesleria-Halde. Ebendort.

- 1910. Aus der Pflanzenwelt Unterfrankens, XI. 1. Die Fels- und Geröll-Lehne.

2. Wellenkalkwälder. Verhandl. Phys.-Med. Ges. Würzburg, N. F., XI.

- 1911. Boden und Klima auf kleinstem Raum. Versuch einer exakten Behandlung des Standortes anf dem Wellenkalk. Jena.

Krause, E. H. L., 1891. Die Einteilung der Pflanzen nach ihrer Dauer. Ber. Deutsch. Bot. Ges., IX.

1892 a. Die Heide. Englers Jahrb., XIV.

- 1892 b. Beitrag zur Geschichte der Wiesenflora in Norddeutschland. Ebendort, XV.

- Die natürliche Pflanzendecke Norddentschlands. Globus, LXI.

- Die Existenzbedingungen der nordwestdeutschen Heidefelder. Ebendort, LXX.

Kretzer, E., 1912. Beziehungen zwischen dem täglichen Gang der Temperatur an der Bodenoberfläche und den obersten Luftschichten. Diss. Berlin.

Krüger, P., 1883. Die oberirdischen Vegetationsorgane der Orchideen in ihren Beziehungen za Klima und Standort. Flora, LXVI.

Kruuse, Chr., 1911. Siehe N. Hartz.

- 1912. Rejser og Botan. Undersögelser i Öst-Grönland, 1898-1902, samt Angmagsalik-Egnens Vegetation. (With English Summary.) Meddelelser om Grönland, IC.

Kuckuck, P., 1897. Utber marine Vegetationsbilder. Ber. Deutsch. Bot. Ges., XV.

- 1900. Uber Algenkulturen im freien Meere. Wissensch. Meeresunters., IV.

- 1905. Strandwanderer. München.

- 1908. Nordseelotse. Hamburg.

- 1910. Uber die Eingewöhnung von Pflanzen wärmerer Zonen auf Helgoland. Bot. Zeitg., 68.

- 1912. Über das Vorkommen der Feigen anf Helgoland. Heimat. Kiel.

K upffer, K. R., 1913. Uber eine schematische Darstellung von Vegetationsformationen. Korrespond.-Blatt Naturforscher-Vereins Riga, LVI. Ref. im Bot. Centralbl., CXXV, 516.

Kurz, Alb., 1912. Die Lochseen und ihre Umgebung (Altwässer des Rheins bei Rheineck). Promotionsarbeit. Arbeiten aus dem Botan. Museum d. Eidgenöss. technischen Hochschule.

Kurz, F., 189:3. Dos viages botínicos al Rio Salado superior. Boletin Acad nac. de Cordoba.

Kurz, S., 1875. Preliminary report on the forests and other vegetation of Pegu. Calcutta. 
Kusnezow, N. J., 1898. Übersicht der in den Jahren 1891-4 über RuBland erschienenen phyto-geographischen Arbeiten. Englers Jahrb., XXVI.

- 1901. Die Vegetation und die Gewässer des europäischen RuBlands. Ebendort, XXVIII.

Kylin, H., och Samuelsson, G., 1916. Nagra kritiska synpunkter p๕̊ beståndsanalyser. Skogsvårdsförn. Tidskr. Stockholm.

Lagerheim, G. de, 1892. Die Schneeflora des Pichincha. Ber. Deutsch. Bot. Ges., X. Lakowitz. Die Vegetation der Ostsee im Allgemeinen und die Algen der Danziger Bucht im Speziellen. Schrift. Nat. Gesellsch. Danzig. N. F., VII.

Lamarck, 1809. Philosophie zoologique. Paris.

Lamson-Scribner, F., 1892. Mt. Kataadn and its Flora. Botan. Gazette, XVII. Lange, Axel, 1909. Witterungseinflüsse 1908-9 im Botanischen Garten in Kopenhagen. Mitt. Deutsch. Dendr. Ges, XVIII, $127 \mathrm{ff}$.

Laurent, Em., Marchal, Em. u. Carpiaux, Em. Recherches expérimentelles sur l'assimilation. Bruxelles.

Lauterbach, 1889. Untersuchungen über Bau und Entwicklung der Secretbehälter bei den Cacteen. Bot. Centralbl., XXXVII.

Lauterborn, Rob., 1910. Die Vegetation des Oberrheins. Verh. Nat.-Med. Ver. Heidelberg, N. F, X, $449 \mathrm{ff}$.

- 1916. Die sapropelische Lebewelt des Faulschlammes natïrlicher Gewässer. Verh. Nat.-Med.Ver. Heidelberg, N. F., XIII.

Lazniewski, W. v., 1896. Beiträge zur Biologie der Alpenpflanzen. Flora, LXXXII.

Lechmere, A. Eckley, 1915. Eine epiphyllische Ulothrix. Nat. Zeitschr. f. Forstu. Landwirtsch., XIII, $30 \mathrm{ff} .2$ Taf.

Leick, E., 1914. Beiträge zum Wärmephänomen der Araceenblütenstände. Mitt. nat. Ver. Neuvorpommern, XLV.

- 1916 a. Über Wärmeproduktion und Temperaturzustand lebender Pflanzen. Biol. Centralbl.. XXXVI, $241 \mathrm{ff}$.

- 1916 b. Die Stickstoffnahrung der Meeresalgen. Naturw. Wochenschr., N. F., XV. Leiningen, W. Graf zu, 1906. Beschreibung von Mooren in der Umgegend von Schongan. Naturw. Zeitschr, Land- u. Forstw., IV.

- 1907. Die Waldvegetation präalpiner bayrischer Moore. Habilitationsschrift München.

- 1908-9. Utber Humusablagerungen in den Kalkalpen in Naturw. Zschr. Land-u. Forstw., VI, VII.

- 1911. Bleichsand und Ortstein in Abh. Naturh. Ges. Nürnberg, XIX, 1.

- 1912. Über Humusablagerungen im Gebiete der Zentralalpen. Naturw. Zschr. Land- u. Forstw., X.

Leist, K., 1889. Einfluß des alpinen Standortes auf die Ausbildung der Laubblätter. Bern.

Leiviskä, J., 1908. Die Vegetation an der Küste des Bottnisehen Meerbusens. Fennia, XXVII.

Lenz, Oskar, 1910. Zur Lateritfrage.

Lesage, P., 1890. Recherches expérimentales sur les modifications des feuilles cbez les plantes maritimes. Rev. Gén. de Bot., II.

- 1904. Sur les rapports des palissades dans les feuilles avec la transpiration. Comptes Rendus, Paris, CXVIII.

Lewis, F. J., 1904. Geographical distribution of Vegetation on the Basins of the Rivers Eden, Tees, Wear and Tyne. Pt. I, II. Journ. Roy. Geogr. Soc., XXIII. 
Lewis, F. J., 1905. Plant remains in the Scottish peat mosses. Pt. I. The Scottish Southern Uplands. Trans. Roy. Soc. Edin., XLI.

- 1912. On induced variations in the osmotic pressure and sodium chlorid. New Phytol., XI.

- and Moss, C. E., 1911. The Upland Moors of the Pennin Chain, in Tansleys Types of Brit. Vegetation, S. 266.

Lidforss, B., 1903. Uber den Geotropismus einiger Frühjahrspflanzen. Pringsh. Jahrb., XXXVIII.

- 1906. Die wintergrüne Flora. Lunds Univ. Årsskr., N. F., Afd. 2, II.

- 1908. Weitere Beiträge zur Kenntnis der Psykroklinie. Lunds Univ. Årsskr., N. F., IV, 2.

- 1909. Uber den biologischen Effekt des Anthokyans.

Lindar, G., 1895. Flechtenstudien I. Dresden.

Lindman, C. A. M., 1883. Om drivfed och andra af hafsströmmar uppkastade naturföremål vid Norges kuster. Göteborg.

- 1899. Zur Morphologie und Biologie einiger Blätter und belaubter Sprosse. Sv.

Vet.-Akad. Handl. Bihang, XXV.

- 1900. Vegetationen i Rio grande do Sul, Sydbrasilien. Stockholm.

- 1913. Some cases of plants suppressed by other plants. New Phytol, XII.

- 1914. Några bidrag till frågan: Buske eller Träd. K. Vetenskaps Akad. Årßbok, XII.

Livingston, B. E., 1901. The distribution of the plant societies of Kent County, Mich. Ann. Rep. Mich. St. Bd. Geol. Surv.

- 1903. The distribution of the upland plant societies of Kent County, Mich. Botan. Gazette, XXXV.

- 1904. Physiological properties of bog water. Ebendort, XXXIX.

- 1905. The relation of soils to natural vegetation in Roscommon and Crawford Counties, Michigan. Ebendort.

- 1906. The relation of desert plants to soil moisture and to evaporation. Carnegie Inst. Washington, L.

- 1907. Evaporation and plant development. Plant World, X, $269 \mathrm{ff}$.

- 1910 \&. A rain-correcting atmometer for eeological instrumentation. Plant World, XIII, $79 \mathrm{ff}$.

- 1910 b. Operation of the porous cupatmometer. Plant World, XIII, 111.

- 1910 c. Relation of soil moisture to desert Vegetation. Botan. Gazette, L.

- 1912. A schematic representation of the water relations of plants, a pedagogical suggestion. The plant World, XV, 244.

- 1913. Temperatur coefficients in plant geography and climatology. Bot. Gazette, LVI. Vergl. Journ. Ecol., II, 179.

- and Jensen, G. H., 1904. An experiment of the relation of soil physics to plant growth. Botan. Gazette, XXXVIII.

- siehe Trelesse, 1916.

Ljungquist, J. E., 1914. Mästermyr. Dissertation. Karlstad. Siehe Bot. Centralbl., CXXVI, 602.

Ljungström, E., 1883. Bladets byggnad inom familjen Ericineae. Lunds Univ. Årsskr., XIX.

Lloyd, F. E., 1908. The Physiology of Stomata. Carnegie institution of Washington. Publicat. No. 82.

Loeske, L., 1900. Die Moosvereine im Gebiete der Flora von Berlin. Abhand. Bot. Ver. Prov. Brandenburg, XLII.

Loew, E., 1893. Anfänge epiphytischer Lebensweise bei GefaBpflanzen Norddeutschlands. Verhandl. Bot. Ver. Prov. Brandenburg.

Warming-Graebner. 3. Auflage 
Lohmann, H., 1902. Die Coccolithophoridae. Archiv f. Protistenkunde, I.

- 1908. Untersuchungen zur Feststellung deś vollständigen Gehaltes des Meeres an Plankton. - Wiss. Meeresuntersuchungen, herausgegeb. v. d. Komm. z. wiss. Untersuchungen d. dentschen Meere. Abt. Kiel, X.

- 1911. Über das Nannoplankton und die Zentrifugierung kleinster Wasserproben proben zur Gewinnung desselben in lebendem Zustande. Int. Revue d. gesamt. Hydrobiol. u. Hydrographie, IV.

- 1912 a. Probleme der modernen Planktonforschung. Verhandl. deutsch. zool. Ges.

- 1012 b. Untersuchungen über das Pflanzen- und Tierleben der Hochsee. Veröffentl. des Inst. f. Meeresk. Berlin, N. F., geogr.-naturwiss. Reihe Heft 1.

- 1912. Beiträge zur Charakterisierung des Tier- und Pflanzenlebens in den von der „Deutschland" während ihrer Fahrt nach Buenos Aires durchfahrenen Gebieten des Atlantischen Ozeans. Int. Rev. d. gesamt. Hydrobiol. und Hydrogr., IV, V.

- 1913. Die Probleme der modernen Planktonforschung. Leipzig. Journ. Eeology, II, 123.

Lothelier, A., 1890. Influence de l'état hygrométrique de l'air sur la production des piquants. Bull. Soc. Bot. France, XXXVII. (Siehe auch Rev. Gen. Bot. XXIV, 1912.)

- 1891. Influence de l'éclairement sur la production des piquants des plantes. Comptes Rendus, Paris, CXII.

- 1893. Recherches sur les plantes à piquants. Rev. Gén. de Bot., V.

Lovén, Hedvig, 1891. Några rön om Algernas anding. Bihang Sv.V.Akad. Handl., XVII.

Lozeron, H., 1902. La répartition verticale du Plankton dans le lac de Zurich de décembre 1900 à décembre 1901. Vieteljahrsschr. d. Naturforsch. Ges. Zürich, XIVII.

Labbock, J., 1899. On Buds and Stipules. Lond.

Lund, P. W., 1835. Bemorkninger over Vegetationen paa de indre Höpletter af Brasilien. K. Danske Vidensk. Selsk. Skrifter, VI.

Lundager, A., 1912. Notes concerning the Vegetation of Germania Land, NorthEast Grönland. Meddelelser om Grönland, XLIII.

Lundström, A., 1888. Am färglösa olje plastider och olje dropparnes biologiska betydelse, in Botan. Notiser; dentsch vgl. Bot. Centralbl., XXXV.

Lyng bye, H. C., 1879-80. Rariora Codana. Vid. Meddel. Naturh. For. Kjöbenhavn.

Lynge, B., 1912. Vegetationsbilleder fra Sørlandets Skjärgaard. Nyt Magaz. f. Naturv., L, $53 \mathrm{ff}$.

Mac.Cool, M. M., 1913. The aetion of certain nutrient and non nutrient bases on plant growth. Memoir No. 2. Cornell University Agric. experim. Stat. Ithaca, New York.

Macdougal, D. T., 1903. See F. V. Colville and D. T. M.

- 1904. Delta and Desert Vegetation. Contribut. from the New York Bot. Garden No. 53.

- 1906a. The vegetation of the Salton Basin. Year-Book Carnegie Inst. Washington, $\nabla$.

- 1906 b. The Delta of the Rio Colora, etc. Contrib. New York Bot. Gard., LXXVII.

- 1907. The Deeert Basins of the Colorado Delta. Bull. Amer. Geogr. Soc.

1912 a. North American Deserts. The Geograph. Journ. XXXIX, 105.

- 1912 b. The water Balance of Desert Plants. Ann. of Botany, XXVI.

- 1914. Action of Euvironic Factors upon Neobeckia. Flora.

McLean, R. C., 1915. The Ecology of the maritime Lichens at Blakeny point, Norfolk. Journ. Ecol., III, 129. 
Kacmillan, C., 1893. On the occurrence of sphagnum atolls in central Minnesota. Minnesota Botan. Stud., I.

- 1896. On the formation of circular Muskeag in Tamarack swamps. Torrey Bull. XXIII.

- 1897. Observations on the distribution of plants along shore at Lake of the Woods. Minnesota Botan. Stud., I.

- 1899. Minnesota plant life. St. Paul, Minn.

Magnin, A, 1886, 1893. Recherches sur la végétation des lacs du Jura. Rev. Gén. de Bot., V.

- 1893. La végétation des Monts Jura. Journ. de Bot.. VIII.

- 1894. Contributions à la connaissance de la flore des lass du Jura suisse. Bull. Soc. Bot. France, XLI. Bot. Centralbl., LXIII, 370 v. XLVII, 208.

- Les lac du Jura. Paris.

- 1904. Les éléments de la Flore calcifuge du Jura. Arch. Fl. Juras, V, S. 33 ff. Magnus, W. Studien an der endotrophen Mykorrhiza von Neottia nidus avis. Morphol. Jahrb., XXXIX.

M alme, G. O. A., 1901. Lafvarnes inbördes kamp för tillvaron. Bot. Notiser. Lund. Marktanner-Turneretscher, G., 1885. Zur Kenntnis des anatom. Baues unserer Loranthaceen. Sitzungsber. Wiener Akad., XCI.

Marsh, A. S., 1915. The maritime Ecology of Holme next the Sea, Norfolk. Journ. Ecology, III, 65-93.

Marloth, 1887 a. Zur Bedeutung der salzabscheidenden Drüsen der Tamariscineen. Ber. Deutsch. bot. Ges., V.

- 1887 b. Das südöstliche Kalahari-Gebiet. Engler, Bot. Jahrb., VIII, 1887.

- 1888. Die Narras. Acanthosicyos horrida Welw. var. Namaquana w. Ebendort, IX.

- 1908. Das Kapland, insonderheit das Reich der Kapflora, das Waldgebiet und die Karroo, pflanzengeographisch dargestellt. - Wissenschaftliche Ergebnisse der deutschen Tiefsee-Expedition 1898-99, herausgegeben von C. Chun. II. 3. Teil. Mit 28 Tafeln, 8 Karten und 192 Abbildungen im Text.

- 1909. Die Schutzmittel der Pflanzen gegen übermäBige Insolation. Ber. Deutsch. bot. Ges., XXVII.

- 1910. The Vegetation of the Sonthern Namib. South Afric. Journ. Science. Capetown.

Marsson, 1907, 1908. Biologische Untersuchungen des Rheines. Publikationend. Kais. Gesundheitsamtes, XXV, XXVIII.

Martin, K. und Reiche, K., 1899. Sümpfe und Nadis in Chile. Verh. Deutsch. Wiss. Ver. Santiago, IV.

Martin8, C., 1857. Expériences sar la persistance de la vitalité des graines flottant a la surface de la mer. Bull. Soc. Bot. France.

Martius, 1840-7. Tabulae physiognomicae. Flora Brasil., I-IX.

Martjanow, N., 1882. Materien zur Flora von Minussinsk (Russisch). Resumee bei Herder in Englers Jahrb., IX.

Martonne, Em. de. Traité de géographie physique. Biogéographie usw., Paris.

Masclef, 1888. Études sur la géographie botanique du Nord de la France. Jour. de Bot., II.

Massart, J., 1893. La biologie de la végétation sur le littoral belge. Bull. Soc Roy. Bot. Belgique, XXXII.

- 1898 a. Un voyage botanique au Sahara. Ebendort, XXXVII.

- 1898 b. Les végétaux épiphylles. Ann. Jard. Bot. Buitenzorg, Suppl., II.

- 1902. L'accomodation individuelle chez Polygonum amphibium. Ball. Jard. Bot.. de l'État ì Bruxelles, I. 
Massart, J., 1903. Comment les plantes vivaces maintiennent leur niveau souterrain. Comment les plantes vivaces sortent de terre au printemps. Bull. Jard. Bot. de l'Etat à Bruxelles, XIV, 113-142.

- 1904. Les conditions d'existence des arbres dans les dunes littorales. Bull. Soc. Cent. Forest. Belgique.

- 1906 a. Vgl. Wery, J.

- 1906 b. Les lianes, leurs moeurs, leur structure. Bull. Soc. Cent. Forest. Belgique.

- 1907-1908. Essai de géographie botanique des districts littoraux et alluviaux de

la Belgique Rec. Inst. Bot. Léo Errera, VII. Annexe 1908.

- 1910. Exquisse de la Géographic Botanique de la Belgique. Bruxelles. Annexe (Abb.). - Rec. Inst. Bot. Léo Errera, VII-

- 1911. Nos arbres. Bruxelles.

- 1912 a. Pour la protection de la nature en Belgique. Bruxelles.

- 1912 b. Le role de l'expérimentation en géographie botanique, in Rec. Inst. Bot. Errera, IX. Bruxelles.

- 1912 c. Sur le littoral Belge. La cinquantième herb. gén., Bull. Soc. Roy. Bot. Belg, LI.

Maximow, N. A., 1912. Chemische Schutzmittel der Pflanzen gegen Erfrieren. I, II, III, in Ber. Deutsch. Bot. Ges., XXX.

Mayer, Ad., 1903. Bleisand und Ortstein, in Die Landwirtsch. Vers. Stat.

Mayr, H., 1890. Die Waldungen von Nordamerika.

Mazé, P., 1899. Les microbes des nodosités des Légumineuses. Ann. Inst. Pasteur, XIII.

Mehner, H., 1906 a. Gartenkultur, Bodenheizung, Klimaverbesserung. GrunewaldBerlin.

- 1906 b. Uber Bodenheizang, in Gartenflora, LV, H. 16, 17.

Meigen, F., 1893. Skizze der Vegetationsverhältnisse von Santiago in Chile. Englers Jahrb., XVII.

- 1894. Biologische Beobachtungen aus der Flora Santiagos in Chile. Trockenschutzeinrichtungen. Ebendort, XVIII.

- 1900. Beobachtungen über Formationsfolge im Kaiserstuhl. Deutsch. Bot. Monatsehr., XVIII.

Melin, E., 1913. Sphagnologische Studien in Tiveden. Arkiv för Botanik, XIII, Stockholm.

Menezes, 1905, 1908, 1912. Contribution à l'étude de la phénologie de Funchal. Bull. de l'Académie de Géogr. Bot.

Menezes, C. A. de, Contribution à l'étude du Deserta grande. Bull. Soc. portug. Sc. nat. V, 2, 1912. Vgl. Botan. Centrlbl. CXXII, 18.

Mentz, A., 1900. Botaniske Iagttagelser fra Ringköbing Fjord. Rambusch, Ringköbing Fjord. Köbenhavn.

- 1902. Träk af Mosvegetationen på jydske Heder. Bot. Tidsskr., XXIV. Kübenhavn.

- 1906-09. Studier over danske Hedeplanters Okologie. I. Genista-Typen. Bot. Tidsskr., XXVII, $153 \mathrm{ff.} \mathrm{II.} \mathrm{Arctostaphylos-Typen.} \mathrm{XXIX,} 260 \mathrm{ff.} \mathrm{Köbenhavn.}$

- 1911. En Foraarsekskursion i Les Landes. Biolog. Arbejder tilegn. Eug. Warming. Köbenhavn.

- 1912. Studier aver Danske Mosers recente Vegetation. Botan. Tidsskr. XXXI.

Meschejeff, V., 1883. Uber die Anpassungen zum Aufrechterhalten der Pflanzen und die Wasserversorgung bei der Transpiration. Bull. Soc. Nat. Imp. Moscou. Meyer, Die Heiden Norddeutschlands, in Burckhardts Aus dem Walde.

Mez, C., 1904. Physiologische Bromeliaceen-Studien, I. Die Wasserökonomie der extrematmosphärischen Tillandsien. Pringsh. Jahrb., XI. 
Mez, C., 1905 a. Neue Untersuchungen über das Erfrieren eisbeständiger Pflanzen. Flora, XCIV.

- $1905 \mathrm{~b}$. Einige pflanzengeographische Folgerungen aus einer neuen Theorie tiber das Erfrieren eisbeständiger Pflanzen. Englers Jahrb., XXXIV, Beibl.

Miall, L. C., 1898. A Yorkshire Moor. Roy. Inst. Gt. Brit., Feb. 1898.

Middendorff, A. T. v., 1867. Reise in dem äußersten Norden und Osten Sibiriens. St. Petersburg.

Miehe, H., 1911. Javanische Studien. Abhandl. math.-phys. Kl., Kgl. Sächs. Gesellsch. Wissensch., IV.

Migula, W., 1909. Pflanzenbiologie. Leipzig.

Minden, von, 1899. Beiträge zur anatomischen und physiologischen Kenntnis Wasser secernierender Organe. Bibl. botan., XLVI.

Minssen, H., 1905. Über die Diffusion in sauren und neutralen Medien, insbesondere in Humusböden. Landwirtsch. Vers. Stat.

- 1907. Zur Frage der Diffusion in sauren und neutralen Medien, insbesondere in Humusböden. Österr. Moorzeitschr., VIII.

Mira, F., 1906. Las Dunas de Guardamar. Mem. Real. Soc. Españ. Hist. Nat, IV.

Mitscherlich, A., 1898. Beurteilung der physikalischen Eigenschaften des Ackerbodens mit Hilfe seiner Benetzungswärme. Diss. Kiel.

Miyake, K., 1902. On the starch of evergreen leaves and its relation to photosynthesis during the winter. Botan. Gazette, XXXIII.

Miyoshi, M., 1909. Utber das massenhafte Vorkommen von Eisenbakterien in den Thermen von Ikao. Bot. Centralbl., LXXI.

- 1909. Über die Herbst- und Trockenröte der Laubblätter. Journ. of the College of Seience, Tokyo, XXVII.

Möller, A., 1902. Uber die Wurzelbildung der ein- und zweijährigen Kiefer im märkischen Sandboden. Zeitschr. f. Forst- u. Jagdwesen $197 \mathrm{ff}$.

- 1903. Untersuchungen über ein- und zweijährige Kiefern im märkischen Sandboden. Ebendort, S. $257 \mathrm{ff}$.

- 1908. Die Nutzbarmachung des Rohhumus (Trockentorf). Kiefernkulturen, in Zeitschr. f. Forst- u. Jagdwesen.

Mohl, H. v., 1848. Über das Erfrieren der Zweigspitzen mancher Holzgewächse. Bot. Zeitg.

Mohr, C., 1901. Plant life of Alabama. Contrib. U. S. Nat. Herb, VI.

Molisch, H., 1897. Untersuchungen über das Erfrieren der Pflanzen. Jena.

- 1903. Die sogenannten Gasvakuolen und das Schweben gewisser Phycochromaceen. Botan. Zeitg., LXI.

- 1908. Die Purpurbakterien. Jena.

- 1910. Die Eisenbakterien. Jena.

Montagne, C., 1844. Mémoirs sur le phénomène de la coloration des eaux de la Mer Ronge. Ann. Sci. Nat., $3^{e}$ sér, II.

Moore, S. Le M., 1895. The phanerogamic botany of the Matto Grosso Expedition. 1891-2. Trans. Linn. Soc. Lond.. 2nd Ser., IV.

Morren, 1866. Récherches expérimentales pour déterminer l'influence de certains gaz industriels in Rep. Internat. Hortic. London.

Morton, Friedr., 1912. Die Vegetation der norddalmatinischen Insel Arbe. Osterr. Bot. Zeitg. LXII.

- 1914. Die biologischen Verhältnisse der Vegetation einiger Höhlen im Quarnerogebiete. Österr. Bot. Zeitg. LXIV.

Moseley, W. N., 1875. Notes on the Freshwater Algae obtained at the boiling springs of Furnas, St. Michaels, Azores, and their neigbourhood. Journ. Linn. Soc. Lond., XIV. 
Moss, C. E., 1906. Rep. Brit. Ass.

- 1907. Geographical distribution of vegetation in Somerset: Bath and Bridgewater

District. Special Publ. Roy. Geogr. Soc. 1907, 24 pg., 1 map.

- 1910. The fundamental Units of vegetation. Historical development of the concepts of the Plant-Association and the Plant-Formation. New Phytologist, IX.

- 1913. Vegetation of the Peak District. Cambridge University Press. - Referat von Tansley in Journ. Ecology, I, $275 \mathrm{ff}$.

- Rankin, W. M. and Tansley, A. G., 1910. The woodlands of England. New Phytologist, IX.

Müller, K., (Augustenberg), 1916 a. Untersuchungen an badischen Hochmooren. Nat. Zeitschr. Land- u. Forstwirtsch. XIV, $36 \mathrm{ff}$., $393 \mathrm{ff}$.

- 1916 b. Die geographische und ökologische Verbreitung der europäischen Lebermoose. Rabenhorst Krypt. fl. VI. 2.

- 1916 c. Zur geographischen Verbreitung der europäischen Lebermoose und ihre Verwertung für die allgemeine Pflanzengeographie. Ber. Deutsch. Bot. Ges., XXXIV, $212 \mathrm{ff}$.

- 1916 d. Über Anpassungen der Lebermoose an extremen LichtgenuB. Ebendort, $142 \mathrm{ff}$.

Müller, P. E., 1871. Om Ädelgranen i nogle franske Skove. Tidsskr. f. Pop. Fremst.

- 1886. Bemerkungen über die Mycorhiza der Buche. Bot. Centralbl., XXVI.

- 1887 a. Studier over Skovjord. Tidsskr. f. Skovbrug III og VII, 1878 og 1884.

(Studien über die natürlichen Humusformen und deren Einwirkung anf Vegetation und Boden. Berlin 1887.)

- 1887 b. Om Bjergfyrren, Pinus montana Mill.; Tidsskr. f. Skovbrug, VIII, IX, XI.

- 1894. Om Regnormenes Forbold til Rhizomplanterne. Oversigt Kongl. DanskeVid. Selsk.

- 1899. Zur Theorie der Ortsteinbildung. Englers Jahrb., XXVII. Beibl. 63.

- 1902. Sur deux formes de Mycorhizes chez le pin de Montagne. Oversigt Kongl. Danske Vid. Selsk. Forh.

- 1903. Om Bjergfyrrens Forhold til Rödgranen i de jydske Hedekulturer. Tidsskr. f. Skovbrug, Suppl. Hefte.

- og Weis, F., 1906. Studier over Skov- og Hedejord. I. Om Kalkens indvirkning på Bögemor. Det forstlige Forsögsvåsen, I.

-, Rördam, K., Helms, Johs, und Wöldike, E. H., 1910. Bidrag til Kundskab om Rödgranens Väkstforhold i midtjydsk Hedebund. Ebendort.

- a. Weis, Fr., 1913. Studier over Skov- og Hedejord. III. Forsög over forskellige Kalkmängders Indflydelse paa Bögens Udvikling paa Morbund. Ebendort.

- u. Helms, J., 1913. Forsøg med Anvendelse of Kunstgødning til Grankultur. I. Midtjydsk Hedebund. Det forstl. Fors. Danm. III.

M ünch, 1915. Beobachtungen über Exhitzung der Bodenoberfläche im Jahr 1914. Nat. Zeitschr. Forst- u. Landw, XIII, $249 \mathrm{ff}$.

Münst, Max 1911. Ortsteinstudien im oberen Murgtal. Mitt. Geol. Abt. Württ. Stat. Landesamts VIII.

Nadson, G., 1900. Die perforierenden (kalkbohrenden) Algen und ihre Bedeutung in der Natur. Script. Bot. Hort. Univ. Petropolitanae, XVIII.

Nägeli, C., 1865. Bedingungen des Vorkommens von Arten und Varietäten innerhalb ihres Verbreitungsbezirkes. Sitzungsber. Münchener Akad.

- 1872. Verdrängung der Pflanzenformen durch ihre Mitbewerber. Ebendort.

Nakano, H., 1911. The vegetation of lakes and swamps in Japan. I. Teganuma. Bot. Mag. Tokyo, XXV.

- 1913. Lehengeschichte der Stengel-Bulbillen einiger Angiospermen in Journ. of the College Univ. Tokyo, XXVIII. 
Nathansohn, A., 1906. Utber die Bedentang vertikaler Wasserbewegungen für die Produktion des Planktons im Meere. Abhand. Math.-Phys. K1. K. Sächs. Ges. Wiss., XXIX, 5.

- 1908. Über die allgemeinen Produktionsbedingungen im Meere. Int. Revue d. gesamt. Hydrobiol. u. Hydrgr., I.

- 1909. Vertikalzirkulation und Planktonmaxima im Mittelmeer. Int. Revue d. gesamt. Hydrobiol. u. Hydrogr., II.

- 1910. Stoffweohsel der Pflanzen. Leipzig.

- 1912. Allgemeine Botanik. Leipzig.

- siehe Gran, H. H.

Nathorst, A. G., 1883 a. Nya bidrag till kännedomen om Spetsbergeus kärlvăxter. Sv. Vet. Akad. Handl., XX.

- 1883 b. Studien über die Flora Spitzbergens. Englers Jahrb., IV.

Nazarow, P., 1886. Recherches zoologiques des steppes des Kirguiz. Bull. Soc. Imp. Nat. Moscou, LXII.

Neger, F. W., 1897 a. Die Vegetationsverhältnisse im nördlichen Araucanien. Englers Jahrb., XXIII.

- 1897 b. Zur Biologie der Holzgewåchse im südlichen Chile. Ebendort.

- 1901. Pflanzengeographisches aus den südlichen Anden und Patagonien. Ebendort. XXVIII.

- 1913. Biologie der Pflanzen. Stuttgart.

- 1915 a. Der Eichenmehltan. Naturw. Zeitschr. Forst- u. Landwirtsch., XIII, 1 ff.

- 1915 b. Die Standortsbedingungen der Omorikafichte. Ebendort, $76 \mathrm{ff}$.

- 1915 c. Die Stärkeökonomie der grünen Pflanze. Ebendort, 370 ff.

Negri, G., 1905. La vegetazione della collina di Torina. Accad. Real. Sci. Torino. 1904-5.

- 1914. Le unità ecologische fondamentali in fitogeografia. R. Academia d. Scienze di Torino.

Nehring. 1890. Uber Tundren und Steppen.

Nichols, G. E., 1913. The Vegetation of Connecticut, I. Virgin forests. Torreya, XIII, 89, 199. Journ. Ecology, I, 306. - Summer evaporation intensity as a determining factor in the distribution of regetation in Connecticut. Bot. Gazette, LVI.

- 1914. III. Plant Societies on Uplands.

Nienburg, W., 1911. Die Nutationsbewegungen junger Windepflanzen. Flora N. F. II. $117 \mathrm{ff}$.

Niklewski, Bron., 1905. Untersuchungen über die Umwandlang einiger stickstofffreier Reservestoffe während der Winterperiode der Bäume. Beitr. Bot. Centrabl. XIX. 1.

Niklewski, M., 1907. Ein Beitrag zur Kenntnis Wasserstoff oxydierender Mikroorganismen. Bull. Ac. sc. Cracovie. Cl. Math. Nat.

Nilsson, A., 1887. Studier öfver stammen såsom assimilationsorgan. Götheborg Vet. Sälsk. Handl., XXII.

- 1896 a. Om örtrika barrskogar. Tidsskr. f. Skogshushållning.

- 1896 b. Om Norrbottens växtlighet med särskild hänsyn till dess skogar. Ebendort.

- 1897. Om Norrbottens myrar och försumpade skogar. Ebendort.

- 1899. Några drag ur de svenska växtsamhällenas utvecklingshistoria. 2 pts. Bot. Not.

- 1900. Sydsvenska ljunghedar. Tidsskr. f. Skogshushållning.

- 1902 a. Svenska växtsamhällena. Tidsskr. f. Skogshushållning.

- 1902 b. Zur Ernährungsökonomie der Pflanzen. Naturforskaremötet, Helsingfors.

- 1903. Om bokens utbreding och förekomstätt i Sverige. Tidsskr. f. Skogshush. 
Nilsson, H., 1898. Einiges über die Biologie der schwedischen Sumpfpflanzen. Bot. Centralbl., LXXVI.

Noll, 1893. Vorlesungsnotiz z. Biologie d. Succulenten. Flora, LXXVII.

Norén, C. O., 1906. Om vegetationen på Vänerns Sandstränder. Bot. Stud. tillägnade Kjellman. Upsala.

Norton, J. B. S., 1897. A bibliography of literature relating to the effecte of wind on plants. Trans. Kansas Acad. Sei., XVI.

Novopokrovskij, J., 1914. Kurze Mitteilung über eine Reise nach den auf Sandböden gelegenen Forstrevieren der Donschen Kosaken. Englers Jahrb. L.

Örsted, A. S., 1844. De regionibus marinis. Elementa topographiae historiconaturalis freti Oresund. Havniae.

Öttli, M., 1903. Beiträge zur Őkologie der Felsflora. Dissert., Zürich. Schröter, Botanische Exkursionen, Heft III. Zürich, 1905.

Ohlendorff, O. Beiträge zur Anatomie und Biologie der Früchte und Samen einheimischer Wasser- und Sumpfpflanzen. Dissert. Osnabrück. Englers Jahrb. XLIV.

Olbricht, K.. 1909. Grundlinien einer Landeskunde der Lüneburger Heide. Stuttgart, m. Abb. u. 8 Taf.

Oliver, F. W., 1907 a. An experiment in co-operative field-work in botany. Trans. S. E. Union Sci. Soc.

- $1907 \mathrm{~b}$. The Bouche d'Erquy in 1907. New Phytologist, VI.

- and A. G. Tansley, 1904. Methods of surveying vegetation on a large scale. Ebendort. III.

- 19i1. Shingle beach communities. In Tansley Types of Britisch Vegetation, 354.

- 1912. The shingle beach as a plant habitat. New Phytologist. XX. (Journ. Ecol. I. 52).

- 1913. Some remarks on Blakeney Point, Norfolk. The Journ. of Ecology. I. 4.

- u. Salisbury, E. J., 1913 a. Vegetation and mobile Ground as illustrated by Suaeda fruticosa on Shingle. Journ. of Ecol. I, $249 \mathrm{ff}$.

- $1913 \mathrm{~b}$. Topography and vegetation of Blakeney Point, Norfolk. London. Ref. Journ. Ecol., III, 239.

01 sen, C., 1914. Vegetationen i Nordsjällandske Sphagnummoser. Botanisk Tidsskrift, XXXIV.

Olsson-Seffer, P., 1905. The principles of phytogeographic nomenclature. Botan. Gazette, XXXIX.

- 1909 a. Relation of soil and vegetation on sandy sea shores. Botan. Gazette, XLVII.

- 1909 b. Hydrodynamic factors influencing plant-life on sandy sea shores. New Phytologist, VIII.

Oltmanns, F., 1885. Die Wasserbewegung in der Moospflanze und ihr Einfluß anf die Wasserverteilung im Boden. Cohns Beiträge, IV.

- 1892. Über die Kultur- und Lebensbedingungen der Meeresalgen. Pringsh. Jahrb. XXIII.

Ostenfeld, C. H., 1899, 1905. Skildringer af vegetationen i Island, I-IV. Bot. Tidsșkr., XXII, XXVII.

- 1898-1900. Plankton, in Iagttagelser over Overfladevandet etc. Kjöbenhavn.

- 1903. Phytoplankton from the sea around the Färöes. Botany of the Färöes, II.

- und Wesenberg-Lund, 1906. A regular fortnightly exploration of the Plankton of the two Icelandic Lakes Thingvellirvatn and Myvatn. Proc. R. Soc. Edinburgh, $\mathrm{XXV}, 2$. 
Ostenfeld, C. H., 1908 a. Aalegrässets (Zostera marina) Väkstforhold og Cdbredelse i vore Farvande. Ber. Danske Biol. Stat., XVI. On the ecology and distribution of the Grasswrok (Zostera marina) in Dan. Waters.

- 1908 b. The Land-Vegetation of the Färöes. Botany of the Färöes, Copenhagen, III.

- $1908 \mathrm{c}$. The Phytoplankton of the Aral Sea and its affluents. Wiss. Ergebn. Aralsee Exp., VIII. St. Petersburg.

- 1909. On the immigration of Biddulphia sinensis Grev, and its occurrenee in the North Sea during 1903-1907. Meddelelser fra Kommiss. f. Havundersügelser, Serie Plankton I, No. 6.

- 1910-13. Halosphaera and Flagellata; Bacillariales; Schizophycese in Bull. trimestriel, Résumé des observations sur le plankton 1902-08.

- - 1913 a.- 16. De Danske Farvandes Plankton i Aarene 1898-1901. Resumé en français. Danske Vid. Selsk. Skr. 7 R. IX og 8 R. II, 2. - Ref.: Journ. Ecology, I, 178-188. Botan. Centralbl. CXVI, 619.

- $1913 \mathrm{~b}$. The Plankton Work of the International Investigation of the Sea in the years 1902-1912, in C. F. Drechsel, Mémoire sur les travaux du Conseil permanent international pour l'exploration de la mer pendant les années 1902-1912. Copenhague. (Autorreferat in Botan. Centralbl. CXXVI, 621).

- 1915 a. On the Geographical Distribution of the Sea grasses. Proc. Roy. Soc. Victoria, XXVII, N. S., II.

- 1915 b. Skildringer af Vest Australiens Natur särlig dets Planteväkst. Geogr. Tidsskr. Köbenhavn, XXIII.

Ostwald, W., 1903 a. Theoretische Planktonstudien. Zool. Jahrb., XVIII.

- $1903 \mathrm{~b}$. Über eine neue theoretische Betrachtungsweise in der Planktologie. Forschungsber. Biol. Stat. Plön, X.

Overton, E., 1899. Beobachtungen und Versuche über das Auftreten von rotem Zellsaft bei Pflanzen. Pringsh. Jahrb., XXXIII.

Psczoski, J., 1004. Vegetationsverhältnisse im Dnjeperschen Kreise des Taurischen Gouvernements. Ber. Neuruss. Naturforscherges., XXVI.

Pallis, Marietta, 1911. Aquatic and Fen formations, in: Tansley, Types of Brit.Veget., 214. Palmgren, A., 1912. Hippophaës rhamnoides auf Aland. Acta Soc. pro Fauna et Flora fennica, XXXVI. nr. 3.

- 1915. Studier öfver Löfängs områdena på Åland. Ebendort XLII, nr. 1.

Pammel, L. H., 1905. A compar. Study of veg.; Proc. Dav. Ac. X.

- 1909. Flora of Northern Jowa Peat Bogs. Report Jowa Geological Survey, XIX (1908).

- 1916. Observations in the Colorado Desert. The Plant World, XVIII.

Parish, S. B., 1903. A sketch of the Flora of Southern California. 2 pts. Botan. Gazette, XXXVI.

Paul, H., 1907. Was sind Zwischenmoore. Österr. Moorzeitschr.

- 1908. Die Kalkfeindlichkeit der Sphagna und ihre Ursache nebst einem Anhang über die Aufnahmefähigkeit der Torfmoose für Wasser. Mitteil. d. Kgl. Bayr. Moorkulturanstalt, II. Stuttgart.

Paulsen, Ove, 1904, 1908. Plankton investigations in the waters round Iceland and in the north Atlantic in 1903, 1904. Meddelelser fra Kommiss. f. Havundersögelser. Serie Plankton, I, 1, 8.

- 1908. Peridiniales. Nord. Plankton, hrsg. von Brandt u. Apstein, 18, Kiel.

- 1911. The plankton on a submarine bank. Biologiske Arbejder tilegnede Eug. Warming. Köbenhavn.

- 1912. Studies on the vegetation of the Transcaspian Lowlands. The second Danish Pamir Expedition. Copenhagen. 279 S., 79 Fig. (Auszug in Journ. Ecol., I, 133.) 
Paulsen, Ove, 1915a. Den internationale plantegeografiske Ekskursion i Amerika 1913. Geografisk Tidsskrift, XXIII. Köbenhavn.

- 1915 b. Saltonsöen i Syd-Kalifornien. Nordisk tidskrift. Stockholm.

Pavillard, J., 1905. Recherches sur la flore pélagique (Phytoplankton) de l'étang de Thau. Montpellier.

- 1912. Essai de nomenclature phytogéogr. Bull. soc. Languedoc. géogr.

- 1913. L'évolution périodique du plankton végétal dans la Méditerranée occidentale. Ass. Fr. Avanc. Sc., XLI. (Journ. Ecol. II.)

Pax, F., 1896. Uber die Gliederung der Karpathenflora. Jahresber. Schles. Ges. Vaterl. Kultur.

- 1898. Das Leben der Alpenpflanze. Zeitschr. Deutsch-Öst. Alpenv., XXIX, $61 \mathrm{ff.}$

- 1898-1908. Grundzüge der Pflanzenverbreitung in den Karpathen. Engler-Drude, Veget. d. Erde, II (I, 1898), X (II, 1908).

Pearson, H. H. W., 1899. Botany of the Ceylon Patanas. Journ. Linn. Soc. Lond, XXXIV.

Pechuel-Loesche, 1882. Die Loango-Expedition. Leipzig.

Peirce, G. J., 1898. On the mode of dissemination and on the reticulations of Rsmalina reticulata. Bot. Gazette, XXV.

Penzig, C., 1902. Die Fortschritte der Flora des Krakatau. Ann. Jard. Bot. Buitenzorg, 2. sér., III.

- and Chiabrera, 1903. Contributo alla conoscenza della piante acarofile. Malpighia, XVII.

Petersen, H. E., 1908. Anatomy of Aretic Ericineae. Meddel. om Grönland, XXXVI.

- 1908 b. Diapensiaceae. Ebendort.

Petersen, C. G. Johs., 1914. Om Bœndeltangens (Zostera marina) Aars Produktion i de danske Farvande. Mindeskrift for Japetus Steenstrup. Köbenhavn.

- 1915. Om Havbundens Dyresamfund i Skagerak osv. Beretning fra Den danske biologiske Station, XXIII.

Petersen, O. G., 1896. Stivelsen hos vore Träer under Vinterhvilen. Danske Vid. Selsk. Oversigt.

- 1898. Ettudes sur les phénomènes vitaux des racines des arbres. K. Danske Videnskab. Selsk. Oversigt. - 1903. Tidsskr. f. Skoovdsen, XV, A.

Pethybridge, C. G. and Praeger, R. L., 1905. The vegetation of the district lying south of Dublin. Proc. Roy. Irish Acad., XXV.

Petkoff, St., 1910. La flore aquatique et algologique de la Macédonie du S. O. Philippopoli.

Petry, 1889. Die Vegetationsverhältnisse des Kyffhäusergebirges.

Pfeiffer, Th. Beziehungen zwischen Bodenorganismen und Stickstoffverwertung der höheren Pflanzen. 80. Jahresb. Ges. vaterl. Kultur. Breslau, S. 4.

Pfitzer, E., 1870, 1872. Beiträge zur Kenntnis der Hautgewebe der Pflanzen. 3 Teile. Pringsh. Jahrb., VII, VIII.

Philippi, R. A., 1858. Botanische Reise nach der Provinz Valdivia. Bot. Zeitg., XVI. Picado, C., 1912. Comptes rend., CLIV, 607.

Pick, H., 1881. Beiträge zur Kenntnis des assimilierenden Gewebes armlaubiger Pflanzen. Diss., Bonn.

- 1882. Uber den EinfluB des Lichtes auf die Gestalt und Orientierung der Zellen des Assimilationgewebes. Bot. Centralbl., XI.

Pieters, A. J., 1894. The plants of Lake St. Clair. Bull. Michigan Fish Commiss, II, Lansing.

- 1901. The plants of western Lake Erie. U. S. Fish Commiss. Bull., 1901. Washington. 
Pilger, R., 1902. Beitrag zur Flora von Mattogrosso. Englers Jahrb., XXX.

- 1913. Pflanzengeographie. Das Leben der Pflanze, III. Stuttgart, Kosmos.

Piper, C. V., 1906. Flora of the State of Washington. Contrib. U. 8. Nat. Herb., XI. Podpêra, J., 1904. Studien über die thermophile Vegetation Bøhmens. Englers Jahrb., XXXIV.

- und Laus, H. Beiträge zur Phytographie Mahrens. I. Die Halophytenvegetation. Mitteil. d. Kommiss. z. naturwiss. Durchforsch. Mahrens.

Poeverlein, H., 1912. Der Siegeszug des Frühlingskreuzkrautes (Senecio vernalis) in der Pfalz. Pfälz. Heimatkunde, VIII, $127 \mathrm{ff}$., 165.

Pohle, R., 1903. Pflanzengeographische Studien über die Halbinsel Kanin und das angrenzende Waldgebiet. Aet. Hort. Petropolitani, XXI.

- 1907. Vegetationsbilder aus Nord-Rubland. Karsten u. Schenck, Vegetationsbilder, V, 3, 4, 5 .

Polak, Joh. Maria, 1897. Beitrag zur Kenntnis der Selbstansiedelung einer Wiesenflora. Sitzungsber. Deutsch. naturw.-med. Ver. Bôhmen, Lotos.

Pond, R. H., 1905. The biological relations of aquatic plants to the substratum. U. S. Fish Commiss. Rep., 1903.

Pool, R. J., 1913. A Study of the vegetation of the Sandhills of Nebraska. Minnes. Botan. stud., IV, 3, t. 26-40. Ref. Journ. Ecol., IV, 51.

Porsild, Morten P., 1902. Bidrag til en Skildring af Vegetationen paa Cen Disko. Meddel. om Grönland, XXV.

- 1912. Vascular plants of West-Greenland. Meddel. om Grönland, L.

Post, H. von, 1862. Studier öfver nutidens koprogena jordbildningar, gyttja, torf och mylla. Sv. Vet. Akad. Handl., IV. Ubersetzt von Ramann in Landwirtsch. Jahrb., XVII.

Potonié, H., 1906. Klassifikation und Terminologie der rezenten brennbaren Biolithe und ihrer Lagerstätten in Abh. Kgl. PreuB. Geolog. Landesanstalt N. F., XLIX.

- 1908. Die rezenten Kaustobiolithe und ihre Lagerstätten. Bd. I. Die Sapropelithe. Ebendort LV, 1.

- 1911. Bd. II. Die Humusbildungen, 1. Teil. Ebendort LV, 2.

Potonié, R., 1913. Uber die xerophilen Merkmale der Pflanzen fenchter Standorte. Naturw. Wochenschr. N. F., XII.

Pound, R. and Clements, F. E., 1898-1900. The Phyto-geography of Nebraska. I. General Survey, Lincoln, Nebr.

- 1898. The vegetation regions of the Prairie Province. Bot. Gazette, XXV.

Preuß, H., 1908. Die Vegetationsverhältnisse der Tucheler Heide. Jahrb. d. westpreub. Lehrervereins für Naturkunde, II-III.

- 1910 a. Die Vegetationsverhältnisse der westpreuBischen Ostseeküsse. 33. Bericht westpreub. Botan.-Zool. Ver. Danzig.

- 1910 b. Die Salzstellen des norddeutschen Flachlandes und ihre Bedeutung für die Entwicklung unserer Halophytenflora. Mitt. Geol. Inst. Königsb. No. IX.

Preu B, P., 1901. Expedition nach Central- und Südamerika. Berlin.

Price, R., 1911. The roots of some North African Desert-Grasses. New Phytologist, $\mathbf{X}$.

Priestley, J. H., 1911. The pelophilous formation of the left bank of the Severn estuary. Proc. Bristol Nat. Soc. 3. (Vergl. Journ. Ecol., I, 53.)

- 1913. The quadrat as a method for Field Excursion. Journ. Ecol., I.

Purpus, A. and C. A., 1907. Arizona. Karsten u. Schenck, Vegetationsbilder, IV, 7. Purpus, C. A., 1907. Mexikanische Hochgipfel. Ebendort V, 8.

Pütter, A., 1909. Die Ernährung der Wassertiere und der Stoffhaushalt der Gewässer. Jena. 
Rabanus, Ad., 1915. Beiträge zur Kenntnis der Periodizität und der geographischen

Verbreitung der Algen Badens. Ber. Nat. Ges. Freiburg i. B., XXI.

Raciborski, M., 1898. Biologische Mitteilungen aus Java. Flora, LXXXV.

Radde, 1899. Grundzüge der Pflanzenverbreitung in den Kankasusländern. Leipzig.

Ramann, E., 1886. Der Oststein und ähnliche Secundärbildungen in den Alluvial-

und Diluvialsanden. Jahrb. Preuß. Geol. Landesanst., 1885.

- 1890. Die Waldstren and ihre Bedeutung für Boden und Wald. Berlin.

- 1893. Forstliche Bodenkunde und Standortslehre. Berlin.

- 1895. Organogene Ablagerungen der Jetztzeit. N. Jahrb. Miner., Beil. X, 1894.

- 1905. Bodenkunde, 3. Aufl., 1911. Berlin.

- 1906. Einteilung und Benennung der Schlammablagerungen. Monatsber. Deutsch. Geol. Ges.

- 1911. Die zeitlich verschiedene Nahrangsaufnahme der Waldbäume. Zeitschr. Forst- u. Jagdw.

Rankin, W. M., 1911 a. The Lowland Moors, in Tansley Types of Brit. Vegetation, S. 246 .

- 1911 b. Salt marsh of the Hampshire Coast. Ebendort.

Rasch, W. Über den anatomischen Bau der Wurzelhaube einiger Glumifloren und seine Beziehungen zur Beschaffenheit des Bodens. Diss. Berlin.

Raunkiär, C., 1889 a. Vesterhavets Öst- og Sydkysts Vegetation. Borchs Kollegiums Festskr. Kjøbenhavn.

- $1889 \mathrm{~b}$. Notes on the vegetation of the North Frisian Islands and a contribution to an eventual flora of these islands. Bot. Tidsskr., XVII. Kjøbenhavn.

- 1895-9. De danske Blomsterplanters Naturhistorie, I. Kjøbenhavn.

- 1905. Types biologiques pour la géographie botanique. Oversigt Danske Vidensk. Selskab, 347-438.

- 1907 a. Planterigets Livsformer og deres Betydning for Geografien. Kjøbenhavn.

- 1907 b. Vegetationsbilleder fra Dansk Vestindien. Bot. Tidsskr., XXVIII.

- 1908. Statistik der Lebensformen als Grundlage für die biologische Pflanzengeographie. Beihefte z. Bot. Centralbl., XXVII.

- 1909 a. Livsformen hos Planter paa Ny Jord. D. V. S. Skrifter. 7. R., VIII.

- 1909 b. Formationsundersögelse og Formationsstatistik. Bot. Tidsskrift, XXX.

- 1911. Det arktiske og det antarktiste Chamäphytklima. Biologiske Arbejder tilegnede Eug. Warming.

- 1912. Measuring apparatus for Statistical Investigations of Plantformations. Bot. Tidsskr., XXXIII.

- 1913. Formationsstatistiske Undersögelser paa Skagens Odde. Bot.Tidsskr., XXXIII.

- 1914. Sur la végétation des alluvions méditerranéennes françaises. Mindeskrift for Japetus Steenstrup. Köbenhavn.

Ravn, F. Kölpin, 1894. Om flydeevnen hos fröene af vore vand- og sumpplanter. Bot. Tidsskr., XIX.

Rayner, M. C., Jones, W. N. and Tayleur, J. W., 1911. The Ecology of Calluns vulgaris of the Wiltshire and Berkshire Downs. New Phytologist, $\mathbf{X}$.

Rayner, M. C., 1913. The Ecology of Calluna vulgaris. New Phytologist, XII. (Vergl. Journ. Ecol., I, 59.)

Rechinger, K., 1908 a. Samoa. Karsten n. Schenck, Vegetationsbilder, VI, 1.

- 1908 b. Vegetationsbilder aus dem Neu-Guinea-Archipel. Ebendort VI, 2.

- 1910. Botanische und zoologische Ergebnisse einer wissenschaftlichen Forschungsreise nach den Samoainseln, dem Neu-Guinea-Archipel and den Salomonsinseln. Denkschriften der Wiener Akademie, LXXXV.

Redway, 1904. The treeless plains of the United States. Geogr. Journ., III. 
Reed, H. S., 1902. A survey of the Huron River Valley. Bot. Gazette, XXXIV.

- 1905. A brief history of ecological work in Botany. The Plant World, VIII.

Reiche, K., 1893. Über polster- und deckenförmig wachsende Pflanzen. Santiago.

- 1907. Grundzüge der Pflanzenverbreitung in Chile. Engler u. Drude, Die Vegetation der Erde, VIII.

Reid, C. Origin of the British Flora. London.

Rein, J., 1879. Der Fugi-no-yama und seine Besteigung. Petermanns Mitteil.

- 1881. Japan. Leipzig.

Reinhardt, J., 1850. Nogle Bemaerkninger om den Indflydelse de idelige Markbrande have udövet. Videnskab. Meddel. Naturh. Foren. Kjöbenhavn.

Reinke, J., 1889. Algenflora der westlichen Ostsee. Ber. Kommiss. wiss. Unters. Dentsch. Meere, VI.

- 1903 a. Die zar Ernährung der Meeresorganismen disponiblen Quellen an Stickstoff.

Ber. Deutsch. Bot. Ges., XXI.

- 1903 b. Die Entwicklungsgeschichte der Dünen der Westküste von Schleswig. Sitzungsber. Berliner Akad.

- 1903 c. Botanisch-geologische Streifzüge an den Küsten des Herzogtums Schleswig.

Wiss. Meeresunters., N. F., VIII. Kiel u. Leipzig.

- 1904. Zur Kenntnis der Lebensbedingungen von Azotobacter. Ber. Deutseh. Bot. Ges., XXII.

- 1909. Die ostfriesischen Inseln. Studien über Küstenbildung und Küstenzerstörung.

Wissensch. Meeresuntersuchungen, herausgeg. von der Kommiss. z. wissensch.

Untersuchung der deutschen Meere. N. F., X. Ergänzungsheft.

- 1911, 1912. Studien über die Dünen unserer Ostseeküste. II, III, IV. Wissenschaftliche Meeresuntersuchungen, XV, Abt. 2.

- 1915. Studien über die Dünen unserer Ostseekïste. Hinterpommern. 1. Abhandl.

Nr. 5 aus Wissenschaftl. Meeresuntersuchungen. Kiel. N. F, XVII.

Reiter, H., 1885. Die Consolidation der Physiognomik. Graz.

Resvoll, Thekla R., 1903. Den nye vegetation pas lerfaldet $i$ Værdalen. Nyt Mag. f. Naturvid., XLI.

- 1906. Pflanzenbiologische Beobachtungen aus dem Flugsandgebiet bei Röros im inneren Norwegen. Ebendort XLIV.

- Vækstlivet i Romsdals Amt. „Norges Land og Folk“.

- 1909 a. Vækstlivet i Nordre Trondhjems Amt. Ebendort.

- 1909 b. Uber die Winterknospen der norwegischen Gebirgsweiden. Nyt Mag.

f. Naturvid., XLVII.

- 1913. Vækstlivet i Kristians Amt. "Norges Land og Folk".

- 1913-14. Bundvegetationen i vore skoger. Tidsskrift for Skogbruk.

Resvoll-Holmsen, Hanna, 1909. Om Jordbunds-strukturer i Polarlandene og planternes Forbold til dem. Nyt Mag. f. Naturvid., XLVII. Kristiania.

- - 1912. Om Vegetationen ved Tessevaud i Lom. Vidensk. Selsk. Skrifter 1912. Kristiania.

- _ 1913. Exploration du Nord-Ouest du Spitsberg sous les Auspices de S. A.S. de Prince de Monaco. V. Observations botsniques. Monaco.

- _ 1914 a. Fra Skogene i det nordligste Norge. Tidsskrift for Skogsbruk, No. 6.

- 1914 b. Statistiske Vegetationsundersögelser fra Foldalsfjeldene. Vidensk. Selsk. Skrifter, Math. naturw. Kl., No. 7.

- 1914 c. Statistiske Vegetationsundersögelser fra Maalselvdalen i Tromsö Amt. Ebendort 1913, No. 13.

Ricome, H., 1903. Influence du chlorure de sodium sur la transpiration et l'absorption de l'eau chez les végétaux. Comptes Rendus, Paris. 
Rikli, M., 1899. Der Säckinger-See und seine Flora. Mitteil. Bot. Mus. Eidgenöss. Polytech. Zürich.

- 1903. Botanische Reisestudien auf einer Frühlingsfahrt durch Korsika. Zürich.

- 1907 a. Das Lägerngebiet. Mitteil. Bot. Mus. Eidgenöss. Polytech. Zürich, IX.

- $1907 \mathrm{~b}$. Botanische Reisestudien von der spanischen Mittelmeerküste. Vierteljahrschr. Naturhist. Ges. Zürich, LII.

- 1907 c. Kultur- und Naturbilder von der spanischen Riviera. Zürich.

- 1907 d. Zur Kenntnis der Pflanzenwelt des Kantons Tessin. Ber. Zürcherischen Bot. Ges., X.

- 1907 e. Spanien. Karsten u. Schenck, Vegetationsbilder, V, 6.

- 1909. Die Arve in der Schweiz. Neue Denkschr. d. Schweiz. Naturf. Ges., XLIV.

- 1910. Vegetationsbilder aus Dänisch-Westgrönland. 6 Tafeln in Karsten u. Scheneks Vegetationsbilder.

- 1911. Richtlinien der Pflanzengeographie. Abderhalden, Fortsch. d. naturwiss. Forschung, III.

- 1912. Lebensbedingungen und Vegetationsverhältnisse der Mittelmeerländer und der atlantischen Inseln. Jena.

- 1913. Beiträge zur Pflanzengeographie und Florengeschichte der Kaakasuslänủer und Hocharmenien. Verhandl. d. Schweiz. Naturforsch. Gosellsch. 96. Jahresversammlung. Franenfeld.

- 1915. Kreta und Sizilien. Karsten u. Sehenck, Vegetationsbilder, 13. R., H. 1-2. Taf. 1-12.

- und Schröter, C., 1912. Vom Mittelmeer zum Nordrand der Sahara. Vierteljahresschr. d. naturforsch. Gesellsch. Zürich, LVII.

- Sehröter, C. und Tansley, A. G., 1912. Vom Mittelmeer zum Sahara-Atlas. Karsten u. Schenck, Vegetationsbilder, $\mathbf{X}$.

Robbins, W. W., 1910. Climatology and vegetation in Colorado. Bot. Gazette, XLIX. Roberts, Edith A., 1914. The plant successions of the Holyoke Range. Bot. Gazette, LVIII.

Robinson, B. L., 1904. The problems of Oecology. Congress of Arts and Science, Universal Exposition, St. Louis, V.

Römer, Jul., 1910. Pflanzen auf der Wanderschaft. Kosmos.

Rohland, P., 1915. Die Kolloide der tonigen und Humusböden. Nat. Zeitschr. Forstu. Landw., XIII, $360 \mathrm{ff}$. (weiter Litteratur).

Rosen, F., 1909. Charakterpflanzen des abessinischen Hochlandes. Karsten u. Schenck, Vegetationsbilder. VII, 5.

Rosenberg, 0, 1897. Uber die Transpiration der Halophyten. Öfvers. K. Sv. Vet. Akad. Förh.

Rosenvinge, L. Kolderup, 1889-90. Vegetationen i en sydgrönlands Fjord. Geogr. Tidsskr., $\mathrm{X}$.

- 1896. Det sydligste Grönlands Vegetation. Meddel. om Grönland, XV.

- 1899. Om Algevegetationen ved Grönlands Kyster. Ebendort mit französ. Resümee. Meddel. om Grönland, XX.

- 1903. Sur les organes piliformes des Rhodomelacées. Overs. K. Danske Vid. Selsk.

- 1905. Sur les algues étrangères rejetées sur la côte occidentale da Jutland. Bot. Tidsskr., XXVII.

- 1911. Remarks on the hyaline unicellular hairs of the Florideae. Biolog. Arbejder tilegnede Eug. Warming.

Ross, H., 1887. Beiträge zar Kenntnis des Assimilationsgewebes und der Korkentwicklung armlaubiger Pflanzen. Diss, Freiburg. 
Rother, Gust., 1912. Uber die Bewegung des Kalkes, des Eisens, der Tonerde and der Phosphorsäure and die Bildung des Ton-Eisenorthsteines im Sandboden. Diss., Berlin.

Rothert, W. C., 1913. Beobachtungen an Lianen. Bulletin de l'Aoad. d. sciences de Cracovie. Série B.

Roux, C., 1900. Traité des rapports des plantes avec le sol. Montpellier.

Roux, M. le, 1907. Recherches biologiques sur le lac d'Annecy. Annales de biologie lacustre, II.

Royer, Ch., 1870. Loi de niveau chez les plantes. (Considérations sur les parties sousterraines des plantes). Bull. Soc. bot. Françe, XVII.

- 1881. Flore de la Côte d'Or. Paris.

Rudmose Brown, R. N., 1912. Botany of the Voyage of S. Y. "Scotia". 1. The Problems of Antarctic plant life, und 10 andere Aufsätze über antarktische Pflanzen. Edinbourgh and London.

Rübel, E., 1908. Untersuchungen über das photochemische Klima des Berninahospizes. Vierteljahrschr. Naturforsch. Ges. Zürich, LIII.

- 1912. Pflanzengeographische Monographie des Berninagebietes. Englers Bot. Jahrb., XLVII.

- 1913 a. Die Pflanzengesellsehaften des Berninagebietes. Englers Bot. Jahrb., XLIX (siehe Journ. Ecology, I, 139).

- 1913 b. Ökologische Pflanzengeographie, in Handwörterbuch der Naturwissenschaften, IV.

- 1914 a. Heath and Steppe, Macchia and Garigue. Journ. Ecology, II.

- 1914 b. The Forests of the Western Caucasus. Journ. Ecology, II.

- 1914 c. Die Kalmückensteppen bei Sarepta. Englers Jahrb., L.

- 1915 a. Die internationale pflanzengeographische Exkursion durch Nordamerika 1913. Actes de la Société Helvétique des sciences naturelles. 1915, II Partie.

- 1915 b. Ergänzungen zu Brockmann-Jerosch und Rübels „Einteilung der Pflanzengesellschaften". Ber. Deutsch. Bot. Ges., XXXIII, s. $1 \mathrm{ff}$.

- 1915 c. Die auf der ${ }_{n}$ Internationalen pflanzengeographischen Exkursion ${ }^{4}$ durch Nordamerika 1913 kennen gelernten Pflanzengesellschaften. Englers Jahrbücher, LIII.

- 1916. Vorschläge zur geobotanischen Kartographie. Beitr. geobot. Landesaufn., I.

-, Schröter and Brockmann-Jerosch. Programme für geobotanische Arbeiten. Ebendort II.

Rydberg, P. A., 1895. Flora of the sand-hills of Nebraska. Contrib. U. S. Nat. Herb., III.

Sachs, C., 1888. Aus den Llanos. Leipzig.

Sachs, J. von., 1859. Uber den Einfluß der chemischen und der physikalischen Beschaffenheit des Bodens auf die Transpiration. Landw. Vers.-Stat., I.

- 1865. Handbuch der Experimental-Physiologie der Pflanzen.

Sachsse, R., 1888. Lehrbuch der Agrikulturchemie.

Saint-Lager, 1895. L'appétence chimique des plantes et la concurrence vitale. Lyon. Samuelsson, G., 1910 a. Scottish Peat Mosses. Bull. of the Geol. Inst. Uppsala, X.

- 1910 b. Regionförskjutningar inom Dalarne. Sv. Bot. Tidskr., IV. Stockkolm.

- 1916 a. Om den ekologiska växtgeographiens enheter. Sv. Bot. Tidskr., X.

- 1916 b. Studien über die Vegetation bei Finse im inneren Hardanger. Nyt Mag. Nat., LV (1917), t. I-VII.

- 1916 c. Uber den Rückgang der Haselgrenze ... Bull. Geol. Inst. Ups., XIII, 93 ff.

- 1916 d. Uber die Vegetation der Hochgebirgsgegenden von Dalarne. Upsala.

- siehe Kylin. 
Sarauw, G. F. L., 1893. Rodsymbiose og Mykorrhizer. Bot. Tidsskr., XVIII. Enthält eine ausführliche Bibliographie.

- 1898. Lyngheden, Oldtiden. Aarb. f. Nord. Oldkynd. og Hist. Köbenhavn.

- 1903-4. Sur les mycorrhizes des arbres forestiers et sur le sens de la symbiose des racines. Rév. Mycol.

Sauvageau, 1890. Observations sur la structure des feuilles des plantes aquatiques. Journ. de Bot., IV.

- Siehe auch viele Artikel über die Anatomie und Morphologie der Potamogetonaceae, Hydrocharideae und anderer Familien in demselben Journal, 1888, 1890, 1891, 1894.

Sauvageau, C., 1907 a. Le Sargassum bacciferum, la mer des Sargasses et l'Océanographie. C. R. Soc. Biol., LXII, $1082 \mathrm{ff}$.

- 1907 b. Le verdissement des huîtres par la diatomée bleue. Bull. Station biol. d'A reachon, $1 \mathrm{ff}$.

- 1908. Sur deux Fucus récoltés à Arcachon. Bull. Station biol. d'Arcachon.

Schacht, H., 1859. Madeira and Tenerife. Berlin.

Schade, F. A., 1912. Pflanzenökologische Studien an den Felswänden der sächsischen

Schweiz. Englers Bot. Jahrb., XLVIII, 119, 1 Tafel, 29 Fig. Ref. in Journ.

Ecology. I, 51.

Schantz, siehe Briggs.

Schenck, A., 1903. Südwest-Afrika. Karsten und Schenck, Vegetationsbilder, I, 5.

Schenck, H., 1884. Über Strukturänderungen submers vegetierender Landpflanzen.

Ber. Deutsch. Bot. Ges., II.

- 1886 a. Vergleichende Anatomie der submersen Gewächse. Biblioth. Bot., I.

- $1886 \mathrm{~b}$. Die Biologie der Wassergewächse. Bonn.

- 1889 a. Über das Aërenchym. Jahrb. f. wiss. Bot., XX.

- 1889 b. Über die Luftwurzeln von Avicennia tomentosa und Laguncularia racemosa.

Flora, LXXII.

- 1892, 1893 a. Beiträge zur Biologie und Anatomie der Lianen. Bot. Mitteil. \&.

d. Tropen, IV, V.

- $1893 \mathrm{~b}$. Utber die Bedeutung der Rheinvegetation für die Selbstreinigung des

Rheines. Centralbl. f. allgem. Gesundheitspfl.

- 1903 a. Vegetationsbilder aus Brasilien. Karsten und Schenck, Vegetationgbilder, I, 1.

- 1903 b. Tropische Nutzpflanzen. Ebendort, 1, 3.

- 1905 a. Mittelmeerbäume. Ebendort, III, 4.

- 1905 b. Vergleichende Darstellung der Pflanzengeographie der subantarktischen

Inseln. Wiss. Ergeb. Deutsch. Tiefsee-Exped., II.

- 1905 c. Über Flora und Vegetation von St. Paul und Neu-Amsterdam. Ebendort.

- 1908. Alpine Vegetation. Vegetationsbilder von Karsten und Schenck, VI, 5-6.

- und Karsten, G., 1903-8. Vegetationsbilder. Jena. Südbrasilien, Tropische Nutzpflanzen, Strandvegetation Brasiliens., Mittelmeerbäume.

Schiffner, V., 1914. Ein Kapitel aus der Biologie der Lebermoose. Festschr. Aschersons 70. Geburtst., $118 \mathrm{ff}$.

Schilling, A. J., 1894. Anatomisch-biologische Untersuchungen über die Schleimbildung der Wasserpflanzen. Flora, LXXVIII.

Schimper, A. F. W., 1884. Über Bau und Lebensweise der Epiphyten Westindiens. Bot. Centralbl., XVII.

- 1888a. Die Wechselbeziehnngen zwischen Pflanzen und Ameisen. Jena.

- 1888 b. Die epiphytische Vegetation Amerikas. Bot. Mitteil. a. d. Tropen, I.

- 1890. Uber Schutzmittel des Laubes gegen Transpiration vornehmlich in der Flora Javas. Monatsber. Berliner Akad., VII. 
Schimper, A. F. W., 1891. Die indo-malayische Strandflora. Bot. Mitteil. a.d. Tropen, III.

- 1893. Die Gebirgswälder Javas. Forstl.-Naturw. Zeitschr., II.

- 1898. Pflanzengeographie auf physiologischer Grundlage.

Schinz, H., 1893. Die Vegetation des deutschen Schutzgebiets in Südwest-Afrika. Koloniales Jahrb, VI.

Schirmer, H., 1893. Le Sahara. Paris.

Schlecbter, 1904. Die Vegetationsformationen von Neu-Caledonien. Englers Jahrb., XXXIII, Beibl. 73.

- 1900. Westafrikanische Kantschuckexpedition. Berlin.

Schmidt, Joh., 1899. Om ydre faktorers Indflydelse paa Lovbladets anatomiske Bygning hos en af vore Strandplanter. Bot. Tidsekr.. XXI. Kjöbenhavn.

- 1904. Bidrag til Kundskab om Skuddene hos den gamle Verdens Mangrovetroer. Ebendort, XXVI.

- 1906. Vegetationstypen von der Insel Koh Chang im Meerbusen von Siam. Karsten und Schenck, Vegetationsbilder. III, 7, 8.

1914. Ref. von E. J. Allen: Uber die Zucht der Plankton-Diatomee Thalassiosira gravida Cleve in künstlichem Seewasser. Fischerboten, VII, 1915.

Schomburgk, R., 1841. Reisen in Guiana am Orinoco.

Schorler, B., 1897. Gutachten über die Vegetation der Elbe und ihre Bedeutung für die Selbstreinigung derselben. Dresden.

- 1900. Das Plankton der Elbe bei Dresden. Zeitschr. f. Gew.-Kunde, I.

- 1914. Die Algenvegetation an den Felswänden des Elbsandsteingebirges. Abhandl.

d. Naturw. Ges. "Isis" in Dresden.

Schouw, J. F., 1822. Grundträk til en almindelig Plantegeografie. Kjöbenhavn. Deutsche Ausg. Berlin, 1823.

Schreiber, H., 1898. Wiesen der Randgebirge Böhmens. Staab.

Schrenk, H. v., 1898. On the mode of dissemination of Usnea barbata. Trans. Acad. Sei. St. Louis, III.

Schröder, 1872. Die Einwirkung der schwefligen Săure anf die Pflanzen, in Landw. Versuchsstationen.

Schröder, B., 1900. Vgl. Seligo.

- 1903. Utber den Schleim und seine biologische Bedeutung. Biol. Centralbl., XXIII.

Schröder, J. v., 1878. Forstchemische und Pflanzenphysiologische Untersuchungen. Dresden.

Schröter, C., 1895. Das St. Antöniental im Prätigan in seinen landwirtschaftlichen und pflanzengeographischen Verhältnissen. Landw. Jahrb. d. Schweiz, IX.

- 1897. Die Schwebeflora unserer Seen. Neujahrsbl. Naturf. Ges. Zürich, XCIX.

- 1902. Siehe Schröter u. Kirchner.

- 1004. Siehe auch Kirchner, Loew u. Schröter.

- 1904-8. Das Pflanzenleben der Alpen. Zürich.

- 1908. Eine Exkursion nach den Canarischen Inseln. Zürich.

- 1912. Einige Vergleiche zwischen Britischer und Schweizerischer Flora. New Phytolog., XI, $277 \mathrm{ff}$.

- 1913. Genetische Pflanzengeographie. Handwörterbuch der Naturwissenschaften, IV.

- 1914. Polsterpflanzen; vergl. Hauri.

- und Kirchner, O., 1896-1902. Die Vegetation des Bodensees. BodenseeForschungen, 9. Abschn., Lindau, 6. B., I, II.

- und Früh, J., 1904. Die Moore der Schweiz, Bern.

- und Rikli, M., 1904. Botanische Exkursionen in Bedretto-, Formazza- und Boвco-Tal. Botan. Exkurs. u. Pflanzengeogr. Stud. Zürich. 
Schröter, C., et Wilczeck, E., 1904. Notice sur la flore littorale de Locarno.

Boll. soc. Ticinese Sci. Nat., I.

Schube, T., 1885. Beiträge zur Kenntnis der Anatomie blattarmer Pflanzen. Breslau. Schübeler, F. C., 1886-8. Norges växtrige. Christiania.

Schütt, F., 1892. Analytische Planktonstudien. Kiel.

- 1893. Das Pflanzenleben der Hochsee. Kiel.

Schütte, 1893. Die Tucheler Heide. Abh. Landesk. Prov. Westpr., V, Danzig.

Schumann, K., 1889. Einige weitere Ameisenpflanzen. Verh. Bot. Ver. Brandenb., XXXI (1888), $113 \mathrm{ff}$.

- 1899 a. Gesamtbeschreibung der Kakteen. Monographia Cactacearum. Neudamm.

- 1899 b. Die geographische Verbreitung der Kakteen. Abh. kgl. preuB. Akad.

Wissensch.

Schwab, F., 1904. Uber das photochemische Klima von Kremsmünster. Denkschr. Wiener Akad., LXXIV.

Schwarz, A. Einige Beiträge zur Kenntnis der pflanzengeographischen Verhältnisse in Keuper um Nürnberg usw. Abh. naturh. Ges. Nürnberg, X.

- 1892. Flora von Nürnberg-Erlangen. I. Allgemeiner Teil. Nürnberg, 185 S. m. Karten.

Schweinfurth, G., 1874. Im Herzen von Afrika. Leipzig und London.

- 1910. Siehe Deuerling.

- und Diels, L. Vegetationstypen aus der Kolonie Eritrea. Karsten und Schenck, Vegetationsbilder, II, 8.

Schwendener, S., 1874. Das mechanische Prinzip.

- 1889. Die Spaltöffnungen der Gramineen und Cyperaceen. Sitzungsber. Berliner Akad.

Scott-Elliot, G. F., 1900. The formation of new land by various plants. Ann. Andersonian Nat. Soc., II.

- 1905. Acacias in various places. A study in ąsociations. Trans. Bot. Soc. Edinb., 23.

- 1906. The geographical functions of certain water-plents in Chile. Geogr. Journ.

Scribner. Siehe Lamson-Scribner.

Seckt, 1914. Die Puna von Atacama. Petermanns Mitteilungen.

Seiner, F., 1910. Trockensteppen der Kalahari. Karsten und Schenck, Vegetationgbilder, VIII, 1.

Seler, Ed., 1914. Zwei Frühlingsmonate in Yukatan. Festschr. Ascherson 70. Geburtsr., $371 \mathrm{ff}$.

Seligo, A. Untersuchungen in den Stuhmer Seen, mit 9 Tabellen und 10 Tafeln. Anhang: Schroeder, B., Das Pflanzenplankton PreuBischer Seen. Herausg. v. Westpr. Bot.-Zool. Ver. u. v. Westpr. Fisch.-Ver. Danzig.

Sendtner, 0., 1854. Die Vegetationsverhältnisse Südbayerns.

- 1860. Die Vegetationsverhältnisse des Bayerischen Waldes. München.

Senft, 1888. Der Erdboden.

Sernander, R., 1894. Studier öfver den gotländska vegetationens utvecklings historia. Diss., Upsala.

- 1896. Nagra ord med anledning of Gunnar Anderssons Svenska växtvärldens historia. Bot. Not.

- 1898. Studier öfver vegetationem i mellerste Skandinaviens fjälltrakter. I. Om tundra formationer i svenska fjelltrakter. Overs. K. Sv. Vet. Akad. Handl.

- 1899. II. Fjallväxter i barrskogsregionen. Ebendort, Bihang XXIV.

- 1900. Studier öfver de sydsvenska Barrskogarnes Utveklingshistoria. Ebendurt, Bihang XXV. 
Sernander, R., 1901. Den skandinaviska vegetationens spridningsbiologie. Zur Verbreitungsbiologie der skandinavischen Pflanzenwelt. Berlin u. Upsala.

- 1906. Entwurf einer Monographie der europäischen Myrmekochoren. K. Sv. Vet. Akad. Handl., XLI.

- 1909. De scanodaniska torfmossarnas stratigrafi. Geol. Fören. Förh., XXXI, $423 \mathrm{ff}$. Stockholm.

- 1912. Studier öfver Lafvarnes Biologi. I. Nitrofila Lafvar. Svensk Botan. Tidskrift, VI, $803 \mathrm{ff}$.

Setchell, W. A., 1912. Kelps of the United States and Alasks. Washington.

Shantz, H. Le R., 1905. A study of the vegetation of the Mesa Region east of Pike's Peak: The Bouteloua Formation. Botan. Gazette, XLII, 1906.

- 1907. A biological study of the lakes of the Pike's Peak Region. Trans. Amer. Micros. Soc., XXVII.

- 1911. Natural vegetation as an indicator of the capabilities of land for crop production in the great plains area 1911. U. S. Dept. Agric. Bur. Pl. Industry, Bull. No. 201.

- 1912. The wilting coefficient. Botan. Gazette. LIII.

Shelford, V. E., 1915. Principles and Problems of Ecology as illustrated by Animals. Journ. Eeol., III, 1.

Sherff, Earl E., 1912. The vegetation of Skokie Marsh, with special reference to subterranean organs and their interrelationships. Botan. Gazette, LIII. Auch: Plant World, XVI, 1913. Journ. Eoology, I, 195.

Shreve, Forrest, 1912. Cold air drainage. The Plant World XV.

- 1913. The direct effects of Rainfall on Hygrophilous vegetation. Journ. Eco$\log y$, II.

- 1914. A montane Rain-Forest. Carnegie Institution of Washington, No. 199. Ref. Journ. Ecol., III, 244.

Shnll, G. H., 1914. The longevity of submerged seeds. The Plant World, XVII.

Siegrist, R., 1913. Die Auenwälder der Aare. Aaran.

- 1914. Über die Gehölaformationen der Aareufer. Schweizerische Zeitschr. f. Forstwesen, LXV.

Sievers, Fr., 1909. Utber die Wasserversorgung der Flechten. 38. Jahresber. d. landw. Schule zu Helmstedt. Vergl. Zeitschr. f. Bot., II, 115.

Simmons, H. G., 1910. Floran och vegetationen i Kiruna. Land. Vergl. Englers Jahrb. XLVIII. Journ. Ecology, I, 64.

Skottsberg, C., 1904. On the zonal distribution of South Atlantic and Antarctic vegetation. Geogr. Journ.

- 1905. Some remarks upon the geographical distribution of vegetation in the colder southern hemisphere. Ymer. Stockholm.

- 1906. Vegetationsbilder aus Feuerland, von den Falklandsinseln und von Südgeorgien. Karsten und Schenck, Vegetationsbilder, IV, 2, 3.

- 1907 a. Om växtligheten å några tångbädder i nyländska skärgården i Finland. Svensk botan. Tidsskr., I.

- 1901 b. Blommar och insekter på Skabbholmen i Roslagen sommaren 1901. Svensk botan. Tidsskr., I.

- 1909 a. Pflanzenphysiognomische Beobachtungen auf dem F'euerlande.

- 1909 b. Studien über das Pflanzenleben der Falklandsinseln. Wissensch. Ergebnisse Schwed. Südpolar-Exped. von Dr. O. Nordenskjöld, IV.

- 1910. Botanische Ergebnisse der schwedischen Expedition nach Patagonien und dem Feuerlande. K. Svenska Vetensk. Akad. Handl., XLVI, No. 3. 
Skottsberg, C., 1912 a. The vegetation in South Georgia. Ebendort, IV, 12. Vergl. Journ. Ecology, I, 240.

- 1912 b. Die Vegetationsverhältnisse des Graham-Landes. Wissensch. Ergebnisse Schwed. Südpolar-Exped. 1901-03. Journ. Ecology, I, 248.

- 1913. A Botanical Survey of the Falklands Islands. K. Svenska Vetensk. Akad. Handl., L. Vergl. Journ. Ecology, II, 63.

- 1914. Studien über die Vegetation der Juan Fernandez-Inseln. Botanische Ergebnisse der Schwedischen Expedition nach Patagonien und dem Feuerlande 1907-1909, IV. K. Svenska Vetensk. Akad. Handl., LI, No. 9.

- 1915. Notes on the relations between the Floras of subantarctic America and New Zealand. The Plant World, XVIII, $129 \mathrm{ff}$.

Smith, F. G., 1901. On the distribution of red color in vegetative parts in the New England Flora. Botan. Gazette, XXXII.

Smith, R., 1898. Plant associations of the Tay basin. Proc. Perthshire Soc. Nat. Hist., II.

- 1899. On the study of plant associations. Nat. Sci., XIV. Edinburgh.

- 1900 a. Botanical Survey of Scotland. I. Edinburgh District; II. North Perthshire District. Scot. Geogr. Mag., XVI.

- $1900 \mathrm{~b}$. On the seed dispersal of Pinus sylvestris and Betula alba. Ann. Scott. Nat. Hist.

Smith, William G., 1902. The origin and development of heather moorland. Scott. Geogr. Mag., XVIII.

- 1903. Notes on the vegetation of ponds. The Naturalist.

- 1904-5. Botanical Survey of Scotland. III, IV, Forfar and Fife. Scott. Geogr. Mag., XX, XXI.

- 1911 a. Arctic alpine Vegetation, in Tansleys "Types of Brit. Vegetation".

- $1911 \mathrm{~b}$. The Heath formation. Ebendort.

- 1911 c. Grass Moor Association. Ebendort.

- 1912. Anthelia: an arctic alpin plant association. Scott. Bot. Review, I. Ref. Journ. Ecology, I, 62.

- 1913. Raunkiärs "Lifeforms" and statistical methods. Journ. Ecology, I, 16.

- 1914. Notes on Danish Vegetation. Journ. Ecol, II, 65-70.

- and Crampton, C. B., 1914. Grassland in Britain. Journ. Agricult. Science, VI. Journ. Ecology, II.

-, Moss, C. E. and Rankin. W. M., 1903. Geographical distribution of vegetation in Yorkshire. I. Leeds and Halifax District; II. Harrogate and Skipton District. Geog. Journ., XXI.

Snell, K., 1907. Untersuchungen über die Nahrungsaufnahme von Wasserpflanzen. Flora, XCII.

- 1912 a. Über das Vorkommen von keimfähigen Unkrantsamen im Boden. Landwirtsch. Jahrb.

- 1912 b. Der Transpirationsstrom der Wasserpflanzen. Ber. Deutsch. Bot. Ges. $\mathrm{XXX}, 361 \mathrm{f}$.

Snow, L. M., 1902. Some notes on the ecology of the Delaware coast. Botan. Gazette, XXXIV.

- 1913. Progressive and retrogressive changes in the plant associations of the Delaware coast. Botan. Gazette, LV. Vergl. Journ. Ecology, I, 77.

Sokolow, N. A., 1894. Die Dünen. Bildung, Entwicklung and innerer Bau. Berlin. Solms-Laubach, 1909. Cruziferenstudien I. Capsella Hegeri. Bot. Ztg.

- 1905. Die leitenden Gesichtspunkte einer allgemeinen Pflanzengeographie. Leipzig. 
Sorauer, P., 1886. Handbuch der Pflanzenkrankheiten. I. Die nicht parasitären

Krankheiten. 2. Aufl, Berlin.

- 1902. Uber die Prådisposition der Pflanzen für parasitare Krankheiten. Antritts vorl. Berlin.

- 1905. Frostwirkungen bei unseren Kulturpflanzen. Nachr. Klub d. Landw. Berlin.

- 1906 a. Experimentelle Studien über die mechanische Wirkung des Frostes bei

Obst- und Waldbäumen. Landw. Jahrb., XXXV, 469.

- 1906 b. Die mechanischen Wirkungen des Frostes. Ber. Deutech. Bot. Ges., XXIV, $43 \mathrm{ff}$.

- 1909. 8. Auflage des Handbachs I. Berlin.

- 1910. Wie unsere Wälder erkranken. Zeitschr. f. Pflanzenkrankh., XX, $176 \mathrm{ff}$.

Späth, H. L. Der Johannistrieb. Ein Beitrag zur Kenntnis der Periodizität and Jahrringbildung sommergrüner Holzgewächse. Berlin.

Spalding, V. M., 1904. Biological relations of certain desert shrubs. I. The creosote bush in its relation to water supply. Botan. Gazette, XXXVIII.

- 1909 a. Problems of local distribution in arid regions. Amer. Nat., XLIII, $472 \mathrm{ff}$.

- $1909 \mathrm{~b}$. Distribution and Movements of Desert Plants. Carnegie Institution, Washington, V.

- 1909 c. Present problems in plant ecology. Smithson. Rep. S. 453 ff.

Stäger, Rob., 1908. Beitrag zur schweizerischen Epiphytenflora. Naturf. Ges. Bern. Stahl, E., 1880 a. Utber den Einfluß von Richtung und Stärke der Beleuchtung anf einige Bewegungserscheinungen im Pflanzenreiche. Bot. Zeitg., XXXVIII.

- 1880 b. Über den EinfluB der Lichtintensität auf Struktur und Anordnung des Assimilationsparenchyms. Ebendort.

- 1881. Uber sogenannte KompaBpflanzen. Jena. Zeitschr. f. Naturw., XV.

- 1883. Über den Einfluß des sonnigen oder schattigen Standortes auf die Ausbildung der Laubblätter. Ebendort, XVI.

- 1888. Pflanzen und Schnecken, in Jenaische Zeitschr. f. Naturw., XXII.

- 1893. Regenfall und Blattgestalt. Ann. Jard. Bot. Buitenzorg, XI.

- 1894. Einige Versuche über Transpiration und Assimilation. Bot. Zeitg., LII.

- 1896. Uber bunte Laubblätter. Ein Beitrag zur Pflanzenbiologie. Ann. Jard. Bot. Buitenzorg, XIV.

- 1900. Der Sinn der Mycorhizenbildnng. Eine vergleichend-biologische Studie. Pringsh. Jahrb., XXXIV.

- 1904 a. Die Schutzmittel der Flechten gegen TierfraB. Häckel Festschr., Jena.

- 1904 b. Mexikanische Nadelhölzer. Mexikanische Xerophyten. Karsten und Schenck, Vegetationsbilder, II, 3, 4. Vergl. auch Karsten, G.

- 1909. Zur Biologie des Chlorophylls, Laubfarbe und Himmelslicht, Vergilbung und Etiolement. Jena.

Stange, B., 1892. Beziehungen zwischen Substratconcentration, Turgor und Wachstum bei einigen phanerogamen Pflanzen. Bot. Zeitg., I.

Stapf, 0, 1888. Der Landschaftscharakter der persischen Steppen und Wüsten. Österr.-ungar. Revue.

- 1894. On the flora of Mount Kinabaln in North Borneo. Trans. Soc. London, IX.

- 1904. Die Gliederung der Gräserflora von Südafrika. Festschr. Ascherson 70. Geburtst., $391 \mathrm{ff}$. mit Karte.

Starr, A. M., 1912. Comparative anatomy of dune plants. Botan. Gazette, LIV. Ref. in Journ. Eeology, I, 197.

Stebler, F. G., 1897. Die Streuwiesen der Schweiz. Landwirtsch. Jahrb. d. Schweiz

- 1899. Die Unkräuter der Alpweiden und Alpmatten. Ebendort. 
Stebler, F. G., und Schroeter, 1889, 1892. Beiträge zur Kenntnis der Matten und Weiden der Schweiz. Die Wiesentypen der Schweiz. Landwirtsch. Jahrb. d. Schweiz, VI.

- und Volkart, A., 1904. Der Einfluß der Beschattung auf den Rasen. Beiträge zur Kenntnis der Matten und Weiden der Schweiz, XV. Landwirtsch. Jahrb. d. Schweiz.

Steenstrup, Japetus, 1841. Geognostik-geologisk undersögelse at Skovmoserne Vidnesdam og Lillemose $i$ det nordlige Själland, ledsaget af sammenlignende Bemärkninger, hentede fra Danmarks Skov-, Kjär- og Lyngmoser i Almindelighed. Danske Vid. Selsk. Afhand., IX, 1842. Der Sonderabdruck erschien 1841.

Steenstrup, K. J. V., 1877-8. Overfladevandets Varmegrad, Saltmängde og Farve i Atlanterhavet. Vid. Meddel, Naturh. For. Kjöbenhavn.

- 1901. Om Bestemmelsen of Lysstyrken og Lysmängden. Meddel. Grönland, XXV.

Stéfansson, S., 1894; 1896. Fra Islands Växtrige, II, III. Vid. Meddel. Naturh. For. Kjöbenhavn.

Steiner, H., 1912. Das Plankton und die makrophytische Uferflora des Luganersees. Dissert. Zürich.

Stenström, K. O. E., 1895. Über das Vorkommen derselben Arten in verschiedenen Klimaten an verschiedenen Standorten mit besonderer Berücksichtigung der xerophil ausgebildeten Pflanzen. Flora, LXXX.

- 1905. Studier öfver expositionens inflytande på vegetationen. Red. af H. Hesselman. Ark. f. Bot., IV. Stockholm.

Steppuhn, 1895. Bot. Centralbl., LXXII.

Stöhr, 1879. Über das Vorkommen von Chlorophyll in der Epidermis der Phanerogamen-Laubblätter. Sitzungsber. Akad. Wien.

Stoppel, Rose, 1910. Uber den Einfluß des Lichtes auf das Öffnen und Schließen einiger Blüten. Zeitschr. f. Bot., II.

Stopes, M. C., 1907. The "xerophytic" character of the Gymnosperms. Is it an "oecological" adaptation? New Phytologist, VI.

Süchting, H., 1912. Kritische Betrachtungen über Humussäuren, Humus und Humusböden. Fühlings Landw. Ztg., LXI.

Süring, R., 1912. Temperatur-Anomalien im Sandboden. 28. Jahresber. Berl. Zweigver. Deutschen Meteor. Ges. f. 1911. Berlin.

Svedelius, N., 1901. Studier öfver Østersjöns Hafsalgflora. Dissert. Upsala.

- 1904. On the life-history of Enalus acoroides. Ann. Roy. Bot. Gard. Peradeniya, II.

- 1906. Ecological and systematic studies of the Ceylon species of Caulerpa. Ceylon Marine Biolog. Rep. No. 4.

Swellengrebel, N., 1905. Über niederländische Dunenpflanzen. Beihefte z. Bot. Centralbl., XVIII.

Sylvén, N., 1904. Studier öfver vegetationen i Torne Lappmarks björkregion. Ark. f. Bot., III. Stockholm.

Szabo, Z., 1907. Eine pflanzengeographische Skizze der Sudeten. Bull. Soc. Hong., XXXVII.

Tacke, Br., 1896. Die nordwestdeutschen Moore, ihre Nutzbarmachung und ihre volkswirtschaftliche Bedeutung. Verh. 11. Deutscher Geographentag, Bremen.

Tanfiljew, G., 1894. Die Waldgrenzen in SüdruBland. St. Petersburg.

- 1898. Pflanzengeographische Studien im Steppengebiete. St. Petersburg.

- 1902. Die Baraba und die Külundinsche Steppe im Bereiche des Altai-Bezirkes. St. Petersburg. 
Tanfiljew, G., 1905. Die südrussischen Steppen. Result. Sci. Congr. Internat. Bot. Vienne, 1905.

Tanner-Fullemann, 1907. Contribution à l'étude des lacs alpins. Le Schøonen. bodensee. Bull. Herb. Boissier, 2. sér., VII.

Tansley, A. G., 1904. The problems of ecology. New Phytologist, III.

- 1911. Types of British Vegetation. London, Cambridge.

- 1913 a. The international phytogeographical excursion in the British Isles (1911). Cambridge.

- 1913 b. A universal classification of plant-communities. Journ. Ecol., I.

- 1914. Presidential addres in The British Ecological Society. Jonrn. Ecol., II, $184-202$.

- and Fritsoh, F. E., 1905. Sketches of vegetation at home and abroad. I. The Flora of the Ceylon littoral. New Phytologist, IV.

Thellung, A., 1915. Pflanzenwanderungen unter dem Einfluß des Menschen. Engl. Bot. Jahrb., LIII, $37 \mathrm{ff}$.

Thode, 1890. Die Küstenvegetation von Britissh Kaffrarien. Englers Jahrb., XII.

- 1894. Die botanischen Höhenregionen Natals. Ebendort, XVIII.

Thornber, J., 1901. Studies in the vegetation of the state. I. The prairie grass formation in Region. Bot. Surv. of Nebraska, V, Lincoln, Nebr.

Thoroddsen, Th., 1914. An account of the physical geography of Iceland, with special reference to the Plant-Life. In the Botany of Iceland, I, Part 2. Copenhagen.

Thuret, G., 1873. Expériences sur des graines de diverses espèces plongées dans de l'eau de mer: Arch. Sci. Phys. Nat., XLVII.

Thurmann, J., 1849. Essai de phytostatique, appliqué à la chaine du Jura. Berne.

Tilden, J. E., 1898. Observations on some west American thermal algae. Botan. Gazette, XXV.

Tischler, G., 1905. Ubber die Beziehungen der Anthocyanbildung zur Winterhărte der Pflanzen. Beiheft Bot. Centralbl, XVIII.

Traaen, A. E., 1914. Untersuchungen über Bodenpilze aus Norwegen. Nyt Magazin for Naturvidenskaberne.

Trabut, 1888. Les zones botaniques de l'Algérie. Assoc. Française pour l'Avancem. d. Sci. Congrès d'Oran.

Transeau, E. N., 1903. On the geographic distribution and oecological relations of the bog plant societies of Northern North America. Botan. Gazette, XXXVI.

- 1905a, 1906. The bogs and bog flora of the Huron River Valley. Ebendort, $\mathrm{XL}, \mathrm{XLI}$.

- 1905 b. Forest centers of Eastern America. Amer. Nat., XXXIX.

- 1913. The vegetation of Cold Spring Harbor, Long Island. The Plant World, XVI, Ref. in Journ. Ecol. I, 236 ff.

Treitz, P., (a). Was ist Verwitterung. Budapest.

- (b). Die Bestimmung physiologisch wirkenden Kalkgehaltes in Weinböden, Budapest.

Trelease, Sam. F., u. Livingston, B. E., 1916. The daily March of transpiring power as indicated by the Porometer and by standardized hygrometric Paper. Journ. Ecol., IV, 1.

Treub, M., 1888. Notice sur la nouvelle flore de Krakatau. Ann. Jard. Bot. Buitenzorg, VII.

- 1908. La forêt vierge équatoriale comme association. Ann. Jard. Buitenzorg. 2. Ser., VII.

Tschlaplowitz, 1892. Humus und Humuserden. Oppeln. 
Tschirch, A., 1881. Ubber einige Beziehungen des anatomischen Baues der Assimilationsorgane auf Klima und Standort, mit spezieller Berücksichtigung des Spaltöffnungsapparates. Linnaea, XLIII.

- 1882. Beiträge zu der Anatomie und dem Einrollungsmechanismus einiger Grasblätter. Pringsh. Jahrb. wiss. Bot., XIII.

Tubeuf, C. v., 1901. Studien über die Schüttekrankheit der Kiefer. Arb. Biol. Abt. Land- u. Forstw. K. Gesundheitsamt, II, 1.

- 1903 a. Die Gipfeldürre der Fichten in Nat. Zeitschr. Land- u. Forstw.

- 1903 b. Über den anatomisch-pathologischen Befund bei gipfeldürren Nadelhölzern. Ebendort (vergl. auch weitere Arbeiten dort) u. a.

- 1905. Beobachtungen über elektrische Erscheinungen im Walde. Ebendort.

- 1906. Über sogenannte Blitzlöcher im Walde. Ebendort.

- 1907 ff. Über die Lebensweise der Misteln. Versch. Artikel vergl. Nat. Zeitschr. Land- u. Forstwirtsch., V ff.

- 1915. Kann der Efeu den Bäumen schädlich werden? Ebendort, XIII, 476 ff., 5 Abbild.

- 1916. Schilderungen und Bilder aus nordamerikanischen Wäldern. Ebendort, XIV, $513 \mathrm{ff}$.

Ulbrich, E., 1907. Über europäische Myrmekochoren in Verh. Bot. Ver. Brandenb., IL.

- 1912. Pflanzenwelt des Plagefenn. Conwentz Beitr. Naturdenkmalpfl., III. Abb. u. 's Taf.

- 1915. Die Vegetationsverhältnisse des Rinnengebietes bei Strausberg i. M. Verl. Bot. Ver. Prov. Brandenb., LVII.

Ule, E., 1900. Verschiedenes über den Einfluß der Tiere auf das Pflanzenleben. Ber. Deutsch. Bot. Ges., XVIII, S. $122 \mathrm{ff}$.

- 1901. Die Vegetation von Cabo Frio an der Küste von Brasilien. Ebendort XXVIII.

- 1903. Das Übergangsgebiet der Hylaea zu den Anden. Englers Jahrb., XXXIII.

- 1904. Epiphyten des Amazonengebietes. Karsten u. Schenck, Vegetationsbilder, II, 1.

- 1905. Blumengärten und Ameisen des Amazonengebietes. Ebendort III, 1.

- 1906 a. Ameisenpflanzen des Amazonasgebietes. Ebendort IV, 1.

- 1906 b. Ameisenpflanzen. Engl. Bot. Jahrb., XXXVII, 235 ff.

- 1908 a. Die Pflanzenformationen des Amazonasgebietes, II. Ebendort XL u. Beibl.93.

- 1908 b. Das Innere von Nordost-Brasilien. Karsten u. Schenck, Vegetationsbilder, VI, 3.

- 1915. Die Vegetation des Amazonasgebietes. Verh. Bot. Ver. Prov. Brandenb., LVII, 56 ff., 4 Abbild.

- Schriftenverz. vergl. Harms, Verh. B. V. Brandenb., LVII (1915), $174 \mathrm{ff}$.

Unger, F., 1836. Über den Einfluß des Bodens auf die Verteilung der Gewächse, nachgewiesen in der Vegetation des nordöstlichen Tirols. Wien.

Urban, J., 1909. Zur Hochgebirgsflora von Sto. Domingo, in Symb. Antill., VI. Fasc. II, S. $280 \mathrm{ff}$.

Usteri, A., 1905. Beiträge zur Kenntnis der Philippinen und ihrer Vegetation. Arb. Bot. Mus. Polytech. Zürich, XIV.

Vahl , M., 1904 a. Notes on the summer-fall of the leaf on the Canary Islands. Bot. Tidsskr., XXVI. Kjöbenhavn.

- 1904 b. Madeiras Vegetation. Dissert. Kjöbenhavn.

- 1905. Utber die Vegetation Madeiras. Englers Jahrb., XXXVI.

- 1911 a. Les types biologiqnes dans quelques formations végétales de la Scandinavie. Oversigt. Kgl. Danske Videnskabernes Selskab. 
Vahl, M., 1911 b. Zones et biochores géographiques. Danske Vidensk. Selsk. Oversigt.

- 1912. The vegetation of the Notö. Botanisk Tidsskrift, XXXII.

- 1913. The growth-forms of some vegetative formations of swedish Lapland. Dansk botanisk Arkiv, I, vergl. Journ. Ecol., I, $304 \mathrm{ff}$.

- 1914. Livsformerne i nogle svenske Moser. Mindeskrift for Japetus Steenstrup. Kjöbenhavn.

Vallot, J., 1831. Recherches physico-chimiques sur la terre végétale.

Vanhoeffen, 1897. Die Fauna und Flora Grönlands, in Drygalskis Grönlandsexpedition, II.

Vaupell, C., 1851. De nordsjällandske Skovmoser. Kjöbenhavn.

- 1857. Bögens Indvandring i de danske Skove. Kjöbenharn.

- 1858. Nizzas Vinterflora. Vid. Meddel. Naturh. Foren. Kjöbenhavn.

- 1863. De danske Skove. Kjöbenhavn, 1863.

Vesque, J., 1878. De l'influence de la température du sol sur l'absorption de l'eau par les racines. Ann. Sc. Nat, 6. sér., VI.

- 1882 \&. L'espèce végétale considérée au point de vue de l'anatomie comparée. Ebendort XIII.

- 1882 b. Essai d'une monographie anatomique et descriptive de la tribu des Capparées (Capparidées ligneuses). Ebendort.

- 1883-4. Sur les causes et sur les limites des variations de structure des végétanx. Ann. Agron., IX, X.

- 1886. Études microphysiologiques sur les réservoirs d'eau des plantes. Ebendort XII.

- 1889-92. Epharmosis sive materia ad instruendam anatomiam systematis naturalis.

I. Folia Capparearum, Tab. I-LXXVII. Vincennes.

II. Genitalia foliaque Garciniearum et Calophyllearum. Tab. CLXII. Vincennes.

III. Genitalia foliaque Clusiearum et Moronobearum. Tab. CXIII. Vincennes.

- et Viet, C., 1881. De l'influence du milieu sur la structure anatomique des végétaux. Ann. Sc. Nat., 6 sér., XII.

Vestal, A. G., 1914. Prairie Vegetation of a mountain-front area in Colorado. But. Gazette, LVIII Journ. Ecol., IV, 45-50.

Vestergren, T., 1902. Om den olikförmiga snöbetäckningens inflytande på vegetationen i Sarjekfjällen. Bot. Not.

Vierhapper, F. und Handel-Mazetti, H. von, 1905. Exkursion in die Ostalpen. 2. Internat. Bot. Kongr. Wien.

Vöchting, H., 1874. Beiträge zur Morphologie und Anatomie der Rhipsalideen. Pringsh. Jahrb., IX.

- 1878-84. Uber Organbildung im Pflanzenreich. 2 Bde., Bonn.

- 1888. Utber die Lichtstellung der Laubblätter. Bot. Zeitg., XLVI.

- 1891. Über die Abhängigkeit des Laubblattes von seiner Assimilationstätigkeit. Ebendort XLIX.

- 1893. Uber den Einflaß des Lichtes auf die Gestaltung und Anlage der Blüten. Pringsh. Jahrb., XXV.

- 1894. Uber die Bedeutung des Lichtes für die Gestaltung blattförmiger Cacteen. Ebendort XXVI.

- 1898. Uber den EinfluB niedriger Temperatur auf die SproBrichtung. Ber. Dentsch. Bot. Ges., XVI.

Vogler, P., 1901 a. Beobachtungen über die Bodenstetigkeit der Arten im Gebiet des Albulapasses. Ber. Schweiz. Bot. Ges., XI. 
Vogler, P., 1901 b. Utber die Verbreitungsmittel der schweizerischen Alpenpflanzen. Flora, LXXXIX.

Voigtländer, H., 1909. Unterkältung und Kältetod der Pflanzen. Beitr. z. Biologie d. Pflanzen, IX.

Volkens, G., 1884. Zur Kenntnis der Beziehungen zwischen Standort und anatomischem

Bau der Vegetationsorgane. Jahrb. K. Bot. Gart. Berlin, III.

- 1887. Die Flora der ägyptisch-arabischen Wüste.

- 1890. Über Pflanzen mit lackierten Blättern. Ber. Deutsch. Bot. Ges., VIII.

- 1897. Der Kilimandscharo. Berlin.

- 1902. Die Vegetation der Karolinen. Englers Bot. Jahrb., Bd. XXXI.

- 1903. Der Laubwechsel tropischer Bäume. Vortrag im Verein zur Beförderung des Gartenbaues zu Berlin. Gartenflora.

- 1912. Laubfall und Lauberneuerung in den Tropen. Berlin.

'Vries, H. de, 1901, 1903. Die Mutationstheorie, I, II.

Wagner, A., 1892. Zur Kenntnis des Blattbaues der Alpenpflanzen und dessen biologischer Bedeutung. Sitzungsber. Wiener Akad., CI.

Walker, N., 1905. Pond vegetation. Naturalist.

Wallace, A. R., 1880. Island life. London.

- 1891. Natural selection and tropical nature. Natural Science, V.

W angerin, W., 1912. Über den Reliktbegriff und die Konstanz der Standorte. Festschr.

Prenß. Bot. Ver. Königsberg.

- 1914. Die Entwickelungsgeschichte der pontischen Pflanzengemeinschaften. -

Die gegenwärtigen pontischen Pflanzengemeinschaften Deutschlands. - Beide in Aus der Heimat, Nr. 4.

- 1915 a. Vorläufige Beiträge zur kartographischen Darstellung der Vegetationsformationen im nordostdeutschen Flachland unter besonderer Berücksichtigung der Moore. Berichte d. Deutsch. Bot. Ges.

- 1915 b. Beiträge zur Kenntnis der Vegetationsverhältnisse einiger Moore. 38. Ber. Westpr. Bot.-Zool. Ver., $77 \mathrm{ff}$.

Warburg, 0., 1893. Vegetationsschilderungen aus Südostasien. Englers Jahrb., XVII.

- 1900. Einführung einer gleichmäBigen Nomenclatar in die Pflanzengeographie. Ebendort XXIX, Beibl. 66.

- 1903. Die Kunene-Sambesi-Expedition. Berlin.

Warming, Eug., 1869. En Udfugt til Brasiliens Bjärge. Tidsskr. f. Pop. Fremst.

af Naturv. Ubersetzt von Zeise in Die Natur, 1881, und von Fonsny in

La Belgique Horticole, 1883.

- 1875. Om nogle ved Danmarks Kyster levende Bakterier. Vid. Meddel. Naturh. Foren. Kjöbenhavn.

- 1881-1901. Familien Podostemaceae, I-VI. K. Danske Vid. Selsk. Skrift., 6. R., II, IV, VII, IX, XI; in Engler und Prantl, Natürl. Pflanzenfam., III, 2 a.

- 1883. Rhizophora Mangle L. Tropische Fragmente. II. Englers Jahrb., IV.

- 1884. Om Skudbygning, Overvintring og Foryngelse. Festskr. Naturh. Foren. Kjöbenhavn.

- 1887. Om Grönlands Vegetation. Meddel. om Grönland, XII.

- 1890. Fra Vesterhavskystens Marskegne. Vid. Meddel. Naturh. For. Kjöbenhavn.

- 1891. De psammofile Vegetationer i Danmark. Ebendort 1891.

- 1892. Lagoa Santa. Et Bidrag til den biologiske Plantegeografi. K. Danske Vid. Selsk. Skrift., 6. R., VI. 
W a rming, Eug., 1893 a. Sur la biologie et l'anatomie de la feuille des Velloziacées.

Danske Vid. Selsk. Oversigt (Bull. Acad. Sci.).

- $1893 \mathrm{~b}$. Om et Par af Myrer beboede Trïer. Vidensk. Meddelelser naturh. Forening, Kjöbenhavn.

- 1894. Exkursionen til Fanö og Blaavand i Juli 1898. Bot. Tidsskr., XIX.

- 1895. Plantesamfund. Grundträk af den ökologiske Plantegeografi. Kjöbenhavn.

Deutsche Cbersetzung 1896 bei E. Knoblanch; 2. Auflage 1902 bei P. Graebner.

- 1896. P. E. Müller, nicht E. Ramann, hat die Entstehung des Ortsteins entdeckt.

Englers Jahrb., XXI, Beibl. 53.

- 1897 a. Exkursionen til Skagen i Juli 1896. Bot. Tidsskr., XXI.

- 1897 b. Botaniske Exkursioner. 3 Skarridsö. Vid. Meddel. Naturh. For. Kjöbenhavn.

- 1897 c. Halofytstudier. K. Danske Vid. Selsk. Skrift., 6. R., VIII.

- 1899 a. Planters og Plantesamfunds Kampe om Pladsen. Skandinav. Naturforskermödes Forh., XV. Stockholm.

- $1899 \mathrm{~b}$. On the vegetation of tropical America. Bot. Gazette, XXVII.

- 1901. Om Lövbladformer. I. Lianer. II. Skovbundsplanter. Overs. K. Danske Vid. Selsk. Forh.

- 1902. Der Wind als pflanzengeographischer Faktor. Englers Jahrb., XXXI.

- 1903 a. Die Windfrage. Fortgesetzte Anmerkungen za Prof. Ad. Hansens Publikationen über den Wind. Ebendort XXXII.

- $1903 \mathrm{~b}$. The history of the flora of the Färöes. Botany of the Faroòes. Copenhagen.

- 1904. Den Danske Planteverdens Historie efter Istiden. Unversitetsprogram, Kjöbenhavn.

- 1906. Dansk Planteväkst. I. Strandvegetation. Kjöbenhavn.

- 1907-1909. Dansk Planteväkst. II. Klitterne. Kjöbenhavn.

- 1908 a. The structure and biology of Arctic plants. I. Ericineae. Meddel. om Grönland, XXXVI.

- 1908 b. Om Planterigets Livsformer. Festskr. udg. af Universitetet. Kjöbenhavn.

- 1909 a. Oecology of plants. Oxford.

- 1909 b. The structure and biology of Arctic Plants. IV. Saxifragaceae. Meddel. Grönland, XXXVI.

- 1914. Om Bornholms Panteväkst. Bot. Tidsskr. XXXIII.

- Johannsen, 1909. Lehrbuch der allgemeinen Botanik. Nach der vierten dänischen Ausgabe übersetat u. herausgeg. v. Meinecke. Berlin.

-, Wesenberg-Lund und andere, 1904. Sur les vads et les sables maritimes de la mer du Nord. K. Danske Vid. Selsk. Skrift., 7. R., II.

Warnstorf, C., 1911. Sphagnales-Sphagnaceae in Engler, Das Pflanzenreich.

Watson, J. R., 1912. Plant geography of North Central New Mexico. Bot. Gazette, LIV; vergl. Journ. Ecol., I, 155.

Weavor, J. E., 1914. Evaporation and plant succession in southeastern Washington. Plant World, XVII; vergl. Journ. Ecol., II.

Webber, H. J., 1897. The water hyacinth and its relation to navigation in Florida. Bull. U.S. Dept. Agric., XVIII.

Weber, C. A., 1892. Über die Zusammensetzang des natürlichen Graslandes in Westholstein, Dithmarschen und Eiderstedt. Schrift. Naturw. Ver. SchleswigHolstein, IX.

- 1894 a. Vegetation des Moores von Augstumal. Mitteil. Ver. Förd. Moorkult. im Deutsch. Reiche, XII.

- 1894 b. Veränderungen in der Vegetation der Hochmoore nsw. Ebendort XII.

- 1899. Utber die Moore. Jahresb. Männer v. Morgenstern, III, 3 ff. 
Weber, C. A., 1901. Uber die Erhaltung von Mooren und Heiden. Abh. N. Ver. Bremen, $\mathrm{XV}, 263 \mathrm{ff}$.

- 1902. UUber die Vegetation und Entstehung des Hochmoors von Augstumal im Memeldelta. Berlin.

- 1903. Über Torf, Humus und Moor. Abhandl. Naturw. Ver. Bremen, XVII.

- 1907. Aufbau und Vegetation der Moore Norddeutschlands. Englers Jahrb., XL, Beibl. 90.

- 1908. Die wichtigsten Humus- und Torfarten und ihre Beteiligung an dem Aufbau norddentscher Moore. Festschrift. Berlin 1908.

- 1909. Wiesen und Weiden in den Weichselmarschen. Arbeiten der deutschen Landwirtschafts-Gesellschaft. H. 165.

- 1913. Die Entwicklung der Wiesen und Weiden der Versuchswirtschaft der MoorVersuchsstation zu Bremen. Landwirtschaftliche Jahrbücher, XLIV.

Weber, Leonhard, 1893 in Nat. Verein f. Schleswig-Holstein, X, 11, 13.

Weberbauer, A., 1905. Anatomische und biologische Studien über die Vegetation der Hochanden Perus. Englers Jahrb., XXXVII.

- 1911. Die Pflanzenwelt der Peruanischen Anden. Engler-Drude, Vegetation der Erde, XII.

Weed, W. H., 1887-8. Formation of Travertine and Siliceous Sinter by the Vegetation of Hot Springs. Ann. Rep. U. S. Geol. Surv., IX.

Weiss, J. E., and Yapp, R. H., 1906. Sketches of vegetation at home and abroad. III. "The Karroo" in Angust. New Phytologist, V.

Wendel, Else, 1916. Beiträge zur physiologischen Anatomie der Wurzelknöllchen einiger Leguminosen. Diss. Berlin. Beitr. Allg. Bot., I.

Wery, J., 1906. Sur le littoral belge. Excursions scientifiques, par Jean Massart. Rev. Univ. Bruxelles, 1905-6.

Wesenberg-Lund, C., 1900. Von dem Abhängigkeitsverhältnis zwischen dem Bar der Planktonorganismen und dem spezifischen Gewicht des Süßwassers. Biol. Centralbl., XX.

- 1901. Studier over Sökalk, Bönnemalm og Sögytje. Meddel. Dansk Geol. Foren.

- 1905. A comparative study of the lakes of Scotland and Denmark, I. Proc. Roy. Soc. Edin., XXV.

- 1906-8. Plankton Investigations of the Danish Lakes. I, II. General Part with 46 tables. Copenhagen.

- 1910. Grundzüge der Biologie und Geographie des SüBwasserplanktons, nebst Bemerkungen über Hauptprobleme zukünftiger limnologischer Forschungen. Int. Revue d. ges. Hydrobiol. u. Hydrogr., III.

- 1911. Om nogle ejendommelige Temperaturforhold $i$ de baltiske Söers Littoralregion og deres Betydning. Biologiske Arbejder tilegnede Eug. Warming. Kjöbenhavn.

- 1912. Über einige eigentümliche Temperaturverhältnisse in der Littoralregion der baltischen Seen und deren Bedeutung, nebst einem Anhang über die geogra. phische Verbreitang der zwei Geschlechter von Stratiotes aloides. Internat. Revue d. ges. Hydrobiologie.

Wessely, J., 1873. Der europäische Flugsand und seine Kultur. Wien.

West, C., 1905. A comparative study of the dominant Phanerogamic and Bigher Cryptogamic Flora of aquatic habit, in three Lake areas of Scotland. II. Proc. Roy. Soc. Edin., XXV.

- 1911. The British Freshwater Phytoplankton. Tansley Types of Brit. Vegetatiou S. 196. 
West, W., and West, G. S., 1905. A further contribution to the freshwater plankton of the Scottish lochs. 'Trans. Roy. Soc. Edin., XLI.

- -1912 . On the periodicity of the phytoplankton of some British Lakes. Journ. Linn. Soc. Bot. XL. Vgl. Journ. Ecology I, 204.

Westermaler, M., 1884 Uber Bau and Funktion des pflanzlichen Hautgewebesystems. Pringsh. Jahrb. XIV.

Wettstein, R. v., 1893. Die geographische und systematische Anordnung der Pflanzenarten.

- 1895. Der Saison-Dimorphismus. Ber. D. Bot. Ges, XIII.

- 1897-8. Die Innovationsverhältnisse von Phaseolus coccineus L. (Ph. Multiflorus Willd.). Österr. Bot. Zeitschr., XLVII, XLVIII.

- 1900. Untersuchungen über den Saisondimorphismus bei den Pflanzen. K. K. Akad. Wien, LXX.

- 1902 a. Die Lianen. Vorträge Ver. Verbr. nat. Kenntn. Wien XLII. 11.

- 1902 b. Bemerkungen z. Abhandlung E. Heinrichers: Die grünen Halbschmarotzer. Pringsh. Jahrb., XXXVII.

- I905. Sokotra. Karsten und Schenck, Vegetationsbilder, III. 5.

Wheldon, J. A., and Wilson, Alb., 1907. The flora of West Lancashire. Liverpool.

Whitford, H. N., 1901. The genetic development of the forests of Northern Michigan. Botan. Gazette, XXXI.

- 1905. The forest of the Flathead Valley, Montana. Ebendort, XXXIX.

- 1906. The vegetation of the Lamao Forest Reserve. I, II. Philippine Jour. Sci., I.

- 1911. The Forest of the Philippines. Bull. 10. Dep. Int., Bur. Forestry I, II. Manila.

Whitney, M., 1897. The division of soils. U. S. Dept. Agric., Bur. Soils. Bull. X.

- and Cameron, F. K., 1904. Investigations in soil fertility. U. S. Dept. Agric. Bur. Soils, Bull. XXIII.

Wiesner, J., 1871. Untersuchungen über die herbstliche Entlaubang der Holagewächse. Sitzungsber. Wiener Akad., LXIV.

- 1876 a. Untersuchungen über den Einfluß des Lichtes und der strahlenden Wärme auf die Transpiration der Pflanze. Ebendort LXXIV.

- 1876 b. Die natürlichen Einrichtungen zum Schutze des Chlorophylls. Festschr. Zool.-Bot. Ges. Wien.

- 1887. Grundversuche üb. d. Einfluß der Luftbewegung auf die Transpiration der Pflanzen. Sitzungsber. Wiener Akad., XCVI.

- 1893 a. Ombrophile und ombrophobe Pflanzen. Ebendort CII.

- $1883 \mathrm{~b}$. Photometrische Untersuchungen auf pflanzen-physiologischem Gebiete. Ebendort CII.

- 1894 a. Pflanzenphysiologische Mitteilungen aus Buitenzorg. Ebendort CIII.

- 1894 b. Über den vorherrschend ombrophilen Charakter des Laubes der Tropengewächse. Ebendort CIII.

- 1894 c. Beobachtungen über die fixe Lichtlage der Blätter tropischer Gewächse. Ebendort CIII.

- 1995 a. Beiträge zur Kenntnis des tropischen Regens. Ebendort CIV.

- 1895 b. Untersuchungen über den Lichtgenuß der Pflanzen, mit Rücksicht auf die Vegetation von Wien, Kairo, und Buitenzorg (Java). Ebendort.

- 1897. Untersuchungen über die mechanische Wirkung des Regens auf die Pflanze, usw. Ann. Jard. Bot. Buitenzorg, XIV. 
Wiesner, J., 1898. Beiträge zur Kenntnis des photochemischen Klimas im arktischen Gebiete. Denksuhr. Wiener Akad., LXVII.

- 1899. Uber die Formen der Anpassung der Blätter an die Lichtstärke. Biol. Centralbl., XIX.

- 1900. Untersuchungen über den Lichtgenuß der Pflanzen im arktischen Gebiete. Sitzungsber. Wiener Akad., CIX.

- 1903. Wiesner und seine Schule. Von Linsbauer u. a. Wien.

- 1904. Uber den Einfluß des Sonnen- und des diffusen Tageslichtes auf die Laubentwicklung sommergrüner Holzgewächse. Sitzungsber. Wiener Akad., CXIII.

- 1905. Untersuchungen über den Lichtgenuß der Pflanzen im Yellowstonegebiete und in anderen Gegenden Nordamerikas. Ebendort CXIV.

- 1907. Der Lichtgenuß der Pflanzen. Leipzig.

- 1908. Bemerkungen über den Zusammenhang von Blattgestalt und Lichtgenuß. Sitzungsber. d. K. Akad. d. Wissensech. Wien CXVII. Abt. 1.

- 1909. Photometrische Untersuchungen. Sitzungsber. Akad. Wiss. Wien.

-, Figdor, Krasser, F., und Linsbauer, L., 1896. Untersuchungen über d. photochemische Klima von Wien, Kairo, und Buitenzorg, Java. Denkschr. Wiener Akad., LXIV.

Wilhelm, K., 1883. Über eine Eigentümlichkeit der Spaltöffnungen bei Coniferen. Ber. Dentsch. Bot. Ges., I.

Will, H., 1890. Vegetationsverhältnisse in Süd-Georgien. Die internationale Polarforschung, 1882-3. Die deutschen Expeditionen und ihre Ergebnisse. II. Hamburg.

Wille, N., 1885. Bidrag til Algernes physiologiske Anatomi. Sv. Vet. Akad. Handl., $\mathrm{XXI}$.

- 1887. Kritische Studien über die Anpassungen der Pflanzen an Regen und Tau. Cohns Beiträge zur Biologie der Pflanzen, IV.

- 1897. Om Færöernes Ferskvandsalger og om Ferskvandsalgernes Spredningsmaader. Bot. Notiser.

- 1904 a. Schizophyceen. Nordisches Plankton, Heft XX.

- 1904 b. Die Schizophyceen der Plankton-Expedition. Ergebnisse der in dem Atlantischen Ocean ... 1899 ausgeführten Plankton-Expedition der HumboldtStiftung, hrsg. von V. Hensen.

- 1905. Utber die Schübelerschen Anschauungen in betreff der Veränderungen der Pflanzen in nördlichen Breiten. Biol. Centralbl. XXV.

- 1908. Schizophyceen. Nord. Plankton herausgegeben von Brandt und Apstein, XX.

- 1915. The Flora of Norway and its Immigration. Ann. Miss. Bot. Gard., II, $59 \mathrm{ff}$.

Willis, J. C., and Burkill, T. H., 1895. Observations on the flora of the pollard willows near Cambridge. Proc. Cambridge Philos. Soc., VIII.

- 1903. Studies in the Morphology and Ecology of the Podostemaceae of Ceylon and India. Ann. of the Roy. Botanic Gardens, Peradeniya., I.

Willkomm, M., 1852. Vegetation der Strand- and Steppengebiete der iberischen Halbinsel.

- 1896. Grundzüge der Pflanzenverbreitung anf der iberischen Halbinsel. Engler a, Drude, Vegetation der Erde. Leipzig.

Wilson, W. P., 1889. The production of aerating organs on the roots of swamp and other plants. Proc. Acad. Nat. Ser. Philadelphia. 
Wilson, M., 1911. Plant distribution in the woods of N. E. Kent. I. Ann. of Botany, $\mathrm{XXV}, 857 \mathrm{ff}$.

Wimmenauer, K., 1897. Die Hauptergebnisse zehnjähriger forstlich. phänologischer Beobachtungen in Deutschland 1885-1894. - Ver. Dentsch. forstl. Vers.-Anst. Berlin.

Winge, Ø., 1913. Om Sargassohavet. Botan. Tidsskrift XXXIII.

Winkelmann, F., 1905. Forstbotanisches Merkbuch von Pommern. Berlin.

Winkler, H. 1901. Pflanzengeographische Studien über die Formation des Buchen waldes. Diss., Breslau.

- 1913 a. Versuche über die Ernährung der Mistel, in Naturw. Zeitschr. Forst- u. Landwirtsch. XI.

- 1913 b. Die Pflanzenwelt der Tropen. Das Leben der Pflanze. III. Stuttgart, Kosmos.

Witte, H., 1906. Till de Svenska Alfvarvăxternas ekologi. Uppsala.

Wittmack, L. Utber die Moorwiesen von Zehdenick. (Mehrere Abh. in Landw. Jahrb. u. Ber. d. Deutsch. bot. Ges.)

Wittrock, V. B., 1883. Om snöns och isens flora. Nordenskiöldis Studier och Forskningar. Stockholm.

- 1891. Biologiska Ormbunkstudier. Acta Horti Bergiani, I.

- 1894. On den högre Epifyt-vegetationen i Sverige. Ebendort II.

Woeik of, A., 1887. Die Klimate der Erde. 2 Tle. Jena.

- 1889. Der Einfluß einer Schneedecke anf Boden, Klima and Wetter. Wien.

Woenig, Fr., 1899. Die Pnsztenflora der großen ungarischen Tiefebene.

Wollny, E. Forschungen auf dem Gebiete der Agrikulturphysik. München.

Wohltmann, F., 1892. Handbuch der tropischen Agrikultur. Berlin.

Woodhead, T. W., 1906. Ecology of woodland plants in the neighbourhood of Huddersfield. Journ. Linn. Soc. Lond, XXXVII.

Woods, J. E. T., 1878. The Forests of Tasmania. Journ. Roy. Soc. N. S. Wales, XII. Nature, XXI.

Wortham, W. H., 1913. Some feathures of the sand-dunes in . . Anglesey. Brit. Associat. Reports.

Wulff, Thorild, 1902. Botanische Beobachtungen aus Spitzbergen. Lund.

Yapp, R. H., 1908. Sketches of Vegetation at home and abrood. IV. Wicken Fen. The new Phytologist, 7.

- 1909. On Stratification in the Vegetation of a Marsh, and its Relation to Evaporation and Temperature. Ann. of Botany XXIII.

- 1912. Spiraea Ulmaria L., and its Bearing on the Problem of Xeromorphy in Marsh Plants. Ebendort XXVI. Vgl. Ecology, I, 553.

Yokoyama, J. Tanaka, 1887. Untersuchungen über die Pflanzenzonen Japans. Petermanns Mitteilungen.

Zacharias, 0., 1891. Die Tier- u. Pflanzenwelt des SüBwassers. I, II. Leipzig.

- 1911. Das SüBwasserplankton. Leipzig.

Zailer, V. u. Wilk, L., 1907. Uber den Einfluß der Pflanzenkonstituenten auf die physikalischen und chemischen Eigenschaften des Torfes, in Zeitschr. f. Moorkultur u. Torfverwertung.

Zederbauer, E., 1904. Ceratium hirundinella in den österreichischen Alpenseen. Österr. Botan. Zeitschr, LIV. 
Zederbauer, E., 1906. Vegetationsbilder aus Kleinasien. Karsten und Schenck, Vegetationsbilder, III, 6.

Źmuda, A. J., 1915. Uber die Vegetation der Tatraer Höhlen. Bull. Acad. sc. Cracovie. Cl. Math. Nat. B. $121 \mathrm{ff}$.

Zon u. Graves, 1911. Light in relation to tree growth. Bull. 92. Forrest serv., U. S. Dep. Agricult.

Zukal, H., 1895. Morphologische und biologische Untersuchungen über Flechten. Sitzungsber. Wiener Akad., CIV.

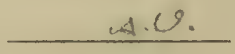




PLEASE DO NOT REMOVE CARDS OR SLIPS FROM THIS POCKET

\section{UNIVERSITY OF TORONTO LIBRARY}

QK Warming, Eugenius

901 Lehrbuch der ökologischen

W288 Pflanzengeographie

1918

BioMed 
